\title{
Licht op het zonneleen Gronsveld: ontwikkeling en instellingen van het Rijksonmiddellijke graafschap Gronsveld (elfde eeuw tot circa 1795)
}

Citation for published version (APA):

van Rensch, T. J. (2015). Licht op het zonneleen Gronsveld: ontwikkeling en instellingen van het Rijksonmiddellijke graafschap Gronsveld (elfde eeuw tot circa 1795). [Doctoral Thesis, Maastricht University]. Maastricht University. https://doi.org/10.26481/dis.20151021tr

Document status and date:

Published: 01/01/2015

DOI:

10.26481/dis.20151021tr

Document Version:

Publisher's PDF, also known as Version of record

Please check the document version of this publication:

- A submitted manuscript is the version of the article upon submission and before peer-review. There can be important differences between the submitted version and the official published version of record.

People interested in the research are advised to contact the author for the final version of the publication, or visit the DOI to the publisher's website.

- The final author version and the galley proof are versions of the publication after peer review.

- The final published version features the final layout of the paper including the volume, issue and page numbers.

Link to publication

\footnotetext{
General rights rights.

- You may freely distribute the URL identifying the publication in the public portal. please follow below link for the End User Agreement:

www.umlib.nl/taverne-license

Take down policy

If you believe that this document breaches copyright please contact us at:

repository@maastrichtuniversity.nl

providing details and we will investigate your claim.
}

Copyright and moral rights for the publications made accessible in the public portal are retained by the authors and/or other copyright owners and it is a condition of accessing publications that users recognise and abide by the legal requirements associated with these

- Users may download and print one copy of any publication from the public portal for the purpose of private study or research.

- You may not further distribute the material or use it for any profit-making activity or commercial gain

If the publication is distributed under the terms of Article $25 \mathrm{fa}$ of the Dutch Copyright Act, indicated by the "Taverne" license above, 


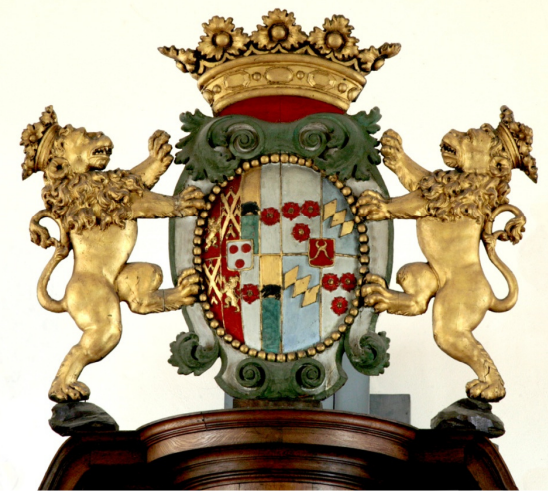

LICHT OP HET ZONNELEEN GRONSVELD

Ontwikkeling en instellingen van het rijksonmiddellijke graafschap Gronsveld (elfde eeuw tot circa 1795)

\section{Proefschrift}

TER VERKRIJGING VAN DE GRAAD VAN DOCTOR AAN DE UNIVERSITEIT MAASTRICHT

OP GEZAG VAN DE RECTOR MAgNificus, Prof. DR. L.L.G. SOETE

VOLGENS HET BESLUIT VAN HET COLLEGE VAN DECANEN

IN HET OPENBAAR TE VERDEDIGEN OP

WOENSDAG 21 OKTOBER 2015 OM 16.00 UUR

DOOR

THEODORUS JACOBUS VAN RENSCH 


\section{Promotor}

Prof. dr. A.M.J.A. Berkvens

Copromotor

Dr. B. van Hofstraeten

\section{Beoordelingscommissie}

Prof. mr. C.H. van Rhee (voorzitter)

Prof. mr. G.R. de Groot

Prof. mr. B.C.M. van Erp-Jacobs (Universiteit Tilburg)

Prof. dr. D. Heirbaut (Universiteit Gent) 
Voorwoord

I Inleiding

1 Opzet van dit boek

2 De begrippen 'land', 'heerlijkheid' en 'graafschap' Gronsveld 22

3 Kleine territoria in de historiografie 24

3.1 Kleine territoria binnen het Heilige Roomse Rijk der Duitse Natie en 24 binnen de Nederlanden als onderzoeksthema

3.2 Kleine territoria als onderzoeksthema in het Limburgse Maasdal 32

4 Archivalische bronnen voor onderzoek 38

4.1 Archieven van het graafschap Gronsveld 38

4.2 Het 'cartularium' van Gronsveld $\quad 43$

4.3 Archieven in München 44

4.4 'Afgedwaalde' archieven $\quad 45$

4.5 Archieven over Gronsveld 47

5 Enkele thema's van onderzoek nader belicht 48

5.1 Territoriumvorming 48

5.2 Heren en graven van Gronsveld $\quad 52$

5.3 Gronsveld en het Heilige Roomse Rijk der Duitse Natie 55

5.4 Bestuurders en onderdanen $\quad 67$

5.4.1 Karakter van het landsheerlijk gezag $\quad 69$

5.4.2 Functionarissen als schakel tussen landsheer en onderdanen $\quad 69$

$\begin{array}{ll}\text { 5.4.3 Rechterlijke colleges } & 70\end{array}$

5.4.4 Geërfden en gemeenten $\quad 72$

5.5 Landsheerlijke rechten als instrumenten van gezagsuitoefening en bron van inkomsten

II Ontstaan en ontwikkeling van Gronsveld als landsheerlijkheid in de late middeleeuwen. Een genealogische en geografische benadering

1 De heren van Gronsveld van de elfde tot het einde van de vijftiende eeuw 79

1.1 De familie De Gru(e)les/Grunsele/Gronsfelt in de elfde en twaalfde eeuw $\quad 80$

1.2 De familie De Houffalise en Gronsveld 84

1.3 De heren Van Gronsveld/Van Stolberg in de dertiende eeuw 87

1.4 Johannes II van Gronsveld, 1303-na 1314

1.4.1 Verwantschap met de familie Van Hafkesdale 92

1.4.2 Levensloop en publiek optreden $\quad 95$

$\begin{array}{ll}\text { 1.4.3 Bezittingen } & 96\end{array}$

1.5 Hendrik I van Gronsveld, 1334-1374 98

1.5.1 Geboorte, huwelijk en overlijden 98

1.5.2 Betrekkingen met Brabant/ambtelijke functies 98 
$\begin{array}{ll}\text { 1.5.3 Financier van de hertog van Brabant } & 102\end{array}$

1.6 Johan III van Gronsveld, 1349-1386 103

$\begin{array}{ll}\text { 1.6.1 Geboorte, huwelijken en overlijden } & 103\end{array}$

1.6.2 Ambtelijke loopbaan en financier $\quad 103$

1.6.3 Een gewelddadig leven en een gewelddadig einde 106

1.7 Hendrik II van Gronsveld, 1382/1386-1401/1404 109

$\begin{array}{ll}\text { 1.7.1 Huwelijken } & 109\end{array}$

$\begin{array}{ll}\text { 1.7.2 Relaties met Brabant } & 111\end{array}$

1.7.3 Boedelscheiding met Christiaan van Ringberg 113

1.8 Hendrik III van Gronsveld, 1407-1474/1476 116

$\begin{array}{ll}\text { 1.8.1 Geboortejaar } & 116\end{array}$

1.8.2 Ouderlijk erfdeel 117

1.8.3 Huwelijk en kinderen $\quad 117$

1.8.4 Ambtelijke activiteiten en relaties met naburige landsheren $\quad 118$

1.8.5 Betrokkenheid bij mijnbouw 119

1.8.6 Erfenissen van de familie Van Oupeye $\quad 120$

$\begin{array}{ll}\text { 1.8.7 Huwelijken van de dochters } & 124\end{array}$

$\begin{array}{ll}1.8 .8 \text { Nadagen en overlijden } & 126\end{array}$

$\begin{array}{ll}1.9 \text { Conclusies } & 127\end{array}$

2 Ontstaan en consolidatie van het Land Gronsveld 131

2.1 De rechterlijke organisatie van het Land Gronsveld aan het einde van de middeleeuwen

2.1.1 Ontwikkeling van de rechtspraak 132

$\begin{array}{ll}\text { 2.1.2 Schepenbanken } & 136\end{array}$

$\begin{array}{lr}2.1 .3 \text { Laathoven } & 140\end{array}$

2.1.4 Het leenhof 146

2.1.5 Hoofdvaart 147

2.2 Ontstaan van het Land Gronsveld en domaniaal grondbezit $\quad 151$

$\begin{array}{ll}\text { 2.2.1 De kaart van } 1754 \text { als uitgangspunt voor onderzoek } & 151\end{array}$

2.2.2 Lenen, keurmeden en cijnzen als onderzoeksobject 154

2.3 Gronsveld en Eckelrade $\quad 155$

$\begin{array}{ll}\text { 2.3.1 Geografisch beeld van Gronsveld } & 155\end{array}$

2.3.2 Geografisch beeld van Eckelrade $\quad 157$

2.3.3 Grenzen van Gronsveld en Eckelrade $\quad 158$

2.3.4 Gronsveld en Eckelrade één parochie 164

2.3.5 Het oorspronkelijk domein van de heren van Gronsveld 165 Landsheerlijk grondberit in volle eigendom te Gronsveld en Eckelrade $\quad 165$ Leengoederen te Gronsveld en Eckelrade $\quad 167$

Wijngaardshof 167

Seutendalsleen 169

Hamersbach 170

Houwert of Hogaert 171

Kleine lenen $\quad 172$

Keurmedige goederen 172

2.3.6 Overige grote geërfden en laathoven 173 
$\begin{array}{lc}\text { 2.3.7 Conclusies } & 174\end{array}$

2.4 Heugem 177

2.4.1 Geografisch beeld en vroegste ontwikkeling 177

$\begin{array}{ll}\text { 2.4.2 Grenzen } & 180\end{array}$

2.4.3 De Luikse heerlijkheid Heugem tot $1363 \quad 182$

2.4.4 Bezittingen van de heren van Gronsveld in Heugem 184

$\begin{array}{ll}2.4 .5 \text { Conclusies } & 185\end{array}$

2.5 Honthem 186

2.5.1 Geografisch beeld en grenzen 186

$\begin{array}{ll}\text { 2.5.2 Ontwikkeling } & 187\end{array}$

2.6 Het Valkenburgse leen De Bijbank 189

2.7 Slenaken $\quad 195$

$\begin{array}{ll}\text { 2.7.1 Naam en geografisch beeld } & 195\end{array}$

2.7.2 Grenzen 195

2.7.3 Parochie 196

$\begin{array}{ll}\text { 2.7.4 Heerlijk goed, keurmeden en lenen } & 197\end{array}$

$\begin{array}{ll}\text { 2.7.5 Schepenbank en heerlijkheid } & 199\end{array}$

$\begin{array}{ll}\text { 2.7.6 Conclusies } & 200\end{array}$

2.8 De Gronsveldse lenen in Vaals, Holset en Einrade 200

2.8.1 Het patronaatsrecht over de kerk van Holset en tiendrecht 200

2.8.2 Schets van de staatkundige verhoudingen en rechterlijke organisatie van

Vaals, Holset, Einrade en Vaalsbroek 201

2.8.3 De Gronsveldse lenen 204

Vaalsbroek. 205

Einrade $\quad 209$

Holset $\quad 211$

Overige grote lenen $\quad 213$

Kleine lenen $\quad 213$

2.8.4 Conclusies 213

2.9 Oost en Sint-Martens-Voeren 214

2.9.1 Oost 214

2.9.2 Sint-Martens-Voeren 219

$\begin{array}{ll}2.9 .3 \text { Conclusies } & 220\end{array}$

III Heren en graven van Gronsveld uit de geslachten Van Bronckhorst Batenburg, d'Arberg Valengin en Toerring-Jettenbach, vijftiende - achttiende eeuw

3 De heren en graven van Gronsveld uit het geslacht Van Bronckhorst Batenburg tot 1617

3.1 Diederik I van Bronckhorst Batenburg ?-1450 223

3.1.1 Huwelijk met Johanna van Gronsveld 223

$\begin{array}{ll}\text { 3.1.2 De afkomst van Diederik } & 224\end{array}$

3.1.3 Activiteiten in Gelre en Kleef $\quad 227$

3.1.4 Pelgrimage naar het Heilig Land 230 
3.1.5 Verdeling van de nalatenschap 231

3.2 Hendrik I van Bronckhorst Batenburg, 1474 (1476)-1493 231

$\begin{array}{ll}\text { 3.2.1 Levensloop } & 231\end{array}$

3.2.2 De familie Van Alpen $\quad 233$

3.3 Diederik II van Bronckhorst Batenburg, 1493-1508 234

$\begin{array}{ll}\text { 3.3.1 Ambten en bezit } & 234\end{array}$

3.3.2 Tussen Habsburg en Gelre $\quad 236$

3.3.3 Verheffing tot Reichsfreiberr 238

3.4 Johan I van Bronckhorst Batenburg, 1508/1511-1558/1559 241

3.5 Willem van Bronckhorst Batenburg, 1558/1559-1563 246

3.6 Jost en Johan van Bronckhorst Batenburg gezamenlijk, 1563-1586 247

3.6.1 Voogdij en opvoeding 247

$\begin{array}{ll}\text { 3.6.2 Oorlogstoestand } & 250\end{array}$

3.6.3 Verwerving van de graventitel 251

3.7 Jost van Bronckhorst Batenburg, 1586-1588 254

3.8 Johan II van Bronckhorst Batenburg, 1588-1617 255

3.8.1 De erfenis van Jost van Bronckhorst Batenburg 255

3.8.2 Huwelijk, schoonfamilie en kinderen 256

3.8.3 Verwerving van Hönnepel 257

$\begin{array}{ll}\text { 3.8.4 Problemen rond Eberstein } & 257\end{array}$

3.8.5 Heer van Gronsveld $\quad 258$

3.9 De familie Van Bronckhorst Batenburg en het protestantisme 259

3.10 Conclusies $\quad 266$

4 De graven van Gronsveld uit het geslacht Van Bronckhorst
Batenburg 1617-1719

4.1 Jost Maximiliaan van Bronckhorst Batenburg, 1617-1662 268

$\begin{array}{ll}\text { 4.1.1 Onverdeelde boedel } & 268\end{array}$

4.1.2 De loopbaan van Jost Maximiliaan tot $1636 \quad 271$

4.1.3 Huwelijk en kinderen 283

4.1.4 Nieuwe actieve militaire dienst, 1645-1648 285

$\begin{array}{ll}\text { 4.1.5 Financiële gevolgen } & 286\end{array}$

4.1.6 Politieke en diplomatieke activiteiten 288

$\begin{array}{ll}\text { 4.1.7 Heer van Gronsveld } & 290\end{array}$

4.2 De erven van Jost Maximiliaan van Bronckhorst Batenburg, 1662-1677 293

4.3 Johan Frans van Bronckhorst Batenburg, 1677-1719 297

4.3.1 Militaire loopbaan $\quad 297$

4.3.2 Johan Frans van Bronckhorst Batenburg in tweede huwelijk 301

$\begin{array}{ll}\text { 4.3.3 Beheer van het graafschap } & 302\end{array}$

$\begin{array}{ll}\text { 4.3.4 De kerk van Gronsveld, monument voor een uitgestorven geslacht } & 305 \\ \text { 4.4 Conclusies } & 306\end{array}$

5 De graven van Gronsveld uit de geslachten d'Arberg Valengin en ToerringJettenbach, 1719-1795

5.1 Maria Anna von Toerring-Jettenbach en Claude Nicolas d'Arberg Valengin, 1719- 
1731

5.2 Maria Josepha Nepomucena d'Arberg Valengin en haar voogd Ignaz Felix von Toerring-Jettenbach, 1731-1746

5.3 Maria Josepha Nepomucena d'Arberg Valengin, 1746-1754, en Maximilian Emanuel von Toerring-Jettenbach, (1746) 1754-1773

5.4 August Joseph von Toerring-Jettenbach, 1773-1795 (1802)

5.5 Conclusies

IV Administratieve structuren en rechterlijke organisatie van Gronsveld in de Nieuwe Tijd, circa 1500-1796

6 Opvolging, inhuldiging en uitvaart van de landsheer

6.1 Opvolging en overdracht van rechten

6.2 De juridische betekenis van landsheerlijke inhuldiging en uitvaart

6.3 Overdracht van Gronsveld en Rimburg aan Jost van Bronckhorst Batenburg, 1586

327

6.4 Inhuldiging van Jost Maximiliaan van Bronckhorst Batenburg, 1619

6.5 Inhuldiging van Johan Frans van Bronckhorst Batenburg, 1677

6.6 Inhuldiging van Maria Anna von Toerring-Jettenbach, 1719 330

6.7 Inhuldiging van Maximilian Emanuel von Toerring-Jettenbach, 1754

6.8 Inhuldiging van August Joseph von Toerring-Jettenbach, $1773 \quad 336$

6.9 Uitvaart- en begrafenisplechtigheden vóór 1754

6.10 Rouwplechtigheden voor Maria Josepha d'Arberg Valengin, 1754

6.11 Rouwplechtigheden voor Maximilian Emanuel von Toerring-Jettenbach, $1773 \quad 349$

6.12 Conclusies

7 Wet- en regelgeving

7.1 Gelaagdheid in en omvang van wet- en regelgeving 356

7.2 Rijkswetgeving in het algemeen 358

7.3 Rijkswetgeving in Gronsveld 361

7.4 In Gronsveld afgekondigde wetgeving 362

7.4.1 Wetgeving op het snijvlak van kerk en staat 362

- Het 'Mandat den floicken ende schelden belangende', 1546

- Afkondiging van de decreten van 'Trente', $1608 \quad 365$

- Wetgeving tegen de dode hand 366

- Twee voorbeelden van Luikse kerkelijke regelgeving in de achttiende eeuw

$\begin{array}{ll}\text { 7.4.2 'Politieke ordonnanties' } & 371\end{array}$

$\begin{array}{ll}\text { 7.4.3 De Gronsveldse Rechtsordnung, } 1671 & 372\end{array}$

7.4.4 Algemene karakteristiek van de wetgeving in de achttiende eeuw 376

7.4.5 Formulier, registratie en bekendmaking van wetgeving 378

7.5 Grafelijke interpretatie van wetgeving
780

$\begin{array}{ll}7.6 \text { Conclusies } & 381\end{array}$ 
8 Landsheerlijke functionarissen tijdens de heren en graven Van Bronckhorst Batenburg circa 1550-1720

8.1 Familieregering 383

8.2 Scholtissen, midden zestiende eeuw - 1628

8.3 'Momboir des heren', begin zeventiende eeuw 387

8.4 Drossaarden, 1596-1624 388

8.5 Rentmeesters, midden zestiende eeuw - 1628

8.6 Christiaan Lamberts, drossaard, circa 1631 - 1668/1669 394

8.7 Rentmeesters, 1628-1667 397

8.8 Wilhelm Veucht, juridisch adviseur, 1660-1694 398

8.9 Engelbert Rippegard, scholtis, 1670-1671? 400

8.10 Willem Kicken, scholtis, drossaard en rentmeester, 1676-1720 401

8.11 Grafelijke commissarissen, begin achttiende eeuw 406

$\begin{array}{ll}8.12 \text { Conclusies } & 407\end{array}$

9 De schepenbanken, circa 1550-1720 409

9.1 De schepenbanken gezamenlijk en afzonderlijk 410

9.2 Benoeming en kwalificatie van schepenen $\quad 412$

9.3 De secretaris of gerechtsschrijver $\quad 413$

9.4 De gerechtsbode $\quad 415$

9.5 Het voogdgeding $\quad 416$

9.6 De 'gemeyn quest' $\quad 420$

9.7 Enkele aspecten van materieel recht en procesrecht $\quad 423$

9.8 Criminaliteit $\quad 426$

9.9 Het hoger beroep $\quad 427$

9.9.1 De Schepenstoel van Aken als hoofd- en appelgerecht 427

9.9.2 Het hoger beroep van Slenaken op Gronsveld en van Gronsveld op Aken 431

9.9.3 De benoeming van een appelcommissaris $\quad 437$

9.9.4 Het appel van Honthem op Heugem en Luik 441

9.9.5 De verhouding tot de Rijkshofraad en het Rijkskamergerecht. 441

9.10 Conclusies $\quad 442$

10 Het leenhof, zestiende eeuw - circa 1720

10.1 Organisatie van het leenhof $\quad 444$

10.2 De administratie van het leenhof $\quad 445$

10.3 Afkalving van het leenhof $\quad 446$

10.4 Het materiële leenrecht $\quad 448$

10.5 Het formele leenrecht $\quad 452$

10.6 Hoger beroep in leenzaken $\quad 453$

10.7 Conclusies $\quad 456$

11 Bestuur en rechtspraak ten tijde van de 'admodiatie', circa 1720-1732 457

11.1 Joannes Godefridus Lebens vestigt zijn gezag als drossaard $\quad 458$ 
11.2 De verpachting van het graafschap aan François Gathoye $\quad 460$

11.3 De dood van Sebastiaan de Montbrison $\quad 461$

11.4 Gathoye's optreden tegen de bevolking 463

11.5 Stagnatie, oplopende spanning en vonnis in de moordzaak de Montbrison $\quad 463$

11.6 Nieuwe geweldpleging en Gathoye verdreven 466

$\begin{array}{ll}11.7 \text { Lebens de baas in het graafschap } & 469\end{array}$

11.8 De terugkeer van Gathoye $\quad 470$

11.9 Grafelijke inmenging: het optreden van commissaris Petit en baron de Bounam $\quad 472$

11.10 Het Rijkskamergerecht doet uitspraak $\quad 473$

11.11 Aken herstelt orde en regelmaat $\quad 474$

11.12 De activiteiten van baron Vincent Philip Anton van der Heyden genaamd

Belderbusch $\quad 476$

11.13 De orde hersteld $\quad 479$

$\begin{array}{ll}11.14 \text { Conclusies } & 480\end{array}$

12 Landsheerlijke functionarissen, 1732-1795 482

12.1 Herstel van normaal bestuur in Gronsveld $\quad 483$

12.2 Josephus Antonius Schmädel, 'Hofrath' en pastoor 486

12.3 Joseph Anton Prummer, secretaris-commissaris $\quad 487$

12.4 Drossaard en 'fiscus' als zelfstandige functies $\quad 495$

12.5 Johan Matthias Oligschläger, rentmeester $\quad 500$

12.6 Johan Frans Lebens, rentmeester 510

12.7 Wolfgang Zollner, directeur, commissaris en rentmeester 513

12.8 Een vergelijking tussen Gronsveld en kleine rijksonmiddellijke territoria in het Maasgebied tijdens de achttiende eeuw 531

12.9 Conclusies $\quad 535$

13 De schepenbanken, circa 1730-1795

13.1 Beeld van de rechtspraak ten plattelande in het Maasgebied in de achttiende eeuw 539

13.2 Beeld van de rechtspraak in Gronsveld, circa 1750-1794 541

13.3 Het hoger beroep $\quad 544$

13.4 Strafrechtspraak en landsheerlijke bemoeienis $\quad 547$

13.5 Het einde van de schepenbank(en) 553

13.6 Conclusies $\quad 556$

14 Het leenhof, circa 1730-1796

14.1 De stadhouder en vicestadhouder van het leenhof 558

14.2 De lenen in Vaals en Holset $\quad 560$

14.3 Verbeteringen in de leenadministratie $\quad 563$

15 (Lands)heerlijke rechten en ander vermogen als instrument van gezagsuitoefening en bron van inkomsten $\quad 565$

15.1 Enkele beschouwingen over de financiële betekenis van de grafelijke rechten en 
inkomsten 566

15.2 Recht van muntslag $\quad 573$

15.3 Recht op herendiensten $\quad 587$

15.4 Recht op werfschelling $\quad 591$

15.5 Recht op banmolens

15.6 Recht van accijns op mout en bier $\quad 595$

15.7 Recht op plaatsing van bijenkorven $\quad 596$

15.8 Recht op winning van mergel $\quad 597$

15.9 Recht van haveschot $\quad 598$

15.10 Recht op toelating van Joden $\quad 599$

$\begin{array}{ll}15.11 \text { Recht van jacht } & 600\end{array}$

$\begin{array}{ll}15.12 \text { Recht van visvangst } & 603\end{array}$

15.13 Recht op houden van duiven $\quad 604$

$\begin{array}{ll}15.14 \text { Recht op aanwas van land } & 604\end{array}$

15.15 Land- en erfpachten $\quad 605$

15.16 Recht op cijnzen en bede $\quad 609$

15.17 Rechten op bossen $\quad 616$

15.18 Rechten op weidegronden $\quad 619$

15.19 Rechten op tienden $\quad 620$

15.20 Recht van patronaat op kerken en collatie van (geestelijke) beneficies 624

15.20.1 Patronaats- en collatierechten in het algemeen 624

15.20.2 Patronaats- en collatierechten in Gronsveld en Eckelrade 628

Pastoraat in Gronsveld en Eckelrade: benoemingen en ervaringen $\quad 628$

Beneficie van Sint-Amandus in Gronsveld $\quad 636$

Beneficie van Onze-Lieve-V roum in Eckelrade 636

Beneficie van Onze-Lieve-V roum in Gronsveld 636

De kosterij in Gronsveld

Kapelanie $\quad 637$

Kerkefabriek in Gronsveld en Eckelrade $\quad 640$

15.20.3 Collatierechten in Heugem 643

Pastoraat in Hengem 643

Kosterij van Heugem $\quad 650$

Kerkfabriek in Heugem 651

15.20.4 Collatierechten in Sint-Martens-Voeren en Slenaken 653

Beneficies in Sint-Martens-Voeren en Slenaken 653

Beneficie van Onze-Lieve-V roum in Slenaken $\quad 654$

Kosterij in Slenaken $\quad 654$

15.20.5 Collatierecht in Holset $\quad 655$

15.20.6 'Patronaatsrecht' over het klooster Hoogcruts 656

$\begin{array}{ll}15.21 \text { Recht van admissie voor openbare ambten } & 658\end{array}$

$\begin{array}{ll}\text { 15.21.1 Notarissen } & 658\end{array}$

15.21.2 De secretaris van de schepenbank als zelfstandig openbaar ambtenaar $\quad 661$

$\begin{array}{ll}\text { 15.21.3 Notariële werkzaamheden van pastoors } & 662\end{array}$

15.21.4 Landmeters 663

$\begin{array}{ll}15.22 \text { Conclusies } & 664\end{array}$ 
16 Belastingheffing binnen het Heilige Roomse Rijk en de geërfden van Gronsveld

16.1 Belastingheffing binnen het Heilige Roomse Rijk 671

$\begin{array}{ll}\text { 16.1.1 Gemeine Pfennig } & 671\end{array}$

16.1.2 Matrikelbelastingen en de Wormser Matrikel van 1521

$\begin{array}{ll}\text { 16.1.3 Belastingheffing door de kreits } & 674\end{array}$

16.1.4 Defensie tegen externe vijanden: Türkensteuer $\quad 675$

16.1.5 De defensie van het Rijk in de eerste helft van de zeventiende eeuw $\quad 676$

16.1.6 De Reichsdefensionalordnung 1681-1682: aanloop en uitwerking 676

16.1.7 Kreissimplum en andere kreitskosten $\quad 680$

16.1.8 Kammerzieler 681

16.1.9 Bijdrage aan het Nederrijns-Westfaalse Rijksgravencollege 682

16.2 Gronsveld en de belastingen voor het Rijk 683

16.2.1 Graaf Johan II van Bronckhorst Batenburg en de invoering van grondbelastingen

16.2.2 De Maastrichtse belastingvrijheid $\quad 688$

$\begin{array}{ll}\text { 16.2.3 Nieuw verzet tegen grondbelastingen } & 691\end{array}$

16.2.4 Een organisatie van geërfden in de zeventiende eeuw? 693

16.2.5 Het reglement op de belastingen van $1718 \quad 694$

16.2.6 Een nieuw begin: de conventie van $1739 \quad 696$

16.2.7 De landsvergadering $\quad 699$

Vergelijking met staten- en geërfdenvergaderingen in naburige territoria 699

Werkwijze van de Gronsveldse landsvergadering $\quad 703$

De Maastrichtse belastingurijheid opnieuw ter discussie $\quad 705$

Het geschil over de belastingen met Slenaken $\quad 708$

16.2.8 De belastingen en bijdragen afzonderlijk beschouwd 710

Römermonate en andere militaire bijdragen na de Reichsdefensionalordnung van 1682

$\begin{array}{ll}\text { Türkensteuer } & 713\end{array}$

$\begin{array}{ll}\text { Overige betalingen aan de Kreits } & 714\end{array}$

Kammerzieler $\quad 715$

De bijdragen aan het Nederrijns-Westfaalse Rijksgravencollege $\quad 717$

16.3 Conclusies

$\begin{array}{ll}17 \text { Gemeenten } & 723\end{array}$

17.1 Gemeenten en kerspelen $\quad 723$

17.2 Ontstaan en aantal gemeenten binnen het graafschap Gronsveld 724

17.3 De putten van Eckelrade, een gemeenschappelijke regeling 'over de grens' $\quad 728$

$\begin{array}{ll}17.4 \text { Besluitvorming } & 729\end{array}$

$\begin{array}{ll}\text { 17.5 Vertegenwoordiging van de gemeente } & 729\end{array}$

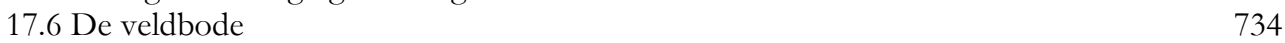

$\begin{array}{ll}17.7 \text { Gemeente en schepenbank } & 735\end{array}$

$\begin{array}{ll}17.8 \text { Gemeente en 'personele omlage' } & 736\end{array}$

$\begin{array}{ll}17.9 \text { Conclusies } & 738\end{array}$ 
V SAMENVATTING

739

Thema en achtergrond van onderzoek

Het ontstaan van het Land Gronsveld en genealogische achtergronden van de heren van Gronsveld in de middeleeuwen

De heren van Gronsveld van de vijftiende tot het einde van de achttiende eeuw

Administratieve structuren en rechterlijke organisatie circa 1500-1796. 748

$\begin{array}{ll}\text { Slotbeschouwing } & 757\end{array}$

VI Summary $\quad 760$

$\begin{array}{ll}\text { Theme and Background } & 760\end{array}$

The Origins of the Land of Gronsveld and the Genealogical Background of the Seigneurs of Gronsveld in the Middle Ages 762

The Seigneurs of Gronsveld from the Fifteenth until the End of Eighteenth Century 766

Administrative Structures and Judicial Organisation from about 1500-1796 769

$\begin{array}{ll}\text { Final Observations } & 778\end{array}$

$\begin{array}{ll}\text { VII Valorisatie } & 781\end{array}$

$\begin{array}{ll}\text { Afkortingen } & 790\end{array}$

$\begin{array}{ll}\text { Onuitgegeven bronnen } & 791\end{array}$

$\begin{array}{ll}\text { Literatuurlijst } & 794\end{array}$

Bijlage 1 Overzicht heren en graven van Gronsveld dertiende eeuw - 1795 (1803) 816

Bijlage 2 Rechtsbronnen $\quad 820$

Inhoudsoverzicht $\quad 820$

Wet- en regelgeving $\quad 823$

Verklaringen betreffende geldend recht 931

Formulieren voor het ‘bannen’ van het voogdgeding 934

Overeenkomsten met inwoners en geërfden over het betalen van belastingen 939

Verheffingen in de adelstand 956

Diversen 961

Curriculum vitae van de auteur $\quad 982$ 


\section{Voorwoord}

Het voorliggende proefschrift heeft betrekking op het kleine, 'rijksonmiddellijke' graafschap Gronsveld, thans gelegen binnen het gebied van de provincie Nederlands Limburg, maar tot 1795 ressorterend onder het Heilige Roomse Rijk der Duitse Natie. Eertijds hoorden daartoe de dorpen en/of gehuchten Gronsveld en Eckelrade, Heugem, Honthem en (tot 1728) Slenaken. De studie kent een lange voorgeschiedenis. Omstreeks 2000 werd door mij gewerkt aan de inventarisatie van het toen nog bij het Rijksarchief Limburg, thans Regionaal Historisch Centrum Limburg, berustende archief van het graafschap Gronsveld. Die keuze was mede bepaald door het feit dat Gronsveld sinds 1994 mijn woonplaats was. Het ging om ongeveer drie strekkende meter archieven van de Gronsveldse schepenbanken en wat losse stukken uit de archieven van de graven van Gronsveld, bij elkaar niet meer dan een fragment van het ooit omvangrijke archief dat door Franse militairen begin 1793 was vernietigd. De ordening werd in 2002 afgesloten met een inventaris onder de titel Archieven van het graafschap Gronsveld en de heerlijkheid Slenaken (tot 1728).

Tijdens de inventarisatie kwam een tot dan toe onbekend handschrift tevoorschijn van de Gronsveldse Rechtsordnung uit 1673. Een tweede, iets afwijkende, versie daarvan was, zo bleek later, al in de jaren zeventig ontdekt en gekopieerd door de Limburgse rechtshistoricus mr. K. J. Th. Janssen de Limpens in het archief van de graven zu Toerring Jettenbach in München. De Toerrings hebben van circa 1730 tot 1800 als graven over Gronsveld geregeerd. Janssen de Limpens, die een grote staat van dienst had als uitgever van Limburgse rechtsbronnen, werkte toen aan de publicatie van rechtsbronnen van Limburgse rijksheerlijkheden, maar zijn onverwachte overlijden op 12 augustus 1980 verhinderde de uitvoering van dit voornemen. $\mathrm{Na}$ de ontdekking van deze twee teksten ontstond het plan daarvan, in combinatie met andere Gronsveldse rechtsbronnen, een nieuwe editie te verzorgen. Uiteindelijk is dat ook gerealiseerd in de vorm van bijlagen in dit boek. Maar wat aanvankelijk als een inleiding daarbij was gedacht, groeide uit tot dit omvangrijke proefschrift.

Historici gaan bij hun onderzoek soms uit van een vraagstelling op basis van een theorie, waar de beschikbare bronnen aan worden getoetst. Maar ook het omgekeerde is mogelijk in die zin dat gaandeweg vooral de omvang en de inhoud van die bronnen een zware stempel drukken op de uitkomst. Dat laatste was bij dit boek zeker het geval. Daarom eerst enkele opmerkingen over die bronnen.

Naast het Gronsveldse archief in Maastricht was bij de heemkundestichting 'Grueles' in Gronsveld een en ander bekend over 'Gronsveldse stukken' in het archief van de graven zu Toerring-Jettenbach in het Staatsarchiv München. Vooral kadastrale kaarten van het graafschap uit het midden van de achttiende eeuw hadden al eerder de aandacht getrokken, maar een goed overzicht van de rest van het archief ontbrak. Een bezoek aan München maakte duidelijk hoeveel materiaal daar nog voorhanden was uit de tijd dat de Toerrings over Gronsveld regeerden. Daarnaast bevatte het archief in München nog stukken uit het archief van hun voorgangers in Gronsveld, de familie Van Bronckhorst Batenburg, waarvan leden vanaf het einde van de middeleeuwen over Gronsveld 
regeerden. Het initiatief van de Stichting 'Grueles' deze stukken in München te laten verfilmen maakte het mogelijk de inhoud ook in Maastricht bij het Regionaal Historisch Centrum Limburg te bestuderen. Dit boek is voor een belangrijk deel gebaseerd op dit verfilmde materiaal.

Ten slotte moet voor het onderzoek naar Gronsveld nog een derde belangrijke, tot dusver voor historisch onderzoek nauwelijks aangeboorde, bron worden genoemd, te weten de sedert 2002 goed ontsloten dossiers van het Rijkskamergerecht, die bij het Regionaal Historisch Centrum Limburg berusten.

De stukken uit de drie hiervoor genoemde fondsen vulden elkaar zodanig aan, dat het verantwoord was op basis daarvan een studie over Gronsveld te verrichten. Met de geheel verschillende overlevering van historische bronnen bleven bepaalde lacunes echter onvermijdelijk. In het bijzonder gold dat voor de late middeleeuwen. Het onderzoek naar de geschiedenis van de heren van Gronsveld uit die tijd is grotendeels gebaseerd op gedrukte teksten uit allerlei archieven. De originelen zijn, op enkele uitzonderingen na, niet meer gecontroleerd. Afgezien van een vluchtige kennismaking zijn ook buiten beschouwing gebleven de archieven van de Schepenstoel van Aken, de NederrijnsWestfaalse Kreits en het Nederrijns-Westfaalse Rijksgravencollege. Deze bevatten zeker nog belangrijk materiaal voor Gronsveld, maar de archieven waarop deze studie is gebaseerd bevatten al zoveel informatie over de betrekkingen met deze instellingen, dat dit voor een globale beeldvorming toereikend werd geacht.

Naast schaarste en gemis aan bronnen was er ook overdaad. In het bijzonder de intensieve briefwisseling uit de achttiende eeuw tussen de graven in München en hun vertegenwoordigers in Gronsveld leverde een schat aan gegevens over het functioneren van bestuur en rechtspraak binnen het kleine graafschap Gronsveld. Soms grepen de schrijvers daarbij ook terug op oudere archieven die thans niet meer in origineel aanwezig zijn. Maar in die correspondentie is het vooral de verwevenheid tussen zakelijke informatie en wetenswaardigheden over het dagelijkse leven die ons - zeer uitzonderlijk voor die tijd als het ware een blik achter de schermen gunt..

Uit de inhoud van de bronnen groeide de wetenschappelijke vraagstelling vanuit rechtshistorische invalshoek die aan deze studie ten grondslag ligt. De kern daarvan is: welke personen, instellingen en organisaties waren betrokken bij wetgeving, bestuur en rechtspraak binnen het rijksonmiddellijk graafschap Gronsveld in de vroegmoderne tijd, welke taken hadden zij en hoe functioneerden zij onderling, welke middelen stonden daartoe ter beschikking en welke relaties werden vanuit Gronsveld onderhouden met het Heilige Roomse Rijk der Duitse Natie?

Hoewel chronologisch niet helemaal correct, zou die vroegmoderne tijd in Gronsveld kunnen beginnen in 1586, het jaar waarin de jonge broers Jost en Johan van Bronckhorst Batenburg aan keizer Rudolf II verzochten om in de stand der rijksgraven te worden verheven. Zij meenden op die titel aanspraak te kunnen maken als telgen van een aanzienlijk, oeroud adellijk geslacht, maar ook als eigenaren van het 'allodium' Gronsveld, een onafhankelijke heerlijkheid waarvoor de aanduiding 'zonneleen' werd gebruikt. Die term, een juridische fictie, moest uitdrukken dat de heren van Gronsveld hun rechten 'aan de zon' ontleenden en verder geen gezag boven zich erkenden dan het rechtstreekse gezag van de keizer en de hoogste staatsinstellingen van het Heilige Roomse Rijk (vandaar ook 
de term rijksonmiddellijk). Die bewering bepaalde de twee centrale vragen van het eerste deel van deze studie: Beriepen de gebroeders van Bronckhorst Batenburg zich terecht op hun bijzondere afstamming en was het gebied waarover zij regeerden inderdaad een volledig onafhankelijk 'zonneleen'? Geprobeerd is daarop antwoord te geven door een onderzoek naar de genealogie van de heren van Bronckhorst Batenburg en hun voorgangers en de manier waarop zij hun onafhankelijkheid ten opzichte omringende grote landsheren wisten te handhaven. Verder is een analyse gemaakt van de ontwikkeling van wat vanaf de vijftiende eeuw het 'Land Gronsveld' wordt genoemd en is het allodiale karakter daarvan onderzocht. Daartoe werd ook de ontginningsgeschiedenis van oorspronkelijk heerlijk grondbezit in kaart gebracht. Het onderzoek maakte duidelijk hoe complex de ontstaansgeschiedenis van dit kleine land was en welke doorwerking dit had op bestuur en rechtspraak tot aan de Franse Revolutie.

De Gronsveldse onafhankelijkheid stond niet gelijk aan volstrekte soevereiniteit. Het Heilige Roomse Rijk der Duitse Natie waarvan Gronsveld lidmaat was, was geen nationale staat in de moderne betekenis van het woord, maar een juridisch gecompliceerde, deels feodale, deels volkenrechtelijke constructie van rijksstanden. Daarbinnen waren de keizer en enkele centrale instituties op rijksniveau (Rijksdag, Rijkskamergerecht, Rijkshofraad) de hoogste gezagsdragers, maar de juridische en financiële relaties van de afzonderlijke lidmaten tot het Rijk werden bepaald door gewoonte en rijksrecht. Van directe gezagsverhoudingen was nauwelijks sprake. Door de verheffing tot graaf klommen de heren van Gronsveld ook op tot rijksstand. Politiek legde het daarmee verbonden stemrecht binnen het Rijk een minimaal gewicht in de schaal, maar het belang school in het als rijksstand vertegenwoordigd zijn in de Rijksdag. Dat verschafte sociale status en opende de weg voor hoge functies binnen het Rijk. Daar hebben de graven van Bronckhorst Batenburg in de zeventiende eeuw ook gebruik van gemaakt. Keerzijde van deze standsverhoging waren de financiële verplichtingen jegens het Rijk in vorm van belastingen die de bevolking van het graafschap moest opbrengen.

In deze studie is geprobeerd de verhoudingen tussen Gronsveld en het Heilige Roomse Rijk der Duitse Natie in kaart te brengen. Voor een goed begrip daarvan was het nodig om op elementair niveau ook enige aandacht te besteden aan de instellingen van het Rijk. In tegenstelling tot de overvloed aan Duitstalige publicaties bestaat daar in het Nederlandse taalgebied nauwelijks literatuur over.

Veel aandacht is besteed aan de manier waarop wetgeving, bestuur en rechtspraak in het Land Gronsveld in de vroegmoderne tijd waren georganiseerd. Verbazingwekkend is de complexiteit daarvan, waarbij moet worden bedacht dat het graafschap ondanks zijn kleine omvang en het geringe aantal inwoners een volwaardig land was. Aspecten die aan de orde komen zijn de verschillende bestuursculturen met een landsheer 'op afstand' (aangezien de graven als regel buiten het graafschap verbleven) en plaatselijke 'familieregeringen' van functionarissen in dienst van de graaf. Verder is onderzocht hoe werd omgegaan met conflicten, tussen de graaf en inwoners, tussen instanties onderling (in het bijzonder bij het hoger beroep in rechtszaken) en tussen groeperingen binnen de bevolking. Het graafschap was zeker geen rimpelloze vijver. In het bijzonder de analyse van conflicten op diverse niveaus leert ons waar de grenzen van macht en onmacht lagen. Verder zijn omvang en betekenis van heerlijke rechten in kaart gebracht en ten slotte is beschreven op 
welke manieren de onderdanen zich voor de behartiging van hun belangen collectief organiseerden. Op die manier ontstaat een samenhangend beeld van een staatje in de zeventiende en achttiende eeuw dat door de graaf als landsheer met een door God gelegitimeerd absoluut gezag werd geregeerd. Tegelijkertijd moest hij op basis van de principes van 'Gute Policey' zorgen voor een goed bestuur en een geordende samenleving waarin onderdanen in rust en godvrezendheid konden werken en leven.

Het onderzoek leverde vaak gedetailleerde informatie uit allerlei bronnen op. Juist door het ontbreken van één goed samenhangend en gestructureerd archief fungeerden die losse fragmenten als mozaïeksteentjes om daaruit een beeld van het totaal samen te stellen. Soms hebben die details een anekdotisch karakter en zijn ze vooral interessant voor de plaatselijke geschiedenis en het dagelijkse leven in het graafschap. Maar in de meeste gevallen schuilt het belang vooral in de mogelijkheden om vergelijkingen mogelijk te maken met andere rijksonmiddellijke territoria in het Maasgebied. Op beperkte schaal zijn in deze studie ook van dit soort vergelijkingen gemaakt. Dat geeft enig zicht op raakvlakken, maar er ligt op dit gebied nog een groot terrein braak. Dikwijls is het lastig gegevens uit slecht toegankelijk en over diverse archieven verspreid bronmateriaal boven water te krijgen. Voor Gronsveld is, geprobeerd dit alles in een zodanige systematiek te verwerken, dat delen van het onderzoek naar Gronsveld ook bruikbaar zijn voor andere plaatsen. De achtergrond van de schrijver als archivaris, vertrouwd met de ordening van archieven, is daarbij zeker merkbaar. De verschillende korte inleidingen en samenvattingen geven de lezer steeds een overzicht van onderwerpen die in soms lange hoofdstukken zijn behandeld. Bij dit alles past ook enige bescheidenheid. Ondanks de omvang van dit boek is Gronsveld niet de navel van de wereld. Evenmin is volledigheid nagestreefd en er kleven zeker nog onvolkomenheden aan.

De laatste hand aan het manuscript werd gelegd op 10 augustus 2015, de feestdag van Sint Laurentius, patroonheilige van de archivarissen. Bijna veertig jaar werk en ervaring als archivaris in de omgang met Limburgse archieven hebben zeker een stempel gedrukt op de manier waarop dit werk is aangevat en met historische bronnen is omgegaan. Op die voor mijn beroepsgroep bijzondere dag spreek ik graag mijn grote dankbaarheid uit naar iedereen die, direct of indirect, heeft bijgedragen aan de totstandkoming van deze dissertatie. In de eerste plaats geldt die erkentelijkheid mijn promotor prof. dr. Louis Berkvens en copromotor dr. Bram van Hofstraeten. Vooral het geduld van eerstgenoemde heb ik met dit steeds groeiende werk op de proef gesteld, terwijl hij met goede raadgevingen en gepaste zorg tijdens onze vrijwel wekelijkse tafelgesprekken probeerde sturing te geven aan de voltooiing van dit werk. Ook mijn andere vaste tafelgenoot, prof. $\mathrm{mr}$. Ton Gehlen, bij wie ik dit werk lang geleden begon, ben ik dankbaar voor zijn wijze raadgevingen en zijn inspanningen om het manuscript te lezen en te corrigeren. Op deze plaats denk ik ook met genoegen terug aan mijn eerste academische leermeester in de rechtsgeschiedenis, prof. mr. Olav Moorman van Kappen. Mijn allereerste college aan de Katholieke Universiteit Nijmegen kreeg ik van hem in september 1971, later werd ik student-assistent en studeerde bij hem af met een scriptie over het Justizkollegium van het Pruisisch Overkwartier in de achttiende eeuw. Met dat onderzoek werd ik mij voor het eerst ten volle bewust van de grote samenhang tussen de 'Limburgse' en de 'Duitse' 
rechtsgeschiedenis. Ook al is niet gekomen tot een promotie bij hem, met dit proefschrift hoop ik toch een belofte uit die tijd in te lossen.

Erkentelijk ben ik ook voor de faciliteiten die mijn werkgevers mij boden, tot 2004 de Rijksarchiefdienst en daarna het Regionaal Historisch Centrum Limburg. De achtereenvolgende voorzitters van het bestuur van het Regionaal Historisch Centrum Jean Jacobs en Joke Kersten informeerden regelmatig naar de voortgang en moedigden mij aan. Met de successieve directeuren Douwe de Graaf, Jacques Giesen en Lita Wiggers lukte het altijd op soepele wijze een balans te vinden met andere dagelijkse werkzaamheden. Mijn tijdregistratie en verlofadministratie klopten nooit, maar oprecht heb ik er naar gestreefd ieder het zijne te geven en niemand onder mijn activiteiten te laten lijden.

Het schrijven van dit proefschrift werd voor het grootste deel in de avonduren, in de betrekkelijke eenzaamheid van de studeerkamer uitgevoerd, in een worsteling met lastig te ontcijferen Duitse teksten, met het doorploegen van 'zware' literatuur en het eindeloos 'googelen' op het internet om ontbrekende informatie op te sporen. In die situatie lucht het wel eens op de vergaarde kennis van je af te praten met collega's, vrienden en bekenden, leeszaalbezoekers en soms toevallige contacten met belangstellenden. Soms leverden die contacten ook aanvullende informatie of literatuur op. In de loop der jaren ben ik de tel kwijt geraakt, maar zonder iemand te kort te willen doen wil ik hier in het bijzonder, in alfabetische volgorde, noemen: Hans van Hall, Jan Hartmann, Hartwig Kersken, Paul en Regina Nève-Sprenger, Harrie Weinberg en de verschillende leden van de Sectie Historie van de Stichting Grueles. Bijzonder dierbare herinneringen heb ik aan de zondagse gesprekken met de in 2010 overleden nestor van de Limburgse en Maastrichtse geschiedenis, broeder dr. Pierre Ubachs. 'Noe sjrief dat 'ns op, jóng!' kreeg ik steeds te horen wanneer ik weer enthousiast vertelde wat ik allemaal over Gronsveld had gevonden.

Dankbaarheid past ook ten opzichte van de al eerder genoemde Stichting Grueles die het initiatief nam voor de verfilming van het bestand Gronsveld in het familiearchief van de graven zu Toerring Jettenbach in het Staatsarchiv München op initiatief van de Stichting Grueles in Gronsveld. Met dit proefschrift is voor het eerst op grote schaal gebruik gemaakt van de inhoud van dit rijke fonds, maar er resteert nog voldoende 'onontdekt' materiaal voor jaren onderzoek. Het is hier ook de plaats om er aan te herinneren dat deze verfilming ook leidde tot kennismaking met Hans Veit Graf zu Toerring Jettenbach, nazaat van de graven Toerring Jettenbach die in de achttiende eeuw over Gronsveld regeerden. De hartelijke contacten die toen zijn gelegd en naderhand bevestigd met bezoeken aan Gronsveld, getuigen van diens warme belangstelling voor Gronsveld dat historisch gezien zo'n grote betekenis voor zijn familie heeft gehad.

In de fase van afronding van een proefschrift groeit ook de druk om een 'schone' tekst in te leveren. Waarschijnlijk is het een illusie te denken dat een manuscript van deze omvang volledig foutloos te maken is. De vele mogelijkheden van tekstverwerking op de computer bergen steeds weer het gevaar van nieuwe vergissingen in zich. Bijzonder dankbaar ben ik daarom degenen die zich als lezers van de hele tekst of gedeelten daarvan hebben ingespannen fouten op te sporen en suggesties te doen voor verbeteringen. Met ere mogen hier worden genoemd mijn promotoren Louis Berkvens en Bram van Hofstraeten, Ton Gehlen, Gilles Jaspars, Willy Keyser-Schuurman, Armand Oprey en Emile Ramakers. 
Dezelfde erkentelijkheid heb ik ook ten aanzien van de leescommissie, prof. mr. Remco van Rhee, prof. dr. Dirk Heirbaut, prof. mr. Beatrix van Erp-Jacobs en prof. mr. René de Groot.

Misschien wordt de geschiedenis van het oude graafschap Gronsveld nergens zo voelbaar als in de Sint-Martinuskerk van Gronsveld. In deze grotendeels door graaf Johan Frans van Bronckhorst Batenburg omstreeks 1700 herbouwde kerk herinneren een grafkelder en een monumentale graftombe, wapenborden en altaren aan het grafelijk verleden van Gronsveld. Eens in de vier jaar, tijdens de Grote Bronck, wordt de herinnering aan de vroegere landsheren levendig gehouden door de schutterij Sint-Sebastianus met het luid voorlezen van het reglement op het vogelschieten van graaf August Joseph zu ToerringJettenbach en het geweersalvo bij de 'generale charge' ter ere van de stichter graaf Jost Maximiliaan van Bronckhorst. Dit boek wil een verbinding vormen tussen de 'stille getuigen' en de levende traditie en daarbij leesgenoegen verschaffen aan iedereen die geïnteresseerd is in de geschiedenis van een kleine staat in het Maasgebied vóór de Franse Revolutie. 


\section{INLEIDING}

\section{Opzet van dit boek}

In 1586 richtten de broers Jost en Johan van Bronckhorst Batenburg, heren van Gronsveld en Rimburg aan keizer Rudolf II het verzoek te worden verheven in de stand der rijksgraven. ${ }^{1}$ Hun overgrootvader voerde al sinds 1498 de titel van 'freyherr des Heiligen Reichs', maar zij meenden nu te beschikken over argumenten die een hogere status rechtvaardigden. Daarvoor wezen zij op het prestige van hun familie, een adellijk geslacht van 'uralten stamme'. Voorts werd betoogd dat zij, volgens gewoonterecht, Gronsveld als zogenoemd allodium, dat wil zeggen als vrije eigendom, 'allain von Godt und der sonnen zu lehen empfangen' hadden. Volgens dit beginsel ontleenden de heren van Gronsveld hun gezag over land en inwoners aan 'God en de zon'. ${ }^{2}$ Toch kende deze 'absolute' onafhankelijkheid in de praktijk ook beperkingen in die zin, dat zij zich beschouwden als lidmaat van het Heilige Roomse Rijk der Duitse Natie en zij erkenden het directe of 'onmiddellijke' gezag van de keizer, aan wie zij direct of onmiddellijk ('ohne alle mittell') waren onderworpen aan de keizer.

Ongeveer 175 jaar later, in 1762, noemde Joseph Anton Prummer, vertegenwoordiger in Gronsveld van de in München residerende graaf Maximilian Emanuel von ToerringJettenbach en rechtsopvolger van de graven van Bronckhorst Batenburg, zijn standplaats Gronsveld 'een in de Nederrijns-Westfaalse Kreits gelegen vrij, rijksonmiddellijk graafschap, met zitting en stemrecht [in de kreitsvergadering en de Rijksdag] en voorzien van alle voorrechten die met de soevereiniteit van een land waren verbonden'. Maar, zo voegde hij daar meteen aan toe: het was 'veel geschreeuw en weinig wol'. ${ }^{3}$

Grote woorden voor een klein gebied. Gronsveld was een typisch voorbeeld van een dwergstaatje binnen het Heilige Roomse Rijk der Duitse Natie, in het grensgebied met de

\footnotetext{
${ }^{1}$ Wenen, Österreichisches Staatsarchiv, Allgemeines Verwaltungsarchiv, RAA (Reichsadelsakten), 49.3. 2 Aan deze juridische fictie ergert zich de Gelderse jurist Fredericus à Sande enigszins in zijn Commentarius in Gelriae et Zuphaniae Consuetudines Feudales, 1, waar hij beschrijft dat er 'in den beginne' (in principio) goederen/domeinen ('praedia') waren, waarop de eigenaren het meest volledige eigendomsrecht konden gelden, en die met geen dienst of of financiële verplichting waren belast. In het Romeinse recht werden die goederen 'res mancipi' en in het Langobardische recht 'allodia' genoemd. Dat waren volgens à Sande, 'die kastelen en heerlijkheden die onze voorouders ongepast en barbaars uitgedrukt 'Sonnenlehen' noemden, alsof ze in leen van de zon werden gehouden en hun recht niet aan een menselijke gunst was ontleend'. Als voorbeelden van de bezitters van dit soort 'lege, onbeduidende gezagsrechten' ('imperia vacua') noemt hij de heer van Bronckhorst ('baro Bronckhorstius') en de heer van Arcen ('dominus in Aerssen'). Maar deze heren waren niet uitgezonderd van het algemene gezag van vorsten en de algemeen geldende rechtsorde. Daarom hield à Sande het er op dat deze particuliere gezagsrechten ooit van een hoger gezag waren afgeleid.

3 'eine in dem Niederrheinisch-Westfälischen Craÿs gelegen imediat freÿe, votum und sessionem - nebst all anderen praerogativen einer landts-souverainitaet (multum clamoris et parum lanae) Reichsgraffschafft', TJ, inv. nr. M 73, fol. 466-472, Prummer aan M.E. von Toerring-Jettenbach 13 november 1762 .
} 
Zuidelijke Nederlanden en Luik. Het graafschap bestond uit niet meer dan een smalle strook grond zuidoostelijk van Maastricht, van de Maas in het westen tot het meest oosteliike punt in Honthem 7,5 kilometer lang en op één plaats niet veel breder dan vierhonderd meter. Tot 1728 hoorde daar ook nog het ongeveer twaalf kilometer ten zuidoosten van Gronsveld gelegen dorp Slenaken bij. De economische betekenis was navenant gering. Binnen het graafschap lagen vijf aan elkaar grenzende dorpen of gehuchten, te weten Gronsveld, Eckelrade, de Bijbank, Heugem en Honthem en, tot aan de verkoop in 1728, de exclave Slenaken. De eerste vijf plaatsen telden rond 1800 samen ongeveer 450 en Slenaken afzonderlijk ook ongeveer 450 inwoners. ${ }^{4}$ Formeel hield het graafschap Gronsveld op te bestaan na de inlijving bij Frankrijk op 1 oktober 1795, maar feitelijk valt die cesuur niet zo scherp aan te geven, aangezien de volledige afwikkeling van deze overgang tot 1803 duurde.

De centrale thema's van dit boek behandelen wetgeving, bestuur en rechtspraak en de rol van de daarbij betrokken gezagsdragers, rechterlijke colleges en organisaties van onderdanen binnen dit graafschap gedurende de vroegmoderne tijd, globaal tussen 1550 en 1800. Concreet gaat het daarbij om 1) de graaf als landsheer en zijn ambtelijke vertegenwoordigers, 2) de vier schepenbanken Gronsveld, Heugem, Honthem en Slenaken, 3) het leenhof van Gronsveld, 4) de geërfden of grondbezitters als standen binnen het graafschap en 5) de collectiviteiten van dorpsbewoners, verenigd in gemeenten. Onderzocht zijn enerzijds de interne administratieve structuren binnen dit territorium, anderzijds de positie van de graaf als rijksstand binnen het Heilige Roomse Rijk der Duitse Natie en de daaruit voortvloeiende relaties tussen Gronsveld en het Rijk, in het bijzonder op het terrein van wetgeving, rechtspraak en belastingheffing. Deze betrekkingen met het Rijk zijn niet als één geheel bij elkaar gebracht, maar verdeeld over de afzonderlijke hoofdstukken.

Om de eerder genoemde personen, colleges en instellingen te kunnen plaatsen binnen een breder kader, is afzonderlijk andacht besteed aan 1) de ontwikkeling van het Land Gronsveld in de late middeleeuwen uit oorspronkelijk kleinere geografische en bestuurlijke eenheden; 2) de adellijke families die over Gronsveld hebben geregeerd, hun stand en de betekenis daarvan voor zowel de individuele leden van deze families als de staatkundige positie van het land; 3) de rechten van de heren van Gronsveld als instrumenten voor de uitoefening van gezag en als bron van inkomsten.

$\mathrm{Na}$ een uiteenzetting over de aanduidingen 'land', 'vrijheerlijkheid' en 'graafschap' Gronsveld wordt in dit deel achtereenvolgens aandacht geschonken aan kleine territoria in de Duitse, de Nederlandse en meer in het bijzonder de Limburgse historiografie. Daarna komt de gecompliceerde overlevering van archivalische bronnen aan de orde, die deels grote lacunes kent, maar anderzijds (in het bijzonder voor de achttiende eeuw) ook zeer

${ }^{4}$ RHCL, Departement Nedermaas, inv. nr. 1037 geeft voor Gronsveld in 1795339 inwoners vanaf 12 jaar en 138 kinderen beneden de 12 jaar. In het midden van de achttiende eeuw was dit misschien nog iets lager. Voor Slenaken (inv. nr. 1063) worden 436 inwoners opgegeven. De inwonerslijst van Gronsveld is gepubliceerd in Boersma, De bevolking van het kanton Eijsden, 113-121. 
rijk is. Daarna worden de belangrijkste onderzoeksthema's toegelicht. In de eerste plaats gaat het daarbij om de laatmiddeleeuwse territoriumvorming, die een bestuurlijke en rechterlijke organisatie opleverde die tot 1795 niet meer fundamenteel veranderde. Een beschrijving van de instellingen in de vroegmoderne tijd is daarom nauwelijks mogelijk zonder daarin ook hun middeleeuwse oorsprong te betrekken. Een tweede reden om wat uitgebreider bij deze ontstaansgeschiedenis stil te staan, was dat voor alle plaatsen moest worden onderzocht of zij voldeden aan de eisen die later aan de status van een 'zonneleen' en rijksonmiddelliik territorium werden gesteld.

In een studie over Gronsveld, waarin land, stand en regerende familie ten nauwste samenhangen, mag een goed gedocumenteerd genealogisch overzicht van de heren van Gronsveld niet ontbreken. Voor de middeleeuwen waren dat de heren uit het geslacht Van Gronsveld, daarna werd Gronsveld tweeëneenhalve eeuw geregeerd door leden van de familie Van Bronckhorst en voor de achttiende eeuw waren het leden uit de geslachten d'Arberg Valengin en Toerring-Jettenbach. Een van de pijlers waarop de status van Gronsveld binnen het Rijk steunde, was de adellijke titel van de heer van Gronsveld. Door standsverheffingen waren de Bronckhorsten opgenomen binnen de kringen van de rijksadel. De erkenning als gelijke in stand vertegenwoordigde een sociaal en maatschappelijk kapitaal, dat voor carrières en bij de keuze van huwelijkspartners kon worden ingezet. Tegelijk met de genealogische overzichten zijn ook aspecten van de familiegeschiedenis van de opeenvolgende heren van Gronsveld beschreven. Dat is niet uitsluitend bedoeld ter verfraaiing van een stamboom, want er bestond een duidelijke wisselwerking tussen stand, bezit en loopbaan. ${ }^{5}$ Vermogensvorming, maar ook het na 1620 bij de familie Van Bronckhorst Batenburg beginnend proces van afbrokkeling van wat vorige generaties aan bezittingen bij elkaar hadden gebracht, zijn alleen goed te begrijpen vanuit hun samenhang met de genealogie. Daarnaast leveren in het bijzonder in de zeventiende eeuw de carrières van de graven Jost Maximiliaan van Bronckhorst Batenburg en zijn zoon Johan Frans voorbeelden van edelen uit het gebied tussen Maas en Rijn, die een rol van betekenis hebben gespeeld in de militaire en diplomatieke geschiedenis van het Rijk in de zeventiende eeuw.

Juridisch betekende de verheffing in de rijksgravenstand, in combinatie met het bezit van een rijksonmiddellijk territorium, ook erkenning als rijksstand, met het recht op deelname aan de politieke besluitvorming op verschillende niveaus binnen het Rijk, ook al was de feitelijke invloed op die besluitvorming minimaal. Als rijksstand was de graaf van Gronsveld stemhebbend lid van de Nederrijns-Westfaalse Kreits en lid van de NederrijnsWestfaalse Gravenbank in de Rijksdag, maar hij was ook onderworpen aan de belastingen van het Rijk en de rechtsmacht van het Rijkskamergerecht en de Rijkshofraad. Dat betekent dat voor een juist inzicht in de externe betrekkingen van Gronsveld ook aandacht moet worden besteed aan de staatsrechtelijke structuren van het Heilige Roomse Rijk.

\footnotetext{
${ }^{5}$ Vgl. Endres, Adel in der Frühen Neuzeit, 49-51, die een samenvatting geeft van de literatuur betreffende de 'verticale' mobiliteit van de adel door eenvoudigweg uitsterven, verlies van vermogen, standsverhoging en verwerving van ambten. Het verdwijnen van oude families en de vervanging door nieuwe wordt wel aangeduid met het het begrip 'Ersatzmoblität'.
} 
Behalve aan externe betrekkingen is in deze studie ook veel aandacht besteed aan beschrijving en analyse van de interne administratieve structuren binnen het graafschap. De graaf oefende als hoogste gezagsdrager in de vorm van 'gute Policey' (zie voor dit begrip Hoofdstukken 3.1 en 7.2) absoluut gezag uit, waarbij wetgeving, bestuur en rechtspraak zodanig waren georganiseerd en met elkaar verweven, dat het leven van de onderdanen veilig en geordend kon verlopen. Daarbij kende het kleine graafschap een complexe bestuurlijke en rechterlijke organisatie. Om gezag te kunnen uitoefenen had de graaf de beschikking over een breed scala aan rechten en bezittingen, die hem inkomen verschaften en waarmee hij het bestuur financierde. Aangezien de graven feitelijk vrijwel steeds buiten het graafschap verbleven, ging het bijna altijd om een bestuur 'op afstand' met toekenning van bevoegdheden aan functionarissen ter plaatse. Zij moesten waken over de handhaving van de rechten van de graaf en de inning van diens inkomsten, maar vervulden tevens een publieke rol, aangezien een deel van die grafelijke inkomsten werd verworven uit overheidshandelen. Verder droegen zij ook een algemene verantwoordelijkheid voor een goed bestuur (dat overigens slechts een minimum aan taken omvatte), de handhaving van het recht en zorg voor openbare orde. Daarmee vormden zij ook het verbindend element tussen de graaf en de onderdanen. Het dienen van die verschillende belangen verliep niet probleemloos aangezien vaak sprake was van corruptie en bevoordeling van familieleden. Een beschrijving van de diverse affaires die zich in de loop van de tijd op dat terrein in Gronsveld afspeelden, geeft een goed beeld van het functioneren van bestuur en rechtspraak binnen een kleine gemeenschap.

Aan de andere kant van het spectrum stonden de onderdanen, afzonderlijk of als collectief. Als individu kon iemand in diverse verhoudingen tot de graaf en het grafelijk bestuur staan: als debiteur van pachten, cijnzen, keurmede, als gebruiker van economische monopolies van de heer (banmolen, accijns op bier, visrecht, winning van mergel et cetera) of als onderworpene aan dwang (herendiensten, verplichte opkomst bij bepaalde gebeurtenissen). Daarnaast kende Gronsveld twee vormen van organisaties op collectieve grondslag. Het oudst waren de gemeenten, waarbij de inwoners van een dorp of gehucht zich organiseerden voor de behartiging van gemeenschappelijke belangen (vooral weiderechten) en de inning van de zogenaamde personele belastingen. Uit deze heffing werden vooral de kosten van militaire overlast betaald. Daarnaast waren er de geërfden, grondbezitters in het graafschap, maar voor een groot deel ook buiten Gronsveld gevestigd. Zij betaalden belasting op grond, waaruit vanaf circa 1600 de belastingen aan het Rijk werden voldaan. Door de regelmatige optredende problemen over deze belastingen, in het bijzonder met de Maastrichtse grondeigenaren, groeide in de loop van de tijd een vastere samenwerking tussen geërfden, die omstreeks 1740 vorm kreeg in een jaarlijkse bijeenkomst van standen van Gronsveld.

\section{De begrippen 'land', 'heerlijkheid' en 'graafschap' Gronsveld}

Het gebied waarover de heren van Gronsveld gezag uitoefenden was klein, maar kende een een ingewikkelde bestuurlijke en rechterlijke organisatie. Gronsveld en Eckelrade vormden wat betreft rechtspraak eeuwenlang samen het ressort van één schepenbank, 
zetelend in Gronsveld, maar ze waren als aparte bestuurlijke eenheden ('gemeenten') van elkaar gescheiden. Het dorp Heugem, het gehucht Honthem en het dorp Slenaken hadden ook ieder afzonderlijk een eigen schepenbank. Slenaken week daarbij in zoverre weer van de andere plaatsen af, dat voor deze plaats vaak de aparte aanduiding 'heerlijkheid' werd gebruikt (zie verder 2.7.5). De zogenoemde Bijbank, een nagenoeg onbewoonde strook grond grenzend aan Eckelrade, vormde een soort aanhangsel met een ingewikkelde en voor verschillende uitleg vatbare juridische status.

Dit samenstel van dorpen en gehuchten onder de noemer land of graafschap Gronsveld leidt tot mogelijke verwarring met het dorp Gronsveld als één van de onderdelen daarvan. Meestal is het onderscheid binnen een context wel duidelijk, maar door verschillende tijdvakken heen wordt een correcte aanduiding van het geheel lastiger. Zo worden in 1396 'die gantze herlicheiden, gerichten, erve ind gude vann Gronssfeldt, van Eckelrode... van Sledenake ind van Hoegem' nog als losse eenheden of jurisdicties opgevoerd. ${ }^{6}$ In de veertiende en vijftiende eeuw noemden de heren uit de elkaar opvolgende geslachten Van Gronsveld en Van Bronckhorst Batenburg zich 'heer tot Gronsveld', waarmee ze het hele gebied bedoelden. Vanaf het einde van de vijftiende eeuw werd gesproken over het 'Land Gronsveld' als aanduiding voor het geheel. Na de verheffing van Diederik II van Bronckhorst Batenburg in 1498 in de stand der rijksvrijheren, werd ook de aanduiding 'frieherlicheyt' gebruikt.7 De verheffing in 1586 van Jost en Johan van Bronckhorst Batenburg in de stand der rijksgraven zorgde ervoor dat als afgeleide van deze titel ook de aanduiding 'graafschap' voor het territorium gangbaar werd. Enige voorzichtigheid met die combinatie van titel in een adelsdiploma en naam van een gebied blijft geboden. Zo spreekt de oorkonde van 1498 over de verheffing in de stand der vrijheren uitsluitend over de persoon en familie van Diederik II van Bronckhorst Batenburg en niet expliciet over diens territorium. ${ }^{8}$ Ook de verheffing in de gravenstand betekent niet automatisch dat het gebied vervolgens een 'graafschap' was.' Als praktische oplossing voor het probleem van de wisselende aanduidingen is er in dit boek als regel voor gekozen tot 1586 te spreken over 'Land' of 'heerlijkheid' en daarna over 'graafschap'. Heel scherp valt de grens echter niet te trekken.

6 ULB Darmstadt, Hs. inv. nr. 2734-2735, 'Cartularium Hurt von Schönecken', fol. 42-48, boedelscheiding tussen Hendrik van Gronsveld en Johanna van Merode 12-3-1396.

${ }^{7}$ Zo kreeg Jost van Bronckhorst Batenburg in 1586 'die uralte frieberlicheyt Gronsfeldt overgedragen: RHCL, Rijkskamergerecht, inv. nr. 76, fol. 131 (modern)-135vo., afschriften van akten over de overgang van Gronsveld.

8 Archief kasteel Rimburg, volgens Hanssen, Die Rimburg, 141 'Mappe 1 No. 23. Original-Urkunde', zie Bijlage 39.

${ }^{9}$ We kunnen in dit verband de waarschuwing citeren van Schmidt, Wetterauer Grafenverein, 2 wanneer hij schrijft: Wenn im folgendem die einzelnen Grafen mit bestimmten Grafschaften identifiziert werden, ist dies eine weitere, für den Beginn der frühen Neuzeit eigentlich unzulässige Abstraktion, da nur die Person des regierenden Grafen das Konglomerat unterschiedlicher Besitz- und Herrschaftsrechte zusammenbielt: der Schritt zur Entpersonalisierung der Herrschaft, der in den Fürstentümern im späten Mittelalter einsetəte, begann in den Grafschaften erst in der frühen Neuzeit. Es dauerte bis weit ins 17. Jabrbundert, bevor die 'Grafschaft' gegenüber dem 'Grafen' eigenständige Konturen gewann. Das Herrschaftsgebiet eines Grafen wurde daher (noch) nicht als ein 'Ganzes' aufgefaß̧. Zie voor dit personaliteits- versus territorialiteitsbeginsel ook hierna Hoofdstuk 16. 


\section{Kleine territoria in de historiografie}

\subsection{Kleine territoria binnen bet Heilige Roomse Rijke der Duitse Natie en binnen de Nederlanden als onderzoeksthema}

Het graafschap Gronsveld was een typisch voorbeeld van wat sinds de negentiende eeuw door de voorstanders van de Duitse eenheid vanwege de machteloosheid van afzonderlijke staten en staatjes enigszins denigrerend werd aangeduid als 'Kleinstaaterei'. Getalsmatig is het beeld van een lappendeken wel begrijpelijk. Het Heilige Roomse Rijk der Duitse Natie was geen nationale staat met nationale taken, maar een volkenrechtelijke constructie, waarbinnen de afzonderlijke staten en staatjes functioneerden. Binnen het hoogste overlegorgaan in het Rijk, de Rijksdag, waren aan het einde van de achttiende eeuw in de Rijksdag bijna driehonderd rijksstanden (keurvorsten, wereldlijke en geestelijke vorsten, abten en abdissen van rijksonmiddellijke kloosters, rijksgraven en rijkssteden) vertegenwoordigd, overigens met zeer ongelijk verdeeld stemrecht. Tot deze groep behoorde ook de graaf van Gronsveld. Daarnaast telde het Rijk ook nog de 'rijksridders' die in totaal over ongeveer 1500 dwergstaatjes regeerden. ${ }^{10}$ Deze groep was als stand niet in de Rijksdag vertegenwoordigd.

Om als volwaardige rijksstand van het Heilige Roomse Rijk der Duitse Natie te worden beschouwd, moest worden voldaan aan een viertal basisvereisten, te weten rijksonmiddellijkheid, landsheerlijke rechten, voldoende adeldom en zitting in de Rijksdag. De combinatie daarvan bepaalde de specifieke plaats binnen het bestel van het Rijk. Tegelijkertijd verschilden de standen die door de banden van Rijk met elkaar waren verbonden ook van elkaar. In feite raakt dit een kernprobleem in de historiografie over territoria binnen het Rijk in het algemeen en de kleinere territoria in het bijzonder, want steeds moet per geval worden bepaald in hoeverre de eerder genoemde criteria in een concrete situatie toepasbaar zijn. Daarbij dient ook rekening te worden gehouden met verschuivingen in tijd, waarbij een rijksstand nog wel of juist niet meer aan de eisen voldoet.

Dit soort onderzoek richt zich in het algemeen op grote territoria. In de geschiedschrijving wordt de betekenis van de kleintjes, hoewel niet weinig in aantal, vaak gemarginaliseerd. Zo was Kleinstaaterei in de vroegmoderne tijd typisch voor een groot deel van het Heilige Roomse Rijk, maar in de geschiedenis domineren namen als Oostenrijk, Pruisen, Beieren of Saksen. In een overzicht van de historiografie met betrekking tot graafschappen in het Rijk vat Busch in 2008 de gangbare opinie daarover aldus samen:

Reichsgrafschaften haben wie andere kleinere Reichsstände in weiten Teilen der historischen Forschung nach wie vor einen eher geringen Stellenwert, der sich durch eine Marginalisierung oder kompletten Nichterwähnung in Publikationen über das Reich

10 Zie voor de enigszins fluctuerende aantallen: Godsey jr., Nobles and nation in Central Europe, 8; Hofmann, Hofmann, Quellen Verfassungsorganismus, 358-365; Gotthard, Das Alte Reich, 19. 
ausdrückt und bereits in der geläufigen Bezeichnung 'mindermächtiger Reichsstand' anklingt. ${ }^{11}$

Toch verdient deze zwart-wit benadering enige nuancering. Vanaf het einde van de vijftiende eeuw groeide bij graven de behoefte zich in regionaal verband te organiseren om hun belangen te behartigen. Zo ontstonden de vier, in totaal ongeveer honderd leden tellende, gravenverenigingen van Schwaben, de Wetterau, Franken en de NederrijnWestfalen, die elk als vereniging in de Rijksdag werden toegelaten, echter met zeer beperkt stemrecht (zie daarover meer Inleiding 5.3 en de Hoofdstukken 4.1.6 en 16.1.9). ${ }^{12}$

Ook binnen de Nederlandse geschiedenis waren kleine onafhankelijke territoria geen onbekend verschijnsel. Binnen het gebied van de Republiek der Verenigde Nederlanden lagen kleine enclaves die een semi-onafhankelijke status pretendeerden. Het ging echter om een gering aantal (afhankelijk van de gebruikte criteria geschat tussen de twintig en dertig) en hun politieke betekenis was onbeduidend. Weliswaar leidde soms het beroep op een bijzondere status tot enig juridisch rumoer, maar feitelijk vielen ze onder de invloedsfeer van de Republiek en onderhielden ze geen formele banden met het Duitse Rijk. De verhoudingen tussen Nederland en Duitsland zijn daarmee wat de betekenis van kleine territoria betreft nauwelijks vergelijkbaar, uitgezonderd de situatie in het midden en zuiden van de tegenwoordige provincie Limburg. Wel zien we net als in Duitsland ook in de Nederlandse historiografie als algemeen verschijnsel dat grote gewesten (Holland voorop) het meest aan bod komen. Kleine, dikwijls in grensstreken gelegen (lands)heerlijkheden worden in het algemeen stiefmoederlijk bedeeld. Hetzelfde speelt ook op regionaal 'Limburgs' niveau, waar het accent meestal ligt op het Overkwartier van Gelre, de Landen van Overmaze of de steden. $\mathrm{Nu}$ is het een feit dat de binnen de Republiek gelegen kleine territoria, bijvoorbeeld in het Gelders-Hollands rivierengebied ${ }^{13}$ en aan de rand van Noord-Brabant, ${ }^{14}$ politiek weinig betekenden. Dat sloot echter conflicten en stekeligheden met machtiger buren niet uit. ${ }^{15}$ Binnen het Duitse Rijk en de Rijksdag was de macht van de kleintjes ook gering - zij worden niet voor niets met de term mindermächtig aangeduid - maar tegelijkertijd werd dat gecompenseerd door het feit dat de keizer juist bij de rijksadel uit deze Kleinstaaten een deel van zijn cliënteel vond als tegenwicht voor het eigengereide optreden van de grote rijksstanden. ${ }^{16}$ Uit deze adel werd bovendien een belangrijk deel van de geestelijke rijksstanden (bisschoppen en abten en abdissen van rijksabdijen) gerekruteerd.

${ }^{11}$ Busch, Herrschen durch Delegation, 16.

${ }^{12}$ In de geschiedschrijving gedurende de laatste decennia zijn, behalve losse artikelen, aan drie laatste ook afzonderlijke monografieën gewijd: Schmidt, Wetterauer Grafenverein; Böhme, Fränkische Reichsgrafenkollegium; Arndt, Reichsgrafenkollegium.

${ }_{13}$ Fockema Andreae, De Nederlandse Staat, 73; Gijswijt-Hofstra, Wijkplaatsen voor vervolgden.

${ }_{14}$ Van der Ree-Scholtens, Grensgebieden.

${ }^{15} \mathrm{Zie}$ in dit verband het voorbeeld genoemd bij De Monté ver Loren/Spruit, Hoofdlijnen, 103-104 over de verhouding begin zeventiende eeuw tussen Maximiliaan van Bronckhorst, heer van Batenburg en de staten van Gelre.

${ }^{16}$ Neuhaus, Das Reich der Frühen Neuzeit, 33; Endres, Adel in der Früben Neuzeit, 8-9; Busch, Herrschen durch

Delegation, 17, Press, 'Die kaiserliche Stellung', 61-62. 
Auteurs die in overzichtswerken de (staatkundige) geschiedenis of juridische status van kleine territoria behandelen, doen dit meestal vanuit een geografische en een inhoudelijke invalshoek. Voorbeelden van die geografische benadering zijn de studies van StengersLimet naar de Terres-Franches in de Spaans Oostenrijkse Zuidelijke Nederlanden, ${ }^{17}$ het werk van Nève over het Rijkskamergerecht en de Nederlanden ${ }^{18}$ en, op wat beperkter schaal, Gijswijt-Hofstra over asielverlening in plaatsen in het Gelders-Hollands rivierengebied, ${ }^{19}$ Van der Ree-Scholtens in haar studie over de grensgebieden in het noordoosten van Brabant $^{20}$ en Berkvens voor de 'rafelrand' van heerlijkheden aan de grens van het Overkwartier van Gelre. ${ }^{21}$ Voor Duitsland kan, ook in verband met het belang voor Gronsveld, worden gewezen op de studie van Arndt over het Nederrijns-Westfaalse gravencollege. 22 Uitgaande van oude of hedendaagse grenzen stellen de auteurs zich de vraag welke juridische criteria van toepassing zijn op plaatsen binnen het gekozen gebied. Als zodanig worden genoemd vertegenwoordiging op landdagen, betaling van belastingen en bijdragen aan de kosten van oorlog, de aanvaarding van 'buitenlandse' jurisdictie in appelzaken, de afkondiging van 'buitenlandse' wetgeving, de huldiging van de landsheer van het naburig territorium, de anwezigheid van bepaalde regalia zoals muntrecht en asielrecht ${ }^{23}$ en de erkenning door kreits en Rijksdag als 'rijksstand'. Over de doorwerking daarin van middeleeuwse juridische constructies zoals leen- en voogdijverhoudingen werd en wordt verschillend geoordeeld. ${ }^{24}$ Deze auteurs passen met die benadering van kleine territoria vanuit een formeel juridische hoek in wezen dezelfde methode toe die contemporaine juristen ook dikwijls hanteerden.

Geografisch breed opgezette studies geven weliswaar een algemene lijn, maar hebben vaak als nadeel dat per plaats alleen in het oog springende zaken of momentopnames worden behandeld. Het probleem wordt ook wel door auteurs onderkend. Stengers-Limet verzucht in de inleiding tot haar werk dat eigenlijk van alle plaatsen grondige detailstudies in de vorm van een monografie nodig zouden zijn. Die studies bestonden voor bepaalde plaatsen, maar men kon slechts hopen dat dit aantal zich beetje bij beetje zou uitbreiden. ${ }^{25}$ Berkvens concludeert hetzelfde naar aanleiding van zijn onderzoek naar Kessenich:

\footnotetext{
17 Stengers-Limet, Les Terres Franches.

${ }_{18}$ Nève, Rijkskamergerecht.

${ }_{19}$ Gijswijt-Hofstra, Wijkplaatsen voor vervolgden.

${ }^{20}$ Van der Ree-Scholtens, Grensgebieden.

${ }^{21}$ Berkvens, Plakkatenlijst Overkwartier I, 81-125.

22 Arndt, Reichsgrafenkollegium, 36-111.

${ }^{23}$ Berkvens, Plakkeatenlijst Overkwartier I, 81-125 en Stengers-Limet, Les Terres Franches, 27-39.

24 Berkvens, Plakkatenlijst Overkwartier I, 84-86 en Berkvens, 'Rijksheerlijkheid Kessenich', met verwijzingen naar relevante literatuur en Berkvens, 'De kanunnik Joannes Stuben'.

25 'il ne saurait être question d'élaborer pour chaque cas une recherche approfondie à caractère de monographie. De tels travaux existent pour certains villages; on peut espérer que petit à petit la collection se complétera', Stengers-Limet, Les Terres Franches, 15.
} 
De staatkundige positie van de zogenoemde vrije rijksheerlijkheden in de Maasvallei [kan] binnen een zeer korte tijdsspanne erg variëren. Zonder bronnenonderzoek te doen kan men te dien aanzien geen betrouwbare uitspraken doen'. ${ }^{26}$

Meer diepgaand onderzoek over een lange periode is niet alleen nodig om overeenkomsten en verschillen tussen plaatsen beter in kaart te brengen, ook moeten allerlei subjectieve, in het vuur van de strijd gedane juridische stelligheden worden getoetst op hun houdbaarheid. Gronsveld levert daarvan al direct een voorbeeld. Zo waren de beweringen van Jost en Johan van Bronckhorst Batenburg in 1586 over Gronsveld als 'zonneleen', de hoge afkomst van de familie en het oude muntrecht in de kern wel juist, maar ze verdienen bij nader inzien toch enige nuancering.

Bij meer gedetailleerd onderzoek per plaats gaat het niet alleen om vaststelling van (juridische) feiten. De strijd om het behoud van onafhankelijkheid was ook een voortdurende worsteling, waarvan de uitslag in belangrijke mate lijkt te worden bepaald door de positie van de heer binnen een netwerk van adellijke standgenoten en de geografische ligging van een gebied. Voor de opbouw van een adellijk netwerk was familiepolitiek van groot belang. Ook publieke eerbewijzen, zoals opname in een aanzienlijke ridderorde, bijvoorbeeld de Orde van het Gulden Vlies, versterkten het groepsgevoel. Verder is opvallend dat militairen of bestuurders in vorstelijke dienst veelal afkomstig waren uit juist adellijke families in het bezit van kleine territoria. In het bijzonder de keizerlijke dienst en het hof in Wenen oefenden sinds de tweede helft van de zeventiende eeuw grote aantrekkingskracht uit op de lagere rijksadel. ${ }^{27}$ Dit soort connecties vormden geen garantie voor het behoud van zelfstandigheid, maar ze droegen daar wel aan bij. Dit betekent dat de geschiedenis van kleine territoria sterk is verweven met adelsgeschiedenis. Studies met een prosopografisch karakter, waarin collectieve biografieën of sociale netwerken worden beschreven, zijn daarom van groot belang. De enkele hierna aangehaalde werken zijn niet bedoeld als een limitatief overzicht en ze verschillen ook duidelijk in benadering van het onderwerp, maar ze laten zien dat voor het Maasgebied zowel naar de 'Nederlandse' als 'Duitse' adel moet worden gekeken. Voor het Maasgebied kan daarbij wat betreft de late middeleeuwen worden gewezen op de studies van Uyttebrouck uit 1975 over edelen in dienst van de hertog van Brabant in de periode 1355-143028 en van Cools uit 2001 over de hoge adel in de Bourgondisch-Habsburgse Nederlanden. ${ }^{29}$ Het werk van Kloosterhuis over de ambtelijke entourage van de aartsbisschoppen van Keulen en de hertog van Kleef en Gulik in de zestiende eeuw kent een ander karakter in die zin, dat de daar beschreven groep van juristen en bestuursfunctionarissen uit zowel edelen als niet-edelen bestaat. ${ }^{30}$ De studie van Arndt over de Nederrijns-Westfaalse rijksgraven ten slotte beschrijft een groep uit de adel die op

${ }^{26}$ Berkvens, 'Rijksheerlijkheid Kessenich', 176.

${ }^{27}$ Endres, Adel in der Früben Nenzeit, 8-9.

28 Uyttebrouck, Gouvernement Brabant, II.

${ }^{29}$ Cools, Mannen met macht.

${ }^{30}$ Kloosterhuis, Erasmusjünger. 
basis van hun stand en territorium een belangengroep vormde om daarmee een stem in de Rijksdag te verwerven. ${ }^{31}$

Veel kleine territoria hadden zich in de middeleeuwen ontwikkeld aan de rand van grotere vorstendommen. De heren van die gebieden kwamen klem te zitten toen vanaf het einde van de middeleeuwen en in de vroegmoderne tijd de grote gewesten in de Nederlanden dezelfde vorst kregen en zich vormen van centraal gezag ontwikkelden. Later ziet men dat binnen de Republiek de Staten Generaal of de gewestelijke staten probeerden deze kleine territoria onder hun invloed te brengen. De regering in Brussel voerde dezelfde politiek voor de Zuidelijke Nederlanden onder Spaans-Oostenrijks bewind. Maar het is te eenvoudig deze druk af te doen als louter machtspolitiek; vaak zochten de betrokken partijen naar een compromis dat recht deed aan de wederzijds aangevoerde argumenten. Dit betekent dat de geschiedenis van die territoria moet worden bestudeerd binnen de context van de algemene staatkundige verhoudingen zoals die bestonden binnen de Zuidelijke Nederlanden of de Republiek.

Anders lagen de verhoudingen in het Maasgebied, waar zich, als voorbode van de latere grens tussen de Nederlanden en het Duitse Rijk, in de loop van de zestiende eeuw een grillige en soms instabiele scheiding aftekende tussen de Bourgondische en de NederrijnsWestfaalse Kreits. Het woord 'kreits' (Duits: Kreis; soms wordt ook wel een variant van het woord 'cirkel' gebruikt) wordt gebruikt als aanduiding voor de administratieve eenheden waarin het Rijk vanaf het begin van de zestiende eeuw (aanvankelijk in zes, later in tien) was verdeeld. De Kreits besloeg een gebied, maar was in essentie een groep van grote en kleine rijksstanden. De exacte begrenzing van het gebied van iedere stand was niet altijd duidelijk. Dat leverde in de zestiende eeuw problemen op toen de Bourgondische Kreits (de Nederlandse gewesten onder Habsburgs gezag) en Nederrijns-Westfaalse Kreits (landsheren in het gebied van de Ardennen en Eifel tot aan de Weser) uit elkaar groeiden. Kon binnen de Nederlanden een geschil over de status van een gebied nog worden beschouwd als een 'interne' kwestie van lokaal of regionaal belang, een probleem met betrekking tot een territorium waarvan de bezitter behoorde tot de rijksstanden, leidde al snel tot diplomatieke verwikkelingen op internationaal niveau. Niet voor niets stelt Nève dat de status van rijksstand de beste bescherming bood voor onafhankelijkheid. ${ }^{32}$

Een gevolg van de onduidelijke grens tussen de Bourgondische en de NederrijnsWestfaalse Kreits is dat bij historisch onderzoek naar kleine territoria in het Maasgebied moet worden gekeken naar de Zuidelijke Nederlanden, Luik en het Rijk. ${ }^{33}$ Dat betekent dat voor een goed begrip van de geschiedenis van sterk met het Rijk verbonden plaatsen

\footnotetext{
31 Arndt, Reichsgrafenkollegium.

32 Nève, Rijkskeamergerecht, 163.

33 Vgl. de vele voorbeelden genoemd bij Stengers-Limet, Les Terres Franches; verder in het bijzonder voor de 'randgebieden' van het Overkwartier van Gelre: Berkvens, Plakekatenlijst Overkwartier I, 112-126; voor Kessenich: Berkvens, 'Rijksheerlijkheid Kessenich'; voor Thorn: Berkvens, 'De kanunnik Joannes Stuben'; voor de na 1632 door de Staten-Generaal als opvolgers van de hertog van Brabant geclaimde soevereiniteit over de 'aanhangsels' van Maastricht (Dorpen van Redemptie, Elf Banken van Sint-Servaas) en de Landen van Overmaas (bijvoorbeeld Elsloo en Terblijt): Nève, Rijkskamergerecht, passim; voor Luikse aanspraken op bijv. Herstal en Petersheim: Nève, Rijkskamergerecht, 329-335 en 451-456.
} 
zoals Gronsveld, Rekem, Wylre, Rijkckholt, Wittem en Thorn, elementaire kennis van de geschiedenis van het Rijk en de instellingen daarvan noodzakelijk is. Het voorkomt ook misvattingen bij popularisering van de geschiedenis. ${ }^{34}$

Nederlandstalige literatuur over het Rijk en zijn instellingen is echter beperkt. Een algemeen overzicht van de geschiedenis in de vroegmoderne tijd, met ook aandacht voor de instellingen, biedt De Boer in Het oude Duitsland. ${ }^{35}$ Wat de instellingen betreft, komt het Rijkskamergerecht er met het werk van $\mathrm{Nève}^{36}$ en de inleiding op de inventaris van de Maastrichtse procesdossiers van het Rijkskamergerecht nog het beste af. 37 Onafzienbaar en met tal van invalshoeken is echter de literatuur aan Duitse zijde. Als een eerste aanzet voor studie kan hier worden gewezen op het bibliografisch overzicht ('Literatur und Quellen'), opgenomen in het onderdeel 'Essays' van de catalogus van de in 2006 te Berlijn gehouden tentoonstelling Heiliges Römisches Reich Deutscher Nation 962 bis 1806, Altes Reich und Neue Staaten 1495 bis 1806. ${ }^{38}$ Daarin zijn ook diverse handboeken opgenomen. Voor een snelle oriëntatie in de ingewikkelde organisatie van het Rijk volstaan ook Kurafübrer met literatuuropgaven, zoals van Neuhaus, ${ }^{39}$ Gotthard, ${ }^{40}$ Stollberg-Rilinger ${ }^{41}$ en het door Wendehorst en Westphal geredigeerde Lesebuch Altes Reich. ${ }^{42}$ Uitgebreidere handboeken van de staatsrechtelijke, politieke en deels ook culturele geschiedenis van het Rijk zijn er van Schmidt, ${ }^{43}$ Stollberg-Rilinger ${ }^{44}$ en Whaley ${ }^{45}$. Wat ouder, maar nog altijd zeer bruikbaar voor de geschiedenis van de instellingen en het recht is het handboek van Conrad. ${ }^{46}$ Voor de visie van 'buitenlanders' op het Rijk kan worden verwezen naar de verschillende bijdragen in de bundel Imperium Romanum. ${ }^{47}$ Een recentere tekstedities van de

\footnotetext{
${ }^{34}$ Een voorbeeld van allerlei (romantisch klinkende) misvattingen levert een passage in een populaire gids over de abdij Thorn in: Sangers/Janssen, Thorn, het witte stadje, 40: 'Het kleine vorstendom Thorn was in 1512 opgenomen in de Westfaalse Kreits en werd zodoende officieel erkend als lid van het Duitse Rijk. De abdis werd rijksvorstin, zetelde in de Rijksdag en het muntrecht was een prerogatief van haar soevereine macht'. Kleine rijksstanden zoals graven en abdissen van rijksonmiddellijke stiften waren in de Rijksdag slechts als groep vertegenwoordigd in één der 'Banken', welke 'Bank' als totaal één stem opleverde. De abdis van Thorn was pas in de zeventiende eeuw rijksstand en ook geen 'vorstin' in de betekenis van het rijksrecht (vgl. Berkvens, 'De kanunnik Joannes Stuben').

${ }^{35}$ De Boer, Het oude Duitsland.

36 Nève, Rijkskamergerecht.

37 Wiech, Reichskammergericht, Prozessakten Maastricht.

${ }^{38}$ Schilling, Heiliges Römisches Reich, Altes Reich und Neue Staaten 1495-1806, Essays, 399-443.

${ }^{39}$ Neuhaus, Das Reich der Frühen Neuzeit.

${ }^{40}$ Gotthard, Das Alte Reich.

${ }^{41}$ Stollberg-Rilinger, Das Heilige Römische Reich Deutscher Nation.

${ }^{42}$ Wendehorst en Westphal, Lesebuch Altes Reich.

${ }^{43}$ Schmidt, Geschichte des Alten Reiches.

${ }^{44}$ Stollberg-Rilinger, Des Kaisers alte Kleider.

45 Whaley, Germany and the Holy Roman Empire en Idem, (vertaald) Das Heilige Römische Reich Deutscher Nation.

${ }^{46}$ Conrad, Deutsche Rechtsgescbichte, in het bijzonder deel 2, 1-230 met een beschrijving van de instellingen en uitgebreide opgave van literartuur.

${ }^{47}$ Schnettger [ed.], Imperium Romanum.
} 
voornaamste bronnen over de organisatie en het staatsrecht van het Rijk is te vinden in het werk van Hofmann. ${ }^{48}$

Voor de geschiedenis van kleine territoria zijn verder van fundamenteel belang de werken van Dotzauer over de Reichskreise in het algemeen ${ }^{49}$ en de studie van Schneider voor de Nederrijns-Westfaalse Kreits in de zestiende eeuw in het bijzonder. ${ }^{50}$ Dotzauer behandelt in zijn werk ook het muntwezen, dat in het bijzonder voor het Maasgebied belangrijk is. Hier maakten immers verschillende kleine landsheren (Gronsveld, Rekem, Thorn) daar aanspraak op. ${ }^{51}$ Dotzauer besteedt ook aandacht aan de rol van de kreitsen bij de organisatie van de rijksdefensie en de daarmee samenhangende belastingheffing, maar een grondige algemene studie op dit terrein ontbreekt. Enigszins wordt dit ondervangen door het werk van Salm over de legerfinanciering in de Dertigjarige Oorlog ${ }^{52}$ en de aandacht die Schindling in zijn werk over het ontstaan van de Altijddurende Rijksdag besteedt aan de 'Reicbsdefensionalordnung' van 1681,53 maar het blijft een lacune in kennis omdat juist de financiering van de defensie een grote rol speelde in de relatie tussen kleine territoria en het Rijk.

In de hiervoor genoemde literatuur ligt het accent vaak op de uitwendige geschiedenis van kleine territoria, met onderwerpen als soevereiniteit, opname binnen grotere staatkundige verbanden, wetgeving, bijdragen aan belastingen en de stand van de adellijke heren. De interne structuren krijgen in het algemeen minder aandacht. In de Nederlandstalige literatuur beschrijft vooral Van der Ree-Scholtens de rechterlijke en bestuurlijke organisatie van de kleine heerlijkheden in noordoost Brabant ${ }^{54}$ en Gijswijt-Hofstra doet hetzelfde, maar dan alleen wat de werking van het asielrecht betreft, voor de heerlijkheden in het Gelders-Hollands rivierengebied. ${ }^{55}$ Busch noemt in zijn overzicht van de literatuur over graafschappen in Duitsland ook enkele voorbeelden waarbij juist op bepaalde aspecten van de interne organisatie de nadruk wordt gelegd..$^{56}$

Een andere, recentere tendens in de geschiedschrijving betreft meer integraal onderzoek naar kleine territoria als voorbeeld van staatsvorming in de vroegmoderne tijd. Een voorbeeld van deze aanpak levert de studie van Busch over het rijksgraafschap SolmsRödelheim..$^{57}$ In vergelijking met grote staten die over volledig tot wasdom gekomen professionele instellingen beschikten, werd vroeger over die Verstaatlichung van kleine territoria nogal eens minachtend gedaan. Toch bleken zij in de praktijk wel degelijk

\footnotetext{
48 Hofmann, Quellen Verfassungsorganismus.

49 Dotzauer, Reichskreise.

50 Schneider, Niederrbeinisch-Westfälische Kreis.

51 Als aanvulling vanuit Nederlands perspectief is nog altijd zeer informatief het al wat oudere werk van

Tangelder, Muntheer en muntmeester, over het muntrecht van de heren van Bergh in de zestiende eeuw.

52 Salm, Armeefinanzierung.

53 Schindling, Die Anfänge des Immerwährenden Reichstags, 177-181.

54 Van der Ree-Scholtens, Grensgebieden.

55 Gijswijt-Hofstra, Wijkplaatsen voor vervolgden.

56 Busch, Herrschen durch Delegation, 20-22.

${ }^{57}$ Busch, Herrschen durch Delegation.
} 
levensvatbaar en functioneerden ze als regel goed zonder hulp van buiten. ${ }^{58}$ Het antwoord op de vraag hoe dat lukte zonder politieke en militaire macht moet worden gezocht in een combinatie van vier elementen.

In de eerste plaats oefende de landsheer, gelegitimeerd door de gratie Gods en de erfelijke rechten van zijn familie, absoluut gezag uit. Die positie verschafte niet alleen autoriteit, ze bood ook de mogelijkheid het land direct en flexibel te besturen, waarbij de geringe omvang eerder een voordeel dan een nadeel betekende.

Ten tweede diende het gezag concreet vorm te krijgen in 'gute Policey', de zorg voor een samenleving waarin onderdanen in godvrezendheid een geordend en veilig bestaan konden leiden. 'Gute Policey' is een term die in het Rijk het eerst aan het einde van de middeleeuwen opduikt. Het omvat de elementen wetgeving, bestuur en rechtspraak zoals we die kennen uit de leer van de Trias Politica of machtenscheiding, maar typerend is juist niet de scheiding, maar hun sterke onderlinge verwevenheid. ${ }^{59}$

Als derde element moet worden genoemd een voortdurende aandacht voor 'economie', het totaalpakket aan landsheerlijke domeinen en rechten, die zowel als bron van inkomsten waren als een instrument om gezag uit te oefenen. In die economie en in de modernisering ervan werd ook geïnvesteerd. Indien enigszins mogelijk diende een verzwakking van de economische positie door deling van het land te worden voorkomen.60 'Gute Policey' en een gezonde economie veronderstelden bij de landsheer en zijn ambtenaren enige bekwaamheid op het terrein van de staathuishoudkunde in de letterlijke betekenis van het woord om een balans te vinden tussen publieke en private belangen.

Ten slotte, als vierde element, waren er de verschillende betrekkingen tussen de landsheer en zijn onderdanen, collectief ${ }^{61}$ of individueel, als belastingplichtige, pachter, werknemer,

\footnotetext{
${ }^{58}$ Gotthard, Das Alte Reich, 17.

59 Voor een samenvattende beschrijving van dit complexe begrip, zie Härter, 'Das Recht des Alten Reiches', 89-91. Wat de inhoudelijke kant van de 'gute Policey' betreft kan hier worden gewezen op de bronedities met inleidingen van het in de jaren negentig van de twintigste eeuw door het Max-PlanckInstitut für Europäische Rechtsgeschichte te Frankfurt onder leiding van Karl Härter en Michael Stolleis begonnen project Repertorium der Policeyordnungen der Frühen Neuzeit. Een tweede reeks van bronedities met inleidingen betreft de door Wolfgang Wüst sinds 2001 verzorgde uitgaven van Die ,gute "Policey im Reichskereis. Zur frühmodernen Normensetzung in den Kernregionen des Alten Reiches (tot 20115 delen verschenen). ${ }^{60}$ Busch, Herrschen durch Delegation, 20-22.

${ }^{61}$ De noodzaak om de voortdurende wisselwerking tussen landsheer en (collectiviteiten van) onderdanen te onderzoeken verwoordt Busch, Herrschen durch Delegation 11-12 als volgt: 'Hier sind neue Ansätze zum Verständnis frühneuzeitlicher Herrschaft $₹ u$ berïcksicbtigen, zu deren wichtigsten Erkenntnissen gebört, dass Herrschaft anders als bislang angenommen - nicht einseitig von oben nach unten, also in der Regel vom Fürsten ausgehend verlief. Sie konnte akzeptan₹orientiert bzw. konsensual, genossenschaftlich und einungsartig, überterritorial oder vernetzt organisiert sein. Allen neuen Forscbungsansätzen ist gemeinsam dass sie die Bedeutung derjenigen Personen und Institutionen ausserbalb der Figur des Landesherren und seiner Administration berausarbeiten und ibren Beitrag zu einer funktionierenden Herrschaftspraxis würdigen, die bislang dem Absolutismusparadigma und der Staatsteleologie untergeordnet wurden. Das macht es möglich frühneuzeitliche Herrschaft heute sowobl als jenseits des 'absoluten Fürsten' als auch seines 'werdenden Staats' zu betrachten und nach anderen - neuen - Begriffen zu suchen. Diese einzelnen Ansätze für die Erforschung kleinerer Reichsstände und für einen anderen Zugang zu ibrer Funktionsweise am Beispiel einer Reichsgrafschaft zu erproben und wenn möglich zu einem übergreifenden Modell frübneuzeitlicher Herrschaft, nämlich dem der 'Herrschaft durch Delegation' zu integrieren, ist eines der wichtigsten Ziele der vorliegenden Arbeit.
} 
leverancier en mogelijk zelfs als delinquent in strafzaken. Die verhouding tot de onderdanen bij het behoud van de interne vrede mag niet worden onderschat. Conflicten tussen landsheer en onderzaten of tussen inwoners onderling konden een verlammende uitwerking hebben op verhoudingen en het land financieel aan de afgrond brengen. ${ }^{62} \mathrm{Bij}$ kleine territoria was vooral het Rijkskamergerecht de instantie die bij dit soort conflicten moest proberen, op afstand en met een gebrekkig systeem van handhaving, de vrede te herstellen.

Wanneer we op basis van voorgaand literatuuroverzicht proberen te komen tot een onderzoeksmodel voor de bestudering van kleine territoria, dan zouden daarbij idealiter tenminste de volgende thema's aan bod moeten komen:

- de vorming van een gebied als staatkundige eenheid;

- de mate van soevereiniteit en onafhankelijkheid in juridisch en fiscaal opzicht, binnen de kaders van het Heilige Roomse Rijk.

- de adellijke heren, hun stand en sociale netwerk;

- de binnenlandse organisatie van wetgeving, bestuur en rechtspraak;

- de 'economie' als bron van inkomsten en instrument om gezag uit te oefenen;

- de onderdanen als collectief (en soms ook individueel) en hun verhouding tot de landsheer.

De manier waarop deze thema's kunnen worden uitgewerkt en de verschillen in accenten die gezet kunnen worden, hangen ook af van concrete omstandigheden, zoals het beschikbare bronnenmateriaal. Ook moet rekening worden gehouden met ontwikkelingen gedurende lange tijd en wisselende strategieën.

De afsluitende vraag is in hoeverre in de bestaande historiografie over Limburg in het algemeen en Gronsveld in het bijzonder, kleine territoria zijn bestudeerd volgens het onderzoeksmodel, zoals dat hiervoor op basis van de algemene literatuur werd geformuleerd.

\subsection{Kleine territoria als onderzoeksthema in het Limburgse Maasdal}

Vóór 1795 bestond het gebied van wat thans de Nederlandse provincie Limburg is, uit een territoriale lappendeken. Een deel van deze gebieden werd sinds de zestiende eeuw gerekend tot de Bourgondische-Habsburgse Nederlanden en raakte daarmee op afstand van het Rijk. Na de Tachtigjarige Oorlog stonden deze territoria onder het gezag van de Republiek of de regering van de Spaanse en later de Oostenrijkse Nederlanden in Brussel. Andere territoria maakten deel uit van de Nederrijns-Westfaalse Kreits en bleven daarmee verbonden met het Rijk. Dat feit op zich al maakt de geschiedenis van deze gebieden afwijkend van die van de Nederlanden. De daarbij horende verdeling van territoria vormt een afspiegeling van de staatkundige verhoudingen binnen het Rijk. Delen van de tegenwoordige provincie vielen onder de hertogdommen Kleef en Gulik, die als vorstendom rijksstand waren. Er lagen drie kleine rijsonmiddellijke territoria, die geregeerd

${ }^{62} \mathrm{Zie}$ in dit verband Gabel, Widerstand und Kooperation, die verschillende voorbeelden geeft van dit soort conflicten. 
werden door een rijksstand, te weten de graafschappen Gronsveld en Wittem en het hoogadellijk stift Thorn met een abdis als landsvrouwe. Ten slotte telde de huidige provincie Limburg nog een reeks kleine, maar niet vertegenwoordigde, rijksonmiddellijke gebieden.

De geschiedschrijving met betrekking tot de 'Limburgse' kleine territoria levert een gemengd beeld op van vermeldingen in overzichtswerken, monografieën en artikelen van substantiële omvang in periodieken. Daarbij valt een worsteling met de 'begrenzing' van het onderwerp op. Vanwege de behoefte aan een systematisch overzicht van het territoriaal versnipperde Maasgebied probeerden historici, en in het bijzonder archivarissen, vanaf het begin van de twintigste eeuw een zekere ordening tussen die gebieden aan te brengen. Dat was nuttig voor de geschiedschrijving en voor de indeling van het archiefdepot bij het Rijksarchief in Limburg, waar archieven van die verschillende plaatsen en gebieden waren samengebracht. Rechter-amateurhistoricus De Wit en rijksarchivaris Flament stelden daartoe in 1911 een overzicht samen, waarbij zij onder de noemer 'Thorn en kleinere Vrije Rijksheerlijkheden uit een of twee plaatsen bestaande' meer dan 25 heerlijkheden samenbrachten. ${ }^{63}$ Vier jaar later maakte Flament in een opsomming van de oude 'rechtsbedeeling' in Limburg weer een nieuwe lijst van 'vrije rijksheerlijkheden' met onderhorige gerechten. ${ }^{64}$ In 1953 werd in het overzicht van de Nederlandse Rijksarchieven een door rijksarchivaris Panhuysen samengestelde lijst van de archieven van 'Vrije Rijksheerlijkheden' in Limburg opgenomen met de navolgende plaatsen: Breust, Elsloo, Gronsveld, Hunsel, Limbricht, Mesch, Poll en Panheel, Rijckholt, Slenaken, Stein, Terblijt, Thorn, Wylre, Wynandsrade, Wittem, Eys, Epen en Mechelen. Bij sommige plaatsen wordt nog een onderverdeling gegeven of een verklarende annotatie toegevoegd. ${ }^{5}$ Deze lijst, die gelijk is aan het overzicht dat Panhuysen in 1967 publiceerde, heeft een zekere bestendigheid en doet nog altijd dienst als basis van het archievenoverzicht bij het Regionaal Historisch Centrum Limburg. ${ }^{66}$ Opvallend bij deze overzichten is het gebrek aan consistentie. Het schuiven met plaatsen was geen kwestie van voortschrijdend inzicht, maar een gevolg van het feit dat 'vrije rijksheerlijkheden' een vergaarbak vormden. Hetzelfde geldt ook voor het vage begrip 'vrije rijksheerlijkheid', waarvan de inhoud niet nader wordt gedefinieerd.

Maar misschien zijn dit soort indelingen ook niet zinvol en verdient een aanpak zoals van Nève bij het Rijkskamergerecht de voorkeur. ${ }^{67} \mathrm{Hij}$ beschrijft alle territoria, groot en klein, in alfabetische volgorde en onderzoekt vervolgens specifiek welke relaties met het

63 De Wit en Flament, 'De vorming der heerschappijen', 43-57. Tot de 'wereldlijke' gebieden werden gerekend Born, Cartils, Eckelrade, Elsloo, Gronsveld, Grevenbicht, Kessenich, Limbricht, Meyel, Obbicht-Papenhoven, Pol en Panheel, Rimburg, Rijkckholt, Slenaken, Stein, Terblijt, Wylre, Wittem en Wynandsrade en onder geestelijk gezag stonden Bemelen, Berg, Breust, Heer-Keer, Mesch, Neeritter en Heel, Thorn en Tweebergen.

${ }^{64}$ Flament, 'De rechtsbedeeling', 57-64: Breust, Gronsveld, Eckelrade, Kessenich, Mesch, Rijckholt, Stein, Thorn, Wittem, Eys, Slenaken, Wylre, Terblijt, Cartils, Wynandsrade, het 'patrimonium van Sint Lambertus te Luik, te weten Heel, Neeritter en Poll en Panheel en ten slotte Rimburg.

${ }^{65}$ De Rijksarchieven in Nederland. Overzicht van de inhoud van de Rijksarchiefbewaarplaatsen, 340-341.

${ }^{66}$ Panhuysen, 'Overzicht archivalische bronnen', 750-753, nrs. 175-197; Delahaye, De Arcbieven in Limburg, 45-48.

${ }^{67}$ Nève, Rijkskamergerecht. 
Rijkskamergerecht bestonden. Op soortgelijke wijze kunnen ook kleinere, met elkaar samenhangende groepjes 'vrije rijksheerlijkheden' op vergelijkbare kenmerken worden onderzocht. Voorbeelden van dit soort 'clusters' kunnen heerlijkheden zijn die een kapittel als heer hadden, zoals Bemelen, de 'Elf Banken van Sint-Servaas', Thorn, Breust en Mesch, of in de middeleeuwen als 'zonnelenen' begonnen plaatsen zoals Meyel, Wylre, Gronsveld en Rijkckholt (die alle vier aan het eind van het Ancien Régime in status verschilden) en ten slotte de rijksonmiddellijke graafschappen Gronsveld en Wittem met het juist over de landsgrens met België gelegen Rekem, die juist heel verschillend begonnen en gelijk eindigden. In dat opzicht ligt een groot terrein braak.

De in 1972 verschenen studie van Nève over het Rijkskamergerecht bevat voor alle door hem onderzochte territoria een uitvoerige bibliografie. Daar willen we hier ook naar verwijzen. In de vier decennia daarna zijn wat betreft 'op het Heilige Roomse Rijk georiënteerde gebieden’ in Limburg resultaten van nieuw onderzoek gepubliceerd en zijn nieuwe archieftoegangen verschenen.

Bij de archieftoegangen moet in de eerste plaats worden gewezen op de in 2002 gepubliceerde inventaris van de 'Maastrichtse' dossiers van het Rijkskamergerecht (waarover hierna meer bij het onderdeel 'archieven' van deze inleiding). ${ }^{68}$ Vooral de uitvoerige inhoudelijke ontsluiting van de dossiers vormt een belangrijke aanvulling op het werk van Nève. Voorts zijn archiefinventarissen met inleiding verschenen van de schepenbanken Stein, ${ }^{69}$ Rijckholt, ${ }^{70}$ Wylre $^{71}$ en Thorn ${ }^{72}$ en van de familie de Bounam de Rijckholt, ${ }^{73}$, alle voorzien van een bibliografie.

Voor inzicht in de politieke cultuur binnen kleine territoria aan de Nederrijn en in het Maasland tussen 1648 en 1794 is van belang de studie van Gabel. ${ }^{74}$ De auteur behandelt daarin conflicten die zich een aantal plaatsen, en in het bijzonder in de kloosterstaat Cornelimünster bij Aken, afspeelden tussen landsheer en onderdanen en tussen onderdanen onderling. De beschreven voorbeelden zijn ook heel herkenbaar voor Gronsveld. Gabel gaat uit van een model zoals dat hiervoor in het overzicht van de algemene literatuur ook door Busch wordt toegepast, waarbij onderdanen georganiseerd als gemeenschap of collectief weerstand boden tegen lasten die de overheid oplegde, bijvoorbeeld diensten of belastingen, in het bijzonder ook belastingen ten behoeve van het Rijk. Tegelijkertijd kon dit collectief opkomen voor bepaalde rechten, zoals gebruiksrechten van heide, bossen en weide of vrijstelling van belastingen en diensten. Op basis van zijn onderzoek distilleert Gabel een vijftien tot twintig 'normen, waarden en principes' die de speelruimte tussen de betrokken partijen bepaalden. Als belangrijkste voorbeelden kunnen hier worden genoemd: algemeen nut, oud gebruik, billijkheid en

68 Wiech, Reichskammergericht, Prozessakten Maastricht.

${ }^{69}$ Van Hees, Inventaris Stein.

70 Keyser-Schuurman, Inventaris Ryckholt.

71 De la Haye, Inventaris Wijlre.

72 De inventaris van het hoofdgerecht Thorn is alleen in manuscriptvorm en via internet raadpleegbaar (website RHCL te Maastricht). De bijbehorende inleiding is afzonderlijk gepubliceerd in: Van Rensch, 'Rechterlijke organisatie Thorn'.

${ }^{73}$ Keyser-Schuurman, Inventaris De Bounam de Ryckholt.

${ }^{74}$ Gabel, Widerstand und Kooperation. 
rechtvaardigheid, vrijheid en wederkerigheid. Tegelijkertijd maakte ook de omgang tussen rivaliserende groeperingen deel uit van de politieke cultuur binnen een kleine samenleving. In dorpsgemeenschappen behorend tot grote landsheerlijkheden werd dit soort lokale conflicten meestal beslecht op centraal landsheerlijk niveau. ${ }^{75}$ Die rol lijkt bij kleine territoria in het Rijk in sterke mate te zijn weggelegd voor het Rijkskamergerecht en de Rijkshofraad. Deze hoogste rijksgerechten konden met hun tussenvonnissen het verloop van een zaak beïnvloeden. Een bijzondere dimensie krijgt hun invloed bij zaken waarin het ging om geschillen over belastingheffing ten behoeve van het Rijk. Gabels onderzoek maakt duidelijk dat het voor een goed begrip van de complexe politieke cultuur in een klein gebied noodzakelijk is zowel de verwevenheid van belangen op plaatselijk niveau inzichtelijk te maken, als tegelijkertijd ook de (on)macht van instanties op het niveau van de kreits en hoogste rijksgerechten om daar invloed op uit te oefenen.

Gedurende de laatste decennia verschenen ook publicaties die betrekking hebben op de rijksonmiddellijke status van bepaalde territoria, zoals de artikelen van Berkvens over Kessenich ${ }^{76}$ en Thorn ${ }^{77}$ en van Weinberg over Wittem. ${ }^{78}$ Wittem kent een met Gronsveld vergelijkbare geschiedenis in die zin dat de heerlijkheid was ontstaan uit een aantal dorpen en gehuchten met een verschillende juridische achtergrond. Pas in 1732 werd dit gebied verheven tot graafschap. Weinberg onderzoekt de lange voorgeschiedenis daarvan, waarbij hij vooral dieper ingaat op de betekenis van de zogenoemde rijksmatrikels. De matrikel was in zijn oorspronkelijke vorm bedoeld als een overzicht van de bijdragen van iedere rijksstand in de belastingen voor het Rijk, maar vermelding op de lijst werd al snel beschouwd als bewijs voor de status van rijksstand. In dezelfde sfeer speelt het artikel van Munsters over rijksonmiddellijkheid en Kammerzieler, de bijdrage an het Rijkskamergerecht, waarin hij dit onderwerp voor Wittem en Stein onderzoekt. ${ }^{79}$ Volledigheidshalve verwijzen we hier ook nog naar Kerpen en Lommersum, weliswaar op Duits gebied gelegen, maar een Brabants leen en in het bezit van de ook 'in Limburg gewortelde' rijksgraven von Schaesberg. ${ }^{80} \mathrm{Al}$ deze studies hebben als gemeenschappelijke kenmerken dat het bij de vaststelling van rijksonmiddellijkheid en de daaruit voortvloeiende fiscale verplichtingen vaak om zeer gecompliceerde rechtsverhoudingen ging, waarover ook de tijdgenoten zeer verschillende opvattingen waren toegedaan.

Het enige overzicht van de geschiedenis van een graafschap in het Maasgebied dat enigszins in de richting komt van het in de Duitse literatuur ontwikkelde onderzoeksmodel voor een klein territorium, is het werk van Verbois over Rekem. ${ }^{81}$ Hoewel Rekem groter was dan Gronsveld (de hoofdplaats Rekem had zelfs stedelijke kenmerken), zijn beide

\footnotetext{
75 Zie in dit verband als voorbeeld Berkvens, Plakkatenlijst Overkwartier I, 76-77, waar het Hof van Gelre te Roermond zelfs reglementen aan dorpen oplegt.

76 Berkvens, 'Rijksheerlijkheid Kessenich'.

77 Berkvens, 'De kanunnik Joannes Stuben'.

78 Weinberg, 'De heerlijkheid Wittem'.

${ }^{79}$ Munsters, 'Rijksonmiddellijkheid en Kammerzieler'.

80 Peters, Geschichte des Geschlechtes von Schaesberg); zie over de status van Kerpen-Lommersum in de zestiende eeuw: Van Peteghem,'Limburg' en Kerpen-Lommersum'.

81 Verbois, Geschiedenis Rekem.
} 
graafschappen goed vergelijkbaar. Een belangrijk verschil is echter de veel omvangrijker archiefoverlevering bij Rekem. ${ }^{82}$ Dat is ook terug te vinden bij Verbois, wiens aandacht vooral gericht is op plaatselijke bijzonderheden en wetenswaardigheden. Bij Gronsveld ontbreken die of zijn ze slechts met moeite te reconstrueren. Maar alleen al wat hij vermeldt over wet- en regelgeving geeft een beeld van de intensieve overheidsbemoeienis op dit terrein. Wegens die aandacht voor details is deze geschiedschrijving interessant om de 'sfeer' binnen een ander klein, rijksonmiddellijk graafschap in de omgeving van Gronsveld te proeven. Tegelijk betekent die sterk intern gerichte, heemkundige belangstelling, in combinatie met de compositie van het geheel, ook de zwakke kant van het boek, want ondanks de titel 'Keizerlijk graafschap' wordt Rekem nauwelijks gepositioneerd als graafschap binnen de totaliteit van het Heilige Roomse Rijk.

Aan het slot van dit historiografisch overzicht willen we ook de belangrijkste literatuur over Gronsveld behandelen. Wanneer we kijken naar monografieën of daarmee gelijk te stellen algemene overzichten, dan moet als oudste voorbeeld daarvan worden genoemd het boek Recherches sur l'Ancien Comté de Gronsveld van Wolters uit 1854. ${ }^{83}$ Het werk past in de lange reeks monografieën van deze veelschrijver, waarbij voor vergelijkbare territoria, adellijke kapittels en heerlijkheden min of meer hetzelfde stramien wordt gevolgd. Wolters schenkt veel aandacht aan genealogie van adellijke families, numismatiek en de tekstuitgave van middeleeuwse oorkonden als 'bewijsstukken'. Ook het boek over Gronsveld kent deze opbouw. Daarmee heeft de verhandeling zeker nut, maar de bruikbaarheid blijft beperkt. In 1875 verscheen als artikel de veel uitgebreider en beter gedocumenteerde 'Histoire de la seigneurie impériale de Gronsveld' van Chestret de Haneffe. ${ }^{84}$ Als een soort echo van deze negentiende-eeuwse publicaties kan worden beschouwd de brochure van Van Daalen uit 1964, waarin de door de heren van Gronsveld geslagen munten worden beschreven. ${ }^{85}$

Naar verhouding veel literatuur heeft betrekking op genealogie en biografie van heren van Gronsveld. We noemen hier een kort artikel van Habets uit 1867 over de grafkelder van de heren Van Bronckhorst Batenburg86, maar vooral twee boeken over Rimburg: van Quix uit $1835^{87}$ en van Hanssen uit 1912.88 Hoewel niet specifiek voor Gronsveld bedoeld, bevatten ze veel informatie over de heren van Gronsveld uit de geslachten Van Gronsveld en Van Bronckhorst Batenburg. Hanssen maakte ook als eerste gebruik van twee belangrijke handschriften voor de middeleeuwse geschiedenis van Gronsveld, te weten het zogenoemde 'Cartularium van de heren van Gronsveld' en het cartularium uit het archief Hurt von Schönecken, opgenomen in de zogenoemde 'Sammlung Alfter' te

82 Archieven aanwezig in Rijksarchief Hasselt, vgl. manuscript-inventaris van J. Grauwels, 'Inventaris Graafschap Rekem', 1968.

83 W(olters), Recherches sur l'ancien comté de Gronsveld.

${ }^{84}$ Chestret de Haneffe, 'Histoire Gronsveld'.

85 Van Daalen, Munten graafschap Gronsveld.

${ }^{86}$ Habets, 'Grafstede'.

${ }^{87}$ Quix, Schloss Rimburg.

88 Hanssen, Die Rimburg. 
Darmstadt (zie over deze beide handschriften Inleiding 4.2 en 4.4). De beste en meest betrouwbare genealogie (hoewel niet helemaal foutloos) van de uitgebreide familie Van Bronckhorst Batenburg blijft echter die van Van Schilfgaarde. ${ }^{89}$

Jost Maximiliaan van Bronckhorst Batenburg, het meest prominente lid uit dit geslacht, kreeg bijzondere aandacht in een artikel van Lahrkamp over de militaire loopbaan van deze graaf van Gronsveld.90 Voorts besteedde Janssen de Limpens aandacht aan hem in een artikel over de geschiedenis van de heerlijkheid Oost. ${ }^{91}$ Interessant is de schets die Weinberg geeft van het leven van Wilhelm Veucht als secretaris en adviseur van Jost Maximiliaan, diens echtgenote Anna Christina von Hardenrath en hun zoon Johan Frans van 1660 tot 1694, vooral ook omdat zijn activiteiten inzicht geven in de betrekkingen tussen de grafelijke familie en het Rijk. ${ }^{92}$ Veucht, die ook werkzaam was voor de heer van Wittem, is een typisch voorbeeld van een advocaat die als vertrouwenspersoon voor zijn opdrachtgever niet alleen praktisch juridische zaken behartigde, maar ook het beleid op juridisch gebied bepaalde en argumenten voor de onderbouwing van bepaalde standpunten leverde..$^{93}$

Voor de achttiende eeuw, toen de graven Toerring-Jettenbach in Beieren door vererving graaf van Gronsveld waren geworden, is ten slotte van belang de studie van Englbrecht. ${ }^{94}$ Zij beschrijft de diverse takken van de familie vooral als een familiegeschiedenis en geeft ook genealogische overzichten. De informatie over leden van de familie die voor Gronsveld echt belangrijk zijn, blijft echter beperkt.

Gedurende de laatste decennia verschenen enkele publicaties van substantiële omvang, die niet direct op Gronsveld betrekking hebben, maar daar wel op een bepaalde manier raakvlakken mee hebben. Als eerste kan worden genoemd de door Hartmann beschreven middeleeuwse ontwikkeling van Breust, Eijsden en Oost, plaatsen die aan Gronsveld grenzen. ${ }^{95}$ De door hem ontwikkelde methode om de middeleeuwse ontginning van het plateau van Eckelrade in kaart te brengen, werd naderhand ook door Hackeng toegepast op enkele van de zogenoemde 'Banken' van het Maastrichtse Sint-Servaaskapittel. ${ }^{96}$

Van geheel andere aard zijn de studies van Gläser ${ }^{97}$ en Kwiatkowski. ${ }^{98}$ Gläser behandelt de prosopografie of collectieve biografie van acht generaties van de familie von Schönau/von Schönforst, bezitters van de gelijknamige heerlijkheid bij Aken, gedurende de periode

89 Van Schilfgaarde, 'De heren van Bronckhorst'.

90 Lahrkamp, 'Kriegserinnerungen Gronsfeld'.

91 Janssen de Limpens, 'Geschiedenis Oost'.

92 Weinberg, 'Wilhelm Veucht'.

93 Een ander voorbeeld van de rol van juristen bij dit soort betrekkingen met het Rijk levert de bijdrage van Berkvens over de kanunnik Joannes Stuben als auctor intellectualis van het 'rijksvorstendom' Thorn (vgl. Berkvens, 'De kanunnik Joannes Stuben').

94 Englbrecht, Drei Rosen.

95 Hartmann, Reconstructie landschap.

96 Hackeng, Middeleeuwse grondberit Sint-Servaaskapittel.

${ }^{97}$ Gläser, Schönau - Schönforst.

98 Kwiatkowski, Herrschaft zwischen Herrschaften. 
1250-1450. Dit geslacht, met als bekendste vertegenwoordiger Reinhard von Schönau/Schönforst (circa 1305-1376), was niet alleen verwant aan de heren van Gronsveld, maar leek daar in doen en laten ook sterk op. Beide, soms bevriende, soms rivaliserende families waren in het bezit van een territorium van eenzelfde omvang, beide traden op als financiers van de hertog van Brabant, vervulden ambten in Brabantse dienst en hadden Brabantse bezittingen in pand. Daarmee leveren Schönau/Schönforst en Gronsveld interessante voorbeelden van twee vooraanstaande Maaslandse adellijke families die zich staande moesten houden in een gebied waar de hertogen van Brabant en van Gulik domineerden.

De studie van Kwiatowski over Anholt in de late middeleeuwen bouwt eigenlijk voort op hetzelfde thema. Het Kleinterritorium Anholt aan de Nederrijn is goed met Gronsveld te vergelijken. Daarnaast bestond ook een direct raakvlak, aangezien beide plaatsen door familiale banden met elkaar waren verbonden. Kwiatkowski beschrijft de interne structuren van Anholt (waarover in verhouding tot Gronsveld aanzienlijk meer materiaal beschikbaar is), maar legt vooral ook de nadruk op de strategieën die de familie ontwikkelde om de zelfstandigheid van hun kleine territorium tussen de hertogdommen Gelre en Kleef te handhaven.

Het voorgaande overzicht laat zien dat in de bestaande literatuur aspecten van de geschiedenis van kleine territoria in het Limburgse Maasgebied vanuit uiteenlopende invalshoeken zijn benaderd, maar het ontbreekt aan integraal onderzoek van één gebied, waarbij al die aspecten in hun onderlinge samenhang zijn bestudeerd. Deze studie over Gronsveld beoogt in die lacune te voorzien, met dien verstande dat de nogal grillig verlopende beschikbaarheid van archiefbronnen soms invloed heeft gehad op de uitvoerigheid bij de behandeling van onderwerpen.

\section{Archivalische bronnen voor onderzoek}

\subsection{Archieven van het graafschap Gronsveld}

In het voorgaande kwam meermalen ter sprake dat het onderzoek naar de geschiedenis van Gronsveld in hoge mate wordt belemmerd door het ontbreken van archieven. Ooit waren de archieven van het graafschap zeer omvangrijk, maar veel is verloren gegaan door de gebruikelijke redenen zoals verwaarlozing, oorlog en delingen binnen de grafelijke familie. Een beeld van wat er was, krijgen we bij het doornemen van de (gebrekkige) inventarissen van de Gronsveldse archieven die in de achttiende eeuw om verschillende redenen zijn gemaakt. Die overzichten bewijzen ook nu nog hun nut, omdat de daarin opgenomen beschrijvingen soms het enige middel zijn om het bestaan van bepaalde instellingen of relaties aan te tonen. Zo vond gedurende een aantal maanden in 1717 een inventarisatie plaats van de Gronsveldse archieven in het kasteel. ${ }^{99}$ De documenten lagen in grote en kleine kisten volledig door elkaar. De samensteller van de lijsten nam de

${ }_{99}$ Te vinden in TJ, inv. nr. M 12, fol. 619-638. 
opschriften over, maar diepgaand was de inventarisatie niet met beschrijvingen zoals 'alderhand correspondens schreibens' en 'alte brief und auslagen'. Over sommige stukken had inventarisator een duidelijk oordeel: 'brief daeraen wenig gelegen' of 'brief weniger nutzen'. Soms tekende hij aan dat de bundel te gelegener tijd nog eens moest worden bekeken. Ondanks deze beperkingen valt toch veel informatie uit de lijsten te halen, zeker wanneer men bepaalde namen vanuit een ander verband kent.

Het gros van de stukken dateerde uit de late zestiende en uit de zeventiende eeuw, maar ook oudere documenten uit de vijftiende eeuw en zelfs een stuk teruggaande tot 1375 , waren aanwezig. Van een omvangrijk middeleeuws bestaand aan oorkonden kan echter niet worden gesproken. Even gevarieerd was de inhoud: correspondentie van leden van de grafelijke familie, procesdossiers, boekhouding en rekeningen. Het betrof niet alleen Gronsveld, maar ook andere plaatsen waar de familie Van Bronckhorst Batenburg bezittingen had gehad zoals Rimburg, Eberstein (ten noorden van het Zwarte Woud) of Alpen (aan de Nederrijn), verder stukken betreffende militaire functies en betrekkingen tussen Gronsveld en het Rijk.

Behalve de familiepapieren van Bronckhorst Batenburg stonden er minstens twee kisten gevuld met documenten van de schepenbanken Heugem, Gronsveld en Honthem. Zo worden, naast losse bundels papieren, van Gronsveld registers genoemd vanaf 1580, van Heugem vanaf 1597 en van Honthem sinds 1615.100

Duidelijk komt naar voren dat deze schepenbanken aanvankelijk een gescheiden administratie per gerecht voerden. Verder wordt melding gemaakt van gemeenterekeningen, (soms dikke) procesdossiers en voornamelijk zestiende-eeuwse boekhouding van cijnzen en renten. De totale omvang van het archief laat zich moeilijk schatten, maar moet enkele strekkende meters hebben omvat.

Een tweede uitgebreide inventarisatie vond plaats in 1745 in het kader van het gerechtelijk onderzoek tegen de frauderende rentmeester en secretaris Matthias Oligschläger. ${ }^{101}$ Het archief lag verdeeld over verschillende vertrekken in het kasteel, onder andere in de 'stoffcamer'102 en de slaapkamer. Tamelijk gedetailleerd beschreven zijn de vrijwel complete series gerechtsprotocollen van Gronsveld, Heugem en Honthem. Verder werden de administratie van het leenhof en boekhoudkundige bescheiden van de rentmeester aangetroffen. Over het familiearchief wordt niet gesproken. Misschien was een deel daarvan verdwenen in de roerige jaren twintig van de achttiende eeuw, toen het kasteel was verpacht en allerlei vreemd volk over de vloer kwam.

Gerechtelijk archief van Slenaken ontbreekt bij deze inventarisaties (wel zijn er gegevens over cijnzen, keurmeden, etc.). Oorspronkelijk zal dit bewaard zijn geweest in Slenaken. Tijdens de verpanding van Slenaken gedurende de jaren 1638-1662 aan Johan Adolf van Imstenrade, heer van Mheer, was het in handen van de pandheer. Bij hem werd het in 1662 door twee vertegenwoordigers van de schepenbank Slenaken aangetroffen en geïnventariseerd. Veel stelde het niet voor. Genoemd worden onder andere 'eenen alden

100 TJ, inv. nr. M 12, fol. 635.

101 RHCL, Rijkskamergerecht 192/1, fol. 260-282 (Q 110).

102 RHCL, Rijkskamergerecht 192/1, fol. 267 (Q 110). Wat precies met de 'stoffcamer' wordt bedoeld, is niet duidelijk. 
ontriffelden schepenregistere', beginnend in 1494, enkele gerechtsrollen uit de zeventiende eeuw en 67 schatlijsten. ${ }^{103}$ Alle documenten keerden terug naar Slenaken en zullen daar ook verder bewaard zijn gebleven, ook na de verkoop van Slenaken aan Wittem in 1728.104

In 1752 trad de uit Ingolstadt geboortige Joseph Anton Prummer in Gronsveld als grafelijk vertegenwoordiger aan. Bijna dertig jaar zou hij in het graafschap werken. Zijn naam duikt in dit boek nog vele malen op en hij moet worden beschouwd als één van de beeldbepalende figuren uit de geschiedenis van Gronsveld in de tweede helft van de achttiende eeuw. Al direct na zijn aankomst klaagde hij over de aangetroffen administratieve chaos. Maanden werden besteed aan het verzamelen van papieren en het op orde brengen van de grafelijke financiën. In het geval van blijvende hiaten zat er niet veel anders op dan helemaal opnieuw te beginnen. Maar zijn inzet werd beloond. Uiteindelijk wist Prummer een systeem van grondboekhouding met bijbehorende kaarten op te zetten, dat in de streek nauwelijks zijns gelijke kende.

Prummer kende dus uit ervaring de waarde van een goede administratie. Maar waakzaamheid bleef geboden. Zo kwam in 1762 een heel pakket stukken over Slenaken uit het archief van Gronsveld door toedoen van een zoon van de vroegere drossaard Johannes Godefridus Lebens terecht bij de paters van Hoogcruts. ${ }^{105}$ Dit materiaal werd in 1987 ontdekt bij de inventarisatie van het archief van Hoogcruts, dat bij het Regionaal Historisch Centrum Limburg berust.

Een catastrofe vond plaats begin februari 1793, toen op het kasteel van Gronsveld gelegerde Franse troepen archieven door het raam naar buiten gooiden en onder de kreet 'guerre aux châteaux' ('oorlog aan de kastelen') opstookten.106 Een klein deel van het archief was nog door Wolfgang Zollner, Prummers opvolger als commissaris en vertegenwoordiger van de graaf in Gronsveld, naar secretaris Lebens in Maastricht gebracht. Ook lagen nog stukken betreffende lopende zaken bij hem thuis. Maar om plaats te maken voor ingekwartierde militairen was alles op een hoop gesmeten. Niet alles was daarmee verloren. Zo lukte het Zollner bij zijn vlucht naar München in 1794 een koffer met bescheiden in boekvorm mee te nemen, die belangrijk konden zijn met het oog op herstel van de grafelijke rechten in de toekomst. In München werden ze aan het onderdeel 'Gronsveld' van het archief van de familie Toerring-Jettenbach toegevoegd. ${ }^{107}$

Intussen kregen ook de Fransen belangstelling voor de archieven. Op 12 april 1796 werd in het departement Nedermaas de wet van 7 messidor jaar II (25 juni 1794) ingevoerd, die

\footnotetext{
103 RHCL, Klooster Hoogcruts, inv. nr. 296.

104 RHCL, Graafschap Gronsveld inv. nr. 560 is een lijst uit 1719 van op Slenaken betrekking hebbende archieven, aangetroffen in Gronsveld. Genoemd worden onder andere een legger van inkomsten, een leenboek en vooral documenten die hadden op processen waarin de heren van Gronsveld betrokken waren.

105 Delahaye, Inventaris Hoog-Cruts, 24-25 en inv. nrs. 998-1020.

106 TJ, inv. nr. M 62, fol. 302-305, Zollner aan graaf 4 maart 1793.

107 De belangrijkste stukken zijn TJ, inv. nr. M 17, leenregister van Gronsveld, beginnend 1743; TJ, inv. nr. M 22, fol. 1-229 'rendambtsregister' en TJ, inv. nr. M 23, manualen en kasboeken van inkomsten uit pachten, cijnzen, heergewaden, accijnzen etc. 1781-1787; TJ, inv. nr. M 42, fol. 1-247, leenregister van Holset, beginnend 1613 en TJ, inv. nr. M 71, reken- en resolutieboek van de geërfden, beginnend 1739.
} 
bepaalde dat de archieven van de opgeheven instellingen, waaronder ook die van de voormalige schepenbanken, moesten worden samengebracht in een departementaal depot. Daar moest een commissie van ter zake kundige burgers, de préposés au triage, een schifting maken van te bewaren en te vernietigen stukken. Een dergelijke commissie werkte vanaf 16 februari 1798 ook in Maastricht in de voormalige proosdij van het Sint-Servaaskapittel aan het Sint-Servaasklooster. De triage vlotte echter niet door gebrek aan capaciteit en tegenwerking van de plaatselijke bestuurders. Voor Gronsveld dachten de nieuwe machthebbers een rijke buit aan archieven binnen te halen. Op 1 mei 1801 verscheen vrederechter Wilhelmi van het kanton Eijsden, gesecondeerd door twee assistenten, bij burgemeester Bouchoms van Gronsveld, voor een vergadering met drie gewezen schepenen van Gronsveld en ex-secretaris Johannes Godefridus Lebens. ${ }^{108}$ Op de vraag waar zich de archieven van de schepenbank bevonden, verwees Bouchoms de heren naar Agnes Petermans, de echtgenote van de gevluchte Zollner. Die vertelde dat haar man met de keizerlijke troepen over de Rijn was getrokken. Van archieven wist ze niet meer dan dat in 1793 veel was vernield. ${ }^{109}$

Het enige schepenbankarchief waar de Fransen de hand op konden leggen, waren de stukken die ex-secretaris Lebens nog thuis had in Maastricht. Dit materiaal werd verzegeld en overgebracht naar de Triagecommissie. Op 30 juli 1801 openden de leden daarvan het pakket en troffen drie registers en vier bundels met processtukken van Gronsveld aan.110 Uit het op 17 september 1801 opgemaakte proces-verbaal blijkt dat alle stukken betrekking hadden op de periode 1788-1796, dus lopende administratie.111 Via de bewaarplaats in de arrondissementsrechtbank in Maastricht, waarheen de stukken na opheffing van de Triagecommissie werden overgebracht, zijn deze documenten omstreeks 1880 overgedragen aan het Rijksarchief in Limburg.

Helemaal de waarheid gesproken had Agnes Petermans niet. Er lagen in haar huis nog fragmenten van de archieven van de schepenbank, evenals stukken die betrekking hadden op het beheer van de grafelijke domeinen. Na haar overlijden op 8 september 1803 in Gronsveld vielen deze documenten toe aan haar kinderen. De Erven Lebens, wonende te Eijsden, hebben omstreeks 1900 ongeveer twee meter Gronsvelds archief, samen met een portefeuille familiepapieren, aan het Rijksarchief in Limburg geschonken. ${ }^{112}$ Het was een mengelmoes van archieven van de schepenbank, van de rentmeester, van de familie Van Bronckhorst Batenburg en van Zollner persoonlijk, waarbij het leeuwendeel uit de achttiende eeuw dateert. Slechts een enkeling zoals de historicus baron Chestret de Haneffe, die in 1875 zijn Franstalige geschiedenis van Gronsveld publiceerde, was vóór de overdracht aan het Rijksarchief op de hoogte van het bestaan van deze archieven. Samen

108 Johannes Godefridus Lebens, laatste secretaris van de schepenbank Gronsveld, benoemd in 1782. Geboren in Rekem 1752, overleden te Maastricht 1821, zoon van Guilhelmus Henricus Lebens, ontvanger en rentmeester van het graafschap Rekem, kleinzoon van drossaard Johannes Godefridus Lebens, zie: Van Heyst, Proeve ener genealogie, 137 en Verzijl, De Maastrichtse tak der familie Lebens, 93-94.

${ }^{109}$ RHCL, Departement Nedermaas, inv. nr. 2135.

110 RHCL, Departement Nedermaas, inv. nr. 2243.

111 RHCL, Departement Nedermaas, inv. nr. 4765, fol. 39-39vo.

112 Verslagen omtrent's Rijks Oude Archieven 1900, 815-816. 
met de stukken die ex-secretaris Lebens al in 1801 had ingeleverd, waren door de schenking van de Erven Lebens de Gronsveldse archieven in het Rijksarchief weer verenigd. Daar werden zij door de auteur van dit boek in 2000 in één inventaris beschreven.

Bij de bezetting van Gronsveld door de Fransen eind 1794 kregen de nieuwe machthebbers ook de beschikking over de eigendommen van de vroegere overheden, in dit geval de Gronsveldse bezittingen van graaf Toerring-Jettenbach. Voorlopig ging men niet verder dan inbeslagname, want formeel moest met het Heilige Roomse Rijk, waartoe de Toerrings behoorden, definitief vrede worden gesloten. Duidelijkheid kwam pas toen het Rijk in 1801 alle gebied ten westen van de Rijn aan Frankrijk afstond. Vervolgens werd op 25 februari 1803 de schade van de Duitse vorsten gecompenseerd met goederen van opgeheven kloosters en geestelijke vorstendommen. Graaf Toerring-Jettenbach ontving als vergoeding voor Gronsveld de abdij Gutenzell, in het grensgebied van het tegenwoordige Duitse deelstaten Beieren en Baden-Württemberg. ${ }^{113}$

Inmiddels waren de ambtenaren der domeinen in het departement Nedermaas begonnen met een inventarisatie van de grafelijke goederen in Gronsveld. Bij gebrek aan documenten verliep dat moeizaam. De spaarzame mondelinge inlichtingen leverden, zoals verwacht, niet veel op. Het was dus belangrijk alsnog de beschikking te krijgen over de door commissaris Zollner naar München meegenomen archieven. Op 17 mei 1803 wendde de prefect van het departement Nedermaas zich tot burgemeester Bouchoms van Gronsveld. Maar die wist slechts wat al bekend was. Hoewel de prefect de zaak op het hoogste niveau aankaartte, bij de Minister van Binnenlandse Zaken in Parijs, viel voorlopig niet meer resultaat te behalen. ${ }^{114}$

Burgemeester Bouchoms dacht het over een andere boeg te moeten gooien. Hij schreef op 14 januari 1804 een briefje aan graaf Joseph August von Toerring-Jettenbach, waarin hij zijn zorgen uitsprak dat door het ontbreken van archieven. Processen dreigden te ontstaan tussen inwoners van Gronsveld. ${ }^{115}$ Dat moest de graaf, die toch altijd het beste met Gronsveld voor had gehad, wel erg aan het hart gaan. Of Zijne Excellentie maar wilde voldoen aan het gerechtvaardigd verzoek de papieren die de inmiddels overleden Zollner had meegenomen, te retourneren. De reactie uit München luidde even ontwijkend als bestraffend. Alle stukken waren uitstekend bij de graaf bewaard, maar ze bevatten geenszins wat Bouchoms dacht. Wanneer de Franse regering meende aanspraak te kunnen maken op bepaalde documenten, dan was de graaf graag bereid daar via de Franse gezant in München gehoor aan te geven. Maar waar haalde de burgemeester de onbeschaamdheid vandaan om te vragen of de graaf aan een verzoek wilde voldoen? Een dergelijke uitdrukking gaf geen pas en in dit geval al helemaal niet, omdat de graaf nog altijd zat te wachten op een brief van de burgemeester over de afhandeling van de nalatenschap van wijlen commissaris Zollner. Daarmee was de toon gezet. Pogingen van de Franse minister van Buitenlandse Zaken om via de gezant in München nog iets los te krijgen, liepen op

113 Maegraith, Das Zisterzienserinnenkloster Gutenzell.

114 RHCL, Departement Nedermaas, inv. nr. 2239.

115 RHCL, Departement Nedermaas, inv. nr. 2239. 
niets uit. De door Zollner meegenomen archieven waren en bleven tot op de dag van vandaag in München. Omdat het Ancien Régime nu definitief ten einde was, raakten ze min of meer in vergetelheid. Slechts een enkeling, zoals de bij het Rijksarchief Limburg werkzame archivaris J.M. van de Venne, bezocht in 1922 München om afschriften te maken van de zogenoemde Gronsveldse leenboeken. ${ }^{116}$ Pas in de jaren zeventig ontstond er nieuwe belangstelling vanuit heemkundige hoek in Gronsveld.

\subsection{Het 'cartularium' van Gronsveld}

Aan het slot van deze beschouwingen over de archieven in Gronsveld moet nog aandacht worden besteed aan een bijzonder handschrift, het 'cartularium' van de heren van Gronsveld. ${ }^{117}$ Het betreft 231 enkelzijdig gefolieerde bladen met afschriften van ongeveer 250 oorkonden uit de tijd tussen 1266 en 1549. Waarschijnlijk is de codex kort na 1550 ontstaan. De afschriften zijn van één hand, maar niet gewaarmerkt en aan het einde ontbreken één of meer bladen. De huidige band is vóór 1890 aangebracht. De codex heeft op de titelpagina in negentiende-eeuws handschrift de titel 'Cartularium der graven van Bronckhorst tot Gronsfeldt 1319-1546'. Met latere hand is achter 'Gronsfeldt' toegevoegd 'en Hönnepel'118. Dezelfde schrijver verwijst op het schutblad ook naar een artikel van R. Scholten in $1891 .{ }^{119}$ Scholten heeft het handschrift echter niet gekend; hetzelfde geldt ook voor Chestret de Haneffe in 1875. ${ }^{120}$ Als eerste maakt Hanssen er uitgebreid gebruik van in zijn boek uit 1912 over Rimburg, waarin hij verwijst naar het 'Lagerbuch Gronsfeld' in het Rijksarchief Maastricht. ${ }^{121}$

Over de vroegere verblijfplaats(en) van het handschrift zelf tasten we in het duister. Op één van de eerste bladzijden staat het concept of afschrift van een in slecht zeventiendeeeuws Frans geschreven briefje van 'Marie Lamberts' aan 'ma trescher amie'. Mogelijk gaat het daarbij om de dochter van Christiaan Lamberts, drossaard van Gronsveld van circa 1631 tot circa 1668/1669. Dat kan er op wijzen dat het handschrift zich in de zeventiende eeuw in Gronsveld bevond. Het wordt in ieder geval niet vermeld bij de inventarisaties in de achttiende eeuw. Het is onbekend op welke wijze dit cartularium in het Rijksarchief in Limburg terecht is gekomen. In ieder geval moet het vóór 1890 zijn geweest en makte het geen deel uit van de Gronsveldse archieven die in 1900 door de Erven Lebens werden overgedragen. Het handschrift werd wel bij dit archief geplaatst en is bij de ordening van de archieven van Gronsveld in 2000 in de inventaris opgenomen.

Niet alleen de herkomst van dit cartularium is een intrigerend probleem, ook blijft het een vraag waar zich de originelen bevonden die er in zijn afgeschreven. Gelet op de jaartallen van de jongste akten is het waarschijnlijk dat het boekwerk werd aangelegd voor Johan II van Bronckhorst Batenburg. Het grootste deel van de oorkonden tot het einde van de vijftiende eeuw heeft betrekking op plaatsen aan de Nederrijn. In het bijzonder het aan de

116 RHCL, Graafschap Gronsveld, inv. nr. 438 en 439.

117 RHCL, Graafschap Gronsveld, inv. nr. 62.

118 Hönnepel, thans gemeente Kalkar.

119 Scholten, 'Geschichte Hönnepel'.

${ }^{120}$ Chestret de Haneffe, 'Histoire Gronsveld'.

${ }^{121}$ Hanssen, Die Rimburg, 315-366, passim. 
Bronckhorsten verwante geslacht Van Alpen is goed vertegenwoordigd. Voor de zestiende eeuw ligt het accent meer op Rimburg en omgeving. Binnen dit totaal zijn wel oorkonden betreffende Gronsveld opgenomen, maar zij vormen een minderheid (het oudste stuk dateert uit 1386). Als bron voor de geschiedenis van Gronsveld voldoet het cartularium daarmee niet helemaal aan de verwachting die de titel wekt.

\subsection{Archieven in München}

Het verlies aan archieven in Gronsveld wordt ten dele gecompenseerd door de directe tegenhanger daarvan, namelijk het onderdeel 'Gronsveld' (circa tien meter) in het zeer omvangrijke archief (in totaal 115 strekkende meter) van de graven Toerring-Jettenbach in het Staatsarchiv München. Dit onderdeel 'Gronsveld' bevat bestanden van verschillende herkomst. Zo zitten er uit de tijd vóór 1720 stukken in uit het archief van Gronsveld en van de familie Van Bronckhorst Batenburg en uit de periode tussen 1720 en 1745 archivalia die betrekking hebben op goederen in Luxemburg, zoals het kasteel Sanem, en de familie d'Arberg Valengin. ${ }^{122}$ Waarschijnlijk zijn deze papieren meegekomen met gravin Maria Josepha d'Arberg Valengin, erfdochter van Gronsveld en Sanem, die een deel van haar jeugd in München doorbracht en daar uiteindelijk in 1746 met haar neef, graaf Maximilian Emanuel von Toerring-Jettenbach trouwde. Veel orde zat er in dit archief niet. De kern van het onderdeel 'Gronsveld' bestaat uit correspondentie van de grafelijke vertegenwoordigers in Gronsveld, Prummer en Zollner, met de graaf, gemiddeld tussen de vijftien en dertig brieven per jaar. ${ }^{123}$ Het was vooral Prummer die naar München schreef, omgekeerd was de briefwisseling minder intensief. Meestal waren het lange epistels volgens een strak model, waarin puntsgewijs verschillende onderwerpen werden behandeld. Het in de grafelijke kanselarij opgestelde antwoord volgde hetzelfde stramien. In het archief in München werden de ingekomen en uitgaande brieven doorlopend genummerd en per jaar afgelegd. Een tweede vaste correspondent over Gronsveldse aangelegenheden was de permanente vertegenwoordiger van de graaf bij het Rijkskamergerecht in Wetzlar. De brieven van deze advocaat waren zo talrijk, dat werd besloten ook die per jaar te bundelen en in de 'afdeling Gronsveld' op te nemen. ${ }^{124}$ In theorie voldeed deze methode om stukken te kunnen terugvinden, maar er werd niet altijd de hand aan de ordening gehouden. In het bijzonder belangrijke rapporten werden nogal eens gelicht en niet meer op de juiste plek teruggezet.

In het archief te München opgenomen werden ook stukken die aanvankelijk om administratieve redenen in Gronsveld berustten en later als documentatie of ter verantwoording van beheer nodig waren. Het meest sprekende voorbeeld daarvan zijn de kaarten op kadastrale schaal van het graafschap, die omstreeks 1754 zijn vervaardigd en in 1780 naar München werden gestuurd. Verder is omstreeks 1780 ook een pakket originele

122 Bijvoorbeeld TJ, inv. nr. M 2, 3, 4 en 35

${ }^{123}$ De aantallen zijn goed vast te stellen op basis van een agenda van ingekomen en uitgaande brieven over de periode 1773-1786 (TJ, inv. nr. M 63).

${ }^{124}$ Bijvoorbeeld TJ, inv. nr. M 43 (1774), TJ, inv. nr. M 44 (1775), TJ, inv. nr. M 45 (1776), TJ, inv. nr. M 46 (1773-1787) en TJ, inv. nr. M 55 (1770-1772). 
rekeningen met bijlagen van rentmeester Johan Frans Lebens over een periode van 25 jaar naar München gezonden.

Aanvankelijk bevond het hele archief van de graven Toerring-Jettenbach zich in het zogenoemde Palais Toerring aan de Karolinenplatz in München, waar het omstreeks 1870 door de historicus Sigmund Riezler werd geordend. De stukken werden verdeeld volgens de plaats waarop ze betrekking hadden, waarbij iedere plaats met een hoofdletter werd aangeduid. Voor het onderdeel Gronsveld werden de letters M en MM gereserveerd. Dit is de ordening die thans nog wordt gebruikt. Helaas zijn de door Riezler gemaakte beschrijvingen weinig gedetailleerd en soms slordig, zodat de bruikbaarheid van zijn werk beperkt is. Een probleem bij de ordening is dat alle stukken betreffende Gronsveld als éen blok zijn geordend, terwijl het gaat om bestanden van verschillende herkomst.

De stukken die zich tot 1935 in het Toerringpalais bevonden, belandden vervolgens in een villa in de Münchense voorstad Bogenhausen en werden ten slotte wegens oorlogsgevaar overgebracht naar het kasteel Winhöring. Van daaruit werden zij in 1962 door Carl Theodor Gaf zu Toerring-Jettenbach aan het Beierse Hauptstaatsarchiv München in bewaring gegeven. Deze bewaargeving werd wegens organisatorische veranderingen in 1977 omgezet in een nieuwe overeenkomst tussen het Staatsarchiv München en Hans Veit Graf zu Toerring Jettenbach, de huidige eigenaar van het archief. ${ }^{125}$

De bewaargeving in 1962 aan een archiefdienst van de overheid vergrootte de toegankelijkheid, maar voor geïnteresseerden in de Gronsveldse historie bleef de reis naar München moeizaam en kostbaar. Nadat in de jaren zeventig op kleine schaal fotokopieën waren gemaakt, werd in de jaren 2001-2002 op initiatief van de Stichting Grueles te Gronsveld, met medewerking van de eigenaar Hans Veit Graf zu Toerring Jettenbach en het Staatsarchiv München, besloten het bestand Gronsveld integraal te verfilmen. De bestaande volgorde van het archief werd, ondanks de daaraan klevende onvolkomenheden, gehandhaafd. Alle stukken binnen één inventarisnummer werden met potlood gefolieerd. De films berusten in het Regionaal Historisch Centrum Limburg en zijn daar ook te raadplegen. Voor deze studie over Gronsveld zijn deze films gebruikt. Verwezen wordt naar de nummers van de inventaris van het bestand ' $M$ ' in München en de met potlood aangebrachte foliëring.

\section{4 'Afgedwaalde' archieven}

Kenmerkend voor adellijke familiearchieven is dat zij vaak per generatie door vererving worden gedeeld of aangroeien en dikwijls op verschillende locaties zijn ondergebracht. Soms vormt zich in de loop van de tijd een soort 'harde kern' van documenten die op een bepaald huis met bijbehorende goederen betrekking hebben en bij verkoop van een goed aan de nieuwe eigenaar worden overgedragen. Deze lotgevallen zijn ook op de archieven van de opeenvolgende heren van Gronsveld van toepassing. Het is onmogelijk een volledig overzicht samen te stellen van alle adelsarchieven waarin stukken betreffende de

125 Stephan, 'Erhebung Törring', 421-425. 
heren van Gronsveld berusten, maar de drie belangrijkste vindplaatsen worden hier genoemd.

Het kasteel van Rimburg was vanaf de vijftiende eeuw tot aan de verkoop aan Arnold von Boeijmer in 1640 eigenlijk de hoofdverblijfplaats van de heren van Gronsveld. Er zal zeker archief zijn bewaard, maar over de omvang valt niets met zekerheid te zeggen. Misschien is bij de verkoop heel strikt alleen archief overgedragen dat betrekking had op Rimburg. In ieder geval is er zeer weinig uit die tijd vóór 1640 over. Dit valt af te leiden uit de bronnen die Hanssen gebruikte voor zijn boek over de geschiedenis van kasteel Rimburg. ${ }^{126} \mathrm{Hij}$ vermeldt als oudste originele oorkonde over Gronsveld uit het archief van Rimburg zelf de verheffing in de stand der rijksvrijheren in 1498 van Diederik II van Bronckhorst Batenburg (zie bijlage 39) Het historisch belang van het stuk is evident, maar strikt genomen is het niet eens een zuiver Gronsvelds document, omdat het in gelijke mate betrekking heeft op Rimburg.

Een aantoonbare deling van archieven vond in ieder geval plaats bij de boedelscheiding tussen Johanna en Aleidis, de dochters van Hendrik III van Gronsveld (overleden tussen 1474 en 1476) en Aleidis van Oupeye. Aleidis kreeg zo'n beetje de eerste keuze, want het gaat om belangrijke documenten zoals de overdracht van Heugem in 1363 en verschillende huwelijkscontracten en boedelscheidingen van de familie Van Gronsveld. Via haar huwelijk met Engelbrecht Nyt van Birgel zijn deze Gronsveldse oorkonden uiteindelijk terecht gekomen in het archief Hurt von Schönecken. Daar werden ze in 1584 als afschriften opgenomen in een grote, tweedelige codex, vervaardigd door de secretaris van de stad Euskirchen. Via de Keulse geestelijke Bartholomeus Alfter (1728-1808), een collectioneur van archivalia, is deze codex uiteindelijk terechtgekomen in Darmstadt, waar hij thans behoort tot de handschriftenverzameling van de Universitäts- und Landesbibliothek Darmstadt. ${ }^{127}$ Het belang van deze codex uit de Sammlung Alfter blijkt ook uit het feit dat Hanssen voor zijn geschiedenis van Rimburg er regelmatig gebruik maakt.

Een tweede adelsarchief waarin originele stukken uit Gronsveld terecht zijn gekomen is het archief van kasteel Eijsden. Het gaat voor het grootste deel om stukken die betrekking hebben op Oost en de laathoven in Oost, die door de verkoop in 1639 van de heerlijke rechten over die plaats aan Hieronymus van Berghe genaamd Trips in het archief van Oost en uiteindelijk door vererving in het archief van Eijsden terecht zijn gekomen. Het conflict over de Gronsveldse lenen in Oost, dat tot 1683 duurde, heeft vervolgens ook gezorgd voor een grote hoeveelheid processtukken in het archief van kasteel Eijsden.

${ }^{126}$ Hanssen, Die Rimburg.

127 ULB Darmstadt, Hs. nrs. 2734-2735. 


\subsection{Archieven over Gronsveld}

Door de grote lacunes in de eigen Gronsveldse archieven, zowel van de heren als van de instellingen, moet veel informatie worden gezocht in andere archieven die stukken over Gronsveld bevatten. Voor de tijd voor circa 1350 gaat het daarbij vooral om oorkonden in klooster en kapittelarchieven in de omgeving, zoals Aken, Aldenbiezen, Herkenrode, Hocht, Houthem Sint-Gerlach, Kloosterrade (Rolduc), Luik, Maastricht, Sinnich en ValDieu, om de voornaamste plaatsen te noemen.

Voor de tijd tussen ruwweg 1350 en 1450 hebben de financiële en ambtelijke relaties tussen de heren van Gronsveld en de hertogen van Brabant veel sporen nagelaten in de vorm van oorkonden in het archief van de hertogen van Brabant te Brussel. ${ }^{128}$ Iets dergelijks geldt ook voor de familie Van Bronckhorst Batenburg in de vijftiende eeuw, maar dan met betrekking tot het hertogdom Gelre. Voor de vijftiende tot het begin van de zeventiende eeuw bieden de leenregisters van de hertogen van Kleef veel informatie over de Nederrijnse bezittingen van de familie Van Bronckhorst Batenburg. ${ }^{129}$ Veel van dit bronmateriaal is uitgegeven in oorkondenboeken of in de vorm van regesten. Als regel werd voor deze studie over Gronsveld met die gedrukte informatie volstaan en werden de originele documenten slechts bij uitzondering geraadpleegd.

Voor de vroegmoderne tijd leveren enkele bestanden uit het fonds Landen van Overmaze bij het Regionaal Historisch Centrum Limburg belangrijk materiaal. Het gaat daarbij vooral om de schepenbank Vaals, Vijlen en Holset en de schepenbank Oost voor de in die plaatsen gelegen Gronsveldse lenen. Daarnaast kunnen genoemd worden de archieven van de schepenbanken Eijsden, Breust en Rijckholt.

Wat de overige bronnen betreft moet worden gewezen op belangrijke archivalia in het archief van het klooster Hoogcruts in Slenaken, het archief van de familie De Bounam de Rijckholt en het familiearchief De Geloes/kasteel Eijsden.

Voor Gronsveld van grote betekenis zijn diverse procesdossiers uit het bestand Rijkskamergerecht dat bij het Regionaal Historisch Centrum Limburg berust. Het gaat hierbij om stukken die na opheffing van het archiefdepot van het Rijkskamergerecht te Wetzlar in 1821 werden verdeeld, waarbij Nederland, hoofdzakelijk in de jaren 1847-1852, in totaal 312 dossiers kreeg toebedeeld. Formeel is het nog steeds Duits eigendom. Deze status maakte het mogelijk dat het bestand in 2001-2002 vanuit het Hauptstaatsarchiv Düsseldorf volgens de daarvoor ontwikkelde richtlijnen gedetailleerd werd geïnventariseerd. ${ }^{130}$ Nève heeft als eerste deze 'Limburgse' procesdossiers gebruikt voor zijn in 1972 verschenen omvangrijke overzichtswerk van de betrekkingen tussen het Rijkskamergerecht en de Nederlanden. Hij behandelt daarbij vooral de uitwendige geschiedenis. De inhoudelijke kant kreeg, op enkele uitzonderingen na (kleinere studies ten behoeve van artikelen), tot op heden nauwelijks aandacht. Deze studie over Gronsveld is het eerste voorbeeld waarbij dat wel is gebeurd. Het betreft zaken die in hoger beroep

128 Zie daarvoor de verschillende delen van Verkooren, Inventaire chartes de Brabant.

129 Dösseler/Oediger, Lehnregister Kleve.

130 Wiech, Reichskammergericht, Prozessakten Maastricht. 
vanuit Gronsveld of Heugem, eventueel met Aken of Luik als tussenstation, aanhangig zijn gemaakt, evenals processen in eerste aanleg, waarbij de graaf zelf als eiser of gedaagde betrokken was. De noodzaak tot meer diepgaande studie lag hier eigenlijk voor de hand omdat deze stukken informatie bevatten, die vanwege de gebrekkige overlevering van de Gronsveldse archieven niet meer uit andere bron valt te achterhalen. Als voorbeelden kunnen hier genoemd worden de gebeurtenissen in roerige jaren tussen 1720 en $1730^{131}$ (zie Hoofdstuk 11) en het proces tegen de frauderende rentmeester Mathias Oligschläger uit het midden van de achttiende eeuw ${ }^{132}$ (zie Hoofdstuk 12.5), die zich alleen aan de hand van dossiers uit het Rijkskamergerecht laten documenteren. De zaak tegen Oligschläger behoort overigens met negen banden $(50 \mathrm{~cm}$.) tot één van de omvangrijkste dossiers uit het totale bestand.

\section{Enkele thema's van onderzoek nader belicht}

\subsection{Territoriumvorming}

Tussen de afzonderlijke plaatsen binnen het graafschap Gronsveld bestonden nog tot het einde van de achttiende eeuw juridische verschillen, die herinneren aan een herkomst van ooit zelfstandige eenheden. Die ontwikkeling van afzonderlijke delen naar een samenhangend geheel vormt het eerste onderzoeksthema van dit boek. Wanneer we in dit kader spreken over 'territoriumvorming', dan passen daarbij enkele opmerkingen vooraf over 'territorium'en 'land' en daarmee samenhangende begrippen Landesherrschaft en Landeshoheit.

Deze twee laatste termen, waarop hierna (Inleiding 5.3) bij de bespreking van het begrip 'rijksstand' en de relatie van Gronsveld tot het Rijk nog uitvoeriger wordt teruggekomen, vallen min of meer samen met de in de Nederlandse rechtshistorische literatuur bekende woorden 'landsheerlijkheid' en 'landsheerlijke rechten' of 'regalia'. Het in dit boek regelmatig gebruikte woord 'territorium', meestal ter aanduiding van een geografisch begrensd gebied, is een anachronistische omschrijving voor een middeleeuwse staat, zoals die pas sinds het eind van de negentiende eeuw in het wetenschappelijk debat opduikt, maar in die betekenis onbekend was in de middeleeuwen. Hetzelfde geldt ook voor het woord 'grens' in de zin van landsgrens. ${ }^{133}$ Die begrippen passen bij de opkomst van staten aan het einde van de middeleeuwen en in de vroegmoderne tijd. Volgens hoogmiddeleeuwse opvatting werd bij Herrschaft in eerste instantie gedacht aan een (rechts)kring van personen over wie een heer overheidsgezag (Hoheit) uitoefende, zulks in samenhang met het 'land' waar de mensen leefden. Het idee van een rechtskring van personen ziet men ook in het feodale recht, waar de leenheer met zijn leenmannen of de hofheer met zijn horigen een rechtskring vormde. Het begrip 'landsheerlijkheid' kan volgens Moraw vanaf de twaalfde eeuw worden gezien als het eindpunt in de ontwikkeling van oudere vormen van adellijke 'Herrschaft', maar het blijft een moeilijk te definiëren

${ }^{131}$ RHCL, Rijkskamergerecht, inv. nr. 71 en 176.

132 RHCL, Rijkskamergerecht, inv. nr. 192 en 193.

133 Schubert, 'Der rätselhafte Begriff 'Land', 16. 
begrip. ${ }^{134}$ Eigenlijk kan men landsheerlijkheid niet definiëren, maar alleen concreet beschrijven. Iedere landsheerlijkheid heeft een eigen gezicht en een verschillend tempo in ontwikkeling. Kenmerkend zijn wel het bezit van domaniale goederen (landerijen, bossen, woeste gronden), het bezit van jurisdictie en regalia, vaak een leenband met de koning en soms ook voogdijrechten over het bezit van kloosters en geestelijke stiften.

In het Nederlandse spraakgebruik prevaleert bij het woord 'landsheerlijkheid' meestal de betekenis van 'gebied' waarover een 'landsheer' overheidsgezag uitoefende, maar formeel is het juister het accent te leggen op de 'onderdanen', waarover een landsheer gezag uitoefent en daarna pas op het land waar deze onderdanen wonen. Die benadering verklaart ook de in onze ogen soms losse structuur binnen middeleeuwse 'staten' met onduidelijke grenzen en diverse 'satellieten', waarmee een bijzondere juridische band bestond. Voor Gronsveld speelt dit probleem ook, zoals we hierna zien bij de Bijbank, de aangrenzende dorpen Oost en Sint-Martens-Voeren en de lenen in Vaals en Holset.

De beschrijving van het ontstaan van het 'land' Gronsveld wordt voorafgegaan door twee inleidende hoofdstukken over de mogelijke herkomst van de oudste heren van Gronsveld. Daarna begint de geschiedenis met de vraag of ooit zoiets heeft bestaan als een kerndomein van die heren in de plaats Gronsveld. Een deel van het antwoord wordt gezocht in de ontginningsgeschiedenis van het gebied. Schriftelijke bronnen uit de middeleeuwen die daar direct informatie over zouden kunnen verschaffen, zijn zeer schaars. Dit betekent dat uitspraken alleen mogelijk zijn op basis van een reconstructie. Uitgaande van de veronderstelling dat het grondbezit van adel en kerkelijke instituties in de loop der eeuwen een bepaalde mate van stabiliteit kende, zou de juridische situatie in later tijd, bijvoorbeeld het midden van de achttiende eeuw, voor een belangrijk deel een afspiegeling kunnen zijn van middeleeuwse verhoudingen.

Op basis van dit uitgangspunt werd reeds door Hartmann ${ }^{135}$ en door Hackeng ${ }^{136}$ voor plaatsen in de omgeving van Gronsveld onderzoek verricht naar de ontstaansgeschiedenis. Beide auteurs werkten daarbij op basis van vroeg-negentiende-eeuwse kadasterkaarten en losse perceelsschetsen uit de achttiende eeuw (voor Berg is er ook een kaart uit de achttiende eeuw). Toevallig zijn de mogelijkheden om die methode ook op Gronsveld toe te passen aanmerkelijk gunstiger, omdat hier een kadastrale opmeting van het hele graafschap (minus Slenaken) uit 1754 bewaard is gebleven (zie uitgebreider daarover Hoofdstuk 2.2.1) Bij die kaarten hoort ook een registratie met gegevens over de grondeigenaren en de juridische status van percelen. Door het in kaart brengen van eigendommen van de heer en van feodale rechten op de grond, is geprobeerd het oorspronkelijk domein van de heren van Gronsveld te reconstrueren of ten minste aannemelijk te maken.

Vervolgens komt aan de orde op welke wijze de heren van Gronsveld hun 'territorium' of gezagsrechten over andere plaatsen hebben uitgebreid, zodat dit uiteindelijk leidde tot een staatkundig en juridisch samenhangend gebied. Daarvoor is bij elke plaats een analyse

134 Moraw, 'Die Entfaltung der deutschen Territorien', 74-79.

${ }_{135}$ Hartmann, Reconstructie landschap.

${ }^{136}$ Hackeng, Middeleeunse grondberit Sint-Servaaskapittel. 
gemaakt volgens dezelfde methode als bij Gronsveld, vooral om vast te stellen of ook hier vroeg bezit van de heren van Gronsveld antoonbaar is. Volledigheidshalve werd in dit verband ook de vraag gesteld of delen van het land Gronsveld mogelijk afsplitsingen zijn van aangrenzende plaatsen. Bij elkaar opgeteld leveren deze plaatsen dan het land Gronsveld' op, zoals we dat in de vijftiende eeuw kennen.

De ontwikkeling van Gronsveld tot land tussen 1300 en 1400 vond plaats in een tijd waarin grote landsheerlijkheden in de omgeving zoals Luik, Gulik en Brabant al min of meer vaste vorm hadden gekregen en de nadruk kwam te liggen op afronding. Ook voor kleine landsheren kwam het er toen op aan hun gebied te consolideren, ter voorkoming van inlijving door een grote buur. De tijd voor de vorming van nieuwe landsheerlijkheden als staatkundige eenheden leek na 1400 voorbij. Voor de heren van Gronsveld gaat dat misschien niet helemaal op. Zo probeerde Diederik II van Bronckhorst Batenburg in 1498, min of meer langs indirecte weg, voor het oorspronkelijk Brabantse leen Rimburg (dat al vanaf ongeveer 1400 in Gronsveldse handen was), de status van rijksonmiddellijkheid - en daarmee ook onafhankelijkheid - te verwerven, maar veertig jaar later werd de oorspronkelijke leenband met Brabant weer hersteld. Een ander interessant geval betreft de poging van Hendrik III van Gronsveld in het midden van de vijftiende eeuw om voor de poorten van de stad Luik een nieuw 'land' rond de baronie Herstal te creëren. Ook dit mislukte.

In deze is verder geen aandacht besteed aan vergelijkingen in territoriale ontwikkeling tussen Gronsveld en andere kleine, zelfstandige gebieden. Dat zou een afzonderlijke studie vergen. Voorshands kan wel worden opgemerkt dat er opvallende parallellen bestaan tussen Gronsveld, Rekem ${ }^{137}$, Wittem ${ }^{138}$, Horn ${ }^{139}$ en het Stift Thorn ${ }^{140}$. Elk van deze territoria is ontstaan uit een samenvoeging van afzonderlijke plaatsen/jurisdicties onder één heer/landsvrouwe. Vaak zijn later de sporen daarvan nog terug te vinden in de rechterlijke organisatie met de regeling van hoofdvaart/appel vanuit de verschillende schepenbanken.

Typisch voor grote territoria of gewesten waren plaatsen die niet tot het 'kernland' behoorden, maar wel door middel van juridische constructies, zoals een leenverhouding, met de landsheer daarmee waren verbonden. ${ }^{141}$ Ook Gronsveld kende een dergelijke

\footnotetext{
137 Verbois, Geschiedenis Rekem, 32-35.

${ }^{138}$ Janssen de Limpens, 'De territoriale ontwikkeling'.

${ }^{139}$ Van de Boel, 'Een onderzoek naar de rechterlijke organisatie', 159-167.

${ }^{140}$ Van Rensch, 'Rechterlijke organisatie Thorn', 48, 64-69.

141 Voor algemene beschouwingen over deze problematiek van 'rafelranden' bij grote landsheerlijkheden in de vorm van 'vrije heerlijkheden', 'onderheerlijkheden' of 'Unterhersschafften' zie: Jansen, 'Unterherrschaft'. Vaak werden die in leen gehouden. Deze vrije heerlijkheden onderscheiden zich van rijksonmiddellijke heerlijkheden in die zin dat vrije heerlijkheden onder de bescherming staan van een vorstelijke landsheer met 'landtfürstliche superioritet' of 'hoche obrichkeit' (vgl. Janssen, o.c., 157-158).In dit verband kan verder worden gewezen op Berkvens, Plakkatenlijst Overkwartier, I, 81-125 waar de criteria voor het al dan niet behoren van enkele 'vrije heerlijkheden' tot het Spaans Overkwartier van Gelre worden uitgewerkt. Ook de door Van der Ree-Scholtens, Grensgebieden, beschreven heerlijkheden aan de rand van het tegenwoordige Noord-Brabant zijn daar voorbeelden van.
} 
'rafelrand'. Als eerste kan hier worden gewezen op de Bijbank, feitelijk een onderdeel van het graafschap, maar een leenverhouding met Valkenburg zorgde tot in de achttiende eeuw regelmatig voor problemen. Een veel lossere band bestond met de respectievelijk aan Gronsveld en Slenaken grenzende dorpen Oost en Sint-Martens-Voeren. Eind veertiende eeuw hadden de heren van Gronsveld daar via vererving de lage heerlijkheid verworven. Daardoor kwamen ze onder Gronsveldse invloed, maar staatkundig behoorden die plaatsen tot het onder Brabants gezag staande Land van Dalhem. Uiteindelijk gingen Sint-Martens-Voeren en Oost in de zeventiende eeuw, een financieel slechte tijd voor de graven van Gronsveld, ook weer als eerste verloren. Een derde 'rafel' vormden de zogenoemde 'uitheemse lenen', in dit geval Gronsveldse leengoederen in Vaals, Holset en Einrade en de patronaatsrechten over de kerk van Holset. De vroegste gegevens hierover gaan terug tot de dertiende eeuw en daarmee lijken deze goederen hun oorsprong te hebben in een zeer oud domein. Aan drie grote lenen, te weten de huizen Vaalsbroek, Holset en Einrade, waren bijzondere rechten verbonden, onder andere op de nabijgelegen grote bossen. Deze 'uitheemse lenen' bleven tot het einde van de achttiende eeuw met Gronsveld verbonden en zij werden ook geadministreerd door het leenhof van Gronsveld.

De band van al deze plaatsen 'in de marge' met Gronsveld was zodanig lang en hecht, dat er in deze studie ook aandacht aan moest worden besteed. Hun lotgevallen zijn ook illustratief voor de problemen die een kleine landsheer als de graaf van Gronsveld had om zijn gezag buiten de eigen landsgrens te handhaven.

Het goederenbezit van de heren van Gronsveld buiten het land Gronsveld en de directe omgeving daarvan vormde geen statisch geheel, maar veranderde per generatie door huwelijk, erfenis en aan- en verkoop. Sommige verwervingen hadden een min of meer duurzaam karakter, zoals het kasteel Rimburg, dat vanaf omstreeks 1400 tot aan de verkoop in 1640 ongeveer tweehonderd jaar als hoofdvestiging van de familie diende. ${ }^{142}$ Verder lagen vanaf de vijftiende eeuw belangrijke bezittingen in het hertogdom Kleef, die gedurende opeenvolgende generaties tot het midden van de zeventiende eeuw in de familie bleven. Aan het einde van de zestiende eeuw kwamen daar door het huwelijk van graaf Johan II van Bronckhorst Batenburg met Sibilla van Eberstein rechten op het graafschap Eberstein, ten noorden van het Zwarte Woud, bij. Zo bereikte het totaal aan bezittingen van de graven Van Bronckhorst Batenburg rond 1600-1620 zijn hoogtepunt. Vervolgens begon een periode van ruim een eeuw waarbij steeds meer bezittingen werden verkocht. Na 1728 bestond het graafschap Gronsveld alleen nog uit Gronsveld en Eckelrade, Heugem en Honthem. Na de overgang van Gronsveld aan de graven ToerringJettenbach in Beieren in $1746 \mathrm{kreeg}$ het graafschap weer een totaal andere positie, omdat deze heren tot dan toe alleen bezittingen hadden in Zuid-Duitsland.

${ }^{142}$ Het zou onjuist zijn om Rimburg te zien als een soort residentie zoals bij grote landsheerlijkheden. Het ontbrak aan een centraal bestuur of een vorm van hofhouding. De heren van Gronsveld reisden langs hun verschillende bezittingen en waren vaak afwezig wegens hun functies in andere territoria. Administratief en bestuurstechnisch bleven alle bezittingen gescheiden. 
Binnen die totaliteit aan goederen in één familie is het land/graafschap Gronsveld altijd een min of meer aparte eenheid gebleven. Die eenheid, met zijn eerder genoemde 'rafelrandjes', staat in deze studie centraal. Andere bezittingen worden slechts behandeld voor zover dit nodig is ter verduidelijking van de maatschappelijke positie van heren van Gronsveld. Maar heel scherp valt de grens niet altijd te trekken, want er bestond toch een bepaalde wisselwerking. Zo vormde het rijke bezit in het hertogdom Kleef de materiële en financiële basis voor de maatschappelijke opgang van de familie in de zestiende eeuw. En hoewel Gronsveld in status belangriiker was dan Rimburg, bleef het kasteel van Rimburg toch lang de feitelijke woonplaats van de familie. De Toerrings bekeken Gronsveld weer vanuit een ander perspectief. Voor hen was het graafschap economisch niet geheel onbelangrijk, maar zij beschouwden dit verre bezit vooral als 'ein ansehentliches lustre' voor hun 'so hoche famille' omdat de daarmee verbonden status van rijksstand hen onderscheidde van de landadel.

\subsection{Heren en graven van Gronsveld}

De geschiedenis van het land Gronsveld kan niet los worden gezien van die van de opeenvolgende heren. Daarom is_een betrouwbare genealogie geen doel op zich, maar een voor historisch onderzoek noodzakelijk instrument. Aangezien de bestaande gegevens in de literatuur dikwijls óf onvolledig óf fout bleken, is geprobeerd deze leemtes zoveel mogelijk op te vullen, zeker wat betreft de hoofdstam van de regerende families. ${ }^{143} \mathrm{Er}$ is daarbij uitdrukkelijk voor gekozen vooral gegevens te gebruiken die zijn ontleend aan (gepubliceerde) oorkonden en niet aan genealogieën uit de literatuur zonder bronvermeldingen. Daarmee zijn deze publicaties niet a priori gediskwalificeerd, maar het is niet verantwoord voor het betoog belangrijke verbindingen binnen een familie te leggen zonder daarvoor bewijsplaatsen te geven.

De speurtocht naar biografische bijzonderheden om het leven van de afzonderlijke heren in te kleuren, levert nogal wisselende resultaten op, een onvermijdelijk gevolg van het feit dat van het familiearchief tot circa 1740 slechts fragmenten bewaard zijn gebleven. Voor de rest van de achttiende eeuw, de tijd van de graven Toerring-Jettenbach, speelt dit probleem veel minder, omdat zij een omvangriik archief hebben achtergelaten. Over hun familiegeschiedenis is ook gepubliceerd. ${ }^{144}$

Ondanks de grote verschillen in bewaard gebleven informatie over de afzonderlijke heren van Gronsveld, levert het totaal meer op dan alleen een verzameling losse wetenswaardigheden. Sociologisch gezien vormt een familiegeschiedenis, ook al bestaat die alleen uit fragmenten, over een lange termijn een soort collectieve biografie, die zicht

143 Niet geheel volledig, maar in de praktijk vrij goed bruikbaar zijn voor de heren van Gronsveld uit de geslachten Van Gronsveld en Van Bronckhorst Batenburg de overzichten bij Hanssen, Die Rimburg en voor het geslacht Van Bronckhorst Batenburg, Van Schilfgaarde, 'De heren van Bronckhorst'.

${ }^{144}$ Englbrecht, Drei Rosen. 
geeft op de 'strategieën' die opeenvolgende generaties, bewust of onbewust, gebruikten om zich maatschappelijk te kunnen handhaven of zelfs te verbeteren. ${ }^{145}$

Het is niet helemaal zeker of de heren van Gronsveld van vóór 1300 ook kunnen worden gekoppeld aan dezelfde naamdragers na die tijd, maar vanaf het begin van de veertiende eeuw begint een ononderbroken genealogie van heren van Gronsveld, die zich ook naar deze plaats noemen. Tussen circa 1300 en 1795 hebben in totaal vier elkaar opvolgende families over Gronsveld geregeerd, te weten Van Gronsveld, Van Bronckhorst Batenburg, d'Arberg Valengin en ten slotte Toerring-Jettenbach. In tijdsduur zijn er grote verschillen, variërend van enkele decennia tot bijna drie eeuwen. Elk van deze geslachten vertegenwoordigt ook min of meer een bepaalde periode in de geschiedenis van Gronsveld. Vanuit dat laatste perspectief zou het beter zijn te spreken over vijf fasen, want vanaf eind zestiende eeuw zette een koerswijziging in met een meer dan voorheen op het Rijk gerichte oriëntatie.

De afzonderlijke fasen kunnen ruwweg als volgt worden getypeerd. In de veertiende en vijftiende eeuw werd het 'Land Gronsveld' gevormd en geconsolideerd. In die tijd speelde ook de vraag in hoeverre het voor een regionaal aanzienlijke adellijke familie nog mogelijk was te midden van machtige buren een onafhankelijk land te vormen en vooral ook te behouden.

Met het huwelijk in 1425 tussen Johanna van Gronsveld en Diederik I van Bronckhorst Batenburg deed dit uit het Gelderse rivierengebied afkomstige adellijke geslacht der Bronckhorsten zijn intrede in Gronsveld. Zij regeerden gedurende een periode van bijna driehonderd jaar tot 1719, toen na het overlijden van graaf Johan Frans van Bronckhorst Batenburg de familie in mannelijke en, op twee nog levende kinderloze, bejaarde zusters na, ook bijna in vrouwelijke lijn was uitgestorven.

Door de alliantie Van Gronsveld - Van Bronckhorst Batenburg begin vijftiende eeuw verschoof de tot dan toe bestaande oriëntatie van de heren van Gronsveld op Brabant en Luik in de richting van de Nederrijn, naar de hertogdommen Gelre en Kleef en een reeks aan de rand van deze hertogdommen gelegen, met Gronsveld vergelijkbare, kleine territoria. Daar kwam het zwaartepunt van de economische, politieke en sociale belangen van de familie te liggen. In dit boek is onderzocht welke relaties leden van de familie Van Bronckhorst Batenburg binnen deze gebieden onderhielden met de hertogen van Kleef en Gelre en de hogere adel in die omgeving (waartoe overigens ook andere takken van de familie Van Bronckhorst Batenburg behoorden). Door deze gerichtheid op het noorden leek Gronsveld zelf aan betekenis voor de familie in te boeten, maar in deze studie is onderzocht wat deze verschuiving van belangen uiteindelijk voor Gronsveld betekende. Er lijkt een verband te bestaan tussen de politieke verwikkelingen in Gelre en Kleef gedurende de eerste helft van de zestiende eeuw en de status van Gronsveld.

De tweede helft van de zestiende eeuw was voor de heren van Gronsveld een moeilijke periode. Zowel Willem van Bronckhorst Batenburg (overleden 1563) als zijn zoon Jost

145 Schmidt, 'Een lengteprofiel', 129-131. Over dit soort onderzoek bij adellijke geslachten en de daarmee samenhangende problemen en vraagstellingen zie: Marra, Allianzen des Adels, vooral 7-11 en Ruppel, Verbündete Rivalen, vooral 11-31 en 73-79. 
(overleden 1588) stierven beiden jong. Als gevolg van oorlogsgeweld verdween Gronsveld bij het beleg van Maastricht in 1579 bijna van de aardbodem. Tegelijk werd deze periode gekenmerkt door een groeiend zelfbewustzijn bij de heren van Gronsveld, in 1586 uitmondend in de verheffing in de stand der rijksgraven. Een centrale vraag is, op welke wijze dit heeft doorgewerkt naar zowel de familie als het land Gronsveld. Voor de familie vertegenwoordigde de titel een 'sociaal-maatschappelijk kapitaal' dat werd ingezet op de huwelijksmarkt of bij carrières van afzonderlijke familieleden. Voor Gronsveld betekende de verheffing in de rijksgravenstand een sterkere betrokkenheid bij kreits en Rijk, die vooral in financiële lasten werd vertaald.

$\mathrm{Na}$ het overlijden in 1719 van graaf Johan Frans van Bronckhorst Batenburg vererfde het graafschap op zijn toen nog kinderloze echtgenote, naderhand gehuwd met graaf Claude Nicolas d'Arberg Valengin. De jaren tussen 1720 en circa 1733 vormden voor Gronsveld een uiterst roerige periode met een kleine 'burgeroorlog' tussen dorpelingen. Deze tumultueuze geschiedenis levert een interessant voorbeeld van de gevolgen van onbestuurbaarheid tijdens zwak landsheerlijk gezag.

$\mathrm{Na}$ het overlijden van gravin Anna Maria von Toerring-Jettenbach in 1730 en graaf Nicolas d'Arberg Valengin in 1731 vererfde Gronsveld op hun enige dochter Maria Josepha. Deze huwde in 1746 haar neef graaf Maximilian Emanuel von ToerringJettenbach. Maria Josepha stierf al in 1754 en daarmee viel het graafschap Gronsveld definitief toe aan haar echtgenoot en de familie Toerring-Jettenbach.

De laatste vijftig jaar van de achttiende eeuw werd het graafschap geregeerd door twee leden van deze familie, graaf Maximilian Emanuel (overleden 1773) en zijn jongere broer August Joseph (overleden 1802).

Feitelijk hield het graafschap Gronsveld op te bestaan op 1 oktober 1795, toen het gebied als onderdeel van het departement Nedermaas bij Frankrijk werd ingelijfd. Toch vormt deze datum niet een abrupte breuk met het verleden. Sommige instellingen functioneerden nog tot begin 1796, graaf August Joseph bemoeide zich op grond van zijn collatierecht met een pastoorsbenoeming in 1798 en pas bij de Reichsdeputationshauptschluss van 1803, toen de gebiedsafstand aan Frankrijk definitief werd, kreeg Joseph August, de zoon van de inmiddels overleden August Joseph, de geseculariseerde rijksabdij Gutenzell, gelegen ten zuiden van Ulm, als schadevergoeding voor het verlies van het graafschap Gronsveld. Het probleem van de begrenzing in tijd is in dit boek pragmatisch opgelost. Als regel is gekeken tot hoe lang de instellingen van het Ancien Régime en rechten uit die tijd feitelijk functioneerden. De veranderingen die de Fransen invoerden en de onderhandelingen tot schadeloosstelling in Regensburg zijn buiten beschouwing gebleven.

De biografische bijzonderheden over de graven Toerring-Jettenbach zijn in dit boek, zeker in verhouding tot de familie Van Bronckhorst Batenburg, beknopt gehouden. Voor een deel wordt daarin ook voorzien door het boek van Englbrecht. ${ }^{146}$ Hoewel de fysieke afstand tussen Gronsveld en München allerminst een beletsel vormde om langs

146 Zie in dit verband het werk van Englbrecht, Drei Rosen. 
schriftelijke weg een stempel op het bestuur van het graafschap te drukken, waren de Toerrings maatschappelijk en politiek vrijwel uitsluitend georiënteerd op Beieren. Daar lag het zwaartepunt van hun bezittingen, bekleedden zij hoge ambten in het landsbestuur en verkeerden zij in kringen van de hoge adel.

\subsection{Gronsveld en het Heilige Roomse Rijk der Duitse Natie}

In het voorafgaande kwamen al enkele malen de graaf van Gronsveld als rijksstand en het graafschap Gronsveld als deel van het Heilige Roomse Rijk der Duitse Natie ter sprake. In deze studie is onderzocht wat dat formeel, maar vooral ook in de praktijk betekende. Daarbij is niet gekozen voor een samenhangende beschrijving van het thema als zodanig. De fragmentarische overlevering van de Gronsveldse archieven bemoeilijkt een systematische bestudering van ontwikkelingen gedurende een lange termijn. Maar in dit boek staan de graaf als landsheer en de instellingen binnen het graafschap centraal. Vaak vormt de relatie met rijksrecht of instellingen binnen het Rijk daarbij een aspect. Omdat het niet praktisch is dit te scheiden, werd gekozen voor een aanpak waarbij de betrekkingen tot het Rijk worden behandeld in directe samenhang met de onderwerpen die voor Gronsveld worden besproken. Meer in het bijzonder gaat het daarbij om

- De erkenning van de graven van Gronsveld als rijksstand en hun betrokkenheid bij de Nederrijns-Westfaalse Kreits, het Nederrijns-Westfaalse Rijksgravencollege en de Rijksdag.

- De invloed en toepassing van rijkswetgeving (meer specifiek de 'Reichspolizeiordnungen', de 'Carolina' en wetgeving ten aanzien van het muntwezen). Veel materiaal daarover is er niet, zodat soms alleen conclusies mogelijk zijn op basis van een nauwkeurige analyse van wat er is bewaard.

- De betrekkingen met de hogere rechtspraak binnen het Rijk, zoals de Schepenstoel van Aken als tusseninstantie bij hoger beroep en het Rijkskamergerecht en de Rijkshofraad als hoogste rechtscolleges binnen het Rijk. Verschillende, soms zeer lang slepende processen, bieden daarvoor ruimschoots materiaal.

- De belastingen die de onderdanen moesten opbrengen ten behoeve van het Rijk, zoals de Römermonate voor de defensie en de Kammerzieler voor het Rijkskamergerecht. Deze afdrachten hangen ten nauwste samen met het ontstaan van een organisatie van 'geërfden' of grondeigenaren binnen het graafschap. Materiaal over deze gecompliceerde materie is beperkt voorhanden, zodat ook hier wordt volstaan met een globale schets. Voorts komen in dit verband ook enkele deelproblemen aan de orde, zoals de betekenis van de zogenoemde 'rijksmatrikels' (lijsten met belastingplichtige landsheren binnen het Rijk), de gevolgen van de splitsing tussen het graafschap Gronsveld en Slenaken in 1728 en het verzet tegen belastingen van buiten Gronsveld wonende grondeigenaren.

Het gaat dus om tamelijk concrete situaties en de houding die de graaf en de inwoners daarbij innamen. Deze kwesties zijn vanuit een juridische invalshoek behandeld en geplaatst binnen het formele kader van het staatsrecht van het Heilige Roomse Rijk der Duitse Natie. Daarnaast kan de vraag worden gesteld of de inwoners van Gronsveld, in 
het grensgebied tussen de Nederlanden en 'Duitsland', ook een gevoel van verbondenheid met die 'Duitse Natie' kenden. Bij Gronsveld krijgt dit een extra dimensie, omdat in de achttiende eeuw de graaf en zijn vertegenwoordigers ter plaatse 'echte' Duitsers waren, afkomstig uit Beieren. In het verlengde hiervan rijst de vraag of er een bepaald gevoel van saamhorigheid bestond met andere kleine rijksonmiddellijke territoria in het Maasgebied. Het is moeilijk in de bronnen op dit soort informatie greep te krijgen. Er worden in deze studie op dit terrein wel enkele interessante observaties gedaan, maar voor meer algemene uitspraken is breed opgezet vergelijkend onderzoek noodzakelijk.

Het staatsrecht van het Heilige Roomse Rijk der Duitse Natie vormde een gecompliceerde constructie met een eigen vocabulaire, zoals die werd gebruikt in de juridische literatuur, de Reichspublizistik. Dat jargon wordt ook regelmatig in deze studie gebruikt. Om de lezer die hiermee niet vertrouwd is toch een handreiking te bieden, worden hierna de beginselen van dit staatsrecht beschreven. Deze korte uitweiding is geenszins bedoeld als een afgewogen visie, maar een beknopte samenvatting van wat in de veelal Duitstalige literatuur te vinden is. Dat is nuttig voor het begrip van de situatie in Gronsveld, maar ook bruikbaar bij de bestudering van andere rijksonmiddellijke territoria in het Maasdal.

Het 'Heilige Roomse Rijk der Duitse Natie' valt niet zo eenvoudig in een definitie te vangen. Over een eenduidige omschrijving liepen de ideeën ten tijde van het Rijk zelf al uiteen. En in de Duitse historiografie van de negentiende en twintigste eeuw - waar vaak wordt gesproken over het 'Oude Rijk', ter onderscheiding van het Tweede Keizerrijk van 1870-1918 en de Derde Rijk van 1933-1945 - wisselen de opvattingen over wat het Rijk niet en wel was, elkaar vaak in één adem af. ${ }^{147}$ Ten dele werd die visie sterk beïnvloed door het politieke klimaat van de tijd, maar de verschillen in opvatting vloeien ook voort uit het feit dat het Rijk een constructie sui generis was, enig in zijn soort. Daarom wordt bij een vergelijking met een staat in de moderne betekenis van het woord vaak begonnen met een omschrijving van wat het Heilige Roomse Rijk der Duitse Natie niet was: geen staat met duidelijk omschreven vaste grenzen, staatshoofd, staatsburgers, parlement, leger of bureaucratie met uitvoerende ambtenaren. Een samenvatting van wat het Rijk wel was, probeert Stollberg-Rilinger te geven in elf punten, maar de uitleg die zij bij deze samenvatting geeft laat al zien dat het niet zo eenvoudig is bondige definities te geven. ${ }^{148}$ De door haar geformuleerde omschrijvingen worden hierna, ook op basis van andere literatuur, nog uitvoeriger toegelicht. Soms wordt een parallel getrokken met de Europese Gemeenschap, maar die vergelijking gaat maar in zeer beperkte mate op. ${ }^{149}$ Ook waren niet alle rijksstanden in dezelfde mate betrokken bij het Rijk. Er bestonden verschillen in stemrecht en sommige rijksstanden hadden zich weten te onttrekken aan de rechtsmacht van de hoogste rijksgerechten. Dat alles neemt niet weg dat er toch een soort imaginaire 'Duitse Natie' bestond, bedacht door humanisten rond 1500 op basis van een mythologisch verleden, waarin 'Germanen' zich hadden bevrijd van het juk der Romeinen.

${ }^{147}$ Liebmann,'Die Rezeptionsgeschichte'; Thamer, 'Das Heilige Römische Reich';

148 Stollberg-Rilinger, Das Heilige Römische Reich Deutscher Nation, 116-120.

149 Zie bijv. Schmidt, 'Das frühneuzeitliche Reich'; Stollberg-Rilinger, Das Heilige Römische Reich Deutscher Nation, 9. 
Als erfgenamen van deze 'Germanen' voelde de 'Duitse Natie' een taalkundige en culturele verbondenheid, zonder dat kan worden gesproken van exclusiviteit. Weliswaar werd vanaf de zestiende eeuw het Hoogduits als cultuurtaal gebruikt, maar daarnaast bestond een grote variatie aan regionale dialecten en werden aan de randen van het Rijk ook nietGermaanse talen gesproken. Verder waren vorsten binnen die Germaanse natie dynastiek sterk verbonden met gebieden buiten het Rijk, zoals de Habsburgers, aartshertogen van Oostenrijk, met de koninkrijken Bohemen en Hongarije en de Hohenzollerns, markgraven van Brandenburg, met Pruisen. ${ }^{150}$ Territoriaal en taalkundig vormde het Rijk dus een moeilijk in grenzen te vatten begrip. ${ }^{151}$

In zijn middeleeuwse oorsprong vormde het Rijk een feodale constructie tussen personen, met de sinds 1356 door de keurvorsten gekozen keizer aan het hoofd van de leenpiramide en geestelijke en wereldlijke rijksvorsten als zijn leenmannen. Daaronder kwamen dan weer de leenmannen van de rijksvorsten. Die feodale verhouding geeft al aan dat de keizer geen staatshoofd in de moderne betekenis van het woord was. Organisatorisch behield het Rijk tot het einde van de vroegmoderne tijd dat karakter van een politieke constructie op feodale grondslag. Rijksstanden deden nog altijd leenhulde aan de keizer. ${ }^{152}$ Het komt ook naar voren in de vergaderingen van de Rijksdag. Daarin hadden alleen als 'rijksstand' (zie over dit begrip hier verder in deze paragraaf) gekwalificeerde personen of hun vertegenwoordigers toegang en stemrecht ('sessio et votum') en niet de afgevaardigden van een land. De middeleeuwse gelaagdheid in standen ziet men in de vroegmoderne tijd ook terug in de Rijksdag, waar duidelijk onderscheid wordt gemaakt tussen de keizer en de colleges van standen, te weten de keurvorsten, de rijksvorsten (met verschillende achtergrond) en de rijkssteden.

Het Rijk kende in de vroegmoderne tijd als organen de keizer, de Rijksdag, de kreitsen en het Rijkskamergerecht en de Rijkshofraad als de hoogste rijksgerechten. Een grondwet ontbrak. In plaats daarvan hanteerden de organen van het Rijk een aantal grondregels van rijksrecht, die werden samengevat met het begrip Reichsverfassung. Deze waren neergelegd in de 'vier geboden'153: de 'Gouden Bul' uit 1356 over de verkiezing van de keizer, de

${ }^{150}$ Het is bijna onmogelijk in enkele zinnen recht te doen an een omschrijving van het begrip 'Duitse Natie'. Voor een korte samenvatting van dit complexe probleem zie Neuhaus, Das Reich der Früben Neuzeit, 3-5 en wat uitgebreider Schmidt, Geschichte des Alten Reiches, 9-32, 349.

151 Voor een samenvattend overzicht van het Rijk als conglomeraat van territoria aan het einde van de middeleeuwen zie Moraw, 'Die Entfaltung der deutschen Territorien', in het bijzonder 63-64. Men dacht bij het Rijk niet aan een vastomlijnd territorium, maar aan een kerngebied in het midden en zuiden van het tegenwoordige Duitsland. De randen van het Rijk werden, al naar gelang de behoefte, soms benadrukt, dan weer onbelangriijk geacht. Het Rijk telde tientallen vorstendommen en honderden kleine territoria van graven en lagere heren.

152 Stollberg-Rilinger, 'Das Reich als Lehnssystem', in het bijzonder 65-66.

153 Von Aretin, Heiliges Römisches Reich, spreekt zelfs over 'tien geboden': De vier hier genoemde, aangevuld met de Concordatae nationis Germanicae (de concordaten van het Rijk met de H. Stoel die de vrijheid van de Rijkskerk garandeerden), de Eeuwige Landvrede (1495), de Wormser Reichsmatrikel (1521), de Reichsexekutionsordnung (1555), de Reichskammergerichtsordnung (1495), de vredesverdragen van het Rijk uit de zeventiende en achttiende eeuw en de Reichsabschiede (besluiten van de Rijksdag). 
Instrumenta Pacis van de Vrede van Westfalen (1648), de Wablkapitulationen of toezeggingen die keizers moesten doen om te worden gekozen en het Reichsherkommen, het rijksgewoonterecht. ${ }^{154}$ Een centrale plaats nam daarbij de Vrede van Westfalen in. Primair was die gericht op herstel van de interne vrede na de Dertigjarige Oorlog door regeling van de confessionele verhoudingen binnen het Rijk. Maar artikel 8 \& 1 van de Vrede van Osnabrück garandeerde de standen van het Rijk ook alle oude rechten en privileges en in het bijzonder het ius territoriale, het recht op Landeshobeit in zowel geestelijke als wereldlijke aangelegenheden voor hun gebied. ${ }^{155}$ Daar kwam voor de standen het recht bij zelf een leger op de been te houden en buitenlandse verdragen te sluiten, mits niet gericht tegen het Rijk.

De middeleeuwse feodaliteit en de gedachten over een moderne staat kruisten elkaar in de hervormingen ten tijde van rooms-koning Maximiliaan van Oostenrijk op de Rijksdag van Worms in 1495. Van de toen bedachte regelingen is, na enkele aanzetten, de invoering van een Reichsregiment als een soort rijksregering mislukt. Hetzelfde lot trof ook een centrale belasting, de Gemeine Pfennig. Duurzamer bleken de Ewiger Landfrieden en de Handhabung Friedens und Rechtens, die een einde moesten maken aan eigenrichting, geweld of vete. Conflictbeslechting diende te geschieden langs juridische weg. Met de instelling van het Rijkskamergerecht in 1495 en de Rijkshofraad in 1498 fungeerden daartoe binnen het Rijk twee rechterlijke colleges op het hoogste niveau. ${ }^{156}$ Deze gerechten speelden een belangrijke rol in de rechtsbescherming van onderdanen tegen hun overheid (Untertanenprozesse) en de verbreiding en acceptatie van het 'geleerde' Romeinse recht. Volmaakt was dit systeem niet, want sommige territoria bleven op grond van hun privileges (ius de non evocando et de non appellando) in meerdere of mindere mate uitgezonderd van de jurisdictie van de hoogste rijksgerechten. Ook de tenuitvoerlegging van vonnissen bleef een zwakke schakel.

Een ander uitvloeisel van de hervormingen was de territoriale verdeling van het Rijk in aanvankelijk zes, sinds 1512 tien kreitsen (Reichskreise), waarin de rijksstanden van een bepaalde regio in Kreistage vertegenwoordigd waren. Iedere kreits ontwikkelde zich organisatorisch op zijn eigen manier en er bestonden ook grote verschillen in activiteit. De voornaamste taken van de kreits lagen in de handhaving van de Eeuwige Landvrede op basis van de Reichsexekutionsordnung van 1555, de organisatie van het rijksleger op basis van de Reichsdefensionalordnung van 1681, het toezicht op de rijksmuntwetgeving (Reichsmünzordnung) en de inning en matiging ('Moderation') van de belastingen die het Rijk vroeg.

\footnotetext{
154 Hofmann, Quellen Verfassungsorganismus, XIV.

155 Hofmann, Quellen Verfassungsorganismus, 189. Betwist was in hoeverre de lagere rijksonmiddellijke adel, de Reichsritter die formeel geen rijksstanden waren, voor hun kleine territoria ook aanspraak konden maken op de garanties van de Vrede van Westfalen. Uiteindelijk werd de gangbare opvatting dat zij zich in feite wat betreft hun Landesherrschaft niet onderscheidden van de rijksstanden (vgl. Endres, Adel in der Früben Neuzeit, 12-13).

156 Over de verhouding tussen Rijkskamergerecht en Rijkshofraad zie: Sellert [red.], Reichshofrat und Reichskammergericht, voor de Rijkshofraad als instellingen zie: Ehrenpreis, Kaiserliche Gerichtsbarkeit und Konfessionskonflikt.
} 
De in 1495 te Worms gehouden Rijksdag wordt wel gezien als de geboorte van de Rijksdag in de vroegmoderne tijd. In de tijd tot 1653/1654 volgden ruim veertig bijeenkomsten van rijksstanden en de keizer. $\mathrm{Na}$ formele afsluiting van de Jüngste Reichsabschied van 1653/1654, die gehouden werd na het einde van de Dertigjarige Oorlog, ${ }^{157}$ kwam vanaf 1663 in Regensburg de Immerwährende Reichstag (Altijddurende Rijksdag) bijeen, die tot 1806 niet meer werd beëindigd met een formele tussentijdse sluiting of Reichsabschied.

In 1495 beraadslaagde Maximiliaan ook voor het eerst met de rijksstanden, verdeeld over drie colleges of 'Kurien' ('Curiae'): de keurvorsten, de rijksvorsten en de rijkssteden. Deze wijze van overleg is vervolgens geïnstitutionaliseerd en functioneerde, met bepaalde aanpassingen, tot 1806. Het initiatief tot regelgeving ging in hoofdzaak uit van de keizer. De beraadslagingen vonden plaats binnen de drie Kurien. Van het resultaat daarvan werd een Reichsgutachten opgesteld, dat vervolgens door keizerlijke bekrachtiging tot Reichsschluss werd. Aan het einde van de Rijksdag werden deze Schlïsse samengevoegd tot het zogenoemde Reichsabschied.

In de Rijksdag kwam een breed spectrum aan problemen aan de orde, die in het overleg tussen keizer en standen moesten worden opgelost. Als zodanig kunnen worden genoemd wetgeving op het gebied van de interne organisatie van het Rijk en handel en economie, de handhaving van de (land)vrede in algemene zin, met als voornaamste elementen rechtsbescherming van mindermächtige landsheren tegen machtige buren, rechtsbescherming van onderdanen tegen lagere rechters en landsheerlijke overheden en ten slotte zorg voor openbare orde en veiligheid. ${ }^{158}$ Verder kon het Rijk oorlog en vrede verklaren en zorgde het voor de organisatie van de defensie en verdediging tegen externe vijanden, in het bijzonder de Turken en later Frankrijk. Na de Vrede van Westfalen uit 1648 vormde ook het vreedzaam naast elkaar leven van de Christelijke confessies een voortdurend onderwerp van zorg.

Om deze taken te kunnen vervullen, diende het Rijk ook inkomsten te genereren. Geld was nodig voor de financiering van de Rijksdag, het Rijkskamergerecht, de handhaving van vrede tussen de rijksstanden en ten slotte de defensie tegen aanvallen van buiten, in het bijzonder de 'Turkse 'erfvijand' in het oosten en later Frankrijk in het westen. De bijzondere belastingen die in de zestiende en zeventiende eeuw werden geheven voor de oorlog tegen de Turken, stonden bekend als Türkensteuer. Belastingheffing verliep binnen het Rijk evenwel moeizaam, omdat men geen strak georganiseerd systeem van belastingheffing en een centrale schatkist kende, maar een organisatie van onafhankelijke rijksstanden was. De betalingsmoraal was niet altijd hoog. Dat leidde vaak tot grote achterstanden.

Gedurende de eerste helft van de zestiende eeuw werd enkele malen de Gemeine Pfennig als personele belasting geheven, maar de inning werd geen succes. Grotere duurzaamheid

157 Zie over deze Rijksdag, die hierna nog meermalen ter sprake komt, onder andere in verband met de toelating van de Nederrijnse-Westfaalse graven en de rol die graaf Jost Maximiliaan van Bronckhorst Batenburg daarin speelde: Stollberg-Rilinger, Des Kaisers alte Kleider, 137-225.

158 Zie de diverse opstellen daarover in Wendehorst/Westphal, Lesebuch Altes Reich, 80-137. 
kende een belasting op basis van een 'matrikel' (Matrikularsteuer), een lijst waarbij iedere rijksstand voor een vast bedrag in geld of aantal manschappen werd aangeslagen. Maatgevend daarvoor werd de op de Rijksdag van Worms van 1521 vastgestelde Allzeit neueste Matrikel.159 Hoewel deze Wormser Matrikel bedoeld was en ook gebruikt werd als basis voor belastingheffing, werd de vermelding van een stand als zodanig op deze lijst beschouwd als bewijs voor de status van rijksstand, met alle daaraan verbonden rechten en (belasting)plichten. Wat dit laatste betreft was er sprake van inschatting van financiële draagkracht, maar werd geen rekening gehouden met de werkelijke draagkracht of veranderingen daarin in de loop van de tijd. Dat maakte het systeem niet erg flexibel. Tegelijk rees met deze lijst van rijksstanden (en dus niet van territoria) de vraag of de aanslag moest worden betaald door de rijksstand of door het land waarover hij regeerde. Die onduidelijkheid zorgde voor veel discussie, hoewel uiteindelijk het Territorialprinzip de overhand kreeg en het land de lasten droeg.

Op het gebruik van de Wormser Matrikel en het bijbehorende jargon als grondslag voor allerlei heffingen en berekeningen wordt nader ingegaan in Hoofdstuk 16.1. Wel kan worden opgemerkt dat het toch al gebrekkige systeem zoals dat in de zestiende eeuw was bedacht, na de Dertigjarige Oorlog, vrijwel was vastgelopen. Daarna is geprobeerd op deelterreinen verbeteringen door te voeren, zoals bij de Jüngste Reichsabscbied van 1654, toen de betaling van de Kammerzieler voor het Rijkskamergerecht nog eens opnieuw werd geregeld. Ook de Reichsdefensionalordnung uit 1681-1682 had ten doel de defensie beter te organiseren. Er werden op dit terrein ook wel successen geboekt, maar de grote manco's bleven het gebrek aan een centrale regie en een efficiënt systeem van inning. Dat had ook gevolgen voor de rechtszekerheid van de belastingplichtige onderdanen. Het Territorialprinzip werd niet zonder slag of stoot geaccepteerd en leidde vaak tot processen, de 'belasting naar behoefte' voor de defensie leverde onverwachte pieken en dalen op, onduidelijk was welke onderdanen voor wat belastingplichtig waren, er vond geen afstemming plaats tussen de opgelegde belastingen en vorderingen van doortrekkende legers en ten slotte leverden langdurige achterstanden in betalingen ook onzekerheid op over de financiële toestand van het land en mogelijk opgebouwde schulden.

Om aan de politieke besluitvorming binnen het Rijk in de vroegmoderne tijd te kunnen deelnemen, moest een landsheer als rijksstand zijn erkend en gekwalificeerd. Daarvoor golden drie criteria:

1) Het bezit van een rijksonmiddellijk (immediat) gebied dat van de keizer direct in leen werd ontvangen of, wat veel zeldzamer was, iemand in vrije eigendom als zogenoemd allodium toebehoorde;

2) Het bezit van Landeshoheit met de daartoe behorende landsheerlijke rechten (regalia) zoals zich die in de middeleeuwen hadden ontwikkeld;

3) Voldoende hoge adellijke geboorte.

Wie een territorium unmittelbar (direct) van de keizer in leen hield of als allodium bezat zonder inmenging van een andere landsheer, kon wat dit punt betreft als rijksonmiddellijk

${ }^{159}$ Gebruikt is de editie bij Hofmann, Quellen Verfassungsorganismus, 40-64. 
worden beschouwd. ${ }^{160}$ Jurisdictie in de vorm van een allodium, ook wel 'zonneleen' genoemd, was betrekkelijk zeldzaam en komt vooral voor bij kleine territoria. Eigenlijk paste het niet in de middeleeuwse opvatting over gezag waarbij jurisdictie van de keizer of rijksvorst in leen of in achterleen werd gehouden. De Gelderse jurist Fredericus à Sande spreekt dan ook in zijn 1625 verschenen Commentarius op het Gelderse en Zutphense leenrecht misprijzend over 'onafhankelijke' kastelen en jurisdicties, waarvoor men 'onzinnig en barbaars' ('inepte et barbare') als een juridische fictie de zon als leenheer had bedacht. ${ }^{161}$ In zijn ogen moesten ook 'zonnelenen' zich voegen binnen de algemene rechtsorde van het Rijk.

Deze omschrijving van rijksonmiddellijk legt het accent op het land en zo werd dat in de praktijk ook vaak gebruikt. Correcter zou het zijn te spreken van een rijksonmiddellijke persoon:

Reichsunmittelbar war im Alten Reich jede natürliche oder juristische Person, die keinem Landesherrn unterstand. Wer von einem Landesherrn regiert wurde (also 'landsässig' war), unterstand dem Kaiser damit nur 'mittelbar'; zwischen den Reichsunmittelbaren und das Reichsoberbaupt bingegen schob sich keine ('mediatisierende') Zwischeninstan₹: ${ }^{162}$

Het tweede criterium voor erkenning als rijksstand was de op Landeshoheit steunende Landesherrschaft, het recht van de landsheer om de hem toekomende rechten of regalia uit te oefenen. ${ }^{163}$ Met voorbijgaan aan de vroegmiddeleeuwse periode, verstaan we daar in beginsel de hoogheidsrechten onder zoals die in de twaalfde en dertiende eeuw werden geformuleerd in onder andere de Constitutio de Regalibus van de Rijksdag van Roncaglia (1158), de Confoederatio cum principibus ecclesiasticis (1220) en het Statutum in favorem principum (1232). Deze regelingen, die werden beschouwd als rijksrecht, bevatten echter geen limitatieve opsomming van regalia en vormden ook geen gesloten systeem. Zij boden een soort kader van overheidsgezag met vaste elementen, zoals rechten op diensten van onderdanen (inclusief krijgsdiensten), het recht op de (organisatorische kant van de) rechtspraak en het recht op boeten, het recht van muntslag, het recht op heerbanen,

${ }^{160}$ Busch, Herrschen durch Delegation, 31 geeft voorbeelden van oorspronkelijk rijksonmiddellijke gebieden die naderhand door leenbanden werden verbonden met een vorst, zonder dat dit een beletsel werd voor rijksonmiddellijkheid. Een interessant geval in dit verband is ook Kerpen-Lommersum bij Keulen. In 1706 werd Johan Frederik von Schaesberg, door keizer Joseph I in de erfelijke stand der rijksgraven verheven. Na de verwerving van de heerlijke rechten over Kerpen en Lommersum werden deze plaatsen, na verbreking van de leenbanden met het hertogdom Brabant, tot rijksonmiddellijk graafschap verheven. Die status stuitte op weerstand van de inwoners. De rijksonmiddellijkheid bleef daarmee gedurende de hele achttiende eeuw een twistappel tussen de hoven van Brussel en Wenen. Uiteindelijk moest graaf August van Schaesberg, onder voorbehoud van zijn status als rijksstand, opnieuw de Brabantse leenhoogheid voor zijn graafschap erkennen (Vgl. Peters, Geschichte des Geschlechtes von Schaesberg); zie over de status van Kerpen-Lommersum in de zestiende eeuw: Van Peteghem, 'Limburg' en KerpenLommersum'.

161 À Sande, Commentarius in Gelriae et Zuphaniae consuetudines feudales, De Monté ver Loren/Spruit, Hoofdlijnen, 44.

162 Gotthard, Das Alte Reich, 16-17.

163 Vgl. Busch, Herrschen durch Delegation, 30: Untrennbar verbunden mit der Vorstellung von frübneuzeitlicher Landesherrschaft sind die Reichsstandschaft und Reichsunmittelbarkeit der Landesherrn'. 
bevaarbare rivieren en overzetveren, het recht van tol- en belastingheffing, het recht op winning van delfstoffen (mijnregaal), het recht op het houden van markt (marktregaal), rechten op de bescherming van Joden (Jodenregaal), recht op woeste gronden (wildernisregaal), rechten op onbeheerde goederen, zoals bijenzwermen, gevonden waardevolle voorwerpen, aanwas van grond bij rivieren of de zee, nalatenschappen zonder erfgenamen, verbeurd verklaarde goederen et cetera. Met deze rechten verbonden was de bevoegdheid functionarissen te benoemen, die met de uitvoering, handhaving of inning van inkomsten waren belast.

Vanaf de dertiende eeuw kregen landsheren de neiging hun regalia uit te breiden met andere rechten, vooral monopolies op economische activiteiten zoals exploitatie van molens, brouwen, het houden van herberg of publieke waag en rechten voor het jagen op of het houden van bepaalde dieren (jacht en visvangst in het algemeen, het houden van konijnen, duiven, zwanen, eenden en valken in het bijzonder).

In beginsel los van deze regalia stonden onroerende eigendommen en opbrengsten daaruit in de vorm van landsheerlijke domeinen zoals bossen, versterkte huizen, hoeven en landerijen. Ze leverden inkomsten in vorm van pachten of verkoop van opbrengsten, maar werden ook uitgegeven in leen of, in het geval van hoeven en landerijen, geëxploiteerd als hofhorig goed tegen betaling van cijnzen, diensten of belastingen bij erfopvolging.

In deze vroegmoderne tijd ontwikkelden deze op feodale grondslag rustende Hoheitsrecbte uit de middeleeuwen zich tot soevereiniteit, die slechts werd beperkt door de organisatorische kaders en de algemene regels van de Reichsverfassung. Een stand maakte deel uit van het Rijk als organisch verband, wat betekende erkenning van de keizer als hoogste gezagsdrager, eerbiediging van het rijksrecht en betaling van de belastingen van het Rijk. ${ }^{164}$

Gecompliceerder waren de verhoudingen ten opzichte van het in 1495 opgerichte Rijkskamergerecht of de evenknie en concurrent daarvan, de 1497-1498 ingestelde Rijkshofraad. Deze instanties fungeerden als appelrechters in hoogste instantie voor de rechtspraak in de afzonderlijke territoria van het Rijk. Ook fungeerden deze gerechten als het forum waarvoor rijksstanden zelf konden worden gedaagd. Maar veel, meestal grote, landsheren hadden zich op grond van soms nog uit de middeleeuwen daterende privileges zoals het 'ius de non evocando et de non apellando' (recht om niet voor een buitenlandse rechter te hoeven verschijnen), kunnen onttrekken aan deze jurisdictie. Dit had tot gevolg dat processen uit kleine rijksonmiddellijke territoria of zaken waarin kleine rijksstanden betrokken waren, bij het Rijkskamergerecht en de Rijkshofraad in de meerderheid waren. Maar ook de kleine landsheren probeerden de gang naar de hoogste rijksgerechten te beperken door introductie van hoger beroep binnen het eigen territorium. Vooral in de achttiende eeuw vond deze praktijk ingang. Een dergelijke tusseninstantie was eenvoudiger voor de inwoners en versterkte de invloed van de landsheer op de rechtspraak ten opzichte van de verre rijksgerechten. Het effect was dat de hoogste rijksgerechten weliswaar niet werden uitgeschakeld, maar de lange weg erheen werd steeds minder bewandeld.

164 Over het probleem dat echte soevereiniteit zich eigenlijk niet verdroeg regelgeving gebaseerd op de Reichsverfassung, zie Von Aretin, Heiliges Römisches Reich 1, 105-109. 
Het derde criterium voor erkenning als volwaardige rijksstand in de vroegmoderne tijd was de aanwezigheid van voldoende adeldom. Voor rijksvorsten van oudsher, zoals hertogen en markgraven, was dat onbetwist. Problemen ontstonden door standsverhogingen. In beginsel kwam het recht daarop als zogenoemd Reservatrecht toe aan de keizer of rooms-koning. Het werd niet alleen gebruikt om rijksgraven tot rijksvorsten te verheffen, maar ook om lagere adel of voor keizer en Rijk verdienstelijke families in de stand van rijksgraaf te verhogen. Zo ontstond naast de oud-grafelijke adel uit de hoge middeleeuwen vanaf de veertiende eeuw nieuwe grafelijke adel door verheffing. ${ }^{165}$

De rijksgraven vielen aanvankelijk buiten de kring van rijksvorsten. Maar sommigen onder hen wisten vanaf de dertiende eeuw hun rechten zodanig uit te bouwen tot Landeshobeit, dat zij als gelijken van de vorsten werden beschouwd en vervolgens ook dikwijls tot rijksvorst werden verheven. ${ }^{166}$ Dit proces was aan het einde van de middeleeuwen nagenoeg tot stilstand gekomen, enerzijds omdat de tijd voor de vorming van grote territoria voorbij was, maar ook omdat de vorsten hun gelederen voor nieuwkomers gesloten hielden. De positie van graven binnen het Rijk is in deze tijd onduidelijk. Waarschijnlijk maakten ze vaak deel uit van het gevolg van rijksvorsten, maar waren ze niet bij de besluitvorming op rijksniveau betrokken. Toen echter aan de beraadslagingen in de Rijksdag te Worms van 1495 voor het eerst enkele rijksgraven deelnamen, schiep dat een precedent voor toelating (in groepsverband) en uiteindelijk ook voor stemrecht in volgende samenkomsten. ${ }^{167}$ Met die aanwezigheid van graven als rijksstand (de groepsgewijze toelating van graven verliep daarna moeizaam) groeide het besef dat wat betreft Landeshoheit uiteindelijk geen principieel verschil meer bestond tussen rijksgraven met hun regalia in rijksonmiddellijke territoria en de rijksvorsten. ${ }^{168}$

De praktische betekenis van deze criteria kan aan de hand van enkele voorbeelden worden toegelicht:

- Edelen die door keizerlijk gunstbewijs waren verheven in de stand der rijksgraven (vooral vanaf de zeventiende eeuw), zonder in het bezit te zijn van een rijksleen of daarmee vergelijkbaar allodium, waren niet rijksonmiddellijk en ook geen rijksstand,

165 Bij wijze van voorbeeld uit Limburg kan hier worden gewezen op de verheffing van graaf Jacob I van Horn in 1450. Andere, latere voorbeelden van verheffingen tot graafschap uit het Maas-Rijngebied zijn Rekem (1620), Wittem (1732) en Wickrath (1752). Voor Kerpen-Lommersum zie. Peters, Geschichte des Geschlechtes von Schaesberg, 187-191.

166 Bijvoorbeeld de graaf van Gelre tot hertog in 1339, de graaf van Gulik in 1356 tot hertog en de graaf van Kleef in 1417 tot hertog. De graaf van Holland en Zeeland is een dergelijke standsverhoging nooit te beurt gevallen. Het laatste voorbeeld van verheffing van een graafschap tot hertogdom was Württemberg in 1495 (vgl. Neuhaus, Das Reich in der Frühen Neuzeit, 32). Incidenteel in de zestiende en vooral in de zeventiende werden adellijke families wegens hun verdiensten voor en loyaliteit aan de keizer in de rijksvorstenstand verheven. $\mathrm{Zij}$ moesten echter het bezit van een rijksonmiddellijk gebied kunnen aantonen (vgl. Endres, Adel in der Frühen Neuzeit, 5).

167 Arndt, Reichsgrafenkollegium, 15.

168 Busch, Herrschen durch Delegation, 33: 'Die Landeshoheit begründete also die Landesherrschaft: Ein Landesherr konnte als solcher auftreten, weil er die Landeshoheit im Sinne quasisouveräner Gewalt besaß, eingeschränkt lediglich durch die lex divina et naturae und die 'guten Gewohnheiten'. 
maar bleven onderworpen aan de landsheer van het gebied waar zij woonden of waar hun goederen lagen. ${ }^{169}$

- Leden van de lagere rijksadel (de Reichsritter) in het bezit van een rijksleen of daarmee vergelijkbaar allodium, waren wel rijksonmiddellijk en daarmee direct onderworpen aan het gezag van de keizer en de hoogste rijksgerechten, maar tegelijkertijd van een zodanig lage geboorte dat zij niet gekwalificeerd waren om als rijksstand toegang te krijgen tot de bijeenkomsten van kreits en Rijksdag. ${ }^{170}$

- Een lid van de rijksonmiddellijke adel (rijksstand of rijksridder) in het bezit van goederen gelegen onder de rechtsmacht van een andere landsheer (bijvoorbeeld met leengoed) gold wat betreft die goederen als landsässig. Geschillen over die goederen bleven onderworpen aan de rechtsmacht van die landsheer. In de praktijk ontstonden nogal eens competentieconflicten, wanneer een rijksonmiddellijke edelman elders als landsässig werd behandeld. ${ }^{171}$

Wie voldeed aan de vereisten voor rijksonmiddellijkheid van land en persoon, in het bezit was van Landeshoheit, van voldoende hoge geboorte was, en bijdroeg in de belastingen van het Rijk, kwalificeerde zich daarmee als rijksstand. Rijksonmiddellijk was wie zichzelf zo noemde en ook door standsgenoten als gelijke werd beschouwd. Daarmee verbonden was het recht van deelname aan de besluitvorming van de Rijksdag, of zoals Gotthard het kernachtig omschrijft:

Die Reichsstandschaft kam Personen oder Korporationen zu, die keinem Landesherrn Untertan waren, ferner selbst Steuern ans Reich entrichteten und deshalb an der Schwelle zur Neuzeit ibr Teilnahmerecht am

${ }^{169}$ Een voorbeeld daarvan waren de graven Toerring-Jettenbach in Beieren, die in 1630 door keizer Ferdinand II in stand der rijksgraven werden verheven (vgl. Stephan, 'Erhebung Törring' en Englbrecht, Drei Rosen, 188-191). Die verheffing, hoewel eervol, vormde ook direct een probleem. Er was toestemming nodig van de landsheer, de keurvorst van Beieren en het ontbrak aan een rijksonmiddellijk territorium. Plagend werd dan ook gevraagd waar het graafschap Toerring eigenlijk lag. Vandaar natuurlijk later de belangstelling voor het 'echte' graafschap Gronsveld.

${ }^{170}$ Een deel van deze rijkstidders, vooral in het zuidwesten van het Rijk en in het Rijngebied verenigde zich 1542 in de Reichsritterschaft, die verder werd onderverdeeld in Kreise en kantons. Gotthard, Das Alte Reich, 19, schat dat er ongeveer 350 families met circa 1600 tot 1700 dwergstaten bij waren aangesloten. Samen met de rijksgraven behoorden zij voor een groot deel tot de clientèle van de keizer, van wie zij ook bescherming genoten. Hun staatkundige positie was gecompliceerd. Enerzijds oefenden zij allerlei heerlijke rechten met bijbehorende jurisdictie over hun onderdanen uit en konden zij volgens de Religievrede van Augsburg uit 1555 de religie van hun onderdanen bepalen (vgl. Endres, Adel in der Frühen Neuzeit, 12-13), anderzijds was het vraag in hoeverre zij ook beschikten over Landeshobeit. Voor het opleggen van belastingen dienden zij zich te schikken naar de regels van het kanton. Zij betaalden belastingen aan het kanton en meestal ook aan de keizer en de defensie van het Rijk, maar meestal geen Kammerzieler voor het onderhoud van het Rijkskamergerecht. Ten aanzien van het Rijkskamergerecht en de Rijkshofraad, wisselde de houding nogal eens. Vgl. verder Endres, Adel in der Frühen Neureit, 10-14 en Neuhaus, Das Reich der Frühen Neureit, 10-14. Voor de rijksridders in de tweede helft van de achttiende eeuw en de eerste helft van de negentiende eeuw zie Godsey jr, Nobles and nation in Central Europe.

${ }^{171}$ Een voorbeeld daarvan zijn de heren/graven van Gronsveld die de heerlijkheden Oost en SintMartens-Voeren, behorend tot het Land van Daelhem, in leen hadden van de hertog van Brabant en de Bijbank moesten verheffen voor het leenhof van Valkenburg. 
Reichstag durchgesetzt hatten. 'Reichsstände' waren also diejenigen 'Reichsunmittelbaren' die Sitz, und Stimme am Reichstag besaßen. ${ }^{172}$

Betrokkenheid bij het Rijk betekende voor een rijksstand eerst en vooral zitting en stemrecht ('votum und sessio') in de kreits en de Rijksdag, met dien verstande dat in de kreits gelijkheid en in de Rijksdag ongelijkheid in stemrecht bestond. De in rang hoogste rijksstanden waren de zeven, later negen keurvorsten, de 'Zuilen van het Rijk', die in de Kurfürstenrat als afzonderlijke curia vergaderden. ${ }^{173}$ De tweede curia werd gevormd door de Reichsfürstenrat. Deze was veel meer heterogeen van samenstelling. Aanvankelijk bestond de opvatting dat hier alleen wereldlijke of geestelijke rijksvorsten aan mochten deelnemen en dat alleen zij als vorsten over volledige Landeshoheit beschikten. Tot de geestelijke rijksvorsten behoorden enkele aartsbisschoppen, verder een hele reeks bisschoppen, zeven abten en proosten van rijksabdijen en de twee grootmeesters van de Duitse Orde en de Johannieters. ${ }^{174}$ De wereldlijke rijksvorsten werden gevormd door oud-vorstelijke geslachten van hertogen, markgraven en, vanaf de zeventiende eeuw, nieuwe, in de rijksvorstenstand verheven grafelijke families. Al deze vorsten beschikten ieder afzonderlijk over een zogenoemde Virilstimme. Daarnaast waren er nog ruim veertig abten, abdissen en proosten van rijksonmiddellijke kloosters en stiften, die in de loop van de zestiende eeuw als niet-vorstelijke, mindermächtige rijksstanden in de Reichsfïrstenrat vertegenwoordigd waren. Uit onze streken waren dat onder andere de abdis van Thorn en de abt van Cornelimünster bij Aken. Zij stemden echter niet hoofdelijk, maar waren verdeeld over twee Prälatenbanken (Schwaben en Rijnland), waarbij per Bank als geheel slechts één stem, een Kuriatstimme, werd uitgebracht. Een vergelijkbare ontwikkeling deed zich in de loop van de zestiende en zeventiende eeuw voor bij de ongeveer honderd rijksonmiddellijke rijksgraven. Ook zij stemden, verdeeld over vier Gräfenbanken (Wetterau, Schwaben, Franken en Nederrijn-Westfalen) groepsgewijs met een Kuriatstimme per Bank. Volledigheidshalve moet als derde curia binnen de Rijksdag nog de Reichstädterat worden genoemd. Daarin waren ruim vijftig rijksonmiddellijke steden vertegenwoordigd die op basis van Landeshoheit over zelfbestuur beschikten. Bij het stemrecht brachten zij echter, verdeeld over twee Banken, slechts twee Kuriatstimmen uit.

Natuurlijk is dit alles een formele benadering. Het zou een miskenning van de politieke werkelijkheid zijn grote rijksvorsten als gelijken op één lijn te plaatsen met de kleine, mindermächtige rijksstanden. Niet zonder reden maakte in 1762 de grafelijke vertegenwoordiger in Gronsveld bij de 'landts-souverainitaet' van zijn rijksgraafschap de smalende opmerking van veel geschreeuw en weinig wol. Veel grote rijksvorsten beschouwden de kleine rijksstanden in hun omgeving toch als een soort van hen afhankelijke satellieten. ${ }^{175}$ Ook de bestuurlijke en rechterlijke organisatie van grote

\footnotetext{
172 Gotthard, Das Alte Reich, 16-17.

173 Aartsbisschoppen van Mainz, Keulen en Trier, koning van Bohemen, Paltsgraaf bij Rijn, hertog van Saksen, markgraaf van Brandenburg, hertog van Beieren en hertog van Brunswijk-Lüneburg (Hannover).

${ }^{174}$ In 1521 de aartsbisschoppen van Maagdenburg, Salzburg, Besançon, Bremen, in 1792 alleen Salzburg en Besançon; in 152146 bisschoppen, in 1792 nog 22; verder drie abten en vier proosten.

${ }^{175}$ Schmidt, Wetterauer Grafenverein, 2.
} 
vorstendommen waren niet vergelijkbaar met die van dwergstaten, wat overigens niet betekende dat deze kleine territoria minder effectief werden geregeerd dan de grote vorstendommen. ${ }^{176}$ Anderzijds mogen deze kleine rijksstanden ook niet helemaal terzijde worden geschoven. Binnen het Rijk golden zij als clientèle van de keizer en steunden zij hem tegen de grote rijksstanden. Daarnaast vervulden leden van de rijksgrafelijke adel vaak functies binnen de keizerlijke hofhouding, de diplomatie of het leger.

Wanneer we de hiervoor genoemde criteria voor een soevereine rijksstand in de vroegmoderne tijd op Gronsveld toepassen, dan kan over de rijksonmiddellijkheid van het allodium Gronsveld en zijn heer geen twijfel bestaan. Wanneer we in 1586 lezen dat Gronsveld 'biss dahero altem herkhommen nach allain von Godt und der sonnen zu lehen empfangen wird', dan was dat misschien iets te pretentieus, want tussen God en de heer van Gronsveld stond nog wel de keizer, maar dan alleen als hoofd van het Rijk en niet als leenheer. Aan andere heren was Gronsveld niet onderworpen.

Ook de vraag of de graaf van Gronsveld in de vroegmoderne tijd Landeshoheit met bijbehorende regalia bezat en daarmee voldeed aan het tweede criterium van rijksstand, laat zich kort en krachtig positief beantwoorden op basis van een 'Specificatie' van rechten die graaf Jost Maximiliaan van Bronckhorst Batenburg omstreeks 1650 liet opstellen. ${ }^{177}$ In willekeurig gekozen volgorde wordt daarin gesproken over hoge en lage jurisdictie van de heer, het muntrecht, de plicht van inwoners te komen werken aan het onderhoud van het kasteel, het recht op de winning van mergel en salpeter, het recht van jacht en visvangst, collatierechten voor de benoeming van pastoors en verschillende kerkelijke beneficies en allerlei inkomsten uit lenen, cijnzen, belastingen, tienden, boetes en verkoop van hout. Het totaal is een opsomming door elkaar, maar met de toevoeging 'en de appendentien ende dependentien van dyen' hield de opsteller nog een slag om de arm. Zo wordt het recht van wet- en regelgeving niet genoemd, maar dit bestond wel degelijk. De strekking was echter duidelijk: de graaf van Gronsveld voldeed met deze regalia en inkomsten ruimschoots aan de criteria voor Landeshobeit.

Het volgende criterium betreft de adeldom. Hoewel de heren van Gronsveld uit het geslacht Van Gronsveld in de veertiende en vijftiende eeuw behoorden tot de hoge adel in het Maasgebied, voerden zij geen ander adelspredicaat dan 'heer'. Na de overgang van het land Gronsveld aan de familie Van Bronckhorst Batenburg in de vijftiende eeuw, gingen zij deel uitmaken van een netwerk van hoge adel in het gebied van Maas en Nederrijn. Met een uitgekiende huwelijkspolitiek en dienstbetrekkingen bij de hertogen van Kleef en Gulik stuurden zij vervolgens bewust aan op standsverhogingen: in 1498 de verheffing van Diederik II van Bronckhorst Batenburg tot rijksvrijheer en in 1586 de verheffing van diens achterkleinzonen Jost en Johan van Bronckhorst Batenburg tot rijksgraaf. Ook aan dit vereiste voor rijksstandschap was dus vanaf 1586 voldaan.

176 Gotthard, Das Alte Reich, 17.

177 Zie Bijlage 44. 
Maar voor een volwaardige rol als rijksstand waren ook 'sessio et votum', zitting en stemrecht in kreits en Rijksdag nodig, evenals de betaling van belastingen aan het Rijk via de kreits. ${ }^{178}$ Als eerste stap in die richting kan worden gezien de deelname aan de bijeenkomsten van de Nederrijns-Westfaalse Kreits in het laatste decennium van de zestiende eeuw. Vanaf die tijd werden ook - onder protest van de onderdanen - belastingen aan het Rijk betaald. De weg naar een zetel in de Rijksdag viel echter nog een lang te gaan. Want hoewel al vanaf de zestiende eeuw voor sommige delen van het Rijk rijksgraven in groepsverband, per Bank, in de Rijksdag vertegenwoordigd waren, duurde het nog jaren voordat ook de graven in het noordwesten van het Rijk daar aanspraak op maakten. Toen in 1653 het mede op initiatief van de Gronsveldse graaf Jost Maximiliaan van Bronckhorst Batenburg opgerichte Nederrijns-Westfaals Rijksgravencollege ook als Bank in de Rijksdag werd toegelaten, voldeed Gronsveld daarmee formeel ook aan het laatste criterium voor een soevereine rijksstand. Het feit dat dit Rijksgravencollege gedurende de eerste decennia van zijn bestaan nauwelijks activiteiten ontplooide, doet daar verder niets aan af.

Wanneer het onderzoek in dit boek zich beperkte tot de vraag of de heer van Gronsveld voldeed aan de vereisten voor rijksstand, dan was het antwoord betrekkelijk snel gegeven. In deze studie komt echter de veel ruimere vraag aan de orde wat het zijn van rijksstand in de praktijk betekende. Op welke wijze beïnvloedde het de maatschappelijke positie en de carrière van heren van Gronsveld? Hoe werkte het door in de relatie tussen de graaf en zijn onderdanen op het gebied van wetgeving, belastingheffing en rechtspraak? Dit soort kwesties is tot nog toe nauwelijks bestudeerd.

Mogen de voor Gronsveld gevonden gegevens ook zonder meer worden toegepast op vergelijkbare, binnen de huidige provincie Nederlands en Belgisch Limburg gelegen gebieden? Nève toont in zijn boek over het Rijkskamergerecht en de Nederlanden aan welke grote verschillen tussen afzonderlijke territoria bestonden in hun betrekking tot de hoogste rijksgerechten. Zelfs binnen het gebied van één landsheerlijkheid zoals Gronsveld konden nog verschillen bestaan. Daarom moet bij vergelijking met andere plaatsen steeds worden bedacht dat het Rijk slechts een juridisch raamwerk vormde, met daarbinnen allerlei juridische varianten. Zo kwamen onder de bezitters van rijksonmiddellijke territoria zelfs edelen voor die zo onbeduidend waren, dat ze niet op matrikels worden vermeld. Duidelijk is dat zij geen deel hadden aan besluitvormingsprocessen op hoger niveau, maar het blijft de vraag of zij wel belastingen betaalden die vanwege het Rijk werden opgelegd. Het voorbeeld geeft aan dat voor algemene uitspraken gedegen onderzoek naar afzonderlijke plaatsen onontbeerlijk is.

\subsection{Bestuurders en onderdanen}

Een groot deel van deze studie behandelt instellingen binnen het graafschap Gronsveld op het gebied van wetgeving, bestuur en rechtspraak. Hoewel het graafschap Gronsveld klein

178 'selbst Steuern ans Reich entrichteten', zoals Gotthard, Das Alte Reich, 16-17, dat noemt. 
was, kende het een complexe administratieve structuur en rechterlijke organisatie, waarvan de onderdelen op diverse manieren tot elkaar in relatie stonden. De graaf was in de eerste plaats als absolutistisch regerende landsheer de hoogste wetgever en bestuurder. Meestal buitenslands verblijvend, oefende hij dat gezag niet zelf uit, maar liet hij zich ter plaatse door één of twee functionarissen in zijn dienst vertegenwoordigen. Deze functionarissen hadden een dubbelrol omdat zij niet alleen bestuurlijke taken uitvoerden, maar ook nauw betrokken waren bij de rechtspraak door de schepenbanken en het grafelijk leenhof. De schepenen op hun beurt kenden ook verschillende loyaliteiten. Zij moesten zorgen voor een goede rechtspraak, maar behartigden ook belangen van de heer en de gemeenschap. De onderdanen ten slotte waren hun heer onderdanigheid en trouw verschuldigd, maar kwamen in de praktijk vooral in aanraking met diens vertegenwoordigers. Voor de rechtspraak waren zij aangewezen op de schepenbanken en het leenhof. Ter behartiging van gemeenschappelijke belangen (bijvoorbeeld gebruiksrechten van weidegronden en, na 1600, de betaling van belastingen en oorlogslasten) organiseerden zij zich in gemeenten en vergadering van geërfden. Tussen deze personen, colleges en groeperingen, ieder met hun eigen belang, bestond een voortdurende wisselwerking. In deze studie is geprobeerd die verbindingen zichtbaar te maken, daarbij ook rekening houdend met de evolutie in tijd.

Het sterke accent dat wordt gelegd op de beschrijving van instellingen lijkt in contrast met de fragmentarische overlevering van de archieven van de heren van Gronsveld tot 1750. Dezelfde beperktheid geldt ook voor de schriftelijke nalatenschap van in Gronsveld verblijvende vertegenwoordigers van de graven. Ook van de archieven van de schepenbanken, het leenhof en de gemeentelijke organisatie zijn alleen maar brokstukken over. Deze overlevering van bronnen (waarover meer uitvoerig Inleiding 4.1 - 4.5) heeft ook consequenties voor het onderzoek. Zo zijn tot het eerste kwart van de achttiende eeuw de beschrijvingen van de instellingen vaak feitelijk en statisch en steunt het betoog dikwijls op enkele losse snippers papier of zijdelingse opmerkingen. Aanvullend materiaal is te vinden in enkele omvangrijke dossiers van processen die in hoogste instantie voor het Rijkskamergerecht werden gevoerd. Het gaat daarbij niet alleen om het juridisch verloop van de zaak, maar ook om materiaal dat in het kader van bewijsvoering werd verzameld. Het onderzoek naar Gronsveld is overigens een van de eerste voorbeelden in Nederland waarbij op ruimere schaal gebruik is gemaakt van de inhoud van dossiers van het Rijkskamergerecht. ${ }^{179}$

Wel goed bewaard is de correspondentie die vanuit Gronsveld in de tweede helft van de achttiende eeuw met München werd gevoerd. De frequente en dikwijls uitvoerige berichtgeving biedt een schat aan informatie. Het gaat daarbij niet alleen om beschrijvingen van feitelijke situaties en gebeurtenissen, maar ook om persoonlijke ervaringen, menselijke verhoudingen, ideeën en overwegingen. Dit levert inzicht in de manier waarop het plaatselijk bestuur functioneerde en hoe de tijdgenoten dat van commentaar voorzagen. Niet onbelangrijk is dat in het bijzonder de grafelijk vertegenwoordiger Joseph Anton Prummer voor zijn berichtgeving ook zelf onderzoek deed in de archieven van Gronsveld. Prummer was geen historicus, maar in de door hem

179 Wiech, Reichskammergericht, Prozessakten Maastricht. 
verzamelde gegevens is informatie bewaard gebleven die in originele vorm verloren is gegaan.

\subsubsection{Karakter van bet landsheerlijk gezag}

De preambule van het door gravin Anna Christina von Hardenrath in 1671 uitgevaardigde landrecht voor Gronsveld geeft een treffende omschrijving van de taak waarvoor een overheid zich gesteld zag: Volgens de gravin behoorde

einer ieden ordentlichen obrigkeit vornembstes ambt in deme zubestehen, das sÿe dahin sorglich sehen solle, auf das die ihro von Gott anbefolchene unterthannen in gleichheit und rechten erhalten und meniglichen die justiz unpartheÿlich und zwar ohne vergebliche und unnöthige uncosten und umbfüehrung erthaillt werdten möge. ${ }^{180}$

Dergelijke teksten werden in de zeventiende en achttiende eeuw in de aanhef van afgekondigde wetten vaak gebruikt. Ze drukken de legitimiteit van het landsheerlijk gezag uit en bevatten tegelijk een opdracht. De landsheer regeerde over door God aan hem 'anbefolchene unterthannen', van wie op hun beurt werd verwacht dat zij zich schikten naar de door God gewilde maatschappelijke orde. Dat gezag kwam de familie toe krachtens erfrecht, was 'lege absolutus', absoluut bij de gratie Gods, maar had tegelijkertijd ook kenmerken van een maatschappelijk contract tussen de graaf en zijn onderdanen. Het moment bij uitstek om die band tussen landsheer en onderdanen zichtbaar te maken was de inhuldiging (en in bepaalde mate ook de uitvaart) van een nieuwe landsheer. Onderzocht is op welke wijze de graven van Gronsveld en hun vertegenwoordigers daaraan zowel organisatorisch als inhoudelijk invulling gaven.

\subsubsection{Functionarissen als schakel tussen landsheer en onderdanen}

Zelfs bij heel kleine landsheerlijkheden was altijd wel iets aanwezig van een administratieve stuctuur met bestuurlijke en rechterlijke organisatie. Primair dienden de daarbij betrokken functionarissen loyaal te zijn aan hun heer en op te komen voor diens economische belangen. Tegelijk met de toename van wetgeving in de landsheerlijkheden vanaf de zestiende eeuw vormde ook controle een wezenlijk element van de bestuurscultuur. ${ }^{181}$ Daarbij moet niet alleen worden gedacht aan repressie, maar ook de handhaving van regelmaat in bijvoorbeeld financiële verslaglegging. Daarmee vervulden functionarissen de rollen van als dienaar van hun heer, uitvoerder en controleur van de samenleving. Een gevolg van dit systeem was dat die verschillende facetten ook terugkeren in ambtsinstructies, met een interne kant, gericht op het particuliere belang van de heer alsook extern, gericht op de bevolking. Overigens strekte dit systeem in een statische maatschappij niet onmiddellijk tot nadeel van onderdanen die gebaat waren bij stabiele

180 Zie bijlagen 7A-B.

${ }^{181}$ Janssen, 'Neue Wege und Formen’, 133-134. 
stucturen en publieke veiligheid. Het belang van de landsheer bij goede orde in zijn eigen economie diende, zeker in een kleine landsheerlijkheid, ook de samenleving.

Een bijzonder probleem voor het functioneren van de ambtenaren in Gronsveld vormde het vaak langdurig verblijf van de heer buitenslands. Tijdens de regeringen van Jost Maximiliaan en Johan Frans van Bronckhorst Batenburg, van ruwweg 1620 tot 1720, was de graaf niet alleen voortdurend afwezig, maar ook moeilijk bereikbaar. Na 1720 verbleef de graaf zelfs permanent ver buiten de landsgrens, eerst in Luxemburg en na 1730 in München. Daarmee berustte het 'gezag van alledag' vrijwel volledig bij functionarissen in dienst van de graaf. Vervolgens werd door cumulatie van ambten veel macht geconcentreerd bij één of twee personen. Sociologisch gezien waren deze mensen veelal afkomstig uit een regionale, onderling met elkaar verweven burgerlijke elite, die voor verschillende plaatsen in de streek bestuurders leverde. In die zin kan worden gesproken over familieregeringen. Familiebanden betekenden ook familiebelangen, met bijna inherent daaraan nepotisme en corruptie. Dat leverde een dubbel probleem op, want de graaf moest zien dat hij zijn 'ambtenaren' in de greep hield, terwijl de onderdanen soms worstelden met de vraag of zij het gezag van deze mensen wel konden erkennen.

Er kan in Gronsveld worden gesproken van drie periodes van dit soort familieregeringen, vanaf 1630 van de familie Lamberts, vanaf 1670 de families Veucht en Kicken en na 1720 tot het einde van de achttiende eeuw de familie Lebens. Vanaf omstreeks 1747 moest rekening worden gehouden met een nieuw verschijnsel, vreemdelingen uit Zuid-Duitsland en de aanwezigheid van een permanente vertegenwoordiger van graaf ToerringJettenbach. Geheel in de geest van het verlicht absolutisme regeerden deze vertegenwoordiger het graafschap als een soort 'onderkoning', maar wel op basis van voortdurende aanwijzingen en instructies uit München.

\subsubsection{Rechterlijke colleges}

Hoewel rechtshistorische leerboeken met verwijzingen naar grafelijke landgerechten, hofgerechten van horigen en 'buurspraken' van vrije geërfden theorieën geven over het ontstaan van de middeleeuwse schepenrechtspraak ten plattelande, ${ }^{182}$ moeten we vaststellen dat de schriftelijke bronnen de aanwezigheid van schepenbanken in het Maasgebied pas vanaf de dertiende eeuw vermelden. ${ }^{183}$ Zo ook in Gronsveld. Die rechtspraak verliep in die tijd volgens een in deze streken klassiek patroon, gebaseerd op principes die nog uit het vroegmiddeleeuwse recht stamden. Vanaf de late middeleeuwen en in de vroegmoderne tijd leidde een vertegenwoordiger van de heer, anngeduid als scholtis, schout, soms ook ambtman of drossaard, de rechtszitting, hij vorderde van de (meestal zeven) schepenen vonnis in een geschil tussen inwoners of bij de beoordeling van een strafbaar feit en hij was ook belast met de tenuitvoerlegging van vonnissen in strafzaken en soms de executie in civiele zaken. Het geheel aan organisatorische en

182 Zie bijvoorbeeld De Monté ver Loren/Spruit, Hoofdlijnen, 117-118.

183 Venner, 'Schepenen op het platteland', 3; Van Asseldonk, De Meierij ontrafeld, 64, 254, 277, 297, 309310 stelt hetzelfde vast voor de Meijerij van 's-Hertogenbosch. De eerste schepenbanken worden genoemd aan het einde van de twaalfde eeuw, meestal echter pas in de dertiend of veertiende eeuw. 
uitvoerende taken van de scholtis wordt aangeduid als het 'rechterschap in de oude zin', terwijl de schepenen als 'oordeelvinders' de rol van 'rechter in de moderne zin' vervullen. In principe verliep ook de rechtspraak bij geschillen over leengoederen en hofhorige of laatgoederen volgens dezelfde lijnen. De leenmannen of horigen vormden het leengerecht of hofgerecht dat vonnis wees en de leenheer of hofheer, meestal vervangen door zijn 'stadhouder', vervulde de rol van 'rechter in de oude zin'.

De heer of zijn vertegenwoordiger was verantwoordelijk voor de organisatorische kant van de rechtspraak en rechtshandhaving. Tegelijk had hij ook een financieel belang, bijvoorbeeld bij de opbrengst van boetes. Schepenen namen in de relatie tussen heer en onderdanen een bijzondere plaats in. Zij werden meestal uit de kring van plaatselijke grondbezitters benoemd door de heer (er zijn ook voorbeelden van coöptatie, maar wel met beëdiging door de heer) en legden aan hem een eed van trouw af. Soms vervulden zij bij het 'voogdgeding' of 'jaargeding', een rechtszitting waarvoor een collectieve opkomstplicht van de inwoners gold, voor de dorpsgemeenschappen ook uitvoerende of controlerende werkzaamheden uit, waarbij de grens met rechterlijke werkzaamheden niet altijd scherp valt te trekken.

Schepenen waren dus leden van de plaatselijke gemeenschap, maar geen democratisch gekozen representanten van de bevolking. Ook behoorden zij niet tot de directe entourage van de heer, maar waren wel dikwijls verwant met personen in dienst van de graaf. Op grond van hun benoeming behoorden zij in het algemeen belang op te komen voor een goede rechtspraak, maar zij behartigden ook belangen van de heer en het collectief van de inwoners in de vorm van de gemeente. In die positie hing het af van de feitelijke machtsverhoudingen in hoeverre zij beïnvloedbaar waren.

Het land Gronsveld telde vier schepenbanken, te weten Gronsveld (met Eckelrade), Heugem, Honthem en (tot 1728) Slenaken. Verder was er één heerlijk leenhof. De gegevens over mogelijk nog andere leenhoven en laathoven zijn schaars (Zie Hoofdstuk 2.1) De vroegste vermeldingen van deze schepenbanken dateren respectievelijk uit de dertiende, veertiende en vijftiende eeuw en die van het leenhof van het einde van de veertiende eeuw. Hoe en wanneer deze instellingen zijn ontstaan, is niet bekend, maar ze passen in het patroon zoals we dat ook kennen van andere dorpen in de omgeving. Hun plaats in het systeem van de rechterlijke organisatie van laagste tot hoogste instantie komt elders Hoofdstukken 2.1, 9, 10, 13 en 14) aan de orde. Alle schepenbanken hadden lage, hoge en middelbare jurisdictie, wat betekende dat zij bevoegd waren in civiele, boetstraffelijke en lijfstraffelijke zaken. ${ }^{184}$

De ontwikkeling van de rechterlijke organisatie van het land Gronsveld was in het midden van de vijftiende eeuw afgerond en bleef, met enkele aanpassingen ter verbetering van de efficiëntie, in hoofdlijnen bestaan tot aan de Franse Tijd. In deze studie is geprobeerd een beperkt aantal aspecten van (vooral de uitwendige) geschiedenis op hoofdlijnen in kaart te brengen. De mogelijkheden voor inhoudelijke bestudering van de rechtspraak zijn

${ }^{184}$ Het begrip 'middelbare jurisdictie' komt in Gronsveld voor, maar wordt niet helder omschreven, zie Hoofdstuk 2.1.2). 
beperkt. Een grote handicap bij het onderzoek vormt immers het verlies van de ooit omvangriike rechterlijke archieven in 1793. Anderzijds verschaffen de dossiers van zaken in hoger beroep bij het Rijkskamergerecht aanvullende informatie. Datzelfde geldt ook voor de rapporten over het functioneren van de rechtspraak, die de vertegenwoordigers van de graaf naar München stuurden.

Punten waaraan aandacht wordt besteed zijn de verhouding van het landrecht versus het rijksrecht, de verbetering van efficiency door een personele unie bij de bezetting van de afzonderlijke schepenbanken, procedures als het voogdgeding/jaargeding en de 'gemeyn inqueste', verder de problematiek van het hoger beroep in samenhang met de geschillen daarover met de Schepenstoel van Aken en, in de tweede helft van de achttiende eeuw, de directe interventie in ernstige strafzaken door de graaf zelf. Voor het einde van de achttiende eeuw wordt ook gekeken in hoeverre ideeën uit de Duitse Verlichting in Gronsveld doorsijpelden.

Een thema dat vooral met de interne verhoudingen binnen het gerecht te maken heeft, handelt over de rolverdeling tussen schepenen en de juridisch geschoolde functionarissen. In de loop van de tijd ontwikkelde zich in de praktijk een arbeidsverdeling waarbij het juridische handwerk werd overgelaten aan die 'beroepskrachten'. Verder groeide vanaf de zeventiende eeuw de invloed van advocaten uit de stad die als externe adviseurs het concept voor eindvonnissen maakten. Daarmee lijkt de rol van de schepenen steeds meer inhoudsloos, maar het is de vraag in hoeverre nu juist op dit punt, in de relatie tussen 'beroepskrachten' en schepenen, het verschijnsel van familieregeringen en beïnvloeding doorwerkte. Dat dit problemen kon opleveren en zelfs uit de hand kon lopen, blijkt in Gronsveld uit enkele geruchtmakende processen uit de tijd tussen 1720 en 1750, toen machtsmisbruik en geweldpleging leidden tot een absoluut dieptepunt in de rechtspraak. Schepenen speelden daar als pionnen van rivaliserende partijen ook een rol in.

\subsubsection{Geërfden en gemeenten}

Onderdanen waren door het afleggen van een eed bij de inhuldiging eerbied en gehoorzaamheid verschuldigd an de heer, maar gedroegen zich niet als volgzame schapen. Zij organiseerden zich voor de behartiging van gezamenlijke belangen als collectief. In het graafschap Gronsveld gebeurde dat in een geërfdenvergadering van grondbezitters en in de vorm van 'gemeenten' per dorp of gehucht. Dit soort organisaties - meestal op dorpsniveau - is in verschillende varianten en samenstellingen ook elders bekend. ${ }^{185}$ Geërfdenvergaderingen en gemeenten waren geen op democratische leest geschoeide vertegenwoordigende lichamen. Deelname en stemrecht werden bepaald door grondbezit, stand of privilege. Deze instellingen hadden een tweeledig doel: de zorg voor de inning van belastingen en het beheer van gemeentelijke gronden en voorzieningen ten algemenen nutte.

185 Voor een uitvoerige studie van gemeenten in het Land van Dalhem en het hertogdom Limburg, juist ten zuiden van Gronsveld, zie Dumont, Les Communautés villageoises, passim. Voor meer literatuur over het verschijnsel 'gemeente'zie de literatuuropgave bij Hoofdstuk 17. 
Grote landsheerlijkheden kenden sinds de late middeleeuwen vergaderingen waarin geestelijkheid, adel, steden en soms afgevaardigden van dorpen als 'staten' of 'standen' bij elkaar kwamen om te vergaderen over de belangen van hun land. Dat betrof in hoofdzaak de collectieve handhaving van de privileges van het land en de verdeling en inning van belastingen. De samenstelling van de staten en de machtsverhoudingen verschilden naar tijd en plaats. Zo waren de staten van de gewesten die samen de Republiek der Verenigde Nederlanden vormden, na 1581 zelf de dragers van de soevereiniteit in hun provincie, maar ook in de Spaans-Oostenrijkse Zuidelijke Nederlanden en in het prinsbisdom Luik speelden staten tot het einde van het Ancien Régime een belangrijke rol als tegenspelers van de centrale regering. ${ }^{186}$ In absolutistisch geregeerde territoria ziet men in de loop van de zeventiende en achttiende eeuw vaak een afnemende betekenis. Zij werden niet meer geraadpleegd of misten de kracht zich aan de veranderende tijd aan te passen.

Gewestelijke staten zijn als historisch verschijnsel vooral onderzocht voor grote en middelgrote landsheerlijkheden. Ook kleine territoria kenden in beginsel vergelijkbare organisaties (in het Maasgebied bijvoorbeeld het stift Thorn en graafschap Horn), maar hun geschiedenis is tot op heden nauwelijks in kaart gebracht. Waarschijnlijk ontstonden de meeste in de loop van de zestiende en zeventiende eeuw. Soms lijkt het te gaan om wat men zou kunnen noemen staten in 'embryonale' vorm, een ontwikkelingsfase tussen 'echte' staten en instellingen op dorpsniveau. Iets dergelijks lijkt in Gronsveld het geval te zijn met de vergadering van geërfden, de grondeigenaren in het graafschap Gronsveld. Deze organisatie lijkt zijn oorsprong te vinden in de oppositie tegen de invoering van grondbelastingen ten behoeve van het Rijk, om vervolgens te evolueren tot een structureel overleg met de graaf over deze betalingen. Het over geërfden in het graafschap Gronsveld aanwezige archiefmateriaal is, zeker vóór 1750 , schaars. Daardoor is het moeilijk een volledig beeld te krijgen van de ontwikkeling en het functioneren van de geërfdenvergadering over een lange periode. Toch is geprobeerd een reeks aspecten nader te belichten, zoals de strijd met de Maastrichtenaren over bijdragen in de belastingen, de werkwijze na 1750 en de overeenkomsten en verschillen met vergelijkbare organisaties in naburige territoria.

De tweede vorm van collectiviteit in het graafschap was de gemeente, gevormd door de inwoners van een dorp of gehucht. Het begrip 'gemeente' of 'kerspel' als zodanig komt vanaf de veertiende eeuw in het Maasgebied voor. ${ }^{187}$ In omvang variëren ze van gehuchten tot grote plaatsen. De gemeente had de kenmerken van een vereniging van inwoners, waarbij het de vraag was in hoeverre dit collectief ook zelfstandig drager van rechten kon zijn. Binnen de gemeente werd overlegd over het beheer van gemeenschappelijke eigendommen, in het bijzonder weide- en heidegronden. Vanaf de zestiende eeuw werd vaak ook de inning van belasting en betaling van oorlogslasten per gemeente georganiseerd.

186 Voor de staten in het prinsbisdom Luik zie de diverse hoofdstukken in Dubois, e.a., Les institutions publiques, 237-308; voor Limburg en de Landen van Overmaas zie Goossens, Études sur les États de Limbourg. Voor het Overkwartier zie: Venner, Inventaris archief Staten van het Overkwartier.

187 Zie voor meer literatuur Hoofdstuk 17.1. 
Voor het graafschap Gronsveld zijn de bronnen over gemeenten uit de periode voor circa 1750 zeer schaars. Toch is geprobeerd op basis van dit weinige materiaal het ontstaan van gemeenten binnen het graafschap in kaart te brengen. Vervolgens komen enkele aspecten van de organisatie, besluitvorming en vertegenwoordiging naar buiten toe aan de orde. Daarbij is ook sprake van een bepaalde spanning in de verhouding tot de graaf. Voor het einde van de achttiende eeuw wordt dan nog in gegaan op de rol van de gemeente bij de inning van de zogenoemde personele belastingen op het vee.

\subsection{Landsheerlijke rechten als instrumenten van gezagsuitoefening en bron van inkomsten}

In Hoofdstuk 15 wordt een overzicht gegeven van de rechten en eigendommen van de graven van Gronsveld vanuit drie invalshoeken, te weten hun betekenis als 'statussymbool', hun betekenis voor bestuur en rechtspraak binnen het graafschap en ten slotte hun betekenis als bron van inkomsten. De onderlinge verhouding tussen de beschrijving van al die aspecten kon daarbij niet altijd even evenwichtig zijn, omdat de beschikbare bronnen nogal ongelijk zijn verdeeld naar tijd en inhoud.

In de rechtshistorische literatuur worden diverse indelingen van (lands)heerlijke rechten of regalia gehanteerd. ${ }^{188}$ Kenmerkend was dat ze op de een of andere manier berustten op publiek gezag of een monopolie waar de heer aanspraak op maakte. Tegelijkertijd vormden ze ook een onderdeel van het private vermogen van de rechthebbende. Het 'kernrecht' wordt gevormd door het recht op rechtspraak, het zogenoemde 'rechterschap in de oude zin', waarbij de heer of zijn vertegenwoordiger recht vorderde en zorgde voor de tenuitvoerlegging van het vonnis, met eventueel aanspraak op boeten. Van lage heerlijkheid wordt gesproken bij rechtspraak over civiele en boetstraffelijke zaken; hoge heerlijkheden gaven rechtsmacht om recht te vorderen voor misdrijven waar straf aan lijf en leden op stond.

Andere 'klassieke' heerlijke rechten waren het recht op diensten en werkzaamheden van de onderdanen (landsverdediging, meewerken als schepen aan de rechtspraak, vrachtdiensten, onderhoudswerk aan wegen, waterlopen, dijken en aan het kasteel), verder rechten op diverse belastingen en tollen (brouwen, overdracht van onroerend goed), rechten op het gebruik van bossen, woeste gronden en bevaarbare rivieren, rechten op economische monopolies zoals muntslag, het houden van markten, het verplichte gebruik van de heerlijke molen, jacht- en visrechten en het recht op het houden van bepaalde dieren (bijen, duiven, zwanen).

Rond deze heerlijke rechten waren ook bijkomende rechten van niet-regale oorsprong gegroepeerd, zogenoemde 'accrochementen' (in het westelijk deel van Nederland vaak 'ambachtsgevolgen' genoemd). Deze waren zeer gevarieerd en konden bestaan uit benoemingsrechten voor publieke ambten (gerechtsbode, gerechtsschrijver,

188 Zie hierover bijv. De Blécourt, 'Heerlijkheden en heerlijke rechten', passim, De Blécourt/Fischer, Kort begrip, 218-245; De Monté ver Loren/Spruit, Hoofdlijnen, 101-119, 125-134; Moorman van Kappen, 'Tets over heerlijkheden en heerlijke rechten', 16-36; Ketelaar, Oude zakelijke rechten, passim; Vera, ...dat men het goed van den ongeboornen niet mag verkoopen, passim. 
schoolmeester), rechten met een meer immaterieel karakter zoals een bijzondere plaats in de kerk of huldeblijk in de vorm van geschenken bij bepaalde gelegenheden, het monopolie op het houden van een stier, dekhengst of beer et cetera. Collatierechten (het recht om als 'patroon' van een kerk of kerkelijk beneficie de pastoor of bedienaar voor te dragen) en tiendrecht (het recht op een tiende deel van de opbrengst van gewassen of veeteelt), werden, als voortvloeiend uit eigendomsrecht op kerkelijk goed, niet tot de heerlijke rechten gerekend, maar waren vaak wel in het bezit van de heer. Heerlijke rechten konden zijn gecombineerd met grondbezit en een versterkt huis, maar noodzakelijk was dit niet. ${ }^{189}$

Een probleem is dat de indelingen van rechten volgens juridische criteria, zoals in de rechtshistorische literatuur meestal gebeurt, in de praktijk niet goed hanteerbaar zijn. ${ }^{190}$ Het is niet altijd eenvoudig vast te stellen wat juridisch gezien heerliike rechten zijn. Soms kan dat alleen worden beoordeeld op basis van nauwkeurig onderzoek naar de herkomst. Rechten zoals periodieke betalingen in de vorm van cijnzen of betalingen van een bepaald bedrag bij overgang van leenroerige of hofhorige goederen kunnen ook worden gezien als een uitvloeisel van een bepaalde vorm van grondexploitatie. Het is verder de vraag of een classificatie op basis van zuiver juridische criteria ook past in het beeld dat bezitters van heerlijke rechten daar zelf van hadden. Gronsveld levert daar al direct een voorbeeld van. In de al genoemde 'Specificatie' van rechten van de graven van Gronsveld uit circa 1650 worden alle rechten en inkomsten, ongeacht herkomst of karakter, op één hoop geveegd. Diezelfde benadering ziet men ook in de achttiende eeuw.

Tegen het einde van de middeleeuwen groeide het besef dat overheidsgezag meer was dan alleen een verzameling monopolies en rechten. De landsheer diende voor de realisering van het al genoemde 'bestuursconcept' van 'gute Policey' te beschikken over een breed spectrum aan bevoegdheden. Daarin speelden de oude heerlijke rechten en hun 'aanhangsels' een rol. Enerzijds bleven ze gewoon in stand en hielden ze hun betekenis als bron van inkomsten, maar ze vormden ook de opstap naar een bepaald beleid. Regalia in de vorm van een economisch monopolie konden bruikbaar zijn om daarmee ontwikkelingen op het gebied van handel en nijverheid te sturen. De bevoegdheid tot wetgeving bood de mogelijkheid tal van aspecten van het dagelijks leven in overeenstemming te brengen met gedrag dat de overheid wenselijk achtte. Als laatste voorbeeld kunnen we het collatierecht voor kerkelijke beneficies noemen, dat de weg effende voor intensieve bemoeienis met kerkelijke aangelegenheden.

Naast 'gezagswaarde' hadden landsheerlijke rechten ook economische betekenis. Ze waren als vermogensrechten erfelijk, overdraagbaar en handhaafbaar tegenover eenieder die er inbreuk op maakte. In die zin waren het gewoon bronnen van inkomsten. Die economische benadering sluit, zeker voor de vroegmoderne tijd aan op het beeld van de

189 Zie voor deze opsommingen: De Blécourt, ‘Heerlijkheden en heerlijke rechten’ (I) 85-86.

190 Zie bijvoorbeeld De Blécourt/Fischer, Kort begrip, 226-234; De Monté ver Loren/Spruit, Hoofdlijnen, 114-133. 
landsheerlijkheid als een soort onderneming, een idee dat ook bij de tijdgenoten leefde. Voor de kas van de heer maakte het niet uit op welke titel hij geld ontving.

Een laatste aspect van heerlijke rechten was ook hun toenemende betekenis als statussymbool. Een bijzonder voorbeeld daarvan levert misschien het muntrecht, dat kleine landsheren vanaf het einde van de middeleeuwen en de zestiende eeuw hanteerden als bewijs van hun landsheerlijkheid. Gronsveld is daar een voorbeeld van. Maar ook in de zeventiende en achttiende eeuw kochten in de Nederlanden rijke burgers heerlijkheden om daarmee de titel 'heer van' te verwerven. ${ }^{191}$ Dat speelde bij het graafschap Gronsveld in die vorm geen rol, maar ook hier ziet men dat in de achttiende eeuw met uiterste zorgvuldigheid werd gelet op de handhaving van bepaalde rechten, zelfs als ze economisch weinig betekenden. Ieder recht, hoe onbeduidend ook, kon het aanzien van de heer alleen maar bevestigen.

Tegenover deze veranderende betekenis van landsheerlijke rechten stonden ook veranderende opvattingen over acceptatie bij de onderdanen. Herendiensten, economische monopolies, tiendrechten, jachtrecht en betalingen op basis van feodale verplichtingen werden steeds meer beschouwd als onrechtvaardige voordelen ten behoeve van een geprivilegieerde klasse. Botsingen tussen de heer en de onderdanen over de uitoefening van dit soort rechten waren in de vroegmoderne tijd dan geen zeldzaamheid en de revoluties tegen het einde van de achttiende eeuw richtten zich vooral tegen dit soort rechten.

In deze studie is geprobeerd alle rechten waarover de heren van Gronsveld beschikten, in kaart te brengen en hun betekenis voor het bestuur en als bron van inkomsten toe te lichten. Een strakke indeling is niet aangehouden. Bij de rechten met een financiële component is ook gekeken naar de volgorde zoals die in sommige bronnen wordt aangehouden. Zo plachten vanaf de zestiende eeuw de rentmeesters inkomsten volgens een min of meer vast stramien te verantwoorden. Het aantal bewaard gebleven rekeningen is weliswaar beperkt, maar met een aantal ijkpunten gedurende tweehonderd jaar leveren ze toch een dwarsdoorsnede van ontwikkelingen over een lange periode. Op dezelfde wijze gestructureerd waren in de tweede helft van de achttiende eeuw de uitvoerige rapportages van de grafelijke commissarissen over de heerlijke rechten als bron van inkomsten.

Enkele rechten zijn niet in dit hoofdstuk opgenomen, omdat ze in samenhang met andere onderwerpen worden behandeld. Zo is een afzonderlijk hoofdstuk gewijd aan de rechten van symbolische aard, gericht op erkenning van het gezag, zoals het verplichte eerbetoon van onderdanen bij de inhuldiging en uitvaart van de landsheer of een lid van zijn gezin. $\mathrm{Bij}$ het recht op wet- en regelgeving is een inventarisatie gemaakt van wat er aan wetgeving bekend is. Regelgeving was nooit het resultaat van een democratisch proces 'van onderop', maar vaardigde de landsheer op eigen gezag uit, meestal na voorbereiding door het hem

191 Kooijmans, 'Patriciaat en aristocratisering', 98-100. 
ten dienste staande ambtelijk apparaat. Als geheel valt de oogst nogal mager uit. Uitzondering daarop vormt het uit 1671 daterende Gronsvelds landrecht dat grotendeels een kopie is van het landrecht van het keurvorstendom Keulen (zie bijlagen 7 A-C).

Het recht op de rechtspraak wordt behandeld in samenhang met de schepenbanken en het leenhof. Ook hier is de oogst niet geweldig, omdat de voornaamste bronnen waaruit gegevens zouden moeten worden geput, te weten de archieven van schepenbanken en leenhof, voor het grootste deel verloren zijn gegaan.

De rij wordt geopend met het muntrecht, niet zozeer vanwege de economische waarde, maar als een symbool waaraan een hoge status werd ontleend, ook naar standsgenoten van de graaf toe. Daarna volgen diverse rechten en monopolies met vaak een fiscaal aspect. Ook aan de exploitatie van grond waren diverse rechten en inkomsten verbonden. Over het gebruik van fiscale en economische rechten als middel om de algemene welvaart te verbeteren, valt weinig te zeggen. Op zich bestonden daar in de tweede helft van de achttiende eeuw wel ideeën over, maar verder dan plannen is het nauwelijks gekomen. Uitgebreid aandacht krijgen de verschillende patronaats- en collatierechten. De uitoefening van deze rechten bleef niet beperkt tot de zuiver formele kant van voordracht van geestelijken voor benoeming; ze werden ook duidelijk ingezet om landsheerlijk gezag over de geestelijkheid en de kerkelijke goederen in het graafschap uit te oefenen. In combinatie met de mogelijkheden van regelgeving bestonden er genoeg aanknopingspunten voor het beoefenen van kerkpolitiek, ook al was het op dorpsniveau. Interessant en bijzonder voor het graafschap Gronsveld zijn in dit verband ook de benoemingen van Beierse pastoors in de achttiende eeuw.

Een aantal heerlijke rechten bestond uit fiscale en economische monopolies. Het onderscheid tussen monopolie en belasting is daarbij vaag. Men kan denken aan overdrachtsbelasting voor onroerend goed en accijnzen op bier, maar ook monopolies zoals jacht-, vis- en molenrecht, die verpacht werden en herendiensten, oorspronkelijk een persoonlijke verplichting, maar later grotendeels gefiscaliseerd.

Het laatste cluster van rechten heeft als gemeenschappelijk kenmerk dat ze te maken hebben met betalingen voor het gebruik van grond. Zo was de uitgifte van grond als leengoed of keurmede in oorsprong gebaseerd op een feodaal systeem van rechten en plichten. Dat feodale karakter bestond in theorie tot het eind van het Ancien Régime, maar in de vroegmoderne tijd werden de betalingen voor het bezit van deze goederen toch eerst en vooral beschouwd als een erkenning van het eigendomsrecht van de heer.

Het recht op vaste betalingen voor het langdurig gebruik van grond in de vorm van cijnzen en erfpachten ligt wat betreft oorsprong eveneens gecompliceerd. Sommige cijnzen en erfpachten hebben hun oorsprong in heerlijke rechten (bijvoorbeeld bij ontginning van woeste grond), maar ze kunnen ook zijn ontstaan vanuit middeleeuwse vormen van belegging en kapitaalverschaffing. De 'gewone' landpacht daarentegen (uitgifte van grond door de eigenaar voor een beperkt aantal jaren) was weer gebaseerd op een overeenkomst. Een buitenbeentje in deze groep vormen de tienden, de heffingen op de opbrengst van bepaalde gewassen of op veeteelt. Oorspronkelijk bedoeld voor het 
onderhoud van de kerk, waren de tienden in de loop van de tijd vooral een gewone bron van inkomen voor de tiendheffer geworden. 


\section{Ontstaan en ontwikkeling van Gronsveld als landsheerlijkheid in de late middeleeuwen. Een genealogische en geografische benadering}

\section{De heren van Gronsveld van de elfde tot het einde van de vijftiende eeuw}

De vroegste documenten waarin leden van een familie Van Gronsveld, of een variant op die naam, voorkomen, dateren uit de elfde en twaalfde eeuw. Er bestaat geen direct verband met de plaats Gronsveld en uit de losse namen kan ook geen sluitende genealogie worden samengesteld. Wel leveren deze gegevens een beeld op van het milieu en de omgeving waarin deze personen verkeerden.

Uit de dertiende eeuw zijn er meer bronnen beschikbaar, op basis waarvan ook fragmenten van genealogieën kunnen worden samengesteld, maar het geheel laat nog vele vragen open. Als eerste wordt aandacht besteed aan het adellijk geslacht de Houffalize, dat bezittingen had in Gronsveld en Rijckholt en het mogelijk verband met de heren van Gronsveld. Vervolgens komen dan ook leden van de familie Van Gronsveld aan de orde, die ook werkelijk als heer van Gronsveld moeten worden beschouwd. Belangrijk waren daarbij twee verbindingen, eerst met de familie Van Stolberg, afkomstig van de plaats Stolberg bij Aken en vervolgens, aan het eind van de dertiende eeuw, met de familie van Hafkesdale, een invloedrijk geslacht in het gebied van het tegenwoordige Zuid-Limburg. Er zijn aanwijzingen dat de heren van Gronsveld zich vanaf omstreeks 1300 hebben beschouwd als 'opvolgers' van de op dat moment bijna uitgestorven familie Van Hafkesdale.

Pas vanaf Hendrik I van Gronsveld kan tot het einde van de vijftiende eeuw een lijst van opeenvolgende heren van Gronsveld worden samengesteld. De beschikbare bronnen uit die tijd, veelal oorkonden, geven inzicht in genealogische verbanden en verschaffen informatie over bezittingen, ambten en financiële transacties. Zonder naar volledigheid te streven is, vooral op basis van literatuur, veel van dit materiaal bij elkaar gebracht. Hoewel het geheel daarmee - bijna onvermijdelijk - een enigszins encyclopedisch karakter krijgt, is het toch meer dan alleen een opsomming van feiten. Over een langere termijn wordt de betekenis van bepaalde gebeurtenissen duidelijk herkenbaar en vallen patronen in het handelen van opeenvolgende generaties te ontdekken.

Onderzocht is de wijze waarop, binnen een netwerk van adellijke relaties, in het bijzonder huwelijken en erfenissen wezenlijk hebben bijgedragen tot bezitsvorming. Wat de invloed daarvan op de vorming van het Land Gronsveld in de late middeleeuwen betreft, wordt verwezen naar hoofdstuk 1.

De bronnen uit de veertiende en vijftiende eeuw laten zien dat de heren van Gronsveld over een goed gevoel voor geldzaken beschikten. Gedeeltelijk werd dit fortuin ook besteed aan leningen aan de hertogen van Brabant, in ruil waarvoor weer allerlei ambten en landsheerlijke inkomsten in het hertogdom Limburg en de Brabantse landen in het Maasgebied in pand werden verkregen. Indirect wordt daarmee duidelijk hoe de heren van Gronsveld hebben geprobeerd met hun loyaliteit aan Brabant de zelfstandigheid van hun kleine land ten opzichte van machtige buren te handhaven. Invloed werd niet alleen gekocht met geld, ook het gebruik van geweld werd niet altijd geschuwd. Dat leverde ook 
vijanden en langdurige vetes op. Misschien reikten bij sommige heren van Gronsveld de ambities nog verder en droomden zij van verdere groei van hun territorium. Maar het was binnen de staatkundige constellatie van het Maasgebied van die tijd voor een kleine landsheer te laat om dit soort plannen te kunnen verwezenlijken. $\mathrm{Na} 1450$ valt een duidelijke kentering in die oriëntatie op Brabant waar te nemen en wordt de blik, zowel politiek als wat betreft familierelaties, meer oostwaarts gericht. Cruciaal daarbij was het in 1425 gesloten huwelijk tussen Diederik I van Bronckhorst Batenburg en Johanna van Gronsveld, waardoor de heren van Gronsveld deel gingen uitmaken van de hoge adel uit het gebied van Gelre en Kleef.

\subsection{De familie De Gru(e)les/Grunsele/Gronsfelt in de elfde en twaalfde eeun}

De 'uralte stamme' waarop de gebroeders Jost en Johan van Bronckhorst Batenburg in 1586 zich bij de keizer beriepen als argument voor hun standsverheffing, had niet alleen betrekking op de familie Van Bronckhorst Batenburg, maar gold ook voor de afstamming van de oorspronkelijke heren van Gronsveld. Hoewel de genealogische kennis van de aanvragers waarschijnlijk niet al te hoog moet worden ingeschat (dit probleem komt in Hoofdstuk 3.3.3 uitgebreider aan de orde), leefde misschien toch ergens een besef van 'oeroude adel' bij de heren van Gronsveld. Maar schriftelijke bronnen om die afstamming te bewijzen, zullen in Gronsveldse archieven hebben ontbroken. Zelfs wanneer in de zestiende eeuw in Gronsveld nog een goed familiearchief aanwezig was (wat op zich al valt te betwijfelen), dan nog is het op basis van ervaringen met vergelijkbare archieven onwaarschijnlijk dat dit verder terugging dan de veertiende eeuw. De oudste vermeldingen van personen die mogelijk met Gronsveld in verband zijn te brengen, gaan echter terug tot de elfde en twaalfde eeuw en bevinden zich in archieven van kerkelijke instellingen in een straal van ongeveer vijftig kilometer rond Gronsveld.

In de negentiende eeuw hebben historici geprobeerd op basis van dit materiaal een genealogie samen te stellen. In zijn in 1854 gepubliceerde studie over Gronsveld liet Wolters de familiegeschiedenis beginnen bij 'Wilhelmus de Gronsele' in 1241. ${ }^{192}$ Maar, zo schreef hij: 'Het is moeilijk of liever onmogelijk thans nog de oorsprong van de heren van Gronsveld vast te stellen'. Ruim twintig jaar later dacht Chestret de Haneffe het beginpunt aanzienlijk te kunnen vervroegen met vermeldingen uit de elfde en twaalfde eeuw van diverse personen met de achternaam 'Van Gronsveld' of een variant daarop. Maar ook hij constateerde dat eerst vanaf de veertiende eeuw een samenhangende genealogie kon worden samengesteld. ${ }^{193}$ In essentie geldt die conclusie nog steeds. Goed gedocumenteerd voor de periode tussen 1350 en 1600 is ook het overzicht van Hanssen in zijn geschiedenis van Rimburg, maar hij schreef vooral vanuit het perspectief van de

192 Wolters, Recherches Gronsveld, 6: 'L'origine des sires de Gronsveld est difficile ou plutôt impossible à établir aujourd'hui'.

193 Chestret de Haneffe, 'Histoire Gronsveld', 17. 
geschiedenis van Rimburg. ${ }^{194}$ Specifiek op Van Bronckhorst Batenburg heeft betrekking de door Van Schilfgaarde gepubliceerde genealogie van deze familie. ${ }^{195}$

Wolters, Chestret de Haneffe en Hanssen leverden voor hun tijd verdienstelijk werk, maar er kleven ook beperkingen aan. Intussen zijn meer gegevens bekend dan het materiaal waarop zij steunden en kan de geschiedenis van de vroegste generaties ook door andere, vergelijkbare studies, in een iets bredere, regionale context worden geplaatst. Daarom is het zinvol opnieuw de balans op te maken, ook al is niet gestreefd naar volledigheid. Het gaat niet alleen om namen en verwantschap, maar ook om de vraag over de herkomst van de eerste dragers van de naam 'Van Gronsveld' en wanneer zij daadwerkelijk met de plaats Gronsveld in verband kunnen worden gebracht. Voorts kan soms iets worden gezegd over de sociale status van de heren van Gronsveld.

Enkele opmerkingen moeten hier worden gemaakt over de op het internet circulerende en zich steeds herhalende genealogieën en overzichten van de heren van Gronsveld, onder andere onder diverse trefwoorden in Wikipedia. De waarde daarvan moet uitermate gering worden geacht. Niet alleen lijken de samenstellers een patent te hebben op pertinente verzinsels, het grootste bezwaar is dat personen aan elkaar worden geknoopt zonder enige bronvermelding van de geboden informatie. Dit is des te meer frustrerend, omdat sommige beweringen best een kern van waarheid zouden kunnen bevatten, maar verificatie is onmogelijk. We hebben in deze studie dit soort 'volledig' ogend materiaal grotendeels buiten beschouwing gelaten en ons zoveel mogelijk beperkt tot beschikbare bronuitgaven en literatuur die een betrouwbare indruk maken. Volledigheid is niet nagestreefd en ook onmogelijk. Met inachtneming van de nodige voorzichtigheid is de juiste interpretatie daarvan op zich vaak al problematisch genoeg.

Er zijn uit de elfde en twaalfde eeuw diverse oorkonden bekend met personen die de achternaam De Gruosles, Gru(e)les, Grunsele of Gronsfelt voeren. Alvorens in te gaan op mogelijke genealogische samenhang, volgt eerst een overzicht van de bekende documenten. De vroegste teksten, daterend uit de periode 1033-1035, bestaan uit fragmenten van twee verloren originelen uit het archief van de abdij van StavelotMalmedy. Daarin treedt een zekere Herimannus of Hermannus de Gruosles op als getuige bij een transactie die wordt verricht door Poppo, abt van genoemd klooster. ${ }^{196}$ Twee oorkonden van dezelfde abdij rond 1089 verhalen op welke wijze hoe de inmiddels overleden Poppo bepaalde goederen had verworven. Daar was Herimannus of Hermannus de Gruosles als getuige bij aanwezig geweest. Een zekere Hermannus de Grueles en zijn broer Emino komen we tegen als getuigen in een akte uit 1063, waarin bisschop Tyetwinus van Luik verklaart dat Bruno, graaf van Hengebach, zijn bezittingen te Herve tot zekerheid stelt voor een lening van driehonderd mark bij het kapittel van het Heilig Kruis te Luik. ${ }^{197}$

${ }^{194}$ Hanssen, Die Rimburg.

195 Van Schilfgaarde, 'De heren van Bronckhorst'.

196 Halkin/Roland, Recueil Stavelot-Malmedy, I, 209-211, nrs. 99-100.

197 Regest bij Poncelet, Inventaire Sainte-Croix, 5, nr. 5. Ook vermeld bij Chestret de Haneffe, 'Histoire Gronsveld', 17, waarbij hij in navolging van Ernst, Histoire de Limbourg VI, 107 spreekt over 'Cono' in plaats van 'Emino'. De lezing van Poncelet is evenwel de juiste. 
De vermeldingen uit de twaalfde eeuw beginnen met een document uit 1103 dat betrekking heeft op Giselbertus de Grules. Deze was door de kanunniken van het SintAdalbertstift te Aken aangesteld tot voogd over de parochie Olne. De heren van het stift beschikten in dit dorp over een villa met heerlijke rechten, welk bezit was gebaseerd op een schenking door koning Hendrik II in 1005.198 De hertog van Limburg beheerde als oppervoogd van het stift deze goederen, maar liet zich echter door een fungerend voogd vertegenwoordigen. Over de taakuitoefening van laatstgenoemde ontstonden moeilijkheden. Gesteund door de proost en kanunniken van Sint-Adalbert deed de 'familia' van het stift in Olne in 1103 haar beklag bij koning Hendrik V. Volgens de klagers had Giselbertus de Grules daar namens het kapittel als wettig voogd (legitimus eorum advocatus) zelf moeten optreden, maar liet hij zich vervangen door 'ondervoogden' die de dorpelingen afpersten. De koning besliste dat behalve de hertog ${ }^{199}$ als algemene oppervoogd er nog maar één feitelijke (onder)voogd mocht zijn, wiens gezag ('bannum') afhing van de koning. De voogd kon zich laten vertegenwoordigen door een ondergeschikte, maar deze functionaris mocht beslist geen ondervoogd worden genoemd en mocht zich niet met rechtspraak inlaten. Giselbertus de Grules kreeg uitdrukkelijk opdracht deze voorschriften na te leven. Aan het einde van het koninklijk vonnis worden de personen opgesomd die bij de uitspraak aanwezig waren, waarbij Giselbertus wordt ingedeeld bij de 'vrije mannen' ('liberi homines'). ${ }^{200}$

Een Gislebertus de Grule treedt in 1111 op als getuige in een oorkonde van bisschop Otbert van Luik, waarin deze het kapittel van Sint-Paulus in Luik bevestigt in het bezit van de kerk van Lixhe. De plaats van Gislebertus in de lijst van getuigen is na de geestelijken en vóór de ministerialen, tussen de 'nobiles beneficiati', 201 te weten de graaf van Namen en zijn broer, de graaf van Loon en zijn broer en een zekere Arnulfus de Eleslo (Elsloo). ${ }^{202}$ Dit plaats in de lijst duidt op een hoge status.

In 1137 is opnieuw sprake van een voogd ('advocatus') Giselbertus de Grules bij het SintAdalbertstift. Mogelijk is hij identiek met de voorgaande voogd Giselbertus in Olne, maar vanwege de tijdsspanne van 34 jaar, tussen 1103 en 1137, mag dat niet als vanzelfsprekend worden aangenomen. De zaak betrof ditmaal de opheffing van de onvrijheid van een

\footnotetext{
198 Wisplinghof, Rheinisches Urkundenbuch, 1; 5-7, nr. 4; Stouren, 'Histoire d'Olne', 124-129.

199 Bedoeld is Hendrik I, graaf van Limburg van 1082-1119 en tevens hertog van Lotharingen van 11011106.

200 De tekst van de oorkonde is meermalen in druk verschenen, het laatst en meest volledig bij Meuthen, Aachener Urkunden, 409-411, nr. 166, met vermelding van oudere literatuur. Meuthen beschrijft uitgebreid de diplomatische kenmerken van het stuk en komt tot de conclusie dat het gaat om een schijnbaar origineel, vervaardigd tussen 1130-1135.

201 Waarschijnlijk betekent deze aanduiding adellijke 'leenmannen', mannen die met een beneficium, een leengoed, zijn begiftigd.

202 Thimister, Cartulaire Saint-Paul, 3.
} 
zekere Senneheld, dienstmaagd ('ancilla') van het stift, die was gebonden aan een hof ('curtis') van het kapittel in Vaals. ${ }^{203}$

Uit 1145 en 1148 dateren twee oorkonden, waarin de gebroeders Wynandus en Philippus de Grunsele of Gronsfelt als getuigen optreden. De akte uit 1145 betreft een bevestiging door bisschop Hendrik II van Luik van de schenking van een hof en kapel te 'Scarne' (Scharn, tussen Maastricht en Heer) met land bij de 'Dusenberg' (Dousberg, ten westen van Maastricht) door de edelman ('vir nobilis') Adelbertus de Scarne en zijn vrouw aan de abdij Kloosterrade (Rolduc). Wynandus en Philippus de Grunsele worden aangeduid als 'vrije mannen' ('liberi homines'). ${ }^{204}$

In 1148 is wederom sprake van de bevestiging van een overeenkomst door bisschop Hendrik II van Luik, ditmaal tussen de abdij Kloosterrade en Reinbertus de Milisvort over het goed 'Curlo' (bij Wassenberg). Dit geschiedde in het bijzijn van hertog Hendrik van Limburg, Gerard van Wassenberg en de broers Wynandus en Philippus van Gronsfelt met andere, niet met naam genoemde personen. ${ }^{205}$

Uit het voorgaande overzicht blijkt dat in de elfde en twaalfde eeuw in diverse plaatsen in het gebied tussen Aken, Luik en Maastricht personen met de achternaam De Gruosles/Gru(e)les/Grunsele/Gronsfelt voorkomen, maar uit die gegevens valt geen samenhangende genealogie te construeren. Vóór de elfde eeuw valt niet eens met zekerheid iets te zeggen over goederenbezit. 206

Opvallend is dat noch voor de elfde noch voor de twaalfde eeuw een der genoemde personen rechtstreeks in verband staat met de plaats Gronsveld. Die conclusie druist in tegen de heersende opvatting, zoals onder anderen van Chestret de Haneffe, die niet aarzelt enkelen van hen als heren van Gronsveld te bestempelen. ${ }^{207}$ Misschien liet hij zich daartoe verleiden door de aanwezigheid van de broers Wynandus en Philippus van Gronsveld bij de schenking van Adalbertus de Scarne in 1145, omdat zich dit wel heel dicht bij Gronsveld afspeelde.

Toch bevatten de twaalfde-eeuwse oorkonden enkele overeenkomsten. In de eerste plaats is er de betrokkenheid van Giselbertus (één of meer personen) bij voogdij over goederen

${ }^{203}$ De tekst van de oorkonde is meermalen in druk verschenen, het laatst en meest volledig bij Meuthen, Aachener Urkunden, 413-414, nr. 168, met vermelding van oudere literatuur.

204 Polak/Dijkhof, Oorkondenboek, Kloosterrade, 33-36, nr. 11; oudere uitgave bij Franquinet, Inventaris Kloosterrade, 9-10, nr. 7.

205 Polak/Dijkhof, Oorkondenboek Kloosterrade, 43-46; oudere uitgave bij Paquay, 'Codex documentorum', 226-228. Polak beschouwt deze oorkonde als onecht.

${ }^{206}$ Halkin/ Roland, Recueil Stavelot-Malmedy, verwijzen in hun annotatie naar 'Groules en la terre de Lemborch', gelegen in de gemeente Baelen, hoewel een relatie met Gronsveld misschien meer voor de hand had gelegen. Zeker is dat sinds het begin van de veertiende eeuw de heren van Gronsveld rechten hadden op de laathof Groules in Dolhain-Baelen, een onderleen van het leen- en laathof Del Beuck in HenriChapelle, dat in het begin van de veertiende eeuw door heren van Gronsveld van de hertogen van Limburg in leen werd gehouden (zie hierna Hoofdstuk 1.4.3). Het staat geenszins vast dat die lenen teruggaan op twaalfde-eeuws bezit. Misschien moet de redenering zelfs worden omgedraaid en waren de heren van Gronsveld juist de naamgevers van Groules.

207 Chestret de Haneffe, 'Histoire Gronsveld', 19: 'on ne peut néanmoins les classer avec certitude parmi les seigneurs de ce lieu'. 
van het Sint-Adalbertstift in Aken. Verder ligt er zowel bij Giselbertus als later bij Wynandus en Philippus een verbinding naar de graven/hertogen van Limburg. Het is denkbaar dat de broers Wynandus en Philippus deel uitmaakten van de entourage rond de hertog en uit dien hoofde een rol vervulden bij de uitoefening van voogdijen, zoals bijvoorbeeld in Kloosterrade. Dat zou hun rol als getuigen in Kloosterrader oorkonden verklaren. Verder worden zowel Giselbertus als Wynandus en Philippus aangeduid als 'vrije mannen' ('liberi homines') en Giselbertus ook als 'homo beneficiatus'. Het blijft moeilijk aan te geven wat met deze standen precies wordt bedoeld, maar vrij zeker ging het om mensen, die in rang direct volgden na de hoge adel en waren te onderscheiden van ministerialen. ${ }^{208}$

\subsection{De familie De Houffalise en Gronsveld}

In de dertiende eeuw wordt in Gronsveld en het aangrenzende Rijckholt gesproken over tienden en landerijen toebehorend aan de adellijke familie De Houffalise. De literatuur over de oudste generaties van dit geslacht is verwarrend. De vroegste vermelding van een telg uit deze familie, Wynandus de Altafalesia, zou zijn te vinden in een akte uit 1147, maar de echtheid van deze oorkonde is twijfelachtig en daarmee ook de historiciteit van deze persoon. ${ }^{209}$ Zelfs Laurent, die op grond van de eerder genoemde akte uit 1147 wel gelooft in het bestaan van Wynandus, toont zich vervolgens zeer gereserveerd in zijn biografische gegevens. ${ }^{210}$ Een stap verder gaat De Ryckel, die Winand de Houffalize vereenzelvigt met Winand van Gronsveld, en deze - en passant - ook nog beschouwt als de eerste heer van Rijckholt. Diens broer Philippus zou dan de stamvader van de latere heren van Gronsveld moeten zijn. ${ }^{211}$ Helaas mist deze theorie iedere onderbouwing en ze komt ook als zeer onwaarschijnlijk over.

Meer historische zekerheid krijgen we eerst bij Theodericus (Thierry) de Houffalize. ${ }^{212}$ Mogelijk moet diens eerste publieke optreden worden geplaatst rond 1176-1180, maar pas vanaf 1190 wordt hij regelmatig in de bronnen vermeld. Zijn moeder was een De Walcourt, want in 1204 noemt Werricus de Walcourt hem 'Tirricus de Hufalise', de zoon van zijn zuster. ${ }^{213}$ Deze afstamming in vrouwelijke linie van het aanzienlijke geslacht De Walcourt schijnt voor Theodericus erg belangrijk te zijn geweest. Tweemaal gebruikt hij

208 Zie voor een uiteenzetting over deze problematiek Van Winter, Ministerialiteit Gelre, 11-39.

209 Gedrukt bij De Hofmann, Recherches, 18-19, nr. 13. In deze akte verklaart Dirk van Horne van zijn oom, graaf Arnold van Loon, achtduizend pond Luiks te hebben ontvangen. Sommige auteurs maken van dit document bij hun genealogische bewijsvoering gebruik, Onder anderen Laurent, 'Houffalise', 263 en 420-421; De Ryckel, 'Histoire Bolland', 81-82; Roland, 'Seigneurs de Rochefort', 336-337; Graindor, L'Avouerie Soiron, 13-14 en anderen trekken de echtheid ervan in twijfel: Baerten, Graafschap Loon, 64. 210 Laurent, 'Houffalise', 420-421.

211 De Ryckel, 'Histoire Bolland', 81-82. Deze mening wordt ook nog gevolgd door De Crassier, 'Dictionaire' onder lemma 'Ryckholt' in: PSHAL 70 (1934) 151-152 en Keyser-Schuurman, Inventaris Rijckbolt, 5-6.

212 Zie over hem Laurent, 'Houffalise', 263-269, 421-424; De Ryckel, 'Histoire Bolland', 82-84.

213 Roland, 'Seigneurs de Rochefort', 343, noot 1. 
een zegel met het wapen van Walcourt (een adelaar met gespreide vleugels), terwijl Houffalize een gouden kruis op een blauw veld voert, bezaaid met kleine kruisjes.214 Theodericus was gehuwd met Lutgardis, een zuster van Arnold, heer van Elsloo. Zijn overlijden wordt kort na 1244 geplaatst. ${ }^{215}$ Theodericus wordt beschreven als een markante persoonlijkheid, die in de gebieden rond Namen en Luxemburg een vooraanstaande rol speelde. Een daad van blijvende betekenis vormde de schenking in 1235 van het Sint-Catharinagasthuis in Houffalize aan de augustijner koorheren van Val des Écoliers te Luik. ${ }^{216}$ Voor ons is Theodericus de Houffalize echter interessant om drie andere redenen, te weten zijn functie als voogd van het Sint-Adalbertstift over Olne en Soiron, het bezit van goederen in Gronsveld en ten slotte een mogelijke rol als heer van Rijckholt.

Omstreeks 1189 of 1197 verklaarde proost Conrad van Sint-Adalbert te Aken dat hij samen met Wiggerus de Wegge voor een lening van 31 mark aan Waggerus, de broer van Wiggerus, de voogdij over Olne en Soiron als onderpand had gekregen. Uit de bepalingen over de aflossing valt op te maken dat Waggerus van plan was deel te nemen aan een kruistocht. Misschien behoorden Wiggerus en Waggerus tot een plaatselijk geslacht van ministerialen, die hun 'advocatia' uitoefenden als 'onderaannemers' van de werkelijke voogd, een verschijnsel dat we eerder al zagen bij Giselbertus de Grules. Die echte voogd wordt aan het einde van de tekst genoemd, wanneer Waggerus de voogdij in pand overdraagt 'door de hand van zijn heer' Theodericus de Houffalize ('per manum domini sui domini Theodorici de Hvfalis').

De verdere lotgevallen van Wiggerus en Waggerus zijn onbekend, maar voor Theodericus de Houffalize en het Sint-Adalbertstift bleef de voogdij over Olne en Soiron een bron van voortdurende zorg. Omstreeks 1228 moesten zij zich verweren tegen de aanmatigingen van de broers Lodewicus en Theodericus Monachus, die kennelijk bescherming genoten van hertog Hendrik IV van Limburg. Koning Hendrik VII beval vervolgens de voogd van Aken en de deken van het Onze-Lieve-Vrouwekapittel aldaar dat zij druk moesten uitoefenen op de hertog en diens broer Walram van Monschau (eerstgenoemde als landsheer, de tweede als diens zaakwaarnemer) om de echte voogd, de vrijgeboren ('liber homo') Theodericus de Houffalize, in zijn rechten te herstellen. ${ }^{217}$ Hoe de zaak afliep, weten we niet, maar uiteindelijk kon het Sint-Adalbertstift zijn gezag in Olne niet tegen de vijandige hertog van Limburg handhaven en werd omstreeks 1240, tegen betaling, bescherming gekocht bij de hertog van Brabant. ${ }^{218}$

${ }^{214}$ De Ryckel, 'Histoire Bolland', 83, noot 83.

${ }^{215}$ Laurent, 'Houffalise', 423.

${ }^{216}$ Russe, 'Abbaye Val-des-Écoliers', 328.

217 Meuthen, Aachener Urkunden, 443-445, nr. 188. Meuthen geeft in zijn commentaar een gedetailleerd overzicht van de diverse dateringen van stuk, die liggen tussen 1190-1197. Aan deze lijst kan in dit verband nog worden toegevoegd Laurent, 'Houffalise', 264, die als datering 1190-1197 opgeeft en de datering 1228 een vergissing noemt. Graindor, L'Avouerie Soiron, 14-15 maakt de verwarring nog groter en gebruikt de tekst liefst twee keer, zowel voor 1190 als 1222 !

218 Uitgave van de desbetreffende tekst bij Meuthen, Aachener Urkunden, 451-452, nr. 195; zie ook Stouren, 'Histoire d'Olne', 135-136; Janssen de Limpens, Rechtsbronnen Limburg en Overmaze, CXXVII-CXXVIII. 
In een akte uit 1233 schenkt Theodericus de Houffalise tienden te 'Groele', die hij had gekocht van Henricus de Hemesbagh, aan de cisterciënzerinnenabdij van Val Bénoit bij Luik. ${ }^{219} \mathrm{Hij}$ deed dit met toestemming van zijn echtgenote Lutgardis [van Elsloo] en zijn twee zonen Henricus en Wilhelmus. Opvallend is de naam van de verkoper, Henricus de Hemesbagh, omdat we die misschien in verband moeten brengen met het dorp Eckelrade en de daar gelegen belangrijke hof Hemersbach.

In 1277 werd voor de abdij van Val Bénoît het bezit van de tienden nog eens bevestigd door de Luikse bisschop Hendrik van Gelre. Deze worden omschreven als een leen en tienden met tien malder rogge en twaalf malder spelt uit de grote tiende van Grules ('feodum et decimam necnon et decem modios siliginis cum duodecim modiis avene in majori decima de Grules').220 Behalve tienden bezat Theodericus de Houffalise misschien nog andere eigendommen in Gronsveld, want in 1281 of 1282 wordt in een oorkonde betreffende grenzen van tiendgebieden gesproken over een bunder land die had toebehoord aan de heer van Houffalize ('unum bonuarium quod fuit domini de Hufalisia'). ${ }^{221}$

Ten slotte moet hier worden gewezen op de rol van de leden van de familie De Houffalize als heren van Bolland en Rijckholt. De geschiedenis van de oudste heren van Bolland is zorgvuldig onderzocht door de Ryckel.222. Zijn eerder genoemde opvattingen over Wynandus de Houffalise, die hij vereenzelvigt met Winand van Gronsveld, mag dan wel geen steun vinden in de bronnen, maar Theodericus de Houffalize was waarschijnlijk wel heer van Bolland. Dit wordt afgeleid uit een te Bolland uitgevaardigde oorkonde van 1232, waarin hij ten behoeve van de abdij van Val-Bénoît de schenking van goederen te Elsloo door wijlen zijn echtgenote Lutgardis bekrachtigt. ${ }^{223}$ Van een eventuele bemoeienis van Theodericus met Rijckholt is niets bekend. Dit geldt echter wel voor zijn zoon Henricus de Houffalise. Deze had in Gronsveld en Rijckholt bezittingen, want hij schonk zijn zoon Willames bij diens huwelijk met Yolent de Rullant (Reuland) ${ }^{224}$ een rente te betalen uit onderpanden te 'Gruelle' en 'Richelle'.225 Een andere zoon, Joannes de Houffalise volgde zijn vader op als heer van Bolland en waarschijnlijk ook van Rijckholt. We ontmoeten hem in 1286, wanneer hij aan de Luikse bisschop Jan van Vlaanderen zijn leen Gronsveld en

\footnotetext{
${ }^{219}$ Tekst gedrukt bij Schoolmeesters, 'Diplômes Val-Bénoît', 130-131, nr. IV.

220 Tekst gedrukt bij Schoolmeesters, 'Diplômes Val-Bénoît', 133-134, nr. VIII.

221 Chestret de Haneffe, 'Histoire Gronsveld', 103-105, nr. 4.

222 De Ryckel, 'Histoire Bolland', 79 e.v.

${ }^{223}$ De Ryckel, 'Histoire Bolland', 83; tekst afgedrukt bij Schoolmeesters, 'Diplômes Val-Bénoît', 130, nr. III.

${ }^{224}$ Laurent, 'Houffalise', 283. Hier wordt ook de tekst afgedrukt van de akte uit 1276, waarbij Cuenes de Rullant toestaat dat de heerlijkheid Fraiture wordt aangewezen als zekerheid van deze huwelijksgift voor zijn dochter Yolent. Regest ook bij: Verkooren, Inventaire chartes Luxembourg I, 216, nr. 275.

225 Men zou kunnen denken dat met 'Richelle' niet Rijckholt, maar de heerlijkheid Richelle wordt bedoeld (zie: Janssen de Limpens, Rechtsbronnen Limburg en Overmaze, CXXX-CXXXI) en met 'Gruelle' de grondheerlijkheid Groules bij Dolhain-Baelen (zie: Buchet, Seigneurie Del Beuck, 18-20). Deze identificatie moet echter vanwege de gemaakte combinatie onwaarschijnlijk worden geacht.
} 
Rijckholt met toebehoren ('mon fief de Grule et de Richele et de leur appendices') in leen opdraagt. 226

De verdere geschiedenis van de familie De Houffalise, die zich inmiddels Van Bolland was gaan noemen, kan hier buiten beschouwing blijven. Wellicht moeten leden van dit geslacht inderdaad worden beschouwd als de eerste heren van Rijckholt. Ook nadat het geslacht Van Bolland al lang uit Rijckholt was verdwenen, bestonden er nog banden tussen beide plaatsen, zoals blijkt uit de hoofdvaart die de schepenen van Rijckholt hadden op de schepenbank van Bolland.

Maar moeten leden van de familie De Houffalise ook worden beschouwd als heren van Gronsveld? Concrete bewijzen daarvoor zijn er niet. Het sterkste argument is dat geen bewezen verbinding bestaat met personen die we in de dertiende eeuw als heren van Gronsveld moeten beschouwen. Dat sluit oudere verwantschap niet uit. Misschien wijst het bezit van de voogdij over Olne op familiebanden tussen Giselbertus de Grueles aan het begin van de twaalfde eeuw en Theodericus van Houffalise aan het einde van die eeuw. Ook de oorkonde uit 1233 waarin Theodericus tiendrechten te Groele aan de abdij van Val Bénoît schenkt, maakt ons ook niet veel wijzer. Weliswaar hadden de heren van Gronsveld later tiendrechten in Gronsveld, maar 'Groele' hoeft in dit verband niet exclusief op Gronsveld te slaan en kan ook betrekking hebben op Rijckholt. De kerk van Gronsveld, ten behoeve waarvan tienden in oorsprong werden geheven, was immers parochiekerk voor zowel Gronsveld als Rijckholt. Ook ging het bij deze tienden niet om oud bezit van de Houffalizes, want Theodericus verklaarde dat hij deze eerder had gekocht van Henricus de Hemesbagh. Waarschijnlijk betreft het tienden van grond die kort tevoren in cultuur was gebracht. Ten slotte is de constatering dat er aan het einde van de dertiende eeuw grondbezit van de familie de Houffalise in Gronsveld geweest, te vaag om diepgaande conclusie aan te verbinden.

\subsection{De heren Van Gronsveld/V an Stolberg in de dertiende eeun}

In het navolgend overzicht worden in chronologische volgorde de oorkonden uit de dertiende eeuw behandeld, die betrekking hebben op de familie Van Gronsveld. Aan het slot daarvan worden daaruit de conclusies besproken. Herhaald wordt nog eens dat het hier gaat om gegevens die ook op traceerbare oorkonden zijn gebaseerd.

In een oorkonde uit 1241 bevestigt 'Willelmus', 'edele, heer van Gronsveld' (vir nobilis, dominus de Gronsele), ten behoeve van de abdij van Val-Dieu de overdracht van diverse percelen bos en land gelegen in en bij een plaats die 'Dales' werd genoemd. Die goederen waren al eerder door zijn (niet met naam genoemde) moeder aan de abdij geschonken, maar kennelijk wilde Wilhelmus geld zien, want voor de bevestiging verlangde hij betaling van cijnzen. De tekst vermeldt dat het gaat om vrije eigendom ('francum et liberum allodium'), terwijl ook wordt gesproken over enkele stukken grond die 'mansionarii' (waarschijnlijk boeren, die hun goederen volgens laatrecht in bezit hadden) van Wilhelmus

${ }^{226}$ Bormans/Schoolmeesters, Cartulaire Saint-Lambert, 2, 402-403, nr. 771. 
al eerder aan het klooster hadden verkocht.227 Het aan de oorkonde hangende zegel heeft als afbeelding een schild met lelies en in het midden een kruis, terwijl het randschrift de tekst draagt WILLE[L]MI. DE. STALBURHC.

Deze Wilhelmus van Gronsveld, die zich kennelijk ook Van Stalburch noemt, moet wel dezelfde persoon zijn als Willem, heer van Stalburg, die in 1237 samen met zijn echtgenote Lutgardis, verklaart tweehonderd mark in Keulse munt te hebben ontvangen van hertog Hendrik IV van Limburg. Voor dat bedrag hadden zij onder andere goederen die zij al te 'Holsey' (Holset) bezaten, als leengoed terugontvangen.228 Voorts schonken in 1255 dezelfde Willem, heer van Stalburg en Gronsveld en Lutgardis zijn echtgenote grond aan de cisterciënzerinnen van de abdij Herkenrode bij Hasselt (B). Deze gift werd goedgekeurd door hun zoon Reiner, heer van Stalburg en diens echtgenote Beatrix. ${ }^{229}$

In 1258 gaf bisschop Hendrik van Gelre, bisschop van Luik, opdracht aan de deken van het landdekenaat Maastricht om Reinerus, heer van Stalburg en Gronsveld, te vermanen om de abdij van Herkenrode niet meer lastig te vallen over het bezit van tienden in Gronsveld. Deze tienden waren door de inmiddels overleden Wilhelmus van Stalburg, de vader van Reinerus, met toestemming van zijn echtgenote Lutgardis aan de zusters geschonken. ${ }^{230}$ Wanneer men aanneemt dat Reinerus van Stalburg/Gronsveld in 1255 minstens twintig jaar oud was, dan moet zijn geboortejaar in de midden van de jaren dertig van de dertiende eeuw liggen. Dit correspondeert met de eerste vermelding van zijn ouders in 1237. Willem van Gronsveld/Stalburg zou dan kunnen zijn geboren tussen 1210 en 1220 .

Op naam van Reinerus (Reinardus), edele en heer van 'Grunselt' en zijn vrouw Beatrix staat vervolgens een oorkonde uit 1261, waarin zij wederom een overeenkomst sluiten met een cisterciënzerinnenklooster, ditmaal de abdij van Hocht (B). ${ }^{231}$ Het betreft de verkoop van een hof ('curia') te Eckelrade voor 42 pond Luiks geld. Zowel het zegel van Reinerus als van zijn echtgenote hangen - beschadigd - aan het document. Het eerste laat een schild zien met een kruis en vier lelies en heeft als randschrift: + S. REINARDI....E STOL...C. Het tweede zegel toont in ovaal een vrouwenfiguur met lelie of scepter in de hand, terwijl de tekst van het randschrift luidt: BEATR...IS DOMIN...DE STOLBO...

Tot de derde generatie van deze familie Van Gronsveld moeten we wel 'Johannes, dominus de Grules', rekenen. Deze verklaarde in 1271 af te zien van alle aanspraken op bos, geheten 'Grules' met aangrenzend land, gelegen bij Sint-Martens-Voeren. De monniken van Val-Dieu hadden dit tegen betaling van cijns gekocht van wijlen zijn grootvader of 'voorvader' W[ilhelmus] de Grules ('quondam avo meo'). ${ }^{232}$ Omdat hij geen

227 Tekst gedrukt bij Ruwet, Cartulaire Val-Dieu, 60-61, nr. 74, met beschrijving van het stuk en zegel alsmede literatuuropgave. De plaats 'Dales' kon Ruwet niet verder identificeren.

228 Regest bij Verkooren, Inventaire chartes de Brabant, Ie stuk, Chartes originales, 1, 35, nr. 35.

${ }^{229}$ Regesten bij Daris, Cartulaire Herkenrode, 20 en bij Chestret de Haneffe, 'Histoire Gronsveld', 103.

230 Afgedrukt bij Reusens, 'Documents Herkenrode', 261-262. De auteur vergist zich in de transcriptie, wanneer hij 'Aelburg' schrijft in plaats van Stalburg.

231 Rijksarchief Hasselt, Abdij Hocht, inv. nr. 13. Regest met zegelbeschrijving bij Buntinx, Inventaris Hocht, 11-12, nr. 13; de tekst afgedrukt bij Hartmann, Reconstructie landschap, 314-315.

232 Tekst gedrukt bij Ruwet, Cartulaire Val-Dieu, 163, nr. 174. 
eigen zegel had, vroeg Johannes aan de 'edele heren en ridders' Alexander de Viller, Gerardus de Berghe, 'slotvoogd' ('castellanus') van Dolhain en Theodericus van Haren deze verklaring voor hem te bezegelen.

Mogelijk verwijst deze bevestiging naar de al genoemde overdracht van bos en land door Wilhelmus de Gronsele in 1241. Het feit dat Johannes spreekt over zijn voorvader of grootvader doet vermoeden dat hij een kleinzoon was van Wilhelmus van Gronsveld en Stalburg. Waarschijnlijk was hij al omstreeks 1281/1282 overleden, omdat dan, zoals hierna aan de orde komt, voogden optreden voor de zoon van de heer van Gronsveld.

In de tweede helft van de dertiende eeuw wordt enkele malen zijdelings in oorkonden melding gemaakt van een zekere Rutgerus of Rucherus van Gronsveld. Zo verkochten in 1256 Johannes genaamd Crusen en zijn vrouw Ida land gelegen te Wyck bij Maastricht aan het klooster van de Wittevrouwen te Maastricht, welke gronden leenroerig waren aan ridder Rucherus de Gronselt en Henricus de Oys, genoemd de Wic. ${ }^{233}$ In 1281/1282 wordt gesproken over land in Gronsveld dat vroeger had toebehoord an heer Rutgerus de Grunselt. ${ }^{234}$ Ten slotte scheldt in 1285 graaf Hendrik van Kessel de abdij van Gladbach (D) cijnzen kwijt, die dit klooster moest betalen van bepaalde landerijen in de parochie Keyenburg (D), welke gronden vroeger hadden toebehoord an zekere Rutgerus, zoon van ridder Reynardus de Grunseilt. ${ }^{235}$

De hiervoor genoemde oorkonden leveren een waarschijnlijke genealogie op van ten minste drie generaties:

1) Wilhelmus van Gronsveld-Stolberg $x$ Lutgardis (vermeldingen 1237, 1241);

2) Reinerus van Gronsveld-Stolberg x Beatrix (vermeldingen 1258, 1261);

3) zonen: Johannes (vermeld 1271) en Rutgerus, (vermeld 1256, overleden vóór 1281). Wilhelmus, Reinerus en Johannes worden ook 'heer van Gronsveld' genoemd, zodat mag worden aangenomen dat zij dat ook werkelijk waren. Over Rutgerus bestaat op dit punt onduidelijkheid. Met deze heren begint dus de heerlijkheid Gronsveld.

Een grote vraag blijft aan wie zij dit heerlijk gezag ontleenden. We stuiten hier op een meer algemeen probleem, want in de loop van de tijd hebben historici verschillend gedacht over de herkomst van overheidsgezag (jurisdictie en andere regalia) bij de adel. ${ }^{236}$ De opvatting dat heerlijkheden vooral zouden zijn ontstaan door usurpatie van rechten uit afbrokkelend koninklijk gezag wordt inmiddels als achterhaald beschouwd. Tegenover de theorie van het 'verval' staat de mening dat het gezag van de adel in de hoge middeleeuwen juist het resultaat was van een proces van opbouw, waarbij 'nobiles', stammend uit geslachten die vanouds betrokken waren bij bestuur en rechtspraak, rechten van diverse herkomst, met als kern jurisdictie, tot 'heerlijkheid' wisten te bundelen. Basis daarvoor zouden zijn 'autogene Herrschaftsrechte', dat wil zeggen rechten 'die nicht vom König

233 RHCL, Klooster Witte Vrouwen te Maastricht, inv. nr. 59; regest bij Roosenboom, Inventaris Witte Vrouwen, 67, nr. 6.

234 Afgedrukt bij Chestret de Haneffe, 'Histoire Gronsveld', 103-105, nr. 4.

235 Gedrukt bij Lacomblet, Urkundenbuch II, 476-477, nr. 806.

236 Zie daarover het samenvattend overzicht van Hechberger, 'Adel und Herrschaft'. 
stammten, sondern aus der Hausherrschaft erwuchsen'. 237 Tot deze 'autogene' rechten hoorden rechten uit grondbezit, verder bepaalde overheidsrechten die vroeger al door bepaalde families werden uitgeoefend en soms ook rechten die door usurpatie waren verworven. Zo ontstonden vanaf de twaalfde eeuw naast de 'oud-grafelijke' families nieuwe families die de graventitel voerden. Dit verschijnsel kan zich ook bij lagere adel en 'heren' op plaatselijk niveau bij de vorming van nieuwe 'heerlijkheden' hebben voorgedaan. Een deel van deze heerlijkheden is naderhand leenrechtelijk met grote landsheerlijkheden verbonden geraakt in de vorm van 'onderheerlijkheden'. ${ }^{238}$

Hoe dit proces in concrete gevallen op plaatselijk niveau verliep, valt door gebrek aan bronnen niet meer te achterhalen. Dat geldt zeker ook voor kleine heerlijkheden zoals Gronsveld. Wel moeten we vaststellen dat de mogelijkheden voor het ontstaan van een heerlijkheid hier gunstig waren. De heren van Gronsveld in de dertiende eeuw behoorden duidelijk tot de hogere adel en moeten op grond van hun positie vertrouwd zijn geweest met gezagsuitoefening. Voorts was in Gronsveld sprake van een domein of grondbezit, waarover rechten konden worden uitgeoefend. Het bijzondere van Gronsveld (maar bijvoorbeeld ook van Rijckholt en Wylre) steekt hierin dat het geen afsplitsingen van naburige territoria waren, dat zij hun status als allodium (vrije eigendom) hebben weten te behouden, en dat zij nooit juridisch afhankelijk zijn geworden van een andere grote landsheerlijkheid. Het die vorm van onafhankelijkheid waarvoor in de zestiende eeuw de juridische fictie van het 'zonneleen' werd bedacht.

De diverse goederen buiten Gronsveld waarover in de dertiende eeuw verband met deze heren van Gronsveld wordt gesproken, zien we later weer terug bij de familie. De latere Gronsveldse lenen in Vaals en Holset gaan mogelijk terug op goederen in Holset, waarover in 1241 wordt gesproken. Ook is bekend dat de heren van Gronsveld in de veertiende eeuw veel bezittingen hadden in het hertogdom Limburg en in de omgeving van Val-Dieu.

Het materiaal roept echter nog vele vragen op. Onduidelijk blijft of deze heren van Gronsveld kunnen worden 'vastgeknoopt' aan de personen met de achternaam 'de Grule' of een variant daarvan in de dertiende eeuw. De herkomst of mogelijke afstamming van de Houffalizes blijft daarmee ongewis. Onzekerheid blijft ook bestaan over de verbinding van Gronsveld met Stallburch, Stalburg et cetera. De verschillende schrijfwijzen verwijzen zonder twijfel naar het kasteel Stolberg, de hoogteburcht boven de gelijknamige stad ten oosten van Aken. Het is een plaats met een bewoningsgeschiedenis die teruggaat tot de Romeinse tijd. ${ }^{239}$ Aan de geschiedenis van de vroegst bekende heren van Stolberg zijn in het verleden enkele publicaties gewijd. Daaruit blijkt dat zij het eerst genoemd worden in

237 Hechberger, 'Adel und Herrschaft', 59, met verwijzing naar O. Brunner, Land und Herrschaft. Grundfragen der territorialen Verfassungsgeschichte Österreichs im Mittelalter, 5. Aufl. 1990).

238 Janssen, 'Unterherrschaften'; zie in dit verband ook de bijdrage van Frankewitz, 'Adel und Territorialisierung' met het voorbeeld van de heerlijkheden langs Maas en Rijn die de graven respectievelijk hertogen van Gelre aan hun graafschap/hertogdom Gelre wisten te verbinden door leenopdracht, aankoop, verpanding et cetera.

239 Zie voor beschrijving van kasteel Stolberg en de geschiedenis van Stolberg: Reiners, Kunstdenkmäler Aachen und Eupen, 180 (546) - 185 (551); Keyser, Rheinisches Städtebuch, 387-390; Von Oidtman, 'Burg Stolberg'. 
oorkonden uit de twaalfde eeuw, maar een samenhangende genealogie valt uit die vermeldingen niet te distilleren. De poging die Bornheim gen. Schilling in deze richting heeft ondernomen, is daar een voorbeeld van. ${ }^{240}$ Opmerkelijk is wel dat voor de twaalfde eeuw bij deze heren van Stolberg de voornamen 'Willem' en 'Reinerus', of varianten daarop, voorkomen. Op welke wijze de combinatie Gronsveld-Stolberg is ontstaan, blijft vooralsnog duister. ${ }^{241}$ Vanaf de derde generatie komt dit niet meer voor.

Vraagtekens blijven ook bestaan rond de herkomst van Beatrix, de echtgenote van Reinerus van Gronsveld en van Stolberg. Het is niet onmogelijk dat zij een dochter was van Gerard, heer van Wassenberg en Beatrix van Randenrath, waarmee zij van vaderskant zou afstammen van de hertogen van Limburg. Helaas valt deze veronderstelling vooralsnog niet hard te maken. ${ }^{242}$ Maar afkomst uit een aanzienlijke familie staat wel vast, gelet op het fraaie zegel dat zij voerde. Helaas komt dit niet voor in een recente inventarisatie van Rijnlandse vrouwenzegels uit de dertiende eeuw, zodat niet duidelijk is of er een tweede exemplaar bestaat. ${ }^{243}$ Uit deze studie blijkt wel dat zegels in die tijd

240 Bornheim gen. Schilling, 'Geschichte Reifferscheidt', 110-115. Zo is er het probleem van de verhouding tot het geslacht Von Frenz, dat zich ook van Stolberg noemt: Zie over deze familie ook: Schleicher, Oidtman Sammlung, 6, 236-244.

241 In de genealogie die daarover op Wikipedia wordt gepubliceerd (inzage 1-9-2014) wordt gewag gemaakt van een huwelijk tussen Willem van Stolberg en Lutgardis van Houffalize. Impliciet wordt er daarbij van uitgegaan dat de Houffalize's ook heer van Gronsveld waren. Het is een interessante gedachte, maar iedere bewijsvoering ontbreekt.

242 In de genealogie die daarover op Wikipedia wordt gepubliceerd (inzage 1-9-2014) wordt gewag gemaakt van een huwelijk tussen Reinerus van Stolberg en Beatrix van Wassenberg, een dochter van Gerhard van Wassenberg (- ca. 1254) en Beatrix van Randerode. Gerard was een kleinzoon van hertog Hendrik III van Limburg en Sophie van Saarbrücken. Bewijsvoering van dit alles ontbreekt echter. Toch is een verbinding met de heren van Wassenberg niet onmogelijk. Op basis van wél gedocumenteerde bijdragen van Corsten, 'Gerhard von Wassenberg' en Venner, 'Linne in de dertiende eeuw') komen we tot de volgende stamboom:

Gerard I van Wassenberg, zoon van hertog Hendrik III van Limburg en Sophia van Saarbrücken huwde vóór 1212 met Beatrix, dochter van Rutger van Mereheim. Gerard was in 1225 overleden, Beatrix na 1243. Uit dit huwelijk werden geboren Gerard II van Wassenberg (vermeld 1235-1253, overleden 1254), Hendrik en Rutger (vermeld 1248).

Gerard II van Wassenberg was twee keer gehuwd. Als tweede echtgenote staat vast Elisabeth van Brabant, later vrouwe van Sprimont. Zij overleed na 1260. Over dit huwelijk bestond een probleem, want in 1247 werd het op bevel van de paus wegens bloedverwantschap ontbonden, mogelijk later alsnog gedispenseerd (Rosenkrantz, 'Bijdrage geschiedenis graven Kessel'). Als eerste echtgenote wordt in diverse genealogieën op internet genoemd Beatrix van Randenrath. Bewijsplaatsen ontbreken echter. Vast staat dat uit het eerste huwelijk van Gerard II en Beatrix van Randenrath? een zoon, Gerard III van Wassenberg, werd geboren. Deze was overleden vóór 1259. Verder zou er nog een dochter zijn, die huwde met Reinerus van Gronsveld en van Stolberg. Er zijn, ook zonder harde bewijzen, wel argumenten die pleiten voor afstamming van de echtgenote van Reinerus van Gronsveld en Stolberg uit het geslacht van Wassenberg. Zo voerde ook haar veronderstelde schoonmoeder, Beatrix van Mereheim een vergelijkbaar vrouwenzegel. Verder moet er op worden gewezen dat Reinerus en Beatrix een zoon hadden met de naam Rutger. Deze zou genoemd kunnen zijn naar Rutger van Wassenberg, de oom van Beatrix. Het is opmerkelijk dat deze zoon Rutgerus de Grunselt goederen had in Keyenberg bij Erkelenz, ogenschijnlijk een geïsoleerd bezit, maar vanwege de ligging niet ver van Wassenberg wel verklaarbaar als goederen die van de heren van Wassenberg afkomstig kunnen zijn.

${ }^{243}$ Stieldorf, Rheinische Frauensiegel. 
werden gebruikt door vrouwen uit grafelijke geslachten of daarmee in adeldom vergelijkbare families. ${ }^{244}$

Van Johannes I van Gronsveld weten we ten eerste dat hij in de genealogie van de dertiende-eeuwse heren van Gronsveld past, ten tweede dat hij in 1271 volwassen was, maar waarschijnlijk nog jong omdat hij geen eigen zegel voerde en ten derde dat hij waarschijnlijk heer van Gronsveld was. In de enige oorkonde die van hem bekend is, gebruikt hij de naam Stolberg niet en dat doen de generaties na hem ook niet meer. ${ }^{245}$ Waarschijnlijk is hij niet lang na 1271 overleden, want in 1281 of 1282 deden arbiters een uitspraak in een geschil over de afbakening van tiendgebieden in Breust en Gronsveld tussen enerzijds het kapittel van Sint-Martinus te Luik (tevens heer van Breust) en anderzijds de abdij van Val-Benoit en Johannes van Hafkendale als voogd van Johannes, zoon van de heer van Gronsveld ('mamburnum Johannis pueri domini de Grunselt'). ${ }^{246}$ Uit het feit dat deze Johannes, die we het volgnummer II geven, werd vertegenwoordigd door een voogd mogen we afleiden dat hij op dat moment nog minderjarig was.

\subsection{Johannes II van Gronsveld, 1303-na 1314}

\subsubsection{Verwantschap met de familie V an Hafkesdale}

De naam van de vader of moeder van Johannes II van Gronsveld is niet bekend. Wat betreft leeftijd zou hij een zoon kunnen zijn van Johannes I heer van Gronsveld, die in 1271 optreedt, maar ook afstamming uit een zijlinie, bijvoorbeeld een dochter van Reinerus van Gronsveld en Beatrix, is denkbaar. Interessant is echter de naam van de voogd, Johannes van Hafkesdale. Het ligt voor de hand dat een dergelijke persoon werd gezocht in de familiekring, mogelijk een oom of oudoom. Het is vrijwel zeker dat de naam van deze voogd wijst op verwantschap met een belangrijke adellijke familie uit de dertiende eeuw in het tegenwoordige Zuid-Limburg. Onduidelijk blijft vooralsnog hoe die verbinding precies moet worden gelegd. Naderhand blijken ook het familiewapen en bezittingen van de familie Van Hafkesdale te zijn overgegaan op het geslacht Van Gronsveld. Dit vormt reden genoeg wat uitvoeriger bij dit geslacht stil te staan.

\footnotetext{
${ }^{244}$ Zie over dameszegels uit deze tijd: Diederich, 'Grundzüge Siegelwesens', 98-101 en vooral Stieldorf, Rheinische Frauensiegel, passim.

245 Stieldorf, Rheinische Frauensiegel, 420 en 519, vermeldt dat na het overlijden van Willem IV, heer van Stolberg en Setterich, en zijn echtgenote Mechtild van Reifferscheid, de heerlijkheden Stolberg en Setterich vererfden op hun dochter Hedwig. Deze was eerst gehuwd met Arnold van Gymnich, heer tot Setterich en Heppendorf (1285-1320) en daarna met Arnold van Randenrath. De genealogische samenhang met de familie van Gronsveld is niet duidelijk, maar opmerkelijk is wel dat Arnold van Gymnich en zijn echtgenote in het bezit waren van het Vylener Bos dat in 1319 door ridder Arnold van Gymnich en zijn echtgenote als allodiaal goed aan de abdij Burtscheid werd geschonken. Vgl. verder Hoofdstuk 2.8.2.

${ }^{246}$ Tekst afgedrukt bij Chestret de Haneffe, 'Histoire Gronsveld', 103-105, nr. 4.
} 
De familie Van Hafkesdale ${ }^{247}$ was in de dertiende eeuw een aanzienlijk geslacht, dat zich noemde naar het gehucht Haasdal, gelegen onder Schimmert. ${ }^{248}$ In de genealogie kunnen we vier opeenvolgende generaties in de dertiende eeuw onderscheiden:

I Onbekend ouderpaar. Misschien was de vader Goswinus van Hafkesdale. ${ }^{249}$ Uit dit huwelijk drie broers:

1) Alardus, volgt onder II.

2) Henricus, vermeld 1253 , ridder.

3) Anselmus, vermeld 1253, ridder.

II Alardus van Hafkesdale, in 1217 het eerst vermeld, 250 na 1237 ridder genoemd, ${ }^{251}$ treedt meermalen op als getuige in oorkonden, ${ }^{252}$ makt in 1253 zijn testament, ${ }^{253}$ overleden tussen 1258 en 1265 . Hij voert als wapen een schild met drie koeken of bollen. ${ }^{254}$ Gehuwd met Agnes NN, overleden tussen 1253 en 1265. Kinderen uit dit huwelijk:

1) Henricus, volgt onder III.

2) Hermannus, overleden vóór 1253.

3) Elisabeth, vermeld 1253, begijn 1265 te Maastricht. ${ }^{255}$

III Henricus van Hafkesdale, 1232 het eerst vermeld, ${ }^{256}$ gehuwd met Mechtildis, dochter van Franco van Reulant, voor 1253 als monnik ingetreden in de abdij van Val-Dieu. ${ }^{257}$ Uit het huwelijk zijn drie kinderen bekend:

1) Johannes, volgt onder IV.

2) Elisabeth, in 1253 meerderjarig, volgens testament van haar grootvader bestemd voor het huwelijk.

3) Aleidis, in 1253 minderjarig, volgens testament van haar grootvader bestemd voor de geestelijke stand.

Er wordt beweerd dat Hendrik ook gehuwd is geweest met een dochter van Reinerus van Gronsveld en Beatrix (zie hierna), maar bewijzen ontbreken.

247 Als spellingsvarianten werden onder andere aangetroffen: Hakendale, Haefkesdael, Hafcesdale, Hafkisdale, Havigisdail, Hafkendale, Havekensdale, Haveskendale, Haskedale, Haesdall, Havekesdall Haesdall en Hankesdale. Hier wordt gebruikt Hafkesdale.

${ }^{248}$ Crassier, 'Dictionnaire' onder lemma 'Schimmert', in: PSHAL 70 (1934) 168-169.

${ }^{249}$ Ernst/Lavalleye, Histoire Limbourg, 6, Codex Diplomaticus V alkenburgensis, 7-8, nr. 4 (1190).

250 Polak/Dijkhof, Oorkondenboek Kloosterrade, 135-137, nr. 62; 154-156, nr. 73; Lacomblet, Urkundenbuch II, nr. 70 .

${ }^{251}$ Ernst/Lavalleye, Histoire Limbourg, 6, Codex Diplomaticus V alkenburgensis, 9-10, nr. 6

252 Zie Franquinet, Inventaris St. Gerlach, 6-7, nr. 4 (1232); 9-10, nr. 6 (1241); 12-13, nr. 8 (1254); 14-16, nr. 10 (1258); Grauwels, Regestenlijst Oudenbiezen I., 7, nrs. 21 en 22 (1247), Ernst/Lavalleye, Histoire Limbourg, 6, Codex Diplomaticus Valkenburgensis, 11-12, nr. 9 (1244).

${ }^{253}$ In het kader van de regeling van de nalatenschap worden vier oorkonden uitgevaardigd, waaruit een deel van de genealogische samenhang duidelijk wordt: zie Ruwet, Cartulaire Val-Dieu, 92-99, nrs. 110, 111, 112 en 113. Zie verder de opmerkingen over dit testament bij Ruwet, 'Livre anniversaires Val-Dieu', 48.

254 Beschreven en afgebeeld in Corpus Sigillorum I, 88 nr. 902 en II, zegel 902.

255 Ruwet, Cartulaire Val-Dien, 136-137, nr. 147.

256 Franquinet, Inventaris St. Gerlach, 6-7, nr. 4.

${ }^{257}$ Ruwet, Cartulaire Val-Dieu, 98-99, nr. 113. 
IV Johannes van Hafkensdale, het eerst genoemd in 1253 als kleinkind ('nepotem') van Alardus, keurt in 1265 schenkingen van zijn tante Elisabeth, begijn, goed, ${ }^{258}$ treedt tussen 1273 en 1302 meermalen als getuige op in oorkonden. ${ }^{259}$ In zijn zegel voert hij als wapen een schild met drie koeken of bollen. ${ }^{260}$ Met Johannes van Hafkesdale schijnt de familie in rechte lijn te zijn uitgestorven. ${ }^{261}$

Niet plaatsbaar in dit overzicht zijn Arnoldus van Hafkesdale, die waarschijnlijk begin veertiende eeuw goederen bezat te Maastricht ${ }^{262}$ en de in het obituarium of dodenboek van het klooster van Houthem-Sint Gerlach genoemde Helwigis de Haesdall, Agnes de Havekesdall, Henricus de Haesdall en Gertrudis de Hankesdale. ${ }^{263}$

De heren Van Hafkesdale makkten deel uit van een vaste groep vertrouwelingen en raadslieden rond de heren van Valkenburg, te weten Dirk I (1207((?))-1227), Dirk II (1236-1268) en Walram (1268-1302). ${ }^{264}$ Tot deze kring behoorden ook leden van ZuidLimburgse geslachten als Duker, Van (Borg)Haren en Van Meerssen. Als leenmannen ('feodati') en 'burgmannen' ('castellani') steunden zij de heren van Valkenburg bij militaire operaties. Goede relaties onderhield de familie van Hafkesdale met de norbertinessen van Houthem-Sint-Gerlach (in hun klooster werd voor verschillende leden van de familie een jaargetijde gesticht) en in het bijzonder met de cisterciënzers van Val-Dieu. Henricus van Hafkesdale trad daar na het overlijden van zijn echtgenote in, zijn vader Alardus bedacht de abdij met grote schenkingen en volgens het jaargetijdenboek van het klooster werden op liefst vier data leden van de familie herdacht. ${ }^{265}$

258 Ruwet, Cartulaire Val-Dieu, 139-140, nr. 150.

259 Zie Franquinet, Inventaris St. Gerlach, 21-22, nr. 16 (1273); 26-28, nr. 23 (1288); 33-35, nr. 29 (1302); Grauwels, Regestenlijst Oudenbiezen I, 21, nr. 66 en 67 (1276); 23, nr. 73 (1281), Bormans/Schoolmeesters, Cartulaire Saint Lambert, 2, 276-277, nr. 691 (1277); Ernst/Lavalleye, Histoire Limbourg, 6, Codex Diplomaticus Valkenburgensis, 29-32, nr. 29 (1275); 34-38, nrs. 32 en 33 (1283); 44-45, nr. 42 (1300); Ernst/Lavalleye, Histoire Limbourg, 6, Codex Diplomaticus Limburgensis, 327-329, nr. 266 (1284); Korth, Wipperfürth, 101 (1302).

260 Rijksarchief Limburg te Hasselt, Regestenlijst der oorkonden van de Landkommanderij Oudenbiezen en onderhorige Kommanderijen, nrs, 66 en 67; beschreven en afgebeeld in Corpus Sigillorum I, 88 nr. 903 en 904 en II, zegels 903 en 904.

261 De mogelijke overgang van het wapen aan de heren van Gronsveld komt hierna nog aan de orde. Mogelijk bestaat er ook een relatie met de oudste heren van Schaesberg. Een van de vroegst bekende leden van deze familie, Johan van Schaesberg, kanunnik van het kapittel van Onze-Lieve-Vrouw te Maastricht, gebruikt in 1301 en 1306 een wapen waarop onder een barensteel met drie hangers drie bollen staan afgebeeld, cfr. Ramakers, 'Schaesbergse erfenis', 270. Volgens Franquinet, 'Les Schoonvorst', 229 en Chestret de Haneffe, 'Renard de Schönau', 4-5, zou ook het adellijk geslacht Van Schoonvorst, dat in de veertiende eeuw een belangrijke speelde in de Landen van Overmaze en de hertogen van Brabant financierde, aan de familie Van Hafkesdale verwant zijn.

262 Goederen van wijlen Arnoldus worden vermeld in het testament van Elisabeth de Molendino te Maastricht uit 1350: zie Franquinet, Inventaris Predikeheren, 59-60.

263 Habets, 'Houthem-Sint Gerlach', 183, 185, 186, 193.

264 Zie over deze heren van Valkenburg: Van de Venne, Geschiedenis kasteel Valkenburg, $70-88$ en Corsten, 'Herren Valkenburg', 178-188.

265 Ruwet, 'Livre anniversaires Val-Dieu', 48. 54, 63, 74. 
Hoe de verwantschap tussen de familie Van Hafkesdale en Johan van Gronsveld precies is ontstaan, valt niet met zekerheid te zeggen. Mogelijk was Elisabeth van Hafkesdale, de dochter van Henricus van Hafkesdale, zijn moeder. Zij was immers volgens het testament van haar grootvader bestemd voor het huwelijk. Een andere, maar niet onderbouwde, lezing, geeft Hardenberg, die spreekt over een huwelijk tussen een kleindochter van Wilhelmus van Gronsveld en Stolberg met Rutger van Haasdal.266 Een derde variant is te vinden bij het lemma 'Luitgarda van Stolberg' in de Wikipedia (inzage 30-8-2014) waarbij deze Luitgarda als dochter van 'Reinhard III van Stolberg-Van Aken en Beatrix van Wassenberg' wordt gekoppeld aan Hendrik van Haasdal (die verder allerlei onjuiste kwalificaties krijgt toegevoegd). Het blijft echter speculeren.

$\mathrm{Na}$ het uitsterven (ten minste in rechte lijn) van de familie Van Hafkesdale, is in ieder geval de kern van het familiebezit, de hof Haasdal, overgegaan op het geslacht Van Gronsveld en tot de vijftiende eeuw ook in deze familie gebleven (zie Hoofdstuk 1.7.3 en 1.8.2). Voorts werd door Johannes II van Gronsveld het familiewapen van zijn voorvaderen, een kruis met vier lelies, verruild voor een schild met drie bollen of koeken, het teken van de familie Van Hafkesdale. Naar de reden daarvan kan slechts worden gegist. In ieder geval vormen vanaf die tijd de drie bollen een vast element in het wapen van de heren van Gronsveld. ${ }^{267}$

\subsubsection{Levensloop en publiek optreden}

De eerste keer dat we Johan II van Gronsveld als volwassene zien optreden is in 1303, als getuige voor Dirk III, heer van Valkenburg. ${ }^{268}$ Een jaar later - hij is dan ridder - draagt hij een hoeve, land, bos en cijnzen, gelegen te Sint-Pieters-Voeren, die een zekere Henricus de Campis van hem in leen hield, over aan de commanderij van de Duitse Orde in Aldenbiezen. ${ }^{269}$ In 1308 en 1311 fungeert hij weer als getuige, de eerste keer als leenman van de bisschop van Luik, ${ }^{270}$ de tweede keer bij een bijzondere gelegenheid, de opstelling van het huwelijkscontract tussen Sophia van Berthout, dochter van de heer van Mechelen, en graaf Reinoud van Gelre. ${ }^{271}$ In 1314 wordt Johan enkele malen vermeld als bezitter van

\footnotetext{
266 Hardenberg, 'Heren Schinnen', 56.

267 Het is overigens interessant vast te stellen dat deze drie bollen of koeken ook voorkomen op de wapenschilden van families die mogelijk met de Van Haasdals verwant zijn. Daarbij valt in de eerste plaats te noemen het oude geslacht Van Printhagen. Leden van deze familie hoorden in de dertiende eeuw ook tot de entourage van de heren van Valkenburg, zij hadden diverse bezittingen in Beek en de benaming Printhager Hoven in Beek-Genhout herinnert aan hun activiteit als hoofdontginners van dit gehucht. Maar bovenal wordt in dit verband een verbinding tussen beide families aannemelijk wanneer men bedenkt dat Genhout en Haasdal slechts een steenworp van elkaar verwijderd liggen, vgl. Luijten, 'Hoochlant', 9-11.

${ }^{268}$ Grauwels, Regestenlijst Oudenbiezen I, 33, nr. 102.

${ }^{269}$ Grauwels, Regestenlijst Oudenbiezen III, 821, nr. 2295. Gebrekkig afgedrukt bij Chestret de Haneffe, 'Histoire Gronsveld', 105-106, nr. 5; afschrift in RHCL, Rijkskamergerecht, inv. nr. 230, fol. 23vo.-24. 270 Lahaye, Inventaire Saint-Jean, 132, nr. 261.

271 Regest bij Verkooren, Inventaire chartes de Brabant, Ie stuk, Chartes originales, 1, 171-176, nr. 231; uitgegeven bij Croenen, Oorkonden Berthout, 418-425, nr. 333, met beschrijving van zegel.
} 
leengoederen in het hertogdom Limburg (zie hierna Hoofdstuk 1.4.3). Waarschijnlijk is hij kort daarna overleden.

Wolters beweert dat Johan II was gehuwd met Margaretha, dochter van Werner van Merode. ${ }^{272}$ In die opvatting wordt hij gevolgd door Chestret de Haneffe, die Margaretha een dochter noemt van Werner van Merode en Laura van Binsfeld. Zij zou weduwe zijn in 1326. ${ }^{273}$ Chestret verwijst daarbij naar handschriften van de genealogen Goethals en Le Fort, maar het is twijfelachtig of dezen het bij het juiste eind hebben. In de door Domsta met veel zorg samengestelde genealogie van het geslacht Van Merode komen deze Margaretha van Merode en haar ouders niet voor. ${ }^{274}$ Johan II moet tenminste een zoon en een dochter hebben gehad, namelijk zijn opvolger Hendrik I, heer van Gronsveld, en Catharina, later gehuwd met Hendrik, heer van Bautersem. ${ }^{275}$

\subsubsection{Berittingen}

Bronnen die iets vermelden over bezittingen van Johan II in Gronsveld ontbreken. Beter zijn we geïnformeerd over zijn goederen in het hertogdom Limburg, zoals die genoemd worden in de leenregisters van de hertog van Brabant. Zo bezit Johan in 1314 als Limburgs lenen een hof met toebehoren en twee 'mesurae' (stukken land tussen een kwart en een halve hectare) bij 'Bouken', goederen en een huis te 'Beverle', twee 'hoven bij 'Hanstel' en laatgoederen bij 'Clermont', 'Bilstel' en 'Hemesborch', verder de tiende van 'Bilstel' en de hof in 'Liersdorp', die als borgleen van Limburg wordt gehouden. ${ }^{276}$ Een aantal van deze goederen komt tachtig jaar later terug in een boedelscheiding tussen Hendrik II van Gronsveld en zijn zwager, tevens schoonzoon Christiaan van Rinckberg. Daarin wordt gesproken over huis, hof en erf 'Van den Buecken' in het land van Limburg bij 'Henrichs Capelle', de hof van 'Loheirstorp' en het goed te 'Heymsberch' bij Limburg. Met deze gegevens is de identificatie van de meeste plaatsen niet moeilijk. 'Bouken' of 'Buecken' is de heerlijkheid Beucken of Del Beuck bij Henri-Chapelle. ${ }^{277}$ 'Hemesborch' of 'Heymsberch' bij Limbourg is identiek aan Hèvremont bij Limbourg, de huidige benaming van 'Liersdorp' of 'Loheirstorp' is Lohirville bij Clermont sur Berwinne, 'Bilstel' is een

272 Wolters, Recherches Gronsveld, 8.

273 Chestret de Haneffe, 'Histoire Gronsveld', 21.

${ }^{274}$ Domsta, Geschichte Merode I, 46-47.

275 Hemricourt, 159-160 paragraaf 251: 'Ly deseurnomeis messires Henrys [ sires de Badresen] soy mariat alle sereur monssaignor Henry, saignor de Groules, en la terre de Lemborch' (De genoemde heer Hendrik van Bautersem was gehuwd met de zuster van Hendrik, heer van 'Groules in het land van Limburg). Merkwaardig is dat Hemricourt, op zich niet ten onrechte, verwijst naar Groules in het hertogdom Limburg. Men zou eerder Gronsveld verwachten. Hendrik moet zijn gestorven voor 1333, want in dat jaar wordt zijn echtgenote weduwe genoemd.

${ }_{276}$ Galesloot, Livre Feudataires, 136: 'Johannes de Gruselt, mansionem apud Bouken cum appenditiis et II mesuras terre', Idem, 144: 'Johannes de Gronselt, bona et domum de Beverle et apud Hanstel II hovas terre et mansionarios de Clermont et de Bilstel et de Hemesborch cum suis appendiciis. Item idem, decimam de Bilstel et curtim in Liersdorp tenet in borchleen apud Lymburgum'. Het is onduidelijk waarom een aantal goederen die bij Galesloot worden genoemd, ontbreken bij De Ryckel, 'Cour féodale de Limbourg'. Hij noemt slechts de 'mansionarios' bij Clermont (297) en de 'mensio' (sic!) van Del Beuck. Chestret de Haneffe, 'Histoire Gronsveld', 21, neemt de plaatsen zoals Galesloot die geeft, wel correct over, maar is nogal vrij in de interpretatie van het soort goederen.

277 Buchet, Seigneurie Del Beuck, passim. 
oude aanduiding voor Bilstain bij Limbourg, met 'Clermont' wordt het huidige Clermont sur Berwinne bedoeld en 'Beverle' moet identiek zijn aan de huidige toponiem La Bèverie ten zuiden van Limbourg. Alleen voor de benaming 'Hanstel' werd geen hedendaags equivalent gevonden.

In het voorgaande overzicht valt op dat genoemde lenen liggen in elkaars nabijheid, de omgeving van Henri-Chapelle, Limbourg en Clermont sur Berwinne. Bijzondere aandacht trekt daarbij de heerlijkheid Beucken of Del Beuck. Buchet, die de geschiedenis daarvan heeft onderzocht, stelde vast dat deze zich uitstrekte over Henri-Chapelle, Clermont, Thimister en Bilstain. Hij baseerde die conclusie vooral op gegevens uit de overdrachtsregisters van het leenhof en de laatbank van Beucken; een nauwkeurige grensbeschrijving ontbreekt. Het was een leen van het leenhof van Limburg ${ }^{278}$, waaraan onder andere jachtrecht, grondheerlijke rechten en onderlenen waren verbonden. Nog in de zeventiende eeuw werd daar hoog over opgegeven. ${ }^{279}$ Een leen van Del Beuck was ook de laathof Groules bij Dolhain-Baelen. Aanvankelijk moet dit Groules een landsheerlijk leen zijn geweest, want in het register van Limburgse lenen uit 1314 staan twaalf bunder bouw- en weiland met laten en cijnzen bij Grouls op naam van Arnoldus de Grouls (een overigens niet nader in de genealogie Van Gronsveld in te passen persoon). ${ }^{280}$ In 1581 erkenden de laten van de hof Grouls de heren van Gronsveld en Beucken als hun grondheren. ${ }^{281}$ Volgens het gewoonterecht van het leenhof van Limburg uit 1612 gingen de laten van de laathof Groules ter hoofdvaart naar Del Beuck. ${ }^{282}$

De verdere geschiedenis van deze 'Limburgse' goederen kan hier verder buiten beschouwing blijven, maar het is duidelijk dat rond 1300 de heren van Gronsveld beschikten over aanzienlijk grondbezit, beginnend in het hertogdom Limburg, bijna letterlijk onder de rook van de hertogelijke burcht van Limbourg, en zich daarna voortzettend in noordelijke richting, in het stroomgebied van de Gulp. In dezelfde reeks past ook het eerder genoemde bos van 'Grules' bij Sint-Martens-Voeren, dat in de dertiende eeuw door de heren van Gronsveld aan de abdij van Val-Dieu was geschonken en misschien ook de hierna nog uitvoerig te bespreken heerlijkheid Slenaken.

\footnotetext{
278 Buchet, Seigneurie Del Beuck, 10: 'Ten Bouken, en leschevinage de Henry Capelle, au païs de Lemborch, por ledit relief un cheval, que la vefve dame de Grouselt rachata pour 20 florins de Hollande valant 70 marcs'.

279 Buchet, Seigneurie Del Beuck, 17: Verklaring van Marie-Pétronelle de Caldenborgh, de toenmalige bezitster van de heerlijkheid: 'C'est chose notoire que le fief seigneurial del Beuck est le plus ancien et le plus juridictionel qui soit dans le duché de Limbourg. Le fief a non seulement des arrières-fiefs en quantité, voire même des seigneuries comme Teuven qui en relèvent, mais aussi qu'il appartient encore à la seigneurie del Beuck 119 muids $1 / 2$ d'avoine et espaute, 104 chappons et plusieurs deniers seigneuriaux en diverses juridictions' (Het is bekend dat het heerlijk leengoed Beucken het oudste is in het hertogdom Limburg en daar ook met de meeste jurisdictie voorzien. Het leen heeft niet alleen een menigte achterlenen, met zelfs heerlijkheden zoals Teuven, die daar van afhangen, maar ook horen daartoe 119 1/2 mud haver en spelt, 104 kapoenen en verschillende heerlijke cijnzen in diverse jurisdicties).

280 'circiter XII bonaria terre et prati cum mansionariis et censu apud Grouls'.

281 Buchet, Seigneurie Del Beuck, 19.

282 Janssen de Limpens, Leen-en laathoven, 12.
} 


\subsection{Hendrik I van Gronsveld, 1334-1374}

\subsubsection{Geboorte, buwelijk en overlijden}

Johan II van Gronsveld werd opgevolgd door zijn zoon Hendrik I, waarschijnlijk geboren omstreeks 1310. Zijn eerste publieke optreden dateert uit 1334, als getuige in een lange lijst van ridders en geestelijken, aanwezig bij de leenopdracht van kasteel Rimburg door Gerard van Merode aan hertog Jan III van Brabant. ${ }^{283}$ Hij huwde Mechtildis, dochter van Arnold van de Bongard, heer van Heyden. Uit dit huwelijk werden vier kinderen geboren, te weten Johan, Hendrik, Godert en Catharina.. ${ }^{284}$ Waarschijnlijk overleed Hendrik kort na 1374.

\subsubsection{Betrekkingen met Brabant/ambtelijke functies}

De jaren dertig van de veertiende eeuw waren roerige tijden. Vanaf het begin toonde Hendrik zich een trouw aanhanger van hertog Jan III van Brabant (1312-1355). In 1337 raakte deze in oorlog met de bisschop van Luik, Adolf van der Mark (1312-1344), welk conflict eindigde met de Vrede van Montenaken van 8 april 1338. Tegelijkertijd stond men aan de vooravond van de Honderdjarige Oorlog tussen Frankrijk en Engeland, waarin de Brabantse hertog aanvankelijk partij koos voor koning Eduard III van Engeland. Hendrik van Gronsveld beloofde in 1338 - tegen betaling - de Brabantse hertog met vier goed bewapende mannen bij te staan zolang de oorlog tussen Engeland en Frankrijk duurde. 285 Wolters en Chestret de Haneffe 286 menen een verband te kunnen leggen met een benoeming van Hendrik in 1338 door de Brabantse hertog tot 'senescalcus' of burggraaf van Limburg, een ambt dat het gouverneurschap van hertogdom Limburg en de slotvoogdij van het gelijknamige kasteel omvatte. Dit moet op een vergissing berusten. Omstreeks 1336 was deze functie van burggraaf vergeven aan Reinoud IV, heer van Argenteau. ${ }^{287}$ Mogelijk is deze korte tijd, in 1337, op non-actief gesteld wegens pauselijke excommunicatie, omdat hij in het Brabants-Luikse conflict rechten van het kapittel van Sint-Dionysius in Luik had geschonden. Toen echter na de vrede van Montenaken in 1338 het kerkelijk interdict over Brabant en Limburg werd opgeheven, bleef Reinoud in functie als burggraaf van Limburg. Hij moet dit ambt tot 1348 hebben bekleed. ${ }^{288}$ Vervolgens is

\footnotetext{
283 Verkooren, Inventaire chartes de Brabant, IIe stuk, Cartulaires, deel 2 (1312-1383), 44.

${ }^{284}$ Chestret de Haneffe, 'Histoire Gronsveld', 26; zie ten aanzien van Godert ook RHCL, Klooster antonieten te Maastricht, inv. nr. 3.

285 Verkooren, Inventaire chartes de Brabant, Ie stuk, Chartes originales, 1, 347, nr. 494.

286 Wolters, Recherches Gronsveld, 8 en Chestret de Haneffe, 'Histoire Gronsveld', 22-23. Chestret de Haneffe keert zich ook terecht tegen de verwarring die Quix, Schloss Rimburg, en verschillende genealogen op dit punt veroorzaken, maar hij vergist zich uiteindelijk ook.

287 Publiek optreden bekend in de periode 1318-1358.

288 Poswick, Histoire d'Argenteau, 21-29 en in het bijzonder 23-27. Zie ook Halkin/Roland, Recueil StavelotMalmedy, II, 251-254, nr. 449, waarbij in een oorkonde uit 1348 naast elkaar als getuigen optreden 'Renar, sire d'Argenteal, scenescaul de Lembor...messire Henri de Groule...' Er is geen reden om in navolging van Thisquen, Histoire de Limbourg II, 147-148, met een beroep op Chestret de Haneffe, aan te nemen dat Hendrik van Gronsveld in 1337 korte tijd burggraaf van Limburg zou zijn geweest.
} 
hij opgevolgd door Hendrik I van Gronsveld. Dit stemt ook overeen met een aantal uitgavenposten in de stadsrekeningen van Aken (er bestonden regelmatig contacten tussen de burggraaf en de stad), waarin tot 1346 heer 'R. de Erkentele' (= Reinoud van Argenteau) voorkomt als burggraaf van Limburg, terwijl eerst in 1349 aan Hendrik I van Gronsveld als 'senescalco Lymburgensi' een betaling werd gedaan. ${ }^{289}$

De benoeming van Hendrik I tot burggraaf van Limburg vloeide voort uit zijn bewezen trouw aan de hertog van Brabant. Bovendien had hij waarschijnlijk van zijn vader de bezittingen in de directe omgeving van het kasteel van Limbourg geërfd. Of toen al familiebanden bestonden met de heren van Argenteau is onduidelijk. Voor de latere tijd staat in ieder geval vast dat Hendriks dochter Catharina gehuwd was met Jan van Argenteau, heer van Wilhonrieu, zoon van Reinoud IV van Argenteau en Catharina van Corswarem. ${ }^{290}$

Een benoemingsakte van Hendrik I tot burggraaf is niet bekend, maar waarschijnlijk stortte hij voor de verwerving van die functie, volgens toenmalig gebruik, een flink bedrag in de hertogelijke kas. Een dergelijke investering loonde zich, want het ambt van burggraaf van Limburg verschafte de heer van Gronsveld veel invloed. Als hoogste vertegenwoordiger van de landsheer was hij belast met de zorg voor de openbare orde, de vervolging van misdadigers en handhaving van alle landsheerlijke rechten. Daarnaast behoorde hij tot de belangrijkste adviseurs van de hertog.

Hendrik I van Gronsveld begon zijn carrière onder hertog Jan III van Brabant (overleden 1355), maar diende het grootste deel van zijn loopbaan onder diens dochter hertogin Johanna, gehuwd met Wenceslaus van Luxemburg, een halfbroer van de Duitse keizer Karel IV. Aangezien hertog Jan III alleen dochters had, wenste hij dat al zijn gebieden gezamenlijk zouden vererven op Johanna en Wenceslaus. ${ }^{291}$ Dit echtpaar bevestigde bij de zogenoemde Blijde Inkomste van 3 januari 1356 de privileges die al eerder aan het gewest Brabant waren verleend en zij bezwoeren de ondeelbaarheid van het Brabants territoir. De twee andere dochters, waarvan één was gehuwd met de graaf van Vlaanderen en de ander met de hertog van Gelre, achtten zich evenwel door hun vader benadeeld, wat leidde tot de Brabantse Successie-Oorlog van 1356. Anderhalf jaar later zagen Johanna en Wenceslaus zich, na concessies aan hun Vlaamse zwager, bij het Verdrag van Ath (4 juni 1357) wel in het bezit van Brabant bevestigd, maar hun landsheerlijk gezag bleef vele jaren

289 In dit verband moet worden gewezen op verschillende posten, vermeld in de door Laurent, Aachener Zustände, uitgegeven stadsrekeningen. In de rekening van 1344 (Laurent, 152-153) is sprake van diverse reizen van bodes via Limburg naar 'Erkentele' (Argenteau) en heer 'R. de Erkentele', alsmede (Laurent, 160) wijn voor heer ' $R$, 'burgravio Lymburgensi'. In 1346 (Laurent, 178) is sprake van een zaak waarin de niet met name genoemde burggraaf van Limburg moet antwoorden 'pro domino H. de Grunselt', wat impliceert dat het om twee verschillende personen gaat.

290 Poswick, Histoire d'Argenteau, 28-29; Gläser, Schönau - Schönforst, 258-259. Deze Jan overleed in 1362 in Syrië en werd later bij de minderbroeders in Maastricht bijgezet. Reinoud van Argenteau had nog twee zonen, waarvan er een in 1360 ongehuwd overleed en de ander waarschijnlijk geestelijke was. We mogen dus veronderstellen dat er bij Reinouds kinderen niet veel ambitie bestond het ambt van hun vader over te nemen.

291 Zie over deze opvolging Avonds, 'Brabant en Limburg 1100-1403', 455-457. 
gekenmerkt door instabiliteit als gevolg van binnenlandse onlusten en spanningen met de buurlanden.

De 'oostpolitiek' van Brabant kende sedert het begin van de dertiende eeuw twee doelen: consolidatie en afronding van het gebied 'over de Maas' en beveiliging van de handelsweg naar Keulen, van vitaal belang voor de Brabantse economie. Die staatkundige situatie maakte het politieke spel in deze regio tamelijk ondoorzichtig. Naast grote vorstendommen zoals het prinsbisdom Luik en de hertogdommen Gulik en Gelre, telde het gebied vele kleine territoria, waarvan de plaatselijke heren soms als luis in de pels van hun grote buren fungeerden. In het bijzonder problemen bij de erfopvolging konden snel tot een regionaal conflict uitgroeien. Een voorbeeld levert de opvolging van de kinderloze Dirk van Heinsberg, graaf van Loon. Na diens overlijden in 1361 buitte de prins-bisschop van Luik een tijdelijke zwakte van zijn concurrent, de hertog van Brabant, uit en wist hij in 1366 Loon definitief aan Luik te binden. Voor de politieke verhoudingen was deze annexatie belangrijk, omdat de prins-bisschop met dit bezit een wig dreef tussen het stamland Brabant en de Brabantse territoria 'over de Maas'.

Voor veel problemen zorgde ook de successie van de heren van Valkenburg. Met het overlijden van de kinderloze Jan I van Valkenburg in 1352 stierven de heren van Valkenburg in mannelijke lijn uit. In de periode 1364-1378 kocht hertog Wenceslaus van Brabant successievelijk alle erfgenamen of hun rechtverkriigenden af en bracht daarmee het Land van Valkenburg als een der Landen van Overmaze onder Brabants gezag. Ook Hendrik I van Gronsveld had als vertrouweling van de hertog van Brabant bemoeienis met de kwestie rond Valkenburg. ${ }^{292}$ Het belangrijkste gevolg voor de heren van Gronsveld was echter dat Hendriks zoon Johan III van Gronsveld in 1363 jurisdictie en andere rechten over Heugem verwierf van Walram van Valkenburg, heer van Born, Sittard en Susteren (zie Hoofdstuk 2.4.3) en daarmee voor eeuwen Gronsveld en Heugem aan elkaar bond.

Als burggraaf van Limburg was Hendrik I in eerste instantie verantwoordelijk voor de handhaving van orde en rust in zijn eigen ambtsgebied. Bij de uitoefening van die taak kreeg hij meestal bijstand van een ontvanger en soms nog een 'dapifer', een drossaard voor de handhaving van de rechtspraak. ${ }^{293}$ Maar de werkzaamheden hielden niet op bij de grens van Limburg. Naast contacten met de adel van de streek onderhield Hendrik ook banden met de op twintig kilometer van zijn ambtszetel gelegen machtige rijksstad Aken. Daarvan getuigen zowel talrijke posten in de Akense stadsrekeningen ${ }^{294}$ als brieven, die

292 Waarschijnlijk staan twee oorkonden uit 1361 en 1364 daarmee in verband, die handelen over de afrekening van kosten van conferenties: Verkooren, Inventaire chartes de Brabant, Ie stuk, Chartes originales, 3 , 362, nr. 1911 en Idem, Inventaire chartes de Brabant, Ie stuk, Chartes originales, 4, 110, nr. 2204. Over de Valkenburgse Successie zie: Van de Venne, Geschiedenis kasteel Valkenburg, 111-115 en Corsten, 'Herren Valkenburg', 198-200.

293 Thisquen, Histoire de Limbourg II, 146.

${ }^{294}$ Laurent, Aachener Zustände, passim. Een niet gering aantal van deze posten heeft ook betrekking op de betaling van erewijn, die de stad aan de heer van Gronsveld als gast schonk. Overigens is het de 
betrekking hebben op zijn tussenkomst in kwesties waarin het stadsbestuur betrokken was. ${ }^{295}$ Niet alleen die ambtelijke bezigheden brachten Hendrik naar Aken; hij trok ook jaarlijks een rente van 75 mark uit de stadskas, waarschijnlijk wegens een lening. ${ }^{296}$ Overigens moet hij met dit bedrag tot de kleinere schuldeisers van de stad worden gerekend. Veel lucratiever waren schenkingen, zoals de 223 mark die hij in 1349 ontving om zaken van de stad te 'promoveren'. ${ }^{297}$

Deze contacten 'over de grens' maakten Hendrik I ook geschikt voor zijn rol als Brabantse afgevaardigde bij de handhaving van de zogenoemde landvredes in het gebied tussen Maas en Rijn. ${ }^{298}$. Door de successieproblemen in Loon en Valkenburg en de spanningen tussen Keulen, Gulik en Gelre, vormde de algemene onveiligheid een plaag voor de bevolking en een ernstige bedreiging van de handel tussen Keulen en de kustgebieden. Om die reden sloten in 1351 de aartsbisschop van Keulen, de hertog van Brabant en de steden Keulen en Aken voor een periode van tien jaar een landvredeverbond. Zij stelden daarbij krijgsvolk ter beschikking als een soort politiemacht tegen allerlei vormen van banditisme. Een college van twaalf gezworenen, bestaande uit afgevaardigden van de verdragspartijen, moest oordelen over schendingen van de landvrede.

De politieke situatie in 1361, toen de termijn van het verbond was verstreken, liet vooralsnog geen verlenging toe wegens spanningen tussen Brabant en Keulen. Een nieuw verdrag tussen Brabant en Aken legde evenwel in 1364/1365 de basis voor een landvrede gedurende vijf jaar tussen Brabant, Aken, Gulik en Keulen. Evenals in 1351 werden gezworenen met de handhaving daarvan belast, maar ditmaal kreeg het college, dat inmiddels 24 leden telde, aanzienlijk grotere bevoegdheden. In 1369 werd het verbond wederom verlengd, traden meer leden toe (onder andere de ridderschap van het hertogdom Limburg) en kregen de rechterlijke bevoegdheden van de gezworenen ook in de praktijk reële betekenis. Een derde landvredeverbond voor een periode van vier jaar werd gesloten in 1375, waarna verlengingen volgden in 1378 en 1383.

Hendrik I van Gronsveld was meermalen als diplomaat bij het landvredeverbond betrokken. Zo bemiddelde hij omstreeks 1359 in opdracht van de gezworenen in een geschil tussen de stad Aken en de heren van Schönberg in de Eifel. ${ }^{299}$ Bij het landvredeverbond van 1364 tussen Brabant en Aken werd Hendrik samen met Reinoud van Schoonvorst en Jan van Wittem aangewezen als Brabantse vertegenwoordiger in het

aanduiding 'heer van Gronsveld' in de rekeningen niet altijd duidelijk of Hendrik dan wel zijn zoon Johan is bedoeld.

295 Deze brieven (uit het Akense stadsarchief?) zijn door Quix, Rimburg, passim, gepubliceerd en van commentaar voorzien. Daarna zijn ze door Wolters, Recherches Gronsveld, overgenomen en afgedrukt. Uiteindelijk heeft ook Chestret de Haneffe, 'Histoire Gronsveld', er gebruik van gemaakt. Aangezien de stukken voor het grootste deel zonder jaartal zijn en voor deze studie weinig wezenlijke informatie bevatten, blijven ze hier verder, op enkele details na, onbesproken.

${ }^{296}$ Laurent, Aachener Zustände, 139 (1344); 172 (1346, betaald aan Hendriks vrouw Mechtild); 262 (1376)

${ }^{297}$ Laurent, Aachener Zustände, 212.

298 Zie voor het thema 'Landvredeverbond' de studie van Rotthoff-Kraus, Politische Rolle Landfriedenseinungen. Beperkter van opzet is wat hierover wordt vermeld door Alberts, Overzicht Nederrijnse territoria II, 89-114; voor de landvredes zie verder ook: Gläser, Schönau - Schönforst, 114-175

${ }^{299}$ Rotthoff-Kraus, Politische Rolle Landfriedenseinungen, 83-88. 
college van gezworenen. ${ }^{300}$ Een opmerkelijke zaak waarmee Hendrik zich als gezworene in 1365 geconfronteerd zag, betrof een hierna nog te noemen geschil tussen zijn zoon Johan III en de stad Keulen. Twee jaar later schijnt hij als lid van college van gezworenen te zijn afgetreden wegens betrokkenheid bij een strafexpeditie op Guliks gebied. Gulikse troepen hadden het dorp Jalhay bij Limbourg geplunderd, waarna Luikenaren uit wraak onder aanvoering van de heer van Oupeye, met de heer van Gronsveld als gids, een strooptocht tot diep in Guliks gebied hielden. Zij plunderden verscheidene dorpen en hakten een detachement Gulikse soldaten in de pan. ${ }^{301}$

Het incident was slecht voor Hendriks reputatie als handhaver van de publieke veiligheid, maar zijn prestige bij de hertog en hertogin van Brabant leed er niet onder. Meermalen moest hij met of voor de hertog ten strijde trekken, ondernemingen die niet zonder risico waren en schade konden opleveren. ${ }^{302}$ Ook nam hij in 1371 deel aan de bekende slag bij Baesweiler, die werd geleverd door Brabantse troepen tegen een coalitie van Gulik en Gelre. De slag liep slecht af voor de Brabantse hertog, die in Gulikse gevangenschap raakte, maar ook Hendrik I van Gronsveld leed aanmerkelijke schade. ${ }^{303}$

\subsubsection{Financier van de hertog van Brabant}

Door zijn werkzaamheden ging Hendrik I om met grote geldbedragen. Verschillende oorkonden leggen daarvan getuigenis af.304 Meermalen stelde Hendrik zich borg voor schulden van de Brabantse landsheer en -vrouwe, ${ }^{305}$ meestal samen met anderen, soms ook alleen met zijn zoon Johan III. ${ }^{306}$ Een enkele keer trad hij ook op als deskundige bij de schatting van schade, bijvoorbeeld an het kasteel van Valkenburg. ${ }^{307}$ Hendriks diensttijd eindigde in 1374 met een grote vordering op de hertog en hertogin van Brabant. Liefst 6697 3/4 'oude schilden' (munteenheid) bleven zij hem schuldig bij de afsluiting van zijn laatste rekening als burggraaf van Limburg en als schadeloosstelling voor de verliezen geleden in de slag bij Baesweiler. Voor deze vordering kenden Wenceslaus en Johanna van Brabant de heer en vrouwe van Gronsveld op 17 november 1374 een lijfrente van 250 'oude schilden' toe. 308

\footnotetext{
300 Rotthoff-Kraus, Politische Rolle Landfriedenseinungen, 105; akte afgedrukt bij Lacomblet, Urkundenbuch III, 555-560, nr. 657.

${ }^{301}$ Chestret de Haneffe, 'Histoire Gronsveld', 25-26; Het incident wordt niet vermeld bij Rotthoff-Kraus, Politische Rolle Landfriedenseinungen.

302 Verkooren, Inventaire chartes de Brabant, Ie stuk, Chartes originales, 4, 112-113, nr. 2209).

303 Verkooren, Inventaire chartes de Brabant, Ie stuk, Chartes originales, 5, 144, nr. 3159.

304 Uit de jaren 1358-1366 geeft Verkooren liefst 8 oorkonden uit het Brabants hertogelijk archief die op dit soort transacties betrekking hebben: Verkooren, Inventaire chartes de Brabant, Ie stuk, Chartes originales, 3, 259, nr. 1724; 325-327, nr. 1843-1845; 334, nr. 1860; Inventaire chartes de Brabant, Ie stuk, Chartes originales, 4, 81, nr. 2154; 229-230, nr. 2424.

305 Verkooren, Inventaire chartes de Brabant, Ie stuk, Chartes originales, 4, 384, nr. 2710; 465-466, nr. 2867.

306 Verkooren, Inventaire chartes de Brabant, Ie stuk, Chartes originales, 3, 311, nr. 1818.

307 Verkooren, Inventaire chartes de Brabant, Ie stuk, Chartes originales, 4, 168-169, nr. 2311.

308 Verkooren, Inventaire chartes de Brabant, Ie stuk, Chartes originales, 5, 144, nr. 3159.
} 


\subsection{Johan III van Gronsveld, 1349-1386}

\subsubsection{Geboorte, buwelijken en overlijden}

Van alle middeleeuwse heren van Gronsveld heeft Johan III van Gronsveld in de latere literatuur misschien wel de meeste aandacht getrokken door zijn turbulent leven, dat in 1386 eindigde door een fatale aanslag. ${ }^{309}$ Johans vroegst bekende publieke optreden dateert van 1349, in welk jaar hij meerderjarig moet zijn geweest. ${ }^{310}$ Hij zou omstreeks 1330 kunnen zijn geboren. In eerste huwelijk was hij getrouwd met een vrouwe van Kastenholz (bij Euskirchen) ${ }^{311}$. Begin jaren tachtig van de veertiende eeuw hertrouwde hij met Margaretha, weduwe van ridder Johan van Schoonvorst, dochter van Johan III Scheiffart van Merode en Adelheid van Millendonk. ${ }^{312}$ Beide huwelijken bleven kinderloos.

\subsubsection{Ambtelijke loopbaan en financier}

Evenals zijn vader toonde Johan III zich een uitgesproken aanhanger van de hertog van Brabant. Hij wordt 1364 genoemd als burggraaf van Wassenberg, ${ }^{313}$ welk ambt hij waarschijnlijk had verworven als onderpand voor een geldlening aan de hertog. ${ }^{314}$ Hoe lang hij Wassenberg in bezit hield, is niet bekend. In 1375 gaf het hertogspaar hem opnieuw voor een geldlening het kasteel in bewaring. ${ }^{315}$

Voortdurend sloten Johan en het Brabants hertogspaar financieringsovereenkomsten met verpandingen. Op 16 september 1368 verklaarden Wenceslaus en Johanna van Brabant dat zij 'dat dorp van Beke' in het Land van Valkenburg in pand hadden gegeven aan Johan van Gronsveld voor de schade die hij had geleden in de oorlog tegen de hertog van Gelre.316 In 1371 leende Johan, samen met zijn oom Godert van den Bongard, heer van Heyden en Peter van Retersbeek, geld aan de hertog en hertogin, waarvoor zij een rente uit goederen in Beek en Valkenburg kregen toegewezen. ${ }^{317}$ In 1375 ontving Johan van de Brabantse landsheer en -vrouwe opnieuw een belangrijk onderpand voor een lening van 5500 gulden, te weten de dorpen Eijsden (Land van Valkenburg) en Cadier (Land van

309 Zie over hem vooral Wolters, Recherches Gronsveld, 14-23; Chestret de Haneffe, 'Histoire Gronsveld', 27-41; Hanssen, Die Rimburg, 107-118; Uyttebrouck, Gouvernement Brabant II, 695-696. De navolgende biografische bijzonderheden zijn grotendeels aan deze auteurs ontleend en soms aangevuld en gecontroleerd aan de hand van het bronnenmateriaal dat vooral door Verkooren c.s. is uitgegeven.

310 Chestret de Haneffe, 'Histoire Gronsveld', 27.

311 Zie stamboom bij Hanssen, Die Rimburg, tegenover 130 en Rotthof-Kraus, Politische Rolle Landfriedenseinungen, 152.

312 Domsta, Geschichte Merode I, 74-75; Stieldorf, Rheinische Frauensiegel, 511-512; Gläser, Schönau - Schönforst, 223-224, 249

313 Verkooren, Inventaire chartes de Brabant, Ie stuk, Chartes originales, 4, 124-125, nr. 2231.

314 Een aantal akten heeft betrekking op de betaling van rente door de hertog aan Jan wegens Wassenberg: Verkooren, Inventaire chartes de Brabant, Ie stuk, Chartes originales, 4, 124-125, nr. 2231; idem, 4, 190, nrs. 2350 en 2351; idem 4, 194, nr. 2359; idem 4, 208, nr. 2385.

315 Verkooren, Inventaire chartes de Brabant, IIe stuk, Cartulaires, deel II (1312-1383), 194-195.

316 ULB Darmstadt, Hs. inv. nr. 2734-2735, Cartularium Hurt von Schönecken, fol. 33. Het is niet bekend wanneer deze verpanding is ingelost.

317 Verkooren, Inventaire chartes de Brabant, Ie stuk, Chartes originales, 4, 452, nr. 2842, zie ook: idem, 479480, nr. 2891 en idem, 5, 35-36, nr. 2948; idem, 85-86, nr. 3046; idem, 144-145, nr. 3160. 
Dalhem). Voorwaarde was wel dat beide plaatsen vrij van schuld zouden terugvallen aan de hertog en hertogin, wanneer Johan vóór hen kwam te overlijden. Overleefde Johan het hertogelijk paar, dan erfden zijn nabestaanden de vordering en hielden zij het onderpand tot aan de eventuele aflossing. ${ }^{318}$ Het bezit van Eijsden bood Johan III de gelegenheid op die plaats tol van Luikse Maasschippers te heffen, een belasting die afgevaardigden van de prins-bisschop van Luik tijdens onderhandelingen met Brabant in 1379 als een punt van onenigheid beschouwden. ${ }^{319}$

Omstreeks 1375 kreeg Johan III nog meer taken opgedragen, zoals het beheer van de burcht en het Land van 's-Hertogenrade.320 Vóór 1377 moet hij zijn benoemd tot drossaard van het hertogdom Limburg.321 Toen de hertog in 1378 de kastelen van Gangelt, Waldfeucht en Millen kocht van graaf Frederik van Meurs, vertrouwde hij ook daarvan het beheer toe aan Johan III van Gronsveld. ${ }^{322}$ Mogelijk verwierf Johan omstreeks 1382 voor een lening ook nog het ambt van drossaard van het Land van Valkenburg in pand, maar zekerheid daarover hebben we niet. Dit overzicht van ambten kan nog worden gecompleteerd met de goede betrekkingen met Aken, van welke stad de magistraat hem tenminste sedert 1370 jaarlijks honderd mark voor zijn diensten betaalde. ${ }^{323}$ Naast deze min of meer vaste werkzaamheden verrichtte de heer van Gronsveld voor de hertog ook meer incidentele diensten. Zo was hij in 1378 en 1379 betrokken bij vredesonderhandelingen tussen de prins-bisschop van Luik en de Luikse steden. 324

In 1373 erfde Johan III een groot fortuin van Godert van den Bongard, heer van Heyden, de kinderloze broer van zijn moeder Mechtildis. ${ }^{325}$ Godert was gehuwd geweest met Agnes, dochter van Arnoldus Parvus en Sophia van Merode, weduwe uit een eerder huwelijk van Arnold van Frankenberg. ${ }^{326}$ Arnoldus Parvus, heer van Breitenbend, Palant en Trips, was de stamvader van de adellijke familie Van Palant, behoorde aan het begin van de van de veertiende eeuw tot het stedelijk patriciaat van Aken en trad op als geldschieter van diverse landsheren aan de Nederrijn en in de Nederlanden. ${ }^{327}$

De verwerving van de nalatenschap van Godert was al eerder, op 8 februari 1367, voorbereid met een lening van liefst tienduizend goudgulden door Johan aan zijn oom. ${ }^{328}$

318 Zie hierover Van Hall, Eijsden, een vrijheid, 59-61 en de daar opgegeven literatuur. Van Hall corrigeert ook het vrijwel overal in de literatuur opgegeven jaartal 1370 voor de verpanding in 1375.

319 Bormans/Schoolmeesters, Cartulaire Saint-Lambert, 4, 560-561, nr. 1728.

320 Rotthoff-Kraus, Politische Rolle Landfriedenseinungen, 284.

321 Chestret de Haneffe, 'Histoire Gronsveld', 33.

322 Chestret de Haneffe, 'Histoire Gronsveld', 33.

323 Chestret de Haneffe, 'Histoire Gronsveld', 33.

324 Bormans/Schoolmeesters, Cartulaire Saint Lambert, 4, 540-546, nr. 1716; idem 555-561, nrs 1726 en 1728 .

325 Janssen de Limpens, 'Geschiedenis Oost', 87 noemt (zonder bronvermelding) als overlijdensdatum 5 december 1373.

326 Meyer, Familie Palant, 54-55, noot 130; 62, noot 168.

327 Meyer, Familie Palant, 15-27.

328 Mogelijk is ook 1368, wanneer de akte volgens de Paasstijl is gedateerd. 
Godert stelde daarvoor al zijn kastelen en landerijen tot zekerheid, met de bepaling dat Johan de schuld na Goderts dood direct op die goederen mocht verhalen.

Er is geen overzicht van het totale vermogen van Godert van den Bongard, maar dit moet aanzienlijk zijn geweest. In de eerste plaats hoorde daartoe het slot Heyden, ${ }^{329}$ dat hij sedert 1342 als een Guliks leen in bezit had. Verder bezat hij nog het huis en de lage heerlijkheid Oost, de lage heerlijkheid Sint-Martens-Voeren en, wegens een vordering van drieduizend goudgulden op de hertog van Gulik, pandrechten op de dorpen Richterich, Bank, Steinstrass, Eygelshoven en Berensberg, alle gelegen in de directe omgeving van kasteel Heyden. Het kapitaal van Godert heeft ongetwijfeld een belangrijke bijdrage geleverd aan de verdere vermogensopbouw van de familie Van Gronsveld. Deze erfenis vormde ook het begin van de langdurige bindingen van Gronsveld met Oost en SintMartens-Voeren. Om die reden wordt aan deze heerlijkheden nog bijzondere aandacht besteed in Hoofdstuk 2.9. Tegelijkertijd heeft de nalatenschap waarschijnlijk ook gefungeerd als katalysator in een familievete, die met de moord op Johan eindigde.

De cumulatie van ambten en bezittingen in het gebied tussen Maas en Rijn en zijn dubbele loyaliteit als leenman van de hertogen van Brabant en Gulik, maakten Johan III bij uitstek geschikt om een rol te spelen bij de handhaving van de openbare orde en veiligheid. Daarom werd hij in 1375, samen met de drossaard van Valkenburg, bij de vernieuwing van de landvrede benoemd tot Brabantse vertegenwoordiger in het college van gezworenen. ${ }^{330}$ Daar kwam in 1378 nog de eindverantwoordelijkheid bij voor de inning van de Brabantse tolgelden voor de landvrede. De ontvanger tot dan toe, Tilman van Roide, rentmeester van Limburg, had zijn rekeningen voortdurend met een nadelig saldo afgesloten, maar nu veranderden de verliezen in winst! ${ }^{331}$

Als een der voornaamste vazallen van de hertog van Brabant stond Johan III zijn heer bij in militaire acties. Samen met zijn vader nam hij deel aan de slag bij Baesweiler in 1371, die ook voor hem in krijgsgevangenschap eindigde. Maar misschien werd de pijn later enigszins verzacht door de flinke vordering op de Brabantse hertog, die Johan III aan deze slag overhield en die hij met de verpanding van Eijsden en Cadier wist te verzilveren.

Als gezworene van de landvrede raakte de heer van Gronsveld ook direct betrokken bij militaire operaties van dit college. Zo steunde hij de aartsbisschop van Keulen en de schepenen van die stad in hun strijd tegen de stedelijke raad, een conflict dat bekend staat als de 'Keulse schepenoorlog' (1375-1377).332 In 1380/1381 verleende hij weer militaire steun aan de aartsbisschop bij diens geschillen met de hertog van Kleef.

De laatste grote operatie waar Johan III aan deelnam, was het beleg van het kasteel Reifferscheid in 1385, het gevolg van een conflict tussen de heren van Reifferscheid en leden van het landvredeverbond. De belegerden boden echter zoveel tegenstand, dat de strijd onbeslist (en zonder gezichtsverlies voor één der partijen) eindigde. Johan III van

${ }^{329}$ Gelegen even ten zuiden van Kerkrade-Bleijerheide, thans op Duits gebied.

330 Rotthoff-Kraus, Politische Rolle Landfriedenseinungen, 284, tekst afgedrukt bij Lacomblet, Urkundenbuch III, 658-666, nr. 766.

331 Rotthoff-Kraus, Politische Rolle Landfriedenseinungen, 300.

332 Rotthoff-Kraus, Politische Rolle Landfriedenseinungen, 341. 
Gronsveld presenteerde vervolgens wel bij hertogin Johanna van Brabant de rekening van 5100 'oude schilden', kosten die hij in deze onderneming had voorgeschoten. Johanna, zoals gebruikelijk in geldnood verkerend, beloofde hem als onderpand voor deze schuld in het bezit te laten van Limburg en het Land van 's-Hertogenrade met al hun toebehoren, alsmede de plaatsen Millen, Gangelt en Waldfeucht. ${ }^{333}$

De voorgaande opsomming van leningen en verpandingen laat zien dat Johan III zich had ontwikkeld tot een belangrijk financier van de hertog en hertogin van Brabant, een politiek waarmee hij in het voetspoor van zijn vader trad. Ook al stond hij wat betreft rijkdom in de schaduw van zijn bekende streekgenoot, Reinoud van Schönau, heer van Schoonvorst, de 'huisbankier' van de Brabantse hertog, ${ }^{334}$ zijn bekwaamheid in de omgang met geld deed daar niet voor onder. De 'beleggingsstrategie' van Johan van Gronsveld is duidelijk: hij gebruikte zijn kapitaal voor de verwerving van pandschappen en functies in het grensgebied tussen Limburg, Gulik en Keulen, die niet alleen invloed en prestige in de streek verschaften, maar ook inkomsten opleverden. Ook uitgaven ten behoeve van de landsheer tijdens militaire campagnes leverden vorderingen op, die niet in klinkende munt, maar in verpanding van kastelen en ambten werden omgezet.

Een andere zorg betrof de handhaving van de onafhankelijkheid van het kleine Gronsveld. De overgang van Loon en Valkenburg naar respectievelijk Luik en Brabant toonde aan welke mogelijke dreiging van deze grote territoria uitging. Ook al was de Brabantse hertog een goede buur en vriend, diens expansiedrift vormde altijd een potentieel gevaar. Maar Johans positie ten opzichte van Brabant lijkt mede door zijn geld zo stevig te zijn geweest, dat hij die druk goed kon weerstaan. Misschien mogen we zelfs veronderstellen dat Johan aspiraties in een tegengestelde richting koesterde, namelijk uitbouw van zijn eigen kleine landsheerlijkheid. De verwerving van Heugem in 1363 (waarover meer in Hoofdstuk 2.4.3) vormde daartoe een mogelijke aanzet, zeker in combinatie met de geërfde heerlijkheden Oost en Sint-Martens-Voeren (zie Hoofdstuk 2.9) en de pandrechten op Eijsden en Cadier.

\subsubsection{Een gewelddadig leven en een gewelddadig einde}

Wie bij Johan III van Gronsveld het beeld van een saaie bankier krijgt, vergist zich. Hij was strijdlustig en schuwde het gebruik van geweld niet. ${ }^{335}$ Maar dat was een algemene karaktertrek van de adel in deze streek. In dit verband komt de wijze waarop Johan in 1379 de cisterciënzerinnen van de abdij Val-Bénoît bij Luik dwong de tienden van Gronsveld aan hem te verkopen nog tamelijk onschuldig over. Het commentaar van de religieuzen bij de ogenschijnlijk neutrale tekst van de verkoopakte laat aan duidelijkheid niets te wensen over: de zusters waren gezwicht voor de dreiging van brandstichting en

\footnotetext{
333 Regest van de schuldbekentenis bij Verkooren/Grunzweig, Inventaire chartes de Brabant, IIIe stuk, Chartes originales et cartulaires I (1383-1396), 54, nr. 6217; tekst, aangevuld met een staat van schulden van de hertogin afgedrukt bij Quicke, 'Documents', 119-122, nr. 17 en 17bis.

334 Chestret de Haneffe, 'Renard de Schönau'; Uyttebrouck, Gouvernement Brabant II, 732-733.

335 Over de betekenis van de factor 'geweld' bij laatmiddeleeuwse territoriumvorming, zie enkele inleidende opmerkingen bij Janssen, 'Niederrheinische Territorialbildung', 95.
} 
vernieling door de heer van Gronsveld, 'een man tegen wiens tiranniek optreden zich niemand durfde te verzetten'.336

Maar het kon nog erger. Johan raakte betrokken bij verschillende conflicten die gepaard gingen met plundering, brandstichting en doodslag: in 1349 met een oom en tante van zijn echtgenote over een erfenis, tussen 1365 en 1370 met de stad Keulen over vernielingen en molestaties in Ober- en Niederkastenholz bij Euskirchen en in 1367 wederom een vete met moord en doodslag. Steeds weer probeerden leden van het landvredeverbond de conflicten bij te leggen. ${ }^{337}$

De man die zo vaak het zwaard hanteerde, kwam uiteindelijk ook zelf door geweld om het leven. Aangezien over zijn levenseinde al meermalen is gepubliceerd, ${ }^{338}$ laatstelijk nog uitgebreid door Gläser, ${ }^{339}$ beperken we ons tot een samenvatting van de gebeurtenissen, waarbij we in hoofdzaak steunen op de visie die Gläser over deze aanslag heeft ontwikkeld. Hij vermoedt dat in het bijzonder de verdeling van de rijke nalatenschap van de kinderloze Godert van den Bongard, heer van Heyden, de bron werd van een ernstige familievete. Godert bezat sedert 1342 het huis Heyden als leen van en 'open huis' voor de hertog van Gulik. Door diverse pandschappen had hij verder van de hertog rechten gekregen op dorpen in de omgeving, waar ook goederen van de families Van Schoonvorst en Van den Bongard lagen. Deze families voelden zich bedreigd en ontvingen van de hertog garanties voor het behoud van hun goederen, zulks tegen de zin van Godert. Om Godert in het gareel te houden, verlangde de hertog een nieuwe verklaring dat het huis Heyden voor Gulik openstond. In dit meningsverschil deden vier Gulikse ridders een scheidsrechtelijke uitspraak, inhoudende dat Godert alle pandgoederen tot zijn dood mocht bezitten. Na zijn dood mochten deze niet vererven, maar zouden ze terugvallen aan de hertog. Vervolgens hernieuwde Godert in 1370 de openstelling van het huis Heiden voor de hertog van Gulik.

In 1367 had de kinderloze Godert echter tienduizend gulden geleend van zijn neef Johan III van Gronsveld, met de bepaling dat laatstgenoemde zich voor dat bedrag na Goderts overlijden in het bezit kon stellen van diens nalatenschap. ${ }^{340}$ Feitelijk zagen daarmee Godert en Stas van den Bongard, andere neven van Godert van den Bongard, hun aanspraken op de erfenis van Godert in rook opgaan ten gunste van een aanverwant in de zijlijn. Dit leidde tot heftige twisten. In de tijd dat Johan III van Gronsveld na de slag bij Baesweiler in 1371 gevangen zat, bracht Stas van den Bongard de eer en goede naam van de heer van Gronsveld in diskrediet, onder andere bij het stadsbestuur van Maastricht. Johan had Stas vervolgens in 1372 schriftelijk tot een duel op leven en dood uitgedaagd,

\footnotetext{
336 Schoolmeesters, 'Diplômes Val-Bénoît', 151-152, nr. XXII.

337 Verschillende auteurs maken soms meer, soms minder uitvoerig melding van de conflicten waarin Johan betrokken raakte: Wolters, Recherches Gronsveld, 14-19; Chestret de Haneffe, 'Histoire Gronsveld', 27-29; Hanssen, Die Rimburg, 108-109 en Rotthoff-Kraus, Politische Rolle Landfriedenseinungen, passim.

338 Wolters, Recherches Gronsveld, 22-23; Chestret de Haneffe, 'Histoire Gronsveld', 36-40; Hanssen, Die Rimburg, 110-111.

339 Gläser, Schönau - Schönforst, 219-228.

340 Gläser, Schönau - Schönforst, 183-184.
} 
wat laatstgenoemde ook aanvaardde. Of dit gevecht ook werkelijk plaatsvond, is niet bekend, maar vast staat dat beide kemphanen in leven bleven.

$\mathrm{Na}$ het overlijden van Godert van den Bongard in december 1373 aanvaarde Johan III van Gronsveld diens nalatenschap in volle omvang. In 1374 hernieuwde hertog Willem van Gulik de vroegere verpandingen van de dorpen, maar nu zonder het voorbehoud om de daar gelegen goederen van de families Van den Bongard en Schoonvorst te ontzien. Dit laatste dreef de familie Van Schoonvorst direct in het kamp van Van den Bongard. In maart 1375 verhief Johan III van Gronsveld 'het huys dat man noempt zer Heiden' met al zijn vestingwerken in leen bij hertog Willem van Gulik en Gelre en stelde dit als open huis aan de hertog ter beschikking, uitgezonderd in het geval van een conflict met de bisschop van Keulen. ${ }^{341}$ Daarmee zagen de Bongards hun aspiraties definitief verdwijnen. ${ }^{342}$

Hoe het conflict zich in de daaropvolgende jaren ontwikkelde, is niet bekend. Waarschijnlijk werd het huwelijk dat Johan III van Gronsveld begin jaren tachtig sloot met Margaretha Scheiffart van Merode, weduwe van Johan I van Schoonvorst, als een provocatie beschouwd. Deze verbintenis met een vrouw uit het kamp van zijn rivalen - de Schoonvorsten waren immers bondgenoten van de gebroeders Van den Bongard - maakte de verhoudingen erg gecompliceerd. Margaretha bracht uit haar eerste huwelijk immers een minderjarige zoon en dochter mee, die onder voogden van vaderszijde werden geplaatst. Bovendien was zij door haar eerste huwelijk een schoonzuster van Reinoud II van Schoonvorst, met zijn geld en vele ambten een invloedrijk man aan het Brabantse hof. De vete kwam in de late avond van 25 augustus 1386 tot een dramatische uitbarsting. Ten huize van een zekere Jan van Necken in Aken was een bijeenkomst belegd tussen Reinoud II van Schoonvorst en zijn twee broers Engelbert en Conrad, verder Stas van den Bongard en nog enkele metgezellen. De bedoeling was met Johan van Gronsveld te praten over het bijleggen van geschillen. Terwijl aanvankelijk het gesprek tussen de familie Van Schoonvorst en de heer van Gronsveld in een vriendelijke sfeer verliep, kwam Stas van den Bongard het vertrek binnen. Opeens veranderde de stemming. Engelbert van Schoonvorst trok zijn zwaard en wilde Johan van Gronsveld te lijf, maar werd tegengehouden door Conrad van Schoonvorst. Vervolgens ging Stas, geholpen door twee knechten, tot de aanval over en stak Johan neer. Tijdens het tumult werd ook Conrad, die nog steeds Engelbert vasthield, met de dood bedreigd, maar uiteindelijk slaagde hij er in te ontkomen. Dat de moord in koelen bloede was beraamd, blijkt wel uit het feit dat vlak daarna enkele familieleden van de dader een blik in de kamer wierpen en vervolgens het slachtoffer de rug toekeerden. Enkele dagen later werd Johan begraven in de kerk van de dominicanen in Aken.

Het slachtoffer liet als erfgenamen na zijn weduwe Margaretha Scheiffart van Merode en zijn broer Hendrik II, die hem als heer van Gronsveld opvolgde. Alvorens in te gaan op de afwikkeling van de nalatenschap en de verdere levensloop van Hendrik, moet nog een enkele opmerking worden gemaakt over gebeurtenissen die direct verband hielden met de nasleep van de moord. Hendrik zag het als zijn eerste taak zijn broer te wreken. Al snel

${ }^{341}$ Lacomblet, Urkundenbuch III, 657-658, nr. 765.

342 Zie over dit conflict ook Meyer, Familie Palant, 54-55, noot 130. 
ontaardde dit in een vete, waarbij de partijen en hun aanhangers elkaar te vuur en te zwaard bestreden. Uiteindelijk bracht de aartsbisschop van Keulen in 1389 een verzoening tot stand. Voor de zielenrust van het slachtoffer moesten twee altaren met daaraan verbonden inkomsten en misverplichtingen worden gesticht, één door Godert van den Bongard in de kapel van Bocholtz en het andere altaar door de familie Van Schoonvorst in de kapel van hun huis in Aken. Het eerste altaar werd in 1457 overgebracht naar de kruisheren in Aken, het tweede in 1399 naar de dominicanen in Aken. ${ }^{343}$

\subsection{Hendrik II van Gronsveld, 1382/1386-1401/1404}

\subsubsection{Huwelijken}

Hendrik II van Gronsveld had tot aan de moord op zijn broer enigszins geleefd in diens schaduw, maar plotseling nam zijn loopbaan een geheel andere wending. Hendrik was de eerste keer gehuwd met Margaretha van Printhagen en uit deze echtverbintenis was een dochter, Metza of Mettel geheten, geboren. Van zijn zwager Johan van Printhagen erfde Hendrik een hof in Gronsveld en erfpachten te Noorbeek, Sint-Geertruid en SintMartens-Voeren.

$\mathrm{Na}$ het overlijden van Margaretha was Hendrik in 1382 hertrouwd met Johanna van Merode, dochter van wijlen Werner van Merode, heer van Rimburg, en de op dat moment nog in leven zijnde Aleid van Arkenteel ('Erckenteel', Argenteau). ${ }^{344}$ Maar tegelijkertijd werd deze verbintenis tussen de families Van Gronsveld en Van Merode bevestigd met een tweede huwelijk, namelijk tussen Christiaan, de broer van Johanna, en Mettel, de dochter van Hendrik uit zijn eerste huwelijk. Hoewel men zou verwachten dat Christiaan de achternaam van zijn vader voerde, wordt hij in de bronnen vrijwel steevast aangeduid als Christiaan of Kersken van Ringberg. Die achternaam zullen we hier dan ook gebruiken.

Territoriaal behoorde Rimburg tot het Land van 's-Hertogenrade, waarover de hertog van Brabant landsheer was. De hoge rechtspraak werd uitgeoefend door het hoofdgerecht van 's-Hertogenrade, maar de verhoudingen daarmee waren gecompliceerd (zie verder Hoofdstuk 3.3.3). Het huis Rimburg zelf was een Brabants leen, waaraan heerlijke rechten waren verbonden. ${ }^{345}$ Daartoe behoorde het recht op de middelbare en lage justitie. Een duidelijke omschrijving van het gebied waarover die werd uitgeoefend is te vinden in een 'denombrement' (opsomming) die Johan van Bronckhorst Batenburg in 1544 inleverde bij het leenhof van Brabant. 346 Ten minste vanaf het einde van de vijftiende eeuw bestond er een ook schepenbank bevoegd voor de middelbare en lage rechtspraak. Tot de heerlijke

\footnotetext{
343 Wolters, Recherches Gronsveld, 23-26; Chestret de Haneffe, 'Histoire Gronsveld', 42-44; Hanssen, Die Rimburg, 112.

344 Zie ook over Johanna en haar huwelijk: Hanssen, Die Rimburg, 98-99; over het door haar gevoerde zegel: Stieldorf, Rheinische Frauensiegel, 419.

345 Soms was aanvankelijk alleen een burcht het object van belening; vanaf het einde van de middeleeuwen werden daar soms stilzwijgend, soms uitdrukkelijk, heerlijke rechten bij inbegrepen, zie Janssen, 'Unterherrschaft', 163-164.

346 Hanssen, Die Rimburg, 350-351 (nummer 101).
} 
rechten van het huis Rimburg behoorden verder jacht- en visrechten, molenrecht, recht op accijnzen en recht op bos.

Op Sint-Mattheusdag (21 september) 1382 werd een uitvoerige akte van huwelijkse voorwaarden tussen Hendrik van Gronsveld en Johanna van Merode opgesteld. ${ }^{347}$ Beiden zouden het huis Rimburg ontvangen, maar alleen voor de duur van hun leven. Aleid van Arkenteel kreeg het recht van vruchtgebruik op de hoven Haanrade en Hofstadt, een rente uit het goed Kemenade bij Rimburg en hout uit het Ubacherbos. Christiaan van Ringberg bleef leenheer van alle lenen die onder Rimburg ressorteerden. Voor zijn recht op Rimburg zou Hendrik de schulden van zijn schoonmoeder en zwager/schoonzoon ten bedrage van 3300 gulden overnemen. Mocht Hendrik voortijdig sterven, dan ging het huis Rimburg geheel vrij over naar Christiaan en erfde Johanna de geldvordering van 3300 gulden. De andere goederen van de heerlijkheid Rimburg moesten Christiaan en Johanna samen als broer en zuster delen.

Omdat Mettel van Gronsveld, Hendriks dochter uit zijn eerste huwelijk, nog een kind was, beloofde hij haar te onderhouden tot de leeftijd van twaalf jaar. Ook betaalde Hendrik jaarlijks aan Christiaan zestig gulden. Mettel en Christiaan kregen op Hendriks kosten ieder een paard. Wanneer Mettel twaalf jaar was, ontving zij de hof 'Zu Matterberch'348, de hof in Gronsveld die 'Johans van Pryntzhagen was', de hof 'zu Vrounraide'349 en de 'hof te Eckelrade'. Zolang Hendrik leefde, moest Christiaan zich daarmee tevreden stellen. Wanneer Mettel voor haar twaalfde overleed, beloofde Hendrik alsnog zijn financiële verplichtingen jegens Christiaan na te komen. Met toestemming van zijn broer Johan, heer van Gronsveld, stelde Hendrik als eventueel weduwegoed voor zijn echtgenote ter beschikking al wat Hendrik zou verkrijgen uit de nalatenschap van ridder Godard van Gronsveld, hun beider broer.

Om Christiaans toekomstige aanspraken op het huis Rimburg veilig te stellen, beloofde Hendrik tijdens zijn leven de burcht niet in vreemde handen te geven. Daartoe zou ook het dienstpersoneel op het kasteel de nodige instructies ontvangen. De hele inboedel deelden Christiaan en Johanna gelijkelijk, met uitzondering van 'armburste, vuirebuessen ind alle andere geschutzes so wie man die nuemen mach mit alle ire gereidtschaff, so wie

347 ULB Darmstadt, Hs. inv. nr. 2734-2735, Cartularium Hurt von Schönecken, fol. 21-25; vgl. ook Hanssen, Die Rimburg, 98-100.

${ }^{348}$ Het moet hier gaan om het leengoed Materberg in Elsloo, dat deels leen van de heerlijkheid Elsloo en deels leen van Valkenburg was. In 1383 wordt Hendrik van Gronsveld hiermee beleend. (vgl. Habets, 'Leenen Valkenburg', PSHAL 21 (1884) 255-256, 416-417. De verwarring over deze hof begint bij Hanssen, Die Rimburg, 99 die eerst spreekt van een 'Hof zu Matterberg im Stadtkreis Aachen'. Daarna (101) maakt hij melding van een geschil tussen Christiaan van Ringberg en de stad Aken over landweren 'in der Nähe seines Hofes 'Matterberg oder Fronrath'. In zijn beschrijving van het geschil (100-102) verwijst hij ook naar Quix, Rimburg, 25, maar van een hof Materberg wordt in dit verband geen melding gemaakt.

349 Het betreft hier de hof 'Mittel-Fronrath' in het kerspel Richterich, niet ver van huis Heyden, bij de Worm gelegen. 'Unter-Fonrath' verwierf Hendrik van Gronsveld in 1397 door aankoop van Johan van Kintzwyler. Dit was een leen van de Keurkeulse mankamer in Heerlen, vgl. ULB Darmstadt, Hs. inv. nr. 2734-2735, Cartularium Hurt von Schönecken, fol. 287-381. Johanna van Merode erfde van Johan van Kintzwyler 'Ober-Fronrath'in 1408, vgl. Hanssen, Die Rimburg, 114. 
dy huyde zu dage dae sijnt as da up der burgh blijven sullen'. Mettel en Christiaan erfden na Hendriks dood alles wat hun rechtens toekwam. Omdat Hendrik van Gronsveld Christiaan en Mettel in de kost hield, beloofde Christiaan trouw aan Hendrik en zou hij niet proberen hem de burcht Rimburg afhandig te maken.

In zijn geschiedenis van Rimburg noemt Hanssen 'dieser Tausch für Christian sehr ungünstig,' ${ }^{350}$, maar het is de vraag of dit oordeel terecht is. Er moesten wederzijdse belangen worden veiliggesteld. Aleid van Merode, geboren van Arkenteel, verkeerde in een lastige positie. Zij bewoonde een strategisch belangrijk kasteel, gelegen in het dal van de Worm, in het grensgebied tussen Brabant en Gulik. Van daaruit kon de handelsweg van Keulen naar Brabant worden gecontroleerd. Het krijgskundig belang komt goed tot uitdrukking in de huwelijkse voorwaarden met de bepaling dat alle wapentuig in het kasteel moest blijven. Aangezien Christiaan van Ringberg nog zeer jong was, moest zijn moeder zorgen dat Rimburg in veilige handen bleef. Een verbintenis van haar dochter met Hendrik van Gronsveld bood daarvoor goede mogelijkheden. Via hem ontstond een alliantie met een vooraanstaand adellijk geslacht. Voor Hendrik als jongere broer van de machtige heer van Gronsveld bood het bezit van Rimburg de mogelijkheid een eigen carrière te bouwen en hij had geen dynastieke belangen die een directe bedreiging vormden voor het erfdeel van de nog jonge Christiaan van Ringberg.

Er speelden ook nog financiële motieven een rol. In 1390 verklaarde een getuige dat de voornaamste schuldeiser van Aleid van Arkenteel en Christiaan van Ringberg niemand minder was dan Johan III van Gronsveld. Die had in feite de macht over Rimburg. Hendrik was zijn huwelijk aangegaan met de uitdrukkelijke garantie van zijn broer dat die zijn vordering niet op Johanna van Merode zou verhalen. Ten slotte beloofde Johan dat na zijn overlijden alle vorderingen op Rimburg aan Hendrik en Johanna zouden vervallen. ${ }^{351}$ Het belang van Johan van Gronsveld bij het huwelijk was ook duidelijk, aangezien hij moest voorkomen dat de burcht, die onderpand was voor zijn vordering, in verkeerde handen viel.

\subsubsection{Relaties met Brabant}

Door de dood van Johan III van Gronsveld veranderde de financiële positie van Hendrik ingrijpend. De erfenis omvatte de heerlijke rechten over Gronsveld, Heugem, Honthem en Slenaken alsmede de heerlijkheden die van Godart van den Bongard afkomstig waren, te weten Heyden, Oost, Sint-Martens-Voeren en Höngen in het Land van Millen. Verder waren er de pandrechten op de heerlijkheden Eijsden en Cadier, alsmede een reeks kastelen en ambten in het hertogdom Limburg en de Landen van Overmaze, die alle verbonden waren met schuldvorderingen op de hertog en hertogin van Brabant. Ten slotte bestond het bezit nog uit diverse lenen, cijnzen en uitstaande geldvorderingen. Een deel van deze erfenis moest Hendrik wel delen met Johans weduwe, Margaretha Scheiffart van Merode.

${ }^{350}$ Hanssen, Die Rimburg, 99.

351 ULB Darmstadt, Hs. inv. nr. 2734-2735, Cartularium Hurt von Schönecken, fol. 36. 
Niet alle rechten in deze nalatenschap waren even sterk. In het bijzonder de vorderingen vanwege Eijsden en Cadier leken verloren. In 1375 had Johan III van Gronsveld immers bepaald dat deze dorpen, die hij voor een lening van 5500 gulden in pand hield, zonder aflossing van de schuld aan Brabant terugvielen wanneer hij vóór de hertog en hertogin overleed. Hertog Wenceslaus was al in 1383 gestorven, maar zijn weduwe Johanna leefde nog. Ondanks plannen aan Brabantse zijde om Eijsden en Cadier terug te krijgen, werd de verpanding vooralsnog gehandhaafd. Hoe lang deze situatie precies heeft geduurd is niet bekend, maar in ieder geval tot 1408 bleven beide plaatsen in bezit van de heren van Gronsveld. Vóór 1418 moet aflossing hebben plaatsgevonden, althans voor wat betreft de hoge en lage jurisdictie. Cijnzen, pachten, tol et cetera zijn tot het begin van de zestiende eeuw in Gronsveldse handen gebleven (dat wil zeggen in een zijlinie van de heren van Gronsveld). 352

Meer problemen bracht de bezetting van een reeks ambten die Johan III had verworven als onderpand voor leningen aan het Brabantse hertogshuis. Een deel van die ambten was ook verbonden met het beheer van een kasteel. Tegelijkertijd deed zich binnen het Brabantse landsbestuur een verschuiving van de macht voor ten gunste van Philips de Stoute, hertog van Bourgondië. De alleenstaande en kinderloze hertogin Johanna, in die jaren geconfronteerd met voortdurende agressie van buurland Gelre, zocht steeds meer steun bij Philips. Johanna zag in hem haar opvolger en droeg, onder voorbehoud van vruchtgebruik, in 1390 het hertogdom Brabant over aan Philips. Tegenwerking van de Staten van Brabant hield de uitvoering van deze transactie tegen. Pas in 1401 gingen die akkoord met een landsheer uit het Bourgondische huis. Daarbij viel de keus niet op Philips van Bourgondië, maar diens tweede zoon, de aan het Brabantse hof opgevoede Anton.

Als onderpand voor schulden en dank voor de hulp van Philips had hertogin Johanna hem op 15 februari 1387 haar kastelen, steden en andere bezittingen in de Landen van 'sHertogenrade, Wassenberg en Sprimont en het hertogdom Limburg overgedragen. In feite ontving de hertog van Bourgondië daarmee slechts de blote eigendom, want de bezittingen waren eerst verpand aan Johan III van Gronsveld en nu overgegaan op diens erfgenamen. De verhouding tussen schuldeisers en schuldenaar veranderde daardoor niet wezenlijk. Philips kreeg onder dezelfde voorwaarden als Johanna het recht de pandsom af te lossen. Alle ambtenaren in de betrokken gebieden ontvingen op 12 mei 1387 opdracht trouw aan hun nieuwe heer te zweren. Twee weken later maakte Philips al van zijn recht op aflossing gebruik, maar hij handhaafde Hendrik van Gronsveld als beheerder van de bewuste kastelen en plaatsen. Vanuit het standpunt van de hertog betekende deze nieuwe verhouding een verbetering: geen risico op moeilijkheden met de erfgenamen van Johan III van Gronsveld en toch een band met Hendrik II van Gronsveld, een der machtigste edelen in de streek. 353

Zoals al vermeld is het onduidelijk of Johan III van Gronsveld ook kasteel, stad en Land van Valkenburg in pand had. In ieder geval vertrouwde hertogin Johanna in 1388 aan

352 Van Hall, Eijsden, een vrijheid, 60-62.

353 Voor een overzicht van de navolgende transacties met betrekking tot ambten en pandschappen, zie Chestret de Haneffe, 'Histoire Gronsveld', 44-47 en Hanssen, Die Rimburg, 112-114. 
Hendrik van Gronsveld het beheer van Valkenburg toe voor een lening van 10144 'oude schilden'. ${ }^{354}$ Daarna viel ook dit gebied, gelijk de andere Brabantse bezittingen ten oosten van de Maas, in Bourgondische hand, want in 1389 verwierf hertog Philips ook hiervan de blote eigendom, met handhaving van Hendrik van Gronsveld als drossaard. ${ }^{355}$

$\mathrm{Na} 1390$ lijkt zich in de loopbaan van Hendrik een kentering voor te doen. Philips de Stoute benoemde in 1390 Johan Scheiffart van Merode tot gouverneur van Limburg. ${ }^{356}$ In 1395 loste Philips de schuld op het kasteel van Valkenburg af en werd Hendrik eervol uit zijn ambt als kastelein en drossaard van Valkenburg ontslagen. ${ }^{357}$ Hij koos meer voor functies op de achtergrond, zonder aan invloed in te boeten. Samen met Johan Scheiffart van Merode was hij in die jaren actief als geldschieter voor hertogin Johanna, onder andere in haar strijd tegen Gelre. ${ }^{358}$ Omstreeks 1395 betitelt Hendrik zich als raadsheer van Johanna en Philips, een wat raadselachtige aanduiding, want hij schijnt nooit als zodanig een officiële rol te hebben gespeeld. Anderzijds geeft deze kwalificatie aan dat hij in kringen van het Brabantse hof wel invloed had. ${ }^{359}$

\subsubsection{Boedelscheiding met Christiaan van Ringberg}

Intussen brak de tijd aan om de familiale verhoudingen opnieuw te regelen. Uit het huwelijk van Hendrik en Johanna van Merode waren vijf kinderen geboren: Hendrik, Werner, Johan, Wilhelmina en Aleydis. Hun belangen moesten veilig worden gesteld. Tegelijkertijd moest worden voorzien in de belangen van Hendriks zwager, tevens schoonzoon Christiaan van Ringberg, gehuwd met Mettel, Hendriks dochter uit zijn eerste huwelijk. Volgens het huwelijkscontract van 1382 diende Christiaan zich tot het overlijden van Hendrik tevreden te stellen met een aantal hoven. Rimburg zou hem pas na Hendriks overlijden toevallen. Door de erfenis van Johan III van Gronsveld was Hendriks financiële positie echter volledig veranderd.

Het schijnt dat Christiaan begin jaren negentig op Rimburg woonde. In $1394 \mathrm{kreeg}$ hij een geschil met de stad Aken en gebruikte hij de burcht als uitvalsbasis om burgers van de rijksstad te beroven. Het stadsbestuur stond tamelijk machteloos en verzocht hertogin Johanna van Brabant een einde te maken aan deze vete die haar vazal veroorzaakte. Haar

\footnotetext{
354 Verkooren/Grunzweig, Inventaire chartes de Brabant, IIIe stuk, chartes originales et cartulaires, deel I (13831396), 134, nr. 6461.

355 Quicke, 'Documents', 139-145, nr. 24, Verkooren/Grunzweig, Inventaire chartes de Brabant, IIIe stuk, chartes originales et cartulaires, deel I (1383-1396), 171, nr. 6562.

356 Verkooren/Grunzweig, Inventaire chartes de Brabant, IIIe stuk, chartes originales et cartulaires, deel I (13831396), 188-189, nr. 6613.

357 Quicke, 'Documents', 164-178, nr. 35-36, 38; Verkooren/Grunzweig, Inventaire chartes de Brabant, IIIe stuk, chartes originales et cartulaires, deel I (1383-1396), 273, nr. 6862; 275, nr. 6868.

358 Verkooren/Grunzweig, Inventaire chartes de Brabant, IIIe stuk, chartes originales et cartulaires, deel I (13831396), 197-201, nr. 6639-6641; 6645-6647, 6652; Quicke, 'Documents', 154-156, nr. 28 (bij hem vermeld als 'Chartes de Brabant 6563') en 29.

359 Verkooren/Grunzweig, Inventaire chartes de Brabant, IIIe stuk, chartes originales et cartulaires, deel I (13831396), 273, nr. 6862; Uyttebrouck, Gouvernement Brabant II, 695.
} 
interventie schijnt wel succes te hebben gehad. ${ }^{360}$ Welke rol Hendrik III van Gronsveld daarin speelde is onduidelijk. Zijn naam wordt in het conflict niet genoemd, maar anderzijds was bekend dat ook hij de stad Aken niet gunstig gezind was.

Op 12 maart 1396 kwamen enerzijds Hendrik van Gronsveld en Johanna van Merode en anderzijds Christiaan van Ringberg en Mettel van Gronsveld, in aanwezigheid van Aleid van Arkenteel, een definitieve boedelverdeling overeen. Christiaan behield de hof te Gronsveld, die van Johan van Printhagen was geweest en een (niet nader benoemde) 'hof te Eckelrade'. Verder kreeg hij de hof 'zo Steinenhuys'361 en een erfpacht op de tienden van Höngen. Hendrik stelde ook het bezit van de burcht Heyden met de bijbehorende hof in het vooruitzicht, voorts de hoven 'zo Rosenberch', 'zo Ghehucht' en 'zo Buecken bie der Heyden', 362 maar Christiaan zou die pas verwerven na het overlijden van Hendrik. Onder dezelfde condities werden hem ook de hoven van Haasdal, 'Oeventzel' (Oensel) en 'Vroenrade'363 beloofd. Christiaan wees deze bezittingen aan als weduwegoed voor zijn echtgenote, indien hij mocht komen te overlijden.

Andere goederen die Christiaan onmiddellijk kreeg toebedeeld waren een stadswoning in Aken, heerlijke rechten over Richterich en Eygelshoven inclusief het bedrag waarvoor de hertog van Gulik zijn rechten daarop had verpand en de 'heirlicheit zo Trymmelynt boven Vollemborch gelegen (?)'.

$\mathrm{Na}$ Hendriks dood, en niet eerder, zouden Christiaan en Mettel ontvangen alle goederen en erven afkomstig van wijlen Hendriks zwager Johan van Printhagen, te weten de hof 'zer Nuwerborch' in het Land van Daelhem, de hof 'gelegen zo Oyss' (Oost), de tienden te Nuth en pachten te Bergenhuizen (Noorbeek), Libeek (Sint-Geertruid) en Sint-MartensVoeren. Christiaan verklaarde met de hem toebedeelde goederen tevreden te zijn, ook omdat Hendrik hem en zijn moeder Aleid van Arkenteel in hun zware financiële nood had geholpen met schenkingen en kwijtscheldingen van schulden.

Bij de boedelscheiding werden an Hendrik van Gronsveld en Johanna van Merode toebedeeld

die gantze herlicheiden, gerichten, erve ind gude vann Gronssfeldt, van Eckelrode, van Sent Mertensvoeren, van Sledenake ind van Hoegem, mit den mannen, scheffenen, leenluden, laessen (laten) ind ondersaissen mit den ghichten (gift, collatierecht) van allen kirchen, capellen, proveden ind elteren (prebenden en beneficies van altaren).

Christiaan en Mettel deden daarvan uitdrukkelijk afstand. Verder ontving de heer van Gronsveld de stadswoning in Maastricht en het pandrecht op Mesch, ${ }^{364}$ Eijsden en de

\footnotetext{
${ }^{360}$ Hanssen, Die Rimburg, 100-102.

${ }^{361}$ Ligging onbekend.

362 'Ghehucht' is Geuchterhof ten zuiden van Heyden, 'Rosenberch' lag in het Land van Richterich. ULB Darmstadt, Hs. inv. nr. 2734-2735, Hurt von Schönecken, fol. 52. 'Buecken' is de Bückerhof ten noorden van Heyden, langs de Crombacherbeek, net op thans Duits gebied onder Kerkrade.

363 De vermelding van deze hof is niet geheel duidelijk. Mittel-Fronrath had Christiaan al bij zijn huwelijk in 1382 gekregen, Unter-Fronrath verwierf Hendrik van Gronsveld pas in 1397.

364 Dit pandrecht is niet geheel duidelijk. Mesch was een heerlijkheid in het bezit van het Onze-LieveVrouwekapittel te Aken.
} 
helft van Cadier ${ }^{365}$, de hof Materberg en de hof te Sleiden ${ }^{366}$, in het land van Gulik. Eveneens Gronsvelds familiebezit bleven de goederen in het hertogdom Limburg, zoals 'dat gut ind erve van den Buecken' bij Henri Chapelle en 'alsulche deyle as sij haven an den bliberch zo Lontzemberch'367, het goed en erf van 'Loheirstorp' en het goed te 'Heymsberch' bij Limbourg. Deze Limburgse goederen dienden ook als weduwegoed voor Johanna van Merode, wanneer Hendrik voor haar kwam te overlijden. Alle goederen die Johanna verkreeg uit de nalatenschap van haar moeder, mocht zij behouden en na haar overlijden vererfden die weer op haar kinderen.

De belangrijkste verandering ten opzichte van het huwelijkscontract uit 1382 was dat Hendrik van Gronsveld de burcht en voorburcht van Rimburg met leenmannen kreeg toegewezen. De daadwerkelijke overgang kon eerst plaatsvinden na het overlijden van Aleid van Arkenteel. Tot die Rimburgse goederen behoorden ook pachten en renten te Simpelveld en Bocholtz, zes morgen bos bij Wilhelmstein (tussen Kerkrade en Würselen), een molenpacht te Ubach en een 'handleen' (tot leengoed gemaakte schuldvordering) op de tollen van Maastricht en 's-Hertogenrade. Voorts ontving Hendrik het dorp en de heerlijkheid Höngen, die eertijds verpand waren aan Godert van den Bongard, heer van Heyden, en daarna waren vererfd op Johan III van Gronsveld.

De inkt van de oorkonde van 12 maart 1396 was amper droog, toen 's anderendaags enkele wijzigingen werden aangebracht. In de eerste plaats verklaarde Christiaan van Merode dat Hendrik van Gronsveld hem het 'hantleen' op de tollen van Maastricht en 'sHertogenrade had overgedragen, zolang Hendrik leefde. Na diens overlijden zou dit leen echter weer onmiddellijk terugvallen aan de bezitter van Rimburg. ${ }^{368}$ Veel ingrijpender was echter de bepaling dat Hendrik en Johanna nu reeds aan Christiaan en Mettel overdroegen het huis Heyden en alle andere goederen die hen na Hendriks dood in het vooruitzicht waren gesteld. ${ }^{369}$ Dat was op korte termijn gunstig voor Christiaan, maar het was een tegemoetkoming met haken en ogen. In de eerste plaats bestond het gevaar dat de goederen uit de familie zouden raken, wanneer Christiaan vóór Hendrik overleed en intussen de goederen aan derden had verkocht of vermaakt. Daarom verklaarde Christiaan als een soort borgstelling een bedrag van 7200 oude zware Rijnse guldens schuldig te blijven aan de bezitter van het huis Rimburg.

Maar Hendrik van Gronsveld had ten aanzien van het huis Heyden nog een andere troef in handen. Wijlen zijn broer Johan III had in 1367 aan hun beider oom Godert van de Bongard tienduizend gulden geleend, met het kasteel Heyden als onderpand. Hendrik mocht dan wel intussen Heyden door vererving in eigendom hebben verkregen, daarmee was de tevens door hem geërfde schuldbrief nog niet afgelost. Voorts was Hendrik in het bezit van diverse documenten die, wanneer ze in verkeerde handen vielen, veel problemen voor de bezitter van Heyden konden veroorzaken. Het betrof onder andere de huwelijkse

\footnotetext{
365 De reden dat hier over de helft van Cadier wordt gesproken is waarschijnlijk dat Margaretha Scheiffart van Merode, de weduwe van Johan III van Gronsveld, ook in deze pandsommen gerechtigd was.

366 Schleiden bij Aldenhoven.

367 Bleiberg (Plombières) bij Lontzen. Zie hierover uitvoeriger Hoofdstuk 1.8.5

368 ULB Darmstadt, Hs. inv. nr. 2734-2735, Cartularium Hurt von Schönecken, fol. 42.

${ }^{369}$ ULB Darmstadt, Hs. inv. nr. 2734-2735, Cartularium Hurt von Schönecken, fol. 42.
} 
voorwaarden tussen Godert van den Bongard en diens echtgenote Agnes van Breydenbent (mogelijk een titel voor aanspraken van de familie van Agnes) en bepaalde schriftelijke garanties van de hertog van Gulik over de status van Heyden als Guliks leen en open huis voor de hertog. Om aan deze mogelijke dreigingen voor Christiaan als bezitter van Heyden een einde te maken, schonk Hendrik hem en Mettel op 8 april 1399 de schuldvordering van tienduizend gulden, alsmede alle documenten die op Heyden betrekking hadden. ${ }^{370}$

Waarschijnlijk voelde Hendrik met het klimmen der jaren zijn levenseinde naderen. Op 3 september 1401 verklaarden Christiaan van Ringberg en zijn echtgenote Mettel dat Hendrik hen 'in sijnen levende lijve' het huis Heyden en alle daarop betrekking hebben vorderingen en documenten volgens de daarover gesloten contracten had overgeleverd. Zij bevestigden nog eens dat zij gedurende het leven van Hendrik het huis Heyden en de hof van Niederfronrath, de Geuchterhof en de Bückerhof op hun kosten zouden beheren en bewaren. Hendrik zou zich intussen tevreden stellen met de hof Rosenberch, de hoge en lage jurisdictie in het Land van Richterich, cijnzen en pachten in Horbach en Richterich, visserij in de grachten en vijvers rond het huis Heyden, beemden bij Steinbusch, Wilhelmstein en 'Rade' en ten slotte 'zer Banck mit den kaelkulen so wie ind wa die gelegen sijn, gehorende zer Heyden, zo Richtergin off irgen anders' ${ }^{371}$ Enkele weken later, op 11 november 1401, gaf Christiaan van Ringberg aan zijn zuster Johanna finale kwijting wegens ontvangst van alle roerende goederen en huisraad, waarop hij uit de erfenis van Hendrik aanspraak zou kunnen maken. ${ }^{372}$ Mogelijk werden daarmee roerende goederen bedoeld die tot de inboedel van huis Heyden behoorden. Uit de tekst blijkt duidelijk dat Hendrik nog leefde, maar waarschijnlijk was hij niet meer in staat zelf op te treden. Wanneer Hendrik II van Gronsveld overleed is niet bekend, maar het tijdstip moet liggen vóór april 1404.

\subsection{Hendrik III van Gronsveld, 1407-1474/1476}

\subsubsection{Geboortejaar}

Hendrik II werd als heer van Gronsveld en Rimburg opgevolgd door zijn gelijknamige eerste zoon, Hendrik (III). ${ }^{373}$ De tweede zoon, Werner 'de Oude' werd stamvader van de familie Van Gronsveld-Nivelstein-Kellersberg, een zijtak van het geslacht Van Gronsveld, die eind achttiende eeuw in mannelijke lijn uitstierf. 374 Het vroegst bekende publieke optreden van Hendrik III van Gronsveld dateert uit 1407, toen hij de stad Maastricht hielp

370 ULB Darmstadt, Hs. inv. nr. 2734-2735, Cartularium Hurt von Schönecken, fol. 25-26.

371 ULB Darmstadt, Hs. inv. nr. 2734-2735, Cartularium Hurt von Schönecken, fol. 51-52. Vanwege onduidelijke interpunctie in de originele tekst is de strekking niet helemaal duidelijk. Bedoeld is kennelijk het gehucht Bank ten noorden van Richterich met kolengroeves behorende tot Heyden en gelegen in Richterich.

372 ULB Darmstadt, Hs. inv. nr. 2734-2735, Cartularium Hurt von Schönecken, fol. 58.

373 Zie over hem Wolters, Recherches Gronsveld, 28-29, overigens zeer onduidelijk omdat hij geen onderscheid maakt met Hendriks vader; Chestret de Haneffe, 'Histoire Gronsveld', 49-57; Hanssen, Die Rimburg, 118-126; Uyttebrouck, Gowvernement Brabant II, 695.

${ }^{374}$ Hanssen, Die Rimburg, 126-130. 
bij een beleg door de Luikenaars. ${ }^{375}$ We mogen aannemen dat hij op dat moment tenminste achttien jaar oud was, wat zijn geboortejaar op omstreeks 1390 brengt. Met 1382 als huwelijksjaar van zijn ouders betekent dit, dat zijn zusters Wilhelmina en Aleidis waarschijnlijk ouder waren.

\subsubsection{Ouderlijke erfdeel}

Een akte van boedelscheiding tussen Hendrik III en zijn twee broers en twee zusters is niet bekend, waardoor we de verdeling moeten afleiden uit de latere feitelijke verhoudingen. Als oudste zoon erfde Hendrik de heerlijkheid Gronsveld cum annexis, het kasteel van Rimburg en de heerlijkheden Oost en Sint-Martens-Voeren. Over het erfdeel van Werner 'de Oude' van Gronsveld is weinig bekend. ${ }^{376}$ Waarschijnlijk bezat hij goederen op Guliks gebied en mogelijk erfde hij ook oud Gronsvelds bezit in het hertogdom Limburg. ${ }^{377}$ De derde broer, Johan, was kanunnik te Aken en kreeg als geestelijke waarschijnlijk zijn erfdeel in geld uitgekeerd. Hij overleed omstreeks 1431.378 Hendriks zuster Wilhelmina huwde in 1404 met Andries van Merode, heer tot Frankenberg. ${ }^{379}$ De bruid bracht bij haar huwelijk een bedrag van drieduizend Rijnse guldens in en deed voor de rest afstand van haar ouderlijk erfdeel. ${ }^{380}$ De jongste zuster, Aleidis, trouwde met Johan Schellart van Obbendorf. ${ }^{381}$ Beiden waren in 1454 kinderloos overleden. Dit betekende dat al wat Aleidis aan vaste goederen bij haar huwelijk had ingebracht, weer terugkeerde naar Hendrik III, Werner de Oude en Wilhelmina. Beide broers en zuster deelden deze erfenis in 1454. ${ }^{382}$ Het betrof onder andere de hof te Printhagen in Gronsveld, de Overste Hof te Fronrath en de halve hof te Neder-Fronrath (in de heerlijkheid Heyden) en de halve hof te Haasdal. Hendrik III kreeg de hof te Printhagen en de halve hof te Neder-Fronrath, Werner ontving de halve hof te Haasdal en Wilhelmina ten slotte erfde de Overste Hof te Fronrath. Ieders erfdeel werd geschat op een waarde van 78 malder rogge, waarbij de erfgenamen overeenkwamen waardeverschillen te compenseren.

\subsubsection{Huwelijke en kinderen}

Hendrik III huwde met Aleidis, dochter van Adam, heer van Oupeye, Herstal en Vivegnis en Cunegonde van Juppleu, vrouwe van Merlemont sur Orne en Avennes in de

\footnotetext{
375 Chestret de Haneffe, 'Histoire Gronsveld', 49; Franquinet, 'Sièges de Maestricht', 216-217, 235.

376 Nadere bijzonderheden over hem bij Hanssen, Die Rimburg, 115-117.

377 ULB Darmstadt, Hs. inv. nr. 2734-2735, Cartularium Hurt von Schönecken, fol. 301-302: in 1493 noemt Johan Hurt von Schönecken, heer tot Oupeye, ridder Werner van Gronsveld, heer 'zo denn Boecken' (= zoon van Werner de Oude) zijn zwager en vriend. Buchet, Seigneurie Del Beuck, is onduidelijk over het bezit van Del Beuck in deze periode.

${ }^{378}$ Hanssen, Die Rimburg, 127.

${ }^{379}$ Hanssen, Die Rimburg, 117.

380 Diverse contracten in ULB Darmstadt, Hs. inv. nr. 2734-2735, Cartularium Hurt von Schönecken, fol. 53-55, 58-65.

${ }^{381}$ Hanssen, Die Rimburg, 117.

382 ULB Darmstadt, Hs. inv. nr. 2734-2735, Cartularium Hurt von Schönecken, fol. 391-393.
} 
Haspengouw. ${ }^{383}$ Een jaartal of huwelijkscontract is niet bekend, maar het huwelijk moet vóór 1415 zijn gesloten. Aleidis van Oupeye zou zijn overleden in 1447.384 Waarschijnlijk werd zij begraven in de minderbroederkerk in Maastricht, waar later ook haar echtgenoot zijn laatste rustplaats vond.

Uit het huwelijk van Hendrik III van Gronsveld en Aleidis werden twee dochters geboren. Johanna, de oudste, trouwde in 1425 met Dirk van Bronckhorst Batenburg. In de literatuur wordt zij vaak Catharina, of Johanna Catharina genoemd, ${ }^{385}$ maar de bronnen geven steevast alleen de naam Johanna. De tweede, Aleidis, huwde in 1429 met Engelbrecht Nyt van Birgel. Verder wordt in de literatuur nog een derde dochter vermeld, die gehuwd zou zijn met Johan Huyn van Amstenrade.386 Dit moet echter op een vergissing berusten. In latere familiedocumenten van Hendrik III van Gronsveld komt dit echtpaar niet voor. Wel had Hendriks broer Werner 'de Oude' van Gronsveld, behalve vier zonen, ook nog een schoonzoon, genaamd Johan Huyn van Amstenrade. ${ }^{387}$ Op grond daarvan mogen we concluderen dat aan het gezin van Werner de Oude ${ }^{388}$ nog een dochter (Johanna?) moet worden toegevoegd.

Ten slotte had Hendrik III nog een natuurlijke dochter Johanna, die in tweede huwelijk getrouwd was met Johan van Holset. ${ }^{389}$ Ten tijde van haar weduwschap trad Hendrik III op als haar voogd. Waarschijnlijk was zij dezelfde als 'Johanne die begijne, meine bastartz dochter' die in 1472 bij een boedelscheiding door Hendrik III een weide kreeg toebedeeld. 390

\subsubsection{Ambtelijke activiteiten en relaties met naburige landsheren}

Afgezien van de hierna nog te bespreken problemen rond Herstal, toonde Hendrik III zich vooralsnog een trouw aanhanger en geldschieter van de hertog van Brabant. Zo was hij in 1423 afgevaardigde van hertog Jan IV tijdens onderhandelingen in Maastricht over de aflossing van het verpande Land van 's-Hertogenrade. ${ }^{391}$ In 1425 ontving hij op grond van oude Brabantse schuldbekentenissen ten behoeve van zijn vader, de heerlijkheid Ath of Beaumont in onderpand. ${ }^{392}$ Functies als drossaard, slotvoogd en dergelijke in dienst van

383 Chestret de Haneffe, 'Histoire Gronsveld', 50. Over Herstal en de relatie met de heren van Oupeye zie: Poncelet, 'Herstal et Vivegnis', 118-124; Yans, 'Le destin diplomatique', 491-493.

384 Chestret de Haneffe, 'Histoire Gronsveld', 55; Hanssen, Die Rimburg, 125. In ieder geval leefde zij nog in 1439, zie TJ, inv. nr. 11 fol. 449-463, 467-471 en 581-584, afschrift van oorkonde van schout en schepenen van Gronsveld uit 1439.

385 Chestret de Haneffe, 'Histoire Gronsveld', 55-56; Hanssen, Die Rimburg, 125.

386 Chestret de Haneffe, 'Histoire Gronsveld', 56; Hanssen, Die Rimburg, 125.

387 ULB Darmstadt, Hs. inv. nr. 2734-2735, Cartularium Hurt von Schönecken, fol. 10-13.

388 Hanssen, Die Rimburg, 126.

389 ULB Darmstadt, Hs. inv. nr. 2734-2735, Cartularium Hurt von Schönecken, fol. 138-139,

390 ULB Darmstadt, Hs. inv. nr. 2734-2735, Cartularium Hurt von Schönecken, fol. 17-21. Chestret de Haneffe en Hanssen schrijven dat zij in 1472 was overleden.

391 Verkooren/Graffart, Inventaire chartes de Brabant, IIIe stuk, Chartes originales et cartulaires, deel IV (14151427), 231, nr. 10076.

392 Verkooren/Graffart, Inventaire chartes de Brabant, IIIe stuk, Chartes originales et cartulaires, deel IV (14151427), 286, nr. 10242. Zie ook ULB Darmstadt, Hs. inv. nr. 2734-2735, Cartularium Hurt von Schönecken, fol. 26-27, oorkonde van 22 april 1424, waarbij hertog Jan IV hem wegens een vordering uit 
naburige landsheren pasten in de traditie van Hendriks voorouders. Zo was hij van augustus 1429 tot waarschijnlijk medio 1434 kastelein en drossaard van Limburg en van augustus 1429 tot augustus 1431 ook ontvanger van de hertogelijke inkomsten van Limburg. ${ }^{393}$ Tussen 1437 en 1442 wordt hij genoemd als drossaard van het Land van 'sHertogenrade. ${ }^{394}$ Voorts stond Hendrik tijdelijk in Luikse dienst. ${ }^{395}$ Het totaal aan ambtelijke functies overziende, krijgt men niet de indruk dat hier het zwaartepunt van Hendriks belangstelling lag. Mogelijk speelde ook een rol dat na 1450 de relaties met Brabant bekoelden.

\subsubsection{Betrokkenheid bij mijnboum}

In de boedelscheiding tussen enerzijds Hendrik II van Gronsveld en Johanna van Merode en anderzijds Christiaan van Ringberg en Mettel van Gronsveld van 1396, werd aan eerstgenoemde toebedeeld 'alsulche deyle as sij haven an den bliberch zo Lontzemberch'. Deze passage vormt het oudste bewijs van betrokkenheid van de familie Van Gronsveld bij de ertswinning in de omgeving van Kelmis, Moresnet en Plombières. In het midden van de veertiende eeuw was in dit gebied een bescheiden begin gemaakt met de winning van lood- en zinkerts (galmei, kalamijn). Deze laatste delfstof was noodzakelijk voor de productie van messing. Door Yans is beschreven hoe sinds de vijftiende eeuw de hertogen van Brabant, in het bijzonder uit het Bourgondische huis, als landsheren van het hertogdom Limburg, op basis van het mijnregaal begonnen met een echte mijnbouwpolitiek. ${ }^{396}$ Yans onderscheidt ongeveer tien mijnen, waarvoor nu eens afzonderlijk, dan weer in combinatie, aan particuliere ondernemers landsheerlijke concessies werden verleend. Die moesten behalve pachtgeld ook een deel van de opbrengst in de vorm van tienden afdragen aan de ontvanger der landsheerlijke inkomsten.

Uit de door Yans bestudeerde stukken blijkt tweeërlei betrokkenheid van de familie Van Gronsveld bij de mijnbouw. Zo ontving Hendrik III in de jaren 1433-1434 een deel van de mijntienden als vergoeding voor een lening van 311 gulden aan de hertog. ${ }^{397}$ Het meeste betrokken bij de ertswinning was echter Hendriks broer Werner 'de Oude'. Deze had samen met zijn compagnon Gerard van Haaren diverse vorderingen op de hertog en inde daarvoor sinds 1436 de landsheerlijke inkomsten van alle mijnbouw in Limburg. Na uitkoop van zijn zakenpartner begon Werner in 1451 voor zichzelf met de exploitatie van

1389 van wijlen Hendrik II van Gronsveld van 1732 'alde schilden' (munt) aan hertogin Johanna van Brabant en een vordering uit 1403 twee ambten met alle bijbehorende inkomsten belooft, te weten Beaumont en ? (in de tekst niet ingevuld), zodra de hertog Henegouwen met geweld onder zijn macht heeft gebracht.

393 Zie voor precieze data van benoemingen Yans, Histoire économique de Limbourg, 235 en 237; zie ook Uyttebrouck, Gouvernement Brabant II, 695.

${ }^{394}$ Hanssen, Die Rimburg, 120-121. Het Land van 's-Hertogenrade was toen overigens door de hertog van Brabant verpand aan Jan van Heinsberg.

395 De Noüe, 'Promenade Beaufays', 511: 1430 slotvoogd en gouverneur van Franchimont.

${ }^{396}$ Yans, Histoire économique de Limbourg.

397 Yans, Histoire économique de Limbourg, 137. 
de galmeimijn van La Vieille Montagne, maar hield daar drie jaar later al weer mee op. ${ }^{398}$ Er kunnen verschillende redenen voor die voortijdige beëindiging zijn geweest: Alle exploitanten kampten met hoge investeringen, technische problemen en meningsverschillen met de stad Aken over het mijnregaal en het landsheerlijk gezag over het gebied.

Hoe lang Werner uiteindelijk bij de mijnbouw betrokken bleef, is niet bekend. Van Hendrik III staat in ieder geval vast dat hij nog in 1472 een aandeel had in de 'Blyenberg', want in een boedelverdeling uit dat jaar kent hij dit recht toe aan zijn kleindochter Johanna van Birgel en haar echtgenoot Johan von Schönecken. ${ }^{399}$ De betekenis daarvan kan echter niet groot meer zijn geweest, aangezien in die tijd de Bourgondische hertogen streefden naar een staatsmonopolie op de kalamijnwinning en de handel in lood.

Het valt moeilijk te becijferen welke betekenis de laatmiddeleeuwse Limburgse mijnbouw heeft gehad voor de vermogensvorming binnen de familie Van Gronsveld. Een bron van geweldige rijkdom kan het niet zijn geweest, want we weten dat investeringskosten en het risico voor de pachters hoog waren en de kansen op verlies reëel. Daar staat tegenover dat leden van de familie Van Gronsveld zich als heffers van de mijntienden meestal aan de veilige kant bevonden. Maar misschien moet het belang van de winning worden geplaatst binnen een andere context. Bij de exploitatie was een groep kapitaalkrachtige personen betrokken, bestaande uit zowel burgers (uit Aken, maar ook uit Vlaanderen) als ook edelen uit families, waarmee de heren van Gronsveld op een of andere manier een relatie onderhielden, hetzij in positieve (Van Welkenhuizen, Van Wittem) of meer negatieve zin (Van Nassau). Kennelijk gold binnen deze kringen de Limburgse ertswinning als een interessante bezigheid. Een tweede aspect van deze specifieke mijnbouw is een mogelijke relatie met de uitoefening van het muntrecht door de heren van Gronsveld. In Hoofdstuk 15.2 zal nader op deze problematiek worden in gegaan.

\subsubsection{Erfenissen van de familie $V$ an Oupeye}

De familie van Hendriks echtgenote Aleidis stond als aanzienlijk bekend. ${ }^{400}$ De basis voor dat prestige was vooral gelegd door Lambert van Oupeye, de grootvader van Aleidis. Deze had als 'maarschalk' in dienst van de prins-bisschop van Luik een succesvolle militaire carrière doorlopen. Buiten zijn krijgskundige activiteiten bekleedde Lambert ook functies als gouverneur van Bouillon en werd hij belast met diplomatieke taken bij de bemiddeling in geschillen. 401

Ook zakelijk bleek Lambert succesvol. Oorspronkelijk had Oupeye een deel gevormd van het Karolingische domein van Herstal, maar was daar later van afgescheiden en eind dertiende eeuw leenroerig gemaakt aan de prins-bisschop van Luik. ${ }^{402}$ Lambert van Oupeye verhief de heerlijkheid Oupeye in 1345 voor het leenhof van Luik, maar lijkt

398 Yans, Histoire économique de Limbourg, 123, 137, 142-143.

399 ULB Darmstadt, Hs. inv. nr. 2734-2735, Cartularium Hurt von Schönecken, fol. 17-21.

400 Zie genealogie bij De Borman/Poncelet, Oeuvres Hemricourt, Miroir des nobles II, 323.

401 Poncelet, 'Les Maréchaux d'armée', 238-243.

402 Poncelet, 'Herstal et Vivegnis', 120, noot 1. 
daarnaast te hebben gestreefd naar een soort herstel van het oude domein Herstal. Het allodium Herstal was van oudsher Brabants eigendom en werd door de hertogen van Brabant beschouwd als een soort 'kroondomein', maar makkte geen deel uit van het hertogdom. ${ }^{403}$ Als apanage voor een zijlinie van de hertogelijke familie, kreeg dit allodium steeds meer het karakter van een Brabants leen en werd het aldus onder Brabantse soevereiniteit gebracht. Met het uitsterven van deze zijlinie van het hertogelijk huis kwamen de rechten over Herstal in het bezit van Jean de Gossoncourt alias Goetsenhoven, die deze in 1370 weer doorverkocht aan Lambert van Oupeye. ${ }^{404}$ In 1370 verhief Lambert de heerlijkheid Herstal voor het leenhof van Brabant. 405 Onbelast was Herstal niet. Er rustte een jaarlijkse renteschuld op van vijfhonderd gulden, welke vordering via vererving uiteindelijk terecht kwam bij Engelbrecht I van Nassau, heer van Breda.

Waarschijnlijk is ook de heerlijkheid Vivegnis omstreeks 1370 in het bezit van Lambert van Oupeye gekomen. De leenverheffing in Luik vond plaats in 1374.406 Deze heerlijkheid vormde evenals Oupeye een afsplitsing van Herstal, maar had door diverse enclaves een onduidelijk grensverloop, waarover zelfs nog in de achttiende eeuw onenigheid bestond. De juridische situatie van Vivegnis was gecompliceerd en de landsheerlijke rechten waren betwist tussen de prins-bisschop van Luik en de hertog van Brabant. Laatstgenoemde claimde voor Vivegnis een zekere afhankelijkheid van Herstal. De inwoners van Vivegnis voelden zich echter meer aangetrokken tot Luik dan tot Herstal en slaagden er 1429 in om in de banlieu van Luik te worden opgenomen.

Naast de aan elkaar grenzende heerlijkheden Oupeye, Herstal en Vivegnis, strategisch gelegen voor de poorten van de stad Luik, verwierf Lambert van Oupeye door zijn huwelijk met Aleidis van Lummen gezegd van Hermalle, in 1356 de heerlijkheid Chaumont en Ghistoux, een Luikse enclave in Brabant, gelegen ten zuidoosten van Brussel. ${ }^{407}$ De heerlijkheid Chaumont was echter zwaar belast met schulden aan de norbertijnen van Bonne-Espérance te Estinnes (bij Binche). Van deze vorderingen, voortkomend uit achterstallige tiendpachten, was in 1366 bepaald dat die binnen een termijn van zeventig jaar moesten zijn afgelost.

Uit de nalatenschap van Lambert van Oupeye erfde diens zoon Adam van Oupeye, de schoonvader van Hendrik III van Gronsveld, de heerlijkheden Oupeye, Herstal en Vivegnis. De tweede zoon, Jean van Oupeye, erfde de heerlijkheid Chaumont en noemde zich meestal naar dit bezit Jean van Chaumont. Hij was gehuwd met Elisabeth van Glymes, telg uit een bekende bastaardlinie van het Brabantse hertogelijk huis. ${ }^{408}$ Sinds het einde van de veertiende eeuw waren leden van de familie Van Glymes in het bezit van de heerlijkheid Bergen op Zoom.

403 Zie over Herstal: Nève, Rijkskamergerecht, 329-331.

404 Poncelet, 'Les Maréchaux d'armée', 238; Yans, 'Le Destin diplomatique', 490-491.

405 Poncelet, 'Herstal et Vivegnis', 120.

406 Poncelet, 'Herstal et Vivegnis', 120.

407 Bormans, 'Seigneuries féodales', 226; Poncelet, 'Les Maréchaux d'armée', 242-243, noot 8.

408 Zie over deze familie: Van Ham, Macht en gezag, passim en in het bijzonder 55-58. 
Maatschappelijk mocht de familie Van Oupeye dan wel in hoog aanzien staan, financieel ging het haar minder voor de wind. Zeker gold dit voor Adam van Oupeye. In 1398 leende hij bij zijn broer Jean een bedrag van zevenduizend goudgulden, onder andere met de bedoeling om de schuld op Herstal af te lossen. Maar uiteindelijk kwam daar niets van terecht. Omdat er niet meer werd betaald, stelde het leenhof van Brabant in 1402 Engelbrecht I van Nassau als schuldeiser in het bezit van Herstal. Die verhief vervolgens de heerlijkheid in leen. ${ }^{409}$ Adam van Oupeye wenste zich hier allerminst bij neer te leggen, wat leidde tot wederzijdse vijandelijkheden.

Het probleem werd nog groter door het kinderloos overlijden van Jean van Oupeye omstreeks 1415. Zijn weduwe, Elisabeth van Glymes, was niet van zins bij te dragen in de aflossing van de rente op Herstal en hield ook hardnekkig vast aan haar vordering van zevenduizend goudgulden op haar zwager Adam van Oupeye. Ook hier toonde Adam zich een onwillige debiteur, want hij loste niets af.

Om uit de impasse te komen, werden de financiële problemen voorgelegd aan Jan van Beieren, elect-bisschop van Luik. Op 1 februari 1415 deed deze uitspraak in de geschillen tussen Engelbrecht I van Nassau en Adam van Oupeye.410 In de eerste plaats werd vastgesteld dat de oorspronkelijke obligaties met een rente van vijfhonderd gulden per jaar op het land van Herstal hun geldigheid behielden. De achterstand, intussen opgelopen tot 8500 gulden (er was dus zeventien jaar niet betaald!), moest Adam alsnog binnen vastgestelde termijnen voldoen. Als tegenprestatie zou Engelbrecht van Nassau Herstal overdragen aan Hendrik III van Gronsveld, inmiddels gehuwd met Aleidis, de dochter van Adam, of aan Adam zelf. Engelbrecht gaf de nodige garanties dat Hendrik door de hertog van Brabant met Herstal werd beleend. Wanneer Adam van Oupeye nalatig was met zijn betalingen, mocht Engelbrecht van Nassau na vijftien dagen zijn vordering alsnog verhalen op het Land van Herstal en dit als eigen goed gebruiken.

$\mathrm{Na}$ de uitspraak van Jan van Beieren in 1415 schijnt in eerste instantie Adam van Oupeye met Herstal te zijn beleend. Maar na enkele jaren wenste hij de heerlijkheid af te staan aan zijn schoonzoon Hendrik III van Gronsveld. Een daartoe strekkend verzoek aan hertog Jan IV van Brabant werd op 22 maart 1423 gehonoreerd. ${ }^{411}$

Daarmee waren de moeilijkheden allerminst opgelost. Nog altijd rustte op Herstal de schuld van zevenduizend gulden, die Elisabeth van Glymes van haar overleden echtgenoot had geërfd en deze vordering wilde zij te gelde maken. Daarom wees in 1434 het leenhof van Brabant de heerlijkheid Herstal aan haar toe. Hendrik van Gronsveld bleek echter niet van zin te wijken, waarna Elisabeth haar vordering verkocht aan Antoine, heer van Croy, een der invloedriikste edelen aan het Brabantse hof. De heer van Croy werd vervolgens op 13 juli 1435 met Herstal beleend, maar de inwoners van Herstal, die Luiks burgerrecht bezaten, bleven trouw aan Hendrik van Gronsveld. In 1439 gaf Philips van Bourgondië, hertog van Brabant, opdracht aan Hendrik om Herstal te ontruimen voor de heer van

409 Yans, 'Le destin diplomatique', 494-495.

${ }^{410}$ ULB Darmstadt, Hs. inv. nr. 2734-2735, Cartularium Hurt von Schönecken, fol. 69-72.

411 ULB Darmstadt, Hs. inv. nr. 2734-2735, Cartularium Hurt von Schönecken, fol. 77-78. De akte van belening is gedateerd 22 maart 1422 volgens de jaarstijl van Kamerijk (Paasstijl), wat betekent dat het jaar volgens jaardagstijl 1423 is. 
Croy, maar vooralsnog maakte de heer van Gronsveld weinig aanstalten. Medio 1444 werd het menens. De prins-bisschop en de hertog kwamen tot overeenstemming en op 9 september 1444 verscheen graaf Johan van Nassau in opdracht van de hertog van Brabant in Herstal, vergezeld van afgevaardigden van de Luikse bisschop en het Luikse stadsbestuur. Jan van Nassau nam de heerlijkheid formeel in bezit, zette de door Hendrik van Gronsveld ter plaatse benoemde meier af en stelde daarvoor een nieuwe functionaris aan. ${ }^{412}$

Voor Hendrik III van Gronsveld moet het verlies van Herstal een bittere pil zijn geweest. Waarschijnlijk gold dit ook voor zijn schoonzoon Engelbrecht Nyt van Birgel, die in 1429 was gehuwd met Hendriks dochter Aleidis. Engelbrecht Nyt had van zijn vader de heerlijkheid Saive, grenzend aan Herstal, tegelijk met het kasteel van Saive, als huwelijksgift meegekregen. Hendrik van Gronsveld op zijn beurt schonk het jonge paar de hof 'De la Motte' gelegen op de grens van Saive en Herstal, evenals een jaarrente of pacht van 200 mud spelt, te beuren uit goederen onder Herstal.413

Lonkte daarmee voor Van Birgel het perspectief van de heerlijkheden Saive, Herstal, Vivegnis en Oupeye als één groot domein in één hand voor de poorten van Luik? Het pakte precies tegenovergesteld uit. ${ }^{414}$ Want als nasleep van het feit dat Antoine van Croy het land van Herstal aan Hendrik van Gronsveld had 'ontweldicht' (met geweld ontnomen), hield zelfs de betaling van de rente van tweehonderd mud op. Bovendien begon Van Croy nog een proces over de status van het 'grensgeval' van de hof De la Motte die tot Herstal zou behoren. Dit debacle veroorzaakte ook tussen Engelbrecht Nyt en zijn schoonvader ongenoegen. Om de schade te compenseren schonk Hendrik hem in 1452 een schuldbekentenis van 1732 'oude schilden' ten laste van de hertog van Brabant. 415

Hendrik III van Gronsveld kreeg behalve Herstal nog een tweede lastige erfenis. Door het overlijden van Jean van Oupeye in 1415 was de heerlijkheid Chaumont en Ghistoux teruggevallen op diens vader, Adam van Oupeye. Deze verhief 1416 de heerlijkheid in leen bij het leenhof van de bisschop in Luik. Maar nog altijd stonden op deze heerlijkheid de zevenduizend gulden ten behoeve van Jeans weduwe Elisabeth van Glymes. Op welke wijze Adam van Oupeye dat bedrag dacht af te lossen, is niet duidelijk, maar waarschijnlijk was hij dat ook helemaal niet van plan. Volgens de bisschoppelijke leenregisters lijkt Adam het bezit van Chaumont te hebben overgedragen aan Elisabeth van Glymes, maar behield hij zelf het recht van vruchtgebruik. Dit recht makkte hij weer te gelde door verpandingen. Als laatste erfde Hendrik van Gronsveld dit vruchtgebruik. Het lange wachten moe, droeg Elisabeth haar vordering over aan Jean van Tilly, heer van Opprebais. ${ }^{416}$ Uiteindelijk

\footnotetext{
412 Hanssen, Die Rimburg, 120; Lequarré, 'Terre franche de Herstal', 89-90

413 Zie voor het huwelijkscontract van 1429: ULB Darmstadt, Hs. inv. nr. 2734-2735, Cartularium Hurt von Schönecken, fol. 1-3.

${ }^{414}$ Zie voor de problemen tussen de heer van Croy en Engelbrecht Nyt van Birgel ook Poncelet, 'La seigneurie Saive', 280-281.

415 ULB Darmstadt, Hs. inv. nr. 2734-2735, Cartularium Hurt von Schönecken, fol. 113-114.

${ }^{416}$ Bormans, S., Seigneuries féodales, 226-227.
} 
zouden deze financiële geschillen in 1437 moeten eindigen door arbitrage, maar het is de vraag of dit ook werkelijk is gelukt. ${ }^{417}$

Intussen drukte op Chaumont, behalve de vordering van Elisabeth van Glymes, ook nog de oude schuld ten behoeve van de abdij van Bonne-Espérance. Midden jaren veertig van de vijftiende eeuw ontstonden grote problemen over de aflossingstermijnen. Hendrik III van Gronsveld en Boudewijn van Glymes, een neef van Elisabeth, die ook nog vorderingen had, raakten daarbij verwikkeld in twee procedures met de abdij, één voor het bisschoppelijk leenhof van Luik, de andere voor de officiaal van de bisschop. Een complicatie vormde de vraag of in deze zaak met aspecten van zowel tiendrecht als erfrecht de wereldlijke of de geestelijke rechter bevoegd was. De uiterst gecompliceerde procedure pakte met een vonnis van het leenhof uiteindelijk ongunstig uit voor Hendrik III van Gronsveld en Boudewijn van Glymes. ${ }^{418}$ Ook hoger beroep op de keizer en de aartsbisschop van Keulen mocht niet baten en in 1452 liet de prior van Bonne-Espérance zich te Luik met Chaumont belenen. Voor Hendrik van Gronsveld kreeg de zaak nog een bittere nasleep, want uiteindelijk moest hij ook opdraaien voor de vorderingen die Boudewijn van Glymes nog van vroeger had op Adam van Oupeye.

Bij elkaar hadden de erfenissen van zijn schoonfamilie Hendrik III niets anders opgeleverd dan schulden, verspilde energie en in rook opgegane illusies. Zeker het verlies van Herstal moet zwaar hebben gewogen, aangezien hier de mogelijkheden lagen voor een klein, onafhankelijk gebied. Maar de ervaringen met het Bourgondische hof in Brabant en de hoge adel van dit gewest moeten bij Hendrik hebben geleid tot herbezinning op de traditionele goede betrekkingen met deze buur.

\subsubsection{Huwelijken van de dochters}

Aangezien Hendrik en Aleydis slechts twee dochters hadden, eindigde daarmee de voortzetting van het geslacht Van Gronsveld in mannelijke lijn. Dit betekende dat met grote zorgvuldigheid moest worden gezocht naar huwelijkspartners. Voor de oudste dochter Johanna werd dit in 1425 Diederik van Bronckhorst Batenburg, telg uit een der voornaamste adellijke families uit het Gelderse rivierengebied. Door dit huwelijk bleef Gronsveld bijna drie eeuwen met de naam van deze familie verbonden. In Hoofdstuk 3.1.1. wordt nader op dit huwelijk ingegaan.

Aleidis, de tweede dochter van Hendrik III van Gronsveld en Aleidis van Oupeye, huwde in 1429 met Engelbrecht Nyt van Birgel, zoon van Frambach van Birgel, erfmaarschalk van Gulik, en van Johanna van Huckelhoven, vrouwe van Eschweiler. De keuze van deze bruidegom was duidelijk ingegeven door familiale en territoriale belangen. Door het ambt van erfmaarschalk behoorde de familie tot de hoogste adel van het hertogdom Gulik. Maar de vader van de bruidegom, Frambach van Birgel, was als bezitter van de heerlijkheid Saive, grenzend aan Herstal, ook de directe buurman van Hendrik III van

417 ULB Darmstadt, Hs. inv. nr. 2734-2735, Cartularium Hurt von Schönecken, fol. 2046-2050.

${ }_{418}$ Voor het aanzienlijk aantal oorkonden dat op deze procedure betrekking heeft zie ULB Darmstadt, Hs. inv. nr. 2734-2735, Cartularium Hurt von Schönecken, passim. 
Gronsveld.419 Deze Luikse connectie maakte het ook zonder problemen mogelijk dat Frambach in 1419 optrad als raadsman en thesaurier van prins-bisschop Jan van Heinsberg en als maarschalk die een detachement van het Luikse leger aanvoerde in de kruistocht tegen de Hussieten. ${ }^{420}$ Voor Hendrik moet een verbintenis van zijn dochter met de toekomstige erfgenaam van Saive aantrekkelijk zijn geweest met het oog op zijn strijd om het behoud van Herstal. Maar er kunnen ook nog oudere familiale banden een rol hebben gespeeld. Baldewin van Birgel, een broer van Frambach, was gehuwd met Margaretha van Oupeye, een oudtante van Hendriks echtgenote Aleidis van Oupeye. ${ }^{421}$ Het huwelijkscontract tussen Engelbrecht Nyt van Birgel en Aleidis van Gronsveld werd in aanwezigheid van acht familieleden en vrienden gesloten op 20 januari 1429.422 De leeftijden van bruid en bruidegom zijn niet bekend, maar Aleidis moet nog erg jong zijn geweest, want Hendrik van Gronsveld beloofde zijn dochter nog drie jaar in de kost te houden. Frambach van Birgel schonk als huwelijksgift voor zijn zoon een rente van driehonderd mud spelt, met als onderpand goederen in Charneux en 'Charnoy'. Voorts gaf hij de heerlijkheid Saive en stelde hij de daar gelegen burcht als woning ter beschikking. $\mathrm{Na}$ het overlijden van Frambach zou Engelbrecht de kastelen van Tomburg (in de VóórEifel, ten zuiden van Rheinbach) en Eschweiler erven. Hendrik III van Gronsveld bracht voor zijn dochter de hof 'Ter Motte' in, gelegen op de grens van Saive en Herstal, alsmede een rente van tweehonderd mud spelt gevestigd op goederen in Herstal (aflosbaar met tweeduizend Rijnse guldens). Ook goederen die in de toekomst nog van de kant van Aleidis van Oupeye, of van Johan Schellart van Obbendorf, oom van de bruid, zouden worden geërfd, vielen uiteindelijk aan het bruidspaar toe. Voorts ontving Engelbrecht van zijn schoonvader een leengoed van de heer van Heinsberg ter waarde van honderd Rijnse guldens per jaar. Ten slotte werden diverse regelingen getroffen voor het geval van vroegtijdig overlijden van Engelbrecht of Johanna. Samengevat komen die er op neer dat

\footnotetext{
${ }^{419}$ De heerlijkheid Saive was in het midden van de veertiende eeuw door huwelijk in het bezit gekomen van Gilles van Charneux. Aangezien de heerlijkheid verdeeld was geraakt onder diverse schuldeisers, spanden zijn drie zonen Arnold, Walterus en Adolf zich in Saive voor de familie te behouden, waarin zij ook grotendeels slaagden. $\mathrm{Na}$ het overlijden van Arnold van Charneux (waarschijnlijk 1366) vererfde zijn aandeel in Saive (het grootste) op zijn zoon Gilles. Behalve de heerlijkheid Saive bezat Gilles ook nog goederen in Charneux. Omdat Gilles kinderloos overleed, vermaakte hij zijn aandeel in Saive aan zijn nicht Elisabeth van Broich, omstreeks 1380 gehuwd met Engelbert Nyt van Birgel. Tegelijkertijd hadden ook de afstammelingen van Adolf van Charneux aanspraken. Diens oudste zoon Gilles 'qui n'eut pas de grande conduite' stierf kinderloos, drie broers traden in de geestelijke stand. (Poncelet, 'La seigeneurie Saive', 268-273). De enige dochter Alix, huwde met Dirk van Moyland of Mulland, heer van Jehanster, burgemeester van Luik, overleden 1404. (Borman/Poncelet, Oeuvres Hemricourt, Miroir des Nobles II, 310). In 1421 erkende zijn kleinzoon Adam van Moyland dat Frambach van Birgel oudere rechten op Saive had. Omdat hij Frambach als vader en vriend beschouwde en voornemens was geestelijke te worden, deed hij tegen betaling van achthonderd Hollandse guldens afstand van zijn rechten op Saive (Poncelet, 'La seigneurie Saive', 274-275, ULB Darmstadt, Hs. inv. nr. 2734-2735, Cartularium Hurt von Schönecken, fol. 640-641, 2004-2005). Uiteindelijk huwde Adam toch, maar Saive bleef volledig in het bezit van Frambach van Birgel.

420 Poncelet, 'Les Maréchaux d'Armée', 251-252.

421 Zijn broer Frambach benoemde hem tot banierdrager van het Luikse leger, zie Poncelet, 'Les Maréchaux d'Armée', 251-252.

422 ULB Darmstadt, Hs. inv. nr. 2734-2735, Cartularium Hurt von Schönecken, fol. 1-3.
} 
de langstlevende het vruchtgebruik van de nalatenschap erfde, maar dat vaste goederen terugkeerden naar de kant van de familie vanwaar ze waren gekomen.

\subsubsection{Nadagen en overlijden}

De laatste twintig jaar van het lange leven van Hendrik III worden niet gekenmerkt door bijzonder spectaculaire gebeurtenissen. $\mathrm{Na}$ het verlies van Herstal vroegen in de jaren vijftig de problemen over Chaumont veel aandacht. De betekenis daarvan kan enigszins worden afgemeten aan het grote aantal stukken over die kwestie, dat in het zogenoemde 'Cartularium Hurt von Schönecken' is afgeschreven (gedeeltelijk zelfs dubbel!). Hendriks verhouding tot de steden Aken en Luik liet na 1450 ook te wensen over, ${ }^{423}$ terwijl de vriendschappelijke banden met Maastricht, van welke stad Hendrik als adellijke buitenpoorter het burgerrecht bezat, juist werden aangehaald. In 1465 nam zelfs een detachement troepen onder leiding van de inmiddels bejaarde heer van Gronsveld deel aan plundertochten in het land van Luik en Loon, die vanuit Maastricht werden georganiseerd. ${ }^{424}$

Toen Hendrik III zijn levenseinde voelde naderen, schonk hij op 30 september 1472 voor zijn zielenheil een jaarrente van één mud rogge aan de Onze-Lieve-Vrouwebroederschap van Merkstein. ${ }^{425}$ Ter vermijding van latere onenigheid onder zijn erfgenamen stelde hij in hetzelfde jaar een akte op om bepaalde goederen aan kleinkinderen en achterkleinkinderen te doen toekomen. ${ }^{426}$ Zelfs Hendriks natuurlijke dochter Johanna werd met een perceel weiland bedacht. De tekst van het document is opgesteld in de 'ik'-vorm en werd mede bezegeld door Hendriks dochter Johanna, zijn schoonzoon Engelbrecht Nyt van Birgel, zijn kleinzoon Hendrik van Bronckhorst Batenburg en Johan Hurt von Schönecken, echtgenoot van zijn kleindochter Johanna van Birgel.

Een aantal passages uit de lange lijst van erfstellingen verdient hier nadere aandacht. Zo zou de hof Printhagen in Gronsveld vererven op Johanna van Birgel onder voorbehoud van het recht van vruchtgebruik voor Engelbrecht Nyt van Birgel. Interessant is dat Engelbrecht Nyt en zijn schoonzoon Johan Hurt von Schönecken min of meer opdracht kregen het proces over Chaumont voort te zetten. Kennelijk knaagde deze inmiddels toch echt verloren zaak nog altijd aan Hendriks gemoed.

Het huis Oost met zijn toebehoren, het goed de Houwert in Heugem en Hendriks aandeel in Slenaken, samen waard honderd Rijnse guldens per jaar, mocht Johanna van Gronsveld levenslang gebruiken. $\mathrm{Na}$ haar overlijden zouden deze goederen toevallen aan haar kleindochter Aleidis. Johanna moest als tegenprestatie daarvoor wel haar kleindochter bij zich in huis opnemen. ${ }^{427}$ Johanna kreeg ook het gebruik van het huis in Maastricht met huisraad, maar zonder goud en zilver. Na haar dood vererfde dit huis aan haar zoon

${ }^{423}$ Chestret de Haneffe, 'Histoire Gronsveld', 53-54; Hanssen, Die Rimburg, 121-122.

${ }^{424}$ Hanssen, Die Rimburg, 124.

425 Hanssen, Die Rimburg, 325, nr. 52.

426 ULB Darmstadt, Hs. inv. nr. 2734-2735, Cartularium Hurt von Schönecken, fol. 17-21.

427 Deze Aleidis was een dochter van Johanna's zoon Hendrik van Bronckhorst Batenburg, gehuwd met Catharina van Alpen. Zij ontbreekt in de door Van Schilfgaarde gepubliceerde genealogie Van Bronckhorst. 
Hendrik van Bronckhorst Batenburg. De huizen te Aken en 'Zu Raide'(?) met huisraad ontvingen de kleindochter Johanna van Birgel en haar echtgenoot Johan Hurt von Schönecken.

Hendrik moet hebben gedacht dat hij na deze regeling met een gerust geweten zijn ogen kon sluiten. Maar de zaak liep anders af. Want na zijn overlijden verscheen Johanna van Gronsveld op 10 april 1476 voor schepenen van Maastricht met de mededeling dat de regeling, die haar vader in 1472 had getroffen en zelfs door naaste verwanten mede was bezegeld, uiteindelijk vooral bedoeld was geweest om vrede te bewaren met hun vader Hendrik. Men had geenszins afstand willen doen van rechten die in eerdere huwelijkse voorwaarden waren vastgelegd. Omdat de scheiding 'van geinre werde en was' verklaarde Johanna deze in het vuur te hebben geworpen. ${ }^{428}$

Volgens het opschrift op zijn grafsteen die nog aanwezig is in de voormalige minderbroederskerk aan de Sint Pieterstraat in Maastricht, overleed Hendrik III op 7 maart 1474. We nemen de juistheid van datum en jaar hier aan op gezag van de verschillende auteurs die dit grafschrift vermelden, maar de tekst op de steen is moeilijk leesbaar. ${ }^{429}$ Erg ver kan de datum niet afwijken, want het jaar moet liggen tussen 1472 en 1476. Dit betekent dat Hendrik de voor die tijd zeer hoge leeftijd van ongeveer 85 jaar heeft bereikt. Niet ten onrechte noemt hij zich daarom in een brief aan het stadsbestuur van Aken uit 1462 'Heynrich van Gronsselt der Alde', ${ }^{430}$ hoewel deze aanduiding eigenlijk was bedoeld om hem te onderscheiden van zijn neef Hendrik van Gronsveld 'de Jonge', een zoon van zijn broer Werner. ${ }^{431}$

\subsection{Conclusies}

De vroegste vermeldingen van personen met de achternaam 'De Grules' of een variant daarvan zijn uit de elfde en twaalfde eeuw, maar het is niet mogelijk op basis daarvan een samenhangende genealogie te construeren. Wel gaat het om personen uit het gebied tussen Aken en Luik en het is ook duidelijk dat het adellijke personen betreft, die connecties onderhielden met het kapittel van Sint-Adalbert in Aken en de graaf/hertog van Limburg. Verbindingen met Gronsveld ontbreken.

In de dertiende eeuw heeft het adellijk geslacht Van Houffalize bezittingen in Gronsveld (land, tienden), maar het is, ondanks vroegere suggesties daartoe in de literatuur, niet mogelijk een verbinding te leggen met de heren van Gronsveld.

\footnotetext{
428 ULB Darmstadt, Hs. inv. nr. 2734-2735, Cartularium Hurt von Schönecken, fol. 32-33. Er is echter toch een tekst van bewaard gebleven, zoals blijkt uit het ULB Darmstadt, Hs. inv. nr. 2734-2735, Cartularium Hurt von Schönecken, fol. 17-21, waar de verdeling is opgenomen in een notarieel afschrift uit 1542 .

${ }^{429}$ De grafsteen wordt o.a. genoemd en beschreven bij Chestret de Haneffe, 'Histoire Gronsveld', 55; Hanssen, Die Rimburg, 125; Tummers, 'Begraven en grafzerken', 32.

430 Chestret de Haneffe, 'Histoire Gronsveld', 114-115, nr. 18.

431 ULB Darmstadt, Hs. inv. nr. 2734-2735, Cartularium Hurt von Schönecken, fol. 136-137.
} 
Vanaf de jaren dertig van de dertiende eeuw tot het begin van de veertiende eeuw kan van verschillende generaties van een familie Van Gronsveld een fragmentarische genealogie worden opgesteld, waarbij personen ook met de plaats Gronsveld in verband zijn te brengen. Het materiaal blijft echter schaars. Het belangriikste zijn de schenking van tienden door Wilhelmus van Gronsveld aan de cisterciënzerinnenabdij van Herkenrode, de verkoop in 1261 van een hof te Eckelrade door Reinerus van Gronsveld en zijn echtgenote Beatrix aan de cisterciënzerinnen van Hocht en de vertegenwoordiging van de minderjarige Johannes I van Gronsveld in 1281 bij de oplossing van een geschil over tiendgrenzen. Verhoudingsgewijs vaak komen vermeldingen voor van bezit in het hertogdom Limburg en in het Land van Daelhem.

Opvallend is dat bij de twee eerste generaties de naam Gronsveld wordt gekoppeld aan Stolberg. Op welke wijze die alliantie is ontstaan, valt niet te zeggen, maar dit moet zijn gebeurd in de eerste helft van de dertiende eeuw. De weinige documenten die over de familie van Gronsveld/van Stolberg bekend zijn, geven duidelijk aan dat de heren van Gronsveld behoorden tot de hogere adel ('nobiles') in een gebied van ongeveer 25 kilometer rond Aken.

Van Johannes I van Gronsveld, die we tot de derde generatie moeten rekenen, is vrijwel zeker dat hij afstamde van Wilhelmus van Gronsveld/Stolberg, maar hij voerde de naam Stolberg niet meer. Waarschijnlijk is hij jong gestorven, want zijn opvolger Johannes II van Gronsveld, was in 1281/1282 nog minderjarig.

Aan het einde van de dertiende eeuw moeten zich binnen de familie Van Gronsveld/van Stolberg belangrijke veranderingen hebben voorgedaan. Mogelijk is het geslacht in rechte lijn uitgestorven. Het is daarom niet geheel zeker of Johannes II een zoon van Johannes I was. Mogelijk is ook verwantschap met eerdere heren van Gronsveld langs de vrouwelijke lijn.

Zeer belangrijk voor de verdere geschiedenis van de familie Van Gronsveld is an het einde van de dertiende eeuw een alliantie met het geslacht Van Hafkesdale, maar hoe die verbinding precies is ontstaan, blijft vooralsnog onduidelijk. Het stamhuis van de familie van Hafkesdale bevond zich in Haasdal bij Schimmert. In de dertiende eeuw speelden leden van deze familie een belangrijke rol in de omgeving van de heren van Valkenburg. Zij onderhielden nauwe betrekkingen met de cisterciënzerabdij van Val-Dieu en het norbertinessenklooster van Houthem-Sint Gerlach. Omstreeks 1300 moet de familie zijn uitgestorven en zijn de goederen overgegaan op de heren van Gronsveld. Johannes II van Gronsveld heeft ook het wapen van Van Hafkesdale, een schild met drie bollen of koeken, overgenomen. Uiteindelijk worden deze drie bollen ook in het wapen van Gronsveld gevoerd.

Johannes II van Gronsveld wordt vanaf 1303 tot 1314 regelmatig vermeld, bijvoorbeeld als bezitter van diverse landsheerlijke lenen in de omgeving van Limbourg. Dit bezit bevestigt nog eens het vermoeden dat de herkomst van het geslacht van Gronsveld gezocht moet worden in het hertogdom Limburg of het gebied juist ten noorden daarvan.

Hendrik I van Gronsveld (vermeld 1334-1374) is de eerste van het geslacht Van Gronsveld van wie we een beeld van levensloop en carrière hebben. Hij behoorde duidelijk tot de aanhangers van de hertog van Brabant. Hij was vanaf 1349-1374 burggraaf 
van het kasteel van Limbourg en daarmee feitelijk gouverneur van het hertogdom Limburg. Daarnaast was hij op diverse manieren betrokken bij de behartiging van Brabantse belangen in de streek (Brabantse aanspraken op Valkenburg, contacten met stad Aken, deelname in 1371 aan de slag bij Baesweiler, lidmaatschap van het zogenoemde landvredeverbond). De steun aan de hertog van Brabant had ook duidelijk een financiële component. Er gingen grote sommen geld door zijn hand en hij werd een belangrijke financier van de Brabantse hertog.

Hendriks zoon Johan III van Gronsveld (1349-1386) zette de politiek van zijn vader verder. Ook hij toonde zich een uitgesproken aanhanger van Brabant. Als tegenprestatie voor grote geldleningen aan de hertog en hertogin van Brabant kreeg hij een reeks Brabantse landsheerlijke kastelen, ambten en heerlijkheden in het Maasgebied in onderpand. Die leverden geld en invloed op. Johan III werd daarmee een van de grote financiers van het Brabantse hertogshuis. Zijn succes werd nog verhoogd door de omvangrijke erfenis in 1373 van zijn oom Godert van den Bongard, heer van Heyden. Johan lijkt ook duidelijk te hebben gestreefd naar consolidatie en uitbouw van zijn 'stamland' Gronsveld. In 1363 schonk Walram van Valkenburg hem het dorp Heugem. In $1370 \mathrm{kreeg}$ hij voor een lening aan de hertog en hertogin van Brabant de dorpen Eijsden en Cadier in onderpand. Vervolgens kwamen daar door de erfenis van Godert van den Bongard in 1373 de heerlijke rechten over het aan Slenaken grenzende dorp Sint-MartensVoeren en het nagenoeg aan Gronsveld grenzende dorp Oost bij. Binnen een tijdsbestek van twintig jaar kreeg de heer van Gronsveld daarmee zeggenschap over een krans van dorpen rond Gronsveld, waarvan (met uitzondering van Heugem) de hertog van Brabant landsheer was. Hier lijkt bijna een bewuste ambitie van gebiedsuitbreiding achter te steken, hoewel het vraag rijst hoe realistisch in die tijd echte territoriale expansie ten koste van het machtige Brabant was.

Johan III was een man die niet terugdeinsde voor geweld om zijn doelen te bereiken. Die karaktertrek bracht hem, in combinatie met de afgunst die zijn rijkdom bij anderen wekte, in conflict met andere adellijke families in de omgeving. Uiteindelijk werd hem dat in 1386 als slachtoffer van een moordaanslag noodlottig.

Door de moord op Johan III van Gronsveld kreeg zijn broer Hendrik II plotseling een geheel andere rol dan hem aanvankelijk op grond van zijn geboorte en huwelijk was toebedacht. In vergelijking tot zijn broer was hij niet erg vermogend en zijn huwelijk met Johanna van Merode, dochter van de heer en vrouwe van Rimburg, bood ook geen glanzende perspectieven. Maar plotseling werd hij nu één van de rijkste en machtigste edelen van de streek en werd van hem, als belangrijk financier van de hertog van Brabant, ook inbreng op politiek gebied verwacht. De politieke situatie in het hertogdom Brabant was op dat moment niet erg stabiel. De oude hertogin Johanna steunde steeds meer op haar neef Philips de Stoute, hertog van Bourgondië. De verhouding van Hendrik van Gronsveld tot Johanna en de Bourgondiërs schijnt goed te zijn geweest. Hendrik bleef een belangrijke geldschieter voor Brabant en werd tegelijkertijd door hertogin Johanna zeer welwillend behandeld ten aanzien van de pandsommen van Eijsden en Cadier, die strikt juridisch genomen eigenlijk al waren afgeschreven. 
Hendrik maakt de indruk een risicomijdend financier te zijn geweest. Hij wist goed met grote bedragen aan geld om te gaan en slaagde er in het familievermogen in stand te houden. Dat was ook nodig, want zijn dochter uit zijn eerste huwelijk en drie zonen en twee dochters uit het tweede huwelijk moesten van een erfdeel overeenkomstig hun stand worden voorzien. In het bijzonder de boedelscheiding met zijn zwager/schoonzoon Christiaan van Ringberg werd wegens de ingewikkelde familieverhoudingen enkele malen onderwerp van een uitvoerige regeling. Uiteindelijk wist hij daarbij vanaf 1396 het kasteel Rimburg blijvend voor zijn familie te verwerven. Het was een verbintenis met langdurige gevolgen, want gedurende een periode van 240 jaar fungeerde Rimburg meestal als hoofdresidentie van de heren van Gronsveld. Wel bleven Rimburg en de bijbehorende goederen administratief altijd gescheiden van het eigenlijke Gronsveldse familiebezit.

De gedetailleerde akte van boedelscheiding tussen Hendrik van Gronsveld en Christiaan van Ringberg uit 1396 vormt ook inhoudelijk een soort ijkpunt in de ontwikkeling van de landsheerlijkheid, want het is de eerste tekst waarin Gronsveld, Heugem, Eckelrade en Slenaken, worden beschreven als een bij elkaar horend kernbezit van de heren van Gronsveld.

Hendrik III van Gronsveld (vermeld 1407-1474/1476) erfde als oudste zoon de huizen en heerlijkheden Gronsveld en Rimburg. Zijn huwelijk met Aleidis van Oupeye leidde tot een verbintenis met een vooraanstaand Luikse adellijk geslacht, met het vooruitzicht op verwerving van de heerlijkheden Oupeye, Herstal en Chaumont. Uiteindelijk liep dit op een grote teleurstelling uit en verloor Hendrik Herstal en Chaumont. Deze affaires brachten hem dan wel niet aan de bedelstaf, maar het verlies van deze bezittingen, in combinatie met een fors bedrag aan proceskosten, moeten voor de gefortuneerde heer van Gronsveld een financiële aderlating hebben betekend. Deze gang van zaken maakte ook een einde aan aspiraties om een vooraanstaande positie te verwerven in het Luikse en in Waals Brabant. Vanaf die tijd komt ook een einde aan de bijna traditionele band tussen de heren van Gronsveld en Brabant. Hoewel er geen duidelijke aanwijzingen bestaan voor een slechte relatie met de hertogen van Bourgondië, lijken deze nieuwe machthebbers in de Zuidelijke Nederlanden niet onmiddellijk Hendriks favoriete keus te zijn geweest.

Aangezien Hendrik en zijn echtgenote slechts twee dochters hadden, vereisten de belangen van de familie een bijzonder zorgvuldige keus van huwelijkspartners. Die werden gevonden in de persoon van Diederik van Bronckhorst Batenburg, telg uit een vooraanstaande familie uit het Gelderse rivierengebied, en in Engelbrecht Nyt van Birgel, de toekomstige erfmaarschalk van het hertogdom Gulik. Die allianties, en in het bijzonder geldt dit voor de verbintenis met Brockhorst Batenburg, leidden ook tot een politieke heroriëntatie voor de heren van Gronsveld. Tot dusverre was die vooral gericht op geweest op Brabant, Limburg en Luik. De komende generaties raakten echter veel meer betrokken bij ontwikkelingen in Gelre, Kleef en Gulik. 


\section{Ontstaan en consolidatie van het Land Gronsveld}

Het graafschap Gronsveld telde met Gronsveld, Eckelrade, Heugem, Honthem en Slenaken vijf dorpen of gehuchten. Hoewel het om gescheiden dorpen ging, vormden Gronsveld en Eckelrade, voor zover de bronnen teruggaan, altijd één 'corpus' met de juridische band van één schepenbank. Financieel waren beide plaatsen echter gescheiden. De Bijbank, ten oosten van Eckelrade, die de heer van Gronsveld onder de benaming 'halve heerlijkheid Eckelrade' in leen hield van het leenhof van Valkenburg, vormde daarbij een 'aanhangsel', met tot het einde van het Ancien Régime een gecompliceerde juridische status. Op de betekenis van de Bijbank als voorpost van Valkenburgse expansie wordt bij de bespreking van Honthem nog teruggekomen. Heugem, Honthem en Slenaken hadden ook ieder een eigen schepenbank.

Tegen het einde van de veertiende eeuw moet voor het eerst een idee van een vaste band tussen die plaatsen onder één heer zijn ontstaan. Centraal in dit hoofdstuk staat de vraag hoe dit 'Land Gronsveld' zich, met het dorp Gronsveld als uitgangspunt, in de late middeleeuwen heeft ontwikkeld. Aan het slot wordt aandacht besteed aan Gronsveldse leengoederen in de omgeving van Vaals en de rechten van de heren van Gronsveld in Oost en Sint-Martens-Voeren. Met deze 'uitheemse' bezittingen werd vanuit Gronsveld een lange en duurzame juridische band onderhouden.

De juridische indeling van het Land Gronsveld ligt ook ten grondslag aan de indeling van dit hoofdstuk. Daarom wordt begonnen met enkele beschouwingen over de rechterlijke organisatie van schepenbanken, laatbanken en leenhof. Deze werkwijze heeft als voordeel dat bepaalde begrippen die later bij de analyse van de geografische ontwikkeling op de basis van de juridische status van grond worden gebruikt, minder toelichting nodig hebben.

Het proces van territoriumvorming laat zich slechts beperkt volgen met behulp van concrete, eigentijdse bronnen uit de middeleeuwen. Alleen de verwerving van jurisdictie over Heugem door de heer van Gronsveld ligt in een oorkonde uit 1363 vast. Op onbekende tijdstippen in de veertiende, mogelijk al aan het einde van dertiende eeuw, moeten de heren van Gronsveld ook de heerlijke rechten over Slenaken en Honthem hebben verworven.

Voor de reconstructie van de territoriumvorming is voor alle plaatsen ongeveer dezelfde opzet gekozen. Na een geografische beschrijving wordt onderzocht op welke wijze de dorpen zijn ontstaan, met als centrale vraag of grootgrondbezit als basis voor de verwerving van de heerlijke rechten valt aan te wijzen. Een uitstekende basis voor een dergelijke analyse bieden de in 1754 voor het hele graafschap (minus Slenaken) vervaardigde kaarten op kadastrale schaal. Uitgangspunt is de veronderstelling dat de infrastructuur en perceelindeling van de grond zoals die in het midden van de achttiende eeuw bestonden, niet wezenlijk verschilden van de situatie in de late middeleeuwen. Hetzelfde gold waarschijnlijk ook voor de juridische status van de grond. Eens op een perceel gevestigde leenplicht, cijnsrecht of het recht van keurmede veranderde in de loop der eeuwen nauwelijks. Er werd weinig afgekocht. Rechten verdwenen meestal door wanbetaling. Wanneer nu de juridische verhoudingen van grote aantallen percelen zoals die omstreeks 1750 bestonden, op een kaart worden 'terug geprojecteerd' naar een verder 
verleden (de zogenoemde 'retrogressieve' methode), dan verliezen kleine veranderingen in de loop der tijd hun betekenis en ontstaat door het grote aantal een beeld van de middeleeuwse bezitsverhoudingen. Dit gedetailleerde onderzoek geeft niet alleen een indruk van de ontginningsgeschiedenis per dorp, maar laat ook de verschillen daartussen zien.

Aandacht is ook besteed aan de angrenzende plaatsen, niet alleen ter vergelijking, maar ook om te onderzoeken of delen van het land Gronsveld misschien zijn ontstaan als afsplitsingen van naburig gebied. Die vraag is relevant omdat de heerlijkheid Gronsveld later wordt voorgesteld als een allodium, een van niemand afhankelijk 'zonneleen'.

\subsection{De rechterlijke organisatie van het Land Gronsveld aan het einde van de middeleeuwen}

\subsubsection{Ontwikkeling van de rechtspraak}

De rechtspraak uit de Karolingische en postkarolingische periode heeft in het Maasgebied nauwelijks sporen nagelaten. Misschien zijn nog oude vormen van koninklijke rechtspraak blijven bestaan, maar in dit territoriaal sterk versnipperde gebied was het vooral de regionale adel die zich van de rechtspraak meester maakte (zie meer daarover Hoofdstuk 1.3, waar wordt gesproken over de vroegste vermeldingen van heerlijke rechten van de heren van Gronsveld). 'Recht op de rechtspraak' betekende dat de adellijke heer, in navolging van de taken van de vroegere graven uit de Karolingische en postkarolingische tijd, zorgde voor de organisatorische kant van de conflictbeslechting. Hij riep de bijeenkomsten samen waar de vrije mannen moesten verschijnen, wees uit die vergadering de 'oordeelvinders' aan en zorgde voor de eventuele tenuitvoerlegging van het vonnis. Vanaf de elfde en twaalfde eeuw kennen we het meestal drie of vier keer per jaar in een dorp gehouden 'ongeboden ding' ('voogdgeding' of 'placitum') waarvan de heer of diens vertegenwoordiger 'voogd' of 'advocatus' de leiding had. Vaak droeg de bevolking bij die gelegenheid ook belastingen in natura of geld af. Bij een toename van procedures voldeed dit systeem steeds minder voor een vlot verloop van de rechtspleging. Daarom ontstonden in de elfde eeuw binnen geestelijke immuniteiten of afsplitsingen daarvan, vaak binnen een stedelijke context, de eerste schepenbanken met een permanent karakter, waar schepenen ('scabini') als vaste 'oordeelvinders' recht spraken. Die ontwikkeling zette zich vanaf de twaalfde eeuw ook door op het platteland. Meestal op initiatief van de plaatselijke wereldlijke of geestelijke heer werd, naast het oude 'placitum', een schepenbank gesticht.

Een tweede factor die toename van schepenrechtspraak bevorderde, was de toenemende invloed van de heer op de rechtspraak door opeising van het monopolie op de uitoefening van geweld en toenemende zorg voor openbare orde en veiligheid als vanuit publiek belang. Het moderne onderscheid tussen publiek- en privaatrecht bestond niet. Aanvankelijk werden geschillen vooral beslecht door betaling van een afkoopsom aan de benadeelde partij en 'vredegeld' aan de heer. Dat gold ook voor geweldpleging gericht tegen personen of tegen goederen. Vanaf de elfde eeuw groeide het besef dat met de bestraffing daarvan, ook zonder een klager en los van de schade van de benadeelde of zijn familie, een algemeen belang was gediend. Zo ontstond het strafrecht, waarbij door de 
overheid aangestelde schepenen ook uit naam van de overheid een vonnis velden. Daarnaast moest recht worden gesproken in conflicten tussen inwoners onderling en was het noodzakelijk ambtshalve uitspraak te doen in zaken die juist geen onderwerp van geschil vormden. In het bijzonder ging het daarbij om voorzieningen in de familierechtelijke sfeer en gerechtelijke bevestiging van de overdracht van onroerend goed.

De derde ontwikkeling die aan de vorming van schepenbanken heeft bijgedragen, is de 'doorgroei' van laathoven of laatbanken. ${ }^{432}$ Deze gaan terug op een middeleeuwse vorm van exploitatie van grootgrondbezit, met een hof ('curtis' of 'villa') als middelpunt, waarvan de bijbehorende grond door horigen of laten tegen betaling van een bepaalde cijns of belasting werd bewerkt. Wereldlijke of geestelijke heren als bezitters van een hof oefenden als grondheer rechtsmacht uit over de met de hof verbonden gronden. Vaak wordt het laatrecht ook geassocieerd met persoonlijke onvrijheid en gebondenheid aan de grond, maar dit verschijnsel was in de Nederlanden aan het einde van de middeleeuwen vrijwel overal verdwenen. 433 Het hofgerecht, bestaande uit de hofheer of zijn vertegenwoordiger ('villicus') en vertegenwoordigers uit de laten (laatschepenen), sprak recht in geschillen waarbij laatgoed onderwerp van geding was.

De in Latijnse teksten vaak als 'mansionarius' aangeduide laat bezat een sterk recht op de grond, maar moest rekening houden met de beperkingen voortvloeiend uit het formele eigendomsrecht van de laatheer. Dat uitte zich in de eerste plaats in de verplichting van de laat tot periodieke afdracht van een cijns in geld of in natura. Bij nalatigheid kon de heer zich op het goed verhalen. De laat moest als bezitter van het goed bij de heer (tegen betaling) vergunning vragen voor overdracht of vestiging van een zakelijk recht als bijvoorbeeld hypotheek. De laatheer (of zijn vertegenwoordiger) en andere laten in hun hoedanigheid van laatgerecht 'stonden over' die transactie.

Het meest ingrijpend bij laatrecht waren misschien de gevolgen bij overlijden van de laat. De heer had dan recht op een nieuwe 'verheffing' of 'boekzetting', waarvoor moest worden betaald. Wanneer dit achterwege bleef, kon het goed terugvallen aan de heer. Op sommige laatgoederen drukte het bijzondere recht van keurmede, wat betekende dat de heer zich bij overlijden van de laat het beste stuk vee, paard, huisraad of werktuig uit de inboedel van de hof mocht toe-eigenen. Uit het wezen van keurmede vloeit voort dat het recht in beginsel rustte op een plaats waar zich inboedel bevond, dus een huis of hoeve. Onbebouwde grond waarop keurmede rust, betreft bijna altijd een perceel waarop eertijds een huis stond. Overigens werden keurmeden vanaf de zeventiende eeuw meestal niet meer in natura, maar in geld voldaan.

\footnotetext{
${ }^{432}$ De meeste recente verhandelingen, waarin Zuid-Limburgse laathoven een grote rol spelen zijn te vinden bij Hartman, Reconstructie landschap en Hackeng, Middeleeunse grondberit Sint-Servaaskapittel, passim. Een inventarisatie van laathoven werd gepubliceerd door Janssen de Limpens, Leen- en laathoven, echter zonder inleiding, maar wel met uitgave van enkele laatrechten. Diverse laatrechten zijn uitgegeven bij Habets, Limburgsche wijsdommen; Janssen de Limpens, Rechtsbronnen Gelders Overkwartier, Janssen de Limpens, Rechtsbronnen Limburg en Overmaze. Zie verder ook: Gehlen, 'De 'laetschappe' van huize Vlodrop' en Van Hall, Eijsden, een vrijheid, 119-120, 123-127.

${ }^{433}$ Hartmann, Reconstructie landschap, 303-304.
} 
Laathoven en laatgoederen komen in allerlei vormen voor, al naar gelang aard en zwaarte van de last die op de grond drukte. Hartmann beschrijft in zijn onderzoek over Breust en Eijsden voor Zuid-Limburg het 'ideaaltype' van een dergelijke hof in zijn meest volledige vorm: een centraal gebouw of hof, in eigen beheer geëxploiteerd of met verpacht land, verder landerijen die van de hof worden 'gehouden' tegen betaling van een jaarlijkse cijns en ten slotte een rechtbank, samengesteld uit de heer en rechthebbenden op de laatgoederen. ${ }^{434}$ Dit 'basismodel' kende echter in de praktijk vele varianten. Lang niet altijd waren de vier genoemde kenmerken aanwezig en bestonden ook per hof verschillen in het geldend recht, zodat het moeilijk blijft een eenduidige definitie van het begrip 'laatgoed' te geven.

Bij laatgerechten werd vroeger nog wel eens automatisch een hoge ouderdom aangenomen, maar noodzakelijk is dat beslist niet. Nader onderzoek heeft uitgewezen dat veel hoven waarschijnlijk laatmiddeleeuwse constructies zijn. ${ }^{435}$ Reorganisaties van laathoven waren niet ongebruikelijk en een complex aan laatgoederen kon als geheel worden verkocht of samengevoegd met andere laatgoederen. ${ }^{436}$

Een laathof groeide soms uit tot schepenbank. In de middeleeuwen voltrok zich die ontwikkeling meestal geleidelijk en geruisloos, zodat die achteraf vaak moeilijk valt te reconstrueren. In de vroegmoderne tijd vonden ook officiële verheffingen plaats. Een goed voorbeeld daarvan levert de toestemming die graaf Johan II van Bronckhorst Batenburg in 1608 vroeg aan de aartshertogen Albert en Isabella, landvoogden van de Spaanse Zuidelijke Nederlanden, om de laathof Gronsvelderhof of hof van Batenborch te Oost om te zetten in een 'dingbancke van eenen scholtis ende seven schepenen met eenen clerck ende eenen gerichtsbode'. Naast opwaardering vond bij laathoven soms ook 'devaluatie' plaats en bleef van de laathof niet veel meer over dan een 'laat- of cijnskaart' zonder hof of laatgerecht. Feitelijk was niet meer dan een (verhandelbaar) register van landerijen, die met een bepaalde cijns of rente aan de laatheer belast waren.

Hoewel de laathof dus teruggaat op een middeleeuwse vorm van grondexploitatie, bleek de hof als instituut met zijn rechtspraak en als bron van inkomsten voor de laatheer tot aan het einde van het Ancien Régime vaak goed bestand tegen de tand des tijds. Het hing van de plaatselijke verhoudingen af hoe sterk het laatgerecht met zijn jurisdictie stond ten opzichte van de schepenbank. Sommige laatbanken genoten zoveel gezag dat zij met hun rechtspraak over laatgoed de bevoegdheden van de schepenbank evenaarden. Maar vaak werd bij bijvoorbeeld de volledige overdracht nog de tussenkomst van de schepenbank ter bekrachtiging vereist. Ook voor de daadwerkelijke tenuitvoerlegging van vonnissen van het laatgerecht, bijvoorbeeld toewijzing aan de laatheer na wanbetaling, moesten de schepenen 'immissie' verlenen.

De oudste voorbeelden van schepenbanken ten plattelande in de omgeving van Gronsveld dateren uit de twaalfde eeuw: Meerssen in 1145 en een viertal 'hoven' ('curiae') van het kapittel van Sint-Servaas circa 1165, behorend tot wat later de Elf Banken van het kapittel

434 Hartmann, Reconstructie landschap, 298-299.

435 Hartmann, Reconstructie landschap, 301-302.

436 Hartmann, Reconstructie landschap, 300. 
heet. ${ }^{437}$ Voor Breust neemt Van Hall, met enige voorzichtigheid, aan dat er in de tweede helft van de twaalfde eeuw schepenen waren. .38 In de loop van de dertiende eeuw groeit het aantal vermeldingen. Een goed voorbeeld daarvan levert de door Nève beschreven situatie in Maastricht. De Luikse en de keizerlijk/Brabantse schepenbank in de stad dateren waarschijnlijk uit de twaalfde eeuw, worden aan het begin van de dertiende eeuw het eerst genoemd, maar pas na 1250 vaardigen de schepenen op eigen naam oorkonden uit betreffende de overdracht van onroerend goed. Opvallend vaak hebben oorkonden van stadsschepenen betrekking op de overdracht van onroerend goed op het platteland, niet alleen in Roermond ${ }^{439}$ maar (in de beperkte periode tussen 1253 en 1262) ook in Maastricht $t^{440}$. Voor het complexe vraagstuk van de rol van schepenen als getuigen of rechters bij de beoorkonding van de overdracht van onroerend goed, verwijzen we naar de relevante literatuur. ${ }^{441}$ Voor Gronsveld zijn daar door het ontbreken van bronnen geen uitspraken over te doen.

Naast schepenbanken en laatbanken moeten hier als derde instelling belast met rechtspraak ook de leenhoven worden genoemd. Feodaliteit kent in West-Europa een historie tot het begin van de middeleeuwen. In oorsprong ontving de leenman of vazal van zijn heer bepaalde rechten of landerijen en moest hij daarvoor in de oorlog gewapende ruiterdienst verrichten. Tussen leenheer en vazal ontstond daarmee een band van wederzijdse trouw en steun. Een element daarvan vormde de dingplicht, dat wil zeggen de verplichting van de leenman als bezitter van leengoed om samen met zijn leenheer deel te nemen aan de rechtspraak (zowel de contentieuze als vrijwillige rechtspraak) over goederen die de heer in leen had gegeven. Binnen deze rechtskring gaf de heer leiding en vorderde hij van de verzamelde leenmannen recht. Verder was de leenman verplicht bij de aanvaarding van een leengoed, aan de heer 'hulde te doen'. Hij moest het leen 'verheffen', een eed van trouw aan de leenheer zweren (met wederkerig steun van de heer) en een 'heergewaad' betalen als erkenning van het eigendomsrecht van de heer. Ook voor rechtshandelingen met betrekking tot leengoed was toestemming van de leenheer vereist. Vanaf de dertiende eeuw raakte de feodaliteit steeds verder van zijn oorspronkelijke doel verwijderd. Door veranderingen in de methodiek van oorlogvoering was het niet langer reëel nakoming te eisen van de militaire verplichtingen die met vazalliteit waren verbonden. Ook de steeds verdergaande splitsing van lenen in achterlenen leidde tot versplintering van feodaal goed. De aanspraken van een leenman op zijn leengoed tendeerden naar een erfelijk recht, vergelijkbaar met eigendom. Uitgifte van grond op basis van leenrecht lijkt daarmee een normale vorm van grondexploitatie te zijn geworden. ${ }^{442}$

De leenrechtspraak vond aanvankelijk vooral op ad hoc basis plaats, maar werd aan het einde van de middeleeuwen geïnstitutionialiseerd in de vorm van permanente

${ }^{437}$ Hackeng, Middeleeunse grondberit Sint-Servaaskapittel, 81-85.

${ }^{438}$ Van Hall, Eijsden, een vrijheid, 130-131.

${ }^{439}$ Venner, 'Schepenen op het platteland', 79.

440 Nève, De dertiende-eeunse schepenoorkonden, XXXIX-XLI.

${ }^{441}$ Venner, 'Schepenen op het platteland', 15 en de daar genoemde literatuur.

${ }^{442}$ Ook opdracht van grote allodia als leengoed is een bekend verschijnsel. Of omzetting van allodia in leengoed ook gebeurde bij kleinschalig grondbezit omwille van een grotere rechtszekerheid bij de overdracht van onroerend goed, zoals bij de omzetting van allodia in cijnsgoed, is niet duidelijk; vgl. Hartmann, Reconstructie landschap, 302. 
leengerechten, leenhoven of leenkamers. Deze bogen zich over de beslechting van geschillen betreffende leengoederen en waren bevoegd 'te staan over' rechtshandelingen met betrekking tot het leengoed. De rol van de leenheer werd daarbij meestal overgenomen door een plaatsvervanger of stadhouder, terwijl de personele bezetting van het leengerecht werd gerecruteerd uit een beperkte groep leenmannen. De toenemende verschriftelijking van gerechtelijke procedures aan het einde van de middeleeuwen had ook invloed op de leenrechtspraak in die zin, dat men begon met de anleg van leenboeken waarin de lenen werden geadministreerd.

Ondanks verstarring en verval bleven bepaalde principes van de feodaliteit tot het einde van het Ancien Régime intact. Dat gold voor het leenhof als instelling, maar ook voor formaliteiten, zoals verheffing van het leen na overlijden, de eed van trouw, de betaling van een 'heergewaad' als erkenning van het eigendomsrecht van de heer en het vragen van toestemming voor rechtshandelingen. Voor de leenheer vormden het heergewaad en de verschillende vergunningen vooral een bron van inkomsten.

\subsubsection{Schepenbanken}

Schepenen van een 'hof van Gronsveld ('scabini curie de Grunselt') worden het eerst genoemd in 1261, bij de verkoop door Reinerus van Grunselt en zijn echtgenote Beatrix van hun hof te Eckelrade met vijf gebouwen ('curiam nostram sitam in villa de Eckelrode cum quinque edificiis') aan de abdij Hocht. ${ }^{443}$ Abdis en convent van Hocht moeten, wanneer zij een 'mansionarius' (een bezitter) voor hun hof aanwijzen, dit doen ten overstaan van de schepenen van de hof Grunselt ('coram scabinis curie de Grunselt'). Bij de rechtshandeling als zodanig zijn de schepenen niet direct betrokken; zij worden ook niet met naam genoemd. Welke juridische status deze 'curia de Grunselt' precies had, wordt uit de tekst verder niet duidelijk. Het zou een laathof met laatschepenen kunnen zijn, maar ook een volwaardige schepenbank.

Ook bij de volgende vermelding van Gronsveldse schepenen, in 1363 bij een overeenkomst tussen het klooster Sinnich en de Maastrichtse schepen Godefridus de Vinea (zie daarover meer Hoofdstuk 2.3.5 sub 'Wijngaardshof), vervullen de schepenen slechts een bijrol. ${ }^{444}$ Het gaat om een bijzondere gelegenheid en een bijzonder gezelschap. Plaats van handeling was het stadshuis van het klooster Sinnich achter de kapel van Maria Minor ('Maria Luttelre' of 'Maria ten Oever' in de Mariastraat) te Maastricht. De akte werd opgesteld door een notaris in aanwezigheid van twee Maastrichtse schepenen. Met toestemming van de zusters van Sinnich en de bevoegde kerkelijke autoriteiten droeg 'magistra' (overste) Catharina de Brodersberch grond in Gronsveld over aan Godefridus de Vinea, schepen van Maastricht, tegen betaling van een jaarlijkse pacht. Godefridus stelde daarvoor tot onderpand een cijns, rustend op zijn huis en goed 'de Vinea' (de Wijngaard) in de Sint Jorisstraat (= Grote Staat) in Maastricht. De twee Maastrichtse schepenen als getuigen verklaarden dat hun collega op juiste wijze het onderpand gerechtelijk had verbonden. Verder waren bij deze transactie aanwezig Wolter geheten

443 Hartmann, Reconstructie landschap, 215-216, 314-315.

444 Afgedrukt bij Polak/Dijkhof, Oorkondenboek Kloosterrade, 323-325, nr. 179; uitvoerig regest bij Brouwers, Histoire Sinnich, 137, nr. 49, afschrift in RHCL, Abdij Kloosterrade, inv. nr. 1736. 
Kotzeneir, bakker en scholtis van Gronsveld, de Gronsveldse schepenen Willelmus de Eckelrode, Gerardus gezegd Pouwe, Hubertus de Eckelrode en Joannes Kaufstert en verder Nicolaas de Abensdale, priester van het convent Sinnich, Johannes de Cervo en Reinerus de Vinea, burgemeesters van Maastricht, Paulus Ostienbecker, clericus, en Godefridus, een familielid van Godefridus de Vinea. Aan het slot werd de akte bekrachtigd met het conventszegel van Sinnich, het zegel van Godefridus de Vinea en het merk van de notaris.

De oudste oorkonde, voor zover thans bekend, waarbij scholtis en schepenen van Gronsveld zelfstandig optreden, dateert uit 1439.445 Daarin wordt ook het gebruik aangekondigd van 'onsen gewoonen hoofs segel'.446 Helaas zijn de weinige bewaarde afdrukken van het schepenzegel ernstig gehavend, maar op een exemplaar uit 1532 valt met enige moeite nog te zien dat de afbeelding bestaat uit helm met vederbos, waarboven drie bollen, afkomstig uit het wapen van de heren van Gronsveld, als helmteken zijn aangebracht. 447

De betrokkenheid van schepenen van Gronsveld bij de verkoop van een hof te Eckelrade in 1261 wijst al op de band die altijd tussen Gronsveld en Eckelrade heeft bestaan. In de 'Specificatie' van het graafschap omstreeks 1650 wordt van de dorpen Gronsveld en Eckelrade gezegd dat zij samen één 'corpus' vormden, met één schepengerecht, voorzien van 'besonder macht...van hoeghe, middele ende leghe jurisdictie'. Hoewel Gronsveld en Eckelrade gerechtelijk één 'corpus' vormden en ook kerkelijk één parochie, waren het gescheiden 'gemeenten' (zie daarover Hoofdstukken 2.3.4 en 17.2), waartussen in het Savelsbos een grens liep voor het weiderecht van het vee. Zo werden tijdens een rechtszitting van 16 mei 1749 getuigen gehoord 'over het poinct van pasturagie tusschen die van Gronsfeldt ter eenre ende die van Eckelrade, dependentie deeser graefschappe ter andere zijde', waarna de grens met stenen werd gemarkeerd. ${ }^{448}$

De oudste vermeldingen van een 'curtis' of hof te Heugem dateren uit $1155^{449}$ en $1213 .{ }^{450}$ In 1334 wordt gesproken over een 'ville' te 'Hoyn'.451 De vroegste vermelding van

445 Verschillende afschriften in TJ, inv. nr. M 11, fol. 449-461, 467-471 en 581-584.

446 Gronsveldse schepenakten uit de vijftiende eeuw zijn zeldzaam: Franquinet, Oorkonden en bescheiden Predikheren 105-106, nr. 82 (akte uit 1478); RHCL, Graafschap Gronsveld, inv. nr. 62 ('cartularium van Gronsveld), fol. 144-145; akte uit 1484; RHCL, Parochie H. Martinus Maastricht Wyck I, inv. nr. 164 (akte uit 1488).

447 RHCL, Graafschap Gronsveld, inv. nr. 426. Hoe lang dit schepenzegel werd gebruikt, is niet bekend. Vanaf de achttiende eeuw werd een nieuwe stempel gebruikt, met een middellijn van $3,4 \mathrm{~cm}$. (RHCL, Collectie Zegelstempels RAL, inv. nr. 80). Daarop staat afgebeeld Sint Martinus te paard (de kerkpatroon) die met een zwaard zijn mantel doorsnijdt voor een bedelaar. Op de rug draagt de heilige een schild met drie bollen, bekroond door een gravenkroon. Het randschrift luidt: S. SCAB. IUSTITIAE GRONSFELDENSIS (Schepenzegel van het gerecht van Gronsveld).

448 Van den Boorn, 'Limieten', 143-144. De grensbeschrijving valt op een tegenwoordige kaart niet meer helemaal te reconstrueren, maar ruwweg was de oostelijke helft van het Savelsbos Eckelrader weidegebied. Genoemd worden grensstenen bij de Eerste Plass tegenover de Monsdelle en de steen tussen de Hoogen Bergh en de Dalecamer.

449 Pauselijke bul van 24 juli 1155, waarin kerk van Luik onder andere wordt bevestigd in het bezit van curtis in 'Hoin', zie: Bormans/Schoolmeesters, Cartulaire Saint-Lambert, 1, 74-76, nr. 45. 
schepenen in Heugem is, voor zover bekend, te vinden in een akte uit 1364.452 Daarin worden drie schepenen genoemd als borgen in een contract over de verpachting van tienden in Heugem door het kapittel van Onze-Lieve-Vrouwe te Maastricht. We mogen daaruit afleiden dat ten minste vanaf het midden van de veertiende eeuw een schepenbank in Heugem bestond. Of die is ontstaan uit de 'curtis' Heugem uit de twaalfde eeuw komt bij de beschrijving van Heugem nog aan de orde. De eerste volledige oorkonde op naam van de 'dengbanck ende heerlicheyt van Hoegem' dateert overigens pas uit 1417 en betreft een vonnis op naam van scholtis en zeven schepenen in een erfeniskwestie. ${ }^{453}$ In de tekst wordt uitvoerig de voorgaande procedure beschreven en daarna wordt het stuk bezegeld met 'ons gewoenliken hoefs siegele des wir in desen ende in geliken saken daechlix plegen te gebruken'. Van het zegel is een fragment bewaard, maar op latere gave exemplaren uit de vijftiende eeuw is de $\mathrm{H}$. Michaël afgebeeld onder een gotische nis, met als randschrift 'Sigillum scab. de Hoeghem'. Van oorkonden van de schepenbank Heugem zijn uit de vijftiende eeuw in verhouding tot Gronsveld relatief veel exemplaren overgeleverd. Alleen al het archief van het Onze-Lieve-Vrouwekapittel te Maastricht telt van 1417 tot 1495 een tiental exemplaren. ${ }^{454}$

De oudste schepenakte van Honthem dateert pas uit 1515 en betreft een vonnis van de schepenen. ${ }^{455}$ De tekst wijkt af van het bij dit soort oorkonden gebruikelijke stramien van een tamelijk vastomlijnde volgorde. Misschien ontbrak het bij deze kleine bank aan gewenning. Een eigen bankzegel lijkt er toen nog niet te zijn geweest. Er wordt bezegeling door de scholtis en drie schepenen aangekondigd, maar twee schepenzegels zijn thans niet meer aanwezig. Van de overige schepenen wordt gezegd dat zij geen zegel hebben.

De vroegste vermeldingen van scholtis (richter) en schepenen 'des hoeffs van Sledenacken' zijn te vinden in drie akten uit 1370 en betreffen de overdracht van een rente aan het klooster Sinnich. ${ }^{456}$ In alle drie de gevallen verklaren de schepenen dat zij geen eigen schepenzegel hebben en wordt scholtis Arnold van Sledenacken gevraagd te zegelen. Eén keer zegelt ook Hendrik II, heer van Gronsveld, mee. In 1465 verklaren de schepenen 'der banck van Slenaken' nog steeds 'egheynen hoeffs ziegel' te hebben en wederom zegelt de scholtis. Toch moet ook in deze tijd de schepenbank een gevestigde instelling met een geregelde administratie zijn geweest. Zo wordt in 1526 van Cloes

\footnotetext{
450 Bisschop Hugo de Pierrepont geeft onder ander 'curtis' in 'Hoiens' in leen aan Walram van Limburg, zie: Bormans/Schoolmeesters, Cartulaire Saint-Lambert, 1, 173-174, nr. 111; Poncelet, Actes Hugues de Pierrepont, 112-113, nr. 108; zie ook Van Hall, Eijsden, een vrijheid, 39.

451 Bormans/Schoolmeesters, Cartulaire Saint-Lambert, 3, 450-459, nr. 1180, zie verder ook Van Hall, Eijsden, een vrijheid, 56.

452 Doppler, 'Schepenbrieven O.L. Vrouw', nr. 115.

${ }^{453}$ Doppler, 'Schepenbrieven O.L. Vrouw', nr. 265.

454 Zie regesten daarvan bij Doppler, 'Schepenbrieven O.L. Vrouw', nrs. 265, 297, 356, 432, 449, 450, 484, 506, 509, 542.

455 RHCL, Klooster Kruisheren Maastricht, inv. nr. 708.

456 Brouwers, Histoire Sinnich, 141, nr. 57. Het onder nr. 59 opgegeven jaartal 1351 is een drukfout en moet zijn 1371; afschriften van de drie oorkonden in RHCL, Rijkskamergerecht, inv. nr. 26, fol. 18-23.
} 
Pluechmeker gezegd dat hij daar meer dan dertig jaar als 'banckschrijver' in dienst was geweest. 457

Het jaar 1526 kan ook om een andere reden voor de schepenbanken als een soort drempel naar de vroegmoderne tijd worden beschouwd. Johan I van Bronckhorst Batenburg sloot toen met de 'gemeine undersaten meines erflantz van Grunsfelt' een overeenkomst over de afkoop van herendiensten (zie bijlage 34) waarbij elk van de vier banken van Gronsveld, Heugem, Slenaken en Honthem het stuk moest bekrachtigen met honnen schependomstoils heuffsiegell en vervolgens een authentiek afschrift van de 'originall heuftbriefe' in hun schepenkist deponeren. 458

De voorgaande schets laat zien dat de rechterlijke organisatie van het Land Gronsveld waarschijnlijk omstreeks 1375 zijn beslag had gekregen. Alleen over de bank Honthem kan, bij gebrek aan bronnen, nog worden gedacht aan een later tijdstip. Het moeten vanaf het einde van de veertiende eeuw 'normale' dorpsschepenbanken zijn geweest, 'besonder macht hebbende van hoeghe, middele ende leghe jurisdictie', zoals de 'Specificatie' van het graafschap van omstreeks 1650 dat in een soort standaardformule uitdrukt. De vier banken beschikten daarmee over volledige rechtsmacht. Bij hoge jurisdictie ging het daarbij, op vordering van de heer of zijn vertegenwoordiger, om de berechting van misdrijven tegen personen of goederen, delicten die aan lijf of leden (inclusief de doodstraf) of met verbanning en zware boeten werden gestraft. Lage rechtspraak omvat de beslechting van geschillen tussen personen over onroerend goed, overeenkomsten en 'civiele' delicten zoals belediging en eenvoudige mishandeling, die met een boete werden afgedaan. Tot de lage rechtsmacht behoort ook de vrijwillige of voluntaire rechtspraak in niet-conflictueuze zaken, zoals de beoorkonding van de overdracht en bezwaring van onroerend goed en het treffen van voorzieningen in de familierechtelijke sfeer. Het begrip 'middelbare jurisdictie' kent weliswaar een min of meer vaste plaats in opsommingen van jurisdictie, maar vormt een grijs gebied. Soms worden daartoe zaken gerekend, zoals de berechting van overtredingen en boetstraffelijke zaken, die op andere plaatsen weer onder lage rechtspraak vallen. De praktische betekenis van het onderscheid was echter bij een schepenbank met volledige rechtsmacht niet zo groot.

De hier gegeven competentieverdeling geeft slechts een schets op hoofdlijnen. Naar tijd en plaats zijn afwijkingen mogelijk. Sommige ernstige inbreuken op het landsheerlijk gezag (belediging van de landsheer, valsmunterij) reserveerde de heer meestal voor zich. Daarnaast moet ook rekening worden gehouden met kerkelijke rechtspraak op het terrein van familie- en erfrecht.

Tot de activiteiten van de schepenen worden vaak ook wetgevende en bestuurlijke taken als vertegenwoordigers van de dorpsgemeenschap gerekend. Het is de vraag in hoeverre dat ook op de schepenbanken in het Land Gronsveld van toepassing is. Voor de middeleeuwen is daarover niets bekend. De vroegste gegevens betreffende inwoners die zich in 'gemeenten' organiseren, dateren pas uit het begin van de zestiende eeuw (zie

457 RHCL, Rijkskamergerecht, inv. nr. 95, fol. 14.

458 
hierna Hoofdstuk 17.2). Ook voor wetgeving in de vorm van verordeningen lijkt altijd het zwaartepunt te hebben gelegen bij de landsheer.

\subsubsection{Laathoven}

Naast vier schepenbanken kende het Land Gronsveld aan het einde van de middeleeuwen nog enkele laathoven of laatbanken. De gegevens daarover zijn echter schaars en soms ook onduidelijk. De oudste vermelding is te vinden in de al eerder genoemde verkoop van de hof 'met vijf huizen' te Eckelrade uit 1261 aan de abdij van Hocht. Hartmann plaatst de hof in het gebied van de Bijbank, een 'aanhangsel' van Gronsveld, grenzend aan Eckelrade. Enkele jaren daarna werd deze hof verplaatst naar Sint-Geertruid. Misschien kan de oorspronkelijke situering tamelijk nauwkeurig worden bepaald op een terrein aan de zuidzijde van de Eckelrader Dorpsstraat, dat volgens het leenregister van Gronsveld uit 1743 onder de naam 'het Clooster' bekend stond als een klein leen van Gronsveld. ${ }^{459}$ Of er een verband bestaat tussen deze hof uit 1261 en andere keurmedige goederen die we later in Eckelrade aantreffen (zie daarover Hoofdstuk 2.3.5 sub 'keurmedige goederen'.) is onduidelijk.

Mogelijk bestond er nog een 'hof in Eckelrade. In de huwelijkse voorwaarden tussen Mettel van Gronsveld en Christiaan van Ringberg uit 1382 en een boedelscheiding tussen enerzijds Hendrik van Gronsveld en Johanna van Merode en anderzijds Christiaan van Ringberg en Mettel van Gronsveld in 1396 wordt in beide gevallen gesproken over een 'hof te Eckelrade', echter zonder nadere aanduiding. ${ }^{460}$

De hof Printhagen was oorspronkelijk een goederencomplex, dat waarschijnlijk rond 1380 aan de heren van Gronsveld is toegevallen uit de nalatenschap van Johan van Printhagen. Diens zuster Margaretha van Printhagen was gehuwd met Hendrik II van Gronsveld. ${ }^{461}$ Het geslacht Van Printhagen heeft zijn oorsprong in de omgeving van Beek. Op welke wijze de Printhagens aan hun hof in Gronsveld zijn gekomen, is niet duidelijk. Feit is dat men over diverse bezittingen in de omgeving van Gronsveld beschikte, zoals een hof te Oost (later daar bekend als een zelfstandige laathof Printhagen) en pachten te 'Bergerhusen' (Bergenhuizen onder Noorbeek), Libeek (Sint-Geertruid) en Sint MartensVoeren). ${ }^{462}$ De ligging van de hof moet in Gronsveld zijn geweest, maar de exacte plaats is onbekend.

$\mathrm{Na}$ het overlijden van Hendrik II van Gronsveld vererfde de hof op zijn jongste dochter Aleydis, gehuwd met Johan Schellart van Obbendorf. Omdat zij kinderloos overleed, deelden haar broer Werner de Oude en zuster Wilhelmina in 1454 de hof Printhagen toe aan hun broer Hendrik III van Gronsveld. ${ }^{463}$ Bij een boedelscheiding in $1472 \mathrm{kreeg}$ Hendriks schoonzoon Engelbrecht Nyt van Birgel, gehuwd met Aleidis van Gronsveld,

${ }_{459}$ TJ, inv. nr. M 17, fol. 204: 'Palm Bessems is lehenman van eenen hoff genaemt het Clooster, waerop sijn huijs tegenwoordig staet....; vgl. ook fol. 214: 'Jan de Bije is leenman van ses groot rooden weijde genaemt het Cloister...'

${ }_{460}$ ULB Darmstadt, Hs. inv. nr. 2734-2735, Cartularium Hurt von Schönecken, fol. 21-25.

461 ULB Darmstadt, Hs. inv. nr. 2734-2735, Cartularium Hurt von Schönecken, fol. 21-25; fol. 42-48.

462 ULB Darmstadt, Hs. inv. nr. 2734-2735, Cartularium Hurt von Schönecken, fol. 42-48.

463 ULB Darmstadt, Hs. inv. nr. 2734-2735, Cartularium Hurt von Schönecken, fol. 391-393. 
het vruchtgebruik van Printhagen met een opbrengst van twaalf malder rogge per jaar, toegewezen. ${ }^{464}$ Hoewel deze transactie vier jaar later 'van geinre werde' werd verklaard, ${ }^{465}$ maakt ze duidelijk dat Printhagen in die tijd nog steeds als een afzonderlijke eenheid bestond.

Meer gedetailleerde gegevens over de omvang van Printhagen zijn te vinden in de rekening van de heerlijkheid Gronsveld over 1536/1537, toen de hof in ieder geval nog als een administratieve eenheid bestond. ${ }^{466}$ Daarin wordt gesproken over vijf malder rogge erfpacht in Gronsveld, gewone pacht uit ruim twaalf bunder land te Gronsveld en ruim zes bunder te Eckelrade alsmede cijnzen in de vorm van kapoenen, was en geld te Gronsveld, Eckelrade en Maarland. Onder Heugem lagen achttien bunder land, verdeeld over twee stukken. Onduidelijk blijft bij dit alles in hoeverre een volledige scheiding bestond met de goederen van de hof Printhagen onder Oost. Onzeker blijft ook of de Gronsveldse hof als laathof heeft gefungeerd. Waarschijnlijk aan het einde van de zestiende eeuw is Printhagen opgegaan in de rest van de landsheerlijke landerijen.

Vaag blijft de informatie over het 'Seutendaelsleenhof. Het Seutendaelsleen was één van 'grote' lenen van het leenhof van Gronsveld (zie daarover Hoofdstuk 2.3.5 sub 'Seutendaelsleen'). De meeste goederen, in totaal 25 à 26 bunder land, lagen in het grensgebied tussen Gronsveld en Rijckholt. Of er ook een echte hof is geweest, blijft onduidelijk. Volgens het Gronsveldse leenboek uit 1743 was aan dit leen 'die gerechtigheyt eenes lehenhoffs' verbonden, maar het bestaan van een subaltern leenhof komt nogal onwaarschijnlijk voor. ${ }^{467}$

Eén van de grootste grondeigenaren binnen het Land Gronsveld was de armentafel van de Grote Heilige Geest te Maastricht. De vroegste vermelding van deze 'pieuze fundatie' belast met armenzorg in Maastricht, dateert uit 1265. ${ }^{468}$ In de loop der tijden verwierf de armentafel in de dorpen rond Maastricht veel grond en cijnzen. Een lijvige legger van eigendommen en inkomsten uit 1456 makt dit al duidelijk. ${ }^{469}$ De Grote Heilige Geest bezat binnen Gronsveld ruim elf bunder en ruim vier bunder in Eckelrade. De grootste concentratie bevond zich echter met ruim $25^{1 / 2}$ bunder grond onder Heugem. De landerijen van de Grote Heilige Geest in Gronsveld lagen verspreid in verschillende velden, vooral aan de zuidkant, tegen de grens met Rijckholt. De vroegste specificatie is te vinden onder twee kopjes in de eerder genoemde legger uit 1456. De eerste groep draagt als titel: 'Dit sijn die cees en capuyn van Gronselt comende van heren Johans van Gruysbeeck', gevolgd door een opsomming van cijnzen en erfpachten met hun onderpanden. Volgens het slot van deze tekst moest men deze cijnzen heffen 'des sondaechs noe Sint Mertens dach ende men moet heffen onder den heer'.

464 ULB Darmstadt, Hs. inv. nr. 2734-2735, Cartularium Hurt von Schönecken, fol. 17-21.

465 ULB Darmstadt, Hs. inv. nr. 2734-2735, Cartularium Hurt von Schönecken, fol. 32-33.

466 RHCL, Graafschap Gronsveld, inv. nr. 172.

467 TJ, inv. nr. M 17, fol. 1 (oud).

468 Nève, De dertiende-eeunse schepenoorkonden, 27-34, nr. 1265.02.03 Testament van Lenvallus.

${ }^{469}$ RHCL, Armentafel Grote Heilige Geest te Maastricht, inv. nr. 1. 
De tweede groep inkomsten heeft als titel: 'Dit sijn alsulcke erfguede als te Groesselt ghelegen sijn, comende van joffr. Belen van Gruysbeeck en es eyn vrij geswoeren loethoeff en leenghoey'. Wat met de daarna nog enkele malen gebruikte term 'lheengoey' precies wordt bedoeld, blijft vaag. Het kan betekenen dat de armentafel haar goederen beheerde vanuit één instelling, die tegelijk als laat- en leenhof fungeerde, maar mogelijk werd er alleen maar het leengoed als zodanig mee bedoeld. Evenals bij het Seutendaelsleen moet een subaltern leenhof voor onwaarschijnlijk worden gehouden. Wellicht bestaat samenhang met de eerder genoemde goederen van Johan van Gruysbeeck. In ieder geval werd de tweedeling uit de vijftiende-eeuwse legger rond 1700 nog steeds in de boekhouding van de armentafel gebruikt met een onderscheid tussen diverse bezittingen onder Gronsveld, Heugem en Rijckholt en anderzijds 'chinsen van den laethoff van Gronsvelt'.470

Over de ouderdom van de laathof van zowel Johan van Gruysbeeck als Bele van Gruysbeeck valt weinig concreets te zeggen. Het lijken laatmiddeleeuwse constructies zonder een centrale hof. Een grootse geschiedenis hebben ze in ieder geval, ook al vanwege hun bescheiden omvang, niet gehad.

Ook in Heugem moet de armentafel van de Grote Heilige Geest een laathof hebben gehad. In de oudste legger van deze instelling uit 1456 staan onder het kopje 'Dit sijn dye cees en capuyn van den leenhoef van Hoeghem' diverse goederen en inkomsten vermeld. ${ }^{471}$ Van zeven huizen in het dorp wordt gezegd dat deze zijn belast met betaling van kapoenen (gecastreerde hanen) en geld. Verder beurde de armentafel een erfpacht van $71 / 2$ mud rog 'op den leenhoeff ende alle dye land den hoeff tuhorende ende dat te Hoeghum gelegen, te weten omtrint 21 boenre land, zoe land, zoe beempt'. Hoewel wordt gesproken over een leenhof, lijkt deze term niet geheel correct en moet een laathof zijn bedoeld. De benaming schijnt ook nooit anders te zijn geweest dan 'de hof tot Heugem'. In de - slecht overgeleverde - administratie van de Grote Heilige Geest kan de geschiedenis van de hof maar gedeeltelijk worden gevolgd. In een legger uit 1702-1704 worden nog altijd de cijnzen 'des hoffs Heugom' als een aparte eenheid geboekt. ${ }^{472}$ Maar de herkomst van de landerijen, die op dat moment in pacht of erfpacht zijn uitgegeven, valt niet goed te koppelen aan oudere gegevens.

Op welke wijze de Grote Heilige Geest deze hof heeft verworven, is niet bekend, maar het was in ieder geval een leen van de prins-bisschop van Luik. In dit verband nagekeken zijn leenopdrachten bij het bisschoppelijk leenhof van 1558 tot 1725 , maar het is goed mogelijk dat bij nader onderzoek nog vermeldingen uit zowel vroeger als later tijd tevoorschijn komen. In de onderzochte periode worden elf verheffingen door of op naam van ontvangers van de armentafel vermeld $(1558,1559,1566,1579,1582,1599,1614$, $1665,1680,1721,1725) .{ }^{473}$ Sommige opdrachten spreken in algemene zin over een

470 RHCL, Armentafel Grote Heilige Geest te Maastricht, inv. nr. 11.

${ }^{471}$ HCL, Armentafel Grote Heilige Geest te Maastricht, inv. nr. 1.

472 HCL, Armentafel Grote Heilige Geest te Mastricht, inv. nr. 12.

${ }^{473}$ Luik, Archives de l'État, Cour feodale, inv. nr 79, fol. 49-50vo (1559); inv. nr. 80, fol. 125vo-126 (1566); inv. nr.88, fol.225 (1599); inv. nr. 105, fol. 62vo-63 (1665) ; inv. nr 108, fol. 321 (1680); inv. nr. 
(laat)hof te Heugem, andere bevatten tevens een specificatie of 'denombrement' van bijbehorende landerijen en cijnzen. In de leenverheffing van 1599 wordt vermeld dat de hof eertijds in brand was gestoken door krijgsvolk.

De grensgenoten die in sommige leenopdrachten worden genoemd, zijn nauwelijks bruikbaar om de juiste ligging vast te stellen. Het lijdt evenwel geen twijfel dat die moeten worden gezocht net ten zuiden van het dorp, in de hoek die wordt gevormd door de Maarlanderweg en de Koestraat. Op de kaart van 1754 - waarop behalve nummers, namen van eigenaren en straatnamen nauwelijks andere bijzonderheden zijn vermeld staat opmerkelijk genoeg voor dit perceel genoteerd 'Den grooten H. Geest. Verloren hof'. Dit 'verloren' slaat waarschijnlijk op een teloorgaan door overstroming van de Maas in de jaren dertig of veertig van de achttiende eeuw.

De hof Ter Warden was een Luiks leen in Heugem, dat eind vijftiende eeuw in Gronsveldse handen is gekomen. De geschiedenis van de hof kan in de Luikse bisschoppelijke leenregisters worden gevolgd tot begin veertiende eeuw. Op 12 april 1314 verhief Arnuldus de Hoghen te Maastricht 24 bunder bouwland en anderhalve bunder weiland met zes hofhorige goederen, gelegen naast Wijck, in de plaats genaamd Hoghen ('XXIIII bonuaria terre arabilis et I bonuarium cum dimidio prati cum VI mansionariis iuxta Wick in loco dicto Hoghen').474 Vervolgens vinden gedurende de veertiende en vijftiende eeuw regelmatig nieuwe leenverheffingen plaats. ${ }^{475}$ Op een onbekend tijdstip moet Ter Warden in het bezit zijn gekomen van Werner 'de Oude' van Gronsveld, de broer van Hendrik III, heer van Gronsveld.

Volgens een procesdossier uit 1512 hadden zijn drie zonen Werner ('de Jonge'), Hendrik en Gerard besloten dat na het overlijden van één van hen alle onroerend goed in de familie moest blijven en niet mocht worden vervreemd. ${ }^{476}$ De langstlevende van dit drietal was Gerard van Gronsveld, licentiaat in de rechten en kanunnik van het Sint-Adalbertstift te Aken ${ }^{477}$ en hem viel het leen toe 'vermitz erfgerechtigheitt' als erfgenaam van zijn broer

115, fol. 182vo-183vo (1721); inv. nr. 115, fol. 412vo (1725); vgl. ook aantekeningen in HCL, Collectie De Crassier, inv. nr. 30, sub Gronsveld.

${ }^{474}$ Poncelet, Livre fiefs église de Liège, 5.

475 In 1318 door Johannes de Gheleerke, zoon van Gossuinus de Mayo van Maastricht van 'ongeveer 22 bunder land, ongeveer 30 solidi cijns en ongeveer 18 kapoenen', welke goederen hij had verkregen van Johannes de Aurea Barba (Poncelet, Livre fiefs église de Liège, 220-221); in 1355 door Jehan de Ghilenkerken als opvolger van zijn vader Jehan de Ghilenkerke, ridder; in 1392 door Florentius Weilde, schepen van Maastricht van 'unam curiam ...cum domistadio' en 23 'bonuaria, insimul vel necon censibus, caponibus, cormedis et aliis suis juribus pertinentibus et attinentibus' ('een hof met behuizing en 23 bunder met cijnzen, kapoenen, keurmeden en alle andere bijbehorende rechten'); in 1453 op 21 april door Jehan de la Noefvecourt voor Marye dochter van Jehan de Souret, ridder, van de hof van Heugem bij Maastricht, ook genaamd de hof Ter Warden, samen ongeveer 23 bunder met kapoenen, keurmeden etc.; in 1453 op 23 mei door Jehan de la Falloise en Jehan de Pollen, nadat in gevolge uitspraak in arbitrage afstand is gedaan door Jehan le Batard de la Neuve Court en zijn echtgenote Marye, dochter van Jehan de Souret. De gegevens over de beleningen in de periode 1390-1453 zijn ontleend aan RHCL, Collectie De Crassier, inv. nr. 30, sub 'Gronsveld'. De Crassier maakt verwijzingen naar de originele leenregisters, maar in het kader van dit onderzoek heeft geen nacontrole meer plaatsgevonden.

476 RHCL, Rijkskamergerecht, inv. nr. 16.

477 Sommige bronnen spreken ook van een kanonikaat bij het Onze-Lieve-Vrouwestift te Aken. 
Werner. ${ }^{478}$ In 1491 verhief Reynerus van Eckelroide voor hem 23 bunder land direct tot de hof Ter Warden horende, evenals andere gronden 'also fern derselfft mitt alsolchen seinen zugehorungen' aan de bisschop van Luik leenroerig waren 'und anders nit auch in geiner ander weiss, dairvon gemelter Reyner offentlich protestirt hatt'.

Gerard van Gronsveld achtte zich echter niet het compromis gebonden, herriep dit en verkocht in 1501 zijn goederen te Eijsden aan Diederik van Bronckhorst Batenburg. 479 Daarna verkocht hij de hof Ter Warden aan Johan I van Bronckhorst Batenburg. Maar na Gerards overlijden kwamen familieleden die afstamden van Gerards neven Werner en Gerard Huyn van Amstenrade tegen deze vervreemding in verzet met de stelling dat deze transactie in strijd was met de overeenkomst tussen de drie broers om geen onroerend goed buiten de familie te vervreemden. ${ }^{480}$ In eerste aanleg spanden zij een proces aan voor de schepenen van Heugem, maar na hoofdvaart op hun collega's van de stad Luik, stelden de schepenen van Heugem de klagers in het ongelijk. Daarna gingen de erven in beroep bij het Rijkskamergerecht. De afloop van de zaak is niet bekend, maar waarschijnlijk visten zij ook daar achter het net. 481 Johan I van Bronckhorst Batenburg was en bleef in het bezit van Ter Warden. In 1527 deed Hendrik van Holset genaamd Oost namens hem in Luik leenhulde voor de 'hof van Heugem'...'wylcken hoff anders genompt is den hoff van den Warden...met ouch den chynsen, capounen, kuermeden, boeten ende andere gerechticheyt'. ${ }^{482}$ In een soort postscriptum na de gebruikelijke formaliteiten maakte Henrick van Holset een voorbehoud voor het geval later mocht blijken dat de goederen niet leenroerig waren aan de bisschop van Luik. Dan zou de leenopdracht niet als een verworven recht van de bisschop worden beschouwd en wilde Van Bronckhorst Batenburg het geld terug dat hij voor de verheffing had betaald.

In de leenakten tot 1527 wordt voor Ter Warden steeds 23 à 24 bunder land als omvang opgegeven. Volgens een specificatie uit omstreeks 1590 bestond Ter Warden uit een 'bouplaats', een 'misthoff, een 'kalverhoff' en een moestuin met boomgaard. Daarna volgt de beschrijving van 25 grote en kleine percelen met hun ligging en grensgenoten. De 'winne' (pachter) hield circa 48 bunder land en $9^{1 / 2}$ bunder weide in pacht, in totaal dus $571 / 2$ bunder. Een beschrijving rond 1600 van eigendommen van de heren van Gronsveld vermeldt een omvang van 55 bunder akker- en weideland. Daarnaast worden nog eens afzonderlijk genoemd 16 bunder 'in den gevelte van Hueghem' en enkele 'aengedreven wertgens' bij de Maas. ${ }^{483}$ Waarschijnlijk moeten daarbij nog worden opgeteld de apart vermelde achttien bunder 'uyt den hoff van Printhagen tot den hoff van Heugem

${ }^{478}$ RHCL, Graafschap Gronsveld, inv. nr. 62, fol. 141-141vo.

${ }^{479}$ RHCL, Familie De Geloes/Kasteel Eijsden, inv. nr. 417-419.

480 RHCL, Rijkskamergerecht, inv. nr. 16. Deze Werner en Gerard Huyn van Amstenrade moeten zonen zijn van een zuster (Johanna?) van de drie broers die gehuwd was met Johan Huyn van Amstenrade.(vgl. Hoofdstuk 1.8.3).

481 Zie verder ook RHCL, Familie De Geloes/Kasteel Eijsden, inv. nr. 420, akte voor schepenen van Eijsden, 1515, waarbij de neven van Gerard van Gronsveld verzoeken in het bezit te worden gesteld van goederen van hun oom.

482 RHCL, Familie De Geloes/Kasteel Eijsden, inv. nr. 424.

${ }^{483}$ RHCL, Familie De Geloes/Kasteel Eijsden, inv. nr. 423. 
gedaen'. ${ }^{484}$ Volgens de rekening van de heerlijkheid Gronsveld van 1536/1537 lagen onder Heugem achttien bunder land van de hof Printhagen, verdeeld over twee stukken. ${ }^{485}$.

Het is moeilijk de door heel Heugem verspreid liggende landerijen precies te lokaliseren. Het grootste deel, zowel bouw- als weiland, moet worden gezocht in de directe omgeving van de dorpskern, met een zekere concentratie in het Maasveld. Maar ook in het Vroendel en bij De Heeg worden percelen genoemd. Ook de opgaven van de omvang van Ter Warden verschillen, maar duidelijk is dat vanaf het einde van de middeleeuwen steeds meer grondbezit van de heren van Gronsveld in Heugem met Ter Warden werd verbonden. Dit verklaart misschien ook de voorbehouden die bij de leenverheffingen in 1491 en 1527 werden gemaakt. Het oorspronkelijk leenobject omvatte immers slechts 23 bunder, en het was niet ondenkbaar dat toevoegingen in de vorm van allodiaal goed allengs met het oorspronkelijk leen zouden samensmelten.

De plek van de 'bouplaats' Ter Warden lijkt te zijn teruggevonden bij archeologische opgravingen in het najaar van 1994.486 Ten oosten van het MTB-gebouw aan de Molensingel te Heugem kwamen resten van een versterkte hoeve met grachten tevoorschijn. Het terrein bestond uit een lichte, maar omvangrijke verhoging in het midden van een laagte. Er werden de resten aangetroffen van meerdere grachtenstelsels uit de twaalfde en dertiende eeuw, verder bouwsporen van een schuur uit omstreeks 1200, een brug van rond 1300 en mergelfunderingen uit de veertiende en vijftiende eeuw. Het gevonden aardewerk dateert uit het begin van de dertiende eeuw tot en met de zestiende eeuw. Op negentiende-eeuwse kadasterkaarten is de vierkante vorm van het terrein goed herkenbaar, maar ook op de kaart van het graafschap Gronsveld uit 1754 valt het perceel onmiddellijk op door vorm en inkleuring.

Er zijn verschillende argumenten om de hof Ter Warden op deze site te lokaliseren. In de eerste plaats weten we dat de hof in de nabijheid van het Heugemer Broek lag en dat het zwaartepunt van het grondbezit van de hof in de omgeving van het Maasveld moet worden gezocht. Voorts stemmen de archeologische vondsten uit de twaalfde tot en met de zestiende eeuw overeen met de schriftelijke vermeldingen van vlak na 1300 tot bijna 1600. In die tijd moet ook aan de bewoning een einde zijn gekomen. Ook geeft de omvang van het terrein aan dat het om een aanzienlijke hof gaat en ten slotte staat het perceel in 1754 nog altijd op naam van de graaf van Gronsveld. Waarschijnlijk zijn de gebouwen in de laatste decennia van de zestiende eeuw als gevolg van oorlogshandelingen vernield.

Ter Warden lijkt bouwkundig en economisch in oorsprong te voldoen aan de kenmerken van een laathof, maar van een laatgerecht blijkt niets. In de loop van de zestiende eeuw is dat karakter van laathof helemaal verloren gegaan. Er werd steeds meer grond van andere herkomst aan toegevoegd en na het verdwijnen van de gebouwen zijn de landerijen als afzonderlijke percelen door de graaf in pacht uitgegeven.

484 RHCL, Familie De Geloes/Kasteel Eijsden, inv. nr. 424.

485 RHCL, Graafschap Gronsveld, inv. nr. 172.

486 Panhuysen e.a., 'Archeologische kroniek', 223-229. 


\subsubsection{Het leenhof}

Tot de rechterlijke organisatie moeten we ook het leenhof van de heren van Gronsveld rekenen. De werkingssfeer daarvan was overigens niet beperkt tot het Land Gronsveld, maar omvatte ook 'uitheemse' (buiten Gronsveld gelegen) lenen, vooral in Oost, Vaals en Holset en 'strooigoed' in de vorm van losse percelen grond in plaatsen in de omgeving.

Volgens de 'Specificatie' van het graafschap Gronsveld uit omstreeks 1650, bezat de heer van Gronsveld 'eene seer schoene leencaemere, behelsende sesendertich groete theenen ende dry hondert cleyne theenen luttel meer off min'. Van de 36 grote lenen is van ongeveer de helft de ligging precies bekend. Binnen het Land Gronsveld lagen de lenen in hoofdzaak in de dorpen Gronsveld en Eckelrade en een beperkt aantal in Slenaken. Hierna zal in het bijzonder aan de lenen in die plaatsen aandacht worden besteed in verband met de vraag of aan het ontstaan van die plaatsen heerlijk grootgrondbezit ten grondslag heeft gelegen. De begrippen 'groot' en 'klein' slaan overigens niet op de omvang, maar op de hoogte van het bedrag dat bij verheffing of opdracht voor het leenhof aan 'heergewaad' moest worden worden betaald, namelijk vijftien goudgulden voor een groot leen en één goudgulden voor een klein leen. Maar in de meeste gevallen waren de grote lenen ook in werkelijkheid omvangrijk.

De gegevens over het leenhof van Gronsveld in de late middeleeuwen zijn uiterst summier. In een proces uit 1551 voor het leenhof over een leengoed in Sint-MartensVoeren, werd een uittreksel geproduceerd uit een leenboek beginnend in 1377.487 Dit moet het oudste leenboek zijn geweest. Ook de langdurige processen uit het midden van de zeventiende eeuw tussen graaf Jost Maximiliaan van Bronckhorst Batenburg en de heren van Oost over de leenroerigheid van enkele laathoven in Oost leveren extracten uit leenboeken op, beginnend in 1395 en vervolgens 1460, 1519 en 1581.488 Prummer schrijft in 1757 in een rapport over het leenhof over de leenboeken die er in zijn tijd nog waren:

Von lehen, das ist lehen-, saal- oder läger-, dan belehnungs-büecheren seint zwar 3, von anno 1460, 1 von anno 1522 und 1 von anno 1558 verhandten; in betrachtung aber das von dennen ersten dreÿen eins mit dem anderen nit ÿbereins kommet, die leztere zweÿ nur excerpta aus dennen ersteren und eines wie das andere in keiner rechten verfassung seÿe, als kan von keinen anderen zur haubtsach ainige attention oder gebrauch gemacht werdten. ${ }^{489}$

De conclusie bij dit overzicht van leenadministratie vanaf 1377 is dat vanaf het laatste kwart van de veertiende eeuw een weliswaar niet vlekkeloze, maar toch geregelde registratie van lenen plaatsvond. Voor een klein leenhof is dit vroeg, zeker in vergelijking met de oudste leenregistraties van naburige grote landsheerlijkheden zoals Brabant $(1312)^{490}$, Gelre (1326) ${ }^{491}$ of Valkenburg (1381).492

${ }^{487}$ RHCL, Rijkskamergerecht, inv. nr. 230, fol. 17vo. Johan I van Bronckhorst Batenburg contra Johan van Cortenbach, commandeur van de Duitse Orde te Sint-Pieters-Voeren.

488 RHCL, Familie De Geloes/Kasteel Eijsden, inv. nr. 317.

489 TJ, inv. nr. M 13, 'Information über die Verfassung', fol. 126.

${ }^{490}$ Leenders, K. 'Het oudste leenboek van Brabant'.

${ }^{491}$ Van Doorninck, Het oudste leenactenboek. 
Het jaartal 1377 voor het oudste leenboek kan samenhangen met een reorganisatie van de leenadministratie na de erfenis in 1374 van de heerlijke rechten over Oost en SintMartens-Voeren door Jan II van Gronsveld van Godert van den Bongart. In beide plaatsen lagen lenen die later in Gronsveld werden verheven. Het belangrijkste leen onder Oost bestond sinds het midden van de vijftiende eeuw uit een complex van drie afzonderlijke laathoven, waarvan er bij één, de Kemerlingshof, vaststaat dat deze in 1407 aan Gronsveld leenroerig was. Onduidelijk blijft of deze lenen onder Oost moesten worden beschouwd als oorspronkelijke 'uitheemse lenen' van Gronsveld, of in het kielzog van de vererving van heerlijke rechten door de heren van Gronsveld zijn meegekomen. Deze kwestie werd in de zeventiende eeuw, na de verkoop van de heerlijke rechten over Oost, een van de oorzaken voor langdurige processen.

Het leengerecht bestond uit de stadhouder en vier of vijf leenmannen. Soms vervulde de stadhouder een dubbelrol en fungeerde hij tegelijkertijd als leenman. Dit verschijnsel zien we ook vaker bij schepenbanken, waar de scholtis tevens als schepen optrad. Leenmannen moesten leendrager zijn, dat wil zeggen zelf in het bezit van leengoed zijn, al was het maar een klein leen. De eerste volledige vermelding van het leengerecht is te vinden op het titelblad van het leenboek uit 1460:

Int jaer Ons Heeren duijsent vierhondert und sestich soo ist dit leen bouch gemaeckt overmits Johan Mor van Gronsvelt als stadthouder, Johan Schervel van Bern, Johan Mor van Eckelraede, Johan Haegen van Gronsvelt, Lampert van Cadier, Johan Schamperts van Gronsvelt als lehenmannen also sij allen die leenguter usser allen den lehenbucher genoemen und beiden anderen gehadt naeder bester formen und manieren alsman can und mach gelich hier nach volgende ist.

Wanneer dit opschrift de volledige bezetting van het leenhof aangeeft, dan komen we voor de vijftiende eeuw uit op vijf leenmannen. Over het formele en materiële Gronsveldse leenrecht in de middeleeuwen ontbreken gegevens. Daarom wordt dit onderwerp behandeld bij de beschrijving van het leenhof in de vroegmoderne tijd.

\subsubsection{Hoofdvaart}

Het overzicht van de rechterlijke organisatie in de late middeleeuwen moet worden afgesloten met enkele opmerkingen over de positie van de Gronsveldse schepenbanken in het systeem van de hoofdvaart. Gegevens over hoofdvaart en/of hoger beroep zijn voor deze periode uiterst summier. De ontwikkelingen op dit gebied in de vroegmoderne tijd, na de instelling van het Rijkskamergerecht, worden te bestemder plaatse (Hoofdstukken 9.9 en 10.6) in dit boek behandeld.

De rechtsgang van de 'hoofdvaart' of het 'te hoofde gaan' kent twee vormen. In het eerste geval ging het om een gecompliceerde zaak waarbij schepenen niet tot een beslissing konden komen omdat zij de zaak 'niet wijs' waren. Zij gingen dan 'te hoofde' bij een

${ }^{492}$ Het geregeld bijhouden van de leenadministratie van Valkenburg lijkt terug te gaan tot 1381, zie RHCL, Landen van Overmaze, inv. nrs. 738, 742. Originelen uit die tijd zijn niet meer bewaard. 
andere schepenbank om 'lering' te halen. Het hoofdoordeel werd vervolgens in de vorm van een bindend advies door de schepenen van de lagere instantie op eigen naam 'uitgedragen'. De hoofdvaart moet worden onderscheiden van het 'vonnis schelden' of 'valsschelden', dat meer het karakter had van 'wraking' waarbij een der partijen of een andere belanghebbende de oordeelsvinder betichtte van een onrechtvaardig vonnis. ${ }^{493}$

Naast en uit deze procudure van advisering ontwikkelde zich het hoger beroep, niet in gang gezet door de schepenen, maar op verzoek van partijen die bij een hogere instantie vroegen om herziening. Die hogere instantie kon een hoofdgerecht zijn, maar ook een apart ingesteld hof van appel. In de tijd van de zich ontwikkelende procedure van hoger beroep gaf de hogere instantie vaak een bindend oordeel dat de lagere rechter binnen zijn eigen bank moest 'uitdragen'. ${ }^{494}$ Naderhand, bij volledig ontwikkeld hoger beroep of appel, werd dit 'uitdragen' van het vonnis achterwege gelaten en was het oordeel van de hogere instantie direct bindend.

Over de relatie tussen hoofdvaart, oordeel schelden en hoger beroep bestaat veel literatuur, waarheen we hier kortheidshalve verwijzen. ${ }^{495}$ In de praktijk blijkt het echter niet zo eenvoudig de verschillende rechtsgangen terminologisch precies van elkaar te scheiden. Dat komt ook omdat men zich bij al deze procedures vaak tot dezelfde hogere instantie wendde. De middeleeuwse hoofdvaart kent tal van piramidevormige constructies, waarbij schepenen van de ene bank naar de andere ter lering gaan in twee, drie en soms wel vier instanties. De achtergrond van het ontstaan van dergelijke ketens is niet altijd duidelijk. Bij steden is gewezen op de hoofdvaart van een dochterstad op een moederstad, maar even talrijk zijn de hoofdvaarten van dorpsschepenbanken op stedelijke banken of tussen dorpsschepenbanken onderling. Hoofdvaart kon plaatsvinden binnen het territoriale verband van één landsheerlijkheid, maar er zijn vele voorbeelden van hoofdvaart vanuit het 'buitenland'. Maar ook binnen één territorium volgde de hoofdvaart niet altijd een gelijk aantal instanties.

In het Maasgebied ontwikkelde zich een aantal belangrijke schepenbanken tot hoofdgerecht die aan de top van een hoofdvaartpiramide stonden. ${ }^{496}$ Voor het Overkwartier van Gelre was dat de schepenbank van Roermond ${ }^{497}$ en voor het graafschap Loon de hoofdbank van Vliermaal, maar veruit het belangrijkste waren de Oberhof of de Schepenstoel van Aken ${ }^{498}$ en de stadsschepenbank van Luik. ${ }^{499}$ De Schepenstoel van Aken had zich aan het einde van de dertiende en gedurende de veertiende eeuw ontwikkeld tot hoofdvaartgerecht met een uitgebreid ressort. In 1270 betitelt het gerecht zich in een uitspraak voor de schepenbanken van het kapittel van Sint-Servaas te Maastricht over het daar geldende erfrecht als 'koninklijke zetel van de keizerstad Aken, hoofd van het Heilige Rijk benoorden de Alpen' ('regalis sedis et imperialis urbis Aquensis, que caput cis Alpes

\footnotetext{
493 Van Hall, Eijsden, een vrijheid, 171-172.

${ }^{494}$ Nève, Rijkskamergerecht, 264-265.

495 Hermesdorf, 'Te hoofde gaan'; De Monté ver Loren/Spruit, Hoofdlijnen, 160; Nève, Rijkskamergerecht, 260-265, Jacobs, 'Is het wel de rechter die recht vindt?', 28-31; Van Hall, Eijsden, een vrïbeid, 167-170.

496 Voor een overzicht zie Janssen de Limpens, Leen-en laathoven.

${ }^{497}$ Janssen de Limpens, Geldersche Wysenissen; Venner, Het Hoofgerecht Roermond.

${ }_{498}$ Schwabe, 'Der Aachener Oberhof.'

${ }_{499}$ Zie daarover Van Hall, Eijsden, een vrijheid, passim met de daar opgegeven literatuur.
} 
est Sacri Imperii').500 Deze hoofdvaart heeft zich langs gewoonterechtelijke weg ontwikkeld, maar in Aken werd voor de bijzondere status van het gerecht graag teruggegrepen op een vermeend privilege van Karel de Grote. Dat is ook door latere koningen en keizers in algemene, voorzichtige bewoordingen bevestigd, te beginnen met een privilege van keizer Karel IV uit 1356.501

Een groot probleem bij het onderzoek naar de hoofvaart op Aken vormt het ontbreken van het schepenarchief dat, op fragmenten na, bij de grote stadsbrand in 1656 verloren is gegaan. Er zijn slechts enkele lijsten bekend van plaatsen die in de late middeleeuwen hoofdvaart op de Schepenstoel hadden. ${ }^{502}$ Op basis daarvan heeft Schwabe in zijn studie over de geschiedenis van de Schepenstoel een 'Verzeichnis der rechtsuchenden Gerichte' samengesteld. ${ }^{503}$

Ook de schepenbank van Luik genoot als hoofdgerecht groot gezag. Rond vijfhonderd steden en dorpen binnen het prinsbisdom en de steden van het graafschap Loon gingen hier ter hoofdvaart, zodat vanaf de dertiende eeuw binnen een groot gebied min of meer geünificeerd Luiks recht werd gebruikt. ${ }^{504}$ Van de plaatsen in de omgeving van Gronsveld kan worden gewezen op het sedert eind veertiende eeuw tot het Land van Valkenburg behorende Eijsden, waar de hoofdvaart op Luik vanaf 1463 in het midden van de zestiende eeuw werd verlegd naar het hoofdgerecht van Valkenburg 505 , verder de aan het kapittel van Onze-Lieve-Vrouw te Maastricht toebehorende heerlijkheid Bemelen ${ }^{506}$ en de heerlijkheid Sint Pieter.

Ook de schepenbanken in het Land Gronsveld maakten deel uit van dit systeem van hoofdvaart. Een 'echo' daarvan is te vinden in de 'Specificatie' van het graafschap omstreeks 1650:

Van den gericht van Gronsfelt wordt geappelleert in civilibus voer heeren schepenen der stadt van Aecken ende van daer naer de Caemer van Spier.

500 O.a. afgedrukt bij Schwabe, 'Der Aachener Oberhof' I, 113.

${ }^{501}$ Schwabe, 'Der Aachener Oberhof' I, 92-101.

502 In de literatuur beschreven zijn: de lijst van Loersch, betrekking hebbende op de de periode 1415 1425, 1503-1517, 1531-1539 en 1559-1602, gepubliceerd door Franquinet, 'Les appels d'Aix-la-Chapelle'; een waarschijnlijk door de Schepenstoel zelf opgestelde lijst uit de tweede helft van de zestiende eeuw, zie: Schwabe, 'Der Aachener Oberhof II, 61 en Meulleners, 'Eenige bladzijden Obbicht en Leuth', 163164); een waarschijnlijk omstreeks 1614 opgestelde lijst, berustend in het Haus-, Hof- en Staatsarchiv te Wenen, betrekking hebben op de periode 1416-1613, zie: Schwabe, 'Der Aachener Oberhof' II, 62; de zogenoemde 'Lijsten Kemp', in drie varianten, betrekking hebben op de periode 1401-1461, zie Schwabe, 'Der Aachener Oberhof' II, 62-63; een 'Verzeichnis deren Untergerichteren ...' in de Sammlung Loersch, zie Schwabe, 'Der Aachener Oberhof, 64.

${ }^{503}$ Schwabe, 'Der Aachener Oberhof' II, 61-112.

${ }^{504}$ Gilissen, Historische Inleiding tot het recht, 268; Van Hall, Eijsden, een vrijheid, 180. Een lijst uit het einde van de vijftiende eeuw van schepenbanken die op Luik hoofdvaart hadden is afgedrukt bij De Borman, Échevins de Liège, 549-554.

505 Van Hall, Eijsden, een vrijheid, 178-184

${ }^{506}$ Franquinet, Inventaris O. L. Vrouwekerk, I, 178-183, nr. 155, 'cleernis der schepenen van Bemelen 1416, waarbij zij verklaren: 'ende onse banck steyt te Busdom recht van Ludic ende wir hoelen te Ludic voir die scepen onse hoefft ende leringe'. 
Van den gericht van Huegem wordt geappelleert naer heeren schepenen van Luyck.

Van Hontem naer Hugem ende van daer naer Luyck, ut supra.

Van Slenaecken wordt geappelleert naer Gronsfelt ende van daer naer Aecken, als voer.

Het is inderdaad een 'echo' omdat in de tekst niet wordt gesproken over hoofdvaart, maar over appel, dat na de instelling in 1495 van het Rijkskamergerecht (aanvankelijk in Spiers, later in Wetzlar) de hoofdvaart in zijn oorspronkelijke vorm had verdrongen. Maar de 'tocht langs de instanties', zoals de hoofdvaart die voordien kende, veranderde daarmee niet. De schepenbank van Slenaken had hoofdvaart op Gronsveld en vervolgens gingen de schepenen van Gronsveld naar de Schepenstoel van Aken. De schepenbank van Honthem ging 'ter lering' naar de schepenen van Heugem, die op hun beurt weer naar de schepenen van Luik trokken. Althans, dat was, zoals we hierna zien, de hoofdregel. Door het ontbreken van middeleeuwse archieven van de schepenbanken van Gronsveld en Aken en de deels vernielde archieven van Luik, zijn we over de hoofdvaarten vóór 1500 zeer summier ingelicht. Pas na 1500 zijn er dossiers van processen in hoger beroep (!) op het Rijkskamergerecht, waarin de weg via Aken of Luik duidelijk wordt.

De zogenoemde 'Lijst Kemp' geeft voor Gronsveld gedurende de periode 1400-1461 34 hoofdvaarten op Aken. ${ }^{507}$ Hoeveel er daarvan in eerste aanleg voor de bank van Slenaken zijn begonnen, is onbekend. De gang van Gronsveld naar Aken is op zich niet zo opmerkelijk en past goed binnen de rol die de Schepenstoel van de rijksstad vervulde als hoofdgerecht voor tal van kleinere heerlijkheden in een verre omgeving. Overigens logenstraft de hoofdvaart van Gronsveld op Aken de opvatting van sommige auteurs, dat bij uitstek plaatsen afkomstig uit oude koningsdomeinen hun weg naar Aken zochten. ${ }^{508}$ Er valt geen enkele relatie te leggen tussen Gronsveld en koningsgoed.

De vermelding bij Schwabe van een specifieke hoofdvaart van Heugem op Aken op 8 juni $1418^{509}$ en een algemene vermelding bij Loersch ${ }^{510}$ stelt ons voor een probleem. Want Heugem komt vervolgens wel voor op de lijst van plaatsen met hoofdvaart op Luik uit het einde van de vijftiende eeuw. ${ }^{511}$ Verder zijn er appelzaken van Heugem op Luik en het Rijkskamergerecht uit $1512^{512}$ en $1533^{513}$ en op Luik alleen uit 1639.514 Gaat het daarmee in 1418 om een incident, een vergissing of misschien een slecht gespelde naam? We moeten het antwoord bij gebrek aan nadere gegevens schuldig blijven, maar vooralsnog houden we het met de gang van Heugem naar Aken op een uitzondering die de regel bevestigt. Want hoofdvaart en later het appel van Heugem op Luik lijkt de vaste regel te zijn. Dat is ook goed verklaarbaar, wanneer men weet dat de heerlijkheid Heugem in de dertiende eeuw in het bezit van de prins-bisschop van Luik was en pas veel later, via een omweg, in 1363 in handen van de heren van Gronsveld is gekomen.

\footnotetext{
${ }^{507}$ Schwabe, 'Der Aachener Oberhof' II, 78

508 Nève, Rijkskamergerecht, 257-259.

509 Schwabe, 'Der Aachener Oberhof II, 78

510 Franquinet, 'Les appels d'Aix-la-Chapelle', 302: 'Hoeghem, bey Valkenburgh'.

511 De Borman, Échevins de Liège, 551.

512 RHCL, Rijkskamergerecht, inv. nr. 16.

513 RHCL, Rijkskamergerecht, inv. nr. 295.

514 Daris, 'Les Cours de justice Liège', 23.
} 
Gegevens over de schepenbank van Honthem dateren pas van het begin van de zestiende eeuw. Er is één appel bekend van Honthem op Heugem uit $1664^{515}$ en dit minimale gegeven bevestigt de rechtsgang tussen Honthem en Heugem zoals die ook in de 'Specificatie' van het graafschap rond 1650 wordt vermeld.

Over middeleeuwse hoofdvaarten van het heerlijk leenhof van Gronsveld ontbreken gegevens. In het midden van de zeventiende eeuw werd dit een punt van strijd met de Schepenstoel van Aken (zie daarover Hoofdstuk 10.6). Wel is bekend dat het leenhof fungeerde als hoofdgerecht voor drie Gronsveldse laathoven in Oost (zie Hoofdstuk 2.9.1).

\subsection{Ontstaan van het Land Gronsveld en domaniaal grondberit}

\subsubsection{De kaart van 1754 als uitgangspunt voor onderzoek}

In 1752 deed de uit Beieren afkomstige Joseph Anton Prummer zijn intrede in Gronsveld als vertegenwoordiger van graaf Maximilian Emanuel von Toerring-Jettenbach. Prummer wist niets van Gronsveld en zag zich geconfronteerd met enkele mensen die de plaatselijke situatie bijna volledig uit hun hoofd kenden. Verder stelde hij vast dat de grafelijke goederen in de voorgaande decennia slecht waren beheerd. Tegen de inmiddels ontslagen rentmeester liep een groot proces wegens fraude. Prummer wilde verandering met een tweeledig doel. In de eerste plaats wilde hij meer inzicht in de grafelijke inkomsten in vorm van pachten, cijnzen en belastingen op onroerend goed, waarop de graaf als landsheer aanspraak maakte. Verder was Prummer direct na zijn aankomst verwikkeld geraakt in een heftig debat met de (grotendeels Maastrichtse) grondeigenaren ('geërfden') in het graafschap over de grondbelasting. Het conflict kende een voorgeschiedenis van 150 jaar en de politieke discussie over deze problematiek komt in Hoofdstuk 16.2 en in het bijzonder 16.2.7 uitvoerig aan de orde. Om meer duidelijkheid in de financiën te krijgen, was een nauwkeurig inzicht in de grondeigendommen noodzakelijk. Dat leidde tot het besluit om van het hele graafschap kaarten op kadastrale schaal met bijbehorende leggers te laten vervaardigen.

Op 21 september 1754 werd een ordonnantie gepubliceerd met het bevel aan alle grondeigenaren een beschrijving van hun grondbezit 'aan te brengen'. Vervolgens kreeg de landmeter Arnoldus Schutjes de opdracht alle gronden op te meten en in kaart te brengen. Het hele gebied kreeg een indeling in secties en alle percelen werden voorzien van een nummer met de naam van de eigenaar. Prummer maakte vervolgens leggers met per perceel de naam van eigenaar en de op de grond drukkende zakelijke lasten in vorm van cijnzen, keurmedigheid of leenplicht. Bij elkaar verschaften de kaarten met de grondboekhouding in één oogopslag een samenhangend beeld van de geografie en de juridische eigendomsverhoudingen in het midden van de achttiende eeuw. Het geheel lijkt uiterlijk op een kadaster, maar met dit begrip is voorzichtigheid geboden. Deze administratie vormde geen openbaar, voor iedereen raadpleegbaar systeem van

515 RHCL, Graafschap Gronsveld, inv. nr. 275. 
grondboekhouding, maar diende uitsluitend het belang van de graaf en de heffing van de grondbelasting.

Omstreeks 1780 zijn de losse kaartbladen van de secties voor een deel aan elkaar geplakt en naar München gestuurd, zodat men zich daar een goed (cartografisch) beeld van het hele graafschap kon vormen. In zijn huidige vorm bestaat het werk uit acht kaarten (één voor Heugem, vier voor Gronsveld, één voor Eckelrade, één voor Honthem en één voor de Bijbank). ${ }^{516}$ Die overbrenging betekende ook de redding, want door de opname in het archief van de graven Toerring-Jettenbach bleef hun de vernietiging bespaard die het grootste deel van de Gronsveldse archieven twaalf jaar later trof bij de inval van de Franse troepen.

De kaart van 1754 is een momentopname van het graafschap, maar waarschijnlijk vertoont het weergegeven beeld van wegen en bebouwing veel gelijkenis met de situatie in de late middeleeuwen. Ook de grote vernielingen in de Tachtigjarige Oorlog (in het bijzonder ten tijde van het beleg van Maastricht in 1579) hebben niet geleid tot fundamentele wijzigingen in de infrastructuur. Er mag daarom worden verondersteld dat een grote mate van continuïteit bestond tussen het landschap van de late middeleeuwen en dat van de achttiende eeuw. Aldus vormt deze kaart een goede basis voor de hierna volgende beschrijving van de geografische situatie van Gronsveld.

Een vergelijkbare continuiteit is, in hoofdlijnen, ook aannemelijk voor de juridische situatie van de grond. Middeleeuwse rechten en verhoudingen kenden vaak gedurende honderden jaren stabiliteit, zeker bij geestelijke instellingen of adellijke heren. Daarmee is het mogelijk een vroegere toestand te reconstrueren op basis van een latere situatie (de zogenoemde retrogressie). Voorbeelden van dergelijke studies in de omgeving van Gronsveld zijn de onderzoeken van Hartmann naar het ontstaan van Breust, Eijsden en Oost ${ }^{517}$, van Hackeng naar het grondbezit van kapittel van Sint-Servaas te Maastricht ${ }^{518}$ en van Coun voor het gehucht Smeermaas, juist ten noorden van Maastricht, onderdeel van de rijksonmiddellijke heerlijkheid Pietersheim. ${ }^{519}$ Enige voorzichtigheid is gepast voor al te snelle conclusies. Zo maakt het leenrecht onderscheid tussen uitgegeven en opgedragen lenen. In het eerste geval ontving de leenman of vazal uit de eigendom van de heer bepaalde rechten of landerijen in leen. Maar ook de omgekeerde weg werd gevolgd en ging het om omzetting van vrije eigendom of allodiaal goed in leengoed door opdracht van de eigenaar aan een heer. In dat geval vormt het leen dus geen afspiegeling van oorspronkelijk heerlijk goed.

Hartmann beschrijft gedetailleerd de ontstaansgeschiedenis van de verschillende dorpen binnen de heerlijkheden Eijsden en Breust en betrekt daarin ook nadrukkelijk allerlei fysisch-geografische elementen. Verhoudingsgewijs veel aandacht krijgt ook de methodiek van onderzoek zelf. Uitgangspunt vormden de 'rapporten van aanbreng' uit 1619,

516 TJ, inv. nr. M 80.

517 Hartmann, Reconstructie landschap, passim.

518 Hackeng, Middeleeuwse grondbezit Sint-Servaaskapittel.

519 Coun, Het gehucht Smeermaas. 
specificaties van onroerend goed die door de eigenaren bij het gerecht moesten worden ingeleverd. Daarbij werden voor ieder perceel, naast oppervlakte en eigendom, ook de daarop rustende cijns- en leenverplichtingen genoteerd. Op basis daarvan probeerde Hartmann een vroeg zeventiende-eeuwse gebiedsopname in geschreven vorm te verbinden met kadasterkaarten uit het begin van de negentiende eeuw. Aangezien overzichtskaarten uit het Ancien Régime ontbraken, dienden losse perceelschetsen uit diverse tijden als hulpmiddel om een brug te slaan tussen ouder en jonger kaartmateriaal.

Een wat andere benadering koos Hackeng. Hij gebruikte de retrogressieve methode voor bestudering van het middeleeuws grondbezit van het Sint-Servaaskapittel te Maastricht en werkte dit vervolgens uit voor de dorpen Vlijtingen, Hees, Berg, Grandville en Lens. Door de combinatie van gegevens over cijnzen en pachten uit laatmiddeleeuwse rekeningen en leggers met documenten over de verkoop van de kapittelgoederen als nationaal domein in de Franse Tijd, probeerde hij het oorspronkelijk grondbezit van het kapittel in een dorp te reconstrueren. Ook hier vormden losse schetsen van percelen uit de achttiende eeuw een belangrijk hulpmiddel voor de verwerking van het materiaal in kadastrale kaarten uit de jaren dertig van de negentiende eeuw.

De studie van Coun is niet zozeer gericht op de ontginnings-, maar op de bewoningsgeschiedenis van het gehucht Smeermaas. Hoewel op de rechtshistorische benadering van het werk wel iets valt af te dingen (zo wordt onvoldoende scherp onderscheid gemaakt tussen keurmede en cijnzen) is het resultaat opmerkelijk. Hij laat de keurmedigheid zien van ongeveer 35 huizen in nagenoeg aaneengesloten bebouwing langs de twee doorgaande wegen, zoals die aan het einde van de achttiende eeuw nog bestond. Hij volgt de bewoningsgeschiedenis daarvan tot in de zestiende eeuw, maar het is duidelijk dat het gaat om een middeleeuwse oorsprong, waar een planmatige uitgifte van bouwplaatsen tegen het recht van keurmede aan ten grondslag ligt.

Het onderzoek van Hartmann en Hackeng was bedoeld om antwoord te krijgen op de vraag hoe middeleeuwse dorpen waren ontstaan en welke rol het grootgrondbezit van kerkelijke instellingen en adellijke heren daarbij speelde, onder andere door ontginningsactiviteiten. Dezelfde vraag kan worden gesteld voor de dorpen en gehuchten van het Land Gronsveld. In beginsel is de eerder beschreven methode daarvoor bruikbaar. Door het in kaart brengen van de juridische status van grond kan duidelijk worden of plaatsen zijn gesticht op basis van adellijk of kerkelijk grootgrondbezit. Hartmann en Hackeng moesten noodzakelijkerwijs veel aandacht besteden aan de 'projectie' van hun bronnen op negentiende-eeuwse kaarten. Dat probleem speelt voor Gronsveld niet, omdat het basismateriaal hier annwezig is in de vorm van kaarten op kadastrale schaal uit het midden van de achttiende eeuw. (De situatie in Gronsveld is enigszins vergelijkbaar met die in Smeermaas, waar ook achttiende-eeuwse schetsen van de huiskavels voorhanden zijn). Daarnaast kan de juridische status van de grond in die tijd gemakkelijk worden vastgesteld met behulp van 'rapporten van aanbreng' en registers waarin feodale, middeleeuwse rechtsverhoudingen van leenroerigheid, keurmedigheid en cijnsplicht staan opgetekend. 


\subsubsection{Lenen, keurmeden en cijnzen als onderzoeksobject}

Het onderzoek van Hartmann en Hackeng maakt voor respectievelijk Breust/Eijsden en Berg duidelijk hoe van de elfde tot de dertiende eeuw vanuit het Maasdal de hogere gelegen delen van het plateau van Eckelrade en Sint-Geertruid werden ontgonnen. Ontginningen werden ondernomen vanuit een hof die als het middelpunt van een domein met grootgrondbezit kan worden beschouwd. Wanneer men kijkt naar de geografische structuur van Gronsveld en Eckelrade, dan is er weinig verbeeldingskracht nodig om te zien dat zich hier een vergelijkbare ontwikkeling heeft voltrokken.

Om het oorspronkelijk domein van de heren van Gronsveld in kaart te brengen zijn uit de achttiende eeuw drie rechtsverhoudingen onderzocht, namelijk goederen die in volle eigendom aan de heer toebehoorden, vervolgens goederen die in leen werden uitgegeven en ten slotte goederen die tegen het recht van keurmede werden uitgegeven. Formeel was de heer eigenaar van leengoederen en keurmedige goederen, maar de leenman of de bewoner van het keurmedig goed had daarop een zakelijk recht.

De rechtstoestand van lenen en keurmedigheid kenmerkt zich door een hoge mate van stabiliteit en continuiteit.520 Daarmee komen deze goederen - naast goederen in volle eigendom - bij uitstek in aanmerking voor onderzoek naar de omvang van het oorspronkelijk heerlijk domein. Buiten beschouwing gebleven zijn huizen en landerijen waarvan de eigenaar jaarlijks een bedrag in de vorm van 'cijnzen' en erfpachten aan de heer betaalde. Onderzoek naar de eventuele domaniale herkomst van dit soort goederen is zeer gecompliceerd. Cijnsrecht kan zijn ontstaan door uitgifte van grond als laatgoed tegen betaling van een jaarlijkse cijns ter erkenning van het recht van de heer, maar kan ook teruggaan op middeleeuwse vormen van kredietverlening. Ook voor Gronsveld speelt deze problematiek. Volgens de 'rapporten van aanbreng' uit 1754 bleek ongeveer negentig procent van de grond op de een of andere manier met cijnzen te zijn belast. Zo gezien zou de vraag naar het oorspronkelijk heerlijk domein snel zijn beantwoord. Maar in de bespiegelingen die Prummer in 1761 aan cijnzen wijdt (waarover meer in Hoofdstuk 15.16), komt naar voren hoe diverse soorten cijnzen administratief een onontwarbare kluwen van allerlei lasten vormden. Daar kwam bij dat door samenvoeging of splitsing van kavels het naderhand vaak niet meer mogelijk was een cijns nog naar het oorspronkelijke stuk grond te herleiden.

Gevoelsmatig lijkt keurmedigheid te passen binnen een systeem van hofhorigheid, waarbij de horige in een afhankelijkheidsverhouding tot de heer stond, maar het is de vraag of dit later ook nog werkelijk zo werd ervaren. De in geld te kapitaliseren keurmede drukte als een zakelijke last op het onroerend goed en verschilde daarmee niet wezenlijk van bijvoorbeeld het heergewaad, dat voor een leen moest worden betaald. Leenman en laat stonden even sterk tegenover hun heer. Zowel leen- als laatrecht lijken in de late middeleeuwen door eigenaren van kleinere domeinen te zijn gebruikt als middel om grond

${ }^{520}$ Een goed voorbeeld van die continuïteit levert de studie van Coun, Het gehucht Smeermaas. 
te exploiteren, in het bijzonder bij ontginningen. Waarom nu eens voor de ene, dan weer voor de andere constructie werd gekozen, valt achteraf moeilijk vast te stellen.

\subsection{Gronsveld en Eckelrade}

\subsubsection{Geografisch beeld van Gronsveld}

De bewoningsgeschiedenis van Gronsveld reikt terug tot ver in de prehistorie, wanneer men tenminste begint met de bijna industriële ondergrondse vuursteenwinning vierduizend jaar geleden in het Savelsbos, tussen Rijckholt en Sint-Geertruid. ${ }^{521}$ Waarschijnlijk woonden deze 'mijnwerkers' niet bij hun werkterrein, maar in het Maasdal, waar vruchtbare grond en water overvloedig aanwezig waren. Belangrijke bodemvondsten uit de Bronstijd of Vroege IJzertijd zijn voor deze plaats niet bekend, zodat we moeten gissen naar mogelijke menselijke activiteiten gedurende deze tijdperken.

Enkele decennia voor het begin van onze jaartelling veroverden Romeinse troepen het Maasdal. Waarschijnlijk waren bij hun komst vooral delen van de rivierdalen in ZuidLimburg in cultuur gebracht, terwijl de plateaus nog bebost waren. In de daarop volgende eeuwen werden deze hoger gelegen gronden geleidelijk aan ontgonnen, met grote agrarische bedrijven ('villae') als centra. In het tegenwoordige Zuid-Limburg zijn ongeveer tachtig van deze behuizingen bekend, met een concentratie langs een denkbeeldig getrokken lijn tussen Maastricht en Heerlen. ${ }^{522}$ Het is daarom niet vreemd dat ook in het dicht bij Maastricht gelegen Gronsveld tal van sporen van Romeinse bewoning zijn aangetroffen, maar restanten van een echte 'villa' zijn niet bekend. ${ }^{523}$

Met het vertrek van de Romeinen verdwenen ook de grote boerderijen. De bevolking nam af en het cultuurland raakte weer begroeid met bos. Daarmee verdwenen ook de bestaande infrastructuur en verkaveling van de grond. De vroegste middeleeuwse nederzettingen in Zuid-Limburg worden in die tijd aangetroffen in de directe nabijheid van de Maas of op de oeverwallen van de rivier. Vanuit het Maasdal werden het hoger gelegen middenterras en uiteindelijk ook het plateau zelf ontgonnen. Zo ontstonden van de elfde tot de dertiende eeuw op het middenterras, tussen het plateau en de vochtige graslanden langs de rivier, de typisch noord-zuid georiënteerde straatdorpen, waarvan Rijckholt en Gronsveld, maar ook dorpen als Heer, Amby en Cadier, voorbeelden zijn. Het oudste deel van die lintbebouwing wordt meestal gesitueerd aan de oostzijde, de hoge kant van de straat, om te voorkomen dat het water van de weg de huizen binnenliep. ${ }^{524}$

\footnotetext{
521 Zie daarover uitvoerig: Rademakers, [red.], De prehistorische vuursteenmijnen van Ryckholt-St. Geertruid en Renes, Zuidlimburgse Cultuurlandschap, 35-36 met verwijzing naar de daar genoemde literatuur.

522 Zie voor een overzicht met kaartjes Renes, Zuidlimburgse Cultuurlandschap, 36-38.

523 Zie daarover in het bijzonder de verschillende publicaties uit de negentiende eeuw, waarin tal van vondsten in de vorm van aardewerk, fragmenten van dakpannen worden vermeld, alsmede een bronzen saterkopje: Caumartin, 'Souvenirs et promenades à Gronsveld'; Habets, 'Notice sur quelques découvertes'; Habets, 'Over Romeinsche voorwerpen te Gronsveld gevonden'. In het bijzonder het gebied ten noordwesten van het kasteel is archeologisch zeer rijk.

524 Renes, Zuidlimburgse Cultuurlandschap, 49, 55.
} 
Wanneer we kijken naar de plattegrond van Gronsveld, dan zien we aan de noordzijde van het dorp een soort knooppunt van wegen met de Molenweg (richting Heer), de Maastrichterweg (de doorgaande route vanuit Heugem door het Savelsbos naar Eckelrade) en ten slotte de Dorpsstraat (hoofdweg door het dorp, zuidwaarts richting Rijckholt). Van secundair belang waren de Slakweg en de 'straat achter het dorp'. Laatstgenoemde liep achter de bebouwing aan de oostzijde van de Dorpsstraat, ging daarna over in de Schillingstraat en ten slotte, richting Rijckholt, in de Voerenweg. Een andere weg van secundair belang, die opvalt door zijn lengte, was het Wijngaardswegske, ten westen van het dorp, beginnend bij het kasteel en ten slotte, richting Heugem, uitkomend op de Maastrichterweg. Typisch voor het wegenpatroon waren de verschillende op de Dorpsstraat uitkomende 'stegen' (Putsteeg, Hennemetttensteeg of Snijderssteeg, Kleine Steeg of Manskessteeg en Duistersteeg of Fiassteeg), die toegang gaven tot de weilanden in het Broek.

De bebouwing, vrijwel volledig gesitueerd langs de Dorpsstraat, levert een goed voorbeeld van een straatdorp in de vorm van een zogenoemde lineaire nederzetting. De kaart uit 1754 laat aan de oostzijde van de straat een min of meer gesloten huizenrij zien vanaf het begin van het dorp in het noorden tot aan de Oeslingersteeg/Veldsteeg/Holegracht. Tegenover de kerk zijn de kavels het kleinst en waarschijnlijk ook het oudst. Ten zuiden van de Oeslingersteeg wordt de bebouwing veel opener. Min of meer hetzelfde patroon kan worden vastgesteld voor de westzijde van de Dorpsstraat. Komende vanaf het noorden is de bebouwing tot aan de kerk vrij dicht. Daarna vormen kerk en kasteel met het omliggend terrein als het ware één groot blok, aan de zuidzijde begrensd door de Putsteeg. Verder zuidwaarts, richting Rijckholt, liggen nog maar weinig huizen.

Achter de bebouwing aan de westzijde van de Dorpsstraat begon het Gronsvelder Broek, op de kaart van 1754 aangeduid als 'gemeyne weyde', waar de inwoners hun vee lieten grazen. Ten noorden en oosten van het dorp lagen de bouwlanden. Het veld aan de noordkant sloot aan op het Vroendel, grond ressorterend onder de jurisdictie van Heugem. De percelen bestonden in de achttiende eeuw uit afwisselend grote en kleine kavels, waarbij vooral de percelen in eigendom van de graaf, opvallen door hun omvang. Langs een hellend deel van dit veld liep de Grub, de uitloop van een droogdal dat zich door het Savelsbos slingert en langs het plateau van Eckelrade via Honthem uiteindelijk begint bij Bruisterbosch. Het akkerland ten zuiden van de Grub vertoont op de kaart van 1754 een verkaveling van grotere en kleine percelen, met ook hier opvallend veel grote stukken in grafelijk bezit. Verder zuidwaarts, richting Rijckholt, werd de strook akkerland tussen het Savelsbos en het dorp smaller en vormden de hellingen van het Savelsbos een natuurlijke begrenzing. Het zuidelijkste deel van deze strook, ter hoogte van de Voerenstraat, bestond uit veel kleine, langgerekte percelen in oost-west richting.

Ongeveer in het midden van het dorp bevinden zich de kerk en het kasteel. Van het oude kasteel, dat vanaf de late middeleeuwen tot het midden van de zeventiende eeuw werd uitgebouwd tot een imposante burcht met een weerbaar karakter, resteren nog slechts fundamenten en enig opgaand muurwerk. Nadat het gebouw in de loop van de achttiende 
eeuw in verval was geraakt, werd het in 1827 afgebroken. Op de grondvesten liet de eigenaar Andreas Adolf Gadiot in 1833 een landhuis in Tudorstijl bouwen. Archeologisch onderzoek van de ondergrond ontbreekt, zodat we ons voor de ouderdom van het eerste kasteel moeten oriënteren op zichtbare overblijfselen. De vroegste delen van de burcht worden gedateerd in de dertiende eeuw, dezelfde tijd waarin ook de eerste kerk van Gronsveld werd gebouwd. Toch valt de mogelijkheid van een vroegere stichting niet uit te sluiten. ${ }^{525}$ In ieder geval wordt de ligging op een hoog terrein vaak gezien als een teken van hoge ouderdom. ${ }^{526}$

\subsubsection{Geografisch beeld van Eckelrade}

Het dorp Eckelrade ligt tamelijk centraal op het plateau ten oosten van het Savelsbos. Aan de westzijde vormt de rand van het plateau de natuurlijke afscheiding met Gronsveld. Vanuit Gronsveld was het plateau via drie hoofdtoegangen bereikbaar: in het noorden de weg richting Cadier door het droogdal van de Grub langs de Dor; in het midden, richting Sint-Geertruid, de Maastrichter Weg langs de Trichterberg en ten slotte in het zuiden via de Scheggelderdel en Schonegrub. In het noorden werd het plateau omsloten door de Grub, beginnend in de Dor tussen de Riessenberg en de Wijngaardsberg en, zich daarna in oostelijke richting voortzettend langs het Kruisveld (Cadier) en de Bertenberg, de Honsberg en het Blankenbergerveld, om ten slotte te eindigen als grens tussen Gronsveld en Honthem. Naar het zuiden (Sint-Geertruid) en oosten (Bijbank) was het open veld wel geaccidenteerd terrein, maar er liepen geen duidelijk natuurlijke grenzen.

De bebouwing van Eckelrade lag in de achttiende eeuw bijna helemaal geconcentreerd langs twee doorgaande wegen, de Dorpsstaat en de weg naar Cadier (thans Klompenstraat in de bebouwde kom en de voortzetting daarvan in de Keerestraat). De Dorpsstraat begon ter hoogte van hoeve Hemersbach als aftakking van de Maastrichterweg - de doorgaande route van Gronsveld naar Sint-Geertruid - en vormde in oostelijke richting de verbinding met het gehucht Honthem. Deze Dorpsstraat was tevens de grens met Sint-Geertruid, welk dorp viel onder de jurisdicties van Breust en Eijsden. Vanuit het noorden komt de Keerestraat ter hoogte van de kerk uit op de Dorpsstraat. De vorm van het geheel sluit goeddeels aan bij het bekende type van straatdorpen met lintbebouwing. Achter de huiskavels bevonden zich weilanden en boomgaarden, daarachter begonnen de velden met bouwland. De achttiende-eeuwse verkaveling laat een afwisselend beeld zien van enkele zeer grote en verder middelgrote en kleine percelen. Deze velden waren vanaf de doorgaande wegen bereikbaar via kleine veldwegen.

525 Marres/Van Agt, Monumenten Zuid-Limburg, 185-187.

526 Renes, Zuidlimburgse Cultuurlandschap, 55, bijschrift bij figuur 49. Volgens de auteur lagen jongere kastelen, zoals dat van het nabijgelegen Rijckholt, in lage, natte gebieden, waar de aanleg van een waterhoudende gracht mogelijk was. Over het oorspronkelijk karakter van de burcht heeft de schrijver een onduidelijke mening. Nu eens (77) spreekt hij over de mogelijkheid van een mottekasteel, dan weer (91) over het ontstaan van de burcht uit een gewone boerderij. 
De historische ontwikkeling van Eckelrade in de middeleeuwen is voor een deel (in het bijzonder het Breuster/Eijsdense deel) uitvoerig bestudeerd door Hartmann. ${ }^{27}$ Hij plaatst het ontstaan van het dorp in de twaalfde eeuw en beschouwt de bebouwing in de omgeving van de kerk langs de noordzijde van de hele Dorpsstraat en langs beide kanten van de Klompenstraat als de kern van de nederzetting. Hierna (Hoofdstuk 2.3.7) komt aan de orde dat in de groei van de kern waarschijnlijk twee fasen moeten worden onderscheiden. De meeste aandacht schenkt Hartmann echter aan het gebied ten zuiden van Eckelrade, behorend tot Sint-Geertruid. Hij maakt daarbij een verdeling in drie min of meer parallel lopende stroken. Het noordelijkste deel bestond overwegend uit grond die onder Breust ressorteerde. De middelste baan werd gevormd door een smalle, wigvormige strook van Rijckholter cijns- en leengoederen. ${ }^{528}$ Het is duidelijk dat deze insnijding het resultaat was van ontginning vanuit Rijckholt via het droogdal van de Schonegrub. Het gebied ten zuiden van deze Rijckholter goederen bestond afwisselend uit blokken Breuster grond en goederen die ressorteerden onder de laathof van Hocht.

\subsubsection{Grenzen van Gronsveld en Eckelrade}

Gronsveld en Eckelrade grensden binnen het graafschap aan Heugem, Honthem en de Bijbank. Het precieze verloop van de 'limieten' tussen Gronsveld en Heugem is niet bekend, maar valt met behulp van de beschrijvingen van onroerend goed in de 'rapporten van aanbreng' en de kaarten uit 1754 ongeveer vast te stellen. De grens verliep zeer onregelmatig en volgde nauwelijks natuurlijke scheidingen in het terrein. De grens begon in het uiterste westen bij de Schaapbroekweg, liep daarna langs het Heugemer Broek en de Slek, kruiste de Maastrichterweg van Gronsveld naar Heugem, boog daarna af in oostelijke richting door het Rekout, kruiste de weg van Gronsveld naar Heer en liep daarna oostwaarts door het Vroendal om ten slotte bij de Hel uit te komen op de Keerderweg. Deze weg werd daarna gevolgd tot aan de Hotsboom, het hoogste punt van Gronsveld, waar de limieten van Heugem, Gronsveld en Cadier samenkwamen.

Strikt genomen raakte Eckelrade slechts op één punt aan Honthem, bij 'der Stegbuchel', waar de grenzen van de Bijbank, Honthem en Eckelrade bij elkaar kwamen. Vanaf dat punt vormde de weg van Honthem naar Eckelrade in zuidwestelijke richting, tot aan het begin van de bebouwing van Eckelrade, de grens tussen Eckelrade en de Bijbank. De grens tussen de Bijbank en Honthem liep vanaf 'der Stegbuchel' in zuidoostelijke richting via de Grub richting Bruisterbosch. Het was niet veel meer dan een doorgang met een breedte van circa 325 meter.

Gronsveld en Eckelrade grensden vier keer aan buitenlands gebied. Als eerste noemen we de heerlijkheid Cadier. ${ }^{529}$ Vanaf ongeveer de Hotsboom liepen de limieten met Cadier min of meer parallel met het droogdal van de Grub door het Savelsbos en daarna, aan de

${ }^{527}$ Hartmann, Reconstructie landschap, 73-78.

528 Zie Hartmann, Reconstructie landschap, bijlage kaart 2, waar deze stroken zijn ingetekend.

${ }^{529}$ Over de vroege geschiedenis van Cadier is zeer weinig onderzoek verricht. Nog altijd van belang is Habets, 'Notice seigneurie Cadier'. 
noordzijde van het plateau van Eckelrade, langs de Honsberg en het Blankenbergerveld tot aan Honthem, op de plek die op de kaart van 1754 wordt aangeduid als 'der Stegbuchel'. Daar kwamen Gronsveld, Honthem en Cadier samen. Deze grens met Cadier langs de Grub is duidelijk herkenbaar als een natuurlijke scheiding, maar kan tegelijkertijd ook als een soort grensweg worden beschouwd, die vanuit Gronsveld toegang gaf tot Eckelrade en Honthem.

Ten zuiden van Eckelrade lag het dorp Sint-Geertruid, ressorterend onder Breust en Eijsden. Breust en Eijsden waren twee zelfstandige heerlijkheden, maar worden in één adem genoemd omdat hun gebieden als een mozaïek door elkaar lagen. Ook SintGeertruid was op die manier verdeeld. Beginnend bij de meest oostelijke bebouwing van Eckelrade, liep in westelijke richting de Eckelrader Dorpsstraat langs het huis Hemersbach tot aan het 'drielandenpunt' Gronsveld, Rijckholt en Breust/Eijsden. Bijna overal vormde de as van de weg hier de grens. Ten zuiden daarvan lagen de velden van Sint-Geertruid. Het fenomeen van een weg als grens was in dit gebied een bekend verschijnsel en komt bijvoorbeeld ook voor bij de scheiding tussen Cadier en het gehucht Keer, behorend tot Heer. Waarschijnlijk kent deze weg door Eckelrade een hoge ouderdom omdat hij een directe verbinding vormt tussen het Maasdal en Honthem. In die plaats geeft hij aansluiting op twee oude, doorgaande handelswegen, de Limburgerstraat en de Valkenburgerweg. Daarnaast volgt een deel van de Dorpsstraat ook een natuurlijk tracé vanwege het op sommige plaatsen aanzienlijke hoogteverschil tussen de noord- en zuidzijde.

Deze grensweg met Breust/Eijsden werd voor een deel onderbroken door limieten met de heerlijkheid Rijckholt. Vervolgens grensde Gronsveld opnieuw westwaarts aan Breust/Eijsden door het Maarlander en Gronsvelder Broek, tot aan de scheiding met Heugem. Een exacte afbakening was hier moeilijk, want het Broek was onverdeeld bezit, waarop zowel de inwoners van Gronsveld, Rijckholt, Oost en het tot Breust en Eijsden behorende gehucht Maarland weiderechten bezaten. Nog tot in de negentiende eeuw vormden deze rechten regelmatig een bron van conflicten. ${ }^{530}$ Verder westwaarts ging de grens tussen Gronsveld en Breust en Eijsden over in die van Heugem met Breust/Eijsden.

Bij onderzoek naar het ontstaan van Gronsveld en Eckelrade rijst de vraag of er wellicht sprake kan zijn van afsplitsingen van buurgebieden. Daarom worden hier kort ingegaan op de geschiedenis van deze plaatsen.

\footnotetext{
530 Voorbeelden van limietscheidingen tussen Gronsveld, Breust en Eijsden uit 1399, 1502 en 1547 zijn te vinden in een proces over grensconflicten tussen Gronsveld en Eijsden uit 1675-1676. Het conflict van 1675-1676 begon met het lokken van schapen vanaf Eijsdens grondgebied naar Gronsveld, waarop beslag op Gronsveldse paarden volgde, die op Eijsdens gebied graasden, zie: RHCL, Familie De Geloes/Kasteel Eijsden, inv. nr. 626. Een voorbeeld van een conflict uit de achttiende eeuw betreft in 1737 het graven door 'die van Gronsvelt' van een afwateringssloot door de 'gemeente en pascuagie' van Breust en Eijsden. Daardoor was een deel van de weidegrond niet meer bereikbaar. Op last van de Staten-Generaal in Den Haag moest de stadhouder van het Land van Valkenburg de Gronsveldenaren aanmanen de sloot weer dicht te gooien, zie RHCL, Familie De Geloes/Kasteel Eijsden, inv. nr. 1142.
} 
De kleine heerlijkheid Cadier behoorde tot het zogenoemde graafschap of Land van Daelhem. ${ }^{531}$ Dit gebied ontleende zijn naam aan de rond 1075 gebouwde hoogteburcht boven het riviertje de Berwinne. De territoriale ontwikkeling van het graafschap laat zich slechts gedeeltelijk volgen. Waarschijnlijk is het ontstaan uit delen van de Luikergouw uit de Karolingische periode, met het koninklijk domein van 's-Gravenvoeren als middelpunt. Het Land van Daelhem moet al bij zijn ontstaan tamelijk verbrokkeld zijn geweest door enclaves van onafhankelijke heerlijkheden en kerkelijke immuniteiten die het gebied doorsneden. Rond 1160 kwam het landsheerlijk gezag in handen van de graven van Hochstaden (Hoisten aan de Erft bij Neuss). Als gevolg van een oorlog tussen Conrad van Hochstaden, aartsbisschop van Keulen, en hertog Hendrik II van Brabant, moest Dirk II van Hochstaden, een neef van Conrad, in 1244 het Land van Daelhem afstaan aan Brabant. Naderhand werd het gebied samen met twee andere Brabantse territoria ten oosten van de Maas, het Land van Valkenburg en het Land van 's-Hertogenrade, gerekend tot de Landen van Overmaze.

Cadier vormde de meest noordelijke exclave van Land van Daelhem. Toch was de afstand naar de grens van het Land van Daelhem hemelsbreed niet groot, want tussen het Daelhemse dorp Mheer (in het bijzonder het gehucht Banholt) en de uiterste grens van Cadier liggen weliswaar twee aparte jurisdicties (Honthem en Breust-Eijsden met Bruisterbosch), maar het is een afstand van nauwelijks twee kilometer.

Waarschijnlijk is Cadier ontstaan tussen 1100 en 1250 als ontginning vanuit het Maasdal. De geografische vorm met lintbebouwing is vergelijkbaar met die van andere dorpen op of aan de rand van het plateau. Opmerkelijk was de grens met het aanpalende gehucht Keer, dat onder de jurisdictie van de schepenbank Heer viel.532 Ook Keer bestond uit lintbebouwing en vormde een tweelingdorp met Cadier (Cadier en Keer zijn trouwens de Romaanse en Germaanse variant van dezelfde naam), maar beide plaatsen waren juridisch van elkaar gescheiden door een grens over de as van de Dorpsstraat. Hetzelfde verschijnsel hebben we ook gezien bij de grens tussen Eckelrade en Breust-Eijsden.

In de twaalfde of an het begin van de dertiende eeuw moet 'Cadirs' een eigen kapel hebben gekregen, die afhankelijk was van de parochiekerk van Heugem. De dorpelingen beschikten op zondag over een kapelaan, maar bleven voor hoogtijdagen, doop, huwelijk en begrafenis aangewezen op Heugem. Vooral in de winter was die weg bezwaarlijk. Om die reden kregen de bewoners in 1266 het recht in hun eigen kerk een doopvont te plaatsen en konden er ook huwelijken en begrafenissen plaatsvinden. ${ }^{533}$ Voorts was men ontslagen van de verplichting om op de vier voornaamste kerkelijke hoogtijdagen van het jaar (Kerstmis, Pasen, Pinksteren en Allerheiligen) naar Heugem te gaan. Alleen bleven de parochianen van Cadier onderworpen aan de seend (een periodieke zitting van de

531 Zie voor een korte schets over het ontstaan van het graafschap Daelhem en de rechterlijke organisatie Janssen de Limpens, Rechtsbronnen Limburg en Overmaze, XXX-XXXIV.

532 Zie over de grenzen van Keer: Van de Venne, Geschiedenis Heer, 20-25 en 177-187, met kaart.

533 RHCL, Kapittel O.L.Vrouw Maastricht, inv. nr. 1403, tekst afgedrukt bij Franquinet, Inventaris $O$. L.V rouwekerk I, 29-32, nr. 17. 
kerkelijke rechtbank) wanneer die in Heugem werd gehouden en moesten zij deelnemen aan de ban- of veldprocessies vóór het feest van Hemelvaart. ${ }^{534}$

Over de juridische verhoudingen binnen Cadier gedurende de late middeleeuwen zijn weinig bronnen voorhanden. In 1370 verpandde hertog Wenceslaus van Brabant de heerlijke rechten over de dorpen Eijsden en Cadier aan Johan III van Gronsveld voor een lening van 5500 gulden. 535 Uit 1429 dateert de eerste (?) vermelding van een schepenbank. ${ }^{536}$ Uit deze gegevens mogen we met enige voorzichtigheid concluderen dat ten minste in de tweede helft van de veertiende eeuw Cadier een aparte heerlijkheid vormde met een eigen schepenbank. Anders dan men misschien op grond van de kerkelijke situatie zou verwachten, is van juridische banden tussen Cadier en Heugem niets bekend. Sterker nog, Heugem heeft, zoals hierna in Hoofdstuk 2.4.3 aan de orde komt, als oorspronkelijk Luiks bezit, een heel andere historie dan Cadier.

Binnen de heerlijkheid Cadier nam het ten oosten van het dorp gelegen goed Blankenberg een bijzondere plaats in. ${ }^{537}$ Oorspronkelijk bestond Blankenberg uit een versterkt huis te midden van een blok aaneengesloten landerijen met een oppervlakte van circa 100 bunder. $\mathrm{Al}$ voor 1380 moet het goed zijn gesplitst in twee afzonderlijke delen, te weten Groot Blankenberg met ongeveer 75 bunder en Klein Blankenberg dat 25 bunder telde. Groot en Klein Blankenberg stonden te boek als een zogenoemd groot leen van het leenhof van Valkenburg. De oudste leenverheffingen dateren van 1381.538 Opmerkelijk is dat Blankenberg bijna een spiegelbeeld vormt van de hierna nog te bespreken Bijbank, eveneens een Valkenburgs leen. Beide lenen raakten bij de smalle doorgang tussen Eckelrade en Honthem zelfs aan elkaar.

Zoals de juridische status van de Bijbank voor problemen in Gronsveld zorgde, zo vormde ook de status van Blankenberg binnen Daelhems gebied een bron van moeilijkheden. In 1571 en 1577 weigerde de heer van Blankenberg mee te betalen in de belastingen van het Land van Daelhem. Walter Hoen van Hoensbroek, heer van Blankenberg, beweerde in 1627 zelfs dat zijn domein helemaal niet ressorteerde onder Cadier, maar altijd had behoord bij Honthem en dus vrij was van de dorpsschatting van Cadier. De Raad van Brabant verwierp die opvatting zonder veel omhaal van woorden en bepaalde dat Blankenberg voor een-derde in de belastingen van Cadier diende bij te dragen.

\footnotetext{
534 '..in sinodo et rogationibus sicut hactenus consueverunt singulis annis accedere tenebuntur..' Het woord 'sinodus' kan het beste worden omschreven als een rechtszitting waarbij onder leiding van de aartsdiaken, diens officiaal of de landdeken recht werd gesproken in zaken van kerkelijk recht; vgl. Van Rensch, 'De aartsdiaken van Haspengouw', 192-193. 'Rogationes' zijn volgens Grotefend, Taschenbuch Zeitrechnung, 93: 'die drei Tage vor Himmelfahrt, auch auf die ganze Woche angewendet; zie ook Buchberger, Lexicon Theologie, VI, 600 onder lemma 'Litanei': 'Die litania minor...die allg. Bezeichnung für die 3tägigen Bittgänge vor Christi Himmelfahrt od. Rogationes'.

535 Verkooren, Inventaire chartes de Brabant, IIe stuk, Cartulaires, deel II (1312-1383), 173.

536 Doppler, 'Schepenbrieven St. Servaas', 131, nr. 1293.

537 Zie Habets, 'Notice seigneurie Cadier', 160-168, waaraan de navolgende gegevens zijn ontleend.

${ }^{538}$ Habets, 'Leenen Valkenburg', in: PSHAL 21 (1885) 273-280.
} 
De geografische ontwikkeling van Gronsvelds buren Eijsden en Breust is zelfs voor middeleeuwse verhoudingen opmerkelijk. ${ }^{539}$ Een reden hier wat uitvoeriger bij stil te staan is dat die ontwikkeling grote parallellen vertoont met die van Gronsveld en Heugem. De kernen Breust en Eijsden in het Maasdal kunnen bogen op een hoge ouderdom, maar het valt moeilijk te zeggen welke plaats de 'oudste papieren' bezit. Er zijn redenen om aan te nemen dat Eijsden al in de negende eeuw bestond, maar de oudste schriftelijke bron, die met zekerheid op deze plaats betrekking heeft, dateert tussen 1168 en $1174 .{ }^{540}$ In 1213 gaf de bisschop van Luik zijn hoven te Simpelveld, Eijsden en Heugem in leen aan Walram, zoon van de hertog van Limburg. Waarschijnlijk kreeg Eijsden in die periode de status van 'vrijheid' (een tussenstadium in de ontwikkeling van dorp tot stad) waar Luiks recht gold. 541

Omstreeks 1280 kwamen de heerlijke rechten over Eijsden als onderleen van de hertog van Limburg in handen van de heer van Valkenburg. Nadat de Limburgse Successieoorlog in de slag bij Worringen in 1288 ten gunste van de hertog van Brabant was beslist, bleef Eijsden Valkenburgs bezit, maar deed de heer van Valkenburg daarvoor leenhulde bij de hertog van Brabant (zie voor een parallelle ontwikkeling bij Heugem, waar ook een deel van de hiervoor genoemde bronnen aan de orde komt Hoofdstuk 2.4.3) Door de overgang van het hele Land van Valkenburg aan Brabant in het midden van de veertiende eeuw bleef Eijsden onder Brabants gezag 542 en deelde in de verdere lotgevallen van de Landen van Overmaze. Als gevolg van het Partagetractaat van 1661 traden de Staten Generaal in de rechten van de hertog van Brabant en maakte Eijsden sinds die tijd deel uit van het Staatse Land van Valkenburg.

De hof Breust zou hebben behoord tot het fundatiekapitaal van het door bisschop Eraclius van Luik (959-971) gestichte kapittel van Sint-Martinus te Luik. ${ }^{543}$ Mogelijk is Breust afkomstig uit koninklijk domeingoed. Het kapittel van Sint-Martinus bezat in Breust jurisdictie, die volgens een oorkonde uit 1157 werd uitgeoefend in een 'placitum' (geboden ding of rechtszitting) onder leiding van een advocatus of villicus. Later werd de hoge, middelbare en lage rechtspraak, volgens het gebruikelijke patroon, uitgeoefend door een college van zeven schepenen. ${ }^{544}$

Breust wordt wel beschouwd als een rijksonmiddellijke heerlijkheid, maar het is de vraag of die opvatting volledig houdbaar is. Zo verklaarde de Luikse prins-bisschop Lodewijk van Bourbon in 1481 dat hij oppervoogd over Breust was, maar dat de plaats zelf moest worden beschouwd als een 'een zuiver allodium van de kerk van Sint Martinus' ('purum et verum allodium ecclesie sancti Martini'), op geen enkele wijze verbonden met het 'land Luik of graafschap Loon' ('patria Leodiensi aut comitatu Lossensi'). Een eeuw later beweerden de schepenen van Luik precies het tegenovergestelde en moest volgens hen

539 Zie voor Breust en Eijsden: Hartmann, Reconstructie landschap, passim; Van Hall, Eijsden, een vrijheid, passim; Nève, Rijkskamergerecht, 379-383; De Ryckel, 'Notice Breust', 3-22.

540 Hartmann, Reconstructie landschap, 273-275.

${ }^{541}$ Van Hall, Eijsden, een vrijheid.

542 Hartmann, Reconstructie landschap, 277-278.

543 Voor Breust zie Hartmann, Reconstructie landschap, 285-292.

544 Oorkonde afgedrukt bij Hartmann, Reconstructie landschap, 313-314. 
Breust worden beschouwd als Luiks gebied ('est tenu pour pays de Liège'). ${ }^{545}$ Tussen deze twee uitersten moeten we opmerken dat het kapittel van Sint-Martinus zelf ook niet rijksonmiddellijk was, en dus als heer van Breust ook niet als een rijksonmiddellijke stand 'in de dop' kan worden beschouwd. Daarom lijkt het, bij gebrek aan verder onderzoek, vooralsnog het meest veilig Breust te rekenen tot één van de vele terres franches, kleine gebieden tussen de grotere landsheerlijkheden, waarvan de wetgevende, rechterlijke en fiscale onafhankelijkheid moet worden beoordeeld aan de hand van concrete situaties.

Waarschijnlijk aan het einde van de elfde eeuw werd vanuit de woonkernen Breust en Eijsden in oostelijke richting begonnen met de ontginning van het hoger gelegen plateau. Zo gaf het kapittel van Sint-Martinus in 1157 ongeveer 35 hectare grond tegen betaling van een jaarlijkse cijns ter ontginning uit aan zeven inwoners van Breust. Op deze plaats ontstond naderhand het gehucht Bruisterbosch. Op min of meer op dezelfde wijze moeten ook nederzettingen als Sint-Geertruid, Herkenrade, Moerslag en Libeek zijn ontstaan. Van deze plaatsen groeide Sint-Geertruid het snelst. In 1178 wordt gesproken over een aan de parochiekerk te Breust onderhorige kapel 'op de berg', die werd bediend door een kapelaan. In 1222 ontving de Sint-Gertrudiskapel 'in de ontginning' ('in sarto') het doop- en begraafrecht, waardoor ze feitelijk als parochiekerk onafhankelijk werd van Breust. ${ }^{546}$

In de eerste fase van de ontginning gingen de kolonisten weinig systematisch te werk. Pas in de loop van de tijd ontstond een min of meer aaneengesloten, open landschap. Daarin lagen de afzonderlijke delen van de heerlijkheden als grotere of kleinere blokken land door elkaar. Waarschijnlijk heeft deze manier van werken ook de merkwaardige territoriale vervlechting van de heerlijkheden Eijsden en Breust bepaald. Ongeveer tweederde van de grond viel onder de jurisdictie van Breust, de rest onder Eijsden. Dat zorgde ook voor een ingewikkelde juridische constellatie, waarbij de rechtspraak over onroerend goed was verdeeld tussen de schepenbanken van Breust en Eijsden al naar gelang het Breuster of Eijsdense grond betrof.

Ten zuiden van Gronsveld lag de kleine heerlijkheid Rijckholt die, afgezien van een klein stukje door het Savelsbos, van Gronsveld werd gescheiden door een nagenoeg rechte lijn, die in het westen en oosten aansloot op de limieten van Breust en Eijsden. Rijckholt bestond uit niet veel meer dan een gehucht met enkele huizen en een kasteel. Van oudsher vormden Rijckholt en Gronsveld samen één parochie.

Bij de beschrijving van de leden van de familie de Gru(e)les/Grunsele in de twaalfde eeuw kwam al de opvatting aan de orde dat Rijckholt in de eerste helft van de twaalfde eeuw zou zijn ontstaan als afsplitsing van Gronsveld. Enig bewijs daarvoor ontbreekt echter. Toch hebben Gronsveld en Rijckholt gemeenschappelijke kenmerken, die duiden op een waarschijnlijk gelijktijdig ontstaan. In de eerste plaats kan worden gewezen op de kerkelijke eenheid, want beide plaatsen vormden één parochie. Verder vertonen de ligging en langgerekte vorm van beide nederzettingen grote gelijkenis. In oostelijke richting strekte het gebied van Rijckholt zich uit tot op het plateau en deze uitloop is duidelijk het

545 De Ryckel, 'Notice Breust', 5; Nève, Rijkskamergerecht, 380-381.

546 Hartmann, Reconstructie landschap, 63-64. 
resultaat van ontginning volgens het patroon dat we ook van naburige dorpen kennen. Verder beschikten de heren van Rijckholt volgens de kaart van 1754 in Gronsveld over anzienlijk grondbezit, geen gesloten blok maar wel veelal grote kavels, en opmerkelijk genoeg vaak direct grenzend aan landerijen van de heren van Gronsveld. De oorsprong daarvan kan teruggaan op middeleeuwse ontginningen uit de tijd dat ook de velden rond Gronsveld in cultuur werden gebracht. Die ontginning zou ook de rechte grens tussen beide heerlijkheden kunnen verklaren.

Ten slotte claimden de heren van Rijckholt, net als die van Gronsveld, voor hun gebied de status van allodium, een 'zonneleen'. Een attest daarover van het schepengerecht van Rijckholt uit 1726 heeft zelfs in de rechtshistorische literatuur uit de negentiende en twintigste eeuw enige bekendheid verworven. ${ }^{547}$ Schout en schepenen verklaarden daarin dat zij een document uit 1469 bezaten, met de mededeling dat huis en heerlijkheid Rijckholt aan niemand leenroerig waren, maar moesten worden beschouwd als een 'leen an der sonnen ontfangen'. Dit zonneleen droeg niet bij in algemene schattingen, 'Türkenstuir' of andere belastingen van het Duitse Rijk. Een ander, in hetzelfde attest genoemde document (uit de zestiende eeuw?) ontkende eveneens het bestaan van een leenverhouding met een andere heer of banden met 'eenig creyts van het rooms ryck of andersints'

Omdat het attest in 1726 als 'bewijs' voor Rijckholts onafhankelijkheid werd gepresenteerd in een juridisch gevecht met de schepenen van Aken, ${ }^{548}$ bestaan er gerechtvaardigde twijfels over de objectiviteit van het stuk. Het komt nogal onwaarschijnlijk over dat in 1469 in Rijckholt een verklaring over vrijdom van Türkensteuer werd afgegeven, terwijl de eerste aanzetten voor de daadwerkelijke invoering van een dergelijke belasting in het Rijk pas in de jaren 1467-1471 van de grond kwamen. Zo snel drongen nieuwigheden hier waarschijnlijk niet door. Ook de kreitsindeling ontstond pas in de eerste helft van de zestiende eeuw. Misschien is het minuscule Rijckholt gewoon aan de aandacht van de opstellers van de matrikels ten behoeve van de rijks- en kreitsbelastingen ontsnapt. Dit soort nalatigheid werd later geïnterpreteerd als 'bewijs' van belastingvrijdom. Maar deze bedenkingen laten onverlet dat de schepenen van Rijckholt in essentie het gelijk aan hun kant lijken te hebben. Er is niets van een leenverhouding met het Rijk of een andere naburige heer te vinden.

Bij al deze betrekkingen en overeenkomsten tussen Gronsveld en Rijckholt moet echter worden benadrukt dat er geen spoor van een juridische relatie tussen beide plaatsen valt te ontdekken: geen hoofdvaart tussen schepenbanken en geen leenverhoudingen. De wel veronderstelde verwantschap tussen de heren van Gronsveld en Rijckholt in de twaalfde eeuw is ook al uiterst twijfelachtig. Dat pleit allemaal tegen een gemeenschappelijke herkomst. Misschien moeten zowel Gronsveld als Rijckholt beide worden gezien als oorspronkelijke adellijke, allodiale domeinen die in dezelfde tijd en op dezelfde wijze zijn ontstaan.

547 Afgedrukt bij Habets, Limburgsche wijsdommen, 397, welke tekst Habets, volgens eigen mededeling, heeft overgenomen van Grimm, Weisthümer III, p.865.

548 RHCL, De Bounam de Ryckholt, inv. nr. 487. 


\subsubsection{Gronsveld en Eckelrade één parochie}

Gronsveld en Eckelrade vormden samen met Rijckholt ook een eenheid als parochie, met een kerk toegewijd aan Sint Martinus. ${ }^{549}$ Eckelrade beschikte slechts over een hulpkerk, die pas in 1834 tot parochiekerk werd verzelfstandigd. Rijckholt maakte zelfs tot 1956 deel uit van de parochie Gronsveld. De toewijding aan Sint Martinus is een patrocinium dat bij veel kerken in dorpen en steden langs de Maas wordt aangetroffen. Vaak wordt daaraan een hoge ouderdom, vóór het jaar 1000, toegekend. ${ }^{550}$ Toch is het een vraag of Gronsveld binnen dit stramien past, omdat het ontstaan van het dorp, zoals hierna blijkt, van jongere datum moet zijn. Bij gebrek aan archeologische opgravingen valt de ouderdom van de Gronsveldse kerk langs die weg niet te bepalen. Aangenomen wordt dat het onderste deel van de kerktoren de oudste bouwfase vertegenwoordigt en uit de dertiende eeuw dateert. ${ }^{551}$ De vroegste schriftelijke vermelding van de kerk van Gronsveld is te vinden in een oorkonde uit 1258. ${ }^{552}$ Waarschijnlijk moeten we de kerk van Gronsveld beschouwen als een zelfstandige stichting vanaf het begin. Er zijn geen aanwijzingen dat de Gronsveldse kerk is gesticht als filiaal (dochterkerk) van een ander godshuis in de omgeving. Ook is onbekend wie de bouwer van de oudste kerk is geweest, maar het is goed denkbaar dat een relatie moet worden gezocht met de heer. Daarop wijzen de ligging op 'open terrein' vlak naast het kasteel en de rechten van de heer als patroon van de kerk en collator van de pastorie (recht van bindende voordracht bij benoeming van een pastoor). Ook van het altaar van Sint-Amandus, de tweede patroon van de kerk, had de heer het collatierecht. Het recht op de heffing van tienden van bepaalde veldgewassen, kwam in later tijd toe aan de pastoor en de heer, maar de al in Hoofdstuk 1.2 - 1.3 besproken akten over tienden uit de dertiende en veertiende eeuw laten zien dat de heer van Gronsveld oorspronkelijk zeker niet de enige tiendgerechtigde was.

De Sint-Bartholomeuskerk van Eckelrade werd, afgaande op de sporen in het thans nog bestaande gebouw, waarschijnlijk in de veertiende eeuw gesticht als dochterkerk/bijkerk van die van Gronsveld. ${ }^{553}$ De ontwikkeling in Eckelrade lijkt in beginsel goed vergelijkbaar met die van de aangrenzende parochies Cadier en Sint-Geertruid. Maar anders dan deze twee plaatsen, die in de dertiende eeuw zelfstandigheid van de moederkerk in respectievelijk Heugem en Breust verwierven, heeft Eckelrade dat stadium tijdens het Ancien Régime nooit bereikt.

\subsubsection{Het oorspronkelijke domein van de heren van Gronsveld Landsheerlijk grondbezit in volle eigendom te Gronsveld en Eckelrade}

\footnotetext{
549 Zie voor algemene gegevens Simenon, Visitationes Hasbaniae I, 180-182, 275-278.

550 Munsters, 'Verkenning', 461-462 legt verband met Frankisch koningsgoed, Ubachs, Handboek Geschiedenis Limburg, 99 denkt aan dateringen tussen 800 en 1000.

551 Marres/Van Agt, Monumenten Zuid-Limburg, 182.

552 Reussens, 'Herkenrode', 261, nr. XXXVI.

553 Marres/Van Agt, Monumenten Zuid-Limburg, 176.
} 
Het vroegste overzicht van heerlijk grondbezit dateert uit 1439 en is opgenomen in een oorkonde opgemaakt door de schepenen van Gronsveld, waarin Hendrik III van Gronsveld al zijn verpachte landerijen te Gronsveld tot onderpand stelt voor de verkoop van een jaarlijkse rente. ${ }^{554}$ In totaal worden zeventig bunder beschreven. De precieze ligging is niet van alle percelen duidelijk, maar de gebruikte toponiemen, namen van aangrenzende eigenaren en omvang van de stukken lijken veel overeenkomst te vertonen met de latere situatie.

In de daarop volgende decennia zijn hierin slechts beperkt veranderingen opgetreden. Een 'memorie' uit het midden van de zestiende eeuw vermeldt 82 bunder akkerland in diverse percelen rond het dorp, enkele stukken weiland, 25 bunder bos en slaghout of hakhout en de heide genaamd 'der Grotenbosch'.555 Een ander document uit het einde van de zestiende eeuw geeft als aanvulling op deze getallen nog $5 \frac{1}{2}$ bunder aan boomgaarden, weiden en beemden, evenals de 'Resenberch' en 'Bortenberch' die beplant zijn met eiken. Weer iets andere omschrijvingen zijn te vinden in de rekening van de heerlijkheid Gronsveld van 1536/37.556 Daar wordt gesproken over pachten uit 'mijns jonckeren borch-hoff metten bempt..., mijns jonckeren steynberch..., eynen hoeff gelegen neven den borchoff en een bentgen gelegen neven den borch banet'. Als bossen worden genoemd vijf bunder 'Suermans busch', twaalf bunder Savel busch en zeven bunder bos 'geheyten dat Eyckholt, tegen den Resenberch'. De hoeveelheid pachtland wordt becijferd op zeventig bunder 'in den gevelde van Gronsselt' en ongeveer $12^{1 / 2}$ bunder land afkomstig uit de hof Printhagen. De zeventig bunder pachtland komen precies overeen met de eerder genoemde opgave uit 1439.

De getallen voor het midden van de zeventiende eeuw wijken niet sterk van vroegere specificaties af: ' 85 bunder ackerlants 12 groet roeden ende 12 cleyn roeden' (in een andere opgave 84 bunder, 19 grote en 18 kleine roeden), 31/2 bunder weide 'aen ende ontrint den casteel gelegen, beplant met jonge boome,... eene grasplaets gelegen bij den Resenberch... en...den bosch genampt den Resenberch'.

De conclusie luidt dat het landsheerlijk grondbezit te Gronsveld, in eigen beheer of uitgegeven in tijdelijke pacht, vanaf het einde van de middeleeuwen tot het midden van de zeventiende eeuw varieerde tussen de 80 en 85 bunder akkerland. Hiervan moeten worden afgetrokken circa $12 \frac{1}{2}$ bunder land uit de zogenoemde laathof van Printhagen. Naast dit akkerland werden aan het einde van de middeleeuwen ook tussen de drie en vijf bunder weiland en circa 25 bunder bos en heide tot de heerlijke landerijen gerekend. Voorts moeten daar ook nog de door heer zelf gebruikte terreinen en tuinen rond het kasteel bij worden geteld. Er zijn geen redenen aan te nemen dat zich in die verhoudingen tot het midden van de achttiende eeuw grote veranderingen hebben voorgedaan.

Op de kaart van 1754 is te zien dat het landsheerlijk grondbezit in de vorm van pachtland (en mogelijk ook in erfpacht uitgegeven land) was geconcentreerd in de velden ten oosten en noorden van het kasteel. De percelen bestaan in verhouding tot de rest van de verkaveling uit tamelijk grote blokken. Er kan niet worden gesproken van een

554 Diverse afschriften in TJ, inv. nr. M 11, fol. 449-461, 467-471 en 581-584.

555 Beide memories in RHCL, Familie De Geloes/Kasteel Eijsden, inv. nr. 423.

556 RHCL, Graafschap Gronsveld, inv. nr. 172. 
aaneengesloten complex, maar opvallend is dat de 'gaten' tussen de afzonderlijke blokken vaak worden opgevuld met percelen vallend onder het leen van de Wijngaardshof, verder vele kleine lenen en ten slotte enkele grote kavels van de heer van Rijckholt.

Op de kaart van Eckelrade uit 1754 staat bij amper twintig, veelal kleine kavels, het woord 'landtheer' vermeld. De meeste van deze percelen lagen verspreid ten noorden van het Linderveld, zonder een duidelijke samenhang. Misschien zijn sommige van domaniale oorsprong, maar evenzeer kan de eigendom zijn verkregen door aankoop of waarschijnlijker - door gerechtelijke uitwinning wegens onbetaalde schatting of cijnzen. In ieder geval lijken deze losse percelen binnen de totale ontwikkeling van het dorp geen grote rol te hebben gespeeld.

\section{Leengoederen te Gronsveld en Eckelrade 557}

In Gronsveld en Eckelrade lagen in totaal tien 'grote' lenen. Van de vier binnen Gronsveld waren er ook twee in oppervlakte omvangrijk, te weten de Wijngaardshof (77 tot 78 bunder, verdeeld over Gronsveld en Eckelrade) en het Seutendaelsleen (25 tot 26 bunder). De situatie in Eckelrade vertoont overeenkomsten met die in Gronsveld. Het 'vernieuwde' grafelijk leenregister van $1743^{558}$ vermeldt voor dit dorp vijf grote lenen, waarvan er twee, de hof Hamersbach met honderd bunder en de Houwert of Hogaert met veertig bunder ook echt groot zijn.

De andere 'grote lenen' kenden een bescheiden omvang. In Gronsveld betreft het een huis en hof aan de 'Dorpsstraat' tegenover de 'Putsteeg' (tegenwoordig de panden Rijksweg 7981) en anderhalf bunder aan de Grub. In Eckelrade lagen twee percelen langs de Trichterweg, naast de huidige hoeve Hamersbach, respectievelijk drie en één bunder groot, evenals twee kavels van twee en vijf bunder naast elkaar bij de zogenoemde Sint Bartholomeushagen, overigens juist over de grens met Breust en Rijckholt.

\section{Wijngaardshof}

Volgens het grafelijke leenregister uit 1743 was het leen van de Wijngaardshof verdeeld tussen vijf rechthebbenden, te weten het klooster Sinnich, de advocaat Canto te Luik, de weduwe van drossaard Lebens, de advocaat Gabrielis in Luik en de weduwe van notaris J.L. Graven. ${ }^{559}$ Van een echte hof in de betekenis van boerderij was in die tijd geen sprake meer. Bij het beleg van Maastricht in 1579 moet de hof zijn beschadigd, want in 1586 wordt een overeenkomst gesloten over herstelwerkzaamheden. ${ }^{560}$ De hof kan daarna bij oorlogshandelingen in de zeventiende eeuw zijn vernield. De ligging van de oorspronkelijke hof is onbekend, maar moet waarschijnlijk gezocht worden aan de noordzijde van het dorp Gronsveld, in de buurt waar de Slakweg en het Wijngaardswegske

\footnotetext{
${ }^{557}$ De beschrijving van de lenen is vooral gebaseerd op het leenregister van 1743 van het grafelijk leenhof van Gronsveld, TJ, inv. nr. M 17.

558 TJ, inv. nr. M 17.

559 TJ, inv. nr. M 17, fol. 11-21.

560 Volgens Caumartin, 'Souvenirs et promenades à Gronsveld', 267-268 zou in 1586 een overeenkomst zijn gesloten tussen de priorin van Sinnich en de heer van Mheer over herstel van de Wijngaardshof. Een bronvermelding van de akte wordt niet gegeven.
} 
bij elkaar kwamen. ${ }^{561}$ Volgens het leenboek heette die plek 'op den Wijngaard' en er lagen zowel percelen van het Wijngaardsleen als enkele kleine lenen. ${ }^{562}$ Het Wijngaardswegske zou dan vanuit deze hof de meest directe verbinding naar het kasteel en het Broek zijn. Volgens de kaart van 1754 bevond zich de grootste concentratie van landerijen van de Wijngaardshof echter in de Dor, het Vroendel, de Kamp en langs de Grub. Tot het verspreide bezit kunnen we verder rekenen enkele percelen tussen de Voerenweg en de Sjêchelder aan de zuidoostzijde van het dorp, evenals onder Eckelrade enkele percelen in de Konijnshagen en de Monsdel.

De eerste vermelding van het Wijngaardsgoed vindt plaats in de al genoemde akte uit 1363 en betreft een overeenkomst tussen het klooster Sinnich en de Maastrichtse schepen Godefridus de Vinea (van den Wijngaard). ${ }^{563}$ De namen Sinnich en Wijngaard vormen een constante factor in de verdere geschiedenis van het leen. Met toestemming van zusters van Sinnich en van de bevoegde kerkelijke autoriteiten droeg 'magistra' Catharina de Brodersberch 23 bunder en een halve morgen bouwland over aan Godefridus de Vinea, schepen van Maastricht, voor een altijddurende pacht van negen mud graan per jaar. Godefridus bezat deze gronden op dat moment overigens al in pacht. De percelen worden als volgt gespecificeerd: drie akkers van vier en twee en een halve bunder en zeven morgen gelegen in het 'Vronendael' op het territoir van Heugem, een halve bunder en een morgen op de plaats geheten 'der Sceilt', vier bunder bij de 'Grebben', vijf bunder bij de 'Rissenbergh', twee bunder bij de hof geheten 'Grymartshof', twee bunder bij 'De Steen' en twee bunder bij de plaats geheten 'der Kempe'. De landerijen werden geacht te ressorteren onder de 'curia' of jurisdictie van Gronsveld, maar wanneer naderhand het tegendeel mocht blijken, dan zou Catharina alsnog voor overdracht voor het bevoegde gerecht zorgen. Godefridus stelde tot onderpand voor zijn verplichtingen beschikbaar een cijns van twee mark per jaar, rustend op zijn huis en goed 'de Vinea' (De Wijngaard) in de Sint Jorisstraat (= Grote Staat) in Maastricht.

De in de oorkonde genoemde toponiemen 'Vronendael' (Vroendel), 'Grebben' (Grub), 'Rissenbergh' (Riessenberg) en 'Kempe' (Kamp) komen nog steeds voor in het gebied waar zich ook in de achttiende eeuw een concentratie van landerijen van de Wijngaardshof bevond. Verder bevat de oorkonde een aantal opmerkelijke elementen. In de eerste plaats lijkt onduidelijkheid te bestaan over de jurisdictie over de gronden. Een deel lag op Heugems gebied, en tegelijkertijd wordt gezegd dat de landerijen ressorteerden onder de curia van Gronsveld. Kennelijk bestond over de grens tussen Gronsveld en Heugem onzekerheid, die in overeenstemming lijkt met het grillige verloop daarvan. Merkwaardig is verder dat op geen enkele wijze wordt gerefereerd aan de leenroerigheid van de grond. Ook van mogelijke tussenkomst van de heer van Gronsveld blijkt niets. Dit kan er op duiden dat de Wijngaardshof in 1363 nog allodiaal goed was en pas naderhand in leen

561 In de volksmond bestond voor deze plek de toponiem 'aon 't mörke', misschien een herinnering aan muurwerk dat nog lang zichtbaar is geweest. Interessant is dat ook Habets, 'Notice sur quelques découvertes', 249-250 de Wijngaardshof in deze omgeving situeert.

562 TJ, inv. nr. M 17, fol. 163, 172.

563 Afgedrukt bij Polak/Dijkhof, Oorkondenboek Kloosterrade, 323-325, nr. 179; uitvoerig regest bij Brouwers, Histoire Sinnich, 137, nr. 49, afschrift in RHCL, Abdij Kloosterrade, inv. nr. 1736. 
werd opgedragen, maar waarschijnlijker is dat de overgeleverde gegevens niet volledig zijn. 564

Vast staat dat het leen van de Wijngaard vier eeuwen later, in het midden van de achttiende eeuw, nog duidelijk de sporen vertoont van een middeleeuws goederencomplex, ontstaan door ontginningsactiviteiten in het grensgebied tussen Heugem en Gronsveld. In de omgeving van het droogdal van de Grub, tot aan de rand van het plateau, lijken percelen meestal op kleinschalige wijze in cultuur te zijn gebracht met een onregelmatige verkaveling, die naderhand door nog delingen en samenvoegingen werd versterkt. De Grub door de Dor vormde vervolgens via het Savelsbos de natuurlijke toegang tot het plateau van Eckelrade, waar ook nog enkele landerijen van de Wijngaardshof lagen.

Het ligt voor de hand dat de ontginningen hebben plaatsgevonden op initiatief van het klooster Sinnich. ${ }^{565}$ Dit convent van reguliere kanunnikessen was in 1243 gesticht voor adellijke religieuzen, die tot dan verbleven in de abdij van augustijner koorheren te Kloosterrade en in een klein zusterhuis in Scharn. ${ }^{566}$ Voor het werk op het veld werden lekenbroeders en dorpelingen uit de omgeving ingezet. Of de naam Vro(n)endael een verbastering is van Vrouwendaal valt niet met zekerheid te zeggen.

De veronderstelde betrokkenheid van Sinnich vertoont grote overeenkomsten met ontwikkelingen, zoals Hartmann die beschrijft voor Breust/Eijsden en het plateau van Sint-Geertruid. In Eijsden bezat de in 1202 gestichte cisterciënzerabdij Val-Saint-Lambert te Seraing al vóór 1220 een 'grangia' (hof), Zesenhoven of Gesenhoven genaamd. Vanuit deze hof zijn ook gronden tussen Caestert en Withuis, tot aan de rand van het plateau ontgonnen, zodat een omvangrijk agrarisch complex met een laathof als middelpunt ontstond. ${ }^{567}$

Het tweede voorbeeld betreft de hof in of bij de Bijbank in Eckelrade, die Reinerus, heer van Gronsveld, en zijn echtgenote Beatrix in 1261 verkochten aan de cisterciënzerinnen van Hocht. Ook deze hof, die korte tijd later naar Sint-Geertruid werd verplaatst, groeide door verdere aankopen en ontginningen uit tot een complex met een laathof als middelpunt. ${ }^{568}$ Naar analogie van deze voorbeelden kan ook het ontstaan van de Wijngaardshof worden verklaard, waarschijnlijk in het midden van de dertiende eeuw, kort na de stichting van Sinnich in 1243. Uiteindelijk werd het geen laathof, maar een leen van de heren van Gronsveld.

De aanvankelijk veelal door de kloosters zelf geëxploiteerde landerijen werden na 1300 steeds meer in korte of langdurige pacht uitgegeven. Daarmee zette in veel gevallen een proces van versplintering in. Zo moet het ook met het Wijngaardsleen zijn gegaan, want in de oorkonde uit 1363 wordt de al bestaande pacht van Florentius de Vinea omgezet in een

\footnotetext{
564 Over de problematiek van beoorkonding van transacties over onroerend goed ten plattelande door stadsschepenen en de betrokkenheid van schepenen bij de overdracht van leengoed zie Venner, 'Schepenen vóór 1350', passim.

565 Over Sinnich zie: Brouwers, Histoire Sinnich; Polak/Dijkhof, Oorkondenboek Kloosterrade, passim, en Haas, Inventaris Kloosterrade, 17-18.

566 Over dit zusterhuis in Scharn zie Van de Venne, Geschiedenis Heer, 167-168.

567 Hartmann, Reconstructie landschap, 219-225.

568 Hartmann, Reconstructie landschap, 212-219.
} 
langdurige pacht. Mogelijk heeft Florentius daarbij ook de hof verworven, en werd hij aldus de naamgever van het hele leen. In de loop van de zeventiende eeuw is het goed tussen verschillende gerechtigden verdeeld geraakt.

\section{Seutendaelsleen ${ }^{569}$}

Het Seutendaelsleen kwam al ter sprake bij de laathoven. Zijn naam ontleent het leen aan de Maastrichtse schepenfamilie Van Seutendael, waarvan de genealogie teruggaat tot in de veertiende eeuw. De vroegst bekende leenman in de persoon van Dionys van Seutendael wordt pas in 1643 vermeld. $570 \mathrm{Zijn}$ voornaam werd van generatie op generatie binnen de familie gedragen. ${ }^{571}$ Volgens het leenboek van 1743 omvatte het leen in totaal 25 à 26 bunder land, verdeeld over circa 35 'spleten'. De meeste daarvan moeten worden gezocht in de ten zuidoosten van Gronsveld gelegen velden in de Sjêchelder, tussen de Voerenweg en het Savelsbos. In de directe nabijheid lagen nog enkele kleine lenen, verder percelen van het Wijngaardsleen en grond in landsheerlijke eigendom. Ook dit leen maakt de indruk te zijn ontstaan uit ontginningsactiviteiten in de buurt van de Sjêcheldergrub of Schonegrub als toegang tot het plateau van Eckelrade.

\section{Hamersback 572}

Volgens het leenregister van 1743 stonden de goederen van het groot leen Hamersbach in Eckelrade (vaak worden ook de benamingen Hamelsbach en Hemersbach gebruikt) op naam van Jean Pierre de Floen. Een tiental jaren later waren deze bezittingen verdeeld geraakt tussen kapitein de Floen en generaal Gramlich, wier namen op de kaart van 1754 worden vermeld. Volgens een leenverheffing van 1 mei 1758 omvatte het totale leen 71 bunder, 4 grote en 11 kleine roeden. ${ }^{573}$ De oorspronkelijke omvang was echter veel groter, want in 1687 had graaf Johan Frans van Bronckhorst Batenburg de leenroerigheid opgeheven van het deel van Hamersbach dat in het bezit was van baron Henri de Bounam van Rijckholt. ${ }^{574}$ Op grond daarvan mag worden aangenomen dat vrijwel alle allodiale gronden die de heren van Rijckholt in het midden van de achttiende eeuw onder Eckelrade bezaten (ruim 28 bunder) oorspronkelijk ook tot het leen Hamersbach behoorden. Bij elkaar levert dat voor Hamersbach in onverdeelde toestand bijna honderd bunder op.

De landerijen lagen verspreid rond de bebouwde kern van Eckelrade, maar wel in enkele duidelijke concentraties. In de eerste plaats strekt zich van west naar oost een soort doorgang uit, die aan de zuidzijde vanaf het 'drielandenpunt' Gronsveld, Rijckholt en Breust/Eijsden wordt begrensd door de Eckelrader Dorpsstraat (het meest westelijke deel

\footnotetext{
${ }^{569}$ TJ, inv. nr. M 17, fol. 1-9.

570 TJ, inv. nr. M 17, fol. 15 (nieuw), index op de lenen.

571 Genealogie van familie Seutendael in: RHCL, Luikse commissarissen-deciseurs te Maastricht, inv. nr. 140, dossier Louis Seutendael tegen Gerard F. van Buel, 1702.

572 TJ, inv. nr. M 17, fol. 189-191vo. (oud).

573 TJ, inv. nr. M 17, fol. 191-191vo. (oud).

574 RHCL, Graafschap Gronsveld, inv. nr. 366, fol. 64-65, na eerder akkoord over de hof van 17 april 1684 wegens felonie, fol. 59-61.
} 
vanaf kruising bij Hamersbach heet in 1754 Steenbergweg) tot voorbij de bebouwing aan de oostzijde van het dorp, waar de weg overgaat in de Honthemerweg. Aan de noordzijde wordt de grens gevormd door de voet van de Trichterberg, de Hogebergweg, de Linderweg tot in het dorp en daarna in oostelijke richting de Eikstraat tot aan de Grub. In deze langwerpige strook vormt de kerk met de daarbij gelegen bebouwing ongeveer het middelpunt. Ook in noordelijke richting bevonden zich enkele grote blokken (op naam van de baron van Rijckholt) aan weerszijden van de Keerestraat, ruwweg tussen het Slekkeveld en het Linderveld. Opvallend is de grote omvang van sommige percelen (tussen de vier en acht bunder), met als uitschieter het blok ten oosten van het dorp, dat meer dan achttien bunder beslaat.

Het leen Hamersbach lijkt vanwege de ligging van de percelen het typische resultaat van middeleeuwse ontginningen. Van een systematische aanpak kan echter niet worden gesproken. De grote omvang van sommige kavels doet vermoeden dat de initiatiefnemer voor deze ontginningen kapitaalkrachtig moet zijn geweest. Was dat misschien Henricus de Hemesbagh, van wie Theodoricus de Houffalise in 1233 verklaarde dat de tienden te 'Groele' die hij schonk aan de cisterciënzerinnenabdij Val Bénoît, van Henricus afkomstig waren?575 Met dit jaartal als uitgangspunt zouden de ontginningen kunnen worden gesitueerd aan het einde van de twaalfde en het begin van de dertiende eeuw. Mogelijk lag de centrale hof van dit leen oorspronkelijk in de dorpskern en is deze later verplaatst. De huidige hoeve Hamersbach met de daarbij gelegen kapel, gelegen bij de splitsing van de Trichterweg en de Eckelrader Dorpsstraat, ${ }^{576}$ wordt in het leenregister van 1743 immers beschreven als vier bunder, negen groot en twaalf kleine roeden 'bestaende alsnu in een huijs, hoff, weijde en lant met een cleijn capelleken daerop getimmert door den heer Gramlich voorss. ende hem toebehoorende'. ${ }^{577}$

\section{Houwert of Hogaert}

Aan de noordkant van Eckelrade lag aan weerszijden van de Keerestraat een groot leen dat in het leenboek van 1743 wordt beschreven als 'den alingen hoff genaempt Den Houwert...aenhoudende naer inhoudt van 't laeste en andere leenboeken veertigh boenderen lants luttel min oft meer...' Een andere vaak gebruikte benaming voor Houwert is Hogaert. ${ }^{578}$ Helaas bevat de in het leenboek aangekondigde specificatie van de afzonderlijke percelen slechts één vermelding, merkwaardigerwijs omschreven als het parck gelegen tusschen de grebbe en de heerlijckheyt van Cadier, beginnende naer den kant van Gronsfelt'. ${ }^{779}$ Toch is de omvang van het leen gemakkelijk na te gaan met behulp van de legger die bij de kaart van 1754 hoort. 580 Daarin wordt bij alle percelen van dit leen in de marge aangetekend 'Hogaertsleen'. Bij elkaar ontstaat daarmee een blok, dat aan de zuidzijde grenst aan een groot perceel van Hamersbach. Aan de oostzijde vormde een

575 Tekst gedrukt bij Schoolmeesters, 'Diplômes Val-Bénoît', 130-131, nr. IV.

576 Beschreven bij Marres/Van Agt, Monumenten Zuid Limburg, 178-179.

577 TJ, inv. nr. M 17, fol. 190.

578 TJ, inv. nr. M 17, fol. 192-193.

579 TJ, inv. nr. M 17, fol. 192.

580 TJ, inv. nr. M 20. 
droogdal, waarin de Hamersbachweg uitmondt, een natuurlijke scheiding. Hetzelfde kan ook worden gezegd van de Grub aan de noordzijde bij de grens met Cadier en Blankenberg. Aan de westzijde liep de grens midden door een veld genoemd Hinnekuil.

De vorm van de Houwert wijkt af van grote lenen, zoals de Wijngaardshof en het Seutendaelsleen in Gronsveld of Hamersbach in Eckelrade. In de eerste plaats is het een bijna rechthoekig, aaneengesloten blok, slechts op enkele plaatsen 'verstoord' door kleine lenen en landsheerlijk land. Voorts valt de zeer sterke versplintering op; er is slechts één relatief groot perceel aanwezig. Harde feiten met betrekking tot het ontstaan van de Houwert ontbreken. Op grond van de geografische ligging mogen we wel aannemen dat ook dit leen het resultaat is van middeleeuwse ontginning (dertiende - veertiende eeuw?), begonnen vanuit natuurlijke toegangen tot het plateau via de droogdalen of grubben aan de noord- en oostzijde en verder langs de Keerestraat. Mogelijk moet het ontstaan van de Houwert worden gezien in samenhang met andere omvangrijke lenen in de omgeving. Opmerkelijk genoeg wordt het leen aan de zuid- en westzijde omringd door grote percelen van Hamersbach, terwijl in het noorden, op het territoir van Cadier, het grote, bijna aaneengesloten veld van het Valkenburgse leengoed Blankenberg lag.

\section{Kleine lenen}

Verspreid door de velden van Gronsveld en Eckelrade lagen tientallen kleine lenen: in Gronsveld meer dan zestig, in totaal ruim 35 bunder, en in Eckelrade meer dan vijftig, met een totaal van ruim veertig bunder. Veel percelen hadden een kleine tot zeer kleine omvang, soms niet meer dan een strook van enkele meters breed. In Gronsveld bevond zich een concentratie aan de noordzijde van het dorp, in Eckelrade zijn ze vooral in de buitenste 'schil' rond het Linderveld en Slekkeveld te vinden, maar echte systematiek valt niet te ontdekken. Uit de verkaveling zoals die op de kaart van 1754 naar voren komt, valt op te maken dat het oorspronkelijk om grotere blokken ging, die in de loop der tijden verdeeld raakten. Vaak grensden ze aan grote lenen of aan landsheerlijke landerijen en fungeerden als een soort schakels tussen deze grote lenen.

\section{Keurmedige goederen ${ }^{581}$}

De 'Specificatie' van het graafschap uit omstreeks 1650 geeft een aantal van veertig keurmedige goederen, 'daeronder vijff peerts keuren ende dandere zijn koyekeuren', keurmeden die met een paard of een koe moesten worden betaald. Waarschijnlijk is dit aantal nog aan de lage kant, want Prummer wist in de achttiende eeuw voor Gronsveld, Eckelrade, Heugem en Honthem nog 35 keurmedige huizen/hoeven en percelen te achterhalen, exclusief de tien tot twintig keurmeden van de in 1728 verkochte heerlijkheid Slenaken.

Bij de schets van het geografisch beeld van Gronsveld is vermeld dat de bebouwing langs de oostzijde van de huidige Rijksweg, ten zuiden van de tegenwoordige Holegracht, veel opener was dan in de directe omgeving van de kerk. Op die plaats lagen in de achttiende

581 RHCL, Graafschap Gronsveld, inv. nr. 130. 
eeuw vier huiskavels, verdeeld over twee blokken, die als keurmedig te boek staan. Deze bebouwing lijkt duidelijk van jongere datum en is waarschijnlijk ontstaan in de dertiende eeuw bij een uitbreiding van de dorpskern in zuidelijke richting. In het huidige straatbeeld valt dat nog af te lezen bij vier, in mergel opgetrokken, oude huizen.

Een geheel ander beeld geeft Eckelrade. Daar lagen tien met keurmede belaste percelen op een rij, te beginnen aan de oostzijde van de huidige Klompenstraat, ter hoogte van de kruising met de Linderweg en Eikstraat en dan vervolgens langs de Dorpsstraat richting Honthem tot bijna het einde van de toenmalige bebouwing. De enkele gaten die we in de achttiende eeuw constateren, kunnen het gevolg zijn van het feit dat keurmedigheid van een perceel later verloren was gegaan. Duidelijk wijst deze verkaveling op bijna planmatige aanleg, die goed te onderscheiden is van de bebouwing rond de kerk. Welk deel van de dorpskern nu het oudste is, rond de kerk of de rij keurmedige percelen, valt moeilijk te zeggen.

Er dringt zich bij Eckelrade een duidelijke vergelijking op met het gehucht Smeermaas (zie Hoofdstuk 2.2.1), waar ook een nagenoeg aaneengesloten bebouwing van keurmedige huiskavels is vast te stellen. ${ }^{582}$

\subsubsection{Overige grote geërfden en laathoven}

De betekenis van de omvang van het oorspronkelijk heerlijk goed in Gronsveld en Eckelrade kan alleen goed worden beoordeeld in vergelijking met ander grootgrondbezit ter plaatse. De laathoven als complexen van grootgrondbezit zijn al aan de orde geweest en dus laten we deze hier verder buiten beschouwing. Volgens een verzamelstaat, gebaseerd op de 'rapporten van aanbreng' uit 1754, waren er na de landsheer en de 'aandeelhouders' van het Wijngaardsleen en het leen Hamersbach slechts vijf landeigenaren, wier grondbezit in Gronsveld en Eckelrade uitsteeg boven tien bunder. ${ }^{583}$ Het betreft de baron van Rijckholt met ruim 49 bunder, het beneficie van Sint-Amandus in de kerk van Gronsveld met ruim negentien bunder, de armentafel van de Grote Heilige Geest te Maastricht met ruim vijftien bunder, het klooster van de Antonieten te Maastricht met ruim 14 bunder en de Beusdaelshof in de Bijbank en in Eckelrade met ruim vijftien bunder.

De ruim 281/2 bunder Rijckholter grond onder Eckelrade vallen vrijwel geheel terug te voeren op leen Hamersbach, dat in 1687 allodiaal was gemaakt. In Gronsveld lagen de kavels van de heren van Rijckholt verspreid over diverse velden. Sommige percelen vallen op door een verhoudingsgewijs grote omvang: één van meer dan vijf bunder, twee meer dan drie bunder en twee meer dan twee bunder. Opmerkelijk is dat vooral de grote percelen naadloos aansluiten op kavels die in volle eigendom toebehoren aan de heer van Gronsveld en eventueel ook nog op leengoederen. Op de kaart lijken het soms de ontbrekende stukjes in een legpuzzel. Dit kan wijzen op een hoge ouderdom van een deel van Rijckholter grondbezit in Gronsveld, mogelijk zelfs teruggaand tot de tijd dat de heren van Gronsveld hun domein ontgonnen.

582 Coun, Het gehucht Smeermaas.

583 RHCL, Graafschap Gronsveld, inv. nr. 218. 
In Gronsveld en Eckelrade lagen verschillende percelen land, die toebehoorden aan afzonderlijke kerkelijke stichtingen. ${ }^{584} \mathrm{Zo}$ bezat de gecombineerde kerkfabriek van Gronsveld en Eckelrade in de achttiende eeuw 91/2 bunder, en waren er afzonderlijke landerijen voor de vroegmis van Gronsveld, het beneficie van Onze-Lieve-Vrouw in de kapel van Eckelrade en de kosterij van Gronsveld. ${ }^{585}$ Het beneficie van Sint-Amandus in de kerk Gronsveld beschikte met zijn ruim negentien bunder over het grootste vermogen. Ruim zeventien bunder daarvan lagen in Eckelrade. De overige kerkelijke landerijen in Gronsveld lagen verspreid in de verschillende velden. In Eckelrade bevond zich het grootste deel langs de rand van het Linderveld.

Kan een deel van de kerkelijke landerijen wellicht worden teruggevoerd op schenkingen van de heren van Gronsveld en daarmee worden gerekend tot het oorspronkelijk heerlijk domein? Een duidelijk antwoord valt niet te geven, maar het is zeer goed mogelijk. Want het is een feit dat de heer van Gronsveld collator was van de pastorie, het beneficie van Sint-Amandus, het beneficie van Onze-Lieve-Vrouw in Eckelrade en de kosterij en daarmee ook zeggenschap had over die goederen. Het beneficie van Sint-Amandus, dat volgens de overlevering zeer oud moet zijn, werd in 1660 op verzoek van graaf Jost Maximiliaan van Bronckhorst Batenburg zelfs verbonden met de kapel in het kasteel van Gronsveld en zou voortaan worden bediend door de pastoor.

De ruim veertien bunder in Gronsveld, die in de achttiende eeuw voor de Antonieten te Maastricht staan genoteerd,586 moesten volgens de 'rapporten van aanbreng' in het eigen archief van de kloosterlingen ruim negentien bunder bedragen. ${ }^{587}$ Het verschil wordt veroorzaakt door een proces in de jaren dertig van de achttiende eeuw, als gevolg waarvan de paters vier bunder kwijt raakten aan de grafelijke rentmeester Oligschläger. Dit verlies wilden de Antonieten niet erkennen.

Opmerkelijk is dat de herkomst van het grondbezit van de Antonieten in Gronsveld goed is te volgen. In 1355 gaf Hendrik I, heer van Gronsveld, met instemming van zijn zonen Johan, Godert en Hendrik vergunning aan de kloosterlingen om een hof met achttien bunder land te kopen. ${ }^{588}$ Zij kregen onder bepaalde voorwaarden het recht onroerend goed tot een maximum van vijftig bunder te verwerven, maar zover is het nooit meer gekomen. Men kan zich afvragen waar deze vijftig bunder vandaan moesten komen. Bestond de mogelijkheid dat particulieren ooit zoveel grond zouden aanbieden of lagen er in die tijd nog grote stukken op ontginning te wachten? Deze laatste veronderstelling zou betekenen dat nog tot ver in de veertiende eeuw grond werd ontgonnen.

584 Zie voor diverse overzichten RHCL, Parochie H. Martinus Gronsveld, voorl. inv. nr. 12; zie ook Simenon, Visitationes Hasbaniae I, 180-181, 275-276.

585 Vanwege verschillende combinaties van stichtingen is het moeilijk een nauwkeurige specificatie van het bezit te geven. Zo waren het beneficie van Onze-Lieve-Vrouw te Eckelrade en de kosterie te Gronsveld in 1725 tot kapelanie samengevoegd, maar werden ze in 1756 weer gescheiden (akte in RHCL, Parochie H. Martinus Gronsveld, ongenummerd). Voor specificaties van de goederen behorend tot de diverse stichtingen zie ook diverse 'rapporten van aanbreng' uit 1754 in RHCL, Graafschap Gronsveld, inv. nr. 216.

586 RHCL, Graafschap Gronsveld, inv. nr. 216.

587 RHCL, Klooster antonieten te Maastricht, inv. nr. 114.

588 RHCL, Klooster antonieten te Maastricht, inv. nr. 3. 


\subsubsection{Conclusies}

Het onderzoek naar het ontstaan van de heerlijkheid Gronsveld als territorium lijkt op het werk van de archeoloog, die met veel bouwsporen en weinig concrete gegevens probeert een beeld te geven hoe een gebouw er ooit kan hebben uitgezien. Wanneer Gronsveld en Eckelrade zijn ontstaan, valt niet precies vast te stellen. Vergelijkbare ontwikkelingen in de omliggende plaatsen (Bruisterbosch ontginning 1157, Sint-Geertruid in 1178 kapel en 1222 parochie, Cadier in 1266 zelfstandige parochie) leveren een kader tussen globaal 1150 en 1250. Concrete schriftelijke gegevens voor Gronsveld zijn er uit de dertiende eeuw. In 1258 wordt voor het eerst de kerk van Gronsveld genoemd en in 1261 treden schepenen van Gronsveld op voor Eckelrade. De oudste oorkonden waarin heren van Gronsveld worden genoemd en die ook daadwerkelijk met Gronsveld in verband zijn te brengen, dateren eveneens uit de dertiende eeuw. Samengevat wijst dit er op dat Gronsveld in de dertiende eeuw was uitgegroeid tot een min of meer compleet dorp, met Eckelrade als mogelijk gelijktijdige of iets jongere 'uitbreiding'. Dat bevestigt het beeld van een geografische ontwikkeling van de streek zoals Hartmann die schetste voor Breust en Eijsden.

Er is geen enkele aanwijzing dat Gronsveld of Eckelrade is ontstaan als afsplitsing van een groter geheel, dan wel afkomstig is uit een koninklijk domein, of leenbanden onderhield met andere heren of een verleden als kerkelijk bezit kent. Hetzelfde geldt ook voor Eckelrade. Ook de parochie kent geen afhankelijkheidsverhouding met een 'moederkerk' in een naburige plaats.

Aan de eigendomsverhouding van grond, zoals die in het midden van de achttiende eeuw bestonden, valt via retrogressie de ontstaansgeschiedenis van de dorpen gedeeltelijk af te lezen. Wanneer we in Gronsveld (dus exclusief Eckelrade) de tachtig bunder akkerland in eigendom van de heer van Gronsveld, de circa 35 kleine lenen en de vier keurmedige huizen bij elkaar optellen, dan komen we (geschat) op 120 bunder. Ook het Savelsbos kunnen we als heerlijk goed beschouwen. Mogelijk moeten hierbij worden opgeteld circa 65 bunder van de Wijngaardshof (onder Gronsveld) en 25 bunder van het Seutendaelsleen. Ten aanzien van deze grote lenen moet een slag om de arm worden gehouden, want de latere leenverhouding zou kunnen zijn ontstaan uit allodiaal goed dat naderhand in leen is opgedragen. Buiten beschouwing blijft nog de grond, die wellicht ooit door de heer als cijnsgoed is uitgegeven. Bij elkaar komt dat neer op ongeveer tweederde van alle akkerland rond het dorp, dat op de een of andere manier met de heer in verband kan worden gebracht. Helemaal helder is het beeld niet, maar het geeft aan dat in Gronsveld allodiaal grootgrondbezit de basis voor het ontstaan van het dorp moet zijn geweest. Daarbij hoeft ook niet onmiddellijk te worden gedacht aan een aaneengesloten blok. De latere verkaveling wijst eerder op het tegendeel.

Dit beeld sluit ook aan op de algemene ontginningsdrift vanaf de twaalfde eeuw, toen een groeiende bevolking verhoging van de voedselproductie noodzakelijk maakte. Janssen heeft er op gewezen dat de in die tijd opkomende grotere landsheren grote waarde hechtten aan het wildernisregaal, het recht op woeste gronden, omdat zij op basis daarvan 
hun gebied in cultuur konden brengen door uitgifte in leen, uitgifte tegen het recht van keurmede of uitgifte tegen betaling van een jaarlijkse rente of cijns. ${ }^{589}$ Juridisch en maatschappelijk was dat nauwelijks nog bezwaarlijk aangezien de positie van leenman bijna even sterk was als die van een volle eigenaar. Hetzelfde gold ook voor de oorspronkelijk met horigheid verbonden rechten van keurmede en cijns. Deze last was nog wel in een oude vorm 'verpakt', maar de vroeger halfvrije horigen waren intussen geëvolueerd tot vrije onderdanen.

We mogen dan ook wel concluderen dat de heren van Gronsveld een rol hebben gespeeld bij de ontginning van hun domein, hetzij als direct betrokkenen hetzij als stimulator van derden, bijvoorbeeld door uitgifte als leengoed, als keurmedig goed en hoogstwaarschijnlijk ook nog als cijnsgoed. Er zijn daarbij wel duidelijke verschillen tussen Gronsveld en Eckelrade aan te wijzen. Zo is in het dorp Gronsveld de geringe hoeveelheid keurmedig goed opmerkelijk. De aanwezigheid van enkele grote complexen leengoed duidt ook op mogelijke betrokkenheid van anderen, bijvoorbeeld het klooster Sinnich en de laathoven Printhagen en Van Gruysbeeck. Ook het vrij omvangrijke goederenbezit van de heren van Rijckholt gaat waarschijnlijk terug tot de periode van ontginningen. De ontwikkeling van Gronsveld verschilt daarmee van die in de aangrenzende dorpen, waar de ontginningen vooral op initiatief van kapittels en kloosters lijken te zijn ondernomen.

Eckelrade is duidelijk gesticht vanuit Gronsveld, maar het is de vraag of het dorp veel jonger is dan Gronsveld. De ontwikkeling is echter anders verlopen dan in Gronsveld. Opmerkelijk genoeg beschikten de heren van Gronsveld in Eckelrade volgens de gegevens vanaf de zestiende tot en met de achttiende eeuw slechts over een zeer beperkt areaal grond in volle eigendom. Dit bezit maakt bovendien door de verspreide ligging niet de indruk van hoge ouderdom.

Het tweede verschil met Gronsveld is dat in het totale areaal an grond in Eckelrade leenroerige landerijen domineerden. Het betreft veel kleine lenen (meer dan vijftig), maar beeldbepalend waren toch de grote lenen van de Houwert of Hoogaert en Hamersbach. Bij de Houwert valt aan de verkaveling in de achttiende eeuw nog duidelijk de oorspronkelijke vorm van een aaneengesloten blok van circa veertig bunder af te lezen. Een andere structuur bezat het leen Hamersbach, oorspronkelijk ongeveer honderd bunder, verdeeld over een aantal grote kavels. In totale omvang stak het leen Hamersbach daarmee zelfs het grondbezit van de heren van Gronsveld in het dorp Gronsveld naar de kroon. Onzeker blijft echter de herkomst van deze grote lenen. Zij kunnen het resultaat zijn van de uitgifte van oorspronkelijk heerlijk grondbezit, maar kunnen hun leenroerigheid ook te danken hebben aan een latere opdracht aan de heren van Gronsveld. Onduidelijk blijft daarin de figuur van Henricus van Hemesbagh, de naamgever (?) van het grootste leen aan het begin van de dertiende eeuw, die als bezitter van tienden mogelijk ook betrokken was bij ontginningen.

589 Janssen, 'Niederrheinische Territorialbildung', 96-98; zie in dit verband ook Opsommer, 'Omme dat leengoed', 565-566, waarbij het voorbeeld wordt gegeven van de graven van Vlaanderen die in de veertiende en vijftiende eeuw door inpoldering nieuw gewonnen land in leen uitgaven en 241-244 waar de uitgifte tegen rente of erfelijke cijns wordt besproken. 
Een derde opmerkelijk verschil met Gronsveld vormt de bijna gesloten rij van tien keurmedige percelen langs de oostzijde van de huidige Klompenstraat en de Dorpsstraat richting Honthem, duidelijk het resultaat van een planmatige uitleg. Een centrale hof van waaruit deze goederen in exploitatie zijn gegeven, valt echter niet direct aan te wijzen, of het zou de hof moeten zijn die Reinerus, heer van Gronsveld, en zijn vrouw Beatrix in 1261 aan de abdij van Hocht verkochten. De conclusie is dan ook dat op zich aan de latere indeling van de grond in Eckelrade de ontginningsgeschiedenis van het dorp wel valt af te lezen, maar er blijft onduidelijkheid over de personen of instellingen die daarbij betrokken kunnen zijn geweest. Aannemelijk is wel dat de heren van Gronsveld daarin een belangrijke rol hebben gespeeld.

De vraag is hoe de ontwikkeling van Gronsveld en Eckelrade zich verhoudt tot het ontstaan van de rechterlijke organisatie in de late middeleeuwen. De enkele losse vermeldingen uit de periode voor 1375 bieden te weinig houvast om daar diepgaande conclusies aan te kunnen verbinden. Naast de al eerder genoemde 'doorgroei' van oude laathoven kunnen schepenbanken ook als nieuwe instellingen zijn gesticht.

Of aan de in 1261 genoemde 'curia de Grunsele' een laathof ten grondslag heeft gelegen, is onduidelijk. Opmerkelijk is dat noch voor Gronsveld en Eckelrade (en ook niet voor Heugem, Honthem en Slenaken) in later tijd een spoor van één of meer aparte laathoven van de heer valt te ontdekken, met uitzondering misschien van de hof 'met vijf gebouwen' die Reinerus van Gronsveld in 1261 aan de abdij Hocht verkocht. Maar die is uiteindelijk naar Sint-Geertruid verplaatst. Keurmedige goederen (en ook cijnsgoederen) werden in Gronsveld meestal overgedragen ten overstaan van de schepenbank en een enkele maal ook voor het leenhof. Verder is er in plaatselijke benamingen niets wat zou kunnen herinneren aan een ooit bestaan hebbende centrale hof (bijvoorbeeld een vroenhof). Dit laat twee mogelijkheden open. De eerste is dat de schepenbank zich misschien toch heeft ontwikkeld uit één of meer heerlijke laathoven en dat de jurisdictie over de laatgoederen daarin volledig is opgegaan, zonder verder sporen achter te laten. De tweede mogelijkheid is dat de schepenbank naast de laatho(f)(ven) is gesticht en deze vervolgens zodanig heeft overvleugeld, dat de rechtspraak over laatgoederen daarin is overgenomen. Het is zelfs denkbaar dat in de laatste fase van de ontginningen voor de uitgifte van goederen wel voor het regime van het laatrecht als een vorm van grondexploitatie werd gekozen, terwijl er geen laathof meer was.

Van het leenhof van Gronsveld staat vast dat dit ten minste sinds het laatste kwart van de veertiende eeuw was geïnstitutionaliseerd en opgezet als centrale instelling voor het beheer van en de rechtspraak over alle Gronsveldse lenen, niet alleen in het land Gronsveld, maar ook daar buiten (bijvoorbeeld in Vaals en Holset). Opmerkelijk daarbij is het ontbreken van lenen in Heugem (verworven in 1363) en Honthem. Daaruit zou men kunnen afleiden dat het proces van uitgifte van grond onder het regime van het leenrecht in de veertiende eeuw was afgesloten. De vele kleine lenen in de dorpen Gronsveld en Eckelrade kunnen wijzen op een laatste fase in de ontginning, waarbij uitgifte van grond ter ontginning onder het regime van het leenrecht werd gezien als één van de mogelijke vormen van grondexploitatie, net als uitgifte tegen erfpacht of cijns. 


\subsection{Heugem}

\subsubsection{Geografisch beeld en vroegste ontwikekeling}

Evenals Gronsveld werd ook Heugem in 1754 op kadastrale schaal in kaart gebracht. Ook hier mag worden aangenomen dat het geografisch beeld van het dorp in de achttiende eeuw waarschijnlijk niet fundamenteel verschilde van de structuur uit het einde van de middeleeuwen. Op de kaart is te zien hoe de dorpskern ligt ingeklemd tussen enkele doorgaande wegen. Komende vanuit Maastricht/Wyck in de noordwesthoek splitste de weg zich vóór het dorp in drie richtingen. De meest oostelijke route, Maastrichter Weg geheten, leidde langs hoeve 'Vogelzang' direct naar Gronsveld. De middelste weg heette aanvankelijk Vauerstraat, veranderde bij het begin van het dorp in Dorpstraat en eindigde ten slotte op de Koestraat. De meest westelijke tak, Trichter of Maarlander Weg genaamd, vormde de doorgaande route naar Oost, Maarland, Breust en Eijsden. Even ten zuiden van de dorpskern kreeg de weg een vertakking in oostelijke richting, de al eerder genoemde Koestraat. Eigenlijk was deze weg, die bij Vogelzang samenkomt met de Maastrichter Weg, de 'uitvalsroute' naar Gronsveld.

Het stratenplan van het dorp bestond min of meer uit een rechthoek, gevormd door de Maarlander of Trichter Weg in het westen, de Dorpsstraat in het oosten en de Koestraat ter afsluiting in het zuiden. Daartussen liepen dwarsverbindingen, zoals een voetpad ten noorden van de kerk, ten zuiden van de kerk de Kerkstraat en nog zuidelijker de Kattenstraat. De bebouwing van de dorpskern was tamelijk open en lag verspreid langs de verschillende straten en wegen. Heugem kent daarmee een duidelijk andere nederzettingsvorm dan de lintbebouwing van Gronsveld, Heer of Rijkckholt en sluit meer aan op bijvoorbeeld Breust. De huiskavels met tuinen waren klein tot zeer klein. Anders dan men misschien zou verwachten, bevindt de kerk zich niet in het centrum, maar aan de noordwestzijde van het dorp.

Ten oosten van de dorpskern lag bouwland in het Lochterveld. Het gebied ten zuiden van Heugem bestond eigenlijk uit drie stukken, op de kaart van 1754 van west naar oost de secties L, M en N. Sectie L, tussen de Maarlander Weg en de Maas, is daarop groen ingekleurd en bestond, afgezien van een strook bouwland ten westen van de Maarlander Weg, uit weilanden. Binnen sectie $\mathrm{M}$, het middenstuk, op latere kaarten aangeduid als Maasveld, lag vrijwel alleen bouwland. De donkergroen ingekleurde Sectie N, het meest oostelijke gebied, werd gevormd door een dichtgeslibde, met gras begroeide oude Maasarm, een deel van de zogenoemde Heugemer Overlaat die in tijd van hoog water fungeerde als overloopgebied voor de Maas. Ten westen van het dorp stroomde de Kleine Maas met daarachter de eilanden van de Grote en Kleine Weert, voor een groot deel vallend onder de jurisdictie van Sint Pieter.

De verkavelingen van het Lochterveld en het Maasveld vertonen ongeveer hetzelfde patroon. Het zijn merendeels kleine, vaak langwerpige percelen, waarbij soms nog duidelijk uit het grensverloop hun ontstaan uit oorspronkelijk grotere blokken valt af te leiden. Het weidegebied in Sectie M langs de Maas levert een wat ander beeld op. De percelen zijn hier aanmerkelijk groter, waarbij naast landsheerlijk goed vooral de kavels op 
naam van de Maastrichtse familie Boomhouwer, van de familie Vaes van Scherpenberg en van de graaf van Schaesberg opvallen. In de oostelijk gelegen dichtgeslibde Maasarm springen in het oog de grote percelen op het Heugemer Koebroek en de weiden van de hoeve Vogelzang, toebehorend aan de Broederschap der Kapelanen van het kapittel van Onze-Lieve-Vrouw te Maastricht.

Zeer opvallend op de kaart van Heugem is de vreemde, bijna haaks op de nederzetting staande strook grond tot aan de steilrand van het plateau van Eckelrade (de Secties J en $\mathrm{H}$ van de kaart), die eindigt bij de grens met Cadier. Het gebied, met de grafelijke banmolen als middelpunt, bestond geheel uit bouwland. ${ }^{590}$ Vanaf hoeve Vogelzang liep de Heugemer Molenweg kaarsrecht door deze strook, richting banmolen. Ter hoogte van de molen bevond zich de kruising met de weg van Heer naar Gronsveld. Achter de molen ging de Heugemer Molenweg in de richting van Cadier over in de Bronckweg, terwijl een aftakking met de naam Kleine Molenweg in zuidelijke richting, uiteindelijk uitkwam op de weg van Gronsveld naar Eckelrade.

Deze oostelijke 'doorgang' van Heugem naar Cadier was vrijwel geheel verkaveld in kleine tot zeer kleine, meest langwerpige stroken bouwland. De doorgaande wegen fungeerden daarbij als een soort assen, waaraan de kleine percelen met hun smalle zijde grensden. Ook hier is goed te zien hoe deze zijn ontstaan uit grotere blokken. Het meest opvallend is echter de verdeling van de percelen langs de Heugemer Molenweg en langs de weg van Heer naar Gronsveld, waar de verdeling het resultaat van bijna planmatige aangepakte ontginning lijkt te zijn, met de doorgaande wegen als een soort centrale assen.

Over de oorsprong van Heugem valt weinig concreets te zeggen. De plattegrond van het dorp past, zoals al vermeld, bij de nederzettingsvorm zoals we die ook van Breust kennen. Het patrocinium van de parochiekerk, toegewijd aan de Heilige Michaël, kan wijzen op een stichting in de Karolingische periode. ${ }^{591}$ De parochie was niet alleen zeer oud, maar ook (zoals andere oude parochies in de omgeving) zeer uitgestrekt en omvatte oorspronkelijk ook Cadier en Honthem.

De oudste schriftelijke vermeldingen van Heugem dateren uit de twaalfde eeuw. In 1157 bevestigde paus Adrianus IV het kapittel van Onze-Lieve-Vrouw te Maastricht in het bezit van de kerk en tienden van Heugem (ecclesiam de Hogehem cum decima ipsius ville). ${ }^{592}$ Een vergelijkbare oorkonde uit 1186 bevat min of meer een letterlijke herhaling daarvan.593 In andere, hierna nog te noemen documenten, komt Heugem voor onder benamingen als 'Hoin', 'Hoyn', 'Hoiens', waaruit valt af te leiden dat in twaalfde en vroege dertiende eeuw zowel Romaanse als Germaanse (Hogehem) varianten van de naam bestonden. De rechten van het kapittel in Heugem bestonden alleen uit tienden en patronaat, dat wil zeggen het recht om de pastoor te benoemen. Dit laatste overigens werd later door de heer van Gronsveld betwist (zie daarover Hoofdstuk 15.20.3). Van

590 Terzijde dient te worden opgemerkt dat deze molen bekend staat als de molen van Gronsveld, maar in werkelijkheid op Heugems gebied lag.

591 Munsters, 'Verkenning Middeleeuwse kerk', 462.

592 Tekst afgedrukt bij Franquinet, Inventaris O. L.V rowwekerk, I, 8-13, nr. 4.

593 Tekst gedeeltelijk afgedrukt bij Franquinet, Inventaris O. L.V rounekerk, I, 14-15, nr. 6. 
uitoefening van heerlijke rechten is nooit sprake geweest. Evenmin bezat het kapittel in Heugem veel grond. Onzeker blijft hoe en wanneer het Maastrichtse kapittel van OnzeLieve-Vrouwe aan zijn tiend- en patronaatsrechten in Heugem is gekomen. Het aan deze kerk verbonden college van kanunniken zou omstreeks 990 zijn gesticht door de Luikse bisschop Notger. Het is bekend dat de Luikse bisschoppen vanaf de negende tot en met de twaalfde eeuw een belangriijke bijdrage hebben geleverd aan de materiële basis van deze instelling door schenking van tiendrechten in dorpen rond Maastricht. Mogelijk past ook de verwerving van tiendrechten in Heugem binnen dit kader.

De strook Heugems gebied in oostelijke richting laat zien hoe, zoals bij de meeste dorpen in het Maasdal, ook vanuit Heugem waarschijnlijk in de elfde en twaalfde eeuw ontginning richting plateau plaatsvond. Hoewel de grens van het Heugems gebied eindigde bij de rand van het plateau, liep de feitelijke invloed nog veel verder in oostelijke richting. De parochiekerk van Cadier was immers gesticht vanuit Heugem en tussen Heugem en Honthem bestond een nauwe juridische band. De situatie vormt bijna een spiegelbeeld van de ontwikkeling van Breust. Het in 1157 vanuit Breust gestichte gehucht Bruisterbosch ligt ongeveer even ver van Breust af als Honthem van Heugem en de kerk van Cadier is vergelijkbaar met de vanuit Breust gestichte kerk van Sint-Geertruid.

\subsubsection{Grenzen}

De beschrijving van de buitengrenzen van Heugem begint in het uiterste zuidwesten aan de Maas en volgt daarna de wijzers van de klok. Vanaf deze hoek vormde de Maas over een lengte van een paar honderd meter de grens tussen Heugem en Luiks gebied, meer specifiek de heerlijkheid Nivelle-sur-Meuse op de westoever van de Maas, ook genaamd de heerlijkheid van de Vallée. ${ }^{54}$ Deze bestond uit een smalle strook tussen de Sint Pietersberg en de Maas en omvatte de dorpen Lixhe en Lanaye (Ternaaien) alsmede enkele gehuchten. Het meest noordelijke daarvan, Klein Ternaaien, lag tegenover Heugem. Nivelle-sur-Meuse wordt gerekend tot het aloude patrimonium van de bisschoppen van Luik, teruggaand tot de tijd van Sint Lambertus en Sint Hubertus in de zevende eeuw. Formeel bleven de prins-bisschoppen van Luik heer van Nivelle-sur-Meuse tot aan de Franse Tijd, maar vanaf 1616 waren de heerlijke rechten verpand.

De limieten tussen Heugem en Nivelle-sur-Meuse lagen niet nauwkeurig vast, zoals blijkt uit een proces dat in 1575 voor de schepenen van Luik en de Geheime Raad van de prinsbisschop werd gevoerd tussen Agnes van Bylandt, vrouwe van Gronsveld, en de 'inwoenders der Valleyen met die van Ter Nayen (les mannans del Nayen en la Vallee de Meuse) ${ }^{5}{ }^{95}$ Beide partijen maakten aanspraak op een eilandje en een griend aan de oostelijke Maasoever. De afloop van het geschil is niet bekend, maar onduidelijkheden bleven waarschijnlijk bestaan.

Verder noordwaarts grensde Heugem aan Sint Pieter. Deze heerlijkheid, die zoals Nivellesur-Meuse- tot het oudste patrimonium van de Luikse kerk wordt gerekend, stond tot de

594 Zie over deze plaats in het algemeen: Debouxthay, Histoire Nivelle-sur-Meuse, waaraan de navolgende gegevens zijn ontleend.

595 RHCL, Graafschap Gronsveld, inv. nr. 447. 
Franse Tijd onder direct prinsbisschoppelijk bestuur. Het eerste stuk van de grens, aansluitend op die van Nivelle-sur-Meuse liep door het midden van de Maas, tot ongeveer ter hoogte van het huis Hoogeweerd. Zoals ook in het zuidelijker deel van de Maas bestonden hier onduidelijkheden over het precieze grensverloop. Zo klaagde Prummer in 1769 bij de graaf over het voortdurende gebrek aan medewerking van de Luikenaars bij een poging om te komen tot een oplossing over de geschillen rond visrechten in dit gedeelte van de Maas.

Verder noordwaarts, vanaf de Hoogeweerd, liep de grens met Sint Pieter tamelijk grillig over land, midden over de Grote Weerd, op de oostelijke oever van de Maas. Eigenlijk vormde dit een eiland, omdat het werd omspoeld door een riviertak, die de Kleine Maas, Kromme Maas of het Heugemer Water werd genoemd. Deze smalle geul mondde ten noorden van Heugem uit in het Papewater. Ten noorden van de Grote Weerd lag de Kleine Weerd, eveneens een eiland, ingeklemd tussen de Maas en het Papewater, en behorend tot Sint Pieter. Het Papewater vormde hier noordwaarts tot aan Wyck de grens tussen Heugem en Sint Pieter.

Het grillig verloop van deze limieten tussen Heugem en Sint Pieter, zowel over land en als door het water, moet in sterke mate zijn bepaald door veranderingen in het stroomgebied van de Maas. Mogelijk stroomde de rivier hier in de vroege middeleeuwen tussen eilandjes en zandbanken, die voor het grootste deel tot de jurisdictie van Sint Pieter werden gerekend. Waar de scheiding precies liep, valt niet met zekerheid te zeggen, wellicht vrij ver naar het oosten, tot in de buurt van of zelfs samenvallend met de Kleine Maas en het Papewater.

In het uiterste noorden raakte Heugem aan de zogenoemde banmijl van het Maastrichtse stadsdeel Wyck. De jurisdictie over dit gebied was onverdeeld of 'indivies' tussen de prinsbisschop van Luik en de hertog van Brabant als stadsheren van Maastricht. Daarna liep de grens een kort stuk in zuidelijke richting en maakte vervolgens een bijna haakse bocht naar het zuiden door het Wyckerveld, eveneens jurisdictie van Maastricht en ging over in de grens met Heer.

De grens tussen Heugem en Heer begon in het westen met de min of meer natuurlijke scheiding tussen het Lochterveld en het lager gelegen Heerder Koebroek. Daarna volgden de limieten een vrijwel rechte lijn naar het oosten door De Heeg tot aan de weg van Heer naar Gronsveld. Vanaf dat punt maakte de grens eerst noordwaarts een haakse bocht van ongeveer 200 meter, en ging daarna weer verder in oostelijke richting door het Heugemer Vroendel, om ten slotte aan de rand van het plateau van Margraten uit te komen bij de heerlijkheid Cadier. Opvallend is de grotendeels rechte grens door De Heeg tussen Heugem en Heer, die duidelijk een kunstmatige oorsprong heeft en waarschijnlijk werd getrokken bij de ontginning. ${ }^{596}$

Heer behoorde tot één van de zogenoemde Elf Banken van het Maastrichtse kapittel van Sint-Servaas. ${ }^{597}$ Het kapittel bezat in deze plaatsen hoge en lage jurisdictie, tiendrecht en

596 Van de Venne, Geschiedenis Heer, kaart bij 178-179.

597 Zie over Heer: Van de Venne, Geschiedenis Heer, passim; Nève, Rijkskamergerecht, 436-438; Hackeng, Middeleeuwse grondbezit Sint-Servaaskapittel, 57-95. 
patronaatsrecht. Aangenomen wordt dat de meeste van deze 'Banken' zijn ontstaan uit hoven of 'curiae' die tot oude koninklijke domeinen behoorden. Het Sint-Servaaskapittel, dat voor zich zelf aanspraak maakte op rijksonmiddellijkheid, pretendeerde die status ook voor zijn Elf Banken.

De dorpskern van Heer bestond, net als die van Gronsveld, uit lintbebouwing op de rand van het middenterras, tussen laaggelegen broekgronden en het plateau van Cadier en Keer. Opmerkelijk bij Heer is verder de langgerekte geografische vorm in oostelijke richting tot op het plateau van Margraten. De structuur als geheel vertoont veel overeenkomst met die van Breust/Eijsden en Gronsveld.

De grens tussen Heugem en Gronsveld is al in Hoofdstuk 2.3.3 bij Gronsveld beschreven. In hetzelfde Hoofdstuk kwam ook een schets van Breust en Eijsden aan de orde. Volledigheidshalve geven we nog een korte beschrijving van de grens tussen Breust/Eijsden en Heugem. Nadat de grens tussen Gronsveld en Rijckholt was overgegaan in de limieten tussen Gronsveld en Breust/Eijsden, liep deze verder in westelijke richting als scheiding tussen Heugem en Breust/Eijsden. Eerst volgde de grens enkele tientallen meters de Schaapbroekweg, om daarna af te buigen in de richting van de Maas. Er liep vanaf de Schaapbroekweg een rechte lijn naar de Maas, die halverwege de waterlossing van de Zeep kruiste. Die lijn vormde ook de negentiende-eeuwse gemeentegrens. Het bijschrift op de kaart van 1754 doet het echter voorkomen alsof de officiële scheiding tussen de Schaapbroekweg en de Zeep de perceelgrenzen volgt en daardoor iets zuidelijker ligt. Ondanks deze onduidelijkheid lijkt het grootste deel van deze scheidingslijn kunstmatig te zijn getrokken.

\subsubsection{De Luikse heerlijkheid Heugem tot 1363}

Het voorgaande overzicht van de buren van Heugem geeft aan hoezeer het Maasdal ten zuiden van Maastricht met de Luikse kerk was verbonden. Met Nivelle-sur-Meuse en Sint Pieter hadden de Luikse prins-bisschoppen feitelijk zeggenschap over de hele westelijke Maasoever vanaf Haccourt tot Maastricht. Bij dit bisschoppelijk bezit moeten in feite ook de goederen van de Luikse kerkelijke instellingen worden opgeteld, zoals van de kapittels van Sint-Jan en Sint-Paul met hun heerlijke rechten in respectievelijk Kanne, Eben-Emael en Wonk. Voorts bezat de zeer oude vrouwenabdij, later het stift van Munsterbilzen, de heerlijkheid Haccourt. Een vergelijkbaar beeld levert de oostelijke Maasoever op vanaf Visé, sinds 983 toebehorend aan de bisschop van Luik, en daarna noordelijker Breust en Eijsden. Toch moet niet de indruk worden gewekt van een oorspronkelijk aaneengesloten geheel. Veel meer lijkt sprake te zijn geweest van een serie hoven in combinatie met kleine nederzettingen langs de Maas, al dan niet voorzien van een parochiekerk. Aan die hoven was ook jurisdictie over de inwoners verbonden. Met dit Luikse overwicht aan beide oevers van de Maas, tot aan de poorten van Maastricht, maakte de prins-bisschop ook aanspraak op het stroomregaal op de Maas en de visrechten op de rivier. ${ }^{598}$

598 Debouxhtay, Histoire Nivelle-sur-Meuse, 105-106. 
Tegen deze achtergrond wekt het geen verbazing dat ook Heugem in deze reeks past. De oudste vermelding is te vinden in een bul gedateerd 24 juli 1155, waarin paus Adrianus IV de kerk van Luik onder andere bevestigt in het bezit van curtes of hoven in 'Senplouoir', 'Hoin', 'Toiz', 'Veruier', 'Niuellam' en 'Sanctum Petrum in Traiecto' (geïdentificeerd als Simpelveld, Heugem, Theux, Verviers, Nivelle-sur-Meuse en Sint Pieter). ${ }^{59}$ Nog geen twee maanden later, op 7 september 1155, vaardigde keizer Frederik I een privilege met dezelfde strekking uit. ${ }^{600}$ Daarin worden in algemene zin genoemd 'Sint Pieter, Heugem [en] al wat de kerk van Sint Lambertus bezit in Maastricht' ('Sanctum Petrum, Hoyn, quicquid in Traiecto tenet ecclesia beati Lamberti').

Een volgende vermelding van Heugem is te vinden in een oorkonde uit 1213, waarbij bisschop Hugo de Pierrepont hoven ('curtes'), gelegen te 'Saintplouoir', 'Haspre' en 'Hoiens' (Simpelveld, Eijsden en Heugem), in leen geeft aan Walram, zoon van de hertog van Limburg. ${ }^{601}$ Daarna zwijgen de bronnen over 'Hoyens' tot 1334. In dat jaar deed de Franse koning Philips VI een scheidsrechterlijke uitspraak tussen hertog Jan III van Brabant en Adolf van der Mark, bisschop van Luik. De bisschop kreeg daarin opdracht te bewijzen dat 'les villes de Saint Plouvoir, de Hoyn et de Aspre' in leen worden gehouden van de Luikse kerk. Slaagde hij daarin, dan moest de hertog daarvoor leenhulde doen. ${ }^{602}$ De voorgeschiedenis van dit conflict gaat waarschijnlijk terug tot de tijd vóór 1288, het jaar van de slag bij Worringen. Er zijn aanwijzingen dat kort tevoren de hertog van Limburg de lenen die hij van de Luikse kerk in bezit had, in onderleen had gegeven aan de heer van Valkenburg. In 1289 deed Walram van Valkenburg daarvoor leenhulde aan de hertog Jan I van Brabant, de overwinnaar van Worringen, waarbij de rechten van de prinsbisschop van Luik als opperleenheer werden veronachtzaamd.

Als uitvloeisel van de uitspraak van de Franse koning beleende hertog Jan III van Brabant op 23 oktober 1334 Dirk (IV) van Valkenburg met lenen 'die ruerende syn van den hertoghrike van Lymborch'. Daaronder wordt expliciet 'den hof tot 'Esde' genoemd. Sommige auteurs, zoals Janssen de Limpens, beschouwen deze belening als het begin van de band tussen Eijsden en het Land van Valkenburg. Hartmann en vervolgens ook Van Hall zijn echter van oordeel dat de belening van 1334 vooral moet worden gezien als voortzetting van een al veel langer bestaande verhouding. ${ }^{603}$

De curtis Heugem moet na de belening van Walram van Limburg in 1213 ongeveer dezelfde weg als Eijsden zijn gevolgd. Opmerkelijk is dat 'Hoyn' in de uitspraak van de Franse koning van 30 augustus 1334 wordt genoemd en vervolgens in de belening van 23 oktober 1334 ontbreekt. Naar de reden daarvan kunnen we slechts gissen, maar het is een

\footnotetext{
599 Bormans/Schoolmeesters, Cartulaire Saint-Lambert, 1, 74-76, nr. 45.

600 Bormans/Schoolmeesters, Cartulaire Saint-Lambert, 1, 76-80, nr. 46.

601 Bormans/Schoolmeesters, Cartulaire Saint-Lambert, 1, 173-174, nr. 111; Poncelet, Actes Hugues de Pierrepont, 112-113, nr. 108; zie ook Van Hall, Eijsden, een vrijheid, 39.

602 Bormans/Schoolmeesters, Cartulaire Saint-Lambert, 3, 450-459, nr. 1180, zie verder ook Van Hall, Eijsden, een vrijheid, 56.

${ }^{603}$ Hartmann, Reconstructie landschap, 277-278 met overzicht van de relevante bronnen; Van Hall, Eijsden, een vrijheid, 56-57.
} 
feit dat ook Heugem in Valkenburgs bezit is gekomen. Dat blijkt uit een oorkonde van 5 december 1363, waarbij Walram ('Walraven') van Valkenburg, heer van Born en Sittard ('Sittlich') het dorp van Heugem met alle bijbehorende rechten schenkt aan Johan (III) van Gronsveld 'omme gherechter gonsten liefden ind dienstes willen, die uns her Johan vurss. gedaen heet'. ${ }^{604}$ Deze Walram was een zoon van Jan van Valkenburg, heer van Born (overleden 1356) en een neef van Dirk IV van Valkenburg.605 Op de een of andere manier (direct als Luiks leen of als Limburgs-Brabants achterleen) moet Walram bij een deling in het bezit van Heugem zijn gekomen, zoals Dirk IV van Valkenburg met de rechten van zijn voorvaderen op Eijsden werd beleend. Maar de eventuele Luikse leenroerigheid van Heugem is verloren gegaan, want later wordt Heugem onbetwist als allodiaal beschouwd. Welke 'liefde en dienst' lagen aan deze schenking uit 1363 ten grondslag? In de successiestrijd na het overlijden van Jan van Valkenburg in 1352, maakte ook Walram anspraken op de erfenis, maar hij moest daar in 1365 van afzien, na een uitspraak van het Landvredeverbond. Zocht Walram in dit conflict misschien steun van de heer van Gronsveld en was Heugem daar een tegenprestatie voor? Het is denkbaar, want Hendrik I van Gronsveld was een prominent lid van het college dat de landvrede moest handhaven.

\subsubsection{Bezittingen van de heren van Gronsveld in Hengem}

De vroegste gegevens over grondbezit van de heren van Gronsveld in Heugem dateren uit 1417. Het gaat daarbij om twee stukken bouwland 'in den gevelte van Hoghum', samen ongeveer 19 à 20 bunder, die tot onderpand werden gesteld voor een jaarrente. Het betreft waarschijnlijk percelen in het Maasveld en in De Heeg. ${ }^{606}$ Ander grondbezit, dat later genoemd wordt, is waarschijnlijk afkomstig uit de hof Ter Warden en de hof Printhagen.

Toen Prummer in de jaren vijftig en zestig van de achttiende eeuw de landsheerlijke eigendommen en inkomsten in ieder dorp van het graafschap Gronsveld inventariseerde, stelde hij vast dat in Heugem (met uitzondering van enkele perceeltjes in het Vroendel), geen grafelijke lenen lagen. Wel wist hij in totaal negen huizen of percelen land belast met het recht van keurmede te achterhalen. Mogelijk waren er oorspronkelijk meer, maar daarover bestond in de achttiende eeuw geen zekerheid. Aangezien Prummer bij de omwerking van de oude leggers van keurmeden naar nieuwe bij ieder goed ook de naam en het nummer op de kadasterkaart vermeldt, is het (met uitzondering van nummer 2) niet moeilijk de ligging daarvan vast te stellen. Daaruit blijkt dat alle percelen (op één na, ten zuiden van de Koestraat) in de kern van het dorp liggen, tussen de Vauerstraat/Dorpstraat en de Trichter- of Maarlanderweg. De keurmedige percelen lijken te zijn ontstaan rond een centrale hof in de dorpskern en zijn mogelijk terug te voeren op een oude curtis van de prins-bisschop van Luik. Mogelijk zijn deze bij de verwerving van de heerlijke rechten over Heugem in 1363 door de heren van Gronsveld 'overgenomen'.

${ }^{604 U L B}$ Darmstadt, Hs. inv. nr. 2734-2735, Cartularium Hurt von Schönecken, fol. 33.

${ }^{605}$ Genealogie bij Van de Venne, Geschiedenis kasteel Valkenburg, tabel II en III.

606 Op de rente hebben betrekking de oorkonden voor schout en schepenen van Heugem uit 1417 (RHCL, Kapittel O.L.Vrouw Maastricht, inv. nr. 1028, afgedrukt bij Doppler, 'Schepenbrieven O.L.Vrouw', nr. 265) en uit 1420 (RHCL, Kapittel O.L.Vrouw Maastricht, inv. nr. 622; regest bij Doppler,' Schepenbrieven O.L.Vrouw', nr. 297). 
Volledigheidshalve moeten we er op wijzen dat ook in de beleningsakten van Ter Warden melding wordt gemakkt van cijnzen, kapoenen en keurmeden die aan de bezitters van de hof moesten worden betaald. Mogelijk gaat het bij deze omschrijving om een standaardformule, die niet helemaal met de werkelijkheid correspondeert. De reële betekenis valt in ieder geval moeilijk te beoordelen, want in later tijd zijn geen cijnzen of keurmeden specifiek naar deze hof te herleiden. Ook komt het onwaarschijnlijk voor dat de keurmeden in het dorp met Ter Warden samenhangen.

\subsubsection{Conclusies}

Over de ouderdom van Heugem bestaat geen zekerheid. De oudste schriftelijke bronnen gaan terug tot de twaalfde eeuw, maar waarschijnlijk is Heugem aanzienlijk vroeger gesticht rond een 'curia', een laathof toebehorend aan de prins-bisschop van Luik. Heugem past daarmee in de rij van vroeg Luiks bezit langs de Maas. Vanuit het dorp werd, waarschijnlijk in de elfde of twaalfde eeuw, in oostelijke richting een lange smalle strook grond ontgonnen tot aan de rand van het plateau van Eckelrade, welk gebied later valt onder het ressort van de schepenbank Heugem. De invloed van Heugem reikte echter nog verder in oostelijke richting. De kerk van Cadier als een van de kerk in Heugem afhankelijke kapel en de juridische banden met Honthem wijzen daar op.

De heerlijke rechten over Heugem zijn waarschijnlijk begin dertiende eeuw door de prinsbisschop in leen uitgegeven aan de hertog van Limburg en daarna de hertog van Brabant. Als Brabants 'onderleen' kwam Heugem in het bezit van de heren van Valkenburg. In 1363 schonk Walram van Valkenburg, heer van Born en Sittard, het dorp Heugem met alle bijbehorende rechten aan Johan III van Gronsveld. De leenbanden met Luik zijn in deze tijd verloren gegaan.

Er zijn geen aanwijzingen dat de heren van Gronsveld vóór 1363 in Heugem beschikten over een substantiële hoeveelheid grond. De hof Ter Warden, van oorsprong een Luiks leen ter grootte van 24 bunder land, kwam pas in de vijftiende eeuw in Gronsvelds bezit. Door toevoeging van gronden die langs andere weg waren verworven, verdrievoudigde de omvang van de hof in de zestiende eeuw. $\mathrm{Na}$ de verwoesting van de gebouwen kort voor 1600 werd het grondbezit, verspreid over vele losse percelen, door de heren van Gronsveld als pachtland of in eigen beheer geëxploiteerd.

Tussen de vermelding van een 'curtis' in 'Hoin' in 1155, een 'curtis' in 1214, een 'ville' in 1334 en ten slotte schepenen in 1364, ligt een periode van ruim tweehonderd jaar. We mogen daarbij aannemen dat rond 1350 inderdaad een schepenbank bestond, zoals zich die naderhand, in de vijftiende eeuw, in de bronnen presenteert. Heeft die schepenbank zich uit een oude laathof ontwikkeld? We kunnen daarover alleen maar speculeren, maar het is, ook in vergelijking met andere plaatsen, toch waarschijnlijk dat in Heugem een aan de Luikse bisschop toebehorende laathof in een schepenbank is opgegaan. Deze transformatie zou dan moeten zijn afgesloten vóór de overgang van Heugem naar de heer van Gronsveld, dus vóór 1363. Mogelijk hebben tot die hof ook de later als keurmedig bekend staande huizen behoord. De onregelmatige verspreiding daarvan over de dorpskern kan wijzen op een zeer oude structuur, duidelijk afwijkend van de min of meer 
planmatige uitleg die we in Gronsveld en Eckelrade aantreffen. In ieder geval is het onaannemelijk dat deze keurmeden zijn terug te voeren op oud bezit van de heren van Gronsveld, aangezien in het dorp Heugem en gebied direct daaromheen geen spoor van oud Gronsvelds bezit valt te bekennen. Op de juridische banden tussen Heugem en Honthem wordt hierna bij de bespreking van Honthem nader ingegaan.

\subsection{Honthem}

\subsubsection{Geografisch beeld en grenzen}

Geografisch heeft Honthem ongeveer de vorm van een vierkant. De kaart van 1754 laat zien dat de bebouwing in die tijd bestond uit huiskavels met weiland en boomgaarden langs de Honthemer Dorpsstraat en de Limburgerstraat. In een krans daaromheen lagen de velden met akkerland. Bij de verkaveling bevonden zich grotere blokken, maar overheersten toch kleine tot zeer kleine percelen. De velden werden doorsneden door enkele voetpaden en veldwegen, die uitkwamen op de twee doorgaande straten, maar desondanks grensden veel kavels niet direct aan de openbare weg.

Honthem was met Eckelrade verbonden via een smalle doorgang langs de Bijbank. Het gebied grensde aan de westzijde aan de heerlijkheid Cadier (Land van Daelhem), aan de noordkant aan de heerlijkheid Heer (Bank van Sint-Servaas) en aan de zuidzijde aan Breust en Eijsden, meer in het bijzonder het gehucht Bruisterbosch. Deze buren zijn bij de andere delen van het Gronsvelds territoir al besproken. Ten oosten van Honthem lag het gebied van de heerlijkheid Margraten. De grens liep hier van noord naar zuid langs een door het veld getrokken rechte lijn vanaf de weg van Cadier naar Margraten tot op de Broensheimstraat. Na kruising daarvan zette deze scheiding zich verder zuidwaarts voort via de Kattenstraat, om ten slotte te eindigen op een splitsing met de Limburgerstraat, waar ook de limieten van Breust/Eijsden en Margraten bij elkaar kwamen.

Van alle grenzen van Honthem volgde alleen die met Bruisterbosch een natuurlijk tracé langs de Grub. De overige maken een kunstmatige indruk. Het meest duidelijke voorbeeld daarvan levert toch de oostelijke grens met Margraten. De andere limieten volgden het tracé van bestaande wegen.

Margraten, de oostelijke buur van Honthem, vormde oorspronkelijk samen met Gulpen het ressort van één schepenbank. Aangenomen wordt dat het gebied in de elfde eeuw deel uitmaakte van het kernbezit van de heren van Saffenberg, de oudste bekende heren van het Land van Rode. Door het huwelijk in 1136 van Mathilde van Saffenberg met Hendrik II van Limburg verwierven de hertogen van Limburg het Land van Rode en werd het Land van Rode ook betiteld als 's-Hertogenrade. Na de slag bij Worringen in 1288 viel het Land van Rode als onderdeel van de 'Limburgse erfenis' in handen van de hertog van Brabant en verwierf deze het landsheerlijk gezag over dit gebied. De Brabantse soevereiniteit over Margraten is blijven bestaan tot aan de Franse Tijd, met dien verstande dat na het Partagetractaat van 1661 de rol van hertog werd overgenomen door de StatenGeneraal en Margraten deel uitmaakte van het Staatse Land van 's-Hertogenrade. 
Binnen Gulpen-Margraten lag aanvankelijk ook nog een rijksonmiddellijke heerlijkheid met hoge en lage jurisdictie, toebehorend aan het Onze-Lieve-Vrouwekapittel van Aken. In 1559 verpandde Philips II als hertog van Brabant de hoge en lage jurisdictie over Margraten als een zelfstandige heerlijkheid aan de heer van Neubourg en werd voor Margraten een eigen schepenbank opgericht. ${ }^{607}$

\subsubsection{Ontwikekeling}

Op de kaart van 1754 ontbreken in Honthem zowel gronden in volle eigendom van de landsheer als lenen. Dit vormt een groot verschil met Eckelrade, waar lenen juist wel een overheersende plaats innemen. Daarentegen leveren de keurmeden een duidelijke parallel met Eckelrade. Volgens de leggers uit de achttiende eeuw lagen er elf, meestal bestaande uit een huis met omliggend erf. Sommige waren in afzonderliike kavels verdeeld, met één der gerechtigden als 'ophelder', op wiens naam het goed geregistreerd stond. Vijf keurmedige goederen lagen als een nagenoeg gesloten blok langs de noordkant van de Honthemer Dorpsstraat (tegenwoordig Onderstraat), beginnend ter hoogte van de splitsing van de Limburgerstraat, Groenstraat en Slekkesteeg.

Binnen de eerste keurmede, die in de achttiende eeuw verdeeld was tussen Gillis Coymans en de dominicanen en kruisheren van Maastricht, stond een grote hoeve, genaamd Honthemerhof. Aan de overkant daarvan, op de hoek van de Limburgerstraat en Dorpsstraat, lag een onbebouwd perceel, dat de benaming 'De Schepenbank' droeg. Een tweede blok van drie keurmeden lag aan de zuidzijde van de Honthemer Dorpsstraat en Broensheimstraat, te beginnen bij de kruising met de Hinnensteeg en eindigend vlak voor de kruising met de Kattesteeg. Het laatste blok, in de vorm van driehoek, bestond uit slechts één keurmede en werd begrensd door de Hinnensteeg, de Limburgerstraat en de Bouwstraat (op de kaart van 1754 aangeduid als Eckelraederweg).

Honthem moet, evenals de andere dorpen op het plateau, zijn ontstaan uit ontginning. Wanneer we als referentiepunten nemen de stichting van het aangrenzende Bruisterbosch in 1157 en de verzelfstandiging van de parochie Cadier in 1266, dan ligt de tijd waarin dit gebeurde waarschijnlijk tussen 1150 en 1250. Die ontginning moet vooral hebben plaatsgevonden vanuit Heugem en Cadier; met die twee plaatsen bestonden kerkelijke of juridische banden. Misschien mogen we zelfs denken aan verwantschap tussen de naam Heugem (in bronnen uit de twaalfde/begin dertiende eeuw aangeduid als 'Hoin', 'Hoyn' en 'Hoiens') en Honthem. Dat zou een parallel opleveren met Breust, waar de nieuwe stichting Sint-Geertruid ook werd aangeduid als Breust op de Berg.

Uit de latere verkaveling van de grond kunnen we opmaken dat de uitgifte van hoeven tegen het recht van keurmede voor de ontwikkeling van de nederzetting van cruciale betekenis is geweest. De verdeling daarvan over de nederzetting wijst op een min of meer planmatige aanpak aan het begin, zoals we die ook kennen van Eckelrade. Een grote vraag blijft of we deze keurmeden in verband mogen brengen met oorspronkelijk domaniaal goed of een laathof van de heren van Gronsveld of van iemand anders. Daar is in ieder

${ }^{607} \mathrm{Zie}$ over de bestuurlijke en rechterlijke organisatie van Gulpen-Margraten: Janssen de Limpens, Recbtsbronnen Limburg en Overmaze, CXXXIX-CXLVI. 
geval geen spoor van terug te vinden. Verder wijst de verkaveling van de percelen op een ontginning die vooral kleinschalig lijkt te zijn aangepakt.

Het blijft onduidelijk wanneer de heren van Gronsveld jurisdictie over Honthem hebben verworven. We nemen aan dat dit in de veertiende eeuw zijn beslag moet hebben gekregen. Denkbaar is een samenhang met de overgang van de jurisdictie over Heugem in 1363, maar concrete aanwijzingen ontbreken. Opmerkelijk in dit verband is het ontbreken van Honthem in de boedelscheiding tussen Hendrik van Gronsveld en zijn zwager en schoonzoon Christiaan van Ringberg uit 1396, omdat Gronsveld, Heugem, Eckelrade en Slenaken daarin achter elkaar worden opgesomd als een soort kernbezit van de heren van Gronsveld.

Voor het minuscule Honthem bestond een aparte schepenbank met hoge en lage jurisdictie, maar de vroegst gevonden vermelding dateert pas uit 1512.608 Mogelijk levert nader onderzoek nog een enkele oudere oorkonde op, maar een ouderdom die verder teruggaat dan de vijftiende eeuw lijkt onwaarschijnlijk. Het ontstaan van de schepenbank blijft daarmee duister. Mogelijk zou deze bank een afscheiding van die van Heugem kunnen zijn, maar ook denkbaar is een ontwikkeling vanuit een plaatselijke laathof. ${ }^{609}$

Het voorgaande overzicht maakt duidelijk dat Honthem lag op een 'kruispunt' van de heerlijkheden Gronsveld, Breust/Eijsden, Cadier, Heer en Gulpen/Margraten en de Valkenburgse lenen Blankenberg onder Cadier en de Bijbank. Het lijkt alsof de expansie uit verschillende richtingen vanaf de randen van het plateau hier bij elkaar kwam. Tegelijkertijd maakt Honthem niet de indruk een afsplitsing van één van deze territoria te zijn. Het woord 'kruispunt' is overigens niet alleen van toepassing op invloedsferen, maar ook op belangrijke doorgaande handelswegen zoals de Valkenburgerweg en de Limburgerstraat, die hier bij elkaar kwamen. De directe toegang daartoe vanuit Gronsveld en het Maasdal liep via Eckelrade. Dit alles betekent dat Honthem als vooruitgeschoven post strategisch belangrijk moet zijn geweest voor de heren van Gronsveld vanwege de aansluiting op belangrijke handelswegen.

De sterk verbrokkelde jurisdictie binnen een dergelijk klein gebied kan een gevolg zijn van het feit dat de ontginningen niet systematisch verliepen (Breust en Eijsden zijn daar een sprekend voorbeeld van).

Het is daarnaast denkbaar, hoewel daar geen concrete aanwijzingen voor bestaan, dat Honthem een rol heeft gespeeld bij de Valkenburgse expansieplannen in de richting van het Maasdal. Het gehucht ligt immers ingeklemd tussen de twee grote Valkenburgse lenen Blankenberg in Cadier en de Bijbank en het grensde aan Bruisterbosch. Het is bekend dat Walram de Rossige van Valkenburg rechten deed gelden op Breust. In de jaren 1296-1297

${ }^{608}$ RHCL, Klooster kruisheren Maastricht, inv. nr. 708, vonnis van de schepenen van Honthem.

609 Mogelijk moet een vergelijking worden getrokken met de situatie in Oost. De heerlijkheid Oost bestond al in de veertiende eeuw, maar de jurisdictie over de grond werd daar door verschillende laatbanken uitgeoefend. Eerst in $1608 \mathrm{kreeg}$ Oost een eigen schepenbank. Indien men behoefte had aan de tussenkomst van schepenen, werd een beroep gedaan op een naburige bank, terwijl de incidentele gevallen van hoge jurisdictie werden afgedaan vanuit's-Gravenvoeren. 
werd hij echter door de prins-bisschop van Luik gedwongen van deze aanspraken af te zien. ${ }^{610}$ Daarnaast was ook Heugem in het begin van de dertiende eeuw Valkenburgs bezit, zodat in principe ook via die route de weg naar het Maasdal open lag.

\subsection{Het Valkenburgse leen De Bijbank}

Anders dan het woord op het eerst gezicht doet vermoeden, heeft de naam Bijbank geen betrekking op een instelling, maar op een gebied ter grootte van 56 bunder ten zuidoosten van Eckelrade, dat geografisch als een scherpe driehoek stak in het gebied van de aangrenzende heerlijkheden Breust en Eijsden. Enkele huizen aan de zuidzijde van de Groenstraat en de hof te Eckelrade, later Beusdaelshof genoemd, langs de weg van Eckelrade naar Bruisterbosch, vormden de enige bebouwing. Het gebied was een leen, dat door de heer van Gronsveld werd verheven voor het leenhof van Valkenburg en dien ten gevolge een bijzondere juridische status had, wat regelmatig voor juridische complicaties zorgde. De 'Specificatie' van het graafschap Gronsveld uit omstreeks 1650 beschrijft de Bijbank als

binnen het circuyt van Eckelrad eene quantiteyt van erve welcke erven worden genaempt die Bijbanck, wesende een lheen des hoffs van Valckenborch, ende contribueert deselve Bijbanck aen den Coninclijken Maiesteit van Hispanien met d'andere goederen geleghen ende resorteerende onder denselven lheenhoff van Valckenborch.

Wolfgang Zollner, de grafelijke commissaris van Gronsveld, gebruikte in 1780 voor het Staats leenhof van Valkenburg de volgende aanduiding 'de halve heerlijkheijd Ekelraede, genoemt de Ekelraeder Bijbank'... bestaande in de... 'jurisdictie van ontrent 56 bonder'... aan de oost-, zuid- en westzijde omsloten door de heerlijkheden Breust en Eijsden en aan de noordzijde grenzend aan het rijksgraafschap Gronsveld. ${ }^{611}$

Verheffingen van de Bijbank onder de aanduiding 'Eckelrode half' of 'halve heerlijkheid Eckelrade' als groot leen van Valkenburg gaan terug tot 1386. De eerste leenopdracht staat op naam van Hendrik II, heer van Gronsveld. ${ }^{612}$ Maar misschien mogen we de Valkenburgse leenrechten nog 125 jaar vroeger dateren. Toen in 1261 Reinerus van Gronsveld en zijn vrouw Beatrix hun hof te Eckelrade aan de abdij Hocht verkochten, deden zij dit immers met uitdrukkelijke toestemming van hertog Walram van Limburg als hoogste leenheer en van Walram van Monschau, heer van Valkenburg, als onderleenman. ${ }^{613}$ Hiervoor (Hoofdstuk 2.1.3) werd al aangegeven dat er redenen zijn om de oorspronkelijke ligging van deze hof in de directe nabijheid van de Bijbank te plaatsen.

${ }^{610}$ Van Hall, Eijsden, een vrijheid, 47-48.

${ }^{611}$ RHCL, Landen van Overmaze, inv. nr. 3996; zie ook Habets, 'Leenen Valkenburg', in: PSHAL 21 (1884) 260.

612 Habets, 'Leenen Valkenburg', in: PSHAL 21 (1884) 259-260.

${ }^{613}$ Hartmann, Reconstructie landschap, 215 en in het bijzonder noot 499. 
Wanneer de Bijbank wordt aangeduid als 'halve heerlijkheid Eckelrade', dan rijst de vraag of het dorp Eckelrade de andere helft was of dat er zelfs een ongedeelde heerlijkheid Eckelrade heeft bestaan. Echter, voor zover de bronnen terug reiken, tot de dertiende eeuw, vormden Gronsveld en Eckelrade altijd één jurisdictie, met één schepenbank en de heer van Gronsveld als jurisdictieheer. ${ }^{614}$ Waarschijnlijk moet het begrip 'halve heerlijkheid' min of meer letterlijk worden geïnterpreteerd in overeenstemming met de formulering 'Eckelrode half in de belening van 1386, namelijk als heerlijke rechten over de helft van het dorp Eckelrade, meer in het bijzonder het vrijwel onbewoonde gedeelte, bekend onder de naam Bijbank. En de jurisdictie over dit gebied week inderdaad af van die van het 'Gronsveldse Eckelrade'.

Als aanvulling op de bijzondere status van de Bijbank moet worden vermeld dat binnen dat gebied nog een afzonderlijk zogenoemd groot leen van Valkenburg, de Beusdaelshof, lag. Volgens een specificatie uit het einde van de achttiende eeuw, opgemaakt voor het Staats leenhof van Valkenburg, omvatte de Beusdaelshof 28 bunder, verdeeld over negen bunder in de Bijbank, zes onder Eckelrade, twee onder Eijsden en elf onder Breust. Het eigenlijke leen bestond uit twaalf bunder land. De eerste leenverheffing daarvan is bekend uit 1381 en staat op naam van Alryck van Eckelrode ${ }^{615}$ Samenvattend kunnen we concluderen dat de Bijbank bestond uit twee grote Valkenburgse lenen, te weten de heerlijke rechten over 56 bunder land en voorts landerijen (met een hof) ter grootte van twaalf bunder. Hierna zal blijken dat dit onderscheid ook betekenis had voor de jurisdictie.

De juridische situatie binnen de Bijbank zorgde tot het einde van het Ancien Régime voor complicaties. Een uiteenzetting daarover geeft de Gronsveldse secretaris en leengriffier Jacobus Berchmans in een brief van 3 januari 1755 aan zijn oom, drossaard Henricus Lebens. Aanleiding vormde een gerechtelijke procedure van Lebens tegen zekere Peter Wouters uit de Bijbank. ${ }^{616}$ Er werd vermoed dat hij en zijn vrouw eind 1754 betrokken waren bij de dood van hun inwonende tante Geertruid Wouters. Het betrof een geestelijk verwarde vrouw, waarvan het gerucht ging dat zij onder verdachte omstandigheden en niet voorzien van de laatste sacramenten was gestorven. Grafelijk vertegenwoordiger Prummer liet beslag leggen op het lichaam, waarna artsen inderdaad verwondingen aan het lichaam constateerden. Drossaard en 'fiscus' (procureur-fiscaal) Henricus Lebens startte vervolgens bij de schepenbank Gronsveld een gerechtelijk vooronderzoek. Peter Wouters werd gedurende vier maanden op het kasteel van Gronsveld gevangen gezet en zijn vrouw

${ }^{614}$ Bij een boedelscheiding uit 1396 worden aan Hendrik II van Gronsveld toebedeeld 'die gantze herlicheiden, gerichten, erve ind gude vann Gronssfeldt, van Eckelrode, van Sent Mertensvoeren, van Sledenake ind van Hoegem'. Hoewel daarmee de suggestie wordt gewekt dat er toen een heerlijkheid Eckelrade bestond, is deze vermelding in een opsomming als bewijs erg mager. Bovendien kan het begrip 'heerlijkheid Eckelrade' ook nog slaan op de Bijbank.

615 RHCL, Graafschap Gronsveld, inv. nr. 148; RHCL, Landen van Overmaze, inv. nr. 3984; zie ook Habets, 'Leenen Valkenburg', in: PSHAL 22 (1885) 284-286. Het goed wordt daar genoemd 'het leen tot Eckelrade', bestaande uit 12 bunder land. De laatste verheffing in Valkenburg geschiedde in 1760 door de graaf van Hoensbroek, heer van Beusdael en Sippenaken. Vandaar ook de naam Beusdaalshof. In de toelichting verwart Habets dit leen met Hemersbach. Hij heeft zich kennelijk ook zelf onzeker gevoeld getuige de opmerking 'of deze aanteekening betrekking heeft op ons leen, weten wij niet'.

616 RHCL, Graafschap Gronsveld, inv. nr. 295. 
kreeg op bevel van Lebens huisarrest met bewaking van enkele buren. Het gerecht in Gronsveld begon vervolgens met het horen van een reeks deskundigen en getuigen.

Zowel over die getuigenissen als de oproepen voor bewakingsdiensten ontstonden problemen. Eén van de getuigen was Maria Hermans, een buurvrouw van Wouters. Er werd verwacht dat zij interessante informatie kon verschaffen, maar de vrouw maakte bezwaar tegen dagvaarding door het gerecht van Gronsveld om te komen getuigen.Volgens Berchmans woonde zij in de Bijbank 'op de 12 boenderen sorteerende onder het leenhoff van Valkenborg, welke 12 boenderen door de possesseurs derselve tot Valkenborg separaat voor een groot leen moeten gereleveert worden'. Waarschijnlijk bedoelt Berchmans hier grond behorend tot de Beusdaelshof. Deze grond had als Valkenburgs leen een andere juridische status dan de rest van de Bijbank. Dagvaardingen of executies van vonnissen die betrekking hadden op deze twaalf bunder groot leen van Valkenburg, moesten worden uitgevoerd door de bode van het leenhof van Valkenburg, met andere woorden hier had het gerecht van Gronsveld geen zeggenschap.

Berchmans refereert in zijn brief aan een geval omstreeks 1597, toen aan Valkenburger zijde was geprobeerd aan de Gronsveldse jurisdictie over de Bijbank te tornen. De Raad van Brabant in Brussel had dit op 21 november 1599 voor onrechtmatig verklaard, maar omdat het geschil voortduurde, gelastte de Raad op verzoek van de graaf van Gronsveld een conferentie met gedeputeerden van het Land van Valkenburg. De uitkomst daarvan was dat de Gronsveldse jurisdictie werd bevestigd. Naderhand deed zich nog een keer een dergelijk conflict voor met het inmiddels Staatse leenhof van Valkenburg, maar ook toen werd de Gronsveldse jurisdictie over de Bijbank bevestigd, met uitzondering van de twaalf bunder van de Beusdaelshof. De conclusie van Berchmans was duidelijk: Maria Hermans was, als verblijvend op de twaalf bunder, Valkenburgs onderdaan en moest derhalve overeenkomstig de daarvoor geldende regels als 'buitenlandse' worden opgeroepen.

Berchmans beschikte ook over een brief van de Valkenburgse landdrost Van Panhuys, waarin deze bezwaar maakte tegen de waak- en patrouillediensten die aan de bewoners van de Bijbank waren opgelegd. Ook daarover was Berchmans duidelijk. Opdrachten voor dit soort diensten voor bewoners van de Bijbank vielen onder de bevoegdheid van de schepenbank Gronsveld, met uitzondering van personen wonend op de twaalf bunder groot leen.

De zaak Wouters lag aan Gronsveldse zijde uiterst gevoelig. Het betrof een opzienbarend delict en bovendien speelde in dezelfde tijd in Gronsveld een spraakmakend proces tegen vier mannen die van doodslag werden beschuldigd. De grafelijke vertegenwoordiger Prummer, die zich verder inhoudelijk niet met de zaak bemoeide, waren vooral de juridische onduidelijkheden in de Bijbank een doorn in het oog. In een brief van 27 januari 1755 aan de graaf over de arrestatie van Wouters en het verloop van de procedure, hoopte hij:

bij dit proces een gelegenheid te vinden om klaarheid te brengen in de al lang aanslepende problemen wegens de jurisdictie in de Bijbank, waar de Hollanders zich teveel aanmatigen, omdat nu zelfs de inwoners van de Bijbank weigeren te komen na een dagvaarding om een getuigenverklaring af te leggen. Maar ik ben wel van plan hen wegens weerspannigheid met 
arrest op hun persoon te vervolgen; ik geloof daartoe ook bevoegd te zijn en denk dat ik dit niet langer door de vingers mag zien. ${ }^{617}$

Ook drossaard en fiscus (procureur-fiscaal) Henricus Lebens was zich van mogelijke juridische incidenten goed bewust. Dat blijkt uit een slip of the pen in het omvangrijke dossier van de zaak Wouters. In alle stukken betitelt hij zich als 'drossaard en fiscus van het vrije rijksgraafschap Gronsveld'. Alleen één keer gebruikt hij de formulering 'drossard en fiscus deeser graaffschappe en der voorss. Bijbanck'.

Uiteindelijk liep de hele kwestie met een sisser af. Alle getuigen kwamen opdagen en legden hun verklaringen af. Ook voor Wouters eindigde de zaak gunstig. De schepenbank oordeelde dat de drossaard en fiscus niet ontvankelijk was in zijn eis en Wouters werd van rechtsvervolging ontslagen.

Niet alleen de jurisdictie lag gecompliceerd, ook de fiscale verhoudingen waren ingewikkeld. Volgens de 'Specificatie' van het graafschap circa 1650 werd de opbrengst van de schatting van de gronden van de Bijbank afgedragen aan 'den Coninclijken Maiesteit van Hispanien', dat wil zeggen aan de koning in diens hoedanigheid van hertog van Brabant en heer van Valkenburg. Hartmann vermeldt dat in 1619 de schout van Eijsden bij de inventarisatie van landerijen ten behoeve van schatting de Bijbank 'pro memorie' aanbracht onder Breust en Eijsden. ${ }^{618}$ Ook Prummer bevestigde de afdracht van schatting aan Valkenburg nog eens in rapporten uit 1761 en 1768 . Verder betaalden de grondeigenaren niet mee aan de herendiensten en kosten van inkwartieringen in Gronsveld.619 De geschetste verhoudingen zijn ook terug te vinden in de archiefoverlevering bij het Staatse Land van Valkenburg. In de matrikels of repartities van

${ }^{617}$ beÿ disen process gelegenheit zufündten die schon langg herumbgezochent difficultet weegen der jurisdiction in der Bijbanck, von welcher die Holländer zu vill zuaignen möchten, villeicht ins clare zu bringen, indeme die inwohner gemelter Bijbanck bereiths ursach gegeben da s̈̈e auf disseithige citationen ad deponendum zu erscheinen verwaigert, welche unterdessen sub poena ulteroris renitentiae mit personel arrest zuverfolgen vorhabens bin, gleich ich glaube, das man darzue wohl befuegt ist und nicht noch länger durch die finger sehen oder schlaffen darff.

${ }^{618}$ Hartmann, Reconstructie landschap, 76.

${ }^{619}$ TJ, inv. nr. M 73, fol. 566. rapport over cijnzen van Prummer aan M.E. von Toerring-Jettenbach van 25 augustus 1761: 'Bijbanck...Beÿpanckh oder Beÿfang... unter die graffschafts-jurisdiction gehörret..., iedoch beÿ dem ...lehen hof zu Falckhenburg als ein lehen empfangen werdten mues; auch dahin steurbahr ist';TJ, inv. nr. M 73, fol. 548, rapport over de rekeningen van Prummer aan M.E. zuToerring Jettenbach van 29 juni 1768: 'hierzue kommet auch noch ein theill der meridional-seithen des dorffs Eckelraede, so einen district van et[wa] 50 bonderen an häuseren, gärtten, veldteren etc., ausmachet und die Bijbanck...genennet würdt. Dise Bijbanck muess von dem nunmehro, seith der partage der sogenannten Landten Ÿber die Maas dennen General Staatten zuegehörrigen lehenhof von Valckenburg zu lehen empfangen; auch die schätzungen oder steuren dahin, und nit unter Gronsfeldt entrichtet wertdten, wie dan die einwohner derselben mit dennen ÿbrigen graffschaffts unterthannen niemahlen zur scharwerch, einquartierungen onder in ainig andere derleÿ onera gezohen, sonsten aber zaig der gerichtsbüecheren, auch renntambts-, einnambs-, lehen-registeren etc. (in welchen ich sÿe iedoch nunmehro separiert) alzeit mit und unter dennen von Gronsfeldt und der Eckelraeder septentrional seithen vermischet geloffen und gehalten wordten seint.' 
de beden uit de zeventiende en achttiende eeuw wordt de (heerlijkheid) Eckelrade steevast opgevoerd onder de dorpen en lenen van Valkenburg, die in de bede bijdragen. ${ }^{620}$

Hoewel de hele Bijbank, inclusief de twaalf bunder groot leen van de Beusdaelshof, aan de schatting ten behoeve van het Land van Valkenburg meebetaalde, werd de feitelijke inning van het geld georganiseerd vanuit Gronsveld. Dat mag althans worden opgemaakt uit een oproep gedateerd 7 december 1757 en afkomstig van de plaatsvervangend secretaris van Gronsveld. ${ }^{221}$ Alle geërfden konden op 15 december 1757 aanwezig zijn bij een vergadering van 'wethouderen der vrije Rijcxe Graefschappe Gronsfeldt en der Eckelraeder Bijbanck' ten huize van schepen Joannes Lemmens, gelegen in Eckelrade in de Bijbanck. Geagendeerd stond de rekening van Nicolas Gelens over de 'repartitie' van het afgelopen jaar. Voorts werd 'geprocedeert tot eene nieuwe omlaege over het poinct van $\mathrm{Haar} \mathrm{Ho}(\mathrm{og}) \mathrm{Mo}(g e n d e n)$ beede en andere landtslasten'. Hieruit blijkt duidelijk dat er georganiseerd vanuit Gronsveld werd vergaderd over een nieuwe belastingronde ten behoeve van de Hoogmogende Heren Staten Generaal als heren van Valkenburg. Aangenomen mag worden dat de collecteur van de belastingen deze ook bij de ontvanger van het Land van Valkenburg afdroeg. ${ }^{.22}$

De Gronsveldse bemoeienis met de inning van de schatting in de Bijbank komt zijdelings ook ter sprake in de eerder genoemde brief van secretaris Berchmans in de kwestie Wouters. Volgens Berchmans diende een procedure tot uitwinning bij wanbetaling te worden gevoerd voor de schepenen van Gronsveld, tenzij het leengoed van de Beusdaelshof betrof, want daar hadden alleen functionarissen van het leenhof van Valkenburg jurisdictie.

Interessant zijn verder de verschillen in tarieven. Een specificatie van de Beusdaelshof geeft aan dat tegen het einde van de achttiende eeuw de gronden in de Bijbank het tarief volgden van de 'grote Hollandse schat' van Eijsden met acht tot negen gulden per bunder. ${ }^{623}$ Er bestonden overigens grote afwijkingen in de waardering van de grond. In de Bijbank, Eckelrade en Eijsden werd die getaxeerd op vijfhonderd gulden per bunder, terwijl in het aangrenzende Breust het dubbele werd aangehouden. Zelfs die eerste waardering was overigens aan de hoge kant, aangezien het land door gebrek aan bemesting in het derde jaar braak lag. Ook voor de cijnzen van de heren van Gronsveld binnen de Bijbank golden afwijkende tarieven. In een rapport schrijft Prummer dat in het midden van de achttiende eeuw in de Bijbank slechts 51/4 oort per bunder werd geheven, tegen $10 \frac{1}{2}$ oort in Gronsveld en Eckelrade. ${ }^{.24}$

Voor de volledigheid dient hier nog te worden opgemerkt dat de schatting voor de Valkenburgse bede in de Bijbank betrekking had op de 'reële' belastingen, dat wil zeggen de belasting op grond. Voor de 'personele omlaege', de belasting op paarden en rundvee,

${ }^{620}$ RHCL, Landen van Overmaze, inv. nr. 3881.

${ }^{621}$ RHCL, Graafschap Gronsveld, inv. nr. 221.

${ }^{622}$ Tevergeefs is gezocht naar kwitanties daarvan in het archief van de ontvangers van het Land van Valkenburg. De staat van ordening laat echter geen diepgaand onderzoek toe. Bovendien is het onduidelijk op welke wijze de afdrachten van de afzonderlijke dorpen en heerlijkheden van het Land van Valkenburg boekhoudkundig werden verantwoord.

${ }^{623}$ RHCL, Graafschap Gronsveld, inv. nr. 148.

${ }^{624}$ TJ, inv. nr. M 73, fol. 566: 'Bijfanck... 5 1/4 oort; in dem ...gebiett dess dorffs Heugem 7 orth und unter... gebiett dess dorffs Hontem 3 stüber oder 12 oort'. 
werden de weinige bewoners van de Bijbank aangeslagen samen met de rest van Eckelrade.

Een laatste voorbeeld van de ingewikkelde verhoudingen in de Bijbank betreft een geval van afkondiging van wetgeving. Het gaat om een te Maastricht gedrukte ordonnantie van het leenhof van Valkenburg, Staatse Partage, gegeven ter uitvoering van resoluties van de Raad van Brabant van 21 februari en 20 juni 1780 (zie bijlage 22). ${ }^{625}$ De tekst heeft een nogal ingewikkelde opbouw, maar de strekking was duidelijk: de bezitters van StaatsValkenburgse leengoederen kregen opdracht hun leenbezittingen bij het leenhof te komen aangeven.

Het enige voor Gronsveld bestemde exemplaar bevindt zich als los blad in het leenboek van Gronsveld, onderdeel van de archieven van de graven van Toerring Jettenbach. Dat betekent dat het blad min of meer toevallig, samen met het leenregister, in 1792 door commissaris Wolfgang Zollner op zijn vlucht naar München is meegenomen. Deze context is niet onbelangrijk, omdat we daaruit mogen concluderen dat het origineel nooit officieel in München is aangeboden. Een bevestiging daarvan lijkt ook de correspondentie over deze ordonnantie te geven.

Volgens een aantekening op de achterzijde van de gedrukte tekst werd de ordonnantie op 13 augustus 1780 door Zollner bij de schepenbank van Gronsveld ingeleverd. Voor Gronsveld had deze verordening feitelijk alleen betrekking op het leen van de Bijbank als zodanig (dat door de graaf in Valkenburg werd verheven) en de Valkenburgse lenen binnen de Bijbank. Zollner schreef op 21 augustus 1780 aan graaf August Joseph dat de 'Staten Generaal' (in dit verband een ongelukkige benaming voor de gecompliceerde aanduiding van de instantie die de verordening uitvaardigde) hadden verordonneerd dat landsheerlijke leenmannen in de Landen van Overmaze hun lenen moesten aanmelden bij de secretarissen van verschillende leenhoven. Een exemplaar van deze ordonnantie stuurde hij echter niet mee. Omdat ook de graaf vanwege de Bijbank Valkenburgs leenman was, wilde Zollner dit bezit bij het leenhof van Valkenburg aangeven. Op 24 augustus 1780 besloten drossaard en schepenen 'der vrye Rijxe graeffschappe Gronsfeldt en Eckelrader Bijbanck' deze ordonnantie in de Bijbank te laten afkondigen. Publicatie vond plaats door de gerechtsbode op zondag 27 augustus 1780 'opt huys off muyr van Lendert Spits gelegen in de Bijbanck tot Eckelrade als sijnde d'ordinaire affixie plaetse'.

Uit de omzichtige manier van afkondiging komt de onduidelijke staatkundige situatie van de Bijbank tot uitdrukking. Afkondiging van buitenlandse wetgeving kon immers allerlei vragen en problemen oproepen. Zollner lijkt zich daarvan in zijn correspondentie met de graaf heel goed bewust te zijn geweest. Hij spreekt alleen over de evidente, maar probleemloze, verplichting van de graaf om het leen van de Bijbank in Valkenburg aan te melden, maar zwijgt over de afkondiging van de verordening als zodanig.

Op grond van deze voorbeelden valt op de vraag naar de staatkundige situatie van de Bijbank slechts een genuanceerd antwoord te geven. Beschouwt men het recht op heffing van schatting op grond als een belangrijk criterium voor hoogheidsrechten, dan kan de

${ }^{625}$ BHIC, Archief Raad van Brabant, inv. nr. 20, fol. 511-512, resolutie nr. 3529 van 20 juni 1780. 
Bijbank worden gerekend tot het territorium van het Land van Valkenburg. Over die Bijbank of 'halve heerlijkheid Eckelrade' oefende de heer van Gronsveld, met uitzondering van de twaalf bunder van de Beusdaelshof, jurisdictie uit, maar dat was op zich geen ongebruikelijke situatie. Binnen en buiten het Land van Valkenburg bestonden immers meer leenroerige heerlijkheden, die toch tot het territorium van Valkenburg werden gerekend, althans bijdroegen in de landsheerlijke bede.

Anderzijds is het vanuit Gronsvelds perspectief begrijpelijk dat de Bijbank als onderdeel van het graafschap werd gezien. De heer van Gronsveld oefende er jursidictie uit, er golden Gronsveldse wetten, de schepenen van Gronsveld spraken er recht, grond werd overgedargen ten overstaan van de schepenen van Gronsveld en de belasting werd vanuit Gronsveld geïnd. Feitelijk betekende dit een volledige oriëntatie van de Bijbank op Gronsveld. Het is dan ook niet vreemd dat bij de nieuwe vastlegging van gemeentegrenzen in de Franse Tijd de Bijbank zonder veel discussie bij de 'mairie' Gronsveld werd gevoegd.

\subsection{Slenaken}

\subsubsection{Naam en geografisch beeld}

Het dorp Slenaken bestaat uit de gelijknamige dorpskern en de gehuchten Beutenaken, Heyenrath, Hoogcruts en Schilberg. De vroegste vermelding van de naam komt voor als Sledenake in 1253. Etymologisch zou het woord samenhangen met 'sleit', een sterke helling, wat ook past bij de ligging in het dal van de Gulp. ${ }^{626}$ Het is een typisch voorbeeld van een op -enaken eindigende naam, die veel voorkomt in de nabijheid van de RomaansGermaanse taalgrens. Daarbij krijgt het eerste deel van het woord, dat van Germaanse oorsprong is, een Romaanstalige uitgang op -iniacas, die ten slotte weer in gegermaniseerde vorm als -enaken verschijnt. Deze ontwikkeling wordt geplaatst in de vijfde of zesde eeuw. ${ }^{627}$ Het is onduidelijk of de oorsprong van Slenaken in die tijd ligt, maar men denkt aan een ontstaan in het begin van de middeleeuwen, vergelijkbaar met reeks vroege nederzettingen in het stroomgebied van de Geul en haar zijrivieren. ${ }^{628}$

De vroegste bebouwing van Slenaken lag in het rivierdal van de Gulp, waarbij waarschijnlijk aan enkele grote hoeven zoals de Broekhof en Hees, een hoge ouderdom moet worden toegekend. De gehuchten Heyenrath, Schilberg, Hoogcruts en het hoge deel van Beutenaken zijn ontginningen uit de latere middeleeuwen. Belangrijk voor de ontwikkeling van Hoogcruts was de stichting in 1495 van een klooster van reguliere kanunniken van het $\mathrm{H}$. Graf, precies op de grens met Noorbeek. Dit klooster werd voorafgegaan door een kapel, die hier vóór 1428 door buurtbewoners moet zijn gebouwd ter herinnering aan de legende dat op deze plaats een kruis tussen doornstruiken aan een

${ }^{626}$ Tummers, Romaans in namen, 27-28.

${ }^{627}$ Tummers, Romaans in namen, 23.

${ }^{628}$ Renes, Zuidlimburgse Cultuurlandschap, 49-50. 
herder verscheen. Allengs groeide het klooster uit tot de grootste grondbezitter ter plaatse en had uit dien hoofde ook grote invloed op het plaatselijk bestuur.

\subsubsection{Grenzen}

Slenaken grensde aan de noordzijde aan de bank Gulpen-Margraten, behorend tot het Land van 's-Hertogenrade. Ten westen lag oorspronkelijk het ressort van de schepenbank 's-Gravenvoeren (Land van Daelhem). Omstreeks 1364 werd Sint-Martens-Voeren als lage heerlijkheid daaruit losgemaakt (zie verder Hoofdstuk 2.9.2). Het aangrenzende Noorbeek vormde oorspronkelijk eveneens een deel van de bank van 's-Gravenvoeren. De rechtspraak over onroerend goed berustte in Noorbeek hoofdzakelijk bij een aantal plaatselijke laathoven, met als voornaamste die van het kapittel van Sint-Lambertus te Luik. Deze hof, die ook wel de naam 'bancke van Norbeck' voerde, evolueerde omstreeks 1600 tot een schepenbank met lage jurisdictie, waarbij het kapittel van Sint-Lambertus de heerlijke rechten verwierf.

Aan de zuidzijde grensde Slenaken aan Teuven, welk dorp behoorde tot de zogenoemde ban van Montzen of Folkerich, gebied van het hertogdom Limburg. Teuven vormde oorspronkelijk een grondheerlijkheid, leenroerig aan de hof van Del Beuck en was sinds de zeventiende eeuw een hoge heerlijkheid samen met Nurop en Sinnich. ${ }^{629}$

Ten oosten van Slenaken lag het gebied van de heerlijkheid, later het graafschap Wittem, in het bijzonder het ressort van de schepenbank Epen. ${ }^{630}$ De oorsprong van Wittem is niet geheel duidelijk, maar de heerlijkheid lijkt te zijn ontstaan door het samensmelten van oorspronkelijk afzonderlijke eenheden. Volgens een verklaring van de schepenen van Epen uit 1350 hield de heer van Wittem 'dat dorp ende gericht van Epen' in leen van Limburg, met uitzondering van acht leenmannen in het dorp, die de hertog van Brabant toebehoorden. In ieder geval hebben lang banden tussen Wittem en het hertogdom Limburg bestaan.

\subsubsection{Parochie 631}

Oorspronkelijk viel Slenaken onder de uitgestrekte parochie Sint-Martens-Voeren en stond in het dorp slechts een kapel toegewijd aan Sint Remigius. In Sint-Martens-Voeren deed zich de voor het platteland bijzondere situatie voor dat de parochie werd bestuurd door een klein kapittel. Dit bestond uit een deken, tevens pastoor van Sint-MartensVoeren en drie kanunniken, die de kapellen van respectievelijk Sint-Pieters-Voeren, Slenaken en Saint Jean Sart (Sint-Jans-Rode tot in de negentiende eeuw) bedienden. ${ }^{632}$ Men heeft verondersteld dat dit kapittel teruggaat tot de tijd dat de kerk van Sint-MartensVoeren kapel van de koningshof van Voeren was. De juistheid van die opvatting kunnen

${ }^{629}$ Buchet, Seigneurie Del Beuck, 18.

${ }^{630}$ Zie over Wittem: Mosmans, Heeren van Wittem en voor de navolgende gegevens in het bijzonder Janssen de Limpens, 'De territoriale ontwikkeling', 23-30 en Nève, Rijkskamergerecht, 511-516.

631 Zie voor algemene gegevens Simenon, Visitationes Hasbaniae, II, 672-673 alsmede I, 219-222 sub Forum S. Martini.

${ }^{632}$ Ceyssens, Bans de Dalhem, 158; Dumont, Les Communautés villageoises, 176-177. 
we hier in het midden laten, maar zeker gaat het hier om een kerkelijke structuur van een hoge ouderdom. Een met Sint-Martens-Voeren vergelijkbare situatie, maar dan zonder kapittel, treft men overigens ook aan in het aangrenzende 's-Gravenvoeren. Naast de hoofdkerk van 's-Gravenvoeren fungeerden daar de kerken van Mheer, Noorbeek, Aubel ${ }^{633}$ en mogelijk ook Warsage ${ }^{634}$ oorspronkelijk als hulpkapellen, die later de rechten van zelfstandige parochiekerken kregen. Mogelijk is de parochie 's-Gravenvoeren op haar beurt weer ontstaan als een afsplitsing van Sint-Martens-Voeren, ${ }^{635}$ wat op een 'oerparochie' zou kunnen wijzen.

De vroegste schriftelijke vermelding van een kapel te Slenaken dateert uit 1452, zodat we mogen denken aan een stichting uit het einde van de veertiende of het begin van de vijftiende eeuw. ${ }^{636}$ De tienden te Slenaken werden geheven door het kapittel van SintMartens-Voeren, dat ook de bouwlast van de kerk droeg. ${ }^{637}$ Maar wellicht hebben ook de naaste buren van het kerkgebouw, de bezitters van het goed Hees, in die bouw een rol gespeeld. ${ }^{638}$ De oorspronkelijke kapel, '50 voet lang en 30 breed' met een koor van '20 voet breed en 34 hoog', bood behalve aan het hoofdaltaar ook plaats aan twee zijaltaren, toegewijd aan respectievelijk Sint Anna en Onze Lieve Vrouw. ${ }^{639}$ Aan laatstgenoemd altaar was ook een beneficie verbonden met de verplichting van een wekelijkse mis. Aan het einde van de achttiende eeuw is het kerkgebouw nieuw en ook groter dan zijn middeleeuwse voorganger opgebouwd. ${ }^{640}$

Vanaf circa 1570 tot 1676 werd de rector van de kapel van Slenaken door het kapittel van Sint-Martens-Voeren gekozen uit de reguliere kanunniken van het klooster Hoogcruts. Langzaam groeide Slenaken toe naar parochiële zelfstandigheid. In $1636 \mathrm{kreeg}$ de kapel een doopvont, zodat de dorpsbewoners de lange weg met pasgeboren kinderen naar SintMartens-Voeren bespaard bleef. De aanwezigheid van enkele vroeg-zeventiende-eeuwse grafkruisen op het kerkhof bewijst dat er in die tijd ook in Slenaken werd begraven. Volledige onafhankelijkheid als parochie kreeg Slenaken echter pas in $1676 .{ }^{641}$

\subsubsection{Heerlijk goed, keurmeden en lenen}

\footnotetext{
633 Simenon, Visitationes Hasbaniae I-II, 23, 496, 540.

634 Dumont, Les Communautés villageoises, 178.

635 Dumont, Les Communautés villageoises, 175.

636 Maessen, 'Korte schets Slenaken', 19.

637 Maessen, 'Korte schets Slenaken', 31-32.

638 Zie Maessen, 'Korte schets Slenaken', 19, 21-22. De aartsdiakonale visitatieverslagen melden dat de bezitters van Hees als enige leken in de kerk werden begraven en ook bepaalde renten aan de kerk hadden geschonken, maar het stond niet vast dat zij bijzondere weldoeners van de kerk waren geweest: vgl. Simenon, Visitationes Hasbaniae, II, 673.

639 Maessen, 'Korte schets Slenaken', 19.

640 Maessen, 'Korte schets Slenaken', 31-32; Idem, 'Proces kerkbouw Slenaken', 58-60; De ontwerpen van de nieuwbouw uitvoerig beschreven en gedeeltelijk afgebeeld bij Van Agt, Monumenten ZuidLimburg/Vaals, 365-371.

${ }^{641}$ Maessen, 'Korte schets Slenaken', 20-21; zie ook Delahaye, Inventaris Hoog-Cruts, 7-8.
} 
Anders dan bij de overige dorpen binnen het graafschap Gronsveld kan in Slenaken door de gebrekkige overlevering van archiefmateriaal moeilijk onderzoek op basis van retrogressie worden verricht naar oorspronkelijk domaniaal goed. Twee zestiende-eeuwse memories met algemene overzichten van eigendommen van de heren van Gronsveld vermelden voor Slenaken 36 bunder bos, erfpachten voor in totaal 86 malder spelt en 38 malder haver, en cijnzen in de vorm van kippen en kapoenen. ${ }^{642}$ Een oppervlakkige analyse van de heerlijkheidrekeningen uit de zestiende en het begin van de zeventiende eeuw bevestigt dit beeld met de vermelding van inkomsten uit de opbrengsten van bossen, erfpachten, cijnzen, en heerlijke rechten. ${ }^{643} \mathrm{Er}$ lag geen grond die de heer voor eigen rekening liet bewerken of verpachtte. Andere bezittingen, zoals een aandeel in de Broekhof, maken de indruk een late verwerving te zijn. Opvallend, en in vergelijking met de andere Gronsveldse dorpen ook typisch voor Slenaken, is de hoge afdracht als cijns van de graansoort spelt, in waarde vergelijkbaar met de opbrengst van de tienden onder Gronsveld. Waarschijnlijk berust een deel van deze cijnzen op heerlijke rechten, maar het blijft moeilijk op basis daarvan conclusies te trekken over oorspronkelijk domaniaal bezit.

De overgeleverde administratie met betrekking tot de Gronsveldse lenen in Slenaken is zeer summier. Het belangrijkste leengoed was Hees, waarvan de hof lag naast de kerk. In aanzien is deze hof vergelijkbaar met Hamersbach in Eckelrade. De bezitters behoorden tot de lage adel of gedroegen zich althans zo. Die status, met gepretendeerde belastingvrijdom, heeft in de tweede helft van de zeventiende eeuw, toen de hof toebehoorde aan de familie Couven, gezorgd voor veel problemen met de inwoners van Slenaken.

Een (beschadigd) zeventiende-eeuws uittreksel uit een register van het Gronsveldse leenhof, beginnend in 1519, vermeldt Hees met elf bunder land en nog drie morgen later verkregen grond als een groot leen. ${ }^{644}$ De juridische situatie rond het goed moet echter al in de zestiende eeuw complex zijn geweest. Zo bezat leenman Jan van Hees nog een ander groot Gronsvelds leen, bestaande uit niet nader gespecificeerde landerijen, beemden en bos, evenals nog een klein leen. Bovendien rustte ingevolge een contract uit 1507 nog een rente van dertien malder rogge als klein Gronsvelds leen op de hof. Dit viel later niet meer te ontrafelen. Feitelijk was de situatie nog verwarder door vermenging met vreemde lenen. Volgens een 'rapport' uit 1620 hield jonker Lambrecht Couven in leen zeker 'huijs en hoff tot Slenaecken, Hees, met sijne bongaerden, weyden en bempden, meisten in eenen stuck groot sijnde ontrent vier bunder', gelegen bij de kerk, 'met noch diverse andere parthien....het welck goet meestendeil wordt gehouden voor een Gronsfelder ende oock een deel als Bongaerder leen St. Merten'. ${ }^{645}$ (Zie voor het leenhof van de Bongart in SintMartens-Voeren hierna Hoofdstuk 2.9.2).

Net als bij de lenen, is ook de informatie over de keurmedige goederen summier en verwarrend. Het oudste overzicht van de keurmeden 'die men onsen jonckheren van

${ }^{642}$ RHCL, Familie De Geloes/Kasteel Eijsden, inv. nr. 423.

${ }^{643}$ RHCL, Graafschap Gronsveld, inv. nrs. 172-187.

${ }^{644}$ RHCL, Graafschap Gronsveld, inv. nr. 155.

${ }^{645}$ RHCL, Graafschap Gronsveld, inv. nr. 155. 
Batenburch, her tot Gronsfelt, Ringburch etc. geldende is', werd door de schepenen van Slenaken opgenomen in een attest over het Gronsveldse bezit uit $1496 .{ }^{646}$ In totaal worden daarin twaalf keurmeden genoemd, verdeeld over de verschillende gehuchten. Interessant is de vermelding van de herkomst van een deel van de keurmeden. Vier makkten deel uit van de hof van Tzevel, die eerst toebehoorde aan jonker Arnold van Tzevel en daarna aan Pouwels van Sledenaken. ${ }^{647}$ In 1467 droeg diens weduwe Mechteld ten overstaan van schout en schepenen van Slenaken deze keurmeden over aan Hendrik III, heer van Gronsveld. Bij dezelfde transactie verkocht Mechteld nog een hof met drie keurmeden aan de heer van Gronsveld. Na deze zeven volgen nog vijf keurmeden, waarmee het totaal in 1496 op twaalf komt. Een weer heel ander beeld levert een lijst uit 1602 met liefst 22 keurmeden. ${ }^{648}$ Een 'aanbreng' uit 1636 op hetzelfde stuk geeft maar tien keurmeden, maar dit overzicht maakt de indruk niet compleet te zijn. Het juiste aantal keurmeden valt op basis van deze tegenstrijdige informatie niet meer te achterhalen, maar moet liggen tussen de tien en twintig. Duidelijk is dat die slechts ten dele uit oorspronkelijk heerlijk bezit kunnen stammen.

\subsubsection{Schepenbank en heerlijkheid}

Op welke wijze de heren van Gronsveld vaste voet hebben gekregen in Slenaken, valt niet meer vast te stellen. In ieder geval is er geen enkele aanwijzing dat Slenaken een afsplitsing is van een aangrenzend territorium. Het eerste 'harde' bewijs van Gronsveldse betrokkenheid is een oorkonde van de schepenbank van Slenaken, uit 1371, waarin de schepenen Hendrik II, heer van Gronsveld, vragen het stuk mee te bezegelen. Samen met twee andere oorkonden uit hetzelfde jaar toont dat ook het bestaan van een volwaardige schepenbank op dat moment aan. Onbeantwoord blijft de vraag of de schepenbank is ontstaan uit een laathof. Op basis van wat bekend is over lenen, keurmeden en cijnsgoederen kan niet worden geconcludeerd dat een groot domein van de heren van Gronsveld de basis heeft gevormd voor het ontstaan van Slenaken, met uitzondering misschien dan van de bossen. Van een deel van de keurmedige goederen is zelfs bekend dat zij pas in de loop van de vijftiende eeuw werden verworven.

Toch zou de Gronsveldse aanwezigheid in Slenaken wel eens terug kunnen gaan tot in de dertiende eeuw. In dit verband moet worden herinnerd aan de oorkonde uit 1271, waarin Johannes I, 'dominus de Grule', afstand doet van bos en land uit voorvaderlijk bezit, gelegen op een plek genaamd Grules bij Sint-Martens-Voeren, in de buurt van Slenaken. En Johan II van Gronsveld ontving in 1314 van de hertog van Brabant als Limburgs leen het goed Del Beuck onder Henri-Chapelle, waaraan een leenhof was verbonden, met als onderleen de grondheerlijkheid Teuven, grenzend aan Slenaken. Ten slotte moeten we wijzen op de hoofdvaart van de schepenbank van Slenaken op de schepenen van Gronsveld, wat ook op oude juridische banden kan duiden.

Slenaken vormde zonder twijfel een integraal onderdeel van het Land Gronsveld. De schepenbank was ingebed binnen de rechterlijke organisatie, trad regelmatig gezamenlijk

${ }^{646}$ RHCL, Graafschap Gronsveld, inv. nr. 472.

${ }^{647}$ Zie over deze Pouwels van Sledenaken (Paulus van Slenaken) als stichter in 1452 van het beneficie van O.L.Vrouw in de kapel van Slenaken ook: Maessen, 'Korte schets Slenaken', 19-20.

${ }^{648}$ RHCL, Graafschap Gronsveld, inv. nr. 473. 
op met de andere schepenbanken en droeg voor één vierde mee in de belastingen. Desondanks nam Slenaken binnen het graafschap toch een enigszins bijzondere plaats is, wat blijkt uit de aanduiding 'vrije heerlijkheid' Slenaken. In het bijzonder in de zeventiende eeuw wordt die regelmatig term gebruikt. Zo wordt in een overeenkomst tussen graaf Jost Maximiliaan van Bronckhorst Batenburg en de inwoners van Slenaken in 1646 bepaald dat Slenaken 'sal worden gehouden ende geregeert gelijck van all ouden tijden voor een vrij heerlicheyt' (zie bijlage 36). Het Landrecht van Gronsveld uit 1671 draagt de titel 'Graffschafft Gronsfeldt und freÿer herrschafft Schlenackhen Rechts-Ordtnung'. Mogelijk werd deze enigszins 'separatistische' opstelling ingegeven door de ligging als exclave, maar ook door het feit dat in de zeventiende eeuw door verpandingen van de heerlijke rechten over Slenaken de plaats tijdelijk uit het grotere geheel van het graafschap werd losgemaakt.

\subsubsection{Conclusies}

Over de herkomst van Slenaken als bezit van de heren van Gronsveld valt weinig met zekerheid te zeggen. Mogelijk gaat dit terug tot de dertiende eeuw, maar de eerste concrete gegevens dateren pas uit de tweede helft van de veertiende eeuw. Er zijn geen afwijzingen dat Slenaken een afsplitsing is van een aangrenzend gebied, maar evenmin valt een herkomst uit oud adellijk domaniaal goed te bewijzen. Hoewel Slenaken een volwaardig onderdeel van het Land en graafschap Gronsveld was, werd voor de plaats, vooral in de zeventiende eeuw, regelmatig de term 'vrijheerlijkheid' gebruikt.

\subsection{De Gronsveldse lenen in Vaals, Holset en Einrade}

\subsubsection{Het patronaatsrecht over de kerk van Holset en tiendrecht}

De heren van Gronsveld bezaten tot het einde van de achttiende eeuw in Vaals en Holset een groot aantal leengoederen, waarvan kasteel Vaalsbroek en de hoven Einrade en Holset de belangrijkste waren. Bij elkaar opgeteld vormde het een aanzienlijk bezit. Deze goederen werden voor het leenhof van Gronsveld verheven. Hoewel ze als 'uitheemse lenen' onder een andere landsheerlijkheid vielen en er soms ook vanuit het leenhof moeilijk zicht op viel te houden, bleef tot het einde van Ancien Régime een sterke band met Gronsveld bestaan, die ook veel sterker was dan de band tussen Gronsveld en andere heerlijkheden die de heren van Gronsveld in later tijd verwierven. Ze hoorden als het ware tot een soort rafelrand van het Land Gronsveld. Binnen Vaals vormden ze daarmee ook een vreemd element. Dat werd nog versterkt door het feit dat de juiste omvang van deze lenen zeer onduidelijk was, welke verwarring weer aanleiding was voor allerlei juridische pretenties en beweringen die uiteindelijk niet houdbaar bleken te zijn.

In oorsprong gaat de Gronsveldse aanwezigheid minstens terug tot het begin van de dertiende eeuw. Het vroegste bewijs daarvan vormt de in Hoofdstuk 1.3 genoemde oorkonde uit 1237, waarin Willem, heer van Stolberg (en Gronsveld) en zijn vrouw Lutgardis voor tweehonderd mark goederen te Holset in leen opdragen aan hertog 
Hendrik IV van Limburg. Over de herkomst van die goederen valt niets met zekerheid te zeggen, maar het bewijst de Gronsveldse aanwezigheid in die tijd.

Een bijzonder kenmerk van deze lenen is de relatie met de parochiekerk van Holset. Het kerkgebouw is zeer oud. Het oudste muurwerk wordt gedateerd in de elfde eeuw, terwijl de toren, het koor en delen van het schip stammen uit de twaalfde eeuw. ${ }^{649}$ De heren van Gronsveld bezaten het patronaatsrecht over deze kerk. Daarover zijn pas vanaf het einde van de zestiende eeuw concrete gegevens bekend, maar het recht moet van veel oudere oorsprong zijn. Het interessante is nu dat al vanaf het einde van de middeleeuwen als typisch kenmerk van de Gronsveldse lenen wordt genoemd dat het gaat om landerijen die tienden moesten betalen aan de kerk.

\subsubsection{Schets van de staatkundige verhoudingen en rechterlijke organisatie van Vaals, Holset, Einrade en Vaalsbroek.}

Alle Gronsveldse lenen lagen binnen het gebied van de huidige gemeente Vaals. Staatkundig behoorde dit gebied eertijds tot het zogenoemde Land van 's-Hertogenrade, waarvan de graven van Saffenberg de vroegst bekende heren zijn. Margaretha van Saffenberg bracht door haar huwelijk in 1136 met hertog Hendrik II van Limburg 'sHertogenrade aan Limburg. Na de slag bij Worringen in 1288 viel deze erfenis toe aan de hertog van Brabant. Hoewel Limburg en het Land van 's-Hertogenrade an elkaar grensden en in personele unie onder dezelfde landsheer stonden, bleven zij administratief van elkaar gescheiden en vormde 's-Hertogenrade één van de drie Brabantse Landen van Overmaze.

Kerkelijk bestond het middeleeuwse Vaals uit drie parochies, te weten Vaals (Sint-Paulus), Holset (Sint-Lambertus) en Vijlen (Sint-Martinus), de laatste met een afhankelijke kapel te Lemiers. ${ }^{650}$ De bestuurlijke en rechterlijke organisatie was tot het midden van de zeventiende eeuw ingewikkeld. De rechtspraak was oorspronkelijk verdeeld over drie schepenbanken te weten Holset-Vaals, Vijlen en Einrade, ${ }^{651}$ die alle slechts bevoegd waren voor de lage rechtspraak. De hoge jurisdictie berustte bij de hertog van Brabant als landsheer en werd uitgeoefend door het hoofdgerecht van het Land van 's-Hertogenrade. Vanaf het einde van de middeleeuwen zetelde de schepenbank voor Vaals en Holset in Holset. Dit gerecht overvleugelde allengs Einrade en Vijlen, die uiteindelijk opgingen in de bank van Vaals-Holset. Deze inlijving leverde de meeste strubbelingen op bij Vijlen, waar de abdis van Burtscheid bij Aken als grondvrouwe jurisdictie bezat. Janssen de Limpens formuleert het kernachtig aldus: 'Over niets is meer gestreden dan over de rechten van de abdis van Burtscheid in Vijlen'. ${ }^{652}$

\footnotetext{
${ }^{649}$ Van Agt, Monumenten Zuid-Limburg/Vaals, 17-21.

${ }^{650}$ Van Berkum, 'Zaalkerkje Oud-Lemiers', 106-119.

${ }^{651}$ Tussen 1322-1341 wordt nog melding gemaakt van een gerecht te Vaals van de hertog van Limburg, maar waarschijnlijk trad de hertog hier op in zijn hoedanigheid van heer van 's-Hertogenrade. In ieder geval lijkt deze instelling van korte duur te zijn geweest.

652 Janssen de Limpens, Rechtsbronnen Limburg en Overmaze, CLIII.
} 
Daarnaast functioneerden binnen het gebied van de drie genoemde schepenbanken nog enkele grote laathoven die bevoegd waren voor de rechtspraak betreffende laat- en cijnsgoederen.

Einrade vormde letterlijk een grensgeval. ${ }^{653}$ In de eerste helft van de vijftiende eeuw stelden de schepenen van Einrade een 'cleernis' op over de juridische toestand van de heerlijkheid. ${ }^{54}$ De verhoudingen waren, zelfs naar middeleeuwse maatstaven, zeer gecompliceerd. De heerlijkheid lag deels binnen het territoir van het hertogdom Limburg en deels binnen het Land van 's-Hertogenrade. Ter kerke gingen de inwoners in Vaals, Vijlen of Gemmenich. Gerechtelijke bekendmakingen vonden dan ook plaats in drie parochiekerken. De verdeling tussen twee landsheerlijkheden (wel met dezelfde landsheer) had ook consequenties voor de rechtspraak. In de 'cleernis' wordt soms gesproken over 'onderzaten' in algemene zin, dan weer over 'laten' of 'beseese' laten, personen in het bezit van laatgoed. Of deze begrippen elkaar volledige dekken, is niet duidelijk, maar feit is dat in Einrade een belangrijke laathof bestond (zie hierna).

De heer van Einrade bezat binnen de heerlijkheid niet alleen bepaalde heerlijke rechten, waarschijnlijk behoorde hem ook het adellijk huis Einrade toe. Dat kasteel was omstreeks 1600 al lang verdwenen, maar getuigen kenden toen nog uit overlevering het bestaan ervan. ${ }^{655}$ Van dit kasteel moet worden onderscheiden de hof te Einrade, een bij het kasteel gelegen grote boerderij. .56 Binnen Einrade oefende de heer zijn jurisdictie uit door middel van een 'ambtman' en een schepenbank met lage en middelbare justitie. ${ }^{657}$ Van vonnissen van de schepenbank stond hoger beroep open op het hoofdgerecht van 'sHertogenrade. ${ }^{658} \mathrm{Na}$ de oprichting van de 'hoge bank' Holset-Vaals-Vijlen met volledige jurisdictie heeft deze omstreeks 1670 de taken van de bank Einrade overgenomen.

De rechtspraak in Einrade over 'geweltlicke' zaken berustte bij de hoge landsheerlijke gerechten van Limburg en 's-Hertogenrade, waarbij de competentie afhing van de vraag of het delict op Limburgs dan wel 's-Hertogenrader territoir was gepleegd. De landheerlijke officieren van Limburg en 's-Hertogenrade moesten wel voor hun optreden in Einrade de hulp van de plaatselijke ambtman inroepen. Hetzelfde gold ook voor de eventuele uitlevering van een misdadiger die naar Einrade vluchtte. Boetes die de hoge gerechten in Limburg of 's-Hertogenrade in een criminele procedure oplegden, vielen toe an de landsheer, maar de heer van Einrade maakte weer aanspraak op verbeurd verklaard goed. Bij uitlevering van vluchtelingen mocht de ambtman de delinquent zelfs tot op het hemd

${ }^{653}$ Zie over Einrade: Habets, Limburgsche wijsdommen, 117; Janssen de Limpens, Rechtsbronnen Limburg en Overmaze, CXXXVIII-CXXXIX.

${ }^{654}$ Afgedrukt bij Habets, Limburgsche Wijsdommen, 118-121; Janssen de Limpens, Rechtsbronnen Limburg en Overmaze, 372-375. De gedrukte uitgaven zijn gebaseerd op een afschrift waarin wordt gesproken over de heer van 'Wertheim'. Bedoeld is echter 'Wetthem' = Wittem.

655 Belonje, Schymper, 34.

${ }^{656}$ Van Agt, Monumenten Zuid-Limburg/Vaals, 27-30.

${ }^{657}$ Voorbeelden van schepenoorkonden uit 1509 en 1550 bij Höroldt, Urkunden Rösberg, 28-29, nr. 40 en 45 , nr. 73.

${ }^{658}$ Voorbeelden daarvan in RHCL, Landen van Overmaze, inv. nr. 9708. 
uitkleden of, zoals de 'cleernis' het uitdrukt, 'den misdedigen uisdoin op syne lynne cleder und dat behalden'.

De heer van Einrade had het recht verordeningen uit te vaardigen en mocht keurmeesters aanstellen, voor het toezicht (en de accijnsheffing) op bier, zout, en vetwaren. Overtredingen op dit gebied konden zowel door de schepenbank van Einrade als door de hoge landsheerlijke banken worden berecht. De inwoners van Einrade waren vrij van landsheerliike schattingen in Limburg of 's-Hertogenrade, maar wanneer daar een schatting werd opgelegd, mocht de heer van Einrade dit op dezelfde wijze ook bij zijn onderdanen doen. Voorts was men vrijgesteld van landsheerlijke diensten met uitzondering van hulp bij de aanhouding van misdadigers, en dan alleen wanneer dat echt nodig was. Wel moesten de laten 'der klocken volgen und naburschafft helpen halden bynnen hennen kirspel dae sy onder gesessen synt in den lande van Roide off van Limburg', met ander woorden, zij moesten de landsheerlijke 'klokkenslag' van Limburg en 's-Hertogenrade volgen.

Behalve het recht op rechtspraak en belastingheffing bezat de heer van Einrade nog andere heerlijke rechten. Zo maakte hij aanspraak op het 'oorlofsgeld' (belasting op de overgang van onroerend goed, elders ook werfschelling genoemd) en had hij het recht van 'haefstoot' (landsheerlijk recht op de roerende nalatenschap van alleenstaande personen). Een aparte 'cleernis' was gewijd aan het recht van molendwang. ${ }^{659}$ Alle inwoners waren verplicht op de banmolen hun graan aan te bieden. De 'besessen laissen' moesten meehelpen bij de aanleg en het onderhoud van de dijk bij de molen, waarbij de heer als tegenprestatie voor voedsel en drank zorgde.

De heren van Einrade waren ook in het bezit van een uitgebreide laathof/cijnshof met een laatgerecht. Onduidelijk is of deze 'laatcaarte' was verbonden aan de heerlijkheid als zodanig, dan wel aan het huis of de hof Einrade. Opmerkelijk is de ouderdom van de vroegst bekende lijst van laatgoederen, opgetekend in de vorm van een perkamenten rol uit de periode 1370-1380.600 Het valt moeilijk na te gaan in hoeverre de werkzaamheden van de laatbank in de praktijk samenvielen met die van de schepenbank, maar combinaties en overlappingen hebben zich zeker voorgedaan, al was het maar omdat de laathof ook uitgebreide bevoegdheden had voor de contentieuze en vrijwillige rechtspraak over onroerend goed. Aan de zelfstandigheid van de laatbank kwam een einde door een samenvoeging in 1693 met het laatgerecht van Vaalsbroek. ${ }^{661}$

Ter completering van dit overzicht van de rechterlijke organisatie verdienen ook de organisaties van rechthebbenden op de bossen rond Vaals enige aandacht. Als eerste kan

${ }^{659}$ Afgedrukt bij Habets, Limburgsche Wijsdommen, 121-123; Janssen de Limpens, Recbtsbronnen Limburg en Overmaze, 375-377.

${ }^{660}$ RHCL, Parochie Holset, voorlopig inv. nr. 24, perkamenten rol circa 1370-1380. zie ook Doppler, 'Bescheiden nopens 'Einraede', die een akte beschrijft betreffende de overdracht in 1616 van archivalia van de laathof Einrade aan de schout van Vaals.

${ }^{661}$ RHCL, Huis Vaalsbroek, uittreksel uit de gedingrol van de laatbank 1688-1732 bevat bij het jaar 1693 de volgende melding: 'Die zusammenschmelliung der Vaalsbrucher und Einrader gerichts bancken hat mit den 17 nov. 1693 ibren anfang genommen'. 
hier worden genoemd het Vijlener bos (246 bunder in 1819).662 Dit was in 1319 door ridder Arnold van Gymnich en zijn echtgenote als allodiaal goed aan de abdij Burtscheid geschonken. In 1539 sloten de abdis en de 'naoberschap der Vijlener rotten' een overeenkomst over het gebruik van het bos, inhoudelijk eigenlijk de bevestiging van een veel oudere situatie. De gebruiksrechten van dit bos waren verbonden aan bepaalde hoeven en huizen gelegen in de zes buurtschappen of 'rotten' van Vijlen. Voogd, schepenen en keurmeesters van Vijlen oefenden het bestuur uit, stelden boswachters aan, zorgden voor de uitgifte van hout en naleving van de bosreglementen. De berechting van overtredingen lag in handen van een afzonderlijk bosgerecht.

Het tweede grote bos was het Malensbos. Volgens een meting van het einde van de achttiende eeuw besloeg dit 562 kleine morgen 's-Hertogenrader maat. $\mathrm{Na}$ de grensscheiding met België in de negentiende eeuw lag daarvan 107 hectare op Nederlands en 4,5 hectare op Belgisch gebied. De gebruiksrechten waren verdeeld over vier groepen ${ }^{663}$, die elk weer een vast aantal 'gehülsten plaetsen' of huishoudens telden. De jurisdictie over het Malensbos was verbonden met het huis Vaalsbroek. Deze werd zo belangriijk geacht dat de heren van Vaalsbroek sinds de tweede helft van de zeventiende eeuw de titel 'heer van Malensbos' voerden.

De derde bosgemeenschap werd gevormd door de gerechtigden tot het Holseter bos, groot 110 morgen, grenzend aan de noordzijde van het Malensbos. ${ }^{664}$ Hierin waren de hof Holset en de hof Einrade evenals zes hoevenaars gerechtigd. Sinds 1769 werden de hoevenaars van het Holseter bos toegelaten tot de vergaderingen van de hoevenaars van het Malensbos.

\subsubsection{De Gronsveldse lenen}

In tegenstelling tot Gronsveld zijn er van Vaals geen oude kaarten als hulpmiddel bij het onderzoek naar de vraag of aan de Gronsveldse lenen oorspronkelijk een groot domein ten grondslag heeft gelegen. De beschikbare bronnen zijn zeer beperkt en de daarin vastgelegde administratieve gegevens vaak zo verwarrend, dat onduidelijk is wat nu precies onder deze Gronsveldse lenen moest worden verstaan. Dat geldt in het bijzonder voor de huizen Vaalsbroek, Einrade en Holset met al hun toebehoren. In dit onderzoek wordt geprobeerd enige helderheid in die gecompliceerde verhoudingen te brengen, waarbij in zekere zin een vorm van retrogressie wordt toegepast op basis van enkele langdurige

${ }^{662}$ Zie over de geschiedenis van dit bos: Janssen de Limpens, 'Noaberschap Vijlener Rotten'.

${ }^{663}$ De eerste groep bestond uit negen leden, die met de benaming 'morgen' werden aangeduid. Feitelijk waren dat de (adellijke) bezitters van acht grote huizen of hoeven, te weten Vaalsbroek, Lemiers, Holset, Einrade, het goed de Pley in Volkerich, de Gulpener Hof in Harles, de Sint-Adalbertshof in Vaals en het Schaegoed in Vaals. De negende 'morgen' was fictief en werd gevormd door zes 'hoevenaars' uit het hertogdom Limburg. De tweede groep bestond uit 29 hele 'hövener' of 'hoeffener', de derde groep uit dertien halve 'hövener' en in de vierde groep ten slotte waren 23 'keuters' verenigd. De feitelijke zeggenschap over het gebruik van het bos lag, met uitsluiting van alle andere gebülsten, in handen van de 29 volle hoevenaars, verdeeld over drie groepen (zes hoevenaars uit Volkerich (hertogdom Limburg), twaalf uit Vaals, Vaalsbroek en Raren en elf uit Harles en Lemiers. Zie verder ook: Loontjens/Jongmans, 'Het Malensbos', 153-169.

${ }^{664}$ Oppenhoff, 'Vaalsbruch', 30-31, noot 2; Zie verder ook: Loontjens/Jongmans, 'Het Malensbos', 169173. 
processen uit de zestiende en zeventiende eeuw, toen onder andere de status van verschillende goederen onderwerp van geschil was.

Het oudste overzicht van de Gronsveldse lenen in Holset is te vinden in een uittreksel uit de laatmiddeleeuwse leenboeken, dat de Gronsveldse schout Willem Kicken omstreeks 1700 makkte. ${ }^{665}$ Daarin is sprake van vier zogenoemde grote lenen, te weten tien bunder land, gelegen te Lemiers en de hoven Vaalsbroek, Einrade en Holset. Daarna volgt een twintigtal kleine lenen, bestaande uit percelen land. In de loop van de zeventiende eeuw veranderden deze aantallen door delingen en samenvoegingen. Het zogenoemde 'Holseter leenboek' van het Gronsveldse leenhof, waarin de lenen sinds het begin van de zeventiende eeuw werden geregistreerd, vermeldt zeven grote en ongeveer 65 kleine lenen.666 Zo werd de molen van Vaalsbroek in 1614 van het groot leen Vaalsbroek afgesplitst en als apart groot leen verheven. De hof Einrade werd na een jarenlang proces in de zeventiende eeuw gedeeld in een eenderde en tweederde deel, die beide als groot leen te boek stonden. De hof Holset raakte in de zestiende eeuw ook in twee grote lenen verdeeld, maar werd sinds 1754 weer als één groot leen verheven. Ten slotte noemt het leenboek nog een (eertijds bebouwd) perceel van drie morgen als groot leen. Het aantal kleine lenen liep in de achttiende eeuw door deling op tot bijna zestig.

De lange titelbeschrijving van de leengoederen in het vijftiende-eeuwse leenboek verraadt al iets van gecompliceerde juridische verhoudingen: 'Dyt sijnt alsulke lyengueder als te Lemiers gelegen sijnt off daromtrynt, ind so wat te Hoesit thenden gilt dat is man leen te Gronsf[eld]'. Een tekst met dezelfde strekking geeft begin zeventiende eeuw ook het Holseter leenboek: 'Lemmiers ende Holset, soe wat der kercke tot Holset thiende gilt is lehengoet tot Gronsfeldt'. Letterlijk betekenen deze wat cryptische formuleringen dat het ging om lenen bestaande uit land dat tiendplichtig was aan de kerk van Holset. Het probleem was echter dat landerijen en hoven op een bepaald moment niet meer te scheiden waren.

\section{Vaalsbroek}

Het Huis Vaalsbroek kreeg zijn huidige, statige aanzien goeddeels in het midden van de achttiende eeuw, maar gaat in oorsprong tenminste terug tot de veertiende eeuw. ${ }^{667}$ Voor de geschiedenis van Vaalsbroek zijn (beperkt) gegevens te vinden in de Gronsveldse leenadministratie, te weten het eerder genoemde uittreksel uit het laatmiddeleeuwse leenboek, gevolgd door het Holseter leenboek. Van het vroegere huisarchief resteert slechts een schamel restant, maar belangrijk daarin is een laat-achttiende-eeuwse archiefinventaris. ${ }^{668}$ Helaas munten de lastig te ontcijferen beschrijvingen door hun

${ }^{665}$ RHCL, Graafschap Gronsveld, inv. nr. 146.

666 TJ, inv. nr. M 42, leenregister Holset, passim.

667 Van Agt, Monumenten Zuid-Limburg/Vaals, 131-144.

${ }^{668}$ Het archief van kasteel Vaalsbroek berust thans bij het RHCL, heeft een omvang van ongeveer $0,5 \mathrm{~m}$ en heeft vrijwel geheel betrekking op de negentiende eeuw. Het is niet geïnventariseerd. Het oude archief zou bij een brand verloren zijn gegaan, zodat uit de tijd voor 1800 slechts een miniem aantal bescheiden resteert, waaronder een archiefinventaris uit het midden van de achttiende eeuw. Naar deze inventaris 
beknoptheid niet altijd uit in helderheid. Gegevens uit deze inventaris zijn ook verwerkt in een artikel van Oppenhoff over het Malensbos uit 1936.669 Hoewel diens interesse primair uitging naar de geschiedenis van het bos, vermeldt hij ook tal van bijzonderheden over het huis Vaalsbroek. Voor genealogische gegevens uit de zestiende en zeventiende eeuw zijn vooral de leenregisters van de mankamer van het Munsterstift in Aken belangrijk, aangezien eigenaren van Vaalsbroek of hun familieleden veelvuldig worden genoemd als leenman van dat stift. ${ }^{670}$

Volgens een 'cleernis der gerichtsame und jurisdiction van Vaelsbruch' uit 1542 waren aan het huis verbonden een banmolen, een banbrouwerij, het recht van werfschelling op overdracht van onroerend goed, de rechtspraak over verwondingen en vechtpartijen en de aanhouding van plegers van misdrijven. ${ }^{671}$ Deze omschrijving vertoont naar vorm en inhoud veel overeenkomst met ongeveer honderd jaar oudere 'cleernis' over de heerlijkheid Einrade.

De heer van Vaalsbroek was heer van het Malensbos, of, zoals artikel 1 van het bosrecht uit 1510 het formuleert: 'In zu den eersten, soo halden die heuffender ein hierschafft van den Broogh voor ihren overerffheer van den beusch, dae hy heilt dat buschrecht, dat hiernae beschreven steit'. ${ }^{672}$ Hij lette op de naleving van het bosrecht, vertegenwoordigde de bosgerechtigden naar buiten toe, riep de vergaderingen samen en zat het bosgerecht voor. Wanneer iemand als gevolg van een ongeluk of op een andere manier in het bos dood bleef, dan mocht zoals blijkt uit artikel 22 van het bosrecht 'een heer van den Brogh' het slachtoffer 'opheven buyten den hoogen heer' (= de landsheer). In een NB tekent de schrijver aan dat heer van Vaalsbroek het lichaam kon overgeven aan de landsheer wanneer die daar om verzocht of wanneer de heer van Vaalsbroek hem daartoe uitnodigde, want de landsheer had geen eigen toegangsrecht tot de laatgoederen (!) of het bos.

Het in de 'cleernis' van 1542 vermeld recht op overdracht van onroerend goed moet betrekking hebben op de jurisdictie van een met het kasteel verbonden laatbank. Het is hier niet de plaats om diep in te gaan op de bevoegdheden van de laathof, maar uit een tweetal beschrijvingen uit $1648^{673}$ en $1713^{674}$ komt naar voren dat de laten in hoge mate

(met een specifieke manier van nummeren) verwijst ook Oppenhoff regelmatig. Overigens kan men zich afvragen of het archief zo volledig verloren is gegaan bij een brand. Er bevinden zich namelijk bij de stukken in het huisarchief ook getypte afschriften van een gedingrol (1669-1687) en een overdrachtsregister (1684-1693) van de laatbank van huis Vaalsbroek, waarvan de vindplaats der originelen niet bekend is.

669 Oppenhof, 'Vaalsbruch'.

670 Von Coels von der Brügghen, Lehensregister Mannkammer, passim. Zie over het Malensbos en het Holseter Bos verder ook: Loontjens/Jongmans, 'Het Malensbos'.

${ }^{671}$ RHCL, Huis Vaalsbroek, Archiefinventaris achttiende eeuw, 'Extract aus meinen volanten scripturen' onder nummer 9 .

${ }^{672}$ De hierna gegeven beschrijving is een samenvatting van de veel uitgebreidere bijdrage van Oppenhoff, 'Vaalsbruch'. Zie verder ook: Loontjens/Jongmans, 'Het Malensbos'.

673 Zie attest in RHCL, Landen van Overmaze, inv. 2194, bijlage in proces Hans Willem van Schwarzenberch versus Jan Kicken, 1648; ook afgedrukt bij Janssen de Limpens, Leen- en laathoven, 47: 
zelfstandig waren ten opzichte van de schepenen van Holset. Opvallend in een attestatie van 1648 is de passage dat

'van erven ende goederen, die grontgoed van voirs. Vaelsbroeck sijn... meyer ende laetschepenen uyt- ende inganck moeten hebben en verder dat zij gegicht, geguet ende ontfangen moeten worden, zonder dat die vant gericht van Holzet daerover in dyen regard egeene judicature en hebben noch relieff verleenen'.

Hoe omvangrijk de laathof precies was, valt moeilijk te zeggen. Volgens een opgave uit 1587 omvatte het hele goed Vaalsbroek 4071/2 (kleine) morgen (= circa 80 ha). ${ }^{675}$ Waarschijnlijk was een deel daarvan als laatgoed uitgegeven. De versnipperde ligging van gronden leverde in de praktijk problemen op omdat partijen bij overdrachten of procedures soms niet meer zeker wisten of een perceel onder Einrader dan wel Vaalsbroeker jurisdictie viel. Waarschijnlijk werd daarom om praktische redenen besloten in 1693 de laatbanken van Vaalsbroek en Einrade te laten fuseren. ${ }^{676}$

Het Gronsveldse leenboek begint met 'her Nyt van Byrgelen' als 'man vanden hoeff te Broeck'. Deze moet dezelfde zijn als zekere R(?)yt van Birgel, die samen met zijn

Wij meyer ende laetschepenen des laethoffs van Vaelsbroeck in de banck van Holzet, lant van Shertogenraede, attesteren ende doen condt mits desen dat wij hoeden ende houden ende van onsen voersaeten bevonden hebben dat alle gronden van erven ende goederen, die grontgoet van voirss. Vaelsbroeck sijn, voer ons meyer ende laetschepenen uyt- ende inganck moeten hebben, gegicht, geguet ende ontfangen moeten worden, sonder dat die vant gericht van Holzet daerover in dyen regard egeene judicature en hebben noch relieff te verleenen. Attesteren voirders dat 't panhuys ende toebehoerende goederen tot Vaelsbroeck oyck Vaelsbroecker grontgoed sijn ende daervoer worden gehouden vermoegens d'oude charten ende bescheeden'.

Des t'oirconden hebben desen bij onsen secretaris doen onderteeckenen den XXIIII april XVIc ende achtenveertich. Ter ordonnantie als boven. (get.) J. Franck, secretaris.

${ }^{674}$ Verklaring opgenomen in een uitvoerige klacht die de luitenant-drossaard van 's-Hertogenrade over Willem Adolf van Eys genaamd Beusdael, heer van Vaalsbroek, indiende bij de Raad van State: 'Tweedens dan den selven Busdall in voorn[oemde] bancke laet exerceeren een laethoff gecomposeert uyt schout, laeten off schepenen en een boode, voor de welcke hij procedeert tot laste van de ingesetenen, ten eynde haer verkochde goederen niet alleen voor het selve laethoff moeten transporteeren en opbrengen voor rechten van transport, ooick meer als van outs daertoe is staende, maer daer en boven daeraff werffschilling betaelen, alhowel de goederen onder desselffs gepretendeert laethoff niet resorteeren als betaelende chinssen aen Uw Edel Moogende domeynen en vervolgens den werffschill[ing] aen Uw Edel Moogende verschult wesende, ter exclusie van hem Beusdall, die het daerbij niet laet, maer sijn gepretendeert rechten op de meern[oemde] laetgoederen verder extendeert als den souverain off eenich lantheer, overmits denselven wanneer iemandt sijn goedt verkoopt en den inkooper daerbij eenige avantage maeckt, hij het selve tegens allere volckeren recht intreckt ende den kooper affneemt sonder de geheele kooppenningen aen denselven te refondeeren.' Zie RHCL, Landen van Overmaze, inv. nr. 9414, Rekest met appointement van 30 september 1713; concept in RHCL, Landen van Overmaze, inv. nr. 9396. Zie verder ook: Loontjens/Jongmans, 'Het Malensbos', 162-166, 169.

675 RHCL, Huis Vaalsbroek, Archiefinventaris achttiende eeuw, 'Extract aus meinen volanten scripturen', onder nummer 20.

676 RHCL, Huis Vaalsbroek, uittreksel uit de gedingrol van de laatbank 1688-1732 bevat bij het jaar 1693 de volgende melding: 'Die zusammenschmellzung der Vaalsbrucher und Einrader gerichts bancken hat mit den 17 nov. 1693 ihren anfang genommen'. 
echtgenote Lise in den Bruch in 1380 voorkomen als eigenaren van de Sint-Tolbertshoeve in Vaals.677 De adellijke familie Van Birgel, het eerst genoemd in de tweede helft van de dertiende eeuw, was afkomstig van het riddermatig goed Birgel (Kreis Düren). ${ }^{678}$. Vanaf 1336 bezitten leden van de familie het ambt van erfmaarschalk van Gulik en wordt het geslacht gerekend tot de belangrijkste adel van Gulik. De hiervoor genoemde (Engelbrecht) Nyt van Birgel was erfmaarschalk van 1389 tot 1414/1418. Omstreeks 1380 huwde hij met Elisabeth van Broich genaamd Schaafdries, dochter van Simon van Broich en een moeder uit het geslacht Van Mulant. De wijdvertakte familie Van Schaafdries, waar Lysbeth van afstamde, had zijn oorsprong in het Land van Herve (waarschijnlijk Julemont). Met een reeks versterkte huizen beheerste deze clan het noordoostelijk deel van het hertogdom Limburg.

(Engelbrecht) Nyt van Birgel en Lysbeth van Broich hadden vijf kinderen: Frambach, Johan, Simon, Baldewin en Margaretha. De oudste, Frambach, volgde zijn vader omstreeks 1418 op als erfmaarschalk van Gulik, welk ambt hij tot ongeveer 1445 bekleedde. In 1421 was hij tijdelijk maarschalk van het leger van de prins-bisschop van Luik. 679 Zijn broer Baldewin schijnt aanvankelijk te hebben gekozen voor een geestelijke loopbaan als proost van het stift Münstereifel, maar deed daar in 1417 afstand van ${ }^{680}$ en huwde met Margaretha van Oupeye. Dat hij meer voor een wereldlijke loopbaan geschikt was blijkt uit het feit dat zijn broer Frambach als Luiks maarschalk hem in 1421 het bisschoppelijk banier toevertrouwde. ${ }^{681}$ Uit het huwelijk van Baldewin van Birgel en Margaretha van Oupeye werden drie zonen geboren, te weten Daem, Johan en Baldewin. Laatstgenoemde moet dezelfde zijn als jonker 'Balden van den Broeck' die volgens het uittreksel van het Gronsveldse leenregister in 1465 opdroeg 'alsullighe erve als tot Holsaet thiende gilt... der kyrcken van Holsaet'. ${ }^{682}$ Opmerkelijk genoeg wordt hier alleen gesproken over tiendplichtig land en niet over een hof. Hof en landerijen lijken te zijn gescheiden.

Gegevens uit het archief van Vaalsbroek wijzen vervolgens in een heel andere richting dan leenroerigheid an Gronsveld. Volgens oorkonde nummer 1 in de achttiende-eeuwse inventaris van het huisarchief deed de weduwe van Willem Crummel van Nechtersem (= Margriet van Birgel) op 23 januari 1499 afstand van haar recht van vruchtgebruik op Vaalsbroek en andere goederen ten behoeve van Johan (Crummel) van Nechtersem. ${ }^{683}$ Vervolgens wendde Johan zich tot richter en schepenen van de bank Holset, voor wie hij het betreffende goed 'mit einem silbernen pfennig gegen die heilige sonne, wie sich das

677 Zie voor deze akte De Win, Geschiedenis Vaals, 21-22.

678 Over het geslacht Nyt von Birgel zie: von Oidtman, 'Eigenthümer Rittersitze', 258-287.

${ }^{679}$ Poncelet, 'Les Maréchaux d'armée', 251-252.

${ }^{680}$ HStAD, Archiv Jülich-Berg, Jülich Urkunden, nr. 661.

${ }^{681}$ Poncelet, 'Les Maréchaux d'armée', 251-252.

682 RHCL, Graafschap Gronsveld, inv. nr. 146.

${ }^{6} 83$ RHCL, Huis Vaalsbroek, Archiefinventaris achttiende eeuw, 'Extract aus meinen volanten scripturen' nr. 1; Oppenhoff, 'Vaalsbruch', 35. Dat de overgang van Van Birgel naar Crummel van Nechtersen is verlopen via huwelijk en vererving, is duidelijk, maar de juiste genealogische lijnen zijn niet helder. 
von altem gebührt, relevirt hat'. ${ }^{684}$ Deze 'verheffing' wekt de indruk van Vaalsbroek als een allodium, een volledig onafhankelijk 'zonneleen'. Als volgende stap in de verdeling van ouderlijke goederen kwam Johan Crummel op 27 augustus 1500 voor schout en schepenen van de bank Holset een voorlopige boedelscheiding overeen met zijn zwager Johan Bertholffs de Jonge. Laatstgenoemde kreeg alle goederen in het hertogdom Limburg toebedeeld en Crummel ontving de rest. $\mathrm{Na}$ het overlijden van Margriet van Birgel, 'die zen Broich bleifft', zou een definitieve verdeling plaatsvinden, waarbij ook de kosten die Crummel had besteed aan het huis Vaalsbroek, werden verrekend. ${ }^{685}$

Dan volgt in 1523 de verheffing door 'Johan Krumel van Echtersem den Jonge' voor het leenhof van Gronsveld als een groot leen 'den hof van den Broeck myt allen sijnen to behuer soe wo dat gelegen is, myt noch alsulken erff als joncker Balden vanden Broeck ontfangen hadde inde tot Housit thyenden ghylt'. ${ }^{686}$ Het ging hierbij dus om de 'hof en 'erff' dat in Holset tiendplichtig was.

Een 'verheffing' als zonneleen in 1499 en een verheffing bij het leenhof van Gronsveld in 1523 lijken tegenstrijdig. Dat blijft ook later in de zeventiende eeuw een probleem, wanneer de status van Vaalsbroek nog verder wordt opgeklopt en uiteindelijk de StatenGeneraal als landsheer van Vaals een einde aan de pretenties van de toenmalige bezitter maken. Mogelijk zijn deze onduidelijkheden ontstaan door vermenging van oorspronkelijk gescheiden lenen. Wanneer we de teksten van de beleningen letterlijk volgen, dan lijkt het alsof een verschil werd gemaakt tussen de hof en andere landerijen. Wellicht kan een vergelijking worden gemaakt met het naburige Einrade, waar ook verschil wordt gemaakt tussen land, hof en adellijk huis.

Einrade

In 1983 verscheen van de hand van Belonje een uitvoerig gedocumenteerde studie over de geschiedenis van kasteel Schymper te Moresnet (B), waarin ook uitgebreid aandacht wordt besteed aan Einrade. De navolgende gegevens zijn dan ook voor een belangrijk deel aan dit onderzoek ontleend. Belonje vermeldt vanaf 1418 leenverheffingen van huis en heerlijkheid Einrade voor het leenhof van de hertogen van Brabant. Duidelijk is dat Einrade een direct leen van de hertog van Brabant was en dus niet afhing van de landsheerlijke leenhoven van 's-Hertogenrade of Limburg. De administratie van het leenhof van Brabant begint in 1418 met de overdracht van huis en heerlijkheid Einrade door Johan van Pallant, genaamd Carselis van Eupen, aan zijn neef Frederik van Cosselaer-Wittem. ${ }^{687}$

Maar ook de Gronsveldse leenadministratie kent beleningen met betrekking tot Einrade. Het uittreksel uit het oudste leenregister begint met een ongedateerde vermelding uit de eerste helft van de vijftiende eeuw, luidende: 'Her Johan van Wethem is man van den

${ }^{684}$ RHCL, Huis Vaalsbroek, Archiefinventaris achttiende eeuw, 'Extract aus meinen volanten scripturen' nr. 1; Oppenhoff, 'Vaalsbruch', 35.

685 Von Fürth, Beiträge Aachener Patrizier-Familien, 1, 68-69, waar de tekst van de oorkonde, in het bezit van de schrijver, wordt afgedrukt.

686 RHCL, Graafschap Gronsveld, inv. nr. 146.

687 Belonje, Schymper, 57, noot 54. Zie over Jan III en Frederik van Cosselaer-Wittem: Mosmans, Heeren van Wittem, 39-45. 
hoeve te Eynroed ende van lande bij der Lynden gelegen ende is eyn groot lyen'. De eerste gedateerde belening is echter pas van 15 juni 1530, toen Willem van Ghoer voor het leenhof van Gronsveld opdracht deed van 'alsulcke landen als in den hoff tho Eynroed behuerende sijnt ende tot Houset den kyrken thyenden gelden.' Over de heerlijkheid Einrade of het kasteel c.q. adellijk huis Einrade wordt echter in de Gronsveldse beleningen niet gerept. Ook hier zien we hetzelfde verschijnsel als bij Vaalsbroek dat aanvankelijk wordt gesproken over 'de hoeve te Eynroed' en vervolgens alleen over tiendplichtig land.

Dit verschil tussen hoeve en land werd ook onderwerp van een erfrechtelijk geschil in een proces dat vanaf 1580 over Einrade werd gevoerd voor de Raad van Brabant en het leenhof van Brabant in Brussel. Eén van de daarbij spelende vragen was of hier Brabants erfrecht van toepassing was dan wel, vanwege de ligging, het plaatselijk erfrecht van Limburg en 's-Hertogenrade. Voor opvolging in vrouwelijke lijn, waar het hier om ging, viel dat laatste gunstiger uit dan Brabants recht.

Intussen liet Willem Spies tot Ehrenstein, een der pretendenten, zich op 25 september 1610 door stadhouder en leenmannen van Gronsveld met Einrade belenen. 688 Het leenregister formuleert het object van de belening nogal vaag: 'alsulcke landen als in den hoff van Eynraedt gehooren ende der kerkcke tot Holset thienden gelden.' Willem Spies ontving het leen voor hem en zijn 'metgelingen van Ehrenstein sonder eenige praejudicie te trecken in consequentie.' Voorts moest de belening worden beschouwd als een gunst, omdat het goed door 'inobedientie' al lange tijd 'open stond', waardoor het volgens Gronsvelds leenrecht eigenlijk op de leenheer was teruggevallen.

Vooralsnog schijnt Willem Spies an deze belening weinig ruchtbaarheid te hebben gegeven en liep het proces in Brussel, waar inmiddels Margaretha van Reuschenberg de andere procespartij was, gewoon verder. Op 17 september 1613 lag zelfs een vergelijk in het verschiet en werd een ontwerp van scheiding en deling opgesteld. ${ }^{689}$ Maar het mislukte wederom. Volgens een verklaring van schout en schepenen van Einrade van 11 juni 1614 was eind november 1613 de deurwaarder van het leenhof van Brabant in Einrade verschenen om een vonnis van 1609 van het leenhof ten uitvoer te leggen. Daarbij had hij zich begeven op

seeckere busschen, benden ende lant, dewellicke tot Einrade gehoerich der kercken tot Hulset tiende gelden ende Gronsveldische leengoederen sijn...ende insgelicken dat hiebevoren tot Einraede een adelick huys gestaen hefft, op de plaetse wellicke in den Wijer ligt. .990

Het gerecht van Einrade was bereid de grond van de hof Einrade conform de wens van het leenhof van Brabant in drieën te verdelen, maar dan met uitzondering van de tiendplichtige percelen, in totaal 29 bunder, die Gronsvelds leen waren. De partij Spies

${ }^{688} \mathrm{TJ}$, inv. nr. M 42, leenregister Holset, fol. 17-18.

${ }^{689}$ Belonje, Schymper, 33.

${ }^{690}$ Belonje, Schymper, 34, 83-84. De verwijzing naar een oud huis kan zeer goed op waarheid berusten. Naast de tegenwoordige hoeve Einrade ligt een laagte, die lijkt op de gracht rond een gebouw dat een soort woontoren kan zijn geweest. 
beweerde echter dat de deurwaarder van het leenhof van Brabant zijn bevoegdheden had overschreden door zich in te laten met Gronsveldse lenen. Gemakshalve stelden zij die goederen op één lijn met de landerijen waarmee Willem van Ghoer in 1530 door het leenhof van Gronsveld was beleend. Deze gronden moesten immers vanwege hun afhankelijkheid van Gronsveld worden beschouwd als territoir van het Heilige Roomse Rijk, waarover alleen het Rijkskamergerecht in hoogste instantie kon oordelen. ${ }^{691} \mathrm{Zij}$ wilden die dan ook buiten de door het leenhof van Brabant bevolen verdeling houden. Aan de kant van Van Reuschenberg werd betoogd dat de bewuste percelen altijd als één complex samen met de andere goederen van Einrade waren verpacht en bewerkt. Kortom, de Van Reuschenbergs beschouwden Einrade als één geheel en ook wanneer de percelen niet afzonderlijk aanwijsbaar waren, dan kon de massa toch in drie stukken worden verdeeld.

Uiteindelijk kon het beroep van Willem Spies op de Gronsveldse leenroerigheid van een deel van de hof Einrade de deling niet tegenhouden. Op 6 juli 1615 verordonneerde het leenhof van Brabant de verdere tenuitvoerlegging van het vonnis van 16 mei 1609. Een laatste poging van Spies om van het leenhof nog een afzonderlijke 'interpretatie' van de vonnissen van 1609 en 1615 te krijgen mislukte. Op 15 juni 1616 volgde een eindoordeel in de hoofdzaak, waarmee de partij Spies 2/3 van Einrade kreeg toebedeeld en de partij Van Reuschenberg 1/3.692

Ongeveer op hetzelfde moment dat het leenhof van Brabant uitspraak deed, wendden graaf Johan II van Bronckhorst Batenburg en Johan Spies ${ }^{633}$ zich tot het Rijkskamergerecht met het verzoek om Van Reuschenberg een dwangsom op te leggen met als doel het proces voor het leenhof van Brabant te stoppen. De argumenten waren bekend: Einrade hoorde onder het leenhof van Gronsveld, van uitspraken van dit leenhof stond beroep open op de schepenstoel van Aken en de rijksgerechten en ten slotte moest het Gronsveldse leen Einrade worden beschouwd als gebied van het Rijk. Van Reuschenberg wijzigde zijn standpunten evenmin. Einrade was deels Brabants, deels Gronsvelds leen, waarbij het Gronsveldse deel slechts bestond uit dertig tot veertig bunder land. Die grond was altijd bewerkt door de pachter van de boerderij en met de overige landerijen vermengd geraakt. Ten slotte gold bij delingen niet het recht van het leenhof, maar het recht van de plaats waar het leen was gelegen. ${ }^{64}$ Of de zaak bij het Rijkskamergerecht verder is gekomen dan het uitwisselen van standpunten tussen partijen is niet bekend. Maar waarschijnlijk is de zaak niet doorgezet, ook al omdat de graaf van Gronsveld en Spies moeten hebben ingezien dat hun argumenten niet houdbaar waren en de kans op daadwerkelijk interventie door het Rijkskamergerecht gering was. De splitsing van Einrade in $2 / 3$ en $1 / 3$ bleef bestaan tot het einde van de achttiende eeuw. In de latere administratie van het leenhof van Gronsveld bleef Einrade geboekt als twee grote lenen, dus ook met dubbel heergewaad, wat voor de leenheer financieel gunstig was.

${ }^{691}$ Belonje, Schymper, 34.

${ }^{692}$ Belonje, Schymper, 35.

${ }^{693}$ In 1616 had ook een boedelscheiding plaatsgevonden tussen Willem Spies en zijn broer Johan. Johan kreeg daarbij o.a. Ehrenstein en Holset toebedeeld (vgl. Augustus, 'De familie Spies zu Ehrenstein', 45).

${ }^{694}$ RHCL, Rijkskamergerecht, inv. nr. 75. 
Het proces Van Spies contra Van Reuschenberg maakt duidelijk dat de Gronsveldse lenen in Einrade in oorsprong bestonden uit landerijen die geen onderdeel vormden van de hof Einrade en los stonden van de heerlijkheid Einrade. Maar in de praktijk waren die gronden niet goed meer afzonderlijk anwijsbaar, zodat het leek alsof de hele hof Einrade een Gronsvelds leen was. Die indruk wordt later ook bevestigd bij beleningen in de zeventiende en achttiende eeuw, die hier verder buiten beschouwing blijven, maar deze was dus historisch onjuist.

Holset

Over de geschiedenis van de hof van Holset gedurende de middeleeuwen is weinig bekend. De Crassier schrijft in zijn 'Dictionaire Historique' over een 'château patrimonial' in de dertiende en veertiende eeuw. ${ }^{695}$ Voorts vermeldt hij een zekere 'Simon von Holsit, genaamd In den Brucke' die in 1334 optreedt als voogd voor de goederen van de abdis van Burtscheid in Vijlen, maar veel verder brengt deze losse vermelding ons niet. Bij de beschrijving van Vaalsbroek is al vermeld dat deze Simon mogelijk dezelfde is als de vader van Elisabeth van Broich genaamd Schaafdries. Overigens worden ook de Van Holsets gerekend tot de nakomelingen van de familie Van Schaafdries.

In de tweede helft van de veertiende eeuw waren de Van Holsets door huwelijk in het bezit gekomen van kasteel Lontzen, een leen van het Onze-Lieve-Vrouwestift te Aken. Catharina van Holset, dochter van Thomas van Holset, erfde Lontzen in 1396. Door haar huwelijk met Pons I van Welkenhuysen kwam Lontzen in handen van de familie Van Welkenhuysen. De hof te Holset in Vaals moet dezelfde weg zijn gevolgd. In het uittreksel uit het oudste leenboek van Gronsveld wordt zekere 'joncker Pons van Welkenhousen' genoemd als eerste leenman van de 'hoeffe te Houset'. ${ }^{696}$ Door het ontbreken van een jaartal valt echter moeilijk vast te stellen, welke 'Pons' het betreft, aangezien achtereenvolgens grootvader, vader en kleinzoon dezelfde naam droegen.

Pons III van Welkenhuysen, die in 1487 het kasteel en de erfvoogdij van Lontzen in leen ontving van de mankamer van het Onze-Lieve-Vrouwestift in Aken, overleed in 1496 zonder kinderen of broers na te laten. De nalatenschap viel toe aan zijn zussen, religieuzen in de abdij Burtscheid. De strijd die daarna tussen de verschillende erfgenamen uitbrak, valt af te lezen uit de reeks beleningen en transacties, die in de leenregisters van de mankamer van het Onze-Lieve-Vrouwestift met betrekking tot Lontzen zijn opgetekend. ${ }^{697}$ Uiteindelijk kwam een belangrijk deel van de nalatenschap, waartoe ook de hof Holset behoorde, in handen van nichten uit de familie Van Nuwerburch, Van Neubourg of Neufchateau.

Eerst kwam Margaretha van Nuwerburch in het bezit van Holset en haar echtgenoot Balthazar Walde (alias Balthazar Moir van Walde) werd voor haar met Holset beleend. Na het kinderloos overlijden van dit echtpaar vererfde Holset op Margaretha's zuster Catharina van Nuwerburch. Deze was twee keer gehuwd, eerst met Alaert of Adolf van

${ }^{695}$ De Crassier, 'Dictionaire' onder lemma 'Vaels' in: PSHAL 71 (1935) 326.

${ }^{696}$ RHCL, Graafschap Gronsveld, inv. nr. 146.

${ }^{697}$ Von Coels von der Brügghen, LehensregisterMannkammer, 405-407. 
Gulpen en vervolgens met Johan van Celle alias Van Zeel. Uit het eerste huwelijk waren een zoon genaamd Frambach (van Gulpen van Rosmeulen) en een dochter Catharina geboren en uit het tweede huwelijk een dochter Jehenne. Laatstgenoemde trouwde met Frederik van Sombref. Deze kinderen kregen na het overlijden van hun moeder onenigheid over de erfenis. In 1527 werd Frambach van Gulpen genaamd Rosmuelen als erfgenaam van zijn tante door het leenhof van Gronsveld met Holset beleend. ${ }^{698}$ Daarna vonden tussen de drie kinderen verschillende boedelscheidingen plaats. ${ }^{699}$ Vermeldenswaard in dit verband is een deling tussen Frambach van Gulpen genaamd Rosmuelen en zijn zuster Catharina, waarbij de hof Holset tussen hen beiden in twee helften werd verdeeld. ${ }^{700}$

$\mathrm{Na}$ het overlijden van Frambach van Gulpen bereikte zijn dochter Anna, gehuwd met Frambach van Hochkirchen, alsnog een vergelijk met Frederik van Sombref, wat leidde tot een definitieve deling van de hof Holset. Het Holseter leenboek vermeldt daarover:

J[onker] Frambach van Hoochkercken is leenman van den halven hoff tot Holset met sijnen toebehoor ende is deesen halven hoff mits het verdeylen van de vrienden nae doodt j[onker] Frambachs van Gulpen ende sijne huijsfr[ouw] ende kinderen geschiet bij Hoochkercken ende Frederick van Sombreff anno 1540, den 10en augusti, geworden een groot leen. ${ }^{701}$

Daarna volgt de andere helft als groot leen, met als leenman 'J[onker] Frederick van Sombreff erffvocht tot Lontzen'. ${ }^{702}$ Uiteindelijk zijn beide helften van Holset via Catharina, een andere dochter van Frambach van Gulpen genaamd Rosmeulen, en gehuwd met Herman van Eys genaamd Beusdael, in de familie Van Eys genaamd Beusdael terecht gekomen. Op 8 juli 1613 droeg Andries van Eys genaamd Beusdael, beide helften van Holset als afzonderlijke lenen op, onder voorbehoud van het recht van vruchtgebruik van zijn moeder. Daaruit blijkt dat toen beide lenen weer in één hand waren, maar afzonderlijk werden verheven. ${ }^{703}$ Vanaf dat moment kent Holset dezelfde bezitters als Vaalsbroek.

Overige grote lenen

Behalve de hiervoor besproken grote lenen, noemt het uittreksel uit het vijftiende-eeuwse leenboek nog één groot leen, te weten tien bunder land onder Lemiers. Zowel het uittreksel uit het oudste leenboek als het Holseter leenregister vermelden uitdrukkelijk dat het gaat om grond die tiendplichtig is aan de kerk van Holset. Het uittreksel noemt (zonder jaartal) als eerste leenman Herman van Beusdael, opvolger van 'vortijds Palmen van Lemeris'.704 De familie Van Eys genaamd Beusdael had sinds omstreeks 1500 haar

\footnotetext{
698 Tekst van de beleningsakte in RHCL, Rijkskamergerecht, inv. nr. 78, fol. 69vo.-70. Volgens het uittreksel uit het Holseter leenboek werd 'Frambach van Gulpen, den men nuempt van Rosmuelen'in 1527 met de hof Holset beleend, vgl. RHCL, Graafschap Gronsveld, inv. nr. 146.

699 Zie voor de teksten daarvan de afschriften in RHCL, Rijkskamergerecht, inv. nr. 78.

700 Zie voor de tekst daarvan RHCL, Rijkskamergerecht, inv. nr. 78, fol. 38 e.v.

701 TJ, inv. nr. M 42, leenregister Holset, fol. 51.

702 TJ, inv. nr. M 42, leenregister Holset, fol. 55.

703 TJ, inv. nr. M 42, leenregister Holset, fol. 51-52.

704 RHCL, Graafschap Gronsveld, inv. nr. 146.
} 
hoofdzetel in kasteel Lemiers en behoorde als zodanig tot de meest invloedrijke geslachten in Vaals. ${ }^{705}$ Het Holseter leenboek uit het einde van de zestiende eeuw noemt nog enkele grote lenen, bijvoorbeeld 'drij morgen hofs te Holset', een weide, genaamd 'Pijpenhof' en de molen van Vaalsbroek, maar waarschijnlijk zijn dit latere afsplitsingen geweest van Holset of Einrade

\section{Kleine lenen}

In het uittreksel uit het middeleeuwse leenboek wordt een twintigtal kleine lenen beschreven, percelen bouw- en weiland gelegen te Holset en Lemiers. In de achttiende eeuw was dit aantal door versplintering opgelopen tot ongeveer 55. Oorspronkelijk varieerden de meeste lenen in oppervlakte tussen de halve en vier morgen. Alle gronden waren tiendplichtig aan de kerk van Holset. De situering van de lenen maakt duidelijk dat het niet om één groot, oorspronkelijk aaneengesloten complex gaat, maar wel grensden sommige lenen aan elkaar.

\subsubsection{Conclusies}

Gronsveldse anwezigheid in Holset is te volgen tot 1237. Verder berustte het patronaatsrecht over de zeer oude kerk van Holset tot het einde van het Ancien Régime bij de heren van Gronsveld. Vanaf de vijftiende eeuw kennen we Gronsveldse leengoederen in Vaalsbroek, Einrade en Holset, met als gemeenschappelijk kenmerk de tiendplicht aan de kerk van Holset. Mogelijk wijst dat op een ontstaan van het dorp Holset rond een adellijk domein, met de kerk als 'eigenkerk' van de heer en tiendplichtig land dat in leen werd uitgegeven. Opmerkelijk is dat tot het einde van de achttiende eeuw alle Gronsvelds bezit in Holset uitsluitend bestond uit leengoed.

De juiste omvang en beschrijving van de zogenoemde grote lenen was zeer onduidelijk. Een deel van dit tiendplichtig land is zodanig verweven geraakt met goederen behorend tot de huizen/hoven Einrade, Vaalsbroek en Holset, dat ze later nauwelijks meer als aparte vermogenbestanden waren te herkennen. Uiteindelijk heeft dit er toe geleid dat Vaalsbroek, Einrade en Holset in hun geheel als grote lenen bij het leenhof van Gronsveld werden verheven. Aan sommige van deze huizen was ook jurisdictie verbonden, maar daar heeft men zich vanuit Gronsveld nooit mee ingelaten.

\subsection{Oost en Sint-Martens-Voeren}

\subsubsection{Oost}

In de biografische schets van Johan III van Gronsveld werd al beschreven welk fortuin hij in 1373 erfde van zijn kinderloze oom Godert van den Bongard, heer van Heiden. Daartoe behoorden ook de heerlijke rechten in Oost en Sint-Martens-Voeren. Beide plaatsen behoorden tot het Land van Daelhem, maar grensden helemaal of bijna aan Gronsvelds gebied: Sint-Martens-Voeren direct aan Slenaken en de door de heerlijkheden Breust en Eijsden omringde enclave Oost op een steenworp afstand daarvan.

${ }^{705}$ De Crassier, 'Dictionaire', onder lemma 'Vaels' in: PSHAL 71 (1935) 329. 
De gecompliceerde geschiedenis van Oost werd al uitvoerig bestudeerd door Janssen de Limpens en Hartmann en het hierna volgend samenvattend overzicht is dan ook grotendeels gebaseerd op hun publicaties. Voor Sint-Martens-Voeren ontbreekt iets dergelijks. Hier moest in hoofdzaak worden volstaan met een tweetal korte beschrijvingen van de plaatselijke rechtsverhoudingen en door Janssen de Limpens verzamelde aantekeningen over leen- en laathoven. Naar de volledigheid daarvan is geen nader onderzoek gedaan.

Oost was niet meer dan een gehucht van enkele huizen met bijbehorende tuinen en boomgaarden. Het is onduidelijk of de enclave het restant is van een oorspronkelijk groter, aaneengesloten domein, dan wel ooit als 'losse aanwinst' door heren van Daelhem werd verworven. Oost ressorteerde aanvankelijk onder de schepenbank van 'sGravenvoeren en de justitie werd er namens de hertog van Brabant gehandhaafd door landsheerlijke officieren van Daelhem.

Binnen Oost bezat Godert van den Bongard een allodiaal 'huys zu Oys', dat hij in 1357 in leen opdroeg aan de hertog van Brabant. Deze gaf dit vervolgens weer aan Van den Bongard als leengoed terug, samen met alle rechten die de hertog te Oost bezat, uitgezonderd de hoge justitie. Dit 'huys zu Oys' staat ook bekend als kasteel Kloppenburg en lag ten zuidwesten van het dorp. Gebouw en grachten zijn nog zichtbaar op de oudste kadasterkaarten. ${ }^{706}$ Waarschijnlijk moeten we ons de Kloppenburg voorstellen als een grote woontoren met economiegebouwen, omringd door grachten. Een beschrijving uit het begin van de vijftiende eeuw spreekt over een 'steynen torne, huysingen, hoven, hovereysen, ackerlande, bempden, weyden, werden ende wyeren, laeten, cyesen, capunen, erfrenten' ${ }^{707}$ In 1617 verkeerden de gebouwen in een slechte toestand en daarna werden verschillende malen herstellingen uitgevoerd. Getuigenverklaringen uit 1666 spreken van 'eenen grooten tooren oft gebouw van steen... waarop eenighe gevangenen doen tertyt ook hebben geseeten' en van een toren 'waarop de huysluydens wel plachten te vluchten'. ${ }^{708}$

Met de Kloppenburg verbonden was een goederencomplex in de vorm van een laathof, die ook hof van Gronsveld of hof van Batenborch (naar de latere heren van Gronsveld) werd genoemd. De oorspronkelijke omvang daarvan valt niet meer goed vast te stellen, maar er lijkt in de loop der tijden nogal het een en ander aan te zijn veranderd. ${ }^{709}$ Of er ook een aparte hof van de familie Van Printhagen bestond, dan wel dat alleen goederen van de Gronsveldse hof Printhagen in Oost lagen, is niet geheel duidelijk, maar in 1530 waren de goederen van Printhagen in deze hof van Batenborch geïncorporeerd..$^{710}$

${ }^{706}$ Gegevens voor de situering ontleend aan Hartmann, Reconstructie landschap, 228-229, 244.

${ }^{707}$ Hartman, Reconstructie landschap, 244.

708 Janssen de Limpens, 'Geschiedenis Oost', 119.

709 Zie voor een uiteenzetting over deze problematiek Hartmann, Reconstructie landschap, 244-245.

710 Deze ingewikkelde materie kan hier, ook vanwege gebrek aan bronnen, niet in extenso worden behandeld. Opgemerkt wordt de vermelding bij Hartmann (Reconstructie landschap, 244, noot 630) van een notitie eind veertiende eeuw dat Johannes de Printhagen 23 solidi en 2 denaren cijns wegens goederen in Breust betaalt aan het kapittel van Sint-Martinus in Luik, welke verplichting in 1451 blijkt te zijn overgenomen door 'domicellus Heynricus de Gronselt de terris suis ad curiam suam in Oys pertinentibus'. Janssen de Limpens, 'Geschiedenis Oost', 109 noemt een notitie uit 1559 volgens welke 'der hoeff van Printhagen eertytz aan anderen luyden is versat ende verpandt geweest...totten jaere XVc 
Ondanks zijn bescheiden oppervlakte waren de juridische verhoudingen binnen Oost ingewikkeld door de aanwezigheid van verschillende laathoven. Janssen de Limpens en Hartmann kwamen tot acht respectievelijk zes stuks, waarbij de telling van Hartmann correct lijkt: de hof van Gronsveld/Batenborch, de Wachtendonckhof, de Butsartshof, de Eijgenhof of Schrynemeckershof, de Dutsenhof of Pouwels Hoenenhof (bij Janssen de Limpens dubbel geteld) en de grootste en belangrijkste, de hof van Oost alias Kemerlingshof alias hof van Holsit (Bij Janssen de Limpens dubbel). Omdat Hartmanns uiteenzettingen over de benamingen van laatstgenoemde hof enigszins onduidelijk zijn, is enige toelichting gewenst, ook als verduidelijking van de hierna nog te noemen problemen rond leenrechtelijke verhoudingen met Gronsveld.

In 1382 legateerde ridder Theodericus de Oys bij testament zijn 'curia de Oys' met al zijn toebehoren aan Petrus van der Hallen Winandszoon, 'camerarius' of kamerling van de hertog van Brabant. Het ambt van de begiftigde verklaart ook de benaming Kemerlingshof. De tekst van het testament wordt gevolgd door een specificatie van de bijbehorende landerijen, ongeveer 60 percelen met een totale oppervlakte van 57 hectare. ${ }^{711}$ Van de hof wordt gezegd dat hij aan niemand onderhorig, was, maar volledig allodiaal. Twee jaar later, in 1384, droeg Peter van der Hallen de hof over aan zijn vader Winand als onderpand voor een erfrente aan zijn zuster Margriet. ${ }^{712}$. In 1399 gaf Winand van der Hallen ten overstaan van schout en schepenen van Breust 'synen hoef ghelegen te Oys' wederom terug aan zijn zoon Peter. ${ }^{713}$

Via een dochter van Peter, Johanna geheten en gehuwd met Carsilius van Holsit, ontvanger-generaal van het bisdom Luik, vererfde het bezit van Van der Hallen in 1411 naar de familie Van Holsit. ${ }^{14}$ Aldus werd de 'Kemerlingshof mettertijd ook 'hof van Holsit' genoemd. Het geslacht van Holsit, behorend tot de lage adel, maakte ondanks het gemis van heerlijke rechten tot het midden van de zestiende eeuw min of meer de dienst uit in Oost. Die vooraanstaande positie was niet in de laatste plaats te danken aan de verwerving binnen ongeveer anderhalve eeuw van vijf van de zes laathoven binnen het dorp (de Wachtendonckhof, de Butsartshof, ${ }^{715}$ de Dutsenhof, ${ }^{716}$ en de Eijgenhof of Schrynemeckershof. ${ }^{717}$ )

ende XXX. Alsdoen heeft der grontheer denselven hoeff van Printhagen met andere zyne guederen geincorporeert ende daernae by den gronthere van Gronsfelt is geloest ende in haeren ander zyns- ende leenboeken ende goeden geincorporeert worden'. Deze incorporatie uit 1530 was zo belangrijk dat in 1594 wordt gesproken over hof van Printhagen of Batenborch.

711 Hartmann, Reconstructie landschap, 235.

712 Hartmann, Reconstructie landschap, 234, noot 583.

${ }^{713}$ Hartmann, Reconstructie landschap, 234, noot 583; tekst afgedrukt bij Janssen de Limpens, 'Geschiedenis Oost', 130 .

714 Janssen de Limpens, 'Geschiedenis Oost', 111.

715 Janssen de Limpens, 'Geschiedenis Oost', 106, Hartmann, Reconstructie landschap, 235-236.

716 Janssen de Limpens, 'Geschiedenis Oost', 113, Hartmann, Reconstructie landschap, 241-242.

717 Zie over deze hof en de opmerkelijke juridische verhoudingen daaromtrent Janssen de Limpens, 'Geschiedenis Oost', 108-109 en vooral Hartmann, Reconstructie landschap, 237-241. 
Van de 'curia de Oys', die Theodericus de Oys in 1382 vermaakt, wordt gezegd dat deze niemand boven zich erkende en aan niemand verbonden was ('quod dictam curiam cum suis attintentiis nemini cognosceret seu scieret obligatam'). In 1407 staat Carsilius van Holsit genaamd van Roideren echter voor de (inmiddels van naam veranderde) Kemerlingshof in de leenregisters van Gronsveld geboekt als 'man myns jonckeren van Gronsfelt van den hoeve der was Winants Kemerlinghs gelegen tot Oist'. ${ }^{718}$ Dit betekent dat in de voorafgaande jaren een leenverhouding met de heer van Gronsveld moet zijn gecreëerd. Helaas zijn de Gronsveldse leenregisters uit die tijd verloren gegaan, maar in het midden van de zeventiende eeuw zijn daaruit ten behoeve van een langdurig proces over de Gronsveldse lenen in Oost uittreksels gemaakt ${ }^{719}$. Daaruit vernemen we dat vanaf 1465 tot 1565 de Wachtendonckhof, de Kemerlingshof en de Butsartshof samen als één groot leen door leden van de familie Van Holsit voor het leenhof van Gronsveld werden verheven. Deze niet alledaagse combinatie van drie laathoven in één leen, waarbij van geen van de drie een oude leenverhouding met Gronsveld bekend is, geeft de indruk van een constructie uit het begin van de vijftiende eeuw. Hetzelfde moet ook gelden voor de hoofdvaart van meier en laten op het leenhof van Gronsveld als 'hun wettich heuft' voor het halen van lering bij onduidelijkheid over het geldend recht. ${ }^{720}$

Toen Hieronimus van Berghe genaamd Trips in 1594 ten behoeve van zijn moeder Agnes van Holsit het groot leen van de drie laathoven bij het leenhof van Gronsveld verhief, eiste de graaf van Gronsveld daarvan een specificatie of denombrement, wat Hieronimus weigerde. Dit vormde het begin van een ingewikkeld, zich tot 1683 voortslepend conflict. Eén aspect van dit geschil had betrekking op de vraag in hoeverre de oude burcht van Oost, de 'curia de Oys' van Theodericus de Oys in 1382, tot dit leen behoorde. Voor het verdere verloop van deze procedure, waarbij juridische argumenten en gewelddadigheden elkaar afwisselden, kan worden verwezen naar het artikel van Janssen de Limpens. ${ }^{721}$

Het voorgaande overzicht van de laathoven in Oost maakt duidelijk welke dominante rol deze in de plaatselijke verhoudingen speelden. Zij lijken in de loop van de tijd zelfs hun positie te hebben versterkt. ${ }^{722}$ Ook de enigszins uniformerende werking van de hoofdvaart op het leenhof van Gronsveld bracht daarin geen verandering. Alle overdrachten van laatgoed hadden plaats voor de laatbank; hetzelfde gold ook over procedures over cijnzen. Beslaglegging op laatgoed of uitwinning wegens schulden was voor de heer alleen mogelijk

\footnotetext{
718 Met verschillen in spelling afgedrukt bij Janssen de Limpens, 'Geschiedenis Oost', 106 en Hartmann, Reconstructie landschap, 234, noot 564.

${ }^{719}$ RHCL, Familie De Geloes/Kasteel Eijsden, inv. nr. 317.

720 Janssen de Limpens, 'Geschiedenis Oost', 112.

721 Janssen de Limpens, 'Geschiedenis Oost'.

722 Significant in deze is misschien het verlof dat het allodiaal hof in Luik in 1553 geeft aan Johan van Holsit om voor de Eijgenhof een nieuw laatgerecht op te richten ter vervanging van een oudere, kostbare en meer omslachtige vorm van rechtspraak (Janssen de Limpens, 'Geschiedenis Oost', 108-109, 131-134; Hartmann, Reconstructie landschap, 239). Ook het feit dat in het midden van de zestiende eeuw de hof van Holsit zichzelf het recht van groot gebod en immissie toekent, wat normaliter bij een schepenbank berust, vormt daarvoor een aanwijzing (Janssen de Limpens, 'Geschiedenis Oost', 113).
} 
wanneer de debiteur zich op de openbare weg bevond of, zoals een bejaarde getuige in 1611 verklaarde:

Dat eynen Grave van Gronsfelt binnen den dorpe van Oest gheyne voerdere gerechticheyt noch jurisdictie van arrest oft pantschappe en heeft muegen exerceren dan opter gemeyner straeten sonder te muegen arresteren oft panden opte goederen ende erven gehoirende onder den laethoeven toebehoirende den huyse van Oest ${ }^{723}$

Daarnaast schijnen inwoners van Oost vaker voor juridische dienstverlening te zijn uitgeweken naar de schepenen van Breust.

In 1357 had hertog Wenceslaus in tamelijk vage bewoordingen aan Godert van den Bongard overgedragen 'allet dat recht dat wir haven mogen in deme dorpe van Oys bynnen den zunen', ${ }^{724}$ uitgezonderd de rechtspraak in criminele zaken. Wanneer 'ymant dat lyff verbeurden bynnen deme vurscreven dorpe van Oys', dan moest hij an de hertogelijke officieren worden uitgeleverd. Eventueel verbeurd verklaarde goederen vielen vervolgens de heer van Oost toe..$^{725}$ Wat betekende dit nu in later tijd concreet voor de positie van de heren van Gronsveld in Oost? Volgens een specificatie van de heerlijkheid, die Johan I van Bronckhorst Batenburg in 1544 inleverde bij het leenhof van Brabant in Brussel, had de heer van Gronsveld het recht om boetstraffelijke zaken af te doen. ${ }^{726}$ Een van de gelegenheden waarbij dit kon gebeuren was het twee tot driemaal per jaar gehouden voogdgeding. ${ }^{727}$ Verder moesten de inwoners van Oost zich voor procedures over roerende goederen en schuldvorderingen tot de schepenbank van Gronsveld wenden. De dienaren van de heer van Gronsveld konden misdadigers arresteren en moesten de betrokkene dan - zonder eventuele buit - binnen drie dagen uitleveren aan de drossaard van de hertog voor de berechting in de meest nabij gelegen schepenbank van het Land van Daelhem (dus uitdrukkelijk ruimer dan alleen 's-Gravenvoeren).

De beschrijving uit 1544 levert waarschijnlijk een wat geflatteerd beeld op. In werkelijkheid lijken de relaties tussen Gronsveld en Oost regelmatig onder spanning te hebben gestaan. Wanneer in 1608 graaf Johan II van Bronckhorst Batenburg bij de aartshertogen Albert en Isabella toestemming vraagt om voor Oost een eigen 'dingbancke van eenen scholtis ende seven schepenen met eenen clerck ende eenen gerichtsbode’ op te

\footnotetext{
723 Afgedrukt bij Janssen de Limpens, 'Geschiedenis Oost', 91.

724 'zunen': hagen of omheiningen rond het dorp.

725 Janssen de Limpens, 'Geschiedenis Oost', 124; idem, Rechtsbronnen Limburg en Overmaze, 324.

726 'Item hat der herr von Gronsfelt zu Oist den anfanck, kommerslag, gewalten, bruichten, zu scheijden, schlichten und zue componierenn. Item das die undersaissen von Oist von gereider haab und scholt zue Gronsfelt vur dem gericht zu recht kommen und erscheinen muessen, doch furbehalt dem herzog von Brabant alle zeit ein oberherr in criminal sachen die das leib betreffen zu sein. Deselve nach dem anfanck von des herren von Gronsveld officianten an den drosset oder stathelder uf den dritten tag ledig und bloiss von allen denjenigen so beij imen erfunden zu nechster banck des lantz von Dalen ubergeben sollen werden' zie: Hanssen, Die Rimburg, 351-352; Janssen de Limpens, 'Geschiedenis Oost', 87-88.

${ }^{727}$ In de toestemming voor het oprichten van een schepenbank in Oost in 1608 wordt aangehaald dat regelmatig in Oost voogdgedingen werden gehouden.
} 
richten, dan blijkt die spanning al uit de argumentatie. Inwoners van Oost waren in de loop der jaren opgehouden hun recht in Gronsveld te zoeken, omdat zij die plaats als buitenlands gebied, territorium van het Duitse Rijk beschouwden. Zij konden en mochten als Brabantse onderdanen volgens het privilege van de Gouden Bul niet buiten hun eigen land terecht staan. ${ }^{728}$ Een waarschijnlijk namens Hieronimus van Berghe genaamd Trips omstreeks 1620 bij de fiscaal van de Raad van Brabant ingediende memorie bevat een reeks grieven tegen de heer van Gronsveld. ${ }^{729}$ Weliswaar wordt op de rug van het stuk gewaarschuwd dat de tekst in sich unwarhaffich' is, maar de opsomming laat zien dat de verhoudingen slecht waren. Oost was altijd onafhankelijk gebleven als onderdeel van het Land van Daelhem, had nooit schatting betaald aan Gronsveld en ook geweigerd samen met de andere dorpen van het graafschap bij te dragen aan het inhuldigingsgeschenk van de nieuwe heer. Het viel niet te ontkennen dat in het verleden wel eens voogdgedingen of zittingen van het gerecht in Gronsveld waren bezocht, maar dat was gebeurd op vrijwillige basis, ter besparing van de veel langere reis naar 's-Gravenvoeren. Er bestond in Oost een duidelijke vrees voor gelijkschakeling met Gronsveld: men gebruikte daar andere maten (wat bij grond grote problemen kon opleveren) en de herendiensten in Gronsveld zouden aanzienlijk zwaarder op de inwoners drukken.

De scheiding tussen Gronsveld en Oost begon met de toestemming die graaf Johan II van Bronckhorst Batenburg op 15 december 1608 van de aartshertogen Albert en Isabella, kreeg om een schepenbank op te richten. ${ }^{730}$ Feitelijk lijkt dat te zijn neergekomen op een soort 'opwaardering' van de laatbank van de Gronsvelderhof of hof van Batenborch. Met de oprichting van een eigen bank voor hoge en lage rechtspraak voor Oost eindigde ook de bemoeienis van 's-Gravenvoeren op dit terrein. De verkoop van de heerlijke rechten over Oost in 1639 door graaf Jost Maximiliaan van Bronckhorst Batenburg aan Hieronimus van Berghe moest het sluitstuk van deze ontwikkeling vormen, maar een conflict over de vraag of de Gronsveldse lenen daarin ook waren begrepen, zorgde nog tot 1683 voor een vervelende nasleep. ${ }^{731}$

\subsubsection{Sint-Martens-Voeren}

Hoewel gelegen in het Land van Daelhem, was de heerlijkheid Sint-Martens-Voeren een leen van Valkenburg. Aangenomen wordt dat deze leenband omstreeks 1364 ontstond na de overgang van Valkenburg aan Brabant, toen hertog Wenceslaus schulden op het Land van Valkenburg moest aflossen aan Godert van den Bongard. Waarschijnlijk zijn toen heerlijke rechten over Sint-Martens-Voeren aan van den Bongard als compensatie toebedeeld en kreeg de plaats een eigen schepenbank, afgescheiden van de bank van 'sGravenvoeren. Laatstgenoemde instelling bleef echter als hoofdbank in appel fungeren. Of de belangstelling van Van den Bongard voor Sint-Martens-Voeren was gebaseerd op al aanwezig grondbezit, zoals in Oost, valt niet met zekerheid te zeggen. In ieder geval lag er een leen- en laathof, genoemd naar de familie Van den Bongard. Dit subalterne leenhof

728 Janssen de Limpens, 'Geschiedenis Oost', 103-104, 135-136.

729 RHCL, Familie De Geloes/Kasteel Eijsden, inv. nr. 317.

730 Afschrift van dit verlof in RHCL, Familie De Geloes/Kasteel Eijsden, inv. nr. 427.

731 Janssen de Limpens, 'Geschiedenis Oost', 107-108, 136-137. 
ressorteerde onder het landsheerlijk leenhof van Daelhem en er zouden volgens de literatuur vier onderlenen van afhangen. De juistheid van die mededeling is niet gecontroleerd, maar volgens een zeventiende-eeuwse uittreksel uit de 'Bongarder leencarte' lagen in Slenaken tenminste drie grote lenen van dit leenhof. ${ }^{732}$

De wat bijzondere positie van de hof van den Bongard komt ook naar voren aan het einde van een optekening omstreeks 1500 van de heerlijke rechten in Sint-Martens-Voeren. ${ }^{733}$ Daarin wordt namelijk gesteld dat deze vastlegging op geen enkele wijze afbreuk deed aan rechten van de hof Van den Bongard 'in alden gebruick gewest'. Over de overige leen- en laathoven in Sint-Martens-Voeren is slechts weinig bekend. Janssen de Limpens vermeldt een 'leenhof van Gronsveld' (dat in 1773 met dat van Van den Bongard werd verenigd) en verder (correct geteld?) de laathof Van den Graese, de Sint Maartenslaathof, de laathof Kauwenbergh, de Sint Stevenshof, de Coxlaathof en een 'cijnscaerte' verbonden aan de heerlijkheid. In ieder geval hadden de heren van Gronsveld in Sint-Martens-Voeren aan het begin van de zeventiende eeuw recht op een cijns van 118 kapoenen, bijna evenveel als de 115 stuks in het aangrenzende Slenaken. ${ }^{734}$ De bijzondere plaats die het leenhof van Gronsveld innam blijkt ook uit de eerder genoemde memories over heerlijke rechten. Daarin wordt gezegd dat de laatbanken in Sint-Martens-Voeren 'anderen heren of jonckeren toustaende', ter hoofdvaart moeten gaan naar de 'heren hoff. ${ }^{735}$

Godart van den Bongard verwierf over Sint-Martens-Voeren grondheerlijke rechten. Hij benoemde scholtis en schepenen, die geschillen over en de overdracht van onroerend goed behandelden. Verkoop van cijnsgoed vormde voor de heer een belangrijke bron van inkomsten omdat daarvan de zogenoemde werfschelling moest worden betaald (waarschijnlijk vijf procent van de koopsom). ${ }^{736}$ Kwesties over roerend goed en gewone schulden behoorden tot de competentie van de schepenen van 's-Gravenvoeren, maar hun bevoegdheid bleef beperkt. Een schuldeiser die met behulp van de gerechtsbode van 'sGravenvoeren zijn vordering wilde verhalen, kon alleen op de openbare weg arrest leggen op de debiteur. Voor het uitwinnen van onroerend goed diende de gerechtsbode van de grondheer tussenbeide te komen.

Naast deze jurisdictie over de grond had de heer het recht van 'alle gebotte ende verbotte in der kercken' waarmee in het algemeen werd bedoeld de bevoegdheid om plaatselijke verordeningen uit te vaardigen. Meer in het bijzonder gold dit voor het regelen van de jacht en visserij, het houden van geiten en het brouwen van bier. De berechting van overtredingen van plaatselijke verordeningen werd eveneens door de schepenbank behandeld.

Het landsheerlijk gezag over Sint-Martens-Voeren als onderdeel van het Land van Daelhem bleef onbetwist berusten bij de hertog van Brabant. Deze had 'den klockenslach ende den aentast, ouch alle verbotten opter straeten ende voerder niet'. Deze klokkenslag, het recht om inwoners op te roepen tot het verrichten van diensten ten behoeve van het

\footnotetext{
732 RHCL, Graafschap Gronsveld, inv. nr. 155.

733 Janssen de Limpens, Rechtsbronnen Limburg en Overmaze, 285.

734 RHCL, Graafschap Gronsveld, inv. nrs. 181, 183 (rekeningen 1617/1618) 1621/22.)

735 Janssen de Limpens, Recbtsbronnen Limburg en Overmaze, 284.

736 Deze bron van inkomsten wordt tenminste vermeld in de rentmeestersrekeningen van de graven van Gronsveld begin zeventiende eeuw.
} 
land, moet worden gezien als symbool van landsheerlijke rechten. De 'aentast' omvatte de bevoegdheid 'alle criminael saecken, gewalten, metzbruecken te straffen' waarbij de berechting plaats vond in 's-Gravenvoeren. De scholtis van de heer van Gronsveld kon misdadigers arresteren, maar moest deze binnen drie dagen uitleveren aan 'des hertogen amptluiden van Daelhem.'

\subsubsection{Conclusies}

Een exacte vergelijking tussen de heerlijke rechten van de heren van Gronsveld in Oost en Sint-Martens-Voeren valt niet te maken. In beide plaatsen bezaten zij lage jurisdictie met de bijbehorend ge- en verbodsrechten, maar het belangrijkste verschil tussen beide plaatsen was toch dat Sint-Martens-Voeren wel en Oost niet over een eigen schepenbank beschikte. Dat laatste leverde een dubbel nadeel op. In de eerste plaats ontbrak daarmee een instelling die bij uitstek kon dienen voor de handhaving van het heerlijk gezag. Voorts was er geen mogelijkheid om voor het plaatselijk gerecht de overdracht van onroerend goed vast te leggen. Voor de inwoners zal meestal registratie voor een laathof hebben volstaan. Soms werd ook uitgeweken naar de schepenbanken van Gronsveld of Breust, maar het zal moeilijk zijn geweest de werfschelling als overdrachtsbelasting te innen.

De mogelijkheid voor inwoners van Oost om gebruik te maken van de diensten van de schepenen van Gronsveld werd wel benut, maar stuitte in de praktijk op weerstand. Waarschijnlijk veel sterker dan in Sint-Martens-Voeren moeten de bewoners van Oost zich zorgen hebben gemaakt voor inlijving van hun dorp in het gebied van de heren van Gronsveld. Toch lijken de mogelijkheden om dorpen van het Land van Daelhem te annexeren vanaf het einde van de veertiende eeuw eigenlijk al niet meer reëel te zijn geweest. De hertog van Brabant had zich de landsheerlijke rechten en de hoge justitie over beide plaatsen uitdrukkelijk voorbehouden en lette ook op de handhaving daarvan. Zowel Oost als Sint-Martens-Voeren bleef ook bijdragen in de schatting en beden van het Land van Daelhem. Dat betekent dat deze plaatsen voor de heren van Gronsveld vooral hebben gefungeerd als een soort buffer tegen lastige buren, maar voor de verdere uitbouw van hun landsheerlijkheid kwamen zij niet meer in aanmerking. Deze conclusie wordt misschien ook bevestigd door het feit dat na 1620, wanneer de vervreemding van de 'buitengebieden' door de graven van Gronsveld begint, deze heerlijkheden als eerste worden verkocht. 


\section{HeREN EN GRAVEN VAN GRONSVELd UIT DE GESLACHTEN VAN BRONCKHORST BATENBURG, D'ARBERg VALENGIN EN TOERring- JETTENBACH (VIJFTIENDE- ACHTTIENDE EEUW)}

\section{De heren en graven van Gronsveld uit het geslacht Van Bronckhorst Batenburg tot 1617}

Heren van Gronsveld uit het middeleeuwse geslacht Van Gronsveld hadden zich ten opzichte van naburige landsheren, in het bijzonder de hertog van Brabant, moeten handhaven door middel van kredietverstrekking en daarvoor ontvangen onderpanden zoals kastelen, heerlijkheden en ambten. Die druk van mogelijke inlijving nam in de vijftiende eeuw af. Bij de heren van Bronckhorst Batenburg veranderde die oriëntatie en verschoven de belangen door ambten, bezittingen en familiale verbindingen duidelijk in de richting van de hertogdommen Kleef, Gelre en Gulik en de kleine zelfstandige rijksonmiddellijke gebieden aan de rand van deze hertogdommen. In de zeventiende eeuw sloegen achtereenvolgens de graven Jost Maximiliaan en Johan Frans van Bronckhorst Batenburg met hun militaire carrières in Beierse en keizerlijke dienst duidelijk een andere koers in. Daarom is ervoor gekozen hier een cesuur te leggen in de familiegeschiedenis.

Achteraf kan de geschiedenis van een familie worden gezien als een reeks nalatenschappen, waaraan gedurende een reeks van opeenvolgende generaties individuele personen met hun eigen karakter en ambities een bijdrage hebben geleverd. Dan kan worden beoordeeld of binnen een familie bepaalde tradities bestonden, welke - al dan niet succesvolle - strategieën werden gevolgd en welke invloed toevallige omstandigheden zoals kinderloosheid, vroegtijdig overlijden of politieke verwikkelingen daarop hadden. Die benadering is ook gekozen voor het navolgende overzicht. Er is niet gestreefd naar afgeronde biografieën, maar alles wat (grotendeels uit literatuur) bekend is, wordt zodanig bij elkaar geplaatst dat het een indruk geeft van iemands levensloop en carrière. Vaak bevatten die beschrijvingen lacunes, want door het nagenoeg volledig ontbreken van een eigen familiearchief kunnen soms zelfs elementaire levensdata niet eens precies worden vastgesteld. Daar komt bij dat het materiaal uit andere archieven, zoals financiële bescheiden en processtukken, een eenzijdige kijk op de werkelijkheid geeft.

Toch vallen binnen de acht in dit hoofdstuk beschreven generaties wel enkele doorlopende lijnen te ontdekken. Behalve de al genoemde verschuiving van belangen van Gronsveld naar de Nederrijn, moet daarbij in de eerste plaats worden gewezen op de twee standsverhogingen in de rijksonmiddellijke adel, eerst tot rijksvrijheer en vervolgens tot rijksgraaf. Dat vormt een belangrijk thema in dit hoofdstuk. Stand was voor de familie Van Bronckhorst Batenburg belangrijk om zich te onderscheiden van de landadel, maar ook om door andere rijksonmiddellijke adel als gelijkwaardig te worden geaccepteerd. Stand bepaalde de keuze van de huwelijkspartner, opende de deur voor carrières in vorstelijke, keizerlijke of kerkelijke dienst, was belangrijk voor de onderbrenging van ongehuwde zonen en dochters in hoogadellijke kapittels en stiften en bepaalde de positie van de familie (en daarmee ook van het Land Gronsveld) binnen de staatkundige 
verhoudingen van het Rijk. Erkenning als rijksonmiddellijke stand betekende vanaf de zestiende eeuw een soort garantie voor het behoud van zelfstandigheid.

Hoewel de carrières van de heren van Bronckhorst Batenburg grotendeels buiten Gronsveld verliepen (en ook het familieleven zich vooral in Rimburg afspeelde), bestond wel degelijk een wisselwerking tussen Gronsveld, stand en loopbaan. Want ook al verschoven de economische en sociale belangen van de familie naar de Nederrijn, het rijksonmiddellijke zonneleen Gronsveld bleef het fundament waarop de stand van de familie rustte. Dat besef lijkt in het bijzonder na politieke verwikkelingen in het midden van de zestiende eeuw goed te zijn doorgedrongen. De standsverheffingen, in het bijzonder de verwerving van de graventitel, koppelden de heren van Bronckhorst Batenburg en Gronsveld nadrukkelijk aan het Rijk. Daarmee moet de geschiedenis van de heren van Bronckhorst Batenburg en van Gronsveld ook worden geplaatst binnen de kaders van drie grote thema's uit de politieke en kerkelijke geschiedenis van die tijd: de afronding van de Bourgondisch-Habsburgse Nederlanden ten opzichte van het Rijk, de gevolgen voor het Maasdal van de Nederlandse Opstand tegen Spanje en ten slotte de confessionele verhoudingen, ook binnen de verschillende takken van de familie.

$\mathrm{Er}$ is, ten slotte, voor gekozen de geschiedenis van de familie Van Bronckhorst Batenburg te beschrijven zonder vergelijking te trekken met andere families in het bezit van kleine, rijksonmiddellijke territoria. Die vergelijkende adelsgeschiedenis vergt een aparte benadering. Hoe groot de verschillen in ontwikkeling kunnen zijn, wordt duidelijk wanneer men kijkt naar de voorgeschiedenis van de grafelijke families die na 1653 worden toegelaten tot het Nederrijns-Westfaalse Rijksgravencollege. ${ }^{737}$ Daarnaast zou een dergelijk studie moeten worden ingepast binnen het algemene onderzoek naar adelsgeschiedenis in het Rijk gedurende de vroegmoderne tijd, in het bijzonder de sociale mobiliteit binnen de adel, zowel horizontaal door huwelijk als verticaal (nobilitering en nobiliteringspolitiek van de keizer, verarming en uitsterven van families). ${ }^{738}$

\subsection{Diederik I van Bronckhorst Batenburg, ?-1450}

\subsubsection{Huwelijk met Johanna van Gronsveld}

Op vrijdag na Sint-Martinusdag (16 november) 1425 kwamen Diederik van Bronckhorst Batenburg met Hendrik III van Gronsveld en Aleidis van Oupeye, in aanwezigheid van zestien familieleden en vrienden, de voorwaarden overeen voor zijn huwelijk met Johanna, de oudste dochter van Hendrik en Aleidis. ${ }^{739}$ Diederik, die zich 'zoon tot Batenborch en tot Anholt' noemt, wordt het eerst vermeld in $1419 \mathrm{bij}$ een overeenkomst tussen veertien edelen - de meesten onderling verwant - die elkaar voor een periode van zeven jaar wederzijds gewapende steun beloven. ${ }^{740}$ Aangenomen dat Diederik toen net meerderjarig was, moet zijn geboortejaar rond 1402/1403 liggen. De aanduiding 'zoon tot Batenborch

737 Zie voor een overzicht daarvan Arndt, Reichsgrafenkollegium, 36-101.

${ }^{738}$ Zie voor een samenvatting van deze discussie Endres, Adel in der Frühen Neuzeit, 49-55.

739 ULB Darmstadt, Hs. inv. nr. 2734-2735, Cartularium Hurt von Schönecken, fol. 85-89.

${ }^{740}$ Regest bij Van Schilfgaarde, Archief Bergh, Regestenlijst oorkonden, Eerste stuk, 96, nr. 347. Nijhoff, III, Willem en Reinald IV, hertogen van Gelre uit het Huis van Gulik, 368-371, nr. 387. 
en tot Anholt' wordt nog gebruikt tot omstreeks $1429^{741}$, in welk jaar Diederiks vader Gijsbert van Bronckhorst overleed. ${ }^{72}$ De leeftijd van Johanna van Gronsveld moet in 1425 worden geschat tussen de vijftien en twintig jaar.

In de overeenkomst wordt vastgelegd dat Johanna als huwelijksgift van haar ouders in totaal 6500 Rijnse guldens ontvangt, te betalen in verschillende termijnen. In beginsel zullen haar na het overlijden van haar vader de heerlijkheden Gronsveld en Rimburg als erfdeel toevallen. Daarna worden diverse scenario's uitgewerkt voor het geval Johanna alsnog een broer kreeg of wanneer bruid of bruidegom kinderloos overleed. Diederik stelde diverse goederen ter beschikking wanneer Johanna als weduwe achterbleef, te weten een rente van achthonderd Rijnse gulden uit de heerlijkheid Anholt en een woning in Anholt. Wanneer Diederik van zijn vader de heerlijkheid Batenburg had geërfd en van zijn 'moene van Monement'743 de heerlijkheid Roen of Angeraen (in het hertogdom Kleef), ontving Johanna nog een rente van achthonderd gulden en een goede woning in Batenburg.

Door het huwelijk van Diederik en Johanna werden twee families met elkaar verbonden, die zich als standsgelijken beschouwden en beide konden terugzien op een roemrijk voorgeslacht. Hoewel de rol van Diederik als heer van Gronsveld bescheiden lijkt te zijn geweest, kan hij worden beschouwd als stamvader van het geslacht Van Bronckhorst Batenburg als heren van Gronsveld. Om die reden duiden we hem in de opeenvolgende reeks generaties aan met het Romeinse cijfer I. Zijn voornaam wordt in de originele bronnen op verschillende wijzen gespeld, meestal een variatie op de naam Diederik. Die spelling wordt hierna ook aangehouden.

\subsubsection{De afkomst van Diederik.}

De genealogie van het geslacht Van Bronckhorst vormde al meermalen onderwerp van onderzoek, te beginnen bij Van Spaen in $1801^{744}$, goeddeels overgenomen door Van der Chijs in $1853^{745}$ met aanvullingen uit Nijhoffs 'Gedenkwaardigheden? ${ }^{746}$, door Graswinckel in 1925 en 1926 in tabelvorm toegevoegd aan de gedrukte inventarissen van de heerlijkheidsarchieven van Batenburg ${ }^{747}$ en Bronckhorst ${ }^{748}$ en ten slotte, het meest compleet en best gedocumenteerd, gepubliceerd door Van Schilfgaarde in 1957.749 Aan deze 'stamboom van genealogieën' kan weinig nieuws worden toegevoegd. Dat neemt niet

741 1423: regest bij Van Schilfgaarde, Archief Culemborg, Tweede stuk, Regestenlijst (eerste deel) 199, nr. 777; 1424: Dösseler/Oediger, Lehnregister Kleve, 252, nr. 337/1 en 495, nr. 659/6; omstreeks 1429 Graswinckel, Oud-archief Arnbem, Brievenlijst, 9, nr. 24 en 25.

742 Van Schilfgaarde, 'De heren van Bronckhorst', 75.

${ }^{743}$ Tante van moederszijde Elisabeth van Ghemen, wonende te Obermörmter (in die tijd vaak aangeduid als 'Monementen' tussen Kalkar en Xanten. Zij was in het bezit van de heerlijkheid Angeraen of Roen.

744 Van Spaen, Oordeelkundige inleiding 1, 279-287; 309-332.

745 Van der Chijs, Munten Gelderland, 129-153.

746 Nijhoff, Gedenkwaardigheden Gelderland, passim.

747 Graswinckel, 'Archief Batenburg', 136a.

748 Graswinckel, 'Archief Bronkhorst', 82a.

${ }^{749}$ Van Schilfgaarde, 'De heren van Bronckhorst'. 
weg dat bepaalde onduidelijkheden en lacunes blijven bestaan, zeker wat betreft de vroegst bekende generaties.

In de literatuur worden de oudste generaties Van Bronckhorst vanaf de twaalfde eeuw in verband gebracht met Rekem. Onmogelijk is die connectie niet, maar het bewijs voor deze vroege Bronckhorster anwezigheid in Rekem is nogal mager en deels zelf speculatief. Echt vaste bodem onder de voeten hebben we eigenlijk pas met de edelman ('nobilis vir') Gislebertus 'gezegd van Bronckhorst' die in 1237/1238 optreedt in een oorkonde waarbij zekere ridder Willem van Tongeren twee bunder land in 'Radekeym' (Rekem) schenkt aan het norbertinessenconvent aldaar. ${ }^{750}$ Waarschijnlijk moet de oorsprong van de Bronckhorsten worden gezocht in het Gelderse rivierengebied. De door Van Schilfgaarde genoemde Willem van Bronckhorst, komt in de periode tussen 1190 en 1226 enkele malen in oorkonden voor, vooral als getuige voor de graaf van Gelre. ${ }^{751}$ Daarnaast lijdt het geen twijfel dat de heren van Bronckhorst tot het begin van de veertiende eeuw in het bezit waren van de heerlijkheid Rekem. Na het overlijden van Gijsbert van Bronckhorst gaven Gerardus van der Marck en Willem van Bronckhorst aan graaf Arnold van Loon in 1317 kwijtschelding voor het beheer dat laatstgenoemde over de heerlijkheid Rekem had gevoerd en droeg Willem van Bronckhorst onder bepaalde voorwaarden Rekem over aan Gerard van der Marck. ${ }^{752}$

Ook al kent de vroegste geschiedenis der Bronckhorsten onzekerheden en hiaten, duidelijk is dat zij tot de stand der nobiles behoorden en als afstammelingen van oude inheemse adel moeten worden beschouwd. In schrille tegenstelling tot deze adeldom staat het gebied van de heerlijkheid Bronckhorst zelf. Het was in feite niet meer dan het gelijknamige kasteel met het terrein van de voorburcht, een gebied dat wordt gelijkgesteld met het latere stadje Bronckhorst, gelegen in het Gelderse kerspel Steenderen aan de IJssel. ${ }^{753}$ Volgens gegevens uit het midden van de veertiende eeuw omvatte die heerlijkheid zowel de lage als hoge rechtsmacht. Of deze jurisdictie teruggaat op een mogelijk ooit bestaan hebbend graafschap Steenderen, dan wel oorspronkelijk bezit was van de heren van Bronckhorst of op een bepaald tijdstip werd verleend door graven van Gelre, kan hier in het midden blijven. Wel krijgt men de indruk dat het kasteel en de daaraan verbonden heerlijkheid moeten worden beschouwd als een soort 'inplanting' in Gelders territoir.

Hoe dit ook mag zijn, vast staat dat de onafhankelijkheid van Bronckhorst ten opzichte van Gelre zo groot was, dat deze de status van landsheerlijkheid benaderde. ${ }^{754} \mathrm{Er}$ is geen

750 Verbois, Geschiedenis kerken Rekem, 116; tekst afgedrukt bij Daris, 'Documents norbertines Reckheim', 9; Chestret de Haneffe, 'Histoire Reckheim', 75-76. Overigens blijkt uit deze oorkonde dat Gijsbert van Bronckhorst nog een zuster Helena had, die in de genealogie bij Van Schilfgaarde ontbreekt.

751 Van Schilfgaarde, 'De heren van Bronckhorst', 67 met de daar aangehaalde bronnen.

752 Zie Van Schilfgaarde, 'De heren van Bronckhorst', 68-71; Chestret de Haneffe, 'Histoire Reckheim', 24-27 en bijlagen op 78-79.

${ }_{753}$ De Monté ver Loren, 'Gegevens Bronkhorst', 125-128.

754 De hierna volgende (summiere) beschouwingen over de staatkundige positie van Bronckhorst zijn ontleend aan Van Spaen, Oordeelkundige inleiding 1, 270-278; De Monté ver Loren, 'Gegevens Bronkhorst', passim; Nève, Rijkskamergerecht, passim. 
spoor van een leenverhouding, noch met de keizer noch met Gelre; het gebied werd beschouwd als een 'zonneleen', volledig allodiaal goed. ${ }^{755}$ Ook de rechtspraak geschiedde volkomen onafhankelijk. Anderzijds moet die zelfstandigheid ook worden gerelativeerd. Zoals Bronckhorst lagen er vooral aan de rand van de Gelderse Nederkwartieren meer gebiedjes, waarvan de heren in meer of mindere mate aanspraak maakten op landsheerlijke rechten. Bij wijze van voorbeeld kan worden gewezen op Culemborg, Buren, Batenburg, Bergh en Borculo. Sommige golden als allodiaal, andere kenden leenverhoudingen met de keizer of naburige landsheren. Waarschijnlijk kan de oorsprong van een deel van de geslachten, wier namen later met deze gebieden zijn verbonden, worden teruggevoerd op oude inheemse adel. Zij beschouwden zich als standsgelijken van de graven, later hertogen van Gelre, maar stelden zich ook in dienst van de Gelderse landsheren en raakten aldus vanaf het einde van de middeleeuwen steeds meer verbonden met Gelre. ${ }^{756}$ De Bronckhorsten hoorden in de rangorde binnen de Gelderse adel vóór de ridderschap tot de bijzondere groep van de zogenoemde 'bannerheren'. ${ }^{757}$ Voorts makkten de heren Van Bronckhorst ook deel uit van de Zutphense ridderschap en droegen zij - min of meer op vrijwillige basis - in de zestiende eeuw bij aan de landsheerlijke belastingen in het Kwartier van Zutphen. ${ }^{758}$

Tegengesteld aan deze verbondenheid met Gelre waren de pogingen die vanaf de eerste helft van de vijftiende eeuw vanwege de keizer en het Rijk werden ondernomen om de kapitaalkrachtige heren van Bronckhorst te laten meebetalen in de rijksheervaart. ${ }^{759}$ In het de zestiende eeuw werd die status van rijksonmiddellijkheid opnieuw inzet van een conflict. Kortom, de staatkundige positie van Bronckhorst lag, gelijk die van een aantal andere Gelderse 'randgebieden', juridisch gecompliceerd en wisselde naar tijd en omstandigheden.

De Bronckhorsten behoorden als nobiles tot een sociale groep met een hoge mate van standsbewustheid. Huwelijkspartners werden bij voorkeur binnen de eigen kring gezocht. Binnen dit stramien past ook de verbintenis die Willem van Bronckhorst omstreeks 1315 aanging met Johanna van Batenburg, dochter van Dirk van Batenburg en een zekere

\footnotetext{
755 Zie ook: à Sande, Commentarius in Gelriae et Zuphaniae consuetudines feudales, 1-2.; De Monté ver Loren, 'Gegevens Bronkhorst', 127-129.

${ }^{756}$ De Monté ver Loren, 'Gegevens Bronkhorst', 131.

757 Zie over de Gelderse bannerheren: Denessen, 'De Gelderse bannerheren'. In de traditionele Gelderse geschiedschrijving wordt gesproken over vier 'bannerheren', te weten Bronckhorst, Wisch, Bahr (Baer) en Bergh. Volgens het onderzoek van Denessen bestaat deze beperking tot vier pas sinds de zestiende eeuw. Sinds de eerste helft van de vijftiende eeuw, toen nog werd gesproken over een vijftiental, fluctueerde het aantal. Bronckhorst heeft er altijd toe behoord. Functie en rol van de bannerheren is niet duidelijk. Zij komen voort uit de groep van belangrijke heerlijkheidsbezitters. Het is echter de vraag of de titel van bannerheer aanvankelijk niet zo zeer werd afgeleid van het bezit van een bepaalde heerlijkheid, maar vooral een persoonlijke kwaliteit betrof.(Denessen, o.c., 34) Waarschijnlijk is het woord 'bannerheer afgeleid van 'banierdrager' en vervulden zij een rol bij als aanvoerders in militaire dienst. Binnen de Gelderse adel hadden zij ten opzichte van de overige leden van de ridderschap protocollaire voorrangsrechten en fiscale voordelen (vgl. De Monté ver Loren, 'Gegevens Bronkhorst', 130).

758 De Monté ver Loren, 'Gegevens Bronkhorst', 129.

759 De Monté ver Loren, 'Gegevens Bronkhorst', 132-133.
} 
Mechteld. ${ }^{760}$ De heren van Batenburg waren landsheren die hun rechten direct van de keizer in leen hielden en ze mochten zich uit dien hoofde in rang - niet in politieke betekenis - de gelijken achten van buren als de graven van Holland of Gelre. ${ }^{761}$

$\mathrm{Na}$ het overlijden van Gijsbert van Bronckhorst Batenburg in 1356 splitste de stam zich aanvankelijk in drie takken, te weten Bronckhorst, Batenburg en Borculo. Tot een blijvende lijn Bronckhorst-Borculo kwam het echter uiteindelijk niet en deze kwam uiteindelijk weer bij Bronckhorst-Bronckhorst. Deze oudste tak bleef vrij klein en stierf 1553 in mannelijke lijn uit met het overlijden van Jost, heer van Bronckhorst en Borculo (zie meer over hem in hoofdstuk 3.6.3). ${ }^{762}$ De lijn Bronckhorst Batenburg vertakte zich begin zestiende eeuw in de lijnen Anholt, Gronsveld-Rimburg, Stein en Batenburg en ten slotte Angeraen, later Anholt.

De andere hoofdtak Bronckhorst Batenburg werd gevormd door de nakomelingen van Dirk van Bronckhorst Batenburg (gestorven 1406/1407) en Elisabeth van Utenhove. Door het huwelijk van hun enige zoon Gijsbert (vermeld vanaf 1402, overleden 1429) met Margriet van Ghemen, erfdochter van de heerlijkheid Anholt, lukte het twee belangrijke, en in status vergelijkbare, heerlijkheden Batenburg en Anholt in personele unie met elkaar te verbinden. ${ }^{763}$ Hun enige zoon was Diederik of Dirk.

Hoewel de voornaamste bezittingen van leden van de familie Van Bronckhorst aan de rand van of - zo men wil - net buiten de grens van Gelre lagen, speelden opeenvolgende generaties heren Van Bronckhorst uit de verschillende linies een grote rol in de Gelderse politiek. In het bijzonder gold dit voor de dynastieke twisten binnen de hertogelijke familie in het derde kwart van de veertiende eeuw, die bekend staan als de oorlog van de Heeckerens en de Bronckhorsten. Deze oorlog werd voor een niet onbelangrijk deel gevoed en ook uitgevochten door de clans van de Heeckerens en de Bronckhorsten. Het prestige van de Bronckhorsten die in deze burgeroorlog door hun steun aan de hertogen Eduard van Gelre en later aan Willem van Gulik meestal aan de kant van de winnende partij stonden, was er in die tijd niet slechter op geworden. Men vindt hen vermeld als pandheren van heerlijkheden en ambten, hertogelijke raadslieden en geldschieters van de hertog.

\subsubsection{Activiteiten in Gelre en Kleef}

Gegevens over de levensloop en activiteiten van Diederik I van Bronckhorst Batenburg moeten we vooral zoeken in het gebied van de Nederrijn, in of bij de hertogdommen Kleef en Gelre. Nog vóór zijn huwelijk ontving hij in 1424 van de hertog van Kleef

760 Van Schilfgaarde, 'De heren van Bronckhorst', 71.

761 De Monté ver Loren/Spruit, Hoofdlijnen, 102-104 en Nève, Rijkskamergerecht, passim, in het bijzonder 167-172 en 280-281, met de bij beide auteurs opgegeven literatuur.

762 Zie over de strijd over de tot diens erfenis behorende Munsterse lenen; à Sande, Commentarius in Gelriae et Zutphaniae consuetudfines feudales, 108- 111, met genealogie.

763 Van Schilfgaarde, 'De heren van Bronckhorst', 75. 
verschillende rechten te Rade in de Hetter en het ambt Hetter en Aspel in leen, die voordien in het bezit waren geweest van de heren van Anholt. ${ }^{764}$ In 1431 beleende roomskoning Sigismund hem met de heerlijkheden Anholt en Batenburg. ${ }^{765}$ Ten aanzien van Batenburg was dat eigenlijk voorbarig, want op dat moment kon Willem van Gulik geheten Van Wachtendonck, een bastaardzoon van de in 1423 overleden hertog Reinald IV van Gelre, aanspraken op Batenburg doen gelden wegens pandrechten.766 In 1432 verkochten Willem en zijn echtgenote Hermen van Bronckhorst Batenburg, de zuster van Diederik, hun rechten op Batenburg aan Diederik. ${ }^{767}$ Ook in 1432 droeg Diederiks tante van moederszijde Elisabeth van Ghemen hem en zijn zoon Gijsbert (waarschijnlijk zes jaar oud) rechten op de belangrijke hof 'Overmonementen' (Obermörmter) over, voor welke goederen de leenroerigheid aan het kapittel van Xanten werd erkend. Waarschijnlijk behoorde daartoe ook huis en heerlijkheid Rönne ('Angeraen' of 'Roen').768

Zoals vermeld, was Arnold van Egmond in 1423 als hertog van Gelre aan het bewind gekomen. Zijn regering, die formeel vijftig jaar duurde, werd beheerst door strijd met de buurgewesten en dynastieke twisten. In de entourage van deze hertog was ook Diederik van Bronckhorst, geheel in traditie van zijn familie, voorbestemd voor een rol in het ambtelijke bestuur van Gelre. Toch bleven zijn taken beperkt. Waarschijnlijk begon zijn loopbaan omstreeks 1433, in welk jaar hertog Arnold steun en schadeloosstelling aan zijn helper Diederik beloofde. ${ }^{769}$ In 1437 benoemde de hertog hem tot ambtman van het Land van Maas en Waal, welke functie hij tot 1443 uitoefende. Onduidelijk is of hij dit ambt al onmiddellijk of pas korte tijd later als onderpand voor een geldlening bezat. ${ }^{770}$ Aangezien het in dit district aan een goede gevangenis ontbrak, verleende Arnold toestemming om misdadigers op te sluiten in het hertogelijke kasteel Oyen, ${ }^{771}$ welk huis Diederik overigens al sinds 1435 als onderpand in bezit hield. ${ }^{772} \mathrm{Bij}$ de verpandingsovereenkomst wordt

\footnotetext{
764 Dösseler/Oediger, Lehnregister Kleve, 252, nr. 337/1 en 495, nr. 659/6, met een samenvatting van de overeenkomst die over deze leengoederen werd gesloten. In 1430 werd opnieuw leenhulde gedaan, waarschijnlijk in verband met het overlijden van Dideriks vader Gijsbert van Bronckhorst.

${ }^{765}$ Regest bij Van Schilfgaarde, Archief Culemborg, Tweede stuk, Regestenlijst (eerste deel), 231, nr. 915.

766 Zie over hem Nijhoff, Gedenkwaardigheden Gelderland IV, Arnold van Egmond, hertog van Gelre, 113-114, nr. 138 (noot).

767 Van Spaen, Oordeelkundige inleiding 1, 311.

768 Elisabeth van Ghemen, weduwe van Diederik van Monement (Mörmter), was onder andere vrouwe van de heerlijkheid Rönne (Angeraen of Roen), waarvan ook rechten over het kerspel Obermörmter deel uitmaakten. Zie Alders, 'Obermörmter', 316-322; verder Wilkes, Urkunden Xanten, 308, nr. 1361; 310, nr. 1365, 1366; verder Scholten, 'Urkundliches Mörmter und Roen', passim en in het bijzonder 250-253, 256257, 261-263; verder Van Schilfgaarde, 'De heren van Bronckhorst', 85, noot 212a.

${ }^{769}$ Regest bij Van Schilfgaarde, Archief Culemborg, Tweede stuk, Regestenlijst (eerste deel), 237-238, nr. 943.

${ }_{770}$ Regest benoemingsakte bij Graswinckel, 'Archief Batenburg', 139, nr. 5; tekst afgedrukt bij Nijhoff, IV, Arnold van Egmond, hertog van Gelre, 158, nr. 170; zie ook Kuys, Ambtman Nijmegen, 321.

771 Regesten bij Nijhoff, IV, Arnold van Egmond, hertog van Gelre, 167, nr. 176 en Graswinckel, 'Archief Batenburg', 139, regest nr. 6.

${ }_{772}$ Regest bij Van Schilfgaarde, Archief Culemborg, Tweede stuk, Regestenlijst (eerste deel), 249, nr. 992a.
} 
Diederik voor het eerst als hertogelijke raad betiteld, een positie die hem tot een belangrijke adviseur van Arnold maakte. ${ }^{773}$

Inmiddels lijkt de verstandhouding tussen hertog Arnold en Diederik toch enigszins te zijn bekoeld. De hertog verweet hem dat hij vroeger vooral met het oog op zijn eigen voordeel raad en advies had gegeven. ${ }^{774}$ Verder koos Van Bronckhorst Batenburg partij tegen de hertog in een ruzie over het doorsteken van een dijk bij Driel, op zich een onbelangrijk conflict, dat echter tot een kleine burgeroorlog escaleerde. ${ }^{775}$ Ook in de groeiende onvrede over het hertogelijke bestuur moest Diederik stelling nemen. In de verbondsbrief van ridderschap en steden van Gelre in 1436 tegen hun landsheer, staat zijn naam als tweede in de lange lijst van edelen uit het Kwartier van Nijmegen, die deze overeenkomst bezegelden. ${ }^{776}$

Financieel schijnt het Diederik niet slecht te zijn vergaan. Verschillende malen komen we hem tegen als geldschieter, zowel bij de hertog van Gelre als bij de hertog van Kleef. Zo is al vermeld dat hij in 1435 het huis Oyen als onderpand voor een lening ontving. In 1440 werden dit kasteel en het kasteel Dieden wederom tot zekerheid gesteld voor zesduizend gulden. ${ }^{777} \mathrm{Om}$ nog veel grotere belangen ging het in hetzelfde jaar, toen hertog Arnold verklaarde ruim veertigduizend Rijnse guldens schuldig te zijn aan zijn rentmeester Udo Talholt, voor welk bedrag een groot aantal inkomsten uit domeingoederen op de Veluwe en in het Land van Cuijk in onderpand werd gegeven. Daarbij was overeengekomen dat Diederik van Bronckhorst Batenburg deze vordering mocht overnemen, wat hij ook deed. De inlossing van deze zogenoemde Batenburgse Pandschap werd naderhand een bron van grote onenigheid en kreeg uiteindelijk pas een einde in $1683 .{ }^{778}$ Een volgende belangrijke pandschap voor een bedrag van twaalfduizend Rijnse guldens ten laste van de hertog van Kleef betrof goederen en inkomsten in de parochie Uden. ${ }^{779}$ Daarnaast zal Diederik ongetwijfeld een reeks debiteuren voor kleinere bedragen hebben gehad, waarvan we hier, bij wijze van voorbeeld, noemen een schuldbekentenis uit 1450 ten bedrage van 1100 Rijnse guldens ten laste van de heer van Waalwijk. ${ }^{780}$

773 Voorbeelden waarbij Dirk optreedt als medebezegelaar of getuige bij hertogelijke oorkonden zijn te vinden in 1436: Nijhoff, IV, Arnold van Egmond, hertog van Gelre, 128, nr. 155; Lacomblet, Urkeundenbuch IV, 257-258, nr. 219; 1438: Nijhoff, IV, Arnold van Egmond, hertog van Gelre, 166, nr. 175; 1449; Nijhoff, IV, Arnold van Egmond, hertog van Gelre, 244-246, nr. 257.

774 Van Spaen, Oordeelkundige inleiding 1, 312.

775 Nijhoff, IV, Arnold van Egmond, hertog van Gelre, 229, nr. 244; Keussen, Urkundenbuch Krefeld, II, 106, nr. 2437 en Graswinckel, Oud-archief Arnhem, Regestenlijst, 228, nr. 876; Vgl. Moorman van Kappen, 'Historische ontwikkeling Tieler en Bommelerwaarden', 74-77.

776 Regest bij Graswinckel, Oud-archief Arnhem, Regestenlijst, 193, nr. 74; afgedrukt bij Nijhoff, IV, Arnold van Egmond, hertog van Gelre, 130, nr. 158.

777 Regest bij Van Schilfgaarde, Archief Culemborg, Tweede stuk, Regestenlijst (eerste dee), 277, nr. 1111a.

778 Zie over het ontstaan en aflossing van deze Batenburgse Pandschap Nijhoff, IV, Arnold van Egmond, hertog van Gelre, 175-178, nr. 189-193 en 197; 203, nr. 221.

779 Het ontstaan van deze pandschap is niet bekend. Ze wordt vermeld in een oorkonde afgedrukt bij Lacomblet, Urkundenbuch IV, 359-362, nr. 295.

780 Regesten bij Nijhoff, IV, Arnold van Egmond, hertog van Gelre, 249, nr. 266 en Graswinckel, 'Archief Batenburg', 141, nr. 12. 
De hiervoor beschreven activiteiten van Diederik van Bronckhorst Batenburg spelen zich vrijwel uitsluitend af in het Gelderse. Had hij ook een rol in Gronsveld? Hij noemt zich vanaf 1443 in oorkonden niet alleen heer van Anholt en Batenburg, maar voegt aan zijn titulatuur ook regelmatig Gronsveld en Rimburg toe. ${ }^{781}$ Het is echter de vraag of hij zich veel met het bestuur van Gronsveld en Rimburg heeft ingelaten, want hij overleed al omstreeks 1451. Zijn schoonvader Johan III van Gronsveld zat toen nog stevig in het zadel. De kwestie is niet zonder belang in verband met de uitoefening van het muntrecht van de heren van Gronsveld. Van der Chijs beschrijft als eerste munten die door Diederik I van Bronckhorst in Gronsveld zouden zijn geslagen. Waarschijnlijk steunend op die publicatie zijn Chestret de Haneffe en Hanssen er van overtuigd dat Diederik heer van Gronsveld en Rimburg is geweest. ${ }^{782}$ Rechten op Gronsveld en Rimburg vormen in ieder geval na Diederiks overlijden een integraal onderdeel van zijn nalatenschap.

\subsubsection{Pelgrimage naar het Heilig Land}

Rond 1450, een zogenoemd Heilig Jaar, ontstond in de Westerse christenheid een ware golf in pelgrimages, naar Rome en ook naar de heilige plaatsen in Palestina. Mogelijk zouden we nooit iets over Diederiks tocht hebben vernomen, ware het niet dat hij wordt vermeld als reisgenoot van hertog Johan I van Kleef (1448-1481), die een beschrijving van zijn reis liet maken. Verder is er een vijftiende-eeuws lied waarin de tocht van 'de drie landsheren geboren uut Nederlant, Cleve, Hoorne ende Batenborch’ wordt bezongen. Waarschijnlijk was het vertrek begin 1450. Via Venetië reisde het gezelschap per schip naar Palestina, waar Diederik van Bronckhorst Batenburg in Jeruzalem de ridderslag ontving van de hertog van Kleef. Via Rhodos en Cyprus werd teruggevaren naar Ancona in Italië, waarna de heren van Horn en Bronckhorst Batenburg hun reis voortzetten naar Rome. Na een kort verblijf in de Eeuwige Stad, waar juist de pest was uitgebroken, trokken de edelen weer noordwaarts. Begin november 1450 arriveerden zij in Brussel. ${ }^{783}$ Of het een gevolg van de reis was, weten we niet, maar enkele maanden later overleed Diederik. Hij werd begraven bij de minderbroeders in Nijmegen. ${ }^{784}$

\footnotetext{
781 Regest bij Van Schilfgaarde, Archief Culemborg, Tweede stuk, Regestenlijst (eerste dee), 293, nr. 1175 en vidimus afgedrukt bij Nijhoff, IV, Arnold van Egmond, hertog van Gelre, 158, nr. 170.

782 Chestret de Haneffe, 'Histoire Gronsveld', 57, noot 4, waarbij toch enige aarzeling over die muntslag bestaat. Hanssen, Die Rimburg, 131, noemt 1444 als mogelijk beginjaar van Diederiks heerschappij over Gronsveld vanwege een verondersteld overlijden van 'Catharina') = Johanna van Gronsveld in dat jaar. Deze leefde echter nog in 1451 en overleefde haar echtgenoot.

783 Over deze reis en het lied van de drie landsheren zie Habets, 'Pelgrimsreis', passim; Pompen, 'Jacob de Eerste', passim; Chestret de Haneffe, 'Histoire Gronsveld' 59-60; Hanssen, Die Rimburg, 132-133; Scholten, 'Clevische Chronik', 165-166.

${ }^{784}$ Van Schilfgaarde, 'Bronckhorst', 76. Zijn echtgenote leefde nog, anders dan vermeld bij Chestret de Haneffe, 'Histoire Gronsveld', 60 en Hanssen, Die Rimburg, 133.
} 


\subsubsection{Verdeling van de nalatenschap}

Uit het huwelijk van Diederik en Johanna van Gronsveld werden vijf zonen en drie dochters geboren. ${ }^{785}$ Voor die tijd opmerkelijk, ook in adellijke kringen, was dat Gijsbert en Herman, respectievelijk de oudste en derde zoon, universitaire studies volgden, waarschijnlijk in de rechten. ${ }^{786}$ De vierde zoon, Johan, bracht het tot domproost van Münster. Hoewel we van universitaire studie bij edelen in die tijd misschien geen al te hoge verwachtingen mogen hebben, laat deze opleiding zien dat intellectuele vorming bij dit gezin belangrijk werd geacht en dat men open stond voor wat in de wereld te koop was. Dit sluit ook aan bij een onderneming als een bedevaart naar het Heilig Land.

Op 19 maart 1452 kwamen Johanna van Gronsveld en haar kinderen een verdeling van de nalatenschap van Diederik overeen. In principe erfde Gijsbert, de oudste zoon, 'na alder gewointen ende van rechts wegen' alle leengoederen en heerlijkheden, met dien verstande dat hij broers en zusters schadeloos moest stellen. In dit geval kozen de erfgenamen voor een verdeling van de heerlijkheden en kastelen onder de broers, met compensatie in geld wegens over- of onderbedeling en een uitbetaling in geld aan de zusters. Eén zuster, Herburga genaamd, was in 1442 gehuwd met Johan Dickbier, graaf van Megen, ${ }^{787}$ en wordt, waarschijnlijk omdat zij haar erfdeel als bruidsschat had ontvangen, niet in de delingsakte genoemd. Van de meerderjarige kinderen ontving Gijsbert de heerlijkheden Batenburg en Anholt met de Batenburgse pandschap op de Veluwe. Hendrik kreeg de heerlijkheden Gronsveld en Rimburg en een vordering van 400 gulden op het domkapittel van Keulen. Herman erfde de heerlijkheid Uden, renten uit de tollen te Lobith en Cuijk en na de dood van zijn moeder haar huis in Nijmegen en goederen te Ewijk. Aan de twee minderjarige zonen Diederik en Johan werden respectievelijk toebedeeld de heerlijkheid Rönne (= de goederen te Obermörmter) en het huis Oyen. Verder kreeg ieder een aandeel in de Batenburgse pandschap. Aan de twee nog ongehuwde zusters (Margriet en Catharina, alleen deze laatste wordt met naam vermeld) werden vijfduizend Rijnse guldens toegekend, waarbij ieder van de broers zich verplichtte een aandeel in dit bedrag te betalen. Moeder Johanna ontving een bedrag in geld en behield het levenslange vruchtgebruik van haar huis in Nijmegen en de goederen in Ewijk. Waarschijnlijk verbleef zij later veel bij haar vader Hendrik III van Gronsveld.

\subsection{Hendrik I van Bronckborst Batenburg, 1474 (1476)-1493}

\subsubsection{Levensloop}

Hendrik I van Bronckhorst Batenburg moet ten tijde van het overlijden van zijn vader ongeveer vijftien of zestien jaar zijn geweest. Als erfgenaam van Gronsveld en Rimburg heeft waarschijnlijk zijn grootvader Hendrik III van Gronsveld zich om zijn verdere opvoeding bekommerd. Door zijn huwelijk in 1453 - waarover later meer - met Johanna

785 Van Schilfgaarde, 'De heren van Bronckhorst', 76.

786 De Ridder-Symoens e.a., Premier livre procurateurs, 11-13, 42. Gisbert studeerde 1441 in Leuven en 1445 in Orléans, Herman vóór 1449 in Orléans.

787 Van Schilfgaarde, 'De heren van Bronckhorst', 76. 
Catharina van Alpen raakte Hendrik van Bronckhorst Batenburg gelieerd aan een der meest vooraanstaande Kleefse adellijke families. Naderhand kwam langs een andere weg nog een keer dezelfde alliantie tot stand, aangezien zijn schoonvader Johan van Alpen tevens zijn zwager werd door diens huwelijk met Hendriks jongere zuster Catharina van Bronckhorst Batenburg.

Aan de schetsen die Chestret de Haneffe en Hanssen van Hendriks leven geven, valt weinig nieuws toe te voegen. Beide auteurs beschrijven hem als oorlogszuchtig. Het kasteel Rimburg stond bekend als een roversnest. Er wordt melding gemaakt van strijd met de aartsbisschop van Keulen en de hertog van Kleef. Anderzijds moet worden vastgesteld dat in die tijd het hele Maasgebied onrustig was door de militaire acties van de Bourgondische hertog Karel de Stoute. Daarbij valt te denken aan de verwoesting van de stad Luik in 1465 en de gedeeltelijke bezetting van het hertogdom Gelre door Bourgondische troepen. Als kleine landsheer zal Hendrik hebben geprobeerd tussen de verschillende partijen te laveren, waarbij hij zijn eigen belang goed voor ogen hield. Zo bood de onrust in het Luikse een mooie gelegenheid om zich tegen betaling op te werpen als beschermer van het kapittel van Sint-Martinus in Luik voor de bezittingen van dit stift in de heerlijkheden Breust en Rijckholt. Het ligt voor de hand dat hij deze rol niet alleen om redenen van goede nabuurschap op zich nam, want dergelijke protectie kon een eerste stap betekenen naar meer zeggenschap over het gebied van de buurman.

Hendrik van Bronckhorst Batenburg huwde in 1453 met Johanna Catharina van Alpen, dochter van Johan van Alpen en Jutta van Lembeck. Johan van Alpen moet Hendriks vader Diederik van Bronckhorst Batenburg goed hebben gekend, aangezien hij zich bevond in het gevolg van hertog Johan van Kleef bij diens pelgrimage in 1450 naar Palestina. Volgens het huwelijkscontract bracht de bruid onder andere drie hoeven in de Tielerwaard in. Verder zouden volgen haar aandeel in de nalatenschap van haar moeder en, na het overlijden van haar grootmoeder, twee hoeven in het kerspel Keken in de Duffel.

In 1470 trouwde schoonvader Johan van Alpen (overleden 1491), inmiddels weduwnaar, nog een keer en wel met Hendriks jongere zuster Catharina van Bronckhorst Batenburg (overleden 1527). Sinds de verbintenis van de families Van Gronsveld en Van Merode Rimburg in 1382 was dit het tweede voorbeeld van een 'dubbelhuwelijk' met grote gevolgen, aangezien in het bijzonder Hendriks zoon Diederik II van Bronckhorst Batenburg de rijke vruchten van deze allianties plukte. Om die reden komt hierna de aanzienlijke Alpense erfenis nog uitgebreider aan de orde.

Uit het huwelijk van Hendrik en Johanna Catharina werden vier kinderen geboren, te weten Elbert (geestelijk gehandicapt), Diederik II (hierna verder te bespreken), Willem (waarschijnlijk ongehuwd, heer van Langendonck en Dornick, gestorven na 1500) en Otte (gestorven vóór 1493, gehuwd met Johan, heer van Binsvelt). 
Op 6 juli 1493 maakte Hendrik zijn testament, ziek te bed liggend in zijn huis in de Bredestraat te Maastricht. ${ }^{788}$ Daarin wordt uitgebreid gesproken over misstichtingen bij de minderbroeders in Maastricht, in de kerken van Eijsden en Gronsveld en in het klooster Hoogcruts in Slenaken. Naast erfstellingen ten behoeve van zijn kleinkinderen uit het huwelijk van Otte en Johan van Binsvelt alsmede legaten aan personeel, kreeg zijn echtgenote het vruchtgebruik van diverse goederen, onder andere van goederen te Gronsveld. De twee zonen Diederik en Willem beloofden te zijner tijd de nalatenschap in der minne te delen. Waarschijnlijk overleed Hendrik kort na het passeren van dit testament en vond hij, in overeenstemming met zijn laatste wil, zijn laatste rustplaats bij de minderbroeders te Maastricht, in het familiegraf van zijn grootvader.

\subsubsection{De familie Van Alpen}

Vanwege het grote belang van de Alpense erfenis voor de verdere geschiedenis van de familie Van Bronckhorst Batenburg, verdienen de achtergronden van deze familie nadere toelichting. Het geslacht Van Alpen, oorspronkelijk Van Dornick geheten, ontleende zijn naam aan de heerlijkheid Alpen aan de Nederrijn, een leen van de aartsbisschop van Keulen. ${ }^{789}$ Aan het begin van de veertiende eeuw raakten de heren van Alpen in financiële problemen en kwam hun stamgoed door verpanding in handen van de Keulse kerkvorsten, met uitzondering van een aantal verspreid liggende goederen. Hoewel de feitelijke zeggenschap over de heerlijkheid Alpen daarmee voor de familie verloren ging, bleef men de titel 'heer van Alpen' voeren. Nog aan te einde van de vijftiende eeuw werden pogingen ondernomen Alpen terug te winnen.

Aan de neergang van de familie kwam een einde in 1357, toen Arnold van Alpen de burcht Hönnepel bij Kalkar van zijn kinderloos overleden oom Frederik van Hönnepel erfde. ${ }^{790}$ De gecompliceerde juridische en kerkelijke verhoudingen tussen Hönnepel en het buurdorp Niedermörmter, evenals de leenbetrekkingen tussen Hönnepel en de aartsbisschop van Keulen en de hertog van Kleef in de veertiende eeuw kunnen hier verder buiten beschouwing blijven. In verschillende stappen lukte het de inwoners van Hönnepel, gesteund door hun heren, tussen 1381 en 1438 kerkelijk en juridisch onafhankelijk van Niedermörmter te worden. De band tussen Kleef en Hönnepel werd definitief toen Johan van Alpen in 1457 de heerlijkheid in leen opdroeg aan de hertog van Kleef, onder gelijktijdige terugwijzing van eventuele Keulse aanspraken. ${ }^{791}$

Met Hönnepel als basis stegen de rijkdom en het maatschappelijk aanzien van de Van Alpens snel. In de vijftiende eeuw behoorden zij tot de vaste entourage van het Kleefse hertogelijk hof. Het feit dat Johan van Alpen hertog Johan I in 1450 vergezelde op diens

\footnotetext{
788 Afschrift in RHCL, Familie De Geloes/Kasteel Eijsden, inv. nr. 450.

789 Zie voor de middeleeuwse geschiedenis van de heerlijkheid Alpen: Bösken, ‘Beiträge Alpen', 152-171.

790 Voor de burcht Hönnepel zie: Hilger, Kreis Kleve 1, Altkalkar-Huisberden, 107.

791 Zie voor de middeleeuwse geschiedenis van Hönnepel en Niedermörmter: Scholten, 'Geschichte Hönnepel', passim; Scholten, 'Urkundliches Mörmter und Roen', passim; Ilgen, Quellen Herzogtum Kleve, I, Ämter, Erster Band, Darstellung, 126-137.
} 
pelgrimage naar Jeruzalem, onderstreept die rol nog eens. ${ }^{792}$ We komen hem van 1438 tot 1448 en van 1451(?) tot 1482 tegen aan het hoofd van het landdrostambt Kleef, het grootste en belangrijkste van de acht bestuursdistricten waarin het hertogdom was verdeeld..$^{793}$ Een van de voornaamste opgaven van de landdrost betrof, zoals gebruikelijk bij dit soort functionarissen, de bescherming van de grenzen van het hertogdom. Het was dan ook uit strategische motieven dat het in het zuiden bij de Keurkeulse grens gelegen kasteel Winnenthal werd aangewezen als vaste residentie van de landdrost. Johan van Alpen kwam die militaire taak letterlijk duur te staan toen hij in de Soester Vete, het conflict tussen de hertog van Kleef en de aartsbisschop van Keulen over de stad Soest in Westfalen, ${ }^{794}$ door Keulse troepen krijgsgevangen werd gemaakt en pas tegen betaling van een losgeld van tweeduizend Rijnse guldens zijn vrijheid herkreeg. ${ }^{795}$

Ongetwijfeld verschafte het landdrostambt ruime inkomsten aan Johan van Alpen, maar zijn latere fortuin moet goeddeels door erfenissen zijn ontstaan, zoals het huis Eyl bij Huisberden ${ }^{796}$ van zijn echtgenote Jutta van Lembeck, eerder weduwe van Dirk van Eyl $1^{797}$ en de heerlijkheid Hönnepel van zijn neef Elbert van Alpen (overleden tussen 14541457). ${ }^{798}$ Wat de al wat oudere Johan heeft bewogen om in 1470 nog eens te huwen met de veel jongere Catharina van Bronckhorst Batenburg (overleden 1527) is niet duidelijk. Catharina's bruidsschat van vijfduizend gulden was niet gering, maar mogelijk koesterde Johan bij deze jonge vrouw nog hoop op een mannelijke nakomeling. ${ }^{79}$ Het huwelijk bleef echter kinderloos, zodat viel te verwachten dat de Alpense erfenis voor het grootste deel toeviel aan Diederik II van Bronckhorst Batenburg, tegelijkertijd zowel Johans kleinzoon als neef.

\subsection{Diederik II van Bronckhorst Batenburg, 1493-1508}

\subsubsection{Ambten en berit}

Het lijkt er op dat Diederik II al vroeg werd voorbereid op een bestuurlijke rol in het hertogdom Kleef. In 1480 beleende de hertog hem met huis en heerlijkheid Hönnepel, onder voorbehoud van het recht van vruchtgebruik voor zijn moeder Catharina van

\footnotetext{
792 Zie voor meer uitgebreide gegevens over Johan van Alpen: Scholten, 'Geschichte Hönnepel’ 137-141; verder Ilgen, Quellen Herzogtum Kleve, I, Ämter, Erster Band, Darstellung, 22, 129 en idem, Zweiter Band, Quellen, Erster und Zweiter Teil, passim.

${ }^{793}$ Voor het landdrostambt Kleef zie Ilgen, Herzogtum Kleve, Erster Band, Darstellung, 13-24. Stukken over de benoeming van Johan van Alpen afgedrukt bij Ilgen, Quellen Herzogtum Kleve, I, Ämter, Zweiter Band, Quellen, Erster Teil, 331-333, nrs. 300-301.

${ }_{794}$ Zie over dit conflict: Lexicon des Mittelalters, VII, 2023 onder lemma 'Soester Fehde'.

795 Ilgen, Quellen Herzogtum Kleve, I, Ämter, Erster Band, Darstellung, 22, noot 6.

796 Voor Huis Eyl, thans gemeente Bedburg-Hau bij Kleef, zie Hilger, Kreis Kleve 1, Altkalkar-Huisberden, 117-118.

${ }^{797}$ Dösseler/Oediger, Lebnregister Kleve, 144, nr. 181/7-8.

798 Dösseler/Oediger, Lehnregister Kleve, 260, nr. 348/1.

${ }^{799}$ Hanssen, Die Rimburg, 134-136; Regest bij Nijhoff, IV, Arnold van Egmond, hertog van Gelre, 433, nr. 487.
} 
Alpen ${ }^{800}$. In dezelfde tijd werd hij angesteld als adjunct-landdrost, om vervolgens twee jaar later in de functie van landdrost op te volgen ${ }^{801}$. Zijn grootvader droeg hem daartoe een vordering van 5086 gulden op de hertog over, waarvoor het drostambt aan Van Alpen was verpand. Wel kreeg Johan van Alpen het recht nog drie jaar op kasteel Winnenthal te wonen totdat zijn kleinzoon zou trouwen. Kennelijk vormde deze benoeming ook aanleiding Diederik opnieuw te belenen met huis en heerlijkheid Hönnepel.802 Tevens droeg Johan van Alpen aan Diederik over alle rechten en aanspraken op de heerlijkheid Alpen, onder de voorwaarde dat hij alles in het werk zou stellen dit stamgoed voor de familie terug te winnen, nu Johan dat door ziekte en ouderdom zelf niet meer kon. ${ }^{803}$

In 1490 volgde de belening door de hertog met het huis Eyl bij Huisberden (welke belening in 1494 en 1498 werd herhaald en uitgebreid met hoeven te Kivitsward en visrechten te Werrich, omdat nog een regeling moest worden getroffen met Evert van Wilp, een andere rechthebbende op dit huis ${ }^{804}$ ), en in 1503 met een hof te Bimmen. ${ }^{805}$

Diederik was in 1484 gehuwd met Gertrudis van Wylich, dochter van Diederik van Wylich, heer van Diersfort, en Elisabeth van Bylant-Darenburg.806 Van Wylich was erfhofmeester van Kleef en gold als een der aanzienlijkste edelen van het hertogdom. Men mag aannemen dat de bruid een aanzienlijke bruidsschat inbracht. Waarschijnlijk kort na 1500 mocht Diederik ook nog de nalatenschap ontvangen van zijn zwager Steven van Wylich, drost te Lobith. ${ }^{807}$

Door opvoeding en huwelijk was Diederik van Bronckhorst Batenburg sterk op Kleef georiënteerd geraakt. Wanneer hij zijn vader als heer van Rimburg en Gronsveld opvolgde, is niet duidelijk. In 1496 wordt hij heer van Rimburg genoemd en waarschijnlijk was hij toen al in het bezit van Gronsveld. ${ }^{808}$ Maar pas vier jaar later vond met zijn broer Willem scheiding en deling plaats van de nalatenschap van hun ouders. ${ }^{809}$ Diederik kreeg daarbij toegewezen de heerlijkheden Gronsveld, Rimburg en Hönnepel, het huis in Maastricht en diverse boerderijen, landerijen, pachten en renten, voor het grootste deel gelegen aan de Nederrijn, en ten slotte alles wat betrekking had op het landdrostambt Kleef. Willem ontving het kasteel Langendonck, een huis te Emmerich, boerderijen, landerijen, tiend- en visrechten, renten en pachten aan de Nederrijn en in het Gelderse rivierengebied. Aangezien Willem naderhand kinderloos overleed, verwierf Diederik ook nog diens bezit. Waarschijnlijk werden daarbij de aanspraken van zijn neef Werner van Binsfeld, een zoon

800 Dösseler/Oediger, Lehnregister Kleve, 261, nr. 348/2.

801 Ilgen, Herzogtum Kleve, Erster Band, Darstellung, 22, akten afgedrukt bij Idem, Zweiter Band, Quellen, Erster Teil, 450, nr. 366 en 457-459, nr. 373.

802 Dösseler/Oediger, Lehnregister Kleve, 261, nr. 348/3.

${ }^{803}$ Hanssen, Die Rimburg, 140; RHCL, Graafschap Gronsveld, inv. nr. 62, fol. 12vo.-13vo.;

${ }^{804}$ Dösseler/Oediger, Lebnregister Kleve, 144, nr. 181/11-14; 661, nr. 884/3; Hanssen, Die Rimburg, 327, nr. 60.

805 Dösseler/Oediger, Lehnregister Kleve, 64, nr. 81/2.

806 Van Schilfgaarde, 'De heren van Bronckhorst', 77.

${ }^{807}$ RHCL, Graafschap Gronsveld, inv. nr. 62, fol. 39vo.; Hanssen, Die Rimburg, 143 en 328, nr. 66.

808 Lacomblet, Urkundenbuch IV, 585-586, nr. 473.

${ }^{809}$ RHCL, Graafschap Gronsveld, inv. nr. 62, fol. 93-96; Hanssen, Die Rimburg, 142. 
van zijn overleden zuster Otte en Johan van Binsfeld, genegeerd, maar deze zou later echter alsnog proberen zijn recht te halen.

Diederik II van Bronckhorst Batenburg was inmiddels één van de voornaamste edelen aan het Kleefse hof geworden. Twee voorbeelden uit 1496 illustreren zijn positie als vertrouweling van de hertog. Op 25 november 1496 was hij de eerste van de Kleefse edelen die de boedelscheiding tussen hertog Johan en zijn broer Philips bezegelde. ${ }^{810}$ Op die dag vervulde hij dezelfde rol bij de verlovingsovereenkomst die de hertogen Johan II van Kleef-Mark en Willem IV van Gulik-Berg sloten voor hun nog minderjarige kinderen, toekomstige Johan III en Maria. ${ }^{811}$ (Het huwelijk vond pas veertien jaar later plaats).

\subsubsection{Tussen Habsburg en Gelres12}

Een belangrijk thema in de Kleefse politiek in die tijd was de oorlog met het buurgewest Gelre. In 1470 had de Bourgondische hertog Karel de Stoute zich daar gemengd in de familietwist tussen hertog Arnold van Egmond en zijn zoon Adolf. Arnold verpandde toen zijn rechten op het hertogdom aan Karel en Adolf moest in verzekerde bewaring bij de Bourgondiërs blijven. Na het overlijden van Arnold ging Karel de Stoute in 1473 over tot bezetting van Gelre en met de verovering van Nijmegen vielen hem ook Adolfs kinderen Karel en Philippa in handen. Beiden werden naar Vlaanderen gestuurd om daar in overeenstemming met hun stand aan het Bourgondische hof te worden opgevoed. Door zijn oorlogen op verschillende fronten slaagde Karel de Stoute er slechts gedeeltelijk in Gelre te onderwerpen. Zijn dood op 5 januari 1477 bij Nancy leek het einde van de dwingelandij te brengen, maar een half jaar later sneuvelde ook Adolf van Gelre bij het beleg van Doornik.

In het hertogdom Gelre erkenden nu ridderschap en steden de jonge Karel van Egmond, Adolfs enige zoon, als hun vorst, maar voorlopig verbleef deze nog aan het Bourgondische hof. Aartshertog Maximiliaan van Oostenrijk, telg uit het Huis Habsburg, die op 19 augustus 1477 was gehuwd met Maria van Bourgondië, de dochter van Karel de Stoute, dacht er niet aan af te zien van zijn aanspraken op Gelre en zette de Bourgondische politiek tegenover dit gewest voort. In 1481 werden Maximiliaan en Maria als hertog en hertogin van Gelre ingehuldigd. De jonge Karel van Egmond, opgevoed aan het Bourgondische hof, leek voor Maximiliaan geen ernstige bedreiging te vormen. Zo bevond Karel zich in Maximiliaans gevolg, toen deze 1486 in Frankfurt tot rooms-koning werd gekozen en was hij aanwezig bij de kroningsfeesten in Aken. Het jaar daarop streed Karel voor Maximiliaan tegen de Fransen en raakte daarbij in krijgsgevangenschap. De

810 Gedrukt bij Lacomblet, Urkundenbuch IV, 585-586, nr. 473.

811 Gedrukt bij Lacomblet, Urkundenbuch IV, 587-592, nr. 474. Over de geschiedenis van de hertogdommen Kleef en Gulik aan het einde van de middeleeuwen in het algemeen zie Land im Mittelpunkt, passim.

812 Voor de politieke geschiedenis van de territoria aan de Nederrijn in de late middeleeuwen en in het bijzonder deze periode zie: Janssen, 'Die Niederrheinischen Territorien im Spätmittelalter', 115-126. 
Franse koning bleek alleen tegen een zeer hoog losgeld genegen de Geldersman te laten vertrekken.

$\mathrm{Na}$ langdurige onderhandelingen kon Karel van Egmond in maart 1492, na negentien jaar afwezigheid, weer voet op Gelderse bodem zetten. Rooms-koning Maximiliaan was allerminst van plan de jonge hertog te erkennen en Karel zou tot zijn dood in 1538 met wisselend geluk tegen de Habsburgers moeten strijden. Soms onderbrak een bestand of vrede de oorlog, maar overeenkomsten, hoe plechtig ook bezworen, werden slechts geëerbiedigd zolang partijen er voordeel in zagen. Ofschoon Karel van Egmond zich duchtig weerde, voerde hij toch een ongelijke strijd. Zijn succes was soms alleen te danken aan het feit dat zijn tegenstander moest kiezen voor andere prioriteiten. Die tegenstander was niet de geringste, want na de dood van keizer Frederik III in 1493 had zijn zoon Maximiliaan diens positie overgenomen, overigens zonder formeel tot keizer te zijn gekroond. Daarmee werd hij niet alleen de hoogste gezagsdrager in het Duitse Rijk, maar ook leenheer van het hertogdom Gelre.

In dezelfde periode, in 1494, eindigde het regentschap dat Maximiliaan voor zijn zoon Philips de Schone had gevoerd over de Bourgondische gewesten in de Nederlanden. De pogingen van Maximiliaan om Philips in de strijd tegen Karel van Egmond te betrekken hadden aanvankelijk weinig succes. In 1503 verklaarde echter ook Philips, die tot de overtuiging was gekomen dat de verwerving van Gelre zijn dynastieke belangen diende, aan hertog Karel de oorlog. De dood van Philips in 1506 leidde vervolgens zelfs tot een verheviging van de strijd, aangezien Maximiliaan nu opnieuw als regent voor de Bourgondisch-Habsburgse gewesten optrad, ditmaal voor zijn nog minderjarige kleinzoon, de latere Karel V.

Hertog Johan II van Kleef (regerend van 1481-1521) toonde zich in deze strijd om Gelre een trouw aanhanger van het Bourgondisch-Habsburgse huis. Opgevoed aan het Bourgondische hof, had hij in 1477 nog deelgenomen aan de belegering van Nancy, waarbij Karel de Stoute sneuvelde. Daarna was Johan terechtgekomen in het kamp van de Franse koning Lodewijk X, maar in 1483 wisselde hij - onder militaire druk - van partij en zwoer trouw aan Maximiliaan. Zijn voortdurende oorlog tegen Gelre en de verzorging van zijn tientallen onwettige kinderen ruïneerden het land zodanig, dat de Kleefse Staten zich in 1501 genoodzaakt zagen hem onder bestuurlijke en financiële curatele te stellen.

Als een der voornaamste edelen in het hertogdom Kleef stond Diederik II van Bronckhorst Batenburg zijn heer bij in diens strijd tegen Gelre. Er kan nog een reden zijn geweest waarom Diederik de Gelderse hertog minder goed gezind was. Verschillende Gelderse bannerheren, een groep waarmee Diederik zich wat stand en afkomst betreft verwant voelde, hoorden bij het Bourgondisch-Habsburgse kamp, sommigen uit overtuiging, anderen daartoe gedwongen of gedreven door het ontactische optreden van hertog Karel. ${ }^{813}$ In het bijzonder gold dit laatste voor Diederiks neef Jacob van Bronckhorst, heer van Anholt en Batenburg. Aanvankelijk toonde deze zich een

${ }^{813}$ Schmidt, 'Herzog Karl', 567-568; Meij, ‘Gelderland 1492-1543’, 24. 
aanhanger van hertog Karel, maar naderhand werd hij diens gezworen vijand, een keuze die hem uiteindelijk grote financiële verliezen zou brengen. ${ }^{814}$

Onthullend over de rol van Diederik II van Bronckhorst Batenburg in de Gelders-Kleefse twisten en de reputatie van kasteel Rimburg in die tijd zijn enkele passages in de zogenoemde 'Chronijk der Landen van Overmaas'. Daar wordt voor het jaar 1504 vermeld dat 'dee here of jonker van Gronsfelt' zijn 'rouffsloet Reynborch' openstelde voor Kleefse soldaten, welke 'boefven' de Gelderse plaatsen Echt en Nieuwstadt plunderden en brandschatten. Uit wraak trokken die van Nieuwstadt en andere Geldersen naar het Land Gronsveld ind rouffden inde branden ouch die arme huysluyden sonder barmherticheyt' ${ }^{815}$ Heugem werd platgebrand. In 1506 speelden zich soortgelijke taferelen af, toen Gelderse soldaten met Franse huurlingen vanuit Eijsden, Rijckholt, Gronsveld en Heugem huis hielden in de Landen van Overmaze en in de omgeving van Maastricht. ${ }^{816}$. Aldus werd Gronsveld, hoewel eigenlijk ver buiten het eigenlijk krijgstoneel gelegen, door de 'internationale' relaties van zijn heer in conflicten betrokken.

\subsubsection{Verheffing tot Reichsfreiberr}

Diederik van Bronckhorst Batenburg was door zijn bezittingen in het Maasgebied en aan de Nederrijn een vermogend man. In 1498 wist hij echter iets te verwerven dat zijn maatschappelijk aanzien belangrijk verhoogde, namelijk de verheffing tot Reichsfreiberr door rooms-koning Maximiliaan. De oorkonde waarbij dit gebeurde werd uitgevaardigd te Freiburg op 24 juni 1498. Na de gebruikelijke intitulatie geeft Maximiliaan de overwegingen die tot dit besluit hebben geleid. Het was zijn bedoeling personen, wier families zich gedurende verschillende generaties op bijzondere wijze verdienstelijk hadden gemaakt ten opzicht van keizer, koning en Heilig Rijk, met gunstbewijzen te belonen 'unnd irenn stannd, lob unnd ere zu erhohern unnd aus zu braiten'. Van oudsher had het geslacht Van Bronckhorst Batenburg van deze dienstbaarheid blijk gegeven. In aanmerking nemende de verdiensten van 'Dietrich von Brunkorst unnd Battennberg, freyherr zu Rymberg unnd Grunsfeld, herre zu Hanopel’ tegenover koning en Rijk en de verwachtingen die men nog van hem koesterde, verleende de rooms-koning hem 'dise sonder gnad... seine sloss Rymberg unnd Grunsfeld mit seinen zugehorungen' te verheffen tot 'einer rechten herschaft'. Diederik en zijn wettige nakomelingen werden

\footnotetext{
${ }^{814}$ Jacob van Bronckhorst had zijn aanvankelijke steun aan de Gelderse hertog in diens strijd tegen de Bourgondiërs in 1496 moeten bekopen met het verlies van Batenburg aan Maximiliaan van Oostenrijk, terwijl Karel van Egmond zich als 'dank' meester had gemaakt van de Batenburgse Pandschap op de Veluwe. Jacob zocht steun bij de hertog van Kleef en kreeg bij een wapenstilstand begin 1503 Batenburg weer terug, maar voordat het jaar verstreken was, had nu hertog Karel het slot en stadje bezet. Zijn dienstneming bij Philips de Schone leverde Jacob weliswaar eer, aanzien en militaire successen op, maar niet de teruggave van zijn bezittingen. Sterker nog, in 1512 viel ook nog het kasteel Anholt in handen van Karel van Egmond en dit zou pas in 1537 weer volledig bij de familie Van Bronckhorst terugkomen. Wel kreeg hij door Oostenrijkse interventie in 1513 Batenburg terug en ontving hij uit domeinen in de Bourgondische Nederlanden een jaargeld, maar veel profijt heeft hij daar niet van gehad, want hij overleed in 1516. Zie uitgebreid Schmidt, 'Herzog Karl', 551-591.

${ }^{815}$ Habets, 'Chronijk Overmaas', 115.

816 Habets, 'Chronijk Overmaas', 150.
} 
'fur zwewigen zeitten auf dieselbe sein herschafft Rymberg unnd Grunsfeld geadelt unnd gefreiet unnd zu unnsern unnd des Heiligen Reichs freyherrn, auch in derselben stannd, ere, unnd wirde erhebt, gesetzt, gewirdigt unnd gemacht unnd der schargesellschafft unnd gemeinschafft derselben unnser unnd des Heyligen Reichs rechtgeborn edeln freyherrn zugefugt

...

setzen, ordnen unnd wellen aus ytzberurtter unnser kunigelichen macht volkomenheit daz die gemelten slosser Rymberg unnd Grunsfeld mit iren zugehorungen nu furbashin zu ewigen zeitten rechte geadelte herschaft unnd darauf der gemelt Dietrich, freiherr zu Rymberg unnd Grunsfeldt unnd sein elich leibserben unnd derselben erbennserben ires namens, stamens unnd geslechts fur unnd fur ewigelich recht edel freiherrn sein, sich mit iren namen unnd tittel freiherrn zu Rymberg unnd Grunsfeld heissen, nennen, schreiben unnd haltten, unnd von menigelich also geheissen, genennt, geschriben, geeret unnd gehalten werden...'

Maximiliaan bepaalde dat de familie Van Bronckhorst Batenburg voortaan moest worden gerekend tot de 'schargesellschafft unnd gemeinschafft... des Heyligen Reichs rechtgeborn edeln freyherrn' met alle daaraan verbonden rechten en privileges. Wat dat precies betekende, blijft vaag. Deze 'schargesellschafft... des Heyligen Reichs... edeln freyherrn' hoorde met de groep der rijksridders tot de laagste rangen van de rijksadel. Aan de politieke besluitvorming binnen het Rijk hadden zij geen deel. Deze bleef, wat de adel betreft, voorbehouden aan de geestelijke en wereldlijke vorsten. Anderzijds onderscheidden deze edelen zich wel van de niet-rijksonmiddellijke landadel in de grote landsheerlijkheden en de bezitters van (meestal zeer kleine) rijksonmiddellijke territoria, wier adellijke titel beperkt bleef tot 'heer'.

De achtergronden van deze verheffing zijn onbekend. Lag er een verzoek aan ten grondslag of handelde de rooms-koning op eigen initiatief en advies van derden? De formele bewoordingen van de tekst bieden daarvoor weinig aanknopingspunten. Maar het is goed denkbaar dat Maximiliaan ook een beloning wilde geven voor Diederiks steun aan de Bourgondisch-Habsburgse zaak in de strijd tegen Gelre. In ieder geval had dit eerbetoon voor Maximiliaan ook een zekere strategische betekenis, omdat hij daarmee aan de Nederrijn een bondgenoot verwierf in zijn politiek tegen Gelre.

Voor Diederik zelf en zijn nakomelingen vertegenwoordigde deze verheffing een belangrijk maatschappelijk kapitaal. De verheffing sluit ook nauw aan bij een algemeen optredend gevoel van groeiend standsbewustzijn bij Duitse adellijke families vanaf het einde van de vijftiende eeuw en het beeld dat men van zichzelf had. ${ }^{817}$ Centraal daarbij staat het begrip Herkommen, dat eigenlijk een synoniem is van oorsprong, afstamming of ontstaan van een familie, maar ook werd geassocieerd met traditie en gebruik. Families die meenden over onvoldoende Herkommen te beschikken, gaven humanistische geleerden opdracht tot het samenstellen van genealogieën en kronieken, die de afstamming terugvoerden tot de tijd van Karel de Grote of liever nog de Romeinen. Hoe fraaier en

817 Zie daarover in algemene zin Joos, 'Herkommen und Herrschaftsanspruch'. 
geleerder, des te meer aanzien. In de literatuur wordt zelfs gesproken van een Herkommensseuche onder de zestiende-eeuwse adel. ${ }^{818}$ Het is dan ook niet verwonderlijk dat in het adelsdiploma een passage is opgenomen, luidende dat het geslacht Van Bronckhorst Batenburg von 'altterher... in redlichem adelwesenn unnd stannd herkomen' was. Dat zegt overigens niets over werkelijke kennis over de geschiedenis van de eigen voorouders. Soms was die beperkt tot amper meer dan twee generaties. Opmerkelijk in dit verband is dat de familie Van Bronckhorst Batenburg nog maar relatief kort in Gronsveld en Rimburg gevestigd was; de oorsprong lag immers in het Gelderse rivierengebied. In ieder geval wordt nergens expliciet naar vroegere heren van Gronsveld of Rimburg verwezen.

In het verlengde van het voorgaande ligt de bewering dat het geslacht Van Bronckhorst Batenburg van oudsher werd beschouwd als een familie met grote verdiensten voor keizer en rijk. Een nadere onderbouwing daarvan ontbreekt en het is de vraag of deze lof niet voor een deel moet worden gerekend tot het min of meer vaste formulier.

Met een hogere stand stonden ook zakelijke belangen op het spel. Adellijke zonen en dochters die niet voor het huwelijk of opvolging in aanmerking kwamen, hadden toegang tot aanzienlijke kapittels of damesstiften. Om de exclusiviteit van die instituten te bewaren, moesten kandidaten voor een prebende door middel van een kwartierstaat het controleerbare bewijs van hun adellijke afstamming of Herkommen leveren. Families die deze Ahnenprobe konden doorstaan bij bijvoorbeeld de domkapittels van Keulen of Straatsburg, kwalificeerden zich daarmee als leden van de hoge adel.

Volgens de oorkonde van Maximiliaan werden 'sloss Rymberg unnd Grunsfeld mit seinen zugehorungen zu einer rechten herschaft erhebt unnd gemacht' en wilde de rooms-koning 'daz die gemelten slosser Rymberg unnd Grunsfeld mit iren zugehorungen nu furbashin $\mathrm{zu}$ ewigen zeitten rechte geadelte herschaft' zouden zijn. Ook hier rijst de vraag wat daarmee precies wordt bedoeld. Waarschijnlijk staan de begrippen 'heerlijkheid' en 'kasteel' hier als aanduiding voor het territorium waarover heerlijke rechten werd uitgeoefend. Wezenlijker is de passage dat Rimburg en Gronsveld 'zu einer rechten herschaft' werden 'erhebt unnd gemacht', waarbij deze laatste woorden letterlijk genomen een verandering van status impliceren. Was dat voor Gronsveld het geval? Strikt genomen niet. Het was immers al vanouds allodiaal en rijksonmiddellijk gebied, zonder enige leenband met naburige landsheerlijkheden en de heren waren in bezit van regalia.

Voor Rimburg ligt dit minder duidelijk. Lang geleden, in 1323, had Gerard van Merode het kasteel van Rimburg als 'open huis' ter beschikking gesteld aan hertog Jan III van Brabant en vervolgens in 1334 in leen opgedragen. ${ }^{819}$ Daarna schijnen geen leenopdrachten meer te hebben plaatsgevonden. ${ }^{820}$ Daarmee kwam Rimburg staatkundig steeds verder af te staan van het Land van 's-Hertogenrade, tot welke landsheerlijkheid de plaats formeel behoorde. Aan het kasteel waren heerlijke rechten en lage en middelbare

818 Joos, 'Herkommen und Herrschaftsanspruch', 134.

819 Verkooren, Inventaire chartes de Brabant, IIe stuk, Cartulaires, deel 2 (1312-1383), 44.

820 Janssen, 'Unterherrschaft', 161-163, wijst op het verschijnsel dat wanneer een rijksonmiddellijk heer ergens anders leenman van een 'onderheerlijkheid' was, de neiging ontstond om zich ook ten opzichte van die onderheerlijkheid zelfstandig te gedragen en daarvoor zelfs rijksonmiddellijkheid na te streven. 
jurisdictie verbonden en er bestond vanaf het einde van de vijftiende eeuw ook een schepenbank, maar volgens getuigenverklaringen, in 1542 afgelegd voor de schepenbank van Rimburg, had de gerichtsbode van 's-Hertogenrade sinds mensenheugenis geen daden van jurisdictie meer op Rimburgs gebied uitgeoefend. ${ }^{821}$ Inwoners van Rimburg werden te 's-Hertogenrade als 'uijtlandische luijdens' beschouwd en waren niet aan schattingen of andere lasten onderworpen. Over de uitoefening van hoge jurisdictie bestond ook onenigheid, aangezien melding wordt gemaakt van incidenten met de drossaard van 'sHertogenrade. Dit alles roept het beeld op van Rimburg als een vrije heerlijkheid, die de heren van Rimburg zelf als een min of meer onafhankelijk territorium beschouwden. ${ }^{822}$ Tegelijkertijd moeten ze zich ook bewust zijn geweest van de dreiging die in het bijzonder van Brabantse aanspraken kon uitgaan. Tot dan toe hadden zij zich goed weten te handhaven door de sterkte van hun burcht, het bezit van vrije heerlijkheden, de verwantschap met belangrijke adelliike families en goede betrekkingen met Gulik en Brabant. Het privilege van rooms-koning Maximiliaan betekende dan ook niet zozeer een verheffing, maar meer een erkenning van Gronsveld en Rimburg als rijksonmiddellijke gebieden, onafhankelijk van de omringende territoria. In het bijzonder voor Rimburg was dat met het oog op de kwetsbare positie tussen Gulik en Brabant en mogelijke Brabantse leenrechtelijke aanspraken, meer dan welkom.

Diederik II van Bronckhorst Batenburg overleed in november 1508, zijn echtgenote Gertrudis van Wylich eerst in 1523. Beiden werden begraven in het klooster Hagenbusch bij Xanten. Het echtpaar liet drie kinderen na, te weten een dochter Jutta $\left({ }^{*} 1485\right)$ en twee zonen Johan en Diederik.

\subsection{Johan I van Bronckhorst Batenburg, 1508/1511-1558/1559}

Volgens een verklaring van hertog Johan van Kleef vererfde het landdrostambt van Kleef op beide zonen van Diederik van Bronckhorst Batenburg, maar wie uiteindelijk de functie kreeg, hing af van een nadere overeenkomst tussen de broers. ${ }^{823}$ Hoewel Johan al in 1509 landdrossaard wordt genoemd, ${ }^{824}$ volgde een benoeming als zodanig eerst op 15 februari 1511, de dag waarop ook de boedelscheiding plaatsvond. ${ }^{825}$ Johan ontving de heerlijkheden Rimburg en Gronsveld, Eyl en Langendonck, het landdrostambt Kleef en de aanspraken op Alpen, terwijl Diederik met de heerlijkheid Hönnepel tevreden moest zijn. Laatstgenoemde verwierf door zijn huwelijk met Elisabeth Gertrudis van LimburgStyrum ook nog de aangrenzende heerlijkheid Mörmter. Jutta, de zuster van beide broers,

${ }^{821}$ Hanssen, Die Rimburg, 341-343, nr. 96.

822 Het lijkt er een beetje op alsof Rimburg werd beschouwd als een leen dat door verjaring of 'prescriptie' in volle eigtendom was overgegaan. Zie over dit verschijnsel bij lenen: Opsommer, 'Omme dat leengoed', 579-583.

${ }^{823}$ Ilgen, Heryogtum Kleve, Zweiter Band, Quellen, Erster Teil, 511, nr. 412.

${ }^{824}$ Hanssen, Die Rimburg, 329-330, nr. 71.

${ }^{825}$ Hanssen, Die Rimburg, 330, nr. 72-73, Ilgen, Heræogtum Kleve, Zweiter Band, Quellen, Erster Teil, 511-512, nr. 412. 
werd van de erfenis nagenoeg uitgesloten, omdat zij door haar huwelijk met een zekere Wolter Seveling beneden haar stand was getrouwd. ${ }^{826}$ Deze boedelscheiding werd echter een bron van onenigheid. Omstreeks 1523 vond een nieuwe deling plaats, waarbij Johan en Diederik alsnog aan Jutta en haar man een hoger aandeel in de nalatenschap moesten uitbetalen. In 1536 moest Johan nog een keer goederen afstaan aan zijn broer Diederik, omdat deze behoorden bij het kasteel Hönnepel.

Maar Johan I van Bronckhorst Batenburg werd niet alleen geplaagd door onenigheden met broer en zuster, ook zijn verdere familie belaagde hem. Zo liet in 1523 Johans neef Werner van Binsfeld, een zoon van zijn tante Otte, met succes aanspraken gelden op het huis Langendonck. Dit kasteel had Diederik II van Bronckhorst Batenburg na het kinderloos overlijden van zijn broer Willem aan zich getrokken, zonder met zijn zuster rekening te houden. Nog een generatie verder terug reikten diverse aanspraken die de Bronckhorsten uit de linies Stein en An gen Ronne of Angeraen maakten. ${ }^{827}$ De keerzijde van dit alles was dat ook Johan zelf zich meester maakte van andermans goed, in dit geval de tienden van Merkstein, die al eeuwenlang waren verbonden met de scholasterie van het kapittel van Sint-Gereon te Keulen. Uiteindelijk wist Johan de tienden in handen te krijgen tegen betaling van een afkoopsom aan het kapittel, die in belegde vorm 100 goudgulden per jaar moest opbrengen. ${ }^{828}$

Of het er werkelijk zo slecht met Johans financiën voorstond, zoals Hanssen veronderstelt ${ }^{829}$, is niet duidelijk. Wel mag worden aangenomen dat het voeren van een staat als landdrost van Kleef en hoveling bij de hertog, zijn prijs kende. Uit hoofde van die functie raakte hij ook betrokken bij de politieke en religieuze verwikkelingen, die in die tijd aan de Nederrijn en in het Maasgebied voor veel onrust zorgden.

In 1510 huwden, na veertien jaar verloving, Johan, de toekomstige hertog van Kleef-MarkRavensberg en Maria van Gulik-Berg, welke verbintenis ervoor moest zorgen dat de betrokken territoria blijvend in een personele unie werden geregeerd. In 1511 volgde Johan zijn schoonvader ook op als hertog in Gulik-Berg en in 1521, na het overlijden van zijn vader, als Johan III ook in Kleef-Mark-Ravensberg. Aldus werd hij één van de machtigste vorsten in het noordwesten van het Rijk. In politiek opzicht bleek hij een aanhanger van keizer Karel V, wellicht vanuit de gedachte dat diens steun te zijner tijd van pas kon komen bij een poging het hertogdom Gelre als 'territoriale sluitsteen' aan zijn gebieden toe te voegen.

De strijd tussen de Gelderse hertog Karel van Egmond en de Habsburgers sleepte zich inmiddels al decennia voort, met wisselend succes voor beide partijen. De wens van de hertog van Kleef en Gulik leek in vervulling te gaan toen hij in januari 1538 een overeenkomst met de Gelderse staten bereikte, waarin zij Johans zoon Willem kozen als opvolger van de kinderloze Karel van Egmond. Nog vóór het overlijden van Karel vond

${ }^{826}$ Hanssen, Die Rimburg, 144-145.

827 Zie uitgebreider over de verschillende erfeniskwesties Hanssen, Die Rimburg, 145-149.

828 Hanssen, Die Rimburg, 150.

${ }^{829}$ Hanssen, Die Rimburg, 149. 
de inhuldiging plaats. Door het plotseling overlijden van hertog Johan III van Kleef-Gulik op 6 februari 1539 werd de jonge Willem tamelijk onverwacht heer van een groot aaneengesloten gebied, dat politiek gewicht in de schaal legde. Voor keizer Karel V was een dergelijke machtsconcentratie aan de oostgrens van de Habsburgse Nederlanden onaanvaardbaar. Willems zoektocht naar bondgenoten (onder andere door een huwelijk van zijn zuster Anna met koning Hendrik VIII van Engeland en een verbond met koning Frans I van Frankrijk) leverde in de praktijk weinig steun op. Toen keizer Karel V in 1543 de aanval opende, stond hertog Willem dan ook vrijwel alleen. Op 6 september 1543 capituleerde hij voor de keizer in diens legerkamp voor Venlo. De keizer nam hem weliswaar weer in genade aan, maar Gelre moest hij an Karel afstaan.

De laatste fase in de strijd om Gelre kreeg voor Johan I van Bronckhorst Batenburg ernstige gevolgen. In 1537 had hij afstand gedaan van zijn functie als landdrost van Kleef. ${ }^{830}$ Hoewel hij in 1538 nog raadsman van de hertog wordt genoemd, was hij op dat moment al uit Kleef vertrokken en had hij zijn intrek genomen in kasteel Rimburg. ${ }^{831}$ Zijn goede verhouding met hertog Johan III van Kleef-Gulik en daarna met diens zoon en opvolger Willem V ('De Rijke') bleef echter in stand. Op 3 juli 1543 bood hij hertog Willem het sterke kasteel Rimburg als 'open huis' en uitvalsbasis voor Kleefs-GuliksGelders krijgsvolk aan. ${ }^{832}$ Behalve loyaliteit aan de hertog zullen nog andere motieven voor de openstelling hebben gespeeld. Kort te voren was vanuit Maastricht het kasteel van Gronsveld als vijandelijk bezit door troepen van Karel V bezet en was de Poort van Gronsveld, de Maastrichtse stadswoning van de heer van Gronsveld, in beslag genomen. Als beloning voor zijn steun aan hertog Willem mocht Johan van Bronckhorst Batenburg ook rijkelijk delen in buit die de Kleefs-Gulikse soldaten binnenbrachten, waarmee de reputatie van Rimburg als 'roofnest' nog eens werd bevestigd. Hertog Willem V beloofde veel en gaf alle garanties voor de bescherming van Rimburg. Hij stelde Johan de heerliikheden Frentz en Palant in het hertogdom Gulik en goederen in het Land van 'sHertogenrade ter beschikking wegens het verlies van Gronsveld en hij zou geen vrede sluiten voordat de heer van Gronsveld zijn bezittingen weer terughad.

De nederlaag van hertog Willem voor Venlo zorgde voor een ommekeer in de verhoudingen. Wat precies met Johan I van Bronckhorst Batenburg in die maanden is gebeurd, blijft onduidelijk. Uit een brief die Lodewijk van Schore, president van de Raad van State en de Geheime Raad, op 14 november 1543 vanuit Brussel aan landvoogdes Maria van Hongarije schreef, blijkt dat 'de heer van Rimburg' in Brussel werd vastgehouden en daar groot misbaar maakte. 833 Van Schore wilde weten wat met de gevangene moest gebeuren, aangezien deze de termijn had overschreden voor bepaalde dingen die hij moest verrichten in ruil voor wat Karel V hem voor Venlo had toegestaan. Het beste zou, volgens Van Schore, zijn hem zo spoedig mogelijk te berechten en zekerstelling te kriigen met betrekking tot het huis Rimburg.

830 Ilgen, Quellen Herzogtum Kleve, I, Ämter, Erster Band, Darstellung, 22, noot 10.

${ }^{831}$ Hanssen, Die Rimburg, 338, nr. 87.

832 Hanssen, Die Rimburg, 153-154; 343-347, nrs. 98-99.

833 Van Peteghem, 'De pandlossing van vorstelijke domeingoederen', 19. 
De wat cryptische formulering in de brief moet waarschijnlijk aldus worden uitgelegd dat Johan I van Bronckhorst Batenburg werd aangewreven dat hij de burcht Rimburg in de strijd tegen Karel V beschikbaar had gesteld aan diens tegenstander, de hertog van Kleef. Uit de brief van Van Schore valt op te maken dat de keizer hem wel voor Venlo in genade had aangenomen, maar daarvoor op korte termijn een tegenprestatie verlangde. Juridisch gezien had Johan zich immers met zijn partijkeuze schuldig gemaakt aan felonie, ontrouw aan zijn leenheer, aangezien hij tenminste twee lenen, te weten de heerlijkheden Oost (leenroerig aan het landsheerlijk leenhof van het hertogdom Limburg) en Sint-MartensVoeren (leenroerig aan Valkenburg) van Karel V in leen hield.

De boete voor die felonie werd de opdracht tot het doen van leenhulde voor Rimburg. Twee eeuwen eerder, in 1334, was Rimburg ook al in leen opgedragen aan de hertog van Brabant, maar daarna was dat achterwege gebleven. Bij de verheffing van Diederik II van Bronckhorst Batenburg tot Reichsfreiberr in 1498 leek Rimburg zelfs als rijksonmiddellijk te zijn erkend. Met een nieuwe leenverheffing zou deze onduidelijkheid uit de wereld zijn geholpen. Op 4 januari 1544 droeg Johan bij het leenhof van Brabant in Brussel huis en heerlijkheid Rimburg in leen op en hij stelde het kasteel als open huis voor de hertog van Brabant beschikbaar. ${ }^{834}$ De tekst van de eed van trouw als leenman is opmerkelijk in die zin dat de verplichting om Rimburg beschikbaar te houden nog eens wordt bevestigd met een boetebeding van liefst zesduizend goudgulden. Een maand later leverde Johan een 'denombrement' of specificatie in van de goederen en rechten die bij Rimburg hoorden, gevolgd door een notitie met een 'denombrement' voor de heerlijkheden Oost en SintMartens-Voeren. De laatste leenverheffing voor Sint-Martens-Voeren had overigens nog plaatsgevonden in 1537.835 We mogen aannemen dat Gronsveld, indien dat nog bezet was, op dat moment is teruggegeven.

De gedwongen leenverheffing van Rimburg was bedoeld als straf, maar past ook in het kader van de politiek die Karel V voerde ten aanzien van het hertogdom Limburg en de Landen van Overmaze. Nog in 1497 hadden Maximiliaan I en Filips de Schone met het oog op de oorlog tegen Gelre het Land van 's-Hertogenrade verpand aan de hertogen Willem van Gulik en Johan van Kleef. Aanvankelijk werd aflossing van de pandsom op de lange baan geschoven, maar na 1525 stond dit punt in Brussel hoog op de politieke agenda. Zo waren er klachten over machtsmisbruik van ambtmannen van de hertogen van Kleef en Gulik in verpande gebieden die eigenlijk aan de hertog van Brabant toebehoorden. Voorts werden deze grensstreken vanuit strategisch oogpunt steeds belangriiker, vooral ook in de strijd tegen Gelre. Ten slotte streefde de regering naar een territoriale afronding van de Habsburgse Nederlanden en daar pasten onduidelijke verhoudingen aan de randen niet bij. Na het Verdrag van Venlo werd van de pandlossing serieus werk gemaakt. De onderhandelingen begonnen op 2 januari 1544 (Traktaat van Brussel). Misschien berust de zo kort daarop volgende leenverheffing van huis en heerlijkheid Rimburg op 4 januari 1544 op toeval, maar er verdween daarmee wel een lastig obstakel voor de territoriale afronding van het Land van 's-Hertogenrade. Want de

${ }^{834}$ Galesloot, Inventaire Cour féodale I, 309, waar ook de volle tekst van de eed als leenman is afgedrukt. De tekst van de leenopdracht ook afgedrukt bij Hanssen, Die Rimburg, 347-350, nr. 100.

${ }^{835}$ Habets, 'Leenen Valkenburg' PSHAL 21 (1884) 260-261. 
ervaring had geleerd dat van het sterke huis Rimburg, gelegen als een soort wig in het land van 's-Hertogenrade, een ernstige dreiging uitging, wanneer het zich in verkeerde handen bevond.

Door de leenverheffing bij het leenhof van Brabant ging de rijksonmiddellijke status van huis en heerlijkheid Rimburg verloren. De rijksonmiddellijkheid van Gronsveld schijnt verder niet ter discussie te hebben gestaan. Voortaan bleef dit kleine land het enige rijksonmiddellijke territorium van de familie. Voor Johan I van Bronckhorst Batenburg zal de hele gang van zaken moeilijk te verteren zijn geweest. Uiteindelijk werd de bittere pil nog enigszins verguld door hertog Willem van Kleef-Gulik, want op 19 oktober 1546 kreeg Johan opnieuw een benoeming tot landdrost van Kleef. ${ }^{836}$

Op het laatst van zijn leven moet ook de verwerving van de hoge jurisdictie over Rimburg genoegdoening hebben verschaft. Het 'denombrement' (specificatie) dat Johan van Bronckhorst op 4 februari 1544 van het leen Rimburg was tamelijk vaag op het punt van de heerlijke rechten. De heer van Rimburg oefende lage jurisdictie uit, maar de bevoegdheden ten opzichte van het Land van 's-Hertogenrade waren niet goed afgebakend. De mogelijkheid daarin verbetering te brengen deed zich voor toen op 17 februari 1557 koning Philips II als hertog van Brabant voor zeshonderd Carolusgulden de hoge heerlijkheid Rimburg met daartoe behorende goederen, gelegen onder de parochies Marienberg (hertogdom Gulik) en Merkstein (Land van 's-Hertogenrade) aan Johan van Bronckhorst Batenburg verkocht. ${ }^{837}$ Vanuit het Land van 's-Hertogenrade zou voortaan geen jurisdictie meer over Rimburg worden uitgeoefend en zouden ook geen belastingen of diensten worden opgelegd. Wel gehandhaafd bleef voor de heer van Rimburg de plicht voor huis en heerlijkheid leenhulde te doen bij het hertogelijk leenhof van Brabant in Brussel. De latere heren van Rimburg hebben die leenhulde ook steeds gedaan.

De verkoop van de hoge jurisdictie over Rimburg op 17 februari 1557 stond formeel op naam van Johan I van Bronckhorst Batenburg, maar werd feitelijk afgehandeld door zijn zoon Willem. Na een bewogen leven moet Johan I zijn overleden in 1558 of 1559.838 Niet bekend is waar hij werd begraven. Uit zijn eerste huwelijk met Geertruid van Loë liet hij drie kinderen na, de dochters Theodora en Catharina, en een zoon, Willem, die hem opvolgde. Zijn tweede huwelijk met Melchiore van Wyenhorst bleef kinderloos. ${ }^{839}$

\subsection{Willem van Bronckhorst Batenburg, 1558/1559-1563}

\footnotetext{
836 Hanssen, Die Rimburg, 157 en 356-359, nr. 107.

837 Goederen van de heerlijkheid Rimburg lagen onder de parochies Marienberg (in 1510 afgescheiden van Eijgelshoven) en Merkstein, vgl. Hanssen, Die Rimburg, 66-67. Over de verkoop van de hoge heerlijkheid zie: Hanssen, Die Rimburg, 159 en 360 (regest nr. 111). Een afschrift van de akte van verkoop bevindt zich RHCL, Familie De Geloes/Kasteel Eijsden, inv. nr. 422.

838 Zijn zoon Willem deed op 7 juli 1559 leenhulde voor Rimburg bij het leenhof van Brabant.

839 Van Schilfgaarde, 'De heren van Bronckhorst', 78.
} 
In tegenstelling tot de lange 'regeringstijd' van zijn vader, mag die van Willem van Bronckhorst Batenburg uitzonderlijk kort worden genoemd, want hij overleed al in 1563. Willem was gehuwd met Agnes van Bylandt-Halt-Spaldrop, (geboren circa 1530), dochter van Rolmann van Bylandt-Halt-Spaldrop (circa 1508-1556/1558) en van Barbara van Virmond (1505-1565). ${ }^{840}$ Het jonge echtpaar verbleef meestentijds in Sonsbeck, waar ook de drie kinderen Jost, Theodora en Johan werden geboren.

Veel biografische bijzonderheden zijn over Willem van Bronckhorst Batenburg niet bekend. Chestret de Haneffe ${ }^{841}$ en Hanssen ${ }^{842}$ maken alleen melding van grensconflicten tussen de heerlijkheid Rimburg en het Land van Valkenburg.

We moeten in het midden laten of Willem zelf of later zijn weduwe opdracht heeft gegeven voor het fraaie grafmonument, uitgevoerd in rood en zwart marmer, dat in de Sint-Martinuskerk van Gronsveld op het priesterkoor boven op een grafkelder werd geplaatst. ${ }^{843} \mathrm{Op}$ de tombe zijn de namen en wapens van Willem en zijn echtgenote aangebracht, met aan de boven- en onderzijde telkens vier kwartierwapens. De sterfdatum van Willem, 31 maart 1563, is op de graftombe ingevuld, die van Agnes van Bylandt niet. Zij overleefde haar echtgenoot liefst 52 jaar en overleed pas in 1615 te Hönnepel of op huis Eyl in Huisberden. ${ }^{844}$

840 De grootouders aan moederszijde van Agnes waren Ambrosius van Virmond (1470-1539) en Agnes van Palant (circa 1480-1524). Uit dit huwelijk waren geboren 1) Barbara, gehuwd met Rolmann van Bylandt-Halt-Spaldrop; 2) en 3) Klara en Margaratha, beiden nonnen in Engelthal bij Bonn); 4) Anna (geb. 1524), gehuwd met Adriaan van Bylandt tot Well (niet Rheydt, zoals wordt vermeld in de literatuur), circa 1505-circa 1576? Agnes van Bylandt-Halt-Spaldrop had nog vijf broers en zusters. (Vriendelijke mededelingen van Dr. Wolfgang Löhr, Mönchen-Gladbach).

${ }^{841}$ Chestret de Haneffe, 'Histoire Gronsveld', 72-73.

842 Hanssen, Die Rimburg, 162-164.

${ }^{843}$ Zie over deze grafkelder: Habets, 'Een woord over de grafstede'; Witteveen/Eijs, 'De grafkelder der familie Bronckhorst-Batenburg'; Jaspars, 'Grafkelder St. Martinuskerk'; Jaspars,/Kengen/Orbons, 'Raadsels rond de graftombe van Willem van Bronckhorst'. De tombe stond tot 1990 op het priesterkoor, kreeg na een verandering van de inrichting een weinig eervolle plaats in een berghok onder de toren en is in 2011 in de kerk herplaatst. Wat de oorspronkelijke dispositie uit de zestiende eeuw is geweest, valt niet met zekerheid te zeggen, aangezien de kerk rond 1700 geheel is herbouwd.

Er bevinden zich thans twee grafkelders naast elkaar, een grote en kleinere, zie tekening bij Jaspars,/Kengen/Orbons, 21. In de grote ruimte bevonden zich volgens het vroegst bekende verslag van een opening in 1865 zeven loden lijkkisten. Slechts één, die van Jost Maximiliaan van Bronckhorst, overleden in 1663, droeg een inscriptie met de naam van de overledene. (Over de toestand van de kisten zie eerder genoemde literatuur). Het is niet zeker of dit ook de oorspronkelijke grafkelder uit de zestiende eeuw is geweest. Denkbaar is dat de grote ruimte later is gebouwd door Jost Maximiliaan en dat kisten uit een oudere kelder daarin zijn herplaatst. De kleine ruimte ernaast is jonger en volgens een inscriptie op de muur in 1711 gebouwd ('sepulcrum inventum') bij de renovatie/herbouw van de kerk (Jaspars/Kengen/Orbons, 16-18). Hierin werd in 1719 Johan Frans van Bronckhorst Batenburg bijgezet. De graftombe stond tot 1990 eigenlijk foutief boven deze kleine ruimte en niet boven de grote kelder. De conclusie echter van Jaspars/Kengen/Orbons dat de kleine ruimte, waar Johan Frans begraven ligt, het oudste zou zijn, berust op een verkeerde interpretatie van het woord 'inventum'. Dit kan betekenen 'terug gevonden'of 'ontdekt', maar betekent in de combinatie met een bouwwerk of kunstwerk 'gemaakt' of 'ontworpen'.

844 De plaats van overlijden is onduidelijk, maar Hönnepel of Eyl komen het meest in aanmerking. Interessant is dat in de nog bestaande gebouwen van huis Eyl een ongedateerde wapensteen is ingemetseld met het alliantiewapen van Willem van Bronckhorst Batenburg en Agnes van Bylandt.Het 
Willem van Bronckhorst Batenburg was de eerste van zijn familie van wie zeker is dat hij zich in Gronsveld liet begraven. Met de oprichting van een graftombe werd de mode van die tijd gevolgd. Veel belangrijke edelen meenden dat grote grafmonumenten in parochiekerken hun eigen aanzien en dat van hun familie tot uitdrukking brachten. ${ }^{845}$ Zoals de hoge adel zich vroeger vaak met een bepaald klooster had verbonden, zo leek die rol te worden overgenomen door de parochiekerk van de plaats waar men heerlijke rechten had en een kasteel stond dat als stamslot werd beschouwd. Voor Gronsveld kan nog een reden hebben gespeeld juist nu een familiegraf te stichten. Door het verlies van de rijksonmiddellijkheid van Rimburg steunde de stand van rijksvrijheer alleen nog maar op Gronsveld. Het kwam er dus nu op aan zoveel mogelijk het belang van Gronsveld voor de familie te benadrukken. Zeker is dat standsbewustzijn sterk bij deze generaties van het geslacht Van Bronckhorst Batenburg leefde. Willems grootvader had in 1498 het predicaat rijksvrijheer verworven, zijn zonen zouden in 1586 in de gravenstand worden verheven.

\subsection{Jost en Johan II van Bronckhorst Batenburg gezamenlijk, 1563-1586}

\subsubsection{Voogdij en opvoeding}

Toen Willem van Bronckhorst Batenburg overleed werden de drie minderjarige kinderen geplaatst onder de voogdij van Adriaan van Bylandt, ambtman van Gennep, een oom van Agnes aan moederszijde.846 Op 22 juni 1564 verhief Adriaan het huis Eyl voor het hertogelijk leenhof van Kleef onder de voorwaarde dat hij dit goed zou teruggeven zodra de oudste zoon van Willem van Bronckhorst meerderjarig werd.

Omstreeks 1575 moest Adriaan namens zijn pupillen verweer voeren in een groot proces dat Diederik van Millendonk, heer van Drachenfels, in Brussel (voor de Raad van Brabant?) had aangespannen over de nalatenschap van Willem van Bronckhorst Batenburg. ${ }^{847}$ Diederik trad daarbij op voor zijn echtgenote Theodora van Bronckhorst Batenburg, een zuster van Willem. Wat Van Millendonk precies dreef is niet duidelijk, maar in ieder geval maakte hij aanspraak op huis Eyl te Huisberden in het hertogdom Kleef, op de heerlijkheid Gronsveld en mogelijk ook op Rimburg. De zaak deed veel stof opwaaien omdat het een nalatenschap betrof waarvan het belangrijkste deel (Eyl en Gronsveld) buiten Brabant lag, dus onder de jurisdictie van rechters in het Rijk viel en volgens rijksrecht moest worden beoordeeld. Bovendien zouden volgens rijksrecht adellijke dochters alleen maar aanspraak kunnen maken op geld uit de nalatenschap, omdat de onroerende goederen voor de mannelijke nakomelingen van de familie

inschrift luidt: 'GVILHELMI DE BRONCHORST BARONIS IN GRONSFELT AC AGNETE DE BRONCHORST NATE DE BILA(N)T BARONISSE IN GRONSFELT INSIGNIA'. ('Wapens van Willem van Bronckhorst, baron van Gronsveld en Agnes van Bylandt, barones van Gronsveld'), vgl. Hilger, Kreis Kleve 1, Altkalkar-Huisberden, 118 en afb. 408.

845 Tummers, H., 'Enkele figurale grafzerken in de provincie Limburg',

846 Gehuwd met Anna van Virmond, een zuster van Agnes'moeder. Adriaan was sinds 1551 formeel geen heer meer van Well, maar drost van Gennep in Kleefse dienst. Zie over hem: Van Veen, 'Adriaen van den Bylandt'.

847 Zie over hem: v. Oidtman, 'Herren Millendonk', 19-20; Bremer, Herrschaft Millendonk, 99. 
behouden dienden te blijven. Deze visie werd ook verdedigd door de ridderschap van het hertogdom Kleef als belanghebbende in de zaak vanwege het riddermatige huis Eyl. Op verzoek van Adriaan van Bylandt intervenieerde keizer Maximiliaan II bij de Spaanse landvoogd Requesens. Het verdere verloop van de zaak is niet bekend, maar uit het feit dat Jost en Johan later in het bezit van Eyl, Rimburg en Gronsveld komen mag worden afgeleid dat zij uiteindelijk aan het langste eind trokken. ${ }^{848}$

Intussen werd alle zorg besteed aan de opvoeding en scholing van Jost en Johan. Waar deze vorming plaatsvond, is niet bekend, maar zij ontvingen voldoende opleiding voor een vervolgstudie aan een universiteit. Zowel Jost als Johan werd in 1575 ingeschreven bij de heropgerichte 'natio Germanica' van de universiteit van Orléans. ${ }^{849}$ Achtereenvolgens waren zij daar tot 'procurator' gekozen. ${ }^{850}$ Tegelijk met Jost en Johan arriveerden hier ook Assuerus Stroyff (of Streuff) uit Emmerich en 'Gwilhelmus ab Odenhaven' (Willem van Odenhoven) uit Bree (B). Beide namen behoeven enige toelichting omdat ze in de verdere geschiedenis van de heren van Bronckhorst Batenburg een rol spelen. Stroyff komen we in 1569 aan de universiteit van Keulen tegen. ${ }^{851}$ In 1574 schonk hij een manuscript van een Latijnse bijbel aan Johan van Bronckhorst Batenburg.852 Op 21 oktober 1575 promoveerde Stroyff in Orléans tot licentiaat in de beide rechten. ${ }^{853}$ Enkele malen wordt hij daar ook 'assessor' van de 'natio Germanica' genoemd. In 1582 liet hij zich aan de juridische faculteit van Padua inschrijven. Waarschijnlijk arriveerde hij daar samen met Johan van Bronckhorst Batenburg, want ook die meldde zich daar tegelijk met hem aan. ${ }^{854}$ In november 1584 ondertekende Stroyff samen met Johan bij een geldschieter in Venetië een wisselbrief van tweehonderd gouden kronen, die door Johans moeder, Agnes van Bylandt, moest worden betaald. ${ }^{855}$ Stroyff wordt in het stuk 'preceptor' ('leraar') genoemd. Uiteindelijk moet hij zijn academische opleiding hebben afgesloten met een doctoraat in de beide rechten, want in latere documenten voert hij de titel 'doctor'. De gezamenlijke studie met de heren van Bronckhorst is vervolgens omgezet in een arbeidsrelatie. Zeker vanaf 1586 was Stroyff bij Jost van Bronckhorst Batenburg in dienst als raadsman en 'hoofdboekhouder'. Uit de door hem opgestelde rekening over de periode 1586-1588

848 Mogelijk een nasleep van deze zaak was een transactie in 1597, waarbij graaf Johan van Bronckhorst Batenburg landerijen in Eijsden overdroeg aan Johan, heer tot Millendonk en Drachenfels., zieRHCL, Familie De Geloes/Kasteel Eijsden, inv. nr. 425.

849 Ridderikhoff, C.M., e.a., Les Livres des procurateurs de la nation germanique... Troisième livre 1567-1587, passim; zie in het bijzonder 336, Justus en Johannes a Bronckhorst et Batoborch betalen op 28 november 1575 voor immatriculatie en 321, het devies van Justus als procurator: S[it] N[omen] D[omini] B[enedictum]. Legibus et armis optima est gubernatio' (het beste bestuur is met wetten en wapenen').

${ }^{850}$ Tot de 'officiarii '(ambtsdragers) van een 'natio' behoorden in Orleans: de procurator, quaestor, assessor en bibliothecarius. Zij werden door de natio gekozen en hun ambtsduur was drie maanden.

${ }^{851}$ Keussen, Matrikel Universität Köln 4, 66.

852 Manuscript werd in 2000 geveild bij Christie's in Londen (Lot 12 / Sale 6348). Volgens aantekeningen op het schutblad ontving Stroyff het boek van Jean Tornone, doctor in de medicijnen en gaf hij het in 1574 aan Johan van Bronckhorst Batenburg.

853 Ridderikhoff, C.M., e.a., Les Livres des procurateurs de la nation germanique... Troisième livre 1567$1587,337$.

${ }^{854}$ Knod, G., 'Rheinländische Studenten', 153.

855 RHCL, Graafschap Gronsveld, inv. nr. 442. 
blijkt dat hij voortdurend met de meest uiteenlopende, vaak vertrouwelijke, opdrachten voor zijn heer onderweg was. ${ }^{856} \mathrm{Na}$ het overlijden van Jost heeft Stroyff ook voor Johan van Bronckhorst Batenburg gewerkt; zijn naam komt herhaaldelijk voor in de rekeningen van de rentmeester.

Ook de in Orléans 1575 in verband met de gebroeders van Bronckhorst Batenburg opduikende naam van Willem van Odenhoven is interessant, omdat rond 1630 Johan van Odenhoven voor Jost Maximiliaan van Bronckhorst Batenburg drossaard was te Hönnepel bij Kalkar (Zie Hoofdstuk 8.4). Mogelijk was Willem diens vader. Feit is in ieder geval dat later leden van de familie Van Odenhoven behoorden tot de kring van vertrouwelingen van Johan II van Bronckhorst en diens zoon Jost Maximiliaan.

Of de gebroeders Van Bronckhorst Batenburg hun studies met een academische graad afsloten, valt uit de spaarzame informatie niet op te maken. Orléans werd door jonge edellieden vak meer bezocht voor algemene vorming dan voor wetenschappelijke opleiding. ${ }^{857}$ De gebroeders Van Bronckhorst Batenburg voerden in ieder geval later geen academische titels. Maar over belangstelling voor cultuur beschikten zij wel. Zeker geldt dit voor Johan die gedurende langere tijd in Italië verbleef. Waarschijnlijk kwam hij in Padua ook in contact met Antonio Riccoboni (1541-1599), jurist, professor in de klassieke filologie en rethorica en auteur van een tiental boeken, in verschillende plaatsen van Europa uitgegeven. Eén van diens werken, getiteld Praxis rethorica sive de usu rhetoricae etc. werd in 1588 op kosten van Jost in Keulen gedrukt. ${ }^{858}$ Literaire belangstelling blijkt uit posten in de rekening van 1586-1588 voor de aanschaf van boeken over de klassieke oudheid, geschiedenis en recht. 859

Vast staat dat de gebroeders Van Bronckhorst Batenburg ook goede contacten onderhielden met Andreas von Gail, telg uit een Keulse patriciërsfamilie, die van 1583 tot zijn overlijden in 1587 kanselier van de aartsbisschop van Keulen was. Gail, wiens rol bij de verheffing van Jost en Johan in de gravenstand nog aan de orde komt, had als jurist naam gemaakt bij het Rijkskamergerecht en de Rijkshofraad, maar is vooral bekend geworden als auteur van een leerboek over het procesrecht bij het Rijkskamergerecht. ${ }^{860}$ Op grond van dit soort relaties mogen we dus aannemen dat de gebroeders Van Bronckhorst Batenburg goed waren ingevoerd in de rechtsgeleerde wereld.

\subsubsection{Oorlogstoestand}

856 RHCL, Graafschap Gronsveld, inv. nr. 175.

857 Zie Madeline, 'Huguenots à Orléans', 15: 'La reputation de l'Université attirait l'aristocratie qui considerait ce passage comme une étappe obligatoire dans l'éducation nobiliaire. Même si la Noblesse montrait une résistance aux examens universitaires, il était de bon ton de passer quelque temps à Orléans pour recevoir une formation juridique et une éducation mondaine à la française'.

858 De volledige titel luidt: Praxis Rhetorica sive de usu Artis Rhetoricae in tribus generibus causarum \& in orationibus ecclesiasticis libri XVI. Quibus universa Aristotelis Ars Rhetorica \& Hermogenis doctrina de Statibus modo practico \& 12 Orationes explanantur. Gedrukt bij Petrus Haack, Keulen 1588. Het boek wordt wel in enkele bibliografieën genoemd, maar het is niet gelukt een exemplaar te vinden.

${ }^{859}$ RHCL, Graafschap Gronsveld, inv. nr. 175.

860 Zie over Gail, Erler, e.a. Handwörterbuch Rechtsgeschichte, 1, 1371-1373 onder lemma Gail en Kloosterhuis, Erasmusjünger, 578-579. 
De gebroeders Van Bronckhorst Batenburg groeiden op in de tijd dat het Maasdal strijdtoneel in de inmiddels uitgebroken Nederlandse Opstand was geworden. In 1568 viel een leger onder leiding van Willem van Oranje vanuit het Gulikerland de Zuidelijke Nederlanden binnen. De poging van Oranje een algemene opstand tegen koning Philips II te ontketenen mislukte voordat Brabant was bereikt. Intussen leed de plattelandsbevolking aan weerszijden van de Maas ernstig onder plundering en andere gewelddaden. Deze toestand veranderde de daarop volgende jaren niet. Omdat de centrale regering in Brussel door geldgebrek voortdurend niet in staat bleek de Spaanse troepen tijdig te betalen, stroopten muitende soldaten stad en land af. De Pacificatie van Gent (6 november 1576) en het Eeuwig Edict (12 februari 1577) moesten rust brengen en leidden ook tot het vertrek van vreemde troepen uit de Nederlanden, maar de vrede bleef uit. Veel meer werden de verhoudingen tussen de koningsgetrouwen en de aanhangers van de Opstand verscherpt. Vooral in de Noordelijke Nederlanden (Holland, Zeeland, Gelre) maar ook in Vlaanderen probeerden radicale calvinisten de macht te grijpen. De nieuwe landvoogd Alexander Farnese, de latere hertog van Parma, speelde handig in op de tegenstellingen. De terugkeer van een aantal Waalse gewesten onder het gezag van de koning in de Unie van Atrecht (6 januari 1579) werd op 23 januari 1579 gevolgd door een bondgenootschap van een aantal noordelijke gewesten in de Unie van Utrecht. Intussen was Farnese druk doende met militaire middelen de rebellen te onderwerpen. De verovering van het strategisch belangriijke Maastricht kreeg daarbij hoge prioriteit. Nadat in april 1577 de Spaanse troepen de vesting hadden verlaten, streefde het stadsbestuur zowel naar neutraliteit als behoud van een zo groot mogelijke zelfstandigheid. Desondanks leek men steeds meer in het kamp van de opstandelingen terecht te komen. Er was Farnese alles aan gelegen Maastricht in handen te krijgen. In maart 1579 begon hij het beleg en na een hardnekkige verdediging viel de stad op 29 juni 1579 in Spaanse hand. Tal van burgers en soldaten (men schat ongeveer tweeduizend) verloren het leven. De politieke gevolgen van deze verovering waren groot. Niet alleen werd het gezag van Philips II in de stad hersteld, op velen in de Zuidelijke Nederlanden maakte de gebeurtenis een zodanig grote indruk dat men het raadzaam achtte onder het gezag van de koning terug te keren.

De gebeurtenissen uit deze jaren hadden ook hun weerslag op het leven van de bevolking in Gronsveld. De status van Gronsveld als neutraal rijksgebied bood geen enkele bescherming. In een getuigenverhoor uit 1589 wordt verteld dat al in 1568 bij nadering van de troepen van Willem van Oranje de inwoners van Gronsveld have en goed in veiligheid brachten binnen de muren van Maastricht. ${ }^{861}$ Daarna schijnt het normale leven zich weer spoedig te hebben hersteld. Begin 1579 werd de situatie echter zo onveilig dat opnieuw een veilig heenkomen in de stad werd gezocht. Ook de rentmeester van Agnes van Bylandt had een grote hoeveelheid graan in de stad laten brengen, die naderhand verloren was gegaan. ${ }^{862}$

861 RHCL, Graafschap Gronsveld, inv. nr. 93: 'dat ten tijde van den tochte des Prince van Oraignien in den jaer LXVIII ombegrepen d'ingesetene van Gronsvelt sijn voor eenighe tijdt van daer vertrocken door vreese van den tochte van ruyteren ende knechten van den Prince van Oraegnien'.

862 RHCL, Graafschap Gronsveld, inv. nr. 93. 
Ongetwijfeld vielen bij de verovering ook slachtoffers onder deze vluchtelingen en werden eigendommen geroofd en geplunderd. Zeker is dat het platteland in de directe omgeving van Maastricht zodanig verwoest en ontvolkt raakte, dat het jaren duurde vooraleer van herstel sprake kon zijn. ${ }^{863}$ Noch Agnes van Bylandt, noch haar beide zonen konden voor de inwoners van Gronsveld een grote steun zijn. Agnes verbleef meestal op kasteel Rimburg of in de steden Keulen en Aken, terwijl Jost en Johan nog studeerden. De feitelijk hoogste gezagsdragers in Gronsveld waren de rentmeesters, Claas Congaerts sr. en jr.

\subsubsection{Verwerving van de graventitel}

In het voorjaar van 1586 vond een scheiding en deling plaats tussen Agnes van Bylandt en haar beide zonen Jost en Johan en werd de heerlijkheid Gronsveld aan Jost overgedragen. Afkomst en opleiding hadden de jonge heren van Bronckhorst Batenburg gevormd tot standsbewuste edellieden. Het is dan ook niet vreemd dat zij zich vrijwel onmiddellijk daarna tot keizer Rudolf II (1576-1611), residerend in Praag, richtten met het verzoek hun 'freie herrschafft Gronsfeldt zu einer graiffschafft des Reichs sampt allen derselben regalien, recht und gerechtigkeiten allergnedigst zu wurdigen'. Mogelijk heeft ook het huwelijk van Jost met gravin Anna van Oostfriesland bijgedragen aan de poging om te komen tot standsverhoging. Zij was een dochter van graaf Johan van Oostfriesland (15061572), heer van Durbuy, ridder van het Gulden Vlies, gouverneur van het hertogdom Limburg en het Land van Valkenburg864 en Dorothea van Habsburg/Oostenrijk, een natuurlijke dochter van keizer Maximiliaan I. Bij een dergelijke familie paste een overeenkomstige stand.

Ter toelichting werden bij het rekest drie 'memorialen' gevoegd, één van Jost, één van Johan en een derde zonder aanduiding van de herkomst. ${ }^{865} \mathrm{Te}$ oordelen naar het handschrift moet het echter afkomstig zijn van de secretaris van Andreas von Gail.

Jost betoogde dat de vrijheerlijkheid Gronsveld van oudsher onbetwist rijksonmiddellijk was. De heerlijkheid werd 'von Godt und der sonnen' ontvangen, met andere woorden, Gronsveld moest als een zonneleen worden beschouwd. De heer bezat alle gebruikelijke hoge regalia en rechten, waarbij in het bijzonder melding werd gemaakt van het aloude recht om gouden en zilveren munten te slaan. Vervolgens zette hij een betoog op over de herkomst van de familie Van Bronckhorst Batenburg, waarbij de taal plotseling wijzigde van het Duits in het Latijn. Tweehonderd jaar geleden was de erfdochter uit geslacht 'Van Batenburg' getrouwd met Willem van Bronckhorst en sinds die tijd waren naam en wapen van Batenburg aan die van Bronckhorst toegevoegd. Zowel Batenburg als Bronckhorst behoorde tot de hoogste edelen ('primariis baronatibus') van het hertogdom Gelre, waarmee waarschijnlijk de Gelderse bannerheerlijkheden werden bedoeld.

863 TJ, inv. nr. M 11, fol. 393-403, verklaringen van getuigen uit 1657 dat in 1579 Gronsveld en Heugem geheel waren vernield, mensen gevlucht waren en de landerijen vele jaren braak lagen.

864 Zie over hem www.ostfriesischelandschaft.de, Biographisches Lexicon für Ostfriesland, onder lemma 'Enno II', geraadpleegd 10-3-2009 en Van de Venne, Geschiedenis kasteel V alkenburg, 130-131.

865 Het hele dossier van de aanvraag en verheffing bevindt zich in Wenen, Österreichisches Staatsarchiv, Allgemeines Verwaltungsarchiv, RAA (Reichsadelsakten), 49.3. 
Ongeveer tachtig jaar geleden was de baronie Bronckhorst ('Bronckhorstanus...baronatus') ten behoeve van Jost van Bronckhorst tot graafschap verheven. Omdat die kinderloos was overleden, vererfde zijn graafschap, dat niet leenroerig was, aan de graaf Van Styrum. Wat betreft Batenburg, dit was een rijksleen, dat te boek stond 'als ein uhralte frey graiffliche herschaft'. Omdat de heren van Gronsveld zich altijd hadden gedragen als gelijken van graven, zag Jost dit graag officieel vastgelegd in een document waarbij het 'baronatus' Gronsveld werd verheven tot graafschap en de heren Van Bronckhorst Batenburg het recht kregen op de titel van graaf.

Het 'memorial' van Johan van Bronckhorst Batenburg bevatte een betoog met ongeveer dezelfde strekking, waarin werd gewezen op de status van Gronsveld als zonneleen, de regalia en het muntrecht. Aangezien het 'gräfliche stamhaus Bronckhorst' door vererving volgens het Zutphense landrecht in vreemde hand was overgegaan, mochten de beide broers, bannerheren van het Rijk ('frey pannerherrn des Reichs'), zich nu als 'elteste und wappenträger' van de familie beschouwen. ${ }^{866}$ Zij wilden graag hun adellijke voorouders navolgen, die zich verdienstelijk hadden gemaakt ten opzichte van de keizer en de Huizen van Bourgondië en Oostenrijk.

Voorts betoogde Johan dat rooms-koning Maxiliaan I in 1491 Gronsveld tot een 'edell freyherschafft des Reichs' had verheven en dat deze status tot dan toe onbetwist ('sine omni controversia') was gebleven. (Hierbij moet opgemerkt dat hij zich vergiste, aangezien het bewuste diploma werd uitgevaardigd in 1498). Waarom zo de klemtoon werd gelegd op het feit dat Gronsveld 'zonder enige tegenspraak' als vrije heerlijkheid werd beschouwd, is niet duidelijk. Misschien wilde hij daarmee benadrukken dat Gronsveld niet hetzelfde standsverlies had ondergaan als Rimburg. Een ander voordeel van standsverhoging voor het Rijk was dat een graafschap werd 'immatriculiert', met andere woorden werd aangeslagen voor een bijdrage in de rijkslasten volgens de rijksmatrikel.

Het derde 'memorial' vat de argumenten voor een verheffing uit de twee eerdere betogen nog eens samen, zonder daar een wezenlijk nieuw element aan toe voegen. De auteur vermeldt aan het einde kort welke punten expliciet in een gravendiploma moesten worden opgenomen, namelijk dat de heren van Bronckhorst vanouds graven waren, dat Gronsveld een oeroude vrije heerlijkheid was en ten slotte dat de bestaande regalia werden bevestigd, in het bijzonder het muntrecht. Interessant bij de gebruikte terminologie is dat we het regelmatig gebruikte woord 'oeroud' ook terugvinden bij de formele overdracht van de heerlijkheid Gronsveld op 2 april 1586. Blijkbaar moest met die hoge ouderdom indruk worden gemaakt!

In het verzoekschrift aan de keizer gingen de broers ook in op hun eigen politieke en religieuze gezindheid. Zij hadden zich nooit ingelaten met 'verbottener opinion und mainungh', maar altijd het enige zaligmakende geloof, de rooms-katholieke religie, aangehangen. Hun voortdurende trouw aan de koning van Spanje stond boven iedere verdenking. In dit verband maakte Jost melding van het feit dat zijn zwager graaf Maximiliaan van Oostfriesland op 27 april 1586 was toegelaten tot de ridders van het Gulden Vlies. Terwijl de verwantschap met hoge, koningsgetrouwe adel werd benadrukt,

${ }^{866}$ Voor het begrip 'bannerheer' in het algemeen zie Denessen, 'De Gelderse bannerheren', 1317. 
namen de broers tegelijkertijd duidelijk afstand van hun naamgenoten, de heren van Bronckhorst Batenburg die over Batenburg regeerden. Zij wilden op geen enkele wijze in verband worden gebracht met het Batenburgse 'unwesen'. Daarmee wordt bedoeld dat vier calvinistische broers uit deze familietak de partij van Willem van Oranje tegen Spanje hadden gekozen. Dirk en Gijsbert waren op 1 juni 1568 op last van Alva op de Grote Markt in Brussel onthoofd, Willem overleed in 1573 aan oorlogsverwondingen bij het ontzet van Haarlem en Karel was in 1580 te Keulen door een Spanjaard vermoord.867

Werd in het adelsdiploma van 1498 nog tamelijk bescheiden melding gemaakt van het 'von altterher... in redlichem adelwesenn' verkerende geslacht Van Bronckhorst Batenburg, in het verzoek aan de keizer lijkt de Herkommensseuche zich flink van beide broers meester te hebben gemaakt. Op allerlei wijzen werd een historische onderbouwing gegeven van de status van de familie en van de heerlijkheden, niet alleen Gronsveld, maar ook Bronckhorst en Batenburg. Per saldo was die niet eens zo slecht, want een groot deel van de genoemde punten is correct. Maar er kleeft een probleem aan de voorgeschiedenis van de graventitel, zoals die hier wordt gepresenteerd. Omstreeks 1530 was Joost van Bronckhorst, heer van Bronckhorst en Borculo, zich graaf gaan noemen, maar het is zeer de vraag of die titel hem ooit formeel is verleend. Al direct na zijn overlijden in 1553 was daar geen spoor van te bekennen. Wellicht kwam dat zijn weduwe Maria van Hoya wel van pas in haar strijd tegen belastingen die haar en het 'graafschap' vanwege het Rijk en het lidmaatschap van de Nederrijns-Westfaalse kreits werden opgelegd. Zij achtte een verbinding met de Bourgondische kreits voor haar financieel gunstiger. ${ }^{868}$ Maar Maria van Hoya had in deze zaak een beperkt belang. Als weduwe van Joost van Bronckhorst had zich slechts het vruchtgebruik van de heerlijkheden Bronckhorst en Borculo. Over de erfopvolging ontstond een gerechtelijke procedure tussen Ermgard van Wisch, weduwe van graaf Georg van Limburg Styrum, graaf Rudolf van Diepholt en Johan I van Bronckhorst Batenburg, heer van Gronsveld en Rimburg. ${ }^{869}$ Welke belangen Johan precies in deze zaak nastreefde, kunnen we hier in het midden laten, maar het is goed denkbaar dat hij in die juridische strijd al op de graventitel van Joost aasde. Voor zijn kleinzonen (Willem van Bronckhorst Batenburg was jong overleden) zou dat een reden kunnen geweest om voortvarend op verwerving van de graventitel in te zetten.

Op 29 september 1586 vaardigde keizer Rudolf II in Praag het gravendiploma uit. In de tekst werden allerlei elementen en argumenten uit de drie hiervoor besproken 'memorialen' ingevlochten. De 'freyherrschafft Gronssfeldt' met alle rechten en toebehoren werd tot graafschap verheven. Over de status van de familie Van Bronckhorst

867 Manders, Land Maas en Waal, 157-159.

868 De Monté ver Loren, 'Gegevens Bronkhorst', 140-145.

869 Over de erfopvolging van Joost van Bronckhorst zie: De Monté ver Loren, 'Gegevens Bronkhorst', 140-141. De Monté ver Loren stelt dat de strijd over deze nalatenschap een aparte studie zou vergen. Aan strijd over het Munsterse leen Borculo wijdt à Sande, Commentarius in Gelriae et Zutphaniae consuetudines feudales, 107-176 beschouwingen. Hij schrijft nadrukkeliik (108-109) dat na het overlijden van Joost van Bronckhorst een proces werd begonnen tussen 'dominus Rudolphus Comes Diepholdicus, Iohannes Bronchorstius ac Batenburgicus, Dominus in Rymburg, atque Irmgardis Comes Lymburgica'. 
Batenburg drukt het keizerlijk diploma zich als volgt uit: Jost en Johan en hun nakomelingen werden in de stand van de rijksgraven, met alle daaraan verbonden privileges 'von newen erhebt und gesetzt', met andere woorden opnieuw bevestigd. Misschien was deze formulering in combinatie met de verwijzing naar de 'uralten, stattlichen nammen, stammen und geslecht' niet onbelangrijk, omdat daarmee toch een onderscheid ten opzichte van echte nieuwkomers in de gravenstand werd benadrukt.

Voor het keizerlijk gunstbewijs en een mooi adelsdiploma op de gebruikelijke wijze in het Latijn geschreven ('in communi forma latine') dienden wel de nodige leges te worden betaald. Ook hierin speelde kanselier Andreas von Gail een rol en hij schoot zelfs een aanzienlijk deel van het benodigde bedrag voor. Helemaal naar tevredenheid verliep de financiële afwikkeling niet. Op 7 april 1587 betaalde Stroyff 2354 Thaler aan Gail wegens uitgaven door hem 'an der graiffschafft Gronsfeltt zu derselber verhefunng angewant', maar in een brief die Gail op 16 april 1587 aan de vicekanselier in Praag schreef over problemen met het sturen van wissels en de vervaardiging van het adelsdiploma, slaakt hij ook de verzuchting: 'woltt das ich mich der sachen nit angenohmmen unnd den graven uff seinen werth gelassen hatt.'

\subsection{Jost van Bronckhorst Batenburg, 1586-1588}

Terwijl de aanvraag bij het keizerlijk hof in Praag nog in behandeling was, werd Jost door een plotseling verlies getroffen. Begin juli 1586 overleed zijn echtgenote gravin Anna van Oostfriesland in Brussel. Assuerus Stroyff, de vertrouweling van Jost, kreeg op 2 augustus 1586 opdracht het stoffelijk overschot naar Gronsveld over te brengen, waar zij in de grafkelder in de kerk werd bijgezet. ${ }^{870}$ Niets weerhield Jost er daarna nog van dienst te nemen bij het Spaanse leger, waar hij zich onder het commando van graaf Peter Ernst van Mansfeld stelde. Uit de rekening van Stroyff over 1587/1588 blijkt dat hij deelnam aan het beleg van Bonn. Eind december 1587 was deze stad door Maarten Schenck van Nydeggen, legeraanvoerder in dienst van de Staten Generaal, veroverd. In maart 1588 sloeg een Spaans ontzettingsleger zijn tenten voor de stad op, maar de verdediging was hardnekkig. Pas toen Mansfeld zich bij hen voegde, moest de bezetting van Bonn op 29 september 1588 capituleren. De soldaten kregen een eervolle aftocht en trokken naar Rheinberg en het zwaar versterkte vestingstadje Wachtendonck, de laatste plaats in het Overkwartier van Gelre, die nog in Staatse handen was. ${ }^{871}$ Mansveld moest deze haard van verzet tegen het Spaanse gezag in het Overkwartier veroveren met een leger van duizend ruiters en zesduizend man voetvolk. Na zware bombardementen en hevige gevechten zag de commandant van het intussen sterk uitgedunde garnizoen dat verdere tegenstand nutteloos was. Op 20 december 1588 stond Mansfeld vrije aftocht toe.

${ }^{870}$ RHCL, Graafschap Gronsveld, inv. nr. 175. In de door Stroyff opgestelde rekening van de grafelijke financiën over de periode van april 1586 tot juni 1588 staan verschillende posten vermeld die op de overbrenging en bijzetting betrekking hebben.

871 Voor de geschiedenis van Wachtendonck in deze periode en het beleg zie: Henrichs, Geschichte Wacbtendonck, 160-206. 
Jost van Bronckhorst Batenburg was met Mansfeld meegetrokken naar Wachtendonck. Begin december 1588 overleed hij daar, waarschijnlijk door verwondingen bij gevechten, maar zekerheid over de doodsoorzaak ontbreekt. ${ }^{872}$ Of hij in Gronsveld begraven is, valt niet met zekerheid te zeggen.

\subsection{Johan II van Bronckhorst Batenburg, 1588-1617}

\subsubsection{De erfenis van Jost van Bronckhorst Batenburg}

Op het moment dat Jost van Bronckhorst Batenburg overleed, zwierf zijn broer Johan 'im tour ${ }^{273}$ door Italië. Na ontvangst van het nieuws moet hij spoorslags zijn teruggereisd naar Rimburg en Gronsveld om de nalatenschap te aanvaarden. In november en december 1589 vonden de leenverheffingen van Rimburg in Brussel en Sint-Martens-Voeren en de halve heerlijkheid Eckelrade in Valkenburg plaats. ${ }^{874}$

Toch schijnen er problemen te zijn gerezen wegens een merkwaardig document dat moest doorgaan voor het testament van Jost. De precieze details van de zaak zijn niet bekend, maar de kern van de kwestie valt af te leiden uit een verder ongedateerd en ongetekend juridisch advies dat hierover is uitgebracht. ${ }^{875}$ Kennelijk bestond er een document voorzien van handtekening en zegel van Jost, maar ontbraken daarin formaliteiten die voor de rechtsgeldigheid vereist waren. Eigenlijk was het niet meer dan het voornemen een testament te maken. In het stuk was sprake van scholtis en schepenen van het dorp 'Brochhausen', ${ }^{876}$ maar die werden niet met naam en toenaam genoemd. Getuigen waren niet aanwezig. Inhoudelijk viel op het document veel aan te merken. Nergens werd de nog levende moeder van de testator genoemd. Eveneens ontbraken de formele toestemmingen van leenheren om over lenen te mogen beschikken. Kortom, noch formeel noch materieel kon hier sprake zijn van een geldige uiterste wilsbeschikking.

\subsubsection{Huwelijk, schoonfamilie en kinderen}

Johan huwde omstreeks 1595 met gravin Sybilla von Eberstein, dochter van graaf Otto von Eberstein ${ }^{877}$ en gravin Felicitas Colonna von Völs. Sybilla stamde uit een oude en

872 Hanssen, Die Rimburg, 167, schrijft, zonder bronvermelding, dat Jost in het jaar 1589 bij de belegering van Wachtendonck sneuvelde. Dit is echter onjuist. Op 16 december 1588 meldde zijn procureur bij de schepenstoel van Aken in het proces tegen de heer van Esneux dat zijn opdrachtgever Jost van Bronckhorst 'kristlicher gedachtenuss vur der statt Wachtendunck neulicher dage unversehentlich ablivich' was geworden. (RHCL, Rijkskamergerecht, inv. 76, fol. 148 nieuw-148vo.).

873 Uitdrukking gebruikt in juridisch advies over het zogenaamde 'testament' van Jost van Bronckhorst (RHCL, Graafschap Gronsveld, inv. nr. 443).

874 Galesloot, Inventaire Cour féodale I, 218; Habets, 'Leenen Valkenburg', PSHAL 21 (1884) 259-261, Hanssen, Die Rimburg 167-168.

875 RHCL, Graafschap Gronsveld, inv. nr. 443.

876 Hiermee kan zijn bedoeld de schepenbank van het dorp Broekhuizen, ten noorden van Venlo op de westelijke Maasoever gelegen, maar ook het gehucht Broekhuysen ten westen van Wachtendonck. Tegen deze laatste mogelijkheid pleit dat deze plaats niet over een eigen schepenbank beschikte.

877 In de literatuur bestaat verwarring over de naam van de vader. Dyserinck, 'Gouverneurs Maastricht', 10 noemt Philips van Eberstein als vader van de vier dochters en herhaalt dit in Nieuw Nederlandsch Biografisch Woordenboek, 2, 419. Philips van Eberstein was gouverneur van Maastricht van 22 april 1567 tot 
invloedrijke familie uit het noordelijk deel van het Zwarte Woud, maar het geslacht had in de loop der tijden sterk aan glans verloren. De verschillende linies waren confessioneel verdeeld tussen katholiek en luthers, met bij sommigen ook calvinistische sympathieën. Johans schoonvader Otto von Eberstein was een zoon van regerend graaf Wilhelm IV en een jongere broer van Wilhelms opvolger Philips I. Aanvankelijk bezat Otto een kanonikaat bij het domkapittel van Straatsburg, maar hij koos later voor een militaire loopbaan. Die carrière werd hem ook fataal, want tijdens de Spaanse Furie in november 1576 verdronk hij in de Schelde bij Antwerpen. Sybilla's moeder stamde af van het oud adellijk geslacht Völs uit Zuid-Tirol. Leonhard I von Völs (1458-1530) wist door belangrijke ambten en grote rijkdommen het aanzien van zijn familie te verhogen. Hij voegde aan zijn familienaam ook die van Colonna toe, volgens de legende oorspronkelijk afkomstig uit Rome. Toen Otto van Eberstein in 1576 verongelukte liet hij behalve Sybilla nog drie dochters na, te weten Maria ${ }^{878}$, Johanna ${ }^{879}$ en Felicitas ${ }^{880}$.

Uit het huwelijk van Johan en Sybilla werden drie zonen en twee dochters geboren: Jost Maximiliaan (4 oktober 1596), ${ }^{881}$ Gertrud (17 mei 1598), Felicitas (29 juli 1600) Otto Wilhelm (22 januari 1602) en Johan Philips (14 januari 1604). ${ }^{882}$ Sybilla van Eberstein moet bij of kort na de bevalling van het laatste kind zijn gestorven. ${ }^{883}$ De peters en meters werden zoals gebruikelijk, gekozen uit kringen van familie en vrienden. Aan de Bronckhorster kant waren dat vooral (waarschijnlijk katholieke) neven en achterneven uit

begin juni 1568. Anderen, bijvoorbeeld Hanssen, Die Rimburg, 171 noemen Otto van Eberstein als vader. Otto van Eberstein verbleef als commandant van Duitse vendels militairen in Maastricht van 25 februari 1575 tot begin oktober 1576. Dat hij de vader was van Sybilla blijkt uit RHCL, Graafschap Gronsveld, inv. nr. 488, waarin sprake is van een afschrift ten behoeve van Johan van Bronckhorst van een schuldbekentenis uit 1579 van de Staten-Generaal van de Spaanse Nederlanden aan de erfgenamen van wijlen graaf Otto van Eberstein wegens betaling van het garnizoen van 's-Hertogenbosch.

${ }^{878}$ Huwde in 1601 met graaf Eitel Friedrich van Hohenzollern-Hechingen († 1605) als diens derde echtgenote. Zij was katholiek en overleed 1634 te Ramshofen.

${ }^{879}$ Huwde in 1593 met Christoph Frans von Wolkenstein. Zij was katholiek.

880 Ongehuwd, stiftsdame, dekanes en 1604 abdis te Herford, stiftsdame te Essen 1600 met diverse functies, stiftsdame in Vreden 1600 en 1603 proostin, stiftsdame in Elten. Zij was 'gereformeerd'. Zie over haar Küppers-Braun, Frauen des hohen Adels, 310-311.

${ }^{881}$ Deze datum geeft hij later zelf op in zijn autobiografische geschrift 'Comoedia Gronsfeldiana (Vgl. TJ, inv. nr. M. 1).

882 De volgorde van deze lijst is ontleend aan een door Hanssen, Die Rimburg, 171-172 gepubliceerd afschrift van een tekst van pastoor Martinus Nobis aan het begin van het doopregister van Merkstein. Waarschijnlijk is de lijst, die begint met het woord 'Verzeichnus', pas naderhand, na 1604, opgesteld en heeft de pastoor zich bij de eerste twee geboorten vergist. Wanneer Gertrudt werd gedoopt op 17 mei 1598, dan kan Jost niet volgen op 22 november van dat jaar (aangenomen dat kinderen vrijwel onmiddellijk na de geboorte werden gedoopt). Wanneer Jost zou zijn geboren op 22 november 1599, dan bedraagt de afstand met Felicitas, het derde kind, geboren op 29 juli 1600, precies acht maanden. Theoretisch is dit mogelijk, hoewel de termijn zeer krap is.

883 Pastoor Nobis schrijft in zijn lijst van gedoopte kinderen over de grote haast waarmee Johan Philips werd gedoopt. Van de moeder, inmiddels 'wolseligen Gedechtnuss', wordt gezegd dat zij werd getroffen door een 'obnversehentlichen uberfalnen Schwacheit'. In een brief van Johan van Bronckhorst Batenburg an zijn zwager Eitel Friedrich van Hohenzollern-Hechingen van 3 juli 1604 bedankt hij voor het betoonde medeleven bij het overlijden van zijn echtgenote (RHCL, Graafschap Gronsveld, inv. nr. 5). 
de wat verdere linies Hönnepel, Stein en Batenburg. ${ }^{884}$ Opmerkelijk is dat bij drie van de vijf kinderen vrouwen uit hoogadellijke damesstiften waren betrokken. 885

\subsubsection{Verwerving van Hönnepel}

Naast het van zijn broer geërfde Gronsveld en Rimburg werd de verwerving van de heerlijkheid Hönnepel bij Kalkar belangrijk voor Johan II. Deze heerlijkheid was in 1508 na de deling van de nalatenschap van Diederik II van Bronckhorst Batenburg toegevallen aan een andere linie van de familie. Johans kinderloze achterneef Jost van Bronckhorst Batenburg (overleden na 1598) wenste als overtuigd katholiek niet dat zijn bezit overging naar zijn calvinistische broer Diederik, heer van Niedermörmter, maar naar zijn katholieke bloedverwant, graaf Johan II van Bronckhorst Batenburg. ${ }^{886}$

\subsubsection{Problemen rond Eberstein 887}

Grote problemen kreeg Johan met het erfdeel van zijn echtgenote Sybilla van Eberstein. Het ooit zo machtige geslacht der graven van Eberstein bevond zich in de dertiende eeuw op het hoogtepunt van zijn macht, maar daarna zette een proces van neergang in. In 1387 moest graaf Wolf van Eberstein wegens schulden de helft van zijn landsheerlijke rechten verkopen aan zijn buurman, de markgraaf van Baden. Daarmee begon een periode van tweeherigheid voor Eberstein, die uiteindelijk in de zeventiende eeuw leidde tot volledige inlijving van het graafschap bij Baden.

In 1556 voerde graaf Wilhelm IV van Eberstein op vreedzame wijze het lutheranisme in zijn gebied in, waarbij zowel katholieken als protestanten recht op het gebruik van kerken kregen. Wilhelm werd opgevolgd door zijn eveneens evangelisch gezinde zoon Philips I. Omdat deze wegens krankzinnigheid in 1577 de regering moest neerleggen, trad zijn katholieke neef Hauprecht von Eberstein, stammend uit een jongere lijn van de graven van Eberstein, als regent op. Tijdens diens bewind kwam de vrije uitoefening van de protestantse religie steeds meer onder druk te staan. Die nam nog toe toen de katholieke Philips II, markgraaf van Baden en medeheer van Eberstein, na een beroerte van Hauprecht in 1585 de macht overnam en de protestantse kerken liet sluiten.

Met het kinderloos overlijden van Philips I van Eberstein in 1589 stierf de oudste lijn van het gravengeslacht in rechte lijn uit en door het ontbreken van broers die konden opvolgen, vererfde het graafschap naar Philips II van Eberstein, telg uit een jongere zijlijn. Die overgang werd echter aangevochten door de drie nichten van Philips I, dochters van graaf Otto van Eberstein, en in het bijzonder hun echtgenoten graaf Johan II van

${ }^{884}$ Genoemd worden (2x) Jost van Bronckhorst en Batenburg, heer tot Hönnepel (katholiek), Herman Diederik van Bronckhorst, heer tot Stein en Batenburg en Maximiliaan van Bronckhorst Batenburg, heer tot $(\mathrm{Ob})$ Bicht en Stein. Waarschijnlijk stonden deze heren van Stein als katholiek te boek, hoewel deze linies ook aanhangers van het calvinisme kenden.

885 Bij Gertrudt zijn dat Josina van der Marck, abdis van Thorn en Felicitas van Eberstein (protestantse sympathieën), dekanes te Herford (pastoor Nobis schriift 'Coevorden'), bij Jost Maximiliaan is dat Margaretha van Isenburg-Grensau, dekanes te Thorn en bij Otto Wilhelm treedt op Johanna Helena von Stauffen (vgl. Küppers-Braun, Frauen des hohen Adels, passim en vooral 312-313.

886 Van Schilfgaarde, 'De heren van Bronckhorst', 81.

887 Zie over de geschiedenis van graven van Eberstein: Andermann, 'Furnem Geschlecht'. 
Bronckhorst Batenburg, vrijheer Christoph Franz van Wolkenstein en graaf Eitel Friedrich von Hohenzollern-Hechingen. Aan deze twist zat een religieus aspect, want graaf Philips II (1593-1609) was lutheraan met calvinistische sympathieën. Maar er stonden met deze erfenis ook andere grote belangen op het spel, niet alleen wat betreft goederen en inkomsten, maar ook vanwege de status van Eberstein. Het graafschap was vertegenwoordigd in de Schwäbischer Kreis en maakte deel uit van de Schäbischer Grafenverein, die als collectief een Kuriatstimme in de Rijksdag bezat. De ambitieuze vrijheer Eitel Friedrich von Wolkenstein zag in de verwerving van een graafschap bovendien een mogelijkheid tot standsverhoging. De heren oogstten met hun processen succes voor het Rijkskamergerecht, waar zij als katholieken meer keizerlijke protectie dan hun lutherse tegenstanders genoten. Daarnaast gingen de graven van Eberstein in hun juridische strijd zeer onhandig te werk. Uiteindelijk verwierven de heren van Bronckhorst Batenburg en Wolkenstein ieder een kwart van het allodiaal deel van het graafschap Eberstein en moesten de graven van Eberstein zich tevreden stellen met schamele restanten van het eens zo aanzienlijke graafschap Eberstein. ${ }^{888}$

\subsubsection{Heer van Gronsveld}

Er staat slechts een beperkte hoeveelheid archivalische bronnen ter beschikking, die inzicht kunnen geven in het leven en de persoon van Johan II van Bronckhorst Batenburg. Een militaire loopbaan streefde hij niet na. Hij lijkt zich vooral te hebben geconcentreerd op het beheer van zijn goederen en de versteviging van zijn positie als nieuwbakken graaf. De diverse losse feiten die door Hanssen worden vermeld, zijn weinig spectaculair. Het belangrijkste materiaal is bovendien nogal eenzijdig, omdat het vooral om procesdossiers gaat. Als nieuwbakken graaf moest hij erkenning verwerven bij de leden van de Nederrijns-Westfaalse Kreits. Regelmatige betaling van kreitsbijdragen, op te brengen door de verarmde inwoners van zijn gebied, hielp daarbij. Op die manier dacht Johan zich te verzekeren van eventueel militaire steun en handhaving van het omstreden Gronsveldse muntrecht. Daarnaast probeerde hij met strengheid zijn onderdanen herendiensten op te leggen wat tot een langdurig en ernstig conflict voor het Rijkskamergerecht leidde (zie hierover meer Hoofdstuk 15.3 en 16.2.1). Maar er is meer. Gewezen werd al op de conflicten over Eberstein. In 1603 raakte hij in conflict over de mogelijke opheffing van het sepulchrijnenklooster in Hoogcruts. Daar kan aan toe worden gevoegd een proces aan het einde van het leven van de graaf met Hendrik van Velraed, genaamd Meutter, zijn voormalige scholtis en rentmeester van Gronsveld. ${ }^{889}$ Bij elkaar opgeteld geeft dit soort informatie wel een indruk van Johan als persoon. Een zekere heerszucht en strijdlust in juridische zaken kan Johan niet worden ontzegd.

Johan II van Bronckhorst Batenburg overleed medio oktober 1617, waarschijnlijk in Rimburg. De rentmeestersrekening van het graafschap Gronsveld over 1617/1618 bevat

888 Andermann, 'Glanz und Niedergang', 212-213. Op termijn konden de graven van Gronsveld en Wolkenstein hun bezit niet behouden. In de jaren 1673-1676 werd het Gronsveldse deel verkocht om schulden af te lossen, vgl. Andermann, 'Glanz und Niedergang', 213-215 en voor de activiteiten van graaf Johan Frans van Bronckhorst Batenburg daarin Hoofdstuk 4.2)

${ }^{889}$ RHCL, Rijkskamergerecht, inv. nr. 26. 
verschillende posten die betrekking hebben op uitgaven voor de uitvaart en begrafenis. ${ }^{890}$ Daaruit kan worden opgemaakt dat de plechtige uitvaartdienst plaatsvond op of omstreeks 11 december 1617.

\subsection{De familie V an Bronckhorst Batenburg en het protestantisme}

Het rumoer dat na 1517 ontstond over de stellingen van Maarten Luther drong na korte tijd ook door in het Maasgebied en aan de Nederrijn. Deze streken lagen aan alle kanten open voor beïnvloeding door nieuwe stromingen op godsdienstig gebied, niet alleen de ideeën van Luther, maar ook van andere hervormers. Aangezien in de literatuur wordt beweerd dat sommige heren en vrouwen van Gronsveld het protestantisme waren toegedaan, verdient dit aspect enige aandacht, omdat religieuze gezindheid ook politieke en maatschappelijke gevolgen had.

In de tweede helft van de jaren twintig van de zestiende eeuw drongen de ideeën van de hervorming langzaam binnen in het bisdom Luik en de tot het bisdom Keulen behorende hertogdommen Kleef en Gulik. ${ }^{891}$ Vaak is in deze jaren onduidelijk welke geloofsopvattingen nu precies onder de verzamelnaam 'lutherie' schuilgingen. Het echte lutheranisme schijnt in het Maasdal weinig aanhangers te hebben gehad. Anders was dat na 1530 met de wederdopers of anabaptisten, wier prediking in het Land van Loon, in Maastricht en in het westelijk deel van het hertogdom Gulik de nodige aanhangers vond. Omdat deze groepering streefde naar een radicale verandering van de maatschappelijke en politieke orde, werd zij door alle overheden als staatsgevaarlijk beschouwd. De repressie was hevig en tientallen mensen eindigden hun leven op de brandstapel of het schavot. Het echec van het door de wederdopers te Münster gestichte Godsrijk (1534-1535) ontnam echter aan deze beweging een groot deel van haar maatschappelijke dreiging.

Anders lag dit na 1560 voor het calvinisme. De vaak fanatieke aanhangers van deze stroming schuwden geweld niet en oogstten vooral in de steden succes omdat zij hun religieuze belangen wisten te verbinden met de opstand tegen de koning van Spanje. Daar kwam bij dat de overheid vaak weifelend tegen hen optrad. Zo deden zij in Maastricht eind 1566/begin 1567 een greep naar de macht, maar het succes bleek van korte duur en de predikanten werden verdreven. Allengs raakte de stad meer betrokken in de opstand tegen Spanje. Vanaf april 1577 speelden de soldaten van het garnizoen in de stad de calvinisten in de kaart. De protestanten begonnen zich steeds openlijker te gedragen als de nieuwe machthebbers. Uiteindelijk leidde dit tot het Spaanse beleg begin maart 1579, dat eindigde met de verovering van de stad op 29 juni 1579. Die overgang bracht een

${ }^{890}$ RHCL, Graafschap Gronsveld, inv. nr. 181.

${ }^{891}$ Ubachs, Handboek Geschiedenis Limburg, 150-153. Nog altijd belangrijk voor deze periode, ook vanwege de vele aangehaalde bronnen is het werk van Bax, Protestantisme Luik. Ten dele steunt dit werk op dezelfde bronnen die zijn gebruikt bij de verouderde artikelen van Habets, 'Wederdoopers' en 'Aantekeeningen Susteren'. Voor een overzicht van de situatie in het Land van Loon zie Venner, Beeldenstorm Hasselt, in het bijzonder 48-66. Een overzicht van de kerkpolitiek van de hertogen van Kleef en Gulik, met uitgebreide opgave van literatuur, is te vinden bij Jansen, 'Kleve-Mark-Jülich-Berg-Ravensberg', 35-40. 
aanmerkelijke verandering teweeg in de politieke en religieuze verhoudingen binnen Maastricht. Niet alleen keerde de stad terug onder het gezag van koning Philips II (waarbij overigens het bestaande tweeherig bestuur met de prins-bisschop van Luik gehandhaafd bleef), maar ook de calvinisten werden verdreven en onder leiding van onder anderen de jezuïeten werd gewerkt aan krachtige rekatholisering van de bevolking.

De anhangers van de reformatie zorgden niet alleen voor veel onrust in de steden, ook een deel van de adel sympathiseerde met de nieuwe leer of hing deze zelfs openlijk aan. Daarbij ging het niet alleen om de lagere landadel. Ook leden van aanzienlijke geslachten, vaak in het bezit van kleine rijksonmiddellijke territoria of semi-onafhankelijke vrijheerlijkheden, waren te vinden in het protestantse kamp. Floris I van Pallant, graaf van Culemborg en vrijheer van Wittem (1540-1590) was streng katholiek opgevoed, maar ging door zijn huwelijk met de lutherse gravin Elisabeth van Manderscheidt Blankenheim over tot de religie van zijn echtgenote. ${ }^{892}$ Sterk op de voorgrond traden verder Willem van Vlodrop (overleden 1564), heer van Dalenbroek, Odenkerken, Rekem, ObbichtPapenhoven en Grevenbicht, verder zijn broer Balthasar (overleden 1567), heer van Leuth en Rijckholt, Willems schoonzoon Jan Quaedt, heer van Rekem en Wickradt, Balthasar van Vlodrop, heer van Leuth, Rijckholt en Well, graaf Willem van den Bergh, heer van 'sHeerenberg en Stevensweert en voorts de kinderen van Herman van Bronckhorst Batenburg, heer van Stein, en zijn echtgenote Petronella van Praet. ${ }^{893}$ Laatstgenoemden toonden zich bijzonder felle voorvechters van het protestantisme. De religie zorgde voor verdeeldheid binnen families, maar creëerde door onderlinge verwantschap ook een soort netwerk voor de verbreiding van de nieuwe leer, waarbij de min of meer onafhankelijke heerlijkheden als steunpunten voor predikanten dienden.

In beginsel hadden edelen in het bezit van rijksonmiddellijke territoria de juridische vrijheid hun eigen religie te kiezen. Die mogelijkheid was 1555 vastgelegd in de Religievrede van Augsburg, waarbij lutheranisme en katholicisme als gelijkberechtigde confessies binnen het Rijk naast elkaar konden bestaan. Belangrijk was de wederzijdse aanvaarding en erkenning van zowel katholieke als protestantse rijksstanden. Voor 'protestant' gold in beginsel het algemene voorbehoud dat het alleen de lutherse confessie betrof en niet andere gezindten. Voortaan mocht de landsheer de religie van zijn onderdanen bepalen, welk recht later bondig werd samengevat in de formule cuius regio, illius religio. Daarmee kreeg de Vrede van Augsburg het karakter van een Januskop: de rijksstanden verwierven voor zichzelf maximale vrijheid in de keuze van hun religie, 894 maar tegelijkertijd konden zij hun onderdanen grote beperkingen wat betreft hun confessie opleggen.

De religieuze situatie in het Maasgebied is in deze tijd verwarrend, want theorie en praktijk van de Religievrede spoorden niet met elkaar. Het Spaanse bewind in de Nederlanden

892 Mosmans, Heeren van Wittem, 54-58.

${ }^{893}$ Habets, Geschiedenis Bisdom Roermond, 2, 148-150; 158-163; Wouters, Grensland en Bruggehoofd, 196-201; Van Schilfgaarde, 'De heren van Bronckhorst', 82.

${ }^{894}$ Voor de geestelijke rijksvorsten was een voorbehoud gemaakt voor de gevolgen, wanneer zij van confessie veranderden. 
toonde zich weinig tolerant ten opzichte van protestanten en zeker niet ten aanzien van calvinisten. Het was juist deze geloofsrichting waarmee sommige edelen sympathiseerden. Tegelijkertijd vormde het Maasdal de rafelrand van de Spaans-Habsburgse Nederlanden, met vaak onduidelijke staatkundige verhoudingen. En dit gebied kreeg gedurende de eerst decennia van de Tachtigjarige Oorlog zwaar te lijden van de strijd tussen Spaanse troepen en de aanhangers van de Nederlandse Opstand.

Ook de heren van Gronsveld behoorden tot het deel van de adel waar veel aanhangers van de reformatie waren te vinden. Daarbij moet worden bedacht dat zij door ambten en bezittingen sterk waren verbonden met de hertogdommen Kleef en Gulik. Hier heerste op religieus gebied een bijzondere situatie. Al aan het einde van de vijftiende eeuw had Willem IV van Gulik getracht misstanden bij kloosters en in de parochiezielzorg aan te pakken. Zijn zoon en kleinzoon, de hertogen Johan III en Willem V, zetten deze lijn voort. Als landsheren stonden zij voor tolerantie op religieus gebied. In het bijzonder steunend op het gedachtegoed van Erasmus en het humanisme, streefden zij naar hervorming van de Kerk van binnen uit, zonder polarisatie. Zij bewandelden daarbij een weg die het midden hield tussen trouw aan de Moederkerk en sympathie voor de leer van Luther, maar zij behoorden zeker niet tot de volgelingen van de reformator en waren sterk gekant tegen de anarchistische, staatsgevaarlijke wederdopers. Toch leidden allerlei voorschriften en maatregelen uiteindelijk slechts tot een beperkte verbetering van het kerkelijk leven. Zowel de orthodoxe katholieken als overtuigde aanhangers van de hervorming hekelden deze 'derde weg' als een slap compromis. Vanaf de jaren zestig van de zestiende eeuw dreef het steeds radicalere calvinisme hertog Willem in de armen van de contrareformatie. Maar de landsheerliike traditie van afkeer van dwang in religieuze zaken bood zowel aan lutheranen als calvinisten uiteindelijk toch de kans in de verschillende territoria van de hertog vaste voet te krijgen. Zo werden de graafschappen Mark en Berg nagenoeg geheel luthers, in de hertogdommen Berg en Kleef ging de bevolking respectievelijk voor de helft en een derde over tot het protestantisme (gemengd luthers en calvinistisch), terwijl het hertogdom Gulik vrijwel volledig katholiek bleef.

Welke positie namen de leden van de familie Van Bronckhorst met hun belangen zowel aan de Nederrijn als in het Maasdal te midden van deze religieuze stromingen in? De meningen daarover in de literatuur lopen uiteen. Quix schrijft in 1835 dat Johan II van Bronckhorst Batenburg terugkeerde 'zu der Katholische Religion... die sein Grossvater verlassen hatte. ${ }^{\text {}} 95$ Hij beroept zich daarbij op een Akense kroniek zonder verdere bronvermelding. Ook Chestret de Haneffe is van oordeel dat Johan (evenals volgens hem hertog Johan III van Kleef!) een aanhanger van het protestantisme was. ${ }^{896}$ De feiten wijzen echter in een andere richting. In 1533 verbleef een zekere Hendrik Slachtscaep, een ex-priester uit Tongeren 'by Triecht oppen Locht' (d.w.z. tussen Heugem en Maastricht)

895 Quix, Rimburg, 34.

${ }^{896}$ Chestret de Haneffe, 'Histoire Gronsveld', 67-68; idem, waarschijnlijk in navolging van hem Habets, Geschiedenis Bisdom Roermond, 2, 159-160. 
in eynem groszen nouwen huysz. ${ }^{897}$ Deze predikant, ook goed bekend in het Gulikse, die een eigen variant van het anabaptisme leerde, kon zich dus kennelijk op Gronsvelds gebied ophouden, wat mogelijk wijst op tolerantie van de plaatselijke gezagsdragers. Maar lang bleef Slachtscaep niet, want hij sloot zich aan bij de wederdopers in hun 'Godsrijk' te Münster en sneuvelde in 1534 voor de poorten van de stad Soest.

Merkwaardig is het verhaal van Ghys Pannesleger uit Maastricht, die vaak met anderen naar de preek in Gronsveld ging luisteren. Pannesleger was in het bezit van een verdacht 'evangeylien boeck' dat hij in Gronsveld door de pastoor liet 'visitieren'. Onduidelijk blijft of nu de pastoor in Gronsveld toehoorders lokte vanwege zijn rechtzinnigheid in de leer of dat juist het tegenovergestelde het geval was. ${ }^{898}$ Feit is dat Pannesleger op uitdrukkelijk aanraden van de heer van Gronsveld het boekje had verbrand. 899

Een tweede voorbeeld van Johans opvattingen in geloofszaken is het 'Mandat den floicken ende schelden belangende', dat hij in 1546 uitvaardigde. ${ }^{900}$ Daarin werden strenge straffen bedreigd tegen vloeken en godslasterlijke taalgebruik in herbergen. In het bijzonder gold dit voor spotternij over onderwerpen uit de katholieke leer, die sterk werden bestreden door predikanten van diverse protestantse stromingen ('dweill der predicanten lehr bey uch nit viell guetz werket'), zoals de leer van de Drievuldigheid, het Heilig Sacrament en de devotie rond het lijden van Christus. Het 'Mandat' bleef echter niet beperkt tot vloeken en schelden. Naast bepalingen over het sluitingsuur van herbergen werden ook zware straffen in het vooruitzicht gesteld voor samenwoning zonder kerkelijk huwelijk en het plegen van echtbreuk. Deze verordening sluit duidelijk aan op de middeleeuwse opvatting dat overheden met landsheerlijk gezag het recht hadden tot reformatio, op grond waarvan zij zich corrigerend en disciplinerend konden mengen in het kerkelijk leven, zowel van leken als religieuzen. ${ }^{901}$

Eveneens in 1546 aanvaardde Johan I van Bronckhorst Batenburg opnieuw de functie van landdrost van het hertogdom Kleef, waarbij hij zich verplichtte 'wiederteupsche, sacramentierische und andere verdampte secten' volgens de landsheerlijke plakkaten met kracht te vervolgen. ${ }^{902}$ De veronderstelling van Quix en Chestret de Haneffe dat Johan tot het protestantisme zou zijn overgegaan, is dan ook later overtuigend door Hanssen bestreden. ${ }^{903}$ Het verhaal van Pannesleger, dat Hanssen niet kende, bevestigt alleen maar de juistheid daarvan. Hanssen (als priester!) laat zich echter wel kritisch uit over het optreden van Johan tegen het kapittel van Sint-Gereon te Keulen, dat werd gedwongen afstand te doen van de tienden in Merkstein. ${ }^{904}$ Maar waarschijnlijk werd Johan gewoon gedreven door zelfverrijking, en het is zeer de vraag of dit optreden als antikatholiek moet

${ }^{897}$ Habets, 'Wederdoopers', 72; Bax, Protestantisme Luik, 51. Over Slachtscaep in het bijzonder zie Habets, 'Aanteekeningen Susteren', 216-226 en Bax, Protestantisme Luik, passim.

898 Mogelijk was toen al 'heer Gielis' als pastoor in Gronsveld werkzaam, een man die zich, zoals hierna nog wordt beschreven, in de jaren zestig van de zestiende eeuw ontpopte als een vurig en gewelddadig aanhanger van calvinisme.

899 Bax, Protestantisme Luik I, 144-145.

900 Zie Bijlage 2.

901 Schneider, Ius reformandi, 1-32.

902 Hanssen, Die Rimburg, 157, 161.

${ }_{903}$ Hanssen, Die Rimburg, 160-161.

904 Hanssen, Die Rimburg, 150, 160. 
worden uitgelegd. Misschien kleefden aspecten aan deze zaak, die Johans optreden rechtvaardigden, want volgens het compromis dat Johan en de scholaster van Sint-Gereon sloten, mocht eerstgenoemde de tiende behouden tegen betaling van een schadeloosstelling. De daarop volgende bisschoppelijke en pauselijke goedkeuring verwacht men niet bij een transactie in flagrante strijd met de belangen van de katholieke Kerk. Trouwens, ook van een algemene slechte gezindheid tegenover katholieke instituten was bij Johan geen sprake, getuige het feit dat hij goede relaties onderhield met de abdij Kloosterrade..$^{905}$

Over de godsdienstige opvattingen van Johans zoon Willem van Bronckhorst Batenburg zijn geen nadere bijzonderheden bekend. Waarschijnlijk was hij katholiek; er zijn althans geen aanwijzingen in een andere richting. Anders oordeelt Hanssen over Agnes van Bylandt, die hij een 'eifrige Anhängerin der neuen Lehre' noemt. Zij zou een gereformeerde predikant in Rimburg hebben toegelaten. ${ }^{906}$ Toch zijn de argumenten voor deze opvatting bij nadere beschouwing zwak. Zeker is dat Gronsveld begin jaren zestig te maken kreeg met groeiende calvinistische agitatie, die mede werd bepaald door gebeurtenissen in het nabijgelegen Maastricht. Op 15 augustus 1566 werd op de Locht tussen Maastricht en Heugem een hagenpreek gehouden ${ }^{907}$ door Jan Kackhoes (alias Scheitzhabener, van Rumunde, van Gutekoven), een demagoog die veel toehoorders trok. Dat kan wijzen op een zekere tolerantie van de landsvrouwe-regentes. Maar toen Agnes, die op kasteel Rimburg verbleef, door de magistraat van Maastricht over de prediking werd ingelicht, verbood zij deze activiteiten direct.

Vermeldenswaard is ook de rol van een ex-pastoor van Gronsveld, een zekere 'heer Gielis'. De calvinisten, met Kackhoes als één van hun voormannen, begonnen zich steeds openlijker in Maastricht te roeren met onder andere beeldstormerij op 3 november 1566 in de kapel van Maria ten Oever in de Mariastraat. In het kielzog van Kackhoes treffen we 'heer Gielis' aan, wiens huwelijk met zijn huishoudster overigens door de predikant was ingezegend. Gielis deed niet alleen mee bij het beeldstormen, hij beklom na Kackhoes in de Sint-Matthijskerk te Maastricht de preekstoel en riep 'dat het hem leet was dat hy het volck soe bedroghen hadde mette missen ende dat hy wel wilde soe menighen dootslach gedaen te hebben alsoe menighen misse als hy gedaen hadde, hebbende die selve heer Gielis gedaen twee dootslaeghen... ${ }^{908}$ Ook zag men hem met harnas en geweer bij het bewaken van een stadspoort, waar hij burgers bedreigde. ${ }^{909}$ Nergens wordt duidelijk of deze man op enigerlei wijze vanuit Gronsveld opereerde of de steun van de vrouwe van Gronsveld genoot, iets wat men toch wel zou verwachten bij een 'eifrige Anhängerin' van het protestantisme.

\footnotetext{
${ }_{905}$ Hanssen, Die Rimburg, 151.

${ }^{906}$ Hanssen, Die Rimburg, 164, 166, 168.

907 Bax, Protestantisme Luik II, 103, 107, 129.

${ }_{908}$ Bax, Protestantisme Luik II, 153.

${ }_{909}$ Bax, Protestantisme Luik II, 168.
} 
Verder wordt voor de protestantse gezindheid van Agnes aangevoerd dat de slotkapel van huis Rimburg voor de katholieke eredienst werd gesloten. ${ }^{910}$ Als bewijs voor protestantse gezindheid van Agnes is deze langdurige sluiting, indien het verhaal op waarheid berust, niet sterk, want er kunnen allerlei redenen voor zijn geweest.

Tegelijkertijd moeten we vaststellen dat haar oom Adriaan van Bylandt, als voogd van haar minderjarige kinderen en daarmee mede verantwoordelijk voor hun opvoeding, op zijn minst de schijn op zich laadde dat hij protestant was en in 1551 wegens verdenking van ketterij werd gehoord. ${ }^{911}$ Ook bij haar verwanten aan moederszijde, bij de familie Van Virmond, komen protestanten voor.

Hanssen schrijft dat Agnes later door haar tweede zoon Johan werd 'teruggevoerd' tot het katholieke geloof. Het bewijs daarvoor zou zijn de toestemming die zij in 1593 gaf voor de schenking aan de jezuieten van de 'Poort van Rimburg' of 'Poort van Gronsveld', de stadswoning van de familie Van Bronckhorst in de Bredestraat te Maastricht.912 Uit de rol van Agnes bij deze transactie, wordt duidelijk dat zij op dat moment katholiek was, maar nergens wordt er op gezinspeeld dat deze overdracht in verband stond met een terugkeer naar het katholicisme.

Ook van de beide zonen van Agnes van Bylandt mogen we aannemen dat zij katholiek waren. Vanzelfsprekend was dit niet. Vooral onder de Duitse graven waren nogal wat aanhangers en sympathisanten van het protestantisme te vinden, zowel lutheranen, maar ook relatief veel calvinisten. Mogelijk heeft Jost tijdens zijn verblijf in Orléans kennis gemaakt met beide stromingen. De stad en haar universiteit stonden in het midden van de zestiende eeuw bekend als een centrum van Hugenoten. Na de Sint-Bartholomeusnacht in 1572 nam het aandeel protestanten bij zowel de stadsbevolking als studenten echter gestaag af. ${ }^{913} \mathrm{Bij}$ het verzoek in 1586 om te worden verheven in de gravenstand, betuigden Jost en Johan echter beiden hun voortdurende trouw aan de katholieke Kerk. De stelligheid waarmee dit gebeurt, wekt niet de indruk alleen een gelegenheidsargument te zijn geweest.

Gravin Anna van Oostfriesland, de echtgenote van Jost, kwam uit een confessioneel verdeelde familie. Haar grootvader Edzard I Cirksena, graaf van Oostfriesland (14611528) voerde in zijn land de reformatie in. Diens oudste zoon Enno II (1505-1540) ${ }^{914}$, een oom van Anna, was in religieus opzicht onverschillig. Hoewel in naam protestant, liet hij ook rekatholisering toe. Op het einde van zijn leven dacht hij zelfs over terugkeer naar het katholicisme. Tegelijkertijd maakte hij zich meester van de goederen van kloosters en seculariseerde deze instellingen zodanig dat er nauwelijks een spoor van overbleef. Graaf Johan de Oude (1506-1572), Enno's jongere broer en de vader van Anna, was overtuigd

910 Quix, Rimburg, 34; Hanssen, Die Rimburg, 168.

911 Van Veen, 'Adriaen van den Bylandt'.

912 Hanssen, Die Rimburg, 168; RHCL, Jezuïeten Maastricht, inv. nr. 12, fol. 89-90, diverse akten betreffende deze schenking. De familie Van Gronsveld had deze stadswoning als vanaf de vijftiende eeuw. In 1549 vond voor schepenen van Doesburg ook nog een aankoop van een huis in de Bredestraat plaats, zie RHCL, Familie De Geloes/Kasteel Eijsden, inv. nr. 421.

913 Madeline, 'Huguenots à Orléans', 14-17.

914 Zie over hem www.ostfriesischelandschaft.de, Biographisches Lexicon für Ostfriesland, onder lemma 'Enno II', geraadpleegd 10-3-2009. 
katholiek, huwde een natuurlijke dochter van keizer Maximiliaan I, trad in dienst van Karel $\mathrm{V}$ en was ridder van het Gulden Vlies. ${ }^{915}$ Anna ten slotte volgde de religie van haar ouders. Toen zij in 1586 in Brussel overleed, kreeg zij een katholieke uitvaart en werd zij in de grafkelder van de kerk van Gronsveld bijgezet.

Johan II van Bronckhorst Batenburg staat tot zijn overlijden in 1617 bekend als katholiek. Zijn vrouw Sybilla van Eberstein, was waarschijnlijk eveneens katholiek en hun kinderen werden katholiek gedoopt. Maar ook Sybilla stamde uit een confessioneel gespleten familie met in de verschillende takken zowel lutheranen als calvinisten. ${ }^{916}$ Twee van haar zusters waren katholiek, de religieuze overtuiging van haar derde zuster Felicitas (geboren vóór 1576, overleden 1621) is onduidelijk. Zij was stiftsdame en in het bezit van belangrijke ambten bij de hoogadellijke damesstiften van Herford, Essen, Vreden en Elten, maar zou calvinistisch zijn. Haar optreden geeft echter de indruk dat zij een middenpositie tussen de verschillende confessies innam. ${ }^{917}$ Verder was zij meter bij de katholieke doop van haar nicht Gertrud, de dochter van Sybilla en Johan. Na het overlijden van Johan in $1617 \mathrm{kreeg}$ zij mede de voogdij over de minderjarige kinderen opgedragen.

Johan II van Bronckhorst Batenburg moet een zekere affiniteit hebben gehad met de jezuieten. Niet alleen schonk hij zijn stadswoning in Maastricht aan deze orde, in 1603 probeerde hij ook het kwijnende sepulchrijnenklooster van Hoogcruts bij de jezuïetencommuniteit van Aken te incorporeren. De laatste paters van Hoogcruts wisten deze inlijving echter te voorkomen door een beroep op de Raad van Brabant in de Brussel en de pauselijke curie in Rome. ${ }^{918}$ Een ander staaltje van Johans betrokkenheid bij het katholicisme blijkt uit het feit dat in 1608 op zijn bevel de besluiten van het Concilie van Trente werden afgekondigd in de kerken van Gronsveld, Heugem, Slenaken en SintMartens-Voeren. ${ }^{919}$

Wanneer we drie generaties van de familie Van Bronckhorst Batenburg in Gronsveld beoordelen op hun religieuze gezindheid, dan lijken zij het katholicisme trouw te zijn gebleven. Er zijn geen steekhoudende argumenten om hen te beschouwen als lutheranen of calvinisten. Feit is dat zowel hun eigen familie als de kringen waarin zij verkeerden, confessioneel waren verdeeld.

\subsection{Conclusies}

Het huwelijk tussen Diederik I van Bronckhorst Batenburg met Johanna van Gronsveld in 1425 was het begin van een bijna driehonderd jaar durende relatie tussen de familie Van Bronckhorst Batenburg en Gronsveld. Het is echter de vraag of Diederik zelf als heer van

\footnotetext{
915 Zie over hem www.ostfriesischelandschaft.de, Biographisches für Ostfriesland, onder lemma 'Johan der Ältere', geraadpleegd 10-3-2009.

916 Andermann, 'Furnem Geschlecht', 212.

917 Zie over haar: Küppers-Braun, Franen des hohen Adels, passim en in het bijzonder 310-311.

918 Delahaye, Inventaris Hoog-Cruts, 7.

919 Zie Bijlage 3.
} 
Gronsveld heeft geregeerd; zijn schoonvader Hendrik III overleefde hem ongeveer 25 jaar.

Het geslacht Van Bronckhorst stamde af van oude adel en behoorde tot de Gelderse bannerheren, edelen in het bezit van kleine, onafhankeliike territoria, gelieerd aan het hertogdom Gelre. De Bronckhorsten waren in de veertiende en vijftiende eeuw verdeeld in verschillende linies. Hun naam raakte aan het einde van de middeleeuwen verbonden met enkele kleine, onafhankelijke territoria aan de rand van de hertogdommen Gelre en Kleef zoals Batenburg, Anholt en Borculo.

Van Diederiks zoon Hendrik I van Bronckhorst Batenburg, die in Gronsveld opvolgde (1474/1476? - 1493), is weinig bekend. Waarschijnlijk begon zijn regering over Gronsveld pas echt omstreeks 1474-1476, na het overlijden van zijn grootvader Hendrik III van Gronsveld. Van duurzame betekenis voor zijn nakomelingen werd echter de dubbele alliantie met het rijke Nederrijnse adellijk geslacht Van Alpen: Hendrik huwde een dochter van Johan van Alpen en Johan van Alpen huwde op latere leeftijd Hendriks jongere zuster Catharina. Door de verbintenis kreeg de familie Van Bronckhorst Batenburg belangrijke bezittingen in het hertogdom Kleef, maar ook directe toegang tot de entourage van de hertog van Kleef.

De vruchten daarvan plukte Hendriks zoon Diederik II van Bronckhorst Batenburg (1493-1508), die één van de invloedrijkste edelen aan het Kleefse hof werd. Hij steunde de hertog in diens strijd tegen Karel van Egmond, hertog van Gelre en verwierf daarmee ook de sympathie van het Bourgondisch-Habsburgse kamp, dat Gelre bij de BourgondischHabsburgse Nederlanden trachtte in te lijven. Waarschijnlijk bevorderde die partijkeuze ook in 1498 de verheffing van Diederik door rooms-koning Maximiliaan tot Reichsfreiherr en van Rimburg en Gronsveld tot 'einer rechten herschaft'. Voor Gronsveld betekende dat een bevestiging van de rijksonmiddellijkheid, Rimburg werd daarmee feitelijk ontslagen van een inmiddels in vergetelheid geraakte leenband met Brabant.

Johan I van Bronckhorst Batenburg (1508/1511-1558/1559) vervulde eveneens functies in het Kleefse landsbestuur. Ook hij toonde zich een loyaal aanhanger van de hertog van Kleef, maar die keuze bracht hem in grote problemen, toen hertog Willem van Kleef ook opvolgde als hertog van Gelre en daarmee in conflict raakte met Karel V. Na het Verdrag van Venlo in 1543, waarbij Gelre in handen van Karel V viel, betaalde Johan zijn betrokkenheid bij deze strijd met het verlies van de rijksonmiddellijkheid van Rimburg. Voortaan bleef die status alleen voorbehouden an Gronsveld. Die betekenis beseften Johans zoon Willem $(1558 / 1559$ - 1563) en kleinzonen Jost (1586 - 1588) en Johan II (1588 - 1617) terdege. De regeringsperiode van Willem duurde te kort om blijvend invloed te hebben, maar zijn zonen ontvingen tijdens hun minderjarigheid een goede scholing en werden gevormd tot standsbewuste edellieden. Op het moment dat zij meerderjarig werden, vroegen en verkregen zij van de keizer verheffing in de stand der rijksgraven. De twee broers sloten vervolgens ieder een huwelijk in overeenstemming met hun stand: Jost met gravin Anna van Oostfriesland, een kleindochter van keizer Maximiliaan en Johan met gravin Sybilla van Eberstein, telg uit een oeroud, Schwäbisch gravengeslacht. Jost en Anna overleden beiden kort na hun huwelijk kinderloos, waarna Johan II opvolgde. De juridisch goed onderlegde Johan probeerde aan zijn rol invulling te geven door nadruk te leggen op de positie van Gronsveld binnen de Nederrijns- 
Westfaalse Kreits. Daarmee hoopte hij bescherming te verwerven in de oorlog tussen Spanje en de Republiek der Verenigde Nederlanden, waarbij het Maasdal regelmatig strijdtoneel was, maar tegelijkertijd voerde hij nieuwe belastingen ten behoeve van het Rijk in. Dat leidde, in combinatie met zijn eisen tot het verrichten van herendiensten, tot heftige confrontaties met zijn onderdanen. Pas na moeizame onderhandelingen werden die conflicten bijgelegd. Ook het graafschap Eberstein, waarop hij via zijn echtgenote rechten kon doen gelden, bleek een politiek en juridisch wespennest, waar uiteindelijk weinig eer aan viel te behalen.

De zestiende eeuw was een tijd van grote confessionele verdeeldheid die ook binnen de verschillende takken van de familie Van Bronckhorst speelde. De gezindheid van de tak Gronsveld-Rimburg is daarbij door het ontbreken van bronnen die daarover uitsluitsel kunnen geven, niet helemaal duidelijk. De meerderheid van de beschikbare gegevens wijst echter op trouw aan het katholieke geloof, die bij familiale belangen een zekere tolerantie in de omgang met andersdenkenden zeker niet uitsloot. 


\section{De graven VAN GronsVeld Uit Het geslacht VAN BronckHorst BATENBURG 1617-1719}

\subsection{Jost Maximiliaan van Bronckhorst Batenburg, 1617-1662}

\subsubsection{Onverdeelde boedel}

$\mathrm{Na}$ het overlijden van graaf Johan II van Bronckhorst Batenburg in oktober 1617 waren zijn kinderen volwezen. Jost Maximiliaan, de oudste zoon en beoogd opvolger als heer van Gronsveld, was in 1616 vertrokken voor een militaire loopbaan. De overige kinderen, waarvan enkele nog minderjarig, waren nog thuis. De voogdij schijnt te zijn opgedragen aan gravin Felicitas van Eberstein, abdis van Herford, tante aan moederskant, en graaf Van den Berg. Al direct werd op advies van de voogden geld opgenomen.920 Mogelijk zorgde ook nog het overlijden van de hoogbejaarde grootmoeder Agnes van Bylandt in 1615 op huis Hönnepel voor erfrechtelijke complicaties.

Het is een feit dat Jost Maximiliaan in 1617 als nieuwe heer van Gronsveld werd ingehuldigd (zie Hoofdstuk 6.4), maar tegelijkertijd bleef de erfenis voorlopig onverdeeld. Dat was ook raadzaam omdat eerst de kinderen 'onder dak' moesten komen. Verder speelden er verschillende processen voor de Raad van Brabant in Brussel, onder andere over betalingen aan de natuurlijke kinderen van graaf Johan en vorderingen van de gebroeders Streuff, waarschijnlijk kinderen van Assuerus Streuff, de vroegere leraar en adviseur de graaf. In totaal werd ongeveer 1/3 deel van alle uitgaven besteed aan die processen.

Tot de boedelscheiding rond 1640 traden Jost Maximiliaan en zijn jongere broer Otto Wilhelm naar buiten toe vaak gezamenlijk op, zonder dat de onderlinge verhoudingen altijd glashelder zijn. De navolgende voorbeelden maken dat duidelijk. Bij de verkoop van de heerlijke rechten over Sint-Martens-Voeren in 1622 gaven beide broers daarvoor een volmacht. ${ }^{921}$ In financiële stukken van de schepenbank Slenaken uit 1636 en 1638 worden beide broers als heren genoemd. ${ }^{222}$ Op 24 juni 1638 sloot Otto Wilhelm voor zichzelf en voor Jost Maxiliaan een overeenkomst over bepaalde heerlijke rechten met jonker Couven van huis Hees in Slenaken. ${ }^{923}$ Sommige stukken daarentegen staan ook weer op naam van Jost Maximiliaan alleen, zoals een ordonnantie voor Slenaken uit 1636, waarbij aan geestelijke instellingen wordt verboden onroerend goed te verwerven. ${ }^{924}$ Hetzelfde geldt voor de verpanding van de heerlijke rechten over Slenaken aan Johan Adolf van

920 Van Beurden, 'Charters en perkamenten', 106, nr. 99 vermeldt een 'octrooi' van 1 juni 1618 in het archief van huis Well, waarbij toestemming word verleend geld op te nemen voor de kinderen van graaf Johan van Bronckhorst, zulks op raad en advies van 'Felicitas gravin van Ebersteyn abdisse van 't stift van Herwaerden en graaf van den Bergh als momboers dezer kinderen'. De oorkonde bevindt zich echter niet meer in het archief van kasteel Well bij het RHCL, bestand 16.1112A-2, inv. nr. 5099, 'vermist'.

921 RHCL, Landen van Overmaze, Leenhof van Valkenburg ongedeeld, inv. nr. 749, overdracht van 8 oktober 1622 aan Mechteld van den Bongardt, weduwe van Winand van Imstenrade.

$922 \mathrm{vgl}$. RHCL, Hoogcruts, inv. nr. 719: 'lasten van den jaere 1636': reiskosten voor een bezoek aan zowel 'Joest' als 'Otto Willem' in Aken; idem in : 'Repartitie van 24 juni 1638': twee paarden, één voor 'graeff Joest' en één voor 'graeff Odt Willem, onsen genedige heeren'.

923 RHCL, Klooster Hoogcruts, inv. nr. 746.

${ }_{924}$ RHCL, Klooster Hoogcruts, inv. nr. 531. 
Imstenrade, heer van Mheer, op 26 juni 1638. ${ }^{925}$ Mogelijk ging aan deze laatste akte nog een andere vooraf, namelijk een overdracht van de heerlijke rechten over Slenaken door Otto Wilhelm aan Jost Maximiliaan, die deze dan vervolgens door verpanding weer direct te gelde maakt.

Ook bij Rimburg zien we vermeldingen van gezamenlijk beheer. Zo veroordeelt de Raad van Brabant in Brussel in 1631 en 1641 bij een geschil over een cijns op de molen van Eygelshoven beide broers tot betaling. ${ }^{926}$ Volgens Hanssen woonde Otto Wilhelm op Rimburg. ${ }^{927}$ In de tijd rond 1638 was hij als heer van Rimburg met de abdij Kloosterrade verwikkeld in een conflict over het jachtrecht in Abdissenbosch onder Waubach. ${ }^{928}$

Een ander voorbeeld van gemeenschappelijk beheer zien we bij Hönnepel, waar Jost Maximiliaan en zijn zuster Felicitas door hun drossaard Johan van Odenhoven bezit lieten nemen van heerlijkheid, kasteel, molens en andere rechten. Voorts probeerde Felicitas ook rechten te doen gelden op de heerlijkheid Niedermörmter. ${ }^{929}$

Bij geen van deze transacties wordt de derde broer, Johan Philips vermeld. Diens vorderingen op de boedel moeten zijn afgekocht door Otto Wilhelm, zoals laatstgenoemde beweert in een ongedateerde memorie waarin hij klaagt over de boedelscheiding met Jost Maximiliaan. ${ }^{930}$ Mogelijk gebeurde dat bij zijn huwelijk met Margaretha Louise van Ryckel. ${ }^{931}$

Eind jaren dertig werd deling van de boedel toch noodzakelijk, enerzijds door het in 1639 tussen Jost Maximiliaan en Anna Christina von Hardenrath gesloten huwelijk en anderzijds door de hoge schuldenlast waaronder Jost Maximiliaan inmiddels gebukt ging. Die deling verliep in fasen. Mogelijk was Slenaken al in 1638 aan Jost Maximiliaan toebedeeld. Op 22 juni 1640 verkocht hij met uitdrukkelijke toestemming van broer en zusters kasteel en heerlijkheid Rimburg voor negentigduizend rijksdaalders aan Arnold van Boeijmer en Katharina van Splinter. ${ }^{932}$ Uit die opbrengst zouden Gertrud en Felicitas samen achttienduizend rijksdaalders ontvangen, waarvan overigens maar achtduizend ook werkelijk - en dan nog langs een omweg - is betaald. ${ }^{933}$ De koopprijs van Rimburg werd namelijk inzet van een 140 jaar durend proces. Felicitas en Gertrud namen genoegen met het vruchtgebruik van het huis Hönnepel en de vorderingen op Rimburg, echter onder de

925 RHCL, Graafschap Gronsveld, inv. nr. 452.

926 Hanssen, Die Rimburg, 178.

927 Hanssen, Die Rimburg, 174.

928 Hanssen, Die Rimburg, 179.

${ }^{929}$ Scholten, 'Geschichte Hönnepel', 146.

930 RHCL, Graafschap Gronsveld, inv. nr. 459.

931 Van Schilfgaarde, 'De heren van Bronckhorst', 80.

932 Hanssen, Die Rimburg, 180-181.

933 Vgl. TJ, inv. nr. M 53, 659-664, brief van commissaris Prummer van 26 juli 1765 aan graaf Toerring over de stand van zaken in het proces over Rimburg, waarin hij diverse stukken over de verdeling van de opbrengst, bespreekt die in het geding waren ingebracht. In 1648 hadden Gertrud en Felicitas een vordering van twintigduizend 'kayser-gulden' (= achtduizend rijksdaalders) met rente voor burgemeesters en schepenen van Deventer voor een gelijk bedrag verkocht aan Arnold van Haerselte. Die schuld was ook in 1678 door mevrouw Van Boeijmer afgelost en daarmee dus ook feitelijk voldaan. De resterende 10.000 riiksdaalders stonden nog als vordering op Rimburg. Uit het verhaal van Prummer blijkt dat de dames alle moeite hadden gedaan hun geld te krijgen. Voorts had Otto Wilhelm uit de opbrengst van Rimburg drieduizend rijksdaalders ontvangen. 
voorwaarde dat na hun kinderloos overlijden de goederen bij Jost Maximiliaan terugkeerden. ${ }^{934}$

De verhoudingen tussen Otto Wilhelm met Jost Maximiliaan en zusters Felicitas en Gertrud kwamen inmiddels steeds meer onder druk te staan. Ook Otto Willem had een militaire carrière achter de rug, maar het is niet bekend of hij daarbij ook grote schulden had gemaakt. Hij had echter een relatie aangeknoopt met Sibilla Oeller, dochter van Frans Wendel Öller (Oeller of Oiller), die tussen 1617 en 1623 optrad als drossaard van Gronsveld. (zie Hoofdstuk 8.4) Die relatie werd, ook voor de grafelijke familie, een duistere affaire, waar zelfs een latere gerechtelijke procedure geen volledige helderheid over verschafte. ${ }^{935}$ Otto Willem had trouwbeloften gedaan, was die eerst niet nagekomen, maar daarna zou het stel in 1645 toch 'ergens' zijn getrouwd, en kreeg ook kinderen. Sibilla zou protestant zijn geweest of geworden, maar omdat het huwelijk slecht ging, was er (vooral op aandrang van Otto Willems zuster Felicitas ${ }^{936}$ ) geprocedeerd voor de keurvorstelijke raad in Kleef en de officiaal (katholieke kerkelijke rechter) in Keulen om te komen tot ontbinding. ${ }^{937}$ Het was onduidelijk of dat lukte (het koppel had daarna toch als echtpaar samengeleefd), maar op zijn sterfbed had Otto Willem, onder druk van de pastoor en schepenen van Hönnepel, alsnog zijn huwelijk moeten erkennen. Voor zijn familie was dat onverteerbaar. Jost Maximiliaan kon zich niet indenken dat zijn broer met een vrouw van een dergelijke nederige ('schlechte') afkomst zo zijn naam te grabbel had gegooid en Felicitas verweet hem dat hij 'durch einen verächtlichen seinem Standt in dem geringsten nich gleichmessigen Heyrath seinem Geslecht die höchste Unehr und Verkleinerungh hatte zugebracht'. ${ }^{938}$ Daarnaast stak het Felicitas en haar zuster Gertrud ten zeerste dat door dit huwelijk mogelijk goederen uit de familie zouden raken, want zij hadden als meisjes met een kleiner erfdeel genoegen genomen om de carrières van de broers mogelijk te maken. Toen Sibilla na het overlijden in 1651 van Otto Willem haar zoon Johan bij de Kleefse leenkamer liet belenen met Hönnepel ${ }^{939}$ ontstond dan ook een proces over de nalatenschap van Otto Willem en de wettigheid van zijn kinderen. ${ }^{940}$.

Otto Wilhelm moest uit de verkoop van Rimburg geld ontvangen, maar zag vooralsnog niets. Vervolgens werden op 25 april 1641 de goederen tussen Jost Maximiliaan en Otto Wilhelm gedeeld, ${ }^{941}$ waarbij laatstgenoemde huis en heerlijkheid Hönnepel en huis Eyl ontving. Daarbij werd ook een regeling getroffen voor de huisvesting van de ongehuwde

934 LAV, NRW, Abt. Rheinland, Reichskammergericht, inv. nr. 743.

935 LAV, NRW, Abt. Rheinland, Reichskammergericht, inv. nr. 743.

936 Volgens Sibilla had Felicitas haar huwelijk 'kapot gemaakt'.

937 LAV, NRW, Abt. Rheinland, Reichskammergericht, inv. nr. 743.

938 LAV, NRW, Abt. Rheinland, Reichskammergericht, inv. nr. 743, fol. 154.

939 Dösseler/Oediger, Lebnregister Kleve, 261.

940 LAV, NRW, Abt. Rheinland, Reichskammergericht, inv. nr. 743. Er waren drie kinderen, te weten Johan (in 1650 meerderjarig verklaard), Peter (Philip) minderjarig en Maria. (de gegevens bij Hanssen, Die Rimburg, 174 die spreekt over Otto Joseph, gedoopt Rimburg 17 juli 1640, zijn onjuist. Peter Philip en Maria verkopen in 1666 als 'Graf en 'Gräfin' ‘von Gronsfeld und zu Bronckhorst' kasteel en heerlijkheid Hönnepel aan Johann Arnold Freiherr von Quaedt-Wickrath, vgl. Scholten, 'Geschichte Hönnepel', 146147.

941 Hanssen, Die Rimburg, 174. 
zusters Gertrud (overleden tussen 1653 en 1660) en Felicitas (overleden vóór 1673).942) Deze twee dames verbleven meestentijds in Hönnepel, waarvan zij gebruiksrechten hadden. De verdere boedelscheiding tussen Jost Maximiliaan en Otto Wilhelm verliep echter vanwege de eerder genoemde amoureuze perikelen van Otto Wilhelm allerminst vreedzaam. In een tien punten tellende (ongedateerde) memorie somt laatstgenoemde zijn ongenoegens op over roerende zaken die uit Rimburg zouden zijn meegenomen, achtergehouden documenten, de verdeling van de Alpense lenen, over de heerlijkheid Hönnepel die door slecht dijkonderhoud in de Rijn dreigde te verdwijnen, de afkoop van vorderingen van hun broer Johan Philips, et cetera. ${ }^{943} \mathrm{Na}$ zijn overlijden 1650 ontstond dan ook een langdurig proces voor het Rijkskamergerecht. ${ }^{944}$

Samenvattend moeten we vaststellen dat na het overlijden van graaf Johan II van Bronckhorst Batenburg nog tot omstreeks 1640 een onverdeelde boedel bleef bestaan, tenminste tussen twee ongehuwde broers en de twee ongehuwde zusters. Deze situatie is niet zonder belang als achtergrond bij de loopbaan van Jost Maximiliaan en misschien ook van Otto Wilhelm. Jost Maximiliaan ging in deze tijd gebukt onder een zware schuldenlast, grotendeels het gevolg van zijn militaire avonturen. De aflossing daarvan kon nooit uit de opbrengst van het kleine graafschap Gronsveld worden betaald. Een onverdeelde boedel bood meer mogelijkheden, zeker met twee daarin gerechtigde ongehuwde zusters, wier nalatenschap uiteindelijk ook weer aan de familie zou terugvallen. Duidelijk is ook dat de twee zusters zichzelf wegcijferden voor de carrières van hun broers. Maar zelfs met dat geld dreigde na het overlijden van Jost Maximiliaan in 1662 een bankroet.

\subsubsection{De loopbaan van Jost Maximiliaan tot 1636}

Jost Maximiliaan van Bronckhorst werd het bekendste lid van de familie Van Bronckhorst Batenburg uit Gronsveld, eerst als officier en legeraanvoerder in Beierse dienst tijdens de Dertigjarige Oorlog (1618-1648) en later, na de Vrede van Westfalen in 1648, als keizerlijk diplomaat en medeoprichter van het Nederrijns-Westfaalse Gravencollege. In Gronsveld leeft de herinnering aan Jost Maximiliaan nog tot op de dag van vandaag voort in de tradities van de schutterij, die in 1619 met zijn toestemming werd opgericht. Bij de beeldbepalende Gronsveldse molen, gebouwd tussen 1617 en 1624, herinnert een gedenksteen uit 1622 aan Jost Maximiliaan als (belangrijkste) bouwheer. Toch speelde zijn leven zich nauwelijks af in Gronsveld. Helaas zijn over zijn bemoeienissen met betrekking tot het graafschap naar verhouding weinig documenten beschikbaar, zodat het moeilijk is daar een goed beeld van te krijgen. Maar het moet grotendeels een bestuur op afstand zijn geweest. Hij verbleef zelden in het kasteel en woonde, voor zover hij niet onderweg was, meestal in Keulen. Het feitelijk beheer van het graafschap lag in die tijd in handen van de drossaard en de rentmeester.

942 RHCL, Graafschap Gronsveld, inv. nr. 73, akte waarbij graaf Johan van Frans van Bronckhorst verklaart met zijn zuster Anna Justina de nalatenschap van hun tante Felicitas naar beider tevredenheid te hebben verdeeld.

943 RHCL, Graafschap Gronsveld, inv. nr. 459

${ }^{944}$ LAV, NRW, Abt. Rheinland, Reichskammergericht, inv. nr. 743. 
Jost Maximiliaan was gedurende zijn langdurige militaire loopbaan betrokken bij tal van acties en veldslagen en eindigde zijn carrière als bevelhebber van het Beierse leger in de rang van veldmaarschalk. Daarmee heeft hij ook een plaats gekregen in de algemene geschiedschrijving over de Dertigjarige Oorlog en komt zijn naam ook in diverse biografische woordenboeken voor. ${ }^{945}$ Maar die roem mag niet worden overschat, want hij staat in de schaduw van beeldbepalende veldheren zoals Wallenstein, Mansfeld, Tilly, Piccolomini of Pappenheim. Jost Maximiliaan hoort tot het echelon daaronder, een groep legeraanvoerders met opvallend veel namen uit het gebied van de Maas, zoals Huyn van Geleen, Lamboy, Van den Bongard, Van Wittenhorst, et cetera. ${ }^{946}$ Waarschijnlijk leveren naspeuringen in vooral Duitse archieven voldoende materiaal voor een meer uitvoerige beschrijving van zijn leven en werk. Een dergelijke biografie zou zeker waardevol zijn, omdat ze, in combinatie met de hierna nog te noemen ego-documenten, een beeld geeft van de ervaringen van een officier die zelf actief bij de krijgsverrichtingen betrokken was. Maar die ambitie moeten we hier laten rusten. Zelfs de hierna volgende schets van zijn levensloop moet beperkt blijven en berust voor een groot deel op een samenvatting van bestaande literatuur, aangevuld met enkele toevallig beschikbare archivalische bronnen.

De naam van Jost Maximiliaan komt regelmatig voor in de literatuur, waar hij meestal kortweg wordt angeduid als 'Gronsfeld'. Zowel Chestret de Haneffe'947 als Hanssen wijden enkele bladzijden aan hem. ${ }^{948}$ Vele malen duikt zijn naam op bij Bierther. ${ }^{949}$ Kesting ten slotte besteedt aandacht aan de activiteiten van Jost Maximiliaan bij het ontstaan van het Nederrijns-Westfaalse Gravencollege. ${ }^{950}$ Het meest gedetailleerde opstel over hem is echter van Lahrkamp, namelijk zijn in 1959 gepubliceerde artikel getiteld 'Die Kriegserinnerungen des Grafen Gronsveld (1598-1662).951 Lahrkamp begint de met de vaststelling dat er maar zeer weinig Erlebnisberichten zijn overgeleverd van personen die actief betrokken waren bij de krijgshandelingen van de Dertigjarige Oorlog. Dat geldt in het bijzonder voor geschriften van hogere officieren. Een uitzondering daarop vormen de autobiografische aantekeningen van Jost Maximiliaan, die werden verwerkt in Eberhard Wassenberg's boek: Emewerter Teutsche Florus. Mit Animadversionen, Additionen und Correctionen deren in vorigen eingeruckten, ungleichen Hystorien verbessert, der Warbeit restituirt und biss $A(n n) 0$ 1647 continuirt. Amsterdam bey Ludwich Elzeviern A(nn)o 1647. Het boek was een van de vele herdrukken van het in 1635 door Wassenberg (* Emmerich 1610- $†$ na 1668) oorspronkelijk in het Latijn gepubliceerde boek Florus Germanicus...sive Commentariorum de Bello...' over de periode die naderhand bekend werd als de Dertigjarige Oorlog. Van dit boek, in zijn tijd een verkoopsucces, verschenen diverse uitgaven, zowel in het Latijn als het Duits. De in de uitgave van 1647 verwerkte Additionen und Correctionen bij de

945 Zie o.a. de diverse verwijzingen daarnaar bij Chestret de Haneffe, 'Histoire Gronsveld'; Hanssen, Die Rimburg, Lahrkamp, 'Kriegserinnerungen Gronsfeld'.

946 Zie hierover Wouters, Grensland en Bruggehoofd, 326.

947 Chestret de Haneffe, 'Histoire Gronsveld', 77-91.

948 Hanssen, Die Rimburg, 174-182.

949 Bierther, Die Politik Maximilians I.

${ }^{950}$ Kesting,'Geschichte Reichsgrafenkollegiums', 178, 181.

${ }^{951}$ Lahrkamp, 'Kriegserinnerungen Gronsfeld'. 
oorspronkelijke tekst zijn anoniem en stonden lang op naam van graaf Ludwig von Fürstenberg. ${ }^{952}$ Pas later is vastgesteld dat het om de graaf van Gronsveld moest gaan. Lahrkamp baseert zijn schets van de oorlogsbelevenissen van Jost Maximiliaan voor een deel op deze aantekeningen. ${ }^{953}$ Daarmee ontsnapte aan zijn aandacht een in het archief Toerring Jettenbach aanwezige bundel stukken met een handschrift van Jost Maximiliaan getiteld 'Comoedia Gronsfeldiana quae postea fortunae inconstantia in tragoediam mutata variis et miris exempla ornata, quibus moderni exercituum duces exhortantur ne nimis confidunt in principibus in quibus non est salus'. ('Gronsvelds blijspel, door een onstandvastigheid van het fortuin in een tragedie veranderd, opgesmukt met verschillende voorbeelden, waarmee tegenwoordige legeraanvoerders worden aangespoord volstrekt geen vertrouwen te hebben in vorsten, van wie geen heil valt te verwachten'). ${ }^{954}$ Het manuscript wordt vermeld bij Arndt, maar deze besteedt er verder geen aandacht aan. ${ }^{955}$ Anders dan de titel doet vermoeden is de tekst in Duits geschreven. De folio's $3 \mathrm{t} / \mathrm{m} 36$ bevatten een doorlopend verhaal, waarvan het voorwoord is gedateerd Keulen 17 juli 1634. Daarna volgen de folio's 37 t/m 63 en 71 $\mathrm{t} / \mathrm{m} 75$ met losse aantekeningen, beginnend in 1640. Op folio $87 \mathrm{t} / \mathrm{m} 92$ staan aantekeningen in chronologische volgorde over de periode 23 juni t/m 19 juli 1642. De folio's 108 t/m 140 bevatten het notarieel proces-verbaal van het getuigenverhoor van officieren dat op 17 juli 1633 werd gehouden na de Slag bij Hessisch Oldendorf. De folio's $146 \mathrm{t} / \mathrm{m} 152$ ten slotte bevatten de instructie die keurvorst Maximiliaan van Beieren in 1647 aan de graaf van Gronsveld gaf als opperbevelhebber van het Beierse leger. Dit document zou naderhand een belangrijke rol spelen in het proces voor de krijgsraad dat na de verloren slag bij Zusmarshausen (17 mei 1648) tegen Jost Maximiliaan werd gevoerd.

De tekst van de folio's $3 \mathrm{t} / \mathrm{m} 36$ begint in het voorwoord met een uiteenzetting over het onrecht dat de schrijver is aangedaan. Hij wil zijn naam zuiveren onder het motto: 'ein guhter nahm ist besser als golt undt silber'. ${ }^{956}$ Vervolgens zet Jost Maximiliaan zijn bedoelingen uiteen:

Also habe ich mir vohrgenommen der guthen erbahren welt durch offenen truck ahnn tag zu geben wie man mit mir umbgangen, wie unschuldigen unverdienter weis man mich verfolgett undt nuhr aus sonderbahren particular hass undt neidt umb ehr, guht, leib und leben zu bringen resolviert'. ${ }^{957}$

$\mathrm{Na}$ een inleiding over het begin van zijn militaire loopbaan (onder andere zijn optreden in de slag bij Lutter am Barenberge in 1626) vormen de gebeurtenissen in de zomer van 1633, uitmondend in de slag bij Hessisch Oldendorf, het hoofdbestand. Dat komt ook

952 Lahrkamp, 'Kriegserinnerungen Gronsfeld' 89, noot 38.

953 Lahrkamp schrijft dat hij navraag had gedaan naar oorspronkelijke manuscripten, ook in het archief Toerring-Jettenbach, maar zonder resultaat: Lahrkamp, 'Kriegserinnerungen Gronsfeld', 103, 'Umfragen verliefen ergebnislos. In Frage kommen vielleicht bayrische Adelsarchive in die der Nachlass über die Grafen von Törring-Jettenbach gekommen sein könnten'.

954 TJ, inv. nr. M 1, fol. 3.

955 Arndt, Reichsgrafenkollegium, 122.

956 TJ, inv. nr. M 1, fol. 5.

957 TJ, inv. nr. M 1, fol. 6. 
overeen met de datering van 17 juli 1634, toen Jost Maximiliaan zich verongelijkt in Keulen had teruggetrokken en daar zijn verhaal op papier zette.

Hoewel in het voorwoord het plan tot drukken wordt aangekondigd, is het zeer onwaarschijnlijk dat dit gebeurde. Het handschrift was daar ook niet helemaal klaar voor, zoals blijkt uit de in klad geschreven correcties. Verder was Jost Maximiliaan in de tweede helft van 1634 weer in actieve dienst en zullen tijd en rust hebben ontbroken om het werk te voltooien. Maar delen uit de tekst zijn vervolgens wel gebruikt voor de Ernewerter Teutsche Florus van 1647. Deze vaststellingen plaatsen de aantekeningen ook in een wat ander daglicht dan Lahrkamp doet. Hij beschouwt het geschrift vooral als autobiografische memoires (vandaar ook de titel 'Kriegserinnerungen' van zijn studie), maar in feite was het bedoeld als een pamflet waarin Jost Maximiliaan zich meende te moeten rechtvaardigen. Die constatering maakt de inhoud niet minder waardevol, maar maant tot voorzichtigheid bij de beoordeling van de objectiviteit.

Jost Maximiliaan begint de 'Comoedia' met zijn geboortejaar en -datum op 4 oktober 1596 (die zoals al vermeld, afwijkt van wat daarover in de literatuur wordt vermeld). ${ }^{958}$ Zijn 'liebe Eltern' hadden hem 'bey den studiis bis auf das jahr 1616 gehalten'. We weten uit andere bron dat de jonge graaf, evenals zijn broers, huisonderwijs kreeg. ${ }^{959}$ Dat de ouders belang hechtten an intellectuele vorming is niet vreemd. Ook vader Johan II van Bronckhorst Batenburg had een goede opleiding genoten en bezat culturele belangstelling. Jost Maximiliaan bediende zich later in woord en geschrift van het Hoogduits (zijn moeder was uit Schwaben) en hij sprak goed Frans. Ook moet hij over een behoorlijke kennis van Latijn hebben beschikt. Verder is aannemelijk dat hij, zeker in zijn jeugd, het Nederduitse dialect uit zijn geboortestreek sprak, maar voor de rest van zijn loopbaan bleef deze taal toch van ondergeschikt belang.

Rond zijn twintigste trok Jost Maximiliaan de wijde wereld in. Hij koos niet voor de destijds in adellijke kringen gebruikelijke 'grand tour' langs vooral Zuid-Europese cultuurcentra, maar trad in Spaanse en/of Franse legerdienst. Aan het begin van de Coemoedia schrijft hij dat de keuze 'zum kriegsweesen' werd ingegeven door

'eigener darzu habender liebe...mit diser ambition damit ich mein geringes mir von Gott verlihenes talent also möchte ahnwenden auf das ich im fahl der noth dem lieben Teutschen vatterlandt und der catholische religion....dienst zu leisten qualificiret were'. ${ }^{960}$

Die uitspraak kan zijn gekleurd door twintig jaar oorlogservaringen, maar zegt toch iets omtrent zijn motieven. Hij moet zich door afkomst en positie op een bepaalde manier Duits hebben gevoeld, wat daar dan ook precies onder mag worden verstaan. En hij wilde zich inzetten voor de katholieke zaak. Ook daar zullen ervaringen binnen de eigen familie

958 Hanssen, Die Rimburg, 171-172.

${ }_{959}$ Zo betaalde de rentmeester van de graaf in 1612 twee en een half jaar 'verdienst' aan 'meester François Potmans' als 'preceptor' van de jonge graven, RHCL, Graafschap Gronsveld, inv. nr. 180, fol. 62vo. In hetzelfde jaar werd voor de jonge graaf Otto een grammatica en syntaxis gekocht, idem inv. nr. 180, fol. 64vo.

960 TJ, inv. nr. M 1, fol. 7. 
niet vreemd aan zijn geweest. Bij zijn ouders had Jost Maximiliaan in de strijd over het graafschap Eberstein kunnen zien welke gevolgen de oplopende confessionele spanningen binnen het Duitse Rijk hadden.

De graaf verscheen niet met lege handen in het leger. Dat gold trouwens ook voor zijn jongere broers die dienst namen. In 1616 dankte graaf Johan II van Bronckhorst Batenburg voor een 'freywilliger steur und verehrung' van 200 gulden Maastrichts, die iedere schepenbank van het graafschap had opgebracht voor Jost Maximiliaan 'zu seinen Auszug in frembde landen'. Vader en zoon verklaarden dat die bijdrage uitsluitend 'aus guten, freywilligen hertzen' was gedaan en geen precedent betekende, wanneer de twee ander zonen Otto Wilhelm en Johan Philips de wijde wereld introkken. ${ }^{961}$ Het geld was ook nodig. Zo werd alleen al in 1618 voor de drie jonge graven een bedrag van 243 gulden besteed bij de Maastrichtse wapensmid of 'bussemecker' meester Joris Schluyter. Voorts werd meebetaald aan de uitrusting van hun begeleiders en verzorgers. ${ }^{962}$

In 1618 rebelleerde het protestantse Bohemen tegen keizer Ferdinand II. Op 23 mei van dat jaar werden twee leden van de keizerlijke stadhouderlijke raad in Praag uit het raam gegooid (zogenoemde Tweede Praagse Defenestratie). Vervolgens kozen de Boheemse Standen in 1619 de calvinistische keurvorst Frederik V van de Palts tot koning van Bohemen. Deze gebeurtenissen worden beschouwd als het begin van de Dertigjarige Oorlog, maar waren eigenlijk niet meer dan een aanleiding om de toenemende spanningen tussen katholieken en protestanten met geweld te beslechten. Al in 1609 had hertog Maximiliaan I van Beieren de Katholieke Liga opgericht als een defensief verbond tegen de Protestantse Unie van 1608. Lid werden vooral katholieke landsheren uit ZuidDuitsland en de keurvorsten van Keulen, Trier en Mainz. In 1616 ging de Liga door interne meningsverschillen ter ziele, maar toen de keizer in zijn strijd tegen het rebellerende Bohemen steun zocht bij de voormalige leden, volgde in 1619 een heroprichting van de Liga. Daarvoor had de keizer belangrijke toezeggingen gedaan, zoals de belofte aan hertog Maximiliaan dat hij de positie van keurvorst kreeg wanneer Habsburg zegevierde. Het verbond besloot een leger van 25.000 man op de been te brengen onder leiding van de ervaren veldheer Johan Tserclaes graaf van Tilly. In de Slag op de Witte Berg (8 km. buiten Praag) op 8 november 1620 leed Frederik van de Palts echter een vernietigende nederlaag tegen troepen van de keizer en de Liga en vluchtte hij naar de Republiek, waar hij zich in Den Haag vestigde. Vanwege zijn korte regeringsduur van slechts enkele maanden verwierf hij als bijnaam van 'De Winterkoning'.

Tegelijk met de opstand in Bohemen kreeg keizer Ferdinand te maken met problemen in Hongarije. De uit Noord-Hongarije afkomstige calvinistische vorst Bethlen Gábor (15801629) was in 1613 met Turkse hulp uitgeroepen tot vorst van Transsylvanië. Tijdens de Boheemse opstand in 1619 greep hij de macht over een deel van Hongarije. Hij werd op

961 RHCL, Klooster Hoogcruts, inv. nr. 719. Zie verder ook RHCL, Klooster Hoogcruts, inv. nr. 296, met een inventarisatie van het archief van de schepenbank Slenaken uit 1662, waarin aan deze verklaring uitgebreid aandacht wordt besteed.

962 RHCL, Graafschap Gronsveld, inv. nr. 182. 
20 augustus 1620 uitgeroepen tot koning van Hongarije, maar weigerde een kroning omdat hij niet kon rekenen op de steun van de katholieke Hongaarse edelen. Bethlen Gábor steunde Frederik V van de Palts, maar na diens nederlaag in de slag bij de Witte Berg moest hij vrede sluiten met de keizer en zag hij af van zijn aanspraken op de Hongaarse kroon.

De jaren in de Spaanse en/of Franse dienst beschouwde Jost Maximiliaan later als een leerschool 'darinnen meine ermehlte profession geübt werden könte'. ${ }^{963}$ De 'Bohemische Unruh' vormde voor hem aanleiding in 1619 dienst te nemen. Hetzelfde deed zijn broer Otto Wilhelm. In hun op 15 april 1622 te 'Brieoen' (Brillon) in Westfalen getekende volmacht om de heerlijkheid Sint-Martens-Voeren te verkopen, zeggen de broers dat zij: 'in keyserliche majesteit dienst engageert sijn ende ons een compagnie van dryehondert man d'infanterien aenbevoelen is onder het regiment van den collonel le baron d'Anholt'. ${ }^{964}$ Graaf Johan Jacob van Bronckhorst Batenburg, heer van Anholt, was een ver familielid van de twee broers. ${ }^{965} \mathrm{Hij}$ had een regiment voetvolk (drieduizend man), voerde sinds 1619 het bevel over de Rijnlandse troepen van de Liga, trad in 1620 in dienst van Maximiliaan van Beieren en werd in 1622 veldmaarschalk. Jost Maximiliaan kreeg, volgens eigen zeggen, in dit regiment de rang van 'Haubtman'.966

Jost Maximiliaan kreeg zijn vuurdoop in de veldtocht van 1620 tegen Bethlen Gábor, bij een poging de stad Bratislava aan de Donau voor de keizer te veroveren. ${ }^{967}$ Jost Maximiliaan voerde daarbij in de voorhoede het bevel over een detachement van 200 musketiers. De tocht verliep zeer ongelukkig. Eerst verdronk een deel van de manschappen in de Donau en vervolgens raakte Dampierre, de keizerlijke legeraanvoerder, dodelijk gewond bij de bestorming van de stad. Jost Maximiliaan zelf raakte bij de actie lichtgewond.

Ook al was Frederik van de Palts naar de Republiek uitgeweken, zijn aanhangers zetten de strijd voort in de Oberpfalz, in de Rheinpfalz en later ook in Noord-Duitsland. Hij vond een bondgenoot in de protestantse hertog Christiaan van Braunschweig-Wolfenbüttel, administrator van het voormalig bisdom Halberstadt, die vanwege zijn driestheid als bijnaam 'der tolle Halberstädter' kreeg. Samen met de troepen van de huurlingengeneraal Ernst von Mansfeld vocht Christiaan tegen het leger van de Liga onder het bevel van Tilly. In de strijd om de Rheinpfalz leed Christiaan van Braunschweig op 20 juni 1622 een nederlaag. Na een campagne in de Zuidelijke Nederlanden probeerden de hertog en Mansfeld in Noord-Duitsland het verzet tegen de keizer uit te bouwen. Tegelijkertijd trokken keizerlijke troepen en troepen van de Katholieke Liga noordwaarts. Bij Stadtlohn

\footnotetext{
963 TJ, inv. nr. M 1, fol. 7.

964 RHCL, Landen van Overmaze, Leenhof van Valkenburg ongedeeld, inv. nr. 749, volmacht opgenomen in overdracht van 8 oktober 1622 aan Mechteld van den Bongardt, weduwe van Winand van Imstenrade.

965 Van Schilfgaarde, 'De heren van Bronckhorst', 87. Werd in 1621 in de stand der rijksgraven verheven.

966 TJ, inv. nr. M 1, fol. 7.

967 Lahrkamp, 'Kriegserinnerungen Gronsfeld', 82-86.
} 
kwam het op 6 augustus 1623 tot een slag, die wederom eindigde met een zware nederlaag voor Christiaan van Braunschweig. $\mathrm{Na}$ afloop werd Jost Maximiliaan naar keurvorst Maximiliaan van Beieren in München gestuurd om daar van de overwinning kond te doen. 968

Jost Maximiliaan was bij al deze campagnes van de Liga betrokken. In april 1622 verbleef hij met Otto Wilhelm in Westfalen, in augustus 1622 was hij bij Bergen op Zoom en in de herfst van 1622 waren beide broers weer in Rimburg en in Gronsveld, onder andere om in die laatste plaats de nieuwbouw van de molen te bezichtigen. Otto Wilhelm liet zich bij die gelegenheid ook in de nieuwe kleren steken. ${ }^{969}$

De katholieke successen leidden tot groot wantrouwen bij de protestantse Europese mogendheden en de anti-keizerlijke partij binnen het Rijk. De Deense koning Christiaan IV probeerde intussen vacante Noord-Duitse bisdommen onder zijn invloed te brengen. Als heer van enkele Noord-Duitse territoria lukte het hem in 1625 de hoogste militaire bevelhebber te worden van de Nedersaksische kreits en daarmee de belangrijkste voorvechter van de protestantse zaak in dit gebied. De keizer en in mindere mate hertog Maximiliaan van Beieren probeerden zijn opmars te stuiten. Er trokken twee legers naar het noorden, dat van de Liga onder bevel van Tilly langs de Weser en een keizerlijk onder aanvoering van Wallenstein. In deze Deens-Nedersaksische Oorlog voerde Jost Maximiliaan het commando over 1500 musketiers. Hij was inmiddels niet meer bij het regiment Anholt, maar sinds 1623 bij het regiment Herliberg ${ }^{970}$, waar Tilly hem ongevraagd - bij had geplaatst. ${ }^{971} \mathrm{Hij}$ werd bevorderd tot 'obrist leutenant' (ondercommandant bij de regimentsstaf) en later 'obrist' (commandant bij de regimentsstaf). Helemaal naar wens verliep zijn loopbaan niet. Volgens de 'Comoedia' overwoog hij ontslag te nemen, maar bleef hij uiteindelijk toch.

Begin 1626 bevond Jost Maximiliaan, 'bestelter obrister leutenant über ein regiment teutscher knecht', zich in geldnood en wendde zich voor een lening tot graaf Johan Jacob van Bronckhorst en Anholt. 'Umb besseren vortheil zu schaffen und mehreren schaden zu verhueten' wilde hij 3300 rijksdaalders lenen tegen een jaarlijkse rente van 165 rijksdaalders te betalen uit zijn onroerende goederen. Omdat Johan Jacob niet over zoveel contant geld beschikte, werd de lening geplaatst bij een handelaar in Keulen en beloofde de graaf van Anholt daarvoor borg te staan. Als bijzonder onderpand werden gesteld het huis Eyl en alle andere goederen in het hertogdom Kleef. Het contract werd getekend in Keulen op 13 en 17 januari 1626. ${ }^{972}$

968 Hanssen, Die Rimburg, 176.

969 RHCL, Graafschap Gronsveld, inv. nr. 184, rentmeestersrekening 1622/1623, uitgaven aan 'allerley'.

970 TJ, inv. nr. M 1, fol. 8; Weber, 'Gliederung und Einsatz', 407, geeft een overzicht van de regimenten in Beierse dienst. Het regiment Herliberg stond volgens dit overzicht van 1627-1635 onder bevel van 'Gronsfeld'.

971 TJ, inv. nr. M 1, fol. 8.

972 Afschrift van de akte in RHCL, Rijkskamergerecht, inv. nr. 44, fol. 14-17. 
Op 29 juli 1626 onderscheidde de graaf zich bij het ontzet van de vesting Calenberg, die door Deense troepen werd belegerd. ${ }^{973}$ De echte confrontatie tussen de legers van Christiaan IV en Tilly vond evenwel plaats in de Slag bij Lutter am Barenberge (10 km van Salzgitter) op 27 augustus 1626. De Deense koning leed daarbij een nederlaag, met als gevolg dat er een einde kwam aan het Deense overwicht in Noord-Duitsland. Jost Maximiliaan streed in de Slag bij Lutter in de voorhoede. Na afloop zei Tilly tegen hem: 'Jij bent een graaf en hebt gehandeld als een graaf.' Vervolgens had de veldheer hem zijn eigen hoed opgezet en hem 'mit ausdrukligen wordten nechst Gott die victori ascribirt'.974 Jost Maximiliaan mocht de boodschap van de overwinning naar München brengen. Een jaar later accepteerde de graaf de hem - ongevraagd - aangeboden rang van 'generalwachtmeister'. Deze rang maakte hem tot officier binnen de generale staf van het leger, de derde rang onder de opperbevelhebber. ${ }^{975}$

$\mathrm{Na}$ de Slag bij Lutter sleepte de oorlog tegen de Denen zich nog een tijd voort. In de winter van 1627/1628 leidde Jost Maximiliaan de belegering van de vesting Stade. ${ }^{976}$ Later kreeg hij het bevel over alle Liga-troepen in het Stift Bremen. In de Comoedia behandelt Jost Maximiliaan uitgebreid de politieke verwikkelingen rond de Noord-Duitse bisdommen. Zo was hij ook betrokken bij het diplomatieke overleg dat op 22 augustus 1629 leidde tot de vrede van Lübeck. ${ }^{977}$ In 1626 was hij ook al eens betrokken geweest bij een gezantschap van Tilly naar de Standen van Hessen. ${ }^{978}$ Dit soort bijeenkomsten leerden hem de omgangsvormen binnen de diplomatie, een vaardigheid die hem in de rest van zijn leven nog van pas kwam.

De steeds machtiger keizer Ferdinand II wilde met het zogenoemde Restitutie-edict van 1629 alle gebieden en instellingen die na 1552 waren geseculariseerd, teruggeven aan de katholieken. Daartoe hoorde ook een reeks inmiddels protestantse bisdommen in het noorden van Duitsland, waarop de koning van Denemarken eerder al een oog had laten vallen. Doorvoering van dit plan betekende een radicale wijziging van de politieke verhoudingen binnen het Rijk. De landing van koning Gustaaf Adolf van Zweden op de kust van Pommern op 6 juli 1630 doorkruiste deze ontwikkeling. In snel tempo behaalde de koning een aantal militaire successen en de protestanten beschouwden hem als de voorvechter van hun belangen. Dat was ook de reden dat de stad Maagdenburg in augustus 1630 tegen de keizer rebelleerde en een verbintenis met Gustaaf Adolf sloot. Op 6 december 1630 werd tijdens krijgsberaad in Hameln onder leiding van Tilly besloten tot een beleg van de stad. ${ }^{979}$ Uiteindelijk leidde dit tot een bestorming op 20 mei 1631. Daar

973 Lahrkamp, 'Kriegserinnerungen Gronsfeld', 88-89.

${ }_{974}$ Lahrkamp, 'Kriegserinnerungen Gronsfeld', 89-91; voor de letterlijke aanhaling zie TJ, inv. nr. M 1, fol. 10.

975 De gegevens over deze rangen zijn ontleend aan Salm, Armeefinanzierung, 88, 182.

976 Lahrkamp, 'Kriegserinnerungen Gronsfeld', 91.

977 Lahrkamp, 'Kriegserinnerungen Gronsfeld', 91.

${ }_{978}$ Hanssen, Die Rimburg, 175.

${ }^{979}$ Lahrkamp, 'Kriegserinnerungen Gronsfeld', 93. 
nam ook het regiment van Jost Maximiliaan, onder het bevel van Tilly's tweede man veldmaarschalk Gottfried Heinrich graaf zu Pappenheim, aan deel. ${ }^{980}$ Nadat de troepen de stad waren binnengedrongen, volgden plundering en een bloedbad onder de bevolking. In brand gestoken huizen veroorzaakten vervolgens een grote vuurzee die vele slachtoffers eiste en de stad vrijwel geheel in de as legde. In totaal vonden bij de verovering ongeveer twintigduizend inwoners de dood. De slachting van Maagdenburg wordt in de geschiedenis van de Dertigjarige Oorlog beschouwd als een absoluut dieptepunt, waar de graaf van Tilly lange tijd verantwoordelijk voor werd gehouden. 'Maagdenburgiseren' werd een synoniem voor totale verwoesting. Het kan niet anders of de ondergang van de stad moet grote indruk hebben gemaakt op Jost Maximiliaan. Hij schrijft in Der Ernewerte Teutsche Florus dat Pappenheim hem had toevertrouwd dat hij de aanstichter van de brand was geweest omdat hij de vijand wilde verdrijven uit een huis waarin deze zich had verschanst. ${ }^{981}$

Gustaaf Adolf behaalde intussen op andere plaatsen militaire successen en drong door tot diep in Zuid-Duitsland. Eind augustus 1631 versloeg hij in Breitenfeld bij Leipzig het leger van de Liga onder aanvoering van Tilly. Jost Maximiliaan werd vervolgens naar Hessen gestuurd en hij kreeg het militaire commando van delen van de Westfaalse en Nedersaksische Kreits. Op 8 januari 1632 meldde zich echter Pappenheim in opdracht van keurvorst Maximiliaan van Beieren in Wolfenbüttel als opperbevelhebber van het leger van de Katholieke Liga in Noordwest-Duitsland en de graaf van Gronsveld werd onder hem geplaatst. Maar Jost Maximiliaan kon met de vier jaar oudere legeraanvoerder moeilijk overweg. Hij vond hem incompetent en schikte zich met tegenzin in een tweede plaats. Pappenheim ging volgens hem in het Wesergebied met de eer strijken, terwijl hij het werk verrichtte. Er bestonden ook verschillen van inzicht over te voeren tactiek. De graaf van Gronsveld zag het meeste heil in een uitputtingsoorlog, terwijl Pappenheim voorstander was van snelle acties.

Nadat Pappenheim tegen Saksen was opgetrokken, nam Jost Maximiliaan, sinds 10 september 1632 als Generalfeldzengmeister, het bevel over de troepen van de Liga in het Wesergebied van hem over. Die rang plaatste hem binnen de generale staf van het leger onder de opperbevelhebber of veldmaarschalk. Over Pappenheims vertrek liet Jost Maximiliaan zich naderhand weinig vleiend uit. De man had bey seinen abzug von der Weeser kein einiges Pferdt oder anderes ding, so man bey der arthellerie nothwendig haben mues, hinterlassen'. ${ }^{82}$ Uit deze tijd zijn ook enkele brieven over activiteiten van Jost Maximiliaan in het Gronsveldse archief bewaard. ${ }^{983}$ Zo verbleef hij in oktober 1632 in Hildesheim, van waaruit hij onder andere probeerde de bescherming van Keuls gebied in de omgeving van Arnsberg te organiseren en correspondeerde hij met de stad Paderborn over ruiling van gevangenen. In de strenge winter van 1632/1633 bezette hij de steden Höxter en Fulda en de vesting Langwedel. In de Comoedia beschrijft Jost Maximiliaan zijn

980 Hanssen, Die Rimburg, 176.

981 Lahrkamp, 'Kriegserinnerungen Gronsfeld', 93; Junkelmann, 'Feldherr Maximilians', 385 en 394 , noot 67.

982 TJ, inv. nr. M 12, fol. 454 ('Summarische Berechnung').

983 RHCL, Graafschap Gronsveld, inv. nr. 9. 
voortdurende zorgen in deze tijd: te weinig manschappen, maar vooral onvoldoende proviand en geld voor soldij.

Ook militair ging het niet voor de wind. Vaak bleken de Zweedse troepen sterker. Op 14 maart 1633 begonnen de Zweden met een beleg van de stad Hameln. Bij een poging de stad te ontzetten werd op 8 juli 1633 in Hessisch Oldendorf slag geleverd tussen ZweedsHessische troepen en het leger van de keizer en de katholieke Liga. Het treffen eindigde met een nederlaag voor laatstgenoemde partij. De graaf van Gronsveld verloor zijn paard, degen en hoed en moest tot Minden lopen. ${ }^{984}$

In het archief van Gronsveld bevindt zich een brief van Jost Maximiliaan aan de vorstbisschop van Osnabrück, gedateerd 9 juli 1633, waarin hij de ongelukkige afloop bij Hessisch Oldendorf beschrijft.985 De graaf had voorgesteld de vijand te ontwijken of een andere weg te nemen, maar de andere bevelvoerende officieren wilden per se de vijand aanvallen. Zij waren toch niet van zo ver gekomen om alleen Hameln te ontzetten! Jost Maximiliaan waarschuwde dat het beter was de stad te verliezen dan een heel leger, maar ze bleven bij hun mening, met als gevolg de fatale afloop.

Onenigheid binnen de legerleiding was dus een belangrijke oorzaak van het echec, maar Jost Maximiliaan werd daarvoor in hoge mate verantwoordelijk gehouden. Om zich tegen die kritiek in te dekken liet hij op 17 juli 1633, ruim een week na de slag, in een notarieel proces-verbaal bij een ondervraging van diverse getuigen vastleggen wat er allemaal was gezegd en gedaan. ${ }^{986}$

Op 22 juli 1633 schreef hij vanuit Nienburg aan de vorstbisschop van Osnabrück dat hij graag persoonlijk zijn relaas wilde komen doen, maar door ziekte met hoge koorts daartoe niet in staat was. ${ }^{987}$ Intussen had hij alle geld nodig om de restanten van het leger te verzorgen. Zijn rechtvaardiging ten opzichte van de Rijnlandse keurvorsten als leden van de Liga durfde hij niet aan het papier toe te vertrouwen, maar wanneer de mogelijkheid zich voordeed, wilde hij zijn handelwijze graag mondeling toelichten.

Intussen werd de verzorging van het leger een steeds nijpender probleem. Op 10 augustus 1633 berichtte Jost Maximiliaan aan de keurvorsten van Keulen en Mainz dat de vesting Wolfenbüttel hoogstens tot 1 november over proviand beschikte. ${ }^{988}$ Hij hoopte dat zijn collega Huyn van Geleen nog graan kon kopen bij de hertogin van Braunschweig, met wie hij goed bekend was.

Op 31 augustus 1633 schreef Jost Maximiliaan, met verwijzing naar zijn eerdere brieven van 10 en 28 juli, nogmaals aan de keurvorst van Beieren om zich te rechtvaardigen. ${ }^{989}$ Met het al genoemde notarieel verslag wilde hij aantonen wie de ongelukkige afloop van

984 RHCL, Graafschap Gronsveld, inv. nr. 9, Jost Maximiliaan van Bronckhorst Batenburg aan prinsbisschop van Osnabrück, 9 juli 1633.

985 RHCL, Graafschap Gronsveld, inv. nr. 9, Jost Maximiliaan van Bronckhorst Batenburg aan prinsbisschop van Osnabrück, 9 juli 1633.

986 TJ, inv. nr. M 1, fol. 108-140, akte van notaris Herman von der Heide te Nienburg 17 juli 1633.

987 RHCL, Graafschap Gronsveld, inv. nr. 9, Jost Maximiliaan van Bronckhorst Batenburg an prinsbisschop van Osnabrück, 22 juli 1633.

988 RHCL, Graafschap Gronsveld, inv. nr. 9, Jost Maximiliaan van Bronckhorst Batenburg aan keurvorsten van Keulen en Mainz 10 augustus 1633.

989 RHCL, Graafschap Gronsveld, inv. nr. 9, Jost Maximiliaan van Bronckhorst Batenburg aan keurvorst van Beieren, 31 augustus 1633. 
de veldslag had veroorzaakt. Hij was ook bereid dit mondeling toe te lichten. Maar het hielp allemaal niet. De graaf werd als legeraanvoerder ontslagen en trok zich terug in Keulen. Op 13 januari 1634 bood hij Wallenstein, de opperbevelhebber van het keizerlijk leger, nog zijn diensten aan, ${ }^{990}$ maar door de moord op de keizerlijke generalissimus op 26 februari 1634 bleef dat zonder gevolg.

In Keulen werkte Jost Maximiliaan mokkend aan zijn 'Comoedia'. Daarvoor gebruikte hij ook een door hem op 27 september 1633 gemaakte 'Summarische Berechnung' van de inkomsten en uitgaven van het leger gedurende het tijdvak van 19 juli 1632 tot 23 september 1633. ${ }^{991}$ De genoemde bedragen geven een goede indruk van de hoeveelheden geld die omgingen. In totaal werd 114.829 Reichstaler uitgegeven, waarvan alleen al 47.222 Reichstaler voor versterking van de vesting en onderhoud van het garnizoen van Minden en Nienburg. Uit eigen 'beutl' schoot Jost Maximiliaan op verzoek van Pappenheim 7434 Reichstaler voor om de stad Wolfenbüttel van proviand te voorzien. Daarbij was haast geboden, want zonder die leverantie kon de stad niet langer dan veertien dagen standhouden tegen de vijand. Tegenover deze uitgaven stonden in totaal slechts 84.905 Reichstaler aan inkomsten. De belangrijkste bedragen betaalden de stad Dortmund met 24000 Reichstaler, de stad Herford met drieduizend Reichstaler, het graafschap Lippe met tweeduizend Reichstaler en het graafschap Mark met vierduizend Reichstaler. Ook verschillende hoge officieren hadden aanzienlijke bedragen geld voorgeschoten. Het verschil tussen inkomsten en uitgaven leverde een nadelig saldo van 29924 Reichstaler op. Jost Maximiliaan schrijft in de Comoedia dat hem steeds weer spoedige terugbetaling van voorgeschoten geld was beloofd, maar hij zag geen cent. Niet voor niets was zijn geschrift bedoeld als een waarschuwing tegen onbetrouwbare vorsten!

In de zomer van 1634 werd de graaf van Gronsveld weer in genade aangenomen. Waarschijnlijk reisde hij begin augustus met een pas van de Franse koning via Lotharingen naar Beieren. Als commandant van een Beiers regiment nam hij ook deel aan de Slag bij Nördlingen op 6 september 1634. In dat treffen versloeg een keizerlijk-Beiers leger onder het bevel van koning Ferdinand III van Hongarije, de oudste zoon van de keizer, de Zweden. Ferdinand was de nominale opperbevelhebber, feitelijke commandant de generaal in keizerlijke dienst Matthias Gallas (1584-1647). Na Nördlingen zochten vele Duitse vorsten die zich met de Zweden hadden verbonden, weer toenadering tot de keizer.

In het najaar van 1634 trokken de Zweedse troepen zich verder terug uit Zuid-Duitsland en zwermden uit in de richting van de Rheinpfalz. Zij hielden daar ook verschillende steden en vestingen bezet, waar keizerlijke en Beierse troepen onder bevel van Gallas hen uit probeerden te verdrijven. In het verdrag van Parijs van 1 november 1634 verplichtte de Franse koning Lodewijk XIII zich echter tot financiële en militaire steun aan de Zweden en hun protestantse bondgenoten in ruil voor verschillende concessies, zoals de overdracht van garnizoenssteden in de Elzas en de stad Straatsburg.

${ }_{990}$ Lahrkamp, 'Kriegserinnerungen', 99.

991 TJ, inv. nr. M 12, fol. 453-458. 
De graaf van Gronsveld maakte medio oktober 1634 deel uit van een diplomatieke missie naar hertog Nicolaas II van Lotharingen, een teken dat hij nog steeds het vertrouwen van de keurvorst van Beieren genoot.992 Toch knaagde er oud zeer bij hem. Op 19 oktober 1634 schreef keurvorst Maximiliaan aan twee van zijn raadsheren dat Jost Maximiliaan ontevreden was over het verloop van zijn carrière. Hij had daarom aan de hertog van Lotharingen voorgesteld Jost Maximiliaan voorlopig als Generalfeldzeugmeister aan te nemen. Zijn diplomaten moesten echter onderzoeken of de graaf nog voldoende aanzien genoot bij officieren en soldaten en of een bevordering tot veldmaarschalk op positieve reacties kon rekenen. ${ }^{993}$ Die rang zou hem tot bevelhebber van het Beierse leger maken. De weerstand tegen een dergelijke benoeming kwam vooral uit de hoek van de drie Rijnlandse keurvorsten. Zij waren ontstemd over het feit dat Jost Maximiliaan met hen de spot zou hebben gedreven omdat hij, ondanks zijn eerdere degradatie, toch weer, zonder toestemming van de andere leden van Liga, in dienst was genomen. Ze dreigden dat ze zich nog eens zouden bedenken en uit de Liga treden wanneer Gronsveld 'vor ain capo vorgestölt werden solle'.994

De keurvorst van Beieren hield Jost Maximiliaan echter de hand boven het hoofd. Zo maakte de graaf eind oktober 1634 deel uit van een diplomatieke missie naar aartshertog Ferdinand, koning van Hongarije en zoon van keizer Ferdinand II. Jost Maximiliaan van zijn kant dankte de keurvorst voor de aangeboden post van Generalfeldzeugmeister en het in hem gestelde vertrouwen. ${ }^{995} \mathrm{Hij}$ wilde in dienst van de Liga blijven en hoopte op verdere carrière. Die kans kreeg hij in de daarop volgende maanden.

Op 24 november 1634 kreeg hij het bevel voor een aanval op het door Zweden bezette Heidelberg. ${ }^{996}$ Succesvol verliep dat in eerste instantie niet. Op 8 december moest Jost Maximiliaan aan de keurvorst van Beieren melden dat hij door een samengaan van Zweedse en Franse troepen gedwongen was het beleg op te heffen. ${ }^{997}$ Maar een nieuwe poging lukte wel en op 13 december 1634 openden de burgers van Heidelberg vrijwillig de poorten voor hem. Op 23 december 1634 was Jost Maximiliaan echter gedwongen de stad weer over te geven aan de Fransen. Daardoor gingen niet alleen de stad en de daar anwezige artillerie verloren, maar werd ook het keizerlijk leger gedwongen zich terug te trekken. Jost Maximiliaan kreeg vrije aftocht, maar pas later merkten de Fransen dat hij het daarbij overhandigde capitulatieverdrag niet had ondertekend.998 Die kwestie werd naderhand nog een punt van geschil in de verhoudingen tussen keurvorst Maximiliaan en de Fransen.

992 Bierther, Die Politik Maximilians I, 309, nr. 135D.

993 Bierther, Die Politik Maximilians I, 307-308 nr. 135B.

994 Bierther, Die Politik Maximilians I, 307-308 nr. 135B, noot 1.

995 Bierther, Die Politik Maximilians I, 309 nr. 135D.

996 Bierther, Die Politik. Maximilians I, 371-372 nr. 161.

997 Bierther, Die Politik Maximilians I, 384, nr. 171.

998 Bierther, Die Politik. Maximilians I, 410-415, nr. 181. 
Tijdens zijn verblijf in dit gebied maakte Jost Maximiliaan van de gelegenheid gebruik om gewapenderhand het graafschap Eberstein en de stad Gochsheim te bezetten om aldus de onenigheid over dit familiebezit met geweld te beslechten.999

In de eerste helft van 1635 verbleef Jost Maximiliaan vooral in het Generalkriegskommissariat van de Liga in Tübingen en in Vaihingen. Hij adviseerde daar Gallas af te zien van een risicovolle aanslag op Heidelberg of Mannheim. Het was verstandiger de Fransen met afleidingsmanoeuvres bezig te houden. ${ }^{1000}$

De reputatie van Jost Maximiliaan aan het keizerlijk hof in die tijd was niet goed. De gezant van de keurvorst van Keulen berichtte zijn heer dat de legeraanvoerders Mansfeld en Gronsveld er 'in schlechten concepte' stonden, in het bijzonder Gronsveld. De hertog van Lotharingen had hem grondig in het 'teutsch' de waarheid gezegd. Men begreep niet dat de keurvorst van Beieren deze man steeds weer voor een hoge functie nodig had. ${ }^{1001}$

De Vrede van Praag van 30 mei 1635 moest een einde maken aan de strijd tussen enerzijds de keizer en de Katholieke Liga en anderzijds een groot deel van de rijksvorsten. De katholieke Liga werd daarmee ook ontbonden. Maar Zweden en bondgenoot Frankrijk, beducht voor Habsburgs overwicht binnen het Rijk, ratificeerden het verdrag niet en zetten de strijd voort. Als reactie daarop viel vervolgens een keizerlijk leger van twintigduizend man onder leiding van Gallas Lotharingen binnen. Jost Maximiliaan voerde bij die actie een legerkorps van 6500 man aan. Maar het leger van Gallas, die zelf bekend stond om zijn drankzucht en weelderige levensstijl, viel al snel ten prooi aan ziekte en honger. De generaal hield er de bijnaam 'Legerbederver' aan over. Jost Maximiliaan kreeg in deze tijd ook nog eens het probleem in ongenade te vallen bij keurvorst Maximiliaan. Die maakte hem namelijk verantwoordelijk voor een beslaglegging op 300 voeder wijn, die toebehoorden aan landgraaf Georg van Hessen, terwijl Jost Maximiliaan zich van geen kwaad bewust was.

\subsubsection{Huwelijke en kinderen}

$\mathrm{Na}$ zestien jaar oorlog schijnt de graaf van Gronsveld, inmiddels rond de veertig, naar een rustiger leven te hebben verlangd. Op 13 juni 1636 werd hem op eigen verzoek ontslag uit het leger verleend en streek hij weer neer in Keulen. ${ }^{1002}$ Daar knoopte hij een relatie aan met Maria Margaretha Hammann, dochter van een protonotarius bij het Rijkskamergerecht in Spiers. Jost Maximiliaan deed zijn geliefde zelfs huwelijksbeloften die, volgens de rechtsregel 'trouwbelofte maakt trouwschuld', zo sterk moeten zijn geweest dat ze bij verbreking een in rechte afdwingbare vordering wegens schadevergoeding opleverden. Toen de trouwplannen door de komst van een nieuwe liefde voortijdig strandden, tekende Jost Maximiliaan uiteindelijk op 20 maart 1639 voor Maria Margaretha Hammann een

\footnotetext{
999 Bierther, Die Politik, Maximilians I, 542-545, nr. 227. 1000 Bierther, Die Politik Maximilians I, 568-569, nr. 238.

1001 Bierther, Die Politik Maximilians I, 602-603, nr. 248.

1002 Lahrkamp, 'Kriegserinnerungen Gronsfeld', 100.
} 
schuldbekentenis van 3500 Duitse guldens Frankfurter koers 'umb renunciation unnd loskundigung meiner zwischen mir und ihr geschehener Ehegeliebtnüss'.

Van de 3500 gulden die Jost Maximiliaan volgens erewoord beloofde binnen zes maanden te betalen aan zijn ex-verloofde, was bij zijn dood in 1662 nog maar 1700 gulden afgelost. Toen ontstond over betaling van de rest voor het Rijkskamergerecht een proces tegen Anna Christina von Hardenrath, de weduwe van Jost Maximiliaan, juist op een moment dat de familie onder een immense schuldenlast bankroet dreigde te gaan. Uiteindelijk werd zij veroordeeld tot betaling van vijfhonderd gulden. ${ }^{1003}$ Opmerkelijk is dat Jost Maximiliaan eigenlijk hetzelfde deed als wat hij later zijn broer Otto Wilhelm verweet, toen die een relatie (huwelijk?) aanging met Sibilla Oellers, dochter van de drosssaard van Gronsveld en een vrouw van eenvoudige afkomst (zie Hoofdstuk 4.1.1).

$\mathrm{Na}$ de verbroken trouwbeloften koos Jost Maximiliaan voor een nieuwe geliefde (en financieel ook betere partij), Anna Christina von Hardenrath (*1615, †29 januari 1692), dochter van burgemeester Johan von Hardenrath de Jongere en Katharina von Gaill. Waarschijnlijk werd kort na 1636 getrouwd. Anna Christina's familie behoorde tot het Keulse patriciaat. Haar vader Johan von Hardenrath de Jongere was tussen 1584 en 1630 zestien keer burgemeester van Keulen. Volgens de overlevering vervulde hij dat ambt zo voorbeeldig dat zijn opvolgers voor zijn portret moesten zweren op dezelfde wijze hun plichten te zullen nakomen. Hij bezat sinds 1619 een huis in de Sternengasse, dat waarschijnlijk in 1643 als huwelijksgift werd overgedragen aan zijn dochter Anna Christina. De moeder Katharina von Gail, dochter van burgemeester Philipp von Gail, stamde eveneens uit een bekend Keuls geslacht. Haar oom was de bekende jurist Andreas von Gail.

De Hardenraths behoorden tot de adel, maar niet tot de rijksadel. Men kan zich dan ook afvragen of Jost Maximiliaan en zijn echtgenote wel ebenbürtig (gelijk in stand) waren. Het probleem van een niet standesgemäss gesloten huwelijk lag niet zozeer bij een echtpaar zelf, maar werkte door naar volgende generaties. Voor onderbrenging en verzorging van ongehuwde zonen en dochters in (hoog)adellijke stiften moest immers een 'vlekkeloze' adellijke afstamming gedurende drie of vier generaties worden aangetoond. Het gedrag van Jost Maximiliaan wekt de indruk dat hem daar weinig aan gelegen was. Zijn eerste liaison met een notarisdochter wijst daar ook al op.

Misschien was deze opmerkelijke 'huwelijkspolitiek' een familietrekje. Otto Wilhelms huwelijk met een vrouw van burgerlijke afkomst was ook al discutabel en Johan Philips vond een vrouw in kringen van de lagere adel. Het ongehuwd samenwonen van Gertrud en Felicitas was voor de eerste helft van de zeventiende eeuw binnen adellijke kringen ook enigszins ongewoon. Het lag meer in de lijn der verwachting wanneer zij een onderkomen hadden gezocht in een adellijk stift. Alles bij elkaar lijkt het 'sociaal-maatschappelijk kapitaal' dat Johan II van Bronckhorst met de verhoging van stand had verworven, door zijn kinderen met hun afwijkende levensstijl niet echt te zijn benut.

Uit het huwelijk werden zeven kinderen geboren: Otto Wilhelm (1636), Johan Frans (1639), Ernst, Johan Philip Felix, Anna Justina Gertrudis, Klara Sybilla en Maria Anna.

1003 RHCL, Rijkskamergerecht, inv. nr. 84. 
Hoewel nauwelijks gegevens over het privéleven van Jost Maximiliaan en Anna Christina bekend zijn lijkt hij erg op haar gesteld te zijn geweest. Dat zouden we tenminste mogen afleiden uit brieven die Jost Maximiliaan aan haar schreef. Deze beginnen met de aanhef 'Wolgeborne mein herzgen, allerliebster engell' (1647) en 'Wolgeborne mein allerliebstes hertz' (1648 twee maal uit de gevangenis). ${ }^{1004}$ Ook anderszins bevatten de brieven blijken van genegenheid.

Behalve een liefhebbende echtgenote moet Anna Christina ook een krachtige persoonlijkheid zijn geweest, wanneer we kijken naar de manier waarop zij na het overlijden van Jost Maximiliaan als weduwe en voogdes van haar kinderen het graafschap Gronsveld bestuurde. De berg schulden van de familie was bijna niet te overzien. Het positieve oordeel over 'gräfin Christina' werd ongeveer zeventig jaar na haar overlijden nog eens bevestigd door Prummer, de grafelijke vertegenwoordiger in Gronsveld, die haar ' eine scharpf und kluge regentin' noemt.

Jost Maximiliaan raakte door zijn huwelijk goed ingeburgerd in Keulen. Hij bewoonde het huis van zijn echtgenote in de Sternengasse, dat al snel bekend stond als 'Gronsfelder Hof' en leidde daar het leven van een heer van stand. Tekenend voor zijn prestige is het feit dat de in 1630 uit Frankrijk verbannen koningin-moeder Maria de Medici sinds oktober 1641 bij hem onderdak vond en in 1641 peetmoeder van zijn dochter Maria werd. In zijn huis overleed de voormalige koningin van Frankrijk ook op 3 juli 1642.

\subsubsection{Nieuwe actieve militaire dienst $1645-1648$}

In Keulen schijnt Jost Maximiliaan zich met de werving van troepen bezig te hebben gehouden. Zo ontving hij in de eerste helft van 1642 betalingen van keurvorst Maximiliaan voor 'einer neuen werbung' en wierf hij soldaten voor het Spaanse garnizoen van Jülich. ${ }^{1005}$ Begin 1644 probeerde hij ook weer in actieve dienst te komen. In een brief van 23 maart 1644 schreef keurvorst Maximiliaan voor hem aan de aartshertog/koning van Hongarije een aanbeveling om hem in het keizerlijk leger op te nemen. ${ }^{1006}$

Eind 1644 of begin 1645 raakte Jost Maximiliaan betrokken bij een incident met Hessische militairen, die hem arresteerden en naar Kassel brachten, waar landgravin Amalia hem vervolgens met uitgebreide excuses vrijliet. Het voorval baarde veel opzien. Mogelijk zorgde dat er voor dat keurvorst Maximiliaan opnieuw op hem opmerkzaam werd gemaakt. De graaf van Gronsveld kreeg op 15 maart 1645 een post aangeboden als militair bevelhebber voor de Oberpfalz in zijn oude rang van Generalfeldzengmeister. In januari 1647 werd hij gouverneur van Ingolstadt. ${ }^{1007}$ Op 3 mei 1647 stuurde de keurvorst de vloeiend Frans sprekende Jost Maximiliaan naar Parijs, waar hij onderhandelde met kardinaal Mazarin over een verdrag tussen Frankrijk en Beieren. De Beierse troepen zouden zich losmaken van het keizerlijk leger, waardoor de keizer alleen kwam te staan tegenover

${ }^{1004}$ RHCL, Graafschap Gronsveld, inv. nr. 10.

1005 TJ, inv. nr. M 1, fol. 55). Aantekeningen over betalingen in de maanden juni en juli van 1642 wijzen op werving van soldaten voor het Spaanse garnizoen van de vesting Jülich (TJ, inv. nr. M 1, fol. 87-92).

1006 RHCL, Graafschap Gronsveld, inv. 456.

1007 Voor de lotgevallen van Jost Maximiliaan gedurende de jaren 1645-1649 in Beierse dienst zie Lahrkamp, 'Kriegserinnerungen Gronsfeld', 100-104. 
Frankrijk. Toen de graaf van Gronsveld op 27 augustus 1647 terugkeerde, had de keurvorst echter opnieuw een verbond met de keizer gesloten, waardoor zowel Gronsvelds troepen als het keizerlijk leger onder het bevel van Peter Melander, graaf zu Holzappel, moesten samenwerken. Rond dezelfde tijd kreeg de graaf van Gronsveld een bevordering tot veldmaarschalk.

Jost Maximiliaan en Melander konden slecht met elkaar overweg, wat zijn oorzaak vond in hun gemeenschappelijk verleden. In 1633 had Melander in de Slag bij Hessisch Oldendorf gevochten aan protestantse kant en de nederlaag die Jost Maximiliaan daar geleden had, werkte nog altijd in hun onderlinge verhouding door.

$\mathrm{Na}$ kleinere schermutselingen in de herfst van 1647 betrokken de troepen hun winterkwartieren tot het voorjaar van 1648. In april van dat jaar sloten de Franse en Zweedse troepen zich aaneen tot een strijdmacht van dertigduizend man. Het plan was langs de Donau door Beieren op te rukken naar Wenen. Het getalsmatig kleinere Beierskeizerlijke leger versperde daarvoor de weg. $\mathrm{Na}$ een succesvolle opmars van de Fransen en Zweden vond op 17 mei 1648 tussen Burgau en Augsburg de Slag bij Zusmarshausen plaats. De strijd verliep slecht voor de Beiers-keizerlijke troepen. Melander vond de dood op het slagveld en Jost Maximiliaan probeerde met de resterende manschappen stand te houden langs de rivier de Lech. Een veldslag achtte hij niet meer verantwoord. In de nacht van 26 op 27 mei 1648 besloot hij de linie langs de Lech op te geven en terug te trekken in de richting van de Donau. De aftocht leek op een vlucht en Beieren lag daarmee open voor het Frans-Zweedse leger. Omdat Jost Maximiliaan daarvoor verantwoordelijk werd gehouden, liet de keurvorst hem op 3 juni 1648 arresteren en in de vesting Ingolstadt opsluiten. De graaf kwam voor een krijgsraad, waar hij uiteindelijk werd vrijgesproken omdat de keurvorst zelf bevel had gegeven het leger zoveel mogelijk te ontzien. In de brieven die Jost Maximiliaan in 1648 vanuit de gevangenis aan zijn echtgenote schreef laat hij weten 'desperat' te zijn van ellende, verstoken van informatie, wachtend op de vrede en onzeker over de straf die hem boven het hoofd hangt. ${ }^{1008}$

De slag bij Zusmarshausen was het laatste gevecht van de Dertigjarige Oorlog op Duits grondgebied. In de zomermaanden van 1648 bevonden zich de vredesonderhandelingen in Münster en Osnabrück in de eindfase en op 24 oktober 1648 maakte de plechtige ondertekening van de Acta Pacis Westfalicae een einde aan de oorlog. Voor Jost Maximiliaan was de oorlog pas later afgelopen, want hij herkreeg zijn vrijheid eerst in 1649.

\subsubsection{Financiële gevolgen}

Toen Jost Maximiliaan zijn actieve dienst in 1636 beëindigde, had hij uit eigen middelen grote bedragen in de oorlog gestoken en het was de vraag of hij dat geld ooit zou terugzien. Daarnaast leefde hij overeenkomstig zijn stand op grote voet. Het tot ongeveer 1640 onverdeeld gebleven familiekapitaal bood misschien enige bescherming tegen voortijdig bankroet, maar uiteindelijk moesten ook broers en zusters worden uitbetaald. Zijn huwelijk in 1639 bracht Jost Maximiliaan een niet onbemiddelde echtgenote, maar ook haar vermogen reikte niet toe om militaire avonturen te financieren. De nieuwe loopbaan in Beierse dienst in de tijd van 1645 tot 1648 leverde een hoge rang op, maar

1008 RHCL, Graafschap Gronsveld, inv. nr. 10. 
verliep ongelukkig en zal veel geld hebben gekost. Kortom, het leven als militair ging vanaf het begin gepaard met chronisch geldgebrek. Het kon niet uitblijven dat deze situatie gevolgen kreeg voor zijn familiebezit. Het navolgende overzicht maakt dit duidelijk.

Het begon in 1622 met de verkoop van de heerlijke rechten over Sint-Martens-Voeren aan Mechteld van den Bongardt, weduwe van Winand van Imstenrade, vrouwe van Mheer. Daarnaast werd een boedelscheiding met Otto Wilhelm, Gertrud en Felicitas onvermijdelijk. In 1637 bevonden de 'patrimoniële' of erfgoederen zich in een 'miserabelen staet'. ${ }^{1009}$ De regelingen die tussen broers en zusters werden getroffen, kwamen hiervoor al aan de orde (Hoofdstuk 4.1.1). De volgende stap was op 26 juni 1638 de verpanding van de heerlijke rechten over Slenaken voor vijftienduizend gulden Brabants aan Johan Adolf van Imstenrade, heer van Mheer. ${ }^{1010}$ Op 23 februari $1639 \mathrm{kreeg}$ Hieronimus van Berghe genaamd Trips de heerlijkheid Oost met hoge en lage jurisdictie, cijnzen en alle gerechtigheden in pand voor 1200 rijksdaalders. Nog geen jaar later volgde op 3 januari 1640 de definitieve verkoop tegen betaling van een extra bedrag van achthonderd rijksdaalders. ${ }^{1011}$

De financiële druk moet op dat moment hoog zijn opgelopen, omdat Jost Maximiliaan zich enkele maanden later, op 22 juni 1640, genoodzaakt zag het kasteel en de heerlijkheid Rimburg met alle bijbehorende rechten en inkomsten te verkopen aan Arnold van Boeijmer en Katharina van Splinter. Waarschijnlijk verbleef Van Boeijmer meestentijds ook in Keulen en zijn partijen op die manier met elkaar in contact gekomen. Na enig onderhandelen zonk de vraagprijs van 120.000 op 90.000 rijksdaalders, in verschillende termijnen binnen drie jaar te betalen. En op 25 april 1641 vond de boedelscheiding plaats tussen Jost Maximiliaan en Otto Wilhelm, waarbij laatstgenoemde huis en heerlijkheid Hönnepel, het huis Eyl en andere goederen in het hertogdom Kleef ontving. ${ }^{1012}$ Deze deling verliep, zoals hiervoor (zie Hoofdstuk 4.1.1) werd besproken, met grote onenigheid vanwege diens relatie met Sibilla Oeller. Dat Jost Maximiliaan in deze tijd erg krap bij kas zat, blijkt ook wel bij de overdracht van de vordering die Herman Hessing uit Keulen sinds 1626 op hem had. Toen Hessing, na gedeeltelijke aflossing, op 17 maart 1641 nog 2800 rijksdaalders van deze vordering overdroeg aan Corvinus Meinertzhagen, syndicus van de stad Keulen, verklaarde Jost Maximiliaan het kapitaal niet te kunnen aflossen 'dieweil mein gelegenheit nicht ist'. ${ }^{1013}$ Ook deze vordering werd vanaf 1667 weer inzet van een langdurige procedure voor het Rijkskamergerecht.

Met al deze verpandingen en delingen tussen 1638 en 1641 lijkt een direct bankroet te zijn voorkomen, maar daarmee waren de schulden niet verdwenen. In de daarop volgende jaren bleef de financiële situatie precair. Waarschijnlijk bestond rond 1650 ook het plan het graafschap Gronsveld zelf te verpanden of te verkopen. De al meermalen genoemde

\footnotetext{
${ }^{1009}$ LAV, NRW, Abt. Rheinland, Reichskammergericht, inv. nr. 743, fol. 68-70.

1010 RHCL, Graafschap Gronsveld, inv. nr. 452.

1011 Janssen de Limpens, 'Geschiedenis Oost', 136-138.

1012 Hanssen, Die Rimburg, 174. Otto Willem werd met deze goederen als 'manlenen' beleend. Zijn zusters konden daar in niet opvolgen. Wel hadden Felicitas en Gertrud het gebruik van Hönnepel (vgl. LAV, NRW, Abt. Rheinland, Reichskammergericht, inv. nr. 743.

1013 RHCL, Rijkskamergerecht, inv. nr. 44, fol. 24.
} 
'Specificatie der qualiteyten, rechten ende gerechticheyden...der graeffschappe van Gronsfelt...' lijkt met dat doel te zijn opgemaakt. ${ }^{1014}$ Ook werden financiële gaten weer gestopt met andere, meer gunstige leningen. Zo werd de verpanding van de heerlijkheid Slenaken bij Johan Adolf van Imstenrade ingelost en in de jaren 1656-1658 vervangen door een lening van in totaal dertienduizend gulden bij de kloosters Hoogcruts en Sinnich. ${ }^{1015}$ De rente op dit bedrag werd voldaan uit de opbrengst van deze heerlijkheid.

Het is moeilijk een gedetailleerd overzicht te krijgen van alle schulden, maar de lijst met crediteuren moet heel lang zijn geweest. Dat was ook een belangrijke reden waarom na het overlijden van Jost Maximiliaan in 1662 zijn weduwe zo min mogelijk ruchtbaarheid aan de opvolging gaf, bang als zij was dat de schuldeisers direct zouden aankloppen. Het is te eenvoudig deze schulden alleen te zien als een gevolg van de oorlog. Er loopt door deze geschiedenis van verpandingen, verkopen en schuldbekentenissen toch een soort rode draad, van onverantwoord financieel handelen: te grote ambities, een ongelukkige hand van zaken doen en moeilijk kunnen berusten in eenmaal gesloten overeenkomsten. Dat het na zijn overlijden uiteindelijk niet op een bankroet is uitgedraaid, is vooral de verdienste geweest van zijn weduwe Anna Christina.

\subsubsection{Politieke en diplomatieke activiteiten}

$\mathrm{Na}$ zijn vrijlating uit Beierse gevangenschap in 1649 kwam er een definitief einde aan de militaire loopbaan van Jost Maximiliaan. Maar Gronsveld was te klein voor een man die het grootste deel van zijn leven door het Duitse Rijk had gezworven. Zijn belangstelling ging nu uit naar activiteiten op politiek en diplomatiek vlak. Op die manier raakte hij ook betrokken bij de oprichting van een eigen vertegenwoordiging van rijksgraven uit de Nederrijns-Westfaalse en de Nedersaksische Kreits in de Rijksdag.

Sedert de vijftiende eeuw probeerden kleine zelfstandige rijksonmiddellijke heren zoals graven en rijksridders in het zuidwestelijke deel van het Rijk door samenwerkingsverbanden hun landsheerlijk gezag te versterken. Uiteindelijk werd daarbij ook gestreefd naar politieke invloed door middel van stemrecht in de Rijksdag. Zo namen twee vertegenwoordigers van de vereniging van graven uit de Wetterau en het Westerwald deel aan de beraadslagingen van de vorstenraad in de Rijksdag van Worms in 1495. Bij de in 1511 gevormde Wetterauer Grafenverein sloten zich in 1512 ook enkele graven uit het gebied van de Nederrijn en de Eifel aan. Vanaf deze tijd werd de aanwezigheid van de Wetterauer graven in één gezamenlijke bank met één Kuriatstimme in de vorstenraad van de Rijksdag toegestaan. Persoonlijke aanwezigheid van een graaf was toegestaan (werd aanvankelijk zelfs verlangd), maar om de kosten te drukken werd later volstaan met een volmacht voor een (burgerlijke) gezant die ook voor verschillende lastgevers kon optreden.

Iets later dan de Wetterauer graven kregen in 1524 ook de Schwäbische rijksgraven een eigen bank met Kuriatstimme in de vorstenraad van de Rijksdag. De rijksgraven uit Franken

1014 Zie Bijlage 44.

1015 RHCL, Klooster Hoogcruts, inv. nr. 296 en RHCL, Graafschap Gronsveld, inv. nr. 457. 
kregen van keizer Rudolf II in 1595 het recht op een derde Kuriatstimme, maar zij werden pas in 1641 in de rijksvorstenraad opgenomen.

De Noord-Duitse en Westfaalse ('Nederlandse') graven hadden aanvankelijk veel minder behoefte zich op deze wijze te verenigen en politieke invloed uit te oefenen. Hun territoria lagen ver af van het kerngebied van het Rijk in Zuid-Duitsland en hun betrokkenheid bij de keizer was zwakker. In 1579 sloot een aantal van hen zich aan bij de graven van de Wetterau, zoals Oldenburg, Oostfriesland, Schaumburg, Lippe, Bentheim etc. ${ }^{1016}$ De samenwerking verliep moeizaam, niet in het minst omdat de graven uit Westfalen wel aan de besluitvorming deelnamen, maar niet in de kosten wilden bijdragen. In 1615 ontstond daarom het plan een eigen Kuriatstimme voor de Westfaalse graven in de vorstenraad toe te laten, maar door de Dertigjarige Oorlog werd dit voornemen op de lange baan geschoven. Bij de vredesonderhandelingen in Osnabrück in 1645 kwam wederom een afzonderlijke Kuriatstimme ter sprake, maar ook nu werden geen concrete resultaten bereikt. De manier van besluitvorming binnen de gravenbank bleef voor verdeeldheid zorgen. De graven uit de Wetterau hadden de gewoonte op gemeenschappelijke kosten één vertegenwoordiger naar de Rijksdag te sturen, terwijl de Westfaalse graven eigen vertegenwoordigers stuurden. Dat betekende dat bij hoofdelijke stemming de laatste groep de vertegenwoordiger van de Wetterau kon overstemmen, terwijl zij niet eens meebetaalden. Vervolgens besloten de graven uit de Wetterau dat alleen hun vertegenwoordiger, de graaf van Nassau-Saarbrücken, op de Rijksdag het stemrecht kon uitoefenen. Een aantal 'Westfaalse' graven, waaronder de graven van Gronsveld, Manderscheid-Blankenheim, Manderscheid-Gerolstein, Rekem, Salm-Reifferscheid en rijksvrijheer Metternich voor Winneberg en Beilstein, protesteerde tegen deze uitsluiting. Na de opening van de Rijksdag in Regensburg eind 1652 kwamen deze heren of hun vertegenwoordigers vanaf januari 1653 in afzonderlijke vergaderingen bij elkaar en eisten herstel van de oude toestand. In een diarium, een soort dagboek, waarschijnlijk van de hand van een secretaris van een graaf van Manderscheid, over de periode januari - medio oktober 1653, wordt van de onderhandelingen verslag gedaan. ${ }^{1017}$ Daaruit blijkt dat de kritiek zich in eerste instantie richtte tegen de aanspraken van de graaf van Nassau-Saarbrücken op het stemrecht. Maar ook onderling bestond onenigheid tussen de Westfaalse graven. Toen Nassau-Saarbrücken een keizerlijk bevel tot toelating van de Westfaalse graven naast zich neer legde, besloot de rijksvorstenraad in de Rijksdag de Wetterauer Kuriatstimme op te schorten, tot het bevel van de keizer was opgevolgd. De strijd was daarmee geenszins beëindigd, want de Wetterauers volhardden in het stemrecht van hun vertegenwoordiger en eisten ook betaling van de Westfalen.

Medio juli 1653 werd beraadslaagd over mogelijkheden de rijksgraven als eigen stand in de rijksdag toe te laten. Daarbij werd duidelijk dat de pijn niet alleen zat bij het stemrecht, maar dat het ging om stand en rang der graven in het algemeen. Zelfs de toelating van gravinnen als hofdame aan het keizerlijk hof was een punt van discussie. Gedacht werd aan een verbond van graven en de nog niet vertegenwoordigde rijksridders, met eventueel aansluiting bij de geestelijke prelaten in de rijksdag Uiteindelijk is het grotendeels bij plannen gebleven. Maar op 13 augustus 1653 stond keizer Ferdinand III de Westfaalse

1016 Kesting, 'Geschichte Reichsgrafenkollegiums', 176.

1017 ULB, Darmstadt, Hs. 2750 ('Sammlung Alfter'). fol. 1-28. 
graven een eigen bank met Kuriatstimme in de Rijksdag toe, overigens tegen betaling van 3500 rijksdaalders. Na de keizerlijke toelating accepteerde ook de rijksvorstenraad op 13 december 1653 de nieuwe Kuriatstimme voor de inmiddels dertig leden tellende groep. Officieel droeg deze de naam Nedersaksisch-Westfaals Rijksgravencollege, maar omdat de meeste graafschappen aan de Nederrijn en in Westfalen lagen, werd meestal gesproken over het Nederrijns-Westfaalse Rijksgravencollege en in de achttiende eeuw vaak alleen nog over het Westfaalse Rijksgravencollege.

De besprekingen van de graven of hun gezanten in 1653 vonden meestal plaats onder voorzitterschap van graaf Johan IV van Rietberg en Oostfriesland (regeerperiode 16401660). Daarnaast speelde ook Jost Maximiliaan een vooraanstaande rol. In eerder genoemd 'diarium' wordt hij vertegenwoordiger van de klagende graven genoemd. ${ }^{1018}$ Zo werden de graven van Rietberg en Gronsveld later ook beschouwd als de eerste directeuren van het Nederrijns-Westfaalse Gravencollege. Maar veel konden zij niet uitrichten, want na het einde van de Rijksdag op 17 mei 1654 vertrokken de gezanten weer huiswaarts. Hoewel de leden van het gravencollege beseften dat voor de uitoefening van het stemrecht een min of meer bestendige deputatie nodig was, lukte het niet overeenstemming te bereiken over de personele bezetting en financiering van een 'Direktorium'. Zo raakte de zaak op de lange baan en bestond na het overlijden van de graaf van Rietberg in 1660 en van Jost Maximiliaan in 1662 ook het voorlopig Direktorium niet meer. Bij de opening in 1663 van de zogenoemde Altijddurende Rijksdag was het gravencollege niet vertegenwoordigd. In de daarop volgende decennia eigenden de leden van de vorstenraad, die tevens in het bezit van een graafschap waren, zich de Kuriatstimme van het Nederrijns-Westfaalse Gravencollege toe. Pogingen in dit oneigenlijk gebruik van het stemrecht verandering te brengen mislukten. Pas in 1698 kwam een soort heroprichting van het college tot stand met de protestantse graaf Friedrich Adolf zur Lippe en de katholieke graaf Salentin Ernst von Manderscheid als nieuwe directeuren.

\subsubsection{Heer van Gronsveld}

Hiervoor werd al geconstateerd dat Jost Maximiliaan in de beeldvorming een belangrijke plaats in de Gronsveldse geschiedenis inneemt, maar dat zijn persoonlijke bemoeienis met de dagelijkse gang van zaken binnen het graafschap zeer beperkt was. Eigenlijk geldt dat ook al vanaf zijn jeugd. Na zijn inhuldiging op 1 november $1617 \mathrm{kwam}$ hij nog incidenteel in Gronsveld. Vanaf 1617 was Jost Maximiliaan betrokken bij de bouw van een nieuwe banmolen, waarop de inwoners van het graafschap hun graan moesten laten malen. Een ingemetselde gedenksteen uit 1622 herinnert aan de graaf als stichter ${ }^{1019}$, hoewel de eerste steenlegging op 18 juli 1617 nog door de rentmeester van de graaf tijdens de regering van

${ }^{1018 ` d e r ~ k l a g e n d e r ~[G r a f e n] ~ M a n d a t a r i u s ~ u n d ~ D i r e c t o r ', ~ U L B, ~ D a r m s t a d t, ~ H s . ~} 2750$ ('Sammlung Alfter'). fol. 15 , sub 1 maart.

1019 Marres/Van Agt, Monumenten Zuid-Limburg, 192. De tekst op de steen luidt: JOEST MAXIMILIAN GRAFF VON/ BRONCKHORST UND ZU GRONSFELT/ FREYHEER ZU BATTENBORGH UND/ RIMBURH HEER ZU ALPEN ET/ HUNNEPEL ME FIERI FECIT 1622. 
Johan II plaatsvond. ${ }^{1020}$ Bijna van steen tot steen is in de rentmeestersrekeningen uit de jaren 1617-1624 de bouw van deze windmolen langs de huidige Rijksweg, even ten noorden van Gronsveld, gedocumenteerd. Dit voor de omgeving beeldbepalende gebouw wordt nog altijd aangeduid als 'molen van Gronsveld', maar staat op oorspronkelijk Heugems territoir, thans gemeente Maastricht.

Even duurzaam als de stenen molen werd de op Sacramentsdag (30 mei) 1619 opgerichte 'broederlijcke schutterye' Sint Sebastianus in Gronsveld. Een vergelijkbare vereniging bestond al in Slenaken sinds 1614. Strikt genomen was Jost Maximiliaan niet de stichter van de schutterij, want het reglement zegt dat de vereniging werd opgericht 'mit consent van onsen genedigen heeren, heeren graeff Joest Maximiliaen'.1021 De graaf schoot wel als eerste de vogel af op tweede Pinksterdag en schonk een zilveren schuttenvogel. Een aantal bepalingen uit het reglement makt nog steeds deel uit van een gevestigde traditie, zoals het vogelschieten op Pinkstermaandag, het 'brengen' van de vogel door de koning in de door hem gekozen tapperij, de deelname aan de Sacramentsprocessie, de schuttenmis met jaardienst voor de overleden leden met het bezoek aan hun graven en het recht op het keizerschap voor degene die de vogel drie maal achter elkaar afschiet.

Naarmate Jost Maximiliaan intensiever bij de oorlog betrokken raakte en meer verantwoordelijkheden in het leger kreeg toebedeeld, verbleef hij minder in Gronsveld. Het feitelijk beheer van het graafschap werd vooral overgelaten aan de drossaard en/of rentmeester. In het bijzonder Christiaan Lamberts oefende de functie van drossaard zeer lang uit, van circa 1631 tot circa 1668/1669. Achteraf kunnen we constateren dat in de tijd van Jost Maximiliaan bestuur op verre afstand de gebruikelijke regeringsvorm voor het graafschap Gronsveld werd. Weliswaar verbleven zijn voorvaderen meestal in Rimburg of op bezittingen aan de Nederrijn, maar ze bezochten toch met een zekere regelmaat Gronsveld. Johan Frans, de opvolger van Jost Maximiliaan, zou evenals zijn vader het grootste deel van zijn leven buiten Gronsveld doorbrengen en slechts zelden in het graafschap komen. In de achttiende eeuw zijn de graven Toerring-Jettenbach (althans de mannelijke leden van de familie) zelfs nooit in Gronsveld geweest.

Terwijl Jost Maximiliaan buiten zijn graafschap zijn talenten in de oorlog beproefde, kreeg Gronsveld zijn eigen Tachtigjarige en Dertigjarige Oorlog. Vooral de Maasveldtocht door de Staatse troepen onder leiding van Frederik Hendrik in 1632, eindigend met de verovering van Maastricht, betekende het begin van een voortdurende oorlogstoestand in het Maasgebied. De Nederlandse Tachtigjarige en de Duitse Dertigjarige Oorlog lopen hier door elkaar. Er zijn over deze periode naar verhouding weinig bronnen die direct betrekking hebben op de gebeurtenissen in Gronsveld. Maar een 'Memorie' over de oorlogslasten die het graafschap gedurende de periode 1632-1657 moest opbrengen, laat zich lezen als een kroniek van de oorlogsellende, met voor bijna ieder jaar vermeldingen

1020 RHCL, Graafschap Gronsveld, inv. nr. 181, rekening 1617/1618.

${ }^{1021}$ Dat de tekst van het reglement van de schutterij bewaard is gebleven, danken we aan een proces dat in 1666 voor de schepenbank van Eijsden werd angespannen door Willem en Hendrik Blonden uit Ryckholt tegen Jan Pluegmakers, Claes Berchmans en Jan Berchmans als leden van de overheid van de schutterij, zie RHCL, Landen van Overmaze, inv. nr. 5273. 
van gedwongen leveranties, inkwartieringen en plunderingen. ${ }^{1022}$ Dat beeld wordt ook bevestigd in de rekeningen van de schepenbank Slenaken. ${ }^{1023}$ Er moest worden betaald ten behoeve van keizerlijke, Lotharingse, Hessische, Franse, Zweedse, Staatse en Spaanse troepen. Bescherming tegen overlast kon worden gekocht door schriftelijke of levende 'sauvegardes'. In het laatste geval werd tegen kost en inwoning een detachement soldaten ingekwartierd, meestal in het kasteel.

In 1643 bezette een zeventigtal soldaten onder aanvoering van een zekere ritmeester Cauwenberch in Hessische dienst het kasteel van Gronsveld. De soldaten plunderden de inboedel en het archief van het kasteel en roofden bij de boeren in de hele streek tot aan Luik en Aken. Ook de kerk van Gronsveld werd geplunderd (een jaar eerder was dat ook al gebeurd). Daarbij werd niet alleen het gebouw beschadigd, ook een deel van het huisraad van de Gronsveldenaren ging verloren, omdat zij dachten in het kerkgebouw een veilige opslagplaats voor hun bezittingen te hebben gevonden. Om aan deze overlast een einde te maken, begonnen twee detachementen soldaten uit Luik en Aken op 14 juli aan een belegering van het kasteel. Op 16 juli volgde de inname en werden de bezetters over de kling gejaagd. Cauwenberch eindigde zijn leven door ophanging aan een raam. $\mathrm{Na}$ afloop van de slachting werden brieven gevonden waaruit bleek dat Cauwenberch in verbinding stond met de Grignoux, de oppositie in Luik tegen het bewind van prinsbisschop Ferdinand van Beieren. ${ }^{1024}$

De jaren veertig waren erg onveilig voor Gronsveld en omgeving en Jost Maximiliaan verbleef met zijn jonge gezin in de Gronsvelder Hof in Keulen, voor zover hij niet in krijgsdienst onderweg was. In die stad werden ook de kinderen geboren. Na de Vrede van Westfalen in 1648 veranderde er voor Gronsveld niet zoveel. De 'Memorie' van oorlogslasten vermeldt nog tot 1657 voor ieder jaar oorlogscontributies aan Staatse en vooral Lotharingse troepen. Lotharingers plunderden ook in 1653 nog een keer de kerk. Pas vanaf omstreeks 1657 lijkt de graaf zich min of meer permanent in Gronsveld te hebben gevestigd, voor zover hij niet voor diplomatieke reizen onderweg was. Mogelijk uit het midden van de jaren vijftig stamt een ongedateerde notitie van Jost Maximiliaan, waaruit blijkt dat hij boordevol plannen stak voor Gronsveld en Slenaken: de bouw van grote stallingen voor allerhande vee, de bouw van een zogenoemde 'rosmolen' bij de windmolen, de aanleg van een wijngaard met de bouw van een woning voor de wijngaardenier, mogelijke aankoop van een groot stuk gemeentegrond of ruiling tegen andere landerijen, een overeenkomst met de onderdanen over gezamenlijke beplanting van de gemeentegrond met fruitbomen, verplaatsing van de molen in Slenaken en exploitatie daarvan in eigen beheer alsmede bouw van een oliemolen aldaar. Daarna stonden de bouw

1022 TJ, inv. nr. M 33, fol. 1-21.

1023 Zie bijv. RHCL, Graafschap Gronsveld, inv. nrs. 519-535 en dubbelen daarvan in RHCl, Klooster Hoogcruts, inv. nr. 719.

1024 Zie over de bezetting door van het kasteel door Cauwenberch: Chestret de Haneffe, 'Histoire Gronsveld', 9-11. Chestret de Haneffe geeft al aan dat de in de kronieken genoemde aantallen van belegeraars schromelijk overdreven waren. De gebeurtenissen worden ook vermeld in de eerder genoemde 'memorie' van de oorlogslasten 1632-1657. 
van een pastorie en een wijnhuis op het programma, alsmede een boerderij in Heugem. Ten slotte wilde de graaf ook de Broekhof in Slenaken zelf gaan exploiteren. ${ }^{1025}$

Van al deze voornemens zijn enkele zaken ook gerealiseerd, zoals de aanleg van een wijngaard en de herbouw van een watermolen in Slenaken, van andere plannen is uiteindelijk niet veel terecht gekomen. ${ }^{1026}$ Er speelden na 1657 andere prioriteiten. Zo bemoeide Jost Maximiliaan zich tamelijk intensief met problemen over enkele grote Gronsveldse lenen die lagen in de in 1639 verkochte heerlijkheid Oost. Dat leidde weer tot spanningen met de schepenstoel van Aken als instantie voor hoger beroep in de rechtspraak. Een ander periodiek optredend probleem vormden de bijdragen van de Maastrichtse geërfden aan de rijks- en kreitsbelastingen wegens hun Gronsvelds grondbezit. Jost Maximiliaan voerde daarover vanaf 1657 moeizame onderhandelingen, die in 1660 tot een akkoord leidden.

\subsection{De erven van Jost Maximiliaan van Bronckhorst Batenburg, 1662-1677}

Jost Maximiliaan overleed op 24 september 1662. Of dit in Gronsveld was of elders, is niet duidelijk. Het stoffelijk overschot werd te Gronsveld in de grafkelder onder het priesterkoor van de Sint-Martinuskerk bijgezet. ${ }^{1027} \mathrm{Na}$ het overlijden van Jost Maximiliaan stond zijn weduwe Anna Christina von Hardenrath voor een zware opgave. De oudste zoon, Otto Wilhelm, was bezig met academische studies. Hij stond in 1657 ingeschreven bij de universiteit van Mainz en wisselde die plaats in 1660 voor een studie rechten in Leuven. Op 27 augustus 1662, vlak voor het overlijden van zijn vader, trad hij toe tot de orde van de jezuïeten in Wenen. ${ }^{1028}$ De keuze voor Wenen zal mede zijn bepaald door de relaties van Jost Maximiliaan met het keizerlijk hof. De overige zes kinderen waren nog minderjarig. Tot (toeziend) voogd over de kinderen werd benoemd Johan Philip von Schönborn, aartsbisschop en keurvorst van Mainz, maar voor de feitelijke opvoeding van haar kinderen zorgde Anna Christina zelf. Het is niet bekend of haar positie als weduwe was geregeld in een eerder contract van huwelijkse voorwaarden of een testament van Jost Maximiliaan, maar het lijkt, gelet op de gebruiken in adellijke kring, niet onwaarschijnlijk dat een voorziening is getroffen. Jost Maximiliaan had haar in 1658 het tijdelijk bezit van de heerlijkheid Slenaken overgedragen. ${ }^{1029}$ Bovendien moet zij ook over geërfd vermogen van haar ouders hebben beschikt. ${ }^{1030}$ Maar dit laat onverlet dat de nalatenschap van Jost Maximiliaan vooral bestond uit schulden en lopende processen.

1025 TJ, inv. nr. M 1, fol. 47-48.

1026 RHCL, Klooster Hoogcruts, inv. nr. 1003. De financiering gebeurde door een soort inzameling onder de inwoners, in ruil waarvoor de graaf belastingen aan het Rijk betaalde.

1027 Voor het nog in de kerk aanwezige rouwbord zie Jaspars, 'Rouwborden als bidprentje'.

1028 Data ontleend aan Gatz/Janker, Die Bischöfe, 49-50, onder lemma 'Bronckhorst zu Gronsfeld, Otto Wilhelm Reichsgraf von (1640-1713)' door M.F. Feldkamp.

${ }^{1029}$ RHCL, Graafschap Gronsveld, inv. nr. 453.

1030 Over dat bezit ontbreken nadere bijzonderheden, maar er wordt naar verwezen in het testament van Clara Sibilla van Bronckhorst, weduwe De Ligneville, van 1 juni 1723, RHCL, Rijkskamergerecht, inv. nr. 27, fol. 163vo.-164. Daarin kriigen haar executeurs-testamentair opdracht zo spoedig mogelijk een einde te maken aan de processen over goederen in Westfalen, afkomstig uit de nalatenschap van haar moeder, 
In belangrijke mate moet Anna Christina voor de behartiging van haar belangen hebben gesteund op haar raadsman Wilhelm Veucht. ${ }^{1031}$ Deze jonge jurist had Jost Maximiliaan al vanaf 1660 regelmatig bijgestaan bij diens diplomatieke werk en de afhandeling van juridische zaken. Veucht ontpopte zich nu tot steun en toeverlaat van Anna Christina. Al in oktober 1662 was hij met haar op reis naar Eberstein om daar zaken te regelen. Ook vertegenwoordigde hij de gravin op de kreitsdag van $1667 .{ }^{1032}$

Of Anna Christina na het overlijden van Jost Maximiliaan ook als landsvrouwe werd ingehuldigd, is niet bekend. In documenten uit die tijd presenteert zij zich nadrukkelijk als voogdes en regentes. Zo werd de volmacht voor Veucht om deel te nemen aan de kreitsdag van 1667 uitgeschreven in vormündtschaffts nahmen unsers freundlich vielgeliebten herrn sohns Johan Franzens...'1033 Het landrecht voor Gronsveld uit 1671 (waarover meer uitvoerig Hoofdstuk 7.4.3 en Bijlagen 7A-B) staat op haar naam als 'vormundt[erin] und regentin'.

Naarmate de kinderen ouder werden, moesten voorzieningen worden getroffen voor hun toekomstige levensonderhoud. Otto Willem was na zijn noviciaat in Wenen eerst professor aan het jezuïetengymnasium aldaar en vanaf 1667 in Passau. Tussen 1667 en 1672 studeerde hij theologie, eerst in Graz en vervolgens in Rome, waar hij tot priester werd gewijd. ${ }^{1034}$

De tweede zoon, Johan Frans, koos evenals zijn vader, voor een militaire loopbaan. Hij trad in 1664 in Spaanse dienst en was in 1667 kapitein bij de cavalerie. Wilhelm Veucht probeerde al eens - tevergeefs - te bemiddelen voor een functie van Johan Frans als 'craysobrist', een hoge officiersplaats bij de troepen van de Nederrijns-Westfaalse Kreits. ${ }^{1035}$ Voor de jongere Ernst Maximiliaan keek Veucht naar een prebende in een kapittel, maar daarvoor stonden de kansen slecht zonder voldoende kapitaal. ${ }^{1036}$

De militaire loopbaan van Johan Frans, maar ook eventuele huwelijken van de dochters kostten geld. Zij zouden immers van een bruidsschat moeten worden voorzien. Verder moesten er voorzieningen komen voor de twee jongste zonen. De behoefte aan contanten voor de opgroeiende kinderen leverde spanningen op, niet in het minst omdat uiterste spaarzaamheid was geboden. Zo opende Johan Frans in 1672 buiten medeweten van zijn moeder onderhandelingen met de markgraaf van Baden over verkoop van het Gronsveldse aandeel in het graafschap Eberstein. Zijn motieven waren duidelijk behoefte

meer in het bijzonder 'contre l'acheteur du bien de Haan, que contre le baron de Plettenberg comme aussi de faire decider le proces contre le baron de Raesfelt Ostendorf.. Zie ook RHCL, Graafschap Gronsveld, inv. nr. 75: ongedateerde staat van proceskosten tussen Anna van Justina van Bronckhorst en de heer Von Raesfeldt Ostendorf.

1031 Weinberg, 'Wilhelm Veucht', 83 e.v.

1032 Weinberg, 'Wilhelm Veucht', 90.

1033 RHCL, Klooster Hoogcruts, inv. nr. 1001.

1034 Data ontleend aan Gatz/Janker, Die Bischöfe, 49-50, onder lemma 'Bronckhorst zu Gronsfeld, Otto Wilhelm Reichsgraf von (1640-1713)' door M.F. Feldkamp.

1035 Weinberg, Wilhelm Veucht, 90.

1036 Weinberg, Wilhelm Veucht, 90. 
aan geld en snelle carrière in het leger. ${ }^{1037}$ Zodra deze plannen uitlekten, maakte gravin Anna Christina duidelijk dat zonder haar inwilliging geen geldige overeenkomst tot stand kon komen. Om dat standpunt kracht bij te zetten werd ook de aartsbisschop van Mainz als voogd van de kinderen ingeschakeld.

Uiteindelijk leidde dit op 10 februari 1673 tot twee overeenkomsten die in Aken werden gesloten. In het eerste document verklaarde gravin Anna Christina dat zij haar zoon Johan Frans de 'gräffliche regirung überlassen undt cedirt' had, echter onder de verplichting 'den statum des gantzen gräfflichen hauses exacte zu examiniren'. ${ }^{1038}$ Daartoe zou het verstrooid geraakte familiearchief moeten worden onderzocht op papieren die een licht wierpen op 'vatter- undt altvatterliche vertheilung undt magscheid'. Natuurlijk waren dergelijk naspeuringen nuttig om alle schulden in kaart te brengen, maar kennelijk werd ook rekening gehouden met mogelijke aanspraken wegens vroegere delingen. Op zich was die gedachte niet zo vreemd, want er waren diverse familiecontracten uit het verleden met een soort open einde. Ten tweede verplichtte Johan Frans zich te zorgen voor het onderhoud van zijn jongere broers Ernst Maximiliaan en Johan Philips tot hun meerderjarigheid. Ten slotte mochten de al in dienst zijnde adviseurs en ambtenaren van de grafelijke regering alleen met toestemming van de voogden worden vervangen.

In een tweede akte werden de bepalingen van deze overdracht verder uitgewerkt. ${ }^{1039}$ Volgens de overwegingen daarbij viel een financiële ondergang van het aloude grafelijke huis van Gronsveld alleen nog maar af te wenden door verkoop van het graafschap Eberstein. Dat gebeurde niet alleen ten behoeve van schuldeisers, maar er moest ook in de dotatie van de inmiddels meerderjarige dochters worden voorzien. Gelet op de moeilijke financiële situatie nam Anna Justina genoegen met een bedrag van tweeduizend rijksdaalders en kregen Clara Sibilla en Maria Anna ieder vierduizend rijksdaalders. Daarvoor deden zij afstand van al hun aanspraken op het graafschap Gronsveld. Het verschil in uitkering werd billijk gevonden omdat Anna Justina uit een andere erfenis inmiddels ook een aanzienlijk legaat had ontvangen. ${ }^{1040}$ De dames waren bereid dit bedrag tegen een rente van vijf percent te beleggen in het graafschap Gronsveld, zodat daarmee vreemd kapitaal kon worden afgelost. Mocht het graafschap in de toekomst schuldenvrij worden, dan zouden de zusters daar ook profijt van hebben.

1037 Weinberg, Wilhelm Veucht, 93-94.

1038 Zie hierover Weinberg, 'Wilhelm Veucht', 93-94 en 112, noot 55. In tegenstelling tot de verwijzing naar archief Vrije Rijksheerlijkheid Wittem bij Weinberg in noot 55 moet de vindplaats worden gecorrigeerd in Generallandesarchiv Karlsruhe, Bestand 144 Amt Gernsbach inv. nr. 566 (vriendelijke mededeling H. Weinberg).

1039 Zie hierover Weinberg, 'Wilhelm Veucht', 93-94. De akte is ook in druk uitgegeven in een brochure behorend bij een proces van Clara Sibilla van Bronckhorst Batenburg tegen de weduwe van Johan Frans van Bronckhorst Batenburg, RHCL, Rijkskamergerecht, inv. nr. 27, fol. 75-86. Een afschrift hiervan bevindt zich in RHCL, Vrije Rijksheerlijkheid Wittem, voorl. nr. 286. Zie ook Weinberg, 'Wilhelm Veucht', 93-94.

1040 Waarschijnlijk ging het hier om een legaat van haar tante Felicitas van Bronckhorst Batenburg, de zuster van Jost Maximiliaan. Op 17 maart 1673 verklaarde Johan Frans dat hij met zijn zuster Anna Justina tot een vergelijk is gekomen over de verdeling van gelden afkomstig uit de nalatenschap van hun tante Felicitas van Bronckhorst Batenburg (RHCL, Graafschap Gronsveld, inv. nr. 73). 
$\mathrm{Na}$ de uitbetalingen aan zijn zusters, verplichtte Johan Frans zich te betalen voor zijn twee jongere broers 'zu continuation der angefangenen studien'. Aan het einde van het contract lijkt gravin Anna Christina zich voor haar kinderen weg te cijferen. Want hoewel uitdrukkelijk wordt gezegd dat de overeenkomst was bedoeld om haar een leven 'nach gräflichen stands gebühr' mogelijk te maken, verklaarde zij vanwege de slechte financiële situatie tevreden te zijn met vierhonderd rijksdaalders. Verder kreeg zij jaarlijks levenslang 150 vat haver, drie wagens hooi, twee wagens stro en het nodige brandhout.

De overeenkomsten lijken helder, maar roepen toch enkele vragen op. Zo is onduidelijk of het contract ook betrekking had op de heerlijkheid Slenaken, die Jost Maximiliaan in 1658 had overgedragen aan zijn echtgenote Anna Christina. Want in juli 1675 wordt nog steeds voor de schepenbank van Slenaken op verzoek van 'haere excellentie ons genedige vrouwe gravinne' geprocedeerd tegen een zekere Peter Steens ${ }^{1041}$ Ook liet om onduidelijke redenen de gerechtelijke inschrijving van de overeenkomsten uit 1673 geruime tijd op zich wachten. Pas op 12 april 1676 verleende Johan Frans zijn drie zusters het recht van hypotheek op het graafschap. Die akte werd vervolgens op 16 oktober 1677 ten overstaan van schepenen van Gronsveld 'gerealiseerd', dat wil zeggen ingeschreven in de registers van de schepenbank. ${ }^{1042}$ In het geval van achterstallige betaling konden zij hun vordering op het graafschap verhalen. Wel behield Johan Frans het recht om te allen tijde de schulden te mogen aflossen. Voorts schijnt Johan Frans pas op 25 maart 1677 te zijn ingehuldigd, echter met zo min mogelijk ruchtbaarheid om geen schuldeisers te alarmeren.

$\mathrm{Na}$ de boedelscheiding gingen de verschillende familieleden ieder huns weegs. In 1677 trouwde Johan Frans met Eleonore Philipine von Fürstenberg-Heiligenberg. Het was een verbintenis die een heel netwerk van invloedrijke relaties met zich meebracht. Niet onmogelijk is dat Veucht bij de totstandkoming van dit huwelijk een bemiddelende rol heeft gespeeld. ${ }^{1043}$

Vóór het huwelijk met Eleonore Philipine was een buitenechtelijke dochter van Johan Frans geboren. Plaats van geboorte en naam van de moeder zijn niet bekend, maar het kind werd later Magdalena Herten of Harten genoemd. Op 10 december 1696 werd ten overstaan van notaris Veugen te Maastricht door drossaard Kicken van Gronsveld, daartoe gemachtigd door de graaf, samen met Magdalena een contract met de zusters annunciaten te Maastricht-Wyck gesloten over haar intrede in het klooster. In totaal werd daarvoor duizend gulden betaald, alsmede een rente van 150 gulden per jaar. Voorts zag de graaf af van aanspraken die hij kon maken op twee percelen land van de annunciaten, gelegen in Gronsveld, omdat daarvoor in het verleden bepaalde belastingen niet waren betaald. ${ }^{1044}$ In zijn testament uit 1706 vermaakte Johan Frans haar nog een rente van

${ }^{1041}$ RHCL, Graafschap Gronsveld, inv. nr. 586, sub juli 1676.

1042 Zie tekst daarvan in gedrukte memorie in RHCL, Rijkskamergerecht, inv. nr. 27, fol. 85vo.

1043 Weinberg, 'Wilhelm Veucht', 96-98.

1044 TJ, inv. nr. M 15, fol. 629-631. 
vijftig Rijnse guldens per jaar. Opvallend is de buitengewoon goede relatie die de drie zusters van Johan Frans later blijken te hebben met Magdalena. ${ }^{1045}$

Twee zusters van Johan Frans zijn getrouwd: Anna Justina met de baron Ferdinand Louis van Eynatten, heer van Thys (1636-1696) en Clara Sibilla met graaf Henri Philippe de Ligneville. Beide huwelijken bleven kinderloos. De jongste dochter, Maria Anna, bleef ongehuwd. Over haar verblijf in de jaren tachtig en negentig van de zeventiende eeuw is niets bekend. Mogelijk was zij bij haar moeder Anna Christina, die op 29 januari 1692 te Keulen overleed. ${ }^{1046}$

Van de studie van de twee jongste broers, waarover in 1673 wordt gesproken, kwam niet zoveel terecht, want beiden kozen voor het leger. Johan Philips sneuvelde in 1678 op twintigjarige leeftijd bij het beleg van Freiburg im Breisgau, terwijl Ernest Maximiliaan in 1690 de dood vond in Bosnië in de strijd tegen de Turken.

Merkwaardig genoeg ontbreekt Otto Willem, de oudste broer van Johan Frans, in de akten uit 1673. Na zijn priesterwijding werkte hij als professor in de ethiek, logica en fysica in Graz. In 1676 werd hij naar Passau overgeplaatst, maar verliet vervolgens de jezuïetenorde op 7 november 1676 vanwege de juridische problemen waarin zijn moeder verwikkeld was. Als wereldgeestelijke moet hij daarna een prebende hebben verworven aan het kapittel van Sankt Johann in Osnabrück. Hij keerde vervolgens terug naar Passau en promoveerde daar in 1679 tot doctor in de theologie en de beide rechten. Daarmee bezat hij de kwalificaties voor hoge geestelijke ambten, die hij uiteindelijk ook zou verwerven. ${ }^{1047}$ Zoals hierna nog aan de orde komt, speelde hij in de jaren tachtig en negentig ook nog een rol bij het bestuur van het graafschap Gronsveld.

\subsection{Johan Frans van Bronckhorst Batenburg, 1677-1719}

\subsubsection{Militaire loopbaan}

$\mathrm{Na}$ zijn huwelijk moet graaf Johan Frans hebben gezocht naar mogelijkheden om in het leger carrière te maken. Tijdens de kreitsdag van de Nederrijns-Westfaalse Kreits te Duisburg van 1681 pleitte Veucht tevergeefs voor een post bij de aanstaande 'werbung und austheilung der Crais-chargen'. Er was Johan Frans al een keer eerder een op te richten 'Schwäbisches Regiment' beloofd, maar dat plan was geschrapt. ${ }^{1048}$ Daarna moet Johan Frans zijn heil in Wenen hebben gezocht en lijkt hij bij het keizerlijk hof snel een voet tussen de deur te hebben gekregen. Zo deed de keizerin op 18 mei 1682 bij de

1045 Dit blijkt bijvoorbeeld uit betalingen die rentmeester Willem Kicken gedurende de eerste twintig jaar van de achttiende eeuw aan haar doet. Zie TJ, inv. nr. M 64, diverse rentmeestersrekeningen.

1046 Genealogische gegevens ontleend an Hanssen, Die Rimburg, 182 en de stamboom in de gedrukte memorie behorend bij het proces tussen Clara Sibilla van Bronckhorst Batenburg en Maria Anna von Toerring-Jettenbach, RHCL, Rijkskamergerecht, inv. nr. 27, fol. 75vo. Het testament van Anna Christina von Hardenrath bevond zich in het Historisches Archiv van Keulen, maar is thans niet beschikbaar.

1047 Data ontleend aan Gatz/Janker, Die Bischöfe, 49-50, onder lemma 'Bronckhorst zu Gronsfeld, Otto Wilhelm Reichsgraf von (1640-1713)' door M.F. Feldkamp. Volgens Knod, 'Rheinländische Studenten', 167 zou hij in november 1677 zijn ingeschreven bij de universiteit van Padua en was hij in 1678 'prosyndicus' van de universiteit van Keulen.

1048 Weinberg, 'Wilhelm Veucht', 98. 
markies van Savona, gouverneur-generaal van de Zuidelijke Nederlanden, een persoonlijke anbeveling om graaf Johan Frans alle mogelijke hulp en protectie te verlenen.1049 Mogelijk had dit betrekking op de slepende problemen rond de verkoop van Rimburg, waarover bij de Raad van Brabant in Brussel een proces aanhangig was. In 1683 tooit Johan Frans zich met de titel van 'Camerheer van sijne Keijserlycke Mayesteit'. 1050

In hetzelfde jaar werd zijn inzet voor het leger dringend noodzakelijk. In het voorjaar van 1683 trok een Turks leger van sultan Mehmed IV onder het bevel van grootvizier Kara Mustafa Pasha op vanuit de Balkan richting Wenen. Op 14 juli van dat jaar sloegen de Turken het beleg voor de stad, maar op 11 en 12 september werden zij door een gecombineerd leger van de keizer en zijn bondgenoten met troepen van de Poolse koning Jan III Sobieski verslagen. De Turken trokken zich vervolgens terug naar Hongarije, waarna de Heilige Liga, een verbond tussen Polen, Het Heilige Roomse Rijk, Venetië, Toscane, Rusland en Malta, gesloten in maart 1684, de Grote Turkse Oorlog voortzette tot aan de Vrede van Karlowitz in januari 1699.

Graaf Johan Frans bevond zich begin 1683 in het keizerlijk leger. Voor zijn echtgenote Eleonore Philipine had hij 'vertreckende tegens den Turck' een schriftelijke volmacht achtergelaten om de zaken in het graafschap te regelen. Met dat document verscheen de gravin op 3 november 1683 voor de schepenen van Slenaken en verklaarde 'haer gemael oock in corten daegen te volgen'. ${ }^{1051} \mathrm{Zij}$ gaf daarom algemene volmacht aan haar schout Willem Kicken om in haar afwezigheid alles te doen wat in haar belang kon zijn. Verder werd gerechtelijk vastgelegd dat Johan Frans zijn echtgenote het bezit van de heerlijkheid Slenaken toekende wanneer hij onverhoopt niet uit de strijd terugkeerde.

Maar in tegenstelling tot zijn twee broers en zwager overleefde Johan Frans de oorlog. In 1684 was hij 'Obristen von ein Regimernt zu Pferdt'. ${ }^{1052}$ Waarschijnlijk was dit het (uiteindelijk toch gekregen) 'Schwäbisches Katholisches Kreis-Regiment zu Pferd'. Vanaf 1686-1691 nam hij daarmee deel aan veldslagen tegen de Turken. ${ }^{1053} \mathrm{Zijn}$ verrichtingen in de oorlog leidden ook tot bevorderingen. Hij werd in 1688 keizerlijk Generalfeldwachtmeister

${ }^{1049}$ RHCL, Graafschap Gronsveld, inv. nr. 460.

1050 RHCL, Graafschap Gronsveld, inv. nr. 118, benoeming van Jan Potmans tot koster van Heugem 14 april 1683. In november 1684 (ondertekening van het akkoord ter beëindiging van de geschillen met het klooster Hoogcruts) wordt hij genoemd ‘dero Römischer Kaijserlichen Mayestät Cammerherr', vgl. RHCL, Klooster Hoogcruts, inv. nr. 519.

1051 RHCL, Graafschap Gronsveld, inv. nr. 462.

1052 RHCL, Klooster Hoogcruts, inv. nr. 519.

1053 Gegevens ontleend aan website www. hzk-sig.de/ van 'Hohenzollern-Kürassiere Sigmaringen e. V'. Deze vereniging zet de tradities voort van de sinds 1664 bekende 'Kreisreiterei' van de Schwäbische Kreis. Sinds 1672 droeg dit de naam 'Katholisches Kreis-Regiment zu Pferd'. Onder bevel van graaf Johan Frans van Gronsveld (in de website abusievelijk Joseph Franz genoemd), nam dit 'Kreis-Kürassier Regiment (katholisch)' deel aan de oorlogen tegen de Turken: 14 augustus 1686 Slag bij Ofen (als Buda tegenwoordig deel van Boedapest); 12 augustus 1687 slag bij de berg Harsany (Mohacs); 11 augustus 1688 tot 9 september 1688 belegering en inname van Belgrado onder veldheer prins Eugenius van Savoye); 19. augustus 1691 slag bij Szlankament, in het leger van Markgraaf Wilhelm Ludwig von Baden ('Türkenlouis'). 
en in 1689 Generalwachtmeister in het leger van de Schwäbische Kreis. ${ }^{1054}$ Maar de graaf wilde hogerop. Het daarvoor benodigde geld verwierf hij als volgt. Op 2 mei 1691 tekende hij te Wenen een contract waarbij hij zijn zogenoemde 'Niederländische lehncammer' met goederen in het hertogdom Kleef, in de omgeving van Rheinberg en Moers, overdroeg aan Carl Dietrich Otto Fürst zu Salm, heer van Anholt. ${ }^{1055}$ In de eerste plaats draaide die transactie om geld, maar er lagen ook diepere motieven aan ten grondslag, zoals hierna nog aan de orde komt. Johan Frans bedong een levenslang recht op alle inkomsten uit dit leenhof, alsmede een jaarlijks bedrag van vijfhonderd rijksdaalders. Met het oog op de naderende 'conferierung deren hohen kriegs chargen' moest de Fürst verder beloven zijn invloed bij de keizer aan te wenden voor een 'avancement' in keizerlijke dienst, in het bijzonder een 'General Veldt Marschals Lieutenant Stelle'. Verder wilde de graaf dat hem bij eerste gelegenheid een vrijgekomen regiment werd toegekend. Het plan lukte en Johan Frans werd in 1692 benoemd tot veldmaarschalk-luitenant. In 1696 voert hij als titel 'Roomschen Keijserlijcken Maijesteit Generael Velt Marchal ende overste van een regiment courasiers'. ${ }^{1056}$

Over het verdere verloop van zijn militaire loopbaan is tot nu toe niet veel meer bekend dan wat Flament daarover al schreef in het Nieuw Nederlandsch Biografisch Woordenboek en dat is weer grotendeels gebaseerd op vermeldingen in verschillende delen van het Theatrum Europaeum. ${ }^{1057}$ Zo nam de graaf van Gronsveld op 11 september 1697 als veldmaarschalk-luitenant deel aan de slag bij Senta aan de Tisza, waar een Oostenrijks leger onder bevel van prins Eugenius van Savoye de Turken een zware nederlaag toebracht. Johan Frans werd daarna in rang bevorderd tot generaal der cavalerie. $^{1058}$

Nog maart kort na de vrede van Karlowitz in 1699 veroorzaakte de in 1702 uitgebroken Spaanse Successieoorlog een nieuw conflict tussen de Europese machten. Hierin kwam de Franse koning Lodewijk XIV met als bondgenoot Spanje te staan tegenover een alliantie van de Oostenrijkse Habsburgers, de Republiek en Engeland. Het Heilige Roomse Rijk bleef neutraal, maar beide partijen vonden steun onder de Duitse rijksvorsten. Keurvorst Maximiliaan II Emanuel van Beieren, in de Turkse Oorlog de trouwe bondgenoot van Oostenrijk, koos uit onvrede over het uitblijven van een beloning voor die steun, de kant van Frankrijk, terwijl Frederik I, koning in Pruissen, zich aansloot bij de geallieerden. Door de Beierse keuze voor Frankrijk, werd Zuid-Duitsland een belangrijk strijdtoneel. In de slag bij Blenheim of Höchstädt (ten zuidwesten van Donauwörth) op 13 augustus 1704 brachten de geallieerden onder aanvoering van de hertog van Marlborough en prins Eugenius van Savoye het gecombineerde Franse en Beierse leger een zware nederlaag toe.

1054 Weblink Antonio Schmidt-Brentano: Kaiserliche und k.k. Generäle (1618-1815, Österreichisches Staatsarchiv, Abteilung Kriegsarchiv, sub Gronsfeld, Johann Franz v., Bronckhorst, geraadpleegd 1-102014.

1055 TJ, inv. nr. M 77, fol. 648-660.

1056 TJ, inv. nr. M 15, fol. 629.

${ }^{1057}$ Flament, 'Jan Frans van Bronckhorst'.

1058 Theatri Europaei continuati Funffzehender Theil, 118, 123. 
Keurvorst Maximiliaan II vluchtte naar de Zuidelijke Nederlanden en Beieren kwam onder Oostenrijks militair bestuur.

In de 'annalen'1059 van de Spaanse Successieoorlog in Zuid-Duitsland komt graaf Johan Frans meermalen voor. Zo werd hij eind december 1703 naar Passau gestuurd om deze voor Oostenrijk strategisch belangrijke stad te verdedigen tegen een mogelijk bezetting van Beieren. ${ }^{1060}$ Door verschillen in strategisch inzicht tussen de prins-bisschop van Passau, kardinaal Johan Philip graaf von Lamberg, het keizerlijk hof in Wenen en Johan Frans viel de stad begin 1704 in Beierse handen. De schuldvraag van dit debacle leidde tot een diplomatiek incident op hoog niveau. Teruggekeerd in Wenen verbreidde graaf Johan Frans het verhaal dat de val van Passau een gevolg was van geheime afspraken tussen von Lamberg en de Beierse keurvorst. De van ontrouw betichte prins-bisschop liet een memorandum over de gebeurtenissen in Passau opstellen en zond dit naar de Rijksdag in Regensburg. Daarin beklaagde hij zich over het feit dat een 'subaltern' keizerlijk generaal ongestraft de reputatie van een rijksvorst als de bisschop van Passau te grabbel kon gooien. Op 23 februari 1704 verzocht de Rijksdag inderdaad bij de keizer om genoegdoening. Die kwam er ook op 23 mei 1704 met een antwoord waarin kool en geit werden gespaard. Aan het hof werd aangestuurd op een verzoening. De goede naam en eer van de prins-bisschop waren boven alle twijfel verheven, maar ook de graaf van Gronsveld viel niets te verwijten.

Het voorval heeft de verdere loopbaan van Johan Frans niet geschaad. Begin augustus 1704 werd hij benoemd tot generaal-veldmaarschalk in keizerlijke dienst. ${ }^{1061}$ Of hij vervolgens ook betrokken was bij de slag bij Blenheim op 13 augustus 1704 is niet bekend. In het jaar daarop verscheen hij op 15 mei met een leger van achtduizend man voor de poorten van München en de dag erna capituleerde de stad. Lang verbleef Johan Frans niet in München. Na klachten van de Keizerlijke Administratie voor Beieren werd hij op 6 juni 1705 door keizer Joseph I als militair bevelhebber van de stad ontslagen.

In de daarop volgende jaren was Johan Frans meestentijds in het Rijnland gestationeerd, maar over zijn activiteiten is weinig bekend. Op 14 mei 1706, toen hij in Frankfurt zijn testament maakte, noemt hij zich keizerlijk 'wurcklicher cammerer, general feldmarchall und obrister über ein regiment Curassierer'. In 1710 volgt achter zijn naam de aanduiding 'conseiller intime et chambellan de sa Majesté Imperiale, president du conseil de guerre en Autriche, general feldtmareschal, commandant les armées de sa dite Majesté sur le Haut Rhin et colonel d'un regiment des cuirassiers'. ${ }^{1062} \mathrm{Hij}$ probeerde daar als bevelhebber bij

1059 Gedoeld wordt hier op de grote reeks getiteld Theatrum Europaeum, waar hierna naar wordt verwezen. 1060 Voor de gebeurtenissen in Passau zie Theatri Europaei Siebenzehender Theil, 73, 81-86.

1061 Weblink Antonio Schmidt-Brentano: Kaiserliche und K.k. Generäle (1618-1815, Österreichisches Staatsarchiv, Abteilung Kriegsarchiv, sub Gronsfeld, Johann Franz v., Bronckhorst, geraadpleegd 1-102014.

1062 TJ, inv. nr. M 77, fol. 623, benoeming van Willem Adolf van Eys genaamd Beusdael tot stadhouder der lenen 22 juni 1710. Flament, 'Jan Frans van Bronckhorst', noemt deze akte, maar geeft geen bronvermelding. 
de kreits geld te krijgen voor het versterken van de verdedigingslinie tegen Frankrijk, maar mocht geen slag leveren tegen de Fransen omdat dit de geallieerde krijgsoperaties in de Zuidelijke Nederlanden in gevaar kon brengen. Eind 1710 droeg hij het commando over en vertrok naar Wenen, mogelijk om daar aan het hof taken op zich te nemen. ${ }^{1063}$ In 1716 werd hij benoemd tot gouverneur en kapitein-generaal van het hertogdom Luxemburg en het graafschap Chiny. Daar overleed hij in 1719, omstreeks tachtig jaar oud.

\subsubsection{Johan Frans van Bronckhorst Batenburg in tweede bunvelijk}

In 1691 leefde bij Johan Frans duidelijk de gedachte dat uit zijn huwelijk met Eleonore Philipine von Fürstenberg geen wettige afstammelingen meer zouden voortkomen. Maar toen de gravin in 1702 overleed, deden zich nieuwe mogelijkheden voor. Begin 1706 hertrouwde hij met de veertien- of vijftienjarige Beierse gravin Maria Anna von ToerringJettenbach, dochter van Franz Joseph en Maria Ursula van Grammont. ${ }^{1064}$ Het leeftijdsverschil tussen bruidegom en bruid bedroeg rond de vijftig jaar! Misschien moet gravin Anna Maria worden beschouwd als 'oorlogsbruid', die Johan Frans leerde kennen tijdens zijn verblijf als militair commandant van München in 1705-1706. De bruid stamde af van oeroude Beierse adel die aan het begin van de achttiende eeuw drie linies kende: Toerring-Stein, Toerring-Jettenbach en Toerring-Seefeld. ${ }^{1065}$ In 1630 had keizer Ferdinand II deze drie linies het predicaat 'rijksgraaf' verleend.1066 Op zich verschafte deze titel aanzien, maar het ontbrak de familie aan een rijksonmiddellijk territorium, wat gevoelig lag voor erkenning door standsgenoten binnen de rijksadel.

In zijn op 14 mei 1706, dus kort na het huwelijk, eigenhandig opgestelde testament benoemde Johan Frans, na aftrek van legaten aan zijn nog levende broer en zusters, Maria Anna, zijn 'hertz liebsten Gemahlin welche durch sonderbahre Schickung und Verhangnus Gottes unss mit gantzlichen vergnügen vermählet worden' tot zijn enige erfgename, uiteraard voor zover er geen mannelijke erfgenaam werd geboren. ${ }^{1067}$ Noch zijn (enige in leven zijnde) broer bisschop Otto Willem noch zijn zusters zouden iets te vorderen hebben op het graafschap omdat zij van al hun aanspraken afstand hadden gedaan. Dat was iets te kort door de bocht, zou later blijken. Hoewel deze uiterste wil min of meer volgens standaardbepalingen is opgesteld, maakt het stuk bij nadere beschouwing toch een enigszins merkwaardige indruk. Ondanks het feit dat het huwelijk tussen een oudere man en een zeer jonge vrouw nog maar kort geleden was gesloten, wordt toch gesuggereerd dat men al een aantal jaren gehuwd was en nog dacht aan meerdere kinderen. Omdat het een eigenhandig geschreven testament betreft, is het mogelijk dat de graaf bepaalde passages aan andere voorbeelden heeft ontleend.

Uit het huwelijk van Johan Frans en Anna Maria werd op 4 maart 1713 in Wenen een dochter geboren, Anna Justina. Op 19 maart werd in Gronsveld een speciale mis

\footnotetext{
1063 Theatri Europaei Neunzehender Theil, 19, 37-38.

1064 Englbrecht, Drei Rosen, 305 en Tafel V.

1065 Voor de geschiedenis van deze familie zie Englbrecht, Drei Rosen.

1066 Stephan, 'Erhebung Törring'.

1067 Een afschrift bevindt zich in RHCL, Rijkskamergerecht inv. nr. 27 (proces De Ligneville tegen Toerring Jettenbach, fol. 59-71.
} 
opgedragen voor 'haere Excellentie Madame', waarna een maaltijd werd aangeboden aan de pastoor, kapelaan en twee paters en de organist van het klooster Lichtenberg van de minderbroeders-observanten in Sint Pieter. Op 22 maart kwam de gardiaan van het klooster feliciteren 'wegens de jonge geboren gravinne'. ${ }^{1068}$ Het prille geluk werd echter spoedig wreed verstoord, want het kind overleed op 25 oktober 1715 in Wenen. Het kindertal bleef tot dit ene kind beperkt. Johan Frans, die sinds 1716 militair gouverneur van Luxemburg was, overleed in deze stad op 7 april 1719. Zijn stoffelijk overschot werd bijgezet in de grafkelder van de familie onder het priesterkoor in de kerk van Gronsveld. ${ }^{1069}$

\subsubsection{Beheer van het graafschap}

Het langdurig verblijf van Johan Frans buiten Gronsveld betekende ook bestuur van het graafschap op afstand. De dagelijkse gang van zaken werd geregeld door drossaardrentmeester Willem Kicken en door Wilhelm Veucht. Belangrijke zaken werden voorgelegd aan Otto Willem van Bronckhorst. Waarschijnlijk verbleef die na zijn promotie in Passau meestentijds in Keulen en had hij daar bestuursfuncties bij de aartsbisschoppelijke curie. Zo werd hij in 1688 commissaris voor het benedictinessenklooster 'Ad Sanctos Maccabaeos' in Keulen.1070 In 1684 zou hij zijn benoemd tot kanunnik van het kapittel van Sint-Lambertus in Luik, nadat daar door het overlijden van Waltère de Liverlo een prebende was vrijgekomen. Maar hij liet zich volgens De Theux niet als kanunnik opnemen en deed afstand ten behoeve van BertrandJean de la Naye. ${ }^{1071}$ Merkwaardig is dat hij daarna in allerlei stukken toch steeds kanunnik van Luik wordt genoemd. ${ }^{1072}$

Graaf Otto Willem trad in de jaren tachtig meermalen op als vervanger van zijn broer. In 1684 tekende hij in die hoedanigheid de overeenkomst die een einde moest maken aan de geschillen met de kloosterlingen van Hoogcruts. ${ }^{1073}$ In 1687 zette zowel Otto als Ernst hun handtekening onder een akte waarbij Johan Frans de leenroerigheid van het belangrijke Gronsveldse leen Hamersbach ophief. ${ }^{1074}$ Eveneens in 1687 was graaf Otto Willem (vanuit Keulen) nadrukkelijk betrokken bij een jurisdictiegeschil dat speelde in processen tussen Willem Veucht en jonker Couven uit Slenaken. ${ }^{1075}$ Het beeld van regelmatige bemoeienis met en aanwezigheid in Gronsveld stemt ook overeen met een verklaring rond 1720 van drossaard en rentmeester Willem Kicken, dat hij zijn jaarrekeningen van het graafschap tot 1693, bij afwezigheid van graaf Johan Frans, in handen had gegeven van diens broer Otto Willem. Daarna waren deze stukken in het archief gedeponeerd. En in 1761 schrijft grafelijk commissaris Prummer dat eertijds ‘

\footnotetext{
1068 TJ, inv. nr. M 64, fol. 408, rentmeestersrekening 1713.

1069 Er was voor hem in 1711 een aparte grafkelder gebouwd onder het priesterkoor, zie Jaspars/Kengen/Orbons, 'Raadsels rond de graftombe van Willem van Bronckhorst', 16-23.

1070 Janssen/Lohmann, Der Weltklerus, 501, nr. 498.

1071 De Theux, Chapitre de Saint Lambert, 3, 307.

1072 RHCL, Graafschap Gronsveld, inv. nr. 464: 1687 'domheer tot Luijck”.

1073 RHCL, Klooster Hoogcruts, inv. nr. 519.

1074 RHCL, Rijkskamergerecht, inv. nr. 10, fol. 49.

1075 RHCL, Graafschap Gronsveld, inv. nr. 464.
} 
dess... regierenten herrn grafen Johann Frantz geistlichen herrn bruederen Otto Wilhelm, so in dess ersteren abweesenheit die graffschafft ainige jahr cum libera administriert hatte'. 1076

Otto Willem had dus ervaring met het bestuur van het graafschap, maar vooralsnog alleen als vervanger. Dat kon na 1690 veranderen. Zijn broer Ernst Maximiliaan sneuvelde in 1690 in Bosnië en zijn zwager, graaf Henri Philippe de Ligneville, was in 1688 omgekomen bij het beleg van Belgrado. Daarmee ontstond een reële kans dat Otto Willem als enige nog levende directe mannelijke bloedverwant van Johan Frans diens erfgenaam werd. Die mogelijkheid werd heel nadrukkelijk meegewogen bij de al genoemde overeenkomst tot overdracht van de 'Niederländische lehncammer' aan de Fürst zu Salm in 1691. De tekst begint met een uitvoerige overweging dat Johan Frans de laatste man uit het grafelijk huis van Gronsveld was, die rechthebbende op de leenkamer kon zijn. Echter, er viel noch van hem noch van zijn enige nog levende broer, die geestelijke was, een nakomeling te verwachten. Daarmee groeide de kans op grote onenigheid over de nalatenschap. Maar even belangrijk was te voorkomen dat de leenkamer 'in de dode hand' terecht kwam, wat met een geestelijke als erfgenaam niet ondenkbaar was.

Of dit soort overwegingen ook speelden rond de mogelijke opvolging binnen het graafschap Gronsveld is niet duidelijk, maar hier kon op termijn een probleem ontstaan. Immers, ook de drie zusters van Johan Frans waren kinderloos. Vooralsnog was die vraag evenwel niet actueel. Johan Frans stortte zich in de oorlog tegen de Turken en Otto Willem maakte carrière in kerkelijke dienst. Laatstgenoemde werd op 24 april 1693 in Keulen gewijd tot titulair-bisschop van Columbrica en vervolgens benoemd tot wijbisschop en vicaris-generaal van Osnabrück. ${ }^{1077}$ Osnabrück was een geestelijk vorstendom, dat na de Vrede van Westfalen alternatief door een lutherse of katholieke bisschop werd geregeerd. Zo was ten tijde van de benoeming van Otto Willem de protestantse prinsbisschop August von Braunschweig-Lüneburg in Osnabück aan het bewind. Voor de perioden dat een protestantse bisschop of een katholiek zonder de vereiste wijdingen regeerde, verrichtte een wijbisschop de handelingen die aan het bisschopsambt zijn verbonden. Een van de eerste ambtshandelingen van de nieuwe bisschop was op 28 mei 1693 de wijding tot priester van Hendrik Nicolaas Fibus in de huiskapel van het kasteel van Gronsveld. ${ }^{1078}$

$\mathrm{Na}$ zijn benoeming in Osnabrück kon Otto Willem zich nauwelijks meer met de feitelijke gang van zaken in het graafschap bemoeien. De zwaarte van het werk liet dat ook niet toe. ${ }^{1079} \mathrm{Na}$ het overlijden van August von Braunschweig-Lüneburg in 1698 koos het

\footnotetext{
1076 TJ, inv. nr. M 73, fol. 592, terloopse opmerking in brief over cijnzen van Prummer aan M.E. von Toerring-Jettenbach 25 augustus 1761.

1077 Data ontleend aan Gatz/Janker, Die Bischöfe, 49-50, onder lemma 'Bronckhorst zu Gronsfeld, Otto Wilhelm Reichsgraf von (1640-1713)' door M.F. Feldkamp.

1078 Janssen/Lohmann, Der Weltklerus, 397, nr. 182.

1079 Otto Willem had het als vreemdeling moeilijk in Osnabrück. Hij werd met tegenzin geaccepteerd door het domkapittel en de aartsdekens, die regionaal delen van het bisdom bestuurden, weigerden hun macht in te perken. Vgl. Fink, 'Ein Urteil des Weihbischofs Otto von Bronkhorst.'
} 
domkapittel Karl Joseph van Lotharingen tot opvolger, maar omdat die pas achttien jaar oud was, werd Otto Willem tot co-administrator en vicaris-generaal van het bisdom benoemd. ${ }^{1080}$ In 1702 kwam daar een benoeming als apostolisch-vicaris van de Noordelijke Missiegebieden (Scandinavië en Noord-Duitsland) bij. In 1709 werd dit reusachtige missiegebied in tweeën gesplitst. Otto Willem werd toen apostolisch-vicaris voor Zweden, Denemarken en de Noord-Duitse bisdommen Lübeck, Schwerin en Hamburg. Hij overleed op 5 april 1713 in Osnabrück en werd daar in de jezuïetenkerk begraven. Op 5 juli van dat jaar werd voor hem in de kerk van Gronsveld een uitvaartdienst gehouden. ${ }^{1081}$

Eén keer in de voorgaande jaren leek de opvolgingsvraag actueel te worden toen het gerucht de ronde deed dat Johan Frans in den vreemde was overleden. Op 1 juni 1698 gaf Otto Willem vanuit Osnabrück een volmacht aan zijn zuster Clara Sibilla om namens hem het graafschap in bezit te nemen. ${ }^{1082}$ Het bleek echter voorbarig en Johan Frans keerde levend uit de oorlog terug. Het voorval maakt wel duidelijk dat Otto Willem in het voorkomende geval zeker niet van plan was van aanspraken op Gronsveld af te zien.

Na 1700 lijkt het bestuur van het graafschap Gronsveld in de praktijk vrijwel geheel in handen te zijn gekomen van drossaard en rentmeester Willem Kicken. Er werden zeker contacten vanuit Gronsveld met graaf Johan Frans onderhouden, maar de intensiteit daarvan blijft onduidelijk. De gegevens in enkele bewaard gebleven rentmeestersrekeningen uit die tijd geven in ieder geval niet de indruk van veelvuldige communicatie. In Hoofdstuk 8.10 zullen we zien dat Kicken het in beginsel niet slecht deed en het graafschap ook goed door de lastige tijd van de Spaanse Successieoorlog loodste, maar met het klimmen der jaren werd zijn administratie slordiger en raakte hij steeds meer verstrikt in plaatselijke partijstrijd. Nadat Johan Frans in 1716 in Luxemburg was gestationeerd, nam de directe bemoeienis van de graaf met Gronsveld ook weer toe. Zo hield hij zich bezig met de regelmatig terugkerende problemen rond de bijdrage van Maastrichtse instellingen in de grondbelasting van het graafschap. Ook begon hij zich op het laatst ernstig zorgen te maken over rechtmatigheid en doelmatigheid van het beheer van Kicken, maar hij overleed voordat hij echt kon ingrijpen.

De rentmeestersrekeningen uit de twee eerste decennia van de achttiende eeuw laten zien dat Johan Frans na aftrek van alle noodzakelijke uitgaven feitelijk nauwelijks iets overhield aan het graafschap. Wel met grote regelmaat verschenen in Gronsveld de drie zusters van Johan Frans, te weten de weduwe Anna Justina van Eynatten, de weduwe Clara Sibilla de Ligneville en de ongehuwde Maria Anna. Zij hadden vroeger hun erfdeel in het graafschap laten zitten en maakten nu aanspraak op rente of uitbetaling van een equivalent daarvan.

1080 Data ontleend aan Gatz/Janker, Die Bischöfe, 49-50, onder lemma 'Bronckhorst zu Gronsfeld, Otto Wilhelm Reichsgraf von (1640-1713)' door M.F. Feldkamp. Soms wordt Otto Willem ook wijbisschop van Münster genoemd, maar een dergelijke benoeming heeft hij waarschijnlijk nooit gehad. Enkele malen trad hij wel in het bisdom Münster op, maar alleen bij wijze van assistentie met bijzondere machtiging. Zie daarover Tibus, Gescbicbtliche Nacbricbten Weibbischöfe, 199-204.

1081 TJ, inv. nr. M 64, rekening rentmeester 1713, fol. 408.

1082 RHCL, Vrije rijksheerlijkheid Wittem, voorl. nr. 286. 
Enkele voorbeelden maken duidelijk aan welke verhoudingen moet worden gedacht. In 1710 zijn op een totaal van 4813 gulden aan inkomsten 1619 gulden voor de graaf (direct besteed aan noodzakelijke uitgaven voor het graafschap), 650 gulden voor Clara Sibilla en 740 gulden voor Maria Anna. In 1718 zijn op een totaal van 10.353 gulden aan inkomsten 904 gulden voor Clara Sibilla en 1200 gulden voor Anna Maria. Soms werden de bedragen in gedeeltes overgemaakt, soms kwamen de dames met personeel naar Gronsveld en vonden ook uitbetalingen in natura plaats.

Het is niet bekend hoe Johan Frans zich gedurende zijn laatste levensjaren verstond met zijn zusters, maar mogelijk raakte de sfeer toch vertroebeld. Want uit het proces dat Clara Sibilla na het overlijden van Johan Frans aanspande tegen diens weduwe en haar schoonzuster Maria Anna von Toerring-Jettenbach blijkt niet alleen een zekere frustratie over het feit dat een erfenis aan hun neus voorbijging, maar zij voelde zich ook onrechtvaardig behandeld omdat de contracten over de boedelscheiding uit de jaren zeventig van de zeventiende eeuw eigenlijk onder dwang van de omstandigheden waren aangegaan en alleen nadeel hadden opgeleverd. ${ }^{1083}$

Het uitblijven van uitbetaling door Johan Frans aan zijn zusters van hun erfdeel zegt misschien ook iets over de financiën van de graaf. Zijn vader Jost Maximiliaan was bijna failliet gegaan aan zijn langdurige militaire loopbaan. De met schulden begonnen Johan Frans lijkt zijn leven in dat opzicht beter te hebben geëindigd. Er zijn geen aanwijzingen voor bovenmatige schulden en hij schijnt zelfs bouwplannen te hebben gehad voor het kasteel van Gronsveld. Anderzijds leverde het graafschap Gronsveld weinig rendement op.

\subsubsection{De kerk van Gronsveld, monument voor een uitgestorven geslacht}

Johan Frans was de laatste mannelijke telg van het geslacht Van Bronckhorst Batenburg in Gronsveld. Dat besef moet bij hem en zijn naaste familie ook een rol hebben gespeeld bij zijn bemoeienissen met het kerkgebouw van Gronsveld. Die kerk verkeerde aan het einde van de zeventiende eeuw in een zodanig bouwvallige toestand dat met uitzondering van de toren en een deel van het priesterkoor, tot herbouw werd besloten. De plicht tot bouw en onderhoud lag in principe bij de twee tiendheffers, waarbij de graaf verantwoordelijk was voor het schip en de pastoor voor het priesterkoor. Of de oude kerk een dwarsbeuk of zijbeuk had, is niet bekend, maar bij de nieuwbouw kwam er een dwarsbeuk op kosten van de gemeente. Over de tijdsduur van de herbouw is maar weinig bekend. In 1695 protesteerden de inwoners van Eckelrade bij de graaf tegen het feit dat zij door 'dye van Gronsvelt' met geweld werden gedwongen bij te dragen in de reparatie van de toren en kerkhofmuur, terwijl zij hun eigen kerk en kerkhof hadden. Omdat een beslissing uitbleef en het probleem aansleepte, werden in 1713 die klachten nog eens herhaald. ${ }^{1084}$ Ook de parochianen uit Rijckholt lagen dwars. Tussen 1700 en 1701 voerden zij een proces tegen pastoor Goffin over hun verplichting bij te dragen in de reparatie. ${ }^{1085}$ De genoemde

1083 RHCL, Rijkskamergerecht, inv. nr. 27.

1084 TJ, inv. nr. M 40, 843-846.

1085 RHCL, Kerkelijke rechtbanken en bisschoppelijke commissarissen te Maastricht 1498-1842, inv. nr. 93. 
jaartallen wijzen er op dat de herbouw in fasen plaatsvond gedurende een periode van ongeveer tien jaar in de tijd rond 1700 .

$\mathrm{Na}$ voltooiing van het gebouw kreeg de inrichting alle aandacht. In zijn testament uit 1706 - dat doordrenkt is met vrome overwegingen - legde Johan Frans vast dat hij na zijn dood wilde worden bijgezet bij zijn voorouders in de kerk van Gronsveld. Verder schonk hij 'zu Erbauung des grossen verguldeten altars in der Pfarkirchen', duizend Rijnse guldens, waarvoor ter ere Gods en tot nagedachtenis aan hem, Johan Frans, 'ein sauberes Gemahlde so die Heijlige Dreyfaltigkeit und vor dieser die Mutter Gottes kniend' moest worden aangeschaft. Uiteindelijk werd het altaar niet verguld, maar het schilderij is in de gewenste vorm in 1710 vervaardigd door de Luikse kunstenaar E. Fisen en het siert nog altijd het hoogaltaar. ${ }^{1086}$ Het geheel wordt bekroond door het alliantiewapen Van Bronckhorst Batenburg en Toerring-Jettenbach. In 1711 lieten Johan Frans en zijn echtgenote Anna Maria een nieuw orgel plaatsen, dat werd gebouwd door de Luikse orgelbouwer Philippe le Picard. Ook dit instrument werd bekroond met het alliantiewapen van de schenkers. In 1719 ten slotte schonk Johan Frans een kostbare zilveren stralenmonstrans, vervaardigd door zilversmid Le Fauconnier uit Luxemburg. ${ }^{1087}$

In de zuidbeuk van de kerk liet bisschop Otto Willem een barokaltaar plaatsen toegewijd aan Sint-Amandus, de tweede patroon van de kerk (Thans altaar toegewijd aan Sint Joseph). In de top van de omlijsting is het wapen van de stichter aangebracht. De tegenhanger van dit altaar is in de noordbeuk het Onze-Lieve-Vrouwealtaar, waarvan de omlijsting wordt bekroond met het alliantiewapen van Anna Justina van Bronckhorst en baron Ferdinand Louis van Eynatten. Anna Justina overleed 12 januari 1707 te Luik en haar lichaam werd daarna overgebracht naar Gronsveld. ${ }^{1088}$

Natuurlijk kan deze financiering van dit barokke ensemble worden gezien als een toevallige uiting van vrijgevigheid en godsdienstzin van de schenkers, maar met drie altaren en een orgel, alle voorzien van het familiewapen, sloten zij af wat hun voorvader Willem van Bronckhorst Batenburg 150 jaar eerder met de plaatsing van een imposante graftombe op het priesterkoor van de kerk was begonnen: een laatste rustplaats die tegelijk een blijvende, monumentale herinnering was voor het roemrijke geslacht Van Bronckhorst Batenburg in Gronsveld.

\subsection{Conclusies}

In de geschiedenis van de graven van Bronckhorst Batenburg gedurende de periode 16171719 domineren de namen van Jost Maximiliaan (geboren 1596, overleden 1662) en Johan

\footnotetext{
1086 Marres/Van Agt, Monumenten Zuid-Limburg, 182.

1087 Jaspars/Kengen/Orbons, 'Raadsels rond de graftombe van Willem van Bronckhorst', 14, met beschrijving van tekst en chronogram op de monstrans.

1088 TJ, inv. nr. M, 64 fol. 247 (rentmeestersrekening 1707) uitgaven voor overbrenging en bijzetting van het stoffelijk overschot. Zie verder ook TJ, inv. nr. M 41, fol. 41, notariële verklaring 17 januari 1707 van de pastoors van St. Etienne te Luik en van Gronsveld over laatste wilsbeschikkingen van de 'baronne de Thys', geboren gravin van Gronsveld. Anders: Jaspars/Kengen/Orbons, 'Raadsels rond de graftombe van Willem van Bronckhorst', 12, waar als overlijdensdatum 12 januari 1709 wordt opgegeven.
} 
Frans van Bronckhorst Batenburg (geboren 1639, overleden 1719). De jaartallen van hun beider regeringsperiodes zijn wat gecompliceerder, aangezien de nalatenschap van graaf Johan II tot ongeveer 1640 een onverdeelde bleef, waarbij Jost Maximiliaan als oudste formeel graaf van Gronsveld was, maar ook zijn broer Otto Wilhelm aan de regering deelnam. Na het overlijden van Jost Maximiliaan in 1662 voerde zijn weduwe Anna Christina von Hardenrath als regentes en voogdes het bewind over haar nog minderjarige kinderen. Pas in 1677 kon Johan Frans na boedeldeling zelfstandig de regering aanvaarden, met dien verstande echter dat hij tot de jaren negentig wegens afwezigheid nog regelmatig door zijn broer Otto werd vervangen.

Zowel Jost Maximiliaan als Johan Frans hebben militaire carrières gemaakt, de eerste in Beierse dienst tijdens de Dertigjarige Oorlog, de tweede in keizerlijke dienst in de strijd tegen de Turken en in de Spaanse Successieoorlog. Daarnaast heeft Jost Maximiliaan zich in de laatste tien jaar van zijn leven verdienstelijk gemaakt als diplomaat in keizerlijke dienst en medeoprichter van het Nederrijns-Westfaalse Gravencollege. Johan Frans heeft in de geschiedschrijving en in het historisch bewustzijn in Gronsveld altijd enigszins in de schaduw gestaan van zijn vader, maar het is de vraag of dat terecht is. Alleen heeft Jost Maximiliaan met zijn belevenissen in de Dertigjarige Oorlog letterlijk 'een betere pers' gekregen.

De keuze voor een militaire loopbaan binnen het Rijk kan worden gezien als een duidelijke trendbreuk binnen de familie. Dat gold niet alleen voor Jost Maximiliaan en Johan Frans, maar ook voor enkele van hun broers. Tot 1617 hadden de Bronckhorsten zich vooral regionaal, in het Maasdal en aan de Nederrijn, geprofileerd. Maar de ruimere blik op de wereld die graaf Johan II moet hebben gehad door zijn verblijf in Italië en het huwelijk met de Schwäbische gravin Sybilla von Eberstein, kan de kinderen hebben beïnvloed. Mogelijk maakte ook het tragische lot van Jost van Bronckhorst Batenburg, die al snel na aanvaarding van de regering over Gronsveld in actieve militaire dienst was overleden, indruk op zijn jonge neven. Verder kunnen persoonlijke ambities en zakelijke redenen een rol hebben gespeeld bij de keuze voor het leger. Het graafschap Gronsveld en het familiekapitaal waren te klein om alle kinderen overeenkomstig hun stand van passend levensonderhoud te voorzien. Dat verklaart misschien ook waarom niemand van de kinderen werd ondergebracht in een adellijk geestelijk stift. Enigszins buiten de toon valt Otto Wilhelm, wiens geestelijke loopbaan zeer bescheiden begon met intrede bij de jezuieten en ten slotte eindigde als wijbisschop van Osnabrück. In die laatste functie heeft hij zeer verdienstelijk werk verricht, maar een positie als 'missiebisschop' in het grotendeels protestantse Noord-Duitsland verschafte weinig macht of rijkdom.

Met de keuze voor het leger kunnen de graven van Gronsveld worden beschouwd als typische representanten van het verschijnsel dat het Maasdal en het Luikerland in de zeventiende eeuw een soort kweekvijver vormden voor adellijke geslachten die krijgsoversten in keizerlijke of vorstelijke dienst leverden. ${ }^{1089}$ Een militaire loopbaan was

1089 Wouters, Grensland en Bruggehoofd, 326-327. 
ongewis. Men kon rijk uit de oorlog terugkeren, sneuvelen of geruïneerd raken. Dat laatste trof Jost Maximiliaan die, belaagd door schuldeisers en familieleden, een groot deel van zijn voorvaderlijk erfdeel door gedwongen verkoop zag verdampen (Oost, Sint-MartensVoeren, Rimburg, de bezittingen an de Nederrijn). Na zijn overlijden moesten zijn erfgenamen het graafschap Eberstein te gelde maken. Daar kwam bij dat door het langdurig verblijf in het buitenland het beheer van het graafschap grotendeels moest worden overgelaten aan plaatselijke functionarissen die vaak meer op hun eigen voordeel dan dat van hun heer bedacht waren. Krijgsroem had dus een prijs, die met het familiekapitaal werd betaald. Het was vooral te danken aan Anna Christina von Hardenrath, de weduwe van Jost Maximiliaan, dat een volledig bankroet werd voorkomen. Haar zoon Johan Frans lijkt het per saldo financieel beter te hebben gedaan, maar ook zijn start op de maatschappelijke ladder verliep door geldgebrek moeizaam.

Geldgebrek loopt daarmee als een rode draad door de familiegeschiedenis van de zeventiende eeuw. Misschien is dat ook één van de redenen geweest dat men er nauwelijks in slaagde het maatschappelijk kapitaal dat de titel van rijksgraaf opleverde, door huwelijken met partners uit dezelfde stand te verzilveren. Alleen de twee huwelijken van Johan Frans vormen daarop een uitzondering, maar deze leverden geen (volwassen) kinderen op. Het feit dat Johan Frans van Bronckhorst Batenburg en zijn drie broers en drie zusters zonder nakomelingen overleden, leidde er toe dat de familie in 1719 in mannelijke lijn in Gronsveld uitstierf. 


\section{De graven en gravinnen van Gronsveld uit de geslachten d'Arberg Valengin en Toerring-Jettenbach 1719-1795}

\subsection{Maria Anna von Toerring-Jettenbach en Claude Nicolas d'Arberg Valengin, 1719-1731}

De overgang van het graafschap na het overlijden van Johan Frans van Bronckhorst Batenburg op zijn echtgenote gravin Maria Anna von Toerring-Jettenbach verliep allerminst soepel. Haar opvolging werd bestreden door Clara Sibilla, de zuster van Johan Frans, wat leidde tot een proces bij het Rijkskamergerecht. ${ }^{1090}$ Maar uiteindelijk werd het pleit beslecht in het voordeel van Maria Anna, althans in die zin dat zij het graafschap Gronsveld kreeg.

De jonge weduwe bleef niet lang alleen. In 1721 huwde zij graaf Claude Nicolas d'Arberg Valengin, afkomstig uit een van oorsprong Zwitserse familie, die in de zeventiende eeuw in de Zuidelijke Nederlanden tot aanzien was gekomen. Claude Nicolas moet op 30 mei 1683 zijn geboren ${ }^{1091}$ als zoon van Claude Nicolas d'Arberg Valengin en Anna Theodora gravin von Daun en Sassenheim/Sanem (bij Luxemburg) ${ }^{1092}$ Claude Nicolas verwierf van zijn moeder kasteel en heerlijkheid Sanem. Daar vestigde het echtpaar zich ook. Anna Maria von Toerring-Jettenbach beviel op 4 maart 1722 van een dochtertje dat werd gedoopt onder de naam Maria Josepha Nepomucena Francisca à Paolo.

Over Claude Nicolas als heer van Gronsveld is weinig bekend, maar een warme belangstelling voor het kleine graafschap koesterde hij niet. Hij kwam er wel eens, maar hield zijn betrokkenheid beperkt tot het meest noodzakelijke en gaf letterlijk en figuurlijk de voorkeur aan regering op afstand. Gronsveld moest vooral een vaste bron van inkomsten worden, zonder al te grote zorgen. Ook zijn echtgenote moet het graafschap nauwelijks uit uit eigen aanschouwing hebben gekend, laat staan dat zij er ooit had gewoond. Ook zij bemoeide zich niet met het bestuur.

Een probaat middel om van Gronsveld een vaste bron van inkomen te maken leek verpachting of 'admodiatie'. D'Arberg vond in de persoon van Jean Gathoye uit Soumagne een 'admodiator' die bereid was 1750 rijksdaalders per jaar voor het graafschap te betalen. Deze overeenkomst werd op 10 september 1723 bij een notaris in Luxemburg schriftelijk vastgelegd. ${ }^{1093}$ Voor dat bedrag kreeg de pachter vanaf 1 december 1723 gedurende negen jaar recht op alle heerlijke rechten en inkomsten, inclusief herendiensten, jacht en visserij. Dit jachtrecht schijnt voor de pachter erg zwaar te hebben gewogen, misschien vanwege zijn liefhebberij, maar zeker ook als adellijk statussymbool. Uitgesloten van de overeenkomst bleven het stadhouderschap bij het leenhof, het benoemingsrecht van drossaard en schepenen en collatierechten voor geestelijke ambten. De bouwkosten

\footnotetext{
1090 RHCL, Rijkskamergerecht, inv. nr. 27.

1091 Volgens tekst op rouwbord in de Sint-Martinuskerk in Gronsveld.

1092 Uit het huwelijk van Claude Nicolas d'Arberg Valengin en Anna Theodora von Daun en Sassenheim was ook nog een dochter Olympe-Hippolyte. Dezed huwde met Charles Baptiste Baptiste graaf de Lallemand, baron de Waitte. De gravin de de Lallemand de Waite was later betrokken bij de verwikkelingen die zich in 1730-1731 voordeden rond de voogdij van Maria Josepha.

1093 RHCL, Rijkskamergerecht, inv. nr. 71/1, fol. 72-77vo.
} 
van het kasteel bleven ook voor rekening van de graaf. Verder mocht de pachter zijn zoon François in zijn plaats stellen of, in het geval van overlijden, diens broer Henri.

In het proces voor het Rijkskamergerecht over de financiële afwikkeling van dit pachtcontract, vifftien jaar later, schildert de advocaat van graaf Toerring de achtergronden van deze transactie en de nieuwe pachter. ${ }^{1094}$ Het is zeker een gekleurd verhaal, maar kan in grote lijn toch op waarheid berusten. De jurist schrijft dat de oude Gathoye eigenlijk 'fuhrman' was, wat waarschijnlijk moet worden vertaald als transportondernemer, in die tijd een kapitaalintensieve activiteit. In de jaren 1721 en 1722 gaf hij meermaals kleine geldbedragen en ook goederen aan graaf d'Arberg Valengin en won daarmee diens vertrouwen. Dat ging zover dat de graaf hem in 1722 een verguld zilveren 'erhnsehentliches...taffel-service' voor zestienduizend gulden toevertrouwde. ${ }^{1095}$ Mogelijk was het een onderpand voor een lening, maar de graaf gaf tegelijk aan dat Gathoye, na voorgaande toestemming, de stukken ook mocht verkopen. Daarna had de graaf hem voor honderdduizend gulden edelstenen gegeven (waaronder een diamant ter waarde van zevenduizend rijksdaalders) die ook met toestemming van de graaf mochten worden verkocht. Waarschijnlijk hadden de Gathoye's verstand van de handel in dit soort kostbaarheden. Als sluitstuk van de financiële transacties volgde de verpachting van het graafschap.

De ongeveer tien jaar durende 'admodiatie' groeide uit tot een van de meest roerige periodes in de geschiedenis van het graafschap. In Hoofdstuk 11 komt uitgebreid aan de orde hoe in Gronsveld op weinig zachtzinnige wijze om de macht werd gevochten tussen de Gathoye's en drossaard Johan Godfried Lebens. De graaf d'Arberg Valengin trad in deze affaires uiterst terughoudend, om niet te zeggen laks op, een houding waarvoor hij uiteindelijk zelfs door het Rijkskamergerecht werd berispt. 5.2 Maria Josepha Nepomucena d'Arberg Valengin en haar voogd Ignaz Felix von Toerring-Jettenbach,
1731-1746

Gravin Anna Maria von Toerring-Jettenbach overleed te Luxemburg op 26 september 1730. Nog geen vier maanden later, op 19 januari 1731, stierf ook graaf Claude Nicolas d'Arberg Valengin. ${ }^{1096}$ De twee snel op elkaar volgende sterfgevallen waren niet alleen tragisch voor hun enige kind, er ontstond ook een groot probleem over de voogdij. De juridische strijd daarover werd in zekere zin het sluitstuk van de problemen met Gathoye.

Op 17 januari 1731, twee dagen voor zijn overlijden maakte graaf d'Arberg Valengin zijn testament ten overstaan van de pastoor van de Sint-Nicolaasparochie te Luxemburg. Hij wilde begraven worden in de kerk van Sanem, bij zijn echtgenote. Er waren verschillende legaten voor vrome en goede doelen. De kern van het testament draaide echter om de toekomst van zijn dochtertje. Hij verzocht zijn zuster, gravin Olympe Hypolite de

1094 TJ, inv. nr. M 76, fol. 13-17.

1095 TJ, inv. nr. M 76, fol. 16.

1096 Zijn rouwbord met die sterfdatum hangt in de Sint-Martinuskerk van Gronsveld. Het werd overigens pas bijna 25 jaar later vervaardigd. 
Lallemand de Waitte te Besançon, de belangen van het kind te behartigen en te zorgen voor een opvoeding overeenkomstig haar stand. Voor het geval zij daaraan niet kon voldoen, vroeg Claude Nicolas dezelfde gunst aan zijn zwager, graaf Ignaz Felix von Toerring-Jettenbach. Het meisje werd aangewezen tot enige erfgename, met als voogd de baron (Vincent Philip Anton van der Heyden genaamd) Belderbusch, heer van Montzen, voor wat betrof de bezittingen in Gronsveld. Aan de Provinciale Raad van Luxemburg werd gevraagd een voogd aan te wijzen voor het beheer van de goederen in Luxemburg. $\mathrm{Na}$ het overlijden moesten zilverwerk, meubels en paarden worden verkocht voor onderhoud van het weeskind en eventuele aflossing van schulden, rustend op het graafschap Gronsveld. Uitgezonderd van vervreemding bleven juwelen en verguld zilveren toiletgerei van de gravin.

Op het eerste gezicht was het testament helder. De benoeming van Belderbusch leek geheel in overeenstemming met de wil van Claude Nicolas. Er bestond al langere tijd vriendschappelijk contact tussen beiden en Belderbusch hielp de graaf ook zakelijk. Later overlegde Belderbusch diverse brieven, waaruit bleek hoe groot het vertrouwen was dat d'Arberg in hem stelde. Op 30 augustus 1730 had de graaf hem steun gevraagd in de droevige situatie waarin hij zich na het overlijden van zijn echtgenote bevond. Dat werd op 20 september 1730 gevolgd door het verzoek voor het weeskind te zorgen wanneer hij er niet meer was. Op 20 december 1730 vertrouwde hij hem de behartiging van al zijn belangen toe, wat op 7 januari 1731 nog eens werd gevolgd door het verzoek op te komen voor de belangen van het kind dat zo op Belderbusch gesteld zou zijn.

Enkele dagen na de begrafenis kwam de zoon van de gravin de Waitte, luitenant in het Franse leger, overhaast naar Sanem en vertrok de volgende dag met het weeskind naar zijn moeder in Bourgondië. Getuigen vertelden later dat hij juwelen, zilverwerk en documenten had meegenomen. Op 10 februari 1731 schreef de gravin de Waitte aan Belderbusch hoe verheugd zij was dat haar nichtje was meegenomen op uitdrukkelijke wens van haar overleden broer. In deze en volgende brieven schonk zij Belderbusch het volste vertrouwen dat hij de zaken van het kind goed zou behartigen. Zelf zou zij zich bekommeren om de opvoeding van dit lieve kind, dat alle aandacht verdiende.

Over dat 'meenemen' van een kind was graaf Ignaz Felix von Toerring-Jettenbach in München een heel andere mening toegedaan. Hij stelde zich op het standpunt dat de bepalingen in het testament niet konden worden beschouwd als een echte benoeming van een voogd. Als de meest naaste mannelijke bloedverwant moest hij in aanmerking komen voor de voogdij. Een complicatie vormde het 'internationaalrechtelijke karakter' van de erfenis met goederen onder verschillende jurisdicties: Gronsveld viel onder het Heilige Roomse Rijk en Sanem behoorde tot de Zuidelijke Nederlanden. Bijzonder boos was Ignaz Felix over de ontvoering van zijn nichtje naar Frankrijk, midden in de winter, zonder rekening te houden met het slechte weer en mét ontvreemding van kostbaarheden. Met deze actie was het kind buiten de jurisdictie van het Rijk en de Zuidelijke Nederlanden gebracht. Hij beklaagde zich op 28 februari 1731, met een steunbetuiging van de keurvorst van Beieren, bij de aartshertogin-landvoogdes van de Oostenrijkse Nederlanden in Brussel over deze even brutale als beledigende ontvoering. Dergelijk 
geweld op zich moest al een reden zijn iemand de voogdij te weigeren. Graaf Toerring Jettenbach verzocht daarom haar tussenkomst bij het Franse hof opdat het kind en de verdwenen goederen terugkeerden naar Sanem. ${ }^{1097}$ De landvoogdes zegde die steun ook toe, maar gaf tegelijkertijd opdracht aan de Raad van Luxemburg de zaak verder te onderzoeken. ${ }^{1098}$

Graaf Toerring-Jettenbach wendde zich vervolgens tot de Provinciale Raad van Luxemburg. Daar werd raadsheer baron de Heyden benoemd tot bewindvoerder en voorlopig voogd, maar verder beschouwde het college het verzoek van de graaf als het begin van een proces met de gravin de Waitte. Daar voelde Ignaz Felix weinig voor en hij schreef opnieuw naar de landvoogdes in Brussel. Intussen wierp Belderbusch zich, met steun van gravin de Waitte, op als de feitelijke machthebber in Gronsveld. Zo zorgde hij er ook voor dat zijn vriend Gathoye, de vroegere pachter van het graafschap, weer vrij spel kreeg (Zie over de vele problemen over de verpachting van het graafschap Gronsveld aan François Gathoye uitvoerig Hoofdstuk 11). In augustus en oktober 1732 drongen drossaard en schepenen van Gronsveld met klem bij graaf Ignaz Felix aan op snelle maatregelen. Zij deden het voorstel een plaatsvervangend administrator voor Gronsveld te benoemen, bijvoorbeeld de licentiaten d'Oliva ${ }^{1099}$ of Alstorff, leden van het stadsbestuur van Aken Die hadden al eerder in Gronsveld bij de conflicten rond Gathoye orde op zaken hadden gesteld en kenden dus de situatie ter plaatse. ${ }^{1100}$

Intussen kwam de gravin de Waitte met een ander plan. Zij wilde baron de Bounam van Rijckholt laten benoemen tot 'administrator' van het graafschap Gronsveld. Toen baron de Heyden in Luxemburg daar lucht van kreeg, adviseerde hij graaf Toerring Jettenbach dringend stappen te ondernemen bij het Rijkskamergerecht. De Bounam was al verwikkeld in een proces met de jonge gravin als erfgename van haar vader en dus kon worden gesproken van verstrengeling van belangen. ${ }^{1101}$ Ignaz Felix kreeg daarmee, naast de ontvoering, een tweede argument om aan de bemoeienis van de gravin de Waitte een eind te maken. Op 5 januari 1732 werd de interventie ingeroepen van de Beierse assessor bij het Rijkskamergerecht. ${ }^{1102}$ Dit leidde er toe dat het Rijkskamergerecht op 23 januari 1732 aan Belderbusch beval zich van verdere bemoeienis met de voogdij te onthouden. Voorlopig kreeg het stadsbestuur van Aken 'die interims administration zu Gronsfeld' opgedragen. ${ }^{1103}$ Op 9 februari 1732 wees de magistraat uit haar midden de regerende

1097 TJ, inv. nr. M 14, fol. 523-525, I.F. von Toerring-Jettenbach aan aartshertogin-landvoogdes 28 februari 1731.

1098 TJ, inv. nr. M 14, fol. 527-529, graaf Visconti te Brussel aan I.F. von Toerring-Jettenbach 9 maart 1731.

1099 Alexander Theodor von Oliva (hij noemt zichzelf meestal d'Oliva of Oliva), geboren 1691, overleden 1767, licentiaat in de rechten, schepen van Aken 1723-1767, van 1729 tot en met 1766 negentien keer burgemeester van Aken, wordt genoemd 'eine der tüchtigsten Persönlichkeiten...die im 18. Jahrhundert das Schöffenamt verwalteten', vgl. Von Coels von der Brügghen, 'Die Schöffen des Königlichen Stuhls', 473-478 en Von Coels von der Brügghen, 'Die Aachener Bürgermeister', 74-75.

1100 TJ, inv. nr. M 32, fol. 3, nr. 2 (3 augustus en 2 oktober 1731).

1101 TJ, inv. nr. M 32, fol. 6, nr. 3.

1102 TJ, inv. nr. M 32, fol. 7-8, nr. 5.

1103 TJ, inv. nr. M 32, fol. 9-10, nr. 10. 
burgemeester en schepen d'Oliva aan als degene die deze taak moest uitvoeren. ${ }^{1104}$ Daarop vooruitlopend schreef d'Oliva een dag eerder aan graaf Toerring Jettenbach welke chaos Belderbusch in Gronsveld had aangericht. ${ }^{1105}$ Gathoye was weer in het zadel geholpen en alle vroegere maatregelen om het bestuur in Gronsveld op orde te brengen, waren ongedaan gemaakt.

D'Oliva wist op dat moment nog niet dat de rechters in Wetzlar op 6 februari 1732 graaf Toerring-Jettenbach tot administrator van Gronsveld hadden benoemd. Op 13 februari 1732 d'Oliva de graaf daarmee feliciteren en koppelde hij aan deze gelukwens de vraag of hij eventueel verdere orders moest afwachten. ${ }^{1106}$ Die brief kruiste zich met een schrijven van graaf Ignaz Felix aan d'Oliva van 16 februari, waarin deze hartelijk werd bedankt voor zijn inspanningen. Hem werd verzocht zich verder te bekommeren om de belangen van de 'pupillin' en goed contact te houden met baron de Heyden in Luxemburg, die zorgde voor het beheer van Sanem. ${ }^{1107}$

Waarschijnlijk kort na de toewijzing van de voogdij aan graaf Toerring-Jettenbach is gravin Maria Josepha begin 1732 bij gravin de Waitte weggehaald en voor haar verdere opvoeding overgebracht naar het klooster van de zusters van Onze-Lieve-Vrouw in Luxemburg. In een brief van 17 december 1732 aan graaf Ignaz Felix geeft de overste van het klooster hoog op over de leerlinge. Zij groeide van dag tot dag in schoonheid en wijsheid, leerde goed van buiten, las even gemakkelijk boeken in het Duits als Frans, bad de misgebeden in het Latijn, danste, zong en speelde klavecimbel. Regelmatig kwam ook baron de Heyden om haar te onderrichten. Hij was als een vader voor haar, maar tegelijk vroeg ze waarom haar oom nooit op bezoek kwam. Wanneer ze nog een paar jaar bij de zusters bleef, zou het meisje uitgroeien tot een perfecte jonge dame. Ze was ook goedhartig en klaagde dat ze geen zakgeld kreeg om bedienden die voor haar iets deden, te belonen. Ter geruststelling van Ignaz Felix kon de overste van de zusters melden dat men er veel energie in had gestoken om het kind af te helpen van de invloed die slechte mensen op haar hadden uitgeoefend. ${ }^{1108}$

Het verblijf in Luxemburg eindigde eerder dan verwacht. In de herfst van 1733 raakte Frankrijk betrokken bij de Poolse Successieoorlog. De Franse krijgsoperaties vonden vooral plaats in het Rijnland en zo raakte ook de vesting Luxemburg bedreigd. Begin 1734 werd gravin Maria Josepha veiligheidshalve door de zusters naar een klooster in Mainz overgebracht. Toen ook die stad door Franse troepen werd bedreigd, zorgde graaf Ignaz Felix, die persoonlijk in Mainz verbleef, dat zijn nichtje eerst naar Mannheim werd geëvacueerd. Dat ging niet zonder slag of stoot. De zusters wilden het kind naar Mannheim begeleiden, maar dat stuitte toch op bezwaren. Zij konden niet zomaar het klooster verlaten. Het was de vraag of zij in geval van nood voldoende bescherming konden bieden. Met veel moeite slaagde Ignaz Felix er in twee adellijke dames te vinden

1104 RHCL, Rijkskamergerecht, inv. nr. 71/1, fol. 105-116vo.

${ }_{1105}$ RHCL, Rijkskamergerecht, inv. nr. 71/1, fol. 105-116vo.

1106 RHCL, Rijkskamergerecht, inv. nr. 71/1, fol. 105-116vo.

1107 TJ, inv. nr. M 32, fol. 13, nr. 18 en 19 (16 februari 1732).

1108 TJ, inv. nr. M 2, fol. 681-687. 
die zich over zijn nichtje wilden ontfermen en haar begeleiden. Maar Maria Josepha wilde het klooster alleen in gezelschap van de zusters verlaten. Ook de zusters vonden een scheiding ongewenst en wilden het kind zelf brengen. Die houding leidde bij Ignaz Felix tot het vermoeden dat de zusters wel erg veel invloed op de jonge gravin hadden. Hij zette echter door en Maria Josepha werd veilig door één van de dames in Mannheim afgeleverd. $\mathrm{Na}$ een verblijf aldaar van enkele weken, dreigde ook die stad bij de oorlog betrokken te raken. Ignaz Felix besloot daarom zijn nicht over te brengen naar München.

Graaf Toerring-Jettenbach had ongetwijfeld de beste bedoelingen met de evacuatie van zijn nichtje, maar hij haalde zich daarmee wel het ongenoegen van het hof in Brussel op de hals. Op 28 juni 1734 werd vanwege de aartshertogin-landvoogdes geëist dat de jonge gravin werd teruggebracht. In een uitgebreid antwoord probeerde Ignaz Felix zich te rechtvaardigen. De communicatie langs diplomatieke weg was niet goed gelopen en het Rijnland werd wegens de oorlog steeds onveiliger. Met Franse troepen in de buurt vreesde de graaf dat mogelijk de jonge graaf de Waitte nog opdook. Ignaz Felix wierp ver van zich de beschuldiging af dat hij zijn nicht had ontvoerd. Hij was haar voogd, alles was te goeder trouw in volle openheid gebeurd en hij zou het zich altijd hebben verweten wanneer hij het kind in gevaarlijke omstandigheden had achtergelaten. In dat opzicht was dus iedere vergelijking met de jonge graaf de Waitte volstrekt misplaatst. Graaf Toerring-Jettenbach hoopte dus op begrip en welwillendheid bij de aartshertogin-landvoogdes, maar verklaarde tegelijkertijd niet van plan te zijn het kind naar Luxemburg terug te sturen. Hij had als voogd de meeste rechten en zijn huis was uitstekend geschikt voor de opvoeding van een meisje van stand.

Of Ignaz Felix het gevraagde begrip van Brussel kreeg, is niet bekend, maar hij hield Maria Josepha onder zijn hoede in München. Baron de Heyden bleef belast met het beheer van Sanem en burgemeester d'Oliva zette zijn werk als administrator van Gronsveld voort. Zoals in Hoofdstuk 12.1 wordt besproken, zond de graaf bij gelegenheid een commissaris als zijn tijdelijke, speciale vertegenwoordiger naar Gronsveld. Het proces met Belderbusch sleepte nog een aantal jaren aan, maar had weinig repercussies op de situatie in het graafschap. Al met al leek de rust na de roerige jaren twintig weer langzaam terug te keren. Wel ontwikkelde zich stilaan een probleem met Joannes Matthias Oligschläger, de rentmeester en secretaris van de schepenbank, die zich op schaamteloze wijze verrijkte. Diens praktijken kwamen echter pas volledig aan het licht na 1746, toen hij werd aangeklaagd wegens corruptie. Maria Josepha was toen al gehuwd.

Maria Josepha kwam na haar overbrenging naar München terecht in een heel andere wereld dan het provinciale Luxemburg of het leven binnen de beslotenheid van kloostermuren. Ignaz Felix was als Oberstlandzengmeister, Konferenzminister, Generalfeldmarschalleutnant en Hofkriegsratspräsident een van de meeste invloedrijke personen an het hof van keurvorst Karl Albrecht. Hij steunde de keurvorst in diens aspiraties om na het overlijden van keizer Karel VI tot keizer te worden gekozen. De Habsburgse successie was immers, bij gebrek aan mannelijke nakomelingen, een probleem. In de Pragmatieke Sanctie had keizer Karel VI vastgelegd dat de Oostenrijkse erflanden 
ondeelbaar waren. Zijn dochter Maria Theresia, gehuwd met Frans Stephan van Lotharingen, zou hem opvolgen. Maar de geldigheid van die regeling werd betwist, onder anderen door Karl Albrecht van Beieren, die gehuwd was met aartshertogin Maria Amalia van Habsburg, een nicht van Karel VI. Als aanloop naar verwerving van de keizerskroon investeerde Karl Albrecht in de jaren dertig flink in de opbouw van een leger. Voorts werd ingezet op een coalitie met de niet altijd even betrouwbare bondgenoot Frankrijk. Verantwoordelijk voor dit werk was graaf Ignaz Felix. Maar Beierse hulp aan de keizer in de oorlog tegen de Turken in 1737 eindigde met zware verliezen voor het leger van de keurvorst.

Toen keizer Karel VI in oktober 1740 overleed, stonden de kansen voor Karl Albrecht om keizer te worden er slecht voor. Maar met hulp van Frankrijk, Spanje, Pruisen en SaksenPolen vond de keurvorst zich in juli 1741 sterk genoeg de oorlog tegen Oostenrijk te beginnen. Na militaire successen liet hij zich in december 1741 in Praag tot koning van Bohemen kronen. Met diplomatieke druk en grote bedragen aan Frans geld slaagde Karl Albrecht erin zich door de keurvorsten onder de naam Karel VII tot keizer te laten kiezen. Op 12 februari 1742 werd hem de keizerskroon op het hoofd gezet. Maar in militair opzicht ging het Beieren niet voor de wind. Op 17 januari 1742 verloor Ignaz Felix als Beiers bevelhebber een treffen met Oostenrijkse troepen in de buurt van Braunau. Een dag na de keizerskroning capituleerde München en werd het keurvorstendom Beieren door Oostenrijkse troepen bezet. Karel VII was een keizer zonder land en inkomsten. Graaf Ignaz Felix von Toerring-Jettenbach werd voor dit echec verantwoordelijk gehouden. Hij kreeg op 13 augustus 1742 ontslag als opperbevelhebber van het Beierse leger, maar bleef minister voor de buitenlandse zaken. In de daaropvolgende jaren wisselde het krijgsgeluk voor de keizer. In oktober 1744 heroverde hij Beieren, maar begin 1745 bezetten de Oostenrijkers opnieuw een deel van zijn land.

Karel VII overleed volkomen onverwacht op 20 januari 1745. Hij werd als keurvorst van Beieren opgevolgd door zijn zoon Max III Joseph. Deze benoemde Ignaz Felix opnieuw tot opperbevelhebber, maar de graaf was wegens ziekte pas op 17 maart 1745 in de gelegenheid aan de besprekingen van het oppercommando deel te nemen. De oorlog werd voortgezet met diverse schermutselingen. Terwijl Ignaz Felix zich voorbereidde op een slag tegen de Oostenrijkers, haakten de Franse en Hessische troepen als bondgenoten af. De jonge, onzekere Max III Joseph stuurde op advies van de Oostenrijkse partij onder zijn raadgevers aan op vrede. Op 22 april 1745 werd te Füssen een voorlopig verdrag getekend. De keurvorst erkende de Pragmatieke Sanctie en beloofde zijn stem bij de keuze van Franz Stephan van Lotharingen, de echtgenoot van Maria Theresia, tot keizer. Op hun beurt erkenden de Oostenrijkers de legitimiteit van de overleden Karel VII als keizer, kreeg Max III Joseph zijn keurvorstendom weer terug en betaalde Maria Theresia een aanzienlijk bedrag om Beieren een bankroet te besparen.

Ignaz Felix was over dit verdrag van Füssen niet geïnformeerd. Juist op het moment van de vrede stond de bevelhebber tegenover een oprukkend Oostenrijks leger. Om het risico van een capitulatie en gevangenneming van zijn troepen te voorkomen, zond hij de keurvorst een plan om de Oostenrijkers aan te vallen. Kreeg hij die toestemming niet, dan verzocht hij van zijn functie als opperbevelhebber te worden ontheven. Met deze ongehoorzaamheid haalde Ignaz Felix zich de ongenade van de jonge keurvorst op de 
hals. Hij werd inderdaad per kerende post ontslagen. De Weense partij aan het keurvorstelijk hof zorgde er aanvankelijk voor dat graaf Toerring-Jettenbach min of meer uit München werd verbannen. Toen de publieke opinie zich tegen de vrede met Oostenrijk keerde, werd hij weer in ere hersteld, maar bleef hij verder zonder verdere politieke invloed.

Het gezinsleven van Ignaz Felix week in deze jaren wel af van het normale patroon. Uit het huwelijk met zijn echtgenote gravin Maria Theresia von Arco waren zeven kinderen geboren. Daarvan bereikten er slechts twee de volwassenheid, te weten de oudste zoon Maximiliaan Emanuel (1715-1773) en de jongste zoon August Joseph (1728-1802). Drie kinderen waren al overleden toen Maria Josepha in München arriveerde, twee meisjes stierven daarna in 1740 respectievelijk 1744. De zorg voor de opvoeding van de jonge gravin van Gronsveld zal in de praktijk vooral in handen zijn geweest van de echtgenote van Ignaz Felix. Het is waarschijnlijk dat Maria Josepha door de positie van haar voogd ook aan het keurvorstelijk hof bekend raakte met de hoogste adellijke kringen in Beieren.

In 1744 voegden zich drie weeskinderen uit een zijlijn van de familie, de graven von Toerring Stein, bij het gezin. Daarmee moest Ignaz Felix ook zorgen voor de opvoeding van deze drie meisjes. Maria Josepha d'Arberg Valengin begon intussen op huwbare leeftijd te komen. Of Ignaz Felix al vanaf het begin vastomlijnde plannen met zijn pupil had, is niet duidelijk. De gravin van Gronsveld vormde toch een enigszins apart geval. Zij was niet rijk en haar bezittingen lagen ver weg van Zuid-Duitsland. Maar uit dynastiek oogpunt was het rijksonmiddellijke Gronsveld interessant vanwege de zetel in de Nederrijns-Westfaalse Kreits en de Nederrijns-Westfaalse Grafenbank in de Rijksdag. Tegelijk was het de vraag of de gravin d'Arberg Valengin wat betreft adeldom helemaal voldeed aan de criteria voor Ebenbürtigkeit zoals die voor de rijksadel golden. Aan moederszijde hoorden de Toerrings sinds 1630 tot de stand der rijksgraven, maar zij waren niet in het bezit van een rijksonmiddellijk territorium. De Arbergs voerden weliswaar de titel graaf, maar niet langer dan twee generaties en zij behoorden tot buitenlandse adel.

Een aardig voorbeeld van het 'meedenken' over een geschikte huwelijkskandidaat levert een ongedateerde brief (waarschijnlijk circa 1741) van de administrator d'Oliva van Gronsveld aan graaf Ignaz Felix. Hij had contact gehad met de graaf d'Argenteau, 'trefoncier' (regerend kanunnik) van het kapittel van Sint-Lambertus in Luik. Deze hoge kerkelijke functionaris wist te vertellen dat zijn neef, de zoon van de generaal graaf Merci d'Argenteau, een oogje had laten vallen op de gravin d'Arberg Valengin en de mogelijkheid van een huwelijk overwoog. De jonge graaf van Argenteau was achttien en volgde op dat moment nog een opleiding aan de ridderacademie van Turijn. De jongeman zou van zijn vader het graafschap Merci kunnen krijgen, dicht bij Sanem, alsmede het kasteel van Argenteau. Merci was tussen de zevenduizend en achtduizend pattacons waard en Argenteau het mooiste kasteel van het land van Luik. Samen zou dat het paar dertigduizend pattacons aan inkomsten opleveren. De 'trefoncier' wilde hen ook nog tot universele erfgenamen benoemen met een dotatie van zestienduizend Duitse guldens. 
D'Oliva verwachtte dat een dergelijke verbintenis zeker goedkeuring bij de bevolking zou wegdragen en het huis Gronsveld tot ongekende glans brengen. ${ }^{1109}$

Ignaz Felix had echter andere plannen en arrangeerde een huwelijk tussen Maria Josepha en zijn oudste zoon Maximilian Emanuel. Dat werd op 3 januari 1746 gesloten. Het bezwaar dat bruid en bruidegom volle neef en nicht waren, werd opgelost met een pauselijke dispensatie. In het huwelijkscontract was bepaald dat Maximilian Emanuel ook de titel graaf van Gronsveld zou voeren en zijn vrouw bij alle voorkomende gelegenheden mocht vertegenwoordigen. Met dit huwelijk eindigde ook formeel de voogdij van Ignaz Felix.

\subsection{Maria Josepha Nepomucena d'Arberg Valengin 1746-1754 en Maximilian Emanuel von Toerring- Jettenbach, (1746) 1754-1773.}

Graaf Maximilian Emanuel bekommerde zich al snel om de goederen die zijn echtgenote in het huwelijk had ingebracht. Maar de tijd was ongunstig. Gronsveld werd geconfronteerd met de gevolgen van de Oostenrijkse Successieoorlog (1740-1748), die in het bijzonder in de jaren 1747 en 1748 grote schade aanrichtte. Maar landsheerlijke bemoeienis was dringend gewenst. Drossaard en fiscus Hendrik Lebens (door de graaf in zijn functie bevestigd) was een gerechtelijke procedure gestart tegen de van grootschalige fraude verdachte rentmeester Joannes Mathias Oligschläger. Uiteindelijk sleepte die affaire zich tientallen jaren voort (zie Hoofdstuk 12.5). Verder werd een einde gemaakt aan de nog (zeer beperkte) bemoeienis van d'Oliva als appelcommissaris van de Gronsveldse schepenbank. Ook hier bestonden twijfels over het functioneren van de man.

Misschien bracht dit soort ervaringen Maximilian Emanuel ertoe bij voorkeur bestuurlijke en kerkelijke functies in Gronsveld met mensen uit Beieren te bezetten. Uiteraard leverde het verschil in taal een nadeel op, maar dat gold alleen richting de bevolking. De graaf had behoefte aan betrouwbare en snelle rapportages, geschreven door mensen die het Hoogduits uitstekend in geschrift en woord beheersten.

In het verleden waren er incidenteel voor korte of langere tijd grafelijke vertegenwoordigers naar Gronsveld gezonden, maar dat voldeed in de praktijk onvoldoende. Graaf Maximilian Emanuel besloot tot de benoeming van een permanente vertegenwoordiger. Sedert medio 1748 was dat Josephus Antonius Schmädel (of de Schmadel), die de functies van pastoor van Gronsveld (de graaf had het collatierecht) en grafelijk vertegenwoordiger combineerde. Wegens ziekte, weinig daadkracht en heimwee van de pastoor werd dit geen succes.

Een krachtig bestuur was echter dringend gewenst, enerzijds vanwege de schade van de Oostenrijkse Successieoorlog (1740-1748) en anderzijds vanwege enkele grote rechtszaken voor de schepenbank, waarmee publiek belang was gemoeid. Ter vervanging van Schmädel werd medio 1752 Joseph Anton Prummer, geboortig uit Ingolstad, als grafelijk vertegenwoordiger naar Gronsveld gestuurd. Zijn achtergronden en werkzaamheden komen hierna in verschillende hoofdstukken nog meermaals aan de orde, maar daarop

1109 TJ, inv. nr. M 43, fol. 562-565, d'Oliva aan I.F. von Toerring-Jettenbach, waarschijnlijk 1741. 
vooruitlopend kan al worden gezegd dat deze ambtenaar gedurende meer dan 25 jaar zijn stempel op Gronsveld heeft gedrukt.

Prummer ontving ter voorbereiding op zijn reis naar Gronsveld op 8 juli 1752 een uitgebreide instructie om het grafelijk gezag in Gronsveld te consolideren. Op weg naar zijn nieuwe standplaats moest hij echter eerst de verkoop van kasteel Sanem en de afwikkeling van de Luxemburgse zaken regelen wat de nodige tijd vergde. De volgende opdracht betrof het organiseren van een formele inhuldiging van Maximilian Emanuel als landsheer. Tijdens de voorbereiding van die plechtigheid ontving Prummer het bericht dat op 17 februari 1754 gravin Maria Josepha d'Arberg Valengin in München was overleden aan een 'hydropisie universelle' of 'herz-wasserzucht', een ziekte waaraan zij al een aantal jaren leed. ${ }^{1110}$ De volgende dag deelde de grafelijk secretaris Xaver Prummer zijn broer in Gronsveld per brief het overlijden mee, met de opdracht zo snel mogelijk na de bekendmaking te zorgen voor een plechtige rouwdienst. ${ }^{1111}$ Omdat men in München (ten onrechte) vermoedde dat Joseph Anton Prummer nog in Luxemburg verbleef, arriveerde de brief als nagezonden post pas op 14 maart 1754 in Gronsveld. Nadere instructies die op 14 maart in München werden uitgevaardigd, arriveerden in Gronsveld op 22 maart 1754. Na een plechtig requiem voor de overleden gravin volgde op 2 april de plechtige inhuldiging van graaf Maximilian Emanuel. Deze gebeurtenis vormt in zoverre een mijlpaal in de geschiedenis van het graafschap, dat daarmee de familie Toerring-Jettenbach definitief haar intrede deed in Gronsveld. Een jaar na het overlijden van Maria Josepha huwde Maximilian Emanuel de jonge gravin Auguste von Seinsheim. Het huwelijk bleef kinderloos.

Het bestuur van graaf Maximilian Emanuel droeg een duidelijk ander karakter dan dat van zijn voorgangers. Voor het eerst sinds 150 jaar kreeg Gronsveld, afgezien van de korte regeerperiode van graaf Claude Nicolas d'Arberg Valengin, een landsheer zonder een echte militaire loopbaan. Hij was wel als Obristlandzengmeister verantwoordelijk voor legermaterieel, maar had als Hofkammerpräsident en Geheimer Konferenzminister vooral belangstelling voor economie en staatsfinanciën. Gelet op de lege staatskas was dat ook dringend noodzakelijk. Zelf gaf hij het goede voorbeeld met de oprichting van een papiermolen, een potloodfabriek en een spiegelfabriek. Daarnaast had hij wetenschappelijke belangstelling en stond hij aan de wieg van de oprichting van de Beierse Academie van Wetenschappen. ${ }^{1112}$ Deze achtergronden speelden ook een rol bij de manier waarop Maximilian Emanuel het graafschap Gronsveld benaderde. De nieuwe graaf had niet alleen een voorkeur voor het benoemen van landgenoten, zijn behoefte aan informatie over Gronsveld was bijna onverzadigbaar. Dat betrof niet alleen bestuur, maar

1110 Maria Josepha werd begraven in de kruisgang van het franciscanenklooster in München. De bekende kunstenaar Johan Baptist Straub vervaardigde een monumentale epitaaf in grijs en rood marmer. Het schild met de naam van de overledene wordt bekroond door het alliantiewapen en begeleid door een vrouwenfiguur die de huwelijkse trouw symboliseert. Na de afbraak van het franciscaneklooster in 1802 werd het monument verplaatst naar de St.-Georgskirche in München-Bogenhausen, zie Lieb, St. Georg in München-Bogenhausen, 51-55.

1111 TJ, inv. nr. M 14, fol. 1091-1094, Xaver Prummer in München aan Joseph Anton Prummer in Gronsveld 18-2-1754.

1112 Englbrecht, Drei Rosen, 313-313. 
ook natuurlijke gesteldheid, landbouw en veeteelt, economie et cetera. Door regelmatige correspondentie wilde hij op de hoogte worden gebracht van alle lopende zaken. Daarnaast stelde Prummer een reeks, meestal breedsprakige rapporten op over onderwerpen die hij van belang achtte voor grafelijke rechten en inkomsten. Een aantal daarvan komt hierna bij de beschouwingen over de grafelijke domeinen nog aan de orde. Op die wijze was het bestuur van Maximilian Emanuel een bestuur op afstand, maar tegelijkertijd intensiever dan het in de anderhalve eeuw daarvoor ooit was geweest.

\subsection{August Joseph von Toerring-Jettenbach, 1773-1795 (1802)}

Maximilian Emanuel overleed op 13 maart 1773. Hij werd opgevolgd door zijn jongste broer August Joseph (1728-1802), Hofratsvizepräsident. Hoewel minder ondernemend als zijn broer, zette hij in zakelijk opzicht diens beleid voort. Maar karakterologisch verschilde August Joseph van zijn broer. Men schreef hem 'bösartigen Gemütseigenschaften eines Misanthropen' en 'hypochondrischen Zustände' toe. ${ }^{1113}$ Of hij zich als hypochonder allerlei kwalen inbeeldde, valt niet met zekerheid te zeggen, maar zijn reputatie als 'mensenhater' wordt uit verschillende bronnen bevestigd. Hij begon zijn regering met de mededeling dat zijn broer veel te toegeeflijk was geweest en dat hij de touwtjes strak zou aantrekken. Van zijn ondergeschikten eiste hij blinde gehoorzaamheid, punctuele rapportages en financieel uiterst zuinig beheer. Zijn latere vertegenwoordiger in Gronsveld, Wolfgang Zollner, laat zich in brieven aan zijn vriendin Thérèse weinig vleiend uit over de graaf, omdat deze weigerde met Zollners huwelijksplannen in te stemmen. Ook ten opzichte van zijn eigen kinderen gedroeg August Joseph zich hardvochtig. Uit zijn huwelijk met Maria Elisabeth von Lerchenfeld werden elf kinderen geboren, waarvan er zeven volwassen werden, maar alleen de oudste zoon, Joseph August (1753-1826), trouwde. Aan een relatie met een burgermeisje makkte vader August Joseph resoluut een einde. ${ }^{1114}$ De overige broers en zusters traden in de geestelijke stand, maar of dit helemaal vrijwillig gebeurde? De jongste zoon Anton Cajetan, die waarschijnlijk geestelijk niet helemaal in orde was, werd door zijn vader 'verbannen' naar de broeders Alexianen in Keulen. Vrijwel ieder direct contact met de wanhopige jongen werd verbroken. Voor zover behoefte aan communicatie bestond, liep die via Gronsveld en moest Zollner daar voor zorgen.

August Joseph werd de laatste regerende graaf van Gronsveld. Per 1 oktober 1795 werd het graafschap met de Oostenrijkse Nederlanden, het prinsbisdom Luik en de territoria van de Republiek der Verenigde Nederlanden in het Maasgebied als onderdeel van het Departement Nedermaas bij Frankrijk ingelijfd. Vooralsnog bleef onzeker wat met de grafelijke eigendommen (kasteel, landerijen, bossen) zou gebeuren. Die werden onder sekwester (bewind) van de Franse domeinen gesteld. De vele problemen die daaruit voortvloeiden, worden in Hoofdstuk 12.7 besproken. Maar op 2 maart 1801 bepaalde de Franse minister van Financiën dat deze goederen definitief aan de Franse staat toevielen.

1113 Englbrecht, Drei Rosen, 314

1114 Englbrecht, Drei Rosen, 335. 
Er zijn geen bronnen bekend waaruit expliciet blijkt hoe August Joseph tegenover al deze revolutionaire veranderingen stond. De reacties op de brieven die na 1795 vanuit Gronsveld naar München werden gestuurd, wekken de indruk dat de graaf eigenlijk niet goed besefte wat zich precies in het verre Gronsveld afspeelde. Maar de politieke ontwikkelingen in Europa gaven weinig hoop op behoud van Gronsveld. In de Vrede van Campo Formio van 17 oktober 1797 stond Oostenrijk de Zuidelijke Nederlanden definitief af aan Frankrijk. In een geheim artikel was beloofd mee te werken aan de uiteindelijke overdracht door het Rijk van de hele linker Rijnoever aan Frankrijk, onder de voorwaarde dat de rijksvorsten die door deze afstand schade leden, werden gecompenseerd. In het Congres van Rastatt van december 1797 werd deze schadeloosstelling uitgewerkt, maar door het uitbreken van de Tweede Coalitieoorlog uitgesteld. Pas de Vrede van Lunéville van 9 februari 1801 regelde de gebiedsafstand van de linker Rijnoever aan Frankrijk met compensatie voor de wereldlijke rijksvorsten door secularisatie van de geestelijke vorstendommen. De feitelijke opheffing van de geestelijke vorstendommen vond begin februari 1803 plaats bij de Reichsdeputationshauptschluss van Regensburg. Joseph August, de opvolger van de in 1802 overleden August Joseph, werd voor het verlies van Gronsveld gecompenseerd met de rijksonmiddellijke cisterciënzerinnenabdij Gutenzell in Schwaben, ten zuiden van Ulm. Staatsrechtelijk betekende dit dat Joseph August zich nu Reichsgraf von Toerring-Jettenbach Gutenzell noemde. Met deze schadeloosstelling werd graaf Toerring-Jettenbach op dezelfde wijze behandeld als de graven van Wittem, Rekem en de heer van Slenaken, die tijdens het Ancien Régime via de Nederrijns-Westfaalse Grafenbank als Kuriatstimme in de rijksvorstenraad van de Rijksdag waren vertegenwoordigd. Ook deze graven ontvingen compensatie in Duitsland. ${ }^{1115}$ Daarmee verschilde hun positie met die van de heren van rijksonmiddellijke gebieden die niet in de Rijksdag waren vertegenwoordigd, zoals Rijckholt, Wylre en Stein. Die verloren hun heerlijke rechten aan de Franse staat, maar behielden hun bezittingen in de vorm van kasteel en landerijen.

Lang heeft de zelfstandigheid van de Reichsgrafschaft Gutenzell niet geduurd. Zestien Duitse vorsten sloten in 1806 de Rijnbondakte en traden daarmee uit het Rijk. Door het neerleggen van de keizerskroon door Frans II in 1806 hield het Heilige Roomse Rijk feitelijk op te bestaan. Het verdrag maakte ook de weg vrij voor mediatisering, de annexatie van kleine rijksgraafschappen door de grote vorsten. In het bijzonder in Zuidwest-Duitsland maakten de koninkrijken Beieren en Württemberg en het groothertogdom Baden een einde aan de vroeger voor dit gebied zo typische Kleinstaaterei. De graven behielden hun bezittingen krachtens burgerlijk recht, maar verloren hun soevereiniteit. Op grond van deze bepalingen kwam ook Gutenzell onder de soevereiniteit van koning Frederik I van Württemberg. Graaf Joseph August von Toerring-Jettenbach Gutzenzell stribbelde tegen, weigerde naar de inhuldiging van de koning te komen, maar

1115 Hofmann, Quellen Verfassungsorganismus, 329-358 met tekst van de Reichsdeputationshauptschluss: 34, graaf d"Aspremont-Lynden wegens Rekem de abdij Baindt en een rente uit Ochsenhausen; 341, graaf Plettenberg wegens Wittem en Eys de plaatsen Miedingen en Sullmingen alsmede bossen en renten; 342, graaf Schaesberg wegens Kerpen-Lommersum het Amt Tannheim (Ochsenhausen) en renten; 342, graaf Toerring wegens Gronsveld de abdij Gutenzell; 342, graaf Goltstein wegens Slenaken diverse renten. 
moest uiteindelijk toegeven. ${ }^{1116}$ Als Standesherren gold voor deze gemediatiseerde rijksgraven en vorsten een bijzonder adelsrecht, dat in de Duitse Bondsakte van 1815 werd bevestigd. ${ }^{1117} \mathrm{Zij}$ hoorden tot de Hochadel, hadden recht op bijzondere aanspreektitels en privileges en werden beschouwd als ebenbürtig, in rang gelijk aan de regerende vorstenhuizen. Vooral dit laatste recht was belangrijk bij de keuze van huwelijkspartners, aangezien leden van een Standesherrliches Haus en Fürstliches Haus als gelijk in rang werden beschouwd en huwelijken niet als een mesalliance of als morganatisch golden. De huwelijken die de Toerrings in de negentiende en twintigste eeuw sloten met personen van vorstelijke bloede zijn een goed voorbeeld van de uitwerking van deze bepalingen. Achteraf gezien loopt er daarmee een directe lijn van de Toerrings als rijksgraven van Gronsveld, via de Reichsgrafschaft Gutenzell, naar de erkenning in 1815 als Standesherr en de Ebenbürtigkeit aan de Europese vorstenhuizen.

\subsection{Conclusies}

De tijdvakken 1719-1746 en 1746-1795 dragen in de geschiedenis van Gronsveld een duidelijk verschillend karakter. De eerste periode kende het graafschap veel onrust en een zwak bestuur, de tweede verliep rustig en kende een stabiel bestuur.

De regering van graaf Nicolas d'Arberg Valengin en zijn echtgenote begon al onder slecht gesternte wegens problemen over de nalatenschap van Johan Frans van Bronckhorst Batenburg. De graaf, die namens zijn vrouw Gronsveld vanuit Luxemburg moest besturen, verpachtte in 1723 voor een periode van negen jaar de heerlijke rechten over het graafschap. Zijn gebrek aan betrokkenheid makkte de weg vrij voor een periode van partijstrijd, geweld en corruptie. Nadat de gravin en de graaf in 1730 en 1731 kort achter elkaar waren overleden, lieten zij hun minderjarig kind Maria Josepha een desolate boedel na. Het was vooral te danken aan het krachtig optreden van haar voogden graaf Ignaz Felix von Toerring-Jettenbach (die zijn rol eerst op andere familieleden moest bevechten) en de Akense burgemeester d'Oliva namens de stad Aken, dat de verhoudingen enigszins stabiliseerden. De periode van voogdij, die duurde tot het huwelijk van Maria Josepha in 1746, was echter te onzeker om te komen tot echte hervormingen.

Dankzij Ignaz Felix kwam de jonge gravin d'Arberg terecht in de kringen van de hoge Beierse adel en het hof van de keurvorst. Daar makkte zij ook de veelbewogen politieke en militaire loopbaan van haar voogd mee. Door het huwelijk dat Maria Josepha in 1746 sloot met haar neef graaf Maximilian Emanuel von Toerring-Jettenbach, de oudste zoon van Ignaz Felix, werd de band tussen Gronsveld en de familie Toerring Jettenbach bestendigd. Of het een gearrangeerde verbintenis, een huwelijk uit liefde of een combinatie van beide was, valt niet te zeggen, maar voor de grafelijke familie Toerring-Jettenbach betekende het een stap hoger op de maatschappelijke ladder. De Toerrings behoorden tot de oudste en rijkste Beierse adel en voerden sedert 1630 de titel 'rijksgraaf, maar het ontbrak aan een rijksonmiddellijk territorium. De verwerving van het rijksonmiddellijke graafschap Gronsveld maakten hen nu ook tot rijksstand.

1116 Maegraith, Das Zisterzienserinnenkloster Gutenzell, 232-233.

1117 Hofmann, Quellen Verfassungsorganismus, 404-407. 
$\mathrm{Na}$ het vroegtijdig overlijden van Maria Josepha in 1754 zette haar echtgenoot Maximilian Emanuel de regering voort. Omdat zijn huwelijk met Maria Josepha en ook zijn tweede huwelijk met Auguste Isabelle von Seinsheim kinderloos bleven, werd hij na zijn overlijden in 1773 opgevolgd door zijn jongste broer August Joseph († 1802). August Joseph was tot de inlijving van Gronsveld bij Frankrijk in 1795 de laatste regerende graaf van Gronsveld.

Hoewel de twee broers, die bij elkaar ongeveer vijftig jaar over het graafschap regeerden, karakterologisch sterk van elkaar verschilden, vertoonde hun bewind veel overeenkomsten. Hoewel zij volgens hun titulatuur niet 'von Gottes Gnaden' regeerden, gedroegen zij zich wel als typische representanten van verlicht absolutistisch denken. Hun gezag komt zelfbewust, absoluut, streng en afstandelijk, maar zeker niet onrechtvaardig of hardvochtig over. Verder bespeurt men bij hen, ook vanwege hun betrokkenheid bij het Beierse landsbestuur en het beheer van hun omvangrijke goederen in Beieren, duidelijk belangstelling voor economie, al was het maar om van Gronsveld een renderend bezit te maken.

De beide broers waren voor het beheer van het graafschap aangewezen op de medewerking van functionarissen uit Gronsveld zelf. Tegelijkertijd koesterden zij daartegen wantrouwen, niet in het minst vanwege taalverschillen. De benoeming van functionarissen afkomstig uit Beieren leek een betrouwbaar middel om zich ten minste voor een deel van loyale functionarissen te voorzien. Dat dit systeem maar gedeeltelijk functioneerde komt hierna nog aan de orde bij de behandeling van het bestuur in de achttiende eeuw. Verder bestond er een bijna onverzadigbare vraag naar informatie en wetenswaardigheden over Gronsveld, uit nieuwsgierigheid - de graaf was er zelf nooit geweest - maar ook om controle te kunnen uitoefenen. Ten slotte verliep het bestuur bureaucratisch en werden zelfs ogenschijnlijk onbelangrijk ogende zaken schriftelijk ter beslissing in München voorgelegd.

De inlijving van Gronsveld bij Frankrijk in 1795 maakte een einde an het grafelijk bewind. De in 1803 toegekende compensatie voor dit verlies in de vorm van de geseculariseerde rijksabdij Gutenzell leverde slechts drie jaar een rijksgraafschap Gutenzell op. In 1806 werd Gutenzell gemediatiseerd en bij het koninkrijk Württemberg geannexeerd. Als voormalige bezitters van rijksonmiddellijke en in de Rijksdag stemhebbende graven kregen de Toerrings echter na 1815 de status van Standesherren en werden zij wat betreft stand gelijkwaardig (ebenbürtig) aan families van vorstelijke bloede. 


\section{ADMINISTRATIEVE STRUCTUREN EN RECHTERLIJKE ORGANISATIE VAN GRONSVELD IN DE NIEUWE TIJD, CIRCA 1500-1796}

\section{Opvolging, inhuldiging en uitvaart van de landsheer}

Het landsheerlijk gezag over Gronsveld was erfelijk. In dit hoofdstuk behandelen we de vraag hoe opvolging en overdracht van gezag verliepen, op welke wijze de onderdanen geacht werden hun landsheer en -vrouwe in te huldigen en de laatste eer te bewijzen en welke juridische betekenis moest worden toegekend an de daarbij behorende formaliteiten. Het daarvoor voorgeschreven protocol vormde als 'Zeremonialwissenschaft' een onderdeel van de toenmalige rechtswetenschap. De meeste aandacht in dit hoofdstuk wordt besteed aan uitvaarten en inhuldigingen in 1754 en 1773, omdat daar uitgebreide beschrijvingen van bewaard zijn gebleven. Voor de voorafgaande periodes is de informatie over deze gebeurtenissen in Gronsveld zeer beperkt. Er zijn vooral financiële gegevens en ook stukken over problemen rond de opvolging.

In 1754 ging het eerst om de rouwplechtigheden voor de op 17 februari van dat jaar in München overleden Maria Josepha d'Arberg Valengin en daarna de inhuldiging van graaf Maximilian Emanuel von Toerring-Jettenbach. Met de organisatie van deze plechtigheden zag de onervaren Joseph Anton Prummer zich als de grafelijke vertegenwoordiger in Gronsveld zich gesteld voor een delicaat probleem. Want hoe politiek onbeduidend het graafschap ook was, zowel bij inhuldiging als uitvaart ging het om belangrijke publieke rituelen. Natuurlijk verschilden de plechtigheden in juridische betekenis, maar in beide gevallen makkte een nauwkeurig protocol de stand en het aanzien van de graaf duidelijk, zowel naar de onderdanen als naar adellijke buren in de omgeving.

De inhuldiging en de rouwplechtigheden die Prummer in 1754 organiseerde, kregen bijna twintig jaar later een herhaling, toen in 1773 graaf Maximilian Emanuel overleed en werd opgevolgd door zijn jongste broer August Joseph. Grotendeels verliepen deze plechtigheden volgens hetzelfde draaiboek. Van een volledig vastgelegde etiquette kan men na twee keer nog niet spreken, maar de aanzetten daartoe waren zeker aanwezig. De bewaard gebleven verslagen bevatten niet alleen juridisch interessante gegevens, door hun gedetailleerdheid zijn ze ook cultuurhistorisch belangwekkend en in deze vorm uitzonderlijk voor het Maasgebied. De beschrijvingen laten zien met welke gevoeligheden zowel binnen als buiten het graafschap rekening moest worden gehouden. Verbazingwekkend zijn de omvang en kosten van vooral de uitvaartplechtigheden. In zijn gedetailleerde verslagen makt Prummer ons deelgenoot van de problemen waarop hij stuitte en de afwegingen om tot bepaalde beslissingen te komen. Helaas wordt nergens vermeld waar hij zijn inzichten op baseerde. Mogelijk kende hij literatuur over dit soort onderwerpen en had hij in Zuid-Duitsland ook voorbeelden van inhuldiging en uitvaart in de praktijk meegemaakt.

\subsection{Opvolging en overdracht van rechten}

Hoewel nergens als zodanig vermeld, schijnt men bij het overlijden van een landsheer te zijn uitgegaan van het beginsel 'le roi est mort, vive le roi', dat wil zeggen dat het gezag als 
zodanig onmiddellijk en van rechtswege overging op de erfgenaam. Los daarvan stond de kwestie wie in een concreet geval de rechtmatige erfgenaam was. Ook een directe inhuldiging was, zoals we zullen zien, niet strikt noodzakelijk om landsheerlijk gezag uit te oefenen. Bij erfopvolging hadden - zo blijkt uit de praktijk - mannen voorrang op vrouwen en de oudste zoon op de jongere broers. Volledige zekerheid over die regel bestond er niet, want zowel bij het overlijden van graaf Johan II van Bronckhorst in 1619 als bij het overlijden van Jost Maximiliaan in 1662 zijn er signalen die wijzen op strubbelingen tussen broers. Mogelijk ging het daarbij ook om de vaststelling van de hoogte van het erfdeel. Wanneer de graaf bij zijn overlijden een weduwe en minderjarige kinderen achterliet, nam de moeder als voogdes en regentes (en meestal ook als vruchtgebruikster) het grafelijk gezag waar. Op het moment van meerderjarigheid vond dan formele overdracht plaats.

Gronsveld was geen majoraat of familiefideï-commis, een regeling waarbij het stamgoed van de familie ondeelbaar was en alleen in mannelijke lijn kon vererven. ${ }^{1118}$ Er bestond geen testament of contract waaruit men een dergelijke last zou kunnen afleiden. Integendeel, de geschiedenis laat voorbeelden zien van vererving in vrouwelijke lijn, zoals bij het overlijden van Johan Frans van Bronckhorst in 1719, toen zijn echtgenote Maria Anna von Toerring-Jettenbach erfde. Zij op haar beurt liet eveneens één dochter als erfgename na. Delen van het graafschap waren ook vervreemdbaar, zoals bleek uit de verkoop van de rechten over Slenaken in 1728.

Een onbeduidend, maar op zich interessant incident rond de kwestie van het majoraat speelde zich af rond de jaarwisseling van 1780. 'Directeur' Wolfgang Zollner, de pas in Gronsveld benoemde opvolger van commissaris Prummer, was benaderd door oudburgemeester Joppen van Maastricht met de vraag of graaf Toerring-Jettenbach misschien geld wilde lenen. Zollner liet doorschemeren dat daar inderdaad sprake van was met het oog op mogelijke terugkoop van de heerlijkheid Rimburg. Het zou om een aanzienlijk bedrag gaan, meer dan Joppen had verwacht en beschikbaar had. Hij probeerde daarom een medefinancier te vinden. Maar volgens Zollner had een of andere 'schwarzer Geist' Joppen naar het huis van Prummer in Maastricht gevoerd, waar mevrouw Prummer hem een verhaal op de mouw speldde dat Gronsveld een 'majorat' of 'fideicommissum familiae' was. Een dergelijke last maakte het graafschap veel minder waard als onderpand voor een geldlening, omdat de positie van de graaf in dat geval niet veel sterker was dan die van vruchtgebruiker. Mevrouw Prummer vertelde dat Zollner misschien zelf niet eens van dat 'majorat' op de hoogte was, want hij verbleef nog maar kort in het land, terwijl haar man al bijna dertig jaar de zaken van het graafschap had behartigd. Joppen blies onmiddellijk het plan van de lening af. Hoewel Zollner bezwoer dat het allemaal gelogen was, achtte Joppen het niet verantwoord geld te steken in een project met een onzeker onderpand. Uiteindelijk ging de hele lening niet door, maar het incident is interessant omdat hier nog eens pertinent werd ontkend dat Gronsveld een majoraat of familiefideïcommis was. Voor Zollner kreeg de affaire nog een nasleep in die zin dat hij de graaf

1118 Zie voor dit begrip: Erler e.a., Handwörterbuch Rechtsgescbicbte I, 1071-1074 onder lemmata Familienfideikommiß en Familienstammgüter. Zie ook voor een voorbeeld daarvan wat betreft de heerlijke rechten van de koning van Pruisen op Hooge en Lage Zwaluwe: Peele, Een vitzonderlijke erfgenaam, in het bijzonder 60-70. 
vroeg zijn recente benoeming voor de buitenwereld nog eens goed duidelijk te maken. Want het verhaal vormde het zoveelste bewijs dat de 'Prummerische' met haar 'eingewurzelte Regierungssucht' zich nog altijd mengde in de Gronsveldse zaken, hoewel haar man met emeritaat was. ${ }^{1119}$

Wanneer het graafschap vererfde op een vrouw, kon de uitoefening van het grafelijk gezag ook worden overgedragen aan haar echtgenoot. Bij het huwelijk van Maria Josepha d'Arberg Valengin met Maximilian Emanuel von Toerring-Jettenbach waren daarover bepalingen opgenomen in het huwelijkscontract. Waarschijnlijk is dit ook gebeurd bij de huwelijkse voorwaarden tussen Maria Anna von Toerring-Jettenbach en Claude Nicolas d'Arberg Valengin. In deze gevallen oefende de man op eigen naam de volle rechten over het graafschap uit, zonder dat sprake was van delegatie. Het omgekeerde kwam ook voor, zoals blijkt uit de overdracht van de heerlijke rechten over Slenaken door Jost Maximiliaan van Bronckhorst aan zijn echtgenote Anna Christina von Hardenrath in 1658.

\subsection{De juridische betekenis van landsheerlijke inhuldiging en uitvaart}

Er bestonden in het recht vele vormen van huldiging en eedsaflegging, zoals bij de benoeming van rechters of bestuurders en de hulde die de leenman zijn leenheer bracht. We beperken ons hier tot de inhuldiging van de landsheer door de inwoners van het land als eerste publieke onderwerping aan het staatsgezag en een plicht waar geen enkele onderdaan zich aan mocht onttrekken. ${ }^{1120}$ De eed van trouw werd door publieke functionarissen, onderdanen en leenmannen individueel of collectief afgelegd. Daarna kon door middel van symbolische handelingen worden overgegaan tot de feitelijke inbezitneming. Overigens maakte huldiging als zodanig iemand niet tot onderdaan; die status bezat iemand al van rechtswege door geboorte en woonplaats. Daarom kon landsheerlijk gezag ook zonder formele inhuldiging worden uitgeoefend.

Het was algemeen aanvaard dat een rijksstand ook huldiging mocht eisen van buitenlanders, in het bijzonder personen die grondbezit hadden binnen zijn territorium. De gevraagde onderwerping was onvolledig in die zin, dat ze slechts in relatie stond met dit onroerend goed.

Er bestond geen eensluidende mening of de landsheer na de inhuldiging ook de rechten van zijn onderdanen moest bevestigen. Volgens de meest gangbare opvatting vloeide die wederkerigheid voort uit het natuurrecht: wie iets uitdrukkelijk vraagt, moet het ook uitdrukkelijk mondeling of schriftelijk bevestigen. Voor zover dit schriftelijk gebeurde, vond de ondertekening eigenlijk alleen maar plaats na de inhuldiging.

In grote territoria was het gebruikelijk dat de landsheer een reis maakte langs steden en districten om zich ter plaatse te laten inhuldigen. De noodzaak van een dergelijke tocht, waarmee veel tijd en geld gemoeid konden zijn, werd bepaald door bestaande gebruiken

1119 TJ, inv. nr. M 59, fol. 31-38, Zollner aan A.J. von Toerring-Jettenbach 19 januari 1780.

${ }_{1120}$ Zie hierover in algemene zin: Holenstein, Die Huldigung en in het bijzonder voor de opvattingen over de huldiging door onderdanen, 65-73; zie verder Stollberg-Rilinger, Rituale, 103-106, weliswaar betreffende inhuldiging van koningen, maar niet principieel verschillend van iedere vorm van inhuldiging door onderdanen. 
en gewoontes. Betwist was of in iedere stad of in ieder dorp een formele registratie van inhuldiging moest plaatsvinden.

Inhuldiging zou een publiek feest moeten zijn, maar op wiens kosten? In sommige streken bestond een 'huldigingsregaal', een landsheerlijke belasting om geschenken, maaltijden en traktaties voor de bevolking te financieren. ${ }^{1121}$ Ook over de betekenis van geschenken aan de nieuwe landsheer bestonden verschillende opvattingen. Dit soort giften had weinig te maken met genegenheid, maar moest de juridische betekenis van de huldiging bevestigen. Daarnaast herinnerden de geschenken aan de oude plicht van de onderdanen om bij te dragen in het onderhoud van hun heer. ${ }^{1122}$

Niet alleen de inhuldiging, ook het ceremonieel bij uitvaartplechtigheden van de landsheer had staatsrechtelijke betekenis. Aan de grote Europese vorstenhoven waren middeleeuwse rituelen en gebruiken rond inhuldiging en uitvaart in de loop van de zeventiende en achttiende eeuw verfijnd tot een gedetailleerd protocol. Als toonaangevend golden de koninklijke hoven van Spanje en Frankrijk en het keizerlijk hof in Wenen, maar ook de talloze grote en kleine vorstenhoven in Duitsland richtten zich naar deze voorbeelden. In de achttiende eeuw werden in Duitsland deze gebruiken bestudeerd in de Zeremonialwissenschaft. ${ }^{1123}$ Dat bleef niet beperkt tot louter bestudering van (praktische) regels van etiquette, want aan het ceremonieel lagen ook fundamentele opvattingen ten grondslag over de verhouding tussen vorst en onderdaan, de verhouding tussen vorst en religie en de legitimatie van gezag. De auteurs van eigentijdse publicaties over de Zeremonialwissenschaft moeten dan ook gedeeltelijk worden gezocht in kringen van juristen en beoefenaren van het staatsrecht. Dezelfde groep had ook om praktische redenen belangstelling voor de inhuldiging, want juristen in vorstelijke dienst waren nogal eens betrokken bij de organisatie van dit soort plechtigheden.

De middeleeuwse uitdrukking 'le roi ne meurt jamais' ('de koning sterft nooit') betekende in de vroegmoderne tijd dat het overlijden van de heerser, in wiens persoon het absoluut gezag was geconcentreerd, bij uitstek het moment was om de continuïteit van vorstelijke macht en waardigheid te demonstreren. ${ }^{124}$ In de literatuur bestonden ook beschrijvingen met afbeeldingen van lijkstoeten voor vorstelijke en hooggeplaatste personen. Daarop is de samenstelling van deelnemende groepen en het meedragen van grote wapenborden te zien. Naast het bij deftige begrafenissen algemene gebruik om het interieur van kerken met zwarte doeken te behangen, werd voor uitvaarten van vorstelijke of hooggeplaatste personen bij de ingang van het priesterkoor een katafalk met zerk, een zogenoemd castrum doloris, opgericht. ${ }^{1125}$ Dit bestond uit een bouwsel van lichte houtsoorten en karton, bekroond door een dak of baldakijn, met op de vier hoeken en langszij kaarsen. Het geheel werd bekleed met zwarte draperieën en behangen met wapenborden. In het castrum doloris werkten architect (voor het ontwerp), dichter (voor zinspreuken) en schilder (voor

1121 Holenstein, Die Huldiging, 468-472.

1122 Holenstein, Die Huldiging, 464-467.

1123 Algemeen hierover: Vec, Zeremonialwissenschaft.

1124 Vec, Zeremonialwissenschaft, 295-296.

1125 Zie: Lexicon des Mittelalters II, 1569, onder lemma 'castrum doloris'. 
wapenborden en emblemata) samen aan één kunstwerk, bedoeld om de toeschouwers te imponeren. Dergelijke bouwsels gaan in oorsprong terug op de laatmiddeleeuwse uitvaartliturgie voor hooggeplaatste personen en vonden in de tijd van renaissance en barok overal ingang. De kist met het stoffelijk overschot van de overledene kon onder dit bouwsel staan, maar meestal was dat niet het geval. Soms was de landsheer ver weg overleden, of moest, wanneer het lichaam wel ter plaatse was, de begrafenis snel gebeuren. De voorbereiding van een plechtige rouwdienst vergde tijd. Eigenlijk was de aanwezigheid van een lichaam of afbeelding van de overledene ook niet noodzakelijk, omdat het castrum niet zozeer betrekking had op de gestorvene als persoon, maar op allegorische wijze diens macht, ambt en de waardigheid uitbeeldde.

\subsection{Overdracht van Gronsveld en Rimburg aan Jost van Bronckhorst Batenburg, 1586}

Het vroegste voorbeeld van overdracht van de heerlijkheid Gronsveld dateert uit 1586. Volgens het huwelijkscontract tussen Willem van Bronckhorst Batenburg en Agnes van Byland kreeg Agnes het recht van vruchtgebruik op alle goederen van haar echtgenoot, wanneer zij als weduwe met minderjarige kinderen achterbleef. Voorwaarde was wel dat zij voor haar kinderen zorgde en niet hertrouwde. Op 1 februari 1586 sloten Agnes en haar twee zonen Jost en Johan op kasteel Rimburg, in het bijzijn van Johan heer tot Millendonk en Otto van Bylandt, een overeenkomst waarbij Agnes de heerlijkheden Gronsveld en Rimburg (onverdeeld) overdroeg. Voor zichzelf behield zij het huis Eyl in het hertogdom Kleef, met alle daartoe behorende goederen. ${ }^{1126}$

Dit contract vormde de eerste fase van een verdere verdeling. Op 26 maart 1586 verklaarde Johan van zijn rechten op Gronsveld en Rimburg ${ }^{1127}$ afstand te doen voor een jaarlijkse uitkering van vierhonderd 'pistolette cronen', onder voorbehoud van rechten die zijn moeder nog kon doen gelden. Op 2 april 1586 verscheen doctor Assuerus Stroyff voor schepenen van Gronsveld, voorzien van een door Johan getekende volmacht, op grond waarvan aan Jost van Bronckhorst was overgedragen 'die uralte frieherlicheyt Gronsfeldt vurss. mit allen derselver hochheiden ende gerechtigkeyden, niet daervan aff noch uytgescheiden'. De broederlijke deling van 26 maart moest als ingelast bij deze

1126 Deze gegevens zijn ontleend aan een akte opgemaakt door de schepenen van Rimburg op 20 december 1589 en afgeschreven in een procesdossier van het Rijkskamergerecht van een geschil tussen Jost Maximiliaan van Bronckhorst Batenburg en Johan Arnold van Argenteau over de betaling van een erfpacht van 63 malder en vier vat rogge (RHCL, Rijkskamergerecht, inv. nr. 76, fol. 131 (modern)135vo.). Schepenen verklaarden in 1589 dat Johan van Bronckhorst Batenburg een op papier geschreven overeenkomst van scheiding en deling had getoond tussen hem, zijn broer en hun moeder. De schepenen verwerkten de tekst daarvan grotendeels in hun verklaring, zonder dat echter van een vidimus of authentiek afschrift in strikt technische zin kan worden gesproken.

1127 Aangenomen wordt dat de overdracht zowel Gronsveld als Rimburg omvatte, hoewel laatstgenoemde plaats in de verklaring van de schepenen van Rimburg van 20 december 1589 niet uitdrukkelijk wordt vermeld. Daar kunnen verschillende redenen voor zijn, variërend van slordigheid bij de 'bewerking' van de oorspronkelijke overeenkomst tot praktisch onderscheid tussen de twee verschillende heerlijkheden. 
overdracht worden beschouwd. Dezelfde rechtshandeling vond daarna ook plaats voor stadhouder en leenmannen van het leenhof van Gronsveld. ${ }^{1128}$

Of na de overdracht nog een inhuldiging plaatsvond, is niet bekend. Jost vertrok vrij snel naar het leger en overleed begin december 1588 in de buurt van Wachtendonck. Zijn broer graaf Johan II van Bronckhorst keerde terug uit Italië en volgde hem op. Waarschijnlijk werd de nieuwe graaf wel plechtig ingehuldigd. In de processen die Johan II in de periode 1599-1611 tegen zijn onderdanen voerde, wordt daar terloops enkele keren aan gerefereerd. ${ }^{1129}$ Verder was het een oud gebruik dat de onderdanen bij de aanvaarding van de regering een 'verehrung oder charitativum subsidium' aan de heer aanboden. In het geval van graaf Johan II hadden de inwoners nog eens negenhonderd gulden extra geschonken voor opbouw van het kasteel. (Naderhand werd in de processen de betekenis van deze bijdragen onderwerp van geschil).

\subsection{Inbuldiging van Jost Maximiliaan van Bronckhorst Batenburg, 1617}

Johan II van Bronckhorst Batenburg overleed medio oktober 1617. Over de inhuldiging van diens zoon Jost Maximilaan vond Prummer in 1753 een los blad papier met de tekst van een eed van trouw. ${ }^{1130}$ In de marge stond de aantekening dat de inwoners van Gronsveld Jost Maximiliaan als nieuwe landsheer hadden gehuldigd. Tevens bevatte de tekst in afschrift een renversaal of tegenbrief, waarin de graaf beloofde alle rechten, vrijheden en privileges van zijn onderdanen te handhaven. Nadere details over plechtigheden ontbraken, wat volgens Prummer ook wel verklaarbaar was. Na het overlijden van Johan II van Bronckhorst Batenburg zou er onenigheid zijn geweest tussen Jost Maximiliaan en zijn broers Otto Willem en Hendrik. Jost Maximiliaan liet echter zijn eerstgeboorterecht gelden. Nog voordat het geschil was beslist, zou hij Gronsveld in bezit hebben genomen zonder daar ruchtbaarheid aan te geven. Ook de inhuldiging zou zonder openbare plechtigheden hebben plaatsgevonden. ${ }^{1131}$

Bij dit verhaal moeten vraagtekens worden geplaatst. Het is een feit dat de nalatenschap van Johan II in 1617 voorlopig onverdeeld bleef wegens de minderjarigheid van een deel van de kinderen. In Hoofdstuk 4.1.1 is beschreven dat het pas omstreeks 1640 tot een scheiding en deling kwam. In de jaren daarvoor trad Jost Maximiliaan soms afzonderlijk, dan weer samen met zijn broer Otto Wilhelm als graaf op. Maar uit de waarschijnlijk niet door Prummer geconsulteerde rekening van de grafelijke rentmeester over het jaar

\footnotetext{
1128 Gegevens ontleend aan akten afgeschreven in een procesdossier van het Rijkskamergerecht van een geschil tussen Jost Maximiliaan van Bronckhorst Batenburg en Johan Arnold van Argenteau over de betaling van een erfpacht van 63 malder en vier vat rogge (RHCL, Rijkskamergerecht, inv. nr. 76, fol. 131 (modern)-135vo.

1129 RHCL, Rijkskamergerecht, inv. nrs. 17, 72, 73, 74.

1130 TJ, inv. nr. M 5, fol. 35-39, Prummer aan M.E. von Toerring-Jettenbach 24 november 1753.

1131 Prummer ontleende deze gegevens aan een brief van de toenmalige rentmeester (Frans Wendel) Öller op Rimburg aan drossaard Huckelhoven te Gronsveld.
} 
1617/1618 blijkt dat de inhuldiging bepaald niet in stilte verliep en door samenloop met een andere gebeurtenis zelfs een dramatisch karakter kreeg. ${ }^{1132}$

Volgens de rekening arriveerde Jost Maximiliaan op 31 oktober 1617 vanuit Rimburg in Gronsveld. Op dezelfde dag legden 'die hausluijdt' van Gronsveld, Eckelrade, Honthem, Slenaken en Oost op het kasteel de eed van trouw af. Vervolgens kregen zij op kosten van de nieuwe landsheer in hun eigen dorp een traktatie. Het feest srond echter in schril contrast met een kort daaraan voorafgaande gebeurtenis. Op 16 oktober 1617 was in Honthem 'eynen sodomitischen jongen' gevangen genomen op verdenking van seksuele handelingen met een kalf. $\mathrm{Na}$ een proces voor de schepenbank, waarbij ook de pijnbank werd aangewend, volgde op 31 oktober het vonnis: dood door verbranding. Ook het kalf zou worden geslacht en gevild. Het vonnis werd waarschijnlijk nog dezelfde dag of de dag erna voltrokken. ${ }^{1133}$ De kosten van de executie kwamen ten laste van de graaf. De beul ontving een afgerond bedrag van 80 gulden voor toepassing van de pijnbank en de verbranding 'weil het I(hre) G(enaden) erste justitie was'. De andere uitgaven hadden betrekking op het loon van de twee werklui, de vilder, de schepenen en gerechtsdienaren en de maaltijden voor de aanwezige geestelijken. Men was in deze harde tijden wel het een en ander aan menselijke wreedheid gewend. Vele slachtoffers van hekserijprocessen eindigden hun leven op de brandstapel, maar een feestelijke inhuldiging volgend op deze 'erste justitie' van de graaf kan niet anders dan bizar worden genoemd.

\subsection{Inhuldiging van Johan Frans van Bronckhorst Batenburg, 1677}

$\mathrm{Na}$ het overlijden van Jost Maximiliaan van Bronckhorst Batenburg op 24 september 1662, nam zijn weduwe Anna Christina von Hardenrath als voogdes en regentes de regering waar ten behoeve van haar zeven, deels nog minderjarige kinderen. Misschien was ook niet helemaal zeker wie tot heer van Gronsveld was voorbestemd, want de oudste zoon Otto Willem, geboren in 1636, was vlak voor het overlijden van zijn vader ingetreden bij de jezuïeten. Wanneer die zijn geestelijke loopbaan voortzette was zijn jongere broer Johan Frans de eerste in sucessie.

Die opvolging had de nodige voeten in de aarde, want in die tijd liepen de spanningen binnen de familie op. Johan Frans had dringend geld nodig om een militaire loopbaan te financieren, terwijl het graafschap zwaar was belast met schulden. Tegelijk bleek moeder Anna Christina niet toeschietelijk met geld, omdat zij de belangen van de andere kinderen voor ogen moest houden. In 1673 werd overeenstemming bereikt over een boedelscheiding. De contracten die betrekking hebben op de overgang van het graafschap en de compensatie van broers en zusters, zijn in Hoofdstuk 4.2 beschreven. Maar pas vier

1132 RHCL, Graafschap Gronsveld, inv. nr. 181, rentmeestersrekening 1617/1618. Zie verder de beschrijving van deze zaak door Jaspars, 'Tempora mutantur'.

1133 De datum van de voltrekking kan slechts uit indirecte gegevens worden afgeleid. De arrestatie vond volgens de rekening plaats op 16 oktober en gedurende de gevangenschap werden voor veertien dagen maaltijden voor de jongen in rekening gebracht. De executie moet dus omstreeks 1 november hebben plaatsgevonden. 
jaar later schijnt men daarmee zover te zijn gevorderd, dat een formele inhuldiging van Johan Frans kon plaatsvinden.

Het eerste bewijs daarvan vond Prummer bij zijn onderzoek in 1754 in een 'original prothocoll' (waarschijnlijk een rolregister of overdrachtsregister van de schepenbank Gronsveld) van 25 maart 1677. Daarin stond het verslag van de eedsaflegging door 'schutz' (waarschijnlijk is bedoeld scholtis of drossaard), schepenen, stadhouder en leenmannen van het leenhof en onderdanen. Uitdrukkelijk was afgesproken deze inhuldiging 'geheim' te houden, al zal dit niet al te strikt moeten worden geïnterpreteerd. Waarschijnlijk was het de bedoeling zo min mogelijk ruchtbaarheid aan de gebeurtenis te geven. Een mogelijke reden was dat op dat moment verschillende processen liepen, waarin schuldeisers beslag hadden laten leggen op het graafschap. Verder was ook de scheiding en deling tussen de broers en zusters nog niet afgerond.

\subsection{Inbuldiging van Maria Anna von Toerring-Jettenbach, 1719}

Graaf Johan Frans van Bronckhorst overleed op 7 april 1719 in Luxemburg. Volgens zijn testament viel de nalatenschap toe aan zijn echtgenote, gravin Maria Anna von ToerringJettenbach. Maar zijn zuster Clara Sibilla van Bronckhorst Batenburg, weduwe van Henri Philippe de Ligneville, maakte eveneens aanspraken op Gronsveld. De gezagsdragers binnen het graafschap en een minderheid van de onderdanen kozen, na juridisch advies, partij voor Maria Anna. Daarom was haast geboden om haar aanspraken zeker te stellen. Op 15 maart 1719 schreef de gravin aan de keizerlijke luitenant Olislagers, een oudgediende van Johan Frans, die waarschijnlijk al enkele jaren grafelijke zaken in Gronsveld behartigde, dat zij voor de inhuldiging niet op een paar tonnen bier keek. Daarnaast wilde ze haar onderdanen wijn schenken, afkomstig van de plaatselijke wijngaard, om daarmee hun genegenheid te winnen. ${ }^{1134}$

Prummer vond later bij zijn onderzoek naar de gebeurtenissen een 'prothocolls extract' van 22 maart 1719 (zie bijlage 41). Volgens dit geschrift zwoeren de stadhouder van het leenhof, drossaard, gerechtssecretaris en aantal onderdanen op die datum de eed van trouw aan gravin Maria Anna, vertegenwoordigd door advocaat Petit (uit Luxemburg). Prummer vermoedde dat vanwege de bijzondere omstandigheden de plechtigheid in beslotenheid plaatsvond. Het is echter merkwaardig dat hij geen melding maakt van een tweede inhuldiging op 8 april 1719, hoewel die toch nauwelijks onopgemerkt kan zijn gebleven. Maar misschien is het verslag daarvan hem pas later onder ogen gekomen. Hoe dit ook mag zijn, het proces-verbaal van de inbezitneming is in de vorm van een extract uit het gerechtsprotocol bewaard gebleven en bevat een uitgebreide beschrijving van het ceremonieel.

Op 8 april 1719 verschenen drossaard Willem Kicken en de heer Olislagers ter terechtzitting in het kasteel van Gronsveld. Zij toonden de zes schepenen en de

${ }_{1134}$ TJ, inv. nr. M 5, fol. 35-39, Prummer aan M.E. von Toerring-Jettenbach 24 november 1753. 
'pleuraliteyt der inwoonderen' een daags tevoren door de gravin Toerring Jettenbach ondertekende en gezegelde Franstalige 'authorisatie ende commissie', luidende dat zij samen met de 'raad ende regent' J.G. de Witte opdracht hadden het graafschap Gronsveld in bezit te nemen. ${ }^{1135}$ Verder overlegden zij een uittreksel uit het testament van Johan Frans van Bronckhorst Batenburg, waarin deze zijn echtgenote tot universeel erfgename had benoemd. De Witte schijnt niet bij deze plechtigheid aanwezig te zijn geweest, maar zijn naam komt wel voor onder de minuut van het proces-verbaal. Daar wordt van hem gezegd dat hij aanwezig was geweest bij de inbezitneming in Honthem en Heugem.

$\mathrm{Na}$ overlegging van de benodigde documenten stonden de schepenen toe dat Kicken en Olislagers de symbolische handelingen voor de inbezitneming verrichtten. De beschrijving daarvan doet sterk denken aan gebruiken bij de overdracht van onroerend goed, zoals die ook van andere plaatsen bekend zijn. ${ }^{1136}$ In de zogenoemde 'tweede zaal' van het kasteel werden hout en stro aangestoken, waarna het vuur onmiddellijk met water werd geblust. Aldus waren 'vlamme ende roeck' opgegaan. Vervolgens ging het tweetal naar de kleine keuken, pakte de haal (zaagvormig ijzer) met de daaraan hangende ketels uit de schouw en plaatste deze weer terug. De (kennelijk openstaande) deuren van de keuken en de poort van het kasteel werden gesloten en weer geopend. Daarna begaf het gezelschap zich naar de tuin, waar de schepenen ' reijs ende aerde' verleenden, wat gebeurde door het afbreken van enkele boomtakken en het uitsteken van een graszode en een kluit aarde. Ten slotte werd de minuut van het proces-verbaal met de handtekeningen van Kicken, Olislagers, De Witte en de schepenen door secretaris J.G. Lebens 'in hoeden van dese weth' geregistreerd in het overdrachtsregister van het gerecht. Door deze inschrijving of realisatie werkte de inbezitneming ook in juridische zin ten opzichte van derden die eventueel aanspraak maakten.

\footnotetext{
1135 Waarschijnlijk wordt hier bedoeld Jacob Ignatius de Witte de Limminghe, geboren Aken 1685, overleden Aken 1765, zoon van Adrian Johann de Witte en Maria Elisabeth de Beyens. Hij was schepen te Aken vanaf 1720 en in de daaropvolgende jaren meermalen lid van de stedelijke raad. Zijn vader was van 1676-1720 schepen te Aken. Jacob Ignatius de Witte ontmoeten we voor het eerst in 1718, wanneer hij als appelcommissaris in Gronsveld vonnis wijst in een proces tussen Thijs Lemmens en Gerard Raemaeckers. Waarschijnlijk is hij dezelfde als de 'raad De Witte' die in 1718 voor graaf Johan Frans van Bronckhorst Batenburg onderhandelingen voert in Maastricht over de bijdrage in de schatting door Maastrichtse burgers. Zie over hem: Von Coels von der Brügghen, 'Die Schöffen des Königlichen Stuhls', 471-473.

${ }_{1136}$ Zo ontstaken in Geleen in 1638 de erfgenamen van zekere Willem Hamers vuur in diens huis en doofden dit weer als teken van inbezitneming (Van Dijck, 'Het Haardvuur'). In 1680 namen de nieuwe bezitters van de Merwyckshof in Herten bezit van hun hof door het open en dicht maken van de deuren, het op- en neertrekken van de haal in de haard en het stoken en laten roken van vuur (G[oossens], 'Rechtsgebruiken'). Ten slotte hadden de nieuwe eigenaren in de schuur gedorst en waren zij alle stallen binnengelopen. Dat deze wijze van bezitneming niet beperkt bleef tot hoeven of landerijen toont een voorbeeld van de heerlijkheid Terblijt. Toen in 1694 de heer van die plaats overleed en zich moeilijkheden voordeden over de erfenis, meldde zich een van de erfgenamen bij de schepenbank om de heerlijkheid in bezit te nemen. Daarbij liep hij onder andere 'in des heeren weyden' om door het 'ontfangen ende opnemen van risch ende aerde' zijn rechten vast te leggen (G[oossens], 'Formaliteiten').
} 


\subsection{Inbuldiging van Maximilian Emanuel von Toerring-Jettenbach, 1754}

Op 8 juli 1752 vaardigde graaf Maximilian Emanuel von Toerring-Jettenbach in München een uitgebreide instructie uit voor Joseph Anton Prummer ter voorbereiding op diens vertrek naar Gronsveld. Punt 4 betrof de opdracht om te onderzoeken wanneer de Gronsveldenaren voor de laatste keer hun landsheer hadden ingehuldigd. Mocht dit nog niet ten aanzien van Maximilian Emanuel zijn gebeurd, dan moest Prummer met een bijzondere volmacht van de graaf alsnog de daarvoor benodigde formaliteiten verrichten. ${ }^{1137} \mathrm{Al}$ direct na zijn aankomst in Gronsveld constateerde Prummer dat ten aanzien van inhuldigingen niets was geregeld. Ook na het overlijden van gravin Maria Anna von Toerring-Jettenbach in 1730 en graaf Claude Nicolas d'Arberg Valengin in 1731 zou geen inhuldiging hebben plaatsgevonden van de nieuwe landsvrouwe, de minderjarige gravin Maria Josepha d'Arberg Valengin. Maar mogelijk was er toch iets geregeld. Uit een brief van rentmeester Oligschläger van 22 januari 1730 weten we dat graaf Claude Nicolas op 19 januari 1730, een jaar vóór zijn overlijden, met enig vertoon in Gronsveld verbleef. Enkele inwoners van het graafschap werden toen bestraft omdat zij verzuimd hadden aanwezig te zijn bij de verplichte opkomst van de onderdanen. ${ }^{1138}$

Nadat de kwestie van de voogdij over de minderjarige gravin Maria Josepha tussen graaf Ignaz Felix von Toerring-Jettenbach en baron Belderbusch op 6 februari 1732 in het voordeel van eerstgenoemde was beslecht, werden door administrator d'Oliva namens de graaf alle gerechtelijke functionarissen in Gronsveld opnieuw beëdigd (zie daarover meer Hoofdstuk 11.13). Tot een formele inhulding kwam het echter niet. Ook na het huwelijk van Maria Josepha met Maximilian Emanuel von Toerring-Jettenbach (en daarmee het einde van haar voogdij) was inhuldiging achterwege gebleven. Omdat Prummer niemand vond die betrouwbare inlichtingen over het passende ceremonieel kon verschaffen, zou onderzoek in het Gronsvelds archief uitsluitsel moeten brengen. Drukke werkzaamheden rond de verkoop van de heerlijkheid Sanem in Luxemburg verhinderden een snelle voortgang, maar op 24 november 1753 kon Prummer zijn bevindingen naar München zenden. ${ }^{1139}$

In afwachting van nadere instructies ontving Prummer de tijding dat gravin Maria Josepha op 17 februari 1754 was overleden. Daarmee was het graafschap op grond van de akte van huwelijkse voorwaarden overgegaan op graaf Maximilian Emanuel. Andere pretendenten waren er niet. Door dit sterfgeval werd het urgent een inhuldiging voor de graaf te organiseren. De brief waarin de grafelijk secretaris Xaver Prummer in München zijn broer Joseph Anton in Gronsveld het overlijden meedeelde, bevatte al een opdracht in die zin. ${ }^{1140}$ Een daarop volgend schrijven van de graaf van 14 maart 1754 bevestigde dat nog eens. Prummer moest handelen 'ohne alle ceremonien und in möglichster stille', maar

1137 TJ, inv. nr. M 5, fol. 55-74, instructie van 8 juli 1752.

1138 TJ, inv. nr. M 15, fol. 797-804, Oligschläger aan graaf d'Arberg Valengin 22 januari 1730.

1139 TJ, inv. nr. M 5, fol. 35-39, Prummer aan M.E. von Toerring-Jettenbach 24 november 1753.

1140 TJ, inv. nr. M 14, fol. 1091-1094, Xaver Prummer te München aan Prummer 18 februari 1754. 
kreeg de vrijheid daar naar eigen goeddunken invulling aan te geven. ${ }^{1141}$ Waarschijnlijk ging deze brief ook vergezeld van een nieuwe instructie voor de inhuldiging. ${ }^{1142}$

Prummer zag zich opgezadeld met een technisch-juridisch probleem. Zijn instructie uit 1752 kon hij niet meer gebruiken, want die was formeel vervallen door het overlijden van de gravin. Onoverkomelijk was dat niet, want de graaf was als erfgenaam op grond van de akte van huwelijkse voorwaarden, in het bezit van het graafschap gekomen. ${ }^{1143}$ Lastiger was de titulatuur van de graaf, zoals die kennelijk op eerdere modelbrieven voor een inbezitneming was vermeld. Naast de uitgebreide opsomming van alle Beierse ambten en bezittingen stonden daarop ook 'freyherr zu Eckelraed und Rimburg, herr zu Sanem'. Prummer kon echter geen enkel stuk vinden waarin sprake was van een 'vrijheerlijkheid Eckelrade'. Sanem was intussen verkocht en Rimburg al meer dan honderd jaar weg uit de familie. Johan Frans van Bronckhorst Batenburg had die titel nog wel gebruikt, waarvoor Prummer als verklaring gaf dat Rimburg bij de geboorte van de graaf nog Bronckhorster bezit was. Tijdens zijn leven had hij nog steeds aanspraak gemaakt op die heerlijkheid vanwege het al meer dan honderd jaar slepende proces over de onbetaalde koopprijs. ${ }^{1144}$ Maar uiteindelijk leek het Prummer verstandig iedere verwijzing naar Rimburg achterwege te laten. Het was ten slotte een Brabants leen en een rijksonmiddellijke graaf ToerringJettenbach kon maar beter niet als Brabants vazal te boek staan. ${ }^{1145}$

Vooralsnog eiste de organisatie van de uitvaart op 26 maart alle aandacht op. Pas daarna kon van de inhuldiging werk worden gemaakt. De instructies bepaalden dat een nauwkeurige lijst van alle ingezetenen en onderdanen moest worden opgesteld. Dat gold ook voor personen die buiten de jurisdictie van het graafschap woonden, waarmee de buitengeërfden en leenmannen werden bedoeld. Voorts diende een keizerlijk openbaar notaris, in aanwezigheid van twee getuigen, een zorgvuldig relaas van de gebeurtenis te maken. Dit verslag moest naar München worden gezonden.

Er was de volgende afloop voor de plechtigheid voorzien. Eerst moesten Prummer, alle landsheerlijke ambtenaren, de notaris, de getuigen en de schepenen 's morgens de mis bijwonen, waarna het gezelschap zich begaf naar de plaats waar gewoonlijk de inhuldiging plaatsvond. Na een korte toespraak van Prummer zou de secretaris van het gerecht de lastgeving van de graaf voorlezen. Aan de hand van de inwonerslijsten werd de aanwezigheid gecontroleerd, waarna Prummer van iedereen moest vragen met opgestoken vingers de eed van trouw, hulde en gehoorzaamheid aan de landsheer te zweren. Daarna diende iedere aanwezige persoonlijk deze eed te bekrachtigen met een handdruk. Prummer als vertegenwoordiger van de landsheer beloofde dat de graaf zijn onderdanen zou beschermen en handhaven in al hun oude rechten, gewoonten en privileges. Daarna konden alle landsheerlijke ambtenaren en functionarissen aan het volk worden gepresenteerd, opdat eenieder hen met passende eerbied zou bejegenen. De samenkomst zou worden afgesloten met een plechtig Te Deum. De instructie was niet compleet zonder

1141 TJ, inv. nr. M 5, fol. 109, Uittreksel uit brief van M.E. von Toerring-Jettenbach aan Prummer 14 maart 1754.

1142 TJ, inv. nr. M 5, fol. 11-18, ongedateerde instructie voor inhuldiging van de landsheer.

1143 TJ, inv. nr. M 14, fol. 1081-1086, Prummer aan M.E. von Toerring-Jettenbach 31 maart 1754.

1144 TJ, inv. nr. M 14, fol. 1071-1073, Prummer aan Xaver Prummer te München 1 april 1754.

1145 TJ, inv. nr. M 5, fol. 98, Prummer aan M.E. von Toerring-Jettenbach 5 april 1754. 
een financiële paragraaf. De graaf wilde graag worden geïnformeerd over het 'decorum' waarmee vroegere inhuldigingen gepaard gingen en de kosten dienden daarmee in verhouding te blijven.

Uit het verslag van de inhuldiging dat Prummer op 4 april 1754 aan de graaf stuurde, blijkt dat de instructie vrij nauwkeurig is gevolgd. Maar behalve interessante details over het feitelijk verloop van de plechtigheid, beschrijft hij ook zijn psychologische aanpak. Prummer meende op grond van zijn eerdere instructies dat het voorschrift om 'ohne caeremonien' van het graafschap bezit te nemen, aldus moest worden uitgelegd, dat de voorbereiding van de inhuldiging in stilte gebeurde. Zelfs de datum die hij in gedachte had, 2 april, bleef tot het laatste moment geheim. De voornaamste reden daarvoor was dat hij feestelijkheden en drinkgelagen wilde vermijden; er heerste immers publieke rouw in het graafschap wegens het overlijden van de gravin.

Eerst ontbood Prummer de Akense keizerlijke notaris Johann Heinrich Krämer voor 1 april naar Gronsveld. Vervolgens kreeg de gerechtsbode opdracht met spoed de vier burgemeesters van Gronsveld, Heugem, Eckelrade en Honthem, alle schepenen en de gerechtssecretaris in de 'ordinaris gerichtscammer' te roepen. In aanwezigheid van de notaris toonde Prummer zijn lastgeving om het graafschap in bezit te nemen en een uittreksel uit de akte van huwelijkse voorwaarden van 1 januari 1746 tussen de graaf en wijlen zijn echtgenote. De aanwezigen kregen te horen dat Prummer daartoe feitelijk de volgende dag wilde overgaan, 's ochtends om negen uur op het kasteel.

De burgemeesters kregen opdracht lijsten te maken van alle (dat wil zeggen alle mannelijke, meerderjarige) dorpelingen en hen voor de inhuldiging op de aangegeven tijd en plaats op te roepen. Zij verzochten echter voor hun medebewoners ontheffing van de plicht persoonlijk te verschijnen, omdat veel mensen door het slechte weer achterstand hadden met het werk op het veld. Uit 'sonderbaere consideratie en speciale gratie' stond Prummer dat toe, onder de voorwaarde dat de burgemeester van Gronsveld tenminste vier inwoners zou afvaardigen en de burgemeesters van Eckelrade, Heugem en Honthem ieder twee. Voorts dienden de burgemeesters bij de afwezigen na te vragen of iemand bezwaar maakte tegen de eed van trouw of zelfs weigerde die af te leggen. ${ }^{1146}$

Prummer overwoog dat het in essentie niet nodig was dat iedere inwoner persoonlijk verscheen. Ook door vertegenwoordiging kon iemand aan zijn plicht voldoen. Het argument van het aanhoudend slechte weer gold voor de inwoners van Heugem en Honthem. Mogelijk werd gedacht aan moeilijk begaanbare wegen. Maar om geen afgunst te wekken, ging Prummer ook voor Gronsveld en Eckelrade akkoord met een delegatie, hoewel dat in zijn ogen eigenlijk een teken van gemakzucht was. Verder viel van een kleinere groep ook minder gevaar voor ordeverstoring te duchten, want met dit onberekenbare boerenvolk ('unbedachten pauer-volckh, besonders hierzu landt') wist je maar nooit wat kon gebeuren. Niet dat iets van opstandigheid bij de inwoners van Heugem en Honthem bekend was, maar die van Gronsveld hadden zich bij een vroegere verandering van de regering nogal geroerd. Bij een menigte kon de vlam snel in de pan slaan. Maar, zoals Prummer in zijn brief aan de graaf zelf toegaf, er zat een addertje onder

1146 TJ, inv. nr. M 5, fol. 117-119, uittreksel uit de extraordinaris gerechtsrol van Gronsveld van 1 april 1754. 
het gras ('anguis in herba'). Want terwijl de Gronsveldse deputatie zich de volgende ochtend onder leiding van de burgemeester opmaakte om naar het kasteel te gaan, liet Prummer weten dat hij er, ondanks zijn eerder verleende vrijstelling, toch op rekende dat iedereen op de lijst persoonlijk aanwezig was. De mensen woonden ten slotte om de hoek en de plechtigheid eindigde rond de middag, zodat er weinig verzuim zou zijn. Op dezelfde wijze werden ook de inwoners van Eckelrade onder druk gezet. Met deze min of meer gedwongen opkomst hoopte de achterdochtige Prummer meteen iedere vorm van rebellie de kop in te drukken.

Volgens instructie moest de inhuldiging beginnen met een mis in de parochiekerk. Prummer had met pastoor Schmädel afgesproken dat wegens de nog altijd afgekondigde openbare rouw voor de overleden gravin, een eenvoudige dienst volstond. Maar uiteindelijk liet de pastoor wegens ziekte verstek gaan en een vervanger was niet zo gauw te vinden. Om dezelfde reden kon na afloop van de inhuldiging ook geen Te Deum worden aangeheven.

Maar de inhuldiging vond ook zonder Gods lofprijzing doorgang. Om tien uur 's morgens verscheen Prummer in de grote zaal van het kasteel van Gronsveld, vergezeld van de notaris, de secretarissen van de schepenbanken van Breust en Berneau als getuigen en verder drossaard Hendrik Lebens en de waarnemend rentmeester Johan Frans Lebens. Bij de twee getuigen was er op gelet dat zij van buiten het graafschap kwamen, maar hun ambt bekleedden in plaatsen die tot het Heilige Roomse Rijk behoorden. De stadhouder van het leenhof, baron de Goeswin, die uit Luik moest komen, had zich verlaat. In de zaal van het kasteel waren de gerechts- en leengriffier Jacob Berchmans en drie schepenen respectievelijk leenmannen aanwezig. Op het voorplein wachtten de burgemeesters, de officiële afgevaardigden van Heugem en Honthem en de verzamelde onderdanen uit Gronsveld en Eckelrade die, op enkele (wettig verhinderde) uitzonderingen na, allemaal waren komen opdagen. Prummer stelde later met tevredenheid vast dat zich onder zijn 'kudde' geen enkel 'schurftig schaap' ('ovis scabiosa') bevond.

$\mathrm{Na}$ de begroeting las notaris Krämer nogmaals alle officiële documenten voor. Prummer nam plaats aan een grote tafel, geflankeerd door de drossaard en de notaris. Daarna zochten ook de overige aanwezigen een plaats. Prummer hield een toespraak, waarin hij nogmaals meedeelde dat hij gerechtigd was de huldiging namens de landsheer in ontvangst te nemen. Met passend ('gezimmenten) respect werd alles aangehoord. Daarna riep Prummer alle aanwezigen op de graaf als hun landsheer te erkennen en hun taken plichtsgetrouw volgens hun instructies te blijven uitvoeren. Staande werd gezamenlijk een eed gezworen, die ieder afzonderlijk met een handdruk bekrachtigde. De gerechts- en leenbode Adam Goessens en de intussen gearriveerde baron de Goeswin, werden afzonderlijk beëdigd.

Vervolgens werden de vier burgemeesters met hun inwonerslijsten binnengeroepen. Zij verklaarden dat door de veldbodes alle inwoners waren opgeroepen. De notaris controleerde de presentie aan de hand van de lijsten. Daarna las hij met luide stem een door Prummer opgestelde tekst voor, waarin de inwoners werden aangemaand hun landsheer te huldigen en trouw en gehoorzaamheid te zweren. Zij verklaarden, mede namens de afwezigen: 
Alles wat mij hier wordt voorgehouden en mij uitvoerig is uitgelegd, zweren ik en mijn hier afwezige lastgevers als getrouwe en gehoorzame onderdanen met ijver te zullen nakomen, zo waarlijk God en alle heiligen mij en mijn lastgevers mogen helpen. ${ }^{1147}$

Deze eed werd door ieder persoonlijk bij Prummer met een handdruk bezegeld. Vervolgens beloofde Prummer namens de graaf dat deze het oude 'heerkomen' met daaraan verbonden rechten en privileges van zijn onderdanen zou handhaven.

Conform zijn instructie ging Prummer over tot installatie en presentatie van alle landsheerlijke ambtenaren en leden van de schepenbank en het leenhof, met de vermaning dat zij eenieder recht zouden laten wedervaren.

Daarna overhandigde de drossaard plechtig aan Prummer de sleutels van het kasteel, een kluit aarde, een graszode, twee twijgen van een fruitboom en twee van een wilde boom ten teken dat hij het kasteel, het land en alles wat daarop aan vruchten, gras, houtopstanden, et cetera aanwezig was, in bezit nam. Daarmee was dit deel van de plechtigheid afgelopen en wensten de aanwezigen Prummer geluk. Die makkte een rondgang door het kasteel, opende de deur van de grote zaal en van de keuken, de voordeur van het hoofdgebouw en ten slotte de deur van de grote buitenpoort. Het hele gezelschap begaf zich naar de kerk, waar Prummer volgens oud gebruik de grote klok luidde. Daarmee was het officiële gedeelte afgesloten. Prummer droeg de notaris nog eens uitdrukkelijk op van de hele plechtigheid een proces-verbaal op te stellen. Na een kort gebed in de kerk verliet het gezelschap tegen één uur 's middags het gebouw.

Prummer nodigde baron de Goeswin en de notaris uit voor een maaltijd. De drossaard, schepenen en de twee getuigen van de notaris kregen bij secretaris Berchmans te eten, waarbij men ook enkele door Prummer beschikbaar gestelde flessen wijn mocht nuttigen. De vier burgemeesters, de afgevaardigden van Honthem en Heugem, de vier oudste inwoners van Gronsveld en de twee oudste van Eckelrade konden terecht bij brouwer Blonden, die hen op bier en een bescheiden maaltijd trakteerde. Over een algemene traktatie voor de bevolking wordt niet gesproken.

\subsection{Inbuldiging van August Joseph von Toerring-Jettenbach, 1773}

De inhuldiging van de nieuwe landsheer in 1773 verliep volgens vrijwel hetzelfde draaiboek als die van 1754. Voor het officiële verslag maakte Prummer gebruik van de diensten van Joannes Pael, keizerlijk en pauselijk notaris in Maastricht-Wyck. Deze keuze was opmerkelijk, want Pael schijnt een soort 'vrijgevestigd' notaris te zijn geweest, die in de omgeving van de stad in rijksonmiddellijke gebieden werkte (zie meer over hem Hoofdstuk 15.21.1). Een probleem voor Prummer was dat Pael het Hoogduits in zijn

1147 'Allen dem jennigen was mir jetzo vorgehalten wordten und wohl ausfürlich verstandten habe, solchen will sowohl ich als die abwesente unsere constituenten und gewaltgeber als getreu und gehorsambe unterthannen fleissig nachkommen und geleben, als wahr mir und gemelt unseren constituenten Gott helffe und alle seine heyllige'. 
ogen onvoldoende beheerste. Er werden aanvankelijk twee getuigen van buiten Gronsveld gevraagd, Bartholomeus Wijers, schout van Kanne en secretaris van de schepenbank Breust en de drossaard van Breust, tevens scholtis van Moelingen. Laatstgenoemde kwam niet opdagen en bij gebrek aan een vervanger koos Prummer pastoor Meijers van Gronsveld in diens plaats. Belangrijk was dat de getuigen afkomstig waren uit een gebied behorend tot het Rijk.

Op 5 mei 1773 presenteerde Prummer zich bij de schepenen. Hij toonde de officiële bescheiden uit Beieren waaruit bleek dat August Joseph, rijksgraaf von ToerringJettenbach, de enige erfgenaam was van zijn overleden broer Maximilian Emanuel. Verder was er een door de graaf getekende volmacht van 5 april 1773. Prummer had de vier burgemeesters opgeroepen en vroeg een gerechtelijk bevel dat zij moesten zorgen voor een oproep aan alle inwoners (bedoeld waren de mannelijke gezinshoofden) om de volgende dag om negen uur's morgens persoonlijk ter beëdiging op het kasteel aanwezig te zijn. Voorts dienden zij een lijst van alle inwoners in te leveren.

De volgende dag verschenen Prummer, de notaris en getuigen voor de schepenen en werden alle eerder getoonde documenten opnieuw voorgelezen. Daarna legden de schepenen, de aanwezige leenmannen, de secretaris, de gerichtsbode en de grafelijke jager en boswachter de eed van trouw af. Vervolgens verschenen de burgemeesters, ieder met de inwonerslijst van hun dorp. Die lijsten werden gecontroleerd, waarna de inwoners per dorp werden binnengeroepen: eerst Gronsveld, vervolgens Eckelrade, daarna Heugem en ten slotte Honthem. De notaris las de gevraagde eed voor:

Ghij alhyer tegenswoordige inwoonders ende onderdaenen deser immediate vrije Rijckx graeffschappe Gronsfeldt sult sweeren tot Godt almachtigh eenen corporeelen eedt dat gij aan Sijne Excellentie den hooghgebooren heere, heere August des Heylighen Roomschen Rijckx Grave van Terring Jettenpach ende Gronsfeldt als tegenswoordighen regeerenden rechtmaetigen erffeygendom ende sovereyne landtsheere deser rijckxgraefschappe Gronsfeldt met allentgene in eeniger maniere daertoe gehoort offte daervan affhangt, sult huld, getrouw gehoorsaem, gewilligh ende onderdaenigh wesen aen alle hooghdesselfs ordonnantiën, gebotten ende verbotten, getrouw gehoorsaem, neerstigh ende gewilligh naerkoemen alsmede hooghdesselffs nut ende voordeelen ten allen tijde, soo veel aen u is, vervoorderen ende schaede, hinder offte naerdeel waerschouwen ende affkeeren, gevolgelijck allentgene voltrecken, doen offte laeten wat redelijck, eerlijcke, gehoorsaeme, goede ende getrouwe onderdaenen ende inwoonders aen hunne landtsheerschap schuldigh ende verplicht zijn te voltrecken, doen ofte te laeten.

De burgemeesters verzochten alvorens de eed uit te spreken, handhaving van hun oude rechten, wat Prummer beloofde. Daarna spraken zij met drie opgestoken vingers de notaris na:

Allentgene mij nu is voorgehouden ende ick wel duydelijck verstaen hebbe, beloove ick als eenen getrouwen ende gehoorsaemen onderdaen neerstelijck naer te koemen ende t'achtervolgen, als waer mij Godt helpe ende alle Sijne Heyligen.

Vervolgens begonnen de symbolische handelingen van inbezitneming. Prummer kreeg de sleutels van het kasteel, maakte de deuren van diverse vertrekken en van de grote 
toegangspoort open en dicht, liet rook opgaan door de haard, kreeg een kluit aarde en takken van fruitbomen en struikgewas aangereikt. Ten slotte begaf het gezelschap zich naar de kerk waar Prummer de grote klok luidde. Het geheel werd afgesloten met een maaltijd voor de notaris, schepenen, getuigen, burgemeesters en de twee oudste inwoners van ieder dorp. Over een verdere traktatie van de inwoners zweeg de zuinige Prummer in alle talen.

Op 3 juni stuurde Prummer zijn verslag van de rouwplechtigheden en inhuldiging met de afrekening naar München. De graaf toonde zich zeer tevreden, op één punt na. Wanneer vroeger, in 1719, na het overlijden van graaf Johan Frans van Bronckhorst Batenburg, de inwoners bij een inhuldiging waren onthaald ('ergötzet und regaliert'), dan diende dit nu alsnog te gebeuren. Bij de meestal niet zo toeschietelijke graaf August Joseph woog traditie kennelijk zwaarder dan zuinigheid. Hij wachtte daarom op voorstellen van Prummer. Als sluitstuk van de plechtigheid kreeg Prummer verder opdracht van de regeringswisseling mededeling te doen aan het bestuur van de kreits.

\subsection{Uitvaart- en begrafenisplechtigheden vóór 1754}

Over uitvaarten en begrafenissen van heren van Gronsveld is tot het einde van de zestiende eeuw weinig bekend. De tussen 1472 en 1476 overleden Hendrik III van Gronsveld werd naast zijn echtgenote Aleidis van Oupeye begraven in de (oude) minderbroederskerk in Maastricht. Van de opvolgende familie Van Bronckhorst Batenburg weten we alleen van de in 1493 gestorven Hendrik I, de kleinzoon van Hendrik III van Gronsveld, dat hij in dezelfde kerk werd bijgezet. Diederik II van Bronckhorst Batenburg (overleden 1508) en zijn echtgenote Gertrudis van Wylich (overleden 1523) werden begraven in het klooster Hagenbusch bij Xanten. Van Johan I van Bronckhorst Batenburg (overleden 1558 of 1559) is de laatste rustplaats onbekend.

Johans zoon Willem I van Bronckhorst Batenburg (overleden 31 maart 1563) had onder het priesterkoor van de Sint-Martinuskerk van Gronsveld een grafkelder laten bouwen, met daarboven een fraaie graftombe uitgevoerd in rood, grijs en zwart marmer. Met dit familiegraf lijkt Willem de betekenis van Gronsveld voor de stand van zijn familie tot uitdrukking te hebben willen brengen. Opvolgende graven van Gronsveld en hun familieleden uit het geslacht Van Bronckhorst Batenburg vonden hier dan ook tot 1719 hun laatste rustplaats.

Of Willems oudste zoon en opvolger Jost I van Bronckhorst Batenburg, omgekomen bij het beleg van Wachtendonck (D) in december 1588, ook in Gronsveld is begraven, valt niet met zekerheid te zeggen. Wel is bekend dat anderhalf jaar eerder zijn begin juli 1586 overleden echtgenote, gravin Anna van Oostfriesland, in Gronsveld werd bijgezet. In de rekening van de grafelijk raadsman Assuerus Stroyff staan diverse posten genoteerd die betrekking hebben op de overbrenging van het stoffelijk overschot van Brussel via Namen en Maastricht naar Gronsveld en de bijzetting in het graf. ${ }^{1148}$ Gegevens over eventueel gehouden plechtige rouwdiensten in Gronsveld ontbreken. Mogelijk is daar ook bewust

1148 RHCL, Graafschap Gronsveld, inv. nr. 175. 
van afgezien wegens de desolate toestand waarin Gronsveld op dat moment verkeerde, na de oorlogsschade door het beleg van Maastricht in 1579. Interessant in dit verband is wel de betaling op 7 februari 1587 van een 'maler' voor het schilderen van 'vier wappen auf das grab zu Gronsfelt'.

Dankzij de rekening van de grafelijke rentmeester over het jaar 1617-1618 krijgen we een indruk van de plechtigheden rond de begrafenis van graaf Johan II van Bronckhorst Batenburg. ${ }^{1149}$ Johan II moet zijn gestorven medio oktober 1617. De plaats van overlijden is niet bekend. In ieder geval verbleef het stoffelijk overschot enige tijd op kasteel Rimburg. Op 26 november werd vanuit Gronsveld zestien el zwart laken naar Rimburg gestuurd.

De plechtige uitvaartdienst vond plaats op of omstreeks 11 december 1617, in aanwezigheid van kinderen, familie, genodigden en onderdanen. Hoewel de verschillende posten in de rekening geen volledig beeld van de plechtigheid geven, maken ze duidelijk dat de uitvaart met het nodige vertoon geschiedde. Acte de présence gaf onder anderen 'de heer van Wolkenstein', waarmee waarschijnlijk werd bedoeld Johans zwager Christoph Franz von Wolkenstein. De uitvaart was een kostbare aangelegenheid. Er werden betalingen gedaan voor het openen van de grafkelder en voor de huur in Luik van zwarte draperieën om de kerk en de 'cameren te behangen'. Twee schrijnwerkers waren veertien dagen in de weer met de 'kisten', luchters, banken en een baar of katafalk, die met zwartsel werden gekleurd. ${ }^{1150}$ Negentig gulden werden besteed voor 32 kaarsen naast de kist. Op de dag van de uitvaart ontvingen genodigden en de bevolking in totaal zestien gulden voor de offergang in de kerk. Ook de bedragen voor kleding, honoraria en fooien, foerage voor paarden, eten en drinken liepen flink op. Op het menu stonden ganzen, schapen, wildbraad, brood, Hollandse en Limburgse kaas, suikergoed, bier en wijn. De 31/2 aam wijn (tussen 450-540 liter) voor 217 gulden zullen er toe hebben bijgedragen dat de dag niet al te droevig eindigde.

Over de uitvaartplechtigheden van de opvolgende landsheren, de graven Jost Maximiliaan en Johan Frans van Bronckhorst zijn nauwelijks bijzonderheden bekend. Eerstgenoemde overleed op 24 september 1662 en werd in een loden zerk in de grafkelder onder het priesterkoor in de kerk bijgezet. Johan Frans stierf op 7 april 1719 als gouverneur van Luxemburg in de stad Luxemburg of op zijn kasteel Sanem, in de nabijheid van deze stad. Het stoffelijk overschot werd overgebracht naar Gronsveld en daar bijgezet. Gegevens over plechtige uitvaartdiensten ontbreken.

Zijn tweede echtgenote gravin Maria Anna von Toerring-Jettenbach (overleden 1730) en haar tweede man graaf Claude Nicolas d'Arberg Valengin (overleden 1731) werden begraven in Sanem. Prummer merkte in zijn verslag van de rouwdienst voor gravin Maria Josepha op dat in Gronsveld nauwelijks iets aan haar ouders herinnerde. Hun grafsteen in Sanem droeg geen opschrift. Alleen in de kerk van Gronsveld hing een rouwbord voor

1149 RHCL, Graafschap Gronsveld, inv. nr. 181.

${ }^{1150}$ In de teksten wordt regelmatig gesproken over 'kisten'. Dit kan betrekking hebben op een aparte kist voor de katafalk of een dubbele kist voor de bijzetting. Soms was een kist met lood bekleed. 
gravin Maria Anna. Om die reden liet Prummer in 1754 ter completering van de serie in Gronsveld een nieuw bord maken voor Claude Nicolas d'Arberg Valengin (thans nog in de Sint-Martinuskerk aanwezig). Het commentaar dat graaf Maximilian Emanuel naderhand gaf op de rouwplechtigheden in Gronsveld bevatte ook een opdracht om de grafsteen in Sanem te voorzien van een eenvoudig, niet al te kostbaar opschrift. Er werden nauwkeurige instructies gegeven voor de tekst die na de volledige familienaam d'Arberg Valengin en de titel 'graaf van Gronsveld' moest volgen. Hoewel men vraagtekens kon plaatsen bij het bestaan van een aparte heerlijkheid Eckelrade, mocht de titel 'heer van Eckelrade' worden vermeld, omdat die volgens de archieven in München wel voorkwam. 'Heer van Rimburg' was ook toegestaan, omdat over die heerlijkheid nog altijd werd geprocedeerd. De titel 'heer van Sanem', die eigenlijk nooit was gebruikt, kon worden geschrapt, omdat die heerlijkheid inmiddels definitief uit de familie was verdwenen. Een merkwaardige redenering voor iemand die als heer van Sanem was gestorven en daar begraven. ${ }^{1151}$

\subsection{Roumplechtigheden voor Maria Josepha d'Arberg Valengin 1754}

$\mathrm{Na}$ ontvangst van het nieuws dat gravin Maria Josepha d'Arberg Valengin was overleden, besloot Prummer daar niet onmiddellijk ruchtbaarheid aan te geven. Hij wilde eerst, discreet, informatie inwinnen over het protocol dat in deze landstreken gebruikelijk was bij het overlijden van een landsheer of een lid van diens familie. Pas op zondag 17 maart 1754 werd het nieuws van de kansel afgekondigd in de kerken van Heugem, Gronsveld en Eckelrade. Daarnaast had de secretaris van de schepenbank een proclamatie opgesteld, die de gerechtsbode te bestemder plaats aansloeg. Gedurende een periode van een jaar en zes weken gold openbare rouw, waarbij publiek vermaak en dansen ten strengste werden verboden. Vanaf het moment van bekendmaking van het overlijden kleedde Prummer zich in zware rouw. Hij droeg alle landsheerlijke functionarissen op hetzelfde te doen. Volgens oud plaatselijk gebruik verlangden die volledige betaling van rouwkleding uit de grafelijke kas. Het lukte Prummer de heren af te kopen met een bedrag van 35 gulden per man. De wens om ook rouwmantels te vergoeden, willigde Prummer niet in. Hij stond slechts toe dat zij, gelijk andere genodigden, voor de rouwdienst in de kerk huurmantels kregen uitgereikt. Die kleding werd na afloop weer ingeleverd. Daarmee leek iedereen tevreden en de eerstvolgende zondag verschenen ze in nieuwe rouwkleding in de kerk. Prummer wist verder de boot af te houden, toen werd aangedrongen op het vergoeden van rouwkleding voor echtgenotes. De drossaard en de waarnemend rentmeester waren beiden ongehuwd, de weduwe van de vroegere drossaard werd geacht niet meer tot de 'sphera' van de landsheerlijke functionarissen te horen en het voerde te ver ook nog de echtgenote van de secretaris van de schepenbank en het leenhof binnen deze kring te betrekken.

Inmiddels was Prummer naarstig op zoek naar bruikbare informatie voor de organisatie van de rouwdienst. Twee zaken stonden hem duidelijk voor ogen: het ceremonieel moest

1151 TJ, inv. nr. M 14, fol. 1081-1086, Prummer aan M.E. von Toerring-Jettenbach 31 maart 1754. 
passen bij de waardigheid en stand van het grafelijk huis en de kosten dienden binnen de perken te blijven. Wat hij over rouwplechtigheden bij eerder overlijden van graven of gravinnen van Gronsveld wist te achterhalen, is hiervoor reeds beschreven. Niemand kon op grond van eigen ervaring een betrouwbaar verslag geven van de gang van zaken rond de bijzetting van Johan Frans van Bronckhorst. Overdreven veel geld uitgeven wilde hij niet, maar ook onder geen beding uit de toon vallen. Het moest een plechtigheid zijn in overeenstemming met de gebruiken in de streek. Een voorbeeld was Maastricht waar in 1743 rouwplechtigheden waren gehouden voor de overleden Georg Lodewijk van Berghen, prins-bisschop van Luik. Weliswaar was dat niet helemaal vergelijkbaar met Gronsveld, maar de overgeleverde beschrijving van dat ceremonieel vertoont in veel opzichten een opmerkelijke gelijkenis met wat Prummer later in Gronsveld organiseerde. 1152 Verder schrijft Prummer dat hij ook nog inlichtingen wilde inwinnen in de graafschappen Wittem en Rekem. In Wittem was in 1737 in de kapel van het kapucijnenklooster het hart bijgezet van graaf Ferdinand von Plettenberg. Uit een brief die de grafelijke stadhouder of gevolmachtigde voor Wittem, de Akense advocaat Braumann, naar aanleiding van dit overlijden aan de weduwe Plettenberg schreef, blijkt dat men toen in Wittem niet goed wist hoe te handelen met de stoffering van het interieur van de kerk en de oprichting van een 'castrum doloris', een bouwsel van hout en doeken rond een katafalk. ${ }^{1153}$ Recenter was het voorbeeld van de uitvaart van graaf Karel Gobert van Aspremont-Lynden-Reckheim te Rekem in 1749. Op 23 december van dat jaar werd daar een verordening uitgevaardigd met het protocol van de plechtige lijkdienst. ${ }^{1154}$ De daarin opgenomen bepalingen vertonen veel overeenkomst met de plechtigheden die naderhand in Gronsveld werden georganiseerd.

Het resultaat van zijn naspeuringen bracht Prummer tot de conclusie dat in deze streken eigenlijk geen 'ordtnung oder etiquette' voor uitvaartplechtigheden bestond. Iedereen deed wat hem goed dacht, waarbij kosten noch moeite werden gespaard. In het bijzonder de adel wilde de buitenwereld door pracht en praal laten zien hoe belangrijk de overledene was geweest en welk aanzien de familie genoot. Prummer voelde er niet veel voor die gedragslijn klakkeloos na te volgen, maar anderzijds begreep hij dat Gronsveld niet voor de buren kon onderdoen. Uiteindelijk kwam hij tot een hele lijst met aandachtspunten, waarvan hij vond dat ze de leidraad voor een verantwoord ceremonieel vormden.

- Het was, zoals al gezegd, gebruikelijk dat de openbare rouw bij het overlijden van een regerend landsheer één jaar en zes weken duurde. Bij alle kerken binnen een landsheerlijkheid werden gedurende zes weken twee maal daags de klokken geluid.

- Alle overheidsdienaren en ambtenaren droegen op kosten van de landsheer gedurende een jaar en zes weken rouwkleding. Dat gold als regel ook voor echtgenotes. In Gronsveld kwamen daarvoor in beginsel de vrouw van de drossaard en de rentmeester in aanmerking.

- De volgorde van requiemmissen verschilde per plaats. Soms gebeurde dat drie dagen op rij, dan weer verdeeld over zes weken. Het meest gebruikelijk waren twee diensten

1152 Doppler, 'Uitvaart'.

${ }^{1153}$ RHCL, Vrije rijksheerlijkheid Wittem, voorl. nr. 227, brieven Brauman aan gravin Plettenberg 27 april en 8 juni 1737.

1154 Verbois, Geschiedenis Rekem, 89-91. 
op één dag, beide opgeluisterd met muziek. Het maakte overigens wel verschil of het ging om een rouwdienst met of zonder uitvaart.

- Het was gebruikelijk gedurende de gehele ochtend op alle in de kerk aanwezige of nog op te richten altaren onafgebroken missen te lezen, van 's morgens vroeg tot aan het einde van de laatste hoogmis. Daarvoor werden pastoors en kloosterlingen uit de omgeving uitgenodigd. Iedere geestelijke ontving naast het gewone stipendium en een betaling in waskaarsen, nog een apart honorarium van vier tot zes schellingen.

- Er bestonden verschillende gebruiken bij het stofferen van de kerk en altaren met zwarte dwalen en doeken. Het meest gangbaar was bij het overlijden van een regerend heer het hele interieur te bedekken, bij diens echtgenote alleen de helft en bij kinderen alleen het priesterkoor en de altaren.

- Bij de ingang van het priesterkoor werd een zo groot mogelijk 'castrum doloris' met draperieën opgericht, met daarop een kroon. Bij een overledene uit de gegoede burgerij paste een kroon van glad zilver, een lid van een stedelijke magistraat of lagere adel kreeg er een met parels en bij iemand van de hoge adel was deze bezet met edelstenen.

- Bij het 'castrum doloris' en op ieder altaar werden zes extra grote kaarsen geplaatst en daarnaast stonden overal, zoveel als maar mogelijk was, kriskras door elkaar, kleine kaarsen, flambouwen en lampjes.

- Niet alleen aan de altaren en rouwdoeken, maar ook aan fakkels en kaarsen werden in verschillende maten kartonnen bordjes met een afbeelding van een familiewapen bevestigd. De grote schildjes hadden min of meer correcte wapens, de kleinere soms alleen een fantasietekening.

- De was van niet opgebrande kaarsen werd verdeeld onder de aanwezige geestelijken. De bordjes met het wapen kregen de genodigden als herinnering mee.

- Het was gebruikelijk bidprentjes te laten drukken, die ter plaatse werden verdeeld onder de geestelijken en voornaamste kerkgangers. Verder werden die ook aan bekenden in de omgeving verstuurd.

- De heren van alle naburige heerlijkheden en hun voornaamste functionarissen ontvingen een uitnodiging om de plechtigheden bij te wonen. Deze genodigden kregen bij hun aankomst een lange rouwmantel met een lange rouwlint tot op de grond en witte handschoenen uitgereikt. De mantel lieten de gasten na de dienst achter, de handschoenen mocht men meenemen. Mantels met rouwlinten waren ook beschikbaar voor schepenen, burgemeesters en oudste inwoners van de gemeente, maar zij moesten het zonder handschoenen stellen. Tegelijk met de rouwmantel werd ook het geld voor de offergang tijdens de mis uitgereikt, waarbij het bedrag niet te laag mocht zijn. Het was bekend dat daar soms kritisch naar werd gekeken.

- Er diende een groot houten bord op een ijzeren stang te worden vervaardigd, aan beide kanten beschilderd met het familiewapen, versierd met zwarte en witte strikken en aan weerszijden voorzien van tot op de grond afhangende linten. Een der hogere landsheerlijke functionarissen liep met dit schild voorop bij het binnengaan en verlaten van de kerk en bij de offergang. Voor het 'castrum doloris' stond een bidstoel, waaraan het bord gedurende de dienst was bevestigd.

- De wapendrager en de drie eerste personen die de stoet openden waren volledig in het zwart gekleed, met zwarte handschoenen en rouwbanden met zwarte strikken. Zij 
droegen mantels met een lange sleep en hun hoed was voorzien met een lang, dubbel lint. De sleep van de voornaamste persoon werd gedragen door een dienaar, de wapendrager en twee anderen moesten het zonder deze hulp stellen. De overige gasten combineerden hun witte handschoenen met een witte strik op hun hoed.

- Alle ingezetenen waren verplicht persoonlijk in de kerk aanwezig te zijn. In plaatsen waar een schutterij bestond, moest deze 'in trauer parade' acte de présence geven. De buitendorpse geërfden of eventuele standen dienden ook vertegenwoordigd te zijn. Alle aanwezige geestelijken, zowel uit de eigen parochie als van elders, landsheerlijke functionarissen, schepenen, burgemeesters en oudste inwoners moesten na de plechtigheid op een maaltijd worden onthaald.

Er was haast geboden met de vaststelling van de dag voor de rouwplechtigheden omdat de Pasen (14 april) met de daaraan voorafgaande Goede Week naderde, wat allerlei beperkingen oplegde bij een kerkelijke viering. Dinsdag 26 maart leek het meest geschikt. Dat betekende een korte voorbereidingstijd, met bijna onvermijdelijk hogere kosten, want Prummer wist zeker dat men zich hastwerk extra goed liet betalen. En er viel nogal wat voor te bereiden, want van de wegens ziekte voortdurend arbeidsongeschikte pastoor Schmädel van Gronsveld viel geen hulp te verwachten. Hetzelfde gold voor de kapelaan. Behalve de organisatie van de kerkelijke plechtigheden vereiste ook de organisatie van de maaltijd voor een grote groep genodigden na afloop van de dienst veel aandacht. Sommige gasten, in het bijzonder de uitgenodigde geestelijken, dienden trouwens vanwege de vasten aangepast voedsel te krijgen. Prummer zocht derhalve zo snel mogelijk in Luik en Maastricht contact met begrafenisondernemers of betrouwbare lieden, die de organisatie van gedeelten van de plechtigheden voor hun rekening konden nemen. Verschillende ondernemers werden bij hem thuis in Maastricht uitgenodigd, wat leidde tot de volgende afspraken:

- De kleding voor de priesters en misdienaars, de altaarparamenten en zes grote kandelaars konden worden geleend bij de Sint-Martinuskerk in Maastricht-Wyck.

- De 'chor musicanten' van het Onze-Lieve-Vrouwekapittel te Maastricht waren bereid alle diensten gedurende de morgen met gezang op te luisteren voor twintig pattacons of veertig gulden. Dat was meer dan het bedrag dat twee andere 'bandes' vroegen, maar die verlangden boven op hun loon wel gratis eten en drinken.

- Het 'castrum doloris', bestaande uit drie etages, werd aangenomen door Gerard Dorlo te Maastricht, of beter gezegd diens echtgenote, voor 24 pattacons of 48 gulden, zonder het houtwerk en vrachtkosten. Het benedenstuk was omgeven door een balustrade van latten, negen voet hoog, elf voet lang en zeven voet breed. Alles werd behangen met de nodige draperieën, een kussen met een kroon en voorzien van luchters en kandelaars. Mevrouw Dorlo verhuurde voor de deelnemers aan de rouwstoet drie rouwmantels met sleep en 35 gewone rouwmantels in drie uitvoeringen. De firma Dorlo zorgde ten slotte ook voor de passende aankleding van het interieur van de kerk, die volledig werd behangen met doeken van zwarte stof waarop witte kruisen stonden.

- De levering van kaarsen werd aanbesteed bij Arnold Lux in Maastricht, die wegens de omvang van de opdracht kwantumkorting verleende. Naderhand werd afgesproken dat 
de leverancier de kaarsen zwaarder zou doen lijken dan ze in werkelijkheid waren, door ze binnen voor een flink deel hol te maken. Op en bij de drie altaren en bij het 'castrum doloris' stonden in totaal honderd kaarsen met een gewicht van 82 pond. De zes grootste waren, volgens landsgebruik, op zwarte, houten kandelaars naast en op de hoeken van het 'castrum' geplaatst Verder stonden flambouwen langs de zijmuren van de kerk en was de luchter boven het 'castrum' getooid met zes zware kaarsen.

- Prummer liet bij Theodoor op den Kamp in Maastricht wapenschildjes maken in vier verschillende formaten, van elk soort respectievelijk 24, 26, 36 en 80 stuks. De grootste kostten één Rijnlandse gulden per stuk en de kleinste $7 \frac{1}{2}$ kreuzer (15 stuiver), inclusief papier en karton. De meeste schildjes werden aan de kaarsen of kandelaars bevestigd.

Een probleem dat veel aandacht vroeg, betrof de keuze van genodigden. Behalve enkele functionarissen uit Gronsveld, stonden op de lijst edelen en aanzienlijke personen uit de omgeving, alsmede een groot aantal priesters voor de vele missen die gedurende de ochtend in de kerk werden gelezen. Baron de Goeswin in Luik als stadhouder van het grafelijk leenhof en burgemeester d'Oliva in Aken, die vroeger namens de stad Aken de voogdij over de gravin tijdens haar minderjarigheid had uitgeoefend, ontvingen een schriftelijke invitatie. De rest van de uitnodigingen werd gedurende twee dagen door de grafelijk rentmeester te paard rondgebracht. Bezocht werden de graafschappen Rekem en Wittem, de rijksheerlijkheid Pietersheim en de rijksheerlijkheid Rijkckholt, de 'gewone' heerlijkheden Eijsden en Oost, de 'kapittelheerlijkheden' Breust en Heer en de Luikse heerlijkheid Sint Pieter. Het verschilde nogal wie de boodschap ter plaatse aannam. Dat was niet alleen een kwestie van toeval, maar ook van beleefdheid en respect. In Rekem was het de drossaard namens de gravin d'Aspremont, in Wittem de Akense stadssyndicus Brandt voor graaf Plettenberg en in Pietersheim de drossaard namens de markies van Westerlo. Voor Breust trad als zodanig op de drossaard van het kapittel van Sint-Martinus te Luik, voor Heer baron Van Eyll als rijproost van het kapittel van Sint-Servaas in Maastricht en voor Sint Pieter de bisschoppelijk rentmeester van Sint Pieter. Uit de lijst wordt duidelijk welke gedragslijn Prummer volgde. Uitgenodigd werden in de eerste plaats de vertegenwoordigers van de meest nabij gelegen landsheerlijkheden die in status aan Gronsveld gelijk waren, te weten de graafschappen Rekem en Wittem. Opmerkelijk genoeg volgt daarna Pietersheim, weliswaar een rijksheerlijkheid, maar lager in rang en niet aan Gronsveld grenzend. Vervolgens komen de vertegenwoordigers van de aan Gronsveld grenzende heerlijkheden aan de beurt, te weten Eijsden, Oost, Breust, Rijkckholt, Heer en Sint Pieter. De vier laatstgenoemde plaatsen hadden bovendien, in meerdere of mindere mate, ook de status van rijksheerlijkheid. Merkwaardig is dat de buren Cadier en Margraten ontbreken. Ook een officiële afgevaardigde namens de stad Maastricht stond niet op de lijst.

Alle genodigden die een rouwmantel kregen uitgereikt, ontvingen ook van te voren een halve schelling in papier gewikkeld voor de offergang. Prummer legde tijdens de eerste requiemmis een kwart 'zonnepistool' op de offerschaal en de tweede keer een schelling. Voor de genodigden waren ook honderd gedachtenisprentjes bestemd. De rest werd uitgedeeld onder de kloosterlingen en verstuurd naar mensen die niet aanwezig konden zijn. 
Naast deze officiële gasten waren ook alle (mannelijke volwassen) onderdanen van de graaf verplicht te verschijnen. Zij kregen daartoe een aanzegging door de gerechtsbode en hoorden de oproep bovendien op zondag in de drie kerken van het graafschap afkondigen. Een aparte categorie vormden de leden van de schutterij. De kapitein van deze vereniging kreeg opdracht de opkomst van de schutten te regelen.

Daarnaast dienden ook de 'buitengeërfden', de grondeigenaren die stem hadden in de Gronsveldse 'Landsvergadering' (voor het grootste deel Maastrichtse instellingen zoals het kapittel van Onze-Lieve-Vrouw, de armentafel van de Grote Heilige Geest en enkele kloosters) acte de présence te geven. Maar hier kreeg zuinigheid voorrang op het protocol, omdat Prummer vermoedde dat misschien wel erg veel vertegenwoordigers van die instellingen op een invitatie stonden te kijken. Daarom werd afgesproken dat namens deze groep twee Maastrichtse kanunniken voor de kerkelijke en twee Maastrichtse notabelen voor de wereldlijke grondeigenaren werden afgevaardigd.

Het gebruik om gedurende de hele ochtend aan alle altaren missen te lezen, vereiste de aanwezigheid van een groot antal geestelijken, die naderhand ook weer bij de maaltijd moesten aanzitten. Pastoor Schmädel van Gronsveld droeg geen mis op, want hij nam als grafelijke raadsheer deel aan de rouwstoet. Buiten de pastoor van Heugem werden twaalf pastoors en enkele kapelaans uit de omgeving uitgenodigd. Pastoor Thomassen van Wyck, tevens officiaal (kerkelijk rechter) van de aartsdiaken van Haspengouw voor Maastricht en omgeving, en de pastoor van Mesch namen de twee plechtige requiemmissen voor hun rekening. Uiteindelijk zou naast de geïnviteerden nog een 'unberueffener' gast verschijnen de kapelaan van Berneau, die zich had 'eingetrungen'. De groep wereldgeestelijken werd aangevuld met kloosterlingen. Daartoe werden paters dominicanen, augustijnen en kapucijnen uit Maastricht en franciscanen van het klooster Lichtenberg te Sint Pieter uitgenodigd, leden van de vier bedelorden die jaarlijks in Gronsveld 'op termijn gingen' (een collectegang makkten). Verder verschenen er twee reguliere kanunniken van het klooster Hoogcruts, waarmee Gronsveld altijd nauwe betrekkingen had onderhouden.

Afgesproken werd dat de paters van de bedelorden met de missen om zeven uur 's ochtends begonnen, omdat pastoors niet zo vroeg opstonden ('da die pfarrer so fruehe nit an das werckh kommen'). Overigens was het elders niet ongebruikelijk nog vroeger te beginnen. Aan het hoogaltaar werden tot tien uur zeven stille missen gelezen, daarna volgden achter elkaar de twee plechtige requiemmissen en onder het zingen van de sequentie 'Libera me Domine' nog een stille mis, in totaal dus tien. Aan de beide zijaltaren werden in vijf uur tijd per altaar dertien missen opgedragen, wat het totaal brengt op 36 . (In zijn eindafrekening komt Prummer overigens op 37). De hele operatie leek op een estafette die met bijna militaire precisie werd uitgevoerd. Niet alleen waren er vanwege de snelle wisselingen dubbele aantallen paramenten nodig, ook de kleedruimte, die bij gebrek aan een sacristie slechts bestond uit een smalle doorgang achter het hoogaltaar, maakte het nodig dat de priesters elkaar snel aflosten. In de tussentijd moesten de wachtende geestelijken, die niet gewend waren zo lang te moeten toekijken, worden voorzien van thee en brandewijn. De Gronsveldse kapelaan, die tevens de functie van koster uitoefende, 'voerde het commando' over de misdienaartjes. De laatste priester kon pas om half een 's middags beginnen. Voor iedere geestelijke was een stipendium van vier schelling in een 
papiertje gewikkeld, maar behalve de diaken, de subdiaken en de leden van de bedelorden aan wie het geld was nagestuurd, had niemand deze beloning aangenomen. 'Dises ist etwas ausserordentliches' noteerde Prummer, die in het algemeen de geldzucht van de clerus hekelde.

$\mathrm{Na}$ de laatste requiemmis vond brooduitdeling aan de armen plaats, waarvoor in totaal zes malder graan werd ingeslagen. Schepen Van den Boorn, de burgemeesters van de vier dorpen van het graafschap en de gerechtsbode zorgden voor de verdeling. Gezinnen met kinderen in het graafschap ontvingen de grootste broden, de kleine broden waren bestemd voor bezoekers van buiten.

Een groot punt van zorg vormde de begrafenismaaltijd voor de circa veertig genodigden. Enerzijds wenste de zuinige Prummer de kosten in de hand te houden, anderzijds was het nodig een geschikte ruimte te vinden. Hij wist intussen wel dat het hier te lande goed gebruik was flink in te nemen wanneer het gratis was. Daarnaast geneerden de gasten zich niet openlijk aan tafel commentaar te geven en ook de buitenwacht kreeg te horen wanneer het niet beviel. Het was daarom heel moeilijk iemand te vinden die zoiets kon aanbieden. Prummer won informatie in te Luik en Maastricht en kreeg prijzen te horen van drie- tot zeshonderd gulden. Toen vatte hij het plan op alles zelf te verzorgen en gedurende enkele dagen koks of kokkinnen in te huren. Een bijkomend probleem vormden voor sommige genodigden de regels van de geldende vasten, omdat geen vlees mocht worden gegeten. Zoetwatervis was lastig te krijgen en duur, gewone zeevis moest worden besteld en de levering was onzeker, aanbieden van alleen maar stokvis of haring werd beschouwd als niet passend, te meer omdat men vanwege de vastentijd toch al weinig 'patisserie' maakte. Prummer bedacht dus zelf een menu en legde dit aan potentiële 'traiteurs' voor onder het beding dat zij alles moesten leveren, van keukengerei, vuur, tot en met het zout toe. De aannemer moest ook de restanten terugnemen; Prummer zorgde alleen voor de ruimte, tafels en stoelen. Er diende betrouwbaar personeel te zijn, dat het eten van de traiteur en het drinken van Prummer ontving. Het eten moest goed bereid en gekookt zijn, en in voldoende mate aanwezig. Wanneer er te weinig was, zou daarover beslist worden door twee gasten namens de traiteur en drie namens Prummer. Bij de begroting werd uitgegaan van veertig personen. Tot 45 hoefde Prummer niet bij te betalen, daarboven wel per persoon. Waren het er vijf minder, dan moest Prummer er toch veertig betalen, en bij een nog lager aantal kreeg hij korting op de aanneemsom.

Twee traiteurs schreven in voor vier gulden per persoon en schatten het werk op twee dagen. Prummer zag dat hij vanwege de tijdsdruk door een zure appel moest bijten, maar bedacht een list om de prijs te drukken. Hij liet het gerucht verspreiden dat hij op het punt stond met een Luikse firma een overeenkomst te sluiten. Het ging daarbij niet alleen om dit 'tractament', spoedig zouden nog andere maaltijden volgen. Wie zich dus nu coulant opstelde, zou in de toekomst ook de voorkeur genieten. En het werkte. Traiteur De Beche te Maastricht nam het aan voor drie gulden per persoon en het voor de geestelijken aan de vasten aangepaste menu voor $2 \frac{1}{2}$ gulden. De Gronsveldse secretaris Berchmans leverde voor 45 'kreuzer' het 'tractament' inclusief het bier voor de schepenen, burgemeesters en oudste inwoners van het graafschap. Deze groep kreeg dus iets minder te eten dan de deftige gasten. Bij Emonts in Wyck werden een aam moezelwijn en vijftien flessen rode 
wijn gekocht. Koffie, thee, suiker, brandewijn, tabak, pijpen en dergelijke waren naar landsgebruik voor iedereen beschikbaar.

Waar kon een dergelijk grote groep in Gronsveld worden ondergebracht? Het kasteel was bouwvallig, te koud en er kon niet worden gestookt, want de schoorstenen waren al jarenlang niet meer geveegd. Je stikte er van de rook en het brandgevaar was zeer groot. De weduwe van oud-drossaard Lebens beschikte over een huis met twee grote kamers plus een keuken. Als de tussendeur werd uitgenomen, was er plaats voor 55 gasten. De kamers in het huis die Prummer zelf gebruikte, konden dienen als garderobe en uitserveerkamer.

Alles overziende kon Prummer zeggen, zonder zich zelf op de borst te kloppen, dat hij de organisatie tot in de puntjes had geregeld. De proef op de som zou de dag van de uitvaart zijn. De ochtend van dinsdag 26 maart werd ingezet met klokgelui van zes uur tot kwart voor zeven. Om zeven uur begonnen de missen, welke reeks om negen uur werd onderbroken voor een dodenofficie, waarbij bijna de voltallige geestelijkheid meezong. Er was zo'n massale toeloop van nieuwsgierigen uit de omgeving en vooral ook Maastrichtenaren, dat men het 'castrum doloris' bijna omver had gelopen en de priesters bij de altaren in het nauw had gebracht, wanneer niet een sergeant en manschappen van de schutterij de menigte in toom hadden gehouden. Kwart voor negen trok de schutterij met vaandel en geweren op onder leiding van de kapitein, twee luitenants, een vaandrig en een sergeant met spontons (korte lansen). Het gezelschap posteerde zich op het kerkplein. De officieren droegen rouwbanden om de armen en de spontons, vaandel en trommels waren met zwarte stof overtrokken.

Vanaf zeven uur was Prummer in de weer met de ontvangst van gasten en zorgde dat iedereen thee, brandewijn, tabak en rouwkleding ontving. Toen het dodenofficie ver genoeg was gevorderd, ging het gezelschap op weg naar de kerk. Voorop liep de grafelijke rentmeester met het wapenschild, daarna volgde Prummer, wiens sleep werd gedragen door zijn schrijver. Hij werd begeleid door pastoor Schmädel in diens hoedanigheid van grafelijk raadsheer, en de drosaard. Schmädel had alle moeite gedaan om ondanks zijn ziekte zoveel mogelijk de dienst bij te wonen. Achter hen kwamen de genodigden in willekeurige volgorde, daarna de leen- en gerechtsgriffier, schepenen en burgemeesters en vertegenwoordigers van de dorpen en geërfden, in totaal 37 personen, allen voorzien van rouwmantels. Bij het passeren van de schutterij werd de trom geroerd. In de kerk kostte het veel moeite zich door het volk heen te wurmen, alvorens men plaats kon nemen op de met rouwstof behangen stoelen in de kruisbeuk, aan weerszijde van het 'castrum'.

$\mathrm{Na}$ het einde van het dodenofficie begon pastoor Thomassen van Wyck, geassisteerd door diaken en subdiaken, met de eerste requiemmis. $\mathrm{Na}$ het offertorium vond de offergang plaats, waarvoor een misdienaar met een bedekte schaal aan de ingang van koor bij de epistelzijde gereed stond. Vervolgens kon iedere genodigde de pateen kussen. Daarna gingen de kapitein van de schutterij met zijn hele compagnie, volgens het gebruik, ten offer. Ten slotte volgden de overige gelovigen. Bijna iedereen, zowel eigen inwoners als vreemden, namen aan de offergang deel. Het vrouwvolk, dat in onverwacht groten getale was komen opdagen, werd aangevoerd door de weduwe van de vroegere drossaard. 
Aansluitend werd de tweede hoogmis volgens dezelfde procedure opgedragen door de pastoor van Mesch. Daarbij werd het Libera met plechtige muziek gezongen.

Tegen half een was alles afgelopen en vertrokken de genodigden naar de woning van de weduwe Lebens, waar de mantels werden afgedaan. Het wachten was nu op de laatste priesters en afronding van de brooduitdeling. Tegen enen was het zover dat Prummer met zijn 'in 54 meistentheills gar gesundten köpfen bestandtenen compagnie' kon oprukken naar de tafels. Over eetlust viel niet te klagen. De eerste dronk werd met de wens 'requiem aeternam dona eis Domine' uitgebracht op het zielenheil van de overledene. Daarna werd geklonken op het welzijn van de graaf en het grafelijk huis Toerring Jettenbach.

Het eten was zowel in kwantiteit als kwaliteit zo rijkelijk, dat zich daar niemand over kon beklagen. Ook de bediening verliep uitstekend. Prummer constateerde later dat bij enkele paters en pastoors kennelijk het idee leefde dat zij een grote fout begingen, wanneer ze nuchter huiswaarts keerden. Daarom bleek het nodig nog extra wijn te laten aanrukken. Om vijf uur besloot de pastoor van Wyck met het bidden van de psalmen 'Miserere mei en 'de profundis' de maaltijd en begon het afscheid. Om zes uur was iedereen weg, hoewel enkelen nog graag waren blijven plakken.

$\mathrm{Na}$ afloop moest Prummer zorgen voor verdeling van de overgebleven kaarsenwas. De restanten werden gelijkelijk verdeeld onder de kerken van Wyck, Heugem en Eckelrade en de kloosters van de kapucijnen, franciscanen, dominicanen en augustijnen. De zes grote waskaarsen, die bij alle begrafenissen gebruikelijk waren, kreeg de koster van Gronsveld toebedeeld voor zijn bemoeienis, omdat hij anders geen beloning voor zijn diensten ontving.

Het was gebruikelijk aan het kasteel of woonhuis gedurende het hele rouwjaar een in een kostbare lijst gevat wapenschild van de overledene op te hangen, maar omdat de gravin hier niet was begraven, liet Prummer dat achterwege. Wel bestelde hij als blijvende herinnering een vierhoekig rouwbord voor in de kerk, zoals men dat vroeger ook voor de graven van Gronsveld had laten maken.

Prummer keek met voldoening op de dag terug. Hij had een veilige weg gevonden door het mijnenveld van lokale gebruiken en was toch binnen de begroting gebleven. Al met al had de prachtige plechtigheid gestrekt tot eer en glans van de landsheer. In die zin deed hij ook op 31 maart aan de graaf verslag. Inmiddels had Prummer openbare rouw afgekondigd, die inhield dat gedurende een half jaar alle publieke feestelijkheden waren verboden. Eigenlijk gold daarvoor hier te lande een termijn van een jaar, maar Prummer meende dat voor de echtgenote van de landsheer een kortere tijd volstond.

Graaf Maximilian Emanuel toonde zich tevreden over het verslag en de afrekening. In tegenstelling tot Prummer verordonneerde hij echter een rouwperiode van een jaar en zes weken. Verder moesten gedurende zes weken na de uitvaart dagelijks de klokken worden geluid. Ook dienden alle graafschappen van de Nederrijns-Westfaalse Kreits bericht van het overlijden te krijgen. De serie rouwborden in de kerk van Gronsveld moest worden aangevuld. Ten slotte kreeg de pastoor van Gronsveld een mooi kazuifel ten geschenke en 
moesten de kloosters, die bij de uitvaart vertegenwoordigd waren geweest, missen opdragen voor het zielenheil van de overledene. ${ }^{1155}$

Prummer voerde deze instructies stipt uit. De periode van zes weken voor het klokluiden viel zelfs nog iets langer uit en duurde tot aan de hier te lande gebruikelijke zeswekendienst. Ook deze plechtige diensten werden goed bezocht door genodigden en onderdanen.

Daarna stelde Prummer in zijn brief aan de graaf het probleem aan de orde van het versturen van overlijdensberichten aan de graafschappen binnen de Nederrijns-Westfaalse Kreits. Achteraf gezien was het gemakkelijker geweest de benodigde gegevens in adresboeken in München op te zoeken, want Prummer kende geen adressen. De drossaard kon hij niets vragen, want die was op reis. Misschien viel nog informatie in Aken te achterhalen, maar de algemene conclusie luidde dat men in deze streek eigenlijk alleen maar iets wist over de rijksgraven van Rekem en Manderscheid. (Terzijde moet worden opgemerkt dat Prummer Wittem vergat). ${ }^{1156}$ Natuurlijk kan deze hulpeloosheid samenhangen met Prummers onervarenheid, maar het werpt toch ook een licht op de gebrekkige communicatie binnen de Nederrijns-Westfaalse Kreits.

\subsection{Roumplechtigheden voor Maximilian Emanuel von Toerring-Jettenbach, 1773}

Graaf Maximilian Emanuel von Toerring-Jettenbach overleed in het Palais Toerring te München op 13 maart 1773 'an einer wennig tag angedauerten schlafsucht, dann darzue geschlagenen innerlichen brand' of, zoals het in een in het Frans gesteld attest heet 'une letargie de quelques jours et une grangrê qui y est survenue' Hij werd naast zijn overleden echtgenote begraven in de kruisgang van het tegenover zijn woning gelegen franciscanenklooster. ${ }^{1157}$ Zijn enige nog levende jongste broer August Joseph was zijn universele erfgenaam.

Het duurde enige tijd voordat het nieuws van het overlijden in Gronsveld doordrong. Op 27 maart 1773 schreef Prummer in tamelijk zakelijke bewoordingen dat hij had gehoord en in (onbetrouwbare) kranten gelezen dat zijn heer zou zijn overleden. Hij leek in eerste instantie vooral geïnteresseerd in de regeling van praktische zaken die met de erfopvolging te maken hadden. ${ }^{1158}$ Dat schijnt ook in München voorrang te hebben gehad. Op 5 april 1773 stuurde graaf August Joseph de nodige Duits- en Franstalige blanco volmachten om Gronsveld in bezit te nemen op dezelfde wijze als zijn broer dat in 1754 had gedaan. Verder wenste hij een rouwdienst zoals in 1754 voor Maria Josepha was gehouden. Prummer diende na te gaan welke personen of instanties van het overlijden bericht moesten ontvangen. ${ }^{1159}$

\footnotetext{
1155 TJ, inv. nr. M 14, fol. 593-598 M.E. von Toerring-Jettenbach aan Prummer 19 april 1754.

1156 TJ, inv. nr. M 14, fol. 149-151 Prummer aan M.E. von Toerring-Jettenbach 7 mei 1754.

1157 TJ, inv. nr. M 56, fol. 45-46; 49-52; 62.

1158 TJ, inv. nr. M 56, fol. 21-24, Prummer aan A.J. von Toerring-Jettenbach 27 maart 1773.

1159 TJ, inv. nr. M 56, fol. 35-44, A.J. von Toerring-Jettenbach aan Prummer 5 april 1773 en TJ, inv. nr. M

56, fol. 27-29, A.J. von Toerring-Jettenbach aan Geheime Raad van Keurvorst van Beieren 2 april 1773.
} 
Bijna twee weken later moet het officiële bericht in Gronsveld zijn gearriveerd. Op 19 april 1773 schreef Prummer zowel condoleances als gelukwensen voor de nieuwe heer van Gronsveld. Tevens vroeg hij om handhaving in zijn ambt, aangezien door het overlijden in principe zijn dienstbetrekking eindigde. ${ }^{1160}$ Intussen was het nieuws toch ruimer bekend geworden. Al op 17 april stuurde baron de Goeswin, de stadhouder van het Gronsveldse leenhof, vanuit Luik een brief met rouwbeklag naar München, waarin hij zich verwonderde dat de klokken in Gronsveld nog niet luidden ten teken van openbare rouw. ${ }^{1161}$

Prummer zag zich nu voor twee dringende taken geplaatst, te weten de organisatie van de rouwdienst en de inhuldiging van de nieuwe landsheer. Als datum voor de kerkelijke plechtigheden werd 4 mei 1773 vastgesteld, de inhuldiging met voorafgaande formaliteiten zou op 5 en 6 mei plaatsvinden. Prummer wist natuurlijk wel naar welke plaatsen in de omgeving van Gronsveld hij een kennisgeving van het overlijden of uitnodiging moest sturen, maar voor de Nederrijns-Westfaalse Kreits en het Nederrijns-Westfaalse Gravencollege wilde hij volstaan met een bericht aan de directoria van beide colleges. ${ }^{1162}$

Op 10 mei 1773 zond Prummer zijn voorlopig verslag van de kerkelijke rouwplechtigheden en daarop volgende inhuldiging. Daarmee begon over beide onderwerpen een correspondentie gedurende enkele maanden, met uitvoerige verslagen van de gebeurtenissen en de problemen en overwegingen die bij de organisatie een rol hadden gespeeld. Die gedetailleerdheid was niet alleen het gevolg van Prummers breedsprakigheid, het was ook duidelijk dat graaf August Joseph van de kleinste bijzonderheden op de hoogte wilde zijn. Overigens viel de toonzetting bij de graaf aanvankelijk nogal bits uit. Op 30 juni 1773 kreeg Prummer een berisping dat hij wel allerlei informatie had gestuurd, maar de graaf miste een afrekening. Misschien was zijn broer niet zo accuraat en stipt geweest, maar de nieuwe heer hechtte groot belang aan stipte plichtsvervulling. ${ }^{1163}$ Op 3 juli zond Prummer een herziene versie van zijn verslag met de bijbehorende rekeningen naar München. Met hoeveel aandacht graaf Toerring dit las, blijkt uit het feit dat hij vervolgens op veertien punten een nadere toelichting vroeg, niet vanwege kritiek, maar uit pure nieuwsgierigheid om meer inzicht te kriigen in de toestand van het verre Gronsveld.

Eigenlijk beschikte Prummer al over een draaiboek voor de rouwdienst, want volgens zijn instructie moest die op dezelfde wijze worden georganiseerd als in 1754 voor gravin Maria Josepha. Het was zelfs eenvoudiger, want hij had in de loop der jaren de nodige ervaringen verzameld. Prummer had een helder doel voor ogen: het moest voor minder geld dan destijds, maar de plechtigheid mocht in pracht en praal daarvoor niet onderdoen. Een belangriijk voordeel leverde het feit dat hij de verzorging van de maaltijd na afloop van de kerkdienst geheel kon overlaten aan de grafelijke rentmeester en diens echtgenote. Destijds was dat een van zijn grootste zorgen geweest. Bovendien konden sommige

1160 TJ, inv. nr. M 56, fol. 64-67, Prummer aan A.J. von Toerring-Jettenbach 19 april 1773.

1161 TJ, inv. nr. M 56, fol. 33, Leenstadhouder van Gronsveld baron E.B. de Goeswin uit Luik aan A.J. von Toerring-Jettenbach 17 april 1773.

1162 TJ, inv. nr. M 56, fol. 68-83, Prummer aan A.J. von Toerring-Jettenbach z.d., presentatum München 4 mei 1773.

1163 TJ, inv. nr. M 56, fol. 217-222 A.J. von Toerring-Jettenbach aan Prummer 30 juni 1773. 
attributen die de vorige keer speciaal waren gemaakt, zoals het houten geraamte van het 'castrum doloris' en het grote wapenbord, waarmee de rouwstoet werd geopend, met wat aanpassingen opnieuw worden gebruikt.

Om te beginnen liet Prummer in het hele graafschap openbare rouw voor een periode van een jaar en zes weken afkondigen. Tot aan de rouwdienst op 4 mei werden de kerkklokken tweemaal daags geluid. Graaf August Joseph vroeg zich later af of het stilleggen van publiek vermaak geen schade toebracht aan de economie, maar volgens Prummer leverde dat geen enkel bezwaar op. Gedurende het jaar bestond, met uitzondering van (soms) de kermis, toch nergens gelegenheid tot openbaar dansen, noch in herbergen, noch tijdens bruiloften of Vastenavond.

Verder namen Prummer en rentmeester Lebens vanaf dat moment in hun kleding rouw aan. Omdat in het vorige rouwkostuum uit 1754 de mot zat, moesten ze in het nieuw. Ook hun echtgenotes hadden rouw aangenomen. Dit was een verschil met 1754, omdat beide heren toen nog ongehuwd waren. Terwijl mannen konden volstaan met zwarte rouwkleding volgens de gangbare mode, lag dat voor vrouwen veel moeilijker. Er bestond geen algemene klederdracht die een bepaalde stand aangaf. Iedereen handelde naar eigen inzicht, maar dan wel zo, dat men probeerde elkaar de loef af te steken. Voor dames betekende dat volgens Prummer 'eine ganze litaney von trauer-hauben (= rouwhoeden), mantl, mancheten und ich wais nit was allerley'. Elders zou dat als een uitspatting worden gezien, maar hier was het onontbeerlijk. Omdat Prummer op dit terrein niet zo goed op de hoogte was, gaf hij zijn eigen vrouw vijftig gulden en die van rentmeester Lebens 35 om al het nodige aan te schaffen.

Omdat het een rouwdienst voor een regerend landsheer betrof, werd de hele kerk bedekt met zwarte doeken. Die stoffering, inclusief die van het 'castrum doloris', werd voor 24 gulden Rijnlands gegund aan de Maastrichtse begrafenisondernemer Nicolaas van den Berg, een schoonzoon van de inmiddels overleden Dorlo, die in 1754 het werk had aangenomen. Prummer had een bewijs van zijn kunnen gezien bij de begrafenis van de Maastrichtse gouverneur baron d'Aylva. In Gronsveld ging het wel iets bescheidener, maar niet minder smaakvol toe. Iedereen was over het resultaat enthousiast en in het bijzonder het 'castrum' oogstte veel bijval. Het was mooier dan de bouwsels die voor de laatste twee overleden prins-bisschoppen van Luik $(1763,1771)$ in de Onze-Lieve-Vrouwekerk te Maastricht waren opgericht. Bovendien hadden die het dubbele gekost.

De ervaringen die Prummer in 1754 had opgedaan, kwamen nu goed van pas. Net als toen koos Prummer ook nu voor goedkope holle kaarsen. Verder hield hij een lager aantal beschilderde wapenschildjes aan dan de vorige keer, vooral omdat die vaak te zwaar bleken voor bevestiging aan de kaarsen. De Maastrichtse schilder Colombon kreeg opdracht deze schildjes te leveren. Colombon moest ook het grote wapenbord dat in 1754 aan het begin van de rouwstoet was gedragen, voor de nieuwe rouwdienst aanpassen. Ten slotte nam hij de taak op zich om de houten wapenborden in de kerk op te frissen.

Een delicaat onderwerp betrof, zoals gewoonlijk, de lijst van genodigden. In dat opzicht was Prummer sinds 1754 enkele ervaringen rijker geworden. Wederkerigheid stond nu bij hem voorop. Plaatsen die destijds geen afgevaardigde hadden gestuurd of waar Prummer zelf ook niet voor begrafenissen was gevraagd, werden geschrapt. Van de buren werden alleen de baronnen van Rijkckholt uitgenodigd, eigenlijk niet eens zozeer als buren, maar 
vooral als 'buitengeërfden'. Voor de rest werd het een Gronsveldse aangelegenheid, met alleen personen die directe binding met het graafschap bezaten wegens hun functie of grondbezit. De grondeigenaren of buitengeërfden met stemrecht in de Gronsveldse Landsvergadering stuurden in totaal zes vertegenwoordigers. Verder kwamen twaalf afgevaardigden van de schepenbank en dorpen uit het graafschap in aanmerking en ten slotte nog enkele bijzondere gasten, zoals baron de Goeswin, stadhouder van het Gronsveldse leenhof en de heer de Floen als bezitter van het adellijk leengoed Hamersbach onder Eckelrade. Begrafenisondernemer Van den Berg leverde voor Prummer en de gasten, in totaal 29 man, de rouwmantels en handschoenen. Prummer besloot dat hij zelf als 'haupt-kläger' en de rentmeester als drager van het wapenschild in vol ornaat met sleep aan de dienst zouden deelnemen.

In het bijzonder voor de gasten liet Prummer bij Lekens in Maastricht tachtig rouwbrieven drukken. Dat was een precies werk, want de volledige, ingewikkelde titulatuur van de overledene moest er foutloos op staan. Prummer maakte daarvoor gebruik van een oude 'hofcalender', een soort almanak voor de adel. Deze brieven werden aan de genodigden uitgedeeld en bij geestelijken was het gebruikelijk deze teksten in de sacristie op te hangen. Ook de schutterij van Gronsveld werd uitgenodigd in vol ornaat met bijbehorende uitrusting de laatste eer aan de overledene te bewijzen. Het 'ornaat' bestond uit nette kleding, maar er was geen sprake van een uniform. Wanneer er moest worden geparadeerd, placht men ook wel mooie kleren te lenen 'umb ehrlich zu erscheinen'. Als iedereen verscheen, ook de 'buitenlandse' ('auswärthige') leden buiten het graafschap, telde dit gezelschap meer dan tweehonderd man. Bij een dergelijk aantal is het begrijpelijk dat de zuinige Prummer tevreden opmerkte dat hem geen vergoeding of traktatie was gevraagd en hij dus ook niets hoefde te betalen. Naast de speciaal genodigde individuele gasten en groepen vaardigde Prummer ook nog een bevel uit voor alle mannelijke onderdanen, waarin zij 'sye sammentlich zu erscheinen aufgebotten' werden.

De volgorde van kerkelijke plechtigheden bestond uit het gezongen dodenofficie tussen 9 en 10 uur, daarna twee hoogmissen met 'musicalische requiem' en ter afsluiting de gezongen sequentie 'Libera me Domine'. Verder werden gedurende de hele ochtend aan de twee zijaltaren onafgebroken missen gelezen. In totaal waren 21 geestelijken nodig, aanmerkelijk minder dan de 36 of 37 in 1754. De reden was dat Prummer deze diensten niet zoals de vorige keer om zeven, maar om negen uur liet beginnen. Dat spaarde kosten, want in die vroege uren kwamen toch alleen maar kijklustigen, niet uit devotie, maar om zich te vergapen aan het 'apparatum' ('castrum doloris') en de verdere stoffering.

De muzikale opluistering van het geheel lag, gelijk in 1754, in handen van musici en zangers van het Onze-Lieve-Vrouwekapittel te Maastricht. Prummer kwam met hen een honorarium overeen, maar zonder eten en drinken, 'weill ich kenne wie es die musicanten machen', zoals hij later aan de graaf berichtte. $\mathrm{Na}$ afloop van de plechtigheden vond de gebruikelijke brooduitdeling aan de armen plaats.

Een onderwerp dat Prummer de vorige keer veel hoofdbrekens had gekost, was de organisatie van een maaltijd voor de genodigden. Omdat alleen het huis van rentmeester Lebens daarvoor ruim genoeg was, besteedde Prummer de maaltijd bij hem en zijn vrouw uit. De algehele leiding lag in handen van een zuster van mevrouw Lebens en een ingehuurde kokkin. Zij waren bereid voor zestig gulden Rijnlands een fatsoenlijk 
middagmaal naar landsgebruik te verschaffen voor in totaal veertig personen. Tevens zorgden zij voor tafelgerei en bediening. Bij de prijs inbegrepen waren een ontbijt met koffie, thee, sterke drank, tabak en pijpen voor de geestelijken na het mislezen. Over het rookgedrag van de clerus verwonderde de graaf zich later in hoge mate, omdat deze gewoonte volgens hem op een Poolse landdag leek. ('einen Polnischen assemblée nit vil unähnlich siehet'). Maar volgens Prummer was het hier te lande normaal dat geestelijken al bij het ontbijt rookten. Tabaksgebruik was, zoals in Holland, algemeen. Er was eigenlijk niemand die niet's morgens bij koffie of thee een paar boterhammetjes at en een pijpje rookte. Velen namen aansluitend nog 'ein tröpfgen' (brandewijn). Kloosterlingen vormden daarop geen uitzondering en van paters was bekend dat ze nog liever rookten dan sterke drank gebruikten.

$\mathrm{Na}$ alle voorbereidingen werden de diensten op 4 mei letterlijk tussen 7 en 8 uur 's morgens door de kerkklokken ingeluid. Om 9 uur begonnen de eerste missen en de gezangen van het dodenofficie. Buiten op het plein voor de kerkingang stelden zich de twee compagnieën van de schutterij op in slagorde ('en ordre de bataille'). Naderhand kon een deel van het gezelschap, zonder geweer, nog achter in de kerk een plaats krijgen. Maar van buiten viel, met wat goede wil, toch door de deur te zien wat zich binnen in het kerkgebouw afspeelde.

Intussen hadden de genodigden zich verzameld bij de pastorie, waar ook de rouwmantels en handschoenen werden uitgedeeld, in totaal voor 29 personen. Op een teken dat het gezongen dodenofficie ten einde liep, trok de stoet langs de opgestelde schutterij naar de kerk. Voorop liep de rentmeester in rouwmantel met sleep als wapendrager. Daarna volgde Prummer als 'haubt-kläger' ook in mantel met sleep, die werd gedragen door de grafelijke jager. Even zag het er naar uit dat de stadhouder van het leenhof, baron de Goeswin ook een mantel met sleep kreeg, maar omdat hij niet in passende rouwkleding was verschenen - hij droeg rode kousen! - besloot Prummer hem maar niet al te opvallend tussen de overige gasten te laten lopen. Daarna volgden door elkaar de genodigden, schepenen, burgemeesters en oudste inwoners van de dorpen en ten slotte de rest van de mannen en het vrouwvolk, dat werd aangevoerd door de echtgenotes van Prummer en rentmeester Lebens.

In de kerk nam rentmeester Lebens als wapendrager plaats op een stoel voor het 'castrum doloris', Prummer zat op een stoel aan de epistelzijde en voor de overige gasten stonden aan weerszijde van het 'castrum' stoelen die met zwarte stof waren bekleed. Een verschil met de plechtigheid van 1754 was dat één stoel onbezet bleef als symbool voor de lege plaats die de overledene achterliet.

Om tien uur begon de eerste requiemmis, opgedragen door de pastoor van Wyck. Daarna volgde de tweede mis, opgedragen door pastoor Kolb. De pastoor van Heer vervulde de rol van cantor. In beide diensten vond een offergang plaats, eerst voor de genodigden en daarna volgden de schutten met hun spontons, vaandel en geweer naar de grond in de richting van het 'castrum doloris' gekeerd. Overeenkomstig de zeden van het land ('ländtlich, sittlich') noemde Prummer die offergang. $\mathrm{Na}$ de schutters ging het gewone volk ten offer. De missen verliepen verder op de gebruikelijke wijze. Op het moment van de consecratie brachten de schutters buiten met hun geweer een eresaluut voor het Allerheiligste. Aan het 
einde van de vieringen zong het koor de sequentie 'Libera me Domine' alsof het een uitvaart met een werkelijk aanwezig stoffelijk overschot betrof.

Tegen half een waren de kerkdiensten ten einde en konden de genodigden in het huis van rentmeester Lebens aan de maaltijd beginnen. Er stonden drie tafels opgesteld, de eerste voor Prummer en de deftige genodigden (39 personen), de tweede voor schepenen, burgemeesters en dorpsoudsten (achttien personen) en de derde voor knechten en koetsiers van de gasten en de grafelijke jager. In de rapporten die Prummer naar München stuurde, geeft hij een gedetailleerde lijst van de gerechten die voor de eerste en tweede groep werden opgediend. In ieder geval waren de gasten goed van innemen. 'Nederlanders' beweerden vaak dat Duitsers veel aten en dronken, maar volgens Prummer was eerder het omgekeerde het geval. Wanneer hij dat met voorbeelden over het verdere verloop van de maaltijd probeert te illustreren, vermeldt hij terloops nog een aantal roddels over de gasten. Gemiddeld werd ongeveer een fles wijn per persoon geconsumeerd. De meesten dronken Moezelwijn, maar drie man (baron de Bounam van Rijckholt, de heer de Floen uit Eckelrade en baron de Goeswin) hadden samen zes 'flacons' rode wijn genuttigd. In zijn eerste verslag had Prummer die zes flessen per ongeluk allemaal op rekening van de baron van Rijkckholt geschreven, maar in zijn tweede rapport moest hij dit corrigeren. Dat nam niet weg dat van de heer van Rijckholt bekend was dat hij een paar jaar eerder niet terugdeinsde voor het nuttigen van zes flessen goede bourgogne in een keer. En de heer de Floen, nu een bevende oude man, deed daar niet voor onder. Door de drank en het goede eten steeg de stemming. Na het drinken van koffie of thee werd tegen vier uur afgesloten met een tafelgebed en de psalm 'De profundis'. Iedereen was tevreden, de dag was zelfs beter verlopen dan de vorige keer in 1754 en, voor Prummer erg belangrijk, het geheel had 432 gulden Rijnlands minder gekost.

\subsection{Conclusies}

Hoewel in Gronsveld het principe gold van directe overgang van landsheerlijk gezag door erfopvolging zonder de noodzaak tot inhuldiging, bracht dit beginsel in de praktijk toch wel het nodige 'papierwerk' met zich mee. Opmerkelijk zijn de regelmatig terugkerende terughoudendheid bij het organiseren van publieke inhuldigingen wegens onzekerheden over de juiste erfgenaam, onduidelijkheden over nalatenschappen en opvolging bij minderjarige kinderen, problemen met schuldeisers en reacties van de bevolking. Zelfs toen daar geen enkele aanleiding voor bestond, kende Prummer in 1754 nog aarzelingen over de publieke opinie.

Over het protocol van inhuldiging en uitvaart vóór het midden van de achttiende eeuw is weinig concreets bekend. Wat vermeld wordt, wijkt niet wezenlijk af van gebruiken in andere plaatsen bij de overdracht van onroerend goed of overdracht van heerlijkheden. De gang van zaken lijkt ook overeen te komen met de opvattingen zoals tijdgenoten die in de 'zeremonialwissenschaftliche' en juridische literatuur beschreven. Bij de organisatie van de plechtigheden in 1754 in Gronsveld moest Prummer alles zelf bedenken, omdat geen levende herinnering meer aan vroegere plechtigheden bestond. Toch was het geen invented 
tradition, want het resultaat sloot uiteindelijk goed aan bij de in de streek bestaande tradities. De plechtigheden in 1773 vormden daar grotendeels een herhaling van. Opvallend is het grote belang dat werd gehecht aan een uiterst nauwkeurige organisatie, waarbij niets aan het toeval werd overgelaten. De overwegingen die Prummer daarbij geeft, laten zien met welke gevoeligheden allemaal rekening moest worden gehouden.

De gedetailleerde beschrijvingen van inhuldigingen en uitvaarten in Gronsveld in de tweede helft van de achttiende zijn zeldzaam voor het Maasgebied. Cultuurhistorisch bieden ze een blik op de opvattingen over etiquette en gebruiken rond dit soort gebeurtenissen. Interessant is dat het ceremonieel zoals dat bij de rouwdiensten wordt beschreven, voor een deel nog altijd bestaat in de traditionele 'Schuttenmis', de kerkdienst die, volgens het reglement van de Gronsveldse schutterij uit 1619, op maandag na Bronkzondag (tweede zondag na Pinksteren) moet worden gehouden ter herdenking van de overleden leden van de vereniging.

Er zijn redenen om te twijfelen dat de gebeurtenissen zich ook hebben voltrokken, zoals ze door Prummer zijn beschreven. Zijn afwegingen en bedenkingen zijn goed gedocumenteerd en laten zien met welke gevoeligheden hij als organisator meende rekening mee te moeten houden. Voor hem waren de plechtigheden bij begrafenis en inhuldiging demonstraties van landsheerlijk gezag. In dat opzicht lagen ze niet alleen in tijdsvolgorde, maar ook inhoudelijk in elkaars verlengde. Voor beide soorten plechtigheden bestond opkomstplicht voor de bevolking (waarschijnlijk werd dat ook in het algemeen als een verplichting bij landsheerlijke bezoeken beschouwd). Onbeantwoord blijft vooralsnog de vraag hoe de onderdanen er tegenaan keken. Dat maakt ook een volledig oordeel lastig. ${ }^{1164}$ Men krijgt de indruk dat de belangstelling van de inwoners maar matig was. Men deed wat werd verlangd, maar zonder groot feest komen de reacties bij inhuldiging nogal lauw over. De respons op uitvaarten als barok spektakelstuk in de kerk lijkt aanmerkelijk groter te zijn geweest.

1164 Zie over dit probleem van de interpretatie en de opvattingen daarover in de leitartuur: StollbergRilinger, Rituale, 183-188. 


\section{Wet- en regelgeving}

In dit hoofdstuk wordt onderzocht welke wetgeving in Gronsveld werd toegepast, zowel algemene voor het Rijk als specifiek voor Gronsveld geldende regelgeving. Van de beperkte hoeveelheid bewaard gebleven plaatselijke regelgeving is een inventarisatie gemaakt. Daarin komt aan de orde welke positie de graaf als wetgever innam, ten opzichte van het Rijk, ten opzichte van kerkelijke autoriteiten en ten opzichte van de plaatselijke gezagsdragers. Ook wordt andacht besteed aan de landsheerlijke bevoegdheid tot interpretatie. Ten slotte worden de formele aspecten van de regelgeving (redactie en bekendmaking) besproken.

\subsection{Gelaagdheid in en omvang van wet- en regelgeving}

In een commentaar op de Gronsveldse Recbtsordnung van 1671 (zie daarover hierna Hoofdstuk 7.4.3) schrijft Joseph Anton Prummer in 1755 dat hij bij het doorlezen van de gerechtsprotocollen over een periode van tachtig jaar niets had gevonden, waaruit bleek dat dit landrecht in de praktijk was toegepast. ${ }^{1165}$ Wel constateerde hij dat 'baldt nach denn reichs, balt nach dennen brabantischen, balt nach dennen holländtischen, balt nach dennen littischen (Luikse) rechten verfahren wordten seye'. Ruim 140 jaar eerder vernemen we hetzelfde in een processtuk behorend bij het dossier van de zaak van Lambert Couven tegen Beatrix van Birgelen. In die zaak wordt voor het erfrecht van de langstlevende echtgenoot verwezen naar 'notoire costumen der graeffschappe van Gronsfeldt ende anderen omliggenden plaetsen'.1166

Prummers constatering over de afwezigheid van de Rechtsordnung is overdreven, maar wel begrijpelijk omdat deze waarschijnlijk inderdaad weinig werd toegepast. In wezen sneed hij daarmee niet alleen een probleem van de rechtspraak aan, maar ook van de wetgeving waarop die rechtspraak - voor zover het geen gewoonterecht betrof - was gebaseerd. Het blijkt niet zo eenvoudig te omschrijven wat binnen Gronsveld geldende wetgeving was. Daarbij kan onderscheid worden gemaakt tussen externe wetgeving, bijvoorbeeld vanwege het Rijk of kerkelijke autoriteiten, en interne, specifiek voor het graafschap geldende regelgeving.

Als landsheer was de graaf van Gronsveld binnen zijn territorium wetgever in formele en materiële zin, wat betekent dat hij op zijn naam algemene, de onderdanen bindende regels kon uitvaardigen. Aan welke grenzen was hij daarbij gebonden, zowel binnen het kader van de rijkswetgeving, maar ook in de richting van kerkelijke autoriteiten? Bij die 'externe' regelgeving moet worden gedacht aan wetgeving voor het hele Rijk. Het gaat daarbij in het bijzonder om wetgeving in het kader van de door rooms-koning Maximiliaan in 1495 doorgevoerde hervormingen van het Rijk, verder de Reichspolizeiordnungen uit de zestiende eeuw $^{1167}$ en de Peinliche Halsgerichtsordnung van Karel V uit 1532, beter bekend onder de

1165 TJ, inv. nr. M 13, fol. 73-104, rapport met 'Information ÿber die natur und weesenheit deren in der freÿen reichsgrafffschafft Gronsfeldt entlegenen grundten...' bijlage bij brief Prummer aan M.E. von Toerring-Jettenbach 16 juni 1757 (fol. 145-146).

1166 RHCL, Graafschap Gronsveld, inv. 599, tripliek in dit dossier uit 1612.

1167 Weber, Die Reichspolizeiordnungen. 
korte benaming Carolina. ${ }^{1168}$ In ruimere zin kan men daartoe ook rekenen de regelgeving op grond waarvan de rijksstanden moesten bijdragen in de belastingen vanwege het Rijk. De vraag is wat deze externe wetgeving precies betekende en in hoeverre die direct of indirect, door omzetting in specifiek op het graafschap toegesneden regelgeving, toepassing vond.

Behalve de landsheer konden ook (in het geval van Gronsveld buiten het graafschap gevestigde) kerkelijke autoriteiten, in het bijzonder de bisschop van Luik en de aartsdiaken van Haspengouw, regelgeving uitvaardigen. ${ }^{1169}$ De vraag was of daarvoor landsheerlijke goedkeuring (recht van placet) was vereist. ${ }^{1170}$

De hoeveelheid materiële wetgeving in Gronsveld was echter meer dan alleen formeel op naam van de graaf uitgevaardigde regelgeving. Zo werden in de achttiende eeuw verordeningen door de grafelijke vertegenwoordiger uitgevaardigd op basis van delegatie. Soms zijn er ook 'naamloze', ter 'affixie' (openbare afkondiging) in het schepenprotocol ingeschreven verordeningen, waarvan niet helemaal duidelijk is op wiens gezag ze werden uitgevaardigd. Volledigheidshalve zouden we hierbij ook nog moeten noemen 'pseudowetgeving', zoals instructies voor de grafelijke rentmeester of de boswachter.

Hoewel die primair bedoeld waren voor de betrokken personen in dienst van de graaf, zullen de voor het publiek relevante bepalingen wel bekend zijn geweest.

In dit hoofdstuk wordt geprobeerd de verschillende vormen van wetgeving in kaart te brengen. Het blijft moeilijk daar goed zicht op te krijgen, want het totaal aan specifiek voor Gronsveld bedoelde regelgeving is beperkt. Het contrast wordt nog groter, wanneer men de oogst in Gronsveld vergelijkt met die in het - iets grotere - naburige graafschap Rekem. Verbois noemt tientallen ordonnanties en reglementen die daar werden uitgevaardigd. ${ }^{1171}$ Ook de graven Plettenberg lieten zich voor het graafschap Wittem niet onbetuigd. ${ }^{1172}$ Deels valt deze schrale oogst te verklaren uit het verlies van bronnen. Zo wordt in de Rechtsordnung van 1671 verwezen naar een Reglement op de Lenen uit 1593,1173 er is een verordening geweest op het zogenoemde 'aanbrengen' van onroerend goed uit $1733^{1174}$ en in de tweede helft van de achttiende eeuw werd tijdens het voogdgeding een nu niet meer aanwezige 'politieke ordonnantie' voorgelezen (zie hierna). Van andere plaatsen is bekend dat dit soort verordeningen ter handhaving van openbare orde en

1168 Erler e.a., Handwörterbuch Rechtsgeschichte, 592-595 onder lemma Carolina. Teksteditie bij Hofmann, Quellen Verfassungsorganismus, 83-86.

1169 Een overzicht daarvan is te vinden bij Manigart, Paxis pastoralis. Daarin staan, 332-358, ook de statuten voor het aartsdiakonaat Haspengouw afgedrukt. Over de rol van de aartsdiaken zie: Habets, Geschiedenis Bisdom Roermond, 1, 258-286; Van Rensch, 'De aartsdiaken van Haspengouw', 177-178 en de daar opgegeven literatuur.

1170 Over de omgang van de Staten-Generaal met het recht van placet in Maastricht zie: Ubachs, 'Een Maastrichtse placetstrijd 1751-1755' en Van Rensch, 'De aartsdiaken van Haspengouw', 197-198.

1171 Verbois, Geschiedenis Rekem, passim en in het bijzonder de lijsten op de 47-48, 54-55, 57-58, 68-69.

1172 RHCL, Vrije rijksheerlijkheid Wittem, voorl. nr. 1 'Verordeningen 1730-1754'.

1173 Recbtsordnung Titel 6, \$ 7.

1174 RHCL, Graafschap Gronsveld, inv. nr. 210, Aanhef van Ordonnantie op het aanbrengen van de goederen 1754, waarin wordt verwezen naar 'proclama geaffigeert den 24. mey laestleden in het jaer 1733 
veiligheid, uitgebreid kon zijn (zie onder andere het hierna nog te noemen voorbeeld van Heer). Ook het ontbreken van protocollen van de schepenbank, waarin verordeningen werden geregistreerd, vormt in dit geval een groot gemis. Toch rijst de vraag of deze geringe hoeveelheid wetgeving alleen kan worden verklaard uit het verlies van bronnen. Het valt op dat gedurende de tweede helft van de achttiende eeuw in de tamelijk intensieve briefwisseling tussen de Gronsveld en München slechts zelden naar wetgeving wordt verwezen. Mogelijk hangt dit samen met een hierna nog te bespreken verschijnsel dat de vertegenwoordigers van de graaf, in samenwerking met de schepenen, de neiging hadden op basis van delegatie zoveel mogelijk zelf verordenend op te treden en alleen in uiterste noodzaak daar de graaf bij te betrekken. Vaak gebeurde dit als uitvloeisel van kwesties die tijdens het voogdgeding ter sprake kwamen. Zo beschouwd kan men zeggen dat er in deze plaatselijke verordeningen ook wel iets van een democratisch element school.

\subsection{Rijkswetgeving in bet algemeen}

Het tijdperk van echte 'rijkswetgeving' begint in de jaren negentig van de vijftiende eeuw met de hervormingen die door rooms-koning Maximiliaan werden doorgevoerd. Daar doet zich bij de toepassing van rijksrecht en rijkswetgeving het ingewikkelde probleem van de subsidiariteit voor. In beginsel had het plaatselijk gewoonterecht van stad en land voorrang op het rijksrecht, maar het was de vraag hoe beide zich tot elkaar verhielden, want hét rijksrecht als zodanig bestond niet. Vanaf de vijftiende eeuw werd daarvoor steeds meer het ius commune gebruikt, Romeins recht zoals dat aan universiteiten werd onderwezen en geïnterpreteerd. Naast dit 'gemene, geleerde recht' als aanvulling op het landrecht, bestond ook zwak ontwikkelde wetgeving op het hoogste niveau binnen het Rijk. De directe werking van 'rijkswetgeving' vormde echter een probleem, veroorzaakt door zowel de samenstelling van Rijksdag als door het karakter van de wetgeving zelf. In de Rijksdag waren niet de territoria (en al helemaal niet de inwoners) vertegenwoordigd, maar de landsheren als rijksstanden. Het Rijk kende verder geen centrale uitvoerende macht, belast met de afkondiging van wetgeving. Die taak lag bij de afzonderlijke standen, waarbij het altijd de vraag bleef in hoeverre die om politieke of confessionele redenen daartoe bereid waren.

Een tweede knelpunt in de toepassing vormden de aard van de 'Reichsschliusse'. Veelal hadden die, op basis van bepaalde normen, het karakter van algemene richtlijnen, bedoeld om de samenleving te ordenen. Ze dienden daarmee vooral als voorbeeld voor landsheren om deze besluiten in eigen wetgeving te integreren. Er bestond dus een duidelijke relatie tussen de regelgeving van de Rijksdag en de uitwerking daarvan in de afzonderlijke territoria. Het omgekeerde kwam ook voor in die zin, dat soms in oorsprong landsheerlijke wetgeving model stond voor regelgeving door de Rijksdag. Een voorbeeld daarvan levert de 'Bambergensis', de Bambergse 'Halsgerichtsordnung' van 1507, waaraan ook veel werd ontleend voor de 'Peinliche Halsgerichtsordnung Karls $V$ ' ('Carolina') van 1532.1175

1175 Erler e.a., Handwörterbuch Rechtsgeschichte, 592-595 onder lemma Carolina. 
Als derde mogelijkheid konden landsheren, zonder uitdrukkelijke afkondiging, toepassing van rijkswetgeving in hun territoria min of meer stilzwijgend toestaan. Dat schiep natuurlijk onduidelijkheid en in een dergelijke situatie valt toepassing van rijkswetgeving achteraf alleen aan te tonen aan de hand van concrete voorbeelden uit de rechtspraak.

De meest vruchtbare periode voor de 'rijkswetgeving' vormde ongetwijfeld de zestiende eeuw. ${ }^{1176}$ Voor een deel had deze betrekking op regelingen van staats- en bestuursrechtelijke aard, zoals de bijdragen van iedere landsheer in de diverse belastingen ten behoeve van het rijk. Een ander belangrijk aandachtsveld gold de regelgeving op het terrein van de 'Policey' als een onderdeel van het openbaar bestuur en het bestuursrecht. Tussen 1487 en 1603 werden vanwege het Rijk in totaal 51 wetten op het gebied van de 'Policey' afgekondigd. ${ }^{1177}$ Daarbij wordt in de zestiende eeuw nog duidelijk een onderscheid gemaakt tussen 'Policey' en 'recht'. ${ }^{1178}$ In de middeleeuwse traditie speelde 'recht' zich vooral af in de sfeer van wat thans onder privaatrecht wordt verstaan, zoals familie- en erfrecht, eigendomsrecht en verbintenissenrecht. Dit recht lag vast in het plaatselijk gewoonterecht, het canonieke recht of het gerecipieerde Romeinse recht. Op dit terrein werden vanwege het Rijk nauwelijks initiatieven ontplooid.

Geheel anders was dit bij de 'Policey', een stelsel van normen en regels die betrekking hadden op de publieke orde en het algemeen nut, evenals de handhaving van die regels door de wereldlijke overheid. De daarvoor ontwikkelde regelgeving bestreek de meest uiteenlopende terreinen zoals handel en economie, muntwezen, armenzorg, openbare veiligheid, uitoefening van religie, openbare zedelijkheid et cetera. Daarmee gaven keizer en standen uiting aan hun consensus over de binnen het Rijk gewenste ordening van het maatschappelijk leven. Sommige onderdelen van 'Policey'-wetgeving betreffen specifieke terreinen zoals het muntwezen (Reichsmünzordnung van 1559), het notariaat (Reichsnotariatsordnung van 1512) of arbeidsverhoudingen (Allgemeine Zunft- und Handwerksordnung van 1731/1732). Het bekendst en meest veelomvattend zijn echter de drie Reichspolizeiordnungen. Bij de Rijksdag in Augsburg in 1530 kwam de eerste versie tot stand, waarna in 1548 en 1577 herziene en aangevulde teksten werden afgekondigd. De Polizeiordung van 1577 behield zijn geldigheid tot aan de opheffing van het Rijk in 1806. De voorschriften behandelen zeer uiteenlopende onderwerpen, zoals de verhouding tussen heren en onderdanen, de bestrijding van vloeken, godslastering en woeker, regelgeving voor kleding en luxe bij doop, huwelijk en begrafenis, regulering van lonen, prijzen en arbeidsverhoudingen, handelspraktijken in het algemeen en die van bepaalde beroepsgroepen in het bijzonder, toezicht op de kwaliteit van producten, gebruik van maten en gewichten, voorzieningen voor wezen, zorg voor eerlijke arbeidsverhoudingen, omgang met randgroepen binnen de samenleving zoals zigeuners, joden, bedelaars, rondtrekkende speellieden et cetera.

De directe werking van de Reichspolizeiordnungen was beperkt. Weliswaar kenden ze nauwkeurig vastgelegde voorschriften, maar de handhaving daarvan lag in handen van de afzonderlijke standen. Toch schiepen de zogenoemde Ordnungen uit de zestiende eeuw een

1176 Zie Waley, Das Heilige Römische Reich, 1, 452-456.

1177 Weber, Die Reichspolizeiordnungen, 23.

1178 Härter, 'Das Recht des Alten Reiches', 90. 
zekere homogeniteit in de publieke rechtsorde. Zij boden de absolutistisch regerende landsheren een kader om door middel van regelgeving 'gute Policey' in de praktijk te brengen. ${ }^{1179}$ Ze vormden tot aan de opheffing van Rijk in 1806 eerst en vooral een aansporing tot en bron van inspiratie voor eigen landsheerlijke Polizeiordnungen. ${ }^{1180}$ Voorbeelden daarvan zijn terug te vinden in de duizenden wetten en verordeningen die gedurende drie eeuwen in de afzonderlijke territoria werden uitgevaardigd. Aldus werd het dagelijks leven in zowel de publieke als private sfeer gereguleerd en gecontroleerd (Sozialdisziplinierung). Dat strekte zich uit van regels voor feesten en begrafenissen tot zedige kleding en van handel en openbare orde tot verbetering van productiemethoden. In dezelfde sfeer pasten ook hun pogingen om kerkelijke instituties in de meest ruime zin aan de wereldlijke overheid te onderwerpen. Die zucht naar regelgeving diende later, in de achttiende eeuw, niet alleen om het volk in toom te houden. Onder invloed van de Verlichting probeerden vorsten hiermee ook bestuur, rechtspraak en economie te verbeteren en het morele en culturele peil van de bevolking te verhogen.

Ook de belastingwetgeving van het Rijk had voor de inwoners slechts indirecte werking. De defensie, het onderhoud van het Rijkskamergerecht, het (kleine) bestuursapparaat van de kreits en de vertegenwoordiging bij de Rijksdag kostten geld. Voor de betaling van die kosten werden de rijksstanden in de zogenoemde matrikels voor een totaalbedrag aangeslagen, waarna de feitelijke heffing bij de onderdanen door middel van landsheerlijke wetgeving werd geregeld.

Het strafrecht nam tussen recht en 'Policey' een middenpositie in. Begrippen als 'schuld' of 'onschuld' behoren tot het terrein van het recht, maar het materiële en formele strafrecht bevatten ook bepalingen over maatschappelijk ongewenst gedrag en de daarop gestelde sancties. In die zin gaat er ook een ordenende en disciplinerende werking van uit. Maatgevend voor het strafrecht en het strafprocesrecht en de omzetting daarvan in landsheerlijke wetgeving werd de 'Constitutio Criminalis Carolina' of 'Peinliche Halsgerichtsordnung Karls V' van 1532, kortweg de 'Carolina' genaamd. Het woord 'peinlich', afgeleid van het Latijnse 'poena' (straf in de betekenis van straf aan lijf en leden) geeft al aan dat de Carolina bedoeld was voor de berechting van misdrijven, meer in het bijzonder het daarbij te hanteren procesrecht. Delicten in de sfeer van overtredingen werden veelal afgedaan door middel van een boetstraffelijke procedure met civielrechtelijke trekken.

Aangezien de rijksstanden de Carolina veelal beschouwden als een inbreuk op hun Landeshoheit, werd de werking sterk ingeperkt door toevoeging van de zogenoemde 'salvatorische clausule'. Deze hield in dat het in de afzonderlijke territoria geldende strafrecht voorrang had op de 'Peinliche Halsgerichtsordnung. ${ }^{.181}$ Toch moet de invloed van de Carolina daarmee niet worden onderschat. Zoals ook bij andere Polizeiordnungen stond de Carolina op tal van punten model voor landsheerlijke wetgeving. Tegelijk kan worden

1179 Weber, Die Reichspolizeiordnungen; Härter, 'Das Recht des Alten Reiches'.

1180 Härter, 'Das Recht des Alten Reiches', 92.

1181 'Doch wollen wir durch dise gnedige erinnerung Churfürsten, Fürsten vnd Stenden an jren alten wolhergebrachten rechtmessigen vnnd billichen gebreuchen nichts benommen haben', zie Hofmann, Quellen Verfassungsorganismus, 84. 
vastgesteld dat bij meningsverschillen over strafprocesrecht dikwijls passages uit de Carolina werden gebruikt om een bepaald standpunt te onderbouwen.

\subsection{Rijkswetgeving in Gronsveld}

Ondanks de gebrekkige overlevering van de Gronsveldse archieven zijn er nog tal van sporen te vinden die wijzen op de toepassing van rijksrecht. In de eerste plaats moet worden vastgesteld dat Gronsveld zich onderwierp aan de algemene rijkswetgeving zoals die bestond ten aanzien van het Rijkskamergerecht, de Polizeiordnungen, het muntwezen en de belastingen. Een mooi voorbeeld daarvan levert de vraag uit 1765 van graaf Maximilian Emanuel von Toerring-Jettenbach aan zijn vertegenwoordiger Prummer in Gronsveld over de Allgemeine Zunft- und Handwerksordnung van 1731/1732. Prummer antwoordde dat men in het graafschap geen gilden met meesterbrieven, rondtrekkende gezellen en dergelijke kende en derhalve deze regeling ook niet van toepassing was. ${ }^{1182}$ Maar de geldigheid van de regeling van Gronsveld als zodanig stond voor hem kennelijk niet ter discussie. Ook onderwerpt men zich in Gronsveld aan de hoogste rechters in het rijk, zoals blijkt uit een ongedateerd attest van de schepenen van Gronsveld uit de tweede helft van de achttiende eeuw. Daarin wordt verklaard dat het Rijkskamergerecht en de Rijkshofraad te Wenen de hoogste beroepsinstanties zijn voor zover de zaak ten minste in overeenstemming met het rijksrecht appellabel is (bijlage 31). In de ontwerpambtsinstructie voor de grafelijke commissaris Wolfgang Zollner uit omstreeks 1779 werd bepaald dat bij voorkeur de reeds voorhanden zijnde Gronsveldse Rechtsordnung werd toegepast en daarna het gewoonterecht en het gemene geschreven rijksrecht. ${ }^{1183}$

Maar er zijn ook vroegere voorbeelden te geven. Zo wordt tijdens een proces in hoofdvaart van Slenaken op Gronsveld in 1526 gezegd dat de schepenen van Gronsveld de overdracht van onroerend goed beoordeelden 'nae den heyligen rix recht'. ${ }^{1184}$ Volgens de 'Specificatie' van landsheerlijke rechten uit circa 1650 werd het grafelijk jachtrecht 'conform der constitutien van het Heylich Rijck ende der oude observantie in dit cas gehouden'. ${ }^{1185}$ In 1670 kregen de kloosterlingen van Hoogcruts het verwijt dat zij met hun grootschalige verwerving van onroerend goed in de 'dode hand' 'die meenichfuldighe ende immemoriale rijcx ordenung' met voeten hadden getreden. ${ }^{1186}$ Een volgend voorbeeld treffen we aan in de preambule van de Gronsveldse Rechtsordnung uit 1671 (zie hierna), waarin gravin Anna Christina als één van de redenen voor de afkondiging verwijst naar de verschillen tussen het plaatselijk gewoonterecht en het 'beschriben', dat wil zeggen het gerecipieerde, geleerde Romeinse recht.

Voor het strafrecht zijn sporen van toepassing van de 'Carolina' in Gronsveld door het ontbreken van het grootste deel van de schepenbankarchieven zeldzaam. Maar dat er een direct beroep op werd gedaan blijkt uit een 'claglibel von oberheidt und ambttswegen' dat

1182 TJ, inv. nr. M 53, fol. 638-644, Prummer aan M.E. von Toerring-Jettenbach17 juni 1765.

1183 TJ, inv. nr. M 6, fol. 11-26, project ambtsinstructie voor Zollner als commissaris.

1184 RHCL, Rijkskamergerecht inv. nr. 95, fol. 14.

1185 RHCL, Graafschap Gronsveld, inv. nr. 10 (Zie Bijlage 44).

1186 RHCL, Klooster Hoogcruts inv. nr. 534 (Zie Bijlage 6). 
graaf Johan II van Bronckhorst Batenburg in 1607 bij de schepenen van Gronsveld indiende in het proces tegen Adam Neffs en Aussem Kertsgens. Beiden werden beschuldigd van oproer en muiterij tegen het wettig gezag en op dit vergrijp stond, met een verwijzing naar de 'Peinliche Halsgericbtsordnung' de doodstraf.1187 Op zich ligt het voor de hand dat in een rijksonmiddellijk graafschap als Gronsveld de 'Carolina' direct werd toegepast. We zien dat bijvoorbeeld ook in het rijksonmiddellijke stift Thorn ${ }^{1188}$ en in de aan Gronsveld grenzende rijksonmiddellijke heerlijkheid Rijckholt. Die laatste plaats levert in dat opzicht een curieus voorbeeld met een verordening van de heer Jan Maximiliaan de Bounam en zijn moeder uit 1752. ${ }^{1189}$ Zij bepaalden daarin nadrukkelijk dat de schepenen zich voor de bestraffing van 'capitaele delicten' moesten houden aan de 'Peinliche Halsgerichtsordnung, met de toevoeging dat de heer en zijn moeder die bepaling altijd hadden beschouwd als een vanzelfsprekendheid en dat zij ook niet van plan waren daar verandering in aan te brengen. Eigenlijk verwees deze toevoeging naar de 'salvatorische clausule', dat wil zeggen de mogelijkheid voor een landsheer om aanvullende of afwijkende wetgeving uit te vaardigen. ${ }^{1190}$

$\mathrm{Al}$ deze voorbeelden overziende, moeten we concluderen dat in Gronsveld rijksrecht en rijkswetgeving werden toegepast. Het is echter onwaarschijnlijk dat die ook uitdrukkelijk werd afgekondigd. De eerder aangehaalde teksten laten zien dat werd gewerkt met vage verwijzingen naar algemene regels die als min of meer vanzelfsprekend werden beschouwd.

\subsection{In Gronsveld afgekondigde wetgeving}

Gelet op de beperkte hoeveelheid wetgeving in Gronsveld, wordt hierna in een deels systematisch, deels chronologisch overzicht een aantal regelingen afzonderlijk besproken. Vervolgens komen de formele aspecten van de redactie van wetgeving en wijze van afkondiging ter sprake.

\subsubsection{Wetgeving op het snijvlak, van kerk en staat}

Binnen de beperkte hoeveelheid bewaard gebleven Gronsveldse wetgeving nemen onderling zeer verschillende - bepalingen op het snijvlak van kerk en staat verhoudingsgewijs een belangrijke plaats in. Daarom behandelen we die hier als groep.

Het algemene gezag van wereldlijke machthebbers over geestelijken en over onderwerpen die naar hun aard als geestelijk werden beschouwd (huwelijken, testamenten en kerkelijke goederen) was al vroeg omstreden. De Kerk claimde op deze terreinen het monopolie, met uitsluiting van leken. Door het zogenoemde Westers Schisma van 1378-1417, met een paus in zowel Rome als Avignon, had het centrale kerkelijk gezag sterk aan

1187 RHCL, Rijkskamergerecht, inv. nr. 73, fol. 135vo, 142 vo.

1188 RHCL, Hoofdgerecht en het kerspel Thorn, inv. nr. 696 (1697); inv. nr. 713 (1701); inv. nr. 1205 (1773).

1189 RHCL, De Bounam de Ryckholt, inv. nr. 492; Keyser-Schuurman, Inventaris Ryckholt, 15.

1190 Härter, 'Das Recht des Alten Reiches', 92. 
geloofwaardigheid ingeboet. Tegelijk groeide de onvrede over pauselijke belastingen, de handel in ambten en de weelderige levensstijl van hoge geestelijken. $\mathrm{Na}$ het Concilie van Konstanz (1414-1418) werd in beginsel de kerkelijke eenheid weer hersteld, maar tegenstellingen tussen voorstanders van het pauselijk primaat en de conciliaristen, die een sterker gezag aan concilies toekenden en meer klerikale democratie propageerden, bleven zorgen voor spanningen. In het bijzonder tijdens het Concilie van Basel (1431-1447) kwamen die tot een climax. Het pausdom werd steeds minder een universele macht en moest belangrijke concessies doen aan wereldlijke vorsten. Daarmee veranderden bij de opkomende moderne staten in de vijftiende eeuw de opvattingen over hun verhouding tot de Kerk fundamenteel. Vorsten wensten een algemeen gezag over de Kerk in die zin, dat zij invloed kregen op kerkelijke wetgeving, benoemingen en het beheer van kerkelijke goederen.

In Frankrijk leidde dit tot de Pragmatieke Sanctie van Bourges (1438), waarmee de basis werd gelegd voor de later zo genoemde Gallicaanse vrijheden van de Franse kerk. ${ }^{1191}$ De koning kreeg grote invloed op benoemingen en pauselijke belastingen werden beperkt. In het Duitse Rijk kwamen in 1447 de zogenoemde vorstenconcordaten tot stand tussen paus Eugenius IV en keizer Frederik III, waarna paus Nicolaas V in 1448 met keizer Frederik III het Concordaat van Wenen sloot. ${ }^{1192}$ Dit Concordaat werd beschouwd als rijksrecht en bleef tot 1803 van kracht. Op grond daarvan moest de pauselijke curie in overeenkomsten met afzonderlijke landsheren vergaande concessies doen wat betreft kerkelijke wetgeving, de zeggenschap over kerkelijke benoemingen en het recht van reformatio en visitatie van kerkelijke instellingen. Voor de afkondiging van kerkelijke wetgeving makkten landsheren veelal aanspraak op het recht van placet, een formele goedkeuring. Hiermee kwam de weg vrij voor de latere ontwikkeling van zogenoemde landskerken, waarvoor de enigszins overdreven, maar wel veelzeggende uitdrukking Dux Cliviae est papa in terris suis ('De hertog van Kleef is paus in zijn eigen land') werd gebruikt. ${ }^{1193}$.

Het landsheerlijk recht op Reformatio kon geen betrekking hebben op de religio, dat wil zeggen vraagstukken van theologische of dogmatische aard - die bleven voorbehouden aan het kerkelijk leergezag - maar wel op de disciplina, de concrete toepassing van regels in overeenstemming met de bestaande christelijke normen en waarden. Desnoods konden die strafrechtelijk worden gehandhaafd. Onder die disciplina viel ook een verantwoorde omgang met de temporalia van de kerk, de materiële goederen die door gelovigen voor religieuze doelen waren bestemd. Dat betekende dat de landsheer kon optreden tegen misbruiken bij het beheer van aardse zaken en - min of meer logisch daar uit voortvloeiend - ook toezicht daarop kon uitoefenen. Het ius reformandi had dus betrekking op disciplinering en het bestrijden van misbruiken; maatregelen op dit terrein waren daarmee hervormingen met in wezen een behoudend karakter. Daarom moet dit soort ingrepen ook duidelijk worden onderscheiden van de latere reformationes van protestantse signatuur, die juist een vernieuwing van de religio en van bestaande structuren beoogden.

${ }^{1191}$ Lexicon des Mittelalters VII, 166-167, onder lemma 'Pragmatique Sanction'.

1192 Lexicon des Mittelalters IX, 87-89, onder lemma 'Wiener Konkordat'.

1193 Schneider, Ius Reformandi, 31. 
Concordaten en het ius reformandi legitimeerden in de zeventiende en achttiende eeuw stromingen als het Gallicanisme in Frankrijk en Josephisme in de Habsburgse erflanden. Het absoluut gezag van vorsten 'bij de gratie Gods' omvatte in deze tijd een grote mate van zeggenschap over kerkelijke zaken. Deze opvattingen aan de grote Europese vorstenhoven sijpelden ook door naar kleinere landsheren, die voor hun territoria een vergelijkbare politiek voerden.

Bij de heren van Gronsveld zal dit niet anders zijn geweest. Het adagium Dux Cliviae moet hen vanwege de nauwe betrekkingen met de hertogen van Kleef in de zestiende eeuw bekend in de oren hebben geklonken. In de zeventiende eeuw waren de graven Jost Maximiliaan en Johan Frans van Bronckhorst vertrouwd met de opvattingen die bij Duitse vorsten op dit gebied leefden. Hetzelfde gold ook in de achttiende eeuw voor de graven Toerring-Jettenbach. De katholiciteit van de Gronsveldse graven stond als zodanig niet ter discussie, maar in kerkelijke zaken stelden zij zich vaak tamelijk onafhankelijk op.

\section{Het 'Mandat den floicken ende schelden belangende', 1546}

Het eerste voorbeeld van afgekondigde landsheerlijke regelgeving in Gronsveld betreft het 'Mandat den floicken ende schelden belangende', uitgevaardigd door Johan I van Bronckhorst Batenburg op 16 september 1546.1194 Daarin werden strenge straffen bedreigd tegen vloeken en godslasterlijke taalgebruik in herbergen. In het bijzonder gold dit voor spotternij over onderwerpen uit de katholieke leer, die juist sterk werden bestreden vanuit protestantse hoek, zoals de leer van de Drievuldigheid, het Heilig Sacrament en de devotie rond het lijden van Christus. De boete van één goudgulden gold voor de lasteraars zelf. Herbergiers die in hun etablissement gelegenheid tot vloeken gaven, kregen een tapverbod gedurende een jaar. De boete van één goudgulden trof ook iedereen die vloeken hoorde, maar naliet daar aangifte van te doen. Voorts werd het sluitingsuur voor herbergen bepaald op zeven uur in de winter en acht uur in de zomer. Ten slotte kregen ongehuwd samenwonenden de plicht zich ten spoedigste bij de pastoor te melden voor het sluiten van een christelijk huwelijk. Op nalatigheid stond verbeurdverklaring van hun goederen. In dezelfde sfeer paste ook de boete van tien gulden op echtbreuk. Alle boeten zouden ten algemenen nutte, ten behoeve van de armen, worden besteed.

Het stuk was onmiskenbaar bedoeld ter disciplinering van de - katholieke - moraal van de onderdanen. In tal van grote landsheerlijkheden werden sinds het einde van de vijftiende en het begin van de zestiende eeuw vergelijkbare regels uitgevaardigd. ${ }^{1195}$ Ook zonder een uitdrukkelijke verwijzing lijkt de verordening te zijn geïnspireerd op de Reichspolizeiordnung van 1530. Daarin behandelen de hoofdstukken $1 \mathrm{t} / \mathrm{m} 7$ uitvoerig allerlei vormen van godslastering ('Gotteslesterung und Gotts schwüren'), hoofdstuk 8 bestrijdt de dronkenschap en hoofdstuk 33 keert zich tegen echtbreuk en personen die ongehuwd samenwonen ('ausserhalb von Gott auf gesatzter Ehe zusammen wonen'). Daarnaast is er

${ }_{1194}$ RHCl, Graafschap Gronsveld, inv. nr. 62, fol. 210-211. (Bijlage 2); gedrukt bij Hanssen, Die Rimburg, 354-356.

1195 Vgl. Janssen, 'Neue Wege und Formen', 133-134 en 137-139, die wijst op de invoering van wetgeving in de grote Nederrijnse territoria zoals Kleef en Gulik vanaf het einde van de vijftiende eeuw. 
hoogstwaarschijnlijk invloed geweest van de landsheerlijke wetgeving in de Nederrijnse hertogdommen Kleef, Gulik en Berg (Johan vervulde ambten in het hertogdom Kleef), waarbij de vorst het als zijn plicht zag een strenge moraal voor te schrijven en te controleren ter afwending van Gods toorn en bevordering van Gods zegen over het land. ${ }^{1196}$ Voor het behoud van de katholieke religie was het daarom nodig de levenswandel van de gelovigen te disciplineren. Tegelijk hield het 'Mandat' van 1546 zeker ook verband met de maatschappelijke en religieuze onrust van dat moment, veroorzaakt door de verspreiding van de 'nieuwe leer'. De passage dat 'der predicanten lehr bey uch nit viell guetz werket' verwijst daar naar. Het begrip 'vernieuwing' ('nuwerong', 'nuwicheit') kende in de landsheerlijke wetgeving in de grote territoria een negatieve klank en werd in verband gebracht met oproer. ${ }^{1197}$ In het bijzonder moet daarbij zijn gedacht aan het optreden van fanatieke wederdopers. Dat zal ook de heer van Gronsveld niet zijn ontgaan, want ook in de omgeving van Maastricht, werd deze groepering beschouwd als een ernstige bedreiging van de openbare orde.

Met de duidelijke keuze voor de katholieke religie liep het 'Mandat' eigenlijk al vooruit op een beginsel dat enkele jaren later, in 1555, bij de religievrede van Augsburg werd gesanctioneerd. Bij die vrede werden lutheranisme en katholicisme als gelijkberechtigde confessies binnen het Rijk erkend en mocht de landsheer in overeenstemming met de formule cuius regio, illius religio (de landsheer van een gebied bepaalt ook de godsdienst) de religie van zijn onderdanen bepalen. In Gronsveld was dat het rooms-katholicisme.

\section{Afkondiging van de decreten van 'Trente', 1608}

De interpretatie en feitelijke toepassing van de religievrede van Augsburg zorgden echter voor vele problemen. Het verdrag had betrekking op de rijksonmiddellijke vorsten en steden, maar betwist bleef in hoeverre ook de lagere (rijks)adel een ius reformandi bezat. ${ }^{1198}$ Op grond van jurisprudentie van onder andere het Rijkskamergerecht werd dit, als uitvloeisel van landsheerlijk gezag, uiteindelijk ook toegekend aan rijksgraven. Omstreden bleef het recht voor de lagere adel, zoals rijksridders en rijksvrijheren. Het gold zeker niet voor simpele patronaatsheren ten plattelande, veelal leden van de lage adel.

Dat ook de graven van Gronsveld zich bewust moeten zijn geweest van hun bevoegdheid in de zin van de Religievrede van 1555, blijkt uit een verordening die graaf Johan II van Bronckhorst in 1608 uitvaardigde. ${ }^{199}$ De graaf overwoog daarin dat 'hin unnd wieder' de besluiten van het Concilie van Trente waren afgekondigd in het bisdom Luik, waartoe ook de parochies Gronsveld, Heugem en Slenaken als onderdeel van de parochie SintMartens-Voeren hoorden. Inderdaad verliep in het bisdom Luik de invoering van de Trentse Conciliebesluiten nogal moeizaam. ${ }^{1200}$ Met een beroep op zijn zelfstandige bevoegdheid als lidmaat ('einen gliedtmasse') van de Katholieke Kerk achtte de graaf zich daarom verplicht de Conciliedecreten in zijn territorium te laten afkondigen. Alle

1196 Janssen, 'Neue Wege und Formen', 137-139.

${ }^{1197}$ Janssen, 'Neue Wege und Formen', 135.

1198 Schneider, Ius reformandi, 284-288.

1199 RHCL, Graafschap Gronsveld, inv. nr. 236 (Bijlage 3).

1200 Ubachs, Handboek, gescbiedenis Limburg, 205-206. 
betrokken pastoors ontvingen daartoe de nodige instructies. Zoals blijkt uit aantekeningen op de verordening, vond publicatie plaats in Gronsveld, Heugem, Slenaken en SintMartens-Voeren. De precieze juridische grondslag van de afkondiging blijft enigszins dubbelzinnig. Er zitten ook elementen van het recht van placet in, op grond waarvan de wereldlijke overheid moest bewilligen in de afkondiging van kerkelijke wetgeving. Een zekere complicatie leverde verder Sint-Martens-Voeren op. In deze plaats, behorend tot het Brabantse Land van Daelhem, bezat de graaf alleen de lage heerlijkheid, terwijl anderzijds de kapel van het onder grafelijk gezag vallende Slenaken behoorde tot de parochie Sint-Martens-Voeren.

\section{Wetgeving tegen 'de dode hand'}

In allerlei periodes van de geschiedenis bestond weerstand tegen concentratie van onroerend goed bij kerkelijke instellingen. Voor een deel vloeide dat voort uit gewone afgunst, maar aan goederen in de zogenoemde 'dode hand' kleefden ook economische en fiscale bezwaren. Huizen en landerijen werden voor lange tijd onttrokken aan de markt en verder betaalden kerkelijke en semikerkelijke instituten vaak weinig of geen belasting. Daarom trachtten vanaf het einde van de middeleeuwen landsheren door wetgeving de overgang van goederen in de zogenoemde 'dode hand' te beperken of zelfs te verbieden.

De problematiek van kerkelijk grondbezit woog zwaar binnen het graafschap Gronsveld. Het klooster Hoogcruts bezat veel grond in Slenaken, in de omgeving van het convent. Maar ook in Gronsveld, Heugem en Honthem speelden de verschillende Maastrichtse kerkelijke corporaties en de 'pieuze fundaties', instellingen van weldadigheid met een gemengd burgerlijk en kerkelijk karakter, een dominante rol als grootste geërfden. Met aparte ordonnanties uit 1636 en 1670 hebben de graven van Gronsveld daarom geprobeerd bezitsvorming in de dode hand te weren. Maar deze wetgeving stond in een veel oudere traditie. Een toepassing treffen we al aan in de vergunning die Hendrik I van Gronsveld in 1355 verleende aan de antonieten van Maastricht om in zijn gebied een hof met achttien bunder land te kopen. ${ }^{1201}$ De paters mochten meer grond, tot een maximum van vijftig bunder, verwerven, maar bij overdracht daarvan was, al naar gelang het voor de grond geldend juridisch regime, heergewaad, keurmede of tiende penning verschuldigd. Los daarvan moest een jaarlijkse cijns van acht penning per bunder worden betaald. Voor de rest waren de bezittingen vrij van landsheerlijke lasten en kregen de paters gebruiksrechten op de gemene weiden van het dorp. De antonieten hebben daarna geen grond meer in Gronsveld verworven, maar de condities bij de eerste verkrijging maken duidelijk dat, ondanks alle heerlijke welwillendheid, er grenzen werden gesteld.

Een legitiem middel om de nadelen van de dode hand te beperken was wetgeving. Het eerste voorbeeld daarvan werd in 1636 uitgevaardigd door graaf Jost Maximiliaan van Bronckhorst Batenburg. ${ }^{1202}$ Het is de vraag of daarmee direct een algemeen verbod werd beoogd, aangezien de tekst naar de letter alleen betrekking heeft op Slenaken. De graaf verbood 'geestligen conventen, cloesters, capittellen ende diergelicken collegien dye men

${ }^{1201}$ RHCL, Klooster antonieten te Maastricht, inv. nr. 3.

1202 RHCL, Klooster Hoogcruts, inv. nr. 531 (Bijlage 5). 
nompt te wesen van de dode handt' onroerende goederen of goederen die voor onroerend werden gehouden, op straffe van nietigheid te verwerven. De schepenen van Slenaken mochten niet meewerken aan gerechtelijke overdracht.

Het tweede verbod op goederen in de dode hand dateert uit 1670 en werd uitgevaardigd door gravin Anna Christina von Hardenrath, de weduwe van Jost Maximiliaan. ${ }^{1203}$ Interessant is dat als argument daarvoor nog eens wordt verwezen naar 'meenichfuldighe ende immemoriale rijcx ordenung'. Deze verordening uit 1670 kent wel een algemene strekking, maar moet toch vooral worden gezien als een aanscherping van de verordening uit 1636, ingegeven door de

seer groeve ende enorme abuysen in materie van alienatie, coop ende vercoop, cessien ende overdrachten, t'waere van onse leengoederen, met het gheene soe daer aen cleeft, als andere van wat nature dieselve moegen weesen van ons moveerende

waar in het bijzonder het klooster Hoogcruts zich schuldig aan maakte. De schade die de kloosterlingen daarmee aanrichtten, ging verder dan alleen maar de onttrekking van onroerend goed aan het economisch verkeer, want zij braken huizen af en verjoegen de inwoners. Dit alles gebeurde met een beroep op voorrechten die ooit door vroegere graven zouden zijn verleend. Om deze misbruiken te beëindigen werden de bestaande voorschriften over nietigheid van verwerving in de dode hand nog eens herhaald, maar daarnaast zouden de goederen 'sijn ende blijven vervallen in commissum t'onswaerts', met andere woorden, dit soort overdrachten zouden leiden tot verbeurdverklaring, waar nog een boete voor de betrokkenen bovenop kwam.

Een jaar later werd een algemeen verbod op de dode hand opgenomen in de hierna nog te bespreken Gronsveldse Rechtsordnung van 1671. Titel 11 \& 2 bestrafte de verwerving op enigerlei wijze van onroerend goed door geestelijke instellingen zoals kapittels, abdijen, kloosters en conventen met confiscatie door de landsheer. Deze regel bleef in de navolgende decennia levend recht, wat opmerkelijk is, aangezien andere bepalingen uit het landrecht nauwelijks toepassing vonden en daarvan rond 1740 amper nog een gedrukte tekst voorhanden was.

Een merkwaardig voorbeeld van de toepassing, of beter het achterwege blijven daarvan, deed zich voor in 1696, toen Magdalena Herten wilde intreden bij de zusters annuntiaten in Maastricht. Zij was geen gewone adspirant-religieuze, maar de natuurlijke dochter van graaf Johan Frans van Bronckhorst Batenburg. Deze afkomst maakte het noodzakelijk een passende levensstaat in een besloten omgeving te zoeken. Op 10 december 1696 sloot drossaard Kicken namens de graaf een overeenkomst met de overste van de annuntiaten, waarbij in termijnen een bedrag van duizend gulden werd betaald voor inkleding, professie en onderhoud van Magdalena. Na haar professie zou zij nog levenslang twee jaarrentes voor een totaal van 150 gulden ontvangen. Voorts zag de graaf af van zijn recht op

${ }^{1203}$ RHCL, Klooster Hoogcruts, inv. nr. 534 (Bijlage 6). 
confiscatie van onroerend goed in Gronsveld, dat de zusters jaren eerder, in 1685 en 1686, hadden verworven. ${ }^{1204}$

$\mathrm{Na}$ deze uitdrukkelijke opheffing van het recht van confiscatie als gunst voor een bijzonder geval, constateren we veertig jaar later opnieuw een aanscherping van de wetgeving op de dode hand. Volgens de instructie die graaf Ignaz Felix von ToerringJettenbach in 1737 uitvaardigde voor de drossaard van Gronsveld moest deze functionaris uitdrukkelijk in juridische zaken het reglement van 1671 als leidraad nemen en geen goede landerijen of weiden in de dode hand laten komen.

Deze instructie werd actueel toen in 1746 in Gronsveld over de erfenis van de Maastrichtse kannunik Henricus Salden werd geprocedeerd, een van de vele rechtszaken die in Maastricht en omgeving over deze erfenis speelden. Salden had testamentair zijn vermogen, waartoe ook landerijen in het graafschap Gronsveld behoorden, bestemd voor een stichting, genaamd de Rooms-Katholieke Armen in Maastricht. Zijn bloedverwanten vochten deze erfstelling aan met processen voor de schepenbanken in plaatsen waar goederen van Salden lagen, zoals Gronsveld. In deze civiele zaak mengde zich de Gronsveldse drossaard en 'fiscus' (openbaar aanklager) Hendrik Lebens en hij eiste verbeurdverklaring van deze landerijen ten behoeve van de graaf omdat het ging om een strafbaar feit, waarop volgens Titel 11 artikel 2 van de Recbtsordnung confiscatie stond. Het was echter de vraag of de nieuwe stichting van de Rooms-Katholieke Armen te Maastricht als een geestelijke instelling moest worden beschouwd, aangezien het bewuste artikel slechts in algemene zin sprak over 'dennen geistlichen (darunter capitula, abteÿen clösster und conventen zuverstehen) keine unbewegliche güetter unter straff der würcklichen confiscation zu alienieren oder ...zu transferieren'.

In een officiële interpretatie van de wet verklaarde graaf Maximilian Emanuel op 12 januari 1748 dat ook vrome stichtingen zoals gasthuizen, weeshuizen en armenhuizen onder deze wetgeving vielen. Op het verschijnsel interpretatie wordt hierna (Hoofdstuk 7.5 nog teruggekomen. Overigens stemde de graaf naderhand toch in met de verwerving door de Rooms-Katholieke Armen. ${ }^{1205}$

\section{Twee voorbeelden van Luikse kerkelijke regelgeving in de achttiende eeun}

Afkondiging van kerkelijke wetgeving vormde in de relatie tussen landsheer en kerkelijke hiërarchie altijd een teer onderwerp. In het bisdom Luik vaardigden zowel de bisschoppen als de aartsdiakens regelmatig verordeningen in de vorm van 'mandaten', 'edicten' of instructies uit, die de levenswandel van de gelovigen bepaalden. De 'Praxis pastoralis' van Manigart geeft daar een hele reeks van. Ook de bij Manigart afgedrukte Statuten van de diverse aartsdiakonaten, in het geval van Gronsveld het aartsdiakonaat Haspengouw,

\footnotetext{
1204 RHCL, Rijkskamergerecht, inv. nr. 187, fol. 244-245: afschrift van de realisatie deze akte gepasseerd voor notaris J. Veugen te Maastricht op 10 december 1696 voor drossaard, stadhouder en schepenen van Gronsveld op 16 juni 1698.

1205 RHCL, Rijkskamergerecht, inv. nr. 187, fol. 66-67: 'in justitz sachen das reglement de anno 1671 pro norma nehmen....und keine guette, ländtereyen noch wiesen ohne unsern consenz ad manus mortuas kommen lassen'.
} 
regelden kerkelijke verplichtingen. ${ }^{1206}$ Waarschijnlijk werd bij de bekendmaking van dit soort voorschriften gekozen voor mededeling aan de gelovigen vanaf de preekstoel.

Het valt niet meer na te gaan in hoeverre de bij Manigart beschreven regels ook daadwerkelijk in Gronsveld zijn afgekondigd. Uit de achttiende eeuw zijn er twee voorbeelden bekend, die op deze problematiek enig licht werpen. Het eerste geval betreft de benoeming van een officiaal, de kerkelijke rechter van de aartsdiaken van Haspengouw in 1735. Sinds het begin van de zeventiende eeuw had de aartsdiaken voor Maastricht een aparte kerkelijke rechter aangesteld omdat de Maastrichtenaren op grond van hun oude privileges (onder andere de Brabantse Gouden Bul) niet buiten hun stad konden worden gedagvaard. ${ }^{1207}$ In 1735 werd de pastoor van de Sint-Martinusparochie in Maastricht-Wyck tot kerkelijk rechter benoemd door aartsdiaken Michaël Clercx. ${ }^{1208}$ Volgens zijn benoemingsbrief beperkte diens jurisdictie zich niet tot Maastricht, maar strekte deze zich ook uit over een aantal dorpen in de omgeving van Maastricht (de zogenoemde 'Elf Banken' van het kapittel van Sint-Servaas, de 'Redemptiedorpen', Eijsden en Gulpen) onder de soevereiniteit van de Staten-Generaal, maar ook over plaatsen die rijksonmiddellijk waren of daar voor doorgingen zoals Gronsveld, Heugem, Breust, Wylre en Pietersheim. Het benoemingsbesluit werd gedrukt en voorzien van een mededeling waar en wanneer de nieuwe officiaal als kerkelijk rechter zitting hield. Alle pastoors ontvingen een exemplaar met het verzoek mededeling te doen aan de parochianen en een bevestiging daarvan terug te sturen. Het is de vraag of de lijst met plaatsen vanuit staatkundig oogpunt heel doordacht was. In ieder geval lokte deze mededeling over de benoeming van een kerkelijke rechter voor Maastricht en de Staatse dorpen in de omgeving van de stad een scherpe reactie uit bij de Staten-Generaal. Hoe het bericht in Gronsveld werd ontvangen, is niet bekend; het grafelijke gezag was op dat moment nog zwak vanwege de voogdij over de minderjarige gravin Maria Josepha d'Arberg Valengin. In ieder geval is het zeker dat in de loop van de achttiende eeuw de jurisdictie van de officiaal wel werd erkend.

Een tweede, op zich onbeduidende maar wel vermakelijke, kwestie deed zich in 1778 voor rond de deelname van de Gronsveldse schutterij aan de Sacramentsprocessie. Het was een storm in een glas water, maar tegelijk maakt het de gevoeligheden rond kerkelijke wetgeving nog eens goed duidelijk.

Op 28 juni 1778 zond Wolfgang Zollner, toen nog 'commissions sekretär' van Prummer, een uitgebreid verslag van die Sacramentsprocessie of Bronkprocessie naar München. ${ }^{1209}$ Hij beschrijft daarin wie aan de processie deelnam en welke route men trok. Het was een religieuze gebeurtenis waar het hele graafschap zich presenteerde... met uitzondering van de Gronsveldse schutterij. Pas buiten Gronsveld, aan de kant van Maastricht, voegden de vier compagnieën van de schutterij zich bij de stoet, waarna zij de rest van de tijd voorop liepen. Merkwaardig vond Zollner dat gebruik wel, want het vergezellen van het

1206 Manigart, Praxis pastoralis, 332-358.

1207 Van Rensch, 'Aartsdiaken van Haspengouw', 179-199.

1208 RHCL, Parochie H. Martinus Maastricht-Wyck I, inv. nr. 4, fol. 89-92. (Bijlage 12)

1209 TJ, inv. nr. M 58, fol. 168-171, Zollner aan A.J. von Toerring-Jettenbach 24 juni 1778. 
Allerheiligste tijdens de Sacramentsprocessie was immers juist één van de doelstellingen van deze in 1619 opgerichte vereniging.

Zollner hoorde als verklaring dat in het bisdom Luik een verordening bestond die het pastoors ten strengste verbood processies met het Allerheiligste te houden wanneer die door schutterijen of vergelijkbare verenigingen werden vergezeld. Maar hoe de regels precies luidden, kon niemand vertellen. Zollner veronderstelde dat die bepalingen ooit met het oog op handhaving van de openbare orde waren afgekondigd binnen het prinsbisdom Luik, waarvan de bisschop wereldlijk heer was. Maar dat kon niet op Gronsveld van toepassing zijn, want daar bezat alleen de graaf wetgevende bevoegdheid. Bovendien viel op dat deze verordening ook in naburige plaatsen niet strikt werd nageleefd. Vast stond dat de schutterij zich in de voorgaande jaren, ten tijde van pastoor Kolb, niet had laten zien bij de Sacramentsprocessie. Deze zielenherder had met zijn 'pünktlichen und blinden gehorsam' aan kerkelijke wetten altijd strikte naleving van voorschriften gewenst. Kolbs opvolger, pastoor Meijers, bleek minder recht in de leer, althans hij ging akkoord met een pragmatische oplossing. Om onaangenaamheden met zijn superieuren in Luik te voorkomen, kondigde hij ieder jaar van de preekstoel een verbod op het meetrekken van de schutterij af. Niets kon echter verhinderen dat de vier compagnieën van de schutterij zondags 'toevallig' in het veld de processie ontmoetten. Pastoor Meijers waste op die manier zijn handen in onschuld, want hij kon altijd volhouden dat dit alles buiten zijn medeweten, ja zelfs tegen zijn openlijk afgekondigd verbod gebeurde. ${ }^{1210}$

Graaf August Joseph wilde naar aanleiding van dit verslag weten hoe het nu precies met die bisschoppelijke verordeningen was gesteld. ${ }^{1211}$ Het was natuurlijk onbestaanbaar dat een voor het wereldlijk prinsbisdom Luik bestemde regeling ook binnen zijn territorium werd afgekondigd. Vreemd genoeg kon pastoor Meijers zich niet herinneren ooit een Luikse verordening met een processieverbod voor schutterijen te hebben gezien. Navraag bij collegae leverde ook niets op. Dit alles versterkte het vermoeden dat het ging om een circulaire die alleen in het prinsbisdom Luik was afgekondigd. ${ }^{1212}$

Pas enkele maanden later vond pastoor Meijers de oplossing van het probleem in twee bisschoppelijke verordeningen uit 1715 en 1730, afgedrukt in de 'Praxis pastoralis' van Manigart, het handboekje voor pastoors in het bisdom Luik. De teksten daarvan stuurde Zollner naar München. ${ }^{1213}$ In de eerste verordening uit 1715 had bisschop Joseph Clemens van Beieren zich gekeerd tegen het misbruik dat gelovigen zich tijdens langdurige processies te buiten gingen aan drank en eten. Ook achtte hij het ongepast dat de stoet werd vergezeld door ruiters en bewapende manschappen, wat meer deed denken aan oorlog dan aan ingetogen gebed. Een tweede verordening uit 1730 van bisschop George Lodewijk van Bergen herhaalde het verbod van zijn voorganger. Die verordening was zelfs aangescherpt omdat zij zich niet alleen richtte tegen de aanwezigheid van schutterijen, maar ook tegen tableaux vivants waarin Bijbelse verhalen of taferelen uit het leven van heiligen werden uitgebeeld. Dat alles gaf maar aanleiding tot lachen en spot. ${ }^{1214}$

1210 TJ, inv. nr. M 58, fol. 129-132, Zollner aan A.J. von Toerring-Jettenbach 13 augustus 1778.

1211 TJ, inv. nr. M 58, fol. 125-128, A.J. von Toerring-Jettenbach aan Zollner 21 augustus 1778.

1212 TJ, inv. nr. M 58, fol. 121-124, Zollner aan A.J. von Toerring-Jettenbach 1 september 1778.

1213 TJ, inv. nr. M 58, fol. 111-116, Zollner aan A.J. von Toerring-Jettenbach 17 september 1778.

${ }^{1214}$ De bisschoppelijke verordeningen staan ook afgedrukt bij Manigart, Praxis pastoralis, 144-146. 
Op zich was het probleem van de aanwezigheid van schutterijen en folkloristische elementen bij processies in deze streken niet onbekend. ${ }^{1215}$ De kerkelijke overheid zag daarin in de zeventiende en achttiende meer dan eens aanleiding om tegen misbruiken bij processies op te treden. Deze strenge kerkelijke voorschriften vielen meestal niet in goede aarde bij de bevolking, die hardnekkig vasthield aan oude gewoontes. Voor Gronsveld geloofde Zollner niet dat de verordeningen nog bij de tijd waren. Hoewel de 'Praxis pastoralis' van Manigart algemeen werd gebruikt, hoorden de processieverordeningen in ieder geval niet tot de parate kennis van de geestelijkheid. Toen pastoor Meijers een aantal jaren eerder de processie van Gronsveld tot in detail bij de bisschoppelijke autoriteiten in Luik had beschreven, lokte dat daar geen enkele reactie uit. Ook was het onwaarschijnlijk dat overtreders met sancties werden bedreigd. Zelfs de deken van het landdekenaat Maastricht, op dat moment de pastoor van Visé, liet de processie in zijn eigen parochie door schutters begeleiden. De hele kwestie in Gronsveld bleek dus uiteindelijk niet meer dan een storm in een glas water, maar de reacties geven de gevoeligheden haarscherp aan. Zowel de graaf als zijn ambtenaren waakten met argusogen tegen inbreuken op de exclusieve bevoegdheid van de landsheer om wetten uit te vaardigen, ook bij kerkelijke autoriteiten.

\subsection{2 'Politieke ordonnanties'}

Drie keer per jaar hield de schepenbank het zogenoemde voogdgeding, een zitting die in beginsel in het teken stond van rechtspraak over zaken van algemeen plaatselijk belang (zie meer hierover in Hoofdstuk 9.5). Verder werden er ook de lopende rechtszaken behandeld. Alle onderdanen (mannelijke vertegenwoordigers van ieder huishouden) waren verplicht daarbij aanwezig te zijn. Na het 'bannen (afkondigen) van de vrede' als opening van de bijeenkomst, was het gebruikelijk de plaatselijke verordeningen voor te lezen. Van Gronsveld is bekend dat daar in de achttiende eeuw een dergelijke 'politieke ordonnantie' werd afgekondigd.1216 De tekst is niet meer bewaard. Wel overgeleverd is een vroege variant daarop in Slenaken uit 1633.1217 Deze 'Ordinantie ende gebodt unsers ghenadigen heeren' volgt op het bannen van de vrede. Inhoudelijk bestaat er een zekere samenhang met het 'Mandat den floicken ende schelden belangende' uit 1546. In totaal gaat het om elf artikelen betreffende godslastering, ongepast gedrag tijdens kerkdiensten, het sluitingsuur van herbergen, kaart- en dobbelspel, het vangen van duiven, beschadiging van gewassen en wegen, de jacht op klein wild, het loslopen van vee, het afgraven van gemeentegrond en het inslaan van bier door herbergiers. Aangenomen mag worden dat ook in Gronsveld, Heugem en Honthem vergelijkbare teksten werden gebruikt.

In de loop van de tijd konden 'politieke ordonnanties' uitgroeien tot een omvangrijk reglement. Dit blijkt uit de in 1774 vastgestelde 'politieke ordonnantie' van het

1215 Habets, Geschiedenis bisdom Roermond, 2, 378-384. In het bisdom Roermond werd tot het einde van de achttiende eeuw tegen dit soort misbruiken bij processies gewaarschuwd.

1216 RHCL, Graafschap Gronsveld, inv. nr. 255, fol. 22.(21 mei 1766) en inv. nr. 256, fol. 2 (7 januari 1778).

1217 RHCL, Graafschap Gronsveld, inv. nr. 577, (Bijlage 32). 
aangrenzende Heer en Keer, die eveneens tijdens het voogdgeding werd voorgelezen. ${ }^{1218}$ Het ging daarbij om een heel scala aan onderwerpen: de veiligheid in het veld, herbergbezoek, het houden van bepaalde dieren en bestrijding van veeziekten, het gebruik van heide en weidegronden, het onderhoud van wegen en voetpaden, vloeken, geweldpleging en onzedelijk gedrag, het weren van ongewenste vreemdelingen, de bestrijding van brandgevaar, het verbod op verkleden bij Vastenavond, enzovoorts, kortom alles wat binnen de dorpsgemeenschap noodzakelijk werd geacht voor een ordelijk en veilig bestaan.

\subsubsection{De Gronsveldse Rechtsordnung, 1671}

Het meest omvangrijke stuk Gronsveldse wetgeving is ongetwijfeld het landrecht dat onder de wijdlopige titel

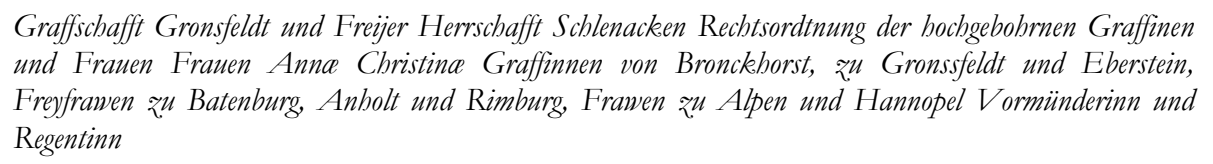

Graffschafft Gronsfeldt und Freïer Herrschafft Schlenacken Rechtsordtnung der hochgebohrnen Graffinen und Frauen Frauen Anna Christina Graffinnen von Bronckhorst, zu Gronssfeldt und Eberstein, Freyfrawen zu Batenburg, Anbolt und Rimburg, Frawen zu Alpen und Hannopel Vormünderinn und Regentinn

in 1671 bij Anton Metternich in Aken werd gedrukt. Van dit uitermate zeldzame boekwerkje bevond zich in 1912 nog een (incompleet) exemplaar in het bezit van kapelaan Hanssen, de auteur van de geschiedenis van Rimburg. ${ }^{1219}$ Helaas werd dit werk in de zogenoemde 'Nalatenschap Hanssen' niet meer aangetroffen. ${ }^{1220}$ Andere gedrukte exemplaren zijn, voor zover bekend, niet meer voorhanden. In de jaren zestig van de twintigste eeuw werd door Janssen de Limpens ${ }^{1221}$ een handgeschreven versie van de Rechtsordnung ontdekt in het archief van de graven Toerring-Jettenbach in München. ${ }^{1222}$ Dit afschrift diende als bijlage bij het uitvoerige rapport dat Joseph Anton Prummer in 1757 schreef over de juridische toestand van de grond en 'derselben bisherrige verfassung' in het graafschap Gronsveld. ${ }^{1223}$ Een tweede exemplaar van de Rechtsordnung kwam omstreeks 2000 tevoorschijn bij de ordening van de archieven van het graafschap Gronsveld bij het Rijksarchief Limburg. ${ }^{1224}$ Ook deze tekst is van Prummers hand. Afgezien van kleine verschillen in spelling en aanduiding van artikelen, zijn beide versies gelijk.

Volgens Prummer was in 1757 'nicht als ein eintzig getruckhtes exemplar mehr verhandten'. Helemaal letterlijk moeten we die uitspraak niet nemen. We zagen al bij de bespreking van de wetgeving op het gebied van goederen in de dode hand dat graaf Ignaz Felix von Toerring-Jettenbach in 1737 de drossaard instrueerde om 'in justitz sachen das

\footnotetext{
1218 Habets, Limburgsche wijsdommen, 85-93.

${ }^{1219}$ Hanssen, Die Rimburg, 280-281.

1220 RHCL, Familie Hanssen te Rimburg.

1221 RHCL, Collectie Janssen de Limpens, inv. nr. 1.

1222 TJ, inv. nr. M 13, fol. 29-69 (Bijlage 7B).

1223 TJ, inv. nr. M 13, fol. 145-146, Prummer aan M.E. von Toerring-Jettenbach 16 juni 1757: fol. 73-104, 'Information ueber die natur und weesenheyt deren....entlegenen grundten'.

1224 RHCL, Graafschap Gronsveld, inv. nr. 87 (Bijlage 7A)
} 
reglement de anno 1671 pro norma' te nemen. Veel indruk maakte dat niet. ${ }^{1225}$ Want toen in Gronsveld in 1746 het proces over de nalatenschap van de kanunnik Salden ontstond, met daarin ook een kwestie van goederen in de 'dode hand', bleken drossaard en schepenen aanvankelijk niet eens van de Rechtsordnung op de hoogte te zijn. Pas gedurende het proces werd een gedrukt exemplaar aangetroffen tussen de in beslag genomen papieren van de vroegere rentmeester Oligschläger. In de tweede helft van de achttiende eeuw wordt in stukken wel enkele malen verwezen naar de Rechtsordnung, maar de indruk bestaat dat de toepassing toch vrij beperkt was. ${ }^{122}$

In de preambule van de Rechtsordnung verklaarde gravin Anna Christina dat iedere overheid de plicht had de aan de haar door God toevertrouwde onderdanen onpartijdig recht te laten wedervaren, tegen zo min mogelijk kosten. Om een einde te maken aan de rechtsonzekerheid in Gronsveld, waarbij partijen zich beriepen op 'gemeine landt- oder aber absonderlich hergebrachte von dennen beschribenen rechten abweichente gewohnheiten', waren deze 'gewohnheiten' nu op schrift gesteld. Al wat daarvan afweek en niet alsnog uitdrukkelijk was erkend, werd 'vor nichtig und krafftlos erklert'. In gevallen waarin de Rechtsordnung niet voorzag, diende te worden geoordeeld volgens de 'gemeinen beschribenen rechten', het gerecipieerde geleerde Romeinse recht.

Toch zet deze preambule ons op het verkeerde been wat betreft de schriftelijke vastlegging van Gronsvelds gewoonterecht. Janssen de Limpens ontdekte dat de Rechtsordung voor bijna tachtig procent een letterlijke kopie is van de in 1663 door de Keulse keurvorst/aartsbisschop Maximiliaan Hendrik van Beieren uitgevaardigde Cöllnische Rechts-Ordnung. Sterker nog, zelfs de inleiding bestaat vrijwel geheel uit een herhaling van de Keurkeulse tekst.

De Gronsveldse Rechtsordnung telt achttien titels of hoofdstukken, de Keurkeulse zestien. In beide teksten ligt sterk de nadruk op erfrecht en goederenrecht, in het bijzonder het recht betreffende onroerend goed. Aan de Keurkeulse Rechtsordnung is een hoofdstuk toegevoegd over het erfrecht van de leden van de ridderschap. Ook het hoofdstuk over het leenrecht in Keurkeulen wijkt af van dat in Gronsveld. Gronsveld had eigen leenrecht, waarbij ook werd verwezen naar een leenreglement van graaf Johan II van Bronckhorst Batenburg uit 1593. Verder zijn in Gronsveld afzonderlijke titels gewijd aan erfpachten en keurmeden en aan het einde volgt een hoofdstuk over procesrecht. Deze verschillen zijn goed verklaarbaar. Erfrecht bij ridderschap speelde in Gronsveld geen rol, terwijl keurmeden en erfpachten hier juist wel nadere regelgeving vroegen. Ook de toevoeging van een hoofdstuk over procesrecht valt voor Gronsveld goed te begrijpen, aangezien het daar in Gronsveld aan ontbrak. De inhoudelijke kanten van de Rechtsordnung blijven hier verder buiten beschouwing. De titels met betrekking tot keurmedige goederen en

1225 RHCL, Rijkskamergerecht, inv. nr. 187, fol. 96-98.

1226 TJ, inv. nr. M 18, fol. 8-69 'Keurboek 1726-circa 1792': fol. 46vo.-47, gerechtelijke uitwinning van keurmedig goed te Eckelrade 1761, met verwijzing naar gedrukte Rechtsordnung; TJ, inv. nr. M 21 fol. 391 393 uittreksel brief A.J. von Toerring-Jettenbach aan Prummer 6 september 1775. Prummer had onlangs nog gewezen op de Rechtsordnung (in het Duits) van 1671; TJ, inv. nr. M 6, fol. 11-26: verwijzing naar de Rechtsordnung in een ontwerp-ambtsinstructie voor Zollner, april 1780. 
leengoederen en evenals het procesrecht komen in de Hoofdstukken 9.7, 10.4 en 10.5 nog aan de orde.

\begin{tabular}{|c|c|c|}
\hline Versie Maastricht & Versie München & $\begin{array}{l}\text { Cöllnische Rechts-Ordnung } \\
1663\end{array}$ \\
\hline $\begin{array}{l}\text { Titulus I } \\
\text { Vom testament und letzten } \\
\text { willens vermachtnus }\end{array}$ & $\begin{array}{l}\text { Titulus I } \\
\text { Vom testament und letzten } \\
\text { willens vermachnuss }\end{array}$ & $\begin{array}{l}\text { Titulus I } \\
\text { Von testament und letzten- } \\
\text { willens vermächnuß }\end{array}$ \\
\hline $\begin{array}{l}\text { Titulus secundus } \\
\text { Vom erbschafft ohne testa- } \\
\text { ment in aufsteigenter linien }\end{array}$ & $\begin{array}{l}\text { Titulus II } \\
\text { Von erbschafft ohne testament } \\
\text { in auf steigender linien }\end{array}$ & $\begin{array}{l}\text { Titulus II } \\
\text { Von erbschafft ohn testament } \\
\text { in auffsteigender linien }\end{array}$ \\
\hline $\begin{array}{l}\text { Titulus tertius } \\
\text { Von erbfolgung in abstei- } \\
\text { genter linien }\end{array}$ & $\begin{array}{l}\text { Titulus III } \\
\text { Von erbfolgung in } \\
\text { absteigender linien }\end{array}$ & $\begin{array}{l}\text { Titulus III } \\
\text { Von erbfolgung } \\
\text { absteigender linien }\end{array}$ \\
\hline $\begin{array}{l}\text { Titulus quartus } \\
\text { Von erbung der elteren mit } \\
\text { und neben } \quad \text { dess } \\
\text { verstorbenen kündts brueder } \\
\text { und schwes-ter oder } \\
\text { derselben künderen }\end{array}$ & $\begin{array}{l}\text { Titulus IV } \\
\text { Von erbung der elteren mit und } \\
\text { neben dess verstorbenen kindts } \\
\text { bruder und schwester oder } \\
\text { derselben kinderen }\end{array}$ & $\begin{array}{l}\text { Titulus IV } \\
\text { Von erbung der elteren mit } \\
\text { und neben des verstorbenen } \\
\text { kindts bruder- und schwester- } \\
\text { oder der derselben kinderen }\end{array}$ \\
\hline $\begin{array}{l}\text { Titulus quintus } \\
\text { Von erbung auf der seithen } \\
\text { linien seu lineæ collateralis } \\
\end{array}$ & $\begin{array}{l}\text { Titulus V } \\
\text { Von erbung auf der seithen } \\
\text { linien seu lineæ collateralis }\end{array}$ & $\begin{array}{l}\text { Titulus V } \\
\text { Von erbung auff der } \\
\text { seitenlinien } \\
\text { Titulus VI } \\
\text { Wie deren von der ritterschafft } \\
\text { töchter, wie auch die söhn } \\
\text { (wan deren mehr als einer im } \\
\text { leben) ihre elteren und sich } \\
\text { under-einander erben }\end{array}$ \\
\hline $\begin{array}{l}\text { Titulus sextus } \\
\text { Von denen lechen und deren } \\
\text { succesion }\end{array}$ & $\begin{array}{l}\text { Titulus VI } \\
\text { Von dennen lehnen und deren } \\
\text { succesionen }\end{array}$ & $\begin{array}{l}\text { Titulus VII } \\
\text { Wie die lehn in diesem } \\
\text { ertzstifft geerbt werden sollen }\end{array}$ \\
\hline $\begin{array}{l}\text { Titulus septimus } \\
\text { Wie eheleuthe einander er- } \\
\text { ben sollen }\end{array}$ & $\begin{array}{l}\text { Titulus VII } \\
\text { Wie eheleuth einander erben } \\
\text { sollen }\end{array}$ & $\begin{array}{l}\text { Titulus VIII } \\
\text { Wie eheleute einander erben } \\
\text { sollen }\end{array}$ \\
\hline $\begin{array}{l}\text { Titulus octavus } \\
\text { Von dem besitz oder posses- } \\
\text { sion der erledigten } \\
\text { erbschafft }\end{array}$ & $\begin{array}{l}\text { Titulus VIII } \\
\text { Von besitz oder possession der } \\
\text { erledigter erbschafft }\end{array}$ & $\begin{array}{l}\text { Titulus IX } \\
\text { Von dem besitz oder gewehr } \\
\text { der erledigter erbschafft }\end{array}$ \\
\hline $\begin{array}{l}\text { Titulus nonus } \\
\text { Von der einkündtschafft }\end{array}$ & $\begin{array}{l}\text { Titulus IX } \\
\text { Von der ein kündtschafft }\end{array}$ & $\begin{array}{l}\text { Titulus X } \\
\text { Von der einkindtschafft }\end{array}$ \\
\hline
\end{tabular}




\begin{tabular}{|c|c|c|}
\hline $\begin{array}{l}\text { Titulus decimus } \\
\text { Von vormundtschafften }\end{array}$ & $\begin{array}{l}\text { Titulus } \mathrm{X} \\
\text { Von vormünderschafften }\end{array}$ & $\begin{array}{l}\text { Titulus XI } \\
\text { Von vormünderschafften }\end{array}$ \\
\hline $\begin{array}{l}\text { Titulus undecimus } \\
\text { Von khauffen und } \\
\text { verkhauffen. }\end{array}$ & $\begin{array}{l}\text { Titulus XI } \\
\text { Von kauffen und verkauffen }\end{array}$ & $\begin{array}{l}\text { Titulus XII } \\
\text { Von kauffen und verkauffen }\end{array}$ \\
\hline $\begin{array}{l}\text { Titulus duodecimus } \\
\text { Vom einstandt oder } \\
\text { bescheidt zu latein ius } \\
\text { retractus genant }\end{array}$ & $\begin{array}{l}\text { Titulus XII } \\
\text { Vom einstandt oder bescheidt } \\
\text { zu latein ius retractus genant }\end{array}$ & $\begin{array}{l}\text { Titulus XV } \\
\text { Vom einstand oder widerzug, } \\
\text { zu latein ius retractus genant }\end{array}$ \\
\hline $\begin{array}{l}\text { Titulus decimus tertius } \\
\text { Von pfandtschafften, zu } \\
\text { latein de pignoribus et } \\
\text { hÿpothecis }\end{array}$ & $\begin{array}{l}\text { Titulus XIII } \\
\text { Von pfandtschafften zu latein } \\
\text { de pignoribus et hÿpothecis }\end{array}$ & $\begin{array}{l}\text { Titulus XIII } \\
\text { Von pfandtschafften }\end{array}$ \\
\hline $\begin{array}{l}\text { Titulus decimus quartus } \\
\text { Von pfachtungen }\end{array}$ & $\begin{array}{l}\text { Titulus XIV } \\
\text { Von pfachtungen }\end{array}$ & $\begin{array}{l}\text { Titulus XIV } \\
\text { Von pfachtungen }\end{array}$ \\
\hline $\begin{array}{l}\text { Titulus decimus quintus } \\
\text { Von erbpfachten }\end{array}$ & $\begin{array}{l}\text { Titulus XV } \\
\text { Von erbpfachten }\end{array}$ & \\
\hline $\begin{array}{l}\text { Titulus decimus sextus } \\
\text { Von churmuthen, zu latein } \\
\text { de curmediis }\end{array}$ & $\begin{array}{l}\text { Titulus XVI } \\
\text { Von churmuthen, zu latein de } \\
\text { curmedis }\end{array}$ & \\
\hline \begin{tabular}{l}
\multicolumn{3}{c}{ Titulus decimus septimus } \\
Von verjährung der \\
stehenten rhenten oder \\
zünsen
\end{tabular} & $\begin{array}{l}\text { Titulus XVII } \\
\text { Von verjahrung der stehender } \\
\text { rhenten oder zinsen }\end{array}$ & $\begin{array}{l}\text { Titulus XVI } \\
\text { Von verjahrung der stehender } \\
\text { rhenten oder zinsen }\end{array}$ \\
\hline $\begin{array}{l}\text { Titulus decimus octavus } \\
\text { Von den gerichteren und wie } \\
\text { mann sich dabeÿ sowohl in } \\
\text { procedendo als judicando } \\
\text { zuverhalten. }\end{array}$ & $\begin{array}{l}\text { Titulus XVIII } \\
\text { Von den gerichteren und wie } \\
\text { mann sich dabeÿ so wohl in } \\
\text { procedendo als judicando zu } \\
\text { verhalten }\end{array}$ & \\
\hline
\end{tabular}

Het Keurkeulse landrecht gold in het stift of keurvorstendom Keulen, in de met het stift (door leenbanden) verbonden onderheerlijkheden, in het zogenoemde Vest Recklinghausen, in de stad Rhens en in het Keurkeulse Ambt Zeltingen aan de Moezel. Gerecipieerd werd Keurkeuls recht in het graafschap Mörs, in de zogenoemde 'Gräfliche Lande' van de rijksheerlijkheid Dyck met de heerlijkheid Schelsen (Elsen) ${ }^{1227}$ en mogelijk ook in het hertogdom Aremberg in de Eifel. ${ }^{1228}$ Met uitzondering van Aremberg gaat het

1227 Maurenbrecher, Die Rheinpreußischen Landrecbte, 465-474), Arndt, Reichsgrafenkollegium, 77-78.

1228 Maurenbrecher, Die Rheinpreußischen Landrechte, 327-334. 
om territoria die aan Keurkeulen grensden of onder Keurkeulse invloed stonden. De reden dat in Gronsveld Keurkeuls recht werd ingevoerd moet worden gezocht in persoonlijke relaties. Landsvrouwe gravin Anna Christina von Hardenrath was een Keulse burgemeestersdochter, verbleef veel binnen de stad Keulen en kende dus het Keulse recht. Maar de feitelijke bewerking en aanpassing voor Gronsveld heeft zij waarschijnlijk overgelaten aan haar raadslieden. Prummer vermoedde in zijn toelichting op de Rechtsordnung dat 'der damahlige Gronsfeldt[ische]r that von Veucht und schultheiss Rippegard, von welchen zweÿen einer (wie allerdings darfür halten mues), dise Rechtsordtnung abgefasset hat'. Prummer wist niet dat de Rechtsordnung een kopie van het Keurkeulse landrecht was, maar constateerde dat de auteur(s) wel goed op de hoogte was/waren van de 'reichs und geschribenen rechten, keines weegs aber in hieländti[sche] sprach, gewohnheiten, herkomen und observanz versiert (bedreven) gewesen'.

Met zijn vermoedens betreffende het auteurschap van de Rechtsordnung kan Prummer wel eens dicht bij de waarheid zitten. Zekere scholtis Engelbert Rippegard wordt in 1671 in Gronsveld vermeld, maar over hem zijn verder nauwelijks bijzonderheden bekend (zie over hem Hoofdstuk 8.9). Anders is het gesteld met Wilhelm Veucht, licentiaat in de beide rechten, sinds 1660 raadsman van graaf Jost Maximiliaan van Bronckhorst Batenburg en, na het overlijden van de graaf, van diens weduwe Anna Christina von Hardenrath en zoon Johan Frans van Bronckhorst Batenburg. (zie meer over Veucht in Hoofdstuk 8.8) Gedurende 34 jaar groeide een hechte band tussen de jurist en de Gronsveldse grafelijke familie. Veucht beschikte behalve over kennis van het geleerde Romeinse recht zeker ook over kennis van het inheemse gewoonterecht (in zoverre is Prummers veronderstelling over gebrek aan kennis op dat terrein bij een auteur als Veucht onjuist), maar het is duidelijk dat, met uitzondering van enkele specifiek op Gronsveld toegesneden hoofdstukken, bewust is gekozen voor een kopie van het Keurkeulse recht.

\subsubsection{Algemene karakteristiek van de wetgeving in de achttiende eeuw}

Voor de periode tussen 1718 en 1789 valt de oogst aan wet- en regelgeving in het graafschap Gronsveld vrij beperkt uit en voor de eerste helft van de achttiende eeuw zelfs ronduit mager. Het betreft circa twintig verordeningen, afhankelijk van de vraag of bepaalde twijfelgevallen worden meegeteld. Inhoudelijk zijn wel enkele accenten te plaatsen. In totaal vijf regelingen (waarvan één niet bewaard) hebben betrekking op de 'aanbreng' van onroerend goed ten behoeve van de grondbelasting. De meest uitgebreide uit 1754 geeft gedetailleerde voorschriften over de manier waarop de gevraagde gegevens moesten worden aangeleverd. ${ }^{122}$ Dit materiaal werd ook de basis voor de opmeting van het graafschap op kadastrale schaal.

De tweede, verhoudingsgewijs goed vertegenwoordigde groep, zijn verordeningen in de sfeer van openbare orde en veiligheid, zoals bestrijding van vernieling, baldadigheid en geweldpleging, een verbod op maskerade bij Vastenavond, nachtelijke wacht- en patrouillediensten et cetera. Veelal betreft het uitbreiding of aanscherping van onderwerpen die in beginsel tijdens het voogdgeding in de 'politieke ordonnantie' werden voorgelezen.

${ }^{1229}$ RHCL, Graafschap Gronsveld, inv. nr. 210 (Bijlage 13). 
De derde groep bestaat uit een restcategorie, met een reglement op de heffing van schatting uit 1718, 1230 twee regelingen op het gebied van gerechtskosten en de manier van procederen uit $1724^{1231}$ en $1731^{1232}$ (waarvan onzeker is of deze ooit formeel zijn afgekondigd) en de ordonnantie op de aardappeltienden (1776)..$^{1233}$

De redactionele vormgeving kent grote verschillen, een aspect dat nog aan de orde komt. Opvallend is dat slechts drie verordeningen, uit 1718, 1734 en 1776, direct en volledig op naam van de graaf staan. Alle andere zijn 'naamloos' of op basis van een vorm van delegatie door de grafelijke vertegenwoordiger uitgevaardigd of getekend. Die delegatie wordt ook enkele malen als zodanig vermeld. Dit betekent dat de graaf als landsheer slechts bij uitzondering werd gemengd in plaatselijke regelgeving.

Een interessant voorbeeld van dergelijke manier van besluitvorming binnen alleen de schepenbank biedt het uitvoerige reglement op de gerechtskosten van 2 mei 1724. Dit werd 'gearresteert in judicio tot Gronsfelt' en getekend door drossaard Johannes Godefridus Lebens 'onder genaede approbatie nochtans van Sijne Hooghgraffelijcke Excellentie onsen genaedigen lantheere' (= Claude Nicolas d'Arberg Valengin). Daarvoor werd dus grafelijke goedkeuring nodig geacht. Onzeker is of die approbatie er ooit is gekomen, want in die tijd stapelden de interne conflicten binnen het graafschap zich zodanig op, dat het eindigde met een chaos in bestuur en rechtspraak.

Grafelijke wetgeving is derhalve zeldzaam. Curieus in dit verband is de Duitstalige grafelijke verordening op de heffing van de aardappeltienden, vastgesteld op 30 oktober 1775, waarvan een Nederlandstalige versie, met enkele kleine wijzigingen, op 21 februari 1776 , in het gerechtsprotocol van Gronsveld werd geregistreerd en afgekondigd. Nu was de aanleiding tot deze verordening ook bijzonder, omdat ze te maken had met het in Hoofdstuk 17.5 nog te bespreken proces van 1773 tot 1785 over de vraag of van aardappelen, een in die tijd betrekkelijk nieuw cultuurgewas, tienden mochten worden geheven. In de herfst van 1775 dacht Prummer met een verordening duidelijkheid te kunnen verschaffen. Hij stelde daarvoor een concept op, volgens hetwelk graaf August Joseph moest besluiten om 'von landtsherrlicher macht zu statuieren und zuverordtnen' op welke wijze voortaan de heffing van aardappeltiende diende te gebeuren. Inhoudelijk kreeg dit concept in München goedkeuring, maar in de op 30 oktober 1775 vastgestelde, vrij korte, eindversie kreeg de wetgevende bevoegdheid van de graaf tot drie maal toe een bijzonder accent met toevoegingen als: 'so erkleren, ordnen und gebietten wür aus landsherrlich- gesetzgebenter macht', 'an disen geschiehet unser landesherrlichen gesetzgebende will' en 'zu bekräfftigung dises unser landsherrlichen gesezgebenden wahren will und befehls'. Gelet op het karakter van de alles en iedereen controlerende graaf August Joseph kunnen deze passages nauwelijks toeval te zijn. Er moest, zeker bij een enigszins oproerige stemming onder de bevolking, duidelijk worden gedemonstreerd dat de graaf als landsheer alle wetgevende bevoegdheid bezat, ook om daarmee aan

${ }^{1230}$ TJ, inv. nr. M 40, fol. $931-934$ (Bijlage 8).

1231 RHCL, Graafschap Gronsveld, inv. nr. 88 (Bijlage 9).

1232 RHCL, Rijkskamergerecht, inv. nr. 71, fol. 595-596 (Q 242, Bijlage10).

1233 TJ, inv. nr. M 21, fol. 302-305 (Bijlage 19). 
geschillen een einde te maken. (we zullen zien dat daar ook nog de grafelijke bevoegdheid tot interpretatie van wetgeving werd gekoppeld).

Van de verordeningen uit de tweede helft van de achttiende eeuw staat er, behalve de eerder genoemde verordening over de aardappeltienden, slechts één formeel op naam van de graaf, te weten de verordening van 1789 over het aanbrengen van gronden. ${ }^{1234}$ Het stuk heeft echter als plaats van uitvaardiging Gronsveld en is bekrachtigd ('locus sigilli') door grafelijk commissaris/directeur Zollner. Men kan zich dus afvragen of het gaat om een door graaf August Joseph zelf uitgevaardigd stuk.

In twee gevallen uit 1754 en $1766^{1235}$, eveneens over het aanbrengen van gronden, wordt bij de uitvaardiging een beroep gedaan op 'Authoriteyt, gegeven by de HoochGraeffelijcke Commissie' als een aan de grafelijke vertegenwoordiger gedelegeerde algemene, bevoegdheid tot regelgeving. De eerste keer vindt bekrachtiging plaats door Prummer als commissaris en Jacobus Berchmans als secretaris, de tweede keer wordt volstaan met een 'ter ordonnantie' van schepen en waarnemend secretaris Johan Frans Lebens.

De verordeningen op het gebied van handhaving van de openbare orde uit de periode 1755-1786 bevatten zelfs geen enkele verwijzing naar de uitvaardigende persoon of instantie. Meestal staat er 'ter ordonnantie' bij met de handtekening van de secretaris. Bij de registratie in het schepenprotocol zou nog kunnen worden gedacht aan het gemakshalve weglaten van formaliteiten, maar waarschijnlijk werden ze ook in deze 'naamloze' vorm bekend gemaakt.

\subsubsection{Formulier, registratie en bekendmaking van wetgeving}

Het formulier van wetgeving in diplomatische zin bevat elementen die volgens een min of meer vast stramien terugkeren. De gebruikelijke volgorde bestaat uit de intitulatio (naam en titel van de uitvaardigende persoon), het adres (degene tot wie het stuk is gericht) en een groet. Daarna volgen de narratio (motieven en overwegingen die tot de regelgeving hebben geleid) en de dispositio (de eigenlijke regelgeving). Het einde of eschatocol bevat de datum, de validatie of bekrachtiging in de vorm van zegelaankondiging of handtekening en eventueel de mention de service, de handtekening van de functionaris belast met de uitvoering.

Wanneer we de hiervoor besproken wetgeving van de heren van Gronsveld op die kenmerken beoordelen, dan blijkt de 'vormvastheid' nogal te wisselen. Echte modellen voor de redactie van teksten ontbraken. Soms zal een plakkaat van een naburig gebied als bron van inspiratie hebben gediend, dan weer bedacht de opsteller een eigen formulering. Waarschijnlijk was dat een gevolg van de kleinschalige organisatie en het ontbreken van bureaucratische tradities. Bovendien verbleef de graaf als hoogste wetgever veelal buiten het graafschap.

De ordonnantie op de verwerving van goederen in de dode hand van 1670 spreekt in algemene zin van inregistreeren in... prothocollen, naer dat sij behoorlijck ter

1234 TJ, inv. nr. M 17, fol. 66 (Bijlage 28).

1235 RHCL, Graafschap Gronsveld, inv. nr. 210 (Bijlagen 13 en 16). 
gewoonlijcker plaetsen sall weesen gepubliceert ende geaffigeert' en 'publiceeren, condigen ende uytroepen... daer men gewoonlick is sulcke uytroepinge ende publicatie te doen'. Daarmee worden de drie meeste gebruikelijke manieren van bekendmaking genoemd: vastlegging in het schepenprotocol, mondelinge afkondiging en aanplakking.

Registratie van verordeningen in rolregisters of transportregisters van de schepenbank was in veel plaatsen gebruikelijk. Zo ook in Gronsveld. Alleen valt dit hier slechts vast te stellen voor een 25-tal jaren in de tweede helft van de achttiende eeuw. De teksten zijn zonder aanhef, werden meestal 'ter ordonnantie' getekend door de secretaris en aan het einde volgt het relaas van de gerechtsbode die de voor de publicatie heeft gezorgd.

Voor een deels ongeletterde bevolking was mondelinge bekendmaking geen overbodige luxe. Gebruikelijk was voorlezing van de 'politieke ordonnantie' en de aanvullingen daarop tijdens het voogdgeding. Daarnaast vond ook afkondiging plaats in de kerk. De ordonnantie op de naleving van het Concilie van Trente werd in 1608 door de pastoor na de mis in de kerk bekend gemaakt, in aanwezigheid van drossaard en schepenen. Maar dit gebeurde ook regelmatig voor niet-kerkelijke zaken, zoals blijkt uit een incident in 1755 . Pastoor Kolb, die in onmin leefde met Prummer, beklaagde zich bij graaf Maximilian Emanuel dat de gerechtsbode allerlei mededelingen in de kerk afriep (openbare verkopen, maar ook verordeningen en bekendmakingen), wat (volgens de pastoor) nergens anders dan in Gronsveld gebeurde. Volgens Kolb was dat in strijd met de waardigheid van Gods huis en hij beweerde dat het al lang zou zijn afgeschaft wanneer de graaf er van wist. ${ }^{1236}$. Gehoor vond de pastoor echter niet bij de graaf, want bemoeienis met afkondiging van grafelijke verordeningen en mededelingen lag erg gevoelig en de graaf liet zich niet door een pastoor de wet voorschrijven.

'Affixie ad valvas' was na registratie en mondelinge afkondiging de derde vorm van publicatie, die ook werd gebruikt voor gerechtelijke bekendmakingen. Dit diende te geschieden binnen alle dorpen en gehuchten van het graafschap, maar niet iedere verordening werd overal op dezelfde plaats aangeplakt. In Heugem, Gronsveld en Eckelrade en in Slenaken werden daarvoor de kerkdeuren gebruikt. In Honthem en in de Bijbank bevond zich geen kerkgebouw. In Honthem bevestigde de bode de bekendmakingen aan een lindeboom ${ }^{1237}$ en in de Bijbank werd gekozen voor aanplakking aan een particuliere woning. ${ }^{1238}$ :

De laatste mogelijkheid voor verspreiding was druk. Dit gebeurde met de Rechtsordnung van 1671 en bijvoorbeeld met twee ordonnanties op het aanbrengen van landerijen uit 1754 en 1789. De aanbreng van landerijen werd daarbij zowel bekend gemaakt 'ad valvas', als door

1236 TJ, inv. nr. M 14, fol. 831-834, Kolb aan M.E. von Toerring-Jettenbach 20 maart 1755).

1237 RHCL, Graafschap Gronsveld, inv. nr. 256, 22 februari 1778, fol. 38, bekendmaking gerechtelijke proclamatie op de lindeboom te Honthem; idem fol. 41, 8 maart 1778; TJ, inv. nr. M 21, fol. 301-306, gerechtsdag te Gronsveld 21-2-1776, waarbij wordt besloten verordening over aardappeltienden bekend te maken op de gewone plaatsen (kerkdeuren) te Gronsveld, Heugem, Eckelrade en 'op de lindenboom' in Honthem.

1238 RHCL, Graafschap Gronsveld, inv. nr. 221, de oproep 1757 voor een vergadering van geërfden aan het huis van schepen Lemmens, wonende in de Bijbank; TJ, inv. nr. M 17, fol. 66, ordonnantie 1780 over de leengoederen 'opt huys off muyr van Lendert Spits gelegen in de Bijbanck tot Eckelrade als sijnde d'ordinaire affixie plaetse' (Bijlage 22). 
overhandiging van gedrukte teksten aan de vier burgemeesters van Gronsveld, Eckelrade, Heugem en Honthem, in het bijzonder ter verspreiding onder de vele pachters. Zij konden dit vervolgens meedelen aan de eigenaren van de grond, die veelal buiten het graafschap woonden en hier dus niet ter kerke gingen.

\subsection{Grafelijke interpretatie van wetgeving 1239}

De graaf was als landsheer niet alleen de hoogste wetgever in zijn gebied, hij had ook het recht die wetgeving bij onduidelijkheid of onzekerheid over de inhoud uit te leggen. Er zijn daarvan uit de achttiende eeuw twee voorbeelden bekend.

Het eerste geval betreft de uitleg van Titel 11 artikel 2 van de Rechtsordnung van 1671, waarbij het op straffe van confiscatie aan geestelijke instellingen wordt verboden op enigerlei wijze onroerend goed 'in de dode hand' te verwerven. Aanleiding was het al genoemde proces over de nalatenschap van de in 1745 overleden Maastrichtse kanunnik Maximiliaan Hendrik Salden. Het is niet duidelijk van wie het verzoek om interpretatie uitging, maar op 12 januari 1748 vaardigde graaf Maximilian Emanuel in München een verklaring over 'den wahren verstandt' uit. ${ }^{1240} \mathrm{Om}$ an alle twijfel een einde te maken achtte hij het noodzakelijk op basis van zijn landsheerlijk gezag en wetgevende macht hier een interpretatie te geven. ${ }^{1241} \mathrm{Hij}$ besliste dat niet alleen abdijen, kloosters en kapittels onder het verbod op vervreemding in de dode hand vielen, maar alle 'pia corpora' zoals gasthuizen, armen- en weeshuizen, seminaries enzovoorts. Dit verbod gold voor alle onroerende zaken en al wat van rechtswege als onroerend werd beschouwd. Opdat deze 'declaration und erlautterung' algemeen bekend raakte, werd publicatie bevolen. Volgens het bewaard gebleven afschrift vond publicatie plaats op 15 februari 1748 ten overstaan van schepenen, drossaard en fiscus en de vertegenwoordigers van de procederende partijen.

Het tweede voorbeeld betreft de interpretatie van de op 10 januari 1776 uitgevaardigde en op 21 februari 1776 in het schepenprotocol geregistreerde ordonnantie op de aardappeltiende. Op 10 mei 1776 richtten de burgemeesters van het graafschap zich tot graaf August Joseph in München met het verzoek deze ordonnantie ' $t$ 'interpreteeren ende te modereeren' in die zin dat er geen tienden van aardappels meer werden geheven. Verder zagen zij graag dat de tiendheffers verplicht werden bij te dragen in het onderhoud van de kerktoren en in ieder dorp een stier en een beer voor de varkens te houden, zoals dat in andere plaatsen gebruikelijk was. Op 21 augustus 1776 werd vanuit München een besluit naar Prummer gezonden. Die zorgde voor een vertaling in het Nederlands, evenals een omzetting of bewerking zodanig dat hij 'bij speciale commissie belast', de inhoud hiervan aan de aanvragers kon meedelen. Dit geschiedde in de vorm van een 'Verclaaringe van

1239 Zie hierover meer algemeen: Jacobs, 'Is het wel de rechter die hetr recht vindt?', 40-42.

1240 RHCL, Rijkskamergerecht, inv. nr. 187, fol. 66-67vo. (Q 14).

1241 'von landtsherrlicher oberbotmässigkeit wegen und in crafft des uns zustehenden reichsständischen jurislegislatorii eine interpretationem authenticam hierüber ergehen zu lassen' 
resolutie' die door Prummer op 6 september 1776 werd getekend en vervolgens werd voorgelezen en schriftelijk medegedeeld. ${ }^{242}$

Inhoudelijk viel de beslissing kort uit. Het verzoek was 'strijdende tegens de geregtigheijt, dus ongefondeert' en er viel noch inhoudelijk noch juridisch een reden te bedenken om iets te veranderen aan de ordonnantie. Op het verzoek de tiendheffers bijzondere verplichtingen op te leggen kon de graaf geen beslissing nemen. Indien de bewoners meenden ergens recht op te hebben, stond het vrij dit 'bij behoorige wegen van recht te soecken'. Wanneer Prummer van de bekendmaking aan de burgemeesters bij de graaf verslag doet, spreekt hij duidelijk geïrriteerd over een niet passend verzoek ('unstathafften gesuech'). De verhoudingen waren door het geschil over de tienden gespannen, Prummer voelde zich al snel gepasseerd wanneer iemand zich rechtstreeks tot de graaf wendde en hij was niet gediend van - indirecte - kritiek op hem als ontwerper van de ordonnantie op de aardappeltiende.

Het is lastig op basis van slechts twee voorbeelden te komen tot een juiste positionering van het recht op interpretatie van wetgeving binnen het totaal aan bevoegdheden van de graaf. In beide gevallen gaat het om uitleg binnen het kader van een proces, waarbij landsheerlijke belangen in het geding waren. Aangezien uitleg van de wet in een concreet geval in beginsel tot de taak van de rechter hoort, kan men denken aan Kabinetsjustiv, een ingreep van de landsheer in de rechtsgang met het doel daarmee een bepaalde afloop te bereiken. Toch wijzen deze twee verklaringen in een andere richting. In 1748 wordt uitdrukkelijk verwezen op het recht tot interpretatie als uitvloeisel van de wetgevende bevoegdheid van een rijksstand. De uitleg bij de ordonnantie op de aardappeltienden in 1776 is op dit punt minder expliciet, maar de kort daarvoor gepubliceerde ordonnantie legde, zoals hiervoor al besproken, zeer sterk de nadruk op de wetgevende bevoegdheid van de graaf. In dezelfde sfeer past een bepaling in de omstreeks 1779 ontworpen ambtsinstructie voor commissaris Wolfgang Zollner. Daarin wordt bepaald dat bij onduidelijkheden in het recht of de wet, de landsheer daarvan op de hoogte moet worden gebracht. ${ }^{1243} \mathrm{Al}$ deze gevallen lijken voor beelden van een meer algemene praktijk, waarbij de wetgever het recht van interpretatie had voor het geval een wet onduidelijk was of op een bepaald punt zweeg. ${ }^{1244}$

\subsection{Conclusies}

In de voor Gronsveld geldende wetgeving kunnen verschillende lagen worden vastgesteld. Enerzijds was er het algemene rijksrecht zoals de 'Peinliche Halsgerichtsordnung' ('Carolina') uit 1532, dat direct werd toegepast, anderzijds werden ook bepalingen uit de Reichspolizeiordnungen gerecipieerd en omgezet in specifiek op Gronsveld toegesneden regelgeving. De graaf was als landsheer de hoogste wetgever binnen zijn territorium en hij

${ }^{1242}$ TJ, inv. nr. M 21, fol. 685-687, 6 september 1776, 'Verclaaringe van resolutie' van de graaf, zulks naar aanleiding van een Franstalig verzoekschrift van de burgemeesters.

1243 TJ, inv. nr. M 6, fol. 11-26, ontwerp ambtsinstructie voor Zollner als commissaris.

1244 Jacobs, 'Is het wel de rechter die het recht vindt?', 40-42. 
had de bevoegdheid in twijfelgevallen over de uitleg van bepalingen een algemeen verbindende interpretatie te geven. Een onafhankelijke houding, zowel formeel als inhoudelijk, werd aangenomen ten aanzien van regelgeving door kerkelijke autoriteiten.

De hoeveelheid voor Gronsveld uitgevaardigde regelgeving is, in vergelijking met andere territoria, tamelijk beperkt. Een aantal regelingen staat op naam van de graaf zelf, een ander deel, veelal in de sfeer van openbare orde en de 'aanbreng' van landerijen voor belastingheffing, werd opgesteld door de plaatselijke autoriteiten, zoals drossaard, schepenen, secretaris en/of de grafelijke vertegenwoordiger, waarbij laatstgenoemde zich beriep op door de graaf aan hem gedelegeerde bevoegdheden.

Het meest omvangrijke stuk wetgeving is de Rechtsordnung voor Gronsveld uit 1671, die inhoudelijk echter vrijwel geheel een kopie is van de van de Cöllnische Rechts-Ordnung uit 1663. Alleen de hoofdstukken over het recht op de leengoederen en keurmeden, evenals het procesrecht, wijken daar van af. De Rechtsordnung behandelt vooral zakenrecht en erfrecht, waarbij het onduidelijk blijft of de bepalingen in de praktijk ruime toepassing vonden.

Ten slotte zijn onderzocht de formele aspecten van de wet- en regelgeving. Daaruit blijkt dat de redactionele vormgeving in de praktijk weinig vast was. De bekendmaking van regelgeving geschiedde vanaf de tweede helft van de zeventiende eeuw door registratie in het schepenprotocol, mondelinge bekendmaking, door aanplakking op verschillende plaatsen en soms door verspreiding in druk. 


\title{
8 Landsheerlijke functionarissen tijdens de heren en graven Van Bronckhorst Batenburg circa 1550-1720
}

\begin{abstract}
Voor het bestuur van het graafschap Gronsveld beschikte de graaf over functionarissen in vaste dienst, zoals een scholtis en/of drossaard en een rentmeester. Daarnaast maakte hij vanaf de tweede helft van de zeventiende eeuw gebruik van juridische adviseurs. Deze functionarissen behoorden vaak generaties lang tot dezelfde families. Hierdoor ontwikkelden zich op den duur in Gronsveld familieregeringen die, gebruik makend van de vaak langdurige afwezigheid van de graaf, door onderlinge verwantschap en opeenhoping van ambten, het plaatselijk bestuur beheersten. Op basis van vooral biografisch materiaal is geprobeerd deze machtsverhoudingen inzichtelijk te maken. Over de inhoudelijke kant van het werk is weinig materiaal beschikbaar. Een beperkt aantal rentmeestersrekeningen uit het begin van de zeventiende eeuw geeft enig zicht op het werk van de rentmeester in de praktijk. Ook blijkt de financiële verantwoording door de rentmeester regelmatig problemen op te leveren.
\end{abstract}

\subsection{Familieregering}

De begrenzing in tijd, waarvoor in dit hoofdstuk is gekozen, loopt van het midden van de zestiende eeuw tot 1719 , het einde van de regeerperiode van heren en graven uit het geslacht Van Bronckhorst Batenburg. Oudere gegevens zijn er nauwelijks. Na 1719 breekt vooreerst een verwarde en roerige periode voor Gronsveld aan, waarin bestuur en rechtspraak in het ongerede raken. Pas eind jaren veertig treedt hierin een stabilisatie op. Tussen 1617 en 1719 kende Gronsveld twee graven met uitzonderlijke lange regeerperiodes, namelijk Jost Maximiliaan van 1617-1662 en diens zoon Johan Frans 16771719. ${ }^{1245}$ Diezelfde tijd kent ook twee zeer lange ambtsperiodes van drossaards, namelijk van Christiaan Lamberts (circa 1630-1669) en van Willem Kicken (1676-1719). Laatstgenoemde was ook nog gedurende vele jaren grafelijk rentmeester. Daaraan moet worden toegevoegd de langdurige diensttijd van Wilhelm Veucht, tussen 1660 en 1694 de invloedrijke juridische adviseur van de familie Van Bronckhorst en later ook appelcommissaris. Dergelijke lange periodes zorgen ook voor een bepaalde mate van bestuurlijke continuïteit.

Er zijn over de in dit hoofdstuk beschreven functies en ambten slechts weinig gegevens die de inhoudelijke kant van het werk belichten. Vaak blijft het beperkt tot min of meer algemene aanduidingen of routinematige activiteiten. De overlevering van bronmateriaal is zodanig gebrekkig dat zelfs de samenstelling van een sluitende rij van opeenvolgende functionarissen problemen oplevert. Het best gedocumenteerd is nog het werk van de rentmeester. Een aantal rekeningen uit de tijd rond 1600 geeft inzicht in de veelomvattende taak van deze 'manager' en financieel beheerder van de grafelijke

1245 Gemakshalve laten we hier de nuancering met betrekking tot onverdeelde boedels en het bewind van gravin Anna Christina von Hardenrath over haar nog minderjarige kinderen buiten beschouwing. 
'economie'. Desondanks is toch geprobeerd na te gaan in hoeverre de verschillende ambten in grafelijke dienst in de loop van de tijd veranderden of juist continuïteit kenden.

Het langdurige verblijf van de graaf buiten Gronsveld betekende dat de aangestelde functionarissen hun bestuur op basis van delegatie moesten uitoefenen. Hoe dit systeem in Gronsveld gedurende de zeventiende eeuw precies werkte, valt bij gebrek aan bronnen niet goed na te gaan. Duidelijk is wel dat deze functionarissen over een grote mate van vrijheid van handelen beschikten. Hun loyaliteit gold echter niet alleen hun heer, maar vooral ook hun familie. Zo kan in Gronsveld duidelijk worden gesproken van familieregeringen, waarbij ambtelijke functies van vader op zoon overgingen of waarbij men binnen één familie elkaar de banen toeschoof. Na verloop van tijd wisselden de aan de macht zijnde families elkaar af, soms op een niet zachtzinnige manier.

Daarnaast werden diverse ambten in één persoon verenigd. Op zich was die opeenhoping niet vreemd, want afzonderlijk leverden ze geen dagvullende bezigheid op. Cumulatie was ook noodzakelijk om een passend inkomen te verwerven. In Gronsveld ontvingen in 1621 de scholtis en rentmeester ieder afzonderlijk 150 gulden als basisinkomen Het was op zich niet onredelijk, maar te weinig om volgens een bepaalde stand van te kunnen leven. Daarvoor waren aanvullende emolumenten uit gerechtskosten, opbrengsten van boeten en bepaalde aan een ambt verbonden voordelen, zoals gratis hout uit het bos, noodzakelijk.

Het verschijnsel van familieregeringen was ten tijde van het Ancien Régime alom verbreid. Het historisch onderzoek daarnaar concentreert zich tot op heden vooral op stedelijke elites. ${ }^{1246}$ De situatie op het platteland komt, ondanks de massale beoefening van de genealogie gedurende de laatste decennia, veel minder uit de verf. Ook voor de 'Limburgse' territoria staat dit onderzoek naar lokaal bestuur nog in de kinderschoenen. In dit verband kan worden verwezen naar de studie van Dumont over de dorpsgemeenschappen in het Land van Daelhem en het hertogdom Limburg, die spreekt van 'des dynasties de mandataires'.1247 Als voorbeelden van andere plaatsen in de omgeving van Gronsveld met dit verschijnsel kunnen worden genoemd de heerlijkheid Wylre, waarvan De la Haye lijsten van bestuurders publiceerde ${ }^{1248}$ en Rekem met de drossaarden in de zeventiende eeuw. ${ }^{1249}$ Daarmee wordt duidelijk dat familieregering in Gronsveld bepaald geen plaatselijk verschijnsel was.

De machtsbasis van deze lokale elites was complex. In de eerste plaats moet onderscheid worden gemaakt tussen gekozen en benoemde ambtsdragers. Gekozenen, zoals burgemeesters, schatheffers en soms ook schepenen, moesten steunen op het vertrouwen van de bevolking. Voor het behoud van macht werd soms ook de inzet van minder eerbare middelen niet geschuwd. Benoemde functionarissen zoals een scholtis, drossaard,

1246 Zie voor een (al iets ouder: 1996) algemeen overzicht van prosopografisch onderzoek en onderzoek naar groepen: De Jong, 'Prosopografie, een mogelijkheid'. In dit verband kan nog eens worden gewezen op zijn opmerking (214): 'De burgerlijke elites in andere gewesten en in de Generaliteitslanden, alsmede die tijdens de zeventiende eeuw hebben echter in veel mindere mate geprofiteerd van de vlucht die het prosopografisch onderzoek heeft genomen. Gelet op de discussies over onder andere nationale identiteit en Hollandocentrisme, is het te hopen dat hieraan spoedig iets zal veranderen.'

1247 Dumont, Les Communautés villageoises, 446-460.

1248 De la Haye, Inventaris Wijlre, 37-47.

1249 Verbois, Gescbiedenis Rekem, 144-148. 
rentmeester of secretaris moesten daarentegen vooral de gunst van de heer zien te winnen en te behouden. Eventuele kritiek op hun functioneren vanuit de bevolking diende binnen de perken te blijven en de verantwoording van het financieel beheer moest voor de heer acceptabel te zijn. Dat leverde bij beëindiging van een dienstverband nog wel eens problemen op. Maatschappelijk was de grens tussen beide groepen echter vaag, aangezien ook benoemde ambtsdragers vaak werden gerekruteerd uit vooraanstaande families ter plaatse.

Het was de vraag in hoeverre buiten de inheemse families ook vreemdelingen een rol konden spelen in het plaatselijk bestuur, in het bijzonder bij benoemde ambtsdragers. Voerden de heren van de kleine zelfstandige territoria, die zelf meestal ver buiten hun heerlijkheid of graafschap verbleven, daarin een bewuste politiek? Een interessante variant daarop in de omgeving van Gronsveld vormen na 1632 de Staatse Landen van Overmaze, waar de schepenbanken en de hogere bestuursfuncties voor een belangrijk deel werden bezet met mensen uit de, niet in Maastricht geboren, gereformeerde bovenlaag in de stad. ${ }^{1250}$ Enerzijds ging het daarbij om een bewuste politiek van de Staten-Generaal om ambten met protestanten te bezetten, anderzijds was de groep waaruit deze mensen voorkwamen, ook onderling verwant. Waarschijnlijk gebeurde hetzelfde ook met katholieke regenten uit Maastricht voor de onder katholiek gezag staande gebieden in de omgeving. ${ }^{1251} \mathrm{Om}$ de juiste betekenis van dit verschijnsel echter te kunnen beoordelen, zou verder onderzoek naar de Maastrichtse stedelijke elites in de zeventiende en achttiende eeuw noodzakelijk zijn.

Voor Gronsveld heeft dit probleem een bijzondere dimensie omdat hier in de tweede helft van de achttiende eeuw een aantal echte vreemdelingen in het bestuur werd benoemd. In Hoofdstuk 12.1, 12.3 en 12.7 komt aan de orde hoe zij zich ten opzichte van de plaatselijke elite gedroegen en of dit verschil maakten ten opzichte van vroegere periodes. Een andere kwestie betreft de professionaliteit van ambtsdragers. Over de geringe kennis van schepenen wordt tot het einde van de achttiende eeuw veelvuldig geklaagd. Maar ook over de opleiding van personen die min of meer beroepsmatig betrokken waren bij bestuur en rechtspleging staat men soms verbaasd. Zo wordt van Gillis van Munstar, tussen 1548 en 1581 scholtis en rentmeester in de rijksonmiddellijke heerlijkheid Wylre nog gezegd dat hij niet kon lezen en schrijven. ${ }^{1252}$ In de loop van de zeventiende eeuw lijkt zich een zekere professionalisering te voltrekken en worden, ook bij familieregeringen, steeds vaker de meer belangrijke ambten bekleed door universitair opgeleide juristen. Die scholing zal ook zijn bevorderd naarmate zich binnen een familie een soort bestuurlijke traditie ontwikkelde.

In de conclusies aan het einde van dit hoofdstuk wordt gekeken in hoeverre het beeld dat wij uit Gronsveld hebben, aansluit op de hiervoor genoemde thema's. De verschillende

\footnotetext{
1250 Munier, 'De Calvinisering'.

1251 Verbois, Geschiedenis Rekem, 142 geeft als voorbeeld Lambert Vriens, scholtis van Rekem 1611-1633, rentmeester van de H. Geest te Maastricht en verschillende jaren schepen, gezworene en burgemeester in deze stad.

1252 De la Haye, Inventaris Wijlre, 37.
} 
functionarissen hadden ambtshalve of in nevenfuncties ook bemoeienis met de schepenbank(en) en het leenhof, bijvoorbeeld als stadhouder of secretaris. Dit aspect blijft hier verder buiten beschouwing en komt bij de behandeling van de afzonderlijke rechterlijke colleges aan bod.

\subsection{Scholtissen, midden zestiende eeuw - 1628}

De rol van de scholtis in Gronsveld, zoals we die voor de laatmiddeleeuwse periode hebben beschreven, lijkt tegen het einde van de zestiende eeuw te zijn veranderd. Weliswaar bleef zijn taak als rechter in de oude zin in de kern inhoudelijk hetzelfde - hij sprak de 'banformule' uit bij het voogdgeding en vorderde namens de heer een vonnis van de schepenen - maar zijn betrokkenheid bij (in het bijzonder de vrijwillige) rechtspraak wijzigde. Vrijwel alle middeleeuwse overdrachtsakten van Gronsveld staan op naam van scholtis en schepenen, maar vanaf de zestiende eeuw waren bij de overdracht van onroerend goed vaak alleen twee of drie schepenen aanwezig.

Het is de vraag of de scholtis ook regelmatig aanwezig was bij processen. Van zaken voor de schepenbanken van Gronsveld en Heugem uit de zestiende en zeventiende eeuw zijn alleen uittreksels uit de gerechtelijke rollen ten behoeve van hoger beroep overgeleverd. Daarin treedt inderdaad de scholtis op, maar het betreft wel processen van enig belang. De situatie in Slenaken, waar gerechtsrollen uit de zestiende en zeventiende eeuw bewaard zijn, geeft een wat ander beeld. Tot circa $1590 \mathrm{komt}$ de scholtis nauwelijks in de stukken voor $^{1253}$ en staan de geregistreerde activiteiten op naam van alleen 'de schepenen' of het 'gerecht'. Er was overigens wel een scholtis, zoals blijkt uit een overdracht van een hof belast met keurmede voor scholtis en schepenen in $1467^{1254}$ en een gezamenlijk met de schepenen afgegeven gerechtelijke verklaring uit $1561 . .^{1255}$ Die spaarzame vermeldingen van de scholtis kunnen het gevolg zijn van een bewust gekozen formulering, maar het is ook mogelijk dat vaak zittingen werden gehouden zonder scholtis of onder leiding van een schepen die diens rol op zich nam. Op zich was dat geen ongebruikelijke constructie.

$\mathrm{Na} 1591$ verandert het beeld in Slenaken. Vanaf die tijd vonden zittingen plaats onder leiding van de scholtis of, nog vaker, een functionaris met de titel 'stadhouder'. Daarnaast bleef ook het oude systeem, waarbij alleen schepenen worden genoemd, bestaan. De functie van stadhouder wordt, voor zover bekend, in deze tijd in verband met de schepenbanken van Heugem en Gronsveld niet genoemd. Het blijft daarom onduidelijk of dit optreden van een stadhouder een typisch plaatselijke ontwikkeling voor Slenaken betreft.

Ook al is de betrokkenheid van de scholtis bij de werkzaamheden van de schepenbank niet altijd even duidelijk, de indruk bestaat dat hij in de praktijk vaak verstek liet gaan en zich liet vervangen door een schepen. Dat hing ook samen met een verandering in het

${ }^{1253}$ RHCL, Graafschap Gronsveld, inv. nr. 570: Enkele van de sporadische voorbeelden van het optreden van de scholtis namens de heer in de gerechtsrol van 19 januari 1574 en 8 november 1583 .

1254 RHCL, Graafschap Gronsveld, inv. nr. 472.

1255 RHCL, Graafschap Gronsveld, inv. nr. 466. 
takenpakket door de combinatie met andere ambten, zoals het stadhouderschap bij het leenhof of de functie van grafelijk rentmeester. Zo wordt Willem van Caestert vermeld als scholtis in $1550^{1256}$ en in $1552 / 1553^{1257}$, maar is hij in 1557 ook stadhouder van het Gronsveldse leenhof. ${ }^{1258}$ Ook Reiner van Gelder (overleden in 16131259) wordt in 1581 tegelijk stadhouder van het Gronsvelds leenhof en scholtis genoemd. ${ }^{1260}$ In 1589 komt hij voor als scholtis in de gerechtsrol van Slenaken ${ }^{1261}, 1592$ krijgt hij van de graaf als scholtis volmacht mee te werken aan een overdracht van landerijen in Eijsden ${ }^{1262}$ en in 1594 treedt hij nog op als stadhouder van het leenhof. ${ }^{1263}$

Waarschijnlijk was Hendrik van Velraedt genaamd Meuter de eerste die zijn werk als scholtis combineerde met de veelomvattende taak van grafelijk rentmeester. In die hoedanigheden komt hij voor van 1608 tot 1614 of begin 1615.1264 In de jaren 1610-1613 trad hij tevens op als stadhouder van het grafelijk leenhof. ${ }^{1265}$ Voorts was hij scholtis van de in 1608 nieuw opgerichte schepenbank van Oost ${ }^{1266}$ en schepen van Breust. De combinatie van rentmeester, scholtis en stadhouder van het leenhof treffen we na 1616 ook aan bij zijn opvolger Hans Jacob van Huckelhoven (1616-1628).

\section{3 'Momboir des heren', begin zeventiende eeun}

Terwijl in Gronsveld enerzijds het ambt van scholtis werd verenigd met andere functies, werden tegelijkertijd aan het begin van de zeventiende eeuw ook taken, vooral op het gebied van de rechtspleging, afgesplitst. Zo trad in strafzaken of zaken waarmee landsheerlijk belang was gemoeid, een afzonderlijke 'momboir des heren' op als een soort

1256 RHCL, Graafschap Gronsveld, inv. nr. 78

${ }^{1257}$ RHCL, Graafschap Gronsveld, inv. nr. 174.

1258 RHCL, Familie De Geloes/Kasteel Eijsden, inv. nr. 317, uittreksel uit het leenboek van Gronsveld 1557.

${ }^{1259}$ Bij Belonje, 'Genealogische en heraldische gedenkwaardigheden', 141 wordt in de Sint-Servaaskerk te Maastricht de navolgende grafsteen vermeld: 'Hier ligt Begraven der Edele / ende Erentfeste Reyner van / Gelre Stadthelder der Graafschap Gronsfeld / Gestorven Anno 1613 den 20 July / Bidt Godt voor die siele / ind der Hoogweirdigen Heer Winandt van Gelder / Canonic deser Kercken / ende 20 Iaeren Deecken / Sterf den 1en Iyni Ao 1634'. Reiner van Gelre moet omstreeks 1538 zijn geboren. Bij een getuigenverhoor in 1589 (RHCL, Graafschap Gronsveld, inv. nr. 93) geeft hij de leeftijd van 51 jaar op. 1260 RHCL, Familie De Geloes/Kasteel Eijsden, inv. nr. 317, waarin zich diverse uittreksels bevinden van het leenboek van het Gronsveldse leenhof, in 1581 eigenhandig vernieuwd door Reiner van Gelder 'doen ter tijt stadthouder ende schouteth der graefschap van Gronsfelt'.

${ }^{1261}$ RHCL, Graafschap Gronsveld, inv. nr. 570, op 6 maart en 6 juni 1589.

1262 RHCL, Familie De Geloes/Kasteel Eijsden, inv. nr. 425.

${ }_{1263}$ RHCL, Familie De Geloes/Kasteel Eijsden, inv. nr. 317, waarin zich diverse uittreksels bevinden van het leenboek van het Gronsveldse leenhof.

1264 RHCL, Rijkskamergerecht, inv. nr. 26, Jaartallen zijn ontleend aan gegevens in een proces tussen graaf Johan van Bronckhorst en Hendrik van Velraedt genaamd Meuter over de financiële afrekening wegens zijn ambtstijd van 1608-1614.

1265 TJ, inv. nr. M 42, Leenboek van Holset.

1266 RHCL, Familie De Geloes/Kasteel Eijsden, inv. nr. 317, uittreksel van voogdgeding gehouden te Oost 10 januari 1610. 
procureur van de graaf. Het woord 'momboir' betekent voogd, maar als 'momboir des heren' is het een gebruikelijke aanduiding voor de vertegenwoordiger van de (lands)heer in strafzaken. Daarnaast kon hij ook optreden bij de behartiging van andere, civielrechtelijke belangen van de landsheer. De aanstelling van een dergelijke functionaris betekende een taakverlichting voor de scholtis, die tegelijk ook rentmeester en stadhouder van het leenhof was. Daarnaast werd hij verlost van een dubbelrol, wanneer hij de zitting van het gerecht moest leiden en tegelijk als rentmeester de belangen van de heer vertegenwoordigde.

Voorbeeld van een dergelijke 'momboir' in Gronsveld is in 1607 Reiner Daniëls bij een geschil over grondaanwas langs de Maasoever. ${ }^{267}$ We komen hem ook tegen als schepen en, na circa 1600, in Slenaken als gemachtigde van de rentmeester bij de gerechtelijke invordering van cijnzen en pachten. In de jaren 1617-1624 wordt in de rekeningen van de rentmeester een vaste post opgenomen voor het salaris van de momboir des heren, wat wijst op een zekere duurzaamheid van het ambt. ${ }^{1268}$ Ook in Slenaken trad sedert 1603 , naast scholtis en stadhouder, een zekere Heyn Steyns met regelmaat op als momboir des heren. De man schijnt daarnaast een soort praktijk als procureur te hebben uitgeoefend, want hij vertegenwoordigde, zelfs al lang voor 1603, ook andere procespartijen.

Het blijft bij gebrek aan bronnen onduidelijk hoe lang dit systeem van 'momboir des heren' in strafzaken in gebruik bleef. Eerst in de achttiende eeuw duikt de benaming 'fiscus' op voor de functionaris die in een vergelijkbare rol namens de landsheer optreedt als aanklager in strafzaken.

\subsection{Drossaarden, 1596-1624}

Naast de scholtis en momboir des heren komt sinds het eind van de zestiende eeuw in Gronsveld de drossaard in beeld. De eerste vermelding van een dergelijke functionaris is te vinden in de rentmeesterrekening van Johan van Vaels uit 1596/15971269, waar wordt gesproken over een zekere drossaard Betz. Vanaf 1601 komt in de processen tussen graaf Johan van Bronckhorst en zijn onderdanen als drossaard voor Henrich Kelterhausen 'von Bropach' (Braubach am Rhein). ${ }^{1270}$ In 1604 treedt hij op als stadhouder van het grafelijk leenhof, is betrokken bij de vervolging van een geval van belediging in Slenaken en wordt op zijn verzoek in die plaats een getuigenverhoor afgenomen in verband met

\footnotetext{
${ }^{1267}$ RHCL, Graafschap Gronsveld, inv. nr. 270, Reiner Daniëls als momboir van de heer tegen Hendrik Couwenberch 1607

1268 RHCL, Graafschap Gronsveld, inv. nr. 181-185. Gedurende de jaren 1617-1620 wordt als zodanig genoemd Lodewijk Graven.

1269 RHCL, Graafschap Gronsveld, inv. nr. 178.

1270 RHCL, Rijkskamergerecht, inv. nr. 72, fol. 58-58vo. (1601); inv. nr. 73, fol. 97 (1607) en fol. 99 (1608); zie verder ook RHCL, Graafschap Gronsveld, inv. nr. 454 (1608); In hetzelfde jaar verblijft hij in Frankfurt am Main in een kwestie over een schuldbekentenis, in 1579 door de Staten-Generaal van de Spaanse Zuidelijke Nederlanden afgegeven aan wijlen Otto van Eberstein, de schoonvader van graaf Johan van Bronckhorst (RHCL, Graafschap Gronsveld, inv. nr. 488).
} 
grensschendingen door de schatheffer en gerechtsbode van Noorbeek. ${ }^{1271}$ In $1606^{1272}$ en 16071273 spelen er opnieuw grensconflicten met Noorbeek, waarbij Kelterhausen wordt genoemd. Tot 1624 komt zijn naam in de rentmeesterrekeningen voor.

Tenminste vanaf 1612 is Frans Wendel Öller (Oeller of Oiller) als drossaard in dienst ${ }^{2774}$. In de rentmeestersrekening over dat jaar wordt de betaling van zijn salaris van vijftig rijksdaalders of 130 gulden verantwoord. ${ }^{1275}$ In 1617 was hij aanwezig bij de verbranding van een jongen uit Honthem wegens ontucht met een kalf.1276 Zijn naam blijft in de rekeningen tot 1623 regelmatig opduiken. Oeller zou de zoon zijn geweest van een predikant in de buurt van Esslingen aan de Neckar. Hij was als knecht meegekomen met Johan II van Bronckhorst Batenburg, vervolgens in Rimburg opgeklommen tot secretaris van de graaf en had zijn loopbaan geëindigd als drossaard van Gronsveld. Hij was twee keer gehuwd, eerst met Catharina en toen met haar zuster Maria van Roermond, herbergiersdochters. Laatstgenoemde was eerst keukenmeid, daarna gouvernante op Rimburg. Uit dit huwelijk was ook een dochter, Sibilla, geboren.1277 Deze sloot later een omstreden huwelijk met Otto Wilhelm van Bronckhorst, dat voor een schandaal - en een proces - binnen de grafelijk familie zorgde (zie Hoofdstuk 4.1.1 en 4.1.5).

In de rentmeestersrekeningen verschijnen in deze tijd in Gronsveld ook leden van de familie (van) Od(d)enhoven, kenneliik intimi van de graaf, die worden betiteld als drossaard (Godart 1618, Herman 1622). Een zekere Johan van Odenhoven wordt in 1633 vermeld als drossaard van Hönnepel. ${ }^{1278}$

Ook wordt genoemd een zekere 'drossard Strub', waarschijnlijk een zoon van Assuerus Streuff, eertijds de begeleider van graaf Johan tijdens diens verblijf in Italië en een vriend van de familie.

$\mathrm{Al}$ deze vermeldingen wijzen er op dat de graven van Bronckhorst meer dan één drossaard in dienst hadden. Het blijft echter onduidelijk of die ook vast aan één plaats waren verbonden. Voor Gronsveld blijkt in ieder geval uit de rekeningen dat de drossaard hier wel met een zekere regelmaat verbleef, eventueel samen met vrouw en kinderen, maar er niet woonde. ${ }^{1279}$

1271 RHCL, Graafschap Gronsveld, inv. nr. 570, op 12 oktober en 23 december 1604; RHCL, Rijkskamergerecht inv. nr. 25, fol. 21 vo. (12 juli 1604).

1272 RHCL, Graafschap Gronsveld, inv. nr. 449.

1273 RHCL, Graafschap Gronsveld, inv. nr. 570, 17 juli 1607

1274 RHCL, Graafschap Gronsveld, inv. nr. 180, fol. 37-38, diverse ontvangsten van geld uit handen van drossaard Frans Wendel Oeller in Rimburg en RHCL, Rijkskamergerecht inv. nr. 26, fol. 44vo., verklaring van graaf Johan van Bronckhorst 18 oktober 1612: drossaard 'Frans Wendel'.

1275 RHCL, Graafschap Gronsveld, inv. nr. 180.

1276 RHCL, Graafschap Gronsveld, inv. nr. 181.

1277 LAV, NRW, Abt. Rheinland, Reichskammergericht, inv. nr. 743.

1278 Scholten, 'Geschichte Hönnepel', 146.

1279 Waarschijnlijk had de drossaard voor Gronsveld zijn vaste domicilie op het kasteel van Rimburg. Bevestigingen daarvan zijn te vinden in de uitgaven die in de rekeningen worden verantwoord, zoals die van 1617-1618, voor een pond Spaanse zeep 'soo die drossardtinne myt op Rimburg hefft genomen (RHCL, Graafschap Gronsveld, inv. nr. 181.) en die van 1622-1623 voor een paar Spaanse leren muiltjes, die door graaf Otto Willem aan de 'drossardtinne' op Rimburg werden geschonken (RHCL, Graafschap Gronsveld, inv. nr. 184). 
Het valt bij alle genoemde activiteiten van drossaarden op dat deze vrijwel steeds verband houden met zaken waarbij het gaat om hoge rechtspraak of typisch landsheerlijke belangen (processen van de graaf, grensgeschillen). Volgens de rekening van 1621-1622 gaf de drossaard ook 'pardon' (kwijtschelding) van een straf. ${ }^{1280}$ Het is verder opmerkelijk dat zowel Kelterhausen als Öller van Duitse afkomst zijn. Die achtergrond maakte hen in ieder geval geschikt om de belangen van Johan van Bronckhorst binnen het Rijk te behartigen. Samenvattend mogen we concluderen dat de drossaard in deze tijd kon optreden als vertegenwoordiger van de heer bij de vervolging van zware vergrijpen, maar toch in het bijzonder als vertrouwensman van de graaf waakte over diens landsheerlijke rechten en belangen.

\subsection{Rentmeesters, midden zestiende eeuw - 1628}

De rentmeester had ongetwijfeld de meest veelomvattende taak in het Gronsveldse bestuur. Hij was verantwoordelijk voor het beheer van de landsheerlijke goederen en rechten en in het bijzonder de inkomsten daaruit. Daarnaast betaalde hij zowel de 'staatsuitgaven' als particuliere uitgaven van de graaf en diens familie. Aangezien vrijwel iedereen in het graafschap ergens in de boekhouding van de rentmeester voorkwam, bezat het rentmeesterschap duidelijk een publiek karakter. Deels speelden de werkzaamheden zich in het openbaar af, zoals tijdens de zittingsdagen voor de betaling van cijnzen in anwezigheid van de schepenen en bij het voogdgeding, waar de rentmeester door middel van een bijzondere juridische procedure achterstallige betalingen als preferente schulden kon opeisen. Maar de taak van de rentmeester beperkte zich niet tot louter boekhoudkundige werkzaamheden. Hij was in feite de verantwoordelijke voor de dagelijkse bedrijfsvoering in of rond het kasteel van Gronsveld.

Het ambt van rentmeester vererfde dikwijls van vader op zoon. In de zestiende eeuw zien we dat bij drie generaties van de familie Congartz. Rentmeester Claes Congartz de Oude (gestorven in 15541281) werd opgevolgd door zijn zoon Claes Congartz de Jonge. In zijn aanstellingsakte van 30 juni 1559 noemt Willem van Bronckhorst hem zijn 'geboren onderdaan'. ${ }^{1282}$ Het was een herbenoeming door de nieuwe heer, want er is al een eerdere rekening van 'Cloes Congartz der Jonghe' van 1552/1553. Twee elementen vallen op in de in vrij algemene bewoordingen geformuleerde aanstellingsakte. In de eerste plaats ontving Claes als honorarium de twintigste penning (vijf procent) van alle grafelijke inkomsten, een soort prestatiebeloning dus. Voorts moest hij alle andere ambten opgeven, met uitzondering van het ambt van gerichtsschrijver bij de schepenbanken in de heerlijkheid Gronsveld. Er werd dus gekeken naar het aantal nevenbetrekkingen, opmerkelijk in een tijd waarin opeenhoping van functies juist gebruikelijk was. De combinatie van rentmeester en gerichtsschrijver komt daarna in de zeventiende eeuw vaker voor en had

1280 RHCL, Graafschap Gronsveld, inv. nr. 183.

1281 Zijn grafsteen op het kerkhof rond de kerk van Gronsveld wordt vermeld bij Belonje, 'Genealogische en heraldische gedenkwaardigheden', 85: 'Hyr is Begraūe clais Gōgartz der alde Ao 1554.'

1282 RHCL, Graafschap Gronsveld, inv. nr. 92. 
ook een praktische kant, aangezien de graaf bepaalde inkomsten uit rechterlijke activiteiten beurde.

$\mathrm{Na}$ het overlijden van Willem van Bronckhorst in 1563 brak niet alleen een zware periode aan voor diens weduwe Agnes van Bylandt en haar opgroeiende kinderen, ook de rentmeester had het niet gemakkelijk. Het beleg van Maastricht door Spaanse troepen in 1579 betekende een ware catastrofe. In Gronsveld en Heugem stond amper nog een huis overeind, de bevolking was gevlucht en er was gebrek aan graan en vee. Nog vele jaren later lagen de akkers er desolaat bij. Onder die omstandigheden was het erg moeilijk pachten en cijnzen te innen. Claes Congartz de Jonge had vóór het beleg flinke hoeveelheden graan vanuit Gronsveld naar Maastricht in veiligheid gebracht. Naderhand kregen zijn erfgenamen daarmee grote problemen, omdat de rentmeester ervan werd beschuldigd graan voor uitdeling aan de armen van Gronsveld en graan van de landsvrouwe Agnes van Bylandt op zijn eigen zolder te hebben opgeslagen. Hoe zwaar die tijd voor Claes Congartz de Jonge was blijkt uit een verklaring van zijn zoon Willem tijdens een getuigenverhoor in 1589. De rentmeester was in 1579 bij Agnes van Bylandt op kasteel Rimburg gekomen en beklaagde zich 'dat hij oudt begonst te werden ende dat den dienst van rentmeesterschap hem niet langher daeromme en diende'. De tijden waren zodanig 'dat hij nyet en sach hoe dat hij van den volcke soude connen betalighe crijghen deur den overloepe van de chrijsvolcke'. Op zijn verzoek om ontslag had Agnes geantwoord: 'Neen heer rentmeester, ghij en moght mij soo nyet verlaeten'. Toen Claes volhield, zei ze: 'Wel, wye maken wij den van uwe kinderen rentmeester?' Daarop antwoordde Claes: 'Het is mij al even eens die mevrouwe gelieft; den eenen is mij soo lieff als den anderen'. Daarop had Willem, de oudste zoon van Claes, het rentmeesterschap aanvaard. ${ }^{1283}$ Claes Congartz de Jonge moet vóór de lente van 1583 zijn overleden. Hoe lang Willem Congartz in functie bleef, is niet geheel duidelijk. In de gerechtsrol van Slenaken komt hij in 1586 en 1589 voor als rentmeester, maar mogelijk heeft dat nog betrekking op de voorgaande diensttijd. ${ }^{1284}$

Ook bij de volgende rentmeesters is sprake van een opvolging van vader op zoon. Karel van Vaels, die in 1589 het eerst wordt genoemd ${ }^{1285}$, droeg zijn ambt in 1596 over aan zijn zoon Johan van Vaels. ${ }^{1286}$ Deze bleef, zoals blijkt uit diverse vermeldingen in de gerechtsrol van Slenaken, minstens tot 1601 in functie als rentmeester.

In de jaren daarna schijnt het rentmeesterschap te zijn waargenomen door Reiner of Reichard Daniëls. Eerder hebben we gezien dat hij ook optrad als 'momboir des heren'. Een vaste bezetting van het ambt begint weer met Hendrik van Velraedt genaamd Meuter (1608-1615).

\footnotetext{
1283 RHCL, Graafschap Gronsveld, inv. nr. 93, getuigenverhoor 26 augustus 1589.

1284 RHCL, Graafschap Gronsveld, inv. nr. 570, rol van 21 mei 1596 en 24 oktober 1589.

1285 RHCL, Graafschap Gronsveld, inv. nr. 570, rol van 11 oktober 1589: Caerle van Vaels, rentmeester.

1286 RHCL, Graafschap Gronsveld, inv. nr. 570, rol van 22 oktober 1596: rentmeester Vaels 'der Alde' en zijn zoon, rentmeester; rol van 3 december 1596: Johan van Vaels, de huidige rentmeester, Caerle van Vaels, de vroegere rentmeester. Zie verder RHCL, Graafschap Gronsveld, inv. nr. 177, de eerste rekening van Johan van Vaels, 1595-1596.
} 
Jaarlijks legde de rentmeester in een rekening verantwoording af van zijn beheer. De rentmeestersrekening van Claes Congartz de Oude over het boekjaar 1536-1537 vormt het vroegste voorbeeld van een dergelijke financiële verslaglegging. ${ }^{1287}$ Er zijn uit de tijd van de heren van Bronckhorst tot 1720 slechts enkele rentmeesterrekeningen overgeleverd uit de zestiende en het begin van de zeventiende eeuw en verder nog enkele exemplaren uit de jaren 1704-1718. Dat betekent dat we voor het midden van de zestiende tot het begin van de achttiende eeuw slechts een beperkt beeld hebben van inkomsten en uitgaven en de verschuivingen daarin. Zo blijken bijvoorbeeld an het begin van de achttiende eeuw inkomsten uit noten, fruit, tuingewassen en zelfs een kleine wijngaard substantieel te zijn, terwijl die aan het begin van de zeventiende eeuw ontbreken.

De rekenplicht, en zeker bij de rekening na beëindiging van de diensttijd, bleek in de praktijk nogal eens moeilijkheden op te leveren. Daar zijn verschillende redenen voor. In de eerste plaats maken de graven uit deze tijd, en dat geldt in het bijzonder voor Johan I van Bronckhorst Batenburg, niet de indruk gemakkelijke werkgevers te zijn geweest. Door wisselende opbrengsten en soms onverantwoord hoge uitgaven - op bevel van de graaf! kleefden aan het financieel beheer risico's voor de rentmeester. Verliezen werden niet in dank afgenomen en dit verhoogde de kans in ongenade te vallen. Daarnaast bracht de vrijheid van handelen voor de rentmeester ook bepaalde verlokkingen met zich mee, zeker wanneer de grens tussen 'mijn' en 'dijn' niet scherp werd getrokken en de rentmeester ook tekorten met eigen geld moest aanvullen. Dat leidde nogal eens tot de neiging bij 'winst' het omgekeerde te doen.

Dat de afrekening uit de hand kon lopen blijkt de affaire met rentmeester Hendrik van Velraedt genaamd Meuter. Van zijn jaarrekeningen als rentmeester zijn geen exemplaren bewaard gebleven, maar duidelijk is dat zijn financiële handel en wandel al tijdens zijn loopbaan onderwerp van een hooglopend geschil was. ${ }^{1288}$ Het begon in 1612, toen de graaf de rekeningen over 1609-1611 voorlopig goedkeurde onder het voorbehoud dat alsnog bepaalde bewijsstukken werden ingeleverd. Verder waren deze rekeningen afgesloten met een nadelig saldo voor de graaf van ongeveer 3200 gulden. De rentmeester schoot het bedrag voor en de graaf gaf hem daarvoor bepaalde goederen in onderpand, zoals de Rijckholter tienden, de inkomsten uit alle boeten onder de tien goudgulden en de gelden voor het verheffen van leengoederen. Voorts verschafte hij hem ook nog bouwmaterialen.

Van Velraedt genoot op dat ogenblik nog het vertrouwen van de graaf, maar dat slonk in de loop van 1615 zienderogen. Nadat eerst de rekeningen tot begin 1610 waren ingeleverd, moest de graaf wachten op de rekening van 1610/1611. Bovendien verlangde de graaf de afgifte van een nieuwe versie van het leenboek van het leenhof, dat de rentmeester had vervaardigd. Begin oktober 1615 liet Van Velraedt eindelijk door een notaris de rekeningen over 1612, 1613 en 1614 bezorgen. Toen de rentmeester echter op 17 december 1615 nog geen antwoord binnen had, beriep hij zich op een clausule in zijn instructie, die bepaalde dat wanneer niet binnen twee maanden op een toegezonden rekening was gereageerd, deze als goedgekeurd werd beschouwd.

${ }^{1287}$ RHCL, Graafschap Gronsveld, inv. nr. 172.

1288 Zie daarvoor RHCL, Rijkskamergerecht, inv. nr. 26. 
Intussen was Van Velraedt bij de Raad van Brabant in Brussel tegen de graaf een procedure over de afrekening begonnen. Hij achtte deze instantie daarvoor bevoegd, omdat de graaf feitelijk woonde op kasteel Rimburg, gelegen in de Landen van Overmaze en daarmee als Brabantse onderdaan kon worden beschouwd. De rentmeester maakte daarmee een strategische fout, want het was een onvergeeflijke belediging een rijksonmiddellijke graaf te dagvaarden voor de Raad van Brabant in een geschil dat betrekking had op een rijksonmiddellijk gebied. Graaf Johan II van Bronckhorst Batenburg zon dus op wraak. Op 22 december 1615 verhoorden de schepenen van Breust verschillende getuigen over een plan om Van Velraedt te overvallen. Die vertelden dat op last van de graaf elf mannen met 'roeren'(geweren) waren opgeroepen (enkele verstrekte de graaf zelf) en deze troep moest proberen de rentmeester in de bossen rond Slenaken te vangen en - liefst levend - naar Gronsveld te brengen. Het plan mislukte omdat het beoogde slachtoffer niet kwam opdagen.

Langzaam escaleerde de zaak. Begin 1616 startte jonker Couven uit Slenaken voor de schepenbank van Rijkckholt een proces tegen de rentmeester omdat deze bijna 850 gulden uit de schepenkist van Gronsveld zou hebben ontvreemd. Later kwamen daar nog andere beschuldigingen van verduistering bij. Van Velraedt liet als tegenmaatregel inwoners van Gronsveld, waaronder een schepen, in Eijsden arresteren. De rentmeester durfde daarna uit vrees voor zijn leven geen voet meer op Gronsveldse bodem te zetten. Uiteindelijk daagde graaf Johan zijn tegenstander voor het Rijkskamergerecht. Dit sprak in scherpe bewoordingen zijn afkeuring uit over het feit dat de rentmeester tegen de graaf, een inwoner van het Rijk, een proces was begonnen voor een Brabants gerecht in een geschil dat op een rijksonmiddellijk territorium betrekking had. De rentmeester werd veroordeeld tot afgifte van alle papieren van de graaf die hij nog in bezit had. In oktober 1617 liet Van Velraedt door de gerechtsbode van Breust op het kasteel van Gronsveld een verklaring bezorgen waarin hij zich bereid verklaarde aan die beslissing van het Rijkskamergerecht gevolg te geven, maar dan alleen in Breust, Mesch of Rijkckholt, plaatsen die ook onder het Rijk vielen. Ten aanzien van de procedure voor de Raad van Brabant hield hij nog een slag om de arm. Hoe de zaak precies is geëindigd, is niet bekend. Vast staat dat Van Velraedt genaamd Meuter nog een aantal jaren verbleef in plaatsen in de buurt van Gronsveld en daar ook ambten als scholtis of schepen bekleedde. Gronsveld zal te heet onder zijn voeten zijn geworden.

Wanneer Hendrik van Velraedt genaamd Meutter precies werd ontslagen, is niet duidelijk. Op 7 april 1617 verklaarden de pachters van Hemersbach dat zij de pacht van 1615 op het kasteel van Gronsveld hadden betaald bij een zekere Adolf Pil, rentmeester van de graaf. Het jaar daarop was pacht betaald bij Hans Jacob van Huckelhoven. ${ }^{289}$ Van hem zijn rekeningen bewaard over de periode 1617-1624. Afgaande op zijn activiteiten bij het leenhof moet hij omstreeks 1628 zijn werkzaamheden hebben beëindigd. Van Huckelhoven was mogelijk afkomstig uit Roermond of Sittard. In die plaatsen behoorde de familie tot het patriciaat. ${ }^{1290}$ Voor zijn benoeming in Gronsveld was hij werkzaam als

${ }^{1289}$ RHCL, Rijkskamergerecht, inv. nr. 25, fol. 23vo.

1290 Jansen, 'De familien Heister en Huckelhoven'. 
scholtis in het graafschap Horn. ${ }^{1291}$ Mogelijk werd hij aangetrokken op grond van aanbevelingen door leden van de familie Van Odenhoven, met wie hij verwant was. ${ }^{1292}$ Ook zijn ambtsperiode werd afgesloten met problemen over de eindafrekening. Zonder lering te trekken uit de handelwijze van zijn voorganger, maakte hij eveneens de fout graaf Otto van Bronckhorst als representant van diens afwezige broer Jost Maximiliaan voor de Raad van Brabant te dagvaarden. Te elfder ure zag Van Huckelhoven de onjuistheid daarvan in, want op 31 mei 1631 verklaarden hij en zijn zoon Bado, licentiaat in de rechten, dat zij 'tot hun leedwezen' een procedure voor de Raad van Brabant hadden aangespannen, aangezien de administratie waarover het geschil ging, op rijksgebied was gevoerd. 1293

\subsection{Christiaan Lamberts, drossaard, circa 1631-1668/1669}

$\mathrm{Na}$ het vertrek van Van Huckelhoven bleef de plaats van drossaard enige tijd vacant. Op de post werd geaasd door jonker Diederich Couven, bezitter van het Gronsveldse leengoed Hees te Slenaken. Op 20 december 1630 en 6 juli 1631 tekende graaf Otto Willem van Bronckhorst Batenburg, samen met zijn broer graaf Jost Maximiliaan mederegent van Gronsveld, voor hem op huis Rimburg een volmacht als grafelijke vertegenwoordiger op de vergadering van de kreits in Keulen. Op 15 januari 1632 schreef Jost Maximiliaan hem dat over de invulling van de vacature zou worden beslist na terugkeer van de graaf. Helaas voor Couven viel de keus op Christiaan Lamberts uit Eijsden. ${ }^{1294}$ De eerst bekende brief aan Lamberts als drossaard dateert van 16 januari 1633, zodat we mogen aannemen dat hij in de loop van 1632 is benoemd. ${ }^{1295}$ In het adres staat nog als verblijfplaats Eijsden opgegeven; daarna vestigde hij zich in Gronsveld. Vanaf het begin voerde hij de titel drossaard. De eerste akte waarin hij in de volle breedte zijn bevoegdheden ten toon spreidt, dateert uit 1636 en betreft de benoeming van Paulus Potmans tot koster van Heugem: 'Ich heer ende meester Christiaen Lamberts, der rechten licentiaet ende drossard der graeffschappe Gronsfelt, doen kondt ende eenen yegelijcken weeten hoe dat ich uyt crachte van de commissie mij gegeven bij den hooch ende

\footnotetext{
1291 Er zijn verschillende vermeldingen van een Hans Jacob van Huckelhoven vóór 1617 in het tegenwoordige Midden-Limburg. Een begin zeventiende-eeuws handschrift over het Landrecht van Thorn is, heeft een ex libris van Hans Jacob van Huyckelhoven, scholtis dero graeffschapt Horn' (Gemeentearchief Roermond, Oud-archief van de stad Roermond, inv. nr. 1922); in 1609 is Joannes Jacobus van Huckelhoven als getuige en 'goede vriend' aanwezig bij de verpachting van een hof te Offenbeek door de kruisheren te Roermond (RHCL, Klooster kruisheren Roermond, inv. nr. 133, fol. 118vo.-119); in 1608 en 1609 is hij leenman bij het leengerecht van het graafschap Horn (RHCL, Graafschap Horn, inv. nr. 74, fol. 451-452).

1292 De families van Odenhoven en Van Huckelhoven waren met elkaar verwant via de familie Van Heister.

1293 RHCL, Graafschap Gronsveld, inv. nr. 94.

1294 RHCL, Graafschap Gronsveld, inv. nr. 557.

1295 RHCL, Graafschap Gronsveld, inv. nr. 13.
} 
welgeboeren heeren Just Maximiliaen Graeve van Bronckhorst...etc. ${ }^{1296}$ Niet een echt bescheiden man!

Het geboortejaar van Christiaan moet liggen in het begin van de jaren negentig van de zestiende eeuw. De geboorteplaats is onbekend; in aanmerking komen Breust/Eijsden, maar ook het naburige Moelingen. Zijn broer Matthijs was daar later scholtis en schepen. ${ }^{2297}$ De familie Lamberts (de naam wordt verschillend gespeld) was in Eijsden/Moelingen tamelijk wijd vertakt. Ze stond bekend als kapitaalkrachtig en behoorde tot de bovenlaag van de bevolking. Christiaan huwde Johanna Donckert en uit deze verbintenis werden tenminste vijf kinderen geboren. ${ }^{1298}$

Net als de onduidelijkheid over het exacte begin van Christiaans loopbaan, is ook het precieze einde daarvan niet bekend. Zijn overlijden moet liggen tussen de laatste weken van 1668 en half maart 1669. ${ }^{1299}$ Volgens een akte van 15 november 1670, gepasseerd voor stadhouder en schepenen van Eijsden, liet hij drie erfgenamen na: zijn dochter Maria, gehuwd met Antonius Bemelmans, zijn zoon Egidius, advocaat bij de Raad van Brabant te Brussel en zijn gelijknamige zoon Christiaan, pastoor in Gronsveld. ${ }^{1300}$

Christiaan senior studeerde rechten, mogelijk in Leuven, en voerde na afsluiting van zijn studie de titel 'juris utriusque licentiatus' (licentiaat in zowel het kerkelijke als wereldlijke recht). Begin jaren twintig van de zestiende eeuw moet hij zijn benoemd tot griffier of secretaris van de schepenbank Eijsden. Waarschijnlijk verrichtte hij zijn werk tot ieders tevredenheid en dat gold zeker voor Arnold de Lamargelle, heer van Eijsden. In een ongedateerd concept van een soort 'bevorderingsvoorstel' valt te lezen dat De Lamargelle hem tot zijn 'agent' wilde benoemen, belast met de 'direction' van alle processen die hij voerde. Voorts werd hij benoemd tot permanent vervanger van de veelvuldig afwezige scholtis van Eijsden, met alle daaraan verbonden emolumenten. ${ }^{1301}$

Toch kon dit gunstbewijs Lamberts niet blijvend aan Eijsden binden en moet hij de overstap naar het ambt van drossaard van Gronsveld als een promotie hebben beschouwd. De aanvaarding van die functie betekende niet dat hij van zijn werk in Eijsden afstand deed. ${ }^{1302}$ In een verzoekschrift aan Margaretha van Bocholtz, de vrouwe van Eijsden, legde hij uit dat het 'somwijlen' moeilijk was in Eijsden aanwezig te zijn, zeker bij buitengewone, niet geplande zittingen van het gerecht. Daarom vroeg hij toestemming

\footnotetext{
1296 RHCL, Graafschap Gronsveld, inv. nr. 118.

1297 RHCL, Landen van Overmaze, inv. nr. 5329, akten van 28 april en 3 september 1641.

1298 Tossanus in 1617, Maria in 1618, NN in 1620 en de zonen Christiaan en Egidius op onbekende plaatsen en tijdstippen.

1299 Het laatste document waarin hij wordt genoemd betreft een akte van 18 december 1668, die voor hem en schepenen van Slenaken passeert (RHCL, Klooster Hoogcruts, inv. nr. 178). In een vonnis van schepenen van Rijckholt van 30 maart 1669 wordt gesproken over zijn erfgenamen (RHCL, De Bounam de Ryckholt, inv. nr. 681).

1300 RHCL, Landen van Overmaze, inv. nr. 5378. Egidius komt niet voor bij Nauwelaers, Histoire des avocats.

1301 RHCL, Landen van Overmaze, inv. nr. 4959.

1302 Voor de loopbaan van Lamberts in Eijsden en het einde daarvan zie RHCL, Landen van Overmaze, inv. nr. 4959.
} 
schepen Willem Mieckens 'in sijnen naeme' te belasten met het griffierschap en de oudste schepen het ambt van scholtis te laten waarnemen.

Het schrijverschap van Mieckens was geen lang leven beschoren en het werk werd door Lamberts, met toestemming van de heer van Eijsden, vanaf circa 1635 overgedragen aan Nicolaas Tosses. Ook dit bleek een ongelukkige keuze, want de man werd verdacht van financiële manipulaties. In het voorjaar van 1642 sprak Arnold de Lamargelle de drossaard aan op het feit dat het ambt van secretaris van Eijsden nog steeds voor onbepaalde tijd was uitbesteed aan Tosses. De heer van Eijsden verweet hem dat hij door zijn vertrek als griffier 'qualijck recognosceerde de weldaden die hij van den remonstrant $(=\mathrm{De}$ Lamargelle) hadde ontfangen.' Lamberts antwoordde publiekelijk 'met tselve griffierschap nyet van doen te hebben ende dat hij hetselve wederom stelde in handen ende ter dispositie des remonstrants (i.e. De Lamargelle)'. Deze stekelige conversatie kende echter een heel andere achtergrond dan alleen de bezetting van het ambt van griffier en had alles te maken met de zakelijke belangen van Lamberts in Eijsden. Lamberts had in ruil voor een lening van tienduizend gulden aan Eijsden het gebruiksrecht gekregen van veertien bunder Eijsdense gemeentegrond, het Broek genaamd. ${ }^{1303}$ Arnold de Lamargelle wenste zich niet bij deze transactie neer te leggen omdat hij meende oudere rechten op deze gemeentegrond te hebben. Deze kwestie, waaruit blijkt dat Lamberts stevig in partijstrijd in Eijsden verwikkeld was, leidde tot pesterijen en langdurige processen bij de Raad van Brabant in Brussel. Uiteindelijk hield Lamberts zijn veertien bunder gemeentegrond. $\mathrm{Na}$ zijn overlijden verkochten in 1670 zijn erfgenamen hun rechten op het Eijsder Broek aan Johan Pesters, luitenant-stadhouder en voogd van het Land van Valkenburg en zijn echtgenote Maria Ghijsen. ${ }^{1304}$

Hoewel drossaard Lamberts in Gronsveld een lange staat van dienst heeft, is buiten het routinematig werk bij de schepenbank, betrekkelijk weinig bekend over zijn activiteiten. Vanaf 1638 treedt hij ook op als stadhouder van het Gronsvelds leenhof. Nadat graaf Jost Maximiliaan van Bronckhorst de pandsom van de heerlijkheid Slenaken in 1658 had ingelost, werd Lamberts daar als scholtis bij de schepenbank aangesteld ${ }^{1305}$ en verscheen hij er met enige regelmaat, overigens meestal met de titel drossaard.

Lamberts moet het niet gemakkelijk hebben gehad in een tijd dat het graafschap gebukt ging onder oorlogshandelingen en overlast van soldaten. Als voorbeeld van de ellende kunnen hier worden aangehaald de plunderingen van de kerk van Gronsveld in 1642, 1643 en 1652 door achtereenvolgens Hessische soldaten, soldaten van het garnizoen van Aken en Lotharingse troepen. In 1643 bezette en plunderde ritmeester Cauwenberch met zeventig man het kasteel en terroriseerde de omgeving. (zie Hoofdstuk 4.1.7) De drossaard schoot uit eigen middelen 1600 gulden voor om de druk op de financieel uitgeperste bevolking enigszins te verlichten.

\footnotetext{
1303 Voor deze geschillen over het Broek zie RHCL, Landen van Overmaze, inv. nr. 5376.

1304 RHCL, Landen van Overmaze, inv. nr. 5378.

1305 RHCL, Graafschap Gronsveld, inv. 581, besluit van graaf Jost Maximiliaan van Bronckhorst van 3
} november 1658. 
Maar het was niet alleen de oorlog die het leven moeilijk maakte. Vanaf 1660 had Jost Maximiliaan van Bronckhorst een goede relatie opgebouwd met de jonge, ambitieuze jurist Wilhelm Veucht, die als 'Gräflich Gronsfeldischer Rhat' de graaf bijstond bij diens politieke activiteiten binnen het Rijk. ${ }^{1306} \mathrm{Na}$ het overlijden van Jost Maximiliaan in $1662 \mathrm{kreeg}$ Veucht als steun en toeverlaat van de gravin-weduwe en haar kinderen grote invloed in het graafschap. Veucht behoorde duidelijk tot een andere generatie dan Lamberts en had waarschijnlijk weinig op met de zittende machthebbers in Gronsveld. In 1667, twee jaar voor het overlijden van Lamberts en twee jaar voor de taakbeëindiging van rentmeester en gerechtsgriffier Lambert Lousberchs ${ }^{1307}$, schreef Veucht aan de gravin over de invulling van de ontstane en de te verwachten vacatures:

Wohl würden Ew[er] Ex[cellenz]. thun das Sie einen bequemen man zum drost und rentmeisters dienst befürderten, und wider einen anderen der die secretariat beij Ew[er]

Ex[cellenz] und beij den Gerichteren vertrette: besser zweij bequeme leuth als 25 lappen. ${ }^{1308}$

Met de 'lappen' of vodden moet Veucht drossaard Lamberts voor ogen hebben gehad. Diens laatste jaren brachten inderdaad weinig vreugde. Zo was de verhouding met de scholtis van het aangrenzende Rijkckholt wegens rechtszaken over onbetaalde rekeningen gespannen. ${ }^{1309}$ Waarschijnlijk waren er ook problemen rond de financiële verantwoording van zijn beheer. In een inventaris van het Gronsveldse kasteelarchief uit 1717 wordt gesproken over een (niet meer aanwezig) proces van de graaf tegen drossaard Lamberts over zijn beheer ('puncti administrationis'). ${ }^{1310}$

Een dieptepunt moet voor de oude man zijn geweest het gedrag van zijn zoon Christiaan, de pastoor van Gronsveld. Het einde van dit drama hoefde hij niet meer mee te maken, maar het begin was al pijnlijk genoeg. Pastoor Lamberts raakte in 1665 ernstig in opspraak wegens relaties met verschillende vrouwen en het laten plegen van abortus. Hij zou dus gerechtelijk moeten worden vervolgd en wel door zijn vader, de drossaard. Of dat ook gebeurde is niet bekend. Vooralsnog schijnt de pastoor op vrije voeten te zijn gebleven. Maar in 1670, vader Lamberts was inmiddels overleden, ging het weer mis en leek de pastoor helemaal dolgedraaid (zie hierover Hoofdstuk 15.20.2).

\subsection{Rentmeesters, $1628-1667$}

De gegevens over rentmeesters gedurende het midden van de zeventiende eeuw zijn erg schaars. De omstreeks 1628 afgetreden Van Huckelhoven opgevolgd door Jan Hanssen.

\footnotetext{
1306 Weinberg, 'Wilhelm Veucht'.

1307 De grafsteen van 'Lambericht Lvvsberchs' overleden 21 september 1679, bevindt zich op het kerkhof van de Sint-Martinuskerk van Gronsveld, zie Belonje, 'genealogische en heraldische gedenkwaardigheden', 85 .

1308 Weinberg, 'Wilhelm Veucht', 94.

1309 RHCL, De Bounam de Ryckholt, inv. nr. 681.

1310 TJ, inv. nr. M 2, fol. 494.
} 
Hij wordt als zodanig genoemd in 1631, 1638, 16391311 en $1642 .{ }^{1312}$ Tot 1644 komt hij nog voor als leenman in het Gronsveldse leenhof. Wanneer hij zijn functie precies beëindigde, is niet helemaal duidelijk. Er staat weliswaar nog voor 1643 een betaling door hem genoteerd, maar in een inventaris van de archieven in het kasteel van Gronsveld worden al rekeningen genoemd van zijn opvolger Lambert Lousberch uit 1642, 1643 en 1644. ${ }^{1313}$ Mogelijk is er sprake geweest van afbouw wegens ziekte of ouderdom.

Hanssen werd, zoals vermeld, opgevolgd door Lambert Lousberch. Deze wordt in 1638 genoemd als notaris ${ }^{1314}$ en was tenminste al vanaf 1641 secretaris van de schepenbank Heugem. Deze combinatie van de functies van secretaris en rentmeester bleef bestaan tot zijn overlijden omstreeks $1667 .{ }^{1315}$ Als secretaris van de schepenbanken werd hij toen opgevolgd door zijn zoon, eveneens Lambert geheten. Het is onduidelijk wie de taak van rentmeester overnam. $\mathrm{Na}$ de dood van drossaard Lamberts rond de jaarwisseling 1668/1669 wilde gravin Anna Christina, ook op aandrang van haar raadsman Veucht, veranderingen. Bovendien was Lambert Lousberch jr. nog erg jong (begin twintig). Mogelijk bleef de post daarom enkele jaren formeel onbezet en werd het werk waargenomen, totdat drossaard Willem Kicken in 1676 als rentmeester werd benoemd. Uiteindelijk zou Lousberch op latere leeftijd, tussen 1710 en 1714, toch nog rentmeester worden, mogelijk om de taak te verlichten van drossaard Kicken, die tot dan toe ook rentmeester was geweest. ${ }^{1316}$

\subsection{Wilhelm Veucht, juridisch adviseur 1660-1694}

Als juridisch adviseur en later appelcommissaris lijkt Wilhelm Veucht in Gronsveld de eerste representant van een nieuw soort functionarissen in grafelijke dienst, namelijk juridisch geschoolde raadslieden, die incidenteel bijzondere opdrachten als commissaris vervulden en processen in hoger beroep afhandelden. Die positie kon zeer invloedrijk zijn. Wilhelm Veucht begon zijn loopbaan als juridisch adviseur in Gronsveldse dienst omstreeks 1660; hij moet in de tweede helft van 1694 zijn overleden. Aan zijn leven en loopbaan is recentelijk door Weinberg een biografische schets gewijd en op diens bevindingen steunt de hierna volgende samenvatting. ${ }^{1317}$ De geboorteplaats van Veucht is onbekend. Mogelijk stamde hij uit een van de dorpen van de baronie Wittem. Aan zowel

\footnotetext{
1311 TJ, inv. nr. M 10, fol. 459 463: Volgens een overzicht van jaarlijkse betalingen door de rentmeester aan de rector van het zogenoemde Happartbeneficie in de Sint-Martinuskerk te Maastricht-Wyck werd in 1631, 1638 en 1639 geld ontvangen van Jan Hanssen als rentmeester, in 1640 en 1641 van de dochter van Jan Hanssen en in 1643 weer van Hanssen als rentmeester.

1312 RHCL, Rijkskamergerecht, inv. nr. 77, fol. 42-43, uittreksel uit de rekening van Jan Hanssen. De laatste betaling is van 6 oktober 1642 .

1313 TJ, inv. nr. M 2, fol. 494, inventarisatie van het archief 27 juli 1717.

1314 RHCL, Graafschap Gronsveld, inv. nr. 359.

1315 In 1664 was hij nog secretaris van Heugem (RHCL, Graafschap Gronsveld, inv. nr. 275). Zie verder RHCL, Graafschap Gronsveld, inv. nr. 420. In deze akte van 25 november 1668 wordt gesproken over erfgenamen.

1316 RHCL, Graafschap Gronsveld, inv. nr. 95.

1317 Weinberg, 'Wilhelm Veucht'.
} 
vaders- als moederszijde had hij familieleden die op de een of andere manier betrokken waren bij juridisch werk. Wilhelm studeerde zelf kerkelijk en wereldlijk recht en behaalde daarin de graad van licentiaat. Hij huwde in 1655 in Maastricht met Maria Graven, eveneens afkomstig uit een juristenmilieu. Haar broer Dionysius Graven was licentiaat in de rechten en vele jaren schepen in Maastricht.

In die tijd begon Veuchts carrière. Hij werkte in 1654 als syndicus of juridisch vertegenwoordiger van de abt van Cornelimünster en was van 1655-1657 tijdelijk drossaard van de heerlijkheid Wittem en vanaf 1657 daar ook rentmeester. Verder verrichtte hij ook voor Wittem werkzaamheden in Brussel, Bonn en Düsseldorf. Vanaf 1660 assisteerde hij graaf Jost Maximiliaan van Bronckhorst Batenburg bij diens diplomatiek werk. Op die manier raakte hij betrokken bij diverse belangrijke dossiers, zoals de inbreuken door de steden Amsterdam en Hamburg op het postmonopolie van graaf Turn und Taxis binnen het Duitse Rijk, de vertegenwoordiging van Gronsveld binnen het Nederrijns-Westfaalse Gravencollege en de geschillen tussen Gronsveld en de Maastrichtse burgers die weigerden belasting te betalen over hun grondbezit in het graafschap.

$\mathrm{Na}$ het overlijden van Jost Maximiliaan in 1662 werd Veucht steun en toeverlaat van gravin Anna Christina. Hij probeerde de zakelijke en juridische belangen van de gravin zo goed als hij kon te behartigen. Zo vertegenwoordigde hij Gronsveld op de bijeenkomsten van de kreits en keek hij uit naar carrièremogelijkheden voor de kinderen. Mogelijk was hij ook betrokken bij de invoering van het Gronsveldse landrecht in 1671.

Rond 1672 moest Veucht bemiddelend optreden in een crisis binnen de grafelijke familie omdat Johan Frans van Bronckhorst Batenburg probeerde achter de rug van zijn moeder om het Bronckhorster aandeel in het graafschap Eberstein te verkopen. Uiteindelijk werd in 1673 een compromis bereikt, met als resultaat toch de verkoop van Eberstein, de beëindiging van de voogdij over Johan Frans en de overdracht van de regering aan hem.

Ook graaf Johan Frans van Bronckhorst Batenburg bleef gebruik maken van de diensten van Willem Veucht. Mogelijk heeft de jurist een rol gespeeld bij de totstandkoming van het huwelijk van de Gronsveldse graaf met gravin Eleonore Philippine von Fürstenberg in 1677. Veucht kende de zeer invloedrijke Fürstenbergs vanuit zijn eerdere diplomatieke contacten. Een ander belangriik thema betrof de deelname aan de kreitsdag van 1681. Daar moest de raadsman zich inzetten voor drie zaken: een correcte bijdrage van Gronsveld in de lasten van de kreits, pogingen om graaf Johan Frans een financieel aantrekkelijke militaire betrekking te krijgen (wat mislukte) en ten derde de verdediging van de rijksonmiddellijke status van Slenaken tegen aanspraken van de regering van de Spaanse Zuidelijke Nederlanden. Op zich kreeg hij voor dit laatste de steun van de kreits, maar het conflict dreigde vervolgens zonder oplossing te verzanden. Uiteindelijk wist Veucht ook hier in 1684 een compromis te bereiken.

Wilhelm Veucht gebruikte zijn positie ook om familieleden bepaalde functies toe te schuiven. Zijn neef Willem Kicken werd scholtis van Gronsveld en kreeg later een bevordering tot drossaard. Een andere neef, Johannes Graven, was notaris en schepen te Gronsveld en secretaris van de schepenbank Slenaken. Diens zoon Johannes Ludovicus 
Graven was eveneens notaris te Gronsveld. Willem van Hoven, gehuwd met Veuchts nicht Anna Elisabeth Kicken, was in 1670 secretaris van de gravin van Gronsveld. Een dochter van dit echtpaar was weer gehuwd met de al genoemde Johannes Ludovicus Graven. Deze familiepolitiek werd door rechtzoekenden met scheve ogen bekeken. Een voorbeeld daarvan treffen we aan in de 'corte deductie' die de advocaat van Johan Lindeloof in 1677 bij het leenhof van Gronsveld indiende in lang slepend proces tegen de abdij Sinnich. ${ }^{1318}$ Het leenhof had in die zaak een bepaalde kwestie ter afdoening overgelaten aan 'commissaris' Veucht. Lindeloof voelde zich onrechtvaardig behandeld door Veucht 'als commissaris in bijweesen sijnen neeve s[injeu]r. Kicken'. Verderop klaagde hij 'dat heer Kicken over het vonnisse metten licentiaet Vught geseeten heeft had overlegd] ende dyen oock is suspect [bevoordeeld] te houden'.

Behalve aan zijn familie dacht Veucht ook aan eigen belangen en status. In 1674 bewilligde de keizer in zijn verzoek tot verheffing in de adelstand. Hij werd vooral wegens zijn verdiensten ten tijde van graaf Jost Maximiliaan van Bronckhorst Batenburg opgenomen in de ridderstand en kreeg ook het 'Palatinat', de bevoegdheid binnen het Rijk notarissen te benoemen en academische graden te verlenen. Voorts was hij als ridder vrij van plaatselijke belastingen en stond hij onder protectie van de keizer.

Een belangrijke rol speelde Veucht na 1680 in het conflict tussen de schepenbanken van het graafschap Gronsveld en de Schepenstoel van de stad Aken over het hoger beroep van Gronsveld op Aken. Tenminste vanaf 1684 vervulde Veucht zelf de functie van appelcommissaris. (zie over deze kwestie uitvoeriger Hoofdstuk 9.9.3). Veucht kwam daarmee in juridisch mijnenveld terecht. Hij had persoonlijke belangen vanwege zijn functie alsmede vanwege processen waarin hijzelf partij was. Anderzijds diende hij als burger van Aken loyaal te zijn aan deze stad. Toen na 1690 het conflict tussen Aken en Gronsveld dreigde te escaleren met represailles van Akense zijde tegen Gronsveldenaren, kwam Veucht in een benarde positie. Met tijd rekken en ontwijkende antwoorden probeerde hij tussen de klippen door te laveren, wat tot aan zijn overlijden in 1694 ook aardig schijnt te zijn gelukt. Intussen had Veucht in de laatste jaren in Gronsveld een sterke machtspositie opgebouwd. Het grafelijk gezag was door het buitenlands verblijf van Johan Frans van Bronckhorst Batenburg zwak, terwijl Veuchts neef Willem Kicken als drossaard en rentmeester alle touwtjes in handen had.

\subsection{Engelbert Rippegard, scholtis, 1670-1671(?)}

$\mathrm{Na}$ het overlijden van drossaard Lamberts begin 1669 en het debacle rond diens zoon kwam een einde aan de invloed van de familie Lamberts in Gronsveld. De voorkeur van gravin Anna Christina von Hardenrath voor een scholtis of drossaard uit de directe omgeving van Gronsveld zal enigszins zijn bekoeld. De functie van drossaard werd opgevuld door een zekere Engelbert Rippegard, die echter alleen de titel scholtis voerde.

1318 RHCL, Graafschap Gronsveld, inv. nr. 276. 
Afgaande op de naam moet hij een vreemdeling zijn. Hij wordt in Gronsveld vermeld van medio 1670 tot herfst $1672 . .^{1319}$ Rippegard heeft dus waarschijnlijk twee tot drie jaar gewerkt en zijn ambtsperiode zou niet meer dan een voetnoot zijn geweest, ware het niet dat een mededeling uit veel later tijd hem misschien toch een bijzondere betekenis voor Gronsveld geeft. Bij de bespreking van de Gronsveldse Rechtsordnung uit 1671 kwam al aan de orde dat Prummer in 1755 scholtis Rippegard hield voor (één van de) auteur(s) daarvan. ${ }^{1320}$

\subsection{Willem Kicken, scholtis, drossaard en rentmeester, 1676-1720}

Rippegard werd opgevolgd door een zekere 'doctoer Wyer', die slechts zeer korte tijd in Gronsveld moet zijn gebleven en waarover verder niets bekend is. ${ }^{1321}$ Daarna trad in de persoon van Willem Kicken wederom een scholtis aan met een zeer lange ambtsperiode. Uit stukken van een proces dat hij in de jaren1721-1724 voerde tegen de gravin zu Toerrring Jettenbach en haar echtgenoot de graaf d'Arberg Valengin over de afrekening van zijn beheer als rentmeester, kunnen we afleiden dat hij omstreeks 1645 is geboren ${ }^{1322}$, waarschijnlijk in Mechelen of Epen (baronie Wittem) als zoon van Johan Kicken en Catharina Veucht. De jonge Kicken studeerde rechten en behaalde daarin de graad van licentiaat, maar het is niet bekend aan welke universiteit hij zijn opleiding kreeg. Waarschijnlijk is hij na zijn studie in Gronsveld geïntroduceerd door zijn oom van moederszijde, Wilhelm Veucht.

Op 14 april 1676 verklaarde graaf Johan Frans van Bronckhorst in een Latijnse akte dat Willem Kicken hem al jaren trouw en deskundig had gediend en dat hij om die reden in Gronsveld en Slenaken werd benoemd tot locum tenentem, praetorem et receptorem nostri comitatus Gronsfeldensis ac dominii nostri in Schlenaecken necnon in secretarium curiae nostrae feudalis ', dus 'plaatsvervanger' (stadhouder), 'rechter' (scholtis) en 'ontvanger' (rentmeester) van Gronsveld en Slenaken alsmede secretaris van het leenhof. ${ }^{1323}$ Later schreef Kicken dat die eerdere trouwe dienst had bestaan uit tien jaar gratis werk voor de grafelijke familie. ${ }^{1324}$

1319 In 1670 was hij als schepen anwezig bij een getuigenverhoor over de misdragingen van pastoor Christiaan Lamberts (TJ, inv. nr. M 10, fol. 23-25, verhoor van 8 juli 1670). In 1671 treedt hij op als stadhouder van het leenhof. Op 18 oktober 1672 zat hij als scholtis het voogdgeding in Gronsveld voor (RHCL, Graafschap Gronsveld, inv. nr. 671). Bij inventarisatie van archieven in het kasteel in 1717 werd ook een bundel papieren aangetroffen betreffende 'Rippegard und andere rechnung' (TJ, inv. nr. M 12, fol. $630 \mathrm{sub}$ 49).

1320 TJ, inv. nr. M 13, fol. 13-24, Prummer aan graaf 9 november 1755.

1321 RHCL, Graafschap Gronsveld, inv. nr. 369, getuigenverhoor voor 'doctoer Wyer' als 'richter' en twee schepenen in 1675; ook vermeld in Graafschap Gronsveld, inv. nr. 411, ongedateerde boedelscheiding tussen de erfgenamen van Jan Lousberch en Amelia Neffs.

1322 RHCL, Rijkskamergerecht, inv. nr. 114. In 1722 wordt vermeld dat hij ongeveer 77 jaar is.

${ }^{1323}$ RHCL, Rijkskamergerecht, inv. nr. 114, fol. 25.

${ }^{1324}$ Die mededeling kan in beginsel juist zijn. Er is een zogenoemde 'beschrijfbrief' uit 1664 bewaard van een proces dat na de eerste aanleg voor de schepenbank van Honthem in hoger beroep werd voortgezet voor de schepenbank van Heugem.(RHCL, Graafschap Gronsveld, inv. nr. 275). Het stuk is getekend door secretaris Lousberchs, maar is geschreven in het karakteristieke handschrift van Kicken. 
In de loop der jaren rees de ster van Kicken. Op 16 juni 1683 kende graaf Johan Frans hem een salarisverhoging toe van honderd gulden en verleende hem opnieuw het stadhouderschap van het leenhof met alle bijbehorende emolumenten. ${ }^{1325}$ Of Kicken daarmee ook zijn functie als secretaris van het Gronsveldse leenhof opgaf, is niet duidelijk. Het leenhof lijkt in die tijd geen aparte secretaris te hebben gehad. Misschien werden de inschrijvingen verricht door de stadhouder zelf of één van de leenmannen.

Vervolgens gaf op 3 november 1683 gravin Eleonore Philippine von Fürstenberg, de echtgenote van Johan Frans van Bronckhorst, aan de scholtis alle volmachten om namens haar de heerlijkheid Slenaken te besturen.1326 De gravin bereidde zich voor op vertrek naar haar echtgenoot die op dat moment in het keizerlijk leger tegen de Turken vocht en het was onzeker of en wanneer zij en de graaf zouden terugkeren. De oorlog liep echter goed af voor Johan Frans en Kicken verrichtte zijn werk naar volle tevredenheid. Daarom verleende de graaf hem op 11 mei 1685 de gunst voortaan de titel 'drossaard' in plaats van 'scholtis' te mogen voeren. ${ }^{1327}$

Uit het schriftelijk materiaal dat van Kickens activiteiten bewaard is gebleven, krijgt men de indruk dat hij een druk bezet man was, die zijn tijd vooral besteedde aan zijn taak als rentmeester. Er ging veel geld door zijn handen. Een extract uit zijn afrekening voor de jaren 1676 tot en met 1683 geeft een totaal aan inkomsten van 31.477 gulden en aan uitgaven 30.854 gulden. ${ }^{1328}$ Ook inkwartiering van en leveranties aan militairen veroorzaakten veel werk en zorg. Tijdens de Negenjarige Oorlog (1688-1697) ging Gronsveld zwaar gebukt onder bijdragen aan de Nederrijns-Westfaalse Kreits, de inkwartiering van Brandenburgse troepen en de levering van grote hoeveelheden foerage aan het Franse leger.

De volgende krachtproef voor Kicken vormden de jaren van de Spaanse Successieoorlog van 1702-1713. Formeel was dit een rijksoorlog en dus raakte Gronsveld als rijksgebied en lid van de Nederrijns-Westfaalse Kreits bij het conflict betrokken. Voor de bevolking betekende het wederom een grote financiële last. Met gevaar voor eigen leven zette Kicken zich dag en nacht in voor de belangen van het graafschap en de graaf. Dat verklaarden althans burgemeesters, oud-burgemeesters, enkele schepenen en vooraanstaande inwoners van Gronsveld in 1719.1329 Maar er vielen ook andere geluiden te beluisteren. In 1709 klaagden inwoners van Gronsveld bij graaf Johan Frans over zware schattingen, terwijl van die belastingopbrengsten geen rekening en verantwoording werd afgelegd. Twintig jaar eerder (dus ten tijde van de Negenjarige Oorlog) had men honderd dukaten opgebracht voor een akkoord met de Fransen over de oorlogscontributie. Het geld was in handen van de secretaris gesteld, die had veertien dagen niets gedaan en toen staken de Fransen vier huizen in brand. Het geld was nog steeds verdwenen. Let wel, het verwijt betrof de secretaris, maar het is nauwelijks denkbaar dat de drossaard er niet bij betrokken was. Er waren ook allerlei vrachtdiensten voor het leger verricht, waarvoor wel

1325 RHCL, Rijkskamergerecht, inv. nr. 114, fol. 85.

1326 RHCL, Graafschap Gronsveld, inv. nr. 462.

1327 RHCL, Rijkskamergerecht, inv. nr. 114, fol. 87-87vo.

1328 RHCL, Rijkskamergerecht, inv. nr. 114, fol. 27-28.

${ }^{1329}$ RHCL, Rijkskamergerecht, inv. nr. 114, fol. 93-94. 
betaling was beloofd, maar niets uitgekeerd. Toen in 1717 de rekeningen van de schatheffers werden gecontroleerd, bleken die een achterstand te hebben van 12.300 gulden, waar nog 11.260 gulden bij moest worden opgeteld aan belastingschuld van Maastrichtenaren die in Gronsveld landerijen bezaten. Ook voor dit financieel beheer moet de drossaard mede verantwoordelijk zijn geweest. ${ }^{1330}$

Rond 1710 deed Kicken een stap terug. Zijn werkzaamheden als rentmeester werden tenminste voor de periode 1710-1714 (gedeeltelijk?) overgenomen door Lambrecht Lousberch, de secretaris van de schepenbank. ${ }^{1331} \mathrm{Na} 1715$ hernam Kicken weer zijn werk als rentmeester. In 1710 moet hij ook zijn afgetreden als stadhouder van het grafelijk leenhof, want in dat jaar benoemde graaf Johan Frans baron Willem Adolf van Eys genaamd Beusdael, heer van Vaalsbroek, tot erfstadhouder. ${ }^{1332}$ De overdracht schijnt zonder problemen te zijn verlopen en Kicken bleef nog wel als leenman bij zittingen aanwezig.

Kicken groeide dus in de loop der jaren uit tot een machtig man in het graafschap. Vanaf de jaren negentig woonde hij ook in het kasteel, wat zijn status nog verhoogde. Maar als zelfbenoemde onderkoning maakte hij ook vijanden. Graaf Johan Frans van Bronckhorst Batenburg hield tot zijn levenseinde vertrouwen in Kicken, maar vlak voor diens overlijden leken ook bij hem twijfels te ontstaan. Waarschijnlijk begin 1718 beklaagde de drossaard zich wegens zijn gevorderde leeftijd over de steeds zwaardere lasten van zijn ambt en vroeg hij om een assistent. Op 21 maart 1718 antwoordde de graaf dat hij inderdaad iemand gevonden had 'welcher die drey erforderte sprachen besitzet, ein jurist und practicus, ein mensch wohl possessionirt'. Aan het einde van de brief wordt de toon wat dreigender, want de man moest helpen veranderingen door te voeren 'ursach dass der jetzige fuess mir gar nicht gefalt und drehet nicht $\mathrm{zu}$ meinem vortheil und interesse'. ${ }^{1333}$ Dat het financieel beheer inderdaad moeizamer werd blijkt ook uit bewaard gebleven rekeningen van Kicken als rentmeester over de jaren 1704-1718.1334 Deze maken een slordige indruk met veel doorhalingen en soms foutieve berekeningen. Het is dan ook niet vreemd dat daar na zijn pensionering in 1719 een groot proces over ontstond.

Wellicht was de assistent waarover de graaf sprak een zekere luitenant Olislagers, die als luitenant in het keizerlijk leger onder Johan Frans had gediend. Vanaf omstreeks 1719 tot 1722 treedt iemand met deze naam in Gronsveld op die zich 'officier' (feitelijk dus

\footnotetext{
1330 RHCL, Rijkskamergerecht, inv. nr. 71/2, fol. 311-314.

1331 RHCL, Graafschap Gronsveld, inv. nr. 95.

1332 TJ, inv. nr. M 14, fol. 218-219. Willem Adolf van Eys genaamd Beusdael, geboren circa 1645, overleden 1729, heer van Zweibrüggen, schepen van Aken 1672-1729, zie over hem uitvoeriger: Von Coels von der Brügghen, 'Die Schöffen des Königlichen Stuhls', 408-411.

1333 RHCL, Rijkskamergerecht, inv. nr. 114, fol. 89.

1334 TJ, inv. nr. M 64, rekeningen rentmeester Kicken 1704, 1707, 1710, 1713, 1715, 1717, 1718.
} 
scholtis) noemt. 1335 Tussen hem en de nieuwe drossaard Johannes Godefridus Lebens boterde het volstrekt niet. ${ }^{1336}$

In 1719 overleed Johan Frans van Bronckhorst Batenburg in Luxemburg en ontbrandde de strijd over de erfenis tussen zijn echtgenote Maria Anna gravin von ToerringJettenbach en zijn zuster Clara Sibilla, weduwe van de in 1688 gesneuvelde graaf Henri Philippe de Ligneville. Van die strijd werd drossaard Kicken uiteindelijk min of meer slachtoffer. Hij schijnt geen uitgesproken tegenstander van gravin Toerring-Jettenbach te zijn geweest, maar had wel vijanden, die tot haar kamp behoorden. Kicken noemt later de secretaris van de schepenbank, Johannes Godefridus Lebens, zijn 'Hauptfeind'. De oorzaak daarvan lag - onder andere - in een conflict over een stuk grond, dat zich begin 1716 afspeelde tussen Lebens en Johannes Ludovicus Graven, schepen van Gronsveld, secretaris van Slenaken en (al wat verder) familie van Kicken. Lebens had toen moedwillig een paard van Graven neergeschoten en daarmee een groot schandaal veroorzaakt. Kicken en de stadhouder van het leenhof Willem Adolf van Eys genaamd Beusdael schorsten daarop Lebens uit zijn ambt. Hoe de zaak eindigde is niet bekend, maar het was duidelijk dat Lebens wrok koesterde. Hij vond medestanders in de grafelijke 'commissarissen' Petit, de Witte en Olislagers. Dit drietal (waarover hierna meer) had graaf Johan Frans van Bronckhorst Batenburg en zijn echtgenote al eerder als raadsman bijgestaan.

Nadat gravin Maria Anna von Toerring-Jettenbach eind maart en begin april 1719 bezit had genomen van het graafschap, kreeg Kicken in september 1719 huisarrest. Hij mocht zijn woonruimte in het kasteel niet verlaten en contacten met de buitenwereld werden beperkt. Deze maatregel moet zijn goedgekeurd door de gravin, maar als echte aanstichters wees Kicken later Lebens, Petit, De Witte en Olislagers aan. Van het huisarrest van Kicken, dat meer dan een jaar duurde, bestaan twee versies. Kicken beklaagde zich naderhand bij het Rijkskamergerecht over het hem aangedane zware onrecht en de verklaringen die hem, een oude man, zouden zijn afgeperst. Zijn tegenpartij tilde aan dit alles niet zo zwaar. De drossaard genoot bewegingsvrijheid binnen het kasteel en in de tuinen en dineerde met de commissarissen van de gravin. Bovendien was het logisch dat men in die tijd de poort van het kasteel gesloten hield, 'da die gronsfeldische graffschafft in zertheilung war wegen der rebellen welche die frau von Ligneville umb da von besitz zu nehmen haben hinein führen wollen'. ${ }^{1337}$

De beschuldigingen aan het adres van Kicken spitsten zich toe op twee punten. Hij zou gelden uit de grafelijke kas hebben verduisterd en onder andere naam bij diverse personen hebben belegd. Verder had hij sinds 1682 geen rekening en verantwoording meer afgelegd van zijn financieel beheer als rentmeester. De drossaard verweerde zich op alle mogelijke manieren. Om zijn geloofwaardigheid te vergroten, gaven op 10 november 1719 twee

$1335 \mathrm{Hij}$ is bijvoorbeeld aanwezig bij de inhuldiging van graaf en gravin d'Arberg Valengin en van hem zijn er ook brieven uit 1721 aan de graaf d'Arberg Valengin (TJ, inv. nr. M 8, fol. 289-300) waaruit blijkt dat hij zich als 'officier' gedroeg. Op 15 maart 1721 (fol. 294) schrijft hij dat hij lange tijd in het gevolg is geweest van graaf Johan Frans.

1336 TJ, inv. nr. M 8, fol. 291: 'Le drossard ecrira sans doute beaucoup des choses contre moi'.

${ }^{1337}$ RHCL, Rijkskamergerecht, inv. nr. 114, fol. 47. 
burgemeesters, twee oud-burgemeesters, de pastoor van Heugem, twee schepenen en vier vooraanstaande inwoners een verklaring af waarin zij de bejaarde drossaard complimenteerden met zijn onberispelijke staat van dienst, zijn inzet en het feit dat hij zich nooit had laten corrumperen. ${ }^{1338}$ Natuurlijk was deze adhesiebetuiging welkom, maar het is opvallend dat ook namen ontbreken, zoals die van de pastoor van Gronsveld en van andere schepenen. Een gevolg van de partijstrijd of angst voor represailles?

Het verwijt van verduistering wierp Kicken ver van zich af en hij meende de rechtmatigheid van alle beleggingen te kunnen aantonen. Op zijn beurt beschuldigde hij zijn belagers van diefstal van geld en frauduleus handelen. Voorts bestreed Kicken dat hij nooit rekenschap van zijn beheer als rentmeester had afgelegd. Van 1676 tot 1683 waren zijn rekeningen goedgekeurd, daarna had hij geprobeerd bij de op veldtocht zijnde graaf goedkeuring te krijgen, maar dat was niet gelukt. Kicken voerde aan dat hij het graafschap altijd had bestuurd overeenkomstig de wens van de graaf, dat hij bevorderd was en salarisverhoging had gekregen. Zijn rekeningen tot 1693 had hij bij afwezigheid van graaf Johan Frans in handen gegeven van diens broer, bisschop Otto van Bronckhorst, en daarna waren deze stukken in het archief gedeponeerd. De rekeningen van 1693 tot 1709 waren nagekeken door gedeputeerden van de graaf en daarna aan het archief toegevoegd. ${ }^{1339}$ Over de rekeningen na dat jaar wordt niet gesproken. Het is niet duidelijk in hoeverre Kicken daar volledig verantwoordelijk voor was, aangezien van 1710 tot en met 1714 de functie van rentmeester feitelijk werd uitgeoefend door Lambert Lousberchs. ${ }^{1340}$ Feit is wel dat zich nu nog in het archief rekeningen bevinden van Kicken over de jaren 1704, 1707 en 1718 en dat de rekeningen van 1710 en 1713 in het handschrift van Lousberchs zijn. Met uitzondering van één rekening van Lousberchs, draagt echter geen enkel exemplaar de handtekeningen van goedkeuring.

Er was dus het een ander mis met het financieel beheer van Kicken, maar het blijft de vraag of alle aantijgingen helemaal terecht waren. Geen uitweg meer ziende, zwichtte Kicken uiteindelijk door de dreiging van gevangenis. Hij tekende, om van alles af te zijn, op 2 september 1720 de hem voorgelegde akte met een vergelijk over zijn schulden. ${ }^{1341}$ Later beweerden Kickens belagers dat hem bedenktijd was gegeven, maar dat ontkende de drossaard. Het is niet bekend wanneer Kicken zijn functies precies beëindigde. Op 2 september 1720 wordt hij nog drossaard genoemd. Volgens de benoemingsbrieven van zijn opvolgers als drossaard in Gronsveld en griffier van het Gronsveldse leenhof, die de graaf d'Arberg Valengin uitvaardigde op 20 november 1720, deed Kicken 'vrijwillig afstand' van al zijn vroegere functies. ${ }^{1342}$

Uiteindelijk werd Kicken vrijgelaten en wendde hij zich op 1 oktober 1721 tot het Rijkskamergerecht in Wetzlar om deze onder dwang afgegeven schuldbekentenissen nietig

\footnotetext{
1338 RHCL, Rijkskamergerecht, inv. nr. 114, fol. 93-94.

1339 RHCL, Rijkskamergerecht, inv. nr. 114, fol. 91.

1340 RHCL, Graafschap Gronsveld, inv. nr. 95. De afrekening met Lousberchs over de jaren 1710-1714 vond plaats in 1720 .

${ }^{1341}$ RHCL, Rijkskamergerecht, inv. nr. 114, fol. 58

1342 RHCL, Rijkskamergerecht, inv. nr. 71/1, fol. 266 en 548.
} 
te laten verklaren. ${ }^{1343}$ Aanvankelijk achtte het gerecht zich niet bevoegd. Pas nadat Kicken annemelijk had gemaakt dat voor hem in Gronsveld geen recht viel te verwachten in een proces tegen de graaf en gravin d'Arberg Valengin, waren de rechters bereid de zaak aan te nemen. In de procedure die tot medio 1722 liep, gaven partijen hun visie op de feiten ongeveer in overeenstemming met het hiervoor gegeven relaas. Het uittreksel uit de gerechtsrol geeft voor 4 april 1724 de vermelding 'completum', maar zonder eindvonnis, zodat de uitslag ongewis blijft.

\subsection{Grafelijke commissarissen, begin achttiende eeun}

Bij Wilhelm Veucht zagen we al welke belangrijke rol juristen speelden als commissaris belast met incidentele taken. Tijdens de regering van graaf Johan Frans moet een soort vaste kern van adviseurs zijn ontstaan. Een aanwijzing daarvoor is te vinden in een klaagschrift van de 'onderdruckde, miserabele ende vervolghde ingesetenen' van Eckelrade aan de graaf van 28 januari $1713 .{ }^{1344} \mathrm{Zij}$ protesteerden daarin tegen de knevelarijen, opsluiting, dwangmaatregelen en gerechtelijke vervolgingen die hen ten deel vielen omdat zij weigerden mee te betalen aan de opbouw van de kerk in Gronsveld. Zij verzochten bij de graaf rechtsbescherming tenminste 'tot tijt ende wijle dese saecke zij ondersocht bij d'heeren commissarissen in saecke gheensints geïnteresseert zijnde (= geen belang hebbend) bij zijne hooggrafelijcke excellentie te deputeren, welcke deputatie mits desen oytmoedelijck wordt versocht'. We mogen uit deze zinsnede afleiden dat de graaf, wanneer daartoe aanleiding bestond, een delegatie naar Gronsveld stuurde. Eén of meer van de commissarissen behandelden ook dossiers van de schepenbank in hoger beroep (zie daarover Hoofdstuk 9.9.3).

In 1719, direct na het overlijden van graaf Johan Frans van Bronckhorst Batenburg, verschijnen er drie 'commissarissen' ten tonele, de heren Olislagers, J.G. de Witte en G Petit. De eerste was oud keizerlijk luitenant geweest onder graaf Johan Frans, de tweede advocaat te Aken en de derde was advocaat en syndicus van de stad Luxemburg. De Witte ontmoeten we het eerst in 1718 wanneer hij voor graaf Johan Frans van Bronckhorst onderhandelingen voert in Maastricht over de bijdrage in de schatting door Maastrichtse burgers. Petit wordt in 1719 zowel 'mandatair generaal', 'commissaris' en 'commissaire general' van de gravin van Gronsveld genoemd. ${ }^{345}$ Op 22 maart 1719 vertegenwoordigde Petit gravin Toerring-Jettenbach bij haar inhuldiging in Gronsveld. Op 7 april tekende zij wederom een 'authorisatie ende commissie' met hetzelfde doel voor luitenant Olislagers, drossaard Willem Kicken en raadsheer J.G. de Witte. In hetzelfde jaar krijgt 'commissaris Witte' een bundeltje stukken overhandigd betreffende moeilijkheden met de schatrekeningen in Slenaken. Petit, Olislagers en De Witte verrichtten ook het onderzoek naar de rekeningen van drossaard Kicken en rentmeester Lousberchs. En in de jaren twintig, wanneer Gronsveld wordt geteisterd onder zware bestuurlijke problemen, treden de heren Petit en De Witte ook enkele malen als grafelijk commissaris op.

1343 RHCL, Rijkskamergerecht, inv. nr. 114, fol. 12-14.

1344 TJ, inv. nr. M 40, fol. 843-846, rekest 28 januari 1713.

1345 RHCL, Graafschap Gronsveld, inv. nr. 121. 


\subsection{Conclusies}

Wanneer men de lijst van functionarissen in vaste dienst van de graaf over een periode van 150 jaar (1570-1720) overziet, dan valt daarbij het geringe aantal op. Het gaat om gemiddeld twee personen, exclusief juridische adviseurs zonder vast dienstverband. Waarschijnlijk komt dat aantal overeen met de situatie in vergelijkbare territoria zoals Rekem (mogelijk iets meer), Wittem en Wylre (mogelijk iets minder). In de tijd dat Willem Kicken de functies van drossaard en rentmeester in één persoon verenigde, lijkt het zelfs nog minder dan twee te zijn geweest. De hoeveelheid werk van de rentmeester hing ook samen met het gebruik van het kasteel. Ten tijde van graaf Johan II van Bronckhorst Batenburg aan het begin van de zeventiende eeuw en van gravin-weduwe Anna Christina von Hardenrath in de jaren zestig en zeventig was er veel activiteit; in andere periodes stond een groot deel van het gebouw leeg.

Gedurende anderhalve eeuw kwamen er nieuwe functies bij, zoals die van drossaard eind zestiende eeuw. Sommige ambten verdwenen en keerden naderhand weer terug en ook werden functies op verschillende manieren gecombineerd of gesplitst ('momboir des heren' los van het scholtisambt, en de combinaties van scholtis en rentmeester en van drossaard en rentmeester). In dat opzicht zat er wel enige beweging in het bestuur, maar de manier van werken bleef conservatief en verliep volgens vaste procedures. Zo levert een vergelijking tussen de financiële verantwoording en verslaglegging van de rentmeester rond 1600 en rond 1700 geen wezenlijke verschillen op. Dat conservatisme zal zijn bevorderd door de vaak lange ambtstijd van functionarissen en de uitzonderlijke lange regeerperiodes van de graven Jost Maximiliaan en Johan Frans van Bronckhorst Batenburg.

Duidelijk is dat in Gronsveld en omgeving kan worden gesproken van verschillende generaties familieregering: de rentmeesters Congartz en Lousberch, bij drossaard Lamberts en zijn zoon die ook pastoor in Gronsveld was, en de families Veucht en Kicken. $\mathrm{Na}$ Kicken werd na 1720 de macht overgenomen door de familie Lebens, die gedurende de rest van de achttiende eeuw een dominante rol in Gronsveld speelde. Dat betekent echter niet dat deze mensen niet voor hun taak waren berekend. Er werd binnen deze families ook geïnvesteerd in (vooral juridische) scholing. Familieregering betekende in het graafschap Gronsveld wel werkelijke macht zonder veel toezicht, want de graven resideerden meestal niet ter plekke en waren vanwege hun dienst in het leger vaak zelfs nauwelijks bereikbaar.

De overgang van de ene familie op de andere verliep niet altijd zachtzinnig en kreeg vaak het karakter van zowel figuurlijk als letterlijk een afrekening. In figuurlijke zin ging het om het uitvechten van oude vetes, zoals tussen Lamberts en Veucht en daarna tussen Kicken en Lebens. In letterlijke zin lijkt de eindafrekening van de rentmeester bijna een structureel probleem op te leveren, zoals blijkt uit de voorbeelden van Van Velraedt, Van Huckelhoven en Kicken. Daarmee haalde men zich niet alleen de ongenade van de graaf of gravin op de hals, het vormde meestal ook de inleiding van een machtswisseling. 
Binnen het circuit van de regerende families bestond ook een kleine instroom van personen van buitenaf, in de gevallen dat de graaf of gravin als vertrouwenspersoon mensen aantrok die van elders bekend waren. Dat geldt voor drossaarden ten tijde van Johan II van Bronckhorst Batenburg, scholtissen onder gravin Anna Christina von Hardenrath en de juridische adviseurs die Anna Christina en later haar zoon Johan Frans van Bronckhorst Batenburg bijstonden. Terwijl in de laatste decennia van de zeventiende en het begin van de achttiende eeuw de drossaard/rentmeester de interne angelegenheden binnen het graafschap regelde, drukten deze raadgevers vooral hun stempel op het beleid, bijvoorbeeld in kwesties zoals het hoger beroep op Aken en de belastingconflicten met Maastricht. 


\section{De schepenbanken, circa 1550-1720}

In Hoofdstuk 2 kwam aan de orde op welke wijze zich uit het ressort van de vier oorspronkelijk zelfstandige schepenbanken Gronsveld (en Eckelrade), Heugem, Honthem en Slenaken een kleine landsheerlijkheid ontwikkelde. Formeel bleef deze rechterlijke organisatie (minus het in 1728 verkochte Slenaken) tot het einde van de achttiende eeuw intact. Naar buiten toe is die scheiding niet altijd even duidelijk, omdat de functies bij de schepenbanken door dezelfde personen werden uitgeoefend.

Alle schepenbanken waren bevoegd voor de contentieuze hoge, middelbare en lage rechtspraak, in civiele en criminele zaken, de vrijwillige rechtspraak (in hoofdzaak overdracht en bezwaring van onroerend goed). Procesrechtelijk kan onderscheid worden gemaakt tussen het voogdgeding (elders ook jaargeding genoemd), dat wil zeggen drie of vier zittingen op vaste tijdstippen gedurende het jaar, en zittingen ('genachtingen') waarbij kortere termijn werd geprocedeerd, meestal van veertien dagen tot veertien in civiele zaken en nog korter in criminele zaken. Hoewel het voogdgeding moet worden gezien als de oudste en oorspronkelijk reguliere vorm van rechtspraak, waren in de praktijk de veertiendaagse 'genachtingen' de meest gebruikelijke vorm van procederen. Geleidelijk aan werd het voogdgeding daarmee steeds meer beschouwd als de uitzondering op 'normale' rechtspraak. Dat bijzondere karakter werd nog eens onderstreept door de zaken die er aan de orde kwamen. Het ging daarbij om kwesties met een zeker publiek belang zoals overtredingen van gemeentelijke verordeningen, schuldvorderingen van de heer of van de kerk en voorlezing van gemeentelijke verordeningen. Er werden ook wel 'gewone'civiele procedures behandeld, maar die waren in de minderheid.

Van het voogdgeding moet worden onderscheiden de procedure van de 'gemeyne (in)queste', maar een duidelijke grens valt tussen beide procedures niet te trekken. De 'gemeyne (in)queste' is een vorm van strafrechtspraak wegens vergrijpen tegen publieke eigendommen of handelingen in strijd met moraal en kerkelijke voorschriften

Een aparte laatbank voor rechtspraak over keurmedige goederen en cijnsgoederen bestond in Gronsveld in de vroegmoderne tijd niet; de rechtspraak daarover vond plaats bij de schepenbanken en soms ook bij het leenhof. Een afzonderlijk leenhof was bevoegd voor de rechtspraak over leengoederen. Soms werd ook samengewerkt met een schepenbank.

Omdat maar weinig bewaard is gebleven van de rechterlijke archieven, is het moeilijk goed zicht te krijgen op de rechtspleging in de praktijk. Toch resteert voldoende materiaal voor een algemeen beeld van de instellingen en het toegepaste recht. Verder zal de manier van procederen bij de Gronsveldse gerechten niet bijzonder zijn afgeweken van de situatie bij naburige schepenbanken.

Een belangrijk aspect van de uitwendige geschiedenis van de rechtspraak betreft ten slotte de organisatie van het hoger beroep of appel, zowel binnen het graafschap, als naar buiten, naar Luik en Aken en uiteindelijk het Rijkskamergerecht. Vooral het beroep op de Schepenstoel van Aken heeft in de zeventiende eeuw voor veel problemen gezorgd. 


\subsection{De schepenbanken gezamenlijk en afzonderlijk}

In een rapport dat commissaris Prummer in 1768 opstelde over de manier van werken bij de schepenbanken, schrijft hij:

Gronsveld, Heugem en Honthem hadden nog niet zo heel veel jaren geleden ieder hun eigen gerechtsbank en hoewel het dezelfde drossaard, schepenen en secretaris waren, moesten ze zitting houden in Gronsveld, Heugem en Honthem, zoals ze ook afzonderlijke gerechtsprotocollen en gichtboeken moesten bijhouden. ${ }^{1346}$

Hoewel deze mededeling uit het midden van de achttiende eeuw dateert, is de stap naar de zestiende en zeventiende eeuw minder groot dan het lijkt, omdat heel lang dezelfde werkwijzen werden gevolgd. Tussen die banken bestonden ook verschillen in griffietarieven. ${ }^{1347}$ Maar uiteindelijk bleek de scheiding op termijn niet houdbaar, want, zo vervolgt Prummer:

omdat de leden van het gerecht met drie aparte zittingsdagen nog geen droog brood konden verdienen, om nog maar te zwijgen van beleg met kaas en boter, wordt tegenwoordig alles in Gronsveld behandeld, met uitzondering van de zogenoemde, hier te lande gebruikelijke voogdgedingen ('placita generalia') die vier keer per jaar in Honthem en Heugem worden gehouden. ${ }^{1348}$

Mogelijk kwam men voor die voogdgedingen samen in een herberg of in een woonhuis, want gerechtslokalen schijnen in Heugem en Honthem al in de zeventiende eeuw niet (meer) te hebben bestaan.

De schepenbank Slenaken is altijd zelfstandig blijven functioneren, hoewel ook hier personele banden met Gronsveld voorkwamen, vooral bij de functies van scholtis en secretaris. In de tekst van akten presenteerde Slenaken zich vaak op een enigszins afwijkende manier met de aanhef 'schepenen der vrijheerlijkheid Slenaken', daarmee aangevend dat Slenaken toch enigszins losstond van de andere plaatsen.

Niet alleen de schepenbanken, ook het leenhof en de schepenbank van Gronsveld werkten vaak gecombineerd. Die samenwerking was heel praktisch, omdat bijvoorbeeld in

1346 'vor noch nit so langen jahren' hadden Gronsveld, Heugem en Honthem ieder 'seine besondere gerichts-panckh gehabt; das ist, wan es auch eben die nembliche drossard, scheffen und secretarius gewesen seint, so haben doch die gerichts-täg zu Gronsfeldt, Hontem und Heugem, wie auch die gerichts prothocolla und gücht-büecher ieden orths separatim gehalten werdten müessen', TJ, inv. nr. M 73, fol. 547, Prummer aan M.E. von Toerring-Jettenbach 29 juni 1768.

1347 Zie Bijlage 9.

1348 'nunmehro aber, weillen die gerichts-leuth das trockhene brodt für ieden tag nit darbeÿ verdiennen könten, wan sÿe anstatt eines (wo sÿe doch noch nit vill mehrer als käs und butter darzue eroberen) dreÿ verschidene gerichts-täg halten müessten, würdt alles zu Gronsfeldt allainig verhandlet, ausgenohmen das die sogenante landts gebräuchli[che] vogt-geding (placita generalia) das jahr 4 mahl auch noch in locis zu Hontem und Heugem gehalten werdten.' 
processen over onroerend goed vaak tegelijkertijd werd geprocedeerd over zowel allodiale als leengoederen. ${ }^{1349}$

We kunnen de scheiding en samenwerking tussen de schepenbanken ook toetsen aan de archiefvorming, zoals die blijkt uit een tweetal inventarisaties van gerechtelijke archieven uit 17171350 en $1746 .{ }^{1351}$ Het samengaan van instellingen blijkt daarbij uit het feit dat alle archieven bij elkaar op één plaats, het kasteel van Gronsveld, in enkele kisten werden bewaard. De lijsten van Gronsveld beginnen met een 'gerichtsprothocol ex Gronsfelt 1580 mit transporten'. Mogelijk was dit een deel met zowel gerechtsrollen als 'gichten', ingeschreven transportakten van onroerend goed en hypotheekakten. De zeventiende eeuw kent daarna voor de rolregisters hiaten tot 1677 , vervolgens loopt de serie vrijwel aaneengesloten door tot 1746. De Gronsveldse gicht- of overdrachtsregisters beginnen in 1611 en gaan ononderbroken door tot 1746. Voor de bank Heugem zien we een min of meer gelijk beeld. Het oudste rolregister begint in 1597. Daarna zijn er hiaten tot 1677 en vervolgens is weer een aaneensluitende reeks. De serie gichten begint in 1626 en eindigt in 1746. Sommige delen overlappen elkaar en voor enkele jaren worden hiaten geconstateerd. Opmerkelijk is een gichtregister uit de periode 1673-1677, dat kennelijk voor Gronsveld en Heugem tegelijkertijd werd gebruikt.

Voor Honthem geeft de inventaris van 1717 gerechtsprotocollen (waarschijnlijk rollen) voor 1615 en 1618, evenals een ongedateerd protocol van voogdgedingen. Verder waren er gerechtsprotocollen uit de jaren 1677-1719, 1704-1725 en 1726-1742. De twee gichtregisters begonnen in 1602 en eindigden in 1731, waarbij 1685 ontbrak. Opvallend is dat de delen niet verder teruggaan dan het einde van de zestiende eeuw. Mogelijk is veel verloren gegaan omstreeks 1579, toen Gronsveld tijdens de belegering van Maastricht vrijwel helemaal werd verwoest.

Dat er naast registers ook afzonderlijk per bank dossiers werden gevormd, blijkt uit een proces uit 1664 van Simon Reynaerts en Lambert van der Schoer tegen Hendrik Blonden. ${ }^{1352} \mathrm{Na}$ een proces in eerste aanleg voor de schepenen van Honthem, werd de zaak in hoger beroep voortgezet in Heugem. Van het dossier is slechts éen stuk bewaard, een zogenoemde 'beschrijfbrief', waarin drossaard en schepenen van Heugem als 'wettich overhoeft' het in eerste aanleg gevormde dossier bij hun 'besondere goede vrienden', de drossaard en schepenen van Honthem, opvorderen. Op zich is dit soort beschrijfbrieven van een hogere naar een lagere instantie niets bijzonders, maar binnen de kleinschalige verhoudingen van het graafschap Gronsveld komt het toch komisch over wanneer men zichzelf officieel bezegelde stukken toestuurt.

1349 Een voorbeeld van een gecombineerd vonnis van schepenbank en leenhof betreft de hierna (Hoofdstuk 9.9.3) nog te bespreken zaak Lindeloof tegen het klooster Sinnich (RHCL, Graafschap Gronsveld, inv. nr. 276.

${ }^{1350}$ De eerste bestandsopname dateert van 13 augustus 1717 en is vrij summier, zie TJ, inv. nr. M 12, fol. 619-638.

1351 De tweede inventarisatie vond plaats op 22 november 1746 in het kader van het grote proces tegen de van fraude verdachte grafelijke rentmeester Matthias Oligschläger: zie RHCL, Rijkskamergerecht, inv. nr. 192/1 fol. 279. De lijsten van aangetroffen boekwerken in de 'stoffcammer' zijn tamelijk gedetailleerd. 1352 RHCL, Graafschap Gronsveld, inv. nr. 275. 
De ogenschijnlijk heldere scheiding tussen schepenbanken wordt minder duidelijk wanneer we kijken naar de aanhef van willekeurig gekozen losse schepenenakten, die ten behoeve van partijen werden uitgegeven: 'schepenen van het graafschap' of 'grafelijk gerecht tot Gronsveld' $\left.(1669,1681,1699),{ }^{1353}\right)$ 'schepenen van het gerecht des graafschaps Gronsveld en leenmannen' $(1644,1656,1659)$, 1354 'schepenen der banken van Gronsveld en Heugem'(1641), 1355 'schepenen van het grafelijk gerecht van Gronsveld en der bank van Heugem'(1664), ${ }^{1356}$ en 'schepenen te Heugem' (1676). ${ }^{1357}$ Uit dit soort formuleringen blijkt dat de scheiding tussen de schepenbanken aan de hand van de tekst van de akten niet altijd even scherp valt te trekken.

\subsection{Benoeming en kwalificatie van schepenen}

Concrete gegevens over werving en benoeming van schepenen zijn tot de jaren twintig van de achttiende eeuw zeldzaam. Pas in de roerige jaren 1720-1732 komen enkele meer principiële kanten daarvan aan de orde. (Zie voor deze periode Hoofdstuk 11). Een concrete afspraak over de benoeming van schepenen valt voor Slenaken te lezen in een overeenkomst die graaf Jost Maximiliaan van Bronckhorst Batenburg en de inwoners in 1646 sloten:

Dat de voorss. vrijheerlicheydt Slennacken sal worden gehouden ende geregeert gelijck van all ouden tijden voor een vrij heerlicheyt, becleet van eenen offitier oft scholtis ende schepenen van inwonderen ende geerffden derselve heerlicheydt bij Sijne Excellentie met kennysse ende cuere der justitie daertoe aen te stellen, dien welcke dadministratie absolut sullen hebben soe in criminele als civile saecken... ${ }^{1358}$

Formeel berustte het benoemingsrecht van schepenen bij de graaf, maar de feitelijke keuze geschiedde door coöptatie binnen een kring van verwante families. Tot de echte schepenfamilies in Slenaken behoorden de families Vincken, Crutserclaes, Geusenbrouwers en Pleiers. Waarschijnlijk verliep voor Gronsveld, Heugem en Honthem de keuze op dezelfde wijze. Ook Gronsveld kende een aantal typische schepenfamilies, zoals Lousberchs, Neffs, Berchmans, Roffarts, Pluechmekers en Graven. De namen van dit 'plattelandspatriciaat' duiken eveneens op bij het leenhof van Gronsveld en als schepen, secretaris of notaris bij schepenbanken in omliggende plaatsen zoals Rijckholt, Eijsden, Breust, Oost en Mheer.

Formeel telde de schepenbank zeven leden, maar meestal was de bezetting minder. Schepenen waren vaak lastig te krijgen. Zoals Prummer al constateerde, viel met het schepenambt geen droog brood te verdienen. Schepenen ontvingen geen salaris, maar werden betaald uit de opbrengst van de gerechtskosten. Bovendien kon men zich met het

\footnotetext{
1353 RHCL, Graafschap Gronsveld, inv. nrs. 405, 407, 359

1354 RHCL, Graafschap Gronsveld, inv. nrs. 399, 400, 401.

1355 RHCL, Graafschap Gronsveld, inv. nr. 412.

1356 RHCL, Graafschap Gronsveld, inv. nr. 403.

1357 RHCL, Graafschap Gronsveld, inv. nr. 412.

1358 Zie Bijlage 36.
} 
werk allerlei onaangenaamheden op de hals halen. Een minder aantal schepenen volstond echter ook. In Titel $18 \$ 7$ van de Gronsveldse Rechtsordnung was bepaald dat een vonnis van drossaard, scholtis en drie schepenen rechtsgeldig was. Verder werd vaak gebruik gemaakt van de 'truc' dat de scholtis, drossaard of secretaris tevens als schepen fungeerde. Ten slotte was voor routinematige bezigheden zoals het horen van getuigen of passeren van akten een beperkte bezetting voldoende. Wanneer dan in een enkel geval voor een eindvonnis toch een volle bank nodig was, bestond de mogelijkheid tijdelijk een schepen uit een andere bank erbij te halen of te 'assumeren'.

Voor een benoeming tot schepen was vereist dat de kandidaat onroerend goed binnen het graafschap bezat. Daar kon alleen bij uitzondering van worden afgeweken, onder de voorwaarde dat de betrokkene ten minste gegoed was op rijksonmiddellijk gebied, waardoor hij 'bedwingbaar' was binnen het Heilige Roomse Rijk. Dit hield verband met de mogelijke aansprakelijkheid van een schepen of verhaal op diens vermogen. Vonnissen van het Rijkskamergerecht of de Rijkshofraad waarbij een schepen werd veroordeeld, konden immers alleen ten uitvoer worden gelegd binnen het Rijk. Dat betekende voor Gronsveld dat schepenen uit Brabantse territoria, waarover het Rijkskamergerecht geen jurisdictie had, in beginsel niet voor benoeming in aanmerking kwamen, tenzij zij ook op rijksgebied waren gegoed.

$\mathrm{Na}$ benoeming legde de schepen een eed af in handen van de scholtis of drossaard. Het oudste (ongedateerde) voorbeeld van een eedformulier dateert uit de eerste helft van de zestiende eeuw. Volgens deze tekst zwoer de schepen trouw aan de heer (in dit geval Johan I van Bronckhorst Batenburg). Hij moest zich ten volle inzetten voor het algemeen belang, onomkoopbaar zijn en de beraadslagingen van de schepenen geheimhouden. De formaliteiten rond een benoeming dienden ook bij de schepenbank te worden geregistreerd, maar bij gebrek aan archief valt niet na te gaan of dit ook gebeurde. Uit het feit dat in de jaren twintig van de achttiende eeuw werd geklaagd over die administratie, valt af te leiden dat het nogal eens aan zorgvuldigheid ontbrak.

Over de voor het schepenambt vereiste inhoudelijke kwalificaties ontbreken tot het midden van de achttiende eeuw de bronnen. Hoge eisen zullen echter niet zijn gesteld, wanneer we afgaan op het negatieve beeld dat van het schepenambt in het midden van de achttiende eeuw wordt geschetst (zie Hoofdstuk 13.2). Het is een beeld dat waarschijnlijk ook van toepassing is op de voorgaande eeuwen:

\subsection{De secretaris of gerechtsschrijuer}

Vaste gerechtsschrijvers, 'bankschrijvers' of secretarissen werden - zeker op het platteland - pas aan het einde van de middeleeuwen aangesteld. ${ }^{1359}$ In een proces in Slenaken tussen Andreas van den Hove genaamd van Carsveld tegen Willem van Franckenberg wordt in

1359 Voor de opkomst van het ambt van gerechtssecretaris en daarmee samenhangende archiefvorming zie Van Rensch, 'Van kisten en kompen', 79-84. 
1526 gezegd dat Cloes Pluechmeker daar meer dan dertig jaar 'banckschrijver' was geweest. ${ }^{1360}$ Dat zou ongeveer kunnen kloppen met de gegevens van een inventarisatie van het archief uit 1662, toen werd geconstateerd dat de oudste stukken teruggingen tot 1494 en 1497.1361

De behoefte aan een dergelijke functionaris groeide door de toenemende eis van schriftelijke vastlegging van het procesverloop (uittreksels uit de rolzittingen waren onder andere noodzakelijk voor procedures in hoofdvaart en appel). Ook bestond behoefte aan de registratie van documenten met betrekking tot onroerend goed, waaraan publieke bewijskracht werd toegekend. In het eerder genoemd procesdossier van Van den Hoven tegen Van Franckenberg valt te lezen dat van overdracht van onroerend goed 'van stonde aen' in het schepenregister aantekening werd gehouden 'om dat gycht ind guedinge anders nyet dan myt testimonium van gericht getuycht ind veryficiert mach werden'. Van die laatmiddeleeuwse en vroeg zestiende-eeuwse registratie was echter, zoals blijkt uit de eerder genoemde inventarisaties van archieven, aan het begin van de achttiende eeuw niets meer bewaard.

In het graafschap Gronsveld werd de secretaris door de graaf benoemd. Hij was degene die, zoals Prummer het in 1755 samenvatte, verslagen maakte, afschriften verstrekte en protocollen en dossiers bewaarde. Rijk werd iemand daarvan niet. De secretaris ontving geen vast salaris maar werd betaald uit griffierechten ('sportulen'), die hij moest delen met de scholtis/drossaard en schepenen. Van die kosten kreeg hij, evenals de drossaard, 2/11 deel (iedere schepen ontving $1 / 11$ deel). Alleen al om die reden was een cumulatie met andere functies noodzakelijk. Secretaris was een beroep dat veelal binnen een zelfde familie bleef en soms van generatie op generatie werd uitgeoefend. In Gronsveld is de familie Lousberchs daar een goed voorbeeld van. Zo volgde Lambert Lousberchs junior omstreeks 1669 zijn vader Lambert senior op. Laatstgenoemde moet al jaren eerder moeite hebben gehad zijn ambt uit te oefenen. ${ }^{1362}$ Volgens de tekst op de steen van het familiegraf Lebens-Lousberchs in de kerk van Gronsveld overleed Lambert junior op 6 februari 1735 op 87-jarige leeftijd; hij moet dus omstreeks 1648 zijn geboren. ${ }^{1363}$ Hij huwde Agnes Neffs en zijn broer Jan trouwde eerst met Amelia Neffs en na haar overlijden met Johanna Roffarts, allemaal dames uit Gronsveldse schepenfamilies. Een andere broer, Christiaan Lousberchs, werd secretaris in Mheer en beëdigd procurator in Aubel, Sint-Martens-Voeren en Noorbeek. ${ }^{1364}$ Lambert Lousberchs junior moet tussen 1706 en 1714 zijn opgevolgd door zijn schoonzoon, notaris en procureur Johannes Godefridus Lebens. ${ }^{1365}$ Mogelijk gebeurde dit omstreeks 1710, toen hij gedurende enkele jaren de taak van grafelijk rentmeester op zich nam. Daarna bereikte hij als alom

${ }^{1360}$ RHCL, Rijkskamergerecht, inv. nr. 95, fol. 14.

1361 RHCL, Klooster Hoogcruts, inv. nr. 296.

1362 RHCL, Rijkskamergerecht, inv. nr. 77, fol. 38 betreft een door Lousberchs getekend attest uit 1657.

Het handschrift is erg beverig.

1363 Belonje, 'Genealogische en heraldische gedenkwaardigheden', 83.

1364 RHCL, Rijkskamergerecht, inv. nr. 71/2 fol. 610-613.

1365 RHCL, Graafschap Gronsveld, inv. nr. 359: in 1706 is Lebens notaris, Lousberchs secretaris. Volgens inv. nr. 359 is Lebens in 1714 secretaris. 
gerespecteerd ambteloos burger een hoge leeftijd. Voor zijn tijdgenoten was hij een vraagbaak die alles over Gronsveld wist en zelfs lang na zijn dood leefde die faam voort. Prummer schrijft in 1757 over hem dat hij 'meer dan negentig (?) jaar oud, het grootste deel van zijn leven had gewerkt als landmeter, procureur, notaris, bijzitter in het leenhof, secretaris van de schepenbank en het leenhof en ten slotte grafelijk rentmeester. Tot aan zijn dood werd hij beschouwd als een afgod en orakel in grondzaken'. ${ }^{1366}$

Lousberchs schoonzoon en opvolger Johannes Godefridus Lebens werd waarschijnlijk geboren te Eijsden in 1678. Hij stamde uit een vergelijkbare familie als Lousberchs. Zijn vader Wilhelmus Lebens was notaris en procureur te Eijsden, vanaf 1680 secretaris van de schepenbank Eijsden, vanaf 1697 secretaris van de banken Berneau en Mesch en schepen van 's-Gravenvoeren in 1719. Zijn moeder Catharina Ruth was een dochter van Joannes Ruth, notaris, secretaris en schepen te Eijsden. ${ }^{1367}$ De jonge Lebens zal onder deze omstandigheden in Anna Lousberchs een ideale partner hebben gezien om twee belangrijke families met elkaar te verbinden. Maar vader Lousberchs weigerde toestemming. Hij meende dat bruid en bruidegom in de verte familie van elkaar waren. In dat huwelijksbeletsel moest door de kerk worden gedispenseerd. Het geschil liep zo hoog op dat de bruid het ouderlijk huis ontvluchtte en het jonge paar stadhouder en schepenen van Eijsden verzocht de huwelijksroepen in de kerk conform het Echtreglement voor de Staatse Landen van Overmaze doorgang te laten vinden. ${ }^{1368}$

Uiteindelijk hebben Lousberchs en zijn dochter en schoonzoon zich met elkaar verzoend en volgde Lebens zijn schoonvader op. Het voorval is om verschillende redenen interessant. De precieze graad van verwantschap tussen de echtelieden kan verder buiten beschouwing blijven, maar het voorbeeld onderstreept nog eens de sterke verwevenheid tussen de families die bestuur en rechtspraak in handen hadden. Daarnaast tekent deze aanloop naar het huwelijk Lebens en zijn vrouw als mensen die zich niet lieten weerhouden om tegen oppositie in hun wil door te zetten. Die eigenschap zou een grote rol spelen bij de problemen waarmee Lebens als drossaard van Gronsveld in de jaren twintig van de achttiende eeuw werd geconfronteerd.

\subsection{De gerechtsbode}

De gerechtsbode vervulde de rol van deurwaarder voor de schepenbanken. Hij betekende de gerechtelijke documenten aan partijen en zorgde voor beslaglegging op goederen. In Gronsveld werd de bode begin achttiende eeuw ook wel aangeduid als 'sergeant'. In

1366 'in ÿber die 90 jahr alt dan die mehriste zeit seines lebens als landtmesser, procurator, notarius, lehenmann, gericht- und lehenschreiber, auch rentmeister in bedienung gewesen, dan bis in seinen todt als das oraculum und der abgott in allhiesigen grundtsachen gehalten wordten, auch heutiges tags noch dafür reclamiert würdtet'. Zie TJ, inv. nr. M 13, fol. 73-104, Prummer aan M.E. von Toerring-Jettenbach 16 juni 1757: 'Information ueber die natur und weesenheyt deren....entlegenen grundten'. Prummer vergist zich overigens met die negentig jaar, want Lousberchs overleed op 87-jarige leeftijd.

1367 Voor de genealogie van de familie Lebens zie Van Heyst, 'Proeve ener genealogie' en Verzijl, 'De Maastrichtse tak der familie Lebens'.

1368 RHCL, Landen van Overmaze, inv. nr. 5577. De zaak speelde rond 1700. 
hoeverre hij politionele taken verrichtte, valt moeilijk te zeggen. De graaf had immers een of meer boswachters in dienst en daarnaast hield de veldbode of veldschut toezicht in het veld en bij de gemeentegronden. Zoals de schepenen en gerechtsschrijver werd ook de bode in beginsel uit de gerechtskosten betaald. Daarnaast ontving de bode van Gronsveld uit de grafelijke kas twee malder rogge en kregen de collega's van Heugem, Honthem en Slenaken ieder één malder rogge. Voorts beschikten de bodes van Gronsveld en Heugem over een eigen stukje land en had de bode van Slenaken van oudsher 'voor zijn moeite' recht op drie en een half ei, te betalen van de eieren die als cijns an de heer werden afgedragen. ${ }^{1369}$

\subsection{Het voogdgeding}

We kunnen het voogdgeding zien als een voortzetting van het vroegere 'geboden ding', de rechtszitting waaraan de hele dorpsgemeenschap onder leiding van de voogd als de vertegenwoordiger van de heer, deelnam. Vrijwel ieder dorp in het gebied van het oude hertogdom Limburg en de Landen van Overmaze met de aangrenzende territoria kende een voogdgeding. ${ }^{1370}$ Als regel werden drie bijeenkomsten per jaar gehouden: meestal in de week na Driekoningen (soms ook na Kerstmis), in de week na Pasen of Beloken Pasen, terwijl de derde dag wisselde. Het meest gebruikelijk waren de week na Sint-Jan (24 juni) en de week na Sint-Remigiusdag (1 oktober $)^{1371}$ Soms worden ook vier voogdgedingen gemeld. ${ }^{1372}$

We zouden het voogdgeding kunnen zien als een plechtige zitting waarmee een nieuw 'seizoen' van de rechtspraak werd geopend. Daarna volgden de 'genachtingen', gewone, tweewekelijkse zittingen. Die 'hiërarchie' van de rechtszittingen wordt goed verwoord in de costumen en gebruiken van de hoofdbank van 's-Hertogenrade uit de tweede helft van de zestiende eeuw. ${ }^{1373}$ Die beginnen met de bepaling dat drie keer per jaar 'generaele voeghtgedinghe' werden gehouden, te weten na Driekoningen (6 januari), na Pasen en na Sint-Gillisdag (1 september). In de tussenliggende weken konden 'die onderdaenen malckanderen... met behoorlyck lantrecht aenspreecken' tijdens de 'ordinarisse gerichtsdagen van vierthien daeghen tot vierthien daeghen'.

Het bijzondere karakter van het voogdgeding kwam tot uitdrukking in bepaalde formaliteiten. Namens de voogd werden (meestal in de kerk) de mannelijke inwoners opgeroepen om op een bepaalde dag an het voogdgeding deel te nemen. Er gold in beginsel opkomstplicht, dat wil zeggen afvaardiging van tenminste een volwassen man per

${ }^{1369}$ RHCL, Graafschap Gronsveld, inv. nr. 181.

1370 Hoewel de wortels van het voogdgeding ver teruggaan, levert een besluit uit 1500 van de zogenoemde Elf banken van het kapittel van Sint-Servaas te Maastricht een voorbeeld van het instellen van een voogdgeding in de bank van Grootloon (bij Tongeren), waar eerder nooit een voogdgeding was geweest, vgl. Habets, Limburgsche wijsdommen, 82.

1371 Sint-Jan, Sint-Remigius en Sint-Andries (30 november) waren ook de gebruikelijke dagen voor het betalen van pacht. Bij een geschil over pachtbetaling kon dan meteen worden geprocedeerd.

1372 Bijvoorbeeld in Beek met Sint-Jan en Sint-Remigius, vgl. Janssen de Limpens, Rechtsbronnen Limburg en Overmaze, 468.

1373 Janssen de Limpens, Rechtsbronnen Limburg en Overmaze, 355-356. 
huishouden. Het is de vraag of dat als een zware last werd ervaren, want de gekozen dag viel samen met de afsluiting van een periode van feest (kersttijd, paastijd en ook Sint-Jan gold als een zondag). Grote opkomst kon ook tot problemen leiden. Zo verboden de schepenen van 's-Hertogenrade in een 'cleernis' uit 1510 niet alleen het thuisblijven, maar ook het vele rumoer in de kroeg ('vil geruechts' in 'byerhuyseren'). Zo eindigde de dag, waarin vele kleine boetes werden opgelegd, dikwijls toch nog in een vrolijke stemming. Met de 'banformule' opende de voogd, de scholtis of de drossaard namens de heer de zitting. Van diverse schepenbanken zijn banformules bekend, allemaal met ongeveer dezelfde opbouw en formaliteiten. ${ }^{1374}$ Onder aanroeping van God en heiligen werd ten behoeve van de rechtzoekende 'vrede gebannen' of afgekondigd. Dat betekende een vrijgeleide voor iedereen om zijn zaak voor te leggen, met uitzonderingen van personen die zich aan bepaalde ernstige misdrijven schuldig hadden gemaakt. Vervolgens werden de schepenen door de voogd 'gemaand' recht te spreken. Het voogdgeding is daarmee een bijzondere zitting van de schepenbank en geen volksrechtspraak. Soms werden aan het begin van de bijeenkomst ook de plaatselijke 'bankrechten' voorgelezen, een mengeling van plaatselijke verordeningen, aangevuld met regels van procesrecht. In dezelfde sfeer lag ook het vastleggen van nieuw recht of gewoonterecht in 'cleernissen' of uitspraken.

Het algemene karakter van het voogdgeding blijkt tevens uit de behandelde onderwerpen. In de eerste plaats betrof het klachten over onderhoud of beschadiging van wegen en waterlossingen, verder overtreding van voorschriften over maten en gewichten en ongeoorloofd gebruik van gemeentelijke bossen en weidegronden. Onduidelijk is of het daarbij alleen gaat om de berechting van personen die bij een overtreding waren betrapt, of dat er ook een soort algemene plicht tot aangifte voor de inwoners bestond. Deze kwestie is van belang met het oog op de hierna nog te noemen procedure van de 'generale inqueste'. In de privaatrechtelijke sfeer lag het opstarten van 'gewone' civiele procedures in het algemeen en de gerechtelijke uitwinning van onroerend goed wegens onbetaalde pachten, grondrenten en cijnzen in het bijzonder. ${ }^{1375}$ Ook al lopende zaken werden voortgezet. Ten slotte werd het voogdgeding gebruikt om functionarissen te benoemen, zoals keurmeesters van maten en gewichten of bosmeesters die toezicht hielden op de bossen.

Van de vier schepenbanken binnen het graafschap Gronsveld zijn er tot het begin van achttiende eeuw wel vermeldingen van voogdgedingen, maar voor nadere bijzonderheden zijn we, met uitzondering van Slenaken, vooral op tweede helft van de achttiende eeuw aangewezen. Het is echter vanwege de vaste procedures en het conservatieve karakter van het voogdgeding aannemelijk dat de gegevens uit de achttiende eeuw in hoofdzaak ook op vroegere periodes van toepassing zijn. Vast staat dat het voogdgeding al in de zeventiende

\footnotetext{
1374 Janssen de Limpens, Rechtsbronnen Limburg en Overmaze geeft voorbeelden van Limbourg uit 1475 (5152), van de laathof van Kloosterrade circa 1600 (415), van Ubach (438-440), van Vijlen zestiende eeuw (451), van Itteren zestiende eeuw (546-547), van Geleen circa 1550 (566-567), van Klimmen 1471(592593), van Meerssen (626-627) en van Schinnen (639). Daaraan kan worden toegevoegd Eijsden, vgl. Flament, 'Limburgsche schetsen/De voogdgedingen', 59.

1375 Zie over deze uitwinnings- of evictieprocedure in de Meijerij van Den Bosch: Lijten, Het burgerlijk proces in stad en Meijerij, 119-149.
} 
eeuw bestond uit een mengeling van 'gemeentelijke' zaken, overtredingen en civiele zaken. ${ }^{1376}$

Het voogdgeding werd in Gronsveld, Heugem en Honthem eens per kwartaal gehouden, bij voorkeur in de maanden januari, april en september, zich waarschijnlijk richtend op Driekoningen, Pasen en het feest van Sint Gilles. ${ }^{1377}$ Slenaken zal een vergelijkbare cyclus hebben gekend. Meestal volgden de bijeenkomsten in de verschillende dorpen kort na elkaar.

Met uitzondering van de schepenbank Honthem zijn de teksten van de banformules overgeleverd (zie bijlagen 32 en 33). ${ }^{1378}$ De oudste en meest uitvoerige is die van Slenaken uit 1633, maar onduidelijk is of die ook het meest authentiek is. De uitgebreide en zorgvuldige formulering wekt de indruk te zijn 'opgepoetst'. De formules voor de andere banken dateren uit de achttiende eeuw en zijn wat eenvoudiger. Onder aanroeping van God en Zijn heiligen en in het bijzonder de patroonheilige van de kerk (Sint Martinus in Gronsveld, Sint Michaël in Heugem, Sint Remigius in Slenaken), werd het voogdgeding geopend vanwege de heer, zijn drossaard, de schepenen en alle aanwezigen. De banformule werd drie, en in Slenaken zelfs vier keer herhaald en afgesloten met de 'aanmaning' van de drossaard naar schepenen om te verklaren of het geding op de voorgeschreven wijze was geopend. In Slenaken werden alle onderdanen op straffe van boete gesommeerd om op dit voogdgeding te verschijnen. Niemand mocht het geding verlaten vooraleer hij de gerechtskosten had betaald.

Tijdens het voogdgeding werden de schepenen gemaand op die dag zitting te houden en iedereen zonder aanzien des persoon recht te verschaffen. Interessant is dat bij de bank van Slenaken de justitiabelen worden verdeeld in geestelijkheid en adel ('der geystlicheydt wat haer toestaet ende den aedeldomme wes hem competert'), rijken en armen, weduwen en wezen en geestelijke instellingen. Volledig gelijkheid tussen deze groepen bestond niet. Personen 'van aedelichen schilde' werden 'gevraagd', 'den hausman' werd 'bevolen'. Mogelijk werd de noodzaak tot tweedeling in Slenaken in het bijzonder gevoeld vanwege de sterke positie die het klooster Hoogcruts en de adellijke bezitters van het goed Hees daar innamen.

Van zonsopgang tot zonsondergang verleende de heer vrijgeleide aan iedereen ongeacht de misdaad waarvan hij of zij beschuldigd werd, met uitzondering van dieven, brandstichters, kerkschenders, verkrachters en plegers van andere 'enorme' delicten. Ook hier is de banformule van Slenaken specifieker. Bij de uitzonderingen van vrijgeleide worden daar nog genoemd misdrijven tegen de landsheer. Wanneer misdadigers elders al boete hadden gedaan, moest men hen behandelen als 'goeden vromen luydens' en dienovereenkomstig recht verschaffen.

\footnotetext{
1376 Een voorbeeld van een civiel proces dat in hoger beroep vanuit Slenaken tijdens het voogdgeding van 18 oktober 1672 op de rol in Gronsveld werd behandeld, is de zaak van de weduwe Van der Couven tegen juffrouw Groottardts en de gemeente Slenaken, vgl. RHCL, Graafschap Gronsveld, inv. nr. 671 1377 Sint Egidius of Gilles valt op 1 september.

1378 RHCL, Graafschap Gronsveld, inv. nr. 252, 256, 257 en 577. Bij Flament, 'Limburgsche schetsen/De voogdgedingen', 60, is een tekst met onbekende herkomst afgedrukt. Het vermoeden van Flament dat deze betrekking heeft op Gronsveld, is juist.
} 
Iedereen die iets te melden had over onrechtmatigheden of crimineel gedrag kon zich aandienen. In Slenaken moest daarvoor gebruik worden gemaakt van diensten van een 'voorspreker'. Klachten konden betrekking hebben op gemeentelijke zaken, zoals het onderhoud van wegen en waterlopen, maar ook op aanstootgevend gedrag tussen inwoners onderling. Prummer schrijft in 1773 dat tijdens de drie voogdgedingen in Gronsveld, Heugem en Honthem geschillen over omheiningen, afwatering van gronden en 'valderens' (hekken ter afsluiting van gemeenschappelijke gronden) werden behandeld. Soms waren daarvoor ook inspecties ter plaatse noodzakeliik. ${ }^{1379}$ In Slenaken moesten de 'keurmeesters', de toezichthouders op bepaalde aspecten van handel of nijverheid, alle overtredingen aanbrengen.

Ook in Slenaken volgde na de banformule de afkondiging van een 'Ordinantie ende gebodt unsers Ghenadigen Heeren'. Daarin werd specifiek melding gemaakt van het onderhouden van bepalingen tegen godslastering, het rondhangen op het kerkhof tijdens kerkdiensten, overtreding van het sluitingsuur van herbergen, het illegaal tappen van bier, dobbel- en kaartspelen, het vangen van duiven, illegaal kappen van hout, het maken van voetpaden, het vernielen van omheiningen of gemeente-eigendommen, de beschadiging of het stelen van gewassen in het veld, het laten loslopen van vee en het overtreden van het heerlijk jachtrecht. Die ordonnantie is waarschijnlijk vergelijkbaar met een 'politieke ordonnantie' die in de achttiende eeuw in Gronsveld werd voorgelezen. ${ }^{1380}$

Volgens Prummer werden in zijn tijd de burgemeesters van de afzonderlijke dorpen aangesteld tijdens het voogdgeding, evenals de veldbode en de dorpsherder. ${ }^{1381}$ Prummers opvolger Zollner schrijft in 1794 dat de burgemeester werd benoemd door de drossaard. ${ }^{1382}$ Waarschijnlijk moeten we deze mededelingen aldus interpreteren dat de benoeming door de drossaard op die dag bekend werd gemaakt, waarna de publieke beëdiging als rechterlijke handeling door de schepenen volgde. Overigens moet daarbij worden opgemerkt dat de functie van burgemeester waarschijnlijk pas in de loop van de zeventiende eeuw is ontstaan (zie daarover Hoofdstuk 17.5). Zoals de burgemeestersbenoeming met de beëdiging min of meer bij het voogdgeding is 'ingeslopen', zo lijkt dat ook te zijn gebeurd met de vaststelling van de 'personele collecte', de belasting op het vee. Die vond op dezelfde dag plaats, maar het woord 'voogdgeding' werd daarin vermeden.

Ondanks dit soort 'onzuiverheden' was het voogdgeding toch vooral een rechtszitting, Interessant in dit verband is de eerste regel van een concept(?)- tarievenverordening op de gerechtskosten uit 1724 waarin staat dat 'alle aensatten soo tot Gronsfelt, Heugem als Hontem behooren te geschieden mette vaeghtgedingen ende andersins niet'. Daarna volgt de bepaling dat 'de dry genachtingen loopen tot Gronsfelt enckelijck van vaeghtgedinge

1379 TJ, inv. nr. M 56, fol. 68-83 Prummer aan A.J. von Toerring-Jettenbach z.d. ('presentatum' 4 mei 1773, brief nr. 7).

1380 Een 'politieke ordonnantie' was bijvoorbeeld ook gebruikelijk in het aan Gronsveld grenzende Rijckholt (acht artikelen) en Heer (54 artikelen), vgl. vgl. Habets, Limburgsche wijsdommen, 75-76 en 85-93.

1381 TJ, inv. nr. M 56, fol. 68-83 Prummer aan A.J. von Toerring-Jettenbach z.d. (presentatum 4 mei 1773, brief nr. 7).

1382 TJ, inv. nr. M 62, fol. 137-143, Zollner aan A.J. von Toerring-Jettenbach 3 juni 1794. 
tot vaeghtgedinge'. Letterlijk houdt dit in dat iedere procedure hoorde te beginnen op het voogdgeding, waarna de zaak van genachting tot genachting werd voortgezet, met uitzondering van Gronsveld waar van voogdgeding tot voogdgeding werd geprocedeerd. Een dergelijk systeem werkte zeer vertragend en het is onwaarschijnlijk dat daar de hand aan werd gehouden. Maar de bepaling als zodanig illustreert de voorrang van het voogdgeding boven de 'ordinaris-zittingen'. In ieder geval was het gebruikelijk dat de rentmeester van de graaf en de 'momboir' (in dit geval 'penningmeester') van de kerkfabriek tijdens het voogdgeding begonnen met de procedure om achterstallige betalingen van renten en cijnzen te verhalen op het onroerend goed waarop die schulden rustten. Waarschijnlijk hing dit ook samen met het feit dat aan dit soort schulden een semipubliek karakter werd toegekend.

\subsection{De 'gemeyn quest'}

In de archieven van het graafschap Gronsveld bevindt zich een tweetal documenten (een katern uit 1550 en een los stuk uit 1603) betreffende een procedure die met de term 'gemeyn quest' wordt aangeduid. ${ }^{1383}$ In het stuk uit 1550 gaat het om zittingen gehouden op 28 februari in Slenaken, op 1 maart in Heugem, op 5 maart in Honthem en Eckelrade en op 6 maart in Gronsveld. Afhankelijk van de grootte van de plaats werden tussen vijf en vijftien personen 'overtuicht' van strafbare feiten: mishandeling, bedreiging, vechtpartijen, weerspannigheid tegen de veldbode, vernieling van omheiningen, wegen en gewassen in het veld, verplaatsing van grensstenen enzovoorts. Ook gedragingen in strijd met de goede zeden werden aangeklaagd: vloeken, dobbelen, schelden en godslastering. $\mathrm{Bij}$ dit laatste vergrijp mag de pastoor van Gronsveld wel een opvallende delinquent worden genoemd. Het onderhouden van buitenechtelijke relaties en verwekken van onwettige kinderen (drie gevallen) werden eveneens aan de kaak gesteld, onder andere het geval van 'Her Peter', een kloosterling van Hoogcruts, die in concubinaat leefde met een gehuwde vrouw, bij wie hij ook een kind had verwekt.

Het stuk van 12 maart 1603 is anders van opbouw en heeft alleen betrekking op Slenaken. Het betreft een 'gemeyn quest' die 'naar oud gebruik van de voorouders' werd gehouden ten overstaan van de drossaard. Oorspronkelijk stond daarachter ook het woord 'schepenen', maar dit is doorgehaald. De tekst begint met een aantal van te voren geformuleerde onderwerpen waarover de inwoners werden ondervraagd: godslastering, overtreding van het heerlijke jacht-, vis- en bosrecht, beschadiging van omheiningen, grenspalen, wegen en 'valderens' (toegangen tot gemeenschappelijke weidegrond) en het voortijdig laten grazen van schapen op stoppelland. Achtereenvolgens werden ruim veertig inwoners onder ede gehoord. De oogst viel mager uit; op enkele ondervraagden na wist niemand iets te melden.

Vermeldingen van een inquestprocedure zijn ook te vinden een dossier van een proces tussen graaf Johan II van Bronckhorst en zijn onderdanen tussen 1608 en 1610. In een attest uit 1608 verklaarden de schepenen van Gronsveld en Heugem dat drossaard

1383 RHCL, Graafschap Gronsveld, inv. nr. 564. 
Kelterhausen in 1602 naar aanleiding van 'policey-mängel und excessen' in Heugem 'nach alth üblicher gewohnheit' alle inwoners door de gerechtsbode had laten oproepen voor een 'gemeine inquisition'. ${ }^{3384}$ In dezelfde zaak verklaarde de graaf stellig dat hij als landsheer bevoegd was in zijn gebied 'inquisitionen unnd visitationen' te houden, tot handhaving van goede 'policey' en wetgeving. Voor die bijeenkomst mocht hij ieder jaar in de parochiekerken een bevel uitvaardigen. ${ }^{1385}$

De 'gemeyne inquest' (het woord is afgeleid van het Latijnse 'inquisitio', onderzoek) is een procedure met wortels die teruggaan tot ver in de middeleeuwen. Volgens vroegmiddeleeuwse opvatting werd onrecht alleen vervolgd op klacht, welk beginsel tot uitdrukking kwam in het adagium 'geen klager, geen rechter'. Geleidelijk ontwikkelde zich de opvatting dat er ook een algemeen belang is gebaat met de vervolging van delicten, onafhankelijk van het slachtoffer of de benadeelde partij. Dit leidde tot zogenoemde 'wroegingsgerichten', waarbij de inwoners van het dorp op een terechtzitting moesten verschijnen om te getuigen wat zij wisten over strafbare feiten van hun dorpsgenoten. ${ }^{1386}$ De 'wroegingsprocedure' kende een wereldlijke en kerkelijke variant. In het eerste geval werden de delinquenten gestraft door de wereldlijke rechter, de tweede variant vinden we terug bij het zogenoemde seendgerecht. Daarbij hield een kerkelijke functionaris (aartsdiaken, landdeken of hun rechter, de 'officiaal') samen met leden van het gerecht een 'seend' (woord afgeleid van' synode') om te oordelen over overtreding van kerkelijke geboden of vergrijpen zoals woeker, bedrog, in het openbaar aanstootgevend gedrag en schending van de seksuele of huwelijksmoraal. ${ }^{1387}$ In de wereldlijke variant van de 'wroegingsprocedure' moesten de inwoners 'commune' delicten melden, waarvan zij kennis droegen. Ook vermoedens en geruchten konden worden aangebracht. De wereldlijke wroegingsprocedure is in sommige streken, zoals Drenthe, nog tot in de achttiende eeuw blijven bestaan. De kerkelijke seend verdween tijdens de reformatie in protestantse gebieden, terwijl in katholieke streken na het Concilie van Trente de officiaal van de bisschop als kerkelijke rechter 'nieuwe stijl' de overtreding van kerkelijke regelgeving door zowel geestelijken als leken beoordeelde. ${ }^{1388}$

In de omgeving van Gronsveld zien we dat de 'gemeyne' of 'generale inquest' vanaf eind veertiende eeuw in Maastricht bekend was in het kader van de seendrechtspraak. ${ }^{1389}$ De aartsdiaken of landdeken kwam daartoe jaarlijks met de schepenen samen. Ter voorbereiding hielden de wijkmeesters in de stad een 'generale inquest' naar het zedelijke en godsdienstige gedrag van de inwoners. In de tijd tussen 1580 en 1632, toen kerkelijke en wereldlijke overheid hier eendrachtig streefden naar een rekatholisering in de geest van het Concilie van Trente, werd de inqueste gebruikt om van de heersende norm afwijkend

\footnotetext{
1384 RHCL, Rijkskamergerecht, inv. nr. 73, fol. 184-185.

1385 RHCL, Rijkskamergerecht, inv. nr. 73, fol. 142.

1386 Fockema Andreae, 'Het bewijs in strafzaken', 80-84.

1387 Over de seend zie: Kuys, Kerkelijke organisatie, 134-141.

$1388 \mathrm{Zie}$ voor het functioneren van een dergelijke geestelijke rechtbank: Venner, Inventaris van het archief van bet officialaat.

1389 Van Rensch, 'De aartsdiaken van Haspengouw', 192-194 en de daar opgegeven literatuur.
} 
gedrag op te sporen. ${ }^{1390}$ Tegelijkertijd raakte de seend die daarop moest volgen, na 1600 steeds meer in onbruik. De laatste vermelding dateert uit 1631.

Van de middeleeuwse seend op het platteland, in het gebied van het tegenwoordige ZuidLimburg, valt in de rechtsbronnen nauwelijks iets concreets terug te vinden. De wereldlijke 'wroegingsprocedure' was wel bekend, bijvoorbeeld in Vijlen in het begin van de zestiende eeuw. Tijdens het voogdgeding dat de abdis van Burtscheid daar als grondvrouwe hield, moesten 'amptluyde' en schepenen 'vrogen' over wegen en paden, grensstenen, mergelkuilen en omheiningen. ${ }^{1391}$ De 'wroich' was ook de aanduiding van de halfjaarlijkse zitting van het bosgerecht, waar recht werd gesproken over kwesties verband houdend met het gebruik van het gemeenschappelijk bos. ${ }^{1392}$ Verder komt het begrip ook voor in de bankrechten van Eys, Wittem, Simpelveld en Bocholtz' ${ }^{1393}$ en bij het voogdgeding in 's-Hertogenrade. ${ }^{1394}$ Typisch voor deze 'wroeging' is steeds de combinatie met het voogdgeding, terwijl de strafbare feiten vrijwel uitsluitend het algemeen belang raken.

In het dorp Itteren, even ten noorden van Maastricht speelt in de jaren 1558-1560 een interessante kwestie over de afkondiging van de generale inqueste. ${ }^{1395}$ Daar liet de plaatselijke heer vanaf de preekstoel door de pastoor een generale inquest afkondigen, waarbij alle inwoners (dat wil zeggen een vertegenwoordiger per huishouden) te bestemder plaats en tijd anwezig moesten zijn om te antwoorden op van te voren geformuleerde vragen. Sommige inwoners gaven gehoor aan de oproep, andere bleven om principiële redenen thuis. Zij maakten niet alleen bezwaar tegen de afkondiging en de hoogte van de boetes, maar vooral tegen het feit dat de inwoners uit eigener beweging moesten komen getuigen over van te voren geformuleerde vragen. Het was 'van alden heercomen gewonlick' dat mensen bij wie een strafbaar feit of onoirbaar gedrag werd vermoed, persoonlijk thuis werden gedagvaard door de gerechtsbode, de veldbode of leden van schepenbank. Dat gold ook voor mogelijke getuigen. Uit de stukken wordt niet helemaal duidelijk wat de inwoners van Itteren in deze zaak precies bedoelden met het 'oude heerkomen'. Misschien hadden ze het vanouds gebruikelijke voogdgeding op het oog, of de gewone procedure voor de schepenbank. Maar om een voogdgeding ging het duidelijk niet. Het was een nieuwe manier van opsporing, gebaseerd op de verplichting voor de inwoners om via de generale inqueste aangifte te doen.

Toen de heer tegen de weigeraars gerechtelijke maatregelen nam in de vorm van beslaglegging op hun goederen, werd 'lering' gevraagd bij de schepenen van Meerssen, de 'hoofdbank' waaraan Itteren onderhorig was. Die oordeelden dat de heer van Itteren een

\footnotetext{
1390 Voor een voorbeeld waarbij de gemeyne inqueste de inleiding vormde voor de berechting van een geval van hekserij zie Evers, 'Een Maastrichts heksenproces in 1612', 203, 207-208.

1391 Janssen de Limpens, Rechtsbronnen Limburg en Overmaze, 450, artikel 6.

1392 Janssen de Limpens, Rechtsbronnen Limburg en Overmaze, 450, 451, 455; zie ook Loontjens/Jogmans, 'Het Malensbos', 159-162.

1393 Habets, Limburgsche wijsdommen, 17, 127, 128, 140.

1394 Janssen de Limpens, Rechtsbronnen Limburg en Overmaze, 408, artikel 19.

1395 RHCL, Landen van Overmaze, inv. nr. 6831.
} 
'gemeyn inqueste' mocht afkondigen en houden op de manier, tijd en plaats die hem paste. Inwoners die weigerden daaraan mee te werken, waren strafbaar.

Duidelijk is dat het bij de inquest in zowel Gronsveld als Itteren als Maastricht niet gaat om rechtspraak door kerkelijke autoriteiten. Sterker nog, geestelijke personen werden op hun gedrag voor het wereldlijk gerecht gedaagd. De oproepen voor de zittingen gingen in 1602 en 1603 ook uitdrukkelijk uit van de drossaard, op bevel van de heer. Verder wijken de data die in Gronsveld en Heugem voor de inquest worden gegeven, ook af van de gebruikelijke dagen voor het voogdgeding. Daarmee lijkt de inquest een zelfstandige procedure ten opzichte van het voogdgeding, hoewel er overlap bestond. Een deel van de in Gronsveld opgesomde delicten zou, voor zover deze betrekking hebben op de omgang met publieke eigendommen, ook kunnen passen binnen het voogdgeding. Het is daarom mogelijk dat in andere plaatsen het onderscheid tussen voogdgeding en inquest niet zo scherp werd aangevoeld. Zowel in Itteren als Gronsveld wordt gesproken over het oud gebruik van de inquest, maar dat betekent op zich niet zoveel. Misschien moeten we in Gronsveld bij de ondervraging uit 1550 een directe relatie leggen met het 'Mandat den floicken ende schelden belangende', dat kort tevoren, in 1546, ter handhaving van openbare orde en zeden was afgekondigd. Daarin wordt ook gesproken over aangifteplicht. Wie bijvoorbeeld godslastering niet meldde, werd gestraft 'des stillschweigens wegen'. Daarmee zouden inquestprocedures zoals in Gronsveld en Itteren moeten worden geplaatst binnen het algemene kader van de 'policey'-wetgeving in de zestiende eeuw, waarbij de overheid streefde naar een zodanige controle over de samenleving, dat onderdanen in godvrezendheid een geordend en veilig leven konden leiden. Hoe lang de inquest in Gronsveld heeft geduurd, valt niet te zeggen. Waarschijnlijk is deze procedure in de loop van de zeventiende eeuw verdwenen dan wel opgegaan in het voogdgeding.

\subsection{Enkele aspecten van materieel recht en procesrecht}

In Hoofdstuk 7 over de wetgeving is er op gewezen dat in Gronsveld verschillende soorten recht werden toegepast: rijksrecht in de vorm van het geleerde, gerecipieerde Romeinse recht, Brabants en Luiks recht en plaatselijk gewoonterecht. Door de gebrekkige overlevering van het schepenbankarchief kan moeilijk worden vastgesteld of veel gebruik werd gemaakt van de op Keuls recht gebaseerde Gronsveldse Rechtsordnung uit 1671. Er zijn, zoals al eerder opgemerkt, goede redenen aan te nemen dat de toepassing beperkt was. Dat gold echter niet (wanneer we in het midden van de achttiende eeuw Prummer mogen geloven) voor het recht met betrekking tot de lenen en de keurmeden, evenals het procesrecht in civiele zaken. De hoofdstukken daarover in de Rechtsordnung hebben specifiek betrekking op Gronsveld, maar ze zijn tamelijk kort (zeven artikelen over leenrecht, drie over keurmede en veertien over procesrecht). Een korte bespreking van het recht van keurmede en het procesrecht in civiele zaken volgt hierna. Het leenrecht komt in Hoofdstuk 10.4 - 10.6 aan de orde. 
De betekenis van de keurmedige goederen voor het ontstaan van de dorpen van het graafschap werd al in Hoofdstuk 2.2.2 en de daarop volgende beschrijvingen van de afzonderlijke plaatsen behandeld. Voor de heer van Gronsveld vormden de keurmeden een bron van inkomsten en de rentmeester was verantwoordelijk voor de registratie daarvan. Dat daar niet altijd de nodige zorg aan werd besteed, blijkt uit het feit dat Prummer in 1758 na een grondig onderzoek het aantal van negen bekende keurmedige goederen wist te verhogen tot liefst 35.1396

Het verlies van keurmeden hing ook samen met het procesrecht bij wanbetaling. $\mathrm{Na}$ overlijden van de 'drager', degene op wiens naam het goed was geregistreerd, moesten diens erfgenamen binnen zes weken aangifte doen bij de heer. Die mededeling ging vergezeld met het verzoek het goed opnieuw te mogen 'verheffen' tegen betaling van een koe of paard als keurmede. Prummer schrijft dat in zijn tijd als sinds mensenheugenis de waarde daarvan in geld werd voldaan. Hij had slechts twee voorbeelden gevonden waar in natura was betaald.

Indien het keurmedig goed was verdeeld onder verschillende bezitters, bleven deze ieder afzonderlijk aansprakelijk voor het totale bedrag aan keurmede. Anderzijds kon de 'drager' die de keurmede betaalde, wel van zijn medebezitters zekerheid eisen voor hun aandeel in de schuld in de vorm van hypotheek op elk willekeurig onroerend goed.

Volgens de Rechtsordnung viel bij wanbetaling het keurmedig goed als zijnde 'caduc' via een procedure van gerechtelijke uitwinning terug aan de heer. Dat verhaalsrecht leverde in de praktijk voor de heer problemen op. Meestal was het bestaan van de keurmede op zich niet zo moeilijk aan te tonen (betalingen in het verleden golden als voldoende bewijs), maar de heer moest om tot zijn recht te komen de procedure volledig tot het einde bij de schepenbank doorlopen (bij dit soort schulden in beginsel van voogdgeding tot voogdgeding).De onwillige debiteur had echter tot het laatst toe de mogelijkheid door betaling aan uitwinning te ontsnappen. Daarmee stonden de proceskosten dikwijls niet meer in verhouding tot de waarde van een paard of koe. Pas Prummer maakte aan dit misbruik van procesrecht een einde door eerst de debiteuren met bewijsstukken van het recht van keurmede te confronteren, om vervolgens te proberen langs minnelijke weg tot betaling te komen.

Bij het procesrecht rijst als de vraag of er verschillen bestonden tussen de afzonderlijke schepenbanken. In een ordonnantie uit 1611 bepaalde graaf Johan II van Bronckhorst Batenburg dat de manier van procederen tussen Gronsveld en Slenaken hetzelfde moest zijn (zie bijlage 4). Een dergelijke uniformering was zeker met het oog op hoofdvaart/hoger beroep van Slenaken op Gronsveld gewenst. Waarschijnlijk bestond een dergelijke gelijkvormigheid ook voor Heugem en Honthem. Maar wanneer we kijken naar de tarievenlijst van de gerechtskosten in 1724, dan zien we daarin behalve verschillen in kosten ook verschillen in procesrecht. Zo kwam hiervoor al het verschil tussen enerzijds Gronsveld en anderzijds Heugem en Honthem ter sprake bij de termijnen waarbinnen werd geprocedeerd. Verder waren in Gronsveld, Heugem en Honthem voor

1396 TJ, inv. nr. M 12, fol. 1163-1184, rapport van Prummer aan M.E von Toerring-Jettenbach 19 oktober 1758. 
een proces drie en in Slenaken vier genachtingen gereserveerd (daarna volgde een eind- of tussenvonnis met bewijsopdracht en verdere wisseling van stukken).

Er bestonden dus minimale verschillen in procesrecht; aanzienlijk groter was het onderscheid in tarieven. Die konden oplopen tot het dubbele van een bedrag. Grosso modo hanteerden Gronsveld en Slenaken dezelfde prijzen en ook bij Heugem en Honthem vielen die grotendeels samen. Volledig identiek waren de bedragen binnen die twee groepen echter niet.

Titel 18 van de Gronsveldse Rechtsordnung beschrijft in veertien artikelen het schriftelijk verloop van een proces met eis, antwoord, repliek, dupliek en bewijsvoering. Merkwaardig genoeg staat er niets over de eis, zoals geformuleerd in het tarievenoverzicht van 1724, dat alle 'aensat' moest beginnen tijdens het voogdgeding. Verschillende bepalingen in de Rechtsordnung waren gericht tegen vertragingstactieken van zowel partijen als advocaten. Ook de vakantieperiodes van het gerecht waren vastgelegd: van 15 juli tot het feest van Sint Bartholomeus (24 augustus) ${ }^{1397}$, van Kerstmis ( 25 december) tot Driekoningen (6 januari) en van acht dagen voor tot acht dagen na Pasen en Pinksteren. Een overzicht van alle processuele momenten en handelingen met de daarbij behorende stukken is te vinden in de specificatie van de kosten voor ieder stuk.

Vonnissen werden met meerderheid van stemmen vastgesteld, waarbij een minimale bezetting van de schepenbank met drie schepenen voldoende was voor een geldige uitspraak. Uitdrukkelijk was de mogelijkheid opengehouden bij ingewikkelde zaken advies in te winnen bij 'onpartijdige rechtsgeleerden' in de stad. ${ }^{1398}$ Het initiatief daartoe kon uitgaan van het gerecht, maar ook van partijen. Dit advies werd vervolgens in de vorm van een vonnis geredigeerd en uitgesproken. Deze procedure was meestal een kostbare aangelegenheid. In een geschil voor het leenhof van Gronsveld - tussen het klooster Sinnich en Tilman Coumans uit 1615 liet graaf Johan II van Bronckhorst Batenburg deze adviesaanvraag daarom toe onder de uitdrukkelijke voorwaarde 'dat sulcx mit den minsten oncosten geschehen moge' en partijen niet met onnodig hoge gerechtskosten werden opgezadeld. ${ }^{3} 399$

Opmerkelijk is dat de Rechtsordnung het doet voorkomen alsof drossaard/scholtis en schepenen in gezamenlijk overleg tot een vonnis kwamen. Waarschijnlijk was dat in de praktijk ook zo. Het feit dat de scholtis soms ook tegelijk als schepen optrad, versterkte dit alleen nog maar. Formeel mocht de drossaard/scholtis de schepenen echter alleen 'manen' tot het geven van een vonnis.

Eén bepaling in de Rechtsordnung behandelt de executoriale verkoop. Nadat het gerecht de vordering aan de schuldeiser had toegewezen en 'immissie' had verleend, kon deze zijn schuld op de debiteur verhalen door openbare verkoop van de goederen die met de schuld waren verbonden (hypothecaire schuld, grondrente, keurmede en heergewaad, pand bij roerend goed). Die veiling werd drie keer gedurende drie maanden door middel van

1397 Patroonheilige van de kerk van Eckelrade.

1398 Zie daarover voor de praktijk in Overijssel, Gelderland en Brabant met opgegeven literatuur: Jacobs, 'Is het wel de rechter die recht vindt?', 34-37.

1399 RHCL, Rijkskamergerecht inv. nr. 222, fol. 25vo. 
aanplakbiljetten bekend gemaakt. Daarna werd er met 'brandende kaars' (de tijd dat een kaars brandde) aan de meestbiedende verkocht. Tot het moment van de veiling kon de debiteur de verkoop voorkomen door betaling van de schuld en reeds gemaakte kosten.

De Rechtsordnung besteedt geen aandacht aan de vrijwillige rechtspraak. In het bijzonder wordt niets gemeld over de bij schepenbanken en leenhoven in de omgeving gebruikelijke procedure van de 'gichting' of 'realisatie' van akten met zakelijke werking, zoals overdracht van eigendom, geldleningen met hypotheekstelling, testamenten et cetera. Sommige akten passeerden direct ten overstaan van scholtis en schepenen, bij andere transacties maakten partijen eerst gebruik van de diensten van een notaris; daarna werd de notariële akte ingeschreven of 'gerealiseerd'. Het was gebruikelijk dat het gerecht door middel van een korte formule verklaarde dat de desbetreffende akte ter realisatie was aangeboden, waarna de tekst in extenso werd ingevoegd. Overigens konden ook andere akten worden gerealiseerd, bijvoorbeeld uittreksels uit gichtregisters van andere schepenbanken, volmachten of onderhandse stukken. Inschrijving was niet verplicht, maar wel gewenst, aangezien in beginsel alleen gerealiseerde akten werking hadden tegenover derden. Ter besparing van kosten lieten partijen soms inschrijving achterwege of gebeurde dit pas jaren later na de vastlegging van de overeenkomst. Immers, wanneer de verkoop bij het gerecht bekend was, moest daarvan ook overdrachtsbelasting in de vorm van 'werfschelling' of 'oorlofsgeld' worden betaald.

\subsection{Criminaliteit}

Gegevens over de strafrechtspleging zijn in Gronsveld door het ontbreken van de schepenbankarchieven nog schaarser dan gegevens over civiele procedures. Enigszins een indruk bieden de opbrengsten van schikkingen of 'composities' in strafzaken, die in rentmeesterrekeningen staan vermeld onder het hoofdje 'breucken'. De opbrengst wisselde sterk en hing ook af van toeval. In de rentmeesterrekeningen uit de zestiende en het begin van de zeventiende eeuw werd regelmatig 'nihil' bij deze post genoteerd. Dat betekent niet altijd het volledig ontbreken van strafbare feiten, want soms zag de heer af van zijn aandeel, maar kreeg de drossaard of scholtis wel zijn deel. Van de jaren dat inkomsten staan genoteerd, noemen we hier 1536-1537 met zeven gevallen van schikkingen, vijf keer wegens het wegnemen van goed waarop de gerechtsbode beslag had gelegd en twee maal wegens het los laten lopen van een koe in het bos. ${ }^{1400}$ Ook voor 1552-1553 worden verschillende bedragen genoteerd, zoals voor een 'exces', gepleegd door de zoon van Dries de Molenaar in Slenaken bij een 'dochter' in het dorp. Van dit bedrag ontving de scholtis een vierde deel en de heer de rest. ${ }^{1401}$ Bij ernstiger delicten, waarbij de drossaard optrad, lag de verdeling anders. Volgens de rentmeestersrekening van $1622 / 1623$ kon een man die in echtbreuk leefde en uit die relatie een kind had verwekt, zijn straf afkopen met betaling van tweehonderd gulden, waarvan eenderde toevloeide aan de drossaard en tweederde aan de heer. ${ }^{1402}$ Waarschijnlijk veranderde de verdeling van

${ }^{1400}$ RHCL, Graafschap Gronsveld, inv. nr. 172.

1401 RHCL, Graafschap Gronsveld, inv. nr. 174.

1402 RHCL, Graafschap Gronsveld, inv. nr. 184. 
boetegelden in de loop van de tijd. Volgens Prummer belandde in het midden van de achttiende eeuw de helft van de boeten in de grafelijke kas en ontving drossaard of fiscus de andere helft. ${ }^{1403}$

Processen die konden eindigen met de doodstraf werden meestal niet afgedaan buiten medeweten van de heer. Natuurlijk wenste die op de hoogte te zijn van ernstige delicten, maar aan de uitoefening van hoge justitie waren ook grote kosten verbonden. In dit verband kan nog eens worden herinnerd aan de terechtstelling in 1617 van een jongen uit Honthem wegens het plegen van seksuele handelingen met een kalf. De kosten beliepen meer dan honderd gulden, welk bedrag ten laste van de grafelijke kas kwam.

\subsection{Het hoger beroep}

\subsubsection{De Schepenstoel van Aken als hoofd-en appelgerecht}

De 'Specificatie' van rechten verbonden aan het graafschap Gronsveld uit 1650 besteedt ook aandacht aan het hoger beroep dat tegen vonnissen van schepenbanken binnen Gronsveld kon worden ingesteld: van Gronsveld op de Schepenstoel van Aken, van Heugem op de schepenen van Luik, en van Aken en Luik ten slotte op het Rijkskamergerecht. De lijn is op zich helder, maar de angel zit in de toevoeging daarna:

Sonder dat nochtans eenighe van de voergenoempde overhoeffden souden hebben eenich particulier gesach, geboth offte spetie van jurisdictie binnen eenige van de voerss. dorpen, ' $t$ waere in materie van executie van hunne vonnissen off andersins.

Voor die formulering is bewust gekozen, want graaf Jost Maximiliaan van Bronckhorst Batenburg toonde zich een uitgesproken tegenstander van bemoeienis uit Aken, zowel wat betreft de vonnissen van de schepenbank Gronsveld als ook vonnissen van het leenhof van Gronsveld (zie daarover meer Hoofdstukken 9.9.2 en 10.6). Feitelijk betekende dit voor Luik en Aken de onmogelijkheid jurisdictie uit te oefenen zonder medewerking van de lagere rechters.

Het is vanwege de verwevenheid van appeldossiers over drie en soms vier instanties lastig een scheiding te maken tussen het appel binnen en buiten het graafschap. Om de verhouding van Gronsveld ten opzichte van de Schepenstoel van Aken in een breder perspectief te plaatsen, is het noodzakelijk eerst aandacht te besteden aan de positie van de Schepenstoel als appelgerecht in de zestiende en vooral de zeventiende eeuw. Daarna worden de Gronsveldse appellen behandeld. Aan de hand van een aantal voorbeelden wordt geprobeerd in grote lijn de procesgang in kaart te brengen. Het betreft alleen gevallen waarvan (meestal alleen fragmenten van) dossiers bewaard zijn gebleven in de

1403 TJ, inv. nr. M 73, fol. 532. 
archieven van het graafschap Gronsveld en het Rijkskamergerecht. Niet onderzocht zijn de archieven in Aken en Luik. ${ }^{1404}$

De rol van de Schepenstoel van Aken als hoofd- en appelgerecht raakte na de oprichting van het Rijkskamergerecht en de Rijkshofraad om verschillende redenen al snel aan erosie onderhevig. Door het Verdrag van Augsburg van 1548 werden de Habsburgse Nederlanden en de Bourgondische Kreits onttrokken aan de jurisdictie van het Rijkskamergerecht en de Rijkshofraad. Daarmee verviel Aken voor plaatsen uit die gebieden als tusseninstantie voor het Rijkskamergerecht. De steeds duidelijker scheidslijn tussen de Bourgondische en de op het Rijk georiënteerde Nederrijns-Westfaalse Kreits, kreeg in de loop van de zestiende en zeventiende eeuw ook gevolgen voor de rechtspraak. Zo maakte de instelling van het college van commissarissen-deciseurs voor Maastricht in 1545-1547 een einde aan het appel op Aken. In de daarop volgende decennia sloten met Maastricht gelieerde gerechten (Elf Banken van Sint-Servaas, de Vroenhof, kerkelijke rechtbanken in de stad) zich daar bij aan. ${ }^{1405}$ Een vergelijkbare ontwikkeling deed zich voor bij het hoofdgerecht Wessem, waarvan het ressort zich aanvankelijk uitstrekte over een reeks schepenbanken in het tegenwoordige Midden-Limburg. Door de feitelijke inlijving van Wessem bij het Overkwartier van Gelre in de tweede helft van de zestiende eeuw werd het appel op Aken in 1586 omgebogen naar het hof van Gelre in Roermond. Het duurde echter ruim een eeuw voordat deze maatregel volledig effect sorteerde. Pas in 1708, tijdens de Spaanse Successieoorlog (1702-1713) verboden de Staten-Generaal, die Wessem tijdelijk bezet hielden, het appel op Aken definitief. ${ }^{1406}$ Ook kleinere (al dan niet rijksonmiddellijke) heerlijkheden aan de rand van Overkwartier, zoals Dalenbroek, Meyel en Obbicht en het thans Duitse Hamb, Millendonck en Hörstgen gingen vanaf de zeventiende eeuw in hoger beroep bij het hof in Roermond. ${ }^{1407}$

Voor de plaatsen aan de rand van het Overkwartier of in de omgeving van Maastricht ging van de nabijheid van een groot territorium of een grote stad een 'aanzuigende werking' uit, maar ook zonder een dergelijke invloed werd voor kleinere rijksonmiddellijke heerlijkheden de gang naar Aken steeds minder vanzelfsprekend. Zo kreeg Rekem in de zestiende eeuw privileges de non-evocando et de non arrestando, waardoor inwoners niet buiten de baronie hoefden terecht te staan. Aken fungeerde nog enige tijd als beroepsinstantie,

1404 De daarvoor in aanmerking komende archieven zijn matig ontsloten. Bovendien is het de vraag of ze veel nieuws bevatten; van de spraakmakende zaken zijn al stukken te vinden in de Maastrichtse dossiers van het Rijkskamergerecht (met Aken als tusseninstantie) en in de archieven van het graafschap Gronsveld.

1405 Van Rensch, 'De rechtspraak van de Commissarissen-Deciseurs'.

1406 Hanssen, Inventarissen Wessem, 19-20.

1407 Berkvens, Plakkatenlijst Overkwartier I, 98-107, 112-125. Een vergelijkbare ontwikkeling, maar dan in omgekeerde richting, is te zien bij het hoofdgerecht Thorn. De uit de middeleeuwen daterende hoofdvaart en later het appel van Thorn op het Gelderse Echt, kwam na 1648 onder druk te staan, toen deze jurisdictie steeds meer werd vertaald in Gelderse soevereiniteit over Thorn. De gang naar Echt werd in 1718 definitief afgebroken door de oprichting van een Raad van Appel voor Thorn, van waaruit in hoogste instantie weer beroep open stond op het Rijkskamergerecht of de Rijkshofraad. De Schepenstoel van Aken kwam daar als tussen instantie niet meer aan te pas, vgl. Van Rensch, 'Rechterlijke organisatie Thorn', 64-71. 
totdat de baron omstreeks 1600 een eigen college van appelcommissarissen instelde, zetelend te Luik. ${ }^{1408}$ Een tweede voorbeeld is Wylre, waar de laatste appelzaak op Aken dateert van 1690-1692. Begin achttiende eeuw benoemde de heer van Wylre een 'Appellations Commissarius'; de eerste vermelding daarvan is van 1723.1409 De in 1689 van alle leenbanden met het hertogdom Limburg bevrijde baronie Wittem kende ook al vanaf 1705 een appelcommissaris. ${ }^{1410}$

Hoe gecompliceerd de relatie met Aken kon zijn, leert het voorbeeld van Rijckholt. We besteden daar iets uitgebreider aandacht aan, omdat de problemen van Rijckholt in tijd deels samenvallen met de moeilijkheden tussen Gronsveld en Aken. Oorspronkelijk kende Rijckholt hoofdvaart/appel op Aken, maar in 1614 werd die rechtsgang de verlegd naar 'sGravenvoeren. In 1616 volgde de aanmaning vanuit Aken om als vanouds te appelleren op de Schepenstoel, maar daarna arriveerde in 1626 weer een bevel uit 's-Gravenvoeren om daar een proces voor het hoofdgerecht te brengen. ${ }^{1411} \mathrm{Om}$ een einde te maken aan de voor de inwoners bezwaarlijke rechtsgang naar Aken, stelde baron Adolf van Wylich in 1671 een 'tribunal commissorial' te Maastricht in, bestaande uit de Maastrichtse licentiaten in de rechten Hellesfort en Stas. ${ }^{1412}$ Een beroep in hoogste instantie op de rijksrechters bleef daarbij mogelijk. Men lijkt bij dit 'tribunal' in dubbele bezetting de rechtspraak van de Maastrichtse commissarissen-deciseurs voor ogen te hebben gehad. In 1681 kwam de reactie uit Aken met de opdracht aan de schepenen van Rijckholt voor een hoger beroep een dossier in te sturen. De weduwe van baron Van Wylich protesteerde en beval de schepenen niet te gehoorzamen. ${ }^{1413}$ In 1684 wees de Schepenstoel de nieuwe heer van Rijckholt, Jean Maximilien de Bounam, op diens verplichting geen andere appellen dan die op Aken toe te laten, maar ook hij wenste niet aan de eis uit Aken te voldoen. Langzaam liepen de spanningen op. Naar aanleiding van een appel dat 'eenige onderdaenen' in 1698 hadden ingesteld, verbood Jean Maximilien de Bounam 'sulcke frivole ende incompetente Acker appellatien'. ${ }^{1414}$ Bepaald niet 'frivool' verliep een crimineel proces dat in 1700 door de schout van Rijckholt werd aangespannen tegen Jan Hendrik Brocken wegens doodslag, brandstichting, afpersing, bedreiging en belediging van de heer. Toen de verdachte aan tortuur werd onderworpen, appelleerde hij via zijn Maastrichtse advocaat Van Leeuwen bij de schepenen van Aken tegen dit dwangmiddel en tegen andere onregelmatigheden bij de procesvoering. De Akense schepenen verlangden daarop dat de schepenen van Rijckholt, de heer Van Rijckholt en de door hem ingeschakelde juristen zich zouden rechtvaardigen. Het gerecht van Rijckholt gaf geen krimp en kreeg vervolgens een (oninbare) boete van zeshonderd goudgulden opgelegd. Uiteindelijk werd Brocken levenslang verbannen uit Rijckholt. De 'stootelijcke injurieuse ende blamable' geschriften van diens advocaat

1408 Nève, Rijkskamergerecht, 462-464.

${ }^{1409}$ De la Haye, Inventaris Wylre, 20-21; 39.

1410 Nève, Rijkskamergerecht, 515-516. De functie van appelcommissaris bleef gedurende de achttiende eeuw bestaan. Niet geheel duidelijk is of nog op de Schepenstoel van Aken werd geappelleerd.

1411 De Wit, 'Inwendige toestanden', 172.

1412 RHCL, De Bounam de Ryckholt, inv. nr. 462.

${ }^{1413}$ De Wit, 'Inwendige toestanden', 172-173.

${ }^{1414}$ RHCL, De Bounam de Ryckholt, inv. nr. 478; vgl. De Wit, 'Inwendige toestanden', 174-175. 
werden onwaardig voor opname in het archief bevonden en buiten de gerechtskamer verbrand. ${ }^{1415}$

Met hun interventie in de zaak Brocken raakten de schepenen uit Aken een gevoelige snaar. Het ging immers om een crimineel proces en daarin was volgens algemene opvatting geen hoger beroep toegelaten. Dit verbod op appel werd soms omzeild door beroep tegen beslissingen van processuele aard, bijvoorbeeld toelating van bewijs, waarbij de kern van de strafzaak buiten beschouwing bleef. Indirect kon dat de uitslag van een proces beïnvloeden. Dat de Akense inmenging juist in een strafzaak de heer van Rijckholt niet zinde, blijkt uit een brief van Jean Maximilien de Bounam uit 1703 aan zijn Gronsveldse buurman, graaf Johan Frans van Bronckhorst Batenburg. Daarin beklaagt hij zich dat de Akense Schepenstoel niet alleen kennis nam van hoger beroep in civiele, maar ook in criminele zaken. In 1708 liet de Bounam door de schepenen van Pietersheim een verklaring opstellen dat in criminele zaken nooit een 'overrechter, noch appel en werdt geadmitteert', ook niet van Aken. ${ }^{1416}$

Omdat het appel op de Maastrichtse commissarissen ook bij de inwoners van Rijckholt op steeds meer weerstand stuitte, liet De Bounam zich iets nieuws invallen. In 1705 sloot hij een overeenkomst met Adriaan Gerard graaf de Lannoy, heer van Bolland, waarbij de schepenbank van Bolland als appelgerecht voor Rijckholt werd aangewezen. De heren grepen daarvoor terug op oude historische banden tussen Rijckholt en Bolland, die door de troebelen van de zestiende eeuw in vergetelheid waren geraakt. In de overeenkomst werden uitdrukkelijk van appel uitgesloten criminele zaken onder welk voorwendsel dan ook, zaken waarbij een publieke boetedoening als straf werd opgelegd en ten slotte alle processen over heerlijke cijnzen, keurmeden en belastingen. Het is de vraag of deze rechtsgang naar Bolland ooit van de grond is gekomen. In de eerste helft van de achttiende eeuw werd nog enkele malen vanuit Rijckholt op Aken geappelleerd en intervenieerden de Akense schepenen ook zijdelings in strafzaken, maar de verhoudingen bleven uiterst stroef. ${ }^{1417}$

Het hiervoor gegeven overzicht is verre van volledig, maar bij elkaar laten de beschreven gevallen een dalende lijn van invloed van de Akense Schepenstoel in de zestiende en zeventiende eeuw zien. Tegelijkertijd lijkt men in Aken daarin toch niet passief te hebben berust. Er werden bedreigingen tegen onwillige schepenbanken geuit en er werd zelfs, zoals we hierna bij Gronsveld zien, ook op beperkte schaal ingegrepen. Maar uiteindelijk ontbrak het de schepenen aan machtsmiddelen om hun gezag werkelijk door te zetten. Deze conclusie verdient in zoverre enige nuancering, dat het hier geschetste beeld berust op een wat eenzijdige benadering vanuit de plaatsen die zich tegen de Akense bemoeienis verzetten. Nader onderzoek zou moeten uitwijzen in hoeverre aan de reacties van de Schepenstoel op individuele gevallen een meer algemene visie ten grondslag lag.

1415 De Wit, 'Inwendige toestanden', 133-141.

1416 RHCL, De Bounam de Ryckholt, inv. nr. 486.

1417 De Wit, 'Inwendige toestanden', 175-176; vgl. ook RHCL, De Bounam de Ryckholt, inv. nr. 484. 


\subsubsection{Het hoger beroep van Slenaken op Gronsveld en van Gronsveld op Aken}

$\mathrm{Na}$ deze beschouwingen over de positie van de Schepenstoel van Aken als appelgerecht, beginnen we met de appellen in Gronsveld. Het eerste voorbeeld van appel vanuit Slenaken op Gronsveld begint in 1525 en betreft een proces tussen het adellijk convent van Sinnich en Claas Kneit over de betaling van achterstallige cijns. ${ }^{1418}$ De schepenbank van Gronsveld wordt als tweede instantie genoemd, maar gegevens over de behandeling daar ontbreken. Iets later, in 1526, begint de zaak van Andreas van den Hove genaamd van Carsveld tegen Willem van Franckenberg over het recht van erfpacht op de Broekhof in Slenaken. 1419 Scholtis en schepenen 'droegen de zaak over' aan de schepenen van Gronsveld als 'unssen wettigen heufft'. Op 1 mei 1527 kregen de schepenen van Slenaken 'geleert' een vonnis in deze zaak 'uyt te dragen vur recht', aan welke opdracht de bank van Slenaken op 4 mei gevolg gaf. Daarbij werd Andreas van den Hove in het gelijk gesteld. Maar Willem van Franckenberg appelleerde

vur dat overheufft des gerichs van Slenaken, te weten vur den wijzen heren der stadt Achen die wyllige eyn heufft synt des gerichtz van Gronsselt om eyn genedigen vonnys van hon te krijgen.

De appellant werd inderdaad in het gelijk gesteld en daarvan gaf de Schepenstoel van Aken op 4 juli 1527 'lering' aan de schepenen van Gronsveld. Dit vonnis werd op 10 juli in Slenaken uitgedragen. Daarna appelleerde Van den Hove bij het Rijkskamergerecht.

In de stukken worden voortdurend de begrippen 'lering' en 'appel' door elkaar gebruikt, wat de indruk wekt van een mengeling tussen hoofdvaart en appel. ${ }^{1420}$ Aan hoofdvaart herinnert de 'lering' van een hogere instantie die moet worden uitgesproken door de lagere rechter. Zo ging de zaak van Aken weer terug naar Gronsveld en vandaar naar Slenaken. Van den Hove ging ten slotte in hoger beroep bij het Rijkskamergerecht tegen een formeel door de schepenbank Slenaken uitgesproken vonnis. Naderhand vroeg het Rijkskamergerecht ook afzonderlijk afschriften van het procesverloop bij de schepenbanken van zowel Slenaken als Gronsveld.

Uit het begin van de zeventiende eeuw zijn er twee appelzaken met Lambert Couven als procespartij. De eerste betreft een geschil met Herman Meisen als klager over de grens van een stuk grond. ${ }^{1421}$ Op 24 augustus 1610 bepaalde het gerecht in Slenaken dat gedaagde Couven binnen tien dagen moest antwoorden. Meisen protesteerde en vond dat direct moest worden gereageerd. Het gerecht hield echter vast aan zijn beslissing en vervolgens werden tot 1 september bewijsstukken overgelegd en getuigen gehoord. Omdat Meisen ondanks een door het gerecht voorgestelde minnelijke schikking een uitspraak verlangde, besloot Couven appel in stellen bij het hoofdgerecht van Gronsveld. Meissen

1418 RHCL, Rijkskamergerecht, inv. nr. 126.

1419 RHCL, Rijkskamergerecht, inv. nr. 95.

1420 Op dit probleem wijst ook Hermesdorf, 'Te hoofde gaan', 40-50. De verwarring wordt in de hand gewerkt door het gebruik van onduidelijke terminologie in de stukken. Daarom valt vaak ook moeilijk vast te stellen of appel volgtijdelijk na hoofdvaart komt, of tegelijk naast elkaar bestond. Nog ingewikkelder woirdt wanneer beide procedures in één en dezelfde zaak worden toegepast.

1421 RHCL, Rijkskamergerecht, inv. nr. 145. 
protesteerde, maar de schepenen verklaarden Couven 'ontfanckbar'. Op 12 oktober 1610 leverden stadhouder en schepenen van Slenaken het dossier in te Gronsveld

'willende hun gegeven decrett [van 24 augustus] nitt sustineren (handhaven), maar stellen de partheye tegen parthye, laetende verder den eersaemen hoeffgericht daerinne te ordinieren naar behoeren'.

Uiteindelijk deed het gerecht van Gronsveld op 17 januari 1611 uitspraak ten gunste van Couven, waarbij Meisen werd veroordeeld tot tweederden van de kosten en Couven eenderde. Tegen dit vonnis ging Meisen in appel bij de schepenen van Aken. Ondanks protest van Couven dat het beroep niet op de juiste wijze was ingesteld, werd de zaak aangenomen. Op 28 november 1614 verklaarde de Schepenstoel het appel echter voor 'desert' en werd Meisen veroordeeld tot betaling van de gerechtskosten volgens de oorspronkelijke verdeelsleutel. Tegen die uitspraak ging Meisen in beroep bij het Rijkskamergerecht. De procedure liep daar tot 1619, maar werd waarschijnlijk nooit met een eindvonnis afgesloten.

De tweede zaak met Lambert Couven als partij betreft een proces dat door hem namens zijn echtgenote en schoonfamilie werd gevoerd tegen Beatrix van Birgelen. ${ }^{1422}$ Daarin wezen de schepenen van Slenaken als eerste instantie op 15 januari 1613 vonnis 'ten manissen van onsen stadhouder ende onder correctie van onssen wettighen hooft'. Couven werd in het ongelijk gesteld, waarna hij zich 'gegravert (bezwaard) bevindende', appelleerde bij het hoofdgerecht Gronsveld met garantstelling voor de kosten. Op het dossier staat dat het appel naar Gronsveld werd overgebracht door stadhouder en schepenen van Slenaken 'willende die voerss. schepenen hun vonnisse nyet sustineren, maer stellende parthie teghen parthie'.

Het is dezelfde passage die ook werd gebruikt bij de overbrenging van de eerder genoemde zaak van Meisen versus Couven in 1610. Kennelijk gaat het om een min of meer vaste formule die past in de overgangssituatie van hoofdvaart naar appel. Anders dan bij de 'lering' in hoofdvaart werd de verdere behandeling en afdoening van de zaak nu door de lagere rechter duidelijk overgedragen aan de hogere instantie. Door als het ware afstand te nemen van het eigen (tussen)vonnis, bleef de lagere rechter verder als 'partij' buiten het geding en kon daar in hoger beroep ook niet meer verantwoordelijk voor worden gehouden.

Dat hoofdvaart en appel nog tot lang in de zeventiende eeuw naast elkaar bleven bestaan en niet zo scherp van elkaar zijn te scheiden blijkt ook uit een passage in een overeenkomst die graaf Jost Maximiliaan van Bronckhorst Batenburg in 1646 met de inwoners van Slenaken sloot na aflossing van de verpanding van Slenaken aan de heer van Mheer (zie Bijlage 36) Daarin kreeg de bank van Slenaken als vanouds de civiele en criminele rechtspraak gegarandeerd 'behoudelick hun wettich overhooft altijt te hebben tot Gronsfelt tsij bij appellatie oft leeringe etc.'

De zaak van Lambert Couven tegen Beatrix van Birgelen laat ook iets zien over de processuele formaliteiten bij appel. Tegen de uitspraak van de schepenen van Slenaken op

1422 RHCL, Graafschap Gronsveld, inv. nr. 599. 
15 januari 1613 kondigde de vertegenwoordiger van Couven op 24 januari alleen hoger beroep aan. Nadat de wederpartij de kans had gekregen daarop te antwoorden, leverden stadhouder en schepenen van Slenaken een afschrift van het proces in te Gronsveld. Vervolgens werd daar verder geprocedeerd, te beginnen met een memorie van 'grieven' van Lambert Couven.

In het midden van de zeventiende eeuw namen de formaliteiten toe. Zo wees op 20 februari 1657 de schepenbank Slenaken tussen Merten Frijns en Claas Crutzerclaes vonnis in een proces over het plaatsen van een omheining. ${ }^{1423}$ Crutzerclaes verloor en ging in hoger beroep. Vervolgens werd een formele akte van appel uitgebracht en zond de schepenbank van Gronsveld 'brieven van mandement' ter opvordering van de stukken naar Slenaken. Met een akte van appel bevestigde de appellant het hoger beroep dat vaak al mondeling ('viva voce'), direct na de uitspraak, was aangekondigd en stelde hij zich tevens garant voor de kosten. Een - voor Gronsveld zeldzaam - voorbeeld van een dergelijke akte van appel bevindt zich in het procesdossier van de weduwe Catharina Couven geboren Hoven, vertegenwoordigd door haar zoon Lambert Couven, tegen de weduwe Catharina van Lamsweert geboren Groottarts en de gemeente Slenaken.1424 Lambertus Couven appelleerde tegen een vonnis van de schepenen van Slenaken en legde daartoe op 18 juni 1671 voor notaris Graven te Gronsveld (tevens secretaris van Slenaken) een verklaring af. Dit stuk werd vervolgens 'geïnsinueerd' of betekend aan de tegenpartij en aan het gerecht van Slenaken.

Een voorbeeld van een mandement van appel of 'beschrijfbrief' levert het al eerder genoemde proces van Simon Reynaerts en Lambert van der Schoer tegen Hendrik Blonden uit 1664, waarbij van Honthem op Heugem wordt geappelleerd (tevens ook het enig bekende appel van Honthem op Heugem). ${ }^{1425} \mathrm{Op}$ een zeer afstandelijke toon en in plechtige bewoordingen (nota bene, de heren schreven wel aan zichzelf!) kregen drossaard en schepenen van Honthem bevel het dossier in eerste aanleg 'besloeten ende beziegelt' in te zenden. Een dergelijk dossier bestond uit een gewaarmerkt afschrift van de rolzittingen in eerste aanleg en de originele processtukken. Vooral het kopiëren van de rol kon bij langdurige processen veel tijd in beslag nemen, waardoor de kosten opliepen. Tevens hield dit mandement via de schepenbank ook een dagvaarding in voor de geappelleerde om in Heugem te verschijnen.

Bij de hiervoor beschreven processen kwam al enkele malen het appel van Gronsveld op Aken ter sprake. Mogelijk leidde dat al in de zestiende eeuw tot wrijvingen, maar echt duidelijke gegevens daarover ontbreken. Pas vanaf de jaren dertig van de zeventiende eeuw ontwikkelden zich enkele processen die gedurende vele jaren de betrekkingen tussen Aken en Gronsveld zouden vergiftigen. Het begon met een kwestie tussen Diederich Couven, bezitter van het leengoed Hees te Slenaken, en de inwoners van Slenaken. Er bestond verschil van mening over de hoogte van de vrijstelling in de belasting, waarop

1423 RHCL, Graafschap Gronsveld, inv. nr. 630.

1424 RHCL, Graafschap Gronsveld, inv. nr. 671.

1425 RHCL, Graafschap Gronsveld, inv. nr. 275. 
Couven als bezitter van een adellijk leengoed aanspraak meende te kunnen maken. ${ }^{1426}$ Aanvankelijk was de verhouding tussen Diederich en de graven van Gronsveld goed, maar na 1630 verslechterde die, niet zo vreemd, want Diederich lijkt een hooghartig en bijzonder koppig karakter te hebben gehad. In 1636 kreeg Couven van graaf Jost Maximiliaan van Bronckhorst Batenburg bevel zijn aandeel in de dorpsbelastingen en andere schulden aan de graaf te betalen. ${ }^{1427}$ Bovendien moest hij ophouden de inwoners van Slenaken te bedreigen. Om aan de problemen een einde te maken, sloten Couven en graaf Jost Maximiliaan en zijn broer Willem Otto in 1638 een vaststellingsovereenkomst, waarin de verplichtingen van Couven werden vastgelegd. ${ }^{1428}$ Dat leidde niet tot de gewenste verzoening. Want enkele jaren later, in 1641, eisten keizerlijke troepen, gelegerd te Linnich bij Jülich, een fors bedrag aan schatting van het dorp Slenaken. Toen de inwoners vergaderden hoe zij het geëiste bedrag bij elkaar konden brengen, vroegen zij ook Diederich om een bijdrage. Die weigerde hooghartig, zei dat hij zou betalen wat hij moest betalen en wenste verder niets met de boeren te maken hebben. Toen werd gevraagd wat hij deed wanneer hij wegens belastingschuld werd gegijzeld, riep hij dat ze hem wel een plaats bij de kachel zouden anbieden, terwijl de 'schellemsche bouren' op water en brood in het gevang kwamen. De Slenakenaren die van een dergelijke houding alleen maar onheil verwachtten, zochten buiten het dorp een veilig heenkomen. Toen de soldaten hun vordering kwamen executeren, namen ze de achtergebleven Couven gevangen en brachten hem naar Linnich. De inwoners van Slenaken stuurden twee afgevaardigden met de mededeling dat ze hem wel wilden vrijkopen, mits hij zijn belastingen betaalde. Maar Couven volhardde in zijn weigering en dreigde zelfs bij de dorpelingen verhaal te halen indien ze hem niet hielpen. Omdat de Slenakenaren verdere militaire executie vreesden, vluchtten zij opnieuw uit hun dorp. Toen de soldaten inderdaad Slenaken binnenvielen, troffen ze niemand meer aan, zodat alleen de paarden van Couven werden meegenomen. ${ }^{1429}$

Toen Diederich merkte dat de dorpsbewoners niet betaalden, liet hij door zijn broer vijfhonderd pattacons opnemen bij kanunnik Goltstein te Aken om zichzelf vrij te kopen. De Erven Goltstein daagden vervolgens Couven voor het gerecht in Slenaken om dat geld terug te krijgen. Diederich stelde zich echter op het standpunt dat de Slenakenaren moesten betalen. Die weigerden met als argument dat Couven een grote schuld aan achterstallige schatting had. Het geld dat hij voor zijn vrijlating had betaald kon in mindering worden gebracht. Couven daagde vervolgens de schatheffers en ingezetenen van Slenaken voor de schepenbank van Slenaken. maar helaas viel het vonnis nadelig voor hem uit en werd hij veroordeeld tot het betalen van 532 gulden. Hij appelleerde bij de

1426 RHCL, Klooster Hoogcruts, inv. nr. 727. In een verzoekschrift van de weduwe van Diederich Couven aan gravin Christina von Hardenrath uit 1676 wordt gesteld dat graaf Johan II van Bronckhorst Batenburg eertijd het huis en goed Heeze had 'verclaert te wesen een vrij adelijck goet en als sulcx geprotegeert ende gesalvegardeert'. Of zij die bewering ook met bewijzen kon staven, is niet duidelijk. De Het heeft in ieder geval niet geleid tot een algehele vrijstelling van belastingen.

1427 RHCL, Graafschap Gronsveld, inv. nr. 557, sub. nr. 41.

1428 RHCL, Graafschap Gronsveld, inv. nr. 557, sub nr. 15.

1429 RHCL, Graafschap Gronsveld, inv. nr. 557, verslag van deze gebeurtenissen in notarieel getuigenverhoor van 1 juli 1659 . 
schepenen van Gronsveld, waarna het dossier op 6 augustus 1648 naar Gronsveld werd overgebracht.

In het daaropvolgend proces bepaalden de schepenen van Gronsveld op 30 mei 1649 dat partijen werden toegelaten tot het leveren van bewijs voor hun wederzijdse vorderingen. In afwachting van een definitief vonnis kreeg Couven opdracht het eerder genoemde bedrag van 532 gulden te betalen. Schatheffers en ingezetenen van Slenaken moesten zich garant stellen voor de terugbetaling indien zij de zaak verloren.

Van deze uitspraak ging Couven onmiddellijk bij de Schepenstoel van Aken in beroep. ${ }^{1430}$ Al op 2 juni 1649 vaardigden de Akense schepenen voor hun collega's in Gronsveld 'als euer unmittelbares kayserlich oberhaubt' zogenoemde 'compulsoriales' uit, een dwangbevel om het dossier naar Aken te sturen. Het gerecht kreeg opdracht om hangende het appel niets meer te ondernemen. Hoewel het bevel door de notaris in Gronsveld aan de schepenen werd betekend, gebeurde er vooralsnog niets. Pas op 27 juni 1650 werden de stukken ingeleverd.

Op 24 april 1651 wees de Schepenstoel van Aken vonnis, dit keer in het voordeel van Couven. Daarvan gingen schatheffers en ingezetenen van Slenaken in appel bij het Rijkskamergerecht. Op 1 juli 1651 gaf het Rijkskamergerecht aan Aken bevel de stukken in te leveren, wat de Schepenstoel op 5 september 1651 accepteerde. Met die acceptatie ging men juridisch gezien ook akkoord met de opschortende werking van het appel, wat een einde moest maken aan verdere bemoeienis van de Schepenstoel. Maar in plaats daarvan gaven de Akense schepenen twee dagen later bevel aan Slenaken toch hun vonnis ten uitvoer te leggen. Daartegen gingen de schepenen van Slenaken ook weer in appel bij het Rijkskamergerecht. Ook het gerecht van Gronsveld ontving een bevel van de Schepenstoel aan hun vonnis te voldoen, wat vervolgens weer vanuit Gronsveld tot protest bij het Rijkskamergerecht leidde. Uiteindelijk stuurde de Schepenstoel op 15 februari 1652 het dossier in de eerste, tweede en derde aanleg wel naar het Rijkskamergerecht, maar ging men ondanks de opschortende werking van het beroep toch door met de executie van het vonnis, zeer tot ongenoegen van het Rijkskamergerecht. ${ }^{1431}$ De schatheffers in Slenaken stelden zich intussen op het standpunt dat zij, onafhankelijk van het geschil over de vordering van Couven, toch de gewone schattingen op de grond konden innen. Omdat Couven weigerde te betalen, werd overgegaan tot gerechtelijke invordering krachtens een provisioneel vonnis van de schepenen van Gronsveld. Couven en zijn echtgenote dreigden daarna inwoners te laten oppakken en paarden en koeien te laten weghalen. Dat bleef niet bij woorden, want op 20 augustus 1652 viel een detachement Akense soldaten Slenaken binnen. ${ }^{1432}$ Couven onthaalde 's morgens de mannen op bier en vervolgens wees een knecht hen de weg naar de juiste adressen. Gearresteerd werden Jan Vincken, stadhouder, schepen en schatheffer en nog drie andere

\footnotetext{
${ }^{1430}$ Er zijn verschillende dossiers over deze kwestie tussen Couven en Slenaken, o.a. RHCL, Graafschap Gronsveld, inv. nr. 557, RHCL, Klooster Hoogcruts, inv. nr. 720 en 975, RHCL, Rijkskamergerecht, inv. nr. 124. Hier wordt, tenzij anders nodig, verwezen naar RHCL, Rijkskamergerecht, inv. nr. 1, waarin afschriften van deze appelzaak zijn opgenomen.

1431 RHCL, Rijkskamergerecht, inv. nr. 1, fol. 20-23.

1432 Getuigenverhoor van schepenen van Slenaken op 9 september 1652 van deze inval in RHCL, Graafschap Gronsveld, inv. nr. 557.
} 
inwoners. De gevangenen werden als gewone criminelen naar Aken overgebracht en opgesloten. De vrouw van Couven dreigde daarna dat nog meer inwoners zouden worden opgehaald.

Aan Akense kant was men voorlopig niet van plan de gevangenen te laten vertrekken. Op 4 februari 1653 gaf het Rijkskamergerecht bevel de mannen vrij te laten, wat op 24 juni nog eens uitdrukkelijk werd herhaald, nadat graaf Jost Maximiliaan van Bronckhorst Batenburg zich borg had gesteld. ${ }^{1433}$ Maar uiteindelijk lieten de Akense schepenen pas op 12 september 1654 de Slenakenaren vrij. ${ }^{1434}$ Het proces voor het Rijkskamergerecht sleepte zich daarna nog decennia voort. Of het tot een echte oplossing is gekomen, is niet bekend. De inval van Akense soldaten bleef echter in het collectieve geheugen van de Gronsveldenaren gegrift als voorbeeld van machtsmisbruik.

Met de zaak van Diederich Couven tegen de gemeente Slenaken had graaf Jost Maximiliaan van Bronckhorst Batenburg alleen zijdelings bemoeienis gehad. In een ander proces speelde hij echter zelf als partij een rol. De zaak kende een lange voorgeschiedenis en begon omstreeks 1585 met een voor de schepenbank van Gronsveld aangespannen proces tussen Johanna van Elderen, vruchtgebruikster van het graafschap Esneux tegen Agnes van Bylandt en haar zoon Jost van Bronckhorst Batenburg over een jaarlijkse rente van 63 malder en vier vat rogge. 1435 Deze rente was in 1439 gecreëerd, maar door oorlogsomstandigheden in de tweede helft van de zestiende eeuw niet meer betaald. Johanna van Elderen verloor haar zaak in eerste aanleg en ging omstreeks 1585 in hoger beroep te Aken. Daar werd zij in 1596 in het gelijk gesteld, waarop de graaf appel aantekende bij het Rijkskamergerecht. Dit verwees de zaak terug naar Aken, waar het proces vanaf 1610 wel op de rol kwam, maar nauwelijks voortgang boekte. Pas in 1639 werd Johan Arnold van Argenteau, graaf van Esneux, in het gelijk gesteld en graaf Jost Maximiliaan van Bronckhorst Batenburg bij verstek veroordeeld. Daartegen ging laatstgenoemde weer in beroep bij het Rijkskamergerecht. Er waren diverse redenen waarom men aan Gronsveldse kant meende niet te hoeven betalen. In de eerste plaats had destijds iedereen onder de oorlog geleden en door de verwoesting van het land was in de naburige territoria wetgeving afgekondigd die debiteuren (gedeeltelijk) van hun schuld ontsloeg. Als kleine landsheerlijkheid moest Gronsveld zich wel aan de buren aanpassen. Ten tweede maakte men bezwaar tegen het verstek. De graaf was wegens de dienst in het leger wettig afwezig geweest en de schepenen in Aken hadden hun vonnis buiten de partijen om beraamd. Ten slotte bestond er verschil van mening over het juridisch karakter van de graanrente, omdat het voor een beroep op verjaring verschil maakte of het een al dan niet aflosbare rente betrof.

Er werden in 1640 en 1641 verschillende 'mandementen' door de Akense Schepenstoel uitgevaardigd om het vonnis van 1639 ten uitvoer te leggen, maar in Gronsveld gaf men letterlijk niet thuis. Eerst was de drossaard, die voor de executie verantwoordelijk zou zijn, lange tijd afwezig. Ook werd de juistheid van het vonnis in twijfel getrokken. Vervolgens probeerde de Schepenstoel met behulp van de Raad van Brabant in Brussel tot executie te

1433 RHCL, Rijkskamergerecht, inv. nr. 1, fol. 51-52vo.

1434 RHCL, Rijkskamergerecht, inv. nr. 1, fol. 51vo.

1435 RHCL, Rijkskamergerecht, inv. nr.76 en 77; zie over deze zaak ook TJ, inv. nr. M. 9. 
komen. De koning van Spanje was immers hertog van Brabant en de graaf van Gronsveld had bezittingen gelegen onder Brabantse jurisdictie. Op 14 april 1643 verstrekte de Schepenstoel nog eens - eigenlijk overbodig - ten behoeve van de graaf van Esneux een attest over de privileges en bevoegdheden van de Schepenstoel ten aanzien van de 'ondergerichten'. Intussen was Jost Maximiliaan van Bronckhorst Batenburg in appel gegaan bij het Rijkskamergerecht in Spiers, wat een probaat middel was om de zaak op de lange baan te schuiven. Uiteindelijk gebeurde dat ook en bleef het proces bij het Rijkskamergerecht tussen 1666 en 1729 rusten. Daarna is nog verder geprocedeerd en gecorrespondeerd tot het midden van de achttiende eeuw.

Helemaal werkeloos keken de Akense schepenen niet toe. Ondanks de procedure in Spiers trachtten zij toch tot executie van hun vonnis uit 1639 te komen. Zo riepen zij in 1657 de hulp in van de Raad van Brabant, maar ook dit liep uit op een mislukking. De houding van Jost Maximiliaan van Bronckhorst Batenburg tegen deze voorgenomen executie geeft een helder beeld van zijn visie op de Akense rechten. De graaf was van mening dat de schepenen van Aken nooit jurisdictie hadden gehad. Als gerecht in tweede aanleg mochten zij zuiver en alleen het vonnis van een lagere rechter bevestigen of herzien. ${ }^{1436}$ Vervolgens konden zij de rechters in eerste aanleg verzoeken (en niet dwingen) dit bevestigde of herziene vonnis ten uitvoer te leggen. Verder ergerde Jost Maximiliaan zich in hoge mate aan het feit dat de heren meenden jurisdictie te kunnen uitoefenen over een rijksstand zoals hij, een graaf en volwaardig, stemgerechtigd lid van de kreits.

Juist ook in 1657 speelde nog een conflict tussen Jost Maximiliaan en de Schepenstoel over het hoger beroep tegen vonnissen van het leenhof van Gronsveld op Aken (zie Hoofdstuk 10.6). Daarbij liepen de gemoederen zo hoog op, dat de graaf dreigde iedereen dood te schieten die het waagde de hulp van het Akense gerecht in te roepen. Daarmee was in het midden van de jaren vijftig het verzet vanuit Gronsveld tegen iedere vorm van inmenging van de Schepenstoel op zijn hoogtepunt.

\subsubsection{De benoeming van een appelcommissaris}

Van een nieuwe appelzaak vanuit Gronsveld naar Aken, in 1662, zijn verder geen details bekend, dus ook geen gegevens over problemen. Het was echter duidelijk dat een oplossing voor het probleem van het hoger beroep noodzakelijk was. Of Wilhelm Veucht, wiens ster in die tijd als juridische adviseur van de grafelijke familie rees, de bedenker van de uitweg was, weten wij niet, maar hij speelde wel een hoofdrol in de nieuwe ontwikkeling. De koerswijziging lijkt te beginnen met een proces voor het Gronsveldse leenhof van aanvankelijk Oda Coumans en later haar neef Johan Lindeloof tegen het klooster Sinnich. ${ }^{1437}$ Het oorspronkelijke geschil ging over aanspraken die Tilman Coumans, de vader van Oda, nog ten opzichte van het klooster Sinnich meende te hebben op grond, behorende tot het leen van de Wijngaardshof in Gronsveld. Dit land was destijds wegens onbetaalde erfpacht uitgewonnen door het klooster. Om aan het al sinds 1612 slepende proces een einde te maken, sloten Lindeloof en Sinnich in 1672 een

1436 'nude et simpliciter appellatam sententiam entweder ... confirmieren oder reformieren.

${ }^{1437}$ RHCL, Graafschap Gronsveld, inv. nr. 276. 
overeenkomst, waarbij eerstgenoemde voor een bepaald geldbedrag van zijn vordering afstand deed. Achteraf voelde Lindeloof zich bekocht en wilde hij de grond terughebben, onder andere met het argument dat een klooster wettelijk gezien geen onroerend goed in de dode hand mocht verwerven.

Lindeloof spande een procedure aan bij het leenhof, maar deze instantie verwees hem naar de gravin van Gronsveld, Anna Christina von Hardenrath. Na het wisselen van de stukken was volgens hem

die sache aber dem herrn licentiaten Veucht umb darinnen im nahmen und von wegen hochgemelte graffinnen zu sententieren, committiert worden.

Op 10 november 1677 wees Veucht vonnis, waarbij Lindeloof in het ongelijk werd gesteld. Die meende niet alleen het juridisch gelijk aan zijn kant te hebben, hij vond Veucht en zijn neef scholtis Kicken ook 'suspect' en partijdig. Bovendien had Veucht geen rekening gehouden met door Lindeloof ingediende rekesten en bewijsstukken. Lindeloof zocht daarom zijn recht in Aken en liet op 23 november 1677 bij een notaris een akte van appel opstellen tegen dit door Veucht als 'agent' van de gravin en commissaris van de zaak ('causae commissarium') gegeven vonnis. Omdat de Schepenstoel van Aken zich eerst een oordeel wilde vormen over de juistheid van het appel, werd de gravin gesommeerd binnen drie weken haar 'opvattingen' in te sturen. Daar werd ook aan voldaan, in die zin dat de gravin weigerde. Anderhalf jaar gebeurde er niets, totdat de gravin begin juni 1679 ter ore kwam dat in het graafschap een bevelschrift van de Schepenstoel zou circuleren. In felle bewoordingen protesteerde zij op 5 juni 1679 tegen het feit dat zij als onderdaan werd behandeld, ${ }^{1438}$ maar in Aken leek men niet onder de indruk. Op 27 juli 1679 zond de Schepenstoel een aanmaning naar de gravin en haar commissaris om op straffe van driehonderd goudgulden alsnog binnen drie weken het dossier in te sturen. ${ }^{1439}$

Helaas is niet bekend hoe de zaak is afgelopen; mogelijk is de kwestie in het daarna volgende gekrakeel over het hoger beroep in het vergeetboek geraakt. Het verhaal is echter om twee redenen interessant. In de eerste plaats werd de jurisdictie van de Schepenstoel over het leenhof van Gronsveld in deze tijd heftig bestreden (zie daarover meer Hoofdstuk 10.6). Men zal dus zoveel mogelijk tegenstand hebben geboden. Maar het is ook het vroegst bekende proces in Gronsveld waarin iemand als commissaris werd aangewezen om een proces af te doen. Volledig appelcommissaris was Veucht nog niet, want hij besliste de zaak na een doorverwijzing, maar het was een stap in die richting. In 1684 gebruikt hij - voor het eerst? - de titel 's-Heerens Grave Raedt ende appellationsrichter'. ${ }^{1440}$

In die jaren liepen de spanningen tussen Gronsveld en de Schepenstoel van Aken opnieuw op. Veucht raakte in 1684 ook persoonlijk betrokken. Hij had als advocaat voor de familie Couven gewerkt, maar omdat de rekening onbetaald bleef, liet hij beslag leggen op hooi van zijn cliënt. Daartegen werd door de familie Couven direct appel ingesteld bij de

${ }^{1438}$ RHCL, Rijkskamergerecht, inv. nr. 1, fol. 75-76, gravin aan Schepenstoel 5 juni 1679.

${ }^{1439}$ RHCL, Graafschap Gronsveld, inv. nr. 276.

1440 RHCL, Klooster Hoogcruts, inv. nr. 519. Vgl. Weinberg, 'Wilhelm Veucht', 100. 
schepenstoel van Aken, omdat het gerecht van Gronsveld of het leenhof van Gronsveld (het huis Hees onder Slenaken waar Couven woonde was een Gronsvelds leen) niet bevoegd zou zijn.

Een tweede kwestie deed zich voor toen mevrouw De Mombrison, bezitster van het goed Hamersbach, op 10 mei 1688 door de schepenen van Gronsveld werd veroordeeld tot het betalen van achterstallige schatting aan de schatheffer van Eckelrade. Zij tekende appel aan bij de Schepenstoel van Aken en de schepenen van Gronsveld ontvingen beschrijfbrieven, maar achteraf bleek de appellante niet de vereiste borgsom van 22 goudgulden bij de schepenbank Gronsveld te hebben voldaan. Om die reden weigerden de schepenen van Gronsveld het dossier naar Aken te sturen. De Schepenstoel legde die weigering, misschien ten onrechte, uit als obstructie. Graaf Otto Willem van Gronsveld, die zijn afwezige broer Johan Frans als graaf van Gronsveld verving, liet op 9 augustus 1688 de schepenen van Aken weten dat zij zich de moeite konden besparen om het appel van mevrouw de Mombrison aan te nemen en dagvaardingen uit te brengen. ${ }^{1441}$ Hij herinnerde nog eens aan de gebeurtenissen uit 1652, toen het gerecht van Aken misbruik had gemaakt van zijn 'ressortrecht' en onschuldige gevangenen bijna had laten 'crepieren'. Verder was hij van mening dat in de loop der jaren de jurisdictie van Aken ten opzichte van rijksonmiddellijke territoria zoals Stavelot, Cornelimünster en andere plaatsen was verminderd en Gronsveld zou natuurlijk in die ontwikkeling volgen.

Een derde kwestie in die jaren betreft een appel van Engel Meijs in een proces tegen Hubert Dupuits. Helemaal duidelijk is de zaak, bij gebrek aan een dossier, niet. Vast staat wel dat Wilhelm Veucht op 10 juni 1690 aan de schepenen van Gronsveld liet weten dat zij, op bevel van de graaf (of diens broer), het dossier gesloten naar hem, in zijn woning te Aken moesten sturen. ${ }^{142}$ Daar kreeg de Schepenstoel lucht van en op 22 augustus verscheen een notaris bij Veucht aan de deur bij zijn andere huis in Wittem om hem over de aanname van dit appel aan de tand te voelen. ${ }^{1443}$ Zo werd hem gevraagd 'ob er mitadministrator der graffschaft wehre?' Veucht antwoordde ontwijkend dat hij 'in den appelations streit keine partheije machen wollte'. De verantwoordelijkheid voor het opstellen van de documenten in de appelzaak van Meijs schoof hij af op zijn zwager notaris Graven, die dat namens de graaf had gedaan. Na dertig jaar dienst bij de graaf moest Veucht aan dit soort opdrachten voldoen. Over allerlei middeleeuwse keizerlijke appelprivileges waarop Aken zich beriep, kon hij, bij afwezigheid van de graaf, niets zeggen. Hij was echter bereid diens broer graaf Otto Willem daarover te raadplegen.

De houding van de Gronsveldse autoriteiten beviel de schepenen van Aken in het geheel niet. Begin oktober 1690 vielen honderd Akense soldaten het graafschap binnen en hielden zich schuil in het bos in de hoop een lid van het plaatselijk bestuur te arresteren. ${ }^{1444}$ De zaak was goed voorbereid, men had zelfs geprobeerd steun te kriigen vanuit het garnizoen in Maastricht, maar één van de mannen dwaalde af, viel in Gronsveldse handen en zo eindigde de overval voortijdig. Een paar weken later, op 31

${ }^{1441}$ RHCL, Rijkskamergerecht5, inv. nr. 1, fol. 27-27vo, graaf Otto Willem aan Schepenstoel 9 augustus 1688.

1442 RHCL, Rijkskamergerecht, inv. nr. 1 fol. 31-31vo.

1443 RHCL, Rijkskamergerecht, inv. nr. 1 fol. 34-36vo.

${ }^{1444}$ RHCL, Rijkskamergerecht, inv. nr. 1, fol. 61-63. 
oktober 1690, vielen zestig Akense soldaten bij een herbergier in Slenaken binnen, in de hoop daar Gronsveldse leden van het gerecht aan te treffen. Maar ze vingen bot. Er was alleen de gerechtsbode uit Gronsveld en die wist te ontsnappen. De invallers namen vervolgens zakken meel uit de molen mee en lieten de herbergier met onbetaalde rekeningen achter. ${ }^{1445}$

Begin januari 1692 vielen opnieuw Akense troepen, die zich voordeden als Franse soldaten, Gronsveld binnen, waar ze schepen Johannes de Beije 's nachts van zijn bed lichtten en ook drie paarden meenamen. De zieke De Beije werd in de cel gestopt en kreeg ondanks het aanbod van borgsom geen toestemming voor een beter onderkomen. De paarden werden verkocht, zogenaamd omdat het gerecht van Gronsveld geen uitvoering gaf aan de bevelen van de Schepenstoel in de zaak Meijs tegen Dupuis. ${ }^{1446}$

Graaf Johan Frans van Bronckhorst Batenburg protesteerde heftig voor het Rijkskamergerecht tegen deze geweldpleging, terwijl de Schepenstoel bij dezelfde instantie klaagde over de inbreuken die de graaf maakte op de appelprivileges van de stad. In een op 1 september 1693 ingediend verweerschrift verklaarde de graaf van Bronckhorst Batenburg 'zu intervenijeren vor allem seine beambten, bedienten und underthanen'. ${ }^{447}$ Hij bestreed de geldigheid van de appelprivileges die vroeger door de keizers Karel IV en $\mathrm{V}$ aan Aken waren verleend. Die betekenden niets, zolang het oorspronkelijke privilege van Karel de Grote, waarop Aken zich beriep, niet boven water kwam. En, gesteld dat zoiets al mogelijk zou zijn, dan nog had dat geen betekenis. Het rijk van Karel de Grote bestond niet meer en de rol van Aken als hoogste keizerlijk gerecht was al lang verdwenen door de instelling van het Rijkskamergerecht en de Rijkshofraad. Aken zelf was daar trouwens 'subaltern' aan. Naar die hoogste rijksgerechten gingen nu ook Stavelot, Cornelimünster en Rekem. Gronsveld deed daar zeker niet voor onder. Tot nog toe had Aken zijn vermeende jurisdictie alleen met geweld kunnen handhaven in processen die om allerlei redenen niet voor appel geschikt waren.

Het proces bij het Rijkskamergerecht lijkt na 1694 te zijn doodgebloed. De Schepenstoel kreeg in die tijd andere prioriteiten dan de achtervolging van weerspannige ondergerechten. Onder borgtocht werd de gevangene vrijgelaten en daarmee was de zaak, feitelijk geëindigd zonder tot een principiële uitspraak te komen. Een toevallige, maar niet onbelangrijke samenloop van omstandigheden was misschien ook het overlijden van Wilhelm Veucht in de tweede helft van 1694.

Toch kwam daarmee geen einde aan de inzet van appelcommissarissen, zoals blijkt uit een proces tussen Thijs Lemmens en Gerard Raemaeckers, dat begon in 1705 en waarin de schepenen van Gronsveld in 1711 vonnis wezen. Het onderwerp van het geschil is niet bekend, maar Ramaeckers appelleerde, waarschijnlijk bij graaf Johan Frans van Bronckhorst Batenburg. Deze wees de Akense advocaat Jacob Ignatius de Witte aan, die, na ingewonnen advies van rechtsgeleerden, op 17 augustus 1718 op het kasteel van

1445 RHCL, Rijskamergerecht, inv. nr. 1, fol. 65.

1446 Zie ook Weinberg, 'Wilhelm Veucht', 104.

${ }^{1447}$ RHCL, Rijkskamergerecht, inv. nr. 1, fol. 42-46. 
Gronsveld vonnis wees.1448 Lemmens voelde zich door deze uitspraak ten hoogste bezwaard en verzocht bij de graaf het rechtsmiddel van 'reformatie' toe te staan. De Witte adviseerde de graaf dit niet toe te staan. ${ }^{1449}$

Uit deze zaak blijkt ten eerste dat ook na 1694 appelcommissarissen werden ingezet. Zolang partijen daar maar geen ruchtbaarheid aan gaven, wist men in Aken van niets. ${ }^{1450}$ Ten tweede moest het appel tegen een vonnis van de schepenbank kennelijk worden ingesteld bij de graaf, die dan een appelcommissaris aanwees. Ook anderszins is er geen enkel spoor van een permanent appelcollege. Ten derde wordt duidelijk dat ook het rechtsmiddel van 'reformatie' (mogelijkheid tot herziening van een vonnis, zonder schorsende werking van eerdere uitspraak) werd toegepast en bij de graaf moest worden gevraagd. Interessant daarbij is dat kennelijk niet is gedacht aan appel bij het Rijkskamergerecht.

\subsubsection{Het appel van Honthem op Hengem en Luik}

Zo veel als er te zeggen is over de gecompliceerde verhouding tussen Gronsveld en Aken, zo weinig is er te vinden over de relatie tussen Honthem, Heugem en Luik. Zoals eerder vermeld is er één geval bekend van hoger beroep van Honthem op Heugem. Van Heugem op Luik zijn er casus uit 1512, $1533^{1451}$ en16391452 bekend. In de twee eerste gevallen werd na Luik in laatste instantie op het Rijkskamergerecht geappelleerd. Het is niet onmogelijk dat nader onderzoek in het Luikse schepenarchief nog andere gevallen oplevert, maar in vergelijking met de voortdurende wrijvingen tussen Gronsveld en Aken lijkt het rond de rechtsgang van Heugem op Luik opmerkelijk rustig te zijn gebleven.

\subsubsection{De verbouding tot de Rijkshofraad en het Rijkskamergerecht.}

Ten slotte moet nog iets worden gezegd over de relatie tussen Gronsveld en de hoogste rechtscolleges binnen het Rijk, het Rijkskamergerecht en de Rijkshofraad. Om met dit laatste te beginnen, er zijn geen voorbeelden uit de zestiende of zeventiende eeuw bekend van zaken die vanuit Gronsveld voor de Rijkshofraad werden gebracht. Wellicht levert nadere ontsluiting van het archief van de Rijkshofraad nog iets op, maar dan zal het hooguit gaan om een incidenteel geval. De positie van het Rijkskamergerecht als hoogste rechter in appel lijkt voor Gronsveld verder onbestreden te zijn geweest, hoewel misschien daar eind zeventiende eeuw door inzet van appelcommissarissen toch een ombuiging heeft plaatsgevonden. Het grootste probleem leverde Aken als tusseninstantie.

\footnotetext{
1448 Zie over De Witte Hoofdstuk 6.6.

${ }^{1449}$ Gegevens over deze zaak in TJ, inv. nr. M 40, fol. 1118-1124.

1450 RHCL, Rijkskamergerecht 176, fol. 53-54, bevat een uittreksel, gedateerd 13 maart 1726, van vroegere appelzaken van Gronsveld naar Aken. Daar wordt over de zaak Raemeckers tegen Lemmens niets gezegd, hoewel die niet zo heel erg oud was.

1451 RHCL, Rijkskamergerecht, inv. nr. 16, Rijkskamergerecht, inv. nr. 295.

1452 Daris, 'Les Cours de justice Liège', 23.
} 


\subsection{Conclusies}

De rechterlijke organisatie van het graafschap Gronsveld in de vroegmoderne tijd bouwde voort op de structuren zoals die aan het einde van de middeleeuwen waren ontstaan. De vier schepenbanken van Gronsveld, Heugem, Honthem en Slenaken bleven als zelfstandige instellingen bestaan en voerden ook gescheiden administratie van processen en registratie van onroerend goed. De tarieven van gerechtskosten en het procesrecht verschilden op kleine onderdelen. Toch was die scheiding in de praktijk niet zo strikt door personele unies bij de bezetting van functies. Dat gold ook voor de samenwerking met het leenhof. Aan de titulatuur valt de scheiding soms wel, dan weer niet af te lezen. Voor de gewone ('ordinaris') rechtszittingen werd meestal in Gronsveld vergaderd. Ook werden archieven van Gronsveld, Heugem en Honthem bij elkaar in Gronsveld bewaard.

De personele bezetting van iedere bank bestond officieel uit zeven schepenen, maar in de praktijk volstond een minder aantal. Schepenen, secretaris en gerechtsbode werden door de graaf benoemd. Het systeem van familieregering met onderlinge verwantschap tussen schepenen, secretaris en drossaard/scholtis werkte in het bijzonder door bij de schepenbanken. Toch kan in de loop van de zeventiende eeuw worden gesproken van professionalisering bij de leidende figuren zoals drossaard/scholtis en secretaris. Zij concipieerden de vonnissen, eventueel na juridisch advies van advocaten in de stad.

Tot het begin van de zeventiende eeuw zijn vier gerechtelijke procedures te onderscheiden, te weten het voogdgeding, de 'ordinaris' procedure in civiele zaken en lichte strafzaken, de 'extra-ordinaris' procedure in criminele en de 'gemeyne quest'. Het plechtig afgekondigde voogdgeding werd in iedere bank drie keer per jaar gehouden. We kunnen dit zien als een voortzetting van het vroegere 'geboden ding' waarbij alle volwassen inwoners verplicht waren aanwezig te zijn. Tijdens het voogdgeding werden civiele processen aanhangig gemaakt, kwamen zaken van gemeentelijke belang en overtredingen van gemeentelijke verordeningen aan de orde en startten de gerechtelijke procedures tegen de achterstallige debiteuren van de heer en de kerk. Ook vond tijdens deze zittingen beëdiging van gemeentelijke functionarissen plaats.

De 'genachtingen' of gewone, 'ordinaris' zittingen voor civiele zaken, werden gehouden van veertien tot veertien dagen. Civiele zaken konden zowel tijdens het voogdgeding als tijden de ordinaris zittingen worden aangebracht. In criminele zaken werd 'extra-ordinaris', op verkorte termijn geprocedeerd.

Over de praktijk van de rechtspraak valt wegens het bijna volledig ontbreken van schepenbankarchieven weinig te zeggen. Veel zal die niet hebben afgeweken van de gang van zaken in omliggende plaatsen. Er werden diverse soorten recht toegepast: plaatselijk gewoonterecht, rijksrecht en op beperkte schaal ook de Gronsveldse Rechtsordnung uit 1671 , in het bijzonder de hoofdstukken over keurmedige en leengoederen, het verbod op goederen in de 'dode hand' en het procesrecht.

De 'gemeyne inquest' ten slotte was een bijzondere procedure gericht op de opsporing van delicten en gedragingen die in strijd waren met de publieke moraal, goede zeden, de kerkelijke geboden of de openbare orde. De grens met het voogdgeding valt niet heel scherp te trekken. Veel is er niet over bekend, er zijn slechts enkele stukken uit de zestiende eeuw. In de zeventiende eeuw is deze procedure verdwenen. 
De middeleeuwse hoofdvaart van Slenaken op Gronsveld en Aken en van Honthem op Heugem en Luik bleef vooralsnog tot in de zeventiende eeuw bestaan. Het hoger beroep zoals zich dit daarnaast aan het einde van de middeleeuwen, door de instelling van het Rijkskamergerecht ontwikkelde, volgde dezelfde weg langs instanties. De grens tussen hoofdvaart en hoger beroep valt aanvankelijk niet heel scherp te trekken, maar uiteindelijk krijgt het hoger beroep de overhand. Binnen het graafschap lijkt dit systeem van hoofdvaart/hoger beroep weinig problemen te hebben opgeleverd. De relatie met de Schepenstoel van Aken kwam daarentegen vanaf het begin van de zeventiende eeuw steeds sterker onder druk te staan. Die ontwikkeling past vrijwel naadloos in het algemene beeld van de neergang van het 'ressort' van de Schepenstoel.

De strubbelingen tussen Gronsveld en Aken vallen in tijd samen met de vergelijkbare problemen die het aangrenzende Rijckholt met Aken had. De drijvende krachten achter het verzet tegen Aken lijken vooral de graaf van Gronsveld en de heer van Rijckholt en hun adviseurs te zijn geweest. Men zal in Gronsveld en Rijckholt over en weer goed op de hoogte zijn geweest van de ontwikkelingen (zoals men in Gronsveld ook de situatie in andere plaatsen kende), maar van een gemeenschappelijk optrekken tegen de vijand in Aken valt nauwelijks iets te ontdekken. Zo hartelijk waren de verhoudingen niet. Elk van beide heren bood een alternatief voor de rechtsgang naar Aken in de vorm van appel op één of twee appelcommissarissen.

De Akense schepenen zagen deze ontwikkelingen met lede ogen aan en bij Gronsveld bleef het niet beperkt tot alleen protest en dreigende woorden. Zelfs geweld werd niet geschuwd om argumenten kracht bij te zetten, maar op langere termijn ontbraken de middelen om de jurisdictie te handhaven.

Aan de andere kant van het spectrum stonden de partijen die voor de schepenbanken procedeerden. Het is opmerkelijk dat zij ondanks alle verbod op appel naar Aken steeds weer opnieuw probeerden daar zaken aanhangig te maken. Blijkbaar hadden zij niet zoveel bezwaar tegen de Schepenstoel. De schepenen van Gronsveld namen in deze conflicten een middenpositie in. Zij durfden hun heer niet voor het hoofd te stoten, maar liepen tegelijkertijd niet voorop in het verzet. 


\section{Het leenhof, zestiende eeuw tot circa 1720.}

De 'Specificatie' van goederen en rechten verbonden aan het graafschap Gronsveld omstreeks 1650 spreekt nog van een 'schoene leencaemere' met 36 grote en driehonderd kleine lenen. Toch was het leenhof in vergelijking met de tijd omstreeks 1600 over zijn hoogtepunt heen. Die afkalving zette zich in de loop van de zeventiende eeuw voort door enkele gevoelige verliezen. Daar kwam bij een hoog oplopende strijd met de Schepenstoel van de stad Aken over het hoger beroep in leenprocedures.

Het leenrecht zelf werd in 1593 door graaf Johan II van Bronckhorst Batenburg vastgelegd in een (verloren) 'Lehenordtnung'. Waarschijnlijk is een groot deel daarvan inhoudelijk opgenomen in de Gronsveldse Rechtsordnung van 1671. Inhoudelijke beschouwingen over dat leenrecht vormen het tweede hoofdthema van dit hoofdstuk.

\subsection{Organisatie van het leenhof}

Organisatorisch veranderde het leenhof na de late middeleeuwen nauwelijks. Bij de zittingen van het leenhof trad als vanouds de stadhouder op als vervanger van de leenheer. Hoogst zelden was de graaf zelf aanwezig. Een enkele uitzondering bevestigt de regel, zoals op 22 maart 1670 toen Jacob Collijn voor graaf Johan Frans van Bronckhorst Batenburg persoonlijk en drie leenmannen verscheen en een klein leen van $4^{1} / 2$ morgen in Lemiers opdroeg. ${ }^{1453}$ Het lijkt voor de jonge en formeel nog niet regerende graaf een soort stage te zijn geweest. Het ambt van stadhouder werd meestal gecombineerd met andere functies, zoals die van scholtis en rentmeester (Hans Jacob van Huckelhoven 1618-1628), secretaris en rentmeester (Lambert Lousberchs 1632-1633) en drossaard (Christiaan Lamberts 1638-1667).

Vanaf 1674 vervulde baron Willem Adolf van Eys genaamd Beusdael (geboren omstreeks 1647, overleden 1729) de rol van stadhouder (over hem zie Hoofdstuk 10.3). Nog tijdens zijn minderjarigheid was hij in 1657 beleend met het huis Vaalsbroek. De baron was regelmatig persoonlijk aanwezig bij zittingen van het leenhof. Tegelijkertijd trad ook drossaard en rentmeester Willem Kicken (1682-1719) op als stadhouder, maar dan waarschijnlijk in de rol van een soort vicestadhouder. Van Eys noemde zich vanaf 1710 'erfstadhouder', een titel waarover Prummer in 1755 schrijft:

'Het stadhouderschap van de lenen is van oudsher beschouwd als een adellijk ambt en lang geleden bij de heren Van Eys genaamd Beusdael in erfelijk bezit geweest....Tijdens de regering van graaf d'Arberg heeft baron De Goeswin hetzelfde recht verworven. Ik weet niet hoe, hij zegt tegen betaling van 25 pistolen (= bepaalde munt). Hij heeft door toedoen van Zijne Excellentie de veldmaarschalk (= graaf Ignaz Felix von Toerring-Jettenbach) van zijn erfelijk recht afstand gedaan, daarom geschiedt de benoeming in het ambt nu naar welgevallen.' ${ }^{1454}$

1453 TJ, inv. nr. M 42 (leenboek van Holset), fol. 219 (nieuw).

1454 TJ, inv. nr. M 13, fol. 13-24, Prummer aan M.E. von Toerring-Jettenbach 9 november 1755: 'Die lehen-statthalterey ist von alten zeitten her vor eine charge noble gehalten und lang zuruckh von dennen herrn von Eys genant Beusdael haereditarie besessen wordten... Von solchen hat unter graf 
Maar Prummer vergist zich. In de eerste plaats laten de oude leenregisters overduidelijk zien dat het stadhouderschap nooit een adelliik ambt ('charge noble') was geweest. Voorts had hij zelf kort tevoren bij de beantwoording van een lange vragenlijst uit München over de meest uiteenlopende onderwerpen vermeld dat Willem Adolf van Eys genaamd Beusdael pas op 22 juni 1710 door graaf Johan Frans van Bronckhorst Batenburg tot erfstadhouder van het leenhof was benoemd. ${ }^{1455}$ Daarna had deze op 20 maart 1727 van zijn functie afstand gedaan ('vor 25 pistollen') ten behoeve van baron Ernst de Goeswin.

De personele bezetting van het leengerecht wisselde. Tot omstreeks 1670 waren meestal vier tot vijf leenmannen aanwezig, daarna twee of drie. Naast stadhouder en leenmannen beschikte het leenhof nog over een secretaris die zorgde voor het bijhouden van de leenboeken, de rollen van de zittingen van het leengerecht en de registratie van akten in de gichtregisters. De leenbode ten slotte was belast met het uitbrengen van dagvaardingen, het leggen van beslag en de 'inleiding' van nieuwe eigenaren na het uitwinnen van leengoed. Het valt moeilijk te zeggen of het leenhof op vaste data zitting hield. Waarschijnlijk heeft men aansluiting gezocht bij de zittingen van de schepenbank, omdat de meeste bij het leenhof betrokken personen dan toch al aanwezig waren. Bij procedures zullen de in rechtszaken gebruikelijke termijnen zijn gehanteerd. Het procesrecht bij het leenhof was gelijk aan dat in civiele zaken. In hoeverre bij het Gronsveldse leenhof in de zeventiende en achttiende eeuw nog werk werd gemaakt van een bepaald ceremonieel, is niet bekend.

Geen enkele functionaris genoot een vaste bezoldiging. De honorering geschiedde uit de opbrengst van de leenverheffingen en griffierechten. Prummer geeft daarvoor in het midden van de achttiende eeuw de verdeelsleutel van $2 / 8$ voor de stadhouder, $2 / 8$ voor de secretaris en $1 / 8$ voor elke leenman. Daarnaast bracht de secretaris voor allerlei stukken 'schrijfrechten' in rekening. De kosten daarvoor staan opgesomd in de concepttarievenverordening voor gerechtskosten uit 1724 (zie bijlage 9) en komen overeen met de bedragen die bij de schepenbanken in rekening werden gebracht.

\subsection{De administratie van het leenhof}

De leenadministratie in de zestiende eeuw borduurde voort op de laatmiddeleeuwse leenboeken. In de langdurige processen uit het midden van de zeventiende eeuw tussen Jost Maximiliaan van Bronckhorst Batenburg en de heren van Oost over de leenroerigheid van enkele laathoven, werden uit de zestiende eeuw extracten uit leenboeken, beginnend in 1519 en 1581 ingeleverd. ${ }^{1456}$ In zijn rapport uit 1757 over het leenhof ${ }^{1457}$ vermeldt

d'Arbergischer regierung dieselbe der baron Goeswin, weis nit recht auf was arth (er saget vor 25 pistollen) mit gleichen jure an sich gebracht. Diser hat durch zuethuen dess $\mathrm{HH}$ Veldtmarechalln hochgräfl. Excellenz auf das erbrecht renuntiert, begleittet also dermahlen solche charge ad nutum revocabiliter

1455 TJ, inv. nr. M 14, fol. 211-219 (z.d.).

1456 RHCL, Familie De Geloes/Kasteel Eijsden, inv. nr. 317. 
Prummer welke oudste leenboeken er waren: uit 1460, 1522 en 1558. Met het register van 1522 kan het door uittreksels bekende boek van 1519 zijn bedoeld. Het leenboek van 1558 kan identiek zijn met het incomplete register dat bij een inventarisatie van archieven in 1746 werd aangeduid als het 'boek met den cram', beginnend in $1561 .{ }^{1458}$

Inhoudelijk waren deze leenboeken niet goed op orde. Een poging tot verbetering werd in 1581 ondernomen door Reiner van Gelder, stadhouder van het leenhof. Van Gelder was ter zake kundig en deed veel moeite de ligging van percelen te beschrijven en systematisch in te delen. Behalve voor de lenen in het graafschap vervaardigde hij ook een 'Gronsfeldischen lehenregister de anno 1581 wegens de lehen gelegen tot Holzet, Vijlen, Lemmiers, Mameles, Harles ende daerontrent'. ${ }^{1459}$

Het leenboek voor Gronsveld 'gebonden in eene halve witte parquemente couvert, overtrocken met hemelsblouw pampijr' zou volgens het latere oordeel van Prummer blijvende waarde hebben gehad, indien volgende generaties de veranderingen hadden bijgewerkt. Maar dat was nagelaten. Dikwijls werd er helemaal niets genoteerd. Een aantekening 'is verheven' had zonder naam of datum niet veel nut. Stadhouder Van Velraed genaamd Meutter probeerde in 1613 een nieuw leenboek samen te stellen, maar bleef halverwege in het werk steken. Pas in 1743 vervaardigde secretaris en vicestadhouder van het leenhof Jacobus Berchmans een volledig herzien leenboek voor de lenen in Gronsveld, Eckelrade, Rijckholt en Breust op basis van het werk van Reiner van Gelder uit 1581. ${ }^{1460}$ Berchmans maakte ook een kopie van het leenboek voor Holset. Dat was beter bijgehouden dan van Gronsveld, maar ook hier waren er grote lacunes.

Behalve leenboeken omvatte het archief van het leenhof ook de gebruikelijke gerechtelijke administratie in de vorm van rolregisters, procesdossiers en 'gichtregisters' voor de overdracht van onroerend goed. Die zijn slechts beperkt overgeleverd in de vorm van uittreksels uit de rollen, incomplete dossiers en een enkel gichtregister van 1671 tot 1726 . Het is de vraag of deze administratie volledig gescheiden werd gehouden van die van de schepenbank, aangezien in de achttiende eeuw voor de zittingen van het leengerecht en de schepenbank soms dezelfde registers werden gebruikt.

\subsection{Afkalving van het leenhof}

Het leenhof van Gronsveld bereikte zijn grootste omvang rond 1600. Daarna begon een periode van afkalving. Bij de 'kleine' lenen was dat een gevolg van slechte administratie,

1457 TJ, inv. nr. M 13, (Information über die Verfassung...) fol. 126: 'Von lehen, das ist lehen-, saal- oder läger-, dan belehnungs-büecheren seint zwar 3 von anno 1460, 1 von anno 1522 und 1 von anno 1558 verhandten; in betrachtung aber das von dennen ersten dreÿen eins mit dem anderen nit ÿbereins kommet, die leztere zweÿ nur excerpta aus dennen ersteren und eines wie das andere in keiner rechten verfassung seÿe, als kan von keinen anderen zur haubtsach ainige attention oder gebrauch gemacht werdten'.

1458 RHCL, Rijkskamergerecht, inv. nr. 192/1. 1, fol. 197. In het leenregister Holset (TJ, inv. nr. M 42) is in 1618 sprake van een 'boeck metten kramp'.

1459 TJ, inv. nr. M 42.

1460 TJ, inv. nr. M 16. 
maar ook van bepaalde eigenaardigheden in het leenrecht die nalatigheid bij de leenmannen in de hand werkten (zie hierna Hoofdstuk 10.4). Daarnaast waren er ook problemen met een aantal 'grote' lenen. Het eerste voorbeeld daarvan heeft betrekking op de het groot leen van drie laathoven, gelegen te Oost. In 1594 weigerde Hieronymus van Berghe genaamd Trips daarvan een specificatie of 'denombrement' in te leveren bij het Gronsveldse leenhof. Het daaruit voorvloeiend proces sleepte zich decennialang voort. Nadat in 1639 de heerlijke rechten over Oost waren verkocht aan Hieronymus, nam de onwil van de kant van de heer van Oost alleen maar toe. In 1648 werd hij daarom door het leenhof van Gronsveld van zijn leen vervallen verklaard. Zijn erfgenaam Johan Jacob van Daun bleek echter in 1656 bereid de leenroerigheid van de laathoven en van de burcht tot Oost te erkennen en wilde daar ook een denombrement van afgeven. Hij hield zich echter niet aan de overeenkomst en ruilde in 1657 de heerlijkheid Oost met al zijn toebehoren met Antonius Candidus van Hoensbroek. Toen ook Van Hoensbroek niet vrijwillig bereid bleek de overeenkomst na te komen, werd hij door het leenhof van Gronsveld daartoe veroordeeld. Van Hoensbroek wendde zich vervolgens tot zowel de Staatse Raad van Brabant in Den Haag als de Schepenstoel van Aken om de Gronsveldse vonnissen nietig verklaard te krijgen. Hoe op de rechtsgang naar Aken werd gereageerd komt hierna nog aan de orde. Een arrest van de Raad van Brabant van 1668 stelde de gravin van Gronsveld in zoverre in het gelijk dat Van Hoensbroek de leenroerigheid van de laathoven en de burcht moest erkennen, maar geen denombrement hoefde in te leveren. De uitvoering van deze uitspraak bracht echter niet de gewenste vrede en in 1683 kwam een akkoord tot stand, waarbij Antonius Candidus van Hoensbroek alle leenrechten van Gronsveld in Oost afkocht voor duizend pattacons. ${ }^{1461}$

Maar ook binnen het graafschap Gronsveld zelf vond afkalving plaats. Zo deed graaf Johan Frans van Bronckhorst in 1684 afstand van zijn rechten als leenheer over ruim 28 bunder leengoed van Hamersbach ten behoeve van de heer van Rijkckholt als compromis over geschillen over achterstallige betalingen en nalatigheid bij het verheffen van het leen. ${ }^{1462}$

Voor problemen van een heel andere aard zorgde de leenman van Vaalsbroek, Willem Adolf van Eys genaamd Beusdael, sinds 1674 stadhouder en vanaf 1710 erfstadhouder van het Gronsveldse leenhof. De verschillende aan Vaalsbroek verbonden rechten vormden

1461 Janssen de Limpens, 'Geschiedenis Oost', 93-95, 107-108, 136-137'; zie ook RHCL, Familie De Geloes/Kasteel Eijsden, inv. nr. 317.

1462 RHCL, Graafschap Gronsveld, inv. nr. 366, fol. 59-61. 1684: akkoord tussen Johan Frans van Bronckhorst Batenburg en de barones van Wylich van Winnendael van Rijckholt. In 1684 deed Johan Frans afstand van zijn aanspraken op de hof Hamersbach die waren ontstaan door felonie en ontbreken van octrooi voor de verkoop van Hamersbach aan Jean Maximilien de Bounam. Laatstgenoemde werd in het volledige bezit gesteld. Er werd verder een akkoord gesloten over de betaling van achterstallige schattingen en de leenroerigheid werd opgeheven: 'zumahlen iennige 28 bonder 11 gross und 191/2 kleine ruethen von angeregten castel Richolt, welche unter dem bezürckh Eckelraede ligen, vorhin lehenbahr an das haus Gronsfeldt gewesen, darvon aber a[nn]o 1682 die feudalitæt durch accord nachgelassen oder villmehrers für allzeit verkauffet wordten, folglich für sich selbsten nunmehro von allen (ausgenohmen die schätzungen) befreÿet seint.' 
een goede voedingsbodem voor conflicten. ${ }^{1463}$ Vanuit zijn functie was Willem Adolf de Gronsveldse belangen zeer toegedaan, maar daarnaast deed hij er alles aan om het aanzien van de aan Vaalsbroek gekoppelde laatbank en de heerlijke rechten over het Malensbos te verhogen. Om het bijzondere karakter daarvan te benadrukken werd Vaalsbroek voortdurend een 'grondheerlijkheid' genoemd. Al snel leverde dat aanvaringen op met de drossaard van 's-Hertogenrade en de schepenen van Vaals-Holset-Vijlen. Volgens de luitenant-drossaard van 's-Hertogenrade gedroeg Van Eys genaamd Beusdael zich als 'den souverain off eenich lantheer...' die zich onrechtmatig meester maakte van de 'werfschelling' (overdrachtsbelasting op onroerend goed), die de Staten Generaal als landsheer toekwam. In het geschil betoogde Willem-Adolf dat Vaalsbroek als adellijk goed én 'keizerlijk leen' (dat wil zeggen leen van het rijksonmiddellijke graafschap Gronsveld) geheel was vrijgesteld van personele belasting en gedeeltelijk vrijgesteld van grondbelasting. Die inzet van leenrecht om de rijksonmiddellijkheid te bewijzen was niet zonder risico voor de andere Gronsveldse lenen in Vaals, want het geschil liep hoog op en kreeg zelfs internationale aspecten toen de Raad van State van de Republiek en de graaf van Gronsveld als lidmaat van het Duitse Rijk er zich mee bemoeiden. Uiteindelijk eindigde de zaak in 1717 met een akkoord tussen de heer van Vaalsbroek en de schepenen van Vijlen-Vaals-Holset. De vele procedures leidden er wel toe dat de erfgenamen van Willem Adolf in 1733 gedwongen waren hun bezittingen in Vaals te verkopen aan Leonard Josef Frans Hieronymus de Lamberts de Cortenbach, die ook al in het bezit van Einrade was.

\subsection{Het materiële leenrecbt $t^{1464}$}

De belangrijkste bronnen voor onze kennis van het materiële Gronsveldse leenrecht zijn, buiten het weinig overgeleverde materiaal uit de administratie van het leenhof zelf, de bepalingen uit Titel VI van de Gronsveldse Rechtsordnung uit 1671, getiteld ' $V$ on dennen Lebnen und deren Succesionen'. Voorts zijn er de rapporten uit de achttiende eeuw die de grafelijke commissarissen maakten, in het bijzonder het rapport van Prummer uit 1757.

$\mathrm{Al}$ eerder kwam de vraag aan de orde in hoeverre de Rechtsordnung in de praktijk toepassing vond. Voor het grootste deel ging het om een directe kopie van de Keulse Rechtsordnung van 1663, met andere woorden, geen inheems Gronsvelds recht. Het leenrecht lijkt daarop een uitzondering te vormen, want Titel VI in de Gronsveldse Rechtsordnung ontbreekt in het Keulse voorbeeld. In $\ 7$ van dit hoofdstuk wordt verwezen naar een 'Lehenordtnung' die graaf Johan II van Bronckhorst Batenburg op 2 augustus 1593 zou hebben

1463 Stukken over deze conflicten zijn te vinden in RHCL, Landen van Overmaze, inv. nrs. 8492, 9396, 9414, 9684. Oorspronkelijk moet een deel daarvan tot één of twee dossiers hebben behoord. Zie ook: Loontjens/Jongmans, 'Het Malensbos', 169.

1464 Voor bepaalde begrippen van het Gronsveldse leenrecht kan onder andere worden verwezen naar de studie van Opsommer, 'Omme dat leengoed', die in het bijzonder het leenrecht van Vlaanderen van de veertiende en vijftiende eeuw behandelt. Een echte vergelijking is echter achterwege gebleven en ook niet mogelijk door gebrek aan bronnen. We beperken ons hier tot een weergave van de belangrijkste bepalingen uit de Rechtsordnung en de gedachten die daarover in de achttiende eeuw leefden bij de grafelijke commissaris Prummer. 
uitgevaardigd. Helaas is de oorspronkelijke tekst daarvan verloren gegaan; zelfs Prummer wist de tekst niet meer te achterhalen. Onbeantwoord blijft daarmee de vraag in hoeverre deze 'Lehenordtnung' origineel Gronsvelds recht bevatte. Opmerkelijk is verder dat in enkele leenrechtelijke procedures rond 1600 geen verwijzingen zijn te vinden naar deze Lehenordtnung, maar indirect bestaat er misschien verband met een hierna nog te noemen proces tegen Willem van Vlodrop, heer van Leuth en Rijckholt. ${ }^{1465}$ In een proces tussen de rentmeester van het klooster Sinnich en Tilman Koumans over de betaling van achterstallige erfpacht (1613-1621) wordt geprocedeerd volgens ' deses leenhoffs ende bancken gewoenten' en 'naer alder costuijmen ende usantien dieses lants'. ${ }^{1466}$ Anderzijds bevat Titel VI van de Gronsveldse Rechtsordnung, zoals hierna nog aan de orde komt, elementen die aan algemene literatuur over het leenrecht lijken te zijn ontleend en niet van oorsprong typisch inheems zijn. Overigens is dit niet zo vreemd, wanneer men bedenkt dat graaf Johan II van Bronckhorst Batenburg een (waarschijnlijk juridische) universitaire vorming had genoten en op de hoogte moet zijn geweest van het algemene leenrecht.

De paragrafen 1 t/m 3 van Titel VI van de Gronsveldse Rechtsordnung hebben betrekking op de vererving van lenen op mannen en vrouwen. Maatgevend voor het toepasselijke rechtsregime zou de tekst van de 'prima investitura', de eerste beleningsakte, zijn. Wanneer de oorspronkelijke leenakte vrouwelijke vererving uitsloot, mocht de leenheer het goed bij gebrek aan mannelijke erfgenamen weer aan zich trekken. Voorts gold voor de bezitter van een dergelijk leengoed het uitdrukkelijke verbod zijn goed zodanig te vervreemden, dat het buiten de familie in mannelijke lijn raakte. In een dergelijk geval kon na de dood van de vervreemder een (mannelijke) bloedverwant in de opgaande (mannelijke) lijn dit goed zonder verdere vergoeding bij de derde naasten. Bij lenen die zowel in mannelijke als vrouwelijke lijn vererfden, hadden bij het ontbreken van mannelijke gerechtigden in directe lijn, afstammelingen van de eerste leenman ('prima investitura') in vrouwelijke lijn voorrang boven zonen en dochters uit jongere takken. Overigens werden vrouwen alleen tot het leen toegelaten indien zij door een man werden vertegenwoordigd.

Volgens Prummer verliep de praktijk anders. Oorkonden waaruit de 'prima investitura' van een leen moest blijken, waren onbekend. Ook de leenregisters vanaf 1460 konden geen uitsluitsel geven over de vraag welk feodaal regime van toepassing was. Misschien waren ooit door het leenhof leenbrieven voor partijen uitgevaardigd, maar die ontbraken. Voor zover bekend, was voor beleneningen nooit onderscheid gemaakt tussen mannen en vrouwen, geestelijke of wereldlijke personen; zelfs rechtspersonen zoals kloosters, waren toegelaten. Wel hadden vrouwen altijd een mannelijke leendrager of 'ophelder' moeten stellen. Prummer kende op die regel slechts één onbelangrijke uitzondering, namelijk een vrouw uit Breust, aan wie in 1743 'ex gratia' direct een klein leen was uitgegeven.

Paragraaf 4 bepaalde dat een leen opnieuw moest worden verheven na het overlijden van de leenheer binnen de termijn van een jaar en zes weken. De leenman of diens erfgenamen dienden eigener beweging een actie tot leenverheffing te starten, op straffe van terugval van het goed aan de leenheer. Volgens Prummer stamde het gebruik om lenen na het overlijden van de leenheer opnieuw te verheffen, uit het rijksrecht. In Holland en Brabant

1465 RHCL, Rijkskamergerecht, inv. nr. 18, 25 en 222.

1466 RHCL, Rijkskamergerecht, inv. nr. 18, inv. nr. 222, fol. 12vo. 
werd deze regel niet gepraktiseerd. Hij had in het archief papieren gevonden waaruit bleek dat gravin Anna Christina von Hardenrath in 1672, één jaar na het verschijnen van de Gronsveldse Rechtsordnung, een dergelijke algemene verheffing had bevolen. Het Maastrichtse stadsbestuur, dat zich opwierp als belangenbehartiger van zijn burgers, maakte bezwaar tegen deze nieuwigheid die groot nadeel opleverde voor de vele Maastrichtenaren met leengoederen onder Gronsveld. De gravin beriep zich op het rijksrecht, maar Maastricht hield vol en leek uiteindelijk an het langste eind te trekken. Noch in de oude, noch in de meer recente administratie van het leenhof was volgens hem iets te vinden van leenverheffingen bij overlijden van de leenheer.

Prummer vergiste zich echter. In 1600 had tussen graaf Johan II en de erfgenamen van Willem van Vlodrop, heer van Leuth, Rijckholt en Well in eerste aanleg een dergelijke zaak gespeeld voor het Rijkskamergerecht. ${ }^{1467}$ In 1567 was Willem van Vlodrop als erfgenaam van Balthazar van Vlodrop, beleend met een 'groot' leen van veertig mud spelt. ${ }^{1468}$ Johan II van Bronckhorst stelde zich op het standpunt dat hij als opvolger van zijn in 1588 overleden broer recht had op een nieuwe verheffing, want, zo schreef zijn advocaat bij het Rijkskamergerecht,

in het leenrecht is uitdrukkelijk voorzien en bepaald dat zodra er een andere leenheer of leenman komt, het leen binnen jaar en dag moet worden erkend en opgedragen en dat op straffe van vervallenverklaring. ${ }^{1469}$

Helaas kwam het in de loop van de procedure niet meer tot een antwoord op deze stelling, want het debat verzandde in gekibbel over de vraag of het leen nog bestond en het feit dat Van Vlodrop niet eerder was aangemaand. Bovendien waren de goederen in Gronsveld inmiddels al verkocht. Ook is onduidelijk of het hier een soloactie tegen de heer van Rijckholt betrof, of dat een algemene leenverheffing werd uitgeschreven. Dit laatste zou, in samenhang met de Lehenordtnung van 1593, wel eens het geval kunnen zijn geweest.

Ook na het overlijden van een leenman moesten diens nabestaanden het leen binnen een één jaar en zes weken opnieuw verheffen, op straffe van intrekking door de leenheer wegens 'kaduukheid' ('caducitaet'). De praktijk verliep anders, zoals Prummer vernam uit de mond van Berchmans, de vroegere vicestadhouder en griffier van het leenhof en oude leenmannen. Wanneer het overlijden niet tijdig werd gemeld, kon de leenheer de nabestaanden in theorie tot onmiddellijke leenverheffing dwingen. Wanneer hij echter dacht bij nalatigheid snel een leen te kunnen intrekken, kwam hij bedrogen uit. De hele procedure lijkt sterk op de gang van zaken bij de in Hoofdstuk 9.7 beschreven verheffing van keurmeden. Ook de leenheer moest een gerechtelijke procedure doorlopen, waarbij aanvankelijk van geding tot geding, met tussenpozen van drie maanden, werd

${ }^{1467}$ RHCL, Rijkskamergerecht, inv. nr. 18. De zaak kwam in eerste aanleg voor het Rijkskamergerecht als forum privilegiatum omdat de gedaagde van adel was en heer van een rijksonmiddellijke heerlijkheid.

1468 RHCL, Rijkskamergerecht, inv. nr. 18, fol. 18.

1469 'in den lehenrechten austrücklich versehen unnd verordnet ist dass so oft ein ander lehenherr oder lehenmann ankombt das lehen innerhalb jars und tags recognoscirt unnd entpfangen werden soll und muss idque sub poena caducitatis', RHCL, Rijkskamergerecht, inv. nr. 18, fol. 21 vo. 
geprocedeerd. Later had men deze termijnen verkort tot drie maal veertien dagen. ${ }^{1470}$ Daarna duurde het nog twee weken voordat het gerecht aan de eiser 'immissie' of inbezitneming kon toestaan. Gedurende de hele procedure had de nalatige bezitter alsnog gelegenheid zijn verzuim te herstellen en mocht hem de leenverheffing niet worden geweigerd. Wel moest hij de gerechtskosten betalen. Zelfs na de 'immissie' kon de gedaagde noch met succes zuivering van zijn nalatigheid aanbieden. Deze mogelijkheden gaven een kwaadwillende leenman bijna een vrijbrief om rustig de actie van de leenheer af te wachten en pas tot verheffing over te gaan wanneer alle uitwegen waren afgesneden. Het gevolg daarvan was dat 'caducitaet' zelden voorkwam.

Eigenlijk leverde tijdige melding van een overlijden binnen zes weken, met tegelijkertijd het aanbod tot leenverheffing, zelfs een groter probleem op, want in een dergelijk geval kon nakoming van de termijn van één jaar en zes weken niet meer worden gevorderd. Dit leidde tot het misbruik dat een leenman pas jaren later eigener beweging ('proprio motu') tot leenverheffing overging. In de tussentijd kon hij wel regelmatig worden aangemaand en zelfs gerechtelijk vervolgd, zonder dat tot 'caducitaet' werd overgegaan. In de leenbrief werd uiteindelijk van eventuele nalatigheid ook geen enkele melding gemaakt.

De Recbtsordnung bepaalde in $\ 5$ van Titel VI dat bij vererving van een leen op een vader met kinderen, de vader het leen moest verheffen en niet de zoon. Met een belening van grootvader op kleinkind werd een generatie overgeslagen, wat betaling van heergewaad bespaarde. Voorts was bij een kind de kans op een nieuwe leenverheffing met bijbehorende kosten natuurlijk veel geringer dan bij een volwassene. Het verbod op het overslaan van een generatie werd in de praktijk met voeten getreden. Sinds jaar en dag was het gebruikelijk kinderen als leendrager aan te nemen. Zelfs volslagen vreemden van drie, vier of vijf jaar konden naar believen als leendrager worden ingezet. De opdracht van het leen diende door de leendrager persoonlijk te gebeuren. Maar bij kinderen werd van de verplichte eed van trouw an de leenheer uitstel verleend tot het bereiken van de meerderjarigheid.

Titel VI $\int 6$ van de Rechtsordnung schrijft voor dat een vazal op straffe van 'caducitaet' zijn leengoed niet mocht vervreemden of met hypotheek bezwaren zonder voorgaande toestemming van de leenheer. Merkwaardig is hier de verwijzing naar de Libri Feudorum, de bekende twaalfde-eeuwse optekening van Lombardisch leenrecht, die later door heel Europa werd verspreid en becommentarieerd. Deze anhaling maakt duidelijk dat Titel VI van de Gronsveldse Rechtsordnung geen zuivere weergave van inheems gewoonterecht is, maar ook elementen uit het gemene, geleerde recht bevat. Mogelijk is dit een voorbeeld van de eigen inbreng van graaf Johan II van Bronckhorst Batenburg in het leenreglement van 1593. Prummer vermeldt dat leenmannen inderdaad verlof vroegen voor vervreemding of bezwaring van hun leengoed (een recent voorbeeld uit zijn tijd was de aanvraag die generaal Grammelich in 1748 had gedaan voor het grote leen Hamersbach), maar daaruit mocht niet worden geconcludeerd dat het voorschrift altijd zo stipt was

1470 In dit verband kan worden verwezen naar wat in Hoofdstuk 9.7 werd gezegd over de termijnen bij civiele processen, te weten dat bij de schepenbank Gronsveld werd geprocedeerd van voogdgeding tot voogdgeding. Volgens de tarievenverordening op de gerechtskosten uit 1724 werd bij het leenhof en in Honthem, Heugem en Slenaken geprocedeerd met termijnen van twee weken. 
opgevolgd of dat er nu rijksrecht werd toegepast. Grammelich en ook anderen hadden de toestemming gevraagd op dringend advies van de Gronsveldse drossaard, die op dat moment een proces voerde over de confiscatie van goederen behorend tot de nalatenschap van de Maastrichtse kanunnik Salden. In dat geschil was de Gronsveldse Rechtsordnung ook als geldend recht gepresenteerd en die actieve toepassing maakte het niet raadzaam regels te overtreden die mogelijk tot 'caducitaet' konden leiden. De laatste jaren voor de komst van Prummer was regelmatig een ducaton geïnd voor het verlof tot vervreemding, maar in een wat verder verleden berustte die betaling min of meer op een toevalstreffer. Een leengoed kon wel tien keer zijn vervreemd, voordat de griffier bij het leenhof dat in de gaten kreeg. Anderzijds was het leenhof ook altijd slap geweest in de handhaving van $\ 6$ en de daarin opgenomen straf.

De Gronsveldse Rechtsordnung behandelde alleen de leenverheffingen na overlijden en het octrooi (toestemming) voor verkoop of bezwaring. Prummer meende dat een leen ook opnieuw moest worden verheven bij verkoop, ook al leefde de oorspronkeliike leendrager nog. In de praktijk bleek het leenhof op dit terrein nalatig, tot schade van de leenheer. In de voorgaande decennia was ook de praktijk ontstaan dat bij verkoop van een deel van een leen (een zogenoemd spleetleen), ook een evenredig deel van het heergewaad moest worden betaald. Dit liet onverlet dat na het overlijden van de 'ophouder' van de massa nog een keer het volle bedrag aan heergewaad diende te worden neergeteld. Deze regels kwamen overeen met het algemene leenrecht en er werd de in de achttiende ook min of meer de hand aan gehouden. In de oude leenregisters vond deze praktijk echter geen steun. Anderzijds was de zogenoemde 'werfschelling' of het 'oorlofsgeld' wel altijd betaald en verrekend. Deze heffing behelsde een soort algemene belasting voor de overdracht van onroerend goed, die voor leengoederen was vastgesteld op de vijftiende penning of 6,33 procent van de koopsom (zie verder over werfschelling en oorlofsgeld Hoofdstuk 15.4).

\subsection{Het formele leenrecht}

Titel VI $\$ 7$ van de Gronsveldse Rechtsordnung schreef voor dat krachtens het leenreglement van 1593 de leenman bij zijn belening een 'reversaal' moest afgeven, een soort kwitantie. Prummer constateerde dat in de periode tussen 1681 en 1712, de tijd waarin de lenen het beste werden geadministreerd, inderdaad dit soort stukken werd uitgevaardigd, maar nadien scheen dit in onbruik te zijn geraakt. Een voorbeeld van een dergelijke tekst uit 1711 voegde hij toe aan zijn rapport voor de graaf. In feite behelsde een reversaal niet meer dan een ondertekende verklaring dat een bepaald leen was ontvangen met de verplichting krachtens zijn eed alles te doen waartoe een leenman 'zufolg deren reichs-üblicher lehen-rechten' gehouden was.

Volgens de rentmeestersrekeningen uit de tijd tussen 1617 en 1624 bedroeg het heergewaad voor een groot leen vijftien goudgulden en voor een klein leen één goudgulden. In het midden van achttiende eeuw stond het tarief voor een groot leen op 87 gulden Brabants voor heergewaad, 1 gulden 17 stuiver kamerlinggeld, 1 gulden bodegeld en wijngeld ten bedrage van $171 / 5$ gulden voor de stadhouder, secretaris en leenmannen. Voor kleine lenen werden de volgende tarieven gehanteerd: een goudgulden heergewaad 
(circa 5 gulden 16 stuiver Brabants), 171/2 stuiver kamerlinggeld, bodegeld 10 stuiver, wijngeld 6 gulden 10 stuiver.

Wat betreft het procesrecht bij contentieuze rechtspraak kunnen we kort zijn. Titel VI $\int 7$ van de Rechtsordnung verklaarde hier het gewone burgerlijk procesrecht van toepassing, zoals dat in Titel XVIII stond beschreven. Over de feitelijke gang van zaken valt niet veel bijzonders te vermelden, aangezien zowel de rollen als procesdossiers slechts zeer fragmentarisch zijn overgeleverd. Waarschijnlijk werd al sinds het begin van de zestiende eeuw van de mondeling gevoerde procedure aantekening gehouden in rollen of protocollen. Bij processen in hoger beroep voor het Rijkskamergerecht werd ook een uittreksel uit die rol meegezonden. In bescheiden mate vond vanaf de zestiende eeuw ook dossiervorming plaats van overlegde bewijsstukken en conclusies van partijen.

De vrijwillige rechtspraak bestond, evenals bij de schepenbanken, uit de 'gichting' of 'realisatie' van akten met zakelijke werking, overeenkomstig de gebruiken bij de schepenbanken. Van het Gronsveldse leenhof is één gichtregister over de periode 1671 1726 bewaard gebleven. De inschrijvingen vonden in beginsel in chronologische volgorde plaats, maar onregelmatigheden en hiaten voor bepaalde jaren wijzen er op, dat men waarschijnlijk losse aktes over een bepaalde periode bij elkaar liet komen en pas achteraf inschreef. Wellicht deden partijen ook niet veel moeite om akten in te schrijven ter voorkoming van de overdrachtsbelasting in de vorm van 'werfschelling' of 'oorlofsgeld'. Bij leengoederen werd de vijftiende penning of 6,66 procent van de koopprijs betaald.

\subsection{Hoger beroep in leenzaken}

Over de mogelijkheid van hoofdvaart en appel of hoger beroep van het leenhof van Gronsveld naar een andere instantie bestond veel onduidelijkheid. Prummer schrijft dat van oudsher werd beweerd 'dat in leenzaken niet naar elders kon worden geappelleerd, maar alleen beroep mogelijk was op 'andere gelijken bij het hof of een groter aantal van hen'; voor de uitleg daarvan zie hierna. ${ }^{1471}$ Tegelijkertijd constateerde hij dat dergelijke processen soms naar Aken (Schepenstoel), dan weer naar Spiers (Rijkskamergerecht) en zelfs naar Brussel (Raad van Brabant) waren 'gesleept'.

Van echte hoofdvaart waarbij het leenhof 'lering' bij een ander gerecht vraagt als basis van een vonnis, zijn bij het leenhof van Gronsveld geen voorbeelden bekend. Een soort tussenvorm treffen we aan in het proces tussen de rentmeester van het klooster Sinnich en Tilman Koumans over de betaling van achterstallige erfpacht uit de Wijngaardshof. Daarin bepaalde het leenhof op 17 juni 1613 dat zaak zodanig 'van importantien' was, dat Koumans werd verzocht een geldbedrag als borgsom te storten 'om te moegen doen vergaderen anderen und alder leenmannen mit denselven rypelyck te consulteren wy

1471 TJ, inv. nr. M 13, fol. 13-24, Prummer aan M.E. von Toerring-Jettenbach 9 november 1755: 'das von disem gericht in lehen sachen anderwärthig hin als ad alios pares curiae aut ad majorem illorum numerum nit appelliert werdten könne'. 
insgelijcken mit rechtsgelierden dieses beeter verstant hebbende'.1472 Of die andere, oude en wijze leenmannen bij een ander leenhof of binnen de kring van Gronsveldse leenmannen moesten worden gezocht, wordt niet aangegeven. Er wordt in ieder geval niet gesproken over een specifiek ander leenhof. In het vervolg van de zaak, wanneer ook graaf Johan II in de kwestie wordt gemengd, geeft de graaf aan partijen het advies om externe juristen te consulteren. ${ }^{1473}$

Het vroegst bekende geval van appel tegen een vonnis van het leenhof van Gronsveld betreft de zaak tussen Maria van Elderen, weduwe van jonker Daniël van Werst tegen jonker Lenert van Ellenbandt in 1539.1474 De procedure in eerste aanleg eindigt in de rol met de neutrale zinsnede dat 'van dit vonnysse off clerenysse joffr. Marye vurss. hefft geappelert'. Het hoger beroep werd direct ingesteld bij het Rijkskamergerecht, dat op 7 januari 1539 aan het 'manhuys' van Gronsveld bevel gaf een afschrift van het proces in eerste aanleg op te sturen.

Op 20 november 1558 wezen leenmannen van Gronsveld vonnis in een geschil tussen Johan I van Bronckhorst Batenburg en Johan van Cortenbach, commandeur van de Duitse Orde te Sint-Pieters-Voeren 'op verbeteren van meer mannen van lien ende op correxie ons E(ersame) wettigen heuft.' ${ }^{1475}$ Van Cortenbach appelleerde vervolgens direct bij het Rijkskamergerecht. Van Bronckhorst Batenburg protesteerde, maar desondanks stuurde het leenhof een afschrift van de procedure in eerste aanleg naar het Rijkskamergerecht, waar de zaak verder werd behandeld. Deze twee voorbeelden, die kunnen worden aangevuld met enkele hier niet genoemde gevallen, maken duidelijk dat tenminste vanaf de zestiende eeuw direct appel werd ingesteld van het leenhof van Gronsveld op het Rijkskamergerecht. Dit komt ook overeen met het algemene gebruik dat van leenhoven zonder verdere tusseninstanties werd geappelleerd op het Rijkskamergerecht. ${ }^{1476}$

Desondanks trekt de formulering in het vonnis van 20 november 1558 de aandacht. Wat werd daar bedoeld met de mogelijke 'correxie' door een wettig hoofd(gerecht)? De Schepenstoel van Aken? In een procedure uit 1616 van graaf Johan II van Bronckhorst Batenburg tegen Willem van Reuschenberg wordt gezegd dat over leengoederen eerst werd geprocedeerd voor de 'mankamer' (leenhof) van Gronsveld, vervolgens bij de Schepenstoel van Aken en ten slotte bij het Rijkskamergerecht. ${ }^{1477}$ Dat zou een al meer dan zestig jaar bestaande praktijk zijn.

Cryptisch in het vonnis is ook de mogelijke verbetering door 'meer mannen van lien'. Dit lijkt de vertaling van het later enkele malen in Gronsveld terugkerend begrip van appel op 'pares curiae', in het algemene leenrecht leenmannen (bij hetzelfde leenhof) die wat betreft rang en stand gelijk zijn aan de partijen. Soms wordt ook gesproken over 'sterkere

1472 RHCL, Rijkskamergerecht, inv. nr. 222, fol. 14vo.

1473 RHCL, Rijkskamergerecht, inv. nr. 222, fol. 25 vo.

1474 RHCL, Rijkskamergerecht, inv. nr. 53.

1475 RHCL, Rijkskamergerecht, inv. nr. 230, fol. 28vo.-29.

1476 Wanneer men kijkt naar de 'Maastrichtse' dossiers van het Rijkskamergerecht, dan blijkt dat vrijwel steeds van alle leenhoven rechtstreeks in appel werd gegaan bij het Rijkskamergerecht, zonder de Schepenstoel van Aken als tusseninstantie.

1477 RHCL, Rijkskamergerecht, inv. nr. 75. 
leenmannen'. Het kon immers gebeuren dat niet-adellijke leenmannen oordeelden in geschil waar edelen bij betrokken waren.

De hiervoor genoemde gevallen leveren geen heldere lijn op. Als regel lijkt men direct van het leenhof in beroep te zijn gegaan bij het Rijkskamergerecht, maar daarnaast kwam ook beroep op 'meer mannen van leen' of de Schepenstoel van Aken voor.

In Hoofdstuk 9.9 is beschreven hoe vanaf het begin van de zeventiende eeuw het hoger beroep van Gronsveld op de Schepenstoel van Aken steeds meer onder druk kwam te staan. Parallel daaraan ontstonden ook problemen over appel van het leenhof op Aken, in het bijzonder naar aanleiding van processen die graaf Jost Maximiliaan van Bronckhorst Batenburg voerde tegen de heren van Oost over de leenroerigheid van het kasteel aldaar en enkele laathoven. ${ }^{1478}$ Op 6 juli 1657 wezen de leenmannen van Gronsveld vonnis tegen Antonius Candidus van Hoensbroek, heer van Oost. Deze kondigde appel aan bij de Schepenstoel van Aken, wat de stadhouder van het Gronsveldse leenhof wegens 'pure nulliteijt' afwees. Op de vraag wie dan wel de 'superior judex' (hogere rechter) was, werd geantwoord dat daarvoor alleen 'ein starckher lehenherr' in aanmerking kwam. Van Hoensbroek liet vervolgens in Aken navragen of de Schepenstoel bevoegd was, want hij wist dat ook in een andere zaak noch de graaf van Gronsveld noch het leenhof deze instantie wilden erkennen. Het antwoord uit Aken was kort en krachtig: de Schepenstoel was op grond van koninklijke en keizerlijke privileges het bevoegde appelgerecht voor het leenhof van Gronsveld. Maar op 25 augustus 1657 was nog niets uit Gronsveld binnen. Wel ging het verhaal dat graaf Jost Maximiliaan geen enkele jurisdictie van de Schepenstoel over het leenhof van Gronsveld duldde en geweld gebruikte tegen iedereen die zich tot Aken wendde. De Schepenstoel wachtte dus tevergeefs op stukken en Van Bronckhorst Batenburg volhardde in zijn standpunt. Op 15 juli 1659 liet hij nog eens formeel voor notaris J. Graven te Gronsveld vastleggen dat tegen het vonnis van de Gronsveldse leenmannen ten onrechte was geappelleerd bij de schepenen van Aken in plaats van 'sterckere mannen' van het leenhof.

Wat nu aan Gronsveldse zijde precies werd bedoeld met het alternatief van 'sterckere mannen' blijft onduidelijk. Titel VI $\int 7$ van de Gronsveldse Rechtsordnung bevat de passage dat van vonnissen van het leenhof 'volgens oud gewoonterecht alleen op sterkere, gelijke personen van het hof mag worden geappelleerd' ('vermög alten herkommens ad majores pares curiae appelliert werdten könne'), maar verdere uitleg ontbreekt. Ook commissaris Prummer zwijgt daar later over. Waarschijnlijk is de kwestie nooit in principiële zin opgelost en bestond daar ook weinig behoefte aan. Het appel van het leenhof was ondergeschikt aan de ontwikkelingen die zich voordeden bij het appel van de schepenbank op Aken. Grote processen voor het leenhof kwamen sinds het einde van de zeventiende eeuw nauwelijks meer voor. Voor de sporadische gevallen dat toch appel werd gewenst, bestond nog altijd de mogelijkheid een appelcommissaris aan te wijzen. De eerste vermelding van een dergelijke functionaris in de persoon van Wilhelm Veucht in 1677 speelde trouwens in het proces tussen Johan Lindeloof en het klooster Sinnich, dat in de Hoofdstukken 8.8 en 9.9.3 werd besproken.

1478 RHCL, Familie De Geloes/Kasteel Eijsden, inv. nr. 317. 


\subsection{Conclusies}

Het Gronsveldse leenhof was wat betreft omvang omstreeks 1600 op zijn hoogtepunt. Daarna begon een periode van afkalving door het verlies van de lenen in Oost en SintMartens-Voeren, het allodiaal maken van lenen en slechte administratie. De interne organisatie van het leenhof veranderde ten opzichte van de middeleeuwse situatie nauwelijks. De functie van stadhouder werd in 1710 een erfelijk ambt.

Het materiële en formele leenrecht van Gronsveld was vastgelegd in de Rechtsordnung van 1671. Mogelijk lag daar een Lehenordtnung van 1593 aan ten grondslag. Voor procedures werd hetzelfde procesrecht gebruikt als bij de schepenbanken. Veel problemen hadden te maken met de verheffing van lenen na overlijden van de leenheer en de leenman. Onduidelijk was of hier rijksrecht moest worden toegepast. Voorts bood het leenrecht ook mogelijkheden voor de leenman om aan zijn verplichtingen te ontsnappen.

Het hoger beroep in leenzaken was evenmin duidelijk geregeld. Er werd rechtstreeks geappelleerd op het Rijkskamergerecht, maar daarnaast bestond ook zoiets als beroep op 'sterckere mannen' of 'pares curiae'. Wel zorgde het hoger beroep in de zeventiende eeuw voor conflicten met de Schepenstoel van Aken, die zich daar ook jurisdictie in toekende. De ontwikkelingen lopen daarbij parallel met de conflicten over het beroep bij de schepenbanken. 


\section{Bestuur en rechtspraak ten tijde van de 'admodiatie', circa 1720-1732}

De moeizame overgang van het graafschap Gronsveld na het overlijden van Johan Frans van Bronckhorst Batenburg in 1719 op diens weduwe Maria Anna von ToerringJettenbach vormde de proloog voor een uiterst roerige periode gedurende ongeveer twaalf jaar. Gronsveld werd het decor voor moord en doodslag. De hoofdrollen waren weggelegd voor drossaard/secretaris Lebens en leden van de familie Gathoye als zijn tegenspelers. Pas vanaf 1732 ontstonden onder het (voorlopig) bewind van graaf Ignaz Felix von Toerring-Jettenbach meer stabiele verhoudingen.

Men kan de jaren tussen 1720-1732 in Gronsveld zien als een moeilijke overgangsperiode tussen 'oud' en 'nieuw', waarin persoonlijke vetes centraal stonden. Maar de betekenis reikt verder. De casus geeft zicht op de politieke cultuur en machtsverhoudingen binnen een klein graafschap als Gronsveld gedurende een periode van zwak landsheerlijk gezag. Daarnaast komt aan de orde welke rol de Schepenstoel van Aken, het Rijkskamergerecht en de Rijkshofraad als externe rechtshandhavers konden en wilden spelen.

In de Inleiding 3.2 van dit boek werd aandacht besteed aan de studie van Gabel over de politieke cultuur in een aantal Rijn- en Maaslandse territoria in de vroegmoderne tijd. ${ }^{1479}$ Daarin analyseert hij een aantal grote, soms generaties aanslepende conflicten tussen heren en onderdanen. Bij de rijksonmiddellijke gebieden besteedt hij aandacht aan Thorn, Rekem, Stein, Kerpen-Lommersum, Millendonck en vooral de langdurige problemen binnen de kloosterstaat Cornelimünster bij Aken. Verspreid over afzonderlijke artikelen, worden ook de perikelen in Stein in de achttiende eeuw tussen de inwoners daar en de heren von Kinsky, beschreven door Munsters. ${ }^{1480}$ Bij deze conflicten overheerst het beeld dat ze zich vooral afspelen in de relatie tussen heer en een collectief van onderdanen dat weerstand biedt tegen belastingen, herendiensten en schending van rechten en privileges. In het rechtshistorisch jargon worden deze processen vaak aangeduid als 'Untertanenprozesse'. ${ }^{481}$ Tegelijkertijd komen ook interne spanningen tussen rivaliserende groeperingen binnen een kleine samenleving aan de oppervlakte.

Kenmerkend voor Cornelimünster vindt Gabel het ontbreken van militaire middelen om orde en rust te handhaven (overigens een algemeen gegeven bij kleine territoria), verder de betekenis die werd gehecht aan het gezag van het Rijkskamergerecht en de Rijkshofraad en ten slotte, ondanks alle interne tegenstellingen, de principiële bereidheid van onderdanen om in gezamenlijkheid met de landsheer mee te werken aan de vorming van een goed landsbestuur, of het nu ging om wetgeving, belastingen of financieel beheer. ${ }^{1482}$

Ieder geschil kent zijn eigen verloop en dynamiek. Dat geldt ook voor de gebeurtenissen in Gronsveld tussen 1720-1732. In de conclusie aan het einde van dit hoofdstuk wordt geprobeerd antwoord te geven op de vraag hoe deze gecompliceerde casus past in het algemene beeld. Ging het hier om een aantal ongelukkige toevallen en uit de hand gelopen

1479 Gabel, Widerstand und Kooperation.

1480 Munsters, 'De strijd tegen het hoogduits'; Munsters, 'Het knuppelen der honden'.

1481 Zie voor dit verschijnsel 'Untertanemprozesse' ook: Janssen, 'Unterherrschaft', 161-162.

1482 Gabel, Widerstand und Kooperation, 332-335. 
persoonlijke conflicten of lag er een diepere problematiek bij kleine rijksonmiddellijke territoria aan ten grondslag?

De beschrijving van de gebeurtenissen in Gronsveld tussen 1720 en 1732 is voor het grootste deel gebaseerd op twee omvangrijke dossiers uit het archief van het Rijkskamergerecht. ${ }^{1483}$ Daarbuiten zijn er weinig andere bronnen. ${ }^{1484}$ Het is lastig dit materiaal overzichtelijk samen te vatten en de elkaar dikwijls tegensprekende verklaringen zijn niet altijd op hun betrouwbaarheid te beoordelen. Door de complexiteit van het verhaal is niet gekozen voor een systematische indeling zoals elders in dit boek, maar voor een chronologische beschrijving. Omdat de meeste gegevens ook uit deze dossiers afkomstig zijn, is gekozen voor een sobere annotatie met alleen een verwijzing naar de belangrijkste stukken.

\subsection{Joannes Godefridus Lebens vestigt zijn gezag als drossaard}

Een van de hoofdrolspelers in de roerige jaren twintig is Joannes Godefridus Lebens. Hij was zijn loopbaan in Gronsveld begonnen als secretaris van de schepenbank en kreeg al snel de reputatie van een man die, zonder veel scrupules, wist wat hij wilde. (zie Hoofdstuk 9.3). Lebens werd op 20 november 1720 door graaf Claude Nicolas d'Arberg Valengin tot drossaard benoemd, nadat zijn voorganger Willem Kicken 'vrijwillig' was afgetreden. ${ }^{1485}$ Waarschijnlijk had hij die benoeming mede te danken aan zijn loyaliteit ten opzichte van Maria Anna von Toerring-Jettenbach, die met veel problemen haar eerste echtgenoot Johan Frans van Bronckhorst Batenburg als landsvrouwe was opgevolgd. Naast zijn benoeming tot drossaard bleef hij ook in functie als secretaris van de schepenbank. Niet iedereen was daarmee gelukkig. De 'officier' Olislagers, die in Gronsveld als scholtis en soort rentmeester fungeerde, meende dat nergens ter wereld de functies van drossaard, secretaris en 'procureur' in één persoon verenigd waren. Lebens wilde de absolute heerschappij in het graafschap, niets kon gebeuren buiten hem om en maakte van dit streven geen geheim. Hij zag zich al in het kasteel wonen, omdat zijn eigen huis te klein was. ${ }^{1486}$

Lebens zorgde al snel voor enkele opzienbarende strafzaken. Het begon in januari 1721 met een gerechtelijk vooronderzoek tegen Franciscus Ruth en Joannes Ludovicus Graven. Zij werden beschuldigd van bedreiging, belediging en samenspanning tegen de graaf, de drossaard en de gerechtsbode. Waarschijnlijk liep de zaak met een sisser af. ${ }^{1487}$ Een mysterieuze brand op 23 maart 1721 die twee schuren volledig in de as legde, zorgde ook

\footnotetext{
1483 RHCL, Rijkskamergerecht, inv. nr. 176 en 71.

1484 De archieven van de schepenbank bevatten vrijwel geen stukken over deze periode. Aanvullend materiaal bevindt zich wel in het archief van de graven Toerring-Jettenbach, maar is verspreid door het hele bestand en valt door deze staat van ordening nauwelijks systematisch te raadplegen. De daar gevonden gegevens berusten dan ook op toevalstreffers. Desondanks geven de dossiers van het Rijkskamergerecht toch wel een samenhangend en afgerond beeld.

1485 RHCL, Rijkskamergerecht, inv. nr. 71/1, fol. 548-548vo.

1486 TJ, inv. nr. M 8, fol. 292-296, Olislagers aan graaf d'Arberg Valengin 15 maart 1721.

1487 RHCL, Rijkskamergerecht, inv. nr. 71/1, fol. 578-583.
} 
voor spanning. ${ }^{1488}$ In april 1721 werd een arrestatiebevel uitgevaardigd tegen Stephanus, Nicolaas en Michaël Schrijnemeeckers. ${ }^{1489}$ Ook hen werd ondermijning van het publieke gezag en het veroorzaken van onrust ten laste gelegd. Waarschijnlijk is het geval gesust of werd de vervolging afgekocht.

Op 18 augustus 1721 werd Gronsveld opgeschrikt door de moord op Egidius Potmans Hij was 'zeer jammerlijk door een geweerschot omgekomen', noteerde de pastoor in het overlijdensregister. ${ }^{1490}$ Drossaard Lebens startte onmiddellijk een gerechtelijk vooronderzoek. ${ }^{1491} \mathrm{Al}$ snel ging het sterke gerucht dat Sebastiaan de Montbrison, een jonge, adellijke cadet in het garnizoen van Maastricht, zoon van Jean de Montbrison en Margaretha de Vos, de adellijke bewoners van Hemersbach in Eckelrade, de dader was. Maar vooralsnog maakte Lebens niet veel aanstalten actie te ondernemen. De jongeman liep met opgeheven hoofd door het dorp, iedereen verwensend die hem met deze moord in verband bracht.

Op 6 juli 1722 kwam Joannes Beckers in Eckelrade om het leven, waarschijnlijk als gevolg van doodslag 's nachts gepleegd door de jeugdige Martinus Vrancken. ${ }^{1492}$ Het was een juridisch ingewikkelde zaak angezien het feit was gepleegd op de doorgaande weg door Eckelrade, die tevens de grens vormde tussen Gronsveld en Breust. Daarom wilde de drossaard van Breust beslag leggen op het lichaam, maar Lebens kwam eerder. Omdat de jonge verdachte de benen had genomen, bedreigde Lebens diens ouders. Die wilden uiteindelijk met tegenzin een boete betalen, hoewel zij op Breuster (dus buitenlands) gebied woonden en het bewijs zwak was. Maar zij bezaten grond in het graafschap Gronsveld en waren daarmee gevoelig voor sancties. ${ }^{1493}$ Lebens trof op 23 augustus 1723 een schikking, waarbij tegen betaling van tweehonderd rijksdaalders vervolging werd afgekocht. ${ }^{1494}$ In wiens zak dat geld vloeide, was naderhand onduidelijk.

Enkele maanden later viel het oog van Lebens weer op de al eerder genoemde Franciscus of Frans Ruth. Waarschijnlijk eind 1722 was Ruth betrokken bij het ingooien van ruiten bij zowel de drossaard als de gerechtsbode. Hij behoorde tot een groepje mannen die elkaar ophitsten en vonden dat de rust in het dorp pas zou terugkeren wanneer de gehate drossaard om het leven was gebracht. Behalve het ingooien van ramen was er nog een plan geweest bij Lebens beenderen van paarden en kadaverresten voor de deur te leggen. Op de een of andere manier trok Ruth in deze zaak de aandacht. Tijdens een gerechtelijk getuigenverhoor op 22 december 1722 kwam een hele lijst van bedreigingen en

\footnotetext{
1488 TJ, inv. nr. M 8, fol. 289-292, Olislagers aan graaf d'Arberg Valengin 31 maart 1721.

1489 RHCL, Rijkskamergerecht, inv. nr. 71/2, fol. 205-206vo.

1490 'Ictu bombardi misserime occisus'.

${ }^{1491}$ RHCL, Rijkskamergerecht, inv. nr. 71/1, fol. 601-602.

1492 'Misere occisus est Joannes Beckers in Eckelraedt nullo Sancte Romane Ecclesie sacramento administratus et in Gronsfeldt honeste sepultus' Jammerlijk omgekomen is Joannes Beckers in Eckelrade, zonder te zijn voorzien van sacramenten van de H. Kerk en is in Gronsveld fatsoenlijk begraven), noteerde de pastoor in het overlijdensregister.

1493 TJ, inv. nr. M 75, fol. 849-852, brief van de eerw. heer Toubon te Gronsveld aan graaf d'Arberg Valengin 3 september 1722.

${ }^{1494}$ RHCL, Rijkskamergerecht, inv. nr. 71/2, 77-78vo.
} 
mishandelingen op tafel. Zelfs zijn eigen vader was daar slachtoffer van geweest. ${ }^{1495}$ Voor Lebens vormde dit alles voldoende reden Ruth op te sluiten in een kerker van het kasteel. Of dat juridisch in orde was en gebeurde met toestemming van de schepenen, is onduidelijk. Uit latere verklaringen krijgt men de indruk dat Lebens de maatregel gewoon doordrukte.

Franciscus Ruth verbleef gedurende achttien maanden in zijn cel, zonder proces. Intussen werden wegens schulden zijn huis en inboedel (tot en met de mestvaalt) verkocht en stond zijn familie op straat. ${ }^{1496}$ Ook van deze zaak had Lebens profijt getrokken. ${ }^{1497}$ Op 5 juni 1724 werd Ruth dood in zijn cel aangetroffen. Op zich was het een natuurlijke dood, maar Ruths weduwe verklaarde later dat haar man op water en brood in een donkere kelder, zonder verwarming was vastgehouden en als een beest in zijn eigen vuil was gestorven. Bij zijn overlijden was niemand aanwezig. ${ }^{1498}$ Meermalen had de vrouw aan Lebens gevraagd waarom haar man zo werd behandeld, maar ze kreeg geen antwoord. Enkele andere inwoners sympathiseerden met de gevangene, maar ook dat stelde de drossaard niet op prijs. Ook zij verdwenen enkele weken in de kerker. ${ }^{1499}$ Er klonken ook tegengestelde geluiden. Medestanders van Lebens verklaarden dat de gevangene goed was verzorgd en de vrouw van Ruth en diens familie werden in een kwaad daglicht gesteld wegens zedeloos gedrag.

De genoemde voorvallen, en in het bijzonder de zaak Ruth, laten zien dat Lebens vanaf het begin met harde hand alle oppositie in de kiem smoorde. Dat lag in zijn karakter, maar hij richtte zich ook bijzonder op dat deel van bevolking voor wie het gezag van de graaf en de gravin nog altijd omstreden was. Mogelijk school daarin ook een element van afrekening met aanhangers van het oude bewind ten tijde van drossaard Kicken. Die harde lijn werd hem later door zijn tegenstanders keer op keer aangewreven.

\subsection{De verpachting van het graafschap aan François Gathoye}

Van de graaf en gravin kreeg Lebens min of meer de vrije hand. Die lieten zich aan Gronsveld niet veel gelegen liggen. Zoals al beschreven in Hoofdstuk 5.1 gaf graaf Claude Nicolas op 10 september 1723 het graafschap Gronsveld tegen betaling van 1750 rijksdaalders per jaar voor een termijn van negen jaar in pacht of 'admodiatie' aan Jean Gathoye uit Soumagne. ${ }^{1500}$ De pachter, een man met veel geld maar ook een wat dubieuze achtergrond als ondernemer, geldverstrekker en handelaar, mocht zijn zoon François in zijn plaats stellen of, in het geval van overlijden, diens broer Henri. Op basis van deze overeenkomst kreeg Gathoye de beschikking over alle heerlijke rechten en inkomsten, inclusief herendiensten, jacht en visserij, maar met uitzondering van benoemingsrechten.

\footnotetext{
1495 RHCL, Rijkskamergerecht, inv. nr. 71/1, fol. 578.

1496 RHCL, Rijkskamergerecht, inv. nr. 71/1, fol. 593597.

1497 RHCL, Rijkskamergerecht, inv. nr. 71/2, fol. 81-82vo.

1498 RHCL, Rijkskamergerecht, inv. nr. 71/2, fol. 81-82vo.

1499 RHCL, Rijkskamergerecht, inv. nr. 71/2, fol. 77-78vo.

1500 In dit hoofdstuk wordt de naam Gathoye aangehouden; vaak komt ook de variant Gauthoye voor.
} 
Het jachtrecht schijnt voor de pachter erg zwaar te hebben gewogen, misschien vanwege liefhebberij, maar ook als adellijk statussymbool.

Met deze familie kreeg Lebens nu te maken. Volgens een latere verklaring van de schepenen van Aken hadden zij aanvankelijk 'di concerto gehandelt' en waren zij 'in guter verständtenis gewesen'. ${ }^{1501}$ Maar al snel verslechterde de relatie, mogelijk vanwege een rechtszaak tegen François Gathoye, wat door de familie als een zware belediging moet zijn opgevat. ${ }^{1502}$ Lebens werd door vader en zonen Gathoye op het kasteel ontboden en daar ontspon zich een twistgesprek, waarbij Henri Gathoye op schoot al onder de tafel een degen gereed hield. Bij andere gelegenheden bood François Gathoye zijn jager geld om Lebens te vermoorden. Maar achter de aanleiding stak ook een diepere oorzaak die voortkwam uit de verhoudingen zoals die door het pachtcontract waren geschapen. De eigenzinnige Lebens was gewend in grote zelfstandigheid hard op te treden tegen onwelgevallige lieden en meende over de admodiator op dezelfde wijze gezag te kunnen uitoefenen. De Gathoye's, evenmin afkerig van geweld, hadden formeel als pachter alleen rechten op inkomsten uit het graafschap, maar gedroegen zich in de praktijk als waren zij de graaf zelf en daarmee ook de baas van Lebens. Dat leidde al snel tot competentieconflicten, bijvoorbeeld bij de verdeling van inkomsten uit boeten, waarop zowel de drossaard als de admodiator aanspraak maakten.

\subsection{De dood van Sebastiaan de Montbrison}

Op zondag 16 januari 1724 trok Sebastiaan de Montbrison vanuit zijn ouderlijk huis Hemersbach in Eckelrade, vergezeld door een hond en gewapend met een geweer, het veld in om te jagen. Tegelijkertijd bevond zich François Gathoye in het veld, op een afstand gevolgd door zijn tuinman Lambertus Werry, beiden voorzien van een geweer. Wat precies tussen De Montbrison en Gathoye gebeurde is niet duidelijk, maar getuigen zagen uit de verte dat de twee mannen hun geweer aanlegden. Vervolgens klonken twee schoten. ${ }^{1503}$ Waarschijnlijk had Gathoye, te oordelen naar de richting van de rook, het eerste gevuurd. Daarna verscheen Lambertus Werry, de derde man, uit de achterhoede. Deze had volgens de getuigen 'de heer Gathoye gevat in sijn armen' en weggebracht. De getuigen zagen dat Sebastiaan de Montbrison dood was en renden naar Hemersbach om hulp te halen. Daarop kwamen familieleden die het lichaam naar huis droegen.

Was de dood van De Montbrison moord of zelfverdediging van Gathoye met een noodlottige afloop? Die vraag kon alleen de drossaard in een gerechtelijk onderzoek beantwoorden, maar door de snelle ontruiming van de plek des onheils waren belangrijke sporen uitgewist. De reacties op de dood waren ook heel verschillend. In condoleancebrieven van graaf d'Arberg Valengin aan de familie van de overledene betuigde hij wel zijn medeleven, maar liet hij het slechte gedrag van de overledene niet

${ }^{1501}$ RHCL, Rijkskamergerecht 176, fol. 43-48vo.

1502 RHCL, Rijkskamergerecht 176, fol. 21-23.

1503 RHCL, Rijkskamergerecht, inv. nr. 71/1, fol. 202-205. 
onvermeld.1504 De graaf verweet de familie ook dat het lichaam direct was afgevoerd zonder onderzoek of toestemming van de schepenen.

Op 6 maart 1724 werd François Gathoye door de schepenen van Gronsveld gehoord, waarschijnliik als verdachte. ${ }^{1505}$ Tijdens de vervolgzitting van 27 maart bleek Gathoye zonder verlof naar Luik te zijn vertrokken. Drossaard Lebens zag daarin voldoende aanleiding 'arrest' op de persoon van de verdachte te vorderen en ook inventarisatie van diens goederen en inkomsten. Bovendien moest hem worden verboden een geweer of degen te dragen.

Terwiil het proces tegen François Gathoye weinig voortgang boekte, vervolgde Lebens wel ijverig de mensen die het lichaam van Sebastiaan de Montbrison hadden getransporteerd. Op 19 juni 1724 wendde Jean François, de broer van het slachtoffer, zich tot de Schepenstoel van Aken met de klacht dat de dood van Sebastiaan niet serieus door de drossaard en schepenen van Gronsveld werd behandeld. ${ }^{1506}$ Naar aanleiding daarvan ontving Jean François een schrijven van graaf d'Arberg Valengin, waarin deze zich verbaasde over de inschakeling van het gerecht van Aken, terwijl toch de graaf de hoogste gezagsdrager binnen Gronsveld was. De schepenen van Aken zagen in deze zaak een mooie aanleiding hun vermeend gezag over Gronsveld weer eens op te poetsen en gelastten het gerecht zich binnen acht dagen te verantwoorden.

Op 31 augustus 1724 stuurden de Gronsveldse schepenen een afgewogen reactie.1507 $\mathrm{Zij}$ ontkenden ooit aan de Montbrison recht te hebben geweigerd, maar hun handen waren gebonden. Zij waren sinds mensenheugenis niet voor de Schepenstoel van Aken verschenen, maar hadden altijd geprocedeerd voor commissarissen die door de graaf waren aangewezen. ${ }^{1508}$ Door deze interventie vreesden zij tussen hamer en aambeeld te komen. Volgens hun eed moesten zij de jurisdictie van de graaf waarborgen, anderzijds werden zij nu vanuit Aken geconfronteerd met dwangmaatregelen ten opzichte van hun persoon en goederen. Enkele schepenen hadden al ontslag gevraagd.

De dreigementen van de Schepenstoel waren niet helemaal loze gebaren. Zo werd Lebens bij een bezoek aan Aken een tijdje gevangen gehouden. Maar de Schepenstoel van Aken kwam uiteindelijk niet veel verder dan een fraai attest op 12 december 1724 dat de 'chevallier de Montbrison' zich had beklaagd over de gang der justitie te Gronsveld, 'ressort de notre judicature', en dat hij daar had moeten procederen over nota bene de beslaglegging op zijn goederen, terwijl de moordenaar van zijn broer nog altijd ongestraft rondliep. ${ }^{1509}$

\footnotetext{
1504 RHCL, Rijkskamergerecht, inv. nr. 71/1, fol. 268-269vo.

1505 RHCL, Rijkskamergerecht, inv. nr. 71/1, fol. 206-209vo.

1506 RHCL, Rijkskamergerecht, inv. nr. 71/1, fol. 532-532vo.

1507 RHCL, Rijkskamergerecht, inv. nr. 71/1. fol. 542-543.

1508 RHCL, Rijkskamergerecht 176, fol. 53-54, bevat een uittreksel, gedateerd 13 maart 1726, van vroegere appelzaken van Gronsveld naar Aken.

${ }^{1509}$ RHCL, Rijkskamergerecht 176, fol. 35-36vo.
} 


\subsection{Gathoye's optreden tegen de bevolking}

Terwijl in de zaak de Montbrison nauwelijks voortgang werd geboekt, begon François Gathoye zijn rechten zodanig te gebruiken dat de bevolking dit als misbruik en dwingelandij ervoer. Zo eiste hij herendiensten, altijd al een gevoelig onderwerp in de relatie tussen heer en onderdanen. Inwoners van Eckelrade kregen de aanzegging te komen 'karweien' op straffe van een boete van zes goudgulden bij niet-verschijnen. ${ }^{1510}$ De mensen weigerden met het argument dat het zaaitijd was en zij volgens hun privileges niet tot deze dienst verplicht waren. Vervolgens bedreigde Gathoye de inwoners en liet hij burgemeester Willem Bemelmans van Eckelrade gevangen zetten. Toen Lebens probeerde verhaal te halen, viel Gathoye woedend uit. Hij wilde desnoods het hele graafschap in brand steken, 'veegde zijn gat af' aan zogenaamde privileges en zou vier of vijf rebellen 'den kopff abschmeissen', wanneer hij na een bezoek aan het Rijkskamergerecht in Wetzlar terugkeerde. Daarheen, zo beweerde hij, zou jij gaan om erkenning als soeverein te krijgen ('umb dermal eins souverainer herr zu sein').

Een volgend slachtoffer van de Gathoyes werd Lambert Retraet. Hij was zo onvoorzichtig geweest op duiven in het veld te schieten en werd door handlangers van Gathoye opgepakt. ${ }^{1511}$ Jean Gathoye, de vader van François, eiste een buitensporig hoog bedrag aan boete. Daarna werd Lambert in de kelder gegooid, kreeg smerig water en brood en werd ziek. Zijn familie betaalde uiteindelijk vijftien rijksdaalders aan Gathoye, die het geld in eigen zak stak. Ook dit voorval is tekenend voor de gezindheid van Gathoye. Wanneer er sprake zou zijn geweest van een jachtdelict, had de drossaard dit moeten vervolgen en had hij formeel ook recht op een deel van boetes. Maar Gathoye speelde voor eigen rechter.

Wanneer de Gathoye's in Gronsveld verbleven, gedroegen zij zich tiranniek tegen de bevolking, maar ze waren in 1725 ook gedurende langere periodes afwezig, onder andere voor plezierreizen met een heel gevolg vier maanden naar Parijs en twee maanden naar Holland. Men beweerde later dat zij voor dertigduizend gulden aan kostbaarheden die graaf d'Arberg Valengin hun had toevertrouwd, hadden verkocht en verbrast. De eerste jaren werd nog pacht voor het graafschap betaald, maar vanaf 1725 hielden die betalingen op. De graaf d'Arberg Valengin zag zich niet bij machte daar iets tegen te ondernemen.

\subsection{Stagnatie, oplopende spanning en vonnis in de moordzaak de Montbrison}

Het leek alsof François Gathoye zorgeloos de bloemetjes buiten kon zetten, maar helemaal zeker van zijn zaak voelde hij zich niet. Hij dacht daarom een sprong voorwaarts te maken met een klacht bij de Rijkshofraad in Wenen, de keizerlijke evenknie van het Rijkskamergerecht. Er werd een verhaal afgestoken over de vreselijke misdaden door drossaard Lebens begaan tegen hem, Gathoye, en andere inwoners van het graafschap. In het bijzonder doelde hij op in de gevangenis gestorven Franciscus Ruth. Inderdaad vaardigde de Rijkshofraad op 28 juni 1725 een keizerlijk 'rescript' uit, waarbij graaf d'Arberg Valengin ten eerste opdracht kreeg Gathoye tegen Lebens te beschermen, verder

1510 RHCL, Rijkskamergerecht, inv. nr. 71/1, fol. 242-245.

${ }^{1511}$ RHCL, Rijkskamergerecht, inv. nr. 71/1, fol. 225-226. 
de in een slechte toestand verkerende justitie te Gronsveld te verbeteren en ten slotte de weduwe Ruth en haar kinderen van voldoende voedsel te voorzien. ${ }^{1512}$ Maar hoe overtuigend het stuk er ook uitzag, later werd getwijfeld aan de echtheid. Hoe Gathoye er ook aan mag zijn gekomen, Lebens of de graaf hebben zich zeker niet kunnen verdedigen tegen deze aantijgingen.

Met het verstrijken van de tijd raakte het proces tegen Gathoye ook om een andere reden in het slop. Waarschijnlijk in de herfst van 1724 of het voorjaar van 1725 namen de Gronsveldse schepenen onder druk van de dreigementen uit Aken collectief ontslag. Men herinnerde zich vroegere conflicten met Aken, met alle risico's van dien. Als reactie vaardigde de graaf op 24 juni 1725 'patenten' uit voor zeven nieuwe schepenen. Drie waren niet uit Gronsveld afkomstig, wat de vraag opriep of dat juridisch wel kon. Het Rijkskamergerecht stelde zich later in deze kwestie op het standpunt dat een schepen in Gronsveld over onroerend goed moest beschikken of minimaal 'onder het Rijk bedwingbaar was', dat wil zeggen zijn domicilie had op grondgebied vallend onder de jurisdictie van het Rijk en het Rijkskamergerecht. Van de Gronsveldenaren weigerden twee hun benoeming te aanvaarden ${ }^{1513}$ en één liet helemaal niets van zich horen.

Ten slotte ontstond er verschil van mening over de beëdiging. Op de een of andere manier waren de benoemingsbrieven in handen van Gathoye geraakt. Lebens beweerde dat uitsluitend hij als drossaard schepenen mocht beëdigen, terwijl Gathoye verkondigde dat dit recht hem als pachter van het graafschap toekwam. Het admodiatiecontract zweeg daarover. Het leidde tot een heftige woordenwisseling, waarbij Gathoye riep dat hij zich niet als een kleine jongen in de hoek liet zetten. ${ }^{1514}$ In zijn ogen representeerde hij de landsheer, dus moesten de benoemingsbrieven in zijn handen blijven en nam hij de eed af. Hij voegde de daad bij het woord in die zin dat drie overgebleven nieuwe schepenen van buiten Gronsveld, in september 1725 de eed aflegden in handen van de griffier van het grafelijk leenhof, in aanwezigheid van Gathoye. De drie benoemde schepenen kwamen voor het eerst bij elkaar tijdens het - verhoudingsgewijs late - voogdgeding op 21 januari 1726. Aangezien drossaard Lebens, tevens secretaris, niet kwam opdagen, legden ze opnieuw de eed af in handen van de leengriffier. ${ }^{1515}$ Graaf Claude Nicolas wenste zich absoluut niet te mengen in dit geschil tussen de drossaard en de pachter van het graafschap. Alle Gronsveldse conflicten deden hem veel verdriet, zo liet hij weten, maar men moest daarvoor maar de juiste rechter zien te vinden; hij voelde zich daarvoor niet bevoegd. ${ }^{1516}$

Drossaard Lebens had als secretaris toegang tot het archief van de schepenbank en kon dus het dossier van de strafzaak tegen Gathoye mee naar huis nemen. Het ging vooral om de stukken van het gerechtelijk vooronderzoek vlak na de dood van Sebastiaan de Montbrison. Later beweerde Lebens dat hij met deze actie wilde zorgen voor veilige

1512 RHCL, Rijkskamergerecht, inv. nr. 71/1, fol. 57.

1513 RHCL, Rijkskamergerecht, inv. nr. 71/1, fol. 254-254vo.

1514 RHCL, Rijkskamergerecht, inv. nr. 71/1, fol. 167-167vo.

1515 RHCL, Rijkskamergerecht, inv. nr. 71/1, fol. 250-251vo.

1516 'je ne suis point leur juge competent'; RHCL, Rijkskamergerecht, inv. nr. 71/1, fol. 312. 
bewaring, maar zonder deze documenten konden nieuwe schepenen geen proces voeren en kon Gathoye de al geschreven getuigenverklaringen niet meer manipuleren. En het zag er naar uit dat het voor Gathoye wel eens slecht kon aflopen, want verdenkingen dat de dood van de Montbrison opzet was, werd steeds concreter. Intussen zorgden de Gathoye's voor nieuwe incidenten. Zo werden enkele inwoners onder bedreiging opgepakt omdat ze hun rekeningen niet zouden hebben betaald. ${ }^{1517}$ Spectaculairder was de actie van Gathoye op 1 oktober 1725 toen hij, vergezeld van zijn handlangers probeerde Lebens thuis te arresteren met de bedoeling hem naar 's-Gravenvoeren te brengen. ${ }^{1518}$ Lebens werd een paar dagen in het kasteel opgesloten, waarna de zaak op 5 oktober als 'misverstand' eindigde met een ogenschijnlijk minnelijke schikking. Een week later vergaderden de heren zelfs over reparaties aan het kasteel.1519

De spanningen in het graafschap liepen op, omdat Gathoye bij de inwoners betaling van pachten en renten eiste. Dat ging gepaard met bedreigingen en geweld, in het bijzonder gericht op personen uit de omgeving van Lebens. Zo werd diens knecht in een kelder van het kasteel vastgebonden aan een paal en lag daar zes dagen in de winterkou op de grond zonder stro en dacht te zullen sterven. ${ }^{1520}$ Ook de tachtigjarige Lambertus Lousberchs, schoonvader van Lebens, werd bedreigd.

Intussen werd van verschillende zijden druk uitgeoefend het nog altijd slepende proces tegen Gathoye voort te zetten. 'Chevalier' Jean François de Montbrison probeerde de Schepenstoel van Aken tot meer daadkracht te bewegen met een dagvaarding voor het Rijkskamergerecht. De schepenen van Aken moesten erkennen dat de zaak al een half jaar stil lag. ${ }^{1521}$ Op 28 februari 1726 vaardigde het Rijkskamergerecht een bevelschrift om de rechtsgang te bespoedigen ('mandatum de administrando celerem justitiam') uit, waarna het nog tot 10 mei 1726 duurde voordat de zaak in Wetzlar op de rol stond. Intussen oefenden de schepenen van Aken toch druk uit op hun ambtgenoten in Gronsveld om de zaak tegen Gathoye voort te zetten. Maar Gathoye was niet plan zich daar aan te storen en meende dat hij bescherming had op grond van zijn documenten van de Rijkshofraad uit Wenen. ${ }^{1522}$

De kern van het probleem lag in Gronsveld. De (incomplete) schepenbank, bestaande uit creaturen van Gathoye, probeerde de zaak te hervatten, maar drossaard/secretaris Lebens verscheen niet. Zonder aanklager en dossier ook geen proces. Met die houding blokkeerde Lebens iedere vorm van wettig procederen. Zelfs dreiging met arrestatie bracht hem niet op andere gedachten. Graaf Claude Nicolas waste te midden van dit geruzie zijn handen in onschuld. Hij kon er niets aan doen, had de drossaard al honderd keer gewaarschuwd en meende dat men maar moest procederen tegen de drossaard wegens plichtsverzuim. ${ }^{1523}$

1517 RHCL, Rijkskamergerecht, inv. nr. 71/1, fol. 218-219.

1518 RHCL, Rijkskamergerecht, inv. nr. 71/, fol. 172-175vo.

1519 RHCL, Rijkskamergerecht, inv. nr. 71/1, fol. 248-249vo.

1520 RHCL, Rijkskamergerecht, inv. nr. 71/1, fol. 216-217vo.

1521 RHCL, Rijkskamergerecht 176, fol. 39-40vo.

1522 'Habstu das gelesen, es ist gutt, habe ein anderes von Wien, je n'obieray pas': RHCL, Rijkskamergerecht 176, fol. 55-56.

1523 RHCL, Rijkskamergerecht, inv. nr. 71/1, fol. 257-258vo. 
Intussen waren de Montbrison, Lebens en Gathoye ieder afzonderlijk druk bezig met verzamelen van bewijsmateriaal. Bij de twee eerstgenoemde resulteerde dat in een reeks verklaringen over knevelarij en geweldpleging door Gathoye en zijn handlangers. Ook kwamen er steeds meer anwijzingen dat Gathoye met voorbedachten rade een confrontatie met Sebastiaan de Montbrison had gezocht. De admodiator op zijn beurt liet de vroegere schepenen dagvaarden om hen te verhoren over corruptie door Lebens en diens schuld aan de dood van Franciscus Ruth. Die getuigen wisten zich echter opvallend weinig te herinneren.

Op 8 april 1726 leek beweging te komen bij de Gronsveldse schepenbank. Maar de onderbezetting vormde nog altijd een probleem. Daarom wendde Gathoye zich opnieuw tot de Rijkshofraad in Wenen, de instantie die hem een jaar eerder, op 28 juni 1725, ook van dienst zou zijn geweest met een 'rescript' waarbij graaf d'Arberg Valengin opdracht kreeg de slecht functionerende rechtspleging in Gronsveld te verbeteren. Met een ingreep door de Rijkshofraad dacht Gathoye tot zijn recht te komen, maar het antwoord uit Wenen liet even op zich wachten. Voorlopig kon hij zich behelpen met drie schepenen van Gronsveld, wier legitimiteit overigens als niet-ingezetenen en het ontbreken van beëdiging werd betwist. Dit drietal werd aangevuld met drie collega's uit Slenaken.

Tijdens het voogdgeding van 6 mei 1726 ten overstaan van dit zestal bepleitte Gathoye dat hij destijds uit zelfverdediging had gehandeld. ${ }^{1524}$ De drossaard had zijn aanklacht niet met bewijs van opzet kunnen onderbouwen.

Op 14 mei 1726 kwamen de schepenen tot een vonnis: $\mathrm{Zij}$ beoordeelden de stukken die Gathoye had geproduceerd als 'suffisant tot sijne decharge', met andere woorden, hij werd vrijgesproken van schuld aan de dood van Sebastiaan de Montbrison. ${ }^{1525}$ De zaak stonk aan alle kanten. Aan de bevoegdheid van de schepenen en de waarnemende secretaris kon ernstig worden getwijfeld en de assisterende schepenen uit Slenaken hadden zich gedistantieerd, ook al omdat het voorstel om advies van onpartijdige rechtsgeleerden in te winnen, werd afgewimpeld.

\subsection{Nieuwe gewveldpleging en Gathoye verdreven}

Gathoye kreeg nu zoveel haast om met Lebens af te rekenen, dat hij het vonnis van 14 mei niet eens afwachtte. Op 7 mei werden 's morgens tegen acht uur circa vijftig man bij het kasteel opgetrommeld, gewapend met geweren 'oder gaffelen'.1526 Zogenaamd vanwege het gerecht kregen ze bevel het huis van Lebens te doorzoeken en alle papieren mee te nemen. Er mocht geweld worden gebruikt. Onderweg begonnen enkele mannen echter aan de rechtsgeldigheid van de order te twijfelen en ze stuurden de burgemeester terug om het stuk te zien. In plaats daarvan kwam Gathoye zelf van het kasteel 'met een vreemd geweer, waarmee, zo werd gezegd, in één keer achttien of negentien kogels

1524 RHCL, Rijkskamergerecht, inv. nr. 71/1, fol. 52-53vo.

1525 RHCL, Rijkskamergerecht, inv. nr. 71/1, fol. 54-55.

1526 RHCL, Rijkskamergerecht, inv. nr. 71/1, fol. 176-179vo. 
konden worden afgevuurd'. 1527 Iedereen werd onder bedreiging met dit 'machinegeweer' gedwongen verder te gaan. De drie veldbodes gingen voorop en zij zagen de vrouw van de drossaard bij de mestvaalt van Lousberchs, waar Lebens woonde. Het drietal probeerde tevergeefs de deur te forceren. Toen riep Gathoye: 'Sacre dieu, ik zal ze met mijn geweer kapotschieten'. Vervolgens liet hij een zware smidshamer halen en daarmee werden de deuren ingeslagen. Het hele huis werd doorzocht, maar men vond niets.

Op 23 mei 1726 kondigde Gathoye een verordening af, waarbij iedereen op straffe van zware boetes werd verboden in het openbaar een geweer te dragen. ${ }^{1528}$ De spanning in het dorp bereikte rond Pinksteren (9 juni) 1726 een climax. Op de zaterdag voor de feestdag bezocht de bejaarde Lambertus Lousberchs, de schoonvader van Lebens, 's morgens de mis in de kerk. Na afloop van de dienst stonden buiten gewapende mannen van Gathoye aan de kerkdeur. De bange Lousberchs bleef in de kerk tot 's avonds zes of zeven uur. Waarschijnlijk in een onbewaakt ogenblik wisten de intussen gealarmeerde Lebens en een van zijn zonen, gewapend met een geweer, in het kerkgebouw te komen en konden ze de oude man ongehinderd meenemen. Vervolgens trokken ze zich veiligheidshalve terug buiten het graafschap.

De volgende ochtend, Pinkstermorgen 9 juni, bezochten de student Willem Lebens, een andere zoon van de drossaard, en een leeftijdgenoot van de familie de Floen de mis. Elk droeg een geweer. Zij gingen in de kerk zitten op de plaats waar gewoonlijk de drossaard zat. Daarna kwam Gathoye binnen, die had deelgenomen aan de processie rond de kerk op het kerkhof. Voorafgaand aan het evangelie hield de pastoor de preek. Vervolgens ging Gathoye weer naar buiten om te praten met zijn knechten. $\mathrm{Na}$ afloop kwam één van hen de kerk binnen, 'ein gross frembdt schiessgewöhr habendt'. Buiten stonden nog meer manschappen van Gathoye met geladen geweer. De kerkgangers waarschuwden de jongens de Floen en Lebens in de kerk te blijven. Die wilden aanvankelijk niet luisteren, maar ze werden door de omstanders tegengehouden. Gathoye stond vloekend en tierend bij de deur en riep dat hij de twee jongemannen zou doodschieten. Het tweetal bleef dus in de kerk, totdat Gathoye uiteindelijk afdroop. 's Middags werd Anna Lousberchs, de echtgenote van Lebens, op weg naar het lof, ook door mannen van Gathoye lastiggevallen. Ze was zo ontdaan dat ze uiteindelijk de kerkdienst moest verlaten. ${ }^{1529}$

1527 'mit ein frembt schiess-gewehr, war auf (wie gesagt wirt) man achtzehn ad neunzehn kügels laden kan zu einem schuss'. Waarschijnlijk ging het hier om een vuurwapen met een zogenoemde gestapelde lading, 'dat wil zeggen dat dezelfde loop met meerdere kogels achter elkaar geladen is, elke kogel met zijn eigen vuurlading van kruit'... Dit systeem bereikte in de Nederlandse geweermakerij van de zeventiende eeuw grote bloei...'Er waren geweermakers die zich hiermee niet tevreden stelden en vuurwapens met gestapelde ladingen ontwierpen die uit meerdere lopen werden afgesloten. Het vuursteenpistool van ca. 1645 door de Maastrichtse geweermaker Jan Kitzen is hiervan een extreem voorbeeld. Het heeft niet minder dan vijf lopen die als een bundel gegroepeerd zijn. Drie van de lopen zijn geladen met respectievelijk vijf, zes en zeven kogels, elk met hun eigen kruitlading en elk bediend door een apart zundgat'. Informatie ontleend aan: Jan Piet Puype, 'De Glorie van de Nederlandse geweermakerij in de zeventiende eeuw. Toelichting bij een speciale tentoonstelling 2004 in het Legermuseum Delft, gepubliceerd als pdf op www.collectie.legermuseum.nl, sub publicaties. (inzage 11-11-2014).

1528 RHCL, Rijkskamergerecht, inv. nr. 71/1, fol. 299-300vo.

${ }^{1529}$ RHCL, Rijkskamergerecht, inv. nr. 71/1, fol. 306-307vo. 
Aan het geweld van Gathoye kwam geen einde. Anderhalve week later werden vijf paarden en negen koeien van Lebens uit de wei gehaald en naar het kasteel gebracht om in het openbaar te verkopen. Protesten hielpen niet. ${ }^{1530}$ Gathoye had ook nog een appeltje te schillen met de familie de Montbrison op Hemersbach. Na het bezoek aan huize Lebens overviel hetzelfde groepje de hoeve. Deuren werden opengebroken, kamers doorzocht, en voorwerpen van koper en tin en zes koeien uit de stal meegenomen. Ten slotte werd mevrouw de Montbrison met een geweer bedreigd en kreeg ze een touw om de arm om haar gevankelijk naar Gronsveld te voeren. Maar op het laatste moment deinsden de mannen er toch voor terug zo op treden tegen een 'pensionaire' van de koning van Frankrijk (zij trok als gunstbewijs een 'pension', een jaargeld van de koning). ${ }^{1531}$

In de aan Gronsveld grenzende territoria werd met zorg gekeken naar de ontwikkelingen in het graafschap. Ook het Rijkskamergerecht in Wetzlar werd op de hoogte gebracht. ${ }^{1532}$ Gathoye had gedreigd de hele familie de Montbrison uit te roeien, van de graaf viel geen hulp te verwachten en de Schepenstoel van Aken deed ook niets. Elisabeth Clara Cecilia de Montbrison schreef aan haar echtgenoot kapitein de Gramlich dat zij in Luik de mannen had ontdekt die haar en haar familie hadden overvallen. Gathoye had gedreigd de familie tot hun dood te achtervolgen en hij zou met zijn bende terugkeren om de vruchten van het veld te roven. De wanhopige vrouw schreef ook de prins-bisschop van Luik om hulp. Kwam die niet, dan kon het 'adieu' onder haar brief wel eens een laatste groet zijn. 1533

Intussen was in de loop van mei bij de Rijkshofraad in Wenen het verzoek van Gathoye behandeld om te komen tot herstel van de schepenbank van Gronsveld. Op 4 juni 1726 besliste de Raad dat graaf d'Arberg Valengin twee maanden tijd kreeg om te voldoen aan het rescript van 28 juni 1725 om orde te scheppen bij de justitie in Gronsveld. Claude Nicolas gaf daarop zijn raadsman De Witte, schepen te Aken, op 21 juli 1726 volmacht drie schepenen in Gronsveld te benoemen.1534 De Witte makkte om onduidelijke redenen niet veel haast, zodat de graaf vervolgens al op 2 augustus 1726 aan drossaard Lebens volmacht verleende om schepenen te benoemen, wanneer De Witte zijn opdracht niet uitvoerde. ${ }^{1535}$ Lebens liet zich deze kans niet ontnemen. Per ommegaande kwam hij op de proppen met zeven personen die tot dan toe nog geen schepenen waren geweest. Of alle formaliteiten rond de beëdiging in acht werden genomen, was naderhand niet duidelijk. Voor nog overgebleven twee schepenen van Gathoye vormde dit een reden op 8 augustus en 19 december hun ontslag in te dienen.

Het Rijkskamergerecht bleek ook niet doof voor de smeekbeden van de familie de Montbrison en gaf op 19 juli 1726 bevel aan de graaf d'Arberg Valengin om Gathoye te

1530 RHCL, Rijkskamergerecht, inv. nr. 71/1, fol. 231-233.

1531 RHCL, Rijkskamergerecht, inv. nr. 71/1, fol. 227-230, 301.

1532 RHCL, Rijkskamergerecht, inv. nr. 71/1, fol. 293.

1533 RHCL, Rijkskamergerecht, inv. nr. 71/1, fol. 317-318.

1534 RHCL, Rijkskamergerecht, inv. nr. 71/2, fol. 423.

1535 RHCL, Rijkskamergerecht, inv. nr. 71/1, fol. 189-196vo., 550-553. 
arresteren en de familie de Montbrison te beschermen. Op 2 augustus ondertekende de graaf een besluit tot aanhouding van Gathoye. Met enthousiasme kweet Lebens zich van deze opdracht. Drie mannen gingen naar het kasteel om daar beslag te leggen op de paarden van Gathoye. Maar dat ging niet zonder slag of stoot. Gathoye werd niet aangetroffen, maar enkele knechten boden flinke weerstand. 's Anderendaags keerde Lebens terug, nu vergezeld door driehonderd gewapende boeren. De nieuwe schepenen hadden toestemming gegeven het kasteel binnen te gaan en de daar aanwezige knechten van Gathoye te arresteren. De Gronsveldenaren bezetten het gebouw, braken alle deuren open en namen mee wat hun gading was, waaronder alle geweren. Bertrand, de knecht van Gathoye, werd in de kerker opgesloten, het overige personeel naar huis gestuurd. Na deze actie bleven circa dertig man, vooral inwoners van Slenaken, voor permanente bewaking in het kasteel achter. De volgende dag ging Henri Gathoye, de broer van François, naar het kasteel en werd op een haar na door een kogel getroffen. De pastoor had uit angst het dorp verlaten. ${ }^{1536}$

\subsection{Lebens de baas in het graafschap}

Lebens was na de bezetting van het kasteel heer en meester in het dorp, tot woede van de heren Gathoye. Voor notaris Graven klaagde Jean Gathoye, de vader van François, dat de drossaard demonstratief op jacht ging en ook aan anderen de jacht toestond. ${ }^{1537}$ Het jachtrecht lag voor Gathoye uitermate gevoelig, maar vormde tevens een gecompliceerd probleem. De Gathoye's hadden het jachtrecht als onderdeel van de grafelijke rechten gepacht, maar tegelijkertijd was het een oud recht van een drossaard in Gronsveld vrij te mogen jagen.

Een van meeste opmerkelijke acties van Gathoye waarmee Lebens werd geconfronteerd was diens toenadering tot de familie de Montbrison. Dat had tot resultaat dat Gathoye de dood van Sebastiaan de Montbrison en de overval op hoeve Hemersbach afkocht. ${ }^{1538}$ Gathoye dacht dat daarmee ook de grond voor het proces tegen hem verviel en de weg vrij was om Lebens aan te pakken. Hij vergiste zich echter in die zin dat bij doodslag dader en nabestaanden zich weliswaar konden verzoenen, maar dat voor remissie of pardon voor strafvervolging bekrachtiging door de landsheer noodzakelijk was. De familie de Montbrison had andere redenen voor deze wisseling van partij. Weliswaar had zij samen met Lebens onder Gathoye geleden, maar zij zagen dat nu vooral als een gevolg van de vete die Lebens met Gathoye uitvocht. Zij voelden zich ook slachtoffers van Lebens. Zij kregen immers het verwijt dat zij het gerechtelijk onderzoek hadden gehinderd omdat zij het lijk van Sebastiaan de Montbrison zonder toestemming hadden vervoerd.

Op 2 oktober 1726 vervoegden zich enkele Gronsveldse schepenen bij hoeve Hemersbach om nadere informatie over die verzoening met Gathoye te krijgen. ${ }^{153}$ Dat leidde tot weinig resultaat, omdat de gezochte personen afwezig waren en de rest niets kon

1536 RHCL, Rijkskamergerecht, inv. nr. 71/1, fol. 59-60.

1537 RHCL, Rijkskamergerecht, inv. nr. 71/1, fol. 85-86vo.

1538 RHCL, Rijkskamergerecht, inv. nr. 71/1, fol. 65-65vo.

${ }^{1539}$ RHCL, Rijkskamergerecht, inv. nr. 71/1, fol. 528-529. 
zeggen. De volgende dag kwamen drie schepenen, vergezeld van de zoon van Lebens, opnieuw bij de Montbrison, de Gramlich en zijn vrouw. ${ }^{1540}$ De zoon van Lebens droeg een geweer. Desgevraagd verklaarde de familie te blijven bij eerdere negatieve opmerkingen over de drossaard. Vervolgens ontstond een woordenwisseling over de bevoegdheid van de schepenen. De gemoederen raakten verhit en het kwam tot een handgemeen. Conrad Wilhelm de Gramlich nam Lebens het geweer af en zette hem op straat. Daar daagde de jongeman hem uit nog eens te herhalen wat hij binnen had gedaan. De schepenen vertrokken, waarna de Gramlich het geweer teruggaf. Mevrouw de Gramlich riep nog tegen haar man: 'Geef mij het geweer, jij bent te bang'. Uiteindelijk liep de zaak toch nog met een sisser af en eindigde ze met een formeel protest namens de drossaard.

De sfeer tijdens de herfst van 1726 bleef gespannen. Lebens liet zijn eigen huis en het kasteel dag en nacht bewaken. Op straat bleef het onveilig, want rondzwervende aanhangers van Gathoye maakten zich schuldig aan mishandeling. Gathoye klaagde intussen bij de graaf dat hij wel nog steeds het graafschap had gepacht, maar feitelijk van zijn gebruik was beroofd. De graaf gaf echter geen krimp. Hij hield vast aan zijn recht drossaard en schepenen te benoemen en geschillen over andere rechten moest de pachter maar buiten de graaf om uitvechten.

\subsection{De terugkeer van Gathoye}

Inderdaad loste Gathoye het probleem op zijn eigen manier op. Op 24 december 1726, de dag voor Kerstmis, verscheen bij het kasteel van Gronsveld een groep van ongeveer 25 gewapende, Waals sprekende mannen onder leiding van Gathoye. De kerels waren geronseld in Luik. Volgens één versie waren ze gewoon in het kasteel binnengelaten op vertoon van een keizerlijk bevelschrift, in een ander verhaal heette het dat zij het gebouw binnendrongen door een openstaand poortje en vervolgens de bewakers overmeesterden. $\mathrm{Na}$ deze bezetting wilden ze naar het huis van de drossaard, waarna één van de mannen vroeg wat ze eventueel moesten doen met de zoon van Lebens. Gathoye antwoordde: 'Meenemen als die daar ook is'.

Gathoye naderde met zes of zeven man het huis van Lebens. Hij was voorzien van 'uitzonderlijk en schrikaanjagend wapentuig' ('extraordinaria et horrenda arma') waarvan werd gezegd dat men er in één keer twintig kogels in kon leggen. De drossaard zelf liet zich niet zien, maar stuurde een van zijn dochters met een kleinzoon naar de pastoor om op de kerkklok alarm te laten slaan. Godefridus, de zoon van de drossaard en de knecht Hubert Reinders stonden in de deuropening. Bertrand, de knecht van Gathoye, eiste de geweren en een paard, waarop de jonge Lebens antwoordde dat ze die niet gaven. De deur ging op slot. Reijnders begaf zich naar de graanzolder om uit het venster te kijken en zag dat een van de Walen zijn geweer op hem richtte.

1540 RHCL, Rijkskamergerecht, inv. nr. 71/1, fol. 530-531. 
Inmiddels was de bevolking door het klokgelui gealarmeerd en dromden mensen samen bij het huis van Lebens. Tierend en scheldend bedreigde Gathoye de omstanders. Hij zwaaide nog met een of ander papier zien en sommeerde een van de aanwezige schepenen mee te gaan naar het kasteel, maar die weigerde. De mannen van Gathoye probeerden vervolgens de deur van het huis te forceren, maar keerden uiteindelijk onverrichter zake terug naar het kasteel.

Kerstmis bracht een kortstondige wapenstilstand, hoewel de toestand gevaarlijk bleef. Op de ochtend van 27 december begon het geweld opnieuw. De zoon van de drossaard bezocht met dertien of veertien gewapende mannen de kerkdienst. Intussen verzamelden de troepen van Gathoye zich in de buurt van de kerk om naar het huis van Lebens te trekken. Toen Gathoye in de gaten kreeg dat de jonge Lebens zich in de kerk bevond, wilde hij die ook in handen krijgen en gaf bevel hem te ontwapenen. De mannen rond Lebens wilden de kerk verlaten, maar andere inwoners hielden hen tegen.

Met een tierende Gathoye voor de deur durfde geen der kerkgangers het gebouw te verlaten. $\mathrm{Na}$ een uur kwam de pastoor naar buiten en waarschuwde Gathoye geen geweld in de kerk te gebruiken. Het was de tijd van het Veertigurengebed en het Allerheiligste stond uitgestald. Ten slotte trokken de mannen zich terug op de kasteelweide en riepen de kerkgangers naar buiten. Gathoye stond klaar met zijn schiettuig waarmee hij twintig kogels kon afvuren. 'Der drossard alhier soll hencken oder er [hij wees op zichzelf] soll hencken', en hij bracht zijn hand naar de hals. $\mathrm{Na}$ enige tijd trok het grootste deel van de troep zich terug in het kasteel en van die gelegenheid maakten de jonge Lebens en Hubert Reijnders gebruik om naar het huis van de drossaard te rennen. Er vielen ook schoten van het grote geweer ('magna bombarde') vanuit de kasteelweide, waarna Hubertus Reijnders terugvuurde en ijlings dekking zocht. $\mathrm{Na}$ deze schietpartij keerde de rust in het dorp weer.

Drossaard Lebens zond per ijlbode een verslag van de ongeregeldheden aan de graaf in Luxemburg. Op 2 januari informeerde die het Rijkskamergerecht in Wetzlar. Voorts gaf hij Lebens opdracht alle gewapende vreemdelingen uit het graafschap te verwijderen. Geweldplegers moesten worden berecht. Lebens beschouwde dit als een vrijbrief om op 8 januari 1727 rond het middaguur het kasteel van Gronsveld te bezetten met dertig tot veertig mannen, bewapend met geweren en hooivorken. ${ }^{1541}$ De arrestatie van de daar aanwezige 'banditen' verliep niet zonder slag of stoot. In één van de kamers trof men François Gathoye aan, die een groot geweer gericht hield op de jonge Adolf de Floen, kennelijk met de bedoeling deze 'vriend' als een soort schild te gebruiken. Gathoye werd ontwapend en gearresteerd. Er werden nog een paar merkwaardige vangsten gedaan, zoals de plaatsvervangend rentmeester van het graafschap Wittem, maar het meest opmerkelijk was iemand die zich 'd'Ardenne' noemde, maar later een broer bleek te zijn van de advocaat Petit, syndicus van de stad Luxemburg, een van de belangrijkste adviseurs van de graaf en diens commissaris voor Gronsveldse zaken. De man beweerde dat hij zich buiten medeweten van zijn broer bij de troep van Gathoye had aangesloten.

${ }^{1541}$ RHCL, Rijkskamergerecht, inv. nr. 71/1, fol. 493-499, 508-511; Rijkskamergerecht 71/2, fol. 58-59. 
Uiteindelijk liet Lebens alle gevangenen los, inclusief Gathoye omdat die beschikte over een vrijgeleide van het Rijkskamergerecht. Wel moest hij beloven geen gewapende mannen meer in het graafschap te brengen en de heer van Rijkckholt bleef met een bedrag van drieduizend gulden borg voor hem.

\subsection{Grafelijke inmenging: het optreden van commissaris Petit en baron de Bounam}

Vanaf april 1727 nam de geweldpleging door Gathoye weer toe. ${ }^{1542}$ Met de grootste moeite werd bloedvergieten voorkomen. Bij deze voortdurende onrust kon zelfs graaf Claude Nicolas niet meer afzijdig blijven. Op 28 mei 1727 tekende hij een algemene volmacht voor zijn adviseur advocaat Petit, syndicus van de stad Luxemburg, om als 'commissarius generalis' orde op zaken te stellen in Gronsveld. ${ }^{1543}$ De man ging voortvarend te werk, maar keerde zich vervolgens niet zozeer tegen Gathoye, maar tegen Lebens. Een duidelijke reden daarvoor ontbreekt, maar er bestond mogelijk toch een connectie tussen Petit en Gathoye. Petit probeerde van de drossaard de nog altijd onder diens beheer zijnde gerechtelijke archieven te krijgen. De onderhandelingen daarover bleven steken in geharrewar over plaats, tijd en voorwaarden

Op 5 juni 1727 kreeg Lebens het dwangbevel de archieven onmiddellijk uit te leveren. Lebens tekende per ommegaande bij een notaris appel aan. De volgende dag bevestigde Petit weer de aanstellingen van de vroeger door Lebens verdreven schepenen en vulde de schepenbank aan met nieuwe leden. ${ }^{1544}$ Lebens werd in al zijn functies geschorst. Op 9 juni gaf de grafelijke commissaris een huiszoekingsbevel voor de woning van Lebens en op 10 juni werd de afgifte van het archief nog eens herhaald op straffe van gevangenneming ('apprehensio corporalis'). ${ }^{1545}$ Dezelfde dag vaardigde Petit een verbod uit voor de inwoners van Gronsveld om zonder toestemming van Gathoye (!) met wapens door het graafschap te gaan. Overtreders werden streng gestraft als rebellen en ordeverstoorders. ${ }^{1546}$ De klap op de vuurpijl kwam toen Petit op 16 juni 1727 Gathoye benoemde tot 'officier crimineel', feitelijk dus drossaard. ${ }^{1547}$

In Gronsveld brak nu bij de bevolking behalve verontwaardiging ook verwarring uit. Niemand wist hoe het nu verder moest met het voogdgeding dat als vanouds door de drossaard werd afgekondigd en waar beslissingen voor gemeentelijke zaken moesten worden genomen. Gathoye voelde zich nu weer sterk genoeg om zijn wil aan de bevolking op te leggen. Verschillende notarissen in de omgeving kregen het druk met verklaringen van getuigen die ieder met hun eigen versie van de waarheid wilden laten vastleggen.

Het was intussen ook voor de graaf duidelijk dat Petit de zaak alleen maar had verergerd. Op 22 augustus $1727 \mathrm{kreeg}$ hij ontslag en werden de door hem genomen maatregelen

\footnotetext{
1542 RHCL, Rijkskamergerecht, inv. nr. 71/1, fol. 661-668.

1543 RHCL, Rijkskamergerecht, inv. nr. 71/2, fol. 10, 87.

1544 RHCL, Rijkskamergerecht 71/2, fol. 11-11vo.

1545 RHCL, Rijkskamergerecht 71/2, fol. 23-26.

1546 RHCL, Rijkskamergerecht $71 / 2$, fol. 14

1547 RHCL, Rijkskamergerecht 71/2, fol. 12-12vo.
} 
ingetrokken. Waarschijnlijk dacht de graaf dat het probleem beter kon worden opgelost door iemand die ter plaatse goed bekend en permanent aanwezig was. Die persoon dacht hij te vinden in de buurman van het graafschap, baron Jean Baptist de Bounam, heer van Rijckholt. Diens aantreden leidde al direct tot de zoveelste wisseling in de bezetting van de schepenbank, want de baron benoemde nu op 28 augustus zijn eigen scholtis of officier van Rijckholt, Michaël de la Haye, tot 'officier' en schepen van Gronsveld. Met nog een schepen uit Rijckholt en de schepenen die door Petit op 6 juni in hun ambt waren hersteld, kreeg Gronsveld vanaf september 1727 twee 'officieren', te weten drossaard Lebens en zijn Rijckholter collega De la Haye, en ook twee schepencolleges, namelijk de door Lebens begin augustus 1726 benoemde schepenen en als tweede de door Petit, en later door de baron van Rijckholt deels bevestigde, deels aangevulde bank. Schepenen in Gronsveld veranderden als het weer. Een jaar later was het Rijkskamergerecht het spoor zodanig bijster, dat er een apart overzicht van moest worden ingediend. ${ }^{1548}$

Jean Baptist de Bounam kreeg al snel in de gaten dat hij zich in een wespennest had gestoken. Maar Gathoye bezorgde de baron nog een heel ander probleem, toen hij er met diens dochter Anne Jeanne Marguerite de Bounam vandoor ging. ${ }^{1549}$ Het stel bereikte Roermond, waar het hof van Gelre op vordering van de vader de dochter terugstuurde naar haar ouders. ${ }^{1550}$ Er werd voor verschillende geestelijke rechtbanken geprocedeerd en uiteindelijk, met dispensatie in de kerkelijke roepen, op 5 oktober 1729 in de kerk van Gronsveld getrouwd, in aanwezigheid van drie getuigen van de kant van Gathoye. Het huwelijk hield stand, maar Anne Jeanne Marguerite werd volledig onterfd wegens ongehoorzaamheid en de schande die zij over haar familie had gebracht. ${ }^{1551}$

\subsection{Het Rijkskamergerecht doet witspraak}

Terwijl Gathoye in de herfst van 1727 in beslag werd genomen door amoureuze perikelen, verplaatste zijn strijd met drossaard Lebens zich vooral naar het Rijkskamergerecht. In een soort papieren oorlog leverden beide partijen stapels verklaringen en adhesiebetuigingen in, waarin ze elkaar zo zwart mogelijk maakten en hun eigen handen in onschuld wasten. Lebens verbleef in november 1727 in Wetzlar om daar zijn verdediging te bespreken.

Het tweede punt betrof de voortdurende weigering van Lebens de archieven van de schepenbank terug te geven. De drossaard voerde aan dat hij volgens zijn eed als secretaris de plicht had te zorgen voor veilige bewaring van de stukken en die veiligheid was niet gegarandeerd. Want om die stukken in handen te krijgen, waren de door Lebens benoemde schepenen afgezet en was Gathoye tot 'officier' in criminele zaken benoemd. Als derde punt van kritiek hekelde Lebens de rol van de graaf die zich voortdurend aan zijn verantwoordelijkheden onttrok.

1548 RHCL, Rijkskamergerecht, inv. nr. 71/2, fol. 419-422vo.

1549 RHCL, Rijkskamergerecht, inv. nr. 71/2, fol. 189-190vo.

1550 RHCL, Rijkskamergerecht, inv. nr. 71/2, fol. 191-192; RHCL, Archief Hof van Gelder te Roermond, inv. nr. 418, dossier nr. 4327; idem inv. nr. 557.

1551 RHCL, De Bounam de Ryckholt, inv. nr. 60. Haar overlijdensbericht uit 1755 bevindt zich RHCL, De Bounam de Ryckholt, inv. nr. 81. 
Eindelijk hakte het Rijkskamergerecht op 28 april 1728 de Gronsveldse variant van de Gordiaanse knoop door:

Ten eerste werd het vonnis van de schepenen van Gronsveld van 14 mei 1726, waarbij François Gathoye was vrijgesproken van schuld aan de dood van Sebastiaan de Montbrison, nietig verklaard. Het proces moest worden overgedaan ten overstaan van een daartoe door de schepenen van Aken uit hun midden aan te wijzen commissaris. Voorts diende over dit dossier het advies van juristen te worden ingewonnen, bijvoorbeeld bij de juridische faculteit van een universiteit. Aken moest zich ook buigen over andere processen van Gathoye voor het gerecht van Gronsveld, zoals de kwestie hoeveel hij als pachter nog had te vorderen van graaf d'Arberg Valengin.

Ten tweede werd de benoeming door graaf d'Arberg Valengin van de advocaat Petit als commissaris voor Gronsveld nietig verklaard omdat de man Luxemburger was. Daarmee volgde het Rijkskamergerecht dezelfde redenering als bij het verbod 'buitenlandse' schepenen in een rijksheerlijkheid te benoemen. Iedere functionaris in een territorium vallend onder de jurisdictie van het Rijkskamergerecht moest onder het Rijk 'bedwingbaar' zijn, dat wil zeggen in persoon en met zijn goederen voor het hoogste rijksgerecht kunnen worden aangesproken voor de uitoefening van zijn ambt. De nietigheid van de benoeming van Petit betekende ook dat door hem genomen besluiten, zoals het afzetten van de drossaard en schepenen en het benoemen van nieuwe schepenen, ipso facto nietig waren. De voorgaande functionarissen werden in hun ambt hersteld, echter met de eis dat Lebens zich diende te onthouden van bemoeienis met het proces tegen Gathoye.

Ten derde werd graaf Claude Nicolas berispt wegens zijn wankelmoedigheid en de verwaarlozing van zijn 'obrigkeitliches ambt'.

Ten vierde moest de graaf alle geschillen over juridische bevoegdheden in appelzaken van de Schepenstoel van Aken en de Rijkshofraad voortzetten voor het Rijkskamergerecht. Hangende deze procedures kon hij uit de juristen van Aken een of twee appelcommissarissen benoemen.

Ten vijfde werden in Gronsveld de ambten van drossaard en secretaris van de schepenbank, zoals Lebens die in één persoon verenigde, gescheiden. Er moest een afsluitbare plaats met een afsluitbare kist komen voor de bewaring van de archieven. Die kist moest zijn voorzien van twee sloten met één sleutel voor de secretaris en één voor de schepenen. Lebens diende de zich onder hem bevindende documenten daarheen over te brengen. ${ }^{1552}$

\subsection{Aken berstelt orde en regelmaat}

Het stadsbestuur van Aken kreeg met dit vonnis een belangrijke rol toebedeeld. De uitvoering van de feitelijke werkzaamheden droeg de raad op aan schepen en raadslid Alexander Theodor d'Oliva. ${ }^{1553}$ Op 26 juni 1728 kon deze berichten dat hij in Gronsveld was geweest en dat drossaard Lebens en de schepenen in hun functies hersteld waren. ${ }^{1554}$

1552 RHCL, Rijkskamergerecht, inv. nr. 71/2, fol. 216-223vo.

${ }_{1553}$ Zie over hem Hoofdstuk 5.2.

1554 RHCL, Rijkskamergerecht, inv. nr. 71/2, fol. 224-225vo. 
Voorts waren door de schepenen ook verschillende processen tussen Lebens en Gathoye evenals tussen Gathoye en de graaf d'Arberg Valengin in behandeling genomen. Er viel natuurlijk tussen de heren een en ander te verrekenen, bijvoorbeeld over gerechtskosten en pachtpenningen voor het graafschap die Gathoye al dan niet moest betalen. Formeel liep het pachtcontract immers nog tot 1 december 1732.

Ook moest deze pachtkwestie worden gescheiden van andere vorderingen die graaf d'Arberg Valengin op Gathoye had wegens leningen en de verkoop van kostbaarheden. Gathoye had immers geprobeerd zijn gederfde inkomsten als pachter te compenseren met gelden uit die verkoop.

Op 25 augustus 1728 beslisten de schepenen van Gronsveld dat de graaf het pachtcontract moest nakomen en zijn inkomsten uit het graafschap moest afstaan. Verder had Gathoye recht op een lagere pachtsom omdat intussen de heerlijkheid Slenaken was verkocht en Lebens bepaalde inkomsten had achtergehouden. D'Arberg Valengin appelleerde 'stante pede et viva voce'. Op 21 maart 1729 gaf Herman Franz Braumann, oud-burgemeester van Aken en appelcommissaris, opdracht aan de schepen hem het dossier te doen toekomen met de bijbehorende 'rationes decidendi', de motivering van het vonnis. ${ }^{1555}$

Graaf d'Arberg Valengin had intussen beslag of arrest laten leggen op bezittingen van Gathoye wegens in bewaring gegeven juwelen. Hoe die zaak precies werd behandeld is niet duidelijk, maar op 9 april 1729 werd in Aken door de Schepenstoel of een door het gerecht aangewezen commissaris bepaald dat het arrest geldig was en dat Gathoye moest betalen.1556 Gathoye appelleerde daartegen bij het Rijkskamergerecht eveneens 'stante pede et viva voce'.

Terwijl over het pachtcontract verder werd geprocedeerd als onderdeel van een veel bredere juridische strijd tussen Gathoye en graaf d'Arberg Valengin, keerden in Gronsveld op gezag van het Rijkskamergerecht en onder Akense leiding meer geregelde verhoudingen terug. Toen d'Oliva in 1729 tot burgemeester van de rijksstad werd gekozen, kreeg hij echter minder tijd zich met de Gronsveldse aangelegenheden bezig te houden. De raad benoemde daarom op 19 augustus 1729 de jurist dr. Laurenz Reiner Altorff tot 'commissarius subdelegatus' voor het praktische werk. ${ }^{1557}$ Met die opdracht begaf Altorff zich naar Gronsveld, waar hij zich met de titel 'Commission' als een soort 'eenpersoons-instantie' onder andere belastte met de verdere instructie van het proces tegen Gathoye over de dood van Sebastiaan de Montbrison. Het Rijkskamergerecht had immers drossaard Lebens verboden daar nog bemoeienis mee te hebben. Tot griffier of 'actuarius' van de 'Commission' werd door Altorff benoemd Johannes Matthias Oligschläger. Laatstgenoemde bevond zich op dat moment in een lastig parket. Omdat Lebens in gevolge het vonnis van het Rijkskamergerecht afstand moest doen van het ambt van secretaris van de schepenbank, had graaf d'Arberg Valengin op 25 oktober 1728 Oligschläger in zijn plaats benoemd. Daaraan waren echter de uitdrukkelijke voorwaarden gekoppeld dat Lebens schadeloos werd gesteld voor het bedrag dat hij destijds voor dit

1555 RHCL, Rijkskamergerecht, inv. nr. 71/2, fol. 349-353vo.

1556 TJ, inv. nr. M 76, fol. 7: afschrift van niet getekend vonnis, dat in Aken werd uitgesproken.

1557 Verslag van de werkzaamheden van Altorff voor het Rijkskamergerecht in RHCL, Rijkskamergerecht, inv. nr. 71/2, fol. 227-232vo. 
ambt had betaald en dat de regeling de goedkeuring kreeg van de 'Commision'. De onderhandelingen schijnen nogal stroperig te zijn verlopen, want in een brief van 5 maart 1731 klaagt Oligschläger over problemen bij de erkenning van zijn grafelijk 'patent'. Maar uiteindelijk lukte het dan toch. ${ }^{1558}$

\subsection{De activiteiten van baron Vincent Philip Anton van der Heyden genaamd Belderbusch}

Op 26 september 1730 overleed gravin Anna Maria von Toerring-Jettenbach en nog geen vier maanden later, op 19 januari 1731, volgde haar echtgenoot Claude Nicolas d'Arberg Valengin, met achterlating van hun minderjarige dochter Maria Josepha als weeskind. Vooralsnog was onduidelijk wie de voogd van het weeskind werd: baron Vincent Philip Anton van der Heyden genaamd Belderbusch of graaf Ignaz Felix Joseph von ToerringJettenbach. Het antwoord op die vraag bepaalde ook wie de feitelijke machthebber in het graafschap werd.

Terwijl zowel voor het Rijkskamergerecht, als voor de landvoogdes van de Oostenrijkse Nederlanden en de Soevereine Raad van Luxemburg op hoog juridisch niveau werd gestreden over de voogdij, begon Belderbusch zich al op voorhand te bemoeien met de Gronsveldse zaken en meer in het bijzonder de activiteiten van d'Oliva en diens vervanger dr. Altorff. Vanaf begin oktober 1731 verbleef de baron op het kasteel van Gronsveld. Een van zijn eerste handelingen was het afzetten van de schepenen die graaf d'Arberg Valengin had benoemd na het vonnis van het Rijkskamergerecht van 28 april 1728.

Op 8 oktober 1731 liet Belderbusch door notaris Schwarz uit Aken een inventaris maken van de inboedel van het kasteel. ${ }^{159}$ Naar aanleiding daarvan schreef Belderbusch op 12 oktober 1731 aan Altorff dat hij ook de aangetroffen papieren, behorend tot de 'commission' van Altorff, door de notaris had laten verzegelen. ${ }^{1500}$ Concreet ging het vooral om stukken van de processen tussen Gathoye, Lebens en de graaf d'Arberg Valengin, zoals die al waren geïnstrueerd ten overstaan van Altorff en de schepenen op het moment dat graaf d'Arberg Valengin nog leefde. Altorff had deze papieren toevertrouwd aan Mathias Oligschläger, de 'actuarius' van 'commission'. Belderbusch verlangde op hoge toon van Altorff tekst en uitleg over diens taak ('une prompte explication des vos sentiments'), want volgens hem was deze opdracht nutteloos, bezwaarlijk en zelfs schadelijk voor het hem toevertrouwde weeskind ('une commission fort inutile et trop onereuse, même nuisible à ma pupille').

$\mathrm{Na}$ de benoeming van nieuwe schepenen ging Belderbusch voortvarend aan de slag met een hervorming van het gerechtswezen. Op 13 oktober 1731 vaardigde hij als 'voogd van het graafschap ('vormundt der graffschafft Gronsfelt') een nieuw, elf artikelen tellend procesreglement uit, met als doel een einde te maken aan de grote wanorde die daar

1558 RHCL, Rijkskamergerecht, inv. nr. 71/2, fol. 392-401vo.

1559 TJ, inv. nr. M 75, fol. 272.

1560 RHCL, Rijkskamergerecht, inv. nr. 71/2, fol. 233-234. 
bestond in de manier van procederen. ${ }^{1561}$ Het is de vraag of dit reglement rechtsgeldig was en bij gebrek aan bronnen kan ook niet worden gecontroleerd of het in praktijk werd toegepast. Maar procesrechteliik was het een interessante regeling omdat de bepalingen afweken van wat algemeen gebruikelijk was bij schepenbanken in de omgeving. Behalve de 'fiscalische anwale, een soort procureur-crimineel als aanklager in strafzaken, waren voortaan bij het gerecht slechts drie beëdigde procureurs toegelaten. Zij konden alleen optreden voorzien van een schriftelijk mandaat van partijen, dat ook moest worden getoond. Deze procureurs namen alle zaken van partijen aan en concludeerden vervolgens schrifteliik of eventueel ook mondeling. Voortaan schreven zij zelf die conclusies in het 'protocoll' en niet meer de 'actuarius' of griffier, zoals tot dan toe gebruikelijk was.

Alle decreten en beslissingen van het gerecht kregen een registratie met dag, datum en namen van partijen en wel zodanig dat daarvan onder aan de bladzijde van het gerechtsprotocol een overzicht stond. Van decreten en vonnissen waarvan de minuut geheim moest blijven, voerde de 'actuarius' een afzonderlijke registratie in boekvorm, die desgewenst aan schepenen kon worden getoond. De gewone of 'ordinaris' zittingen van het gerecht vonden plaats om de veertien dagen op donderdag of, indien dit op een feestdag viel, op vrijdag. Vakanties waren alleen toegestaan voor zover die in denen rechten exprimiret' waren, dat wil zeggen voor zover die algemeen in het gerecht gebruikelijk waren. Diverse artikelen bevatten bepalingen over de gerechtskosten, variërend van het bodeloon tot en met de beloningen van afzonderlijke functionarissen voor hun aanwezigheid of het verrichten van bepaalde handelingen.

In het reglement werd geprobeerd de traditionele manier van procederen te stroomlijnen, maar primair richtten de bepalingen zich tegen de misbruiken zoals die in de voorgaande jaren waren ingeslopen. Vooral de rol van de secretaris veranderde ingrijpend. $\mathrm{Na}$ alle klachten over fraude werd nu de verantwoordelijkheid voor de verslaglegging gelegd bij de procureurs. Voorts moest worden voorkomen dat een secretaris jarenlang de rechtsgang kon frustreren door stukken onder zich te houden. Dat was immers het grote verwijt aan Lebens. Wanneer procureurs over een officiële kopie beschikten, vormde dat niet langer een probleem. Ten slotte zouden vaste termijnen voor de zittingen en vaste tarieven voor gerechtskosten de rechtszekerheid voor de onderdanen verhogen.

Voor Altorff vormden de activiteiten van Belderbusch reden met spoed naar Gronsveld te vertrekken. In het bijzonder het lot van de stukken van het proces tegen Gathoye baarde hem zorg. Altorff vervoegde zich op 15 oktober 1731 op het kasteel, in aanwezigheid van de schepenen van Gronsveld als getuigen en notaris Kicken uit Scharn voor het opstellen van een proces-verbaal. ${ }^{1562}$ Hij trof daar Belderbusch aan én François Gathoye. De bespreking verliep in een vijandige sfeer. Belderbusch volhardde in zijn weigering stukken af te geven. In een kist werden stukken van het proces tegen Gathoye aangetroffen, onder andere de 'feyten van belastinge' van drossaard Lebens tegen Gathoye van 8 maart 1729. Dit stuk was eerder op drie plaatsen verzegeld door commissaris d'Oliva en op één plaats door Lebens, maar deze zegels waren verbroken. Hetzelfde was gebeurd met een stuk getiteld 'ulteriores articuli inquisitionalis' (laatste artikelen van getuigenverhoor). Op de

${ }^{1561}$ RHCL, Rijkskamergerecht, inv. nr. 71/2, fol. 595-596vo.

1562 Voor de diverse verrichtingen van Altorff zie RHCL, Rijkskamergerecht, inv. nr. 71/2, fol. 233-241. 
vraag wie die zegels had verbroken, gaf Belderbusch toe dat hij de dader was. Altorff nam de stukken onder zijn arm en wilde met notaris Kicken en de schepenen vertrekken. Maar dat ging niet zomaar, want intussen had Belderbusch de poort laten sluiten en zei dat de knecht met de sleutel weg was. Uiteindelijk zorgde de ook aanwezige François Gathoye dat toch werd open gedaan en kon het gezelschap het kasteel met de stukken verlaten.

Daags daarna, op 16 oktober, liet Gathoye via zijn notaris een formeel protest tegen deze gang van zaken bij Altorff afgeven. In het bijzonder beklaagde hij zich over de partijdigheid van de schepenen die over hem moesten oordelen. Maar Altorff ontkende dat hij samenspande met de vijanden van Gathoye. Toen Altorff bij Belderbusch nog eens informeerde naar het honorarium dat hem vanwege zijn 'commission' in de zaak Gathoye toekwam, kreeg hij als antwoord dat degene die hem benoemd had, dat ook maar moest betalen. Voor Altorff was toen de maat vol. Het was duidelijk dat Belderbusch er alles aan deed hem te dwarsbomen, terwijl de Akenaar ook nog geen cent beloning ontving.

Het optreden van Belderbusch had alles te maken te maken met zijn strijd tegen graaf Ignaz Felix von Toerring-Jettenbach over de voogdij van de minderjarige gravin Maria Josepha. Bij wijze van voorlopige voorziening belastte het Rijkskamergerecht op 23 januari 1732 het stadsbestuur van Aken met de 'administration' over het graafschap Gronsveld. Vanuit het stadsbestuur werd burgemeester Alexander Theodor d'Oliva met de uitvoering van die opdracht belast. Hij vervoegde zich in Gronsveld en zag welke chaos Belderbusch had aangericht. ${ }^{1563}$ Vervolgens kregen drossaard en schepenen van Gronsveld begin februari ${ }^{1564}$ opdracht van d'Oliva de inboedel van het kasteel weer te inventariseren (dat was in oktober 1731 ook al eens gebeurd), kamers te verzegelen en alle 'unnöthige persohnen' te verwijderen. Desnoods kon die uitzetting - liefst in stilte - geschieden met behulp van de schutterij. Alleen rentmeester Oligschläger mocht in het kasteel wonen. Degenen die door Belderbusch in het kasteel waren 'bestelt', konden bij de inventarisatie en verzegeling aanwezig zijn. Op 18 en 19 februari 1732 vond de boedelbeschrijving plaats. ${ }^{1565}$ Waarschijnlijk kort tevoren had Gathoye al met kar en 'schees' (sjees) 's nachts goederen uit het kasteel laten transporteren naar 's-Gravenvoeren, dus buiten bereik van het Rijk. Bij de grens werd niets aangegeven of gecontroleerd 'omdat het nacht was', zodat zich later ook niet meer liet vaststellen wat precies was meegenomen. Maar een precies onderscheid tussen 'mijn' en 'dijn' was zeker niet gemaakt. Ook bij de inventarisatie van de resterende inboedel ging het er niet zachtzinnig aan toe. Gesloten deuren moesten worden opengebroken, personeel van Gathoye en Belderbusch werd onder bewaking gesteld en mocht pas de volgende ochtend vertrekken. Belderbusch beklaagde zich daar later bitter over. Toen iemand vroeg naar de volmachten van Lebens, antwoordde deze dat men die kon gaan halen waar ze waren uitgevaardigd: bij d'Oliva of het stadsbestuur van Aken.

1563 RHCL, Rijkskamergerecht, inv. nr. 71/1, fol. 105-116vo.

1564 De data genoemd in de brieven (RHCL, Rijkskamergerecht, inv. nr. 71/1, fol. 105-116vo.) zijn zo verwarrend dat een reconstructie van de volgorde der gebeurtenissen niet goed mogelijk is.

1565 TJ, inv. nr. M 75, fol. 343-362. 


\subsection{De orde bersteld}

Op 6 februari 1732 werd dan graaf Ignaz Felix von Toerring-Jettenbach tot voogd benoemd. Op 27 februari 1732 kreeg d'Oliva als beste kenner van de Gronsveldse situatie van de graaf opdracht alles te doen wat in het belang van de minderjarige gravin Maria Josepha kon zijn. D’Oliva accepteerde en begaf zich vervolgens naar Gronsveld, waar hij zich bij drossaard, schepenen, rentmeester en burgemeesters op het kasteel aandiende. ${ }^{1566}$ Hij overhandigde de schriftelijke orders van de graaf, maar omdat men het Duits onvoldoende beheerste, werd de tekst voorgelezen en met een 'besondere anredt' verduidelijkt. Er werd officieel meegedeeld dat graaf Ignaz Felix von Toerring-Jettenbach door het Rijkskamergerecht was benoemd tot voogd van de minderjarige gravin met de opdracht de 'administration' van het graafschap op zich te nemen. Vervolgens legden alle functionarissen en ambtsdragers een nieuwe eed van trouw aan de 'administrator' af. D'Oliva constateerde dat geen register van beëdigingen voorhanden was en verordonneerde dat iets dergelijks moest worden aangelegd, met voor ieder ambt een eedsformule.

Er moesten ook nieuwe functionarissen worden benoemd. Zo waren de functies vacant van bode van het leenhof en van 'keurmeesters' of controleurs van de accijns bij de brouwerijen. De rentmeester mocht een nieuwe huisbode voor het kasteel aanwijzen.

Verder vielen er diverse zaken van publiek belang te regelen. Alle officiële bekendmakingen vonden voortaan plaats op naam van de administrator. Aan de pastoors en andere geestelijken werd gevraagd in het openbaar te bidden voor het welzijn van de administrator en de 'pupillin'.

Er moest ook iets worden gedaan aan de eeuwige ruzies met de Maastrichtse geërfden over hun bijdrage in de belastingen. Drossaard Lebens kreeg opdracht daarover een notitie op te stellen, die ter beoordeling zou worden voorgelegd aan graaf Toerring-Jettenbach. Voorts diende de drossaard in gezelschap van de schepenen en enkele oude mannen de grenzen van het graafschap te inspecteren, maar zonder dat dit ruzie met de buren opleverde.

Ook zakelijke belangen werden geregeld. Aan de intussen bijna ongebreidelde jacht op wild werd per decreet onmiddellijk een einde gemaakt. Drossaard en rentmeester moesten een nauwkeurig overzicht van alle inkomsten en schulden van het graafschap opstellen, inclusief een staat van alles wat Gathoye en Belderbusch uit het graafschap hadden gebeurd of eventueel nog te vorderen hadden. Bijzondere aandacht kregen daarbij de rekeningen van Belderbusch gedurende de tijd dat hij in Gronsveld de scepter had gezwaaid.

Nog altijd waren kamers, zolders en kelders in het kasteel gesloten en Belderbusch wilde geen sleutels afgeven. Het was echter nodig de aanwezige voorraden te inventariseren. Op bevel van het gerecht geschiedde dit onder notarieel toezicht op 17 maart $1732 .{ }^{1567}$ Op 22 maart 1732 schreef d'Oliva aan graaf Toerring dat hij al deze maatregelen had getroffen behoudens de grafelijke goedkeuring. Die volgde, zonder enige reserve.

1566 Voor diens activiteiten zie RHCL, Rijkskamergerecht, inv. nr. 71/1, fol. 105-116vo.

1567 RHCL, TJ, inv. nr. M 75, fol. 301. 
Met de benoeming van graaf Ignaz Felix von Toerring-Jettenbach tot voogd van de gravin d'Arberg Valengin brak een tijd aan, waarin langzaam orde op zaken kon worden gesteld. Met dat doel stuurde de graaf ook zijn 'Gerichtsverwalter' Gürtler meermalen voor langere tijd naar Gronsveld om de situatie goed in kaart te brengen. Een goede inventaris was ook vereist vanwege de voogdij. Twee problemen waren echter niet opgelost. Jean Gathoye, de vader van François, die de oorspronkelijke admodiator of pachter van het graafschap was geweest, meende recht te hebben op een schadevergoeding van maar liefst 150.000 gulden Maastrichter koers wegens gederfde inkomsten uit het graafschap. Daar stond tegenover dat de Gathoye's nog altijd voor meer dan twintig- tot dertigduizend rijksdaalders aan kostbaarheden, juwelen en zilver van de familie d'Arberg Valengin in bezit hadden, exclusief een diamant ter waarde van zevenduizend rijksdaalders, die ze niet konden of wilden teruggeven. Ook Baron Belderbusch kon zich moeilijk bij zijn nederlaag neerleggen. Hij weigerde rekenschap af te leggen voor de periode dat hij de voogdij had uitgeoefend. Voorts hield hij archivalia onder zich die voor het beheer van de goederen van de minderjarige gravin van groot belang waren. Zeer hinderlijk was ook dat Belderbusch zich opwierp als pleitbezorger en belangenbehartiger van Gathoye. De oude Jean Gathoye schijnt zelfs bij Belderbusch te zijn ingetrokken. De geschillen met Belderbusch sleepten nog jaren aan. Ze raakten echter nauwelijks nog de interne gang van zaken binnen het graafschap en blijven om die reden hier ook verder buiten beschouwing.

\subsection{Conclusies}

De benoeming begin 1732 van graaf Ignaz Felix von Toerring-Jettenbach tot voogd over de minderjarige gravin vormde het begin van een langzame, maar toch zekere periode van herstel. In deze tijd werden de fundamenten gelegd voor een stabiele interne organisatie van het graafschap in de tweede helft van de achttiende eeuw.

De problemen in Gronsveld tussen 1720-1732 waren voor een belangrijk deel het gevolg van een ongelukkige samenloop van omstandigheden, maar ze passen daarnaast ook in een breder kader. Het aantreden van Lebens markeert weer een fase in de wisseling van de familieregering en was ook een afrekening met de aanhangers van de vorige drossaard Kicken. Achteraf kan worden vastgesteld dat Lebens daarmee een solide basis heeft gelegd voor de macht van zijn familie voor de rest van de achttiende eeuw. Het is de vraag of zijn bewind buiten een groep directe aanhangers op brede steun van de bevolking kon rekenen. Waarschijnlijk sympathiseerden de meeste inwoners met hem in zijn strijd tegen familie Gathoye, omdat die als arrogante en tirannieke vreemdelingen helemaal niet gewenst waren. Overigens hadden de Gathoye's ook meelopers. Er is sprake van twee rivaliserende kampen, maar iedere vorm van collectiviteit bij de bevolking ontbreekt.

Wat het gebruik van geweld betreft deed Gronsveld niet onder voor andere plaatsen, zoals dat door Gabel voor een aantal rijksonmiddellijke territoria is beschreven. Inhoudelijk wijken de conflicten in Gronsveld echter af van het meer algemene patroon. In andere plaatsen draait het vooral over betaling van belastingen of schending van rechten in de 
relatie tussen de landsheer en een collectiviteit van inwoners. Ook al waren de Gathoye's pachters van (een deel) van de heerlijke rechten, een 'onderdanenconflict' kan men de problemen in Gronsveld niet noemen. Daarmee is de casus Gronsveld een aanvulling op of, zo men wil, een andere invulling van het beeld zoals we dat uit andere plaatsen kennen. Een vergelijking dringt zich op met de problemen enkele decennia later in de heerlijkheid Stein. Ook daar was het landsheerlijk bestuur zwak door verdeeldheid tussen de families die de heerlijke rechten in bezit hadden gekregen. De agressie van de inwoners richtte zich tegen die heren, die weliswaar legitiem aan de macht waren gekomen, maar wat betreft mentaliteit mijlenver afstonden van de leefwereld van hun onderdanen. Tegelijkertijd had echter de drossaard in die plaats ook door combinatie van functies een vrijwel onaantastbare positie verworven. Een dergelijke machtsconcentratie kon in combinatie met een zwak landsheerlijk gezag een explosief mengsel binnen de politieke cultuur in kleine territoria opleveren.

In de jaren tussen 1720 en 1732 valt de uiterst zwakke positie van de Gronsveldse schepenbank op. De schepenen stelden zich zeer passief op en de manier waarop met de voortdurende wisseling van benoemingen werd omgesprongen, zette alle geloof in hun integriteit op het spel. Kennelijk waren de schepenen niet bij machte de dominantie van de drossaard-secretaris te doorbreken. In strafzaken lijkt Lebens de zaken naar zijn hand te zetten. Hoezeer de schepenbank in het ongerede was geraakt blijkt misschien wel uit het merkwaardige procesreglement dat Belderbusch 13 oktober 1731 uitvaardigde, omdat het sterk van de gebruikelijke manier van procederen afweek, vooral wat betreft de rol van advocaten.

Blijft bij het ontbreken van interne correctie de vraag naar de mogelijkheden voor buitenstaanders om in te grijpen. In theorie kon de kreits, al dan niet op verzoek van het Rijkskamergerecht, bij volledige onbestuurbaarheid ingrijpen, maar feitelijk werkte dat nauwelijks. Er zijn in ieder geval geen aanwijzingen dat iets dergelijks is overwogen. Interessant is de positie van de Schepenstoel van Aken. Bij het begin van de problemen in Gronsveld zag het Akense gerecht - indachtig het verleden - kans zich daarin te mengen. Maar de Schepenstoel bleek niet in staat tot daadkrachtig zelfstandig optreden, nog afgezien van de vraag of er voor interventie ook een juridische grondslag bestond. Pas na het vonnis van het Rijkskamergerecht in 1728 kon de Schepenstoel, met mandaat van het Rijkskamergerecht een constructieve rol spelen, niet in het minst door het energiek optreden van de Akense schepen en burgemeester d'Oliva. Ten slotte, het Rijkskamergerecht was als rechtsprekend college door het gebrek aan dwangmiddelen niet in staat zelf direct in te grijpen, maar het vonnis dat in 1728 werd geveld geeft toch blijk van serieuze bekommernis om het recht. Niet alleen werd opdracht gegeven voor een serieuze behandeling van het proces over de dood van Sebastiaan de Montbrison, ook ongewenste combinaties van ambten werden verboden en graaf Claude Nicolas d'Arberg Valengin werd gewezen op de plichten die hij als landsheer had te vervullen. 


\section{Landsheerlijke functionarissen, 1732-1795}

Gebeurtenissen zoals zich die in de periode 1720-1732 in Gronsveld afspeelden, wekken de indruk van een operettestaatje, waar het met orde en recht niet zo nauw werd genomen. Uit de literatuur kennen we een vergelijkbaar beeld wanneer problemen in rijksonmiddellijke plaatsen zoals Cornelimünster ${ }^{1568}$ en $\operatorname{Stein}^{1569}$ worden uitvergroot. Maar het blijft lastig een helder antwoord te geven op de vraag of dit soort situaties typisch was voor deze gebieden. Daarom wordt in de inleidende paragraaf van dit hoofdstuk geprobeerd een impressie te geven van 'normale' verhoudingen binnen kleine rijksonmiddellijke territoria in de achttiende eeuw en een daarbij passend 'profiel' van functionarissen in landsheerlijke dienst.

$\mathrm{Na} 1732$ hing de toekomst van het gezag over het graafschap Gronsveld af van een twaalfjarig weeskind, gravin Maria Josepha d'Arberg Valengin en Gronsveld. Mocht zij voortijdig overlijden, dan was de erfopvolging uiterst onzeker. De door het Rijkskamergerecht benoemde voogd, graaf Ignaz Felix von Toerring-Jettenbach, leek na de roerige jaren twintig de juiste persoon om een krachtig herstel van landsheerlijk gezag in goede banen te leiden. Onder zijn bewind begonnen zich, met hulp van Alexander Theodor d'Oliva, schepen en burgemeester van Aken als medevoogd, de bestuurlijke verhoudingen langzaam te normaliseren. Afgezien van de frauderende rentmeester in de jaren veertig en vijftig, kende het bestuur gedurende de rest van de achttiende eeuw een behoorlijke stabiliteit. Enerzijds was dat te danken aan de manier waarop de opeenvolgende graven Toerring-Jettenbach door persoonlijke bemoeienis - schriftelijk, op afstand - invulling gaven aan hun landsheerlijke gezag, anderzijds zorgde ook de benoeming van capabele functionarissen voor een grotere professionaliteit van het bestuur en een betere bestuurscultuur, hoewel men daar geen overdreven verwachtingen van moet hebben.

In totaal worden zes functionarissen onder de loep genomen die als beeldbepalend kunnen worden beschouwd voor het grafelijk bestuur in Gronsveld in de periode tussen circa 1730 en 1800. Daarbij was het in het geval van de rentmeester Oligschläger onontkoombaar ook ruimschoots aandacht te besteden aan diens frauduleuze praktijken. Het proces daarover gedurende enkele decennia ontwikkelde zich tot een echt 'hoofdpijndossier' voor de graaf en de Gronsveldse bestuurders.

In dit hoofdstuk wordt onderzocht in hoeverre de grafelijke functionarissen in Gronsveld voldeden aan een meer algemeen profiel van de bestuursambtenaar, zoals zich dat binnen Duitse landsheerlijkheden gedurende de achttiende eeuw ontwikkelde. Een interessant aspect daarvan zijn in Gronsveld de opvattingen over titulatuur, waarin ook de verhoudingen tussen heer en ondergeschikte tot uitdrukking kwamen. Het officiële takenpakket komt naar voren in formele, ambtelijke bronnen, zoals instructies, rapportages, procesdossiers en rekeningen, maar daarnaast krijgt het profiel ook vorm in persoonlijke ontboezemingen zoals die in het bijzonder in correspondentie zijn terug te vinden.

1568 Gabel, Wiederstand und Kooperation, 116-336.

1569 Munsters, 'De strijd tegen het hoogduits'; Munsters, 'Het knuppelen der honden'; Munsters, 'Rijksonmiddellijkheid en Kammerzieler'. 
Toch betreft dat alles grotendeels de buitenkant. Zeker in een kleine gemeenschap bepaalden persoonlijke verhoudingen en karakters in hoge mate het functioneren van het bestuur. Vaak is daar niet veel over te vinden. Gronsveld vormt daarop een uitzondering, omdat hier toevallig veel correspondentie tussen de graaf in München en zijn vertegenwoordigers in Gronsveld bewaard is gebleven. De daarin soms uitvoerig beschreven overwegingen en gevoelens, met ook roddel en achterklap, geven inkijk in de wereld achter de officiële gang van zaken en laten zien hoe ambtelijke loopbaan, familierelaties en persoonlijk karakter in hoge mate met elkaar waren verweven.

De graven Van Bronckhorst Batenburg waren politiek, cultureel en beroepsmatig op het Heilige Roomse Rijk georiënteerd, verbleven ook meestal buiten Gronsveld, maar hadden toch hun thuisbasis in het graafschap. Na 1730 kreeg Gronsveld een echte 'Duitse' landsheer en werden ook 'Duitse' functionarissen benoemd. Onderzocht is in hoeverre deze afkomst van invloed was op het plaatselijk bestuur en op welke wijze deze vreemdelingen zich aan de plaatselijke verhoudingen in Gronsveld aanpasten.

De laatste vijftien jaar van de achttiende eeuw stonden in het teken van grote politieke en maatschappelijke veranderingen. Die bepaalden ook in hoge mate zowel het optreden alsook het persoonlijk leven van Wolfgang Zollner, de laatste grafelijke directeurcommissaris van Gronsveld. Weliswaar ging de onrust in de Zuidelijke Nederlanden en in Luik in 1789 nog grotendeels aan Gronsveld voorbij, maar het vormde vanaf 1792 het begin van zeer onrustige jaren met veel overlast en schade. Op de Franse bezetting van het gebied tussen Maas en Rijn eind 1794 volgde per 1 oktober 1795 de inlijving van het Maasgebied bij Frankrijk. Feitelijk kwam daarmee een einde aan het graafschap Gronsveld, hoewel pas de Reichsdeputationshauptschluss begin 1803 dit officieel bezegelde.

\subsection{Herstel van normaal bestuur in Gronsveld}

Vanaf voorjaar 1732 probeerde burgemeester Alexander Theodor d'Oliva van Aken in opdracht van graaf Ignaz Felix von Toerring-Jettenbach in Gronsveld orde op zaken te stellen. Omdat d'Oliva de dagelijkse gang van zaken in het graafschap onvoldoende kende en ook niet permanent aanwezig kon zijn, was hij voor informatie vooral aangewezen op de Luikse baron Ernst de Goeswin, erfstadhouder van het leenhof, op drossaard Lebens en op rentmeester-secretaris Johannes Matthias Oligschläger. Het is twijfelachtig of het advies van eerstgenoemde veel gewicht in de schaal legde. Ook hij woonde niet in Gronsveld en de enigszins minachtende toon waarop jaren later Prummer zich over hem uitlaat, wekt het beeld van een onbenul. Maar dan wel een onbenullige lastpak, want door zijn directe toegang tot de graaf had de man de mogelijkheid achter de rug van d'Oliva om te intrigeren. Zo had hij een dubieuze rol gespeeld bij de verkoop van de heerlijkheid Slenaken in 1728 aan graaf Plettenberg. ${ }^{1570}$ Over drossaard Lebens vernemen we, in tegenstelling tot de voorgaande tijd, opvallend weinig. Hij kreeg in 1737 een nieuwe uitgebreide ambtsinstructie die, in theorie, een einde moest maken aan misbruiken. De derde man, Johan Matthias Oligschläger, in 1728 benoemd als grafelijke rentmeester en

1570 TJ, inv. nr. M 76, fol. 483-488, extract uit brief van d'Oliva aan graaf I.F. von Toerring-Jettenbach 6 maart 1737. 
secretaris van de schepenbanken, leek zich aanvankelijk loyaal tegenover graaf ToerringJettenbach en d'Oliva op te stellen. Gaandeweg kreeg hij greep op de in een chaotische toestand verkerende grafelijke financiën, maar gebruikte die kennis vooral ten eigen nutte, zoals later aan het licht kwam.

Uit een overzicht van de correspondentie tussen d'Oliva en graaf Ignaz Felix von Toerring-Jettenbach uit de jaren 1731-17351571 blijkt dat vooral 'buitenlandse' problemen van Gronsveld centraal stonden. Daar ging ook een bepaalde dreiging van uit. Zo speelde voor de Rijkshofraad in Wenen het proces met graaf Plettenberg over de verkoop van Slenaken en de afwikkeling van schulden waarmee het graafschap Gronsveld was belast. Op een gegeven moment schijnt Plettenberg zelfs de openbare verkoop van Gronsveld te hebben geëist. 1572

Het meest complexe probleem betrof echter de betaling van belastingen door grote Maastrichtse instellingen over hun grondbezit in Gronsveld. Dat geld was nodig om te kunnen voldoen aan de financiële verplichtingen ten opzichte van de kreits, het Rijkskamergerecht en het Nederrijns-Westfaalse Gravencollege. Achterstanden droegen immers altijd het gevaar van militaire executie in zich. Na moeizame onderhandelingen bereikte d'Oliva daarover in 1739 een akkoord (Voor nadere bijzonderheden over deze onderhandelingen zie Hoofdstuk 16.2.6).

Hoewel d'Oliva zijn best deed, dreigde het vele werk hem boven het hoofd te groeien. Hij bekleedde immers ook nog de functie van burgemeester en schepen in Aken. Op 18 februari 1733 liet hij de graaf weten dat het op orde brengen van de Gronsveldse administratie bijna een dagtaak voor drie of vier man was, met als bijkomend probleem dat in Gronsveld geen geschikte kandidaat voor het innen van de belasting te vinden was. ${ }^{1573}$

Aanvankelijk lijkt d'Oliva wel vertrouwen te hebben gehad in rentmeester Oligschläger, maar allengs rezen steeds meer vragen bij diens handel en wandel. Geruchten over onregelmatigheden bereikten langs verschillende wegen ook graaf Ignaz Felix. Deze gaf op 16 februari 1737 zijn 'Amts- und Lehnverwalter' in Jettenbach, Franz Blasii Gürtler, opdracht ter plaatse een onderzoek in te stellen naar de stand van zaken in Gronsveld en alles te doen wat hij in het belang van de landsheerlijke rechten achtte. De jurist Gürtler was een man in wie de graaf het volste vertrouwen stelde. Volgens zijn instructie moest hij enerzijds d'Oliva en baron de Goeswin de helpende hand reiken en anderzijds waren ambtenaren en onderdanen verplicht hem alle medewerking te geven en archieven te openen. ${ }^{1574}$

Gürtler werkte in 1737 gedurende 223 dagen in Gronsveld, waarvan 189 dagen met assistentie van 'Commisionsschreiber' Huefnagel. De specificaties op de afrekening van zijn verblijf geven een goed beeld van zijn werkzaamheden. ${ }^{1575}$ De boekhouding werd

1571 TJ, inv. nr. M 32, fol. 1-65, brievenboek, genummerd 1-103.

1572 TJ, inv. nr. M 32, fol. 53, brief nr. 86 van d'Oliva aan graaf I.F. von Toerring-Jettenbach 13 november 1734.

1573 TJ, inv. nr. M 32, brievenboek, nr. 68, d'Oliva aan I.F. von Toerring-Jettenbach 18 februari 1733.

1574 TJ, inv. nr. M 76, fol. 501-505, 16 februari 1737 en TJ, inv. nr. M 14, fol. 1393-1396, februari 1737.

1575 TJ, inv. nr. M 14 fol. 1257-1359, ‘Commissionsrechnung’ over 1737. 
gecontroleerd en bijgewerkt, afgedwaalde archieven opgespoord en de stand van zaken in enkele langdurige processen, bijvoorbeeld over de heerlijkheid Rimburg, in kaart gebracht. Ook de administratie van de lenen werd onderzocht en verbeterd. Zijdelings raakte Gürtler betrokken bij de onderhandelingen met de Maastrichtse geërfden over de grondbelasting, maar dit bleef in hoofdzaak een taak voor d'Oliva. De reacties die Gürtler vanuit München op zijn rapportages ontving, maken duidelijk dat Gronsveld voor de graaf en zijn kanselarij terra incognita was. Men wilde alles over Gronsveld weten wat er maar viel te weten. ${ }^{1576}$

Uiteindelijk kreeg Gürtler een goed beeld van de financiële situatie. Gronsveld bracht 3800 tot 4000 gulden Beiers op, waar tegenover 3320 gulden aan vaste lasten stonden. De hoogste post daarin bestond uit 2400 gulden rente. Daarnaast zou moeten worden geïnvesteerd in onderhoud van het kasteel, de tuin en de windmolen evenals in enkele langlopende processen. ${ }^{1577}$

Gürtler zorgde voor nieuwe instructies voor de drossaard, de rentmeester/secretaris en een nieuw te benoemen appelcommissaris. De instructies voor drossaard en rentmeester lagen gedeeltelijk in elkaars verlengde. De teksten hebben een enigszins hybride karakter omdat de bepalingen niet alleen interne werking hebben, maar ook regelgeving voor de inwoners bevatten. Het illustreert nog eens de vage grens tussen het publieke en private domein. Verder kwam er een nieuwe regeling voor het hoger beroep bij de schepenbank en probeerde hij meer greep te krijgen op de functie van stadhouder bij het leenhof.

Met nieuwe instructies voor de belangrijkste functionarissen dacht Gürtler orde op zaken te stellen en het graafschap winstgevend te maken. Hij bezocht in de jaren daarna nog meermalen Gronsveld en fungeerde ook als vraagbaak en adviseur voor anderen die uit München naar Gronsveld reisden. Maar na verloop van tijd begon Gürtler steeds meer te twijfelen of in Gronsveld wel de juiste mannen aan het roer stonden. De eigenmachtig optredende rentmeester Oligschläger kreeg nauwelijks tegenspel. Pas in 1746 begon tegen hem een proces wegens fraude, welke zaak uiteindelijk uitgroeide tot een decennialang durende affaire. Zorgen baarde intussen ook het optreden van d'Oliva, die tot appelcommissaris was benoemd.

Pas na het huwelijk van graaf Maximilian Emanuel von Toerring-Jettenbach met gravin Maria Josepha in 1746 eindigde de periode van voogdij en leek voor het graafschap Gronsveld grotere bestuurlijke stabiliteit aan te breken. Maar deze start verliep om drie redenen moeizaam, te weten de Oostenrijkse Successieoorlog (1740-1748) die in 1747 en 1748 grote schade in het graafschap Gronsveld veroorzaakte, het inmiddels gestarte fraudeproces tegen de rentmeester en ten slotte het zwakke optreden van pastoor Schmädel als vertegenwoordiger van de graaf.

1576 TJ, inv. nr. M 14, fol. 211-219, z.d., vraagpunten naar aanleiding van rapport Gürtler, z.d., klad. 1577 TJ, inv. nr. M 14, fol. 313-315, Gürtler (vanuit Jettenbach) aan I.F. von Toerring-Jettenbach 31 januari 1738). 


\subsection{Josephus Antonius Schmädel, 'Hofrath' en pastoor}

Gürtler speelde na 1746 nog als adviseur van de graaf een rol op de achtergrond, maar was intussen tot de overtuiging gekomen dat de behartiging van de grafelijke belangen niet alleen aan plaatselijke functionarissen kon worden overgelaten. Een permanente vertegenwoordiger van de graaf, niet 'besmet' door de lokale politiek, zou beter geschikt zijn. De zuinig aangelegde graaf Maximilian Emanuel dacht een oplossing te vinden met de benoeming van een 'deeltijdvertegenwoordiger' in de persoon van Josephus Antonius Schmädel (ook de varianten Schmadel en De Schmadel komen voor), kandidaat in de theologie en bij de graaf in München in dienst als 'Hofrath' en hofkapelaan. ${ }^{1578}$ In 1746 was hij door de graaf benoemd tot beneficiant van het altaar van Sint-Amandus in de kerk van Gronsveld. ${ }^{1579}$ Deze kerkelijke fundatie, waarvoor de graaf het benoemingsrecht had, was een goed betaalde 'sinecure', in dien zin dat er behalve het opdragen van missen geen andere verplichtingen aan waren verbonden. Het is onduidelijk of Schmädel vervolgens na zijn benoeming in Gronsveld resideerde en daar ook de graaf in bestuurlijke zaken vertegenwoordigde. Maar het beneficie van Sint-Amandus vormde na het overlijden van pastoor Henricus van der Meeren op 5 juli 1747 de opstap voor zijn benoeming tot pastoor van Gronsveld begin 1748. Schmädel deed daarvoor afstand van het beneficie van Sint-Amandus en moet tussen 24 juni en 7 juli 1748 zijn ambt als pastoor hebben aanvaard. Vanaf dat moment was hij ook als 'Hofrath' de vertegenwoordiger van de graaf in Gronsveld.

Schmädel arriveerde in een tijd dat Gronsveld ernstig leed onder de Oostenrijkse Successieoorlog. Ook intern liepen weer de spanningen op over de betaling van grondbelasting door de Maastrichtse geërfden en baarden enkele grote processen bij de schepenbank veel opzien. Het grootste probleem vormde echter Schmädel zelf. Prummer beschreef hem later als iemand met een zwak karakter, die zich als Duitser moeilijk aan land en mensen aanpaste en uiteindelijk van chagrijn was doodgegaan. Gelukkig had de verwaarlozing van de zielzorg volgens Prummer weinig negatieve gevolgen, want 'de parochianen zijn brave lammeren; ook al zou er een heel jaar geen $\mathrm{H}$. Mis gelezen worden of niet worden gepreekt, dan nog blijven zij hun geloof trouw'. ${ }^{1580}$ Zijn mening over die vermeende braafheid stelde hij overigens enige tijd later wel bij. Als ambtenaar werd Schmädel ook geen succes, door zijn karakter, maar ook omdat hij ziekelijk was. In ieder geval liet hij bij zijn overlijden op 24 juni 1754 een administratieve chaos na. ${ }^{1581}$ Het slechte functioneren van Schmädel bleef ook in München in het late voorjaar van 1752 niet onopgemerkt. De benoeming van de jurist Joseph Anton Prummer als fulltime grafelijke vertegenwoordiger in Gronsveld bevestigde dat alleen maar. Met deze man begon in Gronsveld een periode waarin orde en stabiliteit voor lange tijd terugkeerden.

1578 TJ, inv. nr. M 8, fol. 197-199, M.E. von Toerring-Jettenbach aan drossaard H. Lebens 29 juli 1746.

1579 TJ, inv. nr. M 8, fol. 205-207, M.E. von Toerring-Jettenbach aan Schmädel 29 juli 1746.

1580 TJ, inv. nr. M 14, fol. 969-972, Prummer aan M.E. von Toerring-Jettenbach 12 juli 1754.

1581 TJ, inv. nr. M 14, fol. 31-34, Prummer aan broer Xaver Prummer 15 augustus 1754. 


\subsection{Joseph Anton Prummer, secretaris-commissaris}

Het moet in het voorjaar van 1752 zijn geweest dat de omstreeks dertig jaar oude Joseph Anton Prummer in het pas voltooide Palais Toerring aan de Residenzstrasse in München werd ontboden. Prummer was afkomstig uit Ingolstadt. Over zijn geboortejaar en -datum bestond later onduidelijkheid, maar waarschijnlijk zag hij omstreeks 1720 het levenslicht. ${ }^{1582}$ Of Prummer al eerder bij graaf Maximilian Emanuel von ToerringJettenbach in dienst was, is niet duidelijk. Maar hij was bij de familie bekend, want zijn broer Xaver werkte als secretaris in de grafelijke kanselarij. De graaf en gravin dachten in de ambitieuze kasteleinszoon de juiste man te hebben gevonden voor de eervolle, maar ook moeilijke functie als hun vertegenwoordiger in Gronsveld.

$\mathrm{Na}$ enige bedenktijd aanvaardde Prummer de aangeboden 'commission'. Dat was de officiële benaming van het ambt en daarbij hoorde de aanspreektitel 'secretaris'. Pas in het voorjaar van 1773, na de overname van de regering door graaf Joseph August, veranderde dit in 'commissarius' of 'commissaire'. Voor zijn vertrek naar Gronsveld bezocht Prummer eerst Gürtler, die hem alvast bijpraatte. Op 15 juli 1752 begon de reis, maar wegens een omweg om zakelijke redenen over Luxemburg kon Prummer pas op 1 september 1752 voet op Gronsveldse bodem zetten. Gedurende meer dan dertig jaar werd hij daar beeldbepalend voor het plaatselijk bestuur. Hij was een harde werker, doortastend, zeer zelfbewust, streng voor zichzelf en anderen, maar tegelijkertijd iemand met een gecompliceerd karakter. Zijn laatste levensjaren waren eigenlijk tragisch. Hij werd geplaagd door ouderdomskwalen, leed aan drankzucht en raakte door zijn aangetrouwde familie steeds meer verstrikt in plaatselijk gekonkel.

In Gronsveld was pastoor Schmädel de eerste die zijn landsman Prummer over de plaatselijke verhoudingen kon inlichten. Maar de parochieherder was ziekelijk en werd verteerd door heimwee, wat een objectieve voorlichting niet bevorderde. Een vechtpartij met dodelijke afloop in het dorp in de zomer van 1754 makte ook al geen goede indruk. Prummer kreeg al snel gemengde gevoelens over land en volk. Wanneer het zo uitkwam, prees hij de trouw en aanhankelijkheid van de onderdanen, maar tegelijkertijd liet hij zich laatdunkend over hen uit:

Uiterlijk vertoon betekent hier alles...De mensen aanbidden de Heilige Hostie hier alleen omdat die in nu eenmaal een kostbare zilveren houder zit'...1583

'Fatsoenlijke woningen zijn er nauwelijks. Zelfs grotere huizen zijn zeer sober. Bij huizen met een verdieping staat die er alleen op met de bedoeling op te scheppen, maar verder is dit bouwsel onbruikbaar. De beste plaats in huis is de keuken, waar heer, knecht, vee, hond, geit

1582 RHCL, Graafschap Gronsveld, inv. nr. 58, Zollner namens weduwe Prummer aan 'Bruder' 1785. Zollner probeerde meer informatie te krijgen over de doopdatum van zijn voorganger. In Gronsveld was alleen bekend dat in Ingolstad een doop was ingeschreven voor Joseph Anton Prummer op 14 februari 1719, maar dit kind was al op 22 februari daaropvolgend overleden. Er was daarom gevraagd een nader onderzoek in te stellen, omdat mogelijk een vergissing was gemaakt. Maar hoe dan ook, in de eerder genoemde doopakte stond als beroep van de vader 'cereviciarius'(biertapper) vermeld en dat woord moest in een attest voor Gronsveld worden vermeden, omdat dit hier als een oneervol beroep werd beschouwd. 1583 TJ, inv. nr. M 14, fol. 1195-1198, Prummer aan broer Xaver Prummer 6 september 1754. 
en zelfs varkens samenwonen. Er zijn in het hele dorp nog geen twintig bedden te vinden. Zonder geld betekent een voortreffelijk man in dit land niets en mét geld staat een slechterik goed aangeschreven. De bevolking is voor het grootste deel slim, eerzuchtig, ondernemend en zelfbewust, maar gaat ook door voor geraffineerd, wispelturig, achterbaks, wraakzuchtig, strijdlustig, slecht onderricht in geloofszaken en extreem belust op eigenbelang. Er wordt dus heel wat van iemand gevraagd om met dit soort mensen te kunnen omgaan. Zeker voor een Duitser. Ook de taal vormt een probleem. Alles verloopt in het Nederduits of Frans, slechts weinigen verstaan of spreken Hoogduits. Alleen secretaris Berchmans begrijpt enigszins de inhoud van de Duitse brieven. ${ }^{1584}$

Terwijl Prummer zich op zijn werk stortte, zorgden enkele snel op elkaar volgende sterfgevallen voor grote veranderingen: eerst het overlijden van gravin Maria Josepha op 17 februari 1754, daarna op 24 juni 1754 de toch al ziekelijke pastoor Schmädel en op 28 oktober 1755 Jacobus Berchmans, secretaris van het leenhof, keizerlijk notaris, landmeter en vicesecretaris van de schepenbank. $\mathrm{Na}$ het overlijden van de gravin erfde haar echtgenoot het graafschap Gronsveld in volledige eigendom. Met Schmädel ontviel iemand die misschien geen grote hulp was, maar de situatie in Gronsveld wel kende. Diens opvolger, Matthias Josephus Kolb uit Braunau, stond al vanaf het moment van zijn aankomst in Gronsveld in juni 1755 op voet van oorlog met Prummer. Dat drukte voor de komende jaren op de verhoudingen binnen de kleine groep van beeldbepalende figuren binnen de Gronsveldse gemeenschap. Het heengaan van Berchmans had vooral praktische gevolgen voor het dagelijks werk. De man was voor Prummer een echt 'orakel' geweest met zijn kennis over eigendommen en landsheerlijke rechten en inkomsten binnen het graafschap. Bovendien behoorde hij, ook door zijn huwelijk met Anna Catharina Lebens, de oudste dochter van de vroegere drossaard Johannes Godefridus Lebens en van Anna Lousberchs, tot de inner circle van de regerende families binnen het graafschap.

Door de veelvuldige contacten met de familie Lebens is het niet vreemd dat Prummer ook binnen deze kring een echtgenote vond. Hij trouwde in 1755 met Maria Anna Lebens, ${ }^{1585}$ de op één na jongste dochter van de vroegere drossaard Johannes Godefridus Lebens en Anna Lousberchs, een nicht van (de inmiddels nieuwe) drossaard Hendrik Lebens, schoonzuster van Jacobus Berchmans en tante van de latere rentmeester/secretaris Johannes Franciscus Lebens. Met haar werd Prummer dus op allerlei manieren verwant aan de familie Lebens. Het echtpaar vestigde zich in Maastricht, eerst in de Jacobstraat en naderhand op de Kleine Gracht. Het probleem van Prummers afwezigheid in Gronsveld werd in de praktijk opgevangen door het feit dat zijn zwager, rentmeester en secretaris Johan Frans Lebens, in Gronsveld woonde.

De exacte datum van Prummers huwelijk is niet bekend; in Gronsveld staat het huwelijk niet ingeschreven. ${ }^{1586}$ Dat kan te maken hebben met het feit dat tussen het overlijden van pastoor Schmädel op 24 juni 1754 en de komst van zijn opvolger Kolb in juni 1755 een hiaat bestond in het pastoraat. De reden om bij dit detail stil te staan is dat pastoor Kolb

1584 TJ, inv. nr. M 14, fol. 903-911, Prummer aan M.E. von Toerring-Jettenbach 13 augustus 1754. 1585 Gedoopt Gronsveld 19-9-1719, overleden Maastricht 20-4-1809.

1586 Van Heyst, 'Proeve ener genealogie', 136 geeft als huwelijksplaats en datum Gronsveld 8 mei 1755, maar vermeldt daarbij geen bron. 
omstreeks 1756 aan de graaf in München schreef dat het huwelijk Prummer-Lebens onderwerp van roddel was en dat mevrouw Prummer een duister verleden had in Maastricht. Dat verhaal was zo hardnekkig dat Prummers assistent en opvolger Wolfgang Zollner 25 jaar later een 'vriend' in de grafelijke kanselarij in München nog wist te melden dat Anna Maria Lebens twintigduizend (!) gulden had gekregen voor een kind dat een kapitein van het garnizoen Zwitsers in Maastricht bij haar had verwekt. Daarna waren de vader en het kind gestorven en bleef Anna Maria met haar fortuintje als aantrekkelijke huwelijkspartij achter. ${ }^{1587}$ Zo zag je maar weer eens hoe iemand tot zijn geluk kon komen, schamperde Zollner.

In hoeverre dit soort roddel op waarheid berust, valt niet te achterhalen. Kolb had een hartgrondige hekel aan Prummer en Zollner koesterde evenmin waardering voor zijn chef. Ook mevrouw Prummer kreeg van beide heren een slechte pers. Volgens pastoor Kolb was zij een vrouw die tot de 'furien' behoorde. Niet Prummer, maar zij regeerde het dorp. ${ }^{1588}$ Dat beeld komt overeen met wat Zollner later over haar vertelt. Toen hij in april 1778 in Gronsveld arriveerde, noemde hij haar hooghartig, onsympathiek en koel. Zij speelde een rol in de Gronsveldse politieke verhoudingen met een 'hofpartij' rond haar en haar echtgenoot en een 'tegenpartij'. In alle dorpen van het graafschap beschikte zij over vrouwen die voor haar spioneerden om de publieke opinie te peilen. Pijnlijk werd het toen mevrouw Prummer probeerde Zollner op alle mogelijke manieren te koppelen aan haar enige kind, Maria Anna Josepha. ${ }^{1589}$ Zij spiegelde hem de voordelen van de huwelijkse staat voor, die in dit geval bijzonder groot zouden zijn met een echtgenote uit een familie die al meer dan honderd (!) jaar over het graafschap regeerde. Zollner liet zich echter niet ompraten, ook niet toen de druk werd opgevoerd met aanbevelingen van rentmeester Lebens, van de pastoor en zelfs van zijn eigen biechtvader. Hij wist dat de familie Prummer in Gronsveld gehaat was en een verbintenis daarmee zou zijn reputatie geen goed doen. Daarom hield hij vast aan zijn relatie met een zekere Thérèse, zijn aanbeden vriendin in München, een relatie die overigens uiteindelijk op niets uitliep (zie hierna Hoofdstuk 12.6 en 12.7). Met die afwijzing haalde Zollner zich vervolgens de woede op de hals van mevrouw Prummer, die een lastercampagne tegen hem startte.

Prummer trof bij het begin van zijn werk in Gronsveld een grote administratieve wanorde aan. Van de gedrukte Rechtsordnung van Gronsveld uit 1671 vond hij met moeite één beduimeld exemplaar, zodat hij een geschreven tekst naar München moest sturen. De administratie van de lenen, keurmeden, pachten, cijnzen en renten was ten tijde van rentmeester Oligschläger flink in het ongerede geraakt. Bij gebrek aan een kadastrale boekhouding liet zich moeilijk vaststellen op welke percelen bepaalde lasten drukten. Eén van de grote projecten die Prummer vanaf het begin voor ogen had, betrof een kadastrale opmeting van het totale graafschap. Hij wilde helderheid over de juridische situatie van elk

1587 TJ, inv. nr. M 58, fol. 506-514, Zollner aan niet nader genoemde relatie in de grafelijke kanselarij 12 juli 1779 .

1588 TJ, inv. nr. M 14, fol. 957 -962, klaagzang van Kolb aan M.E. von Toerring-Jettenbach, postscriptum, z.d.

${ }^{1589}$ Gedoopt Gronsveld 21 september 1756; er waren ook nog twee jongere dochters, geboren in 1758 en 1761, die beiden overleden in 1761 . 
afzonderlijk perceel. Ook de juridische grondslag van bepaalde grafelijke rechten en inkomsten vereiste nader onderzoek. In de loop van 1754/1755 werd dit project met financiële steun van de geërfden binnen het graafschap gerealiseerd (zie daarover verder Hoofdstuk 2.2.1).

Tegelijkertijd werden alle oude documenten minutieus doorzocht op achterstallige inkomsten en de namen van debiteuren in nieuwe registers vastgelegd, met vermelding van de perceelnummers op de kaarten. Veel tijd moet zijn besteed aan het uitpluizen van vaak moeilijk te ontcijferen folianten in een vreemde taal. Prummer leerde daarmee ook veel over de juridische achtergrond van lenen, keurmeden en cijnzen en de bemoeienissen van de gerechtelijke instellingen. Hij schreef daarover in de loop der jaren voor de graaf enkele uitvoerige verhandelingen: op 16 juni 1757 over het juridisch karakter van grondbezit in Gronsveld in het algemeen ${ }^{1590}$ en de organisatie van het leenhof,, ${ }^{1591}$ op 19 oktober 1758 over de keurmeden, ${ }^{1592}$ op 25 augustus 1761 over de cijnzen ${ }^{1593}$ en op 29 juni 1768 over de heerlijke rechten en inkomsten gedurende de afgelopen 25 jaar. ${ }^{1594}$ (Zie meer daarover in Hoofdstuk 15.1).

Rapportages bleven niet beperkt tot alleen de grafelijke inkomsten en rechten. Prummer zocht ook de achtergronden uit van onderwerpen zoals de organisatie van de parochie, het muntrecht, de belastingen aan de kreits et cetera. Zijn aanpak volgde ongeveer steeds hetzelfde patroon, waarbij onderzoek in het eigen archief een grote rol speelde. Voor zover we kunnen nagaan, documenteerde Prummer zijn berichten meestal zorgvuldig. Die constatering is belangrijk, omdat hij zich soms baseert op intussen verloren archivalia. Maar dat neemt niet weg dat hij bij historische bespiegelingen toch wel eens flink de plank mis sloeg.

Het dagelijks beheer van het graafschap omvatte een veelheid van taken. Vooral economie en verhoging van de opbrengst van het graafschap hadden Prummers belangstelling. Een belangrijke doelstelling was de verbetering van de bosbouw en de fruitteelt. Na de kaalslag in het graafschap door troepen tijdens de Oostenrijkse Successieoorlog in 1747 en 1748 werd fors ingezet op herbebossing, evenals op de aanplant van fruitbomen zoals kersen en noten. Na 1770 vroeg ook de mogelijke restauratie of herbouw van het kasteel veel aandacht. Voorts moest de commissaris contacten onderhouden met andere groeperingen in het dorp, zoals de geërfden en de schepenen. Dat was niet altijd even gemakkelijk, zoals bleek bij conflicten over de betaling van belastingen aan de kreits of de heffing van aardappeltienden, een nieuwe belasting. Soms trad hij in ernstige strafzaken op als advocaat-fiscaal of drossaard bij de schepenbank. Daarnaast fungeerde hij als appelcommissaris voor het zeldzame geval dat tegen een vonnis van de schepenbank hoger beroep werd ingesteld.

Tot Prummers takenpakket behoorde ook het onderhouden van contacten buiten het graafschap. In de directe omgeving van Gronsveld bleven die vooral beperkt tot zakelijke

1590 TJ, inv. nr. M 13, fol. 73-104.

1591 TJ, inv. nr. M 13, fol. 109-146.

1592 TJ, inv. nr. M 12, fol. 1163-1184.

1593 TJ, inv. nr. M 73, fol. 565-597.

1594 TJ, inv. nr. M 73, fol. 509-550. 
aangelegenheden. Zo was er onenigheid met het graafschap Wittem over de verrekening van de bijdragen die Slenaken moest betalen in de belastingaanslagen van de kreits. Ook in Merkstein, waar de graaf tienden bezat en in Vaals waar Gronsveldse lenen lagen, werd de commissaris regelmatig gesignaleerd. Vergaderingen van de Nederrijns-Westfaalse Kreits en het Nederrijns-Westfaalse Gravencollege vroegen een langere reis. Soms ging Prummer daar zelf heen, maar meestal liet hij zich vertegenwoordigen door een advocaat. Veel aandacht werd besteed aan enkele langdurige processen in het buitenland. Zo liep in Brussel al meer dan honderd jaar de kwestie over de afbetaling van de in 1640 verkochte heerlijkheid Rimburg. Bij het Rijkskamergerecht groeide het procesdossier van exrentmeester Oligschläger gestaag.

Een deel van deze hier in het kort beschreven werkzaamheden komt hierna nog uitvoeriger aan de orde. Bij alles was het belangrijk voortdurend en nauwgezet de graaf in München op de hoogte te houden. Hoewel voorzien van volmachten, deed Prummer niet graag iets zonder diens voorkennis of goedkeuring achteraf. Tegelijk wenste de graaf van zijn kant ook goed geïnformeerd te zijn over alles wat zijn rechten of financiën betrof. (Dat laatste bleek overigens in de praktijk een zwak punt). Een en ander resulteerde in een regelmatige berichtgeving, gemiddeld tussen de vifftien en dertig brieven per jaar, vooral van Prummer naar München en in beperktere mate in omgekeerde richting. Meestal waren het lange epistels volgens een strak model, waar de verschillende onderwerpen puntsgewijs in werden behandeld. Het in de grafelijke kanselarij opgestelde antwoord volgde hetzelfde stramien. In het archief in München werden de ingekomen en uitgaande brieven doorlopend genummerd en per jaar afgelegd.

In zijn correspondentie en verslaglegging toont Prummer zich vaak breedsprakig. Maar dit werd in München niet bezwaarlijk gevonden, want daar bestond juist een chronisch gebrek aan kennis over het verre Gronsveld. Ieder detail kon belangrijk zijn. Prummer voorzag daarom de graaf met nieuws en roddels over het graafschap en de verdere omgeving, of het nu ging over politiek, zeden, bokkenrijders, kerkelijke verhoudingen of landbouw. Regelmatig stelde hij het nieuws interessanter voor dan het werkelijk was. Het is aardig te zien hoe Prummer zelf tegen die rol van informant aankeek. In $1776 \mathrm{kreeg}$ hij van de graaf een reprimande omdat hij een hele tijd niets van zich had laten horen. Zo was men in München geïnteresseerd in nieuws over de Amerikaanse onafhankelijkheidsstrijd. Prummer verontschuldigde zich dat hij een slechte 'nouvellist' was omdat hij niet in herbergen of cafés kwam of met mensen verkeerde bij wie je nieuws kon horen. Hij ging slechts van zijn huis in Maastricht naar de kerk, af en toe naar het postkantoor en soms naar Gronsveld en kon dus eigenlijk niets vertellen. Maar daarna hield hij wel bladzijden lang beschouwingen over de Engels-Amerikaanse oorlog en de politieke verhoudingen in Europa, om vervolgens te eindigen met de constatering dat hij meer had geschreven dan de bedoeling was. ${ }^{1595}$

De grafelijke nieuwsgierigheid resulteerde soms in curieuze opdrachten. Zo bezat graaf Maximilian Emanuel een bijzondere belangstelling voor pluimveerassen en was hij zeer

1595 TJ, inv. nr. M 57, fol. 588-629, Prummer aan A.J. von Toerring-Jettenbach 8 januari 1776. 
geïnteresseerd in fretten. Deze speelse beestjes werden ingezet bij de jacht op konijnen, maar waren ook zeer geliefd als huisdieren bij dames uit de betere kringen. Vandaar het grafelijk verzoek of Prummer enkele exemplaren van bijzondere hoenderrassen en een aantal fretten naar München kon sturen. Zeer waarschijnlijk waren ze bedoeld als kerstgeschenken voor de hofhouding van de Beierse keurvorst Max III Joseph, want Prummer spreekt in een brief uit december 1754 de hoop uit dat de diertjes goed werden ontvangen in de hoogste kringen waarvoor ze bestemd waren.

Met veel moeite lukte het fretten te kopen in Maaseik, terwijl voor hoenders contacten werden gelegd tot in het Utrechtse. Het transport naar München werd verzorgd door twee Gronsveldenaren, te weten Adam Simons en Johannes Bouchoms. Laatstgenoemde had met zijn reis een speciaal doel, want hij wilde bij de graaf strafvermindering bepleiten wegens zijn betrokkenheid bij doodslag (zie daarover Hoofdstuk 13.4). Beide mannen arriveerden met hun levende have in München vlak voor Kerstmis 1754. Ter plaatse huurden zij iemand om de manden te dragen, want het was onbestaanbaar wanneer de mensen dachten dat de graaf in Gronsveld zulke slechte onderdanen had, dat die helemaal naar Beieren korven moesten dragen. 'Es ist eine wunderliche nation', schamperde Prummer later over deze Gronsveldse afgezanten, 'Niderländische einbildtung'. Maar eerlijk was eerlijk: de mensen koesterden voor hun landsheer, hoewel ze die nooit hadden gezien, 'besondere liebe' en ze waren trouwhartig. Het was dus goed wanneer de mannen hun opwachting bij de graaf maakten. $\mathrm{Na}$ een verblijf van enkele weken in München arriveerde het tweetal eind januari 1755 weer in Gronsveld en vertelde daar maandenlang honderduit over alles wat ze hadden gezien en meegemaakt. Het op zich curieus verhaal illustreert hoe groot de afstand letterlijk, maar ook figuurlijk, was tussen de landsheer in het verre München en zijn onderdanen in Gronsveld.

Met een bijna slaafse plichtsbetrachting stond Prummer op de bres voor de belangen van de graaf. Een vergelijkbare houding verlangde Prummer ook van de Gronsveldenaren, die hij bijna letterlijk als 'zijn' onderdanen beschouwde. In brieven laat hij dat vaker doorschemeren. De glans van de graaf straalde ook op hem af. Geen grootser moment dan bijvoorbeeld in 1755, toen jonge meisjes an hem een laurierboom anboden bij gelegenheid van het huwelijk dat graaf Maximilian Emanuel na het overlijden van gravin Maria Josepha sloot met Auguste Isabella von Seinsheim. Een ton bier voor de jonkheid van Eckelrade kon er wel af. ${ }^{1596}$ Deze ijdelheid combineerde hij ook met een grote gevoeligheid voor alles wat maar in de verste verte leek op aantasting van zijn gezag.

In religieus opzicht ging Prummer door voor een trouwe katholiek, maar wel met een antiklerikale inslag. Tegen pastoor Kolb koesterde hij al bedenkingen omdat die voor zijn komst medio 1754 in Gronsveld eerst zijn (verplichte) opwachting was gaan maken bij de geestelijke overheid in Luik. Prummer zag daarin aanleiding bij de graaf eens goed uit te pakken tegen de Luikse kerkelijke hiërarchie. ${ }^{1597}$ Bijzondere aversie koesterde hij tegen kloosters en kapittels, die in zijn ogen vooral belust waren op vermeerdering van grondbezit. $\mathrm{Al}$ in zijn eerste grote, algemene rapport over het grondbezit in Gronsveld van

1596 TJ, inv. nr. M 68, fol. 443.

1597 TJ, inv. nr. M 14, fol. 91-97, Prummer aan M.E. von Toerring-Jettenbach 12 december 1754. 
16 juni 1757 beschrijft hij hun slinkse methoden om grond in eigendom te krijgen. Het probleem speelde voor hem ook in de praktijk, aangezien een groot deel van het Gronsveldse grondbezit toebehoorde aan Maastrichtse geestelijke instellingen en hij regelmatig met de vertegenwoordigers daarvan aan tafel zat bij de vergaderingen van geërfden. Anderzijds gedroeg Prummer zich ook wel weer welwillend tegenover religieuzen, mits ze zich maar onderwierpen aan het grafelijk gezag. Zo stond hij in 1777 sympathiek tegenover een (niet doorgegaan) plan van Engelse karmelieten om in het kasteel van Gronsveld een soort opleidingshuis van missionarissen te vestigen. ${ }^{1598}$ Maar per saldo toonde Prummer zich geen vriend van de clerus. Volgens zijn assistent en opvolger Wolfgang Zollner leefde de op zijn oude dag uitgebluste Prummer nog altijd flink op wanneer er werd afgegeven op de paus en de jezuïeten. ${ }^{1599}$

Prummer liep tegen de zestig, toen hij steeds meer werd geplaagd door ouderdomskwalen. Begin 1779 had hij steun nodig om te kunnen lopen en kwam hij weinig buitenshuis. Waarschijnlijk was hij door een paar lichte beroertes getroffen. Hij klaagde over verlammingsverschijnselen en hoofdpijn. Volgens zijn dokter leidde het zittend leven tot een chronisch gebrek aan lichaamsbeweging. Steeds vaker bleven de brieven naar München achterwege. Bij de graaf klaagde Prummer over het vele werk. Daarom kreeg hij in april 1778 Wolfgang Zollner als secretaris toegewezen, een jonge Beierse jurist, ambitieus, leergierig, intelligent, goedhartig en dienstbaar, maar tegelijk een wat dweperige romanticus, met een neiging te overdrijven.

Prummer ontving zijn nieuwe assistent aanvankelijk nogal koel; hij moest zijn plaats goed kennen. Achterdochtig was de oude man ook, want hij hield Zollner overal zoveel mogelijk buiten. Daar had hij ook redenen voor. Want Prummer werd er van verdacht betrokken te zijn geraakt bij financiële malversaties van zijn zwager Johannes Franciscus Lebens. Achteraf viel het allemaal erg mee, maar Prummer voelde er zich toch ongemakkelijk onder.

Het ontluisterend beeld dat Zollner schetst van Prummer in zijn nadagen, lijkt niet helemaal objectief, maar benadert waarschijnlijk toch de werkelijkheid. Vanaf voorjaar 1779 functioneerde het bestuur van Gronsveld niet meer. Het was volgens Zollner feitelijk 'burgerlijk dood' ('civiliter mortuus') en 'Altvatter' (Prummer) reageerde 'wie ein kleines Kind', dat alleen nog maar at, dronk en sliep. Met een consumptie van zes tot acht flessen wijn per dag kan, zelfs bij overdrijving, worden gesproken van een drankprobleem. Geen wonder dat de relatie tussen Prummer en zijn echtgenote onder spanning stond. In feite regeerden zij en haar broer, rentmeester Lebens, het graafschap. Wanneer Zollner uit het huis van 'Altvatter' documenten nodig had, kreeg hij nauwelijks medewerking: er was geen tijd, óf de vrouw óf de dochter lag ziek te bed, óf men had vreemd volk over de vloer. Dat bracht zelfs iemand met engelengeduld tot razernij. Op haar beurt wilde de nieuwsgierige mevrouw Prummer wel alles weten. Wanneer Zollner niets zei, toonde ze zich misnoegd.

1598 TJ, inv. nr. M 8, fol. 233-285, 327-329.

1599 RHCL, Graafschap Gronsveld, inv. nr. 52, Zollner aan A.J. von Toerring-Jettenbach 25 mei 1778. 
Vertelde hij wel iets, dan wist binnen een paar uur de hele stad het en vervolgens het hele graafschap. ${ }^{1600}$

Die vrouwenpraat was tot daar aan toe, maar Zollner stond voor het probleem dat hij zich als secretaris naar buiten toe onvoldoende kon legitimeren als plaatsvervanger. Dat was bijzonder lastig voor de vergadering van de Gronsveldse 'Landstände', met veel Maastrichtse notabelen, want de commissaris moest die bijeenkomst voorzitten en had daar een beslissende stem. Zollner durfde zich ook niet al te zeer bij de graaf op te dringen, bang als hij was om als baantjesjager te worden beschouwd.

Het was duidelijk dat Prummer met pensioen moest. Maar eerst zou hij een 'absolutorium' moeten krijgen, een kwijting wegens zijn financieel beheer en vaststelling van het bedrag dat hij nog aan de graaf schuldig was. Zollner onderzocht daartoe bij rentmeester Lebens de jaarrekeningen vanaf 1753 (!), wat wel enige, maar geen spectaculaire onregelmatigheden opleverde. Maar de uiteindelijke financiële verantwoordelijkheid lag bij Prummer en daar constateerde Zollner een schuld aan de graaf van maar liefst 3162 gulden Rijnlands. Voor dat bedrag moest een regeling worden getroffen. Zollner kreeg medelijden met Prummer, want die zou nu dagelijks daarover van zijn vrouw bitsige opmerkingen ('beissende reeden') te horen krijgen. Hij verzuchtte: 'Die hele familie is zo op geld gebrand, dat je nog eerder een halve liter botermelk uit een vlo kunt persen dan één cent uit deze mensen'.1601 Voor Zollner vormde dit alles aanleiding met kracht te bepleiten om met onmiddellijke ingang de kas van de 'Commission' aan hem toe te vertrouwen. In de daaropvolgende onderhandelingen vroeg Prummer, of beter gezegd vroegen zijn vrouw en dochter, mededogen vanwege de langjarige dienst. De graaf was ook bereid iets toe te geven, maar uiteindelijk duurde het tot een antal jaren na het overlijden van Prummer voordat de kwestie definitief kon worden afgehandeld.

Ondertussen werd gewerkt aan het pensioen van Prummer. Aanvankelijk wilde de graaf 750 gulden per jaar uitkeren, maar Zollner stelde 'uit mededogen en naastenliefde' duizend gulden voor. De commissaris zou wel niet lang meer te leven hebben en had ten slotte meer dan dertig jaar met grote toewijding de familie gediend, waarvan 27 jaar in den vreemde. Een laag pensioen deed ook het aanzien van de graaf geen goed, want Prummers vrouw en dochter zouden daarover luidkeels in de stad misbaar maken. ${ }^{1602}$

Op 20 oktober 1779 werd Prummer met achthonderd gulden op pensioen gesteld, met gelijktijdige benoeming van Zollner tot zijn opvolger. Het besluit was echter alleen in beperkte kring bekend, wat Zollner naderhand nog in de problemen bracht (zie hierna Hoofdstuk 12.7). Daarom werd op 9 februari 1780 het 'emeritaat' van Prummer nog een keer in een meer plechtige vorm bekend gemaakt. De oude commissaris overleed op 13 maart 1782 in Maastricht. Zijn weduwe overleefde hem meer dan 25 jaar en stierf in Maastricht op 20 april 1809.

1600 TJ, inv. nr. M 58, fol. 506-514, Zollner aan niet nader genoemde relatie in de grafelijke kanselarij 12 juli 1779.

1601 TJ, inv. nr. M 58, fol. 489-496, Zollner aan A.J. von Toerring-Jettenbach 5 juli 1779: 'Die ganze Familie ist üeberhaupt auf das Geld so verpirkt dass ich beynahe noch eher aus einer Floh eine halbe Maass Buttermilch als aus ihnen auch nur einen Kreuzer heraus pressen könne'.

1602 TJ, inv. nr. M 58, fol. 73-103, Zollner aan A.J. von Toerring-Jettenbach 31 augustus 1779. 


\subsection{Drossaard en 'fiscus' (openbare aanklager) als zelfstandige functies}

Na 1732 verdwijnt drossaard Johannes Godefridus Lebens meer naar de achtergrond. Hij was uiteindelijk als een soort overwinnaar - voor zover men in dat soort termen kan spreken - uit de strijd gekomen, maar tegelijkertijd drong het inzicht door dat zijn vrijheid van handelen inperking behoefde. Op voorstel van Gürtler werd daarom op 15 augustus 1737 een instructie vastgesteld. ${ }^{1603}$ Voor de functie als zodanig gold een verbod op het zonder toestemming tegelijk aannemen van een andere dienstbetrekking. In het bijzonder was het verboden als advocaat of procureur op te treden in processen gericht tegen de gravin d'Arberg Valengin of haar voogd, graaf Toerring-Jettenbach. Hoewel een vaste bezoldiging gewenst was, lieten de landsheerlijke en gemeentelijke financiën dat niet toe. Daarom kreeg de drossaard het eerst vacant zijnde ambt toegekend, met uitzondering van het 'actuariat', het ambt van secretaris. Dit laatste hield duidelijk verband met de eerdere uitspraak van het Rijkskamergerecht waarbij deze combinatie was verboden. Andere inkomsten van de drossaard bestonden uit de helft van de gerechtelijke boetes en twee kavels kaphout in het bos, maar dan zonder de daarin aanwezige eiken en 'kersbaumen'. Ook reiskosten werden uit de grafelijke kas betaald. Bij elkaar geen vetpot en, zo bezien, was het niet vreemd dat de drossaard zijn functie zonder opgaaf van redenen ieder half jaar mocht opzeggen.

De drossaard moest de jurisdictie van de landsheer handhaven, op de grenzen van het graafschap letten, maandelijks berichten over de belangrijkste gebeurtenissen in het graafschap, de misdaad bestrijden en de openbare orde, in het bijzonder ten aanzien van herbergen, handhaven. Ook het jachtrecht diende strikt te worden nageleefd. De drossaard mocht niet toelaten dat zonder grafelijke toestemming een nieuw huis of nieuwe herberg werd gebouwd of dat vreemdelingen en slechte lieden van buiten zich in het graafschap vestigden.

Voor zijn taken op juridisch gebied gold voor de drossaard de Rechtsordnung van 1671 als leidraad. Hij moest bij het gerecht meehelpen met het verstrekken van informatie aan advocaten en de hem toevertrouwde geschriften goed bewaren, zonder daarvoor iets te mogen berekenen.

De drossaard had in het bijzonder te letten op landsheerlijke inkomsten en rechten. Hij zorgde dat gerechtelijke boetes, de inkomsten uit het heergewaad bij lenen en de keur bij keurmedige goederen werden afgedragen. Hij handhaafde het accijnsrecht en het landsheerlijk recht op confiscatie van onroerend goed dat bij geestelijke instellingen in de dode hand' werd gebracht. Hij hield ook toezicht op het beheer van de rentmeester en controleerde diens rekeningen.

Ten slotte had de drossaard ook bemoeienis met gemeentelijke aangelegenheden. Hij moest er op toezien dat inwoners hun ganzen, geiten, schapen en runderen niet op de verkeerde plaats lieten grazen. Voorts hield hij toezicht op de jaarlijkse rekening en verantwoording van de personele en reële schatting, echter zonder de bevoegdheid uit die gelden betalingen te doen.

1603 TJ, inv. nr. M 76, fol. 491-500, Instructie voor drossaard Johannes Godefridus Lebens 15 augustus 1737. 
In 1755 gaf Prummer aan de graaf een algemene beschrijving van de functie van drossaard, die grotendeels overeenkomt met deze instructie. ${ }^{1604} \mathrm{Hij}$ was voorzitter van de schepenbank ${ }^{1605}$, met een adviserende stem. Zijn salaris betrok hij grotendeels uit de gerechtskosten (2/11 deel van de opbrengst), in die tijd ongeveer zeventig gulden Rijnlands per jaar. Daarvan moest dan nog een bijdrage aan huur en verwarming van het gerechtslokaal worden afgetrokken. Omdat de drossaard niet als ambtshalve klager optrad, moest naast hem iemand het ambt van openbare aanklager of fiscaal ('officium fisci') voor de vervolging van strafbare feiten op zich nemen. In deze tijd werden de ambten van drossaard en fiscus echter wel in één persoon verenigd, waardoor de drossaard de rol van aanklager in een strafzaak met die van voorzitter van het gerecht combineerde. Als fiscus had hij ook recht op een deel van opgelegde boetes, wat met gemiddeld zeventien gulden Rijnlands per jaar niet echt lucratief was. Maar de combinatie van de functies van drossaard en fiscus bood de mogelijkheid de loop van een proces te beïnvloeden en de kosten op te drijven. Daar bestond ook kritiek op, zoals blijkt uit verwijten die aan het gerecht van Gronsveld werden gemaakt in de langdurige processen Salden en Oligschläger, zaken waar Prummer bij zijn komst in Gronsveld mee werd geconfronteerd.

Drossaard Johannes Godefridus Lebens overleed op 24 juli 1741.1606 Graaf Ignaz Felix von Toerring-Jettenbach gaf toestemming de daarmee opengevallen vacature ad interim door één van diens zonen te laten bezetten. Voorwaarde was wel dat die dan werkte onder toezicht van zijn oom, de in Eijsden wonende advocaat Hendrik Lebens, een broer van Johannes Godefridus. ${ }^{1607}$ Er dook evenwel concurrentie op toen rentmeester Oligschläger eigenmachtig zijn zwager, de Maastrichtse advocaat Balthasar Frederik Huberti, als drossaard aanstelde en een zekere notaris Caris uit Maastricht als fiscaal voor strafzaken. Dat leverde enkele jaren van onzekerheid op. Om daar een einde aan te maken, benoemde de graaf op 24 augustus 1745 Hendrik Lebens, de broer van Joannes Godefridus, eerst voorlopig ('provisorio modo') tot drossaard. Op 10 september 1746 werd dit omgezet in een definitieve aanstelling als drossaard en 'fiscus' (procureur-fiscaal). Als richtsnoer voor zijn werk diende de instructie voor zijn broer uit 1737.

Prummer typeerde hem in 1755 als 'een geleerd man, maar een aartsfantast'. Lebens beweerde dat hij op grond van zijn kennis de meest prestigieuze ambten in Luik of Brabant had kunnen krijgen, wanneer hij maar had gewild. ${ }^{1608}$ Prummer dichtte de drossaard geen boosaardigheid of eigenbelang toe, maar hij wist zaken eindeloos te rekken, zonder iets tot een einde te brengen. Onder het motto van juridische precisie was hij met gemak in staat bij de schepenbank een procedure van nog geen kwartier over vier dagen

\footnotetext{
${ }^{1604}$ TJ, inv. nr. M 13, fol. 13-24, Prummer aan M.E. von Toerring-Jettenbach 9 november 1755.

1605 'praeses und hat das directorium von dem scheffenstuehl oder gerichtshof.

1606 De grafsteen van hem, zijn echtgenote en zijn schoonouders bevindt zich in de kerk van Gronsveld, zie Belonje, 'Genealogische en heraldische gedenkwaardigheden', 83.

1607 Van Heyst, 'Proeve ener genealogie', 136.

1608 'Der drossard ist zwar ein gelehrter mann, aber ein ertzt phantast. Wan er nur gewolt, hätte er schon in seinen jungen jahren die ansehentlichste charches in Brabant und Lütticher Land aus freyen antrag in ansehung seiner besitzenten wissenschafft erlangen können'.
} 
uit te smeren. Of je hem nu een goede of een rotte appel gaf, in beide gevallen werd je met een vloed aan woorden even uitgebreid bedankt. De man zou zijn gewicht in goud waard zijn, wanneer zijn woorden en beloftes gelijke tred hielden met zijn daden. Intussen maakte de drossaard wel grote indruk op de schepenen die hem klakkeloos volgden. ${ }^{1609}$ Zeker in gevallen waarin de drossaard ook als fiscus optrad en de belangen van de landsheer vertegenwoordigde, durfden zij niet te opponeren.

$\mathrm{Al}$ direct na zijn aantreden kreeg drossaard Lebens in een proces een rol die hem op het lijf geschreven leek, de 'cause célêbre' over de nalatenschap van in 1745 overleden Maastrichtse kanunnik Maximiliaan Henricus Salden. Deze had bij testament zijn zeer omvangrijke vermogen, waaronder ook landerijen in Gronsveld, bestemd voor de oprichting van een Rooms-Katholiek Armenhuis in Maastricht. Familieleden van Salden vochten voor diverse schepenbanken in Maastricht en omgeving, waaronder ook Gronsveld, deze stichting aan. Daar kreeg de kwestie een andere wending, want men kon de overgang van landerijen naar een Rooms-Katholiek Armenhuis ook zien als verwerving van onroerend goed 'in de dode hand' door een kerkelijk instituut. Volgens de Gronsveldse Rechtsordnung van 1671 was dit soort testamentaire bepalingen niet alleen nietig, er stond ook de straf op van verbeurdverklaring van de vermaakte goederen ten gunste van de landsheer. Lebens kreeg nu als fiscus de taak om in het proces tussen de Erfgenamen Salden te interveniëren en de landerijen op te eisen voor de graaf. Dat baarde nogal opzien vanwege het spanningsveld tussen enerzijds het goede doel en anderzijds het landsheerlijk belang. Voor Lebens vormde de Erfenis Salden, waarover vanaf 1746 eerst in Gronsveld en daarna tot 1753 voor het Rijkskamergerecht in Wetzlar werd geprocedeerd een juridisch interessante kluif, waar hij veel tijd aan besteedde.

Bijna een levenswerk voor de drossaard en fiscus werd het in de herfst van 1746 door hem namens de graaf aangespannen proces tegen rentmeester Oligschläger (waarover hierna meer). Misschien was het karakter van Lebens in deze zaak meer een voordeel dan een nadeel, want Oligschläger en zijn advocaat en zwager Huberti waren tegenstanders die ook stromen inkt nodig hadden om hun juridische argumentaties tot de in de finesses uit te schrijven. In dat opzicht waren partijen aan elkaar gewaagd.

Henricus Lebens overleed te Breust op 13 maart 1772, 89 jaar oud. Het is niet duidelijk hoe lang hij precies in dienst was, maar in 1769 werkte hij nog. ${ }^{1610}$ Op 7 april 1772 richtte zijn neef Willem Henricus Lebens, ontvanger van het graafschap Rekem, zich tot graaf Toerring-Jettenbach met het verzoek zijn zoon Johannes Godefridus in de vacature te benoemen. De familie Lebens had immers al honderd jaar het grafelijk huis gediend, Johannes Godefridus bekwaamde zich in de juridische praktijk en hij legde zich toe op kennis van het Frans. ${ }^{1611}$ De graaf besliste echter op 21 augustus 1772 dat de jongen te onervaren was om nu al een dergelijke functie te kunnen uitoefenen. ${ }^{1612}$

1609 'in allen sachen, wie ihnen der drossard vorpfeiffet, tanzen und wie sye diser leithet, fahren muessen, ohne das sye gegen ihne nur das mündeste zu sagen'.

${ }^{1610}$ RHCL, Graafschap Gronsveld, inv. nr. 318, proces uit 1769.

1611 TJ, inv. nr. M 55, fol. 425, G.H. Lebens aan M.E. von Toerring-Jettenbach 7 april 1772.

1612 TJ, inv. nr. M 55, fol. 427, M.E. von Toerring-Jettenbach aan G.H. Lebens 21 augustus 1772. 
In de daarop volgende jaren nam Prummer zelf de functies van drossaard en fiscus waar. Hij maakte zich daarmee niet geliefd bij de bevolking, want volgens Zollner werd hem verweten dat hij deze taken op zich had genomen uit geldzucht. Er solliciteerden vaak genoeg bekwame advocaten uit Maastricht, maar die waren afgewezen, ook al omdat Prummer bang was dat een nieuwe drossaard misschien iets ondernam tegen bepaalde familievetes in het graafschap. Maar met het klimmen der jaren werd het ambt voor de aan diverse kwalen lijdende commissaris steeds bezwaarlijker en moest de aanstelling van 'secretaris' Zollner in 1778 uitkomst bieden. Het was immers de bedoeling dat die na een korte inwerkperiode zou opvolgen als drossaard en fiscus. Hij werd vervolgens vrijwel onmiddellijk na zijn aankomst door Prummer ingezet. Maar Zollner gaf de graaf te bedenken dat straks de combinatie van een functie als commissaris met het werk van drossaard en fiscus onverstandig was. ${ }^{1613}$ Als commissaris stond men boven de schepenen, als drossaard en fiscus was men van hen afhankeliik. De discussie die Zollner en de graaf verder over dit probleem voerden, komt hierna nog aan de orde, maar had als uitkomst dat de combinatie gehandhaafd bleef.

Medio 1791 pleitte Zollner opnieuw bij de graaf voor een ontkoppeling van de functies:

Ik kan u verzekeren dat het menselijkerwijs voor mij onmogelijk is de mij toevertrouwde taken te vervullen. De functie van drossaard neemt veel tijd in beslag. Als drossaard ben ik in de eerste plaats rechter en als commissaris ben ik in tweede instantie ook rechter, wat niet met elkaar te verenigen is. ${ }^{1614}$

Zollner doelde daarmee op het feit dat hij incidenteel ook als appelrechter van de schepenbank Gronsveld moest optreden. In een op dat moment nog aanhangige procedure met het kapittel van Onze-Lieve-Vrouw over het patronaatsrecht van de kerk van Heugem had het Rijkskamergerecht daarop al kritiek geuit. En had niet al zestig jaar eerder hetzelfde Rijkskamergerecht bevolen de functies van drossaard en secretaris te scheiden? Dit soort vermenging van belangen vond Zollner ongewenst en vormde voor hem reden in zijn plaats de Gronsveldse schepen J.W. Denis uit 's-Gravenvoeren als drossaard voor te dragen.

Dit verzoek willigde de graaf in en op 12 en 13 januari 1792 presenteerde Zollner hem aan de 'gemeente' in Gronsveld en Heugem. ${ }^{1615}$ In een uitvoerige brief dankte Denis voor zijn benoeming en beloofde goed voor het algemeen belang te zullen samenwerken met Zollner. ${ }^{1616}$ Op 1 juni 1794 moest Zollner echter het overlijden op 31 mei van de drossaard melden. ${ }^{1617}$ De man liet een weduwe en twaalf 'onverzorgde' kinderen na. ${ }^{1618}$ Ondanks het feit dat de Franse revolutionairen - bij wijze van spreken - al voor de deur stonden, ontbrak het niet aan sollicitanten. Ook de lage verdiensten weerhielden belangstellenden niet. Zollner beschreef het nog maar eens voor de graaf: zes Franse

1613 TJ, inv. nr. M 58, fol. 516-524, Zollner aan A.J. von Toerring-Jettenbach 15 juli 1779.

1614 TJ, inv. nr. M 62, fol. 492-497, Zollner aan A.J. von Toerring-Jettenbach 31 augustus 1791.

1615 TJ, inv. nr. M 62. fol. 420-438, Zollner aan A.J. von Toerring-Jettenbach 24 januari 1792.

1616 TJ, inv. nr. M 62. fol. 408-410, J.W. Denis aan A.J. von Toerring-Jettenbach 27 januari 1792.

1617 TJ, inv. nr. M 62, fol. 151-153 Zollner aan A.J. von Toerring-Jettenbach 1 juni 1794.

1618 TJ, inv. nr. M 62, fol. 137-143 Zollner aan A.J. von Toerring-Jettenbach 3 juni 1794. 
kronen als vaste bezoldiging, twee karren brandhout ter waarde van acht Franse kronen, en verder onzekere inkomsten uit gerechtskosten en boeten bij veroordelingen. Dat laatste was onbeduidend, want strafzaken werden meestal buiten het gerecht om afgedaan. Kortom, indien een drossaard bekwaam, rechtschapen en onbaatzuchtig was, dan bracht het ambt hem eer en kon hij ook op eerbetoon rekenen. Maar wanneer een drossaard op geld belust was en er viel iets te bekritiseren, dan kon hij ook geen goed meer doen. ${ }^{1619}$

Twee Gronsveldse schepenen ambieerden de functie: Jean Thomas Sarolea en J.G.J. Paulissen. De eerste was al dertien jaar schepen in Gronsveld en twaalf jaar meier van Warsage. ${ }^{1620}$ Paulissen, zoon van de schout van Berneau, was vijf jaar schepen van Gronsveld en had juridische ervaring opgedaan in Maastricht. ${ }^{1621}$ Voor Paulissen ontving Zollner een aanbeveling van baron Van Wassenaar, hoogproost van het kapittel van SintServaas in Maastricht. ${ }^{1622}$ Het schrijven van deze 'würdige und beynahe heiligen' prelaat maakte enige indruk. ${ }^{1623}$ Zollner gaf de voorkeur aan de jonge vrijgezel Paulissen, inmiddels 'adjungierter schultheiss' van 's-Gravenvoeren en keizerlijk notaris, ${ }^{1624}$ maar liet de beslissing over aan de graaf. Wel stelde hij voor tussen beide kandidaten te loten, wanneer hij voor 26 juni 1794, de laatste dag voor de vakantie van het gerecht, geen uitsluitsel had.

De inval van Franse troepen gaf echter andere zorgen. Op 19 september 1794 vluchtte Zollner, terwijl nog steeds niet in de benoeming van een drosaard was voorzien. Op 23 november 1794 kwamen burgemeesters, schepenen, geërfden en hele 'gemeente' van Gronsveld bij elkaar om te overleggen over leveranties aan het Franse leger. Drie dagen later, op 26 november 1794, besloten burgemeesters en schepenen dat in deze situatie de aanstelling van een drossaard en fiscus urgent was. Bij afwezigheid van de commissaris werd daarom schepen Sarolea 'provisioneelijck' in die functie met alle daarbij behorende rechten, benoemd en beëdigd. ${ }^{1625}$

Zollner moet pas in de loop van 1795 op de hoogte zijn gekomen van deze beslissing. Op 12 november ontving Sarolea een brief van hem, waarop de drossaard dezelfde dag antwoordde dat hij daaruit afleidde

dat de keuze van een drossaard, genomen tijdens uw afwezigheid, bij u in de smaak is gevallen, zelfs uw goedkeuring kan wegdragen. Ik hoop dat u mij de eer wilt aandoen uw vriendschap, uw welwillendheid en uw machtige voorspraak voort te zetten en mij an te bevelen in de gunst van onze meester wiens rechten ik niet door het slijk wens te halen, hoewel dit in andere gemeenten wel gebeurd is. Daar heeft men gemeenteraden opgericht, iets dat wij hier nog niet kennen.

In Gronsveld functioneerde nog voor elke 'municipalité' een 'cour avec les bourgmesters de notre comte'. Sarolea lijkt hier te duiden op de periodiek in het graafschap gehouden

${ }^{1619}$ TJ, inv. nr. M 62, fol. 137-143 Zollner aan A.J. von Toerring-Jettenbach 3 juni 1794.

1620 TJ, inv. nr. M 62, fol. 123-127, Sollicitatiebrief van J. Th. Sarolea, 1 juni 1794.

1621 TJ, inv. nr. M 62, fol. 131-133, Sollicitatiebrief van J.G.J. Paulissen z.d.

${ }_{1622}$ TJ, inv. nr. M 62, fol. 122, baron van Wassenaar aan Zollner 2 juni 1794.

1623 TJ, inv. nr. M 62, fol. 116-119, Zollner aan A.J. von Toerring-Jettenbach 6 juni 1794.

1624 TJ, inv. nr. M 62, fol. 137-143, Zollner aan A.J. von Toerring-Jettenbach 3 juni 1794.

1625 RHCL, Graafschap Gronsveld, inv. nr. 257, vergadering 26 november 1794. 
voogdgedingen. De drossaard realiseerde zich echter dat alles goed ging zolang het onwetende volk het woord 'liberté' nog niet kende. Maar voorlopig had men nog middelen gevonden de mensen in bedwang te houden. ${ }^{1626}$ Sarolea kon op de oude voet doorgaan tot 22 februari 1796, de laatste zitting van de schepenbank waarbij hij als drossaard aanwezig was.

\subsection{Johan Matthias Oligschläger, rentmeester}

Johann Matthias Oligschläger was in 1728 door graaf d'Arberg in Gronsveld benoemd als rentmeester en 'actuarius' (secretaris) van de schepenbank, nadat het Rijkskamergerecht op 28 april 1728 in het proces Gathoye de scheiding had bevolen tussen de functies van drossaard en secretaris. Toen vanaf 1731 de voogdij over de minderjarige gravin d'Arberg inzet werd van strijd tussen baron Belderbusch en graaf Ignaz Felix von ToerringJettenbach, koos de rentmeester de partij van laatstgenoemde, de uiteindelijke winnaar. Die houding leverde hem veel krediet op bij de nieuwe machthebber. Maar ook al snel rezen vragen over zijn financiële verantwoording. Op 19 januari 1734 schreef commissaris d'Oliva aan graaf Toerring dat hij met enige moeite een jaarrekening van de rentmeester had gekregen, echter met een tekort van drie- tot vierhonderd rijksdaalders. Vergoelijkend stelde Oliva matiging ('Moderation') voor, omdat die achterstand in hoofdzaak was veroorzaakt door de chaos die Belderbusch en Gathoye hadden achtergelaten. In de toekomst zouden enkele malen per jaar overzichten van de kas moeten worden ingediend, met 1 maart als termijn voor de jaarrekening. Ook diende te worden voorkomen dat Oligschläger nog op eigen gezag herstelwerkzaamheden aan gebouwen liet uitvoeren. ${ }^{1627}$ Met deze voorschriften trachtte Oliva het financieel beheer weer in het rechte spoor te brengen. Maar de uitgebreide instructie voor de rentmeester die Gürtler in 1737 opstelde, geeft aan dat nog veel te verbeteren viel. De door Oligschläger opgestelde rekeningen waren ofwel ondoorzichtig of onvoldoende gecontroleerd. In het later wegens fraude aangespannen proces werden juist de betrouwbaarheid van die rekeningen uit de jaren dertig onderwerp van discussie. Toen kwam aan licht dat posten dubbel waren geboekt om het saldo kloppend te maken.

De uitvoerige instructie voor de rentmeester dateert van 20 augustus 1737. Eigenlijk is die toegesneden op de functies van zowel rentmeester als 'actuarius' (secretaris) van de schepenbank. Sommige bepalingen lijken zo algemeen dat men zich afvraagt waarom ze zijn opgenomen. Maar misschien hadden de ervaringen uit het verleden geleerd dat gewenst gedrag toch niet zo vanzelfsprekend was.

De tekst van de instructie is gericht op een antal onderwerpen. In algemene zin was de rentmeester verplicht tot discretie en geheimhouding. Hij ontving een jaarsalaris van vierhonderd gulden Maastrichts en beschikte over een woning met stallingen in het kasteel. Van dat woongedeelte moest hij de onderhoudskosten betalen. Zijn eigen opslagruimte voor graan diende strikt te worden gescheiden van die van de gravin. Voorts

1626 TJ, inv. nr. M 62, fol. 77-83, Drossaard Sarolea aan Zollner in München 21 november 1795.

${ }_{1627}$ TJ, inv. nr. M 32, fol. 42-44, brief nr. 78, d'Oliva aan I.F. von Toerring-Jettenbach 19 januari 1734. 
moest hij ruimte met slaapgelegenheid onderhouden voor eventueel bezoek van vertegenwoordigers van de landsheer. Alleen in uiterste noodzaak waren dienstreizen op kosten van de gravin toegestaan. De rentmeester stond met al zijn roerende en onroerende goederen borg voor schade, ook brandschade, die door toedoen van hem of zijn personeel mocht ontstaan.

De rentmeester was verantwoordelijk voor de financiële kant van de grafelijke rechten en inkomsten. Daarom werden van hem met enige regelmaat voorstellen verwacht over de manier waarop die inkomsten konden worden verbeterd. Hij moest zorgen dat de inwoners hun schulden aan de gravin betaalden en bij het invorderen van gelden bood de drossaard eventueel de helpende hand. Het was niet toegestaan vorderingen tussen onderdanen en landsvrouwe met elkaar te compenseren. Alle inkomsten en uitgaven dienden correct in de boekhouding te worden verwerkt, met voor de ontvangsten duidelijke en voor één uitleg vatbare kwitanties. Bij de betaling van bodeloon en briefporto moest in de rekening de bestemming van de zending worden aangetekend. Ieder half jaar stuurde de rentmeester een door hem en de drossaard getekend kort overzicht van inkomsten en uitgaven naar de graaf. De jaarrekening werd eind februari opgesteld, daarna ter lezing en controle aan de drossaard gegeven en ten slotte naar München gezonden.

De instructie bevat ook bepalingen ten aanzien van specifieke taakonderdelen. Verpachtingen mochten uitsluitend plaatsvinden in het openbaar. Beschikkingen ten aanzien van verpachtingen moesten altijd geschieden met medeweten van drossaard en schepenen. Als ambtenaar was het de rentmeester niet toegestaan persoonlijk belanghebbende bij de pacht te zijn, omdat de ervaring leerde dat in die situatie andere gegadigden zich terughoudend opstelden. Wanneer duidelijk werd dat rentmeester en pachters een kongsi vormden, moest de verpachting worden stopgezet. Het was ten strengste verboden te verpachten aan personen die buiten het graafschap woonden en geen onroerend goed binnen het graafschap bezaten, tenzij zij borgen stelden. Hetzelfde gold voor mensen die van steun en aalmoezen leefden. Kwijtslag van pacht bij misoogst kon de rentmeester alleen geven na overleg met twee onpartijdige schepenen. Wie twee jaar zijn pacht niet betaalde, verloor zijn pachtgoed, maar de rentmeester bleef verplicht alles te doen om de achterstallen alsnog in te vorderen.

De rentmeester hield toezicht op de verkoop van hout uit de grafelijke bossen. De zogenoemde 'holz lista' waarin een landmeter de kavels hakhout beschreef, werd door de landmeter, drossaard en rentmeester getekend en de landmeter kreeg daarvan een kopie. Bij het uitzetten van de percelen zag de rentmeester er op toe dat de assisterende boswachters de zaak niet in hun eigen voordeel manipuleerden. Eiken dienden te worden gespaard. De hoeveelheden hout werden precies genoteerd, ook het aandeel hout waarop de drossaard en boswachters vanwege hun functie recht hadden. In het verleden hadden de boswachters bij het uitzetten van de kavels stevig gedronken op kosten van de grafelijke kas, maar dat soort verteringen werd nu verboden. Wanneer de bij de houtkap betrokken functionarissen hun verantwoordelijkheden niet nakwamen, moest de rentmeester dat melden.

De rentmeester had een algemene verantwoordelijkheid voor houtopstanden in het graafschap en voor de grafelijke fruitbomen in het bijzonder. Fruitbomen moesten op tijd 
worden gesnoeid en dode bomen vervangen. Vanwege de schade die loslopende geiten aanrichtten, was het toegestaan deze dieren zonder pardon dood te schieten, wanneer ze zich buiten het erf bevonden. Ook moest de rentmeester letten op het weiden van schapen in het bos of het ontstaan van illegale paden over landerijen.

Het toezicht op de betaling van de bieraccijns werd aangescherpt. De accijnsmeesters moesten eens per half jaar een lijst overleggen van de hoeveelheden gebrouwen bier. Er werd op de bieraccijns ook een premie gezet. Van iedere geïnde gulden boven de 150 gulden ontvingen de rentmeester en de twee accijnsmeesters per persoon één stuiver. Om de positie van de eigen brouwers te versterken kregen drossaard en schepenen opdracht er op toe te zien dat in tapperijen alleen bier uit het eigen graafschap werd geschonken. Voor ingevoerd bier moest accijns worden betaald. Op overtreding van die bepalingen stonden flinke boetes, te verdelen onder drossaard, schepenen en aanbrenger.

De rentmeester was ook als secretaris ('actuarius') en schepen bij het gerecht werkzaam. In die hoedanigheid diende hij de bepalingen van de Rechtsordnung van 1671 na te leven. Tot zijn verantwoordelijkheid behoorde de goede bewaring van het archief en de gerechtsprotocollen. Deze combinatie van de functies van 'actuarius' en rentmeester diende ook een praktisch doel. De rentmeester moest kennis hebben van alle overdrachten van onroerend goed om de daarbij behorende belastingen in de vorm van werfschelling, keurmede of heergewaad te kunnen innen. Daarom moest het gerecht van die overdrachten een 'contra-rol' houden, waarin de transacties summier werden aangetekend.

Behalve aan inkomsten besteedde de instructie ook andacht aan (bezuiniging op) uitgaven. Er mocht op uitstaande schulden niets worden betaald aan rente of aflossing zonder toestemming van de graaf. Opdrachten voor herstelwerkzaamheden aan gebouwen die het dagelijks onderhoud te boven gingen, werden slechts gegeven met toestemming van de graaf en na raadpleging van de drossaard en deskundige schepenen.

Klein onderhoud van de windmolen kwam ten laste van de molenaar, groot onderhoud werd slechts betaald na voorgaande beoordeling van de reparatie door de rentmeester. Ook aan drankgebruik op kosten van de landsheer werd paal en perk gesteld. Voor de zitdagen waarop de cijnzen werden geïnd, mocht de rentmeester geen uitgaven voor verteringen opvoeren. De kosten voor het 'karweien', zoals het planten van bomen, het binnenhalen van hooi en het omzetten van graan in de schuur, mochten alleen worden betaald conform de gangbare regels in andere rijksheerlijkheden. Van de uitgifte van bier bij dit soort gelegenheden werd nauwkeurig aantekening gehouden. Uitdrukkelijk verboden bleven betalingen uit de landsheerlijke kas ten behoeve van het 'reëel'. Met dit laatste werden bedoeld alle kosten die samenhingen met de inning en afdracht van grondbelastingen, die in beginsel ten laste van de 'geërfden' kwamen. Dat was al decennia lang een uitermate gevoelig punt in de relatie met de veelal Maastrichtse grondeigenaren (zie daarover Hoofdstuk 16.2).

Ondanks die instructie gedroeg Oligschläger zich steeds meer als heer en meester in het graafschap en ging hij ongestoord zijn gang. Opzienbarend was de aankoop in 1740 van de hoeve Hemersbach te Eckelrade van de Erven de Floen-de Montbrison. Het ging om 
verschillende transacties met onderlinge verrekening van uitstaande schulden, alles bij elkaar voor een waarde van meer dan achttienduizend gulden. Oligschläger hield er daarmee een groot boerenbedrijf met personeel op na. Waarvan bekostigde hij die manier van leven? Bij zijn aankomst in Gronsveld beschikte hij slechts over bescheiden middelen. Gürtlers waarschuwing in 1743 dat de oude chaos in Gronsveld leek terug te keren, werd zeker gevoed door de steeds meer in opspraak rakende rentmeester.

De problemen begonnen al iets eerder, in 1742.1628 De verkoop van de 'Montbrisonse erfenis', zoals het totale goed Hemersbach werd genoemd, zorgde voor tweespalt binnen de familie de Floen. Oligschläger had gebruik, of beter gezegd, misbruik gemaakt van de financiële nood en daarbij werd ook nog eens gesjoemeld met de koopsom. Op papier had hij meer betaald dan hij in werkelijkheid had gegeven. Door die fictieve hogere koopsom werd het voor leden van de familie de Floen die het niet eens waren met de verkoop moeilijk gebruik te maken van het zogenoemde naastings- of beschudrecht. Met dat voorkeursrecht kon de vervreemding van onroerend goed buiten de familie gedurende een wettelijk bepaalde termijn ongedaan worden gemaakt wanneer een bloedverwant hetzelfde bedrag 'met open buidel' bood. De 'beschudder' moest in beginsel die officiële prijs in de akte betalen of bewijzen dat met het bedrag was gefraudeerd.

Met de onenigheid binnen de familie had Oligschläger terecht de dreiging van het beschudrecht voorvoeld. Eleonora Maria Helena de Floen geboren de Montbrison en haar dochters Anna Maria en Helena de Floen, die op Hemersbach woonden, vervoegden zich op 31 juli 1742 op het kasteel van Gronsveld en boden Oligschläger daar met contant geld 'in einen offenen beuthel' de koopsom aan. De rentmeester bestreed het naastingsrecht en weigerde het geld te aanvaarden. De volgende dag al stonden partijen voor het gerecht, dat voor dit geval, omdat het zowel leen- als cijnsgoed betrof, was samengesteld uit een combinatie van het leenhof en de schepenbank van Gronsveld. De kern van het proces draaide in hoofdzaak om de vraag of de actie tot naasting was ingesteld binnen de wettelijke termijn van een jaar en één dag. Het officiële verslag van die zitting is opgesteld in zakelijke bewoordingen, maar in werkelijkheid schijnt het er nogal heftig aan toe te zijn gegaan.

$\mathrm{Na}$ deze aanvankelijk vliegende start stond de zaak vervolgens jarenlang stil tot 17 juli 1749! In de tussentijd bleven moeder en dochters de Floen wel op Hemersbach wonen, terwijl Oligschläger begon met uitgebreide veehouderij en delen van het huis liet afbreken of veranderen in stallen. Al met al was het een vreemde situatie. Als reden voor het langdurig uitstel van het proces werd later de oorlog opgegeven, maar misschien durfden de dames de Floen een confrontatie met de rentmeester niet aan. Maar in 1749 leek het tij gekeerd. Oligschläger verkeerde inmiddels in problemen door het proces wegens corruptie dat tegen hem was aangespannen.

Op verzoek van Eleonora de Floen-de Montbrison gaf graaf Maximilian Emanuel von Toerring Jettenbach op 5 september 1749 de schepenen van Gronsveld opdracht het proces voortvarend af te wikkelen. Maar de zaak werd doorkruist door het intussen ook

${ }^{1628}$ Deze voorgeschiedenis wordt beschreven in RHCL, Rijkskamergerecht, inv. 193, de in 1750 gestarte appelzaak van Johann Matthias Oligschläger tegen Anna Maria de Floen c.s. 
tegen Oligschläger aanhangig gemaakte fraudeproces. Daarin was bepaald dat de rentmeester als voorwaarde voor zijn vrijlating borg moest staan met zijn vermogen. Voor dat vermogen speelde de afloop van het proces over Hemersbach een grote rol. Want wanneer de dames de Floen het geld voor het beschudden contant op tafel legden, had de graaf een gemakkelijk object om zijn vorderingen op de rentmeester te verhalen.

Oligschläger deed er alles aan om de zaak tegen de Floen te vertragen. Op 12 maart 1750 stelde hij appel in tegen een in zijn ogen 'wederrechtelijk' tussenvonnis van de Gronsveldse schepenen en leenmannen en liet dit door een notaris te Aken bij de vroegere Gronsveldse appelcommissaris d'Oliva bezorgen. Maar tot zijn grote verrassing keerde de man terug met Oliva's antwoord dat die daarvoor al jaren niet meer bevoegd was. ${ }^{1629}$

$\mathrm{Nu}$ Oligschläger niet meer wist bij wie hij in hoger beroep kon gaan, adviseerden de schepenen hem om zich tot de landsheer te wenden. Op die goede raad zat rentmeester met zijn lopend proces wegens ambtsmisbruik niet te wachten. Op 8 mei 1750 werden de processtukken door de schepenen van Gronsveld voor consult naar een advocaat in Luik gestuurd, maar die weigerde de zaak in behandeling te nemen. Daarna maakten drossaard Lebens met de schepenen en leenmannen zelf een vonnis dat op 17 juli 1750 werd uitgesproken. De dag tevoren hadden de dames de Floen het bedrag van de koopsom van 17.904 gulden bij het gerecht in bewaring gegeven. De beslissing van leenmannen en schepenen was dat eisers als naaste bloedverwanten terecht binnen de vereiste termijn een beroep op naasting hadden gedaan en de vordering werd toegewezen. Het hoger beroep dat Oligschläger had ingesteld werd ongegrond verklaard.

Nog dezelfde dag tekende Oligschläger bij de schepenbank hoger beroep aan tegen het volgens hem partijdige vonnis van 'ohnerfahrene bauren-richteren'. Oligschläger had alle reden zich bezwaard te voelen. Hij had niet alleen het proces verloren, maar op de bij het gerecht in consignatie gegeven koopsom was onmiddellijk beslag gelegd door de drossaard met het doel dit geld straks te gebruiken voor de schadevergoeding die de rentmeester boven het hoofd hing in het fraudeproces.

Met zijn appel in Gronsveld had Oligschläger duidelijk gemaakt dat hij zich bezwaard voelde, maar omdat hij daarmee niets opschoot, wendde hij zich op 7 september 1750 tot het Rijkskamergerecht in Wetzlar. Op 22 september 1750 verscheen de bode van dat gerecht in Gronsveld om de stukken op te vragen, maar hij keerde onverrichter zake terug. Pas na formeel protest van Oligschläger stuurden de schepenen op 7 november 1750 alsnog een afschrift van het dossier met de motivering van hun vonnis naar Wetzlar.

Uiteindelijk liep de zaak in Wetzlar voor Oligschläger slecht af. Op 17 november 1756 bevestigde het Rijkskamergerecht het vonnis van schepenen en leenmannen van Gronsveld, waarna op 17 maart 1758 voor schepenen en leenmannen van Gronsveld het bevel tot tenuitvoerlegging volgde. Daarbij moest ook nog een beslissing worden genomen over het intussen flink opgelopen bedrag aan gerechtskosten. Dat was niet zo eenvoudig, want Oligschläger verbleef in Maastricht en was daar als rentmeester in dienst van het

1629 RHCL, Rijkskamergerecht, inv. nr. 193, fol. 272: 'das commissariat deren Gronsfeldischen appellations sachen albereiths vor zwey oder dreyen jahren von sich abdiciret, mithin sich im mindesten nicht mehr immisciren könte'. 
kapittel van Sint-Servaas. Dat betekende dat zowel van het indivies laaggerecht van Maastricht als het kapittel rechtshulp nodig was. Die werd ook verleend. Uiteindelijk bleek Oligschläger over deze afwikkeling door het Gronsveldse gerecht niet tevreden en ging hij wederom Wetzlar in hoger beroep. Hij dacht de zaak opnieuw ten principale ter discussie te kunnen stellen, maar werd snel uit de droom geholpen. Op 20 augustus 1758 zonden schepenen en leenmannen van Gronsveld hun visie op de zaak naar het Rijkskamergerecht. Daarin betoogden zij nog eens dat het appel van Oligschläger een herhaling van zetten was. Daarmee lijkt het dossier in Wetzlar te zijn geëindigd.

Hiervoor kwam het proces tegen Oligschläger wegens fraude al enkele keren ter sprake. Processen tegen frauderende rentmeesters waren op zich niets bijzonders, alleen zou deze zaak in tijdsduur en omvang alle voorgaande affaires overtreffen. Het woord omvang moet hier zelfs letterlijk worden genomen, want met negen banden (totaal $50 \mathrm{~cm}$ ) is het een van de dikste dossiers van het Rijkskamergerecht in Maastricht. ${ }^{1630}$ Maximilian Emanuel von Toerring-Jettenbach gaf op 11 september 1746 opdracht aan Oligschläger om voor het einde van maand via een bankier in Luik een wissel te laten trekken op een bank in München ter betaling van een achterstand van drieduizend pattacons, voortvloeiend uit zijn laatst ingediende rekening. Voorts moest over het lopende jaar een overzicht van inkomsten en uitgaven worden ingeleverd. Hoewel stipte naleving van dit bevel werd verwacht, maakte men zich al snel weinig illusies over het resultaat. Daarom volgde op 24 september 1746 een herhaling van de eerdere orders, maar nu met de opdracht de rentmeester in het kasteel, zonder contact met de buitenwereld, op te sluiten wanneer hij op einde van de maand niet aan zijn verplichtingen had voldaan. Bijgevoegd was een acht punten tellende instructie, waarop bij de gevangenneming van de rentmeester moest worden gelet. Er moest worden gekeken of hij direct zijn schuld kon betalen. Verder werd gezocht naar rekeningen en boekhouding en gegevens over niet toegestane leveranties aan doortrekkende troepen. Uitdrukkelijk deed de graaf een beroep op de juridische kennis van drossaard en fiscus Lebens en ook van leensecretaris Jacobus Berchmans, om zowel voortvarend als zorgvuldig te procederen. Discretie naar buiten toe was ook gewenst. Gedurende de hechtenis van de rentmeester konden diens werkzaamheden worden overgenomen door Berchmans, onder het toeziend oog van de drossaard.

Op 7 oktober 1746 kwamen drossaard en fiscus Henricus Lebens en vier schepenen van Gronsveld in buitengewone zitting bijeen. Lebens overlegde zijn instructies. Het feit dat Oligschläger enkele dagen eerder een voorlopige rekening over 1746 had ingeleverd, met het aanbod 1100 gulden Maastrichts te betalen, kon niet voorkomen dat de schepenen een gerechtelijk bevel tot aanhouding gaven. De rentmeester moest worden opgesloten in een kamer in het kasteel en Lebens en Berchmans zouden zijn inboedel doorzoeken. De reden van de opsluiting was vluchtgevaar en vrees voor het voortzetten van malversaties. Er werd namelijk ernstig getwijfeld aan de kredietwaardigheid van Oligschläger. Buiten Hemersbach was er onvoldoende roerend goed en geld om schulden op te verhalen. Op

1630 RHCL, Rijkskamergerecht, inv. nr. 192. 
Hemersbach lag bovendien al beslag vanwege het proces van de Erven de Montbrison/de Floen, terwijl de graaf daar ook nog een vordering had als leenheer, omdat het leen niet correct bij het leenhof was verheven.

Op 14 december 1746 leverde de drossaard en fiscus een 161 punten tellende aanklacht in bij het gerecht, die op 13 februari 1747 nog werd aangevuld tot in totaal 188 punten. De lange en gedetailleerde lijst met klachten liet van het optreden van Oligschläger geen spaan heel. Hij had grafelijke eigendommen en landerijen verwaarloosd en beschadigd, zijn ambt als rentmeester en secretaris misbruikt en zichzelf ten koste van de graaf verrijkt. Op al de in de aanklacht genoemde artikelen werd Oligschläger punt voor punt ondervraagd tot 7 juni 1747. De schepenen kozen in eerste instantie uitdrukkelijk voor een mondeling verhoor en niet voor een geschreven antwoord. Het verweer van de rentmeester was even consistent als gedetailleerd: Beschuldigingen werden ontkend of gebagatelliseerd, hij beriep zich op overmacht of voorgaande goedkeuringen van hogerhand of legde de schuld bij anderen, maar hij gaf op vrijwel geen enkel punt toe. Voorts was volgens hem de tekst van zijn instructie op tal van onderdelen voor verschillende uitleg vatbaar of gaf die hem een bepaalde vrijheid van handelen. Het antwoord maakte duidelijk dat men zich op een lang en moeilijk proces moest voorbereiden. De door de wol geverfde Oligschläger, bijgestaan door de gewiekste Maastrichtse advocaat Huberti, bleek een taaie tegenstander.

In de loop van februari 1747 verzocht Oligschläger vrijlating of tenminste regelmatig vrij contact met zijn raadsman Huberti. Het eerste werd geweigerd, het tweede, ondanks verzet van drossaard, na lang aarzelen toegestaan in die zin dat de gevangene twee keer per week met zijn advocaat mocht spreken, maar alleen in aanwezigheid van twee schepenen. Verder kreeg hij een afschrift van de aanklacht.

Terwijl men nog bezig was met de verhoren en een voorlopige becijfering een vermoedelijke schade van rond de elfduizend gulden, arriveerde begin maart 1747 een brief uit München met de mededeling dat bij het onderzoek van de rekeningen uit 1732 en 1733 verschillende dubbele boekingen van uitgaven waren vastgesteld. Er was dus sprake van fraude. Die originele rekeningen konden echter voorlopig vanwege de oorlogstijd niet met de post naar Gronsveld worden gestuurd. Drossaard Lebens stond daarmee voor de vraag of hij nu een civiele dan wel een criminele procedure tegen de rentmeester moest voeren, want daarvoor golden verschillende procesregels.

Terwijl de tijd verstreek, zat Oligschläger in een kamer op het kasteel en mocht zich niet beklagen. Zijn onderkomen was mooier dan zijn eigen huis en hij kreeg eten van zijn eigen kokkin. Maar liever was hij vrij. Het gerecht stemde daar echter niet in toe omdat de rentmeester onvoldoende zekerheid kon stellen bij een eventuele veroordeling. Terwijl verder werd geprocedeerd met verhoren, arriveerden begin mei 1747 de originele rentmeestersrekeningen over de jaren 1732-1736 uit München. Toen Oligschläger daarover aan de tand werd gevoeld, gaf hij antwoorden in de trant van: ik denk', 'ik geloof of 'misschien is het zo', maar voor de rest bleek hij een en al onwetendheid.

Vanwege zijn voortdurende gevangenschap wendde Oligschläger zich tot het Rijkskamergerecht, dat inderdaad op 27 juni 1747 een 'mandatum de relaxando', een bevel tot invrijheidstelling uitvaardigde. Maar drossaard en schepenen van Gronsveld tekenden bezwaar aan. Dit mondde uit in een vonnis van 17 februari 1748, waarbij het hoogste 
Rijksgerecht bepaalde dat Oligschläger tegen borgstelling van zijn vermogen moest worden vrijgelaten. Het gerechtelijk beslag op zijn roerende goederen werd opgeheven, met uitzondering van het aangetroffen contante geld. De in beslag genomen archieven moesten worden teruggegeven. Verder moest het gerecht van Gronsveld de rekeningen van Oligschläger controleren. Er mocht voorlopig niet meer worden geprocedeerd over andere punten van de aanklacht en de processtukken moesten in aanwezigheid van rentmeester en de drossaard en fiscus worden 'geinrotuleerd '(geïnventariseerd) en voor advies opgestuurd naar een juridische faculteit van een bekende universiteit binnen het Rijk.

De vrijgelaten, maar intussen wel brodeloze Oligschläger, zette nu een opmerkelijke stap: hij huwde op 10 juni 1748 te Maastricht met Johanna Francisca Essers, de schoonzuster van zijn advocaat Huberti. De bruid, dochter van Bartholomeus Essers en Barbara Olislagers, stamde uit een invloedrijke Maastrichtse familie. ${ }^{1631}$ Het huwelijk was tot op zekere hoogte gearrangeerd. Mevrouw Oligschläger liet zich 25 jaar later tegenover Prummer ontvallen dat zij eigenlijk tegen haar zin door haar moeder aan Oligschläger was gekoppeld, maar dat het met de verwachte rijkdom erg was tegengevallen. ${ }^{1632}$ Helemaal ongelukkig werd het huwelijk toch niet, gezien het feit dat zij het in 1774 toch flink opnam voor haar man, toen hem het vuur aan de schenen werd gelegd.

Met zijn huwelijk maakte Oligschläger zijn entree bij een familie met relaties in Maastricht en omgeving. In de eerste plaats kon hij natuurlijk rekenen op de hulp van zijn zwager Huberti. Waarschijnlijk effende zijn andere zwager, Jacob Jozef Essers, sinds 1739 kanunnik bij het kapittel van Sint-Servaas, ook de weg naar de invloedrijke betrekking van rentmeester van dat kapittel. Op 31 augustus 1750 werd hij in die functie benoemd.

Met zijn nieuwe familie en een vast inkomen verkeerde de nu in Maastricht wonende Oligschläger in de positie om zich verder juridisch te kunnen ingraven. Hij kwam alsmaar niet met de gevraagde borgtocht over de brug, bleef over de inhoudelijke kant van de rekeningen vaag en eiste schadevergoeding wegens slecht beheer van zijn eigendommen tijdens zijn gevangenschap. Zijn opponent drossaard en fiscus Lebens bedacht op zijn beurt allerlei juridische constructies om het vonnis van het Rijkskamergerecht zo breed mogelijk te kunnen interpreteren. Zo groeide het proces uit tot een loopgravenoorlog. Gedurende 1748 tot eind 1749 lag de zaak grotendeels stil wegens oorlog en ziekte van de drossaard. Oligschläger gaf nog steeds geen volledige openheid van zaken en probeerde bovendien de schepenen van Gronsveld en de tijdelijke secretaris Berchmans in een kwaad daglicht te stellen. Lebens kreeg het verwijt dat hij als openbaar aanklager en lid van de schepenbank tegelijk partij en rechter was. Voor het gerecht vormde dat aanleiding om op

${ }^{1631}$ Haar vader was afkomstig uit Aken en had in 1690 het Maastrichtse burgerrecht verworven. Mogelijk was zijn echtgenote Barbara Olislagers in de verte nog verwant aan Joannes Matthias Oligschläger, maar duidelijke gegevens daarover ontbreken. Van de in totaal elf kinderen van Bartholomeus en Barbara bereikten vier volwassenheid. Johan Silvester (geboren 1695, overleden 1747), was gehuwd met Helena Isabella van Wevelinckhoven. De tweede zoon, Jacob Jozef (geboren 1709, overleden 1763) verwierf in 1739 een prebende als kanunnik bij het kapittel van Sint-Servaas. De dochter Esther (geboren 1705) huwde in 1732 met Balthazar Frederik Huberti, gezworen raad en schepen te Maastricht, drossaard van Elsloo en syndicus (vaste juridische adviseur) van de balije van de Duitse Orde in Aldenbiezen. 1632 TJ, inv. nr. M 56, fol. 785, Prummer aan A.J. von Toerring-Jettenbach 14 augustus 1774. 
11 februari 1751 te verklaren dat de drossaard zich bij beraadslagingen van de schepenen uit de kamer moest verwijderen. De schepenen beslisten voortaan alleen. Met het advies van een universiteit vlotte het intussen ook niet, want de vertaling van het lijvige dossier vroeg veel tijd.

Intussen was ook Prummer, de nieuwe grafelijke vertegenwoordiger in Gronsveld, direct na zijn komst geconfronteerd met de door Oligschläger achtergelaten chaos. Hij probeerde een minnelijke regeling tot stand te brengen, maar dit leidde slechts tot een verharding van standpunten. De omvang van de fraude viel ook door ontbrekende documenten voor deskundigen nauwelijks vast te stellen.

Op 15 augustus 1754 arriveerde in Gronsveld eindelijk een voorlopig advies van de rechtenfaculteit van Heidelberg. ${ }^{1633}$ Oligschläger werd gesommeerd zich te verweren, maar hij reageerde niet. Het dossier werd vervolgens opnieuw naar Heidelberg gestuurd, waar op 16 september 1755 de uitspraak volgde dat de vorderingen van de drossaard en graaf Toerring Jettenbach moesten worden toegewezen omdat de gedaagde onvoldoende verweer had gevoerd.

Toch had Oligschläger niet helemaal stil gezeten. Hij wendde zich tot het Rijkskamergerecht met een klacht over de behandeling die hem in het graafschap ten deel was gevallen. Terwijl de schepenen van Gronsveld nog werkten aan omzetting van het juridisch advies uit Heidelberg in een vonnis, oordeelde het Rijkskamergerecht op 17 juli 1755 dat Oligschläger voor een deel gelijk had. Er was onvoldoende rekening gehouden met het feit dat sommige schepenen misschien partijdig waren en daarnaast waren de goederen van Oligschläger gedurende zijn detentie niet goed beheerd. Op zich respecteerden de schepenen in Gronsveld die uitspraak, maar dat weerhield hen niet om in hun vonnis van 7 juli 1756 alle verweren en bezwaren van Oligschläger te verwerpen. Tegen die uitspraak ging de ex-rentmeester opnieuw in beroep in Wetzlar.

Zo sleepte de zaak zich voort. Voor Prummer vormde het onderwerp 'Oligschläger' een vast onderdeel van zijn rapportages naar München. In het begin groeide het dossier nog vooral met afschriften van oudere processtukken, maar gaandeweg raakte het proces in het slop. Intussen was duidelijk dat het vermogen van de rentmeester, voor zover zich dat in Gronsveld bevond, in werkelijkheid nogal tegenviel. In 1760 werd dit becijferd op een batig saldo van 11947 gulden Maastrichts of 59731/2 gulden Rijnlands, te weinig om de volledige schade te kunnen verhalen.

Pas het aantreden van de nieuwe graaf August Joseph von Toerring-Jettenbach leidde tot nieuwe pogingen om tot een oplossing te komen. Omdat pogingen om te komen tot een minnelijke regeling mislukten, ${ }^{1634}$ moest het Rijkskamergerecht zich op 17 juni 1774 voor de derde keer in deze zaak uitspreken. Het gerecht stelde vast dat de destijds door de grafelijke commissaris Gürtler voor de jaren 1734 t/m 1736 vastgestelde rentmeesterrekeningen als origineel moesten worden beschouwd. Verder kregen de

1633 Voor het verschijnsel van Aktenversendung aan een Spruchkollegium bij een universiteit zie: Jacobs, 'Is het wel de rechter die recht vindt?', 31-34.

1634 TJ, inv. nr. 56, fol. 588-595 A.J. von Toerring-Jettenbach aan Prummer 22 februari 1774(nr. 9); TJ, inv. nr. M 56, fol. 708-720, Prummer aan A.J. von Toerring-Jettenbach 7/10 mei 1774 (nr. 17). 
schepenen van de stad Aken opdracht een jurist aan te wijzen die met assistentie van een 'tüchtigen und wohlerfahrenen Rechner als actuarius' de rekeningen van 1732 en 1733 en 1737 t/m 1746 helemaal moest onderzoeken.

Toen Prummer het vonnis voor het eerst onder ogen kreeg, toonde hij zich matig enthousiast. Inhoudelijk bevestigde het eerdere uitspraken dat Oligschläger moest betalen, maar de opdracht aan een jurist uit Aken achtte hij een slechte zaak. Zo vond hij het onzin de rekeningen nog eens helemaal opnieuw te onderzoeken, want tot 1746 was alles al uit en te na gecontroleerd. Uiteindelijk besloot Prummer zelf de onderhandelingen met Oligschläger te beginnen. In een brief van meer dan 25 bladzijden voor de graaf beschrijft hij zijn wederwaardigheden, een verhaal vol emotie. Oligschläger riep alleen maar 'in godsnaam' en zuchtte dat hij het niet snapte. Zijn echtgenote, door Prummer de 'Oligschlägerin' genoemd, brak voortdurend in huilbuien uit en speelde theater. ${ }^{1635}$

De confrontatie met de waarheid zal voor haar pijnlijk zijn geweest, omdat in volle omvang duidelijk werd dat het vermogen dat haar man bij het huwelijk had ingebracht, voor het grootste deel van fraude afkomstig was. Nu zou zij destijds door haarzelf aangebracht onroerend goed in Gronsveld moeten verkopen om de schuld te kunnen betalen. Maar Prummer gaf geen krimp. Zo sleepten zich de gesprekken van dag tot dag voort.

Ten slotte gaf het echtpaar Oligschläger toe en werd op 23 september 1774 bij notaris H. Hupkens te Maastricht een overeenkomst vastgelegd. In de eerste plaats droeg Oligschläger een perceel van drie bunder hakhout te Gronsveld aan de graaf over. Voorts moest hij veertienduizend gulden Maastrichts betalen, van welk bedrag hij tweeduizend direct op tafel legde. Van het restant zou tot de aflossing vier procent rente worden betaald. Daarvoor gaf hij ook hypotheek op zijn twee huizen in Maastricht. Namens de graaf beloofde Prummer verder van alle rechtsvorderingen af te zien.

Uiteindelijk kon Prummer op 3 april 1775 met grote opluchting aan de graaf berichten dat er 5375 gulden Rijnlands (10750 Maastrichts) was betaald. Het geld was letterlijk bijeengeschraapt, want afgezien van een aantal goudstukken, bestond het bedrag uit kleine zilveren muntjes. In totaal had Prummer tweeënhalve dag nodig om het geld te tellen. Maar de commissaris had te vroeg gejuicht, want er ontbrak nog 250 gulden Maastrichts. Wederom volgden hoogoplopende discussies. Tegelijkertijd was de handtekening van Oligschläger nodig voor een document met finale kwijting van alle vorderingen. Die akte moest in Wetzlar, Aken en Gronsveld gerechtelijk worden geregistreerd. Uiteindelijk wist Prummer na veel praten de handtekening te krijgen in ruil voor de belofte dat de kosten voor de laatste gerechtelijke formaliteiten ter beëindiging van alle procedures, door de graaf werden gedragen. Op 4 januari 1776 tekenden de partijen het akkoord en vier dagen

$1635 \mathrm{Zij}$ was 'von der gattung iennig niederländtischen weyberen...mit welchen nichts auszurichten ist so lang sy nit (wie es haist) ihr hertz ausgeklaget, ausgeweinet und ausgelähret haben'. (fol. 784) Maar de 'Oligschlägerin' nam het wel op voor haar man en vroeg of het ook echt waar was, waarvan hij beschuldigd werd. 
later kon Prummer de graaf berichten dat na dertig jaar procederen definitief een punt was gezet. ${ }^{1636}$

Hoe het daarna met Oligschläger verder afliep, is niet geheel duidelijk. In 1779 en 1783 wordt zijn naam nog genoemd in verband met transacties met onroerend goed in Maastricht. Plaats en datum van overlijden zijn niet bekend; zijn echtgenote Johanna Francisca Essers overleed op 1 oktober 1793 in Maastricht. ${ }^{1637}$

De zaak Oligschläger was de laatste in de reeks gerechtelijke procedures die tegen Gronsveldse rentmeesters werden gevoerd. Dat betekent niet dat na 1750 alles glad verliep; ook in de tweede helft van de achttiende eeuw moesten soms plooien worden gladgestreken, maar niet meer van deze omvang. De zaak onderscheidt zich van andere door de lange duur en hoogte van de financiële belangen. Oligschläger kreeg de kans te knoeien in een tijd toen de grafelijke administratie zwak was. Uiteindelijk had hij zijn val vooral te wijten aan steeds grotere overmoed en een opzichtig leven als grand seigneur.

Uit het omvangrijke proces wordt duidelijk dat de fraude goed in elkaar zat en aanvankelijk moeilijk te bewijzen viel. Daar kwam bij dat zowel drossaard Lebens als de rentmeester alle juridische middelen uit de kast haalden om hun gelijk aan te tonen. Die hardnekkigheid spoorde niet altijd met een zorgvuldige procedure, getuige het feit dat het Rijkskamergerecht liefst drie keer een voor beide partijen corrigerende uitspraak moest doen. Ook de torenhoge vorderingen aan het begin moesten naderhand worden bijgesteld, hoewel het uiteindelijk toch nog altijd om een substantieel bedrag ging.

Ondanks het moeizame verloop van het proces, kan niet worden gezegd dat de affaire verlammend werkte op het Gronsveldse bestuursapparaat. Dat vormt een groot verschil met de jaren twintig van de achttiende eeuw. De in 1728 door het Rijkskamergerecht bevolen scheiding tussen de functies van rentmeester en drossaard bleek een heilzaam effect te hebben. Weliswaar fraudeerde Oligschläger ook als secretaris van de schepenbank, maar de gevolgen daarvan waren minder ontwrichtend. De tweede reden was dat, ondanks alle tekortkomingen in de procedure, de graaf en zeker zijn permanente vertegenwoordiger Prummer een veel strakkere regie voerden dan vroeger gebruikelijk was.

\subsection{Johan Frans Lebens, rentmeester}

De in de herfst van 1746 tegen rentmeester Oligschläger gestarte gerechtelijke procedure betekende ook het einde van zijn loopbaan in dienst van de graaf. Voorlopig werd het werk overgenomen door Wilhelmus Henricus Lebens, de in 1704 geboren oudste zoon

\footnotetext{
1636 TJ, inv. nr. M 57, fol. 588-629 (618), Prummer aan M.E. von Toerring-Jettenbach 8 januari 1776.

1637 In 1779 was hij nog rentmeester van het kapittel van Sint-Servaas, zie: RHCL, Brabants Hooggerecht Maastricht, inv. nr. 792 (gichten 1779-1781) fol. 101-108, gicht van 26-4-1779; in 1783 was hij gewezen rentmeester, zie RHCL, Graafschap Vroenhof, inv. nr. 340 (gichten 1782-1784) gicht 14-10-1783. Johanna Francisca Essers overleed 1 oktober 1793 in de parochie St. Jacob, woonde toen op de Tongersestraat en werd begraven bij de kruisheren.
} 
van de vroegere drossaard Johannes Godefridus Lebens. ${ }^{1638}$ Met zijn oom Henricus Lebens als drossaard en zwager Jacobus Berchmans als secretaris, leengriffier en notaris leek de macht weer stevig in handen van de familie Lebens. Maar een langdurige loopbaan in Gronsveld schijnt Wilhelmus Henricus niet te hebben geambieerd. Begin 1750 solliciteerde hij naar de functie van raad en rentmeester van het graafschap Rekem. Voorlopig kon het rentmeesterschap worden toevertrouwd aan Jacobus Berchmans. ${ }^{1639}$ Het was een keus bij gebrek aan beter, want er was niemand die de Duitse taal beheerste en over voldoende rekenvaardigheid beschikte. In een brief van Berchmans aan de graaf van 7 maart 1750 sprak hij zijn hoop uit dat in de nabije toekomst zijn nog studerende zoon het werk kon overnemen ${ }^{1640}$ maar twee maanden later werd zijn jongste zwager Johan Frans Lebens (geboren 1717) als geschikte kandidaat naar voren geschoven. ${ }^{1641}$ Wel moesten diens kennis van het Duits en van de rekenkunde worden bijgespijkerd. ${ }^{1642}$

Die kandidatuur kreeg ook de steun van Prummer. Volgens hem was het ambt van rentmeester voor een geschikte kandidaat 'gar kein grosses weesen', maar voor het salaris van tweehonderd gulden Rijnlands moest toch wel worden gewerkt. Daarbij niet meegerekend waren bijzondere emolumenten, zoals de toelage van zes gulden voor stookkosten en circa 25 gulden zogenoemde 'tauschgelder', een soort schrijfloon voor de verpachting van grafelijke landerijen en tienden. Het zou op termijn mogelijk moeten zijn de functies van secretaris, leengriffier en rentmeester te combineren, feitelijk de voortzetting van de situatie zoals die ook bij Oligschläger bestond.

Het was de vraag of Johan Frans Lebens ook goed voor zijn taken was toegerust. $\mathrm{Na}$ de studie van de 'inferiora' (onderbouw middelbaar onderwijs) had hij samen met zijn moeder de huishouding gevoerd. Zijn gedrag was onberispelijk, hij kwam integer over en beschikte over een helder verstand. Door lezen en zelfstudie had hij zich zoveel kennis eigen gemaakt, dat hij in staat moest worden geacht het nodige schrijfwerk te kunnen verrichten. Hij wist voldoende om te kunnen boekhouden en een jaarrekening op te stellen, maar was helaas in rechnungs weesen nit starckh'. Evenmin kon hij bogen op ervaring in de rechtspraktijk. Maar door zijn familiale achtergrond was hij uitstekend ingevoerd in alle zaken die het landsheerlijk belang raakten: 'Die œconomie verstehet er so guett, als der beste hier im landt'. ${ }^{1643} \mathrm{Na}$ het overlijden van Berchmans was hij ongeveer de enige bij wie Prummer met vragen terecht kon.

Op 22 september 1753 werd de aanstelling van Lebens ingeschreven in het gerechtsprotocol van de schepenbank. ${ }^{1644}$ Een dag eerder, op 21 september 1753, ondertekende Prummer 'von commissions weegen' een voorlopige instructie ('provisional instruction'), voor het grootste deel gebaseerd op de instructie voor Oligschläger uit

\footnotetext{
1638 Van Heyst, 'Proeve ener genealogie', 137.

1639 TJ, inv. nr. M 5, fol. 19-34, Instructie M.E. von Toerring-Jettenbach aan drossaard Henricus Lebens 12 maart 1750.

1640 TJ, inv. nr. M 43, fol. 1047-1050 Jacobus Berchmans aan M.E. von Toerring-Jettenbach 7 maart 1750.

1641 Zie over hem Van Heyst, 'Proeve ener genealogie', 137-138.

1642 TJ, inv. nr. M 43, fol. 1067-1073 Jacobus Berchmans aan M.E. von Toerring-Jettenbach 16 mei 1750.

1643 TJ, inv. nr. M 75, fol. 395-411, Prummer aan M.E. von Toerring-Jettenbach 13 november 1755.

1644 Volgens eigen opgave toen in 1779 zijn boekhouding werd gecontroleerd, zie TJ, inv. nr. M 70, fol. 472
} 
1737. ${ }^{645}$ Het is twijfelachtig of die ooit door de graaf formeel is bekrachtigd. In een door Prummers assistent Wolfgang Zollner omstreeks 1779-1780 opgesteld concept van een nieuwe 'Amts-instruction' voor Lebens wordt gezegd dat op dat moment niet meer aanwezig was dan deze voorlopige instructie uit 1753.1646 Lebens ondertekende ook vele jaren stukken met de titel 'gecomitteerde loco secretarii'.

$\mathrm{Na}$ het overlijden van Jacobus Berchmans op 28 oktober 1755 nam Lebens ook tijdelijk de werkzaamheden van leengriffier en secretaris van de schepenbank op zich. Naar die functies ging vervolgens ook zijn grootste belangstelling uit. In het begin was hij zelfs bereid daar het rentmeesterschap voor op te geven, wat echter niet nodig was.

Het lijkt dus alsof Lebens zijn functie als rentmeester gedurende de volgende 25 jaar alleen op basis van een voorlopige aanstelling van Prummer heeft uitgeoefend. Dat is ook kenmerkend voor de verhouding tussen Lebens en zijn dominante zwager Prummer. Feitelijk bepaalde die wat de rentmeester moest doen en Prummer beschouwde zich als de eindverantwoordelijke. Zeker vanaf de jaren zeventig begaf de door ouderdomskwalen geplaagde Prummer zich alleen naar Gronsveld wanneer het niet anders kon. Hij stuurde dan briefjes - meestal in het Frans - met aanwijzingen of vragen voor Lebens.

Het is opmerkelijk dat gedurende meer dan 25 jaar noch door Prummer noch door Lebens 'Rentamts'- of 'Commissions'-rekeningen naar München werden gezonden. Men zou verwachten dat met de affaire Oligschläger leergeld was betaald. Er schijnen wel aanmaningen te zijn geweest, maar die bleven zonder gevolg. Maar in de tweede helft van de jaren zeventig kwamen er in München signalen over onregelmatigheden in de boekhouding. Een van de eerste opdrachten van Zollner in 1779 gold dan ook de controle van de rekeningen van de rentmeester vanaf 1753 .

Op 5 juli 1779 deed Zollner verslag van zijn bevindingen. In de eerste plaats stelde hij vast dat de rekeningen half in het Duits en half in het Nederlands waren opgesteld. Vanaf het begin maakte Prummer de rekeningen voor de rentmeester in het Duits omdat Lebens die taal niet machtig was. Die op zijn beurt wist weer niet wat Prummer allemaal opschreef. De jaren 1776 en 1777 vertaalde Zollner daarom maar zelf. Uit de verificatie bleek dat Lebens inderdaad geen rekenwonder was, zoals al bij zijn aanstelling was opgemerkt. Bij de meeste rekeningen moesten correcties worden aangebracht. Per saldo viel het uiteindelijk nog mee en bleek de rentmeester slechts een bedrag van ruim 34 gulden Rijnlands aan achterstand te hebben. Zollner vroeg zich af of daar geen kwijtschelding voor kon worden verleend, want Lebens had 26 jaar lang uit eigen zak de kosten voor schrijfmateriaal voldaan. Prummer was daar wel eens over aangesproken, maar die vond vergoeding van dat soort kleinigheden aan zijn zwager beneden zijn stand.

Een technisch lastig probleem was dat de laatste gecontroleerde rekening over 1777 voor de graaf een positief saldo liet zien van 5562 gulden Rijnlands. Dit bedrag was in feite een schuld op papier van de rentmeester aan de graaf en bevond zich niet in klinkende munt in de kas. Zollner kreeg daarom opdracht alles in het werk te stellen om dit geld ook werkelijk 'einzutreiben' of op zijn minst te zorgen dat er voldoende zekerheid voor terugbetaling werd gesteld.

1645 RHCL, Graafschap Gronsveld, inv. nr. 96; zie Bijlage 42.

1646 RHCL, Graafschap Gronsveld, inv. nr. 96. 
Zollner beschrijft Lebens in 1779 als ziekelijk, een man van de dag. ${ }^{1647}$ Dat laatste was misschien enigszins overdreven, maar zijn gezondheid was niet goed. Feitelijk verrichtte Zollner al als assistent-rentmeester het meeste werk. Lebens overleed in Gronsveld op 17 juni 1782, drie maanden na zijn zwager Prummer. Zijn weduwe Agnes Petermans (geboren Eijsden 9 augustus 1733) bleef achter met vier minderjarige kinderen. Uiteindelijk hertrouwde zij op 22 augustus 1787 met Zollner. ${ }^{1648}$

\subsection{Wolfgang Zollner, directeur, commissaris en rentmeester}

Wolfgang Zollner zag het levenslicht in Konzell, in Neder-Beieren, volgens eigen zeggen op 31 januari 1746. Waarschijnlijk werd hij geboren in een boerenfamilie. Uit getuigschriften van zijn opleiding blijkt dat hij aan het gymnasium in München een cursus theologie had afgesloten en tussen 1768 en 1772 als stagiaire en schrijver werkte bij een jurist te München, die ook secretaris was in de kanselarij van graaf Toerring Jettenbach. Van 1773 tot 1776 was hij bij de graaf zelf in dienst als 'kanzlei-officiant'. Op het moment van zijn ontslagname in februari 1776 wordt hij betiteld als 'kandidaat' in de filosofie, het kerkelijk recht en de theologie. Zijn vertrek hing samen met de wens zich te bekwamen in de praktijk van 'civil- und criminal-gerichtliche sachen', alsook het brouwerijwezen. Die juridische ervaring deed hij vervolgens gedurende vijf maanden op bij een 'herrschaftliches Gericht' van Freiherr von Lerchenfeldt. Zijn studie aan de universiteit van Ingolstadt sloot hij af met de titel van licentiaat in de beide rechten. ${ }^{1649}$

Rijk was hij niet. Hij moest geld lenen, waarschijnlijk van zijn vriendin Thérèse, om zijn studie te bekostigen. Tot zijn benoeming voor Gronsveld werkte hij wederom in de grafelijke kanselarij en vaak concipieerde hij daar de uitgaande brieven voor Prummer. Zodoende zal hij ook van diens vraag om assistentie op de hoogte zijn geweest. Of hij voor die functie werd gevraagd dan wel solliciteerde, is niet duidelijk. Gemakkelijk viel hem de beslissing niet, want vertrek uit München betekende achterlating van Thérèse, zijn vriendin. Maar hij hoopte dat zij hem naderhand zou volgen. In ieder geval tekende graaf August Joseph op 27 maart 1778 zijn benoemingsbesluit als secretaris van de 'landtsherrlich bevolmechtigten Commission. ${ }^{1650}$ Uit de dertien punten tellende instructie met aanwijzingen voor de reis, arbeidsvoorwaarden en omschrijving van werkzaamheden blijkt dat Zollner bij gebleken geschiktheid zo spoedig mogelijk het ambt van drossaard en fiscus van het graafschap moest overnemen. Voorts werd hem in het stuk meermalen de opvolging van Prummer als commissaris in het vooruitzicht gesteld.

Maar zover was het nog niet. Eerst moest van de reis van halteplaats tot halteplaats een nauwkeurig verslag worden opgesteld, gevolgd door afrekening van het reisgeld. Zollner mocht onderweg een kleine omweg maken om 'was merckwürdighes zu sehen', dat

1647 TJ, inv. nr. M 58, fol. 506-514, Zollner aan onbekende relatie in de grafelijke kanselarij 12 juli 1779.

1648 Van Heyst, Proeve ener genealogie, 137-138. Voor de genealogie van de familie Petermans zie: Boersma, 'Genealogie P(i)etermans, 345-364 en 446-456.

1649 RHCL, Graafschap Gronsveld, inv. nr. 98.

1650 RHCL, Graafschap Gronsveld, inv. nr. 98. 
maakte de reisbeschrijving alleen maar 'angenehm'. In Aken maakte hij zijn opwachting bij burgemeester Richterich, die de grafelijke belangen in Merkstein (tiendrechten) behartigde. Met hem moest hij ook overleggen over een oplossing voor het al ongeveer 140 jaar slepende proces over Rimburg.

Eenmaal aangekomen, diende Zollner zich goed te verstaan met Prummer om van hem alles te horen wat hij voor zijn werk als secretaris en beoogd drossaard en fiscus nodig had. Van belang was dat hij zich de Franse en 'Flamandtische' taal zo snel mogelijk in woord en geschrifte eigen maakte. Hij kon het beste met Prummer oefenen, maar het is de vraag of dat een goed advies was; Prummer was niet sterk in het Nederlands. De correspondentie in het Hoogduits moest Zollner op aanwijzing van Prummer zelf verzorgen. Daarmee werd ook een 'Commissionsschreiber' uitgespaard. De commissaris had altijd een klerk uit eigen zak betaald, inclusief huisvesting en verwarming. Die 'Verpflegungsbeytrag' van tweehonderd gulden kwam nu Zollner ten goede. Daarbij mocht hij kiezen voor uitbetaling in natura of voor geld om een eigen huishouding op te zetten.

De graaf verwachtte dat Zollner zich overal conform zijn benoemingsbesluit presenteerde en kwalificeerde als 'secretaris van de gevolmachtigde landsheerlijke 'Commission', maar dan wel met alle egards voor Prummer. Een dergelijk optreden opende alle deuren en verschafte toegang tot alle geheimen van de rijksheerlijkheid. Zollner moest zo snel mogelijk kennis krijgen van alle Gronsveldse heerlijke rechten en landszaken, met het doel te zijner tijd 'das landstherrlich bevolmächtigte commissariat anzutretten'. Een goede introductie daartoe vormde een onderzoek in het archief. Hij kon dan meteen met Prummer overleggen wat er zoal ten nutte van de landsheer of de onderdanen mogelijk was. Bovendien was men in München ook geïnteresseerd in een 'Sammlung' met informatie over landsheerlijke rechten en functionarissen.

Het salaris bedroeg vierhonderd gulden Rijnlands, te betalen in maandelijkse termijnen, exclusief de bijdrage van tweehonderd gulden van Prummer. Met dit bedrag mocht de secretaris zijn landsheer 'keine Unehre machen'. De inkomsten uit het ambt van drossaard en fiscus vloeiden volledig in de landsheerlijke kas en hadden geen invloed op het traktement. Dienstreizen vonden plaats op kosten van de landsheer.

Ten slotte bevatte de instructie ook nog enkele formaliteiten. Zollner werd in München 'verpflichtet' (beëdigd). Voor opzegging van het dienstverband stond een termijn van zes maanden en de graaf behield het recht de arbeidsvoorwaarden eenzijdig te veranderen.

Zollner vertrok op 31 maart 1778 in München en arriveerde op 13 april in Gronsveld, een iets langere reisduur dan de gebruikelijke elf dagen. Al spoedig vond hij een kosthuis bij een geestelijke, die bij zijn oude moeder en een zuster woonde. Al op de dag van aankomst schreef hij aan zijn vriendin Thérèse over Maastricht: een mooie stad, propere straten en huizen en goed bier. De taal verstond hij half. Er verbleven ook veel Beieren in de stad. De ontvangst bij de familie Prummer was uiterst koel. 
Uit de eerste twee jaren van zijn verblijf in Maastricht en Gronsveld zijn concepten bewaard van een reeks brieven van Zollner aan zijn vriendin. ${ }^{1651}$ Hij beschrijft daarin tal van wetenswaardigheden, maar laat zich ook kennen als een onrustige ziel, een gevoelsmens, onzeker in de liefde, met soms een neiging tot fantasie en overdrijven (zo zouden in Maastricht tijdens het verblijf van een Zwitsers garnizoen 653 onwettige kinderen zijn geboren!1652), soms depressief en dan weer euforisch. Hij voelde zich opgezadeld met de humeurige Prummer en diens familie en soms ook onbegrepen door de graaf, terwijl hij van zichzelf vond dat hij prima werk leverde.

Hij raakte al gauw ingeburgerd, het leven was beter dan in Duitsland en hier werd hij tenminste niet als slaaf behandeld. Maar in buien van neerslachtigheid klonk een andere toon: de inwoners van het graafschap en van Maastricht waren vals en huichelachtig. Hij dacht te zijn gekomen in een land van Huronen en Hottentotten, een tweede Siberië.1653 Die depressiviteit had veel te maken met zijn relatie met Thérèse. Zij werd geïdealiseerd en veel hoger aangeschreven dan de Nederlandse vrouwen: die deden te veel aan mode, waren verwend (lagen tot tien, elf of zelfs twaalf uur in bed) en 'hadden de broek aan'. Zollner deed zijn geliefde verschillende huwelijksaanzoeken en probeerde haar over te halen naar Maastricht te komen. Maar voor een huwelijk was toestemming nodig van de graaf en die weigerde. Bovendien was een flink bedrag gemoeid met de reiskosten. Misschien lieten zich deze hindernissen nog wel overwinnen, maar Thérèse zelf wees eerst een huwelijk af en twijfelde daarna weer. Zij beweerde dat in München roddels over Zollner de ronde deden, wat haar vertrouwen niet versterkte. Rond de jaarwisseling 17791780 breekt de correspondentie af en lijkt Thérèse uit Zollners leven te zijn verdwenen.

Zollners verhouding tot de graaf was ambivalent. In de officiële correspondentie gedroeg hij zich onderdanig en uiterst correct, maar in de privésfeer wisselden de gevoelens nogal eens. Soms liet hij zich lovend uit over zijn broodheer, maar vaker ergerde hij zich aan diens tirannieke oekazes. Diep teleurgesteld was hij door de weigering van de 'veelvraat' toestemming te geven voor een huwelijk: 'Diens onmenselijk hart begrijpt dergelijke gevoelens niet'. ${ }^{1654}$

Maar tegelijk toonde Zollner zich ook ambitieus en ging hij vol ijver aan de slag. Een 'Sprachmeister' gaf hem twee uur les per dag om de taal te leren en hij verdiepte zich in het Gronsveldse bestuur en de grafelijke rechten. Bij die studie leverden Prummer en diens familie meer tegenwerking dan steun. De commissaris was in Zollners ogen corrupt en hetzelfde gold voor rentmeester Lebens, een man die niet uitblonk door werklust. Van bestuur en rechtspraak deugde niets. Zollner brandde van ijver daar verandering in te brengen en opperde allerlei plannen, ook ter verbetering van de economie.

1651 RHCL, Graafschap Gronsveld, inv. nr. 35.

1652 RHCL, Graafschap Gronsveld, inv. nr. 61.

1653 RHCL, Graafschap Gronsveld, inv. nr. 61. 'Huronen' benaming van Franse kolonisten voor NoordAmerikaanse Indianenstam, behorend tot het volk der Irokezen.

${ }^{1654}$ RHCL, Graafschap Gronsveld, inv. nr. 35, Zollner aan Thérèse 12 juli 1779. 
Op 3 juli 1779 besloot de graaf aan Zollner de titel 'Geheimsekretär' toe te kennen. Deze antwoordde blij te zijn met deze bevordering ${ }^{1655}$ maar hij zocht geen titels. De aanduiding 'secretaris' achtte hij voor deze streken minder geschikt, want zo iemand was niet meer dan een schrijver. Vroeger, toen de landsheer zelf in Gronsveld woonde, was er natuurlijk nooit een commissaris geweest. Maar sinds de tijd dat ze buitenslands resideerden, was er altijd een commissaris of administrator geweest, zoals men zag bij burgemeester d'Oliva van Aken, de laatste administrator. De tijden dat zo'n functionaris ontbrak, leverden alleen maar treurige voorbeelden van slecht bestuur. Het was dus noodzakelijk dat iemand de leiding had die vanaf het begin ieder vorm van onrust en onrecht in de kiem kon smoren. Bezwaar maakte Zollner ook tegen de combinatie van de functies van drossaard en commissaris. Dat had al bij Prummer problemen opgeleverd. Het laatste argument voor aanstelling van een commissaris gold diens rol als voorzitter van de Gronsveldse landstanden. In dit college zaten enkele edelen, kanunniken en schepenen uit Maastricht en advocaten. Daar moest de landsheer waardig worden vertegenwoordigd en in geval van nood ook de beslissende stem kunnen geven. Die heren lieten zich niet dirigeren door een 'secretaris'. Zollner verwees in dit verband naar de verslaglegging van de landdag van 1752, toen Prummer door zijn overwicht de geërfden tot belangrijke concessies had weten te dwingen. Samenvattend kwam Zollner tot de conclusie dat het noodzakelijk was een commissaris te benoemen als vertegenwoordiger van de landsheer. Bij een verruiming van diens taken lag het meer voor de hand te denken aan een combinatie met de functie van ontvanger of rentmeester.

Hoewel Zollner zich vrij open uitsprak tegenover de graaf, bleef hij voorzichtig. In een brief van 12 juli 1779 aan een 'vriend' in de grafelijke kanselarij benadrukte hij nog eens zijn vrees argwaan bij de graaf te wekken. Hij verzocht daarom zijn vriend het idee nog eens aan de graaf voor te leggen. ${ }^{1656}$ Ook aan zijn vriendin Therese schreef Zollner dat de graaf kennelijk alleen een drossaard en geen commissaris wilde aanstellen. ${ }^{1657}$ De 'Geheimsekretär' had het goed gezien. Op 12 augustus 1779 liet de graaf weten dat het bij een graafschap met zo weinig opbrengst overbodig was naast een drossaard, rentmeester en een secretaris van de schepenbank en het leenhof ook nog een aparte commissaris te benoemen. Men kon net zo goed aan de drossaard ruimere bevoegdheden verschaffen, zoals vroeger ook wel gebeurde. ${ }^{1658}$

Op 14 augustus 1779 volgde een tweede brief van de graaf aan Zollner. De graaf was beginnen te lezen in de (wanordelijk gearchiveerde) correspondentie met Prummer van de laatste jaren. Het was hem opgevallen dat het schepenengerecht slechts bestond uit ongeletterde boeren en dat de rechtsgeleerde drossaard daarbij slechts een adviserende stem bezat. (In werkelijkheid waren de rollen omgedraaid en dirigeerde de drossaard de schepenen!). Als 'Cheff der Gott geheiligten Justiz' kon de graaf dat niet over zijn kant laten gaan. Daarom was hij voornemens bij het gerecht naast een gegradueerde drossaard ook nog een rechtsgeleerde fiscaal te benoemen, die in strafzaken de landsheer

1655 TJ, inv. nr. M 58, fol. 516-524, Zollner aan A.J. von Toerring-Jettenbach 15 juli 1779.

1656 TJ, inv. nr. M 58, fol., 506-514 Zollner aan onbekende relatie in de grafelijke kanselarij 12 juli 1779.

1657 RHCL, Graafschap Gronsveld, inv. nr. 35 Zollner aan Therese 19-7-1779.

1658 TJ, inv. nr. M 58, fol. 529-540, A.J. von Toerring-Jettenbach aan Zollner 12 augustus 1779. 
vertegenwoordigde en tegelijk in andere zaken als eerste schepen optrad. Zo iemand verdiende ook een passende betaling, wat met alleen inkomsten uit gerechtskosten niet mogelijk was. Daarom moest aan de landstanden een hogere bijdrage voor de rechtspleging worden gevraagd, waarbij de graaf zich bereid verklaarde zijnerzijds ook een bijdrage in de kosten te leveren. Voorlopig zou dat geld door de rentmeester worden geïnd, maar de ervaring leerde dat dit vaak zonder hulp van een drossaard niet goed lukte. Daarom wilde de graaf de functies van drossaard en rentmeester verenigen, zoals vroeger, ten tijde van Willem Kicken.

Ten derde stelde de graaf vast dat de functie van stadhouder der lenen een 'noble charge' was, die levenslang ('ad vitam') aan baron De Goeswin in Luik was toegekend, terwijl het werkelijke werk werd gedaan door een vicestadhouder. Ook die functie wilde de graaf toekennen aan de drossaard als gegradueerd jurist. De bij deze ambten horende emolumenten leverden bij elkaar opgeteld een passend inkomen voor een drossaard. Daarvoor kon de drossaard ook de taken van een landsheerlijk commissaris op zich nemen. Met die constructie had Gronsveld geen behoefte meer aan een eigen 'administrator' of 'commissaris'. Die titel stond de graaf, net als die van 'mederegent' ten diepste tegen ('von herzen odios') Een verwijzing naar de vroegere positie van d'Oliva vond hij niet toepasselijk, want die had in opdracht van het Rijkskamergerecht gewerkt binnen het kader van de voogdij over de minderjarige gravin.

Zollner verklaarde zich vierkant tegen het plan van de graaf. ${ }^{1659}$ Hij herhaalde zijn eerdere argumenten nog eens, maar gooide het tevens over een andere boeg. Een commissaris of administrator was belangrijk voor de eer van de graaf, van het graafschap en van de landsheerlijke dienst, zelfs al bracht het graafschap niets op. Want bij een rijksonmiddellijk gebied draaide het niet zozeer om inkomsten, maar om de rechten en privileges van de heer. Het aanzien van een familie werd niet afgemeten aan inkomsten of geldmiddelen, maar aan ouderdom en privileges. Anders zouden rijke handelaren aanzienlijker zijn dan een rijksvorst of rijksgraaf. Dit aanzien moest men zich door uiterlijkheden verschaffen, zeker in een land zoals hier, waar men alleen daarop werd beoordeeld. Omdat de graaf niet in Gronsveld zelf resideerde en deze uiterlijkheid niet in persoon kon demonstreren, was het des te belangrijker te beschikken over een bestuurder van het graafschap met een bij het aanzien van een rijksgraaf passende titel. Zo iemand kon in Zollners ogen niemand anders zijn dan een gevolmachtigd commissaris of administrator. Die laatste kwalificatie vond hij nog wel het meest passend. Functionarissen met een lagere titel kregen niet de passende achting en eerbied. Intussen was men al decennia gewend aan titels als commissaris of administrator; wanneer dat nu opeens veranderde, zouden de mensen denken dat de graaf zich een dergelijke functionaris niet meer kon veroorloven.

De graaf had overigens aan Zollner het vooruitzicht op het ambt van commissaris gegeven en nu hij de feitelijke werkzaamheden had verricht, was hij eigenlijk ook in functie. Want wie 'in commissie' iets doet, is commissaris. Kortom, de graaf moest zich realiseren dat de eenvoudigste oplossing zou zijn hem, Zollner, als algemeen commissaris of administrator te benoemen, zoals dit ook bij andere rijksheerlijkheden gebruikelijk was. Het veranderde

1659 TJ, inv. nr. M 6, fol. 73-103, Zollner aan A.J. von Toerring-Jettenbach 31-8-1779. 
niets aan de financiën, want de graaf bezat maar één rijksgraafschap. Bovendien, zo verzekerde Zollner, zou hij zijn volmacht niet misbruiken en alleen handelen na vooraf verkregen toestemming van de graaf. Hij eindigde zijn pleidooi nog maar eens met de opmerking niet 'titlsüchtig' te zijn, maar hij verlangde de titel alleen met het oog op de behartiging van de landsheerlijke belangen. Als bijlage aan de brief voegde Zollner het concept toe van een volmacht om de aanstaande vergadering van Gronsveldse geërfden uit te schrijven en voor te zitten. Daarin werd gedaan alsof hij al een algemene volmacht ('commissorium generale') op zak had. Maar in de grafelijke kanselarij werd de tekst grotendeels doorgestreept, met als kern van de aanpassing dat hier slechts sprake kon zijn van een bijzondere volmacht ('commissorium speciale'). ${ }^{1660}$

De graaf liet zich niet gemakkelijk overtuigen. ${ }^{1661}$ Hij dacht dat zijn broer Maximilian Emanuel destijds aan Prummer de titel 'commissaris' had gegeven omdat hij als minister in dienst van de keurvorst zelf geen tijd had zich veel met Gronsveld te bemoeien. Prummer vertegenwoordigde de graaf in grote processen en had daarom ook volmachten nodig. $\mathrm{Nu}$ de zaken veel beter op orde waren, kon daarop worden voortgebouwd en was het onnodig voor Gronsveld een 'commissarius generalis' voor onbepaalde tijd te benoemen. Van een 'administrator', zoals destijds bij burgemeester d'Oliva, kon al helemaal geen sprake zijn. De graaf wenste niet dat de indruk zou worden gewekt dat zijn regering op enigerlei wijze in verband werd gebracht met iets tijdelijks zoals voogdij of gedeelde heerschappij. Hooguit zou in de toekomst misschien mogelijk zijn een administrator te benoemen voor het geval dat Gronsveld en Rimburg weer in één hand kwamen.

Vanwege de steeds slechtere fysieke en geestelijke toestand van Prummer moest toch iets gebeuren. Bij dezelfde brief van 22 september 1779 waarin de commissaris op emeritaat werd gesteld, ontving Zollner een benoeming tot 'Director der landsherrlichen Angelegenheiten'. Het salaris bleef echter onduidelijk, omdat het was berekend in samenhang met het pensioen van Prummer. De graaf wilde niet dat het salaris van Zollner en het pensioen van Prummer in totaal de schatkist hoger zouden belasten dan het bedrag van 1550 gulden dat Prummer tot nog toe had ontvangen. Omdat Prummer achthonderd gulden pensioen was toegezegd, zou er volgens die redenering voor Zollner slechts 750 gulden overblijven.

Terwijl er nog wat plooien rond de benoeming glad moesten worden gestreken, had Zollner op 28 september 1779 al zijn eerste publieke optreden als voorzitter van de landdag. De tijd drong, want het was gebruikelijk deze bijeenkomsten in september te houden. In een brief van 20 oktober 1779 beschrijft hij zijn ontvangst in de vergadering en de redevoering die hij in het Nederduits hield.

Op dat moment moest de formele benoeming nog worden afgerond. In een brief van 9 oktober 1779 bedankte Zollner voor het in hem gestelde vertrouwen en vroeg hij een formeel benoemingsbesluit, dat ook bij de schepenbank kon worden geregistreerd. Maar hij maakte bezwaar tegen de berekening van zijn salaris. Er was hem negenhonderd gulden beloofd en nu leek het op 750 gulden uit te draaien. Zollner vond dat bij het salaris van 1550 gulden van zijn voorganger ook nog diens toelage van 150 gulden voor onkosten moest worden opgeteld, waarmee het totaal op 1700 gulden kwam. Wanneer je van dat

1660 TJ, inv. nr. M 58, fol. 657-658, 13 september 1779.

1661 TJ, inv. nr. M 58, fol. 667-670, A.J. von Toerring-Jettenbach aan Zollner 15 september 1779. 
bedrag achthonderd gulden pensioen aftrok, resteerden voor Zollner negenhonderd gulden. Dat bedrag achtte hij ook nodig omdat hij nog altijd in Maastricht woonde en dus reiskosten had, niet over een ambtswoning beschikte en ook van andere vergoedingen verstoken was.

Op 20 oktober 1779 vaardigde de graaf dan het gevraagde benoemingsbesluit uit, tegelijk met een enigszins vaag geredigeerd besluit waarbij Prummer ontslag werd verleend. Verder ging de graaf door de knieën wat betreft de salariseis van negenhonderd gulden. Het ontslag en de aanstelling schijnen alleen in beperkte kring bekend te zijn gemaakt, wat enkele maanden later een probleem opleverde. Ook zou Zollner wat betreft zijn pleidooi voor de titel 'commissaris' gelijk krijgen naar aanleiding van het volgende incident. ${ }^{1662}$

Zollner werd benaderd door oud-burgemeester Joppen van Maastricht over een mogelijke geldlening aan de graaf. Uiteindelijk bleek die niet nodig, maar ook door roddel van mevrouw Prummer trok Joppen zich terug. Lastig in deze affaire was dat Zollner zich naar buiten toe niet goed kon legitimeren als de nieuwe baas in Gronsveld, want in zijn aanstellingsakte stond alleen de titel 'directeur' en de betekenis van dat woord was hier nauwelijks bekend. Verder stond er ook niet uitdrukkelijk in dat Prummer tegelijkertijd als commissaris was ontslagen. Ten derde was slechts een paar dozijn mensen op de hoogte van deze bestuurswisseling. Voor de graaf vormde dit voorval aanleiding om op 9 februari 1780 een nieuw besluit uit te vaardigen. Daarin werd het 'emeritaat' van Prummer bekend gemaakt. Verder kreeg Zollner niet alleen een aanstelling als directeur van het graafschap, maar ook als commissaris voor alle bijzondere gevallen waarin een dergelijke titel gewenst was. ${ }^{1663}$ De schepenen van Gronsveld ontvingen de uitdrukkelijke opdracht hem in die functie te erkennen en het benoemingsbesluit in de registers van de schepenbank te registreren. ${ }^{1664}$

$\mathrm{Nu}$ Zollner de titel 'directeur' voerde en zich voor bijzondere gevallen ook commissaris mocht noemen, zette hij zich aan het schrijven van een instructie. Tegelijk met een ontwerp-instructie voor de grafelijke jager in Gronsveld vroeg hij op 18 april $1780^{1665}$ ook goedkeuring van een 36 punten tellende 'Amts Instruction für den bey der freyen Reichsgrafschafft Gronsfeldt angestellten Rath, dann Directeur und Commissaire licentiat Wolfgang Zollner'. ${ }^{1666}$ Hij vond die zelf, ondanks de uitvoerigheid, nogal algemeen van opzet, maar het was nu eenmaal onmogelijk voor alle situaties een oplossing te geven.

Inhoudelijk kunnen de diverse artikelen rond bepaalde thema's worden gegroepeerd. Zo had de directeur tot plicht naar beste vermogen de landsheer in alle angelegenheden te adviseren. Discretie en geheimhouding golden daarbij als eerste gebod. De directeur mocht niets openbaren en nam desnoods geheimen mee het graf in. Landsheerlijke verordeningen en aanwijzingen werden nauwgezet ten uitvoer gelegd. Alle belangriike voorvallen moesten worden gemeld en de directeur mocht niets zelfstandig doen zonder

1662 TJ, inv. nr. M 59, fol. 31-39, Zollner aan A.J. von Toerring-Jettenbach 19 januari 1780.

1663 'nicht nur als directeur unser Grafschafft überhaubts, sondern auch als commissarius in special Fällen, wo derley commissarii caracter für ihm erforderlich sein würd, würcklich ernennt und bestelt'.

1664 TJ, inv. nr. M 59, fol. 51-53, besluit A.J. von Toerring-Jettenbach.

1665 TJ, inv. nr. M 59, fol. 103-107, Zollner aan A.J. von Toerring-Jettenbach 18 april 1780.

1666 Tekst van de instructie TJ, inv. nr. M 6, fol. 11-26. 
toestemming, uitgezonderd kleinigheden of in geval van dringende noodzaak. Voor uitvoering van de taken waren een geregelde correspondentie en een geordend archief noodzakelijk (een archiefkast had Zollner al laten maken).

De directeur was vanuit zijn zorg voor 'eine gute Pollicey' verantwoordelijk voor openbare orde, veiligheid, justitie en welzijn. Zo lette hij op de bewaking van de landsgrenzen en werden periodiek, in aanwezigheid van zowel oude als jonge mensen, inspecties van de grensstenen uitgevoerd. Er moest worden voorkomen dat zich in het graafschap gespuis ophield en niemand mocht zich vestigen zonder verlof of attest. Tot de openbare orde behoorde ook de beteugeling van het drankgebruik. Met tapvergunningen moest terughoudendheid worden betracht, omdat anders te veel mensen zouden 'verderben'. Ook het toezicht op het onderhoud van wegen en straten vormde een onderdeel van de 'policey'.

De directeur was 'chef van het Gronsveldse gerecht en lette er op dat iedereen recht werd gedaan, zowel armen als rijken, eigen inwoners en vreemdelingen. In voorkomende gevallen had hij bij het gerecht een adviserende stem ('votum informativum'). In processen werd bij voorkeur eerst de Gronsveldse Rechtsordnung gevolgd en daarna het gewoonterecht en het algemene, geschreven rijksrecht. Delinquenten moesten worden gestraft met een passende straf, waarbij de daad centraal stond en niet allerlei menselijke gevoelens. Wanneer een verduidelijking van het recht nodig was, of een verandering of zelfs een nieuwe wet, dan moest de landsheer daarvan op de hoogte worden gebracht.

Een belangrijk en in de instructie expliciet genoemd onderwerp van 'policey' vormde het toezicht op het beheer van de kerkgoederen en de dienstverrichting van geestelijken. De kerkrekeningen van Gronsveld, Heugem en Eckelrade moesten namens de landsheer worden afgesloten en met beide pastoors worden gecontroleerd. De directeur zag er op toe dat verplichtingen uit kerkelijke fundaties goed werden uitgevoerd, dat het armengeld werd uitgekeerd en renten werden betaald. Wanneer een pastoor, beneficiant of kapelaan overleed, was het zaak te zorgen voor een tijdelijke vervanging om onderbreking van de kerkelijke diensten te voorkomen. Verder diende de landsheer zo spoedig mogelijk in kennis te worden gesteld. Geestelijken die hun functie niet goed vervulden of zich met wereldlijke zaken inlieten, werden door de directeur gewaarschuwd. Hielp dat niet, dan volgde een bericht aan de graaf.

De directeur moest zowel intern als extern opkomen voor de 'regalia' van de landsheer. Naar buiten toe betekende dit een regelmatige afdracht van belastingen aan kreits, Rijkskamergerecht en Gravencollege. Voor betaling daarvan riep de directeur de 'Landsversammlung' van geërfden bij elkaar, welke vergadering hij ook presideerde.

Binnen het graafschap hield de directeur toezicht op handhaving en beheer van de rechten en inkomsten van de graaf. Zo werden voorschriften gegeven over het jachtrecht, het visrecht, de bieraccijns, de banmolen en de tienden. Het molenrecht diende te worden gehandhaafd en moest tijdens de voogdgedingen worden afgekondigd. Een bijzondere studie zou moeten uitwijzen of bij deze molen de inkomsten konden worden verhoogd. Ook de tienden onder Eckelrade en Rijckholt werden jaarlijks aan de meestbiedende verpacht. 
Aangezien de landsheerlijke tuinen en weiden met fruitbomen waren beplant, verdiende het aanbeveling oude bomen te rooien, jonge aan te planten en de fruitoogst aan de hoogste bieder te verkopen. Hout vormde een belangrijke bron van inkomsten. Geen plek mocht onbenut blijven. De directeur zorgde daarom voor onderhoud van alle bossen en houtaanplant en de verantwoorde verkoop van hout uit de landsheerlijke bossen.

Het was de gewoonte de landsheerlijke landerijen en weiden in pacht uit te geven en niet zelf te bewerken. Dat beleid werd ook in de toekomst voortgezet, in samenwerking met de rentmeester. Kwijtschelding van pacht mocht alleen met landsheerlijke toestemming worden gegeven.

Bij geschillen over lenen zag de directeur als leenstadhouder er op toe dat volgens het Gronsveldse leenrecht werd geprocedeerd en dat geen keurmedige goederen werden verdonkeremaand.

Verschillende bepalingen hadden betrekking op de verantwoordelijkheden van de directeur voor andere functionarissen. Zo lette hij er op dat de rentmeester zijn werk goed deed, de onderdanen niet afperste en niemand bevoordeelde. De directeur had ook de bevoegdheid in te grijpen en kon in het uiterste geval de zaak aan de landsheer voorleggen. Van alle inkomsten en uitgaven moest een inzichtelijke boekhouding worden gevoerd. Er mochten zonder toestemming van de directeur geen uitgaven van meer dan tien gulden Maastrichts worden gedaan. De jaarrekening werd jaarlijks op de daarvoor voorgeschreven termijn afgesloten, daarna door de directeur gecontroleerd en van het Nederlands in het Hoogduits vertaald. Het batig saldo, dat niet meer voor de bedrijfsvoering nodig was, werd per wissel naar München overgemaakt.

Aangezien de directeur op allerlei manieren ambtshalve bemoeienis kon hebben met de voordracht en benoeming van functionarissen, diende hij er in het bijzonder voor te waken dat alleen deugdelijke en geschikte personen werden benoemd. Het voortrekken van bepaalde families, zoals tot voor enige tijd in Gronsveld gebeurde, was uit den boze.

Zolang de directeur zijn plichten goed vervulde ontving hij jaarlijks negenhonderd gulden Rijnlands gedurende de tijd dat Prummer nog leefde en pensioen kreeg. Verder werden hem reis- en verblijfskosten toegekend, evenals de geringe emolumenten verbonden aan de functies van leenstadhouder en drosaard.

Voor een groot deel bestaat de instructie uit bepalingen die men daarin ook verwacht, zoals de handhaving van landsheerlijke rechten, de zorg voor de opbrengst uit domeingoederen en afdracht van belastingen aan het Rijk en kreits. Ook de aandacht voor 'policey', zoals zorg voor een goede rechtspleging en openbare orde is gebruikelijk. In die zin is de instructie, zoals Zollner zelf ook erkende, nogal algemeen van opzet. Maar de tekst bevat ook opmerkelijke passages, met verwijzingen naar de eer en het aanzien van het graafschap. Zo moest worden voorkomen dat Gronsveld door achterstallen in de afdrachten aan het Rijk een slechte naam kreeg. Onderhoud van wegen diende het gemak van reizigers, maar ook het aanzien van het graafschap. En de correcte uitkering van armengeld en renten zorgde er voor dat Gronsveld 'in guten credit erhalten' bleef. Dit soort formuleringen lijkt bewust te zijn gekozen en te passen in het pleidooi dat Zollner eerder hield voor de benoeming van een administrator of commissaris na de pensionering van Prummer. Ook daarin werd immers gezinspeeld op de eer en het aanzien dat een 
rijksonmiddellijk graafschap voor de familie Toerring-Jettenbach bracht. Dat woog zwaarder dan inkomsten en de betekenis mocht niet worden ondergraven door een slechte naam en faam als gevolg van falend bestuur.

Een tweede in het oog vallend punt is de verhoudingsgewijs zware nadruk die werd gelegd op het toezicht op het beheer van kerkelijke goederen en het optreden van geestelijken. Voor een deel moet dit zijn ingegeven door de vele moeilijkheden met de pastoors van Gronsveld en Heugem gedurende de voorgaande jaren (zie meer daarover Hoofdstuk 15.20.2 sub 'Pastoraat in Gronsveld en Eckelrade: benoemingen en ervaringen' en 15.20.3 sub 'Pastoraat in Heugem'.) De instructie drukt echter onomwonden uit dat de landsheer grote zeggenschap had over de 'temporalia' (goederen, optreden van kerkelijke functionarissen) binnen zijn graafschap. Dit soort opvattingen sloot aan bij ideeën in de tweede helft uit de achttiende eeuw waarin werd gepleit voor een staatsgezag dat regulerend optrad in kerkelijke aangelegenheden.

Het is onduidelijk of de instructie van Zollner ook formeel door de graaf is bekrachtigd. Die zag liever drie instructies tegelijk, één voor Zollner, één voor de rentmeester en één voor de grafelijke jager. Het is de vraag of dat plan niet is doorkruist door de moord op de jager in november 1780, waarna een definitieve vaststelling in het vergeetboek raakte.

Als commissaris en rentmeester zorgde Zollner voor de gewone bedrijfsvoering met betrekking tot de grafelijke eigendommen, zoals verpachting van landerijen, zorg voor de bossen, de verkoop van fruit, de inning van renten en cijnzen etc. Veel aandacht vroegen het op orde brengen en houden van de administratie van de grafelijke lenen in Vaals, het onderhoud van de kerk van Merkstein en beheer van de tiendrechten in die plaatsen, waar de graaf patronaatsrechten bezat. Ook werd gepraat over mogelijke verkoop van die tiendrechten.

Zollner kreeg gedurende de jaren tachtig te maken met een reeks langdurige aanslepende kwesties, die voor een deel nog stamden uit de tijd van zijn voorganger of van zelfs lang daarvoor. Hier kunnen worden genoemd het geschil over de betaling van aardappeltienden, de conflicten met de oude pastoor Van Bloer te Heugem en het kapittel van Onze-Lieve-Vrouwe te Maastricht over het patronaatsrecht in Heugem.

Voor Gronsveld zelf maakte Zollner zich sterk voor herstel van het kasteel of de bouw van een 'Beamtenhaus', dat kon dienen als onderkomen van het gerecht en voor zijn eigen huisvesting. Deels werd dit probleem opgelost door zijn huwelijk in 1787 met de weduwe van rentmeester Lebens. Vanaf dat moment had hij een woning in Gronsveld en hoefde hij niet meer dagelijks op en neer naar Maastricht te reizen.

Er werden ook plannen gemaakt ter verbetering van de economie. In 1786 zocht Zollner handwerkslieden die het economische leven in Gronsveld een impuls konden geven. ${ }^{1667}$ In 1787 vroeg hij steun bij de graaf voor een reeks plannen zoals de invoer van nieuwe gewassen (papaver, nieuwe soorten vlas, klaver, 'bourgondische' rapen') en het opzetten van linnen- en damastweverijen. Daarvoor konden misschien ook mensen uit Beieren naar

${ }^{1667}$ RHCL, Graafschap Gronsveld, inv. nr. 59, Zollner aan A.J. von Toerring-Jettenbach 3 oktober 1786. 
Gronsveld komen. Verder probeerde hij een beschrijving te krijgen van een Beiers productieproces waarbij brouwers leerden 'Bierbrandtwein' te maken. ${ }^{1668}$ In 1791 wilden de Maastrichtenaren A. Bemelmans en G. Maurissen investeren in een te Gronsveld op te richten 'Hollandse stokerij'. Zij kenden het distillatieproces zoals dat in Schiedam werd toegepast voor het stoken van jenever, wat een kwalitatief goed product opleverde. Om hun bedrijf tegen concurrentie te beschermen vroegen zij gedurende een periode van 24 jaar het monopolie om in Gronsveld een dergelijke stokerij te mogen exploiteren. Voorts wilden zij ontheffing van de verplichting graan te laten malen op de banmolen. ${ }^{1669}$ Zollner zag als voordelen dat Gronsveldenaren hun graan in de eigen woonplaats konden afzetten, het afval leverde uitstekend veevoer en transport van graan en drank kon werkgelegenheid brengen. Maar er waren ook bedenkingen. Een exclusief recht sloot eigen inwoners uit en was nadelig voor mensen die zelf kleine hoeveelheden thuis stookten. Verder zou toch gebruik moeten worden gemaakt van de windmolen, voor zover de capaciteit dat toeliet. Ten slotte moesten de exploitanten worden verplicht aan de inwoners in tijd van nood, wanneer uit omliggende dorpen geen graan werd aangevoerd, tegen een redelijke prijs graan voor brood te leveren. ${ }^{1670}$ Uiteindelijk ging het project niet door omdat op hetzelfde moment de Staten-Generaal voor hun gebied hadden beslist dat in hun gebieden iedereen vrij was een stokerij op te richten. Zollner stelde voor dat ook toe te passen voor Gronsveld. Toekenning van een monopolie aan Bemelmans en Maurissen zou alleen maar aanleiding kunnen geven tot 'patriottische' oprispingen, iets waarvan men in Gronsveld tot nog toe gelukkig gespaard was gebleven. ${ }^{1671}$ Daarmee zagen de twee Maastrichtse ondernemers van hun plannen af.

Zollner was ook verantwoordelijk voor handhaving van openbare orde, veiligheid en rust in het graafschap. In de jaren tachtig deden zich enkele grotere geweldsincidenten in het graafschap voor, zoals in 1780 de doodslag op de grafelijk jager Anton Schwab (zie Hoofdstuk 15.11) en de doodslag begaan door Gerardus Beckers in 1783 (zie Hoofdstuk 13.4). Voor de rest kwam de criminaliteit niet uit boven de gebruikelijke overtredingen, mishandeling en diefstal. Ontwikkelingen in naburige territoria vormden wel een reden tot bezorgdheid. Eind 1784 liepen de spanningen op tussen keizer Joseph II als heer van de Zuidelijke Nederlanden en de Republiek over de vrije doorgang van Antwerpen naar de zee. Het verdrag van Fontainebleau (1785) dat een einde maakte aan het conflict, raakte ook de omgeving van Gronsveld door ruiling van enkele dorpen in de Landen van Overmaze tussen de Republiek en Oostenrijk. Veel ingrijpender waren echter de gebeurtenissen vanaf 1789 in het prinsbisdom Luik en in de Oostenrijkse Zuidelijke Nederlanden.

Onvrede over het bewind van de Luikse prins-bisschop Van Hoensbroek leidde in augustus 1789 tot een opstand van burgers en werklieden. Ondanks een verzoek van de

1668 RHCL, Graafschap Gronsveld, inv. nr. 60, Zollner aan A.J. von Toerring-Jettenbach 8 augustus 1787. 1669 TJ, inv. nr. M 62, fol. 556-559, A. Bemelmans en G. Maurissen (Maastricht) aan Zollner, z.d., (ontvangen 26 februari 1791).

1670 TJ, inv. nr. M 62, fol. 540-553, Zollner aan A.J. von Toerring-Jettenbach 8 februari 1791.

1671 TJ, inv. nr. M 62, fol. 530-533, Zollner aan A.J. von Toerring-Jettenbach 27 februari 1791. 
staten van het prinsbisdom weigerde de inmiddels gevluchte Van Hoensbroek een nieuwe constitutie te geven.

De 'Brabantse' Omwenteling of Revolutie in de Oostenrijkse Zuidelijke Nederlanden richtte zich tegen diverse maatregelen van keizer Joseph II en dan in het bijzonder de reorganisatie van het bestuurlijk en gerechtelijk apparaat en de invoering van belastingen. In januari 1789 achtten de gewesten Henegouwen en Brabant zich niet meer gebonden aan hun eed van trouw aan de landsheer. In de loop van het jaar breidde de opstand zich verder uit. De motieven van de revolutionairen waren zeer verschillend, zowel onvrede over maatregelen van de keizer tegen de kerk als het streven naar een meer democratisch staatsbestel.

Zowel de Luikse als de Brabantse revolutie kreeg aanvankelijk steun van Pruisen. Op 24 november 1789 bezette een Pruisisch garnizoen de stad Luik en belemmerde daarmee ingrijpen van Oostenrijk. De Staten van de gewesten in de Oostenrijkse Zuidelijke Nederlanden verklaarden zich, met uitzondering van Luxemburg, onafhankelijk en verenigden zich op 11 januari 1790 voor de behartiging van hun gemeenschappelijke belangen in de Verenigde Nederlandse Staten.

Maar toen de in juli 1789 uitgebroken Franse revolutie naar de Zuidelijke Nederlanden en het prinsbisdom Luik dreigde over te slaan, zagen Pruisen en Oostenrijk een gezamenlijk belang om het oude gezag te herstellen. Door onderlinge meningsverschillen en het verlies van steun van Pruisen mislukte de Brabantse revolutie. Keizer Leopold II, de opvolger van Joseph II, kon met tamelijk zachte hand het Oostenrijks gezag herstellen.

Als reactie op het herstel van het oude gezag in het prinsbisdom Luik, zochten in de loop van 1792 de Luikse revolutionaire comités aansluiting bij Franse geestverwanten. Prinsbisschop François de Méan, sinds 16 augustus 1792 de opvolger van Van Hoensbroeck, vluchtte voor de tegen het einde van november 1792 binnengevallen Franse troepen. Op 5 maart 1793 heroverden Oostenrijkse troepen de stad Luik en herstelden het prinsbisschoppelijk gezag. In de zomer van 1794 keerden de Fransen echter terug. Zij veroverden op 26 juli 1794 Luik en op 4 november 1794 viel Maastricht in hun handen. Vanaf dat moment begon de ontmanteling van het Ancien Régime in het Maasgebied.

Het waren vooral de gebeurtenissen in Luik en Brabant die Zollner vanaf 1789 nauwlettend volgde. In het neutrale Gronsveld bemande hij een soort uitkijkpost tussen strijdende partijen. Alle nieuws, rijp en groen, feit of gerucht, stuurde hij per ommegaande naar München. Die berichtgeving was ook nodig voor de graaf. Luik behoorde immers, net als Gronsveld, tot de Nederrijns-Westfaalse Kreits. Herstel van orde en gezag in Luik was primair een taak van de kreits, in het bijzonder Pruisen als het grootste lid daarvan, en de standen van de kreits betaalden daar aan mee.

De feiten uit de Luikse en Brabantse Omwenteling zijn op zich wel bekend. Analyse en toetsing van alle brieven van Zollner daaraan voert hier te ver. Wel geven de brieven indirect een goed beeld van de kwaliteit van de nieuwsvoorziening in die tijd. We beperken ons daarom hier tot enkele voorbeelden en vervolgens meer in het bijzonder gebeurtenissen waarbij Gronsveld betrokken was. Eén conclusie valt echter ook zonder diepgaande analyse te trekken: de in juli 1789 uitgebroken Franse Revolutie komt er in de berichtgeving van Zollner slechts met wat terloopse opmerkingen bekaaid af. 
Klaarblijkelijk maakten de gebeurtenissen in Frankrijk minder indruk dan wat zich bij Gronsvelds buren afspeelde. Merkwaardig in dit verband is wel de zakelijke melding van de onthoofding van de Franse koning in 1793: 'Lodewijk XVI heeft de 21e van deze maand opgehouden met te bestaan. U gelieve hier zijn testament aan te treffen.' ${ }^{1672} \mathrm{De}$ tekst van dit in druk uitgegeven testament was toegevoegd. ${ }^{1673}$

Zollners grootste zorg was dat de ‘patrioten' ook aanhang kregen in Gronsveld. Toen Luikse rebellen naar Sint Pieter dreigden te komen, nam de commissaris zijn maatregelen. 'Aangezien dit gepeupel meestal van stelen en roven leeft en Heugem aan Sint Pieter grenst, heb ik al voorbereidingen getroffen om hen warm te ontvangen als ze van plan zouden zijn de inwoners van Heugem te verontrusten', zo kondigde hij zelfverzekerd aan. ${ }^{1674}$ Maar er was ook Brabantse dreiging:

Het Brabantse oproer nadert meer en meer de grenzen van Gronsveld. Een groot gedeelte van het Oostenrijkse leger, aangevuld met Limburgse boeren, heeft zich al verzameld bij Moelingen, Visé en andere omliggende plaatsen op anderhalf uur van Gronsveld om de Brabantse patriotten de doorgang over de Maas en een inval in Limburg te verhinderen. ${ }^{1675}$

Met dit soort citaten zijn Zollners brieven doorspekt. Zelfs de 'traditionele' schermutselingen tussen inwoners van afzonderlijke dorpen plaatste hij binnen het kader van de algemene onrust. Zo schreef de commissaris op 2 augustus 1791:

De Gronsveldenaren willen ook beginnen met de patriot te spelen want ze hebben op 3 juli jongstleden enige inwoners van Heer, Scharn en Bemelen overvallen en met ijzer beslagen stokken zo erg geslagen dat drie ervan zwaar gewond, ja zelfs gevaarlijk aan het hoofd zijn geraakt. Ze zijn niet meer in levensgevaar... Het zijn haatgevoelens die al enige tijd bestaan tussen de Gronsveldenaren en de bewoners van de hierboven genoemde dorpen en die de aanleiding zijn geweest tot bovengenoemd gevecht.... Er schijnt overigens een soort epidemie te heersen onder de boeren. Zij denken dat zij ongeveer verplicht zijn met elkaar te vechten, want ook op 3 juli hebben in omliggende plaatsen bloedige gevechten plaats gevonden, met in Itteren en Veltwezelt dodelijke slachtoffers. Sindsdien is bijna geen zondag of feestdag voorbij gegaan of er zijn in de omliggende plaatsen gevechten geweest. ${ }^{1676}$

Op voorstel van Zollner scherpte de graaf op 23 augustus 1791 de regels voor handhaving van de openbare orde nog eens flink aan. ${ }^{1677}$ Begin januari 1792 speelde Zollner zelfs met de gedachte militairen van de kreits in te zetten bij handhaving van de orde:

1672 TJ, inv. nr. M 62, fol. 314-315, Zollner aan A.J. von Toerring-Jettenbach 26 januari 1793: 'Ludwig der 16te hat Montag den 21ten dieses zu seyn aufgehörret. Euer Reichsgräfliche Excellenz geruhen desselben Testament hieneben zu empfangen'.

1673 TJ, inv. nr. M 62, fol. 320-325.

1674 TJ, inv. nr. M 62, fol. 690-692, Zollner aan A.J. von Toerring-Jettenbach 8 juni 1790.

1675 TJ, inv. nr. M 62, fol. 649-650, Zollner aan A.J. von Toerring-Jettenbach 15 september 1790.

1676 TJ, inv. nr. M 62, fol. 500-503, Zollner aan A.J. von Toerring-Jettenbach 2 augustus 1791.

1677 TJ, inv. nr. M 62, fol. 504-507, A.J. von Toerring-Jettenbach aan de inwoners van Gronsveld 23 augustus 1791 . 
Als Uwe Excellentie toestaat om de in Aken commanderende officier te verzoeken om op mijn vordering zes tot tien man met een sergeant-majoor te zenden dan verwed ik er mijn hoofd onder dat de rust binnen het graafschap voor de komende 50 jaar gewaarborgd zal zijn... Als God de Franse patriotten maar zou kortwieken, dan zou vermoedelijk de benaming patriot in Europa snel vergeten zijn. ${ }^{1678}$

Dat laatste bleek ijdele hoop. Op 20 april 1792 verklaarde Frankrijk de oorlog aan Oostenrijk (Eerste Coalitieoorlog). Een inval van de Fransen in de Zuidelijke Nederlanden liep uit op een nederlaag voor de revolutionairen. Toen de Oostenrijkers en de Pruisen echter de tegenaanval inzetten, werden zij op 20 september 1792 gestopt bij Valmy. Op 6 november werden de geallieerden vervolgens door de Fransen verslagen bij Jemappes, waardoor de Zuidelijke Nederlanden in feite open lagen voor de revolutionaire troepen. In dit gebied werden zij met wisselende gevoelens door de bevolking ontvangen. Sommigen zagen in hen bevrijders, anderen zagen het alleen als een bezetting met alle daarbij behorende problemen.

In november en december 1792 kreeg Gronsveld te maken met overlast van doortrekkende troepen, vooral Oostenrijkse militairen. Maar op 1 februari 1793 arriveerden de Fransen, die het kasteel bezetten. In het gebouw werd alles stuk geslagen, de kelderdeur opengebroken en Zollners wijnvoorraad opgedronken. De archieven van Gronsveld gingen het raam uit en werden opgestookt. Bij Zollner thuis bevond zich de commandopost en de commissaris kreeg bijna dertig personen in de kost. Ook moest hij voor de voeding van de paarden zorgen.

Ondanks een bombardement van 24 februari tot 2 maart hield de vesting Maastricht stand. Op 2 maart werd de belegering opgeheven. Ook op andere plaatsen werd de opmars van de Fransen gestuit door twee nederlagen, op 1 maart 1793 in Aldenhoven (bij Jülich) en op 18 maart 1793 in Neerwinden (bij Sint Truiden). Acht dagen later verklaarde ook het Heilige Roomse Rijk de oorlog aan Frankrijk. Om aan de snel naderende Oostenrijkers te ontkomen, braken de Fransen in allerijl op. In Gronsveld namen ze alle karren en paarden mee. Zollner stond doodsangsten uit. De Fransen zetten hem een geladen geweer op de borst, sloegen een venster stuk en duwden een deel van de tuinmuur om. Dit alles omdat hij een 'satellite d'un despote' was. ${ }^{1679}$

In de loop van 1793 mobiliseerden de teruggeslagen Fransen een volksleger dat in de zomer van 1794 aan een nieuwe invasie begon. Op 26 juni 1794 versloeg bevelhebber Jourdan de geallieerde legers bij Fleurus. Vervolgens viel het besluit heel België te veroveren, waarna het Maas- en Samberleger in september en oktober het Maasgebied bezette. De sterk verdedigde vesting Maastricht moest op 4 november 1794 capituleren. Daarmee was de verovering van de Zuidelijke Nederlanden en het Rijnland feitelijk afgerond.

Gedurende de eerste helft van 1793 had Gronsveld vooral te lijden onder doortrekkende Oostenrijkse en Franse troepen; de oorlogsellende bleef binnen de perken. De volgende

1678 TJ, inv. nr. M 62, fol. 420-437, Zollner aan A.J. von Toerring-Jettenbach 24 januari 1792.

1679 TJ, inv. nr. M 62, fol. 302-305, Zollner aan A.J. von Toerring-Jettenbach 4 maart 1793. 
maanden verliepen tamelijk rustig, maar begin juli 1794 sloeg de paniek toe. Terugtrekkende Oostenrijkse troepen verzamelden zich in de omgeving van Maastricht. Eind juni streken deze 'bevriende' militairen ook in Gronsveld neer en vraten als sprinkhanen alles kaal. Zollner voelde zich door de inkwartiering volledig geruïneerd. Op 9 juli 1794 berichtte hij aan de graaf dat hij in allerijl de (nog resterende) belangrijkste papieren uit het archief bij elkaar had gebracht, die vervolgens 's nachts onder escorte van een Pruisische officier naar het klooster der Alexianen in Keulen werden gebracht (in dat klooster verbleef graaf Sigismund, een zoon van de graaf). ${ }^{1680}$

In de namiddag van 19 september 1794 sloeg de commissaris in gezelschap van zijn oudste stiefzoon zelf op de vlucht. De Fransen bevonden zich al in 's-Gravenvoeren en trokken die dag ook Gronsveld binnen. Zollner ging eerst naar Keulen en zocht daar bij de Alexianen graaf Sigismund op. Vervolgens stak hij de Rijn over en reisde naar München. ${ }^{1681}$ Het is de vraag of Zollner de consequenties van zijn - op zich begrijpelijke actie heeft voorzien. In Frankrijk stonden strenge straffen op vlucht, zoals inbeslagname en verkoop van achtergebleven goederen. Wie op de officiële lijst van 'émigrés' stond, gold als vijand van de Franse republiek.

In de daarop volgende maanden schijnt alle contact met Gronsveld te zijn verbroken. Zollners echtgenote Agnes Petermans en zijn achtergebleven stiefkinderen verkeerden in grote onzekerheid over zijn lot, maar durfden ook geen brieven te schrijven uit angst dat die onderschept werden. Pas begin mei 1795 arriveerde nieuws in Gronsveld. Op 14 mei 1795 reageerde Zollners stiefdochter Maria Anna Lebens enthousiast op dit levensteken. $\mathrm{Zij}$ beschreef de vele problemen met de Franse soldaten en de grote moeite die haar moeder had gedaan om door middel van etentjes drie Franse generaals gunstig te stemmen, zodat nog iets van de grafelijke bossen kon worden gered. Bij navraag naar archieven had Agnes Petermans geantwoord dat de Fransen die bij hun vorige bezoek hadden verbrand.

In de daarop volgende weken hielden de meisjes Lebens hun stiefvader middels brieven op de hoogte. Vooral schonken zij aandacht aan de zware belastingdruk en het bedrag dat hun moeder, Agnes Petermans, had voorgeschoten om de belastingaanslag van de graaf te voldoen. Ook deden zij hun uiterste best bij de autoriteiten een paspoort voor Zollner te bemachtigen, wat niet meeviel. Als vluchteling was hij verdacht. Een pas die voor controle naar Aken was gestuurd, raakte daar zoek en in Maastricht wilde men geen nieuw exemplaar uitschrijven. Vervolgens gaven drossaard, schepenen en 'gemeenteraad' van Gronsveld op 10 september 1795 een lovende verklaring af over Zollner. Hij was niet gevlucht, maar naar Duitsland vertrokken voor familiezaken, hij was een ware dienaar van het recht en een echte vredestichter, die door zijn handelen ondubbelzinnig blijk had gegeven van gehechtheid aan de vrijheid en nooit iets had gedaan ten nadele van de republiek. ${ }^{1682}$

1680 TJ, inv. nr. M 62, fol. 108-110, Zollner aan A.J. von Toerring-Jettenbach 9 juli 1794.

1681 TJ, inv. nr. M 62, fol. 97-99, Zollner aan Maximilian Seidl, werkzaam op de grafelijke kanselarij 23 september 1794.

1682 TJ, inv. nr. M 62, fol. 72-73, drossaard, burgemeesters en secretaris aan de Franse autoriteiten in Maastricht 10 september 1795. 
Toen per 1 oktober 1795 de Oostenrijkse Nederlanden, het prinsbisdom Luik en de territoria van de Republiek der Verenigde Nederlanden in het Maasgebied als Departement Nedermaas door Frankrijk werden geannexeerd, trof hetzelfde lot ook de daartussen liggende kleine rijksonmiddellijke gebieden, zoals Gronsveld. Dat betekende dat de inwoners van het graafschap nu Franse onderdanen waren. Voorts was daarmee de weg vrij voor de invoering van een nieuwe bestuurlijke en rechterlijke organisatie. In de brieven uit Gronsveld die in de volgende maanden nog steeds met enige regelmaat- zij het mondjesmaat - München bereikten, van zowel Zollners stiefkinderen, maar bijvoorbeeld ook van pastoor Meijers en drossaard Sarolea, krijgt deze verandering van het staatsbestel als zodanig verhoudingsgewijs weinig aandacht. Als aanhangers van het Ancien Régime beseften deze briefschrijvers misschien niet direct de draagwijdte van deze annexatie. Hun voornaamste zorg lijkt te zijn geweest het voorkomen van een totale financiële en economische ondergang. Zollner en de graaf stonden op de lijst van de 'émigrés', vijanden dus van de Franse republiek, wier goederen inbeslagname wachtte. Bovendien verklaarde een wet van 12 oktober 1795 dat vluchtelingen onmiddellijk hun openbare functies moesten neerleggen. ${ }^{1683}$ De autoriteiten lieten zich maar moeilijk overtuigen dat Zollner en de graaf niet waren uitgeweken. Ook probeerde men duidelijk te maken dat de graaf als landsheer geen deel uitmaakte van de coalitie tegen Frankrijk en dat hij de strijd tegen Frankrijk noch met geld noch met troepen had gesteund. ${ }^{1684}$

Het tweede probleem vormde de betaling van een torenhoog bedrag aan belasting en de gedwongen staatslening ('emprunt forcé), een last waar alle inwoners zwaar onder gebukt gingen. Ook de goederen van de graaf werden aangeslagen. Agnes Petermans die zich daarvoor als zaakwaarneemster verantwoordelijk voelde, vroeg bij het bestuur van het departement wat haar te doen stond. Het gesprek dat zij daarover voerde eindigde in een woordenwisseling en dreigementen. Later kon ze toch nog een regeling treffen. Daarin stond dat de graaf hier nooit geresideerd had, dus geen émigré was, dat de tienden waren afgeschaft en dat de bossen waren verwoest. Daarenboven telde het gezin van de graaf elf kinderen, wat zeker bij de beoordeling van de belastingaanslag moest worden meegewogen. ${ }^{1685}$

De problemen rond de belastingen hingen als een molensteen om de hals van Zollners familie. De pastoor van Gronsveld beschrijft in een brief van 4 maart 1797 welke problemen er speelden. ${ }^{1686}$ Eerst was de graaf getaxeerd op zesduizend livres, toen twaalfduizend en daarna negenduizend. Het departementaal bestuur zette alle middelen in om tot betaling te komen. Men dreigde Agnes Petermans over te brengen naar Parijs, samen met burgemeester Michel van den Boorn, wanneer zij geen opgave deed van de eigendommen van de graaf. Vervolgens werd geprobeerd de vordering te verhalen op de drossaard. Steeds weer werd aan Gronsveldse kant betoogd dat Zollner geen émigré was en

\footnotetext{
1683 Kamphuis, De invoering van wetgeving, 318-319.

1684 TJ, inv. nr. M 62, fol. 93-94, Henri Meyers, pastoor van Gronsveld, aan Zollner in München 17 november 1795.

1685 TJ, inv. nr. M 62, fol. 43-45, Maria Anna Lebens aan Zollner in München 11 maart 1796.

1686 TJ, inv. nr. M 62, fol. 27-31, Henry Meyers, pastoor van Gronsveld, aan Zollner in München 4 maart 1797.
} 
de graaf geen vijand van de Franse Republiek. Registers van inkomsten waren er niet en het vermogen bestond vooral uit intussen opgeheven tienden en vernielde bossen.

Een dag later, 5 maart 1797, schreven Agnes Petermans en haar dochter Maria Anna aan de graaf, terwijl dochter Emerentia een brief voor haar stiefvader Wolfgang Zollner maakte. ${ }^{1687}$ Kennelijk was de vrouwen door Zollner en de graaf verweten dat zij geen ruggespraak hadden gehouden en eigenmachtig optraden. Zo scheen de graaf zich te hebben beklaagd dat het jachtrecht niet werd onderhouden. Maar wat moest je daarover zeggen in een land waar volgens de Franse wet de jacht vrij was? Zij voelden zich dus in ongenade gevallen en beklaagden zich dat zij al het mogelijk hadden gedaan om het onheil af te wenden:

Uwe Excellentie hoeft aan onze oprechtheid niet te twijfelen. U kunt informatie inwinnen bij zakenmensen, bij de adel, priesters of particulieren of bij wie dan ook of er één familie is die zich beter gedragen heeft en meer geleden heeft ter wille van de belangen van haar heer.

Maar ze zagen graag dat de graaf een deskundige benoemde die over de toestand van de goederen rapport kon uitbrengen.

Emerentia antwoordde haar stiefvader op diens verwijt dat hij geen berichten uit Gronsveld ontving. Zij schreef dat er voortdurend brieven waren gestuurd. Dat was ook waar, want het is een feit dat Zollner alle brieven heeft gekopieerd en die afschriften zijn ook in het grafelijk archief beland. Waarom beweerde hij dit? Misschien om de Franse censuur te misleiden, zodat men niet zou denken dat er regelmatig contact bestond met de Gronsveldse émigré in München? Maar ook Emerentia vroeg orders wanneer de graaf wilde dat Agnes Petermans zich nog langer voor zijn belangen inspande.

Deze correspondentie geeft de indruk dat men zich in München steeds minder een goed beeld kon vormen van wat zich in Gronsveld afspeelde. Tegen steeds maar wisselende, torenhoge eisen van de Fransen hielp geen overleg volgens de geijkte procedures. Die wereldvreemdheid blijkt ook uit de gedachte die in maart 1797 bij Zollner opkwam om naar Gronsveld terug te keren. Sinds de opheffing van de schepenbank was er niemand meer om over de landsheerlijke belangen te waken. Ook suggereerde hij de graaf in een memorandum voor de Franse regering de bijzondere positie van Gronsveld uit te leggen. Op die manier kon misschien worden voorkomen dat het graafschap werd getroffen door hetzelfde lot als het naburige Rekem en Wittem. Dergelijke ideeën stonden mijlenver af van de realiteit in het departement Nedermaas.

Intussen was niet alleen Zollner van zijn familie gescheiden, ook zijn stiefzoon die in 1794 met hem was gevlucht, kon niet terug. De jongeman dreigde in München te ontsporen, Zollner kon hem maar moeilijk in het gareel houden en kreeg daar ook van de graaf verwijten over. Emerentia smeekte daarom haar broer te laten terugkeren. Er was zelfs al

1687 TJ, inv. nr. M 62, fol. 33-36, Maria Anna Lebens en haar moeder aan A.J. von Toerring-Jettenbach 5 maart 1797. 
een baantje voor hem beschikbaar bij de graaf De Geloes in Eijsden. Als ze hem aan het werk konden zetten, was de wortel van het kwaad snel afgesneden. ${ }^{1688}$

Er zijn na 14 april 1797 geen brieven meer bewaard van de kinderen Lebens aan hun stiefvader, zodat we niets weten over verder familiale contacten. Toch zullen die er wel zijn geweest. Tot begin 1799 werd immers ook gecorrespondeerd tussen Zollner en Christiaen Schrijnemaekers, de nieuwe pastoor van Gronsveld, die in München bij de graaf zijn benoemingsbrief ging halen (zie daarover Hoofdstuk 15.20.2 sub 'Pastoraat in Gronsveld en Eckelrade: benoemingen en ervaringen').

Uiteindelijk had de weerstand die Agnes Petermans aan de autoriteiten in Maastricht in zoverre resultaat, dat een beslissing werd gevraagd bij de Minister van Financiën in Parijs. Maar de goederen van de graaf werden intussen wel vanaf maart 1797 onder sekwester (bewind) van de domeinen gesteld. Agnes Petermans moest zich als 'zaakwaarnemer' van de voormalige graaf van Gronsveld in Maastricht melden bij 'burger' Bléron, ontvanger van de nationale domeinen. Onder dreiging van militaire dwang werd haar gevraagd rekenschap af te leggen over de grafelijke inkomsten en uitgaven vanaf de komst van de Fransen. Zij protesteerde en zei dat zij nooit belast was geweest met het toezicht op de bezittingen van de graaf. Maar de heren luisterden slechts ongeïnteresseerd en hielden alles voor zich wat hun maar van nut kon zijn. ${ }^{1689}$ Maar op 12 ventôse an 9 (2 maart 1801) deed de Minister van Financiën een definitieve uitspraak: de graaf was stemhebbend lid van de Nederrijns Westfaalse Kreits, vertegenwoordigd in de Rijksdag en behoorde dus tot de rijksvorsten op de linker Rijnoever wier goederen aan de Franse Republiek toevielen. De grafelijke goederen in Gronsveld werden dus staatseigendom.

Het is duidelijk dat Zollner tijdens zijn verblijf in München in dienst bleef bij de graaf. Er zijn geen aanwijzingen dat hij in deze tijd nog ooit is teruggekeerd naar Gronsveld. Zijn naam duikt weer op in februari 1803, wanneer hij als gevolmachtigde van graaf Joseph August von Toerring-Jettenbach de in dezelfde maand bij de Reichsdeputationshauptschluss opgeheven en geseculariseerde rijksabdij Gutenzell (ten zuiden van Ulm) in bezit neemt. ${ }^{1690}$ Abdis Maria Justina von Erolzheim overhandigde hem de insignia, zegel en wapen evenals tekeningen van de gebouwen. Op 9 maart 1803 nam Zollner namens de graaf officieel bezit van de abdij en moesten de inwoners hun nieuwe landsheer huldigen. De graaf kwam pas op 14 juni 1803 persoonlijk naar Gutenzell en liet zich verder zo weinig mogelijk zien. Het feitelijk beheer van de abdij en het landje Gutenzell werd intussen toevertrouwd aan Zollner. Dat viel niet mee. De abdij bleek zwaar met schulden belast. De zusters wilden graag een goed pensioen, maar kwamen met onrealistische eisen. Vooral de abdis die zich maar moeilijk aan de nieuwe situatie kon anpassen, bleek een lastige en hardnekkige gesprekspartner.

Midden in de tijd dat het debat over het pensioen hoog opliep, werd Zollner op een niet nader bekende dag in de tweede helft van mei 1803 's morgens dood aangetroffen in het

1688 TJ, inv. nr. M 62, fol. 33-36, Maria Anna Lebens en haar moeder aan A.J. von Toerring-Jettenbach 5 maart 1797.

1689 TJ, inv. nr. M 62, fol. 3-5, Maria Anne Lebens aan Zollner in München 14 april 1797.

1690 Maegraith, Das Zisterzienserinnenkloster Gutenzell, 182-1851 
gastenverblijf van de abdij. ${ }^{691}$ Volgens de abdis had hij zich door ophanging van het leven beroofd. Zij prees hem als een bijzonder nobel en rechtschapen mens, iemand die niet opgewassen bleek tegen de zware taak om harde maatregelen door te voeren. Zollner had haar meermaals verzekerd dat graaf Joseph August door leugens en laster tegen haar was opgezet en hij had haar bezworen dat hij onmogelijk iets kon volbrengen wat voor hem zo onrechtvaardig was. De abdis zag in Zollner vooral het slachtoffer van de onbuigzame opstelling van de graaf. Die op zijn beurt prees de grote verdiensten van Zollner, maar makkte ook melding van ziekte die zijn geestelijke weerstand had verzwakt. Dat de waardering gemeend was blijkt uit het feit dat de graaf in de kerkhofkapel van Gutenzell een gedenkplaat liet aanbrengen met een tekst ter herinnering aan zijn dienaar. Omdat er op het moment van overlijden in Gutenzell geen pastoor was, kon eerst Zollners opvolger Valentin Banghard in oktober 1803 een overlijdensakte opstellen, die via München naar Gronsveld werd gestuurd. Het droevige nieuw bereikte Agnes Petermans niet meer. Zij was al enkele weken eerder, op 8 september 1803, in Gronsveld overleden.

12.8 Een vergelijking tussen Gronsveld en kleine rijksonmiddellijke territoria in het Maasgebied tijdens de achttiende eeun

Waren de ontwikkelingen zoals we die in Gronsveld in de tweede helft van de achttiende eeuw aantreffen uitzonderlijk voor deze plaats of passen deze binnen het kader van vernieuwende tendensen? Bij gebrek aan vergelijkend onderzoek is het lastig daarvan bij kleine rijksonmiddellijke territoria een algemeen beeld te schetsen. Wanneer we hier een eerste poging doen tot het maken van een vergelijking, dan is dat niet meer dan een impressie op basis van inhoudelijk zeer verschillende literatuur.

Bij een aantal rijksonmiddellijke gebieden in de directe en wat verdere omgeving van Gronsveld valt voor de achttiende eeuw op dat het landsheerlijk gezag door vererving of verkoop in handen was gekomen van adellijke heren, die ver buiten dit gebied resideerden. Voor Gronsveld zijn dat de graven Toerring-Jettenbach in München, voor Wittem de graven Plettenberg in Westfalen ${ }^{1692}$, voor Stein de baronnen Kinsky in Mörs en Silezië1693, voor Wylre diverse families in het Rijnland ${ }^{1694}$ en voor Slenaken na 1771 graaf Goltstein Breyell, die veelal aan het keurvorstelijk hof in Düsseldorf verbleef. ${ }^{1695}$ Een variant op dit verschijnsel vormt de familie d'Aspremont Lynden, die weliswaar het graafschap Rekem als thuisbasis hield, maar vanaf de achttiende eeuw feitelijk vooral in Wenen en in Hongarije verbleef. ${ }^{1696}$

Het is de vraag welke invloed die fysieke afstand had op de verhouding tussen heer en onderdanen. De meeste kleine rijksonmiddellijke gebieden waren economisch en politiek

\footnotetext{
1691 Maegraith, Das Zisterzienserinnenkloster Gutenzell, 193.

1692 Wolters, Ferdinand von Plettenberg.

1693 Munsters, 'De strijd tegen het hoogduits', 95-96; Munsters, 'Rijksonmiddellijkheid en Kammerzieler', 198

1694 De la Haye, Inventaris Wylre, 8-11.

1695 Arndt, Reichsgrafenkollegium, 108-109.

1696 Verbois, Geschiedenis Rekem, 79-105.
} 
onbeduidend. Het was vooral de titel die status verschafte, wat zwaar woog in de wereld van de adel. Daarnaast maakte een graafschap of baronie te midden van een veelheid aan andere bezittingen deel uit van de 'bedrijfsvoering' als geheel en moest het ook rendement opleveren. Bestuur op afstand vereiste echter een andere organisatie dan bezit onder handbereik. Die aanpak kreeg soms 'koloniale' trekjes, zoals blijkt uit de hierna nog te bespreken politiek om bij voorkeur niet-ingezetenen op bestuursposten te benoemen. Ook de tussen de heer en zijn vertegenwoordiger(s) in de sfeer van informatieverstrekking en controle gevoerde briefwisseling laat soms intensieve bemoeienis van hogerhand zien. Gronsveld is in deze studie als voorbeeld van dergelijk bestuur op afstand onderzocht, maar een vergelijkbare situatie lijkt zich ook in het graafschap Wittem voor te doen. ${ }^{1697}$ Over andere plaatsen kan, bij gebrek aan nader onderzoek, geen uitspraak worden gedaan.

'Duitse' landsheren brachten ook een bepaald type 'Duitse' functionarissen in hun gevolg mee. Zo constateren we een bepaalde voorkeur om niet-ingezetenen uit de heerlijkheid of de directe omgeving met bestuurstaken te belasten. Voor Wittem, Slenaken en Wylre kwamen die voor een deel uit Aken, voor Gronsveld waren het Beieren en in Rekem zelfs een Oostenrijker of Hongaar. ${ }^{1698}$ Thorn levert een gemengd beeld, met vooral verbindingen naar Essen en, aan het einde van de achttiende eeuw, het keurvorstendom Trier. Het gaat bij benoemingen niet uitsluitend om bestuursambtenaren. Zo werden in Gronsveld niet alleen pastoors, maar ook de grafelijke jager en een 'Commissionsschreiber' uit Beieren benoemd. Misschien werden vreemdelingen betrouwbaarder geacht dan functionarissen uit de eigen bevolking, maar het bood personeel in landsheerlijke dienst ook de mogelijkheid door een loopbaan in verschillende plaatsen beperkt carrière te maken. Verder hadden deze mensen, voor zover zij in direct contact stonden met de landsheer, het voordeel dat zij het Duits in woord en geschrift beheersten.

Een tweede typisch verschijnsel voor de achttiende eeuw in verschillende kleine territoria is de benoeming door de landsheer van één vaste vertegenwoordiger in plaats van een collegiaal bestuur ter behartiging van zijn bestuurlijke en zakelijke belangen. Voorbeelden zijn Gronsveld, Wittem, ${ }^{1699}$ Wylre 1700 en Rekem ${ }^{1701}$. Soms fungeerde deze functionaris ook als appelcommissaris voor processen in hoger beroep (Wittem ${ }^{1702}$, Wylre, ${ }^{1703}$ Gronsveld). Rechtspraak door één rechter, maar dan in eerste aanleg, zien we ook in Thorn, waar in 1785 een 'overambtman' werd aangesteld. ${ }^{1704}$

In grote landsheerlijkheden ontwikkelde zich vanaf het einde van de middeleeuwen met de benoeming van ambtenaren voor domeinbeheer en belastingheffing binnen een bepaald

1697 RHCL, Vrije rijksheerlijkheid Wittem, voorl. nr. 221-234, 309 en 313, met correspondentie. De indruk is op basis van een plaatsingslijst van een ongeordend archief.

1698 Verbois, Geschiedenis Rekem, 150-151.

1699 Wolters, Ferdinand von Plettenberg, 73.

1700 De la Haye, Inventaris Wylre, 21.

1701 Verbois, Geschiedenis Rekem, 95-97. De situatie in Rekem is niet helemaal vergelijkbaar met die in de andere territoria.

1702 Wiech, Reichskammergericht, Prozessakten Maastricht, inv. nr. 50 en 103.

1703 De la Haye, Inventaris Wylre, 20-21.

1704 Van Rensch, 'Rechterlijke organisatie Thorn', 71. 
district een bestuursmodel, dat in de loop van de tijd steeds verder werd geperfectioneerd. Het aanvankelijk beperkte aantal taken van deze functionarissen groeide uit tot algemeen bestuur ('gute Policey') op basis van de kameralistiek. Bij deze vorm van bestuur werden systematisch inlichtingen verzameld en verwerkt over samenstelling van de bevolking, de geografie en geschiedenis, de hoeveelheid schatbare grond, de landsheerlijke domeinen, openbare orde en veiligheid, de handel, nijverheid en de infrastructuur, kortom alles wat voor het landsbestuur noodzakelijk was. Op basis van deze statistische informatie over land en volk moest, eventueel op aanwijzing van hogerhand, worden gezorgd voor een economisch goed renderende gebied en verhoging van de welvaart, want dat alleen leverde inkomsten voor de staat op.

Deze ambtenaren vormden, in verschillende rollen, binnen het hun toegewezen district de verbinding tussen het centrale gezag en de onderdanen en hadden op die contacten ook min of meer een monopolie. Als intermediair waren zij belast met de afkondiging van wetten en instructies van hogerhand. Ten slotte fungeerden zij soms ook als 'stootblok' tussen de landsheer en plaatselijke gezagsdragers, zoals adellijke 'onderheren' of vertegenwoordigers van de bevolking. Belastingen werden wel geaccepteerd, maar er moest vaak ook onderhandeld worden. De positie van de bestuursambtenaar vereiste dus niet alleen bestuurlijke, economische en financiële kennis, maar ook vaardigheden op het terrein van onderhandelen en communicatie.

Deze manier van besturen was vastgelegd binnen een raamwerk van instructies en beëdiging. Er werd ook controle uitgeoefend en er stonden sancties op slecht functioneren. Maar het bestuur en detail ter plaatse, interesseerde de centrale overheid maar matig. De regels daarvoor gaven zeker speelruimte, zowel in de manier van handelen maar ook bij conflictbeslechting. ${ }^{1705}$

Het type ambtenaar zoals dat hiervoor werd beschreven komt het eerst voor in grote landsheerlijkheden. Vooral binnen de landen onder Brandenburgs-Pruisisch en Oostenrijks gezag werd dit model van bestuur toegepast. Kleine landsheren hebben dit systeem, met aanpassingen voor hun eigen specifieke situatie, volgens dezelfde principes overgenomen, maar de schaal is natuurlijk veel kleiner. Levend en werkend binnen een strak regime van toezicht, moesten zij vervolgens in den vreemde met de plaatselijke elite tot samenwerking zien te komen. En uiteindelijk was binnen deze verhoudingen de gunst van hun meester alles bepalend. De graaf besliste niet alleen over arbeidsverhoudingen, maar ook over privézaken, zoals toestemming voor een huwelijk.

Werkte de 'verduitsing' alleen door in benoemingen, of raakte die ook instellingen? In het algemeen lijken bij de bestaande bestuurlijke en rechterlijke organisaties in kleine territoria geen grote vernieuwingen te zijn doorgevoerd. Typisch is wel de eerder genoemde voorkeur voor eenhoofdig bestuur en eenhoofdige rechtspraak, terwijl in omringende gebieden meer werd gehecht aan collegiale vormen van bestuur en rechtspraak. Misschien moet dat worden gezien als een uitvloeisel van ideeën over verlicht vorstelijk absolutisme, gericht op doelmatigheid.

1705 Zie over deze manier van besturen, zoals die door de Brandenburgs-Pruisische regering werd toegepast in het hertogdom Magdeburg: Löffler, Dörfliche Amtsträger, in het bijzonder de samenvatting, 217-225. 
Duitse invloed sijpelde wel door in de verslaglegging bij het gerecht. Dossiervorming bij processen in Slenaken, Wittem en Wylre gebeurde naar Duits voorbeeld en de gerechtstaal was meestal Duits. In Stein werd zelfs in 1747 het gebruik van het Hoogduits als officiële taal bij het gerecht voorgeschreven. Dat werd één van de redenen voor een opstand rond 1777-1780. In het gerechtsreglement van 1780 werd weer de 'Hollandse' taal voorgeschreven.

In Gronsveld en Thorn valt daar bij het gerecht weer weinig van te merken en werd in het Nederlands geprocedeerd. Maar taal was zeker een punt van aandacht en vormde ook wel degelijk een hindernis. Zo werd in de overeenkomst tussen de Maastrichtse geërfden in Gronsveld en graaf Toerring-Jettenbach uit 1739 uitdrukkelijk bepaald dat de schatrekeningen 'in de nederduytse taele sullen moeten gestelt worden'. Eind jaren veertig was gerechtssecretaris Berchmans in Gronsveld één van de weinigen die Duits kon lezen en schrijven. Rentmeester Lebens kon geen jaarrekeningen in het Duits opstellen. Prummer had lange tijd een Duitse klerk in dienst, vertaalde zelf stukken, en maakte voor speciale gelegenheden gebruik van een Duitstalige notaris. Er bestond dus wel zoiets als een spanning tussen het Nederduits (Brabants, Hollands) en het Hoogduits, maar in de praktijk werd daar heel verschillend mee omgegaan.

Lastiger te vinden zijn typische ideeën uit de Duitse Verlichting. Toch zijn er wel aanwijzingen voor. Zo probeerde in Thorn vorstin-abdis Maria Cunegonda van Saksen in de jaren zeventig en tachtig van de achttiende eeuw het justitiewezen te moderniseren (uiteindelijk met matig succes). ${ }^{1706}$ Ook in de strafrechtspleging lijkt iets van de Verlichting door te dringen. Opmerkelijk genoeg gingen de beruchte bokkenrijdersprocessen vrijwel geheel aan Wittem, Wylre, Slenaken en Gronsveld voorbij, terwijl deze in de naburige gebieden juist in volle hevigheid woedden. ${ }^{1707}$ Een duidelijke verklaring hiervoor ontbreekt. Mogelijk heeft het te maken met de directe invloed die de landsheer van een klein gebied direct uitoefende op het vervolgingsbeleid.

Een voorbeeld van Verlichtingsdenken uit een heel andere hoek levert aan het einde van de achttiende eeuw in Gronsveld het duidelijke streven om controle te krijgen over de bezittingen, de 'temporalia', van de kerk. Dit soort gedachten lijkt direct ontleend aan politieke stromingen die aan de staat macht over de kerk en kerkelijke goed toekenden.

Wanneer we de voorgaande voorbeelden van Duitse invloeden samenvatten, dan blijkt 'verduitsing' niet een algemeen cultureel verschijnsel te zijn, maar bleef het beperkt tot benoeming van functionarissen en veranderingen in administratieve gebruiken bij de rechtspraak. Fundamentele wijzigingen werden niet doorgevoerd. Het gebruik van de taal als communicatiemiddel tussen overheid en onderdanen kon echter, ook als een aspect van oude rechten en gewoonten, wel degelijk een gevoelige snaar raken.

1706 Zie hierover Berkvens, 'Het nieuwe landrecht van Thorn'; Berkvens, 'Zur Abkurtzung Processualweitlaufigkeiten', 230-240; Van Rensch, 'Rechterlijke organisatie Thorn', 71-72.

${ }^{1707}$ Van Rensch, 'Twee onbekende brieven over bokkerijdersprocessen'. 


\subsection{Conclusies}

$\mathrm{Na}$ de roerige jaren 1720-1732 begonnen zich de bestuurlijke verhoudingen binnen het graafschap tijdens de voogdij van graaf Ignaz Felix von Toerring-Jettenbach over de minderjarige Maria Josepha d'Arberg Valengin Gronsveld langzaam te stabiliseren. Een belangrijke verbetering vormden (althans in theorie) de nieuwe instructies voor de drossaard, rentmeester, secretaris en appelcommissaris. Alleen met rentmeester Oligschläger liep het vervolgens mis. Het in 1745 tegen hem gestarte proces wegens fraude eindigde in een zich tientallen jaren voortslepend 'hoofdpijndossier'. Toch ontwrichtte dit juridisch steekspel het bestuur van het graafschap uiteindelijk niet.

Het voor de zeventiende eeuw typische verschijnsel van 'familieregering' bleef in de achttiende eeuw met de familie Lebens (rentmeester en drossaard) onverkort van toepassing. Dat veranderde ook niet door de komst van vreemdelingen. Weliswaar waren grafelijke vertegenwoordigers zoals Prummer en Zollner voor de legitimiteit van hun gezag niet aangewezen op de mening van de bevolking, maar zij moesten zich wel met de belangrijke families ter plaatse zien te arrangeren. Het ging daarbij niet eens zozeer om de geschiktheid van mensen voor een bepaald ambt, want het opleidingsniveau was zeker niet altijd beneden de maat. Maar familierelaties maakten het moeilijk op te treden tegen andere familieleden. Daarnaast raakte in het bijzonder Prummer door zijn heerszuchtige echtgenote steeds meer in de dorpspolitiek verstrikt. Door zijn lichamelijke en geestelijke aftakeling kreeg zijn aangetrouwde familie Lebens feitelijk vrij spel. Zijn opvolger Wolfgang Zollner trof dan ook een in bestuurlijk opzicht verwaarloosde boedel aan.

Hoewel ook Zollner door zijn huwelijk met Agnes Petermans verwant was aan de belangrijkste familie in het graafschap, lijkt hij minder gevoelig te zijn geweest voor dorpse intriges. Bovendien was zijn echtgenote niet uit Gronsveld geboortig en kon hij de ontwikkelingen in Gronsveld beter zelf in de gaten houden omdat hij ook ter plaatse woonde.

Bijna onuitroeibaar was corruptie. De affaire van de frauderende rentmeester Oligschläger was duidelijk een extreem voorbeeld van gebrek aan toezicht. Maar ook de rekeningen van diens opvolger Johannes Godefridus Lebens bleven nog vele jaren zonder voldoende controle. Van serieuze fraude kan bij hem niet worden gesproken, maar vlekkeloos was de boekhouding niet. Vreemdelingen konden die corruptie niet voorkomen. Dat gold in de jaren dertig en veertig toen Franz Blasii Gürtler enkele maanden in opdracht van de graaf in Gronsveld verbleef, dat gold zeker ook voor Prummer, die zelf al in corruptie verwikkeld raakte.

Vanaf het midden van de jaren veertig moet de graaf in München tot het inzicht zijn gekomen dat een permanent aanwezige vertegenwoordiger in Gronsveld een tegenwicht kon vormen tegen de uitwassen van een familieregering. Dit 'eenhoofdig bestuur op afstand' begon met de benoeming in 1748 van 'Hofrath' Josephus Antonius Schmädel als pastoor èn grafelijk vertegenwoordiger in Gronsveld. Schmädel bleek echter ongeschikt, maar zijn opvolger Joseph Anton Prummer en daarna Wolfgang Zollner werden voor de tweede helft van de achttiende eeuw de beeldbepalende personen in het Gronsveldse bestuur. Zij voldeden in vrijwel alle opzichten aan het beeld van de 'Duitse' 
bestuursambtenaar Hun biografieën laten zien hoe iemand met een eenvoudige afkomst na een universitaire studie, door gedisciplineerd werken in de praktijk, carrière kon maken. De 'deeltijdfunctie' van Schmädel, de combinatie van diverse functies bij Prummer en vooral bij Zollner en de regelmatig opduikende discussies over bezoldiging en titulatuur waren echter ook uitingen van de reserves die in München bestonden over dit soort functionarissen. Deels kwam dat voort uit zuinigheidsoverwegingen en deels ook uit wantrouwen voor teveel zelfstandigheid. De graaf verwachtte dat alle instructies en anwijzingen bijna slaafs werden uitgevoerd. Een systeem van intensieve correspondentie volgens strakke bureaucratische procedures moest die zelfstandigheid inperken. Van grote landsheerlijkheden afgekeken was ook een vorm van kameralistiek waarbij de grafelijke vertegenwoordigers uitgebreide rapporten schreven over de toestand van de grafelijke eigendommen en rechten. Die konden dan weer dienen als basis voor beleidsbeslissingen door de graaf. Daarnaast bestond in München ook anderszins een onverzadigbare honger naar 'nieuws' over zowel het graafschap als de verdere omgeving. Een goed voorbeeld daarvan leveren de berichten die Wolfgang Zollner vanaf 1789 verzamelde over de revolutionaire gebeurtenissen in de Zuidelijke Nederlanden en in Luik.

Ondanks alle strakke richtlijnen en voorschriften had de commissaris of directeur bij de dagelijkse uitoefening van zijn werkzaamheden toch de nodige speelruimte. Door hun quasi monopolie op contacten tussen Gronsveld en München konden zij berichtgeving ook filteren of zelfs saboteren. Zo lukte het Prummer de laatste jaren van zijn bewind aanzienlijk gunstiger bij de graaf in München voor te stellen dan de situatie in werkelijkheid was. 'Ruis op de lijn' ontstond pas wanneer anderen een directe weg naar de graaf vonden. Vooral pastoor Kolb heeft met zijn brievenschrijverij aan de graaf Prummer het leven zuur gemaakt.

Gezag moest de vertegenwoordiger van de graaf uitstralen bij de 'buitenlandse' betrekkingen: de contacten met functionarissen van angrenzende heerlijkheden (het graafschap telde negen buren!) en alles wat de kreits of het Nederrijns-Westfaalse Gravencollege betrof. Ook de zakelijke belangen van de graaf buiten Gronsveld vroegen de nodige aandacht. Zowel Prummer als Zollner kregen bemoeienis met het al sinds 1640 bij de Raad van Brabant in Brussel aanhangige proces over de heerlijkheid Rimburg. Verder dienden de grafelijke tiendrechten in Merkstein goed te worden beheerd, vormde het behoud van de Gronsveldse lenen te Vaals en Holset een regelmatige zorg en ten slotte speelde er een langdurig conflict met Slenaken over de bijdrage aan de belastingen van Rijk en kreits.

De grafelijke vertegenwoordiger was verantwoordelijk voor landsheerlijk bestuur in de vorm van 'gute Policey' voor de onderdanen. Binnen het graafschap zorgde hij dat de grafelijke ordonnanties en instructies werden afgekondigd, hield hij toezicht op alle door de graaf benoemde wereldlijke en geestelijke ambtsdragers, waakte voor openbare orde en veiligheid en gaf hij leiding aan de besluitvorming van de geërfden en de gemeenten.

Verder zorgde de grafelijke vertegenwoordiger voor een verantwoord beheer van landerijen, fruitplantages, bossen, kasteel en molen en waakte over handhaving van de landsheerlijke rechten. De commissaris of directeur nam ook het initiatief in alle maatregelen die moesten leiden tot verhoging van het financieel rendement van het 
graafschap. De rentmeester had daarin als boekhouder een meer volgende rol. Prummer had vooral belangstelling voor bosbouw, Zollners interesse ging meer uit naar nieuwe industriële activiteiten en verbetering van de landbouw. Uiteindelijk is van allerlei mooie plannen weinig terecht gekomen door de politieke onrust vanaf eind jaren tachtig. Daarnaast legde Zollner opvallend veel interesse aan de dag voor het beheer van kerkelijke goederen, misschien een gevolg van het feit dat hij in zijn jonge jaren theologie had gestudeerd.

Het bestuursapparaat was zeer klein: één à twee personen, afhankelijk van de combinatie van functies, met soms nog enige secretariële ondersteuning. Dat betekende veel werk. Het ontbrak zeker niet aan ijver. Prummer en Zollner hebben zich ieder met veel energie op hun taak gestort en geprobeerd daar op hun eigen manier invulling aan te geven. Beiden werkten zeer nauwkeurig. Die eigenschap kwam Prummer goed te pas bij het uitpluizen van oude registers om allerlei grafelijke inkomsten in de vorm van cijnzen, keurmeden, lenen en pachten letterlijk in kaart te brengen. Maar de uiterst kleine bezetting makkte het bestuur ook kwetsbaar bij ziekte en conflicten die in het persoonlijke vlak werden getrokken.

Toevallig is voor Gronsveld in de vorm van zowel officiële als particuliere correspondentie rijkelijk bronmateriaal aanwezig, dat een inkijk geeft in de plaatselijke verhoudingen, de manier waarop de representanten van de graaf met hun onderdanen omgingen en de gevoelens van deze vreemdelingen in Gronsveld. Of deze situatie representatief is voor andere plaatsen, valt bij gebrek aan nader onderzoek niet te zeggen, maar het is denkbaar dat ook elders vergelijkbare situaties bestonden. Prummer en Zollner hadden totaal verschillende karakters. Eerstgenoemde was in de omgang nogal wantrouwend en moeilijk benaderbaar, zeker in de laatste jaren van zijn leven. Bij onderhandelingen gaf hij meestal blijk van grote vasthoudendheid. Ook Zollner wist zijn wil door te zetten, maar hij beschikte over een opener karakter. Afhankelijk als zij waren van de graaf, accepteerden ze diens bevelen. In particuliere correspondentie lieten zij zich echter meermalen misprijzend uit over dit strikte regime. De onderdanen zagen de commissaris of directeur als een soort onderkoning. Hij vormde de schakel met de landsheer. De inwoners van het graafschap konden zich van de graaf immers alleen een beeld vormen via diens vertegenwoordiger. In het bijzonder Prummer voelde zich goed in die rol. Voor het gezag was men niet afhankelijk van de bevolking, maar de publieke opinie binnen het graafschap viel moeilijk te peilen. Men ziet in de brieven naar München meermalen een dubbelhartige benadering. Nu eens werd de bevolking geprezen om haar aanhankelijkheid aan de graaf, dan weer was er sprake van wantrouwen en werden alle slechte eigenschappen breed uitgemeten.

Afgezien van de moeilijke jaren van de Oostenrijkse Successieoorlog eind jaren veertig, toen geallieerde legers het graafschap bijna kaal vraten, verliep het grootste deel van de achttiende eeuw in bestuurlijk opzicht vrij rustig voor het graafschap. Het grootste probleem vormde vanaf 1789 de politieke onrust in het omringende buitenland en, iets later, de revolutie in Frankrijk. Vanaf eind $1792 \mathrm{kreeg}$ het graafschap daadwerkelijke 
overlast, eerst van doortrekkende Oostenrijkse troepen en in februari 1793 de eerste bezetting van Franse soldaten. Nadat de Fransen in de loop van 1793 waren teruggedrongen, keerden zij in herfst van 1794 terug, ditmaal om gedurende twintig jaar te blijven. Per 1 oktober 1795 werd Gronsveld bij Frankrijk ingelijfd en begon de ontmanteling van de instellingen van het Ancien Régime. Voor het rijksonmiddellijke graafschap Gronsveld als lid van het Heilige Roomse Rijk bleef lang onzeker wat dat precies betekende, zo lang er geen vrede met Frankrijk was gesloten.

Zollner vluchtte op de nadering van Fransen in 1794 naar München en keerde niet meer naar Gronsveld terug. Hij bleef in grafelijke dienst en onderhield in de jaren daarna (moeizaam) schriftelijke contacten met zijn echtgenote, stiefkinderen en enkele vertrouwenspersonen in Gronsveld. Gedurende deze periode werd geprobeerd de door de Fransen in beslag genomen grafelijke eigendommen (kasteel, landerijen, bossen) te behouden voor de toekomst. Maar bij de Reichsdeputationshauptschluss in het voorjaar van 1803 verloren de graven Toerring-Jettenbach hun rechten en bezittingen in Gronsveld definitief aan de Franse Republiek. Zollner werd door de graaf belast met het beheer van de opgeheven abdij Gutenzell in Schwaben, die aan de graaf als schadevergoeding was toegekend, maar overleed daar al in de tweede helft van mei 1803. 


\section{De schepenbanken, circa 1730-1795}

In de jaren twintig van de achttiende eeuw waren de Gronsveldse schepenen een speelbal van elkaar bestrijdende facties en wisselden zij, bij wijze van spreken, als de seizoenen. De beperkte hoeveelheid archiefmateriaal van en over de schepenbanken na 1732 wekt de indruk van een tamelijk stabiele organisatie. In dat opzicht past het beeld bij de situatie zoals die ook uit de meeste andere plaatsen in de omgeving bekend is. Alleen de malversaties van rentmeester/secretaris Oligschläger in de jaren dertig en veertig zorgden voor enige beroering.

De bestaande rechterlijke organisatie met de schepenbanken van Gronsveld, Heugem en Honthem bleef in stand. Alleen Slenaken maakte daar sinds 1728 geen deel meer van uit omdat de heerlijke rechten over die plaats waren verkocht aan graaf Plettenberg. Daarmee verloor de bank van Gronsveld ook de positie van hoofgerecht/appelgerecht. Ook de strijdbijl van het hoger beroep op Aken lijkt uiteindelijk te zijn begraven.

Hoewel er formeel drie schepenbanken bestonden, was de personele bezetting van alle drie gelijk. Zittingen werden in Gronsveld gehouden, alleen voor het voogdgeding kwam men nog in Honthem en Heugem bij elkaar. Verder bestond een scheiding op papier in die zin, dat voor de vrijwillige rechtspraak per plaats afzonderlijke registers werden bijgehouden. Een probleem bleef de kwantitatieve en kwalitatieve bezetting van de schepenbanken. Het bleek moeilijk voldoende juridisch onderlegde schepenen te vinden. Ook corruptie en familiebelangen waren gevaren die altijd op de loer lagen. Toch konden de schepenen niet ongecontroleerd hun gang gaan, omdat de graaf in de persoon van een permanent aanwezige vertegenwoordiger enig toezicht hield.

Het einde van de rechterlijke organisatie en de schepenrechtspraak in 1795 en 1796 door de inlijving van het graafschap bij de Franse Republiek verliep zonder grote schokken. Mentaal lijkt het moeite te hebben gekost, maar men voegde zich naar de nieuwe wetgeving.

\subsection{Beeld van de rechtspraak ten plattelande in het Maasgebied in de achttiende eeuw}

In 1772 maakte J.F. van Steelant, advocaat-fiscaal bij de Staatse Raad van Brabant, een rapport over de toestand van de rechtspleging in de Staatse Landen van Overmaze. ${ }^{1708} \mathrm{Hij}$ constateerde tal van gebreken en onregelmatigheden. 'Officieren' en andere ambtsdragers behorende tot de 'staande magistratuur' woonden bijna allemaal in Maastricht, buiten hun ambtsgebied dus, en lieten zich vervangen door personen die ook niet binnen het hun toegewezen ressort woonden. Schepenplaatsen werden aan de meestbiedende verkocht, waardoor rechters er belang bij hadden hun geïnvesteerd kapitaal terug te verdienen. Ook schepenen woonden dikwijls niet in de plaats waar zij waren benoemd. Ten slotte was er het misbruik dat schepenen door cumulatie van ambten vak de functie van secretaris

1708 De hierna volgende samenvatting is gebaseerd op Van Hall, 'Een onderzoek naar de rechtspraak'. 
uitoefenden. Een specifiek probleem betrof de wetgeving in het Nederlands, die in de Waals sprekende Landen van Overmaze vaak niet werd begrepen.

Een belangrijk deel van de strafzaken bestond volgens Van Steelant uit de vervolging van vechtpartijen, vooral na herberg- en kermisbezoek. Veel jongeren waren gewapend met zware stokken, voorzien van metaalbeslag, waardoor schermutselingen eindigden in ernstig letsel of zelfs doodslag. Ook velddiefstal vormde een groot probleem. De justitie trad niet of te langzaam op, waardoor bewijs verloren ging of verdachten de benen namen. Die traagheid ontstond niet alleen door de omslachtige manier van strafvordering, ook de lange tijdsduur van processen met daaraan gekoppeld hoge kosten, weerhielden de officieren van krachtig optreden.

Ook de civiele rechtspraak kwam er bij Van Steelant niet goed af: nodeloos lang, vertragingstactieken, exorbitant hoge kosten en onregelmatigheden bij toepassing van het beslag- en executierecht. Secretarissen verwaarloosden hun taak. Akten werden in het schepenprotocol ingeschreven alsof er getuigen bij waren geweest, terwijl dat in werkelijkheid niet zo was. Inschrijvingen vonden onregelmatig plaats, er werd in de teksten geknoeid en het was een vorm van geldverspilling dat partijen eerst naar een notaris moesten gaan om vervolgens dezelfde akte tegen betaling ter 'realisatie' bij de schepenbank aan te bieden.

De door Van Steelant beschreven situatie was eigenlijk structureel voor de rechtspleging ten plattelande in het hele Maasgebied. In 1783 kwam de Pruisische kanselier Carmer tot vergelijkbare bevindingen voor het Pruisisch Overkwartier van Gelre. Voor het Staatse Overkwartier van Gelre was het niet veel beter. Ook de kleine rijksonmiddellijke territoria leveren een vergelijkbaar beeld op. ${ }^{1709}$

Vanaf omstreeks 1770 werden in de verschillende gebieden wel pogingen tot verbetering of zelfs hervorming ondernomen, maar uiteindelijk leverde dat slechts beperkt resultaat op. ${ }^{1710}$ Voor een belangrijk deel was dat een gevolg van weerstand van gewestelijke of plaatselijke gezagsdragers. Gewestelijke Staten waren nauwelijks bereid bij te dragen in de kosten voor verbetering van de rechtspleging, terwijl adellijke heren in het bezit van heerlijke rechten veranderingen in de personele bezetting van de justitie beschouwden als een inbreuk op hun benoemingsrecht. ${ }^{1711}$ Pas de fundamentele veranderingen in de rechtsbedeling zoals de Fransen die na de inlijving van het Maasgebied bij Frankrijk in 1795 doorvoerden, leidden tot een werkelijke breuk met het verleden.

\footnotetext{
${ }_{1709}$ Algemeen zie: Van Hall, 'Een onderzoek naar de rechtspraak', 85-86; voor het Pruisisch Overkwartier zie: Flament, 'De rechtsbedeeling', 79-87; Van Rensch, 'Het Hof van Justitie van Pruisisch Gelre', 242245; 250, 253 en als voorbeeld van visitatie van een hogere instantie, het Justiz-Collegium te Geldern voor het Pruisisch Overkwartier van Gelre, zie Berkvens, 'De Geheime Tribunalsrath Johann Koenen'. Voor rijksonmiddellijke gebieden zie De Wit, 'Inwendige toestanden' en specifiek voor Thorn zie Berkvens, 'Het nieuwe landrecht van Thorn', 96-97 en Van Rensch, 'Rechterlijke organisatie Thorn', 71-72.

1710 Voor bijvoorbeeld de resultaten daarvan in het Stift Thorn zie Berkvens, 'Het nieuwe landrecht van Thorn', 96-97 en Van Rensch, 'Rechterlijke organisatie Thorn', 71-72; Voor het Pruisisch Overkwartier zie Van Rensch, 'Het Hof van Justitie van Pruisisch Gelre', 250-251 en Flament, 'De rechtsbedeeling', in het bijzonder 79-87, het rapport van minister De Carmer over de justitie.

1711 Zie bijvoorbeeld Van Rensch, 'Het Hof van Justitie van Pruisisch Gelre', 235-242, 251-252.
} 


\subsection{Beeld van de rechtspraak in Gronsveld, circa 1750-1794}

In 1755 beschreef de grafelijk vertegenwoordiger Prummer de schepenen van Gronsveld op een manier die aan duidelijkheid niet veel te wensen overliet. Hij zegt van hen:

De schepenen zijn slechts eenvoudige boeren, die van de praktijk bij het gerecht of van wetgeving niet meer weten dan wat hun gezond verstand, voor zover ze dat hebben, hun ingeeft of wat zich volgens algemeen gebruik en boerenwijsheid in hun hoofd heeft vastgezet. Ze dansen naar de pijpen van de drossaard en ze varen op diens kompas, zonder dat ze daar ook maar iets tegen kunnen inbrengen en ze durven al helemaal niet anders te oordelen of te beslissen dan wat hij hen voorhoudt. ${ }^{1712}$

Ze lieten zich geheel leiden door de drossaard en fiscus, die de zittingen eindeloos rekte. Vooral drossaard Hendrik Lebens toonde zich daar een meester in. Zaken van enige importantie werden na afsluiting van het proces voorgelegd aan advocaten in de stad. Hun advies leverde een conceptvonnis op, dat vervolgens alleen nog maar hoefde te worden uitgesproken. Toch vraagt het beeld van volstrekte afhankelijkheid van derden zoals drossaard of advocaten, enige nuancering. Het gezond boerenverstand was misschien ontoereikend voor het oplossen van complexe juridische vraagstukken, maar sommige schepenen hadden ook een benoeming bij andere banken of waren in de praktijk werkzaam als notaris of secretaris en konden uit dien hoofde toch bogen op praktijkervaring.

Het bleek verder uiterst moeilijk de schepenbank volledig bezet te krijgen, want voor de magere beloning stelde zich nauwelijks iemand beschikbaar. Prummer had op dat moment vier vacatures, niemand meldde zich en mensen die gevraagd werden, weigerden. Zo was het een acuut probleem voldoende schepenen te krijgen voor vonnissen in de zaak Oligschläger. Bereidheid om als schepen op te treden bestond eigenlijk alleen maar bij functionarissen die uit anderen hoofde al met het gerecht van doen hadden, zoals de secretaris of de griffier van het leenhof.

Prummers oordeel over de toestand in Gronsveld sluit bijna naadloos aan bij de voorgaande beschrijvingen van de rechtspraak in de achttiende eeuw. Het in 1746 tegen secretaris en rentmeester Oligschläger aangespannen proces bracht nog eens duidelijk aan het licht hoe de man lange tijd ongemerkt in de gerechtsrollen had kunnen knoeien. Toch legde Prummer niet veel ijver voor hervormingen aan de dag. Hij liet de tot circa 1770 werkzame, hoogbejaarde drossaard Hendrik Lebens ongemoeid. In de jaren daarna trad Prummer zelf vaak als drossaard en fiscus op. Met tegelijkertijd zijn zwager Johan Frans Lebens als secretaris, had Prummer ook niet veel behoefte aan verandering. Sterker nog, zijn assistent en latere opvolger Wolfgang Zollner verweet hem later dat hij bewust

1712 TJ, inv. nr. M 13, fol. 13-24, Prummer aan graaf 9 november 1755: 'Die...scheffen... seint nichts mehr als einfaltige pauren, welche von einen gerichts-praxi, recht oder gerechtigkeit gesätzen oder anderen mehrer nit wissen als was ihnen ihre natürliche vernunfft, so weith oder wenig sich dise erstreckhet, eingibet oder durch allgemainen gebrauch und pauren reglen in kopf gesetztet ist, dan sye also in allen sachen, wie ihnen der drossard vorpfeiffet, tanzen und wie sye diser leithet, fahren muessen, ohne das sye gegen ihne nur das mündeste zu sagen, villmünder... anderst als er es intendiert, zu urtheillen und decretieren getraueten...' 
vreemde juristen voor de functie van drossaard en fiscus had geweerd omdat hij geen pottenkijkers wilde.

In de nadagen van Prummer stond het gerechtswezen er in Gronsveld niet florissant bij. Het rapport dat Wolfgang Zollner in 1779 daarover uitbracht, spreekt boekdelen. ${ }^{1713}$ De schepenbank genoot weinig aanzien, de leden van het gerecht werden slecht betaald en de kwaliteit van de rechtspraak was beneden de maat. Zollner had zich al direct voorgenomen niet alleen een 'Kleine Rechtsordnung' maar ook een 'Taxordnung' te ontwerpen, maar wegens andere werkzaamheden was dit nog niet afgerond. Er bestond weliswaar de in het Hoogduits geschreven Rechtsordnung uit 1671 en een in het Nederduits geschreven 'Taxordnung' (waarschijnlijk doelde Zollner hier op het reglement op de proceskosten van 1724), maar eerstgenoemde was - volgens hem - nooit tot uitvoering gekomen en ook de tweede werd niet goed nageleefd. Helemaal juist was die bewering niet, want bepaalde onderdelen uit de Rechtsordnung van 1671 (wetgeving op het gebied van de dode hand, de bepalingen over keurmeden en lenen) waren wel degelijk toegepast, maar stukgelezen was de Rechtsordnung zeker niet. En bij de gerechtskosten werd nu eens te veel, dan weer te weinig in rekening gebracht. Natuurlijk kon de graaf als landsheer eigen wetten uitvaardigen, maar bij een klein land als Gronsveld was het een kwestie van 'Staatsklugheit' wanneer men zich oriënteerde op het recht van naburige territoria, in het bijzonder Brabant. Er viel overigens bij het schepengerecht niet zo veel bijzonders te behandelen en zelden kwamen ingewikkelde juridische problemen aan de orde. Het meest opzienbarend in honderd jaar waren het proces tegen Oligschläger en het nog lopende geschil met pastoor Van Bloer van Heugem (zie Hoofdstuk 15.20.3 sub 'Pastoraat in Heugem'). Schuldzaken, boedelscheidingen, kleine overtredingen en vechtpartijen stonden het meest frequent op de rol, waarbij de zaak dikwijls met een compromis en zelden met een vonnis eindigde. Wanneer eens een keer een belangrijke zaak speelde, of iemand moest wegens een zwaar delict aan lijf en leden worden gestraft, dan zorgde het gerecht voor de instructie van het proces. Daarna werd juridisch advies bij twee onpartijdige rechtsgeleerden ingewonnen en dat volgden de schepenen bij hun vonnis klakkeloos, of de bank nu met juristen was bezet of niet.

Ook bij de procesgang viel Zollner van de ene verbazing in de andere. Bij verhoor onder ede werd de getuige nooit voorgehouden dat hij een eed moest zweren en de waarheid spreken. De formule 'zo waarlijk helpe mij God en al zijn heiligen', bekrachtigd met een handdruk, werd nooit toegepast. Omdat Zollner dit toch zeer aanstootgevend vond en -'in het bijzonder bij dit volk' - beducht was voor meineed, had hij een eedsformule gemaakt en ingevoerd.

Een niet minder ernstig misbruik betrof het geknoei van schepenen in het gerechtsprotocol. Zo werden processen ingeschreven zonder daarvan eerst iets tegen de drossaard of overige schepenen te zeggen. Het gebeurde zelfs buiten aanwezigheid van een van de partijen.

Voorts deden familiebelangen de geloofwaardigheid van de justitie geen goed. Sinds meer dan een halve eeuw bekleedden leden van de familie Lebens posities bij het gerecht. Een

1713 TJ, inv. nr. M 6, fol. 73-103 Zollner aan A.J. von Toerring-Jettenbach 31-8-1779. 
Lebens was drossaard geweest, een Lebens vervulde de functie van secretaris en de overige vijf schepenen, (waarvan er drie als notaris of procureur werken) behoorden ook tot de familie Lebens of tenminste tot hun ' favorite und creaturen'. Zo was eigenlijk ook de functie van commissaris door het huwelijk van Prummer met een Lebens in handen van die familie gekomen.

Een schepen ontving naast gerechtskosten slechts acht gulden per jaar vast loon. Dat was weinig, maar volgens Zollner voldoende, want er was in de elf maanden van zijn verblijf maar weinig voorgevallen.

Volgens de conventie over de belastingen die in 1739 tussen de graaf en de geërfden of staten van Gronsveld was afgesloten (zie Hoofdstuk 16.2.6 en Bijlage 38), stond het als een paal boven water dat de kosten van de landsheerlijke justitie als 'onus reale' ook ten laste van de 'real-cassa' kwamen. Met andere woorden, het was een 'zakelijke last', die moest worden betaald uit de opbrengst van de grondbelasting. Zollner wilde wel proberen of de geërfden of standen bereid waren meer bij te leggen, maar het was in deze streken niet gebruikelijk veel voor het erebaantje van schepen te betalen. Wanneer je de standen kon bewegen in te stemmen met een salarisverhoging en men bovendien werd vrijgesteld van het huren van een gerechtslokaal, dan moesten toch enigszins bemiddelde en 'wohl practicierte leute' als goede, onpartijdige schepenen zijn te vinden.

De gewone zittingen van de schepenbank werden gehouden in Gronsveld, met eens per kwartaal het voogdgeding in Gronsveld, Heugem en Honthem. Waar men in Heugem en Honthem vergaderde, is niet bekend; waarschijnlijk in een herberg of woonhuis. In Gronsveld hield het gerecht zitting in een onderkomen dat door Zollner werd betiteld als een 'stinkende boerenhut', die ook nog huur kostte. Hij opperde daarom de mogelijke bouw van een nieuw 'Gerichtshaus' in combinatie met een pand dat kon worden gebruikt als dienstwoning en kantoor van de commissaris.

$\mathrm{Al}$ die plannen kostten geld. Zollner durfde niet direct met een voorstel te komen, want hij kon onvoldoende inschatten hoe de standen dachten. Die aarzeling leidde ertoe dat het uiteindelijk bij plannen bleef. De bouw van een 'Gerichtshaus', tegelijk met sloop van het bouwvallige kasteel van Gronsveld, werd onderwerp van jarenlange correspondentie tussen Zollner en de graaf, maar bleef zonder concreet resultaat. En van nieuwe reglementen op de justitie kwam ook niets terecht.

Met de personele bezetting van de schepenbank werd evenmin veel vooruitgang geboekt. Aan het einde van de achttiende eeuw was er nog steeds geen 'volle' bank en trad de secretaris nog altijd op als schepen. Anderzijds slaagde Zollner er toch in een mengeling te krijgen van personen uit Gronsveld en juristen of in de juridische praktijk geschoolde personen uit de omgeving. Voorbeelden van die laatste categorie zijn de benoeming van op 12 januari 1792 van G.J. Paulissen, meier te 's-Gravenvoeren als opvolger van zijn vader J.P. Paulissen ${ }^{1714}$ en W.A. Denis op 3 juli 1794, een zoon van de overleden drossaard J.W. Denis. ${ }^{1715}$

1714 RHCL, Graafschap Gronsveld, inv. nr. 258.

1715 RHCL, Graafschap Gronsveld, inv. nr. 257. 


\section{3 Het hoger beroep}

Het hoger beroep vanuit Gronsveld op de Schepenstoel van Aken had vooral in de tweede helft van de zeventiende eeuw tot grote onenigheid geleid. Begin achttiende eeuw waren de gemoederen enigszins bedaard, maar in de jaren twintig werd de Schepenstoel met de klacht over het uitblijven van de gerechtelijke vervolging van de doodslag/moord begaan op Sebastiaan de Montbrison opnieuw gemengd in Gronsveldse aangelegenheden (zie Hoofdstuk 11). Uiteindelijk belandde deze zaak op de tafel van het Rijkskamergerecht, welke instantie op 28 april 1728 uitspraak deed over intussen een reeks geschilpunten. De schepenen van Aken moesten de zaak Montbrison opnieuw behandelen ten overstaan van een uit hun midden aan te wijzen commissaris. Die taak werd opgedragen aan schepen en raadslid Alexander Theodor d'Oliva. Graaf d'Arberg Valengin kreeg opdracht zijn geschil over de bevoegdheid van het Akense gerecht ten opzichte van Gronsveld ter verdere behandeling voor te leggen aan het Rijkskamergerecht. Hangende deze procedures kon hij uit de juristen van Aken één of twee appelcommissarissen benoemen. Met dit vonnis spaarde het Rijkskamergerecht de kool en de geit. Over de bevoegdheid van de Schepenstoel van Aken als appelgerecht werd geen uitspraak gedaan en de schepenen van Aken hoefden zich niet langer gepasseerd te voelen met een appelcommissaris uit hun midden.

Door het vonnis van het Rijkskamergerecht kreeg d'Oliva voor het eerst te maken met Gronsveld. De intensiteit van zijn bemoeienis groeide in de jaren daarna nog sterker. In de strijd over de voogdij van de minderjarige gravin Maria Josepha d'Arberg kreeg het stadsbestuur van Aken begin 1732 van het Rijkskamergerecht de 'interims administration zu Gronsfeld' opgedragen en werd d'Oliva met de uitvoering daarvan belast. Na toewijzing van de voogdij aan graaf Felix von Toerring-Jettenbach bleef d'Oliva zich op verzoek van de graaf om Gronsveld bekommeren. Die opdracht vervulde hij met verve. Toen Franz Blasii Gürtler midden jaren dertig namens graaf Toerring Jettenbach probeerde bestuur en rechtspraak weer op het juiste spoor te brengen met nieuwe instructies voor drossaard en rentmeester, stuitte hij ook op het nog altijd onopgeloste èn gevoelige probleem van het hoger beroep van Gronsveld op Aken. Om aan de verwarring op dit punt een einde te maken benoemde de graaf - ongetwijfeld op instigatie van Gürtler - op 19 augustus 1737 d'Oliva tot 'Appelationsrichter' of 'Commissarius'. Iedereen die zich bezwaard voelde door een vonnis van de schepenen van Gronsveld, kon bij hem in beroep komen. Drossaard en gerecht moesten hem als zodanig erkennen en respecteren. Hoewel de graaf overtuigd was van d'Oliva's geschiktheid voor de functie, heeft de benoeming ook het karakter van een compromis: de jurisdictie van de Schepenstoel van Aken werd niet erkend, maar ook niet volledig gepasseerd. ${ }^{1716}$

Toch bleek d'Oliva niet aan de verwachtingen te voldoen. Gürtler twijfelde na verloop van tijd aan diens loyaliteit. Zo verdacht hij de commissaris ervan de steeds meer in opspraak rakende rentmeester Oligschläger de hand boven het hoofd te houden. Ook leek d'Oliva gemene zaak te maken met baron de Bounam van Rijckholt, terwijl er tegelijkertijd

1716 TJ, inv. nr. M 76, fol. 447-450, graaf I.F. von Toerring-Jettenbach benoemt Alexander Theodor d'Oliva, burgemeester en schepen van Aken, tot appelrechter en commissaris 19 augustus 1737. 
processen liepen tegen Rijckholt. Gürtler realiseerde zich heel goed dat die zulke negatieve berichten nauwelijks kon geloven, maar drong toch bij de graaf aan op ontslag van de commissaris. ${ }^{1717}$

Met het huwelijk van gravin Maria Josepha d'Arberg met Maximilian Emanuel von Toerring-Jettenbach eindigde formeel ook de bemoeienis van d' Oliva met Gronsveld, voor zover zijn werkzaamheden tenminste voortvloeiden uit de voogdij. Los daarvan stond zijn benoeming als appelcommissaris voor Gronsveld. Maar op 24 november 1746 adviseerde Gürtler de nieuwe graaf om de benoeming van d'Oliva als appelcommissaris formeel in te trekken. De inwoners van Gronsveld konden voor hoger beroep voortaan direct terecht bij het Rijkskamergerecht of de Rijkshofraad. ${ }^{1718}$ Inderdaad nam de graaf op 30 november 1746 een besluit van deze strekking. Het mag nauwelijks toeval heten dat enkele weken eerder, mede op instigatie van Gürtler, bij de schepenbank Gronsveld tegen Oligschläger een procedure was aangespannen wegens corruptie en ambtsmisbruik. In een zaak waarvan de omvang en gevolgen zich moeilijk lieten voorspellen, kon een nietbetrouwbare appelcommissaris als tusseninstantie voor complicaties zorgen. Opmerkelijk genoeg lijkt aan het ontslag doelbewust geen ruchtbaarheid te zijn gegeven. Dat zorgde later, in het proces over de verkoop van de hoeve Hemersbach van de Erven de Floen tegen Oligschläger, nog voor een verrassing.(zie Hoofdstuk 12.5) Want toen Oligschläger in 1750 tegen een vonnis van de schepenen van Gronsveld in appel wilde gaan bij d'Oliva, kreeg hij te horen dat die al jaren geleden als appelcommissaris was ontslagen!

Na 1746 konden de inwoners van Gronsveld voor beroep tegen vonnissen weer terecht bij het Rijkskamergerecht of de Rijkshofraad. Als voorbeelden daarvan kunnen hier worden genoemd het proces tegen rentmeester Oligschläger (zelfs drie keer), het proces over de nalatenschap van kanunnik Salden, het proces van de Floen/de Montbrison tegen Oligschläger en een zaak van het kapittel van Onze-Lieve-Vrouw te Maastricht tegen de inwoners van Heugem over het herstel van de kerk. In het geschil over de betaling van aardappeltienden (zie Hoofdstuk 17.5) werd de hulp van de Rijkshofraad in Wenen ingeroepen. Rijkskamergerecht en Rijkshofraad stonden in concurrentie tot elkaar, maar er lijkt in het Maasgebied een zekere voorkeur voor het Rijkskamergerecht te hebben bestaan.

Toch lagen de mogelijkheden tot appel genuanceerder dan deze voorbeelden op het eerste gezicht doen vermoeden. Het is alleen moeilijk de spaarzame informatie daarover in Gronsveld goed te interpreteren, aangezien van het archief van de schepenbank slechts fragmenten bewaard zijn gebleven. In een ongedateerd concept-attest van de schepenen van Gronsveld 'tot naerricht van de vier borgemeesters van alhyer' worden als appelinstanties voor het graafschap genoemd het Rijkskamergerecht of de Rijkshofraad

bij soo verre de zaake waer van geappelleert word in rechten gefondeert is en haare behoorlijcke requisita volgens de Rijckxrechten heeft en bij dyen niet, staet het aen

1717 TJ, inv. nr. M 5, fol. 309-312, Gürtler (vanuit Jettenbach) aan graaf I.F. von Toerring-Jettenbach 25 juli 1743.

1718 TJ, inv. nr. M 76, fol. 451-453, Gürtler aan graaf I.F. von Toerring-Jettenbach 24 november 1746. 
d'authoriteijd van Sijne Excellentie den heere Rijckxgrave van Gronsfeldt om richters in appel te denomineren naer desselffs hooge beliefte'. ${ }^{1719}$

Het ongedateerde stuk is, vanwege de verwijzing naar de vier burgemeesters, mogelijk opgesteld rond 1780, in het proces over de aardappeltienden. Wat het precies betekende dat een zaak voor appel moest zijn 'in rechten gefondeert ... en haare behoorlijcke requisita volgens de Rijckxrechten heeft', is niet helemaal duidelijk. Waarschijnlijk werd bedoeld dat voor ontvankelijkheid van appel bij het Rijkskamergerecht de zaak moest voldoen aan eisen, zoals een bepaald financieel belang. Sinds 1664 was dat gesteld op zeshonderd Reichstaler. ${ }^{1720} \mathrm{Om}$ in kleinere processen toch de mogelijkheid van hoger beroep te hebben, kon in Gronsveld een partij zich wenden tot de landsheer, die dan een gedelegeerd appelrechter voor deze zaak aanwees. $\mathrm{Er}$ is één voorbeeld van een dergelijk appel bekend en wel het - fragmentarisch bewaarde - dossier van het geschil tussen Hendrik Lousberchs en pastoor van Bloer van Heugem over een strookje grond langs de pastorietuin (zie meer over deze kwestie Hoofdstuk 15.20.3 sub 'Pastoraat in Heugem). In deze zaak ging Van Bloer in beroep tegen een vonnis van de schepenen van Gronsveld. Daarbij speelde de vraag welke termijnen voor appel golden. Op 1 augustus 1764 bepaalden de schepenen dat voor een appel op het Rijkskamergerecht een periode van negentig dagen stond. Wie echter appelleerde

'naer den geeligeerden (bedoeld is: gedelegeerde) rechter door Sijne Hooghgraeff(elijck) Excellentie gestelt, nempe den eerentf[este] heer Commissaris waerover men sich in dit cas geadresseerd heeft',

had slechts dertig dagen ter beschikking. Van Bloer had zich in dit geval niet aan de voorgeschreven termijn gehouden. Uiteindelijk stonden de schepenen op 13 november 1764 het appel toch toe en stelden een datum vast voor inventarisatie en ondertekening van het procesdossier 'ten eijnde van toedraeginge aen den hooghedelen gebooren heer gesubdelegeerden in materie van appel'. Drie dagen later werden drie inventarissen getekend en gezegeld (twee voor partijen, één voor de appelrechter). Verdere gegevens over dit hoger beroep ontbreken, maar de procedure wordt wel duidelijk. Op het verzoek van Van Bloer aan de graaf om een rechter in appel te benoemen, kreeg commissaris Prummer de opdracht de zaak opnieuw te beoordelen. ${ }^{1721}$

Op zich lag de aanwijzing van Prummer als appelrechter voor de hand (een zelfde situatie zien we bijvoorbeeld ook in Wylre), maar het was geen automatisme. Iemand die zich door een vonnis bezwaard voelde, moest zich per geval tot de graaf wenden om een rechter in tweede instantie benoemd te krijgen. Door de fragmentarische overlevering van het archief van de schepenbank valt moeilijk te beoordelen of dit vaak gebeurde, maar de bewaard gebleven rolregisters van de schepenbank wekken de indruk dat het slechts om

1719 TJ, inv. nr. M 17, fol. 247A, losliggend blad, ongetekend en ongedateerd concept, zie bijlage 31.

1720 Wiech, Reichskammergericht, Prozessaketen Maastricht, 28.

1721 Over deze zaak zie RHCL, Graafschap Gronsveld, inv. nr. 254, diverse inschrijvingen fol. 244, 254, 255. 
incidenten ging. Ook Zollner die na zijn aanstelling, eigenlijk tegen zijn wil was benoemd tot drossaard en daarna incidenteel ook als appelcommissaris optrad, vond deze combinatie ongewenst, zo schreef hij in 1791:

Als drossaard ben ik in de eerste plaats rechter en als commissaris ben ik in tweede instantie ook rechter, wat niet met elkaar te verenigen is. Ja, de in Wetzlar spelende zaak over het patronaatsrecht in Heugem (proces over mogelijke opvolging van pastoor Van Bloer JvR) heeft de problemen van een dergelijke onverenigbaarheid van functies al aangetoond. ${ }^{1722}$

\subsection{Strafrechtspraak en landsheerlijke bemoeienis}

$\mathrm{Al}$ eerder werd geconstateerd dat door de vrijwel volledige vernietiging van de archieven van de schepenbank, de primaire bron voor onze kennis over de rechtspraak in de praktijk ontbreekt. Dat geldt ook voor de achttiende eeuw. Wat resteert zijn summiere gegevens over de financiële kant van opgelegde boetes en correspondentie tussen de grafelijke vertegenwoordiger en de graaf in München over de afdoening van enkele grote strafzaken. Daarin komen ook aspecten van landsheerlijke bemoeienis met de strafrechtspraak aan de orde.

Uit overzichten van de grafelijke inkomsten die Prummer voor het tijdvak 1734-1767 opstelde, staat voor de periode 1734-1745 een totaal van 164 gulden aan boetes genoteerd, waarbij voor een aantal jaren zelfs geen enkele bedrag is ingevuld. Gedurende de jaren 1756-1767 werd in totaal 379 gulden geïnd, gemiddeld iets meer dan dertig gulden per jaar. Het grote verschil tussen het eerste en tweede bedrag valt mogelijk te verklaren door fraude van de rentmeester, maar indrukwekkend zijn de inkomsten niet. Meestal ging het om strafzaken die zonder interventie van de graaf werden afgehandeld, zoals mishandeling zonder dodelijk gevolg, vernieling, belediging, overtreding van plaatselijke verordeningen, stroperij et cetera. Volgens Prummer vloeide in het midden van de achttiende eeuw de helft van de boeten in de grafelijke kas en ontving drossaard of fiscus de andere helft. ${ }^{1723}$

Bokkenrijdersprocessen, zoals zich in de achttiende eeuw in de omgeving van Gronsveld afspeelden, zijn het graafschap bespaard gebleven. Slechts één keer, in 1775, moest een verdachte worden uitgeleverd naar het Staatse Land van Valkenburg. Prummer bericht wel uitvoerig naar München over alles wat hij te horen kreeg over de golf aan processen die begon in $1772 .{ }^{1724}$ Uit zijn beschrijvingen blijkt dat hij goed geïnformeerd was. Prummer benadert de processen met een zekere mate van neutraliteit en beschouwt de massale vervolging als een soort kettingreactie, 'ein menschenfressendes feuer' en 'ein böses gewitter', dat zich vanuit Gulik via de Landen van Overmaze in westelijke richting uitbreidde naar het Land van Loon. Prummer hoopte dat Gronsveld daarvan verschoond bleef, want men was in het geheel niet voorbereid op grote processen. Het ontbrak aan

1722 TJ, inv. nr. M 62, fol. 492-498, Zollner aan A.J. von Toerring-Jettenbach 31 augustus 1791.

1723 TJ, inv. nr. M 73, fol. 532.

${ }^{1724}$ Van Rensch, 'Twee onbekende brieven over bokkerijdersprocessen'. 
celruimte en de vraag was wie voor de kosten van vervolging moest opdraaien: de graaf of de standen en geërfden.

Die zakelijke benadering had Prummer ook ten aanzien van de bokkenrijdersprocessen als zodanig. Tekenen van medelijden met de veroordeelden of twijfel aan de juistheid van de vonnissen ontbreken, hoewel hij soms laat blijken dat de manier van procederen niet helemaal zijn stiel is. Ook verbaasde hij zich soms over de passieve houding van inwoners die zich als lammeren naar de slachtbank lieten leiden. Hij had vooral aandacht voor de processen als maatschappelijk verschijnsel en de schadelijke gevolgen daarvan voor de samenleving. Bendes vormden een bedreiging voor het onbeschermde platteland, zeker bij kleine rijksonmiddellijke territoria die niet over eigen troepen beschikten. Maar de sociale gevolgen waren misschien nog ernstiger. Mensen die uit hun woonplaats waren verbannen of voor vervolging gevlucht, vormden als zwervers een bedreiging voor de publieke veiligheid. Verbeurdverklaring van goederen maakte hele gezinnen brodeloos en familieleden van veroordeelden werden generaties lang als eerloos beschouwd. Kortom, in de opvatting van Prummer mocht het strafrecht streng zijn, maar er moest wel rekening worden gehouden met de maatschappelijke gevolgen.

Processen in criminele zaken die konden eindigen met de doodstraf of lijfstraf werden niet afgedaan buiten medeweten van de heer. ${ }^{1725}$ Natuurlijk wenste die op de hoogte te zijn van ernstige delicten, maar aan de uitoefening van hoge justitie waren ook hoge kosten verbonden. Zijn betrokkenheid was ook noodzakelijk in verband met de uitoefening van het recht van gratie of remissie. Uit de tweede helft van de achttiende eeuw zijn enkele gevallen van doodslag bekend, waaruit blijkt op welke wijze de graaf met deze rechten invloed uitoefende.

De eerste zaak betreft de procedure in de jaren 1753-1755 tegen Hans Peter Dupuits, Johannes Bouchoms, Ernest Weijenberg en Joost Kempener wegens de doodslag begaan op Claas Custers uit Heugem. De processtukken zijn verloren, maar van het verloop is door Prummer een uitvoerig verslag voor de graaf opgesteld. ${ }^{1726}$ Alleen de uiteindelijke afloop ontbreekt.

Kort samengevat vormde een caféruzie op 14 januari 1753 de aanleiding. Een kaartspel tussen twee groepjes van vier mannen eindigde met een woordenwisseling. Na vertrek uit de herberg kwamen de heethoofden elkaar op straat opnieuw tegen. Claas Custers zou vloekend en tierend een mes hebben getrokken, waarna Johannes Bouchoms en HansPeter Dupuits hem met knuppels bewerkten. Custers raakte zwaar gewond en overleed uiteindelijk in de nacht van 19 op 20 januari 1753. Frans van de Berg, een kompaan van Custers, werd door Weijenberg en Kempeners toegetakeld, maar zijn verwondingen waren niet dodelijk. $\mathrm{Na}$ hun daad vluchtte het viertal uit angst voor strafvervolging uit Gronsveld.

1725 In de instructie die graaf Maximilian Emanuel von Toerring-Jettenbach voor Prummer in 1752 uitvaardigde stond uitdrukkelijk dat aan de graaf zo spoedig mogelijk het dossier moest worden toegezonden wanneer iemand tot een lijfstraf of ter dood was veroordeeld, om daarover een besluit af te wachten, tenzij de executie in een spoedeisend zaak geen uitstel duldde, zie TJ, inv. nr. M 5, fol 55-68, instructie van M. E. von Toerring-Jettenbach voor Prummer 8 juli 1752.

${ }^{1726}$ TJ, inv. nr. M 50, fol. 78-146. 
Bij lijkschouwing kwam vast te staan dat Custers was gestorven aan de gevolgen van mishandeling. Wanneer de drossaard/fiscus de procedure bij de schepenbank aanhangig makkte, is niet bekend, maar omdat de verdachten 'fugitief' waren, zat er niet veel schot in. Aanvankelijk werd bij verstek geprocedeerd, maar uiteindelijk lieten de verdachten toch van zich horen. Zij wilden de zaak buiten hun eigen aanwezigheid laten verdedigen door een advocaat, maar dit werd op 12 november 1754 door de schepenen, na consultatie van juristen, afgewezen. De verdachten moesten zelf verschijnen. Wel garandeerden de schepenen vrijgeleide gedurende de dagen dat het proces werd gevoerd. $\mathrm{Na}$ afloop konden zij ongehinderd vertrekken, maar verder mochten zij het graafschap niet binnenkomen.

Prummer schreef later dat deze beslissing met het nodige gesteggel gepaard ging. De geraadpleegde advocaten hadden aanvankelijk een vrijgeleide tegen een borgsom van tweehonderd pattacons voorgesteld. Prummer verzette zich daartegen, omdat volgens hem het verlenen van vrijgeleide geen bevoegdheid van de schepenen was, maar een landsheerlijk privilege. Steun voor die opvatting vond hij in de tekst van de banformule van het voogdgeding, waar ook vrijgeleide werd beloofd door de drossaard namens de heer.

Met het vrijgeleide van de schepenen verschenen de verdachten persoonlijk en werd overgegaan tot de inhoudelijke behandeling van de zaak. De verdachten betoogden dat zij uit zelfverdediging hadden gehandeld. Gelet op de reputatie van het slachtoffer alleszins verklaarbaar. Enkele jaren geleden had die Jan Doyen met een mes in de rug dodelijk verwond. Vervolgens was hij uit gevangenschap ontsnapt en in Hollandse dienst gegaan. $\mathrm{Na}$ afloop daarvan was hij weer stilletjes in Gronsveld teruggekeerd. Maar hij maakte zich opnieuw schuldig aan mishandeling. Bij een ruzie tijdens veldwerkzaamheden sloeg hij Jan Pleuchmekers met een zeis de halve arm af. Daarna was hij wederom naar Holland gevlucht en bleef weg tot na de dood van drossaard Lebens. Af en toe vertoonde hij zich in het dorp. Zo was hij tijdens de Vastenavond gesignaleerd in vrouwenkleding. Hij had zich met drank laten vollopen en zich onzedelijk gedragen.

Vervolgens deden zich enkele opmerkelijke gebeurtenissen voor. Kennelijk waren de verdachten niet helemaal gerust over hun vrijgeleide. In ieder geval nam Johannes Bouchoms het besluit op 2 december 1754 persoonlijk naar München te reizen om daar bij de graaf genade te bepleiten. Volgens Prummer rekende hij op mededogen van de graaf omdat Maximilian Emanuel had aangekondigd na het overlijden van zijn eerste echtgenote opnieuw in het huwelijk te treden. Er deed zich bovendien een goede gelegenheid voor, want hij kon reizen in het gezelschap van Adam Simons die door Prummer naar München was gestuurd om daar een kist met jonge fretjes als geschenk voor de graaf af te leveren.(zie Hoofdstuk 12.3). Op 13 december 1754 schreef Prummer voor de graaf een nadere toelichting op dit bezoek. ${ }^{1727}$ Gratie was in zijn ogen voorbarig, want er was nog niemand veroordeeld. En hoe te handelen met andere verdachten wanneer Bouchoms al op voorhand gratie kreeg? Prummer adviseerde daarom de man terug te sturen om het verdere proces te ondergaan. Bij een veroordeling kon hij dan nog altijd genade vragen.

In München kreeg Bouchoms de kans om bij de graaf persoonlijk een verzoek tot gratie in te dienen. Het stuk was mede ondertekend door Ernest Weijenberg. ${ }^{1728}$ In de

1727 TJ, inv. nr. M 14, fol. 99-102.

${ }^{1728}$ TJ, inv. nr. M 50, fol. 138-140. 
veronderstelling dat hen onvermijdelijk verbanning boven het hoofd hing, vroegen zij genade. Hun pleidooi maakte in zoverre indruk, dat de graaf op 3 januari 1755 een algemeen vrijgeleide voor Bouchoms en Weijenberg tekende voor de verdere duur van de procedure. ${ }^{1729}$ Dat viel dus ruimer uit dan het vrijgeleide van de schepenbank. Voorts gaf de graaf opdracht het proces in snel tempo af te handelen. Het vonnis moest voor de tenuitvoerlegging wel ter goedkeuring ('pro confirmatione et ratificatione') aan hem worden voorgelegd.

Op 27 januari 1755 arriveerden Simons en Bouchoms weer in Gronsveld. ${ }^{1730}$ Bouchoms bezorgde het vrijgeleide bij Prummer, die het een week later bij de schepenbank aanbood om ad acta te leggen. Daarbij gevoegd werd een door Prummer ook aan Johan Peter Dupuits verleend algemeen vrijgeleide. Voor Kempeners schijnt een dergelijk stuk niet te zijn uitgevaardigd, aangezien hij buiten het graafschap verbleef. Er werd verteld dat hij tegen betaling de schuld voor de doodslag op zich wilde nemen. De drie andere verdachten waren onbemiddeld en hadden ook in de toekomst niet veel geld te verwachten, maar Kempeners bezat helemaal niets. Hij was uit Oostenrijkse kriigsdienst gedeserteerd en uiteindelijk toch in Gronsveld verschenen. Prummer verleende hem hetzelfde vrijgeleide als de drie anderen, maar Kempeners schrok zo van de verhoren dat hij het eindvonnis niet durfde af te wachten en opnieuw vertrok, ditmaal naar zee. Het was dus de vraag of men hem nog ooit zou terugzien.

Intussen lijkt de publieke opinie in Gronsveld geheel op de hand te zijn geweest van de beklaagden en werd Prummer min of meer verantwoordelijk gehouden voor het negatieve beeld dat men in München van de Gronsveldenaren had. Een publieke demonstratie ten gunste van de delinquenten vond plaats bij feestelijkheden ter gelegenheid van het huwelijk van de graaf in (mei?) 1755. Prummer meldde later dat het 'gesambte corpus der allhiesigen jungfrauschafften, ich will sagen alle ledige unterthanns töchter' de zogenoemde 'mei' was komen steken door aanbieding van een versierde laurierboom. ${ }^{1731}$ $\mathrm{Bij}$ die gelegenheid hadden deze ongehuwde meisjes genade gevraagd voor de verdachten. Prummer had daarop geantwoord dat hij niet bij machte was gratie te verlenen, omdat die bevoegdheid uitsluitend aan de graaf toekwam. ${ }^{1732}$

Toch liep het proces voor de verdachten niet zo gunstig af. Op 24 september 1755 schreef Prummer dat het advies van advocaten was gearriveerd waarin Bouchoms en Dupuits als hoofddaders werden beschouwd. ${ }^{1733}$ Hun verweer van zelfverdediging klonk ongeloofwaardig en volgens de advocaten verdienden Bouchoms en Dupuits de doodstraf door onthoofding en voor Weijenberg en Kempeners werd eeuwigdurende verbanning voorgesteld. De schepenen beslisten conform dit advies en op 24 oktober 1755 stuurde Prummer het vonnis ter bevestiging naar de graaf in München. ${ }^{1734}$ Bijgevoegd werd een

\footnotetext{
1729 TJ, inv. nr. M 50, fol. 136.

1730 TJ, inv. nr. M 12, fol. 613.

$1731 \mathrm{Zie}$ in verband met dit geschenk ook TJ, inv. nr. M 68, fol. 443, rentmeestersrekening 1754: '21 decembris (1755) bezahlt an Christ. Bemelmans von Eckelraede 5 fl. wegens durch bevell von herrn commissarii ein toon bier geliffert aen de jonckmans van Eckelrade auf den tag als de junge dochters ein laurierboom aan welgemelen herrn commissario gebracht hadden'.

1732 TJ, inv. nr. 50, fol. 235-240, Prummer aan M.E. von Toerring-Jettenbach 24 oktober 1755.

1733 TJ, inv. nr. M 12, fol. 594.

1734 TJ, inv. nr. M 50, fol. 235-240.
} 
overzicht van de persoonlijke omstandigheden van de veroordeelden: leeftijden tussen de 22 en 28 jaar, ongehuwd, weinig tot geen vermogen. Geheel vlekkeloos was hun blazoen ook niet. Bouchoms had in Maastricht een buitenechtelijk kind verwekt en was samen met Dupuits ook wel eens bij vechtpartijen betrokken. Maar een echt slechte faam hadden zij niet. Bij het rapport van de commissaris was ook een gratieverzoek van de veroordeelden zelf gevoegd. Prummer meende dat er alles bij elkaar voldoende ruimte bleef om het recht van gratie uit te oefenen en tegelijk toch nog 'justiz administrieren zlassen', maar dit liet hij aan de welwillendheid van de graaf over.

Helaas is de afloop van de zaak niet bekend. Waarschijnlijk is Dupuits in eerste instantie verbannen. Hij huwde in 1764 in Breust en overleed in Gronsveld in 1782. Over de lotgevallen van Bouchoms ontbreken gegevens, maar mogelijk trof ook hem verbanning en is hij niet meer teruggekeerd (hij woonde al ongehuwd samen in Maastricht). Weijenberg huwde in 1758 in Gronsveld (een verbanning kan dus nooit lang hebben geduurd) en overleed daar in 1815. Over Kempeners ontbreken verdere gegevens. ${ }^{1735}$ Wellicht is geprobeerd de kosten van het proces op de veroordeelden te verhalen. Deze beliepen een aanzienlijk bedrag: alleen al de lijkschouwing van het slachtoffer kostte 64 gulden en de twee adviezen van de advocaten tweehonderd gulden. ${ }^{1736}$ Daarbij kwamen nog de gerechtskosten. Maar omdat de vier mannen armlastig waren en er ook in de toekomst niet veel te verwachten viel, zal de grafelijke kas grotendeels voor de kosten zijn opgedraaid.

De tweede grote strafzaak vond zijn oorzaak in een vechtpartij in de late avonduren van 10 juni $1770 .{ }^{1737} \mathrm{Na}$ een bezoek aan de kermis in Heer werden Gerardus Walraeven, Egidius Janssen en Matthias Pleumeeckers tussen elf en twaalf uur 's avonds opgewacht door een groepje jongelui uit Heugem. Eén van hen, Gerardus Beckers, begon met een stok te slaan. Walraeven viel zwaargewond op de grond. Hij werd door zijn vrienden naar huis gebracht en overleed enkele dagen later. Al op 11 juni begonnen de drossaard/fiscus Prummer en de schepenen met het gerechtelijk onderzoek. Het was spoedig duidelijk wie de daders waren. Gerardus Beckers werd door getuigen genoemd als degene die de dodelijke slagen had toegebracht. De verdachte ontkende. Hij zou alleen een metgezel van Walraeven hebben mishandeld. In afwachting van het proces kregen Beckers en zijn kompanen vrijgeleide van de drossaard/fiscus, maar zij achtten het raadzamer buiten het

1735 Gegevens gebaseerd op Paquaij, Geboren, gebuwd. Hij vermeldt ten aanzien van 1) Joannes Petrus Dupuist: geboren 1730, gehuwd te Breust in 1764 met Maria Gertrudis Lambrichts, overleden te Gronsveld 1782; 2) Ernestus Weijenberg: geboren 1729, gehuwd 1758 in Gronsveld met Maria Anna Bica, overleden Gronsveld 1815; 3) Joannes Bouchoms: geboren 1726 in Gronsveld, geen bijzonderheden; 4) Joannes Kempeners: geen nadere bijzonderheden.

1736 TJ, inv. nr. M 68, fol. 439, rentmeestersrekening 1754: 18 februari 1754 betaald 64 gulden 10 stuiver aan de chirurgijns Lucie en Le Gros 'für visitation von das lebendig und totte lichaem von Niclaes Kusters; TJ, inv. nr. M 68, fol. 398, rentmeestersrekening 1754, 13 september 1754 betaald 96 gulden aan advocaat Richterich 'vor advijs ijber dem process in materia homicidii an die person dess Claes Kusters'; TJ, inv. nr. M 68, fol. 442, rentmeestersrekening 1755, 18 oktober 1755 betaald 104 gulden aan advocaat Richterich in zake advies.

${ }^{1737}$ Zie over deze zaak TJ, inv, nr. M 77, fol. 6-59 
graafschap te blijven. Dus werd het proces bij verstek gevoerd. Of het tot een vonnis kwam, is niet bekend, maar waarschijnlijk is het niet. Beckers bleef voortvluchtig en nam gedurende een aantal jaren dienst in het Staatse leger. Pas dertien jaar later zou de zaak tot een definitief einde worden gebracht.

De aanleiding daarvoor was opnieuw een grote vechtpartij, op 8 december 1783. Op de Scharnerweg buiten de Wyckerpoort van Maastricht, raakte een groepje mannen uit Gronsveld slaags met inwoners van Amby. Joannes Schrijnemaekers uit Gronsveld sloeg Nicolaas Theunissen van Amby zo hard, dat deze veertien dagen later aan de gevolgen daarvan overleed. Op 23 december 1783 startte drossaard/fiscus Zollner tegen Schrijnemakers en zijn medeplichtigen bij de schepenbank een proces wegens doodslag. 1738

In het vooronderzoek viel ook de naam van Gerardus Beckers. Aanvankelijk was hij toeschouwer geweest, daarna nam hij actief aan de vechtpartij deel. Het kwam de drossaard en fiscus ter ore dat de sinds 1770 nog altijd officieel voortvluchtige Beckers ook regelmatig in Heugem verbleef. Hij werd gearresteerd en op het kasteel van Gronsveld vastgezet. Vervolgens werd de doodslag op Gerardus Walraeven opnieuw bij de schepenen aanhangig gemaakt. Aanvankelijk ontkende Beckers dat hij de fatale slagen had toegebracht, maar de getuigen die al vroeger waren gehoord, bleven bij hun verklaringen en wezen Beckers als dader aan. Hij werd verdacht van moord, omdat Walraeven destijds opzettelijk en zonder duidelijke aanleiding was opgewacht. Het zag er dus niet goed uit voor Beckers.

Op 3 januari 1784 kreeg graaf August Joseph in München een brief van Zollner voorgelegd, waarin de kwestie Beckers werd beschreven. Zollner wist niet goed wat hij met zaak aan moest: alsnog de doodstraf eisen of een andere lijfstraf? Hij bleek voorstander van gratie of strafvermindering. De dader was ten tijde van het misdrijf nog geen achttien jaar en familieleden van de beklaagde hadden al een verzoek om genade bij het schepengerecht ingediend. Zij wilden met alle mogelijke middelen een terechtstelling voorkomen vanwege de eeuwige schande die dat over de familie bracht. Men was bereid de aanzienlijke kosten van het proces te dragen en te betalen voor langdurige, desnoods levenslange opsluiting. Een dag later lag een smeekschrift van een aantal familieleden van Beckers op het bureau van de graaf. Zij wezen ook op verzachtende omstandigheden en waren zeer beducht voor het verlies van eer voor de familie, wanneer het tot een terechtstelling kwam.

Alvorens een definitieve beslissing te nemen, wenste de graaf een onpartijdig advies ('votum informativum et opinionem impartialem') van de schepenbank. Dit stuurden de schepenen op 31 januari 1784. Zij waren in beginsel van mening dat Beckers diende te worden onthoofd, omdat moord met voorbedachten rade was bewezen. Verzachtende omstandigheden waren de jonge leeftijd ten tijde van het delict evenals het feit dat intussen veertien jaar waren verstreken. Met twintig jaar zou, volgens de schepenen, de zaak zijn verjaard. Zij stelden daarom levenslange opsluiting voor. De daarmee gepaard gaande burgerlijke dood stond gelijk aan een werkelijke dood. De familie werd niet te

1738 RHCL, Graafschap Gronsveld, inv. nr. 335. 
schande gemaakt, zou voor het levensonderhoud zorgen en alle kosten van het proces dragen.

Drossaard/fiscus Zollner was minder enthousiast. De dader was een robuuste, sterke kerel en een potentieel gevaar wanneer hij ooit vrij kwam. Levenslang beschouwde hij als een minimum. Het was zelfs de vraag of daar voldoende afschrikking van uitging. Bovendien diende de indruk te worden vermeden dat doodslag en andere zware misdrijven met boetes konden worden afgekocht. Dat soort ideeën leefde toch al door het systeem van opsporing en strafvordering. Want behoudens aanhouding op heterdaad, mocht een verdachte alleen worden gearresteerd na voorafgaand verlof van het gerecht. Dat kostte tijd en die ruimte bood de dader voldoende gelegenheid om over de grens te vluchten. Uitlevering was meestal niet mogelijk.

$\mathrm{Na}$ advies van zijn eigen ambtenaren in München beslist de graaf uiteindelijk tot het opleggen van de galeistraf, uiteraard na betaling van proceskosten. De reactie van Zollner is opmerkelijk. Overdracht aan Hollandse 'siewerber' of 'sielenverkäufer' was op straffe van kerkelijke excommunicatie verboden. Op de Hollandse vloot waren geen katholieke geestelijken toegelaten en delinquenten liepen daarmee ernstig gevaar voor hun zielenheil. Uitlevering aan de Spaanse of Franse vloot leverde ook problemen op. Frankrijk stond geen transport van geboeide personen over zijn grondgebied toe. De gevangene kon dus gemakkelijk ontsnappen. De Franse admiraliteit zelf nam geen vreemdelingen tegen hun eigen wil op. Beter was daarom levenslange opsluiting, zeker nu de familie ter voorkoming van verlies van eer, wilde betalen. Mogelijkheden daartoe bestonden in Luik.

Uiteindelijk is daartoe ook besloten en na moeizame onderhandelingen was men in Luik bereid Beckers op te nemen. Daar heeft hij waarschijnlijk vastgezeten tot eind 1790 . In september van dat jaar geeft Zollner aan de graaf een positief advies op een gratieverzoek van de vader van Beckers, dat zou leiden tot toestemming om zich weer in Heugem te vestigen.

\subsection{Het einde van de schepenbank(en)}

De vestiging van het Franse bewind in november 1794 kreeg ook voor de schepenbank Gronsveld gevolgen. Voor de rechtspraak in hoger beroep werd op 14 november 1794 een Tribunal Supérieur of Oppertribunaal in Maastricht ingesteld. ${ }^{1739}$ De werkzaamheden van de lagere rechtbanken werden voorlopig gecontinueerd. In burgerlijke zaken nam het Oppertribunaal kennis van hoger beroep tegen vonnissen van lagere gerechten die de waarde van driehonderd pond overschreden. Verder berechtte het tribunaal 'délits et crimes' (misdrijven waarop lijfstraffen stonden) in overeenstemming met de wetten van het land. Daarvoor was bij het tribunaal een openbare aanklager benoemd, die tevens toezicht hield op de strafrechtspleging bij lagere gerechten en ook op de gevangenissen.

Door de annexatie van de Zuidelijke Nederlanden, Luik en delen van het Maasgebied bij Frankrijk per 1 oktober 1795, werd ook hier de Grondwet van 5 fructidor III (22 augustus 1795) van kracht. Die voorzag in de invoering van een nieuwe bestuurlijke en rechterlijke

1739 Zie daarover Hardenberg, Inventaris archieven rechtscolleges, 3-5 en in het bijzonder Gehlen, 'Het Maastrichtse Tribunal Supérieur'. 
organisatie. Aan het hoofd van ieder departement stond een vijfkoppige 'administration centrale'. Verder werd ieder departement onderverdeeld in kantons. Voor de rechterlijke organisatie werd per departement een Tribunal Civil en een Tribunal Criminel ingevoerd en in de grotere steden een Tribunal Correctionel. Voor de kantons werden vredegerechten ingesteld. Het Tribunal Superieur moest op papier met ingang van 10 frimaire IV (1 december 1795) zijn werkzaamheden beëindigen, maar feitelijk gebeurde dit pas op 24 nivôse IV (14 januari 1796). Het Tribunal Civil en het Tribunal Criminel werden in Maastricht geïnstalleerd op 14 januari 1796, het Tribunal Correctionel eerst op 9 februari 1795. 1740

De uiteindelijke indeling van het departement in kantons kostte veel hoofdbrekens en de benoeming van vrederechters verliep moeizaam omdat verschillende kandidaten weigerden. Het duurde daarom enkele maanden voordat het hele departement was voorzien. ${ }^{1741}$ In deze nieuwe organisatie werd Gronsveld ingedeeld bij het kanton Eijsden. Daar werd verhoudingsgewijs al vroeg, op 26 pluviôse IV (15 februari 1796), een vredegerecht geïnstalleerd. ${ }^{174}$

Vanaf eind 1794 beginnen deze veranderingen door te werken in de titulatuur bij het gerecht in Gronsveld en worden de aanduiding voor de zittingen van het gerecht minder vast. Tot juli 1794 werd nog gesproken over drossaard en schepenen van het rijksgraafschap Gronsveld. Na de instelling van het Tribunal Supérieur op 14 november 1794 en de installatie daarvan op 3 december 1794 was het aanvankelijk onduidelijk of het graafschap Gronsveld ook onder de jurisdictie van dit tribunaal viel. In een 'arrêté van 18 frimaire III (8 december 1794) ontbraken de rijksonmiddellijke gebieden Gronsveld, Slenaken, Wylre en Wittem. Twee dagen later kwam een nieuwe concept-indeling tot stand, waarbij Gronsveld, Wylre, Slenaken (en waarschijnlijk ook Wittem) tot het arrondissement Maastricht werden gerekend. Die indeling werd goedgekeurd op 29 frimaire III (19 december 1794). ${ }^{1743}$

Vanaf 23 december 1794 tot 19 februari 1795 noemen drossaard, schepenen en secretaris zich heel neutraal 'van Gronsveld'. De aanduiding 'graafschap' werd vermeden en geleidelijk vervangen door het woord 'gemeente'. Een akte van 22 januari 1795 staat al op naam van 'schepenen der gemeente Gronsveld en bank van Heugem', ${ }^{1744}$ maar pas vanaf 5 juni 1795 wordt het woord 'gemeente' vrijwel steeds toegevoegd. ${ }^{1745}$ De aanhef luidt daarna dan meestal 'wij drossaard en schepenen der gemeente Gronsveld' met als eventuele toevoegingen 'en bank van Heugem', 'en bank van Honthem' of 'en onderhoorige banken'. Maar soms blijft het woord 'gemeente' ook gewoon weg. Op 5 juni 1795 lijkt er met de aanhef 'voor ons burgers... respectieve drossaerd en scheepenen van

\footnotetext{
${ }^{1740}$ Hardenberg, Inventaris archieven rechtscolleges, 6-10.

1741 Ubachs, 'De vrederechter in het departement Nedermaas'.

${ }_{1742}$ Hardenberg, Inventaris archieven recbtscolleges, 30.

1743 Gehlen, 'Het Maastrichtse Tribunal Supérieur', 111-114.

1744 RHCL, Graafschap Gronsveld, inv. nr. nr. 363.

1745 RHCL, Graafschap Gronsveld, inv. nr. 365, fol. 12.
} 
Gronsveld' sprake te zijn van een revolutionaire oprisping, aangezien het woord 'burger' een algemene aanspreekvorm in het revolutionaire Frankrijk was geworden.

Ook bij de rechtszittingen van de schepenbank wordt vanaf augustus 1795 het woord 'gemeente' of de Franse variant daarvan gebruikt. Zo startte op 14 augustus 1795 de 'drossaard der gemeente Gronsveld en onderhorige banken' een procedure in Heugem naar aanleiding van een vechtpartij aldaar. ${ }^{1746}$ Op 10 september 1795 gaven 'drossaard, schepenen en leden van de municipaliteit van de gemeente Gronsveld en aanhangsels' ('drossard, echevins et municipaux de la commune de Gronsfeldt et dependances') een attest over het goed gedrag van Zollner. Het stuk werd ondertekend door drossaard Sarolea, schepen Bouchoms, vier burgemeesters en de secretaris. ${ }^{1747}$ Echt veranderingsgezind toonden de gevestigde autoriteiten in Gronsveld zich vooralsnog niet. We zagen hiervoor al dat Sarolea op 21 november 1795 aan Zollner schreef dat wat hem betrof alles zoveel mogelijk op de oude voet verder ging. ${ }^{1748}$ Het gerecht hield gewoon zittingen en periodiek vond ook het voogdgeding plaats. Zo belegde te Heugem de 'municipaliteijt alhier' op 28 januari 1796 een 'extra-ordinaire vergaederinge', op 29 januari 1796 gevolgd door een vergadering in Gronsveld. 1749

Er werd ook met de Franse autoriteiten samengewerkt. Op 13 februari 1796 begon drossaard Sarolea een proces tegen Lens Gillissen, Maria Helena Bours, echtgenote van Matthijs Gillissen en Elisabeth Gillissen, echtgenote van Joannes Bronckaerts. ${ }^{1750}$ De verdachten waren door 'burger Timmermans als 'accusateur publijck van het Crimineel Tribunal van de Overmaeze' vanuit de gevangenis te Maastricht overgedragen aan Gronsveld op verdenking van diefstal van een stuk hout. De beklaagden hielden echter vol dat zij de paal hadden gevonden als drijfhout in de Maas. Gedurende de dagen van hun verhoor verbleven de verdachten in de gevangenis van het kasteel van Gronsveld. Uiteindelijk kon de drossaard het bewijs van diefstal niet leveren en besloten de schepenen op 22 februari 1796, hun laatste zittingsdag, het drietal voorlopig op vrije voeten te stellen. Dat men worstelde met de veranderde omstandigheden blijkt uit een bijeenkomst die de grootste geërfden, drossaard, schepenen en burgemeesters van Gronsveld, vier maanden na de aanhechting bij Frankrijk, op 9 februari 1796 in Maastricht belegden met het doel ten laste van de gemeente Gronsveld en onderhorige banken vijfduizend gulden op te nemen. Het besluit daartoe eindigde met de woorden 'aldus gedaen en provisioneelijk op de reekenkamer van O. L. Vrouwe te Maestricht in plaetse van onder het graeffelijck territoire geresolveert en geteekent'. ${ }^{1751}$

$\mathrm{Na}$ de installatie van het vredegerecht in Eijsden op 15 februari 1796 was het snel afgelopen met de Gronsveldse rechtspraak. De laatste zitting werd gehouden op 22 februari 1796. De schepenen van 'Gronsveld, eertijds Rijx Graefschappe' wezen op die

\footnotetext{
1746 RHCL, Graafschap Gronsveld, inv. nr. 262.

1747 TJ, inv. nr. M 62, fol. 72-73, drossaard, burgemeesters en secretaris aan de Franse autoriteiten in Maastricht 10 september 1795.

1748 TJ, inv. nr. M 62, fol. 77-83, Drossaard Sarolea aan Zollner in München, 21 november 1795.

1749 RHCL, Graafschap Gronsveld, 257.

1750 RHCL, Graafschap Gronsveld, 262.

1751 RHCL, Graafschap Gronsveld, inv. nr. 365, fol. 45.
} 
dag vonnis in een proces tussen de Gebroeders Van den Berg en Gillis Claessen. De eisers Van den Berg verloren en gingen vervolgens 'viva voce' in appel. Of dat hoger beroep ook werkelijk is doorgezet, is niet bekend. ${ }^{1752} \mathrm{Op} 23$ februari 1796 passeerde voor drossaard en schepenen der gemeente van Gronsveld en bank van Heugem de laatste transportakte ${ }^{1753}$ en de laatste inschrijving op de civiele rol vond plaats op 26 februari $1796 .{ }^{1754}$

\subsection{Conclusies}

Het beeld van de schepenbanken in het graafschap Gronsveld in de achttiende eeuw wijkt in grote lijnen niet af van de situatie zoals die aan het begin van dit hoofdstuk werd geschetst voor andere territoria in het Maasgebied: gebrek aan juridische kennis bij de schepenen, langdurige, omslachtige en kostbare procedures, knoeierij in registers en problemen bij de bezetting van schepenplaatsen. Ook de criminaliteit was vergelijkbaar: vechtpartijen met soms dodelijke afloop, velddiefstal, vernielingen, et cetera. Toch zijn er ook verschillen. Advocaat-fiscaal Van Steelant zocht een belangrijke oorzaak voor de misstanden in de Staatse Landen van Overmaze in het feit dat functionarissen niet binnen hun ambtsgebied woonden. Dat probleem speelt voor Gronsveld minder. Prummer, Zollner, drossaard Hendrik Lebens en secretaris-rentmeester Johannes Godefridus Lebens woonden deels in Gronsveld of waren daar op zijn minst zeer regelmatig te vinden. Schepenen afkomstig uit Maastricht, zoals in het bijzonder bij de bezetting van schepenbanken met protestanten in de Staatse Landen van Overmaze het geval was, komen in Gronsveld niet of nauwelijks voor. De rechtspraak in Gronsveld had duidelijk meer last van gevestigde familiebelangen. Vreemdelingen die in Gronsveld werden benoemd, konden dit systeem niet doorbreken. Pas na 1780 kwam aan die beslotenheid onder Zollner enigszins een einde. Duidelijk was wel dat een belangrijke bron van weerstand tegen verbetering van de justitie zat bij de geërfden of staten, die uit conservatisme en zuinigheid nauwelijks bereid waren te investeren in de justitie. Zollner heeft in de jaren tachtig wel geprobeerd veranderingen door te voeren, maar slaagde daar vanwege de tijdsomstandigheden niet meer in.

Opmerkelijk is dat het graafschap gespaard is gebleven voor de bokkenrijdersprocessen of andere grootschalige vervolging van al dan niet vermeende criminelen. Hetzelfde lijkt ook het geval te zijn geweest in de rijksonmiddellijke territoria Wittem, Wylre en Slenaken. Nader onderzoek zou moeten uitwijzen of hier sprake is van toeval, of dat er toch een wat andere opvatting over de bestrijding van criminaliteit achter stak. In ieder geval lijkt men in Gronsveld terughoudend te zijn geweest met al te rigoureuze bestraffing aan lijf en leden, misschien niet zozeer uit menslievendheid, maar meer om redenen van maatschappelijk nut. Uiteraard diende de graaf als landsheer bij ernstige delicten te zorgen dat recht en genoegdoening werden verschaft aan het slachtoffer, diens familie en aan de overheid. Maar op de delinquent als persoon viel meestal niets te verhalen en de zeer hoge kosten van de procedure en de tenuitvoerlegging van de straf kwamen ten laste van de grafelijke kas. In een grensgebied met tal van ontsnappingsmogelijkheden, betekende

1752 RHCL, Graafschap Gronsveld, inv. nr. 344.

1753 RHCL, Graafschap Gronsveld, inv. nr. 363

${ }^{1754}$ RHCL, Graafschap Gronsveld, inv. nr. 262. 
vlucht ook een oplossing van het probleem. Er werd een dure procedure uitgespaard, het effect was hetzelfde als verbanning, orde en rust waren hersteld en de schande van een veroordeling bleef de familie van de dader bespaard. Vaak werd dan na een aantal jaren oogluikend terugkeer toegestaan, onder de voorwaarde dat de betrokkene een onopvallend bestaan leidde. Maar helemaal zeker van zijn zaak was de delinquent nooit.

Een andere reden voor terughoudendheid met lijfstraffen valt terug te voeren op meer verlichte ideeën over humanisering van het strafrecht. De graaf besliste persoonlijk of er redenen waren om vrijgeleide of strafvermindering toe te staan. Van deze bevoegdheden werden bewust gebruik gemaakt, waarbij opvalt dat de graaf milder oordeelde dan de schepenen.

Aanvankelijk was onzeker hoe het Frans bestuur vanaf herfst 1794 voor het rijksonmiddellijke graafschap Gronsveld zou uitpakken. De rechtspraak functioneerde vooralsnog op de oude voet, hoewel de gewenning aan de nieuwe situatie aarzelend verliep. Maar toen duidelijk werd dat ook Gronsveld als onderdeel van de Franse Republiek deel ging uitmaken van het nieuwe bestel, verliep de invoering van een nieuwe rechterlijke organisatie uiteindelijk vrij soepel. 


\section{Het leenhof, circa 1730-1796}

De malaise die kenmerkend was voor bestuur en rechtspraak in Gronsveld in de jaren twintig van de achttiende eeuw, lijkt enigszins aan het grafelijk leenhof te zijn voorbijgegaan. Wezenlijke wijzigingen in de organisatie of herziening van het leenrecht zijn in de loop van de achttiende eeuw niet meer doorgevoerd. Processen over leengoederen speelden nauwelijks een rol van betekenis. Het leenhof werd vooral een instantie voor registratie van leengoederen. Belangrijk daarvoor was de verbetering van de administratie door herziening van de leenboeken en invoer van gestandaardiseerde leenakten.

Een bron van zorg vormde de handhaving van de rechten op de 'uitheemse' lenen in Vaals en Holset. Hier speelde het probleem van toenemende afhankelijkheid van de medewerking van de plaatselijke autoriteiten voor de handhaving van rechten op buitenlands territoir.

\subsection{De stadhouder en vicestadhouder van het leenhof}

Baron Willem Adolf van Eys genaamd Beusdael, leenman voor het huis Vaalsbroek, was sinds 1674 stadhouder van het leenhof. Hij kreeg in 1710 de titel van erfstadhouder en verkocht zijn ambt ('vor 25 pistollen') in 1727 (hij was toen omstreeks tachtig) aan baron Ernst de Goeswin uit Luik. Inhoudelijk ging het om weinig meer dan een ereambt (de baron verscheen slechts zelden persoonlijk bij het leenhof), maar zijn langdurige ambtstijd zorgde toch voor continuiteit. Begin 1730 berichtte rentmeester Oligschläger aan graaf Claude Nicolas d'Arberg Valengin dat hij al een half jaar niets meer had gehoord van het 'Hohe Lehngerecht' en noch de stadhouder, noch diens substituut had gezien. Ook de leenregisters waren niet onder handbereik. ${ }^{1755}$ De feitelijke werkzaamheden werden uitgeoefend door de drossaard of de secretaris als vicestadhouder, geassisteerd door één of twee leenmannen.

In de jaren dertig kreeg Gürtler, de tijdelijke vertegenwoordiger van de graaf in Gronsveld, bij de verbetering van bestuur en rechtspraak ook de erfstadhouder van het leenhof, baron de Goeswin, in het vizier. Waarschijnlijk was Gürtler niet zo overtuigd van de loyaliteit van de baron wegens diens opstelling in het conflict over de voogdij van de gravin d'Arberg, maar lastig was dat hij wegens zijn adellijke afkomst soms op min of meer vertrouwelijke voet met de graaf correspondeerde. Prummer karakteriseerde de man later als een onbenul met een erebaan, maar ook als een lastige intrigant. Hij vertelt dat Gürtler op de baron druk uitoefende om van de erfelijke aanspraken op zijn ambt afstand te doen en genoegen te nemen met een benoeming voor het leven. Daar stemde de Goeswin ook mee in, waarbij niet was te voorzien dat hij uiteindelijk meer dan vijftig jaar zijn ambt zou behouden.

1755 TJ, inv. nr. M 15, fol. 797-804, Oligschläger aan graaf d'Arberg Valengin 21 januari 1730. 
Grote betekenis voor het leenhof kregen de werkzaamheden van vicestadhouder en secretaris Jacobus Berchmans. Berchmans, tevens notaris en vicesecretaris van de schepenbank, was de vraagbaak voor alles wat met gronden in het graafschap te maken had. Toen Prummer in Gronsveld in het najaar van 1752 in Gronsveld arriveerde, was hij voor zijn kennis over de Gronsveldse lenen in hoge mate aangewezen op de kennis van Berchmans. Diens overlijden op 28 oktober 1755 betekende dan ook een gevoelige slag. In 1743 vervaardigde Berchmans een volledig herzien leenboek voor Gronsveld, Eckelrade, Rijckholt en Breust op basis van het werk van Reiner van Gelder uit 1581.1756 Verder maakte hij een kopie van het leenboek voor Holset. Dat was beter bijgehouden dan dat van Gronsveld, maar bevatte ook lacunes. Met zijn werk legde Berchmans de basis voor de administratieve verbeteringen die Prummer naderhand doorvoerde.

In een rapport van 9 november 1755 over alle ambten in het graafschap, wijdt Prummer ook een passage aan de functie van stadhouder van het leenhof. ${ }^{1757}$ Wegens de voortdurende afwezigheid van baron de Goeswin presideerde Prummer meestal zelf het leenhof met de titel 'commissaris plenipotentiair' van Zijne Hooggrafelijke Excellentie, al dan niet met de toevoeging 'stadhouder'. Die titulatuur gebruikt later ook zijn opvolger Zollner. De secretaris van de schepenbank was zowel leengriffier als leenman. Verder trad in de tijd van Prummer nog maar één andere leenman, tevens schepen, op. Over de inkomsten uit de leges en gerechtskosten waren Prummer en de Goeswin overeengekomen dat eerstgenoemde alle inkomsten ontving, waarvoor hij dan een jaarlijkse vergoeding van drie dukaten betaalde. Later vertelde Prummer tegen Zollner dat hij er met dit bedrag geld op had toegelegd. Tot op zekere hoogte kan dit waar zijn. Bij een telling van de aantallen leenverheffingen tussen 1775 en 1778, leveren de jaren 1766 22, 1768 31, 1775 vijftien en 1778 negen verheffingen op. Voor de andere jaren zijn er geen tot drie verheffingen per jaar geregistreerd.

Toen Zollner rond 1780 tegenover de graaf zijn visie ontvouwde over de opvolging van Prummer, wilde hij het ambt van stadhouder der lenen graag op zich nemen. De zorg over de lenen behoorde toch al tot het takenpakket van Gronsvelds hoogste ambtenaar en er was niet veel tijd mee gemoeid. Bovendien had zich sinds mensenheugenis geen proces over leengoederen meer voorgedaan. Intussen had de dochter van Prummer namens haar vader de overeenkomst met stadhouder de Goeswin over de jaarlijkse uitkering opgezegd. Zollner had gehoord dat de stokoude 'cavalier d'industrie', zoals de baron in Gronsveld en in Luik werd genoemd, nieuwe kandidaten voor de vervanging zocht, maar het liep niet storm. Hij schijnt kort daarna ook te zijn overleden, waarmee de verplichting tot jaarlijkse

1756 TJ, inv. nr. M 16. Berchmans had kennelijk een godvruchtige en literaire bui bij het schrijven van dit boekwerk. Op de eerste bladzijde schreef hij: 'Die wilt begrijpen watter staet leese den tijtel van dit boeck'. Een volgend blad heeft de tekst: 'In honorem sanctissimae Trinitatis Deiparaeque Virginis Mariae'. (Ter ere van de Allerheiligste Drievuldigheid en de Maagd en Moeder Gods) De korte verantwoording van dit 'Nieuwen Leenregister' eindigt met het chronogram: qUare noVUs eXsto, qUaeres? MarsChaLLUs De TörrIng JUssIt. ('Waarom besta ik als een nieuw boek', vraagt gij? De maarschalk van Törring heeft het bevolen). Bij elkaar leveren de Romeinse cijfers het jaartal 1743 op.

1757 TJ, inv. nr. M 13, fol. 13-24, Prummer aan M.E. von Toerring-Jettenbach 9 november 1755. 
uitkering verviel en de bezetting van het stadhouderschap ter vrije beschikking van de graaf kwam.

\subsection{De lenen in Vaals en Holset}

Prummers grootste zorg bij het leenhof betrof het in de loop der tijden sterk geslonken antal 'uitheemse lenen'. In de zeventiende eeuw waren de lenen in Oost verloren gegaan, in 1728 die in Slenaken en rond 1750 dreigden de lenen in Vaals en Holset te ontglippen. Er lagen daar zeven grote en circa 55 kleine lenen. Vanaf het laatste kwart van de zeventiende eeuw neemt het antal verheffingen in het leenboek af. Een mogelijke oorzaak daarvan lag in de problematiek van handhaving van rechten binnen het gebied van een buitenlandse soeverein. Daarvoor was immers medewerking nodig van de plaatselijke autoriteiten. Juist bij de Staatse overheidsdienaren in Vaals was de sympathie voor de Gronsveldse belangen flink bekoeld na de vele aanvaringen met de eigenzinnige Willem Adolf van Eys genaamd Beusdael, heer van Vaalsbroek en stadhouder van het grafelijk leenhof. Met zijn voortdurend beroep op een bijzondere status als leenman van Gronsveld had hij daar weinig vrienden gemaakt. Voor Gronsveld kwam er nog bij dat de bestuurlijke wanorde in de jaren twintig en dertig van de achttiende eeuw binnen het graafschap een krachtig optreden van het leenhof in de weg stond.

De slappe handhaving van de Gronsveldse leenrechten in Vaals en Holset dreigde uit te lopen op ernstig financieel verlies voor de graaf. De openbare verkoop van het groot leen Vaalsbroek ten overstaan van de schepenbank Vaals-Holset-Vijlen, een daad van jurisdictie, vormde voor vicestadhouder en leengriffier Jacobus Berchmans van het Gronsvelds leenhof aanleiding om graaf Ignaz Felix von Toerring-Jettenbach te alarmeren. Op 16 juni 1739 behandelden de Staten-Generaal in Den Haag een brief van 'resident' Van Assendelft te Brussel, geschreven namens 'den Heere Graave van Thering, minister van sijne Churfurstelijcke Doorlughtigheyd van Beyeren'. Daarin verzocht hij een 'ordre' van de Hoogmogenden voor de luitenant-drossaard van het Land van 's-Hertogenrade, waaronder Vaals ressorteerde:

om in het toekoomende niet meer te beletten het verheffen van de leenen in sijn district geënclaveert, maar na drie citatien en convictien voor het leenhof van Gronsveld de executie te permitteeren en daar in de behulpsaeme hand te bieden.

Met andere woorden: de autoriteiten van 's-Hertogenrade werd gevraagd rechtshulp te verlenen bij de tenuitvoerlegging van vonnissen van het leenhof van Gronsveld. Alvorens een definitief besluit te nemen, werd luitenant-drossaard Abraham van den Heuvel (tevens vicehoogschout te Maastricht) verzocht nader advies uit te brengen. Deze kweet zich voortvarend van zijn opdracht en op 6 juli 1739 lag het rapport bij de Hoogmogenden ter tafel. ${ }^{1758}$ Van den Heuvel deed het voorkomen alsof er niets aan de hand was. Hij kon zich niet herinneren dat ooit de uitoefening van de Gronsveldse feodale rechten in Vaals was belemmerd. De plaatselijke autoriteiten wilden best de helpende hand bieden, maar het ontbrak aan een gespecificeerde lijst van Gronsveldse lenen. Die was des te meer nodig

${ }^{1758}$ Nationaal Archief, Archief Staten-Generaal 1550-1796, inv. nr. 5857. 
omdat men niet akkoord kon gaan met de bewering dat alle aan de kerk van Holset tiendplichtige landerijen zonder onderscheid ook leenroerig aan Gronsveld waren. Uit tiendrecht als zodanig kon immers geen feodaliteit worden afgeleid. Men kende verschillende tiendplichtige percelen in Holset en omgeving die als allodiaal goed ten overstaan van de schepenbank waren overgedragen. Bij deze argumentatie moet worden opgemerkt dat Van den Heuvel drommels goed wist welke landerijen tiendplichtig waren aan de kerk van Holset, omdat de Staten-Generaal de tienden in de Landen van Overmaze hadden geconfisqueerd en beheerden als zogenoemde 'geestelijke domeingoederen'.

Het was een feit dat veel lenen al meer dan eeuw niet meer waren verheven, maar eigenlijk viel dat in hoofdzaak te wijten aan nalatigheid van Gronsveldse kant. Procedures over het al dan niet erkennen van feodaliteit als zodanig moesten volgens Van den Heuvel worden gevoerd voor de 'ordinaris' rechter, dat wil zeggen het schepengerecht. Vonnissen van een leenhof konden slechts op basis van een daartoe strekkend officieel verzoek ('requisitorialen') door de 'ordinaris rechter' ten uitvoer worden gelegd. Dit principiële standpunt betekende dat voor dwangmaatregelen ten aanzien van leengoederen altijd de hulp van de schepenbank vereist was. De Staten-Generaal beslisten conform het advies van de luitenant-drossaard, ${ }^{1759}$ maar vervolgens schijnt aan de kant van het Gronsveldse leenhof geen verdere actie te zijn ondernomen.

Dat veranderde met de komst van Prummer in 1752. Bij diens voortvarende aanpak tot herstel van de grafelijke rechten en domeinen kregen de lenen in Vaals voorrang. Op 7 maart 1754 wendde vicestadhouder Berchmans zich tot de schepenbank van Holset-VaalsVijlen met het verzoek beslag te leggen op een perceel Gronsvelds leen. Het ging om het bezit van Bastiaan Lanckohr, die met leenverheffing in gebreke was gebleven. Het viel niet te verwachten dat die, na vergeefse aanmaningen, alsnog gevolg zou geven aan de eis tot verheffing. ${ }^{1760}$ Het schepengerecht besliste echter ten gunste van de eiser. Optimistisch berichtte Prummer aan de graaf in München dat dergelijke vonnissen ook anderen tot inschikkelijkheid konden aansporen.

Het meest bezwaarlijk was eigenlijk het lange tijdsverloop dat met procederen tegen individuele bezitters van leengoederen gemoeid was. ${ }^{1761} \mathrm{Om}$ die reden wendde Berchmans zich op 25 april 1754 tot de schepenbank van Vaals-Holset-Vijlen met het verzoek alle bezitters van lenen te mogen oproepen voor het afleggen van een verklaring, waarin zij de leenroerigheid van hun bezit erkenden of bestreden. Die toestemming werd verleend en op 24 mei 1754 bracht de gerechtsbode de dagvaardingen uit. Zoals te verwachten viel, bleven die niet onweersproken. De oppositie werd aangevoerd door baron Leonard Joseph de Lamberts de Cortenbach en een zekere Anton Weissenburg uit Aken. Eerstgenoemde had veel te verliezen. Hij bezat drie grote lenen, te weten Einrade, Vaalsbroek en Holset, maar alleen Einrade was door hem in 1710 bij het leenhof verheven. De twee andere bezittingen had hij in 1733 zonder verdere inmenging van het leenhof gekocht bij de publieke verkoop door de schepenbank. De rol van Weissenburg is

${ }^{1759}$ Resolutie Staten Generaal 8 juli 1739.

${ }^{1760}$ Het (incomplete) dossier van het proces van de vicestadhouder van het leenhof tegen diverse leenmannen in: RHCL, Landen van Overmaze, inv. nr. 9483.

1761 TJ, inv. nr. M 14, fol. 61-63, Prummer aan M.E. von Toerring-Jettenbach 17 april 1754. 
niet helemaal duidelijk, maar waarschijnlijk fungeerde hij als vertegenwoordiger van de andere bezitters van kleine lenen.

Beide opposanten betoogden dat uit de lijsten van het Gronsveldse leenhof onvoldoende bleek wanneer de laatste leenverheffingen hadden plaatsgevonden. Maar vicestadhouder Berchmans repliceerde dat de dagvaarding slechts ten doel had een verklaring te kriigen betreffende de leenroerigheid van bezit. Wanneer die was erkend, dan volgde in Gronsveld de procedure over de nalatigheid in de verheffing. Overigens moesten de heren zich niet van den domme houden. Weissenburg had na verschillende aanmaningen beloofd aan zijn verplichtingen te voldoen, maar was zijn toezeggingen nooit nagekomen. De Lamberts de Cortenbach wist heel goed dat Vaalsbroek en Holset leenroerig waren. Bovendien mocht van hem op zijn minst een loyale houding ten opzichte van de graaf worden verwacht, aangezien hij zich daartoe als leenman bij de leenhulde wegens Einrade in 1718 al verbonden had. Maar Berchmans bediende hem alsnog op zijn wenken met twee authentieke uittreksels uit de Gronsveldse leenadministratie.

De Lamberts de Cortenbach hield in zijn 'meeste heilige onschuld' ('justissima ignorantia') vol dat hij Holset en Vaalsbroek nooit zou hebben gekocht wanneer hij had geweten dat ze leenroerig waren. Maar tegen de geproduceerde bewijsstukken viel niets in te brengen. Hij verklaarde zich dan ook bereid een van zijn zonen de leenverheffing te laten doen, waarbij hij de hof Holset, die uit twee grote lenen bestond, als één leen wilde laten verheffen. Het eerste voorstel stuitte bij Prummer op bezwaren, maar met de verheffing als één leen wilde graaf Toerring-Jettenbach bij wijze van gunst nog wel instemmen. Vervolgens maakte de Lamberts de Cortenbach nog allerlei bezwaren tegen in zijn ogen onnodig gemaakte kosten, omdat hij zo bereidwillig was mee te werken. Heel langzaam lukte het de tachtigjarige baron over de streep te trekken. Holset als één leen verheffen, was nog wel acceptabel, maar Prummer trapte niet in het voorstel om de lenen op naam van zijn zoon te zetten en zelf het vruchtgebruik te houden. Gezien de hoge leeftijd van de leenman viel immers spoedig een nieuwe verheffing met betaling van heergewaad te verwachten. ${ }^{1762}$ Uiteindelijk deed baron De Lamberts de Cortenbach op 9 november 1754 leenhulde voor Vaalsbroek en Holset. ${ }^{1763}$ Daarna volgden de bezitters van de kleine lenen als vanzelf.

Vanaf die tijd vonden geregeld verheffingen bij het leenhof plaats. Op 16 september 1766 deed Antoine Ulric baron de Lamberts de Cortenbach leenhulde wegens Vaalsbroek, ${ }^{1764}$ maar korte tijd later diende zich een andere liefhebber aan voor Vaalsbroek en Holset, de sinds 1761 in Vaals gevestigde Akense industrieel Johan Arnold von Clermont (geboren 1728). Hij kocht de goederen en deed leenhulde voor het leenhof. ${ }^{1765}$ Vervolgens bouwde hij het verwaarloosde Vaalsbroek uit tot een kleine residentie en wist hij zich door de

1762 Voor de berichten van Prummer aan de graaf over de leenprocedure in Vaals zie: TJ, inv. nr. M 14, fol. 115-119, Prummer aan M.E. von Toerring-Jettenbach 27 sept. 1754); TJ, inv. nr. M 14, fol. 65-67, Prummer aan M.E. von Toerring-Jettenbach 12 oktober 1754; TJ, inv. nr. M 14, fol. 83-88, Prummer aan M.E. von Toerring-Jettenbach 21 nov. 1754.

${ }_{1763}$ TJ, inv. nr. M 42, leenregister Holset, fol. 8 en 53. De datum is ingevuld, de naam ontbreekt, maar moet uit de verdere context worden opgemaakt.

${ }^{1764}$ TJ, inv. nr. M 42, leenregister Holset, fol. 9. Een belening voor Holset is niet ingeschreven.

${ }^{1765}$ TJ, inv. nr. M 42, leenregister Holset, fol. 10 en 53. 
systematische aankoop van landerijen op te werken tot grootgrondbezitter. Hij overleed op 5 december 1795 en was daarmee de laatste leenman van Vaalsbroek en Holset.

Prummer had met zijn actie in Vaals succes gehad, maar zette onvoldoende door. Zijn opvolger Zollner constateerde dat de toestand van de lenen in Vaals nog steeds zorgelijk was. Hij pakte de draad weer op en inderdaad kunnen we constateren dat het aantal leenverheffingen tussen 1780 en 1787 toenam tot gemiddeld acht per jaar.

\subsection{Verbeteringen in de leenadministratie}

In zijn uitvoerig rapport 'Ueber die verfassung und beschaffenheit des lehenhoffs' van 16 juni 1757 geeft Prummer op basis van de Gronsveldse Rechtsordnung uit 1671 beschouwingen over het materiële leenrecht in Gronsveld.1766 Die wetgeving verdiende volgens hem wel aanpassing, maar daarmee was voorzichtigheid geboden. Zo schreef de Rechtsordnung een algemene verheffing na het overlijden van de leenheer voor, maar daadwerkelijke toepassing daarvan zou, gelet op ervaringen in het verleden en kijkend naar de gebruiken in de streek, tot grote oppositie leiden. Ook een strikte toepassing van het terugvalrecht ten behoeve van de graaf bij nalatigheid van een leenman viel niet aan te bevelen. Belangrijker was het voorkomen van problemen door een goede administratie in de leenboeken.

Voorts beschouwde Prummer de gewoonte om lenen op naam van kinderen te zetten als 'unfueg'. Het was niet mogelijk daar helemaal een einde aan te maken, maar een gedeeltelijke oplossing kon bestaan uit handhaving van de eis dat de leenman tenminste meerderjarig moest zijn om de eed van trouw af te afleggen. Prummer bepleitte ook striktere handhaving van het octrooi dat moest worden gevraagd alvorens een leen werd verkocht of met hypotheek bezwaard. De weerstand die dit mogelijk kon opwekken bleef volgens hem beperkt, wanneer met omzichtigheid te werk werd gegaan.

Ten slotte wees Prummer in zijn rapport ook op het oude gebruik om bij een akte van belening een reversaal te maken, een tegenstuk waarbij de leenman verklaarde een leen te hebben ontvangen. Die gewoonte werd niet meer nageleefd. Prummer stelde voor deze regel opnieuw in te voeren en gebruik te maken van door hem ontworpen formulieren. ${ }^{1767}$

Inderdaad zijn ook verbeteringen doorgevoerd. Belangrijk was dat Prummer binnen het kader van een algemeen onderzoek naar de juridische toestand van de grond ook alle lenen binnen het graafschap letterlijk in kaart liet brengen. Het door Berchmans in 1743 vernieuwde leenboek kwam daarbij uitstekend van pas. Van ieder perceel waren de ligging en de naam van de leenman bekend.

Waarschijnlijk al vanaf begin jaren zestig werd strikt de hand gehouden aan de toestemming voor verkoop of bezwaring met hypotheek van leengoed. ${ }^{1768}$ Omstreeks

\footnotetext{
1766 TJ, inv. nr. M 13, fol. 109-142, Information ueber die verfassung und beschaffenheit des lehenhoffs. 1767 TJ, inv. nr. M 13, fol. 161, 30 juli 1757, model van gedrukt reversaal van leenbrief van een leenman ten behoeve van graaf Toerring; fol. 163, 30 juli 1757, model van gedrukte leenbrief voor een leenman van graaf Toerring-Jettenbach.

1768 RHCL, Graafschap Gronsveld, inv. nr. 145, met één voorbeeld van octrooi uit 1765 en een ononderbroken reeks tussen 1782 en 1794.
} 
1760 deden ook voorbedrukte formulieren van leenakten en reversalen hun intrede. De graaf, aangeduid met uitgebreide titulatuur, verklaarde in de leenbrief dat hij door middel van stadhouder en leenmannen aan de met naam genoemde leenman een bepaald goed in leen had uitgegeven. De variabele gegevens werden met de hand ingevuld. Van het goed stonden de belendende percelen opgegeven, evenals de letter en het nummer op de 'caerte figuratif. Van de leenman werd de eed van trouw gevraagd. Op de akte werden eventueel nog aantekeningen gemaakt betreffende de betaling van werfschelling, heergewaad et cetera.

Ook het reversaal werd getekend door de stadhouder en leenmannen, de secretaris van het leenhof en de ontvanger van het leen. ${ }^{1769}$ Maar anders dan vroegere teksten, waarin de leenman slechts erkende een leen te hebben ontvangen, waren de verplichtingen in het door Prummer ontworpen model veel beter beschreven. De leenman verklaarde daarin

sonder voorgaende consent ende octroeye des leen-heerens... niet ... te verkoopen, versetten, verpanden, by testament vermaeken, verdeelen ofte op eenige andere bedenckelijke maniere veralieneeren ofte distraheeren ende ... voorts alles te doen, waer toe eenen getrouwen vasal volgens de Rycxe leen-rechten en die van dit leen-hoff verplicht ende verbonden is te doen ende te laeten... op pœne dat by gebreck van het eene ofte andere, het voorsz. leen-goet in gevolgens de voorsz. leen-rechten ten allen tyden als caduc reëlyck sal zyn vervallen.

Deze oplossing was niet alleen simpel, maar voorkwam ook discussies over de vraag welk leenrecht nu van oudsher in Gronsveld gold. Alles stond er in: de plicht om toestemming voor bepaalde handelingen te vragen, het geldende feodaal recht en het terugvalrecht voor de leenheer. Interessant is Prummers verwijzing naar het rijksleenrecht. Dat gebeurde, zoals hij zelf zegt, duidelijk met de bedoeling en verwachting dat dit leenrecht in Gronsveld langzaam maar zeker wortel zou schieten.

Ten slotte kan worden gewezen op een mogelijk interessante wijziging in de competentie van het leenhof. Het lijkt er op dat Prummer het leenhof mede is gaan inzetten voor de verheffing van keurmedige goederen. In het zogenoemde 'keurboek' van circa 1726-circa 1792 vinden tussen 1735 en 1754 de opdrachten plaats ten overstaan van drossaard en schepenen, terwijl dit daarna gebeurt ten overstaan van commissaris, leenmannen en schepenen, en soms zelfs zonder schepenen. ${ }^{1770}$

Het leenhof van Gronsveld is min of meer geruisloos geëindigd met de inlijving van het graafschap bij Frankrijk in 1795. Het is opmerkelijk dat Wolfgang Zollner op zijn vlucht naar München juist de leenregisters heeft meegenomen; deze bevindt zich nu dan ook nog in het archief van de graven Toerring-Jettenbach. Leefde hij in de verwachting dat deze administratie ooit nog een keer kon worden verzilverd?

${ }^{1769}$ TJ, inv. nr. M 16, lopend van 1762-juli 1792, eerste tachtig folio’s zijn uitgescheurd.

1770 TJ, inv. nr. M 18. 


\section{5 (Lands)heerlijke rechten en ander vermogen als instrument van gezagsuitoefening en bron van inkomsten}

In dit hoofdstuk wordt een overzicht gegeven van ruim twintig, zeer diverse rechten waarop de graaf als heer van Gronsveld aanspraak maakte. De uit de rechtshistorische literatuur bekende en gangbare indeling van rechten vanuit een juridische invalshoek in (lands)heerlijke en niet-heerlijke rechten blijkt daarbij minder geschikt voor een benadering, waarbij vooral wordt gekeken naar doel en functie van rechten. Heerlijke rechten in de klassieke betekenis waren een middel om overheidsgezag en jurisdictie uit te oefenen, maar tegelijk ook bronnen van inkomsten. ${ }^{171}$ Vanuit dit laatste perspectief bestond er boekhoudkundig niet zoveel verschil met andere bronnen van inkomsten zoals erfpachten, en gewone pachten, keurmede, heergewaad en cijnzen. Uiteindelijk draaide het om het geldelijk gewin. Daar komt bij dat van sommige inkomsten, zoals cijnzen of keurmeden, soms moeilijk is vast te stellen of die een heerlijk karakter hebben. Als voorbeeld kan hier worden genoemd de bijzondere juridische procedure die in Gronsveld moest worden gevolgd bij de inning van grafelijke pachten en cijnzen.

Ook bij inkomsten die voortvloeien uit belastingen, concessies en monopolies op een bepaalde activiteit valt dikwijls moeilijk vast te stellen of het hier gaat om eenvoudig belastingheffing of exploitatie van een specifiek heerlijk recht. Patronaatsrechten over kerken en collatierechten over kerkelijke beneficies worden meestal niet gerekend tot de heerlijke rechten, omdat deze voortvloeiden uit het oorspronkelijke eigendomsrecht van de patronaatsheer of collator van de goederen die tot een kerkelijke stichting behoren. Maar het onderscheid met overheidsrechten wordt al vager wanneer deze rechten worden gebruikt als instrument om gezag uit oefenen over de wereldlijke goederen, de 'temporalia' van de kerk.

Wanneer men kijkt naar opsommingen en beschrijvingen zoals die in de vorm van zogenoemde 'denombrementen' (officiële specificaties van in leen uitgegeven heerlijkheden), dan valt op dat ook daarin de meest uiteenlopende rechten door elkaar worden genoemd. Een goed voorbeeld daarvan is de in dit boek meermalen aangehaalde 'Specificatie' van het graafschap uit circa 1650. Dit gebruik bevestigt nog eens dat rechten afzonderlijk juridisch goed benoembaar zijn, maar binnen een totaal spelen die onderscheidingen slechts een ondergeschikte rol.

Toch is de in dit hoofdstuk gekozen indeling niet volstrekt willekeurig. De volgorde berust voor een deel op de manier waarop deze in de bronnen worden gepresenteerd. Buiten behandeling blijven de al afzonderlijk besproken rechten op wetgeving en rechtspraak, het recht op inhuldiging, het recht op de benoeming van functionarissen belast met bestuur en rechtspraak en de rechten van keurmede en inkomsten uit leenverheffingen.

\footnotetext{
1771 Een recente studie over de economische betekenis van heerlijkheden over de periode 1463-1600 levert het artikel van Tops, 'De evolutie van de heerlijke financiën'. Daarin (171, noot 2) wordt ook een overzicht gegeven van de relevante Nederlandse en Belgische literatuur. De auteur begint met de constatering dat (171) dat aan de economische geschiedenis van heerlijkheden veel minder aandacht is besteed dan aan de economische geschiedenis van andere instellingen.
} 
In een inleidende paragraaf wordt aandacht besteed aan de grafelijke rechten en inkomsten als geheel en hun economische betekenis binnen dat totaal. Daarna komen de afzonderlijke rechten en inkomsten aan bod. Begonnen wordt met het muntrecht, dat bij uitstek vanaf de zestiende eeuw een symbool was van de adellijke stand van de landsheer. Daarna volgt een reeks monopolies en belastingen. Bij rechten die samenhangen met de exploitatie van grond, ligt het accent vooral op hun betekenis als bron van inkomen. Uitgebreid aandacht krijgen de patronaats- en collatierechten, die bij de heren van Gronsveld een belangrijke rol speelden. Aan het slot komen nog admissierechten voor enkele publieke ambten aan de orde.

Bij elk recht is zoveel mogelijk aangegeven wat er over bekend is, hoe het werd toegepast en wat het financieel opleverde. De lijst maakt geen aanspraak op volledigheid. Misschien hebben niet alle rechten sporen achtergelaten in het soms onvolledige archief. Sommige rechten komen slechts incidenteel voor, zoals het recht van 'haveschot' (recht op erfenissen van bastaarden) in de zestiende eeuw en de Jodenbelasting aan het eind van de achttiende eeuw, andere kenden een eeuwenlange continuïteit en weer andere waren aanvankelijk belangriij, zoals het muntrecht, maar raakten nadien in onbruik, of lijken pas zeer laat in Gronsveld te zijn geïntroduceerd, zoals de admissie van landmeters aan het einde van de achttiende eeuw. Het geheel aan rechten vormde daarmee geen statisch en gesloten systeem, maar kende een vaste kern met aan de rand wisselende rechten.

\subsection{Enkele beschouningen over de financiële betekenis van de grafelijke rechten en inkomsten}

De overgrote meerderheid van de rechten waarop de graaf als heer van Gronsveld aanspraak maakte, vertegenwoordigde financiële waarde. In feite laat het graafschap zich daarmee vergelijken met een onderneming, waarbij de exploitatie van 'kapitaal' in de vorm van allerlei overheidsrechten en grondbezit, na aftrek van de 'onkosten', uiteindelijk 'winst' moest opleveren. In het geval van de heren van Gronsveld maakte die opbrengst ook weer deel uit van groter familiebezit, maar dit ruime verband laten we hier verder buiten beschouwing.

Alvorens over te gaan tot bespreking van de afzonderlijke rechten en bronnen van inkomsten, willen we hier eerst een indruk geven van die 'onderneming graafschap Gronsveld' als totaal, waarmee ook de economische waarde van de afzonderlijk rechten binnen dat geheel naar voren komt. Het gaat daarbij om een 'steekproef. Voor een aaneensluitend overzicht van het financiële beheer van het graafschap Gronsveld ontbreken ook de bronnen, aangezien tot het midden van de achttiende eeuw slechts een zeer beperkt aantal jaarrekeningen bewaard is gebleven.

Voor die 'steekproef' is, gespreid over de tijd, gebruik gemaakt van de rentmeestersrekeningen uit de periode 1617-1624, een tweetal beschrijvingen van heerlijke rechten en inkomsten van circa 1650 en 1651 (zie bijlage 44), enkele staten van inkomsten rond 1696 en ten slotte een analyse van de rentmeestersrekeningen over de jaren 1734- 
1745 en 1756-1767, die Prummer in 1768 heeft verwerkt in een uitvoerig rapport over de grafelijke rechten en inkomsten. ${ }^{1772}$

In onderstaande tabel wordt een overzicht gegeven van de inkomsten uit heerlijke rechten en grondexploitatie, zoals die in de rentmeestersrekeningen over de jaren 1622-1623 en 1623-1624 zijn verantwoord. Dit stramien werd door de rentmeester ook voor andere jaren op ongeveer dezelfde wijze gevolgd.

Inkomsten graafschap Gronsveld uit heerlijke rechten en grondexploitatie 16221624 in guldens Maastrichter koers

\section{Inkomsten}

Erfpacht raapzaad Gronsveld

Erfpacht Gronsveld

Landpacht Gronsveld

Tienden Gronsveld

Tiende Eckelrade

Landpacht Eckelrade

Erfpacht Eckelrade

Erfpacht tarwe Heugem

Landpacht en erfpacht Heugem

Erfpacht Honthem

Rogge-erfpacht Slenaken

Spelt Slenaken en Oost

Gerst of kortkoren tiende Gronsveld

Haver pacht samen

Kapoenen

Ganzen

Hennen en pullen

Bede

Land- en hofcijnzen

Landen 'ter helschafft' (pacht grond bij kasteel tegen

halfwinning

Suiker

Kruidnagel, muskaat en muskaatbloem

Inkomsten uit hoven en driessen (graslanden)

Verkoop hout uit bos Slenaken

Inkomsten uit 'geldrenten'

Inkomsten uit keurmede

Werfschelling van lenen

Werfschelling Gronsveld en Eckelrade

Werfschelling Slenaken
1622-1623

1623-1624

$\begin{array}{rr}3 & 2 \\ 276 & 243\end{array}$

$2026 \quad 1583$

$249 \quad 195$

$230 \quad 180$

$121 \quad 95$

$154 \quad 120$

$12 \quad 11$

$942 \quad 744$

$418 \quad 326$

$24 \quad 19$

$244 \quad 244$

$156 \quad 156$

$106 \quad 120$

$251 \quad 261$

$101 \quad 101$

$13 \quad 14$

$173 \quad 173$

$120 \quad 120$

11

74

19

124

178

175

60

70

62

128

${ }^{1772}$ TJ, inv. nr. M 73, fol. 474-552, Prummer aan M.E. von Toerring-Jettenbach 29 juni 1768. 
Leenverheffingen

Accijnzen (Inkomsten uit accijns zijn voor de portier van

het kasteel, dus niet verantwoord)

Boetes

Bossen te Gronsveld niet uitgegeven

De munt heeft stilgestaan.

Totaal

Binnen het overzicht valt de grote betekenis van de 'landpacht' in Gronsveld op (verpachting van grond tegen een termijn van zes jaar of een veelvoud daarvan). Van alle inkomsten in granen en peulvruchten te Gronsveld, Heugem, Eckelrade en Honthem bestond in deze twee jaren 42 tot 43 procent uit 'landpacht'. Op het totale inkomen voor 1622-1623 bedroeg dit dertig procent en voor 1623-1624 ongeveer 27 procent. Hetzelfde beeld geeft ook een staat uit 1651 van diverse inkomsten in granen onder Gronsveld, Heugem, Eckelrade en Honthem. Op een totaal van 7612 gulden aan inkomsten uit landpachten, erfpachten en tienden in die plaatsen bestond de helft (3824 gulden) uit landpacht onder Gronsveld. Rond 1695 bedroeg het aandeel 'landpacht' met 2487 gulden ongeveer 58 procent op een totaal van 4263 gulden aan inkomsten uit graan in eerder genoemde plaatsen. De verschillen tussen 1622-1624, 1650 en 1696 kunnen zijn veroorzaakt door toevallige omstandigheden, zoals de graanprijs of het soms wel en soms niet meerekenen van inkomsten, maar het algemene beeld is duidelijk.

In 1768 stelde commissaris Prummer gedetailleerde overzichten samen van de inkomsten van het graafschap Gronsveld voor de jaren 1734-1745 en 1756-1767.1773 Zijn commentaar op iedere post van de rekening komt hierna bij de bespreking van de afzonderlijke rechten en inkomsten nog aan de orde. Ten opzichte van de lijst over de jaren 1622- 1624 ontbreken hier uiteraard de inkomsten uit Slenaken. Verder zijn er nog enkele verschillen in de genoemde heerlijke rechten en inkomsten, maar het stramien als zodanig is niet veranderd. Ten opzichte van de voorgaande eeuw blijkt nog steeds het grote belang van de landpachten, een belang dat door verandering in de manier van verpachting alleen maar groter werd.

\section{Inkomsten van het graafschap Gronsveld 1734-1745 en 1756-1767 in guldens Maastrichter koers}

1734-1745

1756-1767

Landpachten in geld en graan

Erfpachten in geld en graan

Pachten voor tuinen en weide

\begin{tabular}{r|l}
20143 & \multicolumn{1}{|c}{$1756-1767$} \\
7691 & Landpachten in geld en graan \\
& Erfpachten in geld en graan \\
13245 & Erfpachten in geld en graan \\
Pachten voor tuinen en weide
\end{tabular}

1773 TJ, inv. nr. M 73, fol. 474-508. Er zijn fol. 625-649 ook berekeningen voor de periode 1740-1752, maar daarin ontbreken de oorlogsjaren 1746-1749. 
Cijnzen

Werfschelling cijnsgoederen

en allodiale goederen

Werfschelling leengoederen

Leenverheffingen

Keurmeden

Bieraccijnzen

Verkoop van hout

Karweien of 'Scharwerchgeld'.

Bijenstand

Verkoop van fruit

Visserij op de Maas

Boetes

Windmolen

Tiendenpacht

Mergelblokken

Verkoop graan van land-

en erfpachten

Gewone en buiten-

gewone inkomsten

\begin{tabular}{r|r|r}
7117 & Cijnzen & 8330 \\
1177 & Werfschelling cijnsgoederen & 1608 \\
1553 & en allodiale goederen & \\
668 & Werfschelling leengoederen & 1045 \\
116 & Keurmeden & 1313 \\
1784 & Bieraccijnzen & 661 \\
& Houden van duiven & 2010 \\
12636 & Verkoop van hout & 13 \\
1071 & Karweien of 'Scharwerchgeld' \\
164 & Bijenstand & 14765 \\
1276 & Verkoop van fruit & 1080 \\
1176 & Visserij op de Maas & 224 \\
164 & Boetes & 1415 \\
4800 & Windmolen & 1136 \\
8576 & Tiendenpacht & 379 \\
335 & Mergelblokken & 4800 \\
11980 & Verkoop graan van land- & 14455 \\
2808 & en erfpachten & 793 \\
& Gewone en buiten & 1795 \\
& gewone inkomsten & 1578
\end{tabular}

Totaal van inkomsten gedurende twaalf jaar

Gemiddelde aan inkomsten per jaar
8330

-

045

661

2010

1080

1415

379

4800

793

1795

578

121921

10160

Bij dit overzicht moeten enkele kanttekeningen worden geplaatst. Niet opgenomen is het jachtrecht, hoewel dat in 1740 en 1741 voor 47 gulden en van 1743-1745 werd verpacht voor negentig gulden. ${ }^{1774}$ Voor het houden van duiven werd pas vanaf 1750 een bedrag gerekend. ${ }^{1775}$

Tussen de twee blokken van telkens twaalf jaar bestaan aanzienlijke verschillen in inkomsten. De lage opbrengsten in de periode 1734-1745 zijn in de eerste plaats te wijten aan de deplorabele toestand waarin de grafelijke financiën verkeerden na de periode van de 'admodiatie' en de verwaarlozing en fraude van rentmeester Oligschläger. Maar het beheer gebeurde ook op oneconomische wijze, in het bijzonder bij pachten. Met een ander systeem van verpachting wist Prummer bijna een verdubbeling van opbrengsten te krijgen. Ook bij de andere bronnen van inkomsten viel winst te behalen, wat uiteindelijk resulteerde in een gemiddelde verhoging van twintig procent aan inkomsten.

1774 TJ, inv. nr. M 73, fol. 630

1775 TJ, inv. nr. M 73, fol. 635. 
De voorgaande beschouwingen over inkomsten willen we afsluiten met enkele opmerkingen over uitgaven en rentabiliteit van het graafschap. Voor de jaren 1617-1624 levert onderstaande tabel, gebaseerd op een vijftal rentmeestersrekeningen, ${ }^{1776}$ het navolgende overzicht op

$\begin{array}{lrrr}\text { Jaar } & \text { Inkomsten guldens } & \text { Uitgaven guldens } & \text { Verschil } \\ 1617-1618 & 5850 & 5884 & -34 \\ 1619-1620 & 4003 & 4482 & -479 \\ 1621-1622 & 5655 & 4973 & +682 \\ 1622-1623 & 6604 & 8794 & -2190 \\ 1623-1624 & 5708 & 8276 & -2565\end{array}$

De verschillen bij de inkomsten waren een gevolg van het feit dat de betalingen in natura, zoals graan en pluimvee, afhankelijk van de toevallige kwaliteit en marktprijs verschillende opbrengsten hadden. Deze problematiek komt hierna (Hoofdstuk 15.15) nog uitvoeriger aan de orde. Bij de zeer grote tekorten van de jaren 1622-1623 en 1623-1624 moet worden opgemerkt dat hier het beeld wordt vertekend door eenmalige hoge uitgaven. In het eerste jaar zijn onder de 2559 gulden 'ausgaeff aen allerleij sachen' allerlei kosten geboekt voor de aankoop van militaire uitrusting. Jonge edellieden zoals Jost Maxiliaan van Bronckhorst Batenburg en zijn jongere broers, die een carrière in het leger ambieerden, waren duur. Zij moesten goed voor de dag komen en worden voorzien van geweren, pistolen, degens en andere toebehoren van een krijgsman. Ten laste van het boekjaar 1623-1624 kwam een bedrag van 2889 gulden voor de bouw van de windmolen.

Maar naast deze incidenteel hoge posten blonk het bestedingspatroon in deze jaren niet uit door zuinigheid. Zo werd veel geld besteed aan 'Brusselse zaken' en processen (deze post bedroeg soms meer dan één vierde van het totaal aan uitgaven). Ook voor eten en drinken konden de bedragen flink oplopen. Het kasteel van Gronsveld leek in de eerste decennia van de zeventiende eeuw op een herberg, met een komen en gaan van gasten, bodes en werklui, die allemaal van maaltijden, drank (veelal wijn) en haver voor de paarden werden voorzien. De 'montcosten' bedroegen gemiddeld één vijfde deel van de uitgaven. Daarnaast vervulde Gronsveld een soort 'winkelfunctie' voor Rimburg. Het kasteel lag gunstig om inkopen te doen of bestellingen te plaatsen in Maastricht, Visé of Luik. Voortdurend werden fijne stoffen, galanterieën, linten, garens et cetera naar Rimburg gestuurd, vooral voor de jonge gravinnen. Ook werd voor grote bedragen schoeisel besteld, waarschijnlijk in Maastricht, ten behoeve van de grafelijke familie en het personeel. Luxe levensmiddelen, variërend van banket tot kruiden en van Limburgse kaas tot rozijnen, werden eveneens via Gronsveld naar Rimburg gezonden.

Duidelijk is dat met dit uitgavenpatroon op reserves werd ingeteerd. In feite waren dit de voortekenen van de grote financiële problemen waarin graaf Jost Maximiliaan van Bronckhorst Batenburg in de navolgende decennia verzeild raakte.

1776 RHCL, Graafschap Gronsveld, inv. nr. 181-185. 
Behalve een overzicht van de inkomsten makkte Prummer voor de jaren 1734-1745 en 1756-1767 ook overzichten van de uitgaven. Onderling goed vergelijkbaar zijn deze niet. Wel duidelijk is dat Prummer op de uitgaven bijna de helft kon bezuinigen. In het bijzonder het bedrag aan 'rente' wist hij van 40985 gulden tot 11639 gulden terug te brengen. Door verhoging van bijna alle inkomsten en vermindering van uitgaven slaagde Prummer er in de winstgevendheid van het graafschap te verhogen van duizend gulden per jaar naar 6471 gulden per jaar. Dat mag zeker een prestatie van formaat worden genoemd, wanneer men bedenkt dat de economische toestand van het graafschap na de Oostenrijkse Successieoorlog zeer slecht was. 
Uitgaven van het graafschap Gronsveld 1734-1745 en 1756-1767 in guldens Maastrichter koers

$1734-1745$

Totaal uitgaven pro 1734

Totaal uitgaven 1735

Rente ('Stuifftungen und Rennte')

Rente ('Interesse')

Aflossing schulden

Salarissen

Aan de administrator

Herstellingswerkzaamheden

Vracht- en bodeloon

Kortingen op pachten

Bier voor schutterij en werklieden

Diverse dagelijkse uitgaven

Totaal aan uitgaven gedurende twaalf jaar

Gemiddelde aan uitgaven per jaar
$1756-1767$

$\begin{array}{rrr}5937 & & \\ 7257 & & 1667 \\ 14063 \text { Rente ('Stüfttungen und Rennte') } & 0 \\ & & 1163 \\ 40985 \text { Rente ('Interesse') } & 9 \\ & & \\ 2239 & \text { Aflossing schulden } & 4800 \\ 7291 & \text { Salaris rentmeester } & \\ 3044 & & 1549 \\ 2812 & \text { Herstellingswerkzaamheden kasteel } \\ & \text { Herstellingswerkzaamheden } & 2071 \\ & \text { windmolen } & \\ 124 & & 1266 \\ & \text { Boomkwekerij } & 913 \\ 1665 & \text { Kortingen op pachten } & 359 \\ 412 & \text { Bier voor schutterij en werklieden } \\ 649 & \text { Diverse dagelijkse uitgaven } & 4995 \\ \mathbf{8 6 4 7 8} \text { Totaal aan uitgaven gedurende } & 4426 \\ & \text { twaalf jaar } & \mathbf{2} \\ \mathbf{7 2 0 6} & \text { Gemiddelde aan uitgaven per jaar } & \mathbf{3 6 8 8}\end{array}$

Totaalbedragen inkomsten en uitgaven van het graafschap Gronsveld 1734-1745 en 1756-1767 in guldens Maastrichter koers

Totaal inkomsten 1734-1745

98480 Totaal inkomsten 17561767

Totaal uitgaven 1734-1745

Verschil inkomsten-uitgaven

Gemiddelde winst per jaar
86478 Totaal uitgaven 1756-1767

12002 Verschil inkomstenuitgaven

1000 Gemiddelde winst per jaar
121921

44262

77659

6471 


\subsection{Recht van muntslag}

Het lijkt op het eerste gezicht vreemd een overzicht van rechten en inkomsten van de heren van Gronsveld te beginnen met het economisch onbeduidende muntrecht. Maar wanneer in de zestiende eeuw zou worden gevraagd, welk specifiek regaal het meest prestigieus werd gevonden, dan scoorde het recht op muntslag waarschijnlijk zeer hoog. Het wekt daarom geen verbazing dat het muntrecht in 1586 met nadruk werd aangevoerd bij het verzoek in de gravenstand te worden verheven. De grote hoeveelheid Gronsveldse munten geslagen van het midden van de vijftiende tot het begin van de achttiende eeuw, legt de materiële getuigenis van dit recht af. Ook in de numismatische literatuur is Gronsveld goed vertegenwoordigd. ${ }^{1777}$ Zelfs in het romantische geschiedbeeld speelt het muntrecht een rol, al was het maar omdat de 'hagemunterij' (nabootsing van 'goede' munten door munten met een te laag gehalte aan edelmetaal) van Gronsveld graag als valsmunterij wordt voorgesteld, een activiteit waarvan in het Maasland onder anderen ook de heren van Rekem en de abdis van Thorn worden beticht. ${ }^{1778}$

Omgekeerd evenredig aan het grote prestige van het muntrecht is de schaarse overlevering van bronnen daarover in het eigen archief. Uit de tijd van de muntslag zelf blijven die beperkt tot enkele vermeldingen in de rentmeestersrekeningen. ${ }^{1779}$ Verder werd in 1768 door Prummer een rapport met historische beschouwingen uitgebracht naar aanleiding van een plan de muntslag nieuw leven in te blazen. ${ }^{1780}$ Dit betekent dat de schriftelijke informatie over het Gronsveldse muntrecht vooral moet worden gezocht in elders bewaarde bronnen. In het kader van deze studie is daar geen uitputtend onderzoek naar gedaan. Maar een samenvatting van wat uit de literatuur bekend is, levert toch een geschiedenis op hoofdlijnen op, die niet veel afwijkt van de gang van zaken zoals die uit andere plaatsen bekend is. ${ }^{1781}$

De Gronsveldse munten zelf zijn in de literatuur goed gedocumenteerd. Het belangrijkste overzicht is te vinden in het werkje van Van Daalen, maar ook elders in de literatuur duiken nog losse aanvullingen op. Voor deze numismatische aspecten wordt naar deze literatuur verwezen. De toeschrijving van munten aan een bepaalde heer is vooral gebruikt als bewijs dat in die periode muntslag werd uitgeoefend.

Het recht op muntslag hoorde tot de regalia die oorspronkelijk aan de koning/keizer toebehoorden. ${ }^{1782}$ Door verzwakking van het centrale gezag ging de muntslag over op grote landsheren. Een min of meer formele bevestiging daarvan achteraf is te vinden in de concessie die keizer Frederik II in 1220 deed aan de geestelijke rijksvorsten, vastgelegd in

1777 Zie hiervoor onder andere Van der Chijs, Munten leenen Braband en Limburg, 96-113; Wolters, Recherches Gronsveld, 47-58; Van Daalen, Munten graafschap Gronsveld, Lucas, Monnaies Mosanes, 15.1-15.59.

${ }^{1778}$ Flament, 'Limburgsche schetsen / Deftige valsche munters'.

1779 RHCL, Graafschap Gronsveld, inv. nr. 172-187.

${ }^{1780}$ TJ, inv. nr. M 25, fol. 340-366, Prummer aan M.E. von Toerring-Jettenbach 21 maart 1768.

${ }^{1781}$ Een nog altijd uitstekend referentiekader daarvoor biedt, wat betreft de zestiende eeuw, het werk van Tangelder, Muntheer en muntmeester, over het muntrecht van de graven van Bergh, dat goed met dat van Gronsveld vergelijkbaar is.

1782 Over het muntregaal zie: De Monté ver Loren/Spruit, Hoofdlijnen, 127-128. 
de (sinds de negentiende eeuw zo genoemde) Confoederatio cum principibus ecclesiasticis. Korte tijd later, in 1231, volgde een herhaling en uitbreiding daarvan door koning Hendrik VII voor zowel geestelijke als wereldlijke vorsten in het Statutum in favorem principum. Sinds de dertiende eeuw nam ook stedelijke muntslag een aanvang. Het is overigens in dit verband belangrijk onderscheid te maken tussen de muntplaats van een landsheer in een stad en het muntrecht van een stad zelf.

De grote landsheren in het bezit van muntrecht zagen vanaf de veertiende eeuw de noodzaak van een zekere standaardisatie en sloten om die reden ook muntverdragen af. Zo kwam in 1386 tussen de keurvorsten van Keulen, Mainz, Trier en Pfalz een overeenkomst tot stand waarbij de Rijnse gulden een standaardmunt werd, die vervolgens uitgroeide tot de belangrijkste handelsmunt voor het Rijnland. Later werd dit verdrag herhaaldelijk vernieuwd en sloten ook de hertogen van Kleef en Gulik-Berg zich er bij aan. ${ }^{1783}$

Min of meer in navolging van de grote landsheren begonnen in de veertiende en vijftiende eeuw ook edelen in het bezit van onafhankelijke heerlijkheden met muntslag. In het Maasgebied gebeurde dit in de vijftiende eeuw door de heren van Limbricht, Elsloo, Obbicht, Rekem en Gronsveld. ${ }^{1784}$ De bevoegdheid daartoe berustte niet altijd op even duidelijke gronden. Soms was het recht opgenomen in een opsomming van andere rechten of in een min of meer algemene bevestiging van privileges, maar er zijn weinig echte verleningen van muntprivileges bekend. ${ }^{1785}$

Wanneer de Gronsveldse muntslag precies is begonnen, valt moeilijk vast te stellen. Lucas schrijft een zogenoemde 'dubbele mijt' toe aan Johan II van Gronsveld, ${ }^{1786}$ maar de juistheid daarvan is twijfelachtig. Hetzelfde geldstuk wordt immers door Wolters en Van der Chijs bij de munten van Johan I van Bronckhorst Batenburg geplaatst. ${ }^{1787}$ Dit bevestigt het al in de numismatische literatuur over Gronsveld bestaande beeld dat de muntslag pas is begonnen met Diederik I van Bronkhorst-Batenburg (overleden 1450). Van Daalen noemt van hem in totaal negen verschillende te Gronsveld geslagen geldstukken, in het algemeen kleinere munten. ${ }^{1788}$ Door zijn huwelijk in 1425 met Johanna van Gronsveld was Diederik aan de heren van Gronsveld geparenteerd geraakt. Gronsveld en Rimburg zouden hem na het overlijden van zijn schoonvader Hendrik III door vererving moeten toevallen, maar Hendrik overleefde de in 1450 overleden Diederik 24 jaar. Waarschijnlijk is hij dus nooit regerend heer van Gronsveld geweest. Daarmee blijft het een vraag of de latere muntslag in Gronsveld voortbouwt op een hier bestaande oudere traditie. Veel meer valt te zeggen voor de aanname dat Diederik het muntregaal

\footnotetext{
1783 Lexicon des Mittelalters VI, 935 onder lemma 'Münzverein'.

${ }^{1784}$ Zie Van der Chijs, Munten leenen Braband en Limburg, passim en Lucas, Monnaies Mosanes, passim.

1785 Zo gaat bijvoorbeeld de muntslag van de heren van Bergh terug op diverse schenkingen uit de veertiende eeuw, vgl. Tangelder, Muntheer en muntmeester, 5-6.

${ }^{1786}$ Lucas, Monnaies Mosanes, 15.7.

1787 Van der Chijs, Munten leenen Braband en Limburg, 108, plaat X, nr. 14; Wolters, Recherches Gronsveld, 53 , plaat IV, nr. 11.

1788 Van Daalen, Munten graafschap Gronsveld, 16-16.
} 
ontleende aan zijn hoedanigheid van heer van Batenburg en Anholt. In die plaatsen bestond immers wel muntslag.

Volgens schriftelijke bronnen bezat Willem van Bronckhorst-Batenburg al in 1317 muntrecht. ${ }^{1789}$ Munten zijn echter niet bekend. Voor diens weduwe Johanna van Batenburg bevestigde rooms-koning Karel IV in 1349 al haar rechten op Batenburg, waaronder het muntrecht. ${ }^{1790}$ Van Gijsbert I van Bronckhorst-Batenburg (overleden 1356), Dirk van Bronckhorst-Batenburg(overleden 1406/1407) en Gijsbert II van Bronckhorst-Batenburg (overleden 1429) respectievelijk overgrootvader, grootvader en vader van Diederik I van Bronckhorst-Batenburg, stichter van de linie Gronsveld, zijn ook munten bekend. ${ }^{1791}$ Margriet van Ghemen, de moeder van Diederik I, stamde als erfdochter van de heren van Anholt eveneens uit een familie van muntheren. Van Anholt zijn sinds het laatste kwart van de veertiende eeuw munten bekend. ${ }^{1792}$

Gijsbert II van Bronckhorst Batenburg liet zowel in Batenburg als in Anholt munten slaan. De Batenburgse munten stonden bekend om hun slechte kwaliteit en het gebruik ervan werd bijvoorbeeld in Utrecht (1414) en Holland (1415) expliciet verboden. ${ }^{1793}$ In 1434 werd de muntmeester van Batenburg in Deventer veroordeeld wegens valsmunterij en levend gekookt in een speciaal daarvoor gekochte ketel. ${ }^{1794}$

Diederik I van Bronckhorst-Batenburg was dus zowel van vaders- als moederszijde bijna 'genetisch voorbestemd' om munten te laten slaan. ${ }^{1795}$ Met deze achtergrond mag worden aangenomen dat het muntregaal door hem in Gronsveld is geïntroduceerd als een recht dat typisch bij zijn familie hoorde. De productieplaats als zodanig was waarschijnlijk van secundair belang. Diederik I liet namelijk ook munten slaan in Batenburg en Anholt. ${ }^{1796}$ $\mathrm{Na}$ het overlijden van Diederik I van Bronckhorst-Batenburg in 1450 werd de muntslag in Batenburg en Anholt overgenomen door zijn oudste zoon Gijsbert en diens nakomelingen. Aan de tweede zoon, Hendrik van Bronckhorst-Batenburg, stichter van de linie Gronsveld (overleden 1493) worden drie of vier verschillende munten toegeschreven. ${ }^{1797}$ Van diens zoon Diederik II van Bronckhorst-Batenburg (1493-1508) zijn vier munten bekend. ${ }^{1798}$,

De eerste helft van de zestiende eeuw laat een sterke toename van de Gronsveldse muntproductie zien. Dit is geen op zich zelf staand verschijnsel, maar past binnen de

1789 Van der Chijs, Munten van Gelderland, 147.

1790 De Monté ver Loren/Spruit, Hoofdlijnen, 103.

1791 Van der Chijs, Munten van Gelderland, 148-151.

1792 Van der Chijs, Munten van Gelderland, 133-140.

${ }^{1793}$ De Monté ver Loren/Spruit, Hoofdlijnen, 128.

${ }^{1794}$ Van der Chijs, Munten van Gelderland, 138-139.

${ }^{1795}$ In Hoofdstuk 3.1.3 is beschreven dat de vererving van Batenburg van Gisbert II van BronckhorstBatenburg op Diederik I aanvankelijk problematisch was wegens pandrechten van een bastaardzoon van de hertog van Gelre. Pas in 1432 kon Diederik deze aanspraken afkopen en mocht hij zich onbezwaard heer van Batenburg noemen.

1796 Van der Chijs, Munten van Gelderland, 140-142 en 149-150.

1797 Van Daalen, Munten graafschap Gronsveld, 17-18.

1798 Lucas, Monnaies Mosanes, 15.12. 
algemene ontwikkelingen van het muntwezen in deze tijd. ${ }^{1799}$ Door toename van het handelsverkeer groeide de behoefte aan muntgeld, vooral 'zwaar geld' in de vorm van gouden en zilveren munten. Tegelijkertijd steeg het aanbod van edele metalen door gouden zilverwinning in Saksen, Bohemen en de Nieuwe Wereld. In de vraag naar geld werd voorzien door de officiële muntplaatsen van de grote landsheren, maar ook door steden met muntrecht en een aantal kleine muntheren. Maar misschien speelden niet alleen economische motieven een rol. Bij de kleine muntheren lijkt de toegenomen muntproductie ook samen te vallen met een bepaald standsbewustzijn, alsof zij met hun muntregaal ook hun onafhankelijkheid tot uiting wilden brengen. ${ }^{1800}$ Hetzelfde geldt ook voor steden zoals Zwolle, Kampen, Deventer en Nijmegen die zich met hun gepretendeerde muntrechten maar moeilijk konden voegen naar de wensen van de regering in Brussel. ${ }^{1801}$ Maar of het nu om winstbejag of standsbewustzijn ging, muntslag was kennelijk belangrijk genoeg om zich weinig van de koninklijke plakkaten en rijksmuntordonnanties aan te trekken.

De kwaliteit van geld uit deze particuliere muntplaatsen was matig tot slecht en veroorzaakte grote problemen in de handel. Daarom groeide op centraal niveau binnen het Rijk de wens van een beter toezicht op het muntwezen. Die bemoeienis resulteerde onder andere in drie muntverordeningen voor het Rijk uit 1524, 1551 en 1559, waarbij een vaste waardevoet voor de gouden en zilveren munten werd vastgelegd. ${ }^{1802}$ Overigens moet hier worden opgemerkt dat deze overheidsbemoeienis vrijwel uitsluitend betrekking had op goud- en zilvergeld. Kleine munten bleven vooralsnog buiten controle.

Het toezicht op de muntslag was opgedragen aan de kreits, de administratieve eenheden waarin het Rijk na de bestuurshervormingen sinds het begin van de zestiende eeuw was ingedeeld. In het noordwestelijk deel van het Rijk ging het om de Bourgondische en de (Nederrijns-)Westfaalse Kreits. Van de begrenzing van de Bourgondische Kreits bestond aanvankelijk geen helder beeld. Pas bij het Verdrag van Augsburg van 1547 stemde de Rijksdag in met de vorming van een kreits bestaande uit de Niederen Erblande van de vorsten uit het Bourgondisch-Habsburgse huis, in feite de Nederlanden onder het gezag van Karel V. Aangezien de verschillende gewesten binnen deze kreits alle oude rechten, privileges en uitzonderingsposities ten opzichte van het Rijk behielden, bleven ze daarmee in politiek opzicht min of meer onafhankelijk. De Nederrijns-Westfaalse Kreits, die ook delen van het stroomgebied van Rijn en Maas omvatte, strekte zich uit van de Weser tot in de Eifel. In het stroomgebied van Maas en Rijn maakten daar onder andere de hertogdommen Kleef en Gulik, het graafschap Loon en het prinsbisdom Luik deel van uit. Maar tussen beide kreitsen bevond zich een rafelrand van kleine territoria waarvan niet duidelijk was waartoe ze behoorden. Meestal ging het om zelfstandige heerlijkheden, die

\footnotetext{
1799 Zie daarover in algemene zin Tangelder, Muntheer en muntmeester, passim, aan wiens werk een deel van de hierna volgende beschouwingen is ontleend.

1800 Een goed voorbeeld hiervan lijkt de muntslag van Margaretha van Brederode, abdis van Thorn 15321577. Hoewel zij zich baseerde op oude rechten, was zij feitelijk de eerste abdis die van het muntrecht gebruik maakte. In dezelfde tijd stond de positie van Thorn als rijksonmiddellijk stift sterk onder druk. ${ }_{1801}$ Zie voor deze steden in het bijzonder Gropp, Die städtische Münzprägung.

1802 Zie hierover Tangelder, Muntheer en muntmeester, 9-15; Gropp, Die städtische Münzprägung, 54-58.
} 
door leen- of voogdijverhoudingen met een groter naburig territorium waren verbonden. Een deel daarvan stond onder Bourgondisch-Habsburgse invloed. Bij heerlijkheden die tot de Nederrijns-Westfaalse Kreits werden gerekend, speelde het probleem dat de allerkleinste niet officieel in de kreitsbijeenkomsten waren vertegenwoordigd. En het waren vaak juist de heren van deze kleine territoria die zich met muntslag bezighielden.

De door het Verdrag van Augsburg erkende politieke onafhankelijkheid van de Bourgondische Kreits gold slechts beperkt ten aanzien van het muntwezen, want de wetgeving van het Rijk over muntslag vond in beginsel ook in de Nederlanden toepassing. Maar handhaving was problematisch. Hoewel de regering in Brussel binnen de Bourgondische Kreits een centralistische politiek voerde, moest zij tegelijkertijd rekening houden met de oude rechten en privileges van de afzonderlijke gewesten. ${ }^{1803}$ Binnen de Nederrijns-Westfaalse Kreits speelden de 'kreisausschreibende' vorsten, te weten de bisschop van Münster en de hertog van Kleef-Gulik een beperkt sturende rol, maar van centralisme kon hier al helemaal geen sprake zijn. In een dergelijke constellatie lieten de kleine muntheren in het grensgebied zich niet veel gelegen liggen aan de rijkswetgeving.

De Nederrijns-Westfaalse Kreits begon vanaf het midden van de zestiende eeuw met regelmatiger toezicht op de muntslag. ${ }^{1804}$ Vanaf 1566 werden 'Probationstage' gehouden en besloot men de rijksmuntordonnanties te volgen. ${ }^{1805}$ Er werd gestreefd naar eenheid in munt, officiële wisselkoersen, bekendmaking van verboden geld, inrichting van officiële muntplaatsen in rijkssteden en verbetering van het toezicht op afzonderlijke functionarissen zoals muntmeesters, waardijnen (controleurs) en muntstempelsnijders. Voorts stelde men zich tot taak de rechtmatigheid van de muntregalen van de afzonderlijke kreitsstanden te onderzoeken. Juridisch werd onderscheid gemaakt tussen enerzijds het recht om gouden en zilveren munten te slaan en anderzijds kopergeld. Dankzij de regelmatige 'Probation' slaagde men er in de kwaliteit van munten van edelmetaal redelijk op peil te houden. Veel minder goed lukte dit met het massaal aangemaakte kopergeld.

Vanaf de zestiende eeuw krijgen we ook voor het eerst op basis van schriftelijke bronnen een min of meer samenhangend beeld van het productieproces bij de muntslag en de daarbij betrokken personen. Tangelder drukt het aldus kernachtig uit: 'een heerlijke munt was niets anders dan een kleine industriële onderneming, waarbij de kooplieden de afnemers en de muntheer en de muntmeester de ondernemers waren'. ${ }^{1806}$ Er was ten opzichte van de middeleeuwen duidelijk sprake van toenemende professionalisering. De

1803 Voor deze problematiek zie specifiek Gropp, Die städtische Münzprägung.

${ }^{1804}$ Zie in het bijzonder Dotzauer, Reichskreise, 306-308 en Lennartz, 'Probationstage'.

1805 Vgl. Schneider, Niederrbeinisch-Westfälische Kreis, 73-75 over de benoeming van een kreitswaardijn en diens beëdiging 1566, 73-74.

1806 Tangelder, Muntheer en muntmeester, 188. 
drie genoemde partijen speelden daarbij de hoofdrol, bijgestaan door controlerende en uitvoerende functionarissen als de waardijn, de essayeur en de stempelsnijder. ${ }^{1807}$

Het muntregaal kwam toe aan de muntheer, maar de muntslag zelf werd tijdelijk verpacht aan een muntmeester. Diens ambacht laat zich vergelijken met dat van een goudsmid. Muntmeesters en andere personen uit dezelfde bedrijfstak, zoals essayeurs en stempelsnijders, stamden uit onderling verwante families, die ook elkaars beroepsgeheimen kenden. Het systeem van verpachting bracht met zich mee dat muntmeesters van plaats tot plaats trokken. In principe werkten zij voor zowel de officiële muntplaatsen als particuliere muntheren. Daardoor en door de onderlinge verwantschap treffen we steeds dezelfde namen in verschillende plaatsen aan. Een goed voorbeeld daarvan vormt de hierna nog te noemen Peter Bossenhoven, die ook voor de munt in Gronsveld heeft gewerkt.

Muntheer en muntmeester legden hun verhouding contractueel vast in een instructie of commissiebrief. Daaraan voorafgaand moest worden onderhandeld over de voorwaarden, zoals de verdeling van de opbrengst volgens een bepaalde formule. Het ruwe metaal werd geleverd door kooplieden, die het materiaal na omsmelting en muntslag weer afnamen. Die winst voor de muntmeester bestond in beginsel uit de vergoeding die de kooplieden voor het werk betaalden; met de afzet hadden noch hij noch de muntheer iets te maken. Van zijn winst betaalde de muntmeester zijn personeel en aan de muntheer droeg hij de zogenoemde sleeschat af, een vast bedrag van enkele stuivers per geldstuk of een bepaald aantal munten van het totaal aan geslagen geld. Een hoge sleeschat beïnvloedde niet alleen de winst voor de muntmeester, ze verhinderde ook commerciële onderhandelingen met kooplieden, want die zochten uiteraard naar de gunstigste plaatsen om te laten produceren. Dat voordeel kon de muntmeester alleen bieden door zijn eigen marge te verkleinen, omdat het aandeel van de heer immers vaststond. Laatstgenoemde had echter vooral belang bij een hoge omzet. Binnen dit spanningsveld ontstond een belangrijk motief voor knoeierijen; want door verlaging van het gehalte van de munt tijdens het productieproces steeg de winst van de muntmeester.

Naast, of beter gezegd tegenover de muntmeester stonden de stempelsnijder, de essayeur en de waardijn. Zij dienden vooral de belangen van de muntheer. De vervaardiging van de stempel of ponsoen voor de muntslag was zeker bij de nabootsing van bestaande munten een belangrijk werk, omdat een goede imitatie de acceptatie van het geld verhoogde. Een belangrijke rol speelde ook de essayeur, belast met de controle van het gehalte. Hij zag toe op de aanlevering van het metaal door de kooplieden en lette bij het einde van het productieproces op het gehalte van de munt. De waardijn was aanwezig bij de inname van het metaal, beheerde de stempels, hield de boekhouding bij, woog de munten na en zorgde voor correcte afdracht van de sleeschat. Wanneer alles regelmatig verliep, werd van elke slag een steekproef genomen, die in een verzegelde bus werd gestopt. Toch konden alle waarborgen en controles niet verhinderen dat er werd gefraudeerd, vooral met het gehalte. In beginsel was de muntmeester daar verantwoordelijk voor, maar hij werd meestal aangezet door de kooplieden.

1807 De hierna volgende beschouwingen over de verschillende personen die bij de muntslag zijn betrokken, zijn grotendeels ontleend aan Tangelder, Muntheer en muntmeester, passim. 
Deze handelaren vormden de derde partij bij de muntproductie. Zij zijn zelfs te beschouwen als de drijvende kracht en tegelijkertijd blijven het schimmige figuren op de achtergrond. Muntheer en muntmeester moesten instaan voor geheimhouding van hun namen en de muntheer bood ook de nodige bescherming. De handelaren leverden de smeltwaar in de vorm van baren, bestaande munten of voorwerpen van edelmetaal. $\mathrm{Zij}$ bepaalden ook de bestelling van bepaalde munten en wisten waar behoefte aan bestond, wat gangbaar was en waar het geld het beste kon worden afgezet. Bij voorkeur ging het daarbij om gebieden waar een bepaalde munt niet ongunstig bekend stond. Er werd dus door de muntheren vrijwel niet voor de eigen streek geproduceerd. ${ }^{1808}$ De handel oefende ook sterke invloed uit op het 'conterfeitsel', de afbeelding op de munt. De imitatie van een goed bekend staande munt vormde geen probleem, wanneer de kwaliteit van het nieuwe geld maar gelijkwaardig was. Mensen accepteerden nu eenmaal liever een bekende dan onbekende munt.

Maar de namakk kon ook zijn bedoeld om te bedriegen, wanneer de munt een geringere intrinsieke waarde bezat dan ze eigenlijk voorgaf. Wie wilde frauderen, zocht bij voorkeur een muntmeester in dienst van een particuliere muntheer. De officiële koninklijke, en later de gewestelijk muntplaatsen, waren minder geschikt voor duistere praktijken.

Voor de muntproductie was een smidse of atelier nodig, waar het metaal kon worden gesmolten en bewerkt. In een plaats als Bergh beschikte men over een eigen munthuis, maar er bestond ook een zekere voorkeur voor werkplaatsen in kastelen. Dat was ook veiliger met het oog op opslag van edele metalen. Een deel van de benodigde inventaris moet mobiel zijn geweest, aangezien men van plaats tot plaats trok en het muntbedrijf langere tijd stilstond. Aanvankelijk werden de plaatjes metaal met behulp van stempels tot munten geslagen. Tegen het einde van de zestiende eeuw werd heel geleidelijk overgestapt op machinaal persen met behulp van walsen en schroeven.

In de eerste helft van de zestiende eeuw is het meeste geld in Gronsveld geslagen onder de regering van Johan I van Bronckhorst Batenburg (1508-1559). Van Daalen vermeldt voor hem een twintigtal meest gouden en zilveren munten, imitaties van algemeen gangbare geldstukken. ${ }^{1809}$ Interessant is dat de beeldenaar van een aantal munten behalve familiewapens ook een schildje bevat waarop een zon is afgebeeld. Volgens Van Daalen zou dit een verwijzing kunnen zijn naar de status van Gronsveld als zonneleen. ${ }^{1810}$ De gedachte is niet zo vreemd, want dit verband werd naderhand ook gelegd in een (hierna nog te noemen) verhandeling over het Gronsvelds muntrecht van de jurist Joannes Wamesius. ${ }^{1811}$

\footnotetext{
1808 Zie hierover enigszins badinerend: Flament, 'Limburgsche schetsen / Deftige valsche munters' 38-39, waar wordt gezegd dat de bedoeling was Gronsveldse muntjes te verspreiden in Rusland en het Baltisch gebied.

${ }_{1809}$ Van Daalen, Munten graafschap Gronsveld, 18-21.

1810 Van Daalen, Munten graafschap Gronsveld, 19-21.

1811 Johannes Wamesius (Luik 1524-Leuven 1590) jurist en professor in burgerlijk en kerkelijk recht aan de universiteit van Leuven.
} 
Uit de tijd van Johan I dateert ook het eerste schriftelijke gegeven over de Gronsveldse muntslag in de rentmeestersrekening van 1536/1537.1812 Wat precies wordt bedoeld met 'dry hameren' is niet helemaal duidelijk; het kan gaan om drie verschillende muntijzers, maar ook om contractperiodes. In ieder geval vond de productie plaats gedurende een jaar en kon de muntmeester per kwartaal met de heer van Gronsveld afrekenen. De opbrengst van $37 \frac{1}{2}$ Hornse guldens is substantieel, maar niet overdreven hoog, wanneer men dit vergelijkt met bijvoorbeeld de 25 Hornse guldens die werden betaald voor de pacht van de mergelgroeve en de 24 Hornse guldens voor het visrecht in Heugem.

Ook op naam van Johans zoon Willem van Bronckhorst Batenburg staan diverse munten, ondanks diens korte regeringsperiode van 1559 tot 1563, maar de toeschrijvingen zijn niet altijd even zeker. ${ }^{1813} \mathrm{Na}$ zijn vroegtijdig overlijden lijkt de muntslag gedurende lange tijd te zijn gestaakt. Deels kan dit worden verklaard door de minderjarigheid van zijn zonen. Joost van Bronckhorst Batenburg aanvaardde de regering over Gronsveld pas in 1586 en overleed al in 1588. Zijn broer en opvolger Johan II hervatte waarschijnlijk pas weer tegen het einde van de zestiende eeuw de muntslag.

Van de zestiende-eeuwse muntmeesters die in Gronsveld werkten, is alleen de naam van Peter Bossenhoven bekend. Bij een onderzoek dat Prummer in 1768 instelde naar de geschiedenis van het Gronsvelds muntrecht, trof hij een verslag aan van de Probationstag van de Nederrijns-Westfaalse Kreits uit $1614 .{ }^{1814}$ Tijdens die bijeenkomst had graaf Johan II van Bronckhorst Batenburg een akte uit 1561 getoond, waaruit bleek dat Peter Bossenhoven in Gronsveld munt mocht slaan. ${ }^{1815}$ Mogelijk hield dit stuk verband met een proces, dat in die tijd door de fiscaal bij het Rijkskamergerecht werd aangespannen tegen diverse muntheren. Het tweede document betreffende activiteit van Bossenhoven betreft een getuigenverhoor rond de jaarwisseling van 1564/1565. 1816 Bossenhoven werd door de Brabantse hoogschout te Maastricht aangeklaagd voor zowel het Luikse als Brabantse hooggerecht aldaar, omdat hij de koninklijke ( $=$ tevens Brabants-hertogelijke) muntplakkaten had overtreden. Uit het verslag blijkt dat Peter al eerder activiteiten had ontplooid in Gronsveld, Batenburg en Thorn. Deze volgorde is waarschijnlijk niet helemaal willekeurig, want uit andere bron is bekend dat hij van 1556 tot 1559 werkte in Batenburg en sinds 1561 was aangesteld als muntmeester van de abdis van Thorn. ${ }^{1817}$ Daarmee wordt aannemelijk dat Bossenhoven al kort vóór 1556 in Gronsveld actief was. Lang kan hij niet hebben gewerkt, want volgens de rentmeestersrekening van Gronsveld over 1552/1553 stond het muntbedrijf in dat jaar stil. Dit laat onverlet dat hij hier in de daarop volgende jaren nog met tussenpozen werkte. Waarschijnlijk is hij daarna naar

\footnotetext{
1812 RHCL, Graafschap Gronsveld, inv. nr. 172: 'Item die munth tot Gronsfelt deyt mynen joncker dit jar met dry hameren te wercken $371 / 2$ hurns gulden, dan mogen alle verdel jars aff stoen alst hon beliefft. Hy van dit jar ontfangen dry verdel jaers, facit 28 hurns gulden $1 \frac{1}{2}$ stuiver'.

1813 Van Daalen, Munten graafschap Gronsveld, 21-23, vermeldt er ongeveer 12.

1814 TJ, inv. nr. M 25, fol. 340.

1815 TJ, inv. nr. M 25, fol. 341: ein original Instrument in Pergament, welchergestalt vor diesem Jahr 1561 den 26 Jan. die Müntz zu Gronsfeldt etwan Petren Puschenhoven verlehnet und ausgethan gewesen. 1816 Afgedrukt bij Doppler, 'Valsche munten'.

1817 Tangelder, Muntheer en muntmeester, 97.
} 
Maastricht vertrokken. ${ }^{1818}$ Bossenhoven was goed bekend in Maastricht. Hij bezat daar onroerend goed, was keurmeester geweest voor de goud- en zilversmeden en zijn broer Lambert Bossenhoven, fungeerde gedurende het jaar 1566/1567 als peymeester van de stad. 1819

Peter Bossenhoven genoot in het muntbedrijf van zijn tijd een zekere reputatie. ${ }^{1820} \mathrm{Hij}$ moet tussen 1520 en 1525 zijn geboren in Maaseik, waar hij ook overleed rond 1608/1609. Hij stamde uit een familie van goudsmeden en muntmeesters en ook zijn vrouw Adriana van Stockbroeck was afkomstig uit dezelfde kringen. Rond 1560 namen de klachten over Peters werk toe. De muntplakkaten van de regering in Brussel richtten zich vooral tegen de producten van muntplaatsen waar Bossenhoven actief was. Ook bij de Nederrijns-Westfaalse Kreits stonden zijn muntstukken slecht aangeschreven. Hoe de strafvervolging in 1564 is Maastricht afliep, is niet bekend; in het jaar daarop werd Bossenhoven in Keulen gevangen gezet, vooral voor zijn Thornse munten. Maar uiteindelijk wist hij toch zonder al te veel problemen de dans te ontspringen, waarschijnlijk omdat hij de protectie genoot van belangrijke heren, zoals de prins-bisschop van Luik. Nadien was Bossenhoven nog in verschillende plaatsen als muntmeester actief: in 1575 te Hasselt voor de prins-bisschop van Luik, tussen 1577 en 1578 voor graaf Frederik van den Bergh in Hedel en rond 1581 in Stevensweert. Zijn slechte reputatie bleef echter bestaan, want in 1575 belandde hij in Keulen opnieuw in het gevang.

Aan het einde van de jaren vijftig van de zestiende eeuw begon de regering in Brussel met maatregelen tegen de minderwaardige producten die particuliere muntheren en de steden met muntslag op de markt brachten. Deze zogenoemd 'hagemunterij' stond de door Brussel gewenste munteenheid in de weg en was economisch schadelijk. Waardevolle koninklijke en buitenlandse munten werden omgesmolten voor de aanmaak van minderwaardig geld. In het handelsverkeer zorgden de imitaties van goed geld voor veel verwarring. Op 26 november 1558 vaardigde Philips II een plakkaat uit tegen het gebruik van minderwaardig geld, afkomstig uit met naam genoemde muntplaatsen. ${ }^{1821}$ Het betrof munten van de stad Nijmegen, (de steden van) Overijssel, de abdis van Thorn, de graaf van Bergh, de heer van Batenburg, de heer van Rekem en ook de heer van Gronsveld. Diens muntplaats werd zelfs speciaal vermeld:

Ende voirts zijn wij oic geinformeert dat de heere van Gronsfelt bij onser stadt van Maestricht alreede begonst heeft te doen slaen eenen silveren penninck gelijckende onsen halven real, waeruuyt naemaels een groote ongeregelteyt soude mogen rijsen en waere te beduchten dat, indien van onsentwegen daerinne nyet promptelijken versien en worde, die

1818 In tegenstelling tot wat Tangelder, Muntheer en muntmeester, 97-98 schrijft, werd Lambert van Bossenhoven, en niet Peter, in de het jaar 1566/1567 tot Luiks peymeester van Maastricht benoemd. De vergissing is echter verklaarbaar. In het Huldeboek van Maastricht (RHCL, Indivieze raad van Maastricht, inv. nr. 223) staat voor het betreffende jaar weliswaar eerst Peter Bossenhoven vermeld, maar daarna is de naam doorgehaald en vervangen door Lambert.

1819 Tangelder, Muntheer en muntmeester, 96 vermeldt Lambert Bossenhoven in de jaren veertig als burgemeester van Maaseik.

1820 Zie over hem in het algemeen Tangelder, Muntheer en muntmeester, passim en in het bijzonder 96-100.

1821 Terlinden/Bolsée, Recueil des ordonnances, deel 7, Règne de Philippe II, I, 387-391, nr. 178. 
coopluyden, zoe duytsche als andere, in onse munte huere stoffen ende materien gewoenlijck zijnde te leveren, om huer eygen prouffit te doene, huere voirs. materien in vrempde munten souden transporteren om onse restrinctien te schouwene, te weten van zeker deel ende portie van de voirs. materien in cleyne munte te moeten bekeeren...

Het plakkaat werd op 24 oktober 1559 nog eens herhaald, nu gericht tegen Nijmegen, Deventer, Kampen en Zwolle, de graaf van Berg, de heren van Batenburg, Dalenbroek, Rekem en Gronsveld en de abdis van Thorn. ${ }^{1822}$ In de tekst wordt ook verwezen naar klachten vanuit het Rijk en de opdracht die de keizer had gegeven aan de fiscaal bij het Rijkskamergerecht om hiertegen op te treden. Kennelijk sorteerde deze wetgeving toch niet het gewenste effect en moest de druk worden opgevoerd. Op 20 april 1560, 7 december 1560, 17 juni 1561 en 24 maart 1562 werden de plakkaten nog eens herhaald. ${ }^{1823}$

Inderdaad startte de fiscaal bij het Rijkskamergerecht op 13 november 1561 een procedure tegen een aantal muntheren en -steden om zich te verantwoorden voor overtreding van de muntordonnanties van het Rijk. Naast de genoemde steden worden van de kleinere muntplaatsen onder andere genoemd Thorn, Rekem, Batenburg en Bergh. In eerste instantie schijnt dit weinig resultaat te hebben gehad. Op 7 juni 1563 volgde een nieuwe dagvaarding, waarbij de eerdere lijst van gedaagden werd aangevuld, nu ook met de heer van Gronsveld. ${ }^{1824}$ De klacht behelsde dat zij goede keizerlijke gouden en zilveren munten hadden nagemaakt, die ook nog 1/5 minder waard waren. De procedure schijnt nogal moeizaam te zijn verlopen. Vooral Nijmegen en de Overijsselse steden maakten veel werk van hun verdediging. ${ }^{1825}$ Ook de heer van Gronsveld verweerde zich. Volgens het onderzoek van Prummer uit 1768 liet graaf Johan II van Bronckhorst Batenburg op de Probationstag van 1614 een (kennelijk ongedateerde) verhandeling over het Gronsvelds muntrecht zien van de hand van de Leuvense jurist Joannes Wamesius (1524-1590). Dit drie katernen omvattend betoog is opgesteld voor het proces bij het Rijkskamergerecht. Wamesius beweerde dat de heren van Gronsveld sinds onheuglijke tijden gouden, zilveren en koperen munten hadden geslagen. De heer van Gronsveld was wegens zijn heerlijkheid een alleen van God afhankelijke 'authocrator' die noch aan het Rijk noch aan de keizer was onderworpen. Hij hoefde zich dus door de keizer op muntgebied niets te laten voorschrijven. ${ }^{1826}$.

1822 Terlinden/Bolsée, Recueil des ordonnances, deel 8, Règne de Pbilippe II, II, 14-16, nr. 6.

1823 Terlinden/Bolsée, Recueil des ordonnances, deel 8, Règne de Pbilippe II, II, 59-63, nr. 25; 127-131 nr. 59; 218-224, nr. 94; 320-323, nr. 135.

1824 Tangelder, Muntheer en muntmeester, 17-18; Gropp, Die städtische Münsprägung, 70-76.

1825 Zie Gropp, Die städtische Münsprägung, passim.

1826 TJ, inv. nr. M 25, fol. 353-354, ... dan ich habe ein von dem famosen Doctore Joanne Wamesio unterschriben rechtliches Guttachten gefundten, woraus ich siehe es habe der Reichs-fiscal den damahligen Freyherrn Wilhelm von Gronsfeldt weegen von ihme und seinen Herrn Vattern zu Gronsfeldt geschlagen Gelt in die Straff ziehen wollen, worüber gesagter Wamesius auf die Frag welcher gestalten den Fiscalen zubegegnen wäre?, mit seinen schier ganze 3 Pögen haltenden und mit einer Quantitaet von Rechts-sätzen und Authoritaeten beleuchteten Guettachten (nebtst deme dass er auch eine possesionem immemorialem cudendi monetam auream, argenteam et aeream reclamiret) dahin gegangen: der Freyherr von Gronsfeldt seye weegen solcher Freyherrschafft weeder dem Reich noch dem Kayser subject, sondern ein nur von Gott abhangender absolut freyer Herr und Authocrator, also dass er 
Waarschijnlijk is het proces bij het Rijkskamergerecht uiteindelijk verzand ${ }^{1827}$ en bleken de steden en de meeste muntheren bereid zich in 1567 te onderwerpen aan de Probation van de Nederrijns-Westfaalse Kreits. Vanaf 1566 werden regelmatig Probationstage gehouden, waarbij steekproeven van de muntslag op hun gehalte werden gecontroleerd. Tevens volgden onderzoeken naar de rechtmatigheid van het muntregaal, waarop afzonderlijke leden van de kreits aanspraak maakten. Of Gronsveld zich daar ook bij aansloot, valt niet met zekerheid te zeggen, aangezien in deze tijd geen munten werden aangemaakt.

$\mathrm{Na}$ het overlijden van Willem van Bronckhorst Batenburg in 1563 heeft de Gronsveldse munt lange tijd stilgestaan. Pas zijn zoon Johan II heeft na 1588 de draad weer opgepakt, maar het is moeilijk vast te stellen wanneer dat gebeurde. De rentmeestersrekeningen uit de tijd van Johan (1595/1596, 1608/1610 en 1612) noemen de munt niet of vermelden stilstand. Van Daalen onderscheidt een 25-tal varianten, het meeste kopergeld. Pas in 1614 vroeg graaf Johan bij de Probationscommisie van de Nederrijns-Westfaalse Kreits om erkenning van zijn muntrecht. ${ }^{1828}$ Interessant is dat Prummer ruim 160 jaar later in het Gronsveldse archief nog enkele verslagen vond van Probationstage, waaronder ook die van 1614. ${ }^{1829}$ Naast de al eerder genoemde 'bewijsstukken' (de concessie tot muntslag van Peter Bossenhoven uit 1561 en de verhandeling van Wamesius) liet de graaf het keizerlijk diploma van de verheffing in de gravenstand uit 1586 zien, maar daar staat niets expliciet over het muntrecht in. In eerste instantie was men bij de Probationscommissie niet zwaar onder de indruk en de heren moesten er nog eens een nachtje over slapen. Pas in het jaar daarop ging men met de Gronsveldse muntslag akkoord.

De precieze voorwaarden van de concessie zijn niet duidelijk. Mogelijk werd afgesproken dat voor de aanmaak van gouden en zilveren munten werd uitgeweken naar een officiële stedelijke muntplaats in bijvoorbeeld Keulen, Aken of Dortmund. Dit was in later tijd gebruikelijk, maar het onderscheid tussen munten van edel en onedel metaal heeft waarschijnlijk, zoals hierna nog aan de orde komt vanaf het begin een rol gespeeld.

Graaf Johan II van Bronckhorst Batenburg had niet lang plezier van de erkenning, want hij overleed al in 1617. De rentmeestersrekeningen van 1617/1618 en 1619/1620 vermelden daarna dat de munt stil stond. Maar na het overlijden van Johan II lijkt zijn zoon en opvolger Jost Maximiliaan de draad weer op te pakken. Mogelijk stond er in de zestiende eeuw een afzonderlijk munthuis bij het kasteel, zoals in 's-Heerenberg. ${ }^{1830}$ Maar nu werd geïnvesteerd in een werkplaats in het kasteel. Er kwamen nieuwe ramen en de rookafvoer 'boven int alde werck op den grooten sael' werd verbeterd. Het atelier was

auch des Müntzens halber weeder von dem Reich noch von dem Kayser sich etwas fürschreiben zulassen....

${ }_{1827}$ Volgens een instructie 30 april 1569 van de abdis van Thorn voor haar vertegenwoordigers op de Probationstag van de Nederrijns-Westfaalse Kreits had de keizer de 'suspension unserer habender muntzregalien allergenedigst relaxiert'... Zie [Wolters], Notice Thorn, 174-175, nr. 55.

${ }^{1828}$ Lennartz, 'Probationstage', 57 schrijft dat Johan toelating vroeg in 1614.

1829 TJ, inv. nr. M 25, fol. 340.

1830 RHCL, Rijkskamergerecht, inv. nr. 17, fol. 84. Daar wordt gezegd dat in de zestiende eeuw, toen het kasteel grote schade leed, 'die muntz als sein besunder bauw uff dem platz geblieben'. Mogelijk bleef dat ook zo na de restauratie en herbouw van het kasteel omstreeks 1590. 
brandgevaarlijk 'want die foncken flogen daer doer heer'. ${ }^{1831}$ De rekening van 1621/1622 vermeldt dat de gouden en zilveren munten wegens stilstand niets hebben opgebracht. Die omschrijving wijst er duidelijk op dat dit geld als een aparte categorie werd beschouwd. Volgens de voorschriften van de Nederrijns-Westfaalse Probation diende de anmaak daarvan te geschieden in een stedelijke muntplaats, bijvoorbeeld Keulen of Aken. Maar wel werden in Gronsveld grote hoeveelheden kopergeld vervaardigd. Van 22 oktober 1619 tot 7 april 1622 sloegen de gebroeders Caspar en Peter Franssen duiten, waarvan de graaf aan sleeschat 464 gulden 18 $1 / 2$ stuiver beurde. Van 8 april 1622 tot 14 september werkten Linnard Francken en zijn zonen Bernard en Philips in het muntatelier. Hun productie bracht aan sleeschat 154 gulden 141/2 stuiver. ${ }^{1832}$ Het ging dus om substantiële bedragen. Interessant is ook een post in de rekening waarin de betaling van een knecht wordt vermeld om de muntijzers in Rekem op te halen, een bewijs dat tussen de muntplaatsen Gronsveld en Rekem samenwerking bestond.

Onder de graven Jost Maximiliaan (overleden 1662) en Johan Frans van Bronckhorst Batenburg (overleden 1719) is de muntslag met regelmaat voortgezet. De graven werden aangeschreven voor de Probationstage en stuurden meestal een vertegenwoordiger. In 1768 vond Prummer in het kasteelarchief van Gronsveld verslagen of recessen van de Probationstage van 1614, 1657-1660, 1670, 1688, 1695 en 1700.

De Probationstage werden meestal twee keer per jaar gehouden. Het voorzitterschap berustte bij de Kreisdirektoren, maar feitelijk de voornaamste rol speelden de kreitswaardijn en de kreitsstempelsnijder. Zij controleerden de proefmunten die de verschillende muntmeesters tijdens hun werk in de verzegelde muntbussen hadden gestort. Iedere kreitsstand met muntrecht mocht een muntmeester aanstellen, mits deze voldeed aan eisen van vakbekwaamheid en was beëdigd. Hij moest de al eerder genoemde proefstukken in de bus gooien en aantekening houden welke materialen hij had ingekocht en verwerkt. De kreitsstempelsnijder moest de stempel slaan.

In beginsel hield de kreits zich alleen bezig met goud- en zilvergeld. Kleine pasmunt, het kopergeld, mocht alleen met speciale vergunning worden angemaakt. Die toestemming werd niet licht gegeven en alleen maar voor kleine hoeveelheden, want bij dit type geld was de kans op fraude het grootst. Maar algemene acceptatie van die beperking was een ander verhaal. Iedere muntstand had altijd pasmunt laten slaan uit 'schrott und korn' en daarom meenden de meeste kreitsstanden dat degene die muntrecht bezat, ook zonder tegenspraak dit soort geld mocht slaan. ${ }^{1833}$

De kreits drong er op aan alleen in stedelijke ateliers munten te laten vervaardigen. Sinds 1689 mocht muntslag alleen nog in tien steden plaats vinden, te weten Münster, Kleef, Düsseldorf, Paderborn, Osnabrück, Luik, Minden, Keulen, Aken en Dortmund. De rest van de muntslag werd beschouwd als hagemunterij en illegale muntplaatsen werden vanwege de kreits ontmanteld. Graaf Jost Maximiliaan van Bronckhorst schijnt voor Gronsveld te hebben geprobeerd van het atelier in Aken gebruik te maken, maar werd

1831 RHCL, Graafschap Gronsveld, inv. nr. 184.

1832 RHCL, Graafschap Gronsveld, inv. nr. 183.

1833 Dit plaatst de vaak gehoorde klachten over valsmunterij toch in een wat ander daglicht. 
daar geweigerd, mogelijk omdat hij toch al op gespannen voet met het Akense stadsbestuur verkeerde. Zijn zoon Johan Frans liet bij voorkeur munten slaan in Keulen, waarbij hij gebruik makkte van de Keulse muntmeester en ook de Keulse stempelsnijder. Dat liep in 1695 uit op een ruzie met de stempelsnijder van de kreits, die eigenlijk de daarvoor aangewezen persoon was. De kreitswaardijn suste de zaak met de mededeling dat toch ook die stempel was gemaakt door een beëdigd snijder, die nu eenmaal het portret op de beeldenaar beter wist weer te geven!

Geheel probleemloos verliep de Gronsveldse muntslag niet. De uit Sittard afkomstige Dirk Hamer, die als predikant werkzaam was in Groningen, raakte in de jaren 1657-1659 verwikkeld in een crimineel proces omdat hij (waarschijnlijk onschuldig) verboden Gronsveldse munten zou hebben uitgegeven. Het kwam hem uiteindelijk op verbanning en confiscatie van goederen te staan. ${ }^{1834}$ In 1692 besloten de Staten-Generaal in Den Haag dat maatregelen nodig waren tegen de slechte duiten die uit Gronsveld afkomstig waren. Een jood zou daar op het kasteel wekelijks voor duizend pond aan duiten slaan, die dan in vaatjes via de Maas naar Holland werden vervoerd. ${ }^{1835}$ En op de Probationstag van de kreits in 1680 wilde men van de afgevaardigde van graaf Johan Frans van Bronckhorst een bewijs van het muntrecht zien ('diploma juris monetandi'), maar die kon dat niet overleggen. De toning van een dukaat uit 1657 was onvoldoende. Toch liep uiteindelijk ook deze zaak met een sisser af.

Afgezien van dit soort incidenten lijkt de muntslag zonder grote moeilijkheden te zijn verlopen. Toen gravin Maria Anna von Toerring-Jettenbach na het overlijden in 1719 van haar eerste echtgenoot Johan Frans van Bronckhorst opnieuw in het huwelijk wilde treden met graaf Claude Nicolas d'Arberg Valengin, ontving zij bij haar verloving gelukwensen van von der Ketten, een der directeuren van de kreits. Deze maakte bij die gelegenheid ook opmerkingen over het muntrecht. De directeur schreef dat het Gronsveldse muntregaal veertig jaar geleden in twijfel was getrokken, maar de graaf had sindsdien toch ongehinderd zijn recht kunnen uitoefenen. De muntstempels bevonden zich nog bij de weduwe Hilgers in Keulen. Von der Ketten bood de gravin naar beste vermogen zijn dienst aan, wanneer zij munten wilde laten slaan, maar hij moest dan wel over een schone stempel met betere 'schnit' en een beter randschrift beschikken. Maar, zo schreef hij, het munten van kleiner zilvergeld was economisch niet zo interessant, vanwege de hoogte van de zilverprijs. Waarschijnlijk klopt dit advies ook wel enigszins met de praktijk en werd voor Gronsveld vooral kleingeld aangemaakt.

In de jaren twintig van de achttiende eeuw zijn nog wel eens afgevaardigden namens Gronsveld op de Probationstage aanwezig geweest, maar de muntslag hield in deze tijden door de vele interne problemen binnen het graafschap op. In 1768 leek het muntrecht weer actueel te worden, omdat een niet nader genoemde Luikse ondernemer bij graaf

${ }^{1834}$ Flament, 'Limburgsche schetsen / Deftige valsche munters'; Van Daalen, Munten graafschap Gronsveld, 33-35.

1835 Flament, 'Korte inhoud resolutiën Staten-Generaal', 305-306, resoluties van 25 augustus en 9 september 1692. 
Maximilian Emanuel in München het verzoek indiende om Gronsveldse munten te mogen slaan. ${ }^{1836}$ Commissaris Prummer bracht daarover uitvoerig advies uit, waarvoor hij onderzoek deed naar de geschiedenis van het Gronsveldse muntwezen. ${ }^{1837}$ Daarvoor moest hij terugvallen op schriftelijke bronnen, want van de munten zelf had Prummer in werkelijkheid alleen maar een 1/8 stuiver van Johan Frans onder ogen gekregen. Eens te meer een bevestiging van het feit dat het Gronsveldse geld niet in de regionale economie werd gebruikt.

In zijn adviezen over een herleving van het muntregaal stelde Prummer zich aanvankelijk positief op en formuleerde hij de voorwaarden waaronder zoiets kon gebeuren. De oude stempels in Keulen waren intussen verloren. Nieuwe waren dus noodzakelijk, ook al omdat die van vroeger ouderwets waren en niet zo 'curieux' als die welke thans naar Frans model in de mode waren. Dat betekende dus een nieuwe beeldenaar van de graaf. Nog veel belangrijker was de zorg voor goede kwaliteit om de graaf niet te schande te maken. Het was wel zaak dat een ondernemer, die de titel van muntdirecteur, intendant of iets dergelijks kreeg, een deskundige en betrouwbare muntmeester en waardijn benoemde. Verder moest de munt als betaalmiddel in een groot gebied acceptabel zijn. Dat betekende dezelfde standaard als de Gulikse, Luikse en Keulse munt. Keuls en Guliks geld zag men hier niet, Luik sloeg meestal kleiner geld, dat ook in de Brabantse en Staatse territoria in omloop was. In de Landen van Overmaze circuleerden meestal munten van slechtere kwaliteit. De Staatse munt, die in de Republiek als betaalmiddel werd gebruikt, kon men hier vanwege de territoriale versnippering niet handhaven. Luiks geld werd wel aanvaard als pasmunt in het dagelijks verkeer, maar eigenlijk als noodzakelijk kwaad, omdat dit geld geen constante kwaliteit kende. Wanneer de Gronsveldse munten nu tenminste dezelfde intrinsieke waarde als de Luikse bezaten, dan bevorderde dat hun gangbaarheid. Maar verwerving van deze erkenning was niet zo gemakkelijk. Door de hoge grondstofprijs van zilver was het moeilijk winstgevend te munten. Dat was waarschijnlijk de reden dat ook in Luik al een paar jaar geen munt meer was aangemaakt. Zou er winst te behalen zijn, dan had men dat zeker niet gestaakt. Bij het idee om goudgeld te slaan kon Prummer zich niets voorstellen. Er was al sinds zeer lange tijd geen Luiks goudgeld meer uitgebracht. Gangbare munten waren de Louis d'or, de Hollandse dukaten of Brabantse soevereinen. En het was maar zeer de vraag of met gouden munten een goede winst viel te behalen.

Het volgende probleem betrof de toestemming van de kreits. Omdat er geen vaste kreitsdagen waren, verliep de besluitvorming uiterst bureaucratisch en omslachtig. Van alleen maar het peilen van meningen, zonder een officieel verzoek in te dienen, verwachtte Prummer geen effect. De uitkomst van een beslissing door de kreitsdirecteuren was al helemaal onvoorspelbaar. Enerzijds schreven de muntstanden allerlei regelingen voor, anderzijds deden de grote muntstanden onder hen, en zeker Kleef en Gulik, precies waar ze zelf zin in hadden.

Verder deed zich de vraag voor of men niet volgens de vroegere verordeningen gebonden was aan de tien muntsteden. In de kreits hing het antwoord daarop af van de mening die Pruisen over die muntsteden had. Zonder inwilliging van Berlijn was niets mogelijk.

1836 TJ, inv. nr. M 25, fol. 320-323, ontwerp van project voor muntslag, z.d.

1837 TJ, inv. nr. M 25, fol. 340-366, Prummer aan M.E. von Toerring-Jettenbach 21 maart 1768; fol. 324-

338, Prummer aan M.E. von Toerring-Jettenbach 13 juli 1768. 
Maar bij de afweging van alle voor- en nadelen van nieuwe muntslag, moesten bezwaren van economische aard toch de doorslag geven. Wanneer in Gronsveld alleen goud en zilver werd verwerkt, dan konden daarvan nauwelijks voldoende munten worden aangemaakt. Bedrijfstechnisch was dat alleen verantwoord in combinatie met andere activiteiten. Met het steeds duurder worden van grondstoffen als goud en zilver was de winst verwaarloosbaar, wanneer de munten aan een behoorlijk gehalte voldeden.

Alles overwegend kwam Prummer tot het oordeel dat het hele plan van de Luikse ondernemer om in Gronsveld een muntplaats te openen, veel leek op vissen in troebel water, met grote risico's, om nog maar te zwijgen van investeringen. Hij achtte het niet verstandig zaken te doen met iemand die zich op een verliesgevende activiteit ging toeleggen. Het motief daarvoor kon slechts zijn ontduiking van de wettelijke regels. Met andere woorden, de Luikse ondernemer kon alleen winst maken, wanneer hij de graaf in diskrediet bracht. Prummer voelde er dan ook niets voor het hele plan bij de kreitsdirecteuren te presenteren. Slechts één overweging kon hem tot andere gedachten brengen, namelijk wanneer het muntregaal werd aangewend tot meerdere eer en glorie van de graaf. Dat doel scheen Johan Frans van Bronckhorst Batenburg vroeger ook met zijn goud- en zilvergeld voor ogen hebben te hebben gehad. Dan vervielen natuurlijk al de hiervoor genoemde economische bezwaren. In dat geval ging het niet om het geld, maar om de persoon die op de beeldenaar stond. Voor dat doel kon je ook gebruik maken van een bestaande muntplaats en spaarde je eigen personeel uit, om maar te zwijgen van de inrichting van een eigen muntatelier. Met deze mening zat Prummer uiteindelijk toch weer dicht bij één van de belangrijkste redenen waarom het muntrecht vooral in de zestiende eeuw zo sterk was opgekomen, te weten eer en prestige. Dat bleek het graaf Maximilian Emanuel toch niet waard te zijn.

\subsection{Recht op berendiensten}

De heer had in beginsel recht op herendiensten, arbeid van zijn onderzaten. Deze werkzaamheden moeten worden onderscheiden van verplichtingen ten behoeve van de dorpsgemeenschap, zoals onderhoud van wegen, dijken of waterlossingen. Aard en omvang van herendiensten verschilden per plaats, maar er zijn wel enkele algemene kenmerken te geven. De eigenaren van kar en paard moesten vrachtdiensten verrichten bij het binnenhalen van de oogst, hooi of brandstoffen en het vervoer van bouwmaterialen. De minder bedeelden verrichtten het handwerk zoals maaien, hooien, het kappen van hout of sjouwen bij bouwactiviteiten. Andere bekende herendiensten betroffen wachtlopen in tijden van gevaar, bewaken van gevangenen en het ijsvrij houden van grachten.

De diensten stuitten op veel verzet, want ze kwamen eigenlijk altijd ongelegen. Tegen het einde van de middeleeuwen groeide de tendens om ze af te schaffen of af te kopen. Voor de heer was dat niet altijd ongunstig, want tegenover gratis arbeid stonden de kosten van voedsel en drank voor de arbeiders. Maar in plaatsen waar de heer stond op strikte handhaving, dreigde een reëel gevaar voor conflicten. In zijn studie over de politieke cultuur in kleine territoria van het Maas-Rijngebied laat Gabel duidelijk zien dat geschillen over herendiensten ernstige vormen konden aannemen en tot openlijke rebellie 
leidden. ${ }^{1838}$ Een bekende aanleiding van oplopende spanning was de soms zeer ambitieuze (her)bouw van een kasteel, waarvoor de inwoners diensten moesten leveren.

Van oudsher was het gebruikelijk dat ook de onderzaten van het 'erfland Grunsfelt' hun herendiensten leverden 'mitt lijve, wagen ind perden.....aen, op ind binnen meinen sloit Remberg... to weten den waldienst, weikendienst (wachtdiensten)... [en] stein, kalck, erde te graven, bij to foeren, to dragen'. ${ }^{1839}$ Let wel, het ging om diensten vanuit Gronsveld naar Rimburg en niet over werkzaamheden in Gronsveld zelf. Begin zestiende eeuw voelden de inwoners zich door die tochten 'groitlik beswert', omdat zij met hun eigen werk in de knel kwamen, vooral in de zaai- en oogsttijd. Daarom stelden zij in 1526 voor deze diensten af te kopen voor achthonderd Rijnse goudgulden, in termijnen te betalen. Johan I van Bronckhorst Batenburg stemde in met een jaarlijkse aflossing van tweehonderd gulden gedurende vier jaar. Hij mocht voor dat bedrag ook twee borgen uit de onderdanen aanwijzen. Op zijn beurt verklaarde de heer zijn onderdanen ten eeuwigen dage vrij van 'dienst mitt lijve, waigenn ind perde exempt', echter met enkele voorbehouden. In de eerste plaats behield de heer het recht de van oudsher gebruikelijke 'vrijbede' te vragen (zie over deze bede Hoofdstuk 15.16). Voorts bleven de inwoners verplicht boter, kaas, stokvis, graan en ander proviand te vervoeren 'mitt honnen lijve, wagen ind perden'. De laatste uitzondering betrof de mogelijkheid dat de heer in een oorlog verwikkeld raakte. In dat geval bleven de inwoners gehouden alle diensten te leveren als vanouds gebruikelijk was. De overeenkomst werd bekrachtigd met de zegels van Johan I van Bronckhorst Batenburg en van de vier schepenbanken. Authentieke afschriften zouden in elke schepenkist worden bewaard.

Rond 1600 werden de herendiensten (mede) inzet van een reeks processen voor het Rijkskamergerecht in Spiers tussen graaf Johan II van Bronckhorst Batenburg en zijn onderdanen. De kern van dit conflict betrof de introductie door de graaf van nieuwe belastingen ten behoeve van het Rijk en de kreits (zie uitvoeriger hierover Hoofdstuk 16.2.1). Maar de grieven van de bevolking richtten zich ook tegen veelvuldige herendiensten en de hardvochtige manier waarop de mensen werden behandeld. 1840 Wellicht hing dit samen met de verplichte deelname aan bouwwerkzaamheden aan het kasteel van Gronsveld. Omstreeks 1590 moet zijn begonnen met een grootschalige herbouw van het kasteel. De inwoners schonken daar zelfs negenhonderd gulden Brabants voor. De graaf gaf daar later een heel andere interpretatie aan. Het was geen vrijwillige bijdrage, maar een vergoeding waarop hij recht had omdat de inwoners in 1593 buiten hem om gemeentegrond voor eigen gebruik in bezit hadden genomen. ${ }^{1841}$

De zaak begon in 1599 toen graaf Johan door middel van een uitspraak van het Rijkskamergerecht zijn onderdanen wilde dwingen tot betaling van de rijks- en kreitsbelastingen. De inwoners verzetten zich daartegen met de stelling dat zij helemaal niet aan deze nieuwe belastingen onderworpen waren en zij in 1526 alle diensten en

1838 Gabel, Widerstand und Kooperation, passim.

1839 Zie Bijlage 34.

1840 RHCL, Rijkskamergerecht, inv. nr. 17, 72, 73, 74.

${ }^{1841}$ RHCL, Rijkskamergerecht, inv. nr. 17, fol. 28. 
betalingen hadden afgekocht. Er staken meer ongenoegens achter deze argumenten. In de voorgaande decennia had het graafschap ernstig geleden onder doortrekkende troepen en de belegering van Maastricht in 1579. Het land was verwoest en de bevolking verweet de graaf gebrek aan bescherming. Een teer punt vormde de steun die men vanuit Gronsveld bij de regering in Brussel had gezocht om de overlast van Spaanse troepen te verminderen. Daarmee dreigde de rijksonmiddellijkheid van Gronsveld gevaar te lopen. Daarnaast speelden nog verzet tegen vermeende knevelarijen door de graaf en een geschil over eigendom van gemeentegrond in Heugem een rol. Graaf Johan II had daar eigenmachtig een stuk van verkocht en was toen tot zijn ergernis daarvoor voor de schepenbank van Heugem gedaagd, door hem minachtend een 'bauerngericht' genoemd.

In eerste instantie leek graaf Johan II bij het Rijkskamergerecht ongelijk te krijgen, maar naderhand bleken de belastingen ten behoeve van Rijk en kreits onontkoombaar. Intussen ging wel het gerucht dat de onderdanen het recht aan hun kant hadden. Een zekere Johan Meijs, inwoner van Maastricht en secretaris van de schepenbank Heugem, hitste de inwoners op tot ongehoorzaamheid aan de graaf. Deze op zijn beurt liet enkele inwoners gevangen zetten en bedreigde hen wegens oproer met de doodstraf. De zaak escaleerde dusdanig, dat vanaf september 1602 de schepenbank van Heugem haar werkzaamheden staakte en van rebellie kon worden gesproken.

De vraag in hoeverre het graafschap Gronsveld was onderworpen aan de rijks- en kreitsbelastingen wordt in Hoofdstuk 16.2.1 - 16.2.6 behandeld. Wat betreft de afkoop van de herendiensten stelde de graaf zich op het standpunt dat de overeenkomst van 1526 alleen betrekking had op diensten die inwoners van Gronsveld ten behoeve van het huis Rimburg moesten verrichten. Volgens hem waren zij helemaal niet ontslagen van werkzaamheden voor de graaf als (lands)heer van Gronsveld. Daarom was het ook volstrekt normaal dat zij hadden gewerkt voor de opbouw van het kasteel.

Naar de letter van de tekst van de overeenkomst uit 1526 leek de graaf gelijk te hebben en waren alleen de werkzaamheden voor Rimburg en niet voor Gronsveld afgekocht. Dat leidde tot een vermakelijke en voor ons ook interessante discussie. ${ }^{1842}$ De onderdanen beweerden dat vroeger in Gronsveld helemaal geen gebouw stond dat de naam 'Schloss oder adeliche Wohnung' verdiende. Dus waren er ook geen diensten geweest om af te kopen. Er was alleen maar 'ein schlecht (eenvoudig) Burghaus', waar al sinds mensenheugenis geen adellijke personen meer woonden, alleen de dorpsscholtis. De graaf van zijn kant moest toegeven dat een deel van de gebouwen al lang geleden was afgebrand, maar behalve nog overeind staande ringmuren, toren en bruggen, was er nog genoeg woonruimte voor onderbrenging van de scholtis, het gerecht en het leenhof.

Met dit soort stellingen kwamen partijen niet nader tot elkaar. Tegelijk met de hoog oplopende meningsverschillen over de belastingen aan het Rijk, werd nog jaren voor het Rijkskamergerecht geprocedeerd. Pas op 25 maart 1611 kwam een compromis tot stand. In punt 4 van de overeenkomst werd ten aanzien van de herendiensten bepaald dat de regeling uit 1526 van kracht bleef. Zolang de bouwwerkzaamheden aan het huis Gronsveld duurden, konden de inwoners ten hoogste tien maal per jaar worden opgeroepen voor vrachtdiensten en werkzaamheden. Na voltooiing van het kasteel golden

1842 RHCL, Rijkskamergerecht, inv. nr. 17, fol. 50vo.-51. 
de bepalingen uit 1526, met dien verstande dat men van diensten verschoond bleef gedurende de zaaitijd, in augustus en in de herfst. Mocht het huis Rimburg ooit uit handen van de graven van Gronsveld raken (men had kennelijk een vooruitziende blik, want in 1640 gebeurde dat!), dan vervielen daarmee ook de diensten voor dit kasteel definitief.

De herendiensten bleven dus gewoon bestaan. Naar het akkoord werd ook verwezen toen graaf Jost Maxiliaan in 1630 de heerlijkheid Slenaken aan de heer van Mheer verpandde en bij de opsomming van de heerlijke rechten ook gewag werd gemaakt van de diensten die de onderdaenen der banck van Slenaecken met hant, peerdt ende wagens schuldich zijn te doen'. ${ }^{1843}$ Een echo van deze verplichting is nog te vinden in een beschrijving van de heerlijkheid Slenaken uit 1771, behorend bij de (betwiste) voorwaarden van de openbare verkoop van de heerlijkheid:

Der Unterthan, welcher Pferd haltet, ist dem gnädigen Landsherrn jährlichs schuldig vier Spanndiensten, so nach der gewohnlichen Land-Tax gerechnet gegen einen Pattacon, deren aber sich nun vorfinden 24 Gespann, ergo.

Der Unterthan, so mit keinem Pferd versehen, ist jedem Haus, dem Landsherrn jährlichs schuldig zehen Handdiensten, macht auf 58 Haushaltungen gegen 15 Stüber per Tag. ${ }^{1844}$

Ook in de de 'Specificatie der qualiteyten, rechten ende gerechticheyden' van het graafschap omstreeks 1650 wordt over diensten gezegd dat de

onderdaenen van den graeffschap schuldich [sijn] thien mael te moeten commen wercken aen ' $t$ voorss. Huys; die peerdt ende waegen hebben moeten vaeren, die keuters moeten in persoen commen wercken ende allen brieven moeten zij van Gronsfelt op Rimborch draegen, soe dickmael alst nodich is.

De hiervoor beschreven verplichtingen tot 'scharwerch' of 'karweien' hadden vooral betrekking op periodiek, gedurende de loop van het jaar terugkerende diensten. Daarnaast kon zich ook incidenteel de plicht tot opkomst voordoen, bijvoorbeeld bij de bewaking van gevangenen. Een voorbeeld van de overlast die dat veroorzaakte levert een klaagschrift van de inwoners van Slenaken aan graaf Jost Maximiliaan van Bronckhorst Batenburg. ${ }^{1845}$ Het stuk dateert volgens het opschrift op de keerzijde uit 1632. Slenakenaren maakten bezwaar tegen het feit dat zij door de inmiddels overleden drossaard 'Allaerss' (bedoeld zal zijn Öller of Oeller) waren opgetrommeld om in Gronsveld een gevangene te komen bewaken. Dat kostte een reis van twee uur. De 'arme onderdaenen' van Slenaken erkenden dat zij, gelijk de andere inwoners van het graafschap, tot bewakingsdiensten verplicht waren, maar dat gold alleen voor gevangenen in hun eigen dorp. Wanneer de gevangene naar Gronsveld was overgebracht, zouden de Gronsveldenaren die taak moeten overnemen.

1843 RHCL, Klooster Hoogcruts, inv. Nr. 296.

1844 TJ, inv, nr. M 55 fol. 244-245, 'Taxa oder Anschlag der unmittelbaren Reichs-Herrschaft Schlenacken' 1771 .

1845 Rijksarchief Hasselt, Archief Schepenbank Sint-Pieters-Voeren, inv. nr. 34. Met dank aan A. Oprey die mij op dit stuk attent makkte. 
In beginsel rustte de plicht tot het verrichten van diensten op ieder huishouden. Slechts functionarissen in grafelijke dienst waren vrijgesteld. Zo schreef drossaard Lebens in 1729 aan graaf d'Arberg Valengin dat de pastoor van Heugem zich vergiste toen die dacht dat zijn kerkmeester was vrijgesteld. Dat recht gold alleen maar voor de tijd dat de man ook schepen was geweest en in die hoedanigheid de heer gratis diende. ${ }^{1846}$ Ook van de weduwe van Diederich Couven uit Slenaken, die in 1679 bij de gravin van Gronsveld bezwaar maakte dat zij ondanks haar adellijke status en het bezit van het leengoed Hees 'continueelijck was gecommandeert tot alderhande carweijen', werd het beroep op vrijstelling afgewezen, tenzij zij haar uitzonderingspositie uitdrukkelijk kon bewijzen. ${ }^{1847}$ Hoe lang precies van 'karweien' in natura gebruik werd gemaakt, valt niet met zekerheid te zeggen. Het ging dan vooral om onderhoud van de kasteeltuinen en het dorsen van graan, maar grote behoefte aan vrachtdiensten met kar en paard bestond niet meer, aangezien nauwelijks aan het kasteel werd gebouwd. Terughoudendheid was ook geboden omdat de 'winst' van deze gratis arbeid flink werd gedrukt door het gratis bier waarvan het werkvolk werd voorzien. ${ }^{1848}$ In zijn rapport uit 1768 over de grafelijke inkomsten schrijft Prummer dat de inwoners beweerden het 'scharwerchgelt' voor een bedrag van negentig gulden per jaar te hebben afgekocht. Dat bedrag werd ook ieder jaar in de boekhouding opgenomen. Dat was eigenlijk veel minder dan de werkelijke waarde van deze diensten, maar Prummer had zelfs de indruk dat er tot 1739 zelfs helemaal niet was betaald.

\subsection{Recht op werfschelling}

In de 'Specificatie' van het graafschap van omstreeks 1650 worden onder de heerlijke inkomsten vermeld 'werffschilling ofte orloffsgelt in 't leenhoff tot Gronsfelt', verder 'werffschilling off pinninxgelt van chinsgoederen off allodiael goederen die voer de banck tot Gronsfelt vercocht worden' en ten slotte 'werfschilling off pinninxgelt vallende voer de banck van Slenaecken' (in alle gevallen zijn percentage en opbrengst niet ingevuld). In de verpandingsovereenkomst van de heerlijkheid Slenaken uit 1630 wordt gesproken over 'het recht van den twelleffden penninck van alleen erffgoeren'. ${ }^{1849} 140$ jaar later bevat de 'Taxa' van de heerlijkheid Slenaken uit 1771 een vergelijkbare bepaling met de zinsnede 'der herrschaftliche werf-schilling oder zwölfte pfenning von verkauftem allodial-guth'. ${ }^{1850}$ Het woord 'orlof lijkt te verwijzen naar toestemming van de heer. Werfschelling, orlofsgeld en penningsgeld waren volgens deze omschrijvingen synoniemen. De begrippen 'orlofen 'werfschelling' komen ook voor in ander rechtsbronnen uit het tegenwoordige Zuid-Limburg. ${ }^{1851}$

1846 TJ, inv. nr. M 15, fol. 897-900, drossaard J. G. Lebens aan graaf d'Arberg Valengin 12 november 1729.

1847 RHCL, Klooster Hoogcruts, inv. nr. 727.

1848 TJ, inv. nr. M 73, fol. 532-533, 541-42.

1849 RHCL, Klooster Hoogcruts, inv. nr. 296.

1850 TJ, inv. nr. M 55, fol. 244-245, 'Taxa oder Anschlag der unmittelbaren Reichs-Herrschaft Schlenacken' 1771

1851 Habets, Limburgsche wijsdommen, 45 vermeldt voor Wittem de twaalfde penning voor de heer bij cijnsgoed, terwijl leengoed vrij is van 'orloff; Idem, 324, werfschelling bij de laathof Ter Wyer in Heerlen; 
Over de oorsprong en het juridisch karakter van dit soort rechten lopen de meningen in de literatuur uiteen. Voor Nederland is in dit verband het meest bekend de problematiek over het recht van de dertiende penning, dat in de omgeving van Abcoude en Vinkeveen wordt geheven. In de discussie daarover in de literatuur en in diverse processen speelde de vraag of dit recht van 'privaatrechtelijke' dan wel 'publiekrechtelijke' oorsprong was. ${ }^{1852}$ In dit laatste geval moest het worden beschouwd als een heerlijk recht, dat in de Franse tijd was afgeschaft. De gangbare opvatting luidt thans dat het recht in verband staat met de ontginning van woeste grond, waarvoor aan de heer op grond van het zogenoemde wildernisregaal een recognitie moest worden betaald. Daarnaast is er een zekere verwantschap met uitgifte tegen cijns of in erfpacht.

Ketelaar vermeldt de in een procedure aangevoerde mening als zou 'de dertiende penning een recognitie voor een vergunning tot levering voor het plaatselijk gerecht zijn', welke opvatting hij als 'terecht verworpen' kwalificeert. ${ }^{1853}$ Misschien geldt dit voor dertiende penning, maar voor de Zuidelijke Nederlanden is deze gedachtengang nog niet zo vreemd. Godding plaatst voor deze gebieden de grondslag voor deze heffing duidelijk binnen het kader van grondheerlijke verhoudingen. ${ }^{1854}$ De bezitter van cijns- of laatgoed moest aan de grondheer verlof vragen om zijn onroerend goed te verkopen. Deze toestemming werd later gefiscaliseerd in de vorm van afdracht van een bepaald percentage van de koopsom. Hoewel de belasting in beginsel werd geheven van heerlijk goed, constateert Godding dat vanaf de twaalfde eeuw, als gevolg van verdere feodalisering van de grond, ook eigenaren van een allodium er steeds meer toe neigden hun goed te onderwerpen aan de jurisdictie van een landsheer en dus ook 'verlof gingen vragen voor overdracht. ${ }^{1855}$ De algemene conclusie op basis van de literatuur luidt dan ook dat dit soort heffingen moet worden beschouwd als een heerlijk recht.

Zowel in de de rentmeestersrekeningen uit het begin van de zeventiende eeuw alsook in de 'Specificatie' van heerlijke rechten uit 1650 valt op dat uitsluitend over werfschelling in Gronsveld/Eckelrade en in Slenaken wordt gesproken, en niet in Heugem en Honthem. Kennelijk bestond deze heffing daar niet of lagen er geen gronden waarop die van toepassing was. Misschien hangt dit samen met de Luikse afkomst van Heugem en mogelijk Luikse afkomst van Honthem. Het is verder een feit dat in Heugem en Honthem (vrijwel) geen lenen lagen en dat de cijnsgoederen daar waarschijnlijk afkomstig waren van plaatselijke, niet aan de landsheer toebehorende laathoven. Daarmee lijkt de werfschelling samen te hangen met vorming van het graafschap uit afzonderlijke plaatsen die ieder een eigen voorgeschiedenis kenden.

Janssen de Limpens, Rechtsbronnen Limburg en Overmaze, 420 vermeldt uit de rechtsbronnen van de schepenbank Simpelveld in welke gevallen de twaalfde penning als werfschelling wordt geheven.

$1852 \mathrm{Om}$ aan de processen over de dertiende penning een einde te maken, is het recht in 1984 bij wet afgeschaft met ingang van 1 januari 2015.

1853 Ketelaar, Oude zakelijke rechten, 212, noot 21.

1854 Godding, Droit privé, 168-171.

1855 Godding, Droit privé, 156-157. In dit verband kan ook nog gewezen worden op het overzicht dat Venner geeft van de rol van schepenen bij de overdracht van onroerend goed. (Zie Venner, 'Schepenen op het platteland', 14-25. 
Volgens Prummer werd het recht van werfschelling bij de lenen uitsluitend geheven bij koop en verkoop en niet bij verandering van leenheer of leenman of andere vormen van eigendomsovergang. Vermoedelijk gold hetzelfde voor cijnsgoederen. Bij lenen bedroeg het tarief de vijftiende penning (6,6 procent) van de koopsom, voor de overige goederen in Gronsveld en Eckelrade de elfde penning (bijna 9,1 procent) en in Slenaken de twaalfde penning ( 8,3 procent).

\subsection{Recht op banmolens ${ }^{1856}$}

Nog altijd vormt de monumentale windmolen, een zogenoemde torenmolen, ten noorden van Gronsveld een karakteristiek bouwwerk in het dorpsbeeld. ${ }^{1857}$ Een gedenksteen uit 1622 herinnert aan graaf Jost Maximiliaan van Bronckhorst Batenburg als bouwheer, maar de molen werd volgens de rentmeestersrekeningen gebouwd tussen 1617 en 1624 en was dus al begonnen ten tijde van graaf Johan II van Bronckhorst Batenburg. De Gronsveldse molen was een zogenoemde banmolen, waarvan de inwoners verplicht waren gebruik te maken, met uitsluiting van andere molens. Het recht werd in veel plaatsen toegepast en reikt vaak al terug tot ver in de middeleeuwen, maar het is omstreden of het van oorsprong een echt regaal was. ${ }^{1858}$ Het recht van dwang- of banmolen in Gronsveld betekende volgens Prummer in de achttiende eeuw dat alle onderdanen verplicht hun graan naar de molen brachten en het meel daar weer ophaalden. ${ }^{1859}$ Als beloning mocht de molenaar een bepaalde hoeveelheid meel, het zogenoemde 'molster' (scheploon), inhouden. Aangezien de molenaar een officieel en tegelijk fraudegevoelig beroep uitoefende, werd hij beëdigd. De molendwang was niet absoluut. Wanneer het graan drie dagen ongemalen op de molen had gelegen, mocht de klant naar een andere molen gaan. De molenaar kon geen beroep doen op overmacht, bijvoorbeeld gebrek aan wind. Binnen drie dagen windstilte mochten ook vreemde molenaars in het graafschap graan halen en brengen.

Het is de vraag of de molen een voorganger heeft gehad. In de rentmeestersrekeningen vóór 1617 komt geen molen voor. Toch moet die hebben bestaan. In een getuigenverhoor uit 1601 over werkzaamheden in het verleden (midden zestiende eeuw) waren verricht ' $z u$ erbauwung der neuen windt- und rossmuhlen'. 1860 Ook een losse opmerking in een processtuk uit 1607 vormt een aanwijzing voor een eerder bestaan. In een proces tegen Hendrik Couwenberch over het recht van aanwas van grond aan de Maas, wordt in een 'memorie van recht' een globale opsomming van de regalia gegeven, waaronder ook het recht op water en wind. ${ }^{1861}$ Maar het ontbreken van vroege vermeldingen zegt niet alles,

1856 Zie over het recht op windmolen en het recht op de wind, alsmede het onderscheid met dwangmolens Fockema Andreae, 'Recht van den wind'.

1857 Marres/Van Agt, Monumenten Zuid-Limburg, 190-192.

1858 De Monté ver Loren/Spruit, Hoofdlijnen, 132-133; Ketelaar, Oude zakelijke rechten, 192-197.

1859 TJ, inv. nr. M 73, fol. 529-531, Prummer aan M.E. von Toerring-Jettenbach 29 juni 1768.

1860 RHCL, Rijkskamergerecht, inv. nr. 72, fol. 62-63vo.

1861 RHCL, Graafschap Gronsveld, inv. nr. 270. 
want merkwaardig genoeg wordt de molen ook niet vermeld bij de opsomming van de heerlijke rechten in de 'Specificatie' van omstreeks 1650, terwijl daar toch alle reden voor bestond. ${ }^{1862}$

Oorspronkelijk kende het graafschap nog een tweede banmolen, de watermolen op de Gulp in Slenaken. In de rentmeestersrekeningen van 1622/1623 en 1623/1624 wordt gesproken over een erfpacht van zes vat rogge, verschuldigd door Michiel Kevers 'van den waterstraum van sijnder muelen'. Over de ouderdom van deze molen valt niets met zekerheid te zeggen, maar waarschijnlijk gaat de stichting terug tot minstens begin zestiende eeuw. Deze veronderstelling berust op enkele middeleeuws aandoende bepalingen in het pachtcontract dat Willem Straet in 1675 afsloot met de gravin van Gronsveld. ${ }^{1863}$ Naast de gebruikelijke condities over onderhoud van het gebouw en betaling van de pacht moest de molenaar ook leveranties doen ten behoeve van de keuken van de heer, te weten zes pond 'zucker canary' (rietsuiker van de Canarische Eilanden), een pond peper en twee pond gember en een jong vet varken. Het zijn afdrachten die typisch zijn voor pachtcontracten uit de late middeleeuwen en de vroege zestiende eeuw.(vgl. Hoofdstuk 15.16).

Hoewel de molen voor de heer een bron van inkomsten en voor de onderdanen een 'nutsvoorziening' moest zijn, viel de opbrengst in de praktijk tegen. Meestal werd de molen verpacht, maar bouw en onderhoud van gebouw en installaties kostten veel geld (de uitgaven in de rentmeestersrekeningen zijn daar het bewijs van). Merkwaardig is de financiering van de herbouw van de watermolen in Slenaken 1661. Daarvoor werd een schatting negen stuiver op elke bunder grond uitgeschreven, die 278 gulden op bracht. In ruil daarvoor betaalde de graaf dan het Slenakens deel van 27 Römermonate belasting aan het Rijk. ${ }^{1864}$

Tegelijkertijd klaagden de inwoners vaak over oneerlijke praktijken en het gebrek aan concurrentie. In zijn commentaar op de rentmeesterstekening beschrijft Prummer dat de molenpacht in Gronsveld al lang op vierhonderd gulden per jaar stond. Veel meer viel er niet uit te halen. In de eerste plaats kon de huidige pachter, in het bezit van huis, hof en land, er met dit bedrag nog net van leven, maar het was geen vetpot. Verder liet zich niet gemakkelijk iemand anders vinden. Het was immers noodzakelijk dat de pachter onroerend goed tot zekerheid kon stellen. Vakbekwame molenaars waren in deze streek zeldzaam; de beste kwamen uit Brabant.

\footnotetext{
1862 Volledigheidshalve moet nog worden opgemerkt dat de graaf van Gronsveld samen met de vrouwe van Eijsden ook recht had op de banmolen van Eijsden. In 1591 wordt deze molen door graaf Johan van Bronckhorst Batenburg en vrouwe Anna van Groesbeeck, vrouwe tot Geleen gezamenlijk verpacht, zie RHCL, Familie De Geloes/Kasteel Eijsden, inv. nr. 440 en Van Hall, Eijsden, een vrijheid, 164-166. Het is denkbaar dat die molen ook door Gronsveldenaren werd gebruikt.

1863 RHCL, Graafschap Gronsveld, inv. nr. 465.

1864 RHCL, Klooster Hoogcruts, inv. nr. 1003.
} 


\subsection{Recht van accijns op mout en bier}

De heer was vanouds gerechtigd accijns te heffen op het malen van mout en brouwen van bier. De eerste vermelding van deze inkomsten, die per dorp werden geheven, is te vinden in de rentmeestersrekening van 1536/1537.1865 Volgens een getuigenverklaring uit 1589 was het in Gronsveld gebruikelijk

dat de gerichtsboden aldaer hebben ommegegaen in die brouwerije binnen der voorschreve heerlicheyt ende aldaer hebben opgekerft die bieren aldaer gebrouwen' gelijck zij aldaer oock hebben gekerft gehadt die buyten bieren die binnen der heerlicheyt waeren gebracht. ${ }^{1866}$

Daarvan moest dan opgave worden gedaan aan de rentmeester. In de 'banformule' van het voogdgeding te Slenaken uit 1633 wordt gesproken over beëdigde keurmeesters die de herbergen bezochten om de daar aanwezige hoeveelheden bier op te nemen. ${ }^{1867}$ Daarbij werd ook gecontroleerd op illegaal ingevoerd bier (zie bijlage 32). Een voorbeeld van een rondgang levert de afrekening uit 1716 door twee keurmeesters in Slenaken: in totaal waren 164 tonnen gebrouwen en 184 tonnen getapt, bij elkaar ruim 29 gulden accijns. ${ }^{1868}$ Gegevens over accijnsheffing gaan terug tot in de zestiende eeuw, maar de oudste informatie over reglementering dateert uit de tijd rond 1664. Prummer vermeldt in 1768 een ordonnantie van gravin Christina von Hardenrath waaruit bleek dat niemand mocht brouwen zonder bijzondere toestemming. ${ }^{1869}$ De 'officier' (scholtis) had overtreders van deze verordening bij het gerecht aangeklaagd. Inderdaad bevindt zich in het archief van het graafschap Gronsveld een los document uit 1664, dat door vijf gedaagden bij de schepenen is ingediend als antwoord op de eis van de officier. ${ }^{1870} \mathrm{Zij}$ stellen daarin dat het vanouds zonder voorgaande toestemming geoorloofd was te bakken en te brouwen 'hetghene dat tot daeghelijcx onderhoudt van hunnen familien van noode is'. Men kon zich niet herinneren dat een algemene vergunningplicht was ingevoerd of dat ooit van deze particuliere consumptie opgave was gedaan bij controleurs. Hoe de zaak eindigde, is niet bekend, maar Prummer vermeldt dat in zijn tijd iedereen voor particulier gebruik mocht brouwen of laten brouwen 'ohne einen heller accis darvon zubezahlen'. Ook het malen van het daarvoor benodigde mout was accijnsvrij.

Brouwen voor eigen gebruik schijnt dus van oudsher vrij te zijn geweest. Accijns werd alleen geheven op mout en bier, gebrouwen binnen de heerlijkheid en bestemd voor de

\footnotetext{
1865 RHCL, Graafschap Gronsveld inv. nr. 172.

1866 RHCL, Graafschap Gronsveld inv. nr. 93.

1867 In de verpandingsovereenkomst van de heerlijkheid Slenaken uit 1638 (RHCL, Klooster Hoogcruts, imv. nr. 296) wordt gesproken over 'accijs van alle de bieren die binnen de voorss. banck sullen coemen gebrouwen oft vertapt te worden, te weeten van elcke tonne biers eenen pot biers'.

1868 RHCL, Klooster Hoogcruts, inv. nr. 1014.

1869 TJ, inv. nr. M 73, fol. 521-522.

1870 RHCL, Graafschap Gronsveld, inv. nr. 121. Het desbetreffende stuk bevindt zich als retroactum bij stukken over geschillen over de bieraccijns uit de periode 1719-1721.
} 
commerciële verkoop, evenals op bier dat werd ingevoerd. ${ }^{1871}$ Prummer schrijft dat de belasting vroeger één stuiver Brabants per ton (of aam) bedroeg. Deze constatering is juist voor ingevoerd bier, maar in de rekeningen uit het begin van de zeventiende eeuw wordt de manier van berekenen bij brouwers niet altijd duidelijk. ${ }^{1872}$ In die tijd schijnt men meestal na ieder brouwsel te hebben afgerekend, waarbij werd uitgegaan van een vaste hoeveelheid tonnen of amen per brouwketel.

Volgens Prummer werd ook van iedere zak gemalen mout één stuiver accijns in rekening gebracht, maar waarschijnlijk vergist hij zich. Volgens een uittreksel uit de administratie van de windmolen over de periode 1625 tot 1633 werd per zak een halve stuiver betaald. ${ }^{1873}$ Van dit bedrag diende vervolgens een kwart als loon voor de molenaar.

Opmerkelijk is een kwestie die zich in 1721 voordeed. ${ }^{1874}$ Uit bijzondere 'affectie' voor de vele gunsten die graaf Johan Frans van Bronckhorst Batenburg en zijn moeder Anna Christina von Hardenrath aan Gronsveld hadden bewezen, hadden de inwoners besloten vrijwillig een belasting van 8,5 stuiver op een ton bier en een half 'molster' (helft van het officiële scheploon) van iedere partij gemalen mout te betalen. $\mathrm{Na}$ het overlijden van Johan Frans in 1719 vroegen de Gronsveldenaren zich bezorgd af of die vrijwilligheid onder de nieuwe heren misschien in een plicht kon worden omgezet. Volgens een ingewonnen juridisch advies zou dat echter niet het geval zijn.

\subsection{Recht op plaatsing van bijenkorven}

Prummer wijdt in zijn rapport uit 1768 een korte passage aan de belasting op bijenkorven. ${ }^{1875}$ Imkers uit de Kempen brachten jaarlijks bijenvolken naar het gebied ten oosten van de Maas. Ook in Gronsveld plaatsten zij korven, die werden belast met twee stuiver per stuk. De bijenvolken van de eigen inwoners bleven onbelast. Het is de vraag of deze belasting op vreemde bijenkorven erg oud is. In de rekeningen uit de zestiende en begin zeventiende eeuw en de 'Specificatie' van circa 1650 wordt er geen melding van gemakkt.

De opbrengsten in de achttiende eeuw wisselen heel sterk. In de periode 1734 tot 1745 varieert die van 9 tot 74 gulden, met twee merkwaardige, onverklaarbare uitschieters, namelijk 740 gulden in 1740 en 341 gulden in 1744. De tijd tussen 1756 en 1767 geeft een regelmatiger verloop, namelijk tussen de 4 en 46 gulden, met een gemiddelde van 18 gulden per jaar.

\footnotetext{
1871 Zie bijvoorbeeld RHCL, Klooster Hoogcruts, inv. nr. 296 met de akte van verpanding van Slenaken uit 1630, waar bij de heerlijke rechten wordt genoemd 'd'accijs van alleen de bieren, die binnen de voorss banck sullen coemen gebrouwen oft vertapt te worden'.

1872 Vanaf de zestiende tot begin zeventiende eeuw moest de brouwer ook een hele 'brulinck' (varken) of een deel daarvan leveren naar het kasteel van Rimburg. De waarde daarvan werd mede verrekend.

1873 RHCL, Graafschap Gronsveld, inv. nr. 121. Het desbetreffende stuk bevindt zich als retroactum bij stukken over geschillen over de bieraccijns uit de periode 1719-1721.

1874 RHCL, Graafschap Gronsveld, inv. nr. 121.

1875 TJ, inv. nr. M 73, fol. 523-1524, Prummer aan M.E. von Toerring-Jettenbach 29 juni 1768.
} 


\subsection{Recht op winning van mergel}

In de rentmeestersrekening van 1536/1537 wordt melding gemaakt van een pacht van 25 Hornse guldens, die Jan Thijs betaalde voor 'mijns jonckeren steynberch' (Dezelfde Jan Thijs pachtte ook de 'borchhoff 'bij het kasteel). ${ }^{1876}$ Het is de eerste vermelding van het recht van de heer op een mergelgroeve in het Savelsbos. In de rekening van 1552/1553 worden steenhouwers betaald die op bevel van de heer gedurende 26 dagen 'eyn nuwe steyn koyl aen den Resenberch' moesten maken.1877 Op het eerste gezicht lijken de inkomsten uit de mergelwinning gebaseerd op het mijnbouwregaal, het recht van een landsheer op delfstoffen uit de bodem. Dat was volgens een algemene opvatting van juristen uit de zeventiende en achttiende eeuw een regaal, behorende tot de 'Landeshoheit'. ${ }^{1878}$ Het is echter de vraag of hier sprake is van een echt regaal in deze zin. Men kan ook verdedigen dat de heffing op mergel gewoon voortvloeide uit de eigendom van de bovengrond. In dat opzicht zou een parallel kunnen worden getrokken met grafelijk recht op bos, dat mogelijk kan worden teruggevoerd op het bosregaal, maar ook kan samenhangen met de eigendom van de grond.

Een bloeiend bedrijf schijnt de winning van mergel niet altijd te zijn geweest. In de rentmeestersrekeningen rond de jaren twintig van de zeventiende eeuw komen inkomsten uit mergel niet voor. Anders is het in de 'Specificatie' van de heerlijkheid rond 1650. Daarin wordt melding gemaakt van 'eenighe berghen' behorende bij het huis Gronsveld, waarop wijngaarden waren aangelegd. Uit het inwendige van deze bergen

kunnen getrocken worden schoene ende helle santsteynen, bequaem om te bouwen ende andersins om te vercoupen, alsoe daer uyt kan jaerlijx een goet proffijct getrocken worden, in tijde van vreede als voer...

Item in de voerss. bergen sijn veel materien van solpeter gelegen, alsoe dat op ses off seven jaeren men gewoenelijck is daervan te proffiteeren eens de somme van vijftich gulden.

Interessant is deze verwijzing naar de mogelijkheid om salpeter uit mergel te winnen. Op zich is het voorkomen van salpeter in kalksteen een bekend verschijnsel. ${ }^{1879}$ Op welke wijze de winning in Gronsveld plaats vond, wordt helaas niet vermeld.

In het rapport over de landsheerlijke inkomsten van 1768, wijdde commissaris Prummer ook enkele zinnen aan de winning van mergelblokken uit groeves in het Savelsbos. Hij schrijft dat dit werk gedurende de winter werd verricht door werkloze metselaars, die daarmee een voorraad bouwmateriaal aanlegden voor eigen gebruik of voor de verkoop. Eén blok mergel bracht tien stuiver op, waarvan de blokbreker acht en de graaf twee stuiver beurde. In de periode 1730-1745 was het recht verpacht en leverde het tussen de 26 en 32 gulden per jaar op. ${ }^{1880}$ Nadat de grafelijke rentmeester zelf tot inning was overgegaan, steeg dit bedrag per jaar tot ongeveer het dubbele.

1876 RHCL, Graafschap Gronsveld, inv. nr. 172.

1877 RHCL, Graafschap Gronsveld, inv. nr. 174.

1878 Janssen, 'Unterherrschafft', 169-170.

1879 De salpeter komt met vocht uit het gesteente en wordt dan van de mergelwand geschraapt.

1880 TJ, inv. nr. 15, fol. 797-804, rentmeester Oligschläger aan C.N. d'Arberg Valengin 22 januari 1730

(fol. 802): 'der mergelsteinberg ist dem herrn drossard verblieben jaerlichs fur 26 gulden'. 


\subsection{Recht van haveschot}

Het recht van haveschot heeft betrekking op de aanspraak die de landsheer maakte op de nalatenschap van een 'bastaard', iemand die niet was geboren uit een wettig huwelijk en overleden zonder erfgenamen na te laten. ${ }^{1881}$ Tegen het einde van de middeleeuwen verbeterde het successierecht bij bastaarden geleidelijk, bijvoorbeeld door uitbreiding van de mogelijkheid om te erven door bloedverwanten in opgaande (meestal moederlijke) lijn en het recht om bij testament over de nalatenschap te mogen beschikken. Zo werd voor de inwoners van het hertogdom Brabant in 1248 het recht van haveschot door hertog Hendrik II afgeschaft. ${ }^{1882}$

Het recht werd ook toegepast door de heer van Gronsveld. Zo verschenen op 12 april 1561 voor scholtis en schepenen van de bank Slenaken de erfgenamen van Katrijn Hubrechtz, die 'eyn natuerlicker ende bastart geweest is, ende sonder liffz gebort achter tho laeten in Godt verstorven is'. Zij had enig onroerend goed nagelaten, gelegen onder Slenaken, welke goederen aan Willem van Bronckhorst, heer van Gronsveld, als landsheer 'vermoege der Roomschen kayserlycke Rycx rechten' zouden zijn 'erfallen'. De erfgenamen waren evenwel met de heer overeengekomen dat zij de grond mochten behouden tegen betaling van een jaarlijkse pacht van een mud spelt. ${ }^{1883}$

Een tweede vermelding van het recht van de heer op de nalatenschap van personen van onwettige geboorte is te vinden in de 'Specificatie' van het graafschap van circa 1650:

Item alsoe eenen natuerlijcken is commen te sterven tot Eckelrade sonder testament gemackt te hebben off oock kinderen achter te laeten, sijn bij forme van confiscatie den heeren gevallen sijne goederen.

Deze twee teksten hebben duidelijk betrekking op het recht van haveschot, nalatenschappen van bastaarden of natuurlijke kinderen, maar de concrete toepassing daarvan laat nog enkele vragen open. De schepenakte van 1561 bewijst dat het recht in Slenaken gangbaar was. In de 'Specificatie' rond 1650 wordt daar echter geen melding van gemaakt. Die spreekt slechts over 'eenen natuerlijcken... tot Eckelrade'. Deze formulering

1881 Godding, Droit privé, nr. 140, 118-119.

1882 Janssen de Limpens, 'Recht van haefstoot', 181. Janssen de Limpens maakt een onderscheid tussen het recht van haveschot in Brabant en het recht van haefstoot in Limburg, de Landen van Overmaze en naburige territoria. Het in 1248 afgeschafte recht van haveschot had betrekking op de totale nalatenschap van een bastaard. Pas wanneer een bastaard overleed zonder afstammelingen en zonder testament, verviel de nalatenschap aan de landsheer. Het recht van haefstoot, voor het hertogdom Limburg en het Land van Daelhem afgeschaft door hertog Anthonis van Brabant in 1412-1413, hield in dat de landsheer recht had op de roerende goederen van alleenstaanden (niet gehuwd geweest of weduwen en weduwnaars) zonder minderjarige kinderen. Belangrijkste verschil met haveschot is dat dit recht betrekking had op bastaarden, terwijl de (on)wettige geboorte bij haefstoot geen rol speelt. Het recht van haefstoot bestond nog in de achttiende eeuw in Vaals-Holset-Vijlen. Er viel overigens tamelijk gemakkelijk aan te ontkomen door een testament of een zogenoemde haefstotelijke verklaring voor de schepenen, waarbij de eigenaar verklaarde zijn roerend goed over te dragen aan derden, wat na de dood effect moest sorteren.

1883 RHCL, Graafschap Gronsveld, inv. nr. 466. 
moet op een vergissing berusten. Het is nauwelijks denkbaar dat binnen het ressort van de schepenbank Gronsveld een afwijkend erfrecht voor alleen Eckelrade zou hebben gegolden. Wel mogelijk is een gelijkvormig recht tussen Slenaken en Gronsveld, dat afweek van dat in Heugem en Honthem. Dit verschil valt bijvoorbeeld bij de heffing van werfschelling vast te stellen.

Het is twijfelachtig of het recht van haveschot in het graafschap veel betekenis had. In de rentmeesterrekeningen uit het begin van de zeventiende eeuw komt het niet voor en in de achttiende eeuw makkt de in dit opzicht meestal accurate Prummer er ook geen melding van.

\subsection{Recht op toelating van Joden}

Joden golden binnen de christelijke samenleving van het Westen niet als gelijkberechtigde medeburgers. Hun maatschappelijke achterstelling was gefundeerd op theologische opvattingen over de schuld van de Joden aan de dood van Christus. Religieus fanatisme, in het bijzonder aangewakkerd door de kruistochten en afkeer over de door Joden beoefende geldhandel en kredietverschaffing leidden vanaf de twaalfde eeuw tot regelmatig terugkerende vervolging. Voor Joden gold daarom een bijzondere juridische status, waarbij hun positie binnen de maatschappij en hun verhouding tot de overheid werden geregeld in het zogenoemde Jodenrecht. In 1236 werden zij daarom door keizer Frederik II onder keizerlijke bescherming geplaatst, maar wel tegen betaling. Dit recht op protectie werd daarmee een regaal, dat vervolgens ook op landsheren overging en een belangrijke bron van landsheerlijke inkomsten vormde. Aan het einde van de middeleeuwen ontwikkelde zich daarmee per landsheerlijkheid een eigen Jodenrecht, wat in de vroegmoderne tijd leidde tot verschillende manieren van omgang met Joden. In sommige territoria werden zij tegen betaling ('Schutzgeld') gedoogd, in andere echter mochten zij zich niet ophouden. Vanaf de zeventiende eeuw kenden vorstenhoven ook het verschijnsel van 'Hofjuden', die als bankiers voor de vorst werkten en door kredietverschaffing aan de landsheer en adel sociaal aanzien en economische invloed verwierven.

De aanwezigheid van Joden in het Maasgebied wisselde in de loop van de tijd. Maastricht kende vanaf het einde van de dertiende tot het midden van de veertiende eeuw een joodse gemeente. Noordelijker, in Venlo en Roermond, waren Joden gevestigd van het midden van de veertiende tot het midden van de zestiende eeuw en in Sittard, behorend tot het hertogdom Gulik, tot het einde van de zestiende eeuw In de zeventiende eeuw worden Joden sporadisch vermeld. Pas in de loop van de achttiende eeuw ontstonden weer kleine joodse gemeenschappen, in Sittard (1725) en in enkele grote dorpen in de Staatse Landen van Overmaze zoals Heerlen (1725), Eijsden (1779), Gulpen (1786) en Meerssen (vóór 1796). In Maastricht hadden Joden sinds 1782 permanent verblijf.

Voor Gronsveld zijn er uit de zeventiende eeuw twee vermeldingen van Joden. Volgens een aartsdiakonaal visitatieverslag uit 1658 had graaf Jost Maximiliaan van Bronckhorst 
Batenburg twee Joden 'binnengehaald' ('duo judaei quos comes introduxit'). ${ }^{1884}$ Mogelijk had die aanwezigheid te maken met muntslag, zoals het tweede voorbeeld uit 1692 leert, ten tijde van graaf Johan Frans van Bronckhorst Batenburg. Toen was een Jood op het kasteel bezig was met de muntslag van duiten, kleingeld dus, voor export naar Holland. ${ }^{1885}$ Beide voorbeelden lijken enigszins op 'Hofjuden' die in opdracht van de landsheer werkten. Het is echter onwaarschijnlijk dat zij lange tijd in het graafschap verblijf hielden, aangezien het muntbedrijf slechts periodiek werd uitgeoefend.

Aan het einde van de achttiende eeuw is er een nieuw voorbeeld van het Jodenregaal in Gronsveld, dit keer zonder verband met muntslag. In het 'rendambtsregister' van 17811788 staat op de laatste bladzijde vijf gulden 'schudgelt' geboekt 'voor den jode Abraham' gedurende de periode 1781-1786.1886 Kennelijk ging het hier om toelatingsgeld voor een Jood die zich periodiek in het graafschap ophield, bijvoorbeeld als handelaar.

\subsection{Recbt van jacht}

Jachtrecht behoort min of meer tot het standaardpakket aan heerlijke rechten. Zo ook in Gronsveld. De 'Specificatie' van het graafschap uit circa 1650 spreekt van

die volle ende geheele jacht binnen die graeffschappe voerss. ter exclusie ende privatie van eenen yegelijcken, conform der constitutien van het Heylich Rijck ende der oude observantie in dit cas (oude gewoonte in dit geval) gehouden.

Het ging dus niet alleen om jacht in de bossen, maar over alle terreinen in het graafschap. ${ }^{1887}$ Door de aanwezigheid van bossen was het graafschap rijk aan wild, maar de wildstand fluctueerde. Zo schrijft Prummer in 1765 dat vooral werd gejaagd op vossen, hazen, 'hoenders', duiven, plevieren, kievieten, ortolanen, leeuweriken, snippen en 's winters wilde eenden, maar ten opzichte van twintig jaar eerder waren er weinig konijnen wegens een ziekte. ${ }^{1888}$ Konijnen werden ook in het bos, half in het wild, in warandes gehouden. Die bestonden volgens de rentmeestersrekening van 1536/1537 al begin zestiende eeuw en werden toen door de heer zelf gebruikt. ${ }^{1889}$ De 'Specificatie' van het graafschap uit omstreeks 1650 spreekt over 'seer goede ende proffitabele coninsvranghen, gelegen soe in de berghen ende boschen tot Gronsfelt als tot Slenaecken'.

Bijzondere melding maakt Prummer in 1765 van de jacht op wolven. In principe konden deze dieren zich het hele jaar door goed schuil houden in dicht kreupelhout met braamstruiken, maar ze kwamen vooral in de winter, na sneeuwval, uit de Ardennen naar het Maasdal. De wolvenjacht werd geopend op Sint-Hubertusdag (3 november) en daarna

1884 Simenon, Visitiationes Hasbaniae I, 275.

1885 Flament, 'Korte inhoud resolutiën Staten-Generaal', 305.

1886 'TJ, inv. nr. M 22, rendambtsregister' 1781-1788 fol. 229.

1887 RHCL, Klooster Hoogcruts, inv. nr. 296, bevat de akte van de verpanding van de heerlijkheid Slenaken in 1630. Als eerste heerlijk recht wordt daar genoemd 'de volle iacht ende vanck van allen het wiltbraet binnen den geheelen district der voorss. heerlijcheydt ende banck van Slenaecken'.

1888 TJ, inv. nr. M 6, fol. 197-207 Prummer aan M.E. von Toerring-Jettenbach 30 oktober 1765.

1889 RHCL, Graafschap Gronsveld, inv. nr. 172. 
zo vaak gehouden als nodig was. Op die dagen moesten de inwoners zich presenteren met een geweer of deelnemen aan het opdrijven. Voor iedere dode wolf werd een ton bier gegeven, te betalen uit de gemeentekas.

In de rekeningen uit het begin van de zeventiende eeuw staan geen inkomsten uit de jacht vermeld. Dat komt overeen met wat Prummer ook al constateerde, namelijk dat gedurende 150 jaar in de rekeningen geen stuiver inkomsten uit jacht stond aangetekend. Waarschijnlijk was, zoals door oude mensen werd verteld, de jacht altijd aan grafelijke ambtenaren overgelaten. Daarnaast werd de jacht ook met meer of minder succes in gedeeltes verpacht. Rentmeester Oligschläger bericht in 1730 aan graaf d'Arberg Valengin dat de jacht voor twaalf pattacons was uitgezet, maar daar was niemand voor gekomen. ${ }^{1890}$ In 1737 had de grafelijke vertegenwoordiger Gürtler de jacht, bij uitsluiting van ieder ander, tegen $23^{1 / 2}$ Rijnse guldens verpacht aan de drossaard, een groot jachtliefhebber. Ook pastoor Schmädel, die vertegenwoordiger van de graaf was, had alle andere landsheerlijke functionarissen uitgesloten omdat hij het alleenrecht wilde hebben. $\mathrm{Na}$ Schmädel ging alles weer op oude voet verder en schoten de landsheerlijke functionarissen op hazen en gevogelte, maar noch Prummer noch rentmeester Lebens was een groot jachtliefhebber. Buiten deze mensen werd slechts hoogst zelden aan derden vergunning gegeven. Een dergelijke uitzondering vormde de markies De Merode van Pietersheim, die met een aantal officieren een broederschap of zogenoemde 'wolfscompagnie' had opgericht, die her en der op wolvenjacht ging. De heren leverden de geschoten wolven en vossen wel keurig in.

Ondanks het feit dat weinig werd geschoten, nam de wildstand niet echt toe. Volgens Prummer lag dat aan menselijke activiteiten in het veld, aan periodieke overstromingen van laaggelegen land door de Maas en ook aan stroperij door inwoners. Weliswaar moesten de in ieder dorp aangestelde veldbodes daarop streng toezien, maar veel hielp het niet. Van oudsher waren er soms ook boswachters in grafelijke dienst, volgens de rentmeesterrekeningen begin zeventiende eeuw zelfs drie voor zowel Gronsveld, Slenaken als Sint-Martens-Voeren. Later, in de eerste helft van de achttiende eeuw was er in ieder geval nog één voor Gronsveld. Hun belangrijkste taak was toezicht op de bossen en houtopstanden; of zij ook jaagden en toezicht hielden op de wildstand is onduidelijk.

In de eerste jaren van Prummers verblijf in Gronsveld was er geen jager of boswachter. Omdat het toezicht door veldbodes onvoldoende effect scoorde, kwam Prummer op het idee een grafelijk jager aan te stellen, die voor $7 / 8$ deel met de jacht in zijn onderhoud zou kunnen voorzien. Hij kon dan ook beter dan de veldbodes de grafelijke boomaanplant in de gaten houden. Aanstelling van een eigen jager ontsloeg Prummer ook van verpachting van de jacht. Vaak waren die pachters officieren uit het garnizoen die in groepsverband door het veld trokken en veel schade aanrichtten. Zij zorgden regelmatig voor grensincidenten met de naburige heerlijkheden en ten slotte meenden de veelal adellijke

1890 TJ, inv. nr. 15, fol. 797-804, Oligschläger aan C.N. d'Arberg Valengin 22 januari 1730. 
heren ook beleefdheidsbezoeken te moeten afleggen. Prummer hield niet van hun grove mentaliteit en het kostte aan verloren tijd en geld drie keer meer dan de pacht opbracht.

Prummer kreeg zijn zin met zijn pleidooi voor de benoeming van jager en boswachter. De graaf benoemde in 1766 Anton Schwab of acht, waarschijnlijk iemand uit Beieren. De man kreeg een grafelijk livrei aangemeten en patrouilleerde vervolgens door de Gronsveldse bossen. Het lag voor de hand dat Schwab bij het stropende deel van de bevolking niet populair was, maar ook Wolfgang Zollner, die in 1778 als assistent van Prummer in Gronsveld arriveerde, achtte hem 'keinen Schuss Pulfer wert'. ${ }^{1891}$ Of het nu lag aan diens vakbekwaamheid of omgang met mensen, het liep uiteindelijk verkeerd met Schwab af. Op 1 februari 1780 had hij Joannes van den Boorn op stroperij betrapt. Bij het handgemeen dat toen ontstond, raakte de jager flink gewond. De zaak kwam voor het gerecht en Van den Boorn werd tot een flinke boete veroordeeld. ${ }^{1892}$ Op 1 november 1780 vond echter een nieuw incident plaats. Terugkerend van boodschappen in Maastricht, kreeg Schwab onderweg een woordenwisseling met Joannes Lemmens uit Eckelrade. Plotseling sloeg Lemmens de jager met zijn stok en die viel ernstig gewond op de grond. Later werd het slachtoffer gevonden en overgebracht naar Gronsveld, waar hij nog bij machte was de naam van de dader te noemen. Op 8 november 1780 overleed Schwab. Lemmens was inmiddels gevlucht en werd bij verstek door de schepenbank veroordeeld. ${ }^{1893}$

Misschien wijs geworden door deze ervaring werd voor zijn opvolger Gillis Schillings, geboortig uit 's-Gravenvoeren, een uitgebreide instructie opgesteld. ${ }^{1894}$ Daarin was voorgeschreven wanneer en op welke dieren hij moest jagen en hoeveel premie hij per stuk wild verdiende. Konijnen waren in vergelijking met twintig jaar eerder weer uitgegroeid tot een plaag. De jager hield aantekening van alles wat hij verschalkte en van alle bijzondere voorvallen binnen zijn jachtgebied. Het wild moest bij de rentmeester worden ingeleverd, die alles wat bruikbaar was (voedsel, pels) verkocht. Daarmee vormde de jacht een bescheiden bron van inkomsten.

Minstens zo belangriik waren de politionele en toezichthoudende taken. In de eerste plaats betrof dit het optreden tegen stropers en het gebruik van geweld daarbij. Het aannemen van steekpenningen was uiteraard ten strengste verboden. In het veld loslopende honden zonder 'kluppel' mochten worden doodgeschoten. ${ }^{1895}$ De jager lette op dat niemand ongeoorloofd vee in de bossen hoedde, zwervend vee moest hij oppakken en loslopende geiten (schadelijk wegens hun vraatzucht aan jonge planten) mochten zelfs direct worden doodgeschoten. Ten slotte hield de jager ook toezicht op de houtstand. Hij noteerde waar

${ }^{1891}$ RHCL, Graafschap Gronsveld, inv. nr. 52, Zollner aan A.J. von Toerring-Jettenbach 25 mei 1778.

1892 RHCL, Graafschap Gronsveld, inv. nr. 332.

1893 RHCL, Graafschap Gronsveld, inv. nr. 327.

1894 TJ, inv. nr. M 22, fol. 94-105, commissie of instructie voor de jager of boswachter Schillings, 1 februari 1781.

1895 In veel dorpen, zoals bijvoorbeeld in Rijckholt, bestond een verordening op het 'kluppelen' van honden. Die kregen een stok om de hals gebonden, waardoor zij niet meer in staat waren wild op te jagen. 
slechte bomen stonden en lette op onregelmatigheden bij het houthakken in de bossen en tijdens het plukken van kersen.

\subsection{Recht van visvangst}

Visrechten vormden het pendant van het jachtrecht. ${ }^{1896}$ In de verpandingsovereenkomst van Slenaken uit 1638 wordt gesproken over 'die visscherie in en op de riviere van de Gulpe soe wijt ende breit als de voersschreven banck of hoecheijt van Slenaecken haer is extendeerende en ter exclusie van eenen iegelijcken'. ${ }^{1897}$ De 'Specificatie' van het rechten van het graafschap Gronsveld van omstreeks 1650 makkt melding van visrechten 'op der Maesen van Huegem, ende binnen Slenaecken die vischerie op de Gulp, van d'een eynde der heerlijckheyt off jurisdictie aldaer tot het andere, ende is deselve Gulp rijck van forellen off truyten'. 1898 De visvangst in Slenaken was commercieel van betekenis, zoals blijkt uit een verpachtingscontract uit 1688, toen Nicolaas Slangen zeventien pattacons per jaar pacht voor het recht betaalde. ${ }^{899}$ Het is de vraag of er altijd werd verpacht, want in de vroeg-zeventiende-eeuwse rekeningen van het graafschap ontbreekt deze post. Pachter Slangen was overigens verplicht (met korting op de pachtsom) 'een schoetel truyten' bij de graaf op het kasteel te leveren. Verder moest hij gedogen dat de graaf, wanneer die in Slenaken verbleef, ook zelf 'bij maniere van recreatie' zijn hengel uitwierp.

Commissaris Prummer onderscheidt in 1768 twee visplaatsen in Heugem. ${ }^{1900}$ De eerste betrof de oostelijke helft van de Maas, op de plek waar het graafschap grensde aan Luiks gebied. In feite was dat slechts een smalle strook ten zuiden van Sint Pieter, want bij Sint Pieter zelf liep de grens over de oostelijke Maasoever. De tweede visplek, die wel volledig onder Gronsvelds gezag viel, betrof de Oude Maas of Binnen-Maas. Uit overlevering wist Prummer dat dit vroeger goede visgrond was, maar in zijn tijd waren de in- en uitgang van deze zijgeul van de Maas verzand, zodat alleen nog maar bij overstromingen vis naar binnen zwom.

Het visrecht in Heugem schijnt vrijwel altijd verpacht te zijn geweest. Volgens de rekeningen van het graafschap uit de eerste decennia van de zeventiende eeuw werd daar tussen de 60 en 63 gulden voor betaald. De 'Specificatie' van 1650 noemt een opbrengst van 150 gulden, wat erg hoog is, wanneer men bedenkt dat in het midden van de achttiende eeuw nog maar rond de zestig gulden werd neergeteld.

In zijn algemeen rapport over verpachtingen uit 1769 noemt Prummer de visserij op de Maas 'ein wunderliches objectum' waarmee je niet kon doen wat je wilde. Sinds het einde van de zeventiende eeuw woonden in Heugem en in het graafschap Gronsveld geen vissers meer. Er was maar één pachter, een Luikenaar en het waren ook Luikenaars die de

1896 Zie over visrecht: Ketelaar, Oude zakelijke rechten, 218-233.

1897 RHCL, Klooster Hoogcruts inv. nr. 296.

1898 Ook de 'Taxa' van Slenaken, de beschrijving van de heerlijke rechten in verband met de verkoop van de heerlijkheid Slenaken in 1771 (TJ, inv. nr. M, 55, fol. 244-245) vermeldt ook samen met de jacht het visrecht op de Gulp, 'an denen kostbaresten forellen sebr reich'.

1899 RHCL, Klooster Hoogcruts, inv. nr. 1009.

1900 TJ, inv. nr. M 73, fol. 528-529. 
visserij op de Maas tot Roermond domineerden. Dat gebrek aan concurrentie drukte de pachtprijs. Decennialang moest men met de pacht leuren. Werd tussen 1734 en 1739 nog 120 gulden per jaar betaald, daarna zakte de prijs tot zestig gulden per jaar. Met de grootste moeite wist Prummer de prijs van zestig op 96 gulden te brengen. Hij bracht daarvoor het verhaal in de wereld dat de visserij voor de graaf eigenlijk maar een bagatel was. Daarom liet hij de verpachting nog liever schieten dan dat hij op slechte voorwaarden inging. Uiteindelijk werkte die opstelling wel. Prummer vroeg honderd gulden en na twee tot drie maanden bedenktijd hapte een Luikse visser toch toe voor 96 gulden.

\subsection{Recht op houden van duiven}

In zijn rapport uit 1768 schrijft Prummer dat de landsheer als enige in het graafschap duiven mocht houden 'und mag kein unterthan oder inwohner der graffschafft einen offenen tauben-schlag haben'.1901 Het recht op het bezit van een duiventil en het recht van schieten op duiven passen in de bekende reeks van het recht op eendenkooi, zwanendrift, konijnenwarande, enzovoorts. Over de ouderdom van dit recht in Gronsveld valt weinig concreets te zeggen. Er wordt geen melding van gemaakt in de rentmeestersrekeningen uit de zestiende en het begin van de zeventiende eeuw en het ontbreekt ook in de 'Specificatie' van het graafschap rond 1650.

Het ging om een onbelangrijk recht en de betekenis van de duivenmelkerij wisselde nogal. Volgens Prummer werden rond 1700 veel duiven op het kasteel gehouden. Volgens de rekeningen van 1707, 1713, 1715 en 1718 werden in de zomer respectievelijk 366, 333, 238 en 332 paar verkocht. De opbrengsten varieerden tussen de 51 en 92 gulden en waren daarmee op een totaal van tussen de achtduizend en tienduizend gulden aan inkomsten van weinig betekenis. ${ }^{1902}$ In de jaren daarna was de jacht op duiven aan de inwoners tegen betaling van een vast bedrag vrijgegeven. Omstreeks 1760 was volgens Prummer de duivenpopulatie door oorlogen en de 'in hiesigen gegenden eingefahlen durchgehenden tauben-sterb völlig zu grundt gegangen'.

\subsection{Recht op aanwas van land}

Volgens de rentmeestersrekening van 1536/1537 bezat de heer van Gronsveld 'eyn aengedreven wertgen bynnen synen water tot Huegem gelegen' (= weerd, aangeslibde grond langs een rivier), dat toen voor het eerst verpacht werd. Deze aangedreven grond, ontstaan door veranderingen in de loop van de Maas, kwam de heer toe op grond van het regaal van aanwas. ${ }^{1903}$ In zekere zin sproot dit recht voort uit het stroomregaal, het landsheerlijk recht op bevaarbare rivieren. Dat de heren van Gronsveld daar duidelijk aanspraak op maakten, blijkt uit een memorie, in 1607 door Reyner Daniëls als vertegenwoordiger van de graaf opgesteld in een proces tegen Hendrik Couwenberch. ${ }^{1904}$

1901 TJ, inv. nr. M 73, fol. 522-523.

1902 TJ, inv. nr. M 63, 'Rechnungen der Grafschaft Gronsveld 1704-1719', passim.

1903 Zie over het recht van aanwas: Ketelaar, Oude zakelijke rechten, 250-261.

${ }^{1904}$ RHCL, Graafschap Gronsveld, inv. nr. 270. 
In de kern ging het bij die zaak om eigendom van aanwas langs de Maas, waarop beide partijen aanspraak maakten. Van het dossier is slechts één stuk bewaard gebleven, wat beoordeling van de argumenten van de gedaagde moeilijk maakt. Maar het standpunt van de eiser is helder: hij betoogde dat zijn meester over diverse regalia beschikte, waaronder zeker ook het recht op 'alluvien'.

Het recht van aanwas komt ook ter sprake in de overeenkomst die in 1611 ter beëindiging van een reeks processen werd gesloten tussen graaf Johan van Bronckhorst en zijn onderdanen (zie bijlage 35). Er bestond verschil van mening over de vraag wie de rechthebbende was op een aanwas langs de Maas, grenzend aan gemeentelijke weidegrond van de inwoners van Heugem. In de overeenkomst werd vastgelegd dat de graaf daarvan eigenaar was en dat de grens tussen gemeentegrond en eigendom van de graaf werd afgebakend, met dien verstande dat de inwoners het recht hielden via dit land hun vee in de Maas te drenken.

\subsection{Land- en erfpachten}

In het overzicht van de bronnen van inkomst van de heer van Gronsveld werd al gewezen op de grote economische betekenis van de 'gewone pachten' of 'landpachten' en erfpachten. In de achttiende eeuw maakten die meer dan vijftig procent van het totaal uit en dat beeld wijkt niet bijzonder af van de gegevens uit de zeventiende eeuw. Spectaculair was echter de toename van het bedrag van 53059 gulden voor de tijd van 1736-1745 tot 66316 gulden voor de jaren 1756-1767, terwijl de hoeveelheid grond niet toenam. Die stijging was, zoals we hierna zullen zien, het gevolg van een gewijzigde aanpak van de verpachting.

Het rendement van pachtland werd voor de graaf mede bepaald wegens zijn bijzondere positie als grondeigenaar. Hier ziet men de vloeiende grens tussen private eigendom en publieke rechten. Van oudsher waren de landerijen van de heer schat- en belastingvrij, dus de winst werd niet door dit soort lasten gedrukt. In de overeenkomst over de grondbelastingen van de graaf met de Maastrichtse geërfden uit 1739 was dat nog eens uitdrukkelijk vastgelegd (zie bijlage 38). Deze vrijstelling gold echter uitsluitend voor grond die in 1739 aan de graaf in eigendom toebehoorde of had toebehoord, maar in de loop der jaren in vreemde hand was overgegaan. Eventuele nieuwe verwervingen zouden wel aan belasting zijn onderworpen. Dat maakte het voor de graaf niet aantrekkelijk in grond te beleggen. Meer winst zou dus uit verhoging van efficiency en vooral verandering van de manier van betaling moeten worden behaald.

Uitgifte van grond in pacht en erfpacht is een privaatrechtelijke vorm van exploitatie en geen heerlijk recht. Met het begrip 'gewone pacht' of 'landpacht', werd bedoeld de verpachting van bouw- en weiland en boomgaarden gedurende een beperkte termijn. De pachtprijs kon worden voldaan in geld of in natura, meestal graan. In een rapport over pacht uit 1769 noemt Prummer als gebruikelijke termijnen zes, twaalf en zelfs achttien of 
24 jaar. ${ }^{1905}$ Zes jaar was gunstig met het oog op de noodzakelijke vruchtwisseling (de pachter kon gedurende die tijd alle gangbare gewassen verbouwen) en de bemesting die voor rekening van de pachter kwam. Naast deze verschillen in termijnen maakt Prummer ook onderscheid tussen drie verschillende contracten. De eerste pacht was tegen 'halbscheidt', welke begrip vergelijkbaar is met het Nederlandse woord 'halfwin'. Bij dit contract werd de opbrengst aan gedorst graan gelijk verdeeld tussen eigenaar en pachter. Stro en het overig afval kwamen toe aan de pachter, maar de verpachter was verplicht te helpen bij het dorsen. De tweede vorm van pacht bestond uit de levering van een van te voren afgesproken hoeveelheid graan en de derde mogelijkheid betrof de betaling van een bedrag in geld.

De verpachting 'half om half werd door sommigen als het meest gunstig voor eigenaren beschouwd, maar bood tegelijk ruime mogelijkheden voor fraude. Verder was deze methode misschien wel haalbaar bij een paar pachters, maar ondoenlijk bij tientallen. Want waar vond je als verpachter voldoende werkvolk, wanneer in de winter opeens alle pachters aan het dorsen sloegen? Daarom werd in Gronsveld tot 1756 vooral verpacht volgens de tweede methode, de betaling van een bepaald bedrag in graan. Maar ook daar kleefden, zoals hierna nog aan de orde komt, bepaalde bezwaren aan.

Erfpacht onderscheidt zich van landpacht zowel door contractduur alsook de positie van de pachter. Volgens de gebruikelijke terminologie heeft de erfpachter gedurende lange tijd (bijvoorbeeld honderd jaar) een zakelijk recht op de grond en betaalt hij daarvoor aan de eigenaar een bepaald vast bedrag. Maar erfpacht leek in Gronsveld bijna eeuwigdurend, waardoor de pachter zich in de praktijk als eigenaar gedroeg. Daarmee werd ook het onderscheid met cijnzen gering. Het recht op cijns kan zowel een privaatrechtelijke als grondheerlijke oorsprong hebben (zie hierna), maar het verschil met erfpacht is dat de cijnsplichtige eigenaar is van de grond. Bij een praktijk met eeuwigdurende erfpachten maakt dat niet zoveel uit. Het recht van de erfpachter was bijna even sterk als dat van de eigenaar. Beide juridische constructies betroffen in beginsel vaste, niet-aflosbare lasten, waarvoor geen kwijtschelding of vermindering bestond in geval van overmacht bij de debiteur. Bij wanbetaling werd door de heer dezelfde uitwinningsprocedure gevolgd en boekhoudkundig waren het voor hem dezelfde soort vaste jaarlijkse inkomsten. Geen wonder dat daarom in de bronnen het onderscheid niet altijd helder is.

Pacht speelde binnen de Gronsveldse economie een belangrijke rol. Niet alleen bezat de graaf een groot areaal aan grond, ook het grondbezit van personen en instellingen buiten het graafschap, vooral uit Maastricht, was aanzienlijk. Prummer vermeldt dat nog geen derde deel van de grond in eigendom aan Gronsveldse ingezetenen toebehoorde. Oppervlakkig beschouwd leken er in Gronsveld wel een paar grote boeren te wonen, die in het bezit waren van drie of vier paarden en soms gebruik maakten van een dagloner, maar eigenlijk was dat slechts schone schijn. Zij hadden hun grond bij elkaar gepacht van wel vijf tot tien verschillende eigenaren. Ook de meeste keuters, die voor eigen gebruik wat aardappelen of knollen als veevoer verbouwden, waren pachters.

1905 TJ, inv. nr. M 73, fol. 418-453, Prummer aan M.E. von Toerring-Jettenbach 30 maart 1769. 
De schaarste aan pachtland leek aantrekkelijk voor grondeigenaren om hoge pachtprijzen te bedingen. Maar tegelijkertijd moesten zij bij openbare verpachtingen rekening houden met kongsi's van boeren die er op uit waren de prijs te drukken. In zijn toelichting op de rekeningen uit 1768 maakt Prummer daar al melding van, maar in zijn rapport over verpachtingen uit 1769 gaat hij daar uitvoeriger op in. Om te beginnen gunden de boeren elkaar niets en was het voor de eigenaar nauwelijks mogelijk van een pachter af te komen. Vooral in het gebied ten westen van de Maas bestond het risico dat 'armb und fuess ab oder sogar der kopff eingeschlagen werdte', bij een poging bestaande pachtverhoudingen te doorbreken. Zo gewelddadig ging het er in Gronsveld niet aan toe, maar ook daar was in het verleden geprobeerd de grafelijke functionarissen te intimideren.

De pachtlanden bestonden meestal uit grote percelen, zodat alleen boeren in het bezit van een paard die konden aannemen. Maar dat was een minderheid, die bij openbare verpachtingen geheime afspraken maakte om niet tegen elkaar op te bieden. Men bood op elkaars percelen om de schijn te wekken dat het eerlijk verliep, maar tegelijkertijd werd de prijs gedrukt. Zodoende kreeg iedereen uiteindelijk toch wat hij wilde hebben en viste de kleine man achter het net. Prummer had geprobeerd dit soort praktijken te bestrijden door mensen tegen elkaar uit te spelen. In Gronsveld en Eckelrade slaagde hij daar tamelijk goed in en dit leidde, in combinatie met de verpachting tegen geld, tot een aanmerkelijke verhoging van de opbrengst. Alleen in Heugem stootte hij op hardnekkige weerstand.

Prummer geeft enkele voorbeelden van zijn aanpak. Zo lagen in Heugem enkele percelen, waarvoor weinig animo bestond, omdat die door overstroming van de Maas vol kiezel zaten. Uiteindelijk was het toch gelukt daar een liefhebber voor te vinden door verlenging van de pachttermijn tot twaalf jaar. Meestal bleek dit een aantrekkelijke verbetering van de pachtcondities, omdat het de pachter een grotere rechtszekerheid bood.

Bluf en zachte dwang werden toegepast bij een perceel van zes bunder in de Hel bij de Riesenberg of Galgenberg, vlak bij de grens met Cadier. De grond was niet slecht, maar steenachtig en leemhoudend, moeilijk te bewerken door de steile helling, gevoelig voor meeldauw en gelegen in de schaduw van aangrenzend struikgewas. Vanuit Eckelrade en Gronsveld bestond weinig animo voor pacht, omdat het perceel lastig bereikbaar was. Iets gemakkelijker was de toegang vanuit Cadier. In de veronderstelling dat er toch geen liefhebbers waren, wilden enkele boeren uit Cadier die grond wel tegen een zacht prijsje pachten en zij boden een bedrag tussen de tien en dertien gulden per bunder. In hun arrogantie namen ze zelfs niet eens de moeite om tijdens de openbare verpachting te verschijnen. Prummer meende echter dat de grond meer waard was en door verbeteringen in waarde kon stijgen. Bovendien wilde hij die van Cadier een lesje leren. Hij wist enkele Gronsveldse pachters te overtuigen dat zij met hun paarden zouden samenwerken, zodat ze gezamenlijk tegen de steile helling op konden. Verder moest iedere pachter garanderen dat hij zijn perceel ook zelf bewerkte. Onder geen beding mocht met iemand van Cadier worden samengewerkt. Ieder stuk grond, goed of slecht, diende vijftien gulden per bunder op te brengen, maar als tegenprestatie bedroeg de pachttermijn twaalf en geen zes jaar. Ook hier haalde verlenging van de pachttermijn de potentiële gegadigden over de streep. 
Pachten konden in beginsel op twee manieren worden voldaan: in geld of in graan. Betalingen in graan konden worden betaald in natura of worden omgerekend naar geld. Betaaldag was Sint-Andriesdag (30 november), maar de feitelijke betaling mocht worden uitgesteld tot Maria Lichtmis (2 februari) daaropvolgende. Voor de pachten in geld maakte die ruime termijn weinig uit: het bedrag lag vast. Bij de graanpacht kon de pachter echter een lage graanprijs afwachten en vervolgens op het voor hem meest gunstige moment leveren. De verpachter moest dit graan dan op eigen risico te gelde zien te maken. Daarmee liet de opbrengst zich moeiliik voorspellen. Een ander nadeel van deze pacht in natura was dat de verpachter meestal het slechtste of natste graan kreeg geleverd. Het systeem was ook fraudegevoelig. De verpachter die de steeds wisselende marktprijzen van graan niet kende, moest maar vertrouwen op de rechtvaardigheid van zijn rentmeester, want ook die kon met de schommelingen in de graanprijs gemakkelijk ten eigen nutte speculeren.

$\mathrm{Na} 2$ februari hoefde de verpachter leveringen in natura niet meer te accepteren, maar betaalde de debiteur volgens de zogenoemde effractie van Maastricht. Dit bedrag vormde de officiële marktprijs van het graan in de stad, gebaseerd op de gemiddelde koers tussen acht dagen vóór en acht dagen na Maria Lichtmis, verhoogd met één stuiver extra per vat. Dit officiële tarief stond ook bij het gerecht geregistreerd. Daarmee lag de prijs vast, maar door de toevallige hoogte daarvan kon die voor één van beide partijen gunstig of ongunstig uitpakken. De graanprijs was in deze streken weinig stabiel en fluctueerde soms sterk binnen drie tot vier dagen. De pachter liep in dit systeem nog een extra risico wanneer de graansoort waarin hij moest betalen, toevallig erg duur was. Hij mocht dat niet compenseren met een ander gewas waarvan wel een overschot bestond.

Leveranties in natura brachten dus allerlei bezwaren met zich mee. Voor erfpachten waren die gevolgen nog overzienbaar, omdat het verhoudingsgewijs om geringere bedragen ging. Maar bij de landpachten kwamen de nadelen veel duidelijker naar voren. De bedragen voor landpacht in de periode 1734-1745 schommelden dan ook van 1114 gulden tot 2322 gulden per jaar door de verschillen in effractie en varieerden bij het in eigen beheer door de rentmeester verkochte graan van 421 gulden tot 2110 gulden per jaar!

Om niet langer afhankelijk te zijn van de graanprijs, besloot Prummer vanaf 1756 in beginsel alleen nog maar tegen geld te verpachten. Voor de tijdelijke landpachten kon dit systeem bij aanvang van een nieuwe termijn worden ingevoerd, maar hij schijnt deze omzetting ook vrij snel bij erfpachten in graan te hebben toegepast. Deze verandering leidde onmiddellijk tot aanzienlijk hogere opbrengsten: tot 1767 in totaal 39.104 gulden uit landpachten, 2649 gulden uit de erfpachten in geld en 5228 gulden uit de erfpachten die van graan naar geld waren omgezet. In totaal brachten alle pachten gezamenlijk daarmee 46.981 gulden op. De resterende erfpachten in graan, die in eigen beheer door de rentmeester werden verkocht, bedroegen nog slechts 1795 gulden. Daarmee waren de nadelige gevolgen van prijsschommelingen eigenlijk opgeheven. 


\subsection{Recht op cijnzen en bede}

Het onderdeel 'cijnzen' vormt bij de heerlijke inkomsten een gecompliceerde materie, die zelfs voor Prummer in de achttiende eeuw moeilijk te doorgronden was. Twee keer geeft hij daarover in zijn rapporten voor de graaf vrij uitvoerige beschouwingen, namelijk in 1757 over de juridische toestand van de grond en in 1761 over cijnzen in het bijzonder. Het is overigens ook niet altijd duidelijk wat met begrip 'cijns' wordt bedoeld. ${ }^{1906}$ Het valt buiten het bestek van dit boek een uitgebreide verhandeling over dit onderwerp te geven, maar enkele voorbeelden uit recente literatuur kunnen de problematiek illustreren. Hackeng definieert cijns als

alle betalingen van bezitsrechtelijke, personenrechtelijke en hoogheidsrechtelijke aard, zowel in natura als in geld. In enge zin heeft het begrip cijns betrekking op grondheerlijkheid. Met grondheerlijkheid wordt bedoeld het geheel van rechten over in eigendom gehouden grond en daaruit voortkomende rechten die deze grond bewerkten (hofstelsel). In die context betekent het woord cijns: alle periodieke grondheerlijke betalingen in natura en in geld. Binnen die grondheerlijke cijns zijn twee soorten te onderscheiden, namelijk grondcijns en lijfcijns (hoofdcijns, huwelijkscijns, overlijdenscijns). Bij grondcijns gaf de cijnsgever een stuk grond dat hij als allodium of in leen hield, tegen een cijns uit aan een cijnsnemer. Het grote verschil met uitgifte in pacht of erfpacht was, dat de cijnsgever door deze uitgifte in cijns de beschikking kreeg over grondheerlijke rechten ten aanzien van de persoon van de cijnsnemer. Vervolgens kon deze laatstgenoemde het stuk grond vanuit zijn positie van gebruikseigenaar aan weer anderen in pacht of erfpacht geven of er renten op vestigen, maar hij kon dit niet opnieuw tegen grondcijns uitgeven. Aan het einde van de middeleeuwen was de situatie zo gegroeid, dat de naakte eigendom van de cijnsgever enkel nog uit zijn recht op die grondlast en de hieraan verbonden grondheerlijke bevoegdheden bestond.... Daarentegen kon de cijnsplichtige als gebruikseigenaar verder volledig, erfelijk, over de grond beschikken.

Ter onderscheiding van deze heerlijke grondcijnzen wijst Hackeng nog op een tweede groep cijnzen met een andere oorsprong, namelijk cijnzen gebaseerd op een geldleningsconstructie. ${ }^{1907}$ In de administratie van de opbrengsten werd echter meestal weinig onderscheid gemaakt tussen de verschillende cijnzen.

In een gids voor het onderzoek in cijnsregisters uit Brabant wordt cijns, op basis van literatuur en praktijkvoorbeelden, omschreven als

een recht op een jaarlijkse uitkering uit onroerende zaken...uit ambten... of uit het gebruik van andermans recht, bijvoorbeeld de zeggenschap over onontgonnen gronden. Dat recht heeft dan een periodieke, meestal jaarlijkse betaling tot gevolg, hetzij in geld, hetzij in natura...Aanvankelijk werden veel cijnzen in natura vastgesteld...Later werden cijnzen vooral in geld betaald. Ook cijnzen die in natura staan uitgedrukt...kunnen later in geld betaald zijn. Niet losbare (= niet afkoopbare) erfelijke cijnzen die in geld werden betaald, komen we veelal tegen onder de naam 'erfcijnzen'; cijnzen in natura werden vaak

1906 Zie bijvoorbeeld Godding, Droit privé, 162-251, nrs. 231-251; Hartmann, Reconstructie landschap, passim, in het bijzonder 298-305.

1907 Hackeng, Middeleeunse grondbezit Sint-Servaaskapittel, 111-112. 
'erfpachten' genoemd. Overigens worden de termen (erf)cijns, (erf)pacht en (erf)rente veelvuldig door elkaar gebruikt.

Men onderscheidt vier soorten cijnzen, waarvan twee een publiekrechtelijke en twee privaatrechtelijke oorsprong hebben. Van de publiekrechtelijke cijnzen waren het belangrijkste de betalingen gebaseerd op domaniale of grondheerlijke verhoudingen. Deze ontstonden wanneer grondheren land in gebruik gaven tegen betaling van een jaarlijkse vergoeding in de vorm van cijns. De tweede groep heerlijke cijnzen bestond uit een soort recognitie voor het gebruik van heerlijke rechten, zoals het recht van wind en water voor molens of rechten voor het gebruik van woeste grond.

De cijnzen met privaatrechtelijk karakter kenden een totaal andere oorsprong. In het eerste geval stond een particuliere eigenaar onroerend goed in gebruik af tegen betaling van een (erfelijk) jaarlijks bedrag. Het lijkt enigszins op de tegenwoordige erfpacht. Bij de tweede constructie betaalde de eigenaar juist aan een derde een jaarlijks bedrag in ruil voor een bedrag, waarvoor onroerend goed tot onderpand was gesteld. Het leek voor de geldschieter enigszins op een belegging op basis van hypotheek. ${ }^{1908}$

Het is niet eenvoudig om op basis van voorgaande beschrijvingen een helder zicht te krijgen op de diverse cijnzen die in Gronsveld werden geheven. Het was ook een man als Prummer, die daarover in 1757 en 1761 beschouwingen geeft, verre van duidelijk. Alvorens daaraan aandacht te besteden, willen we eerst inventariseren wat de oudere documenten over deze inkomsten vermelden. De belangrijkste bron van informatie daarvoor zijn de rentmeestersrekeningen uit de zestiende en het begin van de zeventiende eeuw en de 'Specificatie' van het graafschap van omstreeks 1650. Het meest 'statische' overzicht biedt misschien de 'Specificatie':

- Havercijns in Eckelrade (7 gulden) en Slenaken (4 gulden)

- Kapoenen in Gronsveld (129 1/2), Eckelrade (77 1/2) Heugem (48), Honthem (15) en Slenaken (112).

- Ganzen in Gronsveld en Eckelrade (87) en Heugem (12).

- Hennen in Eckelrade (8), Honthem (22) en Slenaken (10 1/2).

- Eieren in Slenaken $(101 / 2)$.

- 'Bedegeld' in Gronsveld en Eckelrade (68 gulden), Heugem (48 gulden), Honthem (17 gulden) en Slenaken ( $401 \frac{1}{2}$ gulden).

- 'Cijnzen' in geld in Gronsveld en Eckelrade (73 gulden 8 stuiver), Heugem (28 gulden 3 stuiver), Honthem (12 gulden 4 stuiver), Slenaken (4 gulden 17 stuiver).

- Afdrachten in suiker, muskaat, kruidnagel en was.

De rentmeestersrekeningen rond 1620 geven ongeveer hetzelfde beeld:

- Kapoenen: Gronsveld (129 1/2), Eckelrade (77 1/2), Heugem (48), Honthem (15), Slenaken (115).

- Ganzen: Gronsveld en Eckelrade (87), Heugem (48).

1908 Welings, e.a., Hoenen en kapoenen, 3-7. 
-Hennen en pullen (jonge kippen): Eckelrade (8), Honthem (22), Slenaken (4 1/2).

- Eieren in Slenaken (31/2, komt van oudsher direct toe aan de bode voor zijn moeite).

- 'Bedegeld' in Gronsveld en Eckelrade (65 gulden 8 stuiver), in Heugem (48 gulden), in Honthem (17 gulden 5 stuiver) en in Slenaken (40 gulden 10 stuiver).

- 'Landt sinsen unnd hoff sinsen': Gronsveld en Eckelrade (73 gulden 8 stuiver), Heugem (28 gulden 3 stuiver), Honthem (12 gulden 4 stuiver), Slenaken ( 5 gulden) en Oost (2 gulden).

- Afdrachten in suiker, muskaat, kruidnagel en was. Van circa tachtig bunder land (de opgegeven aantallen variëren tussen de 78 en 84) moest per bunder één pond suiker worden betaald. Bij tien van deze circa tachtig bunders was de officiële afdracht in suiker om een of andere reden omgezet in een pond muskaat en half pond was.

Binnen het totaal aan landsheerlijke inkomsten namen deze cijnzen een niet onbelangrijke plaats in. In de tijd rond 1620 maakten zij tussen de zeven en zestien procent uit van het inkomen en kwamen daarmee op de derde plaats na de 'landpachten' en de erfpachten.

De rentmeestersrekening van 1536/1537, bijna een eeuw eerder, vertoont in grote trekken dezelfde structuur, maar de cijfers zijn niet helemaal vergelijkbaar. In de eerste plaats is het de vraag of de administratie wel volledig is en verder staan de kapoenen en andere cijnzen uit de hof Printhagen nog als een aparte categorie geboekt. Maar er zijn ook duidelijke overeenkomsten: 89 ganzen in Gronsveld en Eckelrade, 15 kapoenen in Honthem en 22 $1 / 3$ hen in Honthem. Ook de 'bede' wordt genoemd. Het betreft een afgerond bedrag van vijftig goudgulden dat 'die ondersaten tslantz Gronsselt mynen joncker jars geven' (de koers daarvan is in de rekening omgerekend naar zeventig gulden).

Samenvattend kunnen in de voorgaande overzichten de volgende vaste categorieën aan cijnzen worden onderscheiden: de afdrachten van pluimvee in de vorm van kapoenen, ganzen, hennen en pullen (jonge kippen) en enkele eieren, vervolgens de 'land- en hofcijnzen' (in de 'Specificatie' rond 1650 aangeduid als 'cijnzen'), daarna de zogenoemde 'bede' en ten slotte de betalingen van suiker, specerijen en was. Waarschijnlijk werd aan het begin van de zeventiende eeuw nog het grootste deel van het pluimvee levend afgedragen. In de rekeningen wordt gesproken over verkoop op de markt van Maastricht of het versturen van pluimvee naar Rimburg. Later werd alles in geld omgerekend. Een curieuze categorie vormen de betalingen in suiker en specerijen. We komen suiker, muskaat, muskaatbloem, kruidnagel en peper ook tegen als 'opgeld' bij de verpachtingen, bijvoorbeeld van tienden. Het schijnt dat deze leveranties in natura plaatsvonden, want in de rekeningen wordt de opbrengst soms niet verantwoord omdat deze specerijen direct naar kasteel Rimburg werden gestuurd.

Komen we nu tot de visie die Prummer in zijn rapport uit 1761 over de cijnzen ontwikkelde. ${ }^{1909}$ Uiterst nauwgezet had Prummer de rommelige en gebrekkige cijnsadministratie van de zestiende eeuw tot het midden van de achttiende eeuw

${ }^{1909}$ TJ, inv. nr. M 73, fol. 565-597. 
bestudeerd. ${ }^{1910}$ Uitvoerig gaat hij in op wat hij noemt de 'gemeine landt-, dan hofzünsen, oder, wie sÿe solche darnach getauffet', 'ordinair' und 'extra-zünsen'. Deze 'landt sinsen unnd hoff sinsen' treffen we ook in de eerder genoemde rentmeestersrekeningen als één groep aan.

Binnen Gronsveld en Eckelrade werd voor de 'gemene' of 'ordinaris' landcijns per bunder $10^{1 / 2}$ oort $^{1911}$ gerekend, percelen in de Bijbank werden aangeslagen voor $5^{1 / 4}$ oort. Interessant is dat de Bijbank (de 'halve heerlijkheid Eckelrade') precies de helft betaalde van Eckelrade. Voor Heugem gold een bedrag van zeven oort per bunder en in Honthem drie stuiver of twaalf oort. Het exacte bedrag per perceel werd berekend in verhouding tot de werkelijke oppervlakte.

De 'gemene' landcijns werd volgens Prummer geheven van alle gronden en huizen binnen het graafschap, ongeacht het gebruik, voor zover dit onroerend goed niet al op een andere manier met de heer van Gronsveld was verbonden door leenroerigheid, erfpacht of betaling van 'extra-cijnzen'. Prummer zag de oorsprong van deze landcijns als een soort erkenning van het recht van hoge jurisdictie van de heer.

Maar de algemene regel kende ook uitzonderingen. Zo waren er toch ook enkele lenen waarop gemene landcijns rustte. Maar de belangrijkste vrijstelling gold voor grond die in eigendom aan de heer van Gronsveld zelf toebehoorde of ooit had toebehoord en later als cijnsvrij was verkocht. Verder betaalde ook de eigenaar van kasteel Rijckholt niet mee aan deze cijns. Die vrijstelling gold zowel voor diens 'gewone' eigendom van ruim 23 bunder in Gronsveld, evenals 28 bunder oorspronkelijk leengoed in Eckelrade (eertijds deel van het leen Hemersbach), waarvan de feodaliteit in 1682 was opgeheven.

De status van kerkelijk grondbezit was onduidelijk. Een algemene vrijstelling voor kerkelijke instellingen binnen of buiten Gronsveld bestond niet. Maar tegelijkertijd was nergens te vinden dat de parochiekerk, de pastoor van Gronsveld of de beneficiant van het Sint-Amandusaltaar ooit enige cijns hadden betaald van hun landerijen. Dat gold ook voor het land van de kapelanie en kosterij. Een titel voor deze kennelijke vrijstelling was onbekend, maar de traditie wilde dat deze kerkelijke fundaties waren gesticht door de heren van Gronsveld en om die reden niet bijdroegen. Volgens de oude registers werd de kerk van Eckelrade wel aangeslagen, maar nergens stonden daadwerkelijke betalingen genoteerd, met uitzondering van de jaren 1718-1723. De beneficiant van het altaar van Onze-Lieve-Vrouw in Eckelrade betaalde weer wel van enkele percelen in Eckelrade en in de Bijbank. Ook de pastoor van Heugem betaalde zijn aanslag.

Naast de gemene landcijnzen werden ook 'hofcijnzen' of 'extra cijnzen' betaald. Een juiste omschrijving van dat begrip ligt ingewikkelder. Prummer zegt daarover:

De hof- of extra-cijnzen bestaan deels uit ganzen, kapoenen, hennen, enkele ponden was...en deels uit de navolgende oude geldsoorten, te weten goudguldens, oortjes of kwart

1910 De belangrijkste stukken van deze administratie, die thans nog in RHCL, Graafschap Gronsveld aanwezig zijn, zijn de inv. nrs. 123 (ernstig beschadigd), 124, 137 en 478, alsmede de rekeningen over de periode 1536-1626, inv. nrs. 172-187.

1911 Een oort(je) is een kleine munt. 
goudguldens, stuivers zwaar geld, oude schellingen, oude groten, denaren en kopieën, verder goud- en oort-goudguldens, en zware stuivers voor de bede. ${ }^{1912}$

Het is de vraag wat hij hiermee precies bedoelt. In de gegevens uit de eerste helft van de zeventiende eeuw wordt het pluimvee als afzonderlijke categorie bij de cijnzen opgevoerd, naast de combinatie van land- en hofcijns. Sloeg de hier genoemde hofcijns in beginsel ook op dit eerder vermelde pluimvee of werd hier nog ander gevogelte bedoeld? Er valt bij gebrek aan nadere gegevens geen definitieve uitspraak over te doen, maar de eerste optie lijkt nog het meest waarschijnlijk. Dit betekent een tweedeling van de hofcijns in de vorm van afzonderlijk genoteerd pluimvee en vervolgens de hofcijns uitgedrukt in geld, die samen met de landcijns in de boeken werd verantwoord. Over het ontstaan van deze hofcijns vermoedt Prummer dat deze op de oorspronkelijke bebouwing was gevestigd:

Zowel uit voormeld boek als de inkomstenregisters kan worden afgeleid dat vroeger de extra-cijnzen, op heel weinig uitzonderingen na, op bebouwde plaatsen waren gevestigd, dus zeer waarschijnlijk bij de oorsprong gevestigd, toen de bebouwing van de dorpen ontstond en de percelen voor woningbouw en hoeves werden aangewezen. ${ }^{1913}$

In de loop der tijden waren percelen verdeeld of huizen afgebroken en was de grond in akkerland omgezet, maar dikwijls viel uit het toponiem nog af te leiden dat er ooit een huis had gestaan.

Tegelijk met de cijnzen werd de 'bede' geheven. Deze stond genoteerd in oude muntsoorten zoals goudguldens, schellingen (twintigste deel van een pond), groten (twaalfde deel van schelling), denaren (kleine munt), et cetera. Omdat cijnzen en bede al sinds mensenheugenis samen in één bedrag werden betaald, was het onderscheid geheel vervaagd. Toch ging het oorspronkelijk om verschillende heffingen. Prummer stelde zelfs vast dat vroeger de waarde van de gulden bij de cijnzen anders werd berekend dan de gulden bij de bede. ${ }^{1914}$

Hij vroeg zich dan ook af wat de oorsprong van de 'bede' was, aangezien hij bij dit begrip in eerste instantie - min of meer voor de hand liggend - dacht aan een algemene landsbelasting, zoals die aan het einde van de middeleeuwen door de staten in verschillende gewesten aan een landsheer werd toegestaan.

1912 'Die hof- oder extra-züns bestehen zum theill in gänsen, capaunen, hienneren, ainigen pfundten wachs ... dan zum theill in folgent alten gelt sorten, nembl[ich] goldtguldten, oort oder viertl-goldtgulden, stüber schwär, alten schillingen, alten grotten oder groschen, deniers und copien, auch goldt- und oortgoldtgulden, dan stüber schwär zur bede', TJ, inv. nr. M 73, fol. 567-568.

1913 'Sowohl aus vorermelten buech als einnambs registeren lasset sich abnehmen, daß vor alters die extrazünsen bis auf ainig gantz wennige, auf hof-stätten gestandten, einfolglich ganz wahrscheinlich beÿ dem ursprung nach maas eingeleget gewesen, als die dörffer bepauet, dan die plätz zu wohnungen und hofgeraithen angewisen', TJ, inv. nr. M 73, fol. 572-573.

1914 TJ, inv. nr. M 73, fol. 613 met staatje van omrekeningen van koersen. De munten bij de bede hadden een andere koers dan de overige munten, bijv. 1 goudgulden was 5 gulden gangbare munt en 1 goudgulden bede was 3 gulden, 15 stuiver en 1 oort gangbare munt. 
Interessant is een passage in de oorkonde uit 1526, waarbij Johan I van Bronckhorst Batenburg instemt met de afkoop van bepaalde herendiensten. Daarin behoudt de heer zich uitdrukkelijk voor 'alle jair unse alde vrijbede to doin verkondigen ind gebieden in onse kirspels kyrken wie von alters gewonliken is'. In de rentmeestersrekening van $1536 / 1537$ wordt gesproken over een afgerond bedrag van vijftig goudgulden aan bede dat de inwoners ten behoeve van de landsheer moesten betalen. ${ }^{1915}$

Let wel, in de oorkonde uit 1526 stond 'verkondigen ind gebieden' en niet 'vragen'. Evenmin was het doel aangegeven. Dat leidde aan het einde van de zestiende eeuw tot grote onenigheid over het karakter van de bede. In de processen voor het Rijkskamergerecht tussen graaf Johan II van Bronckhorst Batenburg en de inwoners van Gronsveld, Slenaken en Heugem wordt daar uitgebreid op ingegaan. ${ }^{1916}$ 'Bede', zo beweerden onderdanen van het graafschap, betekende in het Nederlands geld dat jaarlijks moest worden gevraagd. In dat verzoek konden de onderdanen naar goeddunken en vermogen bewilligen. Voorts verkeerden de inwoners in de veronderstelling dat Gronsveld in de zestiende eeuw geen belastingen aan Rijk en kreits had betaald, omdat de vader en de broer van de graaf die uit de bede hadden voldaan. Graaf Johan II bestreed dit. Hij meende dat de bede een belasting was die de rijksstanden zonder meer krachtens eigen recht mochten opleggen. Dat gebeurde ook in de Neder- en Bovenrijnse Kreits en wel geheel los van belastingen, zoals de Türkensteuer, die keizer en rijksstanden in gezamenlijk overleg uitschreven.

Het karakter van de bede als gevraagde bijdrage was dus omstreden. Die discussie bestond ook bij andere collectieve bijdragen, zoals 'het geschenk' bij een inhuldiging. Misschien komt daarmee ook een andere duiding in zicht. Het algemene begrip 'bede' komt voor het eerst voor in de dertiende eeuw en kan ook een heffing van domaniale aard zijn, ontstaan binnen het kader van het hofstelsel. ${ }^{1917}$ Misschien was dat ook in Gronsveld het geval. Prummer constateerde immers dat van sommige percelen wel cijns, maar geen bede werd betaald, terwijl van andere weer wel bede, maar geen cijns werd afgedragen. Die relatie met een heffing van belasting op grond en de onregelmatigheid daarin kunnen wijzen op een herkomst uit het domaniale stelsel.

Prummer schrijft dat de cijnzen op vaste dagen werden geïnd: van de percelen gelegen onder Gronsveld, Eckelrade, de Bijbank en Breust op Sint-Martinusdag (11 november) en de twee opeenvolgende zondagen in Gronsveld, voor Honthem de eerste drie donderdagen na Driekoningen (6 januari) en voor Heugem de eerste vrijdag na Driekoningen en daarna nog twee vrijdagen, telkens met een interval van twee weken. Wie niet op tijd betaalde, kreeg een boete van $12^{1 / 4}$ stuiver.

De vaste betaaldagen kenden een lange traditie en treffen we al aan in de rentmeestersrekeningen uit de zestiende en zeventiende eeuw. Voor Gronsveld en Heugem zijn die eeuwenlang onveranderd gebleven. De cijnzen van de hof Printhagen werden begin zestiende eeuw, in de tijd dat deze hof nog als zelfstandige eenheid werd

1915 RHCL, Graafschap Gronsveld, inv. nr. 172.

1916 RHCL, Rijkskamergerecht inv. nr. 17, fol. 21vo.-22, 42vo. en 73.

1917 Venner, Venner, 'Schepenen op het platteland', 5-6 met verdere verwijzing naar literatuur. 
geadministreerd, op kerstdag geïnd.1918 Honthem en Slenaken werden oorspronkelijk afgewerkt met één zitdag, respectievelijk zondag en donderdag na Driekoningen. In de vroeger met Gronsveld door personele unie verbonden heerlijkheden Sint-MartensVoeren en Oost vond inning op respectievelijk tweede kerstdag en op 11 november plaats. Bij iedere zitting werden de schepenen op een maaltijd getrakteerd. De betaaldagen vormden een soort feestdag voor het dorp. In 1761 klaagt commissaris Prummer dat de toeloop van volk in Gronsveld op Sint-Martinusdag vroeger zoveel drukte veroorzaakte, dat zelfs de voor die kerkelijke feestdag voorgeschreven vespers werden verwaarloosd.

Samenvattend lijkt de conclusie gewettigd dat cijnzen en bede in Gronsveld heffingen zijn van middeleeuwse oorsprong met een publiekrechtelijk karakter. Door de gecombineerde inning vervaagden de verschillen in de loop der tijden, maar met enige moeite vielen ze toch nog wel te onderscheiden. De verschillen per dorp in de tarieven en ook de soorten cijns (bijvoorbeeld in één dorp wel, in het andere geen ganzen) wijzen op een ontstaan in de tijd toen de heren van Gronsveld hun landsheerlijkheid opbouwden uit afzonderlijke eenheden. Daarbij lijken de extra-cijnzen of hofcijnzen van domaniale oorsprong, gevestigd op het moment dat de grondheer grond in gebruik gaf aan een cijnsnemer tegen betaling van een jaarlijks bedrag. ${ }^{1919}$ De ordinaris landcijns kan, als we Prummer mogen geloven, een andere oorsprong te hebben. Wanneer het waar is dat deze cijns werd geheven over alle allodiale grond die niet al op een andere wijze aan de heer onderhorig was als leen, keurmedig goed of cijnsgoed, dan steekt misschien een kern van waarheid in de hypothese van een heffing als erkenning van het (grond)heerlijk gezag over alle (allodiale) grond binnen een bepaald gebied.

Er zijn verschillende argumenten voor de veronderstelling dat de bede eerst uit de late middeleeuwen dateert, nadat Gronsveld, Heugem, Honthem en Slenaken onder één landsheer waren gekomen. In de eerste plaats valt de naam op, die typisch is voor de late middeleeuwen. Verder gaat het om een afgerond bedrag dat het land moest opbrengen en ten slotte wordt deze heffing, in tegenstelling tot de cijnzen, alleen toegepast in de vier genoemde dorpen en niet in Oost en Sint-Martens-Voeren. Met andere woorden, de bede raakte alleen de plaatsen die de heer van Gronsveld ook daadwerkelijk als hun landsheer erkenden.

In de loop der eeuwen gingen de verschillende heffingen in de boekhouding van de rentmeester steeds meer door elkaar lopen, omdat alles niet per soort belasting, maar bij elkaar per debiteur en per perceel werd berekend. Het wekt enige verbazing dat dit systeem zo lang in stand bleef, want deze vorm van inning was primitief, omslachtig en fraudegevoelig. Toch zijn wel redenen te bedenken waarom niet werd gemoderniseerd. In de eerste plaats werd het geld geïnd door, zoals Prummer meermalen aangeeft, een kleine groep van 'allesweters', mensen die binnen een conservatieve en overzienbare gemeenschap van generatie op generatie over persoonlijke kennis van zaken beschikten en wisten wat rechtens was. Zij hadden geen belang bij verandering. Verder vormden de

1918 RHCL, Graafschap Gronsveld, inv. nr. 172.

1919 Dit stemt overeen met de conclusie van Hartmann, Reconstructie landschap, 300, die voor het aangrenzende gebied van Breust/Eijsden aanneemt dat cijnsverhoudingen in het algemeen van vóór 1400 dateren. 
cijnzen in de leggers van de rentmeester een min of meer van te voren vaststaande bron van inkomsten. Wanneer het verwachte resultaat maar werd behaald, was iedereen tevreden. Onduidelijkheden over eventuele onderpanden van die cijnzen wogen daarom in dit systeem niet zo zwaar.

\subsection{Rechten op bossen}

Het laatmiddeleeuwse bosbezit van de heren van Gronsveld was aanzienlijk. In Gronsveld was dat het grootste deel van het Savelsbos, een hellingbos, gelegen op de rand van het plateau van Eckelrade. Aan de rand lagen ook kleinere percelen hout- en struikgewas, die in eigendom toebehoorden aan particulieren. Daarnaast lagen er bossen in Slenaken en Sint-Martens-Voeren. In deze twee plaatsen vormde het 'bosgeld' zelfs de voornaamste bronnen van inkomen van de heer. Maar door de verkoop van Sint-Martens-Voeren begin zeventiende eeuw en Slenaken in 1728 gingen deze bossen voor de graaf verloren.

In de genoemde plaatsen beheerde de graaf, uiteraard via zijn rentmeester, het bos, stelde hij de boswachter aan, regelde de houtkap en inde de opbrengst van het verkochte hout. Hij beschouwde zich als eigenaar van de grond en gedroeg zich als enige rechthebbende. ${ }^{1920}$ Met opzet wordt gekozen voor een voorzichtige formulering, want ook al gaan deze bosrechten ongetwijfeld terug op middeleeuwse verhoudingen, het is de vraag waar deze op steunden. Enerzijds kan worden gedacht aan het bos- en wildernisregaal, het (lands)heerlijk recht op woeste gronden. De recente studie van Vera over gemene gronden in de Meierij van Den Bosch bevat een overzicht van de verschillende oudere opvattingen over dit regaal. ${ }^{1921}$ Lange tijd bepalend in de Nederlandse rechtshistorische literatuur was de visie van De Blécourt, die onbebouwde gronden rekende tot de 'bona vacantia', goederen zonder eigenaar, die, zoals alle goederen zonder eigenaar (wild, gevonden goederen, aanwas van grond) van rechtswege in eigendom aan de landsheer toebehoorden. Tegenover deze privaatrechtelijke invalshoek staat de opvatting van Van der Linden, die in zijn analyse van de middeleeuwse ontginningsgeschiedenis van het Hollandse veengebied opteerde voor een benadering, waarbij de beschikkingsmacht over wildernis een publiekrechtelijke bevoegdheid was. ${ }^{1922}$ Vera stelt dat het begrip 'wildernisregaal' als typisch overheidsrecht in Brabant pas in de zestiende eeuw opduikt. ${ }^{1923}$ Daarmee zijn zowel de opvatting van De Blécourt over de 'bona vacantia' als basis voor het wildernisregaal als ook die van Van der Linden hier niet houdbaar. In navolging van een studie van Ter Kuile onderzocht Vera de mogelijkheid dat beschikkingsrechten over bossen en wildernis voortvloeiden uit oorspronkelijk grootgrondbezit en grondheerlijke

1920 In de verpandingsakte van de heerlijkheid Slenaken uit 1638 (RHCL, Klooster Hoogcruts, inv. nr. 296) wordt gesproken over 'het slachhoudt van de bosschen welcke wij binnen dese onse voorsschreven heerlicheydt hebben ende gebruycken'.

1921 Vera, ... dat men het goed van den ongeboornen niet mag verkoopen, 128-145.

1922 Zie voor een samenvatting van deze opvattingen, alsmede ook die van Godding, Droit Privé: Vera, ... dat men het goed van den ongeboornen niet mag verkoopen, 128-131. Vera, 132-138 geeft ook een overzicht van de opvattingen van juristen over het wildernisregaal.

1923 Vera, ... dat men het goed van den ongeboornen niet mag verkoopen, 145. 
rechten. ${ }^{1924} \mathrm{Hij}$ komt daarbij tot de conclusie dat grondheerlijke verhoudingen zeer goed het fundament kunnen zijn voor heerlijke gezagsrechten over bossen en woeste gronden. Exploitatie van een grondheerlijk domein met laathoven en horigen was niet beperkt tot de gecultiveerde delen,

ook de woeste gronden speelden een belangrijke rol in de agrarische bedrijfsvoering van die dagen. Vastgesteld kon bovendien worden, dat deze domeinen duizenden hectares konden beslaan, hetgeen impliceert dat er grote complexen woeste gronden deel van konden uitmaken. ${ }^{1925}$

Er valt veel voor te zeggen deze opvatting ook van toepassing te verklaren op de rechten die de heer van Gronsveld op de bossen in zijn territorium had. Wanneer we uitgaan van het ontstaan van Gronsveld als een domein dat vanaf de elfde tot en met de dertiende eeuw werd ontgonnen en waar nog allerlei sporen van oud grootgrondbezit tot het einde van de achttiende eeuw zichtbaar waren, dan ligt het voor de hand dat het tussen Gronsveld en Eckelrade gelegen Savelsbos ook deel uitmaakte van dit oorspronkelijk domein. De exploitatie daarvan geschiedde op basis van het eigendomsrecht en is altijd in hand van de heer van Gronsveld gebleven. Ieder gebruik werd door de graaf geregeld. In de Franse Tijd zijn de bossen dan ook als grafelijke domeinen door de nieuwe machthebbers in beslag genomen. Er valt daarmee wat betreft het gebruik ook een parallel te trekken met het eerder genoemde recht van mergelwinning. Dit grafelijke eigendomsrecht betekent overigens niet het volledig ontbreken van gebruiksrechten van bewoners. Iets van dien aard moet er wel zijn geweest, getuige het feit dat in 1749 de schepenbank een grens voor het weiderecht in het Savelsbos vaststelde tussen Gronsveld en Eckelrade. ${ }^{1926}$ Maar daarmee waren het zeker geen gemeentelijke bossen. Wel konden de inwoners hout kopen tijdens de houtkap, die vanwege de graaf werd gereguleerd.

Het is de vraag of naast het grafelijk recht op de bossen ook een algemeen recht van de heer op vrijstaande bomen en houtopstanden bestond en of de heer ook over een zogenoemd 'pootrecht' beschikte, het recht om bomen te planten voor de erven, langs de weg of op de gemene gronden. ${ }^{1927}$ In rekeningen of reglementen is daar niets over terug te vinden. Wel komt hierna nog aan de orde dat Prummer na 1750 de herbebossing van het door militairen kaalgeslagen graafschap zelf krachtig bevorderde. Dat beleid werd later door zijn opvolger Zollner voortgezet. Het is aannemelijk dat alles wat op openbaar terrein werd geplant langs wegen ook als grafelijk eigendom werd beschouwd. Ook de boswachter had tot opdracht een algemeen toezicht op houtopstanden uit te oefenen.

\footnotetext{
1924 Vera, ... dat men het goed van den ongeboornen niet mag verkoopen, 147-182, met een overzicht van de betekenis van het begrip 'grondheerlijkheid' in Brabant en andere territoria.

1925 Vera, ... dat men het goed van den ongeboornen niet mag verkoopen, 181.

1926 RHCL, Graafschap Gronsveld, inv. nr. 227.

1927 Zie over dit pootrecht: Ketelaar, Oude zakelijke rechten, 154-162;Vera, ...dat men het goed van den ongeboornen niet mag verkoopen, 188-189.
} 
De economische betekenis van de houtverkoop wisselde per jaar. Het aandeel 'bosgeld' binnen het totaal aan grafelijke inkomsten in de periode 1617-1624 liep uiteen van ruim $1 \frac{1}{2}$ procent tot bijna 14 procent. De grote verschillen zijn wel verklaarbaar. Uit de rekeningen blijkt dat de 'uitgifte' van hout werd afgewisseld tussen de verschillende plaatsen. Die uitgifte geschiedde meestal door publieke veiling van een aantal 'slagen', dat wil zeggen afgepaalde stukken van het bos. Zo werd de houtkap in Slenaken in 1617/1718 verdeeld tussen veertien gegadigden. Het ging dus niet ieder jaar om gelijke grootheden, verder kon de veilingopbrengst variëren en ten slotte duurde het een aantal jaren voordat er weer opnieuw kan worden 'geoogst'.

Bij de verkoop van hout moet vooral worden gedacht aan jonge opstand, geriefhout dat werd gebruikt in en rond de boerderij of verstookt als brandhout. $\mathrm{Na}$ de kap werd waarschijnlijk geen nieuwe beplanting aangebracht, maar gewacht op spontane ontwikkeling van nieuwe begroeiing. Deze cyclus van groei en kap volstond onder normale omstandigheden voor een geregelde productie. Grote en langdurige schade kon echter ontstaan door oorlogshandelingen. De 'Specificatie van het graafschap Gronsveld' uit circa 1650 vermeldt dat de Riesenberg in Gronsveld weinig hakhout had opgebracht omdat de bomen waren gekapt door soldaten van het garnizoen van Maastricht. Nog ernstiger waren de verwoestingen een eeuw later, in 1747. Die schade werd aangericht door Britse en Hannoverse troepen, die in de Oostenrijkse Successieoorlog vanaf juli 1747 gedurende zeven weken (in het officieel neutrale Gonsveld!) hun kampementen opsloegen van Heugem tot Rijkckholt. Juist in dat gebied lagen alle velden, weilanden en boomgaarden. De militairen gebruikten het hout niet alleen voor zichzelf, maar ze verkochten het ook met karrenvrachten tegelijk naar Maastricht. Naderhand werd becijferd dat er duizend eiken (waarvan zeshonderd van de graaf), 1730 essen, olmen en populieren, 7400 wilgen en 780 fruitbomen waren omgehakt, in totaal bijna elfduizend grote bomen. Verder waren nog tachtig morgen hakhout van de graaf volledig kaal gemaakt. Daarmee beliep diens schade ongeveer 27750 gulden Brabants, iets meer dan elf procent van het totale schadebedrag van 249119 gulden Brabants van alle inwoners gezamenlijk. Pogingen daar iets van terug te krijgen zijn op niets uitgelopen.

De cijfers die Prummer voor de periode 1736-1745 voor de opbrengst van houtverkoop vermeldt, zijn niet ongunstig, zeker wanneer men in aanmerking neemt dat het vroegere bosbezit in Sint-Martens-Voeren en Slenaken intussen was afgestoten. Binnen een totaal van 98387 gulden aan inkomsten leverde de houtverkoop met 12636 gulden nog altijd een aandeel van bijna 7,8 procent. Toen Prummer in 1752 in Gronsveld arriveerde, trof hij letterlijk een kaal graafschap aan. Hij begon daarom voortvarend met nieuwe aanplant. Dit alles gebeurde met beperkte investeringen in een eigen kwekerij. Die eigen kweek leverde grote voordelen op, want nu kostten tien stammen van vijf tot zeven jaar evenveel als vroeger één stam, die moest worden ingevoerd. Vrijwel alle aanplant bleef nu in leven (vroeger was het net omgekeerd) en het was ook mogelijk goede stammen te selecteren, terwijl de tweede keus nog altijd bruikbaar was als hakhout. Er werd vooral loofhout geplant: olmen, populieren, eiken en kersen. Dennen waren niet verkrijgbaar. Waar het terrein het toeliet, liet Prummer mooie lanen aanleggen. Op lange termijn beschouwde hij dit als een diepte-investering, die geld zou opleveren, maar tegelijkertijd zag hij in de 
verfraaiing van het dorp met bomen ook een waardevermeerdering van het graafschap als zodanig. Stukken die braak lagen of onbenut waren vanwege de mergelondergrond, kregen een beplanting met kaphout.

Prummer zag naast deze campagne tot herbeplanting nog andere mogelijkheden het areaal aan hout uit te breiden. Aankoop van landbouwgrond was ongunstig omdat die goederen met schatting belast waren. Maar terreinen begroeid met struikgewas of bos waren belastingvrij. Twee derde deel van die gronden bevond zich al in grafelijke hand en met enig geduld moest het mogelijk zijn ook de rest te verwerven. Die afronding van grafelijk bezit was om allerlei redenen gunstig: het werd gemakkelijker op te treden tegen houtdiefstal en stroperij, de aankoop kon meestal geschieden tegen een aanvaardbare prijs en op termijn was het economisch rendement van de investering hoger dan bij landbouwgrond.

In hoeverre Prummer ook in deze opzet slaagde, is niet helemaal duidelijk. Tot grootschalige aankoop schijnt hij uiteindelijk niet te zijn overgegaan. Maar afgaande op de opbrengsten mag zijn bosbouwbeleid als geheel succesvol worden genoemd, zeker wanneer men in aanmerking neemt dat hij in een bijna kaal gebied begon. Over de periode 1736-1745 had de houtverkoop 7,8 procent van de grafelijke inkomsten uitgemaakt, terwijl Prummer er in slaagde deze te verhogen tot 8,2 procent.

\subsection{Rechten op weidegronden}

Tussen Gronsveld, Heugem, Oost en Rijkckholt lag het Gronsvelder Broek, een gemeenschappelijk gebied van weide- en broekgronden, waarop de inwoners van Gronsveld vee lieten grazen. (In Hoofdstuk 17.2 en 17.6 van deze studie wordt nader ingegaan op het beheer daarvan door de gemeente). Redenerend vanuit een parallel met de heerlijke rechten op bossen, rijst de vraag of de heer ook rechten kon doen gelden op deze weidegronden. Het is niet zo eenvoudig daarop in de archivalische bronnen een antwoord te vinden, omdat er zeer weinig materiaal voorhanden is. De 'Specificatie' van het graafschap uit omstreeks 1650 is daar vaag over:

Desen behalven is 't voorss. huys [= kasteel van Gronsveld] geleegen vast bij de gemeynte genaempt het Broeck, alsoe dat men met beesten kan daerop jaerlijx een groet proffijct maecken ende onder anderen met schaepen, dye men vermach te hueden ende halden binnen de gansche graeffschappe, sijnde deselve estimaebel 's jaers hondert rijxdaelder.

Het is niet duidelijk of de schrijver hier doelt op bijzondere weiderechten van de graaf op de 'gemeynte' of gewoon de mogelijkheden aangeeft om winstgevend vee, in het bijzonder schapen, te houden. Die vaagheid van de 'Specificatie' had misschien ook wel een reden, want over die rechten bestond verschil van mening. Zo is het niet verbazingwekkend dat tussen de vele geschillen die graaf Johan II en zijn onderdanen omstreeks 1600 voor het Rijkskamergerecht uitvochten, ook onenigheid over weiderechten voorkwam. Het betrof een hier verder niet echt relevante kwestie over verkoop van een stukje grond in Heugem en het verwijt dat de graaf met zijn vee het grasland vernielde. Maar tussen de bewijsstukken bevindt zich ook de tekst van een akte uit 1593, die zicht geeft op de 
verhoudingen. ${ }^{1928}$ Daarin wordt verklaard dat 'vorfahren' (vader, broer?) van graaf Johan II vroeger aan de in zware financiële nood verkerende 'underthanen und ingesessene' toestemming hadden gegeven een stuk van de gemene grond, 'dem dorff zugehoerende', gedurende veertien jaar 'zu versetzen' (waarschijnlijk an een derde als onderpand in gebruik te geven). Die termijn was inmiddels al een tijd verstreken en nu vroegen de inwoners opnieuw toestemming om gedurende veertien jaar een stuk van de gemeentegrond voor akkerbouw te mogen gebruiken. Zij waren bereid daarvoor in twee termijnen vijfhonderd gulden Maastrichts geld aan de graaf te betalen. $\mathrm{Na}$ afloop van deze termijn werd de grond weer aan de gemeente toegevoegd. (Interessant is dat er kennelijk geen grote drang tot duurzame ontginning bestond; in de dorpseconomie vertegenwoordigden gemeenschappelijke weidegronden een eigen waarde).

De overeenkomst uit 1593 lijkt te passen bij een juridisch advies dat een verder onbekende Duitse advocaat in 1686 opstelde over de grafelijke rechten op gemeentegrond. ${ }^{1929}$ Helaas is de verdere context van het stuk niet bekend, zodat onduidelijk blijft voor wie het document was bedoeld. De verschillende overwegingen maken echter een objectieve indruk. Daaruit wordt zonder meer duidelijk dat onzekerheid bestond over de grafelijke rechten op deze gronden. Maar het meest interessante is misschien wel de beschrijving van de casus op zich. Daarin wordt verwezen naar een al meer dan honderd jaar bestaand gebruik (sinds mensenheugenis dus) dat de heer bij verkoop van weidegrond door de gemeente recht had op één derde van de opbrengst. Verder was voor eventuele verkoop van de grond door de gemeente of bezwaring met hypotheek verlof van de heer noodzakelijk.

De advocaat moest nu antwoord geven op verschillende vragen: of de heer zich kon beschouwen als eigenaar van één derde van de weidelanden, of hij dit deel ten eigen nutte mocht gebruiken en of hij scheiding en deling van gemeenschappelijke eigendom kon eisen. De gedetailleerde uiteenzettingen in het advies over de diverse mogelijkheden kunnen hier verder grotendeels buiten beschouwing blijven. De advocaat bleek in het algemeen geen voorstander van onverdeelde eigendom. Maar wanneer men de opvatting was toegedaan dat de graslanden publiek eigendom waren en voor publiek gebruik bestemd, (en dat was onbetwist), dan kon niemand van de gerechtigden als privépersoon daarvan scheiding en deling vorderen. In dat opzicht verschilde de graaf niet van de andere inwoners. Eventuele initiatieven in die richting konden alleen van de inwoners uitgaan. Ook mocht de graaf niets met deze weiden doen wat tot nadeel van de andere inwoners strekte. Maar zowel uit het betoog van de advocaat als de overeenkomst uit 1593 komt naar voren dat de graaf bijzondere rechten had (verlenen van toestemming, deel van de opbrengst) op het moment dat de bestemming van de gemeentegrond wijzigde.

\subsection{Rechten op tienden}

Tiende is het zakelijk recht op een evenredig, meestal tiende, deel van de opbrengst van veldgewassen, aanwas van veestapel (krijtende tiende of bloedtiende), producten van

1928 RHCL, Rijkskamergerecht, inv. nr. 17, fol. 57-58.

1929 RHCL, Graafschap Gronsveld, inv. nr. 122. Het stuk is getekend door een zekere Joh. Heinr. Junglt.(?) S. D. et A. (?) 
dierlijke aard en zelfs delfstoffen, gegroeid of voortgebracht op de grond van een ander dan de tiendheffer. Het object van het tiendrecht kan van plaats tot plaats verschillen. Bij de veldvruchten worden meestal van granen tienden geheven (grove of grote tienden), maar ook op andere gewassen, zoals groenten, vlas of hooi kan tiendrecht van toepassing zijn (smalle tienden). Vaak ontstond verschil van mening over tiendplicht bij de introductie van nieuwe gewassen, zoals in de achttiende eeuw aardappelen en tabak.

Volgens de heersende leer is het tiendrecht van kerkelijke oorsprong en is de opbrengst van de tienden bestemd voor de bekostiging van het kerkgebouw, de inventaris en het levensonderhoud van de priester. $\mathrm{Al}$ vroeg is door leken inbreuk gemaakt op dit systeem en eigenden machtige heren zich tiendrechten toe. Maar ook principieel was het kerkelijk karakter van het tiendrecht niet onbetwist. Er is wel betoogd dat de landsheer, behoudens tegenbewijs, de algemene tiendheffer was en het tiendrecht daarmee dus van regale oorsprong. ${ }^{1930}$ In deze visie past ook de opvatting dat tienden van nieuw ontgonnen grond, de zogenoemde novaaltienden, toekwamen aan de landsheer omdat hem de woeste grond toebehoorde. ${ }^{1931}$

Tiendrechten in lekenhand konden ook ontstaan wanneer een heer een kerk stichtte op eigen grond en uit eigen middelen bekostigde. Weliswaar gold dit als een fundatie in kerkelijke zin, maar de stichter mocht als patroon de pastoor voordragen en hij had recht op de opbrengst van de tienden. Ten slotte werd het beeld van het wereldlijk karakter van tienden nog versterkt door het feit dat veel lekentiendheffers adellijke personen waren die het tiendrecht tot een vast bestanddeel maakten van hun heerlijkheid. Daarom worden tiendrechten, samen met bijvoorbeeld collatierechten, gerekend tot de 'aanhangsels' van heerlijkheden.

In veel plaatsen waren de tienden verdeeld tussen verschillende tiendheffers, die ieder voor hun aandeel ook de bijbehorende financiële verplichtingen op zich namen. Daarmee was ook de bouwlast voor het onderhoud van koor, schip of zijbeuken van de kerk gescheiden. Vaak waren de tiendheffers verplicht voor de dorpsgemeenschap een stier, hengst en beer beschikbaar te stellen. De achtergrond van deze regel was dat tiendheffers ook rechten konden hebben op de opbrengst van de veestapel. ${ }^{1932}$

Niet alleen het kerkgebouw moest worden gefinancierd, ook in het levensonderhoud van de pastoor diende te worden voorzien. ${ }^{1933}$ Naast bijdragen van parochianen, stipendia voor missen en zogenoemde 'stoolrechten' voor toediening van de sacramenten maakte hij aanspraak op een deel van de tienden, de zogenoemde 'congruë portie'. ${ }^{1934}$ Soms ontving hij een betaling van de tiendheffers, dan weer werd hem een eigen aandeel van de smalle

\footnotetext{
1930 De Blécourt/Fischer, Kort begrip, 218-220; zie ook Vera, ... dat men het goed van den ongeboornen niet mag verkoopen, 265-270.

1931 De Blécourt/Fischer, Kort begrip, 221.

1932 In Slenaken, waar het kapittel van Sint-Martens-Voeren tiendheffer was, moest het kapittel van oudsher één of twee stieren ter beschikking stellen. In 1771 ontstond daar een geschil over. Vgl. RHCL, Klooster Hoogcruts, inv. nr. 761.

1933 Van Rensch, 'Onderbetaalde pastoors'.

1934 'stipendium' bedrag dat wordt betaald voor het lezen van een H. Mis; 'stoolechten' (iura stolae) betalingen aan de priester voor doopsel, huwelijk en begrafenis.
} 
of grote tienden toegekend (met daaraan gekoppeld een deel van de bouwlast van de kerk).

De verschillende parochies binnen het graafschap Gronsveld hadden ieder hun eigen tiendheffer. De tienden in Heugem waren in het bezit van het kapittel van Onze-LieveVrouwe te Maastricht. Hetzelfde gold voor Honthem, dat ressorteerde onder de parochie Cadier, sinds 1266 een afsplitsing van Heugem. De tienden van Slenaken, oudtijds een onderdeel van parochie Sint-Martens-Voeren, werden geheven door het kapittel van SintMartens-Voeren. ${ }^{1935}$ De tiendplichtige landerijen van Gronsveld lagen verspreid over Gronsveld, Eckelrade, Rijkckholt en enkele aangrenzende stukken van Breust. Het ging dus in feite vrijwel geheel om de parochie Gronsveld, inclusief Rijkckholt en de hulpkerk van Eckelrade.

De oudst bekende gegevens over de Gronsveldse tiendrechten zijn hiervoor in Hoofdstuk 1.3 al vermeld. In 1233 schonk Theodericus de Houffalise tienden te 'Groele', die hij had gekocht van Henricus de Hemesbagh, aan de cisterciënzerinnenabdij van Val Bénoît bij Luik, welk bezit in 1277 nog eens bevestigd werd door de bisschop van Luik. Voorts was er nog de schenking van 1258 van tienden door Willem, heer van Stolberg en Gronsveld, en zijn echtgenote Lutgardis, aan de cisterciënzerinnen van Herkenrode. Deze gift werd betwist door hun zoon Renerus.

Bij elkaar zijn deze losse vermeldingen onvoldoende om een goed beeld te krijgen van de verdeling van de tiendrechten in de dertiende eeuw. Een hypothese kan zijn dat de tienden in het dorp Gronsveld oorspronkelijk aan heren van Gronsveld hebben toebehoord als stichters van de parochiekerk. Er zijn voldoende aanwijzingen om deze kerk te beschouwen als een eigen kerk, gesticht op het eigen domein. Wellicht moeten de tienden van Eckelrade en Rijckholt daarbij worden gezien als novale tienden van pas ontgonnen land. Maar tegelijkertijd dient te worden opgemerkt dat niets met zekerheid valt te zeggen over de rol van Henricus de Hemesbagh of de heren van Houffalise en dat ook het begrip novale tienden in Gronsveld niet voorkomt. Zelfs over de verdere geschiedenis van het tiendrecht van de zusters van Herkenrode is niets bekend. Mogelijk was Renerus van Gronsveld toch succesvol met zijn oppositie tegen de schenking door zijn ouders en wist hij deze gift ongedaan te maken.

Niet alleen de cisterciënzerinnen van Herkenrode zijn uit Gronsveld verdwenen, het zelfde geldt ook voor hun ordegenoten uit Val Bénoît. In 1379 verkochten deze religieuzen onder dwang hun tiendrechten in Gronsveld aan Johan III van Gronsveld. ${ }^{1936}$ $\mathrm{Zo}$ is waarschijnlijk aan het einde van de veertiende eeuw de verdeling van de tiendrechten

1935 De gedrukte 'Taxa' van de heerlijkheid Slenaken (TJ, inv. nr. M 55, fol. 244-245) vermeldt als tamelijk belangrijke bron van inkomsten ook 'novalien zehend'. Mogelijk berust dit op een vergissing of betreft het een pas laat geïntroduceerd recht van novaaltienden (tienden van nieuw ontgonnen grond). De rekeningen van het graafschap uit het begin van de zeventiende eeuw en de 'Specificatie' uit circa 1650 maken er geen melding van. Evenmin is er iets van terug te vinden in de aartsdiakonale visitatieverslagen (zie Simenon, Visitationes Hasbaniae II, 672).

1936 Schoolmeesters, 'Diplômes Val-Bénoît', 151-152, nr.XXII. 
ontstaan, zoals we die uit de navolgende eeuwen kennen. In de 'Specificatie' van het graafschap Gronsveld rond 1650 wordt de situatie als volgt beschreven:

Item competeert den voerss. huyse die hellicht van de cornthiende, wolthiende ende lammerthiende binnen Gronsfelt, Eckelrade ende Ryckelt, wesende eene parochie, dander hellicht competeert den heeren personaet [pastoor] tot Gronsfelt.

De andere helft van de pastorale tienden lag vooral onder Eckelrade en Rijckholt. Het waren ook meteen vrijwel diens enige inkomsten. Het aantal gestichte missen was klein en de parochianen betaalden niet voor huwelijken en begrafenissen. ${ }^{1937}$ Dat leverde wel praktische problemen op. Na het overlijden van pastoor Schmädel in juli 1754 benoemde graaf Maximilian Emanuel von Toerring-Jettenbach eind augustus Matthias Josephus Kolb uit Braunau tot diens opvolger. Cynisch schreef Prummer aan zijn broer Xaver Prummer dat men de gelukkige mocht feliciteren met zijn nieuwe functie, maar hij hoopte wel dat de man gefortuneerd was. Diens voornaamste bron van inkomsten, de helft van de tienden van Gronsveld, kwam immers pas beschikbaar op Sint-Jansdag (24 juni) van het volgende jaar. De tussenliggende periode moest hij maar zien te overbruggen met de opbrengst van zijn groentetuin en de offergaven bij begrafenissen. ${ }^{1938}$

In zijn rapport over de grafelijke inkomsten uit 1768 schrijft Prummer dat bij de veldgewassen in Gronsveld uitsluitend tienden van granen werden geheven. ${ }^{1939}$ Enkele jaren later kwam daar verandering in, toen de graaf het nieuwe cultuurgewas aardappelen met tienden wilde belasten. Tussen 1773 en 1778 werd daarover een proces met de inwoners van Gronsveld en Eckelrade gevoerd (zie uitvoerig daarover, ook in verband met de gemeente Hoofdstuk17.5) en in 1775 werd in die zin ook een grafelijke verordening uitgevaardigd (zie Bijlage 19).

Bij de schapen werd de woltiende betaald van de geschoren wol en deze moest door de tiendheffers zelf worden opgehaald. Voor de lammertiende gold de Goede Vrijdag van dat jaar als peildatum voor de vaststelling van het aantal tiendbare dieren. Strikt genomen ging het niet om heffing van een tiende, want er hoefde slechts van ieder elfde lam te worden betaald.

In ieder geval vanaf de zestiende eeuw werd de inning van tienden als regel voor een vast bedrag aan derden verpacht. Dit algemeen gebruikelijke systeem bevrijdde de tiendheffer van werk, maar betekende allerminst een garantie voor een vast inkomen, aangezien bij misoogsten of andere vormen van overmacht vaak een beroep werd gedaan op kwijtschelding van een deel van de pachtsom. Merkwaardig is dat volgens de rekeningen uit het begin van de zeventiende eeuw de annemers van de tienden in Gronsveld en Eckelrade boven de pachtprijs nog een toeslag van vijf pond suiker moesten betalen.

1937 Zie Simenon, Visitationes Hasbaniae I, 275-278.

1938 TJ, inv. nr. M 14, fol. 1195-1198, Prummer aan broer Xaver, 6 september 1754.

1939 TJ, inv. nr. M 73, fol. 526-527. 
In de rekening van 1621/1622 maken de graantienden van Gronsveld en Eckelrade ongeveer acht procent van het totaal aan inkomsten uit, in de rekening van 1623/1624 bedraagt dit percentage 6,5 procent. Het ging dus om substantiële bedragen. Daarbij moet worden aangetekend dat voor beide jaren de tienden onder Rijckholt betwist werden en niets opleverden. In vergelijking met voornoemde bedragen was de waarde van wol- en lammertiende marginaal. Begin zeventiende eeuw bedroeg die ongeveer een half procent van de inkomsten.

In het midden van de zeventiende eeuw waren volgens Prummer de tienden in Gronsveld voor vijftienduizend gulden, ver onder de werkelijke waarde, 'absolute verkaufft' aan particulieren. Daarom adviseerde hij in 1765 de graaf deze tienden terug te kopen, zodra zich daartoe de gelegenheid voordeed. Maar het 'absolute' karakter van die verkoop is hoogst onduidelijk. Want tegelijkertijd vermeldt Prummer uit de tienden voor de periodes 1734-1745 en 1756-1767 wisselende opbrengsten per jaar, die respectievelijk 8,7 procent en 11,8 procent van het inkomen uitmaken. Zonder nader onderzoek, dat buiten deze studie valt, is dit verschil vooralsnog niet te verklaren.

\subsection{Recht van patronaat op kerken en collatie van (geestelijke) beneficies}

\subsubsection{Patronaats- en collatierechten in het algemeen}

Patronaats- en collatierechten steunden op de gedachte dat degene die goederen (meestal grond) ter beschikking stelde/schonk voor de bouw van een kerk of het lezen van missen, ook daarna nog als 'patroon' zeggenschap behield over het gebouw of als collator de geestelijke mocht voordragen die de kerkelijke diensten vervulde. Deze zogenoemde 'eigenkerken' pasten goed binnen een algemeen systeem, waarbij wereldlijke personen geestelijke ambtsdragers benoemden, die tegelijk met wereldlijke taken werden belast. Op het hoogste niveau zetten vanaf de tiende eeuw de keizers bisschoppen in als feodale vorsten om delen van het Rijk te besturen. De keizers verleenden daarbij de 'investituur' van zowel de wereldlijke als de geestelijke macht.

Strikt genomen hebben patronaats- en collatierechten een privaatrechtelijke oorsprong, aangezien ze voortvloeien uit het eigendomsrecht op bepaalde goederen. In de literatuur worden ze daarom meestal niet gezien als heerlijke rechten berustend op een vorm van overheidsgezag. In de praktijk valt die grens echter veel minder te trekken. De bezitters van collatie- en patronaatsrechten waren vaak edelen en in opsommingen van 'echte' heerlijke rechten worden collatierechten dikwijls in één adem daarmee genoemd. ${ }^{1940}$ Daar komt bij dat deze rechten, zoals we hierna nog zien, vanaf het einde van de middeleeuwen ook een opstap vormden voor een ruimere uitoefening van overheidsgezag over de kerk.

De 'kerk in handen van leken' heeft ook altijd tegenbewegingen opgeroepen, zoals in de elfde eeuw de Investituurstrijd tussen paus en keizer. In de kern draaide het daarbij om de

1940 De opvatting dat collatie- en patronaatsrechten geen heerlijke rechten zijn, wordt ook krachtig ondersteund door De Blécourt/Fischer, Kort Begrip, 234, die echter tegelijkertijd erkent dat deze rechten vaak werden gecombineerd met heerlijke rechten en dat die combinatie ook als één geheel in leen werd uitgegeven. 
vraag of een geestelijke een kerkelijk ambt gratis of tegen betaling (de zogenoemde simonie) mocht aannemen uit handen van een leek. Kort geformuleerd eindigde dit complexe geschil op het hoogste niveau bij het Concordaat van Worms in 1122 voor het Duitse Rijk aldus, dat de keizer of koning het recht had overheidsgezag ('temporalia' en 'regalia') aan een beoogd geestelijke vorst te verlenen, terwijl de kerkelijke investituur of institutie voor de geestelijke zijde van het ambt bleef voorbehouden aan de paus.

Het beginsel van scheiding tussen geestelijke en wereldlijke macht werd op lager niveau in de twaalfde eeuw verder uitgewerkt ten aanzien van de eigenkerken en juridisch afgesloten door het Vierde Lateraans Concilie (1215). In hoofdlijn kwam het er op neer dat iedere parochiekerk moest beschikken over een 'dos', vaste goederen en inkomsten voor het onderhoud van de kerk en de bekostiging van de eredienst evenals het levensonderhoud van de pastoor. Deze dos werd door een collator of patronus beschikbaar gesteld. Binnen deze dos bestond een scheiding tussen een beneficium voor het levensonderhoud van de priester die met de zielzorg van de parochie was belast en de fabrica, het vermogen bestemd voor onderhoud van het gebouw en de eredienst.

Toegepast op een parochiekerk, had de patroon of collator het recht kandidaten voor het beneficie met het daaraan verbonden ambt van zielzorger (kortweg: de pastoor) te presenteren. De zakelijke inhoud van het beneficie voor de pastoor kon sterk variëren. Het kon gaan om inkomsten uit landerijen, maar soms, zoals in Gronsveld, werd het levensonderhoud gefinancierd uit een deel van de tienden. De basisverplichtingen verbonden aan het beneficie van een parochiegeestelijke ten plattelande bleven overigens meestal beperkt tot de verzorging van de kerkelijke diensten op zondag en de toediening van de sacramenten.

Naast het beneficie voor de pastoor bestonden in veel kerken nog andere beneficies in de vorm van een zelfstandig vermogen waarvoor een priester één of meer missen per week moest lezen. Aan deze verplichting, officium genoemd, was meestal geen zielzorg verbonden. De begrippen beneficie en officie liepen daarom in de praktijk wel eens door elkaar, ook omdat er vormen van officia bestonden die niet als echt kerkelijk beneficie waren erkend. Een echt beneficie diende namelijk ook als titel, als vaste bron van inkomsten, waarover iemand moest beschikken om tot priester te kunnen worden gewijd. Ook hierop was het eerder genoemde systeem van collatie van toepassing. De stichter of diens rechtsopvolger had als patronus het recht kandidaten voor het bezit daarvan met het bijbehorend geestelijk ambt te presenteren bij de bevoegde kerkelijke gezagsdrager (bisschop of aartsdiaken), die vervolgens de institutio, de feitelijke inbezitstelling, verleende.

Een bijzondere positie nam de koster of matricularius in. Deze was belast met het directe beheer van liturgisch vaatwerk en paramenten, moest verschillende keren per dag de klokken luiden, hield het gebouw schoon en zorgde voor zang en orgelspel. Soms hield de koster ook school voor de dorpsjeugd. De financiering van zijn arbeid gebeurde meestal uit verschillende bronnen. In veel plaatsen bestond een met een kerkelijk beneficie vergelijkbare stichting met vaste inkomsten uit landerijen of grondrenten. Daarnaast waren er incidentele bijdragen en offergaven van de parochianen, zoals betalingen voor gezongen missen, betalingen bij huwelijks- en begrafenismissen, kaarsengeld en afdrachten in natura 
zoals eieren, graanschoven of broden die de gelovigen rond bepaalde feestdagen in het jaar leverden.

Het kosterschap was dus een functie ten dienste van de gemeenschap en om die reden hadden in veel plaatsen de inwoners ook invloed op zijn benoeming en controle op zijn werkzaamheden. Tegelijkertijd was het een lekenbeneficie waarvoor de patronus van de kerk geen kerkelijke institutie hoefde te vragen, maar waar hij wel zeggenschap over wenste. De benoeming van de koster bleek daarom in de praktijk wel eens een twistappel tussen patronus en parochie.

$\mathrm{Na}$ de middeleeuwen werd de koster soms 'opgewaardeerd' naar 'geestelijk koster'. De reden daarvoor was dat de koster meer werd betrokken bij de liturgie en belangrijker werd voor orgelspel en kerkzang. Soms werden ook geestelijken tot koster benoemd, die hun inkomsten uit het kosterschap combineerden met het bezit van een klein kerkelijk beneficie. Ook wat betreft de mogelijke onderwijstaken van een koster kon dit voordelen opleveren, aangezien geestelijken meestal beter ontwikkeld waren dan leken. Het handwerk, zoals het schoonhouden van het gebouw, werd dan uitbesteed. In tegenstelling tot het lekenkosterschap berustte het geestelijk kosterschap vaak wel op een kerkelijk beneficie en moest hiervoor ook kerkelijke institutie worden gevraagd.

Naar algemeen kerkelijk recht kwam de institutio toe aan de paus of de bisschop. Afgezien van bepaalde pauselijke 'reservaties' berustte in het bisdom Luik die bevoegdheid echter bij de aartsdiaken of de landdeken. Laatstgenoemde bezat het institutierecht voor de kerken in de laagste rang, de zogenoemde 'kwart kapellen'. De kerk van Holset, waarvoor de graaf van Gronsveld ook collatierecht had, vormt een voorbeeld van die laatste categorie. Deze van de normale kerkelijke bevoegdheden afwijkende rechten van aartsdiakens en landdekens zorgden soms voor verwarring bij buitenstaanders. Zo werden in de achttiende eeuw collatiebrieven voor Gronsveld, die in de grafelijke kanselarij te München waren opgesteld, herhaaldelijk fout geadresseerd aan de bisschop, terwijl de aartsdiaken was bedoeld. Dat lag in Luik erg gevoelig, want Prummer schrijft dat het in een dergelijk geval vanwege de onderlinge na-ijver bij de Luikse kerkelijke autoriteiten veel moeite kostte de plooien weer glad te strijken.

Naast het beneficium voor de pastoor bestond de dos voor de parochiekerk ook nog uit de fabrica of kerkfabriek, het vermogen voor onderhoud van het gebouw, inventaris en eredienst. Het beheer daarvan was opgedragen aan één of meer kerkmeesters of provisoren. De inkomsten van de fabriek bestonden in hoofdzaak uit de opbrengst van landerijen, collectes en betalingen voor kerkelijke diensten, schenkingen door weldoeners en, tegen het einde van de middeleeuwen, een toenemend aantal stichtingen van missen voor het zielenheil van overledenen. Daarnaast werd nog gezocht naar meer incidentele inkomsten, bijvoorbeeld uit de verkoop van gemeentegrond, betaling voor aflaten, et cetera.

In Hoofdstuk 7.4.1 werd beschreven hoe het landsheerlijk gezag over de kerk en kerkelijke instellingen zich in de vroegmoderne tijd ontwikkelde, vooral op het terrein van wetgeving en rechtspraak. Het gezegde 'De hertog van Kleef is paus in eigen land' ('dux Cliviae est 
papa in terris suis') vond brede ingang, gaf landsheren het recht van 'hervorming' ('ius reformandi) en legitimeerde ook het toezicht op de temporalia van de kerk, de goederen die door gelovigen voor religieuze doelen waren bestemd. De oude patronaats- en collatierechten kregen daarmee een dimensie die verder reikte dan alleen de bevoegdheid iemand voor te dragen. Ze vormden een opstap voor daadwerkelijk toezicht op het beheer van goederen en daarmee ook het bedrijven van kerkpolitiek.

Dit soort opvattingen was ook de heren van Gronsveld niet onbekend. Bij de behandeling van het thema 'wetgeving' (Hoofdstuk 7.4.1) zagen we hoe zij probeerden enerzijds de kerkelijke discipline te bevorderen, maar anderzijds ook argwanend stonden ten opzichte van mogelijke inbreuken op hun jurisdictie, in het bijzonder door kerkelijke autoriteiten in Luik. Collatierechten boden daarbij mogelijkheden gezag en invloed uit te oefenen. De graaf van Gronsveld bezat daarvan een aantal, zoals het pastoraat van Gronsveld, Slenaken, Holset en - betwist - Heugem. Verder mocht hij de geestelijken benoemen voor de beneficies van Sint-Amandus in Gronsveld, Onze-Lieve-Vrouw in Eckelrade en een kanonikaat in Sint-Martens-Voeren en de kosters in Gronsveld en - betwist in Heugem.

Het ging niet alleen om benoemingen, maar ook om toezicht op het financiële en materiële beheer van gebouwen en goederen en een efficiënte organisatie van de zielzorg en armenzorg. Natuurlijk waren de kleinschalige verhoudingen binnen Gronsveld niet vergelijkbaar met die in de grote nationale staten. Bovendien speelden ook persoonlijke verhoudingen een grote rol. Lastige pastoors konden voor langdurige conflicten zorgen. Een man als Prummer, in het midden van de achttiende eeuw, had duidelijk antiklerikale opvattingen, in het bijzonder gericht tegen kloosters en kapittels, en maakte daar geen geheim van. Maar tegelijkertijd borrelden bij onenigheid vaak sentimenten en opvattingen op, die principiële verschillen van inzicht over competenties tussen kerk en staat blootlegden. Een voorbeeld daarvan levert het recht van de bisschop of (zoals in het Luikse) de aartsdiaken om parochies en parochiekerken te visiteren en eventuele aanwijzingen aan de patronus te geven.

In het navolgende overzicht wordt getracht aan de hand van een aantal casus duidelijk te maken hoe de wisselwerking van landsheerlijk gezag en kerkelijke autoriteiten functioneerde bij benoemingen en het toezicht op het beheer van goederen. Daarbij konden de belangen van vier partijen zijn betrokken, kerkelijke autoriteiten bij het bisdom, de landsheer, de geestelijken zelf en ten slotte ook de parochianen. Specifiek voor het graafschap Gronsveld lijken de graven Toerring-Jettenbach en hun ambtenaren het collatie- en patronaatsrecht bewust te hebben ingezet als een instrument om gezag over de plaatselijke kerk te verkrijgen.

De bisschop van Luik vormde in theorie in de kerkelijke hiërarchie de tegenspeler van de graaf, maar feitelijk berustte de geestelijke macht hoofdzakelijk bij de aartsdiaken van Haspengouw, die tal van bevoegdheden uitoefende welke naar algemeen canoniek recht aan een bisschop toekomen. De aartsdiakens in het bisdom Luik hadden hun machtspositie al in 1288 erkend gekregen. In de navolgende eeuwen stonden zij zo sterk, dat zij aan het einde van de zestiende eeuw met succes weerstand konden bieden aan de Trentse conciliedecreten die hun rechten moesten inperken. De aartsdiakens hadden 
wetgevende, bestuurlijke en rechterlijke bevoegdheden. Hun gezag strekte zich in principe uit over alle inwoners en kerkelijke instellingen binnen hun gebied, met uitzondering van kapittels en zogenoemde exempte (aan bisschoppelijk gezag onttrokken) kloosters. De rechterlijke bevoegdheden kwamen al ter sprake bij de behandeling van de onderwerpen 'wetgeving'(zie Hoofdstuk 7.4.1 en Bijlage 12) en 'gemeyn quest' (zie Hoofdstuk 9.6). De aartsdiakens konden eigen statuten voor hun gebied uitvaardigen, verleenden de canonieke institutie (werkelijke inbezitstelling) aan kandidaten voor een kerkelijk beneficie en inspecteerden of visiteerden de kerken in hun gebied.

Ieder aartsdiakonaat was verdeeld in een aantal landdekenaten, met aan het hoofd een landdeken, die werd gekozen door alle pastoors van het district. Gronsveld behoorde tot het landdekenaat Maastricht, dat zich met ongeveer het riviertje de Geul als noordgrens, uitstrekte van enkele kilometers ten oosten van Tongeren tot achter Aken en tot in het Land van Herve. De landdeken oefende het recht van institutie en visitatie uit bij de zogenoemde kwart kerken, oorspronkelijk arme kerken die in tegenstelling tot de hele of halve kerken slechts voor een kwart bijdroegen in bepaalde kerkelijke belastingen.

\subsubsection{Patronaats- en collatierechten in Gronsveld en Eckelrade} Pastoraat in Gronsveld en Eckelrade: benoemingen en ervaringen

Gronsveld, Eckelrade en Rijkckholt vormden van oudsher samen één parochie met de kerk van Eckelrade als hulpkapel. De heren van Gronsveld bezaten sinds mensenheugenis het patronaatsrecht van de kerk van Gronsveld en het daaruit voortvloeiende collatierecht van de pastoor. Het beneficie, waar de pastoor zijn levensonderhoud uit bekostigde, bestond uit de helft van de tienden van Gronsveld, Eckelrade en Rijkckholt, de pacht van twaalf tot dertien bunder land en een aantal graanrenten. ${ }^{1941}$ De tienden werden ééns per jaar, met Sint-Jan (24 juni), uitbetaald. Andere inkomsten van de pastoor uit de zielzorg waren verwaarloosbaar. In 1624 wordt gezegd dat de parochianen voor huwelijken aan de pastoor en koster slechts een klein handgeld betaalden. In 1765 schrijft Prummer dat de pastoor de zielzorg gratis verrichtte, met uitzondering van vreemdelingen die in Gronsveld trouwden. Verder moest ook worden betaald voor het eerste kind dat in het nieuwe jaar werd gedoopt. ${ }^{1942}$

Tegenover inkomsten stonden ook verplichtingen. De belangrijkste taak was de zielzorg, maar dat was geen volle dagbesteding. In 1699 telde Gronsveld 49 huizen, Eckelrade 26 en Rijkckholt 14, met in totaal driehonderd communicanten. Omstreeks 1765 waren er 470 communicanten. ${ }^{1943}$ Volgens de zeventiende-eeuwse aartsdiakonale visitatieverslagen las de pastoor van Gronsveld geen jaargetijden of bijzondere missen, zodat mag worden aangenomen dat zijn voornaamste bezigheden beperkt bleven tot de viering van de $\mathrm{H}$. Mis op zon- en feestdagen en de toediening van de sacramenten. Naast de zondagse mis moest de pastoor op eigen kosten een mis laten lezen in Eckelrade.

Alles bij elkaar vormde het pastoraat van Gronsveld een mooi bezit met een overzienbare hoeveelheid werkzaamheden. Maar als tiendheffer diende de pastoor ook op te komen

1941 Simenon, Visitationes Hasbaniae I, 275

1942 TJ, inv. nr. M 53, fol. 538-550, Prummer aan M.E. von Toerring-Jettenbach 18 mei 1765.

1943 TJ, inv. nr. M 53, fol. 472, formulier voor visitatieverslag circa 1765. 
voor een deel van de bouwlast van de kerk, in het bijzonder het priesterkoor. De toren was voor de gemeente. ${ }^{1944}$ Deze verdeling van bouwkosten vormde een bron van onenigheid. Al aan de orde kwam (zie Hoofdstuk 4.3.4) het proces dat de parochianen in 1701 tegen pastoor Goffin voerden over de verdeling van kosten. ${ }^{1945}$ Met dezelfde pastoor was in 1714 een geschil over de betaling van een nieuwe kerkklok. De oude klok was gebroken (mogelijk was dit de klok die in 1623 op kosten van de graaf was gegoten door Frans van Trier ${ }^{1946}$ ) en nu had graaf Johan Frans van Bronckhorst Batenburg voorgesteld een nieuwe, zwaardere, zogenoemde banklok te laten gieten. Vervolgens rees de vraag op wiens kosten dat moest gebeuren, want het maakte kerkrechtelijk en volgens de statuten van het aartsdiakonaat Haspengouw verschil uit of het ging om een eerste, nieuwe klok (dan betaalde de kerkfabriek), een reparatie (dan betaalde de gemeente) of een vervanging (dan betaalde de pastoor daarvan één zesde deel, met eventuele aanvulling door zijn mede-tiendheffer). De zaak liep zo hoog op dat het dossier voor advies werd voorgelegd aan deskundigen in het kerkelijk recht van de universiteiten van Leuven en Keulen. Die oordeelden dat in dit geval de pastoor als tiendheffer gehouden was zijn aandeel in een banklok te betalen, maar voor de rest moesten de graaf en de gemeente over de brug komen. Hoe het geschil is opgelost, is niet bekend, maar omstreeks 1765 hingen er in ieder geval twee klokken, een grote banklok van de tiendheffers en een kleine van de gemeente. ${ }^{1947}$

Een ander, tientallen jaren durend, probleem vormde het ontbreken van passende huisvesting voor de pastoor. Volgens de statuten van het aartsdiakonaat Haspengouw kwam die ten laste van de parochie, maar in de visitatieverslagen van de aartsdiakens in de eerste helft van de zeventiende eeuw valt te lezen dat de pastoor woonde in een 'absurd' bouwseltje in de kerk bij de ingang, met onder een keukentje en voorraadkast en boven een slaapkamer. Kolen en takkenbossen voor de verwarming lagen opgeslagen in de kerk. $\mathrm{Na}$ de herbouw van de kerk begin achttiende eeuw woonden de pastoors niet meer in de kerk, maar hadden zij een provisorisch onderkomen in een huis op een stukje grond bij de kerk, welk perceel in erfpacht aan de graaf toebehoorde. Bij visitaties werd de inwoners steeds voorgehouden dat zij verplicht waren een huis met stallen en schuren te bouwen, maar er gebeurde niets. Wel had graaf Johan Frans van Bronckhorst Batenburg voor dat doel duizend gulden geschonken, maar dat was volgens de pastoors zelfs onvoldoende om een koster fatsoenlijk te kunnen huisvesten. Tijdens een vergadering in 1721 verklaarden de parochianen nog eens 'eenpaarlijk' dat zij niet plan waren een woning voor de pastoor te bouwen, tenzij men hen van een verplichting daartoe kon overtuigen. ${ }^{1948}$

Graaf d'Arberg Valengin verkocht toen het perceel waarop de tijdelijke huisvesting stond aan pastoor Van der Meeren. Die zag daarmee kans op eigen kosten een bescheiden huis te bouwen. Hij verkocht het daarna aan zijn opvolger Schmädel voor drieduizend gulden. Die liet er ook nog eens voor duizend gulden aan vertimmeren, maar nam intussen wel

1944 TJ, inv. nr. M 53, fol. 472, formulier voor visitatieverslag circa 1765.

1945 RHCL, Kerkelijke rechtbanken en bisschoppelijke commissarissen te Maastricht 1498-1842, inv. nr. 93 en TJ, inv. nr. M 40, 843-846.

1946 RHCL, Graafschap Gronsveld, inv. nr. 93.

1947 TJ, inv. nr. M 53, fol. 472, formulier voor visitatieverslag circa 1765

1948 RHCL, Graafschap Gronsveld, inv. nr. 121. 
3500 gulden hypotheek op. Op zich was het pand geschikt als pastorie, maar het viel, gelet op de voorgaande ruzies, niet te verwachten dat de parochie er veel geld in wilde steken. Prummer dacht later dat men misschien hooguit duizend gulden wilde betalen wanneer de pastoor de rest financierde. ${ }^{1949}$

De graaf kon in beginsel zijn collatierecht naar goeddunken uitoefenen, maar moest wel rekening houden met de zogenoemde 'pauselijke maanden'. In gevolge het Concordaat van Wenen van 1448 (zie Hoofdstuk 7.4.1) had de paus het recht te voorzien in de bezetting van lagere beneficies (pastoraat, vicarieën) die gedurende het jaar in oneven maanden openvielen. Dat recht was ook in Gronsveld bekend, zoals blijkt uit het concept van een presentatie die Agnes van Bylandt, vrouwe van Gronsveld, bij de aartsdiaken van Haspengouw deed voor de benoeming van een pastoor in Gronsveld als opvolger van Nicolaas Buisch. Daarin geeft Agnes uitdrukkelijk aan dat het pastoraat vacant was geraakt 'extra Romanam curiam', dat wil zeggen buiten de aanspraken van de Romeinse curie om. ${ }^{1950}$

Over de zielzorgers uit zestiende en zeventiende eeuw is niet veel bekend, maar duidelijk is wel dat het niet altijd de meest geschikte kandidaten waren. Pastoor Christiaan Lamberts, een zoon van drossaard Lamberts, makkte zich schuldig aan schandaleus leven op zedelijk gebied en ernstige geweldpleging en werd daarvoor in de jaren 1666 en 1670 gerechtelijk vervolgd. ${ }^{1951}$ Pastoor Goffin daarentegen was misschien wel een geleerd en godvruchtig man, maar parochianen klaagden dat hun Waalse zielenherder nauwelijks Nederlands sprak en te weinig preekte. ${ }^{1952}$ Over de Maastrichtenaar Henricus van der Meeren (17241747) oordeelde Prummer later dat over diens ijver voor de parochie niet veel lofwaardigs viel te vermelden. ${ }^{1953}$ De volgende pastoor, 'Hofrath' Josephus Antonius Schmädel, was een gunsteling uit de grafelijke hofhouding in München. ${ }^{1954}$ Met deze benoeming beoogde de graaf twee vliegen in één klap te slaan: de betrokkene kon de zielzorg combineren met bestuurstaken. Beide werkzaamheden liepen uit op een fiasco. De man beheerste onvoldoende de taal, was ziekelijk, werkte chaotisch en werd verteerd door heimwee. Zijn overlijden in 1754 'uit chagrijn' kwam dan ook niet helemaal onverwacht.

$\mathrm{Na}$ het overlijden van Schmädel pleitte Prummer bij de graaf voor een goede opvolger. Hij begon zijn adviezen met een reeks waarschuwingen. Liever geen inwoner van het graafschap zelf of iemand uit de buurt en zeker geen Maastrichtenaren, want die

1949 TJ, inv. nr. M 14, fol. 873-879, Prummer aan M.E. von Toerring-Jettenbach 5 september 1754.

1950 RHCL, Familie De Geloes/Kasteel Eijsden, inv. nr. 430. Het stuk draagt het jaartal '1590' maar er is aan geknoeid. Theoretisch zou het jaartal juist kunnen zijn, maar waarschijnlijk is het document ontstaan tussen 1563 en 1586, toen Agnes van Bylandt als regentes-voogdes het bewind over Gronsveld voerde. Het stuk is geadresseerd aan de aartsdiaken, getekend en bezegeld, maar de naam.van een kandidaat ontbreekt. Daarom is het waarschijnlijk een concept, waarbij de naam later moest worden ingevuld.

1951 TJ, inv. nr. M 10, fol. 23-25, fol. 31-34; RHCL, Graafschap Gronsveld, inv. nr. 237, 238.

1952 RHCL, Schepenbank Rijckholt, inv. nr. 121 en verder TJ, inv. nr. M 40, fol. 859-863, pastoor Goffin aan J.F. van Bronckhorst Batenburg 1 januari 1713.

1953 TJ, inv. nr. M 53, fol. 538-550, Prummer aan M.E. von Toerring-Jettenbach 18 mei 1765.

1954 Concept van de presentatie van Schmädel als pastoor door de graaf 23 juli 1747, in TJ, inv. nr. M. 8, fol. $225-230$. 
verdroegen zich slecht met die van Gronsveld. Van vreemdelingen werd wel aanpassingsvermogen gevraagd. Anders kon het iemand vergaan als Schmädel. Enige talenkennis kon zijn nut bewijzen, omdat nogal wat zaken in het Frans werden afgehandeld. Voor de rest vormde de taal geen beletsel een Beier in Gronsveld als pastoor te benoemen. Ook de hoogste bestuursambtenaar in Gronsveld was ten slotte een Duitser. Wel was het voor een pastoor aan te raden voor tien gulden per maand de kapelaan in dienst te houden, want voor iemand die de taal niet kende was het moeilijk biecht te horen, te preken of zieken te zalven. ${ }^{1955}$

Het pastoraat van Gronsveld genoot op zich aanzien en was met een jaarlijkse opbrengst tussen de 1200 en 1500 gulden Rijnlands (tussen 2400 en 3000 gulden Maastrichts) goed betaald. Veel inkomsten uit het lezen van missen vielen in Gronsveld niet te verwachten, want de mensen trokken bij voorkeur naar plaatsen waar dat het goedkoopste kon. Een financieel genie hoefde de pastoor niet te zijn, maar enig zakelijk inzicht was gewenst, na de wanorde van zijn voorgangers. Omdat de tiende pas met Sint Jan (24 juni) in één keer werd uitgekeerd, kon een financiële overbrugging gedurende een kortere of langere periode noodzakelijk zijn. Verder leefde de pastoor van de opbrengst van zijn tuin. ${ }^{1956}$ De Gronsveldse eetcultuur sloeg Prummer niet hoog aan. Een pastoor moest zelf beschikken over kookkunst of een kokkin meebrengen, ander bestond het menu uit stokvis, wortelen en aardappelen in een variatie van boter of mosterd. ${ }^{1957}$

Ook enige diplomatieke talenten waren voor een pastoor gewenst, want in de omliggende plaatsen waren religieus andersdenkenden aan de macht. De parochianen van Gronsveld zelf werden omschreven als brave lammeren: al werd een heel jaar niet gepreekt of mis gedaan, dan nog hielden ze vast aan hun geloof. ${ }^{1958}$ (Dat laatste was misschien wel waar, maar lammeren waren het zeker niet).

Dan bestond er nog altijd het probleem van de huisvesting. De pastorie had de vorige pastoor in eigendom toebehoord en de parochianen waren nauwelijks bereid bij te dragen voor een woning.

Prummer zag dus niet ten onrechte allerlei bezwaren, want de door hem geschetste problemen zouden vrijwel onmiddellijk tot wrijvingen met de nieuwe pastoor leiden. Graaf Maximilian Emanuel presenteerde begin september 1754 Matthias Josephus Kolb uit Braunau, licentiaat in de theologie, bij de aartsdiaken van Haspengouw als nieuwe pastoor van Gronsveld. ${ }^{1959}$ Vanaf het moment van diens aankomst in Gronsveld in de herfst van dat jaar boterde het niet tussen de pastoor en de toch al antiklerikale Prummer. Het waren onverenigbare karakters, maar de heren waren ook aan elkaar gewaagd wat betreft eigenzinnigheid en temperament. Beiden probeerden de graaf voor hun standpunten te winnen, maar Kolb meende nog een extra ijzer in het vuur te hebben met de steun van de Luikse kerkelijke autoriteiten. Prummer op zijn beurt zag in die Luikse

1955 TJ, inv. nr. M 14, fol. 1195-1198, Prummer aan broer X. Prummer 6 september 1754.

1956 TJ, inv. nr. M 14, fol. 1195-1198, Prummer aan broer X. Prummer 6 september 1754.

1957 TJ, inv. nr. M 14, fol. 31-34, Prummer aan broer X. Prummer 15 augustus 1754.

1958 TJ, inv. nr. M 14, fol. 969-972, Prummer aan M.E. von Toerring-Jettenbach 12 juli 1754.

${ }^{1959}$ Concept van de presentatie van Kolb als pastoor door de graaf 28 augustus 1754, in TJ, inv. nr. M 8, fol. 223-224. 
inmenging juist een bedreiging voor de landsheerlijke rechten van de graaf. Hij beschouwde de door de graaf benoemde pastoor als een ondergeschikte van de graaf en dus ook van hem, Prummer, als diens vertegenwoordiger.

Het meeste heikele punt bleek de pastorie. Prummer weerde zich heftig tegen het idee dat de graaf als patronaatsheer of tiendheffer daar op enigerlei wijze in zou moeten voorzien. ${ }^{1960}$ Toen Kolb zich eind november 1754 bij de aartsdiaken in Luik aandiende voor het pastoorsexamen en de bevestiging van zijn ambt, vertelde hij over zijn huisvestingsprobleem. De heren bedachten in een onderonsje al een oplossing. De aartsdiaken of diens vervanger zou naar Gronsveld komen voor een kerkvisitatie en wanneer dan bleek dat er geen pastorie was, kregen de parochianen opdracht er onmiddellijk een te bouwen. 1961 Volgens hun verwachting zou Prummer dat zeker steunen. Maar die dacht daar heel anders over. Volgens hem probeerde de Luikse hoge geestelijkheid op alle mogelijke manieren haar gezag te verstevigen door zich te bemoeien met alles wat maar enigszins geestelijk kon zijn, waarbij de wereldlijke macht de helpende hand moest reiken. Tot dan toe was de aartsdiaken zoveel mogelijk buiten het graafschap gehouden en had men zelfs geen kerkelijke visitatie toegestaan zonder landsheerlijke toestemming of placet. Ook jurisdictie over onderdanen was verhinderd, met uitzondering van zuiver geestelijke zaken. Ten tijde van pastoor Schmädel was dat wel geprobeerd, maar hiertegen had de drossaard geprotesteerd. ${ }^{1962}$

Prummer waarschuwde Kolb dan ook zich niet in te laten met zaken waar hij geen verstand van had. Deze wimpelde af met de opmerking dat het ging om privileges van de geestelijkheid en dat de aartsdiaken wel degelijk bevoegd was. Prummer liet hem weten dat hij een inbreuk op de landsheerlijke rechten niet toestond, waarna Kolb enigszins inbond. Maar niet voor lang. Bij de openbare verkoop van de inboedel van de overleden pastoor Schmädel gedroeg Kolb zich onuitstaanbaar omdat hij niet kon verdragen dat iemand meer bood dan hij. Verder deed Kolb zich graag voor als een 'grand seigneur', maar leefde hij op andermans kosten. ${ }^{1963}$ Helemaal het toppunt voor Prummer was een plan van de pastoor om op een stukje gemeentegrond vóór het huis van Schmädel op gemeentekosten een nieuwe pastorie te bouwen. Wanneer het pand van de Erven Schmädel dan weinig licht meer kreeg, zou het anderen wel de lust ontnemen er nog op te bieden. ${ }^{1964}$

Kolb van zijn kant klaagde ook bij vrienden en bekenden. Hij zat op zwart zaad (zoals voorspeld) door aankoop van een deel van de inboedel van Schmädel, de kosten van de kerkelijke institutie in Luik en het kostgeld dat hij aan rentmeester Lebens betaalde. ${ }^{1965}$ Bitter liet hij zich uit over zijn botsingen met Prummer, maar hij was niet van plan zich

1960 TJ, inv. nr. M 14, fol. 873-879, Prummer aan M.E. von Toerring-Jettenbach september 1754; M 14, fol. 881-884, Prummer aan M.E. von Toerring-Jettenbach 12 oktober 1754; M 14 fol. 885-901, diverse brieven van Prummer aan M.E. von Toerring-Jettenbach over pastorie, herfst 1754; M 14, fol. 1191-1193, Prummer aan X. Prummer 11 september 1754.

1961 TJ, inv. nr. M 14, fol. 91-97, Prummer aan M.E. von Toerring-Jettenbach 12 december 1754.

1962 TJ, inv. nr. M 14, fol. 91-97, Prummer aan M.E. von Toerring-Jettenbach 12 december 1754.

1963 TJ, inv. nr. M 14, fol. 437-440, Prummer aan broer X. Prummer 24 december 1754.

1964 TJ, inv. nr. M 14, fol. 91-97, Prummer aan M.E. von Toerring-Jettenbach 12 december 1754.

1965 TJ, inv. nr. M 14, fol. 809-812 Kolb aan M.E. von Toerring-Jettenbach 23 december 1754. 
door hem als een lam naar de slachtbank te laten leiden ${ }^{1966}$ Dat beloofde niet veel goeds, terwijl Kolb nog niet eens officieel was begonnen, want pas in juni 1755 nam hij daadwerkelijk bezit van het pastoraat.

Begin 1755 probeerde baron de Goeswin, stadhouder van het grafelijk leenhof, nog met matig succes tussen Kolb en Prummer te bemiddelen. Kolb beklaagde zich bij de graaf dat de man die zijn beschermer moest zijn, zich ontwikkelde tot zijn vervolger. ${ }^{1967}$ De jaarwisseling 1755/1756 bood Kolb een mooie gelegenheid nog eens flink bij de graaf te klagen over zijn belager. ${ }^{1968} \mathrm{Na}$ een algemene sneer richting Prummer en de familie Lebens die voortdurend plannen bedachten om de pastoor het leven zuur te maken, volgde een lijst met grote en kleine ongenoegens, variërend van ruzie over de verkoop van de notenoogst waar de pastoor recht op meende te hebben omdat ze afkomstig waren van bomen op de begraafplaats voor ongedoopte kinderen tot en met de benoeming van kerkmeesters. ${ }^{1969}$ Onhandig van Kolb was dat hij bezwaar maakte tegen het afkondigen in de kerk van allerlei mededelingen door de gerechtsbode, wat volgens hem nergens anders gebeurde dan in Gronsveld. ${ }^{1970}$ Dat raakte een terrein waarop de graaf zich niet de wet liet voorschrijven.

De hoog oplopende strijd kende ook principiële kanten. De pastoor constateerde niet ten onrechte dat in Gronsveld gebruiken bestonden die in strijd waren met aartsdiakonale statuten en beriep zich op de Luikse kerkelijke autoriteiten. Voor Prummer viel alles wat maar enigszins met de tijdelijke aangelegenheden van de kerk te maken had, onder landsheerlijk (dus zijn) gezag en de pastoor beschouwde hij als ondergeschikte van de graaf. Luikse inmenging moest zoveel mogelijk buiten de deur worden gehouden.

Helaas moesten de twee kemphanen elkaar nog een aantal jaren verdragen. Een geluk was dat Kolb vaak op reis ging, bijvoorbeeld naar Parijs. De pastoor leed volgens Prummer aan een soort grootheidswaanzin. Zijn 'supereminierende aigenschafften' overstegen het kleinschalige Gronsveld, ${ }^{1971}$ waar het ontbrak aan prinsen en graven om mee te kunnen praten en die hem eerden. ${ }^{1972}$

Eind 1764 ging steeds het gerucht dat Kolb van zijn pastoraat af wilde. Snerend merkte Prummer op dat hij niet vanwege de werkdruk hoefde te vertrekken. Bij de bevolking moet Kolb ook niet erg goed hebben gelegen. In 1758 werden planten bij het zomerhuisje in de pastorietuin vernield en honingraten uit bijenkorven gestolen. In 1765 sneuvelden enkele ruiten van de pastorie. In alle gevallen leverde het gerechtelijk onderzoek geen daders op. ${ }^{1973}$ Uiteindelijk droeg Kolb, met toestemming van de graaf, zijn ambt over aan kapelaan Henricus Meyers als permanente vervanger. Ook dat liep weer uit op allerlei

1966 TJ, inv. nr. M 14, fol. 813-817, Kolb aan onbekende bij M.E. von Toerring-Jettenbach 23 december 1754.

1967 TJ, inv. nr. M 14, fol. 831-834, Kolb aan M.E. von Toerring-Jettenbach 20 maart 1755.

1968 TJ, inv. nr. M 14, fol. 840-854, Kolb aan M.E. von Toerring-Jettenbach 3 januari 1756.

1969 TJ, inv. nr. M 14, fol. 840-854, Kolb aan M.E. von Toerring-Jettenbach 3 januari 1756

1970 TJ, inv. nr. M 14, fol. 831-834, Kolb aan M.E. von Toerring-Jettenbach 20 maart 1755.

1971 TJ, inv. nr. M 53, fol. 504-511, Prummer aan M.E. von Toerring-Jettenbach 29 april 1764.

1972 TJ, inv. nr. M 14, fol. 975-981, Prummer aan M.E. von Toerring-Jettenbach 11 december 1764.

1973 RHCL, Graafschap Gronsveld, inv. nr. 298, 306. 
ruzies. ${ }^{1974}$ Volgens de doop-, trouw- en begraafregisters van Gronsveld aanvaardde Meijers op 23 juni 1767 zijn ambt na de vrijwillige afstand door Kolb. In het archief van het Graafschap Gronsveld bevindt zich nog altijd de tekst van een Latijns tijdvers 'CunCtI pLaUDIMUs' (laten wij allen applaudisseren) waarvan de hoofdletters het jaartal 1767 opleveren. ${ }^{1975}$ Het kan worden uitgelegd als welkomstwens voor pastoor Meijers, maar ook als zucht van opluchting over het vertrek van Kolb (naar Parijs?) Uiteindelijk deed Kolb eind 1777 definitief afstand en keerde hij, voorzien van een loffelijk getuigschrift van de drossaard van Gronsveld en de vicaris-generaal van Luik, als een achtenswaardig man terug naar Beieren. ${ }^{1976}$ Tot zijn overlijden trok hij echter nog pensioen dat door Meijers moest worden betaald.

Ook Christiaan Schrijnemaekers, de laatste pastoor van Gronsveld die nog op basis van het collatierecht werd benoemd, was een duidelijke protegé van de graaf. ${ }^{1977}$ Zelf noemde hij zich 'een geadopteerd kind' van de graaf. 1978 Aangezien over deze benoeming al een gedetailleerde publicatie bestaat, wordt hier volstaan met een samenvatting. Schrijnemaekers, geboren te Gronsveld in 1758, ontving in 1781 van de graaf het benodigde geld voor zijn priesterwijding. Daarna kreeg hij een aanstelling als vicepastoor en primissarius (lezer van de zogenoemde Vroegmis) in Gronsveld. Zowel zijn bekwaamheid als loyaliteit aan de graaf was onbetwist. Er was slechts één vlek op zijn blazoen. In 1784 had hij zijn broer Johannes, die was veroordeeld wegens doodslag, bij diens overbrenging naar de gevangenis aangespoord om te vluchten. Deze poging tot belemmering van de rechtsgang werd hem als vergrijp tegen het landsheerlijk gezag nog lang kwalijk genomen.

Toen in de zomer van 1791 pastoor Meyers ernstig ziek lag en zijn overlijden aanstaande leek, meldden zich al op voorhand kandidaten voor de opvolging. Uit Gronsveld zelf waren er twee gegadigden, te weten Balthasar Smeets, al 24 jaar kapelaan, en Schrijnemaekers. De derde geestelijke in Gronsveld was Wilhelmus Berchmans, met zijn 56 jaar al wat ouder en sinds 1747 beneficiant van het altaar van Sint-Amandus. Grafelijk commissaris Zollner beval op grond van anciënniteit Balthasar Smeets als opvolger van pastoor Meyers aan, hoewel Schrijnemaekers geliefder was bij de parochianen en de geestelijken in de omringende dorpen. Maar uiteindelijk werd de opvolging pas zeven jaar later actueel, want pastoor Meyers herstelde en stierf uiteindelijk op 1 juli 1798.

Het moment van overlijden had nauwelijks ongelukkiger kunnen vallen. Weliswaar was het graafschap sinds 1 oktober 1795 als onderdeel van het departement Nedermaas ingelijfd bij de Franse Republiek en werden er ook Franse wetten afgekondigd, maar als staatkundig onderdeel van het Heilige Roomse Rijk was de toekomst van het gebied onzeker. Op 8 en 12 november 1795 waren in de 'Verenigde Belgische Departementen' de feodale rechten afgeschaft, maar de precieze omvang van dit 'complexum feodale' stond niet vast. Zo bleef onduidelijk of ook collatierechten daartoe hoorden. Voor Gronsveld

1974 TJ, inv. nr. M 14, fol. 859-870, Prummer aan M.E. von Toerring-Jettenbach 7 januari 1768.

1975 RHCL, Graafschap Gronsveld, inv. nr. 240.

1976 TJ, inv. nr. M.14, fol. 963-964).

1977 Zie over hem: Jaspars, 'Perikelen rond pastoorsbenoeming'.

1978 Jaspars, 'Perikelen rond pastoorsbenoeming', 151. 
lijken noch de graaf, noch Zollner, noch de kandidaten voor de opvolging van pastoor Meyers te hebben getwijfeld aan het voortbestaan van dit recht. Bovendien functioneerde de kerkelijke organisatie van het bisdom Luik nog steeds, ook al was het gebrekkig. (Prinsbisschop F.A. de Méan was uitgeweken naar Duitsland, maar had zijn vicaris-generaal, graaf H. de Rougrave, uitgebreide volmachten verleend).

Nog veel gecompliceerder lag op dat moment de verhouding tussen kerk en staat, want de Franse machthebbers hadden gezorgd voor grote verdeeldheid onder de geestelijkheid. De problemen spitsten zich toe op twee vragen, namelijk of geestelijken zogenoemde 'bons', een soort staatsobligaties gefinancierd uit de verkoop van kerkelijk goed, mochten accepteren en, ten tweede, de vraag in hoeverre geestelijken een eed van trouw aan de republiek en de grondwet van het jaar III en haat aan de anarchie en het koningschap mochten afleggen. De kwestie leidde tot grote tweespalt tussen geesteliiken en gelovigen, niet in het minst vanwege de verschillende standpunten die de kerkelijke leiders over de geoorloofdheid van de eed innamen. Bisschop de Méan van Luik, in ballingschap, wees de eed af; zijn vicaris-generaal de Rougrave achtte hem geoorloofd in het belang van de zielzorg. Het percentage beëdigde priesters wisselde sterk per kanton: van honderd procent tot minder dan twintig procent. Beëdigde geestelijken konden rekenen op spot, afkeer en haat van het grootste deel van de gelovigen en hun kerkdiensten werden weinig bezocht.

In het kanton Eijsden legden van de 23 geestelijken er vier de eed af, waarvan drie in Gronsveld, te weten pastoor Meyers, kapelaan Smeets en beneficiant Berchmans. Christiaan Schrijnemaekers weigerde. Jaspars maakt in zijn beschrijving van de perikelen rond de opvolging van Meyers aannemelijk hoe dit verhoudingsgewijs grote aantal beëdigden in Gronsveld valt te verklaren. Meyers was oud, ziek en gemakkelijk te beïnvloeden. Smeets wist dat hij het bij een pastoorsbenoeming moeilijk zou krijgen ten opzichte van de grafelijke protegé Schrijnemaekers en dacht waarschijnlijk zich door de eed acceptabel te maken bij de nieuwe machthebbers. Berchmans lijkt a-politiek te zijn geweest, maar verwachtte door een meegaande houding als geestelijke zonder zielzorg met rust te worden gelaten.

Na het overlijden van Meyers op 1 juli 1798 verleende vicaris-generaal De Rougrave op 26 juli aan Smeets machtiging om vanwege de bijzondere tijdsomstandigheden, voorlopig alle pastorale functies uit te oefenen. Intussen kwamen er in München bij de graaf verschillende sollicitatiebrieven binnen, waaronder van Smeets. Die verzweeg wijselijk dat hij de eed had afgelegd, ofschoon dat wel al in München bekend was. Ook over de houding van Schrijnemaekers had de graaf informatie toegespeeld gekregen. Of Schrijnemaekers zelf direct gesolliciteerd heeft, is niet duidelijk, maar in ieder geval ondernam hij kort na het overlijden van pastoor Meyers een reis naar München om daar zijn zaak persoonlijk te bepleiten. Op 26 juli 1798 werd hij door de graaf ontvangen en kreeg daar te horen dat de keuze op hem was gevallen. Vier dagen later schreef de graaf aan de bisschop van Luik dat Henricus Meyers, 'mijn pastoor in Gronsveld', was overleden en presenteerde hij in zijn hoedanigheid van collator Christiaan Schrijnemaekers als opvolger, een man berekend voor zijn taak, geliefd bij zijn dorpsgenoten en loyaal door zijn weigering de eed af te leggen. 
Vanaf september 1798 werd Schrijnemaekers weer in de omgeving van Gronsveld gesignaleerd, waar hij als niet-beëdigd priester in het geheim zielzorg uitoefende. Na begin 1800 nam de vervolging af en kon hij als pastoor weer min of meer openlijk in zijn parochie functioneren. Het Concordaat tussen Napoleon en paus Pius VII van 1802 moest de verhoudingen tussen kerk en staat weer normaliseren. Bij de omschrijving van het nieuwe bisdom Luik kreeg de kerk van Gronsveld de status van 'succursaal' (hulpkerk) binnen het kanton Maastricht-Noord en ontving Schrijnemaekers een hernieuwde benoeming als pastoor, welke functie hij tot zijn overlijden in 1822 uitoefende.

Schrijnemaekers aanvaardde zijn pastoraat in bijzondere tijden. Dat verklaart ook dat de canonieke institutie niet, zoals gebruikelijk, werd gevraagd bij de aartsdiaken van Haspengouw, maar bij de bisschop van Luik in ballingschap. Opmerkelijk blijft dat ondanks veranderde omstandigheden zo strikt door alle partijen werd vastgehouden aan de vaste procedures. Formeel was het collatierecht geen feodaal recht en dus ook niet door de Franse wetgever afgeschaft. Anderzijds kwam men kennelijk niet op de gedachte dat het met de inlijving van Gronsveld bij Frankrijk feitelijk was afgelopen met de rechten van de graaf in Gronsveld. Ook schijnt niemand zich druk te hebben gemaakt over het levensonderhoud van de pastoor. Zollner betitelde Gronsveld ooit eens als 'eine der besten Pfarreyen in hiesiger Gegend', ${ }^{1979}$ maar door afschaffing van de tienden was de enige substantiële bron van inkomsten voor de pastoor opgedroogd.

\section{Beneficie van Sint-Amandus in Gronsveld}

Behalve het collatierecht van de pastoorsplaats bezat de heer van Gronsveld ook het collatierecht voor het altaar of beneficie van Sint-Amandus in de kerk van Gronsveld. Aan deze stichting was de verplichting van twee missen per week verbonden. In de achttiende eeuw beschikte deze stichting over ruim negentien bunder grond, voor het grootste deel gelegen in Eckelrade. In omvang overtrof dit goederenbezit het beneficie van de pastoor. Volgens pastoor Schmädel leverde het beneficie per jaar honderd pattacons op. In de achttiende eeuw werd van de beneficiant ook gevraagd het orgel te bespelen. ${ }^{1980}$

\section{Beneficie van Onze-Lieve-V roun in Eckelrade}

De heer van Gronsveld had eveneens het benoemingsrecht van de geestelijke voor het beneficie van Onze-Lieve-Vrouwe in de kerk van Eckelrade (te onderscheiden van een gelijknamig beneficie in de kerk van Gronsveld). Met ongeveer twee bunder grond was het niet rijk bedeeld. De geestelijke die in het bezit van deze stichting was, had de plicht eens per week mis te lezen.

\section{Beneficie van Onze-Lieve-V roun in Gronsveld}

Ook in de kerk van Gronsveld bestond een beneficie van Onze-Lieve-Vrouw. Volgens de gegevens voor een visitatieverslag omstreeks 1765 was deze 'annex' aan het pastoraat.

1979 TJ, inv. nr. M 8, fol. 109-112, Zollner aan A.J. von Toerring-Jettenbach 24 juni 1791.

${ }_{1980} \mathrm{Zie}$ voor een voorbeeld van een sollicitatieprocedure en beoordeling van kandidaten TJ., inv. nr. M 14, fol. 1053-1058, Schmädel aan M.E. von Toerring-Jettenbach 23 augustus 1747. 
Deze fundatie bezat een stukje bouwland en een perceeltje bos, maar de opbrengst was gering en te weinig om het misstipendium te betalen. De collator is niet bekend, maar waarschijnlijk was dit ook de graaf.

\section{De kosterij in Gronsveld}

Ook de kosterij van Gronsveld was gebaseerd op een beneficie, maar dan voor leken. Kerkelijke institutie was niet vereist. Oorspronkelijk was aan de functie van 'wereldlijk koster' ook het schoolmeesterschap verbonden. De vaste inkomsten bestonden uit de opbrengst van ruim twee bunder akkerland, vijf vat roggen, schoolgeld en kostersgarven (zogenoemde 'luidgerven') ongeveer 150 tot 200 schoven van allerlei soorten graan voor het luiden van de klok. Verder waren er de 'accidentia', toevallige inkomsten zoals de kaarsen rond de baar, die na een begrafenis overbleven. Ten slotte werd hij nog betaald voor de kerkzang bij gestichte vroegmissen met Pasen en Pinksteren. Alles bij elkaar verdiende een koster in het midden van de achttiende eeuw 180 tot 200 gulden Rijnlands per jaar.

De geschiedenis van het collatierecht voor de kosterij in Gronsveld is niet geheel duidelijk, misschien ook door de vermenging van publieke en kerkelijke taken. Volgens de aartsdiakonale visitatie van 1658 geschiedde de presentatie door de pastoor, maar de verslagen van 1699 en 1712 noemen de graaf als collator. ${ }^{1981}$ Hoe gevoelig dit recht in de praktijk lag, blijkt uit de benoeming die de drossaard namens de graaf in 1705 deed van Joannes Lousberchs. Lousberchs schijnt voor de verwerving van zijn functie steun te hebben gezocht bij de bevolking en sommige 'nabueren' hadden daartoe zelfs schriftelijk hun 'consent' gegeven. Hij kreeg zijn baan, maar tegelijk liet de drossaard afkondigen dat hij deze handelwijze beschouwde als 'eene openbare infractie ende attentaet van de onderdanen op de gerechticheden van sijne Hoochgrafelijke Excellentie haeren gebiedende landheere'. ${ }^{1982}$.

\section{Kapelanie}

In 1725 vond door de vereniging van de beneficies van Onze-Lieve-Vrouw in Eckelrade en de kosterij/schoolmeesterij in Gronsveld een belangrijke wijziging plaats. Volgens de uitleg die Prummer daar in 1765 over geeft, moest de pastoor oorspronkelijk voor eigen rekening op alle zon- en feestdagen in de kerk van Eckelrade een mis laten lezen. ${ }^{1983}$ Feitelijk was dat de vroegmis, waarna in Gronsveld de hoogmis volgde. Twee keer per jaar, op het feest van de kerkwijding in Eckelrade en op het feest van Sint Bartholomeus, de kerkpatroon van Eckelrade, verliepen de diensten in omgekeerde volgorde: eerst vroegmis in Gronsveld, daarna hoogmis in Eckelrade. Volgens Prummer bestond de verplichting voor de pastoor om in Eckelrade mis te laten lezen al sinds mensenheugenis, maar oude documenten daarover ontbraken. De gedachte achter deze regeling was waarschijnlijk dat de pastoor, die uit Eckelrade evenveel tienden trok als uit Gronsveld en Rijkckholt, daarvoor ook een kapelaan in Eckelrade kon onderhouden. Het was echter bekend dat de Gronsveldse parochieherder vaak tegen een gering bedrag de dienst in

1981 Simenon, Visitationes Hasbaniae I, 276.

1982 RHCL, Graafschap Gronsveld, inv. nr. 119.

1983 TJ, inv. nr. M 53, fol. 538-550, Prummer aan M.E. von Toerring-Jettenbach 18 mei 1765. 
Eckelrade uitbesteedde bij een vervanger, zoals de armlastige pastoor van het aangrenzende Sint-Geertruid.

Pastoor Van der Meeren bedacht in 1723 een andere regeling. De aan het beneficie van Onze-Lieve-Vrouw in Eckelrade verbonden wekelijkse mis werd al lang niet meer gelezen, maar de goederen en inkomsten bestonden nog steeds, met jaarlijks een opbrengst van bij elkaar negentig gulden.

Naast het beneficie van Onze-Lieve-Vrouw in Eckelrade bestond in Gronsveld het ook niet echt rijkelijk bedeelde beneficie van de kosterij annex schoolmeesterij. Van der Meeren wilde beide beneficies graag met elkaar verenigen en omzetten in een 'geestelijke kosterij'. De pastoor voegde daar nog ruim drie bunder akkerland pastoriegrond onder Eckelrade aan toe, die jaarlijks hooguit zestig tot zeventig gulden opbrachten. Aldus ontstond een beneficium perpetuum curatum of duurzame kapelanie met daaraan verbonden werkzaamheden op het gebied van de zielzorg. Van der Meeren had nog een menselijk argument voor zijn plan: hij wilde daarmee Johannes Heusschen helpen, zoon van de voormalige gerechtsbode, die al op de titel van de beneficies van Onze-Lieve-Vrouw en de kosterij tot priester was gewijd. De toegeeflijke graaf d'Arberg Valengin stemde daar als collator mee in, uiteraard onder voorbehoud van zijn collatierecht. De bisschop van Luik verleende op 9 maart 1725 toestemming voor de vereniging.

Alles bij elkaar bracht deze kapelanie tussen de 340 en 360 gulden per jaar op. Voor dit niet echt riante inkomen (zonder vrije woning) kreeg de kapelaan een flink takenpakket toebedeeld: 's zomers en 's winters over de berg naar Eckelrade om de vroegmis te lezen, dan naar Gronsveld de hoogmis zingen, catechisatie in Eckelrade en Gronsveld, biechthoren, zieken bezoeken en begraven, alles bij elkaar ongeveer de helft van alle pastoraal werk en dan ook nog het meest onaangename deel voor een karig loon. Inkomsten uit losse missen waren te verwaarlozen. Daarnaast kwam natuurlijk nog het gewone kosterswerk: schoonhouden van de kerk en verzorging van het onderwijs in de school. Misschien waren de bedoelingen van deze regeling goed, maar de uitkomst was onrechtvaardig. De oorspronkelijke beneficies waren immers zonder zielzorg en de pastoor was voor een betrekkelijk klein bedrag verlost van de vroegmis in Eckelrade.

$\mathrm{Na}$ het overlijden van kapelaan Lambertus Bemelmans op 17 mei 1765 kon de graaf als collator een nieuwe kapelaan aanstellen. Er waren verschillende sollicitanten, onder anderen Carl Leonard Wunderer, broer van 'Commissionsschreiber' Paul Joseph Wunderer, de vroegere assistent van Prummer. De man had in de zielzorg in Oostenrijk gewerkt, maar was armlastig en moest voor zijn moeder zorgen. ${ }^{1984}$ De keus viel echter op Henricus Meyers, voor wie de graaf op 4 juni 1765 een collatiebrief uitvaardigde met het verzoek aan de bisschop van Luik de institutie te verlenen. ${ }^{1985}$ Deze voordracht lokte bij Prummer het nodige commentaar uit. In de eerste plaats was het vreemd dat zo weinig jonge geestelijken uit de omgeving reageerden. Waarschijnlijk lieten velen zich afschrikken door de alom bekende onbuigzaamheid ('rigor' en 'haiglichkeit') van pastoor Kolb. Prummer kende de nieuwe kapelaan niet, maar wist dat hij de kerkzang niet goed beheerste, wat voor een koster wel nodig was. 'Dat zou wat worden!' ('also das es ein

1984 TJ, inv. nr. M 53, fol. 628-630, C.L. Wunderer aan M.E. von Toerring-Jettenbach 1 juni 1765.

1985 TJ, inv. nr. M 53, fol. 558-560. 
artiges gesang geben werdte'). Hopelijk was hij wel goed in het schoonhouden van de kerk en ijverig in het onderwijs en de zielzorg. Ten slotte bevatte het grafelijk patent voor de collatie, dat in München was opgesteld, weer eens de gebruikelijke fouten, ten eerste omdat het alleen betrekking had op het beneficie van Onze-Lieve-Vrouw in Eckelrade en vervolgens niet was gericht aan de aartsdiaken, maar aan de bisschop van Luik. Het was dus afwachten hoe men daar in het voor juiste titels en adressen gevoelige Luik op reageerde. ${ }^{1986}$

Maar hoe men het ook keerde of draaide: de last voor deze kapelanie was zwaar in vergelijking met de betaling. Langzaam groeide het besef dat de regeling van 1725 weer ongedaan moest worden gemaakt. Een goede gelegenheid daartoe deed zich voor toen pastoor Kolb in 1767 afstand deed van zijn pastoraat en werd opgevolgd door kapelaan Henricus Meijers. Op 22 september 1767 liet graaf Maximilian Emanuel in München een akte van splitsing van de Gronsveldse kapelanie en kosterij vastleggen, die op 20 november 1767 door de vicaris-generaal van Luik werd bekrachtigd. ${ }^{1987}$ Er kwam nu een vicarie met een kapelaan die dag en nacht in Gronsveld woonde, de vroegmis op zon- en feestdagen in Eckelrade las, op verzoek van de pastoor in Gronsveld celebreerde, in beide dorpen catechismus gaf, biecht hoorde en assisteerde bij alle andere pastorale werkzaamheden. Verder moest hij toezicht houden op de werkzaamheden van de kosterschoolmeester en, voor zover daar behoefte aan bestond, de elementaire beginselen van Latijn onderwijzen.

Deze kapelaan werd voor zijn werkzaamheden betaald uit het vroegere beneficie van Onze-Lieve-Vrouw in Eckelrade. Een belangrijke aanvulling vormden de inkomsten van de zogenoemde Happartsmis, oorspronkelijk een stichting uit 1490 in de SintMartinuskerk in Maastricht-Wyck en later overgebracht naar de kerk van Gronsveld. ${ }^{1988}$ Met de vroegmis in Eckelrade en drie missen per week van de Happartsmis had de kapelaan nu zijn vaste verplichtingen, naast alle andere taken op het gebied van zielzorg. Als nieuwe kapelaan werd benoemd Balthasar Smeets.

De kosterij en het schoolmeesterij verloren in de nieuwe situatie het karakter van een kerkelijk beneficie. Voortaan werden deze taken opgedragen aan een capabele leek, die de graaf naar eigen inzicht kon benoemen of ontslaan. De man moest in Gronsveld wonen, alle kerkornamenten verzorgen, de kerk poetsen, de eredienst met zang opluisteren, geestelijken begeleiden bij de bediening van zieken en de klok luiden. Daarnaast hield hij school voor de jeugd. Betaald werd de koster/schoolmeester uit verschillende bronnen: de

1986 TJ, inv. nr. M 53, fol. 638-644, Prummer aan M.E. von Toerring-Jettenbach 17 juni 1765.

1987 RHCL, Parochie H. Martinus Gronsveld, voorl. inv. nr. 12.

1988 In 1490 was in de Sint-Martinuskerk te Mastricht-Wyck een beneficie met de verplichting van drie missen per week gesticht ter nagedachtenis van de vermoorde Lambertus Happarts (zie RHCL, Parochie H. Martinus Maastricht Wyck I, inv. nr. 79). Voor de betaling waren inkomsten uit landerijen in Gronsveld aangewezen. Omdat er ook andere schulden op dit onderpand rustten, onder ander aan de graaf van Gronsveld, waren deze landerijen door uitwinning in handen van de graaf gekomen. Feitelijk verloor daarmee de stichting in Wyck haar inkomsten. De graaf voelde zich nu als nieuwe eigenaar van dit onderpand in geweten verplicht toch te betalen, onder de voorwaarde dat dit beneficie van Wyck werd overgebracht naar Gronsveld en werd verbonden aan het daar bestaande altaar van Onze-Lieve-Vrouw. Hij stelde daarvoor een jaarlijkse rente van 106 gulden beschikbaar, met de last van drie missen per week. 
opbrengst van de vroegere kosterijstichting, schoolgeld, eieren die de gelovigen met Pasen gaven, de luidgarven (per gezin slechts één schoof, door de hele parochie te verzamelen), overgebleven waskaarsen bij begrafenissen, huwelijksmissen voor vreemdelingen, zang bij jaardiensten et cetera. Verder stond de pastoor hem een klein deel af de tienden, de zogenoemde Hondstiende, gelegen onder Heer, ter waarde van dertig gulden. ${ }^{1989}$

\section{Kerkfabriek in Gronsueld en Eckelrade}

De zeggenschap van de graaf over de parochiekerk bestond uit verschillende elementen. Als patronus kon hij een soort algemene zeggenschap opeisen, als collator droeg hij de pastoor voor en als tiendheffer was hij, samen met de pastoor, volgens de aartsdiakonale statuten ook verantwoordelijk voor het bouwkundig onderhoud van de kerk en de basisuitrusting nodig voor de viering van de liturgie. Het gewone onderhoud moest worden gefinancierd uit de opbrengst van de kerkfabriek. Maar in de praktijk viel de grens tussen plicht en vrijwilligheid bij de tiendheffers niet zo scherp te trekken. Zo kwam hiervoor (Hoofdstuk 4.3.4) al aan de orde dat de graven van Gronsveld de kerk duidelijk gebruikten om hun familie naar buiten toe te representeren.

De vroegste gegevens over de toestand van de kerk in Gronsveld ontlenen we aan de visitatieverslagen van de aartsdiakens van Haspengouw uit de zeventiende eeuw. Het middeleeuwse gebouw verkeerde in die tijd in een slechte toestand. De visitatoren spreken voortdurend over slechte daken en muren en kapotte vensters. In 1658 wordt genoteerd dat een deel van het gewelf van het koor is ingestort. Ook bestond ruzie tussen de scholtis als vertegenwoordiger van de graaf en de pastoor over de verdeling van bouwkosten.

Liturgisch vaatwerk, altaarlinnen en liturgische boekwerken waren in de zeventiende eeuw aanwezig, maar niet altijd voldoende en soms versleten. Het hoofdaltaar was in 1612 ontwijd. Een godslamp brandde zelden of nooit. In 1624 gebruikten de parochianen de kerk als opslagplaats voor kasten, kisten, korven en allerlei huisraad. De afgeschermde woonruimte van de pastoor in de kerk kwam al ter sprake.

Pas na de (grotendeels) herbouw van de kerk omstreeks 1700, gefinancierd door de graaf en de pastoor als tiendheffers en gebouwd met hulp van de parochianen, verbeterde de toestand. Maar wat betreft paramenten, linnen en andere liturgische benodigdheden bleef de situatie zorglijk. Toen Prummer in 1752 in Gronsveldse arriveerde, trof hij de inboedel van de kerk in tamelijk desolate toestand aan. De meeste paramenten verkeerden in een slechte toestand, een processiehemel ontbrak en de godslamp brandde niet. ${ }^{1990}$

De situatie bij de kerk van Eckelrade verschilde niet veel met die in Gronsveld. Er bestond een soort eigen kerkfabriek in de vorm van landerijen waarvan de opbrengst voor de kerk was bestemd, maar die werden tegelijk met die van Gronsveld beheerd. Volgens het visitatieverslag van 1624 was het vroeger vernielde gebouw weer hersteld en de bouwkundige toestand in de zeventiende eeuw voldeed redelijk aan de eisen. De hoeveelheid liturgisch vaatwerk en paramenten was bescheiden, maar voldoende voor de weinige diensten.

1989 RHCL, Parochie H. Martinus Gronsveld, voorlopig inv. nr. 12.

1990 TJ, inv. nr. M 14, fol. 855-858, Prummer aan M.E. von Toerring-Jettenbach juni 1754. 
Over de beheerders van de kerkfabriek(en) van Gronsveld en Eckelrade in de zeventiende eeuw zijn slechts weinig gegevens voorhanden. Twee keer wordt in de visitatieverslagen gezegd dat deze werden benoemd door de graaf, samen met de pastoor en de schepenen. Over de verantwoording van het financieel beheer zijn de verschillende visitatieverslagen niet eensluidend. Volgens de visitatie van 1613 waren er in Gronsveld twee kerkmeesters, die echter al sinds zes of zeven jaar geen rekening meer hadden ingeleverd. In latere jaren wordt telkens één kerkmeester genoemd.

In 1624 noteerde de aartsdiaken dat schout en schepenen de rekening afhoorden, waarbij de pastoor uit minachting ('contempto pastore') bewust werd buitengesloten. De schout beweerde dat hij de registers van de kerkelijke inkomsten onder zijn hoede had en alle financiën naar eigen inzicht afhandelde, omdat zulks noch de pastoor noch de kerkelijke overheid iets aanging. Naderhand schijnt men toch daarop toch enigszins te zijn teruggekomen. In 1658 werd de rekening afgehoord door de pastoor en de 'gemeente', in 1699 geschiedde dit ten overstaan van de graaf, de pastoor en de schepenen. Het visitatieverslag van 1712 noemt voor Eckelrade 'Lambertus Sloesberg' (Lambertus Lousberchs), die rekening en verantwoording aflegde 'zonder tussenkomst van de pastoor'.

De vele onduidelijkheden over het beheer waren niet uitsluitend een gevolg van slordigheid, maar ook van onwil. In een brief van 1 januari 1713 deed pastoor Goffin bij graaf Johan Frans zijn beklag over de manier waarop de schepenen (bij afwezigheid van de drossaard) de vertegenwoordiger van de aartsdiaken bij een visitatie op 24 juli 1712 hadden bejegend. ${ }^{1991}$ Eerst hadden zij bezwaar gemakt tegen de bevoegdheden van de aartsdiaken, vervolgens weigerden ze met allerlei uitvluchten de kerkrekeningen te overleggen en ten slotte ontspon zich een hele discussie over de kosten van een nieuwe klok en de pastorie. In september kwam de vertegenwoordiger van de aartsdiaken terug, maar allerlei beloftes om verbeteringen aan te brengen, bleven zonder resultaat. Goffin lag overigens niet goed bij zijn parochianen vanwege zijn gebrekkige kennis van de landstaal en omdat hem financiële schraapzucht werd verweten.

De gebrekkige financiële verantwoording viel ook Prummer meteen na zijn komst in Gronsveld op. Van administratie van vóór 1728 was niets meer te vinden en over de periode 1728 tot 1752 moesten de rekeningen bij elkaar worden gesprokkeld. Prummer probeerde achterstallige betalingen aan de kerk alsnog te innen. Volgens pastoor Kolb had zijn voorganger Schmädel gemakshalve Prummer en rentmeester Lebens tot kerkmeesters benoemd. ${ }^{1992}$ Verkiezing van een kerkmeester of liever kerkmeesters, (want volgens de statuten van het aartsdiakonaat Haspengouw moesten er twee zijn) gebeurde al lang niet meer. Kolb had geen idee van de kerkfinanciën, want vanaf zijn aankomst waren geen rekeningen overgelegd en kreeg hij geen registers van inkomsten ter inzage. Dat gold trouwens ook voor de verdeling van het armengeld.

1991 TJ, inv. nr. M 40, fol. 859-863, pastoor Goffin aan J.F. van Bronckhorst Batenburg 1 januari 1713

1992 Het is de vraag of dat helemaal waar is. In de kerkrekening van Johan Frans Lebens over 1764 is sprake van een uitgaven volgens 'prothocolle door den kerck-mombaer Rietraet ter ordre van d'heer pastor Schmädel zaliger’ (TJ, inv. nr. M 8, fol. 316). 
Deze situatie bleef in grote lijnen tot het einde van het Ancien Régime gehandhaafd. Rentmeester Johan Frans Lebens voerde van 1757 tot zijn overlijden op 17 juni 1782 de kerkelijke boekhouding van Gronsveld en Eckelrade, deels gescheiden maar uiteindelijk samengevoegd in één rekening. Na zijn dood zette commissaris Zollner dit werk voort tot zijn vlucht naar München in $1794 .{ }^{1993}$ Deze boekhouding maakt de indruk behoorlijk te zijn bijgehouden, hoewel in de volksmond werd gemompeld dat ook hier de familie Lebens zichzelf bevoordeelde. Dat zal in de hand zijn gewerkt door het feit dat de rentmeester een soort particuliere rekening-courantverhouding met de kerkfabriek had. $\mathrm{Na}$ verrekening van inkomsten en uitgaven bleef een positief saldo over, dat de rentmeester vervolgens als een schuld van hem aan de kerk in kas hield. Met dat saldo werd dan de volgende jaarrekening weer geopend. Controle van de rekening vond slechts incidenteel plaats. ${ }^{1994}$ De laatst bekende rekening die werd afgehoord, is die van 1785. De controle vond plaats op 21 maart 1786 afgehoord in aanwezigheid van pastoor Meyers en de burgemeesters van Gronsveld, Eckelrade en Rijkckholt.

Maar alleen financiële controle was niet toereikend. Prummer wilde duidelijk ook zeggenschap over de inboedel van de kerk. Zo liet hij op 25 november 1773 door pastoor Meyers van alle paramenten, koorhemden, zilver- en koperwerk, misboeken en overige gebruiksvoorwerpen een lijst opstellen die met een uitvoerige toelichting naar München werd gestuurd. ${ }^{1995}$ Prummer schetst in een begeleidend schrijven eerst hoe gedurende zijn bewind veel was gedaan om de inventaris op een behoorlijk peil te brengen. Maar omdat nog wel een en ander viel te verbeteren of te vervangen, deed hij daartoe allerlei voorstellen. Tegelijk met die bemoeizucht liet Prummer zijn antiklerikale gezindheid, de recente ervaringen met pastoor Kolb indachtig, nog eens de vrije loop. Tot hun verdriet hadden de landsheerlijke ambtenaren altijd moeten aanschouwen hoe slordig met kostbare kledingstukken werd omgesprongen, alsof het niets kostte. Maar een godslamp voor het Allerheiligste, daar ontbrak het geld voor. Altijd wilden de heren nieuwe, zijden misgewaden, terwijl dat ten plattelande overbodig was. Ook vond Prummer dat men beter zes goede alben kon hebben zonder dure boorden van kant, dan één of anderhalve albe

1993 Lebens en Zollner hielden een manuaal bij, waarin de vaste inkomsten uit pachten en renten van Gronsveld en Eckelrade gescheiden werden geboekt. In het manuaal van 1757 tot en met 1762 stonden verder als een soort kasboek alle uitgaven van 1757 tot 1790 ten laste van de beide kerken door elkaar in chronologische volgorde opgetekend. Vgl. RHCL, Parochie H. Martinus Gronsveld, voorl. inv. nr. 40:manuaal 1757-1762 en kasboek Gronsveld en Eckelrade 1757-1790; voorl. inv. nr. 41, manuaal Gronsveld en Eckelrade 1769-1774, voorl. inv. nr. 42 manuaal Gronsveld en Eckelrade 1775-1780; voorl. inv. nr. 43, manuaal Gronsveld en Eckelrade 1787-1792.

1994 Er zijn (voor zover bekend) twee kerkrekeningen van Gronsveld en Eckelrade samen bewaard gebleven, over de jaren 1764 en 1771 en 1772, die inzicht geven in de methodiek van boekhouden, maar ook de bestuurlijke verhoudingen. (TJ, inv. nr. 8, fol. 311-323 en M 56, fol. 615-629). De inkomsten begonnen met een bedrag dat rentmeester Lebens als positief saldo van de rekening over 1769 en 1770 schuldig was. Daarna volgden de inkomsten in graan in 1771 voor Gronsveld en voor Eckelrade, de inkomsten aan renten en afgeloste vorderingen, een totaal van (afgerond) 3178 gulden. Alle uitgaven bij elkaar beliepen het bedrag van ruim 819 gulden, waarmee de exploitatie sloot met een batig saldo van ruim 2358 gulden. Dit bedrag bleef rentmeester Lebens schuldig an de kerkfabriek en vormde weer het begin van de volgende rekening.

1995 TJ, inv. nr. M 56, fol. 631-641. 
met kant. Er waren trouwens voldoende gewaden met kant voorradig. Het zou niet meer dan netjes zijn wanneer de geestelijken zelf ook eens iets uit eigen middelen bijdroegen in plaats van zich te verrijken ten koste van de kerk.

We mogen uit deze gegevens concluderen dat sinds 1752 de grafelijke ambtenaren de macht over tijdelijke aangelegenheden van de kerken van Gronsveld en Eckelrade volledig hadden overgenomen. Prummers bemoeizucht met kazuifels en wijwaterkwasten maakt duidelijk dat hij ongeveer alles wat met kerkelijke financiën en goederen te maken had, als een onderdeel van het grafelijk bestuur beschouwde. Met de rekening-courantverhouding tussen kerk en rentmeester wordt deze indruk van totale controle alleen nog maar versterkt. Alle uitgaven liepen over de rentmeester, ook voor alles wat de geestelijken kochten en op declaratiebasis betaald kregen. Bij pastoor Kolb stuitte dat nog op weerstand, maar zijn meer gemoedelijke opvolger Meyers liet zich dit alles kennelijk zonder al te veel bezwaar gevallen. Prummers opvolger Wolfgang Zollner ging nog een stap verder omdat hij in zijn eentje de functies van zowel grafelijk commissaris als rentmeester van de kerk combineerde.

\subsubsection{Collatierechten in Heugem \\ Pastoraat in Heugem}

De kerk van Heugem wordt al in de twaalfde eeuw meermalen genoemd als bezit van het Onze-Lieve-Vrouwekapittel te Maastricht. Tot het einde van het Ancien Régime had het kapittel in Heugem het tiendrecht, met daaraan verbonden het bouwlast van de kerk. In de achttiende eeuw leverde dit nog een groot proces op tussen de gemeente Heugem en het kapittel over de vraag voor wiens rekening de bouwkosten van de kerktoren kwamen.

In de oorkonde uit 1266, waarin Cadier van de parochie Heugem was afgescheiden en tot zelfstandige parochie verheven, noemt Gerard van Nassau, aartsdiaken van Luik en proost van het kapittel van Onze-Lieve-Vrouw te Maastricht, zich meermalen patronus van de kerk van Heugem. Aan deze titel ontleende de proost het recht als collator bij de aartsdiaken kandidaten voor het pastoraat van Heugem te presenteren. Terzijde moet worden opgemerkt dat de pastoor van Heugem in 1266 zelf ook als collator de bevoegdheid kreeg om de pastoor van de nieuwe parochie Cadier te presenteren. Dit collatierecht is blijven bestaan tot het einde van de achttiende eeuw.

Toch was het collatierecht van de proost van het Onze-Lieve-Vrouwekapittel te Maastricht niet zo eenduidig als het lijkt. Toen in 1784 grafelijk commissaris Wolfgang Zollner een uitvoerig rapport over het Heugemer collatierecht wilde opstellen, vond hij in het eigen archief wel een bundel met het opschrift 'recht van voordracht' ('ius praesentandi') betreffende Heugem, maar die bevatte slechts fragmenten van dossiers en correspondentie, die betrekking hadden op onenigheid tussen de graaf en het kapittel over het presentatierecht.

Een mogelijke bron om meer te weten te komen over het collatierecht waren de institutieregisters van de aartsdiaken van Haspengouw in Luik. Zollner kreeg daar 
uiteindelijk met de grootste moeite toegang. Zelfs tegen pogingen tot omkoping bleken de Luikse geestelijken bestand. Maar met interventie van de Gronsveldse pastoor Henricus Meyers lukte het uiteindelijk toch 'durch Fraus und Schwendl' de institutieregisters vanaf begin zestiende eeuw tot 1734 (de laatste inschrijving van Heugem) in handen te krijgen. Zijn bevindingen legde Zollner in 1784 vast in een uitvoerige brief aan de graaf in München. ${ }^{1996}$ Hij lijkt grondig te werk te zijn gegaan en het is onwaarschijnlijk dat een nieuwe bestudering van die registers nog veel nieuwe relevante gegevens aan het licht brengt.

Uit de zestiende eeuw vond Zollner voorbeelden uit 1535, 1554 en 1583, waarbij pastoors van Heugem van hun ambt afstand hadden gedaan ('resignatio'), waarna een nieuwe kandidaat de institutie was verleend, telkens na presentatie door de proost van OnzeLieve-Vrouwe, 'die verzekerde dat hem vanwege van zijn abbatiale waardigheid of proosdij het volle recht van collatie of presentatie voor deze parochiekerk toekwam'.1997 Van Gronsveldse zijde leek dat niet te zijn weersproken. Of toch wel? In het archief De Geloes/kasteel Eijsden bevindt zich een originele, door Agnes van Bylandt, weduwe van Willem van Bronckhorst Batenburg, ondertekende en bezegelde voordracht aan de aartsdiaken om na het overlijden van Jonannes Puteus een zekere Cono von Vlatten, kanunnik te Jülich, tot pastoor van Heugem te benoemen. ${ }^{1998}$ Helaas is het stuk gedateerd met het onvolledige jaartal '158'. Mogelijk dateert het document uit het begin van de jaren tachtig van de zestiende eeuw, want in 1586 aanvaardde Johan van Bronckhorst Batenburg de regering. Onomwonden staat in deze presentatie te lezen dat het collatie- en patronaatsrecht van Heugem volledig ('pleno jure') aan de heer van Gronsveld toekwam. Merkwaardig is echter dat het fraai geschreven document zich in het archief De Geloes/kasteel Eijsden bevindt en dus niet lijkt te zijn verzonden naar de aartsdiaken. Samen met de onvolledige datering kan dat er op wijzen dat de vrouwe van Gronsveld in eerste instantie heeft gemeend aanspraak te kunnen maken op het collatierecht van Heugem, maar bij nader inzien toch geen presentatie heeft gedaan bij de aartsdiaken.

Daarmee waren de aanspraken van de graaf op het collatierecht van Heugem geenszins van de baan. Zollner zag in het institutieregister van de aartsdiaken dat na de dood van pastoor Weerts (Zollner schrijft Stoertz) de priester Frans Potmans (andere bronnen spreken over Putmans) 'privative und ohne des probsts zuthun' was gepresenteerd door de graaf. Daarbij stond de aantekening dat de heer van Gronsveld had verzekerd dat hem het recht van presentatie toekwam. ${ }^{1999}$ Tijdens de visitatie door de aartsdiaken op 7 september 1613, toen Potmans pastoor was, werd over het collatierecht opgemerkt dat dit toekwam aan de proost, hoewel de graaf van Gronsveld het pastoraat 'als een nieuwigheid' had vergeven.

1996 TJ, inv. nr. M 60, 241-262, Zollner aan A.J. von Toerring-Jettenbach 31 augustus 1784.

1997 Als voren, fol. 251 'NN institutus est, ad praesentationem [NN, proost van het kapittel van OnzeLieve-Vrouwe te Maastricht] afferentis collationem seu ius praesentandi ad dictam parochialem ecclesiam ad se, dum vacat, pertinere sive abbatialis dignitatis sive praepositurae ratione pleno jure spectare'.

1998 RHCL, Familie De Geloes/Kasteel Eijsden, inv. nr. 430. Onbekend is hoe dit stuk in dit archief terecht is gekomen.

1999 Als voren, fol. 245, 'ad praesentationem generosi comitis de Gronsfeld ad quem ius praesentandi uti afferebat pertinere dignoscitur'. 
$\mathrm{Na}$ het overlijden van Potmans werd op 4 oktober 1614 de priester Johannes Ogeri door zowel de graaf als de proost tegelijk ('cumulative') gepresenteerd, zonder op de rechten van een van beiden inbreuk te willen maken. Iedere collator liet aantekenen als enige over het presentatierecht te beschikken. Bij notariële akte van 23 juni 1623 deed Johannes Ogeri 'allein und privative' in handen van de graaf afstand van zijn pastoraat ten gunste van zekere Egidius Joncque. Deze Joncque werd door graaf Jost Maximiliaan van Bronckhorst Batenburg en de proost van Onze-Lieve-Vrouwe ook weer 'cumulative' gepresenteerd bij de aartsdiaken. In het institutieregister werd ten aanzien van de presentatoren de opmerking geplaatst 'onder voorbehoud van ieders recht voor zover iemand meent dat dit hem toekomt'. ${ }^{2000} \mathrm{Na}$ het overlijden van Joncque (die maar heel kort in functie moet zijn geweest) zou nog in 1623 een zekere Andreas Heezius door de graaf en de proost 'cumulative' zijn gepresenteerd, maar dat stond niet met zoveel woorden in het institutieboek. Ook deze presentatie was geschied op voordracht van zowel proost als graaf.

Bij notariële akte van 7 april 1636 'permuteerde' (ruilde) pastoor Herman Graeven zijn pastoraat met Stephan Columban(us), welke 'permutatio' aan beide 'gewone' collatoren ter bekrachtiging was voorgelegd. Drossaard Lamberts van Gronsveld verleende die op 5 mei 1636 namens de graaf, waarna Columban(us) door de proost 'allein und privative' voor Heugem werd gepresenteerd. Op 20 september 1636 verleende de aartsdiaken de institutie onder het voorbehoud van eventueel recht dat de graaf van Gronsveld kon doen gelden. ${ }^{2001}$

$\mathrm{Na}$ het overlijden van Columban(us) (in 1651?) presenteerde graaf Jost Maximiliaan van Bronckhorst Batenburg Christiaan Lamberts (de zoon van drossaard Lamberts) als pastoor voor Heugem. Dat stuitte op verzet van proost Theodorus van Blanckart, die als tegenkandidaat Theodorus van Spijcker voordroeg. Over deze kwestie voerden beide collatoren een proces voor de officiaal van de aartsdiaken, dat op 22 juni 1652 in het voordeel van de proost werd beslist. Van den Spijcker schijnt echter niet goed bij zijn Heugemer parochianen te zijn ontvangen. Zollner schrijft later dat hij beschikte over een document van 15 februari 1652, waarin drossaard, schepenen en gemeente van Heugem verklaarden dat het collatierecht aan de graaf toekwam, dat het huis van de pastoor was gebouwd op grond van de landsheer en dat Van Spijker een slechte reputatie genoot. Dit protest kon de institutie echter niet voorkomen. Enige tijd later ruilde Van Spijker zijn pastoraat van Heugem met Hendrik van Ass, in welke 'permutatio' de proost op 10 november 1653 bewilligde. De presentatie van Van Ass bij de aartsdiaken lokte aan Gronsveldse zijde geen reactie meer uit.

Dertien jaar herhaalde zich dit tafereel. In 1666 droeg proost Frans Egon von Fürstenberg de priester Johan Moreus voor. Het was overigens de vraag of de proost daartoe op dat moment volgens kerkelijk recht bevoegd was. Waarschijnlijk was het beneficie van het pastoraat van Heugem opengevallen in een zogenoemde 'pauselijke maand'. Sinds 1448 was bepaald dat de paus bij kapittels recht had beneficies toe te kennen die in oneven maanden vacant werden. De Heilige Stoel kon deze bevoegdheid vervolgens als gunst aan

2000 Als voren, fol. 248 'ad quos ius praesentandi salvo jure cuiuslibet pertinere dignoscitur'.

2001 Als voren, fol. 248 'citra praejudicium juris laicalis si quod competit domino comiti de Gronsfeld'. 
derden, zoals universiteiten, overdragen krachtens een zogenoemd 'indult'. In dit geval was dat bij de universiteit van Leuven het geval.

Tegenover Moreus stelde gravin Christina von Hardenrath, de weduwe van graaf Jost Maximiliaan, haar kandidaat en presenteerde een zekere Brugmans, geboortig uit Heugem. Zij vond bij die keuze een interessante bondgenoot in de universiteit van Leuven, die zich beriep op het pauselijk privilege om beneficies in oneven maanden te mogen toekennen. Over deze twee presentaties ontstonden gelijktijdig processen, zowel in Luik bij de kerkelijke rechtbank van de aartsdiaken, als in Leuven. Zollner schrijft dat hij van beide uitspraken afschriften had gezien, waarbij op 3 april 1667 Brugmans in Leuven triomfeerde en Moreus op 4 november 1668 in Luik. Brugmans had het geluk dat hij de steun van de gravin genoot en kon zich dus nu feitelijk in het bezit van het pastoraat van Heugem stellen. Moreus kreeg echter de institutie van de aartsdiaken. Proost Fürstenberg wendde zich toen tot de Staten-Generaal als medeheer van Maastricht en verzocht hulp bij de handhaving van zijn recht. Vervolgens vielen Staatse troepen Heugem binnen, verdreven Brugmans en installeerden Moreus. De Staten-Generaal rechtvaardigden deze ingreep met het argument dat zij volgens het capitulatieverdrag van Maastricht van 1632 waren gehouden de rechten van de proost te beschermen.

Comfortabel moet Moreus zich met deze Staatse bescherming niet hebben gevoeld. Hij deed afstand van zijn pastoraat en na deze resignatie benoemde proost Fürstenberg op 8 juni 1673 Frederik Caenen tot pastoor. In deze presentatie beweerde de proost eenvoudig dat hij het presentatierecht bezat. Van de kant van Gronsveld werd daar niets tegen ingebracht.

$\mathrm{Na}$ het overlijden van Caenen presenteerde proost De la Margelle de priester Willem Roebroeck. In de presentatiebrief van 24 februari 1696 liet de proost eenvoudig opnemen 'dat bekend was dat hij als proost het collatierecht van Heugem bezat'. Ditmaal tekende drossaard Kicken van Gronsveld bij notariële akte van 23 juni 1696 wel protest aan, echter zonder effect. In een brief aan de drossaard van 12 juni 1696 moest de proost toegeven dat hij niet over waterdicht bewijs beschikte om zijn recht te staven. Hij kon zich alleen beroepen op het feit dat het kapittel hem zijn recht had 'verzekerd'.

$\mathrm{Na}$ Roebroeck volgde op 30 mei 1704 de presentatie van Renerus Hermans door proost De Méan. Ook hier maakte drossaard Kicken bij notariële akte formeel bezwaar, maar wederom zonder gevolgen.

De laatste presentatie die Zollner bij zijn onderzoek in 1784 aantrof was vijftig jaar geleden. In 1734 had proost Lambertus van Stockhem de uit Maastricht afkomstige priester Hubertus Severinus Josephus van Bloer (geboren 1701) gepresenteerd, wat geschiedde zonder enig protest aan Gronsveldse zijde. Dit uitblijven van een reactie had waarschijnlijk alles te maken met de naweeën van de bestuurlijke chaos waarin het graafschap in de voorgaande jaren verkeerde. De intussen bejaarde, maar kranige Van Bloer leefde in 1784 nog steeds.

De lange reeks presentaties die Zollner vond, maakt duidelijk dat de Gronsveldse anspraken op het collatierecht van het pastoraat nogal wisselden en niet bijster sterk waren. Feitelijk had bijna altijd de proost zijn kandidaat weten door te zetten en protesten daartegen leverden niet zo heel veel op. Anderzijds waren de Gronsveldse papieren ook 
niet heel slecht, want de proost beschikte evenmin over ondubbelzinnige bewijzen. In de visie van Zollner waren de onregelmatigheden die vroeger hadden plaatsgevonden misschien opzettelijke misleidingen geweest, bang als men was om voor bepaalde benoemingen geen toestemming te krijgen.

Het onderzoek dat Zollner in 1784 naar het collatierecht in Heugem instelde, had alles te maken met de hoge leeftijd van pastoor Van Bloer. ${ }^{2002}$ Menselijkerwijs gesproken zou binnen afzienbare tijd in opvolging moeten worden voorzien. Gevreesd werd dat de pastoor zijn vroegmislezer Aegidius Hermans naar voren zou schuiven, een man wiens denkbeelden en optreden de geestelijke stand weinig eer verschaften en die nog veel erger dan de huidige pastoor zou zijn. (Hermans werd kort daarna ook daadwerkelijk middelpunt van een schandaal). Zollner wilde van de graaf weten hoe hij zich in een voorkomend geval moest gedragen. Verzet tegen de proost leidde ongetwijfeld tot een kostbaar en langdurig proces, met onzekere uitslag. Anderzijds taxeerde Zollner de houding die het kapittel zou innemen. Het was onwaarschijnlijk dat de Staten-Generaal het kapittel militair steunden met een inval in Gronsveld. Schending van het grafelijk territorium bracht de Hoogmogenden in conflict met de keizer en de vorsten van het Heilige Roomse Rijk en daar waren ze, volgens Zollner, in Den Haag 'net zo bang voor als kinderen voor Sinterklaas'. Ten tweede was het de vraag of het presentatierecht wel een proces waard was, gelet op de zakelijke belangen die het kapittel in Heugem had.

Het lag dus aan de graaf of die het collatierecht in Heugem weer wilde activeren. De commissaris had daar wel opvattingen over. Verschillende Heugemer pastoors stonden bekend als 'unruhige Köpfe' die zich graag als 'jachthonden' door de proost lieten gebruiken 'om het wild bijeen te drijven'. Dat 'wild' waren de parochianen, op wie de pastoors druk uitoefenden tijdig de Heugemer tienden en pachten aan het kapittel te betalen. Met een eigen presentatierecht zou de graaf een 'Landeskind' kunnen begiftigen. Een dergelijke gunst kweekte altijd veel goodwill. Dit was overigens wel een ommezwaai in beleid, misschien het gevolg van de slechte ervaringen in Gronsveld met de Beierse pastoors. Verder verschafte het presentatierecht van een pastorie met een waarde van zeshonderd gulden Rijnlands per jaar aanzien in eigen land, zeker ook omdat de pastoor van Heugem zelf collator was van het aangrenzende Cadier. Ten slotte stuurde de proost toch alleen maar geestelijken die men elders niet kon of wilde gebruiken. De recente ervaringen met pastoor Van Bloer leverden wel het beste bewijs hoe een pastoor een parochie te gronde kon richten.

Van Bloer had inmiddels inderdaad een jarenlange reputatie opgebouwd als lastpak voor de autoriteiten binnen het graafschap. Het was allemaal begonnen omstreeks 1763 met een ordinaire burenruzie over een strookje grond naast de pastorie. ${ }^{2003}$ De zaak kwam voor het gerecht en de pastoor verloor in twee instanties. Bij Van Bloer gingen toen alle remmen los. Hij dwarsboomde het gerecht waar hij maar kon, stoorde zich niet meer aan gerechtelijke uitspraken, trok gerechtelijke bekendmakingen van de kerkdeur en bedreigde pachters van de kerk met excommunicatie wanneer ze hem niet gehoorzaamden. Die misachting van het grafelijk gezag dreigde op een verbanning uit te lopen. Door alle

2002 Jaspars, 'Pastoor Van Bloer'.

2003 RHCL, Graafschap Gronsveld, inv. nr. 305. 
procedures raakte Van Bloer financieel aan de grond en werd beslag gelegd op zijn inkomsten. Pas in juni 1787 werd dit beslag door vonnis van de schepenen opgeheven. ${ }^{2004}$

Zollner kreeg van graaf August Joseph min of meer vrije hand. Daarop begaf hij zich op 20 juni 1786 naar een notaris in Luik om daar formeel te laten vastleggen dat het presentatierecht voor het pastoraat van Heugem toebehoorde aan de graaf van Gronsveld. Dit protest werd vervolgens betekend aan de proost, aan pastoor Van Bloer en aan de aartsdiaken van Haspengouw. Het was bedoeld als waarschuwing voor de proost geen nieuwe pastoor in Heugem voor te dragen, terwijl Van Bloer het niet moest wagen, anders dan bij de graaf, ondershands van zijn beneficie afstand te doen. ${ }^{2005}$

Daarmee was de oorlog verklaard. In afwachting van een reactie stelde Zollner voor al op voorhand een presentatie te doen en hij had ook al kandidaten op het oog. Daarmee dacht Zollner de proost te snel af te zijn bij het overlijden van Van Bloer. Van de aartsdiaken waren weinig moeilijkheden te verwachten. Toch groeide aan Gronsveldse zijde enige ongerustheid over mogelijke interventie die de proost zou kunnen inroepen bij de StatenGeneraal, wanneer zijn presentatie niet werd erkend. Tegen een militaire inval was Zollner niet opgewassen en er zou een flink diplomatiek incident ontstaan. ${ }^{2006}$

Voorlopig peinsde de krasse Van Bloer echter nog niet over aftreden. Begin januari 1788 vernam Zollner dat Van Bloer van zijn pastoraat afstand zou hebben gedaan ten gunste van zijn vroegmislezer Hermans. Achteraf bleek het niet waar te zijn. Volgens Zollner was de pastoor nog altijd een krasse knar met een zeer gezonde eetlust. Het gerucht van de resignatie aan Hermans vormde voor Zollner echter een uitstekende aanleiding een al langer bestaand plan uit te voeren: de verdrijving van Hermans uit het graafschap. Na alle rellen, problemen en duistere zaakjes (zie hierna 15.20.3 sub 'kerkfabriek') kreeg deze geestelijke op 14 januari 1788 bevel het graafschap te verlaten. ${ }^{2007}$

De volgende zet in dit schaakspel deed Van Bloer. Nu Hermans weg was, had hij op 6 maart 1789 Godefridus Gillissen, vicaris bij het kapittel van Onze-Lieve-Vrouwe te Maastricht, tot coadjutor aangewezen. Zollner was razend en klom direct in de pen om de graaf in te lichten. ${ }^{2008}$ De volgende stap was de officiële benoeming van Gillissen begin 1789 door paus Pius VI tot coadjutor met recht van opvolging van pastoor Van Bloer.2009. De daarop volgende weken besteedde Zollner veel tijd aan het afwegen van zijn juridische positie in deze zaak. Hij neigde het meest naar de mening dat proost en graaf een 'cumulatief recht van presentatie hadden, dus elk van beide kon een kandidaat voordragen. Ook werd advies ingewonnen bij een professor in de rechten te Bonn en bij

2004 TJ, inv. nr. M 61, fol. 224-236, Zollner aan A.J. von Toerring-Jettenbach 22 september 1787.

2005 TJ, inv. nr. M 60, fol. 470-473 Zollner aan A.J. von Toerring-Jettenbach 5 juli 1786; TJ, inv. nr. M 60, fol. 489-494, Zollner aan A.J. von Toerring-Jettenbach 15 juli 1786.

2006 TJ, inv. nr. M 60, fol. 508-511, Zollner aan A.J. von Toerring-Jettenbach 18 oktober. 1786.

${ }^{2007}$ TJ, inv. nr. M 61, fol. 258-264, Zollner aan A.J. von Toerring-Jettenbach 14 januari 1788.

2008 TJ, inv. nr. M 61, fol. 669-672, Zollner aan A.J. von Toerring-Jettenbach 6 maart 1789.

2009 Het beneficie viel open in een 'pauselijke maand', waardoor niet de proost van het kapittel, maar de paus het benoemingsrecht had. 
de vaste agent van het graafschap bij het Rijkskamergerecht in Wetzlar. Er moesten echter ook directe maatregelen worden getroffen. Hoewel Zollner met genoegen constateerde dat bij de parochianen in Heugem de weerstand tegen Gillissen groeide, wilde hij op naam van de graaf een verordening doen uitvaardigen waarin Gillissen de toegang tot het graafschap, in het bijzonder Heugem, werd ontzegd. De tekst loog er niet om. In de overwegingen waarin de graaf zijn rechten fundeerde, draafde Zollner enigszins door, maar het zou bij Van Bloer een openlijke blijk van onwil en misachting van het grafelijk gezag zijn om in strijd met het uitdrukkeliike protest van 3 juli 1786 toch een coadjutor te benoemen. De pastoor kreeg uitdrukkelijk het verbod de kerksleutels te overhandigen en Gillissen mocht op geen enkele wijze bezit nemen van zijn ambt. Deed hij dit toch, dan moesten drossaard, schepenen en inwoners dat met alle middelen verhinderen. De verordening zou op zondag na de mis voor de verzamelde parochianen worden voorgelezen en aangeplakt. Ten slotte moesten drossaard en schepenen onderzoeken welke notaris zonder verlof van de commissaris de akte van resignatie van de pastoor had opgesteld en in wiens huis dit was gebeurd. Deze landverrader zou ten exempel van eenieder worden bestraft. ${ }^{2010}$

Langzaam maar zeker werd daarmee het conflict rond het presentatierecht naar een climax gedreven. In mei of begin juni 1789 was pastoor Meijers van Gronsveld bij de aartsdiaken geweest om daar na zijn verkiezing tot landdeken van Maastricht de benodigde institutie te krijgen. Het gesprek kwam op de vele problemen over Heugem, waarbij aartsdiaken baron de Loë zich zeer welwillend toonde. Ten aanzien van het presentatierecht kende hij niet alleen het protest van Zollner uit 1786, maar had hij ook zelf in de institutieregisters gezien dat vroeger presentaties door de graaf hadden plaatsgevonden. Daarom was hij voorlopig niet van zin Gillissen institutie te verlenen en dat gold ook voor een kandidaat van de graaf. Eerst moet de zaak worden uitgezocht en indien het pastoraat van Heugem intussen vacant werd, dan volstond de benoeming van een deservitor of waarnemer. ${ }^{2011}$

Het geschil kreeg een heel andere wending met een proces dat proost de Heusch en Gillissen tegen de graaf aanspanden bij het Rijkskamergerecht in Wetzlar, waar zij handhaving van het presentatierecht met betrekking tot het pastoraat van Heugem eisten. Op 30 november 1789 schreef Zollner aan de graaf dat hij een voorlopige beschikking van het Rijkskamergerecht had ontvangen en dat nog meer zou volgen. Het verbaasde Zollner dat de proost had gekozen voor de weg van het recht, nota bene bij het hoogste rijksgerecht, en dat wapengeweld achterwege was gebleven. ${ }^{2012}$

Een dossier van het proces in Wetzlar is niet bekend. Er zijn slechts brieven van Zollner en enkele akten waaruit het verloop van de zaak min of meer te volgen is. Op 18 augustus 1790 schreef Zollner aan de graaf dat hij gereed was met de vertaling en kopiëring van het volumineuze verweerschrift met negentien bijlagen. ${ }^{2013}$ Hij filosofeerde ook over alternatieven voor de presentatie, bijvoorbeeld beurtelings of cumulatief, waarbij de bisschop of aartsdiaken kon kiezen uit twee kandidaten. De zaak werd intussen in Wetzlar

2010 TJ, inv. nr. M 61, fol. 693-702, Zollner aan A.J. von Toerring-Jettenbach 12 maart 1789.

2011 TJ, inv. nr. M 61, fol. 760-763, Zollner aan A.J. von Toerring-Jettenbach 8 juni 1789.

2012 TJ, inv. nr. M 61, fol. 461-470, Zollner aan A.J. von Toerring-Jettenbach 30 november 1789.

${ }^{2013}$ TJ, inv. nr. M 62, fol. 657-659, Zollner aan A.J. von Toerring-Jettenbach 18 augustus 1790. 
hard gespeeld. Zollner was ontstemd over de 'harte ausdrücke' die werden gebruikt. De graaf zou regeren als een despoot, in Gronsveld zou men een 'monstrum' van despotisme proberen in te voeren en Zollner wilde de graaf in het nietige Gronsveld machtiger maken dan de keizer in het Rijk. Over Gillissen liet Zollner zich op zijn beurt niet gunstig uit. Hij was de zoon van een 'verdorbenen' Maastrichtse zilversmid. Gillissen senior was een tijd geleden bij de koster van Heugem ingetrokken, zonder dit volgens de politieverordening bij Zollner te melden. Hij ging langs de deur en spoorde iedereen aan meer partij voor de pastoor dan voor de graaf te kiezen. Bijna was in Heugem een volksopstand uitgebroken (Zollner spreekt van een patriottische beweging, welke term hij overigens gebruikte voor alle opstanden die zich op dat moment in Luik en Brabant afspeelden). Zollner had de koster het dringende advies gegeven de oude Gillissen uit zijn huis te zetten, wat ook gebeurde. ${ }^{2014}$

Op 11 september 1793 moest Zollner aan de graaf berichten dat een week eerder in Wetzlar vonnis was gewezen. Het presentatierecht was uitsluitend toegekend aan de proost, met als voornaamste argument dat de laatste voordracht in 1734 niet door Gronsveld was weersproken. Zollner zag nog wel mogelijkheden verder te procederen, maar daar is het aan de vooravond van de revolutionaire omwentelingen niet meer van gekomen. 2015

Het is onduidelijk of Gillissen uiteindelijk toch in de parochie is komen werken. De 88jarige Van Bloer maakte op 3 december 1790 de laatste aantekening in het doopboek van Heugem, maar hij wordt nog in 1796 pastoor genoemd. Hij overleed op 12 september 1800 te Heugem op 99-jarige leeftijd.

\section{Kosterij van Heugem}

De onduidelijkheden bij het collatierecht voor de pastoor van Heugem bestonden ook voor de kosterij van Heugem. Uit 1636 en 1683 zijn benoemingsbrieven bewaard voor Paulus Potmans senior en junior, uitgevaardigd door of namens de graaf van Gronsveld, waarop vervolgens de pastoor van Heugem met een tegenhandtekening zijn toestemming schreef.2016 Volgens de aartsdiakonale visitaties van 1699 en 1712 geschiedde de benoeming door de pastoor op voordracht van de graaf en de inwoners. 2017 Bij een brief van 26 januari 1793 van Zollner aan de graaf voegde de commissaris een sollicitatie van Lens Beckers uit Heugem met het verzoek hem de kandidatuur te verlenen voor overname van het kosterschap, wanneer zijn oude vader, die hij op dat moment nog assisteerde, het werk zou neerleggen. ${ }^{2018}$ Zollner adviseerde daarin positief. We mogen hieruit opmaken dat de graaf op dat moment waarschijnlijk met uitsluiting van anderen het collatierecht voor de kosterij uitoefende. Misschien was het recht iets minder omstreden, omdat het volgens de genoemde voorbeelden vaak overging van vader op zoon, maar van een vaste gedragslijn is in ieder geval geen sprake.

2014 TJ, inv. nr. M 62, fol. 467-472, Zollner aan A.J. von Toerring-Jettenbach 17 juni 1791.

2015 TJ, inv. nr. M 62, fol. 214-217, Zollner aan A.J. von Toerring-Jettenbach 11 september 1793).

2016 RHCL, Graafschap Gronsveld, inv. nr. 118.

2017 Simenon, Visitationes Hasbaniae I, 359.

2018 TJ, inv. nr. M 62, fol. 314-315, Zollner aan A.J. von Toerring-Jettenbach 26 januari 1793. 


\section{Kerkfabriek in Heugem}

Aan de vele problemen in Heugem in de tweede helft van de achttiende eeuw leek geen einde te komen. Patronus van de kerk en daarmee in laatste instantie verantwoordelijk voor onderhoud van gebouw en inboedel, was het Maastrichtse Onze-Lieve-Vrouwekapittel, maar volgens de visitatieverslagen van de aartsdiaken van 1699 en 1712 werd in Heugem de kerkmeester door de inwoners van de gemeente voorgedragen aan de pastoor. Deze legde rekening en verantwoording af ten overstaan van de pastoor en leden van het gerecht. Er zullen wel eens hiaten tussen hebben gezeten, maar sinds het aantreden van pastoor Van Bloer in 1734 was nooit meer enige rekening gepresenteerd, ofschoon drossaard Lebens, Prummer en ten slotte Zollner daar meermaals mondeling of schriftelijk op hadden aangedrongen. Door de stijgende ouderdom van Van Bloer had de vroegmislezer in Heugem, Aegidius Hermans, zich van de kerkenkas meester kunnen maken en alle geld verbrast. Het was volgens Zollner een vreemde kerel met voor een priester geen 'anständigen conduite'.

Nauwelijks was in juni 1787 het jarenlange beslag op de pastorele inkomsten van Van Bloer, wegens zijn processen opgeheven, of de financiële verantwoording van de kerk werd onderwerp van een nieuw geschil. Begin juli 1787 begaf Zollner zich met twee schepenen en een notaris naar de pastorie van Heugem en eiste daar niet alleen alle kerkrekeningen op, maar ook de registers van inkomsten en uitgaven en alle andere financiële documenten. Hermans weigerde vierkant en zei dat hij door de aartsdiaken tot 'Kirchenvormünder' was benoemd. Hij viel niet onder Zollner, maar onder de aartsdiaken en de commissaris had hem niets te bevelen. Na deze brutale bejegening liep bij Zollner de temperatuur op en hij zei de pastoor en Hermans flink de waarheid. Ook priesters waren onderworpen aan het landsheerlijk gezag. Dat maakte zoveel indruk dat de pastoor en zijn vroegmislezer inbonden en plechtig beloofden binnen vier weken rekening en verantwoording af te leggen. Maar al op de vijfde dag kreeg Zollner van een bevriende notaris in Maastricht ondershands een decreet van de aartsdiaken van Haspengouw toegespeeld, waarin hem en de schepenen van Gronsveld op straffe van excommunicatie werd verboden zich met de parochierekeningen van Heugem te bemoeien. Binnen veertien dagen zouden zij zich moeten verantwoorden.

De commissaris wachtte het verstrijken van de termijn af en liet in een buitengewone zitting van de schepenbank de pastoor dagvaarden met het verzoek beslag te leggen op de pastorale inkomsten, totdat de pastoor en Hermans met de rekeningen kwamen opdagen. Zollner had verwacht dat Van Bloer daartegen in beroep zou gaan, maar dat gebeurde niet. Het kerkvermogen werd nu door een schepen beheerd en Van Bloer kreeg alleen nog de zogenoemde 'congruë portie' uit de tienden ter waarde van 250 gulden Rijnlands, die het kapittel van Onze-Lieve-Vrouw betaalde.

Intussen was een nieuwe rel ontstaan rond vroegmislezer Hermans. Deze had vrijwillig zijn taak neergelegd en ook voor het catechismusonderricht aan de jeugd bedankt, daarmee de eer aan zichzelf houdend omdat hij dacht dat anders de parochianen hem wel zouden afdanken. Deze vroegmis was geen stichting, maar de parochianen betaalden daar sinds tien jaar vrijwillig voor met veertig gulden per jaar, terwijl de pastoor hem kost en inwoning verschafte. $\mathrm{Na}$ de ontslagname wendden de inwoners van Heugem zich tot Zollner met de vraag of ze mochten vergaderen om een nieuwe vroegmislezer aan te 
stellen, want het was in de winter nauwelijks mogelijk de vroegmis in Gronsveld of Maastricht bij te wonen. Ook kregen de kinderen nu geen catechismusonderricht. Zollner gaf toestemming voor een vergadering en de parochianen vonden een pater franciscaan uit het klooster Lichtenberg, gelegen recht tegenover Heugem aan de andere zijde van de Maas, bereid deze dienst te verrichten. Zollner ging met die boodschap naar de pastoor, maar Van Bloer weigerde toestemming, op aandrang van Hermans. Er zat dus niets anders op dan inschakeling van de vicaris-generaal in Luik. Maar Zollner had nog een ander plan. Wanneer hij beschikte over de kerkrekeningen, dan kon hij de onruststoker Hermans uit het graafschap laten zetten. Het nodige bewijs ter rechtvaardiging van die maatregel hield de commissaris al achter de hand. ${ }^{2019}$

De kans voor verdrijving deed zich voor op 13 januari 1789, toen Zollner bij geruchte vernam dat Van Bloer zijn ambt had overgedragen aan Hermans. Achteraf bleek het verhaal ongegrond, maar Zollner liet 's morgens schrifteliik door de gerechtsbode meedelen dat Hermans binnen 24 uur Heugem en het graafschap moest verlaten. Van Bloer kreeg de aanzegging om de nodige voorzieningen te treffen ten aanzien van het door Hermans beheerde kerkengoed. ${ }^{2020}$ De uitzetting van Hermans verliep niet vlekkeloos. Van Bloer wilde Hermans op alle mogelijke manieren behouden, maar een schriftelijke donderpreek kon de pastoor toch overtuigen. ${ }^{2021}$

$\mathrm{Na}$ het vertrek van Hermans kreeg Zollner de beschikking over de kerkelijke boekhouding, maar eigenlijk was er niet veel om in handen te krijgen. Er bestonden geen registers van inkomsten en alles wat er was, verkeerde in de grootste wanorde. Verder bleek Hermans een berg schulden te hebben achtergelaten en kwamen zaken aan het licht die volgens Zollner omwille van de eer van de geestelijkheid maar beter konden worden verzwegen. De commissaris kreeg van de schepenbank toestemming een bewindvoerder, een 'Kirchenprobst' te benoemen. Het probleem was echter dat niemand in het graafschap, ook geen schepen, bereid was zich in dit wespennest te steken. Het gerecht vroeg daarom Zollner of hij misschien dit werk 'aus Liebe zu Gott' op zich wilde nemen. De commissaris verklaarde zich daartoe bereid, ook al omdat hij dit, zoals hij aan de graaf schreef, als een deel van zijn 'Amtsverrichtungen' beschouwde. Maar hij verwachtte wel dat het een werk van lange adem zou worden. ${ }^{2022}$ Interessant genoeg leek Zollner naderhand van kerkelijke zijde gelijk te krijgen met zijn aanpak. Toen pastoor Meijers van Gronsveld eind mei of begin juni 1789 in Luik de aartsdiaken van Haspengouw bezocht en het gesprek op de vele problemen in Heugem bracht, antwoordde de aartsdiaken dat het voor hem heel normaal was dat een kerkmeester of pastoor van zijn financieel beheer verantwoording aflegde bij het plaatselijk gerecht. Hij zou dat ook aan de pastoor van Heugem mededelen. ${ }^{2023}$

2019 TJ, inv. nr. M 61, 224-236 Zollner aan A.J. von Toerring-Jettenbach 22 september 1787. 2020 TJ, inv. nr. M 61, 258-264 Zollner aan A.J. von Toerring-Jettenbach 14 januari 1788.

2021 TJ, inv. nr. M 61, 274-280 Zollner aan A.J. von Toerring-Jettenbach 23 februari 1788.

2022 TJ, inv. nr. M 61, 274-280 Zollner aan A.J. von Toerring-Jettenbach 23 februari 1788.

2023 TJ, inv. nr. M 61, 760-763 Zollner aan A.J. von Toerring-Jettenbach 8 juni 1789. 


\subsubsection{Collatierechten in Sint-Martens-Voeren en Slenaken Beneficies in Sint-Martens-Voeren en Slenaken}

Aan de kerk van Sint-Martens-Voeren was een klein kapittel verbonden, bestaande uit de pastoor, tevens deken van het kapittel, en drie kanunniken. Volgens de aartsdiakonale visitatie van 1699 werden deze kanunniken door de pastoor als deken in het kapittel opgenomen, waarbij zij de eed moesten afleggen geen geheimen van het kapittel te onthullen en in broederschap en vereniging met de kerken van Luik te leven. Deze opmerkelijke organisatie, een mini-kapittel in een uitgestrekte plattelandsparochie, moet teruggaan op veel oudere structuren en houdt mogelijk zelfs verband met een Karolingisch domein in dit gebied. Ieder van de vier geestelijken beschikte volgens een notitie uit circa 1562 over een eigen prebende, 'in welcken prebenden gehoren die kercken tot Slenaken, Sint Petersfoeren ende Sint Jansroyde (= Saint Jean Sart). ${ }^{2024}$. Elk van de drie kanunniken had op zijn beurt het recht op presentatie van een vervangende zielzorger (deservitor, vicaris) voor deze kerken en de pastoor gaf aan die zielzorgers ('pastores') de institutie. ${ }^{2025}$ Volgens een verklaring uit het midden van de zeventiende eeuw vond omstreeks 1621 binnen de 'cluster' van de kerk van Sint-Martens-Voeren en de drie kapellen een soort boedelscheiding plaats. Aanvankelijk deelden de vicarissen de inkomsten van de kapellen gezamenlijk, wat betekende dat zij ook elkaars lasten droegen en uithielpen bij het lezen van missen. Omdat dit in de praktijk nogal omslachtig was, werd in 1621 bepaald dat ieder moest zorgen voor de missen in zijn eigen kapel en ook de inkomsten van die kapel genoot. Omdat in Slenaken de financiële middelen groter waren dan bij de twee anderen, werden de andere plaatsen enigszins gecompenseerd. De kapel van Slenaken groeide overigens pas in de loop van de zeventiende eeuw uit tot een volwaardige parochiekerk. Er werd vanouds begraven, maar in 1636 werd voor het eerst een doopvont geplaatst ${ }^{2026}$ en in 1676 volgde de formele verheffing tot zelfstandige parochie, overigens met behoud van banden met het kapittel van Sint-Martens-Voeren.

De heer van Gronsveld bezat het collatierecht bij twee van de vier prebenden in het kapittel (de pastoor dus meegerekend), terwijl de begeving van de twee andere toekwam aan de rechtsopvolgers van het geslacht Van den Bongart, op dat moment Winant Pytsen. (Leden van het geslacht Van den Bongart waren voor 1373 heren van Sint-MartensVoeren). Een wat ander beeld schetsen de aartsdiakonale visitatieverslagen. Daarin wordt gezegd dat de plaatselijke heer van Sint-Martens-Voeren het presentatierecht voor het pastoraat en de drie prebenden uitoefende. Die heer was in 1613 de graaf van Gronsveld en in 1699 en 1712 de heer van Mheer. Een voorbeeld van uitoefening van het collatierecht door de graaf van Gronsveld ten aanzien van een kanunniksprebende is te vinden in een akte uit 1609, waarin graaf Johan II van Bronckhorst Batenburg er in bewilligde dat Wynandus Alarts, zoon van scholtis Henricus Alarts te Sint-Martens-

\footnotetext{
2024 RHCL, Familie De Geloes/Kasteel Eijsden, inv. nr. 576.

2025 Simenon, Visitationes Hasbaniae, 219: 'Insuper praedicti canonici praesentant singuli ad singulas filiales ecclesias ....ad ecclesiam Fori S. Petri...ad ecclesiam de Slenaken....ad ecclesiam S. Joannis in Sarto et pastor instituit pastores sicut ipsos canonicos'. Idem, 672, bij Slenaken in 1613 en 1624: 'deservitor constituitur a canonico Fori S. Martini'.

${ }^{2026}$ Maessen, 'Korte schets Slenaken', 21.
} 
Voeren, zijn prebende bij het kapittel ruilde met de prebende van Herman Wetzels, pastoor in Gulpen. ${ }^{2027}$

Tiendheffer in Slenaken was het kapittel van Sint-Martens-Voeren, dat ook de bouwlasten droeg. ${ }^{2028} \mathrm{Bij}$ wie het benoemingsrecht van kerkmeesters lag, is onduidelijk. Mogelijk was dat de graaf. Dat zou men kunnen afleiden uit een brief uit 1721 van de 'officier' Olislagers in Gronsveld, waarin hij de graaf verzoekt een andere kerkmeester ('marguiller') in Slenaken aan te stellen in de plaats van Willem Weijckmans, die veel onrust in het dorp had veroorzaakt en naar Aken was vertrokken (over Weijckmans zie hierna bij de kosterij van Slenaken). ${ }^{2029}$

\section{Beneficie van Onze-Lieve-V roun in Slenaken}

In de kapel van Slenaken was in 1452 door zekere Paulus van Sledenaken een beneficie gesticht ter ere van Onze Lieve Vrouw met de last van één mis per week. Aan dit beneficie waren verschillende renten en pachten verbonden. Volgens het visitatieverslag van de aartsdiaken uit 1624 was de graaf van Gronsveld hiervan collator. Het recht wordt ook uitdrukkelijk vermeld in de akte van verpanding van de heerlijkheid Slenaken in 1638. ${ }^{2030}$

\section{Kosterij in Slenaken}

Over de kosterij van Slenaken zeggen de aartsdiakonale visitatieverslagen van 1613 en 1624 dat deze 'annalis' was, wat waarschijnlijk betekent dat de functionaris voor dit werk per jaar werd aangesteld. Wie daartoe bevoegd was, wordt niet vermeld. De koster ontving niet meer dan twee broden van een bepaalde familie en korenschoven.

Gegevens over de collatie in de zeventiende eeuw zijn niet bekend, maar in het begin van de achttiende eeuw kwam dit recht toe aan de graaf van Gronsveld. Dit blijkt uit een enigszins merkwaardig document van 26 januari 1728. Daarin wordt door graaf Claude Nicolas d'Arberg Valengin een vorm van rechtsherstel gegeven aan Willem Weijckmans, voormalig schepen en koster van Slenaken. Deze had zich door verschillende personen laten gebruiken om te handelen tegen het landsheerlijk belang en was daarom uit beide functies ontslagen. Naderhand bleken de beschuldigingen niet op waarheid te berusten en was de graaf bereid de betrokkene weer in zijn functie te herstellen. Het kosterschap was echter inmiddels al aan een ander vergeven, die daarvoor 25 pattacons aan de graaf had betaald. Weijckmans moest voor zijn rechtsherstel dit bedrag volledig aan deze vervanger vergoeden. Omdat hij zelf wegens zijn hoge leeftijd niet meer goed in staat was de kosterij te bedienen, werd deze functie nu door de graaf 'in gnaden' toegekend aan de zoon, Remigius Weijckmans. ${ }^{2031}$

\footnotetext{
2027 RHCL, Graafschap Gronsveld, inv. nr. 467.

$2028 \mathrm{Zie}$ over de bouwgeschiedenis en de geschillen over de herbouw eind achttiende eeuw: Van Agt, Monumenten Zuid-Limburg/ V aals, 365-371.

${ }^{2029}$ TJ, inv. nr. M 8, fol. 292-296, Olislagers aan graaf d'Arberg Valengin 15 maart 1721.

2030 RHCL, Klooster Hoogcruts, inv. nr. 296.

2031 RHCL, Graafschap Gronsveld, inv. nr. 468.
} 


\subsubsection{Collatierecht in Holset}

Het patronaatsrecht en collatierecht van de heren van Gronsveld over de kerk van Holset is van zeer hoge ouderdom en lijkt een grondheerlijke oorsprong te hebben. We hebben al gewezen op de nauwe samenhang tussen de Gronsveldse leengoederen in Vaals, Holset en Einrade en de tiendplicht aan de kerk van Holset.

Er is slechts weinig documentatie beschikbaar over Holset. In 1612 droeg graaf Johan II van Bronckhorst Batenburg bij de aartsdiaken als pastoor voor Laurentius Brewer. ${ }^{2032}$ Het dossier over de invulling van de pastoorsplaats in 1780, vacant na het overlijden op 23 juli 1780 van pastoor Hubertus Aubinet na een ambtsperiode van liefst 46 jaar, geeft een beeld van de manier waarop daarmee door de graaf werd omgegaan. ${ }^{2033}$ Op 27 juli 1780 deed commissaris Zollner daarvan mededeling aan de graaf. ${ }^{2034}$ Hij berichtte dat het pastoraat van Holset 'den Name einer Pfarrey beynahe nicht verdienet' en geen vetpot was. De parochie telde slechts dertien huizen. Zoals elders in de Staatse Landen van Overmaze werden de tienden, eigenlijk de voornaamste bron van inkomsten van een pastoor, beheerd als domeingoed door de ontvanger van de geestelijke goederen. De pastoor kon de tienden alleen tegen betaling van pachtgeld aan de domeinen innen. Om in zijn levensonderhoud te voorzien, was pastoor Aubinet een soort particuliere kostschool voor jongens tussen twaalf en zestien begonnen, waar hij les gaf in Latijn, Frans en Hoog- en Nederduits. Het instituut floreerde en maakte de pastoor tot een vermogend man, die zijn verdiensten in huizen en grond belegde. Dat inkomen bood de mogelijkheid om, bij het klimmen der jaren, op eigen kosten een 'deservitor' aan te trekken, die met de gewone pastorale taken werd belast.

Deze man, Willem Hendrik Wiertz, geboortig van Holset, bleek de enige serieuze kandidaat die zich bij Zollner in Gronsveld voor de opvolging aandiende. Op zich was die geringe belangstelling wel verklaarbaar, want al was Aubinet rijk, de parochie was arm. Wiertz beschikte over alle benodigde papieren, een aanbeveling van Aubinet en een petitie getekend door de inwoners van Holset, waarin zijn kandidatuur werd ondersteund.

Op het eerste gezicht leek de benoeming van een pastoor voor het onbeduidende 'buitenlandse' Holset een routineaangelegenheid, waarmee niet veel eer viel te behalen. Toch speelden voor Zollner wel degelijk politieke motieven een rol. In Holset en Vaals lagen diverse grote en een hele reeks kleine Gronsveldse lenen. Vanuit Gronsveld viel het moeilijk daar goed zicht op te houden en de gebrekkige administratie van die lenen had al meermalen tot problemen geleid. Met Wiertz, van wie na een benoeming een grote loyaliteit mocht worden verwacht, dacht Zollner over een vooruitgeschoven post te beschikken. Niemand kende de plaatselijke familieverhoudingen beter dan een pastoor, geboortig uit Holset zelf. Sterfgevallen van eventuele leenmannen kwamen automatisch ter kennis van de pastoor. Wanneer die namen aan het Gronsveldse leenhof werden doorgegeven, kon actie worden ondernomen om de erfgenamen tot nieuwe verheffing en betaling van heergewaad aan te manen.

Deze overwegingen waren voldoende voor Zollner om Wiertz bij de graaf aan te bevelen. Op 8 augustus 1780 werd in München, na zorgvuldige bestudering van alle stukken, het

2032 D[oppler], P.,'Pastorie te Holzet’.

2033 Zie daarover TJ, inv. nr. M 8, fol. 335-379. Over Aubinet zie: Habets, De Studiebeurzen, 47-48.

2034 TJ, inv. nr. M 8, fol. 351-357. 
grafelijk patent uitgevaardigd, op basis waarvan aan Wiertz de canonieke institutie kon worden verleend. Uit de begeleidende brief voor Zollner blijkt dat zijn overwegingen ten aanzien van de Gronsveldse lenen wel degelijk door de graaf waren meegewogen. ${ }^{2035}$ Zoals gebruikelijk bij collatiebrieven die bij de grafelijke kanselarij in München werden uitgevaardigd, was de tekst weer eens niet aangepast aan de formaliteiten binnen het bisdom Luik. De geadresseerde was de bisschop of zijn vicaris-generaal, terwijl de bevoegdheid tot institutie in het geval van Holset dat slechts de rang van 'kwart kerk' ('quarta capella') bezat, berustte bij de deken van het landdekenaat Maastricht. ${ }^{2036}$ Er schijnt in dit geval niet moeilijk over te zijn gedaan. Landdeken Pironnet, pastoor van Visé, verleende op 20 september 1780 de institutie, maar om onduidelijke redenen kon Wiertz pas op 20 juni 1781 bezit nemen van zijn pastorie.

\subsection{6 'Patronaatsrecht' over het klooster Hoogcruts ${ }^{2037}$}

Binnen het gebied van de heren van Gronsveld lag slechts één klooster, in 1496 gesticht door sepulchrijnen of reguliere kanunniken van de orde van het H. Graf. Gilles de la Croix, rector van de in 1428 gebouwde kapel van Hoogcruts, was in 1493 ingetreden in het klooster van deze orde in Sint Odiliënberg. Met toestemming van de pastoor van SintMartens-Voeren als plaatselijk parochieherder en van de provinciaal van de orde van het H. Graf, werd Hoogcruts in 1496 tot klooster verheven, met Gilles de la Croix als eerste prior. Hoogcruts werd letterlijk een 'grensgeval'. Want de gebouwen lagen deels op het gebied van Slenaken en deels op het gebied van Noorbeek. De grens liep zelfs door de kloosterkerk. Slenaken was rijksonmiddellijk gebied onder het gezag van de heren van Gronsveld, terwijl Noorbeek als deel van het Land van Dalhem onder Brabantse heerschappij viel. Waren de kanunniken nu 'van het Rijk' of Brabanders? De nogal willekeurige manier waarop de religieuzen daar zelf invulling aan gaven, werd een bron van ellende. Een tweede probleem vormde het gestaag groeiende grondbezit van het convent. Dat verschafte de kanunniken veel invloed in de streek, zeker ook in Slenaken, maar daarnaast kostten deze goederen 'in de dode hand' de Gronsveldse schatkist geld door gemis aan werfschellingen.

Het klooster verkeerde aan het einde van de zestiende eeuw, honderd jaar na de stichting, in een desolate toestand. $\mathrm{Na}$ de verwoesting door Spaanse troepen in 1579 waren de conventsgebouwen weer met moeite opgebouwd, maar er woonden nog slechts twee kloosterlingen. Graaf Johan II van Bronckhorst Batenburg, die beweerde dat zijn familie als stichter (!) van het klooster bepaalde rechten op het instituut kon doen gelden, probeerde in 1603 de sepulchrijnen bij de jezuïeten van Aken te incorporeren. De graaf

2035 TJ, inv. nr. M 8, fol. 339-342, A.J. von Toerring-Jettenbach aan Zollner 6 augustus 1780.

2036 In het bijzonder in het bisdom Luik werd verschil gemaakt tussen 'hele', 'halve' en 'kwart kerken'. Deze onderscheiding, die in oorsprong terug lijkt te gaan op een waardering van de welstand van een kerk, had betekenis voor de de hoogte van het bedrag waarvoor een kerk bij kerkelijke belastingen werd aangeslagen (het volle pond, de helft of éénvierde). Bij hele en halve kerken werd de institutie verleend door de aartsdiaken, bij kwart kerken door de in rang lagere landdeken, zie Munsters, 'Verkenning', 463466.

2037 De hierna beschreven problematiek is een samenvatting van het uitgebreidere artikel van Delahaye, 'Het klooster Hoog-Cruts'. 
onderhield goede connecties met deze orde, want hij had al eerder zijn stadswoning in Maastricht aan de jezuïeten geschonken. De twee bewoners van Hoogcruts werden door de graaf gesommeerd met de inlijving akkoord te gaan, maar hun weerstand bleek taaier dan verwacht. De heren ontkenden de rechten van de graaf (waarvoor ook geen bewijs was) en wisten de incorporatie te voorkomen met een beroep op de Raad van Brabant in Brussel en de pauselijke curie in Rome. Die inmenging vanuit Brussel was natuurlijk gemakkelijk, omdat het klooster op de grens van Spaans-Brabants territoir lag. Het proces was overigens niet alleen onaangenaam voor de kloosterlingen, ook hun pachters kregen te maken met gerechtelijke vervolging door de graaf en schepenen van Slenaken.

De affaire laat zien dat de graven van Gronsveld zeggenschap pretendeerden over het klooster, hoewel ten onrechte en uiteindelijk ook zonder succes. Maar daarna kwam het eigenlijk nooit meer goed tussen de partijen. De Bronckhorsten beseften dat de paters bij een confrontatie een geduchte tegenstander vormden. Zij beschikten over kennis, relaties en beheersten als geërfden de dorpspolitiek binnen Slenaken. Feitelijk werd het dorpsbestuur van Slenaken vanuit Hoogcruts bepaald. Daarom wilden de graven van Gronsveld juist dit grondbezit beperken door aanscherping van de wetgeving op het gebied van de 'dode hand'. De landsheerlijke ordonnanties daarover uit 1636 en 1670 waren in beginsel gericht tegen alle verwerving van onroerend door geestelijke instellingen, maar uit de teksten blijkt duidelijk dat Hoogcruts daarvoor de aanleiding vormde (zie Bijlagen 5 en 6).

De tweede confrontatie tussen Hoogcruts en de graaf vond plaats in de jaren 1680-1684. Op 26 februari 1680 drong Johan Frans van Bronckhorst Batenburg met een groepje medestanders het klooster binnen. In de stallen moesten de paarden van de kloosterlingen plaats maken voor die van de graaf en zijn gezelschap. Vervolgens begonnen de invallers aan een stevige schranspartij en plunderden de voorraadkast. De paters werden geschoffeerd en beledigd, maar pogingen van de graaf en zijn kornuiten hen uit het klooster te verdrijven mislukten. De directe aanleiding voor dit drieste optreden van de graaf is niet bekend, maar er waren wel enkele incidenten aan voorafgegaan. Rond 1670 hadden de paters een wapen in hardsteen van de graven van Gronsveld uit hun kerk laten verwijderen. Vervolgens waren er incidenten over het onderbrengen van ongenood bezoek. Evenals zijn grootvader beschouwde Johan Frans van Bronckhorst Batenburg zich als patronus van het klooster en meende hij dit adres te kunnen gebruiken om deftige relaties te herbergen. Begin 1673 weigerden de kanunniken onderdak aan een vriend van de graaf, wat laatstgenoemde uitlegde als felonie (ontrouw van een leenman). Het klooster bezat immers landerijen in leen van de graaf. Rond halfvasten probeerde graaf Johan Frans het zelf ook eens met een gevolg, maar de prior had tot zijn spijt niets in huis om het gezelschap te voeden. Ook slecht viel een verzoek van de paters om te mogen worden vrijgesteld van de 'karweien', herendiensten die de inwoners van het graafschap ten behoeve van de heer moesten verrichten. Ten slotte was er misschien nog een plooi die rimpelloze betrekkingen in de weg stond: een lening van dertienduizend gulden, door Hoogcruts en het klooster Sinnich in 1656 verstrekt aan graaf Jost Maximiliaan van Bronckhorst Batenburg. Deze had dit bedrag gebruikt om daarmee weer de verpande heerlijkheid Slenaken terug te krijgen. De afkeer van graaf Johan Frans tegen de 
kanunniken van Hoogcruts moet heel diep hebben gezeten, te oordelen naar de scheldwoorden die hij en zijn metgezellen in de hitte van de strijd gebruikten. Ook al was het geen geschikt moment voor een diplomatieke woordkeuze, beledigingen aan het adres van de kloosterlingen als 'eenen plumpen bour' en 'dou en bes maer eene beeste... dou en bes maer eenen groeven bour' getuigen van een diepe minachting.

Enkele dagen na zijn inval in het klooster op 26 februari 1680 liet Jan Frans van Bronckhorst Batenburg door het leenhof van Gronsveld beslag leggen op leengoederen van het klooster onder Slenaken. De religieuzen wendden zich vervolgens tot de Raad van Brabant in Brussel en verkregen daar een beslissing op grond waarvan de graaf werd verboden zijn actie voort te zetten. Deze weigerde echter als lidmaat van het Heilige Roomse Rijk zich aan de jurisdictie van de Raad te onderwerpen. Daarna volgde gedurende vier jaar een reeks incidenten, waarin partijen elkaar met beslagleggingen bestookten. Geweld werd niet geschuwd. Hoogcruts vroeg in Brussel zelfs om militaire interventie, maar daar voelde men toch meer voor een diplomatieke oplossing. Het is de vraag of de arrestatie en gevangenneming van de stadhouder van het leenhof van Gronsveld in 1682 bij een bezoek aan Brussel daar erg aan bijdroeg. Een jaar later schoot een stalknecht van de graaf met zijn geweer op de prior en een broeder van het klooster. Uiteindelijk werd duidelijk dat dit zo niet langer kon doorgaan. De juristen Jodoci uit Aken en Willem Veucht werkten namens de betrokkenen aan een oplossing. Eigenlijk was die onmogelijk zonder een grensverlegging, want door de ligging van Hoogcruts zou de jurisdictie onduidelijk blijven. Maar zelfs een keuze daarin kon het conflict niet oplossen, want als Brabander kon men niet voor een buitenlands gerecht worden gedaagd en hetzelfde gold voor de graaf als lidmaat van het Rijk. Tegelijkertijd was Hoogcruts als leenman van Gronsveld ook gehoorzaamheid aan de graaf verschuldigd. Voor deze onmogelijke situatie ontwierpen Jodoci en Veucht in 1684 een compromis, waarbij de wederzijdse pesterijen zouden ophouden. Een echte oplossing was het niet, maar er viel verder gedurende de daarop volgende decennia mee te leven.

\subsection{Recht van admissie voor openbare ambten}

\subsubsection{Notarissen}

De eerste openbare notarissen in de Nederlanden waren actief sinds de tweede helft van de dertiende eeuw. ${ }^{2038}$ De ontwikkeling van het notariaat verliep per gewest verschillend. ${ }^{2039}$ Het ambt werd als nevenfunctie beoefend door geestelijken, maar speelde zich af op kleinschalig niveau. Aanvankelijk werkten notarissen vooral in de steden en in de omgeving van belangrijke kerkelijke instellingen zoals kapittels, waarvoor ook andere schrijfwerkzaamheden werden verricht. Pas in de loop van de veertiende en vijftiende eeuw passeerden zij ook akten op het platteland, meestal in de sfeer van het kerkelijk recht, het personen- en familierecht en het erfrecht.

2038 Zie voor een overzicht van de ontwikkeling in de middeleeuwen: Cappon, 'Inleiding: de continuïteit van het notariaat.'

2039 Zie over de ontwikkelingen in Nederlandse' en 'Belgische' gewesten de verschillende opstellen in: Gehlen/Nève, Het notariaat in de Lage Landen. 
Notarissen ontleenden hun bevoegdheid tot het maken van akten aan een pauselijke en/of keizerlijke benoeming. Voor de keizer was de creatie van notarissen een echt regaal of hoogheidsrecht, dat echter na 1350 veelal werd gedelegeerd aan hofpaltsgraven. Er vond zelfs subdelegatie plaats aan vicehofpaltsgraven. Pauselijke aanstellingen waren zeldzamer. Ook het pauselijk benoemingsrecht werd gedelegeerd aan apostolische paltsgraven. De paltsgraaf beoordeelde de kandidaat voor het notariaat op zijn bekwaamheid en, na een met goed gevolg afgelegd examen, volgde de beëdiging. Aangezien met benoemingen ook geld werd verdiend, werd met de kwaliteitseisen regelmatig de hand gelicht. Kritiek op misstanden leidde in de loop van de vifftiende eeuw tot een roep om hervorming. In 1498 bepaalde de Rijksdag dat in het Heilige Roomse Rijk alleen notarissen mochten worden toegelaten na admissie en beëdiging door het Rijkskamergerecht. De volgende stap in het streven naar kwaliteitsverbetering werd gezet met de Reichsnotariatsordnung van 1512. Die bepaalde dat notarissen zich bij hun werk moesten richten naar het (al)gemene rijksrecht, maar ook naar het landsheerlijke en plaatselijke recht. Toezicht op het notariaat werd een landsheerlijke bevoegdheid. Hoewel admissie al eerder bekend was, werden aldus vanaf de zestiende eeuw landsheerlijke examinering en beëdiging van notarissen, meestal door het gewestelijk hof van justitie, gebruikelijk. Daarnaast bestond ook nog de examinering door het Rijkskamergerecht.

Tot op zekere hoogte vergelijkbaar met notarissen waren de landmeters. Naast het technisch uitmeten van grenzen en grondoppervlakten stelden zij ook akten op, vaak boedelscheidingen, waarbij landerijen tussen erfgenamen werden verdeeld. Voor de landmeter gold, net als voor de notaris, de eis van betrouwbaarheid. Daarom waren ook zij onderworpen aan landsheerlijke admissie.

In het kader van deze studie naar Gronsveld is slechts oppervlakkig onderzoek verricht naar de rol van notarissen. Het daarvoor beschikbare bronnenmateriaal is, mede door het ontbreken van schepenbankarchieven, gering en verspreid. Uit de tijd voor circa 1638 zijn er geen gegevens waaruit blijkt dat notarissen of landmeters hier een vaste praktijk uitoefenden. Waarschijnlijk hebben de inwoners, voor zover nodig, gebruik gemaakt van notarissen in Maastricht of kleinere plaatsen in de omgeving.

Vaak werd het notariaat gecombineerd met de functie van secretaris bij de schepenbank of het leenhof. Het ambt bleef in de familie en ging over van vader op zoon of schoonzoon. Secretaris Lambert Lousberchs senior noemt zich in de door hem als notaris opgemaakte akten in 1638 'openbaar notaris'2040 en van 1647 tot 1660 steeds 'geadmitteerd door de Raad van Brabant', in 1658 met de toevoeging 'tot Gronsfelt residerende'. ${ }^{2041}$ Lambert Lousberchs junior was secretaris, maar werkte na zijn pensionering in 1719 nog als 'notaris imperiaal publycq in Gronsfelt residerende'. ${ }^{2042}$ Zijn schoonzoon Johannes Godefridus Lebens, die hem tussen 1706 en 1714 als secretaris opvolgde en na 1721 ook drossaard werd, gebruikt in 1721 de titels 'notaire et greffier du comté de Gronsfelt' en 'notarius et

2040 RHCL, Graafschap Gronsveld, inv. nr. 359.

2041 RHCL, Notariële archieven berustende in het Rijksarchief in Limburg te Maastricht 1544-1842, inv. nr. 435.

2042 RHCL, Notariële archieven berustende in het Rijksarchief in Limburg te Maastricht 1544-1842, inv. nr. 441. 
scriba comitatus Gronsfeldensis'. ${ }^{2043}$ Diens schoonzoon Jacobus Berchmans, secretaris van het leenhof en een 'allesweter' wat betreft gronden in het graafschap, noemt zich in het tweede kwart van de achttiende eeuw 'keizerlijk openbaar notaris, geïmmatriculeerd en wonend in Gronsveld ('caesareus publicus in Gronsfeld immatriculatus et residens notarius necnon secretarius feudalis ibidem'). Mogelijk bedoelde Berchmans met die 'immatriculatie' een bepaalde vorm van toelating, maar de juiste betekenis van dit woord blijft hier vaag.

Ook bij Johannes Graven, secretaris van de schepenbank Slenaken en schepen te Gronsveld, ging het ambt van notaris over van vader op zoon. Hij passeerde tussen 1650 en 1659 akten als 'openbaar notaris', in 1658 'notaris publycq resideerende binnen Gronssfeldt'.2044 Van zijn zoon Johannes Ludovicus, eveneens secretaris in Slenaken en schepen in Gronsveld, zijn in het gichtregister van het leenhof van Gronsveld tussen 1677 en 1699 diverse akten ingeschreven, aanvankelijk als 'notaris publiek', in 1684 'geadmitteerd door de Raad van Brabant en residerende in Gronsveld' en van 1685-1699 'notaris imperiael publiek, residerende in Gronsveld.2045 In 1725 voert hij dezelfde titel, maar dan in het Latijn. ${ }^{2046}$ Tussen hem en Johannes Godefridus Lebens bestond overigens een flinke vijandschap.

Op basis van deze vermeldingen mogen we voorzichtig concluderen dat tenminste sinds het midden van de zeventiende eeuw de secretarissen van de banken Gronsveld-HeugemHonthem en van de bank Slenaken ook als notaris in Gronsveld werkten op basis van admissie door de Raad van Brabant of keizerlijke toelating. Van expliciete grafelijke admissie zijn geen voorbeelden gevonden. Dit sluit overigens niet uit, dat zoiets toch heeft bestaan. Deze notarissen werkten zowel voor cliënten uit het graafschap Gronsveld als omliggende dorpen, zoals ook omgekeerd concurrentie bestond van notarissen uit Maastricht en plaatsen in de omgeving. Bloeiende praktijken zullen het niet zijn geweest; het ambt van notaris bleef een nevenfunctie.

Het notarieel proces-verbaal van de inhuldiging van graaf Maximilian Emanuel von Toerring-Jettenbach op 1 april 1754 werd niet opgesteld door de Gronsveldse notaris Jacobus Berchmans, maar door de voor dat doel door Prummer ontboden Akense keizerlijke notaris Johann Heinrich Krämer. Voor die keuze kunnen verschillende redenen zijn geweest. Berchmans was als secretaris van het leenhof zelf ook betrokken bij de inhuldiging, verder beheerste hij wel de Duitse taal, maar te weinig om een foutloos verslag te kunnen maken en ten derde was hij ziekelijk. Hij overleed het jaar daarop. Daarna was er in Gronsveld geen notaris meer gevestigd.

${ }^{2043}$ RHCL, Rijkskamergerecht, inv. nr. 114, fol. 58; fol. 59, met opgedrukt zegel.

2044 RHCL, Graafschap Gronsveld, inv. nr. 359; RHCL, Notariële archieven berustende in het Rijksarchief in Limburg te Maastricht 1544-1842, inv. nr. 439.

2045 RHCL, Graafschap Gronsveld, inv. nr. 366. In 1714 is het weer 'notaris publicque' (RHCL, Graafschap Gronsveld, inv. nr. 359.

2046 RHCL, Rijkskamergerecht, inv. nr. 71/2, fol. 81-82: akte van 9 mei 1725: 'notarius caesarius publicus in libero sacri Romani Imperii comitatus Gronsfeldensi prope Traiectum ad Mosam residens'. 
Vanaf 1765 tot 1782 werd in Gronsveld regelmatig gebruik gemaakt van de diensten van Johannes Pael of Paal, openbaar pauselijk en keizerlijk notaris, gevestigd te MaastrichtWyck. Van hem is over deze jaren ook een bescheiden protocol bewaard gebleven. ${ }^{2047} \mathrm{Hij}$ passeerde vooral akten die betrekking hebben op plaatsen buiten Maastricht en de Landen van Overmaze, zoals Bemelen, Wylre, Rijkckholt, Rekem en dorpen in het graafschap Loon. Ook inwoners van Heugem deden regelmatig een beroep op hem. Meestal ging het om testamenten of contracten; akten betreffende overdracht of bezwaring met hypotheek van onroerend goed komen nauwelijks voor. Tekenend voor zijn prestige zijn een procesverbaal dat hij in 1766 opmaakte van een vergadering van de inwoners van Heugem in het geschil met het kapittel van Onze-Lieve-Vrouwe te Maastricht over herstel van de kerktoren ${ }^{2048}$ en het proces-verbaal van de inhuldiging van graaf August Joseph von Toerring-Jettenbach op 5 mei 1773.2049 Toch blijft Pael een enigszins raadselachtige figuur. Hij was afkomstig uit Cornelimünster bij Aken, werd in 1759 als burger in Maastricht aangenomen en woonde met zijn gezin in de Rechtstraat in Maastricht-Wyck. In het wijkregister staat hij vermeld als 'winkelier'. ${ }^{2050}$ Duidelijk is wel dat hij, wonend in Maastricht, buiten het stedelijk notariaat viel en daar ook niet was geadmitteerd. Met zijn akten in zowel het Nederlands als het Duits lijkt hij een notariële praktijk als nevenactiviteit te hebben gehad, die vooral was gericht op rijksonmiddellijke of daarmee in status vergelijkbare territoria en dan in het bijzonder voor akten die geen betrekking hadden op de overdracht van onroerend goed.

\subsubsection{De secretaris van de schepenbank als zelfstandig openbaar ambtenaar}

Ongeveer gelijktijdig met het beëindigen van de activiteiten van Johannes Pael lijkt een einde te zijn gekomen aan het optreden van notarissen. Vanaf eind 1782 begon Johannes Godefridus Lebens onder de titel van 'secretaris van de schepenbank', maar handelend als zelfstandig openbaar ambtenaar, in Gronsveld met het passeren van akten. Hij voerde daarvoor een protocol met gemiddeld ruim dertig akten per jaar. ${ }^{2051}$ Uit de tekst van de akten blijkt niets van enige vorm van landsheerlijke admissie. Misschien werd dat ook niet nodig geacht omdat hij toch al als secretaris was beëdigd. Het verschijnsel van secretarissen van schepenbanken ten plattelande die als een soort notaris zelfstandig akten passeerden, lijkt in de achttiende eeuw vaak voor te komen in de Landen van Overmaze en aangrenzende territoria. Over de exacte verhouding van hun werkzaamheden ten opzichte van de activiteiten van de schepenbanken en de 'officiële' notarissen op het plattelande bestaat geen duidelijkheid.

\footnotetext{
2047 Joannes Pael, 1765-1782, zie: Gehlen, Notariaat Maastricht, 312. RHCL, Notariële archieven berustende in het Rijksarchief in Limburg te Maastricht 1544-1842, inv. nr. 2396.

2048 RHCL, Graafschap Gronsveld, inv. nr. 239.

2049 TJ, inv. nr. M 56, fol. 165-181.

2050 RHCL, Indivieze Raad van Maastricht, inv. nr. 2052.

2051 RHCL, Notariële archieven berustende in het Rijksarchief in Limburg te Maastricht 1544-1842, inv.
} nr. 4791-4797. 


\subsubsection{Notariële werkzaamheden van pastoors}

Behalve notarissen en secretarissen van schepenbanken, maakten ook pastoors ambtshalve officiële akten op. Die bevoegdheid als zodanig bestond al heel lang. In een decretaal van paus Alexander III uit 1171 was bepaald dat pastoors in aanwezigheid van twee of drie getuigen testamenten mochten passeren. ${ }^{2052}$ De naleving van deze regel verliep niet in alle landen hetzelfde, maar in de Nederlanden en in het Heilige Roomse Rijk was dit vrij gebruikelijk. Ook in Gronsveld konden volgens de Recbtsordnung van 1671 pastoors, in aanwezigheid van twee getuigen, testamenten opmaken. ${ }^{2053}$ Akten bleven overigens niet strikt beperkt tot testamenten. Zo kwamen soms ook akten van huwelijkse voorwaarden of akten in kerkelijke aangelegenheden voor, zoals de stichting van missen. Het is vaak moeilijk goed zicht te krijgen op de aantallen omdat veel materiaal verloren is gegaan, maar meestal maakten pastoors op het platteland één of twee akten per jaar op. ${ }^{2054}$ Daarnaast waren er in de steden pastoors of onderpastoors die er een algemene notariële praktijk op na hielden en uit dien hoofde verschillende soorten akten passeerden.

Ook in Gronsveld zijn enkele voorbeelden bekend van akten die door pastoors werden opgemaakt. Op 2 mei 1737 stichtten Adam Pluijmeeckers en Maria Lemmens voor pastoor Henricus van der Meeren twee jaarlijkse vroegmissen te Eckelrade. Het jaar daarop, op 9 november 1738, passeerde voor dezelfde pastoor het testament van Maria Lemmens, waarbij zij een jaargetijde stichtte. Op 5 april 1748 makte voor frater Bernardus Rubens, 'parochiae deservitor' of 'bediender der pastorije', Matthijs Pluijmaeckers zijn testament, waarin hij een jaargetijde stichtte. Rubens nam als 'deservitor' op dat moment het pastoraat waar in de tijd tussen het overlijden van pastoor Van der Meeren in 1747 en de komst van diens opvolger Schmädel (24 juni/7 juli 1748).2055 In geen van de genoemde voorbeelden blijkt iets van een bijzondere landsheerlijke admissie.

Meestal werd de bevoegdheid van de pastoor geacht ook te gelden voor de onderpastoor. Maar over de vervanging van de pastoor bij ziekte of afwezigheid ontstond aan de vooravond van de Franse Tijd in Gronsveld nog een interessant probleem. Op 20 april 1795 passeerde ten overstaan van Christiaan Schrijnemaekers, onderpastoor en vroegmislezer ('primissarius') van Gronsveld, een codicil van Frans Bemelmans, waarin deze een weide legateerde aan Gillis Claessens. Pastoor Meijers was op dat moment ernstig ziek en kon zijn taken niet uitoefenen. Na het overlijden van Bemelmans ontstond tussen zijn erfgenamen onenigheid over de vraag of de eerder genoemde weide buiten de boedelscheiding moest blijven, met andere woorden, of het daarop betrekking hebbende codicil geldig was. De Kinderen Van den Berg als erfgenamen van Bemelmans betoogden voor het gerecht van Gronsveld dat het legaat aan Gillis Claessens ongeldig was, aangezien

2052 Zacharias, Zur Entwicklung des internationalen Testamentenformenrechts, 14-15; Gilissen, Historische Inleiding tot het recht, 651; voor de vraag naar de geldigheid van deze testamenten in het Stift Thorn, zie: Gehlen, 'Testamentaire perikelen', 155-156, 163-164.

2053 Rechtsordnung Gronsveld Titulus I, \$S 2, 4-6.

2054 Gehlen, 'Testamentaire perikelen', 164 noemt voor de drie kleine plattelandsdorpen Grathem, Baexem en Stramproy bij een inventarisatie in 1777 voor de tijd vanaf 1665-in totaal 117 bewaard gebleven testamenten gepasseerd voor pastoors, onderpastoors en kapelaans.

2055 RHCL, Parochie H. Martinus Gronsveld, voorlopig inv. nr. 13. 
de akte was opgemaakt door een priester die geen 'beneficium curatum', een beneficie met zielzorg, bezat. Op zich was dat juist, want aan het lezen van de vroegmis waren geen specifieke werkzaamheden op het gebied van de zielzorg verbonden. De tegenpartij bestreed de eis van zielzorg. Het feit dat Schrijnemaekers was aangesteld als onderpastoor en uit dien hoofde alle normale pastorale taken uitoefende, was voldoende om de rechtsgeldigheid te erkennen. Die mening werd ook gedeeld door de rechtsgeleerde adviseurs die door de schepenen werden geraadpleegd. In het vonnis uit 1796 (datum ontbreekt) werd overwogen dat in Gronsveld van oudsher testamenten en andere akten van uiterste wil mochten passeren ten overstaan van de pastoor of de onderpastoor en twee getuigen. Men beriep zich daarvoor ook op wetgeving van keizer Karel V uit de zestiende eeuw die het maken van testamenten door pastoors en onderpastoors toestond. Het bezit van een beneficie met zielzorg was niet noodzakelijk. De onderpastoor moest alleen zijn aangesteld als vervanger voor alle pastorale taken en niet een toevallige assistent zijn. De vordering van de eiser werd dus afgewezen. ${ }^{2056}$

\subsubsection{Landmeters}

In vergelijking met de notarissen zijn de gegevens over landmeters nog schaarser. Landmeters leerden hun vak in de praktijk bij collega's. Zij vroegen op basis van getuigschriften admissie bij de hoge overheid van een bepaald gebied. Het vroegste voorbeeld van een landmeter in het graafschap levert een opmeting uit 1666 door Jonannes Graven in Slenaken. Graven, die ook werkzaam was als secretaris van Slenaken en notaris, ondertekent nadrukkelijk met 'lantmeter' en hij verrichtte zijn werk in opdracht van de gravin. ${ }^{2057}$ Het gebeurde dus met toestemming van de landsvrouwe, maar het is de vraag of daar een officiële toelating aan ten grondslag lag. Ongetwijfeld zullen in Gronsveld in de zeventiende meer landmeters hebben gewerkt, maar om daar meer helderheid over te krijgen, is nader onderzoek nodig. In 1734 kreeg de in Gronsveld wonende Servaas Bouchoms van de baron van het aangrenzende Rijckholt toelating als landmeter voor die plaats en werd daar als zodanig ten overstaan van de schepenen beëdigd. Servaas presenteerde bij die gelegenheid attesten van drie andere landmeters dat hij zijn vak verstond. ${ }^{2058}$ Het is aannemelijk dat hij ook in Gronsveld werkte.

Op 7 februari 1735 moet Jacobus Berchmans, vice-secretaris van de schepenbank, secretaris van het leenhof, en notaris, tot landmeter in Gronsveld zijn toegelaten. ${ }^{2059}$ Berchmans overleed in 1755. Mogelijk werd daarom een heel grote opdracht, de volledige

\footnotetext{
${ }^{2056}$ De uiteindelijke afloop van de zaak is niet bekend, eiser heeft nog wel beroep ingesteld bij de nieuwe Franse rechtbanken, maar het spoor loopt daar dood.

2057 RHCL, Klooster Hoogcruts, inv. nr. 1002.

2058 RHCL, Graafschap Gronsveld, inv. nr. 102.

2059 In de Stadsbibliotheek Maastricht bevindt zich onder de signatuur SB 130 F 22 een boek van Daniel Schwenkers, getiteld Geometriae practicae novae et auctae libri IV, Neurenberg 1567. Daarin staat als aanduiding van een van de vroegere eigenaren de tekst: 'Jacobus Berchmans geometra in comitatu de Gronsfelt admissus 7 febr. 1735 me utitur' (Jacobus Berchmans, op 7 februari 1735 in het graafschap Gronsveld toegelaten landmeter, gebruikt mij'), vriendelijke mededeling drs. E. Ramakers,

Stadsbibliotheek Maastricht.
} 
opmeting van het graafschap omstreeks 1754-1755 toevertrouwd aan Arnoldus Schutgens uit Puth. 2060

In dezelfde tijd moet ook Peter Bouchoms (geboortig uit Gronsveld) met landmeten zijn begonnen. ${ }^{2061}$ Mogelijk was hij een zoon van Servaas Bouchoms. Op 15 maart 1755 kreeg hij van de Staatse Raad van Brabant in Den Haag het patent om binnen de Staatse gebieden 'de konste van geometrie ofte landmeeterschap' te mogen uitoefenen. Hij was ook in Gronsveld actief, maar zonder admissie. Dat komt naar voren in de tekst van een patent dat graaf August Joseph, waarschijnlijk op aandrang van Zollner, in 1779 voor Bouchoms uitvaardigde. Daarin staat dat de landmeter al meer dan twintig jaar in Gronsveld had gewerkt, zonder van de vorige graaf 'ein ordentliches decret' te hebben ontvangen. Op zijn verzoek kreeg Bouchoms nu formeel admissie en moest hij een eed afleggen bij Zollner als adjunct-commissaris en drossaard. Ook moest hij een register bijhouden van de akten die hij opmaakte. ${ }^{2062}$

Met zijn formele toelating kwam Bouchoms op gelijke voet met landmeter Christiaan Gelens uit Sint-Geertruid. Die vroeg in 1773 bij Prummer toelating om in Gronsveld te mogen werken. Hij dacht daartoe voldoende bekwaam te zijn op grond van eerdere admissies door de Staten Generaal in Den Haag, het kapittel van Sint-Martinus in Luik als heer van Breust en schout en schepenen van Mheer. In het advies dat grafelijk rentmeester Johan Frans Lebens uitbracht, schrijft deze dat 'altoos van alle immemoriale tijden twee geswooren en geadmitteerde landmeeters in dese vrije rijkxe graefschappe Gronsfeldt geweest sijn' tot algemeen nut van de inwoners. Het zou daarom vanwege belang, kwaliteit en prijs van het werk nuttig zijn naast Gelens nog een tweede landmeter toe te laten. ${ }^{2063}$ Waarschijnlijk kreeg Gelens ook zijn vergunning.

Of inderdaad sinds 'immemoriale tijden', zoals Lebens beweerde, in Gronsveld twee landmeters met grafelijke toelating actief waren, valt te bezien. De voorbeelden van Bouchoms en Gelens maken duidelijk dat pas vanaf de jaren zeventig van de achttiende eeuw daadwerkelijk invulling werd gegeven aan het landsheerlijk recht van admissie.

\subsection{Conclusies}

Bij de uiteenzetting in de Inleiding 5.5 van het onderwerp 'Heerlijke rechten' als onderzoeksthema van deze studie, werd al gewezen op de uit de literatuur bekende, maar in de praktijk lastig te hanteren klassieke indeling van regalia, 'sequelen' en rechten voortvloeiend uit gewone eigendom. Zeker bij het allodium of zonneleen Gronsveld vormt dit een probleem. Weliswaar was de heer van Gronsveld als rijksonmiddellijk lidmaat van het Heilige Roomse Rijk onderworpen aan de keizer en het algemene

2060 TJ, inv. nr. M 68, fol. 399, 442, betreffende betalingen aan Arnold Schutgens voor de 'carte figuratif. Schutgens, beëdigd 1751, overleden 1759, wordt ook vermeld bij Harmsen, 'De landmeetkunde', 423. 2061 Peter Bouchoms wordt niet vermeld bij Harmsen, 'De landmeetkunde'.

2062 TJ, inv. nr. M 58, fol. 499-503, stukken behorend bij brief van Zollner aan A.J. von ToerringJettenbach 5 juli 1779 met o.a. patent van Raad van Brabant, 15 maart 1755 en ontwerp-patent van de graaf.

2063 RHCL, Graafschap Gronsveld, inv. nr. 102. Bij Harmsen, 'De landmeetkunde', 420, activiteiten vermeld te Breust en Eijsden 1761-1795. 
rijksrecht - wat willekeur ten opzichte van onderdanen verhinderde - maar verder leidde hij zijn rechten niet af van een hogere gezagsdrager. De kleinschaligheid van het territorium versterkte die onafhankelijkheid nog eens, want in tegenstelling tot grote landsheerlijkheden, waar het landsbestuur was verdeeld over een ambtenarenapparaat, lagen in Gronsveld overheidsgezag en de daarmee samenhangende vermogensrechten in handen van slechts enkele personen.

Niet alleen vormden de verschillende rechten in de praktijk één samenhangend complex, het is vaak ook moeilijk aan ieder afzonderlijk recht een met de literatuur overeenstemmende juridisch juiste duiding te geven. Zelfs bij het recht van muntslag, een ogenschijnlijk evident geval van een regaal, is onbekend waar de heren van Gronsveld deze bevoegdheid op baseerden. Het werd niet direct ontleend aan een koninklijk of keizerlijk privilege en er is geen aanwijzing dat het oorspronkelijk was verbonden met het 'zonneleen' Gronsveld. Veel meer wordt de indruk gewekt van een soort 'familierecht', afgeleid van het Batenburgse muntrecht uit het begin van de veertiende eeuw, dat vervolgens werd 'geïmporteerd' in diverse plaatsen waar de heren van Bronckhorst Batenburg kastelen en heerlijkheden bezaten, waaronder Gronsveld.

Ook rechten die samenhangen met exploitatie van grond, zoals het gebruik van bos en gemeenteweide, de winning van mergel, de verkrijging van aanwassen langs de Maas, de heffing van cijnzen en misschien ook heffing van belasting op de overdracht van onroerend goed, lijken op het eerste gezicht een regale of grondheerlijke achtergrond te hebben, maar bij nadere beschouwing valt ook hier een oorsprong, voortvloeiend uit gewone eigendomsrechten, evenzeer te verdedigen.

Duidelijk meer in de richting van heerlijke rechten gaan belastingen en verplichtingen van inwoners, zoals herendiensten en het recht van haveschot, betalingen voor een monopolie van de heer (gebruik van de molen, brouwen van bier, plaatsen van bijenstand, uitoefenen van bepaald beroep, toelating van Joden) of juist de afscherming van een monopolie zoals jacht, visserij en het houden van duiven. Maar ook hier blijven verschillende inzichten over het juiste juridische karakter van deze rechten mogelijk.

Buiten de klassieke heerlijke rechten blijven dan weer de patronaats- en collatierechten, omdat deze voortvloeien uit de oorspronkelijke eigendom van een kerkgebouw. In Gronsveld ziet men echter vooral in de achttiende eeuw juist een duidelijke ontwikkeling van deze rechten als legitimatie voor meer overheidsinterventie in kerkelijke aangelegenheden.

De algemene conclusie luidt dan ook dat bij het onderzoek naar heerlijke rechten in kleine territoria de uit de literatuur bekende juridische criteria en systematiek weliswaar nuttig zijn, maar niet moeten worden verabsoluteerd. Voor de determinatie van ieder afzonderlijk recht kunnen, afhankelijk van specifieke plaatselijke omstandigheden, verschillende interpretaties mogelijk zijn.

De juridische indeling van een recht als regaal of als uitvloeisel van private eigendom lijkt ook in de dagelijkse praktijk van het landsbestuur geen grote rol te hebben gespeeld. In specificaties en beschrijvingen van rechten worden die onderscheidingen ook niet 
gemaakt. Voor de landsheer draaide het om doel en functie van rechten als uiterlijk teken van zijn stand, als instrument voor de uitvoering van 'gute Policey' en als bron van inkomsten. Die aspecten lopen gedeeltelijk door elkaar. Enkele dwarsdoorsneden kunnen dit verduidelijken. Zo bezat de heer van Gronsveld verschillende rechten die uitdrukking gaven aan zijn aanzien of rechtsmacht, maar economisch weinig gewicht in de schaal legden. Het muntrecht leverde wel geldelijk gewin op, maar de inkomsten waren verhoudingsgewijs gering. De grootste waarde stak vanaf het einde van de vijftiende eeuw in het maatschappelijk prestige dat dit 'regale' recht de adellijke muntheer verschafte. In verschillende kleine territoria in het Maasland, waaronder Gronsveld, vormde het muntrecht een stap in de erkenning als lid van de rijksonmiddellijke adel. Ook het jachten visrecht en het recht op het houden van duiven waren gericht op prestige. Het monopolie daarop paste bij een adellijke levenswijze, maar stelde financieel weinig voor. Het was zelfs denkbaar dat op 'eervolle' rechten geld werd toegelegd, zoals bijvoorbeeld bij herendiensten, wanneer de kosten van eten en drinken voor het werkvolk de opbrengst overtroffen. Ook de exploitatie van de banmolen was wegens de hoge investeringen niet altijd een winstgevende onderneming.

Minder een standssymbool waren de inkomsten uit pachten, erfpachten, cijnzen, tienden en verkoop van hout, maar ze vormden wel het financiële fundament onder de grafelijke economie. De juridische status was ondergeschikt aan het economisch belang. Interessant in dit verband is een vergelijking met de constateringen van Tops voor Westerlo en Herselt in de late middeleeuwen en de zestiende eeuw. ${ }^{2064} \mathrm{Hij}$ stelt vast dat toen in die heerlijkheden de voornaamste bronnen van inkomsten bestonden uit cijnzen en renten uit grond alsmede verpachtingen van bepaalde rechten. Voor Gronsveld ontbreken voor die tijd de gegevens bijna volledig. In de vroegmoderne tijd waren het hier vooral pachten voor landerijen, cijnzen en verpachtingen van rechten die geld opleveren. Dat verschil kan zijn bepaald door tijd en plaatselijke omstandigheden, maar in beide gevallen waren inkomsten uit grond van fundamentele betekenis.

Dat besef van de economische waarde van inkomsten uit grond nam in Gronsveld in de tweede helft van de achttiende eeuw duidelijk toe bij de graaf en zijn vertegenwoordigers. Er werd ingezet op meer rendement door verhoging van de pachtopbrengsten, investering in bosbouw, zuinige bedrijfsvoering en het vermijden van risicovolle projecten. Onbeantwoord blijft de vraag, bij gebrek aan goed vergelijkingsmateriaal, in hoeverre Gronsveld daarmee een uitzonderingspositie innam ten opzichte van vergelijkbare territoria in de omgeving. Maar het paste wel in de lijn die de graven Toerring-Jettenbach voor hun bezittingen in Beieren aanhielden. In keurvorstelijke dienst kregen zij de nodige ervaring met het op orde brengen van de Beierse staatsfinanciën. Op zijn eigen bezittingen vestigde graaf Maximilian Emanuel in 1763 in Jettenbach een papiermolen, in 1766 een potloodfabriek en in 1769 een spiegelfabriek. 2065

2064 Tops, De evolutie van de heerlijke financiën, 174-181,

2065 Englbrecht, Drei Rosen, 312-313. 
In de laatmiddeleeuwse gedachtegang werden heerlijke rechten vooral opgevat als zelfstandige gezagsrechten. Pas met de opkomst van de vroegmoderne staat groeide het besef dat deze rechten ook konden worden ingezet voor het landsbestuur of 'policey' in algemene zin. De vraag is in hoeverre dat in Gronsveld gebeurde. Op het gebied van wetgeving waren de graven van Gronsveld terughoudend. Ook in de organisatie van de rechtspraak werden geen wezenlijke veranderingen doorgevoerd. Met pachten, monopolies, belastingen, tienden en houtverkoop domineerde de graaf zijn gebied in economische zin. Tegenover de inkomsten daaruit stonden ook uitgaven, voor personeel en voor onderhoud en exploitatie van het kasteel. Dat alles bood in beginsel ook de mogelijkheid een economische politiek ter verbetering van de welvaart te voeren. Maar daar lijken de diverse rechten nauwelijks voor te zijn gebruikt. Verbetering van de economie was vooral gericht op verhoging van het inkomen van de graaf.

Pas tegen het einde van de achttiende eeuw lijkt enige aandacht te komen voor verbetering van de volkswelvaart. Een voorbeeld daarvan leveren de redeneringen van commissaris Zollner, toen hem in 1791 door enkele Maastrichtenaren een plan werd voorgelegd voor de oprichting van een jeneverstokerij in Gronsveld. Daarvoor werd een concessie van de graaf gevraagd (de noodzaak daartoe werd kennelijk vanzelfsprekend als een heerlijk recht aangenomen). De aanvragers wilden grotendeels vrijstelling van de verplichting hun graan op de banmolen aan te bieden. Zollner zag allerlei voordelen in een dergelijke onderneming. Ze verschafte werkgelegenheid en de molen zou meer kunnen malen, wat weer een hogere pacht rechtvaardigde. Met het afval van de jeneverstokerij konden de boeren meer vee houden, dat produceerde mest, wat weer leidde tot hogere opbrengst in de landbouw en dus ook hogere pachtinkomsten voor de graaf. Uiteindelijk zijn de plannen door tijdsomstandigheden niet gerealiseerd. Ze laten echter zien hoe - op zeer bescheiden schaal - in Gronsveld aantoonbaar bij een plan werd gedacht vanuit een samenhang tussen verschillende rechten van de graaf, met als uiteindelijk doel voordeel voor zowel de graaf als de ondernemer en de bevolking.

De terughoudendheid van de graven van Gronsveld om hun rechten, buiten de verwerving van inkomsten, in te zetten voor een actief bestuur ontbreekt ten aanzien van hun bemoeienis met kerkelijke zaken. In Hoofdstuk 7.4.1 zagen we al dat zij wetgeving tegen de verwerving van goederen in dode hand uitvaardigden. De ruime aandacht die in dit hoofdstuk an kerkelijke zaken is besteed, is niet alleen terug te voeren op toevallige overlevering van archief. Het is overdreven om in het grafelijk bestuur van een 'bureau kerkelijke zaken' te spreken, maar de reeks patronaats- en collatierechten (al dan niet betwist) bood ruimschoots gelegenheid om plaatselijke kerkpolitiek te bedrijven. Daarbij werden de algemene regels van het kerkelijk recht gerespecteerd, maar er bestond een allergie voor interventie door de Luikse kerkelijke hiërarchie. Gronsveld stond daarin overigens bepaald niet alleen. Tussen 1765 en 1770 speelde zich binnen het graafschap Wittem een jurisdictieconflict af tussen graaf Plettenberg en de bisschop van Luik naar aanleiding van een edict over het beheer van kerk- en armengoederen dat de graaf in 1765 had uitgevaardigd. 2066

${ }^{2066}$ RHCL, Rijkskamergerecht, inv. nr. 198. 
De benoeming in het midden van de achttiende eeuw van Beierse geestelijken tot pastoor in Gronsveld past in hetzelfde kader. Met de aanstelling van 'Hofrath' Schmädel zat duidelijk de bedoeling voor de pastoor ook als landsheerlijk vertegenwoordiger te laten optreden. Zelfs bij de bezetting van het onbeduidende pastoraat van Holset speelde nog de gedachte dat de betrokkene een wakend oog kon houden op de grafelijke belangen in die plaats. De zeggenschap over lagere beneficies zonder zielzorg werd in de achttiende eeuw ook gebruikt om door combinaties en splitsingen van taken verbetering te krijgen in de zielzorg en viering van de kerkelijke liturgie.

Het recht van presentatie van kandidaten voor geestelijke ambten bood overigens geen enkele garantie voor hun geschiktheid. Beierse pastoors in Gronsveld in het midden van de achttiende eeuw vormden om allerlei redenen geen succes. Maar ook bij 'landskinderen' deden zich regelmatig grote problemen voor, variërend van weinig betrokkenheid bij de zielzorg tot crimineel gedrag. Karakterologisch hoorden sommige geestelijke heren tot een bijzonder slag mensen. Dat leverde ook botsingen op met grafelijke ambtenaren en zelfs de landsheer, waarbij in de achttiende eeuw de confrontaties met pastoor Kolb in Gronsveld en pastoor Van Bloer in Heugem een dieptepunt vormden. Het kan toeval zijn dat men in Gronsveld een ongelukkige hand had bij benoemingen, maar mogelijk had het probleem een diepere oorzaak. Eigenlijk waren de geestelijken min of meer vrij in hun doen en laten. Het grafelijk gezag blokkeerde een sterke sturing vanuit de Luikse hiërarchie, maar eenmaal benoemd en voorzien van vaste inkomsten, voelden de geestelijken zich als lid van de geestelijke stand tegelijkertijd ook onafhankelijk van de wereldlijke overheid

Een tweede aspect van landsheerlijk gezag op kerkelijk terrein betrof de grafelijke zeggenschap over de tijdelijke goederen van de kerk. Dit streven bereikte zijn hoogtepunt in de tweede helft van de achttiende eeuw, toen het financieel beheer van de kerken in Gronsveld en Eckelrade vrijwel geheel in handen kwam van de grafelijke ambtenaren. Het sluitstuk vormde de ingreep door commissaris Zollner in 1788 bij het beheer van de kerk in Heugem. Deze ontwikkelingen sluiten bijna naadloos aan bij algemene politieke opvattingen uit die tijd, die een sterk gezag van de staat over de kerk voorstonden. 


\section{Belastingheffing binnen het Heilige Roomse Rijk en de geërfden van Gronsveld}

Het thema 'geërfden' is in Gronsveld onlosmakelijk verbonden met belastingen op grond ten behoeve van het Rijk. In dit hoofdstuk wordt onderzocht hoe vanaf het einde van de zestiende eeuw uit verzet tegen belastingen een organisatie groeide, die men in de achttiende eeuw als een soort 'standenvergadering van de geërfden van Gronsveld' kan beschouwen. Dit verschijnsel, dat zich ook in andere kleine rijksonmiddellijke territoria in de omgeving van Gronsveld voordoet, vormt de laatste uitloop van de algemene geschiedenis van staten- of standenvergaderingen, die bij grote landsheerlijkheden al in de late middeleeuwen begint.

Met 'geërfden' worden de eigenaren van grond aangeduid. De vroegste organisatie daarvan lijkt in Gronsveld te beginnen vlak voor 1600, als reactie op invoering van nieuwe belastingen voor de defensie van het Rijk. Voor die tijd bestonden al de Kammerzieler als bijdrage voor het Rijkskamergerecht en belastingen voor de kreits, maar het is de vraag of die ook werden betaald. Vanaf het midden van de zeventiende eeuw kwamen daar heffingen bij ten behoeve van het Nederrijns-Westfaalse Gravencollege.

De geschiedenis daarvan in Gronsveld is bestudeerd tegen de achtergrond van de algemene belastinggeschiedenis binnen het Duitse Rijk. De in het eerste deel van dit hoofdstuk gepresenteerde uiteenzettingen daarover zijn noodzakelijk om iets te kunnen begrijpen van de manier waarop de belastingheffing en afdracht van het geld in een rijksonmiddellijk graafschap als Gronsveld waren georganiseerd. In de Nederlandstalige historische literatuur is dit een vrijwel onbekend thema van onderzoek. De samenvatting hier, gebaseerd op een beperkte hoeveelheid archivalia en literatuur, is echter niet meer dan een sterk vereenvoudigde weergave van een uitermate complex systeem. De nadruk ligt op verklaring van basisbegrippen die werden gehanteerd voor de fiscale verhoudingen. In het tweede deel van dit hoofdstuk wordt onderzocht hoe deze begrippen in het graafschap Gronsveld werden toegepast. Met de soms gedetailleerde uitleg van de berekeningsmethoden tot op de penning, wordt wellicht een schijn van nauwkeurigheid gewekt, die niet helemaal met de werkelijkheid correspondeert. Toch is die uitwerking zinvol, want het laat iets zien van een systeem waarmee op zich kleine bedragen aan belasting over kleine rijksonmiddellijke territoria werden verdeeld en hoe die bedragen bij wanbetaling tot hoge schulden konden oplopen.

Bij belastingen ging het in de kern om vier doelen, te weten de defensie van het Rijk en het onderhoud van respectievelijk de kreits, het Rijkskamergerecht en het NederrijnsWestfaalse Gravencollege. Het grootste bedrag was bestemd voor de defensie en het onderhoud van troepen. Iedere rijksstand, groot of klein, moest volgens de vaste verdeelsleutel van de 'rijksmatrikel' manschappen of een equivalent daarvan in geld opbrengen. Troepen van het Rijk werden in beginsel alleen defensief ingezet, voor de verdediging tegen vijanden van buitenaf, in het bijzonder de Turken en later ook Frankrijk. Voorts dienden vrede en rust binnen het Rijk zelf te worden gehandhaafd. Het probleem lag echter in de organisatie. Van een centraal geleid leger was geen sprake. Het 
op de been brengen van een rijksleger behoorde tot de belangrijkste taken van de kreits. Aan die troepen voegden de grote rijksstanden soms hun eigen legermacht toe. Grote rijksstanden, zoals Oostenrijk, Pruisen en Beieren, hielden uit eigen middelen een staand leger op de been en bedreven daarmee ook zelfstandig (en niet altijd vredelievend) politiek binnen het Rijk. Daarnaast regeerden sommige rijksstanden over gebieden die geen deel uitmaakten van het Rijk (de Habsburgers over Hongarije, de keurvorsten van Saksen over Polen en de markgraven van Brandenburg over het kernland Pruisen aan de Oostzee) en zij hielden daarvoor ook troepen onder de wapenen. In het bijzonder bij de Habsburgers leidde dit tot de vraag in hoeverre vanuit het Rijk steun moest worden gegeven in de oorlog op de Balkan tegen de Turken.

De organisatie van de defensie was daarom een complexe aangelegenheid. $\mathrm{Na}$ de Dertigjarige Oorlog, die het politieke landschap binnen het Rijk grondig veranderde, werd omstreeks 1680 na veel discussie besloten tot een hervorming van de defensie, die de grondslag bleef voor de legerorganisatie tot het einde van de achttiende eeuw. Het systeem bleef echter uiterst ingewikkeld. Het is ook voor deze tijd na 1680 dat voor Gronsveld de meeste gegevens beschikbaar zijn.

Belastingen speelden een belangrijke rol in de relatie tussen landsheer en onderdanen. De veelvuldige discussie daarover begon al met vraag of volgens het personaliteitsbeginsel de landsheer als rijksstand belastingplichtig was of, volgens het territorialiteitsprincipe, het land. Er bestond in het algemeen consensus dat dit laatste principe leidend was. Maar vervolgens waren er langdurige discussies over de hoogte van de aanslag, de verhouding tot personele belastingen en ten slotte de eventuele vrijstellingen. Die onderwerpen komen aan de orde bij de specifieke geschiedenis van de belastingheffing in Gronsveld. Het begint met de onenigheid omstreeks 1600 tussen graaf Johan II van Bronckhorst Batenburg en zijn onderdanen over de betaling van belastingen. Deze geschillen hadden meer dan één oorzaak. In de eerste plaats beschouwden de grondeigenaren of geërfden deze lasten als een 'nieuwigheid'. Vergelijkbare ongenoegens speelden ook in andere kleine rijksonmiddellijke territoria. Maar het conflict in Gronsveld kan niet worden losgezien van het verzet tegen andere lasten die de graaf oplegde, zoals de herendiensten, waarvan de onderdanen dachten dat zij die in het verleden hadden afgekocht. Een derde reden van ongenoegen lag in de eigendomsverhoudingen binnen het graafschap. Veel grond was in handen van grote Maastrichtse instellingen. De Maastrichtenaren pretendeerden echter sinds onheuglijke tijden belastingvrijdom voor al hun gronden buiten de stad, ongeacht hun ligging. Die houding, waarbij de belastingdruk feitelijk op de inwoners van het dorp werd afgewenteld, vormde voor het omringende platteland een steen des aanstoots en zorgde in verschillende plaatsen tot het einde van de achttiende eeuw voortdurend voor spanningen. Daarom wordt ook aan de achtergrond van die beweerde belastingvrijdom aandacht besteed.

Het verzet in Gronsveld tegen de maatregelen van graaf Johan II leidde meer dan tien jaar tot hooglopende ruzies. Een in 1611 daarover gesloten compromis had uiteindelijk slechts betrekkelijke waarde, want geschillen over de heffing van (grond)belasting laaiden tot het midden van de achttiende eeuw met enige regelmaat op. Een neveneffect van deze 
ontwikkeling was dat de grondeigenaren als tegenspeler van de graaf zich organiseerden in een duurzame vergadering van geërfden of standen.

Ten slotte deed zich in Gronsveld nog een complicatie voor vanwege het feit dat Slenaken in 1728 als heerlijkheid aan Wittem was verkocht. Die overdracht leidde echter vanuit het Rijk niet tot een splitsing van de belastingaanslag, zodat in de achttiende eeuw langdurige discussie ontstond over de verdeling van lasten.

\subsection{Belastingheffing binnen bet Heilige Roomse Rijk 2067}

\subsubsection{Gemeine Pfennig2068}

De belangrijkste hervormingen in het Rijk waartoe de Rijksdag en rooms koning Maximiliaan in Worms in 1495 besloten, hadden betrekking op de organisatie van het Rijk in een vergadering van standen ('Reichsregiment'), een verbod op de middeleeuwse vete en landvredebreuk door afkondiging van een Eeuwige Landvrede, de instelling van het Rijkskamergerecht als hoogste conflict beslechtende instantie binnen het Rijk, een regeling ter handhaving van recht en vrede ('Handhabung des Friedens und Rechts') en ten slotte de heffing van een algemene belasting, de 'Gemeine Pfennig'. Uit de opbrengst van deze algemene belasting voor het hele Rijk voor een periode van vier jaar, moest de oorlog tegen de bedreigers van het Rijk, in het bijzonder de Turkse 'erfvijand', worden bekostigd. Verder was dit geld ook bedoeld om instellingen zoals het Rijkskamergerecht te financieren. De Gemeine Pfennig was, na eerdere mislukkingen in de vijftiende eeuw, de laatste poging een algemene belasting voor het hele Rijk in te voeren. Na het verstrijken van de termijn van vier jaar zou een nieuwe bewilliging, met eventuele verbeteringen, door de rijksstanden moeten plaatsvinden. Vanaf het begin was duidelijk dat de rijksstanden en niet de rooms koning/keizer de beslissende invloed hadden op de grondslagen van de heffing, de wijze van inning en de besteding van het geld.

De Gemeine Pfennig werd vooral beschouwd als een personele belasting, gebaseerd op vermogen. Maar door onwil bij de landsheren, een gebrekkig systeem van invordering en onvoorspelbaarheid van de opbrengst bracht de heffing onvoldoende op. De belasting werd tussen 1495 en 1551 elf keer geheven, daarna niet meer.

2067 Voor de samenstelling van dit overzicht werd onder andere gebruik gemaakt van Conrad, Deutsche Rechtsgeschichte 2, 122-132 in het bijzonder voor de organisatie van het rijksleger en 132-136 voor de belastingheffing; Dotzauer, Reichskereise, passim; Hofmann, Quellen Verfassungsorganismus, 40-51, 232-243; Munsters, 'Rijksonmiddellijkheid en Kammerzieler'; Neuhaus, Das Reich der Frühen Neureit, passim; Neuhaus, 'Defension'; Salm, Armeefinanzierung, passim; Schattkowsky, 'Gemeiner Pfennig'; Whaley, Das Heilige Römische Reich, 1, 626-636; Schindling, Die Anfänge des Immerwährenden Reichstags, 208-215; Schneider, Niederrbeinisch-Westfälische Kreis, 64-73; Erler e.a., Handwörterbuch Rechtsgeschichte, II, 590-592, onder lemma Kammerzieler, III, 389 onder lemma Matrikel; IV, 600-608 onder lemma Reichsheerwesen, 693-696 onder lemma Reichskeriegsverfassung; 773-776 onder lemma Reichssteuern; 1113-1115 onder lemma Römermonat. Voorts zeer bruikbaar was een bundel met aantekeningen en berekeningen in het archief van de abdij Thorn, vgl. RHCL, Abdij Thorn, Inv. d'Hoop nr. 18818.

2068 Zie in het bijzonder: Schattkowsky, 'Gemeiner Pfennig'. 


\subsubsection{Matrikelbelastingen en de Wormser Matrikel van 1521}

Met de 'Ewiger Landfriede' en de 'Handhabung des Friedens und Rechts' uit 1495 brachten rooms koning en rijksstanden hun principiële wens voor een duurzame veiligheid binnen het Rijk tot uitdrukking. Werving en onderhoud van militairen behoorden tot de taken van de kreitsen, de territoriale 'kringen' waarin het Rijk begin zestiende eeuw was ingedeeld. Aanvankelijk had men daarbij vooral oog voor handhaving van de interne rust binnen het Rijk en de bestrijding van de middeleeuwse veten. Handhaving van veiligheid vormde daarmee in de opvatting van de rijksstanden vooral een regionaal probleem, waarvoor de kreitsen zich moesten inzetten. De Reichsexekutionsordnung van 1555 markeert het hoogtepunt in deze ontwikkeling en legitimeerde tot het einde van de achttiende eeuw het recht van de kreits in te grijpen bij problemen in hun regio. Die bevoegdheid laat onverlet dat het vaak lang duurde voordat de rijksstanden binnen een kreits bereid of in staat waren daadwerkelijk troepen in het veld te brengen. Slechts zeer langzaam groeide het besef dat het Rijk permanent moest worden beschermd, niet alleen tegen onrust binnen het Rijk, maar ook permanente dreigingen van buiten, in het bijzonder de Ottomaanse expansie (zie hierna). ${ }^{2069}$

Omdat de heffing van de Gemeine Pfennig geen succes werd, vonden gedurende de eerste decennia van de zestiende eeuw verbeteringen in de belastingheffing plaats op basis van zogenoemde matrikels (Matrikularsteuer). In dit systeem, dat op beperktere schaal al in de vijftiende eeuw was toegepast, stond het totaal van de opbrengst van een belasting in geld of het totaal van te leveren manschappen voor het leger, van te voren vast. Vervolgens werd dit bedrag over de afzonderlijke rijksstanden verdeeld. Daarmee werden in theorie bedoeld de landsheren die als rijksstand gekwalificeerd waren, maar in de praktijk betaalden de landen. Volledig doordacht en beredeneerd was de verdeelsleutel niet, wat nogal eens tot protest leidde wanneer een stand meende dat hij te hoog was aangeslagen. De opbrengsten van de matrikelbelastingen vloeiden niet samen in een algemene rijksschatkist (die bestond ook niet), maar werden aangewend voor drie specifieke doelen, te weten de financiering van de interne en externe defensie van het Rijk, de financiering van het Rijkskamergerecht en de financiering van de kreitsen.

De matrikelbedragen waren in beginsel onveranderlijk, wat zekerheid gaf voor zowel de opbrengst als de belastingdruk. Maar tegelijkertijd kende het systeem daarmee ook nauwelijks flexibiliteit, omdat het moeilijk was de werkelijke behoefte aan manschappen en geld in een concrete situatie te koppelen aan schommelingen in de financiële draagkracht van de belastingplichtige. Wanneer meer dan het in de matrikel genoemde aantal manschappen of geldbedrag nodig was, werd de basissom (het 'simplum') vermenigvuldigd met de factor twee of drie (duplum of triplum). Soms werd ook gewerkt met verhogingen in breuken, bijvoorbeeld anderhalf of $11 / 3$ maal het simplum. Op die manier kon worden ingespeeld op de werkelijke behoeften bij het op de been brengen van een leger.

De in de matrikel genoemde rijksstand kon de belasting verder verdelen onder de inwoners van het territorium ('Territorialprinzip') en deed dat in de praktijk ook. ${ }^{2070}$ Toch had deze wijze van belastingheffing iets tweeslachtigs. Wanneer onderdanen

${ }^{2069}$ Neuhaus, 'Defension', 119-121.

2070 Schattkowsky, 'Gemeiner Pfennig', 194-195. 
protesteerden, betoogden zij vaak dat de landsheer als rijksstand de eigenlijke belastingplichtige was. Een uitwerking van dit beginsel vormde later ook de regel dat veranderingen door deling van een territorium niet tot wijziging van de 'eeuwige' matrikel leidden. Dit betekende dat de oorspronkelijke rijksstand (en daarmee ook diens oorspronkelijke territorium) voor het totaal van de 'onverdeelde boedel' aansprakelijk bleef, waarna het te betalen bedrag onderling moest worden verdeeld. Met dit beginsel kreeg het graafschap Gronsveld te maken door de verkoop van Slenaken in 1728. Dit dorp droeg voor een kwart bij in de matrikelaanslag voor het hele graafschap, maar ook na 1728 bleef Gronsveld verantwoordelijk voor het volle bedrag, waarvan vervolgens een kwart op Slenaken moest worden verhaald.

Maatgevend voor de bijdrage van iedere rijksstand aan de belastingen en de bekostiging van de defensie van het Rijk werd de op de Rijksdag van Worms van 1521 vastgestelde 'Allzeit neueste Matrikel'.2071 Deze 'Wormser Matrikel' bevatte twee componenten. Zo werd voor het eerst de theoretische omvang van een eventueel op te roepen rijksleger bepaald op 4202 ruiters en 20.063 voetknechten, later gemakshalve vereenvoudigd op vierduizend en twintigduizend (het simplum). ${ }^{2072}$ Voor een oorlog van enige omvang leverde het simplum echter te weinig troepen op en daarom werd meestal een vermenigvuldigingsfactor toegepast van twee (duplum), drie (triplum) of drie keer drie (triplum triplicatum).

In het simplum lag vast hoeveel manschappen (contingent) iedere rijksstand moest financieren, welk aantal vervolgens in geld werd omgerekend. Een ruiter kostte tien Rijnlandse guldens en een voetknecht vier gulden per maand. Sinds 1541 werd voor een ruiter twaalf gulden en voor een voetknecht vier gulden per maand gerekend, wat de kosten van een basis leger voor een simplum gedurende een maand op ongeveer 128.000 gulden bracht. ${ }^{2073}$ Die maand werd aangeduid als Römermonat. Dit woord is afgeleid van de kosten die de keizer zou moeten maken voor een tocht met het leger naar Rome om daar te worden gekroond. ${ }^{2074}$ Het is echter een fictieve berekening, want er is nooit vanwege het Rijk hulp voor een dergelijke onderneming verleend.

De Römermonat werd wel de rekeneenheid voor de bekostiging van de oorlog. Maar de hoogte daarvan hing af van het aantal 'simpelen' dat in die maand werd gestopt. Wanneer met die vermenigvuldigingsfactor het maandbedrag was bepaald, werd vervolgens het aantal Monate vastgesteld. Dat correspondeerde niet met een reële tijdsaanduiding, maar was alleen bedoeld als een 'eenheid' om met een bepaalde vermenigvuldigingsfactor een bepaald bedrag te bereiken. Een rekenvoorbeeld kan het voorstaande verduidelijken. Wanneer, zoals in Gronsveld, het simplum volgens de matrikel 12 gulden per maand is, en men besluit dit te verdubbelen met de factor 2, dan levert dit een bedrag van 24 gulden

\footnotetext{
2071 Gebruikt is de editie bij Hofmann, Quellen Verfassungsorganismus, 40-64.

2072 Conrad, Deutsche Rechtsgeschichte 2, 122-124; Dotzauer, Reichskreise, 49; Schattkowsky, 'Gemeiner Pfennig', 194.

2073 De Wormser Matrikel van 1521 geeft een bedrag van 51269 gulden. Het verschil kan te maken hebben met de gebruikte muntsoort.

2074 Erler e.a., Handwörterbuch Rechtsgeschichte, IV, 1113-1115, onder lemma Römermonat.
} 
maand (Römermonat) op. Wanneer besloten wordt 150 van deze 'eenheden' uit te schrijven, dan resulteert dit in 3600 gulden.

De bijdrage van een rijksstand bestond dus uit het bedrag voor het verplichte contingent (simplum of een veelvoud daarvan) maal het aantal uitgeschreven Römermonate. Die aanslag correspondeerde niet altijd met de werkelijke draagkracht, wat leidde tot verzoeken om vermindering. Ook werden veel rekenfouten gemaakt, wat in de hand werd gewerkt door het feit dat eigenlijk niemand een volledig overzicht had van deze financiën. Sommige riiksstanden stonden nog als belastingplichtig te boek, maar betaalden feitelijk niet, hadden achterstanden of vroegen matiging ('Moderation) van de aanslag. 2075 Aan het gebruik van de 'Wormser Matrikel' zaten dus allerlei haken en ogen. De Matrikel kreeg echter betekenis op een heel ander gebied, want vermelding in de lijst kon worden beschouwd als een erkenning dat een bepaalde stand rijksonmiddellijk was. Voor sommige standen was dat zondermeer duidelijk, maar vooral bij de kleine standen waren fouten in de lijst ingeslopen, die naderhand tot onenigheid leidden.

Voor alle duidelijkheid moet nog eens worden benadrukt dat de Römermonat was bedoeld voor troepen in de oorlog. Voor de kosten van garnizoenen en een staand leger werd ook de Römermonat als rekeneenheid gebruikt, maar die moest apart worden betaald.

\subsubsection{Belastingheffing door de kreits 2076}

De inning van de rijksbelastingen behoorde tot de belangrijkste taken van de kreits. Daarbij ging het niet alleen om gelden ten behoeve van de rijksdefensie, maar ook om middelen ter financiering van de eigen organisatie of de uitvoering van een 'Kreisexeleution', de toepassing van dwang tegen een mede-kreitsstand. Belastingplichtig waren niet alleen de in de matrikel genoemde en in de kreitsdag vertegenwoordigde standen, maar ook de niet vertegenwoordigde heren, wier gebied was 'eingekreist'. Toch leverde de uitschrijving van belastingen vaak problemen op. In de eerste decennia na 1521 werden de kreitsen geconfronteerd met de zogenoemde 'vertrokken' standen. Sommige rijksstanden claimden dat zij behoorden tot een andere kreits dan degene bij wie ze waren in gedeeld. Zo waren de oorspronkelijk tot de Nederrijns-Westfaalse Kreits behorende bisdommen Utrecht en Kamerijk terechtgekomen bij de Bourgondische kreits. Als 'rijksstad' aangeslagen steden beweerden geen 'rijksstad' (meer) te zijn, maar tot grote landsheerlijkheden te behoren. Daarnaast waren er nog kleine gebieden die niet waren 'eingekreist' of rijksstanden wier bezittingen onduidelijk waren omschreven. Dat gold bijvoorbeeld voor het hierna nog te noemen geval Bronckhorst. Voor de Nederrijns-Westfaalse Kreits, die in de matrikel van 1521 was aangeslagen voor 17148 gulden, betekenden deze 'uittochten' een verlies van 4672 gulden. ${ }^{2077}$ Weliswaar was een rijksstand na vertrek niet ontslagen van zijn financiële verplichtingen, maar het bleek vaak moeilijk het geld daadwerkelijk te innen, met als gevolg dat de overblijvende standen voor het tekort opdraaiden. In de daaropvolgende decennia bleef daarom de 'Moderation', matiging van de aanslag, voortdurend een heet hangijzer. In 1544 werd op een 'Moderationstag' in Worms wel een overzicht opgesteld van

2075 Dotzauer, Reichskreise, 49; voor de 'Moderation' van de Nederrijns-Westfaalse Kreits zie ook Schneider, Niederrbeinisch-Westfälische Kreis, 68-75.

2076 Dotzauer, Reichskreise, 48-50; Schneider, Niederrheinisch-Westfälische Kreis, 64-85.

2077 Schneider, Niederrbeinisch-Westfälische Kreis, 64-65. 
compensaties tussen de verschillen kreitsen wegens vertrokken Standen, maar pas de Rijksdag van Augsburg in 1548 boekte op dit punt enige vooruitgang door de introductie van een bezwaarprocedure. ${ }^{2078}$ Toen werd bepaald dat standen in ieder geval binnen een kreits het recht hadden bezwaar te maken tegen een aanslag, welke klacht dan ook tot een beslissing moest leiden. Het was een soort hardheidsclausule: de regeling bleef in stand, maar in gevallen dat rigoureuze toepassing tot een onredelijke uitkomst leidde, was matiging mogelijk. In het vervolg stonden daarom dit soort geschillen ook regelmatig op de agenda van kreitsvergaderingen.

\subsubsection{Defensie tegen externe vijanden: Türkensteuer}

In het voorgaande kwam al ter sprake dat de defensie van het Rijk in beginsel was gericht op interne handhaving van orde en rust. Maar het Rijk kende ook bedreigingen van buitenaf, eerst en vooral de Ottomaanse of Turkse expansie, die begon in de tweede helft van de vijftiende eeuw en, met tussenpozen, een voortdurende zorg bleef tot in de achttiende eeuw. Twee keer, in 1529 en in 1683 stonden de Turken voor Wenen. Daarnaast groeide sinds de tweede helft van de zeventiende eeuw in het westen het gevaar van de Franse expansie in de richting van het Rijnland. Meer regionaal beperkt, maar toch zorgwekkend bleken de ervaringen met de Tachtigjarige Oorlog in de Nederlanden, toen troepen van de Republiek en Spanje het strijdtoneel meermaals verplaatsten naar territoria die tot de Nederrijns-Westfaalse Kreits behoorden. ${ }^{2079}$ Dit alles maakte duidelijk dat de defensie van het Rijk niet beperkt kon blijven tot handhaving van de interne orde en veiligheid. Maar gezamenlijk optreden in Rijksverband bleek vaak moeilijk.

Een belangrijk obstakel daarbij vormde de dubbelrol van de rooms koningen/keizers uit het Habsburgse Huis als hoogste gezagsdrager binnen het Rijk én heer van de Oostenrijkse Erflanden. De rijksstanden beschouwden de Habsburgse conflicten buiten het Rijk niet als Rijksoorlogen. Dat gold in beginsel ook voor de verdediging van de Habsburgse gebieden buiten het Rijk, richting Balkan. Toch groeide vanaf de zestiende eeuw bij de kreitsen het besef dat het Rijk als geheel zich moest verdedigen tegen de Turken en dat de bescherming van het Christelijk Europa niet kon worden overgelaten aan alleen de keizer en de landsheren in het oosten en zuidoosten van het Rijk. De kreitsen bleken bereid de keizer hulp te bieden bij de oorlogen tegen de Turken en het onderhoud van 120 forten en vestingen langs de grens.

Aanvankelijk wilde men de oorlog tegen de Turken nog financieren volgens het systeem van de Gemeine Pfennig, maar tijdens de Rijksdag van Neurenberg van 1543 werd besloten deze grondslag voor de belastingheffing te laten vallen en de Wormser Matrikel van 1521 toe te passen. Een uitvloeisel daarvan werd de instelling van een Türkensteuer of Turkenbelasting op basis van Römermonate, die de rijksstanden als een buitengewone belasting moesten opbrengen. ${ }^{2080}$

Vóór 1543 waren de gelden voor de oorlog tegen de Turken vooral gebruikt als 'eilende Hilfe' aan de keizer, een soort noodhulp. De keizer kon uiteraard altijd dit soort directe

2078 Schneider, Niederrbeinisch-Westfälische Kreis, 70; voor de gevolgen daarvan voor de NederrijnsWestfaalse Kreits zie idem, 72-73.

2079 Neuhaus, 'Defension', 120-122.

${ }^{2080}$ Schattkowsky, 'Gemeiner Pfennig', 195-196. 
steun blijven vragen, maar na 1548 werden de gelden vooral besteed aan 'beharrliche Hiffe', structurele hulp voor onderhoud van de grensbeveiliging. Frequentie en omvang van de Turkenbelasting wisselden in de loop der tijden naar gelang de werkelijke dreiging. De belangrijkste periodes daarin lagen tussen 1593 en 1606 ('Derde Oostenrijks-Turkse Oorlog' of 'Lange Turkse Oorlog'), de oorlog van 1663-1664 ('Vierde OostenrijksTurkenoorlog), 1683-1699 ('Grote Turkse Oorlog') en 1714-1718 ('VenetiaansOostenrijkse-Turkse Oorlog'). De Grote Turkse Oorlog (1683-1699) begon met het beleg van Wenen in 1683. Na de ontzetting van de stad door keizerlijke en Poolse troepen werden de Turken geleidelijk aan teruggedrongen en bij de Vrede van Karlowitz van 1699 moesten zij Hongarije en delen van Transsylvanië en Slavonië aan de Habsburgers afstaan.

16.1.5 De defensie van het Rijk in de eerste belft van de zeventiende eeun.

Er bestond aan het begin van de zeventiende eeuw geen rijksleger in de betekenis van een centraal geleide krijgsmacht. Er was een keizerlijk rijksleger, maar daarnaast waren er ook rijkstroepen van Beieren, Saksen en Brandenburg, elk onder leiding van hun keurvorsten. Verder kende de Nederrijns-Westfaalse Kreits een leger, met wisselende Keurkeulse, Beierse en bisschoppelijk-Osnabrückse regimenten. Al deze contingenten opereerden ook in verschillende allianties. ${ }^{2081}$ Die soldaten werden ingezet bij de in 1618 uitgebroken Dertigjarige Oorlog. Volgens de Vrede van Praag (1635), die een einde moest maken aan de oorlog, zou er één rijksleger moeten zijn, gerekruteerd uit de kreitsen, met de keizer als opperbevelhebber. De keurvorsten beslisten dan over oorlog en vrede. Er werden vervolgens ook regelmatig belastingen uitgeschreven voor de financiering van dit rijksleger. ${ }^{2082}$ De Praagse Vrede voorzag vanaf 1 september 1635 tot begin 1637 in een bijdrage van 120 Römermonate. De Keurvorstendag van Regensburg in 1636 bewilligde nog eens in 120 Römermonate en daarna werden door de Rijksdag voor de jaren 1640 en 1641 samen 240 Römermonate uitgeschreven. Het ging dus om grote bedragen, maar vaak bleef onduidelijk voor wie en waaraan die gelden werden besteed, omdat het begrip 'rijksleger' voor meer dan één uitleg vatbaar was.

\subsubsection{De Reichsdefensionalordnung 1681-1682: aanloop en uitwerking2083}

De vredesverdragen van Westfalen van 1648 maakten, op een aantal onbesliste geschilpunten na, een einde aan de Dertigjarige Oorlog. Al tijdens Rijksdag van $1653 / 1654$, de eerste na de vrede, werd aangedrongen op herziening van de rijksdefensie. De discussie stokte echter bij de vraag of de voor onderlinge hulp binnen het Rijk bedoelde Reicbsexekutionsordnung van 1555 voor de kreitsen moest worden 'opgepoetst' of vervangen door een nieuwe regeling. Deze problematiek werd actueel tijdens de Rijksdag van 1663, toen een grote Ottomaanse legermacht Hongarije was binnengevallen. Onder allerlei voorbehouden kenden de rijksstanden de keizer 50 Römermonate als 'eilfertige Hilfe'

${ }^{2081}$ Salm, Armeefinanzierung, 11-13.

2082 Salm, Armeefinanzierung, 13-18.

2083 Voor bronnen zie Hofmann, Quellen Verfassungsorganismus, 232-248; zie verder Conrad, Deutsche Rechtsgeschichte 2, 125130; Schindling, Die Anfänge des Immerwährenden Reichstags, 208-223; Neuhaus, 'Defension', 122-125. Erler e.a., Handwörterbuch Rechtsgeschichte, IV, 600-608 (onder lemma Reichsheerwesen); 693-696 (onder lemma Reichskriegsverfassung). 
toe. Uiteindelijk werden de Turken in 1664 verslagen, waarna de dreiging weer enige tijd uit de lucht was.

In de navolgende jaren werd het Rijk aan de westgrens geconfronteerd met Franse expansiepolitiek: de Devolutieoorlog van 1667-1668 en de aanval op de Republiek, het begin van de Hollandse Oorlog (1672-1678), eindigend met de Vrede van Nijmegen (1678). De reactie vanuit het Rijk was zwak. Niet alleen vond de Franse koning Lodewijk XIV bondgenoten onder enkele rijksstanden, ook een formele oorlogsverklaring van het Rijk aan Frankrijk bleef achterwege. Lodewijk wist uiteindelijk de veroverde rijksgebieden in de Elzas en in Lotharingen blijvend voor Frankrijk te behouden.

Sinds 1672, toen Frankrijk de Republiek binnenviel, stond in ieder geval vast dat de kreitsen verantwoordelijk werden voor oproeping, bewapening en verzorging van rijkstroepen. Maar tegelijk leidde de onmacht van het Rijk tot grote onvrede over die Duitse legers. Er kwamen minder troepen opdagen dan was toegezegd en sommige rijksstanden voerden een eigen politiek of gaven prioriteit aan de opbouw van hun eigen legers. Veel kwaad bloed zette gedurende deze oorlogsjaren de inkwartiering van troepen gedurende de winterperiodes. De grote rijksstanden probeerden de kosten van zowel de winterkwartieren van hun eigen troepen als die van de kreits zoveel mogelijk af te wentelen op de kleine, niet bewapende rijksstanden. Ten slotte moest de keizer na de Vrede van Nijmegen van 1678 zijn leger uit de Zuidelijke Nederlanden terugtrekken naar de Oostenrijkse Erflanden. Daarmee bleef het westen van het Rijk bijna onverdedigd.

Hoewel dit alles de overtuiging versterkte dat de rijksdefensie aan herziening toe was, vlotte het niet met de hervormingsplannen. Wel hadden de oorlogen tegen de Turken en Frankrijk geleid tot nieuwe inzichten over de manier waarop de verdediging beter vorm kon krijgen. Dat gold voor de wijze waarop de leiding van het leger moest worden georganiseerd en de rol die de kreitsen moesten spelen als eerstverantwoordelijken voor het rijksleger. Dit resulteerde in de jaren 1681-1682 in een besluit van de Rijksdag waarbij de Reichsdefensionalordnung werd vastgesteld. Het simplum of de basissterkte van het rijksleger werd gebracht op 40.000 man (28.000 infanteristen en 12.000 cavaleristen met inbegrip van tweeduizend dragonders) te verdelen over tien kreitsen. Ook de contingenten van de kreitsen werden opnieuw vastgesteld, wat voor de Nederrijns-Westfaalse Kreits resulteerde in 1321 ruiters en 2708 infanteristen. Voor de verdere onderverdeling daarvan naar de afzonderlijke standen moest de kreits zorgen (en die viel natuurlijk hoger uit dan het oude simplum van 1521). Uit de kreitskas moesten onderhoud, soldij en bewapening worden bekostigd.

Het hiernavolgende overzicht geeft de verdeling van de troepen in de NederrijnsWestfaalse Kreits en de bijbehorende kosten. 


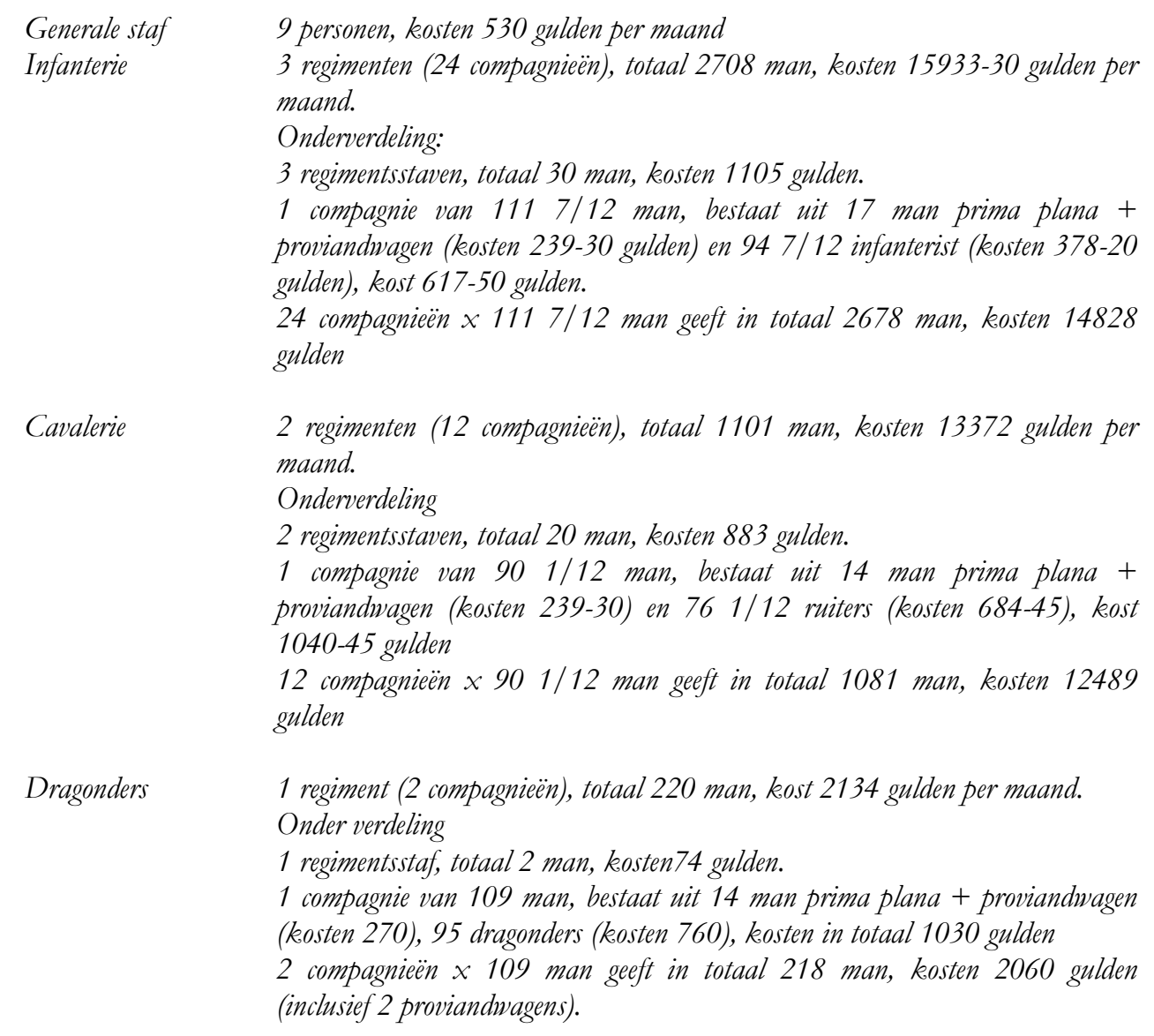

Op volle sterkte telde het kreitsleger daarmee 4038 man, bestaande uit een generale staf van negen man, drie regimenten infanterie (totaal 2708 man), twee regimenten cavalerie (totaal 1101 man) en één regiment dragonders (totaal 220 man). ${ }^{2084}$ Iedere compagnie van rond de honderd man had een groep die tot de zogenoemde 'prima plana' werd gerekend. Deze aanduiding, afgeleid van de eerste bladzijde van de betaalrol van een legeronderdeel, wordt gebruikt voor (onder)officieren en mensen met ondersteunende functies zoals een foerier, barbier, schrijver, kapelaan, tamboer, et cetera. Zoals uit de tabellen te zien is, ging het bij de generale staf en 'prima plana' om aanzienlijke aantallen en forse bedragen. Van de 1101 ruiters werden 20 man regimentsstaf en 168 man 'prima plana' afgetrokken

2084 Als voorbeeld van vergelijkbare berekeningen van de samenstelling van een regiment kan hier worden gewezen op Zech, Das Fürstenbergische Kontingent. 
(restant 913 'gewone' cavaleristen), terwijl bij de 220 dragonders 2 man voor de staf en 28 voor de 'prima plana' op de rol stonden (resteerden 190 dragonders).

Bij oorlogsgevaar kon het dubbele of driedubbele (duplum of triplum) worden gevraagd. Zo werd bijvoorbeeld in 1702 bij het uitbreken van de Spaanse Successieoorlog het rijksleger gebracht op 120.000 man, het drievoudige van het basisleger. De wijze waarop de kreits troepen leverde, wisselde nogal eens. Er waren legeraanvoerders die zelf een detachement op de been brachten en dit door de kreits lieten inhuren, maar daarnaast hielden ook grotere standen binnen de kreits zelf troepen onder de wapenen. Deze mochten aan het kreitscontingent worden toegevoegd.

In beginsel waren de kreitsen verplicht hun contingent als staand leger te onderhouden (miles perpetuus), maar in de praktijk werd daar vaak niet de hand aan gehouden. Voor staand leger of garnizoenen moest apart worden betaald.

Het oorspronkelijke simplum van de Wormser Matrikel voor voetvolk en ruiters werd in 1682 voor de kreits becijferd op 8609 1/3 Rijnse guldens. Voor het permanent onder de wapenen houden van het rijksleger 'nieuwe stijl' waren door de Rijksdag 3 'simpelen' als norm voorgeschreven, wat 3 x 8609 1/3 Rijnse guldens $=25828$ Rijnse guldens aan bijdragen van de kreitsstanden inhield. Het kreitscontingent kostte echter in werkelijkheid totaal 31969 Rijnse guldens per maand, een tekort dus van 6141 Rijnse guldens. Dit flinke verschil werd veroorzaakt door de hoge kosten voor generale staf en 'prima plana', die in het oorspronkelijke simplum niet waren berekend. Deze meerkosten werden de standen dan ook afzonderlijk in rekening gebracht en worden steeds afzonderlijk vermeld.

De Reichsdefensionalordnung van 1682 en de daarop gebaseerde uitvoeringsmaatregelen waren ontoereikend voor de volledige verdediging van het Rijk, maar ze bleven richtinggevend voor de militaire organisatie tot het einde van de achttiende eeuw. Door aanwijzing van de kreitsen als de voor de defensie verantwoordelijke organisaties, kon rekening worden gehouden met specifiek regionale omstandigheden en behoeften. De kleine standen wisten zich in tijd van nood verzekerd van militaire bescherming, terwijl de keizer kon rekenen op de steun van een rijksleger naast zijn eigen troepen. Wel verschilde in de loop der jaren de manier waarop daar door afzonderlijke kreitsen invulling aan werd gegeven. Sommige toonden zich zeer actief, andere verzonken in een zekere machteloosheid.

De prestaties van de Nederrijns-Westfaalse Kreits gedurende de Spaanse Successieoorlog waren niet indrukwekkend. Bij het uitbreken van de oorlog in 1702 werd het rijksleger gebracht op 120.000 man (80.000 infanterie, 40.000 cavalerie), drie maal de sterkte in vredestijd. De Nederrijns-Westfaalse Kreits willigde daarvoor in principe drie maal het kreitscontingent in (3963 ruiters en 8121 infanteristen), maar bracht dit vervolgens weer omlaag tot 3012 ruiters en 6200 man te voet. ${ }^{2085}$ Daarnaast kregen sommige standen nog een extra reductie wegens armlastigheid.

Na de Vrede van Utrecht in 1713 en het Barrièretractaat van 1715 werden de staande troepen (de 'miles perpetuus') afgedankt. Er lagen nog kreitsgarnizoenen in Bonn en Keulen en de kosten daarvoor werden direct op de afzonderlijke kreitsstanden verhaald, meestal

2085 Dotzauer, Reichskereise, 325 
ook met Römermonate als rekeneenheid. Verder betaalden de kreitsstanden tot circa 1770 voor het onderhoud van de 'prima plana'. Daarnaast onderhielden grote landsheren zoals de koning van Pruisen, die wegens het bezit van verschillende territoria in de kreits goed was voor een aantal stemmen in de kreitsvergadering, ook een staand leger. Die troepen konden in bepaalde gevallen vanwege de kreits worden ingezet. Een voorbeeld daarvan is de Luikse Revolutie van 1789, toen Pruisische troepen werden gestuurd om orde en rust binnen het gebied van de kreitsstand Luik te herstellen.

Alleen in de Zevenjarige Oorlog (1756-1763) werd door de kreits meebetaald aan het rijksleger dat bij wijze van Reichsexekution tegen Frederik II van Pruisen werd ingezet. De Rijksdag wilde een leger van 120.000 man in het veld brengen, het triplum volgens de matrikel van 1682. De Nederrijns-Westfaalse Kreits verkeerde in een lastige situatie aangezien Frederik II, de man tegen wie deze Reichsexekution was gericht, een van de uitschrijvende vorsten binnen de kreits was en door de keizer uit dit ambt was geschorst. Desondanks schreven Münster en Jülich een algemene vergadering van kreitsstanden uit. Deze besloten - enigszins lusteloos - toch hun plichten na te komen en bij te dragen aan het rijksleger. Grote militaire prestaties verrichtte de kreits ook dit keer niet. De oorlog leidde voor verschillende standen tot invallen van Pruisische troepen, met alle bijbehorende schade. De Vrede van Hubertusburg (1763) maakte weliswaar een einde aan het conflict, maar leverde een intern verdeeld Kreisdirektorium op, dat de oorlogsschade moest regelen. Daarmee stortte de financiële huishouding van de kreits bijna helemaal in.

Bij het voorgaande overzicht van heffing van Römermonate door de kreits moet nadrukkelijk worden opgemerkt dat dit slechts een deel van de militaire lasten betreft, waar de bevolking onder gebukt ging. Doortrekkende legers, maar ook troepen in winterkwartieren, moesten worden voorzien van voedsel, hout en transport. Dat ging om grote bedragen. Het probleem was dat de Römermonate werden beschouwd als reële, op de grond drukkende lasten, terwijl de andere militaire vorderingen uit de personele belastingen werden voldaan. Dat onderscheid zorgde voor veel ongenoegen, omdat die personele lasten neerkwamen op de inwoners, terwijl de grondeigenaren (voor een groot deel wonend buiten het graafschap) zich daar aan onttrokken.

\subsubsection{Kreitssimplum en andere kreitskosten}

De Nederrijns-Westfaalse Kreits beschikte bij de zogenoemde uitschrijvende vorsten, de grootste standen, over een klein ambtelijk apparaat, waarvoor de overige leden van de kreits betaalden. Ook deze bijdrage werd bepaald door omrekening in geld van het in de Wormser Matrikel genoemde simplum. Daarnaast moest iedere kreitsstand rekening houden met kosten voor afvaardiging van vertegenwoordigers naar de kreitsdagen. Deelname aan een vergadering, die enkele weken kon duren, bracht aanzienlijke kosten met zich mee. De vergaderfrequentie wisselde echter zeer sterk; soms werd jaren niet vergaderd en lag de feitelijke leiding in handen van een Direktorialkonferenz, bestaande uit enkele Kreisdirektoren van de belangrijkste standen (Pruisen, Pfalz-Neubourg, Münster) met ondersteuning van een kleine ambtelijke organisatie. De activiteiten bleven beperkt tot dagelijkse bestuursaangelegenheden, zoals (confessionele) twisten tussen standen, verzoeken om verlichting van financiële lasten, toelating van nieuwe standen, etc. Pas in 1786 werd weer 
een Kreisdirektorialtag uitgeschreven, waarbij ook de sinds 1757 niet meer gecontroleerde boekhouding van de kreits zou worden onderzocht. Daarbij bleek dat veel standen al sinds 1757 geen bijdragen meer hadden betaald en dat nog 11.1647 rijksdaalders aan schulden openstond.

\subsubsection{Kammerzieler2086}

Het Rijkskamergerecht werd, behalve met inkomsten uit processen, vooral gefinancierd met een belasting die Kammerzieler heette, welke woord de meervoudsvorm is van Kammerziel, de halfjaarlijkse betalingstermijn. Oorspronkelijk was voor de bekostiging gedacht aan de Gemeine Pfennig, maar toen bleek dat deze onvoldoende opbracht, werden voor het eerst bij de Reichsabschied van Konstanz in 1507 Kammerivieler ingevoerd. Tot 1544 betaalden zowel de rijksstanden als de keizer daaraan, maar sinds de Reichsabschied van Augsburg in 1548 ontvingen alleen nog de standen een aanslag. Vanaf deze tijd bleven de bijdragen voor het Rijkskamergerecht dan ook volledig gescheiden van andere rijksbelastingen. De kreitsstanden betaalden hun Kammerzieler op de grondslag van de Wormser Matrikel van 1521. De in beginsel onveranderlijke indeling daarvan in rijksstanden had, net als bij de andere rijksbelastingen, tot gevolg dat wijzigingen in de omvang van het territorium van een rijksstand niet leidden tot veranderingen van het bedrag op de matrikel en dat de betrokkenen die aanslag maar onderling moesten verrekenen. Alleen een reeks kleine aanpassingen leidde in de loop van de tijd tot het gebruik van een zogenoemde Usualmatrikel. Daarnaast werd ook geprobeerd Kammerzieler te krijgen van kleine heerlijkheden, die wel rijksonmiddellijk waren, maar wegens ontoereikendheid van hun stand niet op de matrikel voorkwamen.

De hoogte van het bedrag en het aantal Ziele per jaar werden in de loop der tijden regelmatig aangepast. De Jüngste Reichsabschied van 1654, die een reeks bepalingen over organisatie en werking van het Rijkskamergerecht bevatte, bepaalde in paragraaf 14 dat de guldens die tot dan toe op de rijksmatrikel stonden voortaan 'auf Reichs-Thaler übersetzt' werden. ${ }^{2087}$ Voor dit verhoogde bedrag mochten de rijksstanden, zoals ook al vroeger het geval was geweest, hun 'Landtstände, Bürger und Unterthanen zur Beyhülff zuziehen', dat wil zeggen de kosten afwentelen op de inwoners van het land. ${ }^{2088}$ In 1713 gaf de Rijksdag aan de standen voor $1 / 3$ kwijtschelding van de achterstanden omdat het Rijkskamergerecht gedurende langere tijd niet of nauwelijks meer functioneerde. De laatste grote aanpassing in de achttiende eeuw was de Kammergerichts-Usualmatrikel van 1745. Een aparte heffing in de achttiende eeuw werd opgelegd voor de nieuwbouw van het Rijkskamergerecht.

De aanslag werd twee keer per jaar verstuurd, in voorjaar en herfst. Betaald werd hetzij direct bij de Pfennigmeister van het Rijkskamergerecht of in één van de vijf zogenoemde 'Lege-Städte' Neurenberg, Regensburg, Augsburg, Frankfurt en Leipzig. De Jüngste Reichsabschied van 1654 bepaalde dat ieder stand moest betalen in desjenigen Creysescassam oder Leg-Stadt wohin dieselbe gehörig', met ander woorden, de kreitskas werd de

2086 Erler e.a., Handwörterbuch Rechtsgeschichte, II, 590-592 (onder lemma Kammerzieler).

${ }^{2087}$ Hofmann, Quellen Verfassungsorganismus, 199.

${ }^{2088}$ Hofmann, Quellen Verfassungsorganismus, 200. 
plaats waar de Zieler bij elkaar werden gebracht, waarna afdracht aan de KammergerichtsPfennigmeister volgde. ${ }^{2089}$

Hoewel de financiële last van de Kammerzieler voor de afzonderlijke standen overzienbaar was, liet de betalingsmoraal vanaf het begin te wensen over. De oorzaken daarvoor varieerden van onwil en betwisting van de aanslag tot werkelijk onvermogen. Religieuze tegenstellingen tussen lutheranen en katholieken (te denken valt aan de zogenoemde religieprocessen voor het Rijkskamergerecht), onvrede over de invloed op de benoeming van rechters en onvrede over het functioneren van het gerecht speelden een rol.

$\mathrm{Na}$ de Jüngste Reichsabschied van 1654 is geprobeerd schoon schip te maken en opnieuw te beginnen. Maar de slechte betalingsmoraal bleef. Jarenlange achterstanden van op zich kleine bedragen liepen uiteindelijk op tot grote schulden. Jaarlijks verstrekte het Rijkskamergerecht aan de Rijksdag een lijst van achterstanden. Die waren ook niet altijd helder, omdat door de veranderingen van de tarieven niet voor alle jaren hetzelfde werd betaald. Tegen de nalatige standen werd ook de tenuitvoerlegging van betaling uitgesproken, maar in veel gevallen kwam van de inning weinig terecht. Aangezien men voor eventuele executie afhankelijk was van de medewerking van de kreits, hing het dus af van de bereidheid en mogelijkheid van die organisatie om medewerking te geven. Rond 1770 nam de druk om de achterstallige gelden te innen wel toe. Dit hangt ongetwijfeld samen met de visitatie van het Rijkskamergerecht door afgevaardigden van de Rijksdag in de periode 1767-1776. Weliswaar mislukte dit project grotendeels door competentiegeschillen en onderlinge tegenstellingen binnen de visitatiecommissie, maar een gunstig gevolg was wel dat de druk werd verhoogd om de schulden betaald te krijgen.

\subsubsection{Bijdrage aan het Nederrijns-Westfaalse Rijksgravencollege}

$\mathrm{Na}$ een min of meer vliegende start in 1653, waar graaf Jost Maximiliaan van Bronckhorst Batenburg als één der stichters bij was betrokken, leidde het Nederrijns-Westfaalse gravencollege gedurende ongeveer 35 jaar een sluimerend bestaan. Pas na de hervatting van activiteiten rond 1698 ontstonden nieuwe kosten, die over leden werden omgeslagen. Grondslag voor de contributie werd de Wormser Matrikel van 1521, met het daar genoemde simplum van iedere rijksstand als rekeneenheid. Afhankelijk van de benodigde hoeveelheid geld werd een bepaald aantal 'simpelen' opgelegd. Maar deze koppeling tussen contributie voor het gravencollege en de Wormser Matrikel leverde problemen op toen de graven vanaf het einde van de zeventiende en in de eerste helft van de achttiende eeuw bij de Rijksdag of de kreits matiging of 'Moderation' van hun matrikelbijdrage in het algemeen vroegen, meestal wegens de desolate economie van hun gebied. Die matiging werd in een aantal gevallen ook verleend, met als gevolg dat discussie ontstond over de vraag in hoeverre dit ook moest doorwerken op de bijdrage aan het Rijksgravencollege. Desondanks hield het Direktorium van het gravencollege vast aan het standpunt dat het oorspronkelijke bedrag moest worden betaald. Dit kon leiden tot verschillen in bedragen die een rijksstand betaalde aan de kreits en aan het gravencollege.

Een tweede punt van discussie betrof de vraag of het lidmaatschap van het gravencollege ten laste kwam van de graaf - de matrikel was immers gebaseerd op stand - of ten laste

2089 par. 9, zie Hofmann, Quellen Verfassungsorganismus, 199; Neuhaus, Das Reich der Früben Nenzeit, 50. 
van het land, dat wil zeggen de onderdanen (Territorialprinzip). In het algemeen werd de laatstgenoemde opvatting aangehangen en werd het verschuldigde bedrag samen met andere belastingen over de inwoners omgeslagen.

De betalingsmoraal van de leden van het gravencollege liet, zoals ook bij de afdrachten ten behoeve van kreits en Rijk, in veel gevallen te wensen over en leidde tot chronische kastekorten. Sommige leden betaalden niet, andere keken bijzonder kritisch naar hun bijdrage. Dat gold voornamelijk voor de vorsten, zoals de keurvorst van Hannover of de koning van Pruisen, die in de loop der tijd afzonderlijke graafschappen hadden verworven en daarvoor ook contributie bleven betalen.

\subsection{Gronsveld en de belastingen voor het Rijk}

\subsubsection{Graaf Johan II van Bronckborst Batenburg en de invoering van grondbelastingen}

In de Wormser Matrikel van 1521 zoekt men tevergeefs naar Gronsveld. Wel staat vermeld 'der Herr von Bronkorst' met een aanslag van zes paarden, 27 man te voet en 90 gulden. ${ }^{2090}$ Met 'der Herr von Bronkorst' zou dan zijn bedoeld Joost van Bronckhorst, heer van Bronckhorst. Andere lijsten uit de zestiende eeuw geven weer andere cijfers. 2091 Het blijven echter onwaarschijnlijk grote aantallen, die moeten berusten op een vergissing. Mogelijk zijn alle heerlijkheden in het bezit van leden van de familie Van Bronckhorst bij elkaar opgeteld: Bronckhorst, Anholt, Batenburg, Stein, Gronsveld, mogelijk ook nog Rimburg en Alpen. Het is duidelijk dat deze heerlijkheden geen andere samenhang kenden dan dezelfde familienaam van de heer, maar dat wist de opsteller van de lijst niet. In ieder geval maakten Joost en, na zijn overlijden in 1553 ook zijn weduwe, voortdurend bezwaar tegen belastingaanslagen vanwege het Rijk. ${ }^{2092}$ Hoogst waarschijnlijk werd niets betaald.

Het ontbreekt aan gegevens waaruit blijkt dat Gronsveld vóór het einde van de zestiende eeuw bijdroeg aan belastingen van het Rijk. De weerstand rond 1600 tegen de invoering wijst in de richting van iets nieuws. Maar geheel onverwacht waren deze belastingen niet. Graaf Johan II moet door zijn langdurig verblijf in Zuid-Duitsland en zijn juridische kennis goed op de hoogte zijn geweest van de bijdragen van graafschappen aan het Rijk. Door zijn huwelijk met Sibilla van Eberstein was hij zelf ook graaf van Eberstein en bekend met de gang van zaken in de Schwäbische Kreis. Als nieuwbakken graaf en stemhebbend lid van de Nederrijns-Westfaalse Kreits zal hij hebben geprobeerd zijn financiële verplichtingen na te komen. Ook mocht hij de andere leden van de kreits vanwege zijn enigszins discutabele muntrecht niet tegen de haren strijken. Verder nam juist in deze tijd de druk om te betalen toe wegens de financiering van de oplaaiende

2090 Hofmann, Quellen zum Verfassungsorganismus, 49.

2091 De Monté ver Loren, 'Gegevens Bronckhorst', 133-135.

2092 De Monté ver Loren, 'Gegevens Bronckhorst', 134-146. Joost protesteerde ook bij het Rijkskamergerecht tegen een aanslag in de Turkenbelasting, die hem vóór 1543 werd opgelegd, zie: Gelders Archief, Huis Bronckhorst, inv. nr. 15, regesten 99 en 100. 
oorlog tegen de Turken.2093 Tegen de algemene tendens bij de rijksstanden om te betalen kon de graaf niet ingaan. Ten slotte hoopte de graaf ook op directe steun en bescherming van de Nederrijns-Westfaalse Kreits voor zijn eigen landje. Gronsveld lag immers in een grensgebied, bij het beleg van Maastricht door Spaanse troepen in 1579 was het gebied vrijwel compleet verwoest en ook daarna hield de militaire overlast aan.

De bereidheid van graaf Johan II om belastingen in te voeren past ook in het kader een discussie over de overgang van de 'domeinenstaat' naar de 'belastingsstaat', die in de jaren negentig in het Rijk werd gevoerd. Tegenover de oude opvatting dat de regering van een land zich moest bedruipen uit haar eigen domeinen kwam de nieuwe opvatting dat de overheid voor de uitoefening van haar taken belastingen mocht heffen. In grotere gebieden lukte dat wel, bij territoria met zeer weinig inwoners ontbrak het vaak aan een ambtelijk apparaat om belastingen te innen.2094 De situatie in Gronsveld laat een tussenfase zien. Het landsbestuur werd gefinancierd uit de grafelijke domeinen (de verwevenheid tussen het persoonlijk vermogen van de graaf en de bezoldiging van functionarissen bleef feite tot aan de Franse Tijd bestaan), maar de door het Rijk opgelegde belastingen waren te hoog om uit dat vermogen te financieren. Daarvoor was dus een vorm van belastingheffing noodzakelijk.

Tegelijk met de invoering van belastingen vorderde graaf Johan II ook herendiensten van zijn onderdanen, terwijl de Gronsveldenaren meenden dat zij die hadden afgekocht. Zij voerden daarnaast nog aan dat zij de graaf bij zijn aantrede nog een aanzienlijk bedrag hadden geschonken voor de opbouw van het kasteel. Met nog een geschil over de eigendom van gemeentegrond waren alle ingrediënten voor een hevig conflict voorhanden. Want de autoritair ingestelde graaf was niet van plan toe te geven. Misschien was vroeger niet betaald, maar het uitblijven van een gerechtelijke vervolging was dan te danken aan mededogen van de fiscaal van het Rijkskamergerecht en het ontsloeg geenszins van de betalingsverplichtingen.

De problemen begonnen in het midden van de jaren negentig van de zestiende eeuw. In 1594 stemde de Nederrijns-Westfaalse Kreits toe in de betaling van tachtig Römermonate aan de keizer. In 1596 werden vijfhonderd kurassiers tegen de 'erfvijand' (de Turken) bewilligd. Voor dit laatste werd iedere kreitsstand met $13 \frac{1}{2} 2$ 'einfache Römermonate' aangeslagen. Vervolgens stemde de Rijksdag in Regensburg in 1598 nog eens toe in zestig maanden. Daarmee kwam het totaal op 1531/2 maanden. Gronsveld was volgens de matrikel aangeslagen voor één ruiter of twaalf gulden (dat was namelijk volgens rijksbesluit en matrikel de prijs van één ruiter met paard per maand), dus leverde dit een totaalbedrag van 1842 gulden in 'zware' rijksmunt op, exclusief de bijdragen in de kosten van Rijks- en kreitsdagen en de kosten van inning. ${ }^{2095} \mathrm{Op}$ dit bedrag betaalden de Gronsveldenaren 750

2093 Onder de regering van keizer Karel waren er 73,5 Römermonate opgebracht, tussen 1556 en 1609 stond de Rijksdag 409 Römermonate toe. Daar kwamen in de jaren negentig nog bijzonder bijdragen van de kreitsen bij. De bereidheid om te betalen was hoog. Van de rijksstanden betaalde 88 procent. Protesten van afzonderlijke rijksstanden hielpen weinig, de meerderheid besliste, vgl. Whaley, Das Heilige Römische Reich. 1, 441-443.

2094 Whaley, Das Heilige Römische Reich. 1, 629-631.

2095 RHCL, Rijkskamergerecht, inv. nr. 17, fol. 26 (Q 6). 
gulden Brabants 'licht' geld, omgerekend 330 gulden 'zwaar' rijksgeld. Dat betekende een restschuld van 1512 gulden 'zwaar' rijksgeld, exclusief onkosten.

Daarna hoopten de schulden zich in snel tempo op. In 1603 bewilligde de Rijksdag nog eens 86 maanden 'Turkenhulp' à 12 gulden per maand, wat omgerekend, exclusief onkosten, op 1032 gulden kwam. Verder stemde de kreits in met een paar extra maanden aan de keizer. Voor de betaling van deze bedragen hief de graaf van alle gronden binnen het graafschap per bunder (de gebruikelijke eenheidsmaat) een bepaald bedrag, ongeacht de vraag an wie die grond toebehoorde. 2096

$\mathrm{Al}$ deze belastingen stuitten op weerstand bij de Gronsveldenaren, meer in het bijzonder de Maastrichtse poorters of de in deze stad gevestigde instellingen met grond in het graafschap wegens hun vermeende belastingvrijdom. Zij zochten voor dat verzet steun bij de hertog van Brabant als medeheer van Maastricht, in dit geval de Spaanse landvoogd en de Raad van Brabant in Brussel. In 1598 en 1599 klaagde graaf Johan bij landvoogd Albrecht van Oostenrijk dat de Maastrichtenaren weigerden de Turkenbelasting te betalen en de hulp hadden ingeroepen van de Raad van Brabant. ${ }^{2097}$ Hetzelfde deed hij in 1598 ook nog eens bij Albrechts plaatsvervanger, aartshertog Andreas van Oostenrijk. 2098 Gronsveld was volgens de Maastrichtenaren een enclave in Brabants gebied en daarom waren de onder Brabants gezag staande Maastrichtenaren vrijgesteld van belastingen. Dat was een uiterst gevoelig punt, want Brabantse inmenging vormde een bedreiging voor de rijksonmiddellijkheid. Daarom betoogde de graaf dat zijn territorium ook grensde aan rijksonmiddellijk gebied en dat het grond van het Heilige Roomse Rijk was

Om zijn onwillige onderdanen tot betaling van de rijks- en kreitsbelastingen te dwingen, begon graaf Johan II in 1599 een proces bij het Rijkskamergerecht. De grondeigenaren betoogden dat zij helemaal niet aan deze nieuwe belasting waren onderworpen, daar ook nooit aan onderworpen waren geweest en dat zij in 1526 alle herendiensten en andere belastingen hadden afgekocht. De zaak spitste zich toe op twee punten: mocht de graaf bepaalde herendiensten vragen en waren alle grondeigenaren verplicht bij te dragen in de rijks- en kreitsbelastingen? Een bijkomend probleem was dat Gronsveld zwaar leed onder overlast van Spaanse troepen. Gaston de Spinola, de Spaanse stadhouder van Limburg en Overmaze, eiste schriftelijke bewijzen waaruit moest blijken dat het graafschap van Spaanse oorlogscontributie was bevrijd.

In de uitvoerige vertogen die de Gronsveldse grondeigenaren bij het Rijkskamergerecht indienden, gaven zij toe dat in 1596 en 1597 vanwege de voortdurende oorlogscontributies en schattingen een bedrag was betaald, maar dat betrof slechts een deel van de aanslag en het was onduidelijk waaraan dat geld precies was besteed. Een deel zou zijn betaald aan het Rijkskamergerecht. ${ }^{2099}$ Meer principieel stelden zij zich op het standpunt dat sinds

$2096 \mathrm{Al}$ deze berekeningen zijn ontleend aan RHCL, Rijkskamergerecht inv. nr. 17, fol. 18-36vo. (Q 6) en fol. 101-104vo. (Q 20), 'Anæreige' van de advocaat van graaf Johan II van Bronckhorst Batenburg van 14 november 1600 en 28 augustus 1606 .

2097 TJ, inv. nr. M 33, fol. 104-107, Johan van Bronckhorst aan aartshertog Albrecht 13 maart 1598; TJ, inv. nr. M 33, fol. 98-100, concept-brief graaf Johan van Bronckhorst aan aartshertog Albrecht 16 november 1599 .

2098 TJ, inv. nr. M 33, fol. 58-65, brief graaf Johan van Bronckhorst aan kardinaal Andreas van Oostenrijk 1598.

${ }^{2099}$ RHCL, Rijkskamergerecht, inv. nr. 17, fol. 10-15vo. (Q 3). 
mensenheugenis nooit in het graafschap belastingen voor Rijk en kreits waren geheven. De graaf zou dat ook nooit op basis van een rijksmatrikel kunnen bewijzen. En als al betaald was, dan had de graaf dat gedaan buiten hen om, uit de opbrengst van de 'bede'. De onderdanen konden toch moeilijk de financiële gevolgen dragen van het feit dat Gronsveld nog niet zo lang geleden tot graafschap was verheven en op de rijksmatrikel was geplaatst. Dat alles was gebeurd zonder hun inwilliging. Bovendien had de graaf nooit het precieze bedrag van de aanslag bekend gemaakt en zouden in 1526 alle belastingen zijn afgekocht. Ten slotte, wanneer de onderdanen moesten betalen, dan was het onrechtvaardig dat de graaf, die tien keer meer bezat dan zij, zelf niet bijdroeg. In de voorgaande decennia was het land door de oorlog verwoest en de bevolking voelde zich onbeschermd en in de steek gelaten door zijn heer. Kortom, als er moest worden betaald, wilde men waar voor het belastinggeld.

De graaf beschouwde zijn onderdanen vooral als weerspannig. Het graafschap was onbetwistbaar rijksonmiddellijk, had niets uit te staan met de Spaans-Bourgondische Nederlanden en de landsheer kon belastingen ten behoeve van het Rijk opleggen, inclusief de belasting voor de oorlog tegen de Turken. Het argument van de lotsverbondenheid met Brabant was onterecht, want het graafschap was meer omringd door Luiks dan door Brabants territoir. Ook kon de graaf niet worden verweten dat hij onvoldoende bescherming had geboden. De Spaanse overmacht was gewoon te groot en hij moest tegelijk proberen met de Brabantse buren op goede voet te blijven. Het was ook niet waar dat vroeger de onderdanen niet direct in de rijksbelastingen hadden bijgedragen en dat die uit de 'bede' zouden zijn betaald. Bede was in de ogen van de graaf een belasting die uitsluitend ten behoeve van hem, de heer, werd geheven en dus een interne zaak van het graafschap. ${ }^{2100}$ Rijks- en kreitslasten waren volgens de graaf van een andere orde. Iedere rijksstand mocht die van zijn onderdanen vragen.

Het probleem van de graaf was dat hij niet goed aannemelijk kon maken dat Gronsveld al eerder aan de rijksbelastingen had betaald. Hij beweerde niet ten onrechte dat vroeger in de rijksmatrikel de verschillende heerlijkheden van de familie Van Bronckhorst in één aanslag waren gecombineerd, maar daarover ontbrak verdere informatie. Het was de vraag of je daar belastingplicht van Gronsveld uit kon afleiden. Wat de al betaalde gelden betrof, die waren besteed aan de Türkensteuer en vijfhonderd kurassiers. En dat was nog maar een fractie van het verschuldigde bedrag. Graaf Johan rekende voor dat de aanslag 1842 gulden 'zwaar' rijksgeld bedroeg, terwijl omgerekend niet meer dan 330 gulden van dezelfde munt was voldaan. Kortom, men moest de keizer geven wat des keizers was.

Bijzondere aandacht schonk de graaf aan de Turkenbelasting, vooral omdat men in Brussel kennelijk de Maastrichtenaren had aangeraden daar niet mee akkoord te gaan. Volgens hem was het een oude gewoonte dat de Maastrichtenaren de Turkenbelasting betaalden in alle territoria die tot de kreits behoorden, zoals de inwoners van de rijksonmiddellijke gebieden binnen de Nederrijns-Westfaalse Kreits ook in de Spaanse Nederlanden betaalden voor hun daar gelegen goederen.

2100 Het is de vraag of de graaf die vroegere betalingen van belastingen aan het Rijk ook kon bewijzen. Ten aanzien van de 'bede' had hij wel een punt. Over dat begrip bestond in Gronsveld onduidelijkheid (zie Hoofdstuk 15.16). 
In eerste instantie leek Johan II van Bronckhorst Batenburg bij het Rijkskamergerecht ongelijk te krijgen. De graaf wendde zich echter begin 1600 tot de hertog van Gulik als directeur van de kreits met de mededeling dat hij de belastingen van het Rijk had uitgeschreven, maar daarbij weerstand ondervond. ${ }^{2101}$ Voorts verzocht hij van de schepenen van de Rijksstad Aken een attest dat Gronsveld 'eine uralte freije herschafft des Reichs' was, door de keizer tot graafschap verheven en in alles onderworpen aan het Rijk als een rijksstand. ${ }^{2102}$ Die verklaring zal hij wel hebben gekregen. Ook hertog Johan Willem van Gulik oordeelde dat Gronsveld was onderworpen an alle belastingen vanwege het Rijk, inclusief de Turkenbelasting. ${ }^{103}$ Ongetwijfeld heeft dit soort bewijsmiddelen de graaf geholpen om het Rijkskamergerecht van zijn gelijk te overtuigen. Toch bleek dit onvoldoende de onwillige onderdanen tot betaling te bewegen. Zekerheidshalve wendde de graaf zich ook nog eens tot keizer Rudolf II. In het bijzonder stoorde hij zich aan het feit dat Maastrichtenaren of ex-Gronsveldenaren die nu in Maastricht woonden, grond in het toch al verarmde graafschap kochten en zich vervolgens op vrijstelling van belasting beriepen. ${ }^{2104}$ Inderdaad intervenieerde de keizer in februari 1602 bij Albert van Oostenrijk, de Spaanse landvoogd in de Zuidelijke Nederlanden. Hij betoogde daarbij dat de graaf niet kon voldoen aan de hem vanwege het Rijk opgelegde financiële verplichtingen door de steun die de halsstarrige Maastrichtenaren vanuit Brussel ontvingen. ${ }^{2105}$

Intussen was in Heugem de bevolking opgehitst door Johan Meijs, secretaris van de schepenbank en Maastrichtenaar. Het kwam zover dat de schepenen hun werk staakten. Met het nodige machtsvertoon lukte het de graaf deze rebellie de kop in te drukken, maar de verhoudingen bleven zeer gespannen. Ook de processen bij het Rijkskamergerecht sleepten aan, terwijl de schulden steeds verder opliepen. In augustus $1607 \mathrm{kreeg}$ de graaf een keizerlijke aanmaning om voor de periode 1603-1606 in totaal 1236 gulden 'zwaar' geld te betalen. ${ }^{2106}$

Uiteindelijk moest in 1611 een vergelijk tussen de graaf en zijn onderdanen een einde maken aan de steeds onaangenamer wordende processen voor het Rijkskamergerecht. Zeven door partijen aangewezen scheidslieden deden deze uitspraak over de bijdrage in de rijksbelastingen, de herendiensten en rechten op gemeentegronden en aanwassen langs de Maas. Uit de uitvoerige overwegingen voorafgaand aan de eigenlijke beslissing blijkt hoe diep de wrok aan beide kanten zat. Johan Meijs mocht terugkeren als secretaris van de

2101 TJ, inv. nr. M 33, fol. 74-81, brief Johan van Bronckhorst Batenburg aan hertog van Gulik 10 januari 1600 .

2102 TJ, inv. nr. M 33, fol. 52-53, concept-brief Johan van Bronckhorst Batenburg aan stadsbestuur Aken 29 februari 1600.

2103 TJ, inv. nr. M 33, fol. 50-51, 16 maart 1600; zie verder Bijlage 43.

2104 TJ, inv. nr. M 33, fol. 70-73, verzoekschrift van Johan II van Bronckhorst Batenburg aan keizer Rudolf 30 maart 1600

2105 TJ, inv. nr. M 33, fol. 102-103, keizer Rudof aan aartshertog Albert van Oostenrijk 3 februari 1602; T] M 33, fol. 66-67, interventie van keizer Rudolf bij aartshertog Albrecht 13 februari 1602.

2106 RHCL, Rijkskamergerecht inv. nr. 73, fol. 108-109vo. (Q 11), Keizer Rudolf aan Johan van Bronckhorst Batenburg 10 augustus 1607. 
schepenbank Heugem en de bank moest haar werkzaamheden op de oude voet hervatten. Wat betreft de bijdragen in belastingen van Rijk en kreits werd vastgesteld dat die onontkoombaar waren. Wel wilde de graaf zich 'auss gnediger lieb und affection' voor zijn onderdanen inzetten voor matiging van die aanslagen wanneer men uit armoede niet kon betalen. Voorts moest iedereen, zonder uitzondering, op gelijke voet in deze belasting bijdragen, zowel inwoners als 'auslendische als Luttischen, Maestrichter und alle andere in der graeffschafft von iren guetern und erbschafften, soe alda in und under der graeffschafft gelegen'. Zijnerzijds verplichtte de graaf zich naast beste vermogen zijn onderdanen te beschermen.

\subsubsection{De Maastrichtse belastingvrijheid}

Het voortdurende debat over de Maastrichtse belangvrijheid vergiftigde de relatie tussen stad en platteland. Daarom verdient dit punt een nadere uiteenzetting, alvorens in te gaan op een aantal specifieke aspecten rond de bijdrage in Gronsveld. Een kort, verkennend onderzoek over deze problematiek werd door Van de Venne in 1962 gepubliceerd. ${ }^{2107} \mathrm{Hij}$ beperkt zich daarbij tot de relatie Maastricht - Landen van Overmaze, maar de Maastrichtse pretenties betroffen ook andere territoria in de omgeving van de stad. De kern van de kwestie kwam neer op de bewering dat de Maastrichtse burgers volgens hun aloude rechten en privileges vrij waren van belasting voor hun onroerend en roerend goed buiten de stad. Het ging inderdaad om een bewering, want een concreet document als bewijsstuk voor dit recht ontbrak. De weigering belasting te betalen zette de relatie tussen de Maastrichtenaren en de plattelanders onder spanning, want het Maastrichtse grondbezit in de omgeving was aanzienlijk. Ook binnen het graafschap Gronsveld leverde deze kwestie voortdurend stof voor conflicten.

Van de Venne begint zijn overzicht van de conflicten met de geschillen tussen de Maastrichtenaren en Reinoud, heer van Valkenburg (1305-1333), de tijd dat het latere Land van Valkenburg nog niet tot de Landen van Overmaze behoorde. De krap bij kas zittende Reinoud begon belasting te heffen op het grondbezit van Maastrichtenaren binnen zijn gebied en ging zelfs over tot berovingen. De hertog van Brabant nam het op voor zijn Maastrichtse onderdanen, wat gedurende een reeks van jaren leidde tot schermutselingen, belegeringen en steeds weer verbroken vredesverdragen. Op 4 juli 1327 kwam het bij IJzeren tot een kleine veldslag, die later in de geschiedenis bekend stond als de 'Triomf der Maastrichtenaren'.

De perikelen met de heer van Valkenburg zijn het eerste voorbeeld van een conflict over de belastingen, maar voor het onderliggende juridische fundament moeten we te rade gaan bij documenten uit later tijd. Van de Venne maakt daarvoor een sprong van het begin van de veertiende eeuw naar het jaar 1501. Hij beschrijft dat de Indivieze Raad van Maastricht probeerde in Brussel bij aartshertogin Margaretha van Oostenriik en de kanselier van Brabant het recht van belastingvrijdom gehandhaafd te krijgen. Helemaal zeker van hun zaak leken de Maastrichtenaren niet. Misschien toen ook al onopgemerkt en waarschijnlijk evenmin bij Van de Venne bekend is een Maastrichtse 'schepencleernis' over dezelfde

2107 Van de Venne, 'Belastingconflicten'. 
kwestie precies honderd jaar eerder. ${ }^{2108}$ Tot op heden lijkt die aan de aandacht van de historici te zijn ontsnapt. De tekst bestaat eigenlijk uit verschillende akten, die op 23 en 24 november 1401, na een tamelijk omslachtige procedure werden opgesteld. Aangezien ook een aantal criteria voor de belastingvrijdom wordt genoemd, is het zinvol daar wat uitvoeriger bij stil te staan.

Aanleiding voor het geschil vormde de schatting die de ontvanger van het hertogdom Limburg en Landen van Overmaze eiste wegens grondbezit van Maastrichtenaren. Die beweerden daarvan te zijn vrijgesteld volgens aloude privileges van de stad. De Indivieze Raad van Maastricht wendde zich vervolgens tot schout en schepenen van zowel het Luikse als Brabantse Hooggerecht met het verzoek hierover een verklaring voor recht af te geven. Er werd daartoe een getuigenverhoor gehouden met de volgende uitkomst:

- Maastrichtenaren waren vrij van schatting van al hun roerende en onroerende goederen, zolang zij poorter waren.

- Inkomende of nieuwe poorters of degenen die het poorterschap hadden gekocht en in Maastricht woonden, bleven schatplichtig voor de goederen uit de tijd dat zij nog geen poorter waren. Werd de schatting echter verhoogd, dan zou de stad voor hun oude recht opkomen.

- Een vreemdeling die in de stad huwde met een poorter of poorterse genoot dezelfde schatvrijheid als een oud-ingezeten poorter.

- Een poorter die buiten de stad huwde met een vreemde en daarna met zijn partner in de stad ging wonen, waren beiden met hun goederen vrijgesteld van schatting.

- Wanneer een poorter onroerend goed buiten de stad erfde, werd dat schatvrij.

- Een poorterskind dat ongehuwd gedurende een of meer jaren buiten de stad woonde zonder het poorterschap op te geven, behield het poortersrecht zolang het ongehuwd bleef.

- Een inkomende poorter die vóór de verwerving van zijn poorterschap verplichtingen had met betrekking tot onroerend goed of daarop rustende lasten zoals schatting, bleef gehouden tot nakoming van die verplichtingen zonder tussenkomst van de stad bij een geschil daarover.

- Personen behorend tot het gezin van een poorter, zoals meiden en knechten, werden als poorters beschouwd en genoten dezelfde vrijheid gedurende de tijd van hun dienstbetrekking.

Van deze verklaring maakten de schepenen op verzoek van de burgemeesters namens de Indivieze Raad een akte op, waarna de schepenen bevestigden dat zij zich aan deze regels hielden. De burgemeesters verlangden daarnaast ook een door beide gerechten bezegelde oorkonde om die bij de hertog van Bourgondië in diens hoedanigheid van hertog van Brabant te overleggen. Dit weigerden de schepenen met het argument 'dat sij des niet en useirden ende dat recht bij hon des niet en vermocht'. Voor een dergelijke belangrijke

2108 RHCL, Oud-rechterlijk archief Maastricht, bestand 20.254: Diverse rechterlijke, ongesorteerde stukken, doos 54, met handschrift vifftiende-begin zestiende eeuw, afkomstig uit particulier bezit, geschonken door G. Regout. Het manuscript, bevat afschriften van privileges van de stad Maastricht, met fol. 35vo.-38vo. de tekst van 'Clernisse van der scettinge van Overmase'. 
verklaring moest zwaarder geschut in stelling worden gebracht in de vorm van een door notarissen opgesteld en getekend proces-verbaal. Bovendien vroeg de burgemeester aan de bij deze zitting aanwezige dekens en kanunniken van Sint-Servaas en Onze-Lieve-Vrouwe op te treden als getuigen en de zegels van hun kapittels aan de oorkonde te hangen. De geestelijken antwoordden dat een bezegeling alleen mogelijk was naar 'kapittels recht', dat wil zeggen volgens een besluit genomen in een vergadering van het kapittel. Aldus geschiedde. Twee notarissen maakten van de handelingen en verklaringen bij de hooggerechten een akte op, die de volgende dag werd voorgelegd aan achtereenvolgens de kapittelvergaderingen van Sint-Servaas en Onze-Lieve-Vrouw. Daarna volgde ook de bezegeling met de zegels van het kapittel.

De nogal omslachtige procedure laat zien dat bij deze Maastrichtse belastingvrijdom grote financiële belangen speelden, zowel van de Maastrichtse burgers maar ook van de in de stad gevestigde instellingen, zoals de kapittels en kloosters. Eensgezindheid van alle stadsbewoners was dus geboden en dat moest in Brussel ook duidelijk worden. Anderzijds diende het spel ook subtiel te worden gespeeld. De hertog van Brabant hoorde als medeheer van Maastricht weliswaar op te komen voor de rechten van zijn Maastrichtse onderdanen, maar tegelijk verdedigde hij zijn belangen als heer van de Landen van Overmaze. Tussen die tegenstrijdigheden moest de hertog zien te laveren, zonder één van beide partijen tegen zich in het harnas te jagen.

Een tweede interessant aspect van deze kwestie was dat de aanspraken van de Maastrichtenaren kennelijk berustten op oud gewoonterecht, want er wordt op geen enkele wijze verwezen naar vroegere documenten en er waren getuigenverklaringen nodig om helderheid over het geldend recht te verschaffen.

Het derde punt raakt duidelijk de broze relatie tussen stad en platteland. De stad had voor economische groei en verdediging belang bij de komst van nieuwe burgers, maar de dorpelingen die naar de stad verhuisden, benadeelden daarmee de achterblijvers. Zij behielden immers wel onroerend goed in hun vroegere woonplaats, maar betaalden daar vanwege hun Maastrichts burgerrecht geen belasting meer over. Het tekort moesten dan de plattelanders bijpassen. Om daar nu enigszins paal en perk aan te stellen werd in de verklaringen uit 1401 nog eens precies vastgelegd in welke gevallen de poorters belastingvrijdom genoten en wanneer niet.

Of de akte uit 1401 in vergetelheid raakte of op termijn toch niet de gewenste duidelijkheid verschafte, laten we hier in het midden. Honderd jaar later maakte de Maastrichtse raad de zaak opnieuw aanhangig in Brussel, maar zonder blijvend resultaat. Ook in de daaropvolgende eeuwen laaiden conflicten over deze belastingvrijdom steeds weer op, niet alleen in de Landen van Overmaze, maar ook in andere territoria, zoals het graafschap Rekem ${ }^{2109}$ en in Gronsveld. Uiteindelijk toonden zich de Maastrichtenaren in

2109 Verbois, Geschiedenis Rekem, 228-230; zie ook Dormans, 'De financiële verhoudingen', 102, over problemen met buitengeërfden in Gulpen en Margraten, met als gevolg dat de Raad van State in 1717 voor die plaatsen een 'bankreglement' liet opstellen. De zaak lag echter iets genuanceerder dan Dormans het voorstelt, want weliswaar protesteerden de buitengeërfden tegen knoeierij met het bundergetal en te 
de loop van zeventiende eeuw schoorvoetend bereid bij te dragen in de zogenoemde 'reële lasten', dat wil zeggen de schatting en bede geheven op onroerend goed. Heftig verzet bleef bestaan tegen de zogenoemde 'personele lasten', zoals heffingen op het aantal personen van een huisgezin, het bezit van vee of een bepaalde bedrijvigheid. Maar zelfs de bereidheid bij te dragen in de reële lasten leidde niet tot vrede. Zo bestond vaak onenigheid over de correcte opmeting van de grond, over de vraag wat 'reëel' was (grond, maar ook tienden en molens?), over de betaling van oorlogsonkosten uit de reële of personele 'omlage' en de verdeling van lasten tussen de Maastrichtse grondeigenaar en diens pachter ter plaatse. Daarbij kunnen nog worden opgeteld kwesties over de manier van schatheffing en de afrekening daarvan.

\subsubsection{Nieuw verzet tegen grondbelastingen}

Met de overeenkomst tussen de geërfden en graaf Johan II van Bronckhorst Batenburg in 1611 keerde de rust voor enige tijd weer, maar duurzaam was de vrede allerminst. In 1643 nam de schepenbank van Gronsveld gerechtelijke dwangmaatregelen tegen wanbetalers, wat aan Maastrichtse zijde weer represailles uitlokte tegen inwoners van Gronsveld. De prins-bisschop van Luik gaf daarop bevel aan de Indivieze Raad van Maastricht af te zien van dergelijke tegenmaatregelen. ${ }^{2110}$ Enkele jaren later liepen de spanningen weer op. In 1657 vond een bespreking plaats van Jost Maximiliaan van Bronckhorst Batenburg met pensionaris Pesters en de gouverneur van Maastricht. De graaf van Gronsveld verlangde dat alle 'burgerlijcke gronden' in zijn gebied werden 'getaxeerd' (belast) 'mette Roemermaenden van het Rijck'. Elke maand ging het voor het hele graafschap om een bedrag van twaalf gulden. Jost Maximiliaan was bereid de aanslagbiljetten ook bij de Indivieze Raad van Maastricht te overleggen. ${ }^{2111}$

Er werd besloten nader overleg te houden, maar uiteindelijk lijkt dit partijen niet echt tot elkaar te hebben gebracht. Op 30 mei 1659 wendde Jost Maximiliaan zich tot de aartsbisschop-keurvorst van Keulen, tevens prins-bisschop van Luik, medeheer van Maastricht en lidmaat van de kreits, en klaagde over de weigering van de Maastrichtenaren bij te dragen in de rijks- en kreitsbelastingen. De graaf deed het probleem nog eens breedvoerig uit de doeken. Al sinds de tijd van keizer Karel V hadden de Maastrichtenaren zich afgewend van het Rijk en Brabantse bescherming gezocht. Vanaf die tijd bestonden problemen over de betaling van belasting. Hoewel vanuit Gronsveld hulp was gevraagd bij de opeenvolgende keizers, had dat weinig opgeleverd. De rijkste onderdanen van de graaf hadden hun woonplaats Gronsveld verlaten, lieten zich tot burgers van Maastricht maken en eisten vervolgens belastingvrijheid. Vreemd genoeg betaalden de Maastrichtenaren wel in andere plaatsen (?), maar niet in Gronsveld. De Dertigjarige Oorlog had de inwoners zeventigduizend rijksdaalders gekost, plunderingen niet eens meegerekend. Hoe de graaf tot deze berekening komt, is niet helemaal duidelijk, maar uit een staat van onkosten blijkt

weinig zeggenschap, maar de achtergrond was dat in het bijzonder de Maastrichtenaren niet wilden bijdragen.

2110 TJ, inv. nr. M 33, fol. 88-89, bevel van bisschop van Keulen en Luik aan Indivieze Raad van Maastricht 24 november 1643 .

2111 RHCL, Indivieze Raad van Maastricht, inv. nr. 66, fol. 524 (raadsverdrag 15 juni 1657); idem TJ, inv. nr. M 33, fol. 112-113. 
dat in de jaren 1654-1658 in ieder geval 1656 rijksdaalders aan Römermonate werd betaald, omgerekend 2484 gulden, exclusief renten over bedragen die voor de betaling moesten worden geleend. ${ }^{2112}$ Het was onmogelijk de renten en nog openstaande Römermonate te betalen. Uiteindelijk was met de Maastrichtenaren overeengekomen dat ze nog over een periode van zestien jaar zouden betalen. Maar of ze dat ook zouden doen?

Ongeveer per kerende post beval de prins-bisschop aan het stadsbestuur van Maastricht geen maatregelen te nemen tegen Gronsveldenaren vanwege het feit dat het gerecht van Gronsveld overging tot executoriale verkoop van gronden wegens achterstallige belastingschuld. Het was immers voldoende bekend dat betaald moest worden in de plaats waar de grond lag. ${ }^{2113}$ Intussen begon ook de ontvanger van de kreits aanmaningen te schrijven aan de graaf over het uitblijven van geld.2114

Mogelijk onder Luikse druk kwam op 19 augustus 1660 toch een overeenkomst tussen graaf Jost Maximiliaan en de Indivieze Raad van Maastricht tot stand. In de eerste plaats werd erkend dat de stad en haar burgers volledig in het bezit bleven van 'alle haer privilegien, die sij ten regarde van de voors. vrijhijt mogen hebben'. 'Sonder prejuditie' op dit recht beloofden zij eenmalig 'bij forme van subsidie' in zeven jaarlijkse termijnen twee gulden per bunder te betalen, in totaal dus veertien gulden per bunder. Met dit bedrag waren dan alle schattingen en schulden uit het verleden afgekocht. Voor de toekomst zou alleen nog maar worden bijgedragen 'in puer reële lasten, gelijck souden mogen sijn rijcxstueren off romermaenden off degene die daer mede over al gelijck sijn'. Daarmee waren bijvoorbeeld heffingen en leveranties ten behoeve van doortrekkende legers in beginsel uitgesloten. Geschillen werden door arbitrage beslecht. Verder kregen de geërfden of hun vertegenwoordigers ook daadwerkelijk de aanslagbiljetten te zien. Bij de verdeling van lasten zou een vertegenwoordiger van de Maastrichtse geërfden aanwezig moeten zijn. Daarmee kregen zij directe invloed op belasting. Voorts mochten de 'huysliedens' (pachters) die voor de Maastrichtse burgers grond bewerkten voor hun bedrijf of de opbrengsten daarvan niet zwaarder worden belast dan andere inwoners. Ten slotte moest de graaf zich naar vermogen inspannen dat de helft van de 'puere reële lasten' werd betaald door degenen die de grond zelf gebruikten. Voor verpachtende grootgrondbezitters zoals Maastrichtse instellingen was dit alleszins gunstig, want 'kleine' eigenaren (gewone Maastrichtse burgers en Gronsveldenaren) die de grond zelf bewerkten, moesten daarmee al de helft van het totale bedrag aan belasting voor hun rekening nemen.

Met deze overeenkomst waren de criteria voor de belasting nog eens aangescherpt, maar bleef genoeg ruimte over voor verschillen in interpretatie. Zo verzocht de Indivieze Raad van Maastricht op 17 juli 1670 aan de gravin van Gronsveld de vrijlating van een

2112 TJ, inv. nr. M 33, fol. 1-21. Voor de periode 1654-1658 worden daarin 207 Römermonate berekend à 8 rijksdaalders $(=12$ gulden) per maand $=1656$ rijksdaalders. Daar kwamen nog eens 220 rijksdaalders Kammerzieler bij.

2113 TJ, inv. nr. M 33, fol. 90-91, Bevel van bisschop van Keulen en Luik aan Indivieze Raad van Maastricht, 2 juni 1659.

2114 TJ, inv. nr. M 33, fol. 94-fol. 95, kreitspenningmeester aan Jost Maximiliaan van Bronckhorst Batenburg 25 mei 1660. 
Maastrichtenaar die door het Gronsveldse schepenbank wegens achterstallige belastingschuld was gearresteerd. ${ }^{2115}$

Meer principieel van aard was een jaar later de kwestie over de betaling van reis- en verblijfkosten van personen die de gravin afvaardigde naar vergaderingen van de kreits of Rijksdag. De (Maastrichtse) geërfden vonden dat dit soort uitgaven ten laste van de gravin persoonlijk kwamen, omdat ze wel heel ver af stonden van de Römermonate die men voor die reiskosten had toegestaan. Eigenlijk klonk daarin de oude vraag door of belastingen ten laste van de landsheer als rijksstand of ten laste van het land kwamen. Om 'goede correspondentie' te houden, bleken de geërfden bereid een bedrag van honderd dukaten bij te dragen, dit alles met een beroep op het algemeen nut en in de hoop dat de burgers niet meer werden lastiggevallen. ${ }^{2116}$

De spanningen bleven in de daarop volgende jaren bestaan, niet alleen tussen Maastricht en Gronsveld, maar ook met andere 'rijcx plaetsen' in de omgeving. In $1680^{2117}$ en $1692^{2118}$ riep het stadsbestuur van Maastricht de hulp van de Staten-Generaal in om de stedelijke privileges te verdedigen. De Maastrichtse geërfden klaagden dat zij allerlei kosten van doortrekkende legers, inkwartieringen, geschenke, reiskosten et cetera moesten betalen 'tegens het out gebruick volgens dewelcke alleenlijck de baste ende gesette lasten naer boenders getal werden omgeleijt'. In 1712 was de achterstand in betaling van de Maastrichtenaren in Gronsveld opgelopen tot meer dan veertienhonderd gulden. ${ }^{2119}$

\subsubsection{Een organisatie van geërfden in de zeventiende eeuw?}

Wanneer we het verzet van de 'geërfden', en vooral ook de Maastrichtenaren onder hen, tegen de belastingen gedurende de periode tussen 1600 en 1700 overzien, dan rijst de vraag of dat ook leidde tot gezamenlijk optreden in georganiseerd verband. In zekere zin lag hierin ook wel een probleem. Want in grote territoria bestonden staten- of standenvergadering, wier belangrijkste bevoegdheid was al dan niet in te stemmen met de door de landsheer gevraagde belastingen. Een dergelijk structureel overleg ontbrak in Gronsveld.

In de processen tussen graaf Johan II en zijn onderdanen wordt die laatste groep alleen maar in algemene zin aangeduid als 'underthanen', of 'nachparn'. In een notariële volmacht uit 1599 geven drie groepen 'nachparn' uit Gronsveld, Heugem en Slenaken procuratie aan een advocaat om bij het Rijkskamergerecht op treden. Deze 'naburen' werden vervolgens ieder persoonlijk met hun naam genoemd. ${ }^{2120}$ Waarschijnlijk zien we hier hetzelfde verschijnsel als bij de 'gemeente'(zie Hoofdstuk 17.5). Inwoners traden als collectief binnen een dorp op voor een bepaald belang, maar deze groep kende geen duurzaam karakter of rechtspersoonlijkheid. Er vielen bij de geërfden eigenlijk ook geen

2115 TJ, inv. nr. M 33, fol. 128, Brief van Indivieze Raad van Maastricht aan Christina von Hardenrath, gravin van Gronsveld, met verzoek om vrijlating van de op Gronsvelds gebied gearresteerde Antoon Bemelmans 17 juli 1670.

2116 TJ, inv. nr. M 33, fol. 138-140, 21 oktober 1671, Indivieze Raad van Maastricht aan Christina von Hardenrath, gravin van Gronsveld.

2117 RHCL, Indivieze Raad van Maastricht, inv. nr. 927.

2118 RHCL, Indivieze Raad van Maastricht, inv. nr. 928.

2119 RHCL, Indivieze Raad van Maastricht, inv. nr. 929.

${ }^{2120}$ RHCL, Rijkskamergerecht, inv. nr. 73, fol. 9-15. 
gemeenschappelijke eigendommen zoals weide, heide of bossen te beheren, zelfs amper een gemeenschappelijke kas. In essentie waren deze bijeenkomsten een soort voorfase voor wat later tot een meer structurele vorm van overleg uitgroeide. Een andere mogelijke belemmering voor het ontstaan van een vaste organisatie kan zijn geweest de tegenstelling tussen grondeigenaren in de dorpen zelf en de grondeigenaren uit de stad. De eerste groep had direct met het grafelijk gezag te maken en kon zich niet op belastingvrijheid beroepen, terwijl de stedelingen dat op grond van hun vermeende privileges wel deden.

In het midden van de zeventiende eeuw worden de belangen van de Maastrichtse geërfden behartigd door de Indivieze Raad van Maastricht vanuit het perspectief dat de stad waakte over handhaving van de privileges van de poorters. De graaf van Gronsveld onderhandelde en correspondeerde steeds met vertegenwoordigers van de Raad en niet met vertegenwoordigers van de geërfden. Toch moet na 1660 iets zijn ontstaan van een vast overleg tussen de Maastrichtse geërfden. De graaf verplichtte zich immers de aanslagbiljetten voor de belastingen te tonen aan de 'geërffde ende gegoeyde off haere gecommitterde' en deze mochten ook iemand afvaardigen om bij de verdeling en uitschrijving aanwezig te zijn. In een besluit van de schepenbanken van het graafschap uit 1685 valt te lezen hoe dit functioneerde. De Maastrichtse geërfden waren met een brief van drossaard Kicken aan de rentmeester van de armentafel van Grote Heilige Geest opgeroepen om bij het uitschrijven van de schatting aanwezig te zijn. De rentmeester op zijn beurt kreeg het verzoek de oproep 'aen de...voordere borgerie alhier vorts te condigen'. Er was overigens niemand verschenen. ${ }^{2121}$

\subsubsection{Het reglement op de belastingen van 1718}

$\mathrm{Na}$ de Spaanse Successieoorlog (1702-1713) liepen de spanningen over bijdragen in de belasting weer hoog op. Het schijnt dat in Gronsveld beslag was gelegd op landerijen van Maastrichtse geërfden die hun schatting niet hadden betaald. Vervolgens waren deze eigendommen, onder andere van de antonieten en de Armentafel van de Grote Heilige Geest, in het openbaar verkocht. De Maastrichtenaren wendden zich toen tot de StatenGeneraal in Den Haag. Dat leidde in oktober 1718 ten stadhuize van Maastricht, in aanwezigheid van de commissarissen-deciseurs van de Staten-Generaal, tot onderhandelingen tussen de vertegenwoordigers van graaf Johan Frans van Bronckhorst onder aanvoering van diens raadsman en commissaris, de Akense advocaat De Witte en de Maastrichtse geërfden. Uit een verslag van De Witte aan de graaf blijkt dat het overleg uiterst moeizaam verliep en zonder veel resultaat eindigde. ${ }^{2122} \mathrm{Er}$ is een concept van een notitie aan Gronsveldse zijde bewaard gebleven, waarin de op te brengen belastingen in drie klassen werden ingedeeld. ${ }^{2123}$ De tekst is wat rommelig, maar komt er in het kort op neer dat de Maastrichtenaren als niet-ingezetenen van Gronsveld principieel bereid waren Römermonate, Kammerzieler, bijdragen aan de kreits voor de instandhouding van het leger, kosten voor de oorlog tegen Frankrijk en zelfs de kosten voor een geschenk voor de

${ }^{2121}$ RHCL, Klooster Hoogcruts, inv. nr. 1001.

2122 TJ, inv. nr. M 40, fol. 973-980, De Witte uit Gronsveld aan J.F van Bronckhorst Batenburg 29 oktober 1718.

${ }^{2123}$ TJ, inv. nr. M 40, 965-971 Franstalige memorie van J. God. Lebens met een indeling van de verschillende belastingen die in de voorgaande oorlog in Gronsveld waren geheven. 
keizer bij diens inhuldiging als reële lasten, dus drukkend op de grond, te betalen. Alle voorgaande overeenkomsten en uitspraken over die verplichtingen werden daarmee ook erkend. Kosten van de inning en gerechtskosten bij het uitschrijven van de belasting en sluiten van de rekening wilde men ook nog dragen. Als personele lasten werden daarentegen beschouwd uitgaven voor leveranties in geld of natura aan het leger, sauvegardes of militaire beschermingsbrieven, vrachtdiensten, algemene kosten van het landsbestuur en de rechtspraak en geschenken aan de gouverneur van Maastricht. Daar wenste men principieel niet voor te betalen, zelfs al waren die duideliik ten voordele van de Maastrichtse burgers. Grote moeite hadden de geërfden met de uitgaven voor de vertegenwoordiging van Gronsveld bij de Rijksdag. Daarmee werden bedoeld de bijdragen in de kosten van het gezantschap dat het Nederrijns-Westfaalse Gravencollege vanaf circa 1700 in Regensburg onderhield. De Maastrichtenaren vonden het maar ongewoon en nieuw en ze hadden dit, beweerden zij, nooit eerder betaald. Aan Gronsveldse zijde werd duidelijk gemaakt dat de graaf dezelfde rechten bezat als alle andere vorsten binnen het Rijk, dus ook het recht op vertegenwoordiging bij de Rijksdag. De kosten daarvan kwamen ten laste van de onderdanen en het was belachelijk daar nog woorden aan vuil te maken. De Maastrichtenaren wensten deze kosten echter niet als 'reëel', drukkend op de grond, te beschouwen, tenzij men aan Gronsveldse kant kon bewijzen dat een dergelijke afgevaardigde ook werkelijk nut voor de geërfden had.

Het oeverloze gekibbel moe, besloot De Witte zelf een nieuw reglement op de belastingen te ontwerpen en dit voor te leggen aan graaf Johan Frans van Bronckhorst Batenburg, op dat moment residerende in Luxemburg. ${ }^{2124}$ Bijna letterlijk nam Johan Frans dit over in zijn Neue verordnung welcher gestalten die schatz-ausschreibungen in unserer grafschaft Gronsfelt künftighin geschehen' van 10 november 1718.2125 (zie Bijlage 8) Zonder voorafgaand verlof van de graaf mochten geen schattingen worden geheven, tenzij de noodzaak daarvan was aangetoond. De geërfden ontvingen, zoals vanouds gebruikelijk, een schriftelijke uitnodiging om aanwezig te zijn bij de publieke uitschrijving van de schatting. De collecteur of schatheffer die dit voor het laagste bedrag wilde innen, kreeg deze taak toegewezen, met zes procent van de opbrengst als honorarium. Voortaan zou een duidelijk onderscheid worden gemaakt tussen personele en reële lasten en daarom werden op dezelfde dag voor beide belastingen afzonderlijke collecteurs aangewezen. Voor een efficiënt verloop van de inning moesten alle schatplichtige onderdanen, ook zij die buiten het graafschap woonden, per kwartaal betalen, op een tijdstip dat de gerechtsbode op zondag na de kerkdienst afkondigde. Achterstallen van inwoners uit zowel het graafschap als ook buitenlanders konden, met toestemming van de drossaard, direct op onroerend goed worden verhaald.

De collecteurs ontvingen een nauwkeurig overzicht van personen aan wie zij het ontvangen geld mochten afdragen en welke uitgaven zij mochten doen. Eens per kwartaal en uiterlijk één keer per half jaar moest de collecteur bij de drossaard alle kwitanties van betalingen overleggen. De drossaard op zijn beurt mocht geen uitgaven doen zonder voorkennis van de graaf. Ten slotte moest een einde komen an het misbruik dat het

${ }^{2124}$ TJ, inv. nr. M 40, fol. 955-960, 'Project' of concept van voorgaande verordening van 4 november 1718 .

2125 TJ, inv. nr. M 40, fol. 931-934. 
uitschrijven van schattingen vijf, zes of nog meer jaren werd uitgesteld, waardoor onderdanen en geërfden in één keer met een hoge aanslag werden geconfronteerd. Daarom was regelmaat nodig, met minstens één uitschrijving per jaar.

Kenmerkend voor dit reglement is vooral de aandacht voor de gang van zaken rond de schatheffing, met de rechten en plichten van de schatheffers als centraal thema. Kennelijk ging er met die procedures wel eens iets mis, bijvoorbeeld met de afdracht van geld. Het was altijd de vraag of degene die geld in ontvangst nam, er daarna ook voor zorgde dat dit te bestemder plaatse arriveerde. Belangrijk in dit reglement was dat een duidelijk verschil werd gemaakt tussen de personele en reële schatting, het oude geschilpunt tussen inwoners en geërfden. Maar een onderscheid als zodanig loste de kern van het probleem niet op, zolang niet precies werd gedefinieerd wat daar nu precies onder moest worden verstaan.

\subsubsection{Een nieuw begin: de conventie van 1739}

Het is de vraag of het reglement van 1718 uiteindelijk veel heeft opgeleverd. De onderhandelingen met de Maastrichtse geërfden hadden partijen niet echt nader tot elkaar gebracht en vervolgens overleed graaf Johan Frans van Bronckhorst Batenburg nog geen half jaar later. Ten tijde van diens opvolger graaf Claude Nicolas d'Arberg Valengin verviel het graafschap in een bestuurlijke chaos. Eerst nadat graaf Ignaz Felix von ToerringJettenbach in januari/februari 1732 samen met de stad Aken de voogdij had gekregen over de minderjarige gravin Maria Josepha d'Arberg Valengin, trad verbetering op. Vooral de Akense burgemeester d'Oliva deed zijn best om, in goed overleg met zijn medevoogd, weer orde op zaken te stellen. Een van de kwesties die dringend afhandeling behoefde, was de afdoening van de problemen over de schatting met de Maastrichtse geërfden. Met dat doel verordonneerde graaf Ignaz Felix in januari 1734 dat met ingang van dat jaar opnieuw landschatting zou worden uitgeschreven (zie bijlage 11). De tijd drong, want er was intussen al 22 jaar achterstand en er dreigde executie door het Rijk.

Deze verordening vormde een soort inleiding voor een nieuwe regeling. $\mathrm{Na}$ taaie onderhandelingen werd op 2 april 1739 ten stadhuize van Maastricht een elf punten tellend verdrag gesloten (zie bijlage 38). De overeenkomst beoogde het herstel van de 'goede harmonie', maar was anderzijds bedoeld als 'conventie en reglement, welke voor het toecoemende sal dienen voor eene positive weth'. De akte passeerde ten overstaan van enkele gedeputeerden van de Indivieze Raad van Maastricht. Aan Gronsveldse kant trad op burgemeester d'Oliva van Aken als gevolmachtigde van graaf Toerring-Jettenbach, tevens ook 'geauthoriseert door de gemeente en regeeringe van het gemelte graefschappe'. De 'burgers' van Maastricht werden gerepresenteerd door afgevaardigden van Maastrichtse instellingen als grote geërfden in Gronsveld. Op 30 april 1739 werd deze overeenkomst 'in naeme der inwoonders deeser graefschappe Gronsfelt' bekrachtigd door drossaard Lebens, schepen Rietraet, twee 'gedeputeerden' en ten slotte zes inwoners, allen zonder nadere aanduiding van een functie.

Merkwaardig genoeg blijkt nergens in de tekst iets van betrokkenheid van de heerlijkheid Slenaken, welke plaats vroeger altijd één vierde deel in alle rijks- en kreitslasten en oorlogscontributie van het graafschap Gronsveld had bijgedragen. Weliswaar maakte de heerlijkheid Slenaken sinds 1728 geen deel meer uit van het graafschap Wittem, maar 
daarmee waren allerminst de financiële banden met het graafschap Gronsveld verbroken, noch wat betreft de oude schulden en ook niet voor nieuwe lasten die vanwege het Rijk werden opgelegd. Deze verhouding tot Slenaken werd, zoals hierna nog wordt beschreven, nog inzet van een langdurige controverse.

Een deel van de bepalingen had betrekking op het oplossen van bestaande geschillen ('de harmonie'), terwijl de andere artikelen inderdaad een reglement voor de toekomst vormden. Wat betreft de problemen uit het verleden, verplichtte het graafschap Gronsveld zich de openbare verkoop wegens belastingschuld van landerijen van Maastrichtse burgers en instellingen in 1713 ongedaan te maken. Men moest maar zien op welke wijze de kopers van die goederen schadeloos werden gesteld (artikel 1). Er werd een schikking getroffen ten aanzien van grote bedragen schuld, die volgens de inwoners van Gronsveld als 'reële' lasten uit de schatting van de grond moesten worden betaald. Het ging daarbij onder andere om een vordering van ruim 12.500 gulden 'licht geld' van de Erven Boomhouwer in Maastricht en 4400 gulden door de Armen van Gronsveld aan Boomhouwer betaald. Van deze bedragen werd vastgesteld wat ten laste van de geërfden kwam. Het restant zou worden beschouwd als vordering op de inwoners van het graafschap, te betalen uit de opbrengst van de personele belastingen. Daarnaast werd de verdeling van deze schulden met het sinds 1728 niet meer tot het graafschap Gronsveld horende dorp Slenaken vastgelegd (artikel 3). Ook stonden nog zes niet afgesloten rekeningen van collecteurs uit de voorgaande jaren op de agenda van de eerstkomende vergadering. Die moesten zo snel mogelijk worden afgedaan en wel zodanig dat ze geen hindernis meer voor de toekomst opleverden (artikel 10). Ten slotte was er nog het probleem van de erfgenamen van de Maastrichtse kanunnik Salden. Deze had zijn nalatenschap bestemd voor de stichting van een Rooms-Katholiek Armenhuis in Maastricht, maar over deze erfenis werd nu geprocedeerd bij verschillende instanties (zie Hoofdstuk 12.4). Er bestond een gerede kans dat deze erfgenamen weigerden schatting te betalen. In dat geval moest daarover op gezamenlijke kosten van de Gronsveldse gemeenten en geërfden worden geprocedeerd (artikel 11).

Als uitgangspunt voor een nieuwe start werd voor Gronsveld de hoeveelheid schatbaar land ('het getal der boenderen') vastgesteld op 1108 bunder, drie grote en acht kleine roeden, met de mogelijkheid van correctie bij naderhand ontdekte fouten. Tegelijk werd de schatting zoals vanouds voor $3 / 4$ verdeeld over Gronsveld en voor $1 / 4$ over Slenaken. Dat betekende dat $3 / 4$ van een simplum in Gronsveld werd omgeslagen over 1108 bunders, terwijl het resterende kwart ten laste van Slenakense grond kwam. Goederen die 'immuniteit' (belastingvrijdom) genoten, werden gespecificeerd. Voor de graaf waren dit 171 bunder, 4 grote en 151/4 kleine roede, exclusief het ongemeten aandeel in de gemeenteweiden. Toekomstige veranderingen in het grafelijk bezit door bijvoorbeeld nieuwe aankopen, zouden niet van invloed zijn op de schatting. Ook van de pastoriegoederen en goederen van kerkelijke beneficies werden aparte specificaties gemaakt (artikel 2).

Minstens één keer per jaar werd een vergadering gehouden van de geërfden. De convocatie ging uit van de graaf, die ook de onderwerpen op de agenda bepaalde. In deze bijeenkomst had de graaf of zijn vertegenwoordiger één stem. Verder toegang tot de 
bijeenkomst hadden alle leden van het gerecht van Gronsveld, samen goed voor ook één stem en iedere geërfde in het bezit van tien bunder of meer, elk met één stem. De grote geërfden werden ook persoonliik opgeroepen. De 'minder geërffdens uyt de borgerye' (van Maastricht) mochten uit hun midden twee gedeputeerden aanwijzen, die beiden over één stem beschikten. De 'minder geërffdens' in de vier 'gehuchtens' van het graafschap mochten eveneens twee afgevaardigden sturen, ieder met één stem. Het is niet helemaal duidelijk welke plaatsen precies met deze gehuchten werden bedoeld. Voor de personele schattingen telde het graafschap na 1728 vier gehuchten in de vorm van gemeenten, te weten Heugem, Gronsveld, Eckelrade en Honthem, maar de schatting werd van oudsher verdeeld over Heugem, Gronsveld, Honthem en Slenaken. Dat veranderde ook niet na de afsplitsing van Slenaken in 1728. In ieder geval is het een feit dat in de achttiende eeuw regelmatig burgemeesters van Slenaken in de vergadering van geërfden te Gronsveld verschenen. Er werd beslist met gewone meerderheid van stemmen, waarbij de stem van de voorzitter de doorslag gaf wanneer de stemmen staakten (artikel 5).

De vertegenwoordiger van de graaf ontving voor het convoceren van de vergadering en aan vacatiegeld zestig gulden, de drossaard twee rijksdaalders, iedere schepen één rijksdaalder en de secretaris vier rijksdaalders voor het schrijfwerk (artikel 9). De geërfden benoemden, met toestemming van de graaf, een collecteur of ontvanger (artikel 4), die voldoende borg moest stellen voor de uitvoering van zijn taak (artikel 7).

Alle 'memorialien en repartitien der lasten', feitelijk de begrotingsposten, werden door de voorzitter aan de vergadering gepresenteerd, waarna werd vastgesteld welke bedragen als 'reëel' moesten worden beschouwd, dat wil zeggen ten laste van de schatting op onroerend goed kwamen (artikel 6). ${ }^{2126}$ De begrotingen en rekeningen moesten in de nederduytse taele ...gestelt worden' (artikel 5). De collecteur mocht uitsluitend uitgaven doen op basis van het 'memoriael' of de begroting. Daarbuiten was geen enkele betaling toegestaan 'sonder eenige...ordonnantien van wie het oock zij... als nae dat die vooraff door de geërffdens sullen sijn erkent' (artikel 4). De begroting werd getekend door de leden van de vergadering, daarna geregistreerd in boekvorm en in afschrift ter beschikking gesteld aan de collecteur (artikel 6, 9). Tijdens de bijeenkomst van de geërfden moest de collecteur zijn rekening en verantwoording met alle bijbehorende documenten overleggen. Er mocht niet worden gerekend met restanten van vorige jaren (artikel 7). Ook de rekening werd in een register ingeschreven (artikel 9).

Ten slotte verplichtte het gerecht van Gronsveld zich op alle mogelijke manieren de naleving af te dwingen van de pachtcontracten die de Maastrichtse grondeigenaars met hun pachters sloten. In het bijzonder gold dat voor bepalingen over de betaling van schatting. De collecteur van de schatting kon zich bij achterstallige betaling direct verhalen op de goederen van de pachter (artikel 8).

${ }^{2126}$ Over het gebruik het woord 'memoriaal' voor 'begroting' in de Landen van Overmaze zie Dormans, 'De financiële verhoudingen', 91-93. 


\subsubsection{De landsvergadering \\ $V$ ergelijking met staten- en geërfdenvergaderingen in naburige territoria}

In het voorgaande werd al besproken dat in de zeventiende eeuw langzaam iets groeide van een collectiviteit van geërfden, zonder echter vaste vormen aan te nemen. De geschillen in de eerste decennia van de achttiende eeuw lijken toch meer het gevoel voor openbare financiën van het graafschap Gronsveld als land en de invloed daarop van grondeigenaren te hebben gestimuleerd. In de bijeenkomst van 30 april 1739 kwam eerst de 'status patriae' ter tafel, gevolgd door het 'memoriale'. De 'status' was een overzicht van de schulden en financiële verplichtingen van het land, terwijl in het 'memoriale' de bedragen werden genoemd waarvoor de collecteur mandaat om te betalen kreeg. Bij elkaar vormden de twee teksten een soort landsbegroting. In latere jaren werden ze meestal gecombineerd tot één 'memoriael sive status patriae'.

Vanaf 1744 werd de vergadering van geërfden steevast aangeduid als 'landsvergadering'. De deelnemers bleven zich weliswaar meestal 'geërfden' noemen, maar incidenteel werden ook termen als 'geerfde stenden' (1747), 'loffelijcke stenden des landts van Gronsveld' (1755) en 'geërfden en stenden' (1778-1781, 1787, 1789) gebruikt. Om deze ontwikkeling te plaatsen binnen een groter kader, willen we eerst een vergelijking maken met de ontwikkelingen in enkele naburige territoria. Daarbij rijst de vraag of de Gronsveldse 'landsververgadering' van standen en geërfden vergelijkbaar was met soortgelijke colleges in omringende gebieden, waarin de drie 'klassieke' standen, te weten geestelijkheid, ridderschap en 'derde stand' waren vertegenwoordigd. Of kwam deze vergadering van geërfden nauwelijks uit boven het niveau van dorpsvergaderingen, waar alle grondbezitters overlegden over gemeenschappelijke belangen?

Het antwoord op deze vragen is niet zo eenvoudig. In de eerste plaats stond het graafschap Gronsveld wat betreft omvang in geen verhouding tot bijvoorbeeld het prinsbisdom Luik, het hertogdom Limburg of de Landen van Overmaze. Daarnaast wijkt de samenstelling van de standen in deze territoria onderling nogal af. Zo bestond in het prinsbisdom Luik de geestelijke stand alleen uit het kathedraal kapittel van Sint-Lambertus, in het hertogdom Limburg werd die gevormd door de abten van Rolduc en van Val-Dieu en de vertegenwoordiger van het Onze-Lieve-Vrouwekapittel van Aken, terwijl de drie Landen van Overmaze ook ieder een eigen regeling kenden voor de representatie van de clerus. De 'derde stand' in het prinsbisdom Luik bestond uit de 23 zogenoemde 'goede steden', terwijl het platteland eigenlijk niet was vertegenwoordigd. In de staten van Limburg en de Landen van Overmaze ontbraken de steden weer, maar werd het platteland gerepresenteerd door afgevaardigden uit de schepenbanken, met daarbij de aantekening dat de regels per landsdeel verschilden. In het Overkwartier van Gelre bestonden de staten alleen uit ridderschap en steden. ${ }^{2127}$ Hoe passen de Gronsveldse standen binnen deze diversiteit?

Woorden als 'patria', 'landsvergadering' en 'standen' suggereren dat de Gronsveldse geërfden zich min of meer beschouwden als de vertegenwoordigers van het land. Een wezenlijk verschil tussen Gronsveld en territoria met 'klassiek' samengestelde staten is dat

2127 Voor de staten in het prinsbisdom Luik zie de diverse hoofdstukken in Dubois, e.a., Les institutions publiques, 237-308; voor Limburg en de Landen van Overmaas zie Goossens, Études sur les États de Limbourg. Voor het Overkwartier zie: Venner, Inventaris archief Staten van het Overkwartier. 
het criterium voor deelname aan de vergadering in Gronsveld niet werd bepaald door de maatschappelijke positie (adel, geestelijkheid), maar door de eigendom van een bepaalde hoeveelheid grond. Zo stonden de Maastrichtse geestelijke instellingen en een adellijk heer als de heer van Rijckholt op dezelfde voet als de overige geërfden. Anderzijds was er geen evenredige vertegenwoordiging en wogen niet alle stemmen even zwaar vanwege de verdeling tussen de grote en de 'mindere' geërfden die per groep stemden. Het systeem lijkt enigszins op de besluitvorming binnen de rijksvorstenraad in de Rijksdag, waar de grote rijksvorsten ieder een afzonderlijke stem hadden en kleine geestelijke en wereldlijke heren per 'bank' stemden.

Een ander belangrijk verschil tussen de Gronsveldse standen en die in naburige territoria betrof het taakveld. In Gronsveld bleef de bemoeienis van de standen grotendeels beperkt tot de belastingen voor Rijk en kreits en alles wat daarmee samenhing. De grootste zorg van de graaf was dat hij als rijksstand het gevraagde geld bij elkaar kreeg. In de aangrenzende territoria hieven de staten ook belastingen voor de schatkist van de landsheer zelf. Binnen die verhoudingen kon dus een tegengesteld belang ontstaan. Verder kwamen de staten in grote territoria in het bijzonder op voor de handhaving van de privileges en rechten van het land ten opzichte van de landsheer. Dat lag in beginsel buiten de bemoeienis van de Gronsveldse geërfden. Wanneer zich op dat terrein problemen voordeden, lag het debat daarover meer op de weg van de 'gemeenten' (zie bijvoorbeeld Hoofdstuk 17.5 met het conflict over de aardappeltienden in de jaren zeventig en tachtig van de achttiende eeuw).

Een vergelijking tussen de standen van Gronsveld en van naburige grote territoria levert dus grote verschillen op. Blijft over de vraag naar de verhoudingen in naburige territoria die wat betreft omvang en interne organisatie enigszins met Gronsveld vergelijkbaar waren? Algemeen onderzoek daarnaar ontbreekt, maar op basis van een summiere verkenning kan wel iets gezegd worden over de situatie in het graafschap Wittem en de heerlijkheid Wylre, beide rijksonmiddellijke gebieden.

De problemen rond het begrip 'standen' in een klein territorium laten zich goed illustreren aan de hand van een proces dat 'geërfden' van het graafschap Wittem als klagers in de jaren 1753-1754 voor het Rijkskamergerecht voerden tegen hun heer, graaf Frans Joseph von Plettenberg. 2128 De kwestie betrof de manier waarop de schatting voor de buitengewone oorlogslasten uit de jaren 1747-1749 was uitgeschreven (een met Gronsveld vergelijkbaar en bekend probleem) en dan vooral de vraag welke partijen aan de kant van de onderdanen over die verdeling van de lasten meebeslisten. Veelbetekenend in dit verband is de manier waarop partijen elkaar bij het Rijkskamergerecht aanduidden. De eisers noemden zich consequent 'Ritterschafft, auch mehristen theils deren Meistbeerbten und gemeinen Eingesessenen beyder in der Reichsgrafschafft Wittem gelegenen Dörfferen Mechelen und Epen', de gedaagde kwalificeerde zijn opponenten als 'Die unter dem misbrauchten Nahmen der Ritterschafft und mehristentheils der Meistbeërbten litigirenden...' Interessant in dit geschil zijn de diverse retroacta tot 1667, die enig licht werpen op de voorgeschiedenis van deze ridderschap en meestgeërfden. In het proces

2128 RHCL, Rijkskamergerecht, inv. nr. 257. 
werd onder andere overgelegd een oproep door Georg Frederik, graaf zu WaldeckPyrmont en Culemborg, heer van Wittem, uit 1665, geadresseerd aan de 'wohlwürdigen, edlen, ehrenvesten und achtbahren unsern lieben getreuen sämbtliche Ständen unserer frey herrlichkeit Witthem'. Twee jaar later, uit 1667, dateerde een uitgebreide convocatie voor de 'Ständen' of 'Herren Landtständt' van Wittem. Onderwerp van beraadslaging waren de Wittemer bijdrage aan de rijksdefensie en de extra kosten die de graaf maakte voor de militaire bescherming van zijn onderdanen.

$\mathrm{Na}$ 1700, en zeker na 1728, lijkt het woord 'standen' te zijn verdwenen en wordt gesproken over 'Meistbeerbten' (1728, 1740) en 'Landsbeerbte (1737, 1747). Deze 'Meistbeerbte' waren de bezitters van twaalf tot veertien grote hoeven of kasteelachtige behuizingen, veelal leengoederen, in Mechelen, Epen, Eys en Slenaken. Bij de inhuldiging van graaf Ferdinand von Plettenberg als heer van Wittem in 1726 worden zij collectief aangeduid als 'Beerbte und Vasallen'. Sommige van deze geërfden waren van adellijke afkomst, andere behoorden tot het patriciaat van de stad Aken. Het is interessant dat zij zich (voor het eerst?) in het proces over de verdeling van de schatting in 1753 opwaardeerden als een soort stand van 'ridderschap en meestgeërfden', waarbij met 'ridderschap' kennelijk de adellijke bezitters van leengoederen werden bedoeld. Anderzijds beschouwde de graaf dit juist als misbruik van een titel, terwijl de oude benaming 'standen' inmiddels al lang was verdwenen en vervangen door 'geërfden'.

Wie in de zeventiende eeuw de rest van de bevolking vertegenwoordigde is niet helemaal duidelijk. In het genoemde proces voor het Rijkskamergerecht blijkt daar ook onenigheid over te bestaan. In de jaren veertig van de achttiende eeuw worden genoemd per dorp twee à drie 'Vorsteher' die ieder één stem hadden en soms ook de leden van het gerecht die als collectief over één stem beschikten.

De onderwerpen waarover deze standen of geërfden en vertegenwoordigers van de dorpen beraadslaagden, hadden in de eerste plaats betrekking op de schatting en de belastingen ten behoeve van Rijk en kreits. Dat lijkt het overheersende thema te zijn geweest. Maar in een oproep van 1740 krijgt de 'Zusammenkunfft oder Vergaderung deren Meistbeerbten und Vorsteheren deren Gemeinden' uitdrukkelijk opdracht ook over 'Landtsangelegenheiten undt Nothwendigkeiten... reiflich zu überlegen'. Daarbij gaat het om maatregelen tegen landlopers en vagebonden, de bouw van een kostershuis annex school, reparatie van wegen en verbetering van de algemene welvaart, waarvoor de kosten ten laste van de landskas komen. Met deze onderwerpen komen we op terreinen waarop de statenvergaderingen in grote territoria zich ook bewogen.

Het andere met Gronsveld vergelijkbare gebied betreft de rijksonmiddellijke heerlijkheid Wylre, kleiner dan de graafschappen Gronsveld en Wittem en slechts bestaande uit één dorp met enkele gehuchten. De heer van Wylre was geen rijksstand en had geen zitting in de kreitsvergadering. Het is bovendien de vraag in hoeverre Wylre ook bijdroeg in de belastingen van het Rijk en de kreits. Wel werd betaald voor het Rijkskamergerecht. Over de organisatie van de geërfden binnen de heerlijkheid is verder weinig bekend. Toch is de plaats om een andere reden interessant voor een vergelijking met Gronsveld. In het archief van het klooster Hoogcruts bevindt zich een omslag met stukken betreffende een plan tot 
herziening van een 'dorpsreglement' voor Wylre.2129 Het verband met Hoogcruts is duidelijk, omdat de kloosterlingen behoorden tot de belangrijkste grondbezitters en geërfden in Wylre. Uit dien hoofde waren zij bij de opstelling van een dergelijke verordening betrokken. De stukken hebben betrekking op verschillende jaren en zijn als documentatie bij elkaar gebrachte afschriften van dorpsreglementen uit 's-Gravenvoeren (ongedateerd uit de zeventiende eeuw en 1742), Baelen (1696) en Warsage (1728), verder het ontwerp voor een 'Gerichtsordnung' voor Wylre uit 1744 en enkele ongedateerde teksten betreffende een dorpsreglement voor Wylre. Onder de laatstgenoemde stukken bevindt zich het ontwerp ('Project') van een reglement over het beheer van de dorpsfinanciën en het 'policey-wesen' in Wylre, dat in overleg tussen de Akense burgemeester d'Oliva als vertegenwoordiger van de heer van Wylre en de gemeente was opgesteld.2130 Op grond van enkele verwijzingen naar jaartallen in de tekst moet dit document zijn opgesteld omstreeks 1744-1745. Op de achterkant wordt vermeld dat de overeenkomst van de geërfden in Gronsveld in 1737 als 'voorbeeld' was gebruikt. ${ }^{2131} \mathrm{Er}$ zijn inderdaad duidelijke overeenkomsten. Op zich is dat ook niet verwonderlijk, want zowel in Gronsveld als Wylre speelt de Akense burgemeester d'Oliva een belangrijke rol. Net als in Gronsveld wordt ook in Wylre de begroting aangeduid met het woord 'status patriae'. Interessant zijn de bepalingen over de manier van besluitvorming door de geërfden in de 'Landtsversamblung'. De vergadering werd voorgezeten door de heer of diens vertegenwoordiger met stemrecht. Die deed ook de voorstellen. Verder is ook hier sprake van een 'gewogen stemrecht'. De leden van het gerecht hadden gezamenlijk één stem, acht grote geërfden ieder afzonderlijk één stem en voor de overige onderdanen verschenen de twee of drie dorpsmeesters, ook ieder met één stem. Het is niet bekend of dit 'Project' daadwerkelijk is ingevoerd, maar de beschreven organisatie lijkt sterk op die van Gronsveld, met dien verstande dat Wylre kleinschaliger was.

De vergelijking tussen Gronsveld, Wittem en Wylre levert zowel overeenkomsten als verschillen op. In Wittem is in de zeventiende eeuw sprake van 'standen', maar dit begrip verdwijnt in de achttiende eeuw en er wordt dan alleen gesproken over geërfden. Gronsveld laat het omgekeerde zien; daar noemen de geërfden zich in de loop van de achttiende eeuw ook standen. Wittem telde zoveel grote lenen met kasteelachtige huizen dat de deels adellijke bezitters daarvan rond 1750 zichzelf opwaardeerden tot ridderschap. Onder de grote geërfden in Gronsveld bevonden zich wel enkele adellijke personen (de heer van Rijkckholt, de achttiende-eeuwse bezitters van de hoeve Hemersbach in Eckelrade), maar hun aantal was te klein om een echte stand te vormen. Ook de Gronsveldse geërfden met een kerkelijke achtergrond (de Maastrichtse kloosters) hebben zich niet tot een eigen geestelijke stand ontwikkeld.

2129 RHCL, Klooster Hoogcruts, inv. nr. 781.

2130 Het stuk draagt de wijdse titel: 'Project der articulen über die administration der gemeine pfenningen und über das policey-wesen so von seithen der heern beerbten und deputirten tam suo quam communitatis nomine für die Reichsherrschafft Wylre von dahsiger Landsherrschafft bey vermittelung des hochedelgebohren herrn burgemeister von Oliva ersucht werden, gestattet und statuirt zu werden in forma einer allgemeiner und zum gemeinen best und nutzen deyender Landsordnung'.

2131 'ex conventione Gronsfeldensi de anno 1739 ex parte tum ex statutis Wyleranis de 5ta februari 1737'. 
In zowel Gronsveld, Wittem als Wylre is sprake van een 'landsvergadering' bestaande uit meestgeërfden met ieder een eigen stem, de leden van de schepenbank met één stem en meestal twee vertegenwoordigers per gemeente of dorp. In Gronsveld kwam daar nog het collectief van de 'mindergeërfden' als aparte categorie bij. Dit betekent dat de landsvergadering en gemeente in beginsel gescheiden functioneerden. Waarschijnlijk werd ook een standsverschil tussen beide gevoeld. In Gronsveld valt goed te merken dat de kringen rond de grafelijke commissaris met enige achterdocht keken naar de burgemeesters als representanten van de verschillende dorpen en gehuchten. En ook de Wittemer 'ridderschap' zal zich wel verheven hebben gevoeld boven de eenvoudige dorpelingen.

In alle drie de plaatsen hadden de standen of geërfden als kerntaak de verdeling van de schatting. In Gronsveld bleef het daartoe ook beperkt. In Wittem ziet men echter enkele malen ook andere onderwerpen van algemeen bestuur op de agenda geplaatst. Dat lijkt te wijzen in de richting van de activiteiten die de staten in grote territoria ontplooien. Maar deze vorm van overleg moet uit het oogpunt van landsheerlijk gezag niet al te hoog worden aangeslagen, want de voornaamste reden om de geërfden daarbij te betrekken was dat de kosten uit de landskas werden bestreden.

\section{Werkwijze van de Gronsveldse landsvergadering}

$\mathrm{Na}$ de overeenkomst uit 1739 werd een 'Rekenboeck der reële schattingen van het graefschappe Gronsfelt' aangelegd, waarin de geërfden 'haere resolutien en specificatie der lasten als mede de jaerlyxe rekeningen' inschreven. Er schijnen twee registers te zijn geweest: één in Gronsveld en één dat door de Maastrichtse geërfden werd bijgehouden.2132 Dit stramien van besluiten, begrotingen ('memoriael sive status patriae') en rekeningen werd tamelijk consequent gevolgd. Anderzijds is de verslaglegging van de besluiten soms summier en ontbreekt verdere context, waardoor bepaalde passages of berekeningen voor buitenstaanders niet altijd goed zijn te volgen.

Er werd meestal één, soms twee keer per jaar vergaderd. De bijeenkomst stond in beginsel onder leiding van de vertegenwoordiger van de graaf. Tot 1745 was dat burgemeester d'Oliva van Aken als 'administrator', daarna pastoor de Schmädel in Gronsveld, die als grafelijke 'Hofrath' ook met bestuurlijke taken in Gronsveld was belast. De ziekelijke pastoor liet zich regelmatig vervangen door drossaard Henricus Lebens. Begin 1753 maakte Prummer zijn entree en na zijn pensionering werd hij opgevolgd door commissaris Zollner. Aardig is het verslag dat Prummer op 18 februari 1753 naar de graaf stuurde van zijn eerste optreden als voorzitter. ${ }^{2133}$ Alle geërfden waren op drie of vier na om negen uur op het kasteel van Gronsveld verschenen. Prummer werd ontvangen 'mit einer grace und sollemnitet welcher der König in Bohlen (Polen) bey seien Reichstag kaum geschehen mag'. Prummer complimenteerde de heren en verzekerde hen van de landsheerlijke genade, genegenheid en zorg.

2132 TJ, inv. nr. M 71, fol. 238 nieuw, status patriae van 1775 met het registreren van vergaderingen in het 'boeck der geerfdens van Maestricht'.

2133 TJ, inv. nr. M 25, fol. 278-304. 
Volgens een lijst uit 1753 telde Gronsveld twintig grote geërfden, waarvan vijf instellingen: het klooster Sinnich en te Maastricht zowel het kapittel als de broederschap van kapelanen van Onze-Lieve-Vrouw, het klooster der antonieten en de Armentafel van de Grote Heilige Geest. ${ }^{2134}$ Later kwam daar nog het Rooms Katholiek Armenhuis bij. Het aantal aanwezigen tijdens een landsvergadering schommelde meestal tussen de vijftien en vijfentwintig personen, inclusief de aanwezige schepenen en burgemeesters. De particuliere grote geërfden verschenen zelden persoonlijk ter vergadering en lieten zich vertegenwoordigen door een gevolmachtigde. Op de vergaderdag werd ook het nodige aan spijs en drank geconsumeerd; gebruikelijk aan drank was een anker wijn (vaatje van circa 35 liter).

De grafelijke commissaris ontving voor zijn presidium zestig gulden (burgemeester d'Oliva 75 gulden, maar die moest uit Aken komen). Tot de vaste vergoedingen hoorden verder de 'justitierechten' van 36 gulden voor de schepenen en zestien gulden voor de secretaris voor hun aanwezigheid bij het sluiten van de collecteursrekening en de 'repartitie' van de nieuwe rekening. Verder ontving de bode acht gulden voor het 'dragen' van de convocaties. Vele jaren werd een geestelijke tegen een bedrag van vijf gulden ingehuurd voor het notuleren en afschrijven van de begrotingen en rekeningen.

De vergaderingen kenden een min of meer vast verloop. De afgevaardigde van de graaf begon met de te behandelen onderwerpen, meestal aangeduid als propositien sive postulata'. Als vaste punten stonden vrijwel steeds geagendeerd de controle en afsluiting van schatrekening van de 'collecteur' en de 'repartisering' (feitelijk de uitschrijving) van de nieuwe schatting op basis van het goedgekeurde 'memorial sive status patriae'. Enkele malen wordt ook gesproken over de geloofsbrieven of volmachten van de vertegenwoordigers van geërfden. Tot de 'propositien' behoorden ook ingekomen brieven vanwege de kreits of het Rijkskamergerecht, waarbij om bijdragen werd gevraagd. De resoluties of besluiten, meestal summier geformuleerd, werden soms direct achter de 'propositien' geplaatst en sedert circa 1760 apart bij elkaar daarachter.

De geërfden wezen uit hun midden een 'collecteur' voor de schatting aan. Dikwijls bekleedde dezelfde persoon die functie gedurende een aantal opeenvolgende jaren. Voor zijn werk ontving hij vijf procent van het geïnde 'bundergeld'. De collecteur liet op de wijze, die ook gebruikelijk was bij de publicatie van verordeningen, bekend maken wanneer hij in Gronsveld, Heugem, Eckelrade en Honthem zitting hield voor de betaling van schat. ${ }^{2135}$ Soms was hij daarbij zelf aanwezig, dan weer liet hij zich vervangen. De belasting mocht in twee termijnen worden voldaan. De rekening kon worden gecontroleerd tijdens de landsvergadering, maar soms werd dit werk afzonderlijk verricht door gedeputeerden. De uiteindelijke goedkeuring droeg echter de handtekening van alle aanwezige geërfden. Hetzelfde gold ook voor de 'status patriae', de begroting, op grond waarvan de nieuwe schatting werd uitgeschreven of 'gerepartiseerd'. De schatheffer mocht uitsluitend uitgaven doen op basis van die 'status'. Rekening en 'status' werden na de resoluties in het 'reekenboeck' afgeschreven. Omvangrijke documenten waren het niet; de rekening besloeg ongeveer een katern, de 'status' één blad. De rekening kende een vaste opbouw, beginnend met het hoofdstuk 'ontvangsten', dat meestal erg kort was, het saldo

2134 TJ, inv. nr. M 25, fol. 306.

2135 Voorbeeld uit 1776 in TJ, inv. nr. M 71, losliggend blad fol. 3 a. 
van de vorige rekening en vervolgens het totaal van de opbrengst van de schatting. Uitgangspunt daarbij bleef het aantal van 1108 bunders genoemd in het verdrag van 1739 maal twee, drie of zelfs vier gulden per bunder. Het exacte aantal bunders wisselde in de loop der jaren een klein beetje door hermeting of geschillen over individuele belastingplicht.

Een belangrijk hulpmiddel bij de belastingheffing was de in Hoofdstuk 2.2.2 besproken kaart van het graafschap op kadastrale grootte, die Prummer in 1754-1755 liet vervaardigen. Daarvoor moesten alle eigenaren eerst hun grondbezit 'aanbrengen', waarna de landmeter alles in kaart bracht. Aan die kaarten betaalden de geërfden mee, maar met tegenzin.

De vaste benaming voor de 'uitgaven' was 'employe'. Ook deze uitgaven volgden een min of meer vast stramien: renten en aflossingen van schulden, betalingen aan de kreits, het Rijkskamergerecht of Gravencollege, kosten en honoraria voor de geërfdendag etc. Lastig en zeer verwarrend is dat door elkaar werd gerekend in twee soorten guldens, de Rijnse gulden en de Brabantse gulden Maastrichter koers, die de helft van de Rijnse gulden waard was.

\section{De Maastrichtse belastingurijheid opnieun ter discussie}

Sommige elementen in de overeenkomst van 1739 bouwden voort op een al bestaande praktijk, andere waren nieuw. In ieder geval stond nu de principiële bereidheid tot betaling van de Maastrichtse geërfden niet meer ter discussie. Verder moest de overeenkomst regelmaat brengen in de procedure van belastingheffing en dat is ook gelukt. Deze bleef tot het einde van Ancien Régime vrijwel ongewijzigd in stand. Maar onopgelost bleef de oude strijdvraag welke kosten nu precies uit de 'reële kas', de kas met de opbrengst van de grondschatting, moesten worden voldaan. Pas een stevige aanvaring tussen de Maastrichtse geërfden en de inwoners van Gronsveld in de jaren 1752-1753 bracht daarin meer helderheid.

Tijdens de Oostenrijkse Successieoorlog (1740-1748) had Gronsveld zwaar geleden. Volgens een beëdigde verklaring uit 1747 hadden keizerlijk-koninklijke Hongaarse troepen van 1746-1749 in totaal voor 45713 guldens Brabants Maastrichter koers schade aangericht. ${ }^{2136}$ Britse en Hannoverse troepen waren in de zomer van 1747 in het neutrale graafschap neergestreken en hadden daar de velden en houtopstanden vernield. Alleen al aan gekapt hout bedroeg de schade bijna 250.000 gulden. Daar kwamen nog kosten bij wegens geleverde foerage, inkwartieringen, sauvegarden et cetera. In de geërfdenvergadering van 5 juli 1751 werden die kosten gepresenteerd met het verzoek dat

heeren geërfdens hun sullen hebben te verklaeren, singulatim et per vota, (afzonderlijk per stem) oft de selve geïntentioneert zijn tot eenen redelijcke goetdoeninge, vermits de ingesetene der graefschappe Gronsfeldt niet en moeten gecenseert (belast) worden van

2136 TJ, inv. nr. M 25, fol. 227-228. Zie over de schade die was aangericht o.a. TJ, inv. nr. M 25, fol. 368445.

Zie verder over de politiek in de Landen van Overmaze na 1750: Dormans, 'De financiële verhoudingen', 112-116. 
argere conditie als andere omliggende landen, graefschappen en heerlijckheden van het Roomsche Rijck, alwaer de costen en lasten van orlooge door de geerfden pro justa en nae proportie van hunne possessie gedraegen en reëlijck gerepartiseert worden.

$\mathrm{Na}$ dit beroep op redelijkheid verklaarden de geërfden uit Maastricht bereid te zijn

nae proportie van hun boendertall te contribueeren in alles wat reël is, maer geensints in het geene dat personeel oft mixt soude zijn. ${ }^{2137}$

Die toezegging stelde weinig voor, want in de opvatting van de geërfden kwam de oorlogsschade van de inwoners vooral ten laste van de 'personele' en niet de 'reële' schatting. Men weigerde zelfs bij te dragen in de kosten van 'gemengde aard'.

In de vergadering van 23 januari 1753, voortgezet op 5 februari, verlangden de vertegenwoordigers van de Gronsveldse gemeenten bijdragen in vijf soorten kosten: voor sauvegardes, voor de winterkwartieren van het leger, voor geleverd hooi, haver, stro en brood, voor transportdiensten en ten slotte voor uitgaven van diverse functionarissen bij de uitoefening van hun werkzaamheden. Het was de eerste vergadering onder leiding van de nieuwe grafelijke vertegenwoordiger Prummer en hij werd meteen geconfronteerd met hooglopende ruzie. In een uitvoerige brief aan de graaf doet Prummer verslag van zijn belevenissen. ${ }^{2138}$ Een beetje ijdel dicht hij zichzelf daarin een heldenrol toe, maar ook zonder deze persoonlijke inkleuring wordt duidelijk dat de onderhandelingen bijzonder stroef verliepen.

De zaak begon tamelijk onschuldig. De geërfden overlegden in afschrift een staat van oorlogskosten, waarbij vrijwel overal in de marge was bijgeschreven dat het ging om personele lasten. Het stuk zou zijn opgesteld in aanwezigheid van enkele afgevaardigden van het Gronsveldse gerecht bij de Brabantse commissarissen-deciseurs op het stadhuis in Maastricht. Er stond een handtekening voor akkoord onder van rentmeester Olighschläger. Het was allemaal nogal vaag en in eerste instantie leken de Gronsveldenaren wat overbluft door deze 'overeenkomst', maar Prummer had de tegenwoordigheid van geest te vragen waar zich het origineel bevond. 'In het stadhuis van Maastricht', luidde het antwoord, maar daar was het zoek geraakt. Prummer merkte vervolgens op dat de goedkeuring van de graaf als landsheer ontbrak en dat de handtekening van Olighschläger niets waard was. De man stond nota bene op dat moment terecht op verdenking van fraude.

Prummer maakte duidelijk dat hij een dergelijk document niet accepteerde. Maar zelfs wanneer een specificatie van de kosten bestond, dan nog hoefden de geërfden daar niet post voor post bij te vermelden of het 'reëel' of 'personeel' was. Er werd van hen slechts een principieel besluit gevraagd of zij de eerder genoemde vijf soorten kosten 'vor reel anerkennen wollen wie sye dissorths durchgehents also gehalten werden'. Prummers bedoeling was duidelijk. Met een dergelijke erkenning zou in de toekomst dit soort oorlogskosten ook ten laste van de geërfden komen. $\mathrm{Na}$ een rumoerige discussie deden de geërfden een handreiking. Met een eenmalige bijdrage van vijfhonderd pattacons,

2137 TJ, inv. nr. M 71, fol. nieuw 95-96.

${ }^{2138}$ TJ, inv. nr. M 25, fol. 278-304, Prummer aan M.E. von Toerring-Jettenbach 18 februari 1753. 
naderhand verhoogd tot achthonderd (3200 gulden), wilden zij de vordering afkopen. De Gronsveldenaren roken geld. 'Meine guette hungrige Gronsfeldter glaubten sy hörren die Maus pfeiffen', schreef Prummer. Maar het was belangrijk nu niet te snel toe te happen, want Prummer hield hen voor dat zij een bedrag van achtduizend tot tienduizend gulden moesten aanhouden. $\mathrm{Na}$ enig loven en bieden bleken de Maastrichtenaren bereid tot vierduizend gulden te gaan.

Prummer hield voet bij stuk, waarna, zoals hij verwachtte, de geërfden overgingen tot 'ihrer alten practicque': zij wilden binnen zes weken een schriftelijk besluit toesturen. Prummer stond slechts een termijn van zestien dagen toe en weigerde een schriftelijk antwoord. De geërfden moesten persoonlijk in een formele vergadering verschijnen en zich daar uitspreken. De heren protesteerden en beriepen zich op 'oud heerkomen', maar Prummer antwoordde dat hij daarmee niets te maken had, ook al gingen ze terug tot de tijd van Julius Caesar (die - zo schreef Prummer - volgens de overlevering eerst Gronsveld en toen pas Maastricht had gesticht...!). Thans gold de overeenkomst van 1739 en die was helder ten aanzien van de convocatie van vergaderingen door de landsheer. Uiteindelijk eindigde de vergadering om één uur 's middags toch nog enigszins prettig en er werd gegeten en flink getoost op de gezondheid van de graaf.

In de daarop volgende dagen werd achter de schermen druk vergaderd. De geërfden stuurden een kloosterling van de antonieten en een gewiekste advocaat, slimmer dan alle geërfden bij elkaar ('ein super gescheider Holländer') naar Prummer om te onderhandelen, maar die week zelfs na drie uur praten geen duimbreed. In de dagen daarna hoorde Prummer dat de geërfden achtduizend gulden wilden bijdragen, in termijnen af te lossen. Werd dit voorstel niet geaccepteerd, dan was de breuk definitief en moest worden geprocedeerd.

Op 5 februari 1753 vond een nieuwe vergadering plaats en weer raakten de gemoederen verhit. De geërfden verweten de Gronsveldenaren dat deze nog 2300 gulden 'reële' schatting uit het verleden moesten betalen en nog negenduizend gulden achterstallige rente schuldig waren voor een lening die de geërfden vroeger hadden verstrekt om daarmee personele lasten te voldoen. Uiteindelijk boden de geërfden achtduizend gulden, mits de Gronsveldenaren in totaal 3014 gulden als tegenvordering erkenden. Maar Prummer stelde voor die tegenvordering te schrappen. Verder konden de geërfden in hun 'reële kas' een aantal schulden en achterstallige rentebetalingen ten laste van de 'personele kas' overnemen. Bij elkaar opgeteld ging het om een waarde van 10.013 gulden. De geërfden waren akkoord onder de voorwaarde dat deze aanvaarding geen inbreuk maakte op hun rechten in de toekomst. Prummer bleef er echter op hameren dat hij deze betaling toch beschouwde als een erkenning van het 'reële' karakter van de vijf soorten vorderingen, waarmee de hele discussie was begonnen. Met een specificatie van de afzonderlijke kosten wenste hij zich verder niet in te laten.

Tot dan toe was de vergadering tamelijk hoffelijk verlopen, maar echt verhit raakten de gemoederen op het moment dat de geërfden zich alsnog begaven in een discussie over het reële dan wel personele karakter van de uitgaven op de specificatie. Prummer slaagde er niet in hen tot bedaren te brengen. Ten langen leste besloot hij de bijeenkomst te verlaten en voor 20 februari een nieuwe vergadering uit te schrijven. Toen brak zijn finest hour aan. De Gronsveldenaren smeekten hem bijna te blijven, nu een overeenkomst binnen 
handbereik lag. Maar Prummer wees hen terecht met de opmerking hoe dom zij waren om voor tienduizend gulden hun principiële rechten aan de Maastrichtse geërfden te verkwanselen. De weigering van de geërfden om de vijf soorten vorderingen van oorlogsschade als reële lasten te erkennen kon hen in de toekomst wel eens duur komen te staan. In zijn ogen was 'denen Mastrichteren ohnehin schon genueg verkaufft'.

De rumoerige geërfden vielen door die ernst stil en beseften dat het menens werd. Zij schoven twee verse onderhandelaars naar voren. Tot nog toe had de meerderheid volgens Prummer tegen hem vooral 'Barabas' geroepen, een verwijzing naar het Lijdensverhaal waar de Joden kozen voor de misdadiger. Prummer deed eerst of hij doof was, totdat uiteindelijk de (protestantse) afgevaardigde De Roux, rentmeester van de Grote Heilige Geest, 'mit einer calvinischen modification' over de brug kwam. Binnen een half uur draaide die als een blad aan de boom: men was akkoord met de gevraagde vergoeding en de vijf soorten oorlogsschade werden als reële lasten erkend. In de resoluties van de geërfden wordt die uitkomst heel diplomatiek aldus omschreven, dat de geschillen in der minne waren geschikt 'sonder in te treeden welcke posten voor reel, welcke voor personeel gereekent worden'.2139 De zogenoemde specificatie bleef in het resolutieboek van de Maastrichtse geërfden gehandhaafd, totdat de authenticiteit was vastgesteld. Wel werd afgesproken dat in de toekomst zo snel mogelijk overleg moest plaatsvinden tussen de gemeenten en de geërfden, wanneer de Gronsveldenaren oorlogscontributies kregen opgelegd, zodat kon worden bekeken op welke wijze dat het beste kon worden opgelost.

Het geschil tussen (Maastrichtse) geërfden en de Gronsveldenaren, verenigd in hun gemeenten, was daarmee 150 jaar na de eerste strubbelingen met de geërfden, in het voordeel van de gemeenten beslecht. Maar de taaiheid van de onderhandelingen illustreert welke diepe kloof, zowel zakelijk als mentaal, bestond tussen vooral de Maastrichtse grote geërfden en de Gronsveldenaren. Wanneer men bedenkt dat de Maastrichtenaren in vergelijkbare conflicten verwikkeld waren in een reeks dorpen in de omgeving, dan ligt hier misschien een wortel voor de verklaring van de tot op de dag van vandaag nog wel gevoelde tegenstelling tussen de stadsbewoners en de ‘boeren' van het platteland.

\section{Het geschil over de belastingen met Slenaken}

De verkoop in 1728 van Slenaken als afzonderlijke heerlijkheid aan graaf Ferdinand von Plettenberg, op dat moment nog heer van Wittem, werd na een aantal jaren voor Gronsveld een probleem dat voor veel onenigheid zorgde. Het was onbetwist dat de schepenbank Slenaken vanaf het einde van de middeleeuwen voor één vierde deel in alle belastingen en oorlogscontributies binnen het Land en later het graafschap Gronsveld bijdroeg. De rest werd pondsgewijs omgeslagen over de banken Gronsveld, Heugem en Honthem. Sinds het einde van de zestiende eeuw gold de regel dat delingen van landsheerlijkheden in beginsel niet meer leidden tot verdeling van het stemrecht in de kreits of in de Rijksdag. Het kon dus zijn dat één stem door verschillende partijen gezamenlijk werd uitgebracht. Hetzelfde gold ook voor de bedragen in de Wormser

${ }^{2139}$ TJ, inv. nr. M 71, fol. 109-110 (nieuw) resoluties 25 januari en 5 februari 1753. 
Matrikel. De 'hoofddebiteur' van het daar genoemde bedrag bleef aangeslagen voor het oorspronkelijke bedrag en moest het aandeel van afgescheiden gebied zien te verhalen.

Die situatie was na 1728 ook op de relatie tussen Gronsveld en Slenaken van toepassing. Gronsveld stuurde de aanslagen voor Römermonate, Kammerzieler en bijdragen voor garnizoenen van de kreits naar Slenaken, waar Slenaken dan een kwart van betaalde. Soms schoot de schatheffer van Gronsveld het Slenakense deel ook voor. Die verrekeningen verliepen niet altijd vlekkeloos, maar veroorzaakten na 1752 een ernstig meningsverschil na het akkoord dat Prummer met de Maastrichtse geërfden had bereikt. Het begon met onenigheid over de verdeling van de aanslag van de Kammerzieler voor het Rijkskamergerecht, waarvan inwoners van Slenaken beweerden dat hun aandeel al was betaald. Ten tweede weigerde Slenaken te betalen voor de justitie in Gronsveld. Tot dan toe hadden ook de geërfden in Gronsveld dat geweigerd, omdat zij de kosten daarvan als 'personele' lasten voor de Gronsveldse gemeenten hadden beschouwd. Maar vanaf 1752 werden die lasten geacht 'reëel' te zijn, drukkend op grondbezit. In Gronsveld was men van mening dat Slenaken daar aan moest bijdragen. De problemen bereikten echter hun hoogtepunt tijdens de Zevenjarige Oorlog (1757-1763) toen het Franse leger zowel van het graafschap Wittem als van het graafschap Gronsveld tienduizend 'rationen' (eenheden waarin leveranties werden uitgedrukt) foerage eiste. ${ }^{2140}$ Daarbij werd Slenaken in eerste instantie als onderdeel van het graafschap Wittem aangeslagen voor 1500 'rationen'. Het graafschap Gronsveld betaalde ook tienduizend 'rationen' en schoot daarbij 2500 'rationen' voor Slenaken, een kwart van de aanslag voor. $\mathrm{Nu}$ waren in Gronsveld contributies in natura aan het leger, zoals leveranties van hooi, stro, haver en hout, altijd beschouwd als 'personele' heffingen en hadden Slenaken en Gronsveld ieder apart betaald. Maar na de onderhandelingen van Prummer in 1753 met de Maastrichtse geërfden werden die voortaan ook erkend als 'reëel', drukkend op de grond. En dus werd Slenaken als vanouds voor een kwart in deze kosten aangeslagen.

De Gronsveldse 'wisseltruc', waarbij personele belastingen werden omgezet in grondbelasting, stuitte uiteraard op protest in Slenaken. Maar verder was men als onderdeel van het graafschap Wittem met 1500 'rationen' veel goedkoper uit dan met 2500 'rationen' in Gronsveld. Als laatste kwam men in Slenaken nog met andere spitsvondigheid op de proppen. $\mathrm{Na}$ een zeer langdurig proces was door het Rijkskamergerecht in Wetzlar op 9 juli 1755 gevonnist dat de hof Hees in Slenaken met bijbehorende gronden vrij moest zijn van schattingen en contributies. Dat had al vanaf 1638 zo moeten zijn. In totaal ging het daarbij om dertig bunder grond. Volgens Slenaken was in 1739 in de overeenkomst met Maastrichtse geërfden afgesproken dat Gronsveld voor 1108 bunder driekwart (75 procent) van de rijksbelastingen betaalde, terwijl tegenover het kwart van Slenaken (25 procent) 369 bunder stonden. Door het wegvallen van dertig bunder van Hees telde Slenaken nu nog maar (afgerond) 340 bunder schatplichtige grond. Daarmee was de verhouding uit 1739 van $75: 25$ scheef komen te liggen. Dit moest volgens Slenaken 76,5 procent voor Gronsveld en 23,5 procent voor Slenaken worden. Omdat de fout al tot 1638 terugging, wilde men een herberekening van alle betalingen aan rijks- en kreitslasten gedurende bijna 120 jaar!

2140 Zie over deze zaak uitvoerig RHCL, Klooster Hoogcruts, inv. nr. 746. 
Het spreekt vanzelf dat deze Slenaker argumenten aan Gronsveldse zijde niet werden geaccepteerd. Maar de inwoners van Slenaken weigerden het door Gronsveld voorgeschoten bedrag voor 2500 'rationen' terug te betalen, omdat zij al met de andere dorpen van het graafschap Wittem hadden betaald. Dit meningsverschil keerde daarna nog een aantal jaren terug in de geërfdenvergadering van Gronsveld, maar de onderhandelingen verliepen uiterst moeizaam. Uiteindelijk schijnt omstreeks 1771, toen Slenaken weer van Wittem werd gescheiden en als een afzonderlijke heerlijkheid werd verkocht, een compromis te zijn bereikt waarbij Slenaken zijn eigen aanslagen betaalde, maar wel voor een kwart verantwoordelijk bleef voor aflossing van de oude schulden. ${ }^{2141}$

\subsubsection{De belastingen en bijdragen afronderlijk beschouwd Römermonate en andere militaire bijdragen na de Reichsdefensionalordnung van 1682}

De schaarse informatie over de betaling van Römermonate in Gronsveld tot circa 1680 kwam al aan de orde bij het verzet van de geërfden tegen deze heffing (zie Hoofdstuk 16.2.1 - 16.2.5). Er zijn enkele afzonderlijke vermeldingen, maar het ontbreekt aan seriematige bronnen die een beeld zouden kunnen geven van de werkelijke lastendruk. Over de feitelijke afdracht van belastingen door Gronsveld gedurende de decennia na de Reichsdefensionalordnung van 1682 zijn alleen losse aantekeningen en staatjes met berekeningen overgeleverd. De cijfers laten zich door de verschillende berekeningsmethodes en valuta-eenheden niet altijd goed vergelijken. Daarnaast werd soms gewisseld in de samenstelling van de manschappen tussen ruiters en voetvolk, waren er bijkomende kosten en moet rekening worden gehouden met de 'Moderation', een korting op de bijdrage die werd toegestaan wanneer een rijksstand niet bij machte was te betalen. Voor de periode 1739 tot circa 1790 zijn de besluiten en rekeningen van de geërfden wel bewaard, maar het is niet mogelijk alleen op basis daarvan een volledig reconstructie van de Gronsveldse bijdragen in de rijks- en kreitslasten te maken. Zo ontbreken bijvoorbeeld de originele ingekomen stukken voor de vergaderingen. Voor een grondig onderzoek naar de fiscale druk zouden ook andere bronnen, bijvoorbeeld in het archief van de NederrijnsWestfaalse Kreits, moeten worden betrokken. ${ }^{2142}$ Een analyse daarvan, gecombineerd met gegevens uit andere rijksonmiddellijke territoria in het Maasgebied, zou meer licht kunnen werpen op de nagenoeg onbekende fiscale geschiedenis van deze gebieden en hun financiële verhouding tot het Rijk. Die ambitie valt echter buiten de doelstellingen van deze studie. We willen ons hier beperken tot een impressie van de aard en omvang van de betalingen in de praktijk.

Ondanks het ontbreken van een structureel overzicht, geven de beschikbare cijfers wel een indruk van de lasten. Het oude simplum in geld voor de hele kreits van 8609 1/3 Rijnse guldens (zwaar geld) werd nog altijd verdeeld volgens de oude rijksmatrikels. Voor Gronsveld gold het simplum van twaalf zware guldens, omgerekend zestien pattacons of in Maastrichts geld 32 gulden. Dit bedrag bleef onveranderd tot omstreeks 1760, toen een verhoging plaatsvond naar achttien gulden. Ter vergelijking: Gronsveld viel in dezelfde

2141 Verdere gegevens zijn niet bekend, maar RHCL, Klooster Hoogcruts, inv. nr. 762 bevat enkele aanwijzingen voor een compromis.

2142 Het archief van de Niederrheinischer-Westfälischer Kreis bevindt zich in het Landesarchiv Nordrhein-Westfalen, Abteilung Rheinland, te Duisburg. 
categorie als Thorn en Rekem, het prinsbisdom Luik stond voor 1280, het graafschap Wittem voor 28, het stift Cornelimünster voor 48 en de stad Aken voor 204 gulden aangeslagen.

Het is met wisselende sterkteberekeningen en verschuivingen van manschappen tussen infanterie en cavalerie lastig aan te geven voor hoeveel manschappen Gronsveld precies moest betalen. Zo willigde de Nederrijns-Westfaalse Kreits bij het begin van de Spaanse Successieoorlog in 1702 drie maal het kreitscontingent voor het rijksleger in $(3963$ ruiters en 8121 infanteristen), maar verminderde dit vervolgens weer tot 3012 ruiters en 6200 man te voet. ${ }^{2143}$ Grofweg kan echter worden gezegd dat Gronsveld bij een leger op oorlogssterkte voor ongeveer vier ruiters betaalde. Daar waren de kosten voor de 'prima plana', de overhead, niet bij inbegrepen.

Ook eventuele 'Moderation' vertekent het beeld. Zo betaalden Thorn en Rekem, bij een vermenigvuldiging van het simplum van twaalf gulden met de factor $32 / 3$, het bedrag van 44 gulden ter bekostiging van elf man voetvolk ${ }^{2144}$, maar Gronsveld werd wegens toegestane matiging slechts voor 51/2 man aangeslagen. Hetzelfde gebeurde bij de ruiters: 51/2 voor Thorn en Rekem, terwijl Gronsveld slechts $23 / 14$ ruiter betaalde.

De aanslagen in Römermonate geven overigens ook om een andere reden slechts een beperkt beeld van de lastendruk wegens militaire vorderingen. Zo kreeg Gronsveld in de periode 1689, 1690 en 1691 in totaal 570 Römermonate van twaalf guldens opgelegd, zijnde 6840 guldens 'zwaar geld', omgerekend 18240 guldens Maastrichts geld. Daartegenover stond dat in dezelfde tijd meer dan het dubbele aan vorderingen en kosten van inkwartiering van Brandenburgse, Franse en Staatse troepen door de inwoners als 'personele' lasten werd opgebracht. Geen wonder dat onenigheid ontstond over de weigering van de geërfden aan die hoge kosten mee te betalen. Voor de inwoners van het graafschap was het met deze lasten ook moeilijk aan de verplichtingen te voldoen. Toen een aanslag in 1691 van tweehonderd Römermonate niet op tijd werd betaald, kreeg het graafschap in januari 1692 een week lang zeven soldaten uit Luik als 'militaire executie' ingekwartierd. Met zes tonnen bier en een paar nieuwe handschoenen werd geprobeerd met de legerautoriteiten in Aken over de betaling te onderhandelen.

Niet alleen voor het leger te velde, ook voor troepen in garnizoen, moest worden betaald. In 1682 stemde de schepenbank Slenaken in met een bijdrage ter betaling van duizend man krijgsvolk in garnizoen te Keulen en daarnaast nog de betaling voor generale staf, 'prima plana' en onderhoud van de artillerie. Van 1692 tot en met 1697 moest gedurende zestig maanden voor onderhoud van het garnizoen in Keulen een bedrag van in totaal 4320 zware guldens (11520 guldens Maastrichts geld) worden opgebracht. Toen na de Spaanse Successieoorlog, in 1715, een groot deel van het leger werd afgedankt, besloot men vijfduizend man infanterie als garnizoen 'in bruikbare toestand' te houden. Gronsveld betaalde daarvoor twaalf man à vier Rijnse guldens per maand per persoon. ${ }^{2145}$ Buiten de gevraagde 'simpelen' moest nog worden betaald voor de 'prima plana'. Het onderhoud

2143 Dotzauer, Reichskereise, 325.

2144 Vgl. voor de 11 van Rekem: Verbois, Geschiedenis Rekem, 331.

2145 RHCL, Klooster Hoogcruts, inv. nr. 1001. 
daarvan kreeg iedere kreitsstand afzonderlijk in rekening gebracht. Voor Gronsveld ging het daarbij om acht zware guldens per maand, sinds 1753 verhoogd tot negen gulden.

Tijdens de Oostenrijkse Successieoorlog (1740-1747) bleef de kreits formeel neutraal, hoewel Gronsveld veel te lijden had van schattingen, die als 'personele' lasten werden beschouwd en waaraan de geërfden niet meebetaalden. Omdat het rijksoorlog was, werden ook geen Römermonate opgelegd. Dit veranderde tijdens de Zevenjarige Oorlog (17561763). Met de inval in Saksen in 1756 verbrak Frederik II van Pruisen de rijksvrede. Op 9 mei 1757 schreef de Rijksdag dertig Römermonate uit voor een door de kreitsstanden op te brengen rijksleger tegen Pruisen. Twee jaar later in de Gronsveldse 'landsvergadering' van 8 mei 1759, bespraken de geërfden dat keizer, Rijksdag en kreits een 'Rijckx executions armee' op been hadden gebracht 'ter saacken van den tegenwoordigen oorloghe, voor soo veel den selven gedeclareert is als eenen Rijckx oorloghe'. Gronsveld en Slenaken kregen daarvoor opgelegd het 'triplum triplicatum circuli', wat betekende een simplum van drie man, met drie keer verhoogd tot het triplum van negen en dit weer vermenigvuldigd met drie (triplicatum) tot 27 man. Om die 'repartisie' in overeenstemming met de Reichsdefensionalordnung uit 1682 te 'egaliseren' werd er nog een halve man bijgeteld, wat het totaal op 27,5 bracht. Rijksstanden zoals Gronsveld die geen eigen troepen hadden, konden dit aantal, te beginnen met 1 oktober 1757, tot 1 november 1758 afkopen tegen acht Rijnse guldens per man, per maand. Voor Gronsveld kwam dat neer op 220 gulden per maand $(27,5 \times 8)$, gedurende dertien maanden dus 2860 Rijnse guldens. ${ }^{2146} \mathrm{Na} 1$ november 1758 moesten de rijksstanden zonder eigen troepen, zoals Gronsveld, de eenmalige kosten op zich nemen voor hun aandeel in de uitrusting van twee eskadrons en twee bataljons geoefende troepen met artillerie à 67,5 Rijnse guldens per man. Bij 27,5 man kwam dat op een bedrag 1856,25 Rijnse guldens. Voor onderhoud en soldij werd nu 16,5 gulden per man per maand gerekend. Voor een periode van vijf maanden, tot 8 mei 1759 , liep dit bedrag van $27,5 \times 16,5 \times 5$ op tot 2268,75 Rijnse guldens. Bij elkaar opgeteld zou het dus van 1 oktober 1757 tot 8 mei 1759 gaan om 6985 Rijnse guldens. ${ }^{2147}$ Met bidden en smeken lukte het de 27,5 man voor Gronsveld en Slenaken voorlopig verminderd te krijgen tot vijftien à raison van acht gulden per man gedurende achttien maanden, totaal 2160 Rijnse guldens, waarvan 3/4 deel, zijnde 1620 gulden, ten laste van Gronsveld en $1 / 4$ van Slenaken. Ook de bijdrage in de uitrusting van de manschappen werd dienovereenkomstig verminderd. Verdere pogingen om te komen tot reductie bleven vooralsnog vruchteloos.

In de 'landsvergadering' van 8 mei 1759 kwamen nog meer oorlogslasten ter sprake. De inwoners van Gronsveld hadden diverse vrachten stro, haver en hooi aan het Franse leger in Cornelimünster geleverd, bij elkaar 1109 zogenoemde 'complete rationen', waarvoor de geërfden de vergoeding van één gulden per stuk betaalden. Dit was de eerste keer dat het overleg uit de jaren 1752/1753 voor de Gronsveldenaren vruchten afwierp, want vroeger kwam dit soort 'personele' lasten volledig voor rekening van de gemeenten.

${ }^{2146}$ Er wordt vanaf deze tijd gerekend in Rijnse guldens, een equivalent van de eerder gebruikte 'zware Duitse guldens'.

${ }^{2147}$ De resolutie van de geërfden heeft een rekenfout: er staat daar 2168,75; dit vertaalt zich ook door in de optelling: die geeft 6885. 
In de daarop volgende jaren bleven de oorlogskosten op het graafschap drukken: leveranties van foerage voor het leger, opnieuw veertig door de Rijksdag verordonneerde Römermonate en het onderhoud van het kreitscontingent aan troepen. Smeekbeden om vermindering van de bijdragen vonden bij het keizerlijk hof in Wenen geen gehoor. Sterker nog, men drong juist aan op betaling en er werd gedreigd de tijdelijk toegestane vermindering van 27,5 man naar vijftien weer ongedaan te maken. Naderhand lukte het dan toch die vermindering contractueel vast te leggen. Alle bedragen werden uiteindelijk wel betaald, maar dit ging niet zonder het sluiten van leningen. Eind 1762 hadden de geërfden aan oude en nieuwe leningen een totale schuld van 11.050 Rijnse guldens of 22.100 Brabantse guldens Maastrichter koers uitstaan. ${ }^{2148}$

De schulden van de in 1763 geëindigde oorlog drukten nog jaren op de Gronsveldse financiën. Meermalen werd in Wenen aangedrongen op kwijtschelding van de achterstallige bijdragen aan het 'Rijkscontingent', maar zonder veel succes. ${ }^{2149}$ Hoeveel precies is betaald, valt uit de schatrekeningen niet goed af te leiden, aangezien het in de jaren zeventig van de achttiende eeuw gebruikelijk was slechts één bedrag te noteren voor 'Rijkslasten', dat aan commissaris Prummer werd verstrekt om te bestemder plaatse af te dragen.

\section{Türkensteuer}

Met het wisselen van de Turkse dreiging werd ook het graafschap Gronsveld in de Türkenstemer aangeslagen. Zo zagen we al dat in de jaren 1594, 1597/1598 en 1603 respectievelijk 80, 60 en 86 Römermonate werden opgelegd. Al vóór het begin van de Vierde Oostenrijkse Turkenoorlog in 1663, ontving Gronsveld bij de eerste schermutselingen in 1661 een aanslag van 25 Römermonate als 'eilende Hilfe' voor de keizer tegen een simplum van twaalf zware guldens per maand, een totaal van driehonderd zware guldens of tweehonderd pattacons. Het contingent van Gronsveld was aanvankelijk berekend op drie man te paard en drie man te voet, maar werd naderhand omgezet in het goedkopere aantal van negen man te voet. Er kwamen evenwel kosten bij voor soldij, proviand en legermaterieel, waarvoor nog eens aanvullend ruim 254 pattacons (381 zware guldens) werden betaald. 2150

Ook voor de Grote Turkse Oorlog, beginnend in 1683, werd belasting geheven. Volgens een vergadering van de schepenbanken van Gronsveld, Heugem en Honthem in 1685 had graaf Johan Frans gedurende drie jaar het aandeel van het graafschap, bestaande uit drie ruiters en $2 / 3$ dragonder, zelf betaald met 792 pattacons. (= omgerekend 1188 zware guldens.) Daar kwamen aanvullende kosten bij van de 'prima plana', waarvoor Johan Frans gedurende drie jaar 504 pattacons (756 zware guldens) had betaald. Ten slotte werden nog 360 pattacons berekend voor de artillerie (540 zware gulden) en 48 pattacons (72 zware guldens) voor de 'rijckx cassa' (de inning van het geld). Bij elkaar had de graaf daarmee 1704 pattacons of 2556 zware guldens voorgeschoten. In 1687 beloofde graaf Johan Frans

${ }^{2148}$ Vgl. soortgelijke berekeningen voor Rekem, deels hetzelfde als bij Gronsveld, bij Verbois, Geschiedenis Rekem, 332-333.

${ }^{2149}$ Vgl. pogingen in Rekem om ook vermindering te krijgen, Verbois, Geschiedenis Rekem, 333-335.

2150 Berekeningen op basis van gegevens uit RHCL, Klooster Hoogcruts inv. nr. 1001. 
het nog openstaande aandeel van Slenaken in de Turkse oorlogsbelasting ten bedrage van zestig pattacons (negentig zware guldens) voor zijn rekening te nemen ter compensatie van achterstallige belastingschulden die hij zelf had aan het dorp Slenaken. ${ }^{2151}$

De voorgaande cijfers beogen geen sluitend overzicht te geven van de Gronsveldse bijdragen aan de oorlog tegen de Turken. Ze laten alleen zien dat de belasting ook daadwerkelijk werd geheven en wel met forse bedragen. Overigens was de oorlog tegen de Turken in Gronsveld niet alleen bekend vanwege de belasting. In Hoofdstuk 4.3.1 werd al verhaald dat graaf Johan Frans daar actief in meevocht; zijn broer en zwager sneuvelden in deze strijd. Een curieuze herinnering aan de 'Venetiaans-Oostenrijkse Turkse Oorlog' van 1714-1718 is het chronogram, verwerkt in de tekst van de zilveren plaat die Jacob Berchmans in 1718 schonk toen hij koning van de Gronsveldse schutterij werd. De kennelijk op de Vrede van Passarowitz (21 juli 1718) geïnspireerde tekst, luidt: 'aqUILa LUnaM DeVICIt' (de ((keizerlijke)) adelaar heeft de ((Turkse halve)) maan overwonnen') en levert het jaartaal 1718 op. ${ }^{2152}$

\section{Overige betalingen aan de kreits}

Behalve voor het leger te velde en in garnizoen werden in tijd van oorlog ook bijzondere bijdragen gevraagd voor het onderhoud van rijksvestingen buiten de kreits. In 1708 kreeg Gronsveld een aanslag van zes Römermonate voor 'Reparation der Stadt Philipsburg' en in 1716 één Römermonat voor de fortificatie van Kehl en Philippsburg. ${ }^{2153}$

Tot de vaste verplichtingen behoorden ook de aanslagen voor het onderhoud van het bestuursapparaat van de kreits. Aangezien in de achttiende eeuw nog maar zelden een kreitsdag werd gehouden, lag het bestuur in handen van een Direktorialkonferenz met ondersteuning van enkele klerken. Bepaalde functies bleven soms ook gedurende langere tijd wegens bezuinigingen onbezet. Voor het onderhoud van dit kleine ambtelijk apparaat van 'Craijs-bediente' betaalde het graafschap Gronsveld, met inbegrip van Slenaken, jaarlijks in vredestijd een simplum van twaalf gulden per jaar. Dat was op zich overzienbaar, maar de betalingen verliepen onregelmatig. Zo ontving de gravin d'Arberg Valengin in 1727 een aanmaning om de sinds 1713 achterstallige 'simplen' voor het personeel van de kreits te betalen. ${ }^{2154}$

Een zweem van fraude lag in dit verband over een kwestie die tijdens de Gronsveldse geërfdenvergadering van 22 mei 1787 aan de orde kwam. Het graafschap zou sinds 1757 geen Kreissimplum meer hebben betaald. Maar men kon zich herinneren dat in 1773 al 180 Rijnse guldens aan Prummer waren gegeven om dit te regelen (er waren wat problemen met bankiers geweest). Prummer had echter niets afgedragen en daarom stelden zijn

${ }^{2151}$ RHCL, Klooster Hoogcruts, inv. nr. 746.

2152 Keijser-Schuurman, W, e.a., Met zilver zijn ze ombangen, 47.

2153 RHCL, Klooster Hoogcruts, inv. nr. 1001. De vesting Philippsburg ten noorden van Karlsruhe, gebouwd 1623 op het residentiestadje Udenheim van de prins-bisschop van Spiers, werd na 1697 rijksvesting, na 1802 gesloopt. De vesting Kehl, gebouwd zeventiende eeuw, lag als bruggenhoofd tegenover Straatsburg op de oostelijke Rijnoever, de vestingwerken werden na de Tweede Wereldoorlog gesloopt.

2154 RHCL, Klooster Hoogcruts, inv. nr. 1001. 
erfgenamen dit geld alsnog ter beschikking. Uiteindelijk hoefden de geërfden nog maar 189 gulden voor de tijd tussen 1773 en 1788 te betalen.

In tijden dat frequenter werd vergaderd, in de zeventiende en in het begin van de achttiende eeuw, waren er ook kosten van bezoeken aan een kreitsdag in bijvoorbeeld Keulen, Dortmund, Duisburg, Bielefeld of Aken. Soms stuurde Gronsveld zelf een vertegenwoordiger, dan weer werd, om de hoge kosten van een enkele weken durend verblijf te drukken, gebruik gemaakt van een gevolmachtigde 'agent', die vaak tegelijk voor verschillende standen optrad.

\section{Kammerieler}

Of het graafschap Gronsveld vóór het midden van de zeventiende eeuw Kammervieler betaalde, is niet bekend. De aanvankelijk onduidelijke vermelding - of beter gezegd - het ontbreken van een vermelding van Gronsveld op de Wormser matrikel van 1521 zal de betaling niet hebben bevorderd. Daarin werd immers gesproken over de 'Her von Bromkorst' voor alle bezittingen van de familie met die naam, terwijl volgens andere gegevens Gronsveld anno 1602 nog niet eens op de matrikel voorkwam.

Ook na de Jongste Rijksdag van 1654, toen de tarieven voor het Rijkskamergerecht opnieuw, met een verhoging, waren vastgesteld, nam de betalingsmoraal niet bijzonder toe. Rond 1684 werd echter de druk opgevoerd en dreigde het Rijkskamergerecht met executie van de vorderingen door de kreits. In Slenaken lokte dat in 1686 protest uit. ${ }^{2155}$ Daar beweerde men eerst dat de Kammerzieler altijd waren betaald door de graaf 'ohn beijhilff deren gemeinen nachbahren' van Slenaken. Er was nooit een aanmaning ontvangen. Op zich kan dit juist zijn, want de graaf schoot wel vaker belastingen aan het Rijk, zoals Römermonate, voor en verrekende die dan naderhand. Op zich was men bereid te betalen, maar het geld ontbrak gewoon. Ook de rest van het graafschap kon niet betalen. De inwoners waren totaal verarmd door de schade die was opgelopen bij de belegeringen van Maastricht en de Maastrichtse burgers weigerden in de schatting mee te betalen. Wilhelm Veucht, de grafelijke raadsman, klaagde zijn nood bij de ontvanger van het Rijkskamergerecht, maar die liet niets van zich horen. Op 26 oktober 1686 berichtte Veucht aan de kreits dat hij vijftig rijksdaalders kon sturen en 150 zouden nog volgen. Dat was volgens hem 'das eusserste was ich auch denen armseligen underthanen erpressen konn $[\mathrm{t}] \mathrm{e}^{\prime} .2156$

Veel meer viel er inderdaad niet uit te persen. De achterstanden liepen in de jaren daarna weer op. Voor Gronsveld gedurende de periode van circa 1654 tot 1727 becijferde de Pfennigmeister van het Rijkskamergerecht in 1728 op basis van verschillende tarieven, ${ }^{2157}$ valutakoersen, kortingen en boetes wegens te laat betalen, een tekort van 2267

2155 Zie over deze zaak: RHCL, Klooster Hoogcruts, inv. nr. 1007.

${ }^{2156}$ RHCL, Klooster Hoogcruts, inv. nr. 1007.

2157 Gronsveld moest één Ziel van 15 rijksdaalders per half jaar betalen; voor bepaalde periodes werd een verhoogd Ziel van 52 rijksdaalders en dan weer na 'Moderation' de helft ten bedrage van 26 rijksdaalders aangeslagen. 
rijksdaalders. ${ }^{2158} \mathrm{Na} 1728$ werd wel beter, maar toch nog niet regelmatig betaald. Pas vanaf 1752, na het aantreden van Prummer, probeerde het graafschap aan zijn lopende verplichtingen te voldoen en zelfs iets op de achterstanden in te lopen. Prummer wist dat discussies over de interpretatie van aanslagen meestal zonder resultaat bleven. Daarom wilde hij sinds zijn aantreden zoveel mogelijk de lopende aanslagen betalen en een deel van de achterstand aflossen. Prummer was vanaf het begin bang dat Gronsveld vroeg of laat nog eens met die schulden werd geconfronteerd. In verzoeken tot matiging of kwijtschelding zag hij weinig heil. Een gezamenlijke actie in die richting van verschillende rijksstanden in 1741 had duizend Rijnse guldens gekost en niets opgeleverd. Wat zou een individueel verzoek bij de Rijksdag dan wel niet kosten?

Waarschijnlijk vormde de door de Rijksdag verordonneerde visitatie van het Rijkskamergerecht in Wetzlar, die in de jaren 1767-1776 door afgevaardigden van de rijksstanden werd gehouden, voor Prummer aanleiding de financiële verplichtingen van Gronsveld en de achterstallige Kammerzieler nog eens op een rij te zetten. Waarschijnlijk met een zucht van verlichting rondde Prummer op 2 augustus 1772 zijn uitvoerig rapport af. 2159 Het moet dagen onderzoek hebben gekost de betalingsgeschiedenis uit te vlooien. Een complicatie daarbij was de verrekening van het aandeel van Slenaken, waarover in de voorgaande jaren een geschil was ontstaan. Met zijn gedetailleerd overzicht van achterstanden kwam Prummer op een tekort van 1760 rijksdaalders en 141/4 Kreuzer. Dat was aanzienlijk minder dan de 2248 rijksdaalders die de fiscaal van het Rijkskamergerecht eiste. Prummer maakt de indruk grondig te werk te zijn gegaan, waarbij de cijfers moeten worden gehouden voor wat ze waard zijn. De onderliggende originele documenten zijn vrijwel allemaal verloren en daarmee zijn Prummers bevindingen niet meer controleerbaar. Maar zelfs al zouden die bescheiden bewaard zijn, dan nog is het vrijwel onmogelijk de berekeningen te volgen.

Op zich is dat geen probleem, want de cijfers bevestigen de algemene indruk van grote achterstanden. Gronsveld was daar niet uniek in. Het was algemeen bekend dat in het bijzonder de grote rijksstanden forse tekorten hadden. Anderzijds was het Rijkskamergerecht ook nalatig geweest bij het innen van de Kammerzieler. Prummer hoopte en verwachtte dat de visitatie van het Rijkskamergerecht - en mogelijk ook een uitspraak van de Rijksdag - meer helderheid over de betalingen zouden brengen. Maar tegelijk realiseerde hij zich dat daar niet veel van terecht zou komen, want de schuld van de grote rijksstanden was tot astronomische hoogten opgelopen en de kleintjes, zoals Gronsveld, zouden wel het gelag moeten betalen.

Ook al was het door Prummer berekende tekort fors minder dan het bedrag dat de fiscaal van het Rijkskamergerecht eiste, het bleef een aanzienlijke som geld. En de fiscaal liet zich niet eenvoudig afschepen. Prummer zag geen kans dit restant nog op korte termijn af te lossen, tenzij men geld leende. Hij bedacht een afbetalingsregeling. Gronsveld moest bij de kreits en het Rijkskamergerecht duidelijk maken dat men arm was, maar het feit dat men al twintig jaar regelmatig betaalde, kon worden beschouwd als een bewijs van

2158 RHCL, Klooster Hoogcruts, inv. nr. 762, kopieën originelen Collectie Daris, Bisschoppelijk Archief Luik, berekening uit 1728 .

${ }^{2159}$ TJ, inv. nr. M 12 fol. 1191-1215, Prummer aan M.E. von Toerring-Jettenbach 2 augustus 1772. 
gehoorzaamheid en goede wil. Uiteindelijk stemde het Rijkskamergerecht met dit verzoek in. In het 'Reeckenboek' van de geërfden werd de toekomstige aflossing per jaar tot en met 1809 (!) precies gespecificeerd. Voor Slenaken ging het om 373 rijksdaalders 371/2 Kreuzer en voor Gronsveld om 1840 rijksdaalders 591/4 Kreuzer. 2160 De reeks jaartallen tot ver in de toekomst heeft achteraf iets aandoenlijks, want in 1809 behoorde het Rijkskamergerecht, na de Reichsdeputationshauptschluss van 1803, inmiddels tot de voltooid verleden tijd.

\section{De bijdragen aan het Nederrijns-Westfaalse Rijksgravencollege}

Hoewel het Nederrijns-Westfaals Rijksgravencollege al in de jaren 1653/1654 werd opgericht en de graaf van Gronsveld daar als medeoprichter onbetwist lid van was, blijft het een vraag of in de daaropvolgende decennia ook sprake was van daadwerkelijke betrokkenheid. Het Gravencollege ontplooide immers tot circa 1700 nauwelijks activiteiten. Van 1698 werden de leden aangeslagen conform het simplum dat in de Reichsdefensionalordnung van 1682 was vastgelegd. ${ }^{2161}$ Die inkomsten werden in hoofdzaak besteed aan vergaderkosten, het onderhoud van een klein administratief apparaat en incidentele uitgaven. De betalingsmoraal van de leden van het Gravencollege was wisselend en varieerde van onregelmatig tot 'totaalweigeraars'. Geen enkel lid betaalde gedurende de tijd dat het Gravencollege bestond, zijn bijdrage volledig. ${ }^{2162}$

De kosten van het gezantschap bij de Rijksdag in Regensburg betaalden de leden afzonderlijk. ${ }^{2163}$. Een probleem was dat vaak onenigheid bestond over de benoeming van een gezamenlijke afgevaardigde, zodat het moeilijk was met één stem te spreken. Vast staat dat in de jaren tachtig van de zeventiende eeuw vanuit Gronsveld werd betaald voor een vertegenwoordiger bij de Rijksdag. Zo werden in 1685 in een gezamenlijke vergadering van de schepenbanken voor drie jaar 150 pattacons beschikbaar gesteld voor de 'Gronsfeldische gedeputeerden' bij de Rijksdag. ${ }^{2164}$ Over het nut van een dergelijke vertegenwoordiging, bij een slecht functionerende gravenbank, werd verschillend geoordeeld. Bij de bespreking van de onderhandelingen over het Gronsveldse belastingreglement van 1718 kwam al ter sprake dat de Maastrichtse geërfden zich verzetten tegen een bijdrage in deze kosten.

Tot de bijzondere uitgaven van het Rijksgravencollege hoorden ook de geschenken aan de keizer. Zo betaalde het graafschap 270 zware guldens van de honderdduizend gulden die de Grafenbank aan keizer Karel VI cadeau deden bij gelegenheid van diens kroning in 1711 in Frankfurt. ${ }^{2165}$ Hetzelfde deed zich later nog eens voor. Het 'memoriael' van de Gronsveldse geërfden voor 1743 bevat daarover twee begrotingsposten voor de Rijksgravencollege: zes 'simpelen' (72 Rijnse guldens) 'voor den Richsdaghs

\footnotetext{
2160 TJ, inv. nr. M 71, fol. 230-232.

2161 Arndt, Reichsgrafenkollegium, 188.

2162 Arndt, Reichsgrafenkollegium, 190-193.

2163 Arndt, Reichsgrafenkollegium, 190.

2164 RHCL, Klooster Hoogcruts, inv. nr. 1001. Over de communicatie tussen de gezanten bij de Rijksdag omstreeks 1700 zie Friedrich, Drehscheibe Regensburg.

2165 RHCL, Klooster Hoogcruts, inv. nr. 1001.
} 
gesandtschafft' en 'gemeene uijtgave in Franckfort' en 360 Rijnse guldens 48 Kreuzer voor een volledig geüniformeerd infanterieregiment van duizend man, zonder geweren, dat door alle Rijksgraven 'aen haere (sic!) keijserlijcke majestait' gezamenlijk werd aangeboden. ${ }^{2166}$ Het ging hierbij om een geschenk aan Karel VII, die in 1742 in Frankfurt tot keizer werd gekroond. Gronsveld leverde voor dit cadeau zes manschappen en een onderofficier ter waarde van het eerder genoemde bedrag. ${ }^{2167}$ Vlot werd niet betaald, want een jaar later volgde een aanmaning om het restant zo spoedig mogelijk te voldoen.

Het is de vraag of Gronsveld in de roerige jaren twintig en dertig van de achttiende eeuw met een zwak grafelijk gezag, erg betrokken was bij het Nederrijns-Westfaalse Gravencollege, laat staan dat regelmatig werd betaald. Pas nadat graaf Ignaz Felix von Toerring-Jettenbach de voogdij over zijn minderjarige nicht, de gravin d'Arberg Valengin, op zich had genomen, schijnt er weer belangstelling te zijn gekomen. De vergadering van Gronsveldse geërfden van 1739 vermeldt in een lijst van 'reservata' (verwachte uitgaven) een post voor de 'anno $1736 \mathrm{zu}$ Collen auff dem Reichsgraffentag qua deputatus erschienen pro honorario...zu regulieren wäre'. ${ }^{2168}$ Het gaat dus om een betaling achteraf van een afgevaardigde naar een bijeenkomst in Keulen in 1736. Verder werd ook een bedrag van 96 Rijnse guldens gereserveerd voor de 'Craits graven dag' anno 1740.

Uit deze vermeldingen mogen we niet opmaken dat de geërfden daarmee van het nut van bijdragen aan het Rijksgravencollege overtuigd waren. Hun houding wordt omstreeks 1747 goed beschreven door de grafelijke vertegenwoordiger d'Oliva. Het kwam er op neer dat de bedragen voor het Rijksgravencollege zo'n beetje onder de tafel werden gemoffeld. Deelname aan de vergaderingen kostte geld. Daarom was het verstandig op verblijfkosten bij de vergaderingen (al gauw zo'n twaalf weken) te besparen door een combinatie met de vertegenwoordiging van een andere graaf. Voor de rest was het volgens d'Oliva verstandig vragen te voorkomen en de geërfden zoveel mogelijk onkundig te laten van wat in het gravencollege werd besproken. Zo was over de eerder genoemde bijdrage aan een geschenk voor de keizer niets verteld, want de geërfden zouden bezwaar hebben gemaakt wanneer ze precies het doel hadden gekend, met als argument dat de graaf dit soort cadeaus maar zelf moest betalen. ${ }^{2169}$

Maar volledig blind waren de geërfden niet. Tijdens de Gronsveldse Landsvergadering van 22 december 1747 presenteerde drossaard Hendrik Lebens een 'postscriptum' van graaf Toerring-Jettenbach, waarin deze een declaratie ten bedrage van 18.185 Rijnse guldens van Wilhelm Friedrich von Pistorius, de gezant van het gravencollege bij de Rijksdag, onder de aandacht bracht. Het aandeel van Gronsveld in dit enorme bedrag beliep afgerond 320 Rijnse guldens. De rekening kwam vanwege de oorlog op een ongunstig moment, maar in de vergadering van 23 januari 1753 bleek nog niets betaald te zijn. Het was dezelfde bijeenkomst waarin de strijd over de bijdrage van de geërfden in de personele lasten los barstte. In het verslag dat Prummer van deze vergadering geeft, komen ook deze kosten van het gezantschap aan de orde. Hij schrijft dat de geërfden 'absolute nicht wolten

2166 TJ, inv. nr. M 71, fol. 45 nieuw.

2167 Vgl. soortgelijke betaling in Rekem bij Verbois, Gescbiedenis Rekem, 331.

2168 TJ, inv. nr. M 71, fol. 16 nieuw.

${ }^{2169}$ TJ, inv. nr. M 77, fol. 624-627, d'Oliva aan M.E. von Toerring-Jettenbach, ongedateerd (circa 1747). 
schuldig sein den Herrn von Pistorius zu bezahlen, sondern erwiderten dass dergleiche Gesandtschafften Eur Hochgräfliche Excellentz zu bezahlen schuldig wären'. Zij hadden over deze kwestie op twee plaatsen juridisch advies ingewonnen. Prummer antwoordde dat hij geen discussie wenste over de vraag of dit geld verschuldigd was. Dat was een zaak die vanwege het Rijk werd opgelegd. Het ging hem er alleen om of de geërfden deze vordering als 'reëel', dus ten laste van de grondbelasting, erkenden. ${ }^{2170}$ Dat Prummer zich niet wilde inlaten met de juridische vraag naar de grondslag van deze bijdrage is begrijpelijk. Want die vraag raakte een oude en nooit goed opgeloste kwestie. Het onderhouden van een permanente deputatie bij de Rijksdag behoorde weliswaar tot de kernactiviteiten van het gravencollege, maar vertegenwoordigde dit gezantschap nu de graven als rijksstanden of hun territoria? In de loop der tijden was vanwege het Territorialprinzip geaccepteerd dit soort kosten op het land af te wentelen. Maar bij tijd en wijle, bijvoorbeeld wanneer de bijdragen van de Gronsveldse geërfden als zodanig ter discussie stonden, stak dit probleem weer de kop op.

Het is onduidelijk of uiteindelijk toch door Gronsveld in de kosten van het gezantschap bij de Rijksdag is bijgedragen. In de vergaderingen van de geërfden komt het onderwerp niet meer voor, zoals ook het hele gravencollege voor een periode van 25 jaar vrijwel volledig uit het zicht verdwijnt, zeker wat betreft de financiën. Dit moet samenhangen met het feit dat de post van katholieke directeur van het gravencollege na het overlijden van graaf Ambrosius Frans von Virmont vacant raakte en tot 1784 ook onbezet bleef. De protestantse mededirecteur, graaf Friedrich Alexander von Neuwied, werkte herbezetting tegen wegens het getalsmatig toenemend overwicht van het 'Corpus Catholicorum', het katholieke deel binnen het gravencollege. De graaf van Neuwied zette met steun van confessioneel gelijkgezinde graven de zaken van het gravencollege alleen voort. Ook de gezant bij de Rijksdag was protestant en bij voorstellen waarover gestemd werd volgens confessionele lijnen, steunde deze afgevaardigde dan het 'Corpus Evangelicorum'. De katholieke graven legden zich lange tijd bij deze situatie neer. Eerst de jonge katholieke graaf Franz Georg von Metternich-Winneburg (1746-1818) toonde vanaf 1770 duidelijk ambitie de belangen van de katholieke graven beter te behartigen, maar hij moest wachten tot 1784 voordat hij formeel tot mededirecteur van het gravencollege werd gekozen. Toen werd ook het katholieke gezantschap bij de Rijksdag hersteld. In de landsvergadering van 22 mei 1787 behandelden de Gronsveldse geërfden een brief van Metternich-Winneburg als directeur aan de katholieke zijde ('Collegii Lateris Catholici'), waarin een bijdrage in de kosten van een gezantschap bij de Rijksdag werd gevraagd. Op een totale begroting van 1500 Rijnse guldens werd Gronsveld inclusief Slenaken voor 135,75 Rijnse guldens per jaar aangeslagen. ${ }^{2171}$ Die bedragen zijn vervolgens tenminste voor de jaren 1785-1788 betaald.

2170 De belasting behoort tot wat men in Duitsland 'Reallasten' noemt, een last die uitsluitend drukt op de grond en daarop ook moet worden verhaald en niet op de persoon van de debiteur, vgl. De Blécourt/Fischer, Kort begrip, 199. 2171 TJ, inv. nr. M 71, fol. 273-274. 


\subsection{Conclusies}

Als rijks- en kreitsstand droeg de graaf van Gronsveld bij in de vanwege het Rijk en de kreits geheven belastingen. Iedere stand werd op basis van een zogenoemde matrikel aangeslagen voor een vast bedrag. De vermelding in de matrikel werd beschouwd als een bewijs voor rijksonmiddellijkheid. Richtinggevend voor de bijdragen was sedert het begin van de zestiende eeuw de zogenoemde Wormser Rijksmatrikel van 1521 die, ondanks een aantal onvolkomenheden en onduidelijkheden, in beginsel tot het einde van het Rijk in gebruik bleef. Hoewel volgens de matrikel de landsheer als stand belastingplichtig was, werden de belastingen volgens het territorialiteitsbeginsel afgewenteld op het land. Belastingen werden geheven voor de defensie van het Rijk, het onderhoud van de kreitsorganisatie, het Rijkskamergerecht en de vertegenwoordiging van het NederrijnsWestfaalse Gravencollege bij de Rijksdag.

De basisomvang van het rijksleger (infanterie en cavalerie) lag wat betreft het aantal manschappen vast, maar het leger als zodanig bestond uit een samenstel van afzonderlijke eenheden, zoals keizerlijke en Habsburgse troepen, troepen die door kreitsen op de been werden gebracht en staande legers van grote landsheren, zoals de keurvorsten. Sedert 1682 was de organisatie van het rijksleger gebaseerd op de Reichsdefensionalordnung, waarin alle contingenten met aantallen en samenstelling van de manschappen waren vastgelegd. Die basis (en het aandeel dat iedere rijksstand volgens de matrikel daarin moest leveren) werd het simplum genoemd. Wanneer een groter leger nodig was, werd het simplum met een bepaalde factor vermenigvuldigd. De kosten voor het leger in de oorlog werden berekend op basis van de zogenoemde Römermonat.

$\mathrm{Na}$ de Reichsdefensionalordnung bracht de kreits in het geval van oorlog een leger van een bepaalde omvang op de been. In vredestijd werden kleinere of grotere garnizoenen onderhouden. Voorts voorzag de Ordnung ook in een permanent kader van staf en officieren, de 'prima plana', waarvoor de kosten apart in rekening werden gebracht.

Rijkstroepen konden optreden bij de handhaving van orde en veiligheid binnen het Rijk, maar werden vooral ingezet tegen externe bedreigingen, zoals de Turken en later ook Frankrijk. Voor de oorlogen tegen de Turken werd op basis van de eerder genoemde matrikel een speciale belasting geheven, bekend onder de naam Türkensteuer. Afgezien van het speciale doel, verschilde die niet wezenlijk van de gewone belastingbijdragen.

Behalve voor de defensie moesten de rijksstanden ook bijdragen in de instandhouding van de kleine kreitsorganisatie. Het Rijkskamergerecht werd gefinancierd uit de heffing van de zogenoemde Kammerzieler. Ten slotte moet voor de Nederrijns-Westfaalse Kreits worden gewezen op de bijdrage die de graven binnen die kreits vanaf de tweede helft van de zeventiende eeuw opbrachten voor het onderhoud van hun gemeenschappelijke vertegenwoordiging in de Rijksdag ('Grafenbank').

De inning van de diverse belastingen ging in de loop van de tijd gepaard met grote problemen. Soms bestond onduidelijkheid over de manier waarop de belastingplichtige rijksstand in de matrikel stond vermeld. Door de verbrokkelde legerorganisatie en het ontbreken van een centrale kas had niemand een volledig overzicht van de defensiekosten. 
Het werd er niet duidelijker op wanneer armlastige rijksstanden matiging ('Moderation') van hun bijdrage vroegen. Vaak heerste een slechte betalingsmoraal, wat tot grote achterstanden leidde. Dat vormde niet alleen een probleem bij de bijdragen in de oorlogskosten, ook kleine aanslagen, zoals de Kammerzieler voor het Rijkskamergerecht, konden bij decennialange wanbetaling tot grote hoogte oplopen. Aan de andere kant verliep ook de invordering van bijdragen vaak moeizaam.

De bijdrage van het graafschap Gronsveld aan de rijksbelastingen was vergelijkbaar met bijvoorbeeld Wittem en Rekem. Tot circa 1760 stond het simplum voor Gronsveld op twaalf Rijnse guldens, daarna achttien gulden per maand. Daarmee werd een bepaald equivalent aan manschappen betaald (ruiters kostten negen tot twaalf gulden, infanteristen vier gulden per man). Op zich waren die bedragen overzienbaar, maar de verschillende getallen waarmee deze basis werd vermenigvuldigd, makkten de uiteindelijke hoogte onvoorspelbaar.

Gronsveld lijkt pas aan het einde van de zestiende eeuw echt te zijn geconfronteerd met rijksbelastingen. Voor de periode daarvoor ontbreken gegevens, wat kan samenhangen met het feit dat de heer van Gronsveld tot aan de verheffing in de gravenstand geen rijksen kreitsstand was. Bovendien was de vermelding van de heer van Gronsveld op de Wormser Matrikel onduidelijk geformuleerd. De invoering van rijksbelastingen door graaf Johan II van Bronckhorst Batenburg stuitte op grote weerstand bij de grondeigenaren of geërfden in zijn graafschap, in het bijzonder de Maastrichtenaren. Deze beriepen zich niet alleen op het feit dat deze belastingen nieuw waren, hun bezwaar steunde vooral op het (vermeende) privilege dat de Maastrichtenaren voor hun eigendommen buiten de stad vrijgesteld waren van belastingen. Een beroep op dit recht zorgde niet alleen in Gronsveld voor problemen, maar vormde ook met andere dorpen een voortdurende bron van conflicten.. Juist omdat de meningen daarover zo fundamenteel uit elkaar liepen, is in dit onderzoek geprobeerd wat meer zicht te krijgen op deze belastingvrijdom.

De conflicten tussen de graaf en zijn onderdanen eindigden, na enkele processen bij het Rijkskamergerecht, in 1611 met een akkoord, maar leverden geen duurzame vrede op. Tot het midden van de achttiende eeuw lopen geschillen over de belastingplicht van de Maastrichtse geërfden als een rode draad door de geschiedenis. Na een nieuwe belastingverordening in 1718 waren de Maastrichtenaren zover opgeschoven, dat zij in beginsel bereid waren bij te dragen in de zogenoemde 'reële' belastingen (grondbelasting), maar niet in de 'personele' belastingen op het bezit van vee. De opbrengst van de grondbelasting moest strikt beperkt blijven tot de Römermonate en Kammerzieler. Uitgezonderd bleven betalingen van leveranties in geld of goederen aan doortrekkende legers, betalingen aan het Gronsveldse landsbestuur en betalingen van representatieve aard, zoals voor het Nederrijns-Westfaals Gravencollege.

$\mathrm{Na}$ enige tijd stonden de partijen opnieuw lijnrecht tegenover elkaar. In 1739 werd een nieuwe overeenkomst gesloten, die tot het einde van de achttiende eeuw bleef gehandhaafd. Deze loste echter niet alle geschilpunten op en de verhoudingen werden zwaar op de proef gesteld toen na 1750 de financiële gevolgen van de Oostenrijkse Successieoorlog moesten worden geregeld. De pas aangekomen grafelijke 
vertegenwoordiger Prummer slaagde er na uiterst taaie onderhandelingen ook in de kosten van leveranties aan legers als 'reëel', betaalbaar uit grondbelasting, erkend te krijgen. Dit akkoord perkte, na 150 jaar onenigheid, de belastingvrijdom van de Maastrichtse geërfden in hoge mate in. Als grondeigenaren betaalden zij voortaan mee in zowel de Rijksbelastingen, de kosten van oorlogsschade en bepaalde kosten van het Gronsveldse landsbestuur. Een interessante bijkomstigheid van deze onderhandelingen was dat het hele grondbezit in het hele graafschap opnieuw werd geregistreerd en op kadastrale schaal in kaart gebracht.

De problemen over de betaling van belasting hebben er toe geleid dat de geërfden zich geleidelijk aan zijn gaan organiseren ter behartiging van hun gezamenlijke belangen. In de zeventiende eeuw vond wel overleg over het uitschrijven van schatting plaats, maar dit gebeurde niet in georganiseerd en vast verband. Pas na het akkoord van 1739 nam de collectiviteit vastere vormen aan. Er kwam een verdeling van geërfden in groepen, ieder met stemrecht in de vergadering. Verder werd volgens een vast patroon een landsbegroting opgesteld. Vanaf circa 1744 wordt gesproken over de 'standen' of 'standen en geërfden' van het Land Gronsveld. Die laatste combinatie geeft nog het beste het karakter van de vergadering weer. Het lidmaatschap daarvan werd niet bepaald door 'stand (ridderschap, geestelijkheid) maar door grondbezit. Ten opzichte van vergelijkbare territoria zoals Wittem (aanvankelijk 'ridderschap', later meestgeërfden en vertegenwoordigers van de dorpen) en Wylre (alleen geërfden) nam Gronsveld een middenpositie in. De reglementering van de geërfdenvergadering van Wylre was overigens afgeleid van die van Gronsveld.

Ook het taakveld bleef zeer beperkt. Er werd vrijwel uitsluitend gesproken over grondbelasting en dan vooral de belastingen ten behoeve van het Rijk, de kreits, het Rijkskamergerecht en het Nederrijns-Westfaalse Gravencollege. Bijdragen in de kosten van het Gronsveldse landsbestuur waren zeer beperkt en kwamen slechts een enkele keer aan de orde. De Gronsveldse vergadering van standen en geërfden kende na 1739, en zeker na 1754, orde en regelmaat. Er stonden belangrijke problemen op de agenda stonden, zoals de grote oorlogslasten als gevolg van de Zevenjarige Oorlog (1758-1763) en de achterstanden sinds 1654 in de betaling van de Kammerzieler voor het Rijkskamergerecht. Toen rond 1772 invordering dreigde, was de hoogte van het bedrag al opgelopen tot meer dan 1700 rijksdaalders. Uiteindelijk werd daar een aflossingsregeling voor bedacht. Een derde punt van discussie vormde de financiële verhouding met Slenaken, dat tot 1728 als onderdeel van het graafschap in de belastingen was aangeslagen. Enerzijds waren er nog schulden uit de tijd van vóór de afscheiding, anderzijds werd het graafschap ook na de verkoop van 1728 nog altijd als geheel aangeslagen volgens de oude situatie en moest dan het aandeel van Slenaken, een kwart van het totaal) worden verrekend. De onderhandelingen daarover werd nog bemoeilijkt door verschillen van inzicht over de juiste oppervlakte aan schatbare grond. 


\section{Gemeenten}

Binnen het graafschap Gronsveld vormden dorpsgemeenschappen in de vorm van gemeenten de kleinste organisatorische eenheden. In dit hoofdstuk wordt eerst de ontwikkeling van deze gemeenten onderzocht, waarbij het verschil tussen 'oudere' en jongere gemeenten aan de orde komt. Dat lijkt samen te hangen met de aanwezigheid van gemeenschappelijke gronden en de heffing van de zogenoemde personele belasting op vee. Vervolgens komt de rechtspersoonlijkheid aan de orde, meer in het bijzonder de vraag naar eigendommen en schulden en de aansprakelijkheid van inwoners voor die schulden. De organisatorische kant wordt belicht in de thema's 'besluitvorming', 'afbakening met het voogdgeding' en 'vertegenwoordiging'. Bij dit laatste wordt bijzonder ingegaan op de rol van de burgemeester. Ten slotte worden de taken van de gemeente besproken, zoals het toezicht op velden en gemeentegrond, maar vooral de heffing van de personele belasting, waarvoor de gemeente de fiscale eenheid was.

\subsection{Gemeenten en kerspelen}

Het begrip 'gemeente' of 'kerspel' komt vanaf de veertiende eeuw het eerst in geschreven bronnen in het Maasgebied voor. ${ }^{2172}$ De omvang van kerspelen en de interne organisatie verschillen per streek. In de dunbevolkte gebieden van het tegenwoordige Noord-Limburg en in de Kempen ziet men vaak dorpen met een groot areaal aan heide- weide en veengrond. Die plaatsen, bestaande uit een duidelijke dorpskern, met een krans van buurtschappen of gehuchten omgeven door woeste grond, vormden samen één grote gemeente. Voorbeelden daarvan zijn Venray, Horst en Sevenum, maar ook grote dorpen in de Kempen, zoals Lommel, Neeroeteren en Genk. Afhankelijk van de ontginningsgeschiedenis kennen we ook gebieden met kleine gemeenten of kerspelen, veelal gelegen in het tegenwoordige Nederlands Zuid-Limburg of de Haspengouw, het zuidelijk deel van Belgisch Limburg. Goede voorbeelden van heel kleine kerspelen, nauwelijks meer dan gehuchten, binnen het ressort van één schepenbank leveren Wessem met de exclaves van het zogenoemde Buiten-Wessem²173 en Thorn met liefst zeven dorpen/gehuchten. ${ }^{2174}$ Territoriaal kon een gemeente samenvallen met het ressort van één schepenbank of parochie, maar noodzakelijk was dit niet. Er waren allerlei varianten denkbaar. ${ }^{2175}$

2172 Zie in het algemeen over gemeente en kerspel voor Midden-Limburg: Venner, De Meinweg, voor het Land van Dalhem en het oude hertogdom Limburg: Dumont, Les Communautés villageoises; voor de Belgische Kempen: Molemans, 'Achtergronden 18de-eeuwse kadaster'; verder Van Rensch, 'Van kisten en kompen' met de daar opgegeven literatuur.

2173 Hanssen, Inventarissen Wessem, 10-11.

2174 Van Rensch, 'Rechterlijke organisatie Thorn', 52-53

2175 Zo bestond de schepenbank Echt uit drie parochies (Echt, Roosteren en Maasbracht) en vier gemeenten (Echt, Maasbracht, Roosteren en Ohé en Laak). Vlodrop en Posterholt vormden één schepenbank en één parochie, maar twee gemeenten. Broekhuizenvorst, Swolgen en Oyen waren voor 1729 drie gemeenten (Broekhuizenvorst, Swolgen en Oyen), twee parochies (Swolgen, Broekhuizenvorst) 
In oorsprong speelde de gemeente vooral een rol bij het beheer van de gemeenschappelijke heide-, weide- en bosgronden. De betekenis van de gemeente op fiscaal gebied nam vooral toe vanaf de zestiende eeuw bij de inning van belastingen, het aangaan van schulden voor de betaling van oorlogscontributie en de afwikkeling van militaire vorderingen. De overige gemeentelijke taken waren meestal beperkt van omvang en behelsden onderhoud van wegen en waterlopen, bescherming tegen wateroverlast, incidenteel hulp bij handhaven van openbare orde en veiligheid en zorg voor het kerkgebouw, in het bijzonder de kerktoren.

De gemeente had het karakter van een vereniging waarin gezamenlijk werd overlegd tussen de bewoners (meestal de grondeigenaren) van een dorp of gehucht ter behartiging van gemeenschappelijke belangen. Het stemrecht van grote grondeigenaren (geërfden) en kleine eigenaren (keuters) of pachters kon per streek verschillen. Soms gebeurde de besluitvorming door een kleine groep. De uitvoerende taken werden opgedragen aan één of twee burgemeester(s) of aan één of meer schatheffer(s). Dat laatste is niet zo vreemd, want de gemeente vormde een fiscale eenheid bij het heffen van belastingen en de schatheffer was met de inning daarvan belast. ${ }^{2176}$ Hij deed ook de noodzakelijke uitgaven. Omdat dit financieel beheer bij het werk in de gemeente centraal stond (de kern van het archief van een dergelijke gemeente bestaat vaak uit een serie jaarrekeningen met bijlagen), was het niet zo vreemd dat de schatheffer daarin een spilfunctie vervulde.

De gemeente presenteerde zich naar buiten toe als een collectief en als zelfstandig drager van rechten en plichten met eigendommen in de vorm van geld (inclusief schulden) en gemeentegrond. Dikwijls bleven de inwoners van de gemeente ook zelf met have en goed aansprakelijk voor die schulden van de gemeente. Daarom laten zich in de bronnen de begrippen 'gemeente' als aanduiding voor rechtspersoon en als collectief van inwoners vaak niet goed van elkaar scheiden. Er bestond ook nog op een andere manier een wisselwerking tussen eigendommen en financiële verplichtingen, want gemeentegrond diende dikwijls als onderpand voor leningen die de gemeente aanging en soms werd ook grond verkocht om gemeenteschulden af te lossen.

\subsection{Ontstaan en aantal gemeenten binnen het graafschap Gronsveld}

De eerste vermelding van een gemeente binnen het graafschap is te vinden in een proces voor het Rijkskamergerecht uit 1533 tussen Joost van Scharne tegen de inwoners van Heugem (het woord 'kerspel' wordt nooit gebruikt). ${ }^{2177}$ Het betrof een geschil over de eigendom van weidegrond, de Slak geheten, gelegen tussen Gronsveld en Heugem en de aanleg van een weg voor het drijven van vee. De Heugemer gemeentegronden bestonden verder uit een strook grasland tussen het Heugemer Water en de weg aan de westzijde van het dorp en verder, ten oosten van het dorp, in de nabijheid van de hoeve Vogelzang, het

en twee schepenbanken (Swolgen-Broekhuizenvorst en Oyen) (vgl. Van Rensch, 'Van kisten en kompen', 76-77. Onder de hoofdbank van Thorn ressorteerden zeven kerspelen (vgl. Van Rensch, 'Rechterlijke organisatie Thorn', 52-53).

2176 Voor de gemeente als fiscale eenheid zie Molemans, 'Achtergronden 18de-eeuwse kadaster'; Huijs, 'De repartitie van de grote bede'; Van Rensch, 'Rechterlijke organisatie Thorn', 52-53.

2177 RHCL, Rijkskamergerecht, inv. nr. 295. 
zogenoemde Heugemer Koebroek. In het zuidoosten raakte Heugem aan het Heerder Broek, maar ook hier lagen de grenzen niet nauwkeurig vast.

Ook het dorp Gronsveld beschikte over gemeentelijke graslanden in het laaggelegen gebied ten zuidwesten van het dorp (Gronsvelder Broek, Schaapbroek), die grensden aan de heerlijkheden Rijkckholt en Oost alsmede het gehucht Maarland (onderdeel van het conglomeraat Breust en Eijsden). Terzijde moet hier wel worden opgemerkt dat ook de graaf bijzondere rechten op deze broekgronden liet gelden (zie de eerdere bespreking daarvan in hoofdstuk 15.18). Over de oorspronkelijke omvang van de gemeenschappelijke weidegronden valt weinig met zekerheid te zeggen. Het grensverloop van de gemeentegronden was niet overal duidelijk, wat nogal eens aanleiding gaf tot conflicten met inwoners van Rijckholt, Maarland en Oost. Pas in de eerste helft van de negentiende eeuw werden hier de gemeentelijke grenzen officieel vastgesteld. In de loop van de zeventiende en achttiende eeuw veranderde de omvang van de gemeentegrond wanneer de gemeente, om aan geld te komen, grond verkocht. Soms kregen particulieren tegen vergoeding ook tijdelijk grond in gebruik, die dan werd ontgonnen en later weer braak lag. Zo wordt in 1645 van een stuk van het Schaapbroek, waarop de gemeente hypotheek had verleend, gezegd dat dit 'nu onlancx op nieuws wederomme is worden omgeackert'. ${ }^{2178}$

In de archieven vanaf 1600 is regelmatig sprake van terminologische verwarring tussen enerzijds de gemeente als collectief en in die hoedanigheid ook drager van rechten en plichten, de aansprakelijkheid van inwoners als individu en het gemeenschappelijk bezit. Zo wordt in een overeenkomst uit 1593 tussen graaf Johan II van Bronckhorst Batenburg en de inwoners van Gronsveld afwisselend gesproken over 'Underthanen des dorffs', 'gemeynte' als groep en 'gemeynte' als grond. ${ }^{2179}$ In daarop volgende processen tussen 1600 en 1611 voor het Rijkskamergerecht worden afwisselend de begrippen 'sementliche eingesessene nachpar' en de 'dreij gemaindt der dörfer' Gronsveld, Heugem en Slenaken gebruikt. ${ }^{2180}$ Een helder onderscheid tussen 'geërfden' (grondeigenaren, al dan niet buiten het dorp wonend en andere inwoners, bijvoorbeeld pachters, wordt niet gemaakt. Zoals eerder beschreven (Hoofdstuk 16.2) ontwikkelden de geërfden zich pas in de loop van de zeventiende eeuw tot een vast omschreven collectief). Besluiten werden door alle inwoners gezamenlijk of alleen de 'principaelste' van hen genomen, met in het laatste geval, bindende kracht voor allen. Verdere voorbeelden leveren enkele schuldbekentenissen voor oorlogsleningen van de gemeente Slenaken uit het midden van de zeventiende eeuw. Voor stadhouder of scholtis en schepenen van de bank Slenaken verscheen een aantal inwoners (genoemd worden elf, zestien en vier personen), zijnde 'gemeine ingesetenen ende gegoijde deser heerlicheyt', of 'principaelste ingesetenen ende gegoyde'. De comparanten stelden zichzelf en 'de ganse ende saementlicke gemeentenaeren' met hun roerende en onroerende goederen hoofdelijk aansprakelijk voor betaling van rente en aflossing. ${ }^{2181}$ Hierna zullen nog enkele voorbeelden van deze collectieve besluitvorming ter sprake komen.

2178 TJ, inv. nr. M 72, fol. 290-296

${ }^{2179}$ RHCL, Rijkskamergerecht, inv. nr. 17, fol. 57-58 (Q 11).

2180 RHCL, Rijkskamergerecht, inv. nr. 17, 72, 73, 74.

${ }^{2181}$ RHCL, Graafschap Gronsveld, inv. nr. 501, 502, 503; RHCL, Klooster Hoogcruts, inv. nr. 310. 
In de eerder genoemde processen uit de jaren 1600-1611 traden Gronsveld, Heugem en Slenaken gezamenlijk op. Opmerkelijk is het ontbreken van Eckelrade en Honthem. Toch moeten ook deze plaatsen vanaf het einde van de zestiende eeuw in embryonale vorm als gemeenten hebben bestaan. Voor hun afzijdigheid in de processen wordt door de procespartijen een verschillende verklaring gegeven. Volgens de graaf zagen zij, na juridisch advies, in dat Gronsveld, Heugem en Slenaken voor een onjuiste zaak streden. Volgens Gronsveld, Heugem en Slenaken ging het daar helemaal niet om, maar probeerde de graaf alleen maar een wig te drijven tussen de verschillende dorpen. ${ }^{2182}$ Wat er ook van waar moge zijn, er werd wel met de positie van Eckelrade en Honthem geworsteld, zoals blijkt uit formuleringen in akten uit de zeventiende eeuw, waarbij de gemeenten geld leenden. Op 14 december 1645 verschenen voor drossaard en schepenen van de banken Gronsveld en Honthem één van de medeschepenen en de secretaris, die verklaarden krachtens volmacht van de gemeenten Gronsveld, Eckelrade en Honthem 750 gulden te hebben geleend bij Jan Vrencken te Maastricht. De aangehechte volmacht is afkomstig van de drie gezamenlijke gemeenten, te weten Gronsveld 'ende specialyck oock die van Hontem ende Eckelraedt'. ${ }^{2183}$ Twee jaar later, op 13 mei 1647, verschenen voor het gerecht van Gronsveld een schepen, de secretaris en een ingezetene, die krachtens een algemene volmacht uit 1643 verklaarden een bedrag van 775 gulden te hebben geleend om daarmee schade door keizerlijke en Hessische troepen te voorkomen aan zowel de gemeente Gronsveld 'als op den berch' (= Eckelrade). De volmacht uit 1643 op grond waarvan het drietal comparanten handelde, was opgesteld tijdens een bijeenkomst van de 'principaelste' ingezetenen en droeg de namen en kruisjes van 26 personen, zonder onderscheid te maken tussen Gronsveld en Eckelrade. ${ }^{2184}$

De bijzondere positie van Eckelrade en Honthem blijkt ook uit de wat omslachtige formuleringen in gemeentelijke schuldbekentenissen van 13 april 1674. In het ene stuk is sprake van een lening van 1600 gulden bij Christiaan Meijs te Maastricht door de 'tzamentlycke ingesetene van Gronsfelt voorss. neffens die van Eckelraedt ende der banck Honthem, beyde appendicien der voorss. graefschappe'. Het stuk werd getekend door 38 personen. ${ }^{2185}$ In een tweede akte van die dag werd volgens dezelfde voorwaarden een schuld van 1100 gulden aangegaan door de gezamenlijke inwoners van Gronsveld 'neffens die van Eckelrade ende der Bancke van Honthem'. ${ }^{2186}$ Op grond van deze voorbeelden mag worden aangenomen dat de inwoners van Eckelrade en Honthem in de zeventiende eeuw collectief als gemeente optraden.

De wat aarzelende benadering daarvan door de tijdgenoten kan twee oorzaken hebben. In de eerste plaats waren Eckelrade en Honthem in verhouding tot de andere plaatsen zeer klein. $\mathrm{Nu}$ was een kleine omvang van de gemeenten op zich geen uitzondering. Zo vormden binnen het ressort van de aan Gronsveld grenzende schepenbank Heer het dorp

2182 RHCL, Rijkskamergerecht, inv. nr. 17, fol. 33, 47vo.-48.

${ }^{2183}$ TJ, inv. nr. M 72, fol. 290-296.

2184 TJ, inv. nr. M 72, fol. 298-304.

2185 TJ, inv. nr. M 72, fol. 314-316.

${ }^{2186} \mathrm{TJ}$, inv. nr. M 72, fol. 284-286. 
Heer en het gehucht Keer afzonderlijke gemeenten met eigen dorpsmeesters en ook eigen rechten op het Heerder Koebroek. ${ }^{2187}$

De tweede reden voor de bijzondere positie van Eckelrade en Honthem als gemeente kan zijn dat beide plaatsen minder fortuinlijk waren bedeeld met gemeentegrond, het 'basiskapitaal' bij uitstek van een gemeente. Dat schiep een tegenstelling met de dorpen in het Maasdal. Een voorbeeld daarvan zijn ook uit klachten uit 1737 van inwoners van beide plaatsen over hun andeel in de belastingen van het graafschap. Zo betoogden de Eckelradenaren dat hun grond de helft minder waard was dan die in Gronsveld. Zij hadden geen gemene gronden met daarop groeiend geriefhout en hun landerijen waren omzoomd door bossen, waardoor ze leden onder een konijnenplaag. Om die reden werd vermindering van belasting gevraagd, zoals dat ook gebeurde in Eijsden, 's-Gravenvoeren, Noorbeek en Sint-Martens-Voeren. ${ }^{2188}$ Ook Honthem had vergelijkbare klachten. Vroeger, ten tijde van graaf Johan Frans van Bronckhorst, zou daarom slechts 2/3 van de grondlasten zijn betaald. 2189

Helemaal juist is de voorstelling van zaken door Eckelrade niet, want men beschikte over beperkte weiderechten aan de oostzijde van het Savelsbos. Zo vond in 1749 een gerechtelijk verhoor plaats van oude inwoners van Gronsveld en Eckelrade over het 'poinct van pasturagie tuschen die van Gronsfeldt ter eenre ende die van Eckelraede, dependentie deeser graefschappe ter andere zijde'. Het gerecht hield vervolgens een inspectie ter plaatse en stelde de grenzen vast. ${ }^{2190}$ Slechter was het gesteld met de Honthemers. Zij lijken helemaal geen weiderechten te hebben gehad en kregen in 1737 van de burgemeester van de gemeente Gronsveld ten antwoord dat Gronsveld sinds onheuglijke tijden eigen rechten bezat en wat betreft weiderechten en gemene gronden niets met Honthem gemeenschappelijk had. ${ }^{2191}$

Wanneer we de ontwikkelingen gedurende de zestiende en zeventiende eeuw overzien, dan lijken de gemeenten met gemeenschappelijke weidegronden het oudst. Een vergelijking dringt zich op met de situatie in het naburige Breust en Eijsden. In dit territoriaal tussen twee schepenbanken verdeelde gebied met een reeks gehuchten en dorpjes vormden Eijsden op de Berg en Eijsden in het Dal aparte gemeenten. ${ }^{2192}$ In Breust daarentegen wordt in de archieven weliswaar onderscheid gemaakt tussen inwoners van Breust op de Berg en Breust in het Dal, maar beide groepen vormden één gemeente. ${ }^{2193}$

De ontwikkeling van gehuchten zoals Eckelrade en Honthem tot eigen gemeente kan zijn bevorderd door de komst van nieuwe gemeenschappelijke belangen, in het bijzonder de betaling van oorlogslasten, waarmee de inwoners sinds het einde van de zestiende eeuw, en zeker gedurende de lange oorlogsperiode van de zeventiende eeuw, werden

2187 Van de Venne, Geschiedenis Heer, 83-87.

${ }^{2188}$ TJ, inv. nr. M 77, fol. 634-636, 1 juli 1737.

${ }^{2189}$ TJ, inv. nr. M 77, fol. 639-642. Deze bewering werd aan Gronsveldse zijde bestreden.

${ }^{2190}$ RHCL, Graafschap Gronsveld, inv. nr. 227.

2191 TJ, inv. nr. M 77, fol. 639-642.

2192 Van Hall, Eijsden, een vrijheid, 140-141.

${ }^{2193}$ Vriendelijke mededeling H. van Hall op grond van constateringen gedaan bij de inventarisatie van het archief van de schepenbank Breust. 
geconfronteerd. ${ }^{2194}$ Vorderingen van foerage in de vorm van stro, hooi, en hout, vrachtdiensten en 'sauvegardes' (vrijbrieven die moesten beschermen tegen plundering en afpersing) kostten veel geld. Die uitgaven kwamen voor rekening van inwoners, waarbij de financiering geschiedde door een zogenoemde 'personele omlage', een belasting op vee (zie meer daarover hierna). In dringende gevallen werd het op te brengen bedrag geleend, waarna de 'personele omlage' nog decennia werd geheven voor de betaling van rente en aflossing (Zoals besproken in Hoofdstuk 16.2 weigerden de buitengeërfden, grondeigenaren van buiten het graafschap, daaraan mee te betalen).

Iedere woonkern afzonderlijk was aansprakelijk voor het eigen aandeel in deze oorlogslasten en deze 'omlagen' werden per kern geïnd. Dat werkte natuurlijk een financiële zelfstandigheid van Eckelrade en Honthem in de hand. Alleen waren de inwoners daar hoofdelijk aansprakelijk zonder een onderpand in de vorm van gemeentegrond waarop hypotheek kon worden gegeven

\subsection{De putten van Eckelrade, een gemeenschappelijke regeling 'over de grens'.}

De complexiteit van het begrip 'gemeente' als collectief dat schulden kon aangaan, wordt nog eens geillustreerd aan het voorbeeld van een 'gemeenschappelijke regeling' te Eckelrade in de jaren 1786-1789, nota bene over de landsgrens heen. De grens tussen het graafschap Gronsveld en het conglomeraat van de heerlijkheden Breust en Eijsden liep immers dwars door dit dorp. Verder was er nog het aanhangsel van de vrijwel onbewoonde Bijbank. Ondanks deze staatkundige verdeeldheid leefden de mensen toch als één dorp bij elkaar en hadden zij ook gemeenschappelijke belangen. Begin jaren tachtig van de achttiende eeuw kampte het dorp met watergebrek omdat er geen gemeenschappelijke putten waren. Daarom namen de inwoners op 9 juni 1786 het initiatief twee nieuwe putten te laten graven en een bestaande put uit te diepen. ${ }^{2195}$ Het onderhoud van deze putten werd opgedragen aan de Erven Bemelmans onder voorbehoud van de rechten die de erfgenamen van Lambert Vos hadden op de bestaande put. De vergadering waarin dit besluit werd genomen, telde 27 inwoners van het Gronsveldse deel van Eckelrade en de Bijbank en negen personen van het Breuster deel van Eckelrade. Daarnaast waren nog drie personen verschenen die op Eijsdens gebied woonden. De vergadering stond onder leiding van de grafelijke commissaris Wolfgang Zollner en drossaard G. Janssen van Breust, die tevens als notaris een proces-verbaal van deze bijeenkomst opmaakte.

Alle inwoners moesten voor dit werk hand- en spandiensten leveren. Zes personen werden aangewezen om de leiding van het project op zich te nemen. Zij kregen ook de bevoegdheid namens alle inwoners geld op te nemen voor de financiering van het project. Uiteindelijk bleek daarvoor in 1786 duizend gulden nodig te zijn en in 1789 nog eens driehonderd gulden, welk kapitalen konden worden geleend bij Catharina Francisca Petermans in Oost. Voor deze schuld stelden alle inwoners zich met hun roerende en onroerende goederen hoofdelijk aansprakelijk. Tot zekerheid werden de akten van

2194 Dormans, 'De financiële verhouding', 101, plaatst de opkomst van de gemeenten in de Landen van Overmaze als fiscale eenheden in de tweede helft van de zestiende eeuw.

2195 RHCL, Graafschap Gronsveld, inv. nr. 226. 
schuldbekentenis ingeschreven of gerealiseerd in de gicht- of overdrachtsregisters van de schepenbanken. Tevens werd voor rente en aflossing van deze schuld een soort baatbelasting in het leven geroepen op dezelfde voet als de zogenoemde 'personele omlage' (zie hierna). Iedere twee jaar moesten de 'collecteurs' daarvan rekening en verantwoording afleggen bij de commissaris in Gronsveld en de drossaard van Breust. Zoals blijkt uit een inschrijving in het hypotheekregister bestond deze schuld in 1806 nog steeds.

\subsection{Besluitvorming}

De besluiten tot het aangaan van gemeentelijke leningen in de zeventiende eeuw vonden plaats tijdens vergaderingen waar een groep van de belangrijkste inwoners van het dorp aanwezig was. Deze vorm van besluitvorming heeft tot het einde van de achttiende eeuw gefunctioneerd. Daarnaast zijn er voorbeelden van vergaderingen waar bijna de voltallige (mannen en vrouwen) bevolking aan deelnam. Een eerste voorbeeld daarvan betreft een geschil tussen de 'gemeente' Slenaken en graaf Nicolaas d'Arberg Valengin uit 1722 over de teruggave van grond die de gravin van Gronsveld in 1673 voor een geldlening aan de gemeente in onderpand had gegeven. Bijna zeventig inwoners gaven aan de prior van het klooster Hoogcruts en twee dorpsmeesters volmacht om met de graaf te onderhandelen over een minnelijke schikking. ${ }^{2196}$ In een proces van de inwoners van Heugem tegen het kapittel van Onze-Lieve-Vrouw te Maastricht in de jaren 1751-1768 over het herstel van de kerk en kerktoren wordt afwisselend gesproken over vergaderingen van 'onderdaenen en gesaementlijcke parochiaenen', van 'd'inwooners van Heugem' en van 'gemeentenaeren en parochiaenen'. In 1751 zetten (waarschijnlijk) alle inwoners van Heugem hun handtekening of kruisje onder een verzoekschrift aan drossaard en schepenen van Gronsveld. Op 6 juli 1754 machtigden die 'onderdaenen en gesaementlijcke parochiaenen' van Heugem hun burgemeester Laurens Beckers om te procederen tegen het kapittel, waarna ongeveer veertig handtekeningen en kruisjes volgden. Voor de betaling van proceskosten werd rondgegaan met lijsten, waarop de inwoners voor een bepaald bedrag werden aangeslagen. ${ }^{2197}$ Ook het proces uit de jaren 1773-1785 over de invoering van de aardappeltienden (zie hierna) levert vergelijkbare voorbeelden van gezamenlijk optreden op. De hiervoor besproken gevallen lijken er op te wijzen dat meer nog dan bij het aangaan van financiële verplichtingen in de vorm van leningen, in het bijzonder bij besluiten tot het voeren van procedures voor de gemeente (met vaak onzekere uitkomst) de instemming van alle inwoners nodig was.

\subsection{Vertegenwoordiging van de gemeente: de burgemeesters}

Het collectief van de inwoners moest ook naar buiten toe worden vertegenwoordigd. In de zaak uit 1533 tussen Joost van Scharne en de gemeente Heugem gaven de twee 'kirchmeisteren', gevolgd door zes 'vornemblichste des dorps Hogem', namens de naburen te Heugem volmacht aan drie 'anwelde' (advocaten) om hen in rechte te

2196 RHCL, Klooster Hoogcruts, inv. nr. 1019.

${ }^{2197}$ RHCL, Graafschap Gronsveld, inv. nr. 239. 
vertegenwoordigen. In de processen van de gemeenten tegen graaf Johan II van Bronckhorst Batenburg in 1599 deden twaalf inwoners van Gronsveld, veertien van Heugem en vier van Slenaken hetzelfde. Bijzondere kwaliteiten van de comparanten worden niet genoemd, maar uit de namen blijkt dat het om de belangrijkste inwoners van de dorpen ging.

Op de lange termijn werkte de vertegenwoordiging door een grotere groep omslachtig. Waarschijnlijk is eind zeventiende, begin achttiende eeuw in iedere gemeente de functie van burgemeester ingevoerd. In 1692 wordt in Slenaken uitdrukkelijk gesproken over 'dorpsmeesters'.2198 In 1721 liet burgemeester Willem Blonden (van Gronsveld) door de veldbode een vergadering van 'gemeentenaeren' bij elkaar roepen. Hij tekende het verslag van de bijeenkomst met de aanduiding 'nabermeester'. Een ongedateerd rekest uit circa 1720 van de 'onderdaenen deser graefschappe' aan de gravin staat op naam van hun 'borgmeester Sieur Frans Ruth'. ${ }^{2199}$

In de vergadering van 1721 werd gesproken over de mogelijke bouw van een pastorie, de betaling van de bieraccijns en de betaling van bijdragen aan de kreits. Het is de vraag of dit laatste onderwerp formeel wel tot de bevoegdheden van de gemeenten hoorde, want de kreitslasten werden betaald door de geërfden. Mogelijk gaf dit soort bemoeienissen in de eerste helft van de achttiende eeuw voeding aan een landsheerlijk gevoel dat de positie van burgemeester omstreden was. In 'reflexiones' over de personele 'omlage' uit 1739 klaagt d'Oliva als voogd van de destijds minderjarige gravin van Gronsveld en administrator van het graafschap dat de opbrengsten van de personele belasting niet leidden tot afname van gemeentelijke schulden, maar eerder tot toename. ${ }^{2200}$ In die tijd waren de zogenoemde 'personele' schulden opgelopen tot meer dan 25.000 gulden. Het geld ging vooral op aan dure en nutteloze adviezen van advocaten, waarbij de burgemeesters de drijvende krachten waren. Over alles en nog wat werd raad gevraagd, waardoor ook het vertrouwen van de onderdanen in de landsregering daalde. Zelfs over belastingen aan Rijk en kreits werden volkomen zinloos 'Hollandse' advocaten geconsulteerd. Ironisch genoeg vervoegden de gemeenten zich daarna met hun raadslieden bij d'Oliva, die veel beter op de hoogte bleek dan deze juristen. Dit alles had volgens d'Oliva de van nature goedhartige Gronsveldenaren een hard gemoed bezorgd en het was zeker een van de belangrijkste oorzaken van de vele problemen met de burgers van Maastricht. De overeenkomst uit 1739 tussen het graafschap en de stad Maastricht over de 'reële lasten' (grondbelasting) en een (verder niet bewaard gebleven) reglement over de personele 'omlage', waarvan d'Oliva de ontwerper was, moesten daar een einde aan maken. Het toezicht op die personele 'omlage' diende volgens d'Oliva in handen zijn van een landsheerlijke functionaris. Voor burgemeesters was volgens zijn mening geen rol weggelegd:

2198 RHCL, Klooster Hoogcruts, inv. nr. 1001, betreffende een door de drossaard van Gronsveld aan de schatheffer en dorpsmeesters geadresseerde specificatie van uitgaven ten behoeve van de kreits. In de tekst zelf wordt ook gesproken over 'dorpsmeesters.

2199 RHCL, Graafschap Gronsveld, inv. nr. 121.

2200 TJ, inv. nr. M 25, fol. 258-276. Het stuk draagt de titel 'Extractus annotationum mearum... reflexiones auf obiges reglement die persohnal schat:ing betreffend. 
Die sogenante Gronsfeldische burgermeister oder dorffmeister betreffend, so sehe ich nicht worin ihre factiones bestehen, absonderlich ja dermahlen die personal- sowohl als realschatzung durch die landtsherrliche verordtnungen und respective vergleich mit der burgerschafft der Statt Mastricht in vollkhommenste ordtnung gebracht worden.

Wat moesten deze mensen nog doen, nu inning van de belasting was geregeld, drossaard en schepenen voor de justitie zorgden en 'politica' en 'bestraffungen' waren toevertrouwd aan de drossaard?

Ook de toegestane uitgaven uit de belastingopbrengsten lagen precies vast. D'Oliva kon zich indenken dat vanuit de dorpen een of twee gedeputeerden, die men dan 'dorpsmeesters' noemde, naar een jaarvergadering van geërfden werden afgevaardigd om voorstellen te doen voor het algemeen nut van de inwoners. Wanneer dan schatrekeningen werden afgehoord mochten ze twee stuiver presentiegeld ontvangen, maar daar hield het dan ook mee op. Toestanden zoals in het verleden, toen de burgemeesters zich veel meer bemoeiden met de schattingen en daarbij zelfs geen landsheerlijke inmenging wilden dulden, waren voortaan uit den boze. Uitdrukkelijk verklaarde D'Oliva dat hij 'khein burgermeister zu Gronsfeldt anerkhennen wollte noch könnte, er habe dan zuvor die landtsherrliche confirmation über sein ambt beygebracht'. De visie van D'Oliva op het burgemeestersambt werd volledig gedeeld door de graaf. Hij schreef in 1746 dat de aanwezigheid van 'dorfsmaisters' bij het afhoren van rekeningen was toegestaan, maar zij mochten

keines weegs aber in den justitz, crayss und schätzungsweesen, die politica, bestraffungen und dergleichen sich einmischen, vilwenniger von denen reel oder personel abgaben freygelassen, noch der gemeindte mit vacationen, dieten und zährung zum last fahlen. 2201

Volgens commissaris Prummer werden de burgemeesters in zijn tijd aangesteld tijdens het voogdgeding, evenals de veldbode en de dorpsherder. ${ }^{2202}$ Zollner schrijft in 1794 dat de burgemeester werd benoemd door de drossaard. ${ }^{2203}$ De benoeming vond dus plaats op de dag van het voogdgeding, waarbij de inwoners in principe aanwezig waren, maar moet waarschijnlijk toch formeel los worden gezien van het voogdgeding als rechtszitting. Iets dergelijks zien we ook bij de hierna nog te bespreken vaststelling van de personele collecte, die ook op dezelfde dag plaatsvond, maar waarbij het woord 'voogdgeding' werd vermeden. Waarschijnlijk maakte de drossaard de benoeming bekend, waarna de beëdiging als rechterlijke handeling door de schepenen volgde. Met die eed beloofde de burgemeester alles te doen wat in het belang van de dorpsgemeenschap was.

Het systeem met gerechtelijke tussenkomst lijkt enigszins op de procedure die in de naburige gemeente Herkenrade of 'Eijsden op den Bergh' (in de heerlijkheid Eijsden) werd gevolgd. In 1698 kwamen daar de heer van de heerlijkheid Eijsden, een schepen en de secretaris van de schepenbank Eijsden bij elkaar op het huis Libeek. In aanwezigheid van de voornaamste inwoners benoemden zij twee dorpsmeesters en de veldbode, die

2201 TJ, inv. nr. M 25, fol. 103-110, A.J. von Toerring-Jettenbach aan d'Oliva 24 januari 1746.

2202 TJ, inv. nr. M 56, fol. 68-83, Prummer aan A.J. von Toerring-Jettenbach z.d. (presentatum 4 mei 1773).

${ }^{2203}$ TJ, inv. nr. M 62, fol. 137-143, Zollner aan A.J. von Toerring-Jettenbach 3 juni 1794. 
vervolgens werden beëdigd. De aanwezige inwoners mochten eventuele bezwaren kenbaar maken, waarna de heer en de heren van het gerecht (de 'justicieren') de nodige maatregelen konden treffen.2204

De hiervoor genoemde brief van Prummer uit 1773 suggereert dat de burgemeester en veldbode jaarlijks werden benoemd. Helaas zijn geen bronnen bekend aan de hand waarvan dit valt te verifiëren. Feit is echter dat de burgemeesters, afgaande op hun ambtstermijnen, vele jaren in functie bleven. Periodes van meer dan tien jaar waren eerder regel dan uitzondering. Mannen als Hubert van de Bergh (burgemeester Eckelrade vóór 1767 tot tenminste 1792, overleden 1793) en Gillis Coymans (burgemeester Honthem van vóór 1767 tot 1792) bleven minstens 25 jaar in functie. 2205 Dikwijls bleef het ambt ook in de familie. Zo was Michael van den Boorn (burgemeester Gronsveld 1786-1795) een schoonzoon van Joannes Vrancken (burgemeester Gronsveld 1767-1771) en Joannes van den Berg (burgemeester Eckelrade 1794-1795) een zoon van Hubertus van den Bergh.

In het voorgaande werd aangegeven dat in de eerste helft van de achttiende eeuw bewust werd gestreefd naar een sterke inperking van bevoegdheden voor burgemeesters. In de tweede helft van de achttiende eeuw bestond de belangrijkste taak uit bezigheden ten behoeve van de zogenoemde 'personele omlage', de belasting op het vee (zie daarover meer hierna). De burgemeester verrichtte daarvoor de noodzakelijke tellingen bij de inwoners en stelde vervolgens in overleg met drossaard, schepenen en burgemeesters van de andere gemeenten vast welk totaalbedrag deze belasting moest opbrengen. Slechts bij uitzondering belastte een burgemeester zich zelf met het 'collecteren'. Wel waren de burgemeesters aanwezig bij de rekening en verantwoording die de collecteur aflegde ten overstaan van drosaard en schepenen. Verder hield de burgemeester toezicht op de gemeenschappelijke belangen binnen zijn gemeente. Aangenomen mag worden dat hij dit deed in overleg met de veldbode van zijn gemeente (zie hierna). Ook zorgde de burgemeester dat inwoners voor bijzondere gelegenheden werden samengeroepen. Het is niet geheel duidelijk of hij dit op eigen gezag mocht doen, want uit sommige teksten krijgt men de indruk dat de grafelijk commissaris of de drossaard daarvoor toestemming moest geven.

Extern vertegenwoordigde de burgemeester zijn gemeente bij bijvoorbeeld processen of trad hij op als 'eerste' van de inwoners bij officiële gelegenheden, zoals de inhuldiging van een nieuwe landsheer. Alles bij elkaar bleef het een overzienbaar takenpakket, waarvoor de burgemeester van Gronsveld in de tweede helft van de achttiende eeuw jaarlijks twintig gulden ontving en de burgemeesters uit de drie andere gemeenten twaalf gulden, te betalen uit de opbrengst van de 'personele omlage'.

Voor een dergelijk bedrag kon slechts een beperkt aantal uren worden gewerkt en dat was precies de bedoeling. De collecteur van de 'omlage' mocht uit de geïnde belasting niets

2204 RHCL, Landen van Overmaze, inv. nr. 5635.

2205 Voor Heugem: Laurens (Lens) Dassen 1756-1767, Machiel Wintmans 1768-1770, Peter Goessen 1771-1789 en Matthijs Dassen 1790-1795; voor Gronsveld: Joannes Vrancken 1767-1771, Michael Schrijnemaeckers 1772-1774, J. van den Boorn 1776-1785 en Michael van den Boorn 1786-1795, voor Eckelrade: Hubert van den Bergh 1767-1792 en Joannes van den Bergh 1794-1795; voor Honthem: Gillis Coymans 1767-1792 en Peter van Promeren 1794-1795. 
betalen buiten de posten die in de begroting werden genoemd, ook niet op basis van declaraties, tenzij daarvoor bijzondere machtiging was verleend door drossaard en schepenen. Twee grote processen uit de tweede helft van de achttiende eeuw laten zien dat dit strakke beleid in de praktijk tot problemen kon leiden. In het geschil tussen de gemeente Heugem en het kapittel van Onze-Lieve-Vrouw te Maastricht in de jaren 17511768 over het herstel van de kerk en kerktoren ontstonden veel proceskosten en was de burgemeester als representant van de gemeente voortdurend op pad. Daar voorzag de 'personele omlage' niet in, zodat de oplossing werd gezocht in bijzondere 'omlagen' op vrijwillige basis.

Het langdurige geschil tussen de gemeenten en de graaf over de invoering van de aardappeltienden (1773-1785) laat zien wat kon gebeuren wanneer de strenge begrotingsregels niet in acht werden genomen. Het conflict over deze belasting begon in 1773. Veel inwoners waren het oneens met deze tienden. Onder aanvoering van de burgemeesters werden advocaten geraadpleegd, die met hun adviezen het verzet aanwakkerden. Om aan de onrust een einde te maken presenteerde commissaris Prummer op 21 februari 1776 aan de schepenbank een grafelijke verordening van 10 januari 1776, waarbij werd bepaald dat aardappelen die op tiendbare grond werden verbouwd, ook aan tiendrecht waren onderworpen.2206 Maar wat bedoeld was als het laatste woord in deze kwestie, werd uiteindelijk het begin van een juridisch steekspel. Toen eind 1776 werd gedreigd met inning, kondigden de burgemeesters beroep aan bij de Rijkshofraad in Wenen. Op 5 februari 1777 vond een zitting plaats van het schepengerecht van Gronsveld waar alle inwoners van Gronsveld, Eckelrade en Honthem verschenen. Commissaris Prummer waarschuwde voor het gevaar waaraan zij zich blootstelden met hun verzet. Als eerste werd de burgemeester van Gronsveld gevraagd of hij bij zijn standpunt bleef. Toen deze volhardde, werden alle aanwezigen uit Gronsveld afzonderlijk gehoord. Op een enkeling na verklaarde iedereen bij de burgemeester te blijven. Vervolgens leverde de ondervraging van burgemeesters en inwoners van Eckelrade en Honthem hetzelfde resultaat op. Op 7 februari 1777 werd in Heugem een zitting gehouden met dezelfde procedure en dezelfde uitslag. Uiteindelijk liep het beroep bij de Rijkshofraad in 1782 uit op een mislukking voor de inwoners.

(Inmiddels) commissaris Wolfgang Zollner dacht nu tot invordering te kunnen overgaan, maar het verzet bleef. ${ }^{2207}$ Er bleek op 27 april 1785 nog een vonnis van de schepenbank Gronsveld nodig waarbij de inwoners opnieuw werden veroordeeld tot betaling van de aardappeltienden. De burgemeesters wilden hier wederom tegen in beroep gaan, maar dat werd hen met veel moeite door Zollner uit het hoofd gepraat. ${ }^{2208}$ Zijn beschrijving van de manier waarop hij een einde wilde maken aan deze eindeloze procedure, geeft een interessante blik op de financiële kant van de zaak en de vorming van een gemeentelijke kas. Het proces had handenvol geld gekost aan advocaten, gerechtskosten en declaraties van de burgemeesters. Dit alles was, in strijd met de voorschriften, gefinancierd uit de opbrengsten van de 'personele omlagen'. Meestal resteerde van iedere 'omlage' een batig saldo tussen de vijftig en honderd Rijnse guldens, dat aan drossaard en schepenen werd

2206 TJ, inv. nr. M 21, fol. 301-306, 'rechtsdag' Gronsveld 21-2-1776.

2207 TJ, inv. nr. M 21, fol. 133-134, Zollner aan A.J. von Toerring-Jettenbach 14 juni 1782

2208 TJ, inv. nr. M 21, fol. 117-124, Zollner aan A.J. von Toerring-Jettenbach 29 april 1785. 
afgedragen. Maar de collecteurs hadden gedurende achttien jaar geen rekeningen meer overgelegd en het overgebleven geld eenvoudig aan de burgemeesters gegeven. Die beschikten daarmee over financiële middelen om het proces te rekken. Zollner bedacht dat wanneer de collecteurs de overschotten op de juiste plaats afdroegen, de geldbron vanzelf opdroogde. Bij een 'omlage' op vrijwillige basis zouden 99 van de honderd afhaken. Zollner slaagde in zijn opzet en het proces eindigde.

Het proces over de aardappeltienden laat zien dat de bezwaren die d'Oliva in 1739 had tegen al te grote financiële armslag van burgemeesters, nog steeds geldig waren. De beschikbaarheid van geld wakkerde de lust tot procederen aan. Om te voorkomen dat de inwoners door dit eigenmachtig optreden op kosten werden gejaagd, werd de zelfstandigheid van de gemeenten, in het bijzonder in financieel opzicht, aan banden gelegd. Die situatie in Gronsveld was overigens niet uitzonderlijk. Zo werd in 1697 ook in het naburige Herckenrade onder Eijsden bepaald dat de dorpsmeester alleen dienstreizen mochten ondernemen met toestemming van de 'officier' van het gerecht en de vergoedingen daarvoor werden ingeperkt.2209

\subsection{De veldbode}

Iedere gemeente beschikte over een veldbode of veldschut. In Gronsveld, Heugem, Eckelrade en Honthem werd deze op dezelfde wijze aangesteld als de burgemeester, tijdens het voogdgeding op vordering van de drossaard namens de heer, waarna beëdiging plaatsvond. Waarschijnlijk vond dezelfde procedure ook in Slenaken plaats. Het is onduidelijk of het om een benoeming voor onbepaalde tijd ging of dat jaarlijks een herbenoeming plaatsvond. Het benoemingsrecht van de landsheer of landsvrouwe blijkt ook uit een aanbevelingsbrief voor een sollicitant die pastoor Sterckx van Slenaken in 1707 naar de gravin schreef. ${ }^{2210} \mathrm{Hij}$ had een kandidaat op het oog

'die niet alleen bequaem en is om het velt gaede te slaen, maer oock om te jaeghen, om te vischen, om brieven te bestellen herwarts ende derwarts waer het noedigh sal wesen; hij is oock altijt ter handt om ten tijde van oorlogh hier en daer te loepen'.

Waarschijnlijk waren jagen, vissen en koeriersdiensten nevenactiviteiten. Het toezicht op de bossen en de uitoefening van de jacht waren immers in de eerste plaats landsheerlijke aangelegenheden. Zo beschikte de graaf in de zestiende en begin zeventiende eeuw over 'boschwarde' of 'boshoeders' voor Gronsveld, Slenaken en Sint-Martens-Voeren en dezen werden ook uit de grafelijke kas betaald.

De voornaamste taken van de veldbode bestonden uit het toezicht in het veld, het 'schutten' (vangen) van loslopend vee en - voor die van Gronsveld - het 'vrijen' (omheinen?) van het 'gemeene broek', de gemeentelijke weide. Er moest veel worden gelopen, zeker door de bode van Gronsveld. Deze ontving in de tweede helft van de

2209 RHCL, Landen van Overmaze, inv. nr. 5636, 'Reglement van tgeene de dorpsmeesters van Herckenraede sullen genieten voor haare vacatien voor de gemeente'.

2210 RHCL, Graafschap Gronsveld, inv. nr. 101. 
achttiende eeuw jaarlijks uit de ' personele omlage' vier gulden voor een paar schoenen. Verder kregen hij en zijn drie collega's van de andere gemeenten in de 'personele omlage' ieder één gulden belasting van een koe kwijtgescholden. Ten slotte leverde het 'vrijen' van het broek voor de bode van Gronsveld nog 16 stuiver per jaar op. Waarschijnlijk ontvingen de bodes behalve deze vergoedingen uit de 'personele omlage' nog andere emolumenten, zoals vergoedingen voor het bezorgen van brieven of 'schutgeld' voor het vangen van loslopend vee. Het is echter duidelijk dat iemand hier niet van kon leven en dat de werkzaamheden als veldbode altijd een nevenfunctie vormden.

\subsection{Gemeente en schepenbank}

Er bestond een duidelijk onderscheid tussen de gemeenten en de schepenbanken. Niet alleen waren er meer gemeenten dan banken, ook als organisaties verschilden zij volledig van elkaar. Zo werden de schulden die gemeenten aangingen, ook voor de schepenbanken 'gerealiseerd' of ingeschreven als waren het schulden van derden. Verder konden de gemeenten ook voor de schepenbank procederen. Het vroegst bekende voorbeeld daarvan is de procedure voor de bank van Heugem tussen Joost van Scharne en de 'gemeynte' van Heugem in 1533.2211 Ook in het proces van Heugem tegen het kapittel van Onze-LieveVrouw van Maastricht (1751-1768)2212 en het proces over de aardappeltienden (1773$1785)^{2213}$ waren de gemeenten partij. Toch ontstond bij deze laatste zaak het gevoel van belangenverstrengeling, omdat hier alle vier gemeenten een rol speelden. Op zich was het normaal dat schepenen over hun dorpsgenoten recht spraken. Iemand die te zeer persoonlijk betrokken was, kon zich altijd verschonen. Een man meer of minder maakte voor het functioneren van de rechtspraak niet zo veel uit. Wanneer een gemeente als collectief procedeerde, konden de schepenen uit die gemeente zich excuseren, maar ook dan leverden de andere dorpen nog voldoende kandidaten voor de bezetting van de bank. Bij het geschil over de aardappeltienden moesten zes schepenen en de secretaris die zelf allemaal aardappelen verbouwden, recht doen in een proces waarin zij allemaal zelf belanghebbenden waren. Prummer schrijft in 1775 dat ze dus konden worden gewraakt. In theorie was het aanvaardbaar de zaak te behandelen met drie Gronsveldse schepenen die buiten het graafschap woonden (die waren nog het minst betrokken), zeker wanneer één van hen ook nog de rol van secretaris op zich nam. Bovendien konden juridische adviezen van advocaten van buiten het graafschap worden gebruikt. Maar wanneer ook deze drie schepenen van buiten het graafschap voor 'suspect' werden gehouden, was het bijna ondoenlijk anderen te vinden, ook al omdat met dit werk geen droog brood viel te verdienen. ${ }^{2214}$

Ondanks de formele scheiding tussen schepenbank en gemeente, bestond tussen beide toch een nauwe wisselwerking. Commissaris Prummer schrijft in 1773 dat tijdens de drie voogdgedingen in Gronsveld, Heugem en Honthem geschillen over omheiningen,

2211 RHCL, Rijkskamergerecht, inv. nr. 295.

2212 RHCL, Rijkskamergerecht, inv. nr. 299; RHCL, Graafschap Gronsveld, inv. nr. 239.

2213 Zie naast de eerder genoemde correspondentie ook: RHCL, Graafschap Gronsveld, inv. nr. 244.

${ }^{2214}$ TJ, inv. nr. M 21, fol. 359-373, Prummer aan A.J. von Toerring-Jettenbach 18 augustus 1775.) 
afwatering van gronden en 'valderens' (hekken ter afsluiting van gemeenschappelijke gronden) werden behandeld. Soms waren daarvoor ook inspecties ter plaatse noodzakelijk. ${ }^{2215}$ ) In de gerichtsrollen ontbreken dit soort geschillen. Dit betekent dus dat de rechtshandhaving tussen de inwoners in gemeenteliike aangelegenheden plaats vond door de schepenen tijdens het voogdgeding, met andere woorden, dat deze kwesties via de rechtspraak werden afgedaan.

\subsection{Gemeente en 'personele omlage'}

Hiervoor is beschreven hoe de 'personele omlage' waarschijnlijk al in de zeventiende eeuw werd ingevoerd om daarmee oorlogslasten te financieren. Deze 'omlage' bestond in het graafschap Gronsveld uit een belasting op het bezit van vee. De uitschrijving ervan en de controle van de rekening lagen in handen van het gerecht, in samenwerking met de burgemeesters. Er moet een door d'Oliva opgesteld reglement op de inning hebben bestaan als tegenhanger van de overeenkomst uit 1739 tussen Gronsveld en de Maastrichtse geërfden over de 'reële' belastingen. De tekst is verder niet bekend, maar D'Oliva geeft daarover wel enige beschouwingen in zijn eerder genoemde 'reflexiones'. Het beste overzicht van de gevolgde procedures geven echter bewaard gebleven stukken uit de periode 1766-1794.

De uitschrijving verliep volgens een strak en formeel patroon in steeds weer dezelfde bewoordingen, inclusief de merkwaardige methode van berekening. Die starheid vormt wellicht een aanwijzing dat deze methodiek al veel eerder op ongeveer dezelfde wijze werd toegepast. Het begon met een telling in juni door de burgemeester in iedere gemeente van het aantal paarden, veulens, koeien, runderen en schapen. Vervolgens werd 'bij billette van affixie ad valvas ter gewoonlijker plaatse' de bijeenkomst bekend gemaakt, waarbij het eindbedrag van de op te brengen belasting werd vastgesteld. In die vergadering werd ook de 'collecteur' aangewezen.

Deze zitting vond plaats op dezelfde dag als het voogdgeding, maar in de aankondiging wordt dit woord niet gebruikt. Dit wijst er op dat de vaststelling van de 'personele omlage' geen echt onderdeel was van het formele voogdgeding. Beide activiteiten werden om praktische redenen gecombineerd, maar iedere schijn van rechterlijke activiteit door burgemeesters diende te worden vermeden. Bij de feitelijke vaststelling van het belastingbedrag waren betrokken de grafelijke commissaris, de drossaard, de schepenen en de vier burgemeesters. De berekening van het eindbedrag dat de belasting volgens de telling moest opbrengen, geschiedde volgens een methode die men als 'hogere wiskunde' kan betitelen. De oudste vermelding daarvan is te vinden in de 'reflexiones' van d'Oliva uit 1739. Hij schrijft

dass in der grafschafft dermallen praeter propter der anschlag auf 350 ferdt ertrage, welche volgender gestalt berechnet werden, dass 2 khüe ein pferdt, 4 kälber 1 khue, 25 schaaf 1 pferdt ausmachen. ${ }^{2216}$

2215 TJ, inv. nr. M 56, fol. 68-83, Prummer aan A.J. von Toerring-Jettenbach z.d. (presentatum 4 mei 1773). 2216 TJ, inv. nr. M 25, fol. 270. 
De veestapel aan koeien, kalveren en schapen werd dus omgerekend naar paarden. Die wijze van berekenen werd, zoals blijkt uit onderstaand staatje uit 1773, nog steeds gebruikt. Alleen zijn de kalveren vervangen door veulens en zijn runderen toegevoegd.

$\begin{array}{llllll} & \text { paarden } & \text { veulens } & \text { koeien } & \text { runderen } & \text { schapen } \\ \text { Honthem } & 9 & 4 & 33 & 12 & 33 \\ \text { Eckelrade } & 19 & 5 & 49 & 23 & 206 \\ \text { Gronsveld } & 58 & 12 & 154 & 76 & 365 \\ \text { Heugem } & 45 & 12 & 105 & 52 & 297 \\ \text { Totaal } & 131 & 33 & 341 & 163 & 901\end{array}$

Vervolgens werden de veulens, koeien, runderen en schapen omgerekend naar paarden:

33 veulens: $2=16 \frac{1}{2}$ paard

341 koeien: $2=170^{1 / 2}$ paard

163 runderen: $4=40$ paarden en 3 runderen

901 schapen: $25=36$ paarden en 1 schaap.

Daaruit volgde een totaal van 394 'rekenpaarden', 3 runderen en 1 schaap. Bij de vaststelling van de 'omlage' werd dan ook volgens de vaste formulering geconcludeerd dat 't getal der beesten, gereduceert in peerden, monteert ter quantiteijt van drijhondert vier en negentigh peert, 3 runders, een schaep.

Ieder paard werd getaxeerd op twee gulden 'en d'andere beesten naer advenant', waarna het gehele bedrag uitkwam op 789 gulden 11 stuiver en 3 oort.

De precieze reden van deze omrekening van de veestapel in paarden is onbekend, maar verraadt misschien iets over de denkwijze van de inwoners en waardering van bezit. Maatschappelijk gezien stond de eigenaar van vijftig schapen gelijk aan de bezitter van twee paarden.

$\mathrm{Na}$ de vaststelling van het bedrag werd de inning bij opbod uitgegeven aan de meestbiedende 'collecteur', die met zijn roerende en onroerende goederen borg moest staan. Bij wijze van uitzondering nam een burgemeester de taak van collecteur op zich. Vervolgens werd door drossaard, burgemeesters en schepenen het 'memoriaal' opgesteld, een begroting met exacte omschrijvingen van wat uit de 'omlage' mocht worden betaald. Uitgaven daarbuiten werden niet 'gevalideert'. Voor andere kosten waren aparte 'omlagen' nodig. De vaste posten betroffen de rente van schulden die de gemeenten vroeger waren aangegaan, het jaarlijks bedrag voor de afkoop van herendiensten of 'karweien', de honoraria voor drossaard, schepenen, secretaris, bode en collecteur voor hun werkzaamheden ten behoeve van de 'omlage' en ten slotte de vergoedingen voor de burgemeesters en veldbodes. Een variabele post vormde de terugbetaling van belasting voor vee dat in het voorgaande jaar was gestorven. De berekening van dit tegoed geschiedde op basis van een nauwkeurige specificatie.

De laatste officiële handeling op die dag was het afhoren van de collecteursrekening van het voorgaande jaar. Ook deze rekening werd getekend door drossaard, schepenen en burgemeesters. De collecteur kreeg opdracht het batig saldo binnen vier maanden in de 
kas van het gerecht te storten. Daarmee was eigen fondsvorming door de gemeente onmogelijk.

\subsection{Conclusies}

Gemeenten bestonden uit het collectief van de inwoners van een dorp met als doel de behartiging van gemeenschappelijke belangen. Die collectiviteit wordt ook weerspiegeld in de besluitvorming, waaraan alle inwoners (dat wil zeggen mannelijke gezinshoofden) konden deelnemen. Tot het einde van de achttiende eeuw was dit een gebruikelijke manier van vergaderen. Aanvankelijk zorgde een kleine groep dan voor de uitvoering. Waarschijnlijk vanaf het einde van de zeventiende deed de dorpsmeester, of beter gezegd de burgemeester, zijn intrede. De graaf en zijn vertegenwoordigers bekeken deze functionarissen, waar men weinig greep op had, met argwaan omdat zij met hun eigen belangenbehartiging de gemeente meer geld kostten dan opbrachten. Er werd daarom geprobeerd de rol van de burgemeesters zoveel mogelijk te beperken en financiële fondsvorming tegen te gaan.

De oudste bronnen betreffende gemeenten in het graafschap dateren uit de zestiende eeuw en hebben betrekking op Heugem, Gronsveld en Slenaken. Dit zijn ook de plaatsen waar gemeenschappelijke weidegronden lagen. Eckelrade en Honthem, plaatsen waar nauwelijks of geen gemeentegronden lagen, ontwikkelden zich pas in de zeventiende eeuw als gemeenten. Waarschijnlijk hing dit samen met de rol die de gemeenten in deze tijd gingen vervullen als organisatorische eenheid voor de heffing van de zogenoemde personele belastingen. Het is, ook door gebrek aan archivalische bronnen, moeilijk een helder beeld te krijgen van de gemeente als rechtspersoon. Duidelijk is dat zij als collectief eigendommen kon hebben, in het bijzonder gemeenschappelijke weidegronden, en schulden in de vorm van leningen kon aangaan. Voor betaling van rente en aflossing stonden zowel het collectief als de individuele inwoners garant. Ook kon collectief eigendom in de vorm van gemeentegrond als onderpand voor schulden dienen. Het voorbeeld van de Eckelrader putten laat zien dat het relatief eenvoudig was voor een dorpsgemeenschap als vereniging van inwoners schulden aan te gaan en daarvoor zelfs een soort belasting te heffen, terwijl de inwoners als persoon daarvoor met have en goed aansprakelijk waren.

De fiscale taak van de gemeente woog veruit het zwaarst. Met heffingen op het bezit van vee werden vooral de kosten van militaire vorderingen en oorlogslasten gefinancierd. De methode van berekening daarvan met paarden als 'rekeneenheid' was hoogst opmerkelijk. Daarnaast was er het beheer van de gemeentegronden (voor zover aanwezig). Reglementering daarvan en feitelijke beslissingen over het beheer vonden echter plaats tijdens het voogdgeding. Het toezicht op het veld en de gemene grond was opgedragen aan een door de gemeente betaalde veldbode. 


\section{SAMENVATTING}

\section{Thema en achtergrond van onderzoek}

Het Land (graafschap) Gronsveld was tot 1795 een klein, onafhankelijk territorium ten zuidoosten van Maastricht, deel uitmakend van het Heilige Roomse Rijk der Duitse Natie. De heren van Gronsveld voerden vanaf 1498 de titel Reichsfreiherr en vanaf 1586 de titel rijksgraaf. Zij erkenden het directe of 'onmiddellijke' gezag van de keizer en de hoogste instellingen binnen het Rijk en onderwierpen zich ook aan de hoogste wetten van het Rijk, maar beschouwden hun rechten over land en inwoners als vrije eigendom (allodium), ontleend aan 'God en de zon'. In de terminologie van een feodaal georganiseerde samenleving was Gronsveld daarmee een 'zonneleen'. De graaf van Gronsveld genoot binnen de hiërarchie van het Rijk de status van rijksstand en had daarmee (op zeer bescheiden schaal) recht op deelname aan de politieke besluitvorming binnen het Rijk.

Deze studie behandelt wetgeving, bestuur en rechtspraak binnen het graafschap gedurende de vroegmoderne tijd, evenals de manier waarop de daarbij betrokken personen en instellingen daar invulling aan gaven en de middelen en rechten die daartoe ter beschikking stonden. Dit wordt voorafgegaan door een analyse hoe het Land Gronsveld in de late middeleeuwen uit afzonderlijke dorpen is ontstaan. Uitgebreid aandacht krijgt ook de geschiedenis van de heren van Gronsveld, omdat die niet los kan worden gezien van het land. In de middeleeuwen wisten de heren uit het geslacht Van Gronsveld de zelfstandigheid van hun gebied ten opzichte van naburige grote landsheren, in het bijzonder de hertog van Brabant, te handhaven door geldleningen aan de hertogen en de verwerving van ambten in dienst van de hertog. Door de alliantie Van Bronckhorst Batenburg-Van Gronsveld in de vijftiende eeuw verschoof die oorspronkelijke oriëntatie op Brabant (en in mindere mate ook op Luik) rond 1500 naar het hertogdom Kleef en de Duitse Nederrijn. Door de verheffingen van Diederik II van Bronckhorst Batenburg tot Reichsfreiberr in 1498 en van zijn achterkleinzonen Jost en Johan II tot rijksgraaf in 1586 werd de blik duidelijk op het oosten, op het Rijk gericht. Die standsverheffingen zorgden ervoor dat de heren van Gronsveld het rijksonmiddellijk karakter van hun territorium, met alle daaraan verbonden rechten en plichten, steeds meer gingen benadrukken. Met die keuze voor het Rijk stonden zij als het ware met de rug naar de Habsburgse Nederlanden. Het lidmaatschap van de rijksadel effende in de zeventiende eeuw ook de weg voor militaire en diplomatieke carrières in keizerlijke dienst. De relaties binnen die kringen maakten het ook eenvoudiger op te komen voor de onafhankelijkheid van het graafschap en de neutraliteit in oorlogssituaties. Tegelijkertijd kleefden er ook nadelen aan die standsverhogingen. Zo werden vanaf omstreeks 1600 in Gronsveld voorheen onbekende belastingen ten behoeve van het Rijk ingevoerd. Verder had de voortdurende afwezigheid van de graaf ook gevolgen voor de manier waarop het bestuur van het graafschap moest worden georganiseerd.

Op zich waren zeer kleine, zelfstandige gebieden, noch in de Nederlanden noch in het Duitse Rijk een zeldzaam verschijnsel. De Republiek der Verenigde Nederlanden telde binnen haar grenzen verschillende enclaves die als 'vrije heerlijkheden' onafhankelijkheid 
pretendeerden. Maar in de praktijk werden zij toch beschouwd als verbonden met de Republiek. In ieder geval voldeed geen van deze gebieden aan de eisen die aan een rijksstand werden gesteld. Het Heilige Roomse Rijk echter telde meer dan 1800 staten en staatjes, waarvan ongeveer driehonderd als rijksstand in de Rijksdag waren vertegenwoordigd. Door de voorstanders van de Duitse eenheid in de negentiende eeuw werd dit verschijnsel enigszins denigrerend aangeduid als 'Kleinstaaterei'

Binnen het tegenwoordige Nederland telde alleen de provincie Limburg kleine onafhankelijke territoria, die op een of andere manier met het Rijk waren verbonden. (We laten buiten beschouwing de 'Limburgse' delen van de hertogdommen Gulik en Kleef en de met Kleef verbonden enclaves in Noord-Brabant en Gelderland). Met opzet wordt gekozen voor een vage omschrijving, want tussen de territoria bestonden verschillen in status, die van geval tot geval moeten worden beoordeeld. Aan in de literatuur gebruikte verzamelbeschrijvingen als 'vrije rijksheerlijkheden' moet weinig juridische waarde worden toegekend. Slechts drie, te weten Thorn, Wittem en Gronsveld, kunnen uiteindelijk als rijksstand worden beschouwd.

Er bestaat over 'Nederlandse' rijksonmiddellijke gebieden wel literatuur, maar meestal blijft dit beperkt tot deelstudies in de vorm van artikelen. Bij meer omvangrijke verhandelingen krijgen de gecompliceerde verhoudingen tot het Rijk evenmin veel aandacht. Dat ook deze gebieden behoren tot de voorgeschiedenis van het tegenwoordige Nederland is in de historiografie vrijwel aan de aandacht ontsnapt. De enige uitzondering daarop vormt de studie van Nève over het Rijkskamergerecht. Dat betekent dat Nederlandstalige literatuur slechts beperkte bruikbaarheid heeft voor onderzoek. Achtergrondkennis moet vrijwel geheel worden ontleend aan Duitstalige literatuur. Aan die kant speelt het probleem van een nauwelijks overzienbare vloed aan publicaties. In deze studie over Gronsveld is voor de oplossing van dit probleem gekozen voor een middenweg. Op verschillende plaatsen in de tekst is op basis van literatuur in Duitse handboeken en enkele monografieën aandacht besteed aan de structuren en instellingen van het Rijk, voor zover dat noodzakelijk is om bepaalde begrippen binnen een bredere context te kunnen plaatsen.

De relaties tussen Gronsveld en het Rijk waren divers. Op het gebied van rechtspraak fungeerden het Rijkskamergerecht en de Rijkshofraad als hoogste rechtscolleges. Als rijksstand had de graaf zitting in de Nederrijns-Westfaalse Kreits en in het NederrijnsWestfaalse Rijksgravencollege. Via het Rijksgravencollege was hij ook vertegenwoordigd in de Rijksdag. In deze studie is slechts zeer beperkt onderzoek verricht naar de feitelijke rol die Gronsveld binnen deze colleges speelde. Dat geldt ook voor de betrekkingen met andere rijksstanden. Om daar uitspraken over te kunnen doen, is breder, vergelijkend onderzoek nodig. Wel is ruim aandacht geschonken aan het toezicht van de kreits op de uitoefening van het muntrecht en aan de belastingen vanwege het Rijk, die het graafschap Gronsveld moest opbrengen.

Deze studie is, met uitzondering van de middeleeuwse periode en de familiegeschiedenis van de heren van Gronsveld, grotendeels gebaseerd op onderzoek in archieven. In de inleiding is daarvan een overzicht opgenomen. Van de oorspronkelijk in Gronsveld 
gevormde archieven van heren en graven en van de rechterlijke instellingen aldaar is weinig bewaard. Deze stukken zijn in 1793 bij een inval van Franse troepen vernietigd. Het restant bevindt zich bij het Regionaal Historisch Centrum Limburg te Maastricht. Als aanvulling zeer belangrijk zijn de eveneens bij het Regionaal Historisch Centrum Limburg aanwezige dossiers van processen die vanuit Gronsveld voor het Rijkskamergerecht werden gevoerd. In deze studie over Gronsveld is van de inhoud daarvan voor het eerst op ruime schaal gebruik gemaakt. Van groot belang is verder het archief van de graven Toerring-Jettenbach, in bewaring gegeven bij het Staatsarchiv München. Daarin bevindt zich een soort 'tegenarchief' van de administratie in Gronsveld uit de tijd dat graven Toerring-Jettenbach in de achttiende eeuw bemoeienis met Gronsveld hadden. Voorts bevat dit archief retroacta uit vroegere periodes en stukken die in 1793 vanuit Gronsveld naar München zijn meegenomen. De grote hoeveelheid correspondentie uit de achttiende eeuw bevat een uitzonderlijke hoeveel achtergrondinformatie over het functioneren van bestuur en rechtspraak in de achttiende eeuw. Deze is niet alleen interessant voor de in de plaatselijke geschiedenis geïnteresseerde lezer, het geeft ook een beeld van persoonlijke verhoudingen en zakelijke belangen zoals die tussen bestuurders en onderdanen bestonden. De onevenwichtige overlevering van archieven is van invloed geweest op de uiteindelijke presentatie van dit onderzoek. De stukjes van de legpuzzel pasten niet altijd aan elkaar. Daarom zijn soms voor de onderbouwing van bepaalde feiten of ontwikkelingen details sterk uitvergroot, terwijl de grote hoeveelheid materiaal uit de tweede helft van de achttiende eeuw ons weer stelt voor de noodzaak keuzes te maken.

Het ontstaan van het Land Gronsveld en genealogische achtergronden van de heren van Gronsveld in de middeleeunen

De vroegste vermeldingen van adellijke personen met de achternaam 'De Grules' of een variant daarvan dateren uit de elfde en twaalfde eeuw en zijn terug te vinden in het gebied tussen Aken en Luik. Het is niet mogelijk daar een samenhangende genealogie van te maken. Evenmin zijn duidelijk banden met Gronsveld aan te wijzen. Pas in de loop van de dertiende eeuw kan worden gesproken van opeenvolgende generaties van een familie Van Gronsveld, waarvan leden ook heer van Gronsveld waren. Er bestonden in die tijd ook verbindingen met de belangrijke adellijke geslachten Van Stolberg (bij Aken) en Van Haasdal. Waarschijnlijk is de familie Van Haasdal aan het einde van de dertiende eeuw in mannelijke lijn uitgestorven en zijn de goederen en het familiewapen overgenomen door de heren van Gronsveld.

De heren van Gronsveld behoorden in de dertiende eeuw en het begin van de veertiende eeuw tot de aanzienlijke adel, met goederen in het gebied tussen Luik, Aken en Maastricht. Er zijn ook aanwijzingen voor verbindingen met de hertogen van Limburg. Pas bij Hendrik I van Gronsveld (vermeld 1334-1374) wordt het mogelijk een globaal beeld van diens levensloop te krijgen. Hij was als burggraaf van het kasteel van Limbourg aan de Vesdre in dienst van de hertog van Brabant, was betrokken bij de behartiging van Brabantse belangen in het gebied tussen Maas en Rijn en vertegenwoordigde Brabant in het zogenoemde Landvredeverbond. Verder trad hij op als financier van de hertog. 
Hendriks zoon Johan III van Gronsveld (vermeld 1349-1386) trad in de voetsporen van zijn vader. Ook hij onderhield nauwe betrekkingen met de hertog van Brabant, was één van de grote financiers van de hertog en kreeg daarvoor een reeks kastelen en ambten in onderpand. Zijn fortuin nam nog aanzienlijk toe, toen Walram van Valkenburg hem in 1368 het dorp Heugem schonk. Van zijn oom Godert van den Bongard erfde hij de heerlijke rechten over Sint-Maartens-Voeren en Oost. Verder verwierf hij van de hertog van Brabant pandrechten op Eijsden en Cadier. Aan een mogelijk streven al zijn aan elkaar grenzende bezittingen tot één samenhangend geheel te consolideren kwam abrupt een einde toen hij in 1386 werd vermoord.

Johan III werd opgevolgd door zijn broer Hendrik II. Deze had door zijn huwelijk met Johanna van Merode vooruitzichten op het kasteel Rimburg (dat hij in 1396 ook verwierf), maar hij werd door de erfenis van zijn broer één van de rijkste edelen van de streek. Hendrik zette de goede betrekkingen met Brabant voort en bleef één van de belangrijkste geldschieters van de het hertogelijk huis. Door het bezit van Rimburg ontstond een band met Gronsveld, die uiteindelijk bijna 250 jaar duurde. Het kasteel van Rimburg werd de hoofdzetel van de heren van Gronsveld.

Hendrik II werd opgevolgd door zijn oudste zoon Hendrik III van Gronsveld (vermeld 1407-1474/1476), gehuwd met Aleydis van Oupeye. Tijdens zijn regering bekoelden de traditioneel goede betrekkingen met het onder Bourgondische invloedssfeer gekomen Brabant. Aangezien Hendrik en zijn echtgenote slechts twee dochters hadden, stierf te Gronsveld het geslacht Van Gronsveld in mannelijke lijn uit. De oudste dochter Johanna trouwde met Diederik I van Bronckhorst Batenburg, afkomstig uit het Gelderse rivierengebied. Tot 1719 hebben opeenvolgende leden uit dit geslacht over Gronsveld geregeerd.

Typisch voor de ontwikkeling van de grote middeleeuwse landsheerlijkheden was hun geleidelijke groei door annexatie, koop of leenopdrachten van naburige heerlijkheden. Vergelijkbare ontwikkelingen treffen we ook aan bij kleine landsheerlijkheden. In de Nederlanden was dit proces van samenvoeging en deling van territoria aan het einde van de veertiende eeuw grotendeels tot afronding gekomen. Ook het Land Gronsveld, dat zich voor het eerst omstreeks 1400 manifesteert als een samenhangend geheel onder de heren van Gronsveld, was in de voorafgaande eeuw(en) ontstaan uit 'losse onderdelen'. Sporen daarvan waren nog in de rechterlijke en bestuurlijke organisatie tot 1795 zichtbaar.

Voor elk van deze eenheden in de vorm van een dorp of gehucht is een analyse gemaakt van het ontstaan en de overgang naar de heren van Gronsveld. Inzicht daarin was ook van belang voor de vraag of de afzonderlijke delen voldeden aan de later geclaimde status van 'zonneleen' en allodium. Uit het onderzoek blijkt duidelijk dat geen van de plaatsen moet worden beschouwd als afsplitsing van een groter geheel. Vervolgens is geprobeerd op basis van reconstructie van de ontginningsgeschiedenis vast te stellen of aan het ontstaan van de afzonderlijke plaatsen een groot domein ten grondslag kan hebben gelegen. Een dergelijk reconstructie van een middeleeuws landschap is in het verleden al door Hartmann gemaakt voor het aan Gronsveld grenzende Eijsden en Breust. Hij stelde vast dat de dorpen en gehuchten op het plateau van Eckelrade en Sint Geertruid in de elfde en twaalfde eeuw zijn gesticht tijdens de ontginning die vanuit het Maasdal werd 
ondernomen. De door Hartmann gebruikte methode van onderzoek is ook voor de afzonderlijke plaatsen binnen het graafschap Gronsveld toegepast. De eigendomsverhoudingen en rechten op de grond (leenroerigheid, keurmede, cijnsplicht) die op kaarten uit het midden van de achttiende eeuw konden worden aangegeven, mogen worden beschouwd als een afspiegeling van de middeleeuwse ontginningsgeschiedenis.

In grote lijnen zijn de uitkomsten hetzelfde als bij Breust en Eijsden: een ontginning van het plateau vanuit de lager gelegen dorpen Gronsveld en Heugem. Maar er zijn per plaats ook verschillen. Voor Gronsveld was nog in de achttiende eeuw 2/3 van alle grond op enigerlei wijze verbonden met de heer, als volle eigendom van de heer, als leengoed, als keurmedig goed of als cijnsgoed. Daarmee wordt duidelijk dat de basis voor het ontstaan van het dorp moet worden gezocht in een adellijk, allodiaal domein. De ontginning daarvan moet hebben plaatsgevonden in de twaalfde en dertiende eeuw. Dat sluit ook aan bij de vroegste schriftelijke bronnen. Het initiatief voor die ontginningen moet zijn uitgegaan van de heren van Gronsveld, voor eigen rekening of door uitgifte van grond volgens leenrecht of tegen betaling van keurmede of cijns.

Het dorp Eckelrade is als ontginningsdorp vanuit Gronsveld gesticht in de dertiende of het begin van de veertiende eeuw. De ontwikkeling verliep echter anders dan in Gronsveld en de latere gegevens wijzen op een deels planmatige aanleg. Overheersend waren hier landerijen die van de heren van Gronsveld in leen werden gehouden. De heren van Gronsveld beschikten hier nauwelijks over grond in volle eigendom.

De verdere ontwikkeling van Eckelrade tot grotere zelfstandigheid ten opzichte van Gronsveld is in de veertiende eeuw gestagneerd. Het dorp beschikte over een eigen kerk, maar die had slechts de status van hulpkerk van de parochiekerk van Gronsveld. De oudste vermelding van een kerk in Gronsveld dateert uit 1258. Gronsveld en Eckelrade hebben samen altijd onder één schepenbank geressorteerd, die voor beide plaatsen bevoegd was. Schepenen van de 'curia de Grunselt' worden het eerst genoemd in 1261. De schepenbank had hoge en lage jurisdictie. In 'gemeentelijk' opzicht waren Gronsveld en Eckelrade wel gescheiden en vanaf de zeventiende eeuw werd Eckelrade voor de belastingheffing ook als een aparte eenheid beschouwd.

Ten zuidoosten van Eckelrade lag een vrijwel onbewoonde strook grond ter grootte van bijna zestig bunder, de Bijbank of 'halve heerlijkheid Eckelrade' geheten. De heer van Gronsveld hield dit gebied in leen van het leenhof van Valkenburg, maar er werd vanuit Gronsveld jurisdictie uitgeoefend. Ook fiscaal ressorteerde de Bijbank onder Valkenburg. Die situatie zorgde tot 1795 voor onduidelijke staatkundige verhoudingen.

Het dorp Heugem is waarschijnlijk gesticht rond een 'curia', een laathof van de prinsbisschop van Luik. De eerste vermeldingen van Heugem gaan terug tot de twaalfde eeuw. Ook vanuit Heugem werden de hoger gelegen gronden richting het plateau van Eckelrade ontgonnen en wel in de vorm van een lange, smalle strook grond tot aan het Savelsbos en de grens met het dorp Cadier. Mogelijk zijn ook Cadier en het gehucht Honthem op het plateau van Eckelrade vanuit Heugem gesticht.

De heerlijke rechten over Heugem zijn van de prins-bisschop van Luik via de hertog van Limburg en de hertog van Brabant in handen gekomen van de heer van Valkenburg. In 1363 schonk Walram van Valkenburg, heer van Born en Sittard, het dorp Heugem aan Johan III van Gronsveld. Vanaf dat moment makt Heugem een vast onderdeel uit van 
het bezit van de heren van Gronsveld. Mogelijke leenbanden met Luik zijn niet meer bekend. Heugem beschikte in ieder geval in het midden van de veertiende eeuw over een schepenbank met hoge en lage jurisdictie. De schepenen gingen zeker nog tot in de zeventiende eeuw, als herinnering aan oude historische banden, ter hoofdvaart naar de schepenen van Luik. Oorspronkelijk schijnen de heren van Gronsveld weinig grondbezit in Heugem te hebben gehad. Het latere grondbezit is vrijwel allemaal terug te voeren op de hof Ter Warden, maar die kwam pas in de vifftiende eeuw in Gronsvelds bezit. Wel lagen er keurmedige goederen, maar waarschijnlijk zijn die voortgekomen uit de oorspronkelijke hof van de prins-bisschop van Luik.

Ten oosten van Eckelrade lag het gehucht Honthem dat, zoals de andere dorpen op het plateau, is ontstaan uit ontginning, mogelijk vanuit Heugem. Het minuscule Honthem beschikte over een eigen schepenbank met hoge en lage jurisdictie (vroegste vermelding 1512). Op oude banden met Heugem wijst de hoofdvaart van Honthem op Heugem. Hoe en wanneer Honthem in het bezit van de heren van Gronsveld is gekomen, valt niet met zekerheid te zeggen; mogelijk gebeurde dit tegelijk met Heugem. In ieder geval wijkt de ontginningsgeschiedenis van Honthem duidelijk af van die van Eckelrade en Gronsveld. Er lag geen land dat de heer van Gronsveld in volle eigendom toebehoorde en er lagen ook geen leengoederen. Wel telde Honthem enkele keurmedige hoeves.

Tot het vroege bezit van de heren van Gronsveld behoren ook de heerlijke rechten over het dorp Slenaken. De eerste vermelding van Gronsveldse aanwezigheid in Slenaken is te vinden in een oorkonde van de schepenen van Slenaken uit 1371. Deze schepenbank beschikt over hoge en lage jurisdictie. Over de middeleeuwse ontwikkeling van Slenaken valt weinig concreets te zeggen. Mogelijk is de dorpskern zeer oud; later werden enkele buurtschappen ontgonnen. De heren van Gronsveld beschikten over weinig grond in Slenaken, wel over keurmedige goederen en cijnsgoederen, maar het is de vraag of dit teruggaat op oud bezit. Wel heel oud kunnen de rechten op de bossen zijn.

Tot de vroegste bezittingen van de heren van Gronsveld behoren ook de zogenoemde 'buitenlenen' of 'uitheemse lenen'. Het belangrijkste daarvan waren lenen in Holset en Vaals, te weten Vaalsbroek, de hof van Holset en de hof van Einrade. Verder lagen er nog tal van kleine lenen. Gronsveldse aanwezigheid in Holset is te volgen tot 1237. Belangrijke buitenlenen waren ook enkele hoven in de nagenoeg aan Gronsveld en Heugem grenzende heerlijkheid Oost.

Gedurende langere tijd werden ook de heerlijkheden Sint-Maartens-Voeren en Oost (door erfenis verworven omstreeks 1370) vanuit Gronsveld bestuurd, maar formeel vielen deze plaatsen onder Brabants gezag en hebben zij nooit deel uitgemaakt van het Land Gronsveld. Wel maakten inwoners van Oost soms gebruik van rechterlijke diensten vanuit Gronsveld.

Het Land Gronsveld kende aan het einde van de middeleeuwen een rechterlijke organisatie waarvan de ontstaansgeschiedenis uit afzonderlijke dorpen goed valt af te lezen. Er waren vier schepenbanken met hoge en lage jurisdictie, te weten Gronsveld, Heugem, Honthem en Slenaken. Daarnaast kende Gronsveld ook een landsheerlijk leenhof, dat in ieder geval vanaf het laatste kwart van de veertiende eeuw functioneerde. De schepenbanken makkten deel uit van een piramide van hoofdvaart en hoger beroep, 
die liep van Slenaken op Gronsveld, van Gronsveld op Aken op het Rijkskamergerecht en later ook direct van Gronsveld op het Rijkskamergerecht. Van Honthem liep de rechtsgang via Heugem naar Luik en ten slotte ook naar het Rijkskamergerecht. Het hoger beroep bij het leenhof was omstreden.

\section{De heren van Gronsveld van de vijftiende tot het einde van de achttiende eeun}

Het huwelijk van Diederik I van Bronckhorst Batenburg met Johanna van Gronsveld in 1425 vormde het begin van een bijna driehonderd jaar durende relatie tussen de familie Van Bronckhorst Batenburg en Gronsveld. De Bronckhorsten, die de veertiende en vijftiende eeuw in verschillende linies verdeeld raakten, behoorden tot de oeroude adel in het Gelderse rivierengebied en waren in stand vergelijkbaar met de familie Van Gronsveld. Van Diederik I is niet zeker of hij ook daadwerkeliik over Gronsveld heeft geregeerd. Van zijn zoon Hendrik I, die van circa 1475 tot 1493 regeerde, is weinig bekend. Door zijn huwelijk met Johanna Catharina van Alpen verwierf hij belangrijke bezittingen an de Nederrijn. Die Alpense erfenis verschafte ook directe toegang tot de omgeving van de hertog van Kleef. Achteraf gezien is dit het begin van een duidelijke herpositionering van familiebelangen. De goederen in het hertogdom Kleef leverden 150 jaar een belangrijk deel van de inkomsten waarop de welstand van de familie was gebaseerd. Daarmee verschoof ook bij de volgende generaties de belangstelling voor Brabant en Luik in de richting van Kleef en vervolgens ook de Nederrijns-Westfaalse Kreits en het Rijk.

Hendriks zoon Diederik II van Bronckhorst Batenburg (1493-1508) is daar het eerste voorbeeld van. Hij werd één van de invloedrijkste edelen aan het Kleefse hof en steunde de hertog in diens strijd tegen de hertog van Gelre. Voor de status van de familie was belangrijk dat Diederik in 1498 door rooms-koning Maximiliaan werd verheven in de stand der Reichsfreiberren. Bij die gelegenheid werden zowel Gronsveld als Rimburg tot rijksonmiddellijke heerlijkheden verklaard.

Diederiks zoon Johan I van Bronckhorst Batenburg (1508/1511-1558/1559) vervulde eveneens verschillende functies in het Kleefse landsbestuur. Zijn loyaliteit aan hertog Willem van Kleef bracht hem tijdens de conflicten tussen de hertog en keizer Karel V in grote problemen. Na de capitulatie van de hertog bij het Verdrag van Venlo in 1543 moest Johan de Brabantse leenrechten op Rimburg erkennen en verloor Rimburg de status van rijksonmiddellijke heerlijkheid.

De regeringsperiode van Willem van Bronckhorst (1558/1559-1563) duurde te kort om daar veel over te kunnen melden. Na zijn overlijden kregen zijn minderjarige zonen Jost en Johan een goede vorming op academisch niveau. In 1585 werden zij verheven in de stand der rijksgraven. Met deze verheffing en titel legden zij het fundament voor de stand van de familie in de zeventiende en achttiende eeuw en de daarmee verbonden rechten. Jost huwde op standsniveau met gravin Anna van Oostfriesland, een kleindochter van keizer Maximiliaan en zijn broer Johan met gravin Sybilla van Eberstein, telg uit een oeroud, Schwäbisch gravengeslacht. Door dit huwelijk ontstonden ook rechten op het graafschap Eberstein. 
De ontwikkelingen op religieus gebied in de zestiende eeuw zorgden ook voor verdeeldheid binnen de verschillende takken van familie Van Bronckhorst Batenburg. Over de confessionele gezindheid van de Gronsveldse tak is niet veel bekend, maar uit de weinige beschikbare gegevens mag worden afgeleid dat zij katholiek bleven.

Jost van Bronckhorst Batenburg regeerde van 1586 tot 1588, het jaar waarin hij sneuvelde. Hij werd opgevolgd door zijn broer Johan II van Bronckhorst Batenburg. Als graaf van een rijksonmiddellijk gebied kreeg hij toegang tot de Nederrijns-Westfaalse Kreits en zocht hij binnen die kringen ook aansluiting voor de bescherming van zijn belangen. Gronsveld zelf leed ondertussen zwaar onder de gevolgen van de Tachtigjarige Oorlog in het Maasdal. Tijdens de regering van Johan II werd ook voor het eerst in Gronsveld serieus werk gemaakt van belastingheffing voor het Rijk. Dat leidde, in combinatie met eisen tot het verrichten van herendiensten, tot heftige confrontaties met de grondeigenaren binnen het graafschap.

Meer nog dan zijn voorvaderen raakte graaf Johan II georiënteerd op het Rijk. Die lijn werd door zijn opvolger Jost Maximiliaan (1617-1662) voortgezet. Met een militaire loopbaan in Beierse dienst raakte hij betrokken bij diverse belangrijke krijgsoperaties gedurende de Dertigjarige Oorlog. Hij eindigde zijn carrière als veldmaarschalk. In het handschrift getiteld 'Coemoedia Gronsfeldiana', oorspronkelijk opgesteld als een verdedigingsschrift, heeft hij over zijn oorlogservaringen autobiografische aantekeningen nagelaten, die later in Eberhard Wassenbergs Teutsche Florus over de geschiedenis van de Dertigjarige Oorlog zijn verwerkt. Na 1648 was Jost Maximiliaan diplomaat in keizerlijke dienst en medeoprichter van het Nederrijns-Westfaalse Gravencollege. Met dit laatste werd hij een succesvol pleitbezorger voor de graven in het noordwesten van het Rijk om stemrecht te krijgen in de Rijksdag.

Jost Maximiliaan werd opgevolgd door zijn zoon Johan Frans. Ook deze koos voor een militaire loopbaan in keizerlijke dienst. Hij vocht mee in de strijd tegen de Turken en in de Spaanse Successieoorlog en eindigde zijn loopbaan als militair gouverneur van Luxemburg. Het eerste huwelijk met gravin Eleonore Philipine von Fürstenberg bleef kinderloos, uit het tweede huwelijk met gravin Maria Anna von Toerring-Jettenbach werd een dochtertje geboren, dat echter al op zeer jonge leeftijd stierf. Met het overlijden van Johan Frans in 1719 stierf het geslacht Van Bronckhorst Batenburg te Gronsveld in mannelijke lijn uit. Het graafschap vererfde op zijn weduwe Maria Anna von ToerringJettenbach.

Met de keuze voor een militaire carrière behoorden de graven van Gronsveld tot een groep van edelen uit het Maasgebied, die het in de zestiende en zeventiende eeuw tot krijgsoversten in keizerlijke of vorstelijke dienst brachten. Dat gold niet alleen voor Jost, Jost Maximiliaan en Johan Frans van Bronckhorst Batenburg, maar ook voor enkele van hun broers. Met die keuze richtte de blik van leden van de familie zich vooral op perspectieven binnen het Rijk. Een goed voorbeeld daarvan, maar dan buiten de militaire sfeer, vormt ook graaf Otto Willem van Bronckhorst Batenburg, een broer van Johan Frans, die tot wijbisschop van Osnabrück werd benoemd. Er moet financiële noodzaak voor die oriëntatie op het Rijk hebben bestaan. Het kleine graafschap Gronsveld bood geen mogelijkheden alle kinderen van levensonderhoud in overeenstemming met hun 
stand te voorzien. Maar een militaire loopbaan kende ook grote risico's. Jost Maximiliaan rakkte bijna geruïneerd en ook Johan Frans kampte met chronisch geldgebrek. Financiële problemen lopen als een rode draad door de familiegeschiedenis in de zeventiende eeuw en zorgden, in combinatie met onenigheid binnen de familie, ook voor afkalving van het eens zo omvangrijke familiebezit. Op die wijze gingen in een eeuw tijd de heerlijkheden Oost, Sint-Maartens-Voeren, Rimburg, Eberstein en uiteindelijk in 1728 als laatste Slenaken verloren.

Hoewel de graven Van Bronckhorst Batenburg weinig in het graafschap verbleven, beschouwden zij Gronsveld toch als de basis van hun familie. Zij vonden daar ook sinds het midden van de zestiende eeuw hun laatste rustplaats in de Sint-Martinuskerk en hebben met hun bijgedragen aan de restauratie en inrichting van dit gebouw een soort mausoleum voor hun familie gemaakt. In het bijzonder aan Jost Maximiliaan leeft nog de herinnering voort wegens zijn betrokkenheid bij de oprichting van de Gronsveldse schutterij en belangrijkste bouwheer van de windmolen.

$\mathrm{Na}$ het overlijden van Johan Frans van Bronckhorst vererfde het graafschap Gronsveld op zijn echtgenote Maria Anna von Toerring-Jettenbach. Deze hertrouwde met Claude Nicolas d'Arberg Valengin. Uit dit huwelijk werd één dochter geboren, Maria Josepha. Deze huwde in 1746 met haar neef Maximilian Emanuel von Toerring-Jettenbach. Maria Josepha overleed in 1753, Maximilian Emanuel in 1773. Hij werd opgevolgd door zijn jongste broer August Joseph. Deze werd de laatste regerende graaf van Gronsveld.

De regering van Claude Nicolas d'Arberg Valengin (1720-1731) vormt een treurige periode in de geschiedenis van het graafschap. Een groot deel van de grafelijke rechten werd verpacht aan een Waalse gelukszoeker, die vervolgens in ernstig conflict raakte met de Gronsveldse drossaard Lebens en de bevolking van Gronsveld. De bestuurlijke anarchie waarin het graafschap verzeild raakte, geeft een goed voorbeeld van de escalatie en onbeheersbaarheid van problemen wanneer binnen een klein, rijksonmiddellijk territorium facties tegenover elkaar kwamen te staan. Mogelijkheden tot ingrijpen van buitenaf waren uiterst beperkt.

$\mathrm{Na}$ het kort achter elkaar overlijden van Maria Anna von Toerring-Jettenbach in 1730 en Claude Nicolas d'Arberg Valengin in 1731, ontbrandde eerst een strijd over de voogdij over hun minderjarige dochter Maria Josepha. Nadat de voogdij was toegewezen aan haar oom Ignaz Felix von Toerring-Jettenbach keerde de rust binnen het graafschap enigszins terug. Het grafelijk gezag bleef in deze overgangsfase zwak. Pas in de tweede helft van de achttiende eeuw, onder Maximilian Emanuel en August Joseph von Toerring-Jettenbach, keerden geordende verhoudingen terug.

De Toerrings behoorden tot de hoge Beierse adel en voerden sinds 1630 de titel rijksgraaf, maar beschikten niet over een rijksonmiddellijk territorium. Dankzij het bezit van Gronsveld werden zij nu ook rijksstand en kregen daarmee zetel en stem in NederrijnsWestfaalse Kreits en Rijksdag. Het bezit van Gronsveld verhoogde niet alleen het aanzien van de Toerrings, maar daarnaast wilden zij van het graafschap ook een economisch renderend bezit maken. Vooral onder het bewind van hun twee achtereenvolgende vertegenwoordigers in Gronsveld, Joseph Anton Prummer en Wolfgang Zollner, lukte dat vrij goed, maar een rijke bron van inkomsten werd het graafschap niet. De graven zijn 
nooit persoonlijk in Gronsveld geweest, maar regeerden op afstand, door middel van veelvuldige correspondentie. Hun stijl van regeren was, uitgedrukt in een aantal trefwoorden, autocratisch en formeel, afstandelijk en tegelijk op details gericht, zuinig en conservatief, maar ook verlicht, zeer direct naar ondergeschikten, rechtvaardig en zeker niet onwelwillend ten opzichte van de bevolking.

De regering van graaf August Joseph eindigde door de inlijving van Gronsveld bij Frankrijk in 1795. De afwikkeling van de schadevergoeding duurde tot de Reichsdeputationshauptschluss van 1803. De als compensatie toegekende rijksabdij Gutenzell leverde slechts drie jaar een rijksgraafschap Gutenzell op, omdat dit gebied in 1806 door het koninkrijk Württemberg werd geannexeerd. Als voormalige bezitters van rijksonmiddellijk en stemhebbend graafschap kregen de Toerrings na 1815 in Duitsland de status van zogenoemde gemediatiseerde Standesherren en werden zij ebenbürtig aan regerende vorstelijke huizen.

\section{Administratieve structuren en rechterlijke organisatie circa 1500-1796.}

Het grafelijk gezag over Gronsveld ging over door erfopvolging. Bij het begin van de regering nam de graaf het graafschap met formele handelingen ten overstaan van het gerecht in bezit, waarna inhuldiging door de onderdanen volgde. De indruk bestaat dat soms terughoudend werd omgegaan met grote publieke manifestaties wegens problemen binnen de familie. Uit de tweede helft van de achttiende eeuw zijn twee gedetailleerde beschrijvingen van de plechtigheden bij inhuldiging bewaard. Het daarin beschreven protocol geeft een indruk van de opvattingen die bestonden over de verhouding tussen de graaf en zijn onderdanen.

De keerzijde van inhuldiging waren de publieke rouwplechtigheden bij het overlijden van de graaf of zijn familieleden. Over de plechtigheden bij de bijzetting van de leden van de familie Van Bronckhorst Batenburg in de Sint-Martinuskerk van Gronsveld is weinig bekend. In de tweede helft van de achttiende eeuw werden de rouwdiensten tot in het kleinste detail geregisseerde barokke spektakelstukken, bedoeld om stand en het gezag van de overledene voor de genodigden en de in groten getale toegestroomde nieuwsgierigen te demonstreren.

Binnen het graafschap was de graaf de hoogste formele en materiële wetgever. Bij eventuele onzekerheid over de uitleg daarvan, had hij ook het recht op interpretatie. Met wetgeving bewoog de graaf zich binnen de kaders van het rijksrecht, maar hij had op grond van de zogenoemde 'salvatorische clausule' de bevoegdheid er van af te wijken. Bij toepassing van wet- en regelgeving in de rechtspraak valt een bepaalde gelaagdheid vast te stellen. Op de eerste plaats kwam de wetgeving van de graaf als landsheer. Wanneer die ontoereikend was, werd een beroep gedaan op plaatselijk gewoonterecht of op regels van rijksrecht. Ten slotte kon recht worden ontleend aan de wet- en regelgeving uit naburige territoria zoals het hertogdom Brabant of prinsbisdom Luik.

Uit de achttiende eeuw zijn er ook voorbeelden van plaatselijke verordeningen van de schepenbank en van de vertegenwoordigers van de graaf. Formele bekrachtiging daarvan 
door de graaf lijkt niet nodig te zijn geweest. Het is niet bekend of voor de toepassing van kerkelijke wetgeving een formeel recht van 'placet' gold, maar ten opzichte van regelgeving door kerkelijke autoriteiten werd een kritische houding ingenomen. Door de gebrekkige overlevering van archieven is moeilijk goed zicht te krijgen op de totale omvang van de wetgeving, maar de indruk bestaat dat de regelgeving beperkt was. Het meest omvangrijk is de Rechtsordnung voor Gronsveld uit 1671, die vooral zakenrecht en erfrecht behandelt. Inhoudelijk is de tekst vrijwel woordelijk ontleend aan de 'Cöllnische Rechts-Ordnung' uit 1663. Alleen de hoofdstukken over leengoederen, keurmeden en procesrecht zijn van Gronsveldse oorsprong.

De graaf verbleef in de zestiende en zeventiende eeuw zelden in het graafschap; na 1730 is er zelfs nooit meer een bezoek van een graaf geweest. Tot aan het begin van de achttiende eeuw verliep ook schriftelijke communicatie vaak moeizaam. Pas tijdens de regering van de graven Toerring-Jettenbach nam de directe bemoeienis van de graaf toe door een intensieve briefwisseling. Deze situatie bracht met zich mee dat de uitoefening van het grafelijk gezag vanaf de zestiende eeuw tot 1795 bijna altijd was gebaseerd op delegatie. Door dit bestuur op afstand bestond er verschil tussen het formele gezag van de graaf en de werkelijke macht zoals die door zijn ondergeschikten werd uitgeoefend. Het verschijnsel deed zich ook voor in andere rijksonmiddellijke gebieden, waar de heer ver weg woonde. In deze studie zijn de gevolgen daarvan voor Gronsveld bestudeerd, maar nader onderzoek moet uitwijzen welke uitwerking dit op de bestuurscultuur binnen kleine territoria in het algemeen had. Voorbeelden uit Gronsveld maken wel duidelijk dat de grafelijke ambtenaren door gebrek aan leiding en toezicht vaak meer speelruimte kregen dan verantwoord was, zeker wanneer verschillende functies in één persoon werden verenigd.

De belangrijkste functionarissen binnen het bestuur van Gronsveld waren in de zestiende eeuw de scholtis, de drossaard, de rentmeester en na 1750 de vertegenwoordiger van de graaf (met de wisselende titels van secretaris, commissaris en directeur). Combinaties van functies bemoeilijken de samenstelling van een doorlopend overzicht per ambt. Gemiddeld waren twee personen betrokken bij het bestuur en het beheer van de grafelijke eigendommen en financiën. Niet meegerekend zijn de soms ingeschakelde juridische adviseurs en eventueel ondersteunend personeel, zoals een schrijver of bode.

De taken van functionarissen waren omschreven in instructies. Voor de zestiende, zeventiende en de eerste decennia van de achttiende eeuw is daar weinig van bewaard. Pas met een aantal instructies uit de jaren dertig van de achttiende eeuw krijgen we beter zicht op de inhoud daarvan. Instructies waren gericht op de behartiging van de rechten en financiële belangen van de graaf, maar bevatten ook voorschriften over de uitoefening van publiek gezag. Voorbeelden daarvan zijn de bijzondere bevoegdheden van de rentmeester bij de gerechtelijke inning van schulden aan de graaf.

Kenmerkend voor de bij het ambtelijk bestuur binnen het graafschap betrokken personen was dat zij behoorden tot families waarvan de leden elkaar bepaalde functies of ambten toespeelden. Meestal wisselde een familieregering na twee of drie generaties, dikwijls na problemen met de graaf over het financieel beheer. Die overgang kon het karakter krijgen van een afrekening van oude vetes, zoals omstreeks 1720 tussen de aanhangers van de 
oude drossaard Kicken en de nieuwe drossaard Lebens. Het systeem van familieregering bleek ook bestand tegen de komst van vreemdelingen. Zo verbonden de uit ZuidDuitsland afkomstige grafelijke commissarissen Joseph Anton Prummer en Wolfgang Zollner zich door huwelijk met de regerende familie Lebens.

Het elkaar toespelen van functies gebeurde openlijk en werd niet ervaren als iets verwerpelijks. Het leidde zeker niet automatisch tot incompetentie, angezien wel degelijk werd geinvesteerd in opleiding, terwijl ervaring en traditie voordelen konden opleveren voor de continuïteit van het bestuur. De nadelen manifesteerden zich vooral op andere terreinen. Het grootste gevaar school in fraude met de grafelijke financiën. De mogelijkheden daartoe waren door een gebrekkige controle en ondoorzichtige systemen in de boekhouding ruimschoots aanwezig. Het meest spectaculair waren misschien wel de malversaties van rentmeester Joannes Matthias Oligschläger in de jaren dertig en veertig van de achttiende eeuw, maar die waren zelfs voor die tijd buiten alle proporties.

De graven van Gronsveld waren niet blind voor deze problemen, maar het is niet altijd duidelijk of zij dit soort risico's bewust incalculeerden. Zelfs de zakelijk ingestelde graven Toerring-Jettenbach in de tweede helft van de achttiende eeuw kan, ondanks hun striktheid en wantrouwen ten opzichte van ondergeschikten, enige naïviteit op dit gebied niet worden ontzegd. Waarschijnlijk dachten zij door de benoeming van landgenoten als hun vertegenwoordigers loyale medewerkers te vinden, maar het succes daarvan was wisselend.

Commissaris Prummer heeft na zijn aantreden in 1752 gedurende vele jaren noeste arbeid de administratie van de grafelijke domeinen op orde gebracht. Door verbetering van het pachtbeleid, investering in bosbouw en sanering van schulden wist hij de winstgevendheid van het graafschap aanmerkelijk te verhogen. Maar geleidelijk aan raakte hij ook verstrikt in plaatselijke intriges. Door geestelijke en lichamelijke aftakeling liet hij aan het einde van zijn loopbaan veel achterstallig onderhoud na. Toch konden de door hem behaalde resultaten wel een stootje verdragen. Zijn opvolger Wolfgang Zollner zette de lijn van zijn voorganger voort, maar anders dan Prummer, die vooral oog had voor verhoging van het rendement van het graafschap, ontwikkelde Zollner ook plannen voor verbetering van de volkswelvaart. Door de politieke onrust aan het einde van de jaren tachtig van de achttiende eeuw, gevolgd door de inval van de Franse troepen, is daar uiteindelijk weinig van terechtgekomen.

Het is door de vrijwel volledige vernietiging van de archieven van de schepenbanken van Gronsveld, Heugem en Honthem (Slenaken is wel bewaard) moeilijk goed zicht te krijgen op de uitwendige geschiedenis van de schepenbanken en de rechtspraak. De rechterlijke organisatie uit de late middeleeuwen veranderde in de vroegmoderne tijd niet wezenlijk van structuur. Wel kenden de schepenbanken Gronsveld, Heugem en Honthem vanaf de zeventiende eeuw dezelfde personele bezetting. Bij de samenstelling daarvan deed zich het bekende verschijnsel van de familieregering voor, maar geschikte personen voor nauwelijks betaald werk waren moeilijk te vinden. Een 'volle bank' met zeven schepenen was zeldzaam. Vaak vervulde de drossaard of secretaris tegelijkertijd ook de rol van schepen. 
Voor de rechtszittingen werd meestal in Gronsveld vergaderd. Ook de archieven werden in Gronsveld bewaard. Alleen het driemaandelijkse 'voogdgeding' werd nog in iedere plaats afzonderlijk gehouden. Maar tot een administratieve samensmelting kwam het niet en de diverse gerechtelijke registraties bleven gescheiden.

Soms werd over de schepenbanken denigrerend gesproken als een 'boerenrechtbank'. Tot op zekere hoogte is dit wel begrijpelijk. Zo wekt de manier waarop tijdens de roerige jaren twintig van de achttiende eeuw schepenen om de paar maanden wisselden, weinig vertrouwen in de bekwaamheid van de benoemde personen. Ook later waren klachten over misstanden en knoeierijen niet onterecht. Het is echter de vraag of dat allemaal op rekening van de schepenen moet worden geschreven. Formeel gaven zij sturing aan het procesverloop en kwamen dan aan het einde tot een vonnis. Maar in de praktijk was hun rol vooral beperkt tot bemoeienis met de voortgang van zaken. De secretaris en de drossaard zorgden voor de redactie van juridische stukken en in ingewikkelde zaken werd advies van advocaten in de stad gevraagd, dat vervolgens ongewijzigd als vonnis werd overgenomen.

Tot het begin van de zeventiende eeuw kunnen vier vormen van procedures worden onderscheiden: het 'voogdgeding', de 'ordinaris' procedure in civiele zaken en eenvoudige strafzaken, de 'extra-ordinaris' procedure in criminele zaken en de 'gemeyne '(in)quest'. Bij het drie keer per jaar door iedere schepenbank gehouden voogdgeding moesten alle mannelijke inwoners aanwezig of vertegenwoordigd zijn. Tijdens de zitting konden vorderingen met een publiekrechtelijk karakter, zoals schulden aan de graaf of de kerk, aanhangig worden gemaakt. Verder werd geoordeeld over overtredingen van gemeentelijke verordeningen en konden ook gewone civiele processen worden gestart. $\mathrm{Na}$ beëindiging van het voogdgeding werden de niet afgedane zaken voortgezet tijdens de veertiendaagse 'ordinaris' zittingen of 'genachtingen'. Daar konden ook nieuwe civiele zaken worden aangebracht. In spoedeisende criminele zaken werd 'extra-ordinaris', op verkorte termijn, geprocedeerd. De eens per jaar in iedere plaats gehouden 'gemeyne (in)quest' heeft waarschijnlijk bestaan tot het begin van de zeventiende eeuw. Deze procedure had betrekking op de bestraffing van gedrag in strijd met de publieke moraal of kerkelijke geboden.

Sinds 1671 gold de Gronsveldse Rechtsordnung als bron voor het toe te passen materiële en formele recht. Maar waarschijnlijk werden alleen de hoofdstukken over keurmedige en leengoederen, het verbod op goederen in de 'dode hand' en het procesrecht regelmatig toegepast. Voor de rest werd inspiratie gezocht in een mengelmoes van Luiks en Brabants recht, rijksrecht en plaatselijk gewoonterecht. Overigens bestond ook tussen de schepenbanken onderling geen volledige eenheid in het toe te passen recht, zoals blijkt uit de verschillen in proceskosten en gerechtelijke termijnen.

Het leenhof van Gronsveld, zoals dat vanaf het einde van de middeleeuwen bestond, kende in de vroegmoderne tijd nauwelijks organisatorische veranderingen. De functie van stadhouder werd in 1710 een erfelijk ambt, maar in de jaren dertig van de achttiende eeuw kocht de graaf die erfelijke rechten weer af. In personeel opzicht bestond een sterke verwevenheid met de schepenbanken, omdat de functies van stadhouder en leenmannen 
werden bekleed door drossaard, scholtis en schepenen. Soms werd ook voor leenhof en schepenbank tegelijk geprocedeerd, maar de administratie bleef gescheiden.

Het materiële en formele leenrecht van Gronsveld lag vast in de Rechtsordnung van 1671 en was waarschijnlijk gebaseerd op een niet bewaard gebleven Lehenordtnung van 1593. Het procesrecht volgde zoveel mogelijk dat van de schepenbanken. Vanaf de tweede helft van de achttiende eeuw werd echter nauwelijks nog voor het leenhof geprocedeerd.

Wat betreft het aantal lenen bereikte het leenhof in de zestiende eeuw zijn grootste omvang. Daarna begon een periode van afkalving. Door de verkoop van de heerlijkheden Sint-Maartens-Voeren, Oost en Slenaken gingen de daar gelegen lenen verloren. Een voortdurend probleem vormde de discipline om bij overlijden van een leenman of overdracht van een leengoed te komen tot een nieuwe leenverheffing bij het hof. Daarom was het moeilijk de leenadministratie op orde te houden. Een bron van voortdurende zorg vormde de jurisdictie over 'uitheemse lenen' in Vaals en Holset, omdat die op buitenlands grondgebied lagen. Pas in het midden van de achttiende eeuw werden daar de verhoudingen gestabiliseerd.

Als een rode draad door de geschiedenis van zowel de schepenbanken als het leenhof lopen de problemen over hoger beroep. De middeleeuwse hoofdvaartketens van Slenaken-Gronsveld-Aken en van Honthem-Heugem-Luik bleven tot in de zeventiende eeuw bestaan. De overgang van hoofdvaart naar hoger beroep verliep zeer geleidelijk. Als hoogste beroepsinstantie fungeerde vanaf het begin van de zestiende eeuw het Rijkskamergerecht. Vanaf het einde van de zestiende/begin zeventiende eeuw kwam de positie van de Schepenstoel van Aken als 'overbodige' tusseninstantie onder druk te staan. Dat gold niet alleen voor de relatie tussen Gronsveld en Aken, ook andere rijksonmiddellijke plaatsen wilden deze rechtsgang beëindigen. In Gronsveld ontstonden daarover tot in de jaren dertig van de achttiende eeuw regelmatig conflicten, waarbij aan Akense kant de inzet van fysiek geweld niet werd geschuwd.

Het in Gronsveld aangeboden alternatief voor het hoger beroep op Aken werd sinds de laatste decennia van de zeventiende eeuw een door de graaf aangewezen jurist als appelcommissaris. Vergelijkbare ontwikkelingen zijn ook voor andere plaatsen vast te stellen. Tot een echt hof van beroep heeft de appelcommissaris in Gronsveld zich niet ontwikkeld. Daarvoor was het aantal zaken te gering in aantal. Maar deze mogelijkheid van appel betekende een aanmerkelijke besparing in tijd en kosten voor partijen die in hogere instantie een uitspraak wensten. Bovendien leidde het tot een zeer sterke daling van het aantal beroepszaken bij het Rijkskamergerecht. Wel werd nog regelmatig in eerste aanleg bij het Rijkskamergerecht geprocedeerd in de gevallen dat de gedaagde een rijksonmiddellijk persoon was, zoals de graaf.

Ook het Gronsveldse leenhof kende vergelijkbare problemen met de Schepenstoel van Aken als tusseninstantie. Vanaf het begin van de zestiende eeuw werd rechtsreeks appel in gesteld op het Rijkskamergerecht, maar daarnaast bestond ook de mogelijkheid van beroep op een tijdelijk samengesteld hof van 'sterkere leenmannen'. In het midden van de zeventiende eeuw probeerde de Schepenstoel van Aken ook hier (uiteindelijk tevergeefs) een voet tussen de deur te kriigen. Aangezien in de loop van de achttiende eeuw 
nauwelijks nog voor het Gronsveldse leenhof werd geprocedeerd, bleven beroepszaken verder uit.

In Hoofdstuk 15 wordt een inventarisatie gepresenteerd van alle rechten en vaste inkomsten waarover de graaf als heer van Gronsveld beschikte, met uitzondering van het recht van wetgeving en het recht op de rechtspraak. Die zijn afzonderlijk behandeld bij wet- en regelgeving in het algemeen en de schepenbanken. De lijst omvat aanzienlijk meer dan wat gewoonlijk in de rechtshistorische literatuur onder 'klassieke' (lands)heerlijke rechten wordt verstaan. Zeker binnen een klein territorium als Gronsveld waren de juridische, economische en ook symbolische aspecten van rechten nauw met elkaar verweven. Dat blijkt ook uit eigentijdse lijsten, waar allerlei rechten door elkaar worden opgesomd. Systematische indelingen daarvan zorgen voor meer verwarring dan overzichtelijkheid, omdat een benadering vanuit een economische invalshoek heel anders kan worden ervaren dan een juridische benadering. Systematische indeling zegt ook weinig over het werkelijke belang dat aan rechten werd toegekend. Zo geldt het recht op de rechtspraak in de literatuur als de kern van een heerlijkheid, maar de feitelijke bemoeienis van de heer daarmee was gering en de inkomsten daaruit legden meestal niet veel gewicht in de schaal. Voor de heer van Gronsveld had het muntrecht in de zestiende en zeventiende eeuw grote waarde als symbool van staatkundige onafhankelijkheid, maar het leverde, in tegenstelling tot wat men zou verwachten, financieel slechts beperkt gewin. Als laatste voorbeeld van het verschil tussen het theoretische en werkelijke belang kunnen de collatie en patronaatsrechten worden genoemd. Meestal worden deze niet als heerlijke rechten beschouwd, maar in handen van de graaf van Gronsveld verschaften ze juist de legitimatie om zich als overheid intensief met de personele en zakelijke belangen van de kerk te bemoeien. Vergelijkbare situaties zien we ook in andere kleine rijksonmiddellijke gebieden.

Het totaal aan rechten vormde geen statisch geheel. Er bestond wel een vaste kern, maar verder kwamen en verdwenen rechten. Een voorbeeld levert het al eerder genoemde muntrecht, dat na 1719 in Gronsveld niet meer werd uitgeoefend. Een 'nieuwigheid' daarentegen (met zeer geringe feitelijke betekenis) was waarschijnlijk aan het einde van de achttiende eeuw de toepassing van het 'jodenregaal', de belasting die joden moesten betalen wegens hun verblijf binnen het graafschap.

De rekeningen van de rentmeesters uit de zestiende eeuw vertonen grote overeenkomst met de manier waarop de inkomsten in de achttiende eeuw werden verantwoord. Dat weerspiegelt ook de conservatieve omgang met deze rechten. Voor zowel de heer als de onderdanen waren het nauwkeurig omschreven lasten en verplichtingen, waar nauwelijks iets aan kon of mocht worden veranderd. De opbrengsten uit monopolies, vergunningen en belastingen, leverden bij elkaar opgeteld amper de helft van het totaal aan inkomsten. Het meeste inkomen werd behaald met gewone pachten, erfpachten, tienden en cijnzen. Aangezien de daarvoor staande vaste bedragen vaak werden betaald in natura (vooral graan), werd de omzetting van die opbrengst in geld sterk beïnvloed door de toevallige marktprijs. Pas in de tweede helft van de achttiende eeuw leidde de verandering van 
graanpachten en graanrentes in vaste geldbedragen tot aanzienlijke verbetering van rendement.

Van ieder recht waarover de graaf van Gronsveld beschikte is, voor zover de beschikbare bronnen dat toelieten, een beschrijving gemaakt van de juridische betekenis en eventueel ook de economische waarde. De volledigheid van de lijst kan echter niet worden gegarandeerd. Sommige rechten krijgen daarbij een duidelijk accent. Zo neemt het muntrecht een bijzondere positie in, zowel wat betreft de herkomst daarvan, de symbolische waarde en het toezicht daarop.

De uitgebreide aandacht voor patronaats- en collatierechten berust niet op toeval. Deze rechten werden gebruikt voor het bedrijven van (niet altijd succesvolle) kerkpolitiek op plaatselijk niveau. De benoeming van Beierse geestelijken in de achttiende eeuw levert daar een duidelijk voorbeeld van op. De waarde die aan dit recht werd gehecht blijkt wel uit het feit dat zelfs na 1795, toen de heerlijke rechten al waren afgeschaft en Gronsveld bij Frankrijk was ingelijfd, de graaf zich nog met pastoorsbenoemingen bemoeide. Ook werd vooral in de tweede helft van de achttiende eeuw geprobeerd greep te krijgen op het kerkelijk goederenbeheer.

In Hoofdstuk 16 wordt een overzicht gegeven van de belastingen die de graaf van Gronsveld als rijksstand aan het Rijk moest afdragen. Het ging daarbij om betalingen ten behoeve van de defensie van het Rijk, het onderhoud van het Rijkskamergerecht, het onderhoud van de Nederrijns-Westfaalse Kreits en het onderhoud van het NederrijnsWestfaalse Rijksgravencollege, inclusief de vertegenwoordiging van dit College in de Rijksdag. Grondslag voor de belastingheffing was de Wormser Rijksmatrikel van 1521 met een opsomming van alle belastingplichtige rijksstanden.

De belastingen voor de defensie van het Rijk werden berekend in een zogenoemde Römermonat, het bedrag dat nodig was om een leger van (afgerond) vierduizend ruiters en twintigduizend voetknechten gedurende één maand te kunnen financieren. In de matrikel lag vast welk aandeel (het simplum) een rijksstand in deze Römermonat moest betalen. De feitelijke aanslag in de belasting bestond uit het aantal benodigde Römermonate vermenigvuldigd met het simplum of een veelvoud (bijv. drie of negen keer) daarvan, afhankelijk van de werkelijke grootte van het leger. De basisomvang van het rijksleger zoals die in de zestiende eeuw was vastgelegd, werd in 1682 herzien in de zogenoemde Reichsdefensionalordnung, waarbij was bepaald hoeveel troepen iedere kreits moest leveren en hoe groot het simplum van ieder rijksstand daarin bedroeg. Voor de Nederrijns-Westfaalse Kreits kwam dit in totaal op 1321 ruiters en 2708 infanteristen, exclusief de 'prima plana', bestaande uit de legerstaf en lagere officieren. Deze aantallen bleven maatgevend gedurende de hele achttiende eeuw.

De bedragen die in het simplum werden genoemd, werden ook gebruikt als basis voor de heffingen ten behoeve van de Nederrijns-Westfaalse Kreits en het Rijksgravencollege. Het Rijkskamergerecht werd gefinancierd met de zogenoemde Kammerzieler, een halfjaarlijkse bijdrage. De bedragen die daarvoor in de Wormser Matrikel werden genoemd, zijn later enkele keren bijgesteld.

Een onderzoek naar de precieze belastingdruk voor het graafschap Gronsveld is op basis van de Gronsveldse archieven moeilijk, enerzijds door het beperkte aantal bronnen en 
anderzijds door de diverse verrekeningen, kortingen en verschuivingen met manschappen in het leger. Na 1682 bedroeg het simplum voor Gronsveld twaalf Rijnse guldens, na 1760 achttien Rijnse guldens. Omdat voor een Römermonat het simplum meestal werd vermenigvuldigd met de factor drie, betaalde men gemiddeld per maand veertig gulden (drie maal basisbedrag met bijkomende kosten), exclusief de 'prima plana'. Maar in tijd van oorlog kon door een hoog aantal Römermonate en de vermenigvuldiging van het simplum het eindbedrag flink oplopen.

Römermonate werden alleen geheven voor defensie en oorlogen die vanwege het Rijk werden gevoerd, niet voor oorlogen tussen rijksstanden onderling. De belangrijkste oorlogen waar Rijk bij betrokken raakte waren de strijd tegen de Franse expansie aan het einde van de zeventiende en het begin van de achttiende eeuw, verder de Zevenjarige Oorlog (1756-1763), maar vooral de vanaf de zestiende eeuw regelmatige oplaaiende strijd tegen de Turken. De daarvoor geheven Türkensteuer komt ook regelmatig in de archieven van Gronsveld ter sprake.

De betalingsmoraal van de individuele rijksstanden liet vaak te wensen over. Die tekorten ontstonden door onwil of onvermogen van een rijksstand, maar waren ook een gevolg van een gebrekkig systeem van inning. Grote achterstanden waren niet zeldzaam. Zo moest voor Gronsveld in de tweede helft van de achttiende eeuw een regeling worden ontworpen om de gedurende vele decennia opgebouwde achterstand in Kammerzieler voor het Rijkskamergerecht af te bouwen.

In de systematiek van de belastingheffing was de landsheer als rijksstand aansprakelijk voor de betaling, maar het bedrag werd opgebracht door de onderdanen. Binnen het graafschap Gronsveld gebeurde dat met grondbelasting, een zogenoemde heffing op 'het reëel', die de eigenaren of geërfden moesten opbrengen. Waarschijnlijk werd de grondbelasting aan het einde van de zestiende eeuw geïntroduceerd door graaf Johan II van Bronckhorst Batenburg. Dat lokte grote weerstand uit bij de geërfden, in het bijzonder de Maastrichtse instellingen als grootste grondeigenaren binnen het graafschap. Het verzet kwam deels voort uit het feit dat deze belastingen nieuw waren, maar steunde vooral op de mening van de Maastrichtenaren dat zij buiten hun stad van belastingen waren vrijgesteld. Daar kwam bij dat de Maastrichtenaren categorisch weigerden samen met de inwoners van het graafschap mee te betalen in de 'personele' belastingen op huishoudens en het bezit van vee. Die heffingen werden gebruikt voor de betaling van vorderingen die door doortrekkende legers werden opgelegd. De houding van de Maastrichtenaren veroorzaakte ook veel problemen in andere dorpen in de omgeving. Juist omdat de opvattingen over deze belastingvrijdom zo fundamenteel verschilden, zijn wat meer diepgaande beschouwingen gewijd aan de achtergronden van deze problematiek. Het conflict tussen de graaf en zijn onderdanen werd na processen voor het Rijkskamergerecht in 1611 bijgelegd in die zin dat de geërfden in principe bereid waren grondbelasting te betalen. Maar in de loop van de zeventiende en de eerste helft van de achttiende eeuw laaide de onenigheid daarover met regelmaat op. Dat leidde tot nieuwe reglementen met betrekking tot de uitschrijving, inning en besteding van de belastingen. De verhoudingen werden zwaar op de proef gesteld toen na 1750 de financiële gevolgen van de Oostenrijkse Successieoorlog moesten worden afgewikkeld. Uiteindelijk slaagde de 
grafelijke vertegenwoordiger Prummer er na moeizame onderhandelingen in ook de kosten van leveranties aan legers als 'reëel', dat wil zeggen betaalbaar uit grondbelasting, erkend te krijgen.

In de zeventiende en het begin van de achttiende eeuw traden de geërfden wel gezamenlijk op bij problemen over belastingen, maar van een vaste organisatie kan niet worden gesproken. Pas in een akkoord uit 1739 nam de collectiviteit een meer vaste vorm aan. De procedure voor vergadering en het stemrecht van de verschillende belanghebbende partijen werden geregeld. Jaarlijks werden een begroting en een rekening vastgesteld. Vanaf circa 1744 wordt gesproken over de 'standen' of 'standen en geërfden' van het Land Gronsveld. Meestal werd één keer per jaar vergaderd, vrijwel uitsluitend over belastingen. Maar ondanks deze beperkte agenda, kan de vorming van deze standenvergadering worden gezien als een fase in de staatsontwikkeling, die bij grote landsheerlijkheden al aan het einde van de middeleeuwen was begonnen, maar zich nu ook bij kleine territoria doorzette. Vergelijkbare ontwikkelingen zien we ook bij rijksonmiddellijke territoria als Wittem en Wylre.

Naast een organisatie van geërfden telde het graafschap ook een vijftal gemeenten, te weten Gronsveld, Eckelrade, Heugem, Honthem en Slenaken. Deze bestonden uit het collectief van inwoners, met als doel de behartiging van gemeenschappelijke belangen, in het bijzonder de gemeenschappelijke weidegronden, waarop de inwoners hun vee lieten grazen. Vanaf het einde van de zestiende eeuw kwam daar als belangrijke taak bij de heffing van personele belastingen op huishoudens en vooral het bezit van vee, om daarmee de vorderingen van doortrekkende legers te betalen. Daarvoor werd ook geld geleend, waarvoor gemeentelijke eigendommen tot onderpand werden gesteld en de inwoners borg stonden.

Wanneer de afzonderlijke gemeenten zijn ontstaan is niet helemaal duidelijk. De gemeenten Gronsveld, Heugem en Slenaken hadden een middeleeuwse oorsprong. Dat hangt ook samen met het feit dat de inwoners van deze dorpen beschikten over gemeenschappelijke weidegronden. Eckelrade en Honthem lijken pas aan het einde van de zestiende eeuw als gemeente te zijn ontstaan, vooral als gevolg van de heffing van personele belastingen waarmee militaire vorderingen werden betaald. Gemeenschappelijke gronden waren daar nauwelijks voorhanden.

Aan de besluitvorming binnen de gemeente konden alle mannelijke gezinshoofden deelnemen. Hoewel vergaderingen van de gemeente vaak ook om praktische redenen werden gekoppeld aan het voogdgeding (bijvoorbeeld voor de gerechtelijke beëdiging van functionarissen), mogen beide bijeenkomsten niet met elkaar worden vereenzelvigd. Het voogdgeding was een rechtszitting, de gemeentevergadering niet.

Als collectief en eigenaar van gemeenschappelijke gronden én schulden had de gemeente rechtspersoonlijkheid. Enerzijds was het eenvoudig als collectiviteit verplichtingen aan te gaan, anderzijds was het idee van de rechtspersoonlijkheid ook niet sterk ontwikkeld. Bij financiële verplichtingen bleven vaak de inwoners naast de gemeente hoofdelijk aansprakelijk. De vertegenwoordiging van de gemeente lag aanvankelijk in handen van enkele daarvoor aangewezen personen, maar vanaf het einde van de zeventiende eeuw 
wordt gesproken over een dorpsmeester of burgemeester. Diens belangrijkste taak was de samenstelling van de belastinglijsten. Verder stelde de gemeente een veldbode aan om toezicht te houden op het veld en bij de gemeenschappelijke weidegronden.

Door de graaf en zijn ambtenaren werden activiteiten van de gemeenten en in het bijzonder de burgemeester met argwaan bekeken. Zo werd aan het einde van de achttiende eeuw de strijd tegen de invoering van tienden op aardappelen gezien als een voorbeeld van oppositie tegen het grafelijk gezag en geldverspilling ten koste van de inwoners. Daarom werd geprobeerd de rol van burgemeesters in te perken en financiële fondsvorming tegen te gaan.

\section{Slotbeschouwing}

Het is moeilijk voor de vele onderwerpen die in dit boek zijn besproken een balans op te maken die leidt tot één algemene conclusie. Door de concentratie van aandacht op het graafschap Gronsveld lijkt dit in het brandpunt van de geschiedenis te staan. Dat komt uiteraard niet overeen met de historische werkelijkheid. Er lagen in de omgeving van Gronsveld diverse kleine onafhankelijke territoria behorend tot het Heilige Roomse Rijk der Duitse Natie. In dat opzicht nam Gronsveld geen uitzonderlijke positie in. Dat is al helemaal niet het geval wanneer we een vergelijking maken met het tegenwoordige Duitsland, waar ooit tientallen graafschappen deel uitmaakten van het Heilige Roomse Rijk. Wanneer we hierna proberen het graafschap in de vroegmoderne tijd op basis van een aantal trefwoorden in een soort 'profiel' te karakteriseren, dan hoeft de uitkomst daarvan zeker niet specifiek voor Gronsveld te zijn.

De eerste karaktertrek zou kunnen worden samengevat met het woord 'isolement'. Daarbij gaat het niet zozeer om bereikbaarheid in geografische zin, maar om een politiek isolement. Voor de graven die in keizerlijke of Beierse dienst carrière maakten of de graven Toerring-Jettenbach die in Beieren woonden, was het begrip Heilige Roomse Rijk der Duitse Natie een reëel begrip. Verder waren ook de inwoners van het graafschap zeker niet onkundig van wat zich in de buitenwereld afspeelde, maar gevoelsmatig stonden zij op afstand van het Rijk. De betrokkenheid bij besluitvorming binnen het Rijk was minimaal. De samenwerking binnen het Nederrijns-Westfaalse Gravencollege en de NederrijnsWestfaalse Kreits was formeel, maar leverde geen 'netwerk' op. Met andere rijksonmiddellijke territoria in de omgeving, al dan niet met de status van rijksstand, bestonden alleen incidentele contacten. Zelfs met het aangrenzende rijksonmiddellijke Rijckholt waren verhoudingen zakelijk, formeel en niet echt hartelijk.

Het Rijk kreeg in het leven van de Gronsveldenaren vooral betekenis door belastingen en soms door uitspraken van het Rijkskamergerecht. Er moest worden betaald voor de defensie van het Rijk, maar daarmee kon niet altijd militaire overlast worden voorkomen. Tegelijkertijd hield de graaf geen staand leger onder de wapenen, speelden de met de belastingen gefinancierde oorlogen zich meestentijds buiten het graafschap af en bood de status van rijksonmiddellijk graafschap bescherming tegen ongewenste interventie van buren bij conflicten.

Afstand bestond ook tussen het rijksonmiddellijke graafschap en het omringende 'buitenland'. Contacten bleven beperkt tot het strikt noodzakelijke, bijvoorbeeld bij 
rechtshulp of problemen over grenzen. Aan verdergaande samenwerking viel niet te denken. In de tweede helft van de achttiende eeuw kreeg die afstandelijkheid nog een confessioneel tintje in die zin dat de katholieke grafelijke commissarissen in Gronsveld niet gebrand waren op samenwerking met de 'Hollandse' protestantse gezagsdragers in de aangrenzende dorpen.

Een tweede typering betreft het conservatieve karakter van de samenleving, gericht op behoud van het bestaande. Het proces van 'staatsvorming' uit afzonderlijke dorpen was rond 1400 tot stilstand gekomen en had een complexe bestuurlijke en rechterlijke organisatie opgeleverd. In de eeuwen daarna kende die wel enige ontwikkeling en aanpassingen, maar het leidde niet tot fundamentele veranderingen. Ook het bestuur werkte volgens vaste, nauwelijks aan verandering onderhevige procedures. Conservatisme kan worden uitgelegd als stilstand, maar leidde ook tot stabiliteit en rechtszekerheid.

De verschillende dorpen en gehuchten vormden besloten gemeenschappen met de neiging meer voor het belang van hun eigen dorp dan voor het landsbelang op te komen. Die verdeeldheid tussen dorpen komt soms bij conflicten met de graaf tot uiting, wanneer één of meer dorpen zich afzijdig hielden. Het gebrek aan solidariteit werd nog versterkt door de tegenstelling die bestond tussen de fiscale belangen van de geërfden als grondbezitters en de inwoners van de gemeenten. Daar kwam nog bij dat binnen de groep van geërfden personen en instellingen van buiten het graafschap de toon aangaven. Gebrek aan eensgezindheid was zeker een belemmering in verdere ontwikkeling. Toch zijn er ook wel voorbeelden dat de aandacht voor het dorpsbelang positieve kanten kon hebben. Zo kan worden gewezen op het initiatief in Eckelrade om eigen waterputten te bouwen of de strijd van de inwoners van Heugem voor de restauratie van hun kerk.

De derde typering heeft betrekking op de kracht van bestuur en rechtspraak. Op de kwaliteit daarvan viel veel aan te merken, maar de situatie in Gronsveld was niet veel beter of slechter dan die in de omringende gebieden. Er mag binnen Gronsveld worden gesproken van een grote loyaliteit aan de graaf en de landsheerlijke gezagsdragers. Dat betekent niet dat er geen problemen bestonden. Tegenstellingen tussen bepaalde groepen personen konden de verhoudingen binnen een kleine gemeenschap ernstig vertroebelen, maar slechts één keer werkten die echt ontwrichtend. De corruptie binnen het bestuur vormde een chronisch probleem, maar deed vaak meer schade aan de belangen van de graaf dan aan die van de inwoners. De inwoners waren verplicht te betalen voor de heerlijke rechten waarvan de graaf gebruik maakte, maar daar staat tegenover dat de kosten voor het bestuur vrijwel volledig door de graaf werden gefinancierd.

De balans opmakend, mogen we vaststellen dat het graafschap Gronsveld in de loop der eeuwen een op zichzelf staande gemeenschap met conservatieve inslag was, niet vrij van interne problemen, maar voldoende stabiel om als kleine, zelfstandige rijksheerlijkheid te kunnen functioneren. Aan het einde van de achttiende eeuw waren er zeker geen symptomen die de levensvatbaarheid op dat moment bedreigden.

Met de kreet 'guerre aux châteaux' ('oorlog aan de kastelen') waarmee de Franse revolutionairen op 1 februari 1793 de Gronsveldse archieven uit het kasteel gooiden en 
verbrandden, begon de tien jaar durende onttakeling van het graafschap Gronsveld. Formeel eindigde die met de ondertekening op 25 februari 1803 van de Reichsdeputationshauptschluss te Regensburg, waarbij aan graaf Joseph August von ToerringJettenbach de geseculariseerde rijksabdij Gutenzell als schadeloosstelling werd toegekend. Feitelijk was het graafschap al op 1 oktober 1795 als onderdeel van het departement Nedermaas bij Frankrijk ingelijfd en deelde daarmee hetzelfde lot als de andere territoria aan de Maas. Waarschijnlijk koesterden de meeste Gronsveldenaren gemengde gevoelens over deze 'ongewilde revolutie'. Op korte termijn betekende de omwenteling het einde van het gezag van de graaf, verbreking van de banden met het Rijk en vervanging van de bestaande bestuurlijke en rechterlijke organisatie door nieuwe instellingen.

Vanaf het moment van de inlijving maakte Gronsveld voor het eerst in de geschiedenis deel uit van een grote, nationale staat en werden de Gronsveldenaren Franse staatsburgers. Maar of zij zich zo ook voelden? De Gronsveldenaren leden waarschijnlijk onder hetzelfde staatkundige identiteitsprobleem als de andere inwoners van de gebieden van de Maas, die na 1815 als 'Limburgers' door het leven gingen. De staatkundige veranderingen in de negentiende eeuw (1815 Verenigd Koninkrijk, 1830 België, 1839 Koninkrijk der Nederlanden en 1866 opheffing Duitse Bond) maakten van de Limburgers pas langzaam Nederlanders.

Geleidelijk aan verdween daarmee ook de herinnering aan het rijksonmiddellijk graafschap als deel van het Heilige Roomse Rijk uit het collectieve geheugen van de inwoners. De geografische vorm van het oude graafschap bleef vooralsnog behouden in de nieuwe gemeente Gronsveld, maar door de gemeentelijke herindelingen in 1920, 1943, 1982 en 2011 verdwenen ook deze grenzen. Bewaard gebleven zijn de zichtbare herinneringen aan het verleden, zoals de restanten van het oude kasteel, de oude banmolen en de SintMartinuskerk, waar de Bronckhorsten prominent zijn vertegenwoordigd. Maar of deze 'stille getuigen' in de $21^{\text {ste }}$ eeuw nog door iedereen kunnen worden geplaatst in de geschiedenis van de graven van Gronsveld? En dan is er nog eens in de vier jaar de folklore van de Grote Bronk. Nog altijd wordt voorafgaand an het vogelschieten op Pinkstermaandag het in 1778 door graaf August Joseph von Toerring-Jettenbach uitgevaardigde reglement voorgelezen. Na de Sacramentsprocessie geeft de schutterij de 'generale charge' voor 'de stichter' graaf Jost Maximiliaan van Bronckhorst Batenburg. De nieuwe 'schutten' drinken bij hun aanname bier uit de beker, die graaf Maximilian August von Toerring-Jettenbach in 1828 schonk ter herinnering aan de oude banden van zijn familie met het graafschap. Het zijn van generatie op generatie met zorg doorgegeven gebruiken, maar slechts weinigen zullen deze in een volledige historische samenhang kunnen plaatsen. Misschien vormt deze studie over het 'zonneleen Gronsveld' als eertijds onafhankelijk, rijksonmiddellijk graafschap een schakel tussen het nog zichtbare en het in gebruiken beleefde verleden. 


\section{Summary}

\section{Theme and Background}

Until 1795 the land of Gronsveld consisted of a small, independent territory southeast of the city of Maastricht. It formed part of the Holy Roman Empire of the German Nation. From 1498 onwards the seigneurs of Gronsveld bore the title of Reichsfreiherr (imperial baron) and after 1586 the title of Reichsgraf (imperial count). They recognised the direct or 'immediate' authority of the Emperor and the supreme institutions within the Empire, and subjected themselves to the supreme laws of the Empire. However, they regarded their rights to the land and its inhabitants as property over which they had full dominion (allodium), rights which emanated from 'God and the sun'. Thus, in the terminology of a feudally structured community, Gronsveld was a solar feud (Sonnen-Lehn/feudum solare). Within the hierarchy of the Empire, the count of Gronsveld enjoyed the status of imperial estate (Reichsstand) and as such enjoyed a -very modest- right to participate in the political decision-making within the Empire.

This study discusses the legislative, administrative and justice systems within the county during the Early Modern Era, the manner in which these were shaped by the persons and institutions involved, and the means and rights of which these could avail themselves. This is preceded by an analysis of the way in which, during the late Middle Ages the land of Gronsveld originated from separate villages. Extensive attention is also paid to the history of the seigneurs of Gronsveld, since their history is intricately connected with the history of the land. In the Middle Ages the house of Van Gronsveld managed to preserve the independence of their territory vis-à-vis important princes, in particular the Duke of Brabant, by lending money to the dukes and obtaining offices in their service. Because of the alliance between the families of Van Bronckhorst-Batenburg and Van Gronsveld in the fifteenth century, the original orientation towards Brabant (and to a lesser extent Liège) shifted around 1500 to the Duchy of Cleves and the Lower Rhine Region. As a result of the elevation in 1498 of Diederik II Van Bronckhorst-Batenburg to Reichsfreiherr and of his great-grandsons, Jost and Johan II, in 1586 to Reichsgraf, the eyes were clearly cast towards the east, towards the Empire. These elevations made that the seigneurs of Gronsveld increasingly emphasized the immediate character of their territory, with all the rights and obligations attached. By opting for the Empire, they stood with their backs, as it were, to the Habsburg Netherlands. The fact that a person belonged to the nobility of the Holy Roman Empire also paved the way in the seventeenth century for military and diplomatic careers in the service of the Emperor. The relations within these circles also made it easier to defend the county's independence and neutrality in times of war. At the same time, the elevations entailed some disadvantages. Around 1600, for instance, hitherto unknown taxes were introduced in Gronsveld for the benefit of the Empire. The all too frequent absence of the count also affected the way in which the county's administration needed to be organised.

Very small, independent territories were neither a rarity in the Low Countries nor in the German Empire. The Republic of the United Provinces counted several enclaves within 
its borders which claimed to be independent seigneuries. In practice, however, they were considered to be attached to the Republic. In any case, none of these territories met the requirements of an imperial estate. The Holy Roman Empire, however, comprised more than 1,800 states and statelets, some three hundred of which were represented in the Imperial General Assembly (Reichstag) as imperial estates. In the nineteenth century the proponents of German unity referred somewhat disparagingly to this phenomenon as 'Kleinstaaterei', a patchwork of statelets.

Within the present-day Netherlands only the province of Limburg had small independent territories that in one way or another were attached to the Empire, not including the 'Limburg' parts of the Duchies of Gulik and Cleves and the enclaves connected with Cleves in the provinces of Northern Brabant and Guelders. As the status of these territories varied, which had to be determined on a case-by-case basis, a conscious choice has been made for a vague definition. Not much legal weight must be attached to such blanket descriptions as independent imperial seigneuries. Only three territories, namely Thorn, Wittem and Gronsveld, may ultimately be considered imperial estates.

Although there exists literature that deals with the immediate territories of the 'Netherlands', this literature is usually limited to partial studies in the form of articles. Nor do more comprehensive treatises pay much attention to their complex relations with the Empire. It has virtually escaped attention in Dutch historiography that these territories form part of the history of the Netherlands as it is today. The only exception found is the study by Nève on the Reichskammergericht. This means that Dutch-language literature is of rather limited use for research purposes. More in-depth knowledge needs to be retrieved mainly from German-language literature. The problem here is the vast quantity of that literature, making it almost impossible to obtain a comprehensive insight. In order to circumvent this problem, a middle ground was found for the purposes of this study of Gronsveld. At several places in the text, attention is paid to the organisation and institutions of the Empire on the basis of German reference books and a number of monographs, where necessary, so as to make it possible to place certain notions in a broader context.

The relations between Gronsveld and the Empire were diverse. In the area of jurisdiction, the Reichskammergericbt and the Reichshofrat served as the highest-ranking imperial courts. In his capacity of imperial estate, the count sat on the Lower Rhine-Westphalian Circle (Kreis) and the Lower Rhine-Westphalian Corporation of imperial counts, the Reichsgrafenkollegium. As a member of the Reichsgrafenkollegium, he was also represented in the Reichstag. This study contains but a very modest investigation into the actual role of Gronsveld within these imperial bodies. This also holds true for its relations with other imperial estates. Broader comparative research is needed to properly comment on this matter. Extensive research has been conducted, however, into the supervisory role of the Circle in relation to the exercise of the right of coinage and the taxes which the county of Gronsveld was required to collect on behalf of the Empire.

Apart from the medieval period and the family history of the seigneurs of Gronsveld, the study is mainly based on archival research. An overview of these sources has been included in the introduction. Very little has survived in Gronsveld of the original archives 
relating to the seigneurs and counts and the judicial institutions. These records were destroyed as a result of the invasion by French troops in 1793. What remains is preserved by the Limburg Centre of Regional History (Regionaal Historisch Centrum Limburg) located in Maastricht. The files containing records of legal proceedings instituted by Gronsveld before the Reichskammergericht proved to be very important additional sources. These are also found in the Limburg Centre of Regional History. This is the first time that their contents have been extensively used. Of major importance as well are the archives of the Counts zu Toerring Jettenbach, of which custody was given to the Munich State Archives (Staatsarchiv München). These contain a sort of counter-archive of the records kept in Gronsveld in the days of the involvement of the Counts zu Toerring Jettenbach with Gronsveld during the eighteenth century. In addition, the archives contain documents from earlier periods (retroacta) and documents that were removed from Gronsveld and taken to Munich in 1793. The extensive volume of eighteenth-century correspondence reveals an exceptional quantity of background information on the functioning of the administration and the judiciary during the eighteenth century. This information is not only of value to those interested in local history, it also offers an insight into the personal relations and business interests between the administrators and their subjects that existed at the time. The lack of balance with which archives have been passed down has impacted the outcome of the research. Some pieces of the puzzle could not be connected. For this reason, some details may have been quite enlarged for the sake of underpinning certain facts or developments, whereas the large volume of materials relating to the second part of the eighteenth century has required a selective approach.

\section{The Origins of the Land of Gronsveld and the Genealogical Backoground of the Seigneurs of Gronsveld in} the Middle Ages

The earliest records of noble persons carrying the surname 'De Grules', or a variation thereof, date from the eleventh and twelfth century and are found in the area between Aachen and Liège. They do not lend themselves to building a coherent genealogy nor do they show clear ties with Gronsveld. Only in the course of the thirteenth century do we come across successive generations of a Van Gronsveld family, members of whom became seigneurs of Gronsveld. At that time, there were also connections with the noble families of Van Stolberg (near Aachen) and Van Haasdal. The male line of the Van Haasdal family probably died out at the end of the thirteenth century, while the family assets and coat of arms were passed on to the seigneurs of Gronsveld.

In the thirteenth and the early fourteenth century, the seigneurs of Gronsveld belonged to the prominent nobility, owning property in the area between Aachen, Liège and Maastricht. There are also indications as to their connections with the Dukes of Limbourg. It is not until Henry I of Gronsveld (recorded during 1334-1374) that it became possible to obtain a global idea of his life. He was the viscount of the Limbourg castle situated along the river Vesdre and served the Duke of Brabant. As such he was involved in defending the interests of Brabant in the area between the rivers Meuse and Rhine and 
represented Brabant in what is referred to as the 'Landvredeverbond' (Armistice Union). He also served as moneylender to the Duke.

Hendrik's son, Jan III of Gronsveld, (recorded during 1349-1386) tread in the footsteps of his father, equally entertaining close connections with the Duke of Brabant and serving also as one of his major moneylenders, for which he received in return a number of castles as collateral. In 1368 his fortune increased considerably when Walram van Valkenburg presented him with the village of Heugem. From his uncle, Godert van den Bongard, he inherited the seigneurial rights to Sint-Maartens-Voeren and Oost. In addition, he acquired the leases to Eijsden and Cadier from the Duke of Brabant. In 1368 his efforts to consolidate his possessions came to an abrupt end when he was murdered.

Johan III was succeeded by his brother, Hendrik II. The latter had the prospect of acquiring Rimburg castle through his marriage with Johanna van Merode (acquiring it, in effect, in 1396), but, as a result of inheriting his brother's estate, he became one of the wealthiest noblemen in the area. Hendrik continued to entertain good relations with Brabant and remained one of the major moneylenders of the ducal house. The possession of Rimburg created a tie with Gronsveld, which ultimately lasted nearly 250 years. Rimburg Castle became the principal seat of the seigneurs of Gronsveld.

Hendrik II was succeeded by his eldest son, Hendrik III of Gronsveld (recorded during 1407-1474/1476), who had married Aleydis van Oupeye. During his rule, Brabant fell under the sphere of influence of Burgundy, which somewhat soured the traditional good relations with Brabant. Since Hendrik and his spouse only had two daughters, the male line of house of Van Gronsveld died out in Gronsveld. The eldest daughter, Johanna, married Diederik I van Bronckhorst-Batenburg, who hailed from the river area of Guelders. Successive members of this family ruled Gronsveld up to 1719.

Typical of the development of the large medieval principalities was their gradual expansion as a result of annexation or purchase of neighbouring seigneuries or by their commendation (feudum oblatum). Similar developments are found in small principalities. In the Netherlands, this process of joining and dividing territories was virtually complete at the end of the fourteenth century. Around 1400 the Land of Gronsveld, which had been formed from unconnected parts in the preceding centuries as well, reveals itself for the first time as a coherent entity under the seigneurs of Gronsveld. Traces of this remained visible in its judicial and administrative organisation until 1795.

An analysis has been made for each of these units in the shape of a village or hamlet as to their origins and transition to the seigneurs of Gronsveld. It was also important to gain an insight into this because of the question as to whether the separate parts satisfied the subsequently claimed status of 'solar feud' or allodium. The research shows that none of these locations is to be considered as having previously belonged to a larger unit. On the basis of a reconstruction of the history of land cultivation, an attempt was subsequently made to determine whether a large domain could have been at the root of the origin of the separate locations. Hartmann, in effect, made such a reconstruction of a medieval landscape for neighbouring Eijsden and Breust. He concluded that the villages and hamlets on the plateau of Eckelrade and Sint Geertruid had been founded in the eleventh and twelfth century during cultivation undertaken from the Meuse valley. The investigative 
method used by Hartmann has also been applied to the separate locations within the county of Gronsveld. The proprietary relations and the titles to land, such as seigneurial dependency (leenroerigheid), heriot (keurmede, i.e. the seigneurial right to the (prime) property of a serf or tenant upon the latter's death/le droit du meilleur catel), property tax duty (cijnsplicht), which could be indicated on mid-eighteenth century maps, may be considered to reflect medieval cultivation history.

Broadly speaking, the outcome is the same as that in the case of Breust and Eijsden: cultivation of the plateau undertaken from the lower-lying villages of Gronsveld and Heugem. There are local differences, however. Where Gronsveld is concerned, as late as the eighteenth century two-thirds of all land was still bound in one way or another to the seigneur, whether as the seigneur's unencumbered property, as given in feud, as property subject to the right of keurmede or an annual property tax. This makes clear that the basis for the village's origin is found in a noble, allodial domain. Its development must have taken place in the twelfth and thirteenth century. This assumption is in line with the earliest written sources. The initiative for the cultivation of these lands must have been taken by the seigneurs of Gronsveld, either for their own account or by issuing land in feud or against payment of a keurmede or cijns.

The village of Eckelrade was founded as a village cultivated from Gronsveld in the thirteenth or the early fourteenth century. Its development is different from that of Gronsveld, however, and later data points to a partly planned layout. Its predominant features were the arable lands that had been given in feud to the seigneurs of Gronsveld. They possessed almost no full title in land here.

In the fourteenth century, the further development of Eckelrade towards greater independence from Gronsveld stagnated. The village had its own church, but this church only enjoyed the status of auxiliary church to the parish church of Gronsveld. The oldest record of a church in Gronsveld dates from 1258. At all times, Gronsveld and Eckelrade fell within the jurisdiction of the same judicial (and administrative) authority, the schepenbank. The first reference to members of the 'curia de Grunselt' or schepenen, dates from 1261. The schepenbank passed judgment in both capital-crime and minor cases. 'Municipality'-wise, Gronsveld and Eckelrade were separate entities and from the seventeenth century onwards Eckelrade was also considered a separate entity where taxation was concerned.

Southeast of Eckelrade lied a virtually uninhabited strip of land measuring almost 60 'bunder' (ca. 60 hectares), which was referred to as 'Bijbank' or 'condominium of Eckelrade'. Although the seigneur of Gronsveld had been given this area in feud by the seigneur of Valkenburg, it was Gronsveld that exercised jurisdiction over it. Fiscally, the Bijbank fell within the jurisdiction of Valkenburg. Up to 1795, this situation caused ambiguous constitutional relations.

The village of Heugem was probably founded around a 'curia', a court granted by the Prince-bishop of Liège. The earliest records mentioning Heugem date back to the twelfth century. Cultivation of the higher grounds in the direction of the plateau of Eckelrade was also undertaken from Heugem. It concerned a long and narrow strip of land stretching to the Savelsbos (a forest) and the border with the village of Cadier. It is possible that Cadier and the hamlet of Honthem on the Eckelrade plateau were also founded from Heugem. 
The seigneurial rights to Heugem were granted by the Prince-bishop of Liège to the seigneur of Valkenburg by way of the Duke of Limbourg and the Duke of Brabant. In 1363 Walram of Valkenburg, the seigneur of Born and Sittard, presented Johan III of Gronsveld with the village of Heugem. From that moment on, Heugem became a fixed part of the property of the seigneurs of Gronsveld. Possible feudal ties to Liège are no longer found. In any case, in the middle of the fourteenth century, Heugem had its own schepenbank that adjudicated capital-crime and minor cases. It is a fact that the schepenen of Heugem, out of respect for old historical ties, went to the schepenen of Liège as late as the seventeenth century to obtain from the latter a judgment by referral (hoofdvaart). It seems that, originally, the seigneurs of Gronsveld did not possess much land in Heugem. Later landed property can be traced almost in its entirety to the manor of Ter Warden, which only passed to Gronsveld in the fifteenth century. Property subject to keurmede, however, was in effect found there. It probably emanated from the original manor of the Princebishop of Liège.

East of Eckelrade lays the hamlet of Honthem, which like other villages on the plateau, originated as a result of cultivation, probably undertaken from Heugem. Miniscule Honthem had its own schepenbank with jurisdiction over capital-crime and minor cases (earliest record in 1512). The referral by Honthem of a case to Heugem (hoofdvaart) is evidence of the old ties between the two villages. It proved not possible to determine with certainty how and when Honthem became the property of the seigneurs of Gronsveld; it may have occurred simultaneously with Heugem. In any case, Honthem's cultivation history is clearly dissimilar to that of Eckelrade and Gronsveld. It had no land in which the seigneurs of Gronsveld had full title nor did it contain feudal property. Honthem did have several farms subject to heriot (keurmede).

The feudal rights to the village of Slenaken also formed part of the early possessions of the seigneurs of Gronsveld. This was first referred to in an official document drawn up by the local (administrative and) judicial authority (schepenen) of Slenaken dating from 1371. The authority adjudicated capital-crime and minor cases. Nothing much can be said about the medieval development of Slenaken. Its village centre must be very old; in later years a number of neighbouring communities (buurtschappen) were developed. Although the seigneurs of Gronsveld did not possess much land in Slenaken, but they did hold property subject to keurmede and cijns. It is debatable, however, whether this can be traced back to ancient possessions, but the rights to the local forests may be very old rights indeed.

What is referred to as 'buitenlenen' or 'uitheemse lenen' (extraneous feuds) belonged to the earliest possessions of the seigneurs of Gronsveld. The most important were the feuds in Holset and Vaals, namely Vaalsbroek, and the manors of Holset and Einrade. In addition, there were a large number of small feuds. The presence of Gronsveld in Holset is visible until 1237. Several manors in the seigneurie of Oost, virtually adjacent to Gronsveld and Heugem, were major extraneous feuds.

For quite some time the seigneuries of Sint-Maartens-Voeren and Oost (inherited around 1370) were governed from Gronsveld, although, officially, they fell within the authority of Brabant and were never part of the Land of Gronsveld. Inhabitants of Oost did on some occasions avail themselves of the judicial services of Gronsveld. 
At the end of the Middle Ages, the Land of Gronsveld had a judicial organisation, which clearly shows how the land came to be from separate villages. There were four local courts (schepenbanken), which adjudicated capital-crime and minor cases, namely those of Gronsveld, Heugem, Honthem and Slenaken. In addition, Gronsveld had a seigneurial feudal (manorial) court, which functioned in any case from the last quarter of the fourteenth century. The local schepenbanken formed part of a pyramid of referral and appeal, which ran from Slenaken to Gronsveld and from Gronsveld by way of Aachen to the Reichskammergericht and later also directly to the Reicbskammergericht. Judicial procedure ran from Honthem by way of Heugem to Liège and ultimately to the Reichskammergericht. Lodging an appeal with the manorial court was controversial.

\section{The Seigneurs of Gronsveld from the Fifteenth until the End of Eigbteenth Century}

The marriage of Diederik I van Bronckhorst-Batenburg to Johanna van Gronsveld in 1425 formed the beginning of a relation between the families Bronckhorst-Batenburg and Gronsveld that lasted nearly three hundred years. The Bronckhorst family, who during the fourteenth and fifteenth century became divided along different lines, belonged to the ancient nobility of the Guelders river area. Their status was comparable to that of the Van Gronsveld family. It is not certain whether Diederik I actually ruled over Gronsveld. Not much is known about his son, Hendrik I, who ruled from approximately 1475 until 1493. He acquired important possessions in the Lower Rhine region through his marriage with Johanna Catharina van Alpen. The Alpen inheritance also provided direct access to the inner circle of the Duke of Cleves. With hindsight it has become evident that this was the beginning of an unambiguous repositioning of family interests. For 150 years the property in the Duchy of Cleves produced a substantial part of the income on which the prosperity of the family was funded. Thus, the interest shifted, also in subsequent generations, from Brabant and Liège towards Cleves and later to the Lower Rhine Westphalian Circle (Kreis) and the Empire.

Hendrik's son, Diederik II van Bronckhorst-Batenburg (1493-1508) is the earliest example. He became one of the most influential noblemen at the court of Cleves and supported the Duke in his battle against the Duke of Guelders. It was important to the family status that Diederik was elevated in 1498 by the Roman King Maximilian to the estate of Reichsfreiberr. On that occasion, both Gronsveld and Rimburg were declared immediate seigneuries.

Diederik's son, Johan I van Bronckhorst-Batenburg (1508/1511-1558/1559) also served in various capacities in the administration of Cleves. As a result of his loyalty to Duke Wilhelm of Cleves, he found himself in dire straits during the conflicts between the Duke and the Emperor Charles V. Upon the Duke's capitulation in 1543 under the Treaty of Venlo, Johan was obliged to concede Brabant's feudal rights to Rimburg, which lost its status of immediate seigneurie.

Willem van Bronckhorst's rule (1558/1559-1563) did not last long enough to be discussed in detail. Upon his death, his minor sons, Jost and Johan, received a proper academic education. They were elevated to the estate of imperial counts in 1585 . On the grounds of 
their elevation and title, they laid the foundation for the family status and the concomitant rights enjoyed by the family in the seventeenth and eighteenth century. Jost married into his own class with Countess Anna of Oostfriesland, granddaughter of the Emperor Maximilian, while his brother Johan married Sybilla von Eberstein, a descendant of an ancient family of counts from Schwaben. The marriage created rights to the county of Eberstein.

Sixteenth-century religious controversies also led to division within the various branches of the van Bronckhorst-Batenburg family. Not much is known about the religious conviction of the Gronsveld branch, but it may be inferred from the few data available that they continued to profess the catholic faith.

Jost van Bronckhorst-Batenburg ruled from 1586 until 1588, the year in which he fell in battle. He was succeeded by his brother, Johan II van Bronckhorst-Batenburg. As a count ruling over an immediate territory, he was given access to the Lower Rhine-Westphalian Circle and looked for affiliations within these circles to protect his interests. In the meantime, Gronsveld itself suffered greatly from the consequences of the Eighty Years War in the Meuse valley. It was during the reign of Johan II that for the first time a serious effort was made in Gronsveld to collect taxes for the Empire. This and the demands for seigneurial services led to serious clashes within the county.

Even more so than his ancestors, Count Johan II cast his eyes towards the Empire. This approach was continued by his successor, Jost Maximiliaan (1617-1662), who, because of his military career in the service of Bavaria, became involved in various important military operations during the Thirty Years War. At the end of his career he was a field marshal (Feldmarchall). In a manuscript entitled 'Coemoedia Gronsfeldiana', which originally was composed to serve as an apologia, he left autobiographical notes pertaining to his war experience. These were later used in Eberhard Wassenberg's Teutsche Florus on the history of the Thirty Years War. After 1648 Jost Maximiliaan served as a diplomat in the service of the Emperor and was the co-founder of the Lower Rhine-Westphalian Grafenkollegium. As a result of the latter, he became an advocate for the counts in the north-western part of the Empire and successfully campaigned for voting rights in the Reichstag.

Jost Maximiliaan was succeeded by his son, Johan Frans, who also opted for a military career in the service of the Emperor. He fought in the battle against the Turks and in the War of the Spanish Succession, ending his career as military governor of Luxemburg. His first marriage to Countess Eleonore Philipine von Fürstenberg remained childless. From his second marriage to Countess Maria Anna zu Toerring Jettenbach a daughter was born, but this child died at a very early age. With the passing of Johan Frans in 1719 the male line of the house of van Bronckhorst-Batenburg died out in Gronsveld. The county passed to his widow, Maria Anna zu Toerring Jettenbach.

By opting for a military career, the counts of Gronsveld belonged to a group of noblemen from the Meuse valley, who in the sixteenth and seventeenth century managed to rise all the way to commander in the service of either the Emperor or a prince. This did not only hold true for Jost, Jost Maximiliaan and Johan Frans van Bronckhorst-Batenburg, but also for some of their brothers. By this choice, the family focused on perspectives within the Empire. Another good example, outside the military context, is Count Otto Willem van 
Bronckhorst-Batenburg, one of Johan Frans' brothers, who was appointed Weibbischof (suffragan bishop) of Osnabrück. There must have been a financial reason for this orientation on the Empire. The small county of Gronsveld could not provide for all children commensurate to their status. A military career, however, carried great risks as well. Jost Maximiliaan was almost ruined and Johan Frans suffered a chronic lack of funds as well. Financial problems are the main theme throughout the family's seventeenthcentury history and made that, together with family strife, its possessions, which once upon a time had been sizeable, little by little melted away. Thus, in the course of a single century, the seigneuries of Oost, Sint Maartens-Voeren, Rimburg, Eberstein, and eventually Slenaken in 1728 , were lost.

Although the Counts van Bronckhorst-Batenburg very often did not reside in the county, they nevertheless considered Gronsveld their family base. It also served as their final resting place from the middle of the sixteenth century onwards, as they were laid to rest in the church of St. Martin. Through their contributions towards its restauration and its interior, they made the church into a type of a family mausoleum. Jost Maximiliaan is remembered in particular for his involvement in the founding of the civic defence guard (schutterij) of Gronsveld and for his role as the main initiator of the construction of the windmill.

Upon the death of Johan Frans van Bronckhorst, the county of Gronsveld passed to his spouse, Maria Anna zu Toerring Jettenbach. She remarried with Claude Nicolas d'Arberg Valengin. Of this marriage a single daughter was born, Maria Josepha, who in 1746 married her cousin, Maximilian Emanuel von Toerring Jettenbach. Maria Josepha died in 1753 and Maximilian Emanuel passed away in 1773. He was succeeded by his youngest brother, August Joseph. The latter became the last ruling count of Gronsveld.

The rule of Claude Nicolas d'Arberg Valengin (1720-1731) constitutes a sad period in the history of the county. A substantial part of the rights to which the count was entitled, were given in tenure to a fortune seeker from Wallonia, who subsequently found himself in serious conflict with drossaard Lebens, the highest representative of the count in Gronsveld, and the population of Gronsveld. The administrative anarchy into which the county descended, serves as a fine example of problems that spun out of control when factions within a small, immediate territory opposed each other. The possibility of outside intervention was highly limited.

After the death of Maria Anna zu Toerring Jettenbach in 1730 and that of Claude Nicolas d'Arberg Valengin shortly afterwards in 1731, a legal battle was fought over the guardianship of their minor daughter, Maria Josepha. After her uncle, Ignaz Felix zu Toerring Jettenbach, had been appointed as her guardian, the county once again enjoyed a degree of peace and quiet. The authority of the count remained weak during this transitional period. Only in the second half of the eighteenth century under Maximilian Emanuel and August Joseph zu Toerring Jettenbach did orderly relations return.

Although the Toerrings were part of Bavarian high nobility and as of 1630 bore the title of 'imperial count', they did not possess an immediate territory. Owing to their possessing Gronsveld, they also became an imperial estate, thus acquiring a seat and voting rights in the Lower Rhine Westphalian Circle and the Reichstag. The fact that they possessed 
Gronsveld not only increased the status of the Toerrings. They also intended to make the county economically viable. In particular during the administration of Joseph Anton Prummer and Wolfgang Zollner, their two consecutive representatives in Gronsveld, this met with some success, but the county was never a great source of income. The counts themselves never visited Gronsveld, but ruled from a distance through frequent correspondence. Their style of ruling was, in a few catchwords, autocratic and formal, aloof while at the same time focused on detail, thrifty and conservative, but also enlightened, very direct vis-à-vis their subordinates, just and certainly not unsympathetic towards the population.

The rule of Count August Joseph ended in 1795 as a result of the incorporation of Gronsveld into France. The claim for compensation was eventually settled by the 1803 Reichsdeputationshauptschluss, a decision of the last Reichstag session. The imperial abbey of Gutenzell was awarded as reparations, but the imperial county of Gutenzell only lasted three years, because in 1806 the territory was annexed by the Kingdom of Württemberg. After 1815 the Toerrings, as the former possessors of the immediate county with voting rights, acquired the status of 'mediatised' Standesherren in Germany, thereby becoming the equals (ebenbuirtig) of the ruling royal houses.

\section{Administrative Structures and Judicial Organisation from about 1500-1796}

The authority of the counts over Gronsveld was passed down through succession. At the beginning of his rule, the count took possession of the county through official acts performed before the manorial court of Gronsveld, after which he was inaugurated by his subjects. There is a perception that, because of family problems, on occasion restraint was exercised where large public manifestations were concerned. Two detailed records of such inaugural ceremonies from the second half of the eighteenth century have been preserved. The protocol described by these records provides an impression of the views of the relations between the count and his subjects.

The other side of the coin were the public mourning ceremonies upon the death of the count or his relatives. Not much is known about the interment of members of the van Bronckhorst-Batenburg family in the church of St. Martin in Gronsveld. In the second half of the eighteenth century, burial services were made into meticulously directed, baroque pageants intended to show off the status and authority of the deceased before the invited guests and a large crowd of curious bystanders.

The count ranked as the supreme lawmaker of both procedural and substantive law within the county. In the event of uncertainty as to the interpretation of the law, he was also entitled to provide such interpretation. His legislative powers still kept him within the limits of the imperial laws, but he was given the authority under a salvatorian clause (Salvatorische Klause) to depart from these. A certain hierarchy can be observed in the application of legal rules and regulations in the administration of justice. First, the legislation of the count, as ruler of the territory, was applied. If this proved insufficient, local customary law or rules of law of the Holy Roman Empire were invoked. And, finally, 
justice could be inferred from legal rules and regulations of neighbouring territories, such as the Duchy of Brabant or the Prince-bishopric of Liège.

There are also eighteenth-century examples of local ordinances issued by the local judicial authority (schepenbank) and by the count's representatives. Official assent by the count does not seem to have been required. It is not known whether application of canon law required a formal right of 'placet' (assent), but legislation by clerical authorities was viewed with scrutiny. Although, due to the defective preservation of records, it is very difficult to obtain a clear idea of the total volume of legislation, but rule-making seems to have been done on a limited scale. The most voluminous example of a body of law is the Rechtsordnung for Gronsveld dating from 1671, which mainly dealt with property law and inheritance law. The wording had been almost literally taken from the 1663 'Cölnische Rechts-Ordnung', with the exception of the chapters on feudal property rights, rules on heriot (keurmeden) and procedural law, which originated in Gronsveld.

In the sixteenth and seventeenth century, the counts hardly ever resided in the county; no count ever paid the county a visit after 1730 . Until the beginning of the eighteenth century, written communication was often cumbersome. It took until the rule of the counts zu Toerring Jettenbach before, as a result of extensive correspondence, direct involvement by the count became more frequent. This meant that in almost all cases from the sixteenth century until 1795 the count's exercise of authority took place by delegation. This ruling from a distance was responsible for the difference between the count's official authority and the actual power as exercised by his subordinates. The phenomenon also existed in other immediate territories, where the seigneur lived in far-away places. In this study the consequences of this in relation to Gronsveld have been examined, but more research is to show what effect this generally had on the administrative culture within small territories. Examples found in Gronsveld do reveal that, due to a lack of control and supervision, the count's public officials often had more room to manoeuver than was desirable. This was especially the case where various offices were performed by a single person.

In the sixteenth century, the principal officials in the Gronsveld administration comprised the scholtis (chief judicial officer), the drossaard (the count's highest representative) and the rentmeester (the steward), and after 1750 the count's representative, alternately holding the title of 'secretary', 'commissioner' or 'director'. A continuous overview per office is hampered by the practice of joining offices. Not counting the occasionally engaged legal advisors and possible lower staff, such as a scribe or a messenger, in the main, two functionaries, the drossaard and the steward, were involved in the administration and management of the count's property and finances.

The duties of these officials were laid down in instructions. Of these very few have survived with regard to the sixteenth, seventeenth and the early decades of the eighteenth century. Only with the aid of a number of instructions from the thirties of the eighteenth century can a better insight be gained as to their substance. They were aimed at defending the count's rights and financial interests, but also contained rules on the exercise of public authority. Examples are the steward's special powers when public debts had to be claimed through the court. 
The persons involved in the public administration of the county typically belonged to families whose members shared certain posts or offices among themselves. In most cases, such governing families were replaced after two or three generations, often after disputes with the count over their financial management. The transition could take on the character of a settlement of old scores, such as the one between the supporters of the old drossaard, Kicken, and the new drossaard, Lebens. The system of governing families proved resistant to the arrival of foreigners. This is illustrated by the union, though marriage, between county commissioners Joseph Anton Prummer and Wolfgang Zollner from southern Germany and the governing Lebens family.

The openly sharing of posts among themselves was not viewed as reprehensible. It certainly did not automatically lead to incompetence, in as much as people did invest in education and experience and tradition could benefit the continuity of the administration. The disadvantages are found mainly in other areas. The greatest danger was the commission of fraud involving to the count's finances. Poor control and non-transparent systems of bookkeeping provided ample opportunity. The malfeasance committed by steward Joannes Matthias Oligschläger throughout the thirties and forties of the eighteenth century was perhaps the most spectacular. Even measured by the standards of that period, it was exceptionally disproportionate.

The counts of Gronsveld were not blind to these problems, but it is not always clear whether they consciously factored in such risks. In spite of their strictness and mistrust of subordinates, even the business-like counts zu Toerring Jettenbach of the second half of the eighteenth century were undeniably somewhat naive in this area. They probably thought that by appointing countrymen as their representatives, they had found loyal staff, but this assumption was not always borne out by fact.

After assuming his position in 1752, it took Commissioner Prummer many years of toil to bring order to the accounts of the count's domains. By improving tenure policy, investing in forestry and reorganising debts, he managed to increase the county's profitability. However, even he became entangled in local intrigues. At the end of his career, he left the county in a bad state of repair as a result of his physical and mental decline. The results achieved by him were nevertheless quite robust. His successor, Wolfgang Zollner, carried on in the vain of his predecessor, but unlike Prummer, who had mainly focused on increasing the county's profitability, Zollner also developed plans to improve the people's standard of living. As a result of political unrest at the end of the eighties of the eighteenth century and the subsequent invasion by the French, little was realised in the end.

In as much as the archives of the local administrative and judicial authorities (schepenbanken) of Gronsveld, Heugem and Honthem were virtually destroyed (only those of Slenaken have survived), it is difficult to gain an exact picture of the external legal history of these schepenbanken and of the administration of justice. The organisation of the judiciary as existed in the Late Middle Ages did not undergo a fundamental change during the Early Modern Period. The schepenbanken of Gronsveld, Heugem and Honthem made use of the same personnel. In pooling their human resources, the well-known phenomenon of family government emerged, although it was almost impossible to find 
suitable staff prepared to work for a pittance. A complete panel of seven schepenen was a rare phenomenon. In many cases, the drossaard or the secretary also doubled as judges.

Court sessions were usually held in Gronsveld and the archives were kept there as well. Only the voogdgeding, three-monthly court hearings on local community matters, was still held in each location separately. An administrative merger did not take place in the end and court records continued to be kept separately.

Schepenbanken were sometimes belittlingly referred to as 'farmers' courts', which is understandable to a certain degree. The manner in which in the turbulent twenties of the eighteenth century the composition of the schepenbank would change every couple of months, for instance, inspired little confidence in the capabilities of the persons appointed. There were justified complaints about abuse and malfeasance in later years as well. It is debatable, however, whether the members of the schepenbank should be held accountable for all of this. Officially, they conducted the proceedings and passed judgment. In practice, however, their role was mainly limited to monitoring expediency. The secretary and the drossaard occupied themselves with drafting legal documents. In complex cases, the opinion of a town lawyer was sought, which was subsequently adopted in its entirety as judgment.

Until the beginning of the seventeenth century the following four types of proceedings may be distinguished: the 'voogdgeding' dealing with local community matters; 'ordinaris' proceedings in civil matters and minor criminal cases, 'extra-ordinaris' proceedings in criminal cases and the 'gemeyne (in)quest', in which cases of improper conduct were heard. All male inhabitants were required to attend or to be represented at the voogdgeding, which was organised by each schepenbank thrice annually. During the sessions, claims of a publiclaw nature could be brought, such as debts owed to the count or the church. In addition, judgment was passed on infringements of local ordinances and ordinary civil proceedings could be instituted. Upon conclusion of the voogdgeding, cases that had not been finally disposed of could be continued in the fortnightly ordinaris proceedings or in the genachtingen (nightly sessions). New civil cases could also be brought during these sessions. Urgent criminal cases could be tried more quickly in extra-ordinaris proceedings. The annual gemeyne (in)quest was held in each location separately and probably lasted until the beginning of the seventeenth century. These proceedings concerned the punishment of conduct contrary to public morals or the commandments of the Church.

From 1671 onwards the Gronsveld Rechtsordnung was a source of applicable substantive and procedural law. However, only the chapters on property subject to keurmede (heriot) and property given in feud, the prohibition against in manu mortua property and procedural law were probably applied on a regular basis. For the remainder, inspiration was derived from a mishmash of laws from Liège and Brabant, imperial law and local customary law. Full consensus on the applicable law did not exist, incidentally, among the schepenbanken as is evidenced by the differences in procedural fees and court terms.

The manorial or feudal court of Gronsveld as existed from the end of the Middle Ages, hardly underwent any organisational change in the Early Modern Period. In 1710 the position of feudal lieutenant became a hereditary office, but in the thirties of the 
eighteenth century the count reacquired these hereditary rights. The offices of feudal lieutenant and vassal were held by the count's highest representative (drossaard), the chief judicial officer (scholtis) and the schepenen, so they were closely interconnected with the schepenbanken where personnel was concerned. In some instances, proceedings were brought simultaneously before the manorial court and the schepenbank, but the records of these proceedings remained separate.

The substantive and procedural feudal law of Gronsveld laid down in the 1671 Rechtsordnung was probably based on the Lehenordtnung from 1593, which has not survived. Its procedural law followed the procedural law of the schepenbanken, wherever possible. From the second half of the eighteenth century onwards hardly any cases were brought before the manorial court.

As regards the number of feuds, the manorial court had reached its peak in the sixteenth century. A period of steady decline followed. As a result of the sale of the seigneuries of Sint Maartens-Voeren, Oost and Slenaken, the feuds within these were lost. A constant problem concerned the discipline of reacquiring a feud by way of commendation before the manorial court upon the death of a vassal (relief) or the transfer of feudal property. For this reason, it was not easy to keep an orderly feudal administration. A source of constant concern was the jurisdiction over the 'extraneous' feuds in Vaals and Holset, because they were situated in foreign territory. Relations only stabilised in the middle of the eighteenth century.

Problems relating to appeal are a predominant issue throughout the history of both the schepenbanken and the manorial court. The medieval referral process of Slenaken by way of Gronsveld to Aachen and Honthem by way of Heugem to Liège remained intact until the seventeenth century. The transition from referral (hoofdvaart) to appeal was very gradual. From the beginning of the sixteenth century the Reichskammergericht served as the highest appellate court. From the end of the sixteenth/the beginning of the seventeenth century the position of the Schöffenstubl, the royal court of Aachen, came under pressure, because it was seen as 'superfluous' court of interim instance. This did not only hold true for the relation between Gronsveld and Aachen; other immediate locations wished to terminate this procedure as well. Until the thirties of the eighteenth century regularly disputes on the subject arose in Gronsveld, in which on the part of Aachen physical violence was not shunned.

From the final decades of the seventeenth century onwards, the alternative offered in Gronsveld to lodging an appeal in Aachen consisted in the appointment by the count of a lawyer to serve as appellate commissioner. Similar developments have been found at other locations. In Gronsveld the office of appellate commissioner never evolved into a proper appellate court as there were simply too few cases to justify such a court. Nevertheless, this means of appeal meant considerable savings in time and money for parties that wished their case to be heard on appeal. In addition, it led to a considerable drop in appellate cases before the Reichskammergericht. First-instance cases continued to be brought before the Reichskammergericht, if the respondent was a person with an allegiance to the Holy Roman Emperor, such as the count. 
The manorial court of Gronsveld experienced similar problems with the Schöffenstubl of Aachen as an interim-instance court. From the beginning of the sixteenth century onwards appeal was directly lodged with the Reichskammergericht, but there was also the possibility of appeal with a temporary court composed of 'stronger vassals'. In the middle of the seventeenth century, the Schöffenstubl of Aachen tried to get its foot in the door in these proceedings, but its attempt ultimately failed. Since in the course of the eighteenth century hardly any cases were brought before the manorial court of Gronsveld, appellate cases no longer came up.

In Chapter 15, an inventory is provided of all rights and fixed incomes to which the count, as the seigneur of Gronsveld, was entitled, with the exception of the right to legislate and the right to administer justice, which are discussed separately. The list comprises considerably more than what is usually regarded as 'classic' seigneurial rights. In a small territory, such as Gronsveld, the legal, economic and (also) symbolic aspects of rights were particularly intertwined. This is also evidenced by contemporary lists, in which all sorts of rights are randomly summed up. Systematic classification of these will lead to confusion rather than clarity: if approached from an economic perspective, they may be experienced in quite a different way than if approached from a legal perspective. Neither will such a systematic classification contribute much to the actual significance attached to these rights. In the literature, the right to administer justice, for instance, is seen as the core of the seigneurie, but the actual involvement of the seigneur in administering justice was not significant nor was the income gained from it in most cases. Although in the sixteenth and seventeenth century the right of coinage was of great value to the seigneur of Gronsveld, as it symbolised territorial independence, contrary to what one would expect it did not produce much financial gain. The right to propose members of the clergy (collatio and jus patronalus/right of patronage) may be mentioned as a final example of the difference between theoretical significance and importance in practice. Usually, these rights are not seen as seigneurial rights, but in the hands of the count of Gronsveld they afforded him legitimacy as a public authority to intensively interfere in the personal and business affairs of the church. Similar situations obtained in other small immediate territories.

These rights did not form a static whole. A standard core of rights did exist, but for the remainder they came and went. The earlier mentioned right of coinage may serve as an example. After 1719 the right was no longer exercised in Gronsveld. A 'novelty' on the other hand, although of very little actual significance, was probably the application of the 'Jodenregaal, a form of taxation imposed on Jews residing within the county.

The accounts of the sixteenth-century stewards show a close resemblance in the manner in which income was accounted for in the eighteenth century. This also reflects the conservative manner in which these rights were exercised. To both the seigneur and his subjects these were narrowly defined duties and obligations. Changing these was hardly possible or permitted. The revenue from monopolies, licenses and taxes narrowly produced half of the total income. Most income was derived from ordinary land tenures or land leases, tithes and land tax. Since the fixed rates attached to these were often paid in kind, especially grain, conversion of the revenue to money was greatly affected by the 
going market price. It took until the second half of the eighteenth century before the switch from grain tenures and grain levies to fixed sums of money led to a considerably improved return.

Wherever the available sources allowed, a description is given in this study of the legal significance and economic value of each right held by the count of Gronsveld. However, completeness cannot be guaranteed. Some rights have pronounced aspects. The right of coinage, for instance, takes up a special position both in terms of its origin and symbolic value and its supervision.

The extensive attention paid to the rights of patronage and collatio is not coincidental. These rights were used, not always successfully, to conduct church policy at local level. The appointment of Bavarian clergy in the eighteenth century serves as a clear example. The value attached to this right is demonstrated by the fact that even after 1795, when seigneurial rights had already been abolished and Gronsveld had been incorporated into France, the count still interfered in the appointment of parish priests. Especially in the second half of the eighteenth century, an attempt was made to get a grip on the management of church property.

Chapter 16.2 contains a survey of the taxes the count of Gronsveld, as the imperial estate, had to pay to the Empire. These concerned payments for the benefit of the defence of the Empire, the maintenance of the Reichskammergericht, the Lower Rhine-Westphalian Circle and the Lower Rhine-Westphalian Reichsgrafenkollegium, including the latter's representation in the Reichstag. The 1521 Wormser Reichsmatrikel, the Imperial Register of Worms, which listed all taxable imperial estates, formed the legal basis for taxation.

The taxes for the defence of the Empire were calculated in what was called Römermonate (Roman months), the amount required to sustain an army of (rounded off) four thousand horsemen and twenty thousand foot soldiers for one month. The Register laid down which simplum (part) an imperial estate had to pay in this Roman month. The actual tax demand consisted of the number of required Roman months multiplied by the simplum or a multiple thereof, e.g. three or nine times, dependent on the actual size of the army. The basic size of the imperial army as fixed in the sixteenth century was revised in 1682 in the Reichsdefensionalordnung (Imperial Defence Regulation). The Regulation governed the number of troops each Circle was obliged to provide and the amount of the simplum each imperial estate was required to contribute. For the Lower Rhine-Westphalian Circle this amounted to a total of 1,321 horsemen and 2,708 infantrymen, not counting the "prima plana' consisting of the army staff and lower-ranking officers. These numbers continued to be the standard throughout the eighteenth century.

The amounts referred to in the simplum were also used as a basis for the levies imposed for the benefit of the Lower Rhine-Westphalian Circle and the Reichsgrafenkollegium. The Reichskammergericht was funded through a semi-annual contribution called Kammerivieler. The relevant amounts listed in the Register of Worms were subsequently several times adjusted.

It is difficult to conduct research into the precise tax burden of the county of Gronsveld on the basis of the Gronsveld archives, in part because the sources are limited and in part as a result of the various setoffs, discounts and the moving around of troops within the 
army. After 1682 the simplum for Gronsveld amounted to twelve Rheinische Guldens and after 1760 to eighteen Rheinische Guldens. In as much as for each Roman month the simplum was multiplied by a factor of three in most cases, the average monthly payment came to forty Guldens (three times the basic rate plus additional costs), not counting the prima plana. However, in times of war the amount could be ultimately considerably larger due to the large number of Roman months and the multiplication of the simplum.

Roman months were only levied for defence purposes and for wars conducted on behalf of the Empire, not for wars between the imperial estates themselves. The most important wars in which the Empire was involved, concerned the battle against French expansion at the end of the seventeenth and the beginning of the eighteenth century and the Seven Years War (1756-1763), but particularly the wars against the Turks, which regularly flared up from the sixteenth century onwards. At regular intervals, a reference is found in the Gronsveld records to a 'Turks tax' (Türkensteuer) imposed for that purpose.

The payment ethics of the individual imperial estates often left much to be desired. Shortfalls were created by the lack of desire or incapacity of an imperial estate to pay, but they were also the result of a defective collection system. Large arrears were not a rarity. In the second half of the eighteenth century, for example, Gronsveld needed to draft a regulation in order to clear the arrears in Kammerzieler payable for the benefit of the Reichskammergericht that had accrued over many decades.

Under the taxation system, the seigneur as imperial estate was made responsible for the levying of taxes, but the amount payable was met by the subjects. Within the county of Gronsveld this held true for the land tax, a levy on reëel (realty), which the landowners (geërfden) had to cough up. Land tax was probably introduced by Count Johan II van Bronckhorst-Batenburg at the end of the sixteenth century. This was met with much resistance from the landowners, especially those Maastricht institutions that owned the most land within the county. Such resistance was prompted in part by the fact that these were new taxes, but it was mainly based on the view held by those from the city of Maastricht that they were exempt from taxes imposed on their properties outside the city. In addition, the people from Maastricht categorically refused to contribute, together with the inhabitants of the county, to the 'personal' taxes on households and livestock. These levies were used for the purpose of paying the claims laid by the armies that passed through. The stance taken by the landowners from Maastricht also caused considerable problems in other neighbouring villages. Precisely because of these fundamentally different views of tax exemption, this study offers a more in-depth reflection on the causes underlying the issue.

After a number of cases before the Reichskammergericht, the dispute between the count and his subjects was settled in 1611 in the sense that the landowners were prepared, in principle, to pay land tax. However, in the course of the seventeenth century and the first half of the eighteenth century, discord over such taxes flared up again at regular intervals. This resulted in new regulations on the institution, collection and destination of taxes. Relations came under heavy fire when after 1750 the financial consequences of the War of the Austrian Succession needed to be dealt with. In the end, the count's representative, Prummer, managed, after difficult negotiations, to have the costs of supplies to the armies characterised as realty, so that they became payable from land tax. 
In the seventeenth and the beginning of the eighteenth century, the landowners did act jointly when problems arose over issues of taxation, but this did not amount to an enduring collective. Only on the occasion of an agreement in 1739 did such collectiveness take on a more solid form, when a protocol was drawn up relating to meetings and the voting rights to which the various interested parties were entitled. Annual budgets and annual accounts were adopted. From approximately 1744 onwards, references are found to such collective representations as 'standen' (estates) and 'standen en geërfden' (estates and landowners) of the Land of Gronsveld. In the majority of cases, estate meetings were held annually and dealt almost exclusively with taxes. In spite of this limited agenda, the formation of these meetings can be viewed as a step towards state formation, which had already started at the end of the Middle Ages where large principalities were concerned, but which now also manifested itself in small territories. Similar developments are found in the immediate territories of Wittem and Wylre.

In addition to an organisation of landowners, the county had also five local administrations, namely those of Gronsveld, Eckelrade, Heugem, Honthem and Slenaken. These consisted of a collective of inhabitants, which aimed to defend common interests, in particular the common pastures on which the inhabitants put out their livestock to graze. From the end of the sixteenth century onwards an important task was added: the levying of personal taxes on households and especially livestock, with which the claims of passing armies could be met. Money was also borrowed for this purpose, with communal property as collateral and the inhabitants standing surety.

It is not entirely clear when these separate local collectives were formed. The municipalities of Gronsveld, Heugem and Slenaken originated in the Middle Ages. The fact that the inhabitants of these villages shared common pastures is of relevance as well. Eckelrade and Honthem seem to have instituted their local municipal bodies only at the end of the sixteenth century, mainly as a result of the levying of personal taxes with which the military claims were paid. They had hardly any common land.

Local decision-making was the prerogative of the male heads of all the households. Although the meetings of the municipal bodies were, for practical reasons as well, often linked to the voogdgeding (for instance for swearing in officers), these two gatherings must not be seen as one and the same. The voogdgeding heard court cases, the municipal assembly did not.

As a collective that owned common land as well as held claims to common debts, the municipal body had legal capacity. Whereas it was easy to legally bind the collective entity, the concept of separate legal capacity was not yet well-developed. Where financial obligations were concerned, the inhabitants often remained severally liable in addition to the liability of the municipal body. Originally, the people were represented by a small number of persons, who were specifically appointed for that purpose, but from the end of the seventeenth century onwards references to 'dorpsmeester' (village master) and 'burgemeester' (burgomaster) are found. Their principal duty was to draw up tax lists. The municipal body also appointed the rural police officer (veldbode) to guard the fields and the common pastures. 
The count and his public servants followed the activities of these local administrations, especially those of the burgomaster, with suspicion. At the end of the eighteenth century, for example, the battle against the introduction of tithes on potatoes was seen as opposition to the authority of the count and a waste of money at the expense of the inhabitants. For this reason, an attempt was made to curtail the role of the burgomasters and to counter the formation of financial reserve.

\section{Final Observations}

It is difficult to arrive at a single general conclusion that fully covers the large number of subjects discussed in this study. By focusing on the county of Gronsveld, it may seem that the author has ascribed a key role in history to this area. This obviously does not correspond with historical reality. Various small independent territories in the vicinity of Gronsveld were part of the Holy Roman Empire of the German Nation. In that respect, the position of Gronsveld was not exceptional. This is certainly not the case when a comparison is made with present-day Germany, where in the past dozens of such counties formed part of the Holy Roman Empire. An attempt is made below on the basis of a number of catchwords to put together a 'profile' of the county during the Early Modern Period. However, such a profile does not necessarily apply to Gronsveld alone.

The first characteristic may be summarised by the word 'isolation', which refers to political isolation rather than geographical accessibility. To the counts who made their careers in the service of the Emperor or the kings of Bavaria, or to the Counts zu Toerring Jettenbach who resided in Bavaria, the concept of the Holy Roman Empire of the German Nation was a reality. Furthermore, the inhabitants of the county were certainly aware of what was happening in the outside world, but emotionally they were quite removed from the Empire. Involvement in the decision-making of the Empire was minimal. Cooperation within the Lower Rhine-Westphalian Grafenkollegium and the Lower Rhine-Westphalian Circle was merely a formal affair, but no network resulted from it. Only incidental contacts existed with other immediate territories in the area, imperial estates or not. Even relations with the adjacent immediate territory of Rijckholt were business-like, formal and not particularly cordial.

The Empire became mainly of relevance to the lives of the people of Gronsveld through tax duties and on occasion through the judgments of the Reichskammergericht. Contributions were claimed for the defence of the Empire, but such payments could not always prevent the inconvenience caused by the armies. On the other hand, the count did not maintain a standing army, the tax-funded wars were usually fought outside the county and the status of immediate territory offered protection against unwelcome intervention of neighbours in times of conflict.

A similar distance existed between the immediate county and the surrounding 'foreign lands'. Contacts remained limited to what was strictly required, for instance to rendering assistance in criminal matters or in the event of problems regarding borders. Any closer cooperation was not envisaged. In the second half of the eighteenth century, such reservedness gained a confessional aspect in the sense that the count's catholic 
commissioners in Gronsveld were not keen on cooperation with the 'Dutch' protestant authorities of the adjacent villages.

A second characterisation concerns the conservative nature of the community aimed at preserving the status quo. The process of 'state formation' from separate villages, which had come to a halt around 1400, had produced a complex administrative and judicial organisation. Although subsequent centuries saw some developments and adjustments in this area, this did not lead to fundamental changes. The administration performed its duties on the basis of standard procedures that equally hardly underwent change. Although conservativeness may be construed as stagnation, it also led to stability and legal certainty.

The various villages and hamlets formed closed communities which were inclined to defend their own interests rather than those of the country. This lack of unity between villages also manifested itself on occasion during conflicts with the count, when one or more villages would remain on the side-lines. This lack of solidarity was aggravated by the fact that the fiscal interests of the landowners differed from those of the inhabitants of the various village communities, especially so because the individuals and entities that owned land in the county called the tune there. The absence of consensus definitely hampered further progress. Nevertheless, there are instances in which attention for the interests of one's own village would have its advantages. The initiative taken in Eckelrade to construct its own wells or the struggle of the inhabitants of Heugem for the restoration of their church may serve as examples.

The third characterisation relates to the strength of governance and the justice system. Although much criticism could be levelled as to their quality, the situation in Gronsveld was not much better or worse than that in the surrounding territories. It is safe to say that within Gronsveld great loyalty existed to the count and the authorities of the prince. This does not mean that problems did not arise. Divisiveness among certain groups of persons could seriously affect relations within a small community, but only in a single instance did such division have a real disruptive effect. Although corruption within the administration formed a chronic problem, it often caused greater harm to the count's interests than to the interests of the inhabitants. Admittedly, the inhabitants were obliged to pay for the seigneurial rights exercised by the count, but the costs of the administration were almost fully borne by the count.

The conclusion is justified, on balance, that for centuries the county of Gronsveld was a separate, independent community with conservative tendencies, which was not exempt from internal strife, but sufficiently stable to be able to function as an independent imperial seigneurie. At the end of the eighteenth century, there were no signs that its viability was under threat.

The dismantling of Gronsveld, which ultimately lasted a decade, began on 1 February 1793 with the cry 'guerre aux chateaux' ('war to the castles') with which French revolutionaries threw the Gronsveld archives out of the castle and then burned them. It came to an official end with the signing, on 25 February 1803, of the 
Reichsdeputationshauptschluss at Regensburg, under which Count Joseph August zu Toerring Jettenbach was awarded the secularised imperial abbey of Gutenzell as reparations. The county had in effect been incorporated into France on 1 October 1795, as part of the department of Nedermaas, thus suffering the same fate as the other territories situated along the river Meuse. The majority of the Gronsveld people had probably mixed feelings about this 'unwelcome revolution'. In the short run, the revolution meant that the count's authority ended, the ties with the Empire were severed and the existing administrative and judicial systems were replaced by new institutions.

From the moment of its incorporation Gronsveld became part of a large national state for the first time in its history and the people of Gronsveld became French citizens. However, did they consider themselves French citizens? The people of Gronsveld probably suffered from the same constitutional identity problem as did the other inhabitants in the territories along the river Meuse, who after 1815 were known as 'Limburgers'. The constitutional changes of the nineteenth century, i.e. 1815: the United Kingdom of the Netherlands; 1830: Belgium; 1839: the Kingdom of the Netherlands, and 1866: the dissolution of the Confederation of German States, the Deutsche Bund, turned these 'Limburgers', be it slowly, into 'Netherlanders'.

As a result of these developments, gradually the county, the territory immediately bound to the Holy Roman Empire, faded from the inhabitants' collective memory. The municipality of Gronsveld of the nineteenth century still had the geographical shape of the former county. However, as a result of the municipal re-divisions of 1920, 1943, 1982 and 2011, these borders disappeared as well. What has remained intact are such visible reminders of the past as the remnants of the old castle, the old seigneurial flour mill (banmolen) and the church of St. Martin, in which the Bronckhorst family figure prominently. The question that needs to be asked is whether people of the 21 th century will still be able to associate these 'silent witnesses' with the history of the Counts of Gronsveld. Also worth mentioning is the folklore of the 'Grote Bronk', which takes place every four years. To this day, the customary "bird" shooting on Whitsun Monday is preceded by the reading out of a regulation issued by Count August Joseph zu Toerring Jettenbach in 1778. After the Sacrament Procession, the local traditional 'civic defence guard' (schutterij) discharge their rifles (generale charge) to salute 'its founder', Count Jost Maximiliaan van Bronckhorst-Batenburg. At their acceptance, new guard members drink beer from a tankard presented in 1828 as a gift by Count Maximilian August zu Toerring Jettenbach to commemorate the family's ancient ties with the county. These are customs that have been carefully passed down through the generations, but only a few will be able these days to coherently place them in an historical context. May this study of the 'solar feud of Gronsveld', an independent, immediate imperial county in by-gone days, serve as a link between a still visible past and a past experienced in customs.

Translated by Louise Rayar 


\section{VALORISATIE}

\section{Onderwerp van het onderzoek}

'Licht op het zonneleen Gronsveld' is een verhandeling over een regionaal-historisch thema vanuit grotendeels een rechtshistorische invalshoek. De studie bestaat uit twee onderdelen. De kern van het eerste deel heeft betrekking op wetgeving, bestuur en rechtspraak en de daarbij betrokken personen en instellingen binnen een klein, onafhankelijk rijksonmiddellijk land, thans gelegen binnen het gebied van de provincie Nederlands Limburg, maar gedurende de vroegmoderne tijd, tot 1795 ressorterend onder het Heilige Roomse Rijk der Duitse Natie. Bij die beschrijving komen ook aan de orde de middelen en rechten die voor de uitoefening van deze taken ter beschikking stonden.

De grenzen van het onderzoek zijn ruimer getrokken dan alleen de rechtsgeschiedenis in strikte zin. Het geheel wordt voorafgegaan door een analyse van de ontginningsgeschiedenis en het ontstaan van het land Gronsveld omdat deze 'vormgeving' uiteindelijk ook een rol heeft gespeeld bij de status van het gebied en de ontwikkelingen van de instellingen. Ook de heren van Gronsveld kriigen ruime aandacht, aangezien kan worden gesproken van een wisselwerking tussen hun geschiedenis en de (rechts)geschiedenis van het graafschap. De adellijke status van de graaf bepaalde de positie van het land binnen het Rijk en vormde een basis voor loopbanen. In het bijzonder in de zeventiende eeuw maakten de graven van Bronckhorst Batenburg naam als militairen en diplomaten in Beierse en in keizerlijke dienst. Anderzijds leverde het graafschap ook inkomsten ter financiering van deze loopbanen.

De veelvuldige afwezigheid van de graven van Bronckhorst Batenburg leidde tot het ontstaan van bestuur en rechtspraak 'op afstand'. Hun opvolgers in de achttiende eeuw, de Beierse graven von Toerring Jettenbach, zijn zelfs nooit in Gronsveld geweest. Zij lieten zich vertegenwoordigen door een commissaris, die schriftelijke instructies ontving. Door een integrale bestudering van de 'staatsinrichting', de manier waarop dit systeem functioneerde, ontstaan nieuwe inzichten en vinden ook accentverschuivingen plaats ten opzichte van de bestaande rechtshistorische literatuur.

De historische verhandeling wordt afgesloten met een deel, waarin de voor Gronsveld belangrijke rechtsbronnen worden uitgegeven. Het gaat om primaire, over verschillende archieven verspreide bronnen, die in de originele vorm vaak moeilijk zijn te ontcijferen. Voor het grootste deel hebben ze betrekking op regelgeving. Naar deze rechtsbronnen wordt in het eerste deel regelmatig verwezen, maar tegelijkertijd moet deze uitgave ook worden beschouwd als een nuttig instrument voor het verrichten van nieuw onderzoek. Voor rijksonmiddellijke gebieden in 'Limburg' zijn er, op een enkele uitzondering na, geen gedrukte rechtsbronnen beschikbaar. Specifiek voor Gronsveld komt daar bij dat door het vrijwel volledige verlies van de schepenbankarchieven, de weinige nog beschikbare rechtsbronnen zeer verspreid zijn geraakt en vaak in gebrekkige vorm overgeleverd. Met deze rechtsbronnen wordt voortgebouwd op een lange traditie in Limburg, beginnend in 
de negentiende eeuw met de werken van Crahay 2217 en Habets 2218 en in de twintigste eeuw onder anderen voortgezet door Janssen de Limpens ${ }^{2219}$ en Berkvens. ${ }^{2220}$ Voorts is er ook aansluiting met de in Duitsland in de laatste decennia uitgegeven wetgeving op het gebied van de 'Gute Policey' in de vroegmoderne tijd.2221

\section{Belang van (rechts)historisch onderzoek}

Levert de bestudering van een in 1795 als staatkundige eenheid verdwenen graafschap alleen maar dode kennis op, of heeft die ook in onze tijd nog relevantie? Eigenlijk gaat daar aan vooraf het debat over het nut van geschiedbeoefening in het algemeen. Sommigen zien kennis van de geschiedenis als een vorm van algemene ontwikkeling om situaties in het heden vanuit een continuiteit met het verleden te kunnen verklaren. Anderen zijn van mening dat uit het verleden lering kan worden getrokken ter voorkoming fouten in het heden. Soms wordt de geschiedenis gebruikt als middel om mensen bewust te maken van hun eigen identiteit als groep, voor het aankweken van liefde voor het vaderland en nationalisme of juist om zich tegen dit vaderland af te zetten. Naast pedagogische idealen zijn er nog andere redenen om zich in de geschiedenis te verdiepen. Voortbrengselen van materiële cultuur zoals gebouwen en voorwerpen wekken nieuwsgierigheid en trekken toeristen. Mensen beleven plezier aan het lezen over geschiedenis of proberen daar met het onderzoek naar de geschiedenis van stad en streek of hun eigen familie invulling aan te geven.

2217 L. Crahay, Coutumes de la ville de Maestricht, publié par ordre du Roi sous les auspices du Ministre de la Justice par les soins d'une commission spéciale, Bruxelles 1876; L. Crahay, Coutumes du comté de Looz de la seigneurie de Saint-Trond et du comté impérial de Reckbeim, Recueil des anciennes coutumes de la Belgique, Commission royale pour la publication des anciennes lois et ordonnances de la Belgique, Bruxelles 18711897.

2218 Habets, J., Limburgsche wijsdommen, dorpscostumen en gewoonten, bevattende voornamelijk bank- laat- en boschrechten, 's-Gravenhage 1891.

2219 Janssen de Limpens, K.J.Th., Geldersche Wyssenissen van het Hoofdgerecht te Roermond,'t Nye Boeck (14591487), (Werken der Vereeniging tot Uitgaaf der Bronnen van het Oud-Vaderlandsche Recht, $3^{\mathrm{e}}$ reeks, nr. 16), Utrecht 1953; Janssen de Limpens, K.J.Th., Rechtsbronnen van het Gelders Overkwartier van Roermond, (Werken der Vereeniging tot Uitgaaf der Bronnen van het Oud-Vaderlandsche Recht, 3e reeks, nr. 20), Utrecht 1965;Janssen de Limpens, K.J.Th., Rechtsbronnen van het hertogdom Limburg en de landen van Overmaze, Werken der Stichting tot Uitgaaf der Bronnen van het Oud-Vaderlandse Recht no. 1, Bussum 1977.

2220 Berkvens, A.M.J.A., Plakkatenlijst Overkwartier 1665-1794. I, Spaans Gelre. Instellingen, Territorium, Wetgeving (1580-) 1655-1702, Nijmegen 1990; II, Plakkatenlijst Overkwartier 1665-1794, Staats-bezet en Oostenrijks Gelre 91702-1716; 1716-1794), Rechtshistorische reeks van het Gerard Noodt Instituut nr. 25, Nijmegen 1992; Berkvens, A.M.J.A., 'Het nieuwe landrecht van Thorn. Verlicht absolutisme en codificatie onder het bewind van vorstin-abdis Maria Cunegonda van Saksen (1776-1794)', in: PSHAL 134-135 (1998-1999) 85-169; A.M.J.A.Berkvens, Plakkaten, Ordonnanties en Circulaires voor Pruisisch Gelre (1713-1798). Plakkatenlijst Overkwartier Deel III, (Werken uitgegeven door Limburgs Geschied- en Oudheidkundig Genootschap, 22, Maastricht 2012.

2221 Hier kan worden gewezen op de sinds 1996 verschenen tien delen van het Repertorium der Policeyordnungen, uitgegeven door het Max-Planck-Institut für europäische Rechtsgeschichte in Frankfurt am Main en de door Wolfgang Wüst e.a. sinds 2001 uitgegeven reeks: Die „gute" Policey im Reichskreis. Zur frübmodernen Normensetzung in den Kernregionen des Alten Reiches. 
Naast deze baaierd van meningen over de waarde van de geschiedenis is er ook nog het debat over de inhoud van het historisch onderzoek. Moet de nadruk liggen op presentatie van feiten of gaat het juist om een 'verhaal' waarin een beeld van het verleden wordt opgeroepen? Op welke doelgroepen richt de geschiedenis zich en welke onderwerpen moeten daarbij een accent krijgen? En ten slotte is er het probleem van de bronnen: welke bronnen staan ter beschikking, hoe objectief zijn die, welke objectiviteit legt de geschiedschrijver - al dan niet bewust - aan de dag en hoeverre is interpretatie van het verleden ook weer tijdgebonden? Deze in enkele zinnen geschetste brede probleemstelling maakt duidelijk dat het om een gecompliceerd geschiedtheoretisch vraagstuk gaat, met zeer uiteenlopende meningen.

De algemene vragen ten aanzien van de geschiedenis kunnen ook worden gesteld bij de beoefening van de rechtsgeschiedenis. Daar komt bij dat de rechtsgeschiedenis zich beweegt tussen het spanningsveld van de rechtswetenschap en de geschiedbeoefening. Het verbindend element tussen beide is dat zowel het recht als de geschiedenis maatschappelijke verschijnselen zijn. Met Van den Brink kan worden geconcludeerd dat 'rechtsgeschiedenis een onderscheiden, maar niet te scheiden onderdeel [is] van de maatschappijgeschiedenis. De rechtshistoricus is maatschappijhistoricus'.2222 De beoefening van de rechtsgeschiedenis heeft daarmee altijd een maatschappelijke component, of het nu gaat om de bestudering van de historische ontwikkeling van bepaalde rechtsregels of onderzoek naar de ontwikkeling van administratief-juridische structuren binnen een samenleving.

\section{Het verleden als spiegel voor het heden}

In deze studie naar het graafschap Gronsveld gaat het niet zo zeer om de historische ontwikkeling van het materiële recht (het aantal daarvoor beschikbare bronnen is beperkt), maar ligt het accent op het functioneren van een klein land binnen de juridische constructie van het Heilige Roomse Rijk der Duitse Natie. Die verhouding tot het Rijk levert een interessant voorbeeld van een supranationale organisatie met een zwak centraal gezag, een defensie gericht op de verdediging tegen externe vijanden en een systeem van rechtsbescherming gericht op conflictbeslechting tussen de lidmaten van het Rijk onderling en tussen landsheren en onderdanen. In de Duitse historiografie vanaf de jaren zestig van de twintigste eeuw wordt over dit 'Oude Rijk' wel gesproken als een voorafbeelding van de Europese Gemeenschap. Natuurlijk is voorzichtigheid geboden met dit soort vergelijkingen, want het Oude Rijk was een constructie op feodale basis, maar de gedachte erachter laat een model van staatsvorming en samenwerking zien dat ook bij discussies over huidige vormen van Europese samenwerking nog altijd actueel is.

Naast het weidse perspectief van Gronsveld als lid van het Heilige Roomse Rijk der Duitse Natie was er natuurlijk ook de realiteit van een miniatuurstaatje zonder politieke macht of economische betekenis, dat ondanks die kleinschaligheid een gecompliceerde

${ }^{2222}$ H. van den Brink, Rechtsgeschiedenis bij wijze van inleiding, Deventer 1976, 4 
organisatie van bestuur en rechtspraak kende. Toch bleek dat staatje met zijn gesloten politieke cultuur, bestuur op afstand en 'familieregering' eeuwenlang levensvatbaar. Zelfs tegen invloeden van buitenaf bleek deze cultuur bestand. Studies naar mentaliteit en politieke cultuur in dorpsgemeenschappen gedurende de vroegmoderne tijd zijn in het algemeen schaars. Dat hangt ook samen met het beschikbare bronmateriaal. Voor het graafschap Gronsveld geldt precies het omgekeerde. De archieven van de instellingen zijn vrijwel geheel verloren, maar in het bijzonder voor de achttiende eeuw is er veel ander bronmateriaal bewaard gebleven dat door de formele juridische kaders heen, juist een inkijk geeft in de maatschappelijke verhoudingen van die tijd.

Die samenleving in kleine gemeenschappen met hun eigen rechten heeft, zeker in de mentaliteit bij de dorpen in het Heuvelland, sporen achtergelaten tot ver in de twintigste en zelfs de 21 ste eeuw. Wie aspecten van traditionele cultuur binnen dorpsgemeenschappen wil begrijpen, moet zich ook verdiepen in de historische achtergronden daarvan. Hetzelfde geldt ook voor de historische achtergronden van nog steeds bestaande tegenstellingen tussen gemeenschappen. Kennis daarvan is zinvol bij actuele debatten over schaalvergroting, samenwerking tussen dorpen en politieke cultuur binnen het openbaar bestuur

\section{Geschiedenis en identiteitsvorming}

Het voorgaande valt te rangschikken onder de noemer 'wat kunnen wij leren van de geschiedenis'. Maar daarnaast kan kennis van het verleden ook bijdragen aan het antwoord op vragen over identiteit in het heden, verbondenheid met een groep of gedragspatronen van mensen. De behoefte daaraan lijkt juist te groeien in een gecompliceerde maatschappij waarin traditionele patronen verdwijnen. De opkomst gedurende de laatste veertig jaar van historische verenigingen op plaatselijk en regionaal niveau, de beoefening van genealogie als vrijetijdsbesteding en een vloed aan publicaties, variërend van tijdschriften, fotoboeken tot wetenschappelijke verhandelingen, zijn daar uitingen van. Die ontwikkeling heeft zich ook Limburg voorgedaan. Maar wie in deze provincie zoekt naar de historische wortels van de 'Limburgse' identiteit in een iets verder verleden, komt al snel terecht bij ingewikkelde staatkundige verhoudingen, waarbij de geschiedenis van dorp tot dorp kan verschillen. Tot de komst van de Fransen in 1795 bestond 'Limburg' uit een territoriaal sterk versnipperd gebied (achttien verschillende soevereinen) met bindingen naar oost en west, noord en zuid. De bewoners waren vrijwel homogeen katholiek en er werden verwante dialecten gesproken, maar verder bond de inwoners van de gebieden langs de Maas weinig gemeenschappelijks. De door de Fransen opgelegde staatkundige eenheid maakte weliswaar een einde aan de versnippering, maar de politieke verwikkelingen in de negentiende eeuw zorgden door wisselingen in soevereiniteit al evenmin voor een Limburgse identiteit. Tussen 1790 en 1840 wisselden de meeste Limburgers vijf keer van soeverein zonder ooit van woonplaats te veranderen. Een dergelijk klimaat is ongeschikt om nationale gevoelens te ontwikkelen.

Misschien neemt het graafschap Gronsveld bij het zoeken naar de wortels van die identiteit een bijzondere plaats in vanwege de banden met het Heilige Roomse Rijk der Duitse Natie. Er bestaat na tweehonderd jaar nog steeds een vage notie van het in 1795 
opgeheven graafschap en relaties met 'Duitsland' (zie hierna 'Belang voor immaterieel en materieel cultureel erfgoed'), maar wat dit precies betekende is voor hedendaagse inwoners zonder nadere uitleg onduideliik. Deze studie verschaft daarover helderheid, niet alleen voor Gronsveld, maar ook voor andere, vergelijkbare, rijksonmiddellijke gebieden.

\section{Identiteit en grensoverschrijdende geschiedbeoefening}

In een onlangs gepubliceerde voordracht onder de titel ' 175 jaar beide Limburgen: waarom ze toch niet bij elkaar horen' behandelt prof. dr. Ad Knotter de vraag of er zoiets bestaat als een gemeenschappelijke identiteit tussen Nederlands en Belgisch Limburg, gebaseerd op een gemeenschappelijk verleden. ${ }^{2223}$ Hij begint zijn betoog met de stelling dat:

'een aparte identiteit in eigen land nog geen gemeenschappelijke identiteit over de grens heen impliceert. Het gevoel van regionale eigenheid aan beide zijden van de Maas berust niet op dezelfde grondslagen. Belgische en Nederlandse Limburgers verschillen van elkaar omdat ze in andere nationale contexten leven en binnen die andere contexten een eigen geschiedenis hebben gehad'.

Zijn conclusie luidt dat een gemeenschappelijk verleden in een 'Land zonder grenzen' een illusie is, een wensdenken van politici in hun streven naar samenwerking over de grenzen heen. De geschiedenis van deze regio is juist wel een geschiedenis van een land met vele grenzen en een grote diversiteit op het gebied van taal, cultuur, politiek, economie et cetera. Knotter pleit dan ook voor grensoverschrijdende geschiedschrijving, juist om daarmee de ontwikkeling van het gebied dat met de benaming 'Euregio' wordt aangeduid, zichtbaar te maken:

'Juist die verschillen lokken grensoverschrijdende contacten en uitwisseling uit, waardoor er tussen de verschillende regio's toch weer samenhang en samenwerking kan ontstaan'.

Het is niet de bedoeling in dit debat inhoudelijk stelling te nemen (de materie is daarvoor ook te veelomvattend), maar twee elementen springen in het oog. In de eerste plaats gaat het om een meer algemeen pleidooi om door bestudering van de geschiedenis van de regio, en in het bijzonder de verschillen tussen de afzonderlijke delen daarvan, grensoverschrijdende contacten 'uit te lokken'. Een tweede opmerkelijk punt in de tot op heden gevoerde discussie is dat de deling van de provincie Limburg in 1839 vaak wordt voorgesteld als een traumatisch ervaring, die in een einde maakte aan historische verbondenheid met gebieden ten westen of zuiden van het tegenwoordige Nederlands Limburg. Kortom, er leeft het idee dat de scheiding met België in 1839 een historische vergissing was. De onderbouwing van dit soort sentimenten verdient echter een genuanceerde benadering, want het gaat om een complex en lastig te ontrafelen probleem, waarbij feiten en gevoelens door elkaar lopen. Zo is het de vraag of die oude 'lotsverbondenheid' met de 'Belgen' niet berust op een geromantiseerd beeld van de geschiedenis, terwijl de scheiding van 1839 economische en culturele betrekkingen niet in de weg heeft gestaan.

2223 A. Knotter, '175 jaar beide Limburgen: waarom ze toch niet bij elkaar horen', in: De Maasgouw, Tijdschrift voor Limburgse geschiedenis en archeologie 134 (2015) 5-11. 
Opmerkelijk genoeg lijken oude historische banden met gebieden ten oosten van de in 1815 getrokken Nederlandse staatsgrens grens, met 'Duitsland', nauwelijks een rol te spelen, hoewel daar vanuit geografisch en staatkundig oogpunt alle reden voor zou bestaan. De grens van 1815 heeft culturele en economische betrekkingen met het Oosten gedurende de negentiende en twintigste eeuw niet in de weg gestaan, maar de herinnering aan het oude Duitse Rijk als staatkundig verband lijkt in die twee eeuwen nagenoeg te zijn verdampt. Voor deze verwijdering zijn wel enkele verklaringen te geven. Een korte opleving in de vorm van het separatisme in 1848 vond weinig aanhang en het Limburgse lidmaatschap van de Duitse Bond werd eerder als een last dan als een lust ervaren. Er waren taalkundige verschillen en men stond afwijzend tegenover het Pruisisch militarisme, de Pruisische ambtenarenmentaliteit en de antikatholieke Kulturkampf na 1870. In de twintigste eeuw prezen de Limburgers zich eerst, tijdens de Eerste Wereldoorlog, gelukkig te behoren tot het neutrale Nederland en daarna hebben de ervaringen van de Tweede Wereldoorlog diepe sporen nagelaten. Pas met de opkomst van de Euregiogedachte vanaf de jaren zeventig van de twintigste eeuw en de formalisering daarvan als publiekrechtelijke organisaties kan worden gesproken van - soms nog moeizame - structurele samenwerking over de grens, ontdaan van politieke en historische beladenheid.

Tegen die achtergrond kan grensoverschrijdende geschiedschrijving een zinvolle bijdrage aan de discussie over een gemeenschappelijk verleden met 'Duitsland' leveren, ook als tegenhanger van een regionale geschiedschrijving die door inmiddels tweehonderd jaar Nederlandse staatsverband, op Nederland en België georiënteerd is geraakt. Het moet dan wel gaan om een correcte beoordeling van oude historische banden, ontdaan van mythologie en ervaringen tussen buurlanden uit de negentiende en twintigste eeuw. Zoals de nationale staat van de laatste twee eeuwen drempelverhogend werkt in grensoverschrijdende contacten, zo kan het besef van een gemeenschappelijk verleden op een heel andere staatkundige basis juist drempelverlagend werken.

De geschiedenis van Gronsveld als klein, onafhankelijk gebied geplaatst binnen het historische staatsrechtelijk kader van het Heilige Roomse Rijk der Duitse Natie vormt daartoe aan Nederlandse kant een aanzet. Een rechtshistorische benadering ligt daarbij als eerste stap min of meer voor de hand. Het beschikbare bronmateriaal in de vorm van archieven heeft vaak betrekking op wetgeving, bestuur, rechtspraak en en leent zich ook goed voor het maken van vergelijkingen. Daar komt bij dat inzicht in de institutionele geschiedenis een goede basis vormt voor onderzoek vanuit andere invalshoeken.

Een aardig detail is dat politici tegenwoordig graag wat betreft de economische mogelijkheden van Limburg een vergelijking maken met Beieren. Met de Beierse graven von Toerring Jettenbach als heren van Gronsveld levert dat een precedent uit het verleden...

\section{Belang voor immaterieel en materieel cultureel erfgoed}

Hoewel deze studie over Gronsveld tal van aspecten bevat die boven het regionale of plaatselijke belang uit steken, richt ze zich in de eerste plaats toch op geïnteresseerden in de (rechts)geschiedenis van de dorpen die eertijds deel uitmaakten van dit graafschap of 
daarmee waren verbonden. Een dergelijk overzicht, dat tot op heden ontbrak, versterkt ook de bewustwording van de betekenis van het nog bestaande immateriële en materiële culturele erfgoed. Tot dit immateriële erfgoed moet in Gronsveld zeker alles worden gerekend wat samenhangt met de in 1619 gestichte schutterij Sint-Sebastianus (vierhonderdjarig bestaan in 2019) en de vierjaarlijkse viering van de 'Grote Bronk', een evenement waar het grootste deel van de bevolking bij betrokken is. Bij die gelegenheid worden nog altijd de namen van de graven van Gronsveld als stichters en begunstigers publiekeliik genoemd en in ere gehouden. Tot het materiële erfgoed behoren ook de kerken van Heugem, Gronsveld, en Eckelrade en de daarin aanwezige kunstwerken. In het bijzonder in de Sint-Martinuskerk van Gronsveld vormen de graftombe van de heren van Bronckhorst uit de zestiende eeuw en drie monumentale altaren en het orgel uit de twee eerste decennia van de achttiende eeuw, alle voorzien van fraaie wapenschilden, een voor Nederland zeer bijzonder ensemble, dat als een soort 'Gesamtkunstwerk' uitdrukking geeft aan de status van de graven als rijksstand.

Het oude kasteel van de heren van Gronsveld is an het begin van de negentiende eeuw gesloopt, maar nog altijd staan er monumentale restanten boven de grond. In een wat verder verband met Gronsveld staan het kasteel van Vaalsbroek en de kerk van Holset, één van de oudste kerkgebouwen in de provincie, waarover de heren van Gronsveld rechten uitoefenden. Aan het heerlijke recht van banmolen herinnert de nog altijd bestaande monumentale torenmolen in Gronsveld uit 1619. Monumentale panden in Gronsveld, Eckelrade en Honthem zijn deels terug te voeren op een middeleeuwse verkaveling volgens het recht van keurmede. Tot het kleine culturele erfgoed ten slotte horen zeker ook de bij verzamelaars van historische munten bekende Gronsveldse munten. De beschrijving van het Gronsveldse muntrecht bevordert niet alleen de kennis van de numismatiek, maar draagt ook in breder perspectief bij aan het ontmythologiseren van romantische verhalen over 'valsmunterij' van adellijke 'Limburgse' kasteelheren, zoals die vaak in de populaire geschiedschrijving en toeristische sfeer in verschillende plaatsen de ronde doen. Kortom, er zijn tal van gebouwen en voorwerpen die herinneren aan het verleden van het graafschap.

In het verlengde van het voorgaande ligt de betekenis van de analyse van de geografie van het gebied in de middeleeuwen. Daarin wordt voortgebouwd op vroegere studies van Hartmann en Hackeng over de middeleeuwse ontginningsgeschiedenis van het plateau van Margraten en Eckelrade en de ontwikkeling van Breust/Eijsden en Berg. Het graafschap Gronsveld vormt daarin, ook in geografische zin, een schakel. Het letterlijk in kaart brengen van middeleeuwse rechtsverhoudingen geeft inzicht in de ontwikkelingsgeschiedenis van het gebied. Dit landschap is ook een vorm van erfgoed, waarmee de overheid bij de ontwikkeling van beleid rekening houdt, bijvoorbeeld bij planologie en toerisme. In het bijzonder binnen de huidige gemeente Eijsden-Margraten, waar toerisme op basis van landschappelijk belangrijke cultuurhistorische waarden een speerpunt van beleid is (men denke in dit verband aan de verschillende door de gemeente ontwikkelde 'Bronk'- en andere wandelroutes), kan dat een interessante bijdrage leveren bij de invulling van plannen op dit gebied. 


\section{Belang voor de geschiedschrijving: regionaal, nationaal en internationaal}

Deze studie over Gronsveld richt zich primair op plaatselijke geschiedenis, maar tegelijkertijd wordt ook een bijdrage geleverd an de regionale 'Limburgse', aan de nationale Nederlandse en aan de Duitse geschiedschrijving. Hoewel op het grondgebied van de huidige provincie Nederlands Limburg een groot aantal rijksonmiddellijke territoria lag, in het bijzonder in Midden- en Zuid-Limburg, staat de geschiedschrijving daarover nog steeds in de kinderschoenen. Van een synthese is zelfs helemaal geen sprake. Het onderzoek naar Gronsveld vult een deel van deze lacune op.

In de nationale Nederlandse geschiedschrijving overheerst nog altijd het beeld dat het huidige Nederland territoriaal gezien een voortzetting is van de oude Republiek. Weliswaar is bekend dat de Republiek een 'rafelrand' kende in vorm van 'Generaliteitslanden', onder andere in Limburg (waar nog allerlei kanttekeningen bij zijn te plaatsen), maar nagenoeg onbekend is dat er ook nog kleine onafhankelijke gebieden zoals Gronsveld lagen, die eertijds tot het Heilige Roomse Rijk behoorden.

Het belang van Gronsveld voor de Duitse geschiedenis ligt vooral in de rol die de graven van Bronckhorst Batenburg als militairen en diplomaten. De naam 'Gronsfeld' is in de Nederlandse en Limburgse geschiedschrijving vergeten, maar heeft in de Duitse kriigsgeschiedenis en diplomatieke geschiedenis uit de zeventiende en het begin van de achttiende eeuw een bekende klank. Jost Maximiliaan van Bronckhorst Batenburg heeft met zijn geschriften zelfs bijgedragen aan de Duitse geschiedschrijving over de Dertigjarige Oorlog. Zijn zoon Johan Frans speelde een belangrijke rol in de strijd tegen de Turken op de Balkan.

\section{Instrument voor en hulpmiddel bij nieuw onderzoek en ontsluiting van archieven.}

Voor de bestudering van rijksonmiddellijke gebieden is nauwelijks Nederlandstalige literatuur voorhanden en ontbreekt een algemeen overzicht. Het belangrijkste is het veertig jaar geleden verschenen standaardwerk van Nève over het Rijkskamergerecht en de Nederlanden, maar deze verhandeling legt specifiek de nadruk op slechts één van de instellingen van het Rijk en is niet altijd meer actueel. Literatuur in het Engels is in opkomst, maar nog niet echt algemeen; literatuur in het Duits daarentegen is voor buitenstaanders schier onoverzienbaar. Met deze stand van zaken is er voor gekozen 'handboekkennis' van het staatsrecht van het Duitse Rijk en de werking van de instellingen in deze studie over Gronsveld te verwerken. Voor de lezers biedt die toelichting de mogelijkheid om de geschiedenis van de instellingen in een historisch kader te plaatsen. Maar daarnaast vormt het een nuttig hulpmiddel bij een eerste bestudering van de geschiedenis van andere rijksonmiddellijke territoria in zowel Belgisch als Nederlands Limburg en de (nog steeds ontoereikende) ontsluiting van archiefbronnen. Verder vormt deze studie over Gronsveld een aansporing om bronnen te gebruiken die tot op heden nauwelijks bij historisch onderzoek werden betrokken. Dat geldt bijvoorbeeld voor de sinds 2002 ontsloten Maastrichtse procesdossiers van het Rijkskamergerecht. In het specifieke geval van Gronsveld bestond voor dat gebruik ook een directe noodzaak, 
aangezien de rechterlijke archieven grotendeels verloren zijn gegaan, maar ook meer algemeen laat de uitvoerige beschrijving van enkele casus zien welke mogelijkheden deze dossiers voor historisch onderzoek bieden.

Het onderzoek naar het rijksonmiddellijke graafschap Gronsveld kan daarom dienen als model of stramien voor onderzoek naar vergelijkbare territoria, maar levert geen blauwdruk voor geschiedschrijving. 'Rijksonmiddellijkheid' vormt immers een 'containerbegrip', wat betekent dat voorzichtigheid is geboden met generaliserende uitspraken. Want bij de bestudering van afzonderlijke territoria wordt snel duidelijk dat elk gebied specifieke kenmerken had en die (soms kleine) verschillen werken ook door bij een zorgvuldige beoordeling van de staatsrechtelijke toestand. Dat maakt het noodzakelijk soms gedetailleerd in te gaan op plaatselijke situaties. Bij Gronsveld waren de mogelijkheden daartoe door de overlevering van het bronmateriaal enerzijds zeer beperkt en anderzijds ook weer zeer ruim. Uiteindelijk kan dan door een vergelijking tussen verschillende plaatsen een algemeen beeld worden opgeroepen. 


\section{Afkortingen}

AHVN: Annalen des Historischen Vereins für den Niederrhein.

BIAL: Bulletin de l'Institut Archéologique Liègois.

BSAHL: Bulletin de la Société d'Art et d'Histoire du diocèse de Liège.

PSHAL: Publications de la Société Historique et Archéologique dans le Limbourg.

RHCL: Regionaal Historisch Centrum Limburg.

TJ: Toerring Jettenbach.

ULB: Universitäts- und Landesbibliothek Darmstadt.

VROA: Verslagen omtrent's Rijks Oude Archieven.

ZAGV: Zeitschrift des Aachener Geschichtsvereins. 


\section{Onuitgegeven bronnen}

Staatsarchiv München / Regionaal Historisch Centrum Limburg (RHCL) Maastricht

Archiv Toerring Jettenbach, Abteilung Litt. M.

De afzonderlijke inventarisnummers zijn gefolieerd en vervolgens gemicrofilmd. Deze films bevinden zich bij het Regionaal Historisch Centrum Limburg (RHCL) te Maastricht. In de tekst wordt verwezen naar het verfilmde inventarisnummer van het bestand te München (TJ) en vervolgens de folio's.

TJ, nrs. M 1, M 2, M 3, M 4, M 5, M 6, M 8, M 10, M 11, M 12, M 13, M 14, M 15, M 16, M 17, M 18, M 20, M 21, M 22, M 23, M 25, M 32, M 33, M 35, M 40, M 41, M 42, M 43, M 44, M 45, M 46, M 50, M 53, M 55, M 56, M 57, M 58, M 59, M 60, M 61, M 62, M 63, M 64, M 68, M 71, M 72, M 73, M 75, M 76, M 77, M 80.

Regionaal Historisch Centrum Limburg (RHCL) te Maastricht.

Archief Hof van Gelder te Roermond, nr. 418 (dossier nr. 4327), nr. 557.

Archieven Landen van Overmaze, nrs. 749, 2194, 3881, 3984, 3996, 4959, 5273, 5329, 5376, 5378, 5577, 5635, 6831, 8492, 9396, 9414, 9483, 9684, 9708.

Archieven Graafschap Horn, nr. 74.

Archief Indivieze raad Maastricht, nrs. 66, 223, 927-929, 2052.

Archief Luikse commissarissen-deciseurs te Maastricht, nr. 140.

Archief Brabants Hooggerecht Maastricht, nr. 792.

Archief Graafschap Vroenhof, nr. 340.

Oud-rechterlijk archief Maastricht, Ongesorteerde stukken, doos 54, met handschrift afkomstig uit particulier bezit, geschonken door G. Regout.

Archief Armentafel Grote Heilige Geest te Maastricht, nrs. 1, 11.

Archieven van het graafschap Gronsveld en de heerlijkheid Slenaken (tot 1728), nrs. 5, 9, 10, 13, 35, 52, 58, 60, 61, 62, 73, 75, 78, 87, 88, 92-96, 98, 101, 102, 118, 119, 121-124, 130, 137, 145, 146, 148, 155, 172-187, 210, 216, 218, 221, 226, 227, 236-240, 244, 252, 254-258, 262, 270, 275, 276, 295, 298, 305, 306, 318, 327, 332, 344, 359, 363, 365, 366, 369, 399-401, 403, 405, 407, 411, 412, 420, 425, 426, 438, 439, 442, 443, 447, 449, 452-454, 456, 457, 459, 460, 462, 464-468, 472, 473, 478, 488, 501-503, 519-535, $557,560,564,570,577,581,586,599,671$.

Archief Schepenbank Rijckholt, nr. 121.

Archief Hoofdgerecht en het kerspel Thorn, nrs. 696, 713, 1205.

Archief Abdij/Stift Thorn (Inv. d'Hoop) nr. 18818.

Archief Vrije Rijksheerlijkheid Wittem, voorl. nrs. 227, 286.

Archief Graafschap Wittem, inv. nr. 1, 221-234, 309 en 313.

Archief Rijkskamergerecht, nrs. 1, 10, 16, 17, 18, 25-27, 44, 53, 71-78, 84, 95, 114, 126, 145, 176, 187, 192, 193, 222, 230, 257, 295, 299.

Archief Departement Nedermaas, nrs. 1037, 1063, 2135, 2239, 2243, 4765. 
Notariële archieven berustende in het Rijksarchief in Limburg te Maastricht 1544-1842, nrs. 435, 439, 441, 2396, 4791-4797.

Archief Parochie H. Lambertus Holset, voorl. nr. 24.

Archief Parochie H. Martinus Gronsveld, voorl. nrs. 12, 13, 40-43

Archief Parochie H. Martinus Maastricht-Wyck I, nrs. 4, 79, 164.

Archieven Kerkelijke rechtbanken en bisschoppelijke commissarissen te Maastricht 1498-1842, nr. 93.

Archief Kapittel O. L. Vrouwe Maastricht, nrs. 622, 1028, 1403.

Archief Klooster antonieten te Maastricht, nrs. 3, 114.

Archief klooster jezuïten Maastricht, nr. 12.

Archief Klooster kruisheren te Maastricht, nr. 708.

Archief Klooster Witte Vrouwen te Maastricht, nr. 59.

Archief Klooster kruisheren te Roermond, nr. 133.

Archief Abdij Kloosterrade te Rolduc, nr. 1736.

Archief Klooster Hoogcruts te Slenaken, nrs. 178, 296, 310, 519, 531, 534, 719, 720, 727, 746, 761, 762, 781, 975, 998-1020.

Archief De Bounam de Ryckholt, nrs. 60, 81, 462, 478, 484, 486, 487, 492, 681.

Archief De Geloes/Kasteel Eijsden, nrs. 317, 417-425, , 427, 440, 450, 576, 626, 1142.

Archief Huis Vaalsbroek, ongenummerd, uittreksel uit de gedingrol van de laatbank 1688-1732; archiefinventaris 18e eeuw.

Archief Familie Hanssen te Rimburg, ongeordend.

Collectie De Crassier, nr. 30, sub 'Gronsveld'.

Collectie Janssen de Limpens, nr. 1.

Collectie Zegelstempels Rijks Archief Limburg, nr. 80.

Brabants Historisch Informatiecentrum (BHIC) '-s-Hertogenbosch, Archief Raad van Brabant, nr. 20.

Nationaal Archief, 's-Gravenhage.

Archief Staten-Generaal 1550-1796,. nr. 5857.

Archief Kasteel Rimburg, Übach-Palenberg.

Archief 'Mappe 1 No. 23, Original-Urkunde'.

Rijksarchief Limburg, Hasselt.

Archief Abdij Hocht, nr. 13.

Archief schepenbank Sint-Pieters-Voeren,. nr. 34.

Archief Landkommanderij Oudenbiezen en onderhorige Kommanderijen, orkonden nrs, 66 en 67.

Archief abdij Sinnich, inv. nr. 327/2. 
Archives de l'État, Luik.

Archief Cour feodale de Liège, nrs. 79, 80, 88, 92, 105, 108, 115.

Universitäts- und Landesbibliothek, Darmstadt.

Handschriften, nr. 2734-2735 (vroeger Sammlung Alfter 34-35), nr. 2750 (Dagboek Besprekingen Nederrijns-Westfaalse graven 1653).

Österreichisches Staatsarchiv, Wenen.

Allgemeines Verwaltungsarchiv, RAA (Reichsadelsakten), 49.3. 


\section{LITERATUURLIJST}

Agt, J.F. van, De Nederlandse Monumenten van Gescbiedenis en Kunst, De provincie Limburg, ZuidLimburg uitgezonderd Maastricht, Tweede aflevering: Vaals, Wittem en Slenaken, 's-Gravenhage 1983.

Alberts, W. J., Overzicht van de geschiedenis van de Nederrijnse territoria tussen Maas en Rijn, deel II, 1288-1500, (Maaslandse Monografieën 36), Assen 1982.

Alders, A., 'Obermörmter. Das zerissene Dorf, in: Studien zur Gescbicbte der Stadt Xanten 1228-1978 (Keulen 1978) 313-334.

Andermann, K., 'Ein furnem und namhafts Geschlecht in unsern Landen. Glanz und Niedergang der Grafen von Eberstein', in: Grafen und Herren in Südwestdeutschland vom 12. bis ins 17. Jabrbundert, (Kraichtaler Kolloquien 5), Epfendorf 2006, 195-215.

Arndt, J. Das Niederrbeinisch-Westfälische Reichsgrafenkollegium und seine Mitglieder (1653-1806) (Veröffentlichungen des Instituts für Europäische Geschichte Mainz, Abteilung Universalgeschichte, deel 133), Mainz 1991.

Aretin, K.O. Freiherr von, Heiliges Römisches Reich 1776-1806, Reichsverfassung und Staatssowveränität, deel 1-2, (Veröffentlichungen des Instituts für Europäische Geschichte Mainz, Abteilung Universalgeschichte Band 38, Wiesbaden 1967.

Asseldonk, M. van, De Meijerij ontrafeld. Plaatselijk bestuur, dorpsgrenzen en bestuurlijke indeling in de Meijerij van 's-Hertogenbosch, circa 1200-1832, Tilburg 2003.

Avonds, P. 'Brabant en Limburg 1100-1403', in: [Nieuwe] Algemene Geschiedenis der Nederlanden, 2, Middeleeuwen, Haarlem 1982, 452-482.

Augustus, L., 'De familie Spies zu Ehrenstein en het pandheerschap over Kerkrade 15641689', in: Uit Kerkrade's Verleden. Opstellen nitgegeven bij gelegenheid der Schuttersbroederschap St.Sebastianus, z.pl. 1967, 43-61.

Baerten, J. Het graafschap Loon (11de-14de eeuw), (Maaslandse Monografieën 9), Assen 1969.

Bax, W., Het protestantisme in het bisdom Luike en vooral te Maastricht 1505-1557, I, 'sGravenhage 1937.

Bax, W., Het protestantisme in het bisdom Luike en vooral te Maastricht 1557-1612, II, 'sGravenhage 1940.

Belonje, J., 'Genealogische en heraldische gedenkwaardigheden in en uit de kerken der provincie Limburg, met een supplement betreffende de Belgische en Duitse grensgebieden', in: PSHAL 96-97 (1960-1961) 1-526.

Belonje, J., Schymper te Moresnet, Arnhem 1983.

Berkum, A. van, 'Het zaalkerkje van Oud-Lemiers', in: PSHAL 111(1975) 69-187.

Berkvens, A.M.J.A., Plakekatenlijst Overkwartier 1665-1794. I, Spaans Gelre. Instellingen, Territorium, Wetgeving (1580-) 1655-1702, Nijmegen 1990.

Berkvens, A.M.J.A., 'De vrije rijksheerlijkheid Kessenich, van Brabants en Guliks leen tot Gelders 'Territoir', in: PSHAL 122 (1986) 149-177.

Berkvens, A.M.J.A., 'Het nieuwe landrecht van Thorn. Verlicht absolutisme en codificatie onder het bewind van vorstin-abdis Maria Cunegonda van Saksen (1776-1794)', in: PSHAL 134-135 (1998-1999) 85-169.

Berkvens, A.M.J.A., 'De kanunnik Joannes Stuben als auctor intellectualis van het 'Rijksvorstendom' Thorn (1688-1721)' in: Berkvens, A.M.J.A en Rensch, Th.J. van [red.], 'Wordt 
voor Recht gehalden. Opstellen ter gelegenheid van vijfentwintig jaar Werkgroep Limburgse Rechtsgeschiedenis (1980-2005) (Werken uitgegeven door Limburgs Geschied- en Oudheidkundig Genootschap 19) Maastricht 2005, 191-210.

Berkvens, A.M.J.A., 'De Geheime Tribunalsrath Johann Koenen en de visitatie van het Justiz-Collegium in Pruisisch Gelre, 1768-1779' in: Berkvens, A.M.J.A en Rensch, Th.J. van [red.], 'In hoede van recht gekeerd'. Opstellen ter gelegenheid van dertig jaar Werkegroep Limburgse Rechtsgeschiedenis (Werken uitgegeven door Limburgs Geschied- en Oudheidkundig Genootschap 20) Maastricht 2010, 167-188.

Berkvens, A.M.J.A., 'Zur Abkurtzung unnötiger Processualweitlaufigkeiten'. Een bijdrage over de geschiedenis van het Hof van Appel te Thorn 1718-1795', in: Berkvens, A.M.J.A en Rensch, Th.J. van [red.], Wordt voor Recht gehalden. Opstellen ter gelegenheid van vijfentwintig jaar Werkgroep Limburgse Rechtsgeschiedenis (1980-2005) (Werken uitgegeven door Limburgs Geschied- en Oudheidkundig Genootschap 19) Maastricht 2005, 211-240.

Beurden, A.F. van, 'Charters en perkamenten', in: Limburg's Jaarboek 12 (1906) 83-115.

K. Bierther, Die Politik Maximilians I von Bayern und seiner Verbündeten 1618-1650, Zweiter Teil, Neunter Band, Juni 1634-Mai 1635, Briefe und Akten zur Geschichte des Dreißigjäbrigen Krieges) München 1986.

Biographie universelle ancienne et moderne etc...', nouvelle édition, 35, Parijs/Leipzig z.j.

Blécourt, A.S. de, 'Heerlijkheden en heerlijke rechten', in: Tijdschrift voor rechtsgeschiedenis, I, (1918-1919) 45-107, 175-190, 489-519; II, (1920-1921) 42-134 en 163-219.

Blécourt, A. S. de/Fischer, H. F. W.D., Kort begrip van het oud-vaderlands burgerlijk recht, $7 \mathrm{e}$ druk, Groningen 1959.

Boel, W.M. van de, 'Een onderzoek naar de rechterlijke organisatie in de heerlijkheid Horn' in: PSHAL 101 (1965) 159-194.

Boer, D. E. L. de, Het oude Duitsland. Een geschiedenis van de Duitse Landen van 1450 tot 1800 (Amsterdamse Historische Reeks, Kleine Serie, deel 44) Amsterdam 2002.

Boersma, H.J.L.M., De bevolking van het kanton Eijsden in 1796, Maastricht 2002.

Boersma, H.J.L.M., 'Genealogie P(i)etermans' in: Gens Nostra 50 (1995) 345-364 en 446456.

Böhme, E., Das fränkische Reichsgrafenkollegium im 16. und 17. Jahrhundert. Untersuchungen zu den Möglichkeiten und Grenzen der korporativen Politik mindermächtiger Reichsstände. (Veröffentlichungen des Instituts für Europäische Geschichte Mainz, Abteilung Universalgeschichte Band 132, Beiträge zur Sozial- und Verfassungsgeschichte des Alten Reiches, nr. 8, Stuttgart 1989.

Boorn, H. van den, Limieten tusschen Gronsveld en Eckelrade, in: De Maasgouw 1 (1879) 143-144.

Borman, C. de, Les Échevins de la Souveraine Justice de Liège, 2 (Age Moderne), Luik 1899.

Borman, C. de en Poncelet, É., Oeuvres de Jacques de Hemricourt, II, Le Miroir des Nobles de Hesbaye, Brussel 1925.

Bormans, S., 'Seigneuries féodales de l'ancien pays de Liège', in: BLAL 9 (1868) 157-274.

Bormans, S. en Schoolmeesters, E., Cartulaire de l'église Saint-Lambert de Liège, 1-4, Brussel 1893-1900. 
Bornheim gen. Schilling, W., 'Zur Geschichte der Reifferscheidt und ihres Verwantschaftskreises im 12.-13. Jahrhundert', in: AHV N 155/156 (1954) 98-124.

Bösken, W., 'Beiträge zur Geschichte der ehem. Herrschaft Alpen', in: Die Veröffentlichungen des Historischen Vereins für Geldern und Umgegend, Gesamtausgabe, Geldern 1974, 151-211 (reprint van oorspronkelijke uitgave Geldern 1902.

Bremer, J., Die reichsunmittelbare Herrschaft Millendonk, das sind die beutigen Gemeinden Korschenbroich und Pesch..., Mönchengladbach 1939.

Brouwers, D-D., Histoire du chapitre noble de Sinnich de l'ordre de St. Augustin, Verviers 1903. [M. Buchberger ed.], Lexicon für Theologie und Kirche, delen I-X, Freiburg im Breisgau 19301938.

Buchet, A., La seigneurie Del Beuck à Henri-Chapelle, Verviers 1938.

W. Buntinx, W., Inventaris van het archief van de abdij van Hocht (Lanaken), Brussel 1970.

Busch, T., Herrschen durch Delegation. Reichsgräfliche Herrschaft zu Ende des 17. und im 18. Jabrhundert am Beispiel der Reichsgrafschaft Solms-Rödelheim (Quellen und Forschungen zur hessischen Geschichte 156) Darmstadt-Marburg 2008.

Cappon, C.M., 'Inleiding: de continuïteit van het notariaat', in: Gehlen, A.Fl. en Nève, P.L. [red.], Het notariaat in de Lage Landen ( \pm 1250-1842). Opstellen over de geschiedenis van het notariaat in de Lage Landen vanaf de oorsprong tot in de negentiende eeun (Ars Notariatus CXVII) Deventer 2005, 1-29.

Caumartin, 'Souvenirs et promenades à Gronsveld', in: PSHAL 1 (1864) 262-287.

Ceyssens, J., Les bans, seigneuries laiques et immunités ecclésiastiques du pays de Dalhem, spécialement an XVe siècle, Luik 1929.

Chestret de Haneffe, J., 'Histoire de la seigneurie impériale de Reckheim', in: PSHAL 10 (1873) 5-96.

Chestret de Haneffe, J., 'Histoire de la seigneurie impériale de Gronsveld', in: PSHAL 12 (1875) 3-126.

Chestret de Haneffe, J., 'Renard de Schönau, sire de Schoonvorst. Un financier gentilhomme du XIVe siècle', [Extrait du tome XLVII des Memoires couronnés et autres Memoires, publiés par l'Académie royale de Belgique], 1892.

Chijs, P.O. van der De munten der voormalige heeren en steden van Gelderland van de vroegste tijden tot aan de Pacificatie van Gend, Verhandelingen uitgegeven door Teyler's Tweede Genootschap, Haarlem 1853.

Chijs, P.O. van der, De munten der leenen van de voormalige hertogdommen Braband en Limburg, en₹: van de vroegste tijden tot aan de Pacificatie van Gend, Verhandelingen uitgegeven door Teyler's Tweede Genootschap, 26e stuk, achtste gedeelte Haarlem 1862.

Coels von der Brügghen, L. von, 'Die Schöffen des Königlichen Stuhls von Aachen von der frühesten Zeit bis zur endgültigen Aufhebung der reischsstädtischen Verfassung', in: ZGAV 50 (1928) 1-596.

Coels von der Brügghen, L. von, 'Die Aachener Bürgermeister von 1251 bis 1798', in: ZGAV 55 (1933/34) 41-77.

Coels von der Brügghen, L. von, Die Lehensregister der Proptsteilichen Mannkammer des Aachener Marienstifts, (Publikationen der Gesellschaft für Rheinische Geschichtskunde 52), Bonn 1952.

Conrad, H. Deutsche Rechtsgeschichte, I-II, Karlsruhe 1966. 
Cools, H., Mannen met macht. Edellieden en de Moderne Staat in de Bourgondisch-Habsburgse landen (1475-1530), Zutphen 2001.

Corpus Sigillorum Neerlandicorum. De Nederlandsche zegels tot 1300 afgebeeld en beschreven, I-III, 'sGravenhage 1937-1940.

Corsten, S. 'Gerhard von Wassenberg und Horn 1180-1225', in: PSHAL 103-104 (1969) 42-60.

Corsten, S., 'Die Herren von Valkenburg (ca. 1000-1364)', in: PSHAL 120 (1984) 162-200.

Coun, Th., Het gebucht Smeermaas (Lanaken) en zijn bewoners 1499-1796. Bronnen voor de bewoningsgeschiedenis, Lanaken 2013.

Croenen, G., De oorkonden van de familie Berthout 1212-1425, Brussel 2006.

J.P.J.A.M. van Daalen, De munten van het graafschap Gronsveld, Deel II Geschiedenis van Gronsveld, z.pl., 1964.

Daris, J., 'Les Cours de justice de l'ancienne principauté de Liège'in: BIAL 16 (1881) 1-46.

Daris, J., 'Le cartulaire de l'abbaye de Herkenrode' in: Notice sur les églises du diocèse de Liège, IV, Luik 1871, 1-138.

Daris, J., 'Document inédits touchant le couvent des norbertines de Reckheim', in: Bulletin de la Société Scientifique et Littéraire du Limbourg, 10 (z.j) 5-24.

Debouxthay, P.J./Dubois, F., Histoire de la seigneurie de Nivelle-sur-Meuse et de l'ancienne paroisse de Lixhe, Luik, z.j.

Delahaye, R.M. e.a. [ed.], De Archieven in Limburg (Overzichten van de archieven en verzamelingen in de openbare archiefbewaarplaatsen in Nederland, deel XIII, Alphen aan den Rijn 1986.

Delahaye, R.M., Inventaris van de archieven van het klooster Hoog-Cruts te Noorbeek/Slenaken 1512-1798 (1803), Maastricht 1987.

Delahaye, R.M., 'Het klooster Hoog-Cruts: een grensgeval', in: De Maasgoum 101 (1982) 177-196.

Denessen, H., 'De Gelderse bannerheren in de vijftiende eeuw', in Virtus. Journal of Nobility Studies 20 (2013) 11-37.

Diederich, T., 'Grundzüge des Siegelwesens im ausgehenden 13. Jahrhundert', in: Wörringen 1288. Historische Entscheidung im europäischen Nordwesten/Woeringen 1288, keerpunt in de geschiedenis van de Nederlanden en de Landen van de Nederrijn, Keulen 1988, 83-104.

Domsta, H.J., Geschichte der Fürsten von Merode im Mittelalter, I-II, Düren 1981.

Doorninck, P.N. van, Het oudste leenactenboek van Gelre, Haarlem 1998.

Doppler, P., 'Uitvaart van Georgius-Lodewijk van Berghe, prins-bisschop van Luik, te Maastricht gehouden in de O. L. Vrouwekerk', in: De Maasgoum 18 (1896) 73-75.

Doppler, P., 'Schepenbrieven van het kapittel van St. Servaas te Maastricht', in: PSHAL 41 (1905) 50-146.

D[oppler], P.,'Bescheiden nopens den laathof 'Einraede' te Vaals in 1616', in: De Maasgouw 34 (1912) 79-80.

D[oppler], P., 'Pastorie te Holzet' in: De Maasgoum 36 (1914) 32.

Doppler, P.,'Valsche munten te Thorn, Gronsveld en Batenburg geslagen omstreeks 1564', in: De Maasgoum 39 (1919) 59-60.

Doppler, P., 'Schepenbrieven van het kapittel van St. Servaas te Maastricht', in: PSHAL 41 (1905) 50-146. 
Doppler, P., 'Schepenbrieven van het kapittel van O. L.Vrouw te Maastricht (1283-1767)', in: PSHAL 60-63 (1924-1927); PSHAL 60 (1924) 161-249, nrs. 1-140 (jaren 1283-1375); PSHAL 61 (1925) 87-187, nrs. 141-279 (jaren 1375-1420); PSHAL 62 (1926) 247-360, nrs. 280-445 (jaren 1421-1455); PSHAL 63 (1927) 91-292, nrs.446-715 (jaren 1456-1767). (NB Ook verschenen als overdruk met aparte paginering. Bij de annotatie wordt alleen verwezen naar het nummer van het regest).

Dormans, E., 'De financiële verhoudingen en belastingen in de Staatse Landen van Overmaze omstreeks 1750', in: Boels, H. [red.], Overheidsfinanciën tijden de Republiek en het Koninkrijk, 1600-1850, Hilversum 2012, 83-117.

Dösseler, E./Oediger, F.W., Die Lehnregister des Herzogtums Kleve (Das Hauptstaatsarchiv Düsseldorf und seine Bestände 8), Siegburg 1974.

Dotzauer, W., Die deutschen Reichskreise (1383-1806), Geschicbte und Aktenedition, Stuttgart 1998.

[Dubois, S., Demoulin, B., Kupper, J-L. ed.], Les institutions publiques de la principauté de Liège (980-1794) I-II, [Archives Générales du Royaume et Archives de l'État dans les Provinces, Studia 133], Brussel 2012.

Dumont, B., Aux origines des communes. Les Communautés villageoises dans les Pays de Dalhem et de Limbourg XVTe - XVIIIe siècle. Genèse, structutes, évolution (Crédit Communal, Collection Histoire in 8vo 89) Brussel 1994.

Dijck, A.H. van, 'Het Haardvuur als Rechtssymbool', in: De Maasgoun 71 (1957) 69-70

Dyserinck, H. De militaire gouverneurs van Maastricht, 1567-1794, in: PSHAL 27 (1912) $1-234$.

Ehrenpreis, St., Kaiserliche Gericbtsbarkeit und Konfessionspolitik. Der Reichshofrat unter Rudolf II, 1576-1612 (Schriftenreihe der Historischen Kommission bei der Bayerichen Akademie der Wissenschaften, 72) Göttingen 2006.

Endres, R., Adel in der Frühen Neuzeit (Enzyklopädie Deutscher Geschichte Band 18) München 1993.

Englbrecht, J., Drei Rosen für Bayern. Die Grafen zu Toerring von den Anfängen bis beute, München 1993.

[Erler, A., Kaufmann, E. Stammler, W. ed.], Handwörterbuch zur deutschen Rechtsgeschicbte, Berlijn 1971-heden.

Ernst, M.S.P./Lavalleye, E., Histoire du Limbourg suivie de celle des comtés de Daelhem et de Fanquemont, des Annales de l'abbaye de Rolduc, 6, Codex Diplomaticus Valkenburgensis, Luik 1847.

Evers, I.M.H., 'Een Maastrichts heksenproces in 1612, bronnenuitgave met commentaar' in: PSHAL 120 (1984) 201-244.

Fink, 'Ein Urteil des Weihbischofs Otto von Bronkhorst über die kirchlichen Verhältnisse des Hochstifts Osnabrück aus dem Jahre 1696' in: Mitteilungen des Vereins für Geschicbte und Landeskunde von Osnabrück 29 (1904) 93-112.

Flament, A.J.A., 'De rechtsbedeeling op het grondgebied van de tegenwoordige provincie Limburg in 1794. Met een blik op de voorgeschiedenis' in: PSHAL 51 (1915) 1-76.

Flament, A.J.A., 'Limburgsche geschied- en oudheidkundige schetsen / De voogdgedingen', in: PSHAL 52 (1916) 58-60.

Flament, A.J.A., 'Limburgsche geschied- en oudheidkundige schetsen / Deftige valsche munters', in: PSHAL 52 (1916) 37-42. 
Flament, A.J.A., 'Korte inhoud van de resolutiën der Staten-generaal der Vereenigde Nederlanden, gezonden aan de Commissarissen-Instructeurs van Brabantsche zijde te Maastricht', in: PSHAL 51 (1915) 173-316.

Flament, A.J.A. 'Jan Frans van Bronckhorst en Batenburg', lemma in: P.C. Molhuysen en P.J. Blok, [ed.], Nieuw Nederlandsch biografisch woordenboek, deel 1, 476-477.

Fockema Andreae, S. J., De Nederlandse Staat onder de Republiek (Verhandelingen der Koninklijke Nederlandse Akademie van Wetenschappen, Afd. Letterkunde, Nieuwe Reeks, deel LXVIII no. 3) Amsterdam 1974.

Fockema Andreae, S.J., 'Recht van den wind en molendwang', in: Tijdschrift voor Rechtsgeschiedenis I (1918-1919) 431-442.

Fockema Andreae, S.J., 'Het bewijs in strafzaken hier te lande in de middeleeuwen', in: Tijdschrift voor Strafrecht 10 (1897) 47-88.

Frankewitz, S., 'Adel und Territorialisierung in der Grafschaft Geldern im 13. Jahrhundert' in: Rheinische Vierteljahrsblätter 70 (2006) 105-133.

Franquinet, G.D., 'Les siéges de Maestricht, en 1407 et 1408, avec annexes', in: Annales de la Société Historique et Archéologique à Maestricht, 1 (1854-1855) 205-254.

Franquinet, G.D., Beredeneerde inventaris der oorkonden en bescheiden van de abdij Kloosterrade en van de adellijke vrouwenkloosters Marienthal en Sinnich, berustende op 't Provinciaal Archief van Limburg, Maastricht 1869.

Franquinet, G.D., 'Les appels à la cour d'Aix-la-Chapelle', in: PSHAL 9 (1872) 296-310.

Franquinet, G.D., Beredeneerde inventaris der oorkonden en bescheiden van het kapittel van O. L. Vrouwekerk te Maastricht, berustende op het Provinciaal Archief van Limburg, I-II, Maastricht 1870-1877.

Franquinet, G.D., Beredeneerde inventaris der oorkonden en bescheiden van het adelijk klooster St. Gerlach, berustende op het Provinciaal Archief van Limburg, Maastricht 1877.

Franquinet, G.D., Beredeneerde inventaris der oorkonden en bescheiden van het klooster der Predikheeren te Maastricht, berustende op het Provinciaal Archief van Limburg, Maastricht 1880.

Friedrich, S., Drehscheibe Regensburg. Das Informations- und Kommunikatonssystem des Immerwährenden Reichstags um 1700, (Institut für Europäische Kulturgeschichte der Universität Augsburg, Colloquia Augustana 23, Berlijn 2007.

Fürth, A. von, Beiträge und Material zur Geschichte der Aachener Patrizier-Familien I, Aken 1890.

Gabel, H., Widerstand und Kooperation. Studien zur politischen Kultur rheinischer und maasländischer Kleinterritorien (1648-1794) (Frühzeit-Forschungen Band 2), Tübingen 1995.

G[oossens], W. 'Rechtsgebruiken bij het inbezitnemen van de helft van de Merwyckshof te Herten in 1680', in: De Maasgouw 46 (1926) 32.

G[oossens], W., Formaliteiten bij de inbezitneming der heerlijkheid Terblijt in 1694, in: De Maasgoun 51 (1931) 61-62.

Galesloot, L., Le livre des feudataires de Jean III, duc de Brabant, Brussel 1865.

Galesloot, L., Inventaire des archives de la cour féodale de Brabant, I, Brussel 1870.

Gatz, E. en Janker, S.M., Die Bischöfe des Heiligen Römischen Reiches 1648 bis 1803, Berlijn 1990.

Gehlen, A.Fl., Het notariaat in het tweeherig Maastricht, (Maaslandse Monografieën 33), Assen 1981. 
Gehlen, A.Fl., 'Het Maastrichtse Tribunal Supérieur (einde 1794-begin 1796)', in: Van Hellenberg Hubar, B.C.M., Evers, I., e.a. [red.], Maaslands Melange. Opstellen over Limburgs verleden Dr. P.J.H. Ubacbs aangeboden bij gelegenheid van zijn vijfenzestigste verjaardag (Werken uitgegeven door Limburgs Geschied- en Oudheidkundig Genootschap 14), Maastricht 1990, 107-120.

Gehlen, A.Fl., 'De 'laetschappe' van huize Vlodrop onder Gerard Bordels (1655-circa 1685). Een bijdrage over laatrecht in het Gelders Overkwartier van Roermond' in: Berkvens, A.M.J.A. en Gehlen, A.Fl. [red.], Van verminkingsstraf tot vrederechter. Opstellen ter gelegenheid van het twintigiarig bestaan van de Werkgroep Limburgse Rechtsgeschiedenis (1980-2000), Maastricht 2000, 107-128.

Gehlen, A.Fl. en Nève, P.L. [red.], Het notariaat in de Lage Landen ( \pm 1250-1842). Opstellen over de geschiedenis van het notariaat in de Lage Landen vanaf de oorsprong tot in de negentiende eeun (Ars Notariatus CXVII) Deventer 2005.

Gehlen, A. Fl., 'Testamentaire perikelen in het rijksstift Thorn. Een erfrechtelijke casus uit de jaren 1777-1779', in: Broers, E.J.M.F.C. en Kubben, H. [red.], Ad Fontes. Liber Amicorum prof. Beatrix van Erp-Jacobs, Oisterwijk 2014, 151-166.

Gilissen, J., Historische Inleiding tot het recht I-III, Antwerpen 1981.

Gläser, Fl., Schönau - Schönforst. Eine Studie zur Geschichte des rheinisch-maasländischen Adels im Spätmittelalter. Dissertatie Trier 1999, digitale publicatie pdf Universiteitsbibliotheek Trier 2005.via link http://ubt.opus.hbz-nrw.de/volltexte/2005/313/.

Godding, Ph., Le droit privé dans les Pays-Bas méridionaux du $12^{e}$ au $18^{e}$ siècle, Académie Royale de Belgique, Mémoires de la Classe des Lettres, Collection in $4 \mathrm{o} 2^{\mathrm{e}}$ série, T. XIV, fascicule 1-1987, Brussel 1987.

Godsey jr, W.D., Nobles and nation in Central Europe. Free Imperial Knights in the Age of Revolution, 1750-1850 (New Studies in European History), Cambridge 2004.

Goossens, G., Études sur les États de Limbourg et des Pays d' Outremeuse pendant le premier tiers du 18 e siècle. Suivie du texte de la 'Notitia de rebus statuum provinciae Limburgensis' de l'abbé Nic. Heyendal, Kerkrade 1910.

Gotthard, A., Das Alte Reich 1495-1806 (Geschichte kompakt) Darmstadt 2003.

Graindor, M., L'Avouerie et les anciens seigneurs de Soiron/La maison de Woelmont (Archives Vervietoises 10) Verviers 1968.

Graswinckel, D.P.M. 'Het archief van het kasteel Batenburg', in: VROA 48 (1925) tweede deel, 's-Gravenhage 1926, 121-210.

Graswinckel, D.P.M, 'Het archief van het huis Bronkhorst', in: VROA 49 (1926) tweede deel, 's-Gravenhage 1927, 77-182.

Graswinckel, D.P.M., Het Oud-archief der gemeente Arnhem, Tweede stuk, Regestenlijst, Arnhem 1935.

Graswinckel, D.P.M., Het Oud-archief der gemeente Arnhem, Derde stuk, Brievenlijst, Arnhem 1935.

Grauwels, J., Regestenlijst der oorkonden van de landkommanderij Oudenbiezen en onderborige kommanderijen, I-III, Brussel 1966-1967.

Gropp, S.G., Die städtische Münsprägung zu Deventer und Nimwegen 1528/34-1591. Städtischer Partikularismus gegen habsburger Zentralismus in den östlichen Niederlanden, Oer-Erkenschwick 2001. 
Grotefend, H., Taschenbuch der Zeitrechnung des Deutschen Mittelalters und der Neuzeit, Hannover 1971.

Gijswijt-Hofstra, M., Wijkplaatsen voor vervolgden. Asielverlening in Culemborg, Vianen, Buren, Leerdam en IJsselstein van de 16de tot eind 18de eeuw, Dieren 1984.

Haas, J.A.K., Inventaris van de archieven der abdij Kloosterrade, Maastricht 1986. Inventarisreeks Rijksarchief Limburg 36.

Habets, J., Over Romeinsche voorwerpen in eene begraafplaats te Gronsveld gevonden en over eene Romeinsche ara te Odiliënberg bij Roermond' in: Verslagen en mededeelingen der Koninklijke. akademie van wetenschappen. Afd. letterkunde, 3e reeks; deel 2, z.pl. z.j., 73-95.

Habets, J., 'Notice sur quelques découvertes d'antiquités dans le duché du Limbourg', in: PSHAL 2 (1865) 202-259.

Habets, J., 'Houthem-Sint-Gerlach en het adellijk vrouwenstift aldaar', in: PSHAL 6 (1869) 3-254.

Habets, J. 'Een woord over de grafstede der grafelijke familie van Bronckhorst te Gronsfeldt', in: PSHAL 4 (1867) 145-153.

Habets, J., 'Chronijk der landen van Overmaas en der aangrenzende gewesten door eenen inwoner van Beek bij Maastricht', in: PSHAL 7 (1870) 1-332.

Habets, J., 'Een pelgrimsreis van Limburgsche edelen naar het Heilig Land in 1450', in: PSHAL 9 (1872) 205-216.

Habets, J., 'Notice sur la ci-devant seigneurie de Cadier et le château de Blankenberg', in: PSHAL 13 (1876) 133-168.

Habets, J., 'De wederdoopers te Maastricht tijdens de regeering van keizer Karel V', in: PSHAL 15 (1878) 3-236.

Habets, J., 'Aanteekeningen over de opkomst der hervorming te Susteren en omstreken', in: PSHAL 15 (1878) 191-236.

Habets, J., 'De leenen van Valkenburg', in: PSHAL 21 (1884) 152-440; PSHAL 22 (1885) 3-309.

Habets, J., De studiebeurzen in Nederlandsch Limburg: een historisch overzicht der privaatstichtingen voor onderwijs, Venlo 1881.

Habets, J., Geschiedenis van het tegenwoordig bisdom Roermond en van de bisdommen die bet in deze gewesten zijn voorafgegaan.

1. Het oude bisdom Tongeren-Maastricht-Luik, tot het einde der XVIIde eeuw. Historische Schets van het Aartsbisdom Keulen, Roermond 1875.

2. Het oude bisdom Roermond 1559-1801, Roermond 1890.

Habets, J., Limburgsche wijsdommen, dorpscostumen en gewoonten, bevattende voornamelijk bank-laaten boschrechten, 's-Gravenhage 1891.

Hackeng, R., Het middeleeunse grondbezit van het Sint-Servaaskapittel te Maastricht in de regio Maas-Rijn, Maastricht 2006.

Halkin, J. en Roland, C.-G., Recueil des chartes de l'abbaye de Stavelot-Malmedy, dln I-II, Brussel 1909-1930.

Hall, J.H.M.M. van, 'Een onderzoek naar de rechtspraak in de Staatse Landen van Overmaze door de advocaat-fiscaal J.F. van Steelant in 1772', in: Berkvens, A.M.J.A, Gehlen, A.Fl. en Venner, G.H.A. [red.], Ten werentliken rechte. Opstellen over Limburgse rechtsgeschiedenis, Maastricht 1990, 261-297. 
Hall, H. van, Eijsden, een vrijheid met Luikese stadsrechten. Een rechtshistorische schets van de ontwikkeling van een Minderstadt tussen Mas en Rijn (ca. 1300 - ca. 1550) (Maaslandse Monografieën 74) Hilversum 2011.

Ham, W.A. van, Macht en gezag in het markiezaat. Een politiek-institutionele studie over stad en land van Bergen op Zoom (1477-1583), Hilversum 2000.

Hanssen, H., Die Rimburg. Geschichte der Burg, der ehemaligen Herrschaft bezw. freien Reichsherrschaft und der Gemeinde Rimburg, Aken 1912.

Hanssen, J.H., Inventarissen van de archieven der Schepenbank en Gemeente Wessem 1481-1937, Inventarisreeks Rijksarchief in Limburg 37, Maastricht 1986.

Hardenberg, H., Inventaris van de archieven der rechtscolleges, alleensprekende rechters en rechterlijke ambtenaren, van 1794 tot 1841 gefungeerd hebbende op het grondgebied van de tegenwoordige Nederlandsche provincie Limburg, 's-Gravenhage 1949.

Hardenberg, H., 'De heren van Schinnen', in: Libellus Festivus. Een bundel bistorische opstellen aangeboden aan Joseph H.F.H. Linssen bij gelegenheid van zijn 70ste verjaardag op 6 november 1964, Roermond 1964, 47-77.

Harmsen, Th. W., 'De landmeetkunde in het gebied van de tegenwoordige Nederlandse Provincie Limburg, vóór 1794', in: PSHAL 94-95 (1958-1959) 353-467.

Härter, K., 'Das Recht des Alten Reiches: Reichsherkommen, Reichsgesetzgebung und 'gute Policey', in: Wendehorst, S. en Westphal, S. [ed.], Lesebuch Altes Reich (Bibliothek Altes Reich Band 1), München 2006, 87-94 en 255 (literatuuropgave).

Hartmann, J.L.H., De reconstructie van een middeleeuws landschap. Nederzettingsgeschiedenis en instellingen van de beerlijkheden Breust en Eijsden bij Maastricht (10 e-19e eeuw), (Maaslandse Monografieën 44), Assen 1986.

Haye, R.M. de la, Inventaris van de archieven van de heerlijkheid en de schepenbank Wijlre 1464-1797 (1816), (Inventarisreeks van het Rijksarchief in Limburg 49), Maastricht 1993.

Hechberger, W., 'Adel und Herrschaft. Überlegungen zu Voraussetzungen adeliger Herrschaftsbildung im hohen Mittelalter', in: Rheinische Vierteljahrsblätter 70 (2006) 5576.

Hees, A.M.S. van, Inventaris van het archief van de Schepenbank der Vrije Rijksheerlijkheid Stein, (Inventarisreeks van het Rijksarchief in Limburg 13), Maastricht 1976.

Henrichs, L., Geschichte der Stadt und des landes Wachtendonck, Veröffentlichungen des Historischen Vereins für Geldern und Umgegend 74), Geldern 1977 [reprint van uitgave Hüls-Crefeld 1910].

Hermesdorf, B.H.D., 'Te hoofde gaan', in: Verslagen en mededeelingen der Vereeniging tot uitgaaf der bronnen van het Oud-Vaderlandsche Recht 11, (1954) 17-50.

Heyst, M.G.M.A. van, 'Proeve ener genealogie van de Gronsveldse familie Lebens', in: De Limburgse Leeuw 3 (1954-1955), 135-140.

Hilger, H.P., Kreis Kleve 1, Altkalkar-Huisberden (Wesenberg, R. en Verbeek, A. [ed.] Die Denkmäler des Rheinlandes im Auftrag des Landschaftsverbandes Rheinland) Düsseldorf 1964.

Hofmann, F.G. de, Recherches sur le legitime gouvernement de Looz, d'Horne et de Nyel, 3e editie, z.pl. 1799. 
Hofmann, H.H. [ed.], Quellen zum Verfassungsorganismus des Heiligen Römischen Reiches Deutscher Nation 1495-1815 (Ausgewählte Quellen zur Deutschen Geschichte der Neuzeit, Freiherr Vom Stein-Gedächtnisausgabe Band XIII) Darmstadt 1976.

Holenstein, A., Die Huldigung der Untertanen. Rechtskultur und Herrschaftsordnung (800-1800) (Quellen und Forschungen zur Agrargeschichte Band 36) Stuttgart/New York 1991.

Höroldt, D., Die Urkunden des Archivs von Burg Rösberg, (Inventare Nichtstaatlicher Archive, herausgegeben von der Archivberatungsstelle 26), Keulen 1981.

Huijs, Th., 'De repartitie van de grote bede in het hertogdom Gelder, in het bijzonder het Overkwartier van Roermond, 1532-1713' in: Berkvens, A.M.J.A en Rensch, Th.J. van [red.], Wordt voor Recht gehalden. Opstellen ter gelegenheid van vijfentwintig jaar Werk.groep Limburgse Rechtsgeschiedenis (1980-2005) (Werken uitgegeven door Limburgs Geschied- en Oudheidkundig Genootschap 19) Maastricht 2005, 49-108.

Ilgen, Th., Quellen zur inneren Geschichte der Rheinischen Territorien. Herzogtum Kleve, I, Ämter und Gerichte, Erster Band, Darstellung, Bonn 1925, reprint Düsseldorf 1978.

Ilgen, Th., Quellen zur inneren Geschichte der Rheinischen Territorien. Herzogtum Kleve, I, Ämter und Gerichte, Zweiter Band, Quellen, erster Teil, Bonn 1925, reprint Düsseldorf 1978.

Jacobs, B., 'Is het wel de rechter die het recht vindt?', in Broers, E.-J. en Klink, B. van [red.] De rechter als rechtsvormer, Den Haag 2001, 27-46.

Jansen, M., 'De familien Heister en Huckelhoven' in: De Maasgoum 3 (1881) 454-456.

Jansen, W., 'Kleve-Mark-Jülich-Berg-Ravensberg 1400-1600', in: Land im Mittelpunkt der Mächte. Die Herzogtümer Jülich-Kleve-Berg, Kleve 1984, 17-40.

Janssen, J. en Lohmann, F.W., Der Weltklerus in den Kölner Erabistums-Protokollen, ein Necrologium Coloniense in drei Bänden', Keulen 1936.

Janssen, W., 'Niederrheinische Territorialbildung. Voraussetzungen, Wege, Probleme' in: [Ennen, E. en Flink, K. ed.] Soziale und wirtschaftliche Bindungen im Mittelalter am Niederrbein. Referate der 1. Niederrhein-Tagung des Arbeitskreises niederrheinischer Kommunalarchivare (1011. Oktober 1980 in Kleve).

Janssen, W., 'Neue Wege und Formen territorialer Verwaltung am Niederrhein im Übergang zur Frühen Neuzeit', in: Rheinische Vierteljabresblätter 58 (1994) 133-148.

Janssen, W., 'Die Niederrheinischen Territorien im Spätmittelalter. Politische Geschichte und Verfassungsentwicklung', in: Rheinische Vierteljahrsblätter 64 (2000) 45-167.

Janssen, W. 'Unterherrschaft. Anmerkungen zu einem Strukturmerkmal niederrheinischer Territorien in der Frühen Neuzeit', in: Rheinische Vierteljabrsblätter 76 (2012) 152-175.

Janssen de Limpens, K.J.Th., Geldersche Wyssenissen van het Hoofdgerecht te Roermond,'t Nye Boeck (1459-1487), (Werken der Vereeniging tot Uitgaaf der Bronnen van het Oud-Vaderlandsche Recht, 3e reeks, nr. 16), Utrecht 1953.

Janssen de Limpens, K.J.Th., 'Geschiedenis der heerlijkheid Oost', in: PSHAL 100 (1964) 85-147.

Janssen de Limpens, K.J.Th., Rechtsbronnen van bet Gelders Overkwartier van Roermond, (Werken der Vereeniging tot Uitgaaf der Bronnen van het Oud-Vaderlandsche Recht, 3 e reeks, nr. 20), Utrecht 1965.

Janssen de Limpens, K.J.Th., 'De territoriale ontwikkeling der heerlijkheid Wittem' in: De Maasgoun 84 (1965) 23-30. 
Janssen de Limpens, K.J.Th., 'De Noaberschap der Vijlener Rotten 1319-1940. Rechtsgeschiedenis van een bosmark', in: PSHAL 109 (1973) 197-224.

Janssen de Limpens, K.J.Th., Leen-en laathoven in de Maaslandse territoria vóór 1795, (Werken uitgegeven door Limburgs Geschied- en Oudheidkundig Genootschap, 6), Maastricht 1974.

Janssen de Limpens, K.J.Th., 'Het recht van haefstoot in Limburg en Overmaze', in: De Maasgouw 94 (1975) 181-187.

Janssen de Limpens, K.J.Th., Rechtsbronnen van het hertogdom Limburg en de landen van Overmaze, Werken der Stichting tot Uitgaaf der Bronnen van het Oud-Vaderlandse Recht no. 1, Bussum 1977.

Jaspars, E.J.M., 'Tempora mutantur' in: De Maasgouw 88 (1969) 183-186

Jaspars, G., 'Perikelen rond een pastoorsbenoeming te Gronsveld in 1791 en 1798', in: De Maasgouw 96 (1977) 143-158.

Jaspars, G., 'De grafkelder in de St. Martinuskerk te Gronsveld', in: Grueles 1 (1981) 27-32, 45-51.

Jaspars, G., 'Rouwborden als bidprentje', in: Grueles 9 (1989) 70-73.

Jaspars, G.'Pastoor Van Bloer, een herder die schrijlings op zijn kudde zat', in: Grueles 22 (2002) 60-71.

Jaspars, G., Kengen, H. en Orbons, P, 'Raadsels rond de graftombe van Willem van Bronckhorst', in: Grueles 9 (1989) 9-23.

Jong, J. de, 'Prosopografie, een mogelijkheid. Eliteonderzoek tussen politieke en sociaalculturele geschiedenis', in: BMGN 111 (1996) 201-215.

Joos, C., 'Herkommen und Herrschaftsanspruch. Das Selbstverständnis von Grafen und Herren im Spiegel ihrer Chronistik', in: Grafen und Herren in Südwestdeutschland vom 12. bis ins 17. Jahrbundert, (Kraichtaler Kolloquien 5), Epfendorf 2006, 121-155.

Junkelmann, M. S., 'Feldherr Maximilians: Johan Tserclaes Graf von Tilly', in: Um Glauben und Reich. Kurfürst Maximilian I. Beiträge zur Bayerischen Geschichte und Kunst 1573-1657, München 1980, 377-399.

Kamphuis, H.A., De invoering van wetgeving in het Franse departement Nedermaas gedurende het eerste Directoire (Publicaties Rijksarchief Limburg 1) Maastricht 1995.

Kesting, H., 'Geschichte und Verfassung des Niedersächsisch-Westfälischen Reichsgrafenkollegiums', in: Westfälische Zeitschrift. Zeitschrift für vaterländische Geschichte und Altertumskunde, 106 (1956) 175-246.

Keijser-Schuurman, W, Huveneers, H, Jaspars, G., Met zilver zijn ze ombangen. Het zilver van de Koninklijke Schutterij, de Broederschap Sint-Sebastianus, Gronsveld 2004.

Ketelaar, F.C.J., Oude zakelijke rechten. V roeger, nu en in de toekomst. Rechtshistorische Studies 3, Leiden/Zwolle 1978.

Keussen, H., Urkundenbuch der Stadt Krefeld und der alten Grafschaft Mörs, II, Krefeld 19391940.

Keussen, H., Die Matrikel der Universität Köln, 4, 1559-1675, Düsseldorf 1981.

Keyser, E., Rheinisches Städtebuch, Stuttgart 1956 (lemma: Stolberg).

Keyser-Schuurman, W.E.S.L., Inventaris van het archief van de schepenbank Ryckholt 1532-1792, (Inventarisreeks van het Rijksarchief in Limburg 40), Maastricht 1988. 
Keyser-Schuurman, W.E.S.L., Inventaris van het archief van de familie De Bounam de Ryckholt 1545-1957, (Inventarisreeks van het Rijksarchief in Limburg 48), Maastricht 1992.

Kloosterhuis, E.M., Erasmusjünger als politische Reformer. Humanismusideal und Herrschaftspraxis am Niederrhein im 16. Jahrbundert, (Rheinisches Archiv 148), Keulen/Weimar/Wenen 2006.

Knod, G., 'Rheinländische Studenten im 16. und 17. Jahrhundert auf der Universität Padua', in: Annalen des historischen Vereins für den Niederrhein 68 (1899) 133-189.

Kooijmans, L., 'Patriciaat en aristocratisering in Holland tijdens de zeventiende en achttiende eeuw', in: Aalbers, J. en Prak. M., [ed., De bloem der natie. Adel en patriciaat in de Noordelijke Nederlanden, Meppel/Amsterdam 1987, 93-103.

Küppers-Braun, U. Frauen des hohen Adels im kaiserlich-freiweltlichen Damenstift Essen (16051803, (Quellen und Studien. Veröffentlichungen des Instituts für kirchengeschichtliche Forschung des Bistums Essen 8), Münster 1997.

Kuys, J., De ambtman in het Kwartier van Nijmegen (ca. 1250-1543), Nijmegen 1987.

Kuys, J., Kerkelijke organisatie in het middeleeunse bisdom Utrecht, Nijmegen 2004.

Kwiatkowski, I., Herrschaft zwischen Herrschaften. Die Herrschaft Anbolt und die Familie von Bronckhorst-Batenburg. Ein niederrheinisches Kleinterritorium im Spätmittelalter. Dissertatie Bochum 2006, digitale publicatie pdf Universiteit Bochum via link www-brs.ub.ruhr-unibochum.de/netahtml/HSS/.../KwiatkowskiIris/diss.pdf.

Lacomblet, Th.J., Urkundenbuch für die Geschichte des Niederrbeins oder des Erastifts Cöln, der Fürstenthümer Jülich und Berg, Geldern, Meurs, Cleve und Mark un der Reichsstifte Elten, Essen und Werden. Aus den Quellen in dem Königlichen Provinzial-Archiv zи Düsseldorf und in den Kirchen- und Stadt-Archiven der Provinz, II- IV, Düsseldorf 1846-1858.

Lahaye, L., Inventaire analytique des chartes de la collégiale de Saint-Jean l'Évangeliste à Liège, I, Brussel 1921.

Lahrkamp, H., 'Die Kriegserinnerungen des Grafen Gronsfeld (1598-1662)', in: ZAGV 71 (1959) 77-104.

Laurent, Ch., Houffalise, in: [E.Tandel ed.], Les communes Luxembourgeoises, IV, L'Arrondissement de Bastogne, (Annales de l'Institut Archéologique du Luxembourg, 25), Arlon 1891, reprint Brussel 1980.

Laurent, J., Aachener Zustände im XIV Jabrhundert auf Grund von Stadtrechnungen nach den Stadtarchiv-Urkunden mit Einleitung, Registern und Glossar herausgegeben, Aken 1876.

Leenders, K. 'Het oudste leenboek van Brabant', in: Brabants Heem 29 (1977) 10-13.

Lennartz, P., 'Die Probationstage und Probationsregister des niederländisch-westfälischen Kreises’ (Münster 1912) in: Numismatische Zeitschrift 46 (1913), 1-84.

Lequarré, D., 'La terre franche de Herstal et sa Cour de Justice', in: BLAL, 29 (1900) 75166.

Lexicon des Mittelalters, I-IX, München 2002.

Lieb, N., St. Georg in München-Bogenhausen. Eine Dorfkirche hoch über dem Isarufer als bedeutendes Kunstwerk und ihr Friedhof als letzte Rubestätte berühmter Münchner, München, 1987.

Liebmann, E.,'Die Rezeptionsgeschichte des Alten Reichs im 19. und 20. Jahrhundert ' in: Wendehorst en Westphal, Lesebuch Altes Reich, 8-12.

Löffler, U., Dörfliche Amtsträger im Staatswerdungsprozess der Frühen Neuzeit. Die Vermittlung von Herrschaft auf dem Lande im Herzogtum Magdeburg, 17. und 18. Jabrhundert (Herrschaft und 
soziale Systeme in der Frühen Neuzeit, herausgegeben vom Arbeitskreis Militär und Gesellschaft in der Frühen Neuzeit e.V., Band 8, Münster 2005.

Loontjens, H.A. en Jongmans, H.W.K., 'Het Malensbos en het Holsetterbos onder Vaals' in: De Maasgoum 105 (1986) 153-173.

Lucas, P. Monnaies seigneuriales Mosanes, z.pl. (1982).

Luijten, J.J.G., 'Van 'Hoochlant' tot Genhout', 9-11, in: [L.M. Alberigs e.a., red., Genhout, van 'Hoochlant' tot parocbiegemeenschap, (Wat Baek ós bud 12), Beek 1987.

Lijten, M.J.H.A., 'Het burgerlijk proces in stad en Meijerij van 's-Hertogenbosch 15301811', (Brabantse Rechtshistorische Reeks 2), Assen 1987.

Madeline, L., 'Les Huguenots à Orléans vers 1570', in: Bulletin de la Société Archéologique et Historique de l'Orléanais, 14 (1997) 3-20.

Maegraith, J.C., Das Zisterzienserinnenkloster Gutenzell. Vom Reichskloster zur geduldeten Frauengemeinschaft (Oberschwaben-Geschichte und Kultur 15) Epfendorf 2006.

Maessen, H., 'Korte schets der geschiedenis van de parochie Slenaken', in: De Maasgouw 32 (1910) 17-22, 30-32, 34-38, 43-47.

Maessen, H., 'Proces over den kerkbouw te Slenaken', in: De Maasgoun 32 (1910) 58-60.

Manigart, I. H., Praxis pastoralis sen continuatio theologice moralis, Tomus tertius, in quo continentur bulla, constitutiones apostolica et mandata episcopalia diacesis Leodiensis... accedunt decreta synodi diccesance Leodiensis anno 1618 celebrata: statuta generalia ecclesiarum collegiatarum secundarii cleri secundarii Leodiensis necnon statuta archidiaconalia, etiam novissima, Luik, z.d.

Marra, S., Allianzen des Adels. Dynastisches Handeln im Grafenhaus Bentheim im 16. und 17. Jabrbundert, Keulen/Wenen/Weimar, 2007.

Marres, W. en Agt, J.J.F.W. van, De Nederlandse Monumenten van Geschiedenis en Kunst, V, De provincie Limburg, derde stuk: Zuid-Limburg nitgezonderd Maastricbt, 's-Gravenhage 1962.

Maurenbrecher, R., Die Rheinpreußischen Landrecbte, 1, Bonn 1830.

Meij, P.J., 'Gelderland van 1492-1543', in: (J.J. Poelhekke e.a., red.), Geschiedenis van Gelderland 1492-1795, II, Zutphen 1975.

Meulleners, J.L., 'Eenige bladzijden uit de geschiedenis van de rijksheerlijkheden Obbicht en Leuth, benevens eene bijdrage tot het hooger beroep naar Aken', in: PSHAL 24 (1887) 67-166.

Meuthen, E., Aachener Urkunden 1101-1250, (Publikationen der Gesellschaft für Rheinische Geschichtskunde LVIII), Bonn 1972.

Meyer, G., Die Familie von Palant im Mittelalter, (Veröffentlichungen des Max-PlanckInstituts für Geschichte 202), Göttingen 2004.

Molemans, J., 'Achtergronden van het ontstaan van het 18de-eeuwse kadaster in de Limburgse Kempen', in: [H.P. Neuheuser e.a., red. Ontshiting en gebruik van bistorische landkaarten, (Werken uitgegeven door Limburgs Geschied- en Oudheidkundig Genootschap, 10,) Maastricht 1988, 223-253.

Monté ver Loren, J. Ph. de, 'Gegevens over de verhouding van de heerlijkheid Bronkhorst tot het Heilige Roomse Rijk en tot het graafschap Zutphen voor 1570', in: Gelre, Bijdragen en Mededelingen 56 (1957) 125-165.

Monté ver Loren, J.Ph. de / Spruit, J.E., Hoofdlijnen uit de ontwikkeling der recbterlijke organisatie in de Noordelijke Nederlanden tot de Bataafse omwenteling, 6e druk, Deventer 1982. 
Moorman van Kappen, O., 'De historische ontwikkeling van het waterschapswezen, dijken waterschapsrecht in de Tieler- en Bommelerwaarden tot het begin van de negentiende eeuw', in: Tieler en Bommelerwaarden 1327-1977, Tiel/Zaltbommel 1977, 1-230.

Moorman van Kappen, O., 'Iets over heerlijkheden en heerlijke rechten. Voordracht gehouden op de Algemene vergadering van de Nederlandse Adelsvereniging d.d. 8 mei 2004 te 's-Gravenhage', in: Nieuwsbrief 2004 van de Nederlandse Adelsvereniging, 16-36.

Moraw, P., 'Die Entfaltung der deutschen Territorien im 14. und 15. Jahrhundert', in: Landesherrliche Kanzleien im Spätmittelalter. Referate zum VI Internationalen Kongre $\beta$ für Diplomatik, München 1983 (Münchener Beiträge zur Mediävistik und RenaissanceForschung 35) 61-108.

Mosmans, H., De heeren van Wittem. Geschiedkundige Bijdrage, Venlo 1923.

Munier, W.A.J., 'De calvinisering van de colleges van schout en schepenen in de landen van Overmaas vanaf de verovering van Maastricht tot aan het einde van de zeventiende eeuw', in: PSHAL 123 (1987), 42-145.

Munsters, A.J., 'Verkenning van de Middeleeuwse Kerk in Limburg', in: Limburg's Verleden. Geschiedenis van Nederlands Limburg tot 1815, (2), Maastricht 1967, 417-530.

Munsters, A.J., 'De strijd tegen het hoogduits te Stein' in: De Maasgouw 68 (1949) 94-97.

Munsters, A.J., 'Het knuppelen der honden te Stein' in: De Maasgoum 71 (1951) 74-77; idem 72 (1953) 9-20.

Munsters, A.J., 'Rijksonmiddellijkheid en Kammerzieler' in: PSHAL 111 (1975) 189-216.

Nauwelaers, J. Histoire des avocats au Souverain Conseil de Brabant, I-II, Brussel 1947.

Neuhaus, H., Das Reich in der Früben Neuzeit (Enzyklopädie Deutscher Geschichte Band 42)

München 2003.

Neuhaus, H., 'Defension'. Das frühneuzeitliche Heilige Römische Reich als Verteidigungsgemeinschaft' in: Wendehorst/Westphal, Lesebuch Altes Reich, 119-126.

Nève, P.L., Het Rijkskamergerecht en de Nederlanden. Competentie - territoir - archieven, (Maaslandse Monografieën 14), Assen 1972.

Nève, P.L., De dertiende-eeunse schepenoorkonden van Maastricht en Sint Pieter met enige latere transfixen, alsmede een schets van het juridisch statuut van het onroerend goed te Maastricht (Werken uitgegeven door Limburgs Geschied- en Oudheidkundig Genootschap 21) Maastricht 2012.

[Molhuysen, P.C. /. Blok. P.J., red.]Nieun Nederlandsch Biografisch Woordenboek, deel 2, Leiden 1912.

Noüe, A. de, 'Promenade à Beaufays', in: BLAL 14 (1878) 421-524.

Nijhoff, I.A., Gedenkwaardigheden uit de geschiedenis van Gelderland door onuitgegevene oorkonden opgehelderd en bevestigd, I-VI, Arnhem 1830-1875.

Deel III, Willem en Reinald IV, hertogen van Gelre uit het Huis van Gulik, Arnhem 1839.

deel IV, Arnold van Egmond, hertog van Gelre, Arnhem 1847.

Oidtman, E. von, 'Die Herren von Millendonk aus dem Geschlecht der von Mirlaer', in: ZAGV11 (1889) 8-49.

Oidtman, E. von, 'Die Burg zu Stolberg und ihre Besitzer, insbesondere die Edelherren von Stolberg-Frenz-Setterich', in: ZAGV 15 (1893) 1-17.

Oidtman, E. von, 'Die Eigenthümer der Rittersitze Birgel, Boisdorf, Drove und Mozenborn im Kreise Düren', in: ZAGV 24 (1902) 258-294. 
Oppenhoff, J., 'Vaalsbruch und der Malensbusch. Zur Geschichte einer alten Waldgenossenschaft', in: ZAGV 56 (1935) 27-60.

Opsommer, R., 'Omme dat leengoed es thoochste dinc van der weerelt'. Het leenrecht in Vlaanderen in de 14de en 15de eeuw, Brussel 1995.

Ottomeyer, H., Götzmann, J. Reiss, A. [ed., Heiliges Römisches Reich Deutscher Nation 962 bis 1806, Altes Reich und Neue Staaten 1495 bis 1806, Katalog, Dresden 2006.

Panhuysen, G.W.A., 'Overzicht van de archivalische bronnen voor de geschiedenis van Limburg, bewaard in het Rijksarchief in Limburg te Maastricht' in: Batta, E.C.M.A. e.a. [red.], Limburg's Verleden. Geschiedenis van Nederlands Limburg tot 1815, Maastricht 1967, 704780.

Panhuysen, T.A.S.M., Brounen, F., Hulst, R.A., 'Archeologische kroniek van Maastricht 1994', in: PSHAL 131 (1995) 199-232.

Paquaij, A.P.L., Geboren, gehuwd en/ of overleden in ...1600-1900, Eijsden 1997.

Paquay, J., 'Codex Documentorum. Oorkonden en bescheiden der voormalige abdij Kloosterrade', in: PSHAL 40 (1904) 213-302.

Peele, A., Een nitzonderlijke erfgenaam. De verdeling van de nalatenschap van Koning-Stadhouder Willem II en een consequentie daarvan: Pruisisch heerlijk gezag in Hooge en Lage Zwaluwe, 1702-1754, Hilversum 2013.

Peteghem, P.P.J.L. van, 'Limburg' en het vorstelijk domein Kerpen-Lommersum. Keizer Karel gaat keihard door tegen Herman von Wied, aartsbisschop van Keulen', in: Berkvens, A.M.J.A., e.a. [ed.], Flittich erforscht und gecolligeert...' Opstellen over Limburgse rechtsgeschiedenis, Maastricht 1995, 55-75.

Peteghem, P.P.J.L. van, 'De pandlossing van vorstelijke domeingoederen in het hertogdom Limburg en in de Landen van Overmaze (1539-1544)', in: PSHAL 129 (1993) $7-40$.

Peters, L., Geschichte des Geschlechtes von Schaesberg bis zur Mediatisierung. Ein Beitrag zur Erforschung der interterritorialen Verflechtungen des rhein-maasländischen Adels (Maaslandse Monografieën 16), Assen 1972.

Polak, M.S., Dijkhof, E.C., e.a., Oorkondenboek van de abdij Kloosterrade 1108-1381, Den Haag 2004.

Pompen, A., 'Jacob de Eerste, graaf van Horne', in: PSHAL 40 (1904) 3-212.

Poncelet, E., 'La Seigneurie de Saive', in: BLAL 22 (1891) 251-434.

Poncelet, E., Le livre des fiefs de l'église de Liège sous Adolphe de la Marck, Brussel 1898.

Poncelet, E., 'Les Maréchaux d'armée de l'évêché de Liège', in: BLAL 32 (1902) 111- 333.

Poncelet, E., Inventaire analytique des chartes de la collégiale de Sainte-Croix à Liège, I, Brussel 1911.

Poswick, E., Histoire de la seigneurie libre et impériale d'Argentean et de la maison de ce nom, aujourd'bui Mercy-Argenteau, Brussel 1905.

Poncelet, E., 'Herstal et Vivegnis. Souveraineté territoriale, règlements de seigneurie, chartes d'affranchissement', in: Bulletin de la Commission Royale Royale d'Histoire/Handelingen van de Koninklijke Commissie voor Geschiedenis 102 (1937) 6-139.

Poncelet, E., Actes de Princes-évếques de Liège, Hugues de Pierrepont 1200-1229, Brussel 1941.

Press, V., 'Die kaiserliche Stellung im Reich zwischen 1648 und 1740. Versuch einer Neubewertung', in: G. Schmidt, G., [ed.], Stände und Gesellschaft im Alten Reich 
(Veröffentlichungen des Instituts für Europäische Geschichte Mainz, Abteilung Universalgeschichte, Beiheft 29), Stuttgart 1989, 51-80.

Quicke, F., 'Documents concernant la politique des ducs de Brabant et de Bourgogne dans le duché de Limbourg et les terres d'Outremeuse pendant la seconde moitié du XIVe siècle (1364-1396)', in: Bulletin de la Commission Royale d'Histoire, 93 (1929) 67-195.

Quix, C., Schloss und ehemalige Herrschaft Rimburg, die Besitzer derselben, vorzüglich die Grafen und Freiberren von Gronsfeld nebst den umliegenden Dörfern, Aken 1835.

Rademakers, P.C.M. [red.], De prehistorische vuursteenmijnen van Ryckholt-St. Geertruid. Een uitgave van de Afdeling Limburg der Nederlandse Geologische Vereniging bij gelegenheid van haar 50 jarig bestaan, z.pl., z.j.[1998].

Ramakers, E., 'De Schaesbergse erfenis', in: Ontgonnen Verleden. Opstellen over de geschiedenis van oostelijk. Zuid-Limburg aangeboden aan Louis Augustus bij gelegenheid van rijn vijfenzeventigste verjaardag, (Werken Limburgs Geschied- en Oudheidkundig Genootschap 15) Maastricht 1996, 269-296.

Van der Ree-Scholtens, G.F., De grensgebieden in het noordoosten van Brabant ca. 1200-1795. Institutionele en juridische aspecten (Brabantse Rechtshistorische Reeks 6) Assen/Maastricht 1993.

Reiners, H., Die Kunstdenkmäler der Landkreise Aachen und Eupen im Auftrage des Provinzialverbandes der Rheimprovinz ([P.Clemen ed.], Die Kunstdenkmäler der Rheinprovinz im Auftrage des Provinzialverbandes, Band 9.2), Düsseldorf 1912.

Renes, J., De geschiedenis van het Zuidlimburgse Cultuurlandschap, Assen/Maastricht 1988 (Maaslandse Monografieën (groot formaat).

Rensch, Th.J. van, 'Het Hof van Justitie van Pruisisch Gelre. Enkele aspecten van zijn geschiedenis, competentie en de invloed van de achttiende-eeuwse rechtsontwikkeling in Pruisen', in: PSHAL 112 (1977) 192-268.

Rensch, Th. J. van, 'De aartsdiaken van Haspengouw en Maastricht', in: Jenniskens, A.H., Koreman, J.G.J., e.a. [red.], Campus Liber. Bundel opstellen over de geschiedenis van Maastricht aangeboden aan mr. dr. H.H.E. Wouters, stadsarchivaris en -bibliothecaris 1947-1977, bij rijn zeventigste verjaardag (Werken uitgegeven door Limburgs Geschied- en Oudheidkundig Genootschap 8) Maastricht 1982, 176-199.

Rensch, Th. J. van, 'De rechtspraak van de Commissarissen-Deciseurs te Maastricht', in: Jacobs, B.C.M. en Nève, P.L. (red.) Hoven en Banken in Noord en Zuid, Brabantsse Rechtshistorische Reeks, 7, Assen 1994, 39-62.

Rensch, Th. J. van, 'Onderbetaalde pastoors versus het Maastrichtse kapittel van Onze Lieve Vrouwe in de achttiende eeuw', in: PSHAL 131 (1995) 93-115.

Rensch, Th. J. van, 'Van kisten en kompen. Archiefzorg op het Limburgse platteland van de vijftiende tot en met de achttiende eeuw', in: Achter de Minderbroeders. Opstellen over bijzondere stukken en voorwerpen van het Rijksarchief in Limburg, Maastricht 1996, 71-94.

Rensch, Th. J. van, 'Twee onbekende brieven over bokkerijdersprocessen', in: Berkvens, A.M.J.A en Rensch, Th.J. van [red.], Wordt voor Recht gehalden. Opstellen ter gelegenheid van vijfentwintig jaar Werkgroep Limburgse Rechtsgeschiedenis (1980-2005) (Werken uitgegeven door Limburgs Geschied- en Oudheidkundig Genootschap 19) Maastricht 2005, 261-297.

Rensch, Th. J. van, 'De rechterlijke organisatie in het land van Thorn 1500-1796. Een verkenning', in: Berkvens, A.M.J.A. en Rensch, Th.J. van [red.], In hoede van rechte gekeerd. 
Opstellen ter gelegenheid van dertig jaar Werkgroep Limburgse Rechtsgeschiedenis (Werken uitgegeven door Limburgs Geschied- en Oudheidkundig Genootschap 20) Maastricht 2010, 45-76.

Reusens, E., 'Documents relatifs à l'abbaye de Herkenrode', in: Analectes pour servir à l'histoire ecclésiastique de la Belgique, 16 (1879) 221-317.

Ridder-Symoens, H. de; Illmer, D.; Ridderikhoff, C.M., Premier livre des procurateurs de la Nation Germanique de l'ancienne Université d'Orléans 1444-1546, seconde partie, Biographies des étudiants, 1, Leiden 1978.

Ridderikhoff, C.M., Ridder Symoens H. de, Heesakkers, Ch. L., Les Livres des procurateurs de la nation germanique de l'ancienne Université d'Orléans, 1444-1602. Troisième livre des procurateurs de la nation germanique de l'ancienne Université d'Orléans, 1567-1587. Textes des rapports des procurateurs, Leiden/Boston, 2013.

Rijksarchieven in Nederland, De. Overzicht van de inhoud van de Rijsarchiefbewaarplaatsen, 'sGravenhage 1953, 325-357.

Roland, C.G., 'Les seigneurs et comtes de Rochefort', in: Annales de la Société Archéologique de Namur 20 (1893) 329-448.

Roosenboom, H. Th. M., Inventaris van het archief van bet klooster der Witte Vrouwen te Maastricht, (Inventarisreeks Rijksarchief in Limburg 5) Maastricht 1972.

Rotthof-Kraus, Cl., Die politische Rolle der Landfriedenseinungen zwischen Maas und Rhein in der zweiten Hälfte des 14. Jahrhunderts, (Beiheft ZAGV, Band 3), Aken 1990.

Rosenkrantz, E., 'Bijdrage geschiedenis der graven van Kessel', in: De Maasgouw 18 (1896) $59-60$.

Ruppel, S., Verbündete Rivalen. Geschwisterbeziebungen im Hochadel des 17. Jabrhunderts, Keulen/Weimar/Wenen 2006.

Russe, J., 'Abbaye de Notre Dame du Val-des-Écoliers à Liège', in: Monasticon Belge, 2, Province de Liège, 3, Luik 1955, 323-346.

Ruwet, J., 'Le livre des anniversaires de l'abbaye du Val-Dieu (XIIIe - XVIIIe siècles)', in: BSAHL 26, (1950) 39-79.

Ruwet, J., Cartulaire de l'abbaye cistercienne du Val-Dieu (XIIe -XIVe siècle), Brussel 1955.

Ryckel, A. de, 'La cour féodale de l'ancien duché de Limbourg', in: BSAHL 9 (1895) 273455.

Ryckel, A. de, 'Notice sur la libre Seigneurie de Breust', in: PSHAL 27 (1890) 3-22.

Ryckel, A. de, 'Histoire de la seigneurie libre de Bolland', in: BSAHL 21 (1923) 73-257.

Salm, H., Armeefinanzierung im Dreißigjährigen Krieg. Der Niederheinisch-Westfälische Reichskreis 1635-1650 (Schriftenreihe der Vereinigung zur Erforschung der neueren Geschichte E.V.) Münster 1990.

Sande, F. à , Commentarius in Gelriae et Zuphaniae consuetudines feudales cum collatione iurium et consuetudinum quae in Geldriae vicinis ditionibus obtinent, Harderwijk 1625.

Sangers, W. en Janssen, R., Thorn, het witte stadje, Thorn 1982.

Schattkowsky, M. 'Gemeiner Pfennig', in: Wendehorst/Westphal, Lesebuch Altes Reich, 189197.

Schilfgaarde, A.P. van, Het archief van het Huis Bergh, Regestenlijst van oorkonden, Eerste stuk (828-1490), z.pl., 1932.

Schilfgaarde, A.P. van, Het archief der heeren en graven van Culemborg, Tweede en derde stuk, regestenlijst (eerste - tweede deel), 's-Gravenhage 1949. 
Schilfgaarde, A.P. van, 'De heren en graven van Bronckhorst', in: De Nederlandsche Leeuw, Maandblad van het Koninklijk. Nederlandsch Genootschap voor Geslacht en Wapenkunde 74 (1957) 67-88.

Schilling, H., Heun, W., Götzmann, J. [ed.], Heiliges Römisches Reich Deutscher Nation 962 bis 1806, Altes Reich und Neue Staaten 1495 bis 1806, Essays, Dresden 2006.

Schindling, A., Die Anfänge des Immerwährenden Reichstags zu Regensburg. Ständevertretung und Staatskunst nach dem Westfäischen Frieden, (Veröffentlichungen des Instituts für Europäische Geschichte Mainz, Abteilung Universalgeschichte, deel 143), Beiträge zur Sozial- und Verfassungsgeschichte des Alten Reiches, nr. 11, Mainz 1991.

Schleicher, M., Ernst von Oidtman und seine genealogisch-heraldische Sammlung in der UniversitätsBibliothek zu Köln. Aus den bandschriftlichen Aufzeichnungen für den Druck bearbeitet, ergänzt und mit Registern versehen, 6, Keulen 1994.

Schmidt, C., 'Een lengteprofiel van het Hollands patriciaat. Het geslacht Teding van berkhout 1500-1950', in: Aalbers, J. en Prak. M., [ed., De bloem der natie. Adel en patriciaat in de Noordelijke Nederlanden, Meppel/Amsterdam 1987, 129-140.

Schmidt, F., 'Herzog Karl von Geldern-Egmont und Jakob von Bronckhorst, Herr zu Batenburg und Anholt', in: Gelre, Bijdragen en Mededeelingen 15 (1912) 550-592.

Schmidt, G., Der Wetterauer Grafenverein. Organisation und Politike einer Rechskorporation zwischen Reformation und Westfälischen Frieden (Veröffentlichungen der Historischen Kommission für Hessen 52) Marburg 1989.

Schmidt, G., Geschichte des Alten Reiches. Staat und Nation in der Frühen Neuzeit 1495-1806, München 1999.

Schmidt, G., 'Das frühneuzeitliche Reich - Sonderweg und Modell für Europa oder Staat der Deutschen Nation?' in: Schnettger, M. [ed.], Imperium Romanum - irregulare corpusTeutscher Reichs-Staat. Das Alte Reich im Verständnis der Zeitgenossen und der Historiographie, Mainz 2002, 247-278.

Schmidt-Brentano, A., Kaiserliche und k.k. Generäle 1618-1815, Wenen 2006.

Schneider, A., Der Niederrbeinisch-Westfälische Kreis im 16. Jabrbundert (Düsseldorfer Schriften zur Neueren Landesgeschichte und zur Geschichte Nordrhein-Westfalens Band 16) Düsseldorf 1985.

Schneider, B.C., Ius Reformandi. Die Entwicklung eines Staatskirchenrechts von seinen Anfängen bis zum Ende des Alten Reiches, Tübingen 2001.

Schnettger, M. [ed.], Imperium Romanum - irregulare corpus- Teutscher Reichs-Staat. Das Alte Reich im Verständnis der Zeitgenossen und der Historiographie, Mainz 2002.

Scholten, R., Clevische Chronik nach der Originalhandschrift des Gert van der Schuren, Kleef 1884.

Scholten, R., 'Zur Geschichte von Hönnepel und Niedermörmter' in:, Annalen des Historischen Vereins für den Niederrbein insbesondere die alte Erzdiöcese Köln 51 (1891) 104-148.

Scholten, R., 'Urkundliches über die Herren von Mörmter (de Munimento) und das Haus Roen in Obermörmter', in: Beiträge zur Geschichte der Niederrheins. Jabrbuch des Düsseldorfer Geschichts-Vereins 13 (1898) 243-273.

Schoolmeesters, E. 'Diplômes de l'abbaye de Val-Bénoît relatifs à Simpelvelt, Elsloo, Gronsfeld et Vaesraede', in: PSHAL 21 (1884) 126-152.

Schwabe, W., 'Der Aachener Oberhof I, in: ZAGV 47 (1925) 83-159 en II, ZAGV 48-49 (1926-1927) 61-120. 
Sellert, W. [red.], Reichshofrat und Reichskammergericht. Ein Konkurrenzverbältnis (Quellen und Forschungen zur Höchsten Gerichtsbarkeit im Alten Reich 34) Keulen/Weimar/Wenen 1999.

Simenon, G., Visitationes Archidiaconales Archidiaconatus Hasbaniae in dioecesi Leodiensi ab anno 1613 ad annum 1763, I-II, Luik 1939-1940.

Spaen, W.A. van, Oordeelkundige inleiding tot de historie van Gelderland, deel 1, Utrecht 1801; deel 4, Utrecht 1805.

Stengers-Limet, A., Les Terres Franches. Une fiscalité particuliere dans les ancien Pays-Bas, (Anciens Pays et Assemblees d'Etats/Standen en Landen LXXXIV), Kortrijk 1985.

Stephan, M., 'Die Erhebung der Bayerischen Adelsfamilie von Törring in den Grafenstand', in: [W. Koch, A. Schmid, W. Volkert, L. Holzfurtner ed.], Auxilia Historica. Festschrift für Peter Acbt zum 90. Geburtstag, München 2001, 417-437.

Stieldorf, A., Rheinische Frauensiegel. Zur rechtlichen und sozialen Stellung weltlicher Frauen im 13. und 14. Jabrbundert. (Rheinisches Archiv142), Keulen/Weimar/Wenen 1999.

Stollberg-Rilinger, B., Das Heilige Römische Reich Deutscher Nation. Vom Ende des Mittelalters bis 1806, München 2006.

Stollberg-Rilinger, B., 'Das Reich als Lehnssystem', in: Schilling, H., Heun, W., Götzmann, J. [ed.], Heiliges Römisches Reich Deutscher Nation 962 bis 1806, Altes Reich und Neue Staaten 1495 bis 1806, Essays, Dresden 2006, 55-68.

Stollberg-Rilinger, B., Des Kaisers alte Kleider. Verfassungsgeschicbte und Symbolsprache des Alten Reiches, München 2013.

Stollberg-Rilinger, Rituale. (Historische Einführungen 16) Frankfurt am Main 2013.

Stouren, J., 'Histoire de l'ancien ban d'Olne et de la domination des calvinistes dans ce territoire', in: BSAHL 7 (1892) 109-302.

Tangelder, F.B.M., Muntheer en muntmeester. Een studie over het Berghse muntprivilege in de tweede belft der zestiende eeun (Werken uitgegeven door Gelre 27) Arnhem 1955.

Terlinden, Vicomte /J. Bolsée, J., Recueil des ordonnances des Pays-Bas. Deuxième Série 15061700, deel 7, Règne de Philippe II, I contenant les ordonnances du 26 octobre 1555 au 27 aout 1559, Brussel 1957.

Terlinden, Vicomte, /J. Bolsée,J., Recueil des ordonnances des Pays-Bas. Deuxième Série 15061700, deel 8, Règne de Pbilippe II, I contenant les ordonnances du 7 septembre 1559 au 31 decembre 1562, Brussel 1978.

Thamer, H.-U., 'Das Heilige Römische Reich als politisches Argument im 19. und 20. Jahrhundert' in: Schilling, Heiliges Römisches Reich, Altes Reich und Neue Staaten 1495-1806, Essays, 383-395.

Theatri Europaei continuati Funffzehender Theil, das ist abermablige aussführliche Fortsetzung Denckund Merckwürdigster Geschicbten ....vom Jabr 1696 bis zu ende dieses Seculi 1700...

Theatri Europaei Siebenzehender Theil oder aussfübrlich fortgefübrte Friedens- und Kriegsbeschreibung...vom 1704ten Jabr bis Ausgangs 1706ten, Frankfurt am Main, 1718.

Theatri Europaei Neunzehender Theil oder aussfübrlich fortgeführte Friedens- und Kriegsbeschreibung...vom 1710ten Jabr bis zu Ausgang des 1712ten..., Frankfurt am Main, 1723.

Thimister, O.-J., Cartulaire ou receuil de chartes et documents inédits de l'église collégiale de Saint-Paul actuellement cathédrale de Liège, Luik 1878.

Thisquen, J., Histoire de la ville de Limbourg I-II, Verviers 1907-1908. 
Tibus, A., Geschichtliche Nachrichten über die Weibbischöfe von Münster. Ein Beitrag zur Specialgeschichte des Bisthums Münster, Münster 1862.

Tops, B., 'De evolutie van de heerlijke financiën van Westerlo en Herselt (1463-1600)' in: [Deceulaer, H., Libert, M. e.a. red.], Lokaal en internationaal: De archivaris tussen geschiedenis en maatschappij/Du local à l'international. Le rôle des archivistes pour l'bistoire et la société. Liber amicorum Michel van der Eycken, Algemeen Rijksarchief en Rijksarchief in de Provinciën, Studia 153, Brussel 2015, 171-192.

Tummers, H., 'Begraven en grafzerken in de oude Minderbroederskerk te Maastricht', in: [ R. de la Haye, J. van Hall, G. Venner red.], Achter de Oude Minderbroeders. Opstellen over bijzondere stukeken en voorwerpen van het Rijksarchief in Limburg, Maastricht 1996, 11-36.

Tummers, H., 'Enkele figurale grafzerken in de provincie Limburg', in: Timmers Werk, Opstellen over prof. Timmers \& de kunst van het Maasland, Sittard 2007, 170-187.

Tummers, P.L.M., Romaans in Limburgse aardrijkskundige namen, Assen 1962.

Ubachs, P.J.H., 'Een Maastrichtse placetstrijd 1751-1755', in: Jenniskens, A.H., Koreman, J.G.J., e.a. [red.], Campus Liber. Bundel opstellen over de geschiedenis van Maastricht aangeboden aan mr. dr. H.H.E. Wouters, stadsarchivaris en -bibliothecaris 1947-1977, bij zijn zeventigste verjaardag (Werken uitgegeven door Limburgs Geschied- en Oudheidkundig Genootschap 8) Maastricht 1982, 331-343.

Ubachs, P.J.H., Handboek voor de geschiedenis van Limburg (Maaslandse Monografieën 63), Hilversum 2000.

Ubachs, P.J.H., 'De vrederechter in het departement Nedermaas 1796-1801', in: Berkvens, A.M.J.A.. en Gehlen, A.Fl. [red.], V an verminkingsstraf tot vrederechter. Opstellen ter gelegenheid van het twintigjarig bestaan van de Werkgroep Limburgse Rechtsgeschiedenis (1980-2000), Maastricht 2000, 221-247.

Uyttebrouck, A., Le gouvernement du duché de Brabant au bas Moyen Age (1355-1430), II, Brussel 1975.

Vec, M., Zeremonialwissenschaft im Fürstenstaat. Studien zur juristischen und politischen Theorie absolutistischer Herrschaftsrepräsentation (Ius Commune. Veröffentlichungen des Max-Planck Instituts für Europäische Rechtsgeschichte Frankfurt am Main, Sonderhefte, Studien zur Europäischen Rechtsgeschichte 106) Frankfurt am Main 1998.

Venne, J.M. van de, Geschiedenis van het kasteel van Valkenburg, zijn heren en bun drossaarden, Valkenburg 1951.

Venne, J.M. van de, Geschiedenis van Heer, Heer 1957.

Venne, J.M. van de, 'Belastingconflicten tussen Maastricht en de Landen van Overmaas', in: Miscellanea Trajectensia (Werken uitgegeven door Limburgs Geschied- en Oudheidkundig Genootschap 4) Maastricht 1962 (331-338).

Venner, G.H.A., De Meinweg. Onderzoek naar rechten op gemene gronden in bet voormalig geldersGuliks grensgebied circa 1400-1822, (Maaslandse Monografieën 40), Assen/Maastricht 1985.

Venner, G.H.A., Inventaris van het archief van de Staten van het Overkwartier van Gelder 14041794, (Inventarissen Rijksarchief in Limburg 17), Maastricht 1979.

Venner, G.H.A., 'Het Hoofdgerecht Roermond', in PSHAL 122 (1986) 30-99.

Venner, G., 'Schepenen op het platteland in Midden- en Noord-Limburg vóór 1350', in: Berkvens, A.M.J.A en Rensch, Th.J. van [ed.] Wordt voor Recht gehalden. Opstellen ter gelegenheid 
van vijfentwintig jaar Werkgroep Limburgse Rechtsgeschiedenis (1980-2005) (Werken uitgegeven door Limburgs Geschied- en Oudheidkundig Genootschap 19) Maastricht 2005, 1-47.

Venner, G., 'Linne in de dertiende eeuw' in: De Maasgoum 105 (1986) 186-196.

Venner, G.H.A., Inventaris van het archief van het officialaat, de kerkelijke rechtbank van het eerste bisdom Roermond 1599-1797 Publicaties van het Regionaal Historisch Centrum Limburg 4), Maastricht 2014.

Venner, J.G.C., Beeldenstorm in Hasselt 1567, (Maaslandse Mononografieën 48), Leeuwarden 1989.

Vera, H.L.M., ...dat men het goed van den ongeboornen niet mag verkoopen. Gemene gronden in de Meierij van Den Bosch tussen hertog en hertgang 1000-2000, diss. Nijmegen 2011, pdf www.heinvera.nl/proefschrift/Vera, ingezien 6-12-2014.

Verbois, R., Geschiedenis der kerken, kloosters en kapellen van Rekem, Rekem 1965.

Verbois, R., Geschiedenis van Rekem en zijn keizerlijk graafschap, Rekem 1972.

Verkooren, A., Inventaire des chartes et cartulaires du Luxembourg, I, Brussel 1914.

Verkooren, A., Inventaire des chartes et cartulaires des duchés de Brabant et de Limbourg et des Pays d'Outremeuse, première partie, Chartes originales et vidimées, 1, Brussel 1910.

Verkooren, A., Inventaire des chartes et cartulaires des duchés de Brabant et de Limbourg et des Pays d'Outremeuse, première partie, Chartes originales et vidimées, 3, Brussel 1912.

Verkooren, A., Inventaire des chartes et cartulaires des duchés de Brabant et de Limbourg et des Pays d'Outremeuse, première partie, Chartes originales et vidimées, 4, Brussel 1912.

Verkooren, A., Inventaire des chartes et cartulaires des duchés de Brabant et de Limbourg et des Pays d'Outremeuse, première partie, Chartes originales et vidimées, 5, Brussel 1913.

Verkooren, A., Inventaire des chartes et cartulaires des duchés de Brabant et de Limbourg et des Pays d'Outremeuse, IIe stuk, Cartulaires, deel II (1312-1383), Brussel 1962.

Verkooren, A. en Grunzweig, M.A., Inventaire des chartes et cartulaires des duchés de Brabant et de Limbourg et des Pays d'Outremeuse, IIIe stuk, Chartes originales et cartulaires, deel I (1383-1396), Brussel 1961.

A. Verkooren, A. en Graffart, A., Inventaire des chartes et cartulaires des duchés de Brabant et de Limbourg et des Pays d'Outremeuse, derde stuk, Chartes originales et cartulaires, deel IV (14151427), Brussel 1988.

Verzijl, J. 'De Maastrichtse tak der familie Lebens', in: De Limburgse Leeuw 4 (1955-1956) 93-97.

Weber, F., 'Gliederung und Einsatz des bayerischen Heeres im Dreissigjährigen Krieg', in: Um Glauben und Reich. Kurfürst Maximilian I. Beiträge zur Bayerischen Geschichte und Kunst 15731657, München 1980, 400-407.

Weber, M., Die Reichspolizeiordnungen von 1530, 1548 und 1577. Historische Einführung und Editon (Ius Commune. Veröffentlichungen des Max-Planck-Instituts für Europäische Rechtsgeschichte Frankfurt am Main. Sonderhefte. Studien zur Europäischen Rechtsgeschichte 146) Frankfurt am Main 2002.

Welings, Y.J.A., Heijden, C.J.M. van der, Sanders, J.G.M., Hoenen en kapoenen. Gids van cijnsregisters betreffende Noord-Brabant 14e-20ste eeuw, 's-Hertogenbosch 2000.

Weinberg, H., 'De heerlijkheid Wittem: vrij en rijksonmiddellijk?' in: PSHAL 146 (2010) 51-162. 
Weinberg, H., 'Wilhelm Veucht en de graven van Gronsveld 1660-1694' in: PSHAL 143 (2007) 81-115.

Wendehorst, S. en Westphal, S.,[ed. Lesebuch Altes Reich (Bibliothek Altes Reich Band 1), München 2006.

Whaley, J., Das Heilige Römische Reich Deutscher Nation und seine Territorien, 1-2, Darmstadt 2014.

Wiech, M. e.a., Reichskammergericht, Teil 10, Prozessakten des Hauptstaatsarchivs Düsseldorf im Rijksarchief Limburg in Maastricht, Siegburg 2002.

Whaley, J., Germany and the Holy Roman Empire, I-II, Oxford 2012.

Whaley, J. Das Heilige Römische Reich Deutscher Nation, I-II, Darmstadt 2014.

Wilkes, C., Inventar der Urkunden des Stiftsarchivs Xanten (1119-1449), Band 1, Keulen 1952.

Winter, J.M. van, Ministerialiteit en Ridderschap in Gelre en Zutphen, Groningen 1962.

Wisplinghof, E., Rheinisches Urkundenbuch. Ältere Urkunden bis 1100, Erste Lieferung: AachenDeut\%, Publikationen der Gesellschaft für Rheinische Geschichtskunde LVII, Bonn 1972.

Wit, J.J. de, 'Inwendige toestanden in enkele heerlijkheden, maar vooral in de vrije rijksheerlijkheid Ryckholt in de 17e en 18e eeuw', in: PSHAL 52 (1916) 74-187.

De Wit, J.J. de / Flament, A.J.A., 'De vorming der heerschappijen op het grondgebied in (van) Limburg of die zich daarover hebben uitgestrekt van de Romeinse overheersing tot 1814-1817 (ontstaan der provincie Limburg)' in: PSHAL 47 (1911) 1-259.

Witteveen, J. en Eijs, J.J.Th, 'De grafkelder der familie Bronckhorst-Batenburg in het koor der kerk te Gronsveld', in: De Maasgoun 67 (1948) 5-7.

W(olters), M.J., Notice historique sur l'ancien Chapitre Impérial des chanoinesses à Thorn dans la province actuelle de Limbourg, Gend, 1850.

W(olters), M.J., Recherches sur l'ancien comté de Gronsveld et sur les anciennes seigneuries d'Elsloo et de Randenraedt, Gend 1854.

Wolters, L., Ferdinand von Plettenberg. Machtig minister, deskundig diplomaat en bemind bouwheer, Simpelveld/Wittem 2012.

Wouters, H.H.E., Grensland en bruggehoofd. Historische studies met betrekeking tot het Limburgse Maasdal en, meer in het bijzonder, de stad Maastricht (Maaslandse Monografieën 11, Assen 1970. Yans, M., Histoire économique du Duché de Limbourg sous la Maison de Bourgogne. Les forêts et les mines (Académie royale de Belgique, Classe des lettres. Mémoires, deel 38) Brussel 1938.

Yans, M., 'Le destin diplomatique de Herstal-Wandre, terre des Nassau, en banlieu liégeoise', in: Annuaire d'Histoire Liégeoise, nr. 28 (1960) 487-561.

Zacharias, U., Zur Entwicklung des internationalen Testamentenformenrechts des Königreichs der Niederlande (Münsteraner Studien zur Rechtsvergleichung Band 53) Münster 1999.

Zech, Th, Das Fürstenbergische Kontingent des schwäbischen Kreises 1732-1806, Vöhrenbach 1995/2000. 


\section{Bijlage 1}

Heren en graven van Gronsveld dertiende eeuw-1795 (1803)

Wilhelm van Gronsveld en Stolberg, vermeld 1237-1255, overleden vóór 1258, gehuwd met Lutgardis.

Zoon Reiner (volgt).

Reiner van Gronsveld en Stolberg, vermeld 1255-1261, gehuwd met Beatrix.

Kinderen Johan (?) (volgt), Rutger (volgt).

Johan I van Gronsveld, vermeld 1271.

Heer van Gronsveld

Rutger van Gronsveld, vermeld 1256-1285.

Heer van Gronsveld?

Johan II van Gronsveld, 1281 minderjarig, vermeld 1303-1314, overleden vóór 1326?

Heer van Gronsveld.

Hendrik I van Gronsveld, vermeld 1334-1374, overleden kort na 1374, gehuwd met Mechtildis van den Bongard

Kinderen: Johan (volgt), Hendrik (volgt), Godert, Catharina.

Heer van Gronsveld.

Johan III van Gronsveld, vermeld 1349-1386, overleden 1386, gehuwd 1) met NN van Kastenholz en 2) na 1380, met Margaretha Scheiffart van Merode.

Kinderloos, opgevolgd door broer Hendrik II.

Heer van Gronsveld.

Hendrik II van Gronsveld, vermeld 1382-1401, overleden vóór april 1404, gehuwd met 1) Margaretha van Printhagen en 2) (1382) met Johanna van Merode.

Kinderen uit 1) Metza of Mettel en uit 2) Wilhelmina ( $x$ Andries van Merode), Aleydis ( $x$ Johan Schellart van Obbendorf), Hendrik (volgt), Werner ('de Oude'), Johan.

Heer van Gronsveld.

Hendrik III van Gronsveld, vermeld vanaf 1407, overleden 1474-1476, gehuwd vóór 1415 met Aleidis van Oupeye (overleden 1447).

Kinderen: Johanna (x 1425 met Diederik I van Bronckhorst Batenburg), Aleidis (x Engelbrecht Nyt van Birgel), natuurlijke dochter Johanna.

Heer van Gronsveld. 
Diederik I van Bronckhorst Batenburg, vermeld vanaf 1419, overleden 1451, gehuwd 1425 met Johanna van Gronsveld.

Kinderen: vijf zonen en drie dochters. Oudste zoon Gisbert enige erfgenaam met schadeloosstellingen aan broers en zusters. Hendrik (volgt) ontvangt Gronsveld en Rimburg.

Heer van Gronsveld vanaf 1443?

Hendrik I van Bronckhorst Batenburg, vermeld vanaf 1453, overleden 1493, gehuwd 1453 met Johanna Catharina van Alpen.

Kinderen: Elbert (geestelijk gehandicapt), Diederik (volgt), Willem, Otte (x Johan van Binsvelt).

Heer van Gronsveld, tenminste vanaf 1474/1476.

Diederik II van Bronckhorst Batenburg, vermeld vanaf 1480, overleden 1508, gehuwd 1484 met Gertrudis van Wylich, overleden 1523.

Kinderen: Johan (volgt), Diederik, Jutta.

Medeheer van Gronsveld 1493, definitief 1500. In 1498 standsverheffing Reichsfreiberr.

Johan I van Bronckhorst Batenburg, vermeld vanaf 1509, overleden 1558/59, gehuwd met 1) Geertruid van Loë en 2) Melchiore van Wyenhorst.

Kinderen: uit 1) Theodora, Catharina, Willem (volgt).

Reichsfreiherr van Gronsveld na boedelscheiding 1511.

Willem van Bronckhorst Batenburg, vermeld vanaf 1559, overleden 1563, gehuwd met Agnes van Bylandt, overleden 2 mei 1615.

Kinderen: Jost (volgt), Theodora, Johan (volgt).

Reichsfreiberr van Gronsveld 1558/1559.

Jost van Bronckhorst Batenburg, meerderjarig 1586, overleden 1588, gehuwd met Anna van Oostfriesland, overleden 1586.

Reicbsfreiberr van Gronsveld maart-april 1586, verheffing graaf 29 september 1586.

Johan II van Bronckhorst Batenburg, meerderjarig 1586, overleden 1617gehuwd circa 1595 met Sybilla von Eberstein, overleden 1604.

Kinderen: Jost Maximilaan (volgt), Gertrud, Felicitas, Otto Wilhelm (volgt), Johan Philips. Graaf van Gronsveld 1588/1589.

Jost Maximiliaan van Bronckhorst Batenburg, geboren 1596, overleden 1662, gehuwd 1639 met Anna Christina von Hardenrath (1615-1692) (volgt).

Kinderen: Anna Justina (x Ferdinand Louis van Eynatten), Otto Wilhelm, Johan Frans (volgt), Ernst Maximiliaan, Johan Philips, Clara Sybilla (x Henri Philippe de Ligneville), Maria Anna.

Graaf van Gronsveld, ingehuldigd 1617, tot 1641 onverdeeld bezit met graaf Otto Wilhelm van Bronckhorst Batenburg, daarna alleen graaf van Gronsveld. 
Otto Wilhelm van Bronckhorst Batenburg, geboren circa 1600, overleden 1650/1651, gehuwd (?) met Sibilla Oellers.

Medeheer van Gronsveld 1617-1641.

Anna Christina von Hardenrath, weduwe van Jost Maximiliaan van Bronckhorst Batenburg, overleden 1692.

Voogdes en regentes van Gronsveld 1662-1673/1677.

Johan Frans van Bronckhorst Batenburg, geboren circa 1640?, overleden 1719, gehuwd 1) 1677 met Eleonore Philipine von Fürstenberg-Heiligenberg, overleden 1702 en 2) 1706 met Maria Anna, gravin von Toerring-Jettenbach, geboren 1692 (volgt).

Kinderen: uit 2) Anna Justina (1713- 1715);natuurlijke dochter Magdalena Herten.

Graaf van Gronsveld 1673, ingehuldigd 1677.

Otto Wilhelm van Bronckhorst Batenburg, geboren circa 1640?, overleden 1713, 1662 ingetreden bij jezuïeten, later seculier geestelijke, 1693 titulair-bisschop van Columbrica en wijbisschop en vicaris-generaal van Osnabrück.

Regelmatig waarnemer voor graaf Johan Frans van Bronckhorst Batenburg 1684-1693.

Maria Anna von Toerring Jettenbach, geboren 1692, overleden 1730, gehuwd 1721 met Claude Nicolas d'Arberg Valengin.

Gravin van Gronsveld, ingehuldigd 1719, betwist tot 1724 door Clara Sibilla van Bronckhorst Batenburg.

Claude Nicolas d'Arberg Valengin, weduwnaar van Anna Theodora von Daun und Sanem, overleden 1731, gehuwd 1721 met Maria Anna von Toerring Jettenbach.

Kind: Maria Josepha Nepomucena, 1722.

Graaf van Gronsveld 1721.

Jean Gathoye, pachter of 'admodiateur van de heerlijke rechten over Gronsveld', 1723 circa 1732.

Maria Josepha Nepomucena d'Arberg Valengin, met als voogden en regenten Ignaz Felix von Toerring-Jettenbach en stadsbestuur van Aken (administrator d'Oliva), geboren 1722, overleden 1754, gehuwd met Maximilian Emanuel von ToerringJettenbach.

Kinderloos.

Gravin van Gronsveld 1731, onder voogdij 1732-1746, gravin 1746.

Maximilian Emanuel von Toerring-Jettenbach, geboren 1715, overleden 1773, gehuwd met 1) 1746 Maria Josepha Nepomucena d'Arberg Valengin (overleden 1754) en 2) 1755 Auguste Isabella von Seinsheim, overleden na 1805.

Kinderloos. 
Graaf van Gronsveld 1746, ingehuldigd 1754.

August Joseph von Toerring-Jettenbach, broer van Maximilian Emanuel von ToerringJettenbach, geboren 1728, overleden 1802, gehuwd 1753 met Maria Elisabeth von Lerchenfeld, overleden 1811.

Elf kinderen, waaronder Joseph August von Toerring-Jettenbach Gutenzell (volgt).

Graaf van Gronsveld, ingehuldigd 6 mei 1773.

Graafschap Gronsveld als onderdeel departement Nedermaas ingelijfd bij Frankrijk op1 oktober 1795 .

Joseph August von Toerring-Jettenbach Gutenzell, geboren 1753, overleden 1826, gehuwd met Hyazinthe von Sandizell, ontving 1803 geseculariseerde rijksabdij Gutenzell als schadevergoeding voor graafschap Gronsveld. 


\section{Bijlage 2 Rechtsbronnen}

Inhoudsoverzicht

1 Wet- en regelgeving

1 Verordening op de vrachtdiensten voor de heer, ongedateerd (begin zestiende eeuw?). 2 Verordening van Johan I van Bronckhorst Batenburg tegen vloeken en onzedelijk gedrag, 15 september 1546.

3 Verordening van graaf Johan II van Bronckhorst Batenburg tot afkondiging van het Concilie van Trente in het graafschap Gronsveld en in Sint-Martens-Voeren, 20 juli 1608.

4 Verordening van graaf Johan II van Bronckhorst Batenburg op de manier van procederen, 3 september 1611.

5 Verordening van graaf Jost Maximiliaan van Bronckhorst Batenburg tegen verwerving van bezit in de dode hand, 15 oktober 1636.

6 Verordening van gravin Anna Christina von Hardenrath tegen verwerving van bezit in de dode hand, 19 juni 1670.

7A Rechtsordnung van het graafschap Gronsveld en de heerlijkheid Slenaken, 1671.

7B Rechtsordnung van het graafschap Gronsveld en de heerlijkheid Slenaken, 1671.

7C Ertr-Stiffts Cöllnische Rechts-Ordnung.

8 Verordening van graaf Johan Frans van Bronckhorst Batenburg op de schatheffing in het graafschap Gronsveld, 10 november 1718.

9 Reglementen op de proceskosten, 2 mei 1724 en ongedateerd (na 1728).

10 Verordening van baron Belderbusch als 'voogd' van gravin Maria Josepha d'Arberg Valengin, op de stijl van procederen bij de schepenbank Gronsveld, 13 oktober 1731.

11 Verordening van graaf Ignaz Felix von Toerring-Jettenbach als voogd van gravin Maria Josepha d'Arberg Valengin betreffende de inning van de schatting op grond, januari 1734.

12 Benoeming door de aartsdiaken van Haspengouw van pastoor H. D. Nijpels te Maastricht tot officiaal van de aartsdiaken en bekendmaking van de zittingen van het officialiteitsgerecht, 17 januari/1 maart 1735

13 Verordening van de grafelijke commissaris J. A. Prummer op het 'aanbrengen van de gronden' 1754.

14 Verordening wegens illegale houtkap ter hoogte van de Eckelrader 'gemeynte', 17 december 1760.

15 Verordening tegen loslopende varkens, 13 februari 1762.

16 Verordening op het 'aanbrengen van de gronden', 16 augustus 1766.

17 Verordening tegen het maskeren tijdens Vastenavond, 18 februari 1767.

18 Verordening tegen het strooien van vergif in de bossen, ongedateerd (december 1767).

19 Verordeningen van graaf August Joseph von Toerring-Jettenbach op het heffen van de aardappeltiende, 30 oktober 1775 en 10 januari 1776.

20 Verordening op het tappen van bier en brandewijn en het herbergen van vreemdelingen, 7 januari 1778

21 Verordening tegen schelden en geweldpleging, 16 juni 1779. 
22 Verordening van het Leenhof van Valkenburg, Staatse Partage, over de 'aanbreng van leengoederen', 1780.

23 Verordening tegen het 'krouwen'(afrukken) van veldgewassen, 22 april 1780.

24 Verordening tegen vernielingen in de omgeving van de kerk van Gronsveld, 9 april 1784.

25 Verordening betreffende het weiden op de gemeentegrond, z.d. (1784).

26 Verordeningen op de wachtdiensten, 1786.

27 Verordening op het 'karweien' voor het onderhoud van de wegen, 22 mei 1787.

28 Verordening van graaf August Joseph von Toerring-Jettenbach op het 'aanbrengen van de goederen', 1 augustus 1789 .

2 Verklaringen betreffende geldend recht

29 Verklaringen van de schepenen van Gronsveld en Rijckholt over het verhaal van schulden gevestigd op onroerend goed, 17 april 1657.

30 Verklaring van drossaard en schepenen van Gronsveld over het erfrecht van de langstlevende echtgenoot, 24 augustus 1761.

31Verklaring van de schepenen van Gronsveld over de appelrechtspraak, ongedateerd (derde kwart achttiende eeuw?).

Formulieren voor het 'bannen' van het voogdgeding

32 Formule voor het bannen van het voogdgeding en 'politieke ordonnantie' te Slenaken, 1633.

33 Formules voor het bannen van het voogdgeding te Gronsveld en Heugem, ongedateerd (achttiende eeuw).

Overeenkomsten met inwoners en geërfden over het betalen van belastingen

34 Verklaring van Johan I van Bronckhorst betreffende de afkoop van herendiensten door zijn onderdanen, 18 augustus 1526.

35 Overeenkomst tussen de graaf en de inwoners van het graafschap, 25 maart 1611.

36 Overeenkomst tussen de graaf en de inwoners van Slenaken over handhaving van de rechten van Slenaken en verpanding van de heerlijke rechten door de heer, 6 juni 1646.

371660 Overeenkomst tussen graaf Jost Maximiliaan van Bronckhorst Batenburg en de Maastrichtse geërfden in Gronsveld over de betaling van schatting.

38 Overeenkomst tussen Ignaz Felix, graaf von Toerring-Jettenbach, als voogd van gravin Maria Josepha d'Arberg Valengin en de Maastrichtse geërfden te Gronsveld over de betaling van schatting, 30 april 1739 .

Verheffingen in de adelstand

39 Verheffing van Diederik van Bronckhorst Batenburg tot rijksvrijheer door Roomskoning Maximiliaan, 1498. 
40 Verheffing van Jost en Johan van Bronckhorst Batenburg tot graaf door keizer Rudolf II, 1586.

\section{Diversen}

41 Proces-verbaal inhuldiging van graaf als landsheer1719.

42 Instructie voor de rentmeester 1737.

43 Attestatie van hertog Johan Willem van Gulik betreffende de rijksonmiddellijkheid van het graafschap Gronsveld, 16 maart 1606.

44 Beschrijvingen van de rechten en inkomsten van het graafschapGronsveld, circa 1650 en 1651.

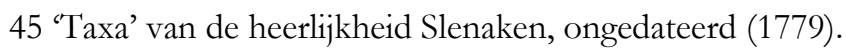




\section{Wet- en regelgeving}

1 Verordening op de vrachtdiensten voor de heer

$$
\text { ongedateerd (begin zestiende eeuw?) }
$$

Ordinanci van den dienst dat korn tot Remburch te fueren gelick mijn joncker in bijwesens sijnre lieffden scholtit, rentmeyster ind Jan Thijs geordonert haet, ind dat ter orsaken dat die halffwynnen sich zeer ongelick ind ongeburlick laden off verfrachten in den dienst.

Item eyn ider wynne der twe pluege haet int velt goen, der sal eynen vollen dienst doen. Item der mar eynen ploech haet, sal noch eynen vur hem spannen ind dar met ouch eynen vollen dienst doen.

Item sal eyn ilck wagen gehalden sijn te laden ind te fueren VI malder roggen ind nyet dar onder.

Item eyn ider wagen der gelijken sal laden VIII malder gersten.

Insgelix yeder wagen sal laden X klein malder spelten ind dergelijken X malder haveren. Item dies vurss. ordinanci wyl ons lieff joncker alsus gehalden ind volbracht hebben ind ingeval yement dit selvyge nyet en achtervolget off ter contrarien dede, sal der selff verbrueckt hebben 1 goltgulden, den mijn joncker op pert ind wagen durch sijnre lieffden dienre opt wyrthuys sal loten verdrincken.

Item aengoende van den loependen dienst sal eyn jeder bode onder sijnen ampt opsicht dar op hebben des geniegen men overscyckt ind eyn mensche tzemlyger wijse gedragen kan, en sal men geyn twe dar tou stellen, ind off yemant des onwyllich were, sal eyn yeder bode onder sijnen ampt eynen anderen hueren op kust ind scade des selven dar der dienst aen were.

RHCL, Arcbieven van het Graafschap Gronsveld en de heerlijkheid Slenaken (tot 1728), inv. nr. 115.

2 Verordening van Johan I van Bronckhorst Batenburg tegen vloeken en onzedelijk gedrag

$$
15 \text { september } 1546
$$

Mandat den floicken ende schelden belangende, in der herlicheyt Grunsfelt publiciert.

Ich Johan von Bronckhorst und Batemburg, vreyherr etc., doin kund allen und jeden underthanen meiner herlichkeytten Grunsfeltt, Hoegem, Slenaken, Huntem und Eckelrade, sampt und besonderenn, nach dem ick in tegliche erfarung gekommen, wilcher maissen ind gestaltt von ittlichen die Heilige Dreifaltigkeytt, sein werdiger gotlicher Naem und bittere smertzliche lijden, mitt sweren floken, krafften ende wunden in wertzhuiseren, 
auch sonsten anderer plaetsen so schentlich, lesterlich, ja dat mehr ist, unchristlich (dan solches keinen gotseligen frommen luitten und christlichen menschen woll ansteht und gebuert und den gotlichen gesetzen, gebotteren und christlicher lehre hoch zu wieder), gelastert und untehret wirdet, deme doch niemantz mit genochsamer ehre vor seine grondlose, gnedige und milde barmhertzigkeit uns, die wij sunst under dem ewigen zorn Gottes hetten bleiben mussen, reichlich und gnediglich erzeigt, begegenen kann. Und dan solches zu groisser verderffnis derselven (so mitt denen gebrechen beschmutzten 2224 beladen) seelen heill und wolfartt wan deme umb so dane boese tungen to stillen mit anderen gezwanck (dweill der predicanten lehr bey uch nit viell guetz werket) vorgekommen wurde, gedeyhen und erreichen kunte, ist mein ernstliche meinong, befehl und gebott, ein jeder sich hernachmals, so dains floikens und schwerens, bey Gotz leiden, Gottes wunden, Gottes marter, krafft und macht, Gottes bloet, Gottes vier elemente, bey dem Sacrament, bey dem oirdell des Hern in wirtzhuiseren oder anderen plaitzen onthalden sulle, bey peen ein goltgulden der darover befunden werde, weret oick saich die sodains anhoereten und nit meinem verordneten pastor oder schultheissen anbrachten, sollen die oder derselve 1 gulden gelt verbrochen hebben, des stillschweigens wegen.

Gleichfalls auch ein wurtt, und soll darzo in jar teits gein bier tappen moegenn.

Idt soll auch kein wurtt in winter teyden na seven uhren und des sommers na achten einige biergelager halden, bey peen eins goltgulden und darto eins jars tappens.

Weren oick etliche die im uneheligen stadt levenden, sollen sich inwendig ein monatz frist (so sonst nicht merkliches damitt so bald geschehe, daran verhinderenn wurde, welches jedoch meinem aldair verordneten pastoir oder schultheiss soll angezeigtt werden) nach christlichem gebruich und woinheitten verhiligen, bey verluist all honer have und vermeidung meiner herlicheyden.

Im fall auch jemandes im ehebruich befunden wurde, soll derselve tom iersten $\mathrm{X}$ goltgulden verbrochen, tom anderen meiner herlicheyt sich to meiden verbuert hebben, sonder gnade.

Damitt dan nu sodain bovengemelte straiffung oder peen nit to oder umb meiner nutzung angestimbt sein, ein jeder gedencken müge, soll alles wes mich derhalven mit bruichen verfallen wirtt, in behof der armen notturftigen, tho love und ehr Gottes angelacht, gekeret und hingewendet werden, darnach sich ein jeder to vermeidong seines schadens allenthalben im bestenn wisse to richten.

Urkund meines hierauf gedrukten secrets. Gegevenn op meinem schloss Rymborch im jair 1546 am XVI dag des monats septembris.

Augustinus Textoris, apostolica authoritate notarius publicus, subscripsit.

Afschrift van authentiek afschrift.

RHCl, Archief Archieven van het Graafschap Gronsveld en de heerlijkheid Slenaken (tot 1728), inv. nr. 62, ('cartularium Gronsveld'), fol. 210-211; gedrukt bij Hanssen, Rimburg, 354-356.

${ }^{2224}$ Lezing onduidelijk. 
3 Verordening van graaf Johan II van Bronckhorst Batenburg tot afkondiging van het Concilie van Trente in het graafschap Gronsveld en in Sint-Martens-Voeren

$$
20 \text { juli } 1608
$$

Wir Johan grave von Bronckhorst und zu Gronssfeldt, freyherr zu Battoburg unnd Rimburg, herr zu Alpen unnd Honnepell, etc., nachdem wir befunden dass hin unnd wieder in dem bisthumb Lüttich den Consilium Tridentinum promulgiert unnd publiciert, unnd dan under solcher diocoesi unsere pastoreyen zu Gronssfeldt, Höegem und St. Mertens Foihren, auch die filial kirche zu Eckelraidt unnd Scleennacken begriffen, wan uns nun als einen gliedtmassen der Heiligen Römischen Catholischen Kirch unnd zu deren wir auch hievor disem professionem fidei geton, gebüeren unnd obligen will, hochermelt Consilium Tridentinum in unser gantzen graffschafft Gronssfeldt bey vorgeschriebenen pastoreyen unnd kirchen gleichfahls offentlich publicieren unnd verkundigen zu lassen, so haben wir hiemit in krafft diser unser commission solches erstes tags geburlichen ins werck zu stellen unnd zu verrichten, dem wurdigen unnd wolgelertten unserem pastoren zu Gronssfeldt und lieben getrewen herrn Wynandten von Gelre, bevelch geben wie dan hieruber unser ernstlicher will unnd meinung ist, dass er solche publication mit einicher verlengerung nicht auffziehen, sondern der obligender schuldigkeit nach alssbaldt in aller gebur fortstellen wolle.

Urkundtlichen unser undersetzten aigen handt und auffgetruckt insiegels, geben unnd beschehen am sechs und zwantzigsten tag dess monatz julii anno (sechs) ${ }^{2225}$ zehenhundert unnd acht.

Johan grave zu Gronsvelt.

Naervolgens dese commission is 't Consilium Tridentinum gepromulgeert ende gepubliceert in de parochiekercke tot Gronsfelt post missarum solemnia, sijnde de geheel gemeinte in der kircken ende sommige schepenen met den heer drossart die tot der publication specialick geroepen was, den X augusti XVI c ende acht, sijnde dies dominica et festum Sancti Laurentii, ende dat deur mij heer Wynant van Gelre in eygener personen. Van dese commission is een copie gelanght aen heer Joris als pastoir tot Hoegem om aldaer oick te doen publiceren ' $t$ Consilium Tridentinum die prescripto ende een andere copie is gesonden ad pastorem Fori Sancti Martini om daer ende tot Sleenaken insgelijcken 't voerss. Consilium te publiceren. Etc.

In dorso in verschillende handen:

Concilium Tridentinum aengande.

Publicatio Concilii Tridentini in Gronsfelt.

1608 - 10 augusti, attestatio publicationis Concilii Tridentini factae in Gronsfeld.

2225 Woord zit onder het opgedrukt plakzegel. 
Origineel met handtekening van graaf Johan II van Bronckhorst Batenburg en opgedrukt zegel.

RHCL, Arcbieven van het Graafschap Gronsveld en de heerlijkbeid Slenaken (tot 1728), inv. nr. 236.

4 Verordening van graaf Johan II van Bronckhorst Batenburg op de manier van procederen

$$
3 \text { september } 1611
$$

Extract uuiter Ir[er] G[enaden] Graeven tot Gronsfelt befelen ende ordinantien de dato den derden septembris 1611 ende dat uuiten Xen artikele van dyen.

Befelen dat nu voertaen sullen werden observeert also well tot Sclenaken als tot Gronsfelt die manieren van 't procederen gelijck men tot Gronsfelt tot nochtoe observert heeft ende dat alsulx mandement hybevorens deur ons tot Gronsfeldt aengaende den gueden soe van wegen dieses kriegts verloeren ende te goeden coup gegeven soude mogen wederomme gewest worden in der kercken doen publiceeren, sall alsoe well platz nemen te Heugem ende Slenaken als tot Gronsfelt.

Onderstondt aldus gescreven.

Johan Grave tot Gronsfelt.

Quod attestor ende was ondertekent Johan Walpots Junior per copiam subscripsit.

Fragment, uittreksel wit het rolregister van het proces tussen Lambert Couven c.s. tegen Beatrix van Birgelen.

RHCL, Archieven van het Graafschap Gronsveld en de heerlijkheid Slenaken (tot 1728), inv. nr. 599, fol. 22 .

5 Verordening van graaf Jost Maximiliaan van Bronckhorst Batenburg tegen verwerving van bezit in de dode hand

15 oktober 1636

Onsen genedighen heer grave Jost Maximilian, graeve van Bronckhorst, Gronsfelt ende Ebrestein, baron van Battenberch ende Rimborch, heer van Alpen, Hunnepell ende Gochesheim, etc., sorge dragende voor de conservatie van sijne gerechticheiden hem alhier bynnen sijne vrijheerlicheit van Schlenacken competerende, doet expres ende scherp beveel, om veel ende verscheiden reden[en] hem daer tou moverende, dat geene geestligen conventen, cloesters, capittellen ende diergelicken collegien dye men nompt te wesen van 
de dode handt en sullen moegen gelden, vercrigen, besitten, noch beerven in eeniger manieren einige gronden van erven, noch andere eerfflicheiden alhier resorterenden, op peine van nulliteitt ende dat de coopen oft contracten in preiuditie van dyen gedaen sullen gehauwden werden voor machteloos, gebieden dairom onse wethouderen van Schlenacken vorss. dat zij op arbetrale straeffe ende departement van haere officien hun niet en sullen verstouten te staen over einige gichten, transporten oft andere acten desen contrarieerden.

Actum XV octobris 1636 ter ordonnantie van mijnen genedigen heere.

Lamberts.

Afschrift.

RHCL, Arcbief klooster Hoogcruts, inv. nr. 531.

6 Verordening van gravin Anna Christina von Hardenrath tegen verwerving van bezit in de dode hand

19 juni 1670

Alsoo t'onser kennisse is gecoemen dat verscheyden ende principaelijck geestelijcke persoenen bij diverse middelen, soo directe als indirecte, daegelijcx trachten in te vueren in onsen graeffelijcken gesach van Gronsfelt, ende wel het meesten onder het gheene van Slenaecken seer groeve ende enorme abuysen in materie van alienatie, coop ende vercoop, cessien ende overdrachten, t'waere van onse leengoederen, met het gheene soe daer aen cleeft, als andere van wat nature dieselve moegen weesen van ons moveerende, naementlijck dat die eerw. heere prior ende conventualen des convents opt Cruys haere soo verre emanciperen, dat sij bij groote impuniteyt presumeren te moegen infringeren ende onder die voeten te brengen die meenichfuldighe ende immemoriale rijcx ordenung ende andere van verscheyden coningen ende princen ieder in sijn gesach ende resoort geemologueert voor perpetuel reglement ende inviolable observantie in materie van verhandelinge der onruerende goederen et de iis non amortisandis, conform aen die geene soo wij succesivelijck in dese onse graeffschappe Gronsfelt sorghfuldelick ende met grooten ernst hebben gestatueert ende naer behooren doen publiceeren ende affigeeren daer sulcx behoorde, die bovengemelde heeren haer vervoorderen ende vervoordert hebben tot noch toe niet alleen inne te coopen, maer selfs haere t'approprieren in haere doode handt alle sorten van immeubele goederen, niet allein van gronden ofte erven, maer oock selfs huysen ende wooningen, dieselve naer lust devasteerende ende afbreeckende tot uytterste schendinge ende desolatie onser meergemelte graeffschap, maer oyck wel tot totale destructie ende verjach onser gemeentenaren ende anderssints, met soodaenighe presumptie ende vermet dat allen die voor verhaelde mesusen ende excessen aen haer voorseyde conventualen soude vrij toestaen uyt crachte van oude possessie, privilegie ende gerechtigheyt, imaginaire geconfirmeert bij wijlen haere excellentie gen. lantheere soo ende gelijck die voorseyde conventualen temerairlick derven astrueeren bij d'ijdele ende 
ondienstige protestatie over het voorverhaelde subiect gedaen soo ende gelijck ons daeraff volcoemen is gebleecken, ende oversulcx tot tegenweer ende redres van dyen hebben, naer rijpe deliberatie goet gevonden anderwerff te reitereren ende vernieuwen alle voorgaende ordonnantien, statuten ende wetten in dese ende andere dergelijcke materien rigoreuselijck gestatueert ende dyen volgents expresselijck te verbieden, soo ende gelijck wij verbieden op desen alle verhandelinge ende verbrengen van allerley immeubele goederen in geestelijcke ende doode handt, directelick ofte indirectelijck, op pene dat alle deselve goederen sullen sijn ende blijven vervallen in commissum t'onswaerts ende die wedersijdens contractanten in eene amende van eene marck gouts boven andere arbitrale naer exigentie der saecken, boven die nulliteyt ende onweerde van allen dusdaenige illicite contracten, waerinne wij deselve uyt onse sonderlinge macht ende weetenheyt verclaeren alreede te sijn vervallen voor het voorleden ende te sullen anderssints vervallen voor het toecoemende sonder eenigh support oft dissimulatie, lastende ende beveelende aen allen onse beampten ende andere justicieeren onser graeffelicker justitien dese onse ordonnantie ende expres bevell naer te coemen ende doen observeeren naer haeren teneur, soo pro 2226 praesenti als præterito et futuro, doende dieselve formelijck inregistreeren in haere prothocollen, naer dat sij behoorlijck ter gewoonlijcker plaetsen sall weesen gepubliceert ende geaffigeert op dat niemant daeraff eenige ignorantie en pretendere, ordonneeren ende beveelen daertoe dat voorseyde onse beampten ende officieren van justitie promptelijck sonder eenigh uytstel oft dilay met alle nerstigheyt sullen ondersoecken bij alle moegelijcke middelen allen dusdaenige voorverhaelde verhandelingen van onruerlijcke goederen verbrocht in doode handt ter contrarien van boven gementioneerde onse ordonnantien, statuten ende edicten bij wyen oft om wat oirsaecke ofte occasie dattet sij sullen volgens ons verclaeren sullen sijn gehouden ende geacht worden voor nul ende van onwerden als voor nu ende ten eewigen daeghe ende dat sij selve als ter onser taefelen vervallen sullen door onse bewinthebbers voor sulcke moegen aengeslaegen ende geregeert worden t'onsen nut ende profijt, boven dat wedersijdens contractanten als vooren als vervallen in d'amende van een marck gouts daer toe ende voldoeninge derselver pene sullen worden als gecondemneerde bij alle riguer van justitie worden reelijck ende effectivelijck geexecuteert, ordonneerende nochmaels dat allen onse beambten ende officieren van justitie ende elck van hun bijsondere soo hun toebehooren sal, dat sij dese tegenwoordighe declaratie, constitutie, edicten ende ordonnantie van stonden aen registreeren, publiceeren, condigen ende uytroepen, elck in den bedrijve ende registeren van sijnder officie daer men gewoonlick is sulcke uytroepinge ende publicatie te doen, opdat niemandt des ignorantie en pretendere ende dieselve onderhouden, observeeren ende achtervolgen, doen ende laeten onderhouden, observeren ende naervolgen onverbreeckelijck nae haer forme ende inhouden sonder tot eenighen tijde yet te doen ofte laeten geschieden ter contrarien in wat manieren dattet sij, procedeerende ende doen procederen tegens die overtreders ende inbreeckers van dyer bij inninge ende executien van penen voorss. ende anderssints rigoreuselijck sonder verdraech, faveur oft dissimulatie, want sulcx is onsen wille ende hochste gebott.

2226 De getranscribeerde tekst geeft hier: 'in'; de twee andere afschriften: 'pro'. 
Gegeven op onsen graeffelijcken borch tot Gronsfelt den 19 daech juny 1670. Des t'oorconde hebben wij onsen segel hieraen doen hangen ende door onsen secretaris doen onderteeckenen.

Ter ordonnantie van haere excellentie mijne gen[edige] vrouwe gravinne van Gronsfelt, etc.

W. van Hoven secretaris subscripsit.

Afschriften.

RHCL, Archief klooster Hoogcruts, inv. nr. 534.

7A Rechtsordnung van het graafschap Gronsveld en de heerlijkheid Slenaken

NB. Bij de editie van deze versie is voor de artikelen van de afzonderlijke hoofdstukeen het $\int$ teken geplaatst vanwege de uniformiteit met een tweede afschrift van de Rechtsordnung in het archief ToerringJettenbach te München (7B). De inhoudsopgave is aangegeven om het overzicht te vereenvoudigen, maar staat niet in het origineel.

Titulus I Vom testament und letzten willens vermachtnus.

Titulus secundus Vom erbschafft obne testament in aufsteigenter linien.

Titulus tertius Von erbfolgung in absteigenter linien.

Titulus quartus Von erbung der elteren mit und neben dess verstorbenen kündts brueder und schwester oder derselben künderen.

Titulus quintus Von erbung auf der seithen linien seu linea collateralis.

Titulus sextus Von denen lechen und deren succesion.

Titulus septimus Wie eheleuthe einander erben sollen.

Titulus octavus Von dem besitz. oder possession der erledigten erbschafft.

Titulus nonus Von der einkïndtschafft.

Titulus decimus Von vormundtschafften.

Titulus undecimus Von kbauffen und verkhauffen.

Titulus duodecimus Vom einstandt oder bescheidt zu latein ius retractus genant.

Titulus decimus tertius Von pfandtschafften, ₹u latein de pignoribus et hÿpothecis.

Titulus decimus quartus Von pfachtungen.

Titulus decimus quintus Von erbpfachten.

Titulus decimus sextus Von churmuthen, zu latein de curmediis.

Titulus decimus septimus Von verjährung der stehenten rhenten oder zünsen.

Titulus decimus octavus Von den gerichteren und wie mann sich dabejy sowobl in procedendo als judicando zuverbalten.

Graffschafft Gronsfeldt[ischen] und freÿer herrschafft Schlenacken Rechtsordtnung der hochgebohrnen gräfin[en] und frauen, frauen Annæ Christinæ, gräfin von Bronkorst zu Gronsfeldt und Eberstein, freÿ frauen zu Batenburg, Anholt und Rimburg, frauen zu Alpen und Honnöpel, vormundt[erin] und regentin. 
Getruckt den $1^{\text {ten } j u l y ̈ ~} 1671$

Wür Anna Christina gräfin von Bronkorst, zu Gronsfeldt und Eberstein, freÿfrau zu Batenburg, Anholt und Rimburg, frau zu Alpen und Hönopel, vormunderin und regentin etc.,

füegen hiemit allen unseren beambten, richteren, schuldtheisen und scheffen, auch all unseren bedienten, unterthannen und sonsten menniglichen, wess standts oder würdten die seÿen, ins gemein zu wissen,

demnach wür beÿ uns betrachtet einer ieden ordentlichen obrigkeit vornembstes ambt in deme zubestehen, das sÿe dahin sorglich sehen solle, auf das die ihro von Gott anbefolchene unterthannen in gleichheit und rechten erhalten und meniglichen die justiz unpartheÿlich und zwar ohne vergebliche und unnöthige uncosten und umbfüehrung erthaillt werdten möge und dan wür unter wehrenter unserer regierung angemerckht das ville schädliche und kosstbahre strittigkeiten beÿ dennen gerichteren aus deme enstandten dass die partheÿen ein oder andererseiths sich entweeder auf gemeine landt- oder aber absonderlich hergebrachte von dennen beschribenen rechten abweichente gewohnheiten berueffen und da solche von dem gegentheill nit gestandten, sonderen widersprochen, eine grosse zeit mit deren beweisthumb hinlauffet, unterdessen aber mancher an seinen rechten mangel leiden oder doch damit zu grossen nachtheill aufgehalten werdten mues, zudeme auch die villerleÿ unterschidtliche gebrauch, so von orth zu orth offtmahl vorgebracht, den richter nicht wennig irr machet,

so haben wür zu vorkommung solcher ungelegenheiten eine nothdurfft erachtet all unser obgemelter graffschafften und frë̈en reichsherrschafften gewohnheiten in schrüfften kürzlich abfassen zulassen und iedermenniglichen kundtzumachen, damit sowohl die partheyen in befangung ihrer processen als die richtere in begreiffung der urtheill sich daraus ohne weithleuffigkeit zu belehrnen und darnach zu achten haben und sollen nun disemnach alle andere gewohnheiten und gebräuche die hierin austruckhlich nicht gesezt und benambset, wie sie auch beschaffen sein mögen, ohne einige ausnamb vor nichtig und krafftlos erklert und erkent sein, sondern außer derselben alle andere fähl nach den gemeinen beschribenen rechten erördert und abgeurtheillt werdten.

Titulus I

Vom testament und lezten willens vermachtnus

\1 In unserer graffschaft Gronsfeldt und herrschafft Schlenackhen ist einem jeden, deme es sonsten vermög gemeiner rechten nicht absonderlich verbotten, ÿber seine haab und güetter ohne underschidt ob sÿe in gereidt, fahrenheiten, beweglichen oder in ligenten unbeweglichen güetteren bestehen, ob sÿe anerwonnen oder angeerbt seÿen, seinen lezten will oder testament aufzurichten erlaubt.

\2 Ein solcher lezter will oder testament mag vor dem geschworrnen gerichtschreiberen, notario oder pastorn des ohrts wo der actus vorgehet und zweÿen schöpfen, oder beÿ 
deren mangel, zween anderen darzue erforderten gezeugen gültig aufgerichtet werdten; es soll aber dasselbe (wan schrifftlich testiert würdt) von dem gerichtschreiberen, notario oder pastorn und zween scheffen oder dennen zween zeugen unterschriben sein.

\3 Wan aber iemandt gerichtlich testieren will, mag er in gegenwarth des gerichtschreibers und zween scheffen sein testament eigenhändtig unterschriben verschlossen und unverschlossen vorbringen und dem gerichtschreibern zum prothocoll zulegen ausantwortten der dan alsbaldt all solchen aus antworttungs actum auf das testament schreiben soll.

$\$ 4$ Will einer sein testament von mundt außprechen, welches auf latein testamentum nuncupativum genennt würdt, soll er den nahmen dessen den er zum erben einsezt und was er sonsten darin begriffen haben will, vor dem gerichtschreiberen, notario oder pastorn und zween scheffen, oder beÿ deren mangel, zween darzue berueffenen zeugen, offentlich und klärlich benennen.

$\$ 5$ Wan ein testierer dess gerichtschreibers, notarii oder pastorns nich mechtig sein kan oder sonsten sich ihrer zu gebrauchen bedenckhens hette, mag er anstatt einer ieder auß disen abgehenter person zween andere zeugen darzue berueffen.

$\int 6$ Da das testament vom mundt ausgesprochen, soll der gerichtschreiber, notarius oder pastor, oder aber wan in mangl deren, zween andere gezeugen gebraucht werdten, iehemandt von dennenselben die vermachtnuss alsobaldten verzeichnen und dem testierer und zeugen vorlesen, zumahlen sonsten hernacher aus dem zeugnus oder ÿbel eingenohmener meinung dess testierers leichtlich irrungen und streitt entstehen könnten, im widrigen da solches nit in acht genommen, soll das testament krafftlos und von unwürdten sein.

$\int 7$ Es stehet einen ieden freÿ ÿber seine verlassenschafft ganz oder zum theill, auch ohne einsezung eines oder mehr universal erben durch lezten willen zuverordtnen, und soll allzeit die codicill clausul, wan sÿe schon nicht gemeldt wordten, darin verstandten werdten, das nemblich der ÿbrige thaill der erbschafft, deren in der vermachtnuss nit gedacht wordten, bey dennen negsten anverwandten welchen solche sonsten von rechts wegen gebührt, und zwar ohne abzug der falcidiæ oder Trebellanicæ verbleiben solle.

$\int 8$ Im fahl nun die erbschafft durch particular oder stuckhweis beschehene vermachtnus ganz erschopfft, also das sich niehmandt vor erben angeben wolte und aber schuldten auf der erbschafft zubezahlen hafften, so sollen die legatarii nach proportion oder ertrag ihrer vermachtnus oder güffte so vill fallen lassen oder beÿtragen als zu bezahlung der schuldten vonnötten, sÿe aber den werth alsolcher gifft (wan nur inventarium oder verzeichnus der ganzen erbschafft gebührent aufgerichtet) nicht verbundten sein.

$\int 9$ Wan elteren unter ihren künderen der theillung halber verordtnung hinterlassen wollen, ist genueg das sÿe ihren willen mit eigenen händten beschriben und mit ihren 
nahmen mit jahr und tag unterzeichnen, und soll solches unter dennen künderen, wan schon keine zeugen darzue gebraucht, gültig sein.

\10 Auf gleiche weis mag ein vatter oder muetter ihren künderen oder beederseiths gross elteren ihren encklen, wan vatter oder muetter vorhero verstorben, auf den fahl sÿe in vogtbahren jahren mit todt abgehen werdten, einen affter erben ansezen in dennen jennigen güetteren die von testierer herriehren, iedoch durch solche substitution oder affter erbsatz des kündts hinterbleibenten vatter oder muetter ihr natürliches anthaill oder nothgebührnus, zu latein legitima genant, nit benennen.

$\int 11$ Ein ieder mag seine erbschafft mit einen fidei commiss oder afftervermachtnus nach belieben beschweren, iedoch soll dennen künderen ihr nothgebührnuss oder legitima allzeit frey bleiben, andere eingesetzte erben aber sollen den viertten theill, zu latein Trebellunicam, davon auszuziehen oder abzukürzen nit befuegt sein, sonderen hierin wie sonsten allenthalben dess testierers verordtnung aufs genauist nachgangen werdten.

\12 Obgemeltes fideicommiss oder affter vermachnus soll weiter als auf den dritten erben den erst eingesezten mit einschliesslich, unerachtet der testierer ein anders verordtnet, nicht gültig sein, sonderen die güetter sobaldt sÿe in die viertte handt vererben, wider in ihre freÿheit kommen und zu deß besizers wühlkühriger disposition stehen.

\13 Wan zweÿ eheleuth zu behueff ihrer künder einsambt testament, wie es nemblich unter ihnen mit beederseiths güetteren gehalten werdten soll, aufrichten, kan nach absterben deß einen der leztlebenter solches nit enderen, sondern ist es auch in seinen eigenen güetteren so vill er deren beÿ stehenter ehe besessen, zu halten schuldtig, in dennen aber hernach im wittib standt erworbenen, bleibt ihm eine ungebundtene handt.

Titulus secundus

Vom erbschafft ohne testament in aufsteigenter linien

\1 Wan vatter oder muetter ohne testament oder ordtnung ihres lessten willens mit hinterlassung eheleiblicher künder (worunter auch die iennige, so zwar unehelich gezeugt aber durch hernachfolgende ehestandt geehliget wordten mitzuverstehen) hinsterben, sollen selbige künder alle vatter- und müetterliche haab und güetter, fahrend und ligent, zugleichen theillen erben, wo aber enckheln oder urenckheln in rechter absteigenter linie verhandten, tretten diselbe allzeit in ihrer abgangener elteren plaz und erben dess verstorbenen anherrn oder uranherrn künder in stamme, gleich wie ihre elteren, wan sÿe noch im leben weren, geerbt hetten.

$\$ 2$ Da aber mann oder frau vorhin im ehestandt gewesen, künder darin gezeugt und nach absterben deß ehegatten zu der zweÿten und mehreren ehe geschritten und darin auch künder gezielet, weillen die künder erster und folgenter ehe der natur und geburth nach ihren gemeinen vatter oder muetter gleich nahe seint, so bleibt es auch der erbschafft halber, billich beÿ verordtnung der allgemeinen beschribenen rechten, das nemblich alle 
solche künder ohne unterschiedt der ehe darin sÿe gebohren, ihren vatter oder muetter in deren zuegebrachten eigenthumblichen oder auch von auf absteigenter oder auch collateral linien durch erbschafft in erster, zweÿter oder ferneren ehe angefallenen güetteren, zu gleichen thaillen erben sollen und mögen, es seÿe dan sach das die pacta der vorgehenten ehe weder der erbschafft eines oder beÿder ehegatten auf den künfftigen fahl des gebrochenen ehepötts eine andere verordtnung mitbringen, dan solche in alle weeg statt haben und denselben ohne wider rödt eingefolget werdten soll.

$\int 3$ Die in ieder ehe anerwonnene ligente und unbewegliche guetter (warin auf jahr renten angelegte gelten, sÿe seÿen losbahr oder nit, ohne unterschidt allzeit und allenthalben mitverstandten werdten) sollen beÿ der iennigen ehekünderen darin sÿe gewohnnen, verbleiben; wie es aber mit deren niesslicher nuzbahrkeit, sodan den fahrenden oder beweglichen güetteren zuhalten, ist hierunter beÿ dem 7 Tit[ulo] der eheleuthen vermeldet.

$\int 4$ Gleich die natürliche künder vermög der gemeinen rechten der muetter, obschon selbige auch eheliche künder gezeugt, eben dennen gleich succedieren, nicht aber dem vatter, so lasset manns dabeÿ ebenfahls bewendten, doch sollen die illustres ausgenomben sein.

\ $5 \mathrm{Im}$ fahl ein sohn oder tochter ehe sÿe das fünff und zweinzigiste jahr ihres alters erfüllet ohne ihrer leiblicher eltern vatter oder muetter wissen und willen sich verheurathet, sollen sÿe zwar dadurch ihres naturlichen anthaills oder legitimæ an der vatter- oder muetterlichen erbschafft nit entsetzt werdten können, weillen sÿe aber andurch eine grosse undanckhbahrkeit gegen ihre eltern begehen, sollen diselbe bey ihren lebzeiten ihnen einig heurath gueth zu geben nit schuldig sein.

$\int 6$ Dennen in geistlichen ordten eingetrettenen söhnen oder töchteren sollen die eltern schuldig sein vor dem gelübt oder profession nach gestalt ihres vermögens eine billichmässige außteur, als etwa von einhundert bis in 300 oder 400 reichsthaller zum hochsten zuverschaffen. Wan mann sich aber beederseiths nit wurdte vergleichen können, soll die obrigkeit darin eine billiche mässigung treffen und damit der geistliche sohn oder tochter von der elterlichen verlassenschafft, wie auch allen beÿ oder seithen fählen genzlich abgeguettet und verziehen sein; wan auch solches durch die geistliche söhn, töchter oder deren ordtens obern versaumbt oder verschoben, soll nichts destowenniger hiernach die obrigkeit die gebührente verordtnung zustellen macht haben.

$\int 7$ Und wan etwa hernach eine solche geistliche persohn nach beschehener profession aus ihrem ordten austretten wurdte, soll dieselbe $\mathrm{zu}$ dem elterlichen oder anderen anerfallenen güetteren durch aus keinen zuetritt mehr haben.

Titulus tertius

Von erbfolgung in absteigenter linien 
$\int 1$ Wan ein kündt mit todt abgehet und keine erben in absteigenter linien, als söhne, tochter und enckhelen oder auch keine brüeder oder schwestern von beeden seithen, noch auch deren künder im ersten gradt verlassen, so erben des gestorbenen kündts vatter und muetter seine verlassene ligente haab und güetter disergestalt, das der vatter die iennige so von vätterlicher seithen und die muetter die iennige so von müetterlicher seithen auf das gestorbene kündt kommen, vorabnehmen, alle ÿbrige aber unter sich gleich theillen.

\2 Wan aber entweeder der vatter oder muetter mit todt abgangen, so erbe das ander, so noch im leben, alle des kündts haab ohne unterschidt woher solche auf das selbe kommen, vor allen anherrn und anfrauen und allen anderen freundten.

\3 Da vatter und muetter nicht im leben, so erben die verlassene güetter, so ligent, die von vätterlicher seithen an das kündt kommen seint, anherr und anfrau von dem vatter vorab, dessgleichen die von müetterlichen seithen kommente ligente haab und güetter anherr und anfrau von der muetter auch vorab, und die andere ÿbrige haab und güetter erben anherr und anfrau von beeden seithen mit ein ander.

\4 Wan aber allein ein anherr oder anfrau, uranherr oder uhranfrau des gestorbenen kündts von vatter oder muetter seithen im leeben, der oder die erben allein so vill als anherr und anfrau, oder uranherr und uranfrau von beeden seithen zusamben, wan sÿe gleich im leben weren.

$\int 5$ Solang ein anherr oder anfrau im leben, werdten uranherr und uranfrau von der erbschafft ohne unterschidt woher die güetter kommen, ausgeschlossen. Wan aber kein anherr und anfrau im leben, so erben die uranherr und uranfrau in allermassen wie von dem anherrn geschriben ist, vor allen anderen verwandten, auch vor den geschwistrigten von einer seithen und derselben künderen.

$\int 6 \mathrm{Da}$ aber das verstorbene kündt an vatter- oder müetterlicher seithen nur einen anherrn oder anfrau, uranherrn oder uhranfrau noch im leben hette, soll zwar, wie oben von vatter und muetter gemelt, ein ieder theill in dennen ligenten güetteren so von seiner seithen herkommen vor ab erben, alle ÿbrige güetter aber in zweÿ gleiche theile, und davon die eine halbscheidt auf den einen anherrn oder anfrau von vatter oder muetter, die andere aber auf beede anherrn und anfrau von der anderen seithen verfallen.

Titulus quartus

Von erbung der elteren mit und neben dess verstorbenen kündts brueder und schwester oder derselben künderen

$\S 1$ Wan das abgestorbene kündt hinter sich vollburtige brüeder oder schwestere oder derselben kündere im ersten glied im leben verlasset, so erben dieselbe mit dess abgestorbenen kündts vatter und muetter oder muetter allein, wan der vatter mit todt abgangen, oder mit dem vatter allein, wan die muetter vorhin verstorben, alsdan mit dem anherrn und anfrauen oder, wan deren auch keine mehr verhandten, mit des 
abgestorbenen kündts uranherrn oder uranfrauen alle haab ohne unterschidt, ie eine persohn sovill als die andere, doch sollen der brueder oder schwester künder, ihrer seÿen vill oder wennig, nit nach dennen haubteren und zahl der persohnen sonderen in staa[m]me, nemblich anstatt ihrer vatter und muetter erben und mehr nicht, dan ihr vatter und muetter geerbt hetten wan sÿe im leben gebliben weren.

$\int 2$ Da nach tödtlichen abgang vatters oder muetter das abgestorbene kündt an einer seithen nicht mehr dan einen an oder uran hünter sich verliesse und auf der anderen seithen zween an oder uran, sambt vollbürdtigen brüederen oder schwesteren, oder derselben künderen, so werdten dieselbige anherrn oder uranherrn, anfrau oder uranfrauen auf der anderen seithen für eine persohn gerechnet und erben beede auch nit mehrer dan eins von des abgestorbenen kündts vollbürdtigen brüederen oder schwesteren oder deren eines künder alle erben mögen.

Titulus quintus

Von erbung auf der seithen linien seu lineæ collateralis

$\int 1$ Wan der verstorbene in ab- oder aufsteigenter linien niemand, sondern vollburdtige brüeder oder schwestern, oder derselben künder im ersten gliedt hinter sich verlasset, alsdan erben dieselbe gleich mit einander vor allen anderen verwandten, auch vor ihrer vollbürdtiger brüeder oder schwester enckelen, wie auch vor brüeder oder schwester von einer seithen.

$\int 2$ Jedoch erben der brüeder oder schwester künder, ihrer seÿen vill oder wennig, mit deß verstorbenen brueder oder schwester, wan deren noch im leben in die staamen und mehr nicht, als ihr vatter und muetter, wan wurdte gelebt haben, geerbt hette.

$\int 3$ Da aber der verstorbene keine vollbürdtige brüeder oder schwester, aber wohl deren künder im leben verlasset, alsdan erben dieselbe, ihrer seÿen von einen oder mehr brüeder oder schwester, vill oder wennig, alle sammentlich in die häubter zu gleichen thaillen.

$\int 4$ So aber keine vollburdtige brüeder oder schwesteren, noch deren künder im ersten glüdt verhandten, alsdan erben die einseithige oder halbburdtige brüeder und schwesteren und deren künder vor allen anderen anverwanthen, auch vor dess verstorbenen vatters oder muetter brüederen und schwesteren, ohne unterschüdt wo die güetter herriehren, auf gleiche weiss wie von den vollburdtigen gemelt wordten.

$\int 5$ Jedoch wan der verstorbene zweÿerleÿ einseithige brüeder oder schwesteren oder deren künder, nemblich eine von dem vatter und die andere von der muetter verlasset, alsdan sollen die brüeder oder schwesteren von der vätterlichen seithen und deren künder im ersten glüdt die iennige ligente güetter, so von dem vatter herriehren, und hingegen die brüeder und schwesteren von der müetterlichen seithen die ligente güetter, so von der muetter herkommen, voraberben, die übrige güetter aber in 2 gleiche theill theillen. 
$\int 6$ Wan keine voll- oder halbpurdtige brüeder oder schwesteren, noch von dennenselbigen künder im ersten glüdt im leeben, so erbt ieder negster blueths verwandter dess verstorbenen verlassenschafft ohne unterschüdt, männlich oder weiblichen staa $[\mathrm{m}]$ mens, es rüehre die verwandtschafft von einem bandt oder von beÿden, auch ohne unterschüdt von welcher seithen die güetter herkommen, und solches in das zehente glüdt der verwandtschafft, dass iedes mahl eine gebuhrt für ein glüdt nach verordtnung der gemein beschribenen rechten zu rechnen.

Titulus sextus

Von denen lechen und deren succesion

$\int 1$ Sollen alle die jennige lechen, worin der tenor primæ investituræ mit claren worthen auf mann lechen gerichtet auch $\mathrm{zu}$ forderist vor rechte mans lechen gehalten und die tochter von deren succession allerdings ausgeschlossen sein und bleiben, sonderen wan der a primo acquirente herkommende mans-stamm außtirbt, alsdan der lehen herr und dessen successores guette macht und fueg haben sollen, allsolch lehen widerumb einzuziehen und ihnen anzuheimschen, inmassen kein vasall auch mit consens deß lehenherrns befuegt sein solle, ein allsolches manns-lechen $\mathrm{zu}$ nachtheill deren a stirpite acquirente herrüehrenten agnaten und ihres daran habenten juris quisiti ohne auch deren special consens zu alienieren, zuversezen, zu permutieren oder zuvereusseren, zumahlen widrigen fahls der a primo acquirente herkommente agnatus wohl befuegt nach todt dess alienantis sothannes feudum frey und ohne restitution deren davor hergeschossener pfennigen einzuziehen und zu repetieren.

$\int 2$ Gleicher gestalt wo die investitur von beederleÿ geslecht, mann- und weibspersohnen, austrucklich meldung thuet, da sollen die töchter oder weibs-persohnen zur succesion der lehen zuegelassen und verstattet, iedoch auf begebenten fahl selbige durch die manns-persohn behörrlich bedient und vertretten werdten.

$\int 3 \mathrm{Zu}$ dennen iennigen lechen, so informiter nemblich ohne meltung mänlich oder weiblichen geslechts bis hierzue conferiert und verlühen wordten, fahls entweeder keine manliche lechen folger oder doch in pari cum fæminis vel remotiori gradu verhandten, alsdan sollen die töchter oder weibs-persohnen a primo acquirente entsprossen, darin zur succession dem alten herkommen gemess admittiert, und also die weib- und männliche agnaten promisive, auch proximiores in gradu remotioribus absque sexus differentia vorgezochen werdten, abermahlen doch mit dem beÿm $2^{\text {ten }}$ gro beschechenen reservato das nemblich sÿe das lechen durch eine manns persohn zu deservieren schuldtig sein sollen.

$\int 4$ Der vasallus solle petione investituræ in jahr und 6 wochen sowohl nach des lechenherrn todt von dessen erben, als nach todt dess vasalli dessen hæredes vom lechen herrn mit gewohlichen homagio und hergeweÿdt proprio motu und ohne einige citation sub pœna caducitatis thuen und dabeÿ gebührente juramentum fidelitatis præstieren. 
$\int 5$ Solte aber ein lehen im leben eines mit künderen versehenen vatters releviert werdten müessen, so solle der vatter, nit aber dessen sohn, das relivium gebührent verrichten inmassen auch alle lechen von den iennigen welchen sÿe vom rechts weegen competieren, selbst releviert werdten sollen.

$\int 6$ Solle der vasallus ohne special consens seines lechen-herrns dass feudum ganz oder einen theill darab unter straff der würckhlichen caducitæt nicht verkauffen, oppignorieren, permutieren, noch einiger weis distrahieren oder alienieren, alles unter ferner Feud[orum] 2. Tit[ulum] 55 durch keÿser Fridericum angezogener straff, und im fahl solches attentiert werdten, solten dem lechen-herrn frë stehen, dass caducierte feudum vermög der lechen rechten freÿ einzuziehen.

$\int 7$ In judicio feudali solle gleich in judicio civili ordinario tit[ulum] 18 procediert werdten, außer das nur der lechen-richter, statthalter oder dessen substitutus nebenst zweÿ mannen von lechen in dess lechen herrn abweesenheit die belehnungen nach vorgangenen von rechts-weegen gehörrigen requisitis und solemnitæten gegen empfang eines von dem vasallo gebenten reversalis zu folg von unseren hochgeehrten vorfahreren herrn Johann, grafen von Bronkorst zu Gronsfeldt etc. den 2 aug[usti] a[nn]o 1593 ausgelassener lechenordtnung thuen, auch alle coram curia feudali vorfahlente processen nebenst obgemelten zweÿ mannen von lechen determinieren und definitive decidieren könne, und solle, gestalt sothanne belehnungen salvo jure cujuscunque und fählende urtheillen vor gültig gehalten werdten sollen, vorbehaltlich iedoch das darab vermög alten herkommen ad majores pares curiæ appelliert werdten könne.

Titulus septimus

Wie eheleuthe einander erben sollen

$\int 1$ Wan unter künfftigen eheleuthen mit vorwissen und belieben der elteren oder in mangl deren mit zueziehung der negsten blueths-verwandten oder freundten heuraths verschreibungen aufgerichtet, beschlossen und angenomben, selbige sollen in allen ihren puncten und articulen unverbrechlich und ohne wider-redt gehalten werdten.

$\int 2$ In solchen heuraths-verschreibungen ist den khünfftigen eheleuthen zuegelassen, nit allein von dem zuegebrachten heurath gueth zuverordtnen, sonderen auch von allen ÿbrigen güetteren, so vill sÿe deren mächtig und ihnen gefällig, einander zuvermachen, und soll allsolche vermachnuss ob sÿe schon auf die erbfolgung ganz oder zum theill der ieztig oder künfftigen güetter gerichtet, unwiderruefflich sein, es geschehe dan die widerrueffung mit beeder eheleuthen guetten willen und belieben.

$\int 3$ Da keine heuraths verschreibung aufgerichtet, auch entweeder gar keine künder aus solcher ehe entsprossen, oder selbige von beeden elteren wider verstorben, soll des leztlebent von beÿden eheleuthen den heuraths pfennig erblich behalten, in allen anderen aber dess erstabgestorbenen zuegebrachten, wie auch beÿ stehenter ehe anerfahlenen ligenten oder unbeweglichen (worunder auch die renntverschreibungen, sÿe seÿen losbahr 
oder unloßbahr, sodan die paarschafft von abgelegten jährlichen renten mit zu verstehen) sein lebenlang, es thue sich dasselb wider verheurathen oder im wittib standt verharren, leebzeitig verbleiben, darÿber aber ein ordentliches inventarium auf das die negste erben des eigenthumbs versichert sein können, beÿ verluesst der leibzucht einer 3 monnathen zeit ferttigen lassen, sodan die güetter in guetten pau- und besserung halten, auch da es von den erben begehrt würdt, dessweegen gebührente caution und versicherung leisten.

\4 Die in stehenter ehe anerworbene ligente güetter sollen alsdan, wan nemblich vorgeseztermassen keine künder noch widrige pacta dotalia oder heuraths versprechungen verhandten, freundttheillig sein, das erstabgestorbenen negsten erben zu einem halbscheidt und dem lezt lebenten ehegatten zu der anderen halbscheidt eigenthumblich zuefallen, iedoch disem von allen solchen güetteren die leibzucht gegen gleichmessige aufrichtung eines inventarii und gebührliche caution auf erforderen, seine lebzeit verbleiben.

$\int 5$ Die fahrnus oder beweegliche güetter thuen dem leztlebenden eigenthumblich und mit vollkommenen recht zuefallen, iedoch selbiges daraus alle unverbrieffte, wie auch die jennige verbrieffte schulden, so nit auff jährliche rennten verschriben, zubezahlen verbundten sein.

\6 Wan aber das erst verstorbene von beeden eheleuthen künder aus selbiger ehe gezeugt hünter sich im leben verlast, alsdan soll zwar das lestlebente ehegatt alle fahrnuss, wie vorgemelt für sich behalten, der heurathspfennig aber und andere zuegebrachte oder beÿ stehenter ehe dem erstabgestorbenen zuegefallen, wie auch die gewohnnene güetter nur leibzichtig sein lebenlang, es greiffe das selbe wider zur anderen ehe oder nit, zu geniessen haben, iedoch auf den wider verheurathungs fahl darÿber ein inventarium aufrichten lassen und in alle weeg darvon die künder nach standts gebühr ehrlich erziehen und außteuren, welche außteurung dan mit zueziehung der negsten freundt, oder wan daraus zwischen ihnen irrung vorfallen wurdte, nach ermässigung der obrigkeit geschehen solle.

$\ 7$ Unter dem nahmen solcher fahrnuss oder beweglichen güetter solle das paare gelt, so nit von abgelegten jahr renten oder verkaufften ligenten stuckhen herriehret, handtschrifften, so nit auf jahr rhennten gestelt, paumb, obst und grass gewachs aber, wan der fahl nach dem ersten martii sich begibet, hauß zünss nach ertrag der von dem lauffenten jahr allschon erschinener zeit, abgehauenes schlag holz, wie auch das umbgehauene, wan die verkauffung noch beÿ leebzeiten des eigenthumbers geschehen, verfallene noch außtendtige pensiones von angelegten capital gelteren, vorräthiger getraidt, silber geschür, khüe, ackher geschür, hausrath und alles was sonst nagllos ist, wie auch die action und ansprach auf dergleichen güetter verstandten werdten. Was aber außer disem dem grundt oder haus anklebet und unter anderen eiserne ofen, preu kössel, blass balgen der schmidten und dergleichen, soll vor unbeweglich gehalten werdten und beÿ dem grundt oder haus verbleiben. 
$\int 8$ Es soll iedoch unter dem kauf- und handlsleuthen hierin disen unterschidt haben, das die jennige wahren und güetter, welche in ihre handlung und gewerb einschlagen und darunter gehörrig, in disen erbungs fahl unter die fahrnuss nicht zurechnen, sondern es damitten sambt den außtehenten buech und gegen schuldten also gehalten werdten, wie oben in viertt[en] und sechsten articulis von dennen ligenten güetteren verordtnet.

\ 9 Da nach gebrochenen ehebett sich begabe, das auf die künder dess verstorbenen vatters oder muetter eintweeder in absteigenten linien oder von der seithen einige erbschafft ab intestato verfiellen, soll der noch ÿberlebente vatter oder muetter davon leibzucht, so lang die künder noch unverheurathet, oder sonsten in vätter- oder muetterlichen unterhaltung sein, zugeniessen haben, nach deren verheurathung aber, oder auch da sÿe gleich nit verheurathet, aber dannoch nach dem funff und zwainzigsten jahr ihres alters einen eigenen rauchen oder haushaltung anstelleten, oder sonsten von dennen elteren sich absönderten, soll ihnen der vatter oder muetter allsolch nach gebrochenen eheböth anerfallenes gueth abtretten und einraumben.

Titulus octavus

Von dem besitz oder possession der erledigten erbschafft

$\$ 1$ Wan ein testament aufgerichtet, soll auf den darin eingesezten erben, oder wann mehr testamenta verhandten, auf den jennigen der in dem lesteren onder jüngsten benambset, und in mangl des testaments auf dem negsten anbewanthen, deme die erbschafft von rechts weegen zuegehört, der besiz oder possession der güetter, sÿe seÿen ligent oder fahrent, so fern sÿe der abgestorbene zu zeit seines todts possediert, ohne einige andere leibliche ergreiffung oder apprehension verfahlen sein und da vielleicht iemandt anders vorlauffen und sich des besizes zunäheren unterstehen wurdte, soll ihm solches zu keinen vortheill gedeÿhen, sondern vill mehr vor ein straffbahre thatt zu halten sein und hingegen der eingesezte, oder wan kein testament verhandten, der negste erb von geblüeth beÿ dem besiz der güetter bis zur ordtentlichen austrag rechtens gehandthabt und manuteniert werdten.

$\int 2$ Und im fahl das testament als manglhaft und ungultig beschuldtiget oder zwischen dennen anbewandten von geblüeth der nache oder proximitæt halber oder sonsten streitt erkennet wurdte, soll summarie darÿber erkant und bis dahin die güetter von dennen gerichteren darunter selbige gelegen, zu behueff des obsigenten theills in verwahr genommen werdten.

Titulus nonus

Von der einkündtschafft

\1 Wan eines von beeden eheleuthen nach absterben des anderen wider zu der zweÿten ehe schreittet, und zuvor oder auch hernach unter wehrenter ehe für guett ansihet zwischen erster und volgenter ehe, oder auch dennen zuegebrachten künderen eine einkündtschafft aufzurichten, soll solches zwar als zu mehrerer erhaltung, liebe und 
einigkeit gereichent, zuegelassen sein, iedoch anderer gestalt nit als mit vorgehent gerichtlicher erkandtnus.

$\int 2$ Worbeÿ dan dise ordtnung gehalten werdten soll, das dennen künderen, da sÿe noch münder jährig, zu solchen actu und handlung ein oder zweÿ curatores (im fahl sÿe vorhin damit nit versehen) angesezt werdten sollen, welche der künder haab und vermögen, so sÿe von ihren verstorbenen vatter oder muetter ererbt, und was sÿe hingegen von dem kunfftigen stieff vatter oder muetter zuerwartten haben können, mit fleis zuÿberlegen und zuerwegen und demnegst dem gericht zuhinterbringen, auch an aÿdts statt ob es dennen künderen besser gethon als gelassen, oder keine merckliche vortheillung darunter verborgen, auszusagen und zu becräfftigen; deme vorgangen alsdan das gerichtliche decret mit ordtentlicher verzeichnus ob und was ein oder anderen thaill zum vortheill voraus vermacht, ertheillt und ausgeferttiget werdten mag.

$\int 3$ In crafft solcher einkündtschafft sollen alsdan die künder voriger ehe mit dennen in folgende ehe gezeugt, in dennen elterlichen güetteren zugleich erben, darunter aber die seithen oder collateral fähl, und was sonsten ein oder anderleÿ künderen durch testament, schenckhung oder anderer titul vermacht und sonst durch sÿe erworben, nicht verstandten werdten.

$\int 4$ Dafern volgents von solchen einkündtschaffeten künderen eines oder mehr beÿ leebzeiten beeder oder eines von dennen elteren mit todt abgehen würdte, soll der angenomene vatter oder muetter, wie auch die schwesteren und brüeder zweÿter ehe nicht anders als die natürliche eltern und vollbürdtige brüeder und schwesteren in dennen der einkündtschafft einverleibten güetteren in die häubter und zu gleichen theillen erben.

$\int 5$ Wan aber beede sowohl natürlich als angenom $[\mathrm{m}]$ ene elteren verstorben und also deren erbungs-fahl sich völlig begeben, soll dise einkündtschafft damit aufgehebt und erloschen sein und die halb-pürdtige ferner nit erben, sondern alsdan der succession halber unter allerseiths geschwistrigen anders nit gehalten werdten, als wan kein einkündtschafft gemacht wäre.

$\int 6$ Da iedoch beÿ aufrichtung dergleichen einkündtschafft andere bedingungen und conditiones abgehandlet und verglichen, soll solchen durch dise ordtnung nicht benommen sein, sonderen dieselbe aufrichtig gehalten und vollzochen werdten.

Titulus decimus

\section{Von vormundtschafften}

$\int 1$ Wan ein vatter oder muetter zu der zweÿten und mehreren ehe schreittet, sollen sÿe ihre künder voriger ehe, sofern die selbe das $25^{\text {te }}$ ihres alters nicht erfüllet, mit vormundteren versehen zulassen schuldtig sein und dafern sÿe solches innerhalb jahrs nach der verheurathung versaumen oder unterlassen wurdten, sollen sÿe sich der leibzucht aller aus voriger ehe auf die künder verfallenen güetter verlustigt gemacht haben, es were 
dan das sÿe rechtmessige ursachen der verhinderung beÿ der obrigkeit vorbringen und erweisen könten.

$\int 2$ Da aber sonsten ein kündt vor erfüllung ermelten $25^{\text {en }}$ jahrs elterlos würdt und demnach kein veniam ætatis vermög gemeiner rechten und darzue gehöriger requisiten erhalten, sollen drossard, schultheiss und scheffen in dennen gerichteren wo die elteren zu zeit ihres absterbens wohnhafft gewesen, demselben inner der negsten 6 wochen vormunder anzusezen, oder im widrigen allen dem münderjährigen daraus erwachseten schaden zuerstatten und guettzumachen verbundten sein.

$\int 3$ Wer demnach von drossarden, schuldtheissen und scheffen zum vormundt benambset würdt, soll dasselbig unweigerlich anzunehmen schuldtig sein und ihme dawider keine entschuldtigung zu statten kommen, es seỹe dan das er vorhin mit zwo anderen vormundtschafften beladen oder aber in solchen streitt mit dennen waisen stundte, daran der mehrere theill ihres vermogens hafftete oder aber in dergleichen officien und bedienungen oder sonsten in solcher leibs unvermögenheit begriffen, die an verwaltung der vormundtschafft kundtbahrlich hinderten; wan sonsten sich iemandt widrigen und die pfleg befohlene waisen dardurch in schaden kommen wurdten, soll er darfür hafften und alles zuersezen angehalten werdten.

\4 Im fahl nun das gericht die negste verwandte dennen sonsten vermög gemeinen rechten die vormundtschafft obläge, darzue ernennen selbige aber aus dem bezürckh des gerichtszwangs gesessen sein wurdten, soll das iennig gericht worunter allsolche benambste vormundtere wohnhafft, alsobaldt auff die erste requisition oder ersuechung dieselbe zu antrettung der aufgetragenen vormundtschafft anhalten oder für den saumbfall selbsten hafften und solchen vermitls erstattung alles schadens zubüessen schuldtig sein.

$\int 5$ Alle vormundere sollen jedes jahrs gleich nach dennen weinnacht feÿertägen, nemblich den 7 jannuarij ihre rechnungen an dem orth wo sÿe angesezt, bey vermeidung würckhlicher straff einlifferen und darauf alsobaldt von der obrigkeit gewise persohnen zu deren dursech[ung] und ÿberlegung verordtnet werdten.

Titulus undecimus

Von khauffen und verkhauffen

$\int 1$ Wan iemandt ligente und unbewegliche güether an sich erkaufft, soll der kauff beÿ dem gericht worunter die güetter gelegen, insinuiert und verkündtet werdten und daselbst durch den verkauffer verzig und ausgang, hingegen an den khäuffer die erbung geschechen und alslang solche verkündtung hinterbleibt, soll der eigenthumb oder proprietet ob ihm schon durch den verkhauffer das gueth eingeraumbet, nit verfallen sein, iedoch ihm wider denselben seine personal action zu vessthalt und erfüllung des khaufs oder im fahl er die liferung oder tradition nicht thuen kan, zu seiner schadtloshaltung unbenommen sein. 
\2 Gleichwie unsere hochgeehrte vorfahrere und wür selbsten verbotten dennen geistlichen (darunter capitula, abteÿen clösster und conventen zuverstehen) keine unbewegliche güetter unter straff der würcklichen confiscation zu alienieren oder auf dieselbe einigermassen wie es den nahmen haben mechte, durch tausch, schenckhung, testament, pfachtungen, pfandtschafft oder sonsten zu transferieren, so haben würs von nun und zu ewigen tagen dabeÿ bewendten lassen wollen.

$\$ 3$ Ein mann oder weib mag bey stehenter ehe so wenig sein angebrachtes als mit ein ander gewohnnenes heurath guett ohne belieben und bewilligen seines ehegatten nit verkauffen oder einiger gestalt vereusseren, sonderen was dessen vorgenohmen, soll crafftlos und nichtig sein.

$\int 4$ Hingegen wan ein weib mit und neben seinen ehemann einen contract aufrichtet, denselben unterschreibet, oder auch vor gericht oder notarien und zeugen sich darzue bekennet, soll sÿe und ihre eigene güetter dafür gleich dem mannschafften und sich darwider keines vorzugs rechtens weeg ihrers angebrachten heurath gueths zu gebrauchen haben.

$\mathrm{Da}$ aber ein mann oder weib nach gebrochenen ehebeth ein stuckh ihres angebrachten eigenthumblichen gueths verkauffet oder versezet, so solle der kauff oder versezung gültig sein, dergestalt doch das dessen künder ihrer legitima dardurch nicht defraudiert werdten.

Titulus duodecimus

Vom einstandt oder bescheidt zu latein ius retractus genant

\1 Wan ein ligentes gueth oder ligenten gueth anklebente gerechtigkeit wie auch unlosbahre zünsen oder rennten verkaufft werdten, sollen die negste bluetsverwandten aus dem vatter- und müetterlichen stammen wo ermelte güetter herkommen, bis in das zehente glüdt (so weith nemblich die erbung vermög des obigen fünfften tituls statt hat) dess einstandts berechtiget sein und sich dess kaufs innerhalb 6 monnath von zeit solcher bey dem gericht verkundtet, insinuiert und die erbung geschechen, anzurechnen gegen würcklicher erstattung der ausgegebenen kauff gelter und anderer nothwendtiger und redtlicher unkosten nächeren oder retrahieren mögen.

\2 Die iennige anbewandte aber, welch aus dem stam[me] des ersten acquirenten oder erwerbers solcher güetter entsprossen, sollen beÿm einstandt aller anderen verwandten, so nit davon entsprossen, vorgezochen werdten.

$₫ 3$ Solte aber zweiffel sein, ob einer aus dem stam[me] des ersten acquirenten were oder nit, unterdessen bekant sein, das derselbe dem verkauffer allein mit verwandtschafft beÿgethann, so solle der jennige beÿ mangl der a stijpite primi acquirentis herkommenter anbewanter gleichwohl zum einstandt berechtiget und zuegelassen werdten. 
\4 Wie gleichfahls wan einer ein gueth vorhin gekaufft, nachmahls aber wider verkaufft, so sollen dessen collateral anverwandte dess einstandt rechts vermög hergebrachter uralter gewohnheit und in crafft dises sich zubediennen befuegt sein.

$\int 5$ Da aber der verkauffer all solchen seinen blueths verwandten den khauff anbietten und verkündten, dieselbe aber sich darzue nit einlassen, noch in den negsten 6 wochen erklären wurdten, sollen sÿe sich ihres einstandts verluestigt gemacht haben.

$\int 6$ Wer zu dem einstandt befuegt ist, soll sich dessen anderer gestalt nit als ihm selbst zum besten und das gueth für sich zubehalten und keinen anderen zugefallen und nuzen, oder in meinung solches etwan baldt umb eines ÿbergewühns willen wider zuverkauffen, gebrauchen, dessen dan er nemblichen in solchem allein kein heimlicher verstandt noch geferthe unterlauffe, wo es begehrt würdt, einen aÿdt schweren solle.

$\int 7$ Wo sich begibt das mehr als ein anbewandter in den kauff zustehen begehrt, soll allemahl der negste grad dem weitheren vorgehen, wehren sÿe aber in gleichen grad, soll sÿe dariber das los entscheiden.

$\int 8$ Da sonsten keine verwanthe verhandten oder selbige nit retrahieren wollen, stehet dem negsten an des verkhauffers gueth anschiessenten nachbahren frey des einstandt rechts sich zu bedienen oder zugebrauchen.

$\int 9$ Dennen geistlichen stüffteren, clössteren und dero persohnen solle die beschüddung nit zuegelassen werdten.

$\int 10$ Dise einstandts gerechtigkeit soll auf tausch oder wechsl auch nit gezochen werdten, sonderen allein im kauffen statt haben, doch das solche tausch oder wechsel gefährlicher weise und durch dergleichen schein die negste freundte von dem einstandt abzuhalten nicht geschechen, sonderen beeder theill nutzen und nothdurfft nach aufrichtiglich vorgenommen und gehandlet werdte, welches dan auch so die negste freundte begehren wurdten, durch die partheÿen beÿ geschwornen aÿdt erhalten und bestettiget werdten soll, wo aber im tausch ein aufgelt gegeben und solches den halben thaill des werths des ertauschenten guetts erreichet, soll es für ein kauff gehalten werdten.

Titulus decimus tertius

Von pfandtschafften, zu latein de pignoribus et hÿpothecis

$\int 1$ Keine pfandtung solle gültig sein, süe werdte dan dem gericht worunter die güetter gehörig, insinuiert und dabeÿ ratificiert und dafern solches nicht geschicht und die güetter hernach an einen anderen verkaufft oder versetzt werdten, soll wider denselben der erste glaubiger oder creditor solcher güetter halber durch aus keine ansprach, wenniger einigen vorzug zu geniessen haben. 
$\S 2$ Da auch schon eine general oder gemeine verpfändtung aller güetter geschücht, soll doch dieselbe dem glaubiger anders kein vorzugs-recht zuaignen, es seÿe dan beÿ iedes orths gericht insinuation geschehen und stehet alsdan zu seiner wahl ohne unterschüdt an welche güetter er sich zum erst und liebsten halten und bezahlt machen wolle, unangesehen neben dem general, auch ein absonderliches unterpfandt in der verschreibung benambset wordten.

\$3 Wan dan obgesetztermassen die verpfändtung vor gericht geschehen, mag der creditor die verpfändte güetter, in was handt sÿe auch hernach gerathen, für seine schuldt verfolgen, ohne das er an seinen haubtschuldtner erst umb execution zuverweisen sein solle.

\4 Die general verpfandtung aller güether wider einen dritten kauffer oder besitzer soll auf die fahrente und bewegliche güetter eheunder kein crafft haben als dieselbe durch gerichtliches verbott præcludiert wordten, dafern aber iemandt nach verboth dieselbe an sich kauffen oder bringen würdte, mag er von dem glaubiger dafür besprochen werdten.

\section{Titulus decimus quartus Von pfachtungen}

$\ 1$ Ein pfachter soll seine pfachtung ohne des pfachtherrns bewilligung einem anderen zuÿberlassen oder iemandt in seine pfacht-jahren eintretten zulassen nicht macht haben.

\2 Wan ein pfachter weegen misswachs oder hagelschlags an seiner pfacht nachlass zu begehren vermeint, soll er vor der ärndte seinen pfachtherrn die besichtigung des schadens anzusagen schuldtig sein, im widrigen keiner nachlassung zu geniessen haben.

\3 Im fahl demnegst der pfachter mit seinem pfachtherrn dess nachlass halber sich nicht vergleichen könte, soll der pfachter den pfachtherrn zutheillung des waxthumbs sambentlicher früchten dieser gestalt zuelassen, das die hardte früchten demselben zur halbscheidt, iedoch gegen erstattung des halben samm korn, halben mähe oder schnidtlohns und halben treschlohns, die sommerfrucht aber zu einem drittl gegen gleichmässiger erstattung dess drittels beriehrter costen verbleibe.

\4 Wan der pfachter der pfachtung wie es sich gebührt und einem fleissigen haushalter obligt, nicht vorstehet, soll der eigenthumbs-herr ihme seine jahren daran zuhalten nicht schuldig, sonderen von dem gueth auszuweisen befuegt sein, dafern auch der pfachter in dem rechten pfacht-jahr seine pfacht nicht bezahlen und doch die früchten,khüe und anderer eingebrachtes zuentfrembden oder sonsten zuverbringen unterstehen wurdte, soll dem pfachtherrn die scheuren, speicher, hoff und ställe zu seiner versicherung zuspörren freÿ stehen. 
$\int 5$ So haus, scheuren oder stallungen durch dess pfachters oder seines hausgesündtes schuldt oder versaumbnuss abgepränt, ist er schuldtig all solchen schaden aus dem seinigen wider zu erstatten.

\6 Weill vermög gemeiner rechten die erbkauff die pfachtungen prechen, so soll auch der kauffer dem pfachter die jahr zahl seiner pfachtung auszuhalten nicht schuldtig sein, sonderen der pfachter gleich in 3 monnathen nach verkündteten kauff aus einem simplen haus, aus einem haus aber daran der ackherpau dependiert und von dem gepfachteten güetteren auf das negst folgende fest Cathedræ Petri weichen, iedoch hat er sich dess schadens halber, so ihme daraus entstehet, an dem verkauffer zuerhollen.

$\int 7$ Gleichergestalt, wan sich zuetragen wurdte, das ein herr der ein haus ausgethann oder verpfachtet aus neu ÿberkommenter nothwendtiger und redtlicher ursach selbst darin wohnen oder pauen müesste, ist er dem pfachter die pfacht jahren zuhalten nit schuldtig, iedoch soll er ihme in solchen fählen zu ersuechung einer anderen wohnung entweeder obgemelte 3 monnath, oder, wan die sach eine nähere ë̈ll erfordert, zeit nach ermessung der obrigkeit verstatten, vorbehaltlich des ihme des ausweichens halber zuewachsenten schadens.

$\left[\int 8\right]^{2227}$

\9 Weillen auch die pfachtung von allzulangen jahren dennen künderen und erben beÿ villerleÿ unterdessen zutragenten enderung öffters zu grossen unstatten gereichet, soll hinführo keine pfachtung lenger als auf zwölff jahren gültig oder verbündtlich sein.

Titulus decimus quintus Von erbpfachten

$\int 1$ Da erfündtlich zwischen dem erbpfachtsherrn und erbpfachttragern einiges instrumentum aufgerichtet zusein, alsdan solle tenor eorundem pactionum observiert werdten.

\2 Wan aber hierab nichts erfündtlich, so statuieren das da der geistliche erbpfacht in zweÿ und der weltliche in drey jahren nit bezahlt sein solte, der emphÿteuta oder erbpfachtstrager alsdan seines dominii utilis verlustig, das erbpfachts gueth dem erbpachtsherrn heimbgefallen und dominium directum cum utili consolidiert seÿe, inmassen solchen fahls das erbpfachts-gueth als caduc dem domino directo auf dessen gesünnen per sententiam adjudiciert werdten kan.

\3 Und solches zwar nit allein, wan einer in beriehrter zeit seinen erbpfacht nit bezahlt, sondern auch wan mehrere erbpfachtstragere so das erbpfachts-gueth ohne consens und bewilligung dess erbpfachtsherrns getheillt und zersplissen, oder doch zwar getheillet mit

2227 Deze paragraaf is bij vergissing weggelaten. Zie voor de ontbrekende tekst van het landrecht uit Munchen 
dess erbpfachtherrns consens dergestalt das gleichwohl der canon oder erbpfacht zusamben bezalt werdten solle, ihr quotam bezalt, deren einer aber nit bezahlt habe, dan solchen fahls das erbpfachts gueth gleich oben caduc und dem erbpfachts herrn heimbgefallen

\4 Obige caducitet greiffet auch platz wan einer sein erbpfachts-gueth ohne consens seines erbpfachtsherrns einigermassen alieniert und zuvor dem selben inner 2 monnathen offeriert gegen selbigen werth und preÿs als ein anderer ihme hat geben wollen.

$\int 5 \mathrm{Da}$ aber in den zweÿ monnathen der erbpfachts-herr allsolchen werth nit geben wolle, alsdan stehet dem emphÿteutæoder erbpfachts-trageren freÿ sein erbpfachts-recht wembe er wolle, und ohne consens zu alienieren, doch an einem solchen der capabl und bequem den darauf stehenten jährlichen erbpfacht zubezahlen.

\6 Besagte caducitet excusiert auch rechtmessige ignoranz, das mann nit gewusst das erbpfachts-gueth erbpfächtig gewesen zusein.

\7 Jedoch kan die caducitet im weltlichen erbpfacht per moram nicht purgiert werdten, unangesehen im geistlichen erbpfacht solche purgatio moræ inner kurzen zeit zuelässig, welche zeit aber weill in den rechten nichts ausgetruckht, als lasset mans billich dem arbitrio judicis heimbgestelt sein.

Titulus decimus sextus

Von churmuthen, zu latein de curmediis

$\int 1$ Nachdeme der churmueth trager gestorben, solle dessen erb oder die iennige, so das churmuethige guett besitzen inner 6 wochen sich beÿ dem churmuths herrn angeben und das churmuth, es seÿe pferdt oder khue, widerumb suechen zu relevieren, widrigenfahls solle das churmuethige dem churherrn crafft dises caduc und heimbgefallen sein, also das selbiges er durch urtheill sich gleich adjudicieren lassen möge.

\2 Und da die churmuthstrager das churmuthige guett versplissen haben solten, also das mann die darzue gehörige stuckh eigentlich nit beÿbringen könne, so sollen destowenniger nicht die ÿbrige sich in esse befündtente bekente stuckh vor dem gantzen churmuth obligiert sein und bleiben, bis daran sÿe die verlohrne oder unbekennte stückher remonstriert und wider beÿgebracht haben, dergestalt das fahls alsolche churmuthstragere unterdessen in obgemelter zeit den gantzen churmuth nit relevieren solten, das alsdan deren anbetreffente churmuthige stückher ipso facto gleichfahls caduciert sein sollen.

$\int 3$ Solten auch die churmuths trager den churmuth vor disem releviert, bezalt oder gestandten haben, die unterpfandt aber bekant sein, als sollen sÿe schuldtig sein an deren statt sufficiente freÿe allodial underpfandt zu assignieren und all solche mit belieben dess churmuths-herrn darzue zu constituieren. 
Titulus decimus septimus

Von verjährung der stehenten rhenten oder zünsen

$\int 1$ Demnach unter dennen rechts gelehrten unterschidtliche meinungen seint ob in jährlichen renten und gefählen die verjährungen platz haben können, so haben wür allen anlass zu irrungen und strittigkeiten vorzukommen, nöthig erachtet diesertweegen ein gewises zu verordtnen, weillen dan die gemeine beschribene, auch vasst aller völckher rechten das in menschlichen handlungen endtlich einmahl ein sicherheit sein und niemandt immerwährenter sorg und forcht des seinigen stehen möge, der jennig auch welcher eine gar lange geraumbe zeit mit seiner forderung stillschweiget, seine versaumbnuss niemandten als ihme selbst zuezumessen hat, so wollen wür das alle dergleichen jährliche rhennten, zünssen und gefähle in vierzig jähriger zeit, wan nemblich darunter keine ansprach oder interpellation darumb geschehen seind würdt, allerdings erlosschen undt getödtet sein und der schuldtner alsdan ferner darumb nicht angefochten werdten soll.

$\int 2$ Gleicher gestalt wan der creditor, glaubiger oder zünsherr seinen jährlichen züns von 40 jahren hero ununterbrochen in einen gewisen valor oder werth empfangen und angenohmen, solle unangesehen in was werth oder lauff das gelt zu zeit contracts gewesen, ein ander weithige reduction, erhoch[ung] oder endterung mit dem schuldtner vorzunemmen nit befuegt sein, sonderen sich ins khünfftig mit eben dergleichen zahlungen begnüegen.

Titulus decimus octavus

Von den gerichteren und wie mann sich dabeÿ sowohl in procedendo als judicando zuverhalten

$\int 1$ Der actor solle seine action oder ansprach durch summarische supplication oder articuliert libell ÿbergeben, und reus oder beklagter nach gehabter copeÿ darauf durch summarisch oder articulierte antworth, zu latein responsion oder aber durch exception befündtenten sachen nach gebührent antwortten.

$\int 2$ Demnach solle der kläger auf sothanne dess beklagtens responsion oder exception gebührent replicieren und seine replic-schrifft mit allen habenten zur sachen nöthigen beweisthumben bestättigen gestalt demnegst der beklagte schuldig sein solle darauf zu duplicieren und darin gegenseithige replicam mit allen habenten elisionibus zu beantwortten.

$\int 3$ Quo prævio solle drossard, schultheiss und scheffen dem alten herkommen gemäss die acta durchlesen, allegatorum probationes fleissig examinieren und nach reifflicher deliberation und erwegung die sach durch definitiv oder interlocutorii urtheill deren beschaffenheit nach unpartheÿlich citatis partibus seu earundem constitutis procuratoribus determinieren. 
$\int 4$ Solle dan die sach durch interlocutor-urtheill zu ferner probation angewisen werdten, alsdan solle der actor oder reus die auferlegte probationes in einer schrüfft genannt probation-conclusion und submission-schrüfft einbringen, welche schrifft nebenst beÿgefüegten probationibus, nachdeme dem gegentheill in copia communiciert, solle derselbe verbundten sein selbige durch enervation oder general contradiction, conclusion und submissions-schrüfft oder nach beschaffenheit durch inhæsion cum submissione zu beantwortten, gestalt nach also beederseithig beschlossener und submittierter sachen drossard, schultheiss und scheffen aus den acten definitive zu sententieren.

$\int 5$ Solte aber drossard, schultheiss und scheffen erachten die sach schwerer importanz zu sein, oder auch von partheÿen begehrt werdten, die acta einen unpartheÿischen rechtsgelehrten auszustöllen, alsdan können die acta einen unpartheÿl[ichen] juris consulto im reich zuegestölt, dess urtheill cum rationibus decidendi eingeholt und demnegst, nach vorgangenen reifflicher consultation, pronuntiert werdten was rechtens.

\6 Da auch drossard, schultheiss und scheffen in votis discrepieren wurdten, sollen die urtheill nach den majoribus verfasset oder sonsten die acta gleichfahls impartiali juris consulto ad referendum zuegestelt werdten.

\ 7 Und weillen es sich öffters begibt, das einige scheffen kranckh oder anderer unumbgenglicher notturfft halber abwesent seint, als ordonieren das alle solchenfahls von drossard, schultheiss und dreÿen schöffen gefalte definitiv urtheill ie und allzeit gültig sein sollen.

\$8 Im urtheillen sollen drossard, schultheiss und scheffen vor allen auf unsere constitutiones reflexion nehmen und selbige nicht ÿber den vorhabenten casum disponieren, alsdan nach den beschribenen allgemeinen rechten urtheillen und die æquitet respicieren, weegen verdamnung in die aufgangene uncosten aber fleissigste obacht haben an temere litigatum vel causa litigandi subfuerit.

$\int 9$ Da nun so weith procediert worden, das mann durch urtheill immision erhalten, alsdan sollen auf sothanne immision die erste proclamatoriales nach ersten monaths früst, die zweÿte nach zweÿten monnath und die dritte nach verlauffenten dritten monnath publice affigiert oder in der kürchen abgelesen werdten, gestalt demnegst das evincierte gueth beÿ subhastation und brennenter körzen dem hechstbiettenten zuverkauffen, vor ablauff obiger terminen aber stehet dem succumbenten freÿ das evincierte gueth vermitls darlegung der pfenningen interesse und verursachter cossten zuredimieren.

\10 Weillen sonsten die partheÿen öffters die sach malitiose durch ihr ausbleiben zu eines oder dess anderen eussersten schaden protrahieren, auch bey lessteren terminen verschaidene erdichte ursachen allegieren, das ihnen noch mehrere termini gestattet werdten möchten, als statuieren das zu verhiettung dessen einer parthey mehr nit dan 3 terminen gestattet werdten, der dritte aber peremptorii, prejudicial und pœnal sein solle, also das da das tempus habentis termini von der parthey nit in acht genohmen und a 
præjudicio salviert wordten, alsdan diss præjudicium oder pœna zu seiner würckhlichkeit gebracht und dem theill so nit vigilliert zum schaden gereichen solle; wurdte aber die parthey ante lapsum termini præjudicialis vigiliert ein impedimentum legale allegiert und zugleich probiert und umb ferner dilation angesuecht und gebetten haben, alsdan solle ein terminus zuverstatten sein.

$\int 11$ Gleich mann ferner erfahren das durch der procuratorn alzulanges recessieren die accidentien nit wenig verlängert werdten, auch dieselbe wissentlich faule unrechtferttige sachen annehmen, und zu dess richters hechster incommodation zuverthettigen unterstehen, so verordtnen unter straff von 3 goldtgulden aus ihren eigenen seckhl defacto zuentrichten, das alle procuratores der partheÿen intention schrifftl[ich] per scripturas seu verbal in scripto mit einer kurzen proposition ad prothocollum zuÿbergeben, auch wissentlich oder notorie unrechtferttige sachen nit vorbringen, wenniger verthettigen, noch ihre feder zu scharpf spizen sollen.

$\int 12$ Ingleichen da partheÿen und procuratores einige richtere vor suspect halten wollen, sollen sÿe ipso instanti in rechten bestehente ursachen der suspectation allegieren und zugleich probieren, widrigenfahls in vorgemelte straff crafft dess würcklichen verfahlen sein

$\int 13$ Gleichergestalt seint crafft diss alle abusen, vermög deren die gegenwärttige partheÿen in judicio auch andere ein tag zuvor, obschon gleich dabeÿ gewesen, citiert wordten, fahls nur dem citato möglich in præfigierter zeit zu comparieren, gültig sein, exceptis diebus feriatis

\14 Damit endtlich ein sicheres weegen der ferien statuiert sein möge, so ordonieren quo ad ordinariam cognitionem das in der ärndt-zeit von $15^{\text {ten }}$ julÿ usque ad festum Bartholomæi, item von Weinnachten bis nach 3 König-tag, item 8 tag vor Osteren und 8 tag hernach, wie auch 8 tag vor Pfüngsten und 8 tag darnach ferix accurate observiert werdten sollen, vorbehaltlich doch des jennigen, so vermög der rechten hierinfahls zuelässig.

Afschrift van een niet meer bewaard gebleven gedrukt origineel, circa 1757 vervaardigd door de Gronsveldse grafelijke commissaris J.A. Prummer.

RHCL, Archieven van het graafschap Gronsveld en de beerlijkheid Slenaken (tot 1728), inv. nr. 87.

7B Rechtsordnung van het graafschap Gronsveld en de heerlijkheid Slenaken

$$
1671 .
$$

De inhoudsopgave is hier aangegeven om het overzicht te vereenvoudigen, maar staat niet in het origineel. 
Titulus I Vom testament und letzten willens vermachnuss.

Titulus II Von erbschafft obne testament in auf steigender linien.

Titulus III Von erbfolgung in absteigender linien

Titulus IV Von erbung der elteren mit und neben dess verstorbenen kindts bruder und schwester oder derselben kinderen.

Titulus $V$ Von erbung auf der seithen linien seu linea collateralis.

Titulus VI Von dennen lebnen und deren succesionen.

Titulus VII Wie eheleuth einander erben sollen.

Titulus VIII Von besitz oder possession der erledigter erbschafft.

Titulus IX Von der ein këndtschafft.

Titulus X Von vormünderschafften.

Titulus XI Von kauffen und verkauffen.

Titulus XII Vom einstandt oder bescheidt zu latein ius retractus genant.

Titulus XIII Von pfandtschafften zu latein de pignoribus et bjpothecis.

Titulus XIV Von pfachtungen.

Titulus XV Von erbpfachten.

Titulus XVI Von churmuthen, zu latein de curmedis.

Titulus XVII Von verjahrung der stehender rhenten oder zinsen.

Titulus XVIII Von den gerichteren und wie mann sich dabejy so wobl in procedendo als judicando zu verbalten.

Graffschafft Gronsfeldt und freÿer herrschafft Schlenackhen Rechts-Ordtnung der hochgebohrnen grafinen und frauen, frauen Annæ Christinæ, grafinen von Bronckhorst zu Gronsfeldt und Eberstein, frëffrauen zu Batenburg, Anholt und Rimburg, frauen zu Alpen und Hannopel, vormünderin. und regentin.

Getruckht zu Aach beÿ Anton Metternich im jahr 1671

Wir Anna Christina gräfin von Bronkhorst zu Gronsfeldt und Eberstein, freÿfrau zu Batenburg, Anholt und Rimburg, frau zu Alpen und Hannopel, vormünderin und regentin etc.,

Fügen hiemit allen unseren beambten, richteren, schultheissen und schöffen, auch allen unseren bedienten, unterthannen und sonsten manniglichen wess standts oder würdten sÿe seÿen, ins gemein zu wissen,

Demnach wir beÿ uns betrachtet einer ieder ordentlicher obrigkeit vornembstes ambt in deme zu bestehen, das sÿe dahin sorglich sehen solle auff das die ihro von Gott anbefohlene unterthannen in gleichheit und rechten erhalten und manniglichen die justiz ohnpartheÿlich und zwarn ohne vergebliche und ohnnnöthige unkösten und umbführung ertheillt werdten möge und dan wir unter wehrender unserer regierung angemerckht das ville schädtliche und kostbahre streittigkeitten beÿ dennen gerichteren aus deme entstandten, das die partheÿen ein oder anderseiths sich entwieder auf gemeine landtsoder absonderlich hergebrachte von dennen beschribenen rechten abweichende gewohnheiten berueffen und da solche von dem gegentheill nicht gestandten, sondern widersprochen eine grosse zeit mit deren beweissthumb hinlaufft, unterdessen aber mancher an seinen rechten mangel leÿden, oder doch damit zu grossen seinen schaden 
und nachtheill auf gehalten werdten mues, zu deme auch die villerleÿ unterscheÿdtliche gebrauch so von orth zu orth offtermahl vor gebracht, den richter nit wenig irr gemacht, so haben wir zu vorkommung solcher ungelegenheiten eine nothdurfft erachtet alle unser obgemelte graffschafft und freÿer reichs-herrschafften gewohnheitten in schrifften kürzlich abfassen zu lassen und iedermanniglichen kundt zu machen, damit sowohl die partheyen in befangung ihrer processen als die richtere in begreiffung der urtheill sich daraus ohne weitlauffigkeit zu belehrnen und darnach zu achten haben; und sollen nun disem nach alle andere gewohnheiten und gebrauche, die hierin austrückhlich nicht gesetzt oder benambt, wie sÿe auch beschaffen seÿn mögen, ohne einige ausnahm vor nichtig und krafft los erkent und erklärt sein, sonderen außer deroselben alle ander fälle nach den gemeinen beschribenen rechten erortert und abgeurtheillt werdten.

Titulus I

Vom testament und letzten willens vermachnuss

$\int 1$ In graffschaft Gronsfeldt und herrschafft Schlenackhen ist einem ieden deme es sonsten vermög gemeiner rechten nicht absonderlich verbotten, ÿber seine haab und gütter ohne unterscheÿdt ob sÿe in gereith, fahrenden, beweglichen oder in ligendten unbeweglichen gütteren bestehen, ob sÿe anerwonnen oder angeerbt seÿen, seinen letzten willen oder testament aufzurichten, erlaubt.

$\$ 2$ Ein solcher letzter will oder testament mag vor dem geschworenen gerichtschreiberen, notario oder pastoren dess orths allwoh der actus vorgehet und zweÿen schöffen, oder beÿ deren mangel, zween anderen darzue erforderten zeugen gültig aufgerichtet werdten; es soll aber dasselb (wan schrifftlich testiert wirdt) von dem gericht-schreiber, notario oder pastoren und zween schöffen oder dennen zweÿen zeugen unterschriben sein.

\3 Wann aber iemandt gerichtlich testieren will, mag er in gegenwarth des gerichtschreibers und zween schöffen sein testament eigenhändtig unterschriben verschlossen und ohnverschlossen vorbringen und dem gericht-schreiber zum gerichtprothocoll zu legen ausantworthen, der dan alsbaldt allsolchen ausantworthungs actum auf das testament schreiben soll.

$\int 4$ Will einer sein testament von mundt außprechen, welches auf latein testamentum nuncupativum genent wirdt, soll er den nahmen dessen den er zum erben eingesetzt und was er sonsten darin begriffen haben will, vor dem gerichtschreiber, notario oder pastoren und zween schöffen, oder beÿ deren mangel, zween darzue beruffenen zeugen, öffentlich und klarlich benennen.

\$5 Wan ein testierer dess gerichtschreibers, notarii oder pastoren nicht mächtig sein kan, oder sonsten zu gebrauchen bedenckhens hette, mag er anstatt einer ieder auß disen obgehender persohnen zween andere zeugen darzu rufen. 
$\int 6$ Da das testament von mundt ausgesprochen, soll der gericht-schreiber, notarius oder pastor, oder aber wan in mangel deren, zween andere zeugen gebraucht werdten, iemandt von denselben die vermachnuss alsobaldt verzeichnen und dem testierer und zeugen vorlesen, zumahl sonsten hernacher aus dem zeugnus oder ÿbel eingenomener meÿnung dess testierers leichtlich irrungen und streitt entstehen könten, im widrigen dahe solches nit in acht genohmen, soll das testament kraftloss und von unwürdten sein.

\ 7 Eß stehet einen ieden freÿ ÿber seine verlassenschafft gantz oder zum theill, auch ohne einsetzung eines oder mehr universal erben durch letzten willen zu verordtnen und alle zeit die codicil clausul, wan sÿe schon nicht gemelt wordten, darin verstandten werdten, das nemblich der ÿbriger theill der erbschafft deren in der vermachnuss nicht gedacht wordten, beÿ den nächsten anverwandten, welchen solche sonsten von rechtsweegen gebürth, und zwar ohne abzug der falcidix oder Trebellanicæx verbleiben solle.

\8 Im fahl nun die erbschafft durch particular oder stuckhweise geschehene vermachung gantz erschöpfft also das nicht niemandt vor erben angeben wolle und aber schuldten auf der erbschafft zu bezahlen hetten, so sollen die legatarii nach proportion oder ertrag ihrer vermachnuss oder giffte so vill fahlen lassen oder beÿtragen, als zu bezahlung der schuldten vonnöthen, sÿe aber ÿber den werth all solcher gifft (wann nur inventarium oder verzeichnuss der gantzer erbschafft gebührent aufgerichtet) nicht verbundten sein.

$\int 9$ Wan elteren unter ihren künderen der theillung halber verordtnung hinterlassen wollen, ist gnug das sÿe ihren willen mit eigenen handten beschriben und ihren nahmen mit jahr und tag unterzeichnen, und soll solches unter den künderen, wan schon keine zeugen darzu gebraucht, gültig sein.

\10 Auf gleicher weis mag ein vatter oder muetter ihren kinder oder beÿderseiths grosselteren ihren enckhlen, wan vatter oder muetter vorher verstorben, auf den fahl sÿe in untogtbahren jahren mit todt abgehen würdten, einen afftererben ansetzen in den jennigen gütteren die vom testierer herrüehren, iedoch durch solche substitution oder affter-erbsatz des kindts hinterbleibenten vatter oder mutter ihr natürliches antheill oder nothgebührnuss, zu latein legitima genant, nit benehmen.

$\int 11$ Ein ieder mag seine erbschafft mit einem fideicommiss oder affter-vermachnuss nach belieben beschweren, iedoch soll dennen künderen ihr nothgebührnuss oder legitima allzeit frey bleiben, andere eingesetzte erben aber sollen den viertten theill, zu latein trebellanicam, davon auszuziehen oder abzukürtzen nit befügt sein, sondern hierin wie sonsten allenthalben dess testierers verordtnung aufs genauist nachgangen werdten.

\12 Obgemeltes fideicommiss oder afftervermachnuss soll weither als auf den dritten erben den erst eingesetzten mit einschliesslich, unerachtet der testierer ein anders verordtnet, nicht gültig sein, sondern die gütter, sobaldt süe in die viertte handt vererben, wider in ihre freÿheit kommen und zu dess besitzers willkühriger disposition stehen. 
\13 Wan zweÿ eheleuth zu behueff ihrer künder einsambt testament wie es nemblich unter ihnen mit beÿderseiths güetteren gehalten werdten soll, aufrichten, kan nach absterben dess einen der letztlebender solches nicht änderen, sondern ist es auch in seins eigenen güetteren so vill er deren beÿ stehenden ehe besessen, zu halten schuldtig, in dennen aber hernach im wittibstandt gewonnen, bleibt ihm eine ungebundtene handt.

Titulus II

Von erbschafft ohne testament in auf steigender linien

$\int 1$ Wan vatter oder muetter ohne testament oder ordtnung ihres letzten willens mit hinterlassung eheleiblichen kinderen (worunter auch die iennige so zwaren unehelich gezeugt aber durch hernach folgenden ehestandt geehliget wordten mit zu verstehen) hinsterben, sollen selbige künder alle vätterliche und mütterliche haab und gütter, fahrend und ligend, zu gleichen theillen erben, woh aber enckelen oder urenckelen in rechter absteigender linien vorhandten, tretten dieselbe allzeit in ihrer abgangener elteren platz und erben mit dess verstorbenen anherren oder uranherren kinderen in stamme, gleichwie ihre eltern, wan sÿe noch im leben wären, würden geerbt haben.

\2 Da aber mann oder frau vorhin im ehestandt gewesen, künder darin gezeugt und nach absterben dess ehegatten zu der zweÿter und mehreren ehe geschritten und darin auch kinder gezielet, weillen die künder erster und folgender ehe der natur und geburth nach ihrem gemeinen vatter oder muetter gleich nahe seint, so bleibt es auch der erbschafft halber, billig beÿ verordtnung der allgemeiner beschribener rechten, das nemblich alle solche künder ohne unterscheidt der ehe darin sÿe gebohren, ihren vatter oder muetter in deren zuegebrachten eigenthumblichen oder auch von ab aufsteigenter oder auch collateral linien durch erbschafft in erster, zweÿter fernerer ehe anerfahlener gütteren, zu gleichen theillen erben sollen und mögen, es seÿe dan sach das die pacta der vorgehenter ehe weegen der erbschafft eines oder beÿder ehegatten auf den künftigen fahl dess gebrochenen ehebeths eine andere verordtnung mit bringen, dan solche in alle weg statt haben und denselben ohne widerredt eingefolgt werdten soll.

$\int 3$ Die in ieder ehe anerwonnene ligende oder unbewegliche güetter (warin auf jahrrenten angelegte gelder, sÿe seÿen lossbahr oder nit, ohne unterscheÿdt allzeit und allenthalben mit verstandten werdten) sollen beÿ derjennigen ehekünderen, darin sÿe gewohnen, verbleiben; wie es aber mit deren niesslicher nutzbahrkeit so von den fahrenten oder beweglichen gütteren $\mathrm{zu}$ halten, ist hiernach beÿ dem 7. Titulo von den eheleuthen vermeldet.

$\int 4$ Gleich die natürliche künder vermög der gemeiner rechten der mutter, ob schon selbige auch eheliche künder gezeugt, eben dennen gleich succedieren, nicht aber dem vatter, so lasset manns dabey ebenfahls bewendten, doch sollen die illustres ausgenohmen sein. 
$\int 5$ Im fahl ein sohn oder tochter ehe sÿe das fünf und zwainzigiste jahr ihres alters erfüllet ohne ihrer leiblicher eltern vatters oder muetter wissen und willen sich verheurathet, sollen sÿe zwar dardurch ihres natürlichen antheills oder legitimæ an der vatter- oder muetterlicher erbschaft nicht entsetzet werdten können, weillen sÿe aber dardurch eine grosse undanckhbarkeit gegen ihre elteren begehen, sollen dieselbe beÿ ihren lebzeitten ihnen einig heuraths-guth zu geben nicht schuldtig sein.

$\$ 6$ Dennen in geistlichen orden eingetrettenen söhnen oder töchteren sollen die elteren schuldtig sein vor dem gelobt oder profession nach gestalt ihres vermögens eine billichmässige außteuer, als etwa einhundert bis in 300 oder 400 reichsthaller zum höchsten, zu verschaffen;. wan mann sich aber dariber beÿderseiths nicht würdte vergleichen können, soll die obrigkeit darinnen eine billiche mässigung treffen und damit der geistliche sohn oder tochter von der elterlichen verlassenschafft, wie auch aller beÿoder seithen fällen gäntzlich abgegüttet und verziehen sein; wan auch solches durch die geistliche söhn, tochter oder deren ordens oberen versaumbt oder verschoben, soll nicht desto weniger hiernach die obrigkeit darin gebiettende verordtnung zu stellen macht haben.

$\$ 7$ Und wann etwa hernach eine solche geistliche persohn nach beschehener profession aus ihren orden austretten würde, soll dieselbe zu den elterlichen oder anderen anerfahlenen güetteren durchaus keinen zuetritt mehr haben.

Titulus III

Von erbfolgung in absteigender linien

$\int 1$ Wan ein kindt mit todt abgehet und keine erben in absteigender linien als söhne, töchter oder enckelen, oder auch keine brueder oder schwesteren von beÿden seithen nach auch deren kinder im ersten grad verlasset, so erben dess verstorbenen kündts vatter und muetter seine verlassene ligende haab und gütter diser gestalt, das der vatter die iennige, so von vätterlicher seithen und die muetter die iennige so von muetterlicher seithen auf das gestorbenes kindt kommen, vorabnehmen, alle ÿbrige aber unter sich gleich theillen.

\2 Wan aber entweder der vatter oder mutter mit todt abgangen, so erbt das ander, so noch im leben, alle dess kindts haab ohne unterscheid woher solche auf das selb kommen, vor allen anherren und anfrauen und allen anderen freundten.

$\int 3$ Da vatter und mutter nicht im leben, so erben die verlassene ligende gütter so von vätterlicher seithen an das gestorben kindt kommen seindt, anherr und anfrau von dem vatter vorab, dessgleichen die von müetterlicher seithen kommende ligende haab und güetter anherr und anfrau von der muetter auch vorab und die andere ÿbrige haab und güetter erben anherr und anfrau von beÿden seithen mit ein ander.

\4 Wan aber allein ein anherr und anfrau, uranherr oder uranfrau des gestorbenen kindts von vatter oder muetter seithen im leben, der oder die erben allein so vill als anherr und 
anfrau oder uranherr und uranfrau von beÿden seithen zusamben wan sÿe zugleich im leben wären.

$\int 5$ So lang ein anherr oder anfrau im leben, werdten uranherr und uranfrau von der erbschafft ohne unterscheidt woher die kommen, ausgeschlossen. Wan aber kein anherr oder anfrau im leben, so erben die uranherr und uranfrau in aller massen wie von den anherren geschriben ist, vor allen anderen verwandten, auch vor den geschwistrigen von einer seithen und derselben kinderen.

$\int 6 \mathrm{Da}$ aber das verstorbene kindt an vatter- oder müetterlicher seithen nur einen anherrn oder anfrau, uranherrn oder uranfrau und an der anderen seithen beÿde sowohl anherrn als anfrau oder uranherren und uranfrau noch im leben hette, soll zwar, wie oben von vatter und muetter gemelt, ein jeder theill in den ligenden gütteren, so von seiner seithen herkommen, vorab erben, alle ÿbrige gütter aber in zweÿ gleiche theile, und davon die eine halbscheid auf den einen anherrn oder anfrau von vatter oder muetter, die andere aber auf beÿde anherren und anfrau von der anderen seithen verfallen.

Titulus IV

Von erbung der elteren mit und neben dess verstorbenen kindts bruder und schwester oder derselben kinderen

$\int 1$ Wan das abgestorben kindt hinter sich vollbürtige brüeder oder schwestere, oder derselben künder im ersten glied im leben verlasset, so erben dieselbe mit dess abgestorbenen kindts vatter und muetter oder muetter allein wan der vatter mit todt abgangen, oder mit dem vatter allein, wan die muetter vorhin gestorben und da weeder vatter noch muetter im leben, alsdan mit den anherrn und anfrauen oder wan deren auch keine mehr vorhandten, mit dess abgestorbenen kindts uranherren oder uranfrau alle haab ohne unterscheidt, ie eine persohn so vill als die andere, doch sollen der brüder oder schwester künder, ihrer seÿen vill oder wenig, nicht nach den haubteren und zahl der persohnen, sonderen in stamme, nemblich an statt ihrer vatter und muetter erben und mehr nicht, dan ihr vatter und muetter geerbt hatten, wan sÿe im leben gebliben weren.

$\int 2$ Da nach tödtlichen abgang vatters oder mutter das abgestorben kindt an einer seithen nicht mehr dan ein an- oder uran hinter sich verliess und auf der ander seithen zween anoder uran sambt vollbürtigen brüederen oder schwesteren oder derselben kinderen, so werdten dieselbige anherren oder uranherrn, anfrau oder uranfrauen auf der ander seithen vor eine persohn gerechnet und erben auch beÿde nicht mehr dan eines von dess abgestorbenen kindts vollbürtigen brüederen oder schwesteren, oder deren eines künder alle erben mögen.

Titulus V

Von erbung auf der seithen linien seu lineæ collateralis 
$\$ 1$ Wan der verstorbener in ab- oder aufsteigender linien niemandt sonderen vollbürtige brüder oder schwesteren, oder derselben kinder im ersten glidt hinter sich verlasset, als dan erben dieselbe gleich mit ein ander vor allen anderen verwandten, auch vor ihrer vollbürtiger brüder oder schwester enckelen wie auch vor brüder oder schwester von einer seithen und derselben kinderen.

\2 Jedoch erben der brueder und schwester kinder, ihrer seÿen vill oder wenig, mit dess verstorbenen brueder oder schwester, wan deren noch im leben, in die stamme und mehr nicht als ihr vatter und muetter, wan würde gelebt haben, geerbt hette.

\3 Da aber der verstorbene keine vollbürtige brüeder oder schwester, aber woll deren kinder im leben verlässet, als dan erben dieselbe, ihrer seÿen von ein oder mehr brüeder oder schwestern vill oder wennig, alle sambtlich in die häubter zu gleichen theillen.

$\int 4$ So aber keine vollbürtige brüder und schwesteren, noch deren kinder im ersten glid vorhandten, alsdan erben die einseithige oder halbbürtige brüder und schwesteren und deren künderen vor allen anverwandten, auch vor dess verstorbenen vatter oder muetters brüederen und schwesteren ohne unterscheidt, wo die güetter herruehren, auf gleiche weise wie von den vollbürtigen gemelt wordten.

$\int 5$ Jedoch wan der verstorbener zweÿerlein einseithige brüder oder schwesteren oder deren künder, nemblich eine von dem vatter und die andere von der muetter verlasset, als dan sollen die brüeder oder schwesteren von der vatterlichen seithen und deren künderen im ersten glid die iennige ligende güetter, so von dem vatter herriehren und hingegen die brüeder und schwesteren von der müetterlicher seithen die müetterliche ligente güetter vor ab erben, die ÿbrige güetter aber in zweÿ gleiche theille theillen.

$\int 6$ Wan keine voll- oder halbbürttige brüder oder schwesteren nach von denselbigen kinder im ersten glied im leben, so erbt ieder nächster bluets verwandter dess verstorbenen verlassenschafft ohn unterscheidt mannliches oder weibliches stammens, es rühre die verwandtschafft von einen bandt her oder von beÿden, auch ohne unterscheidt von welcher seithen die güetter herkommen und solches in das zehente glid der verwandtschafft, dergestalt dass iedesmahls eine geburth für ein gliedt nach der verordtnung der gemeiner beschribenen rechten zu rechnen.

Titulus VI

Von dennen lehnen und deren succesionen

$\int 1$ Sollen alle die iennige lehnen, worin der tenor primæ investituræ mit klahren worthen auf mann lehen gerichtet, auch zu forderst vor recht manlehen gehalten und die töchter von deren succession allerdings ausgeschlossen sein und bleiben, sonderen wan a primo acquirente herkomender mann-stamm außtirbt, als dan der lehen herr von dessen successores gutte macht und fug haben sollen all solch lehen widerumb einzuziehen und ihnen anzuheimschen, in massen kein vasal auch mit consent dess lehen herrn befugt sein 
solle ein all solches mann lehen zu nachtheill deren a stirpite acquirente herriehrender agnaten und ihres daran habenden juris quisiti ohne auch deren special consens zu alienieren, zu versetzen, zu permutieren oder zuvereusseren, zumahlen widrigen fahls der a primo acquirente herkomender agnatus wohl befüegt nach todt dess alienantis sothannes feudum freÿ und ohne restitution deren davor verschossener pfeningen einzuziehen und zu repetieren.

\2 Gleicher gestalt, woh die investitur von beÿderleÿ geslecht, mann und weibs persohnen, austruckhlich meldtung thuet, da sollen die töchter oder weibs persohnen zur succesion der lehnen zuegelassen und verstattet, iedoch auf begebendten fahl selbige durch die manns-persohn behörlich bedient und vertretten werdten.

$\int 3 \mathrm{Zu}$ die iennige lehn, so informierter nemblich ohne meldtung mannlichen oder weiblichen geschlechts bis herzu conferiert und verlihen wordten, fahls entwider mannliche lehen-folger oder doch in pari cum fæminis vel remotiori gradu vorhandten, als dan sollen die töchter oder weibs-persohnen a primo acquirente entsprossen, darin zur succession dem alten herkomen gemess admittirt, und also die weibliche und mannliche agnaten promiscux, auch proximiores in gradu remotioribus absque sexus differentia vorgezogen werdten, abermahlen doch mit dem 2 \beschehenen reservato, das nemblich sÿe das lehen durch eine manns-persohn zu deserviren schuldtig sein sollen.

$\int 4$ Der vasallus solle petionem investiture ein jahr und 6 wochen sowohl nach dess lehenherrn todt von dessen erben als nach todt dess vasalli dessen hæredes von lehenherrn mit gewohnlichen homagio und hergebeÿdt proprio motu ohne einige citation sub pœna caducitatis thuen und dabeÿ gebührendtes juramentum fidelitatis præstieren.

$\int 5$ Solte aber ein lehen im leben eines mit künder versehenen vatters releviert werdten müessen, so solle der vatter, nicht aber dessen sohn das relivium gebührent verrichten in massen auch alle lehen von dem iennigen, welchen sÿe von rechts weegen competieren, selbst releviert werdten sollen.

$\int 6$ Solle der vasallus ohne special consens seines lehenherrn dass feudum gantz oder ein theill darab unter straff der würckhlicher caducitæt nicht verkauffen, oppignorieren, permutieren, noch einiger weis distrahieren oder alienieren, alles unter seiner Feud[orum] 2 Tit[ulum] 55 durch kaÿseren Fridericum angezogener straff und im fahl solches attentiert würde, solte dem lehenherrn freÿ stehen, das caduciertes feudum vermög lehen-rechten freÿ einzuziehen.

\7 In judicio feudali solle gleich in judicio civili ordinario tit[ulum] 18 procediert werdten, außer das nur der lehen richter, statthalter oder dessen substitutus nebenst zweÿ mannen von lehen in dess lehenherrn abweesenheit die belehnungen nach vorgangenen von rechts wegen gehörrigen requisiten und solemnitæten gegen empfangung eines von dem vasallo gebenten reversalis zufolg von unseren hochgeehrten vorfahren herren Johannen grafen von Bronckorst zu Gronsfeldt etc. den 2 augusti anno 1593 ausgelassener lehen-ordtnung 
thun, auch alle coram curia feudali vorfallendten processen nebenst obgemelten zweÿ mannen von lehn determinieren und definitive decidieren könne und solle, gestalt sothanne belehnung salvo jure cujuscunque und fehlendte urtheillen vor gültig gehalten werdten sollen, vorbehaltlich iedoch das darab vermög alten herkommens ad majores pares curix appelliert werdten könne.

\section{Titulus VII}

Wie eheleuth einander erben sollen

\1 Wan unter künfftigen eheleuthen mit vorwissen und belieben der eltern oder in mangl deren mit zueziehung der nächster bluets-verwandten oder freundte heuraths verschreibungen aufgerichtet, beschlossen und angenohmen, selbige sollen in allen ihren puncten und articulen unverbrüchlich und ohne widerred gehalten werdten.

\2 In solchen heuraths verschreibungen ist den künfftigen eheleuthen zuegelassen, nicht allein von dem zuegebrachten heuraths guett zu verordtnen, sondern auch von allen ÿbrigen güetteren so vill sÿe deren mächtig und ihnen gefällig, ein ander zuvermachen und soll allsolche vermachnuss ob sÿe schon auf die erbfolgung gantz oder zum theill der ietziger oder künfftiger güetter gerichtet, unwiderruefflich sein, es geschehe dan die widerrueffung mit beÿder eheleuthen gutten willen und belieben, etc.

\3 Da keine heuraths verschreibung aufgerichtet, auch entweeder gar keine kinder aus solcher ehe entsprossen oder selbige vor beydde elteren wider verstorben, soll das letzt lebent von beÿden eheleuthen den heurathspfenning erblich behalten, in allen anderen aber dess erst abgestorbenen zugebrachten, wie auch beÿ stehenter ehe anerfallenen ligenten oder unbeweglichen (worunter auch die rennts verschreibungen, sÿe seÿen lossbahr oder unlossbahr, sodan die baarschafft von abgelegten jährlichen renten mit zu verstehen) sein leben lang, es thue sich dasselb wider verheurathen oder in widwestandt verharren, leibzüchtig verbleiben, dariber aber ein ordentliches inventarium auf das die nächste erben dess eigenthumbs versichert sein können, beÿ verluest der leibzucht einer dreÿ monnathen zeit ferttigen lassen, sothann die güetter in gutten bau und besserung halten, auch da es von den erben begehrt würdt, dessweegen gebührente caution und versicherung leisten.

\4 Die in stehenter ehe anerwonnene ligente güetter sollen alsdan, wan nemblich vorgesetzer massen keine kinder noch widrige pacta dotalia oder heuraths versprechungen vorhandten, freundtheillig sein, dess erst abgestorbenen nächsten erben zu einer halbscheidt und dem letzt lebendten ehegatten zu der anderen halbscheÿdt eigenthumblich zufallen, iedoch diesen von allen solchen güetteren die leibzucht gegen gleichmässige aufrichtung eines inventarii und gebührliche caution auf erforderen seine lebzeit verbleiben.

$\$ 5$ Die fahrnuss oder bewegliche gütter thun dem letzt lebenten eigenthumblich und mit vollkommenen recht zufallen, iedoch selbiges daraus alle unverbrieffts, wie auch die 
iennige verbrieffte schuldten, so nicht auff jährliche renthen verschriben, zu bezahlen verbundten sein.

$\int 6$ Wan aber das erst verstorbene von beÿden eheleuthen künder aus selbiger ehe gezeugt hinter sich im leben verlässt, als dan soll zwarn das letzt lebendes ehegatt alle fahrnuss, wie vorgemelt, für sich behalten, den heuraths pfenning aber und andere zugebrachte oder beÿ stehenter ehe dem erst abgestorbenen zugefahlen, wie auch die gewonnene güetter nur leibzichtig sein leben lang, es greiffe das selbe wider zu anderer ehe oder nit, zu geniessen haben, iedoch auf den wider verheÿrathungs fahl dariber ein inventarium aufrichten lassen und alle weege darvon die kunder nach standt -gebühr ehrlich erziehen und außteuren, welche außteurung dan mit zueziehung der nächster freundt, oder wann dariber zwischen ihnen irrung vorfallen würdte, nach ermässigung der obrigkeit geschehen soll.

$\int 7$ Unter den nahmen solcher fahrnuss oder beweglicher gütter solle das bahr gelt, so nicht von abgelegten iahr rennten ligenten gütteren herriehret, handtschrifften, so nicht auf iahr-rennten gestelt, baum-obst oder grassgewachs aber, wan der fahl nach dem ersten martii sich begibt, hauß-zinss nach ertrag der von dem laffenten jahr allschon erschienener zeit, abgehauenes schlagholtz, wie auch das unabgehauenes, wan die verkauffung noch beÿ lebzeitten dess eigenthumbers geschehen, verfallene noch außtehente pensiones von angelegten capita -gelteren, vorrathlicher getraÿdt, silbergeschier, viehe, ackher geschier, hausrath und alles was sonst nagel-loss ist, wie auch die action und ansprach auf dergleichen güetter verstandten werdten; was aber außer disem dem grundt oder haus anklebt und unter anderen eisen, ofen, breukessel, blossbalg in der schmitten und dergleichen, soll vor unbeweglich gehalten werdten und beÿ dem grundt oder haus verbleiben.

$\int 8$ Es soll iedoch unter kauff- und handels-leuthen hierin disen unterscheid haben, das die iennige wahren und güetter, welche in ihre handtlung und gewerb einschlagen und darunter gehörrig, in disem erbungs fahl unter die fahrnuss nicht zurechnen, sondern es damitten sambt den außtehenten buech und gegenschuldten also gehalten werdten, wie oben in viert und sechsten articulis von denen ligendten güetteren verordtnet.

$\int 9 \mathrm{Da}$ nach gebrochenen ehebeth sich begabe, das auf die künder dess verstorbenen vatters oder mutter entweeder in absteigenter linien oder von der seithen einige erbschafft ab intestato verfielle, soll der noch überlebenter vatter oder mutter davon die leibzucht, so lang die künder noch unverheurathet oder sonsten in vatter- oder mutterlicher unterhaltung sein, zugeniessen haben, nach deren verheurathung aber oder auch da sÿe gleich nit verheirathet, aber dannoch nach dem funff und zwainzigisten jahr ihres alters einen eigenen rauch oder haushaltung anstehleten, oder sonsten von den elteren sich absönderten, soll ihnen der vatter oder muetter allsolch nach gebrochenen ehebeth anerfahlenes guth abtretten und einraumben.

Titulus VIII

Von besitz oder possession der erledigter erbschafft 
$\S 1$ Wa ein testament aufgerichtet, soll auf den darin eingesetzten erben, oder wan mehr testamenta vorhandten, auf den iennigen der in dem letzteren onder iüngsten benambset, und in mangel dess testaments auf den nächsten anbewandten, deme die erbschafft von rechts-weegen zuegehört, der besitz oder possession der gütter, sie seint ligent oder fahrent, so fern sÿe der abgestorbene zu zeit seines todts possedirt, ohne einige andere leibliche ergreiffung oder apprehension verfallen sein, und da villeicht ijemandt anders vorlauffen und sich des besitzes zu naheren unterstehen wurdte, soll ihm solches zu keinen vortheill oder nutzen weeder in- oder außerhalb rechten gedeÿhen, sondern vill mehr vor ein straffbahre thatt zuhalten sein und hingegen der eingesetzter, oder, wann kein testament vorhandten, der nächster erb vom geblüth beÿ dem besitz der gütter bis zu ordenlichen austrag rechtens gehandthafft und manuteniert werdten.

\2 Und in fahl etwa das testament als mangelhafft und ungültig beschuldtigt oder zwischen den anbewandten vom geblüth der nähe oder proximitæt halber oder sonsten streitt erweckht würdte, soll summarie darüber erkannt und bis dahin die güetter von den gerichtern darunter selbige gelegen, zu behueff dess obsigenten theills in verwahr genohmen werdten.

\section{Titulus IX}

Von der ein kündtschafft

$₫ 1$ Wan eines von beÿden eheleuthen nach absterben dess anderen wider zu der zweÿter ehe schreittet, und zuvor oder auch hernach unter wehrender ehe für gut ansihet zwischen erster und folgenter ehe, oder auch dennen zuegebrachten künderen eine ein-kündtschafft aufzurichten, soll solches zwar als zu mehrer erhaltung liebe und einigkeit gereichent, zugelassen sein, iedoch anderer gestalt nit als mit vorgehenter gerichtlicher erkentnuss.

\2 Wobeÿ dan dise ordtnung gehalten werdten soll, das dennen kinderen, da sÿe noch münderjährig, zu solchen acta und handtlung ein oder zwee curatores (im fahl sÿe vorhin damit nicht versehen) angesetzt werdten sollen, welche der künder haab und vermögen, so sÿe von ihrem verstorbenen vatter oder muetter ererbt, und was sÿe hingegen von dem künfftigen stieff-vatter oder muetter zuerwartten haben können, mit fleis zu ÿberlegen und zu erwegen und dem nächst dem gericht zu hinterbringen, auch an aÿdts statt ob es dennen kinderen besser gethan als gelassen, oder keine merckhliche vervortheillung darunter verborgen, auszusagen und $\mathrm{zu}$ bekräfftigen; deme vorgangen als dan das gerichtliche decret mit ordentlicher verzeichnuss ob und was ein oder anderen theill zum vortheill voraus vermacht, und ausgeferttiget werdten mag.

\3 In krafft solcher einkündtschafft sollen als dan die künder voriger ehe mit dennen so in folgender ehe gezeugt, in dennen elterlichen güetteren zugleich erben, darunter aber die seithen oder collaterall fälle und was sonsten ein oder anderleÿ kinderen durch testament, schenckhung oder andere titul vermacht und sonst durch sÿe erworben, nicht verstandten werdten. 
$\int 4 \mathrm{Da}$ fern folgents von solchen vereinkündtschafften künderen eines oder mehr beÿ lebzeitten beÿder oder eines von den elteren mit todt abgehen würdte, soll der angenohmene vatter oder muetter, wie auch die schwesteren und brüedern zweÿter ehe nicht anderst als die natürliche elteren und vollbürtige brüeder und schwesteren in dennen der einkündtschafft einverleibten güetteren in die haubter und zugleichen theillen erben.

\5 Wan aber beÿde sowohl natürliche als angenomene elteren verstorben und also deren erbungs fahl sich völlig begeben, soll dise einkindtschafft damit aufgehebt und erloschen sein, und die halbbürtige schwesteren und brüeder mit dennen vollbürtigen ferner nicht erben, sondern es alsdan der succession halber unter allerseiths geschwistrigten anders nicht gehalten werdten, als wann keine einkündtschafft gemacht wäre.

$\int 6$ Da iedoch beÿ aufrichtung dergleichen einkündtschafften andere bedingungen oder conditiones abgehandelet und verglichen, soll solchen durch dise ordtnung nicht benommen sein, sondern dieselbe aufrichting gehalten und vollenzogen werdten.

Titulus X

Von vormünderschafften

$\$ 1$ Wan ein vatter oder muetter zu der zweÿten und mehreren ehen schreittet, sollen sÿe ihre künder voriger ehe, so fern die selbe das fünff und zwaintzigiste jahr ihres alters nicht erfüllet, mit vormündteren zuversehen zu lassen schuldtig sein, und dafern sÿe solches innerhalb jahrs nach der verheÿrathung versaumen oder unterlassen würdten, sollen sÿe sich der leibzucht aller aus vorriger ehe auf die künder verfahlene güetter verlüstig gemacht haben, es were dan das süe rechtmässige ursachen der verhinderung beÿ der obrigkeit vorbringen oder erweisen könten.

\2 Da aber sonsten ein kündt vor erfüllung ermeltes fünff und zwanzigisten jahrs elterloss wirdt und demnach kein veniam ætatis vermög gemeiner rechten und darzue gehörriger requisiten erhalten, sollen drossard, schultheis und schöffen in den gerichteren wo die elteren zu zeit ihres absterbens wohnhafft gewesen, demselben einer der nächster sechs wochen vormündere anzusetzen, oder im widrigen allen dem münderjährigen daraus erwachsenten schaden zu erstatten und guettzumachen verbundten sein.

\$3 Wer demnach von drossarden, schultheissen und schöffen zum vormundt benambset wirdt, soll das-selbig unweigerlich anzunehmen schuldtig sein und ihme da wider keine entschuldigung zu statten kommen, es seÿe dan das er vorhin mit wo anderen vormundtschafften beladen oder aber in solchen streitt mit den wäÿssen stundte, daran der mehrer theill ihres vermögens hafftete oder aber in dergleichen officiis und bedienungen oder sonsten in solcher leibs ohnvermogenheit begriffen, die an verwaltung der vormundtschafft kundtbahrlich hinderten; wan sonsten sich jemandt widrigen und die pfleg befohlene wäÿsen dadurch in schaden kommen würdten, soll er darfür hafften und alles zuersetzen angehalten werdten. 
\4 Im fahl nun das gericht die nächste verwandte dennen sonsten vermög der gemeiner rechten die vormünderschafft obläge, darzue ernennen selbige aber aus dem bezürckh dessen gerichts zwang gesessen sein wurdten, soll das iennig gericht, worunter all solche benambstete vormündere wohnhafft, alsobalt auff die erste requisition oder ersuechung dieselbe zu antrettung der aufgetragener vormünderschafft anhalten oder für dem saumfall selbsten hafften und solchen vermittels erstattung alles schadens zu büssen schuldtig sein.

$\int 5$ Alle vormündere sollen iedes iahrs gleich nach dem Weÿnacht feÿertagen, nemblich den 7 januarij ihre rechnungen an dem orth wo sÿe angesetzt, beÿ vermeÿdung willkürlicher straff einlifferen und darauf alsobaldt von der obrigkeit gewisse persohnen zu deren durchseh[ung] und ÿberlegung verordtnet werdten.

Titulus XI

Von kauffen und verkauffen

$\int 1$ Wan iemandt ligente oder unbewegliche güetter an sich erkaufft, soll der kauff beÿ dem gericht worunter die güetter gelegen, insinuiert oder verkündtet werdten und daselbst durch den verkäuffer vertzig und ausgang, hingegen an den käuffer die erbung geschehen und also lang solche verkündtung hinterbleibt, soll der eigenthumb oder proprietæt, ob ihm schon durch den verkauffer sonst das gueth eingeraumbt, nicht verfallen sein, iedoch ihm wider denselben seine personal action zu fest halt[ung] und erfüllung des kauffs, oder im fahl er die liferung oder tradition nicht thun kan, zu seiner schadtloss haltung unbenohmen sein.

$\$ 2$ Gleich wie unsere hochgeehrte vorfahren und wir selbsten verbotten dennen geistlichen (darunter capitula, abtdeyen, clöster und conventen zuverstehen) keine unbewegliche güetter unter straff der würckhlicher confiscation zu alienieren oder auf dieselbe einigermassen, wie es dan nahmen haben möchte, durch tausch, schenckhung, testament, pfachtung, pfandtschafft oder sonsten zu transferieren, so haben wirs vor nun und zu ewigen tagen dabeÿ bewendten lassen wollen.

$\$ 3$ Ein mann oder weib mag beÿ stehender ehe so wenig ein angebrachtes als mit ein ander gewonnenes guet ohe mit belieben und bewilligung seines ehegatten nicht verkauffen oder einiger gestalt veräusseren, sondern was dessen vorgenohmen, soll krafftlos und nichtig sein.

$\int 4$ Hingegen wann ein weib mit und neben seinen ehemann einen contract aufrichtet, denselben unterschreibet, oder auch vor gericht oder notarien und zeugen sich darzue bekennet, soll sÿe und ihre eigene güetter darfür gleich dem mann hafften und sich dawider keines vorzugs rechtens weegen ihres angebrachten heÿraths-guths zu gebrauchen haben. 
$\int 5$ Da aber ein mann oder weib nach gebrochenen ehebeth ein stuckh ihres angebrachten eigenthumblichen guths verkauffet oder versetzet, so solle der kauff oder versetzung giltig sein, dergestalt doch das dessen künder ihrer legitima dardurch nicht defraudirt werdten.

\section{Titulus XII}

Vom einstandt oder bescheidt zu latein ius retractus genant

S 1 Wan ein ligentes gueth oder ligentem guth anklebende gerechtigkeit wie auch unlossbahre zinsen oder renthen verkaufft werdten, sollen die nächste bluets verwandten aus dem vätterlich und müetterlichen stammen wo ermelte güetter herkommen, bis in das zehent glidt so weith (nemblich die erbung vermög dess obigen fünfften tituls statt hat) dess einstandts berechtiget sein und sich dess kauffs innerhalb 6 monnath von zeit solcher beÿ dem gericht verkündtet, insinuirt und die erbung geschehen, anzurechnen, gegen würckliche erstattung der ausgegebener kauffgelter und anderer nothwendtiger und redtlicher unkösten näheren oder retrahieren mögen.

$\S 2$ Die iennige anbewannte aber welche aus dem stammen dess ersten acquirenten oder erwerbers solcher güetter entsprossen, sollen beÿm einstandt allen anderen verwandten so nicht davon entsprossen, vorgezogen werdten.

$\int 3$ Solte aber zweÿfel sein ob einer aus dem stammen dess ersten acquirenten were oder nit, unterdessen bekent sein, das derselb dem verkäufferen allein mit verwandtschafft zuegethann, so solle der iennige beÿ mangel deren a stirpite primi acquirentis herkomender anbewandter gleichwohl zum einstandt berechtiget und zu gelassen werdten.

\4 Wie gleichfahls wan einer gueth vorhin gekaufft nachmahls aber wider verkaufft, so sollen dessen collateral-anverwandten dess einstandts vermög rechts herbrachter uhralter gewohnheit und in krafft dises sich zu bediennen befügt sein.

$\int 5 \mathrm{Da}$ aber der verkäuffer all solchen seinen bluths verwandten den kauff anbiethen und verkündten, dieselbe aber sich darzu nit einlassen, noch in den nächsten 6 wochen erklähren würdten, sollen sÿe sich ihres einstandts verlustig gemacht haben.

$\int 6$ Wer zu dem einstandt befugt ist, soll sich dessen anderer gestalt nit als ihm selbst zum besten und das gueth für sich zubehalten und keinen anderen zugefahlen und nutzen, oder in meinung solches etwan baldt umb eines ÿbergewins willen wider zuverkauffen, gebrauchen, dessen dan er das nemblich in solchem allein kein heimlicher verstandt noch gefärde unterlauffe, woh es begehrt wirdt, ein aÿdt schweren soll.

$\int 7$ Wo sich begibt das mehr als ein anbewandter in den kauff zu stehen begehrt, soll allemahl der nächster grad dem weitteren vorgehen, weren sÿe aber im gleichen grad, soll sÿe dariber das loss entscheÿden. 
$\int 8$ Da sonsten keine verwandten verhandten oder selbige nicht retrahieren wollen, stehet dem nächsten an das verkauffers gueth anschiessenten nachtbahren frey des einstandtsrechts sich zugebrauchen.

$\int 9$ Den geistlichen stiffteren, clösteren und dero persohnen solle die beschüddung nicht zugelassen werdten.

\10 Diese einstandts gerechtigkeit soll auf tausch oder wechsel auch nit gezogen werdten, sondern allein im kauffen statt haben, doch das solche tausch oder wechsel gefährlicher weis und durch dergleichen schein die nächste freunde von dem einstandt abzuhalten nicht geschehen, sonderen beÿder theill nutzen und nothdurfft nach aufrichtiglich vorgenommen und gehandelet werdte, welches dan auch so die nächste freundt begehren würdten, durch die partheÿen beÿ geschwornem aÿdt erhalten und bestättiget werdten soll, woh aber im tausch ein aufgelt gegeben und solches den halben theill dess werths des ertauschenten gutts ereicht, soll es für ein kauff gehalten werdten.

\11 Gleichergestalt, wan ein guett auf anruffen dess glaubigers oder creditoris durch das gericht verkaufft würdt, alsdan hat der einstandt nich statt, sonderen welcher also vor gericht gekaufft hat, soll dabeÿ ohne eintrag der anverwandten gelassen werdten.

Titulus XIII

Von pfandtschafften zu latein de pignoribus et hÿpothecis

$\S 1$ Keine verpfandtung solle gültig sein, sie werdte dan dem gericht, worunter die güetter gehörig, insinuirt und dabeÿ ratificiert, und dafern solches nicht geschicht und die güetter hernach an einem anderen verkaufft oder versetzt werdten, soll wider denselben der erster glaubiger oder creditor solcher güetter halber durch aus keine ansprach, weniger einiges verzugs zu geniessen haben.

\2 Da auch schon eine general oder gemeine verpfandtung aller güetter geschicht, soll doch dieselbe dem glaubiger anders kein vorzugs rechts zueignen, es seÿe dan beÿ iedes orths gericht insinuation geschehen, und stehet alsdan zu seiner wahl ohne unterscheidt an welche güetter er sich zum erst und liebsten halten und bezahlt machen wolle, unangesehen neben den general auch ein absonderliches unterpfandt in der verschreibung benambset wordten.

\3 Wan dan obgesetztermassen die verpfandtung vor gericht geschehen, mag der creditor die verpfandte güettere, in was handt sÿe auch hernach geratten, für seine schuldt verfolgen, ohne das er an seinen haubtschuldtener erst umb excusion zu verweisen sein solle.

\4 Die general verpfandtung aller güetter wider einen dritten kauffer oder besitzer soll auf die fahrende und bewegliche güetter ehender kein krafft haben, als dieselbe durch 
gerichtliches verbott præcludiert wordten, dafern aber iemandt nach solchen verbott dieselben an sich kauffen oder bringen würdte, mag er von dem glaubiger dafür besprochen werdten.

\section{Titulus XIV}

Von pfachtungen

$\$ 1$ Ein pfachter soll seine pfachtung ohne dess pfachts herren bewilligung einen anderen zu ÿberlassen oder iemandt in seine pfacht iahren eintretten zu lassen nicht macht haben.

\2 Wan ein pfachter wegen müsswachs oder hagelschlags an seiner pfacht nachlass zu begehren vermeint, soll er vor der aerndte seinen pfachtherren die besichtigung dess schadens anzusagen schuldtig sein, im widrigen keiner nachlassung zu geniessen haben.

\3 Im fahl demnechst der pfachter mit seinem pfachtherrn dess nachlass halber sich nit vergleichen könte, soll der pfachter den pfacht-herrn zu theillung dess wachsthumbs sambtlicher früchten diser gestalt zu lassen, das die harte früchten demselben zur halbscheidt, iedoch gegen erstattung dess halben sahm korns, halben mähe oder schneidtlohns und halben dreschlohns, sommerfrucht aber zu einen drittheil gegen gleichmässige erstattung dess drittheils berührter kösten verbleibe.

$\int 4$ Wan der pfächter der pfachtung, wie es sich gebürth und fleissigen haushalter obligt, nicht vorstehet, soll der eigenthumber ihme seine jahren daran zu halten nicht schuldtig, sondern von dem guth auszuweisen befügt sein, dafern auch der pfachter in dem letzten pfachtjahr seine pfacht nicht bezahlen und doch die früchten, viehe und ander eingebrachtes zuentfrembden oder sonsten zu verbringen unterstehen würdte, soll dem pfacht-herren die scheuren, speicher, hoff und stähle zu seiner versicherung zu versperren freÿ stehen.

$\int 5$ So haus, scheuren oder stallungen durch dess pfachters oder seines hausgesündts schuldt oder versaumbnuss abgebrandt, ist er schuldtig all solchen schaden aus dem seinigen wider zuerstatten.

\6 Weillen vermög gemeiner rechten die erbkäuff die pfachtungen brechen, so soll auch der kauffer dem pfachter die jahr zahl seiner pfachtung auszuhalten nicht schuldtig sein, sondern der pfachter gleich in drë̈ monnathen nach verkündteten kauff aus einem simplen haus, aus einem haus aber darab der ackherpau dependiert und von dennen gepfachteten güetteren auf das nechst folgentes fest Cathedræ Petri weichen, iedoch hat er sich dess schadens halber, so ihme daraus entstehet, an dem verkauffer zu erhohlen.

$\S 7$ Gleicher gestalt, wan sich zutragen würdte, das ein herr der ein haus ausgethan oder verpfachtet aus neu ÿberkomender nothwendtiger und redtlicher ursach selbst darin wohnen oder bauen müesste, ist er dem pfächter die pfacht jahren zu halten nicht 
schuldtig, iedoch soll er ihm in solchen fählen zu ersehung einer anderen wohnung entwider obgemelte drë monnath, oder, wan die sach eine mehrere eÿll erfordert, zeit nach ermessung der obrigkeit verstatten, vorbehaltlich dess ihm dess ausweichens halber zu wachsendten schadens.

$\int 8$ Im fall hingegen der pfachter mit vorwissen und willen dess herrn nutzliche kösten an die gepfachtete güetter angelegt, soll er ehe ihm gebührliche erstatt[ung] oder vergnügung geschehen, zu weichen nit schuldtig sein.

\9 Weillen auch die pfachtung von all zu langen jahren den künderen und erben beÿ villerleÿ unterdessen zuetragenden änderungen offters zu grossen unstatten gereichet, soll hinfüran keine pfachtung länger als auf zwölff jahren gültig oder verbündtlich sein.

\section{Titulus XV \\ Von erbpfachten}

$\int 1$ Da erfindtlich zwischen dem erbpfachts-herren einiges instrumentum aufgerichtet zusein, alsdan tenor earundem pactionum observiert werdten.

\2 Wan aber hierab nichts erfündtlich, so statuieren das da der geistliche erbpfacht in zwey jahren und der weltliche in 3 jahren nicht bezahlet sein solte, der emphiteuta oder erbpfachts vasal als seines dominii utilis verlustig, das erbpfachts guett dem erbpfachts herren heimbgefahlen und dominium directum cum utili consolidirt seÿe, in massen solchen pfacht das erbpfachts guth als caduc dem domino directo auf dessen gesinnen per sententiam adjudiciert werdten kan.

\3 Und solches zwarn nicht allein, wan einer in berührter zeit seinen erbpfacht nicht bezahlt, sondern auch wan mehrere erbpfachts-tragere so das erbpfachts guth ohne consens und bewilligung dess erbpfachts herrn getheillt und gesplüssen oder doch zwarn getheillt mit dess erbpfachts herrn consens dergestalt das gleich wohl der canon oder erbpfacht zusamben bezahlt werdten solle, ihr quotam bezahlt, deren einer aber nicht bezahlt habe, dan solchen fahls das erbpfachts-gueth gleich oben caduc und von dem erbpfachts-herrn heimgefahlen.

\4 Obige caducitæt greiffet auch platz wan einer sein erbpfachts guth ohne consens seines erbpfachts herren einiger massen alienirt und zuvorn denselben inner zweÿ monnathen offeriert gegen selbigen werth und preÿs als ein ander ihme hat geben wollen.

$\int 5 \mathrm{Da}$ aber in den zweÿ monnathen der erbpfachts herrn all solchen werth nicht geben wolle, als dann stehet dem emphiteutæ oder erbpfachts-trageren freÿ sein erbpfachtrechts wem er wolle und ohne consens zu alienieren, doch an einen solchen der capabel und bequem den darauf jährlichen erbpfacht zubezahlen. 
$\int 6$ Besagte caducitæt excussiert auch rechtmässige ignoranz das mann nicht gewiss daß erbpfachts guth erbpfachtig gewesen seÿe.

\ 7 Jedoch kan die caducitæt ein weltlichen erbpfacht per moram nicht purgirt werdten, unangesehen im geistlichen erbpfacht solche purgatio moræ inner kurtzer zeit zulässig; welche zeit aber, weillen in den rechten nicht ausgetruckht, als lasset man es billich dem arbitrio judicis heimgestellt sein.

Titulus XVI

Von churmuthen, zu latein de curmedis

$\int 1$ Nachdeme der churmuths trager gestorben, solle dessen erb oder die iennige, so das churmuthige guett besitzen, inner sechs wochen sich beÿ dem churmuths-herrn angeben und das churmuth, es seÿe von pferdt oder kuehe widerumb suchen zu relevieren, widrigenfahls solle der churmuthige dem churmuths herrn krafft dises caduc heimgefallen sein, also das selbiges er durch urtheill sich adjudicieren lassen möge.

$\int 2$ Und da die churmuth trägere das churmuthige guth zersplissen haben solten, also das mann die dartzu gehörige stuckhen eigentlich nicht beÿbringen könne, so sollen destoweniger nicht die ÿbrige sich in esse befündende bekente stuckhen vor den gantzen churmuth obligiert sein und bleiben bis daran sÿe die verlohrne oder unbekente stückher remonstrirt und wider beÿ gebracht haben, dergestalt fahls all solche churmuth tragere unterdessen in obgemelter zeit den gantzen churmuth nicht relevieren solten, das als dan deren anbetreffente churmuthige stückher ipso facto gleichfahls caduciert sein sollen.

$\int 3$ Solten auch die churmuths tragere den churmuth vor disen releviert, bezahlt oder gestandten haben, die unterpfändt aber unbekent sein, als sollen sÿe schuldtig sein an deren statt sufficiente freÿ allodial unterpfändt zu assignieren und all solche mit belieben dess churmuths-herrn darzu zu constituieren.

\section{Titulus XVII}

Von verjahrung der stehender rhenten oder zinsen

$\int 1$ Demnach unter den rechts gelehrten unterschidtliche meinungen seint ob in jährlichen renten und gefällen die verjahrungen platz haben können, so haben wür allem anlass zu irrungen und streittigkeiten vorzukommen, nöthig erachtet, disert weegen ein gewisses zuverordtnen; weillen dan die gemeine beschribene, auch fasst aller völckher rechten ihr absehen dahin vornemblich richten das in menschlichen handtlungen endtlich einmahl eine sicherheit sein und niemandt in wehrenter sorg und forcht dess seinigen stehen möge, der ienig auch welcher eine gar lange geraume zeit mit seiner forderung stillschweigt, seine versaumbnusse niemandten als ihme selbsten zuzumessen hat, so wollen wir das alle dergleiche jährliche rennthen, zünssen und gefälle in viertzig jähriger zeit, wan nemblich darunter keine ansprach oder interpellation darumb geschehen sein 
würdt, allerdings erloschen undt getödtet sein und der schuldtner alsdan ferner darum nicht angefochten werdten soll.

$\S 2$ Gleichergestalt wann der creditor, glaubiger oder zins-herr seinen jährlichen züns vor viertzig jahren hero ununterbrochen in einen gewissen valor oder werth empfangen und angenohmen, soll er unangesehen in was werth oder lauff das gelt zu zeit contracts gewesten, ein ander-weithe reduction, erhöh[ung] oder enderung mit dem schuldtner vorzunehmen nit befügt sein, sonderen sich ins künfftig mit eben dergleichen zahlung begnügen.

\section{Titulus XVIII}

Von den gerichteren und wie mann sich dabey so wohl in procedendo als judicando zu verhalten

$\int 1$ Der actor soll seine action oder ansprach durch summarische supplication oder articulirt libell ÿbergeben, und reus oder beclagter nach gehabter copeÿ darauf durch summarisch oder articulierte antworth, zu latein responsion oder aber durch exception befündtenten sachen nach gebührent antworthen.

\2 Demnach solle der kläger auf sothanne des beklagten responsion oder exception gebührent replicieren und seine replic-schrifft mit allen habenden zur sachen nöthigen beweiss-thumben bestättigen, gestalt demnächst der beclagter schuldtig sein solle darauf $\mathrm{zu}$ dupplicieren und darin gegenseithige replicam mit allen habenten elisionibus zu beantworthen.

\3 Quo prævio solle drossard, schultheiss und schöffen dem alten herkommen gemess die acta durchlesen, allegatorum probationes fleissig examinieren und nach reifflicher deliberation und erwegung die sach durch definitiv oder interlocutori urtheill deren beschaffenheit nach ohnparthë̈lich citatis partibus seu earundem constitutis procuratoribus determinieren.

$§ 4$ Solte dan die sach durch interlocutor-urtheill zu ferner probation angewissen werdten, als dan solle der actor oder reus die auferlegte probationes in einer schrifft genannt probation conclusion und submission schrifft einbringen, welche schrifft nebest beÿgefügten probationibus nachdeme dem gegentheill in copia communiciert, solle derselb verbundten sein selbige durch enervation oder general contradiction, conclusion und submission schrifft oder nach beschaffenheit durch inhæsion cum submissione zu beantworthen, gestalt nach also beÿderseiths beschlossener und submittierter sachen drossard, schultheiss und schöffen aus den acten definitive zu intelligiren.

$\S 5$ Solte aber drossard, schultheis und schöffen erachten die sach schwerer importanz zusein, oder auch von partheÿen begehrt werdten die acta einen unpartheÿschen rechtsgelehrten auszustehlen, als dan können die acta einem ohnpartheï̈schen juris consulto im 
reich zugestellt, dessen urtheill cum rationibus decidendi eingeholt und demnächst, nach vorgangener reifflicher consultation, pronuntiert werdten was rechtens.

$\int 6 \mathrm{Da}$ auch drossard, schultheiss und schöffen in votis discrepieren würdten, solle die urtheill nach den majoribus verfasset, oder sonsten die acta gleichfahls impartiali jurisconsulto ad referendum zugestelt werdten.

$\int 7$ Und weillen es sich offters begibt, das einige schöffen kranckh oder anderer unumbgänglicher notthurfft halber abwesend seint, als ordiniren das alle solchen fahls von drossard, schultheissen und dreÿen schöffen gefehlte definitiv urtheill je und alle zeit gültig sein sollen.

$\int 8$ Im urtheillen sollen drossard, schultheiss und schöffen vor allem auf unsere constitutiones reflexion nehmen und daselbige nicht über den bevorhabenten casum disponieren, alsdann nach den beschribenen gemeinen rechten urtheillen und die æquitæt respicieren, weegen verdammung in die aufgangene unkösten aber fleissigste obacht haben an temere litigatum vel causa litigandi subfuerit.

$\int 9 \mathrm{Da}$ nun so weith procediert wordten das mann durch urtheill immision erhalten, als dann sollen auf sothanne immision die erste proclamatoriales nach ersten monaths frist, die zweÿte nach zweÿtem monnath und die dritte nach verlauffenen dritten monnath publique affigirt oder in der kürchen abgelesen werdten, gestalt demnächst das evinciertes gueth beÿ subhastation und brenenter kertzen dem höchst biettenden zuverkauffen, vor ablauff obiger terminen aber stehet dem succumbenten freÿ das evinciertes gueth vermittels darlegung der pfenningen interesse und verursachter kösten zu redimieren.

$\int 10$ Weillen sonsten die partheÿen öffters die sach malitiose durch ihr ausbleiben zur eines oder anderen eusseristen schaden protrahieren, auch beÿ letzterem termin verscheidene erdichte ursachen allegieren, das ihnen noch mehrere termini gestattet werdten möchten, als statuieren das zu verhüettung dessen einer partheÿen mehr nicht dan dreÿ terminen gestattet werdten, der dritte aber peremptorius, præjudicial und pœnal sein solle, also das da das tempus jubentis termini von der partheÿen nicht in acht genohmen und a præjudicio salviert wordten, alsdann dis præjudicium oder pœna zu seiner würckhlichkeit gebracht und dem theill so nicht vigiliert, zum schaden gereichen solle; würdte aber die parthey ante lapsum termini præjudicialis vigilirt ein impedimentum legale allegiert und zugleich probirt und umb ferner dilation angesuecht und gebetten haben, alsdann solle noch ein terminus zu verstatten sein.

$\int 11$ Gleich mann ferner erfahren das durch der procuratorn alzulanges recessieren die audientien nicht wenig verlängert werdten, auch dieselbe wissentlich fauhle unrechtferttige sachen annehmen und zu des richters höchste incomodation zu verthättigen unterstehen, so verordtnen unter straff von 3 goldtgulden aus ihren eigenen shäckhel de facto zu entrichten, das alle procuratores der partheÿen intention schrifftlich per scripturas seu verbale in scripto mit einer kurtzer proposition ad prothocollum ÿbergeben, auch 
wissentlich oder notorie unrechtferttige sachen nicht vorbringen, weniger verthättigen, noch ihre feder zu scharff spitzen.

$\int 12$ Ingleichen da die partheÿen oder procuratores einige richtere vor suspect halten wollen, sollen sÿe ipso instanti in rechten bestehente ursachen der suspectation allegieren und zugleich probieren, widrigenfahls in vorgemelte straff krafft dess würcklich verfahlen sein.

\13 Gleichergestalt seint krafft dises alle abusen vermög deren die gegenwärthige partheÿen in judicio auch andere ein tag zuvorn, ob schon gleich dabey gewesen, citiert werdten, aboliert, und sollen alle citationes fahls nur dem citato möglich in præfigierter zeith zu comparieren gültig sein, exceptis diebus feriatis.

\14 Damit endtlich ein sicheres weegen der ferien statuiert sein möge, so ordinieren quo ad ordinariam cognitionem das in der arnzeit von 15 julÿ usque ad festum Bartolomæi, item von Weinnachtsfest bis nach Dreÿ Königentag, item acht vor Ostern und acht tag darnachern, wie auch acht tag vor Pfingsten und acht darnacher feriæ accuratæ observiert werdten sollen, vorbehaltlich doch dess iennigen so vermög rechten hierinfahls zuelässig.

Afschrift van een niet meer bewaard gebleven gedrukt origineel, bijlage bij brief van 16 juni 1757 van de Gronsveldse grafelijke commissaris J.A. Prummer aan Maximilian Emanuel graaf von ToerringJettenbach te München.

Staatsarchiv München, Archiv Toerring Jettenbach, inv. nr. M 13, fol. $29-69$.

7C Ertz-Stiffts Cöllnische Rechts-Ordnung

NB De inhoudsopgave is hier aangegeven om het het overzicht te vereenvoudigen, maar staat niet in het origineel.

Titulus I Von testament und letəțten willens vermächnuß.

Titulus II Von erbschafft ohn testament in auffsteigender linien.

Titulus III Von erbfolgung in absteigender linien.

Titulus IV Von erbung der elteren mit und neben des verstorbenen kindts bruder-und schwester-oder der derselben kinderen.

Titulus $V$ Von erbung auff der seitenlinien.

Titulus VI Wie deren von der ritterschafft töchter, wie auch die söhn (wan deren mebr als einer im leben) ibre elteren und sich undereinander erben.

Titulus VII Wie die lehn in diesem ertæstifft geerbt werden sollen.

Titulus VIII Wie eheleute einander erben sollen.

Titulus IX Von dem besitz, oder gewehr der erledigter erbschafft.

Titulus XV Von der einkindtschafft. 
Titulus XI Von vormünderschafften.

Titulus XII Von kauffen und verkauffen.

Titulus XIII Von pfandtschafften.

Titulus XIV Von pfachtungen.

Titulus XV Vom einstand oder wider₹ug, ₹u latein ius retractus genant.

Titulus XVI Von verjabrung der stehender rhenten oder zinsen.

Ertz stiffts Cöllnische Rechts-Ordnung des hochwürdigst[en] und durchleuchtigsten fürsten und herren, herren Maximilian Henrichen, ertzbischoffen zu Cölln, des Heiligen Römischen Reichs durch Italien ertzcantzlern und churfürsten, bischoffen zu Hildeßheimb und Lüttig, administratorn der stiffter Berchteßgaden und Stablo, in Obund Niedern Bäyeren, auch der Obern Pfaltz, in Westphalen, zu Engern und Bullion hertzogen, pfaltzgraffen bey Rhein, landgraffen zu Leuchtenberg, marggraffen zu Franchimont $\mathrm{u}$.

cum gratia \& privilegio gedruckt in der churfürstlicher residentz statt Bonn durch Henricum Iansenium, vereydeten buchtrucker anno MDCLXIII.

Wir Maximilian Henrich von Gottes gnaden ertzbischoff zu Cölln, des Heil[igen] Römischen Reichs durch Italien ertzcantzler und churfürst, bischoff zu Hildeßhaimb und Lüttig, administrator zu Berchtesgaden und Stablo, in Ob- und Nideren Bäyren, auch der Oberen Pfaltz, in Westphalen, zu Engern und Bullion hertzog, pfaltzgraff bey Rhein, landtgraff zu Leuchtenberg, marggraf zu Franchimont, etc. fügen hiemit allen unseren geist- und weltlichen räthen, beambten, richteren, vögten, schultheißen, scheffen, bürgermeisteren, auch allen unseren bedienten, underthanen, und sonsten menniglichen, wes standts oder würden die seyen, ins gemein zu wißen; demnach wir bey uns betrachtet, einer jeder ordentlicher obrigkeit vornembstes ambt in deme zubestehen daß sie dahin sorglich sehen solle, auff daß die ihro von Gott unbefohlene underthanen in gleichheit und rechten erhalten, und menniglichen die justitz unpartheylich, und zwar ohne vergebliche und unnöhtige unkösten und umbführung ertheilt werden möge. Und dan wir under wehrender unserer churfürstlicher regierung angemerckt, daß viele schädliche und kostbahre streitigkeiten bey denen gerichteren auß deme entstanden, daß die partheyen ein- oder anderseits sich entweder auff gemeine landts- oder aber absonderliche statt- oder ambts hergebrachte, von denen beschriebenen rechten abweichende gewonheiten beruffen, und da solche von dem gegentheil nicht gestanden, sondern wiedersprochen, eine große zeit mit dern beweißthumb hinlaufft, under deßen aber mancher an seinem rechten mangel leiden, oder doch damit zu großem seinem schaden und nachtheil auffgehalten werden muß, zu deme auch der vielerley underscheidt der gebrauch, so von orth $\mathrm{zu}$ orth offtmahl vorgebracht, den richter nit wenig irr macht: so haben wir, zu vorkommung solcher ungelegenheiten, eine notturfft erachtet, alle dieses ertzstiffts gewonheiten in schrifften kürtzlich abfassen zu laßen, und jedermenniglichen kundt zu machen, damit so wohl die partheyen in befangung ihrer processen, als die richtere in begreiffung der urtheil sich darauß ohne weitläuffigkeit zu belehrnen, und darnach zu achten haben; und sollen nun diesem nach alle andere gewonheiten und gebrauche, die 
hierin außtrücklich nicht gesetzt oder benamset, wie sie auch beschaffen sein mögen, ohne einige außnahm, für nichtig und krafftloß erkent und erklärt sein, sondern außer derselben alle ander fälle nach denen gemeinen beschriebenen rechten erörtert und abgeurtheilt werden.

Titulus I

Von testament und letzten willens vermächnuß

$\int 1$ In unserm ertz stifft aller orthen ist einem jeden, deme es sonsten vermög gemeiner rechten nicht absonderlich verbotten, uber seine haab und güter ohn underscheid, ob sie in gereidt-, fahrenden, beweglichen, oder in ligenden unbeweglichen güteren bestehen, ob sie anerwonnen, oder angeerbt seyen, seinen letzten willen oder testament auffzurichten erlaubt.

$₫ 2$ Ein solcher letzten will oder testament mag vor notario, dem geschwornen gerichtoder stattschreiber, oder pastorn des orts, wa der actus vorgehet, und zween scheffen in den stätten, auff dem land aber zween anderen darzu erforderten zeugen gultig auffgerichtet werden. es soll aber daßelb, wan schrifftlich testirt wirdt, von dem notario, gericht: oder stattschreiber, oder pastorn und denen zween scheffen in den stätten, oder zeugen auff dem landt underschrieben sein, zu pestzeiten aber mögen in denen stätten an statt der scheffen zween andere zeugen, gleich wie auff dem landt, gebraucht werden.

\3 Wan aber jemand gerichtlich testiren will, mag er in gegenwart des gerichtschreibers und zween scheffen sein testament äigenhändig underschrieben verschloßen oder unverschloßen vorbringen, und dem gerichtschreiber zum gerichts protocoll zulegen außantworten, der dan alßbaldt allsolchen außantwortungs actum auf das testament schreiben soll.

$\S 4$ Will einer sein testament von mundt außsprechen, soll er den nahmen deßen, den er zum erben einsetzt, und was er sonsten darin begriffen haben will, vor dem notario, gericht- oder stattschreiber, oder pastorn und zween scheffen in den stätten, und auff dem landt zween dazu beruffenen zeugen offentlich und klarlich benennen.

\5 Wan der testirer des pastorn, gericht- oder des stattschreibers, oder notarii, wie auch in den stätten der scheffen nicht mächtig sein kan /oder sonsten sich ihrer zugebrauchen bedenckens hette, mag er an statt einer jeder auß diesen abgehender person zween andere zeugen dazu beruffen.

$\int 6 \mathrm{Da}$ das testament von mundt außgesprochen, soll der notarius, gericht- oder stattschreiber, oder pastor, oder aber, wan in mangel deren zween andere zeugen gebraucht werden, jemandt von denselben die vermächnus alßbaldt verzeichnen, und dem testirer und zeugen vorlesen, zumahl sonsten hernacher auß dem zeugnus oder ubel 
eingenommener meinung des testirers leichtlich irrungen und streitt entstehen könten, im widrigen, da solches nicht in acht genommen, soll das testament krafftloß und von unwürden sein.

$\int 7$ Gleich wie in diesem ertzstifft löblich hergebracht, daß in denen vermächnüßen durch letzten willen des zeitlichen ertzbischoffen und unserer thumbkirchen zu cölln mit einem turnus oder mehrerm, nach des testirers gutem eiffer, pflegt gedacht zu werden, also sollen die notarii, pastores, oder andere zu verfertigung des testaments oder letzten willens gebrauchende personen den testirer jedesmahls erinneren, berürte gute gewonheit nicht außer acht zulaßen.

$\int 8$ Es stehet einem jedem frey, uber seine verlaßenschafft gantz oder zum theil, auch ohn einsetzung eines oder mehr universal erben durch letzten willen zuverordnen, und soll alzeit die codicil-clausul, wan sie schon nicht gemelt worden, darin verstanden werden, daß nemblich der ubriger theill der erbschafft, deren in der vermächnus nicht gedacht worden, bey den negsten anverwanten, welchen solche sonsten von rechts wegen gebürth, und zwar ohn abzug der falcidiæ oder trebellanicæ, verbleiben solle.

$\int 9 \mathrm{Im}$ fall nun die erbschafft durch particular- oder stückweise geschehene vermächnus gantz erschöpfft, also daß sich nicht niemand für erben angeben wolte, und aber schulden auf der erbschafft zubezahlen hafften, so sollen die legatarii nach proportion oder ertrag ihrer vermächnuß oder giffte so viel fallen laßen oder beytragen, als zu bezahlung der schulden vonnöhten, sie aber uber den wehrt alsolcher gifft (wan nur inventarium oder verzeichnus der gantzer erbschafft gebürend auffgerichtet) nicht verbunden sein.

$\int 10$ Wan elteren under ihren kinderen, der theilung halber, verordnung hinderlaßen wollen, ist gnug, daß sie ihren willen mit äignen händen beschreiben, und mit ihrem nahmen mit jahr und tag underzeichnen, und soll solches under den kinderen, wan schon keine zeugen darzu gebraucht, gultig sein.

\ 11 Auf gleiche weiß mag ein vatter oder mutter ihren kinderen oder beyderseits groß elteren ihren encklen, wan vatter oder mutter vorher verstorben, auf den fall sie in unvogtbaren jahren mit todt abgehen würden, einen affter erben ansetzen in den jenigen güteren, die vom testirer herrühren, jedoch durch solche substitution oder affter erbsatz des kindts hinderbleibendem vatter oder mutter ihr natürliches antheil oder nohtgebürnus, zu latein legitima genant, nit benehmen.

$\int 12$ Ein jeder mag seine erbschafft mit einem fideicommiß oder afftervermächnus nach belieben beschweren, jedoch soll denen kinderen ihr nohtgebürnus oder legitima alzeit frey bleiben, andere eingesetzte erben aber sollen den vierten theil, zu latein trebellanicam, davon außzuziehen oder abzukürzen nicht befügt sein, sondern hierin, wie sonsten allenthalben, des testirers verordnung auffs genawist nachgangen werden. 
\13 Obgemeltes fideicommiß oder afftervermächnus soll weiter als auff den dritten erben, den erst eingesetzten mit einschließlich, unerachtet der testirer ein anders verordnet, nicht gültig sein, sonderen die güter, so baldt sie in die vierte handt vererben, wieder in ihre freyheit kommen, und zu des besitzers willkührlicher disposition stehen.

\14 Wan zwey eheleuth zu behueff ihrer kinder einsambt-testament, wie es nemblich under ihnen mit beyderseits güteren gehalten werden soll, aufrichten, kan nach absterben des einen der letztlebender solches nit enderen, sonderen ist es auch in seinen eigenen güteren, so viel er deren bey stehender ehe beseßen, zuhalten schuldig, in denen aber hernach im wittibstand gewonnenen bleibt ihm eine ungebundene handt.

Titulus II

Von erbschafft ohn testament in auffsteigender linien

\1 Wan vatter oder mutter ohn testament oder ordnung ihres letzten willens mit hinderlassung eheleiblicher kinder (worunder auch die jenige, so zwarn unehelich gezeugt, aber durch hernach folgenden ehestandt geehligt worden, mit zuverstehen) hinsterben, sollen selbige kinder alle vätterliche und mutterliche haab und güter fahrend und ligend zu gleichen theilen erben, wa aber enckelen oder urenckelen in rechter absteigender lineen vorhanden, tretten dieselbe alzeit in ihrer abgangener elteren platz, und erben mit des verstorbenen anhern oder uranhern kinderen in stämme, gleich wie ihre elteren, wan sie noch im leben weren, wurden geerbt haben.

$\S 2$ Da aber man oder fraw vorhin im ehestandt gewesen, kinder darin gezeugt, und nach absterben des ehegatten zu der zweiter und mehreren ehen geschritten, und darin auch kinder gezielet, weiln die kinder erster und folgender ehe, der natur und geburt nach, ihrem gemeinen vatter oder mutter gleich nahe seind, so bleibt es auch, der erbschafft halber, billich bey verordnung der algemeiner beschriebener rechten, daß nemblich alle solche kinder, ohne underscheidt der ehe, darin sie geboren, ihren vatter oder mutter in deren zugebrachten eigenthumblichen, oder auch von ab-, auffsteigender, oder seiten linien durch erbschafft in erster, zweiter, oder fernerer ehe anerfallenen güteren zu gleichen theilen erben sollen und mögen, es seye dan sach, das die pacta der vorhergehender ehe, wegen der erbschafft eines oder beyder ehegatten, auff den künfftigen fall des gebrochenen ehebets, eine andere verordnung mitbringen, dan solche in alle weg statt haben, und denselben ohne widerred eingefolgt werden soll.

$\$ 3$ Die in jeder ehe anerwonnene ligende oder unbewegliche güter (warin auff jahr renthen angelegte gelder, sie seyen loßbar oder nit, ohne underscheid alzeit und allenthalben mit verstanden werden) sollen bey der jeniger ehe kinderen, darin sie gewonnen, verbleiben; wie es aber mit deren nießlicher nutzbarkeit, so dan den fahrenden oder beweglichen güteren zuhalten, ist hierunder bey dem 8. titul von den eheleuthen vermeldet. 
$\int 4$ Im fall ein sohn oder tochter, ehe sye das fünff und zwantzigst jahr ihres alters erfüllet, ohn ihrer leiblicher elteren vatters oder mutter wissen und willen sich verheyrathet, sollen sie zwar dadurch ihres naturlichen antheils oder legitimæ an der vatter- oder mutterlicher erbschafft nicht entsetzt werden können, weilen sie aber dadurch eine große undanckbarkeit gegen ihre elteren begehen, sollen dieselbe bey ihren lebzeiten ihnen einig heyrathguth zugeben nicht schuldig sein.

$\int 5$ Denen in geistlichen orden eingetrettenen söhnen oder töchteren sollen die elteren schuldig sein, vor dem gelübd oder profession, nach gestalt ihres vermögens, eine billigmeßige außstewr, als etwa von einhundert biß in tausend thaler cöllnisch zum höchsten, zuverschaffen; wan man sich aber darüber beyderseits nicht würde vergleichen können, soll die obrigkeit darin eine billiche mäßigung treffen, und damit der geistlicher sohn oder tochter von der elterlicher verlaßenschafft, wie auch allen bey- oder seitenfällen gentzlich abgegütet und verziehen sein; wan auch solches durch die geistliche söhn, töchter, oder deren ordens oberen versaumbt oder verschoben, soll nicht desto weniger hernach die obrigkeit darin gebührende verordnung zustellen macht haben.

$\int 7$ Und wan etwa hernach eine solche geistliche person nach beschehener profession auß ihrem orden außtretten würde, soll dieselbige zu den elterlichen oder anderen anerfallenen güteren durchauß keinen zutritt mehr haben.

Titulus III

Von erbfolgung in absteigender linien

$\int 1$ Wan ein kindt mit todt abgehet, und keine erben in absteigender linien, als söhne, töchter, oder enckelen, oder auch keine brüder, oder schwesteren von beyden seiten, noch auch deren kinder im ersten gradt verlaßet, so erben des gestorbenen kindts vatter und mutter seine verlaßene ligende haab und güter, dieser gestalt, daß der vatter die jenige, so von vatterlicher seiten, und die mutter die jenige, so von mutterlicher seiten auff das gestorben kindt kommen, vorab nehmen, alle ubrige under sich gleich theilen.

$\$ 2$ Wan aber endweder der vatter oder mutter mit todt abgangen, so erbt das ander, so noch im leben, alle des kindts haab ohn underscheidt woher solche auff daßelb ${ }^{2228}$ kommen, vor allen anherren und anfrawen und allen anderen freunden.

$\int 3$ Da vatter und mutter nicht im leben, so erben die verlaßene ligende güter, so von vätterlicher seiten an das gestorben kindt kommen seind, anherr und anfraw von dem vatter vorab, deßgleichen die von mutterlicher seiten kommende ligende haab und güter anherr und anfraw von der mutter auch vorab, und die andere ubrige haab und güter erben anherr und anfraw von beyden seiten mit einander.

2228 Origineel: dasseb 
\4 Wan aber allein ein anher und anfraw, uranher oder uranfraw des gestorbenen kindts von vatter oder mutter seiten im leben, der oder die erben allein so viel, als anher und anfraw oder uranherr und uranfraw von beyden seiten zusammen, wan sie zugleich im leben weren.

$\int 5$ So lang ein anherr oder anfraw im leben, werden uranherr und uranfraw von der erbschafft ohne underscheidt woher die güter kommen, außgeschlossen; wan aber kein anherr und anfraw im leben, so erben die uranherr und uranfraw in aller massen, wie von den anherren geschrieben ist, vor allen anderen verwandten, auch vor den geschwistrigen von einer seiten und derselben kinderen.

$\int 6 \mathrm{Da}$ aber das verstorben kind an vatter: oder mutterlicher seiten nur einen anherrn oder anfraw, uranherrn oder uranfraw, und an der anderen seiten beyde so woll anherrn als anfraw, oder uranherrn und uranfraw noch im leben hette, soll zwar, wie oben von vatter und mutter gemelt, ein jeder theil in den ligende güteren, so von seiner seiten herkommen, vorab erben, alle ubrige güter aber in zwey gleiche theile, und davon die eine halbscheidt auff den einen anherrn oder anfraw von vatter oder mutter, die andere aber auff beyde anherrn und anfraw von der andern seiten verfallen.

\section{Titulus IV}

Von erbung der elteren mit und neben des verstorbenen kindts bruder- und schwesteroder der derselben kinderen.

$\int 1$ Wan das abgestorben kindt hinder sich vollbürtige brüder oder schwestere, oder derselben kinder im ersten gliedt im leben verlaßet, so erben dieselbe mit des abgestorbenen kindts vatter und mutter, oder vatter allein, wan die mutter vorhin gestorben, oder mit der mutter allein, wan der vatter vorhin mit todt abgangen, und da weder vatter noch mutter im leben, alßdan mit den anherren und anfrawen, oder wan deren auch keine mehr vorhanden, mit des abgestorbenen kindts uranherrn oder uranfrawen alle haab ohn underscheidt, je eine person so viel als die andere, doch sollen der brüder- oder schwester kinder, ihrer seyen viel2229 oder wenig, nicht nach den häupteren oder zahl der personen, sonderen in stämme, nemblich an statt ihrer vatter und mutter erben, und mehr nicht, dan ihr vatter und mutter geerbt hetten, wan sie im leben geblieben weren.

\2 Da nach tödtlichen abgang vatters oder mutter das abgestorben kindt an einer seiten nicht mehr, dan ein an- oder uran hinder sich verließ, und auff der ander seiten zween anoder uran sambt vollbürtigen brüderen oder schwesteren, oder derselben kinderen, so werden dieselbige anherren oder uranherren, anfraw oder uranfraw auff der ander seiten beyde für eine person gerechnet, und erben auch beyde nicht mehr, dan eines von des abgestorbenen kindts vollbürtigen brüderen oder schwesteren, oder deren eines kinder alle erben mögen.

${ }^{2229}$ Origineel: veil 
Titulus V

Von erbung auff der seitenlinien

$\int 1$ Wan der verstorbener in ab- oder auffsteigender linien 2230 niemand, sondern volbürtige brüder oder schwesteren, oder derselben kinder im ersten gliedt hinder sich verlaßet, alßdan erben dieselbe gleich mit einander vor allen anderen verwandten, auch vor ihrer volbürtiger brüder oder schwester enckelen, wie auch vor brüder: und schwesteren von einer seiten und derselben kinderen.

\2 Jedoch erben der brüder oder schwester kinder, ihrer seyen viel oder wenig, mit des verstorbenen bruder oder schwester, wan deren noch im leben, in die stämme, und mehr nicht, als ihr vatter oder mutter geerbt hette.

$\int 3$ Da aber der verstorbener keine volbürtige brüder oder schwester, aber wol deren kinder im leben verlaßet, alßdan erben dieselbe, ihrer seyen von einem oder mehr bruder oder schwester viel oder wenig, alle samptlich in die häubter zu gleichen theilen.

$\int 4$ So aber keine volbürtige brüder oder schwesteren, noch deren kinder im ersten gliedt vorhanden, alßdan erben die einseitige oder halbbürtige brüder und schwesteren und deren kinder vor allen anderen anverwandten, auch vor des verstorbenen vatters oder mutter brüderen und schwesteren ohn underscheid, wa die güter herrühren, auff gleiche weise, wie von den volbürtigen gemeldt worden.

$\int 5$ Jedoch wan der verstorbener zweyerley einseitige brüder oder schwesteren, oder deren kindere, nemblich eine von dem vatter und die andere von der mutter verlaßet, alßdan sollen die brüder oder schwesteren von der vatterlicher seiten und deren kinderen im ersten gliedt die jenige ligende güter, so von dem vatter herrüren: und hingegen die brüder und schwestern von der mutterlicher seiten die mutterliche ligende güter vorab erben.

S 6 Wan keine vol- oder halbbürtige brüder oder schwesteren, noch von denselbigen kinder im ersten gliedt im leben, so erbt jeder negster blutsverwanter des verstorbenen verlaßenschafft ohn underscheid mänliches oder weibliches stammens, es rühre die verwandtschafft von einem bandt her oder von beyden, auch ohn underscheidt von welcher seiten die güter herkommen, und solches in das zehend gliedt der verwandtschafft, dergestalt, daß jedesmahls eine geburt für ein gliedt, nach verordnung der gemeiner beschriebener rechten, zurechnen.

\section{Titulus VI}

Wie deren von der ritterschafft töchter, wie auch die söhn (wan deren mehr als einer im leben) ihre elteren und sich undereinander erben

${ }^{2230}$ Origineel: lenien 
$\int 1$ Demnach die gesambte ritterschafft dieses unsers ertzstiffts auff gemeiner landtags versamblung uns zuerkennen gegeben, daß von alters zwar so woll in hiesigem ertzstifft, als anderen benachbarten landen im brauch gewesen, daß zu erhaltung der adlicher familien, stammens und nahmens dem eltisten sohn das also genantes adliches vortheil vorab außgefolgt, wie auch denen töchteren eine sichere summ gelts zur außsteurung und heyraths gutt gegen verzieg der elterlicher verlaßenschafft mit gegeben worden, so aber eine zeithero von etlichen zu verderb und undergang der ritterschafft in streit gezogen werden wollen, und derowegen gebetten, zu verhütung aller künfftiger irrungen dieserthalb eine bestendige verordnung verfaßen, und diesem unserm landtrechten mit einverleiben zulaßen; und dan wir solches der billigkeit, auch anderer benachbarter landen gewonheit gemeeß befinden; so setzen und ordnen wir hiemit: erstlich, daß hinführo besagter von der ritterschafft töchter, wan söhne vorhanden, einen sicheren pfenning oder stück von der erbschafft für heyrahtsgutt von denen elteren oder brüderen anzunehmen und damit sich begnügen zu laßen schuldig sein, und zu den elterlichen erbgüteren ferner und zumahl keinen zugang und ansprach haben, sondern davon außgeschloßen sein und bleiben sollen.

\2 Für solches heyrathsgut sollen vatter, mutter, oder brüder ihren töchteren oder schwesteren ein mehrers nit, als nach ertrag ihrer mittelen oder vermögens, und (da zweiffel oder irrungen darüber vorfielen) der anverwanten gut befinden, nemblich ein-, zwey-, drey-, vier- und zum höchsten fünfftausend reichsdaler, gleich bey der verheyrahtung entweder baar, oder mit jahrlicher pension, gegen gnugsambe versicherung, biß zur abloß, nebenst denen mutterlichen kleinodien und leibs schmuck nach der mutter todt zu geben verbunden sein.

$\int 3$ Da aber nur ein sohn und nicht viel schwesteren vorhanden, das vermögen aber gar groß, alßdan sol in der negster anverwandter und anderer dazu ziehender guter freunden ermeßung stehen, was etwa mehrers vorgemelter summen beyzulegen.

\4 Die ubrige hochzeitliche außrüstung soll auch ehrlich, jedoch weiter nicht, als nach ertrag und proportion des heyrats guts, durch die elteren oder brüder geleistet und gefolgt werden.

$\int 5$ Solchem nach sollen die töchter nit allein von der elterlicher verlaßenschafft, sondern auch von der brüder beyfäll der stock- und stamgüter, auch ohne absonderliche mündtoder schrifftliche renunciation oder verzieg für allerdings abgegütet gehalten werden.

\6 Wan aber einer oder mehr von den brüdern ohn kinder verstirbt, und anerwonnene güter verlaßet, alsdan soll dazu, wie auch zu dem gereiden oder fahrnus den schwesteren nebenst den uberlebenden brüdern und deren vorverstorbener kinderen der zutritt unbenommen sein, und es damit gehalten werden, wie oben in dergleichen erb- und sterbfällen verordnet. 
$\int 7$ Dafern sich ein seit- oder beyfall bey des vatters oder der mutter bruder oder schwester, deren kinderen, oder kindtskinderen und weiter hinab begibt, sollen die töchter und deren kinder, kindtskinder und die von denselben ferner entsprossen, gleichfals von des abgestorbenen hinderlaßenden steck- und stamgüteren, nemblich die von gemeinen elteren herrüren, nach obgesetzter proportion des heyratguts und außrüstung durch des abgestorbenen stams verwandte mit einer summen gelts abgeliebt werden, in allen ubrigen seitfälligen güteren aber mit den brüderen und anderen anverwanten zu gleichen theilen erben.

$\int 8$ Obberürte satz- und verordnung der töchter außsteurung soll alsdan nicht platzhaben, noch die schwestere dem bruder von den elterlichen güteren zu weichen schuldig sein, wan die brüdere alle sich dergestalt mißheyraten würden, daß ihre erben sich zu landtägen under dem ritterstant rechtlicher gebür nicht qualificiren könten, sondern soll in solchem fall denen töchteren bevorstehen, mit selbigen brüderen die elterliche verlaßenschafft ohn abzug eines adlichen vortheils in capita abzutheilen.

$\int 9$ Im fall aber hernacher dergleichen mißheyrahteten brüders nachgelaßene söhne sich wieder an solches standts personen, deren geschlecht und ahneten zu landtägen under dem ritterstandt qualificirt, vermählen würden, soll es widerumb under ihren kinderen in erb- und theilung nach inhalt obiger disposition gehalten werden.

$\int 10$ Wafern die töchter ohn vorwissen und belieben der elteren sich, obwoll an standts gleiche adeliche personen vor dem fünff und zwantzigsten jahr ihrers alters verheyraten würden, sollen sie von ihren elteren bey deren lebzeiten einig heyratsgutt zu fordern nicht befugt sein, sonderen erst nach deren todt das jenig, was denen gehorsamen schwesteren in capitali oder haupt summen mitgegeben, zuerlangen haben, die jenige töchter aber, so sich wider oder ohn ihrer elteren willen mißheyraten würden, sollen nicht allein bey lebzeiten der elteren nichts, sondern auch nach deren absterben mehr nicht, dan den dritten theil deßen, was denen gehorsamen schwesteren zugelegt worden, zu forderen haben.

$\int 11$ Damit nun aber die töchter solches heyrats guts von ihren brüderen, da selbiges von den elteren bey lebzeiten nicht entrichtet, versichert sein mögen, sollen die brüder, ehe sie zur erbtheilung schreiten, mit den schwesteren obgemelter außsteur: und außrüstung halber richtigkeit $\mathrm{zu}$ machen, und sie oder deren vormündere deßfals zu versicheren verbunden, denen töchteren auch dafür die elterliche verlaßenschafft absonderlich (wie ohn das die gemeine rechten mitbringen) verstrickt sein und bleiben.

$\int 12$ Wan nun die schwestere obgesetzter maßen abgegütet, sollen die ritter erb- und güter under denen brüderen mit diesem underscheidt getheilt werden, daß nemblich im fall nur ein eintziges stamhauß oder adelicher sitz vorhanden, solchen der eltister sohn sambt deßen graben und beyfang, auch was darin gelegen, als garten und baumgarten, auch daselbst vorhandenes geschütz und was im haus nagelfast ist, neben darzu gehöriger iurisdiction und darabfallender nutzbarkeit, jagt und wilder fischerey auff fließendem 
wasser vorab ohne einige erstattung nehmen und behalten möge, und annebenst die negst bey dem stamhauß gelegene länderey dem eltisten, die abgelegene länderey aber dem jungeren sohn, jedoch mit dem beding verbleiben, das vom selbigen theil, so in natura besser als das ander, deßfals gebürende erstattung geschehen solle.

\13 Wan aber mehr adeliche häuser oder sitz vorhanden, und der eltister bruder darauß eines erwehlet und vor abgenommen, alsdan soll der zweiter bruder das andere hauß oder sitz ebener gestalt vorauß zunehmen berechtiget sein, und es also fort mit dem dritten und folgenden brüdern, dafern noch mehr haüser vorhanden, gehalten werden.

\14 Im fall der abgestorbener vatter mehr güter aüßerhalb dieses ertzstiffts in anderer herren landen, wo das adelich elterlich vortheil auch in ubung ist, in besitz gehabt, soll der eltister sohn sich alsolches vortheils nur an einem ort zugebrauchen befügt sein, und wan er anders wo ein hauß oder sitz erwehlet, sich deßen in hiesigem ertzstiff nicht anzumaßen haben, sonderen verlustig sein.

\15 Wan aber einer von den brüderen sich mißheyratet, alsdan solle er dieses adelichen vortheils nicht fähig, sondern solche gerechtsame auff den folgenden ständmeßig geheyrateten bruder devolvirt sein.

\16 Dafern nun aber keine söhne vorhanden, in solchem fall soll es wegen des adelichen vortheils mit denen töchteren, gleich wie oben von den söhnen verordnet, gehalten werden.

\17 Obiges alles ist zuverstehen, wan die elteren ihrer güter halber under ihren kinderen oder sonst kein testament oder letzten willen auffgerichtet, dan den selben hierdurch andere disposition ihres gutbefindens zumachen unbenommen sein soll.

\section{Titulus VII}

Wie die lehn in diesem ertzstifft geerbt werden sollen

Alß der lehn succession halber und sonderlich, ob die töchter und weibliche anverwandte derselbigen fähig oder nicht, vor diesem vielfaltig gestritten worden, und aber darüber im jahr 1659, den 28. juny ein vergleich auff gerichtet, so wird derselb zu männigliches nachricht dieser ordnung von wort zu wort einverleibt:

Kundt und zuwißen seye hiemit, alß zwischen dem hochwürdichst[en] und durchleuchsten fürsten und herren, herren Ferdinanden, ertzbischoffen zu Cöllen, des Heiligen Römischen Reichs durch Italien ertzcantzelern und churfürsten, bischoffen zu Paderborn, Lüttig und Munster, administratoren der stiffter Hildesheimb, Bergtesgaden und Stabul, pfaltzgraffen bey Rhein, hertzogen in Ob[ern] und Niedern Bäyern, Westphalen, Engern und Bullion, margaraffen zu Franchimont u. hochseligster gedächtnus, und der löblicher ritterschaff dieses ertzstiffts Cöllen, der lehngüter halber schon vor geraumer zeit irrungen und mißhelligkeiten eingefallen, in dem berürte ritterschafft dafür halten wollen, daß die von diesem ertzstifft dependirende lehn vermög einer unvordencklicher landts gewonheit 
für gemeine durchgehende lehn, deren so woll weibs- als mans personen fähig zuachten seyen, hingegen aber ihre churfürstl[iche] durchl[euchtigkeit] solcher gewonheit nicht gestendig, sondern sich an die gemeine lehnrechte so woll, als von vielen römischen keyseren erlangt $[\mathrm{e}]$ und hergebrachte privilegia, concessiones \& sententias, die alle das wiederspiel nachführen theten, gezogen, und vermög derenselben befugt zu sein vermeint, auff den fall abgehend: und erleschenden manstammens sich deren lehen zunäheren und dieselbe zu ihrer cammer einzuziehen, oder sonst ihrem belieben nach darüber zu disponieren, und dan diese sach anfänglich im jahr 1620 zum comprimis auff gewiße form und $\mathrm{ma} \beta$ gestelt, solches auch hernach im jahr 1639 zu reassumiren nachmals beliebert, folgents aber berürte ritterschafft der jetzt regierender churfürstl[iche] durchl[leuchtigkeit] hertzog Maximilian Henrichen in Beyern u[nd] unserem gnedigsten herren zu mehrmahlen underthenigst zuerkennen gegeben, daß sie mit deroselben, alß ihrem gnedigsten landts fürsten, ungern in proceß und streit stehen wolten, und derentwegen hochflehentlichst gebetten, ihre churfürstl[iche] durchl[euchtigkeit] entweder diese action fallen zulaßen, und die feuda pro communibus zuerkenen, oder aber einen billigmeßigen vergleich darüber behandelen zulaßen, gnedigst geruhen wolten; damit dan nun höchstgemelte churfürst[iche] durchl[euchtigkeit] ihre zu der löblicher ritterschafft tragende näigung und gewogenheit desto mehr an tag geben möchten, so haben sie mit vorwissen und belieben eines hochwürdigen thumbcapittuls in solche gutliche handlung gnädigst einverstanden, welche dan nach vorgangener vilfaltiger mündlicher underredung folgender gestalt geschlossen:

$\int 1$ Erstlich thun ihre churfürstl[iche] durchl[euchtigkeit] austrücklich vorbehalten, auch vorberürte ritterschafft underthenigst und gutwillig nachgeben /daß die jenige lehen, worin der tenor investituræ mit klaren worten auff manlehn gerichtet, auch hinfür an für rechte manlehen gehalten, und die töchter von deren sucession allerdings außgeschloßen sein und bleiben, sondern wan der a primo acquirente herkommender manstam außstirbt, alsdan ihre churfürstl[iche] durchl[euchtigkeit] und deren successores gute macht und fug haben sollen, alsolche lehen wiederumb einzuziehen, und ihnen anzuheimschen; damit auch dieserthalb künfftiglich keine newe irrungen zubefahren, ist alsolcher manlehen halber eine gewiße specification under ihrer churfürstl[iche] durchl[euchtigkeits] insigel verfertiget, und mehrgemelter ritterschafft zur nachrichtung außgeantwortet worden, wamit es gleichwohl diesen verstandt haben soll, daß weilen underschiedliche lehen in solcher specification begriffen, welche durch seligstgemelten churfürsten Ferdinand eingezogen, und anderen ex nova gratia zum manlehn widerauffgetragen, diese qualitas masculinitatis nur die jetzige vasallos und deren lehnfolgere afficiren, im fall aber selbige lehen an der voriger lehnträger an- vel cognatos entweder mit recht oder durch gütliche weg nach inhalt des folgenden dritten articuli wiederumb kommen würden, sollen sie in ihrer voriger natur und eigenschafft verbleiben, und es damit, wie in 4to articulo disponirt, gehalten werden, wabey dan auch dieses verabschiedet, daß niemandt sein lehen zu manoder newen lehen, zu nachtheil deren a stipite acquirente herrürender an- \& cognatorum und ihres daran habenden juris quæsiti, zu machen und auffzutragen befügt sein soll. 
\2 Gleicher gestalt zweytens, wo die investitur von beyderley geschlecht man- und weibs personen außtrücklich meldung thun, da sollen die töchter oder weibs personen zur succesion deren lehen ohn einige waigerung zugelaßen und verstattet, jedoch auff begebenden fall selbige durch eine mansperson behörlich bedient und vertretten werden.

\3 Drittens, obwoln die löbliche ritterschafft zum inständigsten angehalten, daß die jenige lehen, diewelche von der negstvoriger abgeleibter so wol, als jetziger churfürstl[iche] durchl[euchtigkeit] alschon eingezogen, oder anderwertlich conferirt, den prætendirenden anverwandten restituirt und wider eingeraumbt werden mögten; so haben doch ihre churfürstl[iche] durchl[euchtigkeit] sich deßen, weilen res nit mehr integra, beschwert, zumalen ihro sehr bedencklich fallen wolle, da die jetzige possessores mehrentheils selbige lehen mit ansehentlichen geldsummen redimirt, und titulo oneroso an sich gebracht, sich dieserthalb der eviction zuunderwerffen, derentwegen dan beliebt und verglichen, daß alsolche eingezogene und anderwertlich conferirte lehen von dieser transaction zwarn außgeschlossen, jedoch aber den prætendenten der weg rechtens coram paribus curiæ und sonsten quovis meliori modo darzu unverspert gelaßen sein, vor allem aber zwischen denselben und denen possessoribus gütliche vergleichungs handlung angestelt werden soll, die dan ihre jetziger churfürstl[iche] durchl[euchtigkeit] auch dergestalt, wie es der billigkeit zu aller änhligsten sein wirdt, vermittelen zuhelfen sich angelegen sein laßen wollen.

\4 Viertens betreffend die jenige lehen, so informiter, nemblich ohne meldung manlichen oder weiblichen geschlechts, bis herzu conferirt und verliehen worden, laßen ihre jetziger churfürstl[iche] durchl[euchtigkeit] gnädigst geschehen, daß im fall entweder gar keine manliche lehenfolger, oder doch in pari cum fœminis vel remotiori gradu vorhanden, alßdan die töchter oder weibspersonen a primo acquirente entsprossen darin (jedoch der adelicher gewonheit und prærogativæ mit abgütung der töchter unnachtheilig) zur succesion admittirt, und also die weib- und mänliche agnaten promiscue, auch proximiores in gradu remotioribus absque sexus differentia vorgezogen werden, in maßen sie dan denselben auch auff gebürliches gesinnen die investituram unwäigerlich ertheilen wollen, abermals doch mit dem beym zweiten puncto beschehenem reservato, daß nemblich sie das lehen durch eine mansperson zu deserviren, schuldig sein sollen.

\5 Wagegen fünfftens die löbliche ritterschafft sich erklärt, versprochen, und verbunden, daß wan solcher fall sich begeben wirdt, daß die weibspersonen oder aber die jenige manspersone[n], welche sich per linea[m] fœminam qualificiren können, in dem lehen succediren wollen, alßdan sie vorhero jedesmals ihrer jetziger churfürstl[iche] durchl[euchtigkeit] als lehenherren loco recognitionis decimam partem pretii, warauff das lehen in sich quoad vtile dominium geschätzet werden kan, abstatten und entrichten sollen.

$\int 6$ Sechstens ist hiebey außtrücklich bedingt, abgeredt, und verglichen, daß diese transaction alleinig auff die landtsaßische lehen, nicht aber die jenige, welche unmittelbar under dem Reich, oder in anderer fürsten und herren territorio und gebiet gelegen, zuverstehen, sondern ihre churfürstl[iche] durchl[euchtigkeit] und deroselben succesores 
diesertwegen in ihrem vorigen volligen rechten stehen und verbleiben, solches auch hingegen selbigen lehenleuten, so fern sie einiges haben, unbenommen sein solle.Deßen zu urkundt haben ihre churfürstl[iche] durchl[euchtigkeit] diesen vergleich eigenhendig underschrieben, und mit ihrem insigel, wie nit weniger ein hochwürdig thumbcapitul mit seinem sigillo ad causas, so dan der löblicker ritterschafft deputirte mit ihrer underschrifft und rings pitschaffte[n] befestiget. Geschehen Bonn den acht und zwantzigsten junii 1559.

$\int 7$ Hierneben verordnen wir auch, daß in lehn succession nicht solle angesehen werden, ob der jeniger, so erben will, dem abgestorbenen von ein- oder beyden banden anbewandt seye, sondern alleinig, ob er von dem lehnstam mit herrüret, also daß der halbbürtiger bruder oder schwester und deren kinder so woll als volbürtige, wan sie nur a stipite acquirente zugleich entsprossen, zu dem lehen mit zuzulaßen seindt.

\section{Titulus VIII}

Wie eheleute einander erben sollen

\ 1 Wan under künfftigen eheleuten, mit vorwissen und belieben der elteren, oder in mangel deren mit zuziehung der negster blutsverwandten oder freunde, heyraths verschreibungen auffgerichtet, beschloßen, und angenommen, selbige sollen in allen ihren puncten und articulen unverbrüchlich und ohne widerred gehalten werden.

$\int 2$ In solchen heyraths verschreibungen ist den künfftigen eheleuten zugelaßen, nicht allein von dem zugebrachten heyraths gutt zuverordnen, sondern auch von allen ubrigen gütteren, so viel sie deren mächtig und ihnen gefellig, einander zuvermachen, und soll alsolche vermächnus, ob sie schon auff die erbfolgung gantz oder zum theil der jetzigen oder künfftiger güter gerichtet, unwiderrufflich sein, es geschehe dan die wiederruffung mit beider eheleuten gutem willen und belieben.

\ 3 Da keine heyraths verschreibung auffgerichtet, auch endtweder gar keine kinder auß solcher ehe endsproßen, oder selbige vor beyden elteren wider verstorben, soll das leztlebend von beyden eheleüten den heyratspfenning erblich behalten, in allen anderen aber des erstabgestorbenen zugebrachten, wie auch bey stehender ehe anerfallenen ligenden oder unbeweglichen güteren (warunder auch die rentverschreibungen, sie seyen loßbahr oder unloßbahr, so dan die baarschafft von abgelegten jahrlichen rhenten mit zuverstehen) sein lebenlang, es thue sich daßelb wider verheyraten oder im wittibstandt verharren, leibzuchtig verbleiben, daruber aber ein ordentliches inventarium, auff daß die negste erben des eigenthumbs versichert sein können, bey verlust der leibzucht inner drey monaten zeit fertigen laßen, so dann die güter in gutem baw und beßerung halten, auch da es von den erben begehrt wird, deßwegen gebührende caution und versicherung leisten.

$§ 4$ Die in stehender ehe anerwonnene ligende gütter sollen alß dan, wan nemblich vor gesetzermaßen keine kinder, noch widrige pacta dotalia oder heyrats versprechungen vorhanden, freundtheilig sein, des erstabgestorbenen negsten erben zu einer halbscheidt, 
und dem letztlebenden ehegatten zu der anderen halbscheid eigenthumblich zufallen, jedoch disem von allen solchen gütteren die leibzucht gegen gleichmeßige auffrichtung eines inventarii und gebührliche caution auff erforderen, seine lebzeit verbleiben.

$\S 5$ Die fahrnus oder bewegliche gütter thun dem leztlebenden eigenthumblich und mit vollkommenem recht zufallen, jedoch soll selbiges darauß alle unverbrieffte, wie auch die jenige verbrieffte schulden, so nicht auff jahrliche rhenten verschrieben, zubezahlen verbunden sein.

\6 Wan aber das erst abgestorbene von beiden eheleuten kinder auß selbiger ehe gezeugt hinder sich im leben verlast, alß dan soll zwarn das ieztlebend alle fahrnus, wie vorgemelt, für sich behalten, den heyrathspfenning aber und andere zugebrachte, oder bey stehender ehe dem erstabgestorbenen zugefallene, wie auch die gewonnene gütter nur leibzuchtig sein lebenlang, es greiffe daßelb wider zu anderer ehe oder nicht, zugenießen haben, jedoch auff den wieder verheyrahtungs fall daruber ein inventarium auffrichten laßen, und in alle wege darvon die kinder nach standtsgebühr ehrlich erziehen und außsteuren, welche außsteurung dan mit zuziehung der nester freunde, oder wan darvber zwischen ihnen irrung vorfallen würde, nach ermäßigung der obrigkeit geschehen soll.

\7 Unter dem nahmen solcher fahrnuß oder beweglicher gütter solle in diesem ertzstifft das bahr geldt, so nicht von abgelegten jahrrhenten oder verkaufften ligenden gütteren herrühret, handschriffte[n], so nicht auff jahrrhenten gestelt, angesähete feldtfrüchten, wein an den stöcken, wan er vor dem fall mit dem ersten bandt beschloßen, baum-, obßund graßgewachs aber, wan der fall nach dem ersten martii sich begibt, haußzins nach ertrag der von dem lauffenden jahr alschon verschienener zeit, abgehawenes schlagholtz, wie auch das unabgehawenes, wan die verkauffung noch bey lebzeitten des eigenthumbers geschehen, verfallene noch außstehende pensiones von angelegten capital gelderen, pfachtings jahren deren von beiden eheleuten bestandener güter, vorrätlicher wein, getraydt, silbergeschier, viehe, ackergeschier, haußrath, bücher, gewehr, und alles waß sonst nagelloß ist, wie auch die action und ansprach auff dergleichen güter verstanden werden. Waß aber außer diesem dem grundt oder hauß anklebt, und under anderen: eisenofen, brewkeßel, kelter, bläßbalg in den schmitten, und dergleichen, soll für unbeweglich gehalten werden, und bey dem grundt oder hauß verbleiben.

$\int 8$ Es soll jedoch under kauff: oder handelßleuten hierin diesen underscheid haben, daß die jenige waaren und güter, welche in ihre handlung und gewerb einschlagen und darunder gehörig, in diesem erbungsfall under die fahrnus nicht mit zurechnen, sondern es damit sambt denen außstehenden buch- und gegenschulden also gehalten werden, wie oben in viert- und sechsten articulis von denen ligenden gütteren verordnet.

Imgleichen sollen under denen schiffleuten die schiffe und aller dazu gehöriger fahrzeug an segel, ancker, seylen und dergleichen für unbeweglich und erb gerechnet werden.

\9 Da nach gebrochenem ehebeth sich begäbe, daß auff die kinder wegen des verstorbenen vatters oder mutter endweder in absteigender linien oder von der seiten 
einige erbschafft ab intestato verfiele, soll der noch uberlebender vatter oder mutter davon die leibzucht, so lang die kinder noch unverheyrathet, oder sonst in vätter: oder mutterlicher underhaltung sein, zu genießen haben, nach deren verheyrathung aber, oder auch da sie gleich nicht verheyrathet, aber dannoch nach dem fünff und zwantzigsten jahr ihres alters einen eigenen rauch und haußwesen anstelliten, oder sonsten von den elteren sich absonderten, soll ihnen der vatter oder mutter alsolch nach gebrochenem ehebet anerfallenes gut abtretten und einraümen.

Titulus IX

Von dem besitz oder gewehr der erledigter erbschafft

$\int 1 \mathrm{Wa}$ ein testament aufgerichtet, soll auf den darin eingesetzten erben, oder wan mehr testamenta vorhanden, auff den ienigen, der in dem letzteren onder jungsten benambset, und in mangel des testaments auff den negsten anbewanten, deme die erbschafft von rechtswegen zugehört, der besitz oder gewehr der güter, sie seyen ligend oder fahrend, so fern sie der abgestorbener zu zeit seines todts possidirt, ohne einige andere leibliche ergreiffung verfallen sein, und da villeicht jemandt anders vorlauffen und sich des besitzes zunäheren understehen wurde, soll ihm solches zu keinem vortheill oder nutzen weder innoch außerhalb rechtens gedeyen, sondern vielmehr für ein straffbare thatt zu halten sein, und hingegen der eingesetzter, oder wan kein testament vorhanden, der negster erb vom geblüt bey dem besitz der güter, biß zu ordtenlichem außtrag rechtens, gehandhabt werden.

$\int 2$ Und im fall etwa das testament als mangelhafft und ungültig beschuldigt, oder zwischen denen anbewanten vom geblüt der sipschafftt halber oder sonsten streit erweckt würde, soll summarie darüber erkandt und biß dahin die güter von den gerichteren, darunder selbige gelegen, zu behueff des obsigenden theils in verwahr genommen werden.

\section{Titulus X}

Von der einkindtschafft

$\int 1$ Wan eines von beyden eheleuten nach absterben des anderen wider zu der zweiter ehe schreitet, und zuvor oder auch hernach under wehrender ehe für gut ansiehet, zwischen erster und folgender ehe, oder auch denen zugebrachten kinderen eine einkindtschafft auffzurichten, soll solches zwar, als zu mehrer erhaltung liebe und einigkeit gereichend, zugelassen sein, jedoch anderer gestalt nit, als mit vorgehender gerichtlicher erkendtnus.

$\int 2$ Wabey dan diese ordnung gehalten werden soll, daß denen kinderen, da sie noch minderjährig, zu solchem actu und handlung ein oder zween curatores (im fall sie vorhin damit nicht versehen) angesetzt werden sollen, welche der kinder haab und vermögen, so sie von ihrem verstorbenen vatter oder mutter ererbt, und was sie hingegen von dem künfftigen stieff vatter oder mutter zuerwarten haben können, mit fleiß zuuberlegen und zuerwegen, und demnegst dem gericht zu hinderbringen, auch an äydts stat, ob es denen kindere[n] besser gethan als gelassen, oder keine merckliche vervortheilung darunder 
verborgen, außzusagen und zubekräfftige[n], deme vorgangen alßdan darüber das gerichtliche decret mit ordentlicher verzeichnus, ob und was ein- oder anderem theil zum vortheil vorauß vermacht, ertheilt und außgefertigt werden mag.

$\int 3$ In krafft solcher einkindtschafft sollen alßda[n] die kinder voriger ehe mit denen, so in folgender ehe gezeugt, in denen elterlichen güteren zugleich erben, darunder aber die seitenfälle und was sonsten ein oder anderley kinderen durch testament, schenckung oder andere titul vermacht, und sonst durch sie erworben, nicht verstanden werden.

$\int 4$ Dafern folgents von solchen vereinkindtschaffteten kinderen eines oder mehr bey lebzeiten beyder oder eines von den elteren mit todt abgehen würde, soll der angenommener vatter oder mutter, wie auch die schwesteren und brüder zweiter ehe nicht anders, alß die natürliche elteren und volbürtige brüder und schwesteren in denen der einkindtschafft einverleibten güteren in die häubter und zu gleichen theilen erben.

$\int 5$ Wan aber beyde so woll natürlich- als angenommene elteren verstorben, und also deren erbungsfall sich völlig begeben, soll diese einkindschafft damit auffgehebt und erloschen sein, und die halbbürtige schwester und brüder mit denen volbürtigen ferner nicht erben, sondern es alßdan der succession halber under allerseits geschwistrigen anders nicht gehalten werden, als wan keine einkindtschafft gemacht were.

$\int 6$ Da jedoch bey auffrichtung dergleichen einkindtschafften andere bedingungen abgehandlet und verglichen, soll solchen durch diese ordnung nichts benommen sein, sondern dieselbe auffrichting gehalten und volnzogen werden.

Titulus XI

Von vormünderschafften

$\int 1$ Wan ein vatter oder mutter zu der zweiten oder mehrern ehen schreittet, sollen sie ihre kinder vorige ehe, sofern dieselbe das ein und zwantzigste jahr ihres alters nicht erfüllet, mit vormunderen versehen zulaßen schuldig sein, und dafern sie solches innerhalb jahrs nach der verheyratung versaumen oder underlaßen würden, sollen sie sich der leibzucht aller auß voriger ehe auff die kinder verfallener güter verlüstig gemacht haben, es were dan, daß sie rechtmäßige ursachen der verhinderung bey der obrigkeit vorbringen könten.

$\int 2$ Da aber sonsten ein kindt vor erfüllung ermeltes ein und zwantzigjahrigen alters elterloß wirdt, sollen schulteiß oder vogt und scheffen in den stätten, dingstülen oder gerichteren, wo die elteren zu zeit ihres absterbens wonhafft gewesen, demselben inner den nechsten sech $\beta$ wochen vormündere anzusetzen, oder im widrigen allen dem minderjährigen darauß erwachsenden schaden zuerstatten und gutzumachen verbunden sein. 
$\int 3$ Wan die von der ritterschafft mit hinderlaßung minderjahriger kinder versterben, soll der ambtman, in deßen ambts bezirck das adelich hauß, wo der verstorbener seßhafft geweßen, gelegen ist, zu unserer cantzley in denen negsten sechs wochen den todfall sambt seinem gutachten, was für personen zu vormünderen dienlich sein könten, berichten, damit darauff gleicher gestalt ohn verzug dieserthalb die gebür vorgenommen werden möge.

\ 4 Wer demnach von schultheiß und scheffen in denen stätten, dingstülen oder gerichteren, und von unser cantzley under der ritterschafft zu vormund benahmbset wird, soll daßelbig unweigerlich anzunehmen schuldig sein, und ihm dawider keine entschuldigung zustatten kommen, es seye dan, daß er vorhin schon mit zwo anderen vormundtschafften beladen, oder aber in solchem streit mit denen wäißen stünde, daran der meherer theil ihres vermögens hafftete, oder aber in dergleichen officiis und bedienungen, oder sonsten in solcher leibs unvermögenheit begriffen, die ihn an verwaltung der vormündschafft kundbarlich hinderten; wan sonsten sich yemand widrigen, und die pflegbefohlene dadurch in schaden kommen würden, soll er dafür hafften und alles zuersetzen angehalten werden.

$\int 5$ Im fall nun das gericht die negste verwandte, denen sonsten vermög der gemeiner rechten die vormundschafft obläge, dazu ernennen, selbige aber auß dem bezirck deßen gerichtzwangs gesessen sein würden, soll das jenig gericht, warunder alsolche benahmbsete vormündere wohnhafft, alsbald auff die erste requisition oder ersuchung, dieselbe zu antrettung der auffgetragener vormundschafft anhalten, oder für den saumbfall selbsten hafften, und solchen vermittelst erstattung alles schadens zu büßen schuldig sein.

\6 Alle vormündere sollen jedes jahrs gleich nach dem weynacht feyrtagen, nemblich den 7. january ihre rechnungen an dem ort, wo sie angesetzt, bey vermeidung wilkürlicher straff einliefferen, und darauff alsbaldt von der obrigkeit gewisse personen zu dern durchseh- und uberlegung verordtnet werden.

\section{Titulus XII}

Von kauffen und verkauffen

\1 Wan jemand ligende oder unbewegliche gütter an sich erkaufft, soll der kauff bey dem gericht, warunder die gütter gelegen, insinuirt oder verkündet werden, und daselbst durch den verkauffer verzig und außgang: hingegen an den kauffer die erbung geschehen, und alß lang solche verkündung hinderbleibt, soll der aigenthumb auff den kauffer, ob ihm schon durch den verkauffer sonst das gut eingeraumbt, nicht verfallen sein, yedoch ihm wider denselben seine personal action zu vesthalt- und erfüllung deß kauffs, oder im fall er die lieferung nit thun kan, zu seiner schadloßhaltung unbenommen sein.

$\$ 2$ Ein man oder weib mag bey stehender ehe so wenig sein angebrachtes als miteinander gewunnenes guet ohn mitbelieben und bewilligung seines ehegatten nicht verkauffen, oder 
einiger gestalt vereußeren, sondern was deßen vorgenommen, soll krafftloß und nichtig sein.

$\int 3$ Hingegen wan ein weib mit und neben seinem eheman einen contract auffrichtet, denselben underschreibt, oder vor gericht, oder auch vor notarien und zeugen sich dazu bekennet, soll sie und ihre äigene gütter dafur gleich dem man hafften, und sich dawider keines vorzugs rechtens wegen ihres angebrachten heyratsguts zugebrauchen haben.

\section{Titulus XIII \\ Von pfandtschafften}

$\int 1$ Gleicher gestalt soll keine verpfändung gültig sein, sie werde dan dem gericht, warunder die gütter gehörig, insinuirt, und dafern solches nit geschicht, und die güter hernach an einen anderen verkaufft oder versetzt werden, soll wider denselben der erster glaubiger solcher güter halber durchaus keine ansprach, weniger einiges vorzugs zugeniesen haben.

$\int 2 \mathrm{Da}$ auch schon eine general oder gemeine verpfandung aller güter geschicht, oder eine solche privilegyrte forderung, die ein stilschweigendes pfandt nachführet, darauff hafftet, soll doch dieselbe dem glaubiger anders kein vorzugsrecht zuäigenen, es seye dan bey jedes orts gericht die insinuation geschehen, und stehet als dan zu seiner wahl ohn underscheid, an welche güter er sich zum erst- und liebsten halten und bezalt machen wolle, unangesehen neben dem general, auch ein absonderliches underpfand in der verschreibung benahmbset worden.

$\int 3$ Wan dan obgesetzter maßen die verpfandung vor gericht geschehen, mag der glaubiger die verpfändte güter, in was hand sie auch hernach gerahten, fur seine schuld verfolgen, ohn daß er an seinen haubtschuldener erst umb excussion zu verweisen sein solle.

$\int 4$ Die general verpfandung aller güter soll auf die fahrenden oder bewegliche güter wider einen dritten kauffer oder besitzer ehender kein krafft haben, als dieselbe durch gerichtliches verbott præcludirt worden, dafern aber jemand nach solchem verbott dieselbe an sich kauffen oder bringen würde, mag er von dem glaubiger dafur besprochen werden.

\section{Titulus XIV}

\section{Von pfachtungen}

$\int 1$ Ein pfächter soll seine pfachtung ohne des pfachtherren bewilligung einem anderen zuuberlaßen, oder jemand in seine pfachtjahren eintretten zulaßen nicht macht haben. 
$\int 2$ Wan ein pfächter wegen mißwach $\beta$ oder hagelschlags an seiner pfacht nachlaß zubegere[n] vermeint, soll er vor der ärndte seinem pfachtherren die besichtigung des schadens anzusagen schuldig sein, im widrigen keiner nachlaßung zugenießen haben.

\3 Im fall demnegst der pfächter mit seinem pfachtherren des nachlaß halber sich nicht vergleichen könte, soll der pfächter den pfachtherren ${ }^{2231}$ zu theilung deß wachßthumbs sambtlicher früchten dieser gestalt zulaßen, daß die harte früchten demselben zur halbscheidt, jedoch gegen erstattung des halben sahmkorns, halben mähe- oder schnitlohns, und halben dreschlohns, die haber frucht aber zu einem drittheil gegen gleichmäßige erstattung des dritthteils berürter kösten verbleibe.

$\int 4$ Wan der pfächter der pfachtung, wie es sich gebürt und einem fleißigen haußhalter obligt, nicht vorstehet, soll der eigenthumber ihm seine jahren daran zuhalten nicht schuldig, sondern von dem gut außzuweisen befügt sein, dafern auch der pfächter in dem letzten pfachtjahr seine pfacht nicht bezahlen und doch die früchte[n], viehe und ander eingebrachtes zu entfrembden, oder sonsten zuverbringen understehen würde, soll dem pfachtherren die scheuren, speicher, hoff und ställe zu seiner versicherung zuversperren freystehen.

$\int 5$ So hauß, scheuren, oder stallungen durch deß pfächters, oder seines hausgesindts 2232 schuld oder versaumbnuß abgebrandt, ist er schüldig, alsolchen schaden auß dem seinigen wider zuerstatten.

\6 Weilen vermög der gemeiner rechten die erbkäuff die pfachtungen brechen, so soll auch in diesem ertzstifft der kauffer dem pfächter die jahrzahl seiner pfachtung außzuhalten nicht schuldig sein, sondern in den stätten der pfächter gleich in drey monaten nach verkundetem kauff auß dem hauß: auff dem landt aber von den gepfachteten güteren auff das negstfolgendes fest Cathedræ Petri weichen, jedoch hat er sich deß schadens halber, so ihm darauß entstehet, an dem verkauffer zuerholen.

$\int 7$ Gleicher gestalt, wan sich zutragen würde daß ein herr, der ein hauß ausgethan oder verliechen, auß new uberkommender nohtwendiger oder redtlicher ursach selbst darin wohnen oder bawen müste, ist er dem pfächter die pfachtjahren zuhalten nit schuldig, jedoch soll $\mathrm{er} \mathrm{ihm}$ in solchen fällen $\mathrm{zu}$ ersehung einer anderen wohnung entweder obgemelte drey monat, oder, wan die sach eine mehrere eyl erfordert, zeit nach ermessung der obrigkeit verstatten, vorbehaltlich deß ihm des außweichens halber zuwachßenden schadens.

$\int 8$ Im fall hingegen der pfächter mit vorwißen und willen deß herren nützliche kösten an die gepfachtete güter angelegt, soll er, ehe ihm gebürliche erstatt- oder vergnügung geschehen, zuweichen nit schuldig sein.

2231 Origineel: pfachtherherren

2232 Origineel: haußhesindts 
$\int 9$ Weilen auch die pfachtung von alzulangen jahren den kinderen und erben bey vielerley under deßen zutragenden enderungen offters zu großen unstatten gereichet, soll hinfüran keine pfachtung lenger, als auf zwölff iahr gültig oder verbindtlich sein.

\section{Titulus XV}

Vom einstand oder widerzug, zu latein ius retractus genant

\1 Wan ein ligendes gut, oder ligendem gutt anklebende gerechtigkeit, wie auch unlößbare zinsen oder renten verkaufft werden, sollen die negste blutsverwandte auß dem vatterlich- und mutterlichen stammen, wo ermelte güter herkommen, bis in das zehend gliedt (so weit nemblich die erbfolgung vermög des obigen fünfften tituls statt hat) des einstandts berechtiget sein, und sich deß kauffs innerhalb sechs monat, von zeit solcher bey dem gericht verkündet, anzurechnen, gegen erstattung der außgegebener kauffgelder, und anderer nohtwendiger und redtlicher unkösten, näheren mögen.

$\S 2$ Die jenige anbewandte aber, welche auß dem stammen de $\beta$ ersten acquirenten oder erwerbers solcher güter endsprossen, haben sich des einstandts nicht zugebrauchen.

$\int 3 \mathrm{Da}$ auch der verkauffer alsolchen seinen blutsverwandten den kauff anbieten und verkünden, dieselbe aber sich dazu nit einlaßen noch in den negsten sechs wochen erkleren würden, sollen sie sich ihres einstandts verlustig gemacht haben.

\4 Wer zu dem einstand befugt ist, soll sich deßen anderer gestalt nit, als ihm selbst zum besten und das gut für sich zubehalten, und keinen anderen zu gefallen oder nützen, oder in meinung solches etwan baldt umb eines ubergewins willen wider zu verkauffen, gebrauchen, deßen dan er, daß nemblich in solchem allein kein heimblicher verstand noch gefehrde underlauffe, wa es begert wirdt, ein aidt schweren soll.

$\int 5$ Wo sich begibt, daß mehr, als ein anbewandter in den kauff zu stehen begert, soll allemahl der negster grad dem weitteren vorgehen, weren sie aber in gleichen grad, soll sie daruber das loß entscheiden.

\6 Diese einstandts gerechtigkeit soll auff tausch oder wechßel nit gezogen werden, sondern allein im kauffen statt haben, doch daß solche täusch oder wechßel gefährlicher weiß und durch dergleichen schein die negste freunde von dem einstand abzuhalten nicht geschehen, sondern beyder theil nutzen und notturfft nach aufrichtiglich vorgenommen und gehandlet werde, welches dan auch, so es die negste freunde begeren würden, durch die partheyen bey geschwornem aidt erhalten und bestettigt werden soll, wo aber im tausch ein aüffgeld gegeben und solches den halben theil des wehrts des ertauschenden guts erreicht, soll es fur ein kauff gehalten werden.

\11 Gleicher gestalt, wan ein gutt auf anruffen deß glaubigers durch das gericht verkaufft wirdt, alsdan hat der einstandt nicht statt, sondern welcher also vor gericht gekaufft hat, soll dabey ohn eintrag der anverwandten gelaßen werden. 
Titulus XVI

Von verjahrung der stehender rhenten oder zinsen

$\int 1$ Als under denen rechtsgelehrten underschiedtliche mainungen seint, ob in jährlichen renten und gefällen die verjahrungen platz haben können, so haben wir, allem anlaß zu irrungen und strittigkeiten vorzukommen, nöhtig erachtet, diesertwegen ein gewißes zuverordtnen, weilen dan die gemeine beschriebene, auch fast aller völcker rechten ihr absehen dahin vornemblich richten, daß in menschlichen handlungen endtlich einmahl eine sicherheit sein, und niemand in immerwehrender sorg und forcht deß seinigen stehen möge, der jenig auch, welcher eine gar lange geraume zeit mit seiner forderung stillschweigt, seine versaumbnus niemanden, als ihm selbst zuzumessen hat, so wollen wir, daß alle dergleichen jährliche renten, zinsen und gefälle in vierzig jahriger zeit, wan nemblich darunder keine ansprach darumb geschehen sein wirdt allerdings erloschen und getödtet sein, und der schuldner als dan ferner darumb nicht angefochten werden soll.

$\int 2$ Gleicher gestalt, wan der glaubiger oder zinßherr seinen jährlichen zinß von viertzig jahren hero ununderbrochen in einem gewissen valor oder wehrt empfangen und angenommen, soll er, unangesehen in was wehrt oder lauff das geld zu zeit contracts gewesen, ein anderweite reduction, erhöh- oder enderung mit dem schuldner vorzunehmen nit befuegt sein, sondern sich ins künfftig mit eben dergleichen zahlung begnügen

Gedrukt Bonn 1663

8 Verordening van graaf Johan Frans van Bronckhorst Batenburg op de schatheffing in het graafschap Gronsveld

10 november 1718

Neue verordnung welcher gestalten die schatz-ausschreibungen in unserer grafschaft Gronsfelt künftighin geschehen, auch was darbey zu observieren seyn solle, damit allen bishero eingeschlichenen inconvenienten und entstandenen mishelligkeiten pro futuro heilsamblich vorgebieget und man dermalens zu einer richtigkeit gelangen könne.

Sollen in der grafschaft keine umblagen oder schatz-ausschreibungen geschehen man habe dan uns vorhero desshalben gebuhrend belanget die unumbgängliche erforderende noth und beschaffenheit underthänig vorgetragen den statum dess offen stehenden debiti sampt getreuer specification deren zu last der grafschaftliche gemeinden stehenden capitalien samt aufgeschwollenen interesse ingesondert und sodan hierüber unser beliebige gnädige ratification eingelauffen seye. 
Wie künftig hin keine umblagen gestattet werden sollen, es seyen dan die vorige bey offenen thor und fensteren denen underthanen und desshalben beschribenen ausländischen beerbten gebührend berechnet, wie ingleichen der bey denen abrechnungen ordinaire rückständige und der erschöpften gemeinde schuldig geblibene steuer-einnehmer sine distictione personarum würcklich exequiret.

Also solle dessen vorgangen die gnädig ratificierte umblag wie von alters her brauchlich dem underthanen so wohl als ausser dero grafschaft sich aufhaltenden beerbten auf einen gewissen termin zu bestimmten tag und ort von einen zeitlichen drosten kundbar gemachet werden.

Bey eben welcher versammlung eine separation deren personellen und reellen lasten zu dem ende solle vorgenommen, damit zwey schatzheber am selbigen tag und ort auf nachfolgende weise angestellet werden können

Damit auch der underthan und beerbten in dem tantiem so denen schatzhebern ad 6 procento zugeleget werden best möglichst soulagiret werden, als solle die schatzeinnehmungen dem minus offerenti wofern derselb dafür gesessen, zugeschlagen werden. Wie dann auch nichts billichers als das angeordnete schatz-einnehmere in ansehung ihres geringen tantiem dess öfteren annehmen und sonsten mühewaltung enthoben werden.

Also sollen alle schatz-zahlende underthanen auch ausländische beerbten quartaliter den schuldige antheill ihrer quota dergestalt entrichten dass die schatzhebere nicht gehaltenen seyen die säumige weiters weiters an zu mahnen sondern schatzhebere daran seyen damit das verflossene quartal auf einen sonn- oder feyertag nach vollendeten gottesdienst durch hiesigen gerichtsbotten dem underthanen kund gemacht und ihrer schuldigkeit erinnert werde.

Welchem vorgangen werden beide schatz-einnehmere ohne sich weitere mühe zu geben einige anmahnungen oder summationes geschehen zu lassen befugt seyn mit unweigerlichen dess drosten permission die schatz-schuldige underthanen sowohl als die ausländische beerbten üblicher gewonheit nach executive anzuhalten.

Damit ingleichem auch der schatz-einnehmer wissen und gesichert seyn an wen sie die gelde raus zu zahlen haben, auch thuen bey denen abrechnungen keine dispute oder ausschllag widerfahre, als solle mehrgedachte schatz-einnehmern eine pertinente liste vorgelesen auch copeilich mitgetheilet werden wohin und weme die zahlungen zu geschehen sollen mit der warnung ausser denen in gedachter lista exprimirten kosten keine gelder aus zu geben.

Gleichwie auch vonnöthen ist dass die underthanen und beerbten bey denen schatzheberen ihrer gelder halber gesichert, als sollen schatzhebere quartaliter oder zum wenigsten alle 6 monathen dem drosten die ihme angewiesene zahlungen per quittantias originales vorzeigen, den drossart aber solle ohne unseren expressen befehl und vorwissen kein geld ausgeben.

Weilen dann auch verspuhret dass die ausschreibungen öfters auf 5, 6 und mehr jahre verschoben worden, woraus entstanden dass der underthan sowohl als der beerbte auf einmahl grosse summen herzugeben verpflichtet gewesen, als sollen alle jahre die ausschreibungen nach proportion der schulden geschehen damit dem underthanen und beerbten nicht schwer falle ihre schuldigkeiten abzuführen. 
Auf dass nun dieser unserer vor gut befundendener verordnung in allen deren puncten gehorsamlich nachgelebet werde, als haben wir selbige eigenhhändig underzeichnet auch unser gräflicher petschaft vortrucken lassen. So geschehen Luxemburg den 10 november 1718.

L[ocus] S[igilli]

J[ohan] F[ranz] G[raf] z[u]. Gronsfelt.

In dorso: Newe verordnung welcher gestalten die Schatzausschreibunbgen in de grafschaft Gronsfelt ins kunftig geschehen sollen. Luxemburg den 10 november 1718.

Afschrift.

Staatsarcbiv München, Arcbiv Toerring Jettenbach, inv. nr. M 40, folio 931-934.

$V$ an deze verordening is ook een concept bewaard, gedateerd 4 november 1718 (Staatsarchiv München, Archiv Toerring Jettenbach, inv. nr. M 40, fol. 955-960. Te oordelen naar bet bandschrift moet het afkomstig zijn van de grafelijke raadsheer De Witte; deze verbleef op 2 november 1718 in Maastricht.

9 Reglementen op de proceskosten

2 mei 1724 en ongedateerd (na 1728)

Versie $A$

Reglement opgetekend wit een verklaring van Lambert Lousberchs, gedurende veertig tot vijftig jaar secretaris in Gronsveld, vastgesteld door het gerecht van Gronsveld, evenwel behoudens goedkeuring van de graaf.

Versie B

Reglement opgetekend wit een verklaring van Lambert Lousberchs gedurende veertig tot vijftig jaar secretaris in Gronsveld, afschrift van de secretaris van Rijckholt. De versie B is na 1728 (Slenaken komt niet meer voor) en korter dan versie $A$.

Voor deze nitgave is Versie A leidend. De artikelen in Versie B zijn zoveel mogelijk geplaatst tegenover de bijbehorende artikelen nit versie $A$.

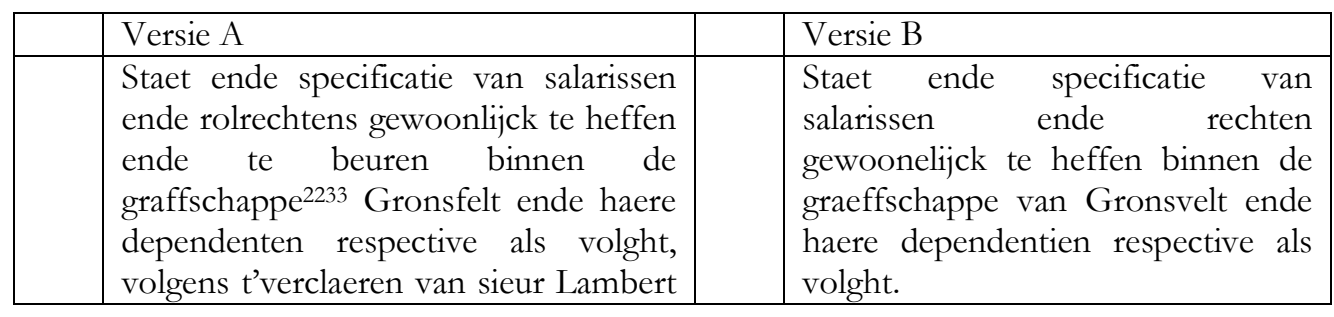

2233 De derde letter is niet leesbaar vanwege een inktvlek in het origineel. 


\begin{tabular}{|c|c|c|c|}
\hline & $\begin{array}{l}\text { Lousbergh, over de } 40 \text { à } 50 \text { jaeren } \\
\text { secretaris geweest sijnde tot Gronsfelt } \\
\text { voorschreven, Heugem ende Hontem, } \\
\text { vernieuwt ende verbetert desen jaere } \\
1724 \text { met last van een yder sich daer } \\
\text { naer te conformeren. }\end{array}$ & & \\
\hline & guldens-stuivers & & guldens-stuivers-deniers \\
\hline 1 & $\begin{array}{l}\text { Voor eerst staet te noteeren dat alle } \\
\text { aensatten soo tot Gronsfelt, Heugem } \\
\text { als Hontem behooren te geschieden } \\
\text { mette vaeghtgedingen ende andersins } \\
\text { niet. }\end{array}$ & 1 & $\begin{array}{l}\text { Voor eerst is het coustuymens dat } \\
\text { alle aensatten behoyren te } \\
\text { geschieden met het vaeghtgedinge } \\
\text { soo tot Gronsfeldt, Heughem als } \\
\text { Honthem G.P.M. }\end{array}$ \\
\hline 2 & $\begin{array}{l}\text { De dry genachtingen loopen tot } \\
\text { Gronsfelt enckelijck van vaeghtgedinge } \\
\text { tot vaeghtgedinge. }\end{array}$ & 2 & $\begin{array}{lrl}\text { Loopende de } & \text { genachtinge } & \text { tot } \\
\text { Gronsvelt van vaeghtgedinge } & \text { tot } \\
\text { vaeghtgedinge, } & & \\
\end{array}$ \\
\hline 3 & $\begin{array}{l}\text { Dogh in het hoogh graeffelijk } \\
\text { leenhoff, tot Heugem, Hontem ende } \\
\text { Slenaecken loopen van vijfthien tot } \\
\text { vijfthien dagen. }\end{array}$ & 3 & $\begin{array}{l}\text { Maer int leenhooff tot Heughem } \\
\text { ende Hontem en elders de } 15 \text { ad } 15 \text {, } \\
\text { 3-3-0. }\end{array}$ \\
\hline 4 & $\begin{array}{l}\text { Eerstelijck voor alle heysschen ende } \\
\text { propositien ter rollen, altercatien, } \\
\text { repetitien ende verschijnen compt aen } \\
\text { justitie naer advenant van de oorkens } \\
\text { ofte alle substantiele sinnen voor elck } \\
\text { oorken op vaeghtgedinge dobbel ofte } \\
\text { twee stuyvers, op andere roldaegen } \\
\text { enckel oft eenen stuyver. }\end{array}$ & $\begin{array}{l}4 \\
5 \\
6\end{array}$ & $\begin{array}{l}\text { Eerstelijck voor alle heysschen ter } \\
\text { rolle comt aen justitie par oorkens } \\
\text { twee stuyvers op vaeghtgedinge, op } \\
\text { andere tijden } 1 \text { stuyvers. } \\
\text { Voor alle te houdene verschijnen, } \\
\text { idem voor de defauten } 1-5-0 \text {. } \\
\text { Item in cas van altercatien worden } \\
\text { daer van gereeckent d'oorkens, oft } \\
\text { alle substantiaele sinnen, elcken ad } \\
\text { eenen stuyver. }\end{array}$ \\
\hline 5 & $\begin{array}{l}\text { Item voor voortsgewijs van elcken } \\
\text { verschijn, op een afgeboth, arrest, etc., } \\
\text { compt aen justitie tot Gronsfelt twee } \\
\text { guldens acht stuyvers, dico } 2-8 \text {. }\end{array}$ & 7 & $\begin{array}{l}\text { Voor verschijnen over affgeboth, } \\
\text { arrest etc. } 2-8-0 \text {. }\end{array}$ \\
\hline 6 & $\begin{array}{l}\text { Tot Heugem ende Hontem dry } \\
\text { guldens dry stuyvers, alle Brabants } \\
\text { Maestrichter cours, dico 3-3. }\end{array}$ & & \\
\hline 7 & $\begin{array}{l}\text { Item voor een decreet van vervolgh } \\
\text { compt aen justitie ubique vijfthien } \\
\text { stuyvers, dico } 0-15 \text {. }\end{array}$ & 8 & $\begin{array}{l}\text { Item voor een decret van vervolgh } \\
\text { comt aen justititie } 0-15-0 \text {. }\end{array}$ \\
\hline 8 & $\begin{array}{l}\text { Item voor eene leer om costen te } \\
\text { libelleeren ofte om te penden etc., } \\
\text { compt aen justitie } 0-11 \text {. }\end{array}$ & 9 & $\begin{array}{l}\text { Item voor het accorderen van eene } \\
\text { leer om te panden } 0-11-0 \text {. }\end{array}$ \\
\hline
\end{tabular}




\begin{tabular}{|c|c|c|c|}
\hline & & 10 & Voor decreet van versteeck 3-0-0. \\
\hline 9 & $\begin{array}{l}\text { Item voor voortsgewijs van elcke } \\
\text { pandtthooninge compt als voor de } \\
\text { voorschreven verschijnen } \\
\text { Gronsfelt 2-8. }\end{array}$ & $\begin{array}{l}11 \\
12\end{array}$ & $\begin{array}{l}\text { Item voor voortsgewijs van elcken } \\
\text { verschijn oft defaut comt als boven } \\
2-8-0 \\
\text { Voor het accorderen van elcke } \\
\text { respective pandthooninge comt te } \\
\text { Gronsfelt aen justitie } 2-8-0 \text {. }\end{array}$ \\
\hline 10 & Tot Heugem ende Hontem 3-3. & 13 & Tot Heugem ende Honthem 3-3-0. \\
\hline 11 & $\begin{array}{l}\text { Item voor het accordeeren van de } \\
\text { derde pandthooninge met den } \\
\text { omslagh ofte executie compt eenen } \\
\text { gulden respectivelijck meer als voor de } \\
\text { anderen, ergo voor Gronsfelt 3-8. }\end{array}$ & 14 & $\begin{array}{l}\text { Voor het accorderen van eene } \\
\text { deerde pantthooninge metten } \\
\text { omslagh ofte executie comt aen } \\
\text { justitie eenen gulden meer als voor } \\
\text { d'andere. }\end{array}$ \\
\hline 12 & Heugem ende Hontem 4-3. & & \\
\hline 13 & $\begin{array}{l}\text { Item voor exhibitien van alle } \\
\text { schryftueren, verbaelen scripto, in } \\
\text { scriptis, ofte dergelijcke compt, tsij dat } \\
\text { sij geteekent sijn ofte niet, mede voor } \\
\text { elck stuck annex, aen justitie tot } \\
\text { Gronsfelt thien stuyvers } 0-10 \text {. }\end{array}$ & 15 & $\begin{array}{l}\text { Voor exhibitie van alle schrifturen, } \\
\text { verbaelen, inscriptis ofte dergelijcke } \\
\text { ongeteekent sijnde comt tot } \\
\text { Gronsfelt } 0-10-0 .\end{array}$ \\
\hline 14 & Slenacken idem, segge $0-10$ & & \\
\hline \multirow[t]{2}{*}{15} & $\begin{array}{l}\text { Tot Heugem ende Hontem } \\
\text { tweentwintig en eenen halfen stuyver, } \\
\text { dico } 1-2 \frac{1}{2} \text {. }\end{array}$ & 16 & $\begin{array}{l}\text { Tot Heughem ende Honthem 1-2- } \\
2 .\end{array}$ \\
\hline & & 17 & $\begin{array}{l}\text { Voor exhibitie van alle autentyque } \\
\text { bescheyden comt aen justitie idem. }\end{array}$ \\
\hline 16 & $\begin{array}{l}\text { Item compt aen justitie voor elcken } \\
\text { articule van dergelijcke schrifturen } \\
\text { ubique sees stuyvers, dico } 0-6 \text {. }\end{array}$ & 18 & $\begin{array}{l}\text { Voor elcken articule van } \\
\text { gearticuleerde schryfturen comt aen } \\
\text { justitie } 0-6-0 .\end{array}$ \\
\hline 17 & $\begin{array}{l}\text { Item voor alle te versoeckene } \\
\text { termijnen bij recht te accordeeren } \\
\text { compt twalf stuyvers, dico } 0-12 \text {. }\end{array}$ & 19 & $\begin{array}{l}\text { Voor alle te versoeckene termijnen } \\
\text { bij recht te accorderen comt } 0-12 \text { - } \\
0 \text {. }\end{array}$ \\
\hline 18 & $\begin{array}{l}\text { Item voor versouck ende accordeeren } \\
\text { van copyen ter rollen ubique als voor } \\
\text { compt twalf stuyvers, dico } 0-12 \text {. }\end{array}$ & 20 & $\begin{array}{l}\text { Voor het verseuck en accorderen } \\
\text { van copyen ter rolle comt } 0-12-0 \text {. }\end{array}$ \\
\hline 19 & $\begin{array}{l}\text { Item voor eene condemnatie in } \\
\text { contumaciam compt aen justitie } \\
\text { ubique vijf gulden, dico } 0-5 \text {. }\end{array}$ & 21 & $\begin{array}{l}\text { Voor eene condemnatie in } \\
\text { contumaciam comt aen het recht } \\
5-0-0 \text {. }\end{array}$ \\
\hline 20 & $\begin{array}{l}\text { Item voor een simpel decreet van } \\
\text { cleene incidenten in saecken te geven } \\
\text { compt aen justitie tot Gronsfelt thien } \\
\text { stuyvers, dico } 0-10 \text {. }\end{array}$ & 22 & $\begin{array}{l}\text { Voor een simpel decret van cleyn } \\
\text { incidenten in saecken te geven comt } \\
\text { aen justitie } 0-10-0 \text {. }\end{array}$ \\
\hline 21 & Tot Slenaecken idem $0-10$ & & \\
\hline 22 & Item tot Heugem ende Hontem compt & 23 & Tot Honthem ende Heughem 1-2- \\
\hline
\end{tabular}




\begin{tabular}{|c|c|c|c|}
\hline & 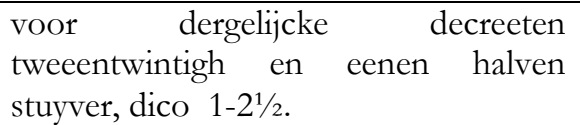 & & 2. \\
\hline 23 & $\begin{array}{l}\text { Item voor een vonnis interlocutoir } \\
\text { eenighsins groot compt aen justitie van } \\
\text { elcke parthye der litiganten acht } \\
\text { gulden, dico 8-0. }\end{array}$ & 24 & $\begin{array}{l}\text { Item voor een vonnis interlocutoir } \\
\text { eenighsints groot comt aen justitie } \\
\text { voor elcke parthye der litiganten } 8- \\
0-0 \text {. }\end{array}$ \\
\hline 24 & $\begin{array}{l}\text { Item voor een vonnis diffinityff over } \\
\text { een formeel proces compt aen justitie } \\
\text { van elcke parthije ten minsten twintigh } \\
\text { guldens offtewel naer proportie der } \\
\text { grootheyt ofte cleenigheyt der acten } \\
\text { processael naer advenant der selve, } \\
\text { voor elcke parthye te proportioneeren, } \\
\text { ergo bij provisie } 20-0 \text {. }\end{array}$ & $\begin{array}{l}25 \\
26\end{array}$ & $\begin{array}{l}\text { Item voor een vonnis diffinityf van } \\
\text { een formeel proces comt aen } \\
\text { justitie ten minsten van elcke } \\
\text { parthye 20-0-0. } \\
\text { Oftewel naer proportie der } \\
\text { grootheyt ofte cleynigheyt der acten } \\
\text { processael naer advenant der selve } \\
\text { voor elcke parthye te } \\
\text { proportioneren, }\end{array}$ \\
\hline 25 & $\begin{array}{l}\text { Ende in cleene saecken ordinarie de } \\
\text { hellight, dico } 10-0 .\end{array}$ & 27 & $\begin{array}{l}\text { Ende in cleyne saecken ordinaire de } \\
\text { hellicht. }\end{array}$ \\
\hline 26 & $\begin{array}{l}\text { Item voor alle te doene stipulatien in } \\
\text { handen van den gerechte, dienende tot } \\
\text { constitutie van procureur, ratificatie } \\
\text { der acten om cautie te presteeren, te } \\
\text { eligeeren domicilie ende dergelijcke } \\
\text { saecken, compt aen justitie tot } \\
\text { Gronsfelt } 2234 \text { thien stuyvers, dico } 0-10 \text {. }\end{array}$ & 28 & $\begin{array}{l}\text { Item voor te doene stipulatie in } \\
\text { handen van den gerichte tot } \\
\text { constitutie van procureur, ratificatie } \\
\text { der acten, cautie te presteren, te } \\
\text { eligeren fixum domicilium oft } \\
\text { dergelijcke saecken, comt aen } \\
\text { justitie } 0-10-0 \text {. }\end{array}$ \\
\hline 27 & Tot Slenaecken idem $0-10$ & & \\
\hline 28 & $\begin{array}{l}\text { Tot Heugem ende Hontem } \\
\text { tweeentwintigh en een halven stuyver, } \\
\text { dico } 1-2^{1 / 2} \text {. }\end{array}$ & 29 & Hontem ende Heughem 1-2-2. \\
\hline 29 & $\begin{array}{l}\text { Item voor vergaederinge in materie } \\
\text { van appellatie, inbreucke, clachte ende } \\
\text { conclusie, mede voor alle ordinaire } \\
\text { vergaederingen des gerichts buyten de } \\
\text { groote vacantie, tsij in de voorschreven } \\
\text { saecken offte andere buyten } \\
\text { gerichtsdagen, compt aen justitie tot } \\
\text { Gronsfelt twee guldens acht stuyvers, } \\
\text { dit alles buyten de oorkens ende } \\
\text { decreeten, dico } 0-8 \text {. }\end{array}$ & $\begin{array}{l}30 \\
32\end{array}$ & $\begin{array}{l}\text { Item voor vergaederinge in materie } \\
\text { van appellatie, inbreuck ofte clachte } \\
\text { comt aen justitie } 2-8-0 \text {. } \\
\text { Item voor extraordinaire } \\
\text { vergaederinge des gerichts buyten } \\
\text { de groote vacantie comt als voor. }\end{array}$ \\
\hline 30 & Tot Slenaecken idem $0-8$ & & \\
\hline 31 & $\begin{array}{l}\text { Tot Heugem ende Hontem compt } \\
\text { daer voor dry guldens dry stuyvers, }\end{array}$ & 31 & Honthem ende Heughem 3-3-0. \\
\hline
\end{tabular}

${ }^{2234}$ In de tekst staat Grondtfelt 


\begin{tabular}{|c|c|c|c|}
\hline & dico 3-3. & & \\
\hline 32 & $\begin{array}{l}\text { Item voor dergelijcke vergaederingen } \\
\text { ten tijde van de groote vacantie compt } \\
\text { over al aen justitien voorschreven } \\
\text { dobbel. }\end{array}$ & 33 & $\begin{array}{l}\text { Item voor dergelijcke vergaederinge } \\
\text { ten tijde van de groote vacantie } \\
\text { comt aen justitie dobbele rechten. }\end{array}$ \\
\hline 33 & $\begin{array}{l}\text { Item voor een gerichtelijcke attestatie } \\
\text { offte declaratie onder den } \\
\text { schepensegel compt aen de respective } \\
\text { gerechten overal buyten de rechten van } \\
\text { den secretaris vijf guldens, dico } 5-0 \text {. }\end{array}$ & 34 & $\begin{array}{l}\text { Item voor eene gerichtelijcke } \\
\text { attestatie ofte declaratie onder den } \\
\text { schepenzegel comt aen het recht } \\
\text { buyten de rechten van den } \\
\text { secretaris 5-0-0. }\end{array}$ \\
\hline 34 & $\begin{array}{l}\text { De rechten van dyen aen den secretaris } \\
\text { eenen gulden offte naer proportie der } \\
\text { groote, dico } 1-0 .\end{array}$ & 35 & $\begin{array}{l}\text { De rechten van den secretaris van } \\
\text { dyen gelijck van alle ordinaire } \\
\text { copyen niet grooter als onderhaelff } \\
\text { folie } 1-0-0 \text {. }\end{array}$ \\
\hline 35 & $\begin{array}{l}\text { Item compt aen de respective } \\
\text { secretarissen voor elck folium van alle } \\
\text { copyen houdende elcke zijde achthien } \\
\text { regulen ende elcken regel ofte lynien } \\
\text { twalf syllaben vijf stuyver, dico } 0-5 \text {. }\end{array}$ & 36 & $\begin{array}{l}\text { Ende voorders van elck folium } \\
\text { houdende elcke sijde } 18 \text { regulen } \\
\text { ende elcken regel ofte linie twaelff } \\
\text { sillaben } 0-5-0 .\end{array}$ \\
\hline 36 & $\begin{array}{l}\text { Item voor het authentiseeren van alle } \\
\text { acten ende copyen compt aen de } \\
\text { respective secretarissen voorschreven } \\
\text { thien stuyvers, dico } 0-10 \text {. }\end{array}$ & 37 & $\begin{array}{l}\text { Ende voor het authentiseren van } \\
\text { alle acten ende copyen, voor elcke } \\
\text { signature } 0-10-0 \text {. }\end{array}$ \\
\hline 37 & $\begin{array}{l}\text { Item voor oepeninge der archyven } \\
\text { compt overal aen de voorschreven } \\
\text { respective gerechten vijf guldens, dico } \\
5-0 \text {. }\end{array}$ & 38 & $\begin{array}{l}\text { Item voor openinge van archiven } \\
\text { comt aen justitie } 5-0-0 \text {. }\end{array}$ \\
\hline 38 & $\begin{array}{l}\text { Item voor eene gerichtelijcke visitatie } \\
\text { offte eene gerichtelijcke partagie ofte } \\
\text { deylinghe eene gerichtelijcke meetinge } \\
\text { offte desgelijcke compt overall aen de } \\
\text { voorschreven respective gherechtens, } \\
\text { buyten de rechten der secretarissen } \\
\text { voor hunne copyen ende der } \\
\text { lantmeeters, sees guldens sees stuyvers, } \\
\text { dico 6-6. }\end{array}$ & $\begin{array}{l}39 \\
40\end{array}$ & $\begin{array}{l}\text { Item voor eene gerichtelijcke } \\
\text { visitatie, eene gerichtelijcke deylinge } \\
\text { comt 6-6-0. } \\
\text { Buyten de rechten van secretaris } \\
\text { sijnder copyen. }\end{array}$ \\
\hline 39 & $\begin{array}{l}\text { Aen den boode respective voor het } \\
\text { selve te condigen twalf stuyvers, dico } \\
0-12 \text {. }\end{array}$ & 53 & Aen den bode $0-12-0$. \\
\hline 40 & $\begin{array}{l}\text { Item voor elcke genachtinge selffs } \\
\text { voor de derde mette conde van } \\
\text { vijfthien dagen tot Gronsfelt, Heugem } \\
\text { ende Hontem, doch niet tot Slenacken } \\
\text { practicabel compt aen de selve }\end{array}$ & $\begin{array}{l}52 \\
55\end{array}$ & $\begin{array}{l}\text { Item voor eene eerste genachtinge } \\
\text { comt aen justitie } 1-0-0 \text {. } \\
\text { Item voor de deerde mette conde } \\
\text { van XV daeghen } 1-0-0 \text {. }\end{array}$ \\
\hline
\end{tabular}




\begin{tabular}{|c|c|c|c|}
\hline & gerechten eenen gulden, dico $1-0$. & & \\
\hline 41 & $\begin{array}{l}\text { Item compt tot Slenacken van het } \\
\text { accordeeren der gewelle naer de } \\
\text { gedecreteerde vierde genachtinge aen } \\
\text { justitie aldaer vier guldens vijf en eenen } \\
\text { halven stuyver, dico } 4-5^{1 / 2} \text {. }\end{array}$ & $\begin{array}{l}56 \\
57\end{array}$ & $\begin{array}{l}\text { Tot Slenaecken voor de vierde als } \\
\text { voor de eerste } 1-0-0 \text {. } \\
\text { Ibidem voor de gewelle comt } 4-5- \\
2 \text {. }\end{array}$ \\
\hline 42 & Voor elcke genachtinge ibidem. & & \\
\hline 43 & $\begin{array}{l}\text { Item voor het accordeeren van de } \\
\text { immissie oftte groot geboth mette leer } \\
\text { van afgeboth, compt aen de } \\
\text { voorschreven vier gerechten acht } \\
\text { guldens elf stuyvers, dico 8-11. }\end{array}$ & 58 & $\begin{array}{l}\text { Item voor het accorderen van de } \\
\text { immissie ofte groot geboth mette } \\
\text { leer van affgeboth comt aen justitie } \\
8-11-0 \text {. }\end{array}$ \\
\hline 44 & $\begin{array}{l}\text { Item voor het accordeeren van de } \\
\text { zaysinne compt aen justitie tot } \\
\text { Hontem ende Heugem dry guldens dry } \\
\text { stuyvers, dico 3-3. }\end{array}$ & $\begin{array}{l}109 \\
110\end{array}$ & $\begin{array}{l}\text { Voor het accorderen van de } \\
\text { zaysinne comt aen justitie tot } \\
\text { Gronsfeldt 2-8-0. } \\
\text { Heughem ende Honthem 3-3-0. }\end{array}$ \\
\hline 45 & $\begin{array}{l}\text { Item de rechten van taxatie sijn overall } \\
\text { aen de voorschreven gerechten den } \\
\text { twintighsten pinninck. }\end{array}$ & 59 & $\begin{array}{l}\text { Item de rechten van taxaet is aen } \\
\text { justitie den twintighsten penninck. }\end{array}$ \\
\hline 46 & $\begin{array}{l}\text { Item voor een decreet van versteck } \\
\text { ofte seclusie compt aen de } \\
\text { voorschreven gerechten overall eenen } \\
\text { gulden, dico } 1-0 .\end{array}$ & 60 & $\begin{array}{l}\text { Item voor een decreet van } \\
\text { versteeck ofte seclusie comt aen } \\
\text { justitie } 1-0-0 \text {. }\end{array}$ \\
\hline 47 & Item voor een arrest ubique $1-0$ & & \\
\hline & & 61 & $\begin{array}{l}\text { Item comt aen eenen thoender ofte } \\
\text { exhibent van eenigh te realiseeren } \\
\text { acte } 0-10-0 \text {. }\end{array}$ \\
\hline 48 & $\begin{array}{l}\text { Item voor eene continuatie ter rolle } \\
\text { compt aen de voorschreven gerechten } \\
\text { overall vier stuyvers, dico } 0-4 \text {. }\end{array}$ & 62 & $\begin{array}{l}\text { Item comt voor eene continuatie } \\
\text { aen justitie } 0-4-0 \text {. }\end{array}$ \\
\hline 49 & $\begin{array}{l}\text { Item voor eene oblatie van te voldoen } \\
\text { ofte eenigh geschryft in te dienen, ten } \\
\text { seckere dagen dienende, compt aen de } \\
\text { voorschreven justitie met den decreet } \\
\text { thien stuyvers, dico } 0-10 \text {. }\end{array}$ & 64 & $\begin{array}{l}\text { Item voor eene oblatie van te } \\
\text { voldoen ofte in te dienen eenigh } \\
\text { geschryft ten seeckeren daeghe } \\
\text { dienende, comt met het decret 0- } \\
10-0 \text {. }\end{array}$ \\
\hline 50 & $\begin{array}{l}\text { Item voor eenighe renuntiatie ter } \\
\text { rollen te doen compt aen de } \\
\text { voorschreven gerechten naer proportie } \\
\text { van de oorkens als voorseyt is. }\end{array}$ & 65 & $\begin{array}{l}\text { Item voor eene renuntiatie van } \\
\text { eenige actie ter rolle gedaen comt } \\
\text { naer proportie der orkens. }\end{array}$ \\
\hline 51 & $\begin{array}{l}\text { Item voor speciale comparitie tsij in } \\
\text { eygene affayrens oftewel voor anderen, } \\
\text { wordt getaxeert voor eenen gemeenen } \\
\text { man eenen gulden, dico } 1-0 \text {. }\end{array}$ & 66 & $\begin{array}{l}\text { Item voor speciale comparitien tzij } \\
\text { in sijne eyghene affairens ofte voor } \\
\text { anderen, wordt getaxeert voor een } \\
\text { gemeyn man } 1-0-0 \text {. }\end{array}$ \\
\hline 52 & Item aen luydens van qualiteyt wordt & 67 & Item aen luydens van qualiteyt nae \\
\hline
\end{tabular}




\begin{tabular}{|c|c|c|c|}
\hline & $\begin{array}{l}\text { getaxeert naer advenant derselve } \\
\text { qualiteyten }\end{array}$ & & proportie der selver qualiteyten. \\
\hline 53 & $\begin{array}{l}\text { Dusdaenigh taxaet wordt oock } \\
\text { geobserveert soo ten reguaerde van } \\
\text { d'eene als d'andere persoonen } \\
\text { voorschreven in cas van eenige te } \\
\text { gevene getuygenisse. }\end{array}$ & $\begin{array}{l}68 \\
69\end{array}$ & $\begin{array}{l}\text { Item voor het geven van } \\
\text { getuygenisse wordt insgelijcken aen } \\
\text { een gemeyn persoon toegestelt } 1-0- \\
0 . \\
\text { ende voorders nae proportie van } \\
\text { een jeders qualiteyt. }\end{array}$ \\
\hline 54 & $\begin{array}{l}\text { Item voor een purgement van eenige } \\
\text { gronden van erven compt aen de } \\
\text { voorschreven vier gerechten seven } \\
\text { guldens vier stuyvers, dico } 7-4 \text {. }\end{array}$ & 70 & $\begin{array}{l}\text { Item voor een purghement van } \\
\text { eenige gronden van erven comt aen } \\
\text { justitie } 7-4-0 \text {. }\end{array}$ \\
\hline 55 & $\begin{array}{l}\text { Item voor een appellatie te doen ter } \\
\text { rolle offte andersins compt aen het } \\
\text { gerechte tot Gronsfelt ofte in den } \\
\text { leenzaele aldaer tweeentwintigh } \\
\text { goudtgulden ofte hondertthien guldens } \\
\text { courant, dico } 110-0 \text {. }\end{array}$ & 97 & $\begin{array}{l}\text { Item voor een appelle ter rolle comt } \\
\text { aen justitie tot Gronsfeldt } 110-0-0 \text {. }\end{array}$ \\
\hline 56 & $\begin{array}{l}\text { Tot Heughem, } \\
\begin{array}{l}\text { Hontem ende } \\
\text { Slenacken compt daer voor vijf } \\
\text { guldens, dico 5-0. }\end{array}\end{array}$ & 98 & Op de andere plaetsen $4-0-0$ \\
\hline 57 & $\begin{array}{l}\text { Item voor consignatie van eenige } \\
\text { documenten ten rechte ofte ter } \\
\text { greffien voor eenigen tijt compt aen de } \\
\text { voorschreven respective gerechten als } \\
\text { hier boven is uytgedruckt voor } \\
\text { exhibitien. }\end{array}$ & 99 & $\begin{array}{l}\text { Item voor consignatie van eenige } \\
\text { documenten ten rechte voor } \\
\text { eenighen tijdt comt aen justitie als } \\
\text { voor exhibitie. }\end{array}$ \\
\hline \multirow[t]{2}{*}{58} & $\begin{array}{l}\text { Item voor collationeeringe eeniger } \\
\text { stucken, inventarisatien van processen } \\
\text { compt aen de voorschreven vier } \\
\text { gerechten ter exclusie van de rechten } \\
\text { van de greffiers, voor het formeeren en } \\
\text { opsetten der inventarissen, } \\
\text { collationeeringen etc., elf guldens, dico } \\
11-0 .\end{array}$ & 100 & $\begin{array}{l}\text { Item voor collationeringhe ende } \\
\text { inventarisatie der processaele } \\
\text { stucken comt aen justitie buyten de } \\
\text { rechten van den secretaris voor het } \\
\text { opstellen van den inventaris etc., } \\
\text { comt segge } 11-0-0 \text {. }\end{array}$ \\
\hline & & 101 & $\begin{array}{l}\text { Item voor eene ontkentenisse ter } \\
\text { rolle gedaen comt aen justitie nae } \\
\text { proportie der orkens. }\end{array}$ \\
\hline 59 & $\begin{array}{l}\text { Item compt aen de greffiers voor } \\
\text { billeth proclamatoriael dienende een } \\
\text { voor al eenen gulden seesthien } \\
\text { stuyvers, dico } 1-16 \text {. }\end{array}$ & 63 & $\begin{array}{l}\text { Item comt aen den griffier voor } \\
\text { elck billeth proclamatoriael } 1-0-0 \text {. }\end{array}$ \\
\hline 60 & $\begin{array}{l}\text { Item voor admissie tot informatie } \\
\text { preparatoir compt de voorschreven }\end{array}$ & 107 & $\begin{array}{l}\text { Voor admissie tot informatie } \\
\text { praeparatoir comt aen het recht 1- }\end{array}$ \\
\hline
\end{tabular}




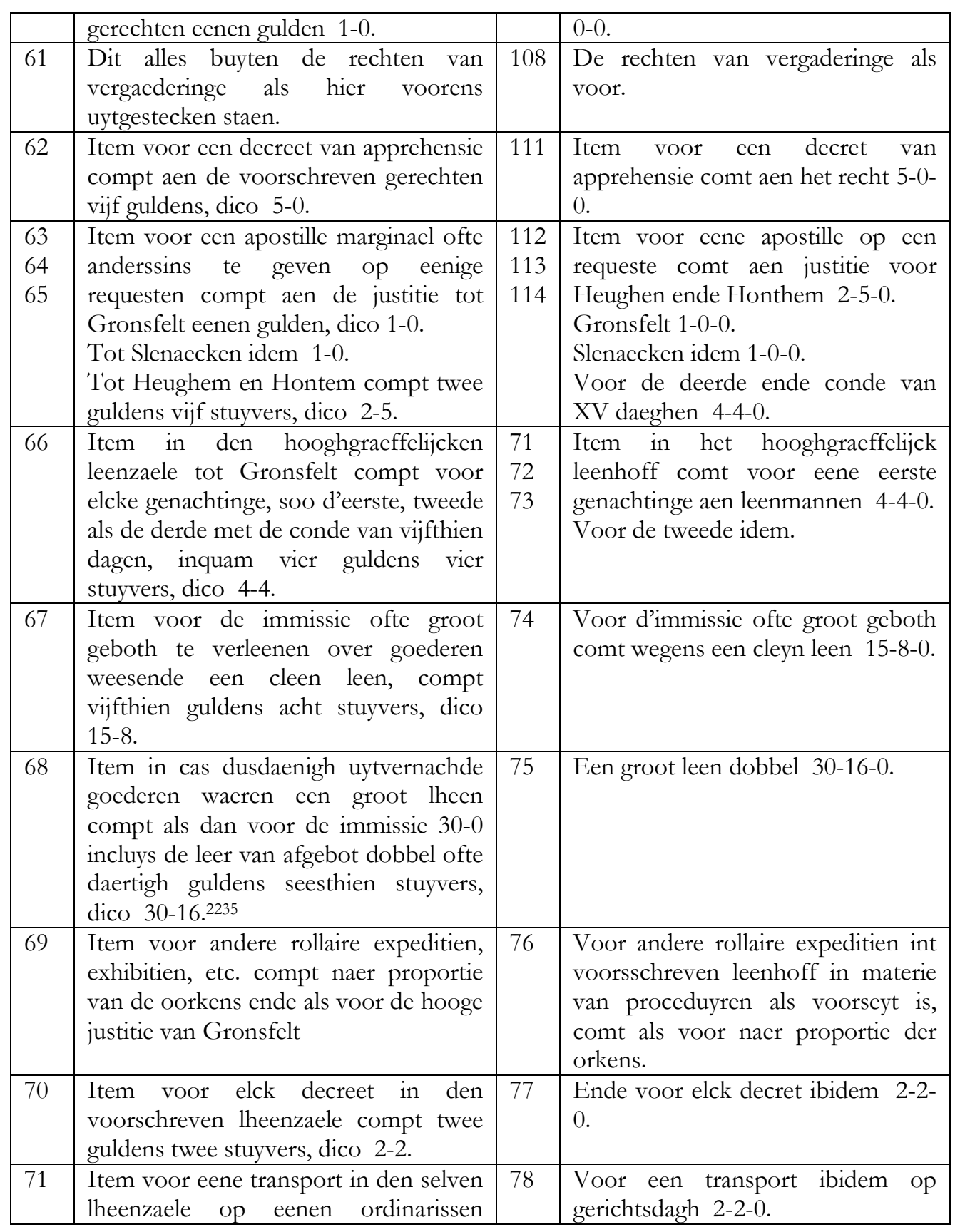

2235 In tekst van het concept, dat bij de uitgegeven tekst is toegevoegd staat hier nog de zin: 'Voor de zaysinne is insgelijcken dobbel in cas van groot lheen'. 


\begin{tabular}{|c|c|c|c|}
\hline & $\begin{array}{l}\text { rechtdagh ofte vergaderinge compt } \\
\text { twee guldens twee stuyvers, dico } 2-2 \text {. }\end{array}$ & & \\
\hline 72 & $\begin{array}{l}\text { Item voor het realiseeren der acten in } \\
\text { den selven leenzaele compt sees } \\
\text { guldens, sees stuyvers, dico } 6-6 \text {. }\end{array}$ & 79 & Voor acten te realiseren $6-6-0$ \\
\hline 73 & $\begin{array}{l}\text { Item buyten gerichtsdage compt daer } \\
\text { bij de vergaederinge als voor. }\end{array}$ & & \\
\hline 74 & $\begin{array}{l}\text { Item voor approbatie van een } \\
\text { testament compt in den selven } \\
\text { lheenzaele thien guldens thien } \\
\text { stuyvers, dico 10-10. }\end{array}$ & & \\
\hline 75 & $\begin{array}{l}\text { Item voor approbatie van een } \\
\text { testament met het verhooren der } \\
\text { getuygens van dyen, den notaris, } \\
\text { pastoor offte andere gequalificeerde } \\
\text { dusdaenigh testament geschreven } \\
\text { hebbende, soo noodigh compt aende } \\
\text { voorschreven respective gerechtens } \\
\text { overall vijf guldens, dico 5-0. }\end{array}$ & 41 & $\begin{array}{l}\text { Item voor approbatie van een } \\
\text { testament met het verhooren der } \\
\text { getuyghens van dien ende notaris, } \\
\text { pastor ofte andere dusdanighe } \\
\text { testament geschreven hebbende, } \\
\text { comt aen justitie } 5-0-0 \text {. }\end{array}$ \\
\hline \multirow[t]{3}{*}{76} & $\begin{array}{l}\text { Item voor het verhooren van getuygen } \\
\text { tsij in materie van thoon, bij informatie } \\
\text { preparatoir offte andersins compt aen } \\
\text { elcken schepen daer over staende ende } \\
\text { vaceerende voor elcken ghetuyge } \\
\text { daertigh stuyvers generaelyck voor de } \\
\text { voorschreven gerichten, dico } 10-10 \text {. }\end{array}$ & 42 & $\begin{array}{l}\text { Item voor het verhooren van eenige } \\
\text { getuygens, tzij in materie van } \\
\text { thoon, bij informatie praeparatoir } \\
\text { oft andersints, alseer twee ofte meer } \\
\text { getuyghen sijn, comt aen elcken } \\
\text { schepen daer over staende te } \\
\text { reeckenen van elcken getuyghen } \\
\text { dertigh stuyvers, is } 1-10-0 \text {. }\end{array}$ \\
\hline & & 43 & $\begin{array}{l}\text { Item alsser maer eenen getuyghen } \\
\text { te verhooren is comt aen de justitie } \\
\text { als voor } 1-10-0 \text {. }\end{array}$ \\
\hline & & 44 & $\begin{array}{l}\text { Ende aen den griffier comt naer } \\
\text { proportie van de vierde paert van } \\
\text { het geheel S.P.M. }\end{array}$ \\
\hline 77 & $\begin{array}{l}\text { Item voor alle acten het sij van cessien, } \\
\text { transporten, ontfanckenissen, } \\
\text { obligatien, constitutien, procuratien } \\
\text { ofte dergelijcke, tsij dat de selve } \\
\text { gepaseert worden voor recht offte } \\
\text { datse worden ten rechten geexhibeert } \\
\text { bij acten notariael etc ten fine van } \\
\text { realisatie compt aen de justitien tot } \\
\text { Heugem, Gronsfelt als Hontem met } \\
\text { het accordeeren van copye dry } \\
\text { guldens, dico 3-0. }\end{array}$ & 45 & $\begin{array}{l}\text { Item voor alle acten van cessien, } \\
\text { transporten, ontfenckenissen, } \\
\text { obligatien, constitutien, procuratien } \\
\text { ofte dergelijcke ten fine van } \\
\text { realisatie met het accorderen van } \\
\text { copye comt aen justitie tot } \\
\text { Gronsvelt, Heughem ende } \\
\text { Honthem 3-0-0. }\end{array}$ \\
\hline
\end{tabular}




\begin{tabular}{|c|c|c|c|}
\hline 78 & $\begin{array}{l}\text { Item voor dergelijcke acten te } \\
\text { passeeren voor den gerichte van } \\
\text { Slenacken compt aen justitie } \\
\text { vijfendaertigh stuyvers, dico 1-15. }\end{array}$ & 102 & $\begin{array}{l}\text { Item voor eene simpele transporte } \\
\text { tot Slenaecken komt } 1-15-0 \text {. }\end{array}$ \\
\hline & & 103 & Voor ontfenckenisse ibidem 1-15-0. \\
\hline 79 & $\begin{array}{l}\text { Item alse aldaer worden voorgebrocht } \\
\text { ten fine van realisatie compt aen } \\
\text { justitie dobbel rechten ofte dry gulden } \\
\text { thien stuyvers, dico 3-10. }\end{array}$ & 104 & $\begin{array}{l}\text { Voor realisatie ibidem dobbel is, 3- } \\
10-0 .\end{array}$ \\
\hline 80 & Het versoeck van copye $0-12$ & 105 & Verseuck van copye $0-12-0$ \\
\hline & & 106 & $\begin{array}{l}\text { Overal dobbele parthyen dobbele } \\
\text { rechten. }\end{array}$ \\
\hline 81 & $\begin{array}{l}\text { Aen den exhibent compt overal thien } \\
\text { stuyvers } 0-10 \text {. }\end{array}$ & & \\
\hline 82 & $\begin{array}{l}\text { Item voor het accordeeren van } \\
\text { proclamatoriaeles dienende tot } \\
\text { vercoop van eenige gronden, van } \\
\text { erven ofte oock van eenige mobiliaire } \\
\text { effecten compt aen de voorschreven } \\
\text { vier respective gerechten eenen gulden, } \\
\text { dico 1-0. }\end{array}$ & 46 & $\begin{array}{l}\text { Voor voortsgewijs ende het } \\
\text { accorderen van proclamatoriales } \\
\text { dienende tot vercoop van eenige } \\
\text { gronden van erven, comt aen } \\
\text { justitie 1-0-0. }\end{array}$ \\
\hline 83 & $\begin{array}{l}\text { Item voor het celebreren van elcken } \\
\text { sitdagh dienende tot vercoop als voor } \\
\text { compt aen de selve gerichten dry } \\
\text { gulden seesthien stuyvers, dico 3-16. }\end{array}$ & 47 & $\begin{array}{l}\text { Voor het celebreren van elcken } \\
\text { sittdagh dienende tot het vercoop, } \\
\text { comt aen justitie 3-16-0. }\end{array}$ \\
\hline 84 & $\begin{array}{l}\text { Item voor het vercoop naer } \\
\text { celebreringhe der gewoonelijcke } \\
\text { sitdagen mette impositie van het } \\
\text { eeuwigh geswijgh ende het } \\
\text { accordeeren van de ontsteckinge der } \\
\text { keersse dienende tot vercoop als voor } \\
\text { ofte totten palmslagh compt aen de } \\
\text { voorschreven vier gerichtens } \\
\text { respective seven guldens vier stuyvers, } \\
\text { dico 7-4. }\end{array}$ & 48 & $\begin{array}{l}\text { Item voor het vercoop eenigher } \\
\text { gronden van erven naer } \\
\text { celebreringe der gewoonelijcke } \\
\text { sittdaegen ende de impositie van } \\
\text { een eeuwigh geswijgh met het } \\
\text { accorderen van de ontsteeckinghe } \\
\text { der keertse ofte palmslagh comt aen } \\
\text { justitie 7-4-0. }\end{array}$ \\
\hline 85 & Voor eene liquidatie idem $7-0$. & & \\
\hline 86 & $\begin{array}{l}\text { Item voor elke te doene reclamme } \\
\text { compt voor de annotitie der selve } \\
\text { enckelijck aen de voorschreven } \\
\text { respective griffiers sonder meer thien } \\
\text { stuyvers } 0-10 \text {. }\end{array}$ & 49 & $\begin{array}{l}\text { Item voor elcke reclamme comt } \\
\text { voor d'annotitie aen den griffier } \\
\text { sonder meer } 0-10-0 \text {. }\end{array}$ \\
\hline 87 & $\begin{array}{l}\text { Item voor eene leer om parthijen te } \\
\text { meugen een afgeboth condigen van } \\
\text { eenige gronden van erven compt de }\end{array}$ & 50 & $\begin{array}{l}\text { Item voor eene leer om parthyen } \\
\text { een afgeboth te condighen van } \\
\text { eenige gronden van erven comt aen }\end{array}$ \\
\hline
\end{tabular}




\begin{tabular}{|c|c|c|c|}
\hline & $\begin{array}{l}\text { selve gerechten respective elf stuyvers, } \\
\text { dico } 0-11 \text {. }\end{array}$ & & justitie $0-11-0$. \\
\hline 88 & $\begin{array}{l}\text { Item compt aen den heer officier voor } \\
\text { permissie van dusdaenigh afgeboth } \\
\text { ende verleeninge van den bode ten fine } \\
\text { als voor eenen gulden, dico } 1-0 \text {. }\end{array}$ & 51 & $\begin{array}{l}\text { Aen den heer officier voor } \\
\text { permissie ende verleeninge van den } \\
\text { boede comt } 1-0-0 \text {. }\end{array}$ \\
\hline 89 & $\begin{array}{l}\text { Capittels, cloosters, gemeentenaeren } \\
\text { ende erfgenamen moeten overal } \\
\text { dobbel betaelen de rechten soo aen de } \\
\text { voorschreven respective vier gerechten } \\
\text { als aen de procureurs als de bodens. }\end{array}$ & 80 & $\begin{array}{lrr}\text { Capittels } & \text { cloosters } & \text { ende } \\
\text { erffgenaemen } & \text { betaelen } & \text { overal } \\
\text { dobbele rechten ende alsoo dobbele } \\
\text { parthye, dobbele rechten. }\end{array}$ \\
\hline 90 & $\begin{array}{l}\text { Item compt aen elcken procureur voor } \\
\text { elcke propositie voor de voorschreven } \\
\text { vier respective gerechten twalf } \\
\text { stuyvers. }\end{array}$ & 81 & $\begin{array}{l}\text { Item aen eenen procureur comt } \\
\text { voor elcke propositie ter rolle } 0-12- \\
0 .\end{array}$ \\
\hline 91 & $\begin{array}{l}\text { Except Slenaecken alwaer alleenelijck } \\
\text { overal is de hellight, ergo Slenaecken } \\
\text { sees stuyvers } 0-6 \text {. }\end{array}$ & & \\
\hline 92 & $\begin{array}{l}\text { Voor elck debath soo noodigh } \\
\text { insgelijck twalf stuyvers } 0-12 \text {. }\end{array}$ & 82 & $\begin{array}{l}\text { Voor elck debath insgelijck, soo } \\
\text { noodigh } 0-12-0 \text {. }\end{array}$ \\
\hline 93 & Slenacken in personaliter $0-6$ & & \\
\hline 94 & In reele saeken dobbel is $0-12$ & & \\
\hline \multirow[t]{3}{*}{95} & $\begin{array}{l}\text { Item compt aen den procureur ten } \\
\text { dage van vonnissen tsij contumatiale, } \\
\text { interlocutoyre off diffinityf, voor } \\
\text { propositie eenen gulden vier stuyvers, } \\
\text { dico } 1-4 \text {. }\end{array}$ & 83 & $\begin{array}{l}\text { Ten daeghe van vonnis, tzij } \\
\text { contumacies, interlocutoir ofte } \\
\text { diffinityf dobbel, is } 1-4-0 .\end{array}$ \\
\hline & & 84 & $\begin{array}{l}\text { Dobbele partyen oock dobbele } \\
\text { rechten. }\end{array}$ \\
\hline & & 85 & $\begin{array}{l}\text { Item in het lheenhof insgelijcke } \\
\text { dobbel als voor en naer proportie } \\
\text { van het banckrecht. }\end{array}$ \\
\hline 96 & $\begin{array}{l}\text { Item voor comparitie ende het } \\
\text { afwachten van den vonnissen diffinityf } \\
\text { insgelijck eene gulden vier stuyvers 1- } \\
4 \text {. }\end{array}$ & & \\
\hline 97 & Voor propositie oock eodem die 1-4. & & \\
\hline 98 & $\begin{array}{l}\text { Item ten dage van immissie compt aen } \\
\text { den procureur voor comparitie ende } \\
\text { propositie tsamen als voor twee gulden } \\
\text { acht stuyvers, dico } 2-8 \text {. }\end{array}$ & & \\
\hline 99 & $\begin{array}{l}\text { Item dage van vercoop ende liquidatie } \\
\text { idem } 2-8 \text {. }\end{array}$ & & \\
\hline 100 & Item compt aen den procureur voor & & \\
\hline
\end{tabular}




\begin{tabular}{|c|c|c|c|}
\hline & 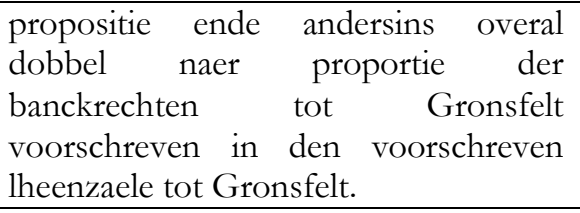 & & \\
\hline 101 & $\begin{array}{l}\text { Item compt aen eenen procureur voor } \\
\text { elck propositie ten tijde van thoon als } \\
\text { mede in materie van clachten ofte } \\
\text { crimineele actien eene gulden vier } \\
\text { stuyvers } 1-4 \text {. }\end{array}$ & $\begin{array}{l}90 \\
91 \\
92\end{array}$ & $\begin{array}{l}\text { Item comt aen eenen procureur ten } \\
\text { tijde van thoon ofte speciale } \\
\text { comparitie telckers wegens simpele } \\
\text { parthye } 1-4-0 \text {. } \\
\text { Buyten sijne propositien. } \\
\text { Idem is practicabel in materie van } \\
\text { clacht } 1-4-0 .\end{array}$ \\
\hline 102 & Slenacken $0-12$. & & \\
\hline 103 & $\begin{array}{l}\text { Item compt aen den selven voor } \\
\text { productie van elcken getuygen vier } \\
\text { stuyvers, dico } 0-4 \text {. }\end{array}$ & 93 & $\begin{array}{l}\text { Voor productie van elcken } \\
\text { getuyghe in materie van thoon } 0-4- \\
0 .\end{array}$ \\
\hline 104 & $\begin{array}{l}\text { Ende verders overal in sulcken cas te } \\
\text { dobbeleeren naer proportie als voor in } \\
\text { cas van extraordinaire dobbel parthijen } \\
\text { dobbel rechten. }\end{array}$ & & \\
\hline 105 & $\begin{array}{l}\text { Item compt aen den bode tot } \\
\text { Gronsfelt in loco voor elck simpel } \\
\text { dagement ofte insinuatie } 0-3 \text {. }\end{array}$ & 86 & $\begin{array}{l}\text { Den bode in Gronsfelt selfs voor } \\
\text { elck dagement oft insinuatie } 0-3-0 \text {. }\end{array}$ \\
\hline \multirow[t]{3}{*}{106} & $\begin{array}{l}\text { Tot Eckelraede, Hontem en Heugem } \\
\text { compt dobbel } 0-6 \text {. }\end{array}$ & 87 & $\begin{array}{l}\text { Tot Eckelrade, Honthem ende } \\
\text { Heughem 0-6-0. }\end{array}$ \\
\hline & & 88 & $\begin{array}{l}\text { Voor afgeboth te condighen van } \\
\text { elcke parthye twaelf stuivers, vide } \\
\text { ante } 0-12-0 \text {. }\end{array}$ \\
\hline & & 89 & Dobbele parthyen dobbele rechten. \\
\hline 107 & $\begin{array}{l}\text { Item aen den bode tot Slenaecken } \\
\text { voor alle dagementen en insinuatien } \\
\text { anderhalfven stuyver } 0-1 \frac{1}{2} \text {. }\end{array}$ & 94 & 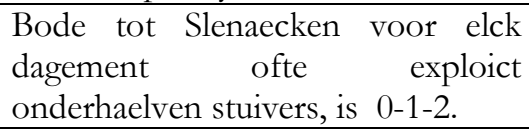 \\
\hline 108 & $\begin{array}{l}\text { Item voor schryftelijck relaes bij de } \\
\text { respective bodens te geven compt } \\
\text { boven hun exploet daer voor dry } \\
\text { stuyvers, dico } 0-3 \text {. }\end{array}$ & 95 & $\begin{array}{l}\text { Voor schryftelijcke inthimatie en } \\
\text { relaes ofte afgeboth } 0-6-0 \text {. }\end{array}$ \\
\hline 109 & $\begin{array}{l}\text { Item voor alle te doen affixiens sees } \\
\text { stuyver } 0-6 \text {. }\end{array}$ & & \\
\hline 110 & $\begin{array}{l}\text { Item compt aen de respective bodens } \\
\text { voor alle dagementen buyten haere } \\
\text { juridictiens, doch niet verder als eene } \\
\text { uyre achthien stuyvers, dico } 0-18 \text {. }\end{array}$ & 96 & $\begin{array}{l}\text { Buyten doorps voor de boedens } 18 \\
\text { stuyvers als het niet verder en is als } \\
\text { eene ure ende voorders naer } \\
\text { proportie } 18 \text { stuivers voor elcke ure } \\
\text { voor gaen en keeren, ergo } 0-18-0 . \\
\text { S.P.M. }\end{array}$ \\
\hline
\end{tabular}




\begin{tabular}{|c|c|c|}
\hline 111 & $\begin{array}{l}\text { Ende soo voorts voor elcke uyre voor } \\
\text { gaen en keeren eensgelijcken achthien } \\
\text { stuyvers } 0-18 \text {. }\end{array}$ & \\
\hline 112 & $\begin{array}{l}\text { Item ten dage van extraordinarissen } \\
\text { vergaederingen compt aen den bode } \\
\text { overal negen stuyvers } 0-9 \text {. }\end{array}$ & \\
\hline 113 & $\begin{array}{l}\text { Als oock ten dage van vonnis diffinityf } \\
\text { van elcke ten selven dage compt aen } \\
\text { eenen procureur voor sijne speciale } \\
\text { comparitie eene gulden vier stuyvers } \\
1-4 \text {. }\end{array}$ & \\
\hline 114 & $\begin{array}{l}\text { Item voor alle decreeten en fauten } \\
\text { compt aen justitie tot Slenacken eene } \\
\text { gulden vijf stuyvers } 1-5 \text {. }\end{array}$ & \\
\hline 115 & $\begin{array}{l}\text { Item compt aen de respective bodens } \\
\text { voor sommatie } 0-6 \text {. }\end{array}$ & \\
\hline 116 & $\begin{array}{l}\text { Item compt aen den selven voor het } \\
\text { afpenden ofte executeeren eene gulden } \\
\text { seven stuyvers } 1-7 \text {. }\end{array}$ & \\
\hline 117 & $\begin{array}{l}\text { Item compt aen de bodens voor } \\
\text { penden en dagen dobbel rechten voor } \\
\text { insinuatie als voor elcken assistent soo } \\
\text { noodigh thien stuyver } 0-10 \text {. }\end{array}$ & \\
\hline 118 & $\begin{array}{l}\text { Dobbel parthye dobbel rechten overal, } \\
\text { als mede op vaegtgedinge dagen. }{ }^{2236}\end{array}$ & \\
\hline & $\begin{array}{l}\text { Aldus gearresteert in judicio tot } \\
\text { Gronsfelt ende gelast naer te comen } \\
\text { desen tweeden mey } \\
\text { seventhienhondertvierentwintigh alles } \\
\text { bij provisie. Ende was geteckent: } \\
\text { J.God. Lebens, drossart der } \\
\text { graffschappe Gronsfelt, onder genaede } \\
\text { approbatie nochtans van Sijne } \\
\text { Hooghgraffelijcke Excellentie onsen } \\
\text { genaedigen lantheere. }\end{array}$ & $\begin{array}{l}\text { Dese rechten aldus affgetrocken } \\
\text { ende geannoteert uytten mont van } \\
\text { sieur Lambert Lousberchs, out } \\
\text { griffier over de } 40 \text { à } 50 \text { jaeren tot } \\
\text { Gronsfelt. } \\
\text { Onderstont: Attestere mits desen. } \\
\text { Was geteekent: Lambert } \\
\text { Lousberchs notarius publicus en } \\
\text { procureur der graeffschappe } \\
\text { Gronsfelt in fidem. } \\
\text { Concordantiam attestor } \\
\text { Ph. J. Pulinckx secretarius et } \\
\text { scabinus in Rijckholt. }\end{array}$ \\
\hline
\end{tabular}

Versie A: RHCL, Archieven van het Graafschap Gronsveld en de heerlijkheid Slenaken (tot 1728), inv. nr. 88; Versie B: RHCL, Archief Familie De Bounam de Rijcholt, inv. nr 490.

2236 In tekst van het concept, dat bij de uitgegeven tekst is toegevoegd staat hier nog de zin: 'Dobbele rechten voor intimatie als voor'. 
10 Verordening van baron Belderbusch als 'voogd' van gravin Maria Josepha d'Arberg Valengin, op de stijl van procederen bij de schepenbank Gronsveld

\section{3 oktober 1731}

\section{N.B. Het is de vraag of deze verordening ooit rechtskracht heeft gehad.}

Baron von Belderbusch vormundt der graffschafft Gronsfelt, nachdeme befunden die grosse unordtnung welche alda im still undt manier ist zu procediren, hat gutgefunden dieses nachfolgendes reglement undt articulen zu statuiren:

Erstlich dass im gericht alda beneben den fiscalischem anwalt drey beeijdigte procuratores seijn sollen welche alle vorkommende partheijen ahnnehmen und bedienen sollen, negst zahlung behorlichen salarii zu wissen fünff stüber lüttigs für jeden termin und zweij undt ein halben stüber für jedes blat papier beijderseiths mit achtzehn regulen beschrieben.

Dass diese procuratores ihre vorkommende sachen ahm gericht sollen müssen vorbringen oder durch proposition und communication mit antworth, replick undt duplic oder auf dem protocoll per verbalem propositionem aut conclusionem durch ihnen selbst auf dem prothocoll und nicht durch den actuarium prout hucusque zu schreiben.

Dass die processen so in communicatorio zu instruiren in originalibus ohn beyderseiths partheijen procuratoren durch den botten insinuiret werden sollen, welcher für diese insinuation gleich auch für alle andere simple undt nicht daurende exploiten im dorff Gronsfelt zu thuen allein haben soll, von jedem exploit fünff stüber undt für jeder uhr nach advenant, von denen anderen ausliegenden dörfferen oder langdaurende exploiten auch fünff stüber.

Dass diese procuratores sollen müssen halten undt reserviren copij von allen ihren schrifften in judicio vorgebracht seindt und von denen decreten auf welchen copije sie sullen thuen stellen die relation des bottens unterzeichnet mit tag undt dato seines exploits.

Dass kein procurator ichtwas soll mogen dienen oder proponiren ohne dass er habe ein schrifftliches mandatum ad litem welches er beij copij soll fügen bij seiner ankünfft beijm gericht

Dass jedes decret in communicatorio nicht hoher bezahlet soll werden mogen als mit dreij schillingen für rechten des gerichts inbegriffen die von den greffier undt für jedes sieben schillingen, id est $3 \frac{1}{2}$ schilling für jede parthij.

Dass in denen decreten regulativis aut definitivis in welchen referiret undt gelesen ist, welches nicht geschehen mag alss beij gewisses ahnersuchen von einer parthij, soll gerechnet werden zweij schilling für jede uhr undt für jeden scheffen undt greffier das doppelte, aber ahn den drossard für jede uhr undt für dennen abwesenden nichts.

Dass der actuarius alle copijen relaxiren soll ohne ahnstandt und nach proportion von zweij undt ein halben stüber per blath ut supra annebens einen schilling für jede unterschreibung die er darauf thuen soll si petatur. 
Dass alle decreten so in communicatorio gegeben ahngezeichnet werden sollen mit tag undt dato gebuhrnussen undt nahmen der partijen undt überschrifft worauf sie gegeben seijen die decreten aber so zum protocollo gegeben werden müssen ordentlich findtbahr seijen auf den fuss jeden protocolls undt von denen vorigen decreten undt urthelen wovon die minute geheimb bleiben muss wovon er actuarius einen besonderlichen register machen undt also allezeit bereith seijn umb dieses register undt originele minuten vorgemelt zeigen zu können ahn denen scheffen im fall nöthig.

Dass die processus communicatorii auf manisse des drossardts undt beij verhindernuss durch den altisten scheffen per manus zweijer mitscheffen undt den gerichtschreiber undt dessen verhindernuss durch einen dritten scheffen aussgefertiget werden sollen undt im fall der extraordinairen versamlungen soll jeder scheffen undt gerichtschreiber allein rechnen können einen schilling für seinen gang undt der drossard das doppelte.

Dass die ordinaire versamlungen seijn sollen von vierzehn $\mathrm{zu}$ vierzehn tagen auf donnerstag undt solcher ain fest tag oder verhindernuss were, auf den negsten folgenden freijtag undt sollen kein andere ferien gehalten werden als in denen rechten exprimiret.

Befehlet also ahm drossard zu Gronsfelt dies vorschriebenes reglement provionell auf sontag morgens publiciren zu thuen undt zu unterhalten thuen, dabeneben befehlet ahn alle unterthanen daselbst selbiges also zu observiren.

In urkundt hat dieses unterzeichnet undt durch den kaijserlichen notarium Schwarz ahn den vorgemelten drossard zur handt stellen thuen.

Actum auf dem grafflichen haus Gronsfelt diesen 13 oktober 1731.

Erat signatum Belderbusch.

Authentiek afschrift, Duitse vertaling van Nederlandse tekst.

RHCL, Archief Rijkskamergerecht, inv. $n r 71$, proces Gathoye tegen graaf d'Arberg Valengin, Q 242, fol. 595-596.

11 Verordening van graaf Ignaz Felix von Toerring-Jettenbach als voogd van gravin Maria Josepha d'Arberg Valengin, betreffende de inning van de schatting op grond

januari 1734

Wir Ignatius Joseph Felix, des Hei[igen] Romischen Reichs-Graf und Herr beyder Herrschafften Törring und Jengling, auch Jettenbach, Aschaw und Modling, Herr der Herrschafften Falckenstein, Neuhauss, Zehl, Simbach, Stallwang, Winhörig, Arbing und Walberg, Ich[rer] Churfürstl[icher] Durchl[aut]in Bayeren würcklich Geheimer- und Conferentz-Rath, Cammerer dess Hoch-Adlichen S[ankt] Georgii Ritter-Ordens GrossCreutz-Herr, Hof Kriegs-Rath Vice Praesident, General Feld-Marschall-Lieutenant und Obrist-Zeugmeister, Obrister über ein Regiment zu Pferd, Erb-Land-Jägermeister in Bayeren, Gemeiner wohl-Löbl[ichen] Landschafft der Orthen Mit-verordtneter- Pfleger zu Trostberg, dan beyder Hoch-Löbl[icher] Ertz- und Domstiffteren Saltzburg und 
Regenspurg Erb-Cammererr und Erb-Marschall, als über vorhandene minderjährige Gräffin von Arberg und Valengin Reichs-Gräfin dieser Graffschafft Gronsfeld allergnädigst anverordneter Vormund.

Entbiethen allen und jeden in dieser Reichs-Graffschafft, Beerbten so wohl als Einwohner und Unterthanen, unseren geneigten und gnädigen Gruss hiemit denenselben zu erkennen anfügend, dass gleich wie Wir von Anfang der übernohmener Administration vor allem dahin eyfferig bedacht gewesen damit diese Reichs-Graffschafft auss so vielen einige zeithero erlittenen verderblichen Troublen wiederumb ins Auffnehmen gebragt und alles eingeschlichene Ohnwesen zeitlich auss dem Weeg geraumbet, mithin allenthalben gute Ordnung zum Nutzen und Trost der Unterthanen und Eingesessenen, so wohl als auch der in dieser Graffschafftlichen Territorio Beerbten Ausswendigen eingeführt, auch derselben Beobachtung festgestellt werden mögte, Wir aber dabey mit sonderbahrem Bedauren verspühret dass hauptsächlich und die mehreste Verwirrung daher entstanden, weilen die so nöthig als ohnumbgängliche jährige Lands-Schatzung durch allerhand fast ärgerlichen Vorwand so gar bis 22 gantzer Jahre hintertrieben worden, wodurch notwendig erfolgen müssen dass die rechtmässige Lands-Creditoren des ihrigen so lange Zeit frustrirt, die Reichs- und Cräyss-Praestanda immerhin rückständig geblieben, der Schulden-Last von Jahr zu Jahr mehr aufgeschwollen und nicht ohnbillig zu befahren seye, dass endlich die so lang bedrohete Reichs-Executiones zur würcklichkeit gebracht werden dörfften, Wir dahero zu gäntzlicher Vorkommung aller bisshero eingewendeter, auch etwa ins künfftig formiren wollender ohnbegründeter Vorwürff sorgfältig verordnet dass zur allgemeiner Gleichhaltung nach eines jeden Gesessenheit die Lands-Matricul von newen aufgerichtet werden solle, wie selbige dann auch dem beschehenen Rapport nach dermahlen zum Perfections-Stand gerathen ist.

Damit nun auch ferner bey künfftigem Empfang so wohl als Aussgab der LandsSchatzungen überall eine proportionirliche Gleichheit gehalten und auch die einnehmende Pfenningen zu allgemeinem dess Lands Nutzen und Notturfft sicherlich verwendet werden sollen, zu dem End thuen Wir hiemit, krafft habender Lands-Obrigkeitlicher Superioritaet und Macht, verordnen und wollen dass an denen einkommenden Collecten oder Land-Schatzungen so für diess Jahr auf zwey Gulden per Bonder angeschlagen werden, alle Jahr den zweyten Montag nach Drey Königen mit vorheriger Läutung der Glocken und Einladung der Meist-Beerbten Rechnung und Anweisung geschehen solle, wie die Gelder alle zu vorgemeldtem End der Lands-Herrlicher Ausschreibung gemäss eingetrieben und verwendet worden seyen.

Damit nun ferner dieser unserer Verordnung von einem jeglichen desto williger als schuldig nachgelebt werde, so thuen Wir anbey nahmens der Minderjähriger, uns durch Kayserl[iche] Authorität anvertrawter Gräfflichen Pupillin hiemit pro lege \& sanctione perpetua die offentliche und willige Erklährung, dass Wir ins künfftig keine LandsSchatzungen aussschreiben werden noch wollen, es seye dann allein zum allgemeinen Nutzen oder allgemeinen Notturft keines Sinns zweiffelend, die in dieser ReichsGraffschafft Begütete und Beerbte werden unsere Lands-Herrliche Sorgfalt von selbsten gezimmend und behörend anzuerkennen wohl wissen. 
Geben München den januarii 1724.2237

L[ocus] S[igilli]

Gedrukt, RHCL, Archief Rijkskamergerecht, inv. nr. 192, Band 1, Q 16, bijlage 49.

12 Benoeming door de aartsdiaken van Haspengouw van pastoor H. D. Nijpels te Maastricht tot officiaal van de aartsdiaken en bekendmaking van de zittingen van het officialiteitsgerecht

$$
17 \text { januari/1 maart } 1735
$$

Mandatum impressum.

Michael Clercx, Cathedralis Ecclesiæ Leodiensis canonicus, in eadem Hasbania Archidiaconus, collegiatæ ecclesiæ S. Dionisii Leodiensis Præpositus.

Reverendo domino Henrico Nijpels ecclesiæ Sancti Martini oppidi Trajectensis pastori, salutem et omne bonum.

Cum archidiaconatus nostri bono regimini nihil tam necessarium sit quam jurisdictionis nostræ archidiaconalis administrationi præficere et commitere viros probos et capaces major vero pars pastorum clericorum et incolarum in oppido Trajectensi et locis circumvicinis commorantium et archidiaconatui nostro subditorum commoditas aliaque motiva exposcant ut præfata jurisdictio in illis partibus non solum exerceatur sed et illius exercitium in longiores moras non differatur, hinc de tua fide, integritate, morum gravitate, experientia et doctrina sufficienter informati et plurimum confidentes, te in officialem nostrum in causis dicti oppidi et pagorum Ultra Mosanorum de Heer, Keer, Cadier, Bergh, Gronsvelt, Heugem, Eijsden et Breust, Bernau, Gulpen, Wijler, Merggraten, S. Gertrudis eidem oppido adjacentium nec non pagorum Cismosanorum Nijl Sancti Servatii, Zepperen, Houpertingen, Russon, Hamal, Grootloon, Vleijtingen, destrictus de Paive et Nedrem, Moupertingen, Lanaeken, Petersem et aliorum qui Statibus Hollandiæ, nec non capitulo Sanct Servatii in dicto oppido ex Undecim vulgo nuncupatis Bancis subsunt et parent ac incolarum et subditorum dictorum pagorum quatenus archidiaconatui nostro subsint, eove jurisdictio nostra archidiaconalis se extendat, creamus, constituimus et deputamus per præsentes commitentes tibi in dictis locis jurisdictionis nostræ tam civilis quam criminalis prout nobis de jure et consuetudine competit, præfatum exercitium cum potestate inquirendi, corrigendi et secundum juris dispositionem puniendi quoscumque excessus et delicta ad cognitionem et jurisdictionem nostram archidiaconalem spectantia et cætera omnia et singula faciendi quæ ad officialem illic nostrum spectant et pertinent, mandamus itaque omnibus pastoribus, præsbiteris, clericis aliisque dictorum oppidi et locorum incolis ac officiatis et archidiaconatui nostro subjectis ut tibi tamquam officiali nostro vicesque nostras supplenti debitos reverentiam et honorem præstent ac deferant in

${ }^{2237}$ Dag niet ingevuld 
quorum fidem presentes sigillo et signatura nostris munitas per notarium inscriptum subscribi iussimus,

Leodiii ex ædibus solitæ nostræ habitationis et residentiæ sub immunitatibus ecclesiæ collegiatæ Sancti Pauli sitis, sub anno Domini millesimo septigentesimo trigesimo quinto januarii die dominica septima.

A latere signatum erat: M. Clercx archidiaconus Hasbanix.

/ab alio latere erat/ Et sigillum ejus majus impressum in hostia rubra.

Infra signatum: De mandato reverendi admodum perillustris ac generosi domini mei canonici ac archidiaconi suprafati speciali Renerus Florentius Fresart, episcopalis Curix Leodiensis et præfati archidiaconatus notarius.

Inferius habebatur uti sequitur:

Requiruntur domini pastores ut in missa parochiali hasce more solito nobis commissas delegationis litteras populo prælegere et annuntiare velint ut in causis archidiaconali jurisdictioni subjectis nos ut judicem delegatum recognoscant noverintque ordinariam nostram diem juridicam statui singulis hebdomadis ad mercurii hora decima matutina nobisque remittatis publicationem rite factam a vobis debite signatam.

Actum Trajecti in domo nostro pastorali hac prima martii 1735.

/Signatum erat/ H. D. Nijpels archidiaconatus Hasbanix officialis Trajecti ad Mosam residens, ibidem Sancti Martini pastor.

Afscbrift van een gedrukte tekst.

RHCL, Archief Parocbie Sint-Martinus in Maastricbt-Wyck, inv. nr. 4, fol. 89-92.

13 Verordening van de grafelijke commissaris J. A. Prummer op het 'aanbrengen van de gronden'

\section{1 september 1754}

Het is, (gelijck gemelt is worden bij een Proclama geaffigeert den 24. Mey laestleden), in het Jaer 1733 door de doenmaelige Hoogh-Graeffelijcke Gronsfeldische Momboirschappe geordonneert worden, dat allen de Goederen en Erven, gelegen in dese Graefschappe Gronsfeldt, hoedanig de selve zyn mochten, met haere nature, maete, lasten en andersints by straff van eene onvermeydelijcke Amende van 50 Pattakons voor jeder Boender getrouwelijck souden aengebrocht worden, op dat alle disordres, abuysen, en differentien, voorgevallen in de voorige jaeren, principalijck in't collecteeren der REEËLE SCHATTINGEN, tenemael geamoveert, en door ' $t$ formeeren van eene ordentelijcke LANDTS-MATRICUL aen alle swaerigheden in't toekomende voor altydt soude konnen geprevenieert worden. 
Maer alsoo dusdaenig heylsaem voornemen niet teenemael tot hierentoe is voltrocken, het welck nochtans tot welvaeren van het gemeene best naer Recht en Reden vereyscht word; soo is men van dien tijdt aen bedacht geweest, om sulcx op de beste en secuerste maniere alnoch werckstellig te maeken, ende heeft men ten dien eynde over de geheele Graefschappe van stuck tot stuck, soo ende gelijck de selve is gelegen, alreets laeten formeeren een PLAN oft CAERTE FIGURATYF.

Dus wilt men den arbeyt en moeyten oock wel aenwenden, om daer uyt een werck te maecken, het welck niet alleen tegenwoordig sal zyn seer voordeelig, maar oock in't toekomende verhoeden veele abuysen, meetingen, ende hermeetingen, differentien, kosten en processen, en een jeder dienen tot een fondament en gestaedige seekerheyt, gelijck by de naeste Landts-vergaderinge voorgebrocht sal worden.

Oversulcx is het oock seer noodtsaeckelijck, dat men wete de natuere en essentie van alle stucken en gronden, om soo wel het eene als het andere in de voorhandene en te maeckene LANDTS-MATRICUL behoorlijck te konnen insereeren ende exprimeeren.

Daeromme soo word uyt krachte der Authoriteyt, gegeven by de Hooch-Graeffelijcke Commissie mits desen serieuselijck geordonneert, dat alle ende jegelijcke, soo in-alsuytgesetene hunne Goederen ende Erven, gelegen in dese Vrye Rycx Graefschappe Gronsfeldt, t'zy Huys, Hof, Landt, Weyden, Bembden, Houtgewas, Driessen, oft wat het immers mach weesen, groot oft kleen, stuck voor stuck op de hier-naer-volgende maniere onfeelbaer sullen hebben aen- te-brengen tusschen dit ende den derthienden Octobris naest-komende, voor de genige, die daer toe sullen worden gedeputeert, ende ten dien eynde in de ordinarisse Gerichts-Camer tot Gronsfeldt sullen vaceeren den 25, 27, en 30. deses maendts September, ende den 2, 4, 7, 9 ende 11. Octobris naestkomende, alle dagen des voormiddags van 8 . tot 12 . ende des naermiddags van 2. tot 4. uren, alswanneer de geenige die meer als vier stucken besitten, sullen zijn gehouden de selve schriftelijck aente-brengen en de geenige, die maar 4. oft minder stucken besitten, konnen de selve mondelings aengeven om geprotocolleert te worden.

De puncten die by het aenbrengen principalijck moeten geexprimeert worden, zyn de volgende.

$1 \mathrm{mo}$ Den Naem en Toenaem der besitters, het Dorp waeronder het aen-te-brengene stuck oft stucken moveeren: de plaetse daer jeder stuck ligt: de naemen der stucken soo sy eenige in't particulier hebben.

2do De tegenwoordige Reigenooten.

3tio De maete met expressie van Boender, groote en kleene Roeden.

4to Oft het is Leen-Chens oft Erf-pacht, \&c. en aen wie, ende met hoe veel de twee laeste zyn belast. Ende

5to oft noch andere lasten, als Koey- Peerts-keuren oft desgelijx daer op zyn geaffecteert. Ende vermits eene gelijck-formige opstellinge en specificatie der Aenbrengers den voorderen arbeyt, daer over te doen, seer kan faciliteeren, soo wilt men des wegen het volgende hier onder stellen, tot een Exempel, waer naer een jeder (observatis observandis) sig kan reguleeren. Te weeten

1 mo Christ. Ruth van Keer brengt aen onder Gronsfeldt, Eckelraede, Heugem oft Hontem, een Stuck Landts, gelegen in't Vroendal, onder 
Blanckenberg, oft in den Kleynhof, genaemt

2

Reyg. ter eenre naer Sonnen opganck NN. ter andere zyde naer Sonnen onderganck NN. Voorhooft naer Sonnen middag NN. en aen het ander hooft NN.

Aenhoudende 1. Boender, 16. groot, 5. kleene Roed.

Weesende Leen-roerig onder Gronsfeldt, oft moet jaerlijcx betaelen 1. gl. 2. st. 1. oort Chens, oft 1. Vat 3. Koppen Roggen jaerlijcxen Erf-pacht aen NN.

Belast met eene Koeye- oft Peerts-keur aen NN.

Mits welcke vertrouwt men dat een jeder dit dienelijck, en seer noodtsaekelijck werck door een tydig en oprecht aenbrengen sal helpen accelereeren ende vervoorderen;

Edoch in cas jemand, tegens alle verwachtinge, daer aen quamp te contravenieeren, soo sal (inhaerendo de voorige Edicten) den dyen, oft de geenige, die jet sullen hebben versweegen, zyn vervallen in eene irremissibile Amende van 50 Pattacons voor jeder Boender, het welck niet, oft te weynig sal zyn aengebrocht, en voor het mindere naer proportie van de maete, die sich by metinge oft andersints sal meer bevinden, als aengebrocht is worden. Ende de geenige die eenige Chens, Erf-pacht, Koeye- oft Peerts-keure verswygen, sullen vervallen zyn van de hellichte der weerdye van den gront, waer op de selve zyn geaffecteert; en sullen de verweegene Leenen gants en geheel in commissum zyn vervallen, en den geenen die soodanige sal aengeweesen hebben, sal, onder verswyginge van synen Naem, genieten de halfscheyt der straffe, daer van voortskomende, maer de geenige die op den gepraefigeerden tydt niet aenbrengen, sullen gehouden worden voor alles versweegn te hebben, ende dienvolgens wegens soodaene versweegene erven vervallen zyn in de voorsz. respective Amendens.

Voorders worden de Pachters, en Half-winnen mits desen vansgelijcken vermaent ende gelast, van sulcx aen hunne respective Heerschappen tydelijck, en sonder uytstel bekent te maecken, op poene dat sy voor den schaede, en alle onheyl daer uyt te resulteeren, sullen moeten instaen, ende op dat niemandt eenige ignorantie kan pretexeeren, is goetgevonden deese niet alleen in publijcken Druck te laeten uytgaen, en by Affixien ad valvas alomme in dese Graefschappe kenbaer te maecken, maer oock eenige deser gedruckde exemplairen aan de vier Borgemeesters van Gronsfeldt, Eckelraede, Heugen, en Hontem ten dien eynde over te reycken ende te behandigen, opdat een jeder sulcx aldaer kan bekomen, ende de noodige informatie daer uyt nemen, en besonderlijck op dat de Pachters en Halfwinnen de selve aen hunne Heerschappen konnen overbrengen, en de selve hun diensvolgens niet konnen ontschuldigen, dat sy van hunne Pachters oft Half-winnen niet zyn worden geinformeert.

Actum Gronsfeldt den 21. September 1754.

(L[ocus] S[igilli]). J.A. PRUMMER Commiss[arius]. (L[ocus] S[igilli]) J. BERCHMANS Secretarius. 
Gedrukt.

RHCL, Archieven van het Graafschap Gronsveld en de heerlijkheid Slenaken (tot 1728), inv. nr. 210.

14 Verordening wegens illegale houtkap ter hoogte van de Eckelrader 'gemeynte'

17 december 1760

\begin{abstract}
Affixie
Alsoo het district en situatie van houdtgewass off bosch gelegen op Bertenbergh tusschen reigenoten respective naer oosten Reyneer Bessems, juffrouwe de weduwe Van Ophem, Jan Lemmens en Servaes Bouchoms, naer westen oock Reyneer Bessems en Mechtild Conincx, boven tegens Eckelraede het velt, onder de Joestekeel en diverse parceelen van houdtgewas daerop aenstoetende, onder pretext van hetselve te wesen Eckelraeder gemeynte, nu eenige jaeren herwaerts door sommige sonder eenigh het minste recht dyen aengaende, sig aengemaetight hebbende door puyre invasie, is worden geusurpeert ende daerenboven nog door de daerbij gebruyckte ongeregeltheden op eene ten uytersten onbetaemelijcke wijse beschaedight en geschent, jae selffs het Edict ten regaerde van de bosschen en het houdtkappen geëmaneert ende door affixie gepubliceert den $8^{\mathrm{e}}$ novembris 1755, door groote temeriteyt overtreden ende gevilipendeert, soo ist dat om dese en meer andere redenen bij gevolgh ten behoorlijcken plaetse en tijde soo noodigh te produceren, mits desen wordt verkondight dat alle en jegelijcke wie het oock wesen mochte, inwoonders off vreemdelingen, sig sullen hebben t'onthouden van eenigh houdt, doorens, ginster oft van wat name het zij, veel off weenigh, in het voorss. district en situatie van houdtgewass, pretense genoemt de Eckelraeder gemeynte, te kappen, te snijden off op eenighe bedenckelijcke maniere aff te doen off verbrengen voor en aleer sig door wettelijcken titel off titels van sijn off hun recht daertoe pretenderende, bij gericht behoorlijck gequalificeert te hebben, waertoe wordt bepaelt den tijd van eenen maendt nae dato van dese affixie ende sulcx onder abitraire straffe naer bevindingen van contraventie boven de geene als bij het Edict van 8en novembris 1755 gestatueert is teegens de overtreders van het selve, te weten van thien goudt guldens off bannissement, ende opdat nyemant eenige ignorantie kan voorwenden, is geordonneert het selve bij deser affixie publyckelijck bekant te maaecken.
\end{abstract}

Afschrift, geregistreerd in het gerechtsprocol van Gronsveld. Herhaling van bet Edict wegens illegale houtkeap van 8 november 1755 .

RHCL, Archieven van het Graafschap Gronsveld en de heerlijkheid Slenaken (tot 1728), inv. nr 254, fol. 45-46. 
15 Verordening tegen loslopende varkens

13 februari 1762

Affixie

Wort hiermede serieuselijck verboeden en een yder verckens hebbende gewaerschouwt van int toecomende soodaenighe sorge te draegen dat hunne verckens niet meer bevonden worden in andermans gaerdens, weijden, velderen als mede op de gemeijnte, op pene dat de eijgenaers derselve voor elck vercken telcke reijse bevonden in andermans gaerdens, weijden, velderen off op de gemeijnte (buyten bonificatie van den gedaenen schaede en ordinairen schot- off pendtpenningh aen den boede) sullen incurreren eene irremissibele amende van twee guldens Brabants Maestrichter cours en op dat nyemant eenighe ignorantie kan praetexeren, is geordonneert dese bij billet van affixie te publiceren. Actum Gronsfeldt den 13e februarij 1762.

(onderstont) Ter ordonnantie (signatum) Joh. Frans Lebens scabini en gecommitteerde loco secretarii.

Volgt relaas van de afkondiging door de gerechtsbode in Gronsveld, Heugem, Eckelrade en Honthem 15 februari 1762.

Afschrift, geregistreerd in het gerechtsprocol van Gronsveld. RHCL, Archieven van het Graafschap Gronsveld en de heerlijkheid Slenaken (tot 1728), inv. nr 254, fol. 117.

16 Verordening op het 'aanbrengen van de gronden'

16 augustus 1766

Alsoo men bevindt dat het zedert het laeste rapport der goederen gelegen onder dese vrye Rijckxe Graeffschappe Gronsfeldt anno 1754 geschiet, sig als nu dagelijcx meer en meer abuysen en differenten opdoen en principaelijck int collecteren der gemeene reele schattingen, sulcx door het veranderen der namen van de possesseurs der gronden en erven te meer dat d'acquesteurs voort meestendeel in faute blijven van hunne goederen, soo op de schattlijsten als elders te laeten aff- en toeschrijven,

daeromme soo wordt hiermede uyt krachte der authoriteyt gegeven bij de Hooghgraeffelijcke Commissie, serieuselijck geordonneert ende geboeden, dat alle ende jegelijcke, soo in- als uytgesetene hunne goederen ende erven gelegen in dese vrye Rijckxe Graeffschappe Gronsfeldt en ap- en dependentien dyer die sij t'zedert voorss. laeste rapport geacquireert hebben, het zij bij koop off verkoop mangelinghe, donatie, successie, scheydinghe en deelinghe, off op wat bedenckelijcke maniere het wesen mocht, het sij huys, hoff, landt, weyden, bembden, houdtgewasch, driessen off wat het immers wesen 
magh, groot off kleen, stuck voor stuck, met hunne situatie van velder off dorpen, naemen, reygenoten, specificatie der nature van gronden, item met de erfflasten daerop geaffecteert en waer van deselve goederen affkoemen, sullen hebben aen te brengen tusschen dit en den sesden septembris naestkoemende, sulcx voor de jenige die daertoe sullen worden gedeputeert ende ten dyen eynde in de ordinaire gerichts-camer tot Gronsfeldt sullen vaceren den 20, 22, 25, 27, 29 en 30 deses loopende maents augusti en den 2 , 4 , en 5 septembris naestkoemende alle daghen des voordemiddags van 7 tot 12 uren ende des naerdemiddaghs van 2 tot 5 uren, als wanneer diejenige die meer als vier stucken besitten sullen sijn gehouden deselve schrijfftelijck aen te brengen en de jenige die maer vier off minder stucken besitten, konnen deselve mondelings aengeven om geprothocolleert te worden en sal yder ter greffie moeten betaelen vijff stuyver per boender off nae proportie van de maete.

Edogh in cas ymandt tegens alle verwachtinge aen dese ordonnantie off gebodt quamp te contravenieren, soo sal sulcken off sulcke die iet sullen hebben versweegen, vervallen sijn in eene irremissibile amende van vijfftigh pattacons voor yder boender, het welck niet off te weenigh sal sijn aengebracht en voor het mindere nae proportie van de maete, die sig bij meetinge off andersints sal meer bevinden als aengebracht is worden, ende de jenige die eenighe chins, erffpacht, koeye- off peerdts-keuren verswijgen, sullen vervallen sijn van de hellichte der waerde van den grondt waerop deselve sijn geaffecteert en sullen de versweegene leenen gans en geheel in commissum vervallen sijn ende den geene die soodaenighe sal hebben aengewesen, sal onder verswijgh van sijnen name, genieten de halffscheydt der straffe daervan voortskoemende ende de jenige die op den gepraefigeerden tijdt niet aenbrengen, sullen gehouden worden voor alles verswegen te hebben ende dyen volgens, wegens soodaene verswegene erven vervallen sijn in de voorss. respectieve amendens.

Voorders worden de pachters en halfwinnen mits desen vansgelijcken vermaent en gelast van sulcx aen hunne respectieve heerschappen tijdelijck en sonder uytstell bekent te maecken op poene dat sij voor den schaede en alle onheyl daeruyt te resulteren sullen moeten instaen en opdat nymandt eenige ignorantie kan praetexeren, is geordonneert dese bij affixien ad valvas en ter gewoonlijcke plaetse kenbaer te maecken en affigeren.

Actum Gronsfeldt den 16en augusti 1766.

Ter ordonnantie.

Johan Frans Lebens, scabinus en gecommitteerde loco secretarii.

Gedrukt.

RHCL, Archieven van het Graafschap Gronsveld en de heerlijkheid Slenaken (tot 1728), inv. nr. 210. 
17 Verordening tegen het maskeren tijdens Vastenavond

18 februari 1767

Affixie

Wort alle en iegelijcke onderdaenen deser vrije Rijxe Graeffschappe Gronsfeldt en ap- en dependentien dyer mits desen serieuselijck gewaerschouwt en scherpelijck verboden gedurende dese vastenavontsdagen sig te verkleeden off masqueren off eenige vastenavontvuyr te maecken off daeraen te helpen contribueren op poene van drye goudtguldens amende, t'incurreren voor elcken en voor elcke reyse die bevonden sal off sullen worden aen dit verboth te hebben gecontravenieert en daertoe direct off indirect geholpen off geassisteert; en sullen alle vremdelingen op voorss. feyten geattrappeert wordende arbitrairlijck gestrafft worden.

Item worden alle onderdaenen en principaelijck de herbergiers hiermede gelast in cas eenige verkleede off gemasqueerde persoonen in herbergen verwacht off onverwacht inquaemen, van deselve te ontbloeden en ontdecken van hunne masques en bij ondervindinge van onderdaenen deselve instantelijck naemkondig te macken aen den hooghgraeffelijcken rentmeester alhyer en bij soo verre dat het vremdelinge waren, deselve opt feyt t'arresteren ende behulpsaeme hand te roepen, tot welcke hulpe en assistentie yder onderdaen mits desen gelast en geboeden wort en bij suymigheydt van welck sullen de herbergiers selffs vervallen in de voorss. gestatueerde amende. Verders sullen d'ouders voor hunne kinders moeten instaen en opdat nymand eenige ignorantie kan praetexeren, is geordonneert dese bij billet van affixie te publiceren.

Actum in judicio tot Gronsfeldt den 18en februari 1767.

Onderstondt/ ter ordonnantie.

Signatum/ Johan Frans Lebens, scabinus en gecommitteerde locoi secretarii.

Afschrift, geregistreerd in het gerechtsprotocol van Gronsveld.

RHCL, Archieven van het Graafschap Gronsveld en de heerlijkheid Slenaken (tot 1728), inv. nr. 255, fol.77.

18 Verordening tegen het strooien van vergif in de bossen

Ongedateerd (december 1767)

Alsoo men bevindt datter soodaenige feytelijckheden begaen worden dat men sig niet ontsien heefft soo tot verdestrueringhe vant hooggraeffelijck wildtbroodt als andermans bestialen vergifft te stroyen op lockvoeder en t'selve te leggen en werpen op de landerijen en in hooghgraeffelijcke bosschen, soo wordt mits desen opt alderscherpste verboeden op poene van arbitraire geldtstraffe en bij gebreck van suficientie op poene van lijffstraffe en bannissement voor alle de jenige die op voorss. feytelijckheden sullen bevonden off geattrapeert worden. 


\title{
Onderstont
}

Ter ordonnantie

Signatum Johan Frans Lebens, scabinus en gecommitteerde loco secretarii.

Volgt relaas van de afkondiging door de gerechtsbode in Gronsveld op zondag 13 december 1767.

Afschrift, geregistreerd in het gerechtsprotocol van Gronsveld.

RHCL, Archieven van het Graafschap Gronsveld en de beerlijkheid Slenaken (tot 1728), inv. nr. 255, fol. $125-126$.

19 Verordeningen van graaf August Joseph von Toerring-Jettenbach op het heffen van de aardappeltiende

\author{
30 oktober 1775 en 10 januari 1776
}

Versie A: Deze verordening is in deze vorm niteindelijk niet afgekondigd, maar vertaald, met een kleine wijziging, op 21 februari 1776 afgekondigd en in het gerechtsprotocol geregistreerd.

B) Deze verordening is geregistreerd in het gerechtsprocol van Gronsveld van 21 februari 1776. De tekst is een enigszins gewijzigde Nederlandse vertaling van de originele, maar niteindelijk niet afgekondigde landsheerlijke verordening van 30 oktober 1775.

Wür August deß Hë̈ligen Römischen Reichs Graf und regierender Landsherr der freÿen Reichsgrafschaft Gronsfelt, Graf von Törring, etc.,

Entbietten unsern scheffengericht, beamten, beerbten und underthannen unsern landsherrlichen grues und gnad zuvor,

und geben hiemit zu vernemmen was gestalten unß so wohl von seithen einiger zehentherren als zehentschuldner unser Reichsgrafschaft Gronsfeld der zweifel vorgetragen worden seye ob der zehent von erdäpfele und allentfahlß in welcher maas gereicht werden solle?

Umb nun diese sach nit ungewiß zu lassen noch strittigkeiten und irrungen auszusetzen, so erkleren, ordnen und gebietten wür aus landsherrlich- gesetzgebenter macht das Erstlich der erdäpfelbau auf zehentbahren gründten allerdings der zehentziehung unterworffen seÿe und dahero von heur anfangend ohnweigerlich solche zehentschuldigkeit begehrt werden möge, iedoch

Andertens wie die natural einhebung villen beschwerlich- und anstossigkeiten auff seithen der zehentherrn sowohl als der zehentschuldneren unterzochen werden könte, so wollen wür zu abschneidung aller derley weitlauffigkeiten hiemit gesezt und bevolchen haben das statt der natural-zehent einhebung ab jede mit erdäpfel gepauten grossen ruthe zehentbahren grunds 8 stüber oder von bonder 8 fl. holländischer wehrung und a proportione dessen auch von mehr oder wenigeren für den zehent ohne einig 
consumptions oder andere freÿheit den zehentherrn jährlich am Martini gereicht und bezalt werden solle.

Drittens gegen solche zehentreichnung solle einige verjährung andergestalten nit gehört noch angesehen werden ausser in dem fahl wenn der zehentherr den erdäpfelzehent gefordert, der zehentschuldner aber solchen geweigert und der zehentherr hierauff $30 \mathrm{jahr}$ ohne unterbruch die würckliche einhebung sothannen zehents erweislich nachgegeben hette, bey solchen umbstand solle der erdapfel zehend befrey- und verjährung platz gegeben werden.

An disen geschiehet unser landesherrlichen gesetzgebende will und befelch worauff in urtheill und rechten unser scheffengericht oder wer immer in unser Reichsherrschafft Gronsfeld recht $\mathrm{zu}$ sprechen befuegt ist genau und schuldigst $\mathrm{zu}$ halten hat. $\mathrm{Zu}$ menniglichs wissenschaft ist diese landsherrliche verordnung in besagter Reichsherrschafft offentlich zu publiciren, auch in vidimirten abschrifften nit nur in hochteutscher sondern auch in landsüblich niederteutscher sprach übersezter in dennen 4 graffschaffts ohrtschafften Gronsfeld, Heugem, Hontem und Ekelraede zu affigiren.

$\mathrm{Zu}$ bekräfftigung dises unser landsherrlichen gesezgebenden wahren will und befehls haben wür gegenwärtiges originale unter unser aigene hand unterzeichnung und furgetruckt angebohrnen landtsherrlichen grösseren insigel ausgeferttigt in unsern dermallige bewohnten pallast der Churbayrischen haubt- und residenzstatt München an der Ÿser den ain und dreÿsigisten monathstag octobris im aintausend sibenhundert fünf und sibenzigist.

August Reichsgraf und Herr v. Gronsfeld v. Törring.

Wij August des Heijligen Roomschen Rijckx Graeffschappe Gronsfeldt, grave van Terring etc., etc.

Onsen schepengerechte, officieren, beërffden ende onderdaenen saluyt ende onse landtsheerlijcke genaede.

Ende geven hiermede te vernemen hoe dat aen ons vanwegens eenige soo thiendeheeren als thiendeschuldenaeren onser Rijckxgraeffschappe Gronsfeldt den twijffel is voorgedraegen off in sulcke onse graeffschappe van aertappelen de thiende, ende int geval, in welcke voege sal worden gegeven?

Om nu dese zaake niet onzecker te laeten noghte aen twist ende verschil bloot te stellen, soo ist dat wij uyt landtsheerlijcke wethgevende macht verclaeren, ordonneren ende gebieden

Eerstelijck dat den aertappelbouw op thiendebaere gronden allezins is aen de praestatie van thiende onderworpen ende dyenvolgens dusdaenige thiendschuldigheijt int toekoemende mag worden geeijscht.

Ten tweeden, aengesien dat door het heffen in natura veele swaerigheeden ende aenstoetelijckheeden soo ter zijde van de thiendeheeren als van de thiende schuldenaeren souden konnen worden veroorsaeckt, soo willen wij tot bestrijdinge van alle dergelijcke wijdtloopigheeden hiermede hebben vastgestelt ende bevoelen dat in plaetse van heffinge der thiende in natura van elcke groot roede thiendbaren gronts met aertappelen bebouwt voor thiende jaerlijcx ontrint Sinte Merten aen den thiendeheer sullen worden gelieffert 
ende betaelt acht stuyvers offt vant boender acht guldens Maestrichter geldt ende van min offt meer nae proportie sulcx sonder eenige consomptie ofte anderen vrijdom.

Ten derden sal tegens dusdaenigen praestatie van thiende eenige verjaeringe niet worden gehoort nogte aengesien, behalven in den val wanneer den thiendeheer de thiende van d'aertappelen gevoordert, daertegens den thiendeschuldenaer deselve geweijgert ende den thiendeheer daernaer dertigh jaeren sonder tusschentijdt de daedelijcke heffinge van soodaenige thiende zoude hebben bewijselijck daergelaeten, sullende in sulcke omstandigheijdt den vrijdom ende verjaeringe der aertappelthiende plaetse grijpen.

Hier door geschiet onsen landtsheerlijcken wethgevende wille ende bevell, waerop in oordeelen ende rechten ons schepengerecht off wie immer in onse Rijckxgraefschappe Gronsfeldt recht te sprecken bevoegt is, hun nauwkeurigh en schuldigst sullen hebben te houden.

Tot wetenschap van elck een is dese onse landtsheerlijcke verordtninge in voormelde Rijckxgraeffschappe opentlijck te publiceren, voorts in copiis vidimatis niet alleen int hooghduytsch maar in landtsgewoonelijcke nederduytsche taele getraduceert in de vier dorpen Gronsfeldt, Heugem, Hontem en Eckelraede t'affigeren.

Tot bekrachtinge van desen onsen landtsheerlijcken wethgevenden waeren wille ende bevell hebben wij tegenwoordiges origineel onder onse eijgenhandt onderteckeninge ende bijdruckinge van onsen aengebooren landtsheerlijcken grooten signet uytgevaardigt ins ons paleijs ter tijdt bewoont van de Keurbeijerische hooffstadt en residentie tot Munchen aen den Izar den thiensten dagh van den lauwmaent int jaer duysent sevenhondert sesse en seventigh.

Was geteckent: August Rijckxgrave en Heer van Gronsfeldt, Grave van Terring. Daerneffens stondt: het signet gedruckt in roede hostie.

In dorso stondt: Exhibitum in judicio tot Gronsfeldt den 21e february 1776.

Leeger stondt: ter ordonnantie: signatum Johan Frans lebens secretaris.

A) Origineel, ondertekend met resten van opdrukt zegel.

Staatsarcbiv München, Archiv Toerring Jettenbach, inv. nr. M 21, folio 633-635.

B) Afscbrift.

Staatsarcbiv München, Arcbiv Toerring Jettenbach, inv. nr. M 21, folio 302-305.

20 Verordening op het tappen van bier en brandewijn en het herbergen van vreemdelingen

7 januari 1778

1778, 7 januarii opt voegtgedinge tot Gronsfeld nae voorlesinge van d'ordonnantie pollitique is verboden van bier en brandewijn te tappen off schincken naer negen uren savons alsmede des sondags en gebode heyligdagen onder den godtsdienst op d'amende van drye goudt gulden voor elcken gast aen dit. 
Item geen vremdelingen te logeren sonder permissie van dheer officier en principalijck die niet voorsien zijn van goede attestatie.

RHCL, Archieven van het Graafschap Gronsveld en de beerlijkbeid Slenaken (tot 1728), inv. nr. 255, fol. 2 .

21 Verordening tegen schelden en geweldpleging

16 juni 1779

Affixie

Wordt mits desen scharpelijck geboeden aen alle en jegelijcke onderdaenen deser vrije Rijckxe graeffschappe Gronsfeldt en ap- en dependentien dyer van gene de minste questie, scheldwoorden, provocatien, vervolgingen, affwachtinge op de wegen, veel weeniger slagerye met off tegens hunnen even naesten te causeren, begaen off bedrijven, op poene dat den jenigen off alle de jenige die als moteurs off oorsaake directe off indirecte geweest zijnde van aen dit heylsaem gebot gecontravenieert te hebben, sall off sullen t'elckens vervallen zijn in eene irremissibile en arbitraele amende en bij faute van insufficientie aen den lijve gestrafft worden.

Item in cas de onpartijdige die aen sulcke feytelijckheden present geweest zijn en inwendig 24 uren tijdt naert begaene geene kennisse daer van aen dheer drossard deser graeffschappe gegeven sullen hebben, sal yder derselve in faute gebleven zijnde, vervallen zijn in eene amende van eenen goudtgulden en verders sullen d'ouders voor de kinders moeten instaen en daer voor recherchabel zijn.

En opdat nymand hiervan eenige ignorantie kan pretenderen, is geordonneert dese bij affixie ad valvas ecclesiarum te publiceren.

Actum Gronsfeldt den 16 junij 1779.

onderstondt

ter ordonnantie, was geteekent.

Johan Frans Lebens secretaris.

Volgt relaas van afkondiging door de gerechtsbode voor de $\mathrm{H}$. Mis bij de kerken van Heugem en Gronsveld op 20 juni 1779.

Afschrift, geregistreerd in het gerechtsprotocol van Gronsveld.

RHCL, Archieven van het Graafschap Gronsveld en de heerlijkheid Slenaken (tot 1728), inv. nr. 256, fol 139-140. 
22 Verordening van het Leenhof van Valkenburg, Staatse Partage, over de 'aanbreng van leengoederen'

1780.

Alzo by ordonnantie van den Edele Moogende Rade en Leenhove van Braband en Landen van Overmaze in dato den 21 februari 1780 en nadere resolutie van den 20 juny daar aan volgende, is worden gestatueerd en geordonneerd,

Dat alle leenhouderen binnen de Landen van Overmaze, Partage van Haar Hoog Moogende, gehouden en verpligt zyn op zeekere daagen, by stadhouder en leenmannen, met behoorlyk interval, van tyd daar toe te praefigeeren, aan de griffiers der voorschreeve leenhoven hunne leenen aan te brengen, en te gelyk over te geeven specificatie van hunne leengoederen, zoo wel die heerlyke jurisdictie hebben, als anderen, met designatie van het geen daar van gesplist ${ }^{2238}$ is geworden, op poene dat dezelve by gebreeke en nalaatigheid van dien, vervallen zullen in eene boete van vyftig guldens hollands geld, de eene helft te appliceeren aan den geene dewelcke zoodanig leen, zal kunnen aanwyzen, de andere helft aan den geene, die de calenge doen zal.

Dat by den aanbreng der leengoederen in de voorschreeve Landen van Overmaze zal moeten gevoegd worden den titel van eigendom der leenbezitteren, mitsgaders de situatie en reigenooten der leengoederen, als meede dat ten aanzien van de gespliste leenen, specificq zal worden opgegeeven het stok- of hoofdleen waaronder het zelve gehoord.

Dat alle zoodanige leenrenten, welke erf en irridimible lasten, of die dewelke van ouds de leenen hebben geaffecteerd, en zelfs leen zyn, even gelyk als alle andere leengoederen by versterf, gifte, verkoop, vermangeling of anderzints, hoe genaamd, verheeven moeten worden; dog dat zulks geene betrekking heeft tot losbaare renten, als alleen in cas van reële actie, zoo en gelyck als in de tweede artikel van de styl en manier van procedeeren voor de Landen van Overmaze in dato 15 october 1663 is gestatueerd.

Dat voorts de leenhouderen van de Landen van Overmaze uit hoofde, van Hun Hoog Moogende waarschouwing in dato den 23 january 1669, volstaan kunnen om van de leengoederen, welke bereid gesplist zyn, of by vervolg gesplist mogte worden, aan stadhouders en leenmannen, waar onder die goederen gehooren, by requeste kennis te geeven en die splissinge, ter griffien te doen registreeren.

Dat eindelyk, voor den aanbreng der leenen by de respective leen griffiers zal worden gedeclareerd op dien voet, als by Hun Hoog Moogende placaaten en resolutien, in datis 16 december 1774 en 17 december 1775 aan de secretarissen voor het formeeren van leggerboeken in de Landen van Overmaze is voorgeschreeven.

Word een iegelyk, die het aangaan mag, weegens heeren luitenant-stadhouder en leenmannen des leenhofs van Valkenborg Overmaze, Partage van Haar Hoog Moogende, by deezen geadverteerd, dat tot den aanbreng der binnelandsche leenen, welke niet gespleeten zyn, by den heer griffier Collard, ten zynen huize te Maastricht, zal worden gevaceerd, van den 1 augusty tot den 14 dito incluys.

2238 In de tekst staat consequent de zetfout 'gesplist' in plaats van 'gesplitst'. De originele tekst is gehandhaafd. 
Voor de binnelandsche leenen, welke gespleeten zyn, van den 15 augusty tot den 31 dito. En voor de buitenleenen, van den 1 september tot den 15 dito, telkens des ochtens van 9 tot 12 uuren.

Wordende teffens, alle leenbezitteren gewaarschouwd, van haare laatst gepresteerde relieven, mede te brengen.

Actum by voorschreeve Heeren. Maastricht den 19 july 1780 .

Ter ordonnantie van de zelve.

Is. Collard.

Te Maastricht, by de Weduwe H. Landtmeter, boekdrukker en boekverkoper, in de Kleine Staat no VII, in de Drie Kroonen.

Van wegens dheeren drossard en schepenen der vrye Rijxe graeffschappe Gronsfeldt en Eckelrader Bijbanck wort mits desen gelast en geordonneert aen alle inwoonders en geërffdens in voorss. Bijbanck, die eenige goederen, renten etc. int geheel off ten deele bezitten in voorn. Bijbanck off binnen de Landen van Overmase Partagie van Haar Hoog Moogende gelegen en sorterende onder den leenhoff van Valckenborg, Dalem off Hertzogenraede, van deselve conform inhoud van voorss. placaat en ordonnantie aen te brengen, op poene van de boete daertoe gestatueert en opdat nymand daer aff ignorantie kan pretenderen 2239 is geordonneert voorss. ordonnantie ter gewoonlijke plaetse in voornoemde Bijbanck t'affigeren.

Actum in judicio der Bijbanck tot Gronsfeldt den 24 augusti 1780.

Onderstondt

ter ordonnantie.

was geteekent, Joh. Frans Lebens, secretaris.

Caspar Paggen gerichtsbode relateert voorenstaende placaat en ordonnatie bij copie authentijck op sondag 27 augusti 1780 des morgens behoorlijck geaffigeert te hebben opt huys off muyr van Lendert Spits gelegen in de Bijbanck tot Eckelrade als sijnde d'ordinaire affixie plaetse toirconde.

In dorso:

Voor 't leen Eckelraad bij den Heeren hof tot Gronsfelt.

Overgebracht naer Gronsfeld den 13den augustus 1780.

Zollner.

Gedrukt te Maastricht, ondertekening met originele bandtekening, het formulier van de afkondiging is in handschrift, evenals de dorsale aantekeningen.

Staatsarcbiv München, Archiv Toerring Jettenbach, inv. nr. M 17, fol. 66.

${ }^{2239}$ In het origineel staat: 'preteneren'. 
23 Verordening tegen het 'krouwen'(afrukken) van veldgewassen

22 april 1780.

Affixie

Wort hier mede het krouwen in andermans vruchten verboeden op alsulcke manieren dat alle jenige die bevonden sullen worden in andermans vruchten te krouwen sonder alvorens met schrifftelijke permissie voorsien te sijn, yder derselve sal vervallen zijn in eene amende van drye goudtguldens en bij insufficientie der betalinge van amende sullen in de gevangenisse met water en broodt op hunne costen gecorrigeert worden;

Verder sullen de ouders voor de kinders moeten instaen en in cas den bode overtuyght wort van sijne bevindinge geen behoirlijck ${ }^{2240}$ raport gedaen te hebben, sal voor d'eerste reijse selffs vervallen sijn in eenen goudt gulden amende en anders op arbitrael correctie En opdat nymand daeraff ignorantie kan pretexeren is geordonneert dese bij billetten van affixie ad valvas te affigeren.

Actum Gronsfeldt den 22 april 1780.

Onderstondt / ter ordonnantie / Was geteckent, Johan Frans Lebens, secretaris.

Volgt relaas van de afkondiging door de gerechtsbode in Heugem en Gronsveld op zondag 23 april 1780 voor de H. Mis.

Afschrift, geregistreerd in het gerechtsprotocol van Gronsveld.

RHCL, Archieven van het Graafschap Gronsveld en de heerlijkheid Slenaken (tot 1728), inv. nr. 256, fol. 202.

24 Verordening tegen vernielingen in de omgeving van de kerk van Gronsveld

$$
9 \text { april } 1784
$$

Word mits deezen opt scharpste verboden van in den kerkhoff of ontrent de kerke van Gronsfeld te krouwen of andersins te spielen of met steenen te werpen op poene dat ider die daertegens zal handelen zal vervallen zijn in eene amende van dry goudgulden tot profijt van 't fabrique der kerke en zullen d'ouders voor de kinders moeten instaen en opdat niemand ignorantie zal konnen pretenteeren, is geordonneert deeze bij billet van affixie te publiceeren.

Actum den 9en april 1784.

Concept van de hand van commissaris W. Zollner.

2240 Deze twee woorden zijn abusievelijk herhaald. 
RHCL, Archieven van het Graafschap Gronsveld en de heerlijkheid Slenaken (tot 1728), inv. nr. 89.

25 Verordening betreffende het weiden op de gemeentegrond

$$
\text { ongedateerd (1784) }
$$

Word mits deezen aen alle inwoonders van Gronsfeld op 't scharpste verbooden van tot den eersten may naestkommende geene beesten, wie deselve naemen moogen hebben, op 't gemeene broeck te doen loopen en weyden op pene dat ider die daertegenss zal handelen zal ipso facto vervallen zijn in eene amende van eenen goudgulden voor ider beest. De stiptelijke onderhouding van deeze ordonnantie wordt zoo meer verwagt als deselve strekt tot 't gemeen best en van d'inwoonders van Rykelt, oost en Maeland van sgelijken onderhouden word. Opdat nu niemand ignorantie hiervan zal konnen pretenteeren is geordonneert deeze bij billet van affixie te publiceeren.

Actum Gronsfeld.

Concept van de hand van commissaris W. Zollner.

RHCL, Archieven van het Graafschap Gronsveld en de heerlijkheid Slenaken (tot 1728), inv. nr. 89.

26 Verordeningen op de wachtdiensten

Van deze verordening zijn twee, niet geheel identieke versies bewaard. De varianten zijn in de annotatie aangegeven.

Alsoo men noch dagelijcks ${ }^{2241}$ hoort dat soo buyten als binnen deese vrijen Rijx Graefschappe Gronsfeld differente onheylen, straedschenderyen en diefstallen sijn geschieden en men diensvolgens vreest dat diergelijke buytenspoorigheeden van tijd tot tijd sullen konnen toeneemen, soo is raedsaem, jae noodig geacht worden dat tot verhoedinge van sulke onheylen en desordres de nachtwachte ${ }^{2242}$ binne deese graefschappe sal worden gehouden ende gecontinueert;

Oversulx word

Eerstelijck aan alle borgemeesters deeser Rijx Graefschappe ${ }^{2243}$ mits deesen wel serieuselijck geordonneert van binnen hunne respectieve dorpen ${ }^{2244}$ regulierelijck alle daegen door de boodens te laeten commandeeren eenige manschap om de nachtwagte 2245

2241 Tekst B: 'immer'

2242 Tekst B: 'wachte'.

2243 alle...Graefschappe', tekst B: 'den borgemeester van...etc'.

2244 'hunne...dorpen', tekst B: 'etc'.

2245 'eenige....nachtwagte', tekst B: 'etc. om daeg- en nagtwaghte'. 
te houden en sullen ten dien eynde alle daegen gecommandeert worden tot Gronsfeld ses mannen, tot Heugem vier mannen, tot Eckelraede vier mannen en tot Hontem twee mannen. ${ }^{2246}$

2dens sullen de gecommandeerde wachters alle avonden ten negen uuren moeten verschijnen bij de respective borgemeesters van hunne dorpen, de welke sullen sijn gehouden te formeeren een exacte lijste van de inwoonders hunner dorpen en alle daegen pertinentelijck te annoteeren de geene die op de wacht sullen trecken;

3 dens moet de wacht gehouden worden door bequaeme persoonen en geen kleene jongens en sullen hun de wachters moeten versien met goed geweer en alle avonden optrecken ten negen uuren en continueeren tot 's morgens vier uuren ${ }^{2247}$;

4dens sal de wacht verbonden sijn continueelijk te patroulleeren en tot Gronsfeld ${ }^{2248}$ particulierelijk t'invigileeren op de kerke, pastorye, rentmeesterye en afgeleegene huysen; 5 dens sal de wacht geene vreemdelingen, bekent of onbekent, laeten passeeren naer thien uuren, maer de selve arresteeren en brengen bij de borgemeesters en aldaer in arrest houden tot dat de selve van geregts weegen sullen sijn geëxamineert.

6dens sal de wacht gehouden sijn, soo haer iemand ontmoed 2249 ofte hoort, of speurt of elders tot drie achtereenvolgende reysen, sonder geschrij te roepen: 'werda?', in cas van geene andwoord den selven vas te packen en in arrest te brengen; ende in gevalle sig soodaenige teegens de wacht ter weer stelden, of de wacht soeken te bekruypen of sig met de vlugt te salveeren, soo sal het in sulken gevalle aan de wacht gepermitteert sijn deselve met alle moogelijke gewelt te soeken apprehendeeren.

7 dens sal de wacht gehouden sijn te verhinderen alle onheyl en buytenspoorigheeden soo op straet als elders voorvallende en bij soo verre de wacht iemand sal attrapeeren eenige straed schenderye, gewelt of inbreuk aan kerk, huysen ${ }^{2250}$, den selven met gewelt vas te packen, ende in cas van oppositie of vlugt zelfs daer op te schieten en alsoo met gewelt in arrest en detentie te brengen.

8dens sal de wacht gehouden worden in alle stilligheyt en sonder eenig geschreeuw, ten waere sij overvallen en overmand wierden door sommige malversanten, in welken gevalle sal de wacht gerug maeken en sullen alle onderdaenen op dat gerug gehouden sijn de wacht te secondeeren en de hulpsaeme hand te houden, soo voorts soodaenige malversanten soo moogelijk te helpen gevangen neemen en in detentie te brengen; 9dens sullen de vrouwspersoonen, t'sij weduwen of ongetrouwde huyshoudende sonder manspersoonen, in cas van suffisantie een manspersoon moeten stellen tot het houden van de wacht;

\footnotetext{
2246 'houden...mannen', ontbreekt in B.

2247 'en alle....uuren', ontbreekt in B.

2248 'tot Gronsfeld', ontbreekt in B.

2249 '6dens...ontmoed', tekst B: '6dens zal de wacht gehouden zijn geene Waelsche of Hoogdeutsche of andere vremde onbekende bedelaers te laeten passeeren maer deselve buyten de limiten deeser graefschap te brengen en aen hun den inganck aldoor te verbieden. Sal de wacht gehouden sijn sooe haer iemand bij nagt ontmoed'.

2250 Toegevoegd in B: 'te doen'.
} 
10dens word mits deesen gereïtereert op eene amende van ses goudguldens t'elkens t'incurreeren t'verboth dat niemand, het sij herbergiers of andere ingesetene eenige vreemdelingen sullen mogen ophouden of logeeren.

11dens sullen alsulke amende van ses goudguldens t'elkens incurreeren degeene die op hunnen tour gecommandeert sijnde, niet en sullen hebben gecompareert op de wacht en op dat niemand eenige ignorantie kan praetexteeren, is geordonneert deese in alle dorpen ter gewoonelijke plaetsen bij affixien te publiceeren.

Actum Gronsfeld den 26en mey 1786.

Ter ordonnantie

Joh. God. Lebens.

Een ongedateerd concept van de hand van Wolfgang Zollner betreft de aanvulling van de nachtelijke wachtdienst met bewaking overdag:

'En omdat door deeze nachtwacht de gemeene zekerheijd noch niet genoeghsaem kann herstelt worden, maer absolute vereijscht word dat aen dergelijken vreemdelingen en vagabunden den inganck in deeze Rijksgraefschap belet word, zoo is dat aen den borgemeester van Gronsfeld noch verders belast word om ook een daegwacht te doen commandeeren en

Eerstelijk zullen alle daegen s'morgenns ten vijf ueren andere ses mannen gecommandeert worden, die boven de Helle en aen t'limit van Keer zullen de wacht houden, verders en

Tweedens zullen op de wintmoele daegelijks s'morgens ten vijf ueren drij wachters gecommandeert worden, van s'gelijken

Derdens zullen twee mannen daeg en nacht ontrent t'huijs van Joannes van den Boorn en twee mannen ontrent t'limit van Rijkolt de wacht houden.

Vierdens zal de wagt boven de Helle en aen de limiten continueerlijk patrouillieeren en aen alle vremdelingen en vagabunden den inganck beletten en deselve met gewelt doen retourneeren.

Vijfdens als een of meer vremdelingen en vagabunden reeds in de graefschap zullen geattrapeert worden, zal de wacht gehouden zijn deselve alstonds naer de naeste limit te brengen en de graefschap te doen ruijmen'.

$V$ an de verordening op de nachtelijke wachtdiensten is nog een (ongedateerd) concept bewaard. In die tekst is de eerste alinea vervangen door een verwijzing naar een algemene jacht op vagebonden.

'Voor den borgemeester van Gronsfeld.

Alzoo men geinformeert is dat niet alleen door t'geheele Luyker Land, maer ook door gantsch Brabant, Holland en alle daeraen gehoorige landen eene generaele jagd op alle vremdelingen, vagabunden en dergelijken suspecte persoonen geordonneert is, en men dienvolgens niet zonder grond vreest, dat zich dergelijke persoonen in deeze vrije Rijksgraefschap zouden konnen vlugten, zoo heft men raedzaem en noodig geacht om geduerende deeze generale jagd in alle dorpen deezer graefschap eene wacht te ordonneeren tot verhoeding en voorkomming van alle onheylen, die daeg en nagt continueelijk patroullieeren moet.' 
Waarschijnlijk een herhaling van de ordonnantie van 26 mei 1786 betreft het waarschijnlijk het volgende concept

'Vermits in alle Brabantsche, Hollandsche, Gulichsche en andere plaetsen op heden den 1 ten eene generaele huijs visitatie en eene generaele jagt op alle vremde bettelaers, vagabonden, joden en andere suspecte persoone op t'rigeurs zal geschieden, die eijndigen zal den 5en deeses, zoo word mits deezen d'ordonnantie van den mond meij laestleeden gereïetereerd en aen den borgemeester serieuselijk gelaest om ingevolge van deselve ordonnantie zonder uijtstel zoo veele gewapende en weerbaere persoonen door den veldboode te doen commandeeren als noodig mochten om alle groote en binnen weegen zoo als ook de passagien in of door de bosschen te beletten, waerbij noch verder geordonneert word om alle dergelijken joden, vagabonden en suspecte persoonen door deeze graefschap passeerende zonder inzicht gevangen te neemen en naer Gronsfeld te brengen en in cas van vlugt zelfs in alle Hollandsche en Brabantsche plaetsen te vervolgen en aldaer te doen arreteeren'.

RHCL, Archieven van het Graafschap Gronsveld en de heerlijkheid Slenaken (tot 1728), inv. nr. 234

27 Verordening op het 'karweien' voor het onderhoud van de wegen

22 mei 1787

Word mits deezen d'ordonnantie bij het laest vogtgeding gegeeven gereïtereert, zoo voorts noch mael serieuselijk gebooden van instantelijk en zonder verderen uytstel alle wegen zoo in het dorp als op t'veld in te hakken, met kiesel te bevaeren en behoorlijk te repareeren. En om eene gelijkheyd hierin te stellen en te verhinderen dat geenen voor den anderen beswaert word, zoo word verders geordonneert:

Eerstelijk dat tot het maeken en repareeren der gemeene weegen zoo in t'dorp als elders ider peerd bij provisie zal moeten vaeren 12 karren kiesel.

Ten tweeden zullen de karren met kiesel wel en loffelijk moeten gelaeden, de zijde blanken in den karren regt gestelt en van achteren en van vooren met stroo belegt worden.

Ten derden zal niemand gecomandeert zijn tot carwye eenen karre kiesel op zijn goed moogen brengen.

Ten vierden zal alle daegen de haefscheyd van karren in 't dorp gecomandeert worden en zal ider der gecomandeerden moeten compareeren op poene van eenen goudgulden t'elkens.

Ten vijfden zal den borgemeester gehouden zijn eene lijste te maeken over de geene die van daeg tot daeg gecomandeert zijn worden en t'effens te annoteeren de karren die ider de gecomandeerdens op zijnen tour gevaaren heft.

Ten sesden zullen tot t'laeden der karren bequaeme persoonen gestelt en geene kinders aengenoomen, maer door den borgemeester weggeschikt worden.

Ten sevenden zullen de laaders beneffens de karren om 7 ueren s'morgens moeten compareeren en tot 11 ueren s'middaegs continueeren en naermiddaeg van 2 tot 6 ueren. 
Ten achtden en zoo veel de publique weegen buyten t'dorp beneffens de veldweegen aengaet, zoo word geordonneert dat deselve ins gelijken door d'eygenaers ofte door de pachters, hetzij ingezetene of uytgezetene, instantelijk worden ingehackt, met kiesel bevaeren, in de middel gehooght en op de behoorlijke brijde gestelt, op poene dat bij gebrek van dien zulke weegen op kosten van de zuymige zullen gerepareert en tot recupereering deezer onkosten de vrugten op het land gearresteert en publiquelijk den meestbiedende verkocht worden.

En opdat niemand eenige ignorantie hiervan zal moogen praetenteeren, maer in $t^{t}$ tegendeel zich idereen voor schade konnen wagten, is geordonneert deeze bij billeten van affixie ad valvas ecclesiarum te publiceeren.

Actum Gronsveld den 22 mey 1787.

Ter ordonnantie.

Ongetekend concept van de hand van grafelijk commissaris W. Zollner.

RHCL, Archieven van het Graafschap Gronsveld en de heerlijkheid Slenaken (tot 1728), inv. nr. 114.

28 Verordening van graaf August Joseph zu Toeering Jettenbach op het 'aanbrengen van de goederen'

\author{
1 augustus 1789
}

\title{
ZYNE EXCELLENTIE DEN REGEERENDEN HEER RYKS-GRAAF VAN GRONSVELD, AUGUSTUS GRAAF VAN TOERRING-JETTENBACH. \&. \&. \&.
}

Geinformeert zynde dat ' $t$ zedert meer als 30. Jaaren geen ordentlyk aanbrengen is geschieden over de goederen, en Erven, gelegen in 't Ryks-Graafschap Gronsveld, en dat alle deze Goederen, en erven 't zedert dien tyd door Scheyden en Deylen, door Koopen en Verkoopen, en zo voorts in groote desordre zyn gekomen, en willende voorzien aan alle verdere verwerringen, daar uit konnende resulteeren, heeft aan Hoogstdeszelfs ondergesch. Raad, en bevolmagtigden Commissaris specialyk aanbevolen, om zonder uitstel een Schriftelyk Rapport te laaten doen, ten eynde, om een ordentlyk nieuw LegerBoek, of Landts-Matricul hier over te konnen formeeren, om alle abuyzen dien aangaande in 't toekomende daar door te eviteeren, en byzonderlyk, om 't Collecteeren der reële Schattingen te faciliteeren.

In gevolge van dit Bevel, en uit kragt der Authoriteyt aan den ondergesch. verleent by de Ryks-Graavelyke Commissie, word alzo hiermede serieuselyk geordonneert, dat alle zo in als uitgezetene Eygenaars en Tochtenaars, alle hunne Goederen en Erven, 't zy Huyzen, Hoven, Land, Weyden, Bembden, Hout-Gewas, Driessen, en zo voorts, gelegen binnen ' $t$ voormeld Ryks-Graafschap Gronsveld, en binnen de Ekelraader Bybank, Stuk voor Stuk, Schriftelyk, en van ider Dorp gesepareert, zullen moeten aanbrengen tusschen dit, en den 28sten dezen Maand Augustus, en zal ten dien eynde in Gronsveld ten Huyze van den 
ondergesch. Commissaris Maandag, Dynsdag en Donderdag van ider Week, voormiddags van 8 . tot 12 . uuren, en naarmiddags van 2. tot 5. uuren, expresselyk gevaceert worden.

Het voorgemeld aanbrengen moet op de naarvolgende maniere geschieden.

Eerstelyk moet hier by geexprimeert worden den Naam en Toenaam der Bezitters, en ' $t$ Dorp, waar onder 't aantebrengene stuk moveert, zo als ook de plaatze, daar ider Stuk ligt, en den Naam, als 't aantebrengene Stuk eenen in 't particulier zal hebben.

Tweedens moet geexprimeert worden de tegenswoordige Reygenooten van ider Stuk.

Derdens moet aangebragt worden de Maate, of groote van ider Stuk, met expressie van Boender, van groote en kleyne Roeden.

Vierdens moet geexprimeert worden, of 't aantebrengene Stuk is Leen-Chins-Erffpagt of ander dergelyken goed, zo voorts, aan wie, en met hoe veel 't zelve is belast?

Vyfdens moet geexprimeert worden, of nog andere Lasten, als Peerds- of KoeyeKeuren 2251 , en dergelyken op 't aantebrengene Stuk zyn geaffecteert? eyndelyk, en

Zesdens moet by zulk Schriftelyk Rapport ook blyk gedaan worden van den Titl, en op wat wyze den tegenswoordigen Bezitter ' $t$ aantebrengene Stuk in eygendom heeft verkreegen, 't zy by Koop, uit Kragte van Testament, of Donatie, ab intestato, of anderzints.

Mits welken is men vertrouwende, dat een ider dit noodzakelyk Werk door een tydig, getrouw, en opregt aanbrengen zal helpen vervoorderen.

In cas nogtans, tegens alle verwagting imand hier aan zal komen te mankeeren, zo is conform aan de voorige Edicten, en Publicatien hier mede de novo gestatueert,

1 mo Dat den geenen, die iets zal hebben verzwegen, zal vervallen zyn in eene irremissible Amende van vyftig Pattacons voor ider Boender, het welk of niet, of te weynig zal zyn aangebragt, en voor het mindere naar Proportie van de Maate, die zig by Meetinge, of anderzints meer zal bevinden, als aangebragt worden.

2do Dat den geenen, die eenige Chins of Erffpagt- of Peerds- en Koeye-KeurenGoederen zal verzweegen, en niet aangebragt hebben, zal t'effens vervallen zyn van de Hellicht van de weerde des gronds, waar op dezelve zyn geaffecteert.

3tio Dat de verzweegene, en niet aangebragte Leen Goederen gansch en geheel in Commissum zullen vervallen zyn.

4to Dat den geenen, die op den geprefigeerden tyd zyne Goederen, en Erven niet en zal hebben aangebragt, zal gehouden zyn, voor alles verzweegen te hebben, en zal dien volgens wegens zodaanig verzweegene Erven ook vervallen zyn in de Amendens hier voor gestatueert.

5to Dat den geenen, die eenig verzweegene Erven zal aangeweezen hebben, onder verzwyging van zynen Naam genieten zal de halfscheyd der Amendens hier van voorts komende, en van 's gelyken hier voorens gespecificeert.

Eyndelyk word aan de pagters, en Half-Winnen hier mede nog serieuselyk gelast, van aan hunne Heerschappen van dit te doene aanbrengen zonder uitstel kennis te geven, op poene, van te moeten instaan voor den schaade, daar uit te resulteeren.

2251 In de tekst staat: Keuten 
En op dat niemand eenige ignorantie zal konnen pretendeeren, is goed gevonden, deze niet alleen in publyken Druk te laaten uitgaan, en by Affixien in dit geheel RyksGraafschap bekent te maaken, maar ook eenige dezer gedrukte Exemplaaren aan de Borgemeesters te behandigen, ten eynde dat ider een de noodige informatien daar uit zal konnen nemen, en dat ider Pagter, of Half-Win een dergelyken Exemplaare aan zyne Heerschap zal konnen overbrengen, vervolgens deze Heerschappen zig niet zullen konnen ontschuldigen, dat zy van hunne Pagters, of Half-Winnen niet en zyn worden geinformeert.

Actum Gronsveld den 1ste Aug. 1789.

L[ocus] S[igilli]

L[i]c[entiaa]t W. ZOLLNER.

Gedrukt.

Staatsarcbiv München, Archief Toerring Jettenbach, inv. nr. M 17, fol. 66. 
Verklaringen betreffende geldend recht

29 Verklaringen van de schepenen van Gronsveld en Rijckholt over het verhaal van schulden gevestigd op onroerend goed

$$
17 \text { april } 1657
$$

Wir drossart undt schöffen dess gräfflichen gerichts zue Gronssfelt bekennen, thuen kundt undt attestieren hiemit wahr zue sein das in unserem gericht wie nicht weniger in anderen benachbarten reichs gerichteren ein sonderbarer brauch, gemeines herkhomen undt alte observantz ist das man keine hypothec umb andere hinderstendige oder aufgeschwolne renten evincieren mag alss umb die zwey letstere gefallne jahr undt müessen alle andere aufgeschwollne census per actionem personalem super res mobiles debitoris gesuecht werden und das die excussio mobilium nottwendig vorher gehen muess ehe man ad immmobilia procedieren kan, welcher gebrauch undt observantz in allen in disen landen gelegenen reichs gerichteren also judicando observiret wirdt, wissen auch nicht das jemahlen ein anders seye observiert worden, erbieten unss demnach dise unsere erwehnte attestation suis tempore et loco quatenus opus sit mit leiblichen aeydt zue befestigen, dessen zue urkundt haben wir dieselbe durch unseren gerichts secretarium underschreiben undt mit unserem gewohnlichen schöffen sigel corroborieren lassen.

Datum Gronsfelt den 17ten aprilis 1657.

Auss befelch von meine obgemelte herren drossardt und scheffen.

Lamb. Lousberchs secretaris dero vurss. graffschafts subscripsit.

Wir schultheiss undt schöffen der freyen reichs herrlichkeit Rickholt zuestehendt dem wolgebornen herren Dieterich Carl freyherren von Willich undt herren von Winenthaal, Dohringen, unserem gnedigen herren certificieren undt attestieren hiemit alss eine aufrechte wahrheit das bey unss und in dem gräfflichen gericht Gronsfelt wie auch bei anderen unss benachbarten reichsgerichteren ein special gebrauch, herkhomen undt alte observantz ist, das man keine hypothec evincieren mag umb andere hinderstendige renten oder pfecht alss umb die zwey letste gefallene jahr undt müessen alle andere aussstehendte per actionem personalem super res mobiles debitoris gesuecht werden und das die excussio mobilium nottwendig vorher gehen muess ehe man auf die immobilia khomen kan, welchen gebrauch undt observantz wir undt unser benachbarte reichs gerichter also judicando observieren undt nicht wissen das jemahlen anderst ist observiert worden. Erbieten auch dise unsere erwehnte attestation im fahl es von nöten zue allen zeiten mit leiblichem aeydt zue befestigen.

Dessen zue urkundt haben wir dise durch unseren gerichts secretarium underschreiben undt mit unserem gerichts sigel becrefftigen lassen. Beschehen den 17ten aprilis 1657.

Locus sigilli.

Johann Blunden secretaris der freyherrlichkeit Rickholt. 
Quod haec copia ex lingua Belgica in Geremanicam fideliter translata sit in sua substantia omnino inventa concordari, attestor ego infrascriptus notarius publicus.

J. Graven notarius publicus subscripsit 1657.

RHCL, Archief Rijkskamergerecht, inv. nr. 77, Q 8, fol. 56, 58, authentieke afschriften in proces van Willem van Argenteau, graaf van Esneux, tegen Jost Maximiliaan van Bronckhorst Batenburg en drossaard en schepenen van Gronsveld.

30 Verklaring van drossaard en schepenen van Gronsveld over het erfrecht van de langstlevende echtgenoot

$$
24 \text { augustus } 1761
$$

N.B. Afgegeven door drossaard en schepenen van Gronsveld op verzoek van Leonardus Nijssen, kanunnik van Hoogcruts, namens de inwoners van Slenaken.

\section{Recordium}

Wij drossard en ondergeschreve schepenen der vrije Rijcxe Graeffschappe Gronsfelt gelesen hebbende den voormelden casus en daeronder staende vraege met behoorlijcke attentie, verclaeren pro recordio dat volgens oudt gebruyck en observantie deser vrije Rijcxe Graeffschappe Gronsfelt waer onder Schlenaecken hiervoorens gehoort heefft, aen Maevia al langhstlevende, boven de lijfftocht der erffgoederen oock in vollen eygendom competeren de mobiliaire goederen, personeele actien en crediten, soodaenigh dat Maevia daer over naer haer welgevallen disponeren kan ter exclusie van haere kinderen, mits betaelende de persoonele schulden, supposito dat, volgens bericht, de legitime gevonden zij in immobilibus.

Actum in judicio extraordinario ut supra.

Joh. Frans Lebens scabinus; J. Th. Ulrici scabinus; H. Lebens, drossard; E. van den Boorn, schepen.

RHCL, Arcbieven van het Graafschap Gronsveld en de beerlijkbeid Slenaken (tot 1728), inv. nr. 254, fol. 91, afschrift, geregistreerd in het gerechtsprocol van Gronsveld. 
31 Verklaring van de schepenen van Gronsveld over de appelrechtspraak

ongedateerd (derde kwart achttiende eeuw?)

Schepenen der vrije Rijckx Graeffschapp Gronsfeldt seggen tot naerricht van de vier borgemeesters van alhyer op hun geproponeerde dat den richter in appel van dit graeffschappe is de supreme Keyserlijcke Caemer van Wetzlaer, off wel den allerhoogsten Rijckxhoffraad van Weenen bij soo verre de zaake waer van geappelleert word in rechten gefondeert is en haare behoorlijcke requisita volgens de rijckxrechten heeft en bij dyen niet, staet het aen d'authoriteyd van Sijne Excellentie den heere Rijckxgrave van Gronsfeldt om richters in appel de denomineren naer desselffs hooghe belieffte.

München, Archief Toerring Jettenbach, inv. nr. M 17, fol 247A, losliggend blad, ongetekend en ongedateerd concept. 


\section{Formulieren voor het 'bannen' van het voogdgeding}

32 Formule voor het bannen van het voogdgeding en 'politieke ordonnantie' te Slenaken

$$
1633
$$

Bannissement ende ordonnantie van vaegtgeding tot Slenacken geregistert uyt den alden pampieren als volgt:

In desen oprichtelichen ende wettenlichen vaegtdinglichen daegh, der heer doet gebieden ban ende vrede van wegen Godt, van himmelrijck, Maria sijner gebenedider moeder ende allen lieven Goddes heylgen ende Sinte Remeyss onsen patron, voorts van wegen onsen ghenedigen heeren, herren Joost Maxmilian Graeff van Gronsfelt ende Bronckhorst, frijheer zu Battenburch ende Rynckburgh, heer zu Alpen ende Hunnepel etc.

Doen oock ban ende vrede van ons scholtisen, schepenen, scrijver ende des boeden ende voorts wegen alln der gennigen die over dit wettelich gedinge cracht oft macht hebben.

Deselve sullen op hunnen richterlichen stoel desen vogtgedinge daege gevrijt sien ende eenene iederen recht ende ordel laetten wedervaren ende aenwijsen wat recht is.

Der geystlicheydt wat haer toe staet ende den aedeldomme wes hem competert, die van aedelichen schilde sijn, denselven bidt man ende den hausman gebeudt man.

Voorder der scholtis sal maenen ende die schepen sullen wijsen ende eenen jederen aenwijsen wat recht is, den rijcken om gelt ende den armen om Goddes will, waerbij der armer sich nyet te beclagen en heeft dat hij durch sijn kennelijck armoet sijn goet recht moist ontbeeren.

Sullen oock sambt anderen dienaeren des rechtens weduwen, weysen, kercken, clausen, Godes ende gasthuysen met corter expeditie van recht, daer sij reden ende recht toe hebben, voerstaen.

Noch soe gyft der heer eenen jederen vrij strack scherm ende geleyde aen diesen gericht ende recht te ersceinnen, recht te geven, recht te nemen, behoudelich ende uytgescheeden mysdaedige persoonen oft menschen die tegens hunen landtheeren mysdaen oft verraeden hadde, kercken, clausen, godes- ende gasthuysen, kinderbedden geschant oft gebrant hadden, dieven, straetteschenders, mortbranders sambt anderen ende dyer gelijcken mysdaedigen persoonen, dieselve moegen hier comen soe sij willen ende van hennen gaen soe sij connen, denselven en sal men dieser vrijheydt nyet laetten genyetten, het en waer dat sij henne mysdaeden op orden ende plaetsen daer des nodich aeffgedraegen, gebettert ende gebeutt hadden ende alsdan sulxs gedaen hedden, sal man op hennen gesinnen denselven, gelijck anderen goeden vromen luydens, recht administreren ende wedervaren laetten.

Noch liet der heer gebieden op die boet die daerop steyt, dat een ieder van den onderdaennen op diesen vaegtdinglichen daegh sal hier present sien, sijne vogtgedinge hueden ende houden, ende sullen vorder opdoen ende aenbringen van wegen, van steggen, gasen ende straetten, valscher maetten, waeren ende gewychte ende vorder allen sgens dair den herren nuts ende proffijt, sambt der gantser gemeynen welvart aen gelegen 
is, waerbij der heer bij sijner hoocheydt ende die gemeynden bij hennen ouden hercomen gehouden moegen werden.

Die keurmeesters sullen luydt hennen gedaenden eedt, wes sij in hennen ampt ende eedt bevonden hebben mysdaen te sien aenbringen, waerbij dat die overtreders gebettert ende geboet, ende ter goeder pollitie der gemeynden onderdaenen gestraeft moegen werden. Sall oock nyemants voer deser banck oft recht sprecken dan alleenlijck met hennen gebeden ende gesworen voersprecke.

Daertoe sal sich oock nyemants absenteren van der banck, hij en heeft ierstelijck den schouteth sijne boet, schepenen conden enden orkonden, sambt scrijver ende baede ende andere dienaeren yedereen sijne rechten ende arbijt betaelt hebben ende dit alles op die boet die daerop steyt, mydts desen bant der heer sijne gedinge ende recht eenmaell, andermael, ten derden ende vierdemaell, heer ${ }^{2252}$ schoutet maent die schepen oft met diesen bannissement genocht gedaen is op dit pas.

Ordinantie ende gebodt unsers Ghenadigen Heeren.

Ien

In den iersten dat nemants van wat staet, conditie oft qualiteit hij sien, hem nyet en vervordere van nu vortaen den Naeme Godes te blaesphemeren met sweren Sijnes Lijffs, Wonden, Bloet oft anderssynts, Godt oft Sijne heylicheydt aengaende, op pene, soe deck sullicx aen iemanden bevonden worde gedaen te sien gevallen in de peen van eenen goltgulden ende den te bekeeren een derde part tot proffijt van den aenbringer ende die andere twe parten tot proffijt van onsen heere etc. Oock sullen die werden ende werdinnen gehouden sien sulcke mysbruycke die in hune tarvernen gebeuren aen te brengen op gelijcke penen alsboven.

$$
\mathrm{II}{ }^{\mathrm{en}}
$$

Ten tweden dat insgelijcken oock nyemants hoe hij sien, hem en vervordere buytten der kercken te gaen clappen opten kerckhoff gedurende het officie der H. Messen ende predicatie, noch oock durende die vespertijt ende loffsanck, op pene alsboven, ende te appliceren als voer.

$$
\text { III }{ }^{\text {en }}
$$

en derden dat egeene werden noch werdinnen hun en vervorderen te tapen naer acht uren te wintertijt ende te somertijt nae negen uren des avents, het en waeren vrembde wandelaers, gaende oft comende, op pene ende applicatie alsboven.

IV en

Ten vierden dat nemants hem en vervoirdere in huysen oft anderssynts op te houden carte spellen, terlinge spellen oft andere oneerbare spelen, hoe die sien, soe tegens die werden ende werdinnen als ouck die geselschap ende elck van hun op pene ende aplicatie alsboven, het waere bij daege ofte nachte.

$V^{e n}$ Ten vijffden dat oock nyemants hem en vervordere andere luydens duyven te vangen met eenige instrumenten die man dencken mochte te huys oft te velde, noch schietten noch ombringen, in wat namen dat het sien mochte op pene ende aplicatie alsboven.

2252 De juiste beginletter is onzeker als gevolg van een doorhaling. 
VIen

Ten seesden dat nemants, wie hij sien, hem en vervordere iemants theunen te nemen oft brecken, noch te houwen, sceneuwen oft scnijden uyten oft andere boomen die andere luydens toebehoirden, noch oick eenige onbehoirlichen wegen oft voetpaedten te maecken over andere luydens erffven, dan die genne die gewoonlich sient, het were bij daege oft bij nachte, op pene ende aplicatie alsboven ende sulx op die pene van drye goltgulden.

VII en

Ten sevenden dat sich nemants, wie hij sien, hem en vervoirdere te jaegen, vangen, schietten eenige haesen, conijnen, veldthoonderen ofte andere gewyltenisse oft gevogels, het waere met sacken, stricken, bussen, bogen oft met eenige anderen onbehoirlichen instrumenten, op pene der sulx dede te verbeuren ende te betalen voer elcke reyse dat hij bevonden mocht wirden, die amende van drye goltgulden, alles t'appliceren alsvoer ende soe der overtreder nyet en hadde den middel om die amende te betalen, soe sal hij gecorrigert worden naer gelegentheyt der saecken ende nyettemin sal den aenbringere van sijne derde part gecontentert worden.

\section{VIII en}

Item vorder dat hem nyemants en vervordere met sijne beesten in iemants bempden, hoven, erffven, het waere met perden, koyen oft andere beesten, sunderlinge bij nachte, noch oock bij daege, te drijven, etten oft weyden in geender manieren oft pene die ierste reyse drye goltgulden te verbeuren ende die te appliceren in der vuegen alsboven, die geinteresserde partie te contenteren naer gelegentheyt van de saecken ende ordinantie van de weth.

\section{$\mathrm{IX}^{\mathrm{en}}$}

Item dat oock nyemants hem en vervordere met nacht oft met daege eenige naburen henne goeden, het weren appelen, perren, reubben, ertten, boonnen, coerren oft eenige andere vruchten te nemen oft beschaedigen onder wat decxel dat het sien mocht, op poenne alsboven, den aenbringer sijne derde part te betaelen.

$$
\mathrm{X}^{\text {en }}
$$

Item dat hem nyemants en vervordere, van wat qualiteyt hij sien, van nu vortaen uyt der gemeynden Slennacken graven ende uytveuren op henne erffven oft anderssynts, noch die selve gemeynden te reumen oft bederven, op pene dan drye goltgulden te verbeuren ende die t'appliceren alsboven.

XIen

Item dat egeen wirden noch wirdinne maer eenderley bier in hinne huysen ende kaelderen in te leggen ende sulx nyet hooger dan op sijne keuren ende sullicx te verbeuren op gelijcke pene als voirseyt, te wetten voer d'ierste reyse op drye goltgulden, voer die tweede reyse doubel, oock dat die werden egeen bier ende sullen tapen, sij en hebben oirloff van de keurmeesters gekeurt sijnde.

RHCL, Archieven van het Graafschap Gronsveld en de heerlijkheid Slenaken (tot 1728), inv. nr. 577. 
33 Formules voor het bannen van het voogdgeding te Gronsveld en Heugem

ongedateerd (achttiende eeuw)

Er zijn drie nagenoeg gelijke versies van deze tekst: $A$ en B, betrekking bebbende op het voogdgeding in Gronsveld en $C$, betreffende het voogdgeding in Hengem. Uitgegeven is de variant $A$, afwijkingen in de andere teksten, verder gaand dan alleen de spelling, zijn in de annotatie aangegeven.

Ick doen bann en vreede van Godt almachtigh, van alle Godts lieve heyligen, van wegens onsen patroon S[in]te Meerten ${ }^{2253}$, van wegens Sijne Hooghgraeff[elijcke] Excellentie ende van wegens dheer drossard, schepenen en der gantzer gemeynte en voor alle de jenige die des rechts van noode hebben.

Voorts soo laet den heer gebieden op die boete dat de schepenen hunnen schepenstoel sullen bezitten en dyen niet ruymen sonder consent des heeren; oock laet den heer gebieden op die boete dat een ieder sijn recht heusch en stil voorstellen sal met eenen gekoeren momboir, soo lieff recht geven als recht nemen;

Nogh soo laet den heer gebieden op die boete dat alle noodtdurfftige armen om Godtswille des rechts ervaeren sal en den rijcken om geldt. ${ }^{2254}$

Item soo geeft den heere desen huydigen dage van den sonnen opganck tot den sonnen 2255 onderganck toe, een ieder vrye geleyde om hunne zaaken te verrichten, uytgenoemen van deser gesteltenisse, naementlijck dieffstal, moordbrenders, kerckenschenders, vrouwenkrachters en dergelijcke enorme delicten, die geen geleyde en meriteren.

Voorts naebeurs laet den heer omvraegen off sig ymand te beklaegen heeft van eenigerley schaede off hinder, hetzij van onrechte weegen off steegen, van reijnen off steynen, van grubben off sloeten, van scheldwoorden off andere criminele zaaken, daemet den landsheer ten voorsten ${ }^{2256}$ en alle goede naebeuren niet verhindert mochten worden, die spreeke nu en swijgen hier naermaels, den heere sal hem een heer zijn.

Soo bann ick dit wettig voegtgedinge einwerff, anderwerff en derdenwerff. ${ }^{2257}$.

Den heer drossard maene die schepenen off genog gebannen is.

Variant A: RHCL, Archieven van het Graafschap Gronsveld en de heerlijkheid Slenaken (tot 1728), inv. nr. 256.

Variant B: RHCL, Archieven van het Graafschap Gronsveld en de heerlijkheid Slenaken (tot 1728), inv. nr. 257.

Variant C: RHCL, Archieven van het Graafschap Gronsveld en de heerlijkheid Slenaken (tot 1728), inv. nr. 252.

2253 Variant C: Sinte Michael.

${ }^{2254}$ Zin luidt in variant B en, in spelling enigszins afwijkend, in variant C: Noch soo laet den heeren gebieden bij der boedt dat een ider sijne gebeurlijke rechten betaelen sal, verders soo sal men alle nooddruftige armen om gods wille des regts ervaeren laeten en den rijken om geld'.

2255 Ontbreek in variant B.

2256 Variant B: overstaen.

2257 Variant B: einmael, andermael en derdemael. 


\section{Overeenkomsten met inwoners en geërfden over het betalen van belastingen}

34 Verklaring van Johan I van Bronckhorst betreffende de afkoop van herendiensten door zijn onderdanen

18 augustus 1526

Die underdanen slantz Grunsfelt hebben joncker Johan von Bronckhorst ind Batemborg den dienst des huiss Remberg aifgeloist.

Ick Johan von Bronckhorst ind von Batemberg, freyher tot Remburg ind Grunsfelt, landrost slantz von Cleve, doin kond allen luiden, bekennen vur mij, meine erven ind naekomlingen mitz diesen apenen brieff dat ind also von alden gebruik her die goede gemeine undersaten meins erflantz von Grunsfelt mij als honen lantheer mitt stedigen diversen dienst einen jeder besonder nae seinem vermogen, mitt lijve, wagen ind perden te dienen aen, op ind binnen meinen sloit Remberg, verplicht ind verbonden geweist sin, to weten den waldienst, weikendienst, stein, kalck, erde te graven, bij to foeren, to dragen, von welcken diversen dienst dieselve meine undersaiten sich groitlik beswert gevonden, alsof solchs boven hon vermogen sein solde, ind mij dat self hon verderfnisse als sij sachten, guetlichen to bedencken to kennen gegeven wie swerlik sij winter ind somerteitz uith honnen eigen werk, so woill in den ougst als binnen der saet in den vurss. meinen dienst gehalden ind verbonden stonden, mij oidtmoedelik biddende ick oen uith genaden vur denselven stedigen dienst enen betemeliken pennik goedentlik solle willen settenn, in sikeren geordinierten terminen, na honnen armen vermoigenn mij eens to betailen, damede sij honne erven ind nacomlingen von den vurgerurten stedigen dienst unbelasticht sin ind dairvon eens vur all befreyet ten ewigen dagen quitiert, ind erflik afgegolden bliven muchten, des ick mij als dairto beweget guotlik underrichten hebbe laiten ind den vurgenanten meinen goeden undersatenn darinne ein vordeyl ind niet dat mein voirtgekiert, so dat wij samen om hen van den vurss. dienst to ontledighen ind quit te schelden vergadert, fruntliken averkomen, geaccordiert ind eins gewoirden seint ener sekeren sommen geltz von acht hondert bescheiden enckele golden Rijnsche gulden, von gewicht of die rechte wert dairvur in anderen goeden gelde ter teit gank hebbende, die vurss. meine undersaiten mij honnen lantherr binnen vier jaren neist nae einander folgende in sekeren dagen ind terminen betailenn sullen, nementlik alle jair twehondert golde gulden wie vurss. daraf der dach ind termin des ersten jairs aingain, begynnen ind gefallen sol Sinte Gillismisse in den jair von seven ind twintich, doch unbefangen Sint Remeismisse neist daernae, sunder langer vertreck betailt te sein, ind voirtan ten vurss. daig ind termin alle jair twehondert der gliken golden gulden, biss totter voller sommen toe der acht hondert golde gulden vurss. innd omme mij alle jars der vurss. twehondert goltgulden ten voirgenoembden daig ind termin in einer alinger sommen unverdeilt betailt waill seker te sijn, so hebben die vurg. meine guode undersaten selfs erkorenn dat ick alle jair uith jegeliken meinen gerichtzbenken des lantz von Grunsfelt soll mogen doen kiesen ind nemen twe von den vurs. meinen undersaiten, als fur meine gewisse burgen, die mij of 
meinen rentmeister von jegelikem jairtermine vurss. secker volckommen betaling doen ind to doen geloven sollen, ind dairomme dieselve meine burgen ouch macht ind bevell heben die vurss. erschienen of gevallen terminen to maenen, op te boeren ind in to fordern soet behoirt.

Ind in gevall dat einich von den vurgenannten undersaten in seiner schattingen dair hij soe bey den nageburen op gesatt of geschatt soll sin, mitz weigering of vertreck goitz teytz nit betailt en hedde, denselven sollen die obgerurten twe burgen dairvor tot allen opgegangen kost en penden doin moegen, geliek of hij des mit allen behoirlikem recht uit verfolgt ind verwonnen were, des wij eigentlik gefurwart hebben.

Ick Johan von Bronckhorst ind von Batemburg, vreiher boven genomt, den vurgenanten guoden luiden meinen getrouwen undersaeten des lantz von Grunsfelt, honnen erven ind naecomlingen weder geloifft ind toegesacht, geloven ind toeseggen bey meiner ehren ind in guoden trouwen vur mij, meine erven ind naecomlingen, in krafft diss briefs, dat sij sementlik indalle undersaten meins lantz von Gronsfelt, geboren ind ungeboren, von nu vortain ten ewigen dagen toe, von den vurss. dienst mitt lijve, waigenn ind perde exempt sein, gefriet ind eens vur all mit den achthondert goltgulden afgegolden bliven sullen, hoen noch honnen nachkomlingen egeynen vorgerorten dienst nimermer gebidden noch angesinnen doin soll, durch mij selffs of jemand anders von minen wegen in egeiner weyse, ind hebb sie dair von erflik ind ewelik quit gegeven ind gescholden, beheltlick mij ind meinen erven alle jair unse alde vrijbede to doin verkondigen ind gebieden aldair in onse kirspels kyrken wie von alters gewonliken ist, uns in gefurwart ind hierinne uytgehalden, ind dat sie ind honne nachkomlingen mij ind meinen erven unse provande, butter, kiess, stockvisch, hering, korn ind dergliken vortain als alle weg gewonlik gewest is, alleyt an to foyren schuldig ind verbonden sin ind bliven sollen so mitt honnen lijve, wagen ind perden.

Innd hierin thienden sollen ouch obgemelten meinen undersaten ind honne naekomlingen oft gefiell dat ick oder meine erven mit enigen hern ten oirloghe quemen oder verliepen, dy tijt desselven oirloigs also lang dat stunde unns mitt schuldigem dienst als ander undersaten honnen herren to doinde verplicht sein, verbunden staen ind blijven.

Ouch so hebb ick Johan von Bronckhorst ind von Batemborg, vreiherr vurss., vur mij, meine erven ind naecomlingen den vurgenoembten meinen goiden undersaiten uith sonderlinger gracien mij dartho bewegend, gegont ind bewilligt, gonnen ind bewilligen, dat sij uith diesen originall heufftbrieve copie autenticque gerichtlick maicken doen, der ein jeder gerichtzbanck meins lantz vurs. eine derselve copien in honnen schepenkomp to bewairen hebben sullen, ingefall of der principaill heuftbrieff verwairloist, loickerachtig, vleckachtig, dunckellachtig, siegelloiss of einich anderssins vheden off brantz halven verluisslick wurde, dat Gott verhuede, dat alsdan die vurss. copien, der were eyne oder mehr, von macht ind werden gehalden sin sullen, alsof der principallbrieff selffs were, geliek unser eine den anderen als lantherr ind undersaiten vurss. soe voill einen jegeliken dat berort tsamen ind besonder te haldenn ind to voldoin, sonder einige indracht, geloefft ind toegesagt hebben, sonder argelist.

In urkund der warheit ind gansser vaster stedicheit heb ick Johan von Bronckhorst ind Batemborg vreyherr tot Remberg ind Grunsfelt meinen eygen siegell mit meinem goiden wissen ind willen vur mij, meine ervenn ind naekomelingen aen diesen brieff doen hangen, 
begeren ind bevelen meine lieve getrouwe scholtit ind schepenn meiner gerichtzbancken Grunsfelt, Huegum, Sleneken ind Honthem ein jeder von den honnen schependombstoils heufftsiegell tot mehrer seckerheitt ind stedicheit aller vorgeroirter puncten aen diesen brieff bey mein siegell hangen willenn, dat wir gerichten vurss. durch bevell uns lieven gnedigen junkeren ind lantherren vurs. ind ter freuntlicher beden der gantzer gemeiner undersaeten boven genoempt gern gedain hebben.

Geschiet ind gegeven in den jair ons Hern duisent vijfhondert sesindtwintich opten donnerstaegh nae Unser Liever Frauwen Hemelfartzdaich.

RHCL, Archieven van het Graafschap Gronsveld en de beerlijkheid Slenaken (tot 1728), inv. nr. 62, afscbrift in 'cartularium Gronsveld', fol. 124v-127; gedrukt bij Hanssen, Rimburg, 331-335.

35 Overeenkomst tussen de graaf en de inwoners van het graafschap

$$
25 \text { maart } 1611
$$

Er zijn nog twee afschriften met enigszins afwijkende spelling bekend, beide in het archief van bet klooster Hoogcruts, inv. nr. 746. Het eerste is van notaris W.F. Devegroote uit 1729, gemaakt op basis van eerdere afschriften van Lambert Lousberchs, secretaris en van Gronsveld en notaris, van Lambert de Vaux, notaris in Maastricht en van H. Berchmans, secretaris in Slenaken wit 1727. De tweede tekst is een afschrift door B. J. de Bebronne, secretaris van de schepenbank in Sinnich van een afschrift van J. Walpots junior, secretaris van het leenhof van Gronsveld uit 1614 en van notaris Nicolai uit 1743. De belangrijkste afwijkingen van de afschriften ten oprichte van de witgegeven telest hebben betrekking op een aanvulling van aan het slot betreffende de bezegeling van de overeenkomst. Die aanvullingen zijn in een noot opgenomen.

In den naemen der heiligen untheilbaeren Drijfaltigkeit, Godt Vaeder, Soen und Heiligen Geistes, Amen.

Kundt und te weeten sij hiemit als eyn lange tijdt her tusschen dem wolgeboeren graven und heeren, heeren Johan graeven von Bronckhorst und zu Gronsfelt, vrij heeren zu Battenborch und Rimborch, heern zu Alpen und Honnepel etc. aen eynen, und irer genaden onderdanen und inwoener der dorffer Gronsfelt, Heugem und Schlenaecken andertheils sich allerley irrungen und gebrechen erhalten, derwegen aen dem hoechloblichs Keyserlichen Camergericht zu Spier hinc inde underscheitliche spruch, forderungh, clag und rechtfertigungh soe daselbst noch unerorttert schweben, doen furgenoemen, dieselbe aber zu groesser weiterunghe geraten und dermaesen damit beschaffen, das die zu vilmahlen aen hant genoemene guetliche tractation jeder zeit zerschlagen und nit aengehen wollen, bis das zu letzt vermittelst abermaliger underthenigen bitt, intercession und underhandtlung der wurdige edlen, ehrnvesten und hoechgeleerten, auch ehrngeachten und voernemen heeren Winandt van Gelre, canunichen und reitprobst tot Sint Servaes in Maestriecht, Godfridt Mutsinnich der rechten licentiaet, Henrichen von Velraet genant Meutter, stathelder und scholtis der graeffschaft Gronsfeldt, Peeter Porta, Johan van 
Herstall, scholtis zu Heer, Merten Gijssen und Johan van Middelberch beidersyts parthyen aller und jeder gebrechen halber auff maes und geding, wie hiernag volgt, gentslich verglechen und verdraegen worden seint.

Erstlich weil wolermelter graeff insonderheyt daarauff starck beharren und voernemen wollen das in den supplicationen und schrifften aen seiten berurter underthonen aen hoechermelten Keyserlichen Camergericht einkomen, ire genaden aen derselben graefflichen reputation fast verunglimpffet weren und deshalben correction, wandel und kere zuvorderst beschehen mueste und aber vermittelst der underhendler eingenoemen bericht und eigentlicher erkundigung sich so vil befunden das die onderdanen ire sachen etwan frembden ubergeben gehabt voer ire persoenen in keine verkleinerliche handlung wider wolgedachten iren genedigen lanthern gewilligt, vielweniger mit deren wissen und willen einige verunglimpffung voergangen, sonder was desfals hinder derselben her geschehen sien mochte, daeran von anfang leidt und misfallen getragen inmaessen sich des jederzeit gegen I[re] G[enade] officier und diener zu derselben entschuldigung erklert haben, demnach ist durch die underhendler, weil sich je kein gefehr bey den underthonen befunden, wie woll mit vilfaltiger muhe und grossen bitten bey I[re]G[enade] soe vil geschalten, gewalten und gearbeitet, das auff voergangen, bekantnus der unbefintlicher ding welcherhalb die verunglimpfung geschehen ist und daneben an I[re] G[enade] zu oftermalen und nun auff das new gelegte, gants underthenige bitt wolermelter graeff ernanten underthaenen was denselben hierover zu ungebeur oder fehrlicher dingh und versaumnuss wegen imputeert werden moegen auss gueden lauterlich remitteert und alles vertziehn und wollen, sich demnach Ire]G[enade] dieselbe ire underthonen wider zu gnaden recommendiert sein und ir nach alter loblicher gewoenheyt voer sich selbst und derselben mit weylant der wolgeboeren frawen, frawen Sibilla geborner graeffin zu Eberstein etc. getzilter drey sohn huldigen laesen.

Zum andern sollen die jenige scheffen und der gerichts secretaris Johan Meiss zu bedienung irer officien weder restitueert werden, dergestalt das Johan Meiss als secretaris von newen in eyt und pflicht zu nemen und under solcher pflicht ohn einige geferde den scheffenkumpff mit protocollen, registeren allen und jeden scriftten und urkonden sampt den scheffen siegel, in aller maesen er denselven kump zu seinen handen und gewaersaem becoemen hat gen Gronsfeldt, scholtis und scheffen wider einzuliferen und weil er des gerichts und scheffen secretaris ist und man seiner personlicher gegenwertigkeyt in loco nit entberen mach, soll er gehalden sijn sich mit der heusliche wonungh sijner gelegenheyt nach wederumb auff Gronsfelt zu begeben und weil I[re]G[enade] alle und jede derselben officier und diener auff derselben belieben und wederruffen in dienst bestelt und aengenoemen haeben, so wollen sich auch dieselb dis orts iren volcoemen willen zu brauchen, vorbehalten haben.

Zum dritten, wiewoll I[re]G[enade] wegen irer pretentien beider ortter zwissen den dorff Heugem und auff der Locht aen den Maestroum gelegen, soe durch die zu Heugem mit irem vieh beweidet worden, sich nit wol zu begeben gewust, sonderen fur eine alluvion und andrift welche derselben accresciert, gehalten, jedoch wollen I[re] G[enade] auff beschehen vilfaltig bitten und begeren hiemit sich solcher pretensien dergestalt zu behoeff der inwohner zu Heugem begeben das der gewas abgepalet und maelstein gesetzt werden sollen, daer mit I[re] G[enade] und derselben erben aen dem jenigen was kunfftiger zeyt 
ferner aenwachsen mochte, von den onderdaenen zu Heugem genies eintrachs zu befahren und derselben innen krafft deses eingewilligte gerechticheyt sich niet weiter als sich die weyde und vietreft aen der Maessen jets bevindet erstrecken solle, sonsten dem inwoneren mit ihrem vieh einer bequemlichen trifft an das wasser alda voerbehalden bleibt, doch mit desem bescheit und geding weil I[re] G[enade] hiebevor Lemmen von Ryckelt dem gerichtsbotten seliger bemelte aen der Locht gelegene weyde in erbpacht voer hondert daller soe einmahll erleght seint ausgeben, ist hiermit entscheyden und verglichen das die inwonner tot Heugem sich mit ermelten Lemmen seliger erben, so viel die hondert daeller betrifft der gebeur und billichkeyt nach eerbarlich vergleichen und zij zu vreden stellen wollen.

Zum vierten, weil der dienst wegen soe I[re] G[enade] von den underthaenen in der graeffschaft Gronsfelt erfordert weil misverstants und ungleiche meinungen voergefallen seynt, soe ist hiemit derenwegen entscheiden und vertragen das I[re] G[enade] die underthanen bey den vertrag so zwisschen I[re] G[enade] althervattern wolseliger gedechtnus und den inwoneren berurter graeffschafft im jaer 1526 auffgericht ist, verbleiben laesen und sonst die onderdaenen in der reichsgraeffschaft Gronsfelt mit dienen nit wijder beswiert werden als die jenige soe peert, waegen oder karren haben, durch das jaer zehenmael, desgelijchen auch diejenige soe niet mit peerden versien, durch ire hant arbeit jeder auch zehenmael die zu den bauw notwendige diensten jaerlichen und soe lang biss der bauw vollendet soll sein und weider nicht verrichten sollen, aber nach vollendongh des baws sol ein jeder soe woll mit peerden als der hant arbeyt die jenige diensten volbrengen welche in obangezogenen vertrach inserirt und man derohalven von alts $\mathrm{zu}$ doen gewoenlich und in gebrauch geweest is und anders noch ferner nit, doch sollen die underthonen wegen der diensten in zeit der saet, augst und herbsts verschoent werden und unbeswert verbleiben. Und weil auch gerurter vertrach im jaer 1526 auffgericht ausgeweiset was fur Rimborgesche diensten daerin reserveert worden, soe ist doch hiemit eingewillicht und den underthonen gnedich toegesagt da sich hernach begebe das bemelte graeffschafft Gronsfelt von Rimborch abgetheilt wurde, das sie alsdan damit der dienst von Gronsfelt auff Rimborch, wie auch auff solchen fal des brieffdragens, so bishero van Gronsfelt op Rimborch gebraucht worden, sollen erlassen seyn, sonsten, so sich dieser negstgesetzter fall nit begebe, soll durch desen vertrach wegen der diensten auff Rimborgh I. G. und denselben erben nichts benoemen sijn.

Zum funfften, sollen alle der graeffschafft inwoner bey recht und loblichen lants gewoenheyt gehanthabt bleiben und daeruber niemant beschweren.

Zum sechsten, ob woll die underthonnen gebetten sie mit Creiss und Reichs steuren nitt beswert zu werden, weil aber I[re] G[enade] zu irer Kayserlichen Mayestät und des Reichs prejudicia innen hierin nit vermoegen zu wilfaren, so wollen doch I[re] G[enade] auss gnediger lieb und affection soe dieselbe zu iren underthaenen traegen auff zutragenden fall ir onvermoegen und verderben, alweg ansehen und sie nach aller moegligkeit entschuldigen helffen, do sie aber der Reichs contribution je nit mochten uberhoben sein, mit einnemung und umblegung der steur billige durchgehende gleicheyt gehalten und niemant, soe woll einlendische als auslendische als Luttischen, Maestrichter und alle andere in der graeffschafft von iren guetern und erbschafften, soe alda in und under der graeffschafft gelegen, wie von alters recht und gebreuchlych, sein quota van der steuren zu 
geben und zu contribueren, eximeirt werden, sonder eyn jeder nach advenant seyn quota und contingent zu geben, schuldich bleiben soll, sonsten wollen I[re] G[enade] sich die underthoenen der gebur nach befohlen sein laessen dieselbe nach moegligkeit zu schutsen und schirmen.

Zum siebenden, was bede, sinssen und ander gulten belangt, sol niemant uber recht vermogen und billige gebeur beschwert werden, sondere es bey der alder gewoenheyt, wie allweeg biss her gebreuchlich, verbleiben.

Zum achten, als van obbernenten underthonnen zu Gronsfelt, Heugem und Schlenaecken wegen an I[re] G[enade] gelangt, wie dass sie fast vill oncosten an die hieroben gereurte processen gewendet und derwegen gebetten diejennige soe auss irem mittel ir quota daer richtich zu machen, sich weigern mochten, durch rechts mittelen anhalten zu laessen, soe ist inen solch irsuchen bewilligt. doch dergestalt das niemant aen auslendischen ortern an lieb oder gut anzuhalden und auch die jenige, soe voer langs vom proces abgestanden und mittler zeyt ires abstants underscheitliche trewe dienste geleistet, in ansehung des lastes soe sie voor andern getraegen, nit so hoech antzuschlagen, als wan sie den proces continueert und dadurch die dienst gleichs den anders underlassen hetten, sondern ein billichmesigs bedencken mit aller bescheidenheyt hierin zu gebrauchen und derwegen durch onser scholtis und scheffen einsehens zu haben.

Letzlichen haben berurte underthaenen zu Gronsfelt, Heugem und Schlenaecken Ihren Genaeden zu wider erlangung derselben gnaden, auch ertzeigung ires underthenigen gutheitzigen willens hiemit Ire] G[enade] presenteert und gegeben die somma van achtzehondert und funfftig gulden brabants, in zweyen termijnen zu bezaln, zu wissen den halben theil auff negstcomendt Remigii deses sesthienhondert und elffden jaers und den andern resternden halben theil auff Remigii des negst folgenden 1612en jaers, des sollen und wollen I[re] G[enade] underthanen zu Eckelraede und Hontem aen dieser summa dreyhondert gulden zubetzalen auff sich nemen und damit sollen beydersijts partyen aller und jeder obberurter irrunge und gebrechen halb gentslich entscheiden und vertragen sein und bleiben und derwegen weiter nichts gegen ein ander suchen oder furnemen.

Das zu waren urkund seint zween vertrags brieff eins inhalts hier uber verferttigt, durch I[re] G[enade] onderschreben neben derselben hierangehenckten insiegel und haben obgedachte onderthanen gebetten scholtis und scheffen zu Gronsfelt voir sij ir gemein scheffen siegel mit hier an zu hangen umb sie ires theils aller und jeder obgesetzter puncten damit zu besagen, welche besiegelunge wir Henrich von Velraet genant Meutter, Hendrich van Oist, Tomas Meussens, Peter Mertens, Reiner Daniels, Peeter Lousberchs, Goddart Linssen und Gerart van Meer als scholtis und scheffen des gerichts Gronsfelt von bitwegen wiegemelt gethon haben und ist van diesen vertragsbrieven einer den onderthanen zu irer notturft in den scheffenkumpf zu Gronsfelt bewaerlichen hintzulegen zugestalt.

Actum ahm funff und zwentzigsten dach des monats martii anno 1611.2258

2258 Afschrift 'Devegroote' vervolgt hier: 'Ende was ondertekent: Johan grave von Bronckhorst und zu Gronsfelt ende Johan Meyss, secretarius der graeffschappe Gronsfelt, ter expresser ordonnantie van scholtis ende schepenen ende ter requisitien der gemeenen naber en inwoonder der graefschap.

Subscripsit. 
Ende is desen tegenwordigen brieve gecollationeert tegen sijn originaelen besiegelden brieff overmits stathelder, scholtis ende schepenen der graeffschafft Gronsfelt mit namen Hans Jacop van Huyckelhoven, derselve Lousberchs, Peter Mertens, Demen Neffs, Jan Hanssen, Kerst Aussems respectiven schepenen ende leenmannen des vurss. graeffschafft ende ende bevonden van worde te worde daermede te accorderen ende in oircont der

Ende is desen tegenwoordighen brieff gecollationeert tegen den originalen besigelden brieff overmits statthelder, scholtis en schepenen der graeffschafft Gronsfeldt met naemen joncker Henrich van Velraet genant Metter, statthelder ende scholtis, Jan Meyss, Thomas Meusens, Gerart van Meer, Peter Mertens, Renier Daniels, Peter Lousberghs ende Geurt Linssen, schepenen ende leenmannen der voorss. graeffschafft ende bevonden van worde te worde daermede te accorderen ende in teicken der waerheyt soo hebben wij gerichten voorss. onseren schepen ampt siegel den wij in diesen ende dergelijcken saecken sijnt gebruyckende hier onder aen desen brieff gehangen ende durch unseren modernen leenschrijver Jan Walpott den Jongen beneffens ons doen underschrijven.

Actum den seventienden martii duysent seshondert ende vierthien.

Signatum J. Walpoth Junior, secretaris des leenhoffs Gronsfeldt.

[Onder aen desen brieff hongen twee houte sigels etc., waeren hangende twee ziegelen in houten custodien.

Dat dese naer collatie is bevonden t'accorderen metten originelen attesteere ick.

Was ondertekent: Lambert Lousberichs notarius.

Leger stont: gecollationert tegens de copie authenticque is dese doenende bevonden t'accorderen bij M. Lamber de Vaux, openbaer notaris in den Raede van Brabant geadmitteert binnen Maestricht residerende t'oirconde.

Was ondertekent: De Vaux notaris

Noch leger staet: Hanc copiam collatione facta cum vera copia authentica de verbo ad verbum concordare attestor.

Ende was getekent: H. Berchmans scabinus et secretaris in Schlenaeken, 10-10-1727.

Concordantiam cum predicta copia authentica attestor W.F. Devegroote notarius publicus 1729.

Afschrift 'De Bebronne' vervolgt hier:

Ende was onderteeckent: Johan graeff van Broeckhorsch und zu Gronsfeldt ende Johan Meys, secretarius der graefschappe Gronsfeldt, ter expresse ordonnantie van scholtis ende schepenen ende ter requisitien der gemeenen naeber en inwoonder der graeffschap.

Subscripsit.

Onder aen desen brief hongen twee groote siegelen.

Ende is desen tegenwordigen brieff gecollationeert tegen den originalen besiegelden brieff oevermits statthelder, scholtis ende schepenen der graeffschafft Gronsfeldt mit namen joncker Henrich van Velraet genant Metter, statthelder ende scholtis, Jan Meis, Thomas Meusens, Gerardt van Meer, Peter Mertens, Renier Daniels, Peter Lousbergh ende Geurt Linssen, schepenen ende leenmannen der voorss. graeffschaft ende bevonden van worde te worde daermede te accorderen ende in teycken der wahrheyt soo hebben wij gerichten voorss. onseren schepen ampt siegel den wij in diesen ende dergelijcken saecken sijndt gebruyckende hier onder aen diesen brieff gehangen ende durch unseren modernen leenschrijver Jan Walpott den Jongen beneffens ons doen onderschriven.

Actum den seventhienden martii duysent seeshondert ende vierthien.

Signatum J. Walpoth Junior, secretaris des leenhoffs Gronsfeldt.

[onleesbare afkorting]

Op den voet van de authentique copie stondt als volght: Praevia collatione cum dicta copia authentica in pergameno scripta concordare testor Nicolai notarius regalis et apostolicus 1743.

Ita esse testor: B.J. de Bebronne, scriba curiae territorialis in Sinnich. 
waerheyt soe hebben wij op spatium van desen gedruckt onsern gemein schepen ampts siegel den wij in desen ende dergelijcken saecken sijnt gebruyckende ende daer beneffens bevoelen unsern leenschrijver diesen in unser aller naem te onderschrijven.

Actum den XIII en november 1621.

Ter ordonnantien van mijn heeren voerss.

J. Waelpots junior, secretarius des leenhoffs Gronsfelt subscripisit.

RHCL, Collectie Dumoulin, inv. nr 44/81. Authentiek afschrift door J. Walpots junior, secretrearis van het leenhof van Gronsveld. Opgedrukt regel verdwenen.

36 Overeenkomst tussen de graaf en de inwoners van Slenaken over handhaving van de rechten van Slenaken en verpanding van de heerlijke rechten door de heer

$$
6 \text { juni } 1646
$$

$V$ an deze overeenkomst zijn er twee versies. Versie $A$ is ongedateerd en voorzien van de originele handtekeningen van de geërfden van Slenaken. Van dere tekst is er ook een achttiende-eeuns afschrift. Versie B, deels beschadigd, is gedateerd 6 juni 1646 en alleen voorzien van de bandtekening van de notaris.

\section{Versie A}

Conditien warop soude moegen getractert ende geconcipiert worden accord tuschen Sijne Excellentie den heer graeff van Gronsfelt etc. ende de onderdannen van de vrijheerlicheydt van Slennacken.

In den iersten soe presenteren de voorss. onderdaennen aen Ire Excellence onderdaenichlich te vereerentot de inloesinge van de pantpeningen der voorss. heerlicheydt het resterende wat den hoff, genompt den Brock, 259 volgens gemackden accordt nyet en sal vermogen te doen, namentlich tot op deselve somme van sevenduysent gulden op te legen de somme van achtduysent gulden, maecken dan tsamen de voorss. pantpeningen ter sommen van XV duysent gulden lopent gelts

Met conditie dat Sijne Excellentie daer voer erfflich ende ewiglich sal ontslaen sijne erffven ende naecomelingen van alsulcke diensten als de voorss. onderdanen aen thuys Gronsfelt van vorjaeren sculdich waren.

Dat de voorss. vrijheerlicheydt Slennacken sal worden gehouden ende geregeert gelijck van all ouden tijden voor een vrij heerlicheyt, becleet van eenen offitier oft scholtis ende schepenen van inwonderen ende geerffden derselve heerlicheydt bij Sijne Excellentie met kennysse ende cuere der justitie daertoe aen te stellen, dien welcke dadministratie absolut sullen hebben soe in criminele als civile saecken, behoudelick hun wettich overhooft altijt

${ }^{2259}$ Broekhof te Slenaken. 
te hebben tot Gronsfelt, tsij bij appellatie oft leeringe etc., sonder voorders oft anders aldaer onderworpen worden te sien.

Dat Sijn Excellentie oft naecomelinge de voorss. heerlicheydt naemaels nyet meer en sullen mogen verpanden noch in den erffcoup vercoopen, emerss den tijt van dartich jaeren ende in geval, daer Godt voir verhueden wil, soe sullen de voorss. onderdaenen ierst ende voir al daer voir mogen instaen ende het naeste sien ende dat in desen gevalle hun alsdan de voorss. acht duysent gulden in aeffcortinge ende erffcoup oft vordere verpantschap sullen dienen in faut van inloessich sullen die voerss. pinneghen dennen ter gemenden en sullen dese vurss. penningen over de geheel heerlicheyt egalick gedraegen werden, elcken naer advenant van sijn goet sonder eenige uyt te scheyden, jedoch sonder prejuditie van eenen jeden der litispendentie in geval van geen accord die van allen ouden tijden schatbar sijn gewest, behoudelick wat aenbelangt het leen ende alodial goeden jonker Couven met sijn adelijcke vrijheydt, en sal hierin nyet getaxeert noch aengeslagen worden, des sal hij aen Sijn Excellentie daervoer tot maintineringe derselve eens erkenen van de somme van.........2260 oft daerop sal met Sijne Excellence comen getractert worden. Hiertoe ende tot onderhoudinge ende voldoeninge hebben d'ondergescreven dese onderteckent ende allen hun goet verbonden, consenteren dat dese in ample forme naer den inhoudt deser sal worden extendert ende int neth gestelt om aen Sijne Excellentie overgesonden te worden.

Des beden wij den oeffeser dat hij ons aen die penninghen wille helpen, des sullen wij ondesaetten vercausenn $[. . .]^{2261}$ en hun verpanden die goederen onder die juredisie geleghen.

Wilhelmus Georgius von Hoeffen / Koieffen zu Heeyss / Jan (?) Vienken / Frans Keerchoff / Steyns Stens / Claes Henraets / + hantecken Ernen Plers / + hanteicken Dries Houten / + hanteicken Lennaert Scheffelich / + hanteicken Frin Vincken / + Jan Hanssen / + Nellis Rompen / + Lennart Pessers.

Versie B

Conditien waerop soude $\mathrm{m}[. .$.$] getractert ende ge[...] worden accordt tusch[...] Excellencie$ den herren $g[. .$.$] van Gronsfelt etc. [...] ende die onderdaennen \mathrm{d}[. .$.$] vrijheerlicheydt van$ Slenna[...].

In den iersten soe presenteren die voorss. onderdaennen aen Sijne Excellentie onderdaenichlijck ende uyt goeder affectie te assisteren totter inloesinge in de pantpenningen der voorss. heerlicheydt met allen d'incompsten daertoe behoerende in allen der maetten deselve tegenwordelijck geïngaigeert is bij hun te supleren tot de somme van seven duysent gulden hercomende van Brockhoff in quitinge van de proceduren rackende tweentwintich muden spelten ende tweentwintich muden haveren die bij jonker Jan Hoven van Carsfelt sullen erlacht wesen de somme van achtduysent gulden Brabants Mastrichter cours, maecken dan tsamen de voorss. pantpenningen der voorss. heerlicheyt alles $t[. .$.$] hove ende tot proffijt van Sijne voorss. Ex[...].$

2260 Bedrag niet ingevuld,

${ }^{2261}$ Tekst beschadigd; waarschijnlijk wordt bedoeld 'vercautioneren' = borg stellen. 
Met conditie dat Sijne voorss. Excellentie den [...] onderdaennen hune erffven ende naecomeli[...] daerentegen sal believen te ontslaen [...] recompenseren van alle alsulcke oepe[...] oft vrachten als de voorss. onderdaennen aen thuys van Gronsfelt soude moegen sculdich ende verbonden wesen.

Dat die voirss. vrijheerlicheydt van Slennaken wederom voortaen sal worden geregeert ten behove van Sijne voorss. Excellence ende gehouden worden op den ouden voet als eene vrijheerlicheydt, becleet van scholtis, statheld ende schepenen van de inwoondere ende geërffde derselve heerlicheydt die Sijne Excellence sal kiesen ende aenstellen uytten cuere als gewonlick.

Welcken schepenstoel sijne volle iudicature ende administratie in der voorss. heerlicheydt sullen moegen hebben absolut over alle saecken soe crimineele als civile behoudelijck te erkennen hun overhooft de heeren van Gronsfelt, tsij bij appelle oft leeringe van saecke etc., sonder voorders oft anderssynts onderworpen te sien.

Dat Sijn Excellentie oft naecomelingen de voirss. heerlicheyt voirders noch naemaels nyet meer en sullen moegen verpanden noch vercoopen emers den tijt van dertich jaeren ende ingevall daernaer, dat Godt verhueden wil, soe sullen de voirss. onderdaennen ierst ende vooral darvoir moegen instaen ende het naeste sien ende dat in dyen gevalle hun alsdan de [...] duysent gulden in aeffcorti[...] voirdere verpandinge oft [...] dienen.

Dat de voirss. penningen over het beg[...] goederen van de voerss. heerlicheydt egali[...] ende int general, elcken naer advenant van sijn goet sullen naer voergaenden repartitie tsijnen pension oft capitael gedraegen worden, sonder yet uyt te scheyden die van allen ouden tijden schatbaer sien gewest.

Behoudelick die leengoederen ende andere alodiael goederen [...] jonker Couven met sijne adelijcke vrijdom sullen bij haere voergaende nature verblijven noch in desen nyet getaxert noch aengeslagen worden, des sal hij oock door sijn particuliere ende maintineeringe derselve met Sijne voorss. Excellence daer over tracteren.

Ten lesten is geresolvert dat dese resolutie sal worden gelievert in handen van den heer drossaert Lamberts om bij hem gesien, oock [...] gedient te worden aen Sijne voorss. Excellence om $[\ldots]$ een vruchtbaere resolutie te ontfangen, verso[...] mij ondergescreven notaris desen te willen in hu[...] naeme te onderteckenen.

Op huyden den VI en juny 1646 oirconde.

G. Houben, notaris $[\ldots]$

RHCL, Archief Klooster Hoogcruts, inv. nr. xxx

37 Overeenkomst tussen graaf Jost Maximiliaan van Bronckhorst Batenburg en de Maastrichtse geërfden in Gronsveld over de betaling van schatting

19 augustus 1660

Alsoo questie ende verschill geresen was om ende ter oorsaecke van diverse lasten, die tot hierwarts toe aen 't graefschap van Gronsvelt sijn overgecomen, die Sijn Excellentie den 
heere grave der selve plaetse in naem en partye doende voor sijn gemeynte pretenderden ten deel te moeten woorden gedragen bij de borgers ende ingesetenen der stadt Maestricht die int voors. graefschap waeren geërft ende gegoeyt naer belangk ende proportie van het bondergetall die sij aldaar waren possiderende, ende ter contrarien de voors. geërfde ende gegoeyde geassistert door haeren magistraat sustineerden daar van te moeten blijven vrij ende geëxemptert, allegerende oude privilegien ende possessie, die sij dienthalven waeren hebbende, waaruyt dan eenige verwijderinge alreede was ontstaan, soo ist dat eyndelyck naar verscheyde gehoudene conferentien, partyen voors. om goede nabuerschap en correspondentie, gelijck van oudts geweest is te onderhouden, getreden sijn in de naarvolgende poincten van accort:

Eerstelijck dat de voors. stadt Maestricht ende haere borgers sullen blijven in geheel in alle haer privilegien, die sij ten regarde van de voors. vrijhijt mogen hebben ende dat sonder prejuditie van dien bij forme van subsidie van de voors. lasten aan Sijne Excellentie den heer grave van Gronsvelt off beveelhebbers van sijne gemeynte van wegen de borgerlijcke erven aldaar gelegen, sal gegeven worden op ieder van haere boenders de somme van verthien guldens eens in sulcken verstaande dat het furnissement der selve sal verdeylt worden op seven toecomende jaaren, waar van ieder jaar van ieder boender gegeven sullen worden twee gulden, maeckende te saemen verthien gulden, mits welcken alle pretensie van schattinge en settinge hoedanich die mochten wesen, die voor den voorleden tijt soude mogen worden gepretendert, sal blijven doot ende te nietten, ende voor het toecomende is expresselijck geconditionert ende gestipuleert dat de gemelte geerfde ende gegoeyde in geenderhande lasten, schattingen off settingen en sullen behoeven te concurreren als alleenlijck in puer reële lasten, gelijck souden mogen sijn rijcxstueren off romermaenden off degene die daer mede over al gelijck sijn, waarover in gevalle dat voor het toecomende enige questie soude rijsen, soo sullen partyen hinc inde haar refereren tot onpartijdige arbiters bij onderlinge consent te verkiesen, die daar over uytspraeck binnen een maent naar overgenomene stucken sullen hebben te doen, van welcke voors. lasten de uytschrijvinge aen de voors. geërffde ende gegoeyde off haere gecommitterde sullen worden getoont ende int omleggen ende verdeylen derselve iemant uyt midden van haar en bij haar te deputeren sal moeten wesen tegenwordig indien haar sulx gelieft, mits welcke de huysliedens cultiverende off houdende de erven der borgeren niet hogers als andere ondersaten en sullen mogen worden gechargert in haar bedrijff ten regarde van de borgers huysen, die sij bewonen off de vruchten die sij genieten van de borgelijcke goederen, ende is oock expresselijck geconditionert voor soo veele in de macht van Sijn Excellentie is, dat de helft van de voors. puere reële lasten, die op de borgerlijcke goederen sullen worden omgeleyt, sal worden gedragen bij de gene die de selve gebruycken off cultiveren ende sijn mits desen partyen veraccordert, die des ter oirconde haere zegels ende signature hier onder hebben geveugt op den 19 augusti 1660.

Was ondertekent: Joost Maximiliaen, Grave tot Gronsvelt.

Ter ordinantie van den Eersamen Raede, getekent:

Antonius Vaes. 
Accort tusschen den heer grave van Gronsvelt ende borgers van Maastricht, opgericht 19 augusti 1660.

Deser copie uytgeschreven anno 1703 ende dient om te weten tot wat lasten den hoff van den Vogelsanck te Hugem gehoorende meestde part onder Gronsvelt gehouden is te betalen ende te concurreren met de borgers voors.

Pro memoria.

Afscbrift in RHCL, Archief kapittel Onze-Lieve-V roune te Maastricht, inv. nr. 2341

38 Overeenkomst tussen Ignaz Felix, graaf von Toerring-Jettenbach, als voogd van gravin Maria Josepha d'Arberg Valengin en de Maastrichtse geërfden te Gronsveld over de betaling van schatting

$$
30 \text { april } 1739
$$

Conventie tusschen de borgers en ingeseetene der stadt Maestricht, geërffdens onder het graeffschappe van Gronsfelt ter eenre ende den heer borgemeester Oliva als gevolmachtigde van Sijne Excell[en]tie den heere grave Van Thörring in qualiteyt als tuteur over de onmondige gravinne van Gronsfelt, alsmede geauthoriseert door de gemeente en regeeringe van het gemelte graeffschap ter andere zijde.

Alsoo zedert een geruijme tijdts herwaerts, niet alleen over het repartiseeren der reële lasten, maer over verscheijde andere poincten tussen de borgers der stadt Maestricht, geërfft onder het graefschappe Gronsfelt en die van de gemeente en regeeringe van het selve graeffschap veele en gedurige verschillen sijn geweest, soo ist dat parthijen ter wegneminge van dien en tot herstellinge van goede harmonie, door tussenspreeken en ten overstaen van d'heeren Van den Heuvel, Van Slijpe en Olislagers als gedeputeerdens uijt den Eed[ele] Achtb[aere] Raed der stadt Maestricht hebben goedtgevonden in te gaen en te sluijten dese naervolgende conventie en reglement, welke voor het toekoemende sal dienen voor een positive weth, waernae sig wedersijts parthijen voortaen sonder tegenspreeken sullen gehouden zijn te gedraegen.

Verobligeert sich de regeeringe en gemeente van Gronsfeld om immediaet naer het teekenen deser conventie te restitueeren ende te doen restitueren alsulcke landerijen als a[nn]o 1713 van de borgers deeser stadt zijn verkoght ter oersaeke van voorgegevene agterstallen van schattingen en particulierlijck aen den praeceptor en clooster van S[in]t Anthonis alhier alle de landerijen en weijden welcke bij proclamatie van den 23 jan[uar]ii 1713 tot Gronsfelt sijn vercoght, als namentlijck 21 groot rooden weijde, doenmaels verbleven aen Meijs Heusken voor 7 guldens de groot roede, nog een boender genaemt het Krompboender en 4 gr[oot] roeden, gelegen in de Slack, verbleeven aen de gemeente voor 13 gulden de gr[oo]t roede en noch10 gr[oo]t roeden verbleven aen Meys Heusken voor $10 \mathrm{~g}$ [ulden]s de groot roede, alsmede aen de fundatie van den Grooten H[eilige] 
Geest binnen Maestricht....als bij proclamatie van den... zijn vercoght en verbleven aen ....ad... ${ }^{2262} \mathrm{de}$ gr[oot] roede, en verder alle andere landerijen, soo er behalven deese eenige nog mochten zijn, welcke op het voorss. voorwenden mogten sijn aengeslagen, in welcker reële en effective possessie en eijgendom de voorige eijgenaers de facto immediaet nae het sluijten deser conventie sullen worden herstelt, sonder gehouden te zijn aen de jegenwoordige besitters eenige vergoedinge te moeten doen uijt wat hoofde het oock zij, alwelke vergoedinge door die van de regeeringe en gemeente van het graefschap privativelijck sal moeten geschieden in dier voegen dat de restitutie der landeryen niet sal mogen worden vertraegt door de jegenwoordige possesseurs op pretext dat die vergoedinge moet vooraff gaen, waer ontrent zij tegens de regeeringe en gemeente in geheel gelaeten worden, alles nogtans onder die conditie, dat ingevalle de regeeringe en gemeende met verificatoire bewijsen conde aentonen dat zij de penningen uijt de landerijen geprovenieert mogten hebben geimpendeert tot ontlastinge van een gemeene schult, de geerfdens so wel als gemeente concerneerende, in sulken geval deese penningen bij de eerste te doene repartitie over alle schatbaere landerijen sullen worden omgeslagen, so verre die in commune commodum zijn geëmploijeert, waer van de wettige bewijsen ter eerster vergaderinge sullen moeten werden overgelegt, sullende bij manquement van soodanig bewijs de generaliteijd niet konnen worden gechargeert, maer de regeeringe en gemeente daermede privativelijck belast blijven ter exclusie der geërffde borgers en andere uijtgesetenen.

2

Dat raekende het getal der boenderen, waer over de reële lasten moeten worden omgeslaegen, sal worden opgevolgt de lijste door die van Gronsfelt overgegeven en hyer bij annex sub $\mathrm{n}$. 1, waer bij het getal der schatbaere landerijen wordt gestelt op één duijsent één hondert en acht boender, drie groot en acht kleijne roeden, voorbehoudens dat ingevalle eenige naedere noch mogten worden ontdeckt, de selve bij deese lijst sullen worden gevoegt en men daermede volgens het gepubliceerde edict sal handelen, over alwelcke landerijen de reële lasten (waervan hier onder noch naeder sal gesprooken worden), jaerlijcks sullen worden omgeslaegen op den voet als van oudts gebruijckelijck, te weeten drie vierde parten over het graefschap Gronsfeld ende een vierde over Sleijnaken, en alsoo sig in het gemelde graefschap bevinden eenige goederen welcke van alle ouder tijden hebben gejouisseert van eene immuniteijdt ontrent het betaelen der lasten, so is onderlinge geconvenieert dese goederen te specificeeren om daer over het toekomende een vasten voet te hebben, ten welken eijnde aen de heer grave van Gronsfelt voor het tegenwoordige en toekomende den vrijdom toegestaen wordt van hondert een en seventig boender, vier groot en vijfthien en een quart kleijn roeden, zijnde de begrootinge der stipaele graeffelijcke goederen, behalven de ongemeete weijden en bempden van het graeffelijck huys, die jaerlijx verpaght worden en oock altoos vrij zijn geweest, van welcke goederen den vrijdom bestendig sal dueren, al wierden eenige der selve door het graeffelijck huijs veralieneert oft verset, waertegen oock alle verdere landerijen, welcke den heer grave mogte komen t'acquireeren, schatbaer sullen blijven sonder eenige vrijdom te mogen pretenderen op voorwenden dat die aen het graeffelijck huijs zijn geannexeert,

2262 De getallen zijn niet ingevuld. 
sullende het bovengenoemde getal van 171 boender, 4 gr[oot] en $151 / 4 \mathrm{kl}[$ eine] roeden in de lijste, hierbij annex sub n. 2 gespecificeert, niet mogen geëxcedeert worden;

verders is wegens eenige landerijen welcke door de voorgaende heeren en graven uijt haere stipale goederen zijn geassigneert ten behoeve van het pastorael personaet en andere beneficien gefixeert het volgende quantum:

voor pastorale landerijen van Gronsfeld thien boenderen, negen gr[oot] en 5 kl[ein] roeden volgens specificatie sub n. 3;

voor de capellanie van Gronsfelt negen boender, een $\operatorname{gr}[\mathrm{oot}]$, thien kle[ein] roeden, volgens specificatie sub n. 4;

voor personaet aldaer negenthien boender en thien groot roeden volgens specificatie sub n.5;

en voor pastorale landerijen onder Heugem ses boenders en twee groot roeden volgen specificatie sub n. 6;

sullende de possesseurs deeser beneficien bij verdere off meerdere acquisitie gehouden zijn nae proportie van het meerdere in den schatt gelijck andere te contribueeren.

3

Dat raekende de specificatie der lasten, welke die van de regeeringe en gemeente van Gronsfeld pretendeeren dat als reël over alle landerijen moeten werden omgeslaegen ende waervan sij de specificatie hier bij annex sub n. 7 hebben overgelegt, de naervolgende schickinge sal worden geobserveert, te weeten dat den post daer aengehaelt sub $\mathrm{n}$. 1, raekende het actueelijck nog resteerende capitael en interesse der Erffgen[aemen] Boomhouer, welcke te samen volgens rekeninge door haer overgegeven soude bedraegen aen capitael en interressen tot den 7 augusti 1737 de somme van fl. 12592-7 ligt, nevens de verdere noch te valle interressen sullen worden omgeslagen over de gem[elde] boenders in het generael, uijtgenomen die van Monbrison, welcke van de lasten tot den jaere 1713 toe sullen vrij sijn, doch in alle andere nae dato voorgevallen sullen moeten contribueren, sonder daer van een vierde aff te trecken voor Sleijnaken, welcke voorgeven haer contingent te hebben betaelt, hoewel tot nog toe sonder bewijs, waer van hier naer nog sal gesprooken worden; dat den post sub n. 2, rakende vier duijsend vier hondert en acht gulden, door de Arme van Gronsfeld aen d'heeren Boomhouer betaelt op rekeninge sijner pretentie en waer van gem[elde] Armen vergoedinge oft restitutie vraegen, sal zijn en blijven tot particulieren last van de regeeringe en gemeente van Gronsfeld sonder de verdere geërfdens daermede te connen belasten, en sulcx ter consideratie der betaelingen door deselve geërffdens voormaels gedaen, sullende daertegens deselve regieringe en gemeente genieten voor haer privativelijck het geene die van Slenaeken in de betaelinge van dit capitael en interresse van de heeren Boomhouer voor haer vierde paert mochten reliquatair zijn, alwelcke afrekeninge oock de gemeente tot haeren privative costen sal connen vragen, sonder de verdere geërffdens daer door in eenige costen off proces te connen inwickelen; dat den post sub n. 3 sal worden gepasseerd mits doceerende van ordentelijck bewijs en quitantie, so nogtans dat in dese en alle andere volgende posten het vierde part van Sleijnaken sal worden afgetrocken; dat van gelijcken den post sub n. 4 sal worden gepasseert onder productie van behoorlijck bewijs en designatie, hoe veel sulcx in oorloghs- en hoe veel in vreedenstijdt comt te bedragen; dat den $5 \& 6$ post mede sullen worden gepasseert, mit docerende van behoorlijcke specificatie van den heer sijndicus Ley, 
soo als oock den 7 post, mits docerende van de uijtschrijvinge geduerende den oorlog, als cesseerende desen post bij tijdt van vreede; dat over den post sub n. 8 bij de vergaderinge sal worden geconvenieert om te sien hoe deselve met eene modique somme af te maken, waertoe iemant namens de generaliteijt der geërffdens sal geëmploijeert worden om sulx uijt te wercken, dog vermits dit achterstal is van twee en tachentig jaeren, en de geërfde borgers tot meert 1693 alle oepenstaende lasten hebben voldaen, hoe die oock genaemt mogen worden, soo als blijckt uijt de transactie van den 20 octobris 1692, soo is geconvenieert dat de geërffde borgers in de te convenieere somme alleenelijck sullen contribueeren nae proportie der oepenstaende jaeren t'zedert meert 1693 naer aftreck van het vierde part van Sleijnaeken, dat de verdere posten in de gem[elde] specificatie gestelt als reservata door de leden op d'eerste vergaderinge sullen worden geëxamineert om uijt de specificatien en documenten van dien te connen demetieeren van welke nature dese posten sijn, reël oft personeel, en als dan nae bevindinge bij de vergaederinge gedisponeert te worden, ten welcken eijnde alle de documenten relatie tot dese posten hebbende, op de eerste te houde vergaderinge sullen moeten worden opengelegt ende geëxamineert.

Dat om ontrent den ontfangst en uijtgaff eens een vaste voet te beraemen en te sorgen dat de gelderen daer het behoort worden geëmploijeert ende niet elders gediverteert, uijt de geërffdens door de vergaderinge hier onder te noemen, met aggreatie van den heer grave sal worden aengestelt eenen collecteur, welcke volgens de repartitien op de vergaderinge der geërffdens te maken, den ontfanck sal doen, alsmede den uijtgaff volgens het memoriael, eensgelijx ter vergaderinge te formeeren, sonder eenige andere ordonnantien, van wie het oock zij, te betaelen, als nae dat die vooraff door de geërffdens sullen sijn erkent, op poene dat andersints die betaelinge niet sullen worden in reekeninge geleden, maer tot des collecteurs prive laste blijven.

5

Dat om deese vergaederinge ordentlijck te connen houden, den heer grave ofte iemandt van sijnent wegen gehouden sal zijn alle leeden jaerlijx eens off soo het de nood vereijst meermaels te convoceeren bij gewoonlijcke beschrijffbrieven met intervall van veerthien daegen, welcke brieven door den bode sullen worden omgebrocht en bestelt, waer voor hij jaerlijx sal hebben twee rijxdaelders eens, sonder meer te konnen voorderen en sal deese vergaderinge bestaen uijt de volgende leeden, te weeten den heer grave off imant van sijnent wegen, welcke aldaer sal presideren en het regt van propositie hebben met eene votive stemme, alle die van den geregte welcke te saemen eene stemme sullen hebben, ieder geërfde welcke thien boender oft meerder besit, welcke ieder eene stemme per se vel per constitutum sullen hebben, en oock separaet sullen moeten geconvoceert worden, sullende de minder geërffdens uijt de borgerije alleen mogen senden twee gecommiteerdens, welcke ider een stemme sullen hebben ende de minder geërffdens in de vier gehugten van het graeffschap oock twee gecommitteerdens, welcke eensgelijckx ider een stem sullen hebben, bij alwelcke vergaderinge alle repartitien en memorialen sullen worden geformeert en de rekeningen opgenomen, welcke in de nederduijtsche taele sullen moeten gestelt worden en sullen de resolutien bij pluraliteijdt van stemmen worden geformeert, de welcke stemmen door den heer presiderende sullen worden opgenomen en in cas van egaliteijt sal gem[elte] praeses met sijne stemme vermogen te concludeeren. 
6

Dat alle memorialen en repartitien der lasten niet sullen konnen worden geformeert als nae dat de lasten door den praeses sullen zijn aen de vergaderinge voorgestelt om geëxamineert te worden, welcke als reël moeten worden gerepartiseert en ter wat somme, waer nae de memoriale repartitie schriftelijck sal worden opgestelt en door de leden getekent, en naderhant in een register geregistreert, van welcke memoriale repartitie copije aen den collecteur tot sijn naerrigt sal worden ter hant gesteld.

7

Dat den collecteur op deese vergaderinge gehouden sal sijn alle jaeren praecies over te leggen sijne rekeninge behoorlijck bekleed met quitantien, en geformeert volgens den memorial, sonder dat hij een jaer in het ander sal mogen laten comen, off eenige restanten in rekeninge stellen, maer de volle verantwoordinge t'elkens doen, waer voor als mede voor goede en trouwe administratie den selven collecteur sal gehouden zijn te stellen suffisante cautie ten genoege der vergaderinge.

8

Dat die van den gerechte sullen gehouden zijn op versoek der borgeren de ingesetenen des graeffschaps die pagters van de borgerlijcke landerijen zijn, te constringeeren door de gewoone regtsmiddelen tot naekominge der pagtsconditien, particulierlijck wegens het aendeel derselve pagters in den schat, volgens conventie tussen den pagter ende verpagter te maeken off gemaekt en sal den collecteur ter invorderinge van den schatt hebben heerlijcke ende reële executie bij summatie, renovatie en executie, welcke sonder dilaij sal voltrocken worden.

Die rekeningen en memorialen door de leeden der vergaderinge geteekent zijnde, sullen alle in een register worden geregistreert en sullen den heer geconstitueerden van den heer grave voor vacatie en presentiegelt, alsmede voor de convocatie der vergaderinge ende het openleggen der lasten jaerlijx genieten sestig gulden, den heer drost voor vacatie op deselve vergaderinge twee rijxdaelders, ider schepen een rijxdaelder, en den secretaris vier rijxdaelders, waervoor hij de formeeringe en registratie der reekeninge ende memorialen sal moeten doen en de nodige copijen aen den collecteur extradeeren.

10

Op d'eerste te houde vergaderinge sal den afgegaene collecteur sijne rekeninge doen wegens de laest omgeleijde schattingen ende rakende de noch openstaende slooten der rekeningen van de collecteurs Meys Heusken, Adam Pluijmakers, J.L. Graven, Nelis Bodderhaye, Jan Utendisch en Godef. Lebens, hebben partijen aengenomen ter eerster vergaderinge te overleggen hoe het import van dien best pro communi commodo sullen konnen werden ingevordert, sonder dat nogtans de examinatie en deliberatie van dien sal moeten de verdere deliberatien en repartitien ophouden oft dilaijeeren.

11

Eijndelijck is geconvenieert dat in gevalle de Erffgenamen Salden wegens 14 boenderen door haer van de gemeente van Gronsfeld gekogt, eenige swarigheijt maeckte om in den schatt te contribueeren, dat alsdan wegens de gemeente soo wel als alle geërfdens tegens de selve Erffg[enamen] op gemeene costen en nulliteijt deeser immuniteyt sal worden gesustineert, waerover de middelen op haere vergaederinge sullen worden beraemt. 
Aldus geconvenieert ende door voorn[oemde] partijen ondertekent nae ingenomen raad door de geërfde borgers van weled[ele] heer borgemeester Lenarts op den tweden april seventhien hondert megen en dertig op den stadthuijse der stadt Maestricht.

Was geteekent:

A.T. Oliva, in hohen nahmen seiner hochgräffl[icher] Excellence wie auch q.q. und in nahmen der gemeinden und einwöhner der grafschafft Gronsfelt; L. van der Veeken q.q.; Mathijs Rietraedt q.q. voor het godtshuijs van S[int] Anthonis; Jac. Coenen q.q.; J. Bruels; Willem de Mee; G.L. van Eyll.

Onder stont: Ten onsen overstaen: Was geteekent: Abr. van den Heuvel; J.L. Olislagers; G. van Slijpe.

Onder stont: Per copiam: Was geteekent: Laur. Ghijsens.

Lager stont: Ratificatum op den 30 aprilis 1739 bij d'onderges[chreven] in naeme der inwoenders deser graefschappe Gronsfeld

Was geeteekent:

J.God. Lebens, drossardt; W.H. Rietraet scab[inus]; Machiel Schrijnemakers als gedeputeerd; J. Berchmans; Joannes Dassen; E. van den Boorn; het merck + Jan van den Bosch; Henricus du Puits.

Afschrift in Staatsarchiv München, Archiv Toerring Jettenbach, inv. nr. 71, fol. 3-10 (fol. 1-8 oud) van het Rekenboeck der rë̈le schattingen van het graefschappe Gronsfelt inhoudende eene conventie gemaeck.t tusschen de heeren geërfdens ende de gemeentenaeren deser graefschappe, haere resolution en specificatie der lasten als mede de jaerlijxe rekeningen zedert den jaere 1739 inclusive'. Andere afschriften, met geringe afwijkingen in spelling, in RHCL, Archieven van het Graafschap Gronsveld en de beerlijkheid Slenaken (tot 1728), inv. nr. 220. 


\section{Verheffingen in de adelstand}

38 Verheffing van Diederik van Bronckhorst Batenburg tot rijksvrijheer door Roomskoning Maximiliaan

$$
24 \text { juni } 1498
$$

Wir Maximilian von Gottes genaden Romischer Kunig, zu allenntzeitten merer des Reichs, zu Hunngern, Dalmatien, Croatien etc. kunig, ertzhertzog zu Osterreich, hertzog zu Burgundt, zu Lotterikh, zu Brabannt, zu Steir, zu Kernntten, zu Crain, zu Lymburg, zu Lutzemburg unnd zu Gheldern, grave zu Habspurg, zu Flanndern, zu Tyrol, zu Phirt, zu Kiburg, zu Arthois unnd zu Burgundt, pfallenntzgrave in Heingew, zu Hollannd, zu Seelannd, zu Namur unnd zu Zutphen, marggrave des Heiligen Romischen Reichs unnd zu Burgaw, lanndtgrave im Ellses, here zu Friesslannd, auff der Wyndischen March, zu Porttennaw, zu Salins unnd zu Mecheln etcetera, bekennen offennlich mit disem brief unnd tun kund allermenigelich wiewol wir aus Romischer kunigelicher hohe unnd wirdtkeit darein wir durch schikung Got des Almechtigen gesetzt, alle zeit geneigt sein aller unnd ieglicher unnser unnd des heyligen Reichs unnderthannen unnd getrewen ere aufnemen unnd pesstes furtzuwennden unnd zu betrachten, so wirdet doch unnser kunigelich gemut nit unbillich mer begirlicher zu dennen, der voreltern in adelichem wesen unnd tugennden herkomen unnd sich gegen unns und dem Heiligen Reiche in gehorsamer unnd williger dinstberkeit fur annder ertzaigen, sy mit noch mer unnd grossern unnsern kunigelichen gnaden zu begaben. Unnd irenn stannd, lob unnd ere zu erhohern unnd aus zu braiten. Wann nu von altterher das geslecht von Brunckorst und Battennberg in redlichem adelwesenn unnd stannd herkomen, unnd unnser vorfarn Romischen keisern, kunigen, unns unnd dem Heiligen Reiche in manigfelttig weyse nutzlich unnd getrew dinstberkeit ertzaigt unnd bewisen, so haben wir solhs auch die annemen getrewen unnd nutzlichen dinst so unns unnd dem Heiligen Reiche unnser unnd des Reichs lieber getrewr Dietrich von Brunkorst unnd Battennberg, freyherr zu Rymberg unnd Grunsfeld, herre zu Hanopel bisher getan hat unnd hinfur in kunfftig zeit wol tun mag unnd sol, angesehen unnd darumb unnd damit annder zu solhen adelichen tugenden unnd guttatten geraitzt werden mit wolbedachtem mut guter vorbetrachtung, zeittigem rate unnd rechteren wissenn dem genannten Dietrichen von Brunkorst unnd Battennberg freyherr zu Rymberg etcetera dise sonder gnad getan unnd im seine sloss Rymberg unnd Grunsfeld mit seinen zugehorungen zu einer rechten herschaft erhebt unnd gemacht unnd ine unnd sein eelich leibserben unnd derselben erbennserben seines namens unnd stamens unnd geslechts fur unnd fur zwewigen zeitten auf dieselbe sein herschafft Rymberg unnd Grunsfeld geadelt unnd gefreiet unnd zu unnsern unnd des Heiligen Reichs freyherrn, auch in derselben stannd, ere, unnd wirde erhebt, gesetzt, gewirdigt unnd gemacht unnd der schargesellschafft unnd gemeinschafft derselben unnser unnd des Heyligen Reichs rechtgeborn edeln freyherrn zugefugt gleichet unnd zugestellet, adeln, erheben, wirdigen, setzen, machen, zufugen, gleichen unnd gesellen ine zu der schargesellschafft unnd gemeinschafft unnser unnd des Heiligen Reichs rechtgeborn edeln unnd freihern, alles von romischer kunigelicher macht volkomenheit eigner bewegnuss unnd rechter wissen in 
craft dits brifs unnd meinen, setzen, ordnen unnd wellen aus ytzberurtter unnser kunigelichen macht volkomenheit daz die gemelten slosser Rymberg unnd Grunsfeld mit iren zugehorungen nu furbashin zu ewigen zeitten rechte geadelte herschaft unnd darauf der gemelt Dietrich, freiherr zu Rymberg unnd Grunsfeldt unnd sein elich leibserben unnd derselben erbennserben ires namens, stamens unnd geslechts fur unnd fur ewigelich recht edel freiherrn sein, sich mit iren namen unnd tittel freiherrn zu Rymberg unnd Grunsfeld heissen, nennen, schreiben unnd haltten, unnd von menigelich also geheissen, genennt, geschriben, geeret unnd gehalten werden, unnd dartzu all unnd iglich gnad, freiheit, ere, wirde, vorteil, gutgewonheit, recht unnd altherkomen in geistlichen unnd weltlichen stennden unnd sachen unnd an allen endenn haben, der allerwirdig teilhafftig unnd empfenngklich sein, auch gebrauchen und geniessen sollen unnd mogen, zu gleicherweise unnd in allermasse als annder unnser und des Heiligen Reichs recht geadelt herrschafften unnd rechtgeborn edel freyherrn, solchs alles haben unnd sich des gebrauchen unnd geniessen von recht und gewonheit von allermenigelich unverhindert, doch unns unnd dem Heyligen Reiche an unnser oberkeit unnd gerechtikeit unvergriffennlich unnd unschedlich, unnd gebieten darauf allenn unnd iglichen unnsern unnd des Reichs fursten, geistlichen unnd weltlichen prelaten, graven, freyenherrn, rittern, knechten, hawbtlewten, vitzthumben, vogtten, phlegern, verwesern, ambtlewten, schultheissen, burgermeistern, richtern, reten, kunigen der wappen erhalden, persevannden, burgern unnd gemeinden, unnd sunst allen anndern unnsern unnd des Reichs unnderthanen unnd getrewen in was wirden, states oder wesenns die sein von obberurtter romischer kunigelicher macht ernnstlich unnd vestigelich mit disem brife unnd wellen daz sy nufurbashin den genannten Dietrichen, freihern zu Rymberg unnd Grunsfeld unnd sein eelich leibserben unnd derselben erbenserben ires namens, stamens unnd geslechts von Rymberg unnd Grunsfeld fur unnd fur ewigelich als annder rechtgeborn edel freyherrn in dem Heiligen Reiche haltten, eren, nennen unnd schreiben, unnd an diser unnser kunigelichen gnaden, erhebung unnd wirdigung nit hindern, noch irren, sonnder sy der also in obgeschribner masse gerulich gebrauchen, geniessen, unnd genntzlich dabey beleiben lassen unnd hiewider nit tun, noch des yemannds zutund gestatten in kein weyse als lieb einem yeden sey unnser unnd des Reichs swere ungnad unnd dartzu ein pene, nemlich sechtzig markh loetigs goldes zu vermeiden die ein yeder so offt er frevennlich hiewider tette, unns halb in unnser unnd des Reichs Camer unnd den anndern halben teil dem obgenannten Dietrichen, freiherrn zu Rymberg unnd Grunsfeld, unnd seinen erben fur unnd fur unableslich zu betzalen, verfallen sein sol, mit urkund ditz briefs besigelt mit unnserm kunigelichen anhanngunden innsigel.

Geben zu Freiburg am vierundzweintzigisten tag des monetz junyus, nach Cristi geburde viertzehennhundert unnd im achtundnewntzigisten, unnser reiche des romischen im dreytzehennten und des Hungrischn im newntn jarn.

Per regem. Fridericus Saxonie dominus elector.

Op de pliek staat: Ad mandatum domini regis in consilio.

Origineel op perkament, aan zijden koord afhangend zegel in rode was, deels beschadigd.

Archief kasteel Rimburg. Hanssen, Die Rimburg geeft op als vindplaats: Mappe 1 no. 23. 
39 Verheffing van Jost en Johan van Bronckhorst Batenburg tot graaf door keizer Rudolf II

29 september 1586.

Wir Rudolff der ander,

[von Gottes gnaden erwöhlter Romischer kayser, zu allen zeitten mehrer dess Reichs, in Germanien, zu Hungarn, Bohaimb, Dalmatien, Croatien und Sclavonien etc. khünig, ertzhertzog zu Osterreich, hertzog zu Burgund, zu Braband, zu Steyer, zu Karndten, zu Crain, zu Lutzenburg, zu Wirtemberg, Ober- und Nider-Schlesien, furst zur Schwaben, Marggrave dess Heiligen Römischen Reichs, zu Burgaw, zu Mähren, Ober- und NiederLaussnitz, gefurster grave zur Habspurg, zu Tirol, zu Pfird, zu Kiburg und zu Gortz etc, landgrave in Elssass, herr auff der Windischen Marck, zu Portenaw, und zu Salins, etc.], bekennen für uns und unsere nachkomen am Reich offentlich mit disem brief und thuen kundt allermeniglich wiewol wir, aus kayserlicher höhe und wirdigkait darein uns der allmechtig Gott nach seinen göttlichen willen gesetzt hat, auch angeborner guete und mildigkait, allzeit genaigt seind allen und yeden unserer und des Hailigen Reichs zugewandten stende und glider ehrwürde, aufnemen und wolfarth zu betrachten und zu befurdern, so ist doch unser kayserlich gemuet billich mehr gewogen und begierlicher die jhenigen deren voreltern und sy von uraltem, stattlichen namen, stammen und geslecht herkomen und sich gegen unsern vorfahren am Reich, Römischen kaysern und khünigen und uns und dem Reiche mit sonderer getrewe embsiger dienstbarkait zu kriegs- und fridens zeitten vor andern guetwillig und standthafftig erzaigen und beweisen, in noch höhern standt und ehren zu erheben und

zu setzen.

Wann wir nuhn guetlich angesehen und wahrgenomen das uralt herkomen und wesen deren von Bronkhorst und Battenburg und uns daneben glaublich fürkomen dass vor zeitten die herrschafft Bronkhorst nit allain ain freye panerherrschafft gewesen, sonder auch zu ainer grafschafft erhebt worden und obwol hernach dieselb grafschafft durch absterben weilend Josten von Bronkhorst alss der kainen ehlichen leibserben verlassen und also des letzten in seiner linien an ain ander frembd geschlecht komen und gefallen, yedoch nichts destoweniger die edlen unsere und des reichs liebe getrewen Jost und Johan von Bronkhorst und Battenburg gebrüeder, freyherrn zu Gronssfeldt und Rimburg, herren zu Alpen, uralte freye panerherren des Reichs, auch yetziger zeitt die eltiste wappenträger desselben gräflichen stammens und geschlechts Bronkhorst seyen und sich yederzeit dem gräflichen standt, dignitet und wirden gemess gehalten und dann ire yetzt innhabende herrschafft Gronssfeldt ain uralte freyherrschafft und uns und dem Hailigen Reich one mittel underworffen seie, auch alle herrlichaiten, freyhaiten und gerechtigkaiten, so andere des Hailigen Reichs freyherrschafften haben mögen, insonderhait auch goldt und silber zu münzen, hergepracht und geübt, so haben wir demnach in gnadigen betrachtung yetzerzelten ursachen auch der angenemen, getrewen, nutzlichen und 
erspriesslichen dienste so bemelter Josten und Johansen, gebrueder von Bronkhorst und Battenburg, freyherrn voreltern, weilend unsern vorfahrn, Römischen kaisern und khünigen, auch sy selbst uns, dem Reich und unsern löblichen heusern Österreich und Burgund zu kriegs und fridens zeitten ungespart ires leibs und vermögens, zu mehrmaln gantz aufrecht und redlich erzaigt und bewisen haben und hinfüro nit weniger zu thuen sich undertheniglich erpieten, auch wol thuen mögen und sollen, mit wolbedachtem muet, guetem zeittigen rath, rechter wissen und aigner bewegnus die vorberürte freyherrschafft Gronssfeldt mit allen iren herrlichaiten, zugehörungen, gerechtigkaiten, altem herkomen und geprauch zu ainer grafschafft gemacht, erhebt und aufgerichtet, ir den titl und namen ainer grafschafft geschöpfft und gegeben, auch obgenante gebrüeder Josten und Johansen und alle inhaber derselben grafschafft sampt iren ehlichen leibs erben und deren erbens erben und nachkomen, mann und frawen personen des namens und stammens von Bronkhorst, gegenwertige und künfftige für und für ehewiglich, so lang deren ainer oder mehr zu yeder zeitt in leben sein werden, in den standt, ehr und wirde unserer und des Hailigen Reichs graven und gravinen von newen erhebt und gesetzt und sy der schaar, gesellschafft und gemainschafft anderer unserer und des Reichs graven und grävinen zugefüegt, zugestellet und vergleicht, inen den titl und namen der graven und grävinnen zu Gronssfeldt gnediglich bewilligt und gegeben, auch sich also zu nennen und zu schreiben, zugelassen und erlaubt, ordnen, machen und richten solche grafschafft auf, erheben, befreyen, ehren, wirdigen, erhöhen und begaben auch gedachte Josten und Johansen von Bronkhorst und die inhaber derselben grafschafft Gronssfeldt, ire eheliche leibs erben und derselben erbens erben mit gräflichen wirden, geben inen den namen und titl, setzen sy auch in den standt, ehr und wirde unserer und des Hailigen Reichs graven und grävinen, zufuegen, gesellen und vergleichen sy zu der schaar, gemainschafft und gesellschaft derselben aus Römischer Kayserlicher macht, volkomenhait wissentlich in crafft diss briefs, und mainen, setzen und wollen dass ermelte freyherrschafft Gronssfeldt nuhn hinfüro ain grafschafft des Reichs und gedachte Jost und Johans von Bronkhorst, sambt allen inhabern solcher grafschafft all ir ehlich leibs erben und derselben erbens erben, mann und frawen personen desselben namens und stammens für und für in ehwig zeitt unsere und des Reichs graven und gravinen zu Gronsfeldt sein, sich also nennen, schreiben, auch von uns und meniglich darfür geehrt, geacht, gehalten, genent, geschriben und erkant werden, und darzu all und jegeliche gnad, herrlichait, freyhait, so wol des hergeprachten goldt und silber müntzens alss andere, auch alle ehr, wirde, vorthail, praeeminentz, recht und gerechtigkait, in versamblungen und ritterspilln, auch mit beneficien auf hohen und nidern stifften, gaistlichen und weltlichen, lehen und ämbtern zu empfahen und $\mathrm{zu}$ tragen und sonst in allen andern sachen, haben deren thailhafftig und empfengkelich sein, sich auch des allen, sonderlich aber des gräflichen titls und namens allenthalben mit allen ehren, sessionen, steen und processionen an allen enden und ortten nach iren ehren, notturfften, willen und wolgefallen frewen und geprauchen sollen und mogen, inmassen andere des Hailigen Reichs grafschafften solches haben und desselben rechtgeborne graven und grävinen sich von rechts oder gewohnhait wegen frewen, geprauchen und geniessen, von allermeniglich unverhindert, doch solle dise unsere erhebung und befreyung uns und dem Hailigen Reich an unsen und sonst meniglich an 
seinen obrigkaiten, rechten und gerechtigkaiten unvergriffen, unabbrüchig und ohne schaden sein, one gevärde.

Und gepieten darauf allen und yeden churfürsten, fürsten, gaistlichen und weltlichen, prelaten, graven, freyen herrn, rittern, knechten, haubtleuthen, landtvögten, vitzdomben, vögten, pflegern, verwesern, ambtleuthen, schuldthaissen, burgermaistern, richteren, räthen, burgern, gemainden und sonst allen andern unsern und des Reichs underthanen und getrewen, was wirden, standts oder wesens die sein, ernstlich und vestiglich mit disem brief und wöllen dass sy mehrberürte freyherrschafft Gronssfeldt hinfüran für ain graffschafft und offtgenante Josten und Johanssen gebrueder und ire nachkomen, inhaber solcher graffschafft desselben namens und stammens Bronkhorst sampt allen iren ehlichen leibs erben und derselben erbens erben, mann und frawen personen, wie obsteht, nuhn fürbashin ehewiglich also für graven und gravinen zu Gronssfeldt ehren, halten, schreiben, nennen und erkennen, sy auch in allen und yegelichen ehrlichen versamblungen, ritterspilln, hohen und nidern stifften und ämptern, gaistlichen en weltlichen, auch sonst an allen ortten und stetten, bey aller und yegelicher ehr, wirde, praeeminentz, vorthail, recht und gerechtigkait deren sich andere graven und grävinen von rechts oder gewohnhait wegen frewen, geprauchen und geniessen, gentzlich darbei pleiben lassen und sy an solchem allem nit hindern, bekomern oder belaidigen, noch das yemandt anderm zu thuen gestatten in kain weiss noch wege, alss lieb ainem yeden sey unser und des Reichs schwere ungnad und straff und darzu ain peen, nemblich hundert markk löttigs goldes zu vermeiden, die ain jeder so offt er freuenlich hierwider thete, uns halb in unser und des Reichs Camer und den andern halben thail vilgenanten graven zu Gronssfeldt und den inhabern derselben graffschafft oder iren erben und nachkomen, so hierwider belaidigt wurden, unnachlesslich zu bezalen verfallen sein solle.

Mit urkundt diss briefs besiglet mit unserm kayserlichen anhangenden insigel.

Datum zu Prag den 29 septembris 1586.

Ruedolff

Jacob Khurtz von Senfftenaw

Ad mandatum etc. Obernburger

Registrata:

Wenen, Österreichisches Staatsarchiv, Allgemeines Verwaltungsarcbiv, RAA (Reichsadelsakten), 49.3. 


\section{Diversen}

40 Proces-verbaal inhuldiging van graaf als landsheer

1719

Zij cond ende kennelijck dat op den achden aprilis duysent sevenhondert ende negenthien voor ons ondergeschreven respective schepenen des hoochgraffelijcken gerechte tot Gronsfelt specialijck sijnde geconvoceert door den gerichtsboode Hartman, sijn op het casteel alhier persoonlijck erschenen d'heer Olislagers, lieutenant ten dienste van sijne keyserlijcke majesteyt beneffens d'heer Wil. Kicken, drossard deser graeffschappe, dewelcke ons ende aen de pleuraliteyt der inwoonderen ende onderdaenen alhier hebbende kennisse gegeven van het droevigh overlijden van Sijne Hoochgraffelijcke Excellentie mijnheer Johan Frantz, graff zu Gronsfelt, Bronchorst ende Ebersteyn, generael feltmarschalk van sijne keyserlycke majesteyts armeen ende gouverneur des hertochdoms Luxembourg, etc. etc., onsen genadigen lantheere, wyens ziele zij den bermheertighsten Godt, Maria Sijne gebenedijde moeder ende den gantschen hemelschen heyr gerecommandeert, tenselven ons oock hebben ter handt gestelt alsulcke commissie ende authorisatie als het aen Haere Hoochgraffelijcke Excellentie vrouwe mevrouwe Maria Anna gebohrne gravinne van Torring ende Jettenbach, gravinne tot Gronsfelt, op haerlieder personen ende op den heere raad ende regent De Witte belyeft heeft te vereeren, sijnde deselve opgestelt in het Fransch ende gedateert den sevenden aprilis 1719 ende bij Haere hoochgemelte. Excellentie eygenhandigh onderteekent ende becraftight met derselver aedelijck pitschaft gedruckt in swarten Spaenschen lacke;

bovendyen is ons door deselve heeren worden geproduceert ende in rechte geëxhibeert extract uyt het testament van Sijne hoochgemelte Excellentie onsen heere graff tot Gronsfelt zaliger aendenckens de dato Franckfurt am Mayn den 14en dagh des maents mey int jaer 1706 sub copia authentica notarii Adams, waerbij doende blijcken dat Sijner Excellentie vrouwe gemalinne was genomineert ende geïnstitueert eenige ende universelen erffgenaeme van de gantsse naerlaetentschappe onses herren graffen van Gronsfelt, tzij van landt, leuthen, nyet daervan uytgenomen, soo hebben die voorschreve heeren gecommitteerde, bij absentie nochtans van den heere raad De Witte, versocht in conformiteyt van den inhoude haerer commissie alhier bij ons wettelijck te worden geadmitteert tot tredinge van de possessie deser graefschappe, heerlijckheyt ende landen van Gronsfelt ende allen ap- ende dependentien derselver geene gereserveert, van wat nature oft naeme die oock souden wezen, ende sijn zij heeren gecommitteerde daertoe bij ons ondergeschreven schepenen geadmitteert onder de formaliteyten daertoe staende;

ende waeraen voldoende, is bij deselve heeren ten overstaen van ons schepenen ende tmeesten deele der onderdanen deser vrij rijxe graeffschappe een vier van holtz ende stroye in den tweeden sale van het castele alhier worden aengesteeken ende immediate daernaer tselve oock met waeter door deselve worden uytgeblust, doende aldus de vlamme ende roeck opvliegen. Van daer is men geweest in het cleyn keuketjen, alwaer zij heeren gecommitteerde hebben den hale erhangen, de daeraen hangende ketens erschoven, 
deselve af- ende opgehangen, item de deure soo van de keuken als oock van de porte des castels van Gronsfelt gesloten ende wederomme geopent ende in der maniere voorschreve geplogen alle acten possessoer;

ende naer dyen sijn wij tsamen gegaen in den gaerden, gehoerende ende annex aen den voorschreven castele, alwaer op gelijck versoeck van de heeren gecommitteerde hun qualitate qua door ons schepenen is verleent ende gegeven reys ende aerde bij afbreeken van de tacken der boomen ende uytstecken van den waes ende grond in den selven gaerde met alle reël ende actuel recht van possessie der landen, weyden, etc., specterende aen desen hoochgraffelijcken huyse, twelck bij deselve heeren voor ende in naeme van Haere Hoochgraffelijcke Excellentie mevrouwe de gravinne tot Gronsfelt, onse tegenwoordige lantvrouwe, is worden aengenomen ende aldus is tgene voorschreven bekeert in hoeden van dese weth ende geleert te registreren ende ten versoecke copye geaccordeert.

Was de minute deser onderteekent als volght:

Wilh. Kicken, drossard als gecommitteerde tot het gene voorschreven;

J.G. Dewitte, ayant êté present al la possession prise à Hontem et Heugem, dependence de la comté;

D'Olislagers in naeme van Haere Hooghgraffelijcke Excellentie possessie genomen hebbende;

Graven, scabinus;

Nelys Baddrey;

Adam Pluemeeckers;

Lamb. Lousberchs;

Lins Kersmekers;

Adam Plueichmaeckeers;

met mij, quod attestor, J. God. Lebens, greffier tot Gronsfelt.

Staatsarcbiv München, Archiv Toerring Jettenbach, inv. nr. M 41, fol. 5-10.

41 Instructies voor de rentmeester

1737 en 1753

De tekst van de instructie voor de rentmeester uit 1737 (Variant A) is, met enkele kleine aanpassingen, in 1753 als 'voorlopige' ('provisional') instructie (Variant B) overgenomen. Dit 'voorlopige' karakter bleef bestaan tot circa 1780. Daarna is door commissaris Zollner gewerkt aan een nieune instructie, waarvan een concept bewaard is. Het is echter de vraag of dit ooit is voltooid en ingevoerd, omdat Zollner zelf het rentmeesterschap op zich nam. Variant $A$ wordt uitgegeven, de wezenlijkle afwijkingen in variant $B$ zijn in de noten opgenomen. 


\section{Instruction vor dem rentmaister zu Gronsfeldt verfasst anno 1737.2263}

Erstlich solle derselbe in dennen ihme anvertrautten herrschäfftlichen geschäfften und verrichtungen treu und verschwigen seyn, die ihme eingehändigte oder zuegefärttigte schrifften in guetten verwahr und in geheimb behalten und niemandt ausser dennen es gebühret hiervon etwas offenbahren.

Er solle allem deme so zum schaden und nachtheill der gräfflichen pupillin als dermahligen landtsfrau 2264 mit schruften, reden oder werckhen zuwider gehandlet würdet, alles fleisses vorkommen und da die hintertreibung dessen nit in seinen kräfften, solle er solches mit einen umbständtigen ambts bericht zeitlich auf uns gelangen lassen. ${ }^{2265}$

3

Er solle von dem herrschafftlichen getraydt, obst, hopfen, heu, landtereÿen, wisen, peunten, nachgrass, weÿden, zehent, holtz, heggen, gebüsch und dergleichen ohne vorgehent, ad valvas ecclesie beschehener affixion und licitation, auch ohne vorwissen und zuerziehung respective unsers 2266 drossards und schepfen nit disponieren, vill weniger hiervon etwas vor sich selbst verpachten, hingeben und verkauffen können, jedoch das von der licitation und pachtnemung die $^{2267}$ beambte allemahl ausgeschlossen sein sollen, ingestalten die erfahrung gegeben das bey deren movement die unterthannen aus zeitlichen respect oder forcht von der vorgehebten licitation gewichen seÿen, wurde er aber unter dennen licitanten eine heimbliche verständtnuss und zusammenhaltung vermerckhen, so kan die verpachtung eingestelt und dess weitheren verhalts an uns ${ }^{2268}$ berichtet werdten.

Bey abgab dess buschs solle er nebst dennen landtmessern und buschhiettern bedacht seÿn das die eichen mit dennen kleinen gebüsch nit abgehackht, sondern von disem separiert und mitler zeit mit besseren vortheill verkaufft, auch wo ein ÿbriger grundt verhandten, junge eichen gepflanzt und vor vieh ${ }^{2269}$ verwahrt werden.

Nachdeme die abgab und verkauffung all vorbenanter sachen an seithen unsers ${ }^{2270}$ drossards und rentmeisters eine ambtliche schuldigkeit ist, neben deme besagt unser ${ }^{2271}$ drosard jahrlich mit 2, und der buschhietter mit einem seill auch diser mit dem sogenanten durchreis-holz belohnet, die landtmesser hingegen von dem kauffer bezahlt werden, so solte die bis anhero beschehene aufrechnung dess trunckhs so anders hiemit abgeschafft und auf die zöhrung an dennen holtz- und busch abgaben ins künfftig nichts mehr passiert seÿn.

2263 Variant B alleen getal '17'.

2264 Variant B 'landtsherrschafft' in plaats van 'gräfflichen...landtsfrau'.

2265 Variant B 'entdeckhen' in plaats van 'auf...lassen'.

2266 Variant B 'dess herrschafftlichen hofrath Von Schmadel dan' in plaats van 'respective unsers'.

2267 Variant B 'der' in plaats van 'die'.

2268 Variant B 'an uns' ontbreekt.

2269 Variant B ‘vor vieh' ontbreekt.

2270 Variant B 'dess' in plaats van 'unsers'.

2271 Variant B 'unser', ontbreekt. 
6

Rentmeister solle nit fueg haben einige schulden ohne unseren ${ }^{2272}$ austruckhentlichen willen und assignation bezahlen zu können, wohingegen demselben allforderst eingebundten würdet die auf diser graffschafft anligente interesse dem herrn Johann Jacob Bähr, gewöhr handleren zu Lick, und ${ }^{2273}$ die pia legata jeden jahrs richtig und ohne verbleibenten ruckhstandt abzuführen.

Er solle nit zuegeben das die unterthannen unter dem praetext einig an die gräflicher pupillin $^{2274}$ machenter forderungen an ihren schuldigkeiten das geringste abziehen oder aufhalten, sondern er solle dise nebst all anderen, wan sye an der ${ }^{2275}$ zahlung nit zuehalten ohne längere zeit versaumbnuss durch die ihme selbst hiemit concedierente executionem paratam zu abführung ihrer schuldigkeit antreiben und bezwüngen, massen ihme auch unser ${ }^{2276}$ drossard auf allem fall hilfreiche handt zu biethen in commissis und umb so weniger eine hinternuss fürzulegen hat als er rentmaister solches an uns ${ }^{2277} \mathrm{zu}$ überschreiben hätte.

\section{8}

Es ist ihme rentmaister nit erlaubt ohne unser ${ }^{2278}$ vorherigen erinnerung und resolution, wie auch ohne vorwissen und zueziehung unsers ${ }^{2279}$ drossards und verständtiger schöpfen einige reparationes die einen species ducaten ÿbersteigen, vorzunehmen oder geschehen zu lassen, wo sonsten auch die handtwerckhsleuth in ihren zötlen die arbeith mehrers als bishero beschehen zu specificieren gehalten seyn sollen.

$$
9
$$

Er hat ein besondere sorg und auffmerckhsambkeit zu tragen, nit allein die landtsherrliche einkünften zu vermehren, sondern auch in bestimbter zeit nach dennen einnambs registern einzubringen und das bezahlte (wan es auch in abschlag beschehen wäre) richting einzuschreiben.

Er solle all dennen jennigen so ihre schuldigkeiten ${ }^{2280}$ abführen, lauttere quittanzen erthaillen mit exprimierung dess gelt- und getraÿdt quanti und für was jahr die zahlung geschehen seye umb andurch sowohl die underthonnen als das ambt in claris und guetten richtigkeit erhalten zu können.

Rentmaister solle hiemit alles ernsts gewahrnet seyn das er an solche leith, die ausserhalb der graffschafft entsessen und mit guetteren der gronsfeldtschen jurisdiction nit unterworffen seint, noch auch einen in der herrschafft, welche wissentlich nit zahlen können und sich auf das allmosen verlassen wollen, einige landtereyen, wisen, busch,

2272 Variant B 'herrschäfflich' in plaats van 'unseren'.

2273 Variant B 'die....und' ontbreekt.

2274 Variant B 'herrschafft' in plaats van 'graflicher pupillin'.

2275 Variant B 'der herrschafft' in plaats van'dennen angesezten'.

2276 Variant B 'der' in plaats van 'unser'.

2277 Variant B 'an uns' ontbreekt.

2278 Variant B 'unser' ontbreekt.

2279 Variant B 'dess' in plaats van 'unsers'.

2280 Variant B 'schuldigkeit' in plaats van 'schuldigkeiten'. 
holtz, obst und anders nit verpachte oder verkauffe, wan er nit selber hierumben gehalten werdten will, ausser es wäre ihme hierumben annemblich guette caution prestiert worden.

12

Wan einer seinen schuldigen landt und wisen pacht zwey gantze jahr nit bezahlt und an ${ }^{2281}$ sich selbsten auch arm und nicht solvendo ist, ${ }^{2282}$ solle er deme das landt oder wisen wider abnehmen und jemandt anders verpachten, den restanten aber mitls einziehung der früchten oder auf all thuenliche arth executive zur bezahlung anhalten.

13

Wan rentmaister das corbey pier an die handtwerchs- und corbey leuth abgibet, solle er ein ordentliches register halten, worein er die abgab mit benehnung dess quanti, der persohn und tags einschreiben, folgents dises register so unser ${ }^{2283}$ drossard zu attestieren hat der jahrs rechnung beylegen.

14

Damit der eine zeithero merckhlich abgenohmene pier-acciss ins kunfftig besser besorgt werdte, so solle sich keiner unserer unterthannen ${ }^{2284}$ unterstehen ein gepreu pier zuthuen, er habe es dan vorhero deme, so zur aufsicht bestölt ist, angesagt, wurdte nun aber dessen ainiger sich verwaigeren oder der visitation sich widersezen, der solle (als offt es bescheht) umb 3 louis d'or gestrafft werdten.

15

Damit aber unsere prauer 2285 -und zwang mühler einen mehrern nutzen fündten mögen, so hat rentmaister durch den drossard und gericht für allzeit zu besorgen das keinen gronsfeldtischen graffschaffts underthannen das pier ausschenckhen verstattet werdte, er habe dann solches bey einen prauer in besagter graffschafft genohmen, oder da er frembdes pier einbringet, der acciss mässigen bezahlung halber strackhs und rödlich angesagt. So nun aber jemandt dagegen handlen oder sich mit ausländtischen pier ohne ansagen und bezahlung dess acciss wurdte erfündten lassen, der solle toties quoties umb 3 luis d'or amendiert und dise auch die in dem vorgehenten puncten anfahlente straffgelter solcher gestalten vertheillt werdten, das hieran ${ }^{2286}$ dem landtsherrn ein, dem drossard auch ein, dan dem gericht und anzaiger mit einander das übrige drittl zuekommen solle.

\section{6}

Rentmeister hat dennen jennigen, so zur visitation der geprau und ausländtischen piers angestehlet seint, alle billiche manutenenz zuverschaffen und sich von ihnen halbjährig eine unterschriben liste, wer, wan und wie vill thonnen geprauet habe, geben zu lassen, folgents dise 2 listen der ambts rechnung beyzulegen.

Damit nun 2287 aber dise verordtnung destomehr befolget und der pier acciss ins aufnehmen gebracht werdte, so verwilligen wür ${ }^{2288}$ hiemit, das hinfüran von jedem gulden

\footnotetext{
2281 Variant B 'für' in plaats van 'an'.

2282 Variant B ‘so' toegevoegd.

2283 Variant B 'unser' ontbreekt.

2284 Variant B 'kein unterthan sich' in plaats van 'keiner unsererer unterthannen'.

2285 Variant B'damit nun aber die prauer' in plaats van 'damit aber unser prauer'.

2286 Variant B'hievon' in plaats van 'hieran'.

2287 Variant B 'nun' ontbreekt.
} 
so die summa ainhundertfünffzig gulden ÿbersteiget, der rentmaister vor sich 1 und vor ${ }^{2289}$ die visitatores 2 , zusamben also 3 styver, abziehen und in rechnung per ausgab schreiben derffe.

Wie die quittschlag ins kunfftig verificiert und eingerichtet werdten sollen, solches ist hinnach folio $10 \mathrm{zu}^{2290}$ dess mehreren zu befündten, indessen ihme rentmaister obgelegen, das er dem veldtschaden mit zwey unpartheylichen schöpfen absehen und nichts wider seine pflicht einschleichen lassen solle.

Die holz lista (worvon die buschmesser eine copiam behalten sollen) muess von disen dan unsern ${ }^{2291}$ drossard und rentmaister unterschriben und derselben alles im jahr verkauffte holtz weyden und dergleichen inseriert werdten, wohingegen das dem puschhütter bishero zuekommene seylholtz (jedoch ohne darinstehenter eichen und kerschbaumen demselben noch ferners in natura passieren solle, ohne dises unter die gelt einnamb zusezen.

$\mathrm{Zu}$ durchziehung der mess-ketten solle der mais- oder durchschlag vom buschhütter aus keiner eigennuzigkeit erweittert, sondern auff 30 hiesige zohl, und bey straff das der buschhütter fur selbes jahr ein ${ }^{2292}$ seillholz verliehren würdte, nit breitter ausgemaisst werden.

\section{1}

Die puschhüetter haben bishero auff der gräflichen pupillin ${ }^{2293}$ unkosten unnöthige zöhrungen zu machen sich unterstandten, dises solle ihnen hiemit abgeschafft und sye mit denen dabey anfahlenten sportlen zufriden seyn.

22

Gleicher gestalten solle er rentmaister weegen einnehmung der züns zur last der landtsherrschafft keine zöhrung aufrechnen können, massen er die züns zu Gronsfeldt im schloss einheben, von dennen jennigen aber so zu Heugem und Hontem an dennen angesezten siztägen ihren züns abzuführen, saumbig oder ungehorsamb seint, jedem 12 styver, wie es vor alters in brauch gewesen, zu seinen profit forderen ${ }^{2294}$ kan.

$$
23
$$

Bey verrechnung der postgelter und pothen löhner solle eine kurze anmerckhung geschechen von dem inhalt umb wissen zu mögen wembe der kosten zu tragen oblige, gestalten er rentmeister absolute zur last der landtsherrschafft nichts bezahlen solle, welches in das reel oder gemeine wesen einschlaget.

\footnotetext{
2288 Variant B 'würdt verwilliget' in plaats van 'verwilligen wür'.

2289 Variant B 'vor' ontbreekt.

2290 Variant B 'folio $10 \mathrm{zu}$ ', ontbreekt.

2291 Variant B 'unsern, ontbreekt.

2292 Variant B 'sein in plaats van 'ein'.

2293 Variant B ‘die herrschafftliche’ in plaats van 'der gräflichen pupillin’.

2294 Variant B 'einfordern' in plaats van 'fordern'.
} 
Er rentmeister solle auf der pupillin 2295 unkosten keine reis noch dieten ohne consens machen können, würdte es aber eine reys zu thuen die wichtigkeit der sach erfordern oder periculum in mora seyn, wo von uns ${ }^{2296}$ die resolution so geschwundt nit erhollet werden kunte, so will mann ihme die zöhrungscösten nach gebühr in rechnung passieren lassen.

Er solle alle 6 monnath ÿber die einnamb und ausgaaben einen summarischen kenner uns zusendten, welcher von ihme und unseren ${ }^{2297}$ drossard unterschriben und darinnen specialiter angemerckhet seyn mues was von dennen liquidierten restantien inner solchen zeit eingebracht wordten seye.

$$
26
$$

Nachdeme eine zeith hero die corbey zu praejudiz und schaden der landtsherrschafft merckhlich verschonnet und das weyden hackhen, baum einsezen, heggen- und hopfen arbeith, heu auffschlagen, strohe bändermachen, trayd umbsezen, so anders mehr auf landtsherrliche unkosten vorgenohmen worden, so hat der rentmeister dessen sich nit mehr zu unterfangen, sondern die corbeyen nach umhalt ${ }^{2298}$ dess recess und andere imediaten reichs herrschäfftlichen gewohnheit zu gebrauchen.

Die getrayder würdt er von vöglen, mäusen und anderem ungezifer, auch reegen und schnee nach möglichkeit besorgen, von den seinigen im castell separiert, auch sonsten die palckhen, thüren und fenster in guetten verwahr und also geschlossener halten, dass solche durch den windt nit eingeschlagen noch sonsten ruiniert werden.

28

Die obst bäum solle er zu rechter zeit puzen und bey abgang der alten guette junge peltzer einsezen, pelzen und pflanzen, auch selbe vom vich verwahren lassen.

Der lämber- und wohlzechent ist in der rechnung wie zur zeit dess rentmaisters Kicken geschehen, specifice vorzutragen, auch ein hierÿber verfaste designation von dem herrn pastorn attestieren zu lassen.

Dem wündtmühler solle er die näglen, schmirben und andere cleinigkeiten nit, die der graflichen pupillin ${ }^{2299}$ zuekommendte reparations unkosten aber erst alsdan bezahlen, da er mühler sich hierumben wirdet gemeldet, und rentmaister das gemachte gesehen, auch vor nothwendig und guett befundten hat.

\section{1}

Rentmeister solle alle vorkommente handlungen, relevien, werffschilling, so anders von zeit zu zeit fleissig in die güchtbüecher, rollen, lehen, koye-keur und andere register ohne offenhaltung eines spatii eintragen und sich bey straff der cassation nit fündten lassen, das etwas unregistrierter, villmünder eine post gefährlicher weis unterschlagen werdte, dises nun zu praecavieren, solle der lehenman in lehen und die schöpfen in gerichtlichen

\footnotetext{
2295 Variant B 'herrschafft' in plaats van 'pupillin.

2296 Variant B ‘von uns' ontbreekt.

2297 Variant B 'den' in plaats van 'unseren'.

2298 Variant B 'corbey nach inhalt' in plaats van 'corbeyen nach umhalt'.

2299 Variant B 'herrschafft' in plaats van 'graflichen pupillin'.
} 
handlungen eine contre-rolle halten und darin die sich anbegebente lehen, werffschilling, koye-keur, amenden und dergleichen casus nur summariter und kurz verzaichnen, auch die rollen dem lehen statthalter oder wer sonsten von hochen landtherrschafft deputiert würdet, auf jedes begehen vorlegen.

32

Er solle auff die landtsherrlicher guetter und zum schloss Gronsfeldt gehörrige landtereyen, wisen, peunten, plantagen und gebusch guette obsicht tragen, das solche nit geschmöllert noch mit neuerlich unbefuegten fahrt- und gehe weg, schaf tribe, geissen oder sonst einigen praejudiz belast werden, und gleichwie zu bessere erhaltung der paumb und höggen die letzt besagte geissen ausserhalb dess eigenthumbers stahl und hof jedermänniglich ohne entgelt todt zu schiessen erlaubt ist, also auch solle rentmaister qua fiscus wider jenne agieren, so die schaaf in busch gehen lassen und da er die remedie bey unserm $^{2300}$ drossard oder buschhüetter nit fundten wurdte, solches uns ${ }^{2301}$ zeitlich zu ÿberschreiben nit ermanglen.

33

Das archiv und gherichts bücher, prothocolla, register und alle andere schrüfften solle er in guetter verwahr aufbehalten, wan er anderst nit will, umb deren abgang oder verluest hergenohmen werden, wurdte es aber die nothdurfft erforderen, unserm lehen statthalter, drossard oder unserm mandatario einiges documentum auszulifern, soll er ihme dagegen einen empfangs schein geben lassen, umb ermeltes document seiner zeit widerumb an sich bringen zu können.

Er solle beeyfert seyn, das reel und gemaine wesen, auch der armen gelter in guetten forthgang und redlich getreuer verrechnung zu erhalten und im fahl sich dagegen an seithen dess drossards, schöpfen oder gemeindte ein hinternuss oder widerlessigkeit ergeben solte, es an uns ${ }^{2302}$ berichtlichen gelangen lassen, damit auch in der bonderzahl und schatz lista seiner zeit kein abgang oder irrung erfolgen möchte, so sollen bey jeden veränderung die besizere umbgeschriben und ihme rentmeister fünff stüber umbschreibgelt bezahlt werden.

35

Soll der rentmeister zu endte dess monaths februarii die ambts rechnung (in welcher bey auszaigung dess rests die ausständten oder restanten specifice vorzutragen seint) zum standt richten, solche mit einer schnur durch ziehen, unterschreiben und forttigen, folgents dieselbe nebst dennen verificationen unserm ${ }^{2303}$ drossard der durchles-, auch gleichmässigen unterschreib- und färtigungswillen auf ein paar täg ÿbergeben, alsdann aber mit seinen bericht zu unsern handten ${ }^{2304}$ einschickhen und zumahlen

36

\footnotetext{
2300 Variant B 'unserm’ doorgehaald.

2301 Variant B ‘uns' doorgehaald.

2302 Variant B' an uns' ontbreekt.

2303 Variant B 'dem herrschafflichen hofrhath und' in plaats van 'unserm'.

2304 Variant B ‘zu unsern handten' doorgestreept.
} 
er rentmeister in dem gericht nit allein als actuarius zu sizen, sondern ${ }^{2305}$ auch als schöpf zu votieren, urtheill und recht mit zu sprechen hat, als wirdet derselbe seines eydts und gewissens erindert, auch auf fleissige les- und observierung der Gronsfeldtischen Rechtsordnung de anno 1671 besonders ad tit. 6, tit.11 par. 2, tit. 14, 15, 16, 17 et 18 kürtze halber angewisen, übrigens und

solle er uns ${ }^{2306}$ von zeit zu zeit bericht erstatten, wie die herrschafftliche einkünfften mit plantagen, einfangen, verpachtungen, sonderheitlich die fischerey und wündtmühle, steingruben, zechent, taubenrecht, jagtbahrkeit und dergleichen, item mit nutzlicher einwechselung oder herbeykauffung frembder grundtstuckhen und güetter verbessert, auch sonsten guette pollicey gehalten und die gemeindte vor armueth und ruin conserviert, folgsamb zu abzahlung ihrer schuldigkeiten jeder zeit in zuelänglichen standt gesezt werden mögen. Da er nun

diser instruction gehorsamblich nachleben, mithin das herrschafftliche interesse beförderen, schaden und nachtheill abwenden würdet, so sollen ihme vor einen jährlichen gehalt vierhundert gulden mastricher cours in rechnung zu bringen bewilliget, annebens für ihne und seine benöthigte leuth in schloss die wohnung, wie bishero ${ }^{2307}$ nebst gewölber, solder und stahlungen vergönnet, hingegen aber derselbe schuldig seyen, die auf seine menage erlauffente reparations-unkosten auf sich zu nehmen, und dessfahls die pupillin 2308 ohne entgelt zu halten, wobey nebens die zimer in mitteren stockhwerckh nebst dennen dahin gehörig noch zimblich guetten 3 lieg bettern, matrazen, polster, küssen, und vier neu wollenen döckhen allzeit sauber, verspört und für die landtsherrschafft oder deren abgeordtnete in bereithschafft verbleiben sollen. Nechtst deme aber und

würdet er rentmeister obligiert seyn, wan durch sein, seiner leuth und arbeither schuld oder hinlässigkeit eine brunst (davon Gott uns genädig bewahren wolle) in dem schloss auskommen oder derselbe wider dise verordtnung erweislich zum nachtheill handlen 2309 würdte, allen andurch erlittenen schaden nach erkantnüss unparrtheylicher leuth guettzumachen und zu bezahlen, zu dem endte und das er dise instruction getreu, redlich und fleissig befolgen wolle, hat er nit allein ${ }^{2310}$ nebst dem salario, all seine mobilia et immobilia, presentia et futura, cum constitutione ordinaria verhypotheciert, sondern auch eine personel caution auff..... ${ }^{2311}$ gulden Rheinisch ausgestölt. ${ }^{2312}$

\footnotetext{
2305 Variant B' nit...sondern' ontbreekt.

2306 Variant B 'uns' ontbreekt.

2307 Variant B 'wie bishero' ontbreekt.

2308 Variant B 'herrschafft' in plaats van 'pupillin'.

${ }^{2309}$ Variant B 'zum schaden und nachtheill der herrschafft handlen' in plaats van 'zum handlen'.

2310 Variant B 'nit allein': ontbreekt.

2311 Bedrag niet ingevuld.

2312 Variant B`sondern.....ausgestölt’ ontbreekt.
} 
Schlüsslich thuen wür uns ${ }^{2313}$ die revocation und aufhebung diser bestellung jeder zeit und nach gefahlen, wan mann ihme rentmaister obiger salarium pro rato bezahlen würdet, vorbehalten getreulich und ohne gefährde. Zu wahren urkhundt dessen haben wür dise instruction respective schalt zötl aigenhändtig unterschriben und unser angebohrnen gräfliches insigl bey gedruckht folgents ihme rentmeister gegen einen revers und aufgeschwornen pflicht eingelifert. ${ }^{2314}$

So geschehen Gronsfeldt den zwanzigisten tag monnaths augusti im sibenzehenhundert siben- und dreyssigsten jahr.

Weithers stehet in dorso unten her:

Heut den 13 februar 1747 nachmittag ungefähr ein viertl nach 3 uhr hat herr Heinrich Lebens, drossard und fiscus diser freyen reichsgraffschafft Gronsfeldt, vor und in nahmen ihro hochgräfliche excellenz unseres gnädigen landtsherrn in judicio zu Gronsfeldt, vor E von dem Boorn, Niclas Beckers und Michael Schrijnemekers, schöpfen, dan Jacob Berchmanns authorisierten loco secretarii, würckhlich ÿbergeben vorstehente instruction de dato 20en augusti 1737 für Johann Mathias Oligschlagers, rentmaister zu Gronsfeldt mit dem ersuechen solche in punctis et clausulis auf gedachten rentmaisters guetter renoviert, approbiert, realisiert und registriert zu halten, welches ihme auch jure domini et cujuscunque salvo nach unserer gerichts panckh rechten verwilliget und operibus legis adscribiert wordten, also geschehen von uns unterzeichneten

waren unterschriben

Niclas Bekers schöpfen

Michael Schrijnmeckers, schöpfen

Englbert von dem Boorn, schöpfen

J. Berchmanns, comittierter loco secretarii.

Weithers stehet noch oberhalb jedoch hiehero bemerckhet:

Heut den 13 en februar 1747 nachmittag ungefehr umb ein viertl nach 3 uhren hat herr Heinrich Lebens beeder rechten licentiat, drossard und fiscus diser graffschafft, vor und in nahmen ihro hochgräfliche excellenz unsers gnadigen landtsherrns vor uns Jacob Berchmanns, Engelbert von dem Boorn und Johann Franz Lebens, respective vice-statthalter und lehen assessorn der hochgräflichen lehen camer allhier nider gelegt die instruction für den rentmaister Johann Mathias Oligschlagers de dato 20en augusti 1737, mit dem ersuechen dieselbe in punctis et clausulis auf gedachten rentmaisters güetter renoviert, approbiert,

\footnotetext{
2313 Variant B 'würdet' in plaats van thuen wür uns'.

2314 Variant B de datumregel, beginnend met 'So geschehen' tot met het einde van de realisaties bij de schepenbank en leenhof ontbreken. In plaats daarvan als laatste zin en afsluiting: 'Zu wahre urkundt dessen hat mann dise provisional instruction respective von commissionsweegen gefärttigter interim ausgestellet, folgents ihme rentmeister gegen einen revers und aufgeschwornen pflicht eingelifert. Den 21 september anno 1753. Joseph Anton Prümmer commissarius propria subscrispit.'
} 
realisiert und registriert $\mathrm{zu}$ halten, welches ihme auch salvo jure domini et cujuslibet nach dises lehen hofs gewohnheit zuegestandten und ad opera legis in feudalibus genohmen wordten ist.

Ware unterschriben

J. Berchmanns vice statthalter und secretarius

Adhuc ulterius

Exhibitum in judicio von herrn fisco den 29a märz 1747.

Collatam hanc copiam cum copia authentica nec non inibi insertas realisationes ex flandrico in germanicum fideliter transsumptas cum suis copiis authenticis, quoad substantiam concordare attestor.

J. Berchmans caesareus publicus in Gronsfeldt residens notarius manu signoque notariatus mei propriis.

RHCL, Archieven van het Graafschap Gronsveld en de beerlijkheid Slenaken (tot 1728), inv. nr. 96.

42 Attestatie van hertog Johan Willem van Gulik betreffende de rijksonmiddellijkheid van het graafschap Gronsveld

\section{6 maart 1606}

Von Gottes gnaden, wir Johans Wilhelm, hertzog zu Gülich, Cleve und Berge, grave zu der Marck und Ravensberg, herr zu Ravenstein, etc., thun kundt hiemit, demnach unnss der wolgeborner unser liever getrewer Johann vonn Bronckhorst, grave zu Gronssfeldt, undertheniglich angelangt und gebetten ime auss allerhandt bewegenden ursachen urkundt und zeugnuss zu ertheilen, was massen bemelte Graffschafft der Röm[ischen] Kay[serlichen] May[estä]tt unserem allergnedigsten herren unnd dem Heiligen Reich allein underworffen, auch dorthin zu Turcken- und andern Reichs unnd gemeinen steuren ire gepür zu leisten verhafft, unnd niemanden anders mitt subiection steur und dergleichen unterworffig seie, dass wir als des loblichen Niederreinischen Westfelischen Kraiss director unnd mitt auss-schreibender Fürst ihme solche zeugnuss nicht verweigeren konnen, wissen uns demnach zu berichtten unnd ist bei Reichs- und Kräysshandlungen gnugsamb erfindlich dass die Graffschafft Gronssfeldt dem Heiligen Reich wie vorgemeldt unterworffen, zue Reichs- und Kraiss steuren gleich andern des Heiligen Reichs Ständen angeschlagen auch solchenn anschlag biss anhero contribuirt und geleistet habe, darüber er billig vonn niemandten $\mathrm{zu}$ allerhöchst g[nediger] Kay[serlicher] May[estä]tt und dess Heyligen Reichs und dieses Creiss praejudico zu beschweren.

Dessen zu urkundt haben wir diss mit unserem handzeichen unnd auffgetruckten secret becrefftigt. Geben auff unser vöstung Gülich am sechszehenden martii anno etc. sechszehenhundert.

Johans Wilhelm, Hertzog zu Gülich, etc.

V[idi]t W. van Nesselrode. 
(onleesbaar) Constant Framot s[subscripsi]t.

Concordat cum orig[inal]i.

Johann Valentin Armbroster lector subs[crip]sit.

Afscbrift

RHCL, Archief Rijkskamergerecht, inv. nr. 17, Q 15, fol. 97-98vo.

43 'Denombrement' of beschrijving van de rechten en inkomsten van de graaf van Gronsveld

Ongedateerd (circa 1650 en 1651)

Specificatie der qualiteyten, rechten ende gerechticheyden, rinten ende incompsten der graeffschappe van Gronsfelt, appendentien ende dependentien van dyen.

Ierst de voerss. graeffschappe is geleegen ontrint der Maesen bij Maestricht ende is gehoerende onder den Westphalischen Creyts, bodem van het H. Rijck.

Consisteerende deselve graeffschappe in vijff dorpen, onder hun hebbende andere gehuchten.

D'yerste dorp is Gronsfelt, het twede is Eckelrade, het derde Huegem, het vierde Hontem ende het vijffde Slenaecken.

Slenaecken heeft onder sich het cloester genaempt het Cruts, met een cleyn gehucht daer bij gelegen, genaempt Beselberch. Item heeft onder sich Beutenaecken ende Heyenraet.

Gronsfelt met Eckelrade is een corpus ende heeft een besonder gericht, bedient doer scholtet, schepenen, secretaris ende bode.

Dandere dry principaele dorpen hebben oock elck een gericht, besonder macht hebbende van hoeghe, middele ende leghe jurisdictie.

Van den gericht van Gronsfelt wordt geappelleert in civilibus voer heeren schepenen der stadt van Aecken ende van daer naer de Caemer van Spier.

Van den gericht van Huegem wordt geappelleert naer heeren schepenen van Luyck.

Van Hontem naer Hugem ende van daer naer Luyck, ut supra.

Van Slenaecken wordt geappelleert naer Gronsfelt ende van daer naer Aecken, als voer.

Sonder dat nochtans eenighe van de voergenoempde overhoeffden souden hebben eenich particulier gesach, geboth offte spetie van jurisdictie binnen eenige van de voerss. dorpen, ' $t$ waere in materie van executie van hunne vonnissen off andersins.

Alleenlijcken binnen het circuyt van Eckelrade is geleegen eene quantiteyt van erven, welcke erven worden genaempt die Bijbanck, wesende een lheen des hoffs van Valckenborch, ende contribueert deselve Bijbanck aen den Coninclijken Maiesteit van Hispanien met dandere goederen geleghen ende resorteerende onder denselven lheenhoff van Valckenborch.

Item binnen Gronsfelt is een aensiennelijck huys off casteel, gelegen in de ronde ende tusschen sijne mueren totten dack toe, doch nyet volcomentlijcken volbouwen ter zijden van den middach, gecost hebbende den bouw van den selven huyse ten minsten 
twintichduysent gulden, tstuck XX stuyvers Maestrichter cours, ende sijn allen die onderdaenen van den graeffschap schuldich thien mael te moeten commen wercken aen ' $t$ voorss. huys, die peerdt ende waegen hebben moeten vaeren, die keuters moeten in persoen commen wercken ende allen brieven moeten zij van Gronsfelt op Rimborch draegen, soe dickmael alst nodich is.

Aen het voerss. huys gehoert van allen ouden tijden het regael recht van de munte, dwelck te voertijden is seer proffitabel gewest ende nyet langher geleeden als vierthien off vijfthien jaeren heeft den rentmeester van Sijne Genaeden noch in reeckeninghe gebrocht ${ }^{2315}$ van 't proffijct van dyen hondert daelder jaerlijx, den daelder ad dertich stuyver Maestrichter cours.

Boven dyen gehoeren totten selven huyse off casteel van Gronsfelt eenighe berghen, seer naer daer bij ende consecutivelijcken bij Maestricht ende der Maesen gelegen, welcke eensdeels sijn beplant met wijngaert ende kan daeraff in tijden des vreets getrocken worden eene goede quantiteyt van wijn.

Uyt het binnenste van de voerss. berghen kunnen getrocken worden schoene ende helle santsteynen, bequaem om te bouwen ende andersins om te vercoupen, alsoe daer uyt kan jaerlijx een goet proffijct getrocken worden, in tijde van vreede als voer.

Item in de voerss. bergen sijn veel materien van solpeter gelegen, alsoe dat op ses off seven jaeren men gewoenelijck is daervan te proffiteeren eens de somme van vijftich gulden.

Vorts gehoert oock totten selven huyse eene seer schoene leencaemere, behelsende sesendertich groete lheenen ende dry hondert cleyne lheenen luttel meer off min.

Allen gichten ende goedenissen, mitsgaeders alle gerichtssaecken, commende op off van de voerss. lheenen, gehoeren ter kennisse van stadthelder ende leenmannen van den selven lheenhoff ende hunne vonnisen en zij nyet appellabel noch reformabel, als alleenlijcken voer sterckere mannen van lheen.

Die theenen die vercocht worden gheven den lheenheer orloffsgelt, als namentlijcken tot Gronsfelt den vijfftiensten pinninck.

Het hergeweyde van elck groet leen als tselve compt verheeven te worden, gheeft aenden lheenheere vijfthien golt gulden, den stadthelder ende leenmannen hunne rechten besonder.

Het heergeweyde van elck cleyn leen belopt aen den heere eenen golt gulden, den stadthelder ende leenmannen hun rechten apart als voer.

Dyen behalven gehoeren totten voerss. huyse off casteel van Gronsfelt viertich keuren, daeronder vijff peerts keuren ende dandere zijn koyekeuren.

Oock gehoert totten voerss. huyse die volle ende geheele jacht binnen die graeffschappe voerss. ter exclusie ende privatie van eenen yegelijcken, conform der constitutien van het Heylich Rijck ende der oude observantie in dit cas gehouden.

Item gehoert totten selven huyse die vischerie op der Maesen van Huegem ende binnen Slenaecken die vischerie op de Gulp, van d'een eynde der heerlijckheyt off jurisdictie aldaer tot het andere, ende is deselve Gulp rijck van forellen off truyten.

2315 In de tekst staat 'geborcht' 
Vorts gehoeren oock totten voerss. huyse seer goede ende proffitabele coninsvranghen, gelegen soe in de berghen ende boschen tot Gronsfelt als tot Slenaecken.

Item gehoert totten selven huyse de collatie van het personaetschap der kercken van Gronsfelt ende der pastorien tot Huegem, doch der heer proest van Onser Liever Vrouwenkercke tot Maestricht pretendeert die collatie van de voorss. pastorie tot Huegem, hoewel t'onrecht soe men verstaet, maer dry off vier van de leste pastoers van Huegem, om twist te schouwen, schijnen neffens die collatie van mijnen genedighen heeren oock eene geïmpetreert te hebben van de voerss. heer proest.

Voerts gehoert oock totten voerss. huyse die collatie van Sinte Amandus-autaer binnen der kercken tot Gronsfelt, gesticht ende rijckelijck begift bij de lieve voerelderen van mijn genedighen heer voerss.

Daerenboven competeert oock aende voorss. huyse die collatie van twee andere autaeren, beyde sub invocatione Beate Marie, soe in der kercken van Eckelrade als in de kercke van Slenaecken geleegen.

Item competeert den voerss. huyse die hellicht van de cornthiende, wolthiende ende lammerthiende binnen Gronsfelt, Eckelrade ende Ryckelt, wesende eene parochie, dander hellicht competeert den heeren personaet tot Gronsfelt.

Desen behalven is ' $t$ voorss. huys geleegen vast bij de gemeynte genaempt het Broeck, alsoe dat men met beesten kan daerop jaerlijx een groet proffijct maecken.

Ende onder anderen met schaepen, dye men vermach te hueden ende halden binnen de gansche graeffschappe, sijnde deselve estimaebel ‘s jaers hondert rijxdaelder.

Item gehoeren totten voorss. huyse veel meer andere schoene gerechticheyden, rinten ende incompsten, hier onder naerder te sien

Ruebsaet een vat, ergo alhier

$\begin{array}{ccl}\text { vat } & \text { cop } & \begin{array}{l}\text { schotel } \\ \text { off } \\ \text { quart }\end{array} \\ 1 & 0 & \end{array}$

Roggenerffpacht tot Gronsfelt

$220 \quad 1$

Des sijn hieraff 24 vat te betaelen tot...2316..jaeren toe incluys, met eenen gulden Maestrichter cours ende naer omloup der voorss. jaeren sijn te betaelen gelijck alle andere erffpachten.

Roggenerffpacht tot Eckelrade metten hoff van den Hoegaert

Roggenerffpacht tot Huegem

Roggenerffpacht tot Hontem

Roggenerffpacht tot Slenaecken, inbegrepen thien vat onlanx

bij mij geacquesteert

Roggen-lantpacht tot Gronsfelt van 85 bunder ackerlants 121283

$97 \quad 1$

$35 \quad 0$

groet roeden ende 12 cleyn roeden, het bunder gereeckent op vijfthien vat, bedraeght

Roggen-lantpacht tot Eckelrade, inbegrepen den pacht van dry 81 morgen geevinceert uyt handen van Melchior Ost

2316 niet ingevuld 
Roggen-lantpacht tot Huegem $563 \quad 3 \frac{1}{2}$

Noch van 56 groet roeden lants, versadt aen Jan van Vaels tot $56 \quad 1 / 20$

Gronsfelt

dico 56

$1 / 2$

Roggen-lantpacht tot Slenaecken, die aen Jan van Vaels betaelt 9

wordt, belopt

Roggen-thiendenpacht tot Gronsfelt, een jaer doer dander $156 \quad 0$

gereeckent op sesentwintich malder, is tsaemen

Roggen-thiendenpacht tot Eckelraade, een jaer doer dander $150 \quad 0$

gereeckent op vijffentwintich malder, in tijde van vrede is

Roggen-thiendepacht tot Ryckelt, een jaer doer dander op 78

derthien malder gereeckent, is

Gerst-thiendenpacht tot Gronsfelt sesentwintich malder, is $\quad 156 \quad 0$

Gerst-thiendenpacht tot Ryckelt derthien malder, is $\quad 78 \quad 0$

Haver-thiendenpacht tot Eckelrade (mits dat aldaer geen gerst $150 \quad 0$

gesaydt wordt) vijffentwintich malder, is

Haver-lantpacht tot Slenaecken opten Broeckhoff 210 0

vijffendartich malder, is tsaemen

Spelten lantpacht opten voerss. hoff tot Slenaecken 210 0

vijffendertich malder, is tsaemen

Desen pacht is versadt aen jonker Jan Hoven van Carsfelt voer

1600 gulden Mastrichter cours ende sweft proces in den Rade

van Brabant in materie van reductie, aldaer beweesen dat ' $t$ surplus van den genyet des pachts belopt veel hoeger als ' $t$ capital metten interest

Spelten erffpacht tot Slenaecken op verscheyden panden ende 268

onderpanden

Haverchins tot Eckelrade

$7 \quad 0$

Haverchins tot Slenaecken

$40 \quad 0$

Haverpacht tot Huegem

62

Capuyn tot Gronsfelt hondert negentwintich eenen halven

Capuyn tot Eckelrade seven ende tseventich eenen halven

Capuyn tot Huegem achtendeveertich

Capuyn tot Hontem vijfthien

Capuyn tot Slenaecken hondert ende twalliff

gulden stuyver

Summa summarum der capuyn is in alles dry hondert een ende 381

tachtentich, elcken capuyn gereeckent ad vijfthien stuyver off een ort rijxdaelders, is tsamen

Gansen tot Gronsfelt ende Eckelrade seventachtich; gansen 99

tot Huegem twallif, het stuck op eenen gulden gereeckent, is

tsaemen 
Hinnen tot Eckelrade acht, tot Hontem tweentwintich, tot 20

Slenaecken thien ende een halve, is tsaemen viertich ende een

halve, het stuck ad thien stuyver is

Eyer tot Slenaecken thien ende een halfft, tstuck ad een ort $0 \quad 2 \frac{1}{2}$

stuyvers is

Bedegelt tot Gronsfelt ende Eckelraade lopt tsaemen jaerlijx $\quad 68 \quad 0$

Bede tot Huegem $48 \quad 4$

$\begin{array}{lll}\text { Tot Slenaecken } & 401 / 2 & 0\end{array}$

$\begin{array}{lll}\text { Tot Hontem } & 17 & 15\end{array}$

Cinsen tot Gronsfelt ende Eckelrade $\quad 73 \quad 8$

$\begin{array}{lll}\text { Tot Huegem } & 28 & 3\end{array}$

Tot Hontem $\quad 12 \quad 4$

Tot Slenaecken $\quad 4 \quad 17$

Suycker tot Gronsfelt belopt op elck bunder lants (der 84 sijn) $121 \quad 15$

oock soe veel ponden suycker, maer thien bonder twee ende eene halve roye betaelen een pont negel ende een half pont wasse, alsoe datter noch blijven vierentseventich pont suyckers ende een half, elck pont gereeckent ad eenen daelder is

Dandere thien ende een halff bonder geven een pont 4

muscatennegel ende een halff pont wasse, tsaemen beloupende

Wolhtienden tot Gronsfelt, Eckelrade ende Ryckelt, doet een jaer doer dandere... ${ }^{2317}$

Lammerthiende doet jaers op die voerss. plaetssen off dorpen...2318

Weyden tot Gronsfelt, als namentlijcken dry ende een halff 105

bonder aen ende ontrint den casteel gelegen, beplant met jonge

boomen, doet jaerlijx elcke roye tot dertich stuyver gereeckent

ende het bunder tot twintich roden is

Eene grasplaets gelegen bij den Resenberch boven op het plat 15

van de Helle, wordt jaerlijx verpacht

Item eenen hoff haldende Christiaen Aussems erffgenaemen, 40

gelt jaerlijx $40 \frac{1}{2}$ vat roggen, te betaelen elck vat met eenen

gulden, is tsamen

Weyden onder Huegem als namentlijcken dry bunder 90

drieschen, versadt aen Herman Libert, het bunder ad twintich

daeler, is tsaemen

Noch twee bunder, een groet rode, vierthien ende een halve 62

cleyn rode, welcke te halden plach Gilet de la Trap, die daerop

een steynen huysken getimmert heft, is nu geëvinceert doer falt

van betaelinge ende guede regeringe, elck bunder gereeckent

ad twintich daeler, is tsaemen

Noch sesendertich groet roeden drieschen welcke die 54

2317 niet ingevuld

2318 niet ingevuld 
rentmeesters altoos gebruyckt ende gehalden hebben, is een bunder sesthien groet roeden, het bunder gereeckent als voer, doet tsaemen

Noch een beveltgen, gelegen bij de voorss. drieschen, dwelck 9

Thijs Vrancken te halden plochte, groet ontrint...2319, doet jaerlijx

Noch een beveltgen dwelck Collas tot Huegem te halden 9 0 plochte, groet ontrint...2320, doet jaerlyx

Noch een beveltgen, gelegen bij het Broeck van Heer, dwelck 10

Heyn Bunden te halden plochte, groet ontrint... ${ }^{2321}$, doet jaerlijx

Noch eene koyweyde tot Huegem, bij het Huegemer Broeck 25 gelegen, groet ontrint vijff bunder, doet jaers

Der Korffweert tot Huegem gelegen in der Maesen, groet 125 ontrint... ${ }^{2322}$

Noch een cleyn grientgen, dwelck onlanx is aengewassen, kan 6 jaerlijx verpacht worden, ontrint

Noch daerbij een cleyn plaets graeswas, vast neffens die 6 gemeynte van Sinte Peter gelegen, soude kunnen verpacht worden, jaerlijx

Den weerdt tot Ost in der Maesen geleegen is groet ontrint die 315 negen bunder, sonder prejuditie van de precise maete, het bunder metten rijsholt gereeckent op vijffendertich gulden (mits dat men nyet hoeft te thuynen) soude bedraegen tsaemen Boschgelt tot Gronsfelt, een jaer doer het ander gereeckent wordt slachholt vercocht voer

Is te noteren dat den bosch genampt den Resenberch tot noch toe wenich slachholts heeft voertgebrocht doer die mennichte van de jonge eyckenboumen die aldaer gewassen sijn, maer nu affgecapt doer het garnisoun van Mastricht, alsoe dat het slachholt nu seer wel is verscheenen te wassen ende wordt een jaer doer dander alhier gestelt

Boschgelt tot Slenaecken, een jaer doer dander gereeckent, belopt...2323

Sonder te reeckenen eene notabele quantiteyt van schoene jonge eyckenboemen aldaer opwassende, welcke alreets eensdeels souden konnen aen bouwholts ende andersins gebruyckt worden

Die vischerie opter Maesen tot Huegem doet jaerlijx

\footnotetext{
2319 niet ingevuld

2320 niet ingevuld

2321 niet ingevuld

2322 niet ingevuld

2323 niet ingevuld
} 
Den werffschilling ofte orloffsgelt in ' $t$ leenhoff tot Gronsfelt belopt, een jaer doer dander gereeckent... ${ }^{2324}$

Werffschilling off pinninxgelt van chinsgoederen off allodiael goederen die voer de banck tot Gronsfelt vercocht worden, belopt een jaer doer dander gereeckent op...2325

Werfschilling off pinninxgelt vallende voer de banck van Slenaecken, belopt een jaer doer dander gereeckent op...2326

Het hergeweyde soe van de groete leenen als cleyn leenen worden een jaer doer dander gestelt op...2327

Kuergelt soe van peertskueren als koykueren, een jaer doer dander gereeckent, worden alhier gestelt op...2328

Accijsgelt van de bieren die binnen der graeffschappe vertapt ofte gebrouwen worden, deen jaer doer dander gereeckent, wordt alhier gestelt op...2329

Bruecken ende boeten soe jaerlijx vallen in de geheele graeffschappe, worden een jaer doer dander gereeckent, alhier gestelt op...2330

Item alsoe eenen natuerlijcken is commen te sterven tot Eckelrade sonder testament gemackt te hebben off oock kinderen achter te laeten, sijn bij forme van confiscatie den heeren gevallen sijne goederen

Ierst eenen weyde groet ontrint ellef of XII roeden, beplant $8 \quad 0$

met boemen, welcke jaerlijx kan gelden off uytbringen

Noch ontrint dry morgen lants welcke kunnen uytbringen 6 jaerlijx vier vat roggen, het vat ad 30 stuyver is

Item is te weeten dat Ire Genade plochten tot Huegem te hebben op seeckere bouwplaetsse, daer den naegelsmet in gewoent heeft, een malder terven jaerlijx, maer mits dat den bouw is verdestrueert worden in het belech van Maestricht ende den pacht nyet en is betaelt worden, is de voerss. erve bij den tegenwordigen rentmeester uytverwonnen worden, alsoe dat het pant staet in plaetsse van de pacht

Staet ende memorie int cort ende somarischer wijse gestelt van de incompsten der graeffschappe van Gronsfelt, de anno 1651, toebehoerende S. Exellence heere Joest Maximiliaen, graeve tot Gronsfelt voorss. etc.

gulden stuiver

\footnotetext{
2324 niet ingevuld

2325 niet ingevuld

2326 niet ingevuld

2327 niet ingevuld

2328 niet ingevuld

2329 niet ingevuld

2330 niet ingevuld
} 
Ierstelijck beloept den erffpacht onder Gronsfelt $74 \frac{1}{2}$ vat 223 roggen, 't vatt tegens 3 gulden, facit in gelde

Den lantpacht onder Gronsfelt van 84 bonder, 19 groet ende 3824

18 clein roeden, inbegrepen 't lant dat der heer drossaert heft, 't

bonder ad 15 vat roggen, beloept $12747 / 8$ vat $1 / 2$ schotel

roggen, 't vat ad 3 gulden, facit in gelde

Die renten welcke in gelde onder Gronsfelt betaelt woorden 168

beloepen

Die thienden van Gronsfelt heeft dit jaer gedaen rogge 70 vat, 224

elck vaet vercocht ad 64 stuiver, doet in gelde

Aen terff 16 vat, 't vat ad 67 stuiver, facit in gelde

Aen spelt $291 / 2$, 't vat ad 30 stuiver, facit in gelde

$44 \quad 5$

Aen gerst 127 vat, 't vat ad 34 stuiver, facit in gelde

Item heeft deselve thienden gedaen aen wicken 19 1/2 vat, 't vat 39 ad 2 gulden, facit in gelde

Item aen haver 38 vat, 't vat ad 22 stuiver, facit 41

Aen boeckweyt 1 vat ad 1

Die Eckelrader thienden heeft dit jaer gedaen aen rogge 95 vat, 304

' $t$ vat vercocht ad 3 gulden 4 stuiver, facit

Aen terff $11 \frac{1}{2}$ vaet, 't vat ad 3 gulden 1 stuiver, facit in gelde 38

Aen wintergerst 11 vat, 't vat ad 2 gulden, facit

Aen spelt 40 vat, 't vat ad 24 stuiver, facit

Item aen haever 168 vat, 't vat ad 1 gulden, facit 168

Aen droegen lycoep

Den erfpacht onder Eckelraet beloept 47 vat roggen, 't vat ad 3141 gulden, facit

Den Hoegaertspacht tot Eckelraet beloept 21 1/2 vat 1/2 schotel 64 roggen, 't vat ad 3 gulden, facit

Den lantpacht onder Eckelraet, inbegrepen het lant dwelck der 210 heer drossaert in winninge heeft, beloept 70 vat $2 \frac{1}{2}$ schotel roggen, 't vat ad 3 gulden, facit

Den erfpacht onder Heugem beloept 35 vat rogge, elck vat ad 3105 gulden, facit

Den lantpacht onder Heugem beloept, inbegrepen tgeene der 1572 heer drossaert heeft, 524 vat roggen, 't vat ad 3 gulden, facit Summa lateris

RHCL, Archieven van het Graafschap Gronsveld en de heerlijkheid Slenaken (tot 1728), inv. nr. 10. 
44 'Taxa' van de heerlijkheid Slenaken, overzicht van heerlijke rechten verbonden aan de heerlijkheid Slenaken, opgesteld ten behoeve van de verkoop van de heerlijkheid.

$$
\text { ongedateerd (1779) }
$$

Taxa oder Anschlag der unmittelbaren Reichs-Herrschaft Schlenacken.

Diese Herrschafft ist zwischen Aachen. Lüttig und Mastricht gelegen, stosset gegen Sonnen-Aufgang an die Reichs-Grafschaft Wittem, gegen Mittag an die Herrschaft Teuven, Untergang an die Herrschaften Mertens-Vouren und Norbeck, Mitternacht an die Herrschaft Gulpen und haltet circa drey Stunden im Umkreis. Mitten durch selbige fliesset die Riviere Gulp, treibet die herrschaftliche Mühle und ist an denen kostbaresten Forellen sehr reich.

Jährliche Einkunften

\begin{tabular}{|c|c|c|c|}
\hline & & Patt[acon]s & $\mathrm{St}[\ddot{\mathrm{u}}] \mathrm{b}[\mathrm{er}]$ \\
\hline $1 \mathrm{mo}$ & Der Hof Schlenacken gibt jährlichen Pacht & 165 & \\
\hline $2 \mathrm{do}$ & $\begin{array}{l}\text { Thut jährlichs drey Frachten, jede gerechnet zu fünf } \\
\text { Guld. }\end{array}$ & 3 & 60 \\
\hline 3 tio & Die herrschaftliche Mühl gibt jährlichen Pfacht & 89 & 40 \\
\hline 4 to & Der jährliche Pfacht von vierzehn Bunder Land & 65 & 20 \\
\hline 5 to & Jährlich zwey Frachten & 2 & 40 \\
\hline 6to & Pfacht von ungefehr sechs Morgen Land & 3 & 60 \\
\hline $7 \mathrm{mo}$ & Pfacht von zwey Bunder Land auf Heyenroth & 7 & 40 \\
\hline $8 \mathrm{vo}$ & $\begin{array}{l}\text { Die Gemeinde Schlenacken zahlet dem gnädigen } \\
\text { Landherrn jährlichs Interesse von tausend Patt[acon]s } \\
\text { mit }\end{array}$ & 40 & \\
\hline 9 no & Zinsgelder, laut Register, jährlichs 1922 Stüber & 24 & 2 \\
\hline 10 & $\begin{array}{l}\text { Korn-Pfacht, laut Register, jährlichs } 15 \text { Fass } 2 \text { Kop, } \\
\text { zu } 30 \text { Stüber per Fass, ergo }\end{array}$ & 5 & 70 \\
\hline 11 & $\begin{array}{l}\text { Spelzen-Pfacht, laut Register, } 207 \text { Fass } 3 \text { Kop, gegen } \\
16 \text { Stüber per Fass }\end{array}$ & 41 & 44 \\
\hline 12 & $\begin{array}{l}\text { Haberpfacht, laut Register, } 18 \text { Fass } 2 \text { Kopp per Fass } \\
15 \text { Stüber }\end{array}$ & 3 & $371 / 2$ \\
\hline 13 & $\begin{array}{l}\text { Zins-Capaunen, laut Register, jährlichs } 35 \text { Stück } \\
\text { gegen } 20 \text { Stüber per Stück }\end{array}$ & 8 & 60 \\
\hline 14 & Hüner zwey Stück mit & & 20 \\
\hline 15 & $\begin{array}{l}\text { Das jährliche Schlagholz auf die herrschafliche } \\
\text { Buschen plus minus }\end{array}$ & 90 & \\
\hline 16 & Die Jagd und Fischerey p.m. & 16 & \\
\hline 17 & Der Novalien Zehend p.m. & 58 & \\
\hline 18 & $\begin{array}{l}\text { Der herrschaftliche Werff-Schilling oder zwölfte } \\
\text { Pfenning von verkauftem Allodia-Guth, wann nur } 24\end{array}$ & 100 & \\
\hline
\end{tabular}




\begin{tabular}{|c|c|c|c|}
\hline & $\begin{array}{l}\text { Bunder jährlichs, nach dem gemeinen Land-Preis } \\
\text { verkauft werden, thut järlichs }\end{array}$ & & \\
\hline 19 & $\begin{array}{l}\text { Die Churmöden werden Jahr per Jahr angeschlagen, } \\
\text { p.m. }\end{array}$ & 11 & \\
\hline 20 & Die Belehnungsgelder & 15 & \\
\hline 21 & Die Bieraccis jährlichs p.m. & 2 & \\
\hline 22 & Die Bruchten oder Amenden p.m. & 10 & \\
\hline 23 & $\begin{array}{l}\text { Der Unterthan, welcher Pferd haltet, ist dem } \\
\text { gnädigen Landsherrn jährlichs schuldig vier } \\
\text { Spanndiensten, so nach der gewohnlichen Land-Tax } \\
\text { gerechnet gegen einen Pattacon, deren aber sich nun } \\
\text { vorfinden } 24 \text { Gespann, ergo }\end{array}$ & 96 & \\
\hline 24 & $\begin{array}{l}\text { Der Unterthan, so mit keinem Pferd versehen, ist } \\
\text { jedem Haus, dem Landsherrn jährlichs schuldig } \\
\text { zehen Handdiensten, macht auf } 58 \text { Haushaltungen } \\
\text { gegen } 15 \text { Stüber per Tag }\end{array}$ & 108 & 60 \\
\hline & & 971 & $73 \frac{1 / 2}{2}$ \\
\hline
\end{tabular}

Jährlichen Ausgabe

\begin{tabular}{|l|l|l|l|}
\hline $1 \mathrm{mo}$ & $\begin{array}{l}\text { Die ordinaire jährliche Schatzung von 49 Bunder 10 } \\
\text { grosse und 14 kleine Ruthen per Bunder zwey Gulden } \\
\text { mit }\end{array}$ & 62 \\
\hline 2do & Die zwey Bunderen No 7 zahlen järlichs der Gemeinde & 2 & \\
\hline 3tio & $\begin{array}{l}\text { Der Hof No 1 zahlet der Kirchen zu Schlenacken } \\
\text { jährlichs }\end{array}$ & $22 \frac{1 / 2}{}$ \\
\hline & \multicolumn{2}{|l|}{$41 / 2$} \\
\hline
\end{tabular}

\begin{tabular}{|l|l|l|}
\hline Bleibet boni zum Empfang p.m. & 944 & 69 \\
\hline
\end{tabular}

\begin{tabular}{l|l|l|}
\hline \multicolumn{2}{|l|}{ Die Gebaue des Hofs und Mühl taxirt } & 2600 \\
$\begin{array}{l}\text { Item die im herrschaftlichen Busch befindliche aufgehende Eichenbäume } \\
\text { p.m. }\end{array}$ & 2000 \\
\hline & & 4600 \\
\hline
\end{tabular}

Der Ankaufer dieser Reichs-Herrschaft Schlenacken ist schuldig, den in der benachbarten Herrschaft Gulpen gelegenen Hof Bercheim gegen ein sicheres proportionirtes aus freyer Hand auszusetzendes Quantum anzuschlagen.

Gedrukt

Staatsarcbiv München, Archiv Toerring Jettenbach, inv. nr. M 55, fol. 244-245. 


\section{Curriculum vitae van de auteur}

Jacques (Theodorus Jacobus) van Rensch werd geboren te Horst 1953, doorliep het gymnasium te Venray, studeerde Nederlands Recht aan de Katholieke Universiteit Nijmegen (1971-1976) en volgde daarna de opleiding Hoger Archiefambtenaar aan de Rijksarchiefschool (1976-1977).

Hij was van 1978-1992 afdelingshoofd Inventarisatie bij Gemeentearchief Maastricht en werkte daar vooral aan de ontsluiting van de oude archieven van Maastricht vóór 1795. Tevens was hij van 1982-1995 docent Geschiedenis en Staatsinrichting aan de Lerarenopleiding in Sittard

In 1992 volgde de overgang naar het Rijksarchief Limburg te Maastricht als hoofd Dienstverlening, plaatsvervangend rijksarchivaris en van 2004-2005 waarnemend rijksarchivaris. Na de fusie van het Gemeentearchief Maastricht en het Rijksarchief Limburg tot Regionaal Historisch Centrum Limburg in 2005 werd hij Rijksarchivaris in Limburg en vanaf 2013 ook provinciearchivaris. Tussen 2005-2009 was hij tevens gemeentearchivaris Thorn.

Gedurende zijn loopbaan inventariseerde hij zelf diverse archieven of was daar bij betrokken (oud-rechterlijke en bestuurlijke archieven, kabinetsarchieven van de commissaris der koningin en kerkelijke archieven). Hij is betrokken bij diverse vakinhoudelijke organisaties in Limburg en de Euregio en verenigingen op het terrein van de regionale geschiedenis.

Onderzoeksactiviteiten en daaruit voortvloeiend publicaties hebben vooral betrekking op geschiedenis van het archiefwezen, aspecten van Limburgse rechtsgeschiedenis, geschiedenis van kerkelijke instellingen en volksvroomheid en laatmiddeleeuwse (beeldhouw)kunst. 